

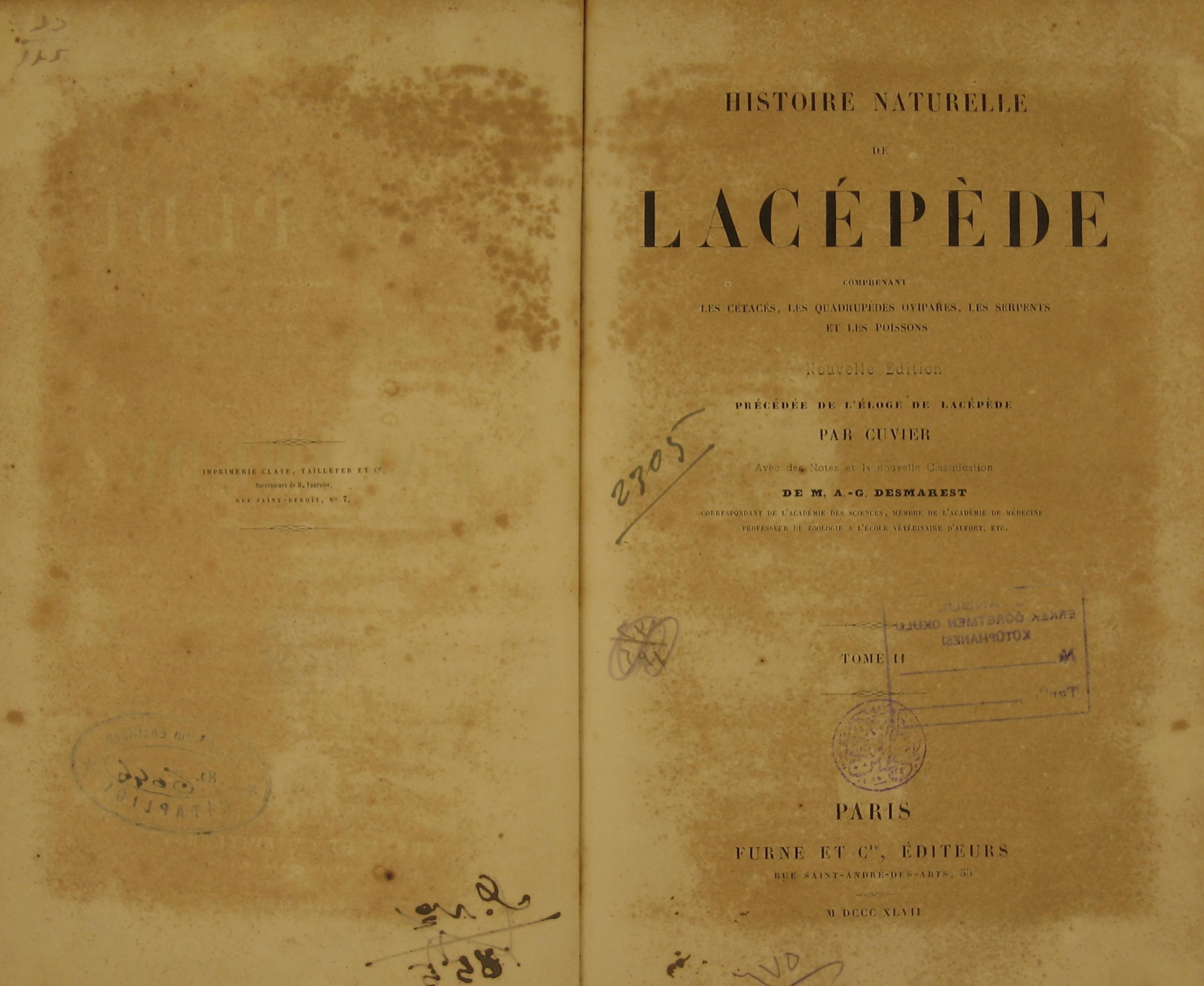




\section{HISTOIRE NATURELLE}

DES POISSONS.

1798. -1805

POISSONS OSSEUX.

Lorsque uous avous, par la pensée, réuni nées; mais elles reparaissent avec un assez autour de nous les diverses espèces de poissons qui peuplent les mers ou les eaux douces du globe, lorsque nous les avons contraintes, pour ainsi dire, a se distribuer en différents groupes, suivant l'ordre des rapports qui les distinguent, nous les avons vues se séparer en deux immenses tribus. D'un cóté ont paru les poissons cartilagineux; de l'autre, les osseux. Nous nous sommes occupés des premiers; examinons avec soin les seconds. Nous avons assez indiqué les différences qui les séparent; exposons donc, au moins rapidement, les ressemblances qui les rapprochent. Elles sont grandes, en effet, ces ressemblances qui les lient. Les formes extérieures, les organes intérieurs, les armes pour attaquer, les boucliers pour se défendre, la puissance pour nager, l'appareil pour le vol, et jusqu'à cette faculté invisible et terrible de faire êprouver à de grandes distances des commotions violentes et soudaines, tous ces attributs que nous avons remarqués dans les cartilagineux, nous allons les retrouver dans les osseux. Nous pouvons, par exemple, opposer aux pétromyzons et aux gastrobranches, les cécilies, les murènes, les ophis; aux raies, les pleuronectes ; aux squales, les ésoces; aux acipensères, les loricaires; aux syngnathes, les listulaires; aux pégases, les trigles et les exocets; aux torpilles et au tétrodon électrique, le gymnote et le silure, également électriques ou engourdissants. A la vérité, les diverses conformations des cartilagineux ue se remontrent dans les osseux qu'altérées, accrues, diminuées, ou du moins differemment combigrand nombre de leurs premiers traits, pour qu'on les reconnaisse sans peine. Elles annoncent toujours l'identité de leur origine; elles ttestent l'unité du modèle d'après lequel Ia nature a faconné toutes les espèces de poissons qu'elle a répandues au milieu des eaux. Et que ce type de la vitalité et de l'animalité de ces innombrables animaux est digne de l'attention des philosophes! II n'appartient pas, en effet, exclusivement à la grande classe dont nous cherchons à dévoiler les propriétés : son influence irrésistible embrasse tous les êtres qui ont reçu la sensibilité. Bien plus, son image est empreinte sur tous les produits de la matière organisée. La nature n'a, pour ainsi dire, créé sur notre globe qu'un seul ètre vivant, dont elle a ensuite multiplié des copies plus ou moins modifiées. Sur la planète que nous habitons, avec la matière brute que nous foulons aux pieds, au milieu de l'atmosphère qui nous environne, à la distance où nous sommes placés des différents corps célestes qui circulent dans l'espace, et sous l'empire de cette loi qui commande à tous les corps et les fait sans cesse graviter les uns vers les autres, il n'y avait peut-être qu'un moyen unique de départir aux agrégations de la matière la force organique, c'est-à-dire le mouvement de la vie et la chaleur du sentiment. Mais comme cette cause première présente une quantité infinie de degrés de force et de développement, et que par conséquent elle a Cuané naissance à un nombre incalculable de résultats produits par les différentes combinaiu. 
ture a pu être aussi admirable par la variété proportions moins propres à une grande variété des détails qu'elle a créés, que par la sublime de mouvements, et surtout par un aplatisse simplicité du plan unique auquel elle s'est as- ment très-marqué. Nous verrons méme ce déservie. C'est ainsi qu'en parcourant le vaste ensemble des êtres qui s'élevent au-dessus de la matière brute, nous voyons une diversité, pour ainsi dire, sans bornes, de grandeurs, de formes et d'organes, devenir, par une suite de toutes les combinaisons qui ont pu ètre réalisées, le principe et le résultat d'une intussusception de substances très-divisées, de l'élaboration de ces substances dans des vaisseaux particuliers, de leur réunion dans des canaux plus ou moins étendus, de leur mélange pour former un liquide nutritif. C'est ainsi qu'elle est la cause et l'effet de l'action de ce liquide, qui, présenté dans un état de division plus ou moins grand aux divers fluides que renferment l'air de l'atmosphère, ou l'eau des rivières et des mers, se combine avec celui de ces fluides vers lequel son essence lui donne la tendance la plus forte, en reçoit des qualités nouvelles, parcourt toutes les parties susceptibles d'accroissement ou de conservation, maintient dans les'fibres l'irritabilité à laquelle il doit son mouvement, devient souvent, en terminant sa course plus ou moins longue et plus ou moins sinueuse, une nouvelle substance plus active encore, donne par cette métamorphose à l'étre organisé le pouvoir de sentir, ajoute à la faculté d'ètre mu celle de se mouvoir, convertit une sujétion passive en une volonté efficace, et complète ainsi la vie et l'animalité.

Nous venons de voir que les mêmes formes extérieures et intérieures se présentent dans les poissons cartilagineux et dans les poissons osseux : les résultats de la conformation prise dans toute son étendue doivent donc étre à peu près les mèmes dans ces deux sous-classes remarquables. Et voilà pourquoi les osseux nous offriront des habitudes analogues à celles que nous avons déjà considérées en traitant des cartilagineux, non-seulement dans la manière de venir à la lumière, mais dans celle de combattre, de fuir, de se cacher, de se mettre en embuscade, de se nourrir, de rechercher les eaux les plus salutaires, la température la plus convenable, les abris les plus sủrs. Voilà pourquoi encore nous verrons dans les osseux, comme dans les cartilagineux, l'instinct se dé grader à mesure que des formes très-delices un corps très-allongé seront remplacés par des croissement de l'intelligence conservatrice, bien plus de régularité dans les poissons osseux que dans les cartilagineux, parce qu'il n'y est pas contre-balancé, comme dans plusieurs de ces derniers, par des organes particuliers propres à rendre à l'instinct plus de vivacité que ne peuvent lui en Oter les autres portions de l'organisation.

En continuant de considérer dans tout leur ensemble les osseux et les cartilagineux, nous remarquerons que les premiers comprennent un bien plus grand nombre d'espèces rapprochées de nos demeures par leurs habitations, de nos besoins par leur utilité, de nos plaisirs par leurs habitudes. C'est principalement leur histoire qui, entrainant facilement la pensée hors des limites et des lieux et des temps, rappelle à notre esprit, ou, pour mieux dire, à notre cœur attendri, et les ruisseaux, et les laes, et les fleuves, et les jeux innocents de l'enfance, et les joyeux amusements d'une jeunesse aimante sur les bords verdoyants de ces eaux romantiques. On ébranle vivement l'imagination en peignant l'immense Océan qui soulève majestueusement ses ondes, et les flots tumultueux mugissant sous la violence des tempétes, et les énormes habitants des mers resplendissants au milieu de l'éclatante lumière de la zone torride, ou luttant avee force contre les énormes moa. tagnes de glace des contrées polaires: mais on émeut profondément l'áme en lui retracant surface tranquille d'un lac qui réfléchit la clarté mélancolique de la lune, ou le murmure léger d'une rivière paisible qui serpente au milieu de bocages sombres, ou les mouvements agiles, les courses rapides, et, pour ainsi dire, les évojouant au milieu d'un ruisseau limpide, troublent seuls le silence et la paix d'une rive ombragée et solitaire. Les premiers tableaux sont pour le genie; les seconds appartiennent à le touchante sensibilité.

' Discours sur la nature des poissons. dont nous avons déjá parlé ', se montrer avec lations variées de poissons argentés, qui, en se
TABLEAU

DEs Gexaes

\section{DES POISSONS OSSEUX.}

\section{DES POISSONS}

Le sang rouge; des vertèbres; des branchies au lieu de poumons.

SECONDE SOUS-CLASSE. POISSONS OSSEUX.

Les partus solides de Finteriaur du corps, osseuses.

PREMIERE DIVISION.

DE LA SECONDE SOUS-CLASSE,

CINQUIÈME DIVISION

DE LA CLASSE DES POISSONS.

Un opercule branchial, at tue membrane branchiale

DIX-SEPTIEME ORDRE

DE LA CLASSE ENTIËHE DES POISSONS, of

PREMIER ONDRE

DE LA PAEMiKHE Divisiox DES OSSEUX -

POISSONS APODES.

Point de nageoires infericures entre le musequ et l'anus,

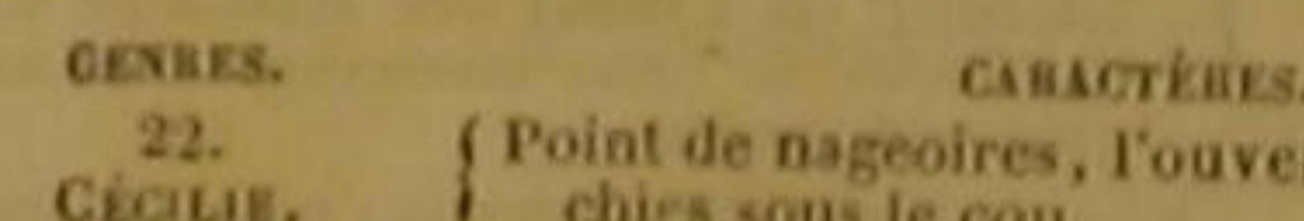

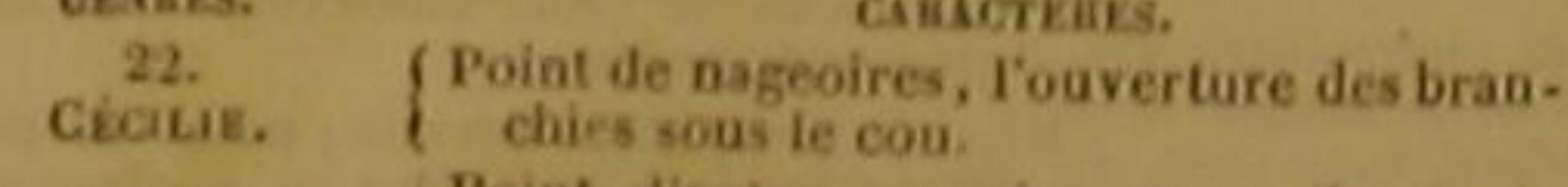

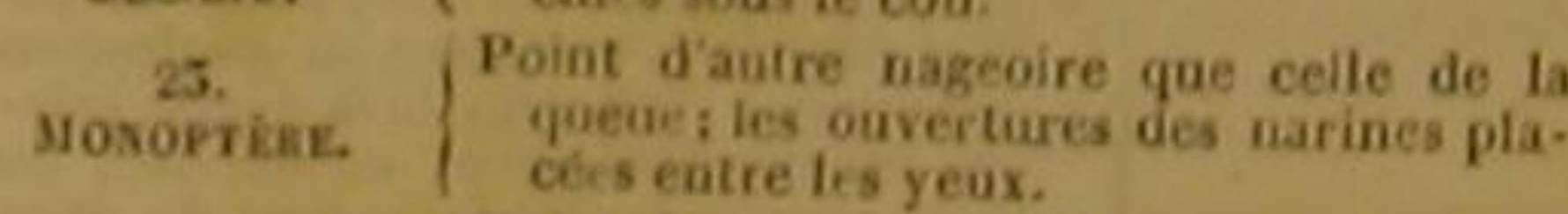

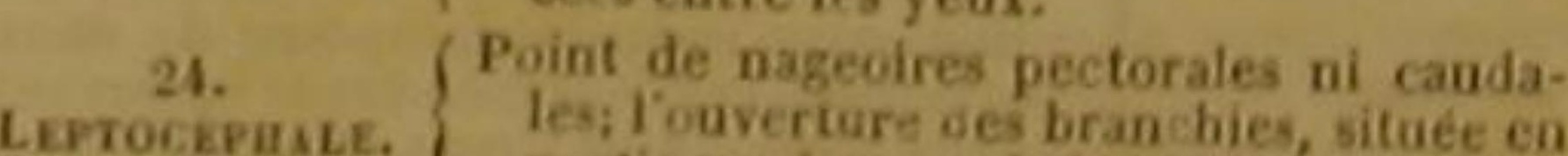

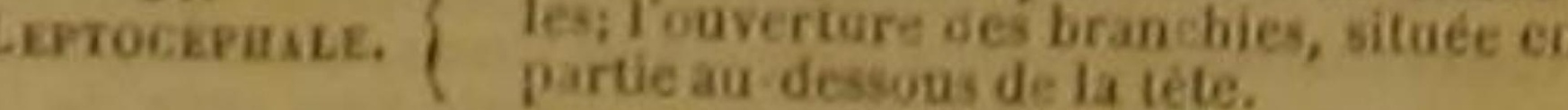
25. $\quad\left\{\begin{array}{l}\text { Des nageoires pectorales et de l'anus; } \\ \text { point de nageoires da dos ni de la } \\ \text { queue. }\end{array}\right.$

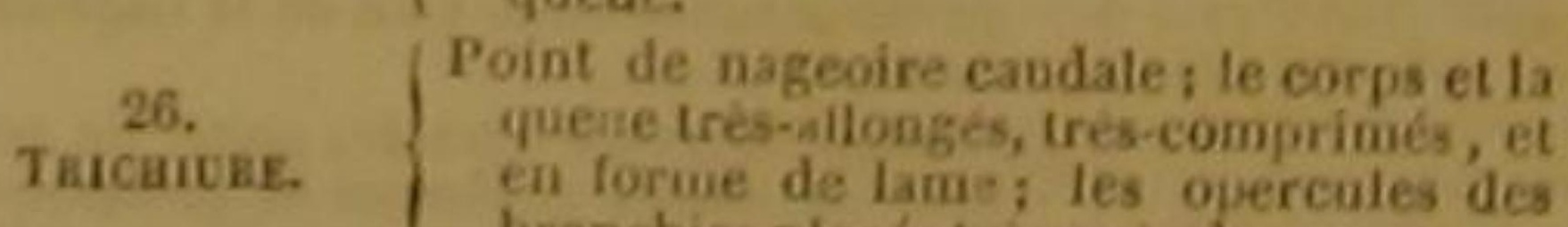
27. Des nagenies placés trés-prés des yeux. NoroptżuE. $\left\{\begin{array}{c}\text { Des nageoires pectorales, de lanus et du } \\ \text { doss point de nageoire cudale; le corps } \\ \text { trés-court. }\end{array}\right.$ Point de nazeoire caudale; le corps et la
queue cylindrigues et tres-allong as re-

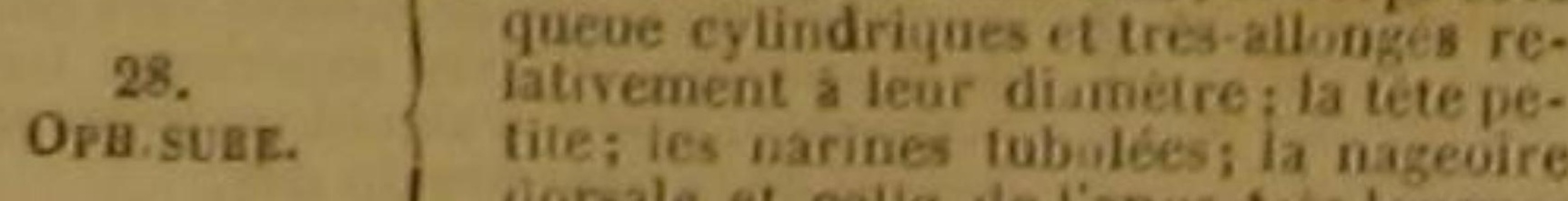

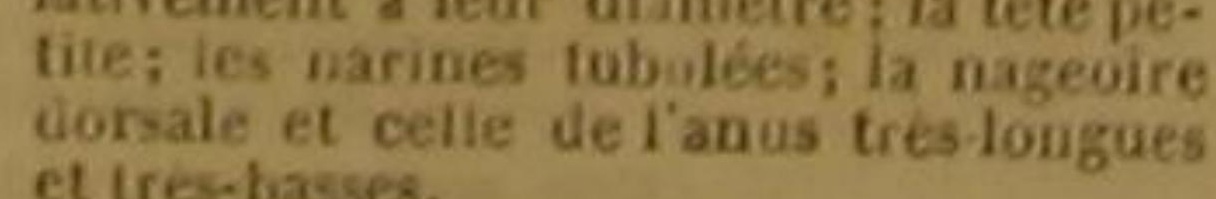

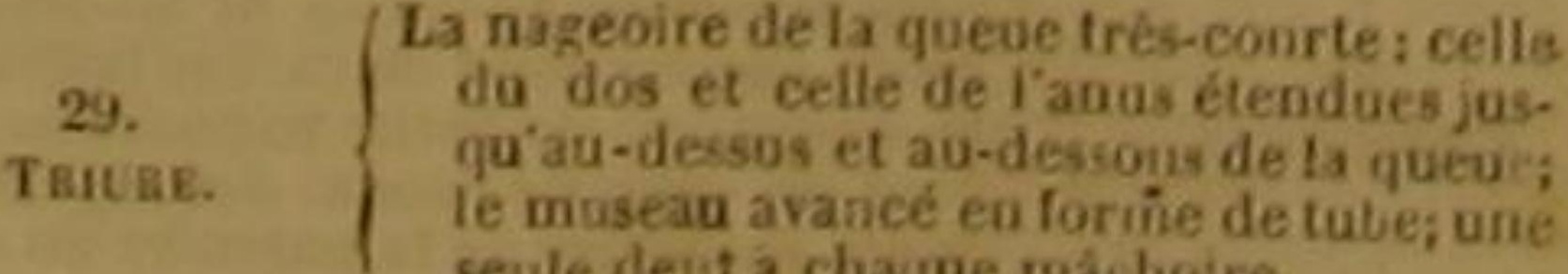

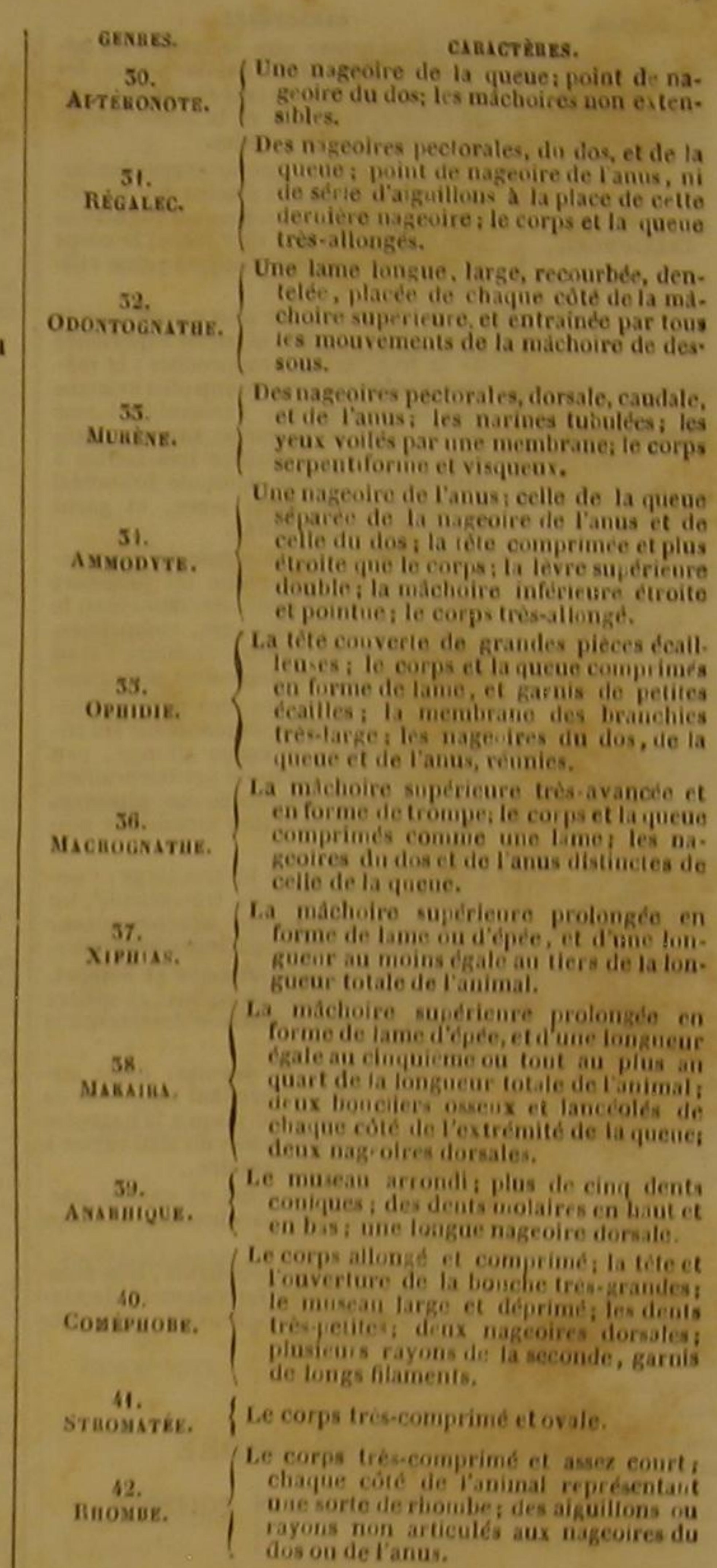

aire du dos de la queues point de na. quecue; poimt de nageoire de lanus, in terutere mageoire; le corps et la queue
tes-allonges. lame longue, large, recourbde, denchaire superieure, et entrainé par tous
its mouvements de la machoiro de des.

itubules; les

serpentiforme et visquedx.
Une naseofre de lanusi celle de ta queue pareo do la nageoire de lanus et de
le du dos i la cole comprime el plas pointue, le choire inféciesse éroito tete couverie de grandes pieces écall Co garnis do pelites ins nageoires du dos, de la

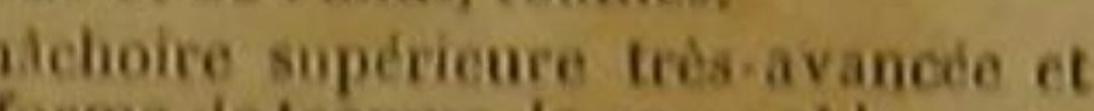
comprimés comme une lime les na.

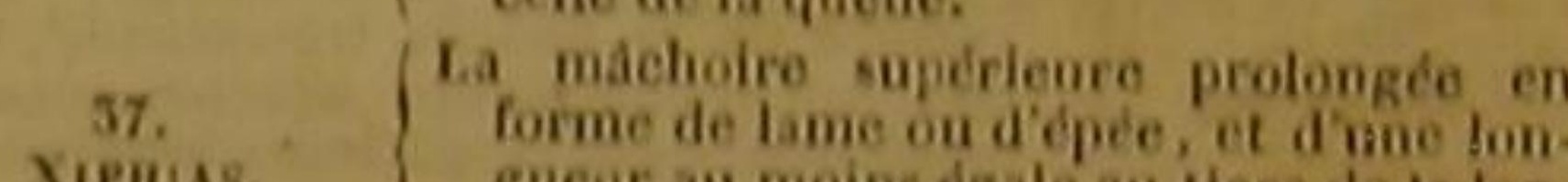
guenr au moins tgale an in
gucur totale de Tanimal. máchoire supécrienre prolongte en gale au cimquieme ou tout au plus an
quart de ia longueur totale de $I_{\text {snimal }}$

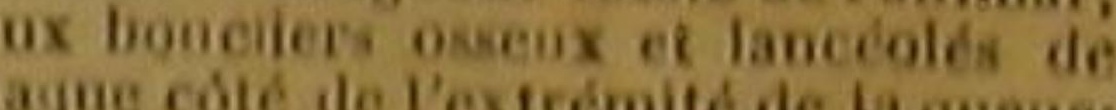
corps allongé et comprimé; la tate et Touverture de la bouche trein arandes
le musean large et deprime; fes dents pres.jentes; denx nageoires dorsales:
plusiens rayons de la seconde, garnis
de tongs filaments.

\{ Le corps trés-comprimé et ovale.

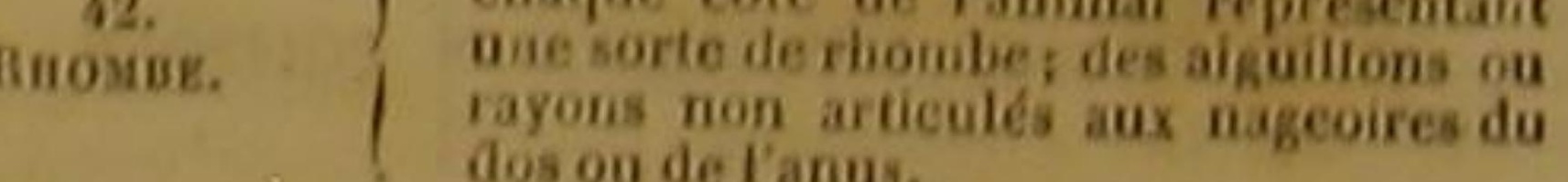

DIX-HUITIEME ORDRE

DE. LA CLASSE ENTIÈRE DES pOISsONs, DEUXIẺME ORDRE

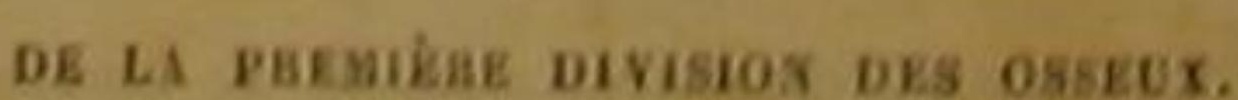
$-$

POISSONS JUGULAIRES.

Des nageoires situées sous la gorge.

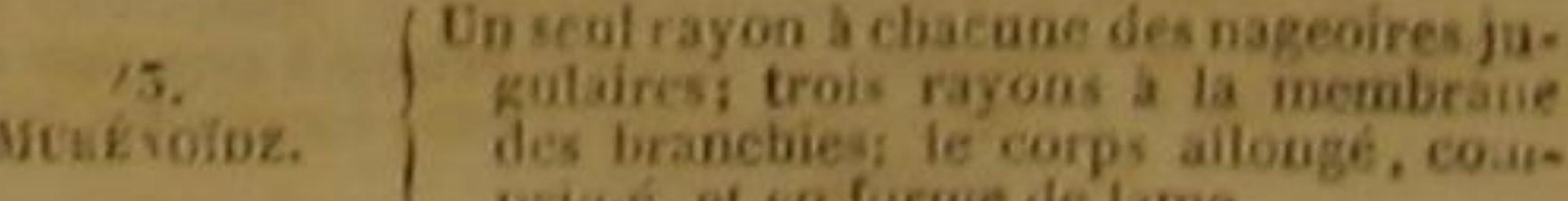




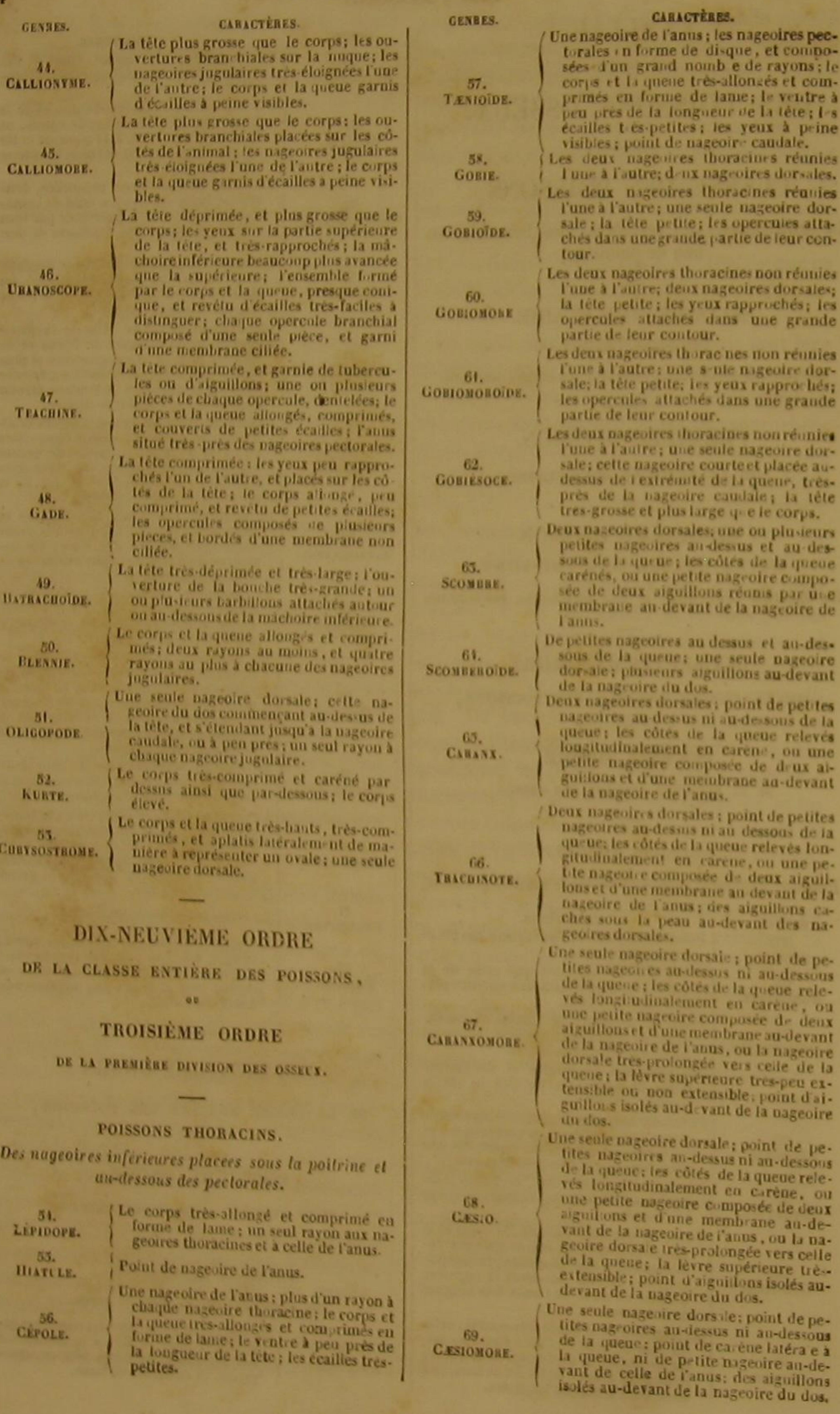

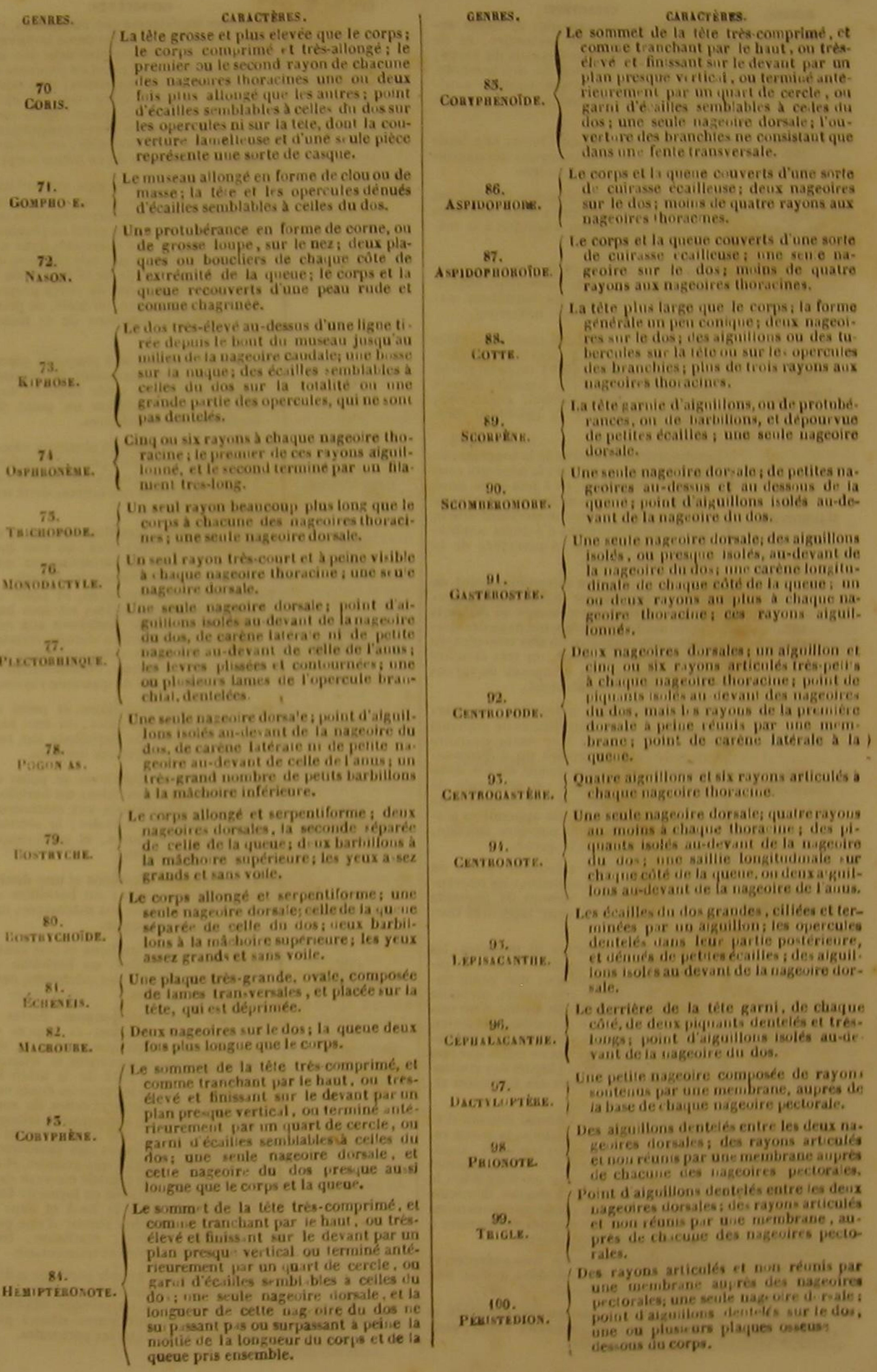


6

IISTOIRE NATURELLE

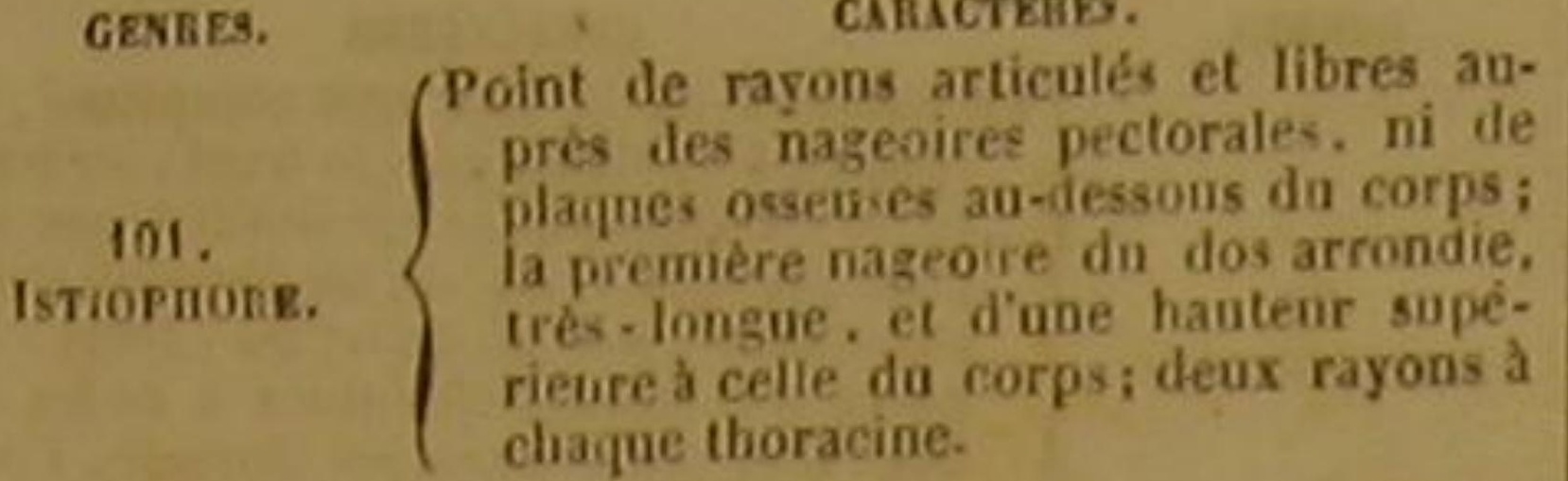

102. Point de nageoire de lanns; une seule

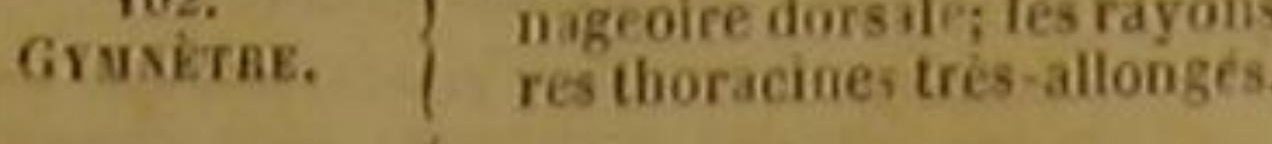

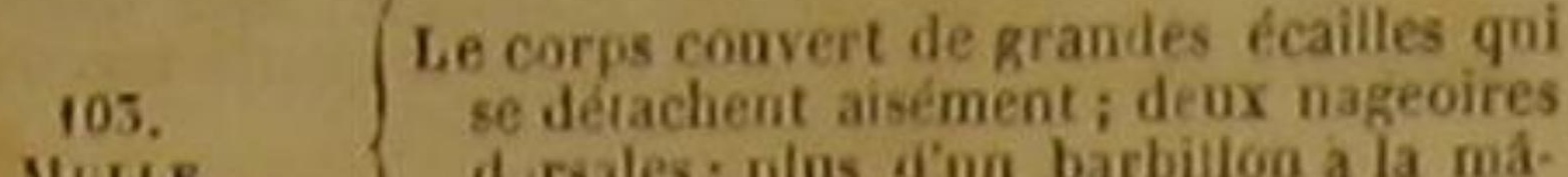

choire inferieure.
Les crailles grandes et faciles a détacher;

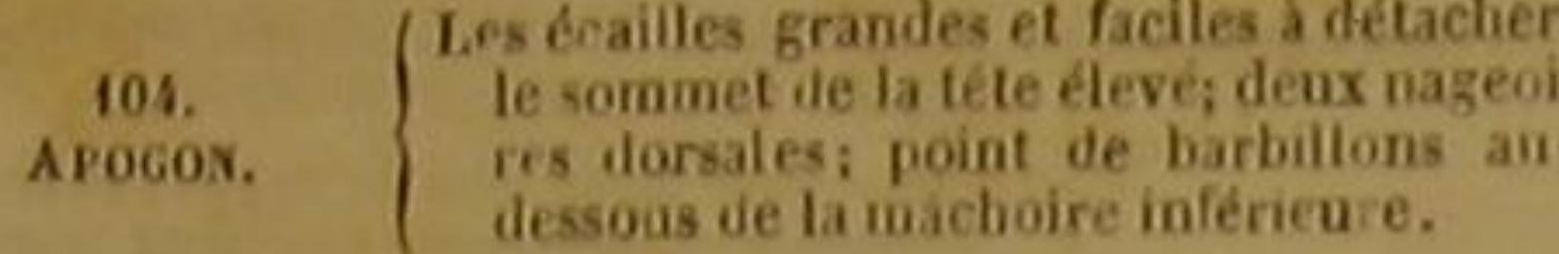

La nageoire de la queue innoblée; celte
nageonire et ies pectorales aussi longues

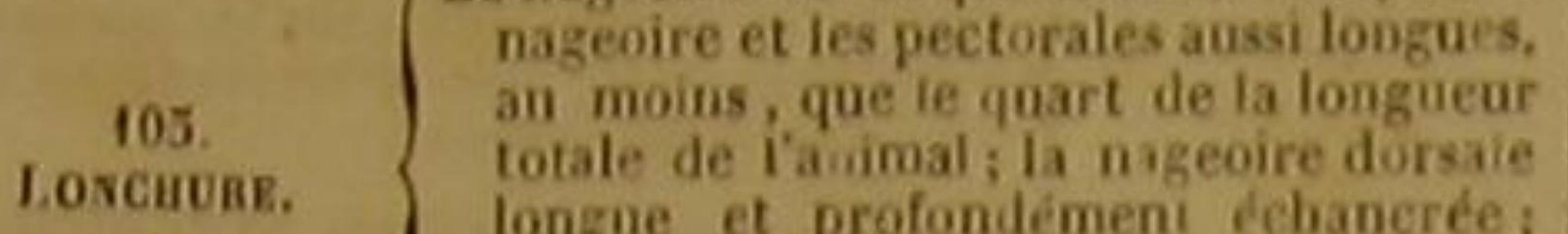

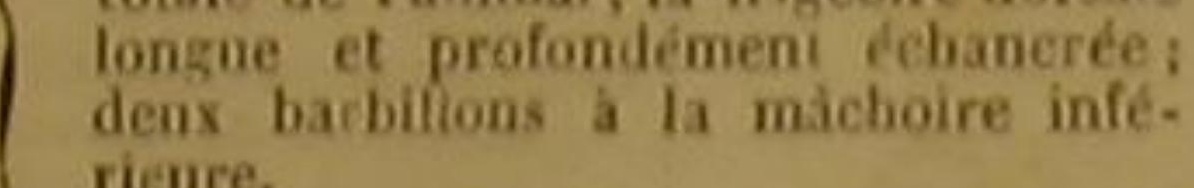

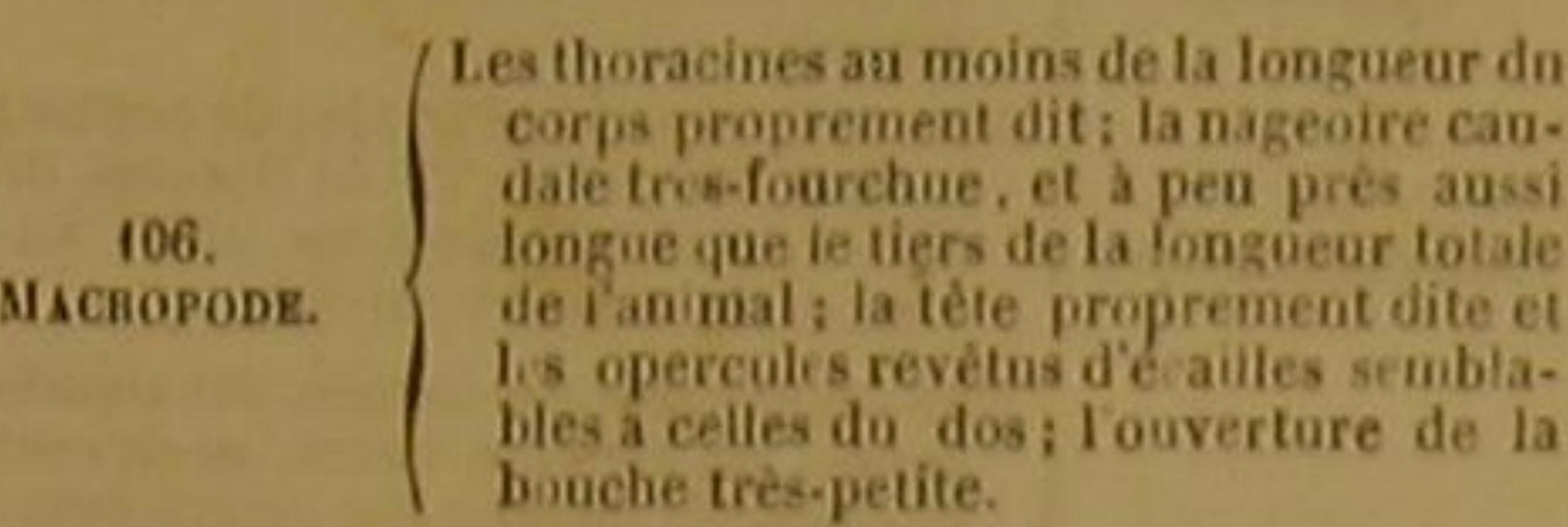

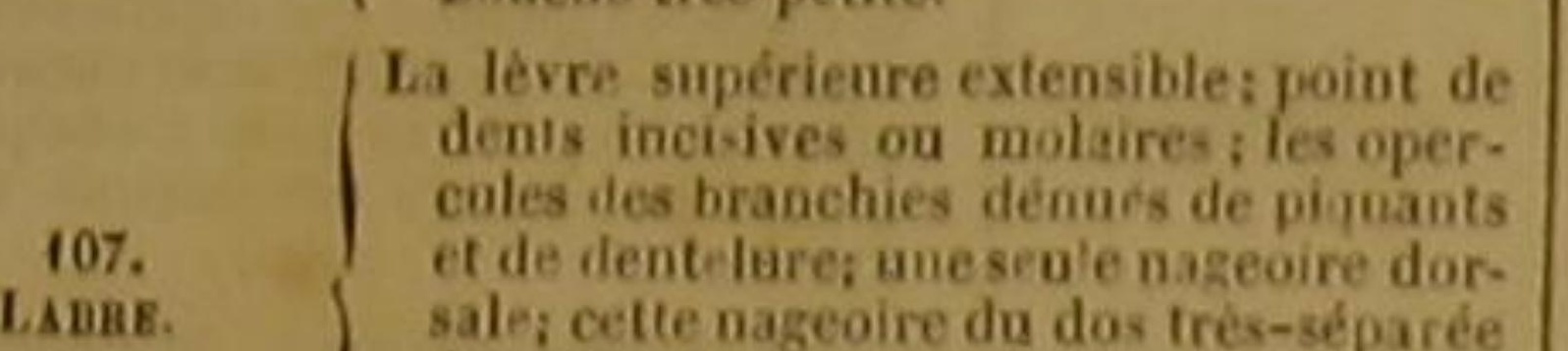

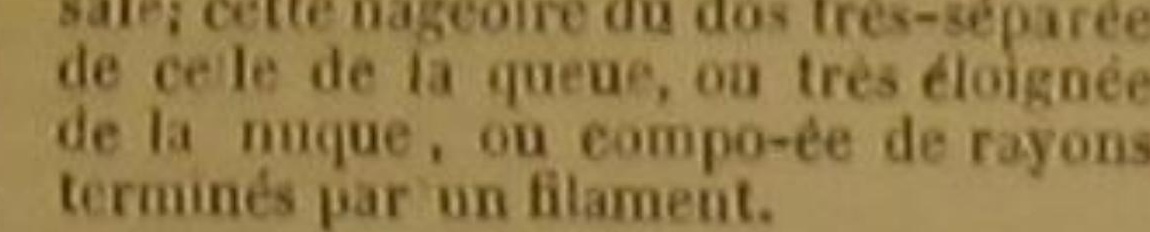

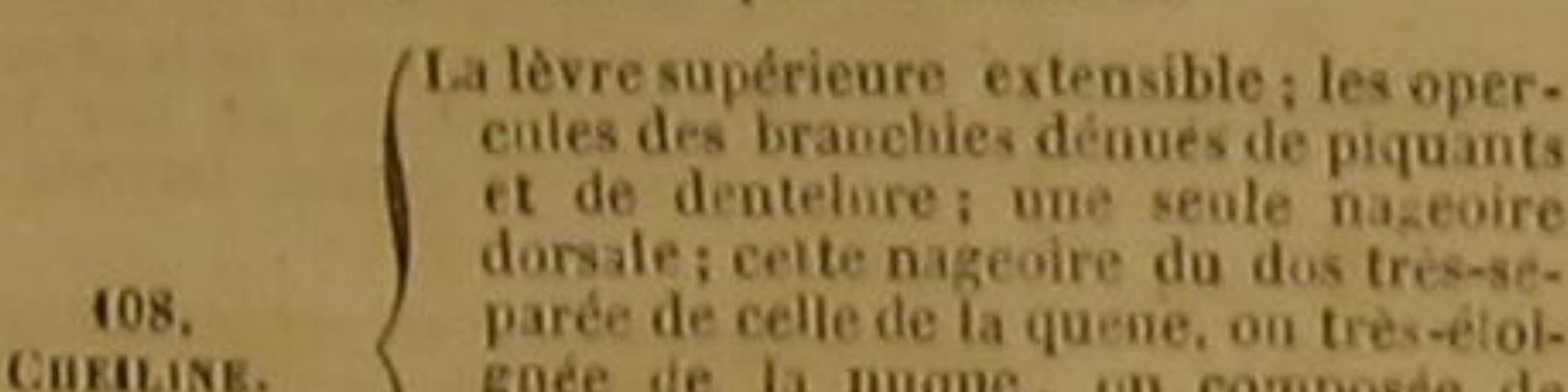

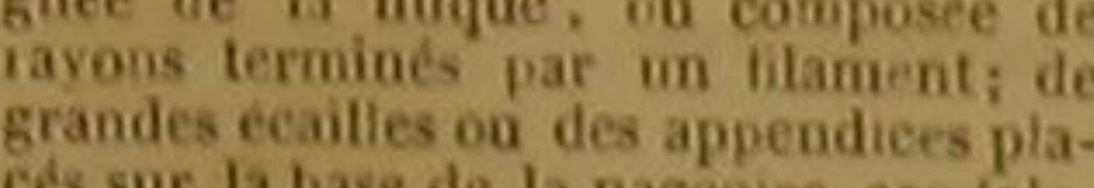

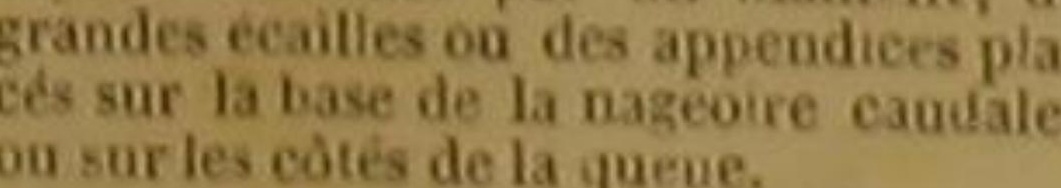

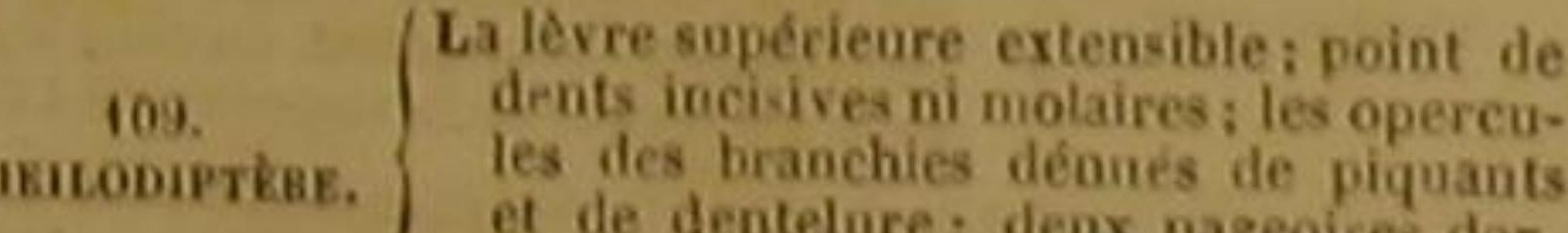
sales

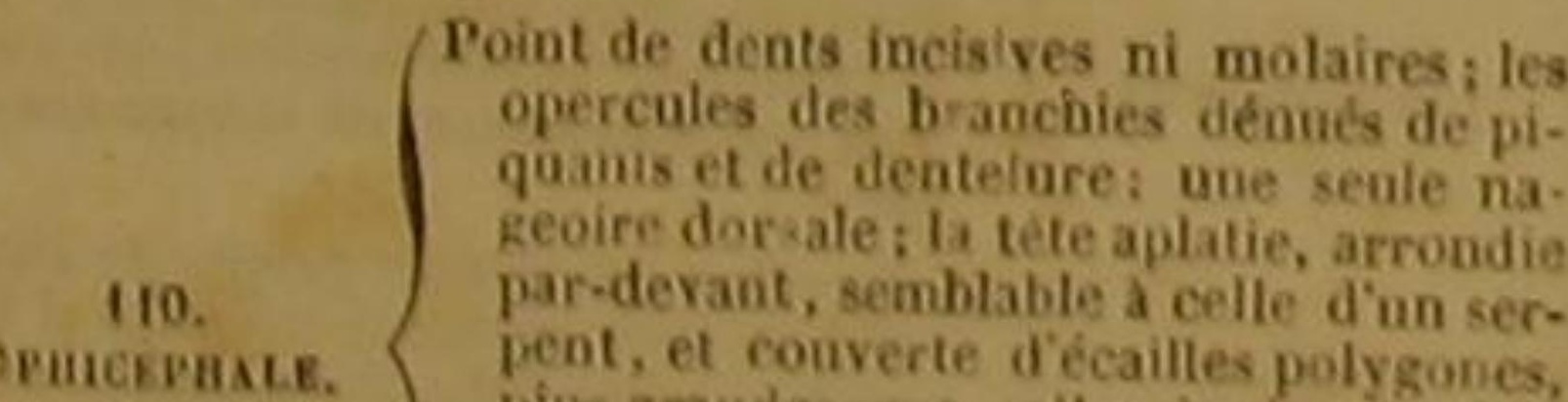

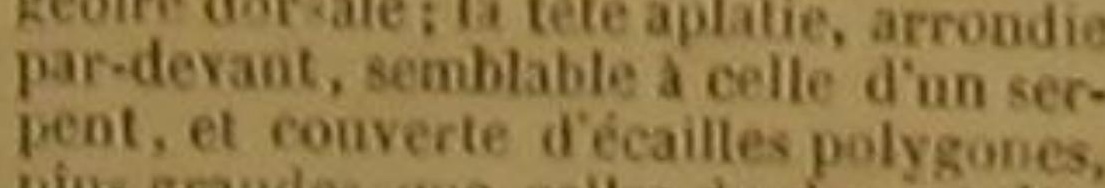

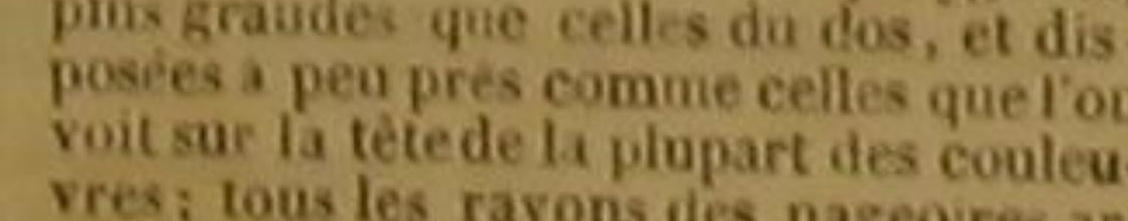
licules.

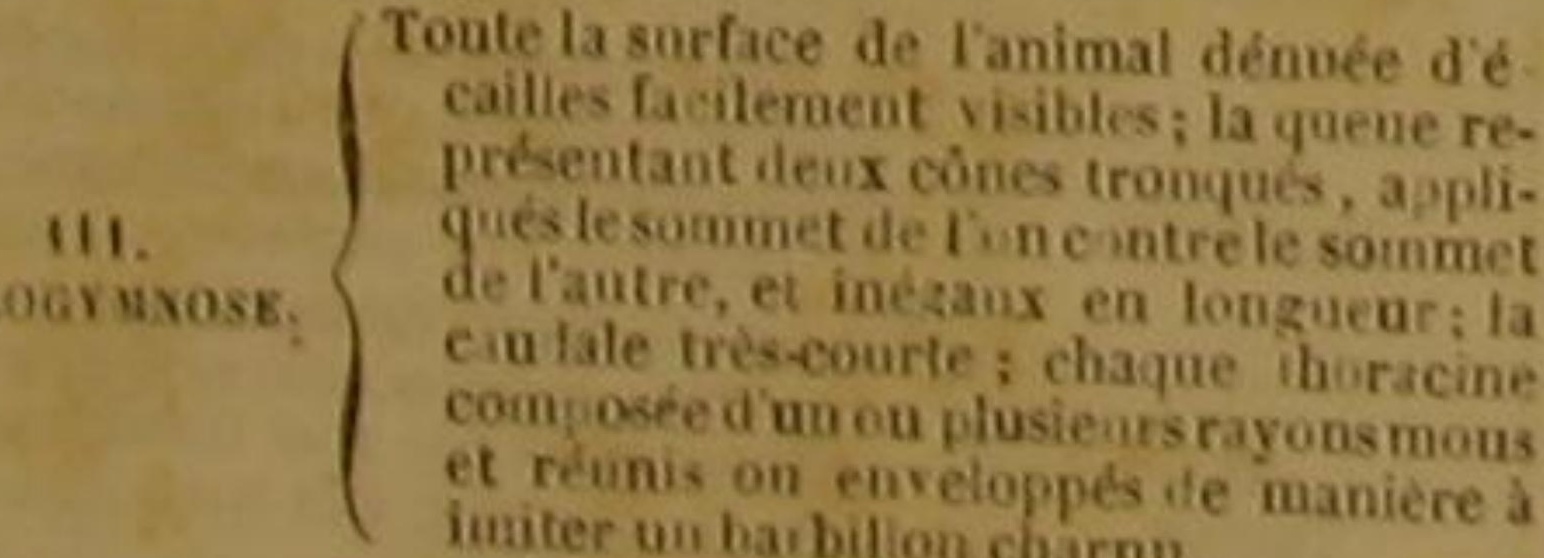

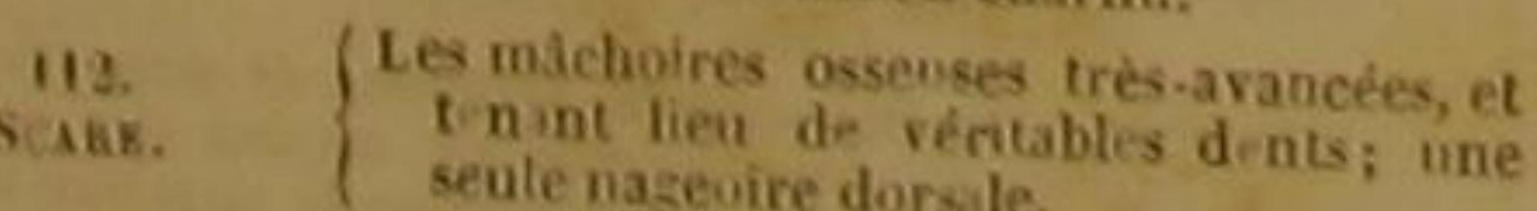

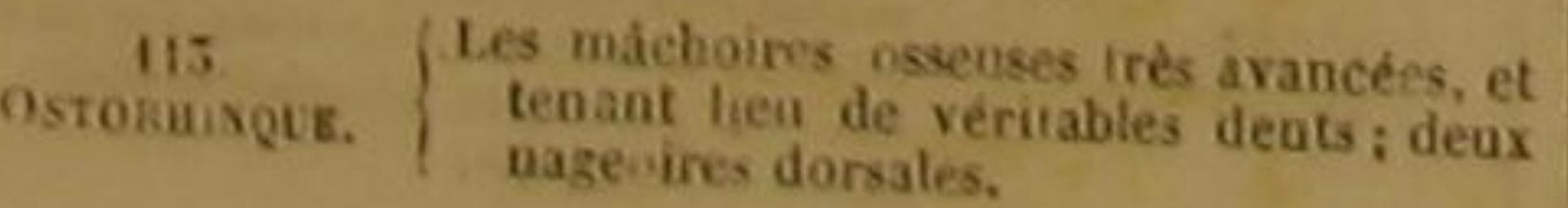

CARACTères.

Les lèvres supérienres pen extensibles, ou
nou extensibles; i ou des dents incisives

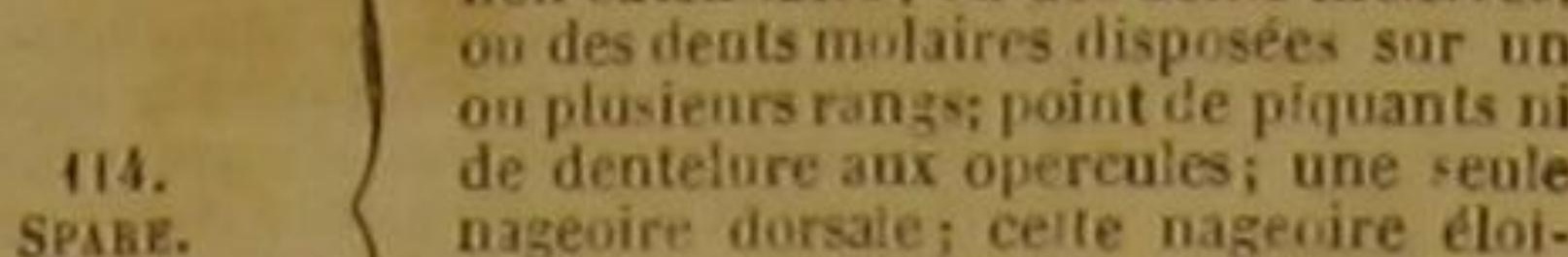

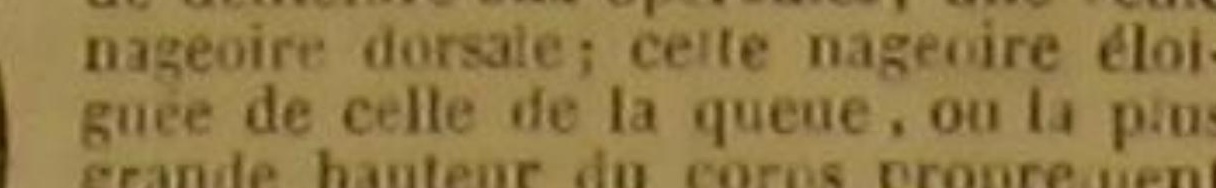

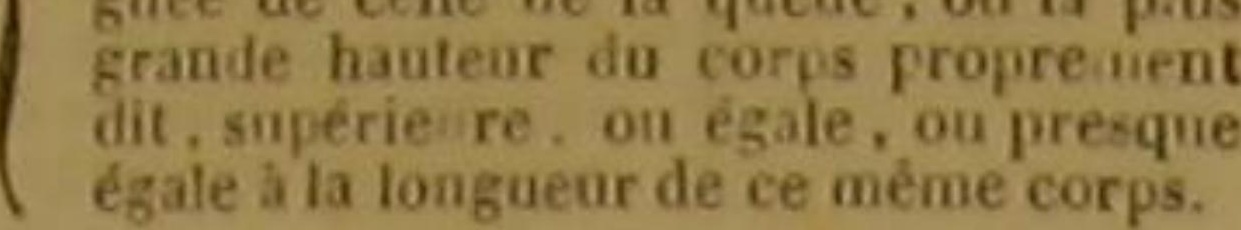

Les lèrres snpérieures peu extensibles,

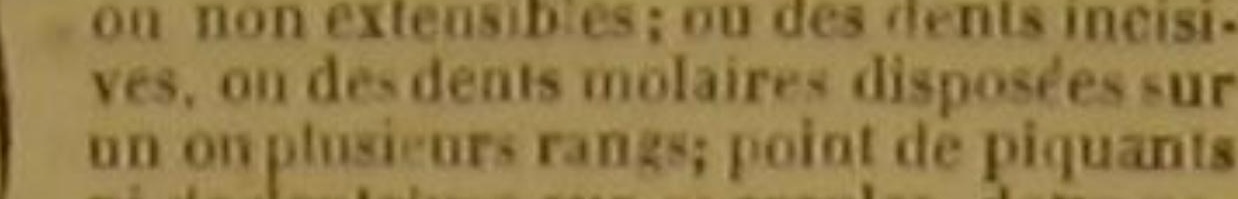

115.
115.

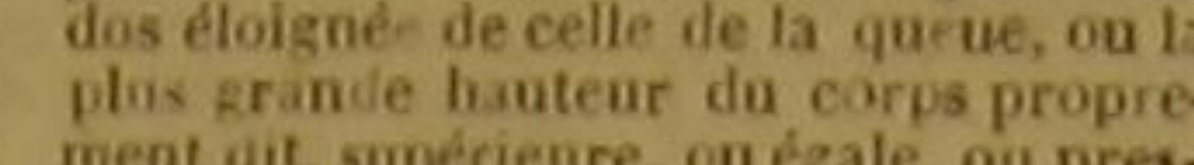
que égale a la longueur de ce méme

Une dentelure à une ou a plusieurs pièces

116.
Liziv.

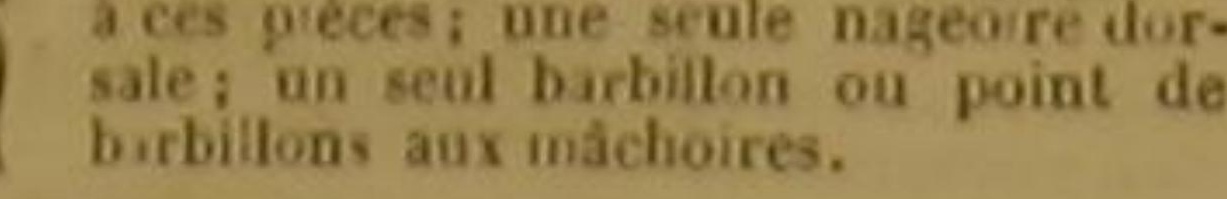

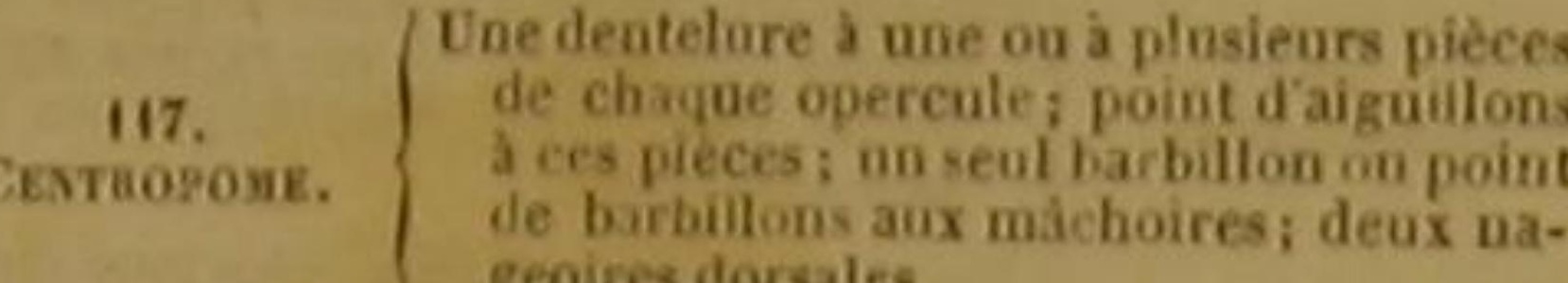

118. (En ou plnsieurs aiguillons et piint de

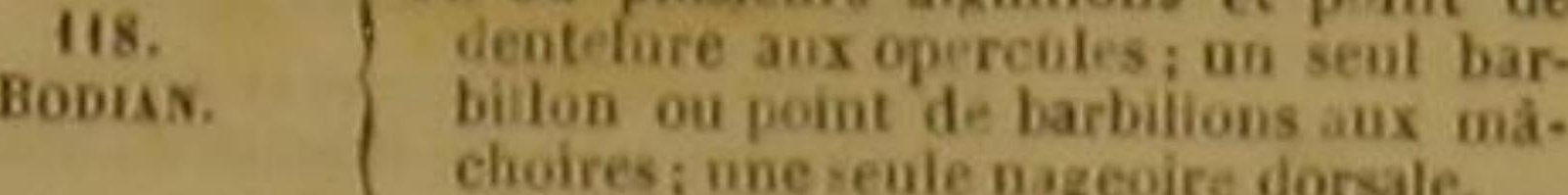

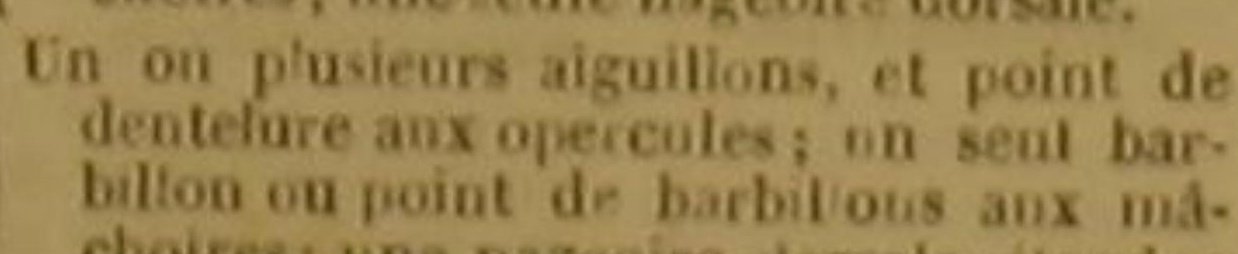

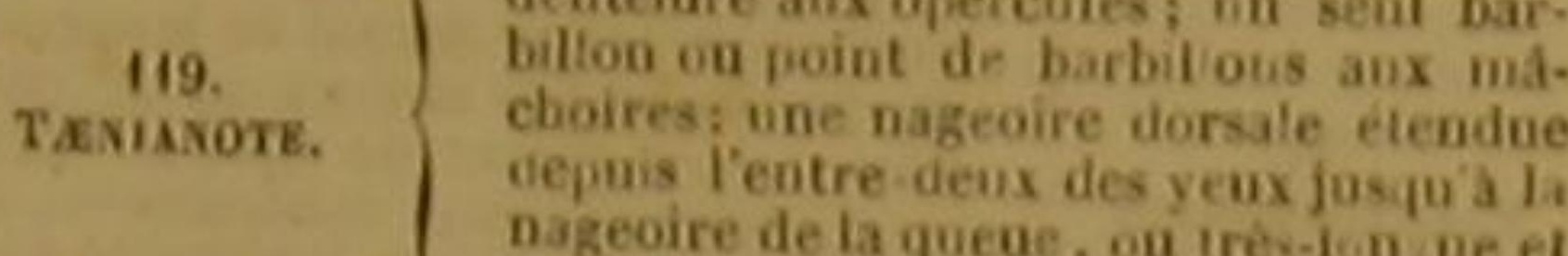

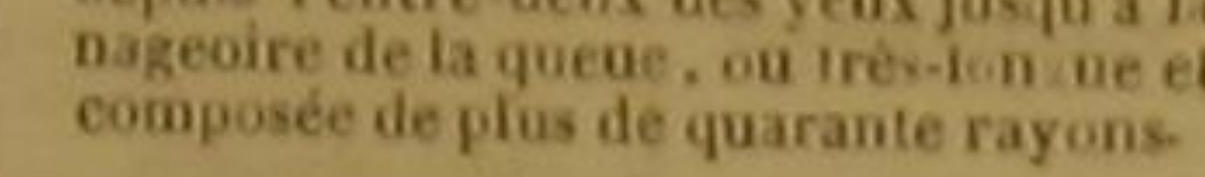

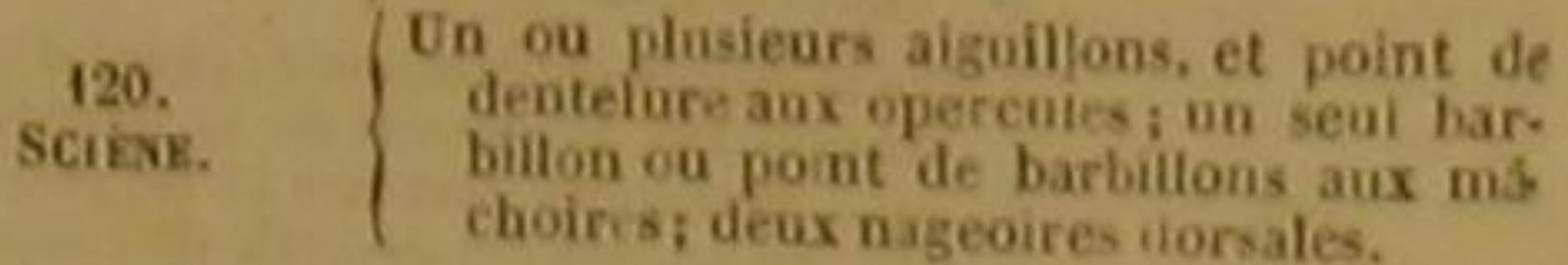

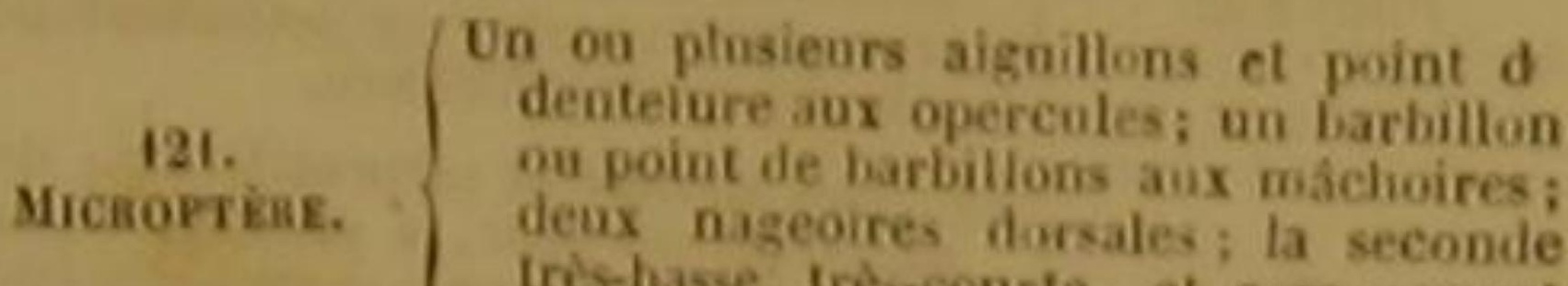

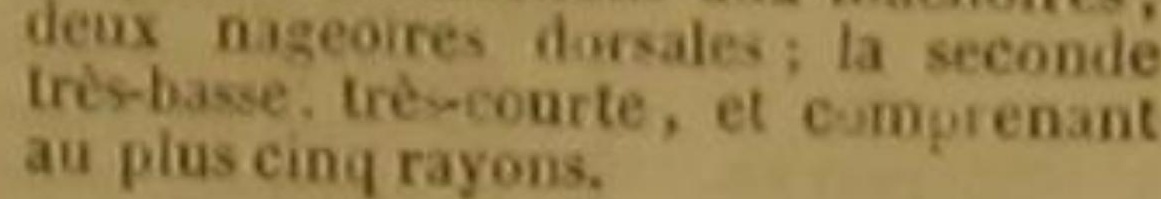

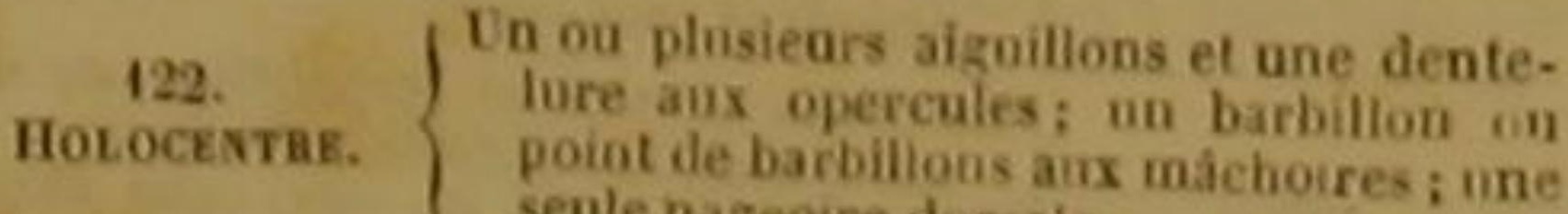

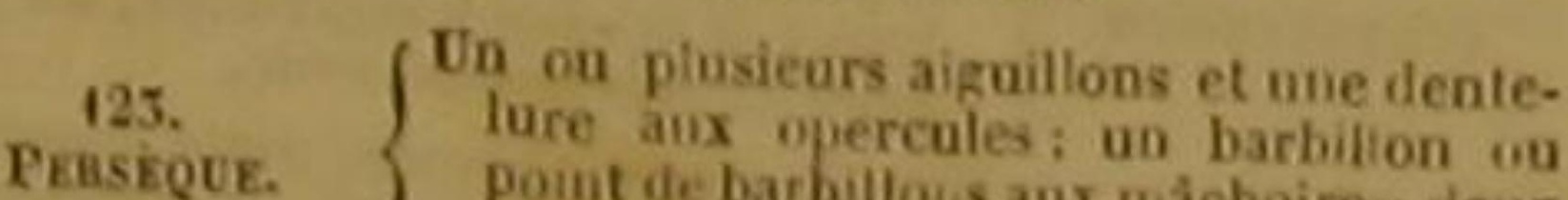
pout de barbillonis aux máchoires; deux
nageoires dorssiles. Plusieurs dents tres-longues, fortes et
recourberes an sommet et aupres de

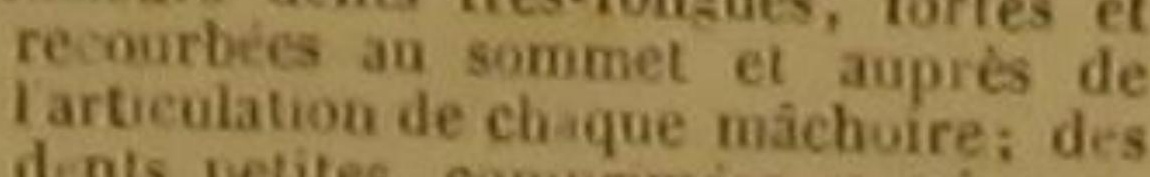

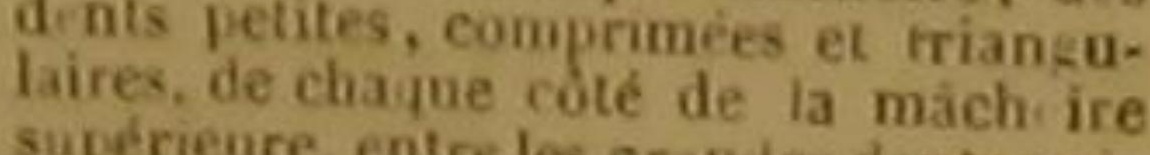
siurs de tariciculation et celles dents voi-

HATPE.

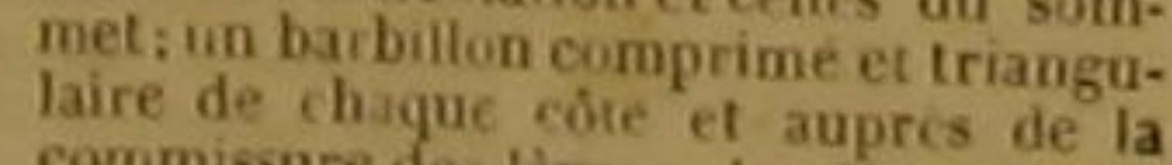
commissure des levres; les thioracines,
Li dorsale et fanale trise-grondes et en

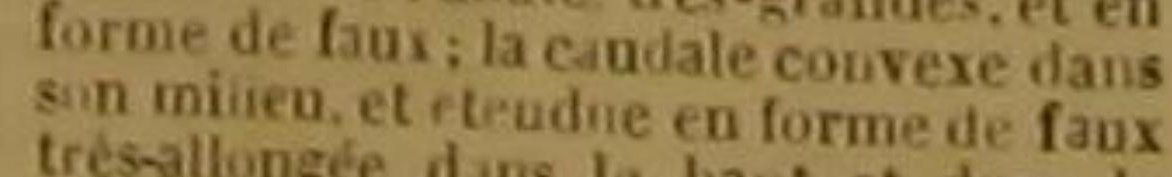
tressallongée dans le bant et dans le

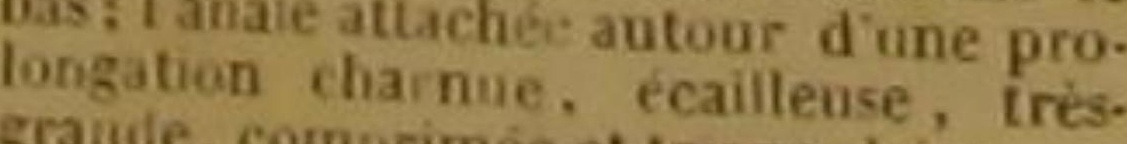

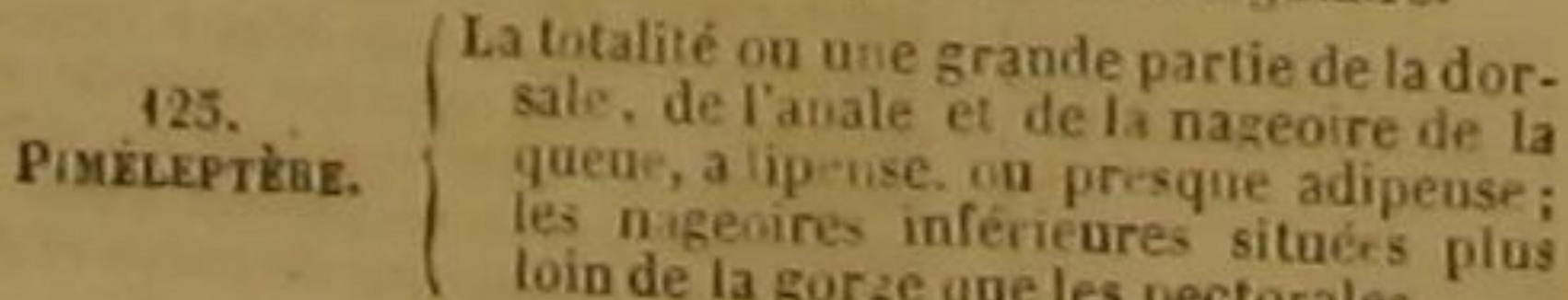

DES POISSONS.

ogNBes.

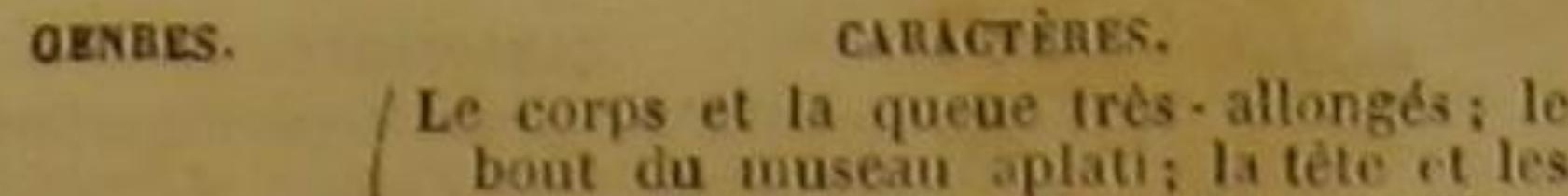

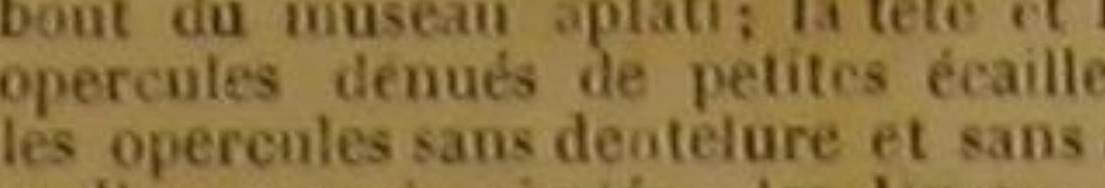

126.
CBELLox.

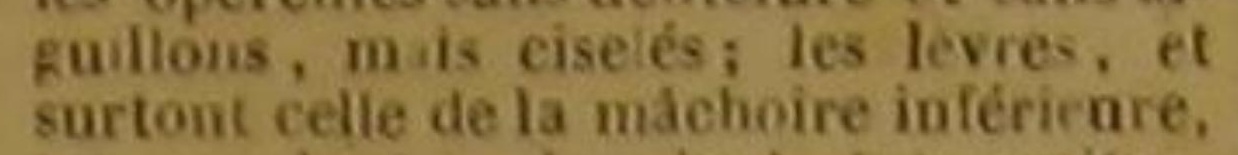
tres-pendantes; les dents tres-peitites;
la darsale basse et trés-longue; les chaque nageoire, aussi mous ou presque

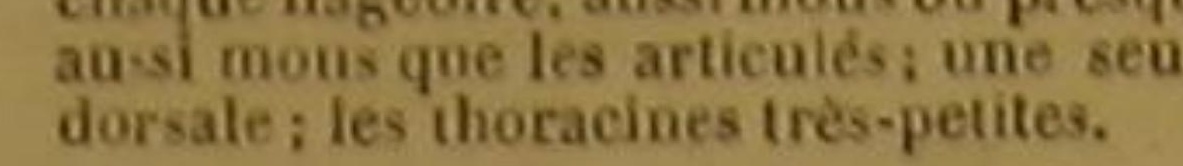

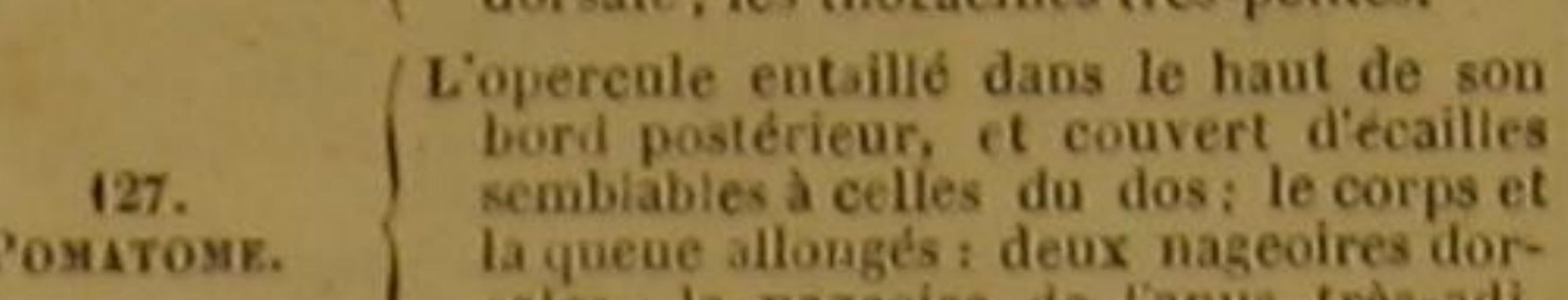

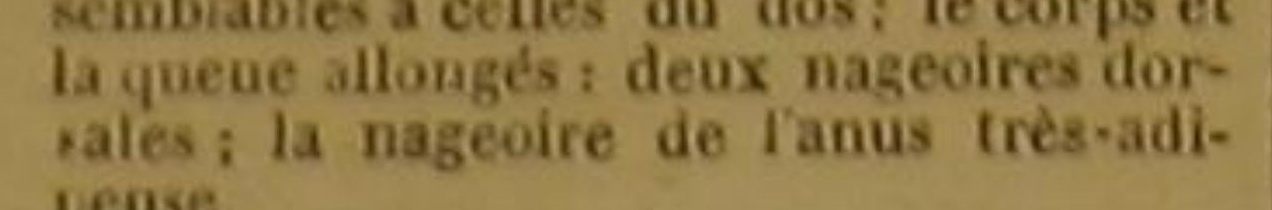

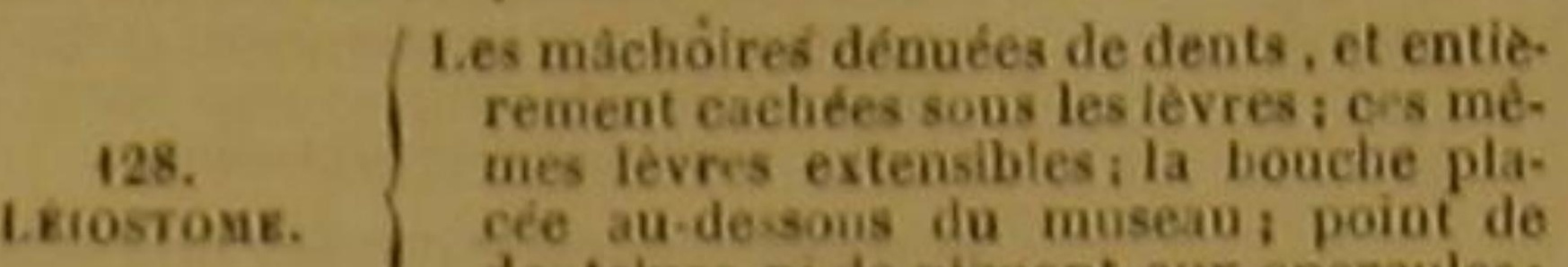

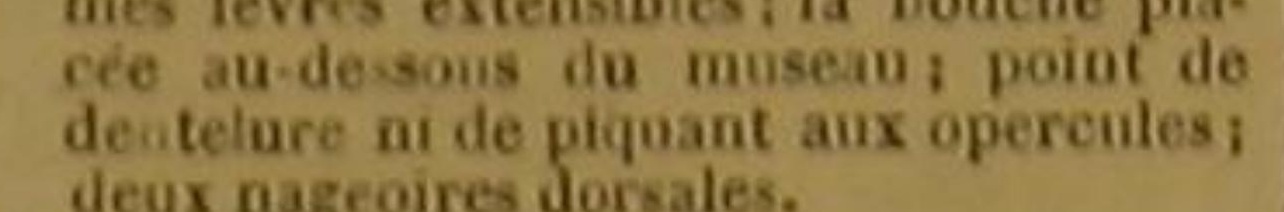

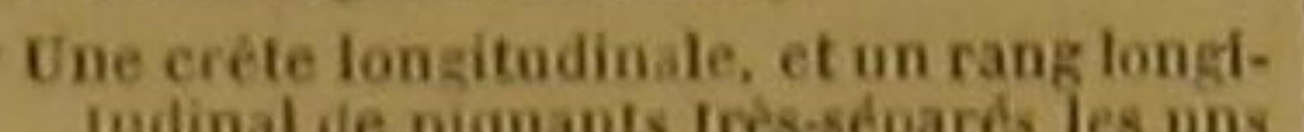

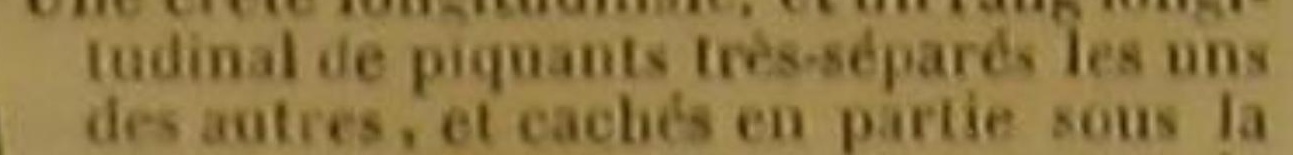

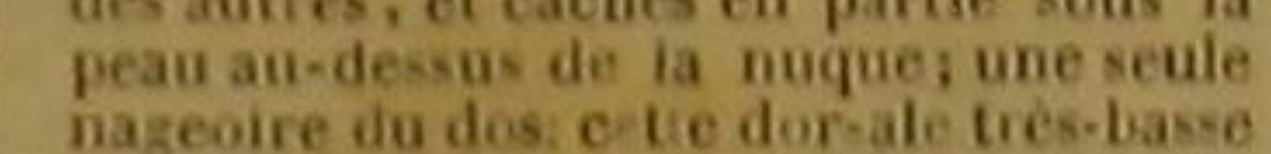

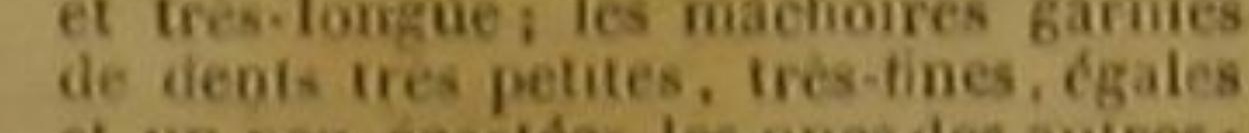

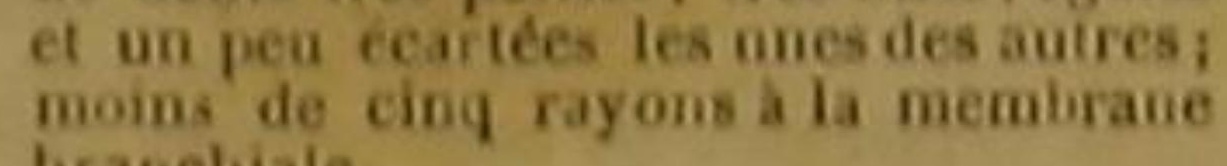
Plusieurs rangs de dents a chaque ma-

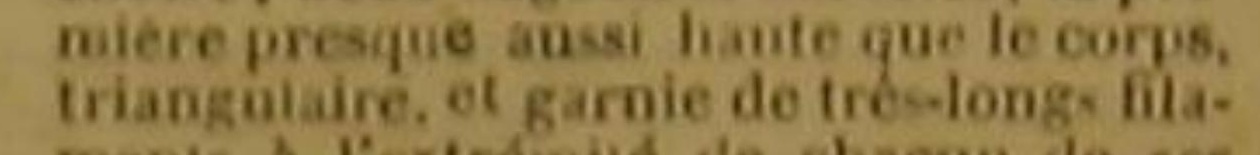
rayons: I a seconde basse et tirss-longues

150.
cnivai

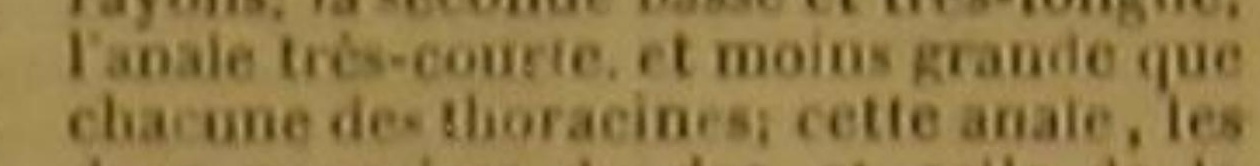

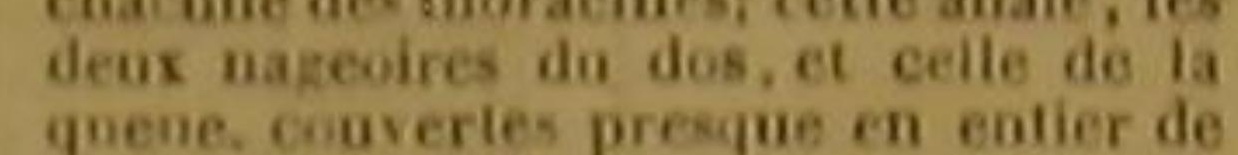

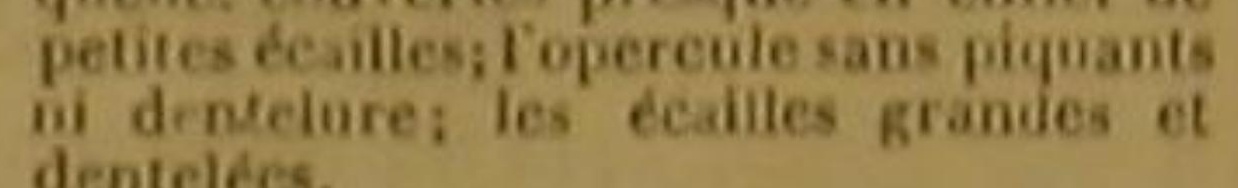

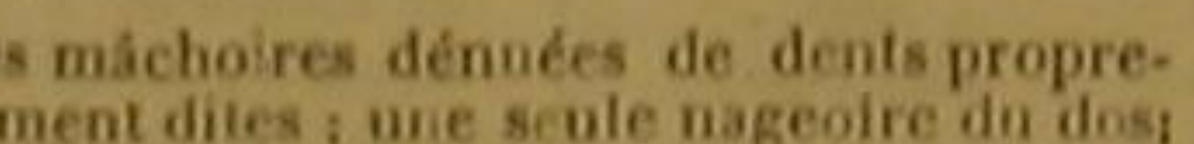

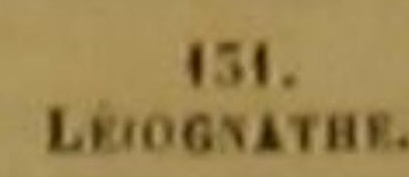

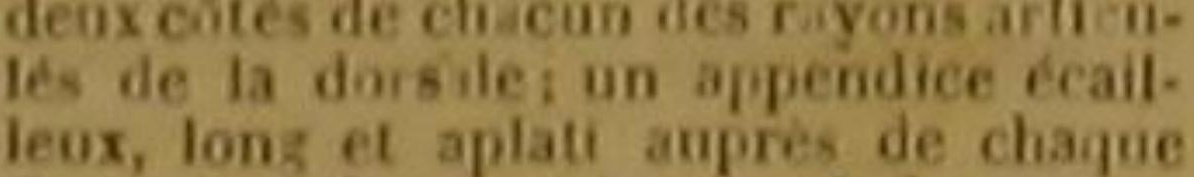

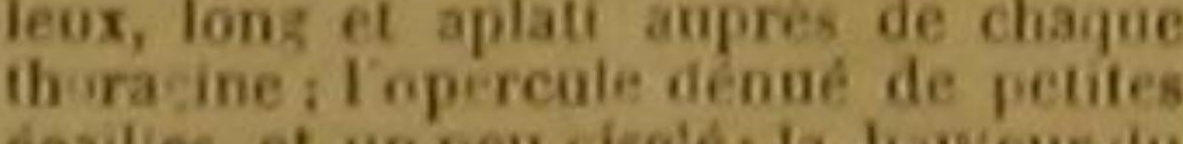
corps écale ou presque egale a la moilie de la longueur totile da poissoll.

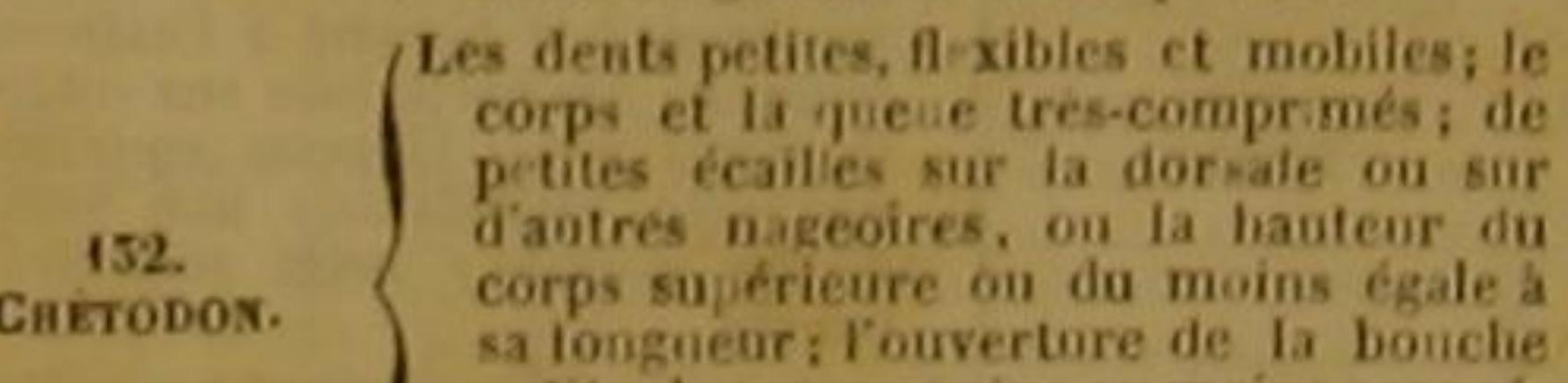
$\underset{\text { Ciktodor }}{152 .}$

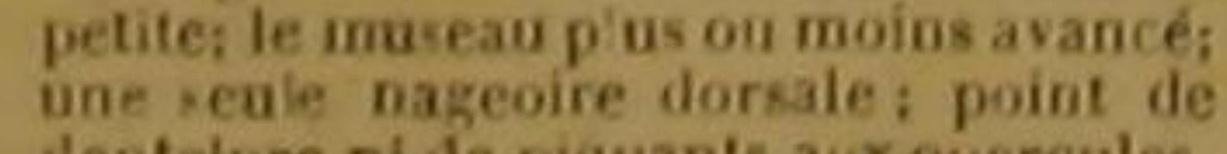

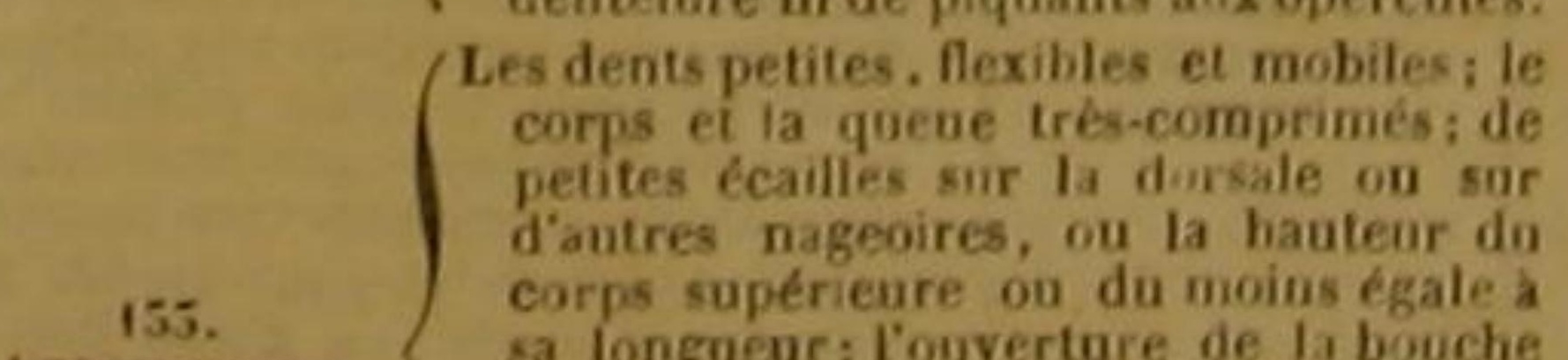

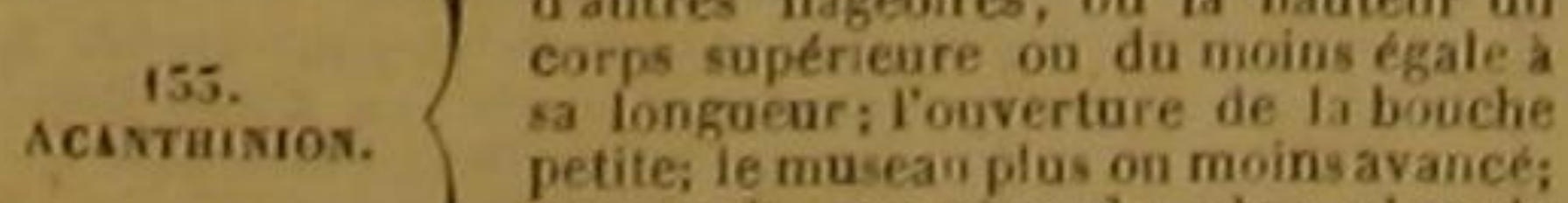
une seule nageoire dorsale; p plus de
denx aizuillons dén de nuts de membrane au-devant de la na-
geoire du dos. Les dents

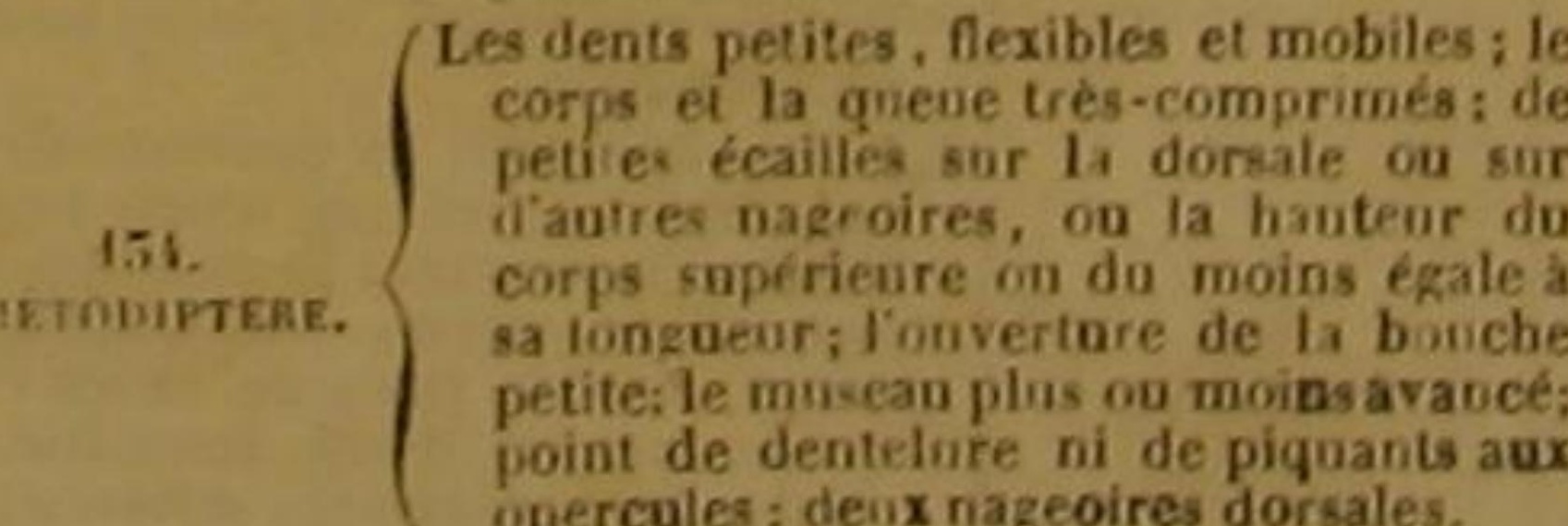

GENRES.

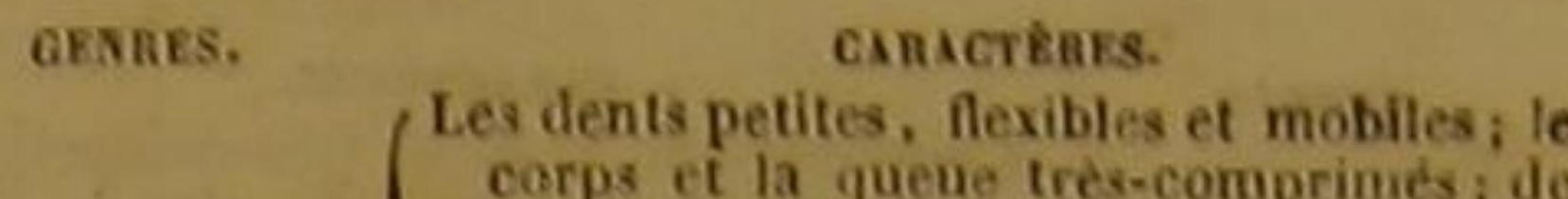

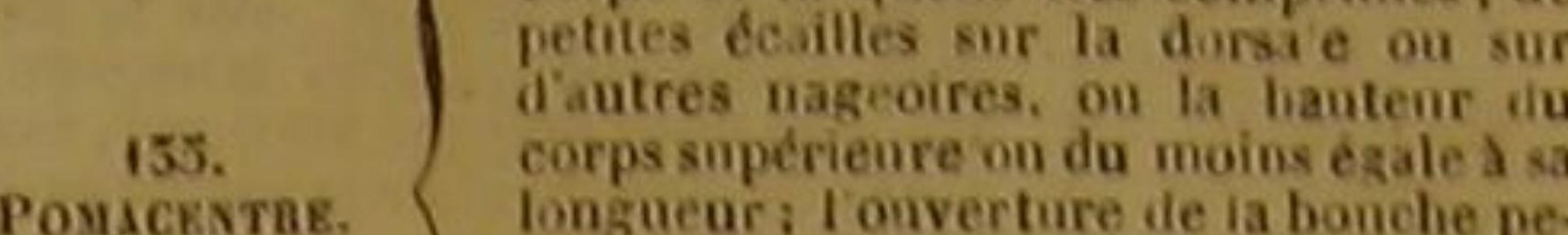
longueur; l ouverture de ia bonclie pe-
tite; le muscau plus ou moins avanee: quents anx pere poimt de longs pi-
queoire dorsale. Les dents petites, nexibles et $m$ thiles ; $t e$

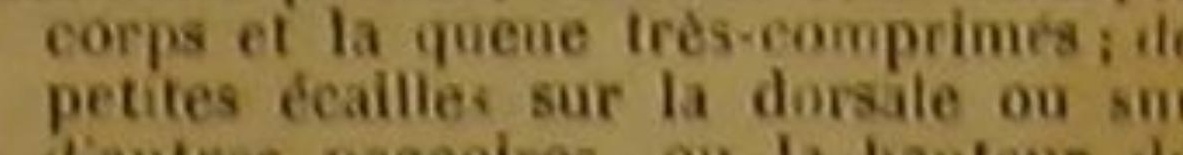

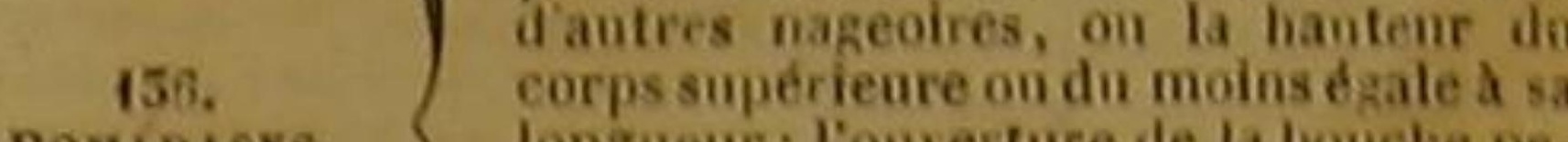

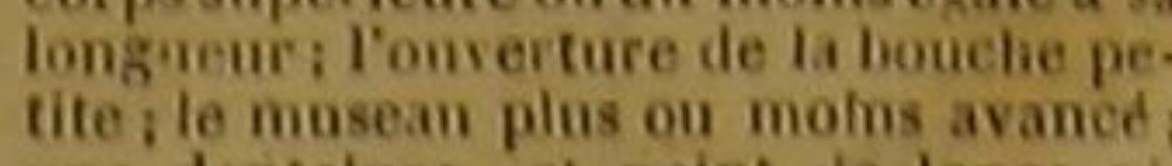

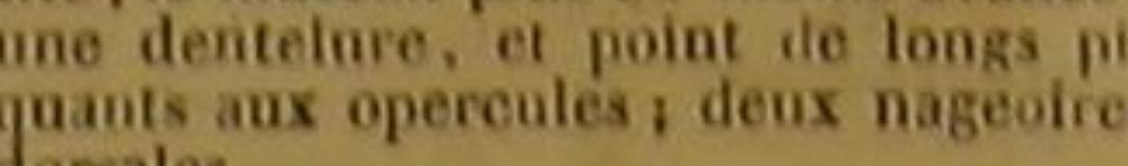
guams aus on
dorsales.

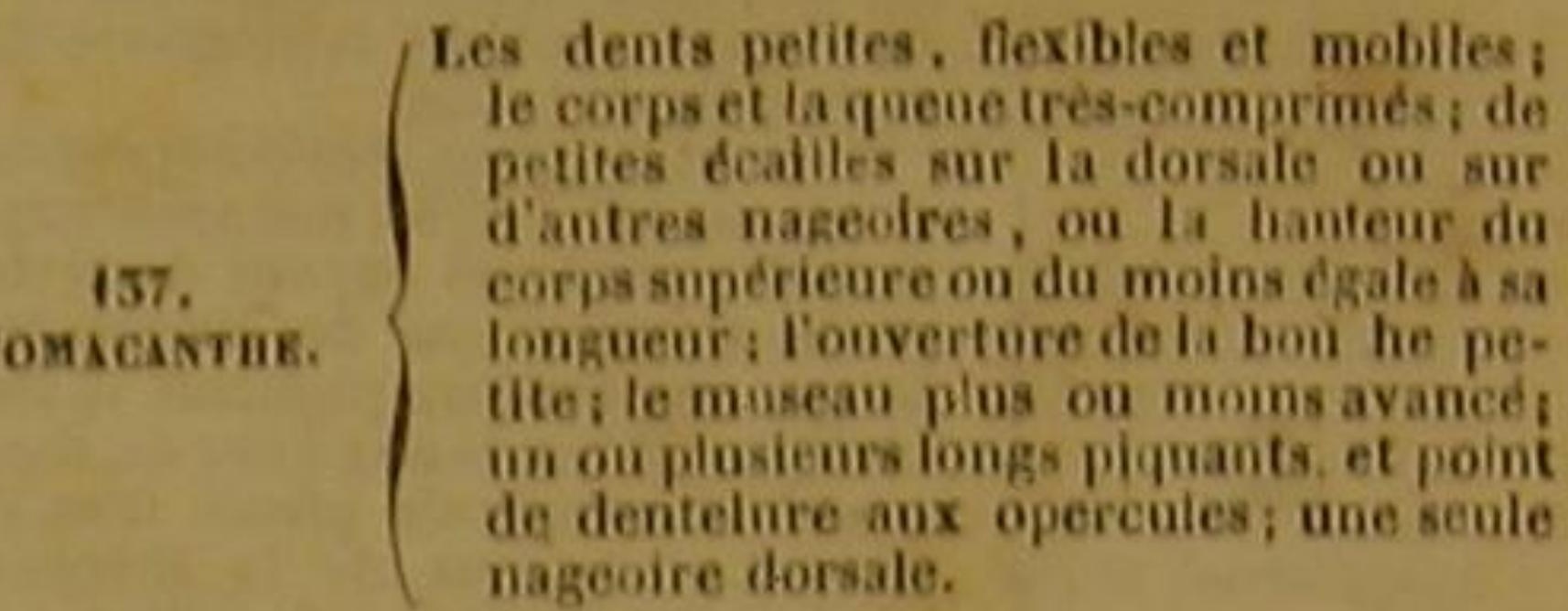

$\left(\begin{array}{c}\text { Les dents pelites, flexibles et motiles; i fe } \\ \text { corps et la cueno tres-comprimés i do }\end{array}\right.$ peitites coil les som la dorale ou sur

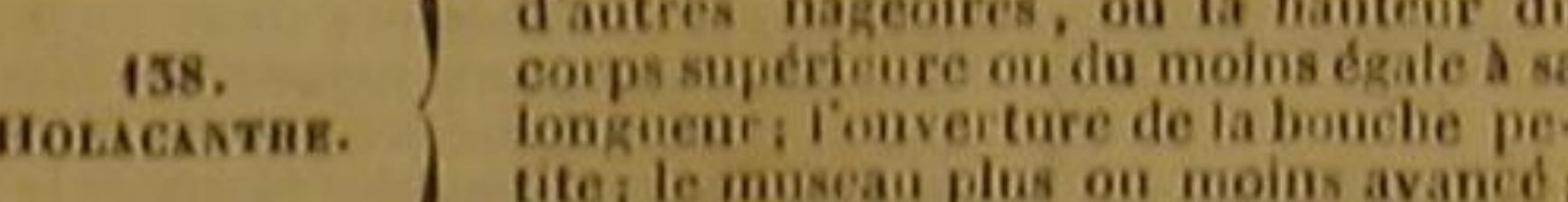

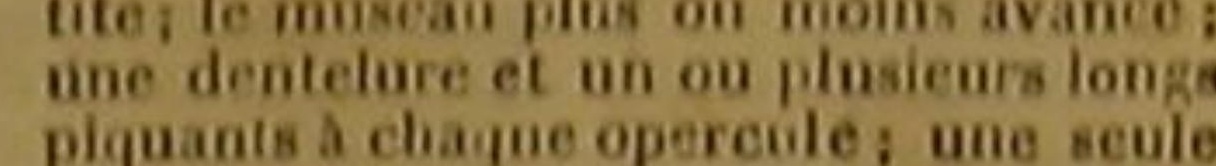
piquanis a chaque.
nageoire dorsale.

Les dents perites, flexibles et mobiles: to Hite

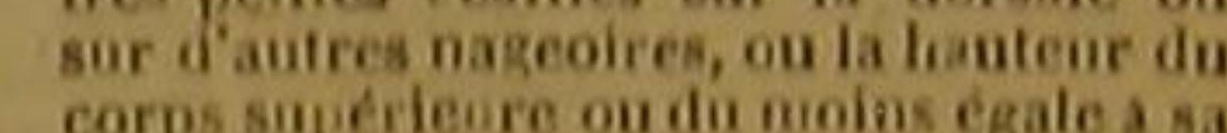

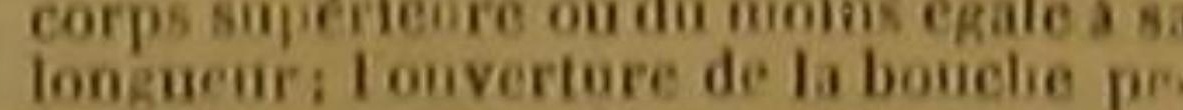

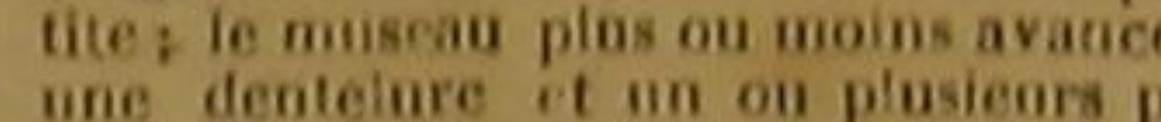
quants a chame opere

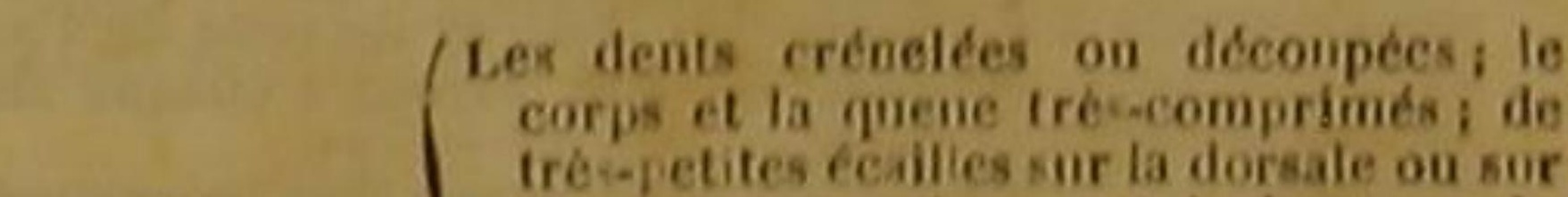
140.
GLYPulsodor.

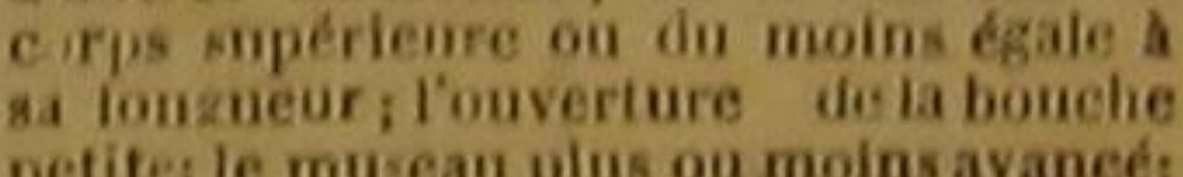
petie; le muecan pium
ine nageoire dorasale.

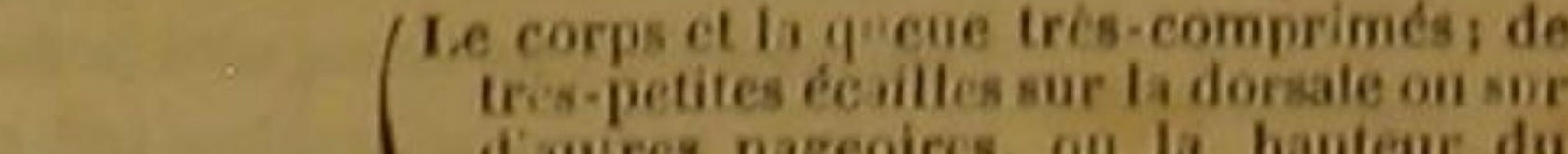

Acsim. 14 .

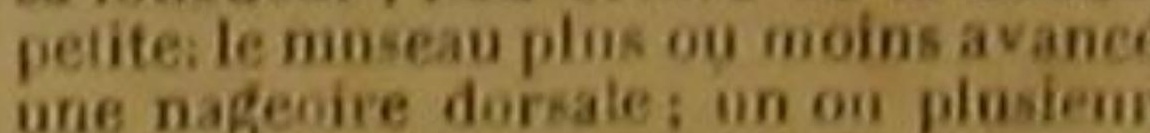
piquants de chaque cóte de la queue.

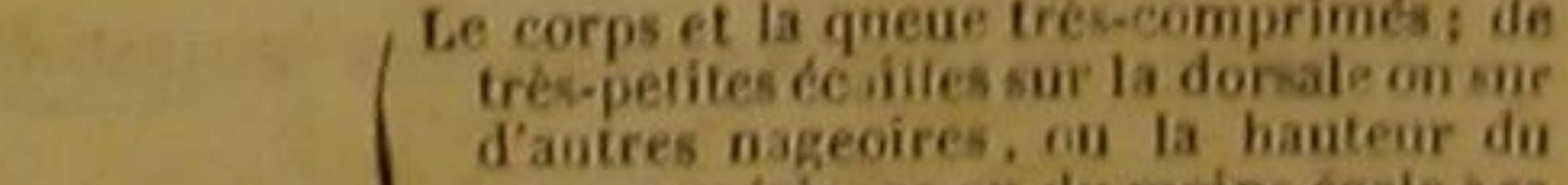

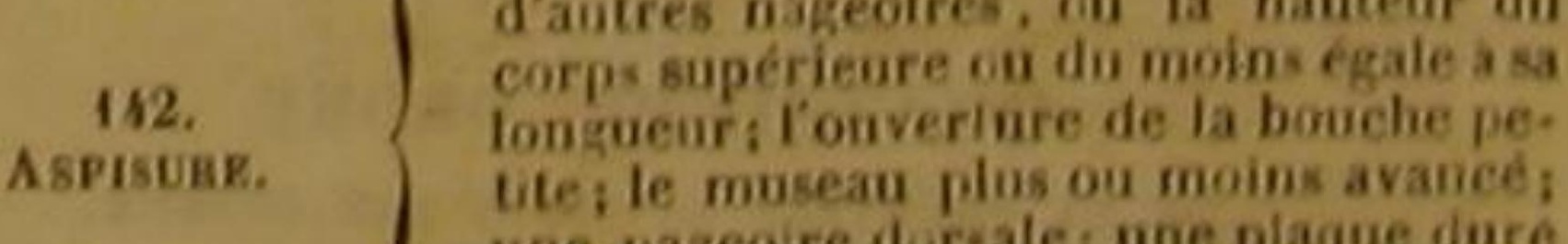

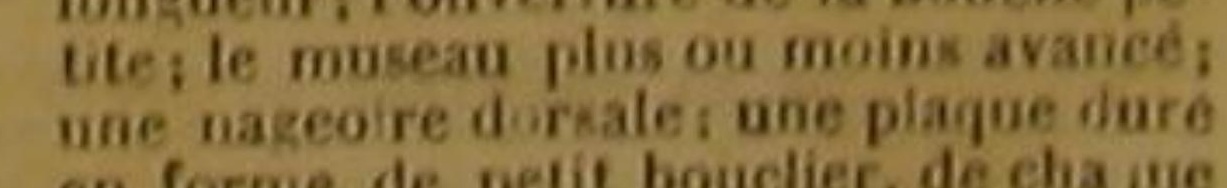

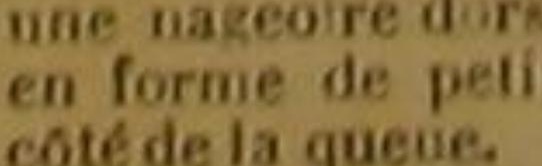

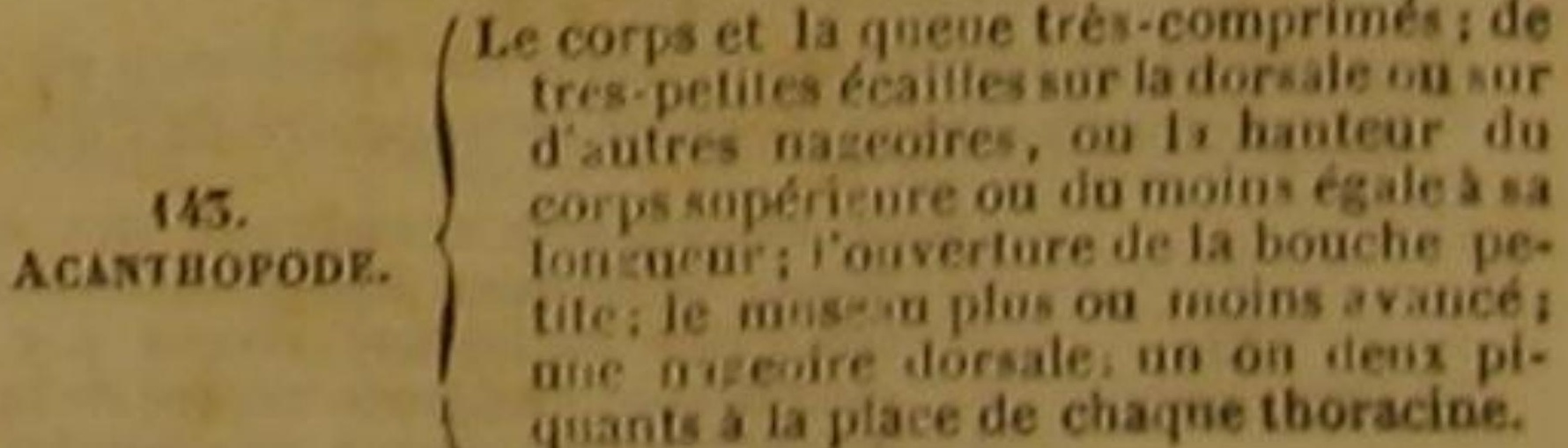


GEKBrs.

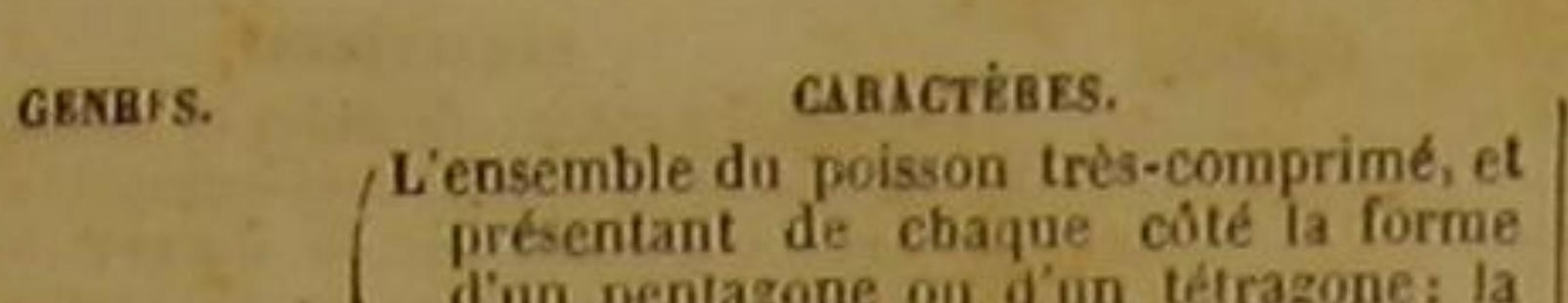

144.
SELL̇ล. ligne du front presine vertica e; la dis-
tance du plus bant de la nuque an-desde la gorge a la nageoire de lanus

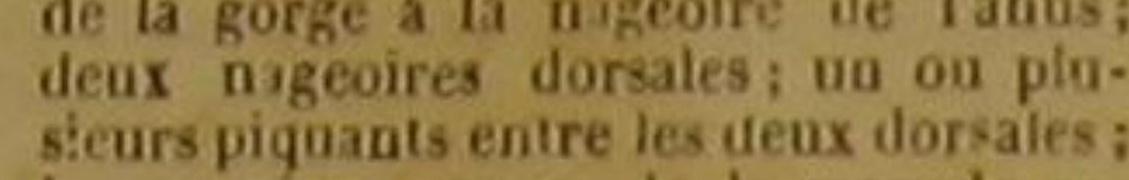
sieurs piquants entre les leux dorsales:
les premers rayons de la secoude nageoire do dos set- ndant an moins au-
dela de léextrémité de ta qu- ue. senle nageoire dorsale; plinsieurs rayons
de celte nageoire terminues par des filaments trés-longs, ou plusieurs piquants
le long de chaque coté de ta nageoire do dos; une membrane verticale placée
transversalement an-dessous de ta le.

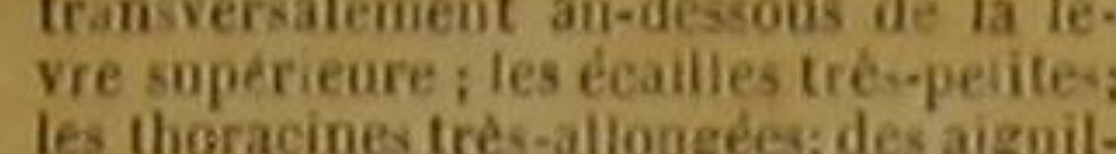
lons au-devant de la nageoire du dos
lons Le corps el la quene trés-comprimés; des
dents aux máthoires; une seule nageoire
dorsale ; piusieurs rayons de celte nageoire terminés par ves filaments tres
longs, 'u plusienrs piquants le long ce
chaque coté cie la lageoire din dos; une

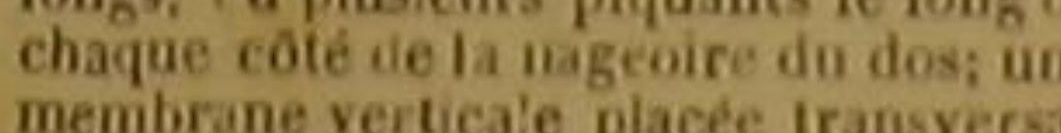
membrane verticale placée transversa.
lement audersous de la levre supec
rieure: les écailles trés-petiless podut rieure: les ecailles tres-petiles; pout
daiguillons au-devant de la nageoire du dos, ni de celle de lamms. Le corps et la quene tres-comprimés; des
deuts aux máchoires; veux nageoires

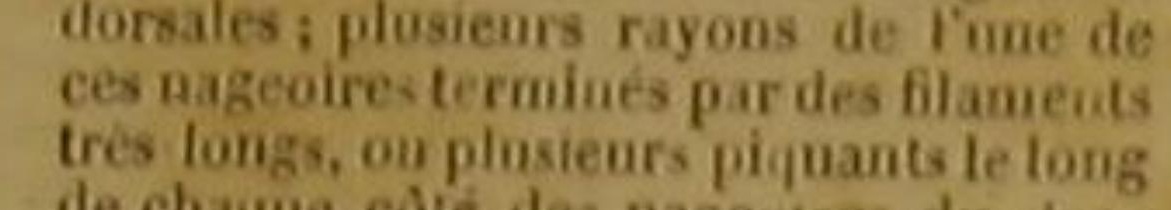

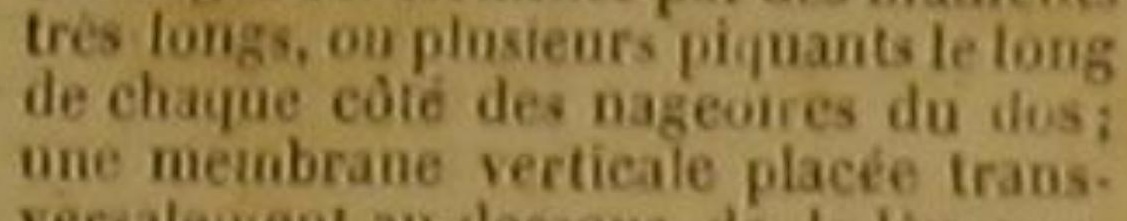
versalement au-dessons de la levress.
périeure; tes $\mathrm{e}$ - ailles trés-petites; point périeure; lese ailles trés-pecites; point
daiguillons au devant de la premiere
ni de la seconde dorsale, ni de la nag. oire de l'anus.
Le cor, s et la queue trés c mprimés; ia por, s et la queue trés c mprimés s a
plus gande tanteur de lanmal egale ou presque eqale a la longneur du corps
et de la queue pris easemble; poiut de ct de la queue pris eusemble; point de
dents anx machoires; noe seule $\mathrm{n}$ geoire dorsale; les écailles trés-petites;
poiut daiguillons an-devant de la mageoire du dos, ni de celle de l'anus:
plus de huit rayons a chaque thoraLe corps et la queue très comprimes et
trêtang

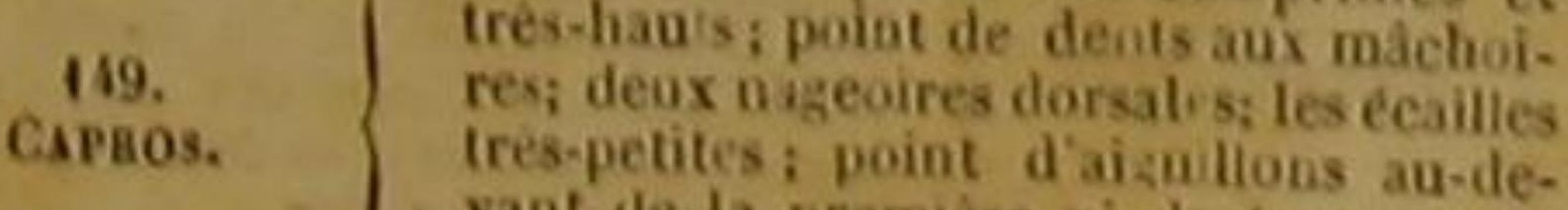
tres-petites; point d'aizullons au-de-
vant de la premiere ni de ta seconde
dorsale, ni de la nageoire de l'sous. 150.
PLkunonkctr. Les deux yeux du mẻme eôté de la tête.

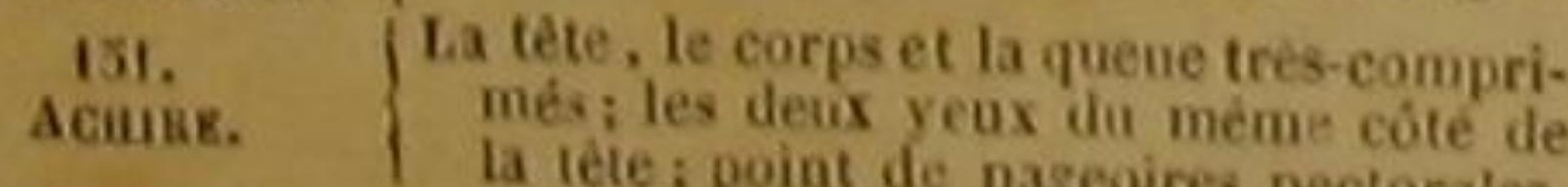
VINGTIÈME ORDRE

dE LA CLASSE ENTIÈRE des POISSONS, QUATRIÈME ORDRE

DE L PAEMLĖa DIVISION DES OSSEUX. POISSONS ABDoMiNaUX.

Des nageoires inferieures placees sur l'abdomen au delà
des pectorales, et en deșa de la nageoire de l'auns.

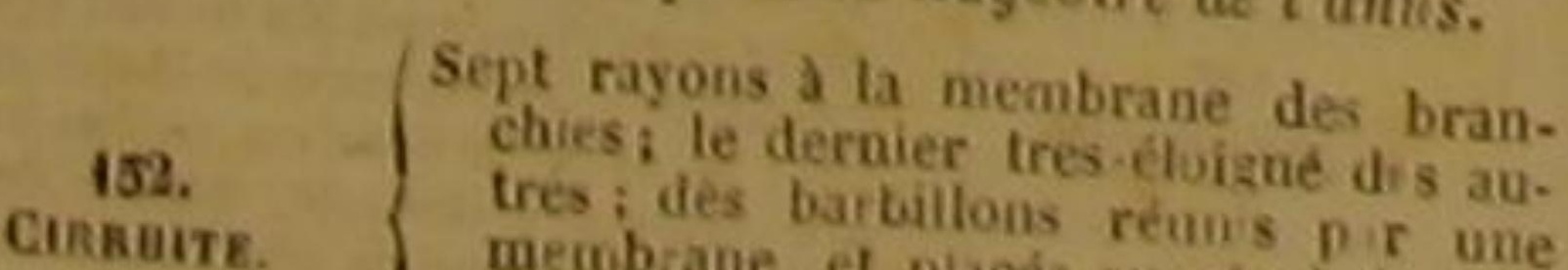

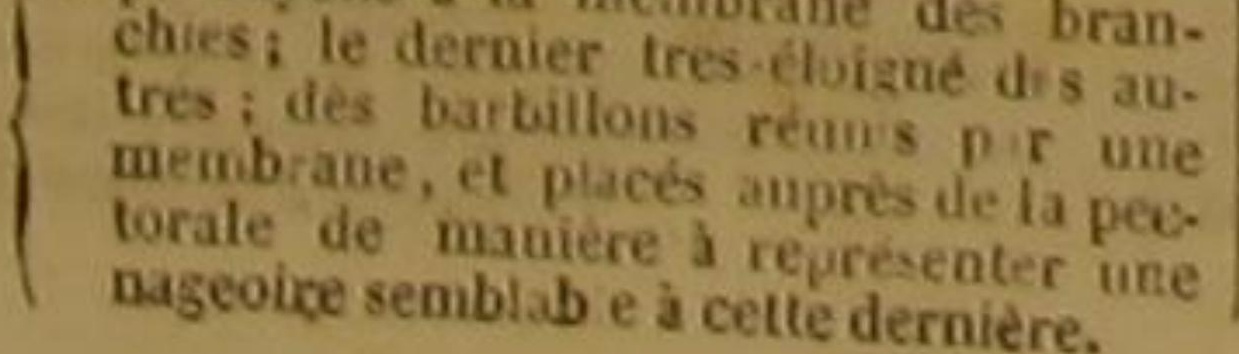

Gevaes.
Chentodietrue.

CABSctéäs.

Le corps et in queue très-comprimes ; la
levre supérienre iouble et extensible

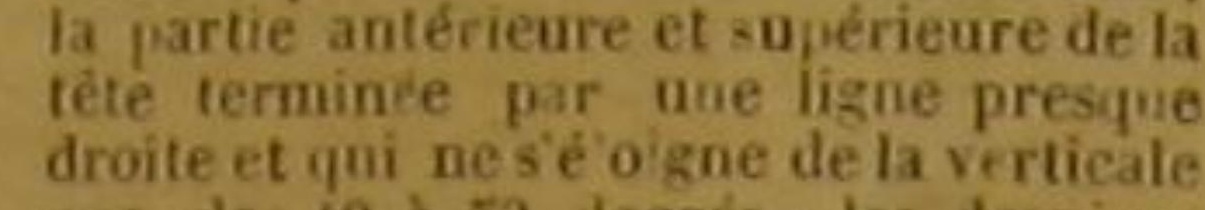

que de 40 a 50 degrés; les derniers
rayons de chaque pectorale très-allon

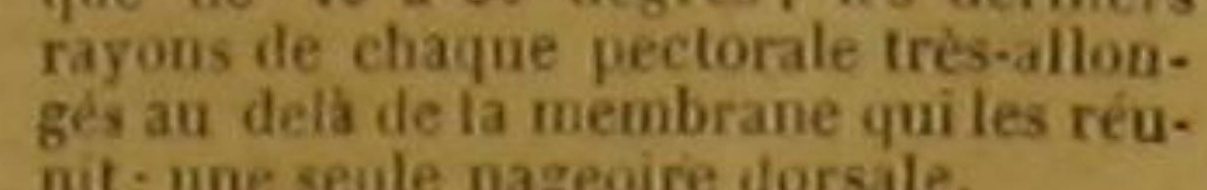

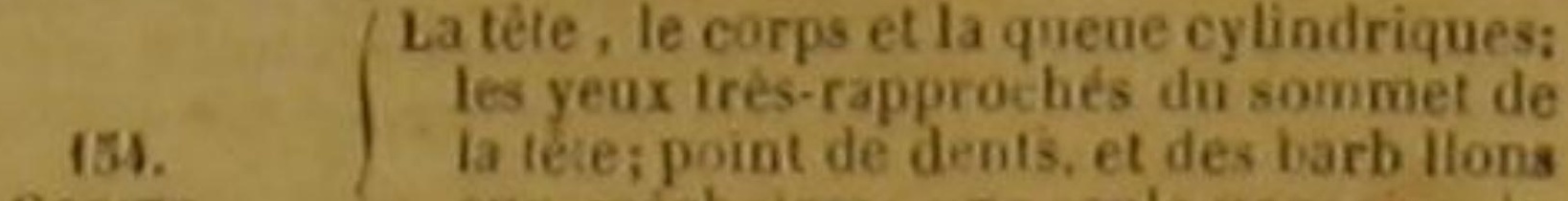

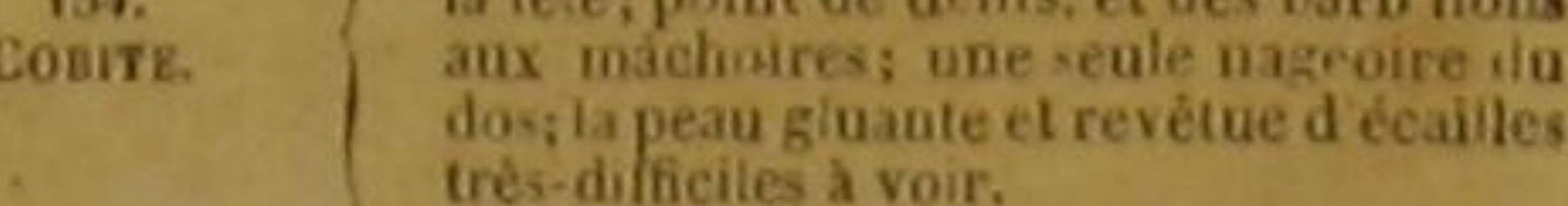
trés-difficiles a voir.

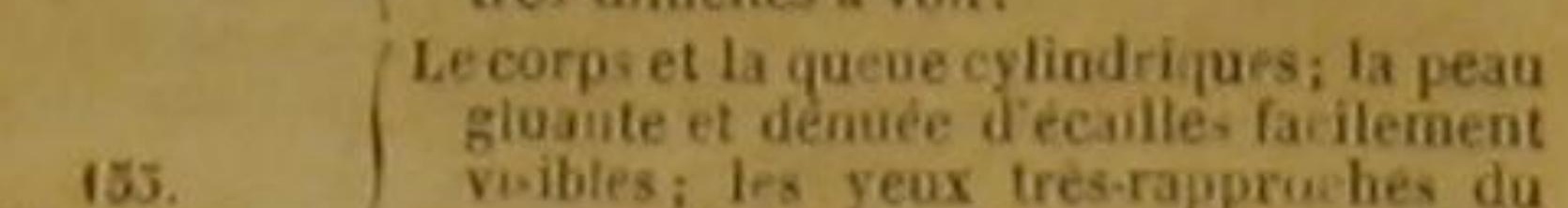

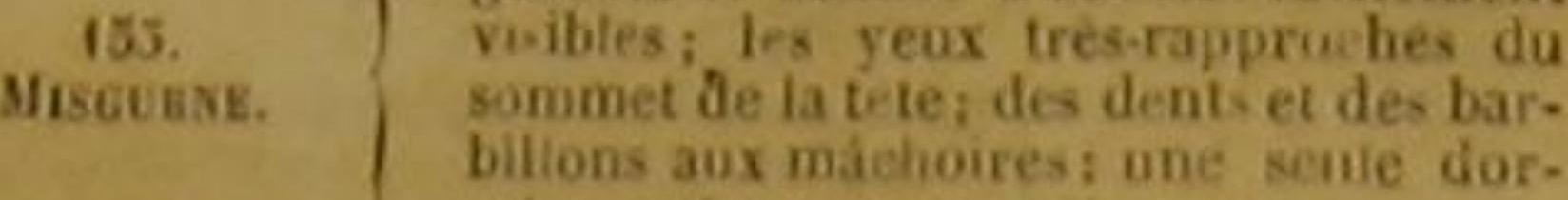
billons aux máchioires: une secte dor-

156. $\quad \begin{gathered}\text { Le corpset la queue presyue cylimdriques: } \\ \text { des barbiltonis et des dents amx maichoi- }\end{gathered}$

156.
ANseleps. $\quad \begin{aligned} & \text { dess une seule nageoire dn dos; ceite } \\ & \text { nageoire teres-courle; denx prunelles a } \\ & \text { chaque cil. }\end{aligned}$

157. Le corps et la queue presque cylindri.

dos.

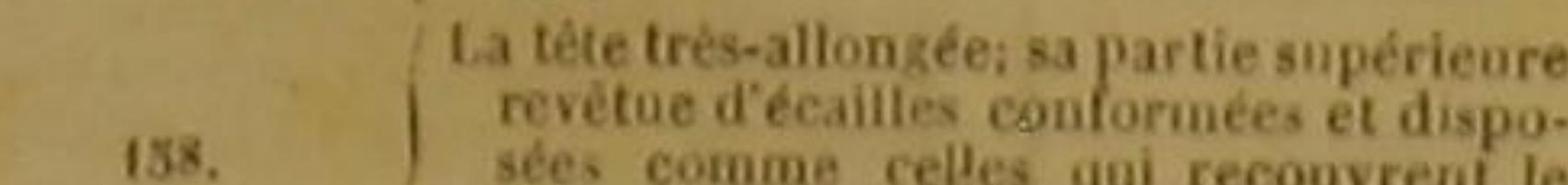
158.
cotuenixe.

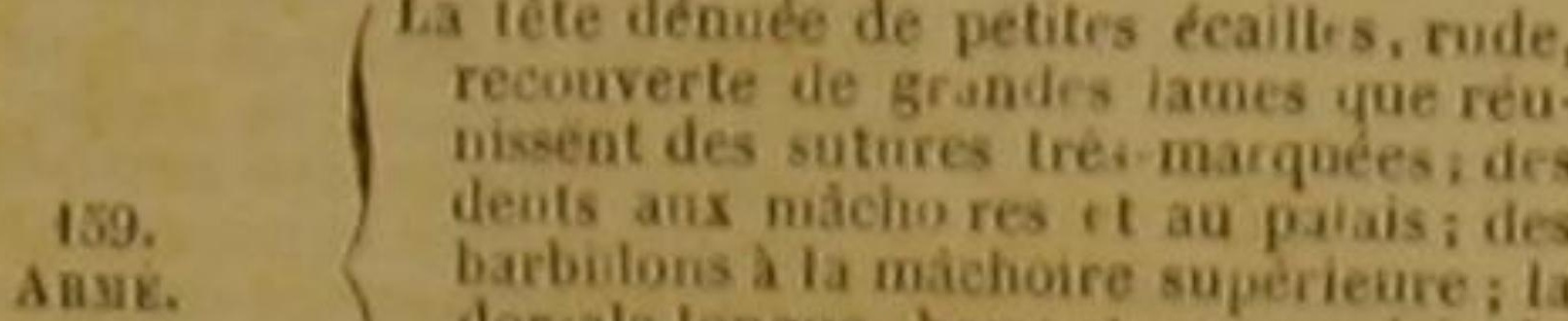

dorsale longue, basse el rapprochée de
la caudate; I anale tres-courte ; plus de
dix rayons a la membrane des brat

dix rayons a la membrane des bran.
ches,

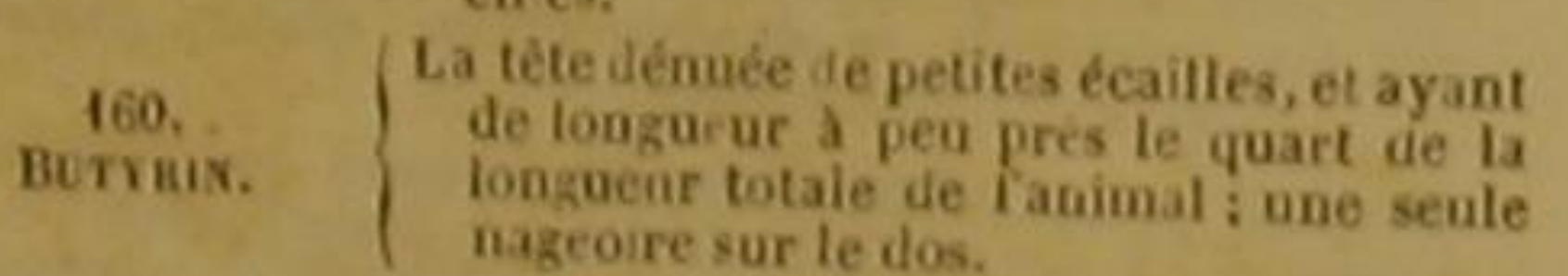

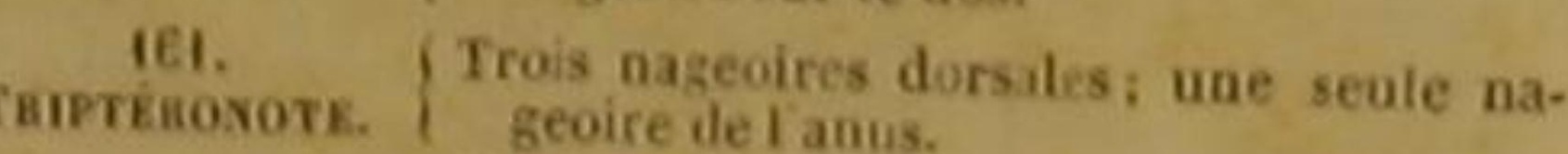

162.
Des barbillons et des dentsaux màchoires;
poimt de nageores dos

poimt de nageores dorsales; une lon-
gue nageoire de lanus

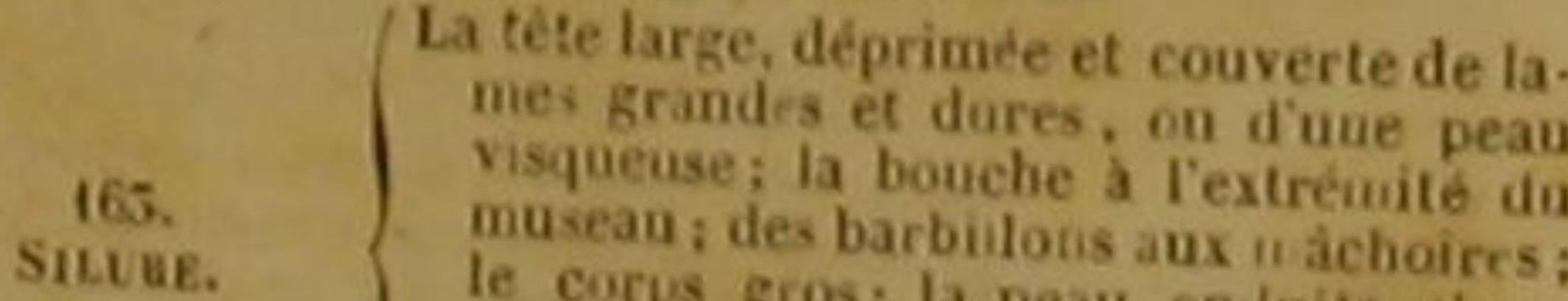

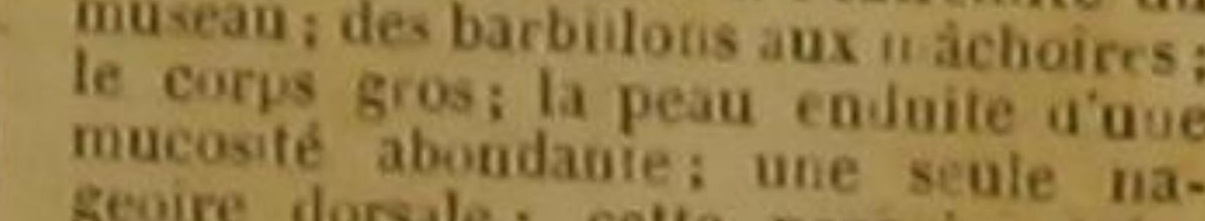

geoire dorsale; cette nageoire tres-
courte.

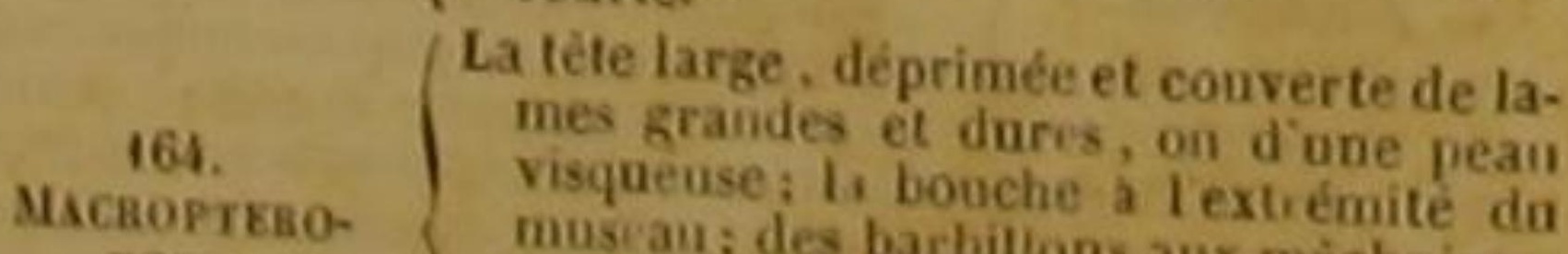

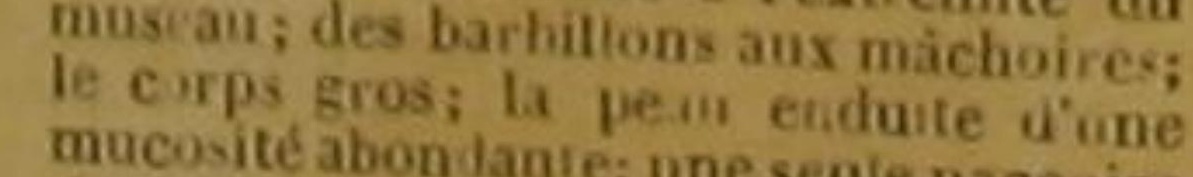
dorsale; cette nageoire tres-longeoir

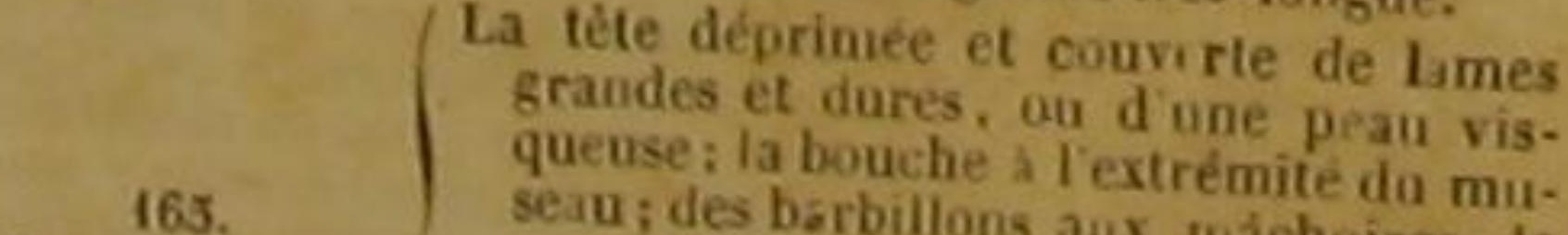
163.
Malaptikgbe.

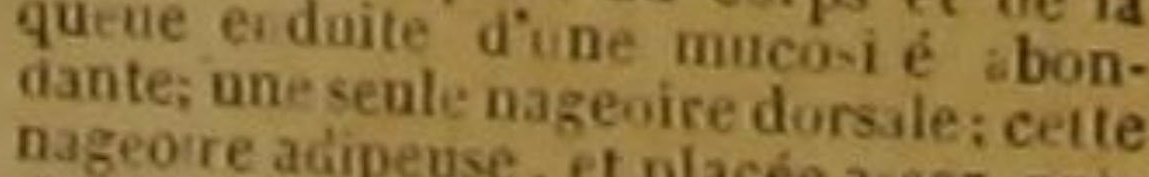
nageorre ad́ipeuse, et placée assez pres
de la candale.

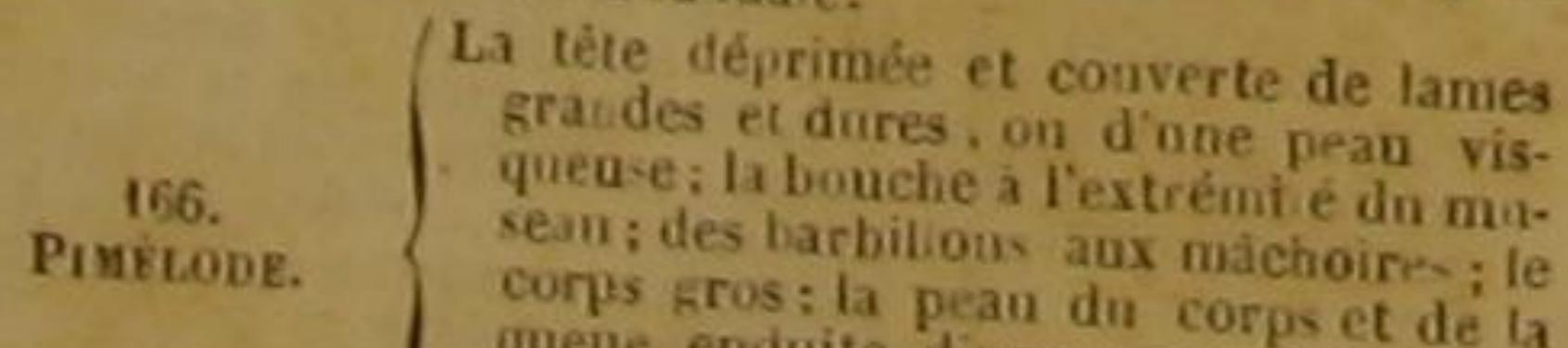

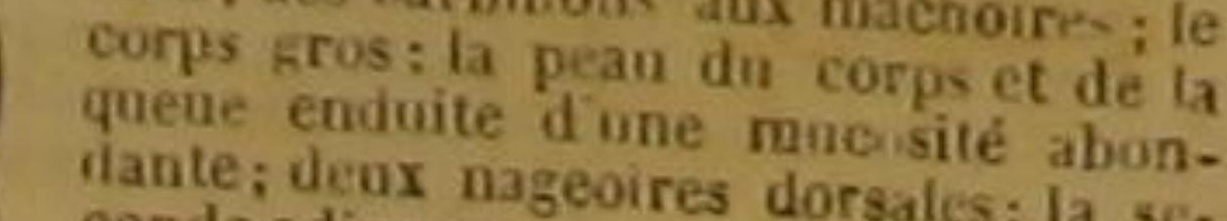

GENRES.

$\left\{\begin{array}{l}\text { La } \\ \text { g } \\ \text { Lats }\end{array}\right.$

167
Doвะ.

168

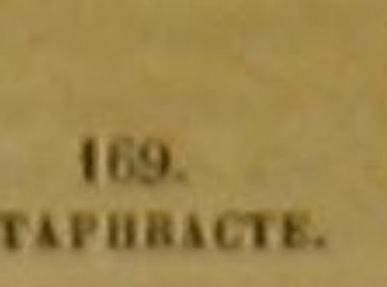

170.
potose.

171.

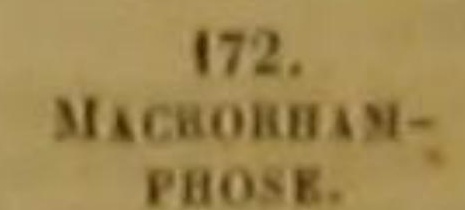

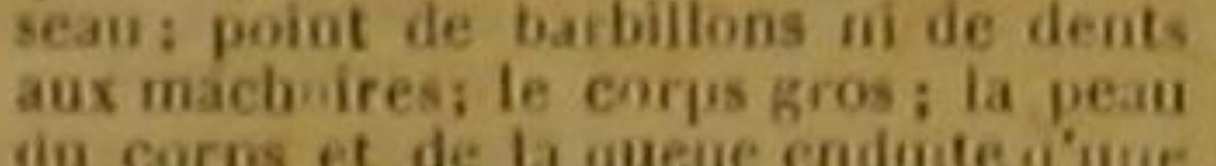

Cestex. 175

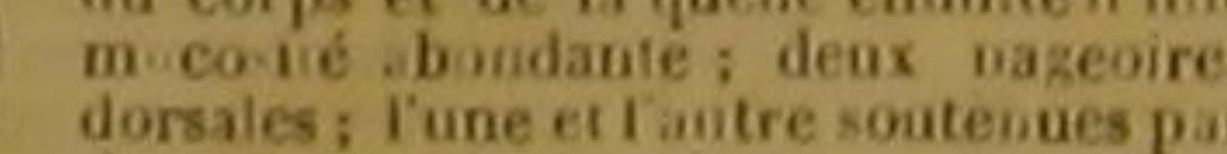

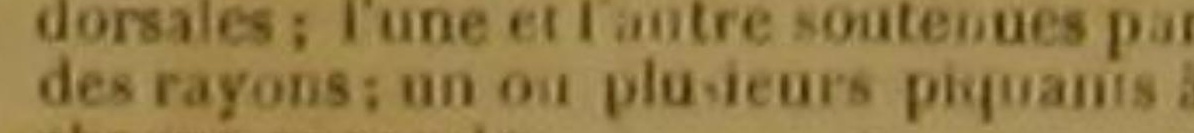

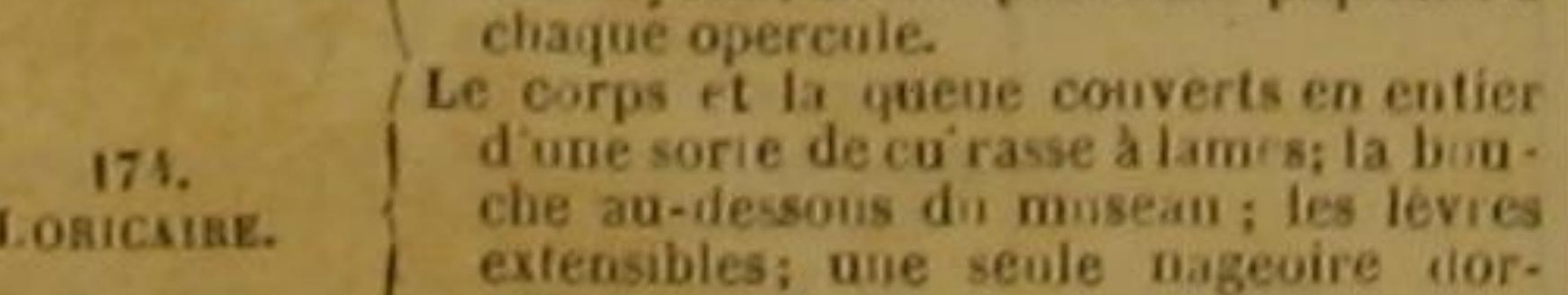

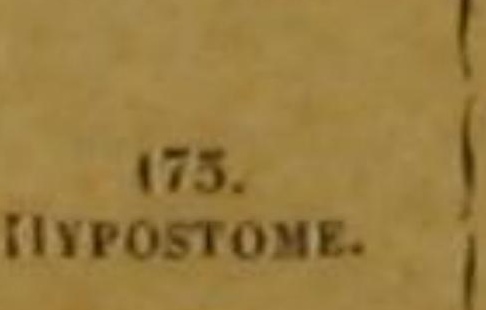
Lale.
ding
ding extensibles; une seule nageoire torпуровтоме. 176.
CORYDo Conyomas. TACBYSLige. the an-dessois din museant; les levres De grandes lames de cliaque cóté don corps et de la queue: la téte couverte de pié-
ces larges kt dures; la bonche a l lestrémité du museen: point de barbillons;
deux nageoires dorrales; plusd'un rayon a chaquie nag-eire din dos.
booche a lextrénité du musean; des queue trésallongés et revetus dine
pean visqueuse; le premier rayou de la

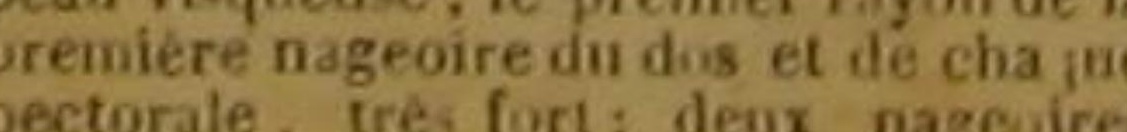
canctiknes.
tête déprimée et couverte de lames

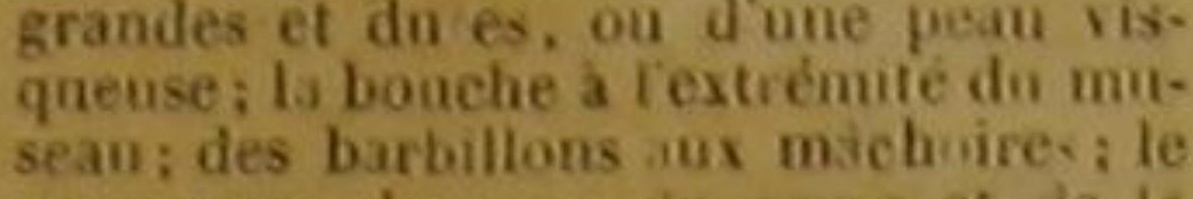
gueue endmite t'une mucrsté abou-

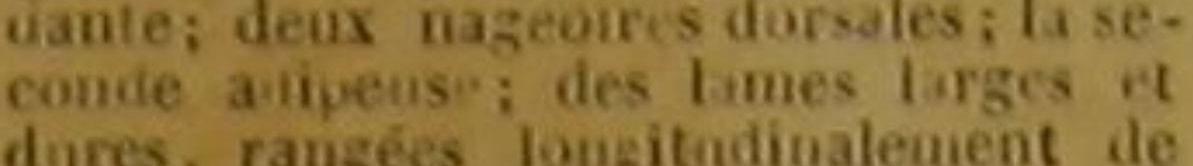
tête dèpr mée et cuaverte de lames gramiles it cures, ou dine pesu vis. seas des tarbiltons aux michores; le
corps grovi la peau in corps et de la dante: denx nagroires dorsales, sunte.

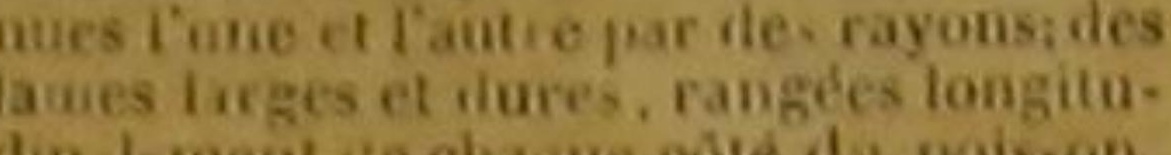
tha téte deprimé el comrerte de lames grandes et dures, ou d mie pean vis. can i des burbillous aux máchoires; le
corps grosi la pean du corps et de ia queue enduite dune macosite abondante; denx nogeoires dorsies; la se-
conde somtenme par un s-nil raycon ides

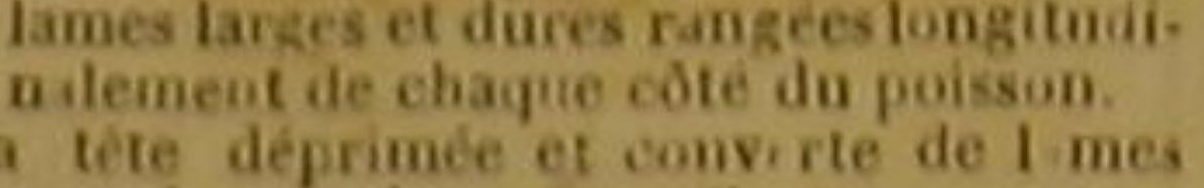
La téte déprimée ef convirte de 1 mes
grandes it dures, on d'uñe pean vis(a)

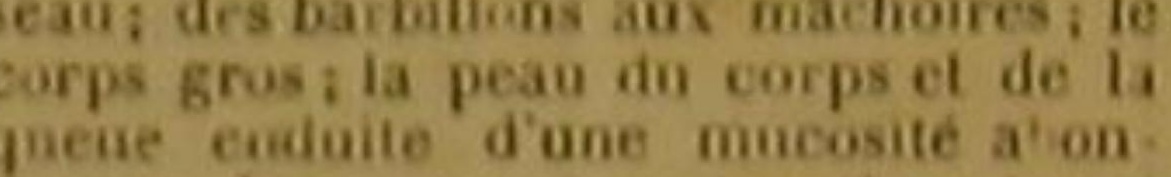
dante; deux nageorrs do sales; a on seLa tête déprimée et converte de lames
grandis et dures, ou d'me pean vis.

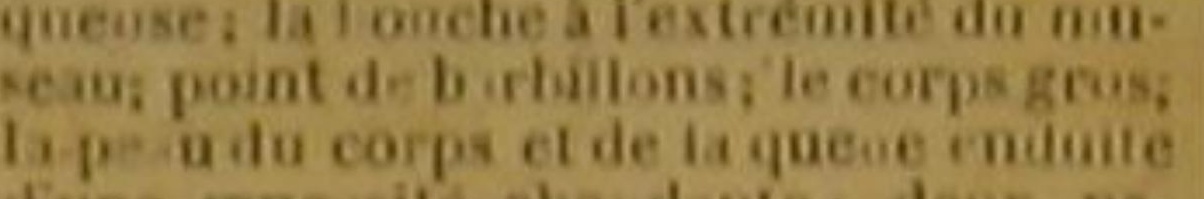
geoires iorsale ; ta seconde a aimeuse. la teie deprimée et couverte de lamis grandes ef dires, ou d'une peau v
quense; la bouche a l exiremite du mi-

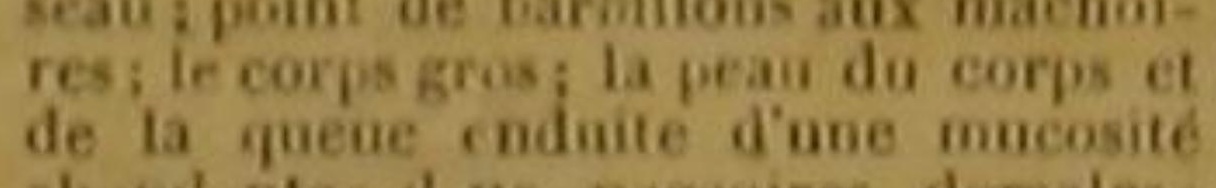

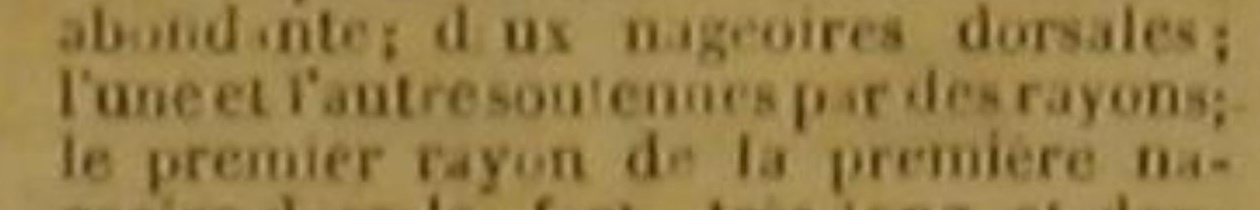

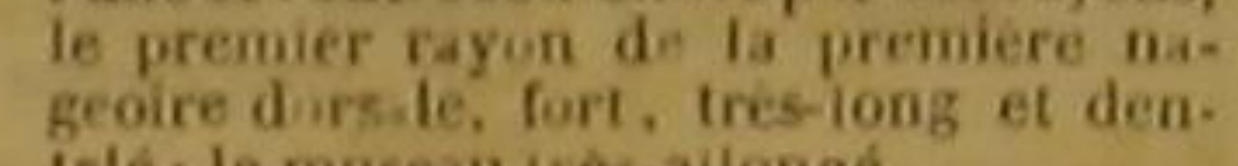
Ielé; le moseau ires allongé.
La téte déprimée et couverte de lames
grandes to dures ou dune pean vis.

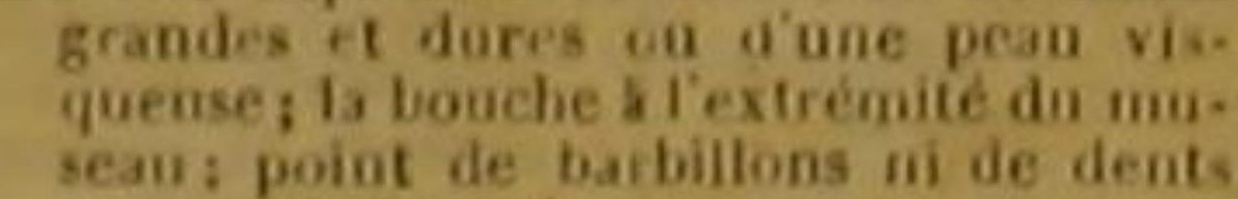

GENKES.

SLMONE. pectorale, trè forl; deux nageirires
dorsales, Fune et Ilautre soatenues par
plus d'on rayon.

$\log _{180}$
CARACTikses.

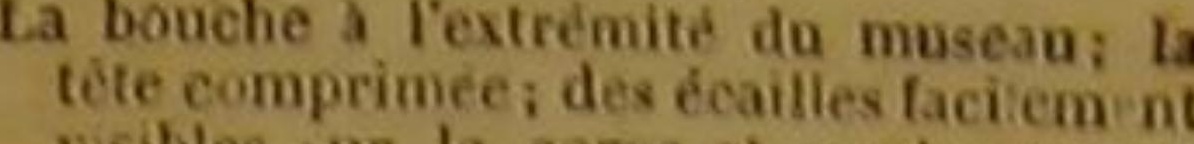
visibles ar le corps et sur la queve
point de grandes lames sur les cathes do rayons denteles, mi de butbillonies, de nageoires dor sales; la seconde adipense
te dénuée ae rayons: la premiere pina près on auss prés de la téte que les
ventrales; plins de quatre riyons de membirane des branchirsi des dent
fortes aux deux michores.

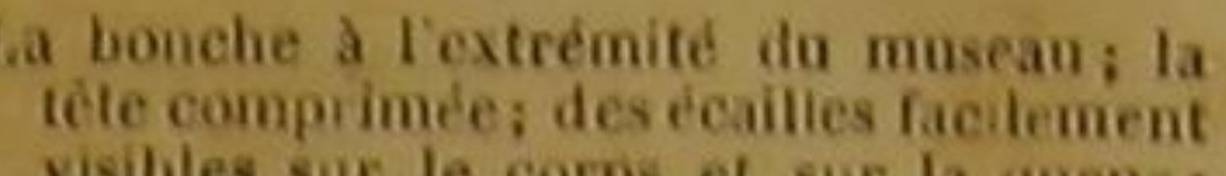

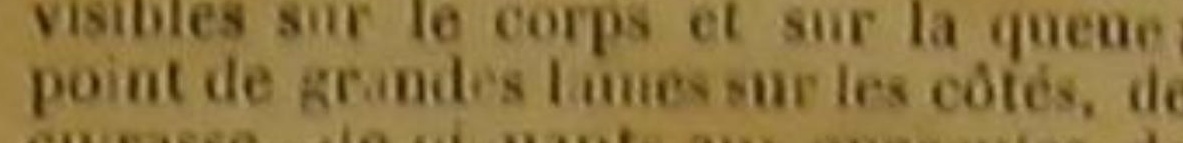

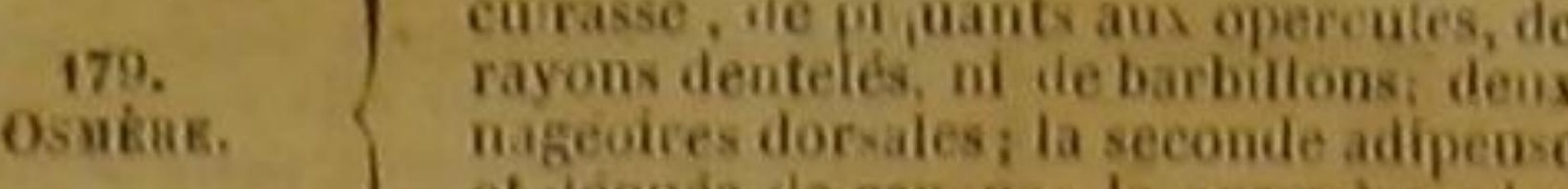
et uéance de rayonss; li premeère plus eloignce de la tète que les ventrales
plas de quatre rayons a la mention hios de quatre rayons a la membirane
destranties; des dents fortes aux deux

La bonche á l'extrémité du musean: la ristes onr to i des écailles facilemen visibles sur le corps ot sur la queue
point de granies lames sm tes coter de rayons denteics, ot de barbillons deux nageoires dorsales ia second
adipene et dénuto de rayons; plisis de quatre rayons s la membrane des bran-
chies; les machoires sans dents. ou a voir.

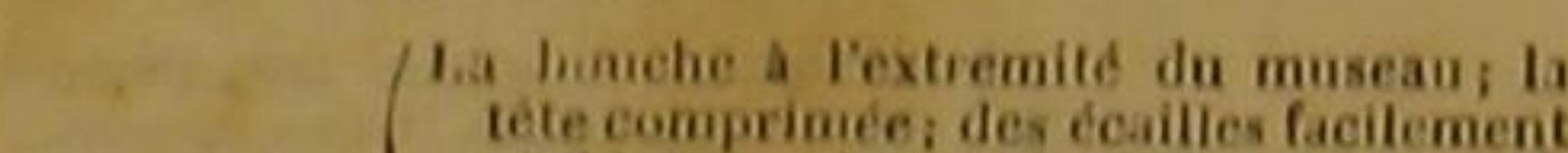

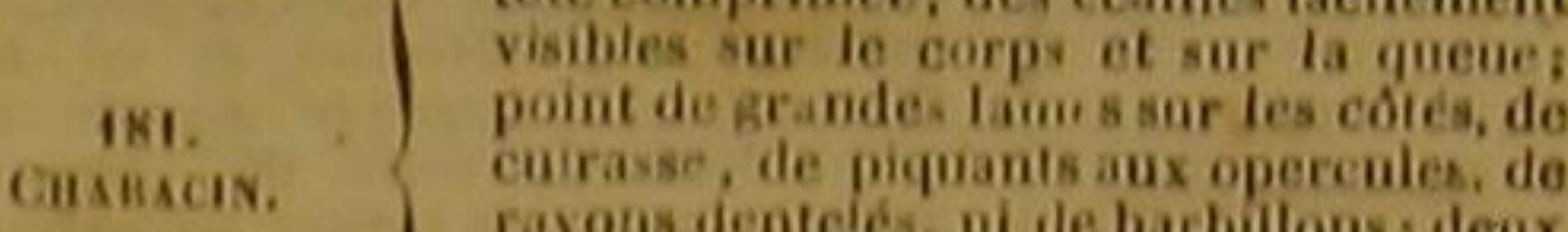
nageoires dorsales. la keconde aulpeuso
et dénuée de rayous i quatro rayons au plus a la membrane des brambies. La bouche a l'extrémité dı museau: I des ícailles facilement visibles sur lo corps et sur ta guene ; point de grandes
lames sur les cotés. do coursuse ide 182.
SEuBAsLax. les, ui de barbilions; deux nageoire

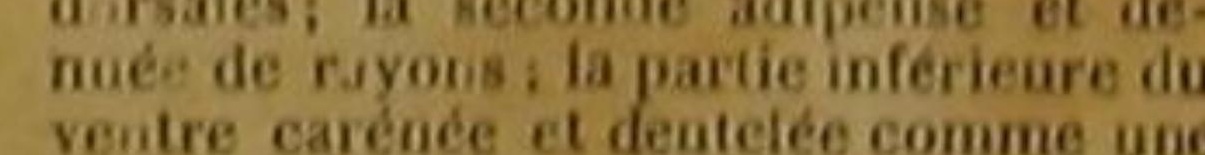

Trente rayons ou plus a la membrane den

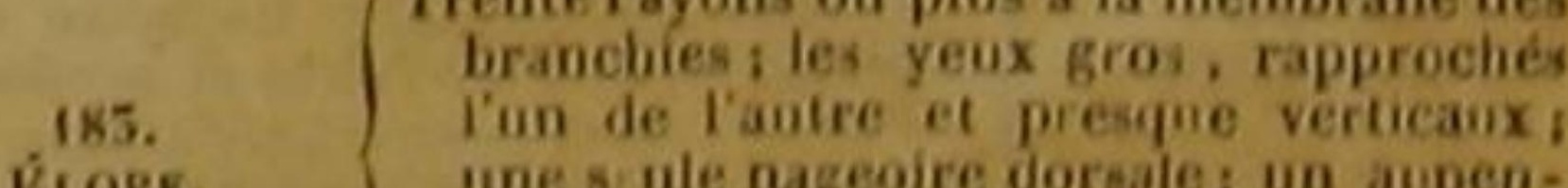
ne s ule nageoire dorsale; un appen-
ceécailleux auprés de chaque nageoire

184.
MEGALOPE. $\quad \begin{gathered}\text { Les yeux très-grands; vingt-quatre rayons } \\ \text { ou plus a ta me mbrane des branchies. }\end{gathered}$

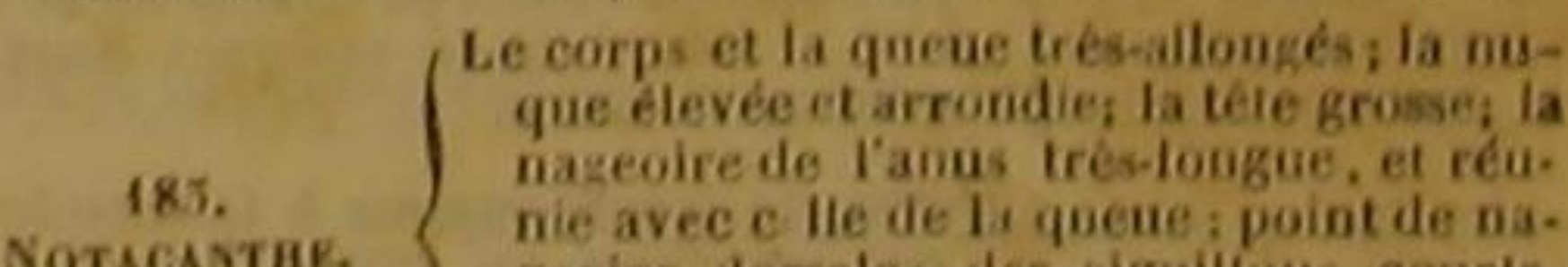

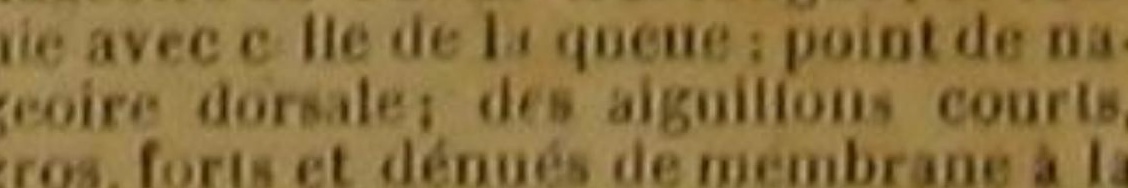
grose foris et dénués de membran
place de cette derniere nageoire.

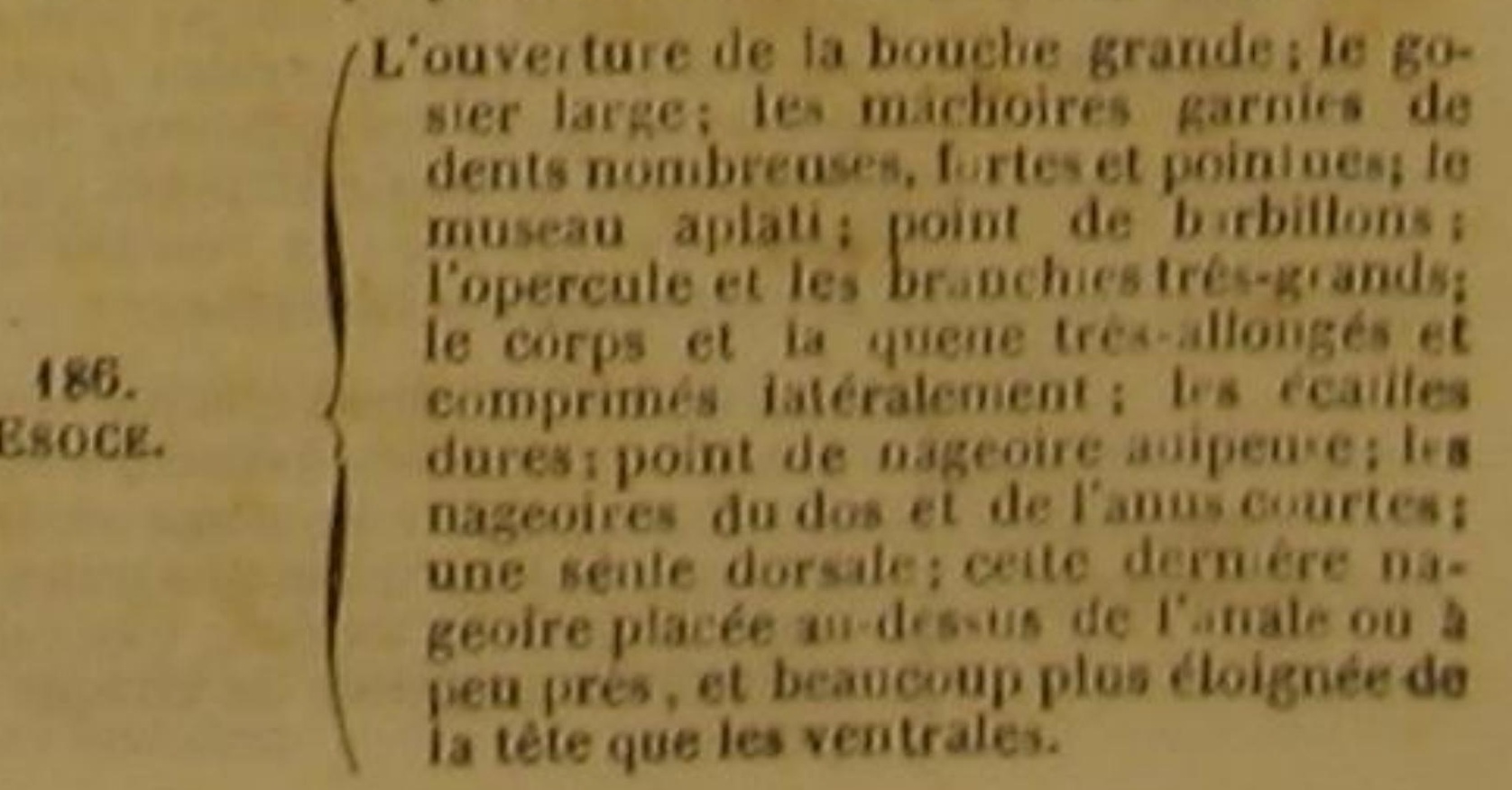


assers.

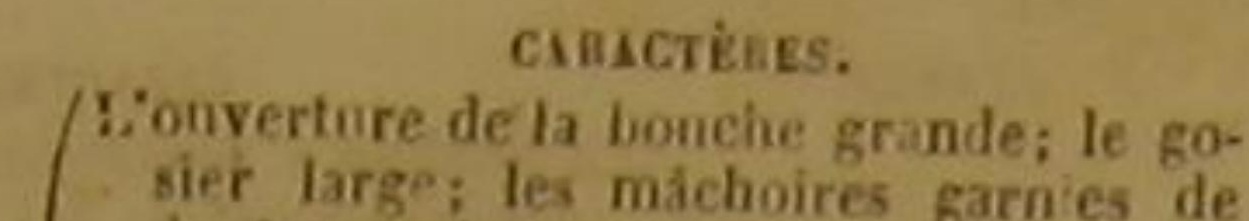
dents nmmbrenses, fortes el pointries;
point de barbillons:

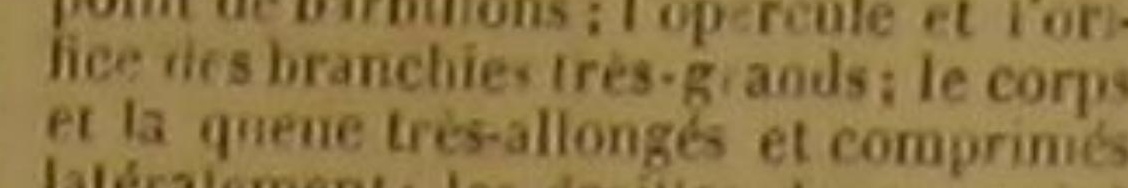
latéralement; les écailies dures: poin

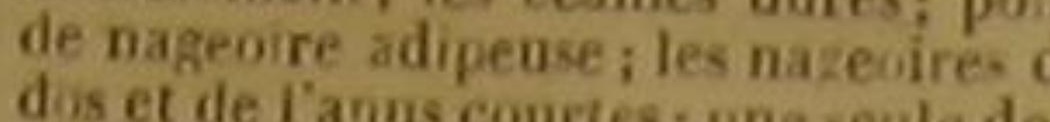

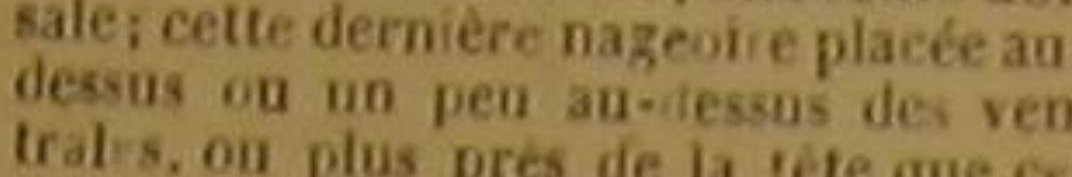
tral-s, on plus pres de la téte que crs
derniéres.

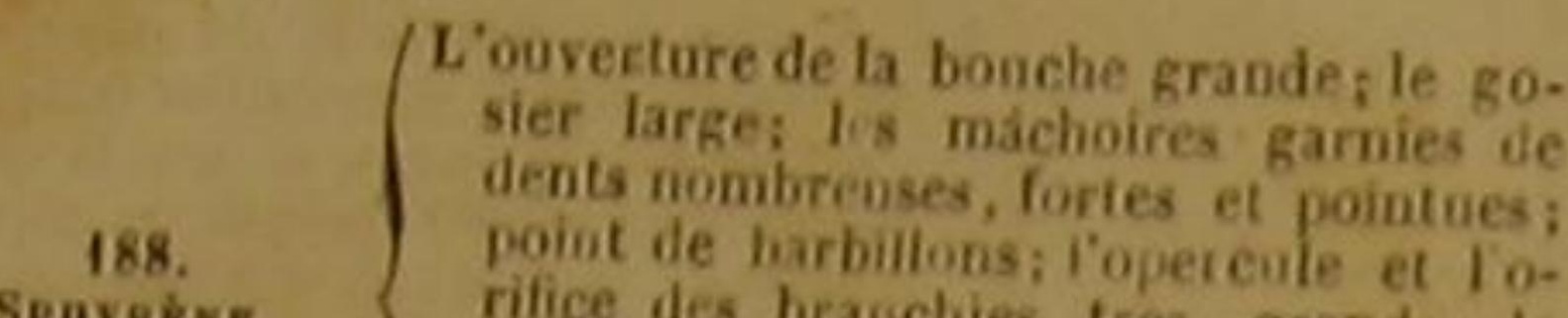

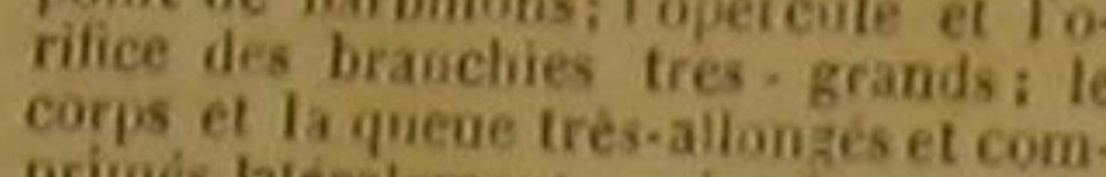
primés lateralemeut; point de nageoire
adipense, les nageoires du dos et de
lanis courtes; deux nageoires dorsales.

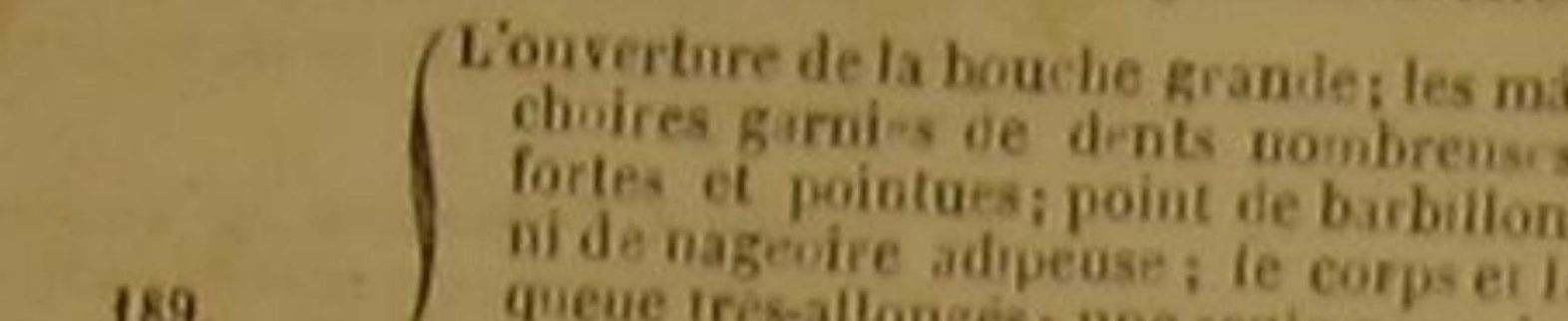
189.
L. pisosio

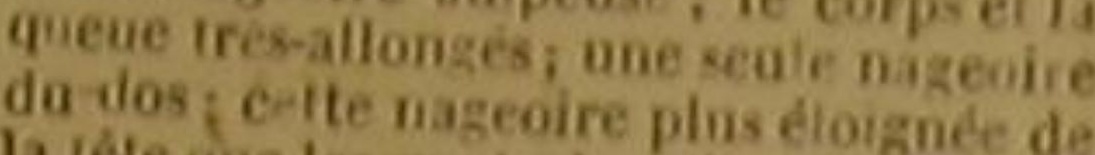

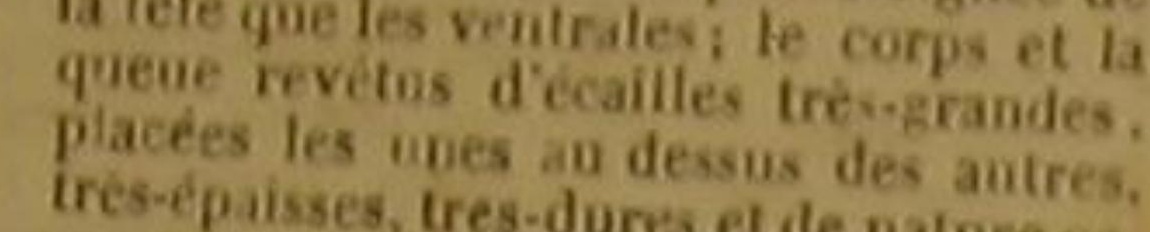

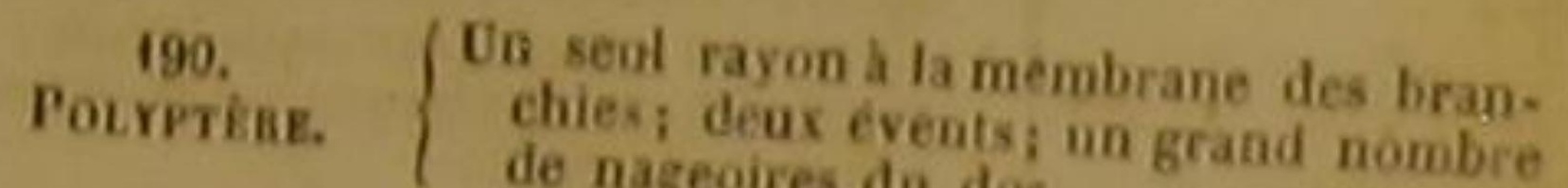

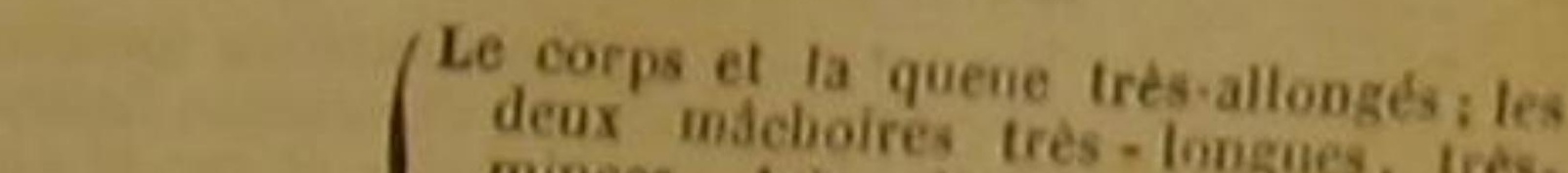
minces, tress-étroiles et en form

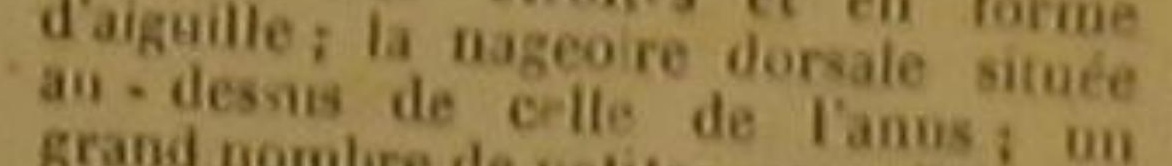

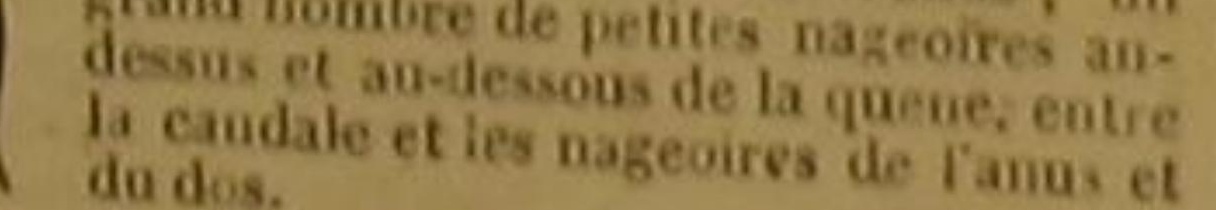

192.
MATULAIRE.

dires tres-etroiles, tress allon. ta bouche a de tube; Fouverture

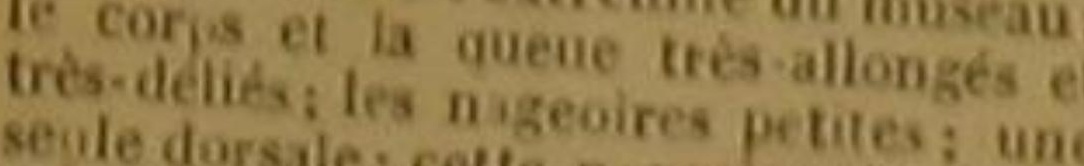

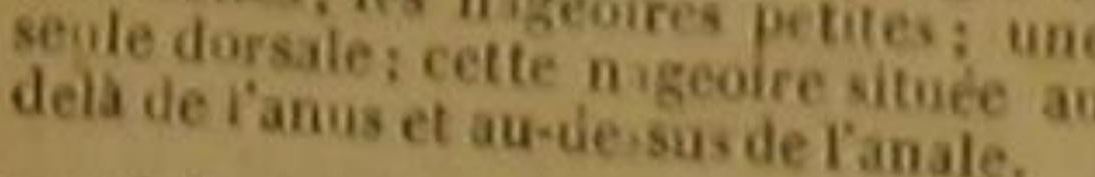

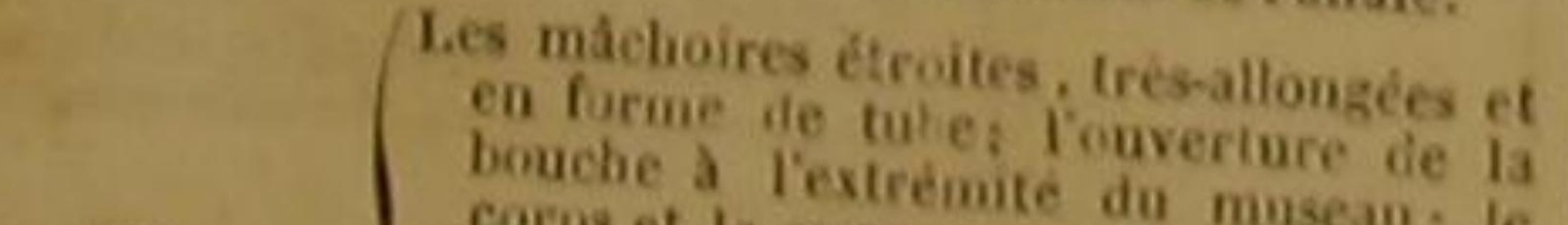

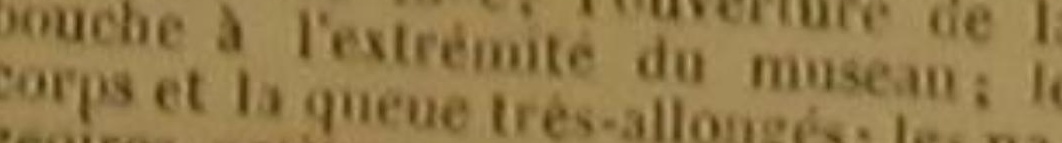

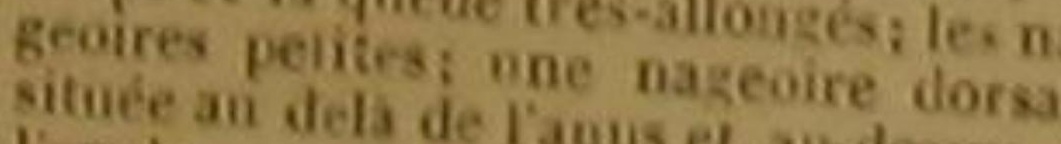

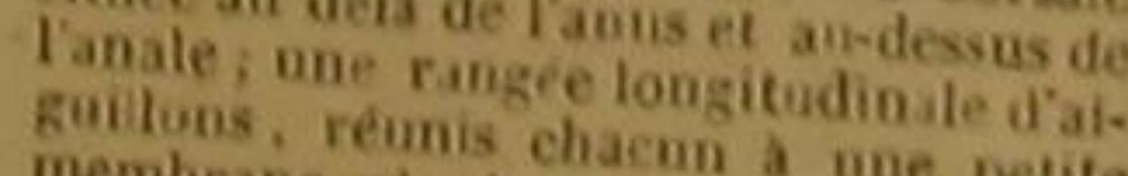
membrane placeec sur le do dos, et tenate
lieu d'une permiere nageoire dorste.

194. Les míchoires étroites, tris-allongeses

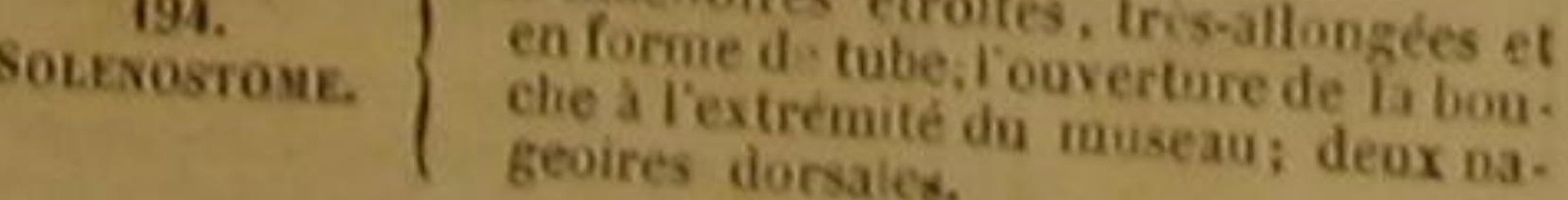

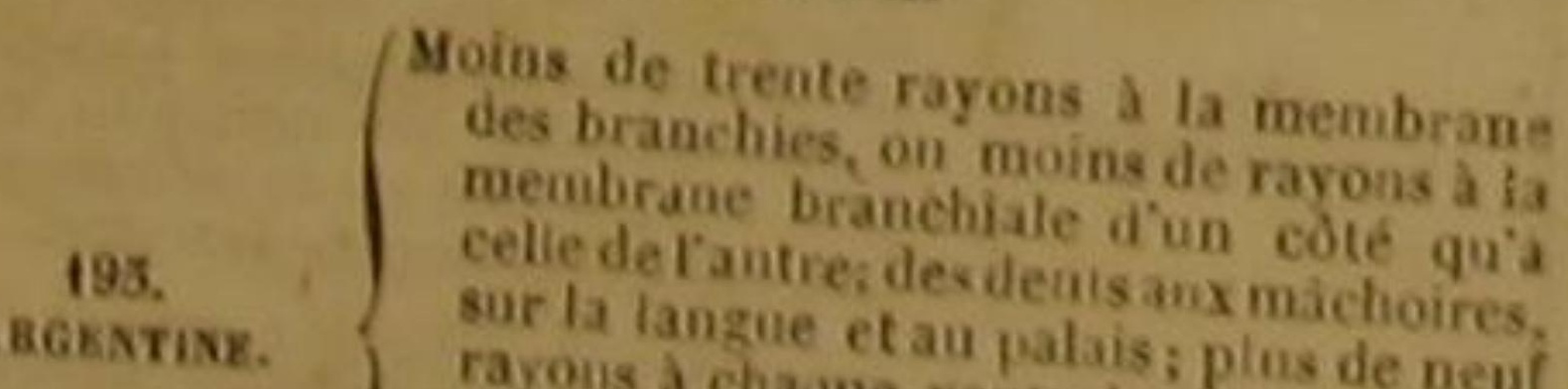

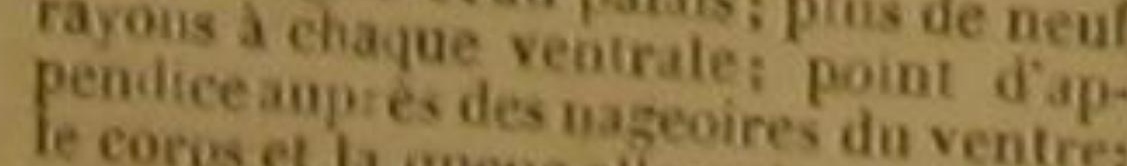

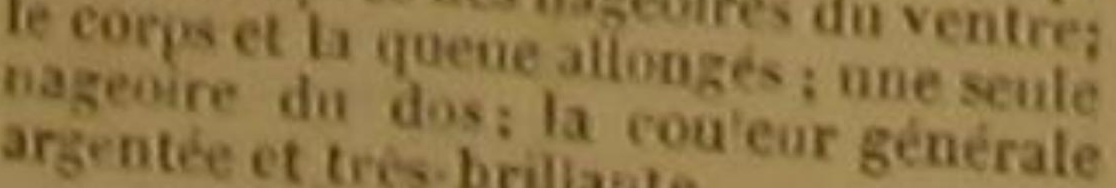

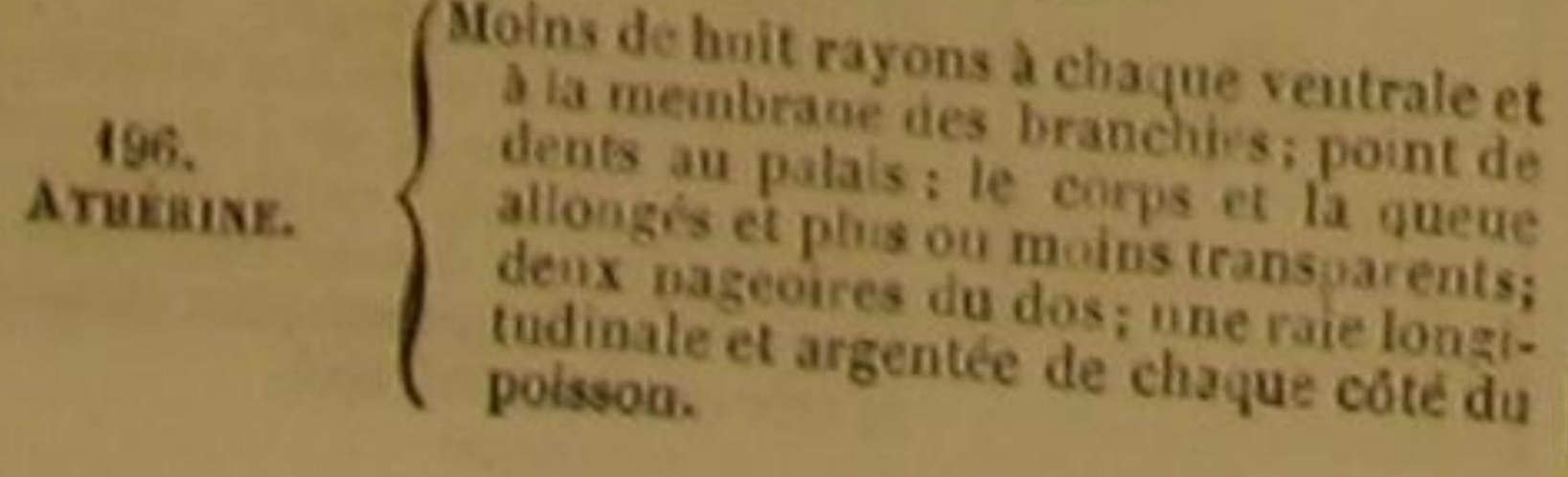

GRXREs. SAnsctêrRs.
Moins de huit rayons à char Moìs de huit rayons à chaque ventrale el
à la membrane des branchies;

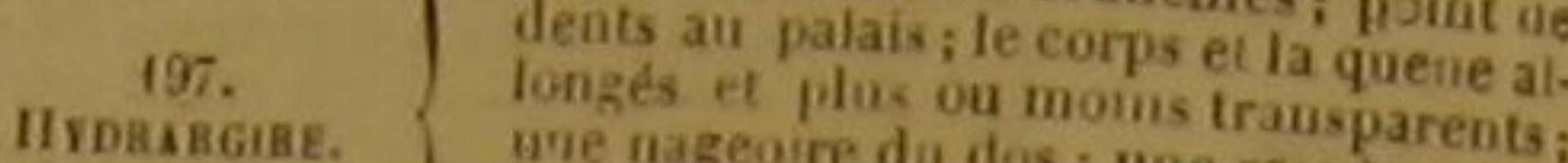

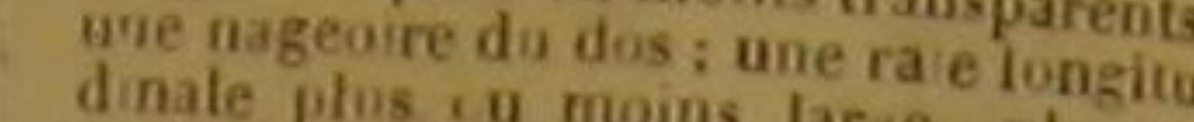

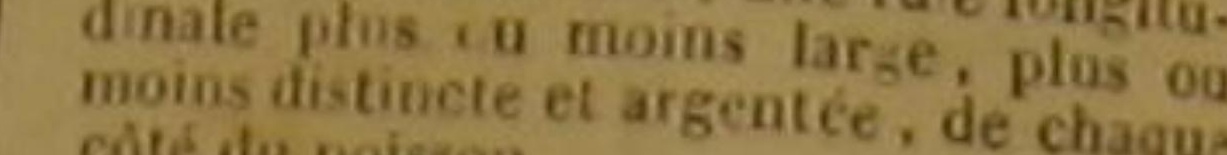
côté dus poisson.

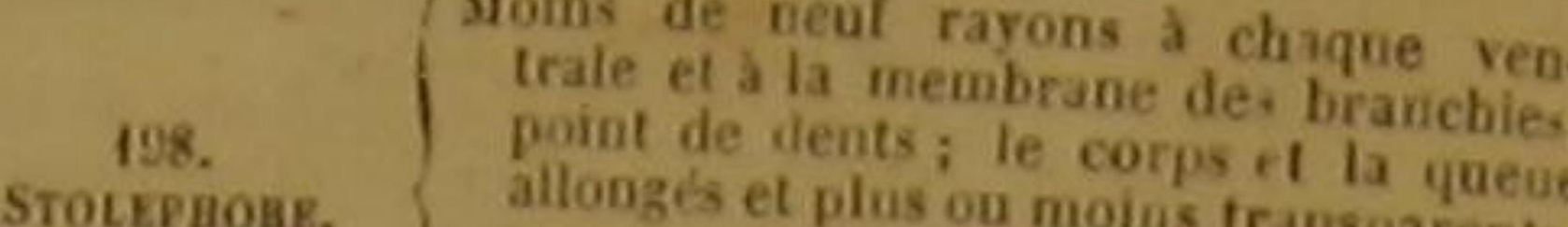
une nazeoire sur le dos ios transparents
gutudinate et aie longitudinale et argentée de chaque coti
du poisson.

199. $\quad \begin{gathered}\text { La máchoire intérieure carénée en de } \\ \text { dans i la téte revéthe de }\end{gathered}$

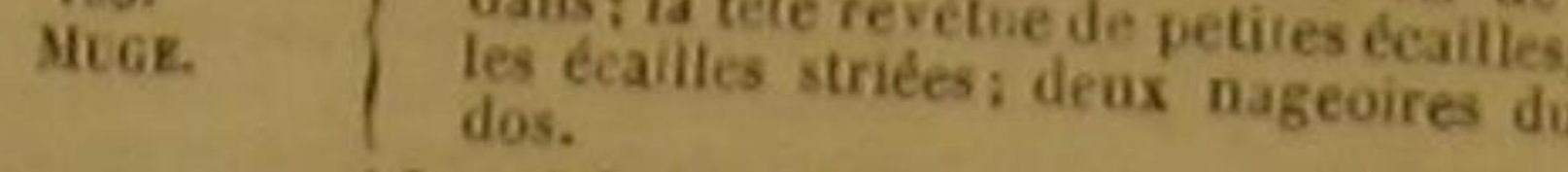

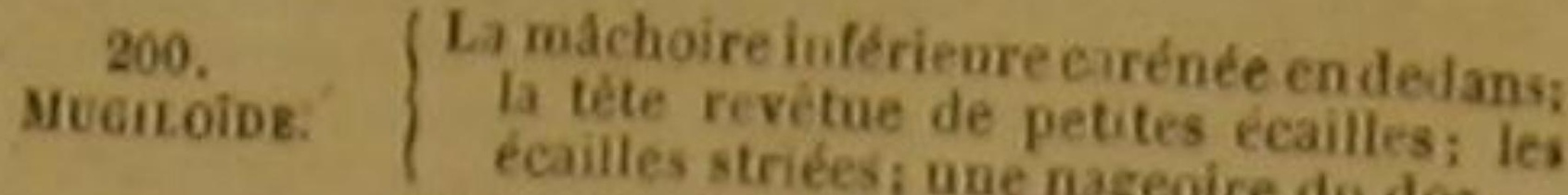

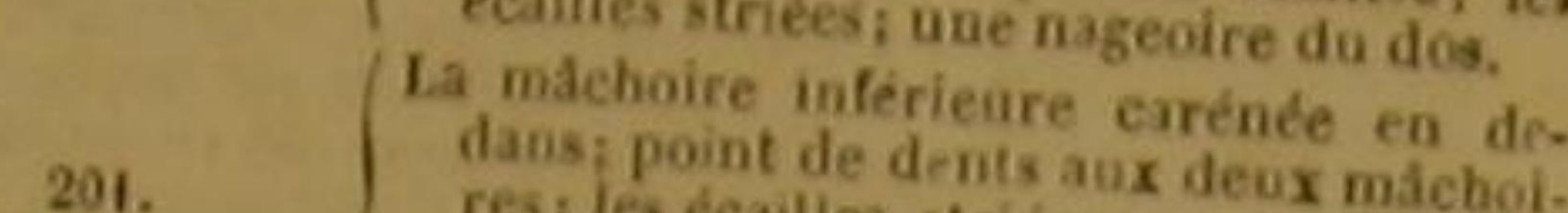

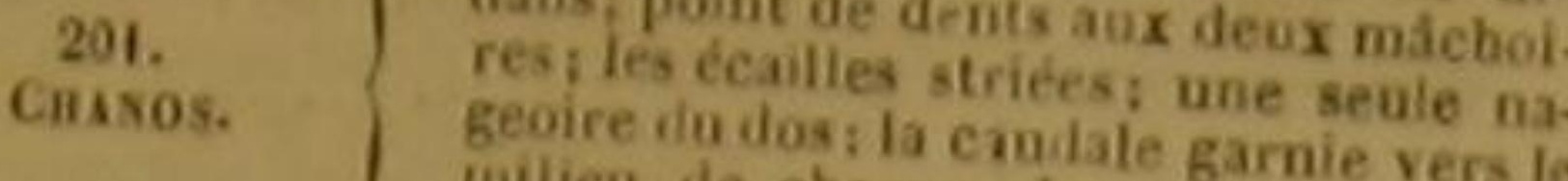
milien de cha on de ses cortés d'ine
sorte dasite membrauese.

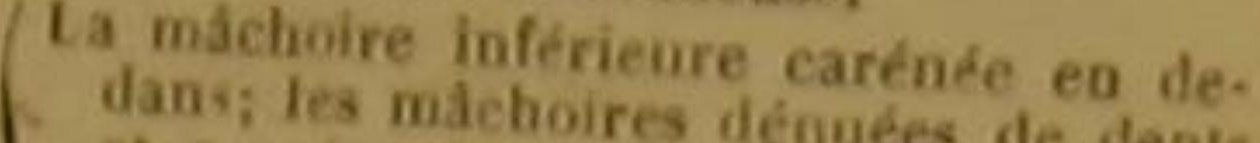
et garnies de petites protubérances

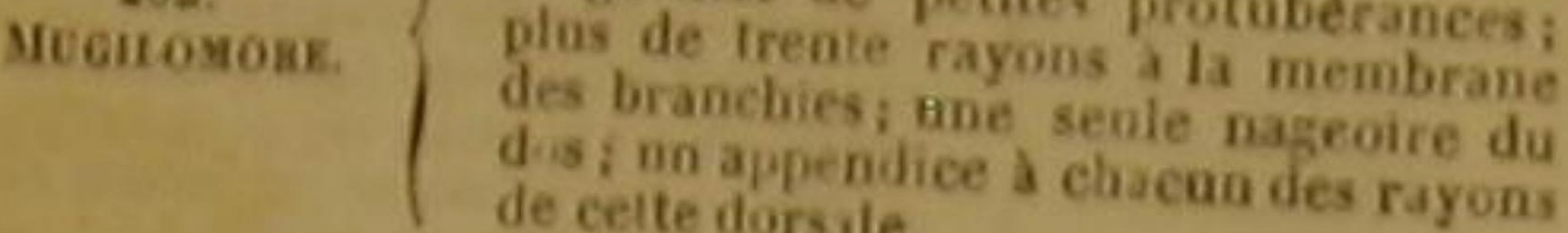

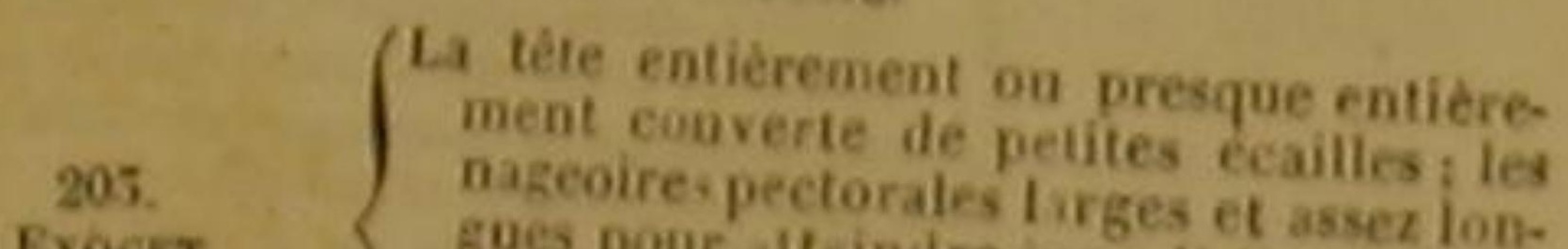
ExockT. $\quad\left\{\begin{array}{l}205 \\ \text { Eues pour att-int }\end{array}\right.$ dix rayons a la membrane des branchies
une feule dorsale; cetle nageoire
tuée felle Tué au-tessus de celle de lanuis.

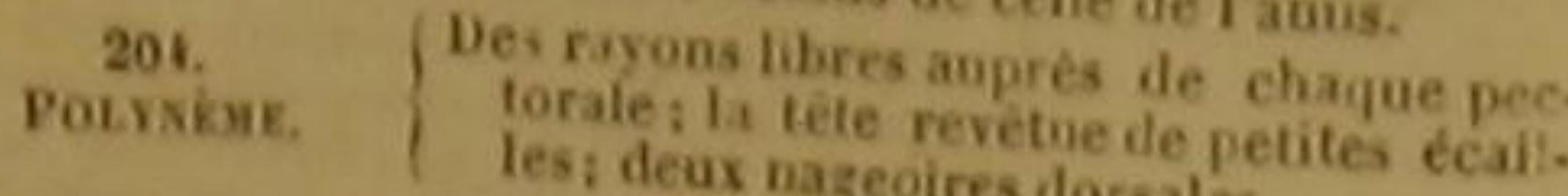

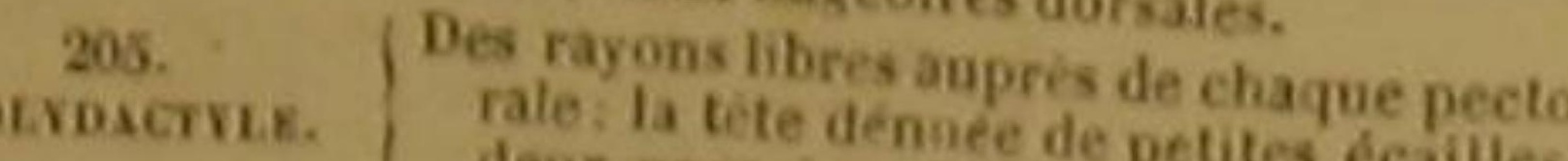

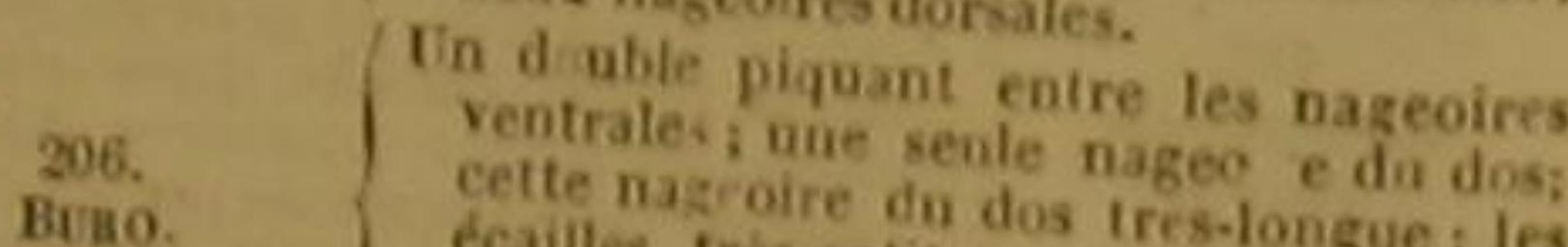

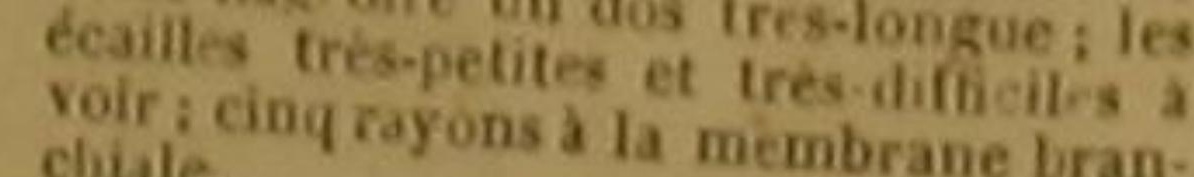

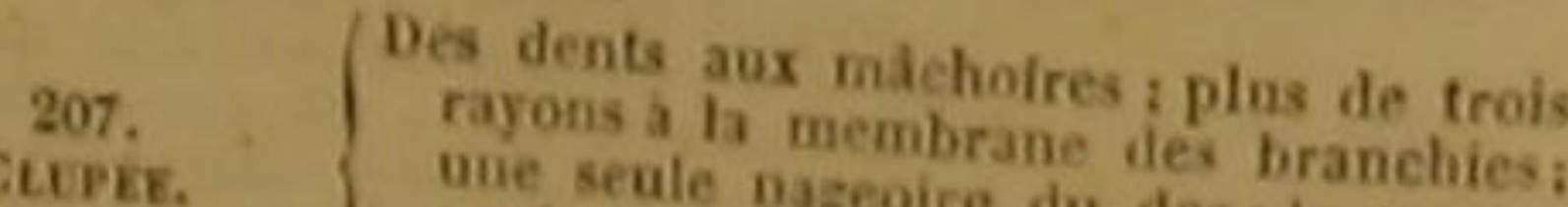

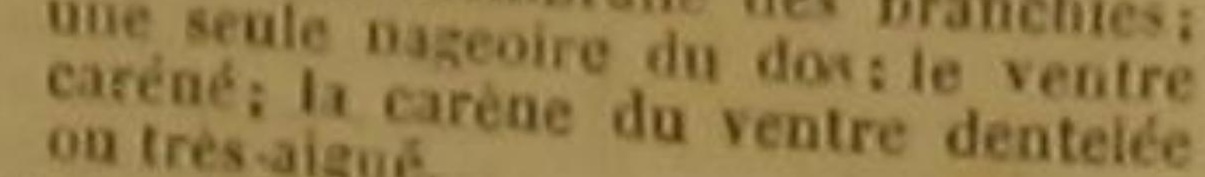

208. $\quad$ Plus de trois rayons à la membrane deo

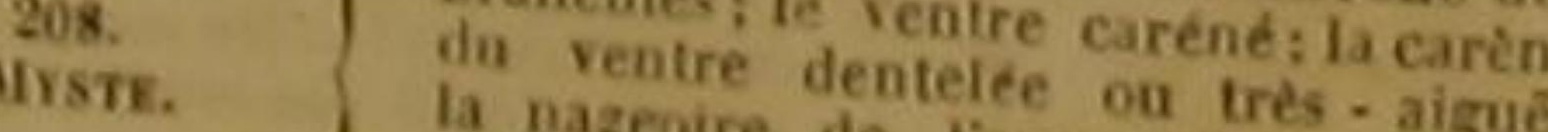

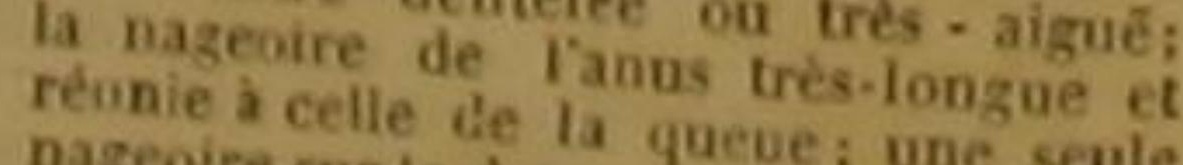
Plins de trois ragos.

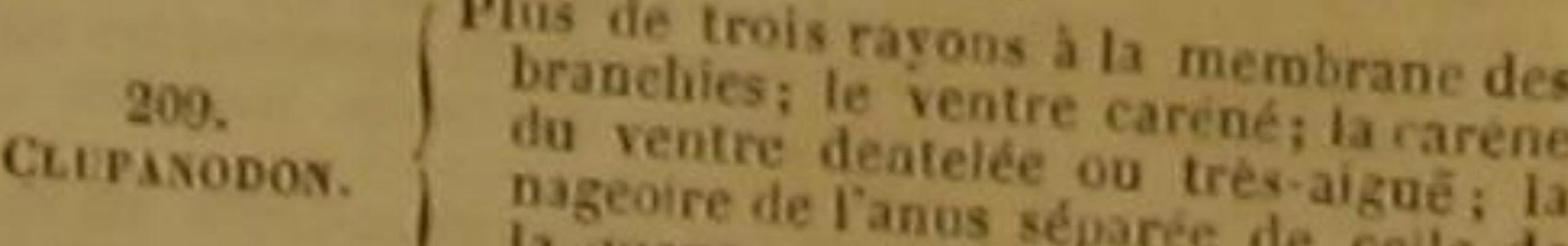
nageoire de lanus séparée de caiguê; ;
la quene; inne senie no point de dents aux máchoires. da dos;

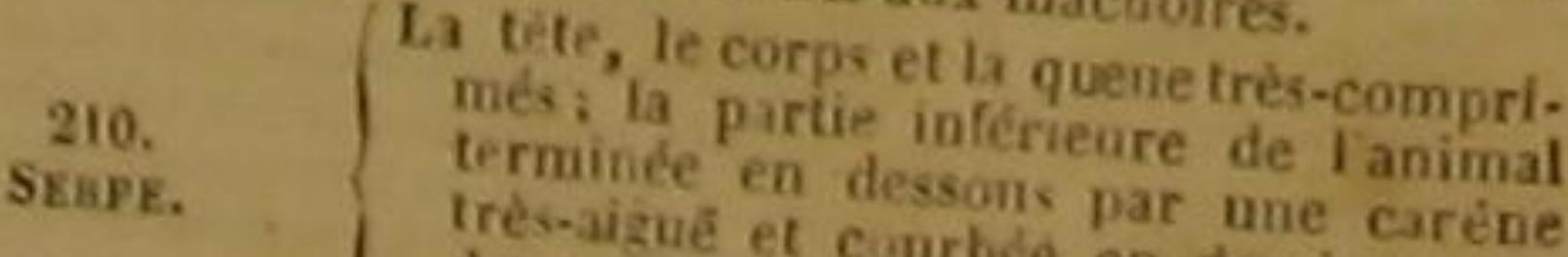

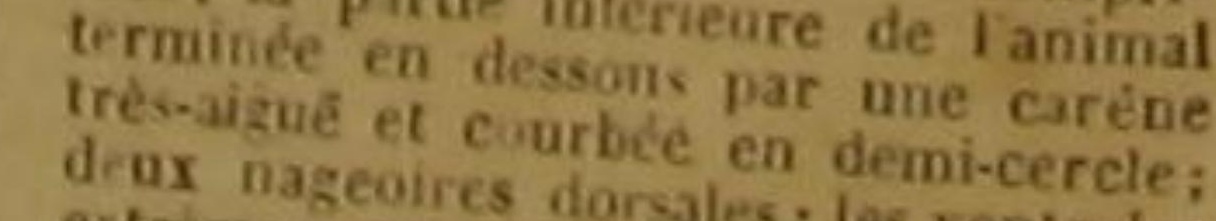

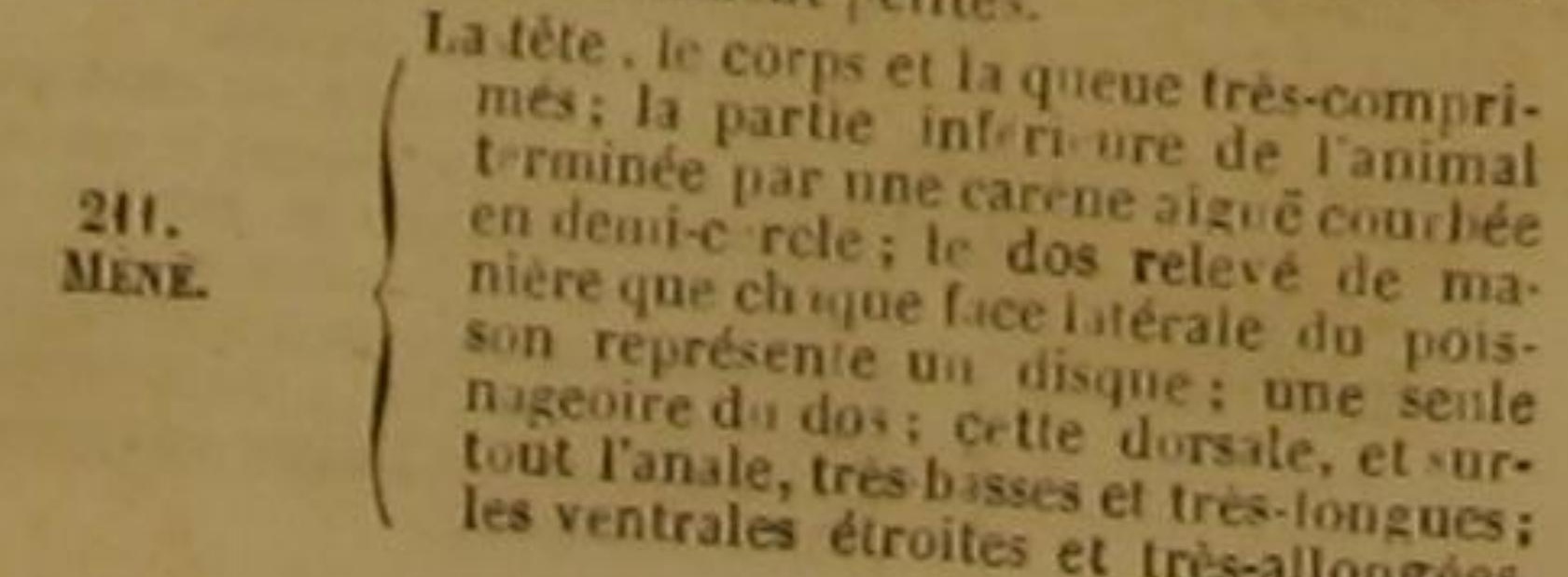

GEXREs. Cansctèses.

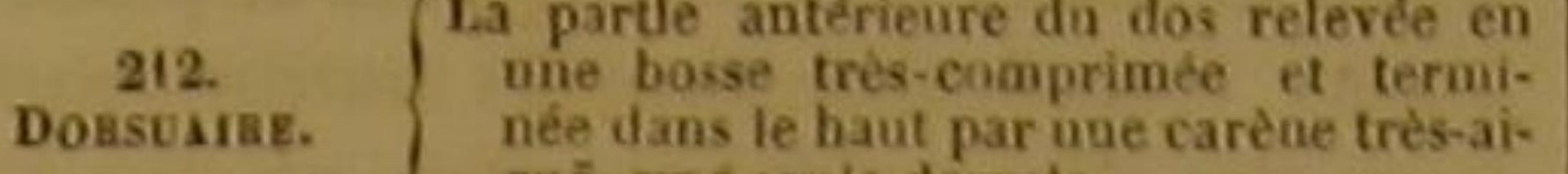
La tète, le corps et la queue très-compri-
més; le dos termine comme le ventre par nue carene aigue et courbee en

213. arembrane branchiale; la tete et les opereules garnis de petites ecailles: les
dents echanerées de maniere yu a lies térienr elies ont la forme dincisives, et qua lintérienr elles sont basses et un
peu reufles; une fosselle au-dessous de chaque ventrale.

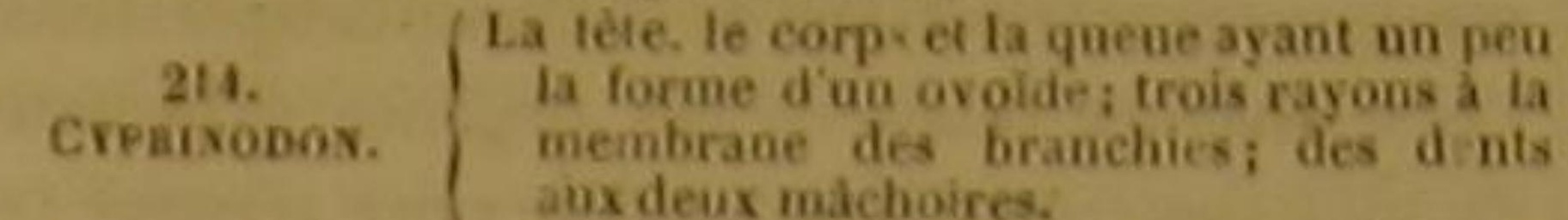

215.
Cypuis. resi une seule nageoire du dos.

SECONDE DIVISION

DE LA SECONDE SOUS-CLASSE,

SIXIÈME DIVISION

DE LA CLASSE DES POISSONS.

Un opercule : point de membrane branchiale.

VINGT-UNIEME ORDRE

DE LA CLASSE ENTIǨRE DES POISSONS,

PREMER ORDRI

DE LA SECORDE DIVISIOX DES OSSRIX.$$
\text { - }
$$

POISsONS APODES.

Point de nageoires infericures entre l'anus et le museau.

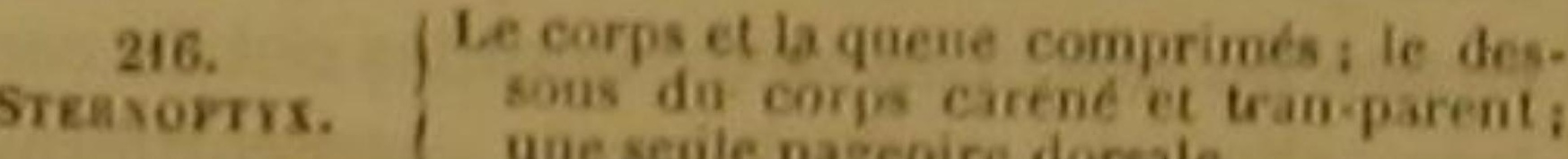

TROISIĖUE DIVISION

DE LA SECONDE 'SOUS-CLASSE,

SEPTIĖME DIVISION

DE LA CLASSE DES POISSONS. Point d'opercule ; une membrane branchiale.

VINGT-CINQUIEMME ORDRE ' DE LA CLASSE ENTIĖBE DES POISSONS, $\because$

PREMIER ORDRE

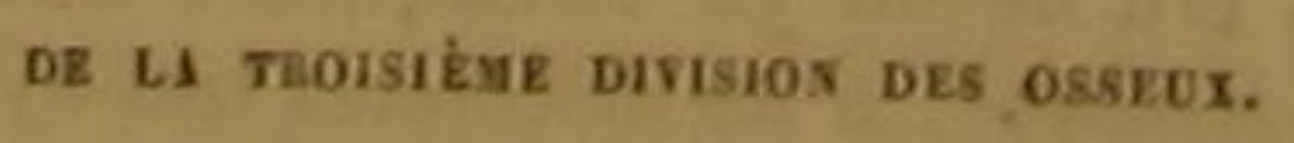

On ne connait point encore de poissors qui appartien- oint de nageoires inferieures entre l'anus et le museau.

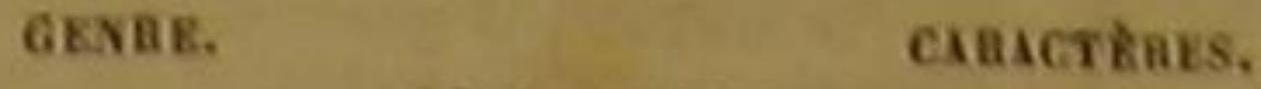

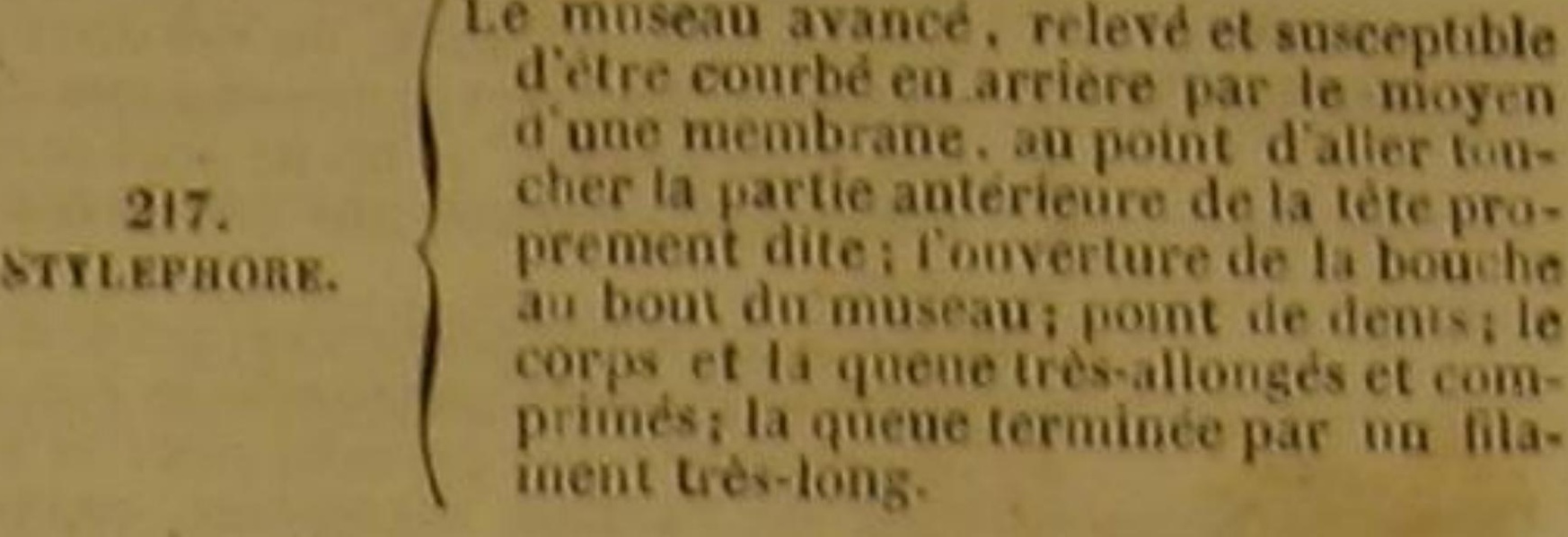

VINGT-HUITIEME ORDRE 1

DE LA CLASSE ENTIÈRE DES POISSONS, or

QUATRIÈME ORDRE

DK LA THOISIĖM DIVISION DEs OSBEUx.

POIssons aBDominaUX.

Des nageoires inferieures placees sur l'abdomen, an delà des pectorales el en deçà de la nageoire de l'anuis.

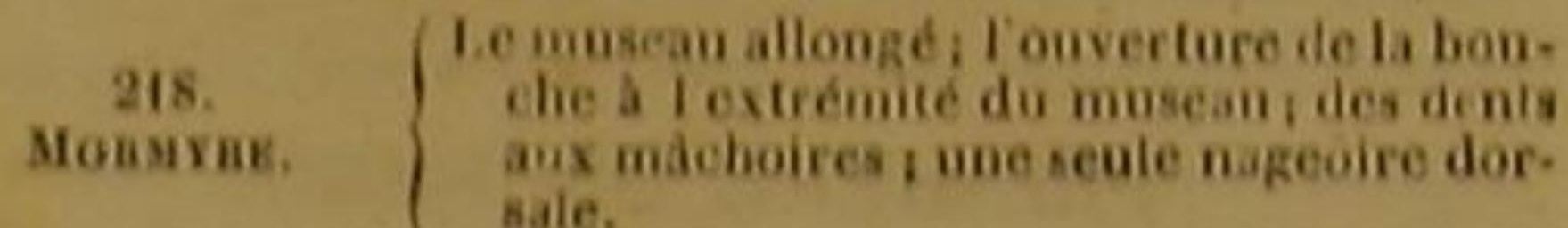

QUATRIEME DIVISION

DE LA SECONDE SOUS-CLASSE,

HUITILME DIVISION

DE LA CLASSE DES POISSONS.

Point d'opercule ni de membrane branchiale.

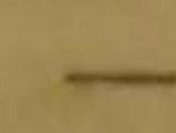

VINGT-NEUVIEME ORDRE ${ }^{3}$

DE LA CLASSE ENTIÈRE DES POISSONS,

PREMIER ORDRE

DE LA gUATRíkie Division des osseux.

Point de nageoires inferieures entre l'anus al le museau.

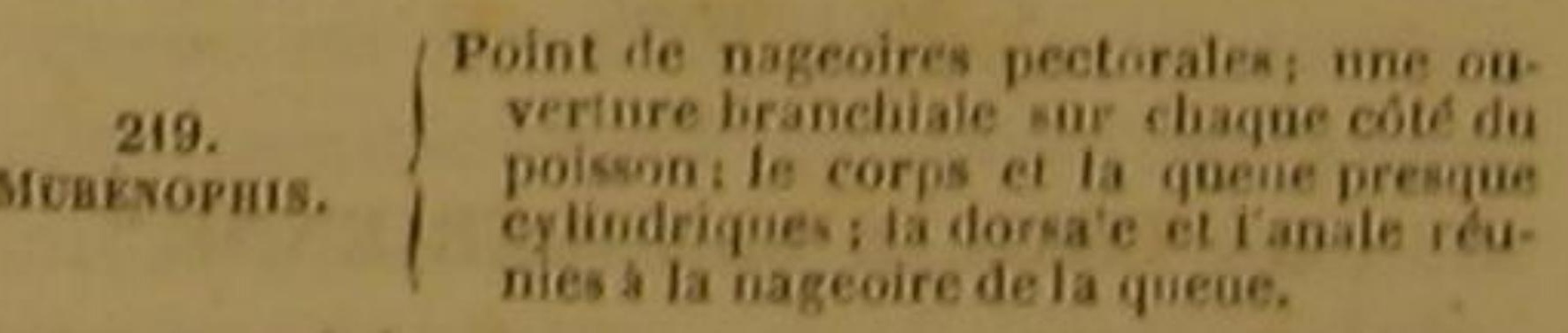
nent an vingt-deuxiéme, au vingt-troisiéme, ni an vingt-qua. trieme ordre. nent an vingt-sixiemene ni au vingt-septieme ordre. 2 On ne connait pas encore de poissons quí appartiennent ou trentieme, an trente-unieme ni an trente deuxienie ordre, Cest-à-dire au second, an troisieme ni au quatrieme ordre Ce la huteme et derniere division des animaux dopt nous 


\section{IISTOIRE NATURELLE}

GEXBES

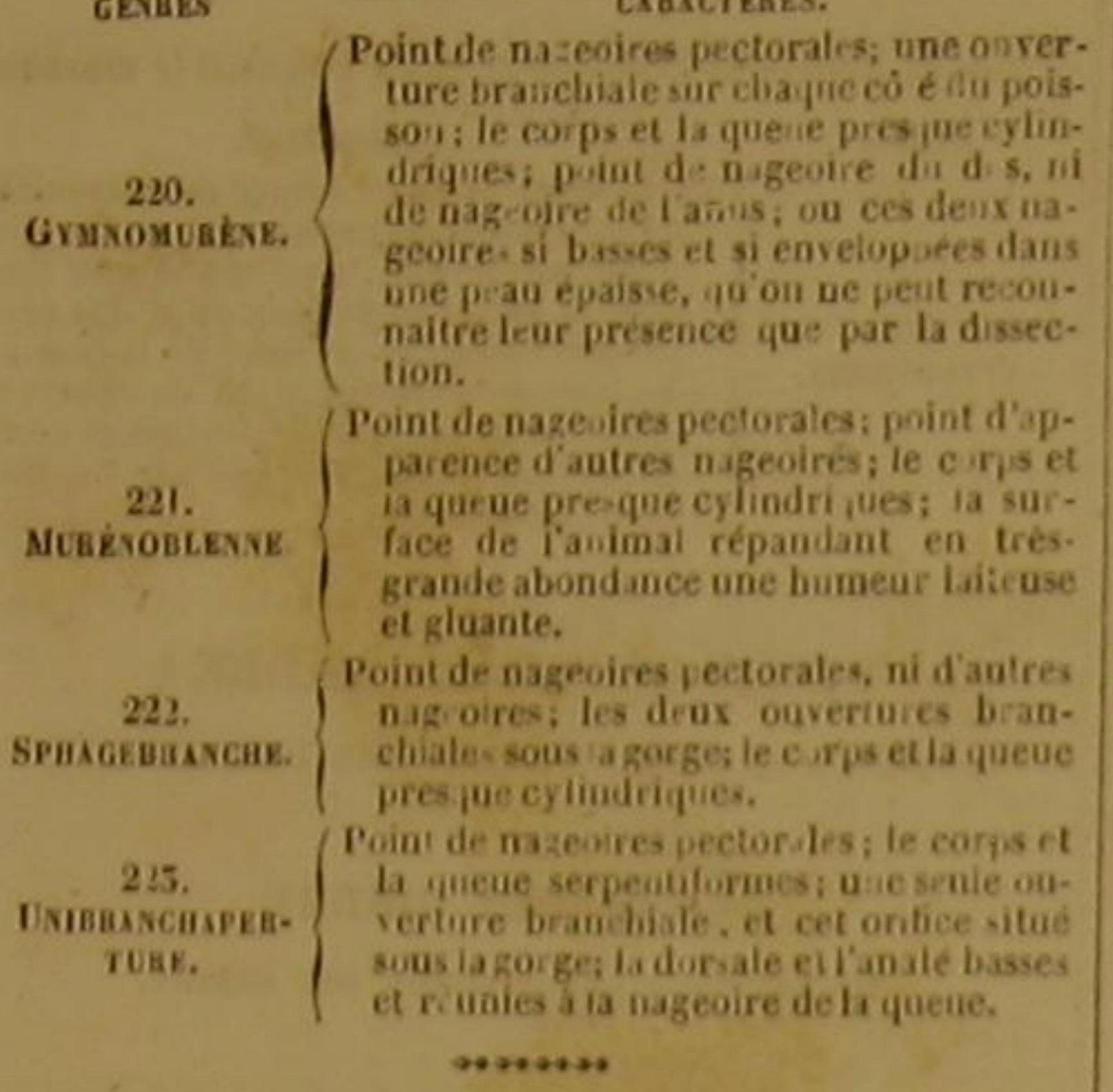

SECONDE SOUS-CLASSE.

polssons OSSEUX.

Les parties solides de l'interieur du corps, osseuses.

PREMIERE DIVISION

Poissons qui ont un opercule et une nembrane des ranchies.

DIX-SEPTIEYE ORDRE

DE LA CLASSE ENTIẺRE DES POISSONS,

PREMIER ORDRE DE LL PAEMíka Divisior des Osseux.

Poissons apodes, ou qui n'ont pas de nageoires inferieures entre le museau et $l$ anus. $-$

VINGT-DEUXIĖME GENRE. LES CÉCHLIES.

Poim de nageoircs, Pourerlure des branchies sous le cous.

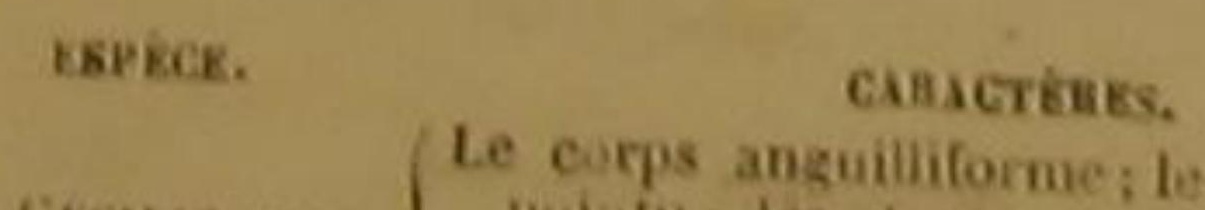

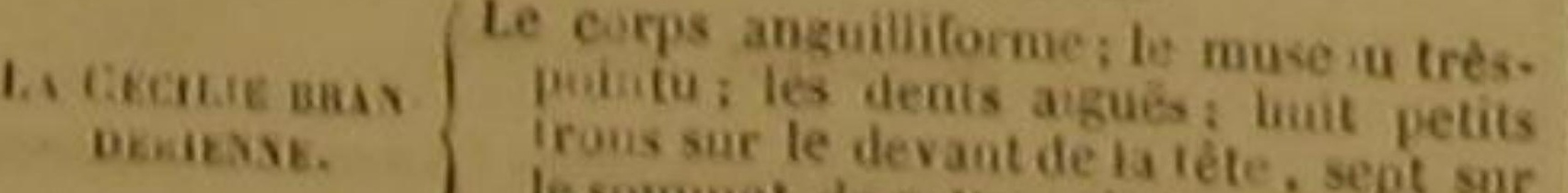

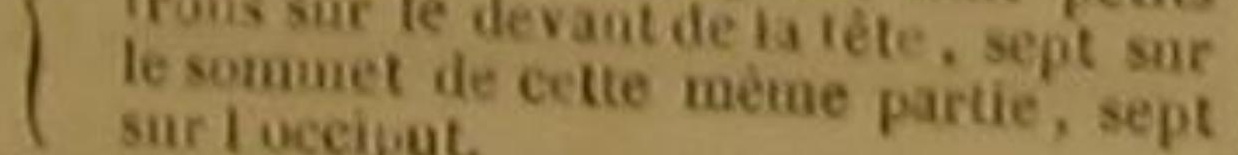

LA CECILIE BRANDÉRIENNE Cæecilia branderiana, Lacep.; Muræna cæea, Li Gmel.; Sphagebranchus cacus, BI., Cur. '.

Nous avons dù nous détermíner d'autant plus aisément à placer les cécilies dans un genre dif-

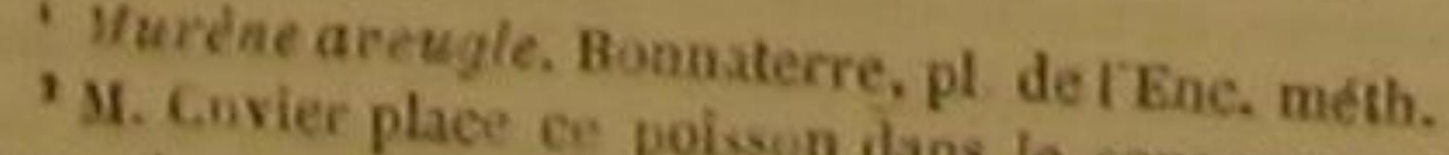
tranche de soi geare AxGulus (Murana). D. férent de toutes les autres familles de poissons osseux, et particulièrement des murènes, parmi lesquelles elles ont été inserites, qu'elles préseutent un caractère distinctif des plus remarquables : elles n'ont absolument aucune sorte de nageoire; et ce défaut constant est d'autant plus digne d'attention, que, pendant longtemps, on a regardé la présence de plusieurs nageoires, ou au moins d'une de ces parties, comme une marque caractéristique de la classe des poissons. Cette absence totale de ces organes extérieurs de mouvement suffirait même pour séparer les cécilies de tous les poissons cartilagineux puisqu'elle n’a encore été observée sur aucun de ces derniers animaux, ainsi qu'on a pu s'en convaincre en lisant leur histoire. D'ailleurs on n'a pas encore découvert un organe de la vue dans les cécilies : elles en paraissent entièremént privées; et, par cette cécité, elles s'éloignent non-seulement de presque tous les poissons, mais mème de presque tous les animaux vertébrés et à sang rouge, parmi lesquels on ne connait encore qu'un mammifere nommé $T y$. phle, et le genre des cartilagineux nommés Gastrobranches, qui aient paru complétement aveugles. C'est done avec les gastrobranches qu'il faut particulièrement comparer les cécilies. D'autres rapports que celui de la privation de la vue les lient d'assez près. Les ouvertures des branchies sont placées sous le corps, dans ces deux genres; mais dans les gastrobranches elles sont situées sous le ventre, pendant que dans les cécilies on les voit sur la partie inférieure du cou, Ces deux familles ont le corps très-allongé, cylindrique, serpentiforme, souple comme celui des murènes, enduit d'une humeur abondante; et on distingue aisément sur la tête des cécilies les principales ouvertures par lesquelles se répand cette viscosité. Dans la seule espèce de ce genre décrite jusqu'à présent, on remarque aisément huit pores ou petits trous sur le devant de la tête, pores sommet de cette méme partie, et sept autres sur l'occiput : ces vingt-deux orifices sont certainement les extrémités des vaisseas sont cerà porter à la extrémités des vaisseaux destinés a porter à la surface du corps la liqueur onetueuse propre à la ramollir et à la lubrifier. Cette même espèce dont Linnée a dú la première connaissance à Brander, et que nous avons eru devoir en conséquence nome Brandérienne, a lès máchoires très-avancées,

DES POISSONS.

de son museau, qui est très-pointu, que l'on voit de chaque cóté, au bout d'un très-petit tube, l'ouverture des narines; et de plus, l'anus est plus près de la tête que de l'extremité de la queue. Cette cécilie vit dans les eaux de la Méditerranée, auprès des côtes de la Barbarie, où elle a été observée par Brander.

Nous n'avons pas vu cette espéce. Nous soupçonnons qu'elle n'a ni opercule ni membrane des branchies. Si notre conjecture a cet égard était fondée, il faudrait oter les cécilies de la place que nous leur avons donnée daus le tableau génèral, et les transporter de la tête du premier ordre de la première division des osseux, au premier rang du premier orde de la quatrième division de ces mèmes osseux.

VINGT-TROISIEME GENRE. LES MONOPTÈHES

Point d'autre nagroire que celle de la queue: les oucertures des narines placees entre les yeur.

E-Pice.

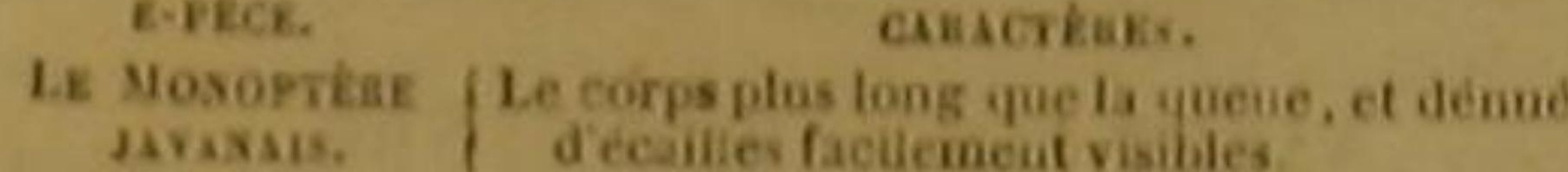

$-$

\section{LE MONOPTERE JAYANAIS '}

Monopterus javanensis, Lacep., Commerson, Cuv. '

Ce poisson n'est pas entièrement privé de nageoires, comme la cécilie brandérienne; mais il n'en a qu'à la queue, et même l'extrémité de cette partie est une sorte de pointe assez déliée, autour de laquelle on n'aperçoit qu à pcine la nageoire caudale. C'est de ce caractère que nous avons tiré le nom de Monoptère, ou de Poisson à une seule nageoire, que nous avons donné au genre, non encore connu des naturalistes, dans lequel nous avons inscrit le javanais; et cette dénomination de Javanais indique le pays qu'habite l'espèce dont nous allons décrire rapidement les formes. Cette espèce se trouve en effet dans le détroit de la Sonde, aupres des còtes de l'ile de Java : elle y a été vue par Commerson, auquel nous devons d'ètre instruits de

' Monopterus javanensis. - . Conger sive anguilla, de

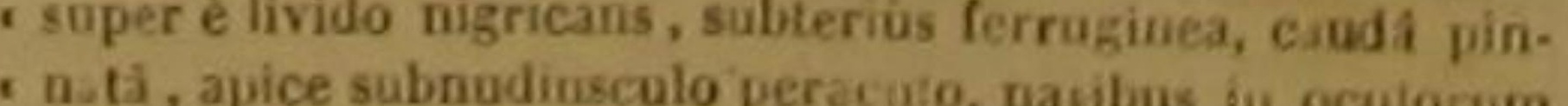
- intercapedine, , Manuscrits de Cormereron, calier so do descriptions zooloziques. 1768 .

M. Cuvier cons rie le geare Monoptìre de M. de Lach pède mis il le considere comme un sous-genre, dans to g are Anguile. $D$. son existence, et qui a laissé dans ses mantserits des observations très-détaillées au sujet des formes et des dimensions de cet animal, qu'il avait rapporté au genre des anguilles ou des congres, parce qu'il n'avait pas fait attention au caractère tiré du nombre des nageoires. Elle y est très-bonne à manger, et si nombreuse en individus, que chaque jour les naturels du pays apportaient une très-grande quantité de ces monoptères javanais au vaisseau sur lequel était Commerson. Son goùt doit ressembler beaucoup a celui des murènes, dont elle a en très-grande partie la conformation et particulièrement le corps serpentiforme, visqueux, et dénué d'écailles facilement visibles. La téte est épaisse, comprimée, bombée cependant vers l'occiput, et terminée en devant par un museau arrondi. Louverture de la bouche est assez grande : la màchoire supérieure n'avance guère au delà de l'inférieure; elles sont toutes les deux garnies de dents courtes et serrées comme celles d'une lime; et une rangée de dents semblables est placée dans l'intérieur de la gueule, tout antour du palais. La base de la langue, qui est cartilagineuse et créusèe pardessous en gouttière, présente deux tubercules blanchâtres. Les ouvertures des narines ne sont pas placées au haut d'an petit tube; on ne les voit pas au-devant des yeux, comme sur le plus grand nombre de poissons, mais au-dessus de ces mêmes organes. L'opercule des branchies', mollasse et flasque, parait comme une duplicature de la peau; la membrane branchiale n'est soutenue que par trois rayons, que l'on ne distingue qu'en disséquant cette mème membrane : les branchies ne sont qu'au nombre de trois de chaque côté; les os qui les soutiennent sont très-peu courbés, et ne montrent, dans leur côté concave, aucune sorte de denticule ni d'aspérité. Si la nageoire caudale renferme des rayons, ils sont imperceptibles, tant que cette nageoire n'est pas altérée; et comme a queue est très-comprimée, cette dernière partie ressemble assez à une lame d'épée à deux ranchants. La ligne latérale, plus rapprochée du dos que du ventre, s'étend depuis les branchies jusqu'à l'extrémité de cette même queue; elle est presque do la couleur de for. Le dos est d'un brun livide et noirâtre; les côtés présentent la mème nuance, asec de petites bandes ransversales couleur de fer : cette dernière teinte s'étend sur tout le ventre. qui est sans 
tache. La longueur des monoptères javanais est | droite et qui règne d'un bout à l'autre du corps ordinairement de près de sept décimètres; leur et de la queue, à une distance à peu près égale leur corps, d'un décimètre; et leur poids, de plus d'un hectogramme.

\section{VINGT-QUATRIĖME GENRE.} LES LEPTOCÉPHALES.

Point de nageoires pectorales ni caudales ; l'ouxerture des branehies siluee en partie au-dessous de la tete.

Espéce. CARICTÉ⿴囗Es.

Le Leptocíphatr
Monisises.

LE - LEPTOCÉPHALE MORRISIEN, ' Leptocephalus Morrisii, Peun., Lino., Gmel., Lac. Cuv. ?

Cette espèce est la seule que l'on connaisse dans le genre des leptocéphales. Elle n'est point entièrement privée de nageoires, comme les cécilies; elle n'est pas réduite à une seule nageoire, comme les monoptères; mais elle n'a point de nageoire de la queue, ni mème de nageoires pectorales; elle ne présente qu'une nageoire dorsale et une nageoire de l'anus, toutes les deux très-longues, mais très-étroites, et dont l'une garnit presque toute la partie supérieure de l'animal, pendant que l'autre s'étend depuis l'anus jusque vers l'extrémité de laqueue. Le morzisieu se rapproche encoredes cécilies par la position des ouvertures branchiales, qui sont situées en partie au-dessous de la tète. Son corps n'est eependant pas eylindrique comme celui des cécilies; il est très-comprimé latéralement; et, comme ses téguments extérieurs sont minces, mous et souples, ils indiquent par leurs plis le nombre et la place des différen. tes petites parties museulaires qui composent les graads museles du dos, des cotés, et du dessous du corps. Ces plis ou ces sillons sont transversaux, mais inclinés et trois fois cont dés, de telle sorte quils forment un double rang longitudinal d'espèces de chevrons brisés, dont le sommet est tourné vers la queue. Ces leux rangees sont situees l'une au-dessus et l'autre au-dessous de la ligue latérale qui est 'Gronov., Zooph., D. 409, tab. 15, 6iz. 5. - Brit. Zool P. 123. - Petite lette, hamegon de mer, Bonaterre, pl. de
IEnc. néth.

par M. Curier. D. du bord supérieur et du bord inférieur du poisson; et chacun des chevrons brisés de la rangée d'en haut rencontre, le long de cette ligne formant avec ce dernier un angle presque droit.

La tête est très-petite, et comprimée comme le corps, de manière que l'ensemble du poisson ressemblant assez à une lame mince, il n'est pas surprenant que l'animal ait une demi-transpa. rence très-remarquable. Les yeux sont gros; les dents qui garnissent les deux mâchoires, trèspetites. Les individus les plus grands n'ont guère plus de douze centimetres de longueur. On trouve les leptocéphales dont nous nous oceupons, auprès de la côte de Holyhead, et d'autres rivages de la Grande-Bretagne; et on leur a donné le nom qu'ils portent a cause du saant Anglais Morris, qui les a observés avee soin.

\section{VINGT-CINQUIEME GENRE.}

$$
\text { LES GYMNOTES }
$$

Des nageoires pectorales et de lamus; point de nageoires du dos ni de la quene.

PREMUER SOUS-GENRE.

$$
\text { La mächoire infrieure plus avancée. }
$$

$$
\text { Espìces. }
$$

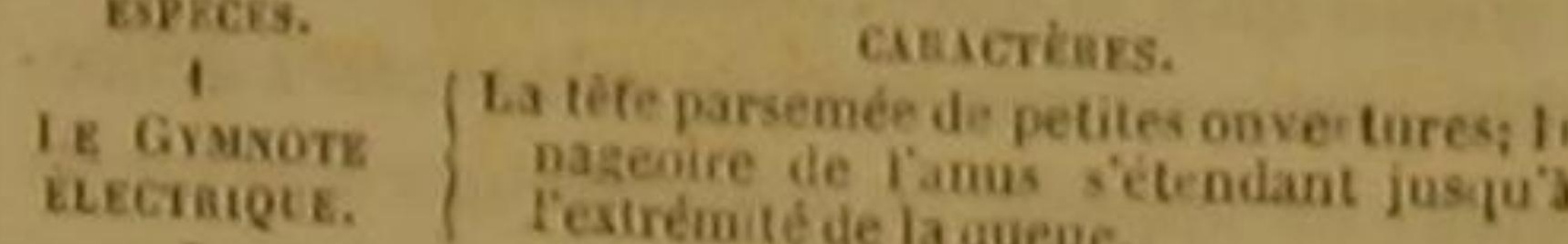

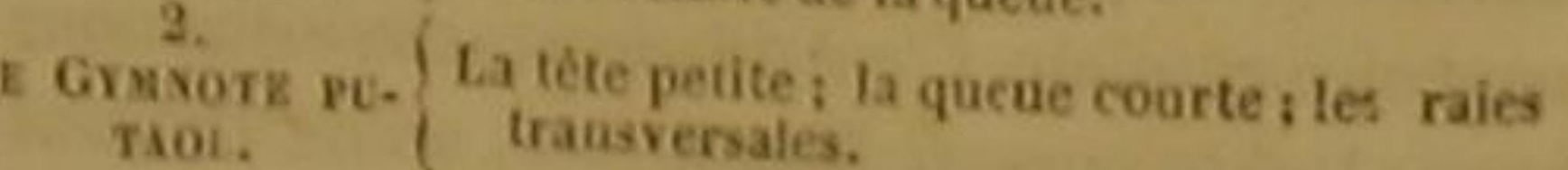

LE Gimotr
uLixc. $\quad \begin{gathered}\text { Deux lobes a la lérre supérieure: la cou } \\ \text { leur blanclie. }\end{gathered}$

SECOND SOUS-GENRE

La michoire supérience plus avancèe.

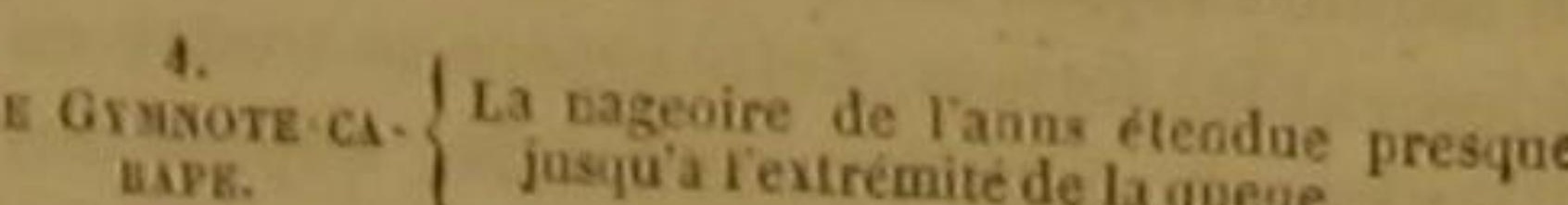

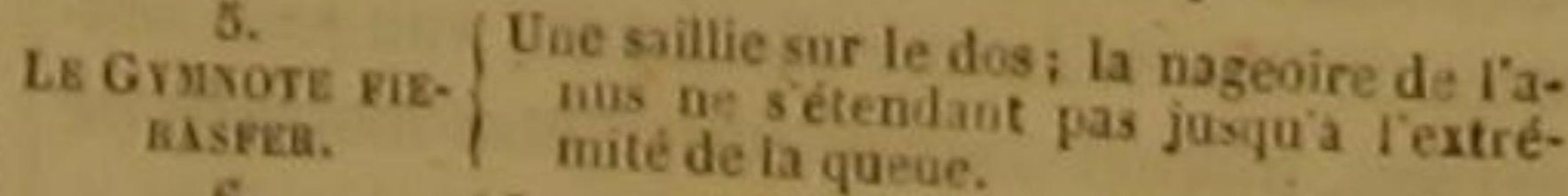

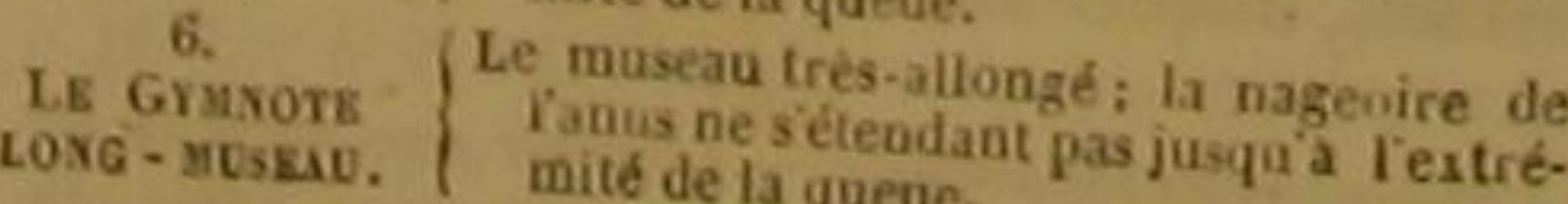
latérale, un de ceux de la rangée d'en bas, en
LE GYMNOTE ELECTRIQUE '. Gymnotus electricus, Linn., Gmel., Lac., BI., Cuv. ${ }^{3}$.

Il est bien peu d'animaux que le physicien doive observer avec plus d'attention que le gymnote auquel on a donné jusqu'à présent le nom d'Electrique. L'explication des effets remarquables qu'il produit dans un grand nombre de circonstances, se lie nécessairement avec la selution de plusieurs questions des plus importantes pour le progrès de la physiologie et de la physique proprement dite. Tâchons donc, en rapprochant quelques vérités éparses, de jeter un nouveau jour sur ce sujet : mais pour suivre avec exactitude le plan que nous nou sommes tracé, et pour ordonner nos idées de la manière la plus convenable, commençons par exposer les caractères véritablement distinctif du genre auquel appartient le poisson dont nous allons écrire I'histoire.

Les cécilies ne présentent aucune sorte de nageoires; les monoptères n'en ont qu'une, qui est située à l'ex trémité de la queue; on n'en voit que sur le dos, et auprès de l'anus des leptocéphales. Les trois genres d'osseux, que nous venons de considérer, sont done dénués de nageoires pectorales. En jetant les yeux sur les gymnotes, nous apercevons ces nageoires latérales pour la première fois, depuis que nous avons passé a la considération de la seconde sous-classe de poissons. Les gymnotes n'ont cependant pas autant de différentes sortes de nageoires que le plus grand nombre des autres

'Sidderris, en hollándais. - Ziller fisch, siller aal, et trill fisch, en allemand. - Gymnote anguille electrique,

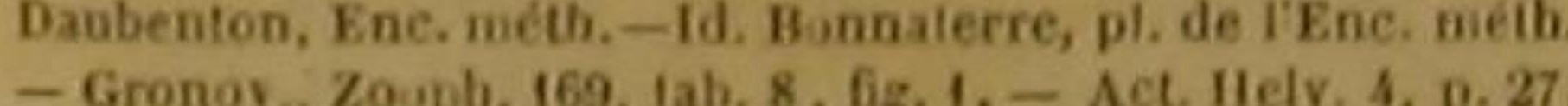
tab. 3, fig. I et5. J. B. Leroy, Journal de phys, elc. Is p. 351. - Anguille trembleuse, anguille torpille de Cayenne, vamont de Bomare, Dict d'hist nat - Siddervis, J. Nic. Séb. Allamand, Act. Haarl. 2, p. 372 - Frantz vander Lott, Act. Harrl. 6, 2. p. 87. - Gymnotus, Muschenbroeck, introd. A, p. 290. - Electrical cel, Hunter, Trans. pais, 65, 2, pi. 9. - Bajon, Journat de phys., junv. 1774; e Hist. de Cayenne, t. 11, p. 287. - Schilling, Diatribe de mortb jaws. Traject. 1770, 8, p. 52 ; et Act. acad Berol. ad an 1770 , Bleur, on torpille. Gurilla pedo, etc, Descript. Zurinmo. Lecwand, 1718 , 198. Meer-ael, id est anjuilla marina Nieuhoffi. Rai, Synopg. pisc., p. 149, n. 4.- Blumenbach, Hanbuch der Naturgesch. p. 268. - Behn, D scription de l'Orérioque. - Williamson, Trans. phil, t. LXV, p, 94. - Torpedo of Surinam, W Bryant, Trans. of the Americ. society, t. 11. p. 166. - Numb fish, or torporific eel, H. Collins Fagg, ibld., L. II, p. 170. R. Maria de Terneyer, Sielta di opuscoli, t. IV, p. 324. Garden, Trans. phil., t. LXV, p. 102.

'Type du sous genre Gymuote proprement dit, dacis ic poissons osseux qu'il nous reste à examiner. En effet, ils n'en ont ni sur le dos, ni au bout de la queue, et c'est ce dénùment, cette espèce de nudité de leur dos, qui leur a fait donner le nom qu'ils portent, et qui vient du mot gree zupuoros dos nu.

L'ensemble du corps et de la queue des gymnotes est, comme dans les poissons osseux que nous avons déjả fait connaitre, très-allongé, presque cylindrique, et serpentiforme. Lesyeux sont voilés par une membrane qui n'est qu'une continuation du tégument le plus extérieur de la tête. Les opercules des branchies sont très grands; on compte ordinairement einq rayons a la membrane branchiale, Le corps proprement dit est très-court, souvent un peu comprimé, et quelquefois terminé par-dessous en forme de carène: l'anus est par conséquenttrèsprès de la tête. Et comme cependant, ainsi que nous venons de le dire, l'ensemble de l'animal, dans le genre des gymnotes, forme une sorte de long cylindre, on voit facilement que la queue proprement dite de tous ces poissons doit ètre extrêmement longue relativement aux autres parties du corps. Le dessous de cette portion est ordinairement garni, presque dans la totalité de sa longueur, d'une nageoire d'autant plus remarquable, que non-seulement elle s'étend sur une ligne très-étendue, mais qu'elle offre même une largeur asséz considérable. De plus, les muscles dans lesquels s'insèrent les ailerons osseux auxquels sont attachés les nombreux rayons qui la composent, et les autres muscles très-multipliés qui sont destinés à mouvoir ces rayons, sont conformés et disposés de manière qu'ils représentent comme une seconde nageoire de l'anus, placée entre la véritable et la queue très-prolongée du poisson, ou, pour mieux dire, qu'ils paraissent augmenter de beaucoup, et souvent même du double, la largeur de la nageoire de lanus.

Tels sont les traits généraux de tous les vrais gymnotes : quelles sont les formes qui distinguent celui que l'on a nommé Électrique?

Cette épithète d'Electrique a déjá été donnée à einq poissons d'espèces très-différentes : a deux cartilagineux et à trois osseux; à la raie torpille, ainsi qu'à un tétrodon dont nous avons déja parlé; à un trichiure, à un silure, et au gymnote que nous décrivons. Mais c'est celuł dont nous nous occupons danis cet article, qui a le plus frappé l'imagination du vulgaire, 
excité l'admiration des voyageurs, et étonné, vants, la préfèrer à toute autre dénomination. le physicien. Quelle a dủ ètre en effet la sur- Mais avaut de montrer en détail ces différent prise des premiers observateurs, lorsqu'ils ont effets, de les comparér, et d'indiquer quelquesvu un poisson en apparence assez faible, assez unes des causes auxquelles il faut les rappor\begin{tabular}{l|l} 
vu un poisson en apparence assez faible, assez & unes des causes auxquelles il faut les rappor- \\
semblable, d'après le premier coup d'oil, a une & ter, achevons le portrait du gymnote électrique
\end{tabular} anguille ou a un congre, arréter soudain, et mal- voyons quelles formes particulières lui ont été gré d'assez grandes distances, la poursuite de départies, comment et par quels organes il nait, son ennemi ou la fuite de sa proie, suspendre à croit, se meut, voyage et se multiplie au milieu l'instant tous les mouvements de sa victime, la des grands fleuves qui arrosent les bords oriendompter par un pouvoir aussi invisible qu' irré- taux del'Amérique méridionale, de ces contrées sistible, l'immoler avec la rapidité de l'éclair au ardentes et humides, où le feu de l'atmosphère travers d'un très-large intervalle, lesfrapper eux- et l'eau des mers et des rivières se disputent mèmes comme par enchantement, les engour- l'empire, où tous les éléments dé la reproducdir et les enchainer, pour ainsi dire, dans le mo- tion ont été prodigués, où une surabondance ment où ils se croyaient garantis, par l'éloigne- de force vitale fait naitre les végétaux et les ment, de tout danger et mème de toute alteinte! animaux vénéneux; où, si je puis employer cette Le merveilleux a disparu mème pour les yeux expression, les excès de la nature, indépendamles moins éclairés, mais l'intérèt s'est aceru et ment de ceux de l'homme, sacrifient chaque l'attention a redoublé, lorsqu'on a rapproché de jour tant d'individus aux espèces; où tous les de-

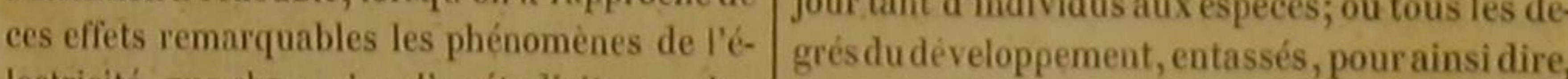
lectricité, que chaque jour l'on étudiait avec plus les uns contre les antres, produisent nécesside succès. Peut-ètre cependant croira-t-on, en rement toutes les nuances du dépérissement lisant la suite de cette histoire, que cette puis- où des arbres immenses étendent leurs branches sance invisible et soudaine du gymnote ne peut innombrables, pressées, garnies des fleurs les étre considérée que comme une modification de plus suaves, et chargées d'essaims d'oiseaux cette force redoutable et en mème temps si fé- resplendissants des couleurs de l'iris, au-dessus conde, qui brille dans l'éclair, retentit dans le de savanes rioyées, ou d'une vase impure que tonnerre, renverse, détruit, disperse dans les parcourent de très-grands quadupèdes ovipares, foudres, etqui, moins resserrée danssescans les parcourent de très-grands quadupèdes ovipares, foudres, etqui, moins résserrée dans ses canaux, et que sillonnent d'énormes serpents aux écailles moins précipitée dans ses mouvements, plus dorées; où les eaux douces et salées montrent douce dans son action, se répand sur tous les des légions de poissons dont les rayons du sopoints des êtres órganisés, en pénètre toute la leil rêfléchis avec vivacité les rayons du soprofondeur, en parcourt toutes les sinuosités, leil reflechis avec vivacité changent, en quelen vivifie tous les éléments. Peut-être faudrait. que sorte, les lames luisantes en diamants, en il, en suivant ce principe et pour éviter toute saphirs, en rubis; où l'air, la terre, les mers, erreur, ne donner, avee quelos et les vivants, et les corps inanimés, tout au poisson que nous examinons, naturalistes, attire les regards du peintre, enflamme l'imaau poisson que nous examinons, que le nom gination du poête, élève le génie du philosophe.

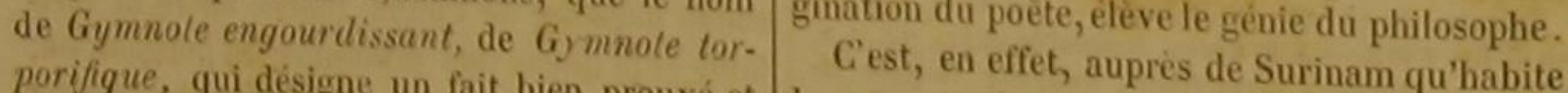
porifique, qui désigne un fait bien prouvé et le gymnote électrique; et il parait mème qu'on indépendant de toute théorie. Néanmoins comme la puissance qu'il exerce devra être rap- n'a encore observé de véritable gymnote que portée dans toutes les hypothèses à une espèce dans l'Amérique méridionale, dans quelques d'électricité; comme ce mot électricité peut parties de l'Afrique occidentale, et dans la Méêtre pris pour un mot générique, commun a diterranée, ainsi que nous le ferons remarquer plusieurs forces plus ou moins voisines et plus de uouveau en traitant des notoptères. ou moins analogues; comme les phénomènes les Le gymnote électrique parvient ordinaireplus imposants de l'électrieité propremènes les ment jusquà la longueur d'un mètre un ou sont tous produits par le prement dite deux décimètres; et la circonférence un ou jet de cet article, et enfin comme le plus orand corps, dans l'endroit le plus gros, est alors de nombre de physiciens lui ont donné depuis trois a quatre décimètres : il a done onze ou longtemps cette épithète d'Électrigue depuis douze fois plus de longueur que de largeur. Sa asons cru devoir, avee ces derniers snous téte est percée de petits trous ou pores très-sen- tinés à répandre sur sa surface une liqueur visqueuse; des ouvertures plus petites, mais analogues, sont disséminées en très-grand nombre sur son corps et sur sa queue : il n'est done pas surprenant qu'il soit enduit d'une matière gluante tris-abondante. Sa peau né présente d'ailleurs aucune écaille facilement visible. Son museau est arrondi; sa máchoire inférieure est plus a vancée que la supérieure, ainsiqu'on a pu le voir sur le tableau du genre des gymnotes; ses dents sont nombreuses et acérées ; et on voit des verrues sur son palais aiusi que sur sa langue qui est large.

Les nageoires pectorales sont très-petites et ovales; celle de l'anus s'étead jusqu'à l'extrémité de la quene, dont le bout, au lieu de se terminer en pointe, parait comme tronqué.

l.a couleur de l'animal est noirâtre, et relevée par quelques raies étroites et longitudinales d'une nuance plus foncée.

Quoique la cavité du ventre s'étende au dela de l'endroit ou est située l'ouverture de l'anus, elle est cependant assez courte relativement aux principales dimensions du poisson ; mais les effets de cette brièveté sont compensés par les replis du canal intestinal, qui se recourbe plusieurs fois.

Je n'ai pas encore pu me procurer des observations bien sủres et bien précises sur la manière dont le gymnote électrique vient à la lumière : il parait cependant qu'au moins le plus souvent la femelle pond ses $\propto u f s$, et qu'ils n'eclosent pas dans le ventre de la mère, comnic ceux de la torpille, de plusieurs autres cartilagineux, et méme de quelques individus de l'espèce de l'anguille et d'autres osseux, avec lesquels le gymnote que nous examinons a de très-grands rapports.

On ignore également le temps qui est nécessaire à ce mème gymnote pour parvenir à son entier développement: mais comme il n'a pas fallu une aussi longue suite d'observations pour s'assurer de la maniere dont il exécute ses différents mouvements, on connait bien les divers phénomènes relatifs à sa natation; phénomènes qu'il était d'ailleurs aisé d'annoncer d'avance, d'après une inspection attentive de sa conformation extérieure et intérieure.

Nous avons déja fait voir ' que la queue des poissons était le principal instrument de leur

- Discours sur la uatuie des pois: ous. natation. Plus cette partie est étendue, et plus, tout égal d'ailleurs, le poisson doit se mouvoir avec facilité. Mais le gymuote électrique, ains que les autres osseux de son genre, a une queue beaucoup plus longue que l'ensemble de la tète et du corps proprement dit; la hauteur de cette partie est assez considérable; cette hauteur es augmentée par la nageoire de l'anus. qui en garnit la partie inférieure: I'animal a done à sa disposition une rame beaucoup plus longue el beaucoup plus haute à proportion que celle de presque tous les autres poissons; cette rame peut done agir à la fois sur de grandes lames d'eau. Les muscles destinés à la mouvoir sont très-puissants, le gymnote la remue avecune agilité très-remarquable : les deux éléments de la force, la masse et la vitesse, sont donc iei réunis; et en effet, l'animal nage avec vigueur et rapidité.

Comme tous les poissons très-allongés, plus ou moins cylindriques, et dont le corps est entretenu daus une grande souplesse par une viscosité copieuse et souvent renouvelée', il agit successivement sur l'eau qui l'environne par diverses portions de son corps ou de sa queue, qu'il met en mouvement les unes après les autres, dans l'ordre de leur moindre éloignement de la téte; il ondule; il partage son action en plusieurs actions particulières, dont il combine les degrés de force et les directions de la manière la plus convenable pour vaincre les obstacles et parvenir a son but; il commence a recourber les parties antérieures de sa queue, lorsqu'il veut aller en avant; il contourne, au contraire, avant toutes les autres, les parties postérieures de cette même queue, lorsqu'il désire d'aller en arrière '; et, ainsi que nous l'expliquerons un peu plus en détail en traitant de l'anguille, il se meut de la méme mauière que les serpents qui rampent sur la terre; il nage comme eux; il serpente véritablement au milieu des eaux.

On a cru, pendant quelque temps, et même quelques naturalistes très-habiles ont publie que le gymnote électrique u'avait pas de vessic aériemue ou natatoire. On a pu étre induit en erreur par la position de cette vessie daus Télectrique, position sur laquelle nous allons revenir en décrivant l'organe torporilique de cet animal. Mais, quoi quil en soit de la cause de cette erreur, cette vessie est entource de plu.

' Garden, a lendroit cieja cite. 
sieurs rameaux de vaisseaux sanguins que Hın-, rope. Ce n'est que vers 1773 que Williamson ter a fait connaitre, et qui partent de la grande à Philadelphie, Garden dans la Caroline, Walsh, te l'épine dorsale Pringle, Magellan, etc., à Londres, ont apere artere qui passe au-dessous de le faire obser- les phénomènes les plus propres à dévoiler le

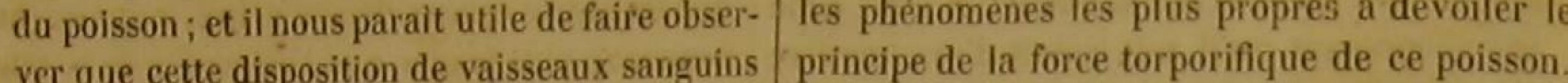
$\begin{array}{lll}\text { ver que cette disposition de vaisseaux sanguins } & \text { principe de la force torporifique de ce poisson. } \\ \text { L'organe particulier dans lequel réside cette }\end{array}$ vertu, et que Hunter a si bien décrit, n'a éte bibliothécaire de l'école centrale de quidans unouvragetrès-intéressantsur la respi- connu qu'à peu près dans le même temps, penration des poissons, a montré comment il serait dant que l'organe électrique de la torpille a été possible que la vessie aérienne de ces animaux vu par Stenon, dès avant 1673, et peut-être mais encore à suppléer à leur respiration et à doit pas être étonné de cette différence entre un maintenir leur sang dans l'état le plus propre gymnote que l'on n'a rencontré, en quelque à conserver leur vie.

Il ne manque donc rien au gymnote électrique de ce qui peut donner des mouvements prompts et longtemps soutenus; ct comme parmi les causes de la rapidité avec laquelle il nagé, nous avons compté la facilité avec laquelle i peut se plier en différents sens, et par conséquent appliquer des parties plus ou moins grandes de son corps aux divers objets qu'il rencontre, il doit jouir d'un toucher plus délieat, et présenter un instinct plus relevé que ceux d'un trèsgrand nombre de poissons.

Cette intelligence particuliere lui fait distinguer aisément les moyens d'atteindre les anjmaux marins dont il fait sa nourriture, et ceux dont il doit éviter l'approche dangereuse. La vitesse de sa natation le transporte dans des temps tres-courts auprès de sa proie, ou loin de ses emnemis; et lorsqu'il n'a plus qu'à immoler des victimes dont il s'est assez approché, ou ż repousser ceux des poissons supérieurs en force auxquels il n'a point échappé par la fuite, il déploie la puissance redoutable qui lui a éte accordée, il met en jeu sa vertu engourdissante, il frappe à grands coups, et répand autour de lui la mort ou la stupeur. Cette qualité torporifique du gymnote électrique découvert, dit-on, auprès de Cayenne, par Vun-Berkel', a été observée daus te mème pays, par le naturaliste Richer, des 1671. Mais ce n'est que quatre-vingts ans, ou environ, après cette époque, que ce mème gymnote a êté de nouveau examiné avec attention par La Condamine, Ingram, Gravesand, Allamand, Muschenbroeck, Gronou, VanderLott, Fermin, Bankroft, et d'autres habiles physieiens qui l'ont vu dañs l'Amérique méridionale, ou l'ont fait apporter avec soine méri-

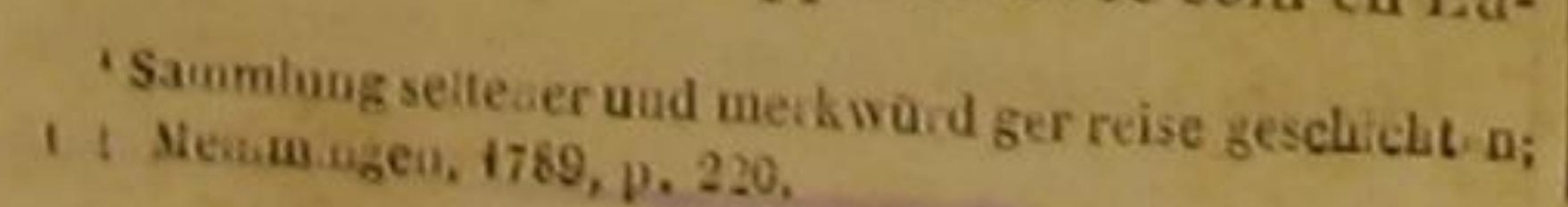
sorte, que dans une partie de l'Amérique méridionale ou del'Afrique, et une raiequi habite sur les côtés de la mer d'Europe. D'un autre côté, le gymnote torporifique n'ayant été fréquemment observé que depuis le commencement de l'époque brillante de la physique moderne, il n'a point été l'objet d'autant de théories plus ou moins ingénieuses, ei cependant plus ou moins dénuées de preuves, que la torpille. On n'a eu, dans le fond, qu'une méme manière de considérer la nature des divềrs phénomènes présentés par le gymnote: on les a rapportés ou à lélectricité proprement dite, ou à une force dérivée de cette puissance. Lit comment des physiciens instruits des effets de l'électricité n'auraient-ils pas été entrainés à ne voir que des faits analogues dans les produits du pouvoir du gymnote engourdissant ?

Lorsqu'on touche cet animal avec une seule main, on n'éprouve pas de commotion, ou on n'en :essent qu'une extrêmement faible : mais la secousse est très-forte lorsqu' on applique les deux mains sur le poisson, et qu'elles sont séparées l'une de l'autre par une distance assez grande. N'a-t-on pas ici une image de ce qui se passe iorsqu'on cherche à recevoir un coup electrique par le moyen d'un plateau de verm garni convenablement de plaques métalliques et connu sous le nom de carreau fulminant Si on n'approche qu'une main et qu'on ne touche qu une surface, a peine est-on frappé; mais on reçoit une commotion violente si on emploie les deux mains, et si en s'appliquant aux deux surfaces, elles les dechargent à la fois.

Comme dans les expériences électriques, le coup reçu par le moyen des deux mains a pu pre assez fort pour donner aux deux bras une paralysie de plusieurs années '.

'Benri Collins Flaggg, a l'enưroit dèji ciť́:
Les métaux, l'eau, les corps mouillés, et toutes les autres substances conductrices de l'électricité, transmettent la vertu engourdissante du gymnote; et voila pourquoi on est frapné au milieu des fleuves, quoiqu'on soit encore à une assez grande distance de l'animal et voilà pourquoi encore les petits poissons pour lesquels cette secousse est beaucoup plus dangereuse, éprouvent une commotion dont ils meurent à l'instant, quoiqu'ils soient éloignés de plus de einq mètres de I'animal torporifique.

Ainsi qu'avec l'électricité, l'espèce d'are de cercle que forment les deux mains et que parcourt la force engourdissante, peut ètre trèsagrandi, sans que la commotion soit sensiblement diminuée; et vingt-sept personnes se tenant par la main et composant une chaine dont les deux bouts aboutissaient à deux points de la surface du gymnote, séparés par un assez graud intervalle, ont ressenti, pour ainsi dire, a la fois, une secousse très-vive. Les différents observateurs, ou les diverses substances facilement perméables à relectricité, qui sont comme les anneaux de cette chaine, peuvent mème ètre éloignés l'un de l'autre de prés d'un décimètre, sans que cette interruption apparente dans la route préparée arrète la vertu torporifique qui en parcourt également tous les points.

Mais pour que le gymnote jouisse de tout son pouvoir, il faut souvent qu'il se soit, pour ainsi dire, progressivement animé. Ordinairement les premières commotions qu'il fa $t$ éprouver ne sont pas les plus fortes; elles deviennent plus vives à mesure qu'il s'évertue, s'agite, s'irrite; elles sont terribles, lorsque, si je puis employer les expressions̉ de plusieurs observateurs, il est livré a une sorte de rage.

Quand il a ainsi frappé a coups redoublés autour de lui, il s'écoule fréquemment un intervalle assez marqué avant qu'il ne fasse ressentir de secousse, soit qu'il ait besoin de donner quelqués moments de repos a des organes quî viennent d'ètre violeniment exercés. ou soit qu'il emploie ce temps plus ou moins court à ramasser dans ces mèmes organes une nouvelle quantité d'un fluide foudroyant ou torporifique

Cependant il parait qu'il peut produire nonseulement une commotion, mais même plusieurs secousses successives, quoiqu'il soit plongé dans l'eau d'un vase isolé, c'est-à-dire d'un vase entouré de matières qui ne laissent passer dans l'intérieur de ce récipient aucune quantité de fluide propre à remplacer celle qu'on pourrait supposer dissipée dans l'acte qui frappe et engourdit.

Quoi qu'il en soit, on a assuré qu'en serrant fortement le gymnote par le dos, on lui otait le libre exercice de ses organes extérieurs, et on suspendait les effets de la vertu dite électrique qu'il possède. Ce fait est bien plus d'accord avec les résultats du plus grand nombre d'ex. périences faites sur le gymnote, que l'opinion d'un savant physieien qui a écrit que l'aimant attirait ce poisson, et que par son contact cette substance lui enlevaít sa propriété tor porílique. Mais, s'il est vrai que des nègres sont parvenus à manier et à retenir impunément hors de l'eau le gymnote électrique, on pourrait croire, avec plusieurs naturalistes, qu'ils emploient, pour se délivrer ainsi d'une commotion dangereuse, des morceaux de bois qui, par leur nature, ne peuvent pas transmettre la vertu électrique ou engourdissante, qu'ils évitent tout contact immédiat avec l'animal, et qu'ils ue le touchent que par l'intermédiaire de ces hois non conducteurs de l'électricité.

Au reste, le gymnote torporifique présente un autie phénomène bien digne d'attention, que nous tácherous d'expliquer avant la fin de cet article, et qui ne surprendra pas les physiciens instruils des lelles expériences relatives aux divers mouvements musculaires que l'on peut exciter dans les animaux pendant leur vie ou après leur mort, et que l'on a nommées galoaniques, a cause de leur premier auteur, M. Galvani. Il est arrivé plusieurs fois ' qu'après la mort du gymnote, il etrait encore, pendant quelque temps, impossible de le toucher sims éprouver de secousse.

Mais nous avons a exposer encore de plus grands rapports entre les effets de l'électricité et ceux de la vertu du gymnote engourdissant.

Le premier de ces rapports trés-remarquables est l'analogie des instruments dont on se sert dans les laboratoires de physique pour obtenir de fortes commotions électriques, avec les oranes particuliers que le gymnote emploie pour faire naitre des ebranlements plus ou moins violents. Voici en quoi consisteut ces organes, que Hunter a très-bien décrits.

' Henri Collius Flagg, à l'endroit deja cité. 
L'animal renferme quatre organes torporifiques, deux grands et deux petits. L'ensemble de ces quatre organes est si étendu, qu'il compose environ la moitié des parties musculeuses et des autres parties molles du gymnote, et peut-ètre le tiers de la totalité du poisson.

Chacun des deux grands organes engourdissants occupe un des côtés du gymnote, depuis l'abđomen jusqu'à l'extrémité de la queue; et comme nous avons déjà vu que cet abdomen était très-court, et qu'on pourrait croire, au premier coup d'œeil, que l'animal n'a qu'une tête et une queue très-prolongées, on peut juger aisément de la longueur très-considérable de ces deux grands organes. Ils se terminent vers le bout de la queue comme par un point; et its sont assez larges pour n'être séparés l'un de l'autre que vers le haut par les muscles dorsaux, vers le milieu du corps par la vessie natatoire, et vers le bas par une cloison particulière avec laquelle ils s'unissent intimement, pendant qu'ils sont attachés par une membrane cellulaire, Idche, mais très-forte, aux autres parties qu'ils touchent.

De chaque côté du gymnote, un petit organe torporifique, situé au-dessous du grand, commence et fiuit à peu près aux mêmes points que ce dernier, se termine de mème par une sorte de pointe, présente par conséquent la figure d'un long triangle, ou, pour mieux dire, d'une longue pyramide triangulaire, et s'élargit néanmoins un peu vers le milieu de la queue.

Eutre le petit organe de droite et le petit organe de gauche, s'étendent longitudinalement les muscles sous-caudaux, et la longue série d'ailerons ou soutiens osseux des rayons trèsd'ailerons ou soutiens osseux des rayons trèsnombreux de la nageoire de l'anus.

Ces deux petits organes sont d'ailleurs séparếs des deux grands organes supérieurs par un membrane longitudinale et presque horizontale, qui s'attache d'un coté à a coison vencale par laquelle les deux grands organes sont écartés l'un de Iautre dans leur partie inférieure, et puí tient, par le cóté opposé, à la pean

de l'animal.

De plus, cette disposition générale est telle, que lorsqu'on enlève la peau de l'une est telle, latérales de la queue du gymnote, on des faces lement le grand dueue du gymnote, on voit facilement le grand organe, tandis que, pour apercevoir le petit qui est au-dessous, il faut oter les muscles latéraux qui accompagnent la óter gue nageoire de l'anus
Mais quelle est la composition intérieure de cun de ces quatre organes grands ou petits ? Lintérieur de chacun de ces instruments en quelque sorte électriques, présente un rand nombre de séparations horizontales, coupées presque à angles droits par d'autres séparations à peu près verticales.

Les premières séparations sont non-seulement horizontales, mais situées dans le sen de la longueur da poisson, et parallèles les unes aux autres. Leur largeur est égale à celle de l'organe, et par conséqueut, dans beaucoup d'endroits, a la moitié de la largeur de I'animal, ou environ. Elles ont des longueurs inégales. Les plus voisines du bord supérieur sont aussi longues ou presque aussi longues que l'organe; les inférieures se termineut plus près de leur origine; et l'organe finit, vers l'extrémite de la queue, par un bout trop aminci pour quion puisse voir sil y est encore composé de plus dune de ces separations longitudinales.

Ces membranes horizontales sont éloígnées l'une de l'autre, du côté de la peau, par̀ un intervalle qui est ordinairement de près d'un millimètre; du côté de l'intérieur du corps, on les voit plus rapprochées, et méme, dans plusieurs points, réunies deux à deux; et elles son comme onduleuses dans les petits organes. Hunter en a compté trente-quatre dans un des deux grands organes d un gymuote de sept décimètres, ou à peu près, de longueur, et quatorze dans un des petits organes du mème individu.

Les séparations verticales qui coupent à angles droits les membranes longitudinales sont membraneuses, unies, minces, et si serrées l'une contre l'autre, qu'elles paraissent se toucher. Hunter en a vu environ deux cent qua rante dans une longueur de vingt-cinq millimètres ou à peu près.

C'est avee ce quadruple et très-grand appareil dans lequel les surfaces ont été multipliées avee tant de profusion, que le gymnote parvient à donner des ébranlements violents, et à produire le phénomène qui établit le šecond des deux principaux rapports par lesquels sa vertu engourdissante se rapproche de la force électrique. Ce phénomène consiste dans des étincelles entièrement semblables à celles que l'on doit à l'électricité. On les voit, con que lon un grand nombre des voit, comme dans prement dites, paraitre dans les petits inter- valles qui séparent les diverses portions de la chaine le long de laquelle on fait circuler la force engourdissante. Ces étincelles ont été vues pour la première fois a Loudres par Walsh, pringle et Magellan. Il a suffi à Walsh, pour les obtenir, de composer uue partie de la chaine destinée a être parcourue par la force torporifique, de deux lames de métal, isolëes sur un carreau de verre, et assez rapprochées pour ne laisser entre elles qu'un très-petit intervalle; et on a distingué avec facilité ces lueurs, lorsque l'ensemble de l'appareil s'est trouvé placé dans une chambre èntièrement dénuée de toute autre lumière. On obtient une lueur semblable, lorsqu'on substitue une grande torpille à un gymnote électrique, ainsi que l'a appris Galvani dans un mémoire que nous avons déjà cité '; mais elle est plus faible que le petit éclair dù à la puissance du gymnote, et l'on doit presque toujours avoir besoin d'un microscope dirigé vers le petit intervalle dans lequel on l'attend pour la distinguer sans erreur.

Au reste, pour voir bien nettement commen le gymnote électrique donne naissance et à de petites étincelles et à de vives commotions, formons-nous de ces organes engourdissants la véritable idée que nous devons en avoir.

On peut supposer qu'un grand assemblage de membranes horizontales ou verticales est un composé de substances presque aussi peu capables de transmettre la force électrique que le verre et les autres matieres auxquelles on a donné le nom d'idioélectriques, ou de non conductrices, et dont on se sert pour former ces vases foudroyants appelés bouteilles de Leyde, ou ces carreaux aussi fulminants, dont nous avons déjà parlé plus d'une fois. Il faut considerer les quatre organes du gymnote comme nous avons considéré les deux organes de la torpille: il faut voir dans ces instrument une suite nombreuse de petits carreaux de I nature des carreaux foudroyants, une batterie composée d'une quantité extrèmement considérable de pièces en quelque sorte électriques. Et comme la force d'une batterie de cette sorte doit sévaluer par l'étendue plus ou moins grande de la surface des carreaux ou des vases qui la forment, j'ai calculé quelle pourrait ètre la grandeur d'un ensemble que l'ou supposerait produit par les surfaces réunies de toutes les ferticales et horizontales que renferment les quatre organes torporifiques d'un ymnote long de treize décimètres, en ne comptant cependant pour chaque membrane que la surface d'un des grands côtés de celte cloison : 'ai trouvé que cet ensemble présenterait une étendue au moins de treize mètres carrés, e'est-à-dire, à très-peu près, de cent vingt-trois pieds également earrés. Si l'on se rappelle maintenant que nous avons eru expliquer d'une manière très-satisfaisante la puissance de faire éprouver de fortes commotions qu'a reçue la torpille, en montrant que les surfaces des diverses portions de ses deux organes électriques pouvaient égaler par leur réunion einquantehuit pieds carrés, et si l'on se souvient en mème temps des effets terribles que produisent dans nos laboratoires des carreaux de verre dont la surface n'est que de quelques pieds, on ne sera pas étonné qu'un animal qui renferme dans son intérieur et peut employer à volonté un instrument électrique de cent vingt-frois pieds carrés de surface, puisse frapper des coups tels que ceux que nous avons déjá décrits.

Pour rendre plus sensible l'analogie quí existe entre un carreau fulminant et les organes torporifiques du gymnote, il faut faire voir comment cette grande surface de treize mètres carrés peut étre électrisée par le frottement, de la mème manière qu'un carreau foudroyant ou magique. Nous avons déja fait remarquer que le gymnote nage principalement par une suite des ondulations successives et promptes qu'il imprime à sa queue, c'est-à-dire à cette longue partie de son corps qui renferme ses quatre organes, Sa natation ordinaire, ses mouvements extraordinaires, ses courses rapides, ses agitations, l'espèce d'irritation à laquelle il peut se livrer, toutes ces causes doivent produire sur les surfaces des membranes horizontales et verticales un frottement suflisant pour y accumuler d'un coté, et raréfier de l'autre, ou du moins pour y exciter, réveiller, accroitre ou diminuer fluide unique ou les deux fluides auxquels on a rapporté les phénomènes électriques et tous les effets analogues; et comme par une suite de la division de l'organe engourdissant du gymnote en deux grands et en deux petits, et de la sous-division de ces quatre organes en et de la sous-division de ces quatre or anes en
membranes horizontales et verticales, les comTunications peuvent n'être pas toujours très- 
faciles ní très-promptes entre les diverses par- $\mid$ qui donne des ramifications aux muscles du dos. Ce nerf se répand entre ces muscles dorles de cegraux et l'épine; il envoie de petites branches le rétablissement du fluide ou des liuides état, jusqu'á la surface extérieure du grand organe, nous venons de parler, dans leur premier état, $\begin{aligned} & \text { jusqu'a la surface exterieure du grand organe, } \\ & \text { dans lequel pénètrent plusieurs de ces rameaux, }\end{aligned}$

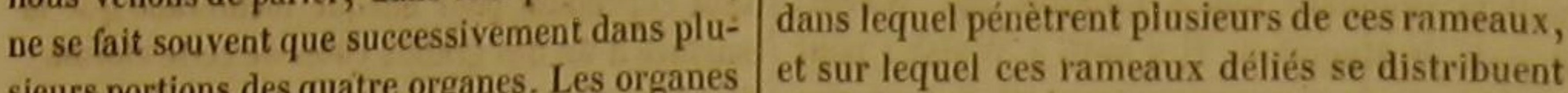
sieurs portions des quatre organes. Les organs en passant entre cet organe et la peau du cóté ne se déchargent donc que par des coups suc- entant. Il continue cependant sa route, cessifs; et voilà pourquoi, indépendamment $\begin{aligned} & \text { de l'animal. Il continue cependant sa route, } \\ & \text { d'abord entre les muscles dorsaux et la vessie }\end{aligned}$

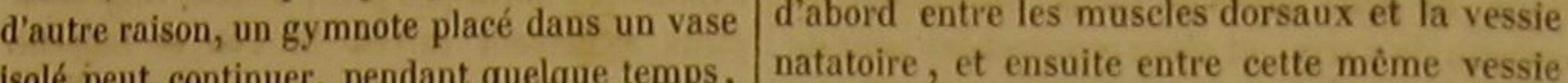
Isolé peut continuer, pendant quelque temps, natatoire et l'organe électrique. Là il se divise de donner des commotions; et de plus, voila pourquoi il peut rester dans les organes d'un gymnote qui vient de mourír, assez de parties chargées pour qu'on en reçoive un certain nombre de secousses plus ou moins vives '.

Et ces fluides, quels qu'ils soient, d'où peuton présumer qu'ils tirent leur origine? ou, pour éviter le plus possible toute hypothèse, quell est la source plus ou moins immédiate de cette force électrique, ou presque électrique, départie aux quatre organes dont nous venons d'exposer la structure?

Cette source est dans les nerfs, qui, dans le gymnote engourdissant, ont des dimensions et une distribution qu'il est utile d'examiner rapidement.

Premièrement, les nerfs qui partent de la moelle épinière, sont plus larges que dans les poissons d'une grandeur égale, et plus que cela ne parait nécessaire pour l'entretien de la vie du gymnote.

Secondement, Hunter a fait counaitre un nerf remarquable qui, dans plusieurs poissons s'étend depuis le cerveau jusque auprès de l'extrémité de la queue en donnant naissance plusieurs ramifications, passe, à peu près, une égale distance de l'épine et de la peau du dos dans la murène anguille, et se trouve immédiatement au-dessous de la peau dans le gade morue. Ce nerf est plus large, tout éga d'ailleurs, et s'approche de l'épine dorsale dans le gymmote électrique, beaucoup plus que dans plusieurs autres poissons.

Troisièmement, des deux côtés de chaque vertebre du gymnote torporifique, part un me

- En des meilleurs troyens de parvenir à la véritable the rie des effels produits par le gymnote engourdisante théoles astres poissous torporitiques, est davoir recure aus belles expériences électriques et aux idées trés-ingénicuses
dont on tronvera lesposition dans nue lettre qui airesse par M. Aldini de I das nue lettre qui m'a éti habile physicien a pubiee dans celte ville, il y a environ un
an (ea 1797 . en nouvelles branches. Ces branches vont vers la cloison verticale que nous avons déjà indiquée, et quí est située entre les deux grand organes électriques. Elles s'y séparent en branehes plus petites qui se dirigent vers les ailerons et les muscles de la nageoire de l'anus, et se perdent, après avoir répandu des ramifications dans cette même nageoire, dans ses muscles, dans le petit organe et dans le grand organe éleetrique.

Les rameaux qui entrent dans les organes électriques sont, à la vérité, très-petits ; mais cependant ils le sont moins que ceux de toute autre partie du système sensitif.

Tels sont les canaux qui font circuler dans les quatre instruments du gymnote le principe de la force engourdissante; et ces canaux le nerfs émanent. Et comment en effet ne pas considérer dans le gymnote, ainsi que dans les autres poissons engourdissants, le eerveau comme la première source de la vertu particulière qui les distingue, lorsque nous savons la soustraction du cerveau d'une torpille anéantit l'électricité ou la force torporifique de ce cartilagineux, lors même qu'il parait encore aussi plein de vie qu'avant d'avoir subi cette opération, pendaut qu'en arrachant le cœur de cette raie, on ne la prive pas, avant un temps plus ou moins long, de la faculté de faire éprouver des commotions et dés tremblements '? nous ne voyous pas de mammifere, de cétacée, d'oiseau, de quadrupède ovipare, ni de serpent, doué de cette faculté électrique ou engourdissante, que l'on a déjà bien constatée au moins dans deux poissons cartilagineux et dans trois poissons osseux, c'est paree qu'il faut, reçoivent eux-mêmes du cerveau, d'oủ tous̀ les par les expériences d'un habile physicien, que Au reste, ne perdons jamais de vue que sl pour donner naissance à cette faculté, et l'abondance d'un fluide ou d'un principe quelconque que les nerfs paraissent posséder et fournir, et un ou plusieurs instruments organisés de manière à présenter une très-grande surface, eapables par conséquent d'agir avee efficacité sur des fluides voisins ', et composés d'ailleurs d'une substance peu conductrice d'électricité, telle, par exemple, que des matières visqueuses, liuileuses et résineuses. Or, de toųs les animaux qui ont un sang rouge et des vertèbres, aucun, tout égal d'ailleurs, ne présente, comme les poissons, une quantité plus ou moins grande d'huile et de liqueurs gluantes et visqueuses.

On remarque surtout dans le gymnote enourdissant, une très-arande abondance de cette matière huileuse, de cette substance non conductrice, ainsi que nous l'avons déjà observé. Cetté onctuosité est très-sensible, mème sur la membrane qui sépare de chaque coté le grand organe du petit; et voila pourquoi, indépendamment de l'étendue de la surface de ses organes torporifiques, bien supérieure à celle des organes analogues de la torpille, it parait possédér une plus granide vertuélectrique que cette dernière. D'ailleurs il habite un climat plus chaud que celui de cette raie, et par conséquent dans lequel toutes les combinaisons et toutes les décompositions intérieures peuvent s'opérer avee plus de vitesse et de facilité: et de plus, quelle différence entre la fréquence et l'agilité des évolutions du gymnote, et la nature ainsi que le nombre des mouvements ordinaires de la torpille

Mais si lies poissons sont organisés d'une manière plus favorable que les autres animaux à vertebres et à sang rouge, relativement à la puissance d'ébranler et d'engourdir. étant donés d'une très-rnarande irritabilité, ils doivent ètre aussi beancoup plus sensibles à tous les effets électriques, beaucoup plus soumis au pouvoir des animaux torporifiques, et par conséquent plus exposés à devenír la victime du gymnote de Surinam ${ }^{2}$

'J'ai publié en 1781, que l'on devajt deduire l explication du plus grand nosibre de phéamèèes éectriques, de la croisement que produit dans I atunite que les corps exercent sur les flnides qui les ervironnent, Ia division de ces mềmes corys en plusieurs parties, et par conséfuent l'augmentatio de leur surface.

- Cest par uae raison semiliatie yue iors qu une torpilie ne Jon: e plas de commotion seasilie, ar oblent des sighes de
Cette-considération peut servir à expliquer pourquoi certaines personnes, et partieulierenent les femmes qui ont une fièvre nerveuse, peuvent toucher un gymnote électrique sans ressentir de seeousse ; et ces faits eurieux rapportés par le savant et infatigable Frédéric Alexandre Humboldt, s'accordent avee ceux qui ont été observés dans la Caroline méridionale par Henri Collins Flagg. D'après ce dernier physicien, on ne peut pas douter que plusieurs nègres, plusieurs Indiens, et d'autres persomnes, ne puissent arreter le cours de la vertu electrique ou engourdissante du gymnote de Surinam, et interrompre une chaine préparée pour son passage; et cette interruption a été produite spécialement par une femme que l'auteur connaissait defuis longtemps, et qui avait la maladie à laquelle plusieurs médecins donnent le nom de fière hectique.

C'est en étudiant les ouvrages de Galvani de Humboldt, et des autres observateurs qui s'occupent de travaux analogues à ceux de ces deux physieiens, qu'on pourra parvenir a avoir une idée plus précise des ressemblances et des différences qui existent entre la vertu engourdissante du gymnote, ainsi que des autres poissons appelés Électriques, et l'électricité proprement dite. Mais pourquoi faut-il qu'en terminant cet article, j'apprenne que les sciences viennent de perdre l'un de ces savants justement célèbres, M: Galvani, pendant que Humboldt, commençant une longue suite de voyages lointains, utiles et dangereux, nous force de méler l'expression de la crainte que le sentiment inspire, à celle des grandes espérances que donnent ses lumieres, et de la reconuaissance que l'on doit à son zèle toujours croissant I

LE GYMNOTE PUTAOL'

Gymotus fesciatus, Lino., Gmel.; Gymnotus Putaol, Lacep; Carapus fasciatus, Cuv. 2 .

Ce gymnote ressemble beaucoup a l'électrique; indépendamment d'autres traits de conune grenoville préparée comme pour les expétriences galva wịues. V oyez Ies Mémoires de Galsani, déjs citis. 'Gymnote pula 1, Bonaterre, pl. de i'Ene, meth. - Pal. las, spicil. zoolog.7, p. 35. - seva, Mas. S. Liso, lud., p. 72. 2. - Car upo. 2, Mareg. Bra ... p.. sha sous-Amre Carape, Carapus, daus le genre Gymavte, Cuv. $\mathrm{D}$. 
formité, il a de mème la máchoire inférieure plus avancée que la supérieure. Sa tête est petite, sa queue courte, sa couleur jaunátre, avec des raies transversales, sou vent ondées, et brunes, ou rousses, ou blanches. Il vit dans les eaux du Brésil '

\section{LE GYMNOTE BLANC ${ }^{2}$.} Gymootus albus, Linn., Gmel., Lacep.; Carapus albus,
Cuv. 3.

Ce gymnote a la mâchoire inférieure plus avancée que la supérieure; il appartient done au premier sous-genre, comme l'électrique et le putaol. Il en differe par sa couleur, qui est ordinairement d'un blanc presque sans tache, par les proportions de quelques parties de son corps, particulièrement par le rapport de son diamètre à sa longueur, et par une espéce de lobe que l'on voit de chaque cóté de la lèvre supérieure, auprès de la commissure des lèvres. Ce poisson se trouve à Surinam et dan les environs, comme l'electrique ${ }^{4}$.

\section{LÉ GYMNOTE CARAPE s,}

Gymnotus Carapo, Lino., Gmel., Lacep.; Gymnotus macrourus, Bi. ‘.

LE GYMNOTE FIERASFER ${ }^{\text {t, }}$ Gymnotus Acus, Linn, Gmel. ; Gymnotus Fierasfer,

ET LE GYMNOTE LONG-MUSEAU ?

fymnolus rostratus, Lino., Gmel.; G) mnotus longiro tratus, Lacep., Scho ; Carapus rosiralus, Cuv, ${ }^{40}$.

Nous croyons pouvoir réunir danscet article la deseription de trois poissons qui, indépen'Ou compte a chaque nageoire pectorale is rayons, et Celle de Tauus 193.

'Gymnotus aibus. - Sẻba, Mus. 5, pl. 52, fig. 5. - Palls,
spic L. zoul. 7. p. 56.

M. Cunsier. D. D.
deraps Curapus, dans le genre Gymnote

Ianus 180 . 'Gymnote carape, Daubenton, Enc. méth. - 14. Bonn 1.. 29. n. 72 . - Gymnotues. - Gronov.. Zooph. 168, Mus. I. nit acad. Lugd. Batav, 1749, p, 600, 65, syo. 45. - Amead. tr. 1, p. 76. - Carapo Brasilien. ab. 11, fig. 6. - Mus. lib. 4, cap. 14, p. 170. - Piso, Hist. bat. Iud. Marcht, Bras,

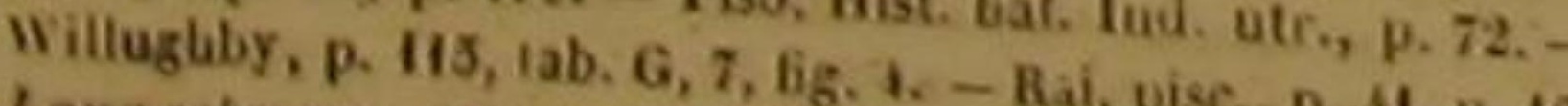

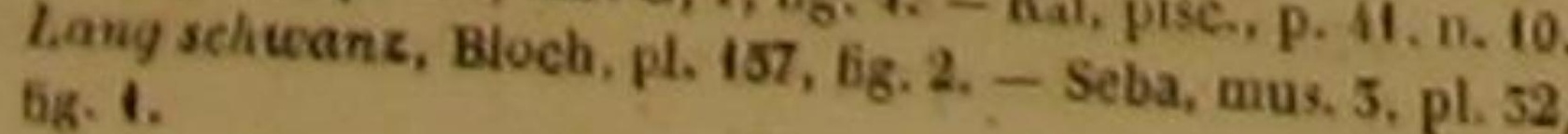

damment des caractères communs a tous les gymnotes, et parlesquels íls se rapprochent l'on de l'autre, sont encore liés par un trait particulier, distinctif du second sous-genre des osseux dont nous uous occupons, et qui consiste dans la prolongation de la mâchoire supérieure, plus avancée que celle de dessous.

Le carape, le premier de ces trois gymnotes, dont on dit que la chair est presque toujours agréable au goût, habite dans les eaux douces de l'Amérique méridionale, et particulièrement dans celles du Brésil. Sa nageoire de l'anus ne s'étend pas tout à fait jusqu'á l'extrémité de la queue, qui se termine par un tilament délié. Sa couleur générale est brune; son dos est noirátre, tacheté de brun ".

Le fierasfer a été décrit pour la première fois par Brunnich, dans son Histoire des poissons desenvirons de Marseille. Il est blanchatre, avec des taches rougeâtres et brunes, qui font paraitre son dos comme nuageux : le bleuatre règue sur sa partie inférieure. La nageoire de l'anus ne s'étend pas jusqu'au bout de la queue. On voit sur le dos une saillie qui n'est pas une nageoire, mais que l'on peut considérer, en quelque sorte, comme un rudiment de cet organe, comme une indication de l'existence de cette partie dans un si grand nombre de poissons, et qui rapproche le genre des gvmnotes de presque toutes les autres familles de ces animaux. Au reste, il est à remarquer que le sen gymnote qui ne vit pas dans les eaux de l'Amérique méridionale, et qu'on trouve dans celles de la mer Méditerranée, est aussi le seul qui présente sur sa partie supérieure une sorte de commencement de cette nageoire dorsale qui appartient à tant d'osseux et de cartilagineux ${ }^{12}$ Des mâchoires très-avancées, et conformées, ainsi que rapprochées l'une de lautre, de maniere à ressembler à un tube, sufbiraient seules pour distinguer le long-museau de tous les au'Du sous.
note, Cuv.

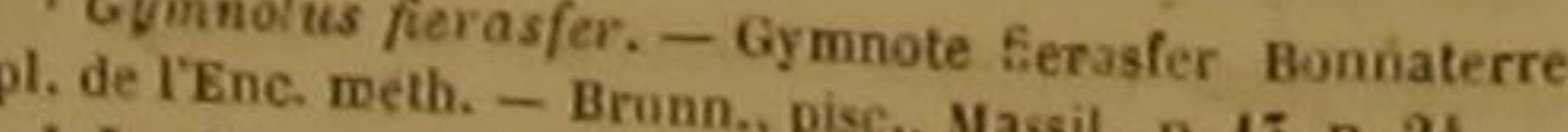
'Le Gynote Fieraster, selon M. Covier, se rapporte

- Gymule miles, Ophidium. D.

Bonnaterre, pl. del'En leng, Daubeuton, Enc. méth. - Id.

fig. 5. - Grouov, Zooph 167, Séba, mis. 5, p. 99, tab. 32. "Du sousgeare Carape, Cur. D.

"On com te à lu membrar. D.

"ine des nazeoires pectorales 10, branchies 5 rayons, à cha"A la membrane des branchies 5 enge liauts 230. nageoires pectorales 16 , a celle de l'anus 50 . à chacune des

DES POISSONS.

tres gymnotes. On voit aisément l'origine de son nom. La nageoire de l'anus est beaucoup plus courte que la queue, qui d'ailleurs finit par une sorte de fil très-délié, comme celle du carape. La couleur est blanchàtre, et diversifiée par des taches irrégulièreśs et brunes. On trouve le long-musean dans l'Amérique méridionale, ainsi que nous venons de l'indiquer '

\section{VINGT-SIXIEME GENRE.}

LES TRICHIURES

Point de nageoire caidale : le corps et la queue tricsallonges, très-comprimes, et en forme de lame; les opercules des branchies placees très-prés des yeux.

Espíces, - eansctìnes.

LE Thíchuene $\left\{\begin{array}{c}\text { La mischoire inférieure plus avancée que } \\ \text { la supérieure. }\end{array}\right.$ LEPTURE.
LETiche

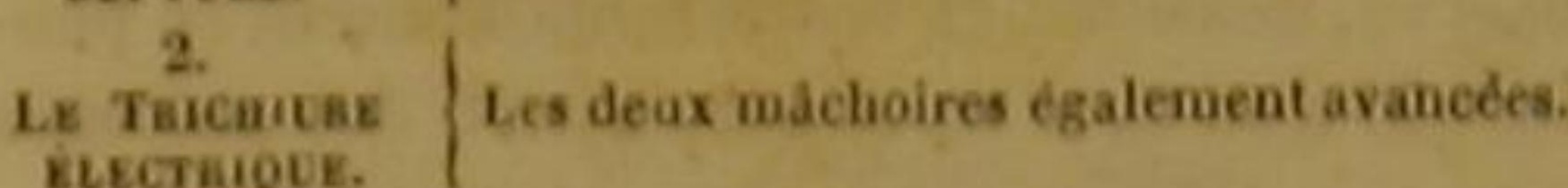

\section{LE TRICHIURE LEPTURE ${ }^{2}$.}

Trichiurus Lepturus, Lino., Gmel., Lacep., Cur. ' .

Les trichiures sont encore de ces poissons apodesquine présentent aucune nageoire à l'extrémité de la queue. On les sépare cependan très-aisément de ces osseux qui n'ont pas de véritable nageoire caudale. En effet, leur corps tres-allongé et très-comprimé ressemble a une lame d'épée, ou, si on le veut à un ruban; etvoila pourquoi le lepture, qui réunit à cette conformation la couleur et l'éclat del'argent, aété nommé Ceintured'argent, ou Ceinture argentée. D ailleurs les opercules des branchies sont placés beaucoup plus près des yeux, sur les trichiures que sur les autres poissons avec lesquels on pourrait les confondre.

A ces traits généraux réunissons les traits particuliers du lepture, et voyons, si je puis em-

- A chaque mageoire pectorale 19 rayons, a celle de l'anus 296.

'Paille-en-cul, par plus, voyageurs et naturalistes. - Trichiure ceinlure dargent, Daubenton, Enc. méth - Id Bonuaterre, pl. de IEnc. méth. - Lepturus, Artedi, spec, 111. - Gymnogaster, Gronov., mus A, N. A. - - Ti

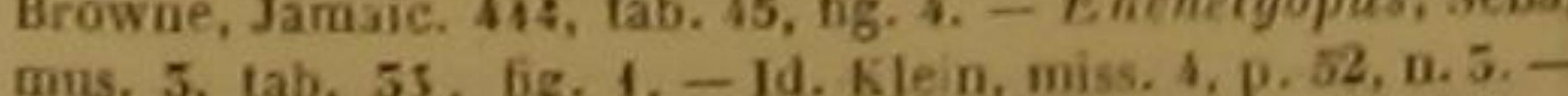
Mucu Brasil, Willoghby, Ichth, tab, G, 7. fig. 7., - Mucu, Harcgr, Brasil 164 - Vbirre, Be 1 aet, Annot, ad Harc: $r$. -Lepturus, Mus. ¿d. fr. 1, 1.-76, tab. 26, fig. 2. - Spits schwanz, B oeh, pl. 158

- M. Cuvier admet le genre Trichiure de Línnće, qui correspond anx genres Leplurus d'artedi et Gymnogaster de Gronovius, D pyer cette expression, cette bande argentine et vivante se dérouler, pour ainsi dire, s'agiter, se plier, s'étendre, se raccoureir, s'avancer en différents sens, décrire avee rapidité mille courbes enlacées les unes dans les autres, monter, descendre, s'élancer, et s'échapper enfin arec la vitesse d'une flèche, ou plutôt, en quelque sorte, avee celle de l'èclair.

La tête du lepture est étroite, allongée, et comprimée comme son corps et sa queue. L'oulverture de sa bouche est grande. Ses dents sont mobiles, au moins en très-grand nombre; et ce caractère que nous avons vu dans les squales, et par conséquent dans les plus féroces des cartilagineux, observons d'avance que nous le remarquerons dans la plupart des osseux qui se font distinguer par leur voracité. Indépendam. ment de cette mobilité qui domne à Panimal ta faculté de présenter ses crochets sous l'angle le plus convenable, et de retenir sa proie avee plus de facilité, plusieurs des dents des máchoires du lepture, et particulierement celles qui avoisinent le bout du museau, sont longues et recourbées vers leur pointe; les autres sont courtes et aiguếs, On n'en voit pas sur la langue, ni sur le palais : mais on en aperçoit de très-petites sur deux os placés vers le gosier.

Les yeux sont grands, très-rapprochés du sommet de la tête, et remarquables par un iris doré et bordé de blane autour de la prunelle.

L'opercule, composé d'une seule lame, et membraneux dans une partie de son contour forme une large ouverture branchiale '. Une ligne latérale couleur d'or s'étend sans sinuosités depuis cet opercule jusqu'a l'extrémité de la queue. L'anus est assez près de la téte.

Les nageoires pectorales sont très-petites et e renferment que onze rayons; mais la nageoire dorsale en comprend ordinairement cent dix-sept, et règne depuis la nuque jusqu'a une très petite distance du bout de la queue.

On ne voit pas de véritable nageoire de l'aaus : a la place qu'occuperait cette nageoire, on trouve seulement de cent à cent vingt, et le plus souvent cent dix aiguillons tres-courts, assez áloignés les uns des autres, dont la premiere moitié, ou a peu près, est recourbée vers la queue, et dont la seconde moitié est fléchie vers la tête.

La queue du lepture, presque toujours trèsOn conpte sept rayons a L membrane des braschies. 
défiée et terminée par une sorte de prolongation | cautions, saute jusque dans les barques et au assez semblable à un fil ou à un cheveu, a fait milieu des pécheurs. Cette bande d'argent si dédonner à ce poisson le nom de Leplure, qui si- corée, si élastique, si vive, si agile, a quelque gnifie petile queue, ainsi que celui de Trichiure, fois plus d'un mètre de longueur.

qui veut dire queue en cheveu, et que l'on a Le lepture vit au milieu de l'eau douce. $0_{n}$ etendu, comme nom génerique a toute la petite ic tie famille dont nous nous oceupons. Cependant, comme cette queue très - longue est en mème temps assez comprimée pour avoir été comparée à une lame, comme le corps et la tête présentent une conformation semblable, et que tous les muscles de l'animal paraissent doués d'une énergie très-soutenue, on supposera sans peine dans le lepture une mobilité rare, une natation très-rapide, une grande souplesse dans les mouvements, pour peu que l'on se rappelle ce que nouis a aons déjà exposé plus d'une fois sur la cause de la natation célère des poissons ' ${ }^{\prime}$. Et en effet, les voyageurs s'aceordent à attribuer au lepture une agilité singulière et une vélocité extraordinaire. S'agitant presque sans cesse par de nombreuses sinuosités, ondulant en différents sens, serpentant aussi facilement que tout autre habitant des eaux, il s'élève, s'abaisse, arrive et disparait avee une promptitude dont a peine on peut se former une idee. Frappant violemment l'eau par ses deux grandes surfaces latérales, il peut se domner assez de force pour s'élancer au-dessus de la surface des fleuves et des lacs; et commeil estcouvert partout de trèspetites écailles blanches et éclatantes, et, si je puis parler ainsi, $d$ une sorte de poussiere d'argent que relève l'or de ses iris et de ses lignes latérales, il brille et dans le sein des ondignes laterales, il brille et dans le sein des ondes, et au milieu de l'air, particulièrement lorsque, $c$ daut à sa voracité qui est tres-grande, anime par une affection puissante, ajoutant par l'effet de ses mouetion paissante, ajoutant par l'effet et des mouvements à la vivacitéde ses couleurs, et déployant sa riche parure sous un ciel ensuivant sa proie are dessus les eaux, et, poursuivant sa proie avee plus d'ardeur que de

' ia collectiou du Muséum rent rme une vasiéte to te

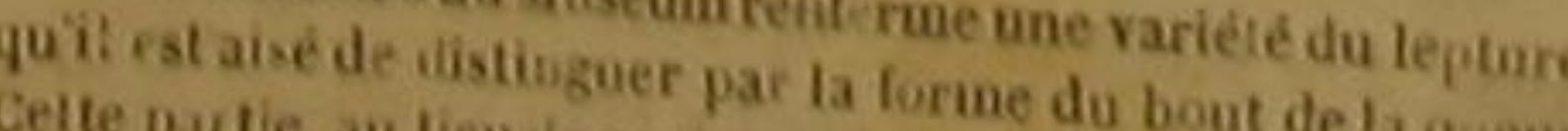
rienteuse, parali con se terminer par ane prolongation

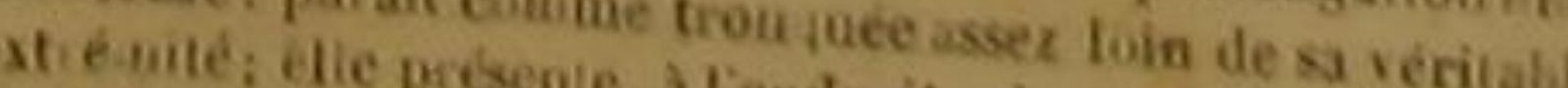

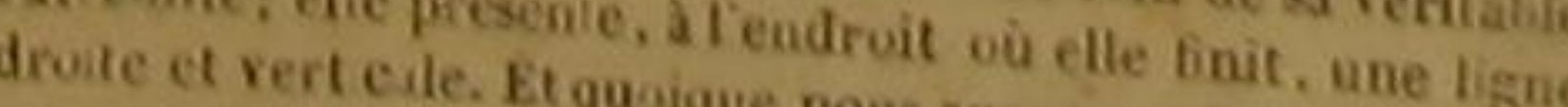
aree ectle confurmation particuliêre, nous vu deus individio

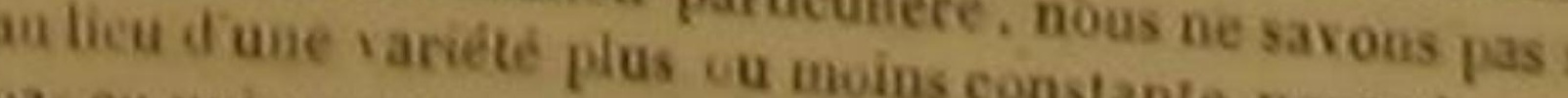

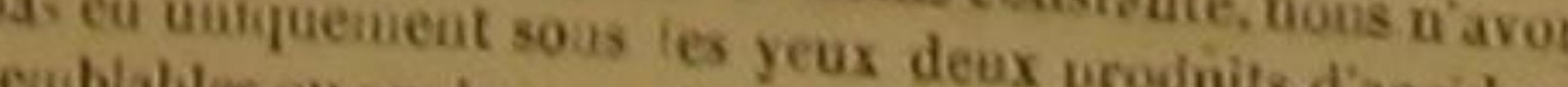

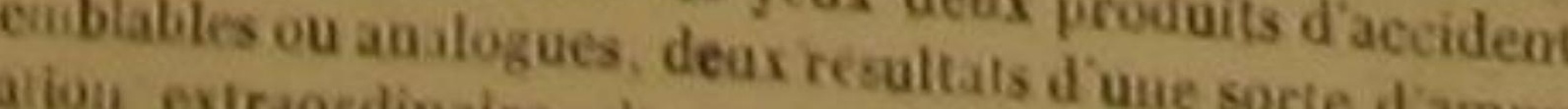
pariai les animaus a sang froid truive plusieurs exempio périe, et qui, pour tes deus indivi its peaveut subir sans en rait emporte la portion la plus détié de lent nous parlous, an le trouve, comme plusieurs aymnotes, dans

I'Amérique méridionale. Il n'est pas étranger néanmoins aux contrées orientalés de l'ancien continent : il se trouve dans la Chine, et nou avons vư une image très-fidele de ce poissor dans un recueil de peintures chinoises donnée par la Hollande à la France, déposées mainte nant dans le Muséum d'histoire naturelle, et dont nous avons déjà parlé dans cet ouvrage.

Au reste, la beauté et la vivacité du lepture sont si propres à plaire aux yeux, à parer une retraite, à charmer des loisirs, qu'il n'est pas sưprenant que les Chinois l'aient remarqué, observé, dessiné ; et vraisemblablement ce peuple, qui a su tirer un si grand parti des poissons pour ses plaisirs, pour son commerce, pour sa nourriture, ne se sera pas contenté de multiplier les portraits de cette espece; it aura voulu anssi en répandre les individus dans ses nombreuses eaux, dans ses larges rivières, dans ses lacs enchanteurs.

Trichiurus electricus, Linn, Gmel., Lacep ; Trichiu-
rus Sivala, Guy,

On a reconnu dans ce trichiure une faculté analogue à celle de la torpille, et du gymuote torporifique. Mais comme, en découvrant ses efféts, on n a observé aucun phénomène particulier propre à jeter un nouveau jour sur cett puissance que uous avons longtemps considéree en traitant du gymnote engourdissant et de la torpille, nous croyons devoir nous contenter de dire que le trichiure électrigue contenter de dire que le trichiure électrique est séparé du lepture, non-seulement par la conformation de ses màchoires, qui sont toutes les deux égalemeut avancées, mais encore par la forme de ses dents, toutes extremente par la forme de ses bout de la queue inement petites. D'ailleurs le le lepture. De plest pas aussi aigu que daus M. Cuvier admet ce poisson dan. 270 .

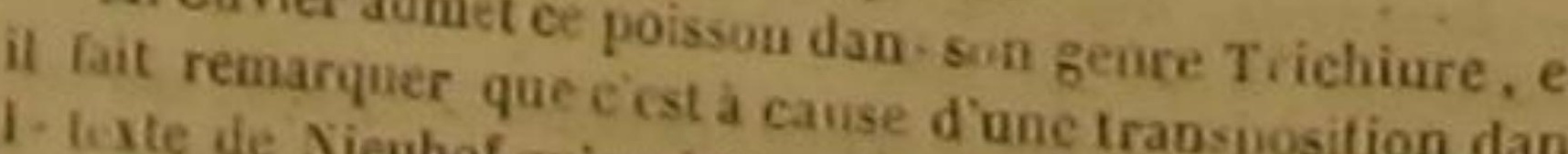

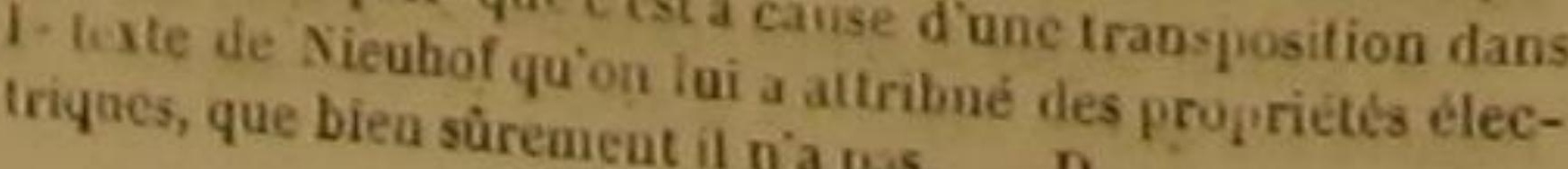

\section{LE TRICHIURE ÉLECTRIQUE '}

l'argent qui décorent ce dernier poisson, il presque en tout, à un gymnote, si on le privait n'offre que des couleurs ternes; il est biun et de la nageoire qu'il a sur le dos.

tacheté. S ill a été doué de la puissance, il est done bien éloigné d'avoir reçu l'éclat de la beauté. C'est dans les mers de l'Inde qu'il exerce le pouvoir qui lui a été départi.

\section{一}

VINGT-SEPTIÈME GENRE. LES NOTOPTÈRES.

Des nageoires pectorales de l'amus et du dos; point de nageoire caudale; le corps tres-court.

Expéces.

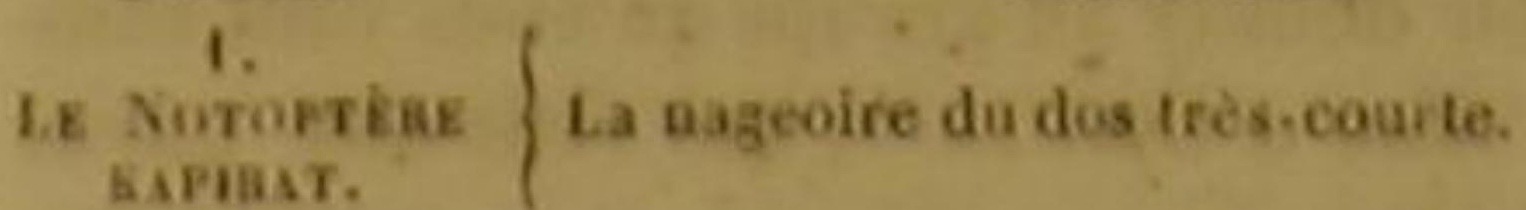

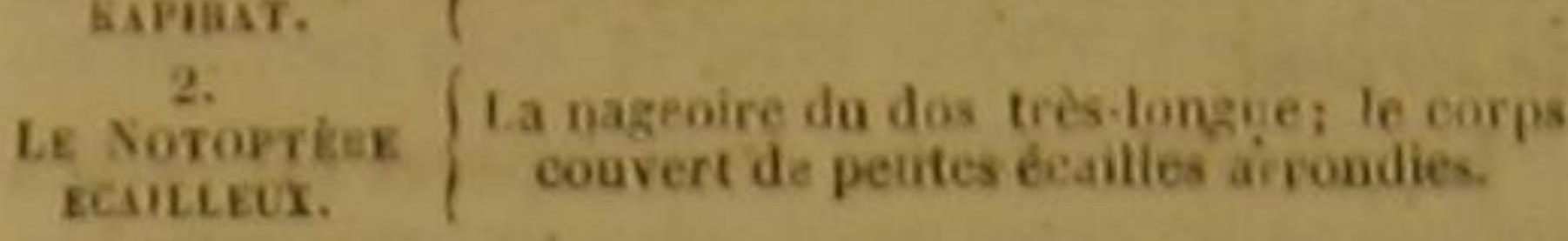
canter.

\section{LE NOTOPTËRE KAPIRAT}

Notopterus K piral, Lacep, Cuv.; Gymootus notopterus, Pallas.; Clupea Synuda, Seho.

Les deux poissons dont nous allons donner a deseription, ont été jusqu'à présent confondus avec les gymnotes: mais la précision que nous croyons devoir introduire dans la distribution des objets de notre ètude, et les principes sur lesquels la classification des animaux nous t paru devoir ètre fondée, ne nous ont pas permis de laisser réunis des poissons dont les uns n'ont reçu le nom de Gymnotes que parce que leur dos est entièrement dénué de nageoire, et d'autres osseux qui au contraire ont une nageoire dorsale plus ou moins étendue. Nous avons donné à l'ensemble de ces derniers le nom génerique de Noloptere, dont plusieurs naturalistes se sont servis jusqu à présent pour désigner le kapirat, la premiere espece de ce groupe, et qui, venant de deux mots grees, dont l'un signifie dos, et l'autre aile ou nageuire, indique la présence d'une nageoire dorsale. Le noms de ces deux genres très-voisins annolcent donc la véritable différence qư les sépare on pourrait mème, a la rigueur, dire la seul différence générique bien sensible et bien constante qui les écarte l'un de l'autre. Le kapirat surtout serait aisément assimile en tout, ou

- Ikan pengay, dansI'Inle. - Gymnotus kapirat. Bos-

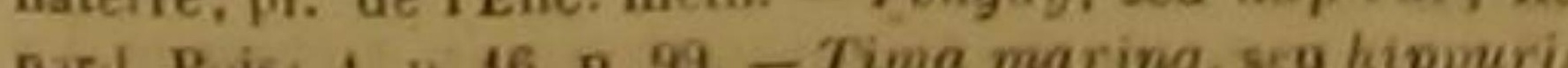
Bonius, Ind cap. 25, r 78

2M. Crvier áloigne ce poisson des gysnontes pour le ra. procher des larengs, dans fordre des poissons maliacepterygiens abd minaux. D. .
Le poisson qui fait le sujet de cet article, se trouve dans la mer voișine d'A mboine. Il ne parvient ordinairement qu'à la longueur de deux ou trois décimètres. Son museau est court et arrondi; on aperçoit une petite ouverture, ou un pore très-sensible, au-dessus de ses yeux qui sont grands. La mâchoire supérieure est garnie de dents égales et très-peu serrées; la máchoire inferieure en présente sur son bord extérieur de plus grandes et de plus éloignées encore les unes des antres; et de plus, on voit sur le bord interieur de cette machoire d'en bas ainsi que sur celui du palais, une série de dents très-petites. L'opercule des branchies est garni d'écailles et membraneux dans son contour. La gorge et l'anus sont très-rapprochés. L'étendue de la nageoire de l'anus ', et la forme très-alongée de la queue, sont assez remarquables pour avoir fait donner au kapirat, par Bontius, le nom d'Hippuris, qui veut dire queue de cheval, Et enfin ce notoptere brille des couleurs do 'or et de l'argent qui sont répandues sur les très-petites écailles dont sa peau est revêtue.

\section{LE NOTOPTĖE ÉCAIILEUX.} Notopterus squamosus, Lacep.; Gymnotus asiaticus, Linn.,Gmel. ?

Comme nous n avons pas vu ce poisson, nou. ne pouvons que présumer qu'il ne présente pas de véritable nageoire caudale. Si le bout de sa queue était cependant garni d'une nageoire distincte et véritablement propre à cette extrémité, il faudrait le séparer des notoptères, et le comprendre dans un genre particulier. Mais si au contraire, et comme nous le pensons, II n'a point de nageoire que l'on doive appeler caudale, il offre tous les caracteres que nous avons assignés au genre des notopteres, et il doit être inscrit á la suite đu kapirat. II differe néanmoins de ce dernier animal, non-seulement parce que sa nageoire dorsale, au lieu d'étre cuurte et de ne renfermer que sept rayons,

1A la membrane des branehies 6 rayous, a la uagecive dia dos 7 , a chacune des nageoires pectorales is, a la nazevin de Ianus 146.

3. Cavier pe fait pas mention de ce poisson, yui, a cause de ses rapport avec le précédent, parait nevoir ére comino

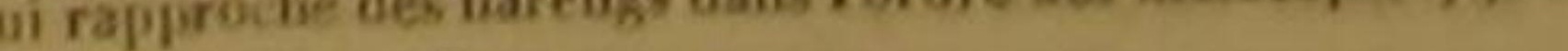
abdom n 1 ux. D. 
rents principes qui nous dirigent dans nos dispresque depuis la nuque jusqu'à la queue, mais encore parce qu'il est revêtu, même sur la tète, d'écailles assez grandes et presque toujours arrondies, qui nous ont suggéré son nom spécifique.

On voit au-devant de chacune de ses narines un petit barbillon qui parait comme tronqué. Il y a sur la tête plusieurs pores très-visibles, et chin tres-petits enfoncements. I es dents sont acérées; et l'entre-deux des brancheś de la mâchoire supérieure en est garni. La ligne latérale est droite, excepté au-dessus de l'anus, où elle se fléchit vers le bas. La couleur de l'écailleux est obscure, avec des bandes transversales brunes. II devient ordinairement un peu plus grand que le kapirat, et il habite, comme ce dernier poisson, dans les mers de l'Asie'.

Tous les vrais gymnotes connus jusqu'à présent vivent dans les eaux de l'Amérique méridionale ou de l'Afrique oceidentale, excepté le fierasfer, que l'on a péché dans la Méditerranée, pendant qu'on ne trouve que dans les mers de l'Asie les notopteres déjà découverts.

\section{VINGT-HUITIEME GENRE.} LES OPHUSURES.

Point de nageoire caudale : le corps et la queue cylindriques et très-allongés relaticement a leur diamitre: la tele petite : les narines tubulees: la nageoire cor-

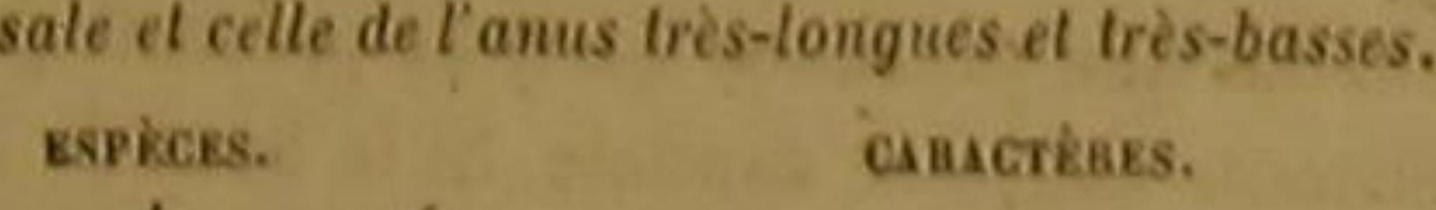

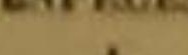

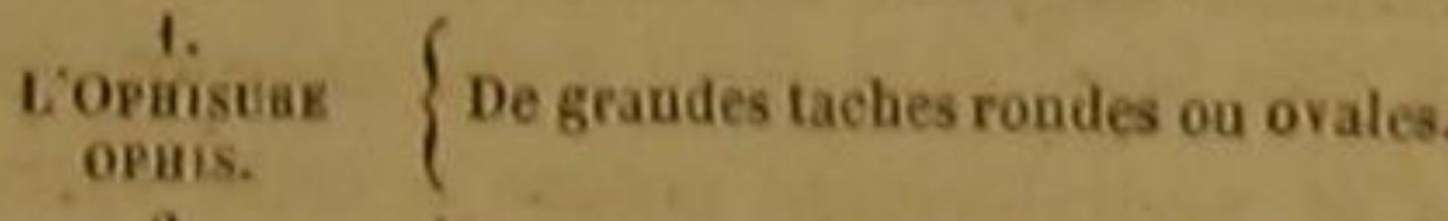
2. OPHISURE SER- $\{$ Point de taches, ou de trés petites taches.
PEXT. 5. Viugt-cinq bandes transversales séparées
lune de lautre par des iniervith

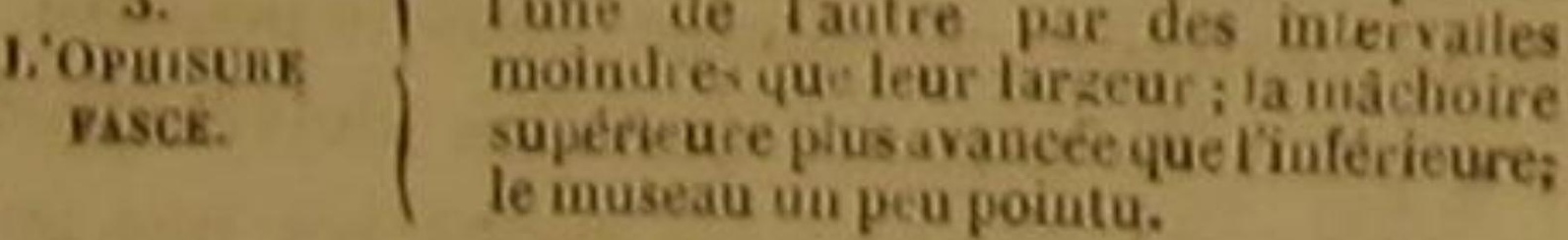
RE OPHIS ${ }^{2}$.

L'OPHISURE OPHIS ${ }^{2}$

Optisirus Ophis, Lacep., Linn.; Muræoa maculosa, Gur."

Ceux qui auront un peu réfléchi aux difféiA la membrane des branchies, 5 rayons. 1. Muréne serpent taché, Daubenton, Ene. méth. - Id Bonnaterre, pl. de I'Enc, mèth. Murcena teres, gracii is

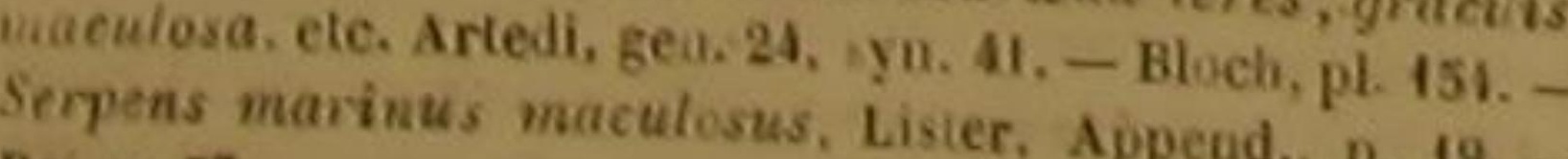

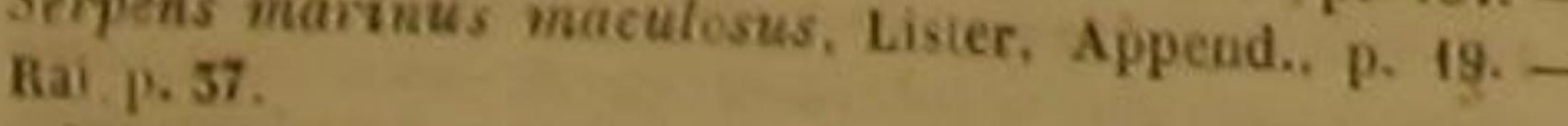
'M. Cu dansle genre Auguille: maisil fait remarguer que Ophisure, opt is de Bloch, pl. 154, cu Ophisurus hyala de Buchanana tributions méthodiques, ne seront pas surpris que nous séparions les deux espèces suivantes du genre des murènes, dans lequel elles ont été inscrites jusquà présent. En effet, elles en different par l'absence d'une nageoire caudale. On pents marins; et comme un des grands rapports qui les lient avec les véritables serpents, consiste dans la forme déliée du bout de leur queue, dénué de nageoire, ainsi que l'extrémité de la queue des vrais reptiles, nous avons cru devoir donner au groupe qu'elles vont composer le nom d'Ophisure, qui veut dire queue de serpent.

La première de ees deux espèces est celle à laquellej'ai conservé le nom particulier d' $O$ phis, qui, en gree, signifie serpent. Son ensemble a beaucoup de conformité avec celui des vérítables reptiles; et sa maniere de se mouvoir sinueuse, vive et rapide, rapproche ses babitudes de celles de ces derniers animaux. Il se contourne d'ailleurs avec facilité; il se roule et déroule; et ces évolutions sont d'autant plus agréables à voir, que ses proportions sont trèssveltes, et ses couleurs gracieuses. Le plus souvent son diamètre le plus grand n'est que la trentième ou mème la ąuarantième partie de sa longueur totale, qui s'étend quelquefo's au dela de plus d'un mètre; et sa petite tète, son corps, sa queue, ainsi que sa longue et trèsbasse nageoire dorsale, présentent sur un fond blane, ou blanchâtre, plusieurs rangs longitudinaux de taches rondes ou ovales, qui, par leur nuance foncée et leur demi-régularité, contrastent très-bien avec la teinte du fond.

On voit des dents recourbées, non-senlement le long des mâchoires, mais encore au palais. L'ophis habite dans les mers européennes '.

\section{L'OPHISURE SERPENT ${ }^{2}$.}

Ophisurus Serpens, Lacep., Cuv.; Muræna Serpens, Linn., Gmel.

Cette seconde espèce d'ophisure est plus

pl. 5, fig. 5, est diune autre espèce voisine de l'O 0 phisure serpent de mer. $\quad$ b.

azeoires pectorales 10 , a la nagenire rayous. a chacume $d$, s lanus 79.

'Murène serpent sans tache, Daubenton, Enc. méth. ' Du sous-geare Ophisure, dans le genre Anguille Cuv. D. leur a depuis longtemps donné le nom de Ser- grande que la premiere : elle parvient fréquenment à la longueur de pres de deux miètres. the habite non-seulement dans les eaux salees voisines de la campagne de Rome, mais encore dans plusieurs autres parties de la mer Méditerranée. Elle y a été nommée plus souvent que presque tous les autres poissons, Serpent marin, et elle y a été connue d'Aristote, qui la distinguait par le mème nom de Serpent marin, de Serpent de mer. Ses habitudes ressemblent beaucoup à celles de l'ophis : ses mouvements sont aussi agiles, ses inflexions aussi multipliées, ses circonvolutions aussi faciles, sa natation aussi rapide, et ses courses ou ses jeux plus propres encore à charmer les yeux de ceux qui sont à portée de l'observer, parce qu'elle offre des dimensions plus grandes, sans cesser d'avoir des proportious aussi sveltes. On ne voit pas sur son corps les taches rondes ou ovales qui distinguent l'ophis. Elle est jaunâtre sur le dos, blanchátre sur sa partie inférieure; et sa nageoire dorsale ainsi que celle de l'anus sont lisérées de noir.

On compte dix rayons a la membrane des branchies, et seize à chacune des nageoire pectorales.

\section{OPHISURE FASCE}

Ophisurus fasciatus, Lacep.

Nous avons vu dans la collection dounée à la France par la Hollande, un ophisuré que nous Frans devoir nommer Fascé. Sa tête était avons cru devoir nommer Fascé. Sa téte était noire; ses yeux étaientvoilés par unemembraue transparente; son cor ps tres-des pectorales arun peu comprime; ; et il

Id. Bonnaterre, pl. de l'Enc. méth. - Murena exacié te. res, etc. Artedi, gen. 24, syo, 41. - Oopis deciarros, Aristot. I. 2, e. 14; et 1. 9. c. 57. - Serpens marinus, Salv., fol. 57, $a$, ad icone mi, et fol 58, a.-Serpent marin, Ronselet. part.1.

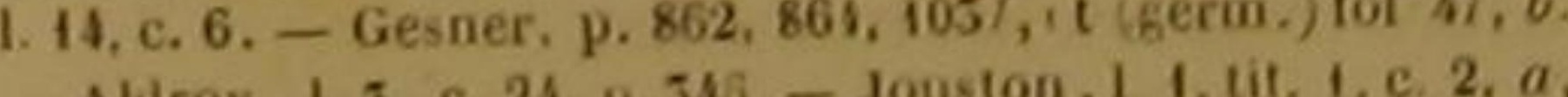

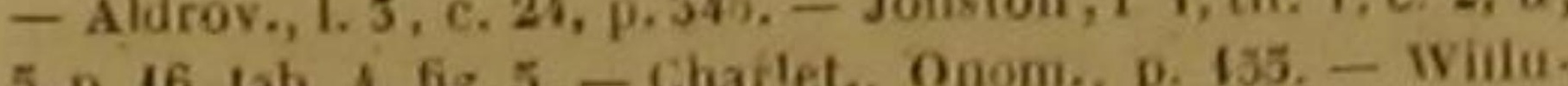

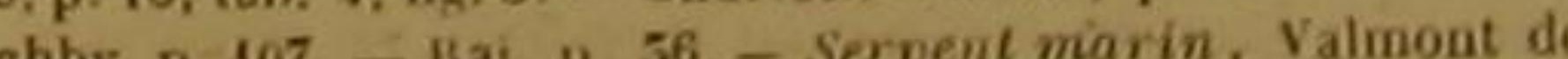

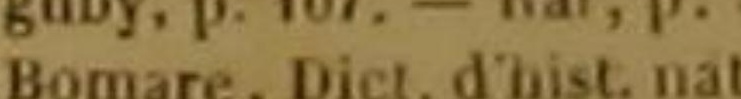

- y. Cuvier ne fait pas mentiou de cetle espéce. D.
VINGT-NEU VIÈME GENRE.

LES TRIURES.

La nageoire de ta queue tres-courte: celle du dos at celle ife l'anus tenduesjusour au-dessus el ant-dessous de celle de la quene: le mus an avance en forme de tube : whe seule dent à chaque mảehoire.

ESPĖCE.

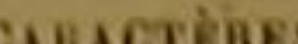

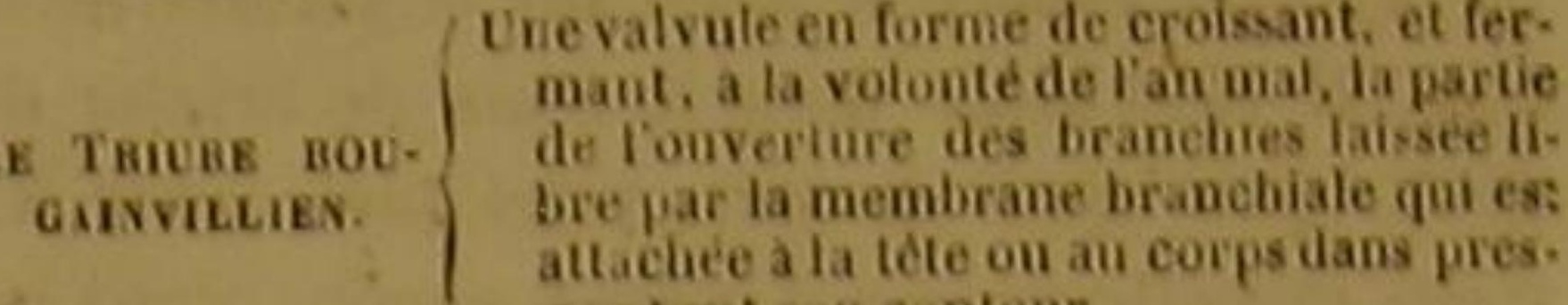
que tout son eonto

LE TRIURE BOUGAINVILLIEN '. Triurus bougainvillianus, Lacep. ?

Nous venons d'écrire l'histoire des poissons apodes renfermés dans la premiere division des osseux, et qui sont dénués de nageoire caudale : examinons maintenant ceux du mème ordre qui en sont pourvus; et commençons par ceux qui n'en ayant qu'une assez courte, lient, par une nuance intermédiaire, les premiers avec les seconds. Plaçons iei, en conséquence, ce que nous avons a dire d'un poisson du premier ordre des osseux, dont les manuserits du savant Commerson nous ont présenté la description, qui n'a été encore observé par aucun autre naturaliste, et que nous avons dù inserire dans un genre particulier.

Nous avons déjá donné le nom de Commerson à une lophie, donnons au poisson que nous allons décrire, le nom de notre fameux navigateur et mon respectable confrère Bougainville, avec lequel Commerson voyageait dans la mer du Sud, lorsqu'il eut occasion d'exami ner le triure dont nous allons parler.

Ce fut entre le 26 et le $27^{\circ}$ degré de latitude australe, et près du 103 ou du $404^{\circ}$ degré de longitude, qu'un hasaid mit Commerson mème de voir cette espèce très-digne d'attention par ses formes extérieures. On venait de prendre plusieurs poissons du genre des scombres. Commerson les ayant promptement disséqués, trouva dans l'estomac d'un seul de ces animaux cinq triures très-entiers, et que la force digestive du scombre n'avait encore alté-

1. Tricaud, ou Bacha de mer; triorus, vel tiplupus vel - triczudus bideas, rictu fistitali, pinmis ventralibus earm,

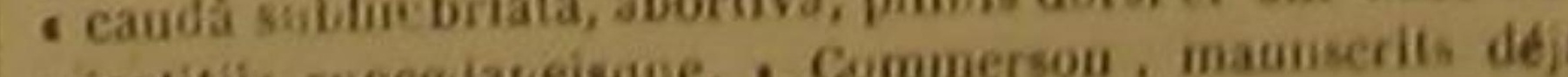
- jectitis succeilateing ¿Ce genre nia point été adupté par les uaturalistes. II. Cu vier ainfit pas mention. $D$. 
HISTOIRE NATUIELLE

rés en aucune manière. Leur forme extraord naire frappa, dit Commerson, les gens de l'équipage, qui s'écrièrent tous qu'ils n'avaient jamais vu de semblables poissons. Quant à lui, il crut, bientôt après avoir retiré ces cîq triures de l'estomac du scombre, en voir plusieurs de la mème espèce se jouer sur la surface de la mer. Il était alors dans le mois de février de 1768. Quoi qu'il en soit, voici quels sont les traits de cette espece d'osseux apode, dont les individus examinés par le très-exact et trèséclairé Commerson, avaient à peu près la grandeur et l'aspect d'un hareng ordinaire.

La couleur du triure bougainvillien est d'un brun rougeâtre qui se change en argenté sous la téte, et en incarnat, ou plutót en vineux blanchâtre, sur les cótés, ainsi que sur la partie inférieure du corps et de la queue, et qui est relevé par une tache d'un blanc très-éclatant derrière la base des nageoires pectorales.

L'ensemble du corps et de la queue est comprimé, et allongé de manière que la longueur totale de I animal, sa plus grande hauteur et sa plus grande largeur, sont dans le mème rapport que 71,18 et 10 . Ce même ensemble est d'ailleurs entièrement dénué de piquants, et révétu d'écailles si petites et si enfoncées, pour aiusi dire, dans la peau a laquelle elles sont attachées, qu'à la première inspection on pourrait croire l'animal entierement sans écailles.

La tète, qui est comprimée comme le corps, et qui de plus est un peu aplatie par-dessus, termine par un museau tres-prolongé fait en forme de tube assez étroit, et dont l'extrémité présente pour toute ouverture de la bouche un orifice rond, et que l'animal ne peut pas un mer.
mend, et que l'animal ne peut pas fer-

Dans le fond de cette sorte de tuyau sont les d'une seule dent osseuses, composées chacune 'ne triangulaire, 0 n'aperçoit pas d'autres dents ni sur le palais, ni sur la langue, qui est très-courte, cartilagineuse, et cependant un peu charnue dans son bout anterieur, lequel est arrondi.

Les ouvertures des novirondi.

Les ouvertures des narimes sont très-petites
tt placées plus près des of et placées plus près des orbites que de l'extrémité du museau. Les yeux sont assez grands peu convexes, depourvus de ce voile membrineux que nous avous fait remarquer sur cetx des gymuotes, des ophisures, et diaur ceux sons; et l iris brille des coule d autres poisl'argent.
C est au-dessous de la peau qu'est placé chaque opercule branchial, qui d'ailleurs est com posé d'une lame osseuse, longue, et en form de faux. La membrane branchiale renferm cinq rayons un peu aplatis et courbés, qu'o ne peut cependant apereevoir qu'a l'aide de I dissection. Cette membrane est attachée à la têté ou au corps dans presque tout son contour de manière qu'èlle ne laisse pour toute ouverture des branchies qu'un trè-petit orifice situé dans le point le plus éloigné du museau. Nous avons vu une conformation analogue en traitant des syngnathes; nous la retrouverons sur les callionymes et sur quelques autres pois. sons : mais ce qui la rend surtout très-remarquable dans le triure que nous faisons connaitre, c'est qu'elle offre un trait de plus dont nous ne comnaissons pas d'exemple dans la classe entiere des poissons ; et voilà pourquoi nous en avous tiré le caractère distinctif du bougainvillien. Cette particularite consiste dans une valvule en forme de croissant, charnue, mollasse, et qui, attachée au bord antérieur de l'orifice branchial, ke ferme à la volonté de P'animal, en se rabattant sur le cóté postérieur. Le triure bougainvillien est done de tous lespoissons con. nus celui qui a reçu l'appareil le plus compliqué pour empècher l'eau d'entrer dans la cavité branchiale, ou de sortir de cette cavité en passant par l'ouverture des branchies; il a un opercule, une membrane et une valvule; et la réunion, dans cet animal, de ces trois moyens d'arréter l'entrée ou la sortie de l'eau, est d'autant plus digne d'attention, que d'apres les expressions de Commerson, il parait que ce triure ne peut pas fermer à sa volonté l'orifice placé a l'extrémit du long tube formé par son museau, et que tube peut servir de passage à l'eau pour entrer par la bouche dans la véritable cavité branchiale, ou pour en sortir.

Mais nous avons assez parlé des organes du triure relatifs à la respiration.

On ne voit pas de ligne latérale bien sensible. Le bas du ventre se termine en carène gue dans presque touté sa longueur; et l'anus, qui est situé à l'extrémité de l'abdomen, consiste dans une ouverture un peu allongée. Les nageoires pectorales sont petites, déligutes, transparentes, paraissent presque trianment douze ou theiz sont déployées, et renferLa nageoire de layous. rayons mous, ou environ, se dirige en arriere; et sa pointe aiguè s'étend presque aussi loin que le bord postérieur de la nageoire de la queue, dont elle réprésente un supplément, et parait même former une partie.

la nageoire dorsale ne se montre pas moin comme une auxiliaire de la nageoire de la queue. Formée d un égal nombre de rayons que celle de l'anus, partant d'un point plus étoigné de la tête, et ayant un tiers de longueur de plus, elle s'étend en arrière non-seulement presque autant que la nageoire caudale, mais encore plus loin que cette dernière. Et comme les deux nageoires dorsale et de l'anus touchent d'ailleurs la queue, cette nageoire eaudale semble, au premier coup d'œil, ètre composée de trois parties bien distinetes; on croit voir trois queues a l'aTriurus, de Triplurus, de Tricaud, c'estàdire d'animal à trois queues, de Bacha de la ner, etc., employées par Commerson, et don nous avons conservé le nom générique de Triunous avous
rets, Triüe. st si courte, que, quoique composée d'un vingtaine de rayous, elle ressemble beaucoup entierement formée. Klle parait frangée, parce que les rayons qu'elle renferme sont mous, articulés, et très-divisés vers leur extrémité.

Le triure bougainvillien n'aurait done pas vraisemblablement une grande force pour nager au milieu des eaux de la mer, si la nature et le peu de surface de sa véritible nageoire caudale n'étaient compensés par la forme, la position et la direction de la nageoire du dos et de celle de l'anus; mais nous pensons, ave Commerson, que, par le secours de ces deu angeoires acessoires, le triure doit se mouvoir avec facilité, et s'élancer avee vitesse dans le sein des mers qu il habite.

Telle est l'image que nous pouvions former lu triure bougainvillien en réunissant les traits précieux transmis par Commerson

Quant à l'organisation intérieure de ce poisson, voici ce qu'en a écrit notre voyageur.

Le foie est d'un rouge très-pâle, parsemé de points sanguins, et composé de deux lobes convexes, inégaux, et dont le droit est le plus grand.

Le canal intestinal est étroit, diminue insensiblement de grosseur depuis le pylore, se renimal; et de la viennent les dénominations de

Au reste, la nageoire caudale proprement dite plus à l'ébauche d un organe qu'à une partie cing fois. Commerson n'a trouvé qu'une matière liquide et blanchâtre dans l'estomac, qui est petit, et placé transversalement.

Le cour est presque triangulaire, d'un rouge pàle, avec une oreillette très-rouge.

Commerson n'a pas vu de vésicule natatoire; mais il ne sait pas si son sealpel ne l'a pas détruite.

Le poids du plus grand des triures bougainvilliens exuminés par ce naturaliste, était, à très-peu près, de 132 grammes.

\section{TRENTIEME GENRE.}

\section{LÉs APTÉRONOTES}

Une iageoire de la queuc : point de nageoire du dos; les mächoires non extensibles.

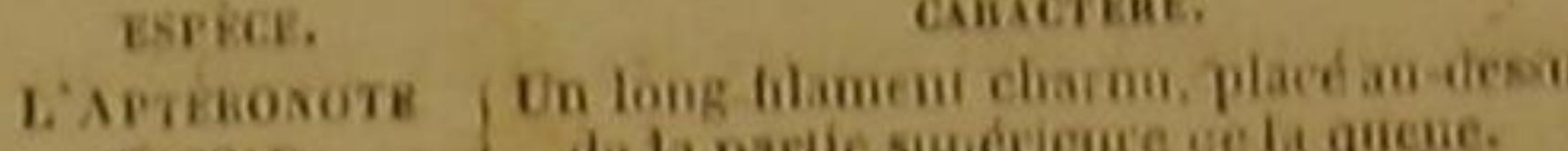

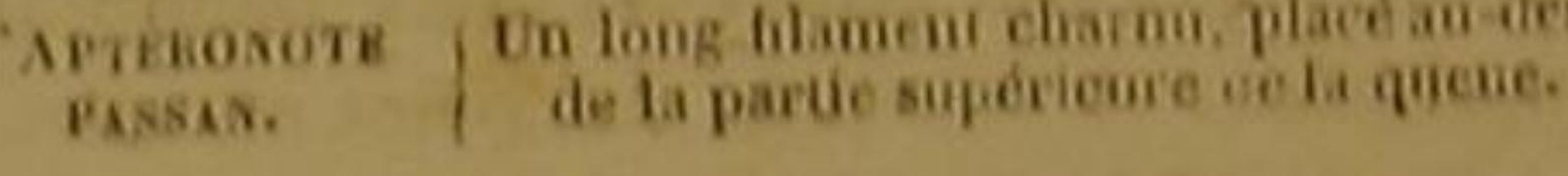

\section{L'APTERONOTE PASSAN ':}

Apteronotus Passan, Lac , Cus. ; Steruarchus albifmons,

Le nom d'Apteronole, qui veut dire sans nageoire sur le dos, désigne la même conformation que celui de Gigniule, qui sig les aym$n u$. Et en effet, le passan, comme les gymnotes, n'a pas de nageoire dorsale; mais nous avons dú le séparer de ces derniers, pareo

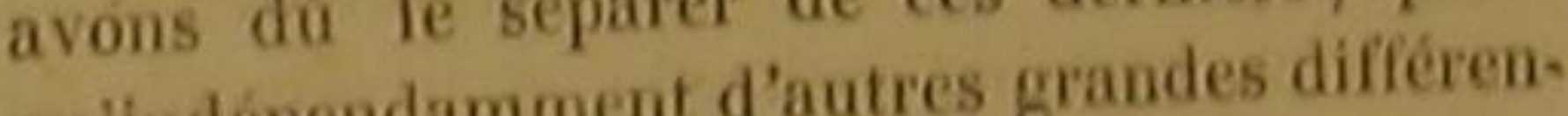
qu'indépendamment d'auto gre ces, il a une nageoire caudate, d'arous done sentent aucun linéament. Nous lavous done sentent aucua lime particulier, auquel cepeninscrit dans un gené pajen aises de donner un dant nous avous ete bien alses do donivoque, nom qui, en faisant éviter toute equivoque, rappelát ses rapports, et, pour ainsi dire, sa rappelat ses la famille des gymnotes.

parente avec la fralle des gès-obtus; la téte

Le passan a le museau tres-obsé in tres. dénuée d'écailles sensibles, et parse humeur petits trous destinés a répandre une homine visqueuse; l'ouverture de la bouche ctés par jusqu'au dela des yeux, qui sont voiles par. membrane comme ceux des gymnotes;

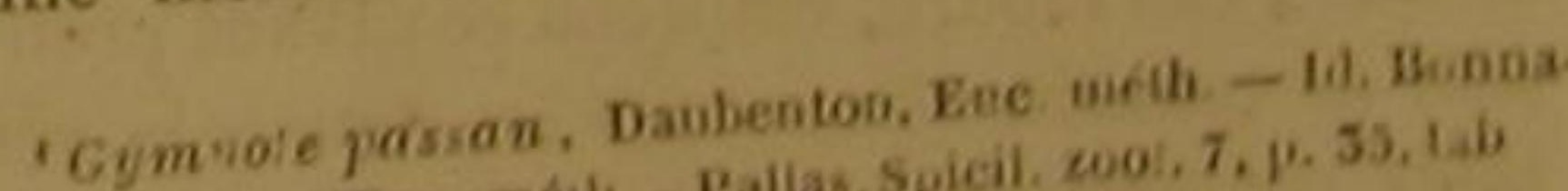

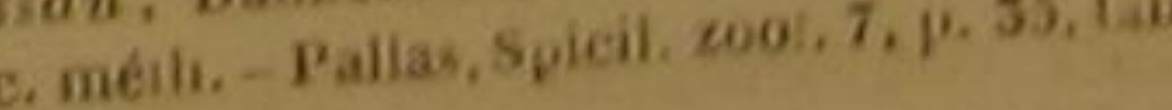
liz 1 . sini Silon.; Gymootos albifrons, Pall, Linn., Gime., mation que celui de Gymnote, qui signifie dos 1). 
les orifices des narines à une distance à peuprès égale des yeux et du bout du museau; et les deux mâchoires festonnées de manière que a mâchoire supérieure présente une portion saillante a son extrémité, ainsi que quatre autres parties avancées, deux d'un côté et deux de l'autre, et que la máchoire inférieure oppose un enfoncement à chaque saillie et une saillie à chaque enfoncement de la mâchoire d'en baut, dans laquelle d'ailleurs elle s'emboite.

Les opercules des branchies sont attachés dans la plus grande partie de leur contour, et les ouvertures branchiales un peu en demicercle.

Par une conformation bien rare, et bien remarquable mème à côté de celle qu'offrent les apodes de la premiêre division des osseux et particulièrement les gymnotes, l'anus est si pres de la tête, qu'il est situé dans le petit espace anguleux qui sépare les deux membrane branchiales, et très-près du point où elles se réunissent. Derrière l'anus, on voit un orifice que l'on croit destiné à la sortie de la laite ou des ceufs

Mais nous allons décrire une conformation plus singulière encore

Vers le milieu de la partie supérieure de l'unimal comprise entre la tête et la nageoire caudale, commence une sorte de filament, ou de lauière charnue très-longue et très-délièe. L savant naturaliste du Nord, le célèbre Pallas, auquel on doit un si grand nombre de decou vertes en histoire naturelle, a le premier fait attention à cette espèce de lanière. En voyant que ce long filament, convexe par-dessus et comme excavé par-dessous, répondait à une sorte de canal longitudinal dont les dimensions paraissaient se rapporter exactement à censions filament, il fut d'abord tenté de croire celles dı avait entaillé le dos de l'anime croire que l'on avait détaché une lanière, aumal, et qu'on en fut retenue que lanière, au point qu'elle ne Il s'apercit que par son extrémité antérieure. II s'apercut cependant bientôt que la conforma. tion qu'il avait sous ses yeux était naturelle mais l'état d'altération dans lequel était apparemment le passan de la collection de l'académie de Pétersbourg, empécha ce savant professeur de comnaitre dans tous ses détails la véritable conformation du filament; èt comme depuis la description publice par ce naturaliste ou n'a pas eru devoir chereher a ajouter a ce qu'il a éerit, la vraie forme de cette portion du passan n'est pas encore connue de ceux qui cul. tivent les sciences naturelles. La voici telle que j'ai pu la voir sur un individu très-bien con. servé qui faisait partie de la collection donnée à la France par la Hollande; et la figure que j'ai fait dessiner et graver, en donnera une idée très-nette

Cette lanière charnue est en effet convex par-dessus, concave par-dessous, attachée pa son gros bout vers le milieu du dos de l'apteronote, et répondant à un canal dont les dimensions diminuent à mesure qu'elle devient plus déliée, ainsi que l'a très-bien dit le professeu Pallas; mais ce que ce naturaliste n'a pas été à mème de voir, et ce qui est plus extraordinaire, e'est que ce filament est attaché aussi par son bout le plus menu, très-près de l'origine de la nageoire de la queue. Lorsqu'on le soulève, on le voit retenu par ses deux bouts, formant une espece d'are dout la queue de l'animal est la corde; et de plus on apercoit trèsdistinctement une douzaine de petits fils qui vont du canal longitudinal à cette lanière, I retiennent comme par autant de liens, sont inclinés vers la nageoire caudale, et se couchent dans le canal longitudinal, lorsqu'on laisse retomber le grand filament dans la longue gouttière qu'il remplit alors en entier.

C'est de la présence de cette lanière que nous avons tiré le caraetère spéeilique du passan.

La nageoire de l'anus commençant très-prè de cette dernière ouverture, s'étend presque depuis la gorge jusqu'a la base de la nageoire caudale; elle comprend de 147 à 152 rayons '.

Le corps et la queue sout couverts d'écailles petites et arrondies.

L'animal est de deux couleurs, d'un noir plus ou moins foncé, et d'un blanc éclatant. Ce blane de neige s'étend sur le museau; il régne ensuite en forme de bande étroite depuis le devant de la téte jusqu'à la partie postérieure de la queue, qui est blanche ainsi que la nageoire caudale, et la dernière partie de celle de l'anus. C'est cette portion très-blanche de la nageoire de l'anus, dont l'image a été oubliée par quelques-uns de ceur qui a été oubliée par quelques-uns de ceux qui ont représenté le passan; et voilà pourquoi on lui a attribué une nageorre celle de la chune des nageoires pe:turales, de 15 a 16 ràjons, a de l'anus beaucoup plus courte que celle qu'il a réellement.

Cet aptéronote parvient quelquefois jusqu'à la longueur de quatre décimetres. On le trouve dans les envirous de Surinam.

\section{TRENTE-UNIEME GENRE.}

LES RÉGALECS.

Des nageoires pectoral-s, du dos, et de la quene ; point de nag oire de l'anus, ni de serie d'aiguillons à lo place de cette dernière nageoire : le corps el la queue tres-allonges.

espices.

Catactéass.
1. Un tong filameal anpré de chaque na.

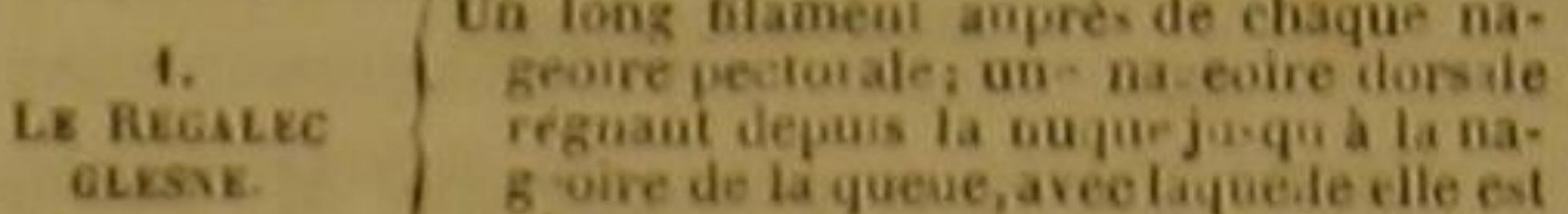
2. La nageoire de la queue lancéalée; les R Rearize LA-
Crolk. -

LE RÉGALEC GLESNE '

Regalecus Glesne, Lac., Cur.; Gymoetrus remipes, Sehn."

Plus on fait de progrès dans l'étude des corps organises, et plus on est convaincu de cette vérité importante, que toutes les formes compatibles avec la conservation des espèces, non-seulementexistent, mais encore sont combinées les unes avec les autres de toutes les manières qui peuvent se concilier avec la durée de ces mèmes especes. L'histoire des poissons apodes de la première division des osseux nous fournit un exemple remarquable de cette variété de combinaisons. Dans les dix-neuf genre de cet ordre, les diverses nageoires du dos, de la poitrine, de l'anus et de la queue, montrent en effet par leur présence, ou par leur absence, un assez grand nombre de modes differents. Les cécilies sont absolument sans nageoires; les monoptères n'en ont qu'une qui est placée au bout de la queue; on en voit deux sur les leptocéphales, dont le dos est garni d'une de ces deux nage ires, pendant que l'autre est situéc entre leur queue et leur anus; les trichiures n'en ont que sur le dos et des deux côtés de la

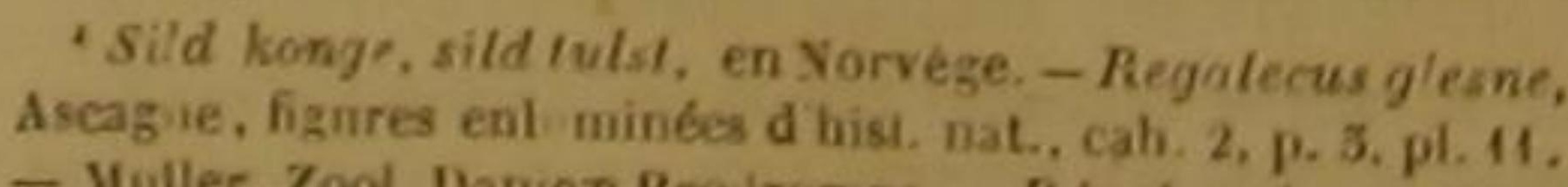

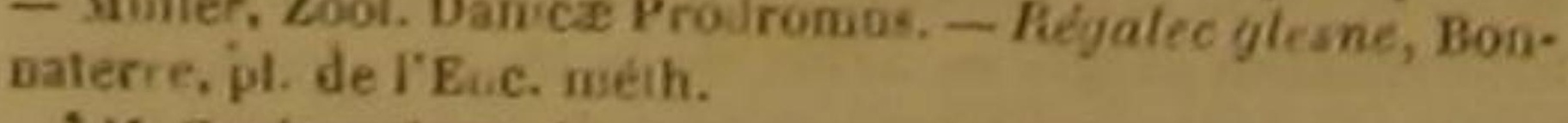
M. Cuvier admet le gr. rapporte le giesne daus ia farmile des acantb optérygiens ta-
nioides. D. pectorales et une de l'auns, en sont dénués sur le dos et à l'extrémité de la queue; les monoptères et les ophisures en déploient uniquement sur le dos, au delà de l'anus, et des deux cótés de la partie antérieure de leur corps; les triures ne rémissent aux nageoires du dos, de la poitrine et de l'anus, que des rudiments d'une nageoire de la queue; on aperçoit une nageoire caudale, deux pectorales et une nageoire de l'anus sur les aptéronotes, mais leur dos est sans nageoire; les quatre sortes de nageoires ont été données aux odontognathes, aux murènes, aux ammodytes, aux ophidies, aux macrognathes, aux xiphias, aux anarhiques, aux coméplores, aux stromatees, aux rhombes; et enfin les régalecs ont reçu une nageoire de la queve, et deux pectorales, sans aucune apparence de nageoire de l'anus.

Cette absence d'une nageoire anale suffirait seule pour séparer le genre des régalees de tous lesautres genres de son ordre, excepté de celu des cécilies, de celui des monoptères, et de celui des trichiures; mais comme les trichiures ont une série d'aiguillons à la place de la nageoire male, que les monopteres n'ont qu'une seule angeoire, et que les cécilies n'en ont pas du lout, on peut dire que cet entier dénúment de nageoire de lanus distingue véritablement les régalees de tous les apodes inscrits dans la première division des poissons osseux, et avec lesquels on pourrait les confondre.

Le naturaliste Ascanius est le premier auteur qui ait fait mention du régalec. On n'a compté jusqu'à présent dans ce genre qu'une espèce que l'on nomme Glesne, et quí habite auprès des côtes de Norvège. Le régalec glesne a d'assez grands rapports avec les trichiures et les ophisures. Le corps et la queue sont trèsallongés et comprimés, les mâchoires armées de dents nombreuses, les opercules composés de cinq ou six pièces, les membranes branchiales soutenues par cinq ou six rayons, les nageoires pectorales tres-petites. Au-dessous de chacune de ces deux dernières nageoires, on voit un filament renflé par le bout, et dont la ioncueur est égale ordinairement au tiers de celle de l'animal. On compte, en quelque sorte, deux nageoires dorsales: la première, qui cependant est une série de piquants plutôt qu'une veritable nageoire, commence des te sommet de la tête, et est composée de huit aiguillons; 
HISTOIRE NATURELLI

la seconde s'étend depuis la nuque jusqu'à la nageoire caudale, avec laquelle elle se réunit et se confond.

Tout le corps du poisson est argenté, semé de petits points noirs disposés en raies longitudinales, et varié dans ses nuances par trois bandes brunes et placees transversalement sur la partie postérieure de la queue.

Comme on le rencontre souvent, ainsi que la chimcre arctique, au milieu des innombrables légions de harengs, qu'il est argenté comme ces derniers animaux, qu'il a l'air de les conduire, et qu'il parvient à des dimensions assez considérables, on l'a nommé, ainsi que la chimère du Nord, Roi des harengs; et c est ce que désigne le nom générique de Régalec, qui lui a été conservé.

\section{LE RÉGALEC LANCEOLÉ'}

Regalecus lanceolatus, Lacep. ?

Nous plaçons dans le mème genre que le glesne une espèce de poisson dont nous avons vu une ligure coloriée, exécutée avee beaucoup de soin, parmi les dessins chinois cédés par la Hollande à la France, et desquels nous avons dẹja parlé plusieurs fois. Nous avons donné à ce régalec, dont les naturalistes d Europe n'ont encore publié aucune description, te nom spécifique de Lancéolé, parce que la nageoire qui termine sa queue a la forme d'un fer de lance. Cet animal est dénué d'une nageoire de l'anus comme le glesne : il a, comme ce dernier os seux, deux nageoires dorsales, très basses et très-rapprochées; mais ces deux nageoires sont, en quelque sorte, triangulaires : la premiere II'est point composée d'aiguillons detachés, la seconde ne se confond pas a vee l'anale comme sur le glesue. Chacun des opercules n'est composé que de deux ou trois pièces, tandis qu'on en compte eing ou six pieces, tandis qu'on du réoalec cinq ou six dans chaque opercule du régalee de Norvège. Le laneéolé a d'ailleurs le corps trés-allongé et serpentiforme, comme le regalee d'Europe; mais ce poisson chinois, au lieu d'étre argenté, est d'une couleur d'or mèlée de brun.

'Ce régice est représenté sous le nom d'Oplidie chi.
nisise, dans la plan be ving-de de cette Histoire das be vingt-derixieme du premier volume

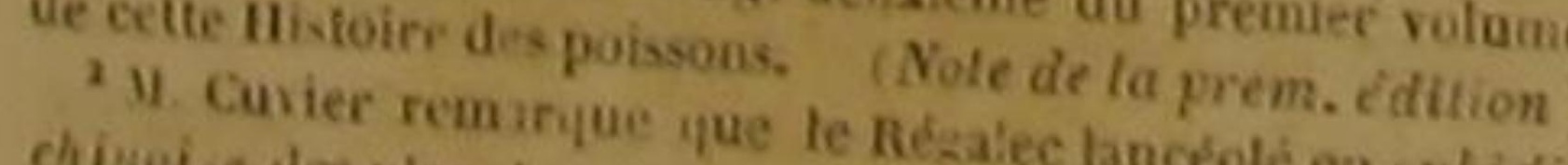

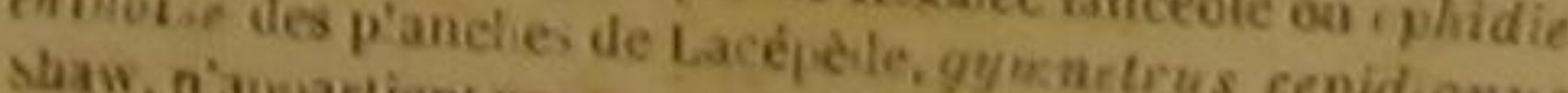
shaw, a spyartieat pas an geore Gymnetre. D.
TRENTE-DEUXIEME GENRE.

IES ODONTOGNATHES

Une lame longue, large, recourbèe, dentriee, placée de ehaque cole de la máchoire superienre', et entraince par tous les nouvemen ts de la machoire de dessous.

ESPÉCE. carsctèras.

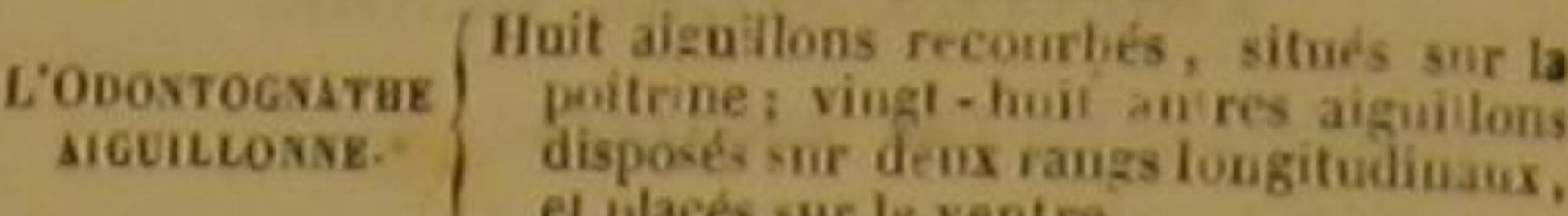

L'ODONTOGNATHE AIGUILLONNE.

Odontognathus mueronatus, Lae., Cuv.; Guath bolus mueronatus, Schn.

Parmi plusieurs poissons que M. Leblond nous a fait parvenir assez récemment de Cayenne, s'est trouvé celui que j'ai cru devoir nommer Odsntognathe aiguillonné. Non-seulement cet osseux n'â encore étẻ décrit par au. cun naturaliste, mais il ne peut être placé dans aucun des genres admis jusqu'à présent par ceux qui cultivent l'histoire naturelle. Sa tète, son corps et sa queue sont très-comprimés. Mais ce qui doit le faire observer avec le plus d'attention, c'est le mécanisme particulier que présentent ses mâchoires, et dont on ne trouve d'exemple dans aucun poisson connu. Montrons en quoi consiste ce mécanisme.

La mâchoire inférieure, plus longue que la supérieure, est très-relevée contre cette derniere, lorsque l'animal a sa bouche entièrement fermée; elle est mème si redressée dans cette position, qu'elle parait presque verticale. Elle s'abaisse, en quelque sorte, comme un pontlevis, lorsque le poisson ouvre sa bouche; et on s'apercoit facilement alors qu'elle forme une espèce de petite nacelle écailleuse, très-transparente, sillonnée par-dessous, et linement dentelée sur ses bords.

Cette màchoire de dessous entraine en avant, lorsqu'elle s'abaisse, deux pièces très-longues, ou, pour mieux dire, deux lames très-plates, irrégulières, de substance écailleuse, un pe recourbées a leur bout postérieur, plus larges a leur origine qu'à leur autre

'3. Cuvier remarame ave re de quiun in lividu mal conservé, $\mathrm{M}$, de Lacépede n'ayant vu naturellement dirigés en avant de ha bo maxi laires étaien

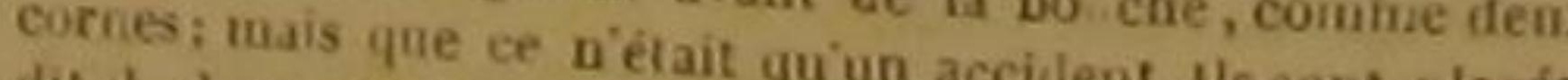

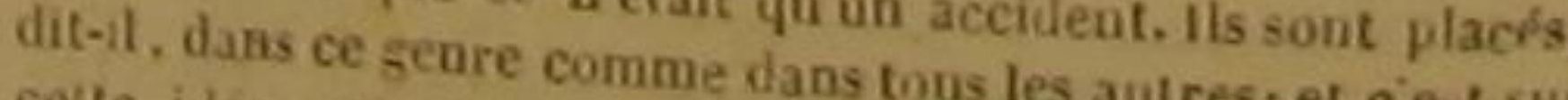
cette idee erronée qu'a élé formé le nom de Gnatholvedur

\section{DLS POISSONS}

lées sur leur bord antérieur, et attachées, l'une | travers des téguments et de chaque cóté dı d'un côté, l'autre de l'autre, à la partie la plus saillante de la mâchoire supérieure. Lorsque ces deux lames out obéi le plus possible au mouvement en en-bas de la mâchoire inférieure, elles se trouvent avancées de manière que leurs extrémités dépassent la verticale que l'on peut supposer tirée du bout du museau vers le plan horizontal sur lequel le poisson repose. C'est au milieu de ces deux pieces que I'on voit alors la mâchoire inférieure abaissée et étendue en avant; et dans cette attitude, le contour de la bouche est formé par cette même mâchoire de dessous, et par les deux lames dentelées qui sont devenues comme les deux cótés de la máchoire supérieure.

Tant que la bouche reste ouverte, les lames dépassent par le bas la mâchoire inférieure; mais lorsque celle-ci remonte pour s'appliquer de nouveau contre la mâchoire supérieure et fermer la bouche, chacune des deux pièces se couche contre un des opercules, et parait n'en étre que le bord antérieur dentelé.

C'est des dentelures que nous venons d'indiquer en montrant le singulier mécanisme des mâchoires de l'aiguillonné, que nous avons tiré le nom gènérique de cet animal, Odlontognathe srgnifiant par un seul mot, ainsi que cela est nécessaire pour la dénomination d'un genre, $a$ machoires dentelées.

Au milien de ces mâchoires organisées d'une maniere si particuliere, on voit une langue pointue et assez libre dans ses mouvements. Les opercules, composés de plusieurs pièces, sont très-transparents dans leur partie postérieure, écailleux et très-argentés dans leur par.ie antérieure. La membrane des branchies, qvi est soutenue par cinq rayons, est aussi aryentée par-dessus ; et il n'est pas inutile de faire bserver à ceux qui auront encore présentes a leur esprit les iđées que notre premier Discours renferme sur les couleurs des poissons, que daus un très-grand nombre d'osseux qui vivent aux environs de la Guyane et d'autres contrées équatoriales del'A mérique, la membrane branchiale est plus ou moins couverte de ces écailles très-petites et très-éclatantes qui argentent les diverses parties sur lesquelles elles sont répandues.

La poitrine, terminée par le bas en carène aiguẽ, présente sur cette sorte d'arête buit aiguillons recourbés. On distingue de plus, au corps, quatorze cótes peu courbées, dont chacune est terminée par un aiguillon saillant a exterieur, et se rébnit, pour former le dessous du ventre, a celle qui lui est analogue dans le cóté du corps opposé à celui auquel elle appartient. Il restalte de cet arrangement, que la earene du ventre est garnie de vingt-huit aiguillons disposés sur deux rangs longitudinaux; e c'est de cette double rangee que vient le nom spécilique d'Aiguillonné, par lequel nous avons cru devoir distinguer le poisson osseux que nous decrivons.

La nageoire de l'anus est très-longue, et s'étend presque jusqu'a la base de celle de la queue, qui est fourchue'.

Eelle du dos est placée sur la queue proprement dite, vers les trois quarts de la longueur totale de l'animal ; mais elle est très-petite.

D'après l'état dans lequel nous avons vu l'individu envoyé au Muséum d Histoire naturelle par M. Leblond, et conservé déja depuis quelque temps dans de l'alcool affaibli, nous pouvons seulement conjecturer que I'odontognathe aiguillonné présente, sur presque tout son corps, le vif éelat de l'argent. Nous le présumons d'autant plus, que cet animal a recu dans les environs de Cayenne, suivant le rapport de M. L eblond, le nom vulgaire de Sardine; nom donné depuis longtemps a une clupée argentee sur une grande partie de sen corps, et qui d’ailleurs n'a aucune ressemblance exté rieure bien frappante avec l'aiguillonné. Comme la sardine, l'odontognathe dont nous parlous est bon à manger, et vit dans l'eau salée. II parvient à la longueur de trois décimètres.

\section{TRENTE-TROISIEME GENRE}

LES MURĖNES.

Des nayeoires pectorales, dorsale, caudale el de l'anusi les narines tubuters: les yeux coiles par une memtrane; le corps serpentiforme ol visqueux.

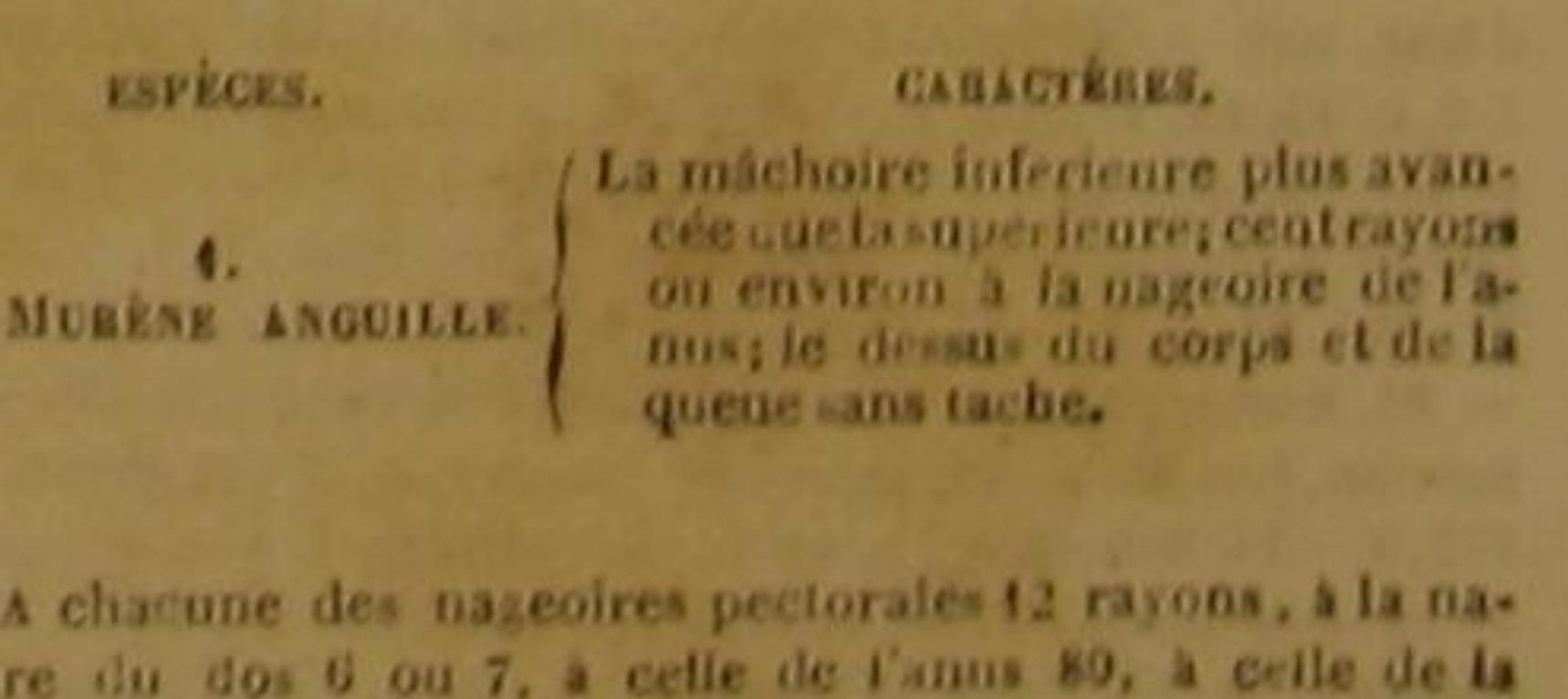
A charune des nazeoires pectorale ta nayos. a la na. geuire 1 iu
queue 19. 
Esrices.

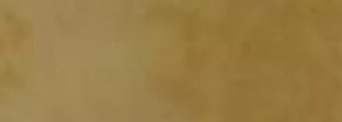

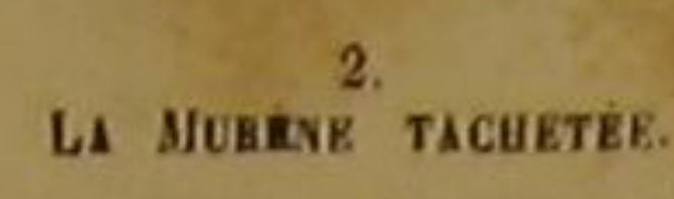
1.a mácboire inférieure plos avan-
cée que Is supérieure; Irente-six rarons on emsiron a la nageore
de lanns; la . ouleor verualre: de pelites tiches noirrs: mue
grandé lachie de chaque cóté el aprés de la $t$

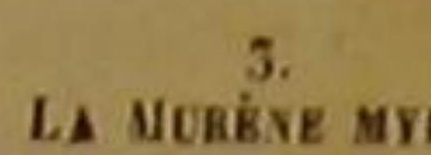

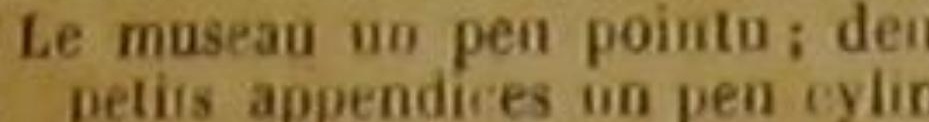

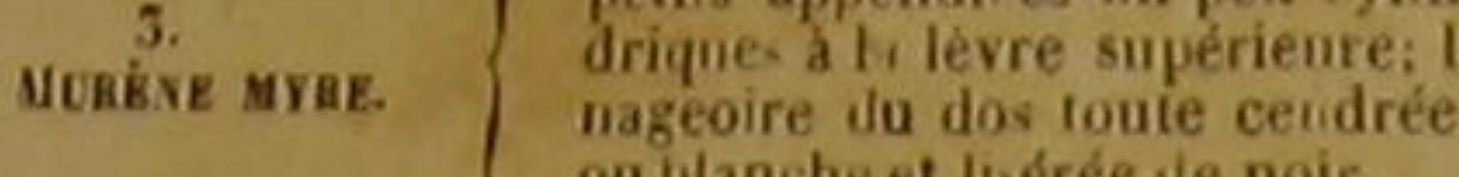
ou blanche et liérée die noir.

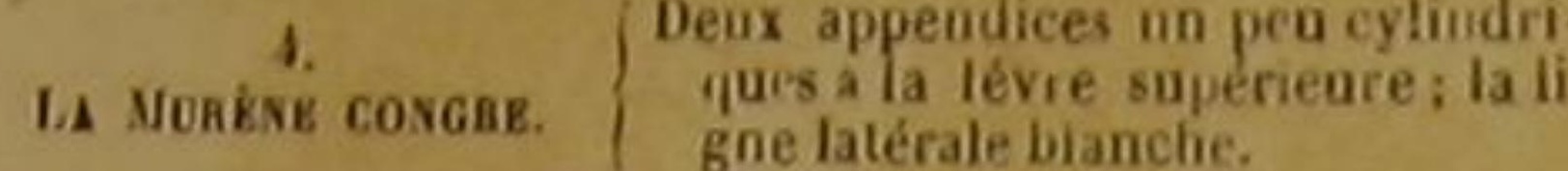

\section{LA MURÉNE ANGUILLE}

Muræna Anguilla, Linu., Cuv., Lacep.

Il est peu d'animaux dont on doive se retracer l'image avec autant de plaisir que celle de la murène anguille. Elle peut être offerte, cette image gracieuse, et à lenfance folâtre, que la variété des évolutions amuse, et à la vive jeunesse, que la rapidité des mouvements enflamme, et à la beauté, que la grâce, la souplesse, la légèreté, intéressent et séduisent, et à la sensibilité, que les affections douces et constantes touchent si profondément, et à la philosophie mème, qui se plait à contempler et le principe et l'effet d'un instinct supérieur. Nous l'avons déjà vu, cet instinct supérieur dans l'énorme et terrible requin : mais il y étai le ministre d'une voracitê insatiable, d'une cruauté sanguinaire, d'une force dévastatrice. Nous avons trouvé dans les poissons électriques une puissance pour ainsi dire magique; mai ils nont pas eu la beauté en partage. Nous

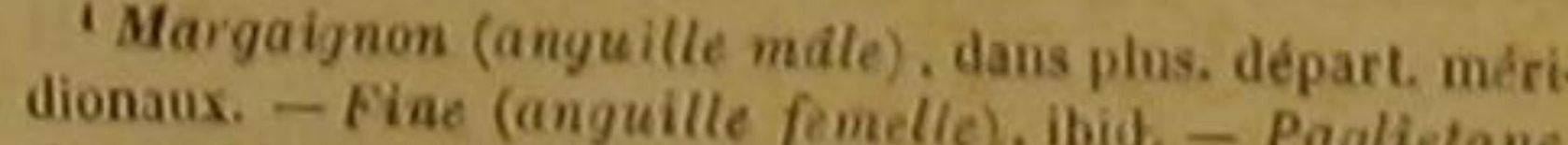
Gavonchi, Musini, dans plus. coutrées ditstie. - Migliode Commachio, do Oésiellix killog *; auprès des lacs ou marai quielle a le mème poids, id - Kuech he lo - Capitoni, lorsde deux kilug., id. - Angui lacei, lorsque son poids nest
que d'en

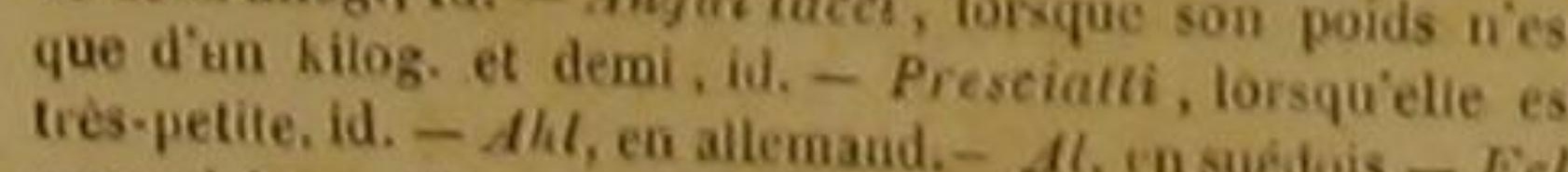
en anglasis. - Muréae anguille. Dasbe.ton, Euc, méh. Ariedi, spece. 66. de l'Enc. méth - Мurana unicolor, ete.

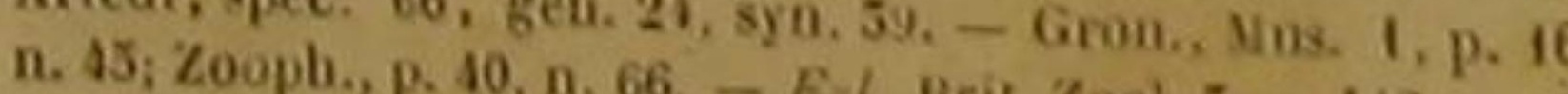
- Bloch, pl. 75. - Anguille, Vitit. Zool. 5, 1, 112, u.12

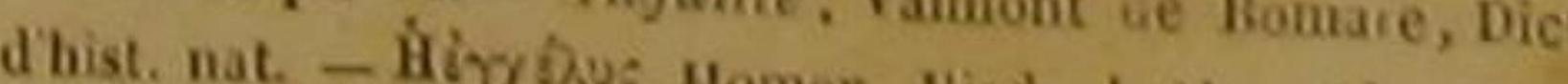
1. 2, c. 15, 15, 17:1.4. c. 8, 11:1.,

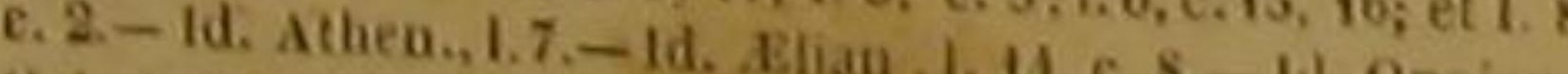
Hal, 1. 1. - Anguilla, Varro, 1. 4. - Id. Plig - Iu. Oppiso,

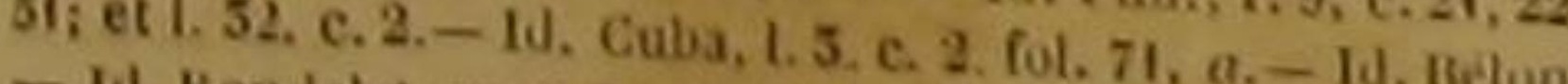

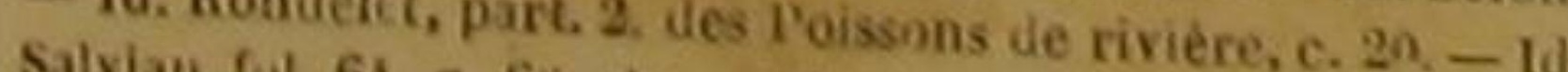
177, $b,-11.54, a, 65$, ete. - Id. Gesner, p. 40; et germ, fol

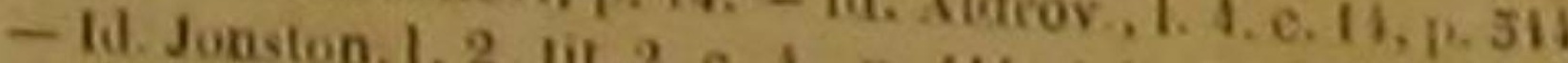
Charlet. p. 153,-14. 2. c. 4, p. 14, tab. 21, fig. 7. -1 Id. Laurent. Roberg. Pis: Iivas, p. 109.-11. Rai, p.57.

avons cu à représenter des formes remarquables; presque toujours leurs couleurs étaient ternes et obscures. Des nuances éclatantes ont frappé nos regards; rarement elles ont eté unies avec des proportions agréables; plus rarement encore elles ont servi de parure à un ètre d un instinct élevé. Et cette sorte d'inteliigence, ee mélange de l'éclat des métaux et des couleur de l'are céleste, cette rare conformation de toutes les parties qui forment un même tout et qu'un heureux accord a rassemblées, quand les avons-nous vus departis avec des habitudes pour ainsi dire sociales, des affections douces et des jouissances en quelque sorte sentimentales? C est cette reunion si digne d'intérét que nous allons cependaut montrer dans l'anguille. Et lorsque nous aurons compris sous un seul point de vue sa forme déliée, ses proportions sveltes, ses couleurs élégantes, ses flexions gracieuses, ses circonıolutions faciles, ses elans rapides, sa natation soutenue, sts mouvements semblables à ceux du serpent, son industrie, son instinet, son affection pour sa compagne, son espèce de sociabilité et tous les avantages que l'homme en retire chaque jour, on ne sera pas surpris que les Grecques et les Romaines les plus fameuses par leurs charmes aient donné sa forme à un de leurs ornements les plus recherchés, et que l'on doive en reconnaitre les traits, de mème que ceux des murénophis, sur de riches bracelets antiques, peut-être aussi souvent que ceux des couleuvres venimeuses dont on a voulu pendant longtemps retrouver exclusivement l'image dans ces objets de luxe et de parure; on ne sera pas même étonné que ce peuple ancien et célebre qui dorait tous les objets dans lesquels il voyait quelque empreinte de la beauté, de la bonté, de la prévoyance, du pouvoir ou du courroux célestes, et qui se prosternait devant les ibis et les erocodiles, eút aussi accordé les honneurs divins à l'animal que nous examinons. C'est aiusi que nous avons vu l'énorme serpent devin obliger, par l'effroi, des nations encore peu civilisées des deux continents, à courber tête tremblante devant sa force redoutable, que l'iguorance et la terreur avaient divinisée; t c'est ainsi encore que par l'effet d'une mythologie plus excusable sans doute, mais bie plus surprenante, car, fille cette fois de la reconnaissance et non pas de la crainte, elle conI sacrait l'utilité et non pas la puissance, les 

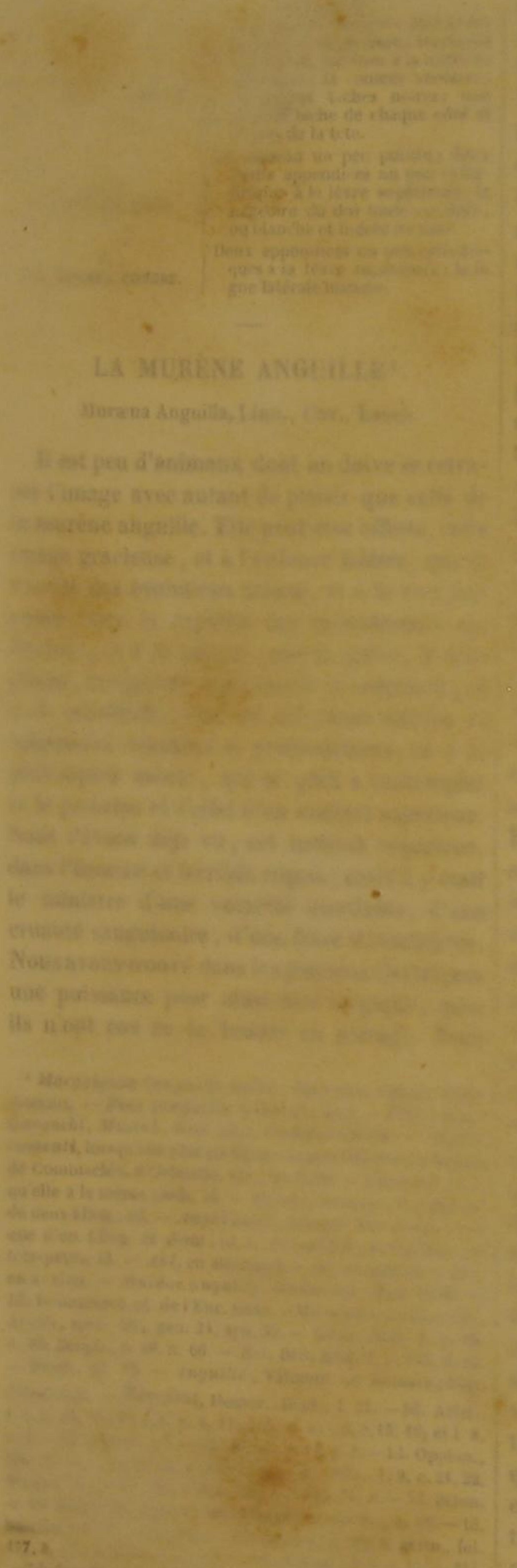

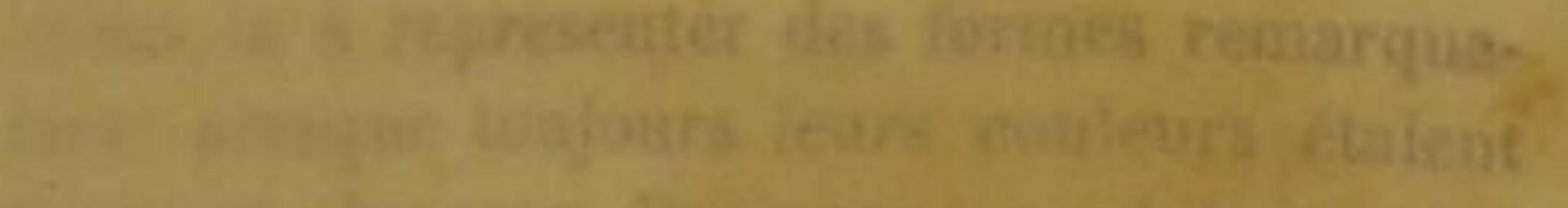

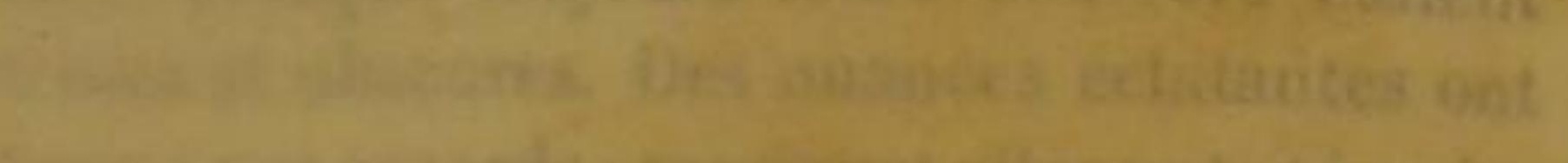

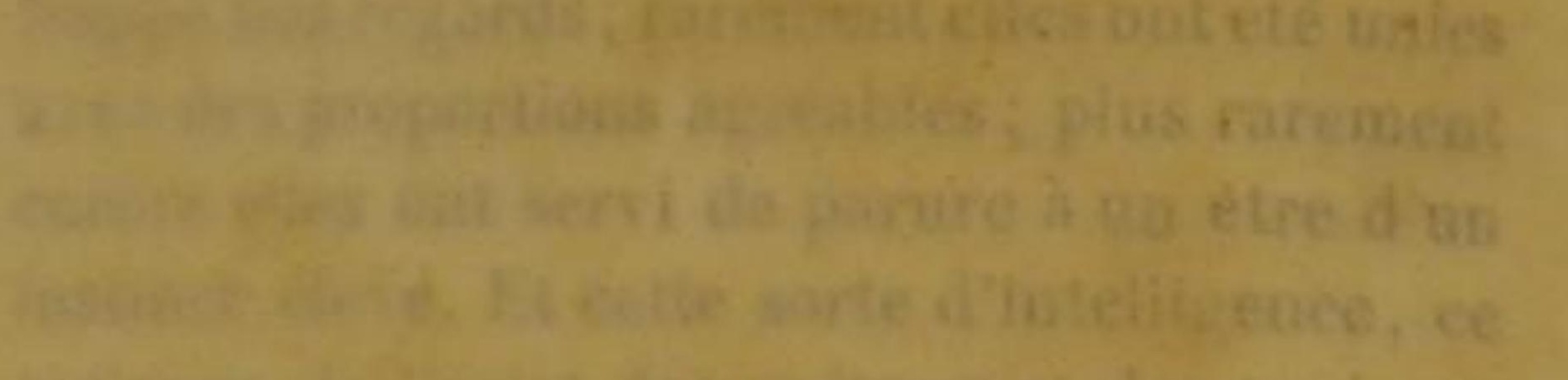

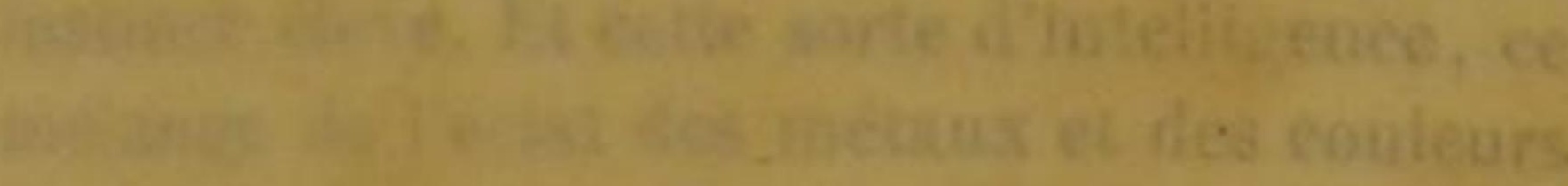

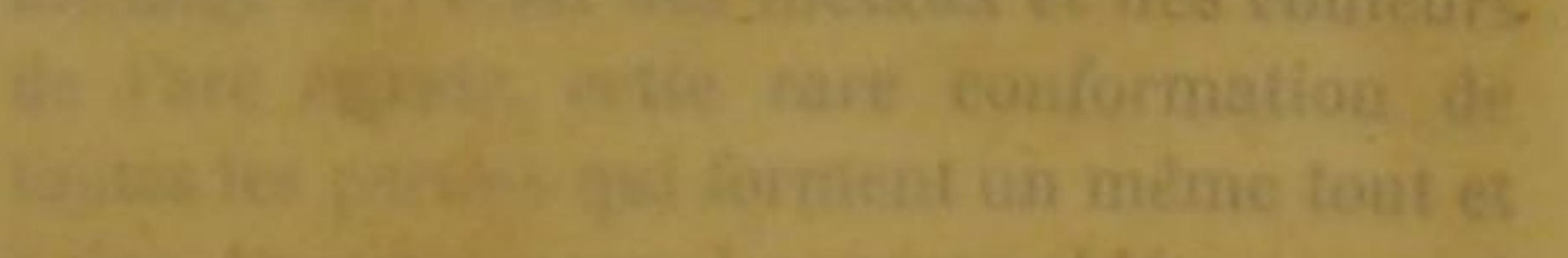

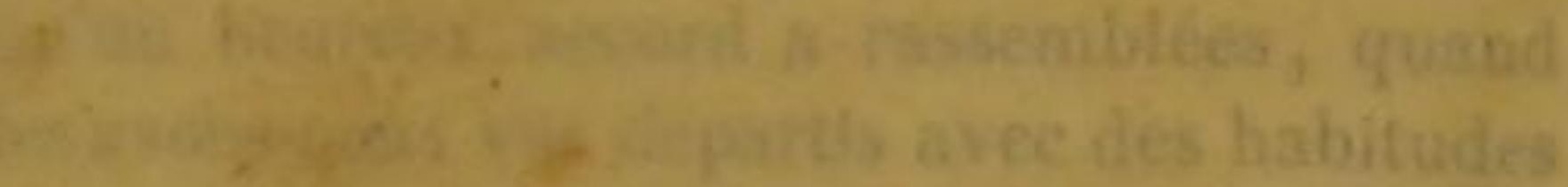

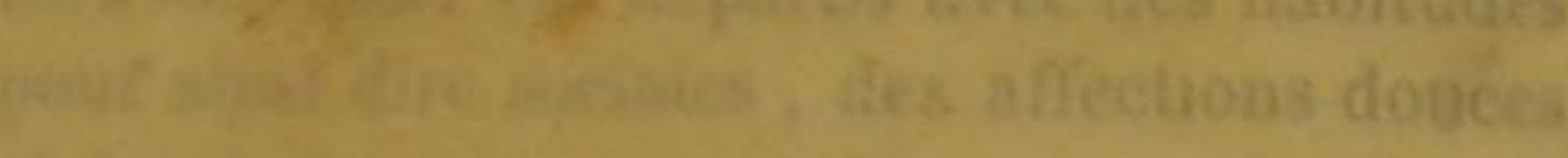

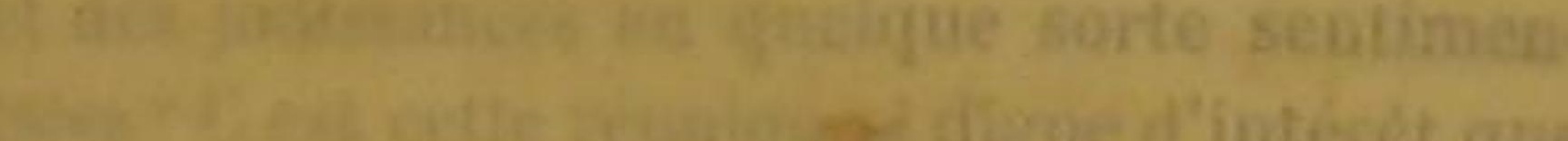

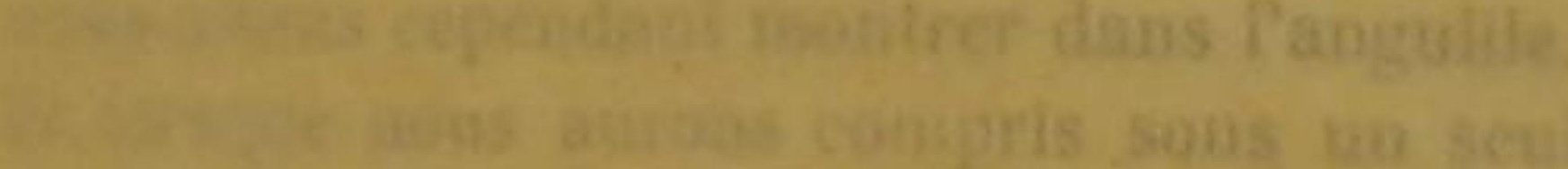

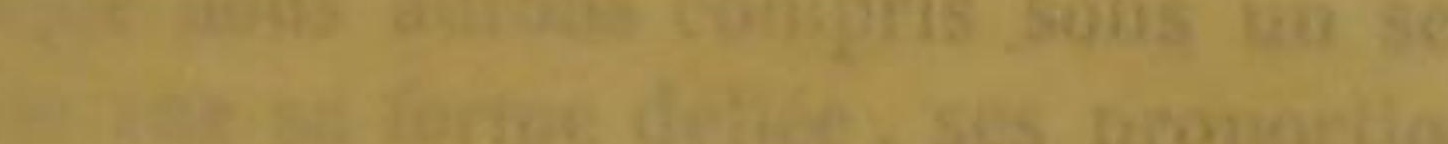

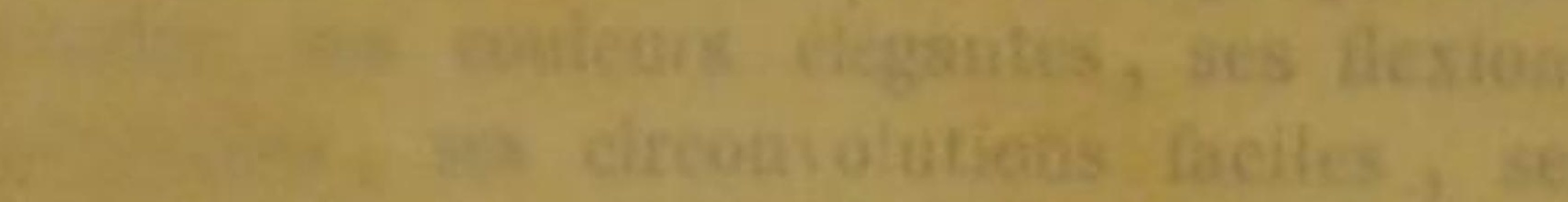

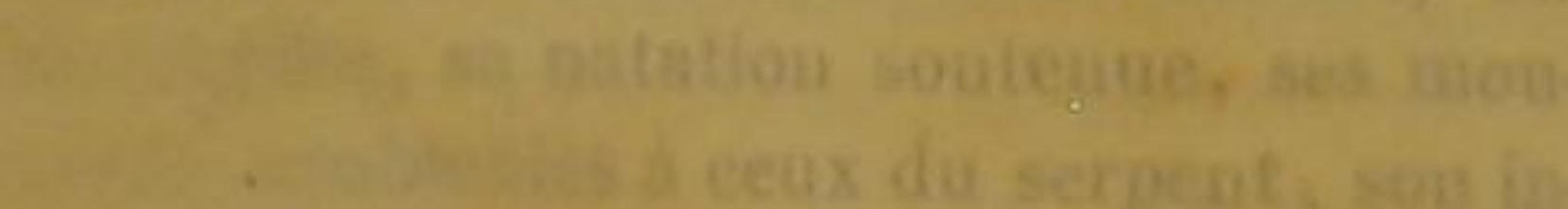

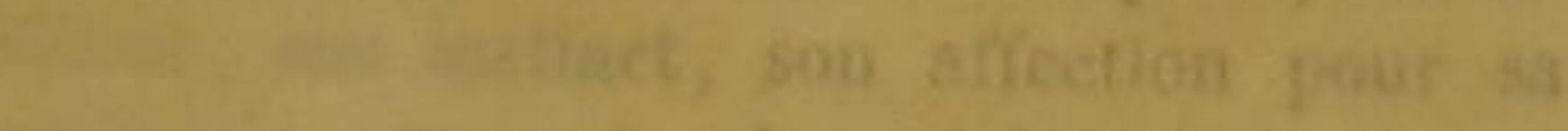

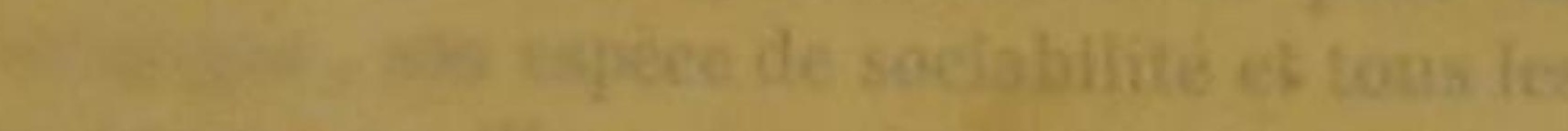

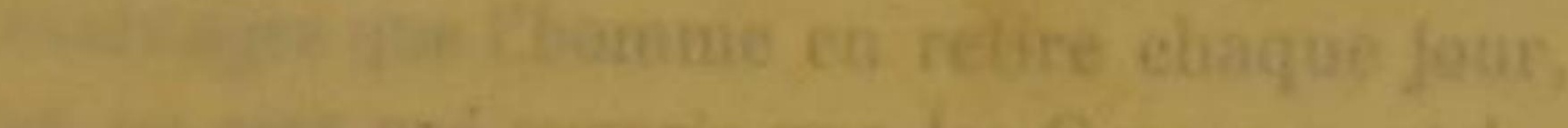
Cower

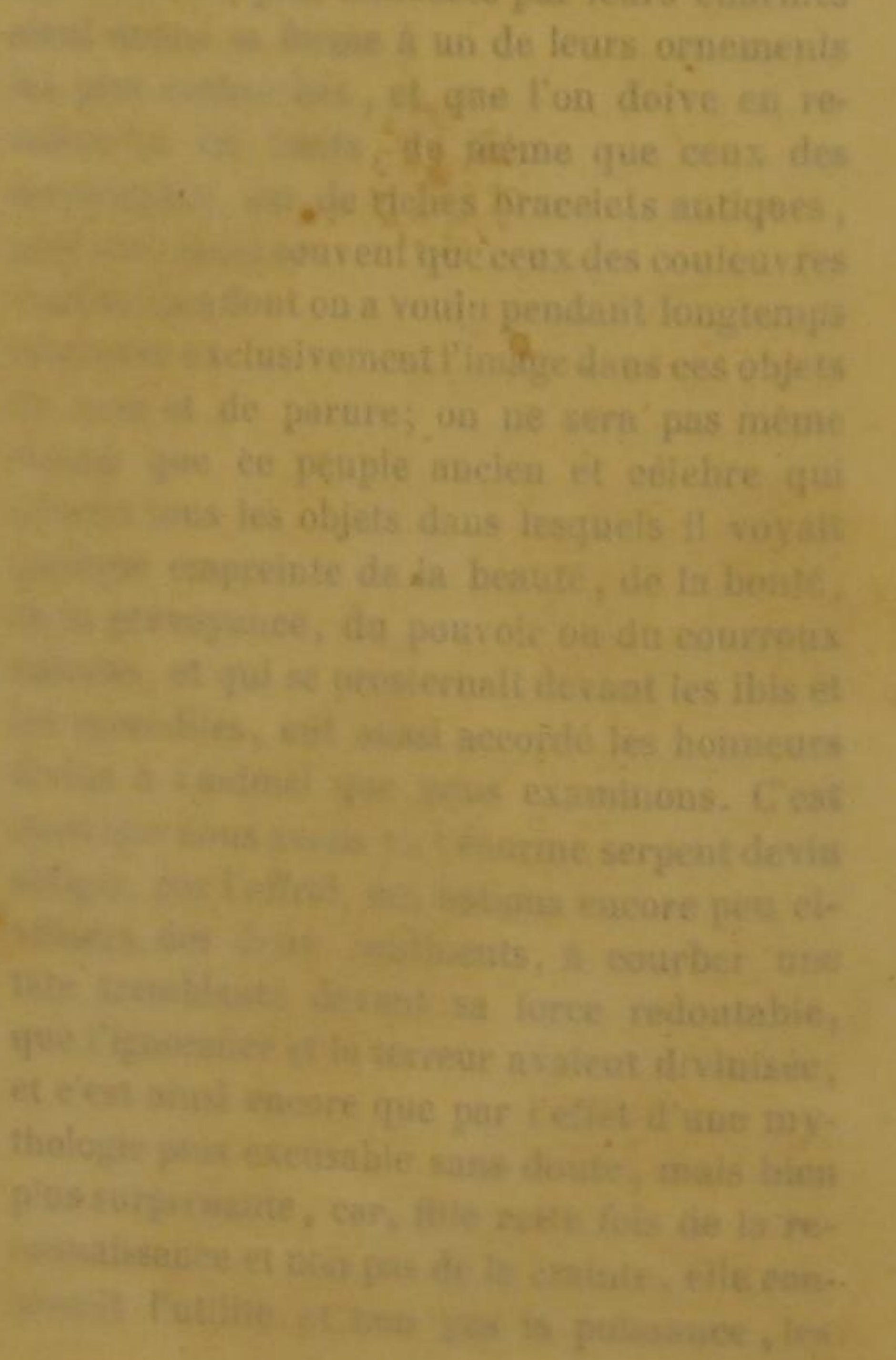

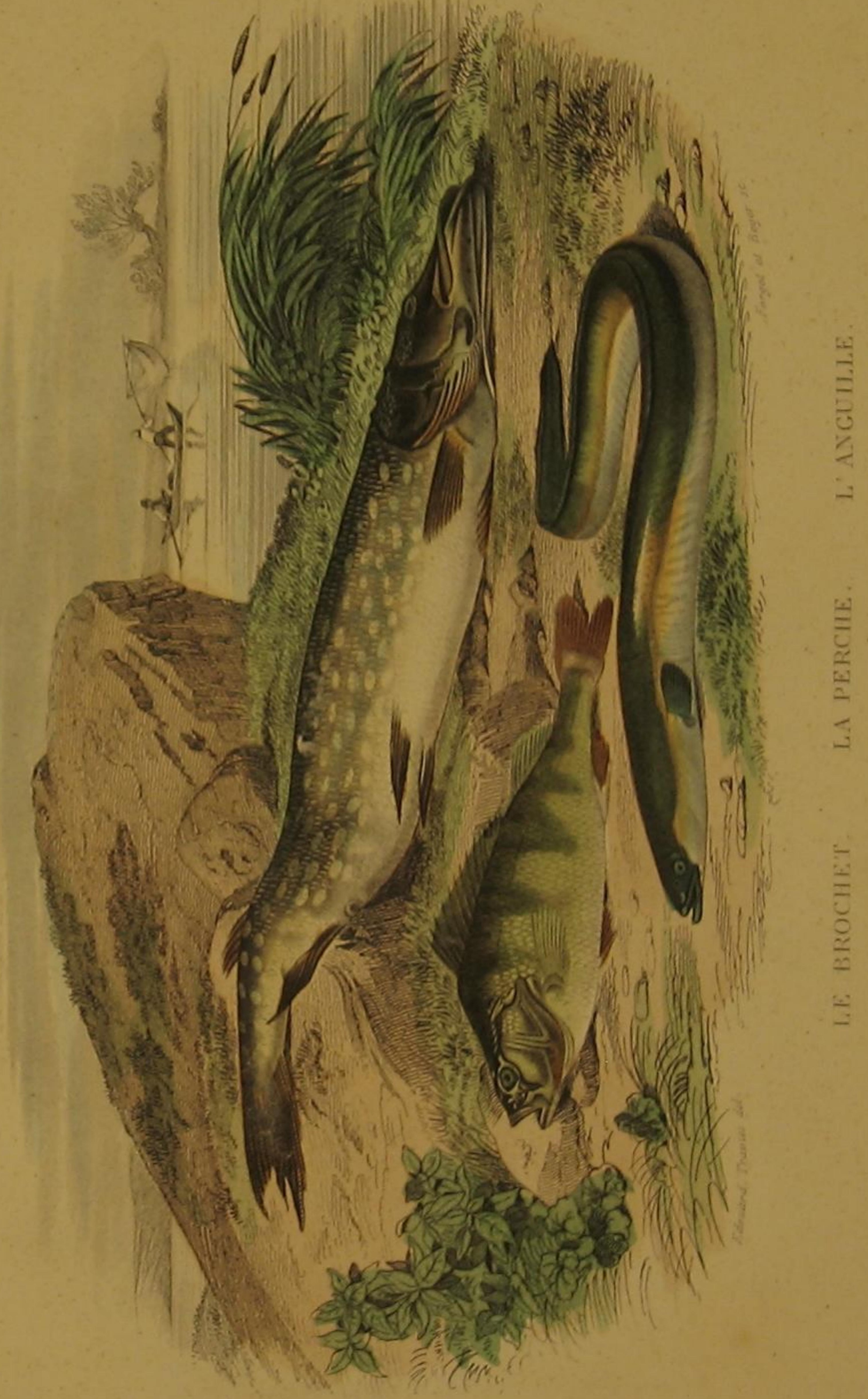


premiers habitants de l'ile Saint-Domingue, de même que les Troglodytes dont Pline a parlé dans son Histoire naturelle, vénéraient leur dieu sous la forme d'une tortue '.

On ne s'attendait peut-ètre pas à trouver dans l'anguille tant de droits à I attention. Quel est néanmoins celui qui n'a pas vu cet animal? Quel est celui qui ne croit pas ètre bien instruit de ce qui concerne un poisson que l'on pèche sur tant de rivages, que l'on trouve sur tant de tables frugales ou somptueuses, dont le nom est si souvent prononcé, et dont la facilité à s'échapper des mains qui le retiennent avec trop de force, est devenue un objet de proverbe pour le sens borné du vulgaire, aussi bien que pour la prudence éclairée du sage? Mais, depuis Aristote jusqu'à nous, les naturalistes, les Apicius, les savants, les ignorants, les têtes fortes, les esprits faibles, se sont occupés de l'anguille; et voila pourquoi elle a été le sujet de tant d'erreurs séduisantes, de préjugés ridicules, de contes puérils, au milieu desquels très-peu d'observateurs ont distingué les formes et les habitudes propres à inspirer ainsi qu'à satisfaire une curiosité raisonnable.

Táchons de démèler le vrai d'avec le faux ; représentons l'anguille telle qu'elle est.

Ses nageoires pectorales sont assez petites, et ses autres nageoires assez étroites, pour qu'on puisse la confondre de loin avec un véritable serpent : elle a de mème le corps très-allongé et presque cylindrique. Sa tête est menue, le museau un peu pointu, et la mâchoire inférieure plus avancée que la supérieure.

L'ouverture de chaque narine est placée au bout d'un très-petit tube qui s'élève au-dessus de la partie superieure de la tête; et une prolongation des téguments les plus exterieurs s'étend en forme de membrane au-dessus des yeux et les couvre d'un voile demi-transparent, comme celui que nous avons observé sur les yeux des gymnotes, des ophisures et des aptéronotes.

Les lèvres sont garnies d'un grand nombre de petits orifices par lesquels se répand une liqueur onctueuse; une rangée de petites ouver-

M. Frauçois (de Neufchàtéau), membre de l' Institut, mè-

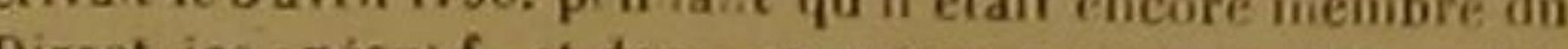

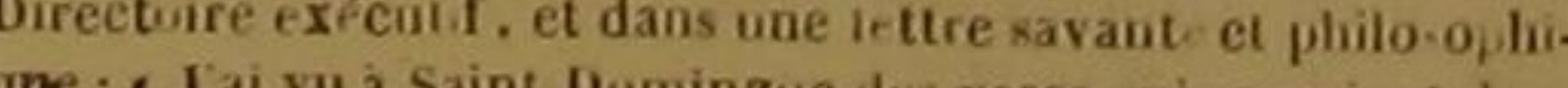
- les cérém a des des premiers h b vasts yui servaieut dans - com iosés diue sorte de lave grossierement tillte, fi ju- rent des torlues. n tures analogues conpose, de chaque cóté de l'animal, la ligne que l'on a nommée latérale; et c'est ainsi que l'anguille est perpétuellement arrosée de cette substance qui la rend si visqueuse. Sa peau est, sur tous les points de son corps, enduite de cette humeur gluante qui a fait paraitre comme vernie. Elle est pénétrée de cette sorte d'huile qui rend ses mouvements très-souples; et l'on voit déjà pourquoi elle glisse si facilement au milieu des mains inexpérimentées qui, la serrant avec trop de force, augmentent le jeu de ses muscles, facilitent ses efforts, et, ne pouvant la saisir par aucune aspérité, la sentent couler et s'échapper comme un fluide '. A la vérité, cette mème peau est garnie d'écailles dont on se sert même, dans plusieurs pays du Nord, pour donner une sorte d'éclat argentin au ciment dont on enduit les édiices : mais ces écailles sont si petites, que plusieurs physiciens en ont nié l'existence; et elles sont attachées de manière que le toucher le plus délicat ne les fait pas reconnaitre sur l'animal vivant, et que mème un œil perçant ne les découvre que lorsque l'anguille est morte, et la peau assez desséchée pour que les petites lames écailleuses se séparent facilement.

On aperçoit plusieurs rangs de petites dents, non-seulement aux deux máchoires, à la partie antérieure du palais, et sur deux os situés audessus du gosier, mais encore sur deux autres os un peu plus longs et placés a l'origine des branchies.

L'ouverture de ces branchies est petite, trèsvoisine de la nageoire pectorale, verticale, étroite, et un peu en croissant.

On a de la peine á distin-uer les dix rayous que contient communément la membrane destinée à fermer cette ouverture; et les quatre branchies de chaque côté sont garnies de vaisseaux sanguins dans leur partie convexe, et dénuées de toute apophyse et de tout tubercule dans leur partie concave.

Les nageoires du dos et de l'anus sont si basses, que la premiere s'élève à peíne au-dessus du dos d'un soixanticme de la longueur totale. Elles sont d'ailleurs réunies à celle de la queue, de maniére qu'on a bien de la peine à déterintner la tin de l'une et le commencement de l'autre; et on peut les considerer comme une bande Le mot murana, qui vient du grec púpuy, lequelsignili 'Letchapper, désigne celle faculté de l'anzuille et de. 'Luter, s'cchapper, désigne celle
autres poissons de sin geure. 
très-étroite, qui commence sur le dos à une cer- l'animal. Ses vertèbres un peu comprimées et taine distance de la tête, sétend jusqu'au bout par conséquent un peu étroites à proportion de de lu queue, entoure cette extrémité, y forme leur longueur, pliantes et petites, peuvent une pointe assez aiguê, revient au-dessous de preter aux diverses circonvolutions qu'elle a l'animal jusqu'à l'anus, et présente tonjours besoin d exécuter. A ces vertèbres qui commu. assez peu de hauteur pour laisser subsister les nément sont au nombre de cent seize, sont atplus grands rapports entre le corps du serpent tachées des côtes très-courtes, retenues par et celui de l'anguille.

L'épaisseur de la partie membraneuse de ces trois nageoires réunies, fait qu'on ne compte que très-dificilement les petits rayons qu'elles renferment, et qui sont ordinairement au nombre de plus de mille, depuis le commencement de la nageoire dorsale jusqu'au bout de la queue.

Les couleurs que l'anguille présente sont toujours agréables, mais elles varient assez fréquemment; et il parait que leurs nuances dépendent beaucoup de láge de l'animal ', et de la qualité de l'eau au milieu de laquelle il vit. Lorsque cette eau est limoneuse, le dessus du corps de la murène que nous décrivons est d'un beau noir, et le dessous d'un jaune plus ou moins. clair. Mais si l'eau est pure et limpide, si elle coule sur un fond de sable, les teintes qu'offre ranguille sont plus vives et plus riantes : sa partie supérieure est diun vert nuancé, quel. quefois mème rayé d'un brun qui le fait ressortir; et le blane de lait, on la couleur de largent, brillent sur la partie inférieure du noisson. D ailleurs la nageoire de lanus est communément lisérée de blane, et celle du dos, de rouge, Le blanc, le rouge et le vert, ces conleurs que la nature sait marier avee tant de grâce, et fondre les unes dans les autres par des nuances si donces, composent done l'une des parures élégantes que l espèce de languille regues, et celle qu'elle déploie lorsqu elle passe sa vie au milieu d une eau claire, vive et pure. Au reste, les couleurs de languille paraissent quelquefois d'autant plus variées par le différents reflets rapides et successifs de la lumière plus ou moins intense qui parvient jusqu'aux diverses parties de lanimal, que les cette murents tres-prompts et très-multipliés de cette murene peuvent faire changer à chaque instant liaspect de ces mémes portions colorees. Cette agilité est secondée par la nature de la charpente osseuse du corps et de la queve de

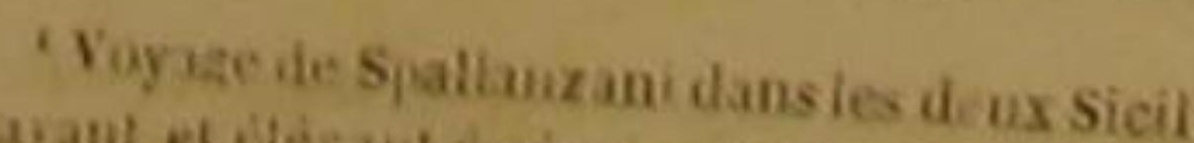

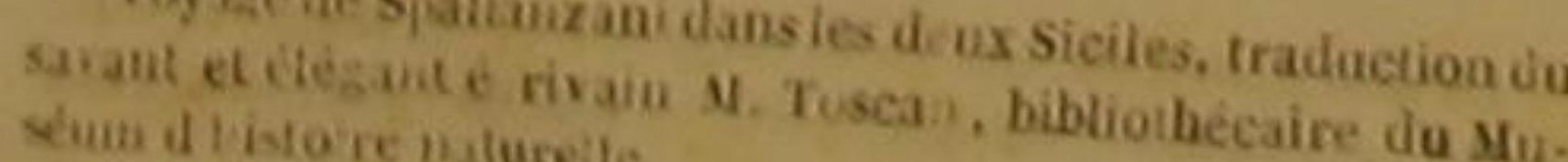
une adhérence très-légère aux apophyses des
vertèbres, et très-propres á favoriser les sinuosités nécessaires à la natation de la murène. De plus, les muscles sont soutenus et fortifiés dans leur action par une quantité très-considérable de petits os disséminés entre leurs divers faisceaux, et connus sous le nom d'arêles proprement dites, ou de petites arêtes. Ces os intermusculaires, que l'on ne voit dans ancune autre classe d'animaux que dans celle des poissons, et qui n'appartiennent mème qu à un certain nombre de poissons osseux, sont d'autant plus grands quils sont placés plus près de la tète; et ceux qui oceupent la partie antérieure de l'animal, sont communément divisés en deux petites branches.

Un instinct relevé ajoute aussi à la fréquence des mouvements; et nous avons dejà indiqué ' que l'anguille, ainsi que les autres poissons osseux te serpentiformes, avait le cerveau plus étendu, plus allongé, composé de lobes moins inégaux, plus développés et plus nombreux, que le cerveau de la plupart des poissons dont i) nous reste a parler, et particulierement de ceux qui ont le corps très-aplati, comme les peuronectes.

Le cœur est quadrangulaire; l'aorte grande le foie rougeâtre, divise en deux lobes, dont le gauche est le plas volumineux; la vésicule du fiel séparée du foie comme dans plusieurs espè. ces de serpents; la rate allongée et triangulaire; la vessie natatoire très grande, attachée a l'épine et garnie par devant d'un long conduit à gaz; le canal intestiual dénué de ces appendices que l'on remarque auprès du pylore de plusieurs espèces de poissons, et presque sans sinuosités, ce qui indique la force des sues digestirs de l'anguille, et en général l'activité de humeurs et l'intensité de son principe vital. Les murènes anguilles parviennt a vital. grandeur très-considérable : il n'est pas trèsItalie, du poids de huit a dix ainsi qu'en hix kilogrammes.
Dans l'Albanie, on en a vu dont on a compare la grosseur à celle de la cuisse d'un homme ; et des observateurs très-dignes de foi ont assuré que, dans des lacs de la Prusse, on en avait péché qui étaient longues de trois à quatre mètres. On a méme écrit que le Gange en avait nourri de plus de dix mètres de longueur; mais ce ne peut étre qu'une erreur, et l'on aura vraisemblablement donné le nom d'Anguille à quelque grand serpent,' à quelque boa devin que l'on aura aperçu de loin, nageant au-dessus de la surface du grand fleuve de I Inde.

Quoi qu'il en soit, la croissance de l'anguille se fail très-lentement; et nous avons sur ia durée de son développement quelques expé. riences précises et curieuses qui m'ont été communiquées par un très-bon observateur, M. Septfontaines, auquel j'ai eu plusieurs fois, en écrivant cette Histoire aaturelle, l'oceasion de témoigner ma juste reconnaissance.

Au mois de juin 1779 , ce naturaliste mit soixante anguilles dans un réservoir; elles avaient alors environ dix-neuf centimètres. $A u$ mois de septembre 1783 , leur longueur n'était qu de quarante à quarante-rrois centimètres : au mois d oetobre 1786 , cette mème longueur n'était que de cinquante-un centimètres; et enfin, en juillet 1788 , ees anguilles n'étaient longues que de cinquante-cinq centimètres au pius. Lilles ne sétaient done allongées en neuf ans que de vingt-six centimètres.

A vee de lagilite, de la souplesse, de la force dans les muscles, de la grandeur dans les dimensions, it est facile à la murène que nous examinons, de parcourir des espaces étendus, de surmonter plusieurs obstacles, de faire de grands voyages, de remonter contre des courants rapides'. Aussi va-t-elle périodiquement, tantót des lacs ou des rivages voisins de source des rivieres vers les embouchures des fleuves, et tantót de la mer vers les sources ou les laes. Mais, dans ces migrations régulières, elle suit quelquefois un ordre différènt de celui qu'observent la plupart des poissons voyageurs. Elle obéit aux mèmes lois; elle est régie de même par les causes dont nous avons tâché $d$ 'indiquer la nature dans notre premier discours mais tel est l'ensemble de ses organes extériem et de ceux que son intérieur renferme, que la ¿Voyage de S jallanzani dans les deux Siciles, iraduit par
M. Tuscan, I. VI, in I/S. température des eaux, la qualite des aliments, a tranquillité ou le tumulte des rivages, la pureté du fluide, exercent, dans certaines circonstances, sur ce poisson vif et sensible, une action très-difrérente de celle qu'ils font éprouver au plus graud nombre des autres poissons non sédentaires. Lorsque le printemps commence de régner, ces derniers remontent des embouchures des fleuves vers les points les plus élevés des rivières; quelques anguilles, au contraire, s'abandonnant alors au cours des eaux, vont des lacs dans les fleuves qui en sortent, et des fleuves vers les côtes maritimes. Dans quelques contrées, et particulièrement auprès des lagunes de Venise, les anguilles remontent, dans le printemps, ou à peu près, de la mer Adriatique vers les lacs et les marais, et notamment vers ceux de Comachio, que la péche des anguilles a rendus célèbres. Elles y arrivent par le PO, quoique très-jeunes; mais elles n'en sortent pendant l'automne pour retourner vers les rivages de la mer, que lorsqu'elles ont aequis un assez grand développement, et qu'elles sont devenues presque adultes '. La tendance a l'imitation, cette cause puissante de plusieurs actions très-remarquables des animaux, et la sorte de prudence qui parait diriger quelques-unes des habitudes des anguilles, les déterminent à préférer la nuit au jour pour ces migrations de la mer dans les lacs, et pour ces retours des laes dans la mer. Celles qui vont, vers la fin de la belle saison, des marais de Comachio dans la mer de Venise, choisissent même pour leur voyage les nuits les plus obscures, et surtout celles dont les ténebres sont épaissies par la présence de nuages orageux. Une clarté plus ou moíns vive, la lumiere de la lune, des feux allumés sur le rivage, suffisent souvent pour les arréter dans leur natation vers les cotes marines. Mais lorsque ces lueurs qu'elles redoutent ne suspendent pas leurs mouvements, elles sont poussées vers la mex par un instinct si fort, ou, pour mieux dire, par une cause si énergique, qu'elles s'engagent entre des rangées de roseaux que les pécheurs disposent au fond de l'eau pour les conduire à leur gré, et que, parvenant sans résistance et par le moyen de ces tranchées aux enceintes dans lesquelles on a voulu les attirer, 
elles s'entassent dans ces espèces de petits, nous venons d'exposer, qui a donné lieu à un pares, au point de surmonter la surface de conte absurde accrédité pendant longtemps, l'eau, au lieu de chercher à revenir dans l'ha- l'opinion de quelquès observateurs très, bitation qui elles viennent de quenter dass lhabitation qu elles viennent de quitter '

Pendant cette longue course, ainsi que pendant le retour des environs de la mer vers les eaux douces élevées, les anguilles se nourrissent, aussi bien que pendant qu'elles sont stationnaires, d'insectes, de vers, d'œufs et de petites espèces de poissons. Elles attaquent quelquefois des animaux un peu plus gros. M. Septfontaines en a vu une de quatre-vingtquatre centimètres présenter un nouveau rapport avec les serpents, en se jetant sur deux jeunes canards éclos de la veille, et en les avalant assez facilement pour qu'on pût les retirer presque entiers de ses intestins Dans certaines circonstances, elles se contentent de la chair de presque tous les animaux morts qu'elles rencontrent au milieu des eaux; mais elles causent souvent de grands ravages dans les rivieres. M. Noèl nous écrit que dans la basse Seine elles détruisent beancoup d'éperlans, de clupées feintes et de bremes.

Ce n'est pas cependant sans danger qu'elles recherchent l'aliment quileur convientlemieux: malgré leur souplesse, leur vivacité, la vitesse de leur fuite, elles ont des ennemis auxquels il leur est tres-difficile d'échapper. Les loutres, plusieurs oiseaux d'eau, et les grands oiseaux de rivage, tels que les grues, les hérons et les cigognes, les péchent avechabileté et les retiennent avec adresse; les hérons surtout les retiennent avec adresse; les hérons surtout ont dans la dentelure d'un de leurs ongles, des espèces de crochets qu'ils enfoncent dans le corps de forts qu'elle fait pour forts qu'elle fait pour glisser au milieu de leurs doigts. Les poissons qui parviennent à une longueur un peu considerable, et, par exemple le brochet et l'acipensère et, par exemple, aussi leur proie; et esturgeon, en font valent tout entie; et comme les esturgeons l'avalent tout entière et souvent sans la blesser, il arrive que, déliée, visqueuse et flexible, elle parcourt toutes les sinuosités de leur canal ile testinal, sort par leur anus, et se canal inune prompte natation, ì une dérobe, par suite. II n'est presque personne nouvelle pourlombric avalé par des canards qui n'ait vu un des intestins de cet oiseau, dont ir de méme tous les replis ; et cepend dont il avait suivi tous les replis; et cependant c'est le fait que etiso. instruits de l'organisation intérieure des animaux, et qui ont dit que l'anguille entrait ains volontairement dans le corps de l'esturgeon, pour aller y chercher des œuf́s dont elle aimait beaucoup à se nourrir. I'histoire d'un poisson, et qui a été vu trop de fois pour qu'on puisse en douter. L'anguille, pour laquelle les petits vers des prés, et même quelques végétaux, comme, par exemple, les pois nouvellement semés, sont un aliment peut-étre plus agréable encore que des œufs ou des poissons, sort de l'eau pour se procurer ce genre de nourriture. Elle rampe sur le rivage nager au milieu des fleuves; elle s'éloigne de l'eau a des distances assez considérables, exécutant avec son corps serpentiforme tous les mouvements qui donnent aux couleuvres I faculté de s'avancer ou de reculer; et après avoir fouillé dans la terre avee son museau pointu, pour se saisir des pois ou des petit vers, elle regagne en serfentant le lac ou la rivière dont elle était sortie, et vers lequel elle tend avec assez de vitesse, lorsque le terrain ne ui oppose pas trop d'obstacles e'est-a-dire de trop grandes inégalités.

Au reste, pendant que la conformation de on corps et de sa queue lui permet de se mouoir sur la terre sèche, lorganisation de ses branchies lui donne la faculté d étre pendant un temps assez long hors de l'eau douce ou salee sans en périr. En effet, nous avons vu qu une des grandes causes de la mort des poissons que l'on retient dans l'atmosphère, est le gesséchement qu éprouvent leurs brandes veines qui produit la rupture des artères et des veines branchiales, dont le sang, qui n'est environnant, tend dancé par un fluide aqueux rompre les d'ailleurs sans contrainte l'anguille membranes qui le contiennent. Mais l'anguille peut conserver plus facilement que beaucoup d'autres poissons I'humidité, et par seaux sanguins de ses branchies; elle dest vaisbranchial l'ouverture de sa bouche; l'orifice trait devoir s introduel un air desséchant paraiétroit et peu allongé; lo en abondance, est très-
Mais voici un trait très-remarquable dans par un mécanisme semblable a celui qui la fait seanx suent la ductilité et la ténacité des vais-

DES POISSONS.

sont placés et conformés de manière à fermer parfaitement cet orifice; et de plus la liqueur gluante et copieuse dont l'animal est imprégné, entretient la mollesse de toutes les portions des branchies. Nous devons encore ajouter que, soit pour étre moins exposée aux attaques des animaux qui eherchent à la dévorer, et à la poursuite des pecheurs qui veulent en faire leur proie, soit pour obeir à quelque autre cause que l'on pourrait trouver sans beaucoup de peine, et qu'il est, dans ce moment, inutile de considérer. l'anguille ne va à terre, au moins le plus fréqueniment, que pendant la nuit. Une vapeur humide est très-souvent alors répandue dans l'atmosphère; le desséchement de ses branchies ne peut avoir lieu que plus dificilement ; et l'on doit voirmaintenant pourquooi, dés le temps de Pline ', on avait observé en Italie que l'anguille peut vivre hors de l'eau jusqu'a six jours, lorsqu'il ne souffle pas un vent méridional, dont l'effet le plus ordinaire, dans cette partie de l'Europe, est de faire évaporer l'humidité avec beaucoup de vitesse.

Pendant le jour, la murène anguille, moins occupée de se procurer I aliment qu'elle désire, se tientpresque toujours dans un repos réparateur, et derobée aux yeux de ses ennemis par un asile qu'elle prépare avec soin. Elle se creuse avee son museau une retraite plus ou moins grande dans la terre molle du fond des lacs et des rivières; et par une attention particuliere, résultat remarquable d'une expérience dont l'effet se maintient de génération en génération, cette espéce de terrier a denx ouvertures, de telle sorte que si elle est attaquée d'un côté, elle peut s'échapper de l'autre. Cette industrié, pareille à celle des animaux les plus précautionnés, est une nouvelle preuve de cette supériorité d'instinet que nous avons dú attribuer à l'anguille dès le moment ou nous avons considéré dans ce poisson le volume et la forme du cervean, l'organisation plus soignée des siéges de l'odorat, et entin la flexibilité et la longueur du corps et de la queue, qui, souples et continuellement humectés, sappliquent dans toute leur étendue à presque toutes les surfaces, en reçoivent des impressions que des écailles presque insensibles ne peuvent ni arrèter, ni eu quelque sorte diminuer, et doivent donner á l'animai un toucher assez vif et assez délicat.

Il est à remarquer que les anguilies, qui, par

' Pline. I. 9. c. 1 . une suite de la longueur et de la flexibilité de leur corps, peuvent, dans tous les sens, agir sur l'eau presque avec la mẻme facilité et par conséquent reculer presque aussi vite qu'elles avancent, pénétrent souvent la queue la première dans les trous qu'elles forment dans la vase, et qu'elles creusent quelquefois cette cavité avec cette mème queue, aussi bien qu'avee leur tète!.

Lorsqu'il fait très-chaud, ou dans quelques autres circonstances, languille quitte cependant quelquefois, même vers le milieu du jour, cet asile qu'elle sait se donner. On la voit très-souvent alors s'approcher de la surface de l'eau, se placer au-dessous d'un amas de mousse flottante ou de plantes aquatiques, y demeurer immobile, et paraitre se plaire dans cette sorte d'inaction et sous cet abri passager ${ }^{2}$. On serait mẻme tenté de croire qu'elle se livre quelquefois à une espèce de demi-sommeil sous ce toit de feuilles et de mousse. M. Septfontaines nous a écrit, en effet, dans le temps, qu'il avait vu plusieurs fois une anguille dans la situation dont nous venons de parler, qu'il était parvenu a s'en approcher, à élever progressivement la voix, a faire tinter plusieurs elefs l'une contre I'autre, à faire sonner tres-prés de lin tête du poisson plus de quarante coups d'une montre a répétition, sans produire dans l'animal aueun mouvement de crainte, et que la murène ne s'ctait plongée au fond de l'eau que lorsqu'il s'était avancé brusquement vers elle, ou qu'il avait ébranlé la plante touffue sous laquelle elle goútait le repos.

De tous les poissons osseux, l'anguille n'est cependant pas celui dont l'ouie est la moins sensible. On sait depuis longtemps qu'elle peot devenir familiere au point d'accourir vers is voix ou l'instrument qui l'appelle et qui lui annonce la nourriture qu'elle préfère.

Les murènes anguilles sont en très-grand nombre partout ou elles trouvent l'eau, la température, l'aliment qui leur conviennent, et ou fles ne sont pas privées de toute sûreté. Voilá pourquoi, dans plusieurs des endroits oú l'on s'est oecupé de la péche de ces poissons, on en pris une immense quantité. Pline a écrit que dans le lac Benaco des environs de Verone, les tempêtes qui, vers la fin de l'automne, en bouleversaient les flots, agitaient, entrainaient et : Voyage de Spallanzani, $L$ VI, p. 134. dres, le 15 joillet 4788 . 


\section{HISTOIRE NATURELLE}

roulaient, pour ainsi dire, un nombre si consi-, machio auprès de Venise, ont cependant jou dérable d'anguilles, qu'on les prenait par mil- d'une santé assez forte, présenté un tempéraliers à lendroit où le fleuve venait de sortir du ment robuste, atteint une vieillesse avancée ' lac. Martini rapporte dans son Dictionnaire, et l'on a, daus tous les temps et dans presque qu'autrefois on en péchait jusqu'à soixante tous les pays, consacré d'autant plus d'instant mille dans un seul jour, et avec un seul filet. à la péche assez facile de cette murène, que sa On lit dans l'ouvvaze de Redi sur les Animaux peau peut servir à beaucoup d'usages, que dans vivants dans les animaux vivants, que lors du plusieurs contrées on en fait des liens assez second passage des anguilles dans l'Arno, c'est- forts, et que dans d'autres, comme, par exemà-dire lorsqu'elles remontent de la mer vers les ple, dans quelques parties de la Tartarie, et sources de ce fleuve de Toscane, plus de deux particulièrement dans celles qui avoisinent la cent mille peuvent tomber dans les filets, quoi- Chine, cette mème peau remplāee, sans trop que dans un tres-court espoce de temps a une si grande abondance dans les marais de Comachio, qu'en 1782 on en pècha 990,000 kilogrammes '. Dans le Jutland, il est des rivages ver's lesquels, dans certaines saisons, on prend quelquefois d'un seul coup de filet plus de neuf mille anguilles, dont quelques-unes pésent de quatreà cinq kilogrammes. Et nous savons, par M. Noēl, qu'a Cléon pres d'Elbeuf, et mème auprès de presque toutes les rives de la basse Seine, il passe des troupes ou plutó des légions si considérables de petites anguilles, qu'on en remplit des seaux et des baquets.

Cette abondance n'a pas empêché le goùt I plus difficile en bonne chère, et le luxe mème le plus somptueux, de rechercher l'anguille, de la servir dans leurs banquets. Cependant sa viscosité, le suc huileux dont elle est imprégnée la difficulté avec laquelle les estomaes délicats en digèrent la chair, sa ressemblance avec serpent, I'ont fait regarder dans certains pays, comme un aliment un peu malsain par les médecins, et comme un étre impur par les esprits superstitieux. Elle est comprise parmi les poissons en apparence dénués d'écailles; que lo lois religieuses des Juifs interdisaient à ce people; et les règlements de Numa ne permettaient pas de les servir dans les sacritices, sur les tables des dieux ${ }^{2}$. Mais les défenses de législateurs, et les recommandations de ceux qui ont écrit sur l'hygiène, out été peu suivies et peu imitées: la saveur agréable de la chies de l'anguille, et le peu de rareté de de la chair l'out emporté sur ces ordres ou de cette espèce, 'est rassure par l'exemple d'un couseils: on d'hommes, a la verité, laborieux, qui, vivare au milieu des marais, laborieux, qui, vivaut d'anguilies, comme te nourrissant que d'anguilies, comme les pécheurs des lacs de $C_{0}$

'Vuyage de Spallanzani, t. VI, p. 151.
'Pline, I. 32, c. 2. désavantages, les vitres des fenétres.

Dans plusieurs pays de I Europe, et notamment aux environs de l'embouchure de la Seine, on prend les anguilles avec des haims ou humeçons. Les plus petites sont attirées par des lombrics ou vers de terre, plus que par toute autre amorce : on emploie contre les plus grandes, des haims garnis de moules, d'autres animaux à coquilles, ou de jeunes éperlans. Lorsqu'on pèche les anguilles pendant la nuit, on se sert d'un lilet nommé Seine drue, et pour la description dnquel nous renvoyons le lecteur à l'article de la Raie bouclée, On substitue quelquefois à cette Seine un autre filet appelé, dans la rivière de Seine, Dranguel, ou Dranguet dru, dont les mailles sont encore plus serrées que celles de la Seine drue; et M. Noel nous fait observer dans une notequ'il nous a adressée, que c'est par une suite de cette substitution, et parce qu'en genéral on exécute mal les lois relatives á la police des pèches, que les pécheurs de la Seine détroisent une grande quantité d'anguilles du premier àge et qui n'ont encore atteint qu'une longueur d'un ou deux décimètres, pendant qu'ils prennent, peut-ètre plus inutilement encore, dans ce méme dranguet, beaucoup de frai de barbeau, de vaudoise, de brème, et d'aures poissons recherchés. Mais l'usage de ce filetà mailles très-serrées n'est pasla seule cause contraire á l'avantageuse reproduction, ou, pour mieux dire, à l'aceroissement convenable des anguilles dans la Seine: M Noēl nous en fait remarquer deux autres dans la note que nous venons de citer. Premièrement, les pécheurs la pèche de riviere ont recours quelquefois, pour a peche de ces murènes, a la Vermille, sorte de corde garnie de vers, à laquelle les très-jeunes individus de cette espèce vienuent s'attacher tres-fortement, et par le moyen de laquelle on

DES POISSONS.

enlève des milliers de cés petits animaux. Secondement, les fossés qui communiquent avec la basse Seine, ont assez peu de pente pour que les petites anguilles, poussées par le flux dans ces fossés, y restent à sec lorsque la marée se retire, et y perissent en nombre extrèmement considérable, par l'effet de la grande chaleur du soleil de juin.

Au reste, c est le plus souvent depuis le commencement du printemps jusque vers la fin de l'automne, qu'on pèche les murènes anguilles avee facilité. On a communément assez de peine à les prendre au milieu de l'hiver, au moins à des latitudes un peu élevées: elles se cachent, pendant cette saison, ou dans les terriers qu'elles se sont creusés, ou dans quelques autres asiles a peu près semblables. Elles se réunissent mème en assez grand nombre, se serrent detrèspres, et s'amoncellent dans ces retraites, ou il parait qu'elles s'engourdissent lorsque le froid est rigoureux. On en a quelquefois trouvé cent quatre-vingts dans un trou de quarante décimetres cubes; et $M$. Noêl nous mande qu'a Aisiey pris de Quillebeuf, on en prend souvent, pendant I'hiver, de très-grandes quantités, en fouillant dans le sable, entre les pierres du rivage. Si l'eau dans faquelle elles se trouvent est peu profonde, si parce peu dépaisseur des couches du fluide elles sont moins à couvert des impressions funestes du froid, elles périssent dans leur terrier, malgré toutes leurs précautions '; et le savant Spallanzani rapporte qu'un hiver fit périr, dans les marais de Commachio, une si grande quantité d'anguilles, qu'elles pesirient 1,800000 kilogrammes ${ }^{2}$.

Dans toute antre circonstance, une grande quantité d'eau n'est pas aussi nécessaire aux murènes dont nous nous occupons; que plusieurs auteurs l'ont prétendu. M. Septfontaines a pris dans une fosse qui contenait à peine quatre cents décimètres cubes de ce fluide, une anguille d'une grosseur très-considérable; et la distance de la fosse à toutes les eaux de l'arrondissement, ainsi que le defaut de toute communication entre ces mèmes eaux et la petite mare ne lui ont pas permis de douter que cet animal n'eút vécu très-longtemps dans cet étroit espace, des effets duquel l'état de sa chair prouvait qu'il n'avait pas souffert ${ }^{3}$.

'Tine-r1. 9. c. 24

'Voyage de Spallanzani, t, v1, p. 154.

'l.eltre de M. Septlantaines, du is juilit 178
Nous devons ajouter néanmoins que si In chaleur est assez vive pour produire une trèsgrande évaporation et altérer les plantes qui croissent dans l'eau, ce fluide peut étre corrompu au point de devenir mortel pour l'anguille, qui s'efforce en vain, en s'abritant alor daus la fange, de se soustraire à l'influeuce funeste de cette chaleur desséchante.

On a écrit aussi que l'anguille ne supportait pas des changements rapides et trés-marqués dans la qualité des eaux au milieu desquelles elle habitait. Cependant M. Septfontaines prouvé plusieurs fois qu'on pouvait la transporter, sans lui faire courir aucun danger, d'une rivière bourbeuse dans le vivier le plús limpide du sein d'une eau froide dans celui d'une eau rempérée. Il s'est assuré que des changements inverses ne nuisaient pas davantage à ce poisson; ét sur trois cents individus qui ont éprouvé ous ses yeux ces diverses transmigrations, et qui les ont essuyées dans différentes saisons, if n'en a péri que quinze, qui lui ont paru ne succomber qu'a la fatigue du transport, et aux suites de leur réunion et de leur séjour tresprolongé dans un vaisseau trop pen spacieux.

Néanmoins, lorsque leur passage d'un réservoir dans un autre, quetle que soit la nature de l'eau de ces viviers, a lieu pendant des chaleurs excessives; il arrive souvent que les anguilles gagnent une maladie épidémique pour ces animaux, et dont les symptomesconsistent dans les taches blanches qui leur surviennent. Nous verrons daus notre Discours sur la manière de multiplier et de conserver les individus des diverses especes de poisson, quels remèdes on peut opposer aux effets de cette maladie, dont les taches blanches et accidentelles dénotent la présence. Les murènes dont nous parlons sout sujettes, ainsi que plusieurs autres poissons, et particulierement ceux que l'homme éleve avee plus ou moins de soin, à d'autres maladies dont nous traiterons dans la suite de cet ouvrage, et dont quelques-unes peuvent étre causées par une grande abondance de vers dans quelque partie intérieure de leur corps, comme, par exemple, dans leurs intestins.

Pendant la plupart de ces dérangements, lors. que les suites peuvent en ètre tres-graves, l'anguille se tient renferme dans son terrier, ou, si elle manque d'asile, elle remonte souvent vers la superficie de l'eau; elle s'y agite, va, revient sans but déterminé, tournoie sur elle-méme, 
ressemble par ses mouvements à un serpent prêt à se noyer et luttant encore un peu contre les flots. Son corps enflé d'un bout a l'autre, et par là devenu plus leger relativement au flvide dans lequel elle nage, la souleve et la retient ainsi vers la surface de l'eau. Au bout de quelque temps, sa peau se fletrit et devient blanche; et lorsqu'elle éprouve cette altération, signe d'une mort prochaine, on dirait qu'elle ne prend plus soin de conserver une vie qu'elle sent ne pouvoir plus retenir : ses nageoires se remuent encore un peu; ses yeux paraissent encore se tourner vers les objets qui l'entourent: mais sans force, sans précaution, sdas intérèt inutile pour sa sủreté, elle s'abandonne, pour ainsi dire, et souffre qu'on l'approche, qu'on l'enlève nième sans qu'elle cherche à s'échapper '.

Au reste, lorsque des maladies ne dérangent pas l'organisation intérieure de l'anguille, lorsque sa vie n'est attaquée que par des blessures, elle la perd assez difficilement; le principe vital parait disséminé d'une manière assez indépendante, si je puis employer ce mot, dans les diverses parties de cette murene, pour qu'i ne puis e etre éteint que lorsqu'on cherche l'anéantir dans plusieurs points a la fois; et, de mème que dans plusieurs serpents et particulièrement dans la vipère, une heure après la separation du tronc et de la tète, l'une et l'autre de ces portions peuvent donner encore des signes d une grande irritabilité.

Cette vitalité tenace est une des causes de la longue vie que nous croyons devoir attribue aux anguilles, ainsi qu'a la plupart des autres poissons. Toutes les analogies indiquent cette durée considérable, malgré ce qu'ont écrit plusieurs auteurs, qui ont voulu limiter la vie de ces murènes à quinze ans, et méme à huit ar nées : et d'ailleurs nous savons, de manière à ne pouvoir pas en douter qu'au bout de six ans une anguille ne pese quelquefois que cinq hectogrammes $^{2}$ : que des anguilles conservées petdant neuf ans n'ont aequis qu'une longur vingt-six centimètres; que ces anguilles, avant d'ettre devenues l'objet d'une observation pré ése avaient déjá dix-neuf centimètrestion préconséquent déjà dix-neuf centimètres, et par conséquent devaient ètre ágées de cinq ou six ans; qu à la fin del'experience elles avaient moinsquatorzeans; qu'à cet âge de quatorzeans

elles ne présentaient encore que le quart ou tout au plus le tiers de la longueur des grandes anguilles péchées dans des lacs de la Prusse ', et qu'elles n'auraient pu parvenir à cette dernière dimension qu'après un intervalle de quatre. vingts ans. Les anguilles de trois ou quatre me. tres de longueur, vues dans des lacs de la Prusse par des observateurs dignes de foi, avaient done au moins quatre-vingt quatorze ans : nous devons dire que des preuves de fait et des témoignages irrécusables se réunissent aux probabilités fondées sur les analogies les plus grandes pour nous faire attribuer une longue vie à a murène anguile.

Mais comment se perpétue cette espèce utile et curieuse ? L'anguille vient d'un véritable cuf, comme tous les poissons. L'œu éclôt le plus souvent dans le ventre de la mère comme celui des raies, des squales, de plusieurs blennies, de plusieurs silures; la pressi $\mathbf{n}$ sur la partie inférieure du corps de la mère facilite la sor. tie des petits déja éclos. Ces faits bien vus, bien constates par les naturalistes récents, sont simples et conformes aux vérițés physiologiques les mieux prouvées, aux résultais les plus sùrs des recherches anatomiques sur les poissons et particulièrement sur l'anguille; et cependant combien, depuis deux mille ans, ils ont été altérés et dénaturés par une tropgrande confiance dans des observations précipitées et mal faites, qui ont séduit les plus beaux génies, parmi lesquels nous comptons non-seulement Pline, mais méme Aristote! Lorsque les anguilles mettent bas leurs petits, communément elles reposent sur la vase du fond des eaux; c'est au milieu de cette terre ou de ce sable humecté qu'on voit frétiller les murènes qui viennent de paraitre à la lumiere : Aristote a pensé que teur génération était due a cette lange ${ }^{2}$. Les mères vont quelquefois frotter leur ventre contre des rochersou d'autres corpsdurs, pour se débarrasser plus facilement des petits déjà éclos dans leur intérieur; Pline a écrit que par ce frottement elles faisaient jaillir des fragments de leur corps, qui s'animaient, et que telle était la seule origine des jeunes murènes dont nous exposons la véritable manière de naitre ${ }^{3}$. D'autres anciens auteurs ont placé cette mème origine dans les chairs corrompues des cadavres des ehevaux ou d'autres animaux jetés dans l'eau, cadavres autour desquels doivent souvent fourmiller de très-jeunes anguilles forcées de s'en nourrir par le défaut de tout autre aliment placé à leur portée. A des époques bien plus rapprochées de nous, Helmont a eru que les anguilles venaient de la rosee du mois de mai ; et Leuwenhoeck a pris la peine de montrer la cause de cette erreur, en faisant voir que dans cette belle partie du printemps, lorsque l'atmosphère est tranquille, et que le calme règne sur l'eau, la portion de ce fluide la plus chaude est la plus voisine de la surface, et que c'est cette couehe plus échauffée, plus vivifiante, et plus analogue à leur etat de faiblesse, que les jeunes anguilles peuvent alors préférer Sehwenckfeld, de Breslaw en Silésie, a fait naitre les murènes anguilles des branchies du cyprin bordelière; Schoneveld, de Kiel dans ie Holstein, a voulu qu'elles vinssent à la lumière sur la peau des gades morues, ou des salmones éperlans. Ils ont pris l'un et l'autre pour de trèspetites murènes anguilles, des gordius, des sangsues, ou d'autres vers qui s'attachent à I peau ou aux branchies de plusieurs poissons. Eller, Charleton, Fahlberg, Gesner, Birckholtz ont reconnu, au contraire, la véritable manière dont se reproduit l'espèce que nous déerivons. Plusieurs observateurs des temps récents sont tombés, à la vérité, dans une erreur combattue méme par Aristote, en prenant les vers qu'ils voyaient dans les intestins des anguilles qu'ils disséquaient, pour des foetus de ces animaux. Leuwenhoeck a eu tort de chercher les œufs de ces poissons dans leur vessie urinaire, et Vallisnieri danslenr vessienatatoire: mais Muller, et peut-ètre Mondini, ont va les ovaires ainsi que les œufs de la femelle; et la laite du mâle a été également reconnue.

D'après toutes ces considérations, on doit eprouver un assez grand étonnement, et ce vit intérèt qu'inspirent les recherches et les doutes d'un des plus habiles et des pius célebres physiciens, lorsqu'on lit dans le Voyage de Spallanzani ', que des millions d'anguilles ont été pêchées dans les marais, les lacs ou les fleuves de l'Italie et de la Sicile, sans qu'on ait vu dans leur intérieur ni œufs ni fœtus. Ce savant observateur explique ce phénomène, en disant que les anguilles ne multiplient que dans la

er; voilà pourquoi, continue-t-il, on n'en trouve pas, suivant Senebier, daus le lac de Genève, jusqu'auquel la chute du Rhóne ne leur permet pas de remonter, tandis qu'on en péche dans le lac de Neufehâtel, qui communique avec la mer par le Rhin et le lac de Bremna. Il invite, en conséquence, les naturalistes à faire de nouvelles recherches sur les anguilles qu'ils rencontreront au milieu des eaux sulées, et de la mer proprement dite, dans le temps du frai de ces animaux, e'est-à-dire vers le milieu de l'automne, ou le commencement de I'hiver.

Les œufs de l'anguille éclosant presque toujours dans le ventre de la mère, y doivent étre fécondés : il est done nécessaire qu'il y ait dans cette espèce un véritable accouplement du male avec la femelle, comme dans celles des raies, des squales, des syngnathes, des blennies et des silures; ce qui confirme ce que nous avons déja dit de la nature de ses affections. Et comme la conformation des murènes est semblable en beaucoup de points á celle des serpents, l'accouplement des serpents et celui des murènes doivent avoir lieu, à peu près, de la méme manière, Rondelet a vu, en effet, le mále et la femelle entrelacés dans le moment de leur réunion la plus intime, comme deux couleuvres le sont dans des circonstances ana. logues; et ce fait a été observé depuis par plu. Dars naturalistes.

Dans l'anguille, comme dans tous les autres poissons qui éclosent dans le ventre de leur mère, les aufs renfermés dans l'intérieur de la femelle sont beaucoup plus volumineux' que ceux qui sont pondus par les espèces de pois. sons auxquelles on n'a pas donné le nom de Vivipares ou de Vipères : le nombre de ces aufs doit done être beaucoup plus petit dans les premiers que dans les seconds : et c'est ce qui a été reconnu plus d'une fois.

L'anguille est féconde au moins dès sa douzième année. M. Septfontaines a trouvé des petits bien formés dans le ventre d'une femelle qui n'avait encore que trente-cinq centimètres de longueur, et qui, par conséquent, pouvait n'être âgée que de douze ans. Cette espèce croissant au moins jusqu'a sa quatre-vingtquatorzième année, chaque individu femelle peut produire pendant un intervalle de quatre. vingt-deux ans; et ceci sert à expliquer la grande quantité d'anguilles que l'on rencontre 
dans les eaux qui leur convienuent. Cependant, ont été à portee d'examiner, et surtout dans

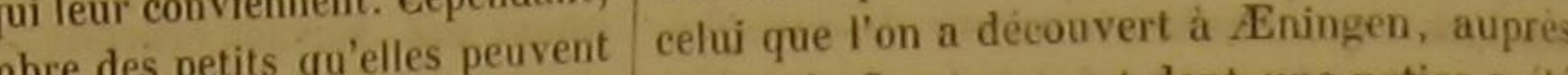
mettre au jour chaque année est très-limite, et du lac dé dans le temps par le célèbre Lavater à que, d'un autre cóté, les accidents, les maladies, l'activité des pếcheurs, et la voracité des grands poissons, des loutres, et des oiseaux d'eau, en détruisent fréquemment une multitude, on ne peut se rendre raison de leur multiplication qu'en leur attribuant une vie et mème un temps de fécondité beaucoup plus longs qu in siècle, et beaucoup plus analogues a la nature des poissons, ainsi qu'à la longévité qui en est la suite.

Au reste, il parait que dans certaines contrées, et dans quelques circonstances, il arrive aux aufs de l'anguille ce qui survient quelquefois à ceux des raies, des squales, des blennies, des silures, etc.; c'est que la femelle s'en débarrasse avant que les petits ne soient éclos; et l'on peut le conclare des expressions employées par quelques naturalistes en traitant de cette murène, et notamment par Redi dans son ouvrage des Animaux vivants dans les animaux vivants.

Tous les climats peuvent convenir à l'anguille : on la pèche dans des contrées trèschaudes à la Jamaique, dans d'autres portions de l'Amérique voísines des tropiques, dans les Indes orientales; elle n'est point étrangère aux régions glacées, a l'Islande, au Groenland; et on la trouve daus toutes les contrées tempérées, depuis la Chine, ou elle a été figurée tres-exactement pour l'intéressanté suite de dessins donnés par la Hollande á la France, et déposés dans le Muséum d' histoire naturelle, jusqu'aux cotes oceidentales du royaume et à ses départements méridionaux, dans lesquels les murènes de cette espèce deviennent très-belles et tres-bounes, particulièrement celles qui vivent dans le bassin si célebré de la poétique fontaine de Vaueluse !

Dans des temps plus reculés et antérieurs aux dernières eatastrophes que le globe a eprouvées, ces mémes murenes ont dủ être aussi très-répandués en Europe, ou du moin très-multipliées dans un grand nombre de contrées, puisqu'on reconnait leurs restes, ou leur empreinte, dans presque tous les amas de poissous pétrifiés ou fossiles que les naturalistes
Nous ne devons pas cesser de nous occuper de l'anguille sans faire mention de quelques murènes que nous considéreron's comme de simples variétés de cette espèce, jusqu’au moment où de nouveaux faits nous les feront re. garder comme constituant des espèces particulières. Ces variétés sont au nombre de einq : deux different par leur couleur de l'anguille commune; les autres trois en sont distinguées par leur forme. Nous devons la connaissance de la première à Spallanzani; et la notice des autres nous a été envoyée par M. Noēl de Rouen, que nous avons si souvent le plaisir de citer.

Premièrement, celle de ces variétés qui a été indiquée par Spallanzani, se trouve dans les marais de Chiozza auprès de Venise. Elle est jaune sous le ventre, constamment plus petite que l'anguille ordinaire; et ses babitudes ont cela de remarquable, qu'elle ne quitte pas pé. riodiquement ses marais, comme l'espèce commune, pour aller, vers la fin de la saison des chaleurs, passer un temps plus ou moins long dans la mer. Elle porte un nom particulier : on la nomme Acerine.

Secondement, des pêcheurs de la Seine disent avoir remarqué que les premières anguilles qu'ils prennent sont plus blanches que celles qui sont pèchées plus tard. Selon d'autres, de méme que les anguilles sont eommunément nent en peu de jours d'une teinte plus foncée lorsqu' on les a mises dans des réservoirs, elles sont plus blanches sur des fonds de sable. Mais, indépendamment de ces nuances plus ou moins constantes que présentent les anguilles communes, on observe dans la Seine une anguille qui vient de la mer lorsque les marées sont fortes, et qui remonte dans la rivière en mème temps que les merlans. Sa tête est un peu menue. Elle est d'ailleurs très-belle et communé ment assez grosse. On la prend quelquefois avec la Seine ${ }^{2}$; mais le plus souvent on la pèche 'Voyage dans les Alpes, par Horace-Bénédict de Saussure, I. IV, $\mathrm{S} 1503$,

Vuyez. a larticle de la Raie bouclece, la descríption du
Gilet appelé Seine. plus rouges sur les fonds de roche, et devien- avec une ligne dont les appâts sont des éperlans et d'autres petits poissons.

Troisiemement, le Pimperneau est, suivant plusieurs pécheurs, une autre anguille de la Seine, qui a la tête menue comme l'anguille blanche, mais qui de plus l'a très-allongee, et dont la couleur est brune.

Quatrièmement, une autre anguille de la même rivière est nommée Guiseau. Elle a la tête plus courte et un peu plus large que l'anguille commune. Le guiseau a d ailleurs le corps plus court; son wil est plus gros, sa chair plus ferme, sa graisse plus délieate. Sa couleur varie du noir au brun, au gris-sale, au roussâtre.

On le prend depuis le Hoc jusqu'à Villequier, et rarement au-dessus. M. Noèl pense que le bon goût de sa chair est dú á la nourriture substantielle et douce qu il trouve sur les banes de l'embouchure de la Seine, ou au grand nombre de jeunes et petits poissons qui pullulent sur les fonds voisins de la mer. Il eroit aussi que cette murène a beaucoup de rapports, par la délicatesse de sa chair, avee l'anguille que l'on pèche dans l'Eure, et que l'on désigne par le nom de Breleau. Les troupes de guiseaux sont quelquefois détrillées, suivant l'expression des pécheurs, e'est-â-dire qu'ils ne sont, dans certaines eirconstances, mêlés avec aucune autre murène; et d'autres fois on péche, dans le mème temps, des quantités presque égales d'anguilles communes et de guiseaux. En péeheur de Villequier a dit a $M$. Noel qu'il avait pris, un jour, d'un seul coup de filet, einq cents guiseaux, au pied du chateau d'Oreher.

Cinquièmement, l'Anguille chien a la tête plus longue que la commune, comme le pimperneau, et plus large, comme le guiseau. Cette partie du corps est d'ailleurs aplatie. Ses yeux sont gros. Ses dimensions sont assez grandes; mais son ensernble est peu agréable à la vue, et sa chair est filamenteuse. On dit qu'elle a des barbillons à la bouche. Je n'aí pas été à mème de vérifier l'existence de ces barbillons, qui peut-ètre ne sont que les petits tubes à l'ex. trémité desquels sont placés les orifices des narnes. L'Anguille chien est très-goulue; et de là vient le nom qu'on lui a donné. Elle dévore les petits poissons qu'elle peut saisir dans les aasses, déchire les filets, ronge même les fils de fre des lignes. Lorsqu'elle est prise à l'hame- con, on remarque qu'elle a avalé l'haim de manière à le faire parvenir jusqu'a l'cesophage, tandis que les anguilles ordinaires ne sont retenues avec l'hamecon que par la partie antérieure de leur palais. On la péche aveo plus de faeilité vers le commencement de l'automne; elle parait se plaire beancoup sur les fonds qui sont au-dessus de Canteleu, Dans l'automne de i 798, une troupe d'Anguilles chiens remonta jusqu'au passage du Croisset : elle y resta troi ou quatre jours ; et n'y trouvant pas apparemment une nourriture sufisante ou convenable, elle redescendit vers la mer'

LA MURENE TACHETÉ ${ }^{2}$. Muræna maculata, Lacep.; Muræna guttata, Linn. ,

ET LA MURÉNE MYRE 3 .

Muræea longicollis, Cur. ; Murana Myrus, Lacep.

Forskael a vu dans l'Arabie la murène ta chetée, et en a publié le premier la description. Cette murène a la máchoire inférieure plus avancée que la supérieure, comme l'anguille, avec laquelle elle a d'ailleurs beaucoup de ressemblance; mais elle endiffere par une callosité placée entre les yeux, par le nombre des rayons de ses nageoires ainsi que de sa membrane branehiale ${ }^{4}$, et par la disposition de ses couleurs. Elle est d un vert de mer, relevé par un grand nombre de taches noires; et une tache plus grande est placée auprès de la tète, de chaque côté du corps.

La myre habite dans une mer très-voisine des contrées dans lesquelles on a péché la tachetée:

' M. Cavier dit que nos pécheurs distinguent quatre sorien d'angnilles. dont il se propose de donner les figures dans son

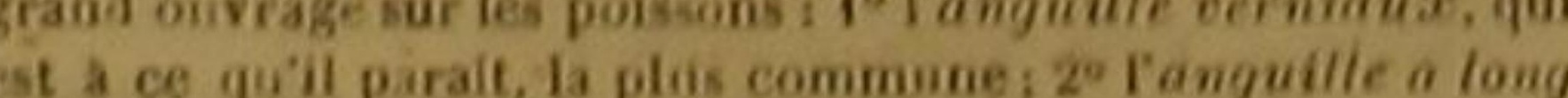
ec. dont le musesu est p us comorimé et pies pointu, 5o tanguille plat bec (grig-eel des Anglais), qui it'a plos aplati et plus olitus, I'ril plus pertit: Ao Fonguille pimper

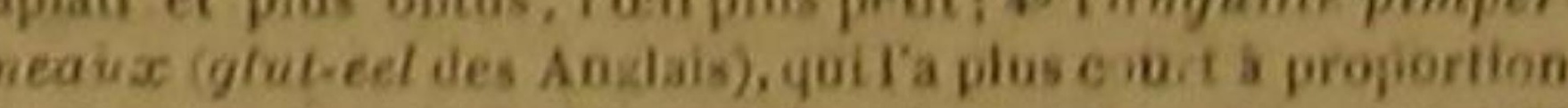
et dont les yeux sont plus grands yua aux autres, Meg. an. i II 349. D.

'Forskaet, Fam. Arab.. p. 22, n. 1, - Murene poncluede, SMuce, pi. de i' Enc. mé b.

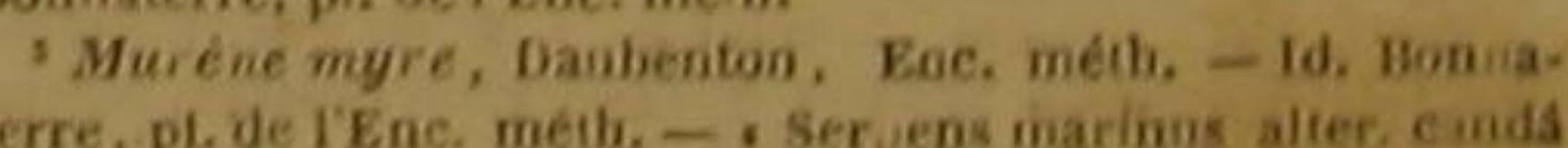

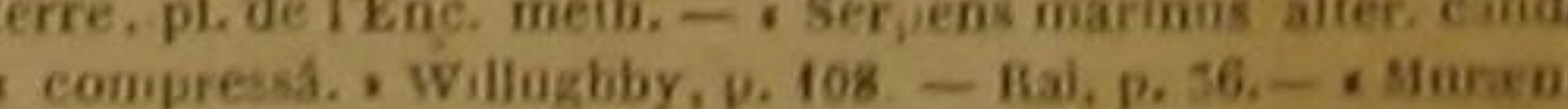
"rosiro acuts, litaris albidis vario, ete. Artedi, gen. 29 , sy. 40.

A ta membrane branchiale de la muréne tachelée 6 rayouss, a la uageoire da dos 65 , a clacune des pectoraies

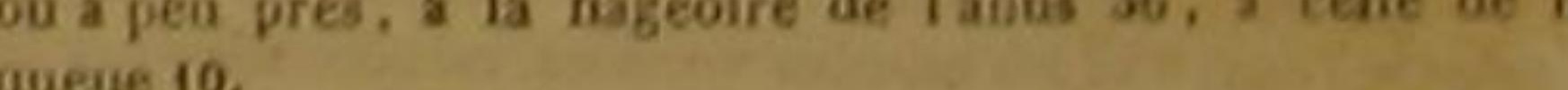


Ia trosve dans la Méditerranée. Son museau est un peu pointu; les bords des mâchoires et le milieu du palais sont garnis de deux ou trois rangées de petites dents presque égales; deux appendices tres-courts et un peu cylindriques appendices tres-courts et un périeure ${ }^{i}$. Plusieurs sont placés sur la lèvre superieure autres transversales, règnent sur la partie supérieure de la téte. La nageoire du dos, celle de la queue et celle de l'anus, qui sont réunies, présentent une belle couleur blanche et un liséré d'un noir foncé. Telles sont du moins les coutleurs que l'on remarque sur le plus grand nombre des myres : mais Forskael a fait connaitre une murèe qu'il regarde comme une variété de l'espèce que nous décrivons, et qui est d' un gris cendre sur toute sa surface ${ }^{2}$. On a soup. çonné que cette variété contenait dans sa téte un poison plus ou moins actif. Pour peu qu'on se souvienne de ce que nous avons dit au sujet des qualités vénéneuses des poissons, on verra sans peine de quelle nature devront étre les observations dont cette variété será I objet, pour que l'opinion des naturalistes soit fixée sur la faculté malfaisante attribuée à ces murènes myres d'une couleur cendrée. Au reste, si l'existence d'un véritable poison dans quelque vaisseau de la tête de cette variété est bien constatée, Il faudra, sans hésiter, la considérer comme une espèce différente de toutes les murènes déjà connues.

LA MURÈNE CONGRE ${ }^{3}$.

Muræua Conger, Limn,, Lacep. ‘

Le congre a beaucoup de rapports avee l'an-

'A la membrane des branchies de la murène myre 10
rayons. A chacue de ses na.

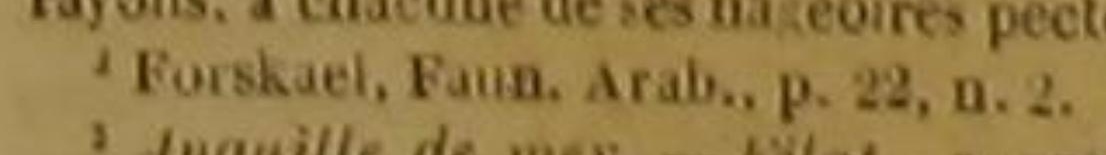

'Anguille de mer. - Fîat, anpres des cótes méridionales ue Frauce. - Conger cel, en Ang eterre. - Bronco, daus plus. coutrees de Illalie. - Murene congre, DonbenLn, Enc. méth. - Id. Bunusterre, pl. de l'Euc, wielb. -

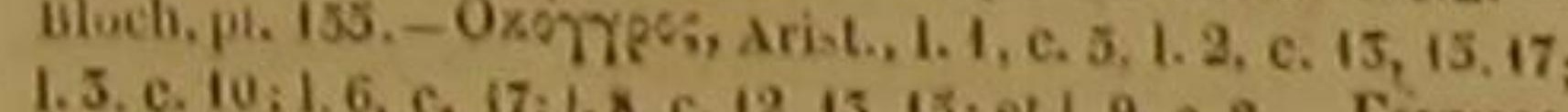

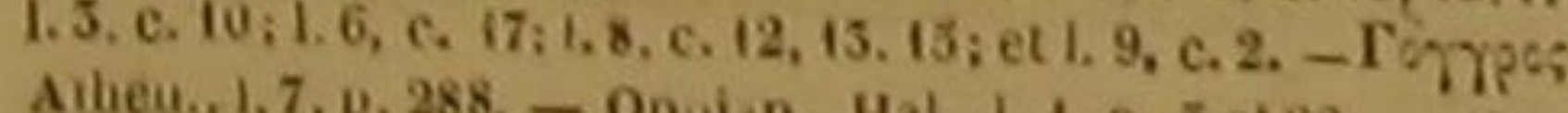

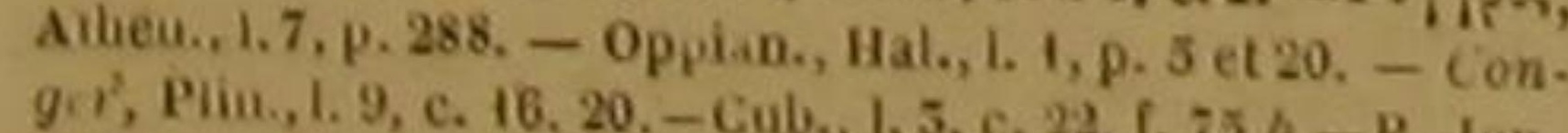

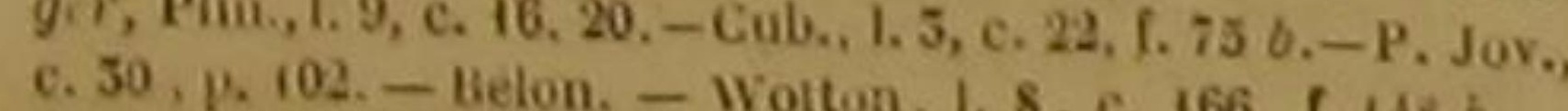

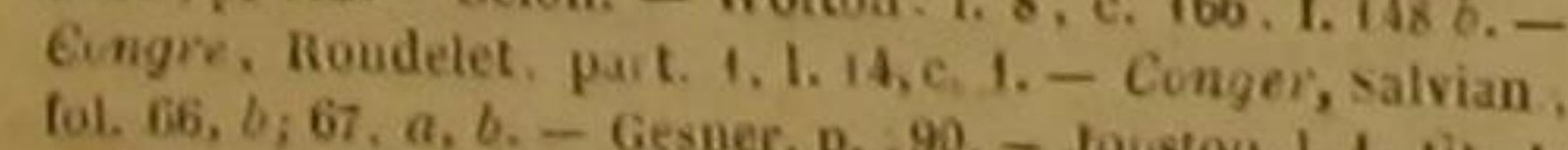

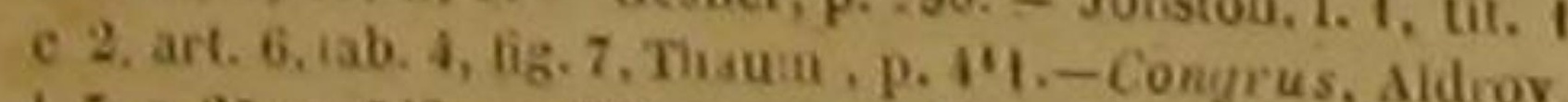
1.5, c. 25, p. 549. - Char eton, p. 125. - Willughthy, p. III - Ras, p. 57. - Congre, angaille de mer, Valimunt de Bo-4. Cuvier forme

pour le congre et les espêceg vore umurène un sinisgenre Jorsale yui commence assez voisines. caractérisées par leur guille : mais il en diffère par les proportions de ses diverses parties; par la plus grande longueur des petits appendices cylindriques placés sur le museau, et que l'on a nommés barbillons; par le diametre de ses yeux, qui sont plus gros; par la nuance noire que présente presque toujours le bord supérieur de sa nageoire dor. sale; par la place de cette nageoire, ordinaire. ment plus rapprochée de la tête; par la manière dont se montre aux yeux la ligne latérale composée d'une longue série de points blanes; par sa couleur, qui sur sa partie supérieure est blanche, ou cendrée, ou noire, suivant les plages qu'il fréquente, qui sur sa partie inférieure est blanche, et qui d'ailleurs offre fréquemment des teintes vertes sur la tète, des teintes bleues sur le dos, et des teintes jaunes sous le corps ainsi que sous la queue; par ses dimensions supérieures à celles de l'anguille, puisqu'il n'est pas très-rare de lui voir de trente à quarante decimètres de longueur, avec une circonférence de près de cinq décimètres, et que, suivant Gesner, il peut parvenir à une longueur de près de six metres; et enfin par la nature de son habitation; qu'il choisit presque toujours au milieu des eaux salées. On le trouve dans toutes les grandes mers de l'ancien et du nouveau continent; il est très-répandu surtout dans l'Océan d'Europe, sur les côtes d'Angleterre et de France, dans la Méditerranée, où il a été très-recherché des anciens, et dans la Propontide, où il l'a été dạns des temps moins reculés'. Ses cufs sont enveloppés d'une matière graisseuse très-abondante.

Il est très-vorace; et comme il est grand et fort, il peut se procurer aisément l'aliment qui lui est nécessaire.

La recherche a laquelle le besoin et la faim le réduisent, est d'ailleurs d'autant mọins pénible, qu'il vit presque toujours auprès de lembouchure des grands fleuves, où it se tient comme en embuscade pour faire sa proie et des poissons qui descendent des rivières dans la mer, et de ceux qui remontent de la mer dans les rivières. Il se jette avec vitesse sur ces animaux; il les empêche de s'éehapper, en s'enortillant autour d'eux comme un serpent autour de sa victime; il les renferme pour ainsi dire dans un filet, et e'est de là que vient le nom de Filat (filet) qu'on lui a donné dans plu' Bélọn, liv. 1, chap. 64.

DES POISSONS.

sieurs départements méridionaux de France. C'est aussi de cette manière qu'il attaque et retient dans ses contours sinueux les poulpes ou sépies, ainsi que les crabes qu'il rencontre dépouillés de leur tèt. Mais s'il est dangereux pour un grand nombre d'habitants de la mer, il est exposé à beaucoup d'eunemis : I'homme le poursuit avec ardeur dans les pays où sa chair est estimée; les très-grands poissons le dévorent; la langouste le combat avee avantage; et les murénophis, qui sont les murènes des anciens, le pressent avee une force supé rieure. En vain, lorsqu'il se défend contre ces derniers animaux, emploie-t-il la faculté qu'il a reçue de s'attacher fortement avec sa queue qu'il replie; en vain oppose-t-il par là une plus grande résistance à la murénophis qui veut l'eutrainer : ses efforts sont bientot surmontés ; et cette partie de son corps, dont il voudrait le plus se servir pour diminuer son infériorite dans ùne lutte trop inégale, est d'ailleurs dévorée, souvent dès la première approche, par la murénophis. On a pris souvent des congres ainsi mutilés, et portant l'empreinte des dents acérées de leur ennemie. Au reste, on assure que la queue du congre se reproduit quelquefois; ce qui serait une nouvelle preuve de ce que nous avons dit de la vitalité des poissons dans notre premiev discours.

Redi a trouvé dans plusieurs parties de l'intérieur des congres qu'il a disséqués, et, par exemple, sur la tunique externe de l'estomac, le foie, les muscles du ventre, la tunique extérieure des ovaires, et entre les deux tuniques de la vessie urinaire, des hydatides à vessie blanche, de la grosseur d'une plume de coq, et de la longueur de vingt-cinq à trente centimètres'.

Sur plusieurs côtes de l'Océan européen, on prend les congres par le moyen de plusieurs lignes longues chacune de cent trente ou cent quarante mètres, chargées, à une de leurs extrémités, $d$ un plomb assez pesant pour n'être pas soulevé par l'action de l'eau sur la ligne, et garnies de vingt-cinq ou trente piles ou cordes au bout de chacune desquelles sont un haim et un appât.

Lorsqu'on veut faire sécher des congres pour les envoyer a des distances assez grandes des

I A la membrane des branchies 10 rayons, a chacune des nageoires pectorales 19, aux trois nazeoires réunies du dos, de la queue el de l'anus, plus de 300 .
II. rivages sur lesquels on les pèche, on les ouvre par-dessous, depuis la tête jusque vers l'extrémité de la queue; on fait des entailles dans les chairs trop épaisses; on les tient ouverts par le moyen d'un bâton qui va dune extrémité à l'autre de I'animal; on les suspend á l'air; et lorsqu'ils sont bien sees, on les rassemble ordinairement par paquets dont chacun pèse dix myriagrammes, ou environ.

\section{TRENTE-QUATRIÈME GENRE.} LES AMMODYTES.

Une nageoire de l'anus ; ritle de la queue stparie de la nageoire de l'anus et de celle du dos; la tele com-

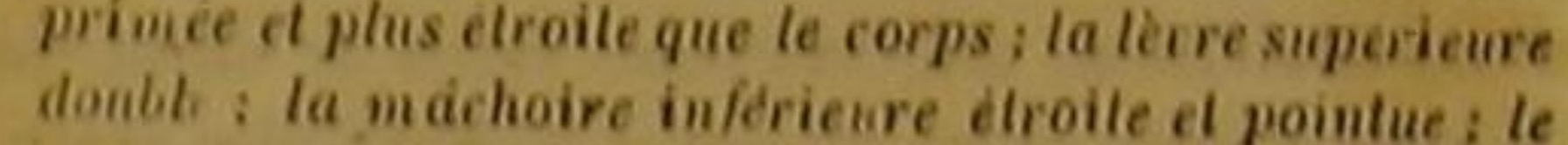

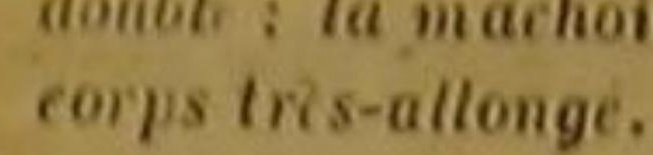

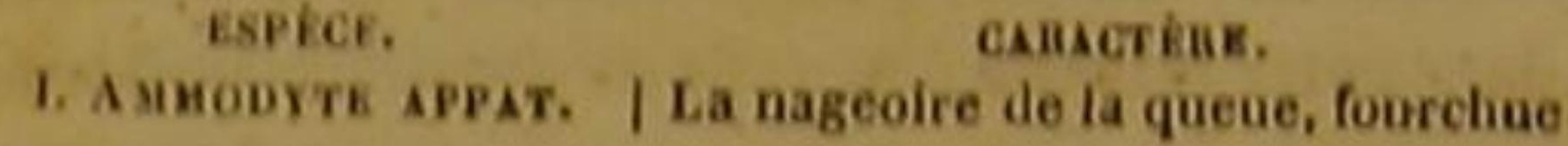

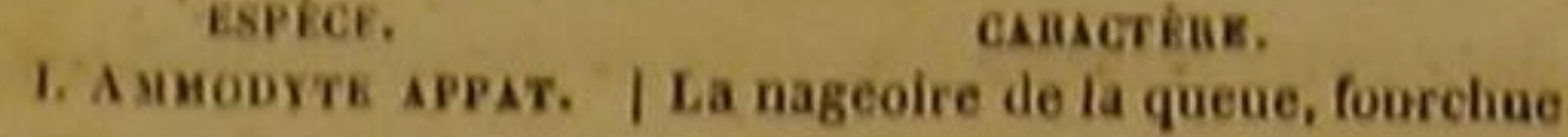

L'AMMODYTE APPAT'. Ammody les tobianus.-Ammodytes alliciens, Lacep. '. On n'a encore inscrit que cette espèce dans le genre de l'ammodyte : elle a beaucoup de arpports avec l'anguille, ainsi qu'on a pu en juger par la seule énonciation des caractères distinctifs de son genre; et comme elle a d'ailleurs l'habitude de s'enfoncer dans le sable des

'sul, en Norvége. - Sandspiring, en Allemagne. Saud eel, launce, Grig, dans son jeune äge, en Augleterre. banemarck. - Ammodyte appát de vose, Daubentun, Euc. méth. - Id Bonuaterre, pi. de I Eno. méth. - Ammedyles, Artedi, gen. 16, spec. 55, syn. 29. - Grouov,, Zoopli.. p. 113, 0. 104; Mus. 1, p. 13, 10. 35. - Faum. Suecic. 30 2 - It. Scàn. 141. - It. Oel. 87. - Mus. Adol. Frid. 1, p. 75, - Bloch, pl.75,
fig. 2, - Piscis sandilz diclus, Salv, Aqual. p. 69, 6, et ig. 2, - Piscis sandis diclus, salv, Aqual, p. 69, 6, et
70,1 . - Sandile Anglorum, Aldrov., Pisc., p. 252, 256, Sandilz, Jonston, Pisc, p., 90 , tab. 21. fig. L. - Sandels or

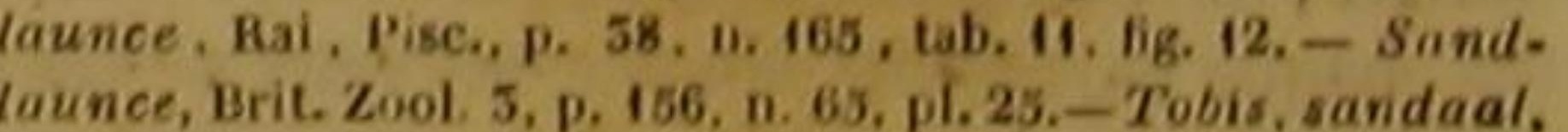
Fisch, naturg Liell. p. HA - Anguille de salle, Valmoni de Bomare, Dict, a bi-t. nat. - Totianus, Selionev.. p. 76. -Ammocalus, exocalus marinus, ammodyles. Gesner. germ., fol. 39. - Ammodyles Gesneri, willoghtiy, p. 113. - Ammodyles Anglorum res us, Jago (iu Hai, syu.), v. 165.
- Anguilla de a arena, Ch. .l., p. 146. - Ammodyles lobia. uus, Ascagoe, pl. I.

2Nos cotes produisent denx especes d ammodytes yoi ont Ce longtormis confondues: $1^{\circ}$ le laucon (A. 10bianus, BL.) a péicules des intermaxillaires trés-couris, et a nageoire dor. sale, commenrant vis-a-vis ia fiu des peciorales; $2^{\circ}$ I'étuille A. lancea, Penin.) a maxillaires plas courts, pedicu es des intermédiaires plus louss, is nageoire dorale commenca.t visea vis le milien des pectorales. - Ils sont ezalement cour. muns sut nus cClcs. Cuv., Reg. adim., L. II, p. 3c0, 2. édit, D. 
HISTOIRE NATURELLE

mers, elle a été appelée Anguille de sable en Suède, en Danemarck, en Angleterre, en Allemagne, en France, et a reçu le nom générique d'Ammodyle, lequel désigne un anima qui plonge, pour ainsi dire, dans le sable. Sa tête comprimée, plus étroite que le corps, et pointue par devant, est l'instrument qu' elle emploie pour creuser la vase molle, et pénétrer dans le sable des rivages jusqu'à la profondeur de deux décimètres ou environ. Elle s'enterre ainsi par une babitude semblable à l'une de celles que nous avons remarquées dans l'anguille, à laquelle nous venons de dire qu'elle ressemble par tant de traits; et deux causes la portent à se cacher dans cet asile souterrain : non-seulement elle cherche dans le sable les dragomneaux et les autres vers dont elle aime à se nourrir, mais encore elle tâche de se dérober dans cette retraite a la dent de plusieurs poissons voraces, et particulièrement des scombres, qui la préfèrent à toute autre proie. De petits cétacées mème en font souvent leur aliment de choix; et on a vu des dauphins poursuivre l'ammodyte jusque dans le limon du rivage retourner le sable avec leurmuseau, et y fouiller assez avant pour déterrer et saisir le faible poisson. Ce goùt très-marqué des scombres et d'autres grands osseux pour cet ammodyte le fait employer comme appât dans plusieurs pêehes; et voilà d'où vient le nom spécifique que nous lui avons conservé.

C'est vers le printemps que la femelle dépose ses œufs très-près de la côte. Mais nous avons assez parté des habitudes de cette espèce: voyon rapidement ses principales formes

Sa màchoire inférieure est plus avancée que la supérîeure; deux os hérissés de petites dents sont placés auprès du gosier; la langue est allongée, libre en grande partie, et lisse; l'orifice de chaque narine est double; les yeux ne sont pas voiles par une peau demi-transparente, comme ceux de l'anguille. La membrane des branchies est soutenue par sept rayons '; l'ouverture qu'elle ferme est très-grande; it les deux branchies antérieures sont garnies, daus leur coneavité, d'un seul rang d'apophysès, tandis que les deux autres en présentent deux rangées. On voit de chaque còté du corps trois lignes latérales; mais au moins une de ces trois ligues parait n'indiquer que la séparation des

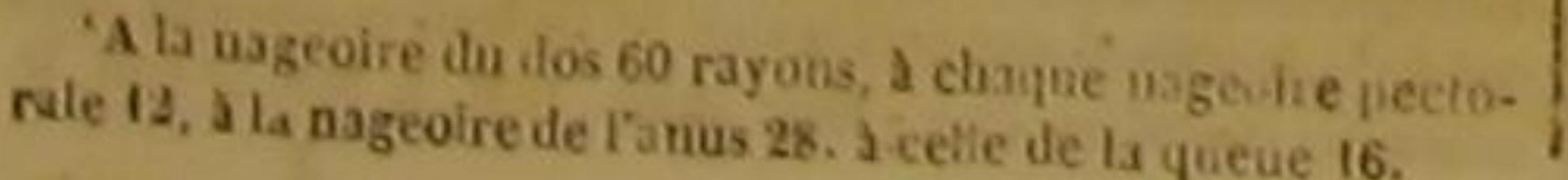

muscles. Les écailles qui recouvrent l'ammodyte appát sont très-petites ; la nageoire dorsal est assez haute, et s'étend presque depuis la tête jusqu'à une très-petite distance de l'extrémité de la queue, dont l'ouverture de l'anus est plus près que de la tête.

Le foie ne parait pas divisé en lobes; un coecum ou grand appendice est placé auprès du pylore; le canal intestinal est grêle, long et contourné, et la surface du péritoine parsemée de points noirs.

On compte ordinairement soixante-trois vertébres avec lesquelles les côtes sont légèrement articulées; ce qui donne à l'animal la facilité de se plier en différents sens, et mème de se roule en spirale, comme une couleuvre. Les inter. valles des muscles présentent de petites arétes qui sont un peu appuyées contre l'épine du dos. La chair est peu délicate.

La couleur générale de l'ammodyte appât est d'un bleu argentin, plus clair sur la partie inférieure du poisson que sur la supérieure. $O_{a}$ voit des raies blanches et bleuâtres placées al. ternativement sur l'abdomen; et une tache brune se fait remarquer auprès de l'anus.

\section{TRENTE-CINQUIEMME GENRE.} LES OPHIDIES.

La tile courerle de grandes piices icailleuses; le corps et la queue comprimés en forme de lame, el garnis de petites écailles; la membrane des branchies trèslarge: les nageoires du dos, de la queue el de lamus remies.

\section{PREMIER SOUS-GENRE.}

Des barbillons aux maichoires.

Espicess.

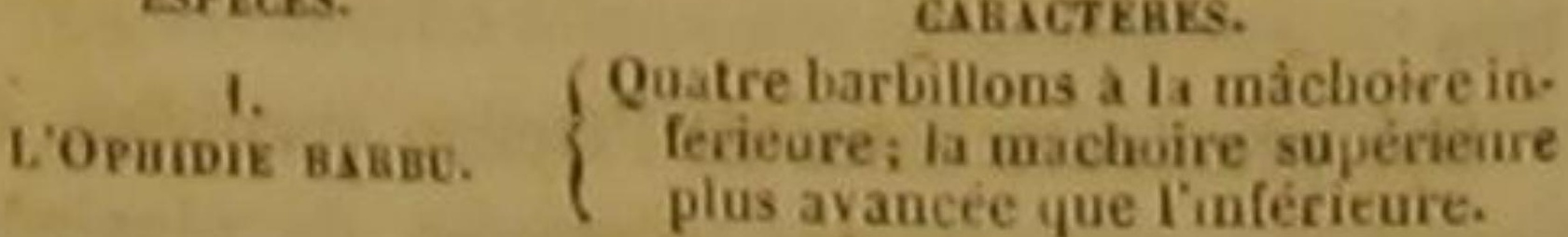

SECOND SOUS-GENRE.

Point de barbillons aux mächoires.

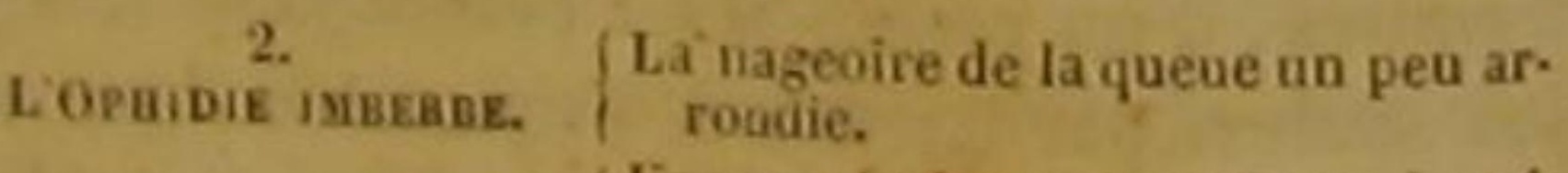

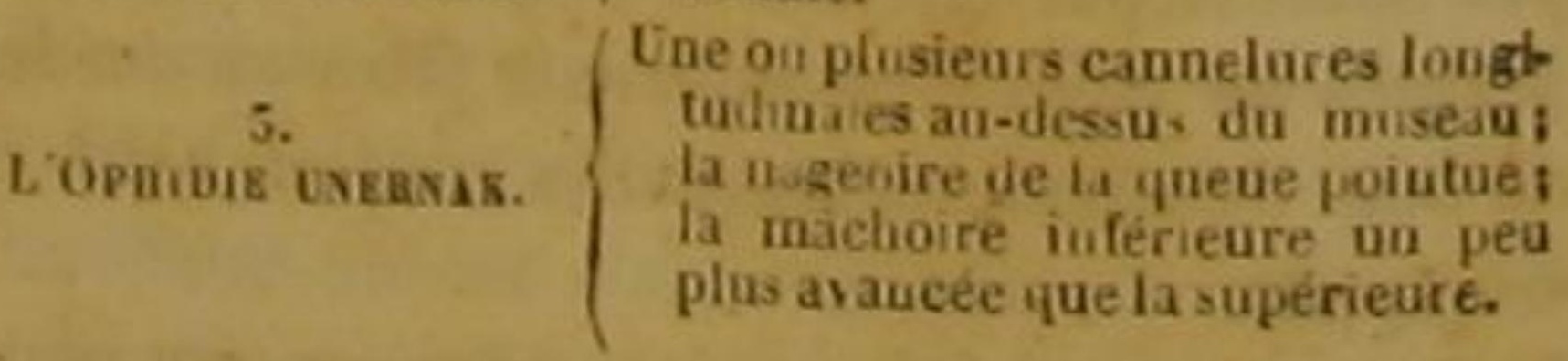

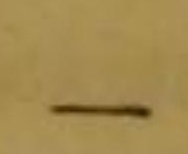

\section{DES POISSONS.}

L'OPHIDIE BARBU ',

Ophidium barbatum, Bl., Lacep., Guv.

I.'OPHIDIE IMBERBE ${ }^{2}$, Opidium imberle, Linu., Soh., Lacep. '. ET L'OPHIDIE UNERNAK •

Ophidium Unernak, Lacep. s.

C'est au milieu des eaux salées qu'on rencontre les ophidies. Lé barbu habite particulièrement dans la mer Rouge et dans la Méditerranée, dont il fréquente mème les rivages septentrionaux, II a beaucoup de ressemblance, aiusi que les autres espèces de son genre, avec les murènes et les ammodytes: mais la réunion des nageoirés da dos, de la queue et de l'anus, suffirait pour qu'on ne confondit par les ophidies avec les ammodytes; et les traits génériques que nous venons d'exposer à la tête du tableau méthodique du genre que nous décrivons, séparent ce mème genre de celui des murènes. Pour achever de donner unge idée nette de la conformation du barbu, nous pouvons nous contenter d'ajouter aux caractères génériques, sous-génériques et spécifiques, que nous avons tracés dans cette table méthodique des ophidies que le barbu a les yeux voilés par une membrane demi-transparente, comme les gymnotes, les murènes, et d'autres poissons; que sa levre supérieure est

Ophidium barbatum. - Donselle, sur les cotes franç. de la seditersanée- Broussonn t, AcL. anglic, 74, I, p. 436,
tab. 25. - Donzelle barbue, Daubeuton, E c. méth. - Id.

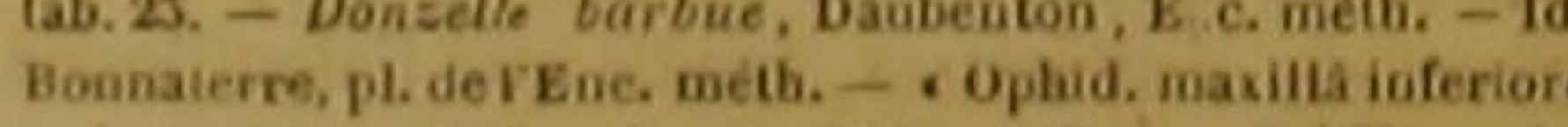
- cirris quaiuor. A Aredi, gen. 25, syn. 42, - O Ophidion piDonselle, Bond sinilis. , Plin,., L 32, c. 0. - Ophidion,

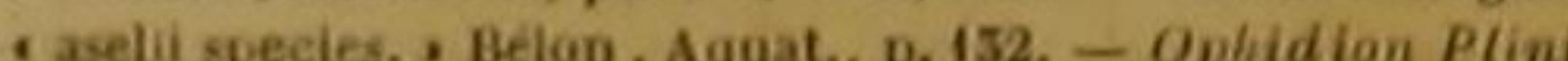

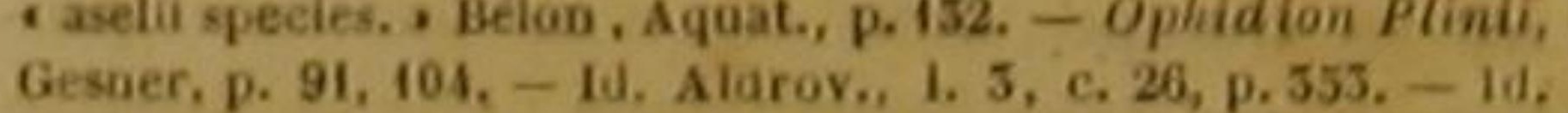
Jonst, L. I tit. 1 C. 2, a, 6, tab. 5, 1. 2. -Ophidion Plinii a Ro deletu, wilinghby, Iehth., p. 112, lab. G, 7, Gig. 6. - Io Rai, P. 38. - Enchelyopus barbatus, Klein, miss. pisc. 4 , p. 32, a. 4. - Ophidium maxilld inferiore breviore, etc., Biunn., Pisc, massil.. p. 15, n. 25.

'Nugnogen, sor pins, rivages de I'Europe sept, -Donzell IE syn. 12, - O phidion Rroum, vel Ophidiunt' tmb, gea. 24, delei, pari. 1. 1. 15, c. 2. - 10. Willoghby, p. 115 - Id. Bai, p. 39. - Id, Schoner., p. 55. - Ophidion, Schelham $r$, Aual, xiph. p. 25, 24. - Fauna suecica, 519. - Brit. Z Zoi., app., L. 95. - Enchel opus flasus imberbis, Klein, Mlis pisc. 4 . p. 53 , n. 3.

des uateratistes qu it ne connait pas tophidium imberbe des ualuralistes du Nord, mais yuil le croit voisin des anavec les Fierasfers, qui forment on sons genre dans sol geare Bouz $=$ lle. D.

'Ol. Fabricii Faun. Groeuladad, p. 141, n. 99. - Donzelle

snernak, Bonnaterre, pl. de TEnc, meth.

'Ce poisson n'est pas cité par M. Cuvier. double et épaisse; que l'on voit de petites dents a sa mâchoire, sur son palais, auprès de son gosier; que sa langue est étroite, courte et lisse; que sa membrane branchiale présente sept rayons ' : que sa ligne latérale est droite, et que l'anus est plus près de la téte que du bout de la queue.

Quant à ses couleurs, en voici l'ordre et les nuances. Le corps et la queue sont d'un argente méle de teintes couleur de chair, relevé sur le dos par dı bleuâtre, et varié par un grand nombre de petites taches. La ligne latérale est bruae; les nageoires pectorales sont également brunes, mais avec un liséré gris; et celles du dos, de lanus et de la queue sont ordinairement blanches et bordées de noir.

Cet ophidie a la chair délicate, aussi bien que I'imberbe. Ce dernier, qui n'a pas de barbillons, ainsi qu'on peut le voir sur le tableau méthodique de son genre, et comme son nom I indique, est d'une couleur jaune. On le trouve non-seulement dans la Méditerranée, où on le pèche particulièrement auprès des cótes méridionales de France, mais encore dans l'Océan d'Europe, et même auprès de rivages très - septentrionaux ${ }^{2}$.

C'est vers ces mêmes plages boréales, et jusque dans la mer du Groenland, qu'habite l'unernak dont on doit la connaissance au naturaliste Othon Fabricius. Sa couleur n'est ni argentce comme celle du barbu, ni jaune comme celle de l'imberbe, mais d'un beau vert que l'on voit régner sur toutes les parties de son corps, excepté sur les nageoires du dos, de l'anus, de la queue, et le dessous du ventre, qui sont blancs. Ses mâchoires sont sans barbillons, comme celles de l'imberbe; sa tête est large, ses yeux sont gros; l'ouverture de sa bouche est trèsgrande ${ }^{3}$. Il est très-bon à manger comme les autres ophidies: mais comme il passe une grande partie de sa vie dans la haute mer, on le rencontre plus rarement.

Il parvient aux dimersions de plusieurs gades, avee lesquels on l'a scuvent comparé, et par conséquent devient plus grand que le barbu, dont la longueur 'n'est ordinairement que de trois à quatre décimètres.

- A La nageoire du dos du barbu 124 rayons, a chacune des 'A la pageore du de lanus 115.

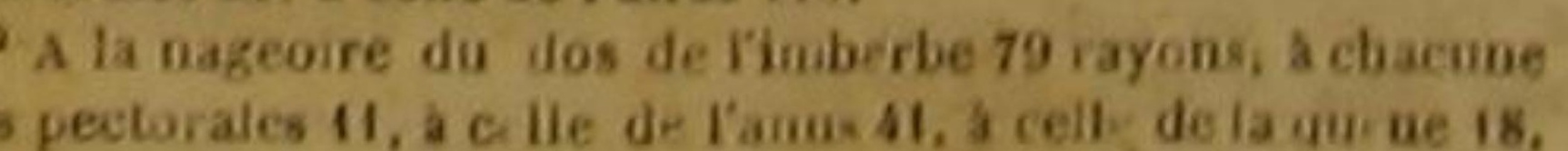

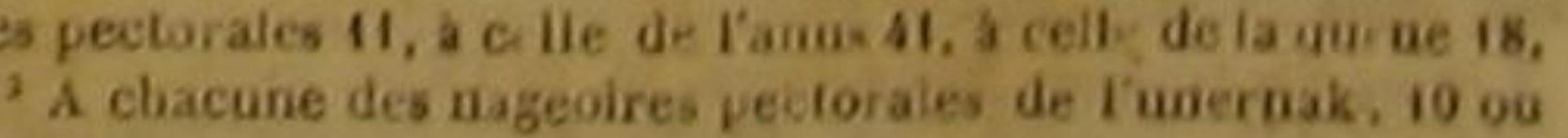


TRENTE-SIXIEME GENRE

LES MaCROGNATHES '

La mächoire supérieure très-arancèe et en forme de trompe; le corps ell la queue comprimés comme une lame; les nageoin
ce le de la queue.

ce le de la queve.

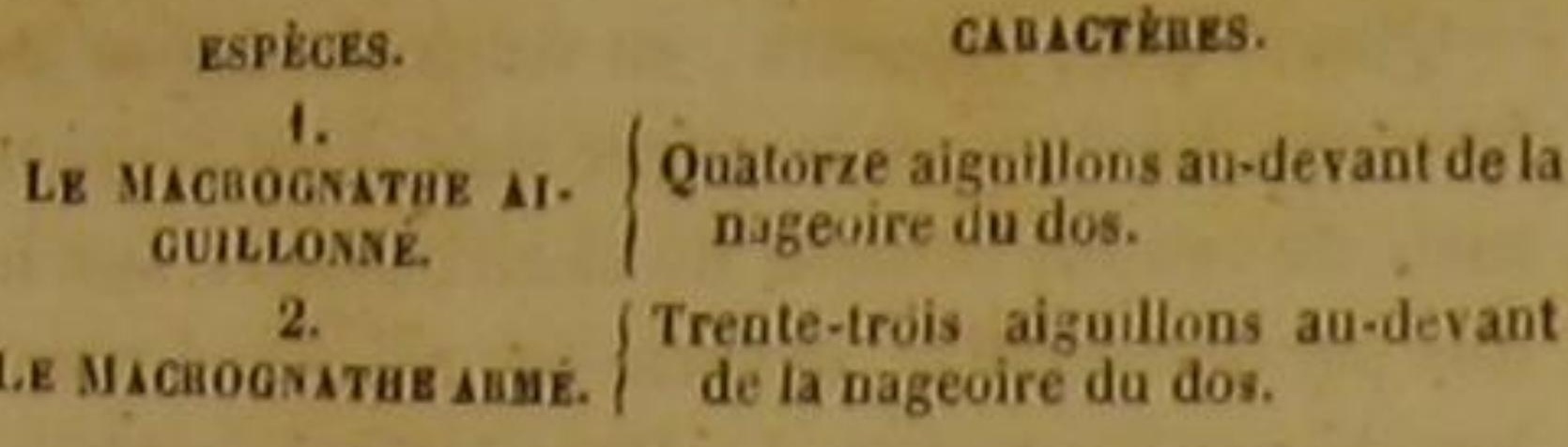

\section{一}

LE MACROGNATHE AIGUILLONNÉ ?

Macrognathus aculeatus, Lacep.; Rhinchobdella orien-

lalis, Bl., Schn., Cuv.; Ophidium aculeatum, BI.

Ce nom générique de Macrognathe, qui sigoilie longue mâchoire, désigne le très-grand allongement de la mâchoire supérieure de l'esèce que nous allons décrire, et que nous avons cru devoir séparer des ophidies, non-seulement à cause de sa conformation qui est très-différente de celle de ces derniers osseux, mais encore a cause de ses habitudes. En effet, les ophidies se tiennent au milieu des eaux salées, et l'aiguillonné habite dans les eaux douces : il y vit despetits vers et des débris de corps organisés qu'il trouve dans la vase du fond des lacs ou des rivières. Sa màchoire supérieure lui donne beaucoup de facilité pour fouiller dans la terre humectée, et y chercher sa nourriture : elle est un peu pointue et extrêmement prolongée; aussi a-t-elle été comparée à une sorte de trompe.

Le docteur Bloch, qui a examiné et décrit avec beaucoup de soin un individu de cette espèce, n'a vu de dents ni à cette mâchoire supérieure, ni à l'inférieure, ni au palais, ni au gosier; ce qui s'accorde avee la nature molle des petits animaux sans défense, ou des parcelles végétales ou animales que recherche l'aiguillonné. L'opereule ḱes branchies n'est composé que d'une lame. Au-devant de la nageoire du dos, on voit une rangée longitudinale de quatorze aiguillons recourbés, et séparés l'un del'autre; et deux autres aiguillons semblables

' Les Macrognathes de M, de Lacépète compiosent, pour Meg, anier, un sous-geure de son genre ПmixchoвoвLLE. ece. anim, 1. II. p. 201. $2^{\circ} \mathrm{ed}$. D.

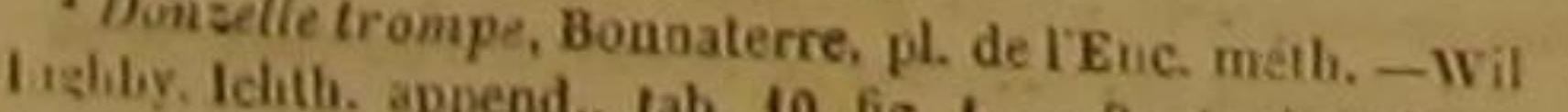
Rai, Pi.c., p. 159, a. 19. - Nieubot, Ind. 2, p. 228, fig. I. sont placés entre la nageoire de l'anus et l'ouverture du même nom, qui est plus loin de la tète que du bout de la queue '

D'ailleurs les couleurs de l'animal sont agréables; sa partie supérieure est rougeâtre, et l'iuférieure argentée. Les nageoires pectorales sont brunes à leur base, et violettes dans le reste de leur surface. Celle du dos est rougeâtre, variée de brun, et remarquable par deux taches rondes, noires, bordées dé blanchâtre, et semblables à une prunelle entourée de son iris. La nageoire de l'anus est rougeâtre avec un liséré noir ; et un bleu nuancé de noir règne sur la nageoire de la queue, qui est un peu arrondie.

La chair de l'aiguillonné est très-bonne a manger. On le péche dans les grandes Indes. II parvient ordinairement à la longuèur de seize à vingt-un centimètres.

\section{LE MACROGNATHE ARMÉ.}

Macrognathus armatus, Lacep.; Rhinchobdella polyseantha, BI., Scho.

Nous avons trouvé un individu de cette espèce encore inconnue aux naturalistes, dans une collection de poissons desséchés cédée par la Hollande à la France avec un grand nombre 'autres objets précieux d'histoire naturelle. Elle diffère de l'armé par plusieurs traits de sa conformation et par sa grandeur : l'individu que nous avons décrit était long de près de rente-six centimètres, tandis que l'aiguillonné 'en a communément qu'une vingtaine de longueur totale. La máchoire supérieure est façonée en trompe : mais elle n'est pas aussi prolongée que dans l'aiguillonné ; elle ne dépasse 'inférieure que de la moitié de sa longueur. Les leux mâchoires sont garnies de plusieurs rangs e très-petites dents, et l'aiguillonné n'en a ni aux mâchoires, ni au gosier, ni au palais. On voit un piquant auprès de chaque œil de l'armé, et trois piquants à chacun de ses opercues. Au lieu de quatorze rayons recourbés, on en compte trente-trois au-devant de la nageoire du dos, et chacun de ces aiguillons disposés en série longitudinale est renfermé en partie dans une sorte de gaine. Les nageoires du dos et de l'anus ne sont pas séparées par un grand inter-

'A la membranie des branchies 6 rayons, a la nageoire du dos 51 , à chacune des nageoires pectorales 16 , a celle de l'a-

\section{DES POISSONS.}

valle de celle de la queue, comme dans l'aiguillonné; mais elles la touchent immédiatement, et n'en sont distinguées que par une petite échancrure dans leur membrane. L'état dans lequel était Lindividu que nous avons examiné, ne nous a pas permis de compter exactement le nombre des rayons de ses nageoires: mais nous en avons trouvé plus de soixante-dix daus celle du dos, et plus de vingt dans chaque pectorale; et cependant le docteur Bloch n'en a vu que seize dans chacune des pectorales de l'aiguillonné, et einquante-un dans la nageoire dorsale de ce dernier macrognathe.

Au reste, l'armé a, comme l'espèce décrite par le docteur Bloch, deux aiguillons recourbés au-devant de la nageoire de l'anus.

Nous ignorons dans quel pays vit le macrognathe armé.

\section{TRENTE-SEPTIÈME GENIE.} LES XIPHIAS.

La mächoire supérięure prolongè en forme de lane on d'pee, et d' une longueur au moins égale au tiers de in longueur tolale de l'animal.

espices.

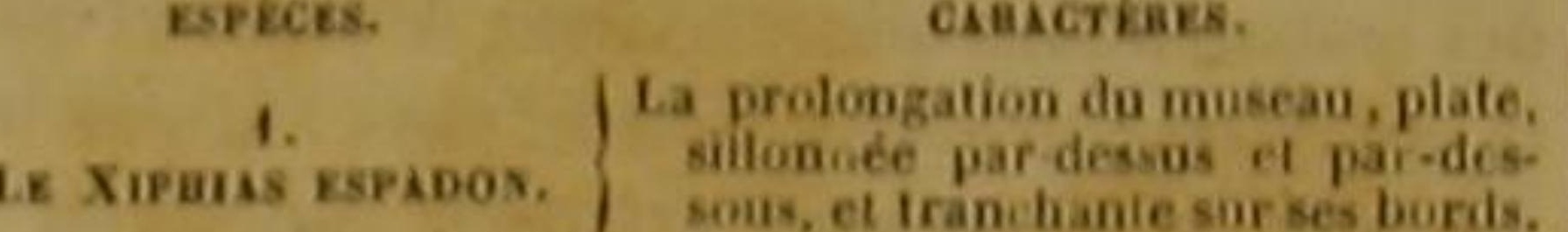

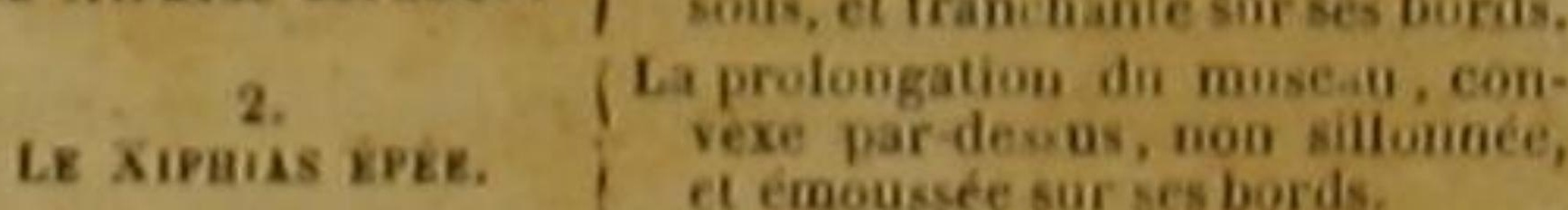

\section{LE XIPHIAS ESPADON '}

Xiphias Gladius, Linn., Bl., Lacep., Cuv.

Voici un de ces géants de la mer, de ces émules de plusieurs cétacées dont ils ont reçu le nom, de ces dominateurs de l'Océan qui réunissent une grande force à des dimensions très

'Sward fisk, en Suedde. - Sword fish, en Angleterre. Pesce spado, Emperador, en Lalie, - Glaive espudon,

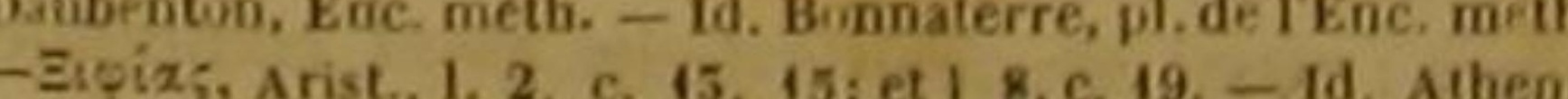
7. p. 514. - Id. Elian., L. 9, c. 40. p. 518; et L. 14, c. 25. 1d. Oppian., 1. 1, p. 8; et 1. 2, p. 48. Xiphias, seu gladius. Plin.. I. 9. c. 15 ; et I. 52, c. 2 et 10. - Wotton, 1.8 189. f.1. 167, b. - Empereur, Rondelet, part, 1.1. 8, c, 11 - Zifius, par plus. anciens anteors. - Xiphias, id est gla dius piscis, Gesner, p. 1049. - Xiphias, seu giadius,
Jonston, 1. 1, tit. 1. e 2, a.3 tab. A, fg. 2. Xiphias piscis Lalinis gladius, willughby, p 461 - Id Rai, $0.52-G 10$ dirs, vel xiphias, Schonev, , 1. 55. - Gladius, Cuta, 1.5, c. 39 . ful. 80, $a$. - Salv., fol. i26, ad icon m., et i27. - Gia. dius, Aldrov, 1. 5. c. 21, p. 352. - Xipinias. Klein, Mis. pisc, 4, p. 17, I. 1, 2, 4. tab. I fig. 2, et lab. 2, fig. 1. - Em

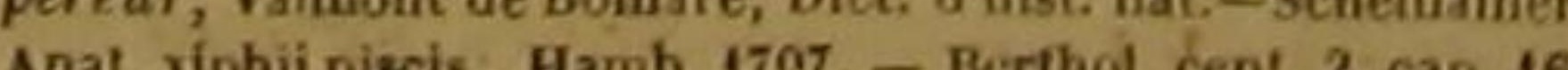

étendues. Au premier aspect, le xiphias espadon nous rappelle les grands acipensères, ou plutôt les énormes squales et méme le terrible requin. Il est l'analogue de ces derniers ; il tient parmi les osseux une place semblable à celle que les squales occupent parmi les cartilagineux; il a recu comme eux une grande taille, des muscles vigoureux, un corps agile, une arme redoutable, un courage intrépide, tous les attributs de la puissance; et cependant tels sont les résultats de la différence de ses armes à celles du requin et des autres squales, qu'abusant bien moins de son pouvoir, il ne porte pas sans cesse autour de lui, comme ces derniers, le carnage et la dévastation. Lorsqu'il mesure ses forces contre les grands habitants des eaux, ce sont plutot des ennemis dangereux pour lui qu'il repousse, que des victimes qu'il poursuit. Il se contente souvent pour sa nourriture, d'algues et d'autres plantes marines; et bien loin d'attaquer et de ehercher à dévorer les animaux de son espèce, il se plait a vec eux ; il aime surtout à suivre sa femelle, lors méme qu'il n'obéit pas à ce besoin passager, mais impérieux, que ne peut vainere la plus horrible érocité. Il parait done avoir et des habitudes douces et des affeetions vives. On peut lui supposer une assez grande sensibilité, et si l'on doit comparer le requin au tigre, le xiphias peut être considéré comme l'analogue du lion

Mais les effets de son organisation ne sont pas seuls remarquables; sa forme est aussi très-digne d'attention. Sa tête surtout frappe par sa conformation singulière. Les deux os de la mâchoire supérieure se prolongent en avant, se réunissent et s'étendent de manière que leur longueur égate a peu près le tiers de la longueur totale de l'animal. Dans cette prolongation, leur matiére s'organise de manièreà présenter un grand nombre de petits cylindres, ou plutot de petits tubes longitudinaux ; ils forment une lame étroite et plate, qui s'amincit et se rétrécit de plus en plus jusqu'à son extrémité, et dont les bords sont tranchants comme ceux d'un espadon ou din sabre antique. Trois sillons longitudinaux règnent sur la surface supérieure de cette longue lame, au bout de laquelle parvientcelui du milieu; et l'on aperçoit un sillon semblable sur la face inférieure de cette mème prolongation. Une extension de l'es 
frontal triangulaire, pointue et très-allongée, concourt à la formation de la face supérieure de la lame, en s'étendant entre les deux os maxillaires, au moins jusque vers le tiers de la longueur de cette arme; et sur la face inférieure de cette lame osseuse, on voit une extension analogue et également triangulaire des os palatins s'avancer entre les deux os maxiliaires, mais moins loin que l'extension pointue de l'os frontal. Ce sabre à deux tranchants est d'ailleurs revètu d'une peau légèrement chagrinée.

La máchoire inférieure est pointue par devant; et sa longueur égalant le tiers de la longueur de la lame tubulée, e'est-á-dire le neu. vieme de la longueur totale de l'animal, il n'est pas surprenant que l'ouverture de la bouche soit grande; ses deux bords sont garnis d'un nombre considérable de petits tubercules trèsdurs, ou plutót de petites dents tournées vers le gosier, auprès duquel sont quelques os hérissés de pointes. La langue est forte et libre dans ses mouvements. Les yeux sont saillants, et l'iris est verdátre.

L'espadon a d'ailleurs le corps et la queu très-allongés. L'orifice des branchies est grand, et son opercule composé de deux pièces; sept ou huit rayons soutiennent la membrane branchiale. Les nageoires sont en forme de faux, excepté celle de la queue, qui est en croissant ' Une membrane adipeuse placée au-dessous d'une peau mince, couvre tout le poisson.

La ligne latérale est pointillée de noir : cette méme coulear règne sur le dos de l'animal dont la partie inférieure est blanche. Les nageoires pectorales sont jaunâtres; celle du dos est brune; et toutes les autres présentent un gris cendré.

L'espadon habite dans un grand nombre de mers. On le trouve dans l'Océan d'Europe, dans la Méditerranée, et jusque dans les mers australes. On le rencontre aussi entre liffique et l'Amérique : mais, dans cés derniers parages a nageoire du dos parait ètre constamment plus grande et tachetée; et c'est aux espadons, qui, par les dimensions et les couleurs de leur nageoire dorsale, composent une variété plus ou moins durable, que l'on doit, ce me semble, rapporter le nom brasilien de Guebucu ${ }^{2}$.

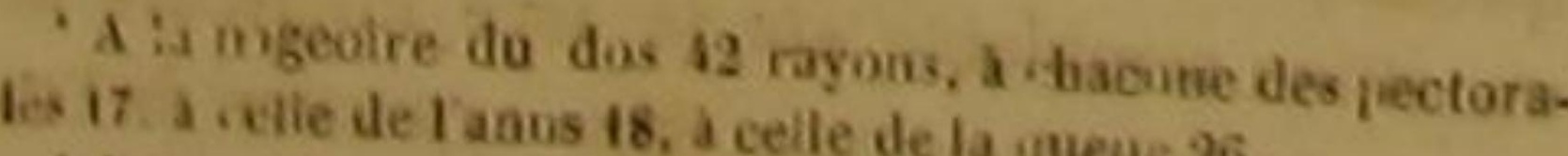
- Toyez Aluregrave, Brasil , 1. 4, c. 15, p. 171.
Les xiphias espadons ont des muscles très. puissants : leur intérieur renferme de plus une rande vessie natatoire; ils nagent avec vitesse; ils peuvent atteindre avec facilité de très-grands habitants de la mer. Parvenus quel. quefois à la longueur de plus de sept mètres, frappant leurs ennemis avec un glaive pointu et tranchant de plus de deux mètres, ils mettent en fuite, ou combattent avec avantage les jeunes et les petits cétacées, dont les. téguments sont aisément traversés par leur arme osseuse, qu'ils poussent ávec violence, qu'ils préeipitent avec rapidité, et dont ils accroissent la puissance de toute celle de leur masse et de leur vitesse. On a écrit que dans les mers dont les côtes sont peuplées d'énormes crocodiles, ils savaient se placer avec agitité au-dessous de ces animaux currassés, et leur percer le ventre avec adresse l'endroit où les écailles sont le moins èpaisses et le moins fortement attảchées. On pourzait même, à la rigueur, croire, avec Pline, que orsque leur ardeur est exaltée, que leur instinct est troublé, ou qu'ils sont le jouet de va. gues furieuses qui les roulent et les lancent, ils se jettent avec tant de force contre les bords des embareations que leur arme se brise, et que a pointe de leurglaive pénètre dans l'épaisseur du bord, et y demeure attachée, comme on y vu quelquefois également implantés des fragments del'arme dentelée du squale scie, ou de la dure défense du narval.

Malgré cette vitesse, cette vigueur, cette dresse, cette agilité, ces armes, ce pouvoir, 'espadon se contente souvent, ainsi que nous venons de le dire, d'une nourriture purement vegétale. Il n'a pas de grandes dents incisives ni aniaires, et les rapports de l'abondance et de la nature de ses sues digestifs avec la longueur et la forme de son canal intestinal, sont tels, qu'il préfère fréquemment aux poissons qu'il pourrait saisir, des algues et d'autres plantes ma. rines : aussi sa chair est-elle assez communément boune a manger, et mẻme tres-agréable au goùt; aussi, lorsque la présence d'un ennemi dangereux ne le contraint pas à faire usage de sa puissance, a-t-il des habitudes assez douces. On ne le rencontre presque jamais seul : lorsqu'il voyage, c'est quelquefois avec un compagnon, et presque toujours avec une compague; et cette association par paires prouve d'autant plus que les espadons sout susceptibles d'affection les uns pour les autres, qu'on ne doit pas supposer qu'ils sont réunis pour atteindre la même proie ouéviter le même ennemi, ainsiqu'ou peut lé croire de l'assemblage désordonné d'un très-grand nombre d'animaux. Un sentiment différent de la faim ou de la crainte peut seul, en produisant une sorte de choix, fairenaitre et conserver cet arrangement deux à deux ; et deplus leur sensibilité doit être considérée comme assez vive, puisque la femelle ne donne pas le jour à des petits toút formés, que par conséquent il n'y a pas d'accouplement dans cette espèce, que cette mème femelle ne va déposer ses oufs vers les rivages de l Océan que lors de la fin du printemps ou au commencement de l'été, et que cependant le mále suit fidèlement sa compagne dans toutes les saisons de l'année.

La saveur agréable et la qualité très-nourrissante de la chair de l'espadon font que dans plusieurs contrées on le pêche avee soin. Souvent la recherche qu'on fait de cet animal est d'autant plus infructueuse, qu'avee son long sabre il déchire et met en mille pièces les filets par le moyen desquels on a voulu le saisir. Mais d'autres fois, et dans certains temps de l'année, des insectes aquatiques s'attachent à sa peau audessous de ses nageoires pectorales, ou dans d'autres endroits d'où il ne peut les faire tomber, malgré tous ses efforts; et quoiqu'il se frotte contre les algues, le sable ou les rochers, ils se cramponnent avec obstination, et le fout souffrir si vivement, qu'agité, furieux, en dé lire comme le lion et les autres grands animaux terrestres sur lesquels se précipite la mouche du désert, il va au-devant du plus grand des dangers, se jette au milieu des filets, s'élance sur le rivage, ou s'élève au-dessus de la surface de l'eau, et retombe jusque dans les barques des pécheurs.

\section{LE XIPHIAS ÉPÉE.}

Xiphias Ensis, Lacep.

La description de cette espèce n'a encore été publiée par aucun naturaliste. Nous n'avons vu de ce poisson que la partie antérieure de la tête : mais comme e'est dans cette portion du corps que sont placés les caractères distinctifs des xiphias, nous avons pu rapporter l'épée à ce genre; et comme d'ailleurs cette méme partie antérieure ne nous a pas seulement présenté les formes particulières à la famille dont nous nous oceupons, mais nous a montré de plus des traits
remarquables et très-différents de ceux de l'espadon, nous avons dú séparer de cette dernière espèce lanimal auquel avait appartenu cette portion, et nous avons donmé le nom d'Épée à ce xiphias encore inconnu.

Voici les grandes différences qui distinguent l'épée de l'espadon, et qui suffiraient seules pour empécher de les réunir, quand bien mème le corps et la queue de l'épée seraient entièrement semblables à la queue et au corps de l'espadon

Dans ce dernier animal, la prolongation est plate : elle est convexe dans l'épée.

L'arme de l'espadon est aigue sur ses bords comme un sabre à deux tranchants : celle de l'épée est très-arrondie le long de ses-cotés, et par couséquent n'est point propre à tailler ou couper

La lame de l'espadon est très-mince: Ia défense de l'épée est presque aussi épaisse, ou, ce qui est ici la même chose, presque aussi haute que large.

On voit trois sillons longitudinaux sur la fince supérieure du sabre de l'espadon, et un sillon egalement longitudinal sur la face inférieure de ce méme sabre; on n'aperçoit de sillon sur aucune des surfaces de la prolongation osseuse de l'épée.

Une extension de l'os frontal, pointue et triangulaire, s'avance au milieu des os maxillaires supérieurs de l'espadon, jusqu'au delà de sa mâchoire inférieure : une extension ana. logue n'est presque pas sensible dans l'épée.

Une seconde extension pointue et triangulaire, appartenant aux os intermaxillaires, se prolonge dans l'espadon sur la face inférieure de l'arme, mais ne va pas jusqu'au-dessus du bout de la mâchoire inférieure : dans l'épée elle dépasse de beaucoup cette dernière extrémité

La peau qui couvre la lame de l'espadon est légèrement chagrinée : celle qui revêt la dé. fense de l'épée présente des grains bien plus aros; et sous les os maxillaires, a l'endroit qui répond à la mâchoire inférieure, les tubercules de cette peau se changent, pour ainsi dire, en petites dents recourbées vers le gosier.

Voila done sept différences qui ne permettent pas de rapporter à la méme espèce l'espadon et V'épée. Il peut d'ailleurs résulter de cette disersité dans la forme des armes, whe variété assez 
IIISTUIRE NATURELLE

grande dans les habitudes, une espèce ayant vateur, d'autant plus que cette espèce ne parai un glaive qui tranche et coupe, et l'autre espèce une épée qui perce et déchire.

Au reste, la portion de la tête d'un xiphias épée, qui nous a montré la conformation que nous venons d'exposer, fait partie de la collection du Muséum d'histoire naturelle.

TRENTE-HUITIËME GENRE. LES MAKAIRAS '.

La mächoire superieure prolongèe en forme de lame ou d'èpée, el d'une longueur égale au cinquième ou fout ait phus an quari de la longuenr totale de T'añimal: deux boucliers osseix et lanceules, de chaque cóté de lextremilè de la queue ; denx nageoires dorsales.

ESPÉCE.

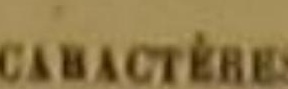

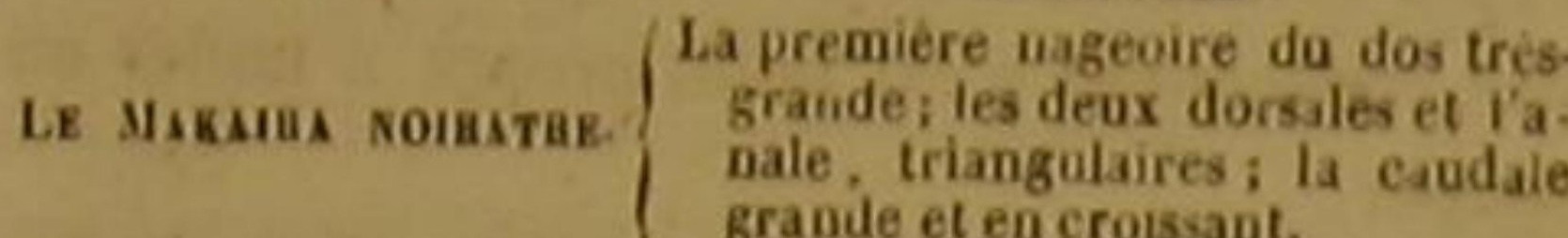
-

LE MAKAIRA NOIRATRE

Makaira nigricans, Lacep., Cuv.; Xiphias makaira,

Ce poisson est digne de l'attention des naturalistes qui ne le comnaissent pas encore. II doit être compté parmi les grands habitants de la ner. L'individu dont nous avons fait graver a figure, avait trois mètres et près de trois décimètres de longueur, sur une hauteur d'un mètre. Le makaira doit jouir d'ailleurs d'une puissance redoutable. Ses mouvements doivent etre prompts; le nombre de ses nageoires, leur ètendue, et la forme de sa queue, lui donnent une natation rapide; et comme les xiphias, à cóté desquels il faut le placer, il porte, à l'extrémité de sa máchoire supérieure, une arme dangereuse, une épée qui perce et qui frappe. Ce glaive est sans doute plus court que celui des xiphias, a proportion des dimensions prines pales de l'animal; mais il est pent-être principales de l'animal; mais il est peut-être plus rort; et nous voyons ainsi réunies dans le mala vigueur, tout la vitesse, l'adresse, les armes, même faire tout ce qui peut donner l'empire, et mème faire exercer une tyrannie terrible sur les faibles habitants de l'Océan.

Il est surprenant qu'avec tous ces attributs, et surtout avec sou grand volume, le makging noirâtre n'ait jamais été remarqué par makaira 's. Cuvier adinet le makaira comme un sous-genre dans
le genre Espabos. D.

pas habiter loin des côtes occidentales de France. Vraisemblablement il aura été vu très-souvent, mais confondu avec un xiphias. Quoi qu il en soit, l'individu dont nous avons fait graver un dessin, avait été jeté très-récemment par une tempête sur un rivage de la mer voisin de $I$ a Rochelle, où il a fait l'étonnement des pêcheurs et l'admiration des curieux. On lui a donné, je ne sais pourquoi, le nom de Makiuira, dont nous avons fait son nom générique. M. Traversay, sous-préfet de La Rochelle, qui est venu à Paris peu de temps après que cet énorme poisson a échoué sur la côte, a eu la complaisance de m'apporter un dessin de cet animal, et une note qui renfermait, avec quelques particularités sur cet osseux, l'indication des principales dimensions de cet apode, que l'on avait mesuré avec exactitude

Ce makaira pesait trois cent soixante-cinq kilogrammes. Des habitants de l'íle de Ré en ont mangé avec plaisir. Sa chair était cependant un peu sèche.

La mâchoire inférieure n'atteignait qu'au milieu de la longueur de la máchoire supérieure. On ne voyait pas de dents. Le sommet de la tête était élevé et arrondi; l'œil gros et rond; 'opercule arrondi par derrière, et composé de deux pièces; chaque pectorale très-étroite, mais presque aussi longue que la mâchoire d'en haut. L'animal pouvait íncliner et replier sa première dorsale; et lorsque cette nageoire était couchée long du dos, elle ne saillait plus que de deux décimètres. L'étendue de l'anale égalait á peu près celle de la seconde nageoire du dos. Les deux boucliers osseux qui revêtaient chaque cóté de l'extrémité de la queue, étaient placés

- Principales dimensions du makaira noiralre.

Longueur tolale. . . . . . . . . .

Hauteur de la máchioire supérieure. . . . . 65

Longueur de premiere dorsale. . . . . . 62 Hauleur de la secoude dorsale.
Hecte Longueur de chaque beuclier ossenx. . . . ${ }^{24}$ Longueur du cóté le plus long de la nageoire de 6 lanus. . . . . . de a nageoire de dalea a Yune pointe du croísant formé par la cau- 41 Nota. - Je recoist du meme croissant. . . . . . 130 Ne note que reçofs de M. Fleurian-Bellevue de La Rochelle, pur moi, et par la the le fils a bien voulu lai remetire meure à ars dar laquelle ce deruier olswrvatenr, qui de makaira est exirémement ré, mapprend que le palais do blanche, et quesu délense ou son épe ast de ce puisson eat arroncie sur ses bords. et que la partie ost nn e, sans sillods, a quelques rapports avec livoire.

DES POISSONS.

'un au-dessus de l'autre, et avaient chacun sa troupeaux sans défense ; et bien loin d'offrir ces pointe tournée vers la tète.

\section{TRENTE-NEUVIEME GENRE.} LES ANARHIQUES.

Le museau arrondi : plus de cing dents coniques o ehaque machoire; des dents molaires en haut et en bas : the congue nageoire dorsale.

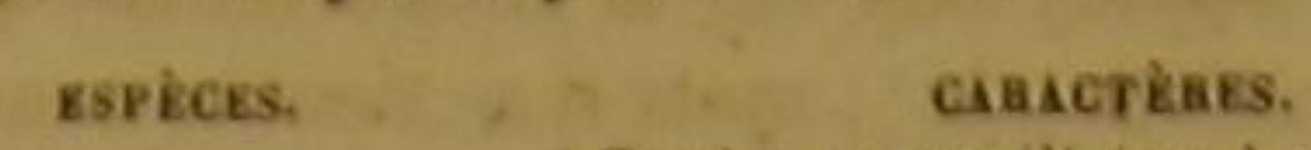

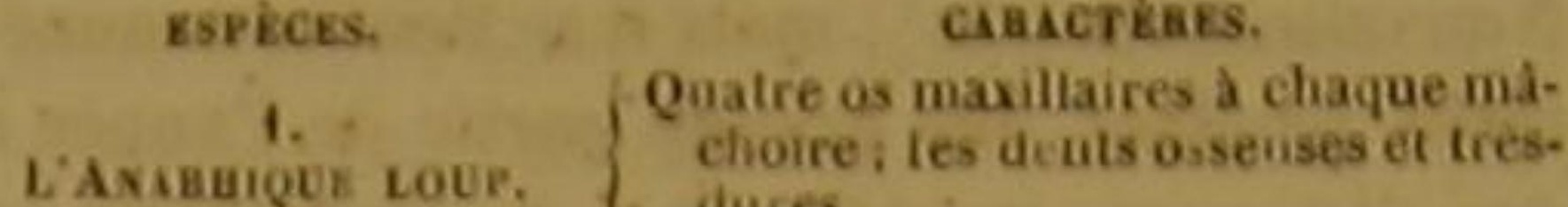

Laviages.

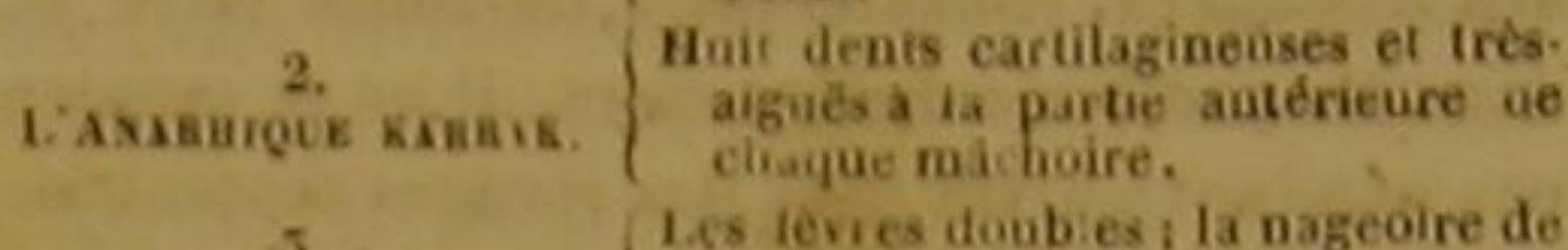

5.
LAsingeve par.
raksis.

L'ANARHIQUE LOUP'

Anarhichas Lupus, Linn., Bl., Cur., Lacep.

Ce poisson peut figurer avec avantage à cóté du xiphias, et par sa force, et par sa grandeur. Il parvient quelquefois, au moins dans les mers tres-profondes, jusqu'á la longueur de cinq mètres; et s'il n'est point armè d'un glaive comme l'espadon et l'épée, s'il ne parait pas se mouvoir au milieu des ondes avec autant d'agilité que ces derniers animaux, il a reçu des dents redoutables et par leur nombre, et par leur forme, et par leur dureté; il présente méme des moyens plus puissants de destruction que le xiphias, et il nage avec assez de vitesse pour atteindre facilement sa proie. Son organisation intérieure lui donne d'ailleurs une trèsgrande voracité. Féroce comme les squales, terrible pour la plupart des habitants des mers, vrai loup de l'Océan, il porte le ravage parm le plus grand nombre de poissons, comme la béte sauvage dont il a reçu le nom, parmi les

- Anarhichas lupus.-Sea-wolf, en Angletérrer-Loupmarin crapaudine, Danbentog, Enc. meti. - Id. Bonnaterre, pl, derinc. meth. - Lupus marinus nosiras, Schonev., fiz. 2. - Lupus marinus Schoneveldil, Jonston, Lab. 47 lughby, D-130, tab. H, 3, fig. 1. - Lupus soverinu, WilPisc. 40. - Anarhichas scansor, Gesner (Gerno.) Gol 65, a - Anarhichas, Ariedi, gen. 25, syn. 38, - Gronov., mus. 1 , p. 16, n. 44: Zooph.., p. 151, 11. 400. - Anarhichas lupme non maculalus. Malier, prodrom. Zool. dall., p. 40. n. 552 - Ot. Fabric. Faun. Groeuland.. p. 158, n. 7. - Lataryns, lab. 24, - sea polf oles - Raven us. Brit Zool. 5. p. 157, marin, lupus marinus piscis, Valmont de Bomare, Dict.

d'hist. Dat. marques d'une affection douce, cette durée dans l'attachement, ces traits d'une sorte de soeiabilité que nous avons vus dans le xiphias, il montre, par l'usage constant qu'il fait de ses armes, tous les signes de la cruauté, et justifle le nom de Ravisseur qui lui a été douné dans presque toutes les contrées et par divers observateurs. Son corps et sa queue sont allongés et comprimés : aussi nage-t-il en serpentant comme les trichiures, ou plutot comme les murènes et le plus grand nombre de poissons de l'ordre que nous examinons; et c'est vraisemblablement parce que les diverses ondulations de son corps et de sa queue lui permettent quelquefois, et pendant quelques moments, de ramper comme l'anguille, et de s'avancer le long des rivages, qu'il a été appelé Grimpeur par quelques naturalistes Sa peau est forte, épaisse, gluante, ainsi que celle de l'anguille; ce qui lui donne la facilité de śéchapper comme cette murene, lorsqu'on veut le saisir; et les petites écailles dont ce tégument est revétu, sont attachées à cette peau visqueuse, ou cachées sous l'épiderme, de manière qu'on ne peut pas aisément les distinguer.

La tête de I'anarhique que nous décrivons, est grosse, le museau arrondi, le front un peu éleyé, l'ouverture de la bouche très-grande; les levres sont membraneuses, mais fortes, et les mâchoires dautant plus puissantes, que chacune de ces deux parties de la tête est composée, de ehaque côté, de deux os bien distincts, grands, durs, solides, réunis par des cartilages, et s'are-boutant mutuellement. C'est au-devant de ces doubles mâchoires qu'on voit, tant en haut qu'en bas, au moins six dents coniques propres à couper ou plutôt à déchirer, divergentes, et cependant ressemblant un peu, par leur forme, leur volume et leur position, à celles du loup et de plusieurs autres quadrupèdes carnassiers. On voit d'ailleurs cinq rangs de dents molaires superieures, plus ou moins irrégulières, plus ou moins convexes, et trois rangs de molaires inférieures semblables. La langue est courte, lisse, et un peu arrondie à son extrémité. Les yeux sont ovales

Il résulte done de l'ensemble de toutes ces formes que présente la tête de l'anarbique bup, que lorsque la gueule est ouverte, cette mème téte a beaucoup de rapports avec celle de quelques quadrupédes, et particulièrement 
HISTOIRE NATURELLE

de plusieurs phoques; et voilà donc cet anarhique rapproché des mammiferes carnassiers non-seulement par ses habitudes, mais encore par la nature de ses armes et par ses organes exterieurs les plus remarquables.

$\mathrm{Au}$ reste, comment le loup ne serait-il pas compris parmi les dévastateurs de l'Océan? II montre ces dents terribles avec lesquelles une proie est si facilement saisie, retenue, déchirée ou écrasée : et de plus, sesintestins étant trèscourts, ne doit-il pas avoir des sucs digestifs d'une grande activité, et qui, par l'action qu'ils exercent sur ce canal intestinal, ainsi que sur son estomac, dans les moments où ils ne contiennent pas une nourriture copieuse, lui font éprouver vivement le tourment de la faim, et le forcent à poursuivre avec ardeur, et souvent à immoler avec une sorte de rage, de nombreuses victimes? Quelques dents de moins, ou plutôt quelques décimetres de plus dans la longeur du canal intestinal, auraient rendu ses habitudes assez douces.

Mais les animaux n'ont pas comme l'homme, cette raison céleste, cette intelligence supérieure qui rappelle, embrasse ou prevoit tous les instants et tous les lieux, qui combat avec succès la puissance de la nature par la force du génie, et, compensant le moral par le physique, et le physique par le moral, aceroit ou diminue à son gré l'intluence de l'habitude, et donne à la volonté l'indépendance et I'empire.

L'anarhique loup, condảmné done, par sa couformation et par la qualité de ses habitudes, à rechercher presque sans cesse un nouvel aliment, est non-seulement féroce, mais très-vorace: il se jette goulument sur ce qui peut apaiser ses appétits violents. Il dévorenon-seufement des poissons, mais des crabes et des coquillages; il les avale mème avee tant de précipitation, que souvent de gros fragments de dépouilles d'animaux testacees, et des coquilles entières, parviennent jusque dans son estomac, quoiqu'il eut pu les concasser et les broyer avec ses nombreuses molaires. Ces coquilles entières ces fragments ne sont cependant pas digéres et ces fragments ne sont cependant pas digérés ou dissous par ses su:s digestifs, quelque actives que soient ces humeurs, pendant le peu de sejour qu'ils font dans un canal intestinal trescourt, et dont le loup est pressé de les chasser, pour les remplacer par des substances nouvelles propres à apaiser sa faim sans cesse renaissante. D ailleurs l'estomac de cet anarhique n'a pas la force nécessaire pour les réduire, par la trituration, en très-petites parties: mais ce poisson s'en débarrasse presque tonjours avec beaucoup de facilité, parce que l'ouverture de son anus est très-considérable et susceptible d'une assez grande extension.

C'est dans l'Océan septentrional que se trouve le loup. On ne le voit ordinairement en Europe qu'á des latitudes un peu élevées; on l'a reconuu à Botany-bay sur la côte orientale de la Nouvelle-Hollande'; mais il se tient communément pendant une grande partie de l'année à des distances. considérables de toute terre et dans les profondeurs des mers; il ne se montre pas péndant l'hiver près des rivages septentrionaux de l'Europe et de l'Amérique; et e'est à la fin du printemps que sa femelle dépose ordinairement ses æufs sur les plantes marines qui croissent auprès des cotes.

Il s'élance avec impétuosité; et malgré cette rapidité au moins momentanée, plusieurs naturalistes ont écrit que sa natation parait lente quand on la compare à celle des xiphias : sa force est néanmoins très-grande, et ses dimensions sont favorables à ses mouvements rapides. Ne pourrait-on pas dire que les muscles de sa tête, qui serre, déchire ou écrase avec tant de facilité, sont beaucoup plus énergiques que ceux de sa queue, tandis que, dans les xiphias, les muscles de la queue sont plus puissants que ceux de la tête, armée sans doute d'un glaive redoutable, mais dénuée de dents, et qui ne concasse ni ne bríse? Nous devons d'autant plus e présumer, que la natation, dont les vrais principes accélérateurs sont dans la queue, n'est ordinairement soumise á aucine cause retardatrice très-marquée, qui ne réside dans une partie antérieure de l'animal trop pesante ou trop etendue en avant. N'avons-nous pas vu que la prolongation de la tête des xiphias égale en longeur le tiers de l'ensemble du poisson? et de quel pouvoir ne doivent pas être doués les muscles caudaux de ces animaux, pour leur impriner, malgré la résistance de leur partie antérieure, la vitesse dont on les voit jouir? Ne pourrait-on pas d'ailleurs ajouter que quand bien même la nature, la forme, le volume et la position des museles caudaux leu donneraient à proportion la mème force dans le loup et dans les xiphias, cet anarhique devrait 'Voyage de Tench, capitaine de la Charlotte, a la baie Bo.
anique, en 7787 .

DES POISSONS.

s'avancer, tout égal d'ailleurs, avee moins de rapidité que ces derniers, påree que sa tête assez grosse, arrondie et relevee, doit fendre l'eau de la mer avee moins de facilité que le glaive mince et étroit des xiphias?

Quoi qu'il en soit de la force de la queve du loup, celle de sa tête est si considérable, et ses dents sont si puissantes, qu'on ne le pêche dans beaucoup d'endroits qu'avec des préeautions particulières. Dans la mer d'Ochotsk, auprès du Kamtschatka, vers le cinquante-troisieme degré de latitude, on cherche à prendre le loup avee des seines ou filets faits de lanieres de cuir, et par conséquent plus propres á résister à ses efforts. Dans ce mème Kamtsebatka, le célèbre voyageur Steller a vu un individu de cette espèce que I on venait de pêcher, irrité de ses blessures et de sa captivité, saisir avec fureur, et briser comme un verre, une sorte de coutelas avec lequel on, youlait achever de le tuer, et mordreavec rage des bâtons et des morceaux de bois dont on se servait pour le frapper.

Au reste, on va avec d'autant plus de constance à la poursuite du loup, qu'il peut fournir une grande quantité d'aliment, et que sa ehair, suivant Ascague, est, dans certaines circonstances, aussi bonue que celle de languille. Les habitants du Groenland le péchent ausși pour sa peau, qui leur sert à faire des bourses et quelques antres ustensiles.

Le loup a été nommé Crapaudine, parce qu'on a regardé comme provenant de cet animal, de petits corps fossiles, connus depui longtemps sous le nom de Bufoniles ou de Crapaudines. Ces bufonites ont reçu la dénomination qu'on leur a donnée dès les premiers moments où l'on s'en est occupé, à cause de l'origine qu'on leur a dès lors attribuée. On a supposé que ces petits corps étaient des pierres sorties de la tète d'un crapaud, en latin Bufo. Ils sont d'une forme plus ou moins convexe d'un côté, plane ou concave de l'autre, d'une figure quelquefois régulière et quelquefois irrégulière, et communément gris ou bruns, ou roux, ou d'un rouge-noirâtre. Par une suite de la fausse opinion qu'on avait adoptée sur leur nature, on les a considérés pendant quelque temps comme des pierres fines du second ordre : mais lorsque l'histoire naturelle a eu fait de plus grands progrès, on s'est bientot aperçu que ces prétendues pierres fiues n'étaient que des dents de poissons pétrifiées, et presque toujours des molaires. Les uns les ont regardées comme des dents d'anarhique, d'autres comme des dents du spare dorade, d'autres comme des dents de poissons osseux, differents de la dorade et de l'anarhique. Ils ont tous eu raison, en ce qu'on doit rapporter ces fossiles à plusieurs espèces de poissons très-pen semblables l'un à l'autre; et telle a été l'opinion de Wallérius. La plus grande partie de ces dents nous ont paru néanmoins avoir appartenu à des dorades ou à des anarhiques. Au reste, il est très-aisé de séparer parmi ces fossiles les dents molaires du loup d'avec celles du spare dorade : les demières on une régularité et une convexité que l'on ne voit pas dans les premières. Mais pour être de quel. que utilité aux géologues, et leur donner des bases certaines d'après lesquelles ils puissent lire sur les corps pétriflés et fossiles quelques points de l histoire des anciennes révolutions du globe, nous tâcherons de montrer, dans notr discours sur les parties solides des poissons, le véritables carnctères des dents d'un assez grand nombre d'espèces de ces animaux.

Le loup est d'un noír cendré par-dessus, et d'un blane plus ou moins pur par-dessous ; ce qui lui donne un uouveau rapport extérieur avec plusieurs cetacées, Mais peut-être ne doit-on recarder que comme une variétéde cette espece, Prnarhique que lon a désigné par le nom de Slrié ', qui présente en effet des stries irrégu-

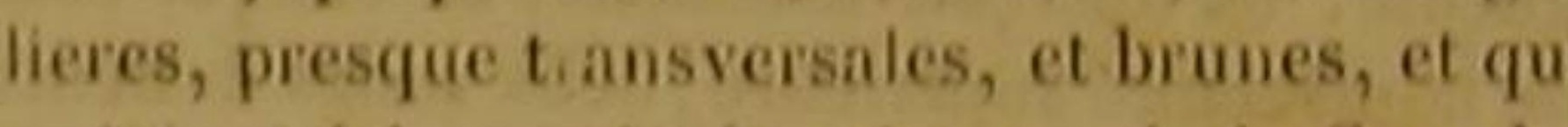
a et peché auprés des Iivages de la GrandeBretagne ${ }^{2}$

L'ANARHIQUE KARRAK ? Inarhichas harak, Lacep.; A. minor, Gius Cuv. ET

\section{L'ANABHIQUE PANTHERIN 4.}

Anarbichas pantherinus, Lacep. '.

Ces deux espéces habitent dans lócéan sep- Anarhichas strigosus, Linnée, ed. de Gmelin. - Brit Zool. 5, n. 65, p. 119

A a membirane des branchies du toup 6 rayons, a la nacelle de lanus 46 , à celle de la yurue 16 ; chacine des pe torales de f'onariąque siré is, et a cetie o la queue din mérue animal is.

'Lup marin karrak, Bonnaterre, pl. de IEne, méth. o1. Fabric. Faun Groeniand, p 159, n 936. - dwariicha minor, Mailer, Prodrom Zool. dan. - Oiafs. Bland., p. 592, t. 12 , - Kun. atsclika, en Russie. - Zoview, Act. Petrop. 1761, 1 p. 271 , ials. 6. 
tentrional, la première dans la mer du Groen-, mes composent chaque opercule branchial; on land, et la seconde dans la mér Glaciale. Elles ne voit pas de ligné latérale. Les nageoires pecont d'aillenrs beaucoup de rapnorts l'une avec l'autre.

Le karrak a les yeux très-gros et rapprochés du sommet de la tête, qui a, dit-on, quelque ressemblance vague avec celle d'un chien. $L$ ouverture de sa bouche est grande; les deux máchoires présentent de chaque côté trois dents aiguës et inégales; et dans l'intervalle qui sépare par-devant ces deux triolets, on compte deux autres dents plus petites.

La nageoire dorsale s'étend depuis le cou jusqu'à une très-petite distance de la nageoire de la queue'.

Le karrak est ordinairement d'un gris noirâtre, et ne parvient pas à des dimensions auss considérables que le loup.

Peut-être le panthérin est-il communémen encore moins grand que le karrak; peut-être at-on eu raison d'éerire que sa longueur ordinaire n'est que d'environ un mètre. On lui a donné le nom que j'ai cru devoir lui conserver, parce que sur un fond plus ou moins jaunátre, et par conséquent d'une teinte assez semblable à la couleur de la panthère, il présente, sur presque toute sa surface, des taches rondes et brunes.

Sa tète est un peu sphérique; ses lèvres sont doubles. Au travers de la large ouverture de sa gueule, on aperçoit aisément, de chaque cóté de la mâchoire supérieure, deux rangs de dent coniques et plus ou moins recourbées, et deux rangées de dents molaires. Entre les quatre rangs de dents coniques, on voit quatre autres dents placées longitudinalement; et entre les quatre rangées de dents molaires, parait sur le palais une série longitudinale de sept dents très-fortes, et dont les deux premières sont ordinairement séparées des autres. La måchoire inférieure est armée, de chaque cóté, de deux rangs de dents molaires, et de deux ou trois raugées de dents coniques.

Les yeux sont grands et assez éloignés l'un de l'autre. La nageoire du dos, qui ne commence qu'à une certaine distance de la nuque, touche celle de la quene; et ces deux derniers caractères suftiraient pour séparer le panthérin du karrak, dont la nageoire caudale est un pen éloignée de celle du dos, et dont les yeux sont rapprochés sur le sommet de la tête. Deux laA la nageoire dorsale du karrak 70 rayons, a chacune des
pectoralies 20 a celle de Tanus 44 , a celle de Is quene 24 . torales sont arrondies comme celle du loup; nageoire de la queue est un peu lancéolée'.

$\mathrm{Au}$ reste, suivant l'auteur russe Zoview, qui a fait connaitre le panthérin, on ne mange guère en Russie de cet anarhique, quoiqu'on y vante la bonté de sa chair.

\section{QUARANTIĖUE GENRE.}

LES COMÉPHORES ${ }^{2}$.

Le corps allongé el comprimé ; la tete el l'ouverhure de la bouche tres-grandes; le museau large $t$ deprime: les dents très-petites; deux nageoires dorsales : plusieurs rayons de la seconde garnis de longs fitaments. espéce. CARCTÉ⿴囗十

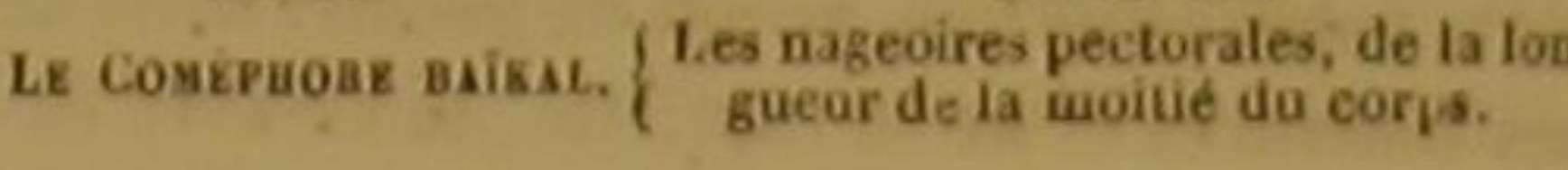

LE COMÉPHORE BAIKAL ${ }^{3}$.

Comephorus baikalensis, Lacep.; Callionymus baikalensis, Pallas.

Ce poisson a déja été déerit sous le nom de Calilonyme; mais il manque de nageoires inerieures placées all-devant de l'anus. Dès lor il ne peut être inscrit ni dans le genre ni mème dans l'ordre des vrais callionymes, qui sont des jugulaires; il doit ètre compris parmi les apodes; et les caractères remarquables qui le distinguent, exigent qu'on le place, parmi ces derniers, dans un genre particulier.

Le celèbre professeur Pallas I'a fait connaitre. Il l'a découvert dans le Baikal, ce lac fameux de l'Asie russe, et si voisin du territoire chinois. Le coméphore que nous décrivons, se tient pendant l'hiver dans les endroits de ce lac ou les eaux sont le plus profondes; et ce n'est que pendant l'éte qu'il s'approche des rivages en troupes nombreuses. Comme plusieurs auttres apodes de la division des osseux, il a le corps allongé, comprimé, et enduit d'une ma. tière huileuse très-abondante. La tète est grande, aplatie par-dessus et par less cótés, garmuseau large; la bouche trè-ouverte ; la mâhoire inférieure plus avancée que la supérieure, 'A la membrane branchiale du panthérin 7 ráyons, à a na.
geoire dirssle 67 , a clacune des pectorales 20 , a ceile de l'zi $\mathrm{L}$, s comie de la quene 20.

Jans le genre CalLiosrus. D. Cuvier, forment un sous-genre - Callionyme baikal, Bo. nie de deux tubercules aupres des tempes; le

DES POISSONS。

et hérissée comme cette dernière, excepte a son sommet, de dents très-petites, crochues et aiguês; la membrane branchiale très-làche, et soutenue par des rayons très-éloignés l'un de l'autre; et la ligne latérale assez rapprochée du dos.

La première nageoire dorsale est peu étendue : mais quinze rayons au moins de la seconde sont terminés par de longs filaments semblables à des cheveux; et cette conformation nous a suggéré le nom générique de Portecheveux ( coméphore), que nous avons donné au baikal. Les nageoires pectorales sont si prolongées, qu'elles égalent en longueur la moitié de l'animal; pour peu qu'elles eussent plus de surface, qu'elles fussent plus facilement extensibles, et que le baikal pút les agiter avec plus de vitesse, ce poisson pourrait non-seulement nager avee rapidité, mais s'élever et parcourir un are de cerele considérable au-dessus de la surface des eaux, comme quelques pégases, les trigles, les exocets, ete. '.

La nageoire de la queue est fourchue ${ }^{2}$.

\section{QUARANTE-UNIEME GENBE.} LES STROMATÉES.

Le corps très-comprime et orale.

EPRices. CAnictiknes.

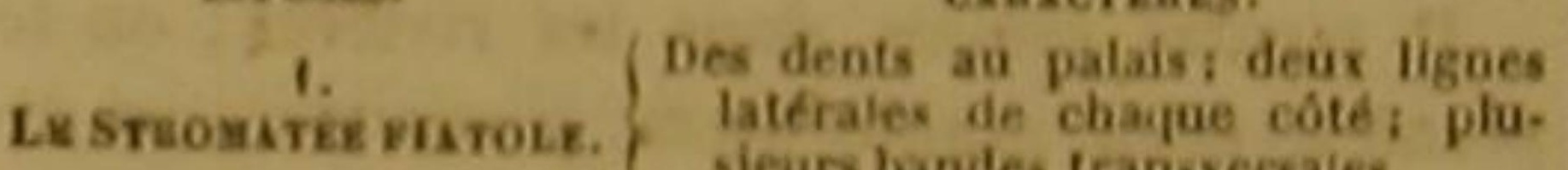
s.eurs bandes transversales.
Point de dents au palais; une seule

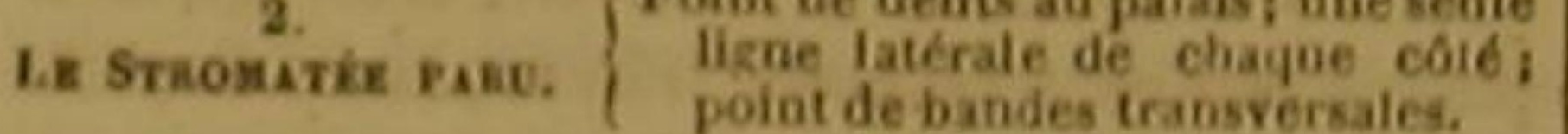

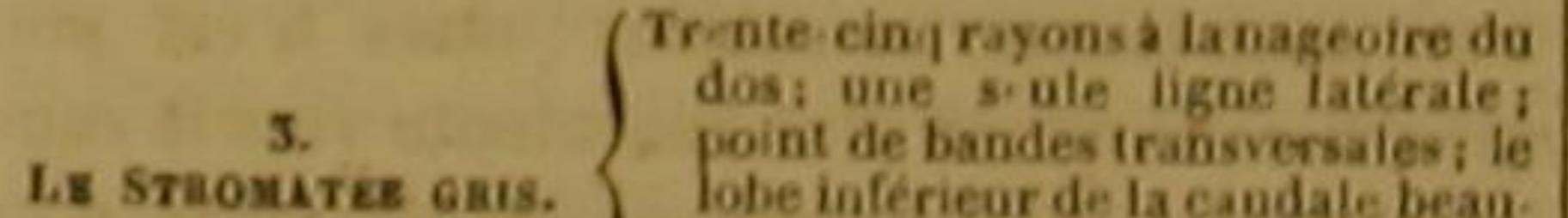

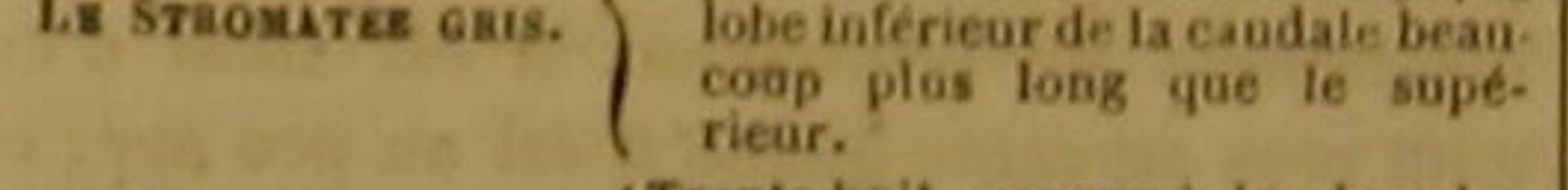

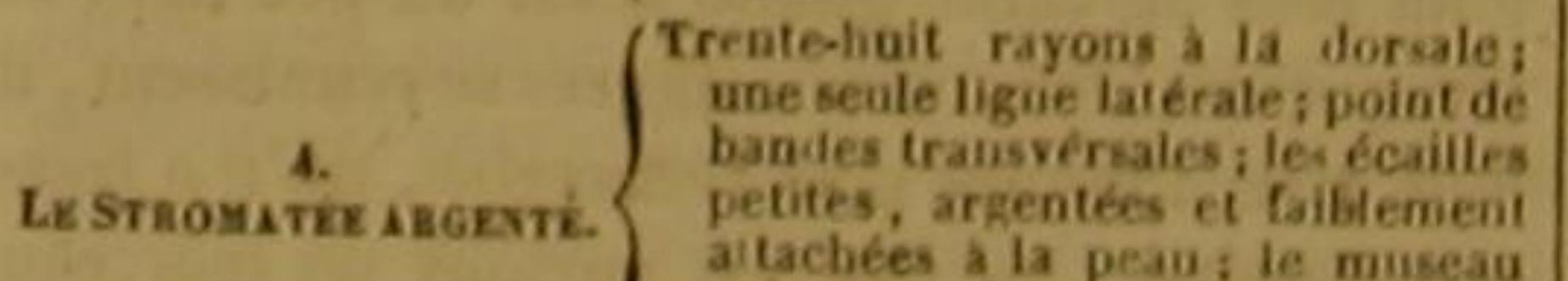
altachées a la pean i le museau
avané en forme de nez, au des.
sous de la nácboire swpérieure. sous de la máchoire supérieure.

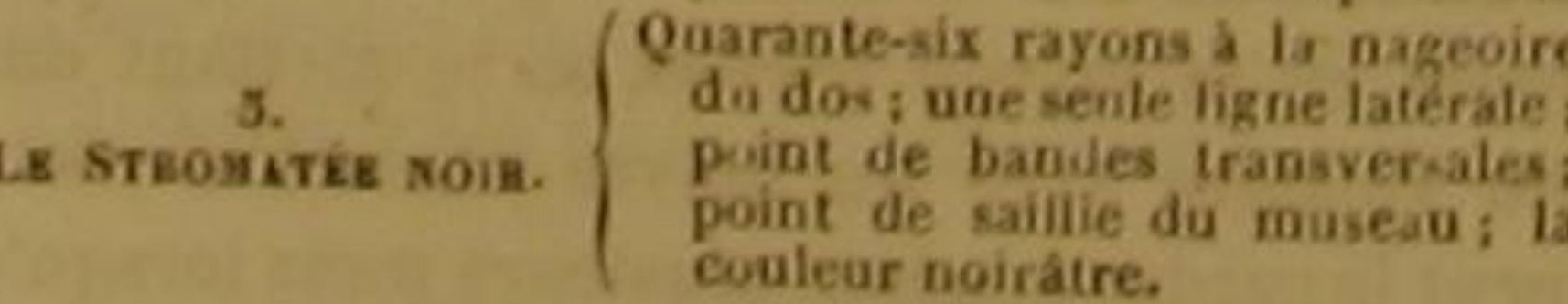
'Discours sur la nature des poissons.
i la membrane des branchies 6 rayo seoire du dos 8 , a la seconde $2 x$ rayons, a la premiere napectorales 15 , a celle de lanus 32 , a celle de la queue 15 .
LE STROMATÉE FIATOLE '

Stromateus Fiatola, Linn., Bl., Laçep., Cuv. '.

Tous les apodes de la première division des osseux que nous avons déjà examinès, ont le corps plus ou moins allongé, cylindrique et serpentiforme. Dans les stromatees, les proportions générales sont bien différentes : l'animal est très-comprimé par les cótés, et les deux surfaces latérales que produit cette compression sont assez hautes, relativement a leur longueur, pour représenter un ovaie plus ou noins régulier. Cette conformation, unique parmi les apodes que nous décrivons, sufit pour empêcher de confondre les stromatée avec les autres genres de son ordro

Parmi ces stromatées, l'espèce la plus anciennement connue est celle que l'on nomme Fiatole, et que I'on trouve dans la mer Méditerranée, ainsi que dans la mer Rouge. Se couleurs sont agréables et brillantes; et leur éelat frappe d'autant plus les yeux, qu'elles sont répandues sur les larges surfaces latérales dont nous venons de parler. Ordinairement ce beau poisson est bleu dans sa partie supéríeure, et blane dans sa partie inférieure, avec du rouge autour des lèvres; et ces trois couleurs, que leurs nuances et leurs reflets marient et fondent les unes dans les autres, plaisent d'autant plus sur la flatole, qu'elles sont relevées par des raies transversales étroites, mais nombreuses, et communément dorées, qui s'étendent en zigzag sur chacun des cotés de l'animal.

La bouche est petite; les máchoires et le palais sont garnis de dents; la langue est large et lisse; chaque coté du corps présente deux lignes latérales, l'une courbe, et l'autre presque droite; la nageoire de la queue est très-four-

'Stromateus fiatola, - Liselte, sur quelques rivages de La mer Adratique. - La mpuga, dans quelques contrees de Galie, - Stromate Ratole, Dabeoton, Enc. méth, - Id. Ben. 19. syn. 35. - Fiatole, et Stromated Hondelet parti, i. 8. c. 20. - Trouehou, Rondelet, part. I, I. \&, c. 19 , Nons verrons dans la suite de cet ouvrage, que le Stromatée decrit dans Rondelet, part 1, L. 5. c. 24, et le Stromateus d'Athenée. L. 7, p. 322. rapporté par Artedi a lésiece que nous examinois, non-seulement n'appartieonent pas a cetle espece ni au genre que nous décrivons, mais méme ne doivent pas etre compris dans iordre des apodes de la premiere division desosseux.) - Fiatola Rome dicla, Jonstoo, L. L, it S, e, I.

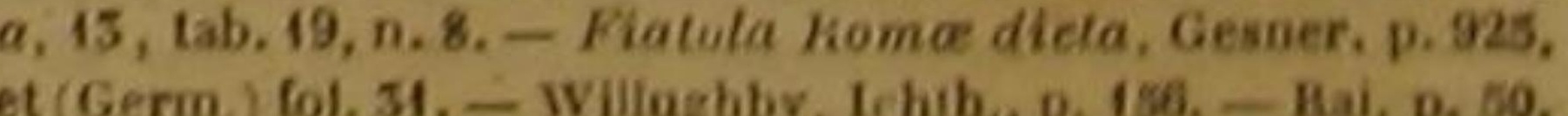
- Fiatole, Valmont de Bomare, Diet, of hist nat. met cetle espéce comme type du genre stro- 
chue '; et si on cherche, par le moyen de la d'ètre doré, est d'un bleu céleste, et qui ne dissection, à connaitre les formes intérieures parvient guère qu'a la longueur de deux ou troi de la fiatole, on trouve un estomac rendu en décimètres. Nous pensons, avec le professeur de la far un etranglement, et Gmelin, que ce stromatée, qui ne parait difféquelque sorte double par un etranglement, et \begin{tabular}{l|l} 
un très grand nombre d'appendices ou de petits & rér du paru que par la couleur du dos, n'est \\
tubes intestinaux ouverts seulement par un & peut-être qu'une variété de cette dernière es-
\end{tabular} bout et placés auprès du pylore.

\section{LE STROMATÉE PARU ${ }^{2}$. Stromateus Paru, Sloane, Lacep. '}

Cette espèce n'est pas peinte de couleurs aussi variées que la fiatole, mais elle resplendit de l'éclat de l'or et de l'argent; l'or brille sur sa partie supérieure, et le dessous de ce poisson réfléchit une teinte argentée très-vive. Elle habite dans l'Amérique méridionale et dans les grandes Indes, particulièrement auprès de Tranquebar; et sa chair est blanche, tendre et exquise.

Sa langue est large, lisse, et assez libre dans ses mouvements ; ses mảchoires sont hérissées de dents petites et aiguẽs : mais on n'en voit pas sur le palais, comme dans la fiatole, et quelques osselets arrondis paraissent aux environs du gosier.

L'ouverture des branchies est très-grande l'opercule composé d'une seule lame bordée d'une membrane. Une seule ligne latérale assez large et argentée règue de chaque côté de l'anmal. Les écailles du paru sont petites, minces et tombent facilement. Cet osseux ne présent jamais que de petites dimensions, non plus que la fiatole : aussi ne se nourrit-il que de ver marins, et de poissons très-jeunes et trèsfaibles ${ }^{4}$.

On trouve dans les eaux du Chili un stromatée déerit par Molina s , dont le dos, au lieu

- A la vageoire dorsale 46 rayons, a chacune des mageoires peet orales 25 , a celle de I anus 34 .

Stromaleus unicolor, Limnée, éd. 12, - stromates stris carens. Bloch, pl. 160, - Stromale paru, Dautenton Sloan. Jamaic a p. asre, pl. de I Enc. meth. - Pampus, pise. 5t. 2 . p. 281 , tab. 250, fig. 4. - Pampus, Kai, ' $\mathrm{u}$.

du geare Stroustres, maissil ne lais le sous-genre Peprilus Bloch qui, seloo lai. represente le Stromats la pi. $\mathbf{6} 60 \mathrm{de}$ noire, Stromateus niger. D. dos 50 , a chacune des bectorales 2 rayons, a la nazeoire du

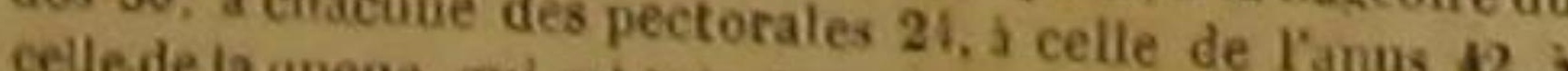
'Melin.. Hist. nat Chil - pourchine, 18. pèce.

LE STROMATÉE GRIS ' Stromateus cinereus, Lacep.; S, griseus, Cuv.

\section{LE STROMATÉE ARGENTÉ ${ }^{2}$,}

Stromatens argenteus, Laeep., Cuv.

ET LE STROMATÉ NOIR ${ }^{3}$.

Stromateus niger, Lacep., ruv. 4

Ces trois poissons que Bloch a fait connaitre, vivent dans les Indes orientales; leur dorsale et leur nageoire de l'anus sont en forme de faux. Le gris a le museau ún peu avancé: l'ouverture de la bouche petite; les deux màchoires aussi longues l'une que l'autre, et garnies tontes les deux d'une rangée de dents fines et très. serrées; le palais uni ; deux orifices à chaque narine; les rayons articulés, et cependant trèscassants; la couleur générale grise; les pectorales rougeátres; une longueur de trois ou qua. tre décimètres ; et une épaisseur de cinq ou six centimètres.

Il n'entre jamais dans les rivières; on te prend avee de grands filets, à une certaine distance des eótes de la mer. On croit qu'il n'a pas de temps fixe pour frayer; aussi le péchegras et sa chair est plus succulente vers le com mencement du printemps; il est aussi d'un goủt plus agréable quand il est un peu âgé; et lorsque ces deux eirconstances se réunissent, il doit ètre d'autant plus recherché, qu'il a trèspeu d'arêtes. Sa tête est surtout un morceau très-délicat. On le conserve pendant quelques jours en le faisant frire et en le mettant dans du vinaigre avee du poivre et de l'ail ; et on peut le garder pendant plusieurs mois lorsqu'on l'a coupé en tronçous, qu'on l'a salé, pressé

'Bloch, pl. 420.

Wallel-wawal, par les habitants de la cóte de Coromaro s. - Bloch, pl. 421.

-Ces trois pour M. Cuvier, qui sont des pamples ou vrais s'romatés Bloch, que M.de Lacépede placait densiar la planche 160 de matée noir. b. t-on dans toutes les saisons: mais il est plu
DES POISSONS.

63

et séché ou mariné avec du vinaigre, du cacao quels la très-grande compression, la hauteur et du tamarin. Quand il est ainsi préparé, on le nomme Karawade.

L'on doit remarquer dans le stromatée argenté l'ouverture des narines, qui est souvent en forme de eroissant, et l'organisation ainsi que la couleur des nageoires, qui ne renferment que des rayons articulés, et qui sont blanchàtres à leur base et bleues à leur extrémité.

Observez, dans le noir, les dents qui sont un peu plus fortes que celles du gris et de l'argenté, la double ouverture de chaque narine, et les écailles, qui sont mieux attachées à la peau que celles du stromatée gris '.

\section{QUARANTE-DEUXIE ME GENRE.}

LES RHOMBES.

Le corps trés-conprimé et asses court: claque colè de Panimat representant une sorle de rhombe; des aignillons ou rayous non articules aux nageoires du dos at de lanus.

ESPÉCE.

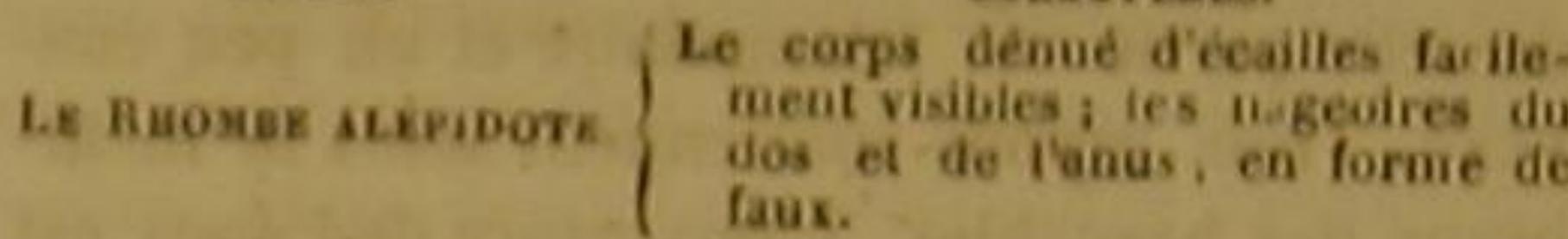

\section{LE RHOMBE ALEPIDOTE ${ }^{2}$}

Rhombus alepidolus, Lacep. '

Ce poisson, que le docteur Garden avait envoyé de la Caroline à Linnée, et que l'illustre naturaliste de Suède a fait connaitre aux amis des sciences, a été inscrit jusqu'à présent dans le genre des chétodons : mais indépendamment de plusieurs autres traits qui le séparent de ces derniers osseux, l'absence de nageoires inférieures placées au devant de l'auus, nonseulement l'écarte du genre des chétodons, mais oblige à ne pas le placer dans le mème ordre que ces thoracins, et à le comprendre dans celui des apodes dont nous nous occupons. Nous l'y avons mis a lont nous nous occupons. Nous 'y avons mis á la suite des stromatees, avec les1' 7 rayons a la membrane brauchiale du stromatée gris, 20 geoire de la queue. 7 a la membrage de Tanus, 20 a li ma. argesté, 21 a cha. 7 a la mensbrane branchiale du stromatée de ia sinene, 7 a lo pechrale, 58 a I anale, 19 a la nageoire 16 à cha que pectorate, 56 a la pranchiale du stromatée noir, 'Clicto lerre, pl. den nud, Daubeaton, Enc. méth. - Id. Bonn Le ginre Thombus genre PEpaitus da geure Stromalce, par est réuni au sso. et la brièveté de l'ensemble formé par son corps et par sa queue, lui donnent beaucoup de rapports. Il en differre cependant par plusieurs caractères, et notamment par la figure rhomboidale de, faces latérales, qui sont ovales dans les stromatées, et par la nature de plusieurs rayons de la nageoire da dos ou de celle de l'anus, dans lesquelles on ne remarque aucune articulation, et qui sont de véritables aiguillons.

La peau de l'aiépidote ne présente d'ailleurs aucune écaille facilement visible; et cette sorte de nudité qui lui a fait attribuer le nom de Nud, ainsi que celui quej'ai cru devoir lui conserver, empécherait seule de le confondre avec les stromatées, et lui donne une nouvelle ressemblance avec les céeilies, les gymnotes, les murènes et plusieurs autres apodes de la première division des osseux.

Ses mâchoires ne présentent qu'un seul rang de dents; on voit de chaque côté de l'animal deux lignes latérales, dont la supérieure suit le contour du dos, et dont l'inférieure est droite, et parait indiquer les intervalles des muscles. Les nageoires du dos et de l'anus sont placées au-dessus l'une de l'autre, et offrent la forme d'une faux; celle de la queue est fourchue'.

Le rhombe alépidote est bleuâtre dans sa partie supérieure. Nous ignorons si on le trouve dans quelque autre contrée que la Caroline.

\section{SUPPLÉMENT \\ aU TABLEAU}

DU GENRE DES CYCLOPTĖRES.

PREMIER SOUS-GENRE.

Les nageoires du dos, de la queue el de l'anus, siparèes l'une de l'autre.

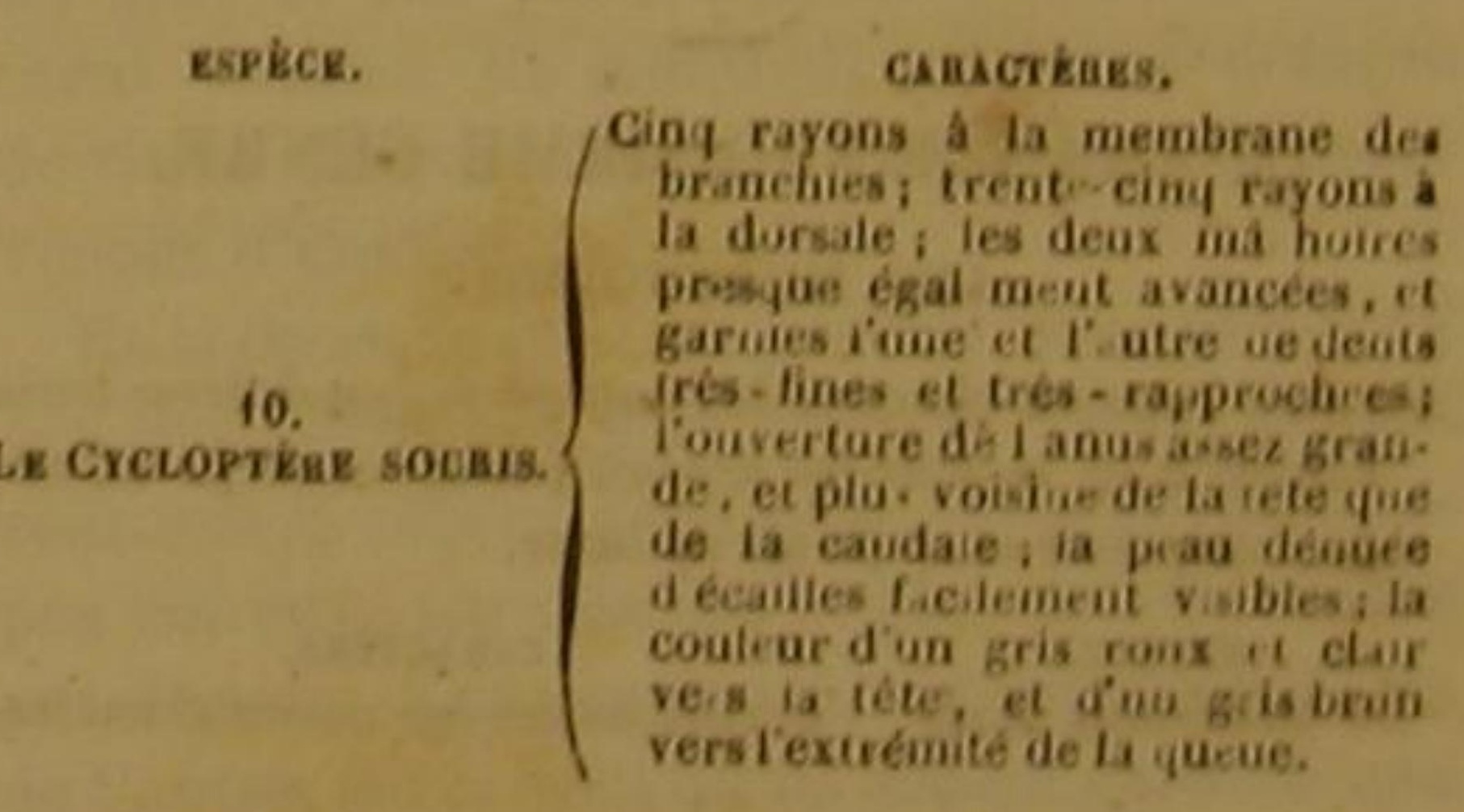

6 rayons a la membrane branctiale, 3 aiguiltons et is rayons articulés a la mageoire dorsale, 24 rayons d clayue nagecire pectorale, 5 aigoilions et 41 rayons artea es 3 is 


\section{HISTOIRE NATURELLE}

LE CYCLOPTĖRE SOURIS '.

Cyclopterus Musculus, Lacep.

M. Noēl nous a envoyé une note très-détaillée sur ce cycloptère. Cet habile observateur a pèché plusieurs individus de cette espece dans les pares de la digue de l'Eure, aupres do Havre. La souris, que l'on prend ordinairement pendant l'automne, a un décimètre de longueur sur vingt-cinq millimètres de largeur. La tête est plus large que haute. La langue occupe une grande partie de la gueule. Le palais est lisse; mais on voit auprès du gosier deux os garnis de petites dents. Les yeux sont petits et ronds. L'ouverture de chaque narine est ovale. Une peau molle rećouvre chaque opercule, qui se prolonge vers laqueueen appendice êmoussé Le corps et la queue sont revêtus d'une peau très-souple. Une petite gouttière, légèrement creusée, est située'sur la nuque. Au milieu des thoracines, qui sont réunies en disque, comme sous tous les cycloptères, et frangées à l'extérieur, on trouve des mamelons plus ou moin nombreux. La caudale est d'un gris cendré ; les autres nageoires sont brunâtres.

Le cycloptère souris, qui tire son nom de sa petitesse, de sa couleur ou de la rapidité de ses mouvements, se nourrit de petits poissons et de chevrettes, on dautres erustacées trèsjeunes ${ }^{2}$

DIX-HUITIEME ORDRE

DE LA CLASSE ENTIÈHE DES POISSONS,

SECOND ORDRE

DE LA PREMik̀n Divisior des OSsEUX.

Porssons jugulaires, ou qui ont des nageoires situees sous la gorge.

\section{QUARANTE-TROISIÈME GENRE.} LES МURE்NOİDES.

Un seul rayon à chacune des nageoires jugulaires; trois rayons à la membraze des branchies: le corps allonge, comprime et en forme de lame.

Espèce. CARActì̀z.

'Cyclopterus musoulus. - Souris de mer, par les péIJ rayons a chasue pave

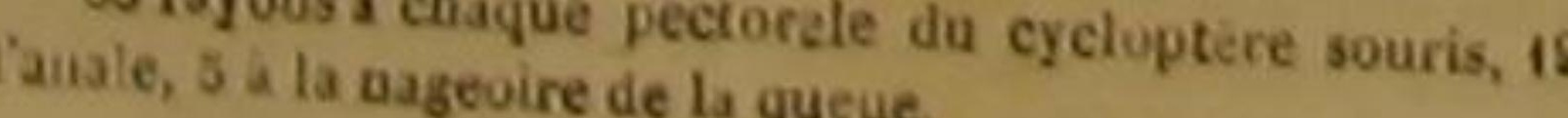

LE MURENOIDE SUJEF 4 . Bleninius murenoides, Sujef; Murænoides Sujef, Lae.?

Ce poisson a été inscrit parmi les blennies, mais il nous a paru en ètre séparé par de gran. des différences. De plus, ses caractères ne permettent de le placer dans aucun autre genre de jugulaires. Nous nous sommes done vus obligés de le comprendre dans un genre particulier; $\mathrm{el}$ comme les deux nageoires qu'il a sous la gorge sont très-petites, composées d'un seul rayon, et quelquefois difficiles à apercevoir, nous l'avons mis á la tète des jugulaires, qu'il lie ave les apodes par cette forme de nageoires inférieures. Il a d'ailleurs des rapports très-nombreux avec les murènes et les trichiures. Son corps es allongé, aplati latéralement, et fait en forme de lame d'épée, ainsi que celui des trichiures; les écailles qui le revêtent sont aussi difficiles à distinguer que celles des murènes et particulièrement de l'anguille. Un double rang de dents garnit les deux mâchoires. La tête présente quelquefois de petits tubercules; le dessus de cette partie est triangulaire et un peu convexe. Trois rayons soutiennent seuls la membrane des branchies. L'ouverture de l'anus est située à peu près vers le milieu de la longueur du corps. La couleur de l'animal est d'un gris cendré qui s'éclaircit et se change en blanchâtre sur la tête et sur le ventre. Ce murénoīde est ordinairement long de deux décimètres; et nous lui avons donné le nom de $S$ ujef, afin de consacrer la reconnaissance que l'on doit au savant quil'a fait connaitre.

\section{QUARANTE-QUATRIĖME GENRE.} LES CALLIONYMES.

La tete plus grosse que le corps: les ouvertures branchiales sur la nuque; les nageoires jugulaires trèsdecaille a peine le corps et la queue garnis d'ecailles à peine risibles.

PREMIER SOUS-GENRE.

$$
\text { Les yeux très-rapprochés l'un de l'autre. }
$$

ESPÈCES.

cinctive

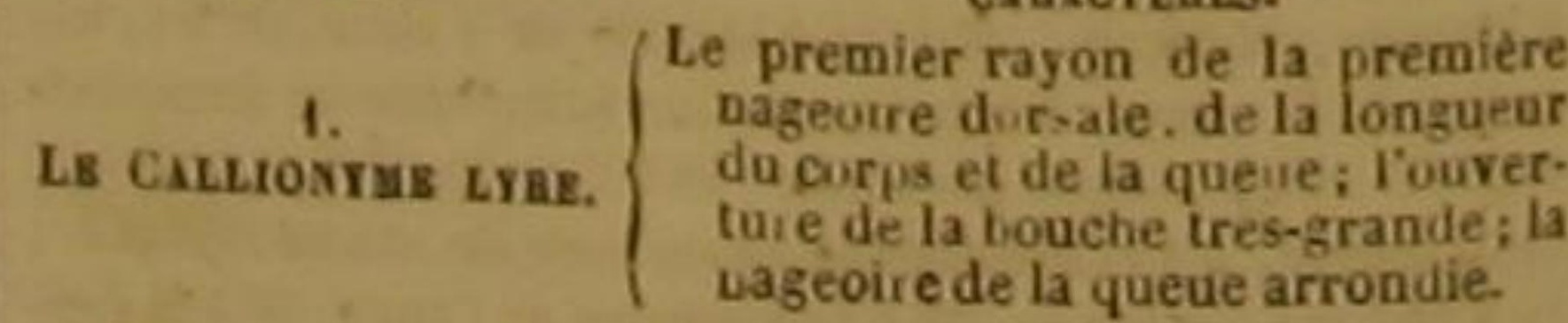

'Sujef, Act. acad. Petropol. 1779, 2, p. 193, tab. 6, fig. 1. "II. Cuvier place ce : Oisson dans le genre B.ennie et le sous.geure Gonelle, qui correspond aux Centronotus de
Schn. D.

DES POISSONS.

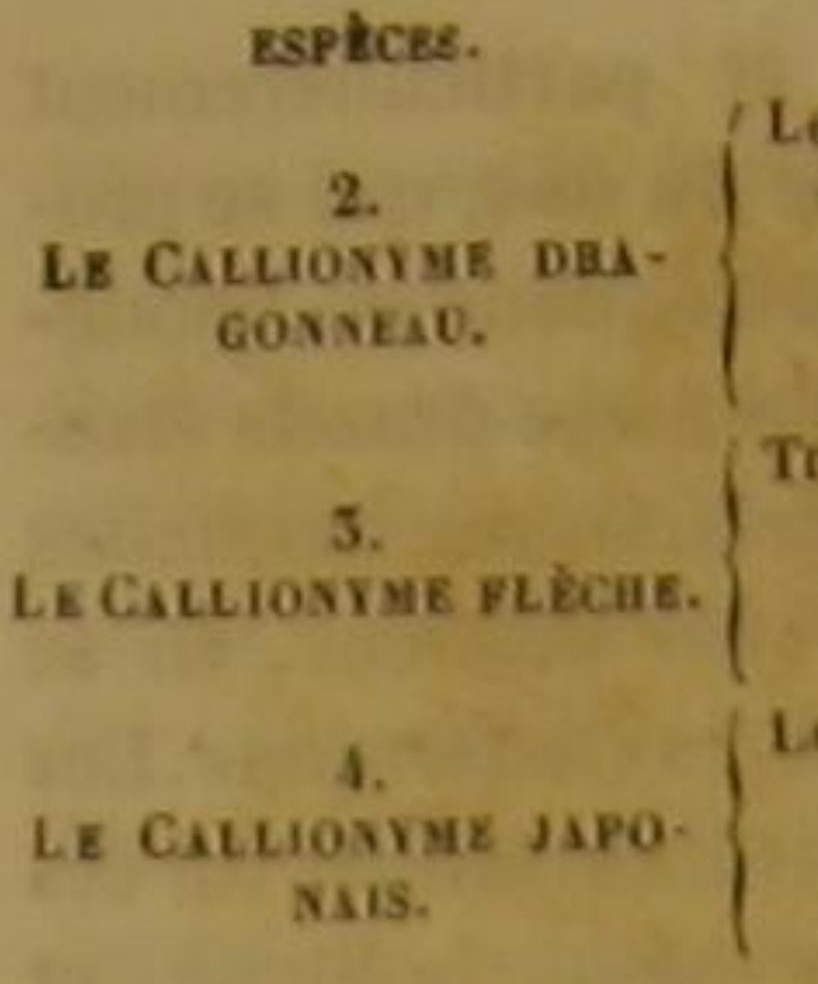

CABCTÈ丶BEs. Les rayons de la première nageoire
du dos bea coup ples couris da dos bea coupp plus cours la queve; t'ourerture

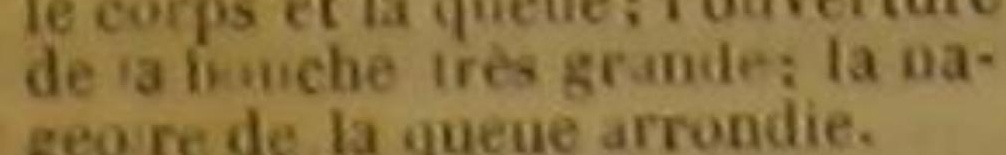
Trois rayons a la membrane de branchie-; louvrriure de la bou-
che petile; la nagevire de la
queue arrondie.

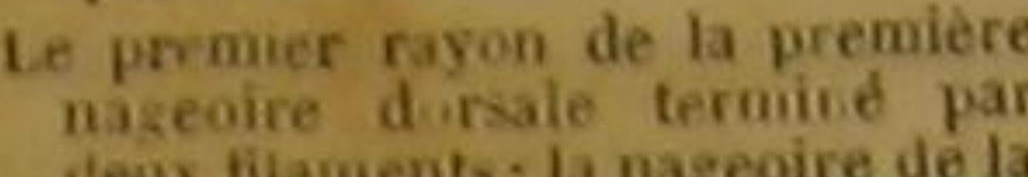
deux filaments
queue fourchuce.

SECOND SOUS-GENRE.

Les yeux très-peu rapprochés l'un de l'autre.

Le Cunsine pois.
ruLE.<smiles>[14CH3]</smiles>

\section{LE CALLIONYME LYRE '}

Callionymus Lyra, Lino., Lacep., Cuv, ,

Callionyme ${ }^{3}$, lyre; quelles images agréables, quels souvenirs touchants rappellent ces deux noms! Beauté céleste, art enchanteur de la musique, toi qui charmes les yeux, et toi qui émeus si profondément les caurs sensibles, ce deux noms ingénieusement assortis renouvellent, pour ainsi dire, en la retraçant à la memoire, votre douce mais irrésistible puissance. Vous que la plus aimable des mythologies fit aaitre du sein des flots azurés ou sur des rives fortunées, qui près des poétiques rivages de la Grèce héroique formátes une alliance si heureuse, confondites vos myrtes avee vos lauriers, et échangeâtes vos couronnes, que vos image riantes embellissent à jamais les tableaux de peintres de la nature : béni soit celui qui, pa deux noms adroitement rapprochés, associa vos

' Lavandière, sur que lques côtes franç. de locéan.-Cal. lionyme lacerl. Daubenton, Ene. méth. - Id. Bonoaterre, pi. de i'Ene. méth. - Faun. suec. 504. - Strom. sondim. - Uranoscop s. ossicalo primo, ete., Gronov., Mus. 4, n. 64. - Cotus, ossiculis pinnx dorsalis longitudine corporis.,

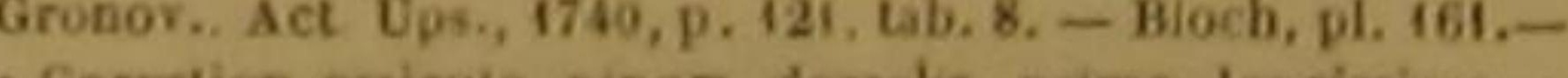

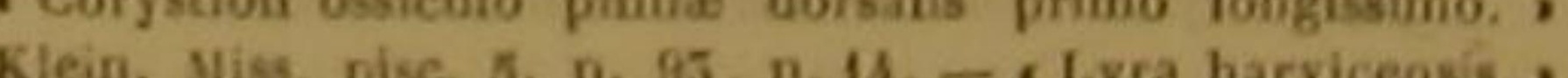

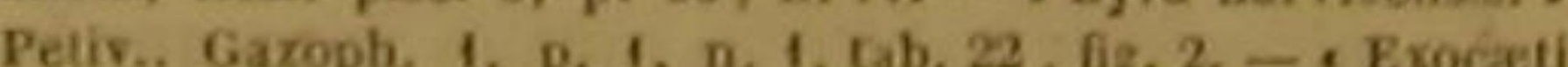
- lertium genus. is seba, Mus. 3 , tab, 50, fig. 7. - Id. Bélon, Aquat., p. 225. - Xellow jurnard, Tyson, Act, angi. 21, D. 205, 1749, fig. 1.-Dracunculus, Gesn., A quat, p. 80; Icon. anim., p.-84. - I Cottos, pinná secunda dorsi albà., Ariedi, Gen, 49, syn. 7. - id. Aldrov., Pisc., p. 262. - Id. Jonst.. Pise, p. 91, tab. 24, fig. 4. - Id. Willoghby, Ichith., tab. H, 6, 6., 3. - Lacert, Rondelet. part. 1, 1. 10, c 11.th. 27, - Dowel, et Souris de mer, Duha, Tr. Trite d 'Dugenre Callionyme, Cav. - Callionyme vieal du grec, et signifie beau nom. emblèmes comme vos deux pouvoirs magiques avaient été réunis, et qui ne voulut pas qu'un des plus beaux habitants d'une mer témoin de votre double origine putt exposer aux regards du naturaliste attentif ses couleurs brillantes, ni l'espèce de lyre qui parait s'élever sur son dos, sans ramener l'imagination séduite et vers le dieu des arts, et vers la divinité qui les anime et dont le berceau fut placé sur les ondes Non, nous ne voudrons pas séparer deux noms dont l'union est d'ailleurs consacrée par le génie; nous ne ferons pas de vains efforts pour empécher les amis de la science de l'étre aussi des grâces; nous ne croirons pas qu'une sévérité inutile doive repousser avee austérité des sentiments consolateurs; et si nous devons chercher à dissiper les nuages que l'ignorance et l'erreur ont rassemblés devant la nature, a déchirer ces voiles ridicules et surchargés d ornements étrangers dont la main maladroite d'un mauvais goùt froidement imitateur a entouré le sanctuaire de cette nature si admirable et si féconde, nous n'oublierons pas que nous ne pouvons la connaitre telle qu'elle est, qu'en ne blessant aucun de ses attraits.

Nous dirons done toujours Callionyme Lyre, Mais voyons ce qui a mérité au poissonque nous allons examiner, l'espèce de consécration qu'on en a faite, torsqu'on lui a donné la dénomination remarquable que nous lui conservons.

Nous avons sous les yeux l'un des premiers poissons jugulaires que nous avons cru devoir placer sur notre tableau; et déja nous pouvons voir des traits très-prononcés de ces formes qui attireront souvent notre attention, lorsque nous décrirons les osseux thoracins et les osseux abdominaux. Mais à des proportions partículières dans la tête, à des nageoires élevées ou prolongées, à des piquants plus ou moins nombreux les callionymes, et surtout la lyre, réunissent un corps et une queue encore un peu serpentiformes, et une peau dénuće d'écailles facilement visibles. Ils montrent un grand nombre de titres de parenté avec les apodes que nous venons d'étudier.

Et si de ce coup d'ceil général nous passons a des considérations plus précises, nous trouverons que la tête est plus large quele corps, trèspeu convexe par-dessus, et plus aplatie encore par-dessous. Les yeux sont très-rapprochés l'un de l'autre. On a écrit qu'ils étaient garnis d'une membrane clignotante: mais nous nous sommes 
assurés que ce qu'on a pris pour une telle membrane, n'est qu'une saillie du tégument le plus extérieur de la tête, laquelle se prolonge un peu au-dessus de chaque cil, ainsi qu'on a pu l'observer sur le plus grand nombre de raies et de squales.

L'ouverture de la bouche est tres-graride; les lèvres sont épaisses, les máchoires hérissées de plusieurs petites dents, et les mouvements de In langue assez libres. On voit à l'extrémité des os maxillaires un aiguillon- divisé en branches dent le nombre parait varier. L'opereule branchial n'est composéque d'une seule lame: mais il est attaché, ainsi que la membrane branchiale, à la tête ou au corps de l'animal, dans une si grande partie de sa eirconférence, qu il ne reste d'autre ouverture pour la sortic ou pour l'introduction de l'eau, qu'une tres-petite fente placée de chaque côté au-dessus de la nuque, et qui, par ses dimensions, sa position et sa figure, ressemble beaucoup à un évent.

L'ouverture de l'anus est beaucoup plus près de la tête que de la nageoire de la queue. La ligue latérale est droite

Sur le dos s'élèvent deux nageoires: la plus voisine de la tète est composée de quatre ou de einq et même quelquefois de sept rayons. Le premier est si allongé et dépasse la membrane en s'étendant à une si grande hauteur. que sa longueur égale l intervalle qui sépare la nuque du bout de la queue. Les trois ou quatre qui viennentensuite sont beaucoup moins longs, et décroissent dans une telle proportion, que le plus souvent ils paraissent étre entre eux et avec le premier dans les mèmes rapports que des cordes d'un instrument destinées à donner, par les seules différences de leur longueur, les fons $u t$, ut octave, sol, ut double octave, et mi, c'està-dire l'accord le plus parfait de tous ceux que la musique admet. Au delà, deux autres rayon plus courts encore se montrent quelquefois et paraissent représenter des cordes destinées a faire entendre des sons plus élevés que le $m i$, et voilà done une sorte de lyre à cordes le $m i$; niquement proporte de lyre à cordes harmoaiquement proportionnées, qu'on a cru, pour ainsi dire, trouver sur le dos du callionyme dont nous parlons; et comment dès lors se serait-on refusé à l'appeler Lyre ou Porte-Lyne'?

A la membrane des branchies 6 rayous, a la premier chacuue des reciorales is. a chacende nageoire da dos 10, res 6. a cello de lanus 10 a celle de la nogerires jugulai-
Les autres nageoires, et particulièrement celle de l'anus et la seconde du dos, qui se prolongent vers l'extrémité de la queue en bandelette membraneuse, ont une assez grande étendue, et forment de larges surfaces sur lesquelles les belles nuances de la lyre peuvent, en se déployant, justifier son nom de Callionyme. Les tons de couleur qui dominent au milieu de ces nuances, sont le jaune, le bleu, le blanc, et le brun, qui les encadre, pour ainsi dire.

Le jaune règne sur les côtés du dos, sur la partie supérieure des deux nageoires dorsales. et sur toutes les autres nageoires, excepté celle de l'anus. Le bleu parait avec des teintes plus ou moins foncées sur cette nageoire de l'anus, sur les deux nageoires dorsales où il forme des raies souvent ondées, sur les cótés où il est dis. tribué en taches irrégulières. Le blanc occupe la partie inférieure de l'animal.

Ces nuances, dont l'éclat, la variété et l'harmonie distinguent le callionyme lyre, sont une nouvelle preuve des rapports que nous avon indiqués dans notre Discours sur la nature des poissons, entre les couleurs de ces animaux et la nature de leurs aliments : nous avons vu que très-fréquemment les poissons les plus richement colorés étaient ceux qui se nourrissaien de mollusques ou de vers. La lyre a reçu une parure magnifique, et communément elle re. cherche des oursins et des astéries.

Au reste, ce callionyme ne parvient guère qu'à la longueur de quatre ou cinq décimètres on le trouve non-seulement dans la Méditerranée, mais encore dans d'autres mers australes ou septentrionales; et on dit que, dans presque tous les climats qu'il habite, sa chair est blanche et agréable au goút.

$$
\text { - }
$$

\section{LE GALLIONYME DRAGONNEAU '.}

Callionymus Dracunculus, Linn., Lacep. ’.

Ce callionyme habite les mèmes mers que la yre, avee laquelle il a de très-grands rapports il n'en differe mème d'une manière trapports; - Callionyme dragonneau, Danbenton. Eac. méth. - IJ.

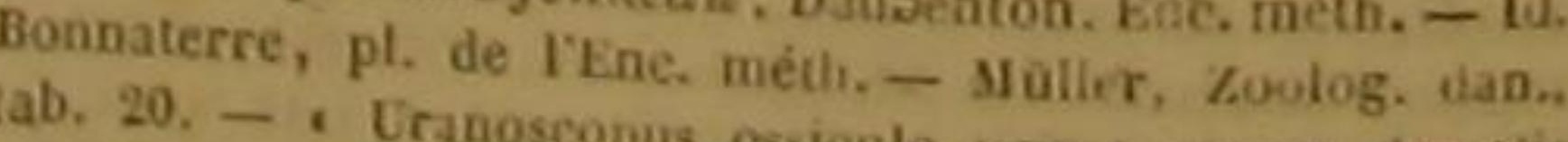
prime unciali, Gropus ossiculo primo punse doraliG. 2. - Surdid dragoned, Mus. 1, n, 65. - Eluch, pl. 162. tab. 27. que parce que sa première dorsa e eatere du callionyme tyre ajoute qu'on le croit sa femeite. D.
D.

DES POISSONS.

67

ble que par la brièveté et les proportions des rayons qui soutiennent la première nageoire dorsale, par le nombre des rayons des autres nageoires ', par la forme de la ligne latérale qu'on a souvent de la peine à distinguer, et par les nuances et la disposition de ses couleurs. Beaucoup moins brillantes que celles de la lyre, ces teintes sont brunes sur la téte et le dos, argentées avee des taches sur la partie inférieure de l'animal; et ces tons simples et très-peu éclatants ne sont relevés communément que par un peu de verdatre que l'on voit sur les nageoires de la poitrine et de I'anus, du verdâtre mêlé à du jaune qui distingue les nageoires jugulaires, et du jaune qui s'étend par raies sur la seconde nageoire dorsale, ainsi que sur celle de la queue.

D'ailleurs la chair du dragonueau est, comme celle de la lyre, blanche et d'un goût agréable. It n'est done pas surprenant que quelques naturalistes, et particulièrement le professeur Gmelin, aient soupşonné que ces deux eallionymes pourraient bien être de la mème espèce, mais d'un sexe différent. Nous n'avons pas pu nous procurer assez de renseignements précis pour nous assurer de l'opinion que l'on doit avoir relativement à la conjecture de ces savants; et dans le doute, nous nous sommes conformés à l'usage du plus grand nombre des auteurs qui ont écrit sur l'ichthyologie, en séparant de la lyre le callionyme dragonneau, qu il sera, au reste, aisé de retrancher de notre tableau méthodique.

\section{LE CALLIONYME FLECHE ${ }^{2}$,}

Callionymus Sagitta, Pall., Lacep., Cur. ET

\section{LE CALLIONYME JAPONAIS ${ }^{3}$.}

$$
\text { Callionymus japonicus, Lacep. }
$$

Ces deux espèces appartiennent, comme la lyre et le dragonneau, au premier sous-genre des callionymes; c'est-à-dire elles ont les yeux très-rapprochés l'un de l'autre. L'illustre Pallas 'A la premiere nageoire dorsale 4 rayons, a la seconde na-
geoire du dos 10 , a chacune des pectorales ig, a chacune des geoire du dos 10 , a chacune des pectorales 19 , a chacune d jagulaires 6 , a celle de 1 anus 9 , a celle de la queue 10 , 'Callionyme flèche, Daubenton, Ene. méth. - Id. Bons Ho,

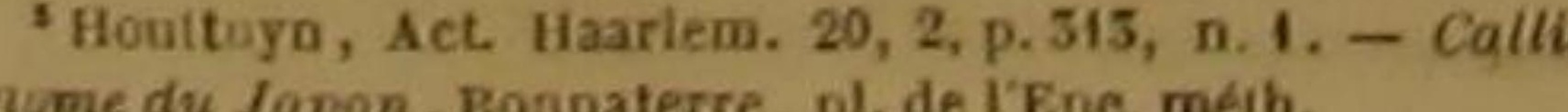

fait connaitre la première, et le savant Houttuyn la seconde.

La flèche decrite par le naturaliste de SaintPétersbourg avait à peine un décimètre de lonvueur. L'espèce à laquelie appartenait cet individu, vit dans la mer qui entoure l'ile d'Amboine; elle est, dans sa partie supérieure, d'un brun mèlé de taches irrégulières et nuageuses d'un gris blanchàtre, qui règne en s'éclaircissant sur la partie inférieure. Des taches ou des points bruns paraissent sur le haut de la nageoire caudale et sur les nageoires jugulaires; une bande très-noire se montre sur la partie postérieure de la première nageoire dorsale; et a seconde du dos, aiusi que les pectorales, sont très-transparentes, et variées de brun et de blane '. Voici, d'ailleurs, les prineipaux caractères par lesquels la flèche est séparée de la lyre. ouverture de la bouche est tres-petite; les léres sont minces et étroites; les opercules des branchies sont mous, et composés, au moins, de deux lames, dont la première se termine par une longue pointe, et présente, dans son bord postérieur, une dentelure très-sensible; on $n$ voit que trois rayons a la membrane branchiale la première nageoire du dos et celle de l'anus sont trè-basses, ou, ce qui est la même chose, forment une bande tres-étroite.

Le nom de Callionyme japonais indique qu'il vit dans des mers assez voisines de celle dans lesquelles on trouve la flèche. II parvient à la longueur de trois décimètres, ou environ. Il présente différentes nuances. Sa première nageoire dorsale montre une tache noire, ronde, et entourée de manière à représenter l'iris d'un wil; les rayons de cette mème nageoire sont noirs, et le premier de ces rayons se termine par deux filaments assez longs, ce qui forme un caractère extrèmement rare dans les divers genres de poissons. La seconde nageoire du dos est blanchâtre; les nageoires pectorales sont arrondies, les jugulaires très-grandes; et celle de la queue est très-allongée et fourchue ${ }^{2}$.

A ta membrane des branehies 5 rayons a la premier dorsale 4 , a la seconde 9 , a chacune des pectorales 11 , I dis. cone des jogulaires 5 , a la nageoire de íaus 8 , a celle de la quene 10. Ala pren ére nageoire dorsale 4 rayons, a la siconde 10, a chacune des pectorales 17 , a chacune des jugulaires 8, celle de l'anus 8 , a celle de la queue, 9. 
LE CALLIONYME POINTILLÉ '

Gallionymus ocellatus. Pall., Cuv.; Callionymus punetulatus, Lacep.

Ce poisson, qui appartient au second sousgenre des callionymes, et qui, par conséquent a les yeux assez éloignés l'un de l'autre, ne présente que de tres-petites dimensions. L'individu mesuré par le naturaliste Pallas, qui a fait connaitre cette espèce, n'était que de la grandeur du petit doigt de la main. Ce callionyme est d'ailleurs varié de brun et de gris, et parsemé, sur toutes les places grises, de points blanes et brillants; le blanchátre règne sur la partie inférieure de l'animal; la seconde nageoire du dos est brune avec des raies blanches t parallèles; les pectorales sont transparentes, et de plus pointillées de blane à leur base, de mème que celle de la queue; les rayons de ces trois nageoires présentent d'ailleurs une ou deux places brunes; les jugulaires sont noire dans leur centre, et blanches dans leur circo férence; et la nageoire de l'anus est blanche sa base et noire dans le reste de son étendue.

Telles sont les couleurs des deux sexes; mais voici les différences qu'ils offrent dans leurs nuances : la première nageoire du dos du mâle est toute noire ; celle de la femelle montre une grande variété de tons qui se déploient d'autant plus facilement que cette nageoire est plus haute que celle du màle. Sur la partie inférieure de cet instrument de natation, s'étendent des raies brunes relevées par une bordure blanche et par une bordure plus extérieure et noire; $e$ sur la partie supérieure, on voit quatre ou cinc taches rondes, noires dans leur centre, entourées d'un cercle blane bordé de noir, et imitant un iris avee sa prunelle.

Ces dimensions plus considérables et ces eouleurs plus vives et plus variées d'un organ sont ordinairement dans les poissons, comme dans presque tous les autres animaux, un apanage du måle, plutôt que de la femelle; et l'on doit remarquer de plus dans la femelle du callionyme pointillé un appendice conique situé au delà de l'anus, qui, ètant très-petit, peut être couché et caché aisément dans une sorte de fossette, et qui vraisemblablement sert l'émission des œufs ${ }^{2}$.

'Pallas, Spicil. zoolog. 8, p. 23, tab. 4, fig. 15. - Callio a is la newabrine pl. de i kne, meti.
Dans les deux sexes, l'ouverture de la bouche est très-petite; les lèvres sont épaisses; la supérieure est double, l'opercule branchial garni d'un piquant, et la ligne latérale assez droite.

\section{QUARANTE-CINQUIĖME GENRE.} LES CALLIOMORES.

La tete plus grosse que le corps; les ouvertures bra chiales placees sur les cótés de l'animal ; les nagroires jugulaires tres-eloigneesi unede l'autre; le corps et la queue garnis d'ecailles à peine visibles.

EsPìck. CABACTÈ⿴囗⿱一一⿻上丨.

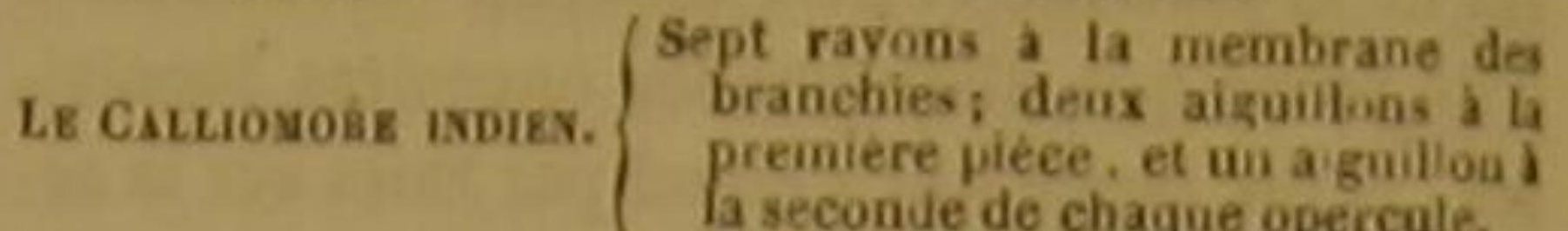

\section{LE CALLIOMORE INDIEN}

Cailiomorus indieus, Lacep.; Callionymus indieus, Linn.; Platycephalus Spatula, Bloch. Cuv. ?.

Ce mot Calliomore, formé par contraction de

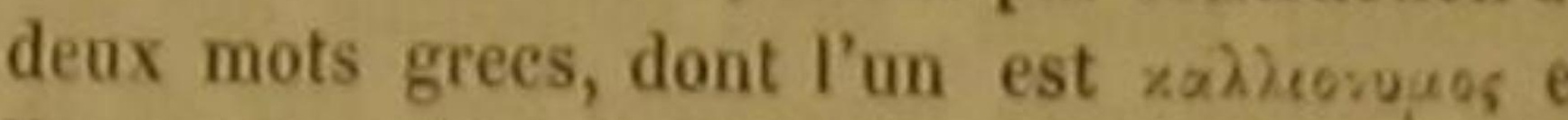
l'autre veut dire limitrophe, voisin, tete., désignent les grands rapports qui rapprochent poisson que nous allons décrire des vrais callionymes; il a mème été inscrit jusqu'à présen dans le mème genre que ces derniers animaux mais il nous a para en différer par trop de caracteres essentiels, pour que les prineipes qui nous dirigent dans nos distributions méthodiques nous aient permis de ne pas l'en séparer Le calliomore indien a des teintes bien différentes, par leur peu d'éclat et leur uniformité, des couleurs variées et brillantes qui parent les callionymes, et surtout la lyre : il est d'un gris plus ou moins livide. L'ensemble de son corps et de sa queue est d'ailleurs très-déprimé, c'està-dire aplati de haut en bas; ce qui le lie avec les uranoseopes dont nous allons parler, et contribue pas peu à déterminer la place qu'il doit occuper dans un tableau général des pois sons. Les ouvertures de ses branchies sont pla. cées sur les cótés de la tête, au lieu de l'étre ur la nuque, comme celles des branchies des callionymes ; ces orifices ont de plus beaucoup de largeur; la membrane qui sert à les fermer aageoire dorsale 4 , a la scconde 8 , à chacune des pectoraa des jugulaires 5 , à celle de l'anus 7 , a ceile tealliongme.

'Selon M. Cuvier, Ie cilliaderre, pi. de I'Enc. méth. Pialycephalus spatie callowore imdien n' est autre que le

\section{DES POISSONS.}

est soutenue par sept rayons; et l'opercule, composéde deux lames, présente deux piquants sur la première de ces deux pièces, et un piquant sur la seconde.

La mâchoire inférieure est un peu plus avancée que celle de dessus; I'on voit sur la tête des rugosités disposées longitudinalement; et le premier rayon de la premiere nageoire dorsale est très-court et séparé des autres ${ }^{1}$.

C'est en Asie que l'on trouve le calliomore indien.

\section{QUARANTE-SIXIÈME GENRE.} LES URANOSCOPES,

La tele deprimee et plus grosse que le corps; les yax sur la partie superieure de la tele, el tres-rapproches. la machoire inferieure beaucoup plus aiancee que lo superieure: I'ensemble forme par le corps el la queue. presque conique, et recétu d'ecailles très-faciles à distinguer: chaque opercule branchial compose d'une seule piece, et garni d'une membrane cilice.

$$
\text { espéces. eansctías. }
$$

LUasoscork ax. \{ Le dos dénué d'écailles épineuses. L Uusoscops aotr- Te dos garni décailles épineuses.
Turs.$$
\text { L'URANOSCOPE RAT² }
$$

Uranoscopus seaber, Linn., Bloch; Uranoscopus Mus,
Lacep.

Les noms de Callionyme et de Trachine, donnés à cet animal, annoncent les ressemblan-

'A la premietre nazeoire dorsale 7 rayons, a la seconde 15 , a chacune des pectorales 20 , a cliacune des jo

mageoire de Fanus 15 , a celle de la queae 11.

'Taperon, sur les cótes de plus. départ. mérid. - Raspecon, ibid. - Mesoro, dans quelques contrees de Titailie. Pesce prete, ithid. - Kascassa bianca, ibid. - Bocca capo, ibid. - Nuxripls,-Uranoscope ral. Daubenton, Enc. néth. - Id. Bonnaterre, pl. de I'Enc. méth. - Ka asuovopos, Aristot., I. 2, c. 15; et 1. 8, c, 15. - Id. Elian, 1. 15, c. 4, Iiem, L. X, f. 177, 35. - Huspoxusts, Oppian., 1. 2, p. 57.

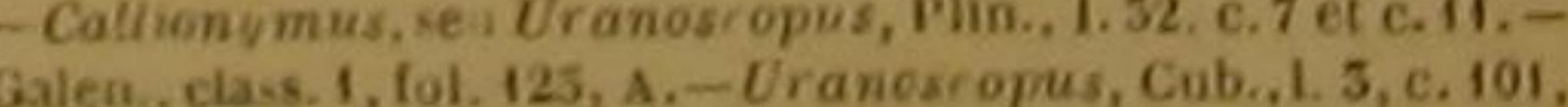
fol. 93, b.-Raspecon, on Tapecon, Rondelet, part. 1, L. 10, e. 12. - Salvian., fol. 196. b, ad icon. et 197, b. et 198. - Aldrov., L. 2, c. 54, p. 265. - Jonston, L. 4. Lit. 3, c. 5. a. 1

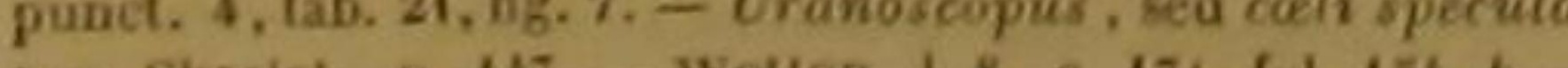
10r, Chariet., p. 177. - Wotban. 1. 8, c. 171, fol. 154, b. -

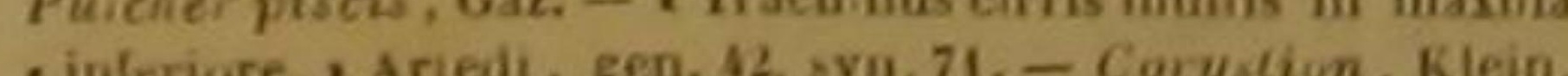

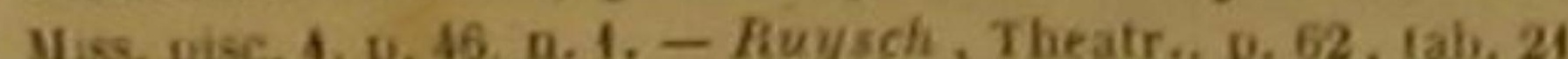
fig. 7. - Belon, Aquat, p. 219. - Gesner, Aquat. p. 135, leon. anim., p. 138. - Callionymus, sea Dranoscopis, Willughby, Ichtb., p. 287 , lab. S, 9. - Rai, Pisc. p. 97, n. 22 - Raspecon, ou Tapecon, Vaimont de Bomare, Dich. d hist. nat. - Kascasse blanche, Dubamel, Traile des péches, part. 2, sect. 5, c. 1, art. 4 . qu'il présente avec les vrais callionymes et vee le genre dont nous nous occuperons après avoir decrit celui des uranoscopes. Nous n'avons pas besoin d'indiquer ces similitudes; on les remarquera aisément. D'un autre cóté, cette dénomination d'Uranoscope (qui regarde le ciel) désigne le caractere frappant que montre le dessus de la tète du rat et des autres poissons du mème genre. Les yeux sont, en effet, non-seulement très-rapprochés l'un de lautre, et placés sur la partie supérieure de la tête, mais tournés de manière que lorsque l'animal est en repos, ses prunelles sont dirigées vers la surface des eaux, ou le sommet des cieux,

La tète, très-aplatie et beaucoup plus grosse que le corps, est d'ailleurs revêtue d'une substance osseuse et dure, qui forme comme une sorte de casque garni d'un très-grand nombre de petits tubercules, s'étend jusqu'aux opercules qui sont aussi très-durs et verruqueux, présente, à peu près au-dessus de la nuque, deux ou plus de deux piquants renfermés quelquefois dans une peau membraneuse, et se termine sous la gorge par trois ou cinq autres piquants. Chaque opercule est aussi armé de pointes tournées vers la queue et engagées en partie dans une sorte de gaine tres-molle.

L'ouverture de la bouche est située à l'extrémité de la partie supérieure de la tête, et I'animal ne peut la fermer qu'en portant vers le haut le bout de sa mâchoire inférieure, qui est beaucoup plus longue que la machoire supérieure. La langue est épaisse, forte, courte, large, et hérissée de très-petites dents. De l'intérieur de la bouche et près du bout antérieur de la mâchoire inférieure, part une membrane laquelle se rétrécit, s'arrondit, et sort de la bouche en filament mobile et assez long.

Le trone et la queue représentent ensemble une espèce de cône recouvert de petites écailles, et sur chaque coté duquel s'étend une ligne latérale qui commence aux environs de la nuque, s'approche des nageoires pectorales', va directement ensuite jusqu'a la nageoire de la queue, et indique une série de pores destinés a laisser échapper cette humeur onctueuse si nécessaire aux poissons, et dont nous avons déjá eu tant d'occasions de parter.

'A la membrane des branchies 5 rayons, al la premiére nageoire dorsile 4 , a la seconde 14,1 chacune des pectorales 1 Je la queve, qui est rectiligne, 12. 
Il y a deux nageoires sur le dos; celles de la | tins, on savait que la vésicule du fiel de cet poitrine sont très-grandes, ainsi que la cau- uranoscope est très-grande, et l'on croyait que dale. Des teintes jaunâtres distinguent ces la liqueur qu'elle contient était très-propre nageoires pectorales; celle de l'anus est d'un à guérir des plaies et quelques maladies des noir éclatant : l'animal est d'ailleurs brun pardessus, gris sur les còtés, et blane par-dessous.

Le canal intestinal de l'uranoscope rat n'est pas très-long, puisqu'il n'est replié qu'une fois; mais la membrane qui forme les parois de son estomac, est assez forte, et l'on compte auprès dupylore, depuis hnit jusqu'à douze appendices ou petits cœoum propres à prolonger le séjour des aliments dans l'intérieur du poisson, et par conséquent à faciliter la digestion.

Le rat habite partieulièrement dans la Méditerranée. Il y vit le plus souvent auprès des rivages vaseux; il s'y cache sous les algues ; il s'y enfonce dans la fange; et par une habitude semblable à celles que nous avons déjà observées dans plusieurs raies, dans la lophie baudroie et dans quelques autres poissons, il se tient en embuscade dans le limon, ne laissant paraitre qu'une petite partie de sa tête, mais étendant le filament mobile qui est attaché au bout de sa mâchoire inférieure, et attirant par la ressemblance de cette sorte de barbillon avec un ver, de petits poissons qu'il dévore. C'est Rondelet qui a fait connaitre le premier cette manière dont l'uranoscope rat parvient à se saisir facilement de sa proie. Ce poisson ne peut se servir de ce moyen de pècher qu'en demeurant pendant très-longtemps immobile, et paissant plongé dans un sommeil profond. Voilà pourquoi, apparemment, on a écrit qu'il dormait plutot pendant le jour que pendant la nuit, quoique dans sou organisation rien n'indique une sensibilité aux rayons lumineux plus vu que celle des autres poissons, destus vive pas dit que le temps de leur sommeil füt le n'a souvent celui pendant lequeil fut le plus souvent celui pendant lequel le soleil éclaire I'horizon'.

Il parvient jusqu'à la longueur de trois décidure, : sa chair est blanche, mais quelquefoi ces deux mauvaise odeur; elle indique, par ques et les mauvaises qualités, les petits mollusques et les vers marius dont le rat aime à nourrir, et les fonds vaseux qu'il préfère. le temps des anciens naturatis prefere. Dè yeux ${ }^{4}$.

\section{L'URANOSCOPE HOUTTUYN²}

Uranoscopus japonieus, Linn., Gmel.; Uranoscopus Houttuyn, Lacep.

Le nom que nous donnons à cet uranoscope est un témoignage de la reconnaissance que les naturalistes doivent au savant Houttuyn, qu en a publié le premier la description.

On trouve ce poisson dans la mer qui baigne les illes du Japon. Il est, par ses couleurs, plus agréable à voir que l'uranoscope rat; en effet il est jaune dans sa partie supérieure, et blane dans l' inférieure. Les nageoires jugulaires scn assez courtes ${ }^{4}$; des écailles épineuses sont rangées longitudinalement sur le dos de l'houttuyn.

\section{QUARANTE-SEPTIÉME GENRE.} LES TRACHNES.

La tele comprimè el garnie de tubercules ou d'aiguilons: une ou plusieurs pièces de chaque opercule, denteles; ; le corps et ta queue allonges et courerts de petites écailles; l'anus situe très-pres des nagcoires pectorales.

Esprèces.

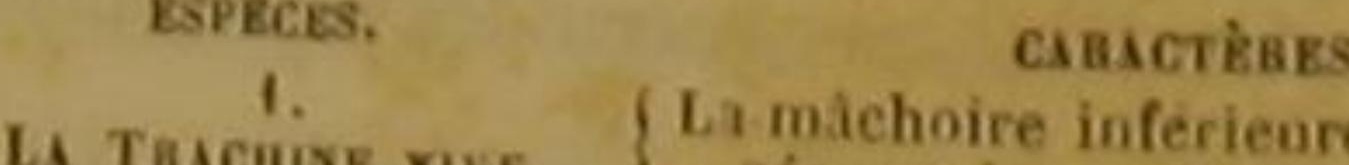

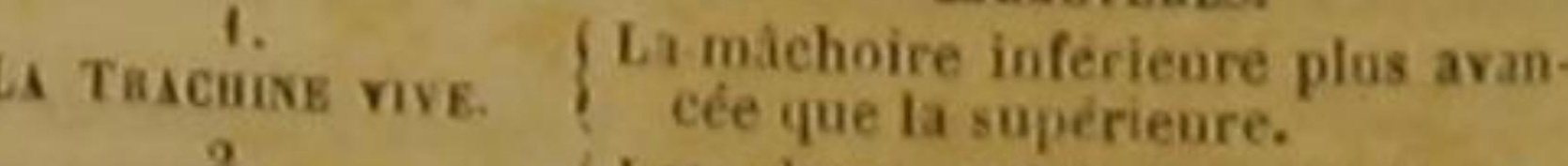

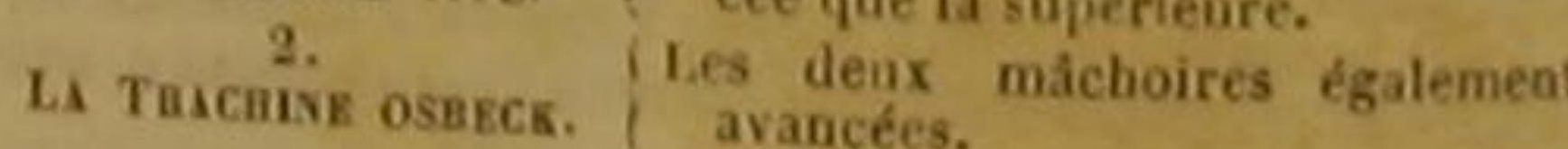

\section{LA TRACHINE VIVE ${ }^{s}$.}

Traebinus Draco, Linn.; Trachinus Vividus, Lacep. ${ }^{6}$. Cet animal a été nommé Dragon marin dès 'Pline, 1. 52, c. 7

Houltuyo, Aet. Haarlem. 20, 2, p. 514. - Uranoscope Sirologue, Bonnaterre, pl. de l'E, p. 514 .

M. Cuyier nadmet pas cente ese. meth. - Jeair an genre Platycephale. D. Ala premiere nageoire dorsale

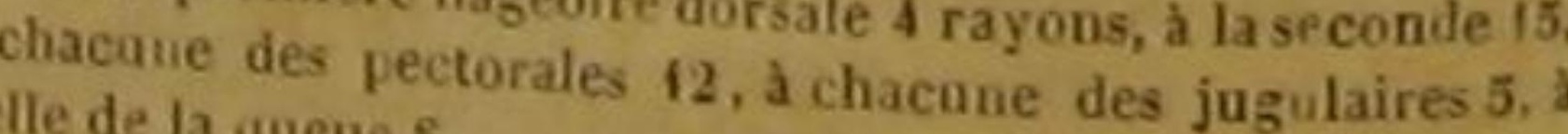
stiver, sur plus.

les rivages de plus. cótes franç. de Tocéan- - Araigne, sar prés de Buyonne. - Trat. mérid. - Saccarailla blanc, audans plus. coutrées de Titialie, en Sicile. - Pisce ragno, - Fjarsing, par les Danois et les Suéssing, en Danemarck. dans plus. pays úu nord de l'Eus leédois. - Sehwert fisch, 

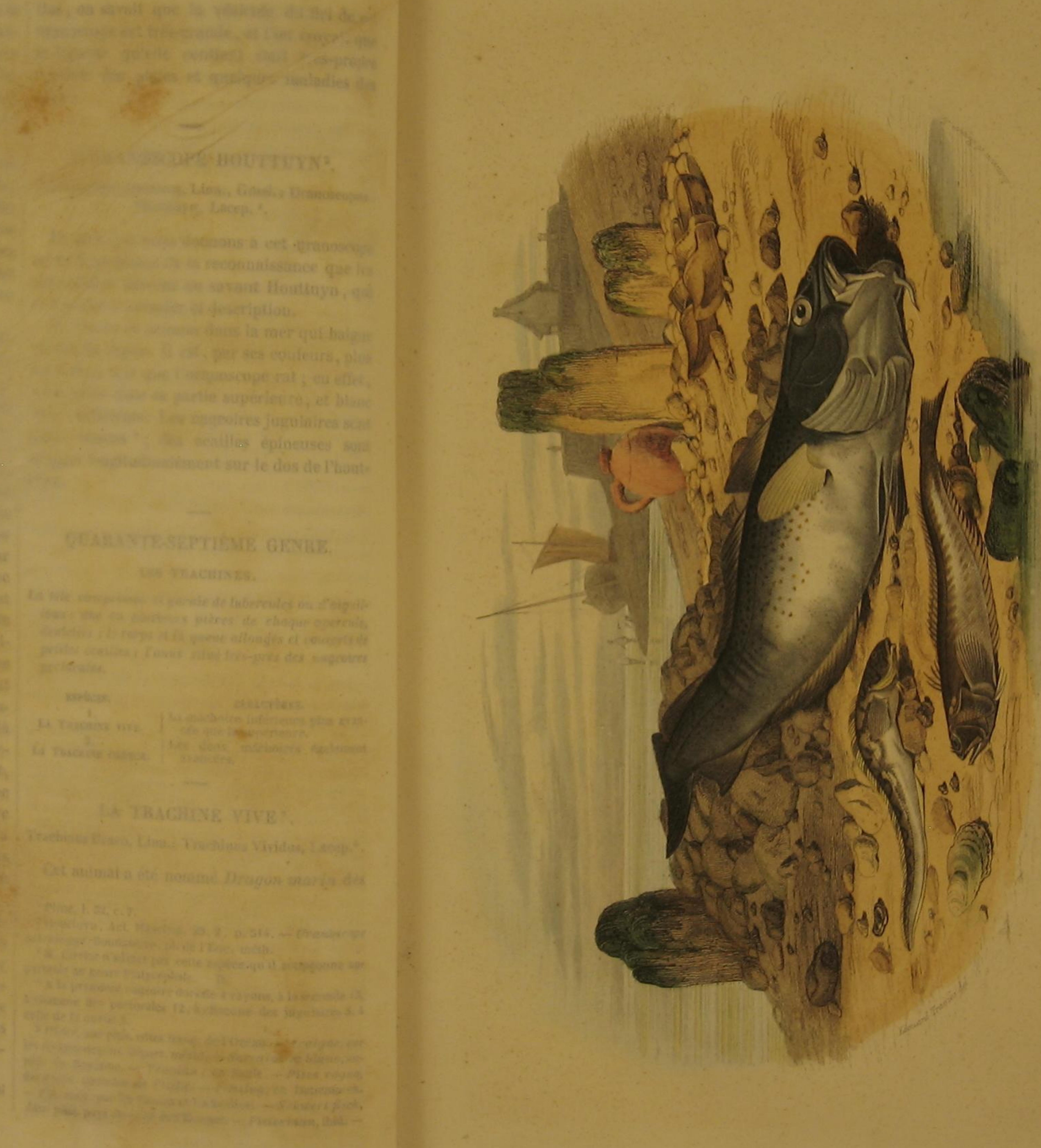

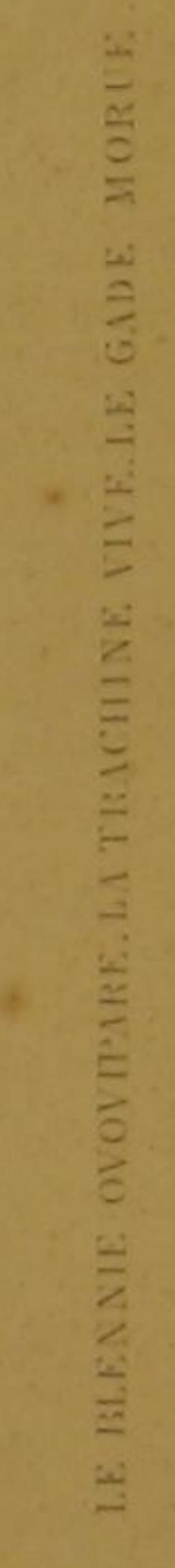


le temps d'Aristote. Et comment n'aurait-il pas, en effet, réveillé l'idée du dragon? Ses couleurs sont souvent brillantes et agréables à la vue; il les anime par la vivacité de ses mouvements ; il a de plus recu le pouvoir terrible de causer des blessures cruelles, par des armes pour ainsi dire inévitables. Une beauté peu commune et une puissance dangereuse n'ont-elles pas teresses créées par l'antique mythologie, ainsi que des fées auxquelles une poésie plus moderne a voulu donner le jour? Ne doivent-elles pas, lorsqu'elles se trouvent réunies, rappeler le sinistre pouvoir de ces êtres extraordinaires, retracer l'image de leurs ministres, présenter surtout à l'imagination amie du merveilleux ce composé fantastique, mais imposant, de formes, de couleurs, d'armes, de qualités effrayantes et douées cependant d'un attrait invincible, qui servant, sous le nom de Dragon, les complots ténébreux des magieiennes de tous les âges, au char desquelles on l'a attaché, ne répand l'épouvante qu'avee l'admiration, séduit avant de donner la mort, éblouit avant de consumer, enchante avant de détruire?

Et afin que cette mème imagination fût plus facilement entraínée au delà de l'intervalle qui

Weever, par les Anglais. - $\Delta$ paxalva, par les Grees mo. derues. - Aranéale, Boisdereau, et Bois de roc. pendant a jenesse de Tanimal, et sur quelques cótes mérid, de France. - Trachine vioe, Danbenton, Enc. méth. - Id
Bonuaterre, pl. de l'knc. méth. - Bloch, pl. 61. - Tr chí- nus maxilla inferiore tomgiore, cirris destitntá. , Artedi

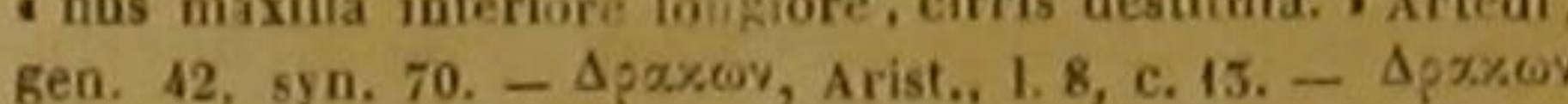
Saìatrioy, Klian., t. i1, c. A1; et I. 14, c. 12. - Oppian., 1. 1. p. 7; et 1. 2, p. 46, - Draco marinus, Plin., 1. 9, c. 27.
- Aruneus, 10., 1. 9, c. 48. - Wotton, 1. 8, c. 178, fol. $158, b$. - Draco, sive Araneus piscis, Salvian, fol. $71, b$. - Araignée de mer, ou Vive, Rondelet, part. 1, 1. 10. c. 10-Draco marinus, Aldrov., I. 2, c. 50, p. 256. - Jooston, 1. A, tit. S, - Draco, sive Aramens Plinii, Gesner, p. 77-Willog 146 , p. 288. tas. S, 10. fig I. - Rai, p. 91. - Aranea, Coba, I. c. 3. fol. 71, b. - Araneus, el Draco marinus, Schoney, p. 16. - Bélon. Aquat., p. 215. - It. scan. 525. - Fanna suecic. 303. - Mûll, prodrom. Zool. danic , n 509. - Trachinus, Gronov, Act. ups. 1742, p. 95.-Id.. Id. Mus. 1. 12, D. 97 ; Z oph., p. 80, D. 274. - Trachinus draco, Brûnn., Klein, yiss. p. 9, n. 50. - Corystion simptici gatea, etc. Zool. 5. p. 169 , n. 7i, tab. 28 - La Vive, Dohamel, Brit, des péches, part. 2, sect. 6 . c. 1 art. 3 -Dragon de mer, Valmont de Bomare, Dict. d'hist nat. - Trachinus draco, Ascigne, pl. 7.

'M. Cnvier a éclairci la synonymie des Vives. Il résuite de son travail que nos rivages en po-sedent quatre especes, ct que la vive commune na a été decrite exactemen que par les anciens ichthyologistes depais kondelet jusquà Artedi el Acadus. Bloch et Lacepede, parmi les modernes, ont concommune les caracteres des autres et ont rapporie a la vive sépare le dragon de la fable, de la Vive de la nature, n'a-t-on pas attribué à ce poisson un venin redoutable? ne s'est-on pas plu à faire remarquer les brillantes couleurs de ses yeux, dans lesquels on a voulu voir resplendir, commedans ceux du dragon poétique, tous les feux des pierres les plus précieuses?

Il en est cependant du dragon marin comme du dragon terrestre'. Son nom fameux se lie d̀ d'immortels souvenirs : mais à peine l'a-t-on aperçu, que toute idée de grandeur s'évanouit; il ne lui reste plus que quelques rapports vagues avec la brillante chimère dont on lui a appliqué la fastueuse dénomination, et du volume gigantesque qu'on était porté à lui attribuer, il se trouve tout d'un coup réduit à de très-petites dimensions. Ce dragon des mers, ou, pour mieux dire et pour éviter toute cause d'erreur, la trachine vive, we parvient, en effet, très-souvent, qu'à la longueur de trois ou quatre décimètres.

Sa tête est comprimée et garnie dans plusieurs endroits de petites aspérités. Les yeux, rapprochés l'un de l'autre, ont la couleur et la vivacité de l'émeraude avec l'iris jaune tacheté de noir. L'ouverture de la bouche est assez grande, la langue pointue; et la mâchoire inférieure, qui est plus avancée que la supérieure, est armée, ainsi que cette dernière, de dents très-aiguës. Chaque opereule recouvre une large ouverture branchiale, et se termine par une longue pointe tournée vers la queue. Le dos présente deux nageoires : les rayons de la première ne sont qu'au nombre de einq ; mais ils sont non articulés, très-pointus et trés forts. La peau qui revèt l'animal est couverte d'écailles arrondies, petites et faiblement attachées : mais elle est si dure, qu'on peut écorcher une trachine vive presque aussi facilement qu'une murène anguille. Il en est de même de l'uranoscope rat; et e'est une nouvelle ressemblance entre la vive et cet uranoscope.

Le dos du poisson est d'un jaune brun; ses côtés et sa partie inferieure sont argentés et variés dans leurs nuances par des raies transversales ou obliques, brunâtres, et fréquemment dorées; la première nageoire dorsale est presque toujours noire ${ }^{2}$.

\section{ovip.}

'A la première nageolre dorsale 5 rayons, a la seconde 21 . 
On trouve dans son intérieur et auprès du $/$ sans cesser d'être très-bonne à manger; et c'est pylore, au moins huit appendices ou petits cœ- à cause de ces trois propriétés qu'elles ont oum.

La vive habite non-seulement dans la Méditerranée, mais encore dans l'Océan. Elle se tient presque toujours dans le sable, ne laissant paraitre qu'une partie de sa tète; et elle a tant de facilité à creuser son petit asile dans le limon, que lorsqu'on la prend et qu'on la laisse échapper, elle disparait en un clin d'œil, et s'enfonce dans la vase. Lorsque la vive est ainsi retirée dans le sable humide, elle n'en conserve

pas moins la faculté de frapper autour d'elle avec force et promptitude par le moyen de ses aiguillons et particulièrement de ceux qui composent sa première nageoire dorsale. Aussi doit-on se garder de marcher nu-pieds sur le sable ou le limon au-dessous duquel on peut supposer des vives : leurs piquants font des blessures très-douloureuses. Mais malgré le danger de beaucoup souffrir, auquel on s'expose lorsqu'on veut prendre ces trachines, leur chair est d'un goùt si délicat, que l'on va trèsfréquemment à la pêche de ces poissons, et qu'on emploie plusieurs moyens pour s'en procurer un grand nombre.

Pendant la fin du printemps et le commencement de l'été, temps où les vives s'approchent des rivages pour déposer leurs aufs, ou pour féconder ceux dont les femelles se sont débarrassées, on en trouve quelquefois dans les manets ou filets à nappes simples, dont on se sert pour la péche des maquereaux. On emploie aussi pour les prendre, lorsque la nature du fond le permet, des dréges ou espèces de filets qui reposent légèrement sur ce même fond, et peuvent dériver avec la marée.

On s'efforce d'autant plus de pècher une grande quantité de vives, que ces animaux nonseulement donnent des signes très-marqués d'irritabilité après qu'ils ont été vidés ou qu'o leur a coupé la tête, mais encore penvent vivi assez longtemps hors de l'eau, et par consé. quent être transportés encore en vie à d'assez grandes distances. D'ailleurs, par un rapport remarquable entre l'irritabilité des muscles leur résistance à la putridité, la chair des trachines vives ne se corrompt pas aisément, et peut étre conservée pendant plusieurs jours, laires 6. a la nageoire de l'anus 25 , a celie de la queue, qui est
uu peu fourchue, 13. recu le nom spécifique que j'ai cru devoir leu laisser.

Cependant, si plusieurs marins vont sans cesse à la recherche de ces trachines, la crainte fondée d'ètre cruellement blessés par les piquants de ces animaux, et surtout par les aiguillons de la première nageoire dorsale, leur fait prendre de grandes précautions; et les accidents occasionnés par ces dards ont été regardés comme assez graves pour que, dans le temps, l'autorité publique ait cru, en France, devoir donner à ce sujet des ordres très-sévères. Les pècheurs s'attachent surtout à briser ou arracher les aiguillons des vives qu'ils tirent de I'eau. Lorsque, malgré toute leur attention, il ne peuvent pas parvenir à éviter la blessure qu'ils redoutent, ceux de leurs membres qui sont piqués, présentent une tumeur accompagnée de douleurs très-cuisantes et quelquefois de fièvre. La violence de ees symptômes dure ordinairement pendant douze heures; et comme cet intervalle de temps est celui qui sépare une haute marée de celle qui la suit, les pêcheurs de l'Océan n'ont pas manqué de dire que la durée des accidents occasionnés par les piquants des vives avait un rapport très-marqué avec les phénomènes du flux et reflux, auxquels ils sont forcés de faire une attention continuelle, à caus de l'influence des mouvements de la mer sur toutes leurs opérations. Au reste, les moyens dont les marins de l'Océan ou de la Méditerranée se servent pour calmer leurs souffrances, lorsqu ils ont été piqués par des trachines vives, ne sont pas peu nombreux; et plusieurs de ces remèdes sout très-anciennement connus. Les uns se contentent d'appliquer sur la partie malade le foie ou le cerveau encore frais du poisson; les autres, après avoir lavé la plaie avec beaucoup de soin, emploient une décoction de lentisque, ou les feuilles de ce végétal, ou des fèves de marais. Sur quelques cótes septentrionales, on a recours quelquefois à de l'urine chaude; le plus souvent on y substitue du sable mouillé dont on enveloppe la tumeur, en tâchant d'empécher tout contact de l'air avec les membres blessés par la trachine.

L'enflure considérable et les douleurs longues et aiguẽs qui suivent la piqûre de la vive, ont fait penser que cette trachine était véritablement venimeuse; et voilà pourquoi, sans doute, on lui a donné le nom de l’araignée, dans laquelle on croyait devoir supposer un poison assez actif. Mais la vive ne lance dans la plaie qu'elle fait avee ses piquants, aucune liqueur particulière : elle n'a aucun instrument propre à déposer une humeur vénéneuse dans un corps étranger, aucun réservoir pour la contenir dans l'intérieur de son corps, ni aucun organe pour la filtrer ou la produire. Tous les effets douloureux de ses aiguillons doivent être attribués à la force avec laquelle elle se débat lorsqu'on la saisit, à la rapidité de ses mouvements, à l'adresse avee laquelle elle se sert de ses armes, à la promptitude avee laquelle elle redresse et enfonce ses petits dards dans la main, par exemple, qui s'efforce de la retenir, à la profondeur à laquelle elle les fait parvenir, et à la dureté ainsi qu'à la forme très-pointue de ces piquants.

La vive n'emploie pas seulement contre les marins qui la péchent et les grands poissons qui l'attaquent, l'énergie, I'agilité et les armes dangereuses que nous venons de décrire : elle s'en sert eussi pour se procurer plus facilement sa nourriture, lorsque, ne se contentant pas d'animaux à coquille, de mollusques, ou de erabes, elle cherche à dévorer des poissons d'une taille presque égale à la sienne.

Tels sont les faits certains dont on peut composer la véritable histoire de la trachine vive. Elle a eu aussi son histoire fabuleuse, comme toutes les espéces d'animaux quí ont présenté quelque phénomène remarquable. Nous ne la rapporterons pas, cette histoire fabuleuse. Nous ne parlerons pas des opinions contraires aux lois de la physique maintenant les plus connues, ni des contes ridicules que l'on trouve, au sujet de la vive, dans plusieurs auteurs anciens, particulièrement dans Elien, ainsi que dans quelques écrivains modernes, et qui doivent principalement leur origine au nom de Dragon que porte cette trachine, et à toutes les fictions vers lesquelles ce nom ramene l'imagination; nous ne dirons rien du pouvoir merveilleux de la main droite ou de la main gauche lorsqu'on touche une vive, ni d'autres observations presque du mème genre : en tâchant de découvrir les propriétés des ouvrages de la nature, et les divers effets de sa puissance, nous n'avons qu'un trop grand nombre à'ocrasions d'ajouter à l'énumération des erreurs de l'esprit humain.
Il parait que, selon les mers qu'elle habite, la vive présente dans ses dimensions, ou dans la disposition et les nuances de ses couleurs, des variétés plus ou moins constantes. Voici les deux plus dignes d'attention.

La première est d'un gris cendré avee des raies transversales, d'un brun tirant sur le bleu. Elle a trois déeimètres, ou à peu près, de longueur.

La seconde est blanche, parsemée, sur sa partie supérieure, de points brunâtres, et disinguée d'ailleurs par des taches de la mème leinte, mais grandes et ovales, que l'on voit également sur sa partie supérieure. Elle parvient à une longueur de plus de trois déeimètres.

C'est vraisemblablement de cette variéte qu'il faut rapprocher les trachines vives de quelques côtes de l'Océan, que l'on nomme sacearailles blanes', et qui sont longues de cinq ou six décimètres.

\section{LA TRACHINE OSBECK 2 .}

Trachinus Osbeck, Lacep. 3.

C'est dans l'Océan Atlantique, et auprès de l'ile de l'Ascension, qu'habite cette trachine, dont la description a été publiée par le savant voyageur Osbeck. Les deux mâchoires de ce poisson sont également avancées, et garnies de plusieurs rangs de dents longues et pointues, dont trois en haut et trois en bas sont plus grandes que les autres; des dents aiguês sont aussi placées auprès du gosier. Chaque opercule se termine par deux aiguillons inégaux en longueur. La nageoire de la queue est rectiligne ${ }^{4}$. Tout l'animal est blanc avec des taches noires. Telles sont les principales différences qui écartent cette espece de la trachine vive.

'Duhamel, a Tendroit déja cité. 'Osteek, Voy. to China, p. 96. - Trachine ponelué, Donnatrre, pl. de I Enc. méth.

'M. Cuvier remarque que ce poisson n'ayant qu'une seule Jorsale et onze rayous epineux a celle nazeore, ne pent étre A

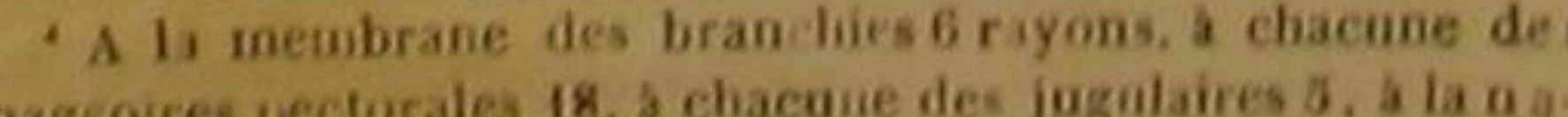
eoire de latuas 11 . a celle de la queue 16. 


\section{QUARANTE-HUITIEME GENRE.}

LES GADES.

La tete comprimée; les yeux peu rapprochés l'un de lautre, et placés sur les cottes de la tete; le corps allongé, peu comprimé, el rerétu de petiles ecailles: les opercules composes de plusieurs pieces et bordés d'une membrane non ciliee.

PREMIER SOUS-GENRE.

Trois nageoires sur le dos; un ou plusieurs barbillon an bout du museau.

ESPECEs. $\begin{gathered}\text { CABACrèzes. } \\ \text { LE GADE MORUE. }\end{gathered}$

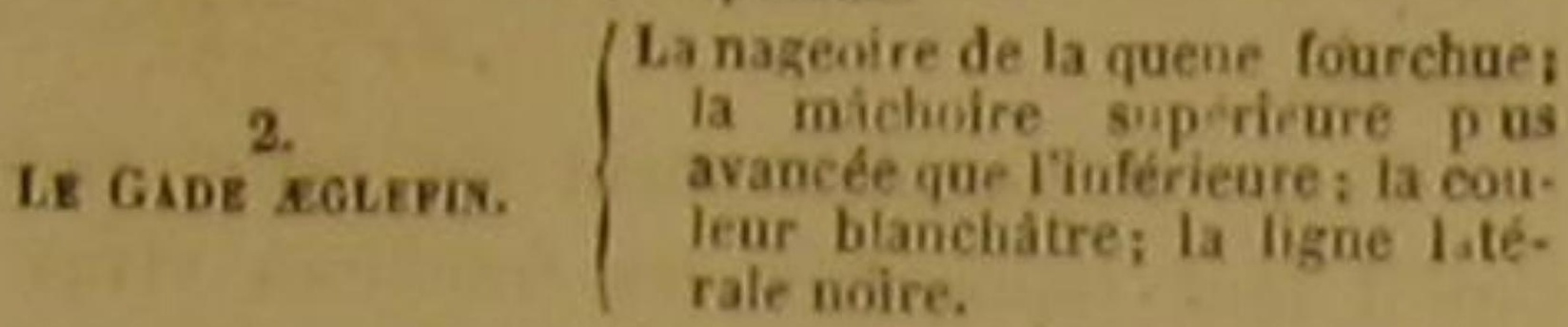

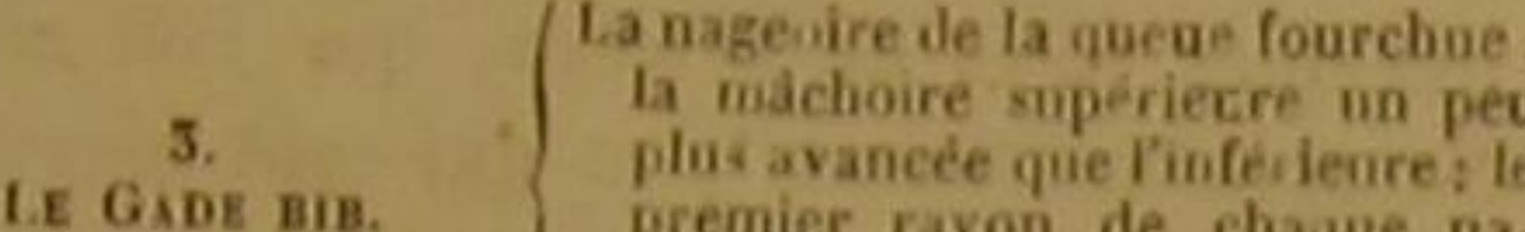
premier rayon de chanue na.
Reoire jugnaire termine par au

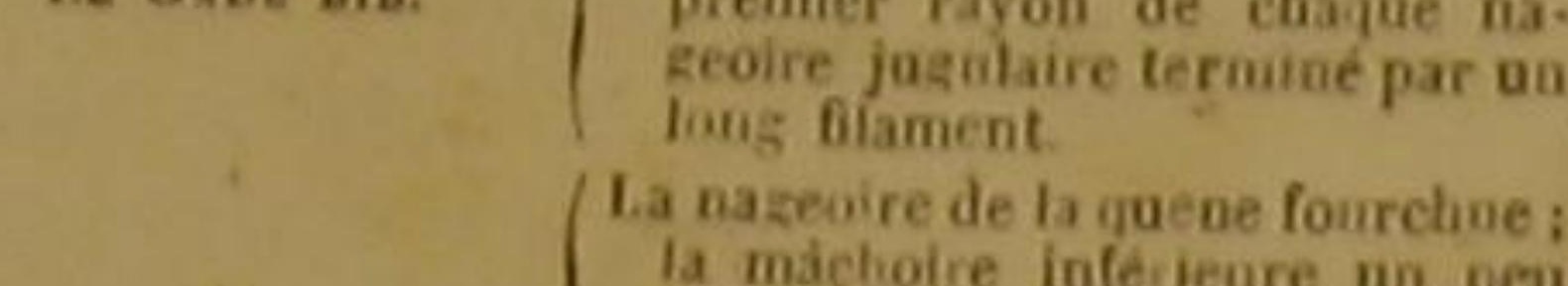

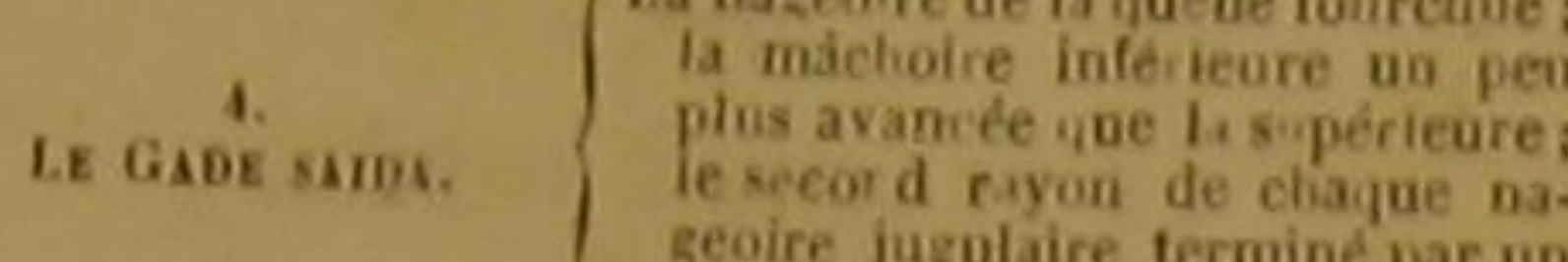
geoire jusulaire terminé par un
loog filament.

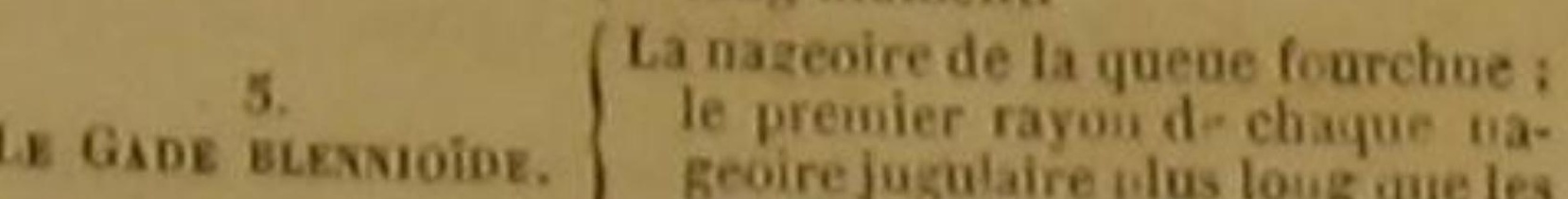
geoire jugulare slus loug que les
a tres, el divise en dens.

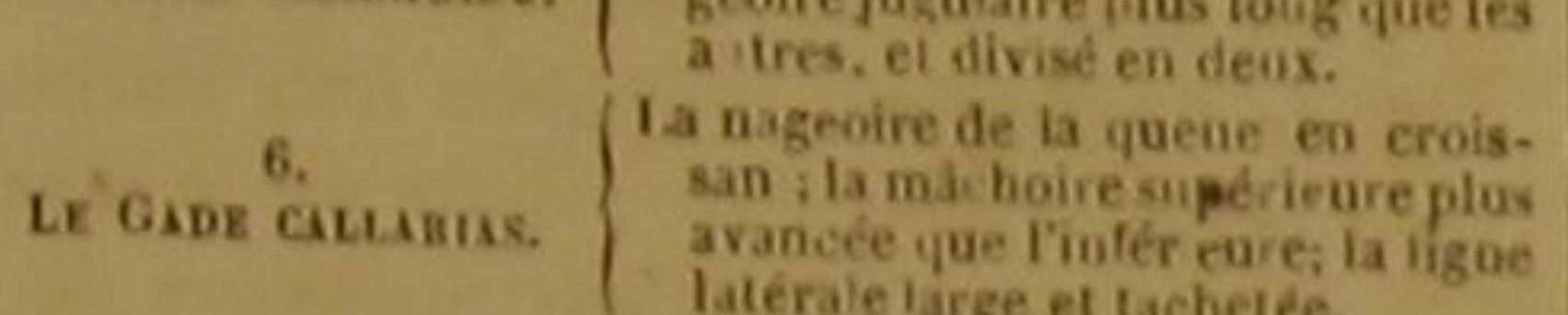

lateraie arge et tacheté.
La naseoire de ta queve en crois.

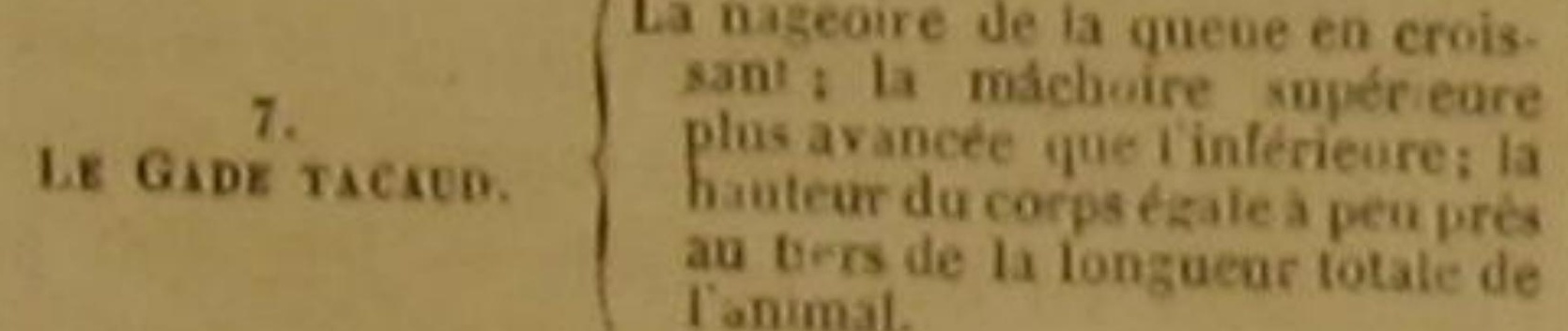

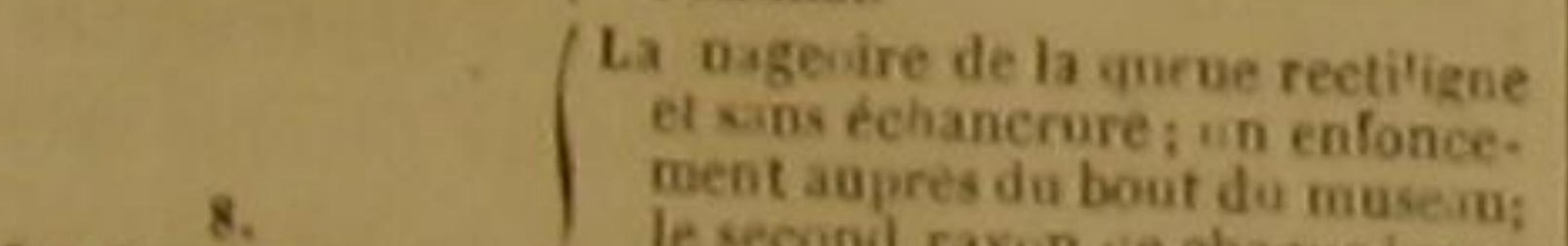

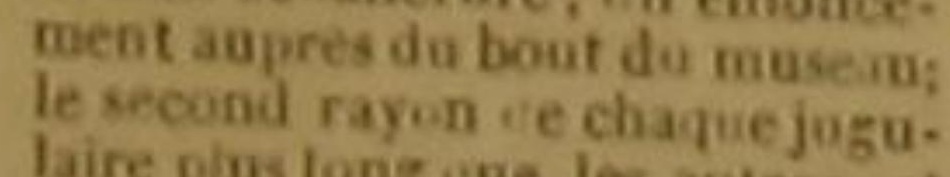

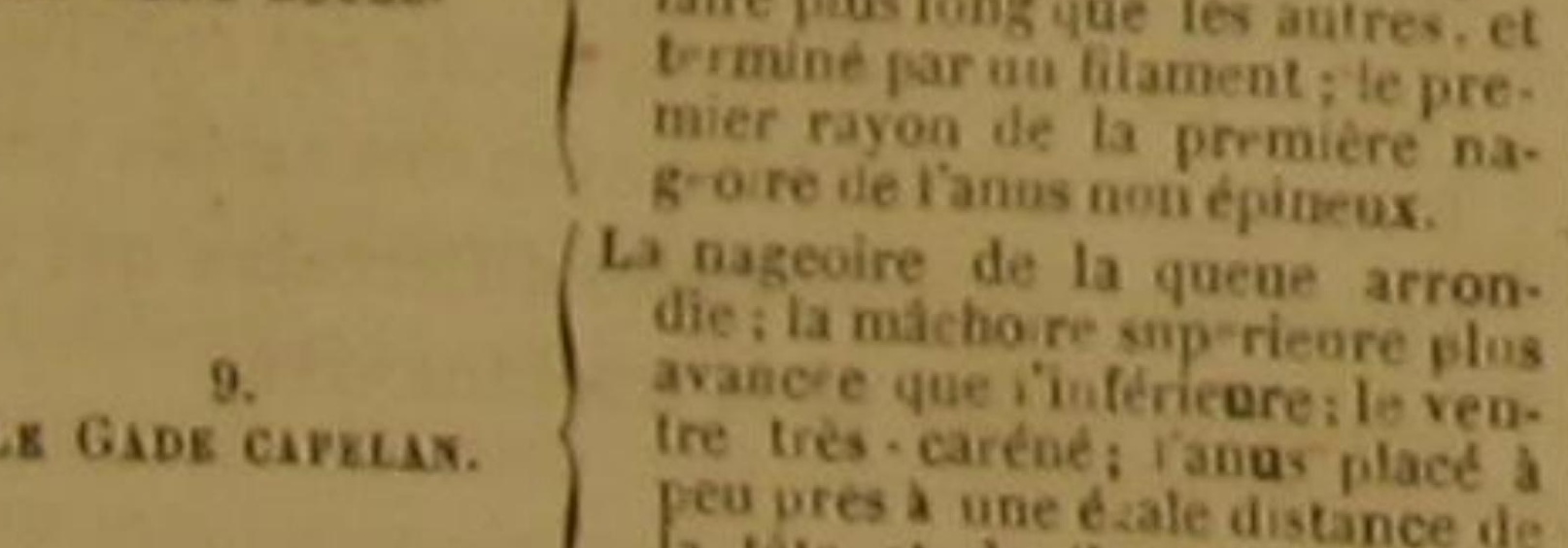
peu pres a yne i cale distance de
a téte et de leatrémité de la
queue. SECOND SOUS-GENRE. Trois nageoires sur le dos ; point de barbillons au bout
du museau,

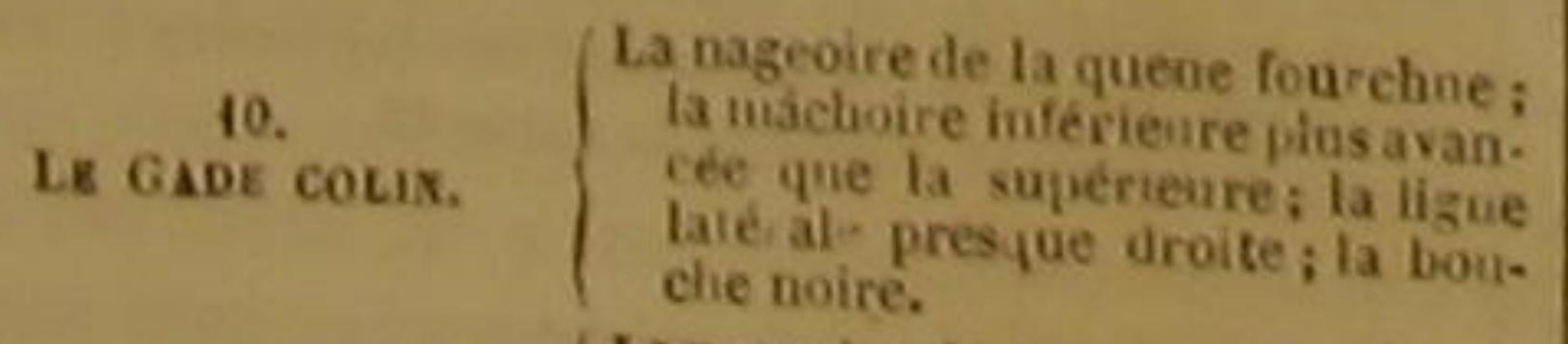

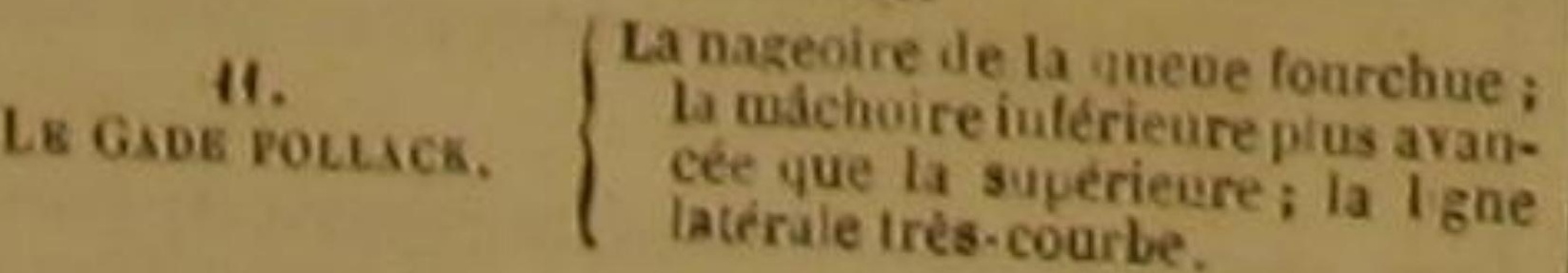

CABICTkBes

La nageoire de la quene fourchn

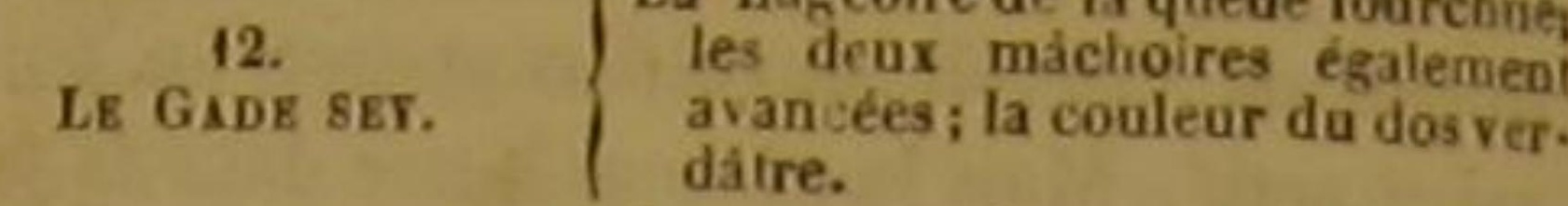

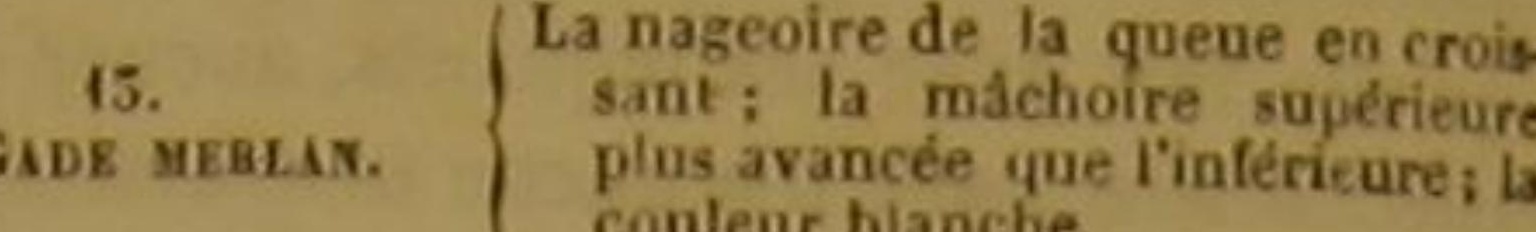
TROISIĖME SOUS-GENRE. Deux nageoires dorsales; un ou plusieurs barbillons au bout du museau.

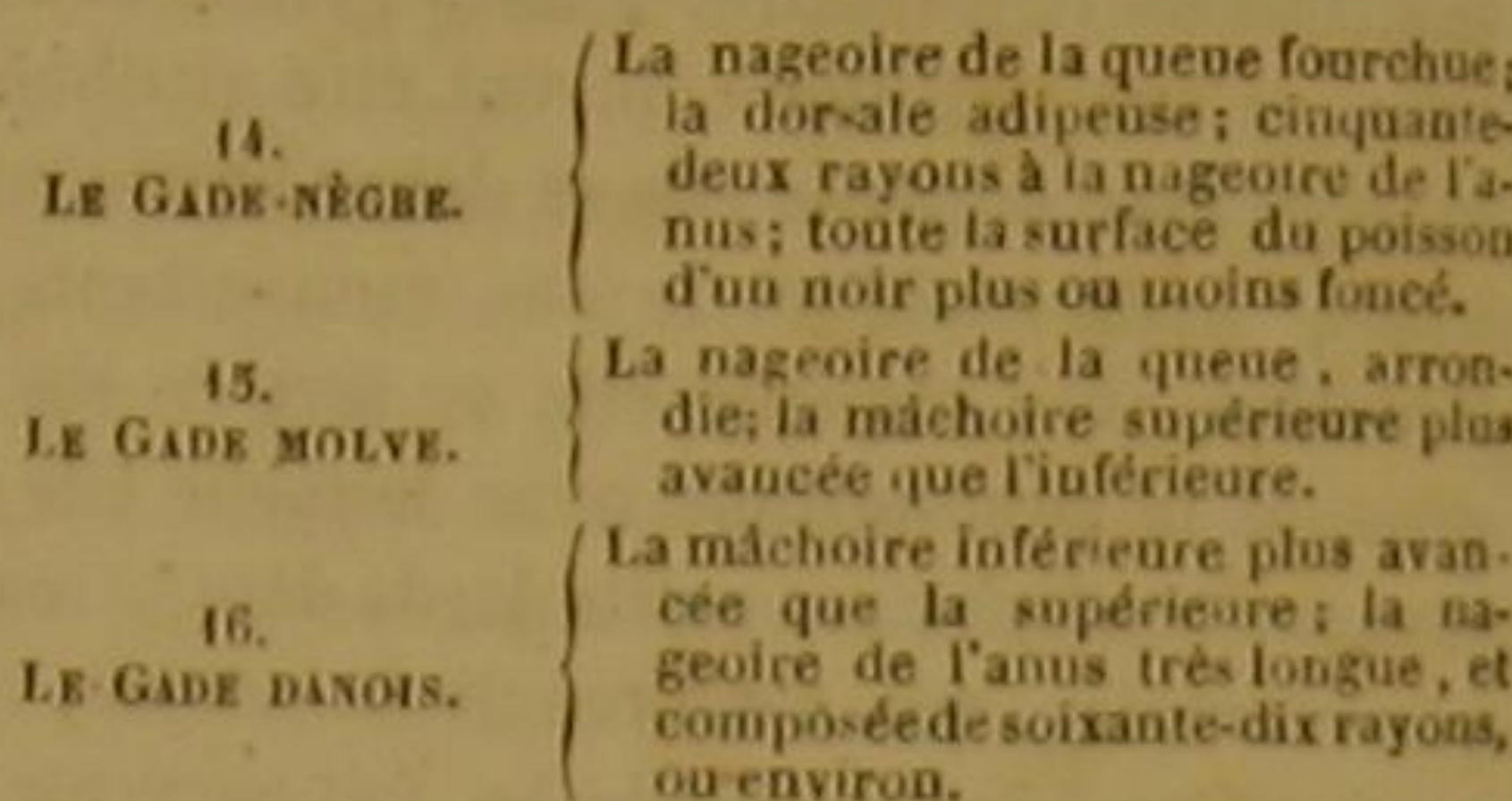

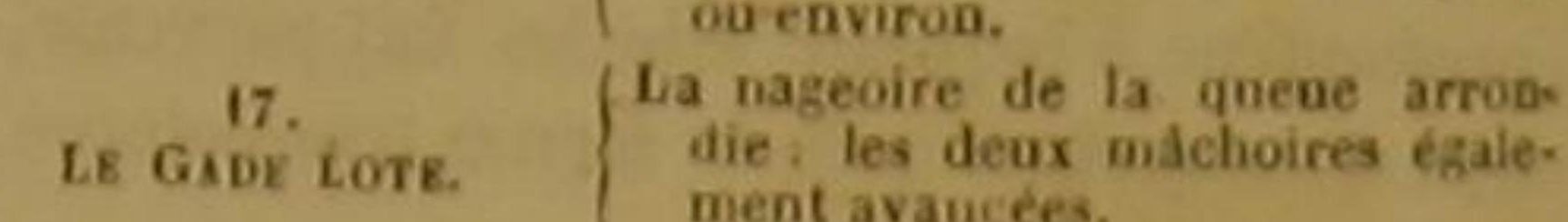

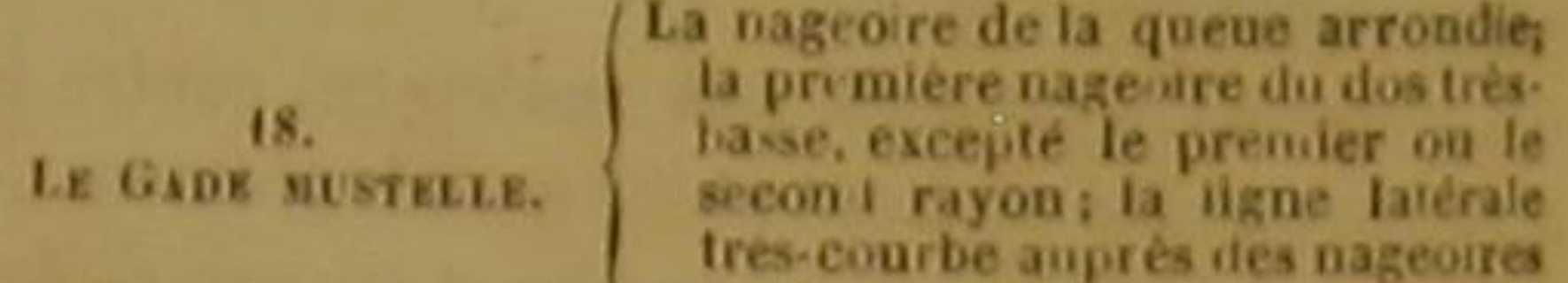
irec-courbe ampres des nageorren
pectorales, et ensuite droile. La nageoire de la queue arrondie:

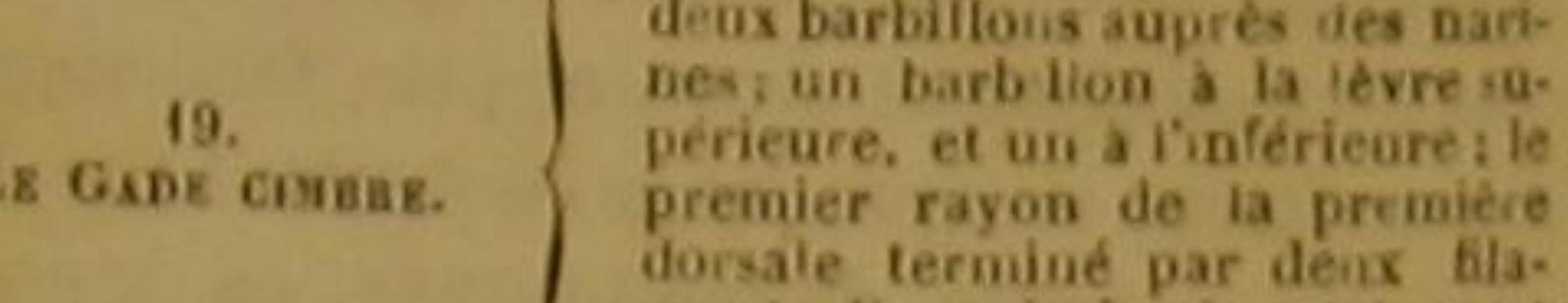

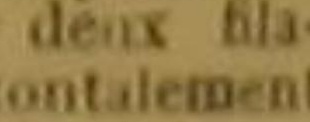

QUATRIẺME SOUS-GENRE.

Deux nageoires dorsales : point de barbillons auprès du bout du museau.

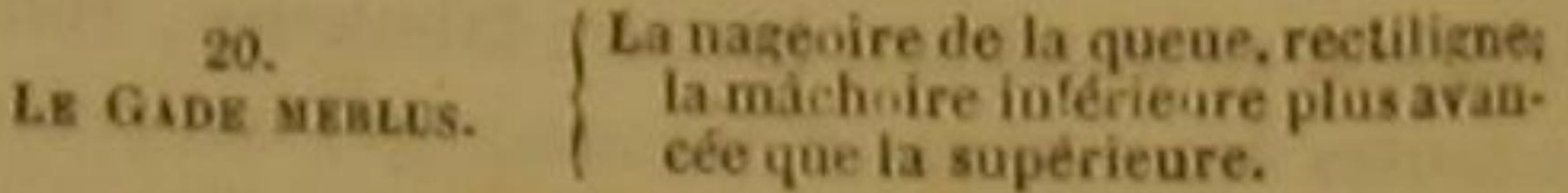

CINQUIĖME SOUS-GENRE.

Une seule nageoire dorsale ; des barbillons au bout du museau.

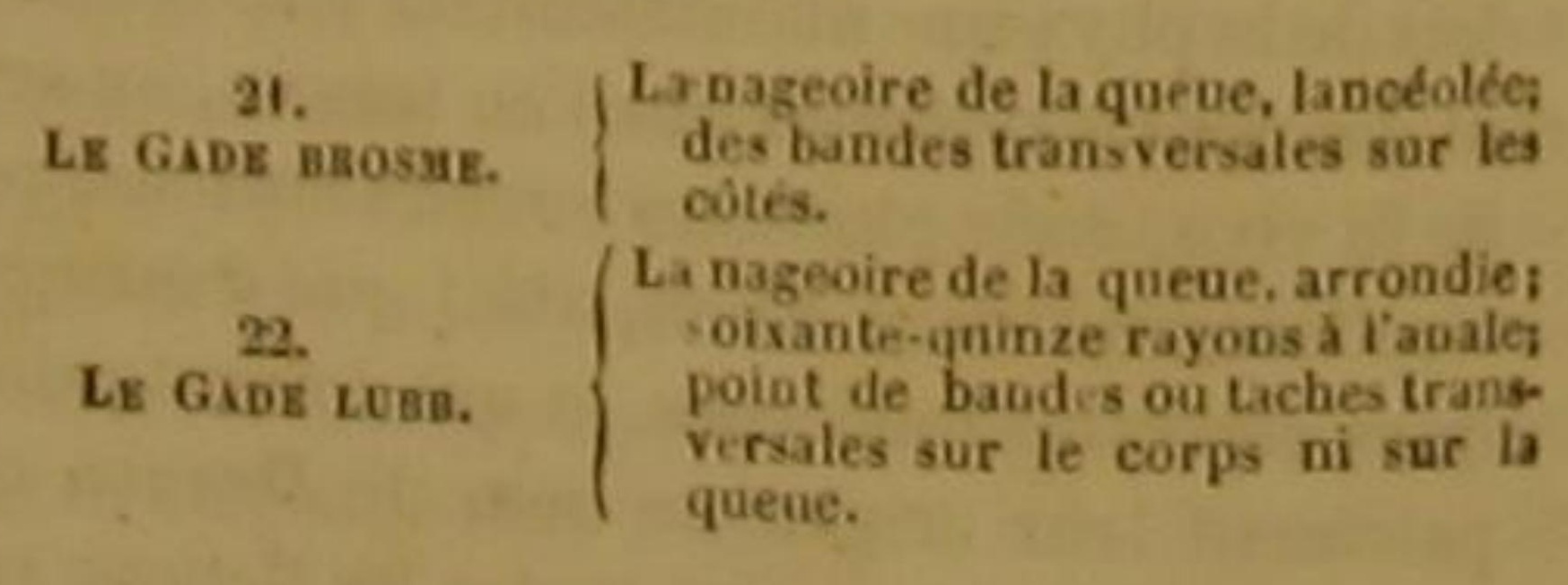
-

LE GADE MORUE !.

Gadus Morrḅua, Linn., Gmel., Lacep., Cuv.

Parmi tous les animaux qui peuplent l'air, lerre ou les eaux, il n'est qu'un très-petit

'Morhuel, dans plus, pays septent. de I'Europe. - Mobillau, ibid. - Cabillaud, ibide. - Cabilimu, ibid. - Cales départ. les pabillaud, ibid, et particulièrement dans

DES POISSONS.

nombre d'espèces utiles dont l'histoire puisse paraitre aussi digne d'interét que celle de la morue, à la philosophie attentive et bienfaisante qui médite sur la prospérité des peuples. L'homme a élevé le cheval pour la guerre, le bouf pour le travail, la brebis pour I industrie, 'éléphant pour la pompe, le chameau pour l'aider à traverser les déserts, le dogue pour sa garde, le chien courant pour la chasse, le barbet pour le sentiment, la poule pour sa table, le cormoran pour la péche, l'aigrette pour sa parure, le serin pour ses plaisirs, l'abeille pour remplacer le jour; il a donné la morue au commerce maritime; et en répandant par ce seul bienfait, une nouvelle vie sur un des grands objets de la pensée, du courage et d'une noble ambition, il a doublé les liens fraternels qui unissaient les différentes parties du globe.

Dans toutes les contrées de l'Europe, et dans presque toutes celles de l'Amérique, il est bien peu de personnes qui ne connaissent le nom de la morue, la bonté de son goût, la nature de ses muscles, et les qualités qui distinguent sa chair suivant les diverses opérations que ce gade a subies : mais combien d'hommes n'ont aucune idée précise de la forme extérieure, des organes intérieurs, des habitudes de cet animal fécond, ni des diverses précautions que l'on a imaginées pour le pêcher avec facilitél et parmi ceux qui s'oceupent avec le plus d'assíduité d'étudier ou de régler les rapports politiques des nations, d augmenter leurs moyens de subsistance, daceroitre leur population, de multiplier leurs objets d'échange, de créer ou de ranimer leur marine; parmi ceux mème qui ont consacré leur existence aux voyages de long

Ciblia , en Subde. - Gade morue, Dabbenton, Enc, méth. - td. Bonnaterre, pl. de l'Enc. métb. - Gadus squa mis cirrato, eris, Bioch, pi. 6i. - Gadus, dorso tripterygio, ore maxima asellorum, secies, Belon - Mormua vulgaris, rhwa. sive Molva ollera, Aldrov, , L 3. c. 6. p. 289-Molca,

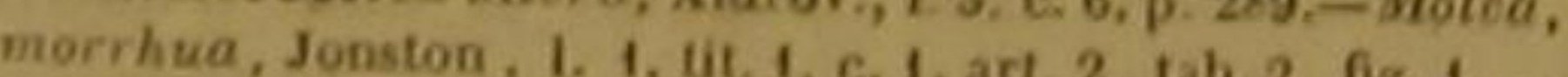
Mutva, vel Morrhua allera, minor, Ger. pis $88,-$ Ieon. an m., p. 71. - Molke, ou Morhue, Rondelet, part i 1.9. C. 15. - Asellus major, Schonev., p. 18. - Charleton, p. 121. - Asellus major vulgaris, Belgis cahilian. , wil lughby, p. 165. - Aselins major vulgaris, , Hai, p. 53, n. .

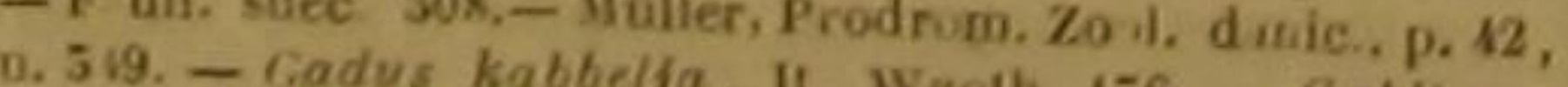
Strom. son im $517,-$. Calleriss W goth. 176. - Cabliau,

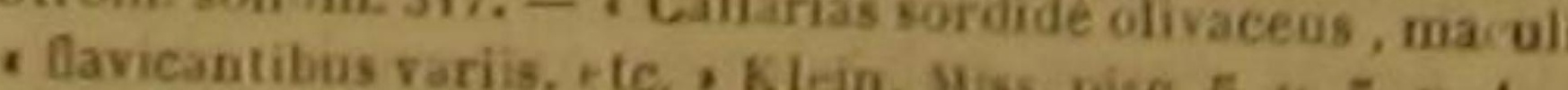

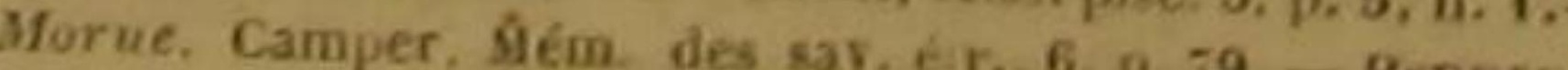
Brit. Zool. 3. p. 172, n. 75. - Morue franclie. Pennan, Traite des pechis, part. 2, sect. 1, c. 1. - Morve, Vileci, de Bomare, Dict, d'ist. nat. - Gadus morhua, Ascague,
cili. 5. p. 3 pl. 27 . cours, ou aux vastes spéculations commerciales, n'est-il pas plusieurs esprits élevés et très-iustruits, anx yeux desquels cependant une histoire bien faite du gade morue dévoilerait des faits importants pour le sujet de leurs estimables méditations?

Aristote, Pline, ni aucun des anciens historiens de la nature, n'ont connu le gade morne: mais les naturalistes récents, les voyageurs, les pécheurs, lès préparateurs, les marins, les commeręants, presque tous les habitants des rivages, et même de l'intérieur des terres de l'Europe ainsi que de l'Amérique, particulièrement de l'Amérique et de l'Europe septentrionales, se sont occupés si fréquenment et sous tant de rapports de ce poisson; ils l'ont va, si je puis employer cette expression, sous tant de faces et sous tant de formes, qu'ils ont dù nécessairement donner à cet animal un tres-grand nombre de dénominations différentes. Néanmoins sous ces divers noms, aussi bien que sous les déguisements que l'art a pu produire, et mème sous les dissemblances plus ou moins variables et plus ou moins considérables que la aature a crées dans les différents climats, il sera toujours aisé de distínguer la morue nonseulement des autres jugulaires de la premiere division des osseux, mais encore de tous les autres gades, pour peu qu'on veuille rappeler les caractères que nous allons indiquer.

Comme tous les poissons de son genre, la morue a la tête comprimée; les yeux, placés ur les côtés, sont très-rapprochés l'un de l'aure, très-gros, voilés par une membrane transparente; et cette dernière conformation donne l'animal la faculté de nager à la surface des mers septentrionales, au milieu des montagnes de glace, auprès des rivages couverts de neige congelée et resplendissante, sans être éblou par la grande quantité de lumière réfléchie sur es plages boréales : mais hors de ces région voisines du cercle polaire, la morue doit voir avec plus de difficulté que la plupart des pois. sons, dont les yeux ne sont pas ainsi recouverts par une pellicule diaphane; et de là est venue l'expression d'yeux de morue dont on s'est servi pour désigner des yeux grands, à fleur de tète et cependant mauvais.

Les mâchoires sont inégales en longueur : la supérieure est plus avancée que l'inférieure, au bout de laquelle on voit pendre un assez grand barbillon. Elles sont armées toutes les deux de 
plusieurs rangées de dents fortes et aiguês. La $\mid$ Les morues parviennent très-souvent à une première rangée en présente de beaucoup plus grandeur assez considérable pour peser un my. (riagramme : mais ce h'est pas ce poids qui in ticolées avec l'un des os maxillaires, de manière à ne se préter à aucun mouvement. Plusieurs de ces dents sont au contraire très-mobiles, c'est-à-dire peuvent être, comme celles des squales, couchées et relevées sous différents angles, à la volonté de l'animal, et lui donner ainsi des armes plus appropriées à la nature, au volume et à la résistance de la proie qu'il cherche à dévorer.

La langue est large, arrondie par devant, molle et lisse : mais on voit des dents petites et serrées au palais et auprès du gosier.

Les opercules des branchies sont composés chacun de trois pièces, et bordés d'une bande souple et non ciliée. Sept rayons soutiennent chaque membrane branchiale.

Le corps est allongé, légèrement comprimé, et revêtu d'écailles plus grandes que celles qui recouvrent presque tous les antres gades. $\mathrm{La}$ ligne latérale suit à peu près la courbure du dos jusque vers les deux tiers de la longueur totale du poisson.

On voit sur la morue trois grandes nageoires dorsales. Ce nombre de trois, dans les nageoires du dos, distingue les gades du premier et du second sous-genre, aissi que l'indique le tableau qui est a la tète de cet article; et il est d'autan plus remarquable, qu'excepté les espèces renfermées dans ces deux sous-genres, les eaux douces, aussi bien que les eaux salées, doiven comprendre un très-petit nombre de poissons osseux ou carthlagineux dont les nageoires dorsales soient plus que doubles, et qu'on n'en trouve particulièrement aucun à trois nageoires dorsales parmi les habitants des mers ou des rivières que nous avons dejà décrits dans cet ouvrage.

Les poissons qui ont trois nageoires du dos, ont deux nageoires de l'anus placées comme les dorsales, à la suite l'une de l'autre. La morue a done deux nageoires anales comme tous les gades du premier et du second sous-genre; on a pu voir sur le tableau de sa famille que premier aiguillon de la première de ces deux nageoires est épineux et non articulé.

Les nageoires jugulaires sont étroites et terminées en pointe, comme celles de presque tous les gades; ; la caudale est un peu fourchue ${ }^{1}$. dique la dernière limite de leurs dimensions. Suivant le savant Pennant, on en a vu, auprès des côtes d'Angleterre, une qui pesait près d quatre myriagrammes, et qui avait plus de dixhuit décimètres de longueur, sur seize décimetres de circonférence á l'endroit le plus gros do corps.

L'espèce que nous décrivons est d'ailleurs d'un gris cendré, tacheté de jaunàtre sur le dos. La partie inféricure du corps est blanche, et quelquefois rougeátre, avec des taches coulen d'or dans les jeunes individus. Les nageoires pectorales sont jaunâtres; une teinte grise dis. tingue les jugulaires, ainsi que la seconde de 'anus. Toutes les autres nageoires présentent des taches jaunes.

C'est principalement en examinant avee soip les organes intérieurs de la morue, que Camper, Monro et d'autres habiles anatomistes, sont parvenus à jeter ungrand jour sur la strue ture interne des poissons, et particulièrement sur celle de leurs sens. On peut voir, par exemple, dans Monro, une très-belle description de l'ouie de la morue : mais nous nous sommes déja assez occupés de l organe auditif des pois. sons, pour devoir nous contenter d'ajouter a tout ce que nous avons dit, et relativement au gade morue, que le grand os auditif contenu dans un sac placé à cóté des canaux appelés demi-circulaires, et le petit os renfermé dans la cavité qui réunit le canal supérieur au ca. nal moyen, présentent un volume assez considerable, proportionnellementâ celuidel'animal que c'est à ces deux os qu'il faut rapporter les petits corps que l'on trouve dans les cabinets d'histoire naturelle, sous le nom de pierres de morue; qu'un troisième os que l'on a découvert aussi dans l'anguille et dans d'autres ossenx dont nous traiterons avant de terminer cet ouvrage, est situé dans le creux qui sert de communication aux trois canaux demi-circulaires; et que la grande cavité qui comprend ces mèmes canaux est remplie d'une matière visqueuse, au milieu de laquelle sont dispersés de petits corps sphériques auxquels aboutissent des ramifications nerveuses.

a la troisième 21 , à chacune des nageoires pectorales 16,1 conde 16 , tagolaires 6 , a la première de l'anus 17 , a la se
De petits corps semblables sont attachés à la cervelle et aux prineipaux rameaux des nerfs. Si de la considération de l'ouie de la morue nous passons à celle de ses organes digestifs , nous trouverons qu'elle peut avaler dans un très-court espace de temps une assez grande quantité d'aliments : elle a en effet un estomae très-volumineux; et l'on voit auprès du pylore six appendices ou petits canaux branchus. Elle est très-vorace; elle se nourrit de poissons, de mollusques et de crabes. Elle a des sues digestifs si puissants et d'une action si prompte, qu'en moins de six heures un petit poisson peut étre digéré en entier dans son canal intestinal. De gros crabes y sont aussi bientôt réduits en chyle; et avant qu'ils ne soient amenés à l'état de bouillie épaisse, leur têt s'altère, rougít comme celui des écrevisses que l'on met dans de l'eau bouillante, et devient très-mou'

La morue est mème si goulue, qu'elle avale souvent des morceaux de bois ou d'autres sub. stances qui ne peuvent pas servir à sa nourriture : mais elle jouit de la faculté qu'ont reçue les squales, d'autres poissons destructeurs, et les oiseaux de proie; elle peut rejeter facilement les corps qui l'incommodent.

L'eau douce ne parait pas lui convenir ; on ne la voit jamais dans les fleuves ou les rivières : elle ne s'approche même des rivages, au moins ordinairement, que dans le temps du frai ; pendant le reste de l'année elle se tient dans les profondeurs des mers, et par conséquent elle doit être placée parmi les véritables poissons pélagiens. Elle habite particulièrement dans la portion de l'Océan septentrional comprise entre le quarantième degré de latitude et le soixantesixième : plus au nord ou plus au sud, elle perd de ses qualités; et voilà pourquoí apparemment elle ne doit pas être comptée parmi les poissons de la Méditerranée, ou des autres mers intérieures, dont l'entrée, plus rapprochée de l'équateur que le quarantième degré, est située hors des plages qu'elle fréquente.

On la pêche dans la Manche, et on la prend auprès des cótes du Kamtschatka, vers le soixantième degré ${ }^{2}$ : mais dans la vaste étendue de l'Océan boréal qu'occupe cette espèce, on peut distinguer deux grands espaces qu'elle semble préférer. Le premier de ces espaces remarquables peut être conçu comme limité : Voyez I'Histoire d Tslande, par Anderson.
Voyage de Lesseps, du Kamtschalka en France. 'un coté par le Groenland et par I'Islande de l'autre; par la Norvége, les côtes du Danemarek, de l'Allemagne, de la Hollande, de lest et du nord de la Grande-Bretagne, ainsi que des iles Orcades; il comprend les endroits désignés par les noms de Dogger-bank, Vellbank et Cromer; et on peut y rapporter les petits lacs d'eau salée des iles de l'ouest de l'Ecosse, où des troupes considérables de grandes morues attirent, principalement vers Gareloch, les pècheurs des Öreades, de Peterhead, de Portsoy, de Firth et de Murray.

Le second espace, moins anciennement connu, mais plus célèbre parmi les marins, renferme les plages voisines de la Nouvelle-Angleterre, du cap Breton, de la Nouvelle-Ecosse, et surtout de l'ile de Terre-Neuve, auprès de laquelle est ce fameux bane de sable désigné par le nom de Grand Banc, qui a près de cinquante myriamètres de longueur sur trente ou environ de largeur, au-dessus duquel on trouve depuls vingt jusqu'à cent mètres d'eau, et près duquel les morues forment des légions très-nombreuses, parce qu'elles y rencontrent en très-grande abondance les harengs et les autres animaux marins dont elles aiment à se nourrir.

Lorsque, dans ces deux immenses portions e mer, le besoin de se débarrasser de la laite ou des oufs, ou la nécessité de pourvoir à leur subsistance, chassent les morues vers les cótes c'est principalement près des rives et des banes couverts de crabes ou de moules qu'elles se rassemblent ; et elles déposent souvent leurs œufs sur des fonds rudes au milieu des rochérs.

Ce temps du frai qui entraine les morues vers les rivages, est très-variable, suivant les contrées qu'elles habitent, et l'époque à laquelle le printemps ou l'été commence à régne dans ces mèmes contrées. Communément c'est vers le mois de février que ce frai a lieu auprès de la Norvége, du Danemarck, de l'Angleterre, de l'Écosse, ete. : mais comme l'ile de TerreNeuve appartient à l'Amérique septentrionale, et par conséquent à un continent beaucoup plus froid que l'ancien, l'époque de la ponte et de la récondation des oufs y est reculée jusqu'en avril.

Il est évident, d'après tout ce que nous venons de dire, que cette époque du frai est celle que l'on a dû choisir pour celle de la péche. I y a donc eu diversité de temps pour cette grande opération de la recherche des morues, selon le 
lieu où on a désiré de les prendre; et de plus, il y a eu différence dans les moyens de parvenir à les saisir, suivant les nations qui se sont occupées de leur poursuite : mais depuis plusieurs siècles les peuples industrieux et marin de l'Europe ont senti l'importance de la pèche des morues, et s'y sont livrés avec ardeur. Dès le quatorzième siècle, les Anglais et les habitants d'Amsterdam ont entrepris cette pèche, pour laquelle les Islandais, les Norvégiens, les Français et les Espagnols ont rivalisé avec eux plus ou moins heureusement; et vers I commencement du seizième, les Français on envoyé sur le grand bane de Terre-Neuve les premiers vaisseaux destinés à en rapporter des morues. Puisse cet exemple mémorable n'ètr pas perdu pour les descendants de ces Francais et lorsque la grande nation verra luire le joo fortuné où l'olivier de la paix balancera sa tête sacrée, au milieu des lauriers de la victoire et des palmes éclatantes du génie, au-dessus des innombrables monuments élevés à sa gloire , qu'elle n'oublie pas que son zèle éclairé pour les entreprises relatives aux péches importantes sera toujours suivi de l'accroissement le plus rapide de ses subsistances, de son commeree de son industrie, de sa population, de sa marine, de sa puissance, de son bonheur!

Dans la première des deux grandes surfaces où l'on rencontre des troupes très-nombreuses de morues, et par conséquent dans celle où l'o s'est livré plus anciennement à leur recherche, on n'a pas toujours employé les moyens les plus propres à atteindre le but que l'on aurait dû se proposer. Il a été un temps, par exemple, o sur les côtes de Norvége on s'était servi de filets composés de manière à détruire une si grande quantité de jeunes morues, et à dépeupler si vite les plages qu'elles avaient affectionnées que, par une suite de ce sacrifice mal entendu de l'avenir au présent, un bâteau monté de quatre hommes ne rapportait plus que six ou sept cents de ces poissons, de tel endroit où il en aurait pris, quelques années auparavant, près de six mille.

Mais rien n'a été négligé pour les pèches faites dans les dix-septième et dix-huitième siècles, aux environs de l'ile de Terre-Neuve.

Premièrement, on a recherché avec le plus grand soin les temps les plus favorables; c'est d'après les résultats des observations faites à ce sujet, que, vers ces parages, il est trèsta qu'on continue la poursuite des morues après le mois de juin, époque à laquelle les gades dont nous écrivons l'histoire s'éloignent à de grandes distances de ces plages, pour chercher une nourriture plus abondante, ou éviter la dent meurtrière des squales et d'autres habitants des mers redoutables par leur férocité. Les mo. rues reparaissent auprès des côtes dans le mois de septembre, ou aux environs de ce mois: mais dans cette saison, qui touche d'un còté à l'équinoxe de l'automne, et de l'autre aux frimas de l'hiver, et d'ailleurs auprès de l'Amé. ríque septentrionale, où les froids sont plus rigoureux et se font sentir plus tot que sous le mème degré de la partie boréale de l'ancieu continent, les tempètes et mème les glaces peuvent rendre très-souvent la pẻche trop incertaine et trop dangereusẻ, pour qu'on se détermine à s'y livrer de nouveau, sans attendre le printemps suivant.

En second lieu, les préparatifs de cette im. portante et lointaine recherche des morues qui se montrent auprès de Terre-Neuve, ont été faits, depuis un très-grand nombre d'années, avec une prévoyance très-attentive. C'est dans ces opérations préliminaires qu'on a suivi avee une exactitude remarquable le prineipe de diviser le travail pour le rendre plus prompt et plus voisin de la perfection que l'on désire; et ce sont les Anglais qui ont donné à cet égard l'exemple à l'Europe commercante.

La force des cordes ou lignes, la nature des hameçons, les dimensions des bátiments, tous ces objets ont été déterminés avec préeision. Les lignes ont eu depuis un jusqu'à deux centimètres, ou à peu près, de cireonférence, et quelquefois cent quarante-cinq mètres de longueur : elles ont été faites d'un très-bon chanvre, et composées de fils très-fins, et cependant très-forts, alin que les morues ne fussent pas trop effrayées, et que les pécheurs pussent sentir aisément l'agitation du poisson pris, relever avec facilité les cordes et les retirer sans les rompre.

Le bout de ces lignes a été garni d'un plomb qui a eu la forme d'une poire ou d'un cylindre, a pesé deux ou trois kilogrammes selon la grosseur de ces cordes, et a soutenu une empile longue de quatre à cinq mètres '. Communé- ment les vaisseaux employés pour la pêche des morues ont été de cent cinquante tonneanx au plus, et de trente hommes d'équipage. On a emporté des vivres pour deux, trois et jusqu'à huit mois, selon la longueur du temps que l'on a cru devoir consacrer au voyage. On n'a pas manqué de se pourvoir de bois pour aider le desséchement des morues, de sel pour les conserver, de tonnes et de petits barils pour y renfermer les différentes parties de ces animaux déjà préparées.

Des bateaux particuliers ont été destinés à aller pécher, mème au loin, les mollusques et les poissons propres à faire des appàts, tels que des sépies, des harengs, des éperlans, des trigles, des maquereaux, des capelans, ete.

On se sert de ces poissons quelquefois lorsqu'ils sont salés, d'autres fois lorsqu'ils n'ont pas été imprégnés de sel. On en emploie souvent avec avantage de digérés à demi. On remplace avec succès ces poissons corrompus par des fragments d'écrevisse ou d'autres crabes du lard et de la viande gátée. Les morues sont même si imprudemment goulues, qu'on les trompe aussí en ne leur présentant que du plomb ou de l'étain façonné en poisson, et des morceaux de drap rouge semblables par la couleur à de la chair ensanglantée; et si on a besoin d'avoír recours aux appáts les plus puissants, on attache aux bameçons le caur de quelque oiseau d'eau, ou même une jeune morue encore saignante; car la voracité des gades que nous décrivons est telle, que, dans les moments ou la faim les aiguillonne, ils ne sont retenus que par une force supérieure á la leur, et n'épargnent pas leur propre espèce.

Lorsque lẹs précautions convenables n'ont pas été oubliées, que l'on n'est contrarié ni par de gros temps ni par des círconstances extraordinaires, et qu'on a bien choisi le rivage ou le banc, quatre hommes suffisent pour prendre par jour einq ou six cents morues.

L usage le plus généralement suivi sur le grand banc, est que chaque pècheur établi dans un baril dont les bords sont garnis d'un bourrelet de paille, laisse plus ou moins filer sa ligne, en raison de la profondeur de l'eau, de la force du courant, de la vitesse de-la dérive, et fasse suivre à cette corde les mouvemenits du vaisseau, en la trainant sur le fond contre lequel elle est retenue par le poids de plomb dont elle est lestée. Néanmoins d'autres marins halent ou retirent de temps en temps leur ligne de quelques mètres, et la laissent ensuite retomber tout â coup, pour empêcher les morues de flairer les appáts et de les éviter, et pour leur faire plus d'illusion par les divers tournoiements de ces mémes appâts, qui dès lors ont plus de rapports avec leur proie ordinaire.

Les mornes devant être consommées à uês distancés immenses du lieu où on les pèche, on a été obligé d'employer divers moyens propres a garantir de toute altération leur chair et plusieurs autres de leurs parties. Ces movens se réduisent à les faire saler ou sécher. Ces opérations sont souvent exécutées par les pècheurs, sur les vaisseaux qui les ont amenés: et on imagine bien, surtout d'après ce que nous avons déja dit, qu'afin de ne rien perdre de la durée ni des objets du voyage, on a établi sur ces bátiments le plus geand ordre dans la disposition du local, dans la succession des procédés, et dans la distribution des travaux entre plusieurs personnes dont chacune n'est jamais chargée que des mêmes détails.

Les mêmes arrangements ont lieu sur la cote, mais avee de bien plus grands avantages, lorsque les marins oceupés de la pêche des movues ont a terre, comme les Anglais, des ctabissements plus ou moins commodes, et dans lesquels on est garanti des effets nuisibles que peuvent produire les vicissitudes de l'atmosphère.

Mais soit à terre, soit sur les vaisseaux, on commence ordinairement toutes les préparations de la morue par détacher la langue et couper la tête de l'animal. Lorsque ensuite on veut saler ce gade, on l'ouvre dans sa partie inférieure; on met à part le foie; et si c'est une emelle qu'on a prise, on ôte les cufs de l'intévieur du poisson : on habille ensuite la morue, c'est-à-dire, en termes de pécheur, on achève de l'ouvrir depuis la gorge jusqu'à l'anus, que les marins nomment nombril, et on sépare des muscles, dans cette étendue, la colonne vertébrale, ce qu'on nomme désosser la morue.

Pour mettre les gades dont nous nous oceupons dans leur premier sel, on remplit, le plus qu'on peut, l'intérieur de leur corps de sel marin, ou muriate de soude; on en frotte leur peau; on les range par lits dans un endroit particulier de l'établissement construit á terre, ou de l'entre pont ou encore de la cale dú batiment, 
si elles sont préparées sur un vaisseau, et on a leur premier, a leur second, a leur troisième si elles sont presuivant qu'on les met en tas poureplace une couche de sel au-dessus de chaque mière, la seconde ou la troisième fois; et comlit. Les morues restent ainsi en piles pendant munément les morues recoivent dix soleils, un, deux ou plusieurs jours, et quelquefois mácé d'étré entièrement séchées.

aussi entassées sur une sorte de gril, jusqu'a ce avant d'etre entien craint la pluie, on les porte sur qu'elles aient jeté leur sang et leur eau; puis on les chanue de place, et on les sale à demeure, en les arrangeant une seconde fois par lits, entre lesquels on étend de nouvelles couches de sel.

Lorsqu'en habillant les morues, on se contente de les ouvrir depuis la gorge jusqu'à l'anus, ainsi que nous venons de le dire, elles conservent une forme arrondie du cóté de la queue, et on les nomme Morues rondes; mais le plus grand nombre des marins occupés de la pèche de Terre-Neuve remplacent cette opération par la suivante, surtout lorsqu'ils salent de grands individus. Ils ouvrent la morue dans toute sa longueur, enlèvent la colonne vertébrale tout entière, habillent le poison à plat; et la morue ainsi habillée se nomme Morue plate.

$\mathrm{Si}$, au lieu de saler les gades morues, on veut les faire sécher, on emploie tous les procédés que nous avons exposés, jusqu'à celui par lequel elles reçoivent leur premier sel. On les lave alors, et on les étend une à une sur la grève ou sur des rochers ', la chair en haut, de manière qu'elles ne se touchent pas; quelques heures après on les retourne. On recommence ces opérations pendant plusieurs jours, avec cette différence, qu'au lieu d'arranger les morues une à une, on les met par piles, dont on aceroit successivement la hauteur, de telle sorte que, le sixième jour, ces paquets sont de cent cinquante, ou deux cents, et mème quelquefois de cinq cents myriagrammes. On empile de nouveau les morues à plusieurs reprises, mais à des intervalles de temps beaucoup plus grands, et qui croissent successivement; et le nombre ainsi que la durée de ces reprises sont proportionnés à la nature du vent, à la sécheresse de l'air, à la chaleur de l'atmosphère, à la force du soleil.

Le plus souvent, avant chacune de ces reprises, on étend les morues une à une, et pendant quelques heures. On désigne les diver empilements, en disant que les morues sout des tas de pierres placés dans des cabanes, ou pour mieux dire, sous des hangars qui n'arretent point l'action des eourants d'air

Quelques peuples du nord de I'Europe emploient, pour préparer ces poissons, quelques procédés, dont un des plus connus consiste a dessécher ces gades sans sel, en les suspendan au-dessus din fourneau, ou en les exposant aux vents qui règnent dans leurs contrées pendant le printemps. Les morues acquièrent par cette opération une dureté égale à celle du bois, d'ou leur est venu le nom de Stock-fist ( poisson en bâton ); dènomination qui, selon quelques auteurs, dérive aussi de l'usage on l'on est, a vant d'appreter du slock-fish pour le manger, de le rendre plus tendre en le battant sur un billot.

Les commerceants appellent dans plusieurs pays, Morue blanche, celle qui a été salée, mais sêchée promptement, et sur taquelle le sel a laissé ủne sorte de croùte blanchâtre. La Morue noire, pinnée ou brumée, est celle qui, par un desséchement plus lent, a éprouvé un commencement de décomposition, de telle sorte qu'une partie de sa graisse, se portant à la surface, et s'y combinant avee le sel, y a produit une espèce de poussière grise ou brune, repandue par taches.

On donne aussi le nom de Morue verle à la morue salée, de Merluche à la morue sèche, et de Cabillaud à la morue préparée et arrangée dans des barils da poids de dix à quinze myriagrammes, et dont une douzaine s'appelle un Lelh, dans plusieurs ports septentrionaux d'Europe.

Mais d'ailleurs un grand nombre de places de commerce ont eu, ou ont encore, différentes manières de désigner les morues distribuées en assortiments, d'après les divers degrés de leurs dimensions ou de leur bonté. A Nantes, par exemple, on appelait grandes Morues, les morues salees qui étaient assez longues pour que cent de ces poissons pesassent quarantecinq myriagrammes; Morues moyennes, celles dont le cent ne pesait que trente myriagrammes; Raguets, ou petites Morues, celles de l'assortiment suivant; et Rebuts, Lingues, ou très-petites Morues, celles d'un assortiment plus inférieur encore.

Sur quelques cótes de la Manche, le nom de Morue gaffe indiquait les très-grandes morues; cing autres assortiments inférieurs étaient indiqués par les dénominations de Morue marchande, de Morue trie, de Raguet ou Lingue, de Morue valide ou Patelel, et de Morueviciée, appellation qui appartenait en effet à la plus mauvaise qualité.

Dansce mème port de Nantes dont nous venons de parler, les morues secches étaient divisées en sept assortiments, dont les noms étaient, suivant l'ordre de la supériorité des uns sur les autres, Morue pivee, Morue grise; Grand marchand, Moyen marchand, * ou Fourillon, grand Rebut et petit Rebut.

A Bordeaux, à Bayonne, et dans plusieurs ports de I'Espagne occidentale, on ne distinguait que trois assortiments de morue, le $\mathrm{Mar}$ chand, le Moyen et le Rebut.

Au reste, les muscles des morues ne sont pas les seules portions de ces poissons dont on fasse un grand usage; if n'est presque aucune de leurs parties qui ne puisse servir à la nourriture de 1'homme, ou des animaux.

Leur langue fraiche et même salée est un morceau délicat; et voilá pourquoi on la coupe avec soin, dès le commencement de la préparation de ces poissons.

Les branchies de la morue peuvent être employées avec avantage comme appât dans la pêche que l'on fait de ce gade.

Son foie peut être mangé avec plaisir: mais d'ailleurs il est très-grand relativement au volume de l'animal, comme celui de presque tous les poissons ; et on en retire une huile plus utile dans beaucoup de circonstances que celle des baleines, laquelle cependant est très-recherchée dans le commerce. Ellé conserve bien plus longtemps que ce dernier fluide, la souplesse des cuirs qui en ont été pénétrés; et lorsqu'elle a été clarifiée, elle répand, en brûlant, une bien moindre quantité de vapeurs.

On obtient avec la vessie natatoire de la morue une colle qui ne le cède guère à celle de l'aeipensère huso, que l'on fait venir de Russie dans un si grand nombre de contrées d'Europé '. Pour la réduire ainsi en colle, on la prépare

: Voyez, dans cette Histoire, lart. de l'Acipensere huso.
Pelit marcliand. u. peu près de la mème manière que celle du huso; on la détache avec attention de la colonne vertébrale, on en sépare toutes les parties étrangèrès; on en ote la première peau, on la met dans l'eau de chaux pour achever de la. dégraisser, on la lave, on la ramollit, on la pétrit, on la façonne, on la fait sécher avee soin; on suit enfin tous les procédés que nous avons indiqués dans l'histoire du huso : et si des circonstances de temps et de lieu ne permettent pas aux pécheurs, comme, par exemple, à ceux de Terre-Neuve, de s'occuper de tous ces détails immédiatement après la prise de la morue, on mange la vessie natatoire, dont le goùt n'est pas désagréable, ou bien on la sale; on la transporte ainsi imprégnée de muriate de soude à des distances plus ou moins grandes; on la conserve plus ou moins longtemps; et lors. qu'on veut en faire usage, il suffit presque toujours de la faire dessaler et ramollin, pour la rendre susceptible de se prêter aux mèmes opérations que lorsqu'elle est fraiche.

La téte des morues nourrit les pécheurs de ces gades et leurs familles. En Norvége, on la donne aux vaches; et on y a éprouvé que mélée avee des plantes marines, elle augmente la quantité du lait de ces animaux, et doit etre préférée, pour leur aliment, ì la paille et au foin.

Les vertèbres, les cótes et les autres os ou arêtes des gades morues, ne sont pas non plus inutiles : ils servent à nourrir le bétail des Islandais. On en donneà ces chiens de Kamtschatka quet'on attelle aux traineaux destinés à glisser sur la glace, dans cette partie septentrionale de l'Asie; et dans d'autres contrées boréales, ils sont assez imprégués de substance huileuse pour être employés à faire du feu, surtout lorsqu'ils ont été séchés au point convenable.

On ne néglige même pas les intestins de la morue, que l'on a nommés dans plusieurs endroits, noues, ou nos; et enfin on prépare avee soin, et on conserve pour la table, les aufs de ce gade, auxquels on a donné la dénomination de rogues, ou de raves.

Tels sont les procédés et les fruits de ces péches importantes et fameuses, qui ont employé dans la même année jusqu'à vingt mille matelots d'une seule nation '.

On aura remarqué sans doute que nous n'a

' La nation anglaise. 
vons parlé que des pècheries établies dans l'hé- | gleterre et de France, on ne s'est pas contenté misphère boréal, soit auprès des cótes de l'an- d'y pêcher les morues que l'on voit de tems cien continent, soit auprès decelles du nouveau. en temps; mais afin d'être plus sûr d'en avots A mesure que l'on connaitra mieux la nature de plus grandes à sa disposition, on $\epsilon$ st parver des rivages des iles ou des continents particu- a y apporter en vie un assez grand nombre d liersdel'hémisphèreaustral, et particulièrement celles que l'on avait prises sur les banes de de ceux de l'Amérique méridionale, tant du Terre-Neuve : on les a placées, pour cet objen côté de l'orient que du côté de l'occident, il est dans de grands vases fermés, mais attachés à présumer que l'on découyrira des plages où aux vaisseaux, plongés dans la mer, et percé la température de la mer, la profondeur des de manière que l'eau salée pût aisément parve eaux, la nature du fond, l'abondance des pe- nir dans leur intérieur. Des pècheurs anglai tits poissons, l'absence d'animaux dangereux, ont ajouté à cette précaution un procédé don et la rareté de tempétes très-violentes et de nous avons déjà parlé dans notre premier Dis très-grands bouleversements de l'Océan, ont ap- cours : ils ont adroitement fait parvenir un pelé, nourrissent et multiplient l'espèce de la aiguille jusqu'à la vessie natatoire de la morue, morue, que certains peuples pourraient aller y et l'ont percée, afin que l'animal, ne pouvan pécher avec moins de peine et plus de succès plus se servir de ce moyen d'ascension, demeoque sur les rives boréales de l'hémisphère are- rât plus longtemps' au fond du vase, et füt tique.

De nouveaux pays profiteraient aiusi d'un des plus grands bienfaits de la nature; et l'espèce de la morue, qui alimente une si grande quantité d'hommes et d'animaux en Islande, en Norvége, en Suède, en Russie, et dans d'autres régions asiatiques ou européennes, pourrait d'autant plus suffire aussi aux besoins des habitants des rives antarctiques, qu'elle est très-remarquable par sa fécondité. L'on est étonné du nombre prodigieuxd'œufs que portent les poissons femelles; aucune de ces femelles n'a cependant été favorisée à cet égard comme celle de la morue. Ascagne parle d'an individu de cette dernière espèce, qui avait treize décimètres de longueur, et pesait vingt-einq kilogrammes; l'ovaire de ce gade en pesait sept, et renfermait néuf millions d'œufs. On en a compté neuf millions trois cent quarante-quatre mille dans une autre morue. Quelle immense quantité de moyens de reproduction! Si le plus grand nombre de ces œufs n'étaient ni privés de la laite fécondante du mâle, ni détruits par divers accidents, ni dévorés par différents animaux, on voit aisément combien peu d'années il faudrait pour que l'espèce de la morue eủt, pour ainsi dire, comblé le vaste bassin eút, mers.

Quelque agréables au goùt que l'on puisse rendre les diverses préparations de la morue séchée, ou de la morue salée, on a toujours préféré avee raison de la manger frajehe prejouir de ce dernier avantage sur plusieurs côtes del'Europe, et particulièrement sur celles d'An- morue de roche), Nous pensons avee M. Noèl de Rouen, qui nous a écrit au sujet de ce poisson, que ce gade n'est qu'une variété de la morue grise ou ordinaire que nous venons de déerire; mais nous eroyons devoir insérer dans l'article que nous allons terminer, l'extrait suivant de la lettre de M. Noēl.

J'ai lu, dit eet observateur, dans un oua vrage sur l'ile de Man, que la couleur de la - peau du Red cod est d'un rouge de vermillon. - Quelques habitants de l'ile de Man pensent - que cette -morue acquiert cette couleur bril- lante parce qu'elle se nourrit de jeunes écre" visses de mer:- mais les écrevisses de mer - sont, dans l'eau, d'une couleur noiratre; - elles ne deviennent rouges qu'après avoir été - cuites. La morue rouge n'est qu'une variété a de l'espèce commune : je suis disposéa croire - que la couleur rouge qui la distingue, lui est - communiquée par les algues et les mousses - marines qui couvrent les rochers sur lesquels - on la pêche, puisque ces mousses sont de - couleur rouge; je le crois d'autant plus vo" lontiers, que les baies de l'ile de Man ont - aussi une variété de mules et dé gourneaux " dont la couleur est rouge... Cette morue - rouge est très-estimée pour l'usage de la - table.

\section{LE GADE AGLEFIN'}

Gados Eglefinus, Linn., Gmel., Bloch., Lacep., Cuv.

Ce gade a beaucoup de rapports avec la morue; sa chair s'enlève facilemènt par feuillets, ainsi que celle de ce dernier animal, et de pres.

- Kallior, Kallie, Kaljor, Kollia, en Suède - Koll, en Danemarck, - Haddock, en Angleterre. - Ĺplefins, Égrefia, par quelques auteurs français. - Gade anon, Danben-
ton, Enc, meth.-Id Bonnaterre, pl. de I'Enc, méth. - - Ga.

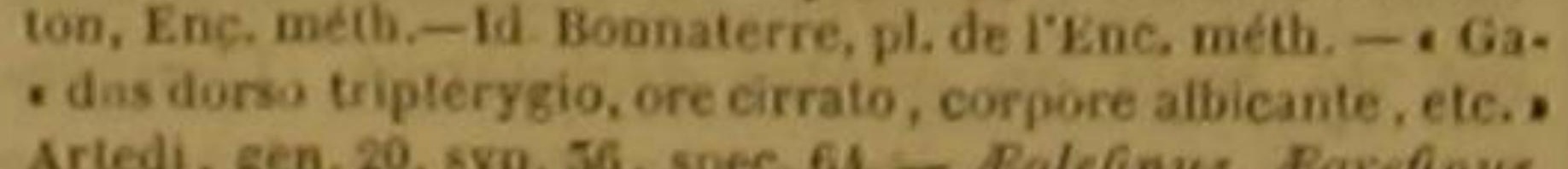

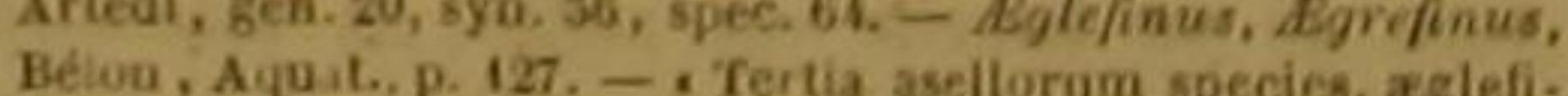
- nos. : Gesner, Aquat., p. 86, 100, ét (Germ.) fol io $\alpha$. - Tertia aseliorum species Rondeletii, aselins majos, Aldrov, 1. 3, c, 1, p. 282. - Asellus minor, Schohev., p. 18. Wilugbuy, p. A7, tab. L, membr. A, n. 2. - Rai, p. 55, n.7. - Fauna suec., P. 305. - Moller, Prodrom. Zool. danic. p. 42 , a. 348. - Gadus kolfa, it. scan, 525. - It. Wgoth

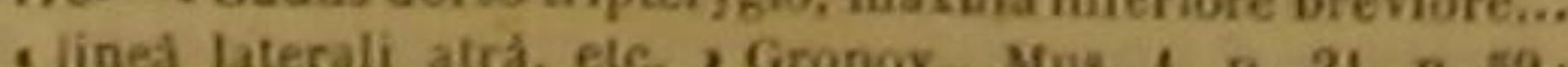
Zooph., p. 99, n. 521. - . Callarias barbatus ex terreo sllth - cans, elc., Klein, Miss pise, 5. p. 6, n. 2. - . Callarias c asellus minor., Jonston, de Piscib., p. 1, tab. 1, fig. 1.Schell fusch, Anders. Island., p. 79. - Hadock, Pennant, Brit Zool. 5, p. 179. - Egrcepa, kondelet, part. 1, liv. 9,

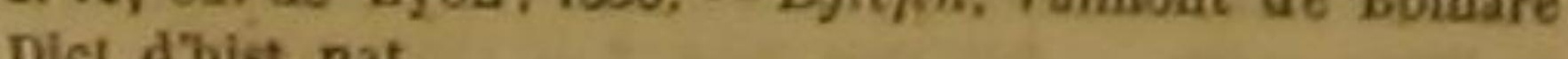

que tous les autres poissons du même genre. On le trouve, comme la morue, dans l'Océan septentrional; mais il ne parvient communément qu'à la longueur de quatre ou einq décimètres. II voyage par grandes troupes qui couvrent quelquefois un espace de plusieurs myriares carrés. Et, ce qu'il ne faut pas négliger de faire observer, on assure qu'il ne va jamaj dans la Baltique, et que par conséquent il ne passe point le Sund. On ne pent pas dire cependant qu'il redoute le voisinage des terres; $\mathrm{car}$, chaque année, il s'approche, vers les mois de février et mars, des rivages septentrionaux de I'Europe, pour la ponte et la fécondation de ses oufs. S'il survient de grandes tempétes pendant son séjour auprès des cotes, il s'éloigne de la surface des eaux, et cherche dans le sable du fond de la mer, ou au milieu des plantes marines qui tapissent ce sable, un asile contre les violentes agitations des flots. Lorsque les ondes sont calmées, il sort de sa retraite sous marine, et reparait encore tout couvert ou d'algues ou de limon.

Un assez grand nombre d'aglefins resten même auprès des terres pendant l'hiver, ou s'avancent, pendant cette saison, vers les rivages auprès desquels ils trouvent, plus aisément que dans les grandes eaux, la nourriture qui léur convient. M. Noël m'écrít que, depujs 1766 , les pécheurs anglais des côtes d'York ont été frappés de l'exactitude avec laquelle ces gades se sont montrés dans les eaux cótiéres, vers le 10 décembre. L'étendue du bane qu'ils forment alors est d'environ trois milles en largeur, à compter de la cote, et de quatrevingts milles en longueur, depuís Flamboroughead jusqu'à l'embouchure de la Fine, audessous de Newcastle. L'espace marin occupe par ces poissons est sí bien connu des pécheurs, qu'ils ne jettent leurs lignes que dans ce même espace, hors de la circonférence duquel ils ne trouveraient plus d'ægléfin, et ne pécheraient e plus souvent, a la place, que des squales attirés par cet immense bane de gades, dont ces cartilagineux sont très-avides.

Lorsque la surface de la mer est gelée auprès des rivages, les pécheurs profitent des fentes ou crevasses que la glace peut présenter dans un nombre d'endroits plus ou moins considérable de la croûte solide de l'Océan, pour prendre facilement une plus grande quantité de ces poissons. Ces gades ont, en effet, I'habitude de se 
(a) Heat, e'est-à-dire Mets de Pladdock ou Eglefin, les vers qui différentes portions de glaces, non pas, comme
on l'a cru, pour y respirer l'air très-froid de de fladdock ou Lendant l'hiver lui servent d'aliment, surtout l'atmosphère, mais pour se trouver dans la cou- lorsqu'il ne rencontre ni harengs, ni œufs de che d'eau la plus élevée, par conséquent dans la plus tempérée et dans celle oủ doivent se réunir plusieurs des petits animaux dont ils aiment à se nourrir.

Si les pêcheurs de ces côtes voisines du cercle polaire ne rencontrent pás à leur portée des fentes naturelles et suffisantes dans la surface de l'Océan durcie par le froid, ils cassent la glace et produisent, dans l'enveloppe qu'elle forme, les anfractuosités qui leur conviennent.

C'est aússi autour de ces vides naturels ou artificiels qu'on voit des phoques chercher a dévorer des æglefins pendant la saison rigonreuse.

Mais cẹs gades peuvent être la proie de beaucoup d'autres ennemis. Les grandes morues les poursuivent; et, suivant Anderson, que nons avons déjà cité, la pẻche des æglefins, qué l'on fait auprès de l'embouchure de l'Elbe, a donné le moyen d'observer d'une manière très-particulière combien la morue est vorace, et avec quelle promptitude elle digère ses aliments. Dans ces parages, les pècheurs d'æglefins laiseut leurs hameçons sous l'eau pendant une marée, e'est-à-dire pendant six heures. Si un aglefin est pris dès le commencement de ces six heures, et qu'une morue se jette ensuite sur ce poisson, on trouve en retirant la ligne, au changement de la marée, que l'æglefin es déjà digéré : la morue est à la place de ce gade, arrétée par l'hameşon; ;et ce fait mérite d'autan plus quelque attention, 'qu'il parait prouver que c'est partieulièrement dans l'estomac et dans les sues gastriques qui arrosent ce viscére, que réside cette grande faculté si souvent remarquée dans les morues, de décomposer avec rapidité les substances alimentaires. $\mathrm{Si}$, au contraire, la morue n'a cherché à dévorer l'æglefio que peu de temps avant l'expiration des six heures, elle s'opiniatre tellement à ne pas s'en séparer, qu'elle se laisse enlever en l'air avec sa
proie.

L'æglefin, quoique petit, est aussi goulu e aussi destrueteur que la morue, au moins proportion de ses forces. Il se nourrit non-seulement de serpules, de mollusques, de crabes, mais encore de poissons plus faibles que lui, et particulièrement de harengs. Les pécheurs lorsqu'
poisson

Il a cependant l'ouverture de la bouche un peu plus petite que celle des animaux de son genre; un barbillon pend à l'extrémité de sa máchoire inférieure, qui est plus courte que celle de dessus. Ses yeux sont grands; ses écailles petites, arrondies, plus fortement attachées que celles de la morue. La première nageoire du dos est triangulaire: elle est d'ailleurs bleuátre, ainsi que les autres nageoires; la ligne latérale voisine du dos est noire, ou tachetée de noir; l'iris a l'éelat de l'argent; et cette mème couleur blanchâtre ou argentée règne sur le corps et sur la queue, excepté leur partie supérieure, qui est plus ou moins brunátre ${ }^{4}$. La qualité de la ehair des aglefins varie suivant les parages où on les trouve, leur âge, leur sexe, et les époques de l'année où on les péche : mais on en a vu assez fréquemment dont la chair était blanche, ferme, très-agréable au goût et très-facile à faire cuire. Eo ma t dans les mois suivants, celle des rglefins de moyenne grandeur est quelquefois d'autant plus délicate, que le frai de ces gades a lieu en hiver, et que par conséquent ils ont eu le temps de reparer leurs forces, de recouvrer leur santé, et de rèprendre leur graisse.

\section{LE GADE BIB}

Gadus luscus, Peno., Lino., Gmel, Cuv.

De mème que l'æglefin, le gade bib habite dans l'Océan d'Europe. Sa longueur ordinaire est de trois ou quatre décimètres. Louverture de sa bouche est petite, sa mâchoire inférieure garnie d'un barbillon, son anus plus rapproché de la tête que de l'extrémité de la queue, sa seconde nageoire dor-

A la première nageoire dorsale 16 rayons, a la seconde 20 . jagulaires 6 , a ia premiere de lanus 22 , a ta seconde des celle de la queue, qui est fourchne, 27 .
3 Bib, Blinds, sur les cotes d'Angleterre. - Mus. ad. fr. . 60. - G Gadus..... ossiculo pinnarum ventralinm, ar. pr. 2 , in setam longam producto. = Ariedi, gen. 21, syn. 35. -

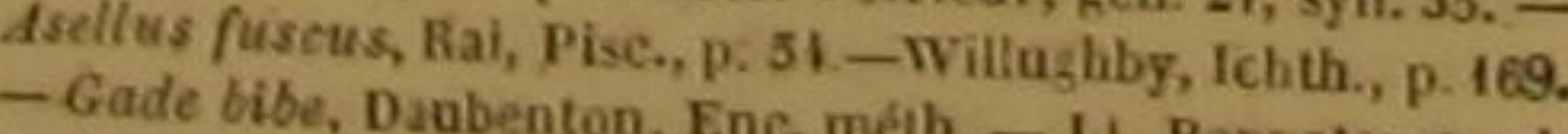

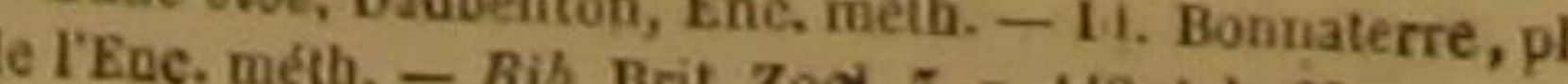

DES POISSONS.

sale très-longue, et le premier rayon de chaeune des nageoires jugulaires, terminé par un filament'. Ses écailles sont très-adhérentes à la peau, et plus grandes à proportion de son volume que celles méme de la morue. Sa partie supérieure est jaunatre ou couleur d'olive, et sa partie inférieure argentée. Sa chair est exquise.

Ses yeux sont voilés par une membrane, comme ceux des autres gades; on a mème cru que le bib pouvait à volonté enfler cette pellieule diaphane, et former ainsi une sorte de poche au-dessus de chacun ou d'un seul de ses organes de la vue. N'aurait-on pas pris les suites de quelque aecident pour l'effet régulier d'une faculté particulière attribuée à I'animal? Quoi qu'il en soit, éest de celte propriété vraie ou fausse que viennent lo nom de Borgne et celui d'Aveugle, donués au gade dont nous partons.

LE GADE SAIDA ?

Gadus Saida, Lepecb., Lion., Gmel., Car.

LE GADE BLENNIOÏDE ${ }^{3}$

Gadus blenniołđes, Pens , Linn_ Gmel., Lac., Cuv.

Ces deux gades ont la nageoire de la queue fourchue. Le premiér a été découvert par le savant Lepéchin, et le second par te célebre Pallas.

Le saida a les deux mâchoires armées de dents aiguẽs et crochues; deux rangées de dents garmissent le palais, et l'on voit auprès du gosier deux os lenticulaires hérissés de petites dents. La mâchoire inférieure est plus avancée que la supérieure, tandis que, dans la morue, læglefin et le bib, celle de dessus est plus longue que celle de dessous. Chaque opercule branchial présente trois lames, l'une triangulaire et garnie de deux aiguilions, I'autre elliptique, et la dernière figurée en croissant. La ligne latérale est droite et voisine du dos. Les na-

A A la premiere nageoire dorsale 13 rayons, a la seconde 25 . jugulaires 6 . A la preafiére de l'anus 31 , a la seconde 18 , a celle de ia queve, qui est fourchioe, 17. 'Lepechin. Nov. Comment. petropol. 18, p. 512. - Gade saida, Bonnaterre, pli. de in Enc. ruét 'Pallas, Spicileg. 20ol. 8, p. 17, tab. 5, fig. 2,-Gade blen-
yo:' e, Bonnaterre, pl. de I'En? meth. geoires dorsales et celles de l'anus sont triangulaires 1 . Le quatrième rayon de la troisième dorsale, le cinquième de la première de l'anus, et le second des jugulaires, sont terminés par un long filament.

Une couleur obseure règne sur la partie supérieure de l'animal, qui d'ailleurs est parsemée de points noirătres distribués irrégulièrement. Des points de la mème nuance relèvent l'éclat argentin des opercules; les cótés du poisson sont bleúátres, Sa partie inférieure est blanche; et le sommet de sa tète, très-noir.

Le saida ne dépasse guère en longueur deux ou trois décimètres. Sa chair est peu suceuleute, mais cependant très-fréquemment mangeable. Il habite la mer Blanche au nord de I'Europe.

Dans une autre mer également intérieure, mais bien éloignée des contrées hyperboréennes, se trouve le blennioide. Ce dernier gade vit en effet dans la Méditerranée : mais comme il n'a presque jamais plus de trois décimètres de longueur, et qu'il n'est pas d'un goùt trèsexquis, il n'est pas surprehant qu'il ait été dans tous les temps très-peu recherché des pécheurs, et qu'il ait échappé aux observateurs de l'ancienne Grèce, à ceux de l'ancienne Rome, et même aux naturalistes modernes, jusqu'à Pallas, qui en a le premier publić la déseription, ainsi que nous venons de lé dire ${ }^{2}$.

II a beaucoup de rapports avec lo merlan, et peut avoir été souvent confondu avec ce dernier poisson. Ses écailles sont petites: la couleur de a partie supérieure de son corps et de sa queue est argentée; toutes les autres portions de la surface de l'animal sont d'un blane d'argent, excepté les nageoires, sur lesquelles on voit des teintes jaunàtres ou dorées.

Les lèvres sont doubles et charnues; les dents très-petites et inégales; la ligne latérale est courbée vers la téte. Le premier rayon de chacune des nageoires jugulaires est divisé en deux; et comme il est plus long que les autres rayons, il parait, au premier coup d'ail, com-

A 1 a premiére nageoire du dos du salida, de 10 s 11 rayons,

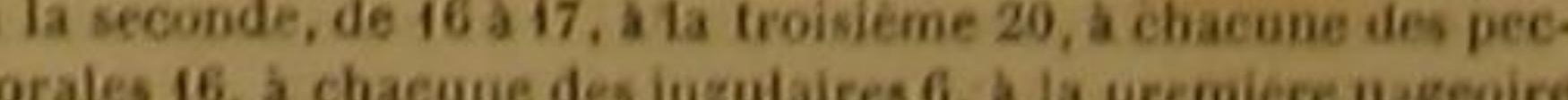
de l'anus 18 , a la sreonde 20 , a celle de la quene, de 21 a 26 'A la membrane branchiale du thennicilie 6 rayons. a ta premiere nageoire dorsale $40 \mathrm{a} 11$, a la seconde 17 , a La troisieme 16, a chacune des pectorales 19 , a chacaue des juzola. res 5 . a la premiere de l'asus 27 , a la secoide 19 , a celle de
la queue 27 . 
poser toute la nageoire : dès lors on eroit ne partie de l'Océan qui baigne les côtes de l'Eudevoir compter que deux rayons dans chacune $\mid$ rope boréale, mais encore dans la Baltique. Il des juglaires du gade que nous décrivons, et se tient fréquemment à l'embouchure des grands des jugulaires du gade que nous decrings, ê fleuves, dans le lit desquels il remonte mème

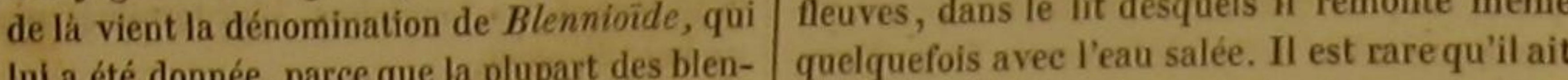

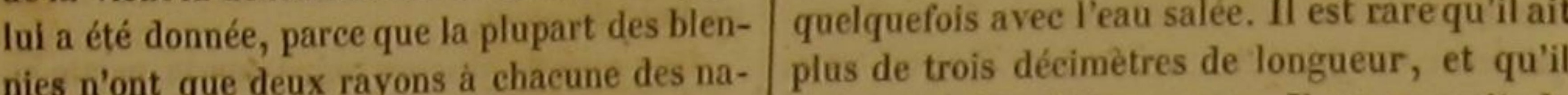
pèse plus d'un kilogramme. Il se nourrit de geoires que l'on voit sous leur gorge.

LE GADE CALLARLAS ', Gadus Callarias, Lina., Gmel., Bl. Lacep., Cuv.

LE GADE TACAUD ${ }^{2}$,

Gadus barbatus, Lian., Gmel., Cuv.; Gadus Taeaud, Lacep.

ET LE GADE CAPELAN ${ }^{3}$

Gadus minutus, Bl., Linn., Gmel; Gadus Capellanus, Lacep.

Le callarias habite non-seulement dans la

- Sua torsk, en Suede. - Gres torsk, en Danemarek, Dorseh, par les Allemands. - Cod, Cod fish, en A ogleterre.

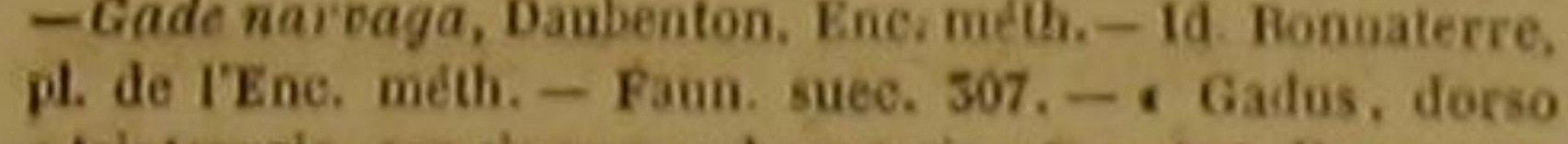
itripterygio, ore cirroso, colore vario, ete, A A redi, gen. 20 ,

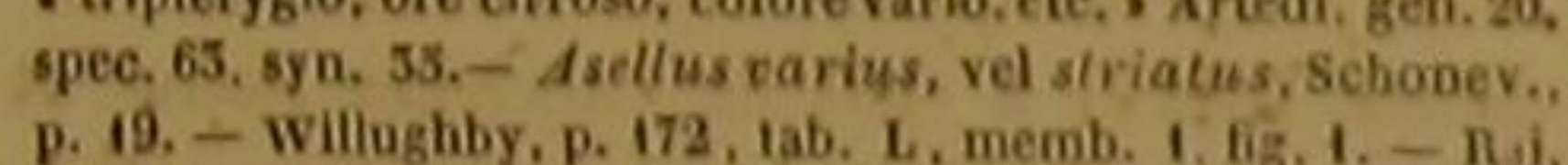
p. 19, - willughby, p. 172, tab. L, memb. 1. fig. 1. - Rsi,
p. 34, n. 8. - Asellus varius, Jonston, tab. 46, 6g. 7. - Roberg., Dissert, de pise. Upsal., p. 14. - Gadus callarias,

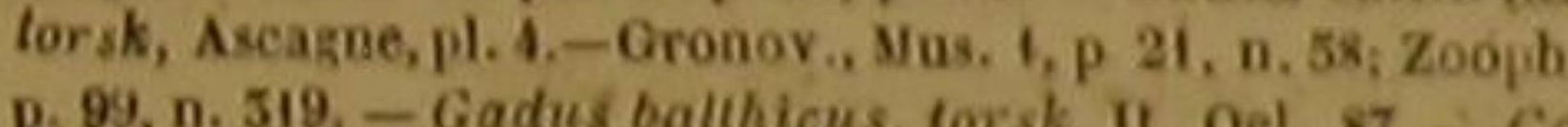

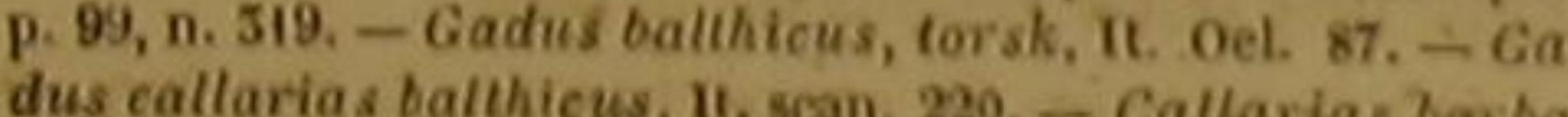
tus, ete, Klein, Miss, pise, 5. p. 6, o. 5; etp. 7, 0. 7. - - Tis, cis... Russis nawaga dietus. , Koelreuter, Nav, Comment. petrop. 14, 1, p, 484. - Muschebout, et Lelopard, Hondeler. part. 1, 1. 9, c. 12, - Muschebout, Valmont de Bomare, Dict.
dhist. bat. hist. uat.

Pouting, Pout, Whiting pout, ea Angteterre, - Fico, ' caput. III. Wgoth. 178, - Strom, sondm. 3i6, n. B, - . G - dus... loogitudine ad hatitudinem tripla. . Artedi, Ren. 21, syn. 37, spec, 63. - Asellhus moltis latus, Lister, appod wi-

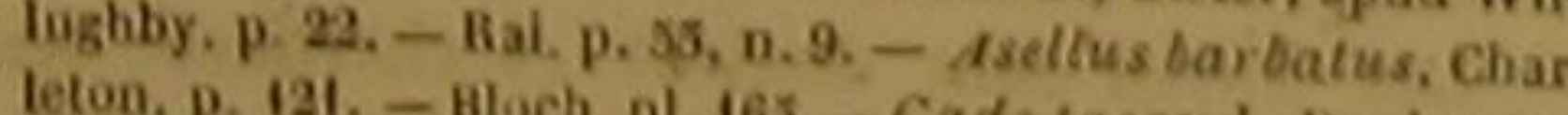

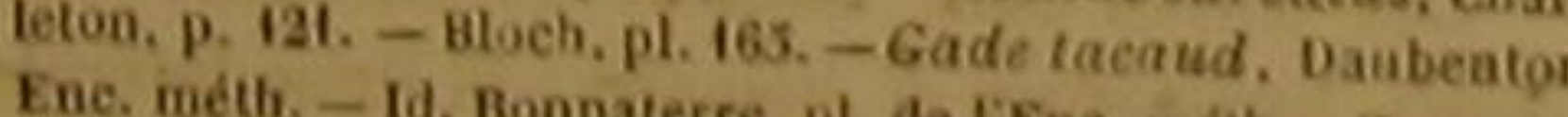

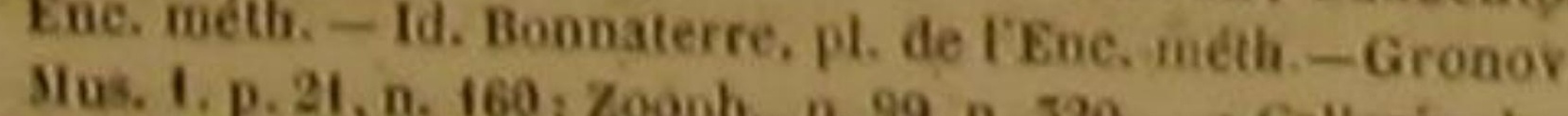
- batis, ditute olivacei coloris, ete. , Klein , Missas pisc 8 , p. 6, n. 3. - Whiting pout, Brit. Zool, 3, p. 348, - Gadus titling, Asesgae, pl. 3 . - Tacaud, Pubamels Traite des pt. ches, part. 3, sect. 1, c. S, art. A. o. 156. pl. 25, 6g. 2. - Mo rue molle, Valmont de Bonare, Diet. d'bist. nat.
IMollo, a Venise. - Poor, Power, do to

novailles. - Gade capelon, Pover, dans le conté de Cor-

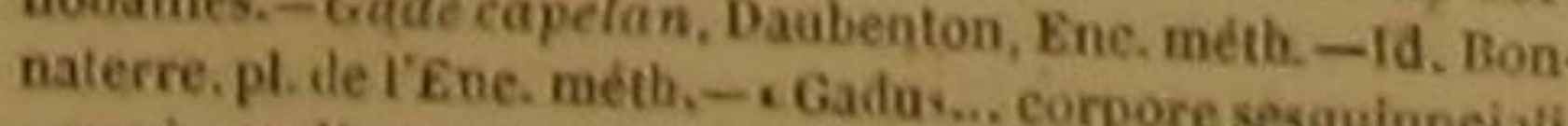

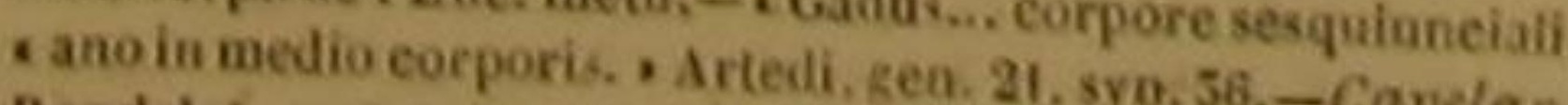
Mendelet. part. 1, 1.6. c. 12,--A Anthix seconda species,

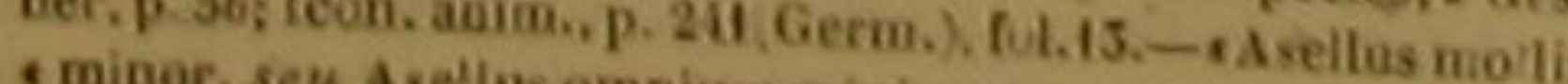
tab. L. - Rai, p. 56, n . 10 ninimus, , Willughby, p. 17 ,

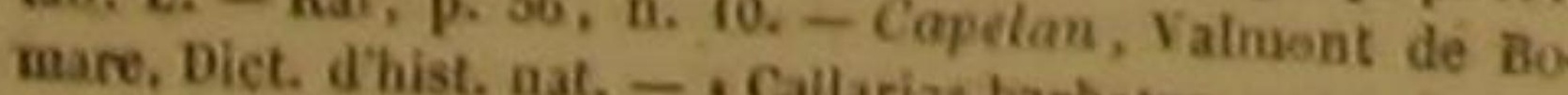
Ctracto, el Callarias..... omniam minimus, ete. , Kleio, $M$ iss.
plsc. - Poor, Brit. vers marius, de crabes, de petits mollusques, de jeunes poissons : sa chair est tendre et d'un goút très-agréable; quelquefois elle est trèsblanche, d'anutres fois elle est verte, et Ascagne rapporte qu'on attribue cette dernière nuance au séjour que le callarias fait souvent près des rivages au-dessus de ces sortes de prairies marines formées par des algues qui se pressent tortues franches devoir la couleur verte de leur chaír à des plantes mariues plus ou moins verdâtres; mais ces tortues en font leur nourriture, et l'on n'a point observé que dans aucune eirconstance le callarias préférát, pour son aliment, des végétaux aux substances animales. Le nombre, la forme et la distribution ainsi que la disposition de ses dents, empéchent de le présumer. Sa mảchoire supérieure est, en effet, garnie de plusieurs rangs de dents aiguês: on n'en veit quelquefois qu un rang à la màchoire de dessous, mais il y en a au palais; et de plus, f'ouverture de la bouche est trèsgrande.

Les écailles qui recouvrent le callarias, sont petites, minees et molles : la lignie latérale est large, et voisine du dos; elle est d'ailleurs taehetée, et voiei la nuance des couleurs des autres parties de l'animal. La tête est grise avec des taches brunes; I'iris jaunâtre; la partie supérieure de l'animal, grise et tachetée de brun comme la tête; la partie inférieure est blanche, et l'on remarque un ton plus ou moins brunatre sur toutès les nageoires '. Mais ce qu'il faut observer, et ce qui a fait donner au gade dont nous parlons, le nom de Vuriable, e'est qu'il est de ces teintes du callarias qui varient avec l'age, ou avec les saisons. Les nageoires, et méme le dessous de l'animal sont rougeâtres; le ventre n'est pas toujours petites taches; celles du corps et de la queue des callarias encore jeunes sont souvent dorées, voit les taches brunátres de la tête acquérir, sur presque tous les individus de l'espèce que sur un fond sablonneux. Nous avons vu les au lieu d'être brunes; et pendant l'hiver

DES POISSONS.

nous décrivons, une couleur d'un beau noir '

Le tacaud est remarquable par la hauteur de son corps qui égale à peu près le tiers de sa longueur totale; les lèvres renferment des portions cartilagineuses; la máchoire inférieure présente neuf ou dix points de chaque coté; les yeux sont grands et saillants, les ouvertures branchiales étendues, les écailles petites et fortement attachées; l'anus est voisin de la gorge, et la ligne latérale se fléchit vers le bas au-dessous de la seconde nageoire dorsale ${ }^{2}$

L'iris est argenté ou couleur de citron; le dos d'un verdatre foncé; les côtés sont d'un blane rougeâtre; la nageoire de la queue est. également d'un rouge pâle; toutes les autres sont olivâtres et bordées de noir; une tache noire parait souvent à la base des pectorales, et une teinte très-foncée fait aisément distinguer la ligne latérale.

Le tacaud parvient à une longueur de cinq ou six décimètres : il s'approche des rivages au moins pendant la saison de la ponte; il s'y tient dans le sable, ou au milieu de très-liauts fueus, à des profondeurs quelquefois très considérables au-dessous de la surface de la mer. II vit de crabes, de saumons, de blennies. Sa chair est blanche et bome a manger; mais souvent un peu molle et sèche. On le trouve dans l'océan de l'Europe sêptentrionale.

Le capelan vit dans les mémes mers que le tacaud et le callarias; mais il habite aussi dans la Méditerranée. Ilen parcourt les eaux en troupes extrèmement nombreuses ; il en occupe pendant l'hiver les profondeurs, et vers le printemps il s'y rapproche des rivages, pour déposer ou féconder ses æufs au milieu des graviers, des galets, ou des fucus. Il est très-petit, et surpasse à péine deux décimètres en longueur. On voit au bout de sa mâchoire inferieure, comme à l'extrémité de celle du callarias et du tacaud, un assez long filament. La ligne latérale est droite; le ventre très-caréné, c'est-à-dire terminé longitudinalement en en-bas par une arête presqueaiguề; l'anus placéà peu prèsà uneégale distance de la téte et del'extrémité de la queue.Son

4 A la première nagecire dorsale du callarias 13 rayons, a la reconde 16 , a la troisieme 18 , a chacune d 5 pectorales 17 , a chacune des jugulaires 6 , a la premiére de $\mathrm{T}$ anus 18 , a la ke
conde 17 , a celle de la queve 26 . 'A la premiere nazeoire dorsale du tacaud is rayons, a is seconde 19, a la troisieme 18, a chacuue des pectorales 18 , a chacune des jugolaires 6 , à la premiére de l'anus 25 , à la te- dos est d'un jaune brunatre, et tout le rested 'une couleurd'argent plusou moins parseméede points noirấtres; l'intérieur de son abdomen est noir. Il se nourrit de crabes, d'animaux à coquille, et d'autres petits habitants de la mer. Les pé cheurs le recherchent peu pour la bonté de sa chair : mais il est fa proie des grands poissons; il est mème fréquemment dévoré par plusieurs espèces de gades, et c'est parce qu'on a vu souvent des morues, des æaletins et des callarias, suivre avec constance des bandes de capelans qui pouvaient leur fournir une nourriture copieuse et facile à saisir, qu'on a donné à ces derniers gades le nom de conducteurs des Callarias, des Aglefins et des Morues '.

\section{LE GADE ROUGE *,} Gadus ruber, Lacep.

\section{LE GADE NEGRE, ET LE GADE LUBB.}

Gadus niger, Lacep. el Gadus Lubib, Lacep ".

Nous avons dit, à la fin de l'article du gade morue, que nous adoptions l'opinion de M. Noè au sujet du gade rouge, et que nous regardions avee lui ce dernier poisson comme une variété de la morue proprement dite: mais depuís la publication de cet article, M. Noèl a fait un voyage dans la Grande-Bretagne; il a observe en Eeosse un très grand nombre de gades rouges; il m'a envoyé les résultats de ses recherches. Nous avons examiné ce travail avec beaucoup d'attention; et nous pensons maintenant ainsi que cet habile naturaliste, que les gades rouges forment une espéce distincte de celle des gades morues.

Les gades rouges sont très-communs dans la mer qui baigne les iles du nord-ouest de l'Ecosse. La fermeté de leur chair leur fait donner le nom de Gades rochers. Ils parviennent souvent à une longueur de plus d'un mètre. Ils ont le ventre large; la tête longue; des dents petites et aiguès aux máchoires, à l'entrée du

- A la premiére nageoire dotiale du capelan 12 rayons, 1 l.

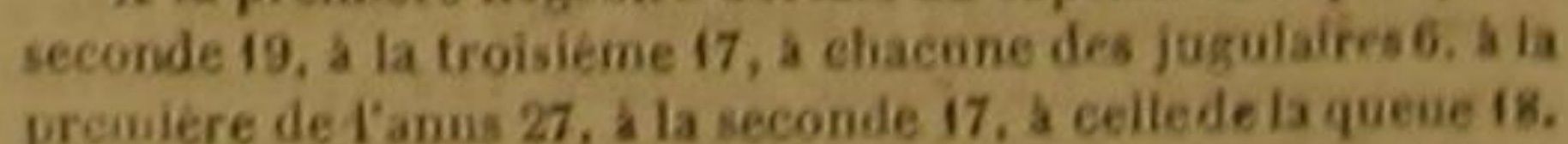
'Bed cod. - Tanny cod. - Roek cod. at Cavier ne fait pas mention des deax premieres de ces èpéces. Le Lubb eat poor tai da sous geare Brosme dass le genre Gale. D. 


\section{HISTOIRE NATURELLE}

palais, dans le voisinage de l'œsophage; un barbillon; une sorte de rainure auprès de la nuque; une caudale élevée; la ligne latérale courbée et blanche, M. Noēl m'éerit qn'on prend de ces poissons à Fécamp, à Dieppe et à Boulogne; qu'on les y nomme Merluches et pelites Merluches; mais qu'ils n'y présentent pas ordinairement les teintes rouges qui ont fait donner leur espèce le nom qu'elle porte.

Le gade nègre a été vu par M. Noēl, dans les eaux de l'ile de Bute en Eeosse, dans le frith de Solway, à Liverpool, dans la rivière de Mersey. Il est long de deux ou trois décimètres; sa machoire inférieure est garnie d'un barbillon ; deux filaments assez longs distinguent chaque jugulaire; la première dorsale ne renferme qu'un rayon qui est articulé.

Il ne faut pas confondre le gade nègre avec des morues nommées Noires quine sont qu'une variété de la morue ordinaire, et dont la peau est en effet noire ou noiratre ' . Ces morues noires habitent daus le lac de Strome, en Mainland, une des iles de Shetland, a un mille ou environ du détroit qui fait communiquer ce lac avee la mer. On les y pêche dans dés endroits dont l'eau est entièrement doưce. Leur chair est de très-bon goût ; ce qui prouve la facilité aveelaquelle on pourrait acclimater, dans des eaux non salées, des morues et d'autreś gades, ainsi que plusieurs autres poissons que l'on ne rencontre encore que dans la mer ${ }^{2}$.

Le $L u b b$ aime les eaux du Kategat, et lès lacs salés de la côte de Bobus en Suède ${ }^{3}$. Il est encore inconnu des naturalistes, ainsi que le gade nègre. Son corps est presque conique; sa queue aplatie; sa longueur de plus d'un metre 4. Les deux màchoires sont presque également avancées : on voit à la måchơre inférieure un barbillon court et délié. L'oeil est grand, I'iris jaune. Les mâchoires, le palais et les environs de l'cesophage, sont garnis de dents; la langue est lisse, blanche et charnue; la ligne laterale, d'abord

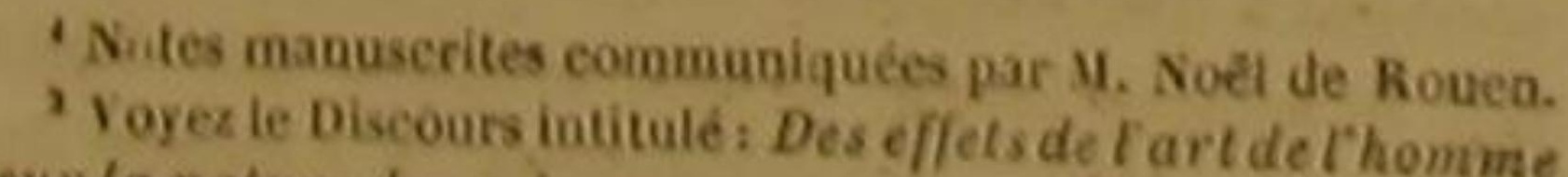
sur la nature dis p issons.
iNotes mamuscrites de I.

7 rayonas a la membrane begine la premiere dorsale, 19 a la secoude, 18 a L L tro séne, ise, 15 a chaque pectorale, 6 a chaque jugulaire, 19 a la première na.

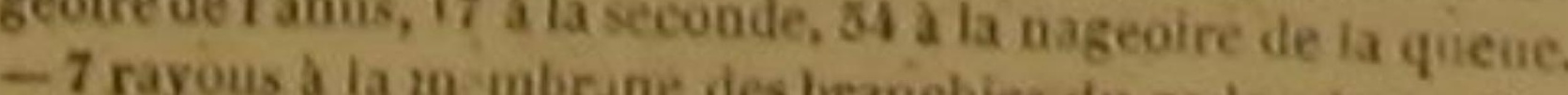
la seconde iagreoire du dos. 20 a chancies du gade négre, 60 a fugulaire, 26 a la cauda'e. -7 rayens a ia mase. 4 a chaque chisie du gade lubb, 105 i la dorsale, 21 a cho bis chaque jugulaire, 36 a la nazeoire de la gueve. aurbe, et ensuite droite; la couleur générale lus ou moins brune ou verdâtre. Une band noiratre s'étend le long de la nageoire du dos, t borde souvent celle de l'anus; une bandelette blanche et une bandelette noire relèvent les nuances de lầ caudale.

LE GADE COLIN ', Gadus carbonarius, Linn., Gmel., BI., Cuv.; Gadus
Col nus, Lacep:

LE GADE POLLACK ${ }^{2}$,

Gadus Pollachius, Linn., Gmel., Cuv., Lacep.

ET LE GADE SEY ${ }^{3}$

Gadus virens, Ascan., Lacep., Cuv.

Ces trois poissons appartiennent au seeond sous-genre des gades: ils ont trois nageoires dorsales, et leurs mâchoires sont dénuées de barbillons; plusieurs ressemblances frappantes rapprochent d'ailleurs ces trois espéces. Voyons ce qui les sépare; - et commençons par déerire le colin.

II ne faut pas confondre ce poisson avee des indiviáus de Pespèee de la morue que des pé-

- Colefiah, dans plas. parties septeut. de rangleterre. Rave poliank, dans plos. parties mérid. de Fangleterre. de I'Enc. béth.- - Galus dorso tripterygo, imberbis, - maxilla inferiore longiore, lined taterali reeti, , Artedi, gen. 20, syn. 34. - - Callirias imberbis, eapite et dorso, car- Ponis instar, nigricintibus. , Klein, Miss. pisc. 5, p. 8, n.2 fish Anglorioh Anglorum, Belon, Aquat., p. 133. - Col-

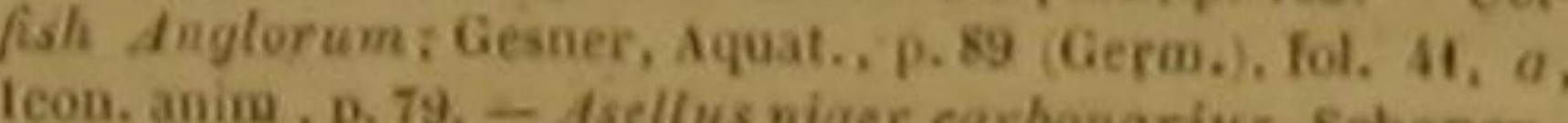
p. 19. - Asellas niger, sen Corbonarius, Charlectionev., Asellus niger, Aldror, tib. 3 . cap. 7, p. 28 - Asellus 121. ger, sive Mollis nigricans, Willughby. p. 168 , tab, L, m.

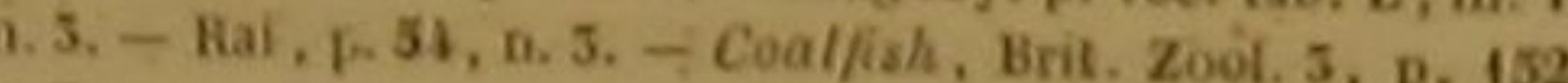
a. 7. A whiting pollack, en Angleterre. - $L y^{\prime \prime}$, dans plus. de lees du Nord. - Lyr blek, Leiblehing, dans plus. partie Bonuaterre, ph. de l'tnc. Dantheaion, Euc. méth. - Id.

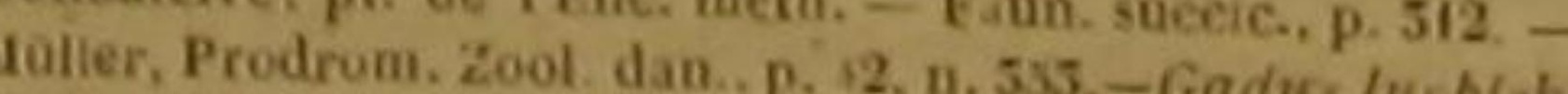
It. Wgoth.. p. 177. - . Gadus dorso tripterygo, lyrblek 4 maxilla Inferioze fongiore, lineá laterali curvi. , Artedi, sen. 20, syn. 35. - Asellus uchiting pollachius, Willughby, p. 167. - Kai, p. 35. n. 2. - Gadus pollachius, Ascagne, De. 5, p1. 20. - Gronov.., Nas. 1. n. 37. - Blo.th, p. 68. Polliack, Brit. Zool 5. p. 15i, Schr, der Berl. naturf. 4, p 147.

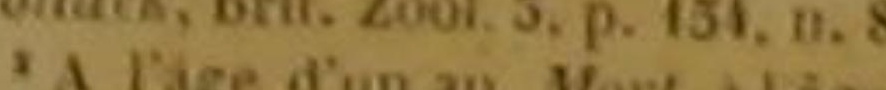

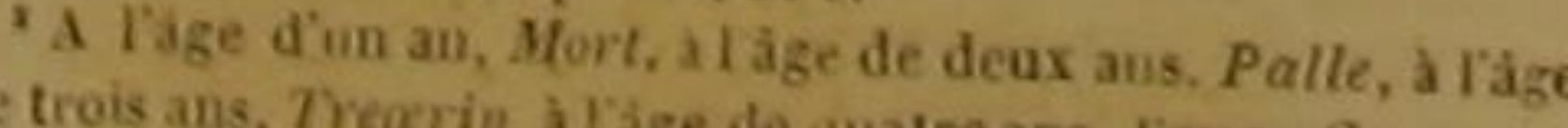
dans la vieillesse. Ufs, sur pluse quatre ans, Sey ou Graasey. Gade sey, Daùienton, Euc. méth. - Id. Bonn terre, pil de IEnc. méth. - Fann. suecie, p. 509, - Maller, Prodrom Zool. dan, p. 45, n. 554 . G Grouo ... Aci. Upsal. 1742, p. 80.
- Gadus rirens, et Sey, Ascugae, cah. 5, pl 21.

DES PUISSONS.

cheurs partis de plusieurs ports occidentaux de France ont souvent appelés Colins, parce qu'ils les avaient pris dans une saison trop avancée pour qu'on pût les faire sécher.

Le vrai colin a ordinairement près d'un mètre de longueur; sa tête est étroite, l'ouverture de sa bouche petite, son museau pointu; ses éeailles sont ovales, et ses nageoires jugulaires très-peu étendues '.

On I'a nommé Poisson charbon ou Charbonnier, à cause de ses couleurs. En effet, la teinte olivâtre qu'il présente dans sa jeunesse, se change en noir lorsqu'il est adulte; les nageoires sont entièrement noíres, excepté celle de la queue, qui n'est que brune, et les deux premières dorsales, ainsi que les pectorales, dont la base est un peu olivâtre; une tache noire très-marquée est placée au-dessous de chaque nageoire pectorale; la bouche est mème noire dans son intérieur; et ces nuances si voisines de celles du charbon paraissent d'autant plus foncées, que la ligne latérale est blanche, que les opercules brillent de l'éclat de l'argent, et que la langue a aussi la blancheur de ce métal

On trouve le colin non-seulement dans r'Océan d'Europe, mais encore dans la mer Pacifique. Dès tes mois de février et de mairs, it s'approche des cótes-d'Angleterre pour y déposer ou féconder des aufs qui ont la couleur et la petitesse des grains de millet, et desquels sortent, au bout de quelques mois, de petits poissons que l'on dit assez bons dans leur jeunesse.

On le peche non-seulement avec des haims, mais encore avec différentes sortes de filets, tels que.des verveux ${ }^{2}$, des guideaux ${ }^{3}$, des demi-folles ${ }^{4}$, des trémaux ${ }^{5}$, ete.

-A la premtece nageoire dorsite ducolin 41 rayons a la seconde 19 , a la troisieme 20 , a chacune des peetorales 21 , a chacune des jugulaires 6 , a la premiere de lanus 25 , a la s. conde 20 , a celle de la queue 26.

'Le ofrecux, on vermier, est un filet en forme de manae, et a rentrée daquel on ajoute un sccond fiet intérieur.

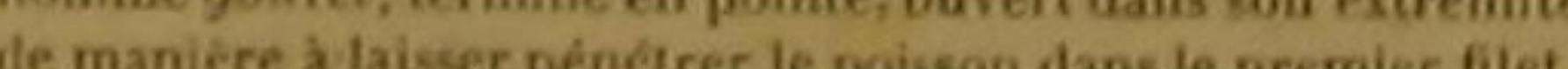

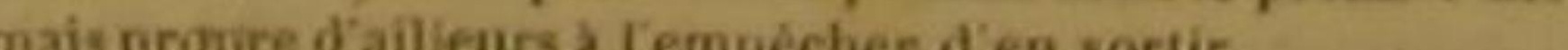
B.t.3 Lepuidenu est ansi no filet en forme de va.en diminnant depais son embonchure jusquanche : i mité. On peit le tendre sur un châssis quíen maintient tembonchure ouverte. Le pius soovent cependant on se contente denfoncer dans le sabie, a la basse mer, des piquets su

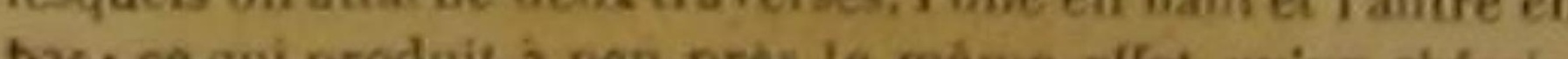
Paor ; gue le prodalt a pea pres le meme effet qu' un chiassis.

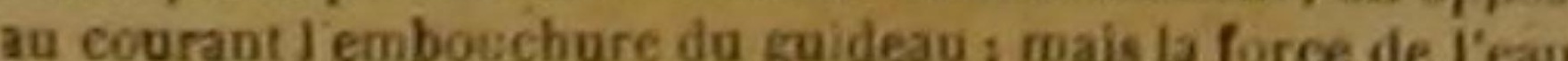

Lorsque la morue est abondante près des cotes du Nord on y recherche très-peu les colins; mais lorsqu'on y péche un petit nombre de morues, on y sale les colins, qu il est assez difficile de distinguer de ces dernières après cette préparation.

Le pollack a, comme le colin, la nageoire de la queue fourchue, et la máchoire inférieure plus avancée que la supérieure; mais la ligne latérale est droite dans le colin, et courbe dans le pollack '. Ce dernier poisson habite, comme le colin, dans les mers septentrionales de IEErope : il se plait dans les parages où la tempete soulève violemment les flots. II voyage par troupes extrèmement nombreuses, cherche moins les asiles profonds, parait plus fréquemment à la surface de l'Océan que la plupart des autres gades, et sait eependant aller chereber dans te sable des rivages l'ammodyte appát, dont il aime à se nourrir. Sa longueur ordinaire est de cinq décimètres. Sa couleur, qui est d'un brun noirâtre sur le dos, s'éclaircit sur les $c \hat{-}$ tés, $y$ devient argentée, et se change, sur la partie inférieare de l'animal, en blane pointillé de brun; l'iris, d'ailleurs, est jaune, avec des points noirs; chaque écaille est petite, mince, ovale, et lisérée de jaune; les nageoires peetorales sont jaunaties, les jugulaires couleur d'or, et celles de l'anus olivâtres et pointillées de noir.

On prend, toute l'année, des pollacks sur plusicurs des rivages occidentaux de France; on y en trouve souvent de pris dans les divers filets préparés pour la péche d'autres espéees de poissons : mais, de plus, il y a sur ces cotes des endroits ou vers le printemps il est très-recherché. On s'est servi pendant longtemps pour le

qui en parcout toute ta longneur, comprime tellement is, Pohsous qui sy renterment, que les gros y sont tués, et ies petits reduibsen une esjece de bonilie. Les piquets sur lesquels on tenid le guidern, portent le nom défatiers. Quel quetois its sont iongs de pres de trois metres; dautres foi

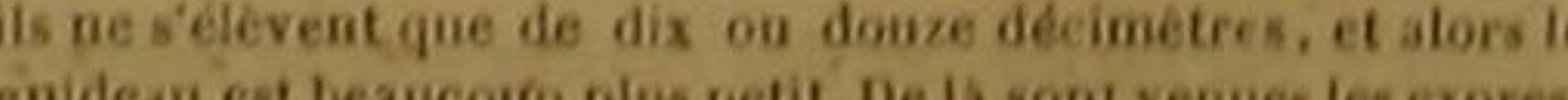
ans de guideas a hiows clatiers et de guideau a bos de thers. - Nous avons placé une courte description de I demi-folle, dans Taricle Raie boucké. - Le trimail est iin tilet composé de trois nappes, dont deux, qui sont de til for cta grandes mailes, se nomment hamaux, et dont ia troisieme, qui flotte entre les deux autres, est d'un fil tin, a pe

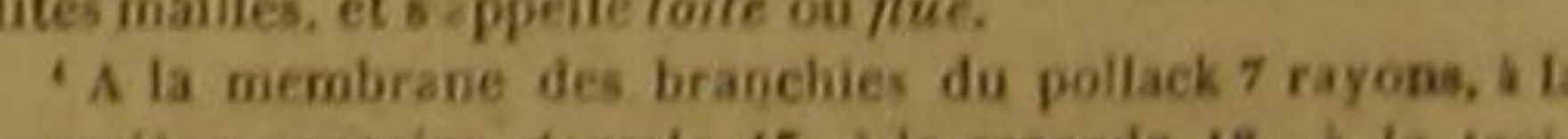
Tremiere tageoire dorsale 15 , a la seconde 18 , a la troi-
ieme 19 , a chacune dia pectorates 19 , a chacune des jugou-

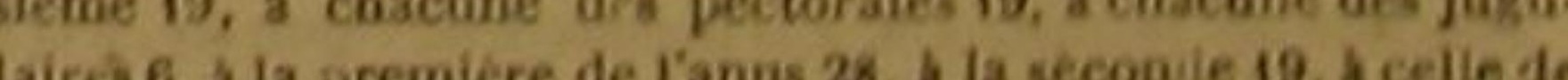
1a queue 12. 
prendre, de petits bateaux portant une ou deux voiles carrées, et montés de six ou huit hommes. On jetait à la mer des lignes dont chacune était garnie d'un haim amorcé avec une sardine, ou avec un morceau de peau d'anguille, Comme le bateau qui était sous voile voguait rapidement, et que les pècheurs secouaient continuellement leurs haims, les pollacks, qui sont voraces, prenaient l'appát pour un petit poisson qui fuyait, se jetaient sur cette fausse proie et restaient accrochés à I'hameçon.

Le sey ressemble beaucoup au pollack; il a mème été confondừ pendant longtemps avec ce dernier gade : mais il en differe par plusieur caractères, et principalement par les dimensions de ses máchoires, qui sont toutes les deux également avancées, trait de conformation qui le sépare aussi de l'espèce du colin; sa ligne laterale est droite, et la couleur de sa partie supérieure est verdâtre ${ }^{1}$.

Les seys sont très-nombreux pendant toute I'aumée sur les côtes de Norvége. IIs y sont l'objet d'un commerce assez étendu; et voila pourquoi ils y ont été observés assez fréquemment et avec assez de soin pour qu'on leur ait donné, selon leur åge, les cing noms différents que nous avons rapportés dans la treisième note de cet artiele, et pour que l'on ait su que communément ils avaient cent trente-cinq millimètres au bout d'uo an, quatre cent trentetrois millimetres à la fin de la troisième année et six cent quarante-neuf millimètres après la quatrième.

Pendant l'été, ils y recherchent beaucoup une variété de hareng nommée Brislings coup les y a souvent péchés avec un filet fait en forme de nappe carrée, interrompu dans son milieu par une sorte de sac ou d'enfoncement, et attaché par les coíns à quatre cordes qui aboutissent à autant de bateaux. Ce filet n'est point garni de flotles, ni de lest : le poids du fil dont il est formé, et des cordes qui le bordent suffit pour le maintenir. Quand les pordent, suffit pour le maintenir. Quand les pécheurs croient avoir pris une quantité suffisante de seys, ils se rapproehent du filet, et en retirent, avee un mane ${ }^{2}$, les poissons qui sont au fond du sae placé au milieu de la napje.

'A ta premiere nageoire dí dos du sey 15 rayons. a la se.

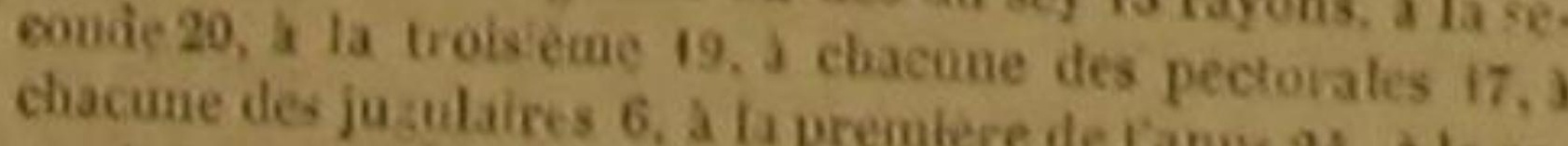

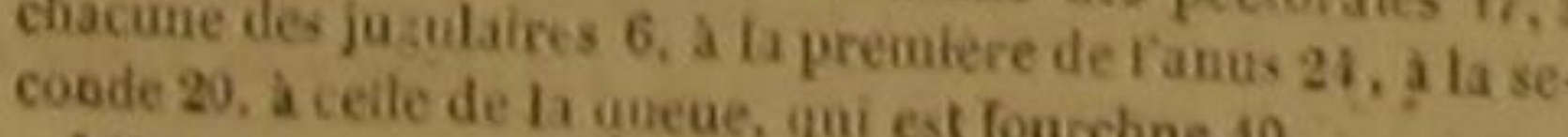
' Voyes, pour la decriptiou du manet, Farticle de chine vive.

\section{LE GADE MERLAN '.}

Gadus Merlangus, Linn., Gmel., Bl., Lacep., Cuv.

De toutes les espéces de gades, le merlan est celle dont le nom et la forme extérieure sont le mieux connus dans une grande partie de l'Europe, et particulièrement dans la plupart des départements septentrionaux de France. La morue mèmen'y est pas un objet aussi familier, à tous égards, que le poisson dont il est ques. tion dans cetarticle; on l'y nomme souvent, on la sert sur toutes les tables, et cependant sa véritable figure y est ignorée dans les éndroits éloignés des rivages de la mer, parce qu'elle n'y parvient presque jamais que préparée, salée; ou séchée, altérée, déformée, et souvent tronquée, Le merlan, au contraire, est transporté entier dans ces mèmes endroits; et la grande consommation qu'ou en a faite l'a mis si souvent sous les yeux, et I'a fait examiner si fréquemment, qu'il a frappé l'imagination des personnes même les moins instruites, et que ses attributs, principalement sa couleur, sont devenus des sujets de provérbes vulgaires. Les nuances qu'il présente sont en effet très-brillamtes : presque tout son corps resplendit de la blancheur de l'argent; et l'éclat de cette couleur est relevé, au lieu đó étre affaibli, par l'oli. vâtre qui règne quelquefois sur le dos, par la teinte noirâtre qui distingue les nageoires pectorates ainsi que celle de la queue, et par une tache noire que l'on voit sur quelques individus, à l'origine de ces mèmes pectorales.

Tout le monde sait d'aillè̀urs que le corps du merlan est allongé, et revétu d'écailles petites, minces et arrondies; que ses nageoires dorsales sont au nombre de trois; qu'il n'a pas de barbillons; que sa måchoire supérieure est plus avancée que l'inférieure. Il nous suffira d'ajou-

'Huilting,en Suède et en Danemarck.--Whiting,en Anglere, pl. de I'Ene, méth. - Faun, suecie. 310 - Cad Bonnater-

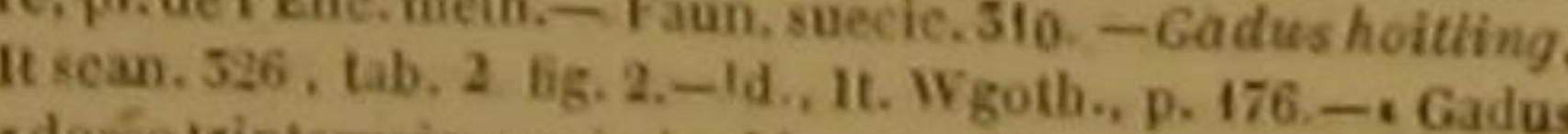
dorso Iripterygio, ore imberbi.. maxillà saperiore longiore Artedi, Ren. 19, syn. 34, spec 62. - \& Secundia asellorum species, Asilhus candidus prinus, S. p. 65. et Germ.. fol. 40, 2.alter, Aldrov., tib. 5 , cap. 5, p. 287, p. 17. - Asellus miner mollis, Cbarleton, p. 121. - Asellus mollis, Jonstonor el

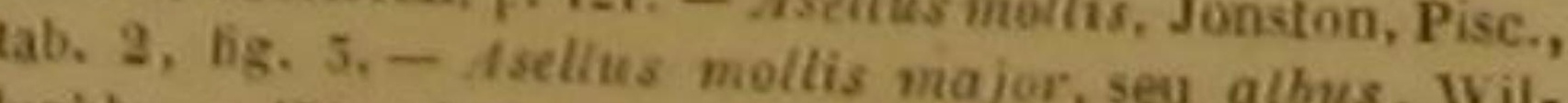
lughby, p. 170, tab. L, m. A, fig. 5. - Rai, p. 55, n. 8.

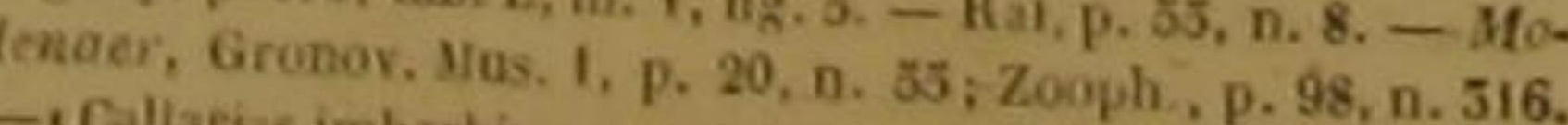
pisc. 5, p. $8,0,5.12$, argentei splendors, etc. , Klein, Miss. pisc, 5, p. 8, n. 5. lab. 5, fig. 2. - Merian, Rondelet, part. 1. Valmont de Bomare, Diet. Zool, 5, p. 133, n. 9. - Merlan. ter, relativement à ses formes extérieures, que cette même mảchoire d'en-haut est armée de plusieurs rangs de dents, dont les antérieures sont les plus longues; qu'on n'en voit qu'une rangée à la mâchoire d'en-bas, qui d'ailleurs montre de chaque côté neuf ou dix points on très-petits enfoncements; que l'on aperçoit sur le palais deux os triangulaires, et auprès du gosier quatre os arrondis ou allongés, lesquels sont tous les six hérissés de petites dents ou aspérités; et enfin que la ligne latérale èst presque droite'.

Si nous jetons maintenant un coup d'œil sur l'intérieur du merlan, nous verrons quâe ce poisson a cinquante-quatre vertèbres. Nous en avons compté cent seize dans I'anguille; mais aussi, quelque allongé que soit le merlan, il présente une forme bien éloignée de celle que montre le corps très-délié des murènes.

Le cour a la figure d'un quadrilatère, avec des angles très-obtus. L'oreillette est grande, ainsi que laorte.

L'estomac est allongé, assez large, un peu recourbé vers le pylore, autour duquel est un très-grand nombre d'appendices intestinaux, ou de petits cocum, formant une sorte de couronne. Le canal intestinal proprement dit est presque de la longueur de l'animal; il se réfléchít vers le diaphragme, va de nouveau vers la queue, se recourbe du côté de l'asophage, et tend ensuite directement vers l'anus, où il parvient trèsélargi.

Le foie, dont la couleur est blanchâtre, se divise en deux lobes principaux : le droit est court et étroit; le second très-long et répandu dans une trés-grande partie de l'abdomen.

La vésicule du fiel communiquè par un canal avee le foie, et par un canal plus grand, avec le tube intestinal auprès des appendices.

Un viseére triangulaire et analogue à la rate est situé au-dessous de l'estomac.

Les reins, d'une couleur sanguinolente, et étendus le long de l'épine du dos, se déchargent dans une vessie urinaire double, voisine de l'anus, et que l'on a souvent trouvée remplie d'une eau claire.

La vessie natatoire est visqueuse, longue, simple, attachée à l'épine du dos. Le canal

'A la membrane des branchies 7 rayons, à la première dorsale 16, a la seconde 18, a la troisieme 19 , a chacune des pectorates 20 , a chacune des jugulaires 6 , a la premiere de néumatique, par lequel elle communiaue a 'extérieur, part de la partie la plus antérieure de cette vessie, et aboutit à l'csophage.

Enfin on voit dans les femelles deux ovaires très-longs, et remplis, lors de la saison convenable, d'un très-grand nombre de petits aufs ordinairement jaunátres.

Le merlan habite dans l'Oeéan qui baigne les côtes européennes. Il se nourrit de vers, de mollusques, de crabes, de jeunes poissons. Il s'approche souvent des riyages, et voilà pourquo on le prend pendant presque toute P'année: mais il abandonne particulièrement la haute mer, non-seulement lorsqu'il ya se débarrasser du poids de ses cuf́s ou les féconder, mais encore lorsqu'il est attiré vers la terre par une nourriture plus agréable et plus abondante, et lorsqu'il y cherche un asile contre les gros animaux marins qui en font leur proie; et comme ces diverses eirconstances dépendent des saisons, il n'est pas surprenant que, suivant les pays, le temps de lo pécher avec succès soit plus ou moins avancé. On a préféré pour cet objet, sur certaines eotes de France, les mois de janvicr et de février; et sur plusieurs de elles d'Angleterre ou de. Follande, on a choisi les mois de l'été.

On le trouve très-gras lorsque les harengs ont déposé leurs cufs, et qu'il a pu en dévorer une grande quantité '. Mais, excepté dans le temps où il fraie lui-mème, sa chair écailleuse est agréable au goùf : elle n'a pas de qualite malfaisante; et comme elle est molle, tendre et légère, on la digere avec facilité, et elle est un des aliments que l'on peut donner avec le moins d'inconvénient à ceux qui éprouvent un gram besoin de manger, sans a voir cependant des sues digestifs très-puissants.

Dans quelques endroits de l'Angleterre et des environs d'Ostende, de Bruges et de Gand, on a fait sécher et saler des merlans après les avoir vidés; et ou les a rendus, par cette préparation, au moins suivant le témoignage de plusieurs observateurs, un mets trés-délicat.

On a écrit qu'il y avait des merlans hermaphrodites. Or en a vu, en effet, dont l'intérieur présentait en même temps un ovaire rempli d'œufs, et un corps assez semblable, au premier coup d'œil, à la laite des poissons mâles : mais

LLettre de M. Noét de Rouen, a is, de Lxéppede, du 12
novembre 1799 
HISTOIRE NATURELLE

cet aspect n'est qu'une fausse apparence; l'on presque tous de roche, tandis que céux des s'est assuré que cette prétendue laite n'êtait eaux de l'Ailly, de Dieppe et de Tréport, sont que le foie, qui est très-gros dans tous les mer- presque tous de vase ou de gravier. En général, lans, et particulièrement dans ceux qui sont M. Noếl pense que le merlan est plus petit et très-gras.

On prend quelquefois des merlans avec des filets, et notamment avec celui que l'on a nommé Drége, et dont nous avons fait connaitre la forme dans l'article de la Trachine vive. Le plus souvent néanmoins on pêche le gade dont nous parlons, avee une vingtaine de lignes, dont chacune, garnie de deux cents hameçons, est longue de plus de cent mètres, et qu'on laisse au fond de l'eau enyiron pendant trois heures.

Au reste, non-seulement la qualité de la chair du merlan varie suivant les saisons et les parages qu'il fréquente, mais encoré sés caractères extérieurs sout assez différents, selôn les eaux qu'il habite, pour qu'on ait compté dans cette espèce plusieurs variétés remarquables et constantes. Nous pouvons en donner un exemple, en rapportant une observation très-intéressante qui nous a été transmise aú sujet des merlans que l'on trouve sur les côtes du département de la Seine-Inférieure, par un naturaliste habile et très-zélé, M. Noèl, de Rouen, que j'ai déjà eu occasion de eiter dans cet ouvrage.

Cet ichthyologiste m'a écrit ' qu'on apercevait une assez grande différence entre les merlans que l'on prend sur les fonds voisins d'Y $Y$ port et des Dalles, près de Féeamp, et ceux que l'on pèche depuis la pointe de l'Ailly jusqua au Tréprt et au delà. Les merlans d'Yport et des Dalles sont plus courts; leur ventre est plos large, leur tête plus grosse, leur museau moins aigu; la ligne que décrit leur dos, légèrement courbée en dedans, au lieu d'être droite; couleur des parties voisines du museau et de la nageoire de la queue, plus brunâtre; la chair plus ferme, plus agréable et plus recherchée.

M. Noel pense, avec raison, qu'on doit attribuer cette diversité dans les qualités de la attriainsi que dans les nuances et les form chair, rieures, à la nature des fonds au-deses extéquels les merlans babitent, et par conséquent celle des aliments qu'ils trouvent à leurequent à Auprès d'Y $Y_{\text {port et de Fécamp }}$, leur portée. Leltre de 'Lettre de $\mathbf{M . ~ N o ̈ l}$ a $\mathbf{M}$. de Lactpede, du 12 novembre
1799. plus délicat sur les bås-fonds très-voisins des rivages, que sur les banes que l'on trouve à de grandes distances des côtes.

\section{LE GADE MOLVE ',} Gadus Molva, Linn , Gmel., Cuv., Lacep. ${ }^{2}$,

\section{ETT LE GADE DANOIS ?}

Gadus dauicus, Lacep. ‘.

De tous les gades, lá molve est celui qui parvient à la longueur la plus considérable, surtout relativement à ses autres dimensions, et particulièrement à sa largeur : elle surpasse souvent celle de vingt-quatre décimetres; et voilà pourquoi elle a été nommée, dans un grạnd nombre de contrées et par plusieurs auteurs, le Gade long. Elle habite à peu près dans-les mémes mers que la morue. Elle se trouve abondamment, comme ce gade, autour de la GrandeBretagne, auprès des cótes de l'Irlande, entre les Hébrides, vers le comté d'York, entre péehe de la méme manière, on luì donne les mèmes préparations; et comme cette espèce présente un grand volume, et d'ailleurs est douée d'une graiade fécondité, elle est, après la morue et le hareng, un des poissons les plus précieux pour le commerce et les plus utiles à industrie.

Dans les mers qui baignent la Grande-Bretague, elle jouit principalement de toutes ses qualités, depuis le milieu de février jusque vers la in de mai, c'est-à-dire dans la saison qui précede son frai, lequel a lieú dans ces méme

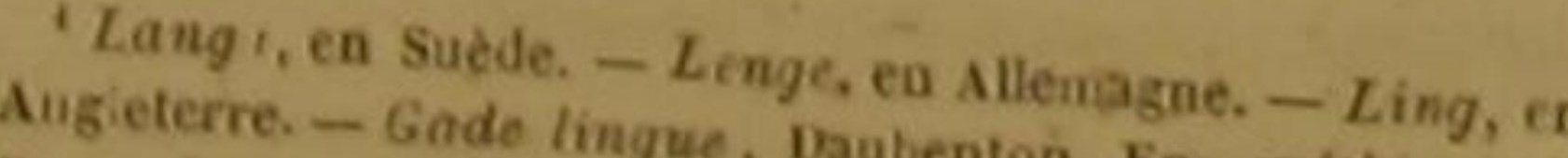

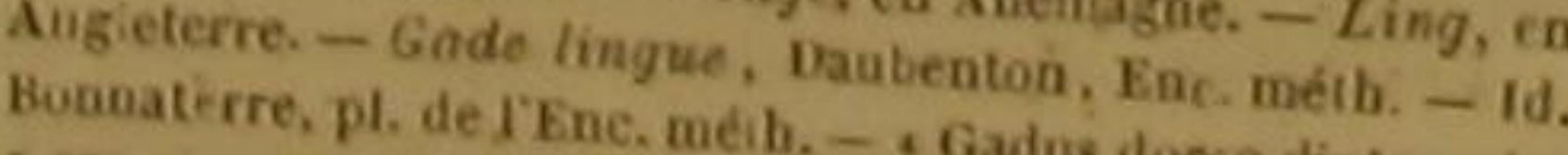
- ore currato, masilla superiore lomgiore. , Artedipterygio, syo. 36 - Motra mojor, Charleton, p. 121. A - Asellius. 22, tab. L, m. 2, D. 2. - Aai, p. $56,-F_{3}$, Willogbby, p. 175, ler, Prodrom. Zool, dan., p. sti, - Faun, suecic. 512 - Mol"goth. 177. - Bloch, pl. 69. . Enchelyopusus lonya, It, wise. 4, p. 88, D. 16. - Bélon, Aquat, popus, Klein, Miss, Aquat, p. 95; Icon. anim., p. 78. - Ling. Bril. Zool., p. 160,
n. 13. ilutiler, Zuol, das Lottes dans le geure Gade. Cuv. D.

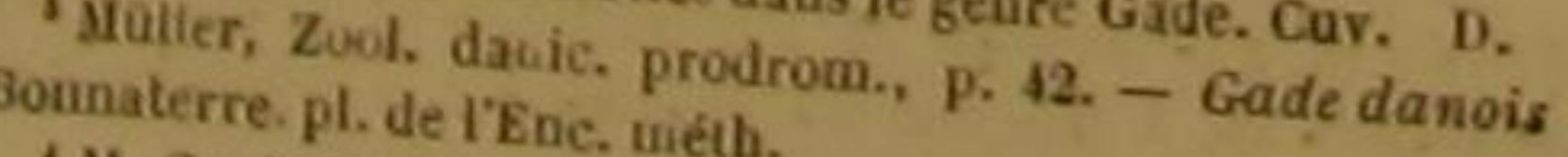
'M. Cuvier ne cite pas cetle espece. D.

DES POISSONS.

mers aux approches du solstice. Elle aime à déposer ses cuifs le long des marais que l'on y voit à l'embouchure des rivières.

Elle se nourrit de crabes, de jeanes ou petits poissons, notamment de pleuronectes plies.

Sa chair contient une huile douce, facile à obtenir par le moyen d'un feu modéré, et plus abondante que celle que peuvent donner la morue ou les autres gades.

Sa couleur est brune par-dessus, blanchâtre par-dessous, verdâtre sur les côtés. La nageoire de l'anus est d'un gris de cendre; les autres sont noires et bordées de blane : on voit de plus une taché noire au sommet de chacune des dorsales'.

Les éeailles sont allongées, petites, fortement attachées ; la tète est grande, le museav un peu arrondi, la langue étroite et pointue.

Le gade danois n'est pas dénué de barbillons, non plus que la molve : comme la molve, il n'a que deux nageoires sur le dos, et appartient par ce double caractère au troisième sous-genre des gades. Sa mâchoire inférieure est plus avancée que la supérieure, ce qui le sépare de la molve; et sa nageoire de l'anus renferme jusqu'à soixante-dix rayons, ce qui le distingue de toutes les espèces comprises dans le sous-genre où nous l'avons inscrit, et mémé de tous les gades connus jusqu'a présent. On en doit la premièré description au savant Müller, auteur du Prodrome dé la Zoologie danoise.

LE GADE LOTE ${ }^{2}$.

Gadus Lota, Linn., Gmel., Cur., Lacep. '.

La lote mérite une attention particulière des naturalistes. Elle présente tous les caractères

-A la membrane des branchies de la molve 7 rayons, a ta premiere nageoire dorsale 15 , a la seconde 65 , a chacune des pectorales 19 , à chacune des jugulaires 6 , a celle de I'anus 69 , a celle de la queve, qui est arrondie, 58 . Motelle, Barbotic, dans queiques depart. de Brance. Barbot, et Burbot, Bel pout; en Angleterre. - Putaet, dans la Beigique ou France septentrionale. - Alvaupe, Oiruppe, Trusch, Treischen, Futten, en Ailemagne. Aalquabbe. Franske giedder, en Danemarck. - Laks, en
Suede et en Norvege. - Nalim, en Rassie. - Gade loike. Danbentón, Eric. méth.-Id. Bonnaterre, pl, de I'Enc. méth. -Gadus lota, Ascagne, cab. 5, 5. ple 28. - Lote, valmont de Bomare, Dict. dhist. nat. - Fauna suecica, 315 . - Noller, Prodrom. Zool. danic., p. A1, n. 315. - k ceireuter, nov. Commeat. petropoi. 19, p. 24. - Sieidinger. Icon. piscium austral., t. 8.- - Bloch, pi. 70. - - Gadus dorso diplerygio.

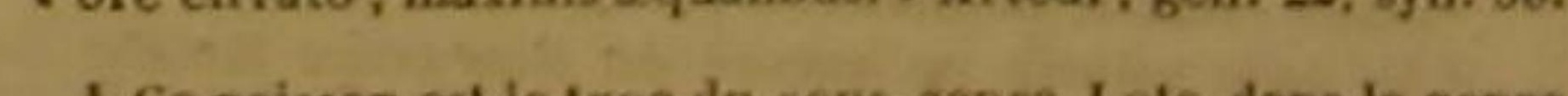
- Ce poisson est le type du sous-genre Lote dans le geare
Gade de M. Cuvier. D. génériques qui appartiennent aux gades; elle doit être inserite dans le mème genre que cets poissons; elle y a toujours été comprise : elle fait véritablement partie de leur famille; et cependant, par un de ces exemples qui prouvent combien les étres animés sont liés par d'innombrables chaines de rapports, elle s'écarte des gades par des différences tres-frappantes dans les formes, dans les facultés, dans les habitudes, dans les goùts, et ne s'éloigne ainsi de ses congénères que pour se rapprocher non-seulement des blennies, qui par leur nature touchent aux gades de très-près, mais encore do plusieurs apodes osseux, particulièrement des murènes, et notamment des anguilles.

Comme ces derviers apodes, la lote a le corps très-allongé et serpentiforme, On voit sur son dos deux nageoires dorsales, mais très-basses et très-longues, ainsi que celle de l'anus; elles ressemblent à celles qui garnissent le dos et la queue des murènes. Les écailles qui la recouvrent sont plus facilement visibles que celles de ces mêmes murènes; mais elles sont très-minces, molles, très-petites, quelquefois séparées les unes des autres; et la peau a laquelle elles sont attachées est enduite d'une humeur visqueuse très-abondante, comme celle de I'anguille : aussi échappe-t-elle facilement, de méme que ce dernier poisson, a la main de ceux qui la serrentavec trop de force et veulent la retenir avee trop peu d'adresse; elle glisse entre leurs doigts, parce qu'elle est perpétuellement arrosée d'une liqueur gluante; et elle se dérobe encore à ses ennemis, parce que son corps, très-allongé et très-mobile, se contourne avee promptitude en différents sens, et imite si parfaitement toutes les positions et tous les mouvements d'un reptile, qu'elle a reçu plusieurs noms donnés depuis longtemps aux animaux qui rampent.

La lote est, de plus, d'une couleur assez

- S Silarus cirro unico in mento., Artedi. spec, 107,- Lole, Rondelet, part. 2 des poissons des lacs, c. 18. - Darbote, t Mustella fluvialitis, wiljughily, p. 125, - Hai, p. - 67.Lota Gallis dicta, Gesner. p. 599 - Lota Galtoram, Jonis ton, lib. 5, tit. 3, cap. 11, p. 168, ab. 29, fig, 10.- Strinuia, sive Botatrissa, Bélon, Aquat, p. 302, - Claria fuciatias.

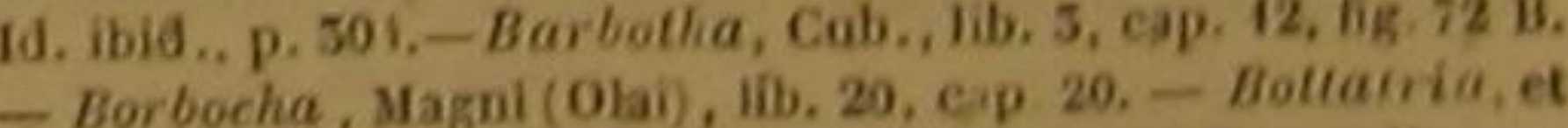
Trisrus, Ssivian., fol 215, $a$, ad ieonem, et B. - Alropa. Trisrus, Saivian., fol. 215, $a$, ad ieonem, e B, - Airopa,
Hildegard, lib. 1, part 4, cap, 25. - Growiv, Mas. 1, p, ai, n. 61; Zooph., p. 97, n. 315. - Eachelyopus subeine.

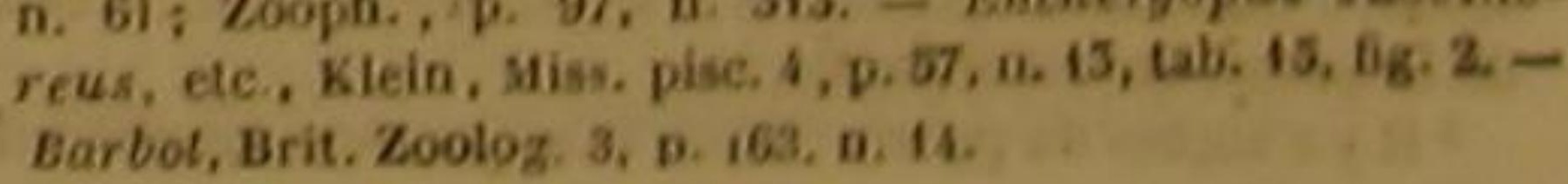


semblable à celle de plusieurs murènes, ou de $\mid$ La lote croit beaucoup plus vite que plusieurs quelques murén ' d'un mètre, et M. Valmont-de-Bomare en a vu $\begin{array}{ll}\text { partie supérieure', de jaune et de brun; et le } & \begin{array}{l}\text { d'un mètre, et M. Vaimont-de-Bomare en a vu } \\ \text { une qu'on avait apportée du Danube à Chan- }\end{array} \\ \text { the rème sur sa partie inférieure. } & \end{array}$

Au heu d'habiter dans les profondeurs de tilly, et qui était longue de plus de douze décil'Océan ou près des rivages de la mer, cumme mètres.

la plupart des osseux apodes ou jugulaires, et particulièrement comme tous les autres gades connus jusqu'à présent, elle passe sa vie dans les lacs, dans les rivières, au milieu de l'eau douce, à de grandes distances de l'Océan; et ce nouveau rapport avec l'anguille n'est pas peu remarquable.

On la trouve dans un très-grand nombre de contrées, non-seulement en Europe et dans les pays les plus septentrionaux de cette partie du monde, mais encore dans. I'Asie boréale et dans les Indes.

Elle préfere, le plus souvent, les eaux les plus ehaudes ; et afin qu'indépendamment de sa légèreté, les animaux dont elle fait sa proie puissent plus difficilemènt se soustraire à sa poursuite, elle s'y cache dans des creux ou sous des pierres; elle cherehe à attirer ses petites viotimes par l'agitation du barbillon ou des barbillons qui garnissent le bout de sa máchoire inférieure, et quil ressemblent ả de petits vers : elle y demeure patiemment en embúscade, ouvrant presque toujours sa bouche, qui est assèz grande, et doñt leș mảehoires, hérissées de sept dents aiguees, peuveñt aisément retenir les insétes aquatiques et les jeunes poissons dont elle se nourrit ${ }^{2}$.

On a écrit que, dans quelques eirconstances, la lote était Vipère, e'est-d-dire que les cufs de cette espèce de gade éclosaient quelquefois dans le ventre mème de la mère, et par, conséquent avant d'avoir été pondus. Cette manière de venir à la lumière n’a été observée dans les poissons osseux que lorsque ces animaux ont réuni un corps allongé, délié et serpentiforme, à une grande abondance d'humeur visqueuse, comme la lote. Au reste, elle supposerait dans ce gade un véritable accouplement du mâle et de la femelle, et lui donnerait une nouvelle conformité avee l'anguille, les blennies et les silures.

' Sa ligue est droite. On compte a sa première nazeoire
dorsale 14 rayons, I la seconde 68 , a chacune des pections les 20 , a chacune des juzulaires 6 , a celle de lanus 67 , a celle de la queue, qui est arrondie, 36.
"Il y a aupres du pylore, 50 ou 40 appendices intestinaug.
Sa chair est blanche, agréable au goût, facile à cuire; son foie, qui est très-volumineux, est regardé comme un mets délicat. Sa vessi natatoire est très-grande, souvent égale en longueur au tiers de la longueur totale de l'animal, un peu rétréeie dans son milieu, terminée par formée d'une membrane qui n'est qu'une continuation du péritoine, attachée par conséquent a l'épine du dos, de manière à ne pouvoir pas en étre séparée entière, et employée dans quel. ques pays à faire de la colle, comme la vessie gaz de l'acipensère huso.

Ses œufs sont presque toujours, comme ceux du broehet et du barbeau, difficiles à digérer, plus ou moins malfaisants; et, par un dernier rapport avec l'anguille et la plupart des autres poissons serpentiformes, elle ne perd que difficilement la vie.

LE GADE MUSTELLE',

Gadus Mustela, Lina., Gmel, Lacep., Cur.; Gadus tricirratus, Bloch?

ET LE GADE CIMBRE ${ }^{3}$.

Gadus cimbrieus, Schn., Laeep., Cuv.

La mustelle a beaucoup de ressemblance - Galea, Pesce moro, Donseltina, Sorge marina, sur

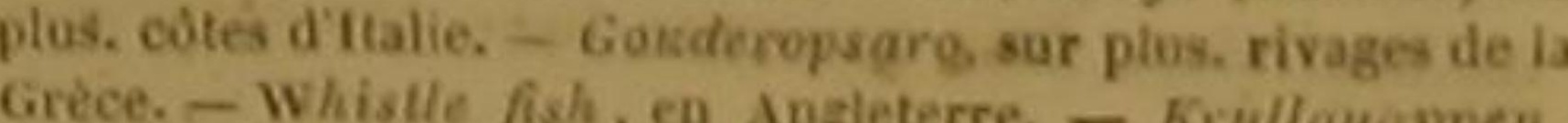
aupres de Hambourg, et dans quelques anties contrées sep. rentrionales. - . Gadus mustella, Gadus trieirratùs $\beta$, $e$ e Gadus russicas $\gamma$. Lianée, éd. de Gmelin.-Gade musielle, Daubenton, Enc. metti. - IJ. Gade la brune. Bonnaterre, d'tist. mat, - mether, Mustelle, valmont de Bomare, Diet. - G Gadus dorso dipterygion. eirris mal. Aanie, p. 42, n. 345. - tuor; inferioris uno. $\rightarrow$ Mus ad fr. 1 - G Gaperioris qua. - terygio, sulca al pinnam dorsi primam, ore cirrato diptedi, gen, 22, syn. 57. - , Gi.lea Venetorum, seü Asellorum Caltera species, , Belon, - \& ld. Mustefla vulgaris, et Mus. Ctella marina tertia., , Gesner, p. 89, 90 et 103, (Germ.) fol. 41, B, et +2, A. - Mustelle vulgaire, Ron lelet, part. A, I. 9 , Type du sous-genre Motelle dans le genre Gade, selon Gade cimbre, Bonnaterre, pl. de l'Enc, méth. 'Le gade peintre est encore du sous-genre Motelle de
A. Cuvier. D. deux prolongations dans sa partie antérieure, avee la lote par l'allongement de son corps, la petitesse de ses écailles, et l'humeur visqueuse dont elle est imprégnée : mais elle n'habite pas, comme ce poisson, au milieu de l'eau douce; elle vit dans l'Océan atlantique et dans la Méditerranée. Elle y parvient jusqu'a la longueur de six décimètres. Elle s'y nourrit de cancres et d'animaux à coquille; et pendant qu'elle est jeune, petite et faible, elle devient souvent la proie de grands poissons, particulièrement de gadès et de plusieurs scombres. Le temps de la ponte et de la fécondation des oufs de cette espèce est quelquefois retardé jusque dans l'automne, ou se renou velle dans cette saison. La mustelle est blanche pa-dessous, d'un brun jaunâtre par-dessus, avee des taches noires et d'un argenté violet sur la tête. Les nageoirés pectorales et jugulaires sont rougeảtres; les autres sont brunes avee đes taches allongées, excepté la nageoire de la queue, dont les taches sont rondes. L'on trouve cependant plusieurs. individus sur lesquels la nuance et la figare de ces diverses taches est constamment différente; et même d'autres individus qui n'eo présentent aucune. Il est aussi des mustelles qui ont quatre barbillons a la mâchoire supérieure d'autres qui n'y en montrent que deux, d'autres eneore qui n'y en ont aucun; et ces diversités dans la forme plus ou moins transmissible par la génération, ayant été comparées, paí plusieurs naturalistes, avee les variétés de couleurs que l'on peut remarquer dans l'espèce que nous examinons, ils ont cru devoir divise les mustelles en trois espèces, la première distinguée par quatre barbillons placés à une đistance plus ou moins petite des narines, la seconde par deux barbillons situés à peu pres de mème, et la troisième par l'absence de tou barbillon à la mâchoire supérieure. Mais aprè avoir cherché à peser les témoignages et á comparer les raisons de cette multiplication d'espèces, nous avons préféré I'opinion du savant professeur Gmelin ; et nous ne considérons l'absence ou le nombre des barbillons de la máchoire d'en haut, ainsi que les dissemblances

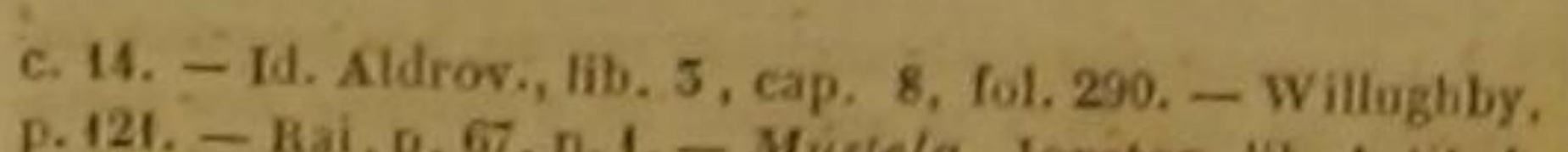
p. 121. - Rai, p. 67, n. 1. - Mussela, Jonston, lib. 1, Lit. I, p. 49. - Mustela marina - - Mustela altera, Schonev.. Mus. 1, p. 21, 0. 2. Act Lertia. - Gronov. Zooph., A.514.

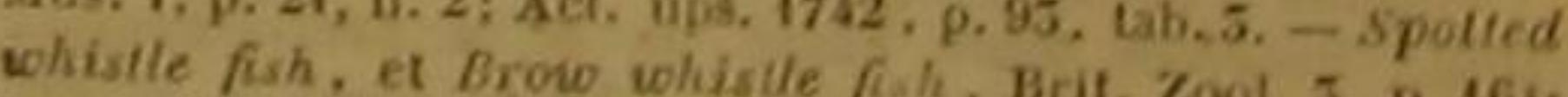
n. 15, et 165, n. 16. - Enchelvopus cirris tribus, p 163 Schril der Berl. Klein, Miss, pisc. 4, p. 57, n. 14. - MValbaum, dans les teintes, que comme des signes de varietes plus ou moins permanentes dans l'espèce de la mustelle.

Au reste, ce gade a toujours un barbillon attaché veìs l'extrèmité de la mâchoire inféieure, soit que la mảchoire supérieure en soit dénuée, ou en montre deux, ou en présente quatre.. De plus, la langue est étroite et assez libre dans ses mouvements. La ligne laterale se courbe vers les nageoires peetorales, et s'étend ensuite directement jusqu'à la queue. Mais ce qu'il ne faut pas passer sous silence, c'est que la première nageoire dorsale est composée de rayons si petits et si courts, qu'il est très-difficile de les compter exactement, et qu'ils disparaissent presque en entier dans une sorte de sillon ou de rainure longitudinale. Un seul de ces rayons, le premier ou le second, est trèsallonge, s'élève par conséquent beaucoup audessus des autres; et c'est cette longueur ainsi que l'excessive brièveté des autres, qui ont fait dire a plusieurs naturalistes que la première dorsale de la mustelle ne comprenait qu'un rayon'

La première nageoire du dos est conformee de la méme manière que dans le gade cimbre, qui réssemblé beaucoup à la mustelle : néanmoins on trouve dáns cette mème partie un des earacteres distinetifs de P'espèce du cimbre. En effet, le rayon qui seul est très-allongé, se termine dans co gade par deux filaments placés l'un à droite et l'autre à gauche, et disposés horizontalement comme les branches de la iettre $\mathrm{T}^{2}$.

De plus, on compte sur les máchoires de la mustelle cinq, ou trois, ou un seul barbillon. Il y en a quatre sur celles du cimbre : deux de ces derniers filaments partent des environs des narines; le troisième pend de la lève supérieure; et le quatrième, de la lèvre inférieure. Le cimbre habite dans l'Océan atlantique, et particulierement dans une partie de la mer qui baigne les rivages de la Suède. Il a été découvert et très-bieu décrit par M. Strussenfeld ${ }^{3}$.

i 5 rayons a la membrane branchiate de la mustelle.

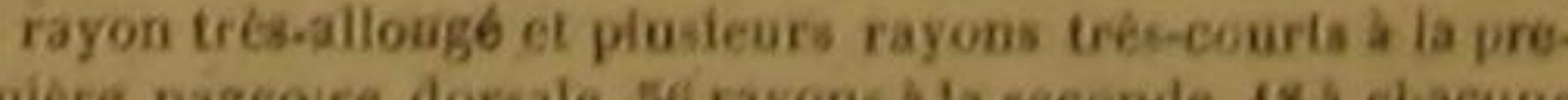
miere nageoire dorale, 56 rayons a a seconde, 18 a ciacuese des pectorales, 6 s chacune des jugulaires, 66 a celle de laaus, 20 a celle de la queve.

"I rayon trés-allongé et plasieurs rayons très-couris a I premiere nageoire donale da gade cimbre, 48 rayons a la se conde, 16 a chacune des pectorales, 7 a ciacuase des jugula.

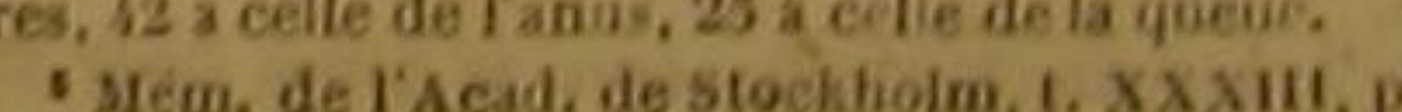




\section{LE GADE MERLUS}

Gadas Merluccius, Linn., Bl.; Cuv. Lacep.

Ce poisson vit dans la Méditerranée ainsi que dans l'Océan septentrional; et voilà pourquoi il a pu ètre comnu d'Aristote, de Pline, et des autres naturalistes de la Grèce ou de Rome, qui, en effet, ont traité de ce gade dans leurs ouvrages. 11 y parvient jusqu à la grandeur de huit ou dix décimètres. Il est tresvorace : il poursuit, par exemple, avec acharnement, les scombres et les clupées; cependant, comme il trouve assez facilement de quoi se nourrir, il n'est pas, au moins fréquemment, obligé de se jeter sur des anímaux de sa famille. Il ne redoute pas l'approche de son semblable. II va par troupes très-nombreuses; et par conséquent il est l'objet d'une pêche trèsabondante et peu pénible. Sa chair est blanche et lamelleuse; et dans les endroits ou l'on prend une grande quantité d'individus de cette espèce, on les sale ou on les sèche, comme on prépare les morues, les seys et d'autres gades, pour pouvoir les envoyer au loin. Les merlus sont ainsi recherehés dans un grand nombre de parages : mais dans d'autres portions de la mer où ils ne peuvent pas se procurer les mèmes aliments, il arrive que leurs muscles deviennent gluants et de mauvais goùt; ce fait était connu dès le temps de Galien. Au reste, le foj̀e du merlus est presque toujours on moreeau très-délicat.

Ce poisson est allongé, revêtu de petites

' Merluso, Asello, Asino, Nasello, en Halie. - Hake, en Angleterre, - Gade grand merius, Daubenton, Enc, meth. Dubamel, Traile, des pe fonc. méth. - Le grand Merhus,

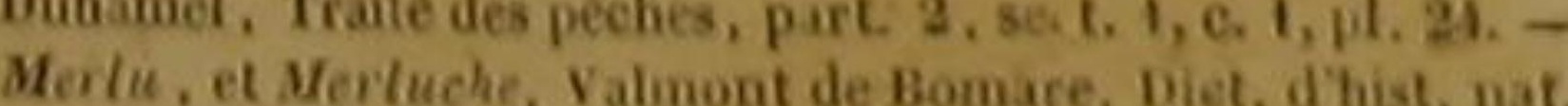

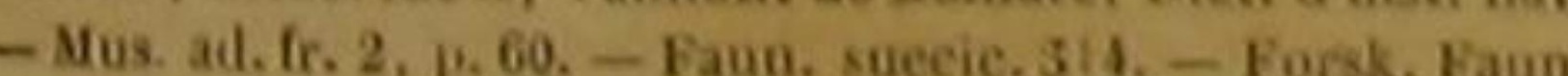
Arabic, p. 19. - Gronar. Zooph., p. 597. n. 315, - MDIt. Prodrom. Zool. danic, p. A1, u. 322, - ot. Fabric. Faup. 6roent., p. 148. - , Gadus dorso dipterygio, maxilla infe-

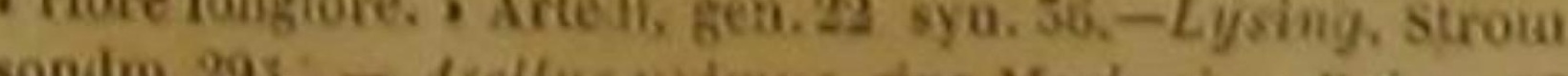

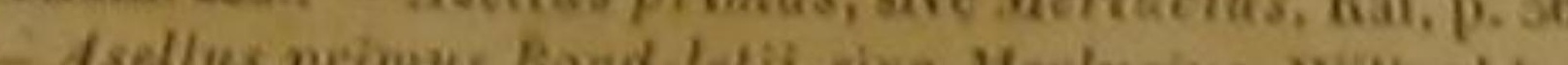

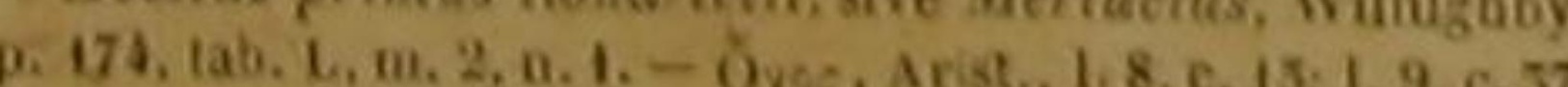

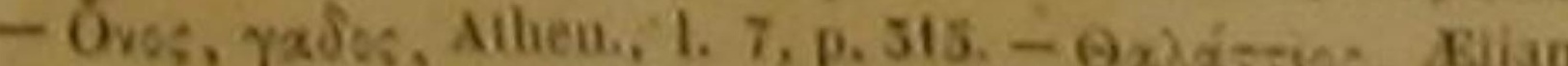

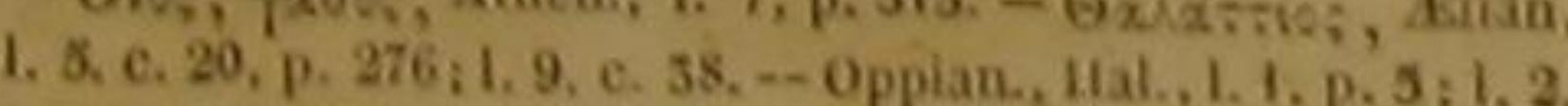
p. 59.-Asellus, Pin, Hist mundi, 1 9, c. 16. 17.-Asellus, Ovid.. v. 131. - Varro, 1. 4. De lingua Latina - Jov., cap. 20 . p. s., - Merius, Kondelet, part. 4, 1. 9, c. 8. - Salv, fol. 75 , p.81, 97, loon, aselus, et primua de merilucio. , Gesner,

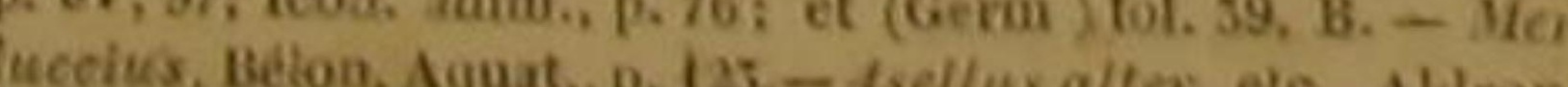

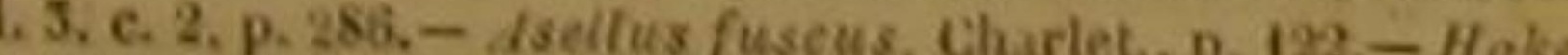
Brit. Zool, 3, p. 136, n. 10. - Jonston, De piscibus, p. 7. tab, 1. fig. 3 ,

gene gade do

écailles, blane par-dessous, d'un gris plus ou moins blanchátre par-dessus; i et c'est à cause de ces couleurs comparées sonvent à celles de l'âne, qu'il a été nommé Anon par Aristote, Oppien, Athénée, Élien, Pline, et d'autres auteurs anciens et modernes. Le nom d'Anon est meme deven, pour plusieurs uaturalistes, wa mot générique qu'ils ont appliqué à plusieurs espèces de gades.

La tête du merlus est comprimée et déprimée ; l'ouverture de sà bouche, grande ; sa ligne latérale plus voisine du dos que du bas. ventre, et garnie auprès de la tête de petite verrues dont le nombre varie depuis einq jusqu'a neuf ou dix : des dents inégales, aiguẽs , dont plusieurs sont crochues, garnissent les mâchoires, le palais et le gosier' .

J'ai trouve dans les papiers de Commerson ne courte description d'un gade à deux nageoires, sans barbillons, et dont tous les autres aractères conviennent au merlus. Commerson la vu dans les mers australes; ce çui confirme mes conjectures sur la possibilité d'établir dans lusieurs parages de Vhémisphère méridional, es péches abondantes de morues et d'autres gades.

Le merlus est si abondant dans la baie de Galloway, sur-la cóte oceidentale de l'Irlande, que cette baie est nommée, dans quelques anciennes cartes, la baie des Hakes, nom donne par les Anglais aux merlus.

\section{LE GADE BBOSUE 2}

Gadus Brosme, Linn., Gmel., Penn., Cuv., Lacep. '.

Nous avons maintenant sous les yeux le cinquième-sous-genre des gades. Les caractères qui le distinguent, sont un ou plusieurs barbillons, avec une seule nageoire dorale. On ne peut encore rapporter qu'une espèce à ce sousgenre, et cette espèce est le brosme.

Ce gade préfere. les mers qui arrosent le Groenland, ou l'Europe septentrionale.

A la daenbrane des branchies 7 rayons, a la premíere nageoire da dos 10, a la seconde 59 , a chacune des pectorales 12 , a chacune des jugulaires 7 , a celie de Ianus 57 , ceile de la queve 20.

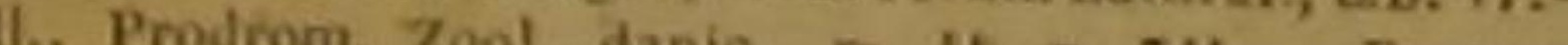
Poutoppid, Noevez 2, danic,, p. 4t, R. 541. - Brosme,

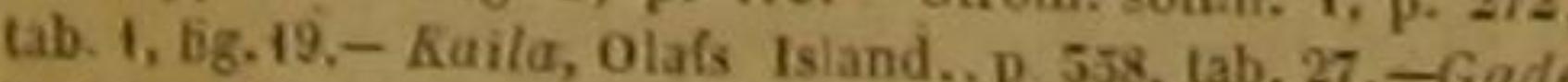
brosue, Bonnaterre, pl. de I'Euc. méth.

Il a la nageoire de la queue en forme de fer de lance, et quelquefois une longueur de près d'un mètre: La couleur de son dos est d'un brun foncé; ses nageoires et sa partie inférieure sont d'une teinte plus claire; on voit sur ses cotés des taches transversales '.

QUARANTE-NEUVIEME GENRE.

LES BATRACHOİDES.

La lele trés-deprimé et très-large: louverture de la bouche tres-grande; un ou phusieurs barbillous attachés autour ou au-dessous de la máchoire inferieure.

resêces

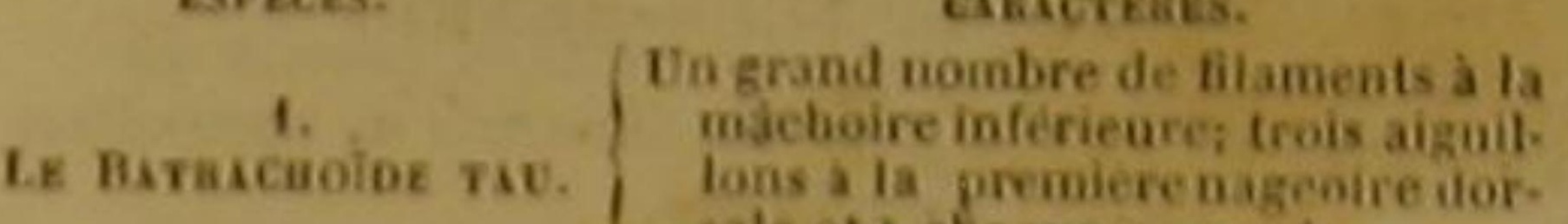

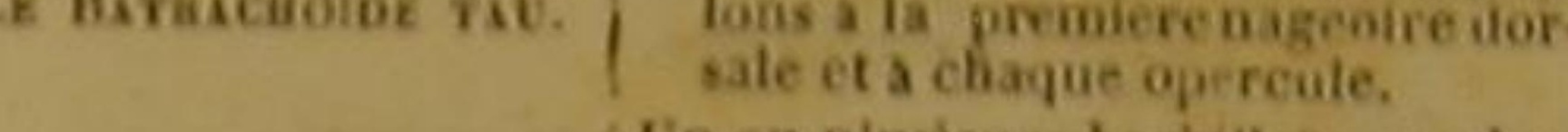

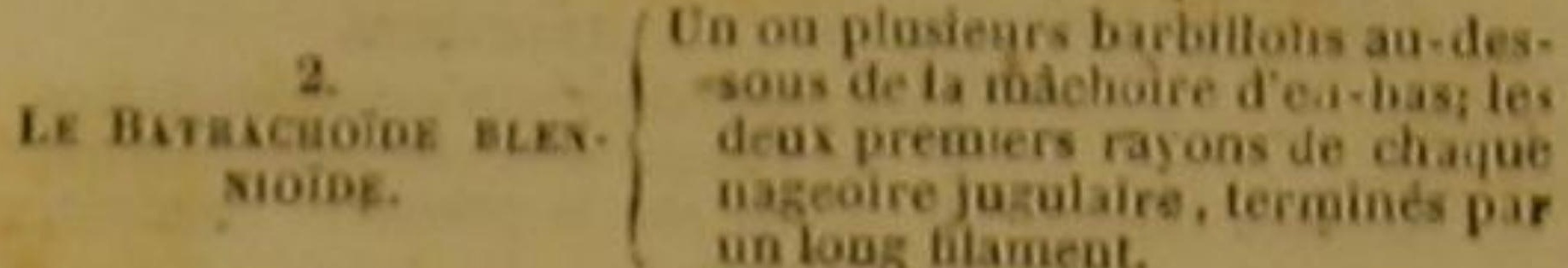
-

LE BATRACHOÏDE TAU ${ }^{2}$

Batrachoides Tau, Lacep.; Batraclius Tau, Sch, Cur.; Lophius Bufo, Mitchill ?

Nous avons séparé le tau des gades, et le blennioìde deś blennies, non-seulement parce que ces poissons n'ont pas tous les traits caractéristiques des genres dans tesquels on les avait inserits en plaçant le dernier parmi les blennies et le premier parmi les gades, mais encore parce que des formes très-frappantes les distinguent de toutes les espèces que peuvent embrasser ces mémes genres, au moins lorsquion a le soin nécessaire de n'établir ces cadres que d'après les principes réguliers auxquels nous tâchons toujours de nous conformer. Nous avons de plus rapproché l'un de Pautre le tau et le blennioide, parce qu'ils ont ensemble beaucoup de rapports; nous les avons compris dans un genre particulier, et nous avens donné à ce genre le nom de Batrachoide, qui désigne la ressemblance vague qu'ont ces animaux avec une grenouille, en grec Bхтрхуos, et qui rap-

'A la nageoire da dos du brosme 100 rayons, a chacune des pectorales 20 , a chacune des jugulaires 3 , a celle de 1 auus 60 , a celle de la queue 50.

Expausangon. - Bloch, pl. 6. fig. 2 el 3. - Gade tau, Bonnaterre, pl. de I Enc. méth. - Gadas tau, Lin. Gmel. Schneider, est admis par de Covier. Oene, ou Batrachus de

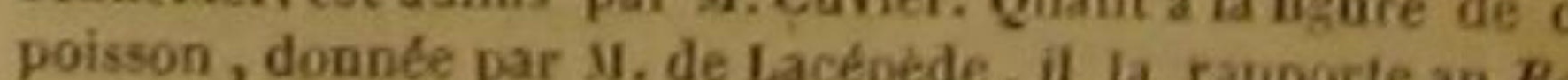
trachus surinamensis de Blochet de Schneider. D. pelle d'ailleurs les dénominations de Grenouil. ler et de Raninus, appliquées par Linnée, Daubenton, et plusieurs autres célèbres naturalistes, au blennioịde.

Le tau habile dans l'Océan atlantique, comme presque tous les gades, dans le genre desquels on avait cru devoir le faire entrer ; mais on l'y a pèché à des latitudes beaucoup plus rapprochées de l'ẽquateur que celles où l'or a rencontré la plupart de ces poissons. On l'a vu vers les cótes de la Caroline, où il a été observé par le doeteux Garden, et d'où il a été envoye en Europe.

Ses formes et ses couleurs, qui sont très-remarquables, ont été fort bien décrites par lo célèbre ichthyologiste et mon savant confrère le docteur Bloch.

II est revétu d'écailles molles, petites, mines, rondes, brunes, bordées de blane, et arrosées par une mucosité très-abondante, comme celles de la lote ct de la mustelle. Le dos et les nageoires sont tachetés de blauc ou d'autres nuances.

La tête est grande et large, le museau trèsarrondi. Les yeux, placés vers le sommet de cette partie et tres-rapprochés l'un de l'autre, sont gros, saillants, brillants par l'éclat de l'or que présente l'iris, et.entourés d'un double rang de petites verrues. Entre ces organes de la ve et la nuque, s'étend transversalement une fossette et une bande plus ou moins irrégulière, de couleur jaune, sur les deux bouts de laquelle on peut observer quelquefois une tache ronde et très-foncée.

Les dents sont aiguès. II n'y en a que deux rangées de chaque côté de la máchoire inférieure; mais la mâchoire d'en haut, qui est beaucoup plus courte, en montre un plus grand nombre de rangs. Une double série de ces mé. mes dents hérisse chaque côté du palaís.

Plusieurs barbillons sont placés sur les côtés de la mâchoire supérieure; un grand nombre d'autres filaments sont attachés à la mảchoire d'en-bas, et disposés á peu près en portion de cercle.

Chaque opercule, composé de deux lames, est de plus armé de trois aiguillons.

Le tau a deux nageoires dorsales; la première est soutenue par trois rayons tres-forts et non articulés. Celle de la queue est arrondie.

Le Tau a été nommé ainsi, a cause de la res. semblance de la bande jaune et transversale 
qu'il a auprès de la nuque, avec la traverse d'un $r$ grec, ou tau':

Le dessin qui représente ce poișson, et que nous avons fait graver, en donne une idée trèsexacte.

\section{LE BATRACHOÏDE BLENNIOÏDẼ ${ }^{2}$}

Basirachoides blennioides, Lacep.; Gadus Raninus, Mull: Bleanius Raninus, Gmel.; Phycis Ranina, Bl. '?

Ce batrachoinde a un ou plusieurs barbillons au-dessous de la mâchoire inférieure. Les deux premiers rayons de chacune de ses nageoires jugulaires sont beaucoup plus longs que les autres: ce qui, au premier coup d'wil, pourrait faire croire qu'il n'en a que deux dans chacune de ces nageoires, comme la plupart des blennies dans le genre desquels on l'a souvent placé, et ce qui m'a engagé à lui donner le nom spécifique de Blennioüde. On le trouve dans les lacs de la Suède, où il parait qu'il est-redouté de tous les poissons moins forts que lui, qui s'écartent le plus qu'ils peuvent, des endroits qu'il fréquente. Quoiqu'it tienne, pour ainsi dire, le milien entre les gades et les blennies, il n'est pas bon á manger ${ }^{4}$.

C'est avec toute raison, ce me semble, que le professeur Gmelin regarde comme une simple variété de cette espèce qu'il rapporte-au genre des blennies, un poisson de l'Ócéań septentrional, dont voici une très-courte description ${ }^{s}$

Il est d'un brun très-foncé. Ses nageoires sout noires et charnues; son iris est jaune; úne mucosité abondante, semblable à celle dont le tau est imprégné, humecte ses éeailles, qui sont petites. Sa tête très-aplatie, est plus large que son corps; I'ouverture de sa bouche très-grande; chaque mâchoire armée d'ụn donble rang de dents acérées et rougeatres, suivant plusieurs

A A la membrane branchiale du tau, 6 rayons, a la première
dorsule 5, a la seconde 25 , a chicune des pectorales 20 , chacune des juswlaires 6 , a chicune des pectorales 20 , queue 12. Euc. vieth. - Id. Fonnaterre, pl. de IFouller, Daubenton, Prodrom. Zool, danic, 11. 559 , - Strom. sondm. 1, p. 559. 1u genier place ce poisson daos le sous-genre Raniceps, -A la membrane bri ate 66, a chacune des a chiale 7 rayons, d la nageoire dorjugulaires 6 , à celle de lanus 60 , a celle de Ia a cbacune des

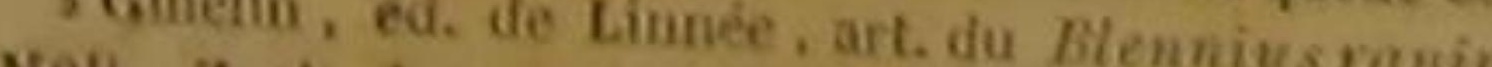

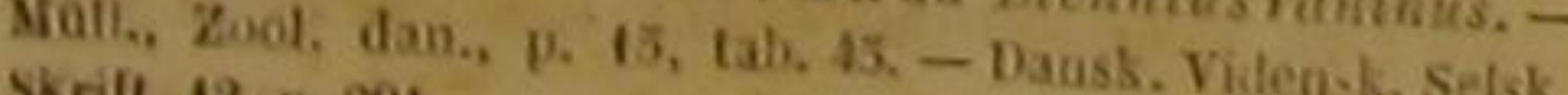

arrondie ; la langue épaisse, musčuleuse, ;evant; te premier rayon de chaque enge sorte de fil delie; et le second rayon des mèmes nageoires prolongé par un áppendice analogue, mais ordinairement une föis plus long que ce filament.

\section{CINQUANTIÈME GENRE} LES BLENNIES.

Le corps et la queue allongès et cimprimés; deux rayons au moins et quatre rayons au plus à chacune des nageoires jugulaires.

PREMIER SOUS-GENRE.

Deux nageoires sur le dos; des filaments ou appendices sur la tle.

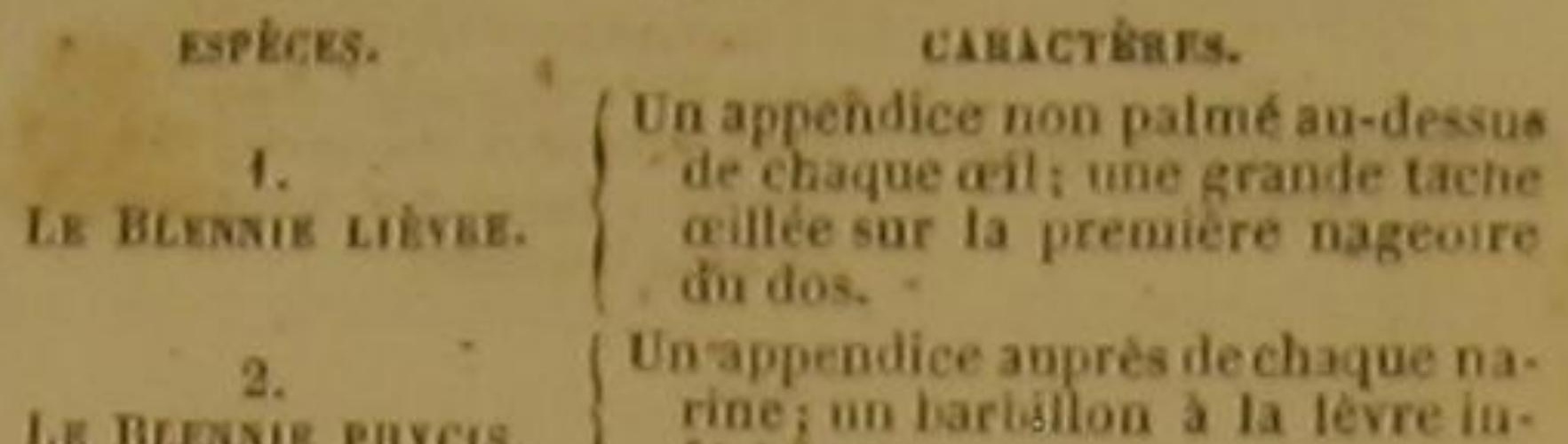

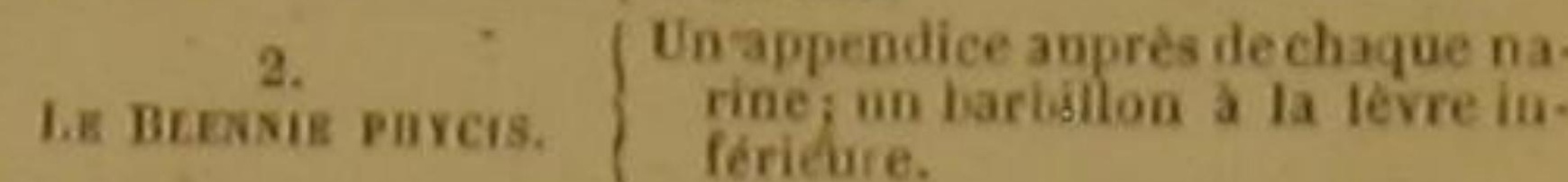

SECOND SOUS-GENRE.

Une seule nageoire dorsale; des filamentsou appendice sur la tete.

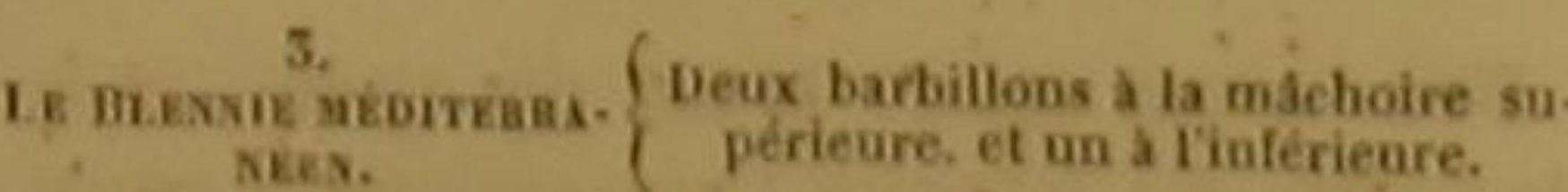
4. En appendice palmé aupris de ch

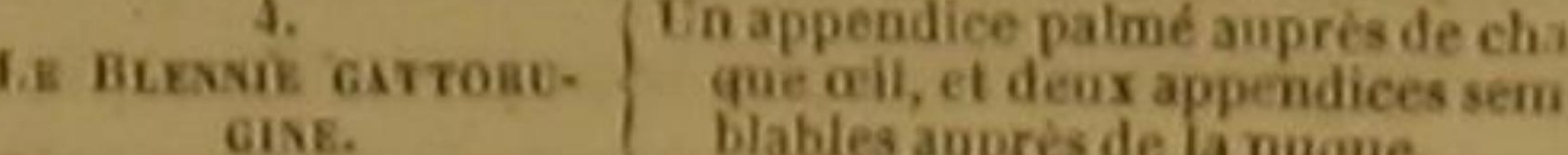
SE.
LE BLexí souach-
LEux.

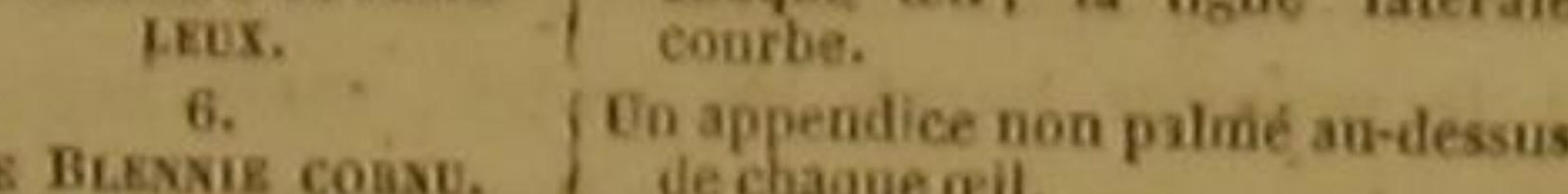

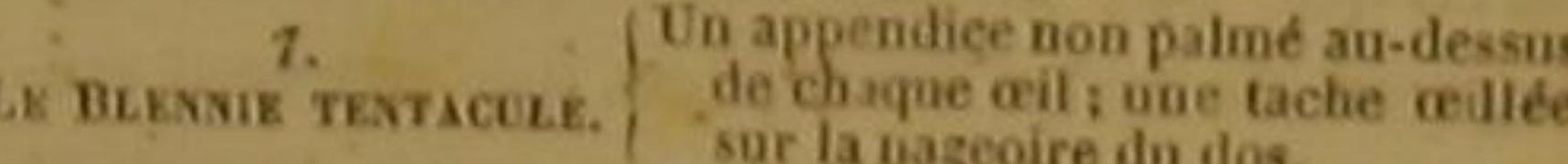

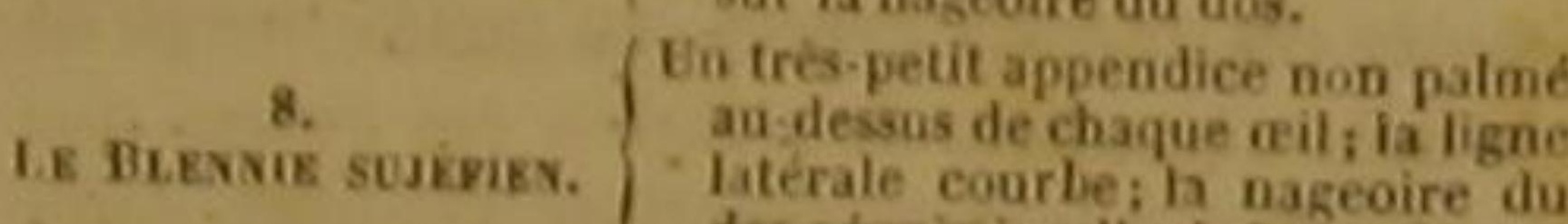
9.
Deux reppendices non palmués entre
les yeux:

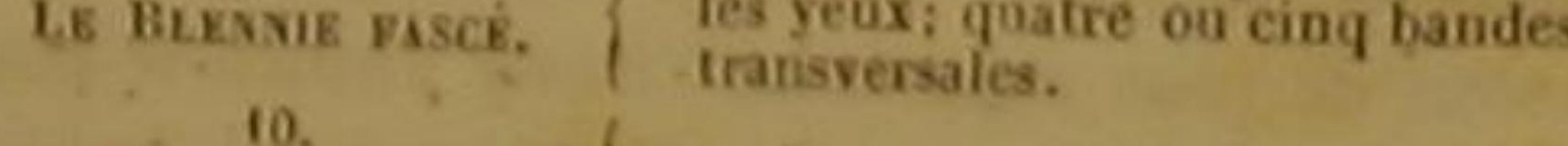

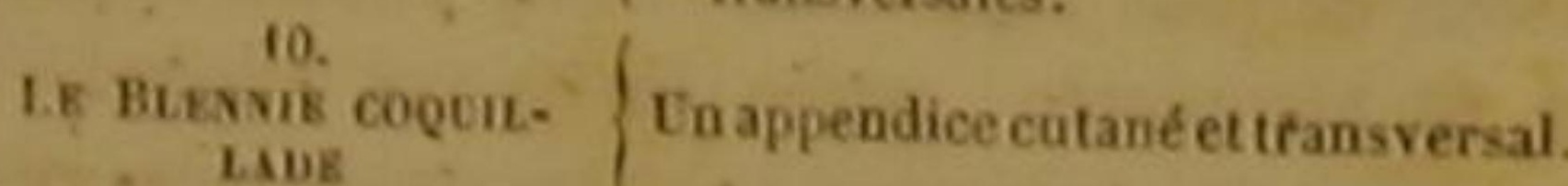

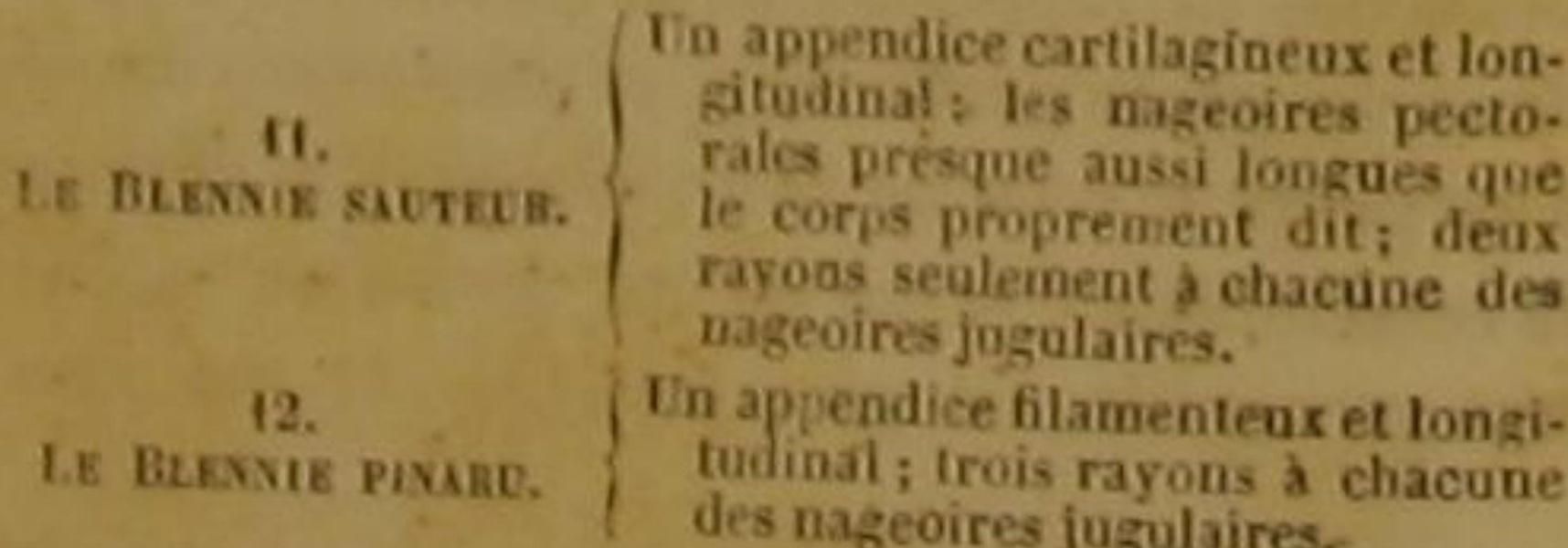

TROISIÈME SOUS-GENRE. Denx nageoires dorsales; point de barbillons ni d'appendices sur latete.

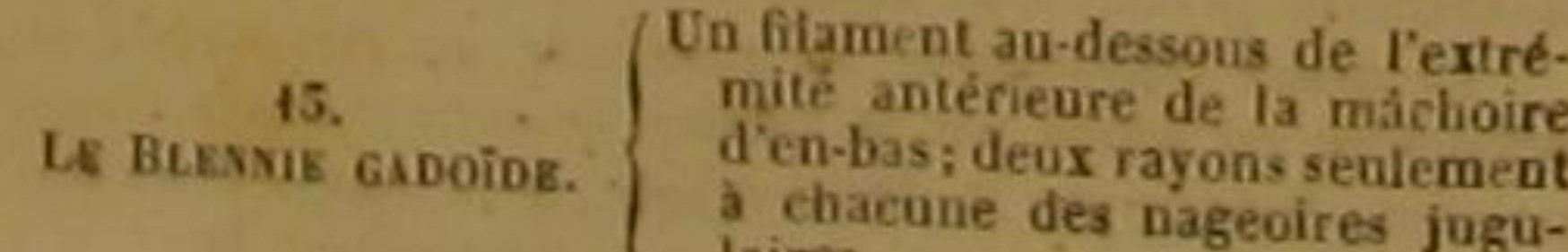

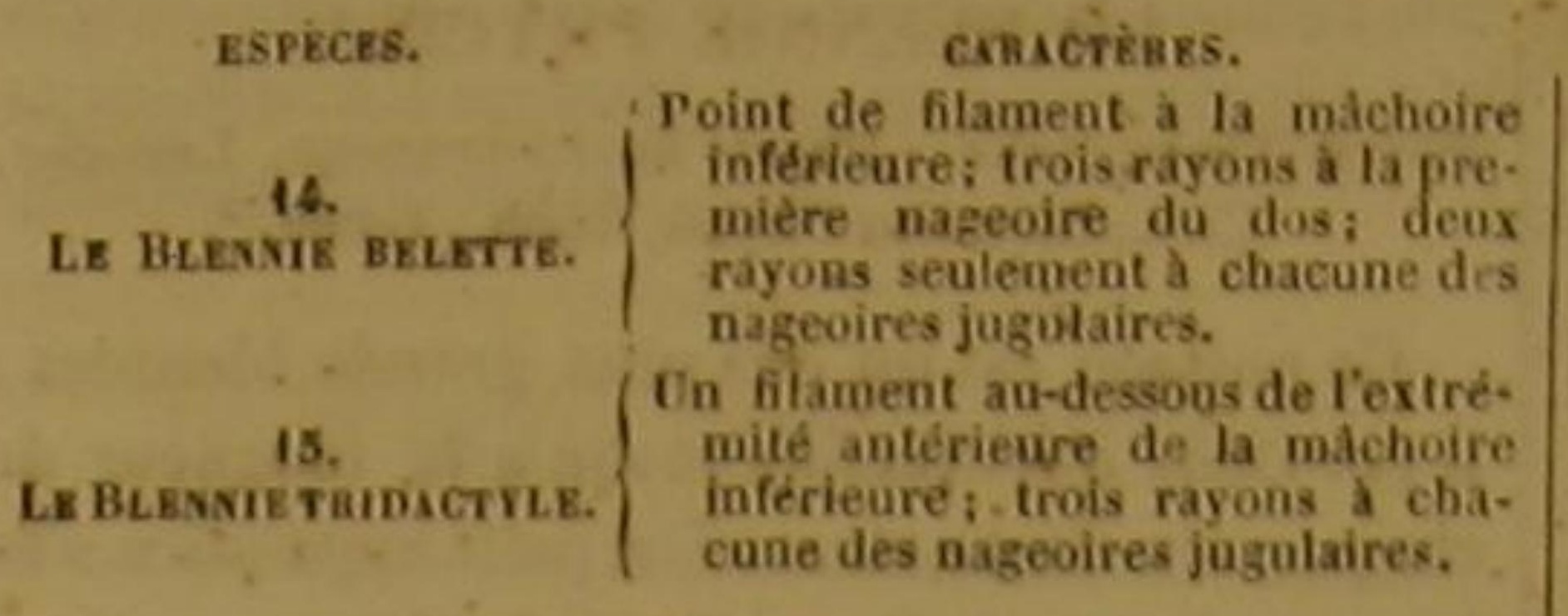

les verra pas aussi nombreux, nussi grands, aussi bons à manger, aussi salubres, aussi recherchés que ces derniers, faire naitre, comme ces mèmes gades, des légions de pécheurs, les attirer aux extrémités de l'Océan, les contraindreà braver les tempêtes, fes glaces, les brumes, etles changer bientôt en navigateurs intrépides, en ouvriers industrieux, en marins habiles et expérimentés ; mais le physicien étudiera avee curiosité tous les détails des habitudes des blếnies; il voudra les suivre dans les différents climats qu'ils habitent; il désirera de connaitre toutes les manières dont ils viennent à la humière, se développent, croissent, attaquent leur proie ou l'attendent en embuscade, se dérobent à leurs ennemis par la ruse, ou leur échappent par leur agilité. Nous ne déerirons cependant d'une manière étendue que les formes et les mœurs des espèces remarquables par ees mèmes mours ou par-ces mèmes formes; nous n'engagerons à jeter qu'un coup d'cil sur les autres. Ou il n'y a que peu de differences á noter, et, ce qui est la mème chose, pen de rapports à saisir; avec des objets déjá bien observés, it ne faut qu'un petit nombre de considerations pour parvenír à voir clairement le sujet de son examen. 21. $\begin{gathered}\text { sur les operenles, } \\ \text { Quelques dents placies vers le bont }\end{gathered}$ lesquelles nous appellerons pendant peu de

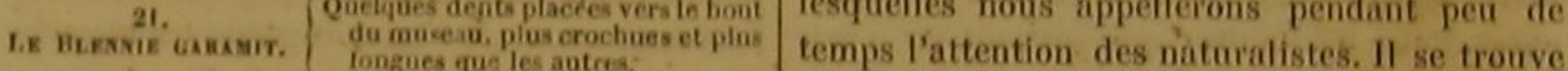

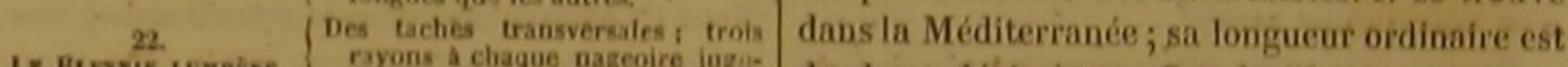
Lx Bleaxi nomèse. Tarre,

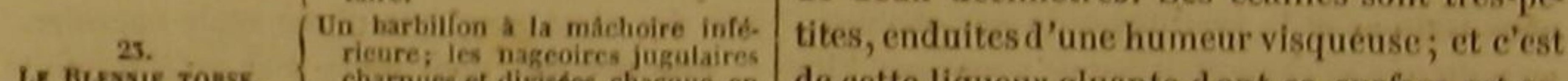
de cette liqueur gluante dont sa surface est arrosée, que vient le mom de Blennius en latio. et de Blennie ou de Blenne en français, qui lui a été donné ainsi qu'aux autres poissons de son genre tous plus ou moins imprégnés d'une substance oléagineuse, le mot Gi.tvogs en gree, sistance oleagineuse,
gnilant mucosite.

Sa couleur générale est verdâtre, avec des bandes transversaleset irrégulières d'unenuance de vert plus voisine de celle de l'olive; ce ver. dâtre est, sur plusieurs individus, remplacé par du bleu, particulièrement sur Je dos. La premièrenageoire dorsale est ou bleue comme le dos, ou olivâtre avec de petites taches bleues et des points blanes; et indépendamment de ces points Lonii, meliüs depictus, Aldrov., bib. 2 , cap. 28 , p. 203. Willoghby, p. 15i, tab. 11, 5, fig. 2, - Rai , . . 72, n. 13.Blennus pinniceps, Klein, Miss, pises, 5. 31. n. 1. - Scor-

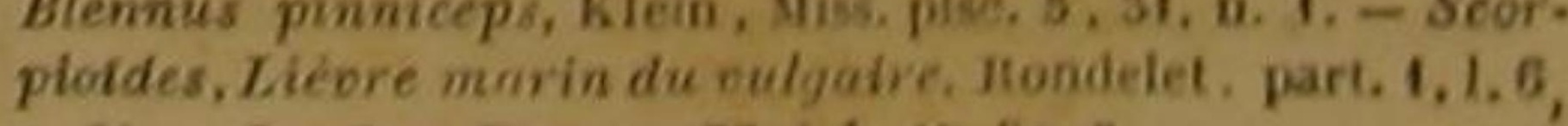


et de ces petites gouttes bleues, elle èst ornée d'une taehe grande, ronde, noire, ou d'un bleu très-foncé, entourée d'un liséré blanc, imitant une prunelle entourée de son iris, reprêsentant vaguement un œil; et voila pourquoi le blenvaguement un œil; et voilà pourquoi le blen-
nie lièvre a été appelé OEillé; i et voilà pourquoi aussi il a été nommé poisson papillon (Butterfly fish en anglais).

Sa tête est grosse, ses yeux sont saillants ; son iris brille de l'éclat de l'or. L'ouverture de sa bouche est grande; ses mâchoires, toutes les deux également avancées, sont armées d'un seu rang de dents étroites et très-rapprochées. Un appendice s'élève au-dessus de chaque cil ; 10 forme de cesappendices, qui ressemblent un peu à deux petites oreilles redressées, rếunie avec la conformation générale du museau, ayant fait trouver par des marins peu difficiles plusieurs rapports entre la tête du lièvre et celle du blennie que nous décrivons, ils ont proclamé ce dernier Lièvre marin, et d'habiles naturalistes ont cru ne devoir pas rejeter cette expression.

La langue est large et courte. II n'y a qu 'une pièce à chaque opercule branchial ; l'anus est plus près de la tête que de la nageoire caudale, et la ligne latérale pius voisine du dos que du ventre.

On compte sur ce blennie deux nageoires dorsales; mais ordinairement elles sont si rapprochées l'une de l'autre; que souvent on a cru n'en voir qu'une seule?

Pour ajouter au parallele entre le poisson dont nous traitons et le vrai lièvre de nos ehamps, on a dit que sa chair était bonne à manger. Elle n'est pas, en effet, désagréable au goût; mais on y attache peu de prix. Au reste, c'est à cet animal qu'il faut appliquer ce que Pline rap. porte de la vertu que l'on attribuait de son temps aux cendres des bleanies, pour la guérison ou le soulagement des maux causés par la présence d'un caleul dans la vessie ${ }^{2}$

'A la première nageoire du dos 11 rayons, a ta seconde is, A chacune des pectorales 12 , a chacune des jugolaires 2 , ,

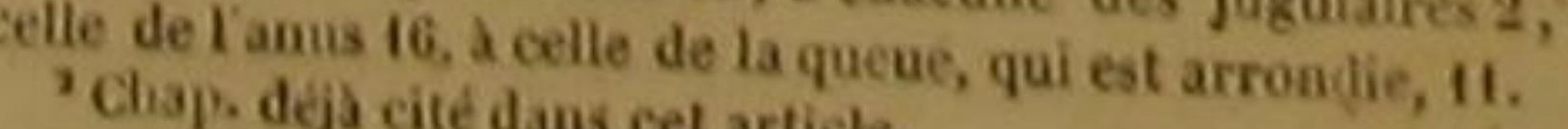

\section{LE BLENNIE PHYCIS 1 .}

Pbycis Tinca, Schn ; Phycis mediterraneus, Laroche, Cur.; Blenuius Phycis, Lian., Gmel.

Ce poisson est un des plus grands blennies: il parvient quelquefois jusqu'à la longueur de cinq ou six décimetres. Un petit appendice s'élève au-dessus de l'ouverture de chaque narine, et sa mâchoire inférieure est garnie d'un barbillon. Ce dernier filament, ses deux nageoires dorsaleset son volume, le font ressèmbler beaucoup à un gade; mais la forme de ses nageoires jugulaires, qui ne présentent que deux rayons, le place et le retient parmi les vrais blennies. Les couleursdu phycis sont sujettes à varier, suivant les saisons. Dans le printemps, il a la tête d'un rougge plus ou moins foncé; presque toujours son dos est d'un brun plus ou moins noirâtre; ses nageoires pectorales sont rouges, et un cercle noir entoure son anus ${ }^{3}$

On trouve ce blennie đans la Méditerranée ${ }^{4}$.

\section{LE BLENNIE MEDITERRANÉEN S.}

Blennius mediterraneus, Lacep. '.

Cette espècé a été jusqu'à présent comprise parmi les gades sous le nom de Méditerranéen ou de Monoplere; mais elle n'a quedeux rayons a chacune de ses nageoires jugulaires, et dèslors nous avons dû l'inscrire parmi les blennies. Nous l'y avons placée dans le second soús-genre, parce qu'elle a des barbillons sur la tète, et que son dos n'est garni que d'une seule nageoire.

Elle tire soin nom de la mer qu'elle habite.

Elle vit dans les mèmes caux salées que le gade capelan, le gade mustelle et le gade merlus, avec lesquels elle a beaucoup de rapports. In-

Mole, dans quelques départ. mérid. - Molere, en Espa gne. - Phico, ea llatie. - Blenne mole, Daubenton, Enc.

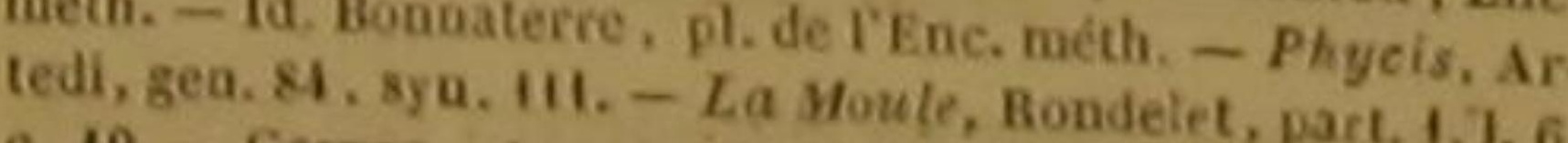
10. - Gesner, Aquat., p. 78, - Willoghby, Ichthyol, 205. - Tinea marina, Rai, Pisc., p. 75. et p. 164, I. 8. p. $160, \mathrm{n} \cdot 12$

'M. Cuvier retire les phycis du gere bla reporter dans celui des Gades où ils forment onie, pur les ' lore. sale 10 , a la screone branchiale 7 rayons, à la premiere dorcune des jugulaires 2 , a celle de $\mathrm{I}$ der pectorales 15 , à chaqui est arrondie, 20. Euc. méth. - Id. Bonnaterre - Gade moroptére, Daubenton "M. Curvier ne bait pas mention de ceclle espéce. dépendanıment des deux filaments situés, sui sa mâchoire d'en-haut, il y en a un attaché à la máchoire inférieure '.

LE BLENNIE GATTORUGINE ${ }^{2}$.

Blennius palnicornis, Penn.; Cuv.; Blenuius Gattorugine, Lacep. :

Le gattorugine habite dans l'Océan atlantique et dans la Méditerranée. II n’a gnère plos de deux décimètres de longueur : aussi ne se nourrit-il que de petits vers marins, de petits crustacées et de très-jeunes poissons. Sa chai est assez agréable au goût. Ses couleurs ne déplaisent pas. On voit sur sa partie supérieure des raies brunes, avee destaches, dont les unessont d'une nuanee clairé, et les autres d'une teinte foncée. Les nageoires sont jaunátres. Il n'y en a qu'une sur le dos dont les premiers rayons sont aiguillonnés 4, et les derniers très-longs. La tête est petite; les yeux sont saillants et très. rapprochés du sommet de la tête ; I'iris est rougeatre. Deux appendices palmés paraissent aupres de l'organe de la vue, et deux autres semblables sur la nuque. Les máchoires également avancées l'une et l'autre, sont garnies d'un rang de dents aiguès, déliées, blanchès et flexibles. La langue est courte; le palais lisse; l'opercule branchial composé d'une seule lame; lanus assez voisin de la gorge, et la ligne làterale droite ainsi que rapprochee du dos.

LE BLENNIE SOUBCILLEUX 5 .

Blennius saperciliosus, BI., Cuv., Lacep. ‘

Les mers de l'Inde sont le séjour habituel de ce blennie. Comme presque tous les poissons

- A la nageoire do dos 54 rayons, à chacune des pectora. .es 15 , a chacune des jugulaires 2 , a celle de Panus 44 . naterre, pl de l'Fugine, Daubenton, Enc. meth.-10. Bon-

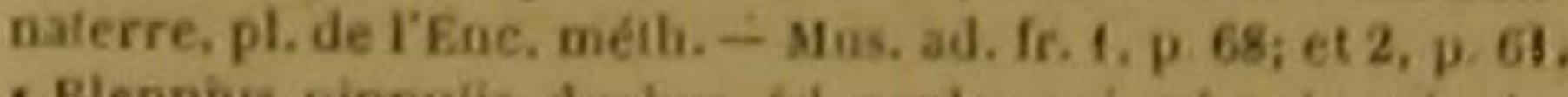

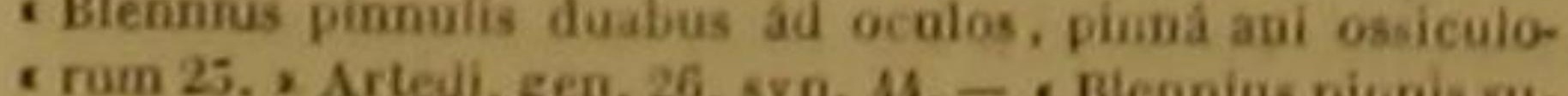

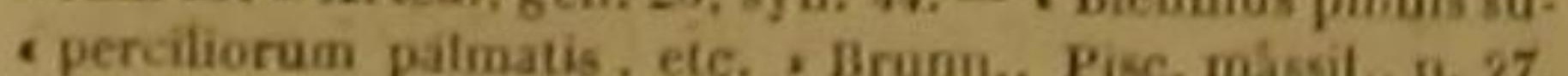
n. 57. - \&lennius capite cristato ex radio inermi, etc. Gronov., Zooph., p. 76, n. 254. - Willnghiby, Ichth., p. 152 , tab. H, 2, Eig. 2. - Fai, Pisc. 72, o. 14. - Galtorugine, Brit Zool. 3, p. 168, n. 2

Du sous-geure des Biennies proprement dites, dins le 46 rayung non articults gale. is rayons a chneries et 14 articulés a la nageoire dor. golyires, 25 y celle sBlernesourcillenx, Daubenton, buc. méth, - Id. BonDaterre, pl. de l'Enc, meth.- - Blegnins piunuliśocularibus
- Du sous-genre Clinus dans le genre Biennie, Cur, De des contrées équatoriales, il a des couleurs agréables et vives '; un jaune plus on n:oins foncé, plus ou moins voisin du brillant do l'or, ou de l'éclat de l'argent, et relevé par de belles taches rouges, règne sur tout son corps. II se nourrit de jeunes crabes et de petits animaux à coquille; et dès lors nous ne devons pas ètıe surpris, d'après ce que nous avons déjả indiquoó plusieurs fois, que ce sourcilleux présente des nuances riches et bien contrastees. Plusieurs causes se réunissent pour produire sur ses téguments ces teintes distinguées : I chaleur du climat qu'il habite, I'abondance de Ja lumière qui inonde la surface des mers dans lesquelles il vit, et la nature de l'aliment qu'il préfere, et qui nous a paru étre un des principes de la brillante coloration des poissons. Mais quoique ce blennie, exposé aux rayons du soleil, puisse paraitre quelquefois parsemé, pour ainsí dire, de rubis, de diamants et de topazes, il est encore moins remarquable par sa parure que par ses habitudes. Ses petits sortent de l'ouf dans lo ventre de la mère, et viennent au jour tout formés. Il n'est pas le seul de son genre dont les cufséclosent ainsi dans l'intérieur de la femelle. Ce phénomène a été particulièrement observé dans le blennie que les naturalistes ont nommé pendant longtemps le Vivipare. Nous reviendrons sur ce fait, en traitant, dans un moment, de ce dernier poisson. Considérons néanmoins déjá que le sourcilleux, que sa manière de venir à la lumière fie, par une habitude peu commune parmi les poissons, avec l'anguille, avec les silures, et peut-étre avec le gade lote, a, comme tous ces osseux, le corps très-allongé, reeouvert d'écailles très-menues, et enduit dune mucosité très-abondante.

Au reste, sa téte est étroite; ses yeux sont saillants, ronds, placés sur les côtés, et surmontés chacun d'un appendice palmé et divisé en trois, qui lui a fait donner le nom qu'il porte. L'ouvertare de la bouche est grande; la langue courte; le palais lisse; la mâchoire d'enhaut aussi avancée que l'inférieure, et hérissée d'un rang extérieur de grosses dents, et de plu- brevissimis palmatis, etc., Amenit, acad, 1, p. 517. Gronov, Mus, 2, 0. 172, Lab. 5, A6. 5; Zooph., p. 75, n. 258. - bloch,

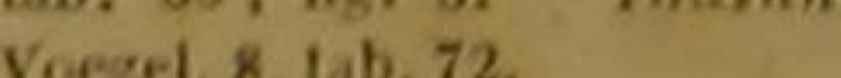
A la nagcoire ar

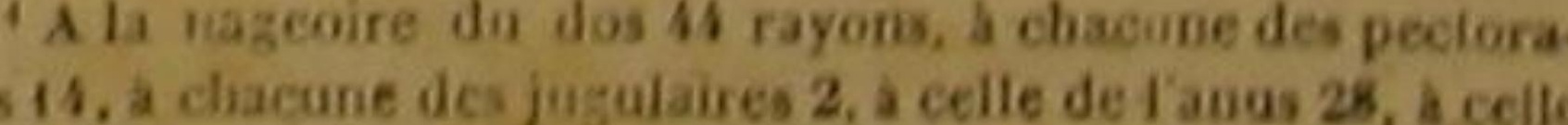
de la iqueise 12. 
sieurs rangées de dents intérieures plus petites et tres-pointues ; l'opercule branchial composé d'une seule lame, ainsi que dans presque tous les blennies; la ligne latérale courbe; l'anus large commé celui d'un grand nombre de poissons qui se nourrissent d'animaưx à têt ou coquille, et d'ailleurs plus voisin de la gorge que de la nageoire caudale. Tous les rayons de la nageoire du dos sont des aiguillons, except les cinq ou six derniers.

LE BLENNIE CORNU ',

Blennius cornutus, Limn., Lacep.

LE BLENMIE TENTACULE் 2 ,

Blennius tentacularis. Linn., Cur.; Bl, tentaculatus, Lacep.

LE BLENNIE SUJÉFIEN ?

Blennius sujeflanus. Lacep,; BI; simus, Limo.

ET LE BLENNIE FASCE ',

Bledvius faseiatus, Linn:, BI.?

Le cornu présente un appendice long, effilé, non palmé, placé au-dessus de chaque oil ; une multitude de tubereules à peine visibles, et disséminés sur le devant ainsi que sur les cotés de la tête; une dent plus longúe que les autres de chaque còté de la mảehoire inférieure; une pean visqueuse, parsemée de points ou de petites taches roussaties: il vit dans les mers de l'Inde, et a été décrit, pour la première fois, par l'immortel Linnée 6 .

Le tentaculé quel'on péche dans la Méditerranée, ressemble beaucoup au cornu; il est allongé, visqueux, orné d'un appendice non palmé au-dessus de ehaque ceil, coloré par points ou par petites taches très-uombreuses. Mais indépendamment que ees points sont d'une teinte

'Blenne cornu, Daubenton, Ene, meittr-Id. Bonnaterre,

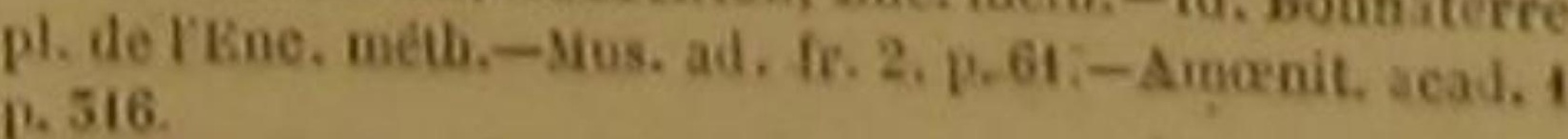
1.. 316

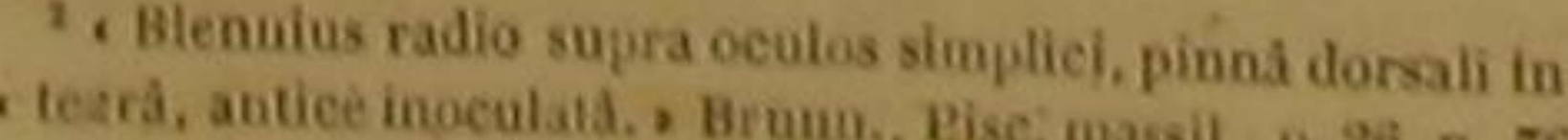
- Blenne nébuleuse, Bounaterre, pl. de I'Ene, méth. 'Sivet, Act. petopoht, 1779, 2, p. 198, tab. 6, fiz, 2, 4, 'Les deus premiess et to wierre, pl. de lEne, weth.

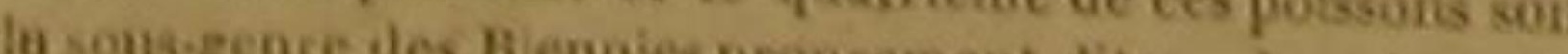

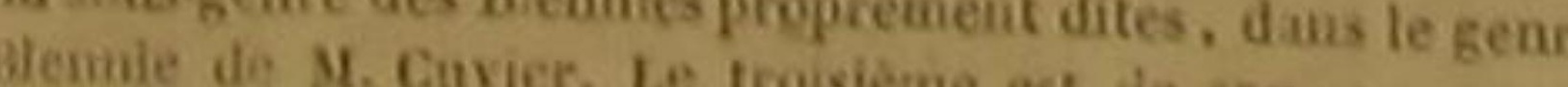
Silarias. D

A la nagcore dorsale du blennie cornu 54 rayons at cha Litus 26 , a celle de la queue 12 . tes-brune, on voit sur la nageoire dorsale une rande tache ronde qui imite un œil, ou, pour mieux dire, une prunelle entourée de son iris De plus, le dessous de la tête montre trois ou quatre bandes transversales et blanches; 1 iris est argenté avec des points rouges; des bandes blanches et brunes s'étendent sur la nageoire de l'anus; les dents sont très-peu iuégales; et enfin, en passant sous silence d'autres dissemblances moins faciles à saisir avec précision, le tentaculé parait différer du cornu par sa taille, ne parvenant guère qu'à une longueur moindre d'un décimètre. Au reste, peut-être, malgré ce que nous venons d'exposer, et l'autorité de plusieurs grands naturalistes, ne faudrait-il regarder le tentaculé que comme une variété du cornu, produite par la différence des eaux-de la Méditerranée à celles des mers de I'Inde. Quoi qu'il en soit, e'est Brunnich, qui a fait connaitre le tentaculé, en décrivant les poissons des environs de Marseille ',

L.e sujéfien a un appendice non palmé an-dessus de chaque œil, comme fe cornu et le tentaculé; mais cet appendice est très-petit. Nous lui avons donné le nom de Sujéfien, parce que le naturaliste Sujef en a publié la deścription. II parvient à fa longueur de plus d un décimètre. Son corps est menu; l'ouverture de sa bouche, placée au-dessous du museau, chacune de ses mâchoires garnie d'une rangée de dents trèscourtes, égales et très-serrées; son opercule branchial composé de deux pièces; sa nageoire dorsale précédée d'une petite élévation ouloupe graisseuse, et réunie à celle de la queue, qui est arrondie ${ }^{2}$.

Les mers de l'Inde, qui sont l'habitation ordinaire du cornu, nourrissent aussi le fascé. Ce dernier blennie est enduit d'une mucosité trèsgluante. Sa partie supérieure est d'un bleu tirant sur le brun, sa partie inférieure jaunátre: quatre ou einq bandes brunes et transversales relèvent ce fond; les intervalles qui séparent ces fáseies, sont rayés de brùnatre; d'autres bandes ou des taches brunes paraissent sur plusieurs nageoires; celle de la queue, qui d'ailleurs est arrondie, montre une couleur grise ${ }^{3}$.

- A la nageoire da dos du tentaculé 34 rayons, a chane des pectorales 14 , a chacune des jugulaires 2 , a celle de l'ais $x$ ceile de la queve 11 . 'A la uageoire dorsale du blennie sujefien 27 rayons. le lanus 17 , i celle te 15 , i chacnue des juguiaires 2 , a ceile A la nageoire do dos da face

DES POISSONS.

Denx appendices nou palmés s'élèvent entre les yeux; la téte, brune par-dessus et jaunatuce par-dessous, est assez petite; l'ouverture branchiale très-grande; celle de l'anus un peu rapprochée de la gorge, et la ligne latérale peu éloiguée du dos.

LE BLENNIE COQUTLLADE ' Blennius Galerita ; Blennius Coquillad, Lacep. ?

On péche ce poisson dans l'Océan d'Europe, ainsi que dans la Méditerranée. Il n'a pas ordinairement deux décimètres de longueur. Sur sa tête parait un appendice cutanê, transversal, un peu mobile, et auquel on a donné le nom de Grele. Il babite parmi les rochers des rivages. Il échappe facilement à la main de ceur qui veulent le retenir, parce que son corps est délié et très-muqueux. Sa partie supérieure est brune et mouchetée. Sa partie inférieure d'un vertfoncé et noíràtre. On a com̌naré à une émeraùde la couleur et l'éclat de sa vésicule du fiel. Sa chair est molle ${ }^{3}$. II vit assez longtemps hors de l'eau, parce que, dit Rondelet, l'ouverture deses branchies est fort petite; ce qui s'accorde avec les idées que nous avons exposées dans notre premier Discours, sur les causes de la mortalité des poissons au millieu de l'air de l'atmosphère. D'ailleurs on peut se souvenir que nous avons placé parmi ceux de ces animaux qui vivent avee plus de facilité hors de l'eau, les osseux et les cartilagineux qui sont pénétrés d'une plus grande quantité de matières huileuses propres a donner aux membranes la souplesse convenable.

pectorales 15 , a chacune des jugulaires 2 , a celle de $\mathrm{i}$ anus 19 , a celle de la queue, qui est arrondie, 11.

Blenne coquillade, Daubenton, Enc. méth. - Id. Bounalerre, pl, de IEnc, méth. - G Blennius cristi capitis transAlauda cristata, Galerita, Rondelet. part. 1. I. 6, c. 21, Aldrovand, 1. 1, c. 25. p. 114. - Jonston, tab. 17, fig. 3. Charlet., p. 157, - Gaterila, Rai, p. 73. - Alauda eristata, sive Galerita, Gesner, p. 17. 20, (Germ.) fol. 4, a. - Willughby, Ichth., p. 154. - Adomis, Bélon, Aquat. 219. Crested blenny. Brit. Zool s. p. 167. - sirom, sondm. 32

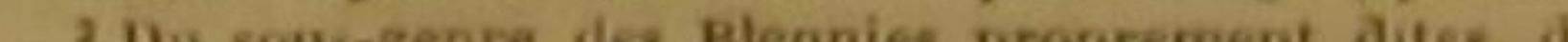
genre Blennie, Cav. D.

'A la nageoire da dos 60 rayons, a chacune des pectirales 10 , a chacune des jogulaires 2 , a celle de lanus 56 , a celle de la queue 16.

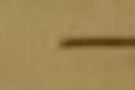

\section{LE'BLENNIE SAUTEUR '}

Blennius saliens, Lacep, Cur. '.

Nous avons trouvé une description très-détailtée et très-bien faite de ce blennie dans les manuserits de Commerson, que Buffon nous a confiés dans le temps, en nous invitant à continuer son immortel ouvrage, On n'a encore rien publié relativement à ce poisson, que le savant Commerson avait eru devoir inserire dans un genie particulier, et nommer l'Altique sauteur. Mais il nous a paru impośsible de ne pas le comprendre parmi les blennies, dont il a tousles caractères généraux, et avec lesquels l'habile voyageur quil l'a observé le premier, a trouvéluimème qu'il offrait les plus grands rapports. Nous osons même penser que si Commerson avait été à portée de comparer autant d'espèces de blennies que nous, les caractères génériques qu'il aurait adoptés pour ces osseux auraíent té tels, qu'il aurait renfermé son sauteur dans leur groupe. Nous avons done remplacé la dénomination d'Altique sauteur par celle de Blennie sauteur, et réuni dans le cadre que nous mettons sous les yeux de nos lecteurs, ce que présentent de plus remarquable les formes et les habitudes de ce poisson.

Ce blennie a été déconvert auprès des rivages et particulièrement des récifs de la NouvelleBretagne, dans la mer du Sud. Il y a été observéen juillet 1768 , lors du célèbre voyage de notre coufrère Bougainville. Commerson l'y a vu se montrer par centaines. Il est très-petit, puisque sa longueur totale n'est ordinairement que de soixante-six millimètres, sa plus grande largeur de einq, et sa plus grande hauteur de huit.

It s'élance avec agilité, glisse avec vitesse, ou, pour mieux dire, et pour me servir de l'expression de Commerson, vole sur la surface des eaux salées; il préfére les rochers les plus exposés a étre battus par les vagues agitées, et la, bondissant, sautant, ressautant, allant, reveant avec rapidité, il se dérobe en un elin d'oeil l'énnemi qui-se eroyait près de le saisir, et qui ne peut le prendre que très-difficilement.

II a reçu un instrument très-propre à lui

‘. Alticns saltatorims, pinñá spuria in eapitis vertice : seu - pinnuáa longitudioali ponè oculos cartilagineà s seu allicus , deenultor, occipite cristato, ore circulari deorsum patalo. . Commerson, Manuscrits dejà cités. a Do sous-geure Salarias, dass le genre Blennie de s. Cu- 
donner cette grande mobilité. Ses nageoires pectorales ont une surface très-étendue, relativementà son volume; elles représentent une sorte de disque lorsqu'elles sont déployées; et leur longueur, de douze millimètres, fait que, lorsqu'elles sont couchées le long du corps, elle atteignent à tres-peu près jusqu'à l'anus. Ce rapport de forme avec des pégases, des scorpènes, des trigles, des exocets, et d'autres poissons volants, devait lui en donner aussi un d'habitude avec ces mèmes animaux, et le douer de la faculté de s'élancer avec plus ou moins de force.

La couléur du blennie sauteur est d'un brün rayé de noir, qui se change souvent en bleuclair rayé ou non rayé, après la mort du poisson.

On a pu juger aisément, d'après les dimensions que nous avons rapportées, de la forme très-allongée du sauteur; mais de plus, il est assez comprimé par les côtés pour ressembler un peu à une lame.

La mạchoire supérieure étant plus longue que l'inférieure, l'ouverture de la bouche se trouve placée au-dessous du museau.

Les yeux sont situés très-près du sommet de la tête; gros, ronds, saillants, brillants par leur iris, qui a la couleur et l'éclat de l'or; et auprès de ces organes, on voit sur l'oceiput une crête ou un appendice ferme, cartilagineux non composé de rayons, parsemé de points, long de quatre millimètres ou environ; arrondi dans son contour, et élevé non pas transversalement; comme celui de la coquillade, mais longitudiualement.

Deux lames composent chaque opercule branchial.

La peau du sauteur est enduite d'une mucosité très-onctueuse.

Commerson dit qu'on n'aperçoit pas d'autre ligne latérale que celle qui indique l'intervalle longitudinal qui règne de chaqque cóté entre les muscles dorsaux et les muscles latéraux '

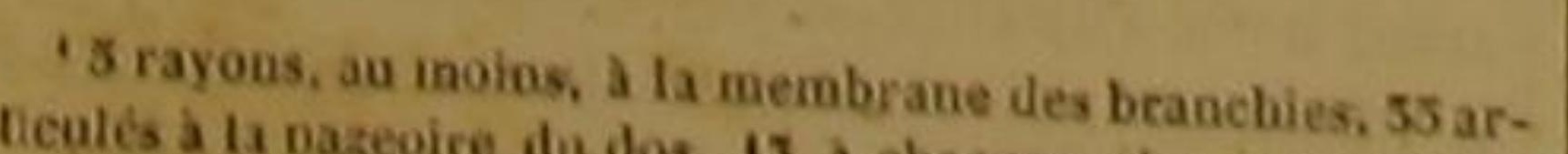
mous et filiforìes á chacune des jugubires, pectorales, lanus, 10 a celle de la qneue, qui est luguatires, 26 a celle de
LE BLENNIE PINARU '

Blennius Pinara, Lacep. ; Blennius pilicornis, Cuv. ’.

Le pinaru ressemble beaucoup au blennie sauteur. Il habite, comme ce dernier poisson, dans les mers voisines de la ligne. Un appendice longitudinal s'élève entre ses yeux, de mème qu'entre ceux du sauteur; mais cette sorte de créte est composée de petits filaments de couleur noire: De plus, le sauteur, ainsi que le plus grand nombre de blenniés, n'a que deux rayons a chacune de ses nageoires jugulaires; et le pinaru a ses nageoires juggulaires soutenues par trois rayons ${ }^{3}$.

La ligne latérale de ce dernier osseux est d'ailleurs courbe vers la tête, et droite dans le reste de sa longueur.

On le trouve dans les deux Indes.$$
\text { - }
$$

LE BLENNIE GADOÏDE *, Blennius gadoides, Lacep.

LE BLENNIE BELETTE 5 ,

Blennius mustelaris, Lino.; Blennius mustela, Lac. ·

\section{ET IE BLENNIE TRIDACTYLE}

Bleunius trydactylus, Lacep. '

Ces trois poissons appartiennent au troisième sous-genre des blenuies : ils ont deux nageoire ur le dos; et on ne voit pas de barbillons n d'appendices sur la partie supérieure de leur rète.

Le gàdoide a été découvert par Brumnich. Ce naturaliste l'a considéré comme tenant I milieu entre les gades et les blennies; et c'est

'Blenné pinaru, Daubeuton, Enc. fréth. - Id. Bunn

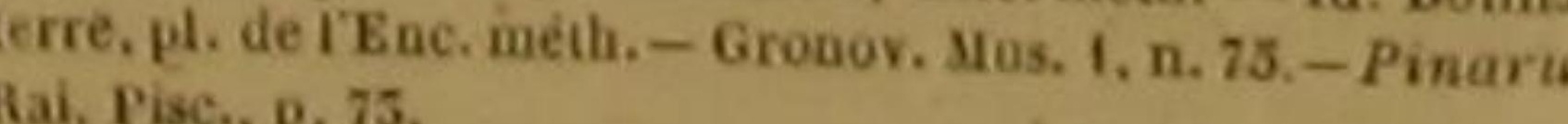
ai, Pisc, p. 75.

Da sous-genre des Blennies proprement dites daus le

os 26 . a chacune des pectiorales 14 , a chons, a la nagevire du res 5 , a celle de $f^{\prime}$ 'nnos 16 , a celle de la queue, qui est arron(ie, 11.

'Brunn., Pi.c. Massil, p. 24, n. 54.-Gade à deux doig/s,

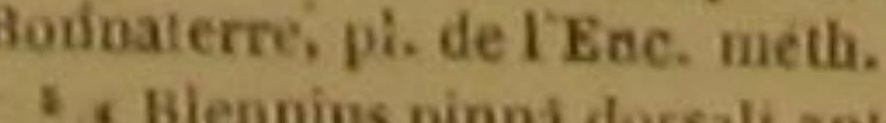

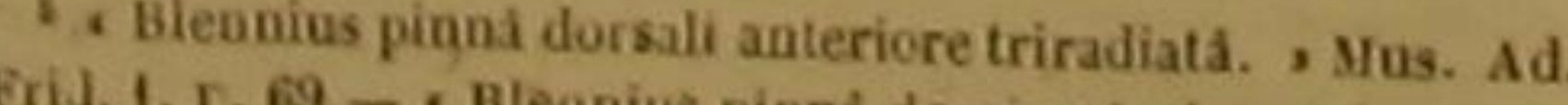
- posteriore 40. Iltit. - Blenne belclle, Diore tiradialá, méth.

- Du soes genre Clinus dans le geore Bleonic, Cur. D.

'Trifurcated, Peonant, Zool. Brit., L. III, P. Cur. D.

rident, Bonnaterre, pl. de l'Enc, méth. III, p. 196.-Gad

M. Cuvier ne mentionne, ni cette

cunie gaduide. $\quad$ D. pour désigner cette position dans l'ensemble des ètres vivants, que je lui ai donné le nom de Gadoìde. Il a été compris parmi les gades par plusieurs célebres naturalistes : mais la nécessité de former les différents genres d'animaux conformément au plusgrand nómbre de rapports qu'il nous est possible d'entrevoir, et de les indiquer par des traits précis et faciles à distinguer, nous a forcés d'exiger pour les deux familles des blennies et des gades, des caractères d'après lesquels nous avons dù placer le gadoide parmi les blennies.

Ce poisson hảbite dans la Méditerranée. II est mou, êtroit, légèrement comprimé. Sa longueur apalogue à celle de la plupart des blennies, ne s'étend guère au-delà de deux déeimètres. Sa mâchoire inférieure est plus courte que la supérieure, marquée de chaque coté de sept ou huit points ou petits enfoncements, et garnie, au-dessous de son bout anterieur, d'un filament souvent très-long.

On voit deux aiguillons sur la nuque; la ligne Latérale est droite.

L'animal est blanchâtre, avec la tête rougeâtre. Des teintes noires règnent sur le haut de la premiere nageoire dorsale, sur les bords et plusieurs autres portions de la seconde nageoire du dos, sur une partie de celle de l'anus, et sur celle de la queue '.

Il est aisé de séparer de cette espèce de blennie celle à laquelle nous conservons le nom de Belette. En effet, ce dernier poisson n'a point de filament au-dessous du museau, et on ne compte que trois rayons à sa première nageoire dorsale ${ }^{2}$. Il a été découvert dans I'Inde.

Le tridactyle a été considéré jusqu'à présent comme un Gade; il a surtout beaucoup de ressemblance avec le gade mustelle et le cimbre. Il a, de même que ces derniers animaux, la première nageoire dorsale cachée presquée en entier dans une sorte de sillon longitudinal, et composée de rayonsqui tous, exceptế un, sont extrèmement courts et difficiles à distinguer les uns des autres. Mais chacune de ses nageoire jugulaires n'est soutenue que par trois rayons

-A la membrane branchiale du blennie gadoide 7 rayons. a premiere nageorire dorsale 10 . a ia seconde 55 , a chacune des pecturates 11 , ą chacune des jugulaires 2 , à celle de i A la premiére nageoire dorst

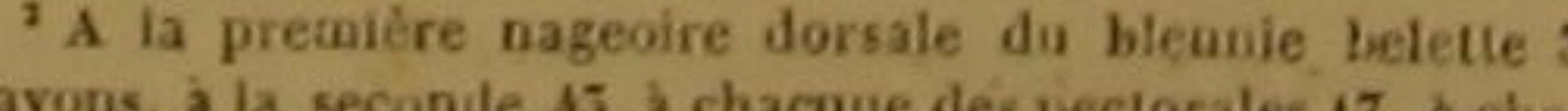
cane des jugulaires 2 , a celle de l'anus 29 . a celle de la et cela seul aurait dù nous engager à le rapporter aux blennies plutót qu'aux gades, Les nageoires jugulaires, ou thoracines, ayant été comparées, aussi bien que les abdominales, aux pieds de derrière des quadrupèdes, les rayons de ces organes de mouvement ont éte assimilés à des doigts; et c'est ce qui a détermìné à donner au blennie que nous examinons, le nom spéeifique de Tridactyle, ou à trois doigts. D'ailleurs, dans cet osseux, les trois rayons de chaque nageoire jugulaire ne sont pas réunis par une membrane à leur extrémité, et cette séparation vers un de leurs bouts les fait paraitre encore plus analogues aux doigts des quadrupèdes.

La tête du tridactyle est un peu aplatie. Ses máchoires sont garnies de dents recourbées celle d'en-bas présente un long barbillon au dessous de son extrémité antérieure.

On voit au-dessus de chaque nageoire pectorale une rangée longitudinale de tubercules, qui sont, en quelque sorte, le commencement de la ligne latérale. Cette dernière ligne se flé

chit très-près de son origine, forme un angle obtus, descend obliquement et se coude de nouveau pour tendre directement vers la nageoire de la queue 1.

La couleur de la partie supérieure de l'animal est d'un brun foncé; les plis des lèvres, et des bords de la membrane branchiale, sont d'un blane très-éclatant.

Ce blennie habite dans les mers qui entourent la Grande-Bretagne; le savant auteur de la Zoologie britannique l'a fait connaitre aux naturalistes.

\section{LE BLENNIE PHOLIS ${ }^{2}$.}

Blennius Pholis, Lino., Gmel, Lacep., Cpr, '.

Les blennies dont il nous reste à traiter, forment le quatrieme sous-genre de la famille que

' 5 rayons a la membrane des branchies du blennie tridacTyie, I rayon tressallongé et plusieurs autres rayous trescourts a 2 premiere pageoire dornale, 45 rayons a ta $x$ conde, wa chacune des pectorales. 5 a caacuse des juzzulaires,

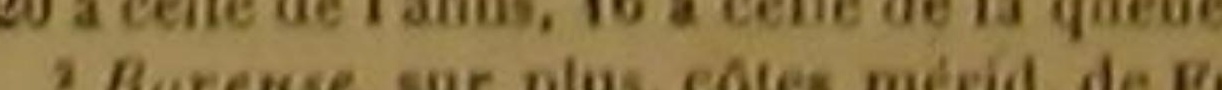

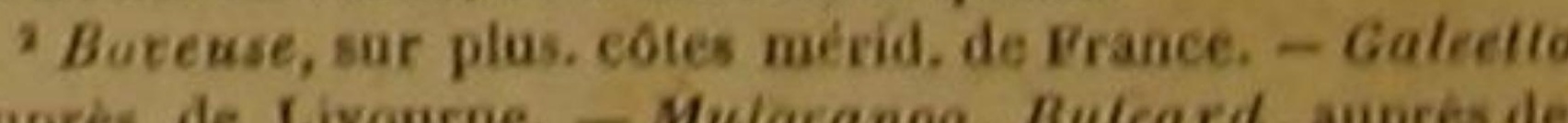
rivages de Cornouaitles en Anzleterre. - Blenne baveuse. Daubenton, Enc. méth. - Id. Bonnaterre, pl. de YKne méth. - Mus. Ad. Frid. 2, p. 62. - \& Bieunius maxilla supe riore iongiore, capite summo acumilato., Artedi, gen. 27 , 'Da sous-genre des Blennies proprement dites daus le

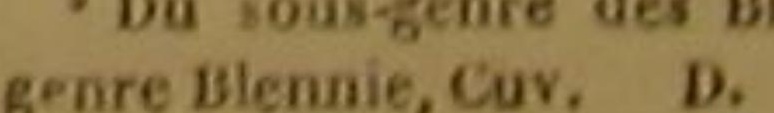


nous considérons; ils n'ont ni barbillons ni ap- , peut devenir la victime de sa témérité, étre poute les deux battants refermés avec qu'une seule nageoire.

Le premier de ces poissons dont nous allons parler, est le pholis. Cet osseux a l'ouverture de la bouche grande, les lèvres épaisses, la mâchoire supérienre plus avancée que- l'inférieure, et garnie, ainsi que cette dernière, de dents aigués, fortes et serrées. Les ouvertures des narines sont placées au bout d'un petit tube frangé. La langue est lisse, le palais rude, l'œil grand, l'iris rougeâtre, la ligne latérale courbe, et Ianus plus proche de la gorge que de la nageoire caudale '.

La couleur du pholis est olivâtre avec de petites taches dont les unes sont blanches, et les autres d'une teinte foncée.

Ce blennie vit dans l Océan et dans la Méditerranée. Il s'y tient auprès des rivages, souvent vers les embouchures des fleuves ; il s'y plait au milieu des algues; it y uage avee agilité; il dérobe aisément à ses ennemis son corps eoduit d'une humeur ou bave très-abondante et tres-visqueuse, qui lui a fait donner un de ses noms; et quoiqu'il n'ait que deux déeinètres de longueur, il se débat avee courage contre ceux qui l'attaquent, les mord avee obstination, et défend de toutes ses forces une vie qu'il ne perd d'ailleurs que difficilement

Il n'aime pas seulement à se eacher au-dessous des plantes marines, mais encore dans I vase; il s'y enfonce comme dans un asile, ou s'y place comme dans une embuseade. II se retire aussi très-souvent dans des trous de rocher, $y$ pénètre fort avaut, et de la vient le non de Perce-pierre qu'on a donné à presque tous les blennies, mais qu'on lui a particulièrement appliqué. Il se nourrit de très-jeunes poissons, de très-petits crabes, ou d cufs de leuirs espèces; il recherche aussi les animaux à coquille et principalement les bivalves, sur lesquels la faim et sa grande bardiesse le portent quelquefois à se jeter san's précaution à l'instant ou il

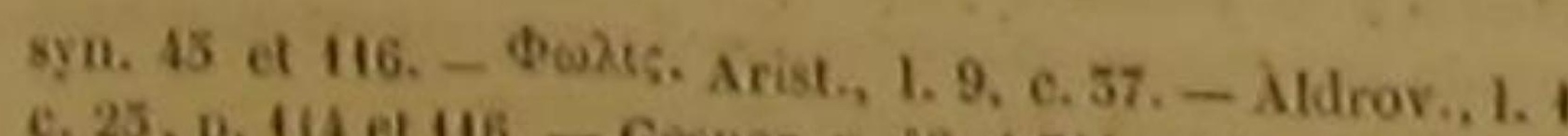
c. 25, p. 114 et $146,-$ Gesiner. p. 18 et 74 ; et (germ.) fol. 4

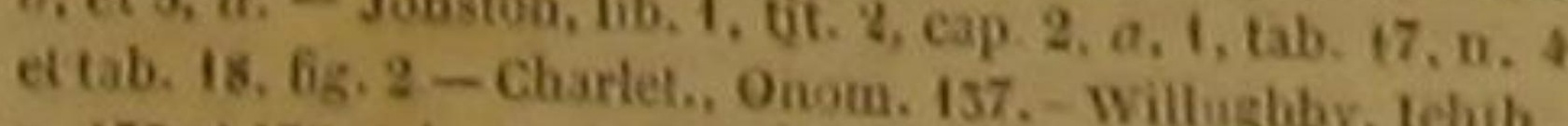
p. 153 et 155, tab. H, 6, fig. 2 et 4. - Rai, p. 75, n. 17 et 7 . - Perce-prerre, Empetrum, Alauda uon cristata, Ba.

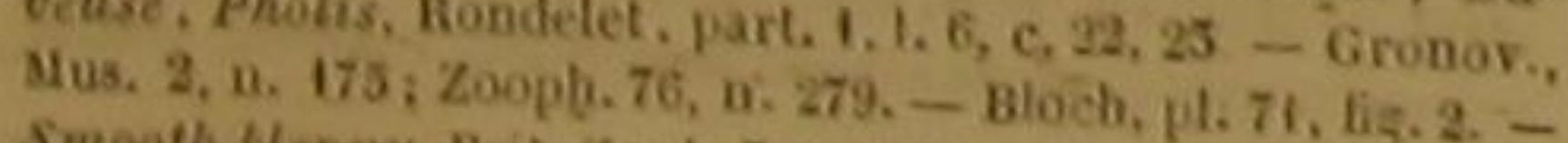

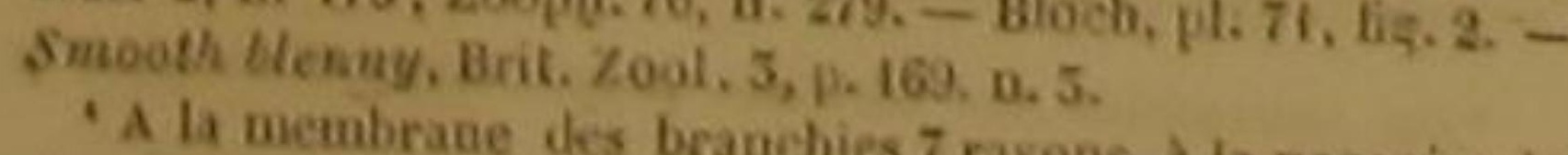
dos 28 , a chacune des pectorales 14 , a cliacune des jugulai-
res 2 . a celle de I'anus 19 , a celle de la queue 10 . force sur lui ; et e'est ainsi que fut pris comme dans un piége, un petit poisson que naus ćroyons devoir rapporter à l'espèce du blennie pholis, qui fut trouvé dans une huitre au moment où 'on en écarta les deux valves, qui devait y ètre renfermé depuis longtemps, puisque l'huitre avait été apportée à un très-grand nombre de myriamètres de la mer, et que découvrit ainsi, I $y$ a plus de vingt ans, dans une sorte d'habitation très-extraordinaire, mon compatriote et mon ancien ami M. Saint-Amans, professeur d'histoire naturelle dàns l'école centrale du département de Lot-et-Garonne, connu depuis ongtemps du public par plusieurs ouvrages rageux voyages dans les hautes Pyrénées '.

$$
\text { - }
$$

\section{LE BLENNIE BOSQUIEN 2 .}

Blennius boseianus, Lacep.

M. Sose, I'un de nos plus savants et plus zélés naturafistes, qui vient de passer plusieurs annềes dans les États-Unis d'Amérique, oủ il a exercé les fonctions de consúl de la république française, a découvert dans la Caroline ce blennie, auquel j'ai cru devoir donner une dénomination spécílique qui rappelât le nom de cet habile naturaliste. M. Bose a bien voulu me eommuniquer la description et le dessin qu'il avait faits de ce bleǹnie : I'une m'a servi à faire un article; j'ai fait graver l'autre avec soin ; et je m'empresse d'autant plus de temoigner iei ma reconnaissance à mon ancien confrère pour cette bienveillante communication, que, peu de temps avant son retour en Europe, il m'a fait remettre tous les dessins et toutes les descriptions dont il s'était occupé dans l'Amérique septentrionale, relativement aux quadrupèdes ovipares, aux serpents et aux poissons, en m'invitant a les publier dans l'Histoire naturelle dont cet article fait partie. J'aurai une graude satisfaction à placer dans mon ouvrage les résultats des observations d'un naturaliste aussi éclairé et aussi exact que M. Bose.

"Voyez le Journal de physique, oct. 1778. morsitans, capite crista nocilla, manuscrits. _. Blennius - fuseo, alboque variegato, pioua anali radiss apice recurvis " Habitat in Caroligs's I Note communiqunée par L L. Rose. très-intéressants, ainsi que par d'utiles et cou.

Le blennie qu'il a décrit. ressemble beaucoup au pholis dont nous venons de parler; mais il en differe par plusieurs traits de sa conformation, et notamment par la proportion de ses máchoires, dont l'inférieure est la plus longue, pendant que la supérieure du pholis est la plus avancée. D'ailleurs l'anus du pholis est plus près de la gorge que de la nageoire eaudale, et celui du bosquien est à une distance à peu près égale de ces deux portions du corps de l'animal '

La tête du bosquien est, en quelque sorte, triangulaire; le front blanchattre est un peu aplati ;'weil petit ; I'iris jaune; chaque mảchoire garnie de dents menues, très-nombreuses et très-recourbées; la membrane branchiale étendue et peu cachée par l'opercufe; le corps comprimé, dénué en apparence d'écailles, gluant, d'une couleur verte foncée, variée de blane, et relevée par des bandes brunes cépendant peu marquées.

Les nageoires sont d'une teinte obscure, et tachetées de brun. Les onze premiers rayons de celle du doss sont plus courts et plus émoussés que les autres. Ceux qui soutiennent la nageoire de l'anus, se recourbent en arrière à leur extrémité: cette nageoire de l'anus et la dorsale touchent celle de la queue, qui est arrondic

Le bosquien a près d'un décimètre de longueur totale; sa hauteur est de vingt-sept millimètres, et sa largeur de neuf.

Cette espèce, suivant M. Bose, est très-cemmune dans la baie de Charleston. Lorsqu'on veut la saisir, elle se défend en mordant son ennemi, comme la murène anguille, avec laquelle elle a beaucoup de ressemblance; et e'est cette manière de chercher à sauver sa vie, que M. Bose a indiquée par le.nom distinctif de morsilans qu'il lui a donné dans sa description latine, et que j'ai dû, malgré sa modestie, changer en une dénomination dietée par l'estime pour l'observateur de ce blennie.

\section{LE BLENNIE OVOVIVIPARE ${ }^{2}$}

Blennius viriparus, Lina., Gmel, ; Blennius ovovivipa-

De tous les poissons dont les petits éclosent 'A la nagenire du dos 50 rayons, à chacune des pectora-
les 12 , a chacune des jugulaires 2 . a celle de íanus 18 , a celle de la queue 12

'Blenne vivipare, Naubenton, Enc, méth. - Id. Bonna. terre, pi. de l'Enc. méth. - Fann. suecic. 517. - Moll. ' Da sous-genre Zuarcés dans le genre Blenniks s lon 'Du sous-genre Zuarcés dans le genre Blenniws s lon
M. Cnvier. D. dans le ventre de la femelle, viennent tout formés ò la lumière, et ont fait donner à leur mère le nom de Vivipurg, le blemnie que nous allons décrire, est P'espèce dans laquelle ce phénomène remarquable a pu ètre observé avec plus de soin et'connu avec plus d'exactitude. Voilà pourquoi on hii a donné le nom distinetif de Vivipare, que rious n'avons pas eru cependant devoir lui conserver sans modification, de peur d'induire plusieurs de nos lecteurs en erreur, t que nous avons remplacé par' celui d'Ovovivipare, afin d'indiquer que s'il n'éclót pas hors du ventre de la mère, s'il en sort tout formé, et dẹja doué de pres̀que tous ses attributs, il vient néanmoins d'un auf, comme tous les poissons, et n'est pas véritablement vivipare dans le sens oú l'on emploie ce mot lorsqu'on parle de l'homme, des quadrupedes ò mamelles, et des cétacées ' Voilà pourquoi nous allons entrer dans quelques détails relativement á la manière de venir au jour, du blennie dont nous écrivons 'histoire, non-senlement pour bien exposer tout ce qui pent concerner cet animal curieux, mais encore pour jeter un nonveau jour sur les différents modes de reproduction de la classe entiere des poissons.

Mais auparavant montrons les traits distineifs et les formes prineipales de ce blennie ?.

L'ouverture de sa bouche est petite, ainsi que sa téte: les máchoires, dont la supérieure est plus avancée que P'inferieure, sont garnies de petites dents et recouvertes par des lèvresépaisses; la langue est courte et lisse comme le palais; deux os petits et rudes sont placés aupres du gosier ; les orifices des narines paraissent chacun au bout d'un petit tube non francé; le ventre est court; l'ouverture de l'anus tres' grande; la ligne latérale droite; la nageoire de

Mus. Ad., Frid. 1, p. 69. - Tanglake, AcL Stockh. 1748, 0.52, tab. 2. - Gronov, Mus, 1, p. 65, n. 145; Zooph, p. 77, n. 205 .

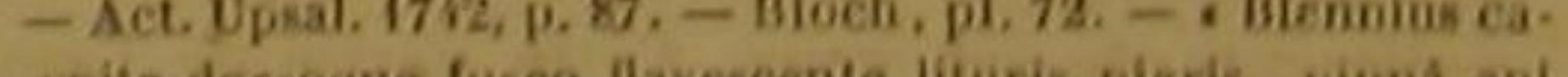

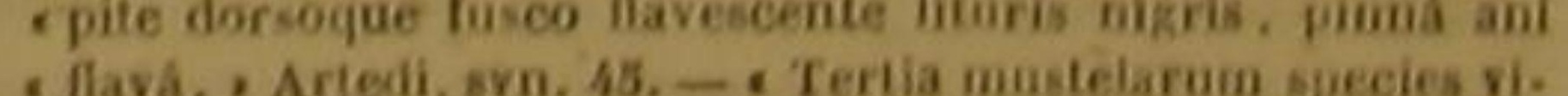
- vipara et marina, Schonev., p. 49.50 - . Mustela marima - visipara., Id., tab. 4, fig. 2, -Jonston, Pisc, p. 1, tab. 46, fig. 8. - A Mustela vivipara schoneveldii. , Wilimgthy, Ichith., p. 122. - Ral, p. 69. - - viviparous blenny. - Bril. Zool. צ, p. 172 . I. 5, tab. 10.

- On pent consufter a ce sojet ce que nous avons ierit dans le Discours sur ia nature des serp sur la nalure des poisson.

27 rayons a la membrane des branchies, 208 chaeune dea nageoires pectorsies, 2 a chacune des jugulaires, 1 as a eelles du dos, de ia yneuce et de ian. 
Ianus composée de plus de soixante rayons, et réunie à celle de la queue; et sôuvent cette dernière se confond aussi avec celle du dos.

Les écailles qui revêtent l'ovovivipare, sont très-petites, ovales, blanches ou jaunàtres et bordćes de noir; du jaune règne sur la gorge, et. sur la nageoire de l'anus; la nageoire du dos est jaunâtre, avec dix ou douze taches noires.

La chair de ce blennie est peu agréable au goùt; aussi est-il très-peu recherché par les pècheurs, quoiqu'il parvienne jusqu'a la longueur de cinq décimètres. Il est en effet extrèmement imprégné de matières visqueuses ; son corps est glissant comme celui des murènes; et ces substauces oléagineuses dont il est pénétré a l'intérieur ainsi qu'à l'extérieur, sont si abondantes, qu'il montre beaucoup plus qu'un grand nombre d'autres osseux, cette qualité phosphorique que l'on a remarquée dans les différentes portions des poissons morts et déja altérés '. Ses arêtes luisent dans l'obscurité, tant qu'elles ne sont pas entièrement desséchées; et par une suite de cette même liqueur huileuse et phosphorescente, lorsqu'on fait cuire son squelette, il devient verdảtre.

L'ovovivipare se nourrit particulièrement de jeunes crabes. Il habite dans l'Océan atlantique septentrional, et principalement auprès des co tes européenues.

Vers l'équinoxe du printemps, les œufs commencent à se développer dans les ovaires de femelle. On peut les voir alors ramassés en pelotons, mais encore extrèmement petits, et d'une couleur blanchátre, A la tìn de mai, au commencement de juin, ils ont acquis un accrolssement sensible, et présentent une couleur rouge. Lorsqu'ils sont parvenus à la couleur 'rouge. Lorsqu'ils sont parvenus à la grosseur d'un grain de moutarde, ils s'amollissent, s'étendent, s'allongent, et dejà l'on peut remarquer à leur bout supérieur deux points noir tres qui indiquent la tête du fơtus, et sont les rudiments de ses yeux. Cétte potus, et sont les rudiments de ses yeux. Cètte partie de l'embryon se dégage la première de la membrane ramollie qui compose l'ouf; bientot le ventre sort aussi de l'enveloppe, revêtu d'une antre membrane blanche et assez trevê d'une autre qu'on puisse apere et assez transparente pour qu'on puisse apercevoir les intestins au travers de ce tégument; enfin la queue, semblable à fil délié et tortueux, n'est plus contenue dans l'euf, dont le petit poisson se trontenue dans entierement débarrassé.

'Discours sur la uature des poisons.
Cependant l'ovaire s'étend pour se prèter au développement des foetus; il est, à l'époque que nous retracons, rempli d'une liqueur épaisse, blanchatre, un peu sanguinolente, insipide, et dont la substance présente des tibres nombreuses disposées autour des faetus comme un léger duvet, et propres à Jes empècher de se froisser mutuellement.

On a prétendu qu'indépendamment de ces fibres, on pouvait reconnaitre dans l'ovaire, des cilaments particuliers qui, semblables à descordons ombilicaux, partaient des tuniques de cet organe, s'étendaient jusqu'aux fotus, et elltraient dans leurs corps pour y porter vraisemblablement, a-t-on dit, la nourriture nécessaire. On rientend pas comment des embryons qui ont vécu pendant un ou deux mois entierement rerfermés dans un œuf, et sans aucune communication immédiate avec le corps de leur mère sont soumis tout d'un coup, lors de la seconde période de leur accroissement, à une manière passive d'étre nourris, et à un mode de circulation du sang, qui n'ont encore été observés que dans les animaux à mamelles. Mais d'ailleurs les observations sur lesquelles on a voulu établir l'existence de ces conduits comparés à des cordons ombilicaux, n'ont pas été convenablement contirmées. Au reste; il suffirait que les fotus dont nous parlons, eussent été pendant les premiers mois de leur vie, contenus dans un véritable œuf, et libres de toute attache immédiate au corps de la femelle, pour que la grande différence que nous avons indiquée entre les véritables vivipares et ceux qui ne le sont pas ', subsistât toujours entre ces mèmes vivipares ou animaux à mamelles et ceux des poissons qui paraissent le moins ovipares, et pour que la dénomination d'Ovovivipare ne cessát pas de convenir au blennie que nous décrivons.

Et cependant ce qui achève de prouver que ces filaments prétendus nourriciers ont une destination bien différente de celle qu'on leur a attribuée, c'est qu'à mesure que les foetus grussissent, la liqueur qui les environnes'épuise peu a peu, et d'épaisse et de presque coagulée qu'elle était, devient limpide et du moins très-peu visqueuse, ses parties les plus grossières ayant éte employées à alimenter les embryons.

Lorsque le temps de la sortie de ces petits animaux approche, leur queue, quí d'abord avait paru sinueuse, se redresse, et leur sert a ' Discours sur la nature des polssons. se mouvoir en differents sens, comme pour chercher une issue hors de l'ovaire. Si dans cet état ils sont retirés de cet organe, ils ne périssent pas à l'instant, quoique venus trop tôt à la lumière; mais ils ne vivent que quelques heures : ils se tordent commede petites murènes, sautillent, et remuent plusieurs fois leurs mâchoires et tout leur appareil branchial avant d'expirer.

On à vu quelquefois dans la même femelle jusqu'à trois cents embryons, dont la plupart avaient plus de vingt-cing millimètres de longueur'

Il s'écoule souvent un temps très-long entre le moment où les œúfs commencent à pouvoir étre distingués dans le corps de la mere, et celui où les petits sortent de l'ovaire pour venir au jour. Après la naissance de ces derniers, cet organe devient flasquê, se retire comme une vessie vide dair; et les mâles ne different alors des femelles que par leur taille, qui est moins grande, et par leur couleur, qui est plus vive ou plus foncée.

Nous ne terminerons pas cet article sans faire remarquer que pendant que la plupart des poissons pélagiens s'approchent des rivages de la mer dans la saison ou ils ont besoin de déposer leurs aufs, les blennies dont nous nous occupons, et qui n'ont point d'œufs à pondre, quittent ces mémes rivages lorsque leurs fatus sont đéjà un peu développés, et se retirent dans l'océan à de grandes distances des terres, pour y trouver apparemment un asile plus sưr contre les pêcheurs et les grands animaux marius qui à cette époque fréquentent tes côtes de locéan, et à la poursuite desquels les femelles chargées du poids de leur progéniture pourraient plus difficilement se soustraire ${ }^{2}$.

Je n'ai pas besoin d'ajouter que les $\propto$ cufs de ces blennies éclosant dans le ventre de la mère, et par conséquent devant être fécondés dans son intérieur, il y a un accouplement plus ou moíns prolongé et plus ou moins intime entre le mâle et la femelle de cette espéce, comme entre ceux des squales, des syngnathes, etc.

- Consulter particulièrement Touvrage de Schoneveld

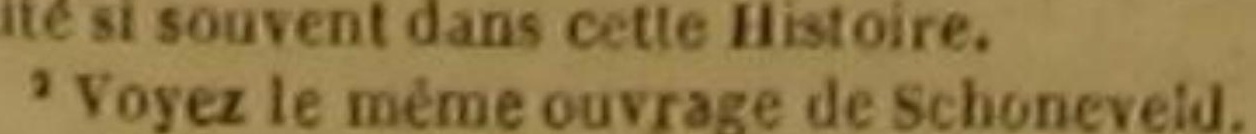

LE BLENNIE GUNNEL '

Blennius Gunnellus, Linn., Gmel, Lacep. ',

Le gunnel est remarquable par sa forme comprimée ainsí que très-allongée, et par la disposition de ses couleurs. Il est d'un gris jaunátre, et souvent d'un olivàtre foncé dans sa partie supérieure ; sa partie inférieure est blanche, ainsi que son iris; la nageoire dorsale et celle de la queue sont jaunes ; les pectorales présentent une belle couleur orangée, qui parait aussi sur la nageoire de l'anus, et qui y est relevée vers la base par des taches très-brunes. Mais ce qui frappe surtout dans la distribution des nuances du gunnel, c'est que, le long de la nageoire dorsale, on voít de chaque cóté neuf ou dix et quelquefois douze taches rondes ou ovales, placées à demi sur la base de la nageoire, et $\partial$ demi sur le dos proprement dit, d'un beau noir, ou d'une autre teinte très-foncée, et entourées, sur plusieurs individus, d'un cercle blane on blanchátre, qui les fait ressembler à ume prunelle environnée d'un iris.

La tête est petite, ainsi que les nageoires jugulaires ${ }^{3}$. Des dents aiguès garnissent les machoires, dout l'inférieure est la plus avancée. La ligne latérale est droite; l'anus p̉lus éloigné de la nageoire caudale que de la gorge.

Par sa forme générale, la petitesse de ses écailles, la viscosité de l'humeur qui arrose sa surface, la flgure de ses nageoires peetorales, le peu de hauteur ainsi que la longueur de celle de on dos, et enfin la vitesse de sa natation, le gunnel a beaucoup de rapports avec la murene anguille : mais il n'a pas une chaír aussi agréable au goût que celle de ce dernier animal. II vit dans l'Océan d'Europe; il s'y nourrit d'œufs de poisson, et de vers ou d'insectés ma-

'Gunnel, d'où vient yunneltus, signifie en anglais, plat bord, et dessigne is forme trés-allongee et tres comprimée du Wennie dont il est question dans cet article, - Butier fash, sur quelques cótes d Angleterre. - Liparis dans quelques

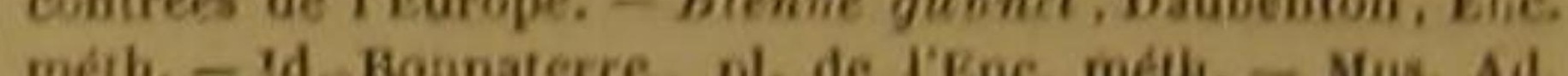
Frid. 1. p. 69. - Faun. Suecic. 318. - Bloch, pl. 65, fig. Ad.- Bennius maenlis circiter decem nigris, ete. Artedi. gen. 27, syn. 45. - Gronov., Mus. 1, n. 77; Zooght, p. 78 . n.267. - Willoghby, Ichth., p. 113 , tab. 6. 8, Eg. 5. - Mai, pisce, p. As, A. A, Gunellus, seba, mas. 5, p. 91, 6ab. 30 , . 6. - Brit Zool. 5, p. 174, D. 4. Gab. 10. 2 Du sous-genre GosskLLk, Cuv, (Muranolded, f. acep.) dans le gerre Blenvie; ou du geare Centronotus de schnei.

- A la nageoire dorale 88 ryyons, a chacone des pectora.

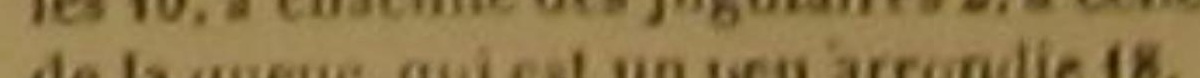


rins ; et il est souvent dévoré par les cartilagi- | excepté les huit derniers, dont six sont plus neux et les osseux un peu grands, ainsi que par longs et deux plus courts que les autres. La les oiseaux d'eau.

Nous croyons, avec le professeur Gmelin, devoir regarder comme une variété de l'espèce dı gunnel, un blennie qui a été décrit par Othon Fabricius dans la Foune du Groenlanid ', et qui ne parait différer d'une manière très-marquée et très-constante de l'objet de cet article que par sa longueur, qui n'est que de deux dé. cimètres, pendant que celle du gunnel ordinaire est de trois ou quatre, par le nombre des rayons de ses nageoires ${ }^{2}$, et par la couleur des taches cillées et rondes ou ovales de la nageoire du dos, dont communément einq sont noires, et einq sont blanchátres ou d'un blane éclatant.

\section{LE BLENNIE POINTILLÉ.}

$$
\text { Blennius punctulatos : }
$$

La description de ce blennien'a encore été publiée par aucun auteur. Nous avons vudans la collection du Muséum d'histoire naturelle, un individu de cette espèce; nous en avons fait graver une figure que l'on trouvera dans cette Histoire,

La tête est assez grande, et toute parsemée, par-dessus et par lés cótés, de petites impressions, de pores ou de points qui sétendent jusque sur les opercules, et nous ont suggéré le nom spécifique de ce blemnie. L'ouvertare de la bouche est étroite; les lèvres sont épaisses ; les dents aiguềs et serrées ; les yeux ronds et très-gros; les écailles très-facilement visibles; les nageoires pectorales ovales et très-grandes, lesjugulairescomposées chacune de deux rayons mous, ou filaments, presque aussi longs que les pectorales. La ligne latérale sé courbe au-dessus de ces mèmes peetorales, descend comme pour les environner, et tend ensuite directement vers la queue. La nageoire du dos, qui commence à la nuque, et va toucher la nageoire caudale, est basse; les rayous en sont garnis de petits filaments, et tous à peu près de la méme longueur.

OO. Fabr. Faun, Groeal, p. 155, n. 110.
i7 rayons a lamemb.

par Othon Fabrieus, so is des baranehies du gunnel decrit des pectorales, 4 a chacone des jughe dorsale, 17 a chacume nus, is a celle de la queue. conserve du Blennius supersoilion comme un individa mal luit, appartieat au suas-genre Clinus, dacs lech, qui, ponr nageoire de l'anus est séparée de la caudale, qui est arrondie '. Un grand nombre de petites taches irrégulières et nuageuses sont répandues sur le pointillé.

LE BLENNIE GARAMIT ${ }^{2}$, Blennius Garamit, Lacep.; Gadus Salarias, Forsk. ';

LE BLENNIE LUMPĖNE 4,

Blennius Lampenus, Walb., Lacep.s.

\section{ET LE BLENNIE TORSK ${ }^{6}$.}

Blenvius Torsk, Lacep. '.

Le garamit a été placé parmi les gades : mais il a êté regardé par Forskaēl, qui l'a découvert, comme devant tenir le milieu entre les gades $\mathrm{et}$ les blennies; et les caractères qu'il présente nou ont forcés à le comprendre parmi ces dernier poissons. Ses dents sont inégales; on en voit de placées vers le bout du museau, qui sont beaucoup plus longues que les astres, et qui, par leur forme, ont quelque ressemblance avec les crochets des quadrupèdes carnassiers. II présente diverses teintes disposées en taches nuageuses; la nageoire dorsale règne depuis la nuque jusqu'à la nageoire eaudale. La ligne latérale est à peine visible, et assez voisine du dos. Ce blennie est long de trois ou quatre décimètres. Il se trouve daus les eaux de la mer Rouge s?

A la nageoire du dos 47 rayons, 1 ehacune des pectorales 17 , a chacune des jugalaires 2 , a eelle de lanus 29 ; celle de la queue 15. 'Consere, pl. de IFnc, métb.

Saprins a in est pas cité par M, Givier qui donne le nom Cattorugine de Fons-genre des Blennies, dont le Blęnnias IVarile du blenne nipipare, Daphe

Bienne lumpine. Bonme Prodrom., Zool. danic., p. ix -- Plernine, méth. - Mall Tangbrosme, Strom. Sondm. 1, p. 515 , n. 4. - Ot. Fabric 5 Da sons. pente Clin. 109.

Strom. Gonim I. a dans le genre Blenoie, Cav. D. 205, n. 89. - Gade torst, Bon - Pennant, Zool. Brit. 5 , ' Espece douteuse. Le nom de Do, pl, de IEnc. méth. dune sur les cites de la Raltigue a moch ou de Torsk se rue, c'est-a-dire à un gade pourva de trois nageo de moi l a deux anales. 11 .

geoire dorsale 36 , d hanchiale du garamit 6 rayons, a la nades jugulaires 36 , a chacune des pectorales 14 , a chacuine
'Gadus garamil. Forsk, Faun, Arab, - Gade garamit. - pinniformibus quasi bifidis. ete. Artedi, syn. ga

DES POISSONS.

111

C'est dans celles de l'Océan d'Europe qu'habite le lumpène. Il y préfere les fonds d'argile ou de sable, s'y cache parmi les fucus des rivages, et y dépose ses œufs vers le commencement de l'étê. Sés écailles-sont petites, rondes, fortêment attachées. Sa couleur est jaunâtre sur la tête, blanchâtre avee des taches brunes sur le dos et les cótés, jaune et souvent tachetée sur la queue, blanche sur le ventre. Ses nageoires jugulaires, par leur forme et par leur position, ressemblent à des barbillons; elles comprennent chacune trois rayons ou filaments, dont le dernier est le plus allongé '.

Le torsk préfere les mers qui arrosent le Groenland, ou celles qui bordent I'Europe septentrionale. Il présente un barbillon, et ce filament est au-dessous de l'extrémité antérieure de la máchoire d'en bas. Ses nageoires jugulaires sont charnues et divisées en quatre appendices. Le ventre est gros et blane; la tête brune: les côtés de l'animal sont jaunátres; les nageoires du dos, de la queue et de l'anus, lisérées de blane. Ce blennie parvient à la longueư dé six ou sept décimètres, et à la largeur d'environ un décimètre et demi ${ }^{2}$.

\section{CINQUANTE-UNIĖME GENRE.}

LES OLGOPODES,

Whe seule nageoire dorsale; cetle nageoire din dos commençant au-dessus de la tete, el s'ctendant jusgu'a la nageoire caudale, on à peu prìs : un seul rayon à chaque nageoire jugulaire.

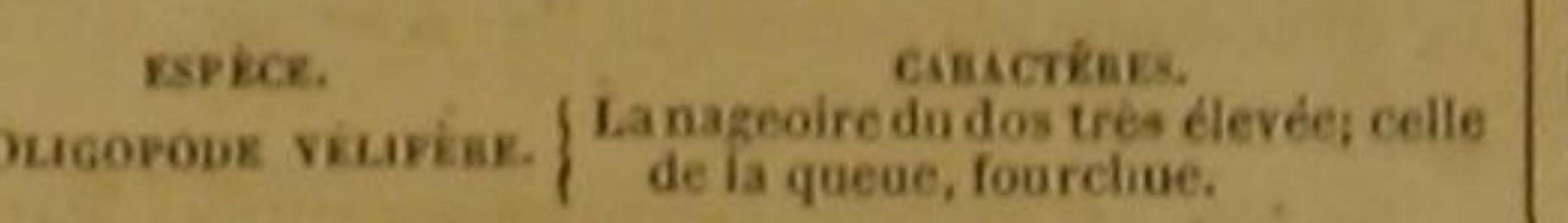

L'OLIGOPODE V'ÉLIFERE '.

Pleraclis velifera, Gronov., Cav,; Oligopodus veliferus, Lac.; Coryphena velifera, Pall. 4.

La position des nageoires inférieures nè permet pas de séparer les oligopodes des jugulaires,

- A la nazeoire dorsale du lumpène 63 rayons a chacune
des pectorales 13 , a chacune des jugulaires 5 , a celle de I'a. des pectorales 13 , a chacune des jugulaires 5 , à celle de l'anus 41 , à celle de la queve 18.

A ia membrane branchiale du torsk 5 rayons, a la nageoire du dos 31 , a chacune des pectorales 8 , a celle de l'a.
uus 21 .

'Pallas, Spicil. zool. 8, p. 19, tab. 5, fig. 1. - Corypheine éventail, Daubenton, Enc. méth. - Id, Bonnaterre, pl. de IẼc. mélh. 4 M. Cuvier place ce geore à la fín de la fimille des Sconberoides dans Yordre des A canthoptérygiens. D. avee lesquels ils ont d'ailleurs un grand nombre de rapports. Nous avons done été obligés de les éloigner des coryphènes, qui sont de vrais poissons thoracins, dans le genre desquels on les a placés jusqu'à présent, et auxquels ils ressemblent en effet beaucoup, mais dont ils differrent cependant par plusieurs traits remarquables. On peut les considérer comme formant une des nuances les plus faciles à distinguer, parmi toutes celles qui lient les jugulaires aux thoracins, et particulièrement les blennies aux coryphènes; mais on n'en est pas moins forcé de les inscrire à la suite des blennies, sur les tables méthodiques par le moyen desquelles on cherche à présenter quelques línéaments de l'ordre naturel des étres animés.

Parmi ces Oligopodes, que nous avons ainsi nommés pour désigner la petitesse de leurs nageoires thoracines, et qui, par ce caractère seul se rapprocheraient beaucoup des blennies, on ne connait encore que l'espece à laquelle nous croyons devoir conserver le nom spécifique de Velifère '.

C'est au grand naturaliste Pallas que l'on en doit la première description. On lui avait apporté de la mer des Indes I'individu sur lequel cette première description a été faite. La forme générale du vélifere est singulière et frappante. Son corps, très-allongé, très-bas et comprimé, est, en quelque sorte, distingué difficilement au milieu de deux immenses nageoires placées, I'une sur son dos, et l'autre au-dessous de sa partie inférieure, et qui, déployant une très. grande surface, mèritent d'autant plus le nom d'Éventail ou de Voile, qu'elles s'étendent, In première depuis le front, et la seconde depuis les ouvertures branchiales jusqu'a la nageoire de la queue, et que d'ailleurs elles s'élévent on s'abaissent de maniereque la ligne que l'on peut tirer du point le plus haut de la nageoire dorsale au point le plus bas de la nageoire de l'anus, surpasse la longueur totale du poisson. Chacune de ces deux surfaces latérales ressemble ainsi à une sorte de losange irrégulier, et eurviligne dans la plus grande partie de son contour. Et c'est a cause de ces deux voiles supérieure et inférieure, que l'on a mal à propos comparées à des rames ou á des ailes, que plusieurs naturalistes ont voulu attribuer à l'oligo-

- A la membrane des branchira 7 rayons, a ceile da dos 55 , a chacane des pectorales 14 , a chacuse des juga. 
pode vélifere la faculté de s'élancer et de se peut montrer la très-grande longueur que nous soutenir pendant quelques moments hors de venons de remarquer.

l'eau comme plusieurs pégases, scorpènes, trigles et exocets, auxquels on a donné le nom de Poissons volants. Mais si l'on rappelle les principes que nous avons exposés concernant la natation et le vol des poissons, on verra que les nageoires du dos et de l'anus sont placées de manière à ne pouvoir ajouter très-sensiblement à la vitesse du poisson qui nage, ou à la force de celui qui vole, qu'autant que l'animal nagerait sur un de ses cótés comme les pleuronectes, ou volerait renversé sur sa droite ou sur sa gauche; supposition que l'on ne peut pas admettre dans un osseux conformé comme le vélifere. Les grandes nageoires dorsale et anale de cet oligopode lui servent done principalement, au moins le plus souvent, a toumer avec plus de facilité, a fendre l'eau avec moins d'obstacles, particulierement, en montant ainsi qu'en descendant, à se balancer avec plus d'aisance, et à se servir de quelques courants latéraux avec plus d'avantages; et,de plus, il peut, en étendant vers le bas sa nageoire de l'anus, et en pliant celle du dos, faire descendre son centre de gravité au-dessous de son centre de figure, se lester, pour ainsi dire, par cette manœuvre, et accroitre sa stabilité. Au reste, le grand déploiement de ces deux nageoires de l'anus et du dos ajoute à la paruré que le vélifère peut présenter; il place en effet, au-dessus et au-dessous de ses cotés, qui sont d'un gris argenté, une surface très-étendue, toute parsemée de taches blanches oú blanchátres, que la couleur brune du fond fait très-bien ressortir.

La tête est couverte de petites écailles; la mâchoire inférieure relevée et garnie de deux rangées de dents; on n'en compte qu'un rang à la mâchoire supérieure. Les deux premiers rayons de la nageoire du dos sont très-courts à trois faces, et osseux. Le premier de la na geoire de l'anus est aussi très-court et la nale sècond est également osseux, mais il est assez long. On voit de chaque côté du corps et de la queue plusieurs rangées longitudinales d'écailles grandes, minces, légèrement striées, échanrées à leur sommet, et relevées à leur base panune sorte de petite pointe qui se loge dans l'éehanerure de l'écaille supérieure. Le corps proprement dit est très-court; l'anus est très-près de la gorge; et voila pourquoi la nageoire anale

\section{CINQUANTE-DEUXIÈME GENRE.} LES KURTES

Lecorps très-comprimé el carézé par-dessus ainsi que par-dessous : le dos éleve.
EsPECE.

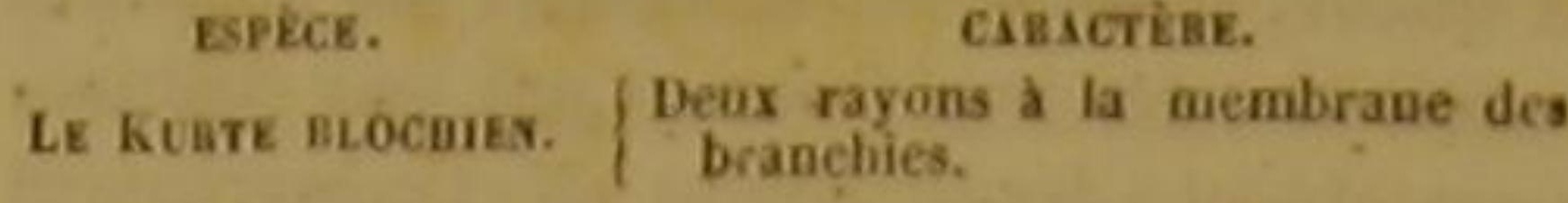
-

LE. KURTE BLOCHIEN ‘

Kurtus indicus, Bloch, Gmel., Cuv.; Kurtus Bloc bianus, Lacep. ${ }^{2}$.

Ce poisson lie les jugulaires avec les thoracins par la grande compression latérale de son corps, qui ressemble beaucoup à celui des zées t des chétodons. Cette conformation lui donne aussi une grande analogie avec les stromatées t c'est pour ces différentes raisons que nous l'avons placé à la fin de la colonne desjugulaires, comme nous avons mis les stromatées à la queue de celle des apodes. Le savant ichthyologiste Bloch nous a fait connaitre cet animal. qu'il a inserit dans un genre particulier, et auquel nous avons eru devoir donner le nom de cétèbre naturaliste.

Le blochiena le corps très-étroit et très-haut; et, de plus, une élévation considérable qui parait sur le dos, et qui ressemble à une bosse, lui a fait attribuer, par le zoologiste de Berlin , la dénomination générique de Kurlus, qui signifie bossu. choire inférieure un peu recourbée vers le haut, plus avancée que la supérieure, et garuie, ainsi que cette dernière, de plusieurs rangées de trèspetites dents; la langue courte et cartilagineuse; le palais lisse; l'œil gros; l'ouverture branchiale étendue; l'opercule membraneux; l'anus assez proche de la gorge; la ligne latérale droite, et nageoire de la queue fourchue ${ }^{3}$.

Il vit dans la mer des Indes; il s'y nourrit

'Bloc

Le bossu, Bonnaterre, pl. de IEnc. 'De la famille des Scombéroídes dans lordre des Acan. '2 rayons a la M. Cuvier. D.

tculé et 16 rayons articutís as la nanchies, 1 rayon non arcune des pectorales, 1 rayon non articulé et os 5 , 15 a chacalés a clacune des jugulaires, a rayons non 5 rayons arti-
Sa tête est grande; son museau obtus; la mâ- de crabes, ainsi que d'animaux à coquille; et, dès iors, il est peu surprenant qu'il brille de couleurs très-éclatantes.

Sa parure est maguifique. Ses écailles ressemblent à des lames d'argent; l liris est en partie blanc et en partie bleu; des taches dorées ornent le dos; quatre taches noires sont placées auprès de la nageoire dorsale; les pectorales et les jugulaires réfléchissent la couleur de l'or, et sont bordées de rouge; les autres nageoires offrent une teinte d'un bleu céleste que relève un liséré d'un jaune blanehâtre.

\section{CINQUANTE-TROISIÈME GENRE.} LES CRRYsostromirs '.

Le ecrps et la queue très-hauts, très-comprimés, et apla tis lateralement de manière à representer mi ovale une seule nagroire dorsale.

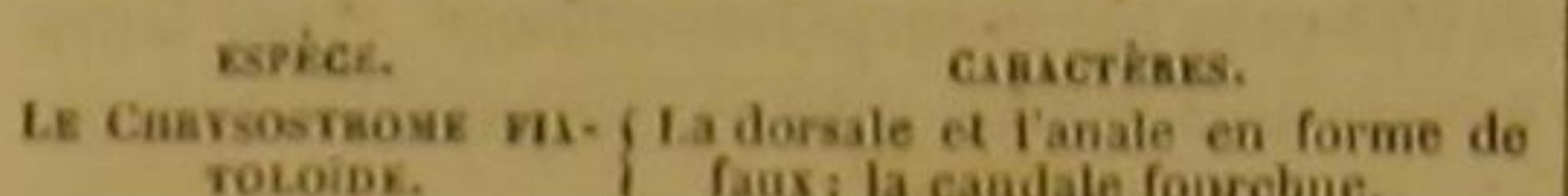
roLoipe.

L.E CHRY SOSTROME FIATOLOÏDE ? Clurysostromus flatoloides, Lacep.

Rondelet a donné la figure de cette espèce, qui a de très-grands rapports avec le stromatée fiatole, mais qui doit étre placée non-seulement dans un genre différent, mais méme dans un autre ordre que celui des stromaties, puisque ces derniers sont apodes, pendant que les chrysostromes ont des nageoires situées au-dessous de la gorge. Nous avons cependant indiqué cette analogie, et par le nom spécifique de Fialoloide, et par la dénomination générique de Chrysostrome, qui vient du mot grec xpugos (or), et d'un autre mot grec oтpâp (tapis, riche tapis), d'ou les anciens ont tiré le nom de Stromatée.

Notre chrysostrome, dont la ressemblance avec la fiatole a si fort frappé les habitants de plusieurs rivages de la Méditerranée, qu'ils lui ont appliqué le nom de ce dernier, se trouve particulierement aux environs de Rome. Sa parure est magnifique. Des raies longitudinales interrompues, et des taches de différentes grandeurs, toutes brillantes de l'éclat de l'or, sont

' Selon M. Cavier, ce genre doit étre sopprimê, car it netel tabili yne sur nae figure de ilondelet qui rejiresente le Sirumatée Fiatoe. Dans celte figure la pectora'e gauche.

'Fiatola, Ronúelet, part 1.1. 3, c. 2i, éd, de Lyon. 1358. iI. répandues sur ses larges cotés, et y représentent une sorte de tapis resplendissant.

La mâchoire inférieure est un peu plus avancée que la supérieure; et les lèvres sont grosses.

SECONDE SOUS-CLASSE.

POISSONS OSSEUX.

Les parties solides de linterieur du corps, osseuses. nesoses

PREMIERE DIVISION. Poissons qui ont un opercule et une membrane des

DIX-NEUVIÉME ORDRE

DE LA CLASSE ENTIÈnE DES POISSONS,

TROISIÈME OHDRE

DE LA PREMLìn Division des osseux.

Poissons thoracins, en qui ont des nageoires inferieures placees sons la poitrine el au-dessous des pectorales.

\section{CINQUANTE-QUATRIEME GENRE.}

LES LÉPIDOPES.

Le corps tris-allongè al comprime en forme de lame in seul rayon anx nageaires thoracines et à celle de ants.

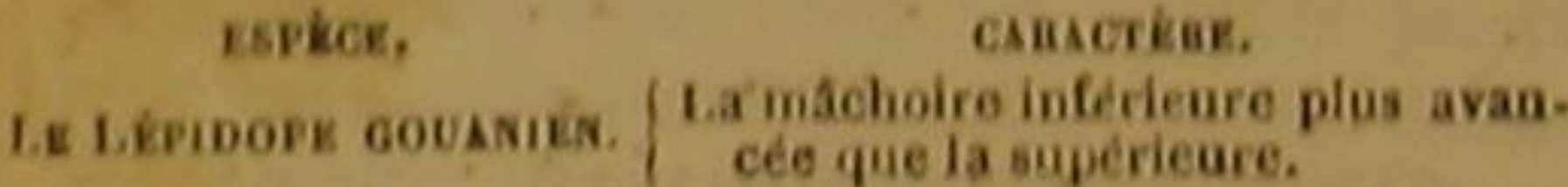

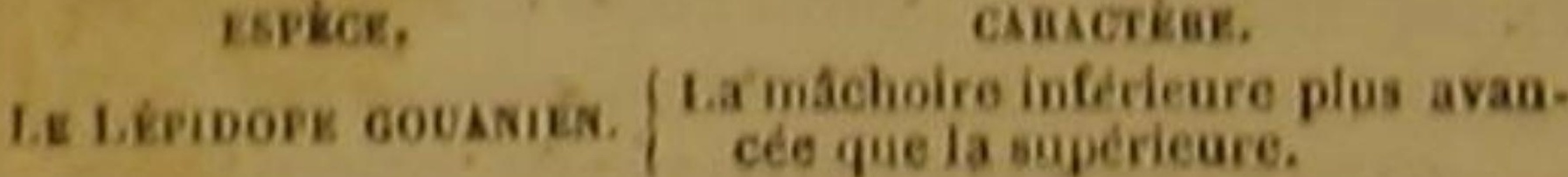

LE LÉPIDOPE GOUANIEN !

Lepidopus argyreus, Cuv,; Lepidopus gouanianus, Lacep. ?

Cette espèce a été décrite, pour la première fois, par mon savant confrère le professeur Gouan, de Montpellier, qui l'a séparée, avec beaucoup de raison, de tous les genres de poissons adoptés jusqu'a présent. Le nom distincti que j'ai cru devoir lui donner, témoigne le ser-

- Gouan, Histoire des poissons, p. 185. - Lépidope jar. refière, Bonnaterre, pl. de 1 Enc. méth. a Ce poisson forme un geure dans la famille des Tínioides de l'ordre des Acanthoptérygiens de M. Cuvier. II a eté de. crit sons les noms de Trichiurus raudatus, par Euphrasen de Trichiurus Gladius, par Holten; id Trichiurus ensiformis, par Vandelli; de Vandellius lusitanicus, par Staw, de Ziphotheea tetradens, par Montagn: de Scarcina ar. gyrea, par
M. Risso. D. 
vice que M. Gouan a rendu aux naturalistes en | des labres, le poisson décrit dans cet artiele: faisant connaitre ce curieux animal.

Cet osseux vit dans la Méditerranée. Il a de tres-grands rapports avec plusieurs apodes, particulièrement avec les leptures et les trichiures. Mais c'est le seul poisson dans lequel on n'ait observé qu'un seul rayon àla nageoire de l'anus, ni à chacune des nageoires inférieores que nous nommons thoracines pour toutes les espèces de l'ordre que nous examinons, parce qu'elles sont situcés sur le thorax. Ces nageoires anale et thoracines du gouanien ont d'ailleurs une forme remarquable: elles ressemblent à une écaille altongée, arrondie dans un bout, et pointue dans Jautre; et c'est de là que vient le nom générique de lépidope, lepidopus, pieds ou nageoires inférieures en forme d'écailles ou écailleux.

La tête du gouanien est plus grosse que le corps, et comprimée latéralement; le museau pointu; la nuque terminée par une arête; chaque mâchoire garnie de plusieurs rangs de dent nombreuses et inégales; l'œil voilé par un membrane, comme dans plusieurs apodes et jugulaires; l'opereule d'une seule pièce; I'onverture branchiale grande et en croissant '; l'anus situé vers le milieu de la longueur totale la ligue latérale peu apparente; la nageoire du dos très-basse et très-lougue, mais séparée de celle de la queue, qui est lancéolée; chaque écaille presque imperceptible; la couleur générale d'un blane argenté.

\section{CINQUANTE-CINQUIEME GENRE.} LES HIATULES.

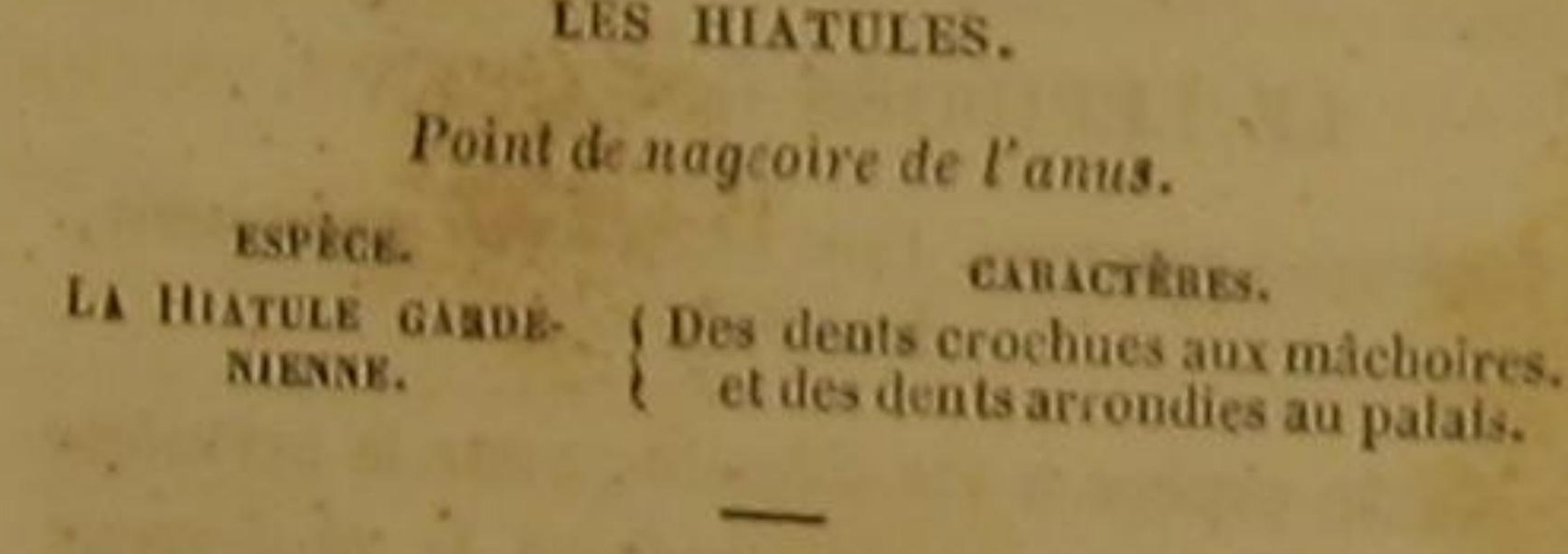

LA HATULE GARDÉNIENNE ${ }^{3}$. Hiatula gardenia, Lacep.; Labrus Hiatula, Linn.,
Guel. .

On a compris jusqu'à présent dans le genre 'A la membrane des branchies 7 rayons, à la mageoire dn
dlos 55 , a chaceme des nge dos 55 , a chacuue des nageoires inférieures ou thoracines I.
a celle de lanus $\mathrm{t}$. a celle de lanus 1.
2 Labre Piain

terre, pl. de IEnce, Daubenton, Enc. méth. - Id. Bonge

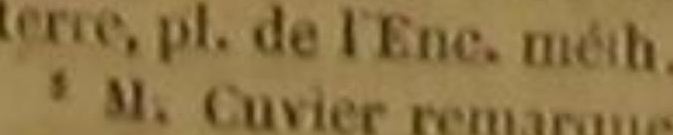

ans uageoire anale, efll gue les biatules sont des labres Bloch (cilt, de Schneid.) a pu le mettre avec les Trachypté.
res. U. mais les principes réguliers de classification auxquels nous croyons devoir nous conformer, s'opposent à ce que nous laissions parmi des osseux qui ont une nageoire de l'anus plus ou moins étendue, une espèce qui en est entièrement dénuée. Nous avons done placé la gardénienn dans un genre particulier; et comme, dans chaque ordre, nous commençons toujours par traiter des poissons qui ont le plus petit nombre de nageoires, nous avons cru devoir écrire le nom des hiatules presque en tête de la coloune des thoracins: elles auraient mème formé le premier genre de cette colonne, si les lépidopes n'avaien pas une nageoire de l'anus extrèmement petite, réduite à un seul rayon, pour ne pas dire à une seule écaille, si de plus ils ne présentaient pas des nageoires thoracines également d'un seul rayon, et si d'ailleurs ils ne se rapprochaient pas de très-près par le corpstrès-allongé, et par leurs formes très-déliées, de la plupart des osseux apodes ou jugulaires.

Le nom distinetif de Gardénienne indique que c'est au docteur Garden qu'est due la découverte de cette espèce, qu'il a vue dans la $\mathrm{Ca}$ roline. On soupçonnera aisément qu'elle doit offrir beaucoup de traits communs avec les labres, parmi lesquels Linnée et d'autres célèbres naturalistes l'ont comptée. Elle a, en effet, comme plusieurs de ces labres, les lèvres ex. tensibles, et les rayous simples de la nageoire dorsale garnis, du cóté de la queue, d'un filament allongé.

Les dents qui hérissent les mâchoires sont crochues; celles qui revètent le palais sont arde sphère. La nageoire du dos est noire dans partie postérieure; l'opercule pointillé sur ses bords; la coulear générale de l'animal variée par six ou sept bandes transversales et noires ; la ligne latérale droite; la nageoire de la queue rectiligne '.

aizullons et 14 rayone des branchles, 17 rayons simple I 5 rayons articulés à chacuese des thoracines, 21 rayongle ta nageoire de la queue. rondies de maniere a représenter une portion rayons a chacune des nageoires pectorales , I ra du dos. 6
CINQUANTE-SIXIÈME GENRE. LES CÉPOLES.

Une nageoire de l'anis; plus d'un rayon à chaque nageoire thoracine s le corps et la quene très-allonges et comprimés en forme de lame : le ventre à peu prés de la longueur de la téte; les ecailles très-petites.

\section{PREMIER SOUS-GENRE.}

Point de rayons simples ou d'aiguillons aux nagevires.

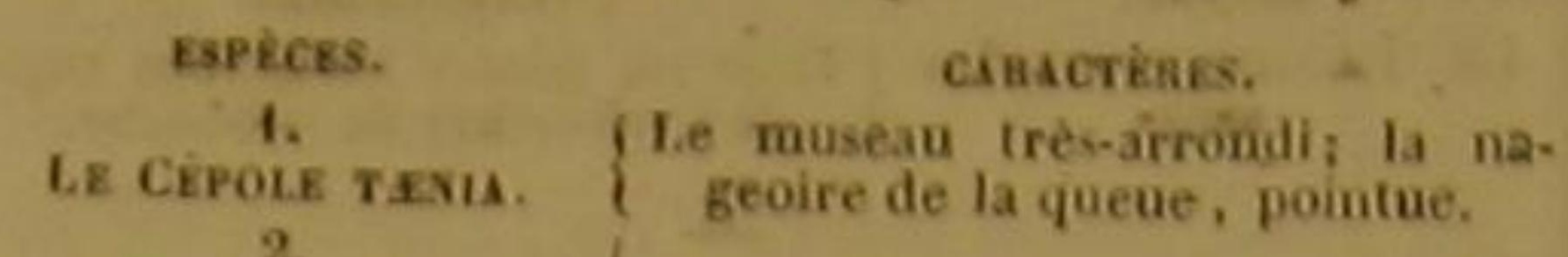

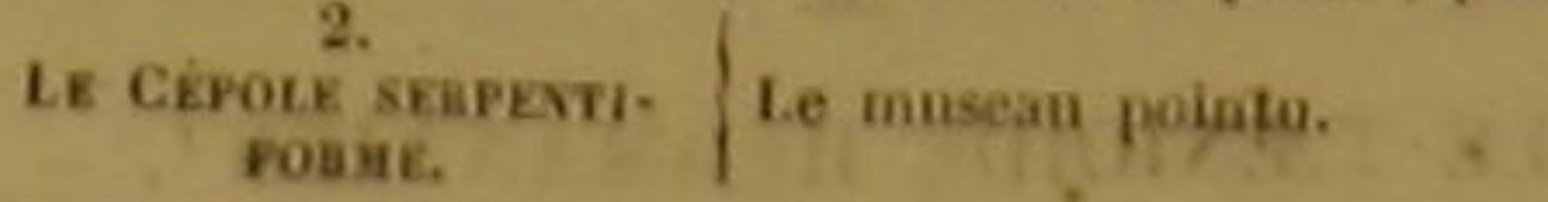

SECOND SOUS-GENRE.

Des rayons simples ou aiguillons aux' nageoires.

5.
LE Cérouk racay.
rekin.

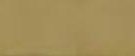

LE CÉPOLE TENIA !

Cepola Teuia, Linn, Gmel, Lacrp,; Cepola rubescens, Lino., Cur.?

Presque tous les noms donnés à ce poisson désignent la forme remarquable qu'il présente: ces mots ruban, bandelette, flamme, lame, épée, montrent en quelque sorte à l'instant son corps très-allongé, très-aplati par les cótés, très-souple, très-mobile, se roulant avec facilité autour d'un cylindre, frappant l'eau avec vivacité, s'agitant avee vitesse, s'échappant comme l'éclair, faisant briller avec la rapidité

' Spase ou épele, dans plus. départ. mériu. - Flamme, Cavagiro. - Freggia, - Villa. - Cépole Iénia, Dauber-

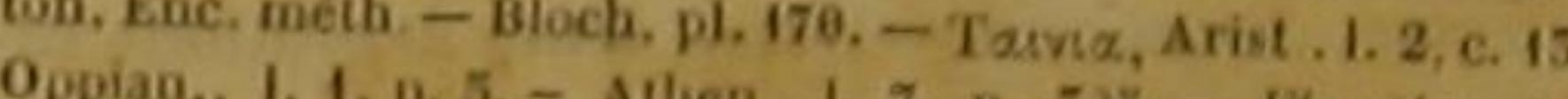
oppian., i. 1, p. 5. - Allien., 1. 7, p. 525. - Flambo, Se Tcenia, Gesner, p. 958, et (germ. fol. 55 , af c. 16, 17, -

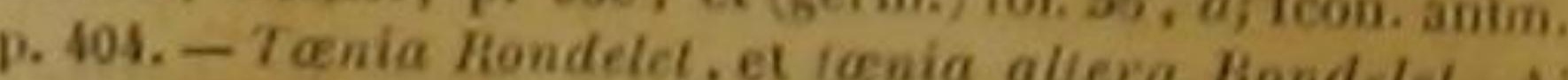
drov., 1. 5, c. 50. p. 569. 570 . - Jonst, p. 25, Rondelel. A. - Chariet. Oaom., p. 126, - - Tania prima Roudeletif, Rai, p. 39. - : Txnia, ichthyopo is Romanis cepole dicts. Wilughby, ichthyol., p. 116. - Tæuia altera Kondeletii. Romare, Dict - Kuban de mer. Flambeau, Valmont d-

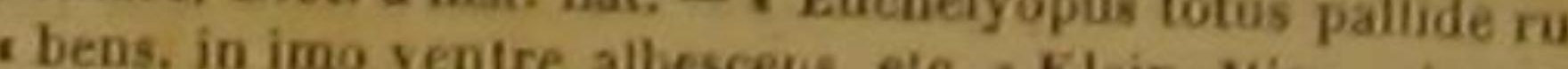
p. 57, n. 10. - Nota. Nous croyons devoir preniss,. pisc. 14. leurs que lorsque nous citons, dans tes différents articles de cetle Histoire, les ouvrages dans lesquels lés anteurs gies do ont précédés ont traité des mémes poissons que nons, et le dessins yu ils oat donnes de ces animaux, nous nentendon des figmes rien lexactitude de leurs descriptions, ni celle diquer qes quils ont pmbliées; notre but est seulement d inteut a telie on telle des ou heus of tervations ge rapporcupés.
115

de la flammie les teintes rouges qu'anime l'éclat argentin d'un grand nombre de ses écailles, disparaissant et reparaissant au milieu des eaux comme un feu léger, ou cédant à tous les mouvements des flots, de la même manidre que les flammes on banderotes qui volligent sir ine sommets des mâts les plus élevés obeissent ì tous les courants de l'atmosphère. Les ondulations par lesquelles ce cépole exécute et manifeste ses divers moûvements, sont d'autant plus sensibles, qu'il parvient à une longueur très-considérable relativement à sa hauteur, et surtout a sa largeur : Il n'est large que d'un très-petit nombre de millimètres, et il a souvent plus d'un mètre de longueur. Le rouge, dont il resplendit, colore toutes ses nageoires. Cette teinte se marie d'ailleurs à l'argent dont il est, pour ainsi dire, revêtu, tantót par des nuances insensiblement fondues les unes dans les autres, tantot par des tảehes très-vives; et remarquons que la nourriture ordinaire de ce poisson si richement décoré consiste en crabes et en animaux a coquille.

Sa tête est un peu large; son museau arrondi; sa mâchoire supérieure garnie d'une rangée, et sa máchoire inférieure de deux rangées de dents aiguès et peu serrées les unes contre les autres; la laugue petite, large et rudes l'espace qui sépare les yenx, très-étroit; l'ouverture branchiale assez grande; l'opercule composé d'une seule lame, et la place qui est entre cet opercule et le museau, percée de plusieurs pores; la ligne latérale droite; la nageoire dorsale très-longue, de mème que celle de l'anus; et la caudale pointue ?

Le corps du tænia est si comprimé, et par conséquent si étroit, ses téguments sont si minces, et toutes ses parties si pénétrées d'une substance oléagíneuse et visqueuse, que lorsqu'on le regarde contre le jour, il parait trés. transparent, et qu'on aperçoit très-facilement une grande portion de son intérieur. Cette conformation et cette abondance d'une matiere huileuse n'annoncent pas une saveur trèsagréable dans les muscles de ce cépole; et en effet on le recherche peu. Il habite dans la $\mathbf{M} e$. diterranée, et y préfere, dit-on, le voisinage des cotes vaseuses.

IA la membrane des branchies 6 rayons, 4 L nageoire d

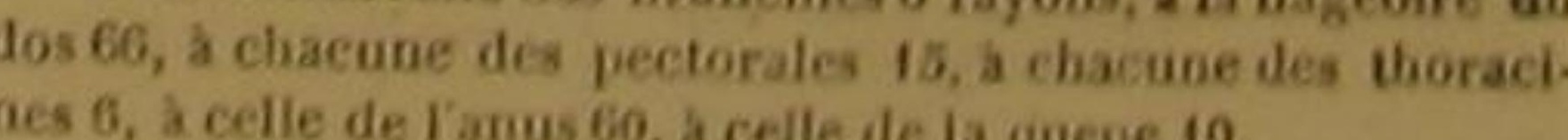


LE CÉPOLE SERPENTIFORME -

Cepola rubescens et Cepola Tænia, Linn., Gmel.; Cepola serpentiformis, Lacep. ${ }^{3}$.

Le tænia a le museau arrondi; le serpentiforme l'a pointu. La nageoire caudale du tænia est pointue; il parait que celle du serpentiforme est fourchue. On a done eu raison de ne pas les rapporter à la même espèce. On a comparé le second de ces cépoles à un serpent; on l'a appelé Serpent de mer, Serpent rouge, Serpent rougeatre; et voilà pourquoi nous lui avons donné le nom distinctif de Serpentiforme. Sa couleur est d'un rouge plus ou moins pâle, avec des bandes transversales, nombreuses, étroites, irrégulières, et un peu tortueuses. L'iris est comme argenté; les dents sont aiguěs, la nageoire du dos et celle de l'anus trèslongues, et assez basses ${ }^{3}$. Le serpentiforme vit dans la Méditerranée, de même que Is tænia.

\section{LE CÉPOLE TRACHYPTĖRE.}

Cepola trachyplera, Lino., Gmcl., Lscep. ‘.

C'est dans le golfe Adriatique, et par conséquent dans le grand bassin de la Méditerranée que l'on a vu le trachyptere. II préfere done les mèmes eaux que les deux autres cépoles dont nous venons de parler. Ses nageoires présentent des aiguillons ou rayons simples, et sont rudes au toucher. Sa ligne latérale est droite, et tracée, pour ainsi dire, par une rangée d'écailles que l'on peut distinguer facilemeat des autres.

¿Ćpole serpent de mer, Daubeaton, Ene. méth, - Id. - Ophidium meeroptheralme. - Mus. Ad. Frid. 2, p. 65. Bruno. Pisc. Massit, p. 28, n. 39. - Ternia s, 1, p. 250. cens dicta. Artedi, syo. 115 . - Serpens marinus ruidesses-

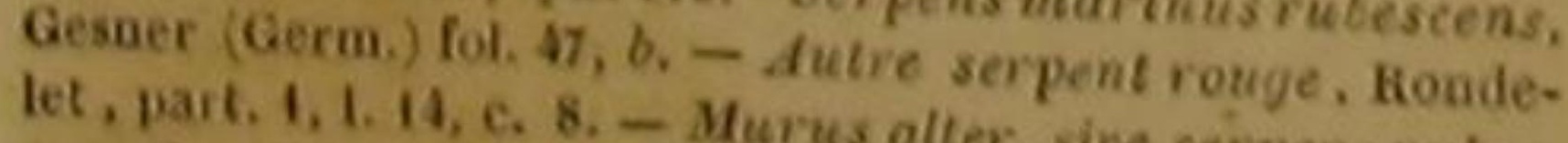
cens Rondeletii, , . 8. - Murus alter, sive seipens rubesspecies censend, w, will. 1. 5, c. 28 , p. 367 , - Teenia potiü 'M. Cuvier (Reg, anim prem, ichth, p. 118.

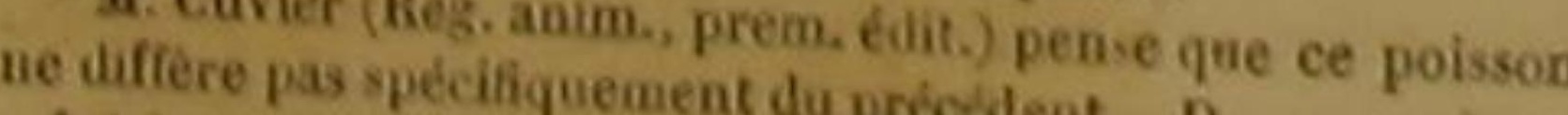
A la nageoire dorsale 69 payones t ch. D. 政 de la queue 12.

ne differe pas des pentchone pas cette especce, qui peut-ëtre

ae diftere pas des précédentes.' D. 1 .
CINQUANTE-SEPTIEME GENRE.

LES TENIOIDDES.

Une nageoire de lanus; les nageoires pectorales on forme de disque, et composees d'un grand nombre de rayons ; le corps et la queue trés-allonges et compri. mes en forme de lame; le ventre à peu prés de la longueur de la tete; les écailles très-petites; les yeux. à peine visibles; point de nageoire caudale.

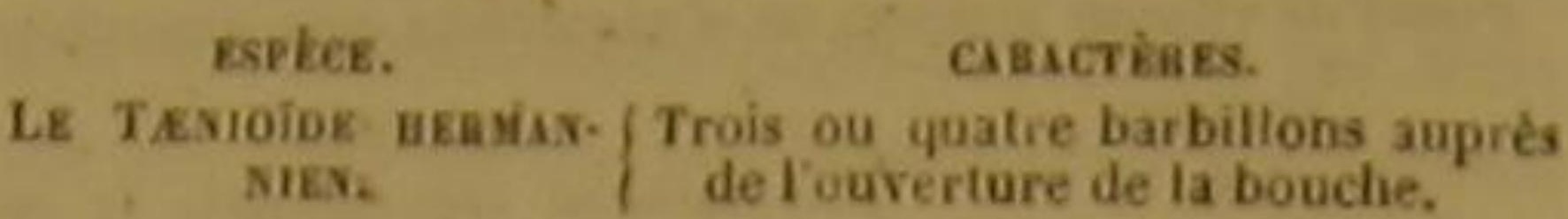

\section{LE TANIOİDE HERMANNIEN'.}

\section{Tænoioides Hermanni, Lacep.; Cepola ceecula, BI.}

Schu.; Gobioides rubieunda, Buch.

Ce poisson, que nous avons dû inserire dans un genre particulier, n'a encore été décrit dans aucun ouvrage d'histoire naturelle. Nous lui donnons un nom générique qui désigne sa forme très-allongée, semblable à celle d'un ruban ou d'une banderole, et très-voisine de celle des cépoles qui ont été appelés Tania. Nous le distinguons par l'épithète d'Hermannien, pour donner au savant Hermann de Strasbourg une nouvelle preuve de l'estime des naturalistes, et de leur reconnaissance envers un profésseur habile qui concourt chaque jour au progres des sciences et particulièrement de l'ichthyologie

Ce tænioide, dont les habitudes doivent ressembler beaucoup à celles des cépoles, puisquil se rapproche de ces osseux par le plus grand nombre de points de sa conformation et qui doit surtout partager leur agilité, leur vitesse, leurs ondulations, leurs évolutions rapides, en differe cependant par plusieurs trait remarquables.

Premièrement, ses yeux sont si petits qu'on ne peut les distinguer qu'avee beaucoup de peine, et qu'après les avoir cherchés souvent pendant longtemps, on ne les aperçoit que comme deux petits points noirs; ce qui lui donne un rapport assez important avec les cécilies.

Secondement, il n'a point de nageoire cau dale; et sa queue se termine, comme celle des trichiures, par une pointe très-déliée, près de l'extrémité de laquelle on voit encore s'étendre

'Ce genre Tæniolde n'est pour M. Cuvier wing sous geure dans le genre Gubous, parmi les Acanthopterygiens
de la famille dis Gobioides. D. la longue et très-basse nageoire dorsale, qui part très-près de la tête, et tire son origine de la partie du dos correspondante à l'anus.

Troisièmement, la nageoire anale est trèscourte.

Nous devons ajouter que la tête de l'hermannien est comme taillée à facettes, dont la figure que nous avons fait graver, montre la forme, les dimensions et la place. La peau de l'animal, dénuée d'écailles facilement visibles, laisse reconnaitre la position des principaux muscles latéraux; on voit des points noirs sur les pectorales, ainsi que sur la nageoire de I anus, et des raies blanchátres sur la tète; les barbillons, situés auprès de l'ouverture de la bouche, sont très-courts, et un peu inégaux en longueur.

\section{GINQUANTE-HUITIEME GENRE.} LES сови

Les dçux nageoires thoracines rèmìies line à l'autre deux nageoires dorsales.

PREMUER SOUS-GENRE.

Les nageoires pectorales atlachices immediatenent au corps de Tanimat.

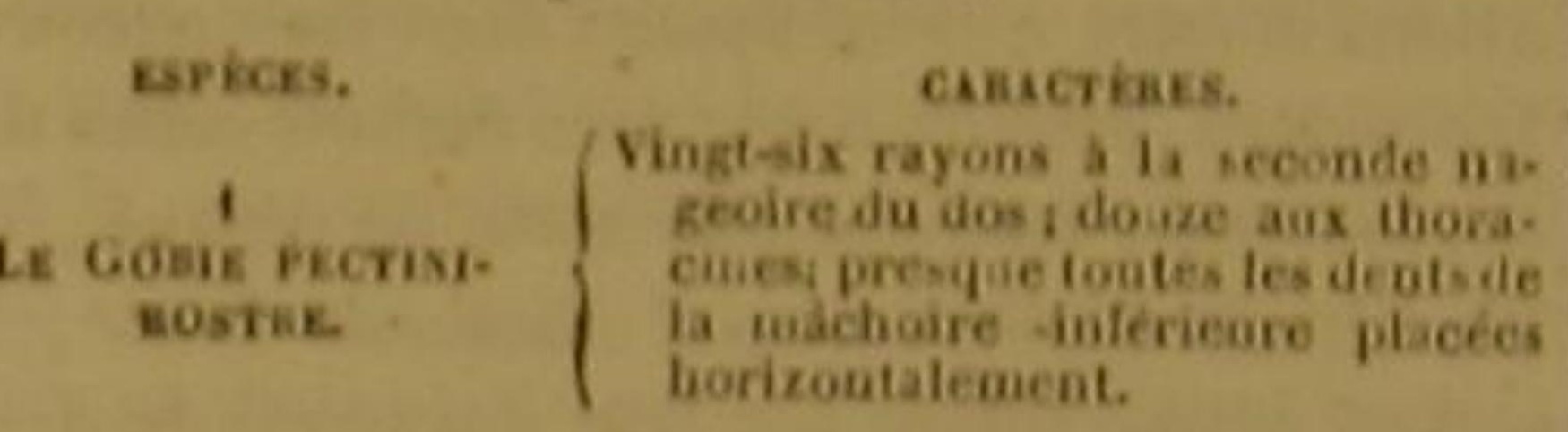

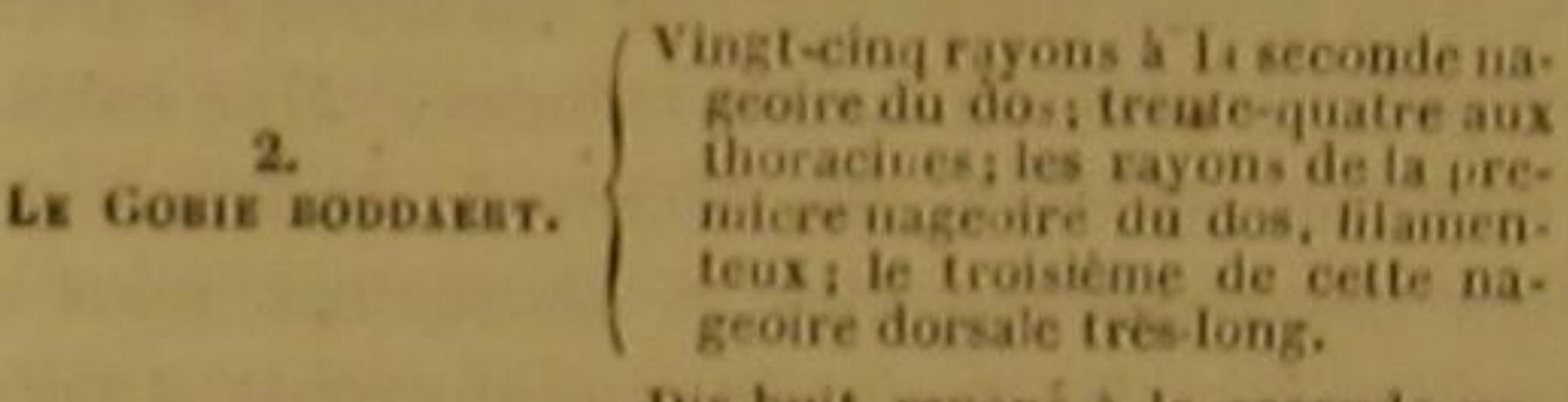

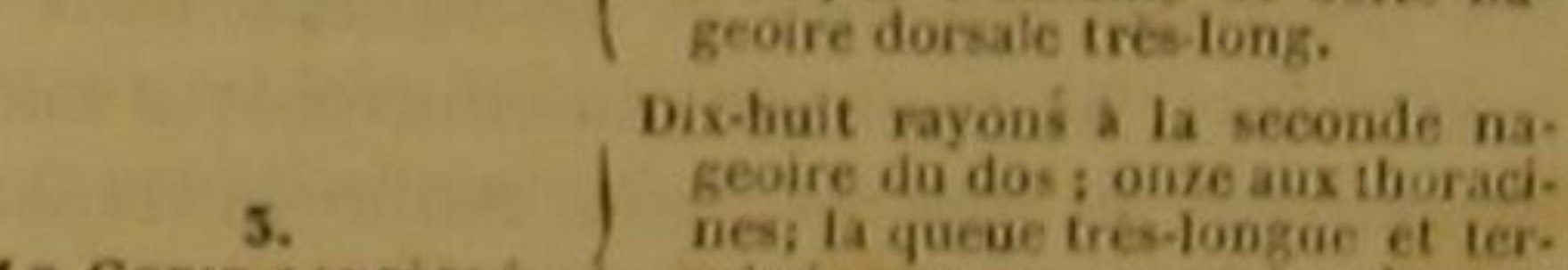

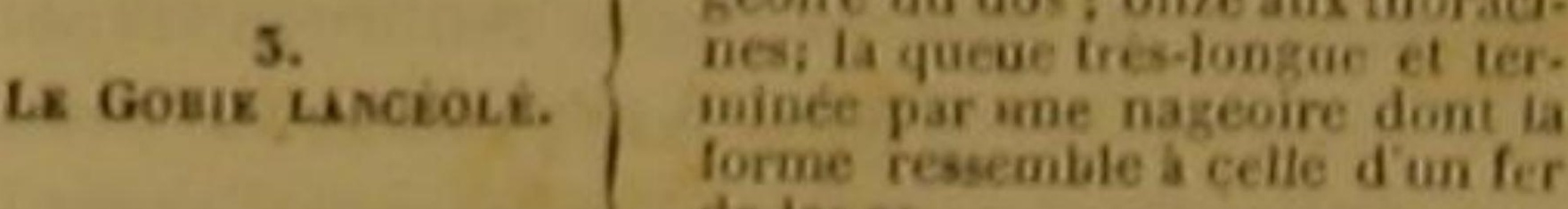

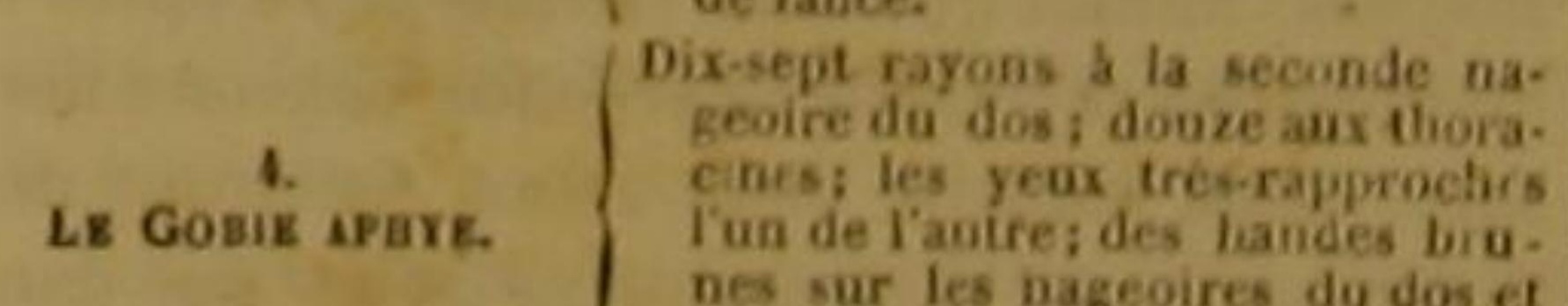

nes sur les nageoires da dos et
de l'anus.

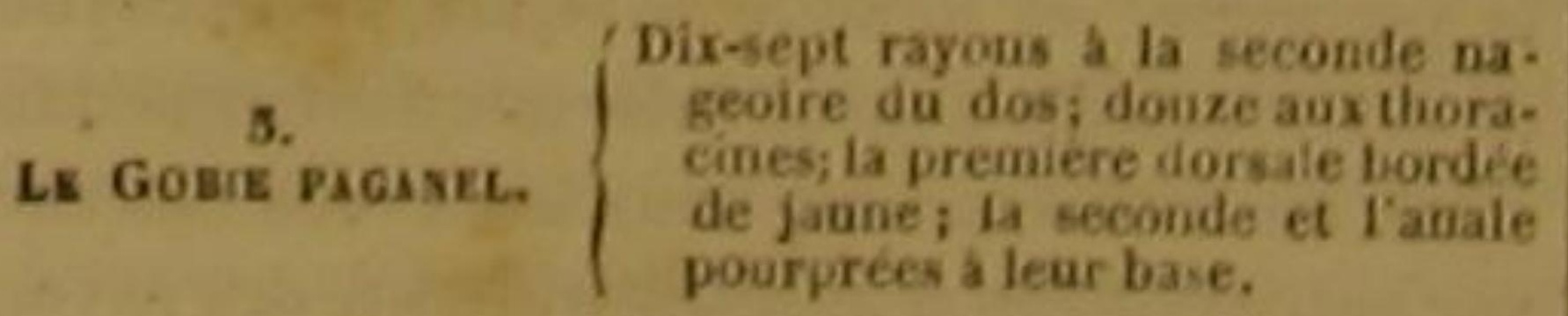

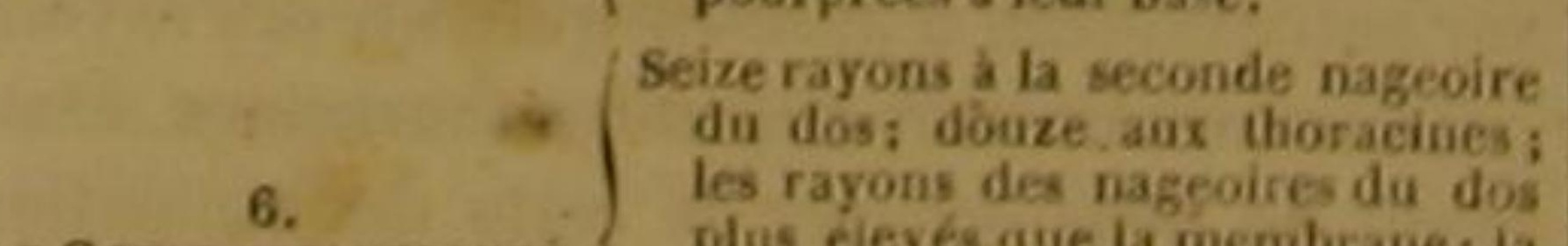

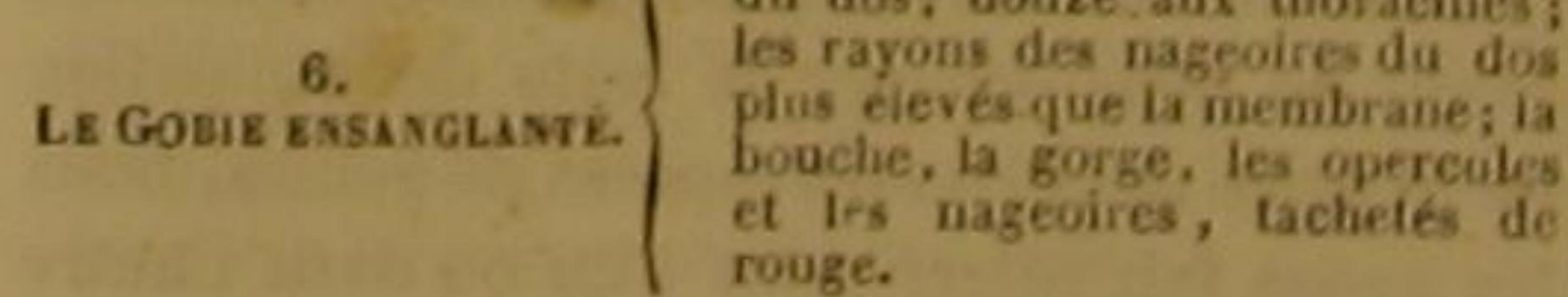

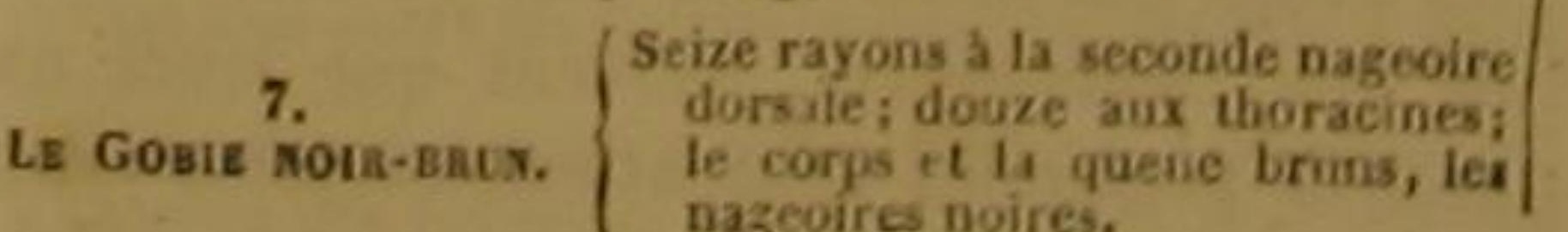

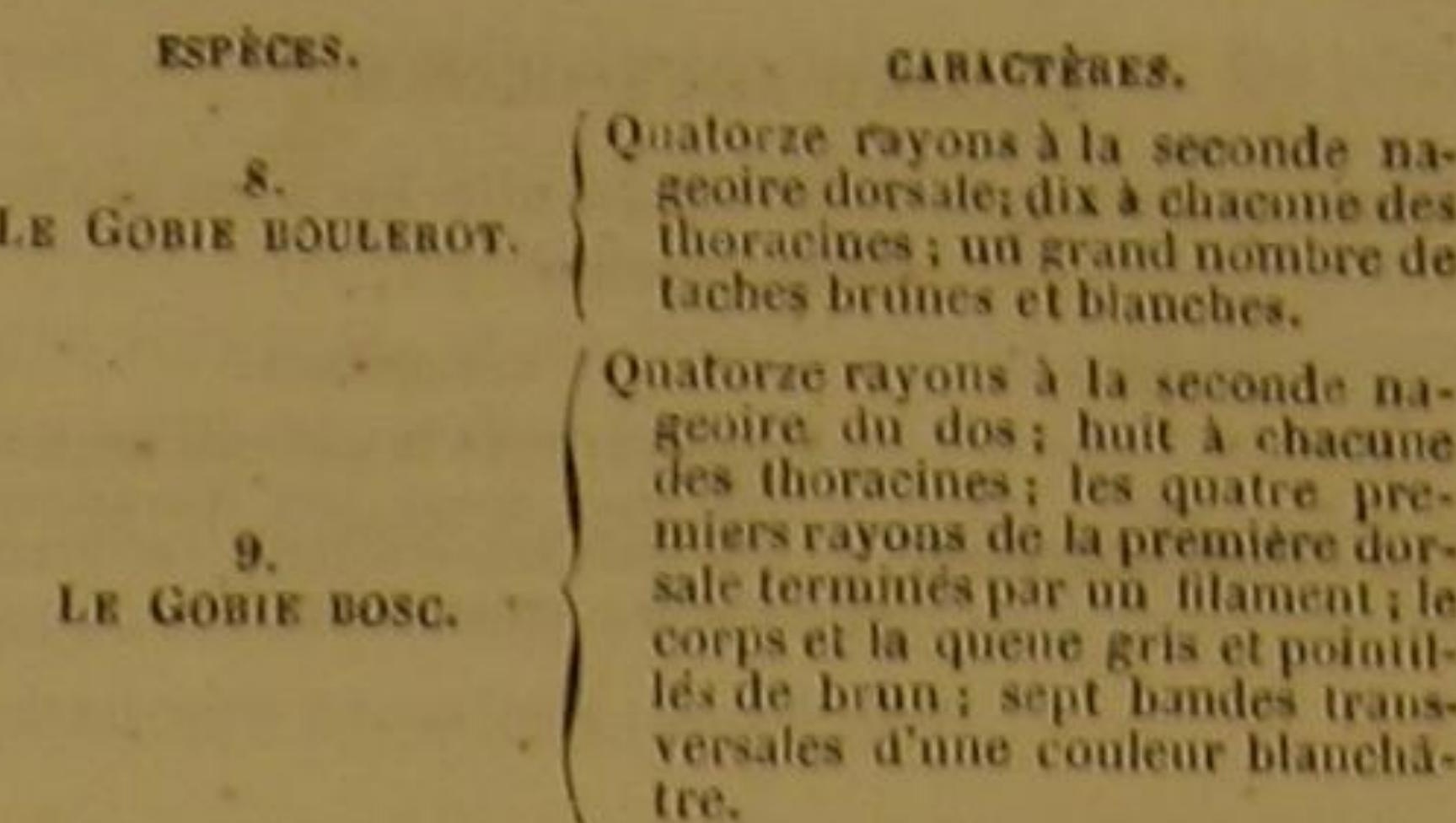

Quatorze rayous a la seconde ma-
keore do dosid douzo aux itora-

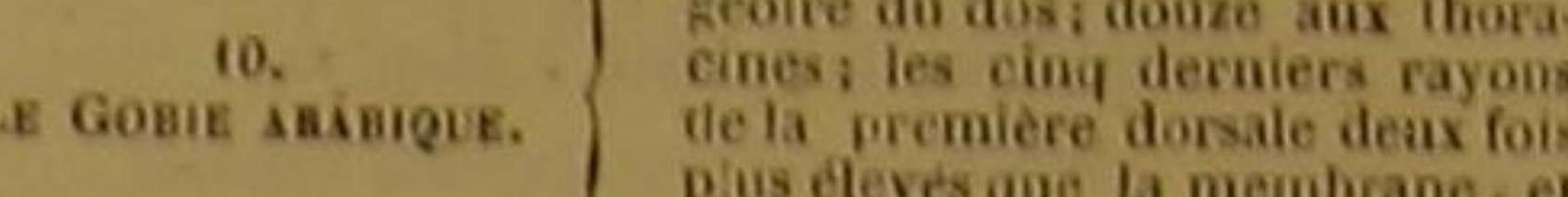
plis devers que Ia membrane,
lermines par un filament rouge.

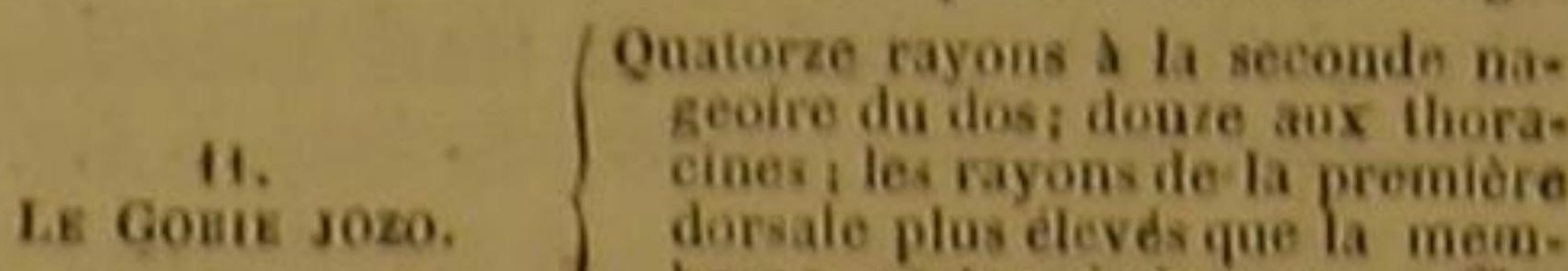
dorsale plus elevés que la mema nent, les thoracioes bleues.

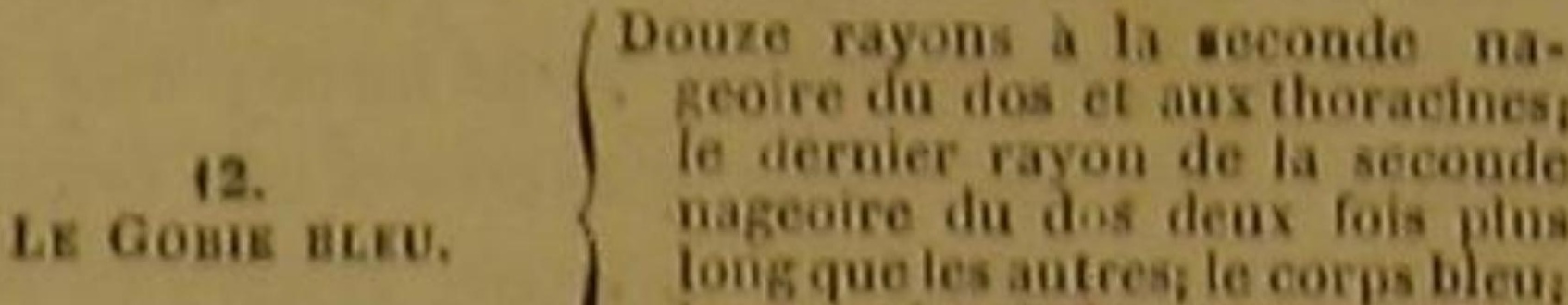
ta nageoire de 1 .
bordede de noir.

(Doure rayons a la seconde na-

15.
15. ricuroipoint do tac
la prealere dorsale.

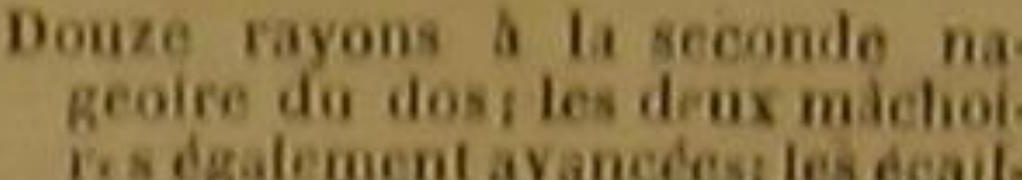

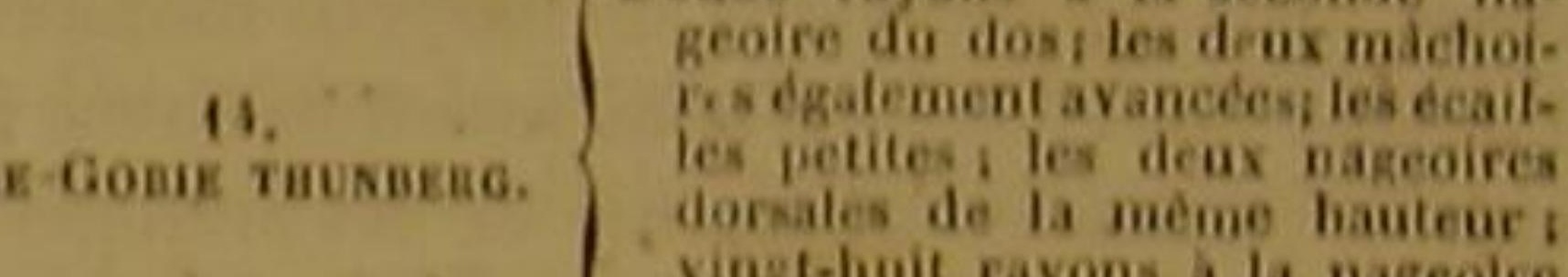
dorales de la mème hauteur:
vinit-hinit rayogs a la nageolre
de la quene.

(Ouze rayous a laseonnde nacoire

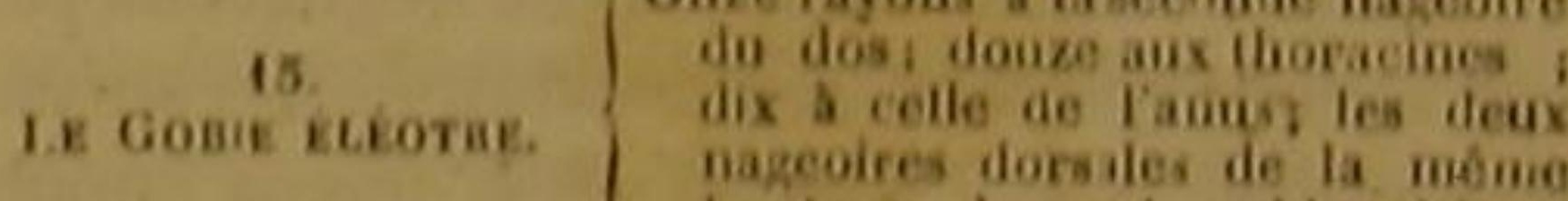

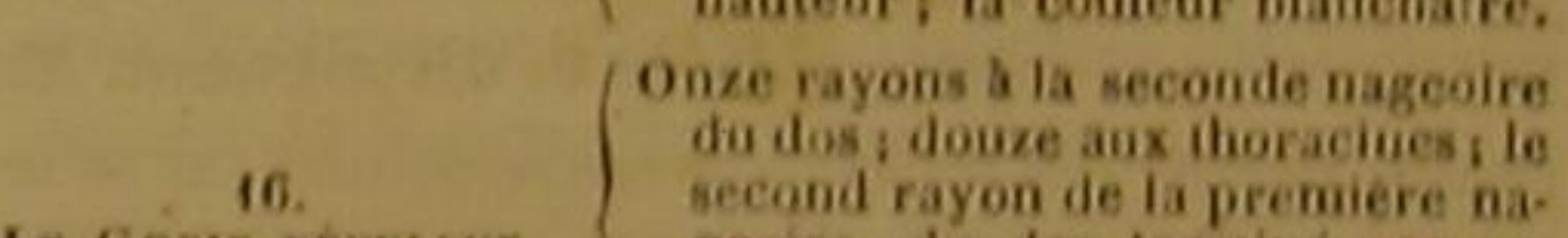

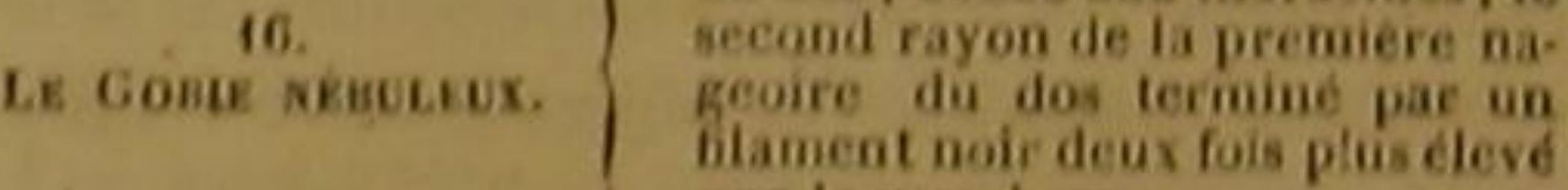
$17 . \quad \begin{gathered}\text { Onze rayons a la seconde nageoire } \\ \text { dorsalo: six a clacune des iloora }\end{gathered}$

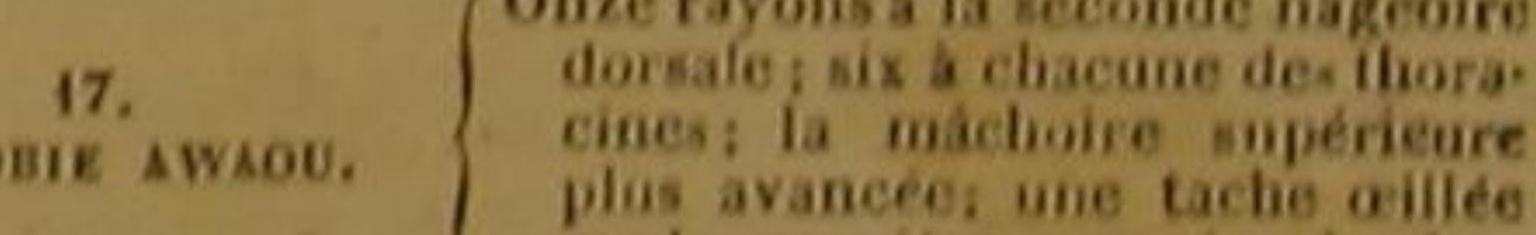

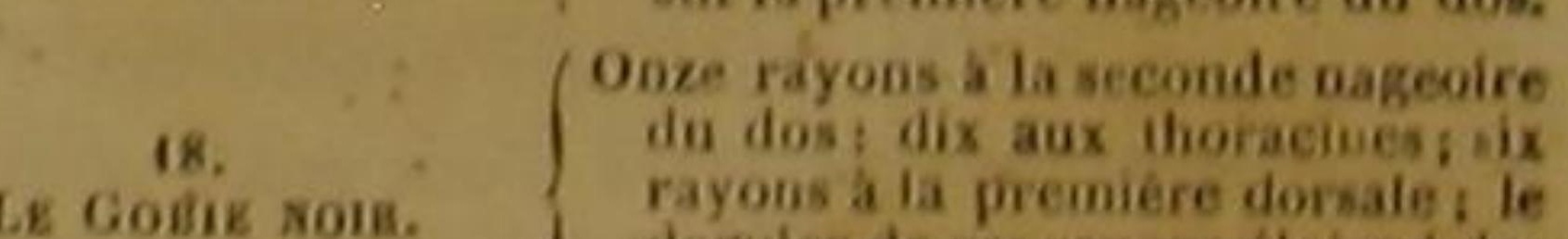
( autres is ta conleur noire.

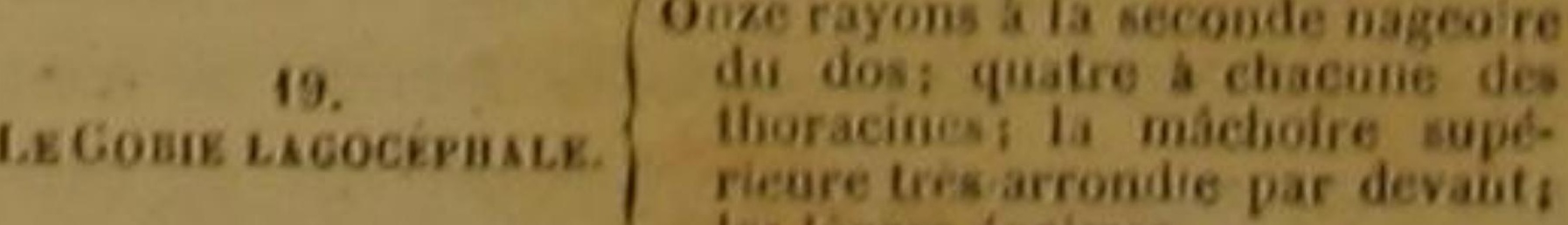

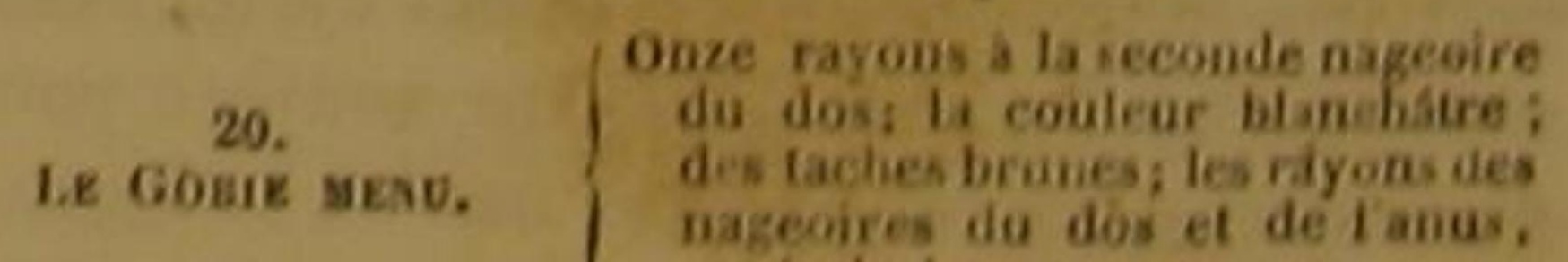

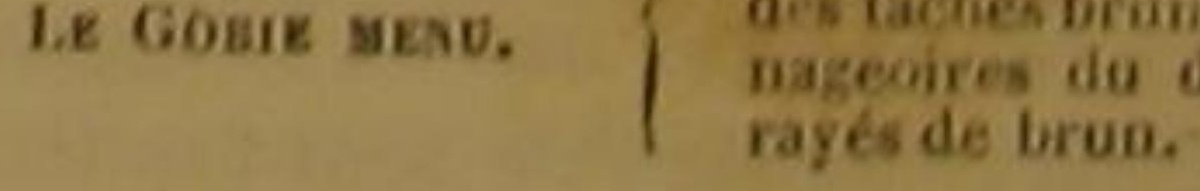
Dix rayons a la seconde nageoire
du dos: douzes anix lioracinesi

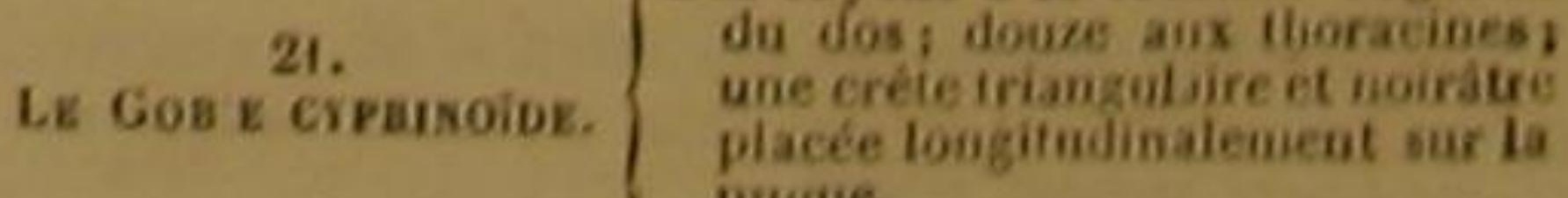


SECOND SOUS-GENRE.

Chacune des nageoires pectorales attachè à ıme prolongation charnue.

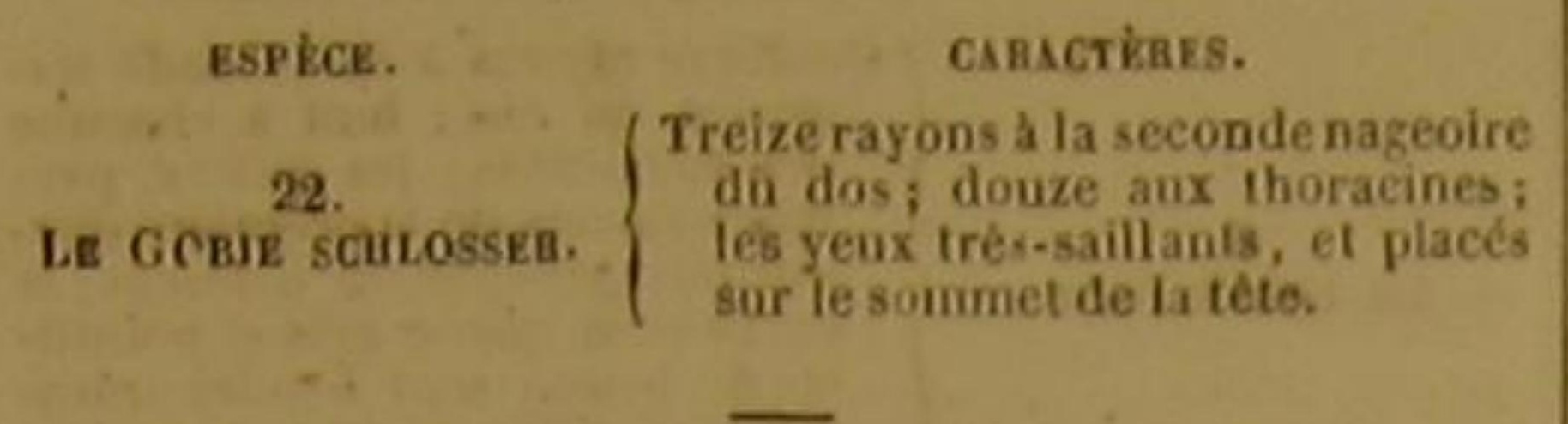

\section{LE GOBIE PECTINIROSTRE '}

Gobius pectinirostris, Lacep, '

Les gobies n'attirent pas l'attention de l'observateur par la grandeur de leurs dimensions, le nombre de leurs armes, la singularité de leurs habitudes; mais le juste appréciateur de êtres n'accorde-t-il sòn interêt qu'aux signes du pouvoir, aux attributs de la force, aux resultats en quelque sorte bizarres d'une organisation moins conforme aux lois générales étrblies par la nature? Ah! qu’au moins, dans la recherche de ces lois, nous échappions aux funestes effets des passions aveugles! Ne peson pas les familles des animaux dans la balance inexacte que les préjugés nous présentent san cesse pour les individus de l'espèce humaine Lorsque nous pouvons nous soustraire avec facilité à linfluence trompeuse de ces préjugés si nombreux, déguisés avee tant d'art, si habile à profiter de notre faiblesse, ne négligeons pa une victoire qui peut nous conduire à des suece plus utiles, à une émancipation moins imparfaite; et ne consultons dans la distribution de rangs parmí les sujets de notre étude, que le veritables droits de ces objets à notre exame ainsi qu'à notre méditation.

Si les gobies n'ont pas reeu, pour attaquer, 'es formes et les facultés qui font naitre la ter reur, ils peuvent employer les manéges multipliés de la ruse et toutes les ressources d'un instinct assez ctendu; s'ils n'ont pas pour se défendre, des armes dangereuses, ils savent disparaitre devant leurs ennemis, et se cacher dans des asiles sürs; si leurs formes ne sont pas très-extraordinaires, elles offrent un rapport très-marqué avec celles des eyclopteres et indiquent par conséquent un nouveau point de contact entre les poissons osseux et les cartilagineux; si leurs couleurs ne sont pas très'Gobie peigne, Daubenton, Ene, méth. - Id, Bunnaterre.

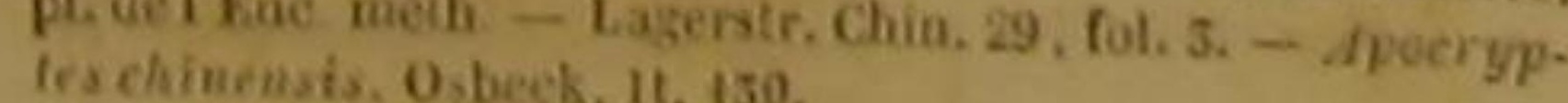

riches, leurs nuancés sont agréables, souvent très-variées, quelquefois méme brillantes; s'il ne présentent pas des phénomènes remarquables, ils fournissent des membranes qui réduites en pảte, ou pour mieux dire, en colle, peuvent servir dans plusieurs arts utiles; si leur chair n'a pas une saveur exquise, elle est une nourriture saine; et, peu recherchée par le riche, eHle peut fréquemment devenir l'aliment du pauvre; et enfin si les individus de cett famille out un petit volume, ils sont en trèsgrand nombre, et l'imagination qui les rassemble les voit former un vaste ensemble. Mais ce ne sont pas seulement les individus qui sont nombreux aans cette tribu; on compte déjà dans ce genre beaucoup de variétés et méme d'espèces. Et comme nous allons faire connaitre plusieurs gobies dont aucun naturaliste n'a encore entretenu le publie, nous avons eu plus d'un motif pour ordonner avec soin I'exposition des formes et des mœurs de cett: famille. Nous avons commencẻ par en séparer tous les poissons qu'on avait placés parmi les vrais gobies, mais qui n'ont pas les caractères distinctifs propres à ces derniers animaux; et nous n’avons conservé dans le genre que nous allons décrire que les osseux dont les uageoires thoracines, réunies à pen près comme celles des cyclopteres, forment une sorte de disque, ou d'éventail déployé, ou d'entonnoir évasé, et qui en mème temps ont leur dos garni de deus nageoires plus ou moins étendues. Une considération attentive des détails de la forme de ces nageoires dorsales et thoracines nous a aussi servi, an moins le plus souvent, à faire reconnaitre les espèces : pour rendre la recherche de ces especes plus facile, nous les avons rangées, autant que nous l'avons pu, d'après le nombre des rayons de la seconde nageoire dorsale, dans laquelle nous avons remarqué des différences spécifiques plus notables que dans la première; et lorsque le nombre des rayons de cette seconde nageoire dorsale a été égal dans deux ou trois espèces, nous les avons inserites sur notre tableau d'après la quantité des rayons qui composent leurs nageoires thoracines. Mais avant de nous occuper de cette détermination de la place des diverses espèces de gobies, nous les avons fait entrer dans l'un ou dans l'antre de deux sous-genres, suivant que leurs nageoires pectorales sont attachées immédiatement au corps, ou que ces instruments de na- tation tiennent à des prolongations charnues Le pectinirostre est, dans le premier sousgenre, l'espèce dont la seconde nageoire dorsale est soutenue par le plus grand nombre de rayons : on y en compte vingt-six '. Mais ce qui suffirait pour faire distinguer avec facilite cegobie, et lui a fait donner le nom qu'il porte, e'est que presque toutes les dents qui garnissent sa mâchoire inférieure, sont couchées do manière à être presque horizontales, et à donner au museau de l'animal un peu de ressemblance avee un peigne demi-circulaire. Ce poisson vit dans les eaux de la Chine.

LE GOBIE BODDAERT ${ }^{2}$

Gobius Boddseri, Lino., Gmel., Cuv.; Gobius Boddaert, Lacep."

On a dédié au naturaliste Boddaert cette espèce de gobie, comme un monument de reconnaissance, vivaut et bien plus durable que tous ceux que la main de l'homme peut élever. $\mathrm{C}$ poisson osseux a été pêché dans les mers de Inde. Il parvient à peine à la longueur de deux décimetres. Il est d'un brun bleuâtro par-dessus, et d'un blane rougeátre par-dessous. Des taches brunes et blanches sont répandues sur la tête; la membrane branchiale et la nageoire de la queue présentent une teinte blanche me lée de bleu; sept taches brunes placées audessus de sept autres taches également brunes, mais pointillées de blane, paraissent de chaque coté du dos; on cercle noir entoure l'ouverture de l'anus; quelques taches couleur de neige marquent la ligne laterale, le long de laquelle on peut d'ailleurs apercevoir de tres-petites papilles; la première nageoire du dos ${ }^{4}$ est parsemée de points blanes; et einq ou six lignes blanches s'étendent en travers entre les rayons de la secoude.

Indépendamment des couleurs dont nous venons d'indiquer la distribution, le boddacrt est remarquable pår la longueur des filaments qui termiuent les rayons de sa premiere nageoire dorsale, et particulierement de celui que l'on 'A la membrarie des branchies 5 rayons, à la premiere na. geoire du dos 5 , a la seconde 26 , a chacune des pectorales 19 ,

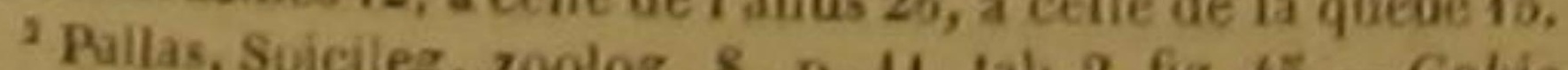

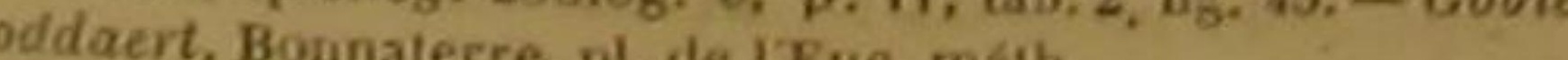

G. bus sous - genre des Gobous proprement dits dans le geare A la première nageoire du dos 5 rayons, à la seconde 25 , boune des pectorales 21 , aux thoracines 34 , a celle de voit à l'extrémité du troisième rayon. De plus, sa chair est grasse, son museau très-obtus; ses lèvres sont épaisses; ses yeux un peu ovales et peu saillants; et au delà de l'anus, on distingue un petit appendice charnu et conique, que l'on a mal à propos appelé petit-pied, pedunculus, péduncule, et sur l'usage duquel nous auron plusieurs occasions dê revenir.

$$
+
$$

\section{LE GOBIE LANCÉOLÉ}

Gobius lanceolatus, Linn., Gmel., Lacep. ',

Ce poisson est très-allongé : la nageoire placée à f'extrémité de sa queue, est aussi trèslongue; elle est de plus très-haute, et façonnée de manière à imiter un fer de lance, ce qui a fait douner à l'animal le nom que nous lui avôn conservé, Le docteur Bloch en a publié une fi gure d'après un dessin exécuté dans le temps sous les yeux de Plumier; et la collection de peintures sur vélin que renferme le Muséum d'histoire naturelle présente aussi une image de ce même gobie peinte également par les soins du, même voyageur, et que nous avons cru devoir faire graver.

On trouve le lancéolé dans les fleuves et les petites rivières de la Martinique, Sa chair est agréable, et il est couvert de petites écailles arrondies. La mâchoire supérieure est un peu plus avancée que l'inférieure. Deux lames composent l'opercule, L'anus est beaucoup plus près de la gorge que de la nageoire caudale. Les rayons de la première nageoire du dos s'élèvent plus haut que la membrane qui les réunit'. Les pectorales et celle de la queue sont d'un jaune plus ou moins mélé de vert, et bordées de bleu ou de violet; on voit, de chãque cóté de la tête, une place bleuátre et dont les bords sont rouges; une tache brune est placée a droite et a gauche près de l'endroit ou les deux ageoires dorsales se touchent; et la couleur rénérale de Tanimal est d'un jaune pâle pardessus; et d'un gris blane par-dessous.

'Bloch, p. 58. hig. 1 et 6. - Grosov. Zooph...p 82. n. 277 b. 4, fig, 4. - Gobius occanicus, Pallas, spie, zool. 8, p.4

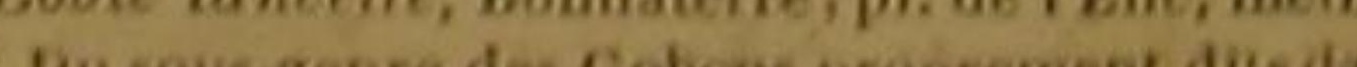
cobous. D. 'A ta membrane des branchide s sayons, a ia preaiere n-

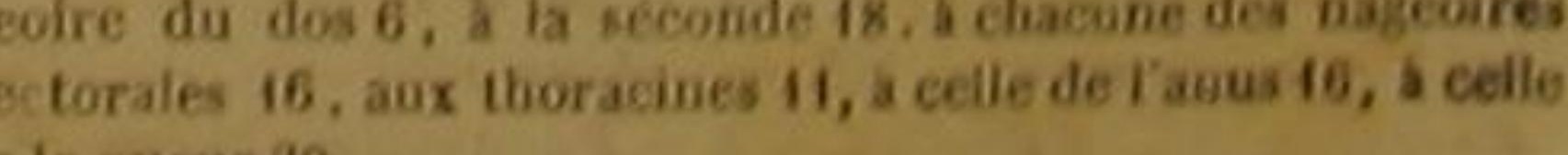
de la queue 20 . Jela 
LE GOBIE APHYE'.

Gobius Aphia, Lion., Gmel., Lacep., Riss. '.

Les eaux douces du Nil, et les eaux salée de la Méditerranée, dans laquelle se jette ce grand fleuve, nourrissent le gobie aphye, dont presque tous les naturalistes anciens $e$ modernes ont parlé, et dont Aristote a fai mention. Il n'a cependant frappé les yeux ni par ses dimensions, ni par ses couleurs : les premières ne sont pas très-grandes, puisqu'il parvient à peine à la longueur d un décimètre ; et les secondes ne sont ni brillantes ni très-variées. Des bandes brunes s'étendent sur ses nageoires dorsales et de l'anus; sa teinte générale est d'ailleurs blanchâtre, avec quelques petites taches noires. Ses yeux sont très-rapprochés l'un de l'autre. Il a été nommé Loche de mer, parce qu'il a de grands rapports avec le cobite appelé Loche de vivière, et dont nous nous entretiendrons dans la suite de cet ouvrage ${ }^{3}$.

\section{LE GOBIE PAGANEL 4,}

Gobius Paganellas, Lacep.

LE GOBIE ENSANGLANTÉ 5 Gobius cruentatus, Lino., Gmel., Lacep., Cuv. '

ET LE GOBIE NOIR-BRUN ? Gobius bicolor, Linn., Gmel.; Gobius nigrofuscus,
Lacep.

Le gobié paganel a été aussi nommé Goujon ou Gobie de mer, parce qu'il vit au milieu des

- Marsto, - Pignolecti, Marsione, sur plus. cośtes de mer Adriatique, - Loche de mer, dans plos. départ. mérid terre, pl. de l'Ene, méth. - Gobius one, méth, - Id Bonìa

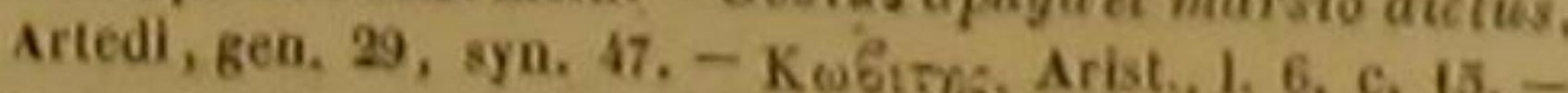

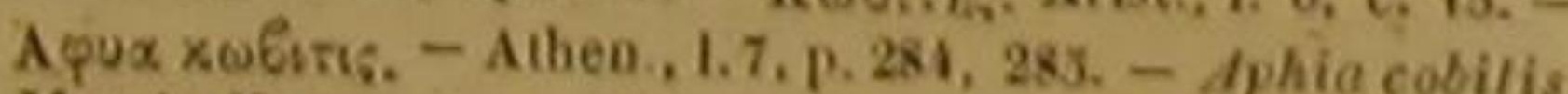
Morsio Venetorum, Aldror., 1. 2, c, 29,88, phia cobilis, Aphye de goution, Rondelet, part.4, 1. 7, c. 2. - Aphuo cobiles, vintughby, p. 207, - Apua cobilles, Bélon. - Apu (germ.) fot. I, b. - Jon, el (germ.) fol, 1, a. - Morsio, id. gobites, gosionaria, Cha, 1. 4. At. S, C. 1. a, 17:- Apua Aristot, - Rai, p. 76. - Aphie, Loche de mer, Valuont de Bomare, Diel, d'hist. nat.

'Du sous-genre des Gobous proprement dits dans le genre
Gobvos. D.

Chacune des pecoroire du dos 6 rayons, a la seconde 17 , uns is, a celle de ha quene, is.

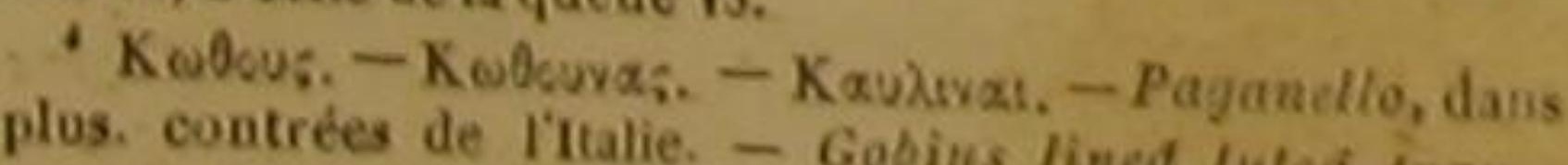
rersa, etc. Artedi, geu. 29, syo 46 - Beut luted tras. de mer, llondelet. part. 1.1.6, c. 16. - Gobius ou goujo-

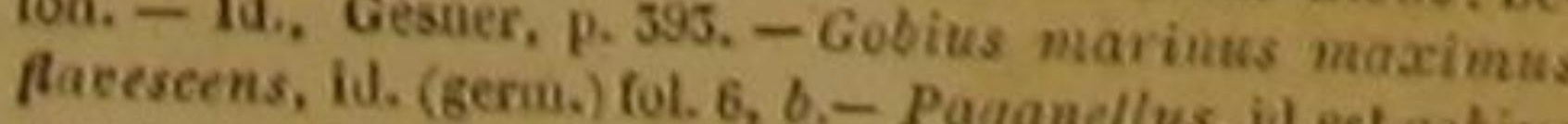
ma jor el subflavus, id., p. 357. - Gobius marinus Robius rochers de la Méditerranée. Il parvient quelque fois à la longueưr de vingt-einq centimètres. Son corps est peu comprimé. Sa couleur générale est d'un blanc plus ou moins mêlé de jaune, ce qui l'a fait appeler Goujon blanc, et au milieu des nuances duquel on distingue aussi quelquefois des teintes vertes, et voilà pourquoi le nom gree de $\chi^{\lambda \omega p a s, v e r t, ~ d ' u n ~ v e r t ~ j a u n e, ~}$ Ini a été donné par plusieurs auteurs anciens. Il a de plus de petites taches noires : sà première nageoire dorsale est d'ailleurs bordée d'un jaune vif; la seconde et celle de. l'anus sont pourprées à leur base: La nageoire de sa queue est presque rectiligne. Il a de petites dents, la bouche grande, l'estomae assez volumineux, le pylore garni d'appendices; et selon Aristote, il se nourrit dalgues, ou de débris de ces plantes marines. Sa chair est maigre, et un peu friable. C'est près des rivages qu'il va déposer ses œufs, comme dans l'endroit où il trouve l'eau la plus tiède suivant l'expression de Rondelet, l'aliment le plus abondant, et l'abri le plus sûr contre les grands poissons. Ces aufs sont plats, et faciles à écraser '

L'ensanglanté est pèché dans la Méditerranée, comme le paganel auquel il ressemble beaucoup: mais lés rayons de ses deux nageoires dorsales sont plus élevés que les membranies. D'ailleurs sa bouche, ses opercules, sa gorge, et plusieurs de ses nageoires, présentent des taches d'un rouge couleur de sang, qui le font paraitre pustuleux. Sa couleur générale est d'un blane påle, avee des bandes transversales brunes; on trouve quelques bandelettes noires sur la nageoire de la queue, qui est arrondie; les thoracines sont bleuátres. Ce poisson a été très-bien décrit par le naturaliste Brunnich ${ }^{2}$.

lenit, Paganellus, seu yobius major ex Gesnero, Aldrov.

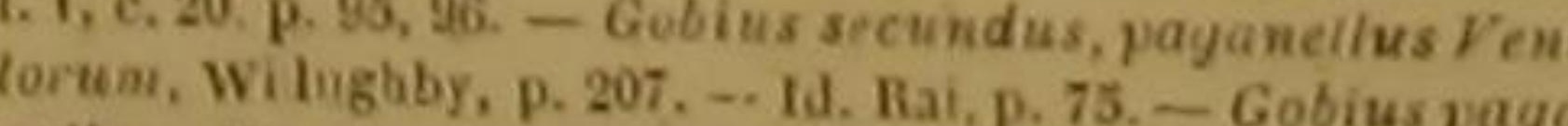
nellus, Has elguist., It. 326. - Gohie goújon de mer, Davbenton, Euc. wéth. - Id. Bomaterre, pl. de IEnc. mélh. Pajanelio, Valmont de Bomare, Dict. d hist. bas.

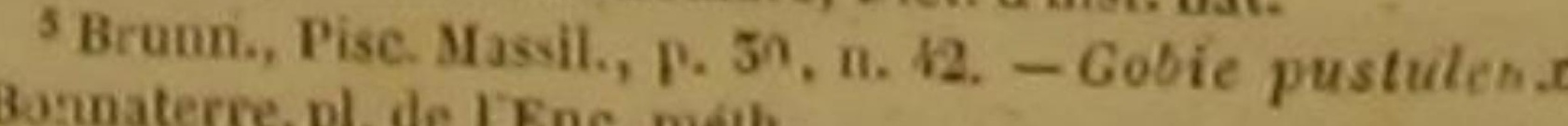

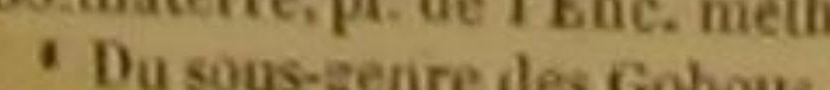

Gobous, Cuv. D. - Gobous proprement dits dans te geure

'Brunn., Pisc, Massil., p. 50, n. A1. - Gobie, goujon pctit Alanaserre, pl. de I Enc. méth.

clacune des pectorales 17 , aux thosyons, a la seconde 17 . uns 16 , a celie de la queue 20

a inx thoraciues 12 , a cellede 16 , a chacune despectorales 19.
Le nom du noir-brun indique ses couleurs distinetives. Il n'offre que deux teintes principales; il est brun et toutes ses nageoires sont noires. Ses formes ressemblent beaucoup à celles de l'ensanglanté, et par conséquent à celles du paganel. II habite les mêmes mers que ces deux gobies; et e'est au savant cité dans la phrase précédente que l'on en doit la connaissance. Il n'a guère qu'un décimètre de longuenr'.

\section{LE GOBIE BOULEROT 2 .}

Gobius niger, Linu., Gmel., Lacep., Cur.,

Le boulerot a êté nommé Gobie ou Goujon noir, parce que sur son dos de couleur cendrée ou blanchátre s'étendent des bandes transversales très-brunes, et que d'ailleurs il est parsemé de taches dont quelques-unes sont blanches ou jaunes, mais dont le plus grand nombre est ordinairement d'un noir plus ou moins foscé, On voit des teintes jaunátres sur la partie inférieure et sur ses opercules. Sa longueur est communément de deux déeimètres. Ses deux mảchoires, aussi avancées l'une que l'autre, sont armées chacune de deux rangs de petites dents; sa langue est un peu mobile; ses écailles sont dures, Ses nageoires thoracines ${ }^{4}$, colorées et réunies de manière à présenter à certains yeux une ressemblance vague avec une sorte

iA la premlère nageoire du dos 6 rayons, a la seconde 16 , a chacube des pectorales 19 , aux thoracines 12 , a celle de tianus 15, A celle de la queue 17 .

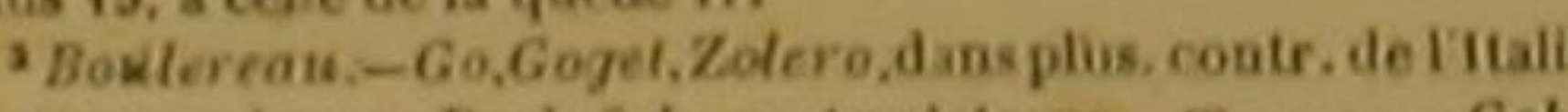
- Sea-gudgeon, lock fish, en Angleterre.-Tpayos. - Gobic IEne, meth.--Sus. Ad. Frid. A, p. 74 ; et 2, p. 64. - Noll. Prodrom. Zool, danic., p. 44. n. 364.- Golimsé nigricanto

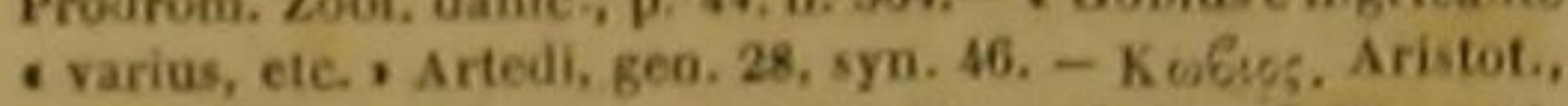
L2, c. 17; I. 6, c. 15; 1. 8, C. 2, 15, 19 ; et I. 9, c 2, 37, - Id. Elian., 1. 2, c. 50. - Athen., 1. 7, c. 59 . - Oppian., 1. 1, p. 7 . et I. 2, p. 46. -Gobia, Plin.1. 9, c. 57. - Columell, I. 8, c 17, Juvenal., Sat. A, A. - Gobio marinus, Salvian, fol. 214, b - Gobio marinus niger, Belon, Aquat., p. 255. - Gesnex, p. $595,595,469$. et (germ.) fol.6. 6. - Boulerot voir, Monlelet, part. A, ... Gobins marinus niger., Rai, p. 76 . - Gubius, rel gobio niger. , Schonev. p. 36. - , Gotius, go- bio, el cobio marinus. - Charlet, 155.- A Apocryptes can- toneasis, $>$ Osbeck, It. 151. - Bloch, pl. 58, fig. 1, 2, 5. - Eleotris capie plagioplateo, maxinis zyuaihbus, ete,, 6 ronov. Mos. 2, p. 47, n. 170; 20ophi, p. 82, H. 220. - Gollo

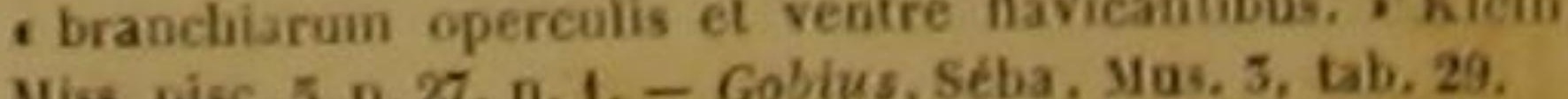

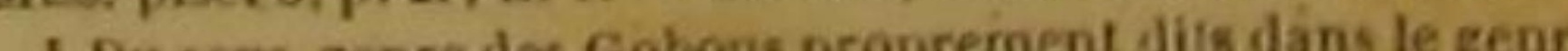
Gobous, Linn. D.

-A la oremiere nageoire da dos 6 rayons, a la sec vive 14 . a chacune des pectorales 18 , a chacune des thoraeines 40,2 celle de Tanus 12 , a celle de la queuc it. de barbe noire, lui ont fait donner le nom de Bone, en gree Tpxyos. Derrière l'anas, parait un petit appendice analogue à celui que nous avons remarqué ou que nous remarquerons dans un grand nombre d'espèces de gobies. $\mathrm{S}$ ᄁ nageoire caudale est arrondie, et quelquefois cet instrument de natation et toutes les autres nageoires sont bleues.

Le boulerot se trouve non-seulement dans l'Océan Atlantique boréal, mais encore dans plusieurs mers de l'Asie, Vers te temps du frai, il se rapproche des rivages et des embouchures des fleuves. Il vit aussi dans les étangs vaseux qui reçoivent l'eau salée de la mer; et lorsqu'on l'y péche, il n'est pas rare de le trouver daus le filet, couvert d'une boue noire qui n'a pas peu contribué à lui faire appliquer le nom de Goujon noir. Sa chair n'est pas désagréable au goút : cependant Juvénal et Martial nous apprennent que sous les premiers empereurs de llome, et dans le temps du plus grand luxe de cette capitale du monde, il ne paraissait guere sur la table du riche et de I homme somptuenx.

\section{LE GOBHE BOSC '.} Gobius Bosc, Lacep., Cur, '; Gobius viridipallidu
Mitteb.

Mon confrère M. Bose a bien voulu me communiquer la description de ce poisson, qu'il a va dans la baie de Charleston de l'Amérique septentrionale.

Ce gobie a la tête plus large que le corps; les deux mâchoires également avancées; les dent très-petites; les yeux proéminents; les orifices des narines saillants; l'opercule branchiol terminé en angle ; et les quatre premiers rayons de la première nageoire dorsale, prolongés chacun par un filament délié.

II parait sans écailles. Sa couleur générale est grise et pointillée de brun. Sept bandes transversales, irrégulières, et d'une nuance plus pâle que le gris dont nous venons de parler, règnent sur les cotés, et s'étendent sur les nageoires du dos, qui d'ailleurs sont brunes comme les autres nageoires ${ }^{3}$.

¿ Gobius alepidoptus, corpore nudo, griseo, fascils sep - Ien pallidis. a Bose, manuscrit déja cite. Gobrosis Cuv. D.

'A L premiere nageolre donale 7 rayons, a la seconde 1 , a chisune des pectorales 18 , aus tioracines 8 , a celie de $\mathrm{H}_{2}$. nus 10.3 celle de la queue, qui est lancéole, is 
On ne distingue pas de ligne latérale.

Le gobie bose ne parait parvenir qu'à de trèspetites dimensions : I'individu décrit par mon savant confrère avait cinquante-quatre millimètres de long, et tireize millimètres de large.

On uè mange point de ce gobie.

$$
\text { - }
$$

\section{LE GOBIE ARABIQUE ',}

Gohius arabicus, Linn., Gmel., Lacep.

ET LE GOBIE JOZO ${ }^{2}$

Gobius Jozo, Linn., Gmel., Lac., Cuv. 3.

Forskael a découvert l'arabique dans la contrée de l'Asie indiquée par cette épithète. Les cinq premiers rayons de la première nageoire du dos de ce gobie sont deax fois plus longs que la membrane de cette nageoire n'est haute. II n'est que de la longueur du petit doigt de la main ; mais sa parure est très-agréable. L'extrémité des rayons dont nous venons de parler est rouge : la couleur de l'animal est d'un brumverdâtre, relevé et diversifié par ungrand nombre de points bleus et de taches violettes, dont plusieurs se réunissent les unes aux autres, et qui paraissent principalement sur toutes les nageoires. On devine aisément l'effet doux et gracieux que produit ce melange de rouge, de vert, de bleu et de violet, d'autant mieux fondus les uns dans les autres, que plusieurs reflets en multiplient les nuances ${ }^{4}$. La peau de l'arabique est molle, et recouverte de petite

' Forsk, Faun. Arab., p. 25, n. 5. - Gobie, goujon cuab Bonnaterre, pl. de IEuc, métl.

Gobits albescens. - Gobius favescens. - Gobie gou I'Enc, méll. - Mus. Ad. Frid, 2, p. 65. - Meterre, pl. de Zoolog. danice, p. 44, n. 563. _, Gobius - Man. Prodron - dorsalis supra membranam assurgentibus, Arteds, pin

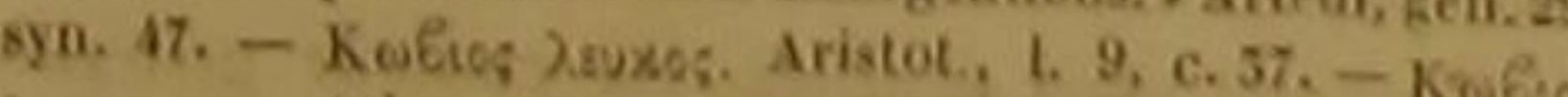
Auxerepes. Athen, L. 7, p. 509. - Eoulerol blanc, Goujo Wanc, llonitelet, parl. 1, 1. 6, c. 18. (ta bigure est exirumeet (germ.) fol. 6, 6. Gobius alous Rondeletii, Aldrov; I. 7, c. 20, p. 97. - C Gobius tertius, jozo Rome, Salvian

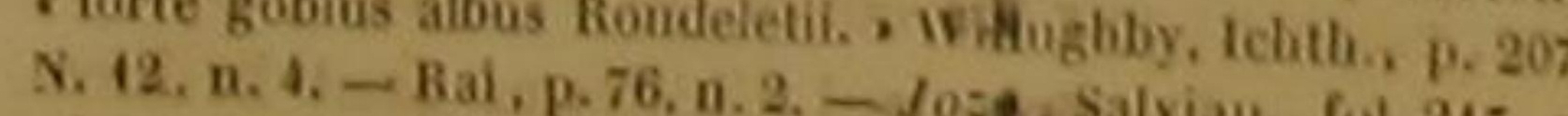
ad iconem. - Gosius albescens, Gronor, Mus, 2, 215, a u, $176 ;$ Zooph., p. 81. n. 275. - Bloch, pl. 107, lie. 5 - comectentes altiüs assurgentibus. , Klein, Miss, pise. p. $27,0.5$.

Du sous-genre des Gobous proprement di is dans le genr A la premiere nazeoire dersale 6 rayons, a la seconde 11 a clacune des pecterales 16 . aux thoracines 12 , a celle de
I'anus 15 , a celle de ta écailles fortement attachées. La nageoire de 3 queue est pointue.

Nous plaçons dans cet article ce que nous avons à dire du jozo, parce qu'il a beaucoup de rapports avec le gobie dont nous venons de parler. Presque tous les rayons de sa première nageoire dorsale sont plus élevés que la mem. brane. Sa tête est comprimée; ses deux mâchoires sont également avancées; sa ligne latérale s'étend, sans s'élever ni s'abaisser, à une distance à peu près égale de son dos et de son ventre. Cette ligne est d'ailleurs noirâtre. L'animal est, en général, blanc ou blanchâtre, avec du brun dans sa partie supérieure; ses nageoires thoracines sont bleues. On le trouve non-seulement dans la Méditerranée, mais dans l'Océan Atlantique boréal : il y vit auprès des rivageś de l'Europe, $y$ dépose ses aufs dans les endroits dont le fond est sablonneux ; et quoique sa longueur ordinaire ne soit que de deux décimètres, il sè nourrit, dit-on, de erabes et de poissons, a la vérité très-jeunes et très-petits. Sa chair, peu agréable au goût, ne l'expose pas à être très-recherchẻ par les pêcheurs; mais il est fréquemment la proie de grands poissons, et notamment de plusieurs gades '.

LE GOBIE BLEU ${ }^{2}$.

Gobius caruteus, Lacep. ${ }^{\prime}$ :

Cette espèce est encore inconnue des naturalistes : elle a été décrite par Commerson. Sa couleur est remarquable : elle est d'un bleu très. beau, un peu plus clair sur la partie inférieure de l'animal que sur la supérieure; cet azur règue sur toutes les parties du poisson, excepté sur la nageoire de la queue, qui est rouge, avec une bordure noire; et comme ce gobie a tout au plus un décimètre ou à peu près de longueur, on eroirait, lorsqu'il nage au milieu d'une eau calme, limpide, et très-éclairée par les rayons du soleil, voir flotter un canon de saphir terminé par une esearboucle.

II habite dans la mer qui baigne l'Afrique orientale, à l'embouchure des fleuves de l'ile Bourbon, où la petitesse de ses dimensions,

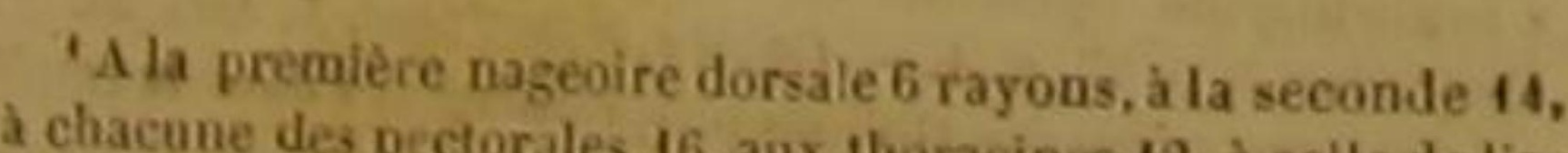
aus 14 , de celle de la queue 16 . 2. Gobio cerruleus, caud

Commerson, manuscrits déja cités, nigro circunscripta. 'Cette espece nést pas mention. que nous venons d'indiquer, fait que les Nègres même dédaígnent de s'en nourrir, et ne s'en servent que comme d'appât pour prendre de plus grands poissons.

Le bleu a le museau obtus, la mâchoire inférieure garnie de dents aiguês et moins menues que celles de la supérieure; les yeux ronds, saillants, et plus éloignés l'un de l'autre que sur beaucoup d'antres gobies; la première nageoire du dos, triangulaire, et composée de rayons qui se prolongent par des filaments audessus de la membrane; la seconde nageoire dorsale terminée par un rayon deux fois plus long que les autres; l'anus à une distance presque égale de la gorge et de la nageoire caudale, qui est arrondie '; et les écailles petites et rudes.

$$
-\cdots
$$

LE GOBIE PLUMIER 2 .

Gobius Plumieri, Biocb., Lac., Cuv. '

Le docteur Bloch a décrit ce gobie d'après des peintures sur vélin dues aux sojns du voyageur Plumier. Le Muséum d'histoire naturelle possède des peintures analogues, dues également au zèle éclairé de ce dernier naturaliste. Nous avons trouvé parmí ces peintures du Muséum l'image du poisson nommé avee raison Gobie Plumier, et nous avons eru devoir la faire graver.

Cet animal, qui babite dans les Antilles, est allongé, mais charnu, trés-fécond, d'une saveur agréable, et susceptible de recevoir promptement la cuisson convenable. Les écailles dont il est revètu sont petites, et peintes de très-riches couleurs. Sa partie supérieure brille d'un jaune foncé ou de l'éclat de l'or; ses côtés sont d'unjaune clair; sa partie inférieure est blanche; et toutes les nageoires ' sont d'un beau jaune, relevé très-souvent par une bordure noire sur celles de la queue et de la poitrine. Quelques autres nuances font quelquefois ressortir sur diverses parties du corps les teintes que nous venons d'indiquer.

- A la mentibrane des branchies 4 rayons, à la premiere nagevire du dos 6 , a la seconde 12 , a chacune des pectora-

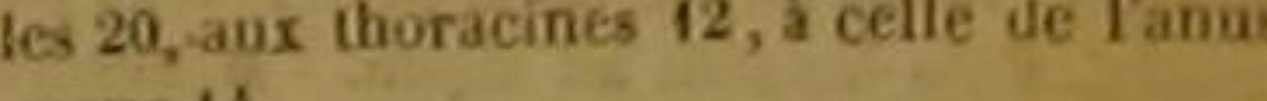
queue 1 it.

Gobie cephale, Bonnaterre, pl. de l'Enc, métb. 'D Di sous-genre de A A première nageoire du dos 6 rayons, a la seconde 12 ,
chacurie des pectorales 12 , à chacune des thoracines 6 ,

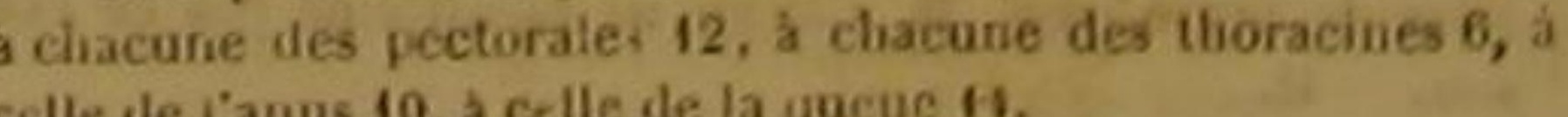

La téte est grande; le bord des Jères char nu; l'ouverture branchiale étendue; l'opercule composé d'une seule lame; la mảchoire supérieure beaucoup plus avancée que l'inférieure ; la ligne latérale droite; la nageoire caudale arrondie; et f'anus situé vers le milieu de la longueur du corps.

\section{LE GOBIE THUNBERG '.}

Gobius Patella, Thunberg, Lacep. ?

Ce poisson, vu par Thunberg dans la mer qui baigne les Indes orientales, a beaucoup de rapports avec l'éléotre de la Chine. Sa longueur est de plus d'un déeimètre. Plusieurs rangées de dents garnissent les máchoires. Le musea ést obtus. Les thoracines sont une fois moins longues que les pectorales; la caudale est arrondie. On ne voit sur l'animal, ni bandes, ni taches; la couleur générale est blanchâtre ${ }^{3}$.

\section{LE GOBIE ELEOTRE ',} Gobius Eleotris, Lacep. ‘. ET

\section{LE GOBIE NÉBULEUX *.}

Gobius nebulosus, Lacep.

Les eaux de la Chine nourrissent l'éléotre, dont la couleur générale est blanchátre, la seconde nageoire du dos aussi élevée que la premiere, et celle de la queue arrondie. Le corps est couvert d'écailles larges, arrondies et lisses et l'on voit une tache violette sur le dos, aupres des opercules ${ }^{7}$.

Le nébuleux a été découvert en Arabie par 'Gobius patellu, Thuaberg, Voysge an Japon.

M. Cuvier ne fait paj mention de cette épece. D. - 5 rayons a la premiére nageoire du dos du gobie thun-

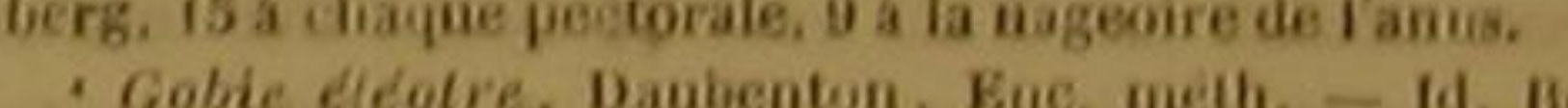

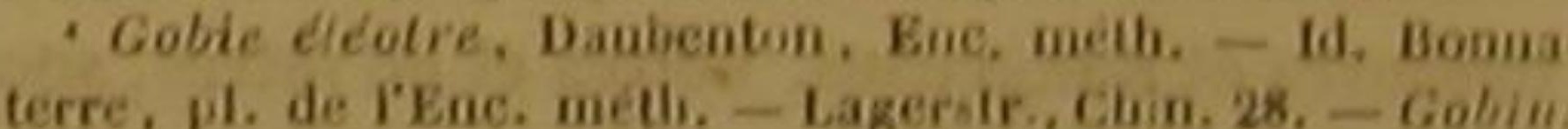
chinensis, O.beck, it. 250 - - Trachinus... piumis ventra.

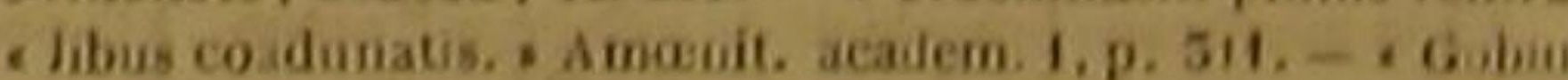
albescens. pionis utrisque dorasilibus altitidine a gaii bus, , Gron. Zooph. 276.

Ce poison an Éleotris de S. Cuvier, daus te geare Gobous. D. - Korskael, Faun. Arsb., p. 24, n. 6.-Gobie nelbuleux Bonnaterre, pl. de l'Enc, métb.

A la menibrane des hranchies de teléotre 5 rayons, a premiére nageoire du dos 6 . A la seconide $11, a$ cha une des pretorales 20 , anx thoracines 12 , a celle deranas 50 , a ceile de 
le Danois Forskael. A peine sa longueur égale- répandues sur son dos; une nuance verdàtre t-elle un décimètre. Ses écailles sont grandes, distingue les nageoires de la queue et de l'anus; rudes, et en losange. La nageoire de la queue des bandes de la mème couleur et d'autres banist arrondie; et voici la distribution des cou- des brunes se montrent quelquefois sur leurs leurs dont ce gobie est peint ${ }^{\text {. }}$.

Sa partie inférieure est d'un blanc sans tache; la supérieure est blanchâtre, avec des taches brunes, irrégulières et comme nuageuses, que I'on voit aussi sur la base des nageoires pectorales, lesquelles sont d'ailleurs d'un vert de mer, et sur les dorsales, ainsi que sur la nageoire de la queue. Cette dernière, les dorsales et l'anale, sont transparentes; l'anale est, de plus, bordée de noir ; les thoracines présentent une teinte brunâtre, et un filament noir et trèslong termine le second rayon de la première nageoire du dos.

LE GOBIE $A$ WAOU ${ }^{2}$.

Gobius ocellaris, Linn., Gmel., Cur. ; Gobius Awaov, Lacep. '.

C'est dans les ruisseaux d'eau douce qui arrosent la fameuse fle de Taiti, au milieu du grand Océan équinoxial ${ }^{4}$, que l'on a découvert ce gobie. Mon confrère l'habile ichthyologiste Broussonnet l'a vu dans la collection du célèbr Banks, et en a publié une belle figure et une très-bonne description. Cet awaou a le corp comprimé et allongé; des éeailles ciliées ou frangées; la tête petite et un peu creusée en gouttière par-dessus; la máchoire d'en - haut plus avancée que l'inférieure, et hérissée de dents inégales; la máchoire d'en bas garnie de dents plus petites; plusieurs autres dents menues, aiguềs et pressées dans le fond de la gueule au-dessus et au-dessous du gosier; I ligue latérale droite; et l'anus situé vers le milieu de la longueur de l'animal, et suivi d'un uppendice conique. Nous n'avons plus qu'à faire connaitre les couleurs de ce gobie.

Son ventre est d'un vert de mer; des teinte obseures et nuageuses, noires et olivâtres, sont

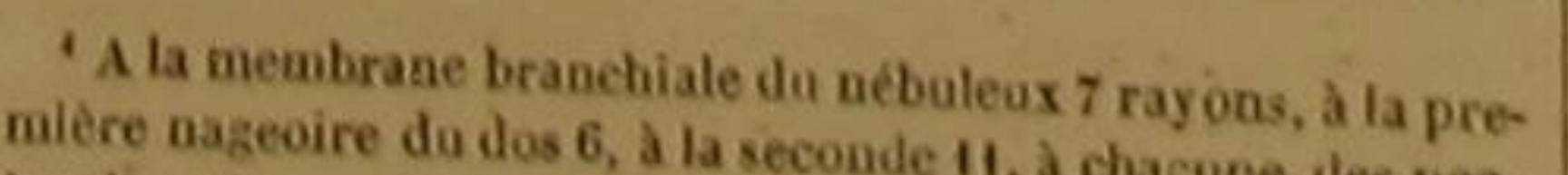
There nageoire du dos 6, a la seconde 11 , a chacune des pecL quene 14.

Honaussonnet, Ieluth. dee. 1, n. 2, tab. 2. Cobie aypaos,

proprement vits. D. rayons et sur ceux de la seconde nageoire du dos '; les pectorales et les thoracines sont noirâtres; et, au milieu de toutes ces teintes sombres, on remarque aisément une tache noire, assez grande, ceillée, et placée près du bord postéricur de la première dorsale.

\section{LE GOBIE NOIR ?}

Gobius Commersonii, Nob,; Gobius niger, Lacep. ‘.

Ce gobie, dont nous avons vu la deseription dans les manuscrits de Commerson, que Buffon nous a remis il y a plus de douze ans, est à peu près de la taille d'un grand nombre de poissons de son genre. Sa longueur n'égale pas deux décimètres, et sa largeur est de trois ou quatre centimètres. Il présente sur toutes les partie de son corps une couleur noire, que quelques reflets bleuátres ou verdâtres ne font paraitre que plus foncée, et qui ne s'éclaircit un peu et ne tend vers une teinte blanchátre, ou plutót livide, que sur une portion de son ventre. Les écailles qui le revétent sont très-petites, mais relevées par une arête longitudinale; sa tête parait comme gonflée des deux côtés. Sa mâchoire supérieure, susceptible de mouvements d'extension et de contraction, dépasse et embrasse l'inférieure : on les croirait toutes les deux garnies de petits grains plutôt que de véritables dents. La langue est courte, et attachée dans presque tout son contour. L'intervalle qui sépare les yeux l'un de l'autre est à peine égal au diamètre de l'un de ces organes. Commerson a remarqué avec attention deux tubercules placés à la base de la membrane branchiale, et qu'on ne pouvait voir qu'en soulevant l'opercule. Il a vu aussi au delà de l'ouverture de l'anus, laquelle est à une distance presque égale

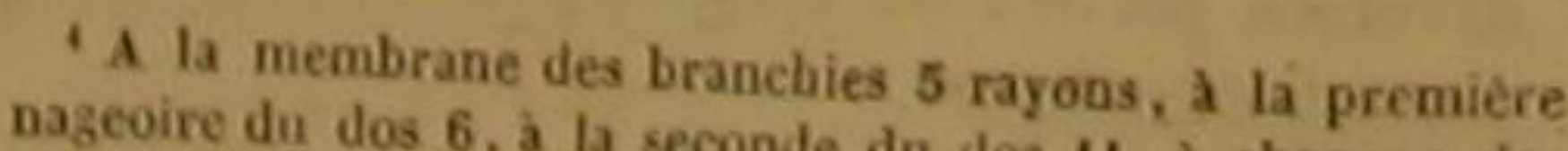

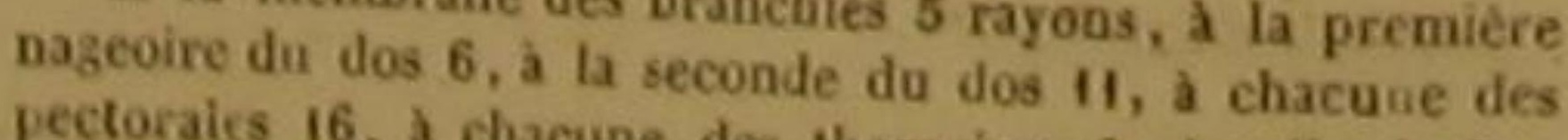
pectoraies 16, a chacune des thoracines 6 , a celle de lanus 11 , a celle de la queue, qui est très-arrondie 22 . - terore remotissimo, villo notabili ad anum. - Munuscrits de Commerson, deja cits.

cette espece, parce que ceivi de Gous Comme-sonii pour M. de Lacépède est déje ceiui de Gobius niger donné par jéce de notre pays, M. Cuvier ne mentionne pas ce nois.
sou. D.
DES POISSONS. de la gorge et de la nageoire de la queue, un bie, lequel est ordinairement de la longueur
appendice semblable à celui que nous avons indiqué en décrivant plusieurs autres gobies, et de noir '

ou petit filament'

Le gobie noir habite dans la portion du grand Océan, nommée, par notre confrère Fleurieu, grand golfe des Indes 2. Il s'y tient à l'embouchure des petites rivières qui se déchargent dans la mer : il préfere celles dont le fond est vaseux. Sa chair est d'une saveir très-agréable, et dailleurs d'une qualité si saine, qu'on ne balance pas à la donner pour nourriture aux convalescents et aux malades que l'on ne rédui pas à une diète rigoureuse.

LE GOBIE LAGOCÉPHALE , Gobius Lagocephalus, Pall, Linn;, Gmel, Lac. ‘, LE GOBIE MENU, Gobius minutus, Pall., Lac. s.

\section{LE GOBIE CYPRINOIDEE ?}

Gobius cyprinoides, Pall, Lac,'?

Le lagocéphale ou Téle-de-lièvre, tire son nom de la forme de sa tête et de ses levres. Cette partie de son corps est courte, épaisse et dénuée de petites écailles. On voít à la mâchoire inferieure quelques dents crochues plus grandes que les autres. La màchoire supéricure est demi-circulaire, épaisse, et recouverte par une lèvre double très-avancée, très-charnue, et fondue en deux comme celle du lièvre: la lèvre d'en-bas présente une échancrure semblable. Le palais est hérissé de dents menues et trèsserrées; les yeux, très-rapprochés l'un de laure, sont recouverts par uné continuation de l'épiderme. On voit un appendice allongé et ar. rondi, au delà de l'anus, qui est aussi loio de la gorge que de la nageoire de la queue; cette derniere est arrondie: I'on ne distingue pas de ligne latérale; et la couleur générale de ce go-

- A la membrane des branchies 4 rayons, à la première na. ge ire du dos 6 , a la seconde 11 , à chacune des pectorales 15 .

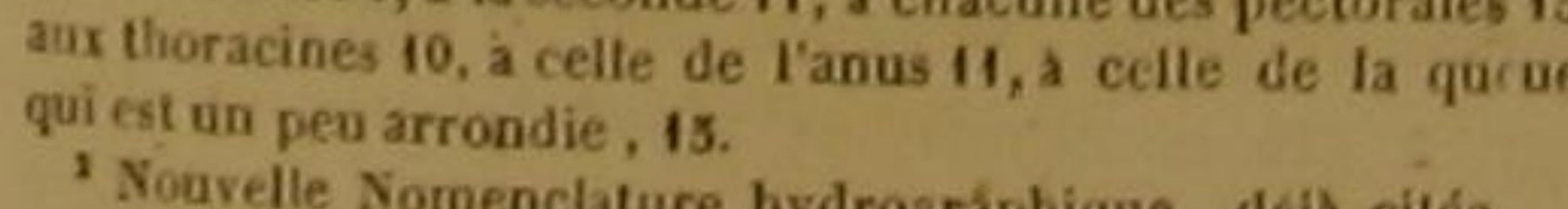
'Nouvelle Nomenclature hydrográphique, deja citée. 'Koireuter, Nov. Comm. Petropolit. 9, p, 428, fig. 5 et 'Do sole de lievre, Bonnaterre, pl. de I Enc. méth. Gobonis, Cav. D.
Des Gobous proprement dits dans le genre 3. Covier ne cir
Le menu, qui ressemble beaucoup a l'aphye, a la tête un peu déprimée; sa langue est grande; gaees I une de l'autre; sa nageoire caudale est rectiligne; et ses teintes, aussi peu brillantes que celles du lagocéphale, consistent dans une couleur de fer disséminées sur sa partie supévieure, et dans de petites raies de la méme nuance ou à peu près, répandues sur les nagoires de la queue et du dos ${ }^{2}$.

On trouve dans les eaux de l'ile d'Amboine le cyprinoìde, que l'on a ainsi nommé à cause du rapport extérieur que ses écailles grandes et un peu frangées lui donnent avec les cyprins, quoiqu'il ressemble peut-être beaucoup plus aux spares. Le professeur Pallas en a publié le premier une très-bonne description. La partie supérieure de ce cyprinoide est grise, et P'inférieure blanchâtre. Ses dimensions sont à peu près semblables à celles du menu. II $a$ la tête un peu plus large que le corps, et recouverte d'une peau traversée par plusieurs lignes trèsdélićes qui forment une sorte de réseau; on voit entre les deux yeux une crète noirátre, triangulaire et longitudinale, que l'on prendrait pour une première nageoire dorsale très-basse; au dela de l'anus, on aperçoit aisément un appendice allongé, arrondi par le bout, et que l'animal peut coucher, a volonté, dans une fossette ${ }^{3}$.

\section{LE GOBIE SCHLOSSER}

Periophthalmus Schlosseri, Schn., Cuv., Gobius Scblosseri, Linn., Gmel., Lac. '.

C'est au célèbre Pallas que l'on doit la description de cette espèce, dont un individu lu

'A la merobrane des branchies du lagocéphale 3 rayoos, 1

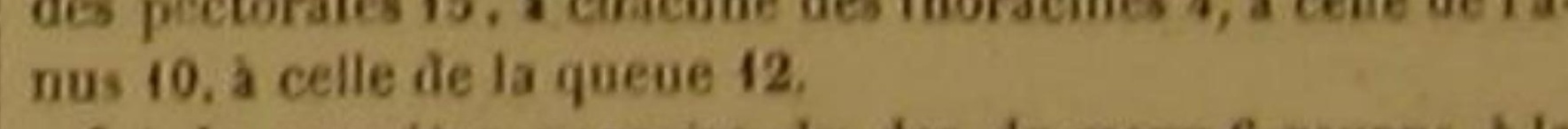
is la premicre n- peoire du.

. '6 rayons a la premiere nazeoire du dos, 10 a t a secorde. 18 a chacune des pectorales, 12 aux thoracines, 1 rayou imple et 9 articulés a celle de l'anos, 15 rayons a celle de ia Tueoe, qui est arrondie.
4 Cabos, - Pallss, Spieil. zoolog. 8, p. 3, tab. 1, 6ig. 1, 2 , 5, 4. - Gobius barbarus, Linnée, - Gobie schlosser, Dau.
benton. Kne, meth. - Id. Bonnaterre, pl. de I'Ene. meth. ses deux nageoires dorsales sont un peu éloicouleur générale blanchatre, dans des taches

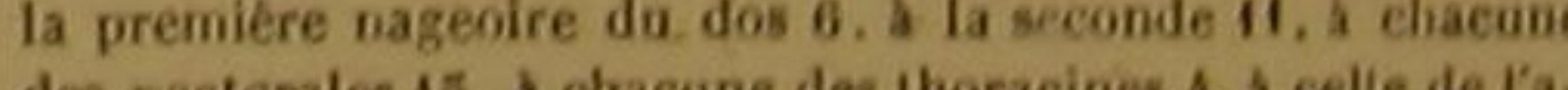
benton, Enc. meth. - Id. Bonnaterre, pl. de I'Ene. meth.
5 Do s ns-genre Periophthalme dans le geare Gobous, Cur. 
avait été envoyé par le savant Schlosser, avec goùt, auprès des côtes de la Chine, ou on la des notes relatives aux habitudes de ce poisson ; pèche, ainsi que dans d'autres contrées orienet le nom de cegobie rappelle lesservicesrendus tales, puisqu'elle sert à la nourriture des Chiaux sciences naturelles par Iami de l'illustre nois qui habitent à une distance plus ou moins

Ce poisson est ordinairement long de deux ou trois décimètres. Sa tête est couverte d'un grand nombre d'écailles, allongée, et cependant plus large que le corps. Les lèvres sont épaisses, charnues, et hérissées, à l'intérieur, de petites aspérités : la supérieure est double. Les dents sont grandes, inégales, recourbées, aiguēs, et distribuées irrégulièrement.

Les yeux présentent une position remarquable : ils sont très-rapprochés l'un de l'autre, situés au-dessus du sommet de la tête, et contenus dans des orbites très-relevées, mais disposées de telle sorte que les cornées sont tournées l'une vers la droite et l'autre vers la gauche.

Les écailles qui revètent le corps et la queue sont assez grandes, rondes et un peu molles. On ne distingue pas facilement les lignes latérales. La couleur générale de l'animal est d'un brun noiratre sur le dos, et d'une teinte plus claire sur le ventre '.

Les nageoires pectorales du schlosser sont, comme l'indiquent les caractères du second sous-geure, attachées à des prolongations charnues, que l'on a comparées à des bras, et qui servent à l'animal, non-seulement à remuer ces nageoires par le moyen d'un levier plus long, a les agiter dès lors avee plus de force et de vitesse, à nager avec plus de rapidité au milieu des eaux fangeuses qu'il habite, mais encore à se trainer un peu sur la vase des rivages, contre laquelle il appuie successivement ses deux extrémités antérieures, en présentant très en petit, et cependant avec quelque ressemblance, les mouvements auxquels les phoques et les lamantins ont recours pour parcourir très-lentement les côtes maritimes.

C'est par le moyen de ces sortes de bras que le schlosser, pouvant, ou se glisser sur des rivages fangeux, ou s'enfoncer dans l'eau bourbeuse, échappe avee plus de facilité à ses ennemis, et poursuit avee plus d'avantage les faibles habitants des eaux, et particulièrement les cancres, dont il aime à faire sa proie.

Cette espèce doit ètre féconde et agréable au - A ta membrane des branchies 5 rayons, I la premiêre naoux tha cos $x$, a la seconde 15 , a chascune des pectorales 16, grande des rivages; et voila pourquoi elle a ete

nommée par les Hollandais des grandes Indes, Poisson chinois (Chineésche vissch).

\section{CINQUANTE-NEUVIEME GENRE.} LES GOBIOİDES.

Les deux nageoires thoracines rèunies $l$ tune à l'autre; une seule nageoire dorsale; la tete petile: les opercules attachés dans une grande parlie de leur contom

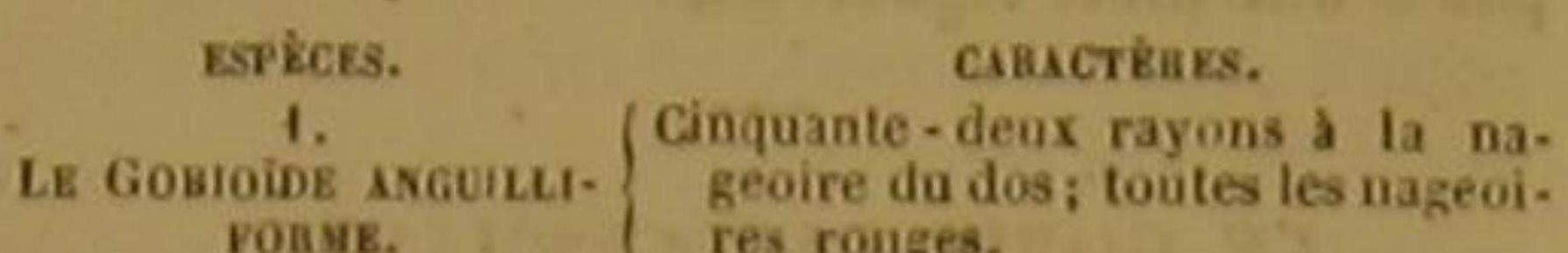

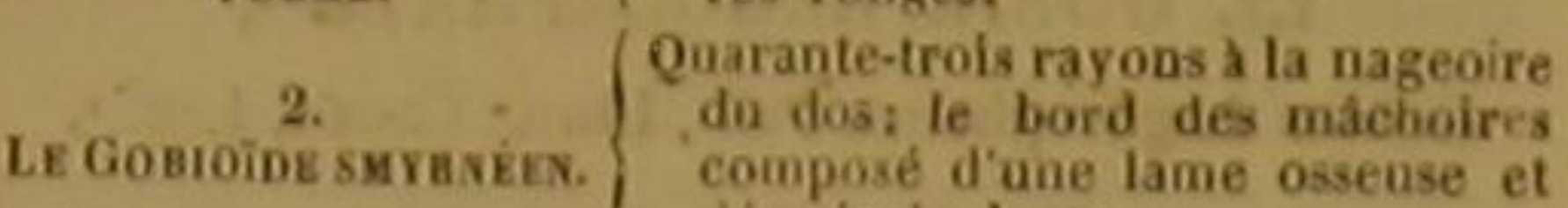

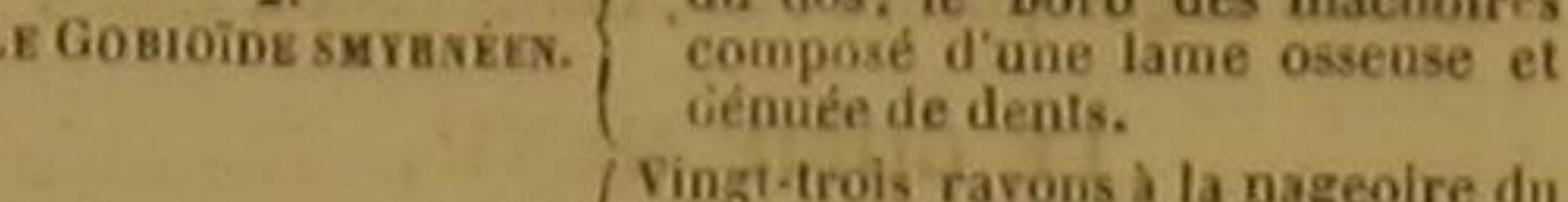

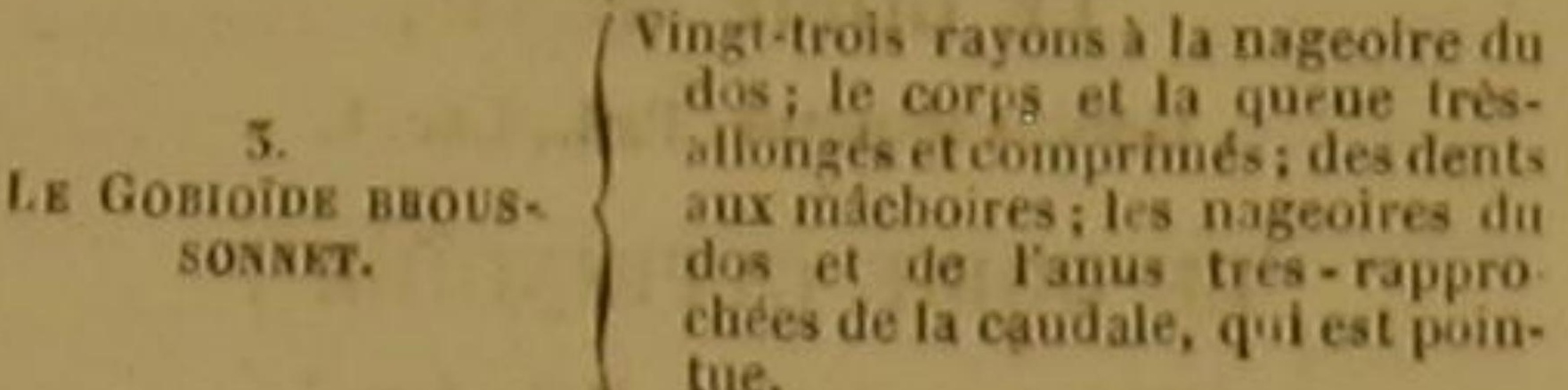
LE GoBıïDe QUETE
nOIEE.

$$
\begin{aligned}
& \text { 40íg QUETE } \\
& \text { 1.a qu }
\end{aligned}
$$

LE GOBIOÏDE ANGUILLIFORME'.

Gobius anguillaris, Linn.. Gmel.; Gobioides anguilliformis, Lacep. ?

C'est dans les contrées orientales, et notamment dans l'archipel de l'Inde, à la Chine, ou dans les lles -du grand-Océan équatorial, que 'on trouve le plus grand nombre de gobies. Les mêmes parties du globe sont aussi celles dans lesquelles on a observé le plus grand nombre d gobioìdes. L'anguilliforme a été vu particulièrement dans les eaux de la Chine.

Comme tous les autres gobioìdes, il ressemble beaucoup aux poissons auxquels nous donnons exclusivement le nom de Gobie; et voila pourquoi nous avons eru devoir distinguer par la dénomination de Gobioìde, qui signifie en forme de gobie, le genre dont il fait partie, et qui a été confondu pendant longtemps dans celui des gobies proprement dits. Il diffère néanmoins de ces derniers, de même que tous 'Goujon anguillard, Daubenton, Enc. méth. - Id. Bon. 'Gerre, pl. de TEnc. méth.
"Ce poisson n'ost pas cilt les osseux dt son geure, en ce qu'il n'a qu'une seule nageoire dorsale, pendant que les gobies en présentent deux. Il a d'ailleurs, ainsi que son nom l'indique, de grands rapports avec la murène anguille, par la longueur de la nageoire du dos et de celle de l'anus, qui s'étendent presque jusqu'à celle de la queue; par la petitesse des nageoires pectorales, qui, de plus, sont arrondies, et surtout par la viscosité de sa peau, qui, étant imprégnée d'une matière huileuse très-abondante, est à demi transparente.

La imâchoire inférieure de l'anguilliforme est garnie de petites dents, comme la supérieure et toutes ses nageoires sont d'une couleur rouge assez vive ',

\section{LE GOBIOIDE SMYRNEEN 2 . Gobioides smyruensis, Lacep '.}

Ce poisson a la tête grosse et parsemée de pores très-sensibles; dès lors sa peau doit être arrosée d'une humeur visqueuse assez abondante.

Une lame osseuse, placée le long de chaque mâchoire, tient lieu de véritables dents : on n'a du moins observé aucune dent proprement dite dans la bouche de ce gobioide.

Les nageoires pectorales sont très-larges, et les portions de celle du dos sont d'autant plus élevées qu'elles sont plus voisines de celle de la queue 4 .

LE GOBIOÏDE BROUSSONNET Gobioides Broussonnetii, Lacep., Cuv.; Gobius oblongatus, Sehn. s.

Nous dédions cette espèce de gobioìde à notre savant confrère M. Broussonnet; et nous cherchons ainsi à lui exprimer notre reconnaissance pour les services qu'il a rendus à l'histoire naturelle, et pour ceux qu'il rend chaque jour à cette belle science dans l'Afrique septentrionale, et particulièrement dans les états de

A A la nageoire dorsale 52 rayons, à chacune des pectorales 12 , aux thoracines 10 , à celle de l'anus 43 , a celle de la queue 12. , Commen!. Petropolit. 9, tab. 9, fig. 5. - Goujon

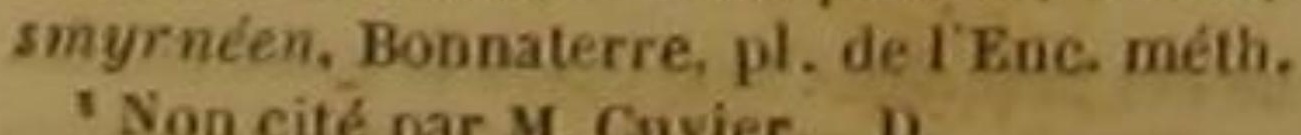

'A a me par M. Cuvier. 1 . ns. à la nageoire du a celle de l'anus 29 , à 5 Type da sous genre Gobioìde admis par M. Cuvier dams
é genre Gobous. D.
Maroc, quil parcourt avec un zèle bien digne d'éloges.

Ce gobioide qui n'est pas encore connu des naturalistes, a les mâchoires garnies de trespetites dents. Ses nageoires thoracines sont assez longues, et réunies de manière à former une sorte d'entomnoir profond; les pectorales sont petites et arrondies; la dorsale et celle de l'anus s'étendent jusqu'à celle de la queue, yui a la forme d'un fer de lance: elles sont assez hautes, et cependant l'extrémité des rayons qui les composent, dépasse la membrane qu'ils soutiennent 4

Le corps est extrêmement allongé, trèsbas, très-comprimé; et la peau quỉ le recouvre est assez transparente pour laisser distinguer le nombre et la position des principaux muscles.

Un individu de cette belle espèce faisait partie de la colleetion que la Hollande a donnée a la nation française; et c'est ce mème individu dont nous avons eru devoir faire graver la figure.

LE GOBIOÏDE QUEUE NOIRE 2 .

Gobioides melanurus, Lacep.; Gobiüs melanurus, Linn., Gmel. '.

C'est à M. Broussonnet que nous devons la connaissance de ce gobioìde, qu'il a décrit sous le nom de Gobie a queue noire, dont la queue est en effet d'une couleur noire plus ou moins foncée, mais que nous séparons des gobies proprement dits, parce qu'il n'a qu'une nageoire sur le dos.

\section{SOIXANTIEME GENRE.}

LES GовHомовеS.

Les deux nageoires thoracines non réunies l'une à l'autre; deux nageoures dorsales; la tite petite; les yeux rapprochis; les opercules altachès dans uie yeux rapproches; les operciln
grande partie de leur contour.

PREMIER SOUS-GENRE.

Les nageoires pectorales allocities immédiatement au corps de l'animal.

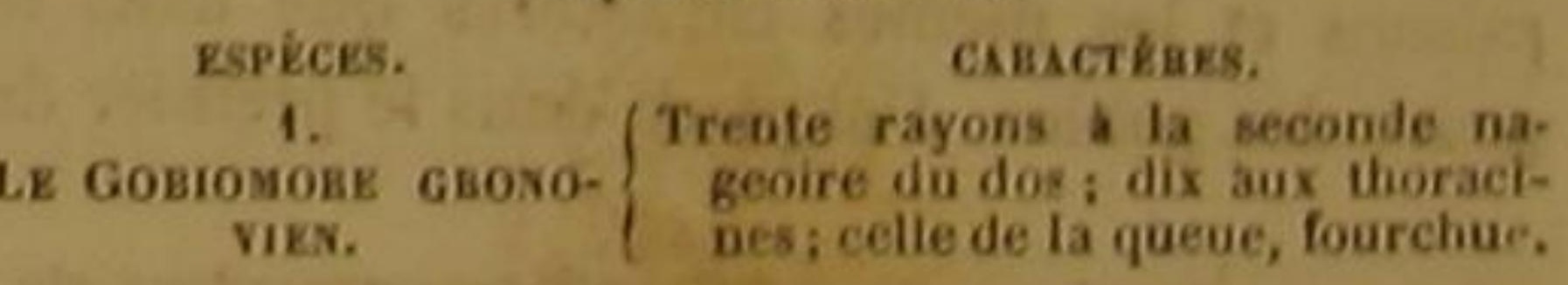

'A la nageoire du dos 25 rayons, a chacune de nageoire thicines 7 , a chacune des pectorales 17 , a celle de 12 us 17 , a celle de la queue 16 .

Droussonnet, Iehth. dec. 1. 


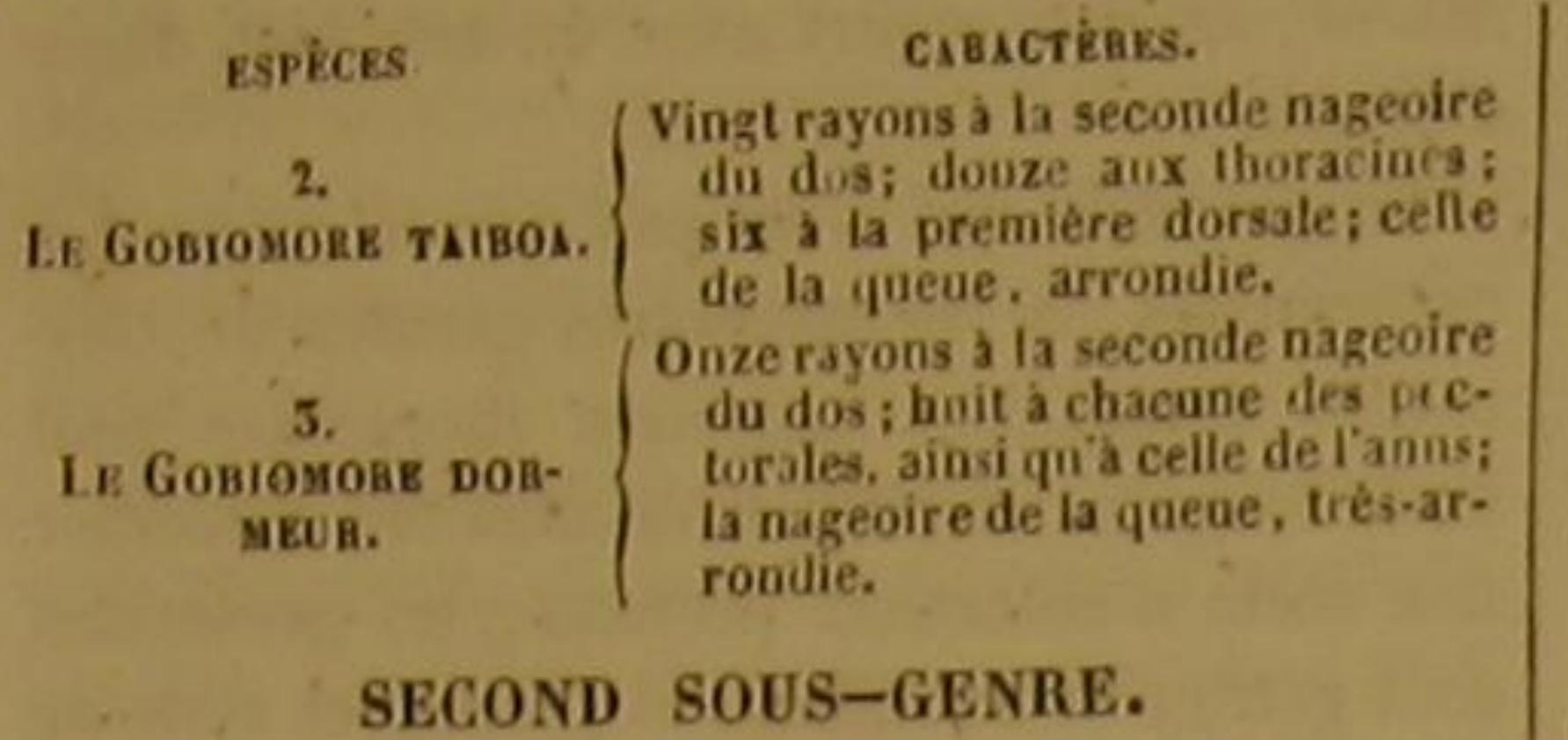

SECOND SOUS-GENRE.

Chacune des nageoires pectorales altachèe à une prolongation charaue.

4.
LE GoBonong KoeL-
BEUTEB. -

LE GOBIOMORE GRONOVIEN '. Gobiomorus Gronovii, Lacep.; Nomeus Mauritii,
Cuv, ?

Les gobiomores ont été confondus jusqu'à présent avee les gobies, et par conséquent avec les gobioides. Je les en ai séparés pour répandre plus de clarté dans la répartition des espèces thoracines, pour me conformer davantage aux véritables principes que l'on doit suivre dans toute distribution méthodique des animaux, et afin de rapprocher davantage l'ordre dans lequel nous présentons les poissons que nous avons examinés, de celui que la nature leur a imposé.

Les gobiomores sont en effet séparés des gobies et des gobioides par la position de leurs nageoires inférieures ou thoracines, qui ne sont pas réunies, mais très-distinctes et plus ou moins éloignées l'une de l'autre. Ils s'écartent d'ailleurs des gobioides par le nombre de leurs nageoires dorsales : ils en présentent deux; et les gobioides n'en ont qu'une.

Ils sont cependant très-voisins des gobies, avee lesquels ils ont de grandes ressemblances et c'est cette sorte d'affinité ou de parenté que j’ai désignée par le nom générique de Gobiomore, voisin ou allié des gobies, que je leu ai donné.

J'ai cru devoir établir deux sous-genres dans le genre des gobiomores, d'après les même raisons et les mèmes caracteres que dans le genre des gobies. J'ai placé dans le premier de

'Gronov. Zooph., p. 82, n. 278. - Cesteus argenteus, etc, Klein, Niss. pisc. 5, p. 21, D. 5. - Mugil a mericnnus, Kai, Pisc., p. 85, 4. 9. - Harder, Marcgrav. Brasil., lib. 4, cap.6,
p. 1s5. p. 103.

M. Cuvier forme avec ce poisson le genre quïl nomme Pasteur, Nomeus, et quili place dans ta famille des Scom-
bres. D. ces deux sous-genres les gobiomores dont les nageoires pectorales tiennent immédiatement aur corps proprement dit de l'animal, et j'a inserit dans le second ceux dont les nageoires pectorales sont attachées à des prolongations charnues.

Dans le premier sous-genre se présente d'abord le gobiomore gronovien '.

Ce poisson, dont on doit la connaissance à Gronou, habite au milieu de la zone torride,

dans les mers qui baignent le nouveau continent. Il a quelques rapports avec un scombre. Ses écailles sont très-petites; mais, excepté celles du dos, qui sont noires, elles présentent une conleur d'argent assez éclatante. Des taches noires sont répandues sur les côtés de l'animal. La tête, au lieu d'ètre garnie d'écailles semblables à celles du dos, est recouverte de grandes lames écailleuses. I.es yeux sont grands et moins rapprochés que sur la plupart des gobies ou des gobioîdes. L'ouverture de la bouche est petite. Des dents égales garnissent le palais et les deux màchoires. La langue est isse, menue et arrondie. La ligne latérale suit la courbure du dos. L'anus est situé vers le milieu de la longueur totale du poisson. Les mageoires thoracines sont très-grandes, et celle de la queve est fourchue.

\section{LE GOBIOMORE TAIBOA ${ }^{2}$}

Gobiomorus Taiboa. Lacep., Eleotris strigatus, Cuv. '

C'est auprès 'du rivage hospitalier de la plus célèbre des iles fortunées, qui élèvent leurs collines ombragées et fertiles au milieu des flot agités de l'immense Océan équatorial, c'est auprès des bords enchanteurs de la belle ile d'Otahiti, que l'on a découvert le taiboa, l'un des poissons les plus sveltes dans leurs proportions, es plus agiles dans leurs mouvements, les plus agréables par la douceur de leurs teintes, les plus richement parés par la variété de leurs nuances, parmi tous ceux qui composent la famille des gobiomores, et les genres qui l'avoisinent.

'A la membrane des branchies 5 rayons, à la première na-

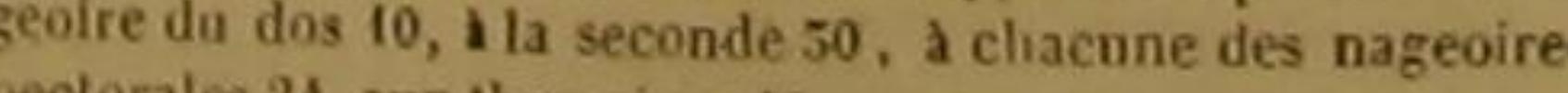
${ }^{2}$ Broussonnet, Ichth 1 .

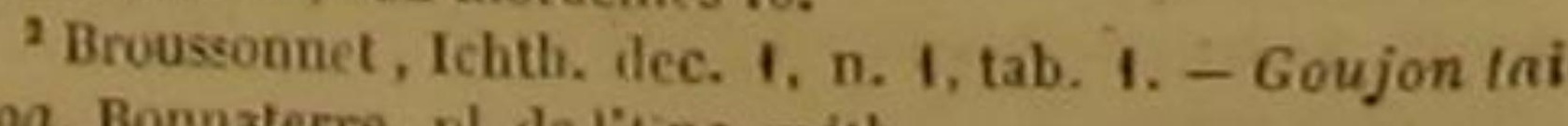

D. Ensenre Éléotris dans le genre Gobous de M. Cin-
DES POISSONS.

Nous en devons la première description à savant voyageur. La mâchoire inférieure de ce M. Broussonnet, qui en a vu des individus dans la collection du célèbre président de la société de Londres.

Le corps du taiboa est comprimé et très-allongé; les écailles qui le recouvrent sont presque carrées et un peu crénelées. La tête est comprimée, et cependant plus large que le eorps. La mâchoire inférieure n'est pas tout à fait aussi avancée que la supérieure; les dents qui garnissent l'une et l'autre sont inégales. La langue est lisse, ainsi que le palais; le gosier hérissé de dents aiguês, menues et recourbées en arrière; la première nageoire du dos, composée de rayons très-longs ainsi que très-élevés; et la nageoire de la queue, large et arrondie '.

Jetons les yeux maintenant sur les couleurs vives ou gracieuses que présente le taiboa.

Son dos est d'un vert tirant sur le bleu, et sa partie inférieure blanchátre; sa tête montre une belle couleur jaune, plus ou moins mélée de vert; et ces nuances sont relevées par des raies et des points que l'on voit sur la tête, par d'autres raies d'un brun plus ou moins foncé, qui règnent auprès des nageoires pectorales, et par des taehes rougeâtres situées de chaque cóté du corps ou de la queue.

De plus, les nageoires du dos, de l'anus et de la queue offrent un vert mélé de quelques teintes de rouge ou de jaune, et qui fait trèsbien ressortir des raies rouges droites ou courbées qui les parcourent, ainsi que plusieurs rayons qui les soutiennent et dont la couleur est également d'un rouge vif et agréable.

\section{LE GOBIOMORE DORMEUR ${ }^{2}$.}

Gobiomorns dormitor, Lac.; Platycephalus dormitator, Bloch, Schn.; Eleotris dormitatrix, Cuv.',

Les naturalistes n'ont encore publié aucune description de ce gobiomore, qui vit dans les eaux douces et particulièrement dans les marais de l'Amérique méridiunale : nous en devons la connaissance à Plumier; et nous en avons trouvé une figure dans les dessins de ce - A la membrane des branchies 6 rayons, a la première

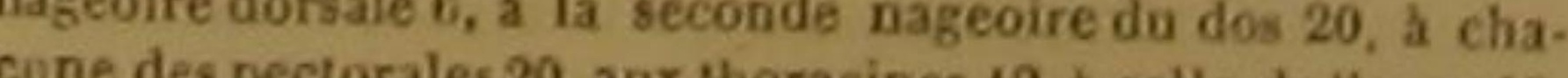
celle de la ypere 22 .

'Cerits de Piumier déposes a las palustris, dessins et ma'Du suus-grure Éléotris dans le zeare Gobous, Cur. 1I. poisson est plus avancée que la supérieure ; la nageoire de la queue est très-arroudie : le nombre des rayons de ses nageoires empéehe d'ail leurs de le confondre avec-les autres gobiomores. On l'a nommé le Dormeur, sans doute a cause du peu de vivacité ou du peu de fréquence de ses mouvements.

\section{LE GOBIOMORE KOELREUTER '.}

Gobiomorus Koelreuteri, Lacep.; Gobius Koelreuteri, Pallas; Pcriophthalmus Koelreuteri, Schn., Cuv. 3.

Le nom de cette espèce est un témoignage de gratitude envers un savant très-distingué, le naturaliste Koelreuter, qui vit maintenant dans ce pays de Bade, auquel les vertus touchantes de ceux qui le gouvernent, et leur zèle trèséclairé pour le progrès des connaissances, ainsi que pour l'aceroissement du bonheur de leurs semblables, ont donné un éclat bien doux aux yeux des amis de l'humanité.

Ce gobiomore, dont les téguments sont mous et recouvrent une graisse assez épaisse, est d'un gris blanchâtre. Ses yeux sont très-rapprochés, et placés sur le sommet de la tête; ce qui lui donne un grand rapport avec le gobie schlosser, auquel il ressemble encore par la position de ses nageoires pectorales, qui sont attachées au bout d'une prolongation charnue très-large auprès du corps proprement dit, et c'est à cause de ce dernier trait que nous l'avons inserit dans un sous-genre particulier, de même que le gobie schlosser.

Les lèvres sont doubles et charnues; les dents inégales et coniques: la mâchoire supérieure en présente de chaque côté une beancoup plus grande que les autres. La ligne latérale parait comme comprimée; l'anus est situé vers le milieu de la longueur totale du poisson; et la nageoire de la queue est un peu lancéolée.

La première nageoire dorsale est brune et bordée de noir : on distingue une raie longitudinale et noiratre sur la seconde, qui est jauuâtre et fort transparente 3 .

Køelreuter, Nov. Comm. Petropolit, 8, p. 121. - Goujon ' 2 ju sous genre Périophthalme dans te genre Gobous, te. Do M. Cuvier. D.
is la membrane

A la membrane des branebies a rayons, a la premiéro 
On voit au delả et tres près de l'anus du go- $\mid$ mes assurés que les deux mảchoires sont garbiomore koelreater, ainsi que sur plusieurs go- nies de plusieurs rangées de dents fortes et bies, et même sur des poissons de genres très- aigués. L'inférieure a de plus un rang de dents différents, un petit appendice conique, que l'on plus fortes, plus garandes, plus recourbées, et a nommé pédoncule génilal, qui sert en effet plus éloignées les unes des autres, que celles à la reproduction de l'animal, et sur l'usage de la mâchoire supérieure.

duquel nous présenterons quelques détails dans la suite de cette histoire, avec plus d'avantage que dans l'article particulier que nous écrivons.

SOIXANTE-UNIEME GENRE. LES GOBTOMOROIDES.

Les deux nageoires thoracines non rèunies l'une à l'autre: une seule nageoire dorsale; la tete petite; les yeux rapprochés; les opercules altachés dans une grande partie de leur conlour.

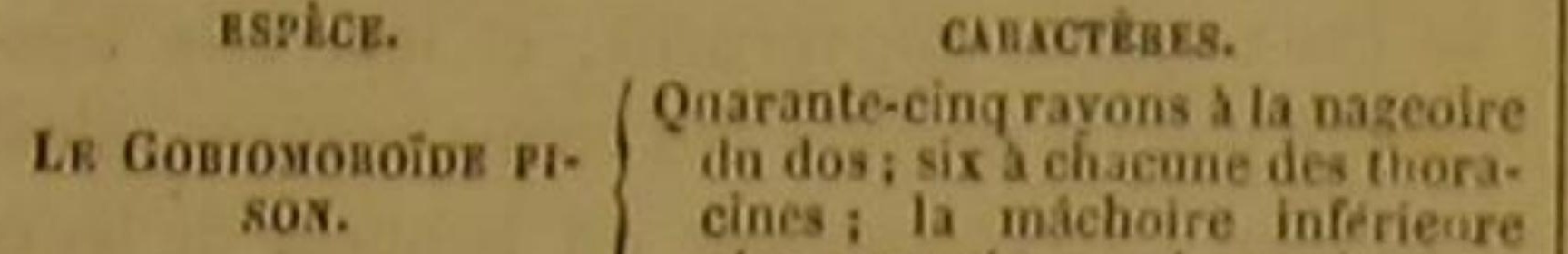
cines; ia máchoire inferéeure
plus avancée que la supérieure.

LE GOBIOMOROIDE PISON '.

Gobiomoroides Piso, Lacep.; Gobius Pisonis, Linn., Gmel.; Eleotris Pisonis, Cur. ${ }^{2}$.

Les gobies ont deux nageoires dorsales; les gobioỉdes n'en ont qu'une, et voila pourquoi nous avons séparé ces derniers poissons des gobies, en indiquant cependant, par le nom générique que nous leur avons donné, les grands rapports qui les lient aux gobies. Nous écartons également des gobiomores, dont le dos es garni de deux nageoires, les gobiomoroīles qui n'offrent sur le dos qu'un seul instrument de natation; et néanmoins nous marquons, par lo nom générique de ces gobiomoroìdes, les resseniblances très-frappantes qui déterminen leur place à la suite des gobiomores.

Le pison a la mâchoire inférieưre plus avancée que la supérieure; sa tète est d'ailleurs aplatie : on le trouve dans l'Amérique méridionale.

En examinant dans une collection de poissons desséchés, donnée par la Hollande à la France, un gobiomoroīde pison, nous nous som-

tirstes 15 , aux thoracines 12 , A celle de 7 anus 11 , a celle de
th yueue is. tac yuewe is.

p. 80, n. 1. - Neot. 5, p. 72 - Amore pixuma, Rai, Pisc., tur, 2. p. 16. n. II:8; Zooph plagioplateo, ete, Gronov.
La tête est comprimée aussi bien que déprimée, et garnie d'éeailles presque semblables par leur grandeur à celles qui revêtent le dos. La nageoire de la queue est arrondie '.

Le nom de cette espèce rappelle l'ouvrage publié par Pison sur l'Amérique australe, et dans lequel ce médecin a parlé de ce gobiomoroīde.

\section{SOIXANTE-DEUXIËME GENRE.}

LES GOBIÉSOCES.

Les deux nageoires thoracines non réunies l'une à l'antre ; une sente nageoire dorsale; celte nageoire trèstrés-près de la nageoire caudale la lite tre la queue, très-près de la nageoire caudale; la tele très-grosse el

Espíck. LE GoBísoce testAR. $\left\{\begin{array}{l}\text { Les lèrres doubles et trés-extensi. } \\ \text { bles; la nageoire de la queue } \\ \text { a.rondie. }\end{array}\right.$ -

LE GOBIÉSOCE TESTAR ${ }^{2}$

Gubiesox cephalus, Lacep; Lepadogaster dentex, Schn.; Cyelopterus nudus, Lion. '.

C'est à Plumier que l'on devra la figure de ce poisson encore inconnu des naturalistes, et que nous avons regardé comme devant appartenir d un genre nouveau. Celle que nous avons fait graver, et que nous publions dans cet ouvrage, a été copiée d'après un dessin de ce célèbre oyageur. Le Testar habite l'eau douce : on l'a observé dans les fleuves de l'Amérique méridionale. Le nom vulgaire de Testar, qui luí a té donné, suivant Plumier, par ceux qui l'ont vu dans les rivières du Nouveau-Monde, indique les dimensions de sa tête, qui est trèsgrosse, et plus large que le corps; elle est d'ailleurs arrondie par devant, et un peu déprimée

is A la nazcoire da dos 45 rayons, a chacune des pectora. Ifs 17 , a chacune des thoracines 6 , a celle de lanus 25 , a
celle de la queue 12 . 2 Cephulus Pre 12.

anuscrits de Plumiatitis major, vulgò lestar, dessins et 3. Mivier place ce poissoson a la Bibliothèque du roi. e des Malacoptérygiens subbrachin des gobous, dans ceterellie (Lepadogaster) où il forme un petit sous-
c. D. dans sa partie supérieure. Les yeux sont trèsrapprochés l'un de l'autre; les lèvres doubles et extensibles. On aperçoit une légère concavité sur la nuque, et l'on remarque sur le dos un enfoncement semblable; le ventre est très-saillant, très-gros, distingué, par sa proéminence, du dessous de la queue. II n'y a qu'une nageoire dorsale; et cette nageoire, qui est trèscourte, est placée au-dessus de l'extrémité de la queue, fort près de la caudale. Nous verrons une conformation très-analogue dans les ésoces; et comme d'ailleurs le testar a beaucoup de rapports avec les gobies, nous avons cru devoír former sa dénomination générique de la réunion du nom de Gobie avec celui d'Ésoce, et nous l'avons appelé Gobiésoce testar.

La nageoire de l'anus, plus voisine encore que la dorsale de celle de la queue, est cependant située en très-grande partie au-dessous de cette mème dorsale : la caudale est done trèsprès de la dorsale et de la nageoire de l'anus; elle est, de plus, très-étendue et fort arrondie'.

La couleur générale de l'animal est d'un roux plus foncé sur le dos que sur la partie inférieure du poisson, et sur lequel on ne distingue ni raies, ni bandes, ni taches proprement dites. Au milieu de ce fond presque doré, au moins sur certains individus, les yeux, dont l'iris est d'un beau bleu, paraissent comme deux saphirs.

\section{SOIXANTE-TROISIÉME GENRE.}

$$
\text { LES scombres. }
$$

Denx nageoires dorsales ; une ou plusieurs petites $\varkappa 0$ geoires au-dessus et au-dessous de la quene; les cobtés de la queue carenes, ou une pelite nagcoire compo-
see de denx aiguillons rémis par une menbrane, au-derant de la nageoire de l'anus.

espetces.$$
\text { cinsctears, }
$$

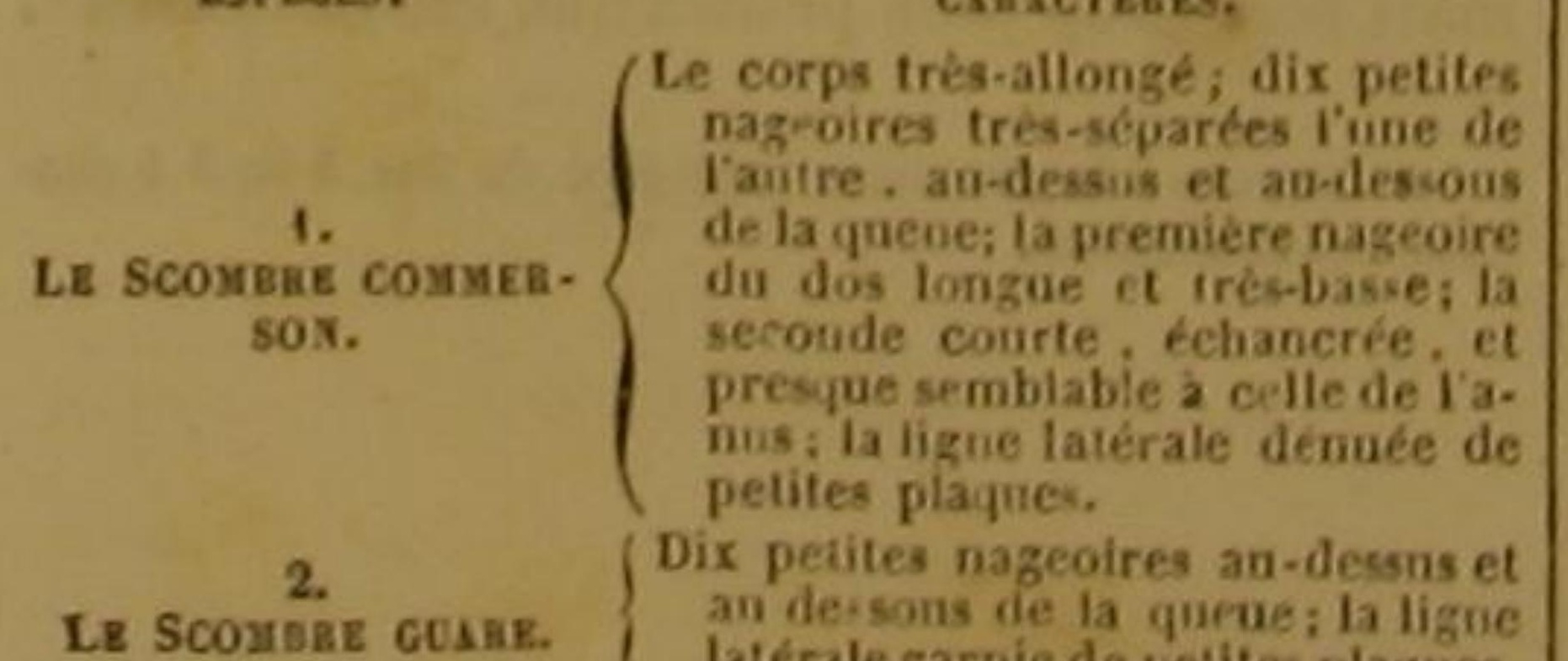

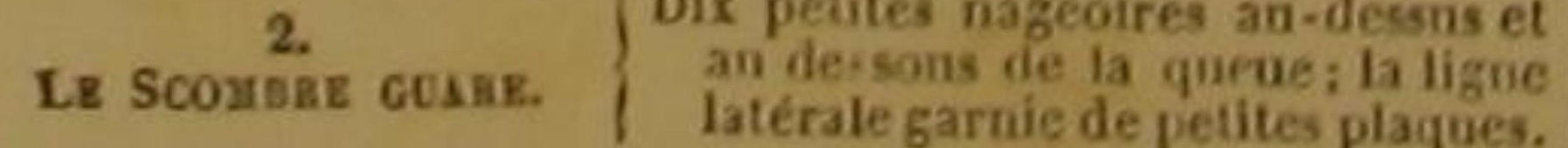

'A la nageoire dn dos 8 rayons, a chacnne des pectorales 11 . a chacune des thoracines 3 , à celle de l'anns 4 ou 5,13
la Caudale 11 .

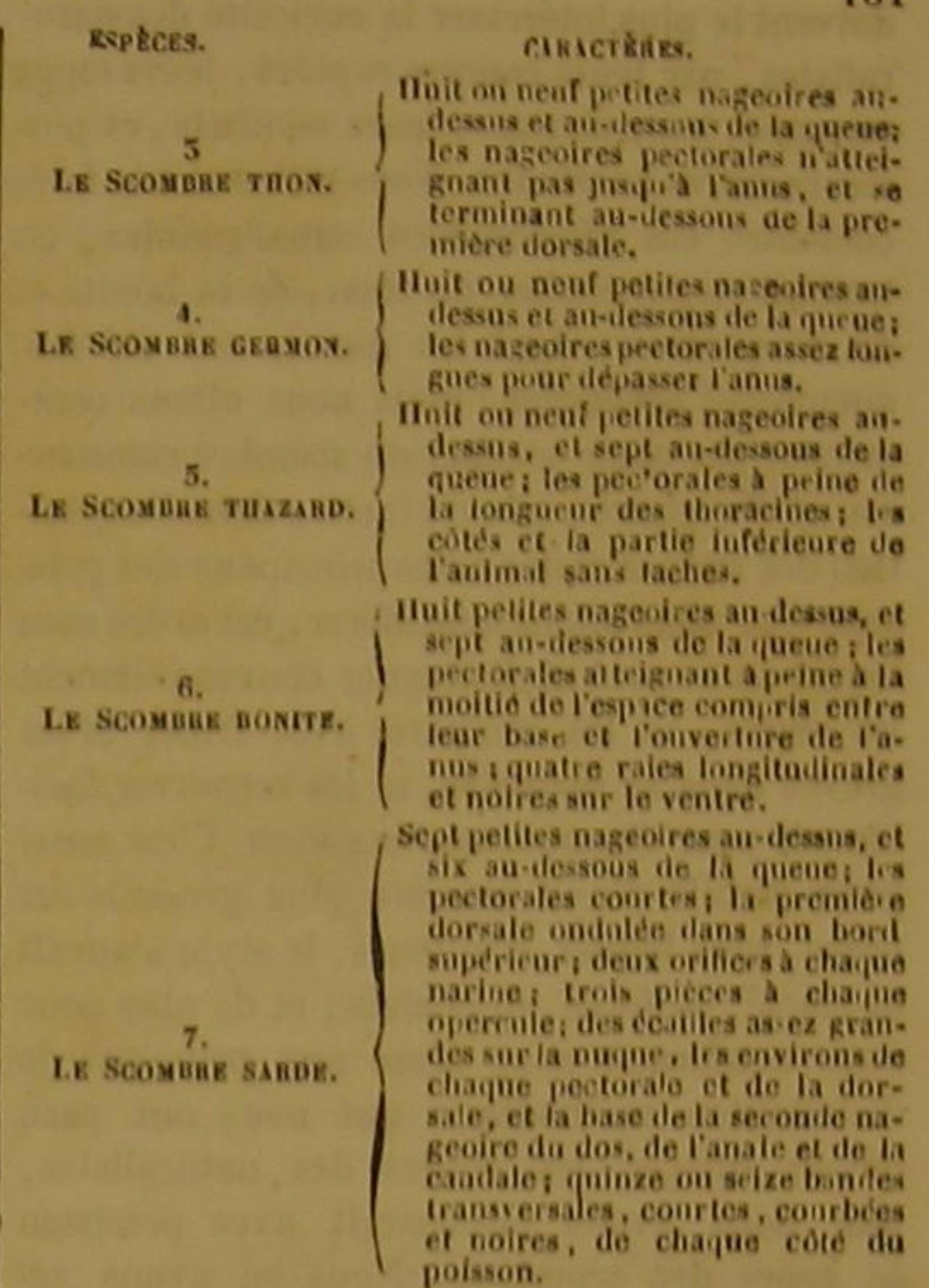

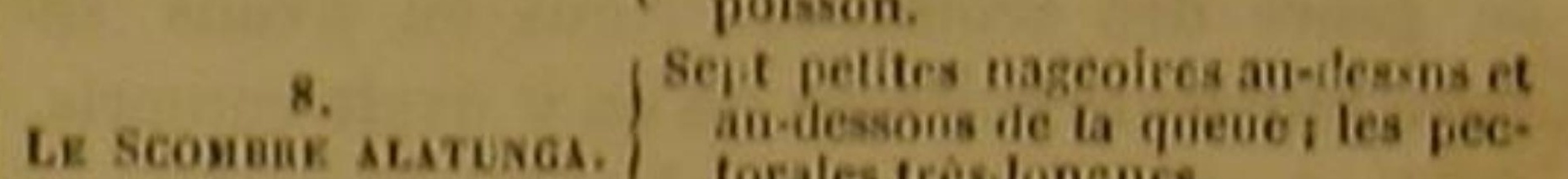

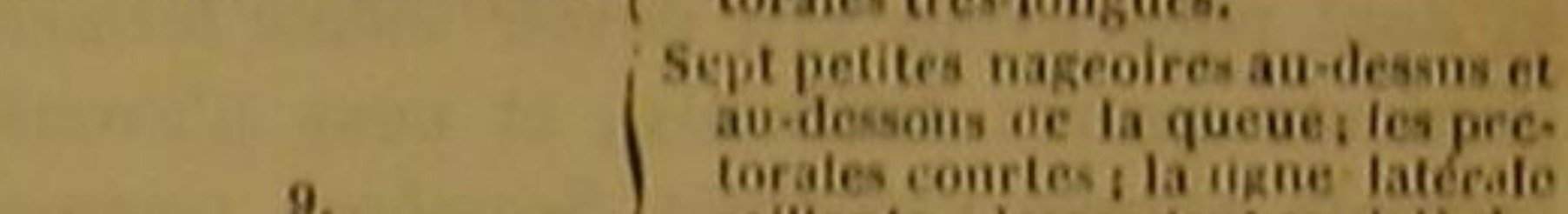

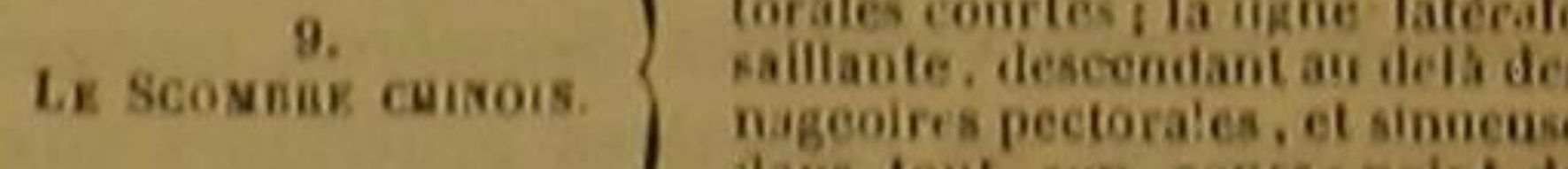

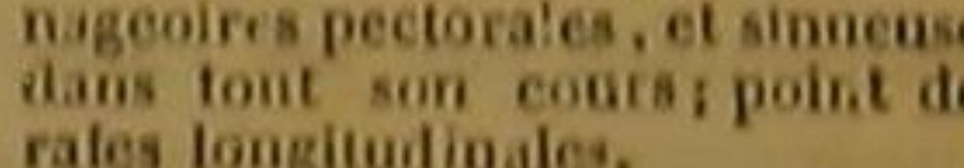

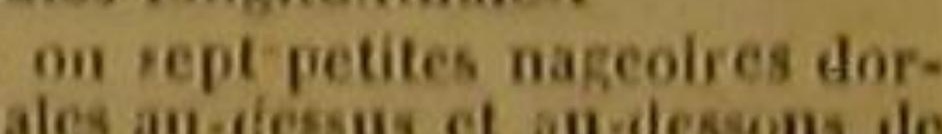

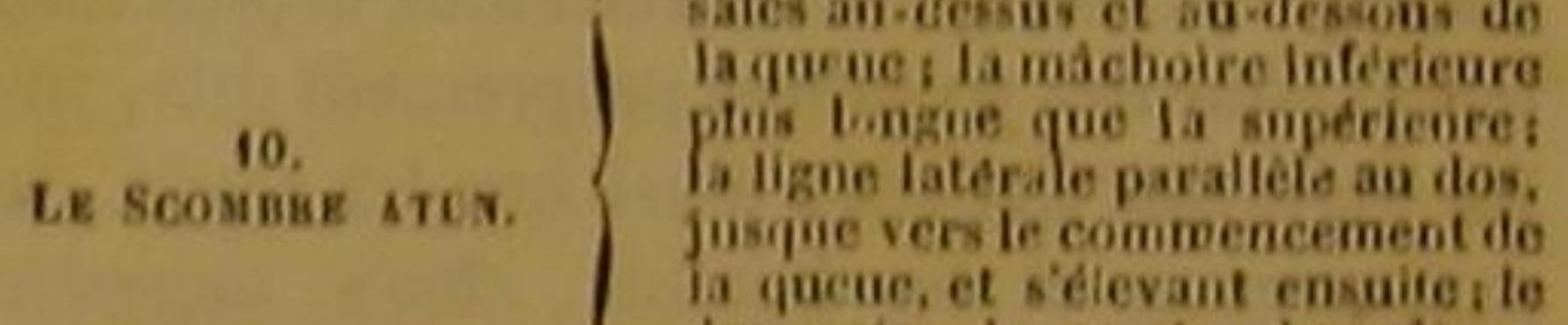
point de laclies nentre brunatire raies.
point

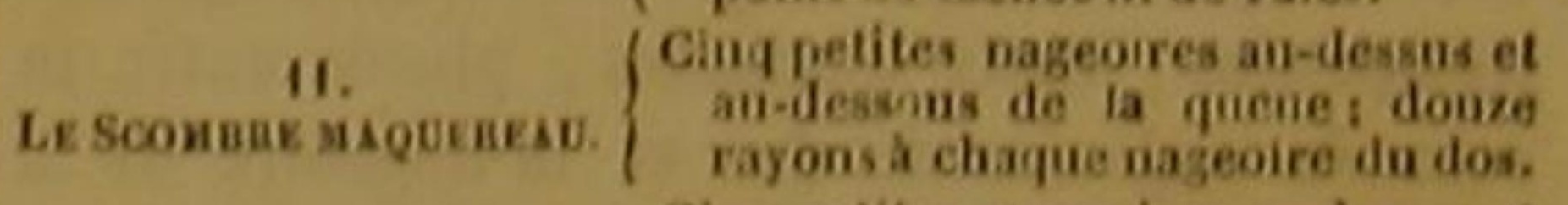

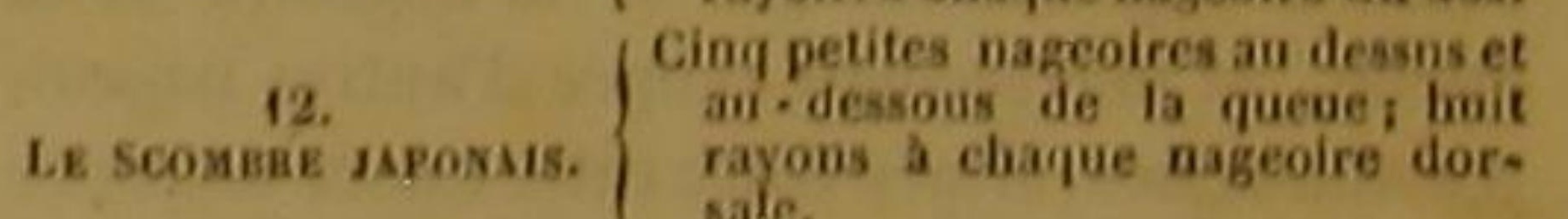
15. $\quad \begin{gathered}\text { Cinq petites nageolres au-drssus at } \\ \text { aut-dessous de la queve: la partie }\end{gathered}$ LE Scorrek doné. $\left\{\begin{array}{l}\text { au-dessous de la queue: la partio } \\ \text { sqpérieure de l'animal conleur } \\ \text { dor. }\end{array}\right.$

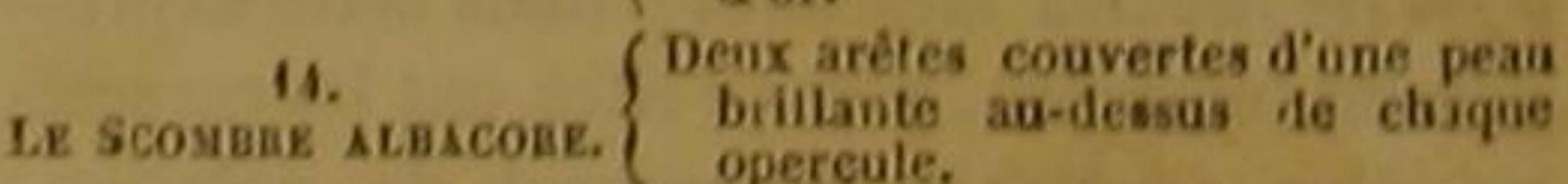

LE SCOMBRE COMMERSON.

Scomber Commerson, Lac, ; Cybiam Commersonil, Cav. '

Le genre des scombres est un de ceux qui

- Da sons-genre Tassard, cybium de M. Cuvier, dans le 
doivent le plus intéresser la curiosité des natu- $\mid$ avons présenté les premiers ceux qui ont le plus ralistes, par leurs courses rapides, leurs longs de ces nageoires additionnelles; et voilà pourvoyages, leurs chasses, leurs combats, et plu- quoi nous commençons par décrire une espèce sieurs autres habitudes. Nous tâcherons de faire de cette famille, que les naturalistes ne connaisconnaitre ces phénomènes remarquables, en sent pas encore, dont nous avons trouvé la fitraitant en particulier du thon, de la bonite et gure dans les manuscrits de Commerson, et à du maquereau, dont les mœurs ont été fré- laquelle nous avons cru devoir donner le nom quemment observées : mais nous allons com- de cet illustre voyageur, qui a enrichi la science mencer par nous occuper du scombre commer- de tant d'observations précieuses.

son et du guare, afin de mettre dans l'exposi- Ce scombre offire dix nageoires supplémention des formes et des actes principaux des pois- taires, non-seulement très-distinctes, mais sons que nous allons considérer, cet ordre sans très-séparées l'une de l'autre, dans l'intervalle lequel on ne peut ni distinguer convenablement qui sépare la caudale de la seconde nageoire du les objets, ni les comparer avec fruit, ni les dos; et dix autres nageoires conformées et disgraver dans sa mémoire, ni les retrouver faci- posées de même règnent au-dessous de la queue. lement pour de nouveaux examens. C'est aussi Ces nageoires sont composées chacune de quatre pour établir d'une manière plus générale cet ou cinq petits rayons réunis par une membrane ordre, sans lequel, d'ailleurs, le style n'aurait légère, rapproehés à leur base, et divergents à ni clarté, ni force, ni chaleur, et de plus pour leur sommet.

nous conformer sans cesse aux principes de Le corps et la queue de l'animal sont d'aildistribution méthodique qui nous ont paru leurs extrèmement allongés, ainsi que les mâdevoir diriger les études des naturalistes, choires qui sont aussi avancées l'une que l'auque nous avons circonscrit avec précision tre, et garnies toutes les deux d'un rang de le genre des scombres. Nous en avons séparé plusieurs poissons qu'on y avait compris, et dont nous avons cru devoir mème former plusieurs genres différents, et nous n'avons présenté comme véritables Scombres, comme semblables par les caractères génériques aux maquereaux, aux bonites, aux thons, et par conséquent aux poissons reconnus depuis longtemps pour des scombres proprement dits, que les thoracins qui ont, ainsi que les thons, le maquereaux et les bonites, deux nageoires dorsales, et en outre une série de nageoire très-petites, mais distinctes, placée entre In seconde nageoire du dos et la nageoire de la queue, et une seconde rangée d'autres nageo res analogues, située entre cette mèmè nageoire de la queue et celle de l'anus. On a donné à ces nageoires si peu étendues et si nombreuses le nom de fausses nageoires; mais cette expression est impropre, puisqu'elles ont les caractères d'un véritable instrument de natation qu'elles sont composées de rayons soutenus par une membrane, et qu'elles ne different que par leur figure et par leurs dimensions, des pectorales, des thoracines, ete.

Le nombre de ces petites nageoires variant suivant les espèces, c'est d'après ce nombre que nous avons déterminé le rang des divers poissons inserits sur le tablean du genre. Nous ents fortes, aiguēs et très-distinctes. seau est pointu; $\mathrm{l}^{\prime}$ il composé de deux lames arrondies dans leur contour postérieur; la première dorsale longue, et très-basse, surtout à mesure qu'elle s'avance vers la queue; la seconde dorsale échancrée par derrière, très-courte, et semblable à celle de lanus; la caudale très-échancrée en forme de croissant; la ligne latérale ondulée d'une manière peu commune, et fléchie par des sinuosités d'autant plus sensibles qu'elles sont plus près de l'extrémité de la queue; et la couleur générale du scombre, argentée, foncée sur le dos, et variée sur les cótés par des taches nombreuses et irrégulières.

Nous n'avons besoin, pour terminer le portrait du Commerson, que d'ajouter que les thoracines sont triangulaires comme les pectorales, mais beaucoup plus petites que ces dernières'. Cune des tonoracin a première nageoire du doo, 5 ou 6 a char cune des thoracines. 


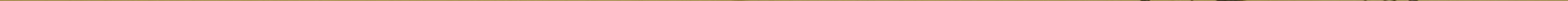


LE SCOMBRE GUARE '.

Seomber guara, Lacep.; Scomber cordyla, Linn. Gmel, ?.

C'est dans l'Amérique méridionale que l'on a observé le guare. Il a, comme le commerson, dix petites nageoires au-dessus ainsi qu'audessous de la queue. Mais indépendamment d'autres différences, sa ligne latérale est garnie de petites plaques plus ou moins dures, et presque osseuses; et l'on voit au-devant de sa nageoire de l'anus une petite nageoire composée d'une membrane et de deux rayons; ou, pour mieux dire, le guare présente deux nageoires anales, tandis que le scombre commerson n'en montre qu'une ${ }^{3}$.

\section{LE SCOMBRE THON 4.}

Scomber Thyonus, Linn., Gmel., Bloch, Lacep.,

$$
\text { Cuv. }{ }^{5} \text {. }
$$

L'imagination s'élève à une bien grande hauteur, et les jouissances de l'esprit deviennent

- Scombre guare, Daubeaton, Ene. méth. - Id. Bonnaterre, pl. de lEnc, néth. - I Scomber lined laterali curva, - Scomber compressus, Latus, ete. , Gronov. Zooph. 507. - Guara tereba. Marcgrav. Brasil. 172. - Traelucrio , brasiliensis. , Ral, Pisc. 93, pl, 346. - Scombre de Rotller, Bloch.

2M. Cuvier ne fait pas mention de celte espéce dans so négne animal. D.

- A la premiere nageoire da dos 7 rayons, a la seconde 9 a chacune des pectorales 15 , a chacune des thoracines 6 , a la premiere de lanus 2 , a la seconde 14,2 colede la durae 20 . Prance. - Alion, dans quelques déparı. mérid. - Toun , auprès de Barseille. - Tonno, sur les cótes de la LigarieTunny fish, Spanish mackrell, en Aogleterre. - Orcynus. - Albacore, dans quelques contrees a Europe. - Talling talling, aux saldives. - Scombre thon, Daubenton, Ene.

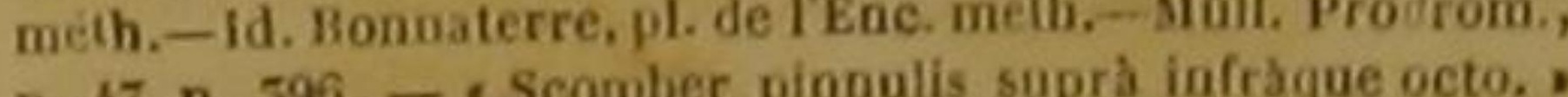

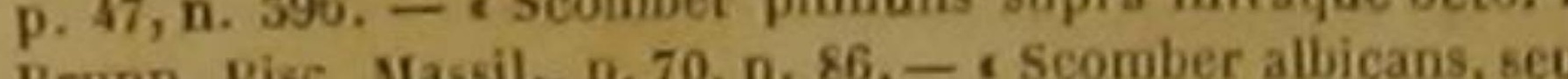
- albecor,, 0 b. It. 60. (II est inntile d'otserver que ces noms d'Albicor, on d'Albecor, Albacor, Albacere, ont éte donnés, par plasieurs voyageurs et par quel jues naturalistes, a différentes especes de scombres, ainsi que nous aurons de nouvelles occasions de le faire rewarquer.) - - Scomber
- pinualis octo seu novem in extremo dorso, sulco ad pinaa

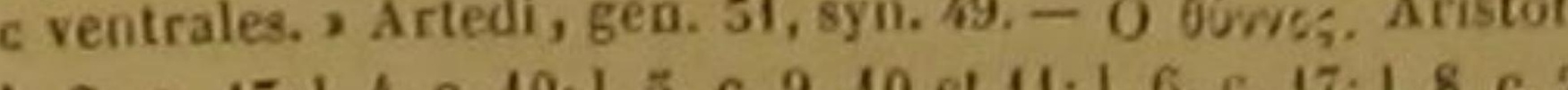
1. 2 , c. 15,1.4, c. $12,15,15$, c 15, 16, 27; et 1. 15. c. 5. 5 et $6 .-10$. Athen, p. 7. p. 504, 502, 505, 519. - Id. Oppian. Hal., I. 2, p. 48. Thunnus, Ovid. Hal., v. 98. - Id. Gaz. A rist. - Id. Aldrov. 1. 5, c. 18, p. 515. - Id. Jonston, 1. 1, tit. 1, c. 2, $a, 1$, tab. 5 , fig. 2. - Thunnus, sive thynnus, llelon. - Id. Gesner,
p. $957,967,1148$, et (germ.) fol. 58, b. - Rai, p. 57 . - Thun- Type du sous-penre Thon dans le genre Scombre. $\mathrm{Car}$ D. bien vives, toutes les fois que l'étude des productions de la nature conduit à une contemplation plus attentive de la vaste étendue des mers. L'antique Océan nous commande l'admiration et une sorte de recueillement religieux, lorsque ses eaux paisibles n'offrent à nos yeux qu'une immense plaine liquide. Le spectacle de ses ondes bouleversées par In tempête, et de ses abimes entr'ouverts au pied des montagnes éeumantes formées par ses flots amoncelés, nous pénètre de ce sentiment profond qu'inspire une grande et terrible catastrophe. Et quel ravissement n'éprouve-t-on pas, lorsque ce mème Océan, ne présentant plus ni l'uniformité du calme, ni les horreurs des orages conjurés, mollement agité par des vents doux et légers, et resplendissant de tous les feux de l'astre du jour, nous montre toutes les scènes variées des courses, des jeux, des combats er des amours des êtres vivants qu'il renferme dans son sein! Ce sont principalement les poissons auxquels on a donné le nom de Pélagiques, qui animent ainsi par leurs mouvements rapides et multipliés la mer qui les nourrit. On les distingue par cette dénomination, parce qu'ils se tiennent pendant une grande partie de l'année à une grando distance des rivages. Et parmi ces habitants des parties de l'Océan les plus éloignées des côtes, on doit surtout remarquer les thons dont nous écrivons l'hístoire. Les divers attributs qu'ils ont reçus de la nature leur donnent une grande prééminence sur le plus graud nombre des autres poissons. C'est presque toujours à la surface des eaux qu'ils se livrent au repos, ou qu'ils s'abandonnent à l'action des diverses causes qui peuvent les déterminer à se mouvoir. On les voit, réunis en troupes très-nombreuses, bondir avec agilité s'élancer avec force, cingler avec la vélocité

nus, vel orcynus, Schonev., p. 75. - Thynnus, Plin., 1. 9 ,

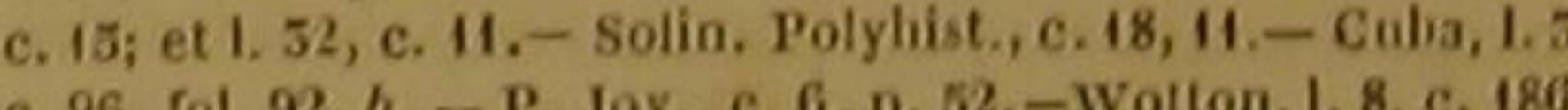

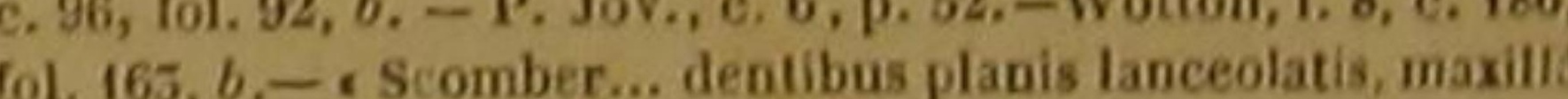
asperiore acula - Lêl. Epist. - S Scomber, pinnulis strinque novem, dorsa dipterygio, etc., Gronov. Zooph. 305. - - Thynnus pinnulis superioribus novem, inferioribus cocto. , Browne, Jamaic. 451 - - Coretta alba Pisonis. Willoghby, Iehthyol, tab. M, 5, fig. 1. - - Thynnus, seu

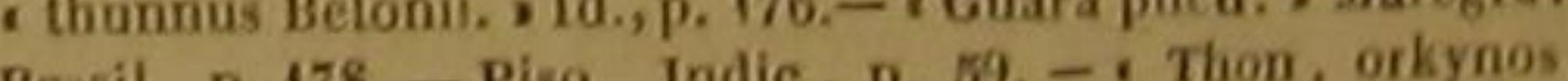

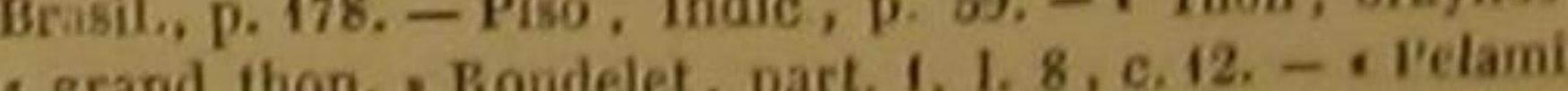

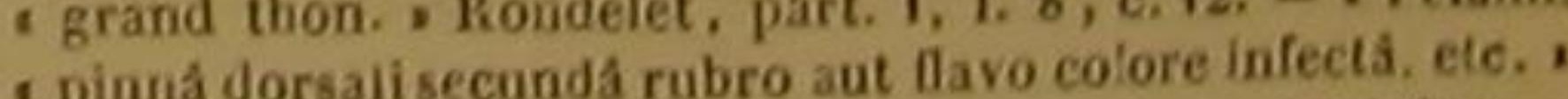
Klein, Miss. pisc. 5, p. 12, n. 5. - , Gros thon, vrai thon. Duhamel, Tra té des péches, part. 2, t, 5, sect. 7, c. 2, art. 1, p. 190 , pl. 8. 
d'une flèche. La vivacité avec laquelle ils échappent, pour ainsi dire, à l'œil de l'observateur, est principalement produite par une queue trèslongue, et qui, frappant l'onde salée par une face très-étendue, ainsi que par une nageoire très-large, est animée par des muscles vigoureux, et soutenue de chaque côté par un cartilage qui accroit l'énergie de ces muscles puissants '.

Lorsque, dans certaines saisons, et particulièrement dans celle de la ponte et de la fécondation des œufs, une nécessité impérieuse les amène vers quelque plage, ils serrent leurs rangs nombreux, et se pressent les uns contre les autres; et les plus forts ou les plus audacieux précédant leurs compagnons à des distances déterminées par les degrés de leur vigueur et de leur courage, pendant que des nuances différentes composent une sorte d'arrière-garde, plus ou moins prolongée, des individus les plus faibles et les plus timides, on ne doit pas etre surpris que la légion forme une sorte degrand parallélugramme animé, que l'on aperçoit naviguant sur la mer, ou qui, nagean au milieu des flots qui le couvrent encore et le dérobent à la vue, s'annonce cependant de loin par le bruit des ondes rapidement refoulées devant ces rapides voyageurs. Des échos ont quelquefois répété cette espèce de bruissement ou de murmure lointain, qui, se propageant alors de rocher en rocher, et multiplié de rivage en rivage, a ressemblé à ce retentissement sourd, mais imposant, qui, au milieu du calme sinistre des journées brùlantes de l'été, annonce l'approche des nuées orageuses.

Malgré leur multitude, leur grandeur, leur forcc et leur vitesse, ces éléments des succès dans l'attaque ou dans la défense, un bruit soudain a souvent suspendu une tribu voyageuse de thons au milieu de sa course : on les a vus troublés, arrêtés et dispersés par une vive décharge d'artillerie, ou par un coup de tonnerr subit. Le sens de l'ouie n'est mème pas, dan ces animaux, le seul que des impressions inat. tendues ou extraordinaires plongent dans une sorte de terreur : un objet d'une forme ou d'une couleur singulière suffit pour ébranler l'organe de leur vue, de manière à les effraver et à interrompre leurs habitudes les plus constantes.

- Yoyez, daus le Discours sur la na'ure des poissons, $c$ que nous avoas dit de la natition de ces animuas.
Ces derniers effets ont été remarqués par plu. Ces n'avaient pas échappé aux navigateurs anciens. Pline rapporte, par exemple, que, dans le printemps, les thons passaient en troupes composées d'un grand nombre d'individus, de la Méditerranée dans le Pont-Euxin ou mer Noire; que, dans le Bosphore de Thrace, qui réunit la Propontide à I'Luxin, et dans le détroit même qui sépare l'Europe de l'Asie, un rocher d'une blancheur éblouissante et d'une grande hauteur s'élevait auprès de Chalcédoine sur le rivage asiatique; que l'éclat de cette roche, frappant subitement les légions de thons, les effrayait au point de les contraindre à se précipiter vers le cap de Byzance, opposé à la rive de Chalcédoine ; que cette direction forcée dans le voyage de ces scombres en rendait la péche très-abondante auprès de ce cap de Byzance, et presque nulle dans les environs des plages opposées; et que c'est à cause de ce concours de thons auprès de ce promontoire, qu'on lui avait donné le nom de y.pugozipxs ou de Corne d'or, ou de Corne d'abondance' Ces scombres sont cependant très-courageux dans la plupart des circonstances de leur vie. Un seul phénomène le prouverait, e'est l'étendue et la durée des courses qu'ils entreprennent. Pour en connaitre nettement la nature, il faut rappeler la distinction que nous avons faite en traitant des poissons en général, entre leurs voyages périodiques et réguliers, et ceux qui ne présentent aucune régularité, ni dans les circonstances de temps, ni dans celles de lieu. Les migrations régulières et périodiques des thons sont celles auxquelles ils s'abandonnent, lorsqu'à l'approche de chaque printemps, ou dans une saison plus chaude, suivant le climat qu'ils habitent, ils s'avancent vers la température, I aliment, l'eau, l'abri, la plage, qui conviennent le mieux au besoin qui les presse, pour y déposer leurs œufs ou pour les arroser de leur liqueur vivifiante, ou lorsqu'après s'ètre débarrassés d'un fluide trop stimulant ou d'un poids trop incommode, et avoir repris des forces nouvelles dans le repos et l'abondance, ils quittent les cótes de l'Océan avec les beaux jours, regagnent la haute mer, et rentrent dans les profonds asiles qu'elle leur offre. Leurs

DES POISSONS.

voyages irréguliers sont ceux qu ils entreprenneut à des époques dénuées de tout caractère de périodicité, qui sont déterminés par la nécessité d'échapper à un danger apparent ou réel, de fuir un ennemi, de poursuivre une proie, d'apaiser une faim cruelle, et qui, ne se ressemblant ni par l'espace parcouru, ni par la vitesse employée à le franchir, ni par la direction des mouvements, sont aussi variables et aussi variés que les eauses qui les font naitre. Dans leurs voyages réguliers, ils ne vont pas communément chereher bien loin, ni par de grands détours, la rive qui leur est nécessaire, ou la retraite pélagienne qui remplace cette rive pendant le règne des hivers. Mais, dans leurs migrations irrégulières, ils parviennent souvent à de très-grandes distances; ils traversent avec facilité, dans ces circonstances, nonseulement des golfes et des mers interieures, mais même l'antique Océan. Un intervalle de plusieurs centaines de lieues ne les arréte pas ; et, malgré leur mobilité naturelle, fidèles à la cause qui a déterminé leur départ, ils continuent avee constance leur course lointaine. Nous lisons, dans l'intéressante relation rédigée et publicée par le général Milet-Mureau, du voyage de potre célèbre et infortuné navigateur La Pérouse ', que des scombres, à la vérité de l'espèce appelée Bonite, mais bien moins favorisés que les thons, relativement a la faculté de nager avee vitesse et avec constance, suivirent les bâtiments commandés par cet illustre vovageur, depuis les environs de l'ile de Pâques jusqu'á l'ile Mowée, l'une des iles Sandwich. La troupe de ces scombres, ou le banc de ces poissons, pour employer l'expression de nos marins, fit quinze cents lieues à la suite de nos frégates : plusieurs de ces animaux, blessés par les foènes ou tridents des matelots français, portaient sur le dos une sorte de signalement qu'il était impossible de ne pas distinguer; et l'on reconnaissait chaque jour les mêmes poissons qu'on avait vus la veille ${ }^{2}$

Quelque longue que puisse être la durée de cette puissance qui les maitrise, plusieurs marins allant d'Europe en Amérique, ou revenant d'Amérique en Europe, ont vu des thons accompaguer pendant plus de quarante jours les

: Voyage de La Pérouse, in-4o, t. II, p. 129. "Voyez ce que nous avons Ecrit sur la vitesse des poisnimagr. vaisseaux auprès desquels ils trouvaient avee racilité une partie de l'aliment qu'ils aiment; cette avidité, pour les diverses substances utritives que l'on peut jeter d'un navire dans mer, n'est pas le seul lien qui les retienne pendant un très-grand nombre de jours auprès des bâtiments. L'attentif Commerson a observe une autre cause de leur assiduité auprès de cerains vaisseaux, au milieu des mers chaudes de l'Asie, de l'Afrique et de l'Amérique, qu'il a parcourues. Il a éerit, dans ses manuscrits, que dans ces mers dont la surface est inondée des rayons d'un soleil brôlant, les thons, ainsi que plusieurs autres poissons, ne peuvent se ivrer, auprès de cette même surface des eaux, aux différents mouvemẻnts qui leur sont nécessaires, sans étre éblouis par une lumière trop vive, ou fatigués par une chaleur trop ardente: Is cherchent alors le voisinage des rivages escarpés, des rochers avancés, des promontoires élevés, de tout ce qui peut les dérober, penmut leurs jeux et leurs évolutions, aux feux de l'astre du four. Une escadre est pour eux comme une forêt flottante qui leur prête son ombre protectrice: Ies vaisseaux, les mâts, les voiles, les antennes, sont un abri d'autant plus heureux pour les scombres, que, perpétuellement mobile, il les suit, pour ainsi dire, sur le vaste Océan, s'avance avec une vitesse assez cale à celle de ces poissons agiles, favorise toutes leurs manœuvres, ne retarde en quelque sorte aucun de leurs mouvements; et voilà pourquoi, suivant Commerson, dans la zone orride, et vers le temps des plus grandes cha leurs, les thons qui accompagnent les bati ments se rangent, avec une attentiou facile à remarquer, du côté des vaísseaux qui n'est pas exposé aux rayons du soleil'.

Au reste, cette habitude de chercher l'ombre des navires peut avoir quelque rapport avec celle de suspendre leurs courses pendant les brumes, qui leur est attribuée par quelques voyageurs. Ils interrompent leurs voyages pour plusieurs mois, aux approches du froid; et, dès le temps de Pline, on disait qu'ils hivernaient dans l'endroít oú la mauvaise saison les surprenait. On prétend que, pendant cette saison rigoureuse, ils préferent pour leur habitation les fonds limoneux. Ils s'y nourrissent de

' Nous parlerons encore de celte ohservation de Commer. son, dins larticle du Scombre germon. 
poissons ou d'autres animaux de la mer plus | Quelques observateurs en ont compté neuf faibles qu'eux; ils se jettent particulièrement dans la partie supérieure et dans la partie infésur les exocets et sur les clupées; les petits rieure de cette portion de l'animal; et, d'après scombres deviennent aussi leur proie; ils n'é- ce dernier nombre, on pourrait être tenté de pargnent pas mème les jeunes animaux de leur croire que l'on peut quelquefois confondre l'esespèce; et comme ils sont très-goulus, et d'ail- pèce du thon avec celle du germon, dont la leurs tourmentés, dans certaines circonstances, queue offre aussi par-dessus et par-dessous huit par une faim qui ne leur permet pas d'atten- petites nageoires : mais la proportion des didre les aliments les plus analogues à leur orga- mensions des pectorales avec la longueur totale nisation, ils avalent souvent avec avidité, dans du scombre, suffira pour séparer avec facilité ces retraites vaseuses et d'hiver, aussi bien que les germons des poissons que nous tâchons de dans les autres portions de la mer qu'ils fré- bien faire connaitre. Dans les germons, ces pecquentent, des fragments de diverses espèces torales s'étendent jusqu'au delà de l'orifice de d'algues.

Ils ont besoin d'une assez grande quantite de nourriture, parce qu'ils présentent communément des dimensions considérables. Pline et les autres auteurs anciens qui ont écrit sur les thons, les ont rangés parmi les poissons les plus remarquables par leur volume. Le naturaliste romain dit qu'on en avait vu du poids de quinze talents ', et dont la nageoire de la queue avait de largeur, ou, pour mieux dire, de hauteur, deux coudées et un palme. Les observateurs modernes ont mesuré et pesé des thons de trois cent vingt-cinq centimètres de longueur, et du poids de cinquante-cinq ou soixante kilogrammes; et cependant ces poissons, ainsi que tous ceux qui n'éclosent pas dans le ventre de leur mère, proviennent d'œufs très-petits: on a comparé la grosseur de ceux du thon celle des graines de pavot.

Le corps de ce scombre est très-allongé, et semblable à une sorte de fuseau très-étendu. La tête est petite; l'œil gros; l'ouverture de la bouche très-large; la màchoire inférieure plus avancée que la supérieure, et garnie, comme cette dernièré, de dents aiguës; la langue courte et lisse; l'orifice branchial très-grand; l'opercule composé de deux pièces; le trone épais, et couvert, ainsi que la queue, d'écailles petites, minces et faiblement attachées. Les petites nageoires du dessus et du dessous de la queue sont communément au nombre de buit ${ }^{2}$.

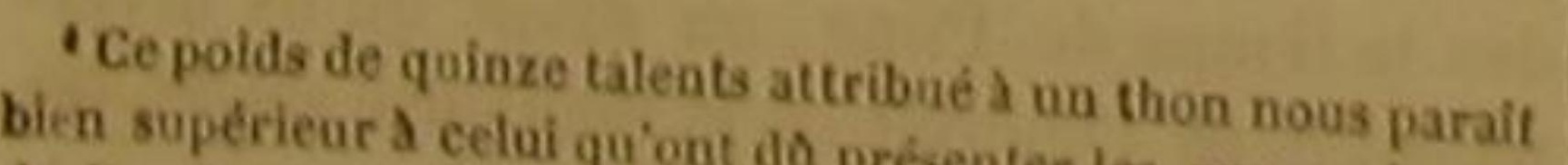
bien supérieur a celui qu'ont do présenter les gros poissons mains, leur centum. décrivons . En effet, le taleat des Rotrologie, p. 761) a 68 ॥. lixres de Fral, selon Paucton (Mé-

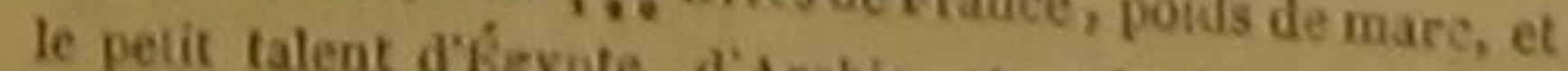
$\frac{1}{\cdots}$ livres de France. Un thon aurait do ic pese $45 \frac{\ldots 1}{10}$ ou 678 tivres, de hat ae un I A la premiere nazeoire dome pas adnissible.
I'anus; et, dans les thons, elles ne sont jamais assez grandes pour y parvenir; elles se terminent à peu près au-dessous de l'endroit du dos où finit la première dorsale. La nageoire de la queue est figurée en croissant : nous avons fait remarquer son étendue dès le commencement de cet article.

Nous avons eu oceasion, dans une autre portion de cet ouvrage', de parler de ces petits os auxquels on a particulièrement donné le nom d'arètes, qui, placés entre les muscles, ajoutent à leur force, que l'on n'apercoit pas dans toutes les espèces de poissons, mais que l'on n'a observés jusqu'à présent que dans ces habitants des eaux. Ces arêtes sont simples ou certaines espèces de poissons, elles aboutissaient à l'épine du dos, quoiqu'elles ne fissent pas véritablement partie de la charpente osseuse d'autres espèces, non-seulement ces arêtes n'é. taient pas liées avec la grande charpente osseuse, mais qu'elles en étaient séparées par differents intervalles. Les scombres, et par conséquent les thons, doivent être comptés parmi ces dernières espèces.

Telles sont les particularités de la conformation extérieure et intérieure du thon, que nous avons eru convenoble d'indicun, que couleurs qui le distinguent andiquer. Les variées, mais agréablesuent ne sont pas trèsvat mais agréables et brillantes: les cótés et le dessous de l'animal présentent l'éclat de l'argent; le dessus a la nuance de l'acier poli; l'iris est argenté, et sa circonférence dorée, extes nageoires sont jaunes ou jaunâtres, excepté la première du dos, les thoracines et

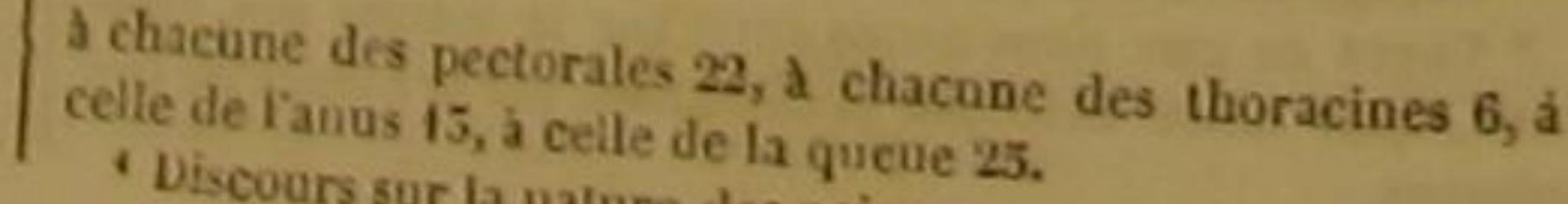
fourchues. Nous avons dit de plus que, dons proprement dite. Nous avons ajouté que, dans la caudale, dont le ton est d'un gris 'plus ou moins foneé.

Les anciens donnaient différents noms aux scombres qui sont l'objet de cet article, suivant l'âge, et par conséquent le degré de développement de ces animaux. Pline rapporte qu'on nommait Cordyles les thons très-jeunes qui, venant d'éelore dans la mer Noire, repassaient, pendant l'automne, dans I'Hellespont et dans la Méditerranée, à la suite des légions nombreuses des auteurs de leurs jours. Arrivés dans la Méditerranée, ils y portaient le nom de Pelamides pendant les premiers mois de leur croissance; et ce n'était qu'après un an que la dénomination de Thon leur était appliquée.

Nous avons eru d'autant plus utile de faire mention ici de cet antique usage des Grees ou Romains, que ces expressions de Cordyle et de Pélamide ont été successivement employées par plusieurs auteurs anciens et modernes dans des sens très-divers; qu'elles servent maintenant à désigner deux espèces de scombres, le Guare et la Bonite, très-différentes du véritable thon; et qu'on ne saurait prendre trop de soin pour éviter la confusion, qui n'a régné que trop longtemps dans l'étude de l'histoire naturelle.

Des animaux marins très-grands et trèspuissants, tels que des squales et des xiphias , sont pour les thons des ennemis dangereux, contre les armes desquels leur nombre et leur réunion ne peuvent pas toujours les défendre. Mais indépendamment de ces adversaires re marquables par leur force ou par leurs dimensions, le thon expire quelquefois victime d'un étre bien petit et bien faible en apparence, mais qui, par les piqứres qu'il lui fait et les tourments qu'il lui cause, l'agite, l'irrite, le rend furieux, à peu près de la même manière que le terrible insecte ailé qui règne dans les déserts brủlants de l'Afrique, est le fléau le plus funeste des pantheres, des tigres et des lions. Pline savait qu'un animal dont il compare le volume à celui d'une araignée, et la figure à celle du scorpion, s'attachait au thon, se placait auprès ou au-dessous de l'une de ses nageoires pectorales, s'y cramponnait avec force, le piquait de son aiguillon, et lui causait une douleur si vive, que le scombre, livré à une sorte de délire, et ne pouvant, malgré tous ses efforts, ni immoler ni fuir son ennemi, ni apai- ser sa souffrance cruelle, bondissait avec violence au-dessus de la surface des eaux, la parcourait avee rapidité, s'agitait en tout sens, et ne résistant plus à son état affreux, ne connaissant plus d'autre danger que la durée de son angoisse, excédé, égaré, transporté par une sorte de rage, s'élançait sur le rivage ou sur le pont d'un vaisseau, où bientót il trouvait dans la mort la fin de son tourment'

C'est parce qu'on a bien observé dans les thons cette nécessité funeste de succomber sous les ennemis que nous venons d'indiquer, I'habitude du succès contre d'autres animaux moins puissants, le besoin d'une grande quantité de nourriture, la voracité qui les préeipite sur des aliments de différente nature, leur courage habituel, I'audace qu'ils montrent dans certains dangers, la frayeur que leur inspirent cependant quelques objets, la périodicité d'une partie de leurs courses, l'irrégularité de plusieurs de leurs voyages et pour les temps et pour les lieux, la durée de leurs migrations et la faciliti de traverser d'immenses portions de la mer, qu'on a très-bien choisi les époques, les endroits t les moyens les plus propres à procurer une péche abondante des scombres qui nous oceupent dans ce moment.

En effet, on peut dire en général qu'on trouve le thon dans presque toutes les mers chaudes ou tempérées de l'Europe, de l'Asie, de l'Afrique et de I'Amérique; mais on ne rencontre pas un égal nombre d'individus de cette espèce dans toutes les saisons ni dans toutes les portions des mers qu'ils fréquentent. Depuis les siècles les plus reculés de ceux dont l'histoire nous a transmis le souvenir, on a choisi certajnes plages et certaines époques de l'année pour la recherche des thons. Pline dit qu'on ne péchait ces scombres dans I'Hellespont, la Propontide et le Pont-Euxin, que depuis le commencement du printemps jusque vers la fin de l'automne. Du temps de Rondelet, e'est-ä-dire vers le milieu du seizième siècle, c'était au printemps, en automne, et quelquefois pendant l'été, qu'on prenait une grande quantite de thons près des cotes d'Espagne, et particulièrement vers le détroit de Gibraltar ${ }^{2}$. On s'oc-

- Hondelet a fait représenter sur la figure du thon quili a publiée, le petit animal dont Pline a parte.

2 On a quelquefois pris un assez grand no ibre de thons anprés de Conil, village voisia de Cadix, pour qu'on ait eerit 
cupe de la pêche de ces anlmaux sur plusieurs scombres thons faites de concert par un grand atvages de France et d'Espagne voisins de l'extrémité occidentale de la chaîne des Pyrénées, depuis les premiers jours de juin jusqu'en novembre; et on regarde comme assez assuré sur les autres parties du territoire français qui sont baignées par l'Océan, que l'arrivée des maquereaux annonce celle des thons qui les poursuivent pour les dévorer.

Ces derniers scombres montrent en effet une si grande avidité pour les maquereaux, qu'il suffit, pour les attirer dans un piége, de leur présenter un leurre qui en imite grossièrement la forme. Ils se jettent avec la même voracité sur plusieurs autres poissons, et particulière. ment sur les sardines; et voilà pourquoi une image même très-imparfaite d'un de ces derniers animaux est, entre les mains des marins, un appát qui entraine les thons avee facilité, On s'est servi de ce moyen avec beaucoup d'avantage dans plusieurs parages, et principalement auprès de Bayonne, où un bateau allant à la voile trainait des lignes dont les haims étaient recouverts $d$ un morceau de linge, ou d'un petit sac de toile en iorme de sardine, et ramenait ordinairement plus de cent cinquante thons.

Mais ce n'est pas toujours une vaine apparence que l'on présente à ces scombres pour les prendre à la ligne : de petits poissons réels, ou des portions de poissons assez grands, sont souvent employés pour garnir les haims. On proportionne d'ailleurs la grandeur de ces haims, ainsi que la grosseur des cordes ou des lignes, aux dimensions et à la force des thons que l'on s'attend à rencontrer; et de plus, en se servant de ces haims et de ces ligues, on cherche à prendre ces animaux de diverses manières, suivant les différentes circonstances dans lesquelles on se trouve : on les prend au doigt $^{\prime}$, à la canne ${ }^{3}$, au libouret ${ }^{3}$, au grand couples.

Mais parlons rapidement de procédés plus compliqués dont se composent les pèches des

Sildonia un revenu de 80,000 ducats. Voyez les Leltres sur
la Grèces de feu mon confrìre la Grees de leu mon confrère M. Guys, L. I, p. 398, 5* ed. simp'e non suspendue à une perche. qui se fait avee une ligne simp.e non suspeudue à une perche.

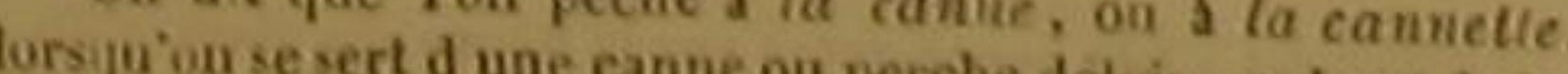
que le ou a empilé un haim, cest-a-dire, au bout de lanombre de marins. Exposons d'abord celle qui a lieu avec des thonnaires; nous nous occupe. rons, ensuite, de celle pour laquelle on construit des madragues.

On domne le nom de thonnaire ou tonnaire à une enceinte de filets que l'on forme promp. tement dans la mer pour arrêter les Thons au moment de leur passage. On a eu pendant long. temps recours à ce genre d'industrie auprès de Collioure, où on le pratiquait, et où peut-être on le pratique encore, chaque année, depuis le mois de juin jusqu'à la fin de septembre. Pour favoriser la prise des thons, les habitants de Collioure entretenaient, pendant la belle saison, deux hommes expérimentés qui, do haut de deux promontoires, observaient l'arrivée de ces scombres vers la côte. Dès qu'ils apercevaient de loin ces poissons qui s'avançaient par bandes de deux ou trois mille, ils en avertissaient les pécheurs en déployant un pavillon, par le moyen duquel ils indiquaient de plus l'endroit où ces animaux allaient aborder. A la vue de ce pavillon, de grands eris de joie se faisaient entendre, et annoncaient l'approche d'une pê. che dont les résultats importants étaient toujours attendus avec une grande impatience. Les habitants couraient alors vers le port, où les patrons des bátiments pêcheurs s'empressaient de prendre les filets nécessaires, et de faire entrer dans leurs bateaux autant de personnes que ces embarcations pouvaient en contenir, ain de ne pas manquer d'aides dans les grandes manœuvres qu'ils allaient entreprendre. Quand ous les bateaux étaient arrivés à l'endroit où les thons étaient réunis, on jetait à l'eau des

polds de plomb. La corde passe au travers d'un morceau de de bois est pance longuear, nunime aralelle, Ce morceau voir lourner peree dans un de ses borts, de manière a poud'ailleurs mintenee a nar de la corde. Cette avalette est dailcurs ma ntenue, a une pelite distance du plemb, par
deux nouds que 'on fait a licorde. l'un au-dessous et l'autre au-dessus de ce morcean de bois. Au bout delayalette op. posé a celui que la corde traverse, on attache une ligne garwie de plusieurs empiles ou petites lignes "qui portent des haims, et quit s int de differentes longueurs, pour ne point sembarrasser ies unes dans les autres. Cet instrument sert tomb portant pour les pécies sedentaires, le poids de

' 'n couple est un fi' de fer un peu courbe, dont chaque haims, et qui est suspendu par le milien a une ligne principale assez longue, el tenue par des pécheurs dont la barque va a la voile. - Voyez, dans Farticle de la Raie boaclie, la déabition dune em-
pite. 
pièces de filets lestées et flottées, et on en / née seize mille thons, dont chacun pesait de dix

formait une enceinte deni-circulaire, dont la concavité était tournée vers le rivage, et dont l'intérieur était appelé jardin. Les thons renfermés dans ce jardin s'agitaient entre la rive et les filets, et étaient si effrayés par la vue seule des barrières qui les avaient subitement environnés, qu'ils osaient à peine s'en approcher à la distance de six ou sept mètres.

Cependant, à mesure que ces scombres s'avançaient vers la plage, on resserrait l'enceinte, ou plutôt on en formait une nouvelle intérieure et concentrique à la première, avee des filets qu'on avait ienus en réserve. On laissait une ouverture àcette seconde enccinte jusqu'à ce que tous les thons eussent passé dans l'espace qu'elle embrassait; et en continuant de diminuer ainsi, par des clotures successives, et toujours d'un plus petit diamètre, l'étendue dans laquelle les poissons étaient renfermés, on parvenait à les retenir sur un fond recouvert uniquement par quatre brasses d'eau : alors on jetait dans ce pare maritime un grand boulier ', espèce de seine, dont le milieu est garui d'une manche. Les thons, après avoir tourné autour de ce filet, dont les ailes sont courbes, s'enfonçaient dans la poche ou manche: on amenait, a force de bras, le boulier sur le rivage; on prenait les petits poissons avec la main, les gros avec des crochets; on les chargeait sur les bateaux pécheurs, et on les transportait au port de Colioure. Une seule pèche produisait quelquefois plus de quinze mille myriagrammes de thons; et pendant un printemps dont on a conservé avec soin le souvenir, on prit dans une seule jour-

- On appelle toulier, sur la côte voisine de Narbonne et

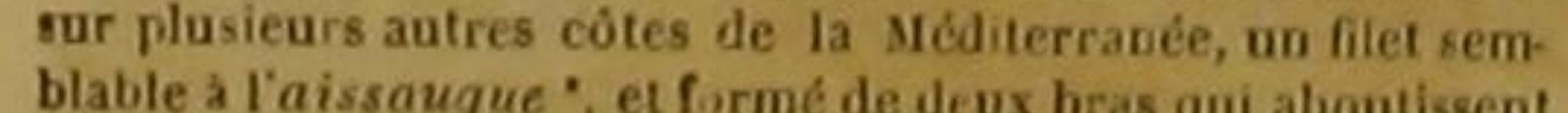
à un ' manche. Son enscmble est composé de pl isiears pièent dont les mailles sont de différentes grandenrs. Pour fiire les bras, on assemb e, 10 douze pièzcs, dites allas, dont les dites de deux doigls, dont les mail cs ont trente sept millimétres en carré́; el 5o dix piècess tie pousal, pousaux $x$ pouceaux, dont les mailles ont pres de deux centimétres dover. verture. Tout cel a-sembiage a diepuis ceut vingt jasuruà à cent quatre-vingts brases de longucur. Quant au corps de la manche, qu on nomme aussi bourse ou coup, il est compose de six pieces, dites de quatre-vingts, dont chaque maille a piéces appelées de drassade, dont et secondement, de huit de linit millimetres.

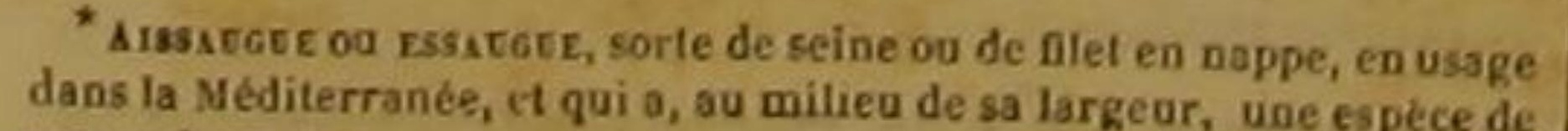
de pocke. a quinze kilogrammes.

Il est des parages dans la Méditerranée où I'on se sert, pour prendre des thons, d'un $n$ let auquel on a donné le nom de scombrière, de combrière, de courantille, qu'on abandonne aux courants, et qui va pour ainsi dire au-devant de ces scombres, lesquels s'engagent et s'embarrassent dans ses mailles. Mais hatonsnous de parler du moyen le plus puissant de s'emparer d'une grande quantité de ces animaux si recherchés; occupons-nous d'une des péches les plus importantes de celles qui ont lieu dans la mer; jetons les yeux sur la péche pour laquelle on emploie la madrague. Nous en a vons dejà dit un mot en traitant de la raie mobular; tachons de la mieux décrire.

On a donné le nom de madrague ' à un grand pare qui reste construit dans la mer, au lieu d'être établi pour chaque péche, comme les thonnaires. Ce pare forme une vaste enceinte distribuée en plusieurs chambres, dont les noms varient suivant les pays : les cloisons qui forment ces chambres sont soutenues par des flottes de liége, étendues par un lest de pierres, et maintenues par des cordes dont une extrémité est attachée à la tête du filet, et l'autre amarrée à une ancre.

Comme les madragues sont destinées à arrêter les grandes troupes de thons, au moment où elles abandonnent les rivages pour voguer en pleine mer, on établit entre la rive et la graude enceinte une de ces longues allées que l'on appelle chasses : les thons suivent cette allée, arrivent à la madrague, passent de chambre en chambre, parcomrent quelquefois, de compartiment en compartiment, une longueur de plus de mille brasses, et parviennent enfin à la dernière chambre, que l'on nomme chambre de la mort, ou corpon, ou corpou. Pour forcer ces scombres à se rassembler dans ce corpou qui doit leur étre si funeste, on les pousse et les presse, pour ainsi dire, par un filet long de plus de vingt brasses ${ }^{2}$, que l'on tient tendu derrière ces poissons par le moyen de deux bateaux, dont chacun soutient un des angles supérieurs du filet, et que l'on fait avancer vers

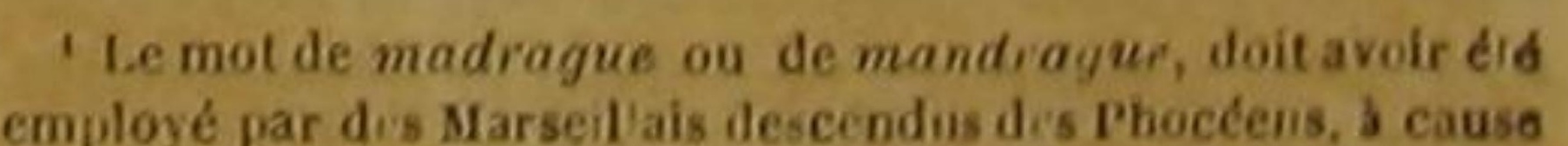
du mot grec p.avdpo, mandra, qui siguifie, arc, enclos, en.

On nomme de filet engarm. 
la chambre de la mort. Lorsque les poissons j au milieu de la paix des plaisirs, les agitations sont ramassés dans ce corpou, plusieurs bar- de la souffrance à côté du calme du bonheur, ques chargées de pècheurs s'en approchent; on la rage de la douleur auprès du délire de la joie; soulève les filets qui composent cette enceinte qu'il cesse d'avoir besoin de ces contrastes horparticulière, on fait monter les scombres très- ribles; et que la tendre pitié ne soit jamais conprès de la surface de l'eau, on les saisit avec la trainte de s'éloigner, en gémissant, de la pompe main, ou on les enlève avec des crocs.

La curiosité attire souvent un grand nombre de spectateurs autour de la madrague; on y accourt comme à une fête; on rassemble autour de soi tout ce qui peutaugmenter la vivacité du plaisir; on s'entoure d'instruments de musique: et quelles sensations fortes et variées ne font pas en effet éprouver l'immensité de la mer, la pureté de l'air, la douceur de la température, l'éclat d'un soleil vivifiant que les flots mollement agités réfléchissent et multiplient, la fralcheur des zéphyrs, le concours des bâtiments légers, l'agilité des marins, l'adresse des pècheurs, le courage de ceux qui combattent contre d'énormes animaux rendus plus dangereux par leur rage désespérée, les élans rapides de l'impatience, les cris de la joie, les acclamations de la surprise, le son harmonieux des cors, le retentissement des rivages, le triomphe des vainqueurs, les applaudissements de la multitude ravie I

Mais nous, qui écrivons dans le calme d'une retraite silencieuse I'histoire de la Nature, n'abandomnons point notre raison au charme d'un spectacle enchanteur; osons, au milieu des transports de la joie, faire entendre la voix sévère de la philosophie; et si les lois conservatrices de l'espèce humaine nous commandent ces sacrifices sans cesse renouvelés de milliers de victimes, n'oublions jamais que ces vietimes sont des étres sensibles; ne cédons à la dure nécessité que ce qu'il nous est impossible de lui ravir; n'augmentons pas par des séductions que des jouissances plus douces peuvent si facilement remplacer, le penchant encore trop dangereux qui nous entraine vers une des passions les plus bideuses, vers vers une des passions les plus hideuses, vers une cruelle insensibilité; effaçons, s'il est possible, du cœur de l'homme cette empreinte encore trop profonde de la féroce barbarie dont il a eu tant de peine à secouer le joug; enchainons cet instinet sauvage qui le porte encore à ne voir la conservation de son existence que dans la destruction; que les lumières de la eivilisation l'éelairent sur sa véritable félicité; que ses regards avident ne cherchent jamais les horreurs de la guerre de ses fètes.

Au reste, il n'est pas surprenant que, depuis un grand nombre de siècles, on ait cherché et employé un grand nombre de procédés pour la péche des thons : ces scombres, en procurant un aliment très-abondant, donnent une nourriture très-agréable. On a comparé le goût de la chair de ces poissons à celui des acipensères es. turgeous, et par conséquent à celui du veau. Ils engraissent avec facilité; et l'on a écrit ' qu'il se ramassait quelquefois une si grande quantité de substance adipeuse dans la partie inférieure de leur corps, que les téguments de leur ventre en étaient tendus au point d'ètre aisément déchirés par de légers frottements. Ces poissons avaient une grande valeur chez les Grees et chez les autres anciens habitants des rives de la Méditerranée, de la Propontide, de la mer Noire; et voilà pourquoi, dès une époque bien reculée, ils avaient été observés avec assez de soin pour que leurs habitudes fussent bien connues. Les Romains ont attaché particulièrement un grand prix à ces scombres, surtout lorsque asservis sous leurs empereurs, ils ont voulu remplacer par les jouissances du luxe les plaisirs de la gloire et de la liberté ; et comme nous ne croyons pas inutile aux progrès de la morale et de l'économie publique, d'indiquer à ceux qui cultivent ces sciences s importantes, toutes les particularités de ce goùt si marqué que nous avons observé dans les anciens pour les aliments tirés des poissons, nous ne passerons pas sous silence les petits déails que Pline nous a transmis sur la préférence que les Romains de son temps donnaient telle ou telle portion des scombres auxquels cet article est consacré. Ils estimaient beaucoup cependant comme difficile à digérer, surtout presque aucuit pas très-frais; ils ne faisaient presque aucun cas des morceaux voisins de nageoire caudale, parce qu'ils ne les trouvaient tête et le dessous du ventre; ils reaucoup la tele dessous du ventre; ils recherchaient aussi le dessous de la poitrine, qu'ils regardaient

DES POISSONS

pas assez gras; et ce qu'ils préféraient à plusieurs autres aliments, était la portion la plus proche du gosier ou de l'osophage. Ces mèmes Romains savaient fort bien conserver les thons, en les coupant par morceaux, et en les renfermant dans des vases remplis de sel; et ils donnaient à cette préparation le nom de Mélandrye (melandrya), à cause de sa ressemblance avec des copeaux un peu noircis de chène, ou d'autres arbres. Les modernes ont employé le mème procédé. Rondelet dit que ses contemporains coupaient les thons qu'ils voulaient garder par tranches ou darnes, et qu'on donnait à ces darnes imbibées de sel le nom de Thonnine ou de Tarentella, parce qu'on en apportait beaucoup de Tarente. Très-souvent, au lieu de se contenter de saler les thons par des moyens à peu près semblables à ceux que nous avons exposés en traitant du gade morue, on les marine après les avoir coupés par tronçons, et en les préparant avee de l'huile et du sel. On renferme les thons marinés dans des barils; et on distíngue avec beaucoup de soin ceux qui contiennent la chair du ventre, préférée aujourd'bui par les Européens comme autrefois par les Romains, et nommés panse de thon, de ceux dans lesquels on a mis la chair du dos, que l'on appelle dos de thon, ou simplement thonnine '.

Comme les thons sont ordinairement trèsgras, il se détache de ces poissons, lorsqu'on les lave et qu'on les presse pour les saler, une huile communément assez abondante, qui surnage promptement, que l'on ramasse avec facilité, et qui est employée par les tanneurs.

Il est des mers dans lesquelles ces scombres se nourrissent de mollusques assez malfaisants pour faire éprouver des accidents graves à ceux qui mangent de ces poissons sans avoir pris la précaution de les faire vider avec soin, et même pour contracter dans des portions de leur corps réparées pendant longtemps par des substances vénéneuses, des qualités très-funestes ${ }^{2}$ : tant Il sembleque sur toutes ses productions, comme dans tous ses phénomènes, la nature préservatrice ait voulu placer un emblème de la prudence tutélaire, en nous montrant sans cesse

'Les anclens faisaient oler les intestins do thon, ainst que les covfs de ce scombre, gui servent encore de nos jours, sur plasieurs côtes, et particaliérement sar celles de la Gréce, a faire une sorle de poutargue. Consultez principalement, a ce sujel, A alu Gelle, I. 10, c. 20. vénéneux, le Disconrs

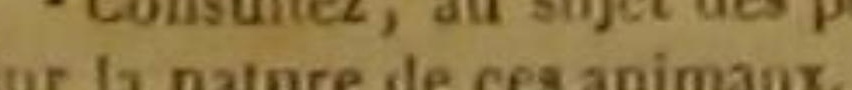

l'aspic sour
la rose.

LE SCOMBRE GERMON'.

Scomber Germo, Lacep.; Scomber Alatunga, Lina., Gmel, 3

Cette espèce de scombre a étéjusqu'à présent confondue par les naturalistes, ainsi que par les marins, avec les autres espèces de son genre. Elle mérite cependant à beaucoup d'égards une attention particulière, et nous allons tácher de la faire connaitre sous ses véritables traits, en présentant avec soin les observations manuscrites que Commerson nous a laissées au sujet de cet animal.

Le germon, dont la grandeur approche de celle des thons, a communément plus d'un mètre de longueur ; et son poids presque toujours au-dessus d'un myriagramme, s'étend quelquefois jusqu'à trois. Sa couleur est d'un bleu noiratre sur le dos, d'un bleu tres-pur et très-beau sur le haut des cótés, d'un bleu arrenté sur le bas de ces mèmes cotés, et d'ane einte argentée sans mélange sur sa partie inférieure. On voit, sur le ventre de quelques individus, des bandes transversales; mais elles sont si fugitives, qu'elles disparaissent avec rapidité lorsque le scombre expire, et mème lorsqu'il est hors de l'eau depuis quelques instants, L'animal est allongé et un peu conique a ses deux extrémités ; la tête revêtue de lames écailleuses, grandes et brillantes; le corps recouvert, ainsi que la queue, d'écailles petites pentagones, ou plutôt presque arrondies.

Un seul rang de dents garnit chacune des deux mâchoires, dont I'inférieure est d'ailleurs plus avancée que la supérieure.

L'intérieur de la bouche est noirâtre dans son contour; la langue courte, un peu large, arrondie par devant, eartilagineuse et rude; le palais raboteux comme la langue; l'ouverture de chaque narine réduite à une sorte de fente; clia-

- Scomber germo. - Iscomber (germo) pinnis pectorali. bos ultra anum productis, pinnulis doralibus novem, vea cités. - Germon, par plas. navigateurs français. - Longue oreille, par d'autres navigateurs.

A. Cuvier forme areo ce poisson et quelques autres un sous-genre de Scombres, sous le nom de Cermon Orcynus. II lui attribue la synoyymio sulvale : dlatura des ita-

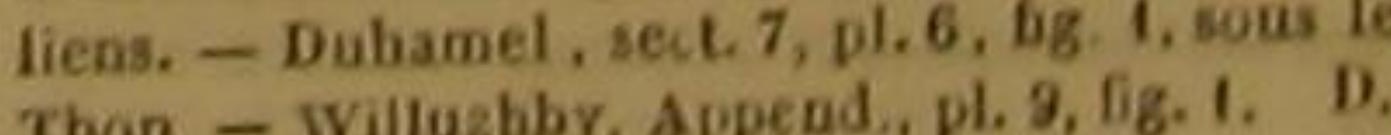


que commissure marquée par une prolongation | sa couleur, est petite et souvent rougeâtre ou triangulaire de la màchoire supérieure; l'œil dorée.

grand et un peu convexe; l'opercule branchial Les petites nagcoires du dessus et du dessous composé de deux pièces dénuées d'écailles sem- de la queue sont triangulaires, et au nombre de blables à celles du dos, resplendissantes de l'é- huit ou de neuf dans le haut, ainsi que dans le clat de l'argent, et dont la seconde s'étend en bas. Ce nombre parait être très-constant dans croissant autour de la première et en borde le les individus de l'espèce que je décris, puisque contour postérieur.

On peut voir au-dessous de cet opercule une membrane branchiale blanchâtre dans sa cireonférence, et noirâtre dans le reste de sa surface; un double rang de franges compose chacune des quatre branchies : l'os demi-circulaire du premier de ces organes respiratoires présente des dents longues et fortes, arrangées comme celles d'un peigne: l'os du second n'en offre que de moins grandes; et l'are du troisième ainsi que celui du quatrième ne sont que raboteux '.

Les nageoires pectorales ont une largeur égale au douzième, ou à peu près, de la largeur totale du scombre; leur longueur est telle, qu'elles dépassent l'ouverture de l'anus, et parviennent jusqu'aux premières petites nageoires du dessous de la queue. Elles sont de plus en forme de faux, fortes, roides, et, ce qu'il faut surtout ne pas négliger d'observer, placées chacune an-dessus d'une fossette, ou d'une petite cavité imprimée sur le côté du poisson, de In même grandeur et de la même figure que cet instrument de natation, et dans laquelle cett nageoire est reçue en partie lorsqu'elle est en repos. Un appendice charnu occupe d'ailleurs, si je puis employer ce mot, l'aisselle supérieure de chaque pectorale.

Une fossette analogue est pour ainsi dire gravée au-dessous du corps, pour loger les nageores thoracines, qui sont situées au-dessous des pectorales, et qui, presque brunes à l'intérieur, réfléchissent à l'extérieurune brunes à l'intérieur, réfléch
gent.

La première nageoire dorsale s'élève au-dessus d'un sillon longitudinal dans lequel l'anima peut la coucher; et elle s'avance comme une faux vers la queue.

La seconde, presque entièrement semblable à celle de l'anus, au-dessus de laquelle on la voit, parsa rigidité, ses dimensions, sa figure et

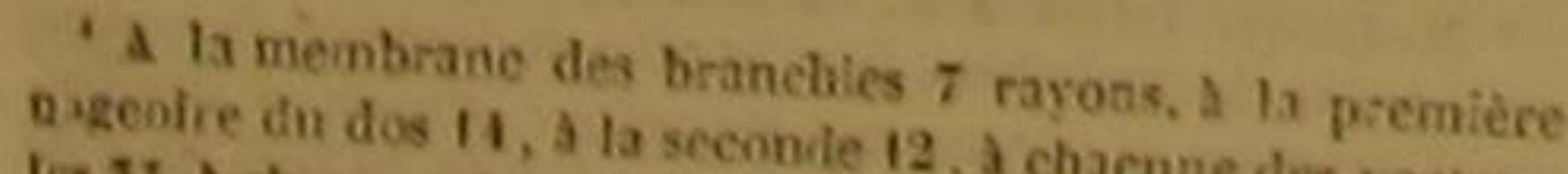
Ios 35 , I chacune des thoracines 7 , A celle de I Ianus 12 , a celle
de la queue 30 .
Commerson assure l'avoir toujours trouvé, et cependant avoir examiné plus de vingt germons.

La nageoire de la queue, découpée comme un croissant, est assez grande pour que la dis. tance, en ligne droite, d'une extrémité du crois sant à l'autre, soit quelquefois égale au tiers de la longueur totale de l'animal. Le thon a également et de mème que presque tous les scombres, une nageoire caudale très-étendue; et nous avons vu, dans l'article précédent, les effets très-curieux qui résultent de ce développement tion.

La ligne latérale, fléchie en divers sens jusqu'au-dessous de la seconde nageoire du dos, tend ensuite directement vers le milieu de la nageoire caudale.

On voit enfin, de chaque cóté de la queue, la peau s'élever en forme de carène longitudinale; et cette forme est donnée à ce tégument, par un cartilage qu'il recouvre, et qui ne contribue pas peu à la rapidité avec laquelle le germon s'élance au milieu ou à la surface des eaux.

Jetons maintenant un coup d'wil sur la conformation intérieure de ce scombre.

Le cour est triangulaire, rougeâtre, assez grand, à un seul mais très-petit ventricule; l'oreillette grande et très-rouge; le commencement de l'aorte blanchâtre, et en forme de bulbe; le fole d'un rouge pâle, trapézoīde, convexe sur une de ses surfaces, hérissé de pointes vers une extrémité, garni de lobules à l'extrémité oppos e, creusé à l'extérieur par plusieurs ciselures, et composéa l'intérieur de tubes vermiculaires, droits, parallèles les uns aux autres, et exhalant une humeur jaunâtre par des conduits communs; la rate allongée comme une languette, noirâtre, et suspendue sous le côté droit du foie; la vésicule du fiel conformée presque comme un lombric, plus grosse par un bout que par l'autre, égale en longueur au tiers de la longueur totale du poisson, appliquée contre la rate, et remplie d'un suc très-vert; l'estomac silloné des rides longitudinales; le canal intestina! deux peu ordinaire du principal instrument de nata- fois replié; le péritoine brunátre; et la vessie natatoire longue, large, attachée an dos et argentée.

Commerson a observé le germon dans le grand Océan austral, improprement appelé mer Pacifique, vers le vingt-septième degré de latitude méridionale, et le cent troisième de longitude.

Il vit pour la première fois cette espèce de seombre dans le voyage qu'il fit sur cet Océan, avee notre célèbre navigateur et mon savant confrère Bougainville. Une troupe très - nombreuse d'individus de cette espèce de scombre entoura le vaisseau que montait Commerson, et leur vue ne fut pas peu agréable à des matelots et à des passagers fatigués par l'ennui et les privations inséparables d'une longue navigation. On tendit tout de suite des cordes garnies d'hameçons; et on prit très-promptement un grand nombre de ces poissons, dont le plus petit pesait plus d'un myriagramme, et le plus gros plus de trois. A peine ces thoracins étaientils hors de l'eau, qu'ils mouraient au milieu des tremblements et des soubresauts. Les marins, rassasiés de l'aliment que cesanimaux leur fournirent, cessèrent d'en prendre : mais les troupes de germons, accompagnant toujours le vaisseau, furent, pendant les jours suivants, l'objet de nouvelles pêches, jusqu'à ce que, les matelots se dégoútant de cette sorte de nourriture, les pêcheurs manquèrent aux poissons, dit le voyageur naturaliste, mais non pas les poissons aux pêcheurs. Le goût de la chair des germons était très-agréable, et comparable à celui des thons et des bonites; et quoique les matelots en mangeassent jusqu'à satiété, aucun d'eux n'en éprouva l'incommodité la plus légère.

Commerson ajoute à ce qu'il dit des germons uneobservation génèrale que nous croyons utile de rapporter ici. Il pense que tous les navires ne sont pas également suivis par des colonnes de scombres ou d'autres poissons analogues â ces légions de germons dont nous venons de parler; il assure même qu'on a vu, lorsque deux ou plusieurs vaisseaux voguaient de conserve, les poissons ne s'atlacher qu'à un seul de ces bátiments, ne le jamaisquitter pour aller vers les antres, et donner ainsi à ce batiment favorisé une sorte de privilége exclusif pour la pèche. Il croit que cette préférence des troupes de poissons pour un navire dépend du plns on moins de subsistance qu'ils trouvent à la suite de ce vaisseau, et surtout de la saleté ou de l'état extérieur du bátiment au-dessous de sa ligne de flottaison. Il lui a semblé que les navires preférés étaient céux dont la carène avait été réparée le plus anciennement, ou qui venaient de servir à de plus longues navigations : dans les voyages de long cours, il s'attache sous les vaisseaux, des fucus, des goèmons, des corallines, des pinceaux de mer, et d'autres plantes ou animaux marins qui peuvent servir à nourrir les poissons et doivent les attirer avec force. Au reste, Commerson remarque, ainsi que nous I'avons observé à l'article du thon, que parmi les causes qui entrainent les poissons auprès d'un vaisseau, il faut compter l'ombre que le corps da bátiment et sa voilurerépandent sur la mer; et dans les climats très-chauds, on voit, dit-il, pendant la plus grande chaleur du jour, ces animaux se ranger dans la place plus ou moins étendue que le navire couvre de son ombre.

\section{LE SCOMBRE THAZARD '}

Scomber Thazard, Lacep. ' .

Ce nom de Tha zard a été donné à des ésoces, à des clupées, et à d'autres scombres que celui dont nous allons parler : mais nous avons cru devoir, avec Commerson, oter cette dénomination à toute espèce de scombre, excepté à celle que nous allons faire connaitre. La description de ce poisson n'a encore été publiée par aucun naturaliste. Nous avons trouvé dans les papiers du célébre compagnon de Bougainville, une figure de ce thazard, que nous avons fait graver, et une notice des formes et des labitudes de ce thoracin, de laquelle nous nous sommes servis pour composer l'article que nous écrivons.

La grandeur du thazard tient le milieu entre celle de la bonite et celle du maquereau; mais son corps, quoique très-musculeux, est plus comprimé que celui du maquereau, ou celui de la bonite.

Sa couleur est d'un beau bleu sur la tête, le dos, et la portion supérieure des parties laté-

'Taso., Tasard, - . Scomber immaculatus, pinnulis - dorsalibus octo, ventralibus septem, pionis pectoralibus 'ventrales vix excedentibus. , Commerson, manuscrits déj 2 M. Cuvier rapporte ce poisson as cous-genre Auxide, Ausis dans le grand genre scombre. Son
Cybium, comprend d'autres especes. D. 
rales; elle se change en nuances argentées et dorées, mêlées de tons fugitifs d'acier poli, sur les bas côtés et le dessous de l'animal.

$\mathrm{Au}$-dessous de chaque ceil, on voit une tache ovale, petite, mais remarquable, et d'un noir bleuatre.

Les nageoires pectorales et les thoracines sont noiratres dans leur partie supérieure, et argentées dans l'inférieure; la première nageoire du dos est d'un bleu brunâtre, et la seconde est presque brune !.

Au reste, on ne voit sur les côtés du thazard, ni bandes transversales, ni raies longitudinales.

La tête; un peu conique, se termine insensiblement en un museau presque aigu.

La måchoịre supérieure, solide et non extensible, est plus courte que l'inférieure, et parait surtout moins allongée lorsque la bouche est ouverte. Les dents qui garnissent l'une et l'autre de ces deux mâchoires sont si petites, que le tact seul peut en quelque sorte les distinguer. L'ouverture de la bouche est communément assez étroite pour ne pouvoir pas admettre de proie plus volumineuse que de petits poissons volants, ou jeunes exocets.

Les commissures soñt noirâtres; l'intérieur de la gueule est d'un brun argenté; la langue, assez large, presque cartilagineuse, très-lisse, et arrondie par devant, présente, dans la partie de sa eirconférence qui est libre, deux bord dont l'un est relevé, et dont l'autre s'étend horizontalement; deux faces qui se réunissent e formant un angle aigu, composent la voủte du palais, qui, d'ailleurs, est sans aucune aspérité. Chaque narine a deux orifices : l'antérieu est petit et arrondi, le postérieur plus visible et allongé. Les yeux sont très-grands et sans voile.

L'opercule, composé de deux lames, recouvre quatre branchies, dont chacune comprend deux rangs de franges, et est soutenue par un os circulaire dont la partie concave offre des dents semblables à celles d'un peigue, trèslongues dans le premier de ces organes, moin longues dans le second et le troisième, trèscourtes dans le quatrième.

C. 6 rayons a la membrane des branchies, 9 a la premier cayons articulés à chacune des pectorguillons et 22 ou 25 rayons artientés a chacune des thectorales, 1 aiguilloa $\mathrm{et}$ geoire de l'anus, 50 a la nageoire de la gues, 12 rayons à ta

Ta tes opercules ne sont revêtus d'aur cune écaille proprement dite : on ne voit de ces écailles que sur la partie antérieure du dos et autour des nageoires pectorales; et celles qui sont placées sur ces portions du scombre, sont petites et recouvertes par l'épiderme. La partie postérieure du dos, les côtés, et la partie infés rieure de l'animal, sont done dénués d'écailles, au moins de celles que l'on peut apercevoir facilement pendant la vie du poisson.

Les pectorales, dont la longueur excède à peine celle des thoracines, sont reçues chacune, à la volonté du thazard, dan̂s une sorte de cavité imprimée sur le côté du scombre.

Nous devons faire remarquer avee soin qu'entre les nageoires thoracines se montre un cartilage xiphoĩde, ou en forme de lame, aussi long que ces nageoires, et sous lequel l'animal peut les plier et les cacher en partie.

La première dorsale peut être couchée et comme renfermée dans une fossette longitudinale ; la eaudale, ferme et roide, présente la forme d'un croissant très-allongé.

Huit ou neuf petites nageoires triangulaires et peu flexibles sont placées entre cette caudale et la seconde dorsale; on en compte sept entre cette méme caudale et la nageoire de l'anus.

De chaque coté de la queue, la peau s'élève en carène demi-transparente, renfermée par derrière entre deux lignes presque paralleles; et la vigueur des muscles de cette portion du thazard, réunie avec la rigidité de la nageoire caudale, indique bien clairement la force de la natation et la rapidité de la course de ce scombre

On ne commence à distinguer la ligne latérale qu'à l'endroit où les cótés cessent d'étre garnis d'écailles proprement dites : composée vers son origine de petites écailles qui deviennent de plus en plus clair-semées, à mesure que son cours se prolonge, elle tend par de faibles ondulations, et toujours plus voisine du dos que de la partie inférieure du poisson, jusqu'à l'appendice cutané de la queue.

L'individu de l'espèce du thazard observé par Commerson avait été pris, le 30 juin 1768 vers le septième degré de latitude austale, aupres des rivages de la Nouvelle-Guince, pee. dant que plusieurs autroneespèce plusieurs autres scombres de la mème espece s'élançaient, à plusieurs reprises, à la surface des eaux, et derrière le navire, pour y salsir les petits poissons qui suivaient ce bátiment.

Le goùt de cet individu parut à Commerson aussi agréable que celui de la bonite; mais la chair de la bonite est très-blanche, et celle de ce thazard était jaunátre. Nous allons voir, dans l'article suivant, les grandes différences qui séparent ces deux espèces l'une de l'autre.

\section{LE SCOMBRE BONITE '.}

Seomber Pelamys, Liun., Gmel., Cur; Scomber Pe-

La bonite a été aussi appelée Pélamide mais nous avons dú prefererer la première dénomination. Plusieurs siècles avant Pline, les jeunes thons qui n'avaient pas encore atteint l'age d'un an étaient déjà nommés Pélamides; et il faut éviter tout ee qui peut faire confondre unc espèce avec une autre. D'ailleurs, ce mot Pélamide, employé par plusieurs des auteurs qui ont éerit sur l'histoire naturelle, est à peine connu des marins, tandis qu'il n'est presque aucun récit de navigation lointaine dans lequel le nom de Bonile ne se retrouve fréquemment. A vec combien de sensations agréables ou fortes cette expression n'est-elle done pas licé Combien de fois n'a-t-elle pas frappé I'imagination du jeune homme avide de travaux, de découvertes et de gloire, assis sur un promontoire escarpé, dominant sur la vaste étendue des mers, parcourant l'immensité de l'Océan par sa pensée, et suivant autour du globe, par ses désirs enflammés, nos immortels navigateurs ! Combien de fois la mémoire fidèle ne l'a-t-elle pas retracée au marin intrépide et fortuné, qui, forcé par l'âge de ne plus chercher la renommée sur les eaux, rentré dans le port paré de ses trophées, contemplant d'un rivage paisible l'empire des orages qu'il a si souvent affrontés,

'Bonnel. - Pelamide. - Scombre felamide, Daubenis scomber... lineis vitrinque juatuor pi de I'Ene, méih. Bonite, Valmont de Bomare, Dict. d'hisis nit. - - I Scomber "pelamis, pionnis superioribus octo, inferior bus septem. 'tænils ventral bus fongrindinahibus quatuor nigris. . Commerson, manuscrits aeja cites. - Scomber, 2, var. B. Ar-

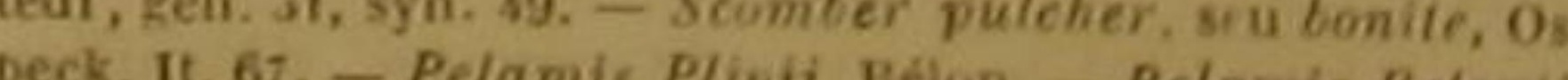

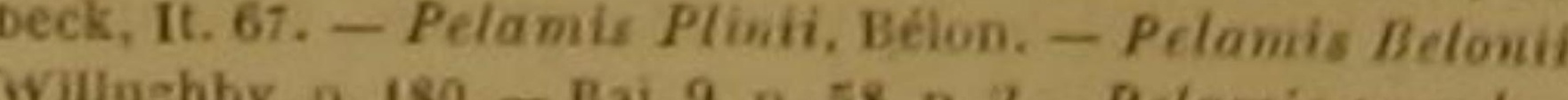

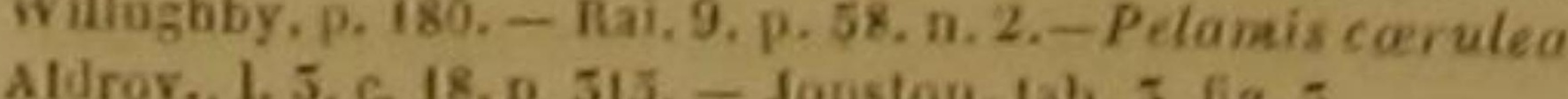

Cav, Dons-genre des Thons dans le grand genre Scombre, rappelle à son âme satisfaite le charme des espaces franchis, des fatigues supportées, des obstacles écartés, des périls surmontés, des plages découvertes, des vents enehanés, des tempetes domptées! Combien de fois n'a-t-elle pas èmu, dans le silence d'une retraite champétre, le lecteur paisible, mais sensible, que le besoin heureux de s'instruire, ou l'envie de rópandre les plaisirs variés de l'occupation de l'esprit sur la monotonie de la solitude, sur le calme du repos, sur l'ennui du déscuvrement, attachent, pour ainsi dire et par une sorte d'enchantement irrésistible, sur les pas des hardis voyageurs! Que de douces et de vives jouissances! Et pourquol laisser échapper un seul des moyens de les reproduire, de les multiplier, de les étendre, d'en embellir l'étude de la seience que nous cultivons?

Cette bonite dont le nom est si connu, est cependant encore assez mal connue ellemème : heureusement Commerson, qui l'a observée en habile naturaliste dans ses formes et dans ses habitudes, nous a laissé dans ses manuscrits de quoi compléter l'image de ce scombre.

L'ensemble formé par le corps et la queue de l'animal, musculeux, épais et pesant, finit par derrière en cone. Le dessus de lá tête, lo dos, les nageoires supérieures, sontad'un bleu noirâtre ; les cotés sont bleus; la partie inférieure est d'un blane argentin : quatre raies longitudinales un peu larges, et d'un brun noirâtre, s'étendent de chaque cóté au-dessous de la ligne latérale, et sur ce fond que nous venons d'indiquer comme argenté, et que Commerson a vu cependant brunátre dans quelques individus; les nageoires thoracines sont brunes; celle de l'anuś est argentée; l'intérieur de la gueule est noiratre; et ce qui est assez remarquable, c'est que l'iris, le dessous de la tête, et même la langue, paraissent, suivant Commerson, revêtus de l'éclat de l'or.

Parlons maintenant des formes de la bonite. La tête, ayant un peu celle d'un cône, est d'ailleurs lisse, et dénuée d'écailles proprement dites. Un simple rang de dents très-petites garnit la mâchoire supérieure, qui n'est point extensible, et l'inférieure, qui est plus avancée que celle d'en haut. L'ouverture de la bouche a la grandeur nécessaire pour que la bonite puisse avaler facilement un exocet.

La langue est petite, étroite, courte, maigre, 
deni-cartilagineuse, relevee dans ses bords; narine voisin de l'œil, unique, et fait en forme de ligne longue trés-étroite et verticale; l'œil très-grand, ovale, peu convexe, sans voile l'opercule branchial composé de deux lames arrondies par derrière, dénnées de petites écailles, et dont la postérieure embrasse celle de devant.

Des dents arrangées comme celles d'un peigne garnissent l'intérieur des ares osseux qui soutiennent les branchies; elles sont trèslongues dans les arcs antérieurs

Les écailles qui recouvrent le corps et la queue, sont petites, presque pentagones, et fortement attachées les unes au-dessus de autres

Chacune des nageoires pectorales, dont la longueur est à peine égale à la moitié de l'espace compris entre leur base et l'ouverture de l'anus, peut étre reçue dans une cavité gravée, pour ainsi dire, sur la poitrine de l'animal, et dont la forme ainsi que la grandeur sont semblables à celles de la nageoire.

On voit une fossette analogue propre à recevoir chacune des thoracines, au-dessous desquelles on peut reconnaitre l'existence d'un cartilage caché par la peau '. La nageojre de l'anus est la plus petite de toutes. La première du dos, faite en forme de faur, et composée uniquement de rayons non articulés, peut être couchée à la volonté de la bonite, et, pour ainsi dire, entièrement cachée dans un sillon longitudinal; la seconde dorsale, placée presque au-dessus de celle de l'anus, est à pein plus avancée et plus grande que cette dernière. La nageoire de la queue parast très-forte, et représente un croissant dont les deux cornes sont égales et très-écartéos.

Entre cette nageoire et la seconde du dos on voit huit petites nageoires; on n'en trouve que sept au-dessous de la queue : mais il faut observer que, dans quelques individus, le dernier lobe de la seconde dorsale, et celui de la nageoire de l'anus, ont pu être conformés de manière à ressembler beauconp à une petite nagcoire; et voilà pourquoi on a cru devoir

'7 rayons 3 la membrane bran biale, is non articules 3 kuillons et 26 ou 27 bas. 12 a la seconde dorsale, 1 ou 2 a rales, 1 aicullon et5 rats a cines, 12 rayons a celle del'anus, 50 a cello cune des thora. compter neuf petites nageoires au-dessus et hui au-dessous de la queue de la bonite.

Les deux côtés de cette mème queue présentent un appendice cartilagineux, un peu dia. phane, élevé en carène, et suivi de deux strie longitudinales qui tendent à se rapprocher vers la nageoire caudale.

La ligne latérale, à peine sensible dans son origine, lléchie ensuite plus d'une fois, devient droite, et s'avance vers l'extrémité de la queue.

La bonite a presque toujours plus de six décimètres de longueur : elle se nourrit quelquefois de plantes marines et d'animaux à coquille, dont Commerson a trouvé des fragments dan l'intérieur de plusieurs individus de cette espèce qu'il a disséqués; le plus souvent néanmoins elle préfere des exocets ou des triures. On la rencontre dans le grand Océan, aussi bien que dans l'Océan Atlantique; mais on ne la voil communément que dans les environs de la zone toride : elle y est la victime de plusieurs grands animaux marins; elle y périt aussi trèsfréqueinment dans les rets des navigateurs, qui trouvent le goût de sa chair d'autant plus agréable, que lorsqu'ils prennent ce scombre, ils ont été communément privés depuis plusieurs jours de nourriture fraiche; et, poisson misérable, pour employer l'expression de Commerson, elle porte dans ses entrailles des ennemis très-nombreux; ses intestins sont remplis de petits tenia et d'ascarides : jusque sous sa plèvre et sous son péritoine, sont logés des vers cucurbitains très-blanes, très-petits, et très-mous; et son estomac renferme d'autre animaux sans vertèbres, que Commerson a cru devoir comprendre dans le genre des sangsues.

Avaut de terminer cet article, nous croyons utile de bien faire connaitre quelques-unes des principales différences qui séparent la bonite du thazard, avec lequel on pourrait la confondre Premièrement, la bonite a sur le ventre des raies noirâtres et longitudinales qui manquent sur le thazard. Deuxièmement, son corps est plus épais et moins arrondi. Troisièmement, elle n'a pas, comme le thazard, une tache bleue sous chaque ceil. Quatrièmement, elle est couverte, sur tout le corps et la queue, d'écailles placées les unes au-dessus des autres : le thazard n'en montre d'analogues que sur le dos et quelques autres parties de sa surface. Cinquiè- mement, sa membrane branchiale est soutenue par sept rayons; celle du'thazard n'en comprend que six. Sixièmement, le nombre des rayons est différent dans les pectorales ainsi que dans la première dorsale de la bonite, et dans les pectorales ainsi que dans la première dorsale du thazard. Septièmement, le eartilage situé au-dessous des thoracines est caché par la peau dans le thazard; il est à découvert dans la bonite. Huitièmement, la queue est plus profoudément échancrée dans la boṇite que dans le thazard. Neuvièmement, la ligne latérale differe dans ces deux scombres, et par le lieu de son origine, et par ses sinuosités. Dixièmement, enfin, la couleur de la chair du thazard est jaunâtre.

Que l'on considère avee Commerson qu'au. cun de ces caractères ne dépend de l'áge ni du sexe, et l'on sera convaincu avee ce naturaliste que la bonite est une espèce de scombre très. differente de celle du thazard dêcrite pour la première fois par ce savant voyageur.

\section{LE SCOMBRE SARDE '.}

Scomber Sards, Bloch, Lacep., Cuv,

Le scombre sarde habite non-seulement dans la Méditerranée, mais encore dans l'Océan. On le péche à la hauteur de France et á celle d'Es. pagne, mais très-souvent à la distance de plusieurs myriamètres des cótes. On le prend nonseulement au filet mais encore à I hamecon. II est d'une voracité excessive. Son poids s'élève jusqu'a cinq ou six kilogrammes. Sa chair est blanche et grasse. Il a la langue lisse ; mais on peut voir, de chaque cóté du palais, un os long, étroit, et garni de dents petites et pointues. Son anus est deux fois plus près de la caudale que de la tête. La couleur générale du poisson varie entre le bleu et l'argenté. La première nageoire du dos est noirâtre; les autres nageoires sont d'un gris mélé quelquefois avee des teintes jaunes ${ }^{3}$.

- Bonile, Germon, sur plus, costes de France. - Boniton, Scale breast, en Aniteterre, - Bruste, en Espagne. magne. - Bise, Rondelet, part I, I s, ch II - Su Allesarda. Bloch, pl. $55 i$. 'M. Cuvier fait uné petite division de cette espéce sous nom de SAEDE, Sarda, dans le grand genre Scombre. D. ha rayons a la membrane branchiale du scombre sarde, 16 a dos, 15 a la ale, 21 aiguillonnés à la première nazeolre du thoracine, it rasunde, 1 aignillonne et 5 articoles a chayuie

\section{E SCOMBRE ALATUNGA}

Scomber Alatunga, Linu., Gmel. ',

Ce scombre, dont les naturalistes doivent la première description au savant Cetti, auteur de I'IVistoire des Poissons et des Amphibies de la Sardaigne, vit dans la Méditerranêe comme le thon. On l'y voit, de mème que ce dernier poisson, paraitre régulièrement a certaine époques; et cette espèce se montre également en troupes nombreuses et bruyantes. Sa chair est blanche et agréable au goút. L'alatunga a d'ailleurs beaucoup de rapports dans sa conformation avec le thon; mais il ne parvient ordinairement qu'au poids de sept ou huit kilogrammes. II n'a que sept petites nageoires au-dessus et au-dessous de la queue; et ses nageoires pectorales sont si allongées qu'elles atteignent jusqu'à la seconde nageoire dorsate. Au reste, il est aisé de voir que presque tous ses traits, et particulièrement le dernier, le séparent de la bonite et du thazard, aussi bien que du thon; et la longueur de ses pectorales ne peut te faire confondre dans aucune circonstance avec le germon, puisque le germon a huit ou neuf petites nageoires au-dessus ainsi qu'au-dessous de la queue, pendant que l'alatunga n'en a que sept au-dessous et au-dessus de cette même partie. II est figuré dans les peintures sur vélin qué l'on possède au Muséum d'histoire naturelle, et qui ont été faites d'après les dessins de Plumier, sous le nom de Thon de l'Océan (thynnus oceanicus), vulgairement Germon.

Sa máchoire inférieure est plus avancée que la supéricure, et sa ligne latérale tortueuse.

\section{LE SCOMBRE CHINOIS.}

\section{Scomber simensis, Lacep."}

Ce scombre n’a encore été décrit par aucun naturaliste européen. Nous en avons trouvé une image très-bien peinte dans le recueil chinois dont nous avons déjà parlé plusieurs fois : il est d'un violet argenté dans sa partie supérieure, et rougeâtre dans sa partie inférieure. Sept petites nageoires sont placées entre la caudale et

'Cetti, Pesc, e anf. di Sard., p. 198. - Scamber alatunya

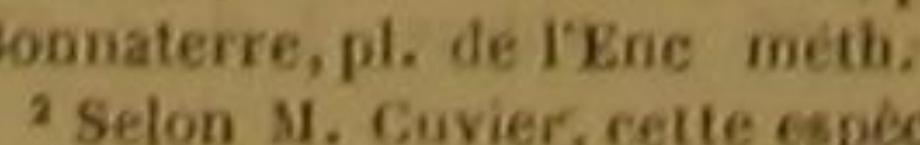
acrit plas baut. 'M. Cuvier I. page 14. D. 
In seconde du dos: on en voit sept autres au- gions nombreuses et rapides de thous, de gerdessous de la queue. Les pectorales sont cour- mons, de thazards, de bonites, et des autres tes; la caudale est très-échancrée. La ligne scombres que nous venons d'examiner, nous
n'avons eu besoin de nous élever par la force de latérale est saillante, sinueuse dans tout son n'avons eu bu'au-dessus des portions de l'Océan générale, elle descend assez bas après avoir de- qu'er passé les pectorales, et se relève un peu en- Pour connaitre maintenant, observer et compasuite. On n'apercoit pas de raies longitudinales rer tous les climats sous lesquels la nature a sur les cotés de l'animal.

\section{LE SCOMBRE ATUN.}

Scomber Atun, Lacep. '

Le voyageur Euphrasen, en allant de Suède a Canton, et de Canton en Suède, en 1782 et 1783, a vu près du cap de Bonne-Espérance, et dans les eaux de l'ile de Java, le Sćombre atun, dont la longueur est quelquefois de plus d'un mètre; la tête comprimée; le museau allongé et pointu; la mâchoire supérieure garnie non-seulement d'uu rang de dents, mais encore de quatre dents aiguēs et plus fortes, placées à son extrémité; l'ceil ovale; l'iris cendré; la caudale fourchue ${ }^{2}$.

\section{LE SCOMBRE MAQUEREAU ${ }^{3}$.} Scomber Scombrus, Linn, Gmel., Lacep., Cur. ‘

Lorsque nous avons voulu parcourir, pour ainsi dire, toutes les mers habitées par les lé-

' M. Cuvier ne fait pas meation de cette espéce. D. aigu llonnés a la première dorsalé, , 10 articulés a la seconde. is a chaque pectorale, 6 a chaque thoracine, 10 ou is a la. nale, 22 a la vageoire de la queue.

Auriol, Verrat, sur plus. cótes mérid. de France. Makrill, en Suede, - Id., en Danemarek. - Mokrel, en Alemagne, - Macarel, en Angleterre. - Macarello, a vallh, en Espagne, - I Venise. - Lacerto, a Naples. - Ca. ropéenues, - Scombre maqueren, dans quelques contrées eu- Id. Bonnaterre, pl. de T'Enc. mét Daubeuton, Enc. méth. mel, Traité des péches, part. 2, sect. 7, c. 1, pl. 1, tig. 1. -

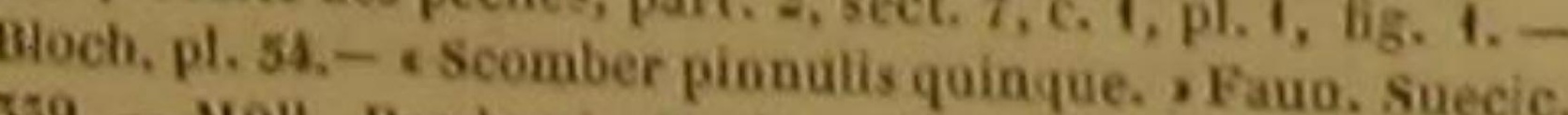
Scomer - Mall. Prodrom. Zoolog. danic., p. 47, a. 393. - anum. $\rightarrow$ Artedi, gen que in extremo dorso, spind brevi ad

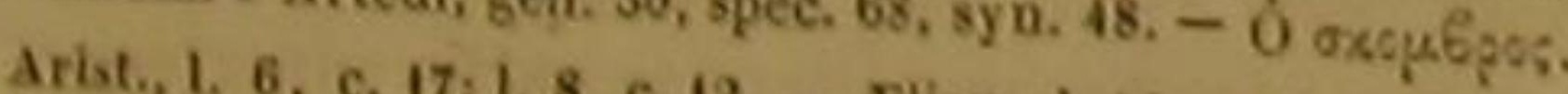
Athen, 1.5, p. 17, 1. 8, c. 12. - Elian., 1. 14, c. 1.p. 798 . et 1.5. - Scomber, Ovid, Halietieut, 1. 1, fol, 108 et 109 lumell., I. 8, c. 17, - Scomber, Plin., 1. 9, c. 15 i. 51, Co-

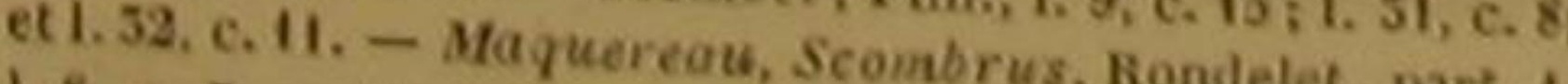
1.8, c. 7. - Scomber, Scombrus, Gesner, 814 , part. (germ.) fol, 57. - schonev., p. 66. - Aldrov., L, 1012; et placé le scombre maquereau, nous devons porter nos regards bien plus loin encore. Que notre vue s'étende jusqu'au pôle du globe, jusqu'a celui autour duquel scintillent les deux ourses. Quel spectacle nouveau, majestueux, terrible, va paraitre à nos yeux! Des rivages couveris de frimas amoncelés et de glaces éternelles, unissent, sans les distinguer, une terre qui disparait sous des couches épaisses de neiges endurcies, à une mer immobile, froide, gelée, solide dans sa surface, et surchargée au loin d'énormes glaçons entassés en montagnes sinueu. ses, ou élevés en pies sourcilleux. Sur cet Océan endurci par le froid, chaque année ne voi réguer qu'un seul jour; et pendant ce jour unique, dont la durée s'étend au delà de six mois, le soleil, peu exhaussé au-dessus de la surface des mers, mais paraissant tourner sans cesse autour de l'axe du monde, élevant ou abaissant perpétuellement ses orbes, mais enchainant toujours ses circonvolutions, commençant, toutes les fois qu îl répond au mème méridien, un nouveau tour de son immense spirale, ne lancant que des rayons presque horizontaux et facilement réfléchis par les plans verticaux des éminences de glace, illuminant de sa clarté mille fois répétee les sommets de ces monts en quelque sorte cristallins, resplendissant sur leurs innombrables faces, et ne pénétrant qu'a peine dans les cavités qui les séparent, rend plus sensible par le contraste frappant d'une Iumiere éclatante et des ombres épaisses, cet étonnant assemblage de sommités escarpées et de profondes anfractuosités.

Cependant la même année voit succéder une nuit presque égale à ce jour. Une clarté nouvelle en dissipe les trop noires ténèbres: les ondes congelées renvoient, dispersent et multiplient p. 270 , - Jonston, 1.1, tit. 5, c. 5, a. 1, punct. 6 , p. 92 . D. 38 - 5 . 9, 11 . - Willogiby, p. 181. - Mackrell, Rai, 188, p. 166, 6. Scombrus, Chariet., p. 147, - Wotton, 1.8, corpore castigato, etc., Klein, Miss. pisc. 5 . Pelamis, tab. 4, fig. 1. - Gronov. Mas. 4, p. 51, n. si, et Zoph, p. 93, a. 501. - Brit. Zool. 5, p. p21, 51, n. si; et Zooph.

DES POISSONS.

daus l'atmosphère la lueur argentée de la lune qui a pris la place du soleil; et la lumière boréale étalant, an plus haut des airs, des feux variés que n'efface ou. ne ternit plus l'éclat radieux de l'astre du jour, répand au loin ses gerbes, ses faisceaux, ses flots enflammés, ses tourbillons rapides, et, dans une sorte de renversement remarquable, montre dans un ciel sans nuages toute l'agitation du mouvement, pendant que la mer présente toute l'inertie du repos. Une teinte extraordinaire parait et dans l'air, et sur les eaux, et sur de lointains rivages; un demi-jour, pour ainsi dire mystérieux et magique, regue sur un vaste espace immobile et glacé. Quelle solitude profonde! tout se tait dans ce désert horrible. A peine, du moins, quelques échos funèbres et sourds répètent-ils faiblemient et dans le fond de l'ètendue, les gémissements rauques et sauvages des oiseaux d'eau égarés dảns la nuit, affaiblis par le froid, tourmentés par la faim. Ce théatre du néant se resserre tout d'un coup; des brumes ćpaisses se reposent sur I Oceean; et la vue est arrètée par de lugubres tènèbres. Cependant la scène va changer encore. Une tempête d'un nouveau genre se prépare. Une agitation intestine commence; un mouvement violen f vient de très-loin, se communiqueavec vitessede proche en proche, s'aecroit en s'étendant, soulève avee force les eaux des mers contre les voûtes qui les compriment; on eraquement affreux se fait entendre; e'est l'épouvantable tonnerre de ces lieux funestes; les efforts des ondes bouleversées redoublent; les monts de glace se séparent, et, flottant sur l'Océan qui les repousse, errent, se choquent, 's'entr'ouvrent, s'écroulent en ruines, ou se dispersent eu débris.

C'estdans le sein même de cet Océan polaire, dont la surface vient de nous présenter l'effrayante image de la destruction et du chaos, que vivent, au moins pendant une saison assez longue, les troupes innombrables des -scombres que nous allons décrire. Lés diyerses cohortes que forment leurs réunions, renferment dans ces mers arctiques d'autant plus d'individus, que, moins grands que les thons et d'autres poissons de leur genre, n'atteignant guère qu'à une longueur de sept décimètres, et doués par conséquent $d$ une force moins considérable, ils sont moins excités à se livrer les uns aux autres des combats meurtriers. Et ce n est pas seulement dans ces mers hyperboréennes que leurs légions comprennent des milliers d'individus. On les trouve également et méme plus nom. breuses dans presque toutes les mers chaudes ou tempérées des quatre parties du mondo, dans le grand Océan, auprès du pôle antarctique, dans l'Atlantique, dans la Méditerranée, ou leurs rassemblements sont d autant plus éterdus, et leurs agrégations d autant plus durables, qu'ils paraissent obéir avec plus de constance que plusieurs autres poissons, aux diverses eauses qui dirigent ou modifient les mouvemer s des habitants des eaux.

Les évolutions de ces tuibus marines sont in pides, et leur nátation est très-prompte, comme celle de presque tous les autres scombres.

La grande vitesse qu'elles présentent lorsqu'elles se transportent d'une plage vers une autre, n'a pas peu contribué a l'opinion adoptée presque universellement jusqu ž nos jours, au sujet de leurs changements périodiques d'habitation. On a cru presque généralement d'après des relations de pécheurs rapportées par Anderson dans son Histoire nalurelle de l'Islande. que le maquereau était soumis a des migrations régulières; on a pensé que les individus de cette espèce qui passaient l'hiver dans un asile plus ou moins sûr auprès des glaces polaires, vosageaient pendant le printemps ou l'été jusque dans la Méditerranée. Tirant de fausses conséquences de faits mal vus et mal comparés, on a.supposé la plus grande précision et pour tes temps et pour les lieux, dans l'exécution de ce transport successif et périodique de myriades de maquereaux depuis le cercle polaire jusqu'aux environs du tropique. On a indiqué l'ordre de leur voyage; on a tracé leur route sur les cartes; et voici comment la plupart des naturalistes qui se sont occupés de ces animaux, les ont fait s'avancer de la zone glaciale vers la zone torride, et revenir ensuite auprès du pole, a leur habitation d'hiver.

- On a dit que, vers le printemps, la grande armée des maquereaux cótoie l'Islande, le Hit. tland, I'Écosse, et IIrlande. Parvenue auprés de cette dernière fle, elle se divise en deux colonnes : I'une passe devant I'Espagne et le Portugal, pour se rendre dans la Méditerranée, oú il parait qu'on croyait qu'elle terminait ses migrations; l'autre paraissait, vers le mois d'avril, auprès des rivages de France et d'Angleterre, s'enfongait dans la Manche, se montrait en mai devant la Hollande et la Frise, e 
150

HISTOIRE NATURELIE

arrivait en juin vers les côtes de Jutland. C'était dans cette dernière portion de l'Océan Atlantique boréal que cette colonne se séparait pour former deux grandes troupes voyageuses: la première se jetait dans la Baltique, d'où on n'avait pas beaucoup songé à la faire sortir; la seconde, moins déviée du grand cercle tracé pour la natation de l'espèce, voguait devant la Norvége, et retournait jusque dans les profondeurs ou près des rivages des mers polaires, chercher contre les rigueurs de l'hiver un abri qui lui était connu.

Bloch et M. Noêl ont très-bien prouvé qu'une route décrite avec tant de soin ne devait cependant pas être considérée comme réellement pareourue; qu'elle étaít inconciliable avee des

observations sùres, prếcises, rigoureuses et très-multipliées, avec les époques auxquelles les maquereaux se montrent sur les divers riváges de l'Europe, avee les dimensions que présentent ces scombres auprès de ces mémes riyages, avec les rapports qui lient quelques traits de la conformation de ces animaux à la température qu'ils éprouvent, ä la neurriture qu'ils trouvént, à la qualité de l'eau dans laquelle ils sont plongés.

On doit ètre convaincu, ainsi que nous l'avons annoncé dans le Discours sur la nature des poissons, que les maquereaux (et nous en dirons autant, dans la suite de cet ouvrage, des harengs, et des autres osseux que l'on a considérés comme contraints de faire périodiquement des voyages de long cours), que les maquereaux, dis-je, passent lhiver dans des fonds de la mer plus ou moins éloignés des côtes dont ils s'approchent vers le printemps; qu'au commencement de la belle saison, its s'avancent vers le rivage qui leur convient le mieux, se montrent souvent, comme les thons, à la surface de la mer, parcourent des chemins plus ou moins direets, ou plus ou moins sinueux, mais ne suivent point le cercle périodique auquel on a voulu les attacher, ne montrent point ce concert régulier qu'on leur a attribué, n'obéissent pas à cet ordre de lieux et de temps auquel ou les a dits assujettis.

On n'avait que des idèes vagues sur la manière dout les mayuereaux étaient renfermés dans lear asile sous-marin pendant la saison plus rigoureuse, et partieulièrement auprès des contrées polaires. Nous allons remplacer ces conjectures par des notions précises. Nous devons cette connaissance certaine à l'observa. tion suivante qui m'a été communiquée par mon respectable collègue, le brave et habile marin, le sénateur et vice-amiral Pléville-lePeley. Le fait qu'il a remarqué est d'autant plus curieux, qu'il peut jeter un grand jour sur l'engourdissement que les poissons peuvent éprouver pendant le froid, et dont nous avons parlé dans notre premier Discours. Ce général nous apprend, dans une note manuscrite qu'il a bien voulu me remettre, qu il a vérifié avee soin les faits qu'elle contient, le long des côtes * du Groenland, dans la baie d'Hudson, auprès des rívages de Terre-Neuve, à l'époque où les mers commencent a y être navigables, e'est-ìdire, vers le tiers du printemps. On voit dans ces contrées boréales, nous écrit le vice-amiral Pléville, des enfoncements de la mer dans les terres, nommés barachouas, et tellement coupés par de petites pointes qui se croisent, que dans tous les temps les eaux y sont aussi calmes que dans le plus petit bassin. La profoudeur de ces asiles diminue à raison de la proximité du rivage, et le fond en est généralement de váse molle et de plantes marines. C'est dans ce fond vaseux que les maquereaux cherchent à se cacher pendant I'hiver, et qu'ils enfoncent leur tête et la partie antérieure de leur corps jusqu'á la longueur d'un dêcimètre ou environ, tenant leurs queues élevéeś verticalement au-dessus du limos. On en trouve des milliers enterrés ainsi à demi dans chaque barachoura, hérissant, pour ainsi dire, de leurs queues redressées le fond de ces bassins, au poini que des marins les apercevant pour la première fois aupres de la cóte, ont craint d'approcher du rivage dans leur chaloupe, de peu de la briser contre une sorte particulière de banc ou d'écueil. M. Pléville ne doute pas que la surface des eaux de ces barachouas ne soit gelée pendant l'hiver, et que l'épaisseur de cett croute de glace, ainsi que celle de la couche de neige qui s'amoncelle au-dessus, ne tempèrent beaucoup les effets de la rigneur de la saison sur les maquereaux enfouis à demi au-dessous de cette double couverture, et ne contribuent à conserver la vie de ces animaux. Ce n'est que vers juillet que ces poissons reprennent un partie de leur activité, sortent de leurs trous, s'élancent dans les flots, et parcourent les grands rivages. II semble mème que la stupeur ou l'engourdissement dans lequel its doiven
DES POISSONS.

131

avoir été plongés pendant les très-grands froids, | tité pour la consommation des pays voisins du ne se dissipe que par degrés: leurs sens parais- lieu de la péche, on prépare eeux que l'on veut sent très-aflaiblis pendant une vingtaine de conserver longtemps et envoyer à de grandes jours, leur vue est alors si débile, qu'on les distances, en les vidant, en les mettant dans croit aveugles, et qu'on les prend facilement au du sel, et en les entassant ensuite comme des filet. Après ce temps de faiblesse, on est souvent forcé de renoncer à cette dernière manière de les pècher; les maquereaux recouvrant entièrement l'usage de leurs yeux, ne peuvent plus en quelque sorte ètre pris qu'à l'hameçon: mais cornme ils sont encore très-maigres, et qu'ils sé ressentent beaucoup de la longue diète qu'ils ont éprouvée, ils sont très-avides d'appáts, et on en fait une pèche très-abondante.

C'est à peu près à la même époque qu'on recherche ces poissons sur un grand nombre de côtes plus ou moins tempérées de l'Europe oceidentale. Ceux qui paraissent sur les rivages de France, sont communément parvenus à leur point de perfection en avril et mai ; ils portent le nom de Chevillés, et sont moins estimés en juillet et aoùt, lorsqu'ils ont jeté leur laite ou leurs aufs.

Les pécheurs des cótes nord-onest et ouest de la France sont de tous les marins de l'Europe ceux qui s'oceupent le plus de la recherche des maquereaux, et qui en prennent le plus grand nombre. Ils se servent, pour pécher ces animaux, de haims, de libourets ', de manets ${ }^{2}$ faits d un fil très-délié, et que l'on réunit quelquefois de manière a former avee ces filets une tessure de près de mille brasses (deux mille cing cents metres) de longueur. Les temps orageux sont tres-souvent ceux pendant lesquels on prend avec le plus de facilité les scombres maquereaux, quí, agités par la tempête, s'approchent beaucoup de la surface de la mer, $e$ se jettent dans les filets tendus a une très-petite profondeur; mais lorsque le ciel est serein et que l'Océan est calme, il faut les chercher entre deux eaux, et la péche en est beaucoup moins heureuse.

C'est parmi les rochers que les fernelles aiment à déposer leurs œufs; et comme chacun de ces individus en renferme plusieurs centaines de mille, il n'est pas surprenant que les maquereaux forment des légions très-nombreuses. Lorsqu'on en prend une trop grande quan-

- Voyez lesplicatiou da mot Hbourcet, a Farticle du Scom-
bre thon. 'Larticle de la Trachine vive renterine une conrte drs- harengs, dans des barils.

La chair des maquereaux étant grasse et fondante, les anciens l'exprimaient pour ainsi dire, de manière à former une serte de substance liquide ou de préparation partieulière, d laquelle on donnait le nom de garum. Pline dit ' combien ce garum était recherché non-seulement comme un assaisonnement agréable de plusieurs mets, mais encore comme un remède efficace contre plusieurs maladies, On obtenai du garum, dans le temps de Bélon et dans plusieurs endroits voisins des côtes de la Méditerranée, en se servant des intestins des maquereaux; et on en faisait unegrande consommation i Constantinople ainsi qu'a Rome, où ceux qui en vendaient étaient nommés piscigaroles.

C'est par une suite de cette nature de leur chair grasse et huileuse, que les maquereaux sont comptés parmi les poissons qui jouissent le plus de la faculté de répandre de In lumière dans les ténèbres'. Ils luisent dans l'obscurité, lors mème qu'ils sont tirés de l'eau depuis trèspeu de temps; et on lit dans les Transactions philosophiques de Londres (ann. 1666, p. 116), qu'un cuisinier, en remuant de l'eau dans laquette il avait fait cuire quelques-uns de ces scombres, vit que ces poissons rayonnaient vivement, et que l'eau devenait trés-lumineuse. On apercevait une lueur phosphorique partout où on laissait tomber des gouttes de cette eau, après l'avoir agitée. Des enfants s'amusèrent á transporter ces gouttes qui ressemblaient a autant de petits disques lumineux. On observa encore le lendemain, que lorsqu' on imprimait a l'eau un mouvement círculaire rapide, elle jetait une lumiere comparable a la clarte de la lune : cette lumière égalait T'éclat de la flamme, lorsque la vitesse du mouvement de l'eau était très-accélérée; et des jets lumineux très-briklants sortaient alors du gosier et de plusieurs autres parties des maquereaux.

Mais avant de terminer cet article, montrons avec précision les formes du poisson dont nous venons d'indiquer les principales habitudes.

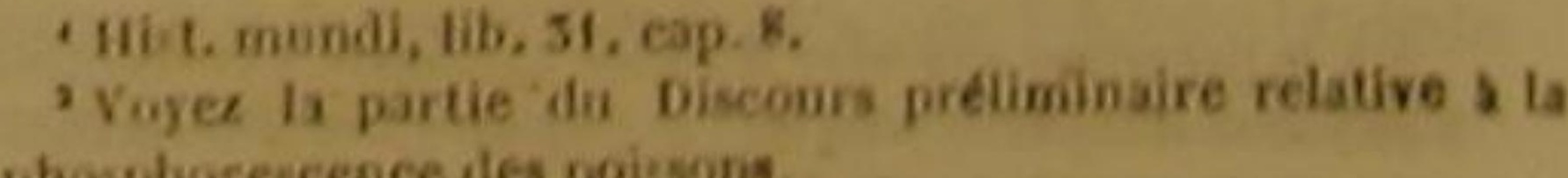


En général, le maquereau a la tête allongée, , nous venons d'entrer, que les fórmes ni les ariouverture de la bouche assez grande, la lan- mes des maquereaux ne les rendent pas plus gue lisse, pointue, et un peu libre dans ses dangereux que Jeur taille pour les autres habimouvements; le palais garni dans tout son con- tants des mers. Cependant comme leurs appétour de dents petites, aiguẽs, et semblables à tits sont très-violents, et que leur nombre leur celles dont les deux mảchoires sont hérissées; inspire peut-être une sorte de confiance, ils la mâchoire inférieure un peu plus longue que sont voraces et même hardis: ils attaquent soula supérieure, la nuque large, l'ouverture des vent des poissons plus gros et plus forts qu'eux: branchies étendue, un opercule composé de et on les a même vus quelquefois se jeter avec trois pieces, le tronc comprimé; la ligne laté- une audace aveugle sur des pèchéurs quì vourale voisine du dos, dont elle suit la courbure; laient les saisir, ou qui se baignaient dans les l'anus plus rapproché de la téte que de la queue; caux de la mer.

les nageoires petites, et celle de la queue fourchue ${ }^{\prime}$.

Telles sont les formes principales du scombre. dont nous écrivons I'histoire: ses eouleurs ne sont pas tout à fait aussi constantes.

Le plus fréquemment, torsqu'on voit ce poisson nager entre deux eaux, et présenter au travers de la couche fluide qui le vernit' pour ainsi dire, tontes les nuances qu'il peut devoir à la rapidité de ses mouvements et à la prompte et entière circulation des liquides qu'il recèle, il parait d'une couleur de soufre, ou plutót on le croirait plus ou moins doré sur le dos; mais lorsqu'il est hors de l'eau, sa partie supérieure n'offre qu'une couleur noirátre ondulée de bleu; de grandes taches transversales et d'une nuance bleuâtre sujette à varier, s'étendent de chaque coté du corps et de la queue, dont la partie inférieure est argentée, ainsi que l'iris et les opereules dés branchies: presque toutes les nageoires sont grises ou blanehatres.

Plusieurs individas ne présentent pas de grandes taches latérales; ils forment une variété à laquelle on a donné le nom de Marchais dans plusieurs pêcheries françaises; et qui est communément moins estimée pour la table que les maquereaux ordinaires.

Au reste, toutes ces couleurs ou nuances sont produites ou modifiées par des écailles petites, minces et molles

Ajoutons que les vertèbres des scombres que nous déerivons, sont grandes, et au nombre de trente ou trente et une, et que l'on compte dans chacun des eótés de l'épine dorsale onze ou douze cótes attachées aux vertèbres par ou cartilages.

On peut voir par les détails dans lesquels

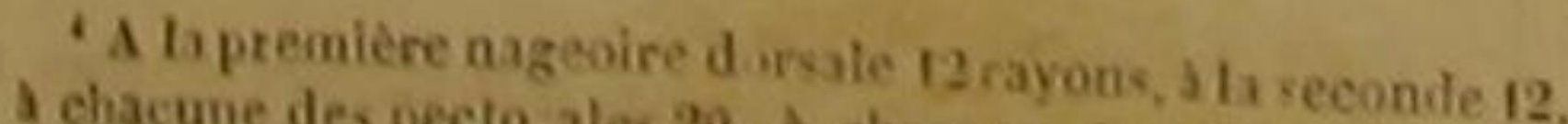

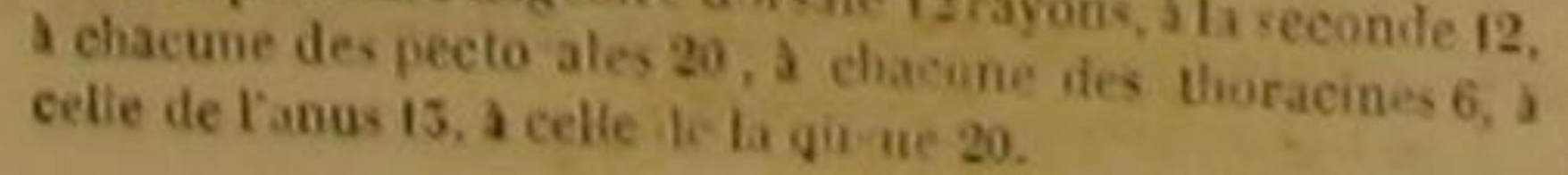

Mais s'ils cherehent à faire beaucoup de victimes, ils sont perpétuellement entourés de nombreux ennemis. Les grands habitants des mers les dévorent; et des poissons en apparence assez faibles, tels que les murènes et les murénophis, les combattent avee avantagé. Nous ne pouvons done écríre presque aucune page de cette Histoire sans parler d'attaques et de défenses, de proie et de dèvastateurs, d'aetions et de réactions redoutables, d'armes, de sang, de carnage et de mort. Triste et horrible condition de tant de milliers d'espèces condamnées à ne subsister que par la destruetion, à ne vivre que pour être immolées ou prévenir leurs tyrans, à n'exister qu'au milieu des angoisses du faible, des agitations du plus fort, des embarras de la fuite, des fatigues de la recherche, du trouble des combats, de la douleur des blessures, des inquiétudes de la victoire, des tourments de la défaite! combien tous ees affreux malheurs se seraient surtout accumulés sur la faible espèce humaine, si la sensibilité éclairée par l'intelligence, et l'intelligence animée par la sensibilité, n'avaient pas, par un heureux accord, fait naitre la société, la civilisation, la science, la vertu! et combien ils pèseront encore sur sa tête infortunée, jusqu'au moment la lumière du gémie, plus généralement répandue, éclairera un plus grand nombre d'hommes sur leurs véritables intérêts, et dissipera les illusions 'de leurs passions aveugles et funestes !

C'est au maquereau que nous croyons devoir rapporter le scombre qu'Aristote, Athénée, Alpar le nom de Colias ', que l'on péche près des

'Scomber colias, Linnée, éd. de Gmelín. - Koxizs.

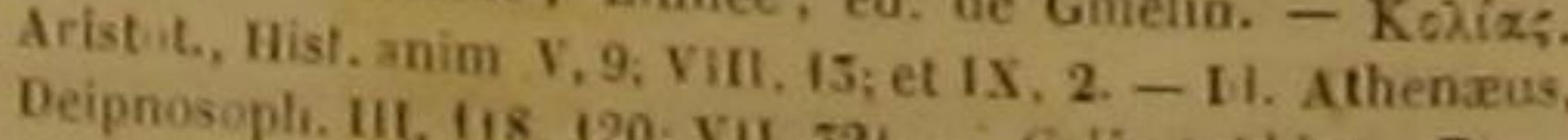

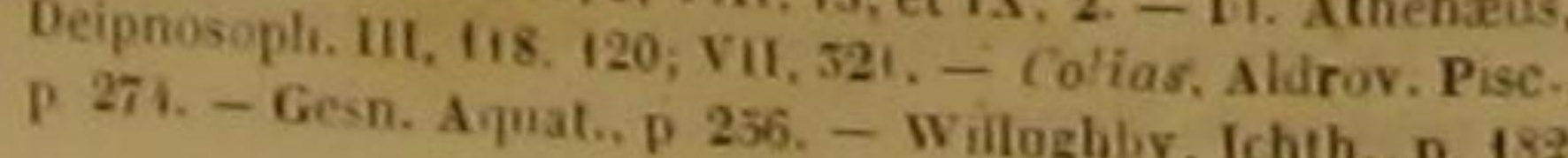
drovande, Gesner et Willughby, ont désigné eotes de la Sardaigne, qui est souvent plus petit que le maquereau, qui en diffère quelquefois par les nuances qu'il offre, puisque, suivant le naturaliste Cetti, il présente un vert gai mèlé à de l'azur, mais qui d'ailleurs a les plus grands rapports avec le poisson que nous venons de décrire. Le professeur Gmelin lui-mème, en l'inserivant à lá suite du maquereau, demande s'il ne faut pas le considêrer comme ce dernier scombre encore jeune.

Au reste quelques auteurs, et particulièrement Rondelet ', ont appliqué cette dénomination de Colias à d'autres scombres que l'on nomme Coguoils auprès de Marseille, qui habitent dans la Méditerranée, qui s'y plaisent. surtout, dans le voisinage des côtes d'Espagne, qui sont plus grands et plus epais que le maquereau ordinaire, et que néanmoins Riondelet regarde comme n'étant qu une variété de ce dernier poisson, avec lequel on le confond en effet très-souvent.

Peut-être est-ce plutôt aux Coguoils qu'aux maquereaux verts et bleus de Cetti, qu'il faut rapporter les passages des anciens naturalistes, et principalement celui d'Athénée que nous venons de citer.

Quoi qu'il en soit, les Coguoils ont la chair plus gluante et moins agréable que le maquereau ordinaire. Ils sont eouverts d'écailles petites et tendres : une partie de leur téte est transparente, qu'on distingue, comme au travers d'un verre, les nerfs qui, du cerveau, aboutissent aux deux organes de la vue. Rondelet ajoute que, vers le printemps, ils jettent du sang aussi resplendissant que la liqueur de la pourpre.

Ce fait nous rappelle un phénomène analogue qui nous a été attesté par un voyageur digne d'estime, et sur lequel nous croyons utile d'appeler l'attention des observateurs.

M. Charvet m'a instruit, par deux lettres, datées de Serrières, dêpartement de l'Ardèche, l'une le 11 octobre, l'autre le 7 novembre de l'an 1796, qu'en 1776 il était occupé dans l'ile de la Guadeloupe, non-seulement à faire une collection de dessins coloriés de plantes, qu'il destinait pour le Jardin et le Cabinet d'histoire naturelle de Paris, et qui furent entièrément

- Lacarlus, Klein, Miss. pisc. 5, p. 122. - . Scomber lat

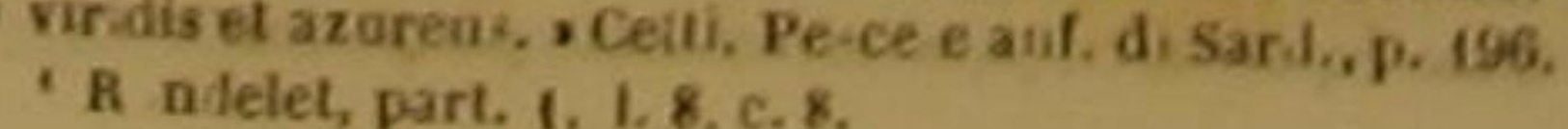

detruits par le fameux ouragan de septembre de cette même année 1776 , mais encore à terminer avee beaucoup de soin des dessins de différentes espèces de poissons pour M. Barbotteau, habitant du Port-Louis, connu par un ouvrage intéressånt sur les fourmis, et correspondant de Duhamel, qui publia plusieura de ces dessins iehthyologiques dans le Traile général des péches.

L.es liaisons de M. Charvet avec les Caraibes, chez lesquels il trouivait de l'ombrage et du repos lorsqu'il était fatigué de parcourir les rochers et les profondeurs des anses, lui procurèrent, de la part de ces insulaires, des poissons assez rares. Ces Caraibes le dirigèrent, dans une de ses courses, vers une partie des rivages del'ile, sauvage, pittoresque et mélancolique, appelée Porle d'enfer. Ce fut auprès de cette cote qu'il trouva un poisson dont il $m$ 'a envoyé un dessin colorié. Cet mimal avait l'air si familier et si peu effrayó des mouvements de M. Charvet, qui se baignait, que cet artiste fut tenté de le saisir. A peine le tenait-il, qu'une fente placée sur le dos du poisson s'entr'ouvrit, et qu'il en sortit une liqueur d'un pourpre vif, assez abondante pour teindre l'eau environnante, en troubler la transparence, et donner à l'animal la facilité de s'échapper, au moment ou l'étonnement de M. Charvet l'empécha de retenir le poisson qu'il avait dans les mains. Cet artiste cependant prit de nouveau le poisson. qui répandit une seeonde fois sa liqueur; mais ce fluide était bien moins coloré et bien moins abondant qu'au premier jet, et cessa de couler, quoique Paminal continuat d'ouvrir et de fermer la fente dorsale, comme pour obér a une grande irritation. Le poisson, rendu à la liberté, ne parut pas très-affaibli. Un second individu de la méme espèce, placé promptement sur une feuille de papier, la teignít de la même manière qu'une eau fortement colorée avèc de la laque; néanmoins, après trois jours, la tache rouge était devenue jaune. Des affaires imprévues, une maladie grave, les suites funèstes du terrible ouragan de septembre 1776, et l'obligation soudaine de repartir pour l'Europe, empéche. rent $M$. Charvet de dessiner et même de décrire, pendant qu'il était encore à la Guadeloupe, le poisson à liqueur pourprée : mais sa mémoire, fortement frappée des traits, de l'allure et de la

propriété de cet animal, lui a donné la facilite de faire en France une description et un dessio 
colorié de ce poisson, qu'il a eu la bonté de me faire parvenir.

Les individus vus par ce voyageur avaient un peu plus de deux déeimètres de longueur. Lears nageoires pectorales étaient assez grandes. La nageoire dorsale étaif composée de deux portions longitudinales, charnues à leur base, terminées dans le haut par des filaments qui les faisaient paraitre frangées, et appliquées l'une contre l'autre de manière-à ne former qu'un seul tout, lorsque l'animal voulait tenir fermée la fente propre à laisser échapper la liqueur rouge ou violette. Cette fente, située à l'origine et au milieu de ces deux portions longitudinales de la nageoire dorsale, ne paraissait pas s'étendre vers la queue aussi loin que cette mème nageoire; mais le fluide coloré, en sortant par cette ouverture, suivait toute la longueur de la nageoire dú dos, et obéissait à ses ondulations.

La peau était visqueuse, couverte d'écaille petites et fortement adhérentes. La couleur d'un gris blanc plus ou moins clair faisait ressortir un grand nombre de petits points jaunes, bleus, bruns, ou d'autres nuances. L'ensemble de formes de ces poissons, et les teintes qu'ils présentaient, étaient agréables à la vue. Ils se nourrissaient de petits mollusques et de vers marins, qu ils eherchaient avee beaucoup de soin parmi les pierres du fond de l'eau, sans se détourner ni discontinuer leurs petites manœuvres avant l'instant ou on voulaut les saisir ; la contraction qu'ils éprouvaient forsqu'ils faisaient jaillir leur liqueur pourprée, était apparente dons toute la longueur de leur corps, mai principalement vers l'insertion des nageoir pectorales.

Ces Teinturiers de la Guadeloupe, car c'est ainsi que les nomme M. Charvet, cherchent un asile lorsque la tempête commence à bouleverser les flots : sans eette précaution, ils résisteraient d'autant moins aux agitations de la mer et aux secousses des vagues impétueuses qui les briseraient contre les rochers, que leurs éeailles sont fort tendres, leurs muscles trèsdélicats, et leurs téguments de nature à se rider bientôt après leur mort.

Ces faits ne suffisent pas pour déterminer l'espèce ni le geare, ni méme l'ordre de ces poissons. Plusieurs motifs doivent done engager les uaturalistes qui parcourent les rivages de la Guadeloupe, a chercher des individus de l'espèee observée par M. Charvet à reconnaj- tre leur conformation, a examiner leurs habi. tudes, à constater leurs propriétés.

\section{LE SCOMBRE JAPONAIS '}

Scomber japonicus, Linn., Gmel., Lacep. ',

Ce scombre n'est peut-être qu'une variété du maquereau, ainsi que l'a soupçonné le professeur Gmelin. Nous ne l'en séparons que pou ous conformer à l'opinion de plusieurs naturalistes, en annonçant aux voyageurs notre doute à cet égard, et en les invitant à le résoudre par des observations.

Ce póisson vit dans la mer du Japon. Sa longueur n'est quelquefois que de deux décimètres; ses mâchoires sont herissées de petites dents; sa couleur générale est d'un bleu clair sa tête brille de la couleur de l'argent; ses écailles sont très-petites; et l'on a comparé l'ensemble de sa conformation à celle du hareng ${ }^{3}$. Houttuyn l'a fait connaitre.

\section{LE SCOMBRE DORE 4 :} Seomber aureus, Lacep, I.

Le nom de ce poisson annonce la riche parure que la nature lui a accordée, et la couleur éclatante dont il est revètu. Il est en effet resplendissant d'or sur une très-grande partie de sa surface, et particulièrement sur son dos. Peutétre n'est-il qu'une variété du maquereau. Le professeur Gmelin a témoigaé de l'incertitude au sujet de l'espèce de ce scombre, aussi bien qu'à l'égard de celle du japonais. Le doré s'éloigne cependant du maquereau beaucoup plus que ce japonais, non-seulement par ses nuances, mais encore par quelques détails de sa conformation, et notamment par le nombre des rayons de ses nageoires.

Quoi qu'il en soit, on trouve le doré dans les mers voisines du Japon, ainsi qu'oń y voit le scombre précédent; et il a été également découvert par Houttuyn.

- Scomt er caralescens, pinnulis quinque spuriis, 3 Honttuyn, Act. Haarl. 20, 2, p. 53, n. 18. - Scombre du Japon, Bosunaterre, pl. de l'knc. méth.

M. Curier ne cite pas celle espece. D.

A chacune des deux nageoires dorsales 8 rayons, i cha. Ianns if, a celles is, a chacnne des thoracines 6 , a celle de 4 Honttivn, det. Harte 20. bre dore, Bonnaterre, Haari. 20, 2, p. 351, n. 19. - ScomC-tle espers niess poide I'Enc. méth.
II n'a au-dessus et au-dessous de la queue que cinq petites nageoires comme le japonais et le maquereau ; et on ne compte que six rayons à sa nageoire de l'anus '.

Nous avons trouvé dans un des manuserits de Plumier, déposés à la Bibliothèque royale, la figure d'un scombre nommé, par ce naturaliste, très-petit scombre d'Amérique (Scomber minimus americanus ), et qui tient, à beaucoup d'égards, le milieu entre le doré et le maquereau. Des raies ondulent en divers sens sur le dos de ce poisson. II n'a que cinq petites nageoires au-dessus et au-dessous de la queue, onze rayons à la première dorsale, neuf à la seconde, et einq à la nageoire de l'anus.

\section{LE SCOMBRE ALBACORE ${ }^{2}$.}

Seomber Albacorus, Lacep, ?

Le nom d'Albacore ou d'Albicore a été donné, ginsi que ceux de Germon, de Thasard, et de Bonile ou Pélamide, à plusieurs espèces de scombres; ce qui n'a pas jeté peu de confusion dans l'histoire de ces animaux. Nous I'appliquons exelusivement, pour éviter toute équivoque, a un poisson de la famille dont nons traitons, et dont Sloane a frit mention dans son Histoire de la Jamaique.

Ce scombre, qui habite dans le bassin des Antilles, est couvert de petites écailles, L'individu décrit par Sloane avait seize décimétre de longueur, et un mètre de circonférence a I'endroit le plus -gros du corps. Ses mâchoires, longues de deux décimètres, ou environ, étaient garnies chacune d'une rangée de dents courtes et aigués. On pouvait voír, au-dessus des opercules, deux arêtes cachées en partie sous une peau luisante. On comptait, au-dessus et audessous de la queue, plusieurs petites nageoire séparées l'une de l'autre par un intervalle de éinq centimètres ôu à peu près. La nageoire de lanus se terminait en pointe, et avait trentedeux centimètres de long et huit centimètres de haut. Celle de la queue était en croissant. Les deux saillies latérales et-longitudinales de la queue avaient plás de deux centimétres d'été

- A ta precuicere nageoire dorsale 9 s.jyons, a chacune des

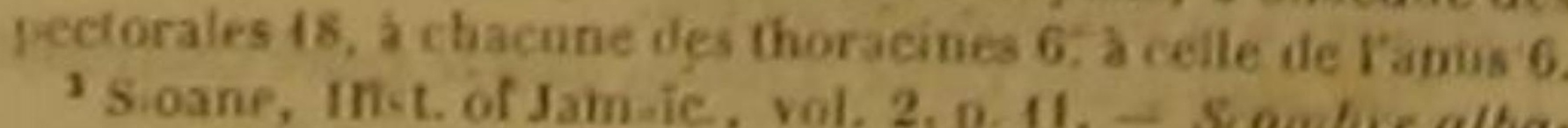

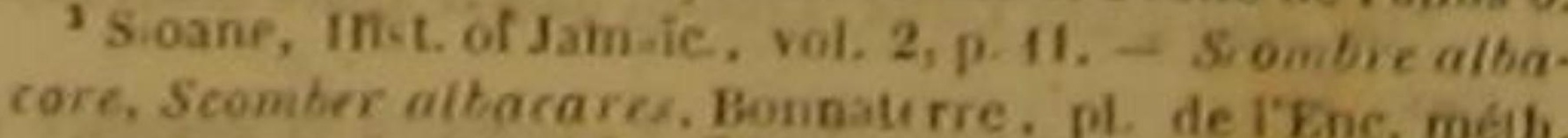

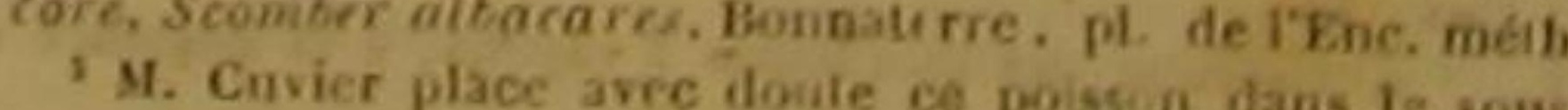
genre Auxive iquíl a établi danis le genre Scombre. D. vation. Plusieurs parties de la surface de l'anmal étaient blanches, les autres d'une conleur foncée.

\section{SOIXANTE-QUATRIÈME GENRF}

LES SCOMBŔROİDRS.

De petites nageoires au-dessus et au-dessous de la quene: une senle nageoire dorsale : plusienrs aiguitfons ardevant de la nageoire du dos.

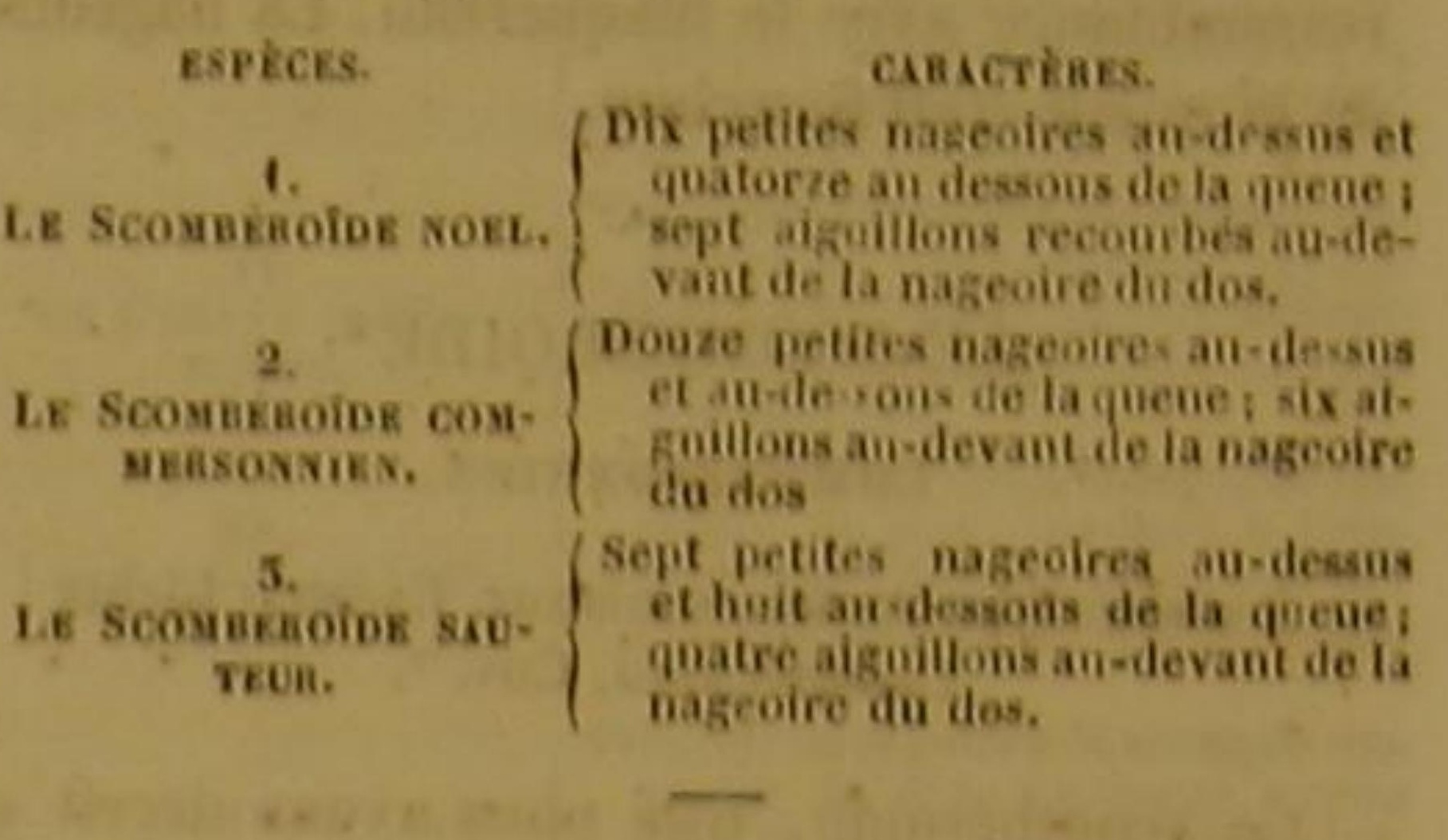

LE SCOMBÉROIDE NOEL.

Scomberoides Noelli, Lacep. '

Aucune des espèces que nous avons eru devoir comprendre dans le genre dont nous allon nous occuper, n'est encore connue des natura listes. Nous avous donné a la famille qu'elle composent le nom de Scomberouide, pour dési gner les rapports qui la lient avec les scombres Elle tient, à quelques égards, le milieu entre ces scombres, auxquels elle ressemble par les petites nageoires qu'elle montre au-dessus et audessous de la queue, et entre les gastérostées dont elle se rapproche par la série d'aiguillons qui tiennent lieu d'une première nageoire dorsale.

Nous nommons Scomberoide Noël la premiêre des trois espèces que nous avons inserites dans ce genre, pour donner une marque solennelle de reconnaissance et d'estime a M. Noél, de Rouen, qui mérite si bien,chaque jour les remerciments des naturalistes par ses travaux, et dont les observations exactes ont enrichí tant de pages de l'histoire que nous écrivons.

Nous l'avons décrite d'après un individu des. séché et bien conservé qui faisait partie de la collection cédée à la France par la Hollande, et envoyée au Muséum d'histoire naturelle.

Ce poisson avait dix petites nageoires au-des- 
sus de la qucue', et quatorze an-dessous de d'autant plus petit qu'elles sont-plus rapprocette même partie. Sépt aiguillons recourbés en chées de la tête ou de la queue. Les nageoires arrière et placés longitudinalement au delà de pectorales ne sont guère plus étendues que les la nuque, tenaient lieu de première nageoire du thoracines. On trouve le commersonnien dans dos; deux aiguillons paraissaient au-devant de la mer voisine du fort Dauphin de l'ile de Ma-

la nageoire de l'anus. Six taches ou petites dagasear.

bandes transversales s'étendaient de chaque coté de lanimal, et lui donnaient, ainsi que lensemble de sa conformation, beaucoup de ressemblance avec le maquereau. La nageoíre de la queue était fourchue.

\section{LE SCOMBÉROIDE:} COMMERSONNIEN.

Scomberoides commersonianus, Lacep. ; Lichia Commersonii, Cuv. '

Ce scombéroìde, que nous avons décrit et fait graver d'apres Commerson, est un poisson d'un grand volume. Sa hauteur et son épaisseur, assez grandes relativement à sa longueur, doivent lui donner un poids considérable. On voit à la place d une première nageoire dorsale, six aiguillons recourbés, pointus, et très-séparés l'un de l'autre, On compte douze petites nageoires au-dessus etau-dessous de la queue ${ }^{4}$. La nageoire caudale est très-fourchue. Deux aiguillons très-distincts sont placés au devant de la nageoire de l'anus; chaque opercule est composé de deux pieces. Les deux mâchoires son garnies de dents égales et aiguês : l'infêrieure est p̀lus avancée que la supérieure. De chaque côté du dos paraissent des taches d'une nuane très-foncée, rondes, ordinairement au nombre de huit, et inégales en surface; la plus grande est le plus souvent située au-dessous de la nageoire dorsale, et le diamétre des autres és

'A la nageoire da dos 9 rayons, a chacune des pectora.
les is a clicune de dho

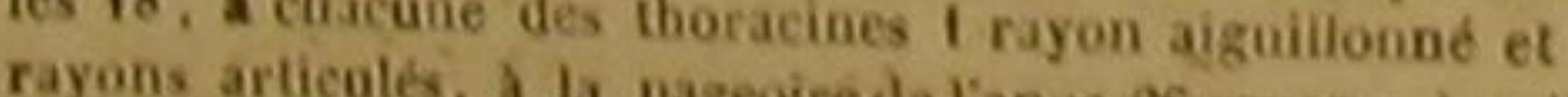
de la queue 26 .

Ccomber pinnulis et anj duodecim circiter vix disincts, spimis in adteriore dorso sex discretis, poné anom - utrinque tex ad octo, ceutiribus supra lineam tateralen déja ciés.

Da sous-gerse
tronote. D.

4 Ce n imbre douse est espressément indiqué dans la des. cription manuscrite de cimmerson, a laquelle nous avon raliste a lasse dus ses paptingt qua au dessin que ce natuet dapres lequel on atribur, fae tous aroas fait graver,

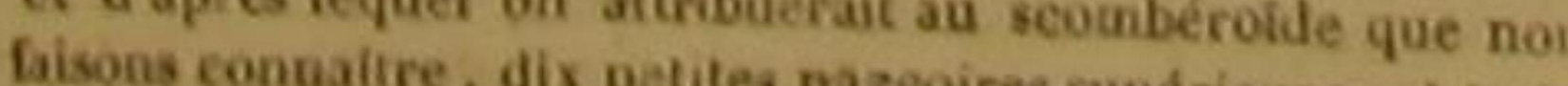
petites nageoires inférieures.

\section{LE SCOMBÉROIDE SAUTEUR '}

Scomberoides saltator, Lacep.; Licbia saliens, Cuv. Scomber saliens, Bloch. ${ }^{2}$.

Nous avons trouvé dans les manuserits de Plumier, que l'on conserve à la Bibliothèque royale, un dessin de ce poisson que nous avons fait graver. Ce naturaliste le nommait petite Pélamide ou petile Bonite, vulgairement le Sauteur. Nous avons conservé au scombéroìde que nous déerivons, ce nom distinctif ou spéeifique de Sauteur; paree qu'il indique la faculte de s'élancer au-dessus de la surface des eaux, et par conséquent une partie intéressante de ses habitudes.

Cet animal a sept petites nageoires au-dessus de la queue; et huit autres nageoires analogues sont placées au-dessous. La dernière de ces petites nageoires, taǹt des supérieures que des inférieures, est très-longue, et faite en forme de faux

La ligne latérale est un peu ondulée dans tout son cours : elle descend d'ailleurs vers le ventre, lorsqu'elle est parvenue à peu près audessus des nageoires pectorales. Deux aiguillons réunis par une membrane sont situés au devant de la nageoire de l'anus. Deux lames composent chaque opereule. La máchoire inférieure s'avance au dela de la supérieure. 0 n compte neuf rayons à la nageoire du dos et a chacune des pectorales ${ }^{2}$. Cette nageoire dorsale et celle de l'anus sont conformées de maniére à représenter une faux. Au lieu d'une première nageoire du dos, on voit quatre aiguillons forts et recourbés qui ne sont pas réunis par une membrane commune de manière à composer une véritable nageoire, mais qui étant garnis chacun d'une petite membrane triangulaire qui les retient et les empêche d'ètre inclinés vers

¿Pelamis minima, vulgò sauteur., Plumier, manuscrits aeposes a la Bibliothèque da Roi.

Wuv. Dos geare Liche, Lichia, dans le genre Ceatronote,
C.

A A chacune des thorácines 7 rayons, a la nageoire de
lanous 13 . la tête, donnent à l'animal un nouveau rapport avee les scombres proprement dits.

On doit regarder comme une variété de notre scombéroide sauteur, le poisson que Bloch a décrit sous le nom de Scombre sauteur, et dont il a donné la figure, pl. 335 .

SOIXANTE-CINQUIĖME GENAE.

\section{LES CABANX}

Denx nageoires dorsales : point de petites nageoires andessus ni au-dessous de la querse : les cốtes de la queue releves tongitudinalement en carène, ou une petite nageoire composce de deux aiguillons et d' wie nembrane au-decaut de la nageoire de l' amus.

PREMIER SOUS-GENRE.

Point d'aiguillon isole entre les deus nageoires dorPoint d aiguiter sales.

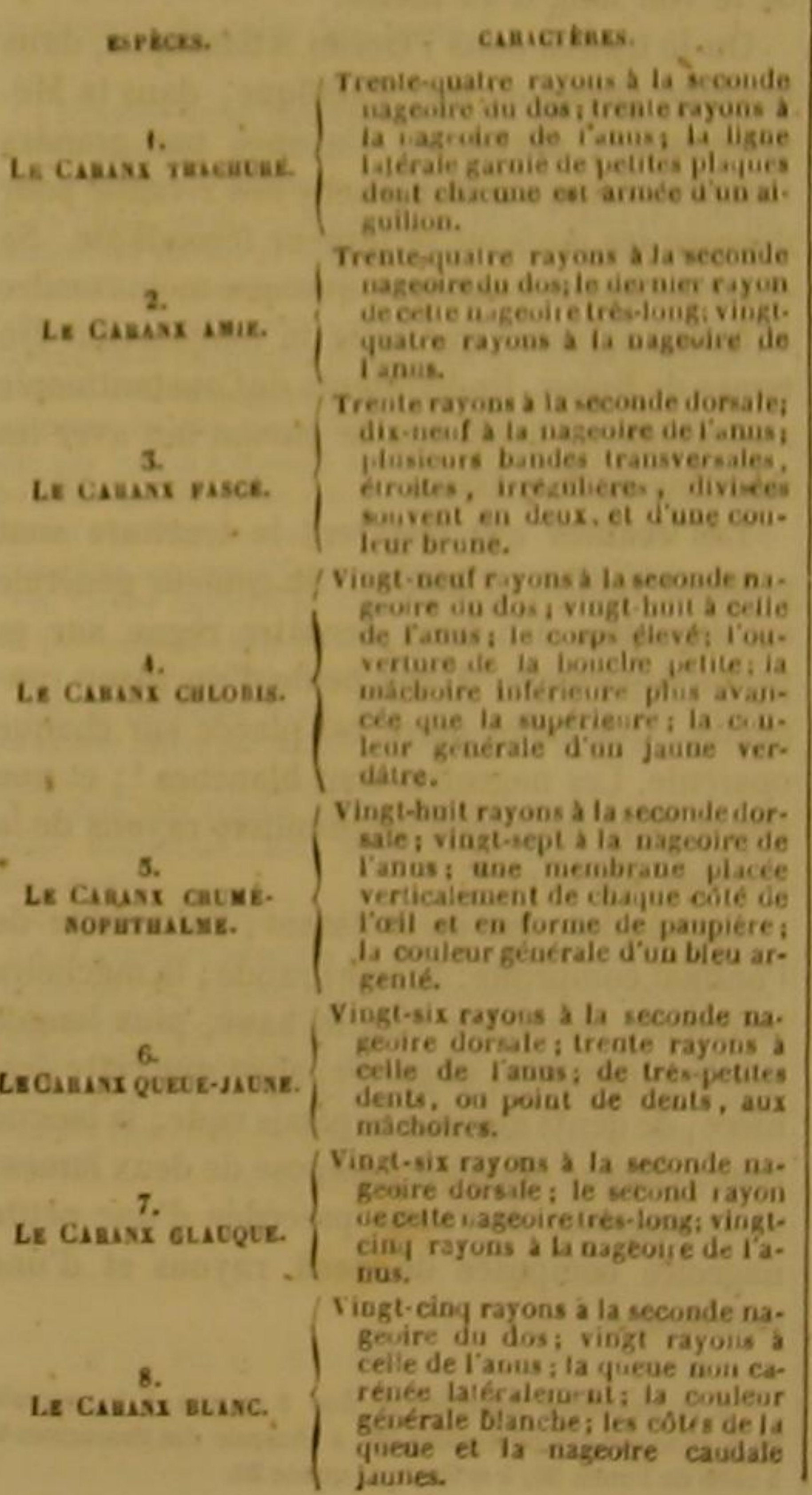

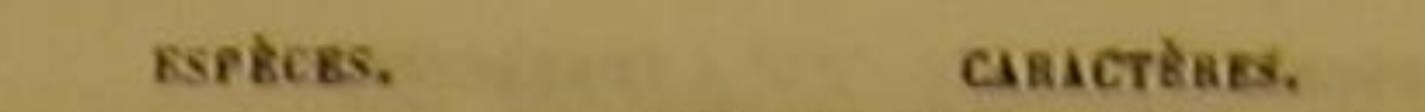

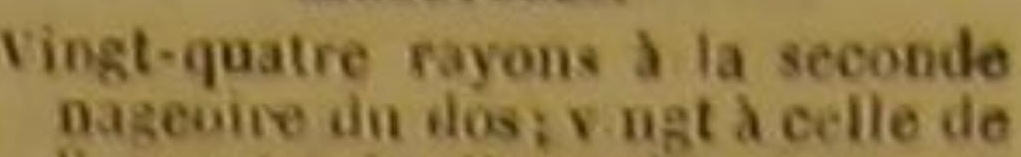

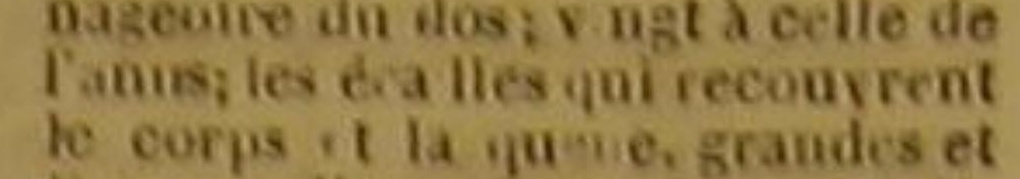

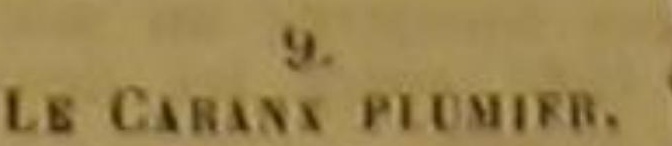

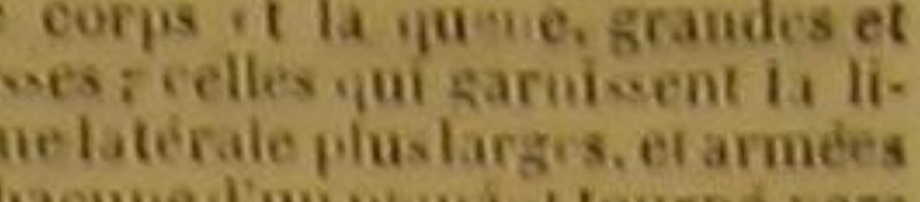

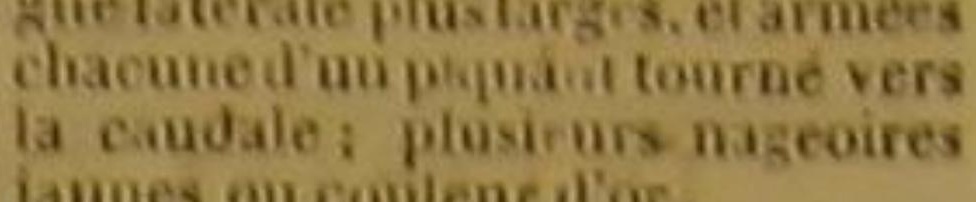
Jaunes on conilearitor.

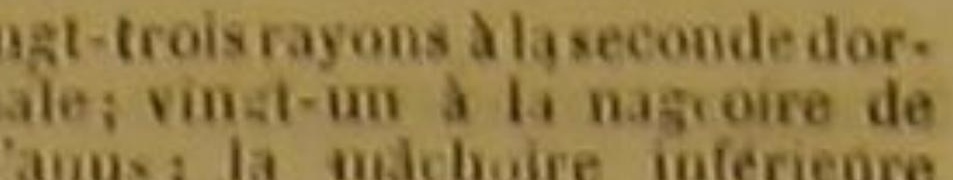
plus avancée yoe la smérieure;

10. a partie pustencene de la ligne
lat rale garnie de lames tres-lar-

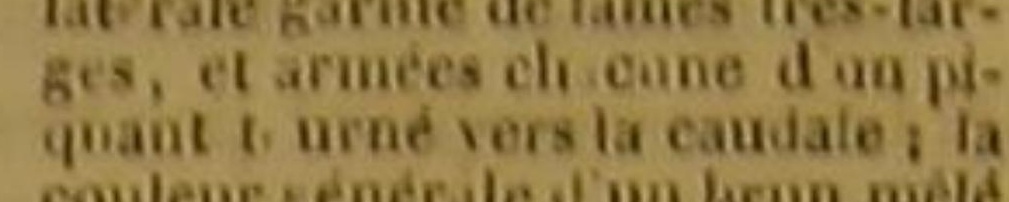
couleur benerule id wi br
de violet it d arkente.

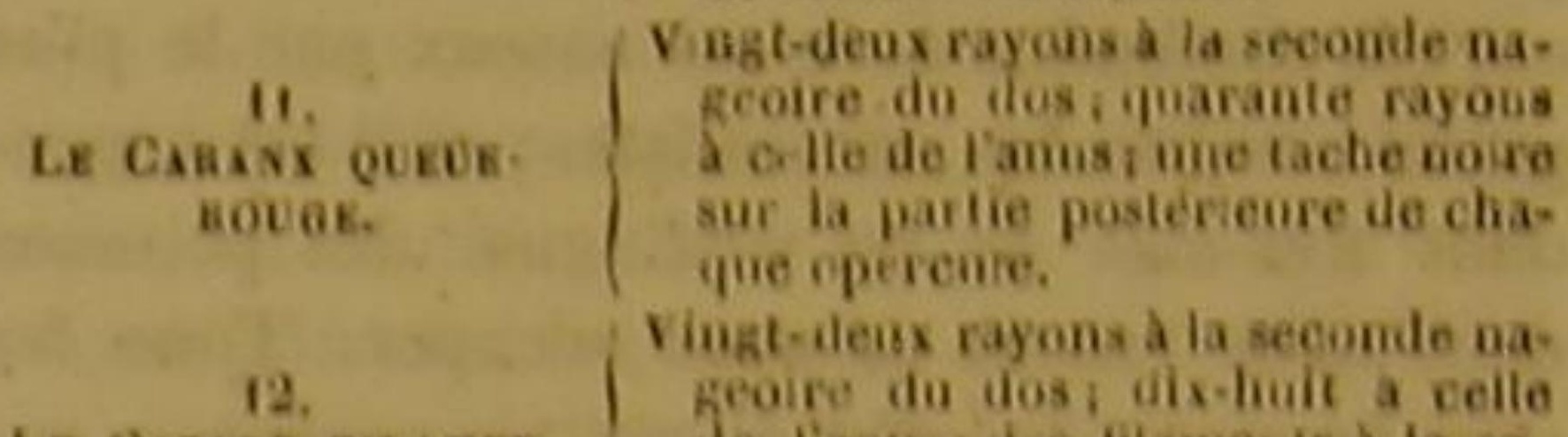

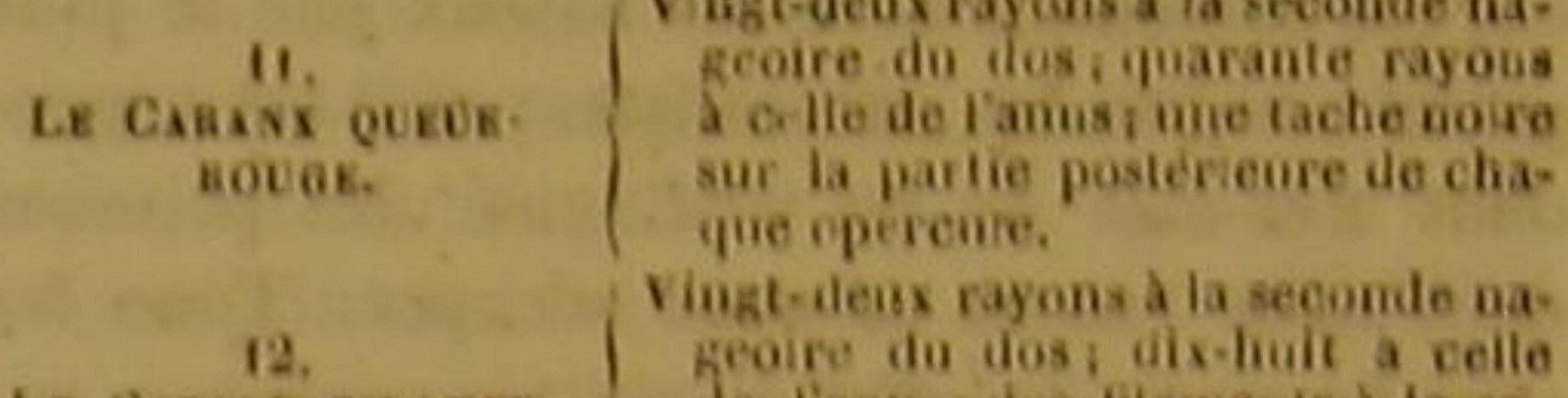

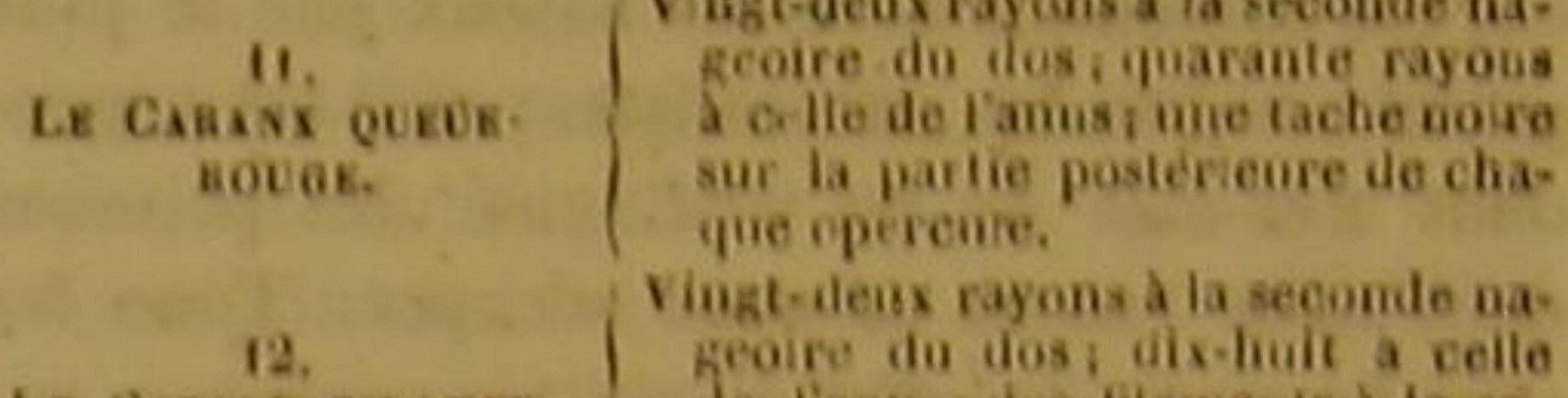

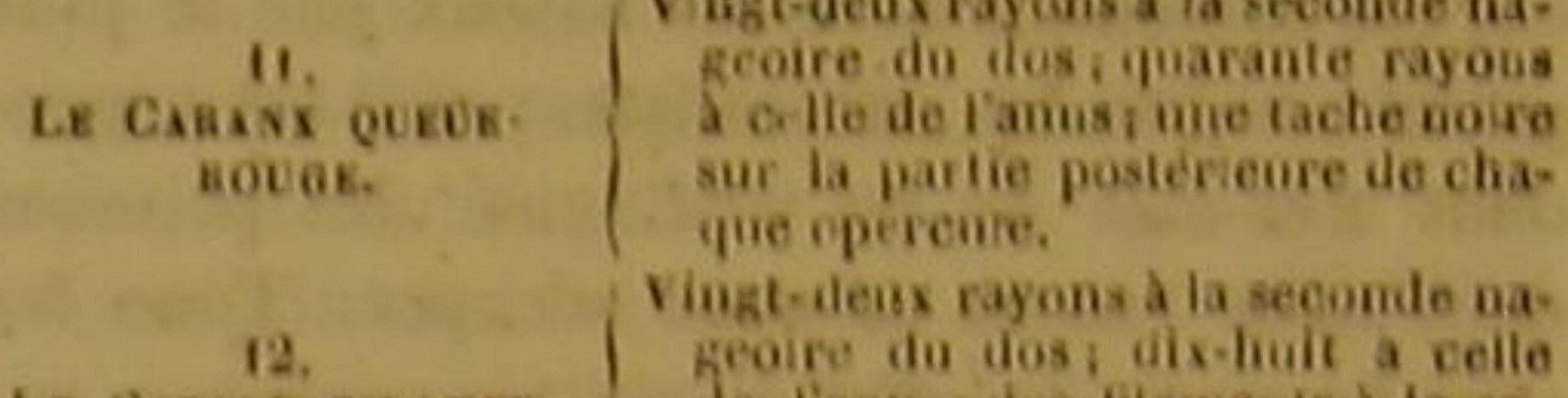

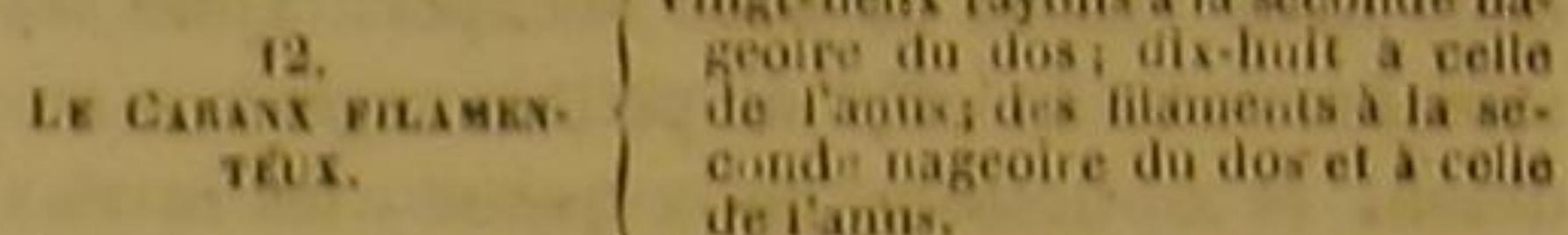

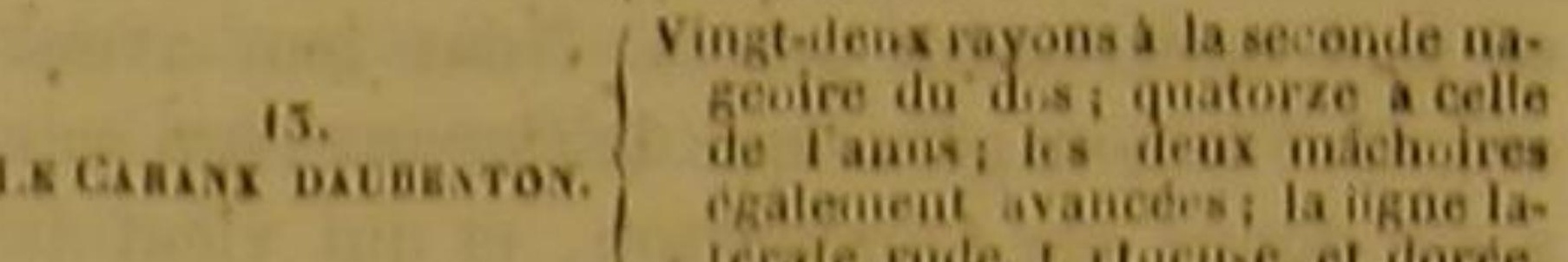
Vings rayons a l i seconde nageoiro

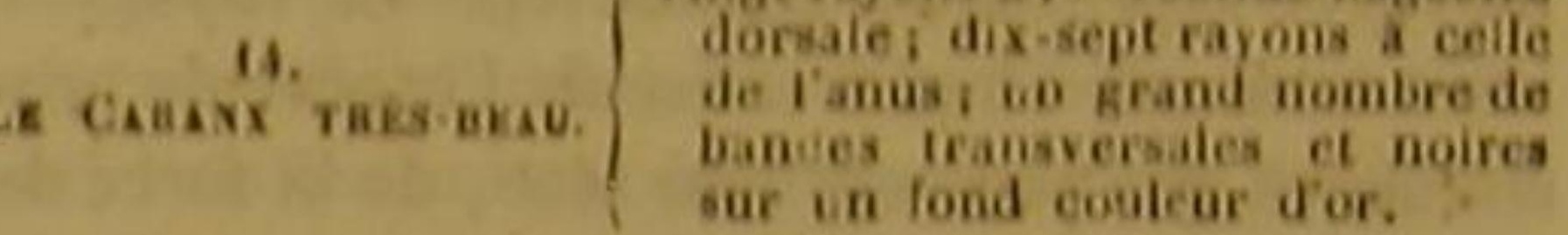
SECOND SOUS-GENIE.

Un ou plusicurs aiguillons isolis entre les deux nageoires Corsales.

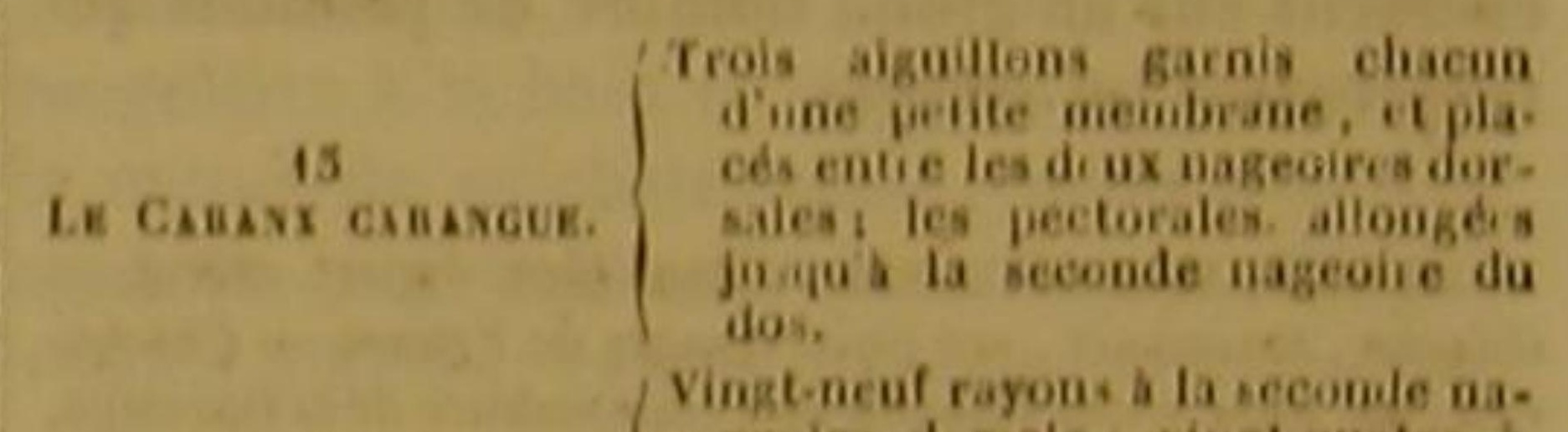

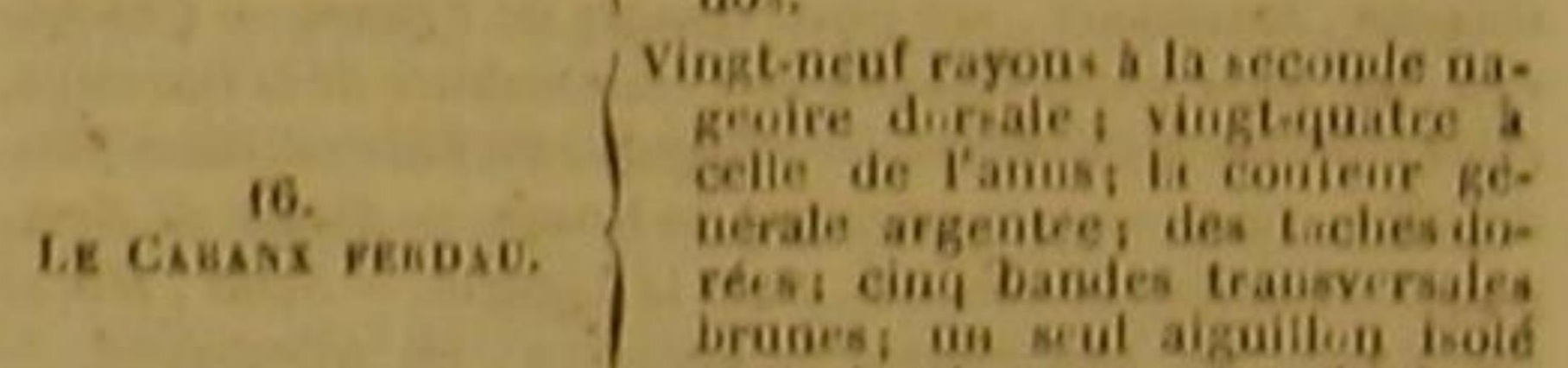
enire les denxnageoirs du dos. Vogt-himit rayons a la seconde na. de lamb les vecinales a celie

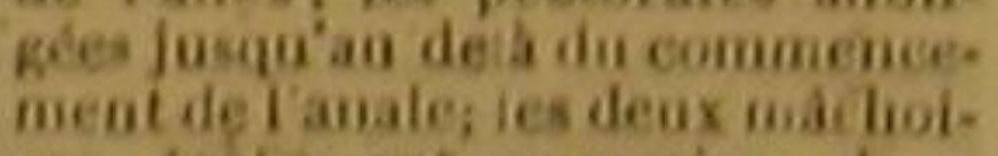
res égarament avancées: d-axorifices a chague nariwe; 4 yarvokine de to cavidule is pling

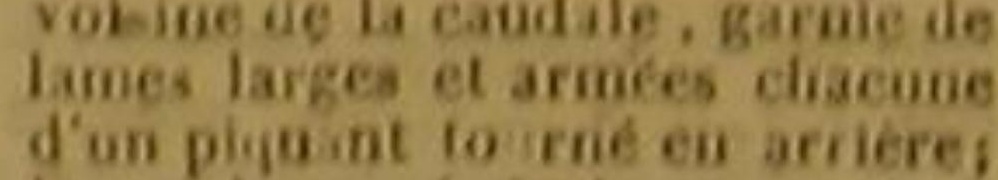

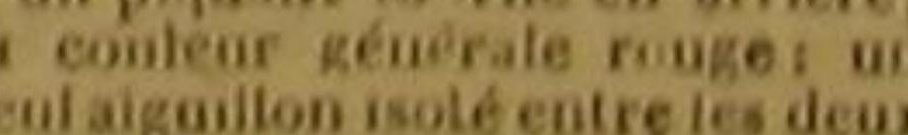
nageolies du dos.

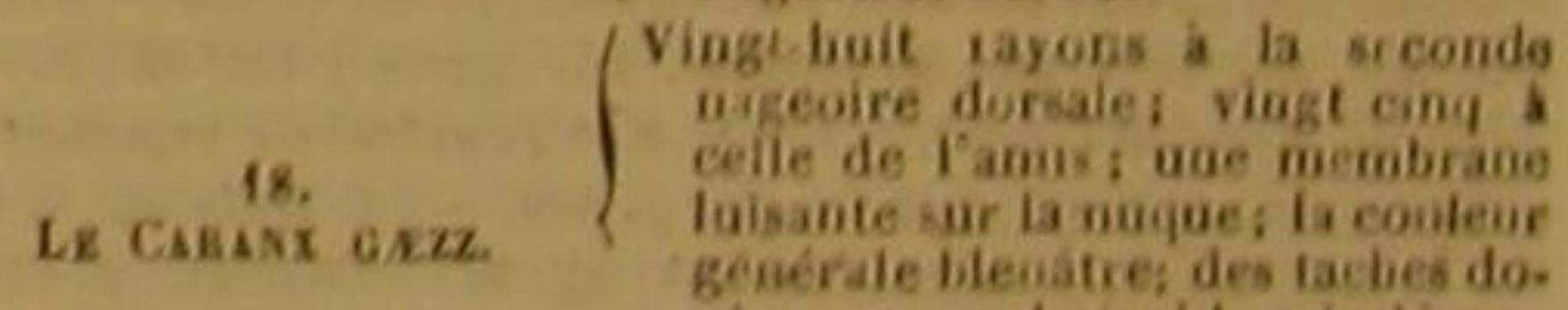

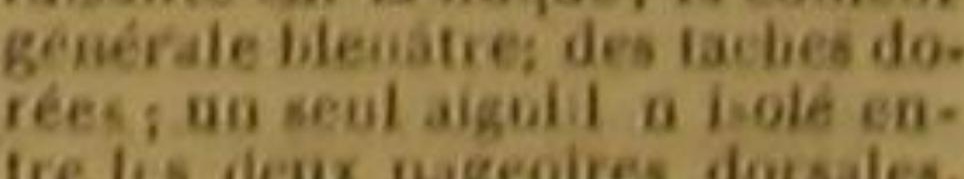
tre lis deux nageoires dorsales. Vingt-deux rayous a a seconde
nageoire du dos: seize a celle de la queve treareieveess la cou leargonerale arzeulé, eclatamie.

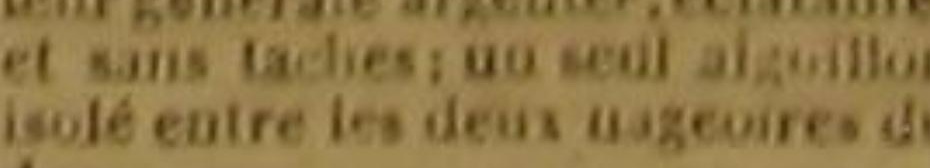


ESPĖCES.

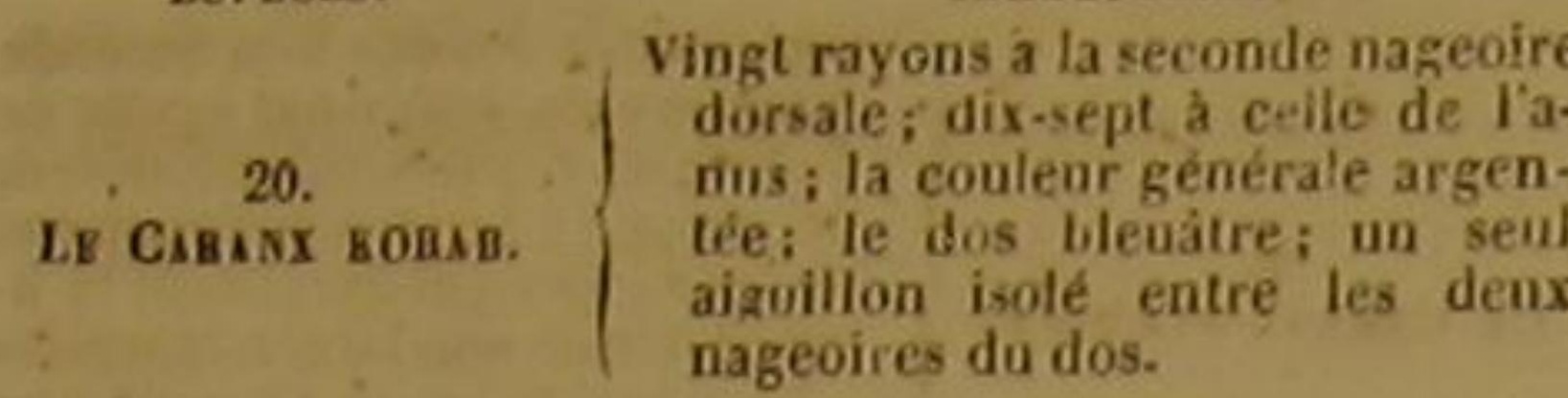

LE CARANX TRACHURE '. Scomber trachurus, Linn.; Caranx trachurus, Lacep.,

Les caranx sont très-voisins des scombres: ils leur ressemblent par beaucoup de traits; ils présentent presque toutes leurs habitudes : ils ont été confondus avec ces osseux par le plus grand nombre des naturalistes; et il est cependant très-aisé de les distinguer deś poissons dont nous venons de nous occuper. Tous les scombres ont en effet de petites nageoires audessus et au-dessous de la queue : les caranx en sont entièrement privés. Nous leur avons conservé le nom générique de Caranx, qui leur a été donné par Commerson, et qui vient du not grec xapa, lequel signifie tête. Ce voyageur les a nommés ainsi à cause de l'espèce de proéminence que présente leur tête, de la force de cette partie, de l'ćclat dont elle brille, et d'ailleurs pour annoncer la sorte de puissance et de domination que plusieurs osseux de ce genre exercent sur un grand nombre de poissons qui fiéquentent les rivages.

- Saurel, Sieurel, Sicurel, dans plus. départ. mérid. Gascon, Gascanel, sur plus. rivages de France - Chich rou, sur plus. cótes voisines de rembouchure de la Garoneet de celle de la Charente. - Maquereaz battard, dans ples. depart. - Sauro, aux environs de Rome. - Pesce di Spa mackrell, en Angleterere, dans la Ligurie. - Scad, Hors Stocker, dans quelques contries de Nord - ea Allemagne. -

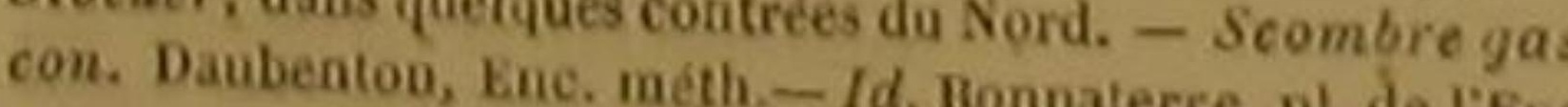
méth. - Bloch, pl. 56. - Sieurel, ou sieure, Val, de l'Enc, Bomare, Dict. dibist. nat. - Mus, Ad. Frid. 1. p. 89 ; et 2 . p. 90. - Hasselquist, 11. 565 et 407, n. 84. - Mall. Prodrom Zoolog. dauic, p. 47, n. 597. - Amæenit academ., 4, p. 249. syn. 80. - T a deredi, gen. 5 Hal. 1. I, p. 5. - Galen. Athen, 1. 7, p. 326. - Id. Oppian Jove, c. 19. p. 86. - Salvian. fol, 79 , s. b. 6 , - Saurus. 1 . certus, sive trachurus. Beton. - Lacertorum gem. - La. trachurum Groci rocaut, ete. Gesner, p. 467 et 552 - Tra Sieurel. Ronderet pas pricatim, Id. (germ) fol. $56, b$. p.75. - Id. Alt part. 1, 1.8,c.6. - Trachurus schooer, Lit. 5, e. 5, art. I, punet, 5, tab. p. 268. - Id. Joniston, L. I. - Trachurus, inllughby, P. 200 , it. S. Charlet.. p. 145. Rai, p.92, u. 8. - Scomber lined laterali. 12, s, 22. - Id. cata, ete. Gronov. Mus. 1, p. 54, D. 80; et Zooph p. 9

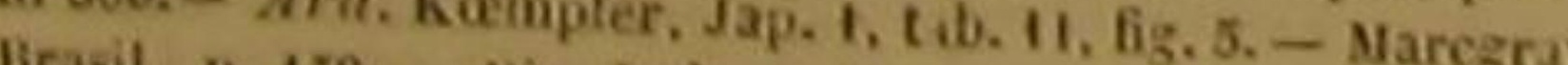
b. 5. - p. 150. - Mis. Lid., p. 5t. - Brit. Zoolog. 5, p. 220 Helret. IV, $p .061, .$. lined laterali .... loricata, etc. Act. ' Du geare Cauaurd
Parmi ces animaux voraces et dangerenx pour ceux des habitants de la mer qui sont trop jeunes ou mal armés, on doit surtout remarquer le trachure. Sa dénomination, qui signifie queue aiguillonnée, vient du grand nombre de piquants dont sa ligne latérale est hérissée sur sa queue, aussi bien que sur son corps : chacun de ces dards est recourbé en arrière, et attaché à une petite plaque écailleuse, que l'on a comparée, pour la forme, à une sorte de bouclier; et la série longitudinale de ces plaques recouvre et indique la ligne latérale.

Lorsque l'animal agite vivement sa queue, et en frappe violemment sa proie, non-sealement il peut l'étourdir, l'assommer, l'éeraser sous ses coûps redoublés, mais encore la blesser avec ses pointes latérales, la déchirer profondément, lui faire perdre tout son sang. D'ailleurs ce caranx parvient à une grandeur assez considérable, quoiqu'il ne présente jamais une longueur égale à celle du thon : il n'est pas rare de le voir long d'un mètre.

On-le trouve dans l'Océan Atlantique, dans le grand Océan ou-mer Pacifique, dans la Méditerranée ; partout il s'avance par grandes troupes, lorsqu'il s'approche des rivages pour déposer ses œufs ou sa liqueur fécondante. Sa chair est bonne à manger, quoique moins tendre et moins agréable que celle du maquereau. Du temps de Bélon, les habitants de Constantinople recherchaient beaucoup le garum fait avec les intestins de ce poisson.

Les écailles qui couvrent le trachure sont petites; rondes et molles. Sa couleur générale est argentée. Un bleu verdâtre règne sur sa partie supérieure. L'iris brille d'un blane rougeâtre. Une tache noire est placée sur chaque opercule. Les nageoires sont blanches '; et une teinte noire distingue les premiers rayons de la seconde dorsale.

La caudale est en croissant; l'ensemble de l'animal comprimé; la tète grande; la mâchoire inferieure recourbée vers le haut, plus longue que la supérieure, et garnie, ainsi que cette dermière, de dents aiguēs; le palais rude ; la langue lisse; chaque opercule composé de deux lames; nageoire composée de deux rayons et d'une membrane.

A4, À la première nageoire da dos 8 rayons, à la seconde a celle de l'anus 50 , a cerlles 20 , a cliaeune des thoracines 6 .
LE CARANX AMIE ',

Seomber Amia, Lino., Gmel.; Caranx Amia, Lacep.; Lichia Amia, Cur. '.

ET LE CARANX QUEUE-JAUNE ${ }^{3}$

Scomber chrysurus, Linn., Gmel.; Caranx chrysurus, Lacep. 4.

Le nombre des rayons que présentent les nageoires du caranx amie peut servir à le distinguer des autres poissons de ce genre, indépendamment des caractères particuliers à cett espèce que nous venons d'exposer dans le tableau des caranx ${ }^{5}$.

La queue-jaune habite dans la Caroline; elle y a été observée par Garden. Son nom vient de la eouleur de sa queue, qui est d'un jaune plos ou moins doré, ainsi que quelques-unes de ses nageoires. Ses dents sont très-petites, trèsdifticiles à voir. On a mème écrit que ses máchoires étaient entièrement dénuées de dents Une petite nageoire à deux rayoís est placée au devant de celle de l'anus ${ }^{\circ}$.

¿ Scomber donso dípterygio, assicolo ultimo pinne dor'sils, secunds pralongo., Artedi, gen. 51, syn. st. pl. de rEne métb. - Nota. II est utile dobservec que les passages des auteurs et les figures des dessinateurs, rappoitio par Artedi, et daprés lai par Daubenton, a leur soombie amie, soot relatifs, non pas a ce poisson, mais au caran en dąue. ou au centronote lyzan, ainsi que oous Tiadiqueron

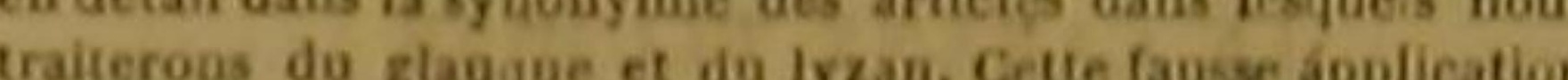
Gile pas Artedia tromped ansil te professeur ponnaterre, fui a fait graver, pour son scombre amie, une figure que Salvian a publiée pour un poison nommé $A m i e$, mais qui ce pendant ne peut appartenir qu'a un centronota lyzan.

Ma. Cuvier rapporte le Seomber Amia, Linn, a ce polsson quit nomme Liche ou Vadigo (dans son genre Centroa til. des figures cittes par Artedi et Linnee, ne peut lui étre rap-

portéc. iaune. Daubeuton, Enc. meth. - Id. Bonnaterre, pl. de 'Enc. méth.

4 Ce poisson n'est páas cité par M. Cavier. D.

5 A la premiere nageoire da dos do caranx amie 5 rayons, thoracines 6 , a celle de I'anus 24 .

- A la premiére nagenice doragle da caranx quenejanog rayons, a la seconde 25 , a chacune des pectoriles 19 , i cha cane des thoracines 6 , a celle de lanus 50 , a celle de ta queuz 22.
LE CARANX FASCE, Caranx fasciatus, Bloch, Lac; Seriola fasciata, Cur. :

LE CARANX CHLORIS ${ }^{2}$,

Caranx Chloris, Bloch, Lacep.; Seriola cosmopolitia,

ET LE CARANX CRUMENOPHTHALME • Scomber crumenophthalmus, Bi.; Caranx crumenophthilmus, Cuv. '.

Remarquez les petites écailles qui revêtent le corps et la queue du fascé; les dents pointue qui garnissent ses mâchoires, sa langue et son palais; la courbure de la partie antérieure de sa ligne latérale; les nuances de sa couleur générale et argentée; les taches brunes de sa tête et de plusieurs de ses nageoires; le jaune et le violet de ses thoracines; le bleu de ses dorsales, de sa eaudale, et de sa nageoire de l'anus 6 :

L'absence de petites écailles sur la tête et les opercules du chloris; la surface lisse de sa langue; l'orifice unique de chacune de sés narines; le peu de distance qui sépare son anus de sa gorge; la longueur de ses pectorales, qui atteignent au delá du commencement de la nageoire de l'anus, et sont, comme la caudale, rougeatres a la base et violettes à l extrémité la nature de sa chair grasse, molle, et trèsagréable aux habitants des rivages africains voisins d'Acara, auprès desquéls on le trouve: Les dimensions de la mâchoire supérieure do cruménophthalme, qui est plus courte que l'inférieure: la surface unie de sa langue et de son palais; les deux orifices de chacune de ses narines; les lames larges et piquantes qui garnis-

wos Les deux premiera de ces poissons appartiennent au genre Sériole de M. Cuvier, et le trolsiéme a son genie Ca. ranx. D.

- 6 rayons a la membrane branichiale du caranx fascé, 18 \& chaque pectorale, 7 rayous aizuilones a la premiere nageoiro du dos, 1 rayon aiguillonné et 5 artiçulés a chaque thoracine, 2 rayous aiguillonnés réouis par une membrane au devani de la asgeoire de fanus, 19 rayons a la nageoire de la queae, in a la membrane branchiale du ciraux chloris, 16 a chaque pectorale. 7 rayons as ailonnes a la premiere dorsule, 4 rayou
siguilionné et 5 rayons articulés a chaque tloracioe, 2 rayons signillonnés rémis par une membrane au devant de ta na. geoire de lanus, 25 rayons a ta candale, 6 a la membrate branchiale du caranx cruménoyhthatme, 20 sa cla que pectorale, 8 rayous aiguillomes a la premiere nage ire du dos, I rayon aiguiltonné el 5 artientés à elaque thoraci e, 2 rayono aiguilionnés réminis par une m raneau-devant de la wa. 
sent la partie postérieure de sa ligne latérale; la couleur grise de ses nageoires; et la blancheur ainsi que la délicatesse de la chair de poisson qui vit auprès de la còte de Guinée.

\section{LE CARANX GLAUQUE '}

Scomber glaucus, Linn., Gm.; Caranx glaucus, Lac. ${ }^{2}$.

Cể poisson, qu'Osbeck a vu dans I'Océan Atlantique, auprès de l'ile de l'Ascension, a été observé par Commerson dans le grand Océan vers les rivages de Madagascar, et particulièrement dans les environs du fort Dauphin élevé dans cette dernière ile. Il habite aussi dans la Méditerránée, où il était très-comnu du temps de Pline, et mème de celui d'Aristote, qui avait entendu dire que ce caran $x$ se tenait caché dans les profondeurs de la mer pendant les tres-grandes chaleurs de l'été. La couleur générale de cet osseux est indiquée par le nom qu'il porte : elle est en effet d'un bleu clair mélé d'une teinte verdátre; quelquefois cependant elle parait d'u bleu foncé et semblable à celui que présente la mer agitée par un vent impétueux: La partie inférieure de l'animal est blanche. On voit souvent une tache noire à l'origine de la seconde nageoire dorsale et à celle de la nageoire de l'anus; et quatre autres taches noires, dont les deux premières sont les plus grandes, sont auss placées ordinairement sur cbaque ligne latérale.

Le second rayon de la seconde uageoire du dos est très-haut, et le premier aiguillon de la première nageoire dorsale est tourné, incliné, et même couché vers la tête. Une petite nageoire à deux rayons précède celle de-l'anus ?

La chair du glauque est blanche, grasse, ét communément de bon goùt.

- Leceia, sur les cótes de ta Ligurie. - Polanda, en esclavon. - Thauxes, en gric:- Derbio, Biche, Cabro'e.

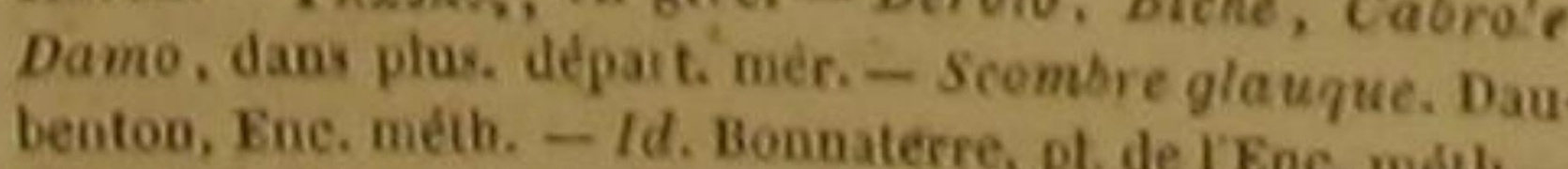
scomber dorso dipterygio, ossiculo secundo pinneth. salis attissimo. Artedi, Beil. 52, syo. 51, - Mus. Ad. Frid. 2, 1. 89. - Scomber Ascensionis. Osbeck, It. 296. - Derbio

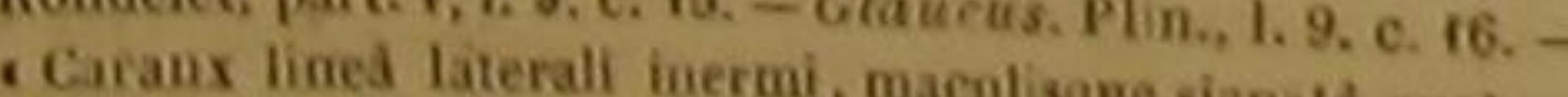

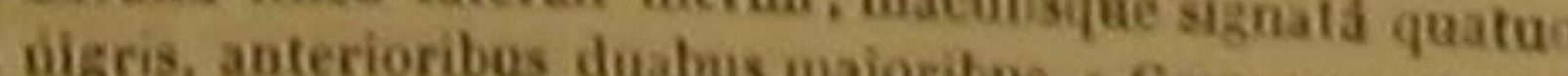

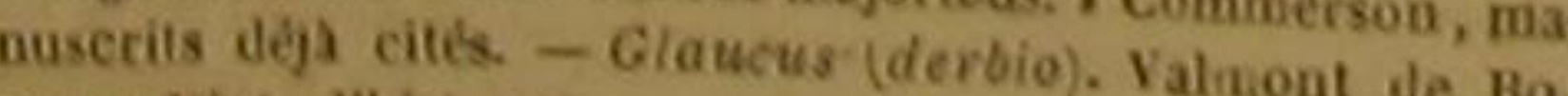
ware, Diet, d'hist, nat.

: Non cité par M. Cuvier. D.

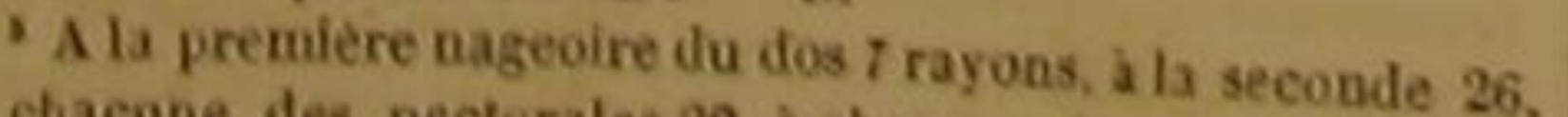
a chacane des pecturales 20 , a chacune des thoracines 5, a
celle de laaus 25,1 celle de la queue, qui est très-four.
LE CABANX BLANC ' Scomber albus, Linn., Gmel.; Caranx albus, Lacep. , ET LE CARANX QUEUE-ROUGE ${ }^{3}$ Scomber Hippos, Linn.; Caranx erythrurus, Lacep.4

La mer Rouge nourrit le earanx blane, que Forskael a décrit le premier, et dont la couleur générale blanche ou argentée est relevée par le jaune qui règne sur les côtés de l'animal et su la nageoire caudale. Un rang de petites dents garnit chaque màchoire: Chaque ligne latérale est revètue, vers la queue, de petites pièces écailleuses. Les écailles proprement dites qui recouvrent ce caranx sont fortement attachées. La première nageoire du dos forme un triangle équilatéral ${ }^{5}$

On voit une petite nageoire composée de deux rayons au-devant de l'anus du blane, aussi bien qu'au-devant de l'anus du caranx queue-rouge. Ce dernier a été observé dans la Caroline par Garden, et à l'ile de Taiti par Forster. II montre une tache noire sur chacun de ses opereules. Sa seconde nágeoire du dos est rouge, comme celle de la queue; les thoracines et l'anale sont jaunes. La partie postérieure de chaque ligne latérale est comme hérissée de petites pointes. Les deux dents de devant sout, dans chaque machoire, plus grandes que les autres ${ }^{\circ}$.

\section{LE CARANX PLUMIER '} Seomber Plomierii, Blo h.; Caranx Plumierii, Lacep.

ET LE CARANX KLEIN ?.

Scomber Kleioii, Bl.; Caraus Kleinil, Lacep., Cuv. “ La tête du caranx plumier est dénuée de pe-

'Forskael, Fauń. Arab, p. 56, o. 73. - Scombre sufnok. 'Noncité par M. Cuvier. D.

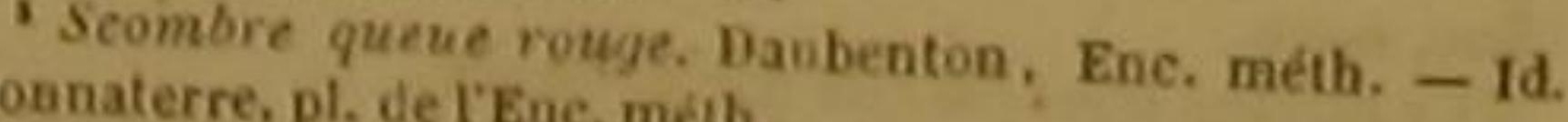

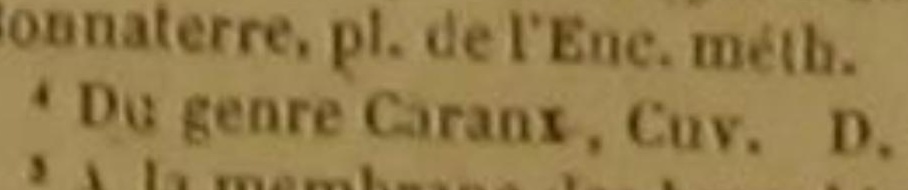

a la premiére nageoire dorale 8 , a caranx blanc 8 rayons. des pectorales 22 , a chacis ne des thoracinde 25 , a chacune nus 20 , a celle de $1 \mathrm{l}$ queue 17 .

rouge 7 rayons, a ta seconde 22 , a chacue du caranx quene. a chacune des thoracires 6 , a celle de l'anus 40 , a celle de

, Bloch,

Bloch, pl, si4:

- Walen-Parcy, par, Cav. D.

- Dugenre Caranx, Cuv, D. Bl., pl. 517, fig. 2.

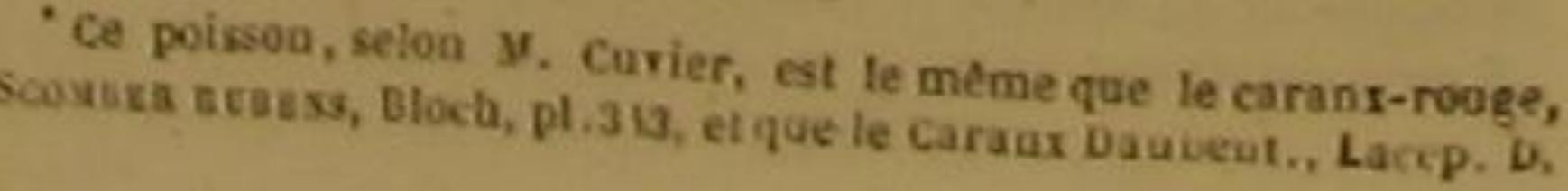

Wiat DES POISSONS.

tites écailles ; l'oritice de chacun de ses orcanes de l'odorat double; la saillie de la partie postéríeure de ses opereules pointue; le bleu argenté de sa couleur générale se trouve relevé par des taches jaunes; ses pectorales et ses thoracines sont azurées. Ce caranx vit dans la mer des Antilles.

Le caranx klein, du Coromandel, a la langue unie, le devant du palais rude etl'arrière-palais lisse; ses nageoires ont des nuances grises; sa longueur n'excède guere trois décimètres; sa chair a un goùt peu agréable et son tissu est presque toujours trop maigre :

\section{LE CABANX FILAMENTEUX ?}

Carans filamentosus, Lac.

C'est au célèbre anglais Mungo-Park que l'on doit la description de ce caranx, que l'on trouve en Asie, aupres des rivages de Sumatra. Le nom de Filamenteux que Mungo-Park lui a donné, vient des filaments qui garnissent la seconde nageoire dorsale, aiusi que celle de l'anus. La couleur générale de ce poisson est argentée, et son dos est bleuatre; ses écailles sont petites, mais fortement attachées. Le museau est arrondi; I'oeil grand; I'iris jaune; chaque mâchoire hérissée de dents courtes et serrées; chaque operécule formé de trois lames dénuées d'écailles semblables à celles du dos; la nageoire caudale fourchue; la petitenageoire qui précède celle de l'anus, composée de deux rayons, dont l'antérieur est le moins grand. Les pectorales sont 'en forme de faux; la première du dos pent être reve dans une fossette longitudinale

45 rayons a chaque pectorale du caranx plumier, 7 aiguillonnes a la premiere dorsale, 6 a cha jue thoracine, 2 aiguiTamus. II \& la caudale, 5 a la membraoe branchiale do ranx klein, 16 a chaque pectorale, 7 rayons aigullionnes bi premièrenageoire do dos, 1 ray on aiguillonné et s arcicoles chaque thoracine, 2 rayons aiguilionnés réunis par une membirane an devant de la nagevire de l'anus, 22 rayous a la nageoire de la queive.

- Scomber filamentosus, Mungo-Park, Trans. de la soc. it la membranedronne pas celle espece. $D$. geoire dorsale 6 rayons aiguillosies 7 rayons, a ia premiére nadu dis 22 rayons, a chacune des vectorales ig, i chacoine tes thoradines 5 , a celle de lanus 18 , a celle de ia çuene 22 .
E CARANX DAUBENTON :

Carans Daubeutonii, Lacep. *

Nous consacrons à la mémoire de i otre illus tre ami Daubenton, ce beau caranx représenté d'après Plumier dans les peintures sur vélin du Muséum d'histoire uaturelle.

Ce caranx a ses deux naggeoires dorsales très. rapprochées: la première est triangulaire, et sontenue par six rayons aiguillonnés; la seconde est très-allongée et un peu en forme de faux ${ }^{3}$. Deux aiguillons sont placés au-devant de la nageoire de l'anus. Les deux máchoires sont également avancées. On voit, à chaque opercule branchial, au moins trois pièces, dont les deux dernières sont découpées en pointe du cóté de la queue. La ligne latérale est tortueuse, rude et dorée. Des taches couleur d'or sont répandues sur les nageoires, La partie supérieure du corps est bleue, et l'inférieure argentée.

LE CARANX TRES-BEAU Scomber speciosus, Lino,, Gmel-; Caranx speciosus,
Lac, Cav.

Ce poisson mérite son nom. Ses éeailles, petites et faiblement àttachées, brillent de P'éclat de l'or sur le dos, et de celui de l'argent sur sa partie inférieure. Ces deux riches nuances sont variées par des bandes transversales, ordinairement au nombre de sept, d'un beau noir, et dont chacune est communément suivie d'une autre bande également d'un beau noir et transversale, mais beaucoup plus étroife. Les nageoires du dos sont bleues, et les autres jaunes. Trois lames composent chaque opercule. Les nageoires pectorales, beaucoup plus longues que les thoracines, sont en forme de faux. Celle de la queue est fourchue.

Forskael a vu ce caranx dans ta mer Rouge Commerson, qui l'a observé dans la partie do

-Trachorus argento-caruleus, aureis maculis notatus. Manuscrils de Plumier.

si. Cavier rapuórte ce poisson a la méme especeo que la caranx rouge, scomber ruber, B1, pl. 362, el que le caran

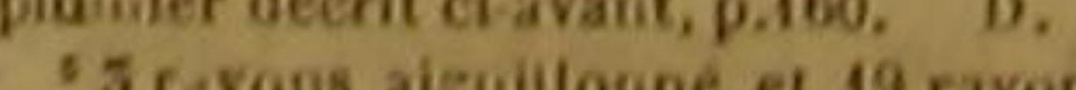

a rayonsarticules a is seconde arge ire da dos 1 rayon aigu llionut et is rayons articulta 'Porskael. Baun. Arab.. p. 5i, n.70.- Seombro ri Bonoaverre, pl. de IEnc. meth. - Carans fiscis transven

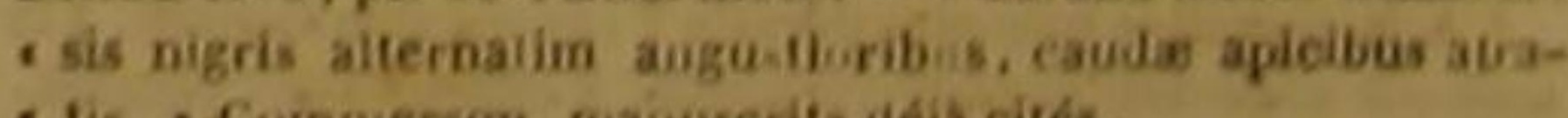
Its. Coinmerson. masiscerits déja cirés. 3 Ce poisson apparieat a ia division des caranx, que 
grand Océan qui baigne l'ile de France et la | par la présence d'un aiguillon isolé placé entre cóte orientale d'Afrique, rapporte dans ses ma- les deux nageoires dorsales. On les trouve tors nuscrits, que les deux individus de cette espèce les quatre dans la mer Rouge ou mer d'Arabie: qu'il a examinés, n’avaient pas plus de six ou ils y ont été observés par Forskael. Le tableau sept pouces (deux décimètres) de longueur, que méthodique du genre Caranx expose les difféles deux pointes de la nageoire caudale étaient rences qui les séparent l'un de l'autre ; il nous très-noires, que les deux máchoires étaient à suffira maintenant d'ajouter quelques traits à peu près également avancées, et qu'on ne sentait aucune dent le long de ces màchoires.

Indépendamment de ces particularités dont les deux dernières ont été aussi indiquẻes par Forskael, Commerson dit que la membrane branchiale était soutenue par sept rayons; que la partie concave de l'are osseux de la premiere branchie était dentée en forme de peigne; que la partie analogue des autres trois ares ne présentait que deux rangs de tubercules assez courts; et que la ligne latérale était, vers la queue, hérissée de petits aiguillons, et bordée, pour ainsi dire, d'écailles plus grandes que celles dil dos '.

LE GARANX CARANGUE 2 . Scomber Carangas, Bl.; Caranx Carangua, Lac. '.

Nous avons consacré à ce caranx le nom spéelfique de Carangue, qu'il a porté à la Martinique, suivant Plumier. La première nageoire du dos est soutenue par sept ou huit aiguillons. Deux aiguillons paraissent au-devant de celle de l'anus. La ligue latérale est courbe et rude ; la partie supérieure du poisson bleue; l'inférieure argentée; et presque toutes les nageoires resplendissent de l'éclat de l'or.

\section{-}

LE CARANX FERDAU 4,

Scomber Ferdau, Lion., Gmel.; Caranx Ferdau, Lae. LE CARANX GASS 5, Scomber Gess, Lino., Gm, Caranx Gess, Lae. LE CARANX SANSUN ,

Scomber Sansun, Linu., Gmel., Carabx Sausun, Lac, ET LE CARANX KORAB ?

Scomber Korab, Linn., Gm.; Caranx Korab, Lacep. .

Ces quatre caranx composent un sous-genre particulier et distingué du premier sous-genre

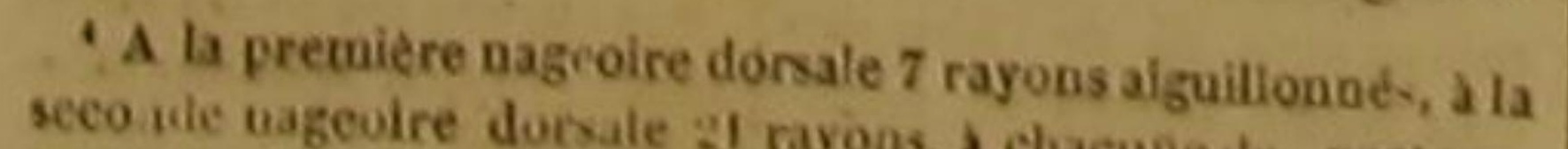
les 22 . a clacune des th raciois is 5 ou 6 . a celle de lanaqui est précedée d'une petite nageoire a 2 rayoas, 21 , a celle
de $\mathrm{t}$ queue 17 . suftira maintenant d'ajouter quelques traits à ceux que présente ce tableau.

Le ferdau montre un grand nombre de dents petites, déliées et flexibles; le sommet de la tête est dénué d'écailles proprement dites et osseux dans son milieu; l'opercule est écailleux; la ligne latérale presque droite; la nageoire can dale fourchue et glauque. Les pectorales, dont la forme ressemble à celle d'une faux, sont blanchâtres ; et une variété de l'espèce que nous décrivons, les a transparentes. On voit au-devant des narines un petit barbillon conique '

Le gæss, qui ressemble beancoup au ferdau, a une petite cavité sur la têtes il peut baisser et renfermer dans une fossette longitudinale sa première nageoire dorsale; sa nageoire caudale est très-fourchue; et sa ligne latérale est courbe vers la tête et droite vers la queue ${ }^{2}$.

Le sansun, qui a beaucoup de rapports avee le gæss et avec le ferdau, présente des ramifications sur le sommet de la téte; une rangée de dents arme ehaque måchoire; la mâchoire supé. rieure est d'ailleurs garnie d'une grandequantité de dents petites et flexibles, placées en seconde ligne. Les nageoires pectorales et les thoracines sont blanches, celle de Panus et le lobe inférieur de la caudale sont jaunes; le lobe supérieur de cette méme candale ést brun comme les dorsales, qui, d'ailleurs, sont bordées de noir ${ }^{3}$

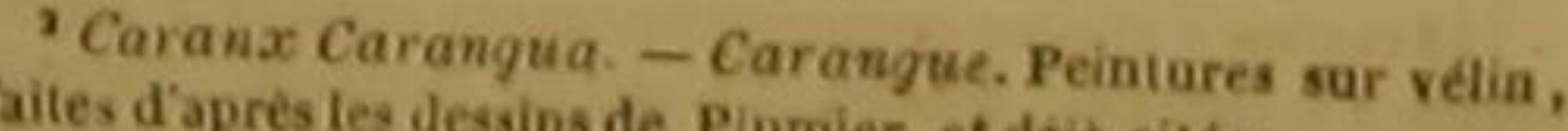
- Daprès les dessins de Piumier, et deja ciltees.

4 Forskael. Fano. de Al, Cavier, D. Bonnaterre, pl. de IFne 'Forskael, Faun. Ane méti

Bonnaterre, pl. de I'Enc méth. 56, n. 75. - Scombre gess. - Forkkael, Faun. Arabic,, p, 56; n. 74.- Scombre tockos. 'Forake, pl. de l'Ene. méth.

'Forssael, Faun. Arabic,. pl. 85, n. 72.-Scumbre Koráb.

"N. Cuvier ne cite. métb.

A la premitre cite aucune de ces especes. D. chacune des pectorales, are dorsale 6 rayons aiguillonnés, 1 aiguillouné el5 rayona articulés, A celle de fa yons. A la premiere nageoire dorsale 7 cayons aigaillonnto a cbacune des pectorales I rayon aiguillonné et 20 rayon, articulés, i chacune des thoracines I rayou aiguillonné et 5 3 A la premiere nageoire dorse 18 ou 19 rayons.

DES POISSONS.

163

Le korab a chaque mâchoire hérissée d'une rangée de dents courtes et comme renflées; I ligne latérale est ondulée vers la nuque, et droite ainsi que marquée par des écailles particulières auprès de la queue. Les nageoires peetorales et les thoracines sont roussảtres; les dorsales glauques ; l'anale transparente et comme bordée de jaune; le lobe inférieur de la caudale jaune, et le supérieur d'un bleu verdâtre '.

LE CARANX ROUGE.

Scomber raber, Bl.; Caranx ruber, Lae, 1.

Le caranx rouge est remarquable par les dents qui hérissent son palais; sa langue très-lisse et un peu libre dans ses mouvements; les deux ouvertures de chacune de ses narines; la facilité avec laquelle il perd les éeailles qui recouvrent son corps et sa queue; les reflets argentés qui brillent sur ses côtés, et le jaune mélé de violet qui se montre sur ses nageoires ${ }^{3}$. On le péche auprès de l'ile de Sainte-Croix.

\section{SOIXANTE-SIXIÉME GENRE.} LES THACH NOTES 4.

Deux nageoires dorsales i poiat de petifes nageoires au dessus ni au-dessous de la queue, les cótes de la queue releces longitudnalement en carene, ou une petile nageoire composee de deux aiguilions et d' une membrane au-derant de la nageoire de T anus ; des aiguillons caches sous la peau, au-decant des nageoires dorsales. espéce.

LE Tuscissons na-
Casua.

guillonnes, a chacune des pectorales I rayon aiguillonne 20 rayons articults, 1 chacune des thoracines 1 rayon aiguilonné et 5 rayons articules, d celle de ia queue 17 ou 48 rayons. premiere nageoire dorsale 7 rayoos agrab, , 8 rayons, a des pectoraies I rayon aigullowné et 20 rayons articuís, a chacune des thoracines 1 rayon alguillonoé et 5 rayou articules. à celle de la queve 17 ou 18 rayons.

3. Cuvier te comsidere comme ne difterant pas specifquement des Caranx Plumier et Dasubeatun décrits p. 160 et is 10.

7 a la premiere dorsale 6 a chabiale, 15 a chaque pectorale, guilloonts reuris par une membrane au-devant de la anBeoire de l'anus, 17 rayous a la caudale. 1.M. Cavier reunit les trachinotes, les acanthinions et les
cassiomores de Lackpede pour ea former le dernier sousBasiomores de Lactpede pour en former le dernier sous
Benre de son geareCentronote. D. -
LE TRACHINOTE FAUCHEUR :

Trachinotus faleatus, Lae., Cuv, 3.

C'est dans la mer d'Arabie qu'habite ce poisson, que Forskael, en le découvrant, crut devoir comprendre parmi les scombres, mais que l'état actuel de la science ichthyologique et nos principes de distribution méthodique et régu ière nous obligent à séparer de ces mèmes scombres et à inserire dans un genre particulier. Nous donnons à cet osseux le nom générique de Trachinole qui veut dire aiguillons sur lo dos, pour désigner l'un des traits les plus distinctifs de sa conformation. Cet animal a toujours en effet auprès de la nuque, des aiguillons cachés sur la peau, et au-devant desquels un piquant très-fort couché horizontalement est tourné vers le museau, et quelquefois recouvert par le tégument le plus extérieur du poisson. La preniére nageoire dorsale, dont la membrane n'est soutenue que par des rayons aiguillonnés, et dont la peau recouvre quelquefois le premier rayon, peut se baisser et se coucher dans une fossette.

La seconde nageoire dorsale et celle de l'anus s ont la forme d'une sorte de faux; ct voila d'où vient le nom spécifique que nous avons conservé au trachinote que nous déerivons.

Ce fauchear, dont la hauteur égale souvent la moitié de la longueur, est revétu, sur le corps et sur la queue, d'écailles minces et fortement attachées; on ne voit pas décailles proprement dites sur les opercules; on n'aperçoit pas de dents aux máchoires, mais on remarque des aspérités à la mâchoire inférieure; la lèvre supérieure est extensible; la ligne latérale est un peu ondulée; les thoracines, plus longues que les pectorales, sont comme tronquées obliquement; il y a au-devant de l'anus une petite nageoire à deux rayons.

La couleur générale de ce trachinote est argentée avec une teinte brune sur le dos. Une nuance jaunâtre parait sur le front. La nageoire caudale est peinte de trois couleurs; elle mon¿ Scomber rhomboidalis, pinna secunda dori et ani - faleatis, = Vorkkael, Yaun. Arabic, p. B7, a. 76. - Scom ore hogel. Bonnaterre, pl. de I'Euc, métb.

te genre Centronote. Cav. 10.

A is prem iere nageoire dorale 5 rayons alguillounes, a cusecunde 1 iayon aiguil ouné et 19 rayons articules. 4 clia cune des pector ales 18 rayons , a chacune des thoracines 6.4

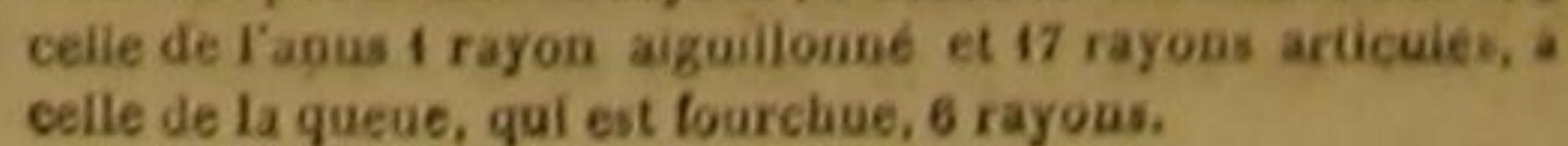
colle de la queue, qui est lourchue, 6 rayous. 
tre du brun, du glauque et du jaune: les thora- | ce qu'ils n'ont qu'une seule nageoire dorsale. cines sont blanchâtrés en dedans, et dorées ou ils leur ressemblent d'ailleurs par un très-grand jaunatres en dehors, ce qui s'accorde avec les nombre de traits, ainsi que leur nom l'indique, principes que nous avons exposés au sujet des Le nombre des rayons de la nageoire du dos couleurs des poissons et mème du plus grand distingue le pélagique, auquel on ne doit avoir

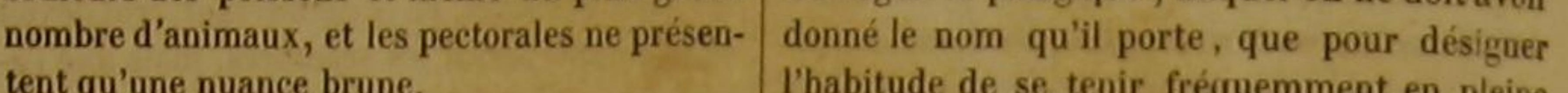
tent qu'une nuance brune.

Il parait par une note très-courte que j'ai trouvée dans les papiers de Commerson, que ce naturaliste avait vu auprès du fort Dauphin de Madagascar, notre trachinote faucheur, qu'il regardait comme un caranx, et auquel il attribuait une longueur d'un demi-mètre.

\section{SOIXANTE-SEPTIEME GENRE}

LES CABANXOMORES '

Une seule nageoire dorsale; point de petites nageoires au-dessus ni au-dessous de la quene: les cótes de la quene releces longitudinalement an carié, ou une nembrane au-derant de la nageoire de lans et une nageoire dorsale tres-prolongee cers celle de la guene la levre superieure tres-peu extensible on nom quencin sible; point daiguillons isolés au-derunt de ia negeoire du dos.

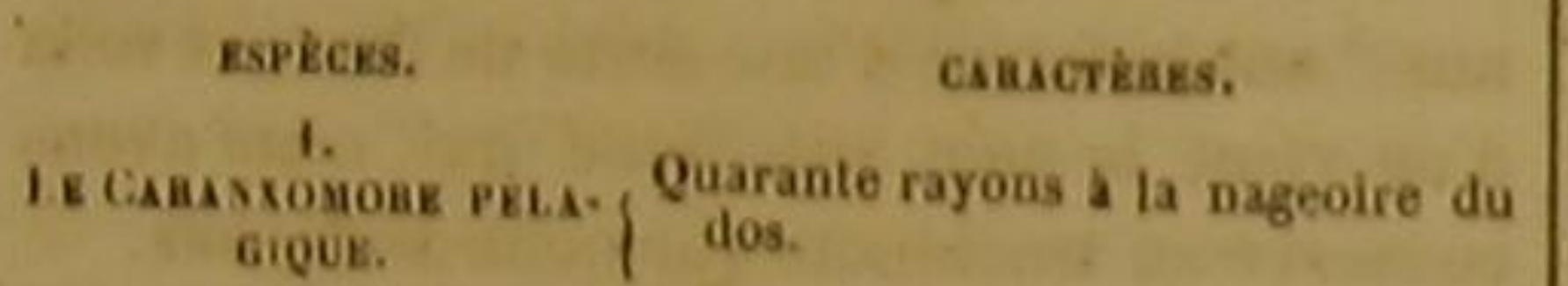

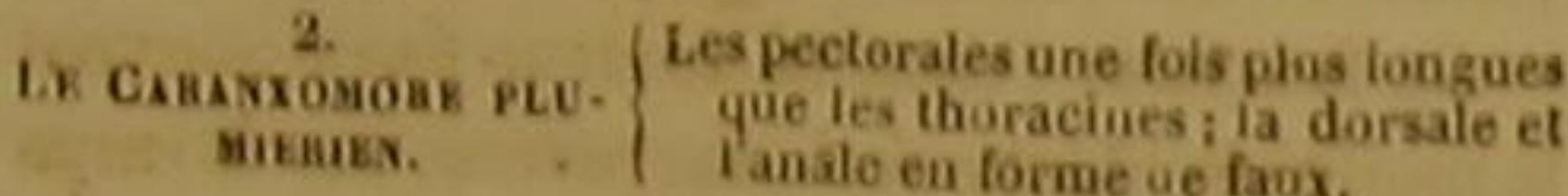

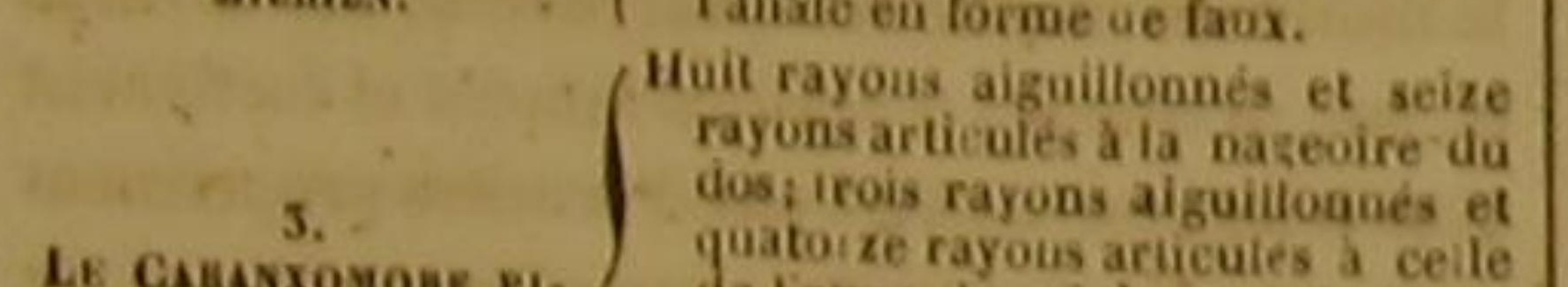

Causxonoas P1-
HTscuzi.

la couleur géaérale d'un viole
argenté.

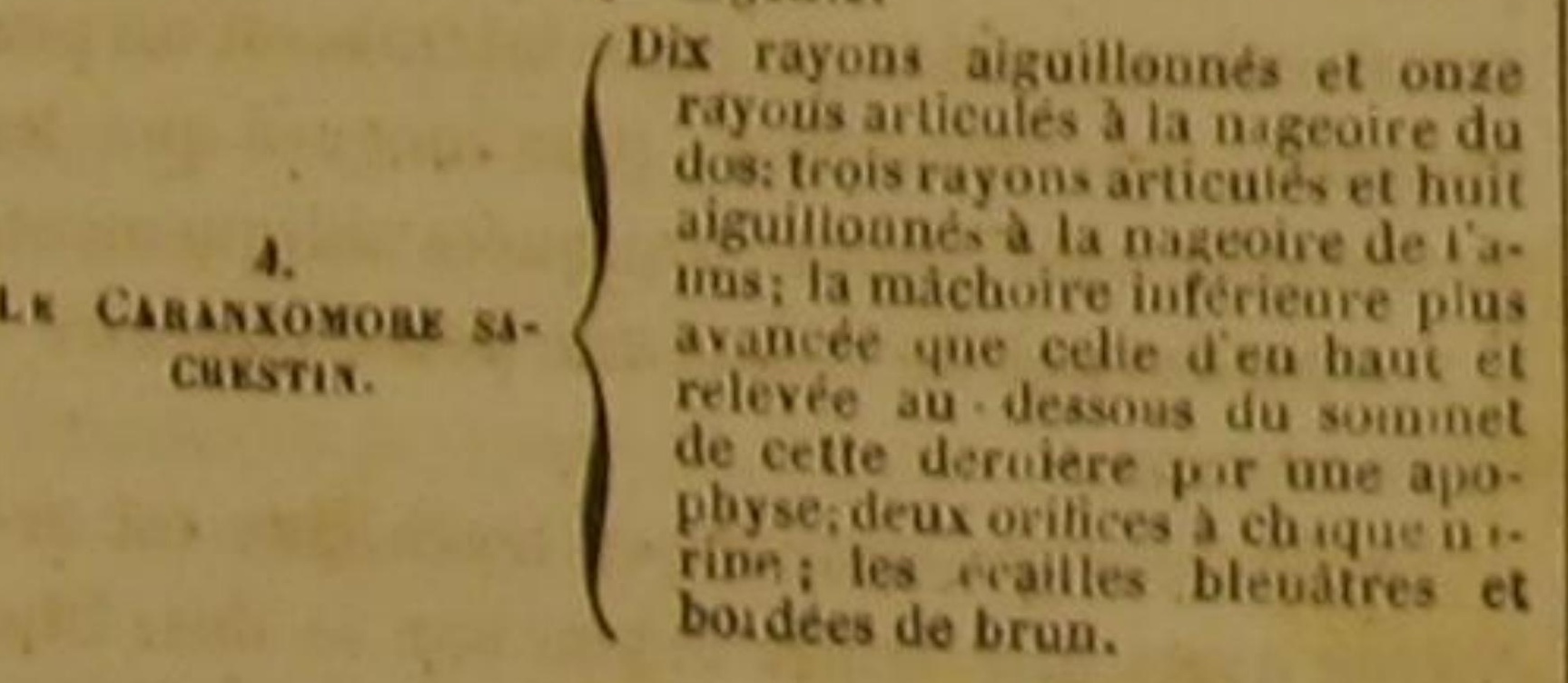
-

LE CARANXOMORE PÉLAgIQUE 2

scomber pelagieus, Lion; Cichla pe'agica, Bloch; Ca rabxomorus pelagicus, Lac., Cur. ?

Les caranxomores different des caranx, en

I. Cuvier considere les caranxomores comme devant former uu sous geure dans son gense Coryphene. D. l'habitude de se tenir fréquemment en pleine mer'.

\section{LE CARANXOMORE PLUMIÉRIEN ?}

\section{Caranxomorus plumierianus, Lae. '}

Parmi les peintures sur vélin du Muséum d'histoire naturelle, se trouve l'image de ce pois. son, dont on doit le dessin au voyageur Plumier. Ce caranxomore parvient à une grandeur considérable, et n'est couvert que d'écailles très-petites. La nageoire dorsale ne commence que vers le milieu de la longeur totale de I'animal; elle ressemble presque en tout à celle de l'anus, au-dessus de laquelle elle est située. La nuque présente un enfoncement qui rend le cràne convexe; la ligne latérale est courbe et rude trois lames composent chaque opercule; les máchoires sont aussi avancées l'une que l'autre; le dessus du poisson est bleu, et le dessous d'un blanc argenté et mèlé de rougeâtre.

\section{LE CARANXOMORE PILITSCHEI *}

Caranxomorus Pilitschei, Lacep. .

Les écailles qui revétent le corps et la queue de ce poisson sont minces, et se détachent facilement; sa ligne latérale suit d'assez près la courbure du dos; sa caudale est fourchue; il ne parvient que très-rarement à la longueur de deux décimètres; ses thoracines et la nageoire de sa queue sont jaunes ou dorées; sa chair est grasse et d'un goùt agréable ; on le trouve souvent en très-grand nombre dans la mér et dans noptère, Daubenton, Enc. métb. - Id. Bonnaterre, pl. de
I'Buc. méth,

Cur. D.

A la nageoire dorsale da pelagique 40 , A chacune des aus 22 , a celle de ta queue. qui est tries-fourchere 20 . de $\checkmark$ Trachurus maximus, squavis minuti sipis. crits de Plumier.

- M. Cuvier ue fit pas mention de celte espece. D. 'Pilischei, en langue malabare. - Scomber minulus. och, pl. 429, fig. 2. les embouchures des neuves qui arrosent- la cồte de Malabar '

\section{LE CARANXOMORE SACRESTIN ${ }^{2}$.} Caranxomorus Sacrestinus, Lac. '

Commerson a laissé dans ses manuscrits une description de ce poisson, qu'il a observé pendant son voyage avee notre collègue Bougainville, et que les naturalistes ne connaissent pas eneore. Les dimensions de ce caranxomore sont assez semblables à celles du scombre maque. reau. Du jaunátre distingue la dorsale et la nageoire de l'anus ; du rouge, les pectorales ; du jaune entouré de bleuattre, les thoracines; du noirâtre, la nageoire de la queue, qui est trèsfourchue.

Le museau est avancé; chaque máchoire armée de dents très-courtes; très-fines et très-serrées; la langue eartilagineuse et lisse; le palais relevé par deux tubérosités; le dessus du gosier garni, ainsi que le dessous, d'une élévation dure et hérissée de très-petites dents; l'wil grand; chaque opereule composé de trois lames, dont la première est revétue de petites écailles, la 'seconde eiselée, la troisième prolongée par un appendice jusqu'à la base des pectorales; chaque cóté de I'occiput strié ou ciselé ; le dernier rayon de la dorsale très-allongé, de méme que la seconde de chaque pectorale ; le dernier de la nageoire de l'anus.

La chair du sacrestin est agréable au goût ${ }^{4}$

\section{SOIXANTE-HUITIĖME GENHE.}

$$
\text { LES CESIOC. }
$$

Line seule nageoire dorsale; point de petites nageoires an-dessus ni au-dessous de la queue; les cotés de la queue relexés longitudinalement en carène. petite nageoire composéc de deux aiguillons et d'une membrane all-derant de la nageoire de l'anus, ou la nagcoire dorsale très-prolongée vers celle de la queue:

i 7 rayons a la membrane branchiale du caranxomore pilitscliei, 16 a chaque pectorale, 1 rayon aiguillonó et 5 articulés s chaque thoracine, 24 rayous a la cauda e. - scizurs e fusco cerwescens, pinuis flavescentibos. dorali et anali retrorsum subulatis, cauda n gra. in sinns cilas - Sacratin. Id Hid. Commerson, manoscrits deja

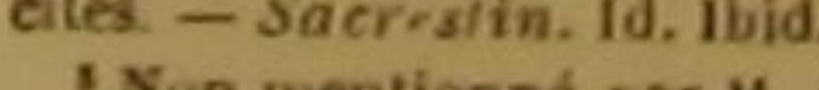

47 rayons a la membrane brauchiale du caranomore crestin, 16 a cha que pectorale, 1 rayon aiguilisnné et 5 arl. eules a chaque thoracine, 17 rayong a la nageoire de la queve.
Is lecre superienre tress-extensible: point d'aiguillons isoles att-decant de la nageoire du dos.

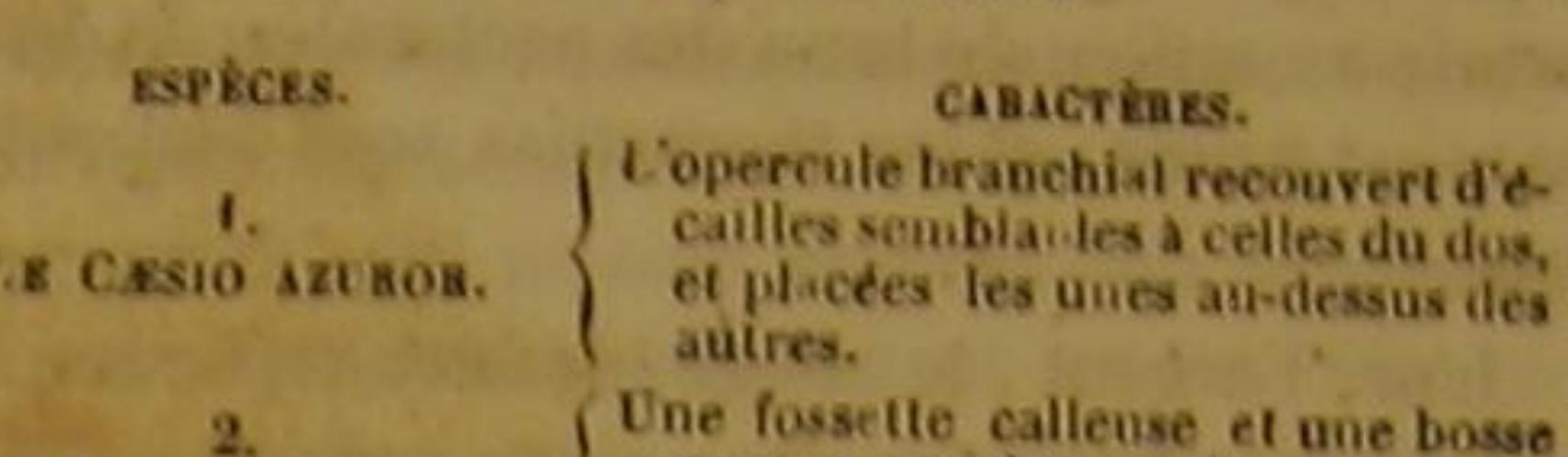

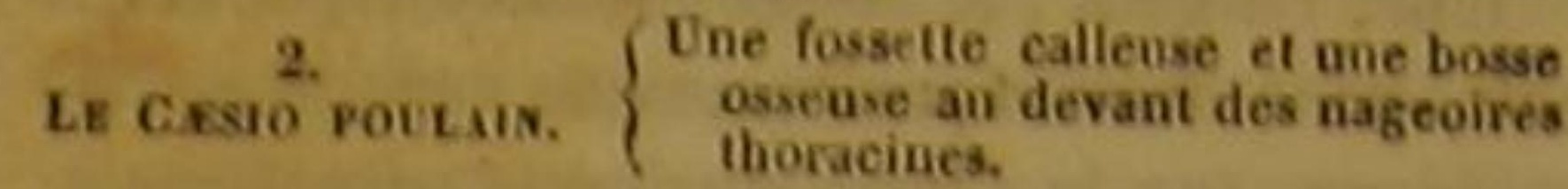

E CESIO AZUROR :

Casio earulaureus, Lac, Cuv.?

Cæsio est le nom générique donné par Commerson au poisson que nous désignons par la dénomination spécifique d'Azuror, laquelle annonce l'éclat de l'or et de l'azur dont il est revétu. Le naturaliste voyageur a tiré ce nom de casio, de la couleur bleuátre, en latin casius, de l'animal qu'il avait sous ses yeux. En reconnaissant les grands rapports qui lient les Casio avec les scombres, il a cru cependant devoir les en séparer. Et c'est en adoptant son opinion que nous avons établi le genre particulier dont nous nous occupons, que nous avons cherché $u$ circonscrire dans des limites preserites, et au. quel nous avons eru devoir rapporter non-seulement le Cussio azuror décrit par Commerson, mais encore le poulain placé par Forskael, et d'après lui par Bonnaterre, au milieu des scom. bres, et inserit par Gmelin parmi les centrogastères.

L'azuror est très-beau. Le dessus de ce poisson est d'un bleu céleste des plus agréables à la vue, et qui, s'étendant sur les cótés de l'animal, y encadre, pour ainsi dire, une bande longitudinale d'un jaune doré, qui règne au-dessus de la ligne latérale, suit sa courbure, et en parcourt toute l'étendue. La partie inférieure du Casio est d'un blanc brillant et argenté.

Une tache d'un noir trés-pur est placée à la base de chaque nageoire pectorale, qui la cache en partie, mais en laisse paraitre une portion, laquelle présente la forme que l'on désigne par le nom de Chevron brisé.

La nageoire de la queue est brune, et bordée dans presque toute sa circonférence d'un

¿Cxsio dorso ceruleo, tenia linis laterali superdicia. - Alaves enie deaursta, rorpore snbteriore a genten, cauil deja cites.

W. Cavier conserve le genre Craio de 31 de Lactutites mais n'y adruet que cetle reale espece. $D$. 
rouge élégant. L'anale est peinte de la mème dorsale très-longue; et celle de la queue pro-

nuance que cette bordure. On retrouve la mème fondément échancrée '.

teinte au milieu du brun des pectorales; la dorsale est brune, et les thoracines sont blanchàtres.

L'or, l'argent, le rouge, le bleu céleste, le noir, sont donc répandus avec variété et magnificence sur le Caesio que nous considérons; et des nuances brunes sont distribuées au milieu de ces couleurs brillantes, comme pour les faire ressortir, et terminer l'effet du tableau par des ombres.

Cette parure frappe d'autant plus les yeux de l'observateur, qu'elle est réunie avec un volume un peu considérable, l'azuror étant à peu près de la grandeur du maquereau, avec lequel il a d'ailleurs plusieurs rapports.

Au reste, n'oublions pas de remarquer que cet éclat et cette diversité de couleurs que nous admirons en taclant de les peindre, appartiennent à un poisson qui vit dans l'archipel des grandes Indes, particulierement dans le voisinage des Moluques, et par conséquent dans ces contrées oủ une heureuse combinaison de Ia lumière, de la chaleur, de l'air, et des autres élèments de la coloration, donne aux perroquets, aux oiseaux de paradis, aux quadrupèdes ovipares, aux serpents, aux fleurs des grands arbres, et a celles des humbles végétaux, l'or resplendissant du soleil des tropiques, et les tons animés des sept couleurs de l'are céleste.

L'azuror brillait parmi les poissons que les naturels des Moluques apportaient au vaisseau de Commerson; et le goùt de sa chair était agréable.

Le museau de ce Casio est pointu ; la lèvre supérieure très-extensible; la mâchoire inférieure plus avancée que celle de dessus, lorsque la bouche est ouverte; chaque mảchoire garnie de dents si petites, que le tact seul les fait distinguer; la langue très-petite, cartilagineuse, lisse, et peu mobile; le palais aussi lisse que la langue; l'cil ovaie et tres grand; chaque opercule composé de deux lames, recouvert de petites écailles, excepté sur les, recouvert de petites écailles, excepté sur les bords, et comme ciselé par des rayons ou lignes convergentes; la lame postérieure de cet opereule conformée en triangle; cet opercule branehial placé au-dessus du rudiment d'une einquième branchie; cavité des ares osseux qui sontiennent las brachies, dentée comme un peigne; la nageoire
LE CESIO POULAIN ?

Cquber Equala, Forsk.; Centrogaster Equnla , Gmel. Cæsio Equulus, Lac.; Equula Caballa, Cuv. '

Ce poisson a une conformation peu com-

Sa tête est relevée pardeux petites saillies al. longées qui convergent et se réunissent sur le front; un ou deux aiguillons tournés vers la queue sont placés ati-dessus de chaque œil; les dents sont menues, flexibles, et, pour ainsidire, capillaires ou sétacées; l'opereule est comme colléa la membrane branchiale; on voit une dentelure à la pièce anterieure de ce mémeopercule; une membrane lancéolée est attachée à la partie supérieure de chaque nageoire thoraeine; la dorsale et la nageoire de l'anus s'étendent jus. qu'à celle de lá queue, qui est divisée et présente deux lobes distincts; et enfin, au-devant des nageoires thoracines, parait une sorte de bosse ou de tubercule osseux, aigu, et suivi d'une petite cavité linéaire, et également osseuse ou calleuse. Ces deux callosités rêunies, cette éminence, et cet enfonicement, onit été com. parés at une selle de cheval ; on a cru qu'ils en rappelaient vaguement la forme; et voila diou viennent les noms de petit Cheval, de petite Jument, de Poulain et de Pouline, donnés au poisson que nous examinons 4

Au reste, ce Casio est revètu d'écailles trèspetites, mais brillantes de l'éclat de l'argent. Il parvient à la longueur de deux décimetres. Forskael l'a vu dans la mer d'A rabié, où il observé aussi d'autres poissons ${ }^{3}$ presque entiè.

-A la membrane branchiale 7 rayons, a la nageoire du dos
rayons aiguillonnés et 15 rayons arlicolts Tectorales 24 rayous a chacenes articulés, a chacune de lauus 2 rayons aisuillonnds et is ragons ation 6 , a celle do de la queue 17 rayons.

Ponsael, Faun. Arabie, p. 58. D. 77. - Seombre petite sil. Curier rerre, pl. de l'Enc, meth.

mer le type dn soms ge poisson du précédeat pour en for-

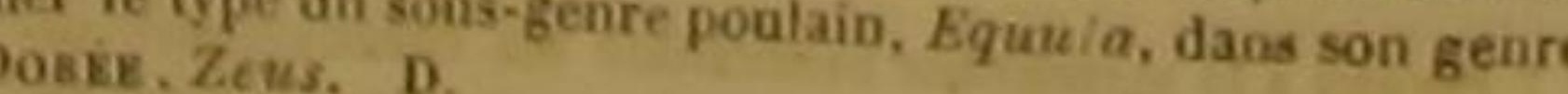
dos 8 rayons aiguil branchies 4 rayons, a la nazeoire The des peetorales 18 rayons, a chacus articules, $2 \mathrm{ch}$. Tryon aiguilionne et 5 rayons articules. a celle de Trans 5 77 rayome. rement semblables au Poulain, qui n'en difterent d'une manière très-sensible que par un ou deux rayons de moins aux nageoires dorsale, pectorale et candale, ainsi que par la couleur glauque et la bordure jaune de ces mèmes nageoires, des thoracines, et de celle de l'anus, et que nous considérerons, quant à présent et de même que les naturalistes Gmelin et Bonnaterre, comme une simple variété de l'espèce que nous venons de déerire.

\section{SOIXANTE-NEUVIÈME GENRE}

LES CASIOMORES ',

Une seule nageoire dorsale; point de petiles nageoires an-dessus ni an-dessous de la quene : point de carène laterale à la queue, ni de petite nageoire au-derant de celle de $f$ amus ; des aiguillons isoles au-decant de la nageoire du dos.

erricas.

CAnscrènes.

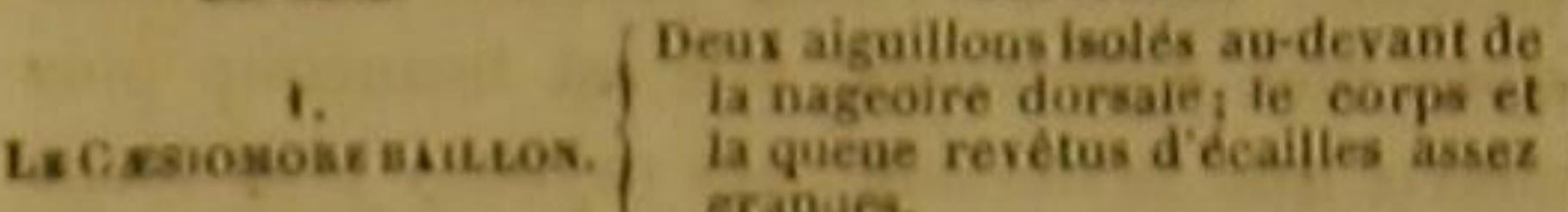

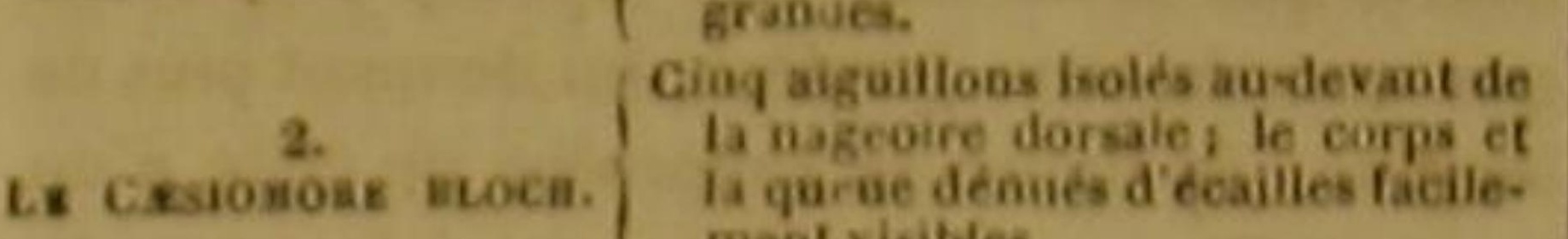

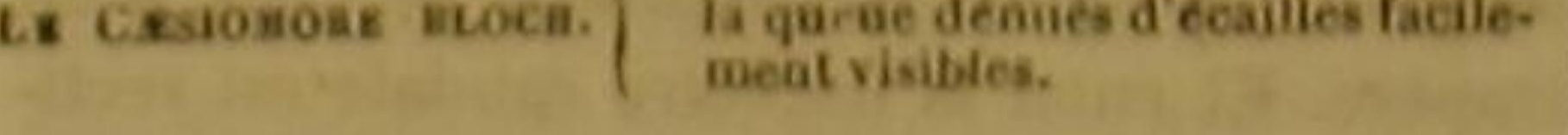
$-$

LE CASIOMORE BAILLON.

Casiomorus Baillonii, Lac,; Trachinotos Baillonii, Cuv.

Nous allons faire connaitre deux cæsiomores; aucune de ces deux espèces n'a encore été décrite. Nous en avons trouvé la figure dans les manuscrits de Commerson ; et elle a été gravée avee soin sous nos yeux. Nous dédions l'une de ces espèces à M. Baillon, l'un des plus zélés et des plus habiles correspondants du Museum d'histoire naturelle, qui rend chaque jour de nouveaux services á la seience que nous cultivons, par ses recherches, ses observations, et les nombreux objets dont il enrichit les collections publiques, et dont M. de Buffon a consigné le juste éloge dans tant de pages de cette Histoire naturelle.

Nous consacrons l'autre espèce à la mémoir du savant et célebre ichthyologiste le docteur Bloch de Berlin, comme un nouvel hommage de l'estime et de l'amitié qu'il nous avait inspirées.

- y. Cuvier remarque qne les trachiautes, les acanibinions et les cesiomores de M. de Lacepede ne different pas asse ponr étre séparts. In les considere cornme formant nn seed
Le cæsiomore bailion a le corps et la queue couverts d'écailles assez grandes, arrondies, et placées les unes au-dessus des autres. On u'en voit pas de semblables sur la tête ni sur les opercules, qui ne sont revêtus que de grandes lames. Des dents pointues et un peu séparées les unes des autres garnissent les deux máchoires, dont l'inférieure est plus avancée que la supérieure. On voit le long de la ligne latérale, qui est courbe jusque vers le milieu de la longueur totale de I'animal, quatre taches presque rondes et d'une couleur très-foncée. Deux aiguillons forts, isolés, et tournés en arrière, paraissent au-devant de la nageoire do dos, laquelle ne commence qu'au delà de l'endroit où le poisson montre la plus grande hauteur, et quí, conformée comme une faux, s'étend presque jusqu'à la nageoire caudale.

La nageoire de l'anus, placée au-dessous de la dorsale, est à peu près de la mème étendue et de la mème forme que cette dernière, et précédée, de mème, de deux aiguillons assez grands et tournés vers la queue.

La nageoire caudale est très-fourchue; les thoracines sont beaucoup plus petites que les pectorales.

\section{LE CAESOMORE BLOCH}

Cessiomorus Blochii, Lacep.; Trachinotus Blochii, Guv.

Ce poisson a beaucoup de ressemblance avec le baillon : la nageoire dorsale et celle de l'anus sont en forme de faux dans cette espèce, comme dans le cesiomore dont nous venons de parler; deux aiguillons isolés hérissent le devant de la nageoire de l'anus; la nageoíre eaudale est fourchue, et les thoracines sont moins grandes que les pectorales dans les deux espèces : mais les deux lobes de la nageoíre caudale du bloch sont beaucoup plus écartés que ceux de la nageoire de la queue du baillon; la nageoire dorsale du bloch s'étend vers la tête jusqu'au dela du plus grand diamètre vertical de l'animal. cinq aiguillons isolés et très-forts sont placés au-devant de cette même nageoire du dos. La nuque est arrondie; la tête grosse et relevée; la mâchoire supérieure terminée en avant, comme l'inférieure, par une portion très-haute, très-peu courbée, et presque verticale; deux lames au moins composent chaque opercule; on ne voit pas de tache sur la ligne latérale, qui 
de plus est tortueuse; et enfin, les téguments "sujet de cet article, il est un peu plus exhaussé les plus extérieurs du bloch ne sont recouverts encore : le sommet du crâne s'arrondit de mad'aucune écaille facilement visible.

\section{SOIXANTE-DIXIÈME GENRE.}

LES COBIS '

La tete grosse ef plus elerie que le corps; le corps comprime et tres-allongé : le premier ou le second rayon de chacune des nageoires thoracines une on denx fois à celles du tos sur les opercules ai sar la titec dabli

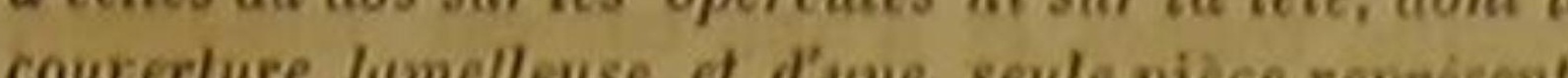
courerlure lumelleus

Espìcrs. CABSCTĖBES

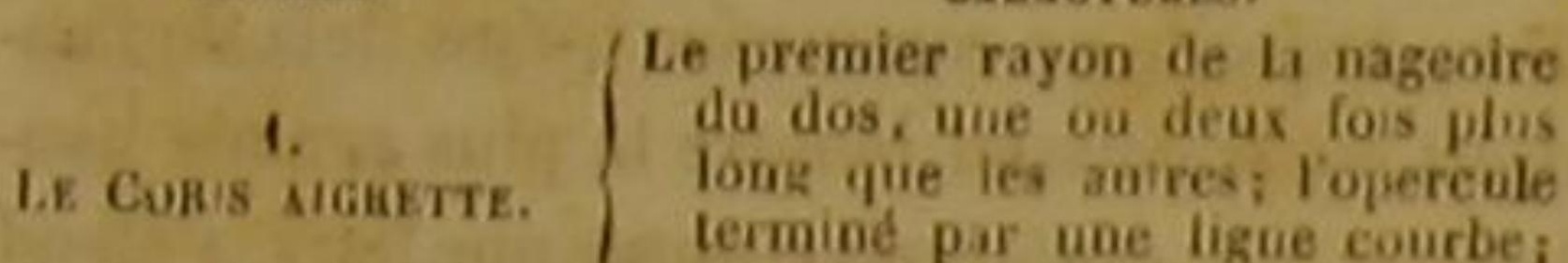

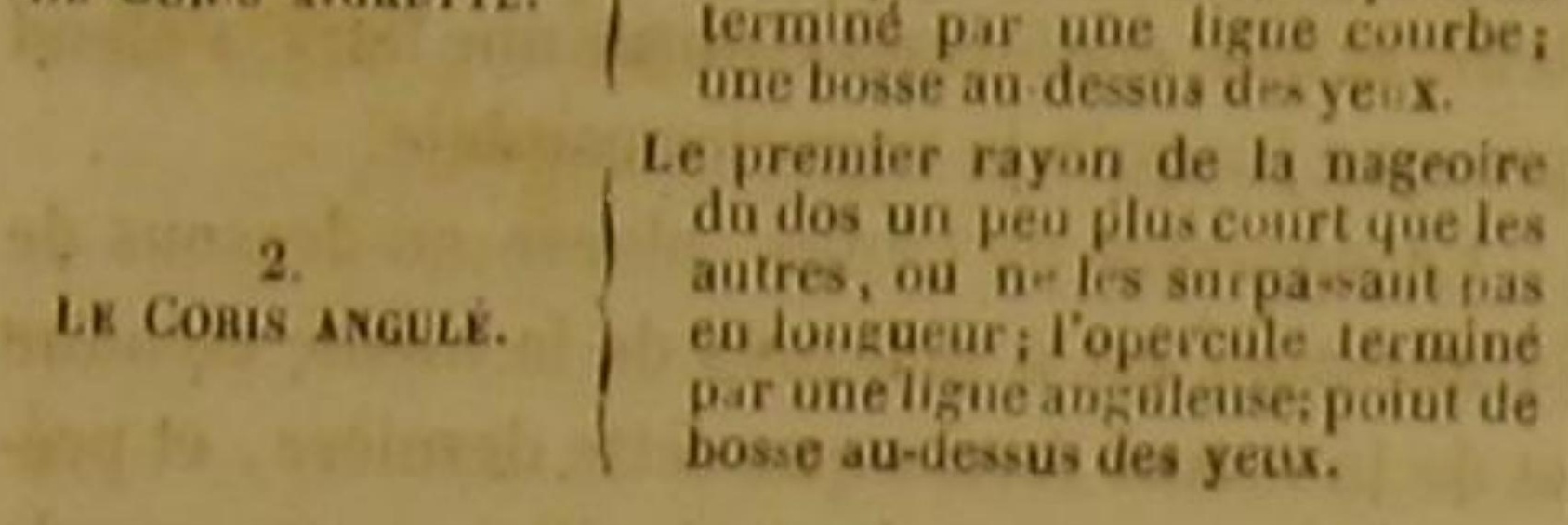

\section{LE CORIS AIGRETTE}

Coris Aygula, Licep. ’

Quelles obligations les naturalistes n'ont-ils pas au célèbre Commerson! Combien de genres de poissons dont ses manuscrits nous ont présenté la description ou la figure, et qui, sans les recherches multipliées auxquelles son zèle n'a cessé de se livrer, seraient inconnus des amis des sciences naturelles! Il a donné à celui dont nous allons parler, le nom de Coris, qui, en gree, siguifie sommet, tête, etc., à cause del'espèce de casque qui enveloppe et surmonte la tête des animaux compris dans cette famille. Cette sorte de casque, qui embrasse le laut les côtés et le dessous du cràne, des yeux et des mảchoires, est formée d'une substance écailleuse, d'une grande lame, d'une seule pièce, qui mème est réunie aux opercules, de manière à ne faire qu'un tout avec ces couve cles des organes respiratoires. L'ensemble que ce casque renferme, ou la téte proprement dite s'élève plus haut que le dos de l'animal, dans tous les coris; mais dans l'espece qui fait le 'As. Cuvier (Reg. anim , $2^{\circ}$ ed.) remarque que les Coris etablis par M. de Lacépede daprés des dessins de Commerqueue tront trouve, oi le desseiles (famille ies Labrớdes) a

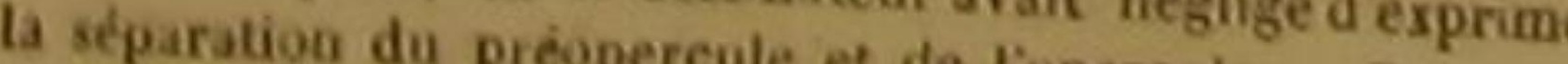
'Ce poisson ne paralt pas difterer de la girelle D.

selon M. Cuvier. D. nière à produire une bosse ou grosse loupe audessus des yeux; et le premier rayon de la nageoire dorsale, une ou deux fois plus grand que les autres, étant placé précisément derrière cette loupe, parait comme une aigrette destinée à orner le casque du poisson.

Chaque opercule est terminé du côté de la queue par une ligue courbe. La lèvre supérieure est double; la mâchoire inférieure plus avancée que la supérieure; chacune des deux ma* choires garnie d'un rang de dents fortes, pointues, triangulaires et inclinées. La ligne latérale suit de très près la courbure du dos. Le premier rayon de chaque thoracine, qui en renferme sept, est une fois plus allongé que les autres. La nageoire dorsale est très-longue, très-basse, et de la même hauteur, dans presque toute son etendue. Celle de l'anus présente des dimensions bien différentes; elle est beaucoup plus courte que la dorsale : ses rayons, plus longs que ceux de cette dernière, lui donnent plus de argeur; sa figure se rapproche de celle d'un rapèze. Et entin la nageoire caudale est rectiigne, et ses rayons dépassent de beaucoup la membrane qui les réunit '

\section{LE CORIS ANGULEUX}

Coris angulatus, Lacep. ${ }^{2}$.

Ce coris difière du précédent par six traits principaux : son corps est beaucoup plus allongé que celui de l'aigrette; le premier rayon de la nageoire dorsale ne dépasse pas les autres ; la ligne latérale ne suit pas dans toute son étendue la courbure du dos, elle se fléchit en enbas, a une assez petite distance de la nageoire caudale, et tend ensuite directement vers cette nageoire; le sommet du crâne ne présente pas de loupe ou de bosse; chaque opereule se prolonge vers la queue, de manière à former un angle saillant, au lieu de n'offrir qu'un contour arrondi; et les deux mâchoires sont également avancées ${ }^{3}$.

'A la nageoire da dos 21 rayons, a chacune des pectoracelle de la quene 10 .

fois par $\mathbf{M}$. de Lacépede, sous le nom de décrit une seconde Labrus nalapterus. D. í la nageoire du do les 13 , a la nageoire de l'anus 15 , a celle de la quene 10 .
SOIXANTE-ONZIEME GENRE.

LES GOMPHOSES '.

Le museau allongé en forme de clou ou de masse, lo tthe th the opercules demues d'ecailles semblables a celles diu dos.

espéces.

1.
Tonte la surface du voisson d'une
conleur blene foncée.

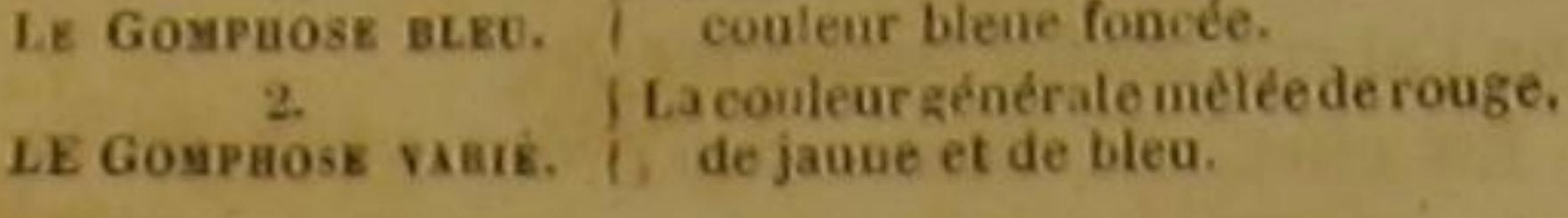

LE GOMPHOSE BLEU ${ }^{2}$

Gomphosus cæruleus, Lacep., Cuv.

Commerson a laissé dans ses manuserits la description de ce poisson qu'il a observé dans ses voyages, que nous avons cru, ainsi que lui, devoir inscrire dans un genre particulier, mais auquel nous avons domné le nom générique de Gumphos, plutôt que celui d' Elops, qui lui a été assigné par ce naturaliste. Le mot gomphos désigne, aussi bien que celui d'élops, la forme du museau de ce poisson, qui représente une sorte de clou; et en employant la dénomination que nous avons préférée, on évite toute confusion du genre que nous décrivons, avec une petite famille d'abdominaux connue depuis longtemps sous le nom d'elops.

Le gomphose bleu est, suivant Commerson, de la grandeur du cyprin tanche. Toute sa surface présente une couleur bleue sans tache, un peu foncée et noirâtre sur les nageoires pectorales, et tres-claire sur les autres nageoires. L'eil seul montre des nuances differentes du bleu; la prunelle est bordée d'un cercle blane, autour duquel l'iris présente une belle couleur d'émeraude ou d'aigue-marine.

Le corps est un peu arqué sur le dos, et beaucoup plus au-dessous du ventre. La tête, d'une grosseur médiocre, se termine en devant par une prolongation du museau, que Commerson a comparée à un clou, dont la longueur est ena e au septieme de la longueur totale de l'animal, et qui a quelques rapports avec le boutoir du sanglier. La mâchoire supérieure est un peu exteusible, et quelquefois un peu plus avancée que l'inferieure; ce qui n'empêche pas que favant-bouche, dont I ouverture est étroite, ne

'. M. Cuvier admet le groupe des Gomphoses, mais seu 2. Elopise un sous-genre dans le genre Labre. D. et operculis trachiogk uuscrits deja citess. forme une, sorte de tuyau. Chaque máchoire est composée d'un os garni d'un seul rang de dents très-petites et très-serrées l'une contre l'autre; et les deux dents les plus avancées de la máchoire d'en haut sont aussi plus grandes qut celles qui les suivent.

Tout l'intérieur de la bouche est d'ailleurs lisse, et d'une couleur bleuâtre.

Les yeux sont petits et très-proches des orifices des narines, qui sont doubles de chaque coté.

On ne voit aucune écaille proprement dite, ou semblable à celles du dos, sur la tète ni sur les opercules du gomphose bleu. Ces opercules ne sont hérissés d'aucun piquant. Deux lames les composent: la seconde de ces pièces s'avance vers la queue, en forme de pointe; et une partie de sa circonférence est bordée d'une membrane.

On voit quelques dentelures sur la partie concave des ares osseux qui soutiennent les branchies.

La portion de la nageoire dorsale qui comprend des rayons aiguillonnés, est plus basse que la partie de cette nageoire dans laquelle on observe des rayons articulés. La nageoire caudale forme un croissant dont les deux pointes sont très-allongées.

La ligne latérale, qui suit la courbure du dos jusqu'a la fin de la nageoire dorsale, oú elle se lechit vers le bas pour tendre ensuite directe. ment vers la nageoire caudale, a son cours marqué par une suite de petites raíes disposées de manière a imiter des caractères chinois.

Les écailles qui recouvrent le corps et la queue du gomphose bleu sont assez larges; et les petites lignes qu elles montrent, les font paraitre comme ciselées '

LE GOMPHOSE, VARIE 2

Gomphosus varius, Lacep., Cuv.

Sur les bords charmants de la fameuse ilc de Taïti, Commerson a observé une seconde espece de gomphose, bien digne, par sa beaute

- 6 rayons a la membrane des bianchies, 8 rayons aiguilGunés 14 rayons articules a la nageoire do dos, 14 raj on secoud se prolonge $e a$ un tilament), 2 rayons argoilionns et 12 raj ons articulés a la nageoire de lanus, 14 rayous. S. Elon rute.

. Elops rubro, ceruleo el flavo variegatus. Commer 
ainsi que par l'éclat de ses couleurs, d'habiter souvent pour lui donner un nom; et comme ils ces rivages embellis avec tant de soin par la avaient facilement saisi un rapport très-marnature. Elle est principalement distinguée de la qué que présente son museau avec le front des première par ces riches nuances qui la déco- animaux fabuleux auxquels l'amour du merrent ; elle montre un brillant et agréable mé- veilleux a depuis longtemps attaché la dénomilange de rouge, de jaune et de bleu. Le jaune nation de Licorne, fls l'avaient appelée la domine dans cette réunion de tons resplendis- Petite Licorne, ou le Licornet, appellation sants; mais l'azur y est assez marqué pour être que j'ai cru devoir conserver.

un nouvel indice de la parenté du varié avec le En effet, de l'entre-deux des yeux de ce gomphose bleu.

poisson part une protubérance presque eylindrique, renflée à son extrémité, dirigée horizontalement vers le bout du museau, et attachée à la téte proprement dite par une base assez large.

SOIXANTE-DOUZIËME GENRE. LES NASONS '.

Une protubirance en forme de corne ou grosse loupe sur le nez; deux plaques ou boucliers de chaque côte de liextrènite de la queue; le corps et la queue recouverts d'une peau rude el comme chagrinée.

C'est sur cette même base que l'on voit de chaque côté deux orifices de narines, dont l'antérieur est le plus grand.

Les yeux sont assez gros.

Le museau proprement dit est un peu pointu; l'ouverture de la bouche étroite ; la lèvre superieure faiblement extensible; la mâchoire d'en haut un peu plus courte que celle d'en bas, et

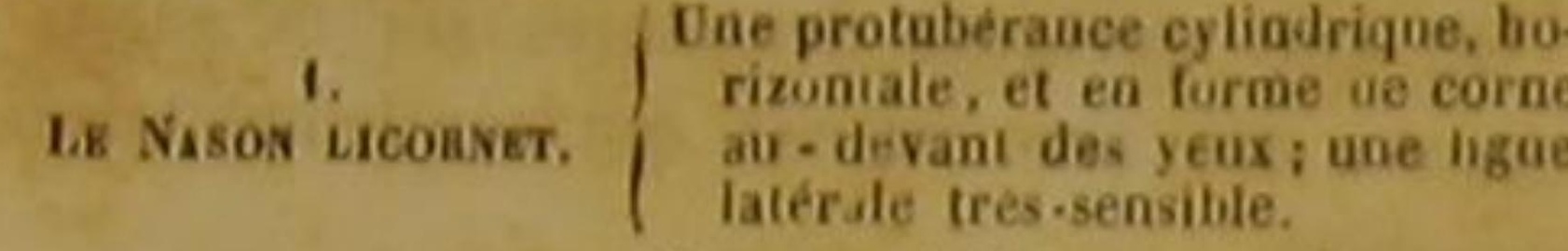

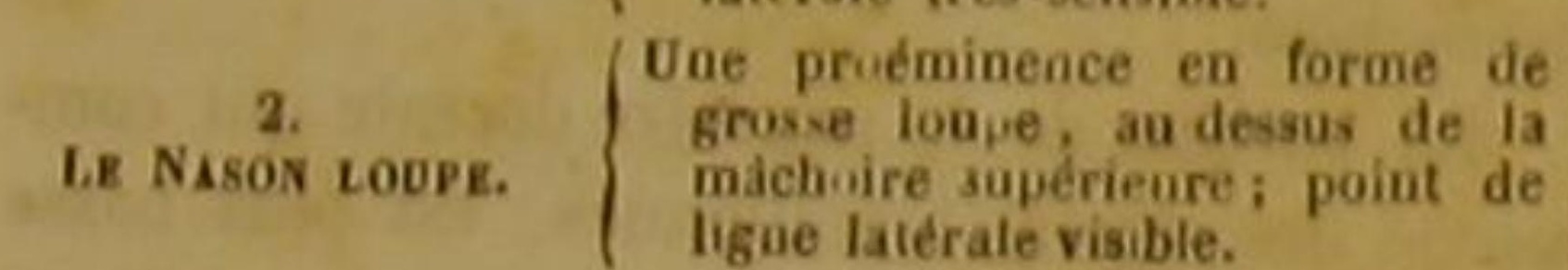
garnie, comme cette dernière, de dents trèspetites, aiguês, et peu serrées les unes contre les autres.

LE NASON LICORNET ${ }^{2}$.

Chatodon frooticornis, Lino., Gmel.; Nason fronticornis, Lacep.; Naseus fronticornis, Cuv.

Sans les observations de l'infatigable Commerson, nous ne connaitrions pas tous les traits de l'espèce du licornet, et nous ignorerions l'existence du poisson loupe, que nous avons eru, avec cet habile voyageur, devoir renfermer, ainsi que le licornet, dans un genre particulier, distingué par le nom de Nason.

La première de ces deux espèces frappe aisément les regards par la singularité de la forme de sa tête; elle attire l'attention de ceux méme qui s'occupent le moins des sciences naturelles. Aussi avait-elle été très-remarquée par les matelots de l'expédition dont Commersou faisait partie : ils l'avaient examinée assez

'Ce genre est admis par M. Cuvier, et placé par tai dens a famille de Theatyes, de l'ordre des Acanthoptérygiens, avec les Sidjans, les A canthures, les Prionures, les Axinures,
el les Pridodons. D.

commens fionticornis fuscus. Licornet des matelots. bic., $, 65,0.88-$ Cin deja cités. - Forskael, Faun. Ara I'Ene, meth.

Des lames osseuses composent les opercules ; au-dessous desquels des ares dentelés dans leur partie concave soutiennent de chaque côté les quatre branchies '.

Le corps et la queue sont très-comprimés, carénés en haut, ainsi qu'en bas, et recouvert d'une peau rude, que l'on peut comparer à celle de plusieurs cartilagineux, et notamment de lis plupart des squales.

La couleur que présente la surface presque entière de l'animal est d'un gris brun; mais la nageoire du dos, ainsi que celle de l'anus, sont agréablement variées par des raies courbes, janes ou dorées.

Cette mème nageoire dorsale s'étend depuis la nuque jusqu'à une assez petite distance de la nageoire caudale.

La ligne latérale est voisine du dos, dont elle suit la courbure; l'anus est situé très-près de la base des thoracines, et par conséquent plus éloigné de la nageoire caudale que de la gorge.

i 5 rayons a l a membrane des branchies, 6 aiguillons e 50 naseoire des thuracines, 2 aj geoire de láanus, 20 rayons a ls 0 rayons articulés a la r. 

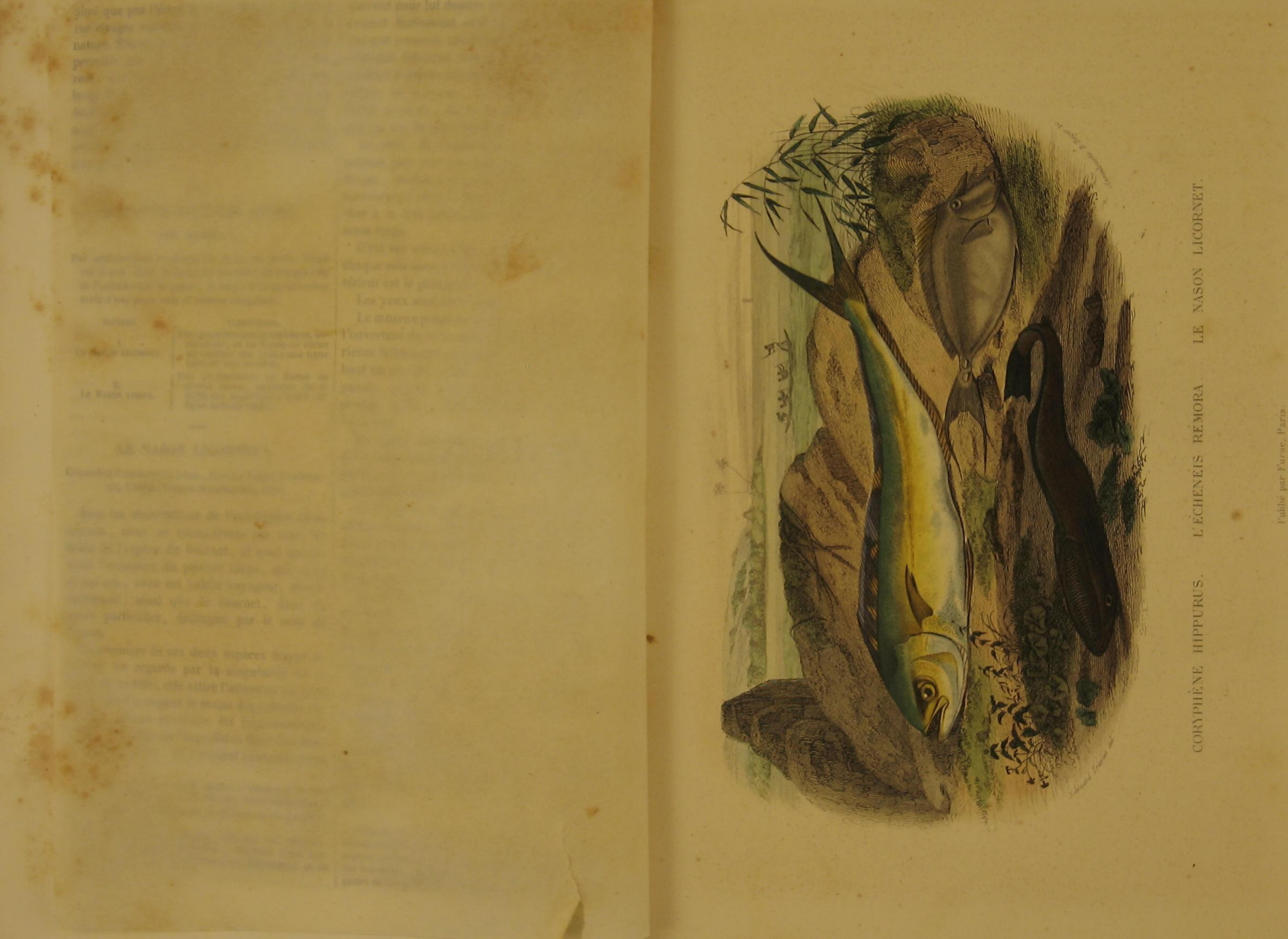
DES POISSONS.

La nageoire de l'anus est un peu plus basse ont mème dit avoir vu une troupe de ces thoraet presque aussi longue que celle du dos.

La caudale est échancrée en forme de croissaut, et les deux cornes qui la terminent sont composées de rayons si allongés, que lorsqu'ils se rapprochent, ils représentent presque un cercle parfait, au lieu de ne montrer qu'un demicercle.

De plus, on voit auprès de la base de cette nageoire, et de chaque côté de la queue, deux plaques osseuses, que Commerson nomme de pelits boucliers, dont chacune est grande, dit ce voyageur, comme l'ongle du petit doigt de l'homme, et composée d'une lame un peu relevée en carène et échancrée par devant.

On doit apercevoir d'autant plus aisément ces deux pièces qui forment un caractère remarquable, que la longueur totale de l'animal n'excede pas quelquefois trente-cinq centimetres. Alors le plus grand diamètre vertical du corps proprement dit, celui que l'on peut mesurer au-dessus de l'anus, est de dix ou onze centimètres; la plus grande épaisseur du poisson est de quatre centimètres; et la partie de la corne frontale et horizontale, qui est entièrement dégagée du front, a un centimètre de longueur.

Commerson a vu le licornet auprès des rivages de lille de France; et si les dimensions que nous venons d'indiquer d'après le manuscrit de ce naturaliste, sont celles que ce nason présente le plas souvent dans les parages que ce voyageur a fréquentés, il faut que cette espèce soit bien plus favorisée pour son développemen dans la mer Rouge ou mer d'Arabie. En effet Forskael, qui l'a décrite, et qui a cru devoir la placer parmi celles de la famille des chétodons, au milieu desquels elle a été laissée par le savant Gmelin et par M. Bonnaterre, dit yu'ell parvient à la longueur de cent dix-huit centimètres (une aune ou environ.) Les licornet vont par troupes nombreuses dans cette mème mer d'Arabie; on en voit depuis deux cents jusqu'à quatre cents ensemble; et l'on doit en étre d'autant moins surpris, que l'on assure qu'ils ne se nourrissent que des plantes qu'ils peuvent rencontrer sous les eaux. Quoiqu'ils n'aient le besoin ni l'habitude d'attaquer une proie, ils usent avec courage des avantages que leur donnent leur grandeur et la conformation de leur tète; ils se defendent avee succes contre des ennemis dangereux; des pécheurs arabes cins entourer avec audace un aigle qui s'était précipité sur ces poissons comme sur des animaux faciles à vaincre, opposer le nombre à la force, assaillir l'oiseau carnassier avec une sorte de concert, et le combattre avec assez de constance pour lui donner la mort.

\section{LE NASON LOUPE'}

Acanthurus Nasus, Shaw; Naso tuberosus,
Lacep.; Naseus tuberosus, Cuv.

Cette espèce de nason, observée, décrite et dessinée, comme la première, par Commerson qui l'a vue dans les mèmes contrées, ressemble au licornet par la compression de son corps et de sa queue, et par la nature de sa peau rude et chagrinée ainsi que celle des squales. Sa couleur gènérale est d'un gris plus ou moins mèlé de brun, et par conséquent très-voisine de celle du licornet; mais on distingue sur la partie supérieure de l'animal, sur sa nageoire dorsale et sur la nageoire de la queue, un grand nombre de taches petites, lenticulaires et noires. Celles de ces taches que l'on remarque auprès des nageoires pectorales, sont un peu plus larges que les autres; et entre ces mèmes nageoires et les orifices des branchies, on voit une place noirátre et très-rude au toucher.

La tête est plus grosse, a proportion du reste du corps, que celle du licornet. La protubérance nasale ne se détache pas du museau autant que la corne de ce dernier nason : elle s'étend vers le haut ainsi que vers les cotés; elle représente une loupe ou véritable bosse. Un sillon particulier, dont la couleur est très-obscure, qui part de l'angle antérieur de l'œeil, et qui règne jusqu'a l'extrémité du museau, circonscrit cette grosse tubérosité ; et c'est audessus de l'origine de ce sillon, et par conséquent très-pres de l'œil, que sont situés, de chaque cóté, deux orifices de narines, dont l'antérieur est le plus sensible.

Les yeux sont grands et assez rapprochés du sommet de la téte; les lèvres sont coriaces; la mâchoire supérieure est plus avancée que l'inférieure, la déborde, l'embrasse, n'est point du tout extensible, et montre, comme la máchoire d'en bas, un contour arrondi, et un seul rang de dents incisives.

- Licorne da loupe c Naseus, naso ad rostrum connat, tuberiformi. , Commerson, manuscrits deja cites. 
Le palais et le gosier présentent des plaque hérissées de petites dents.

Chaque opercule est composé de deux lames. Les ares des branchies sont tuberculeux et dentelés dans leur concavité.

Les aiguillons de la nageoire du dos et des thoracines sont très-rudes' ; le premier aiguillon de la nageoire dorsale est d'ailleurs très-large à sa base; la nageoire caudale est en forme de croissant, mais peu échancrée. On n'aperçoit pas de ligne latérale; mais on trouve, de chaque coté de la queue, deux plaques ou boucliers analogues à ceux du licornet.

Le nason loupe devient plus grand que le licornet; il parvient jusqu'à la longueur de cinquante centimètres.

\section{SOIXANTE-TREIZIĖME GENRE.} LES KYPHOSES ${ }^{2}$.

Le dos très-ellevè all-dessus d'une ligne tirèe depuis le bout du musean jusqu'au milieu de la nageoire caudale : une bosse sur la nuque; des ecailles semblables a celles du dos, sur la totalite ou une grande parlie des ne sont pas deuteles.

esrètce.

LK KYPuose pouble.
Bosse. -

\section{LE KYPHOSE DOUBLE-BOSSE ${ }^{3}$.} Kyphosus bigibbus, Lacep.

Commerson nous a transmis la figure de cet animal. La bosse que ce poisson a sur la nuque, est grosse, arrondie, et placée sur une partie du corps tellement élevée, que si on tire une ligne droite du museau au milieu de la nageoire caudale, la hauteur du sommet de la bosse audessus de cette ligue horizontale est au moins égale au quart de la longueur totale de ce thoracin. La seconde bosse, qui nous a suggéré son

14 ryyous a la membrane des branchies, 5 rayons aignil-
lonnes ei 30 rayons articentes a ta nogese lonues et 30 rayons articules a la nageoire du dos, 17 rayong A chacune des pecturales, 2 aiguillouset 28 rayons articules ia uageoire de ranus, 16 rayous a la nageoire de la yueue.

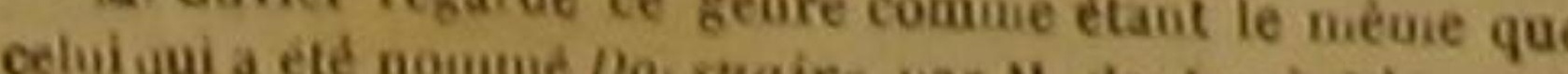
croit aussi qu it ue uiffere pas des uar ax. de lacépede, et il

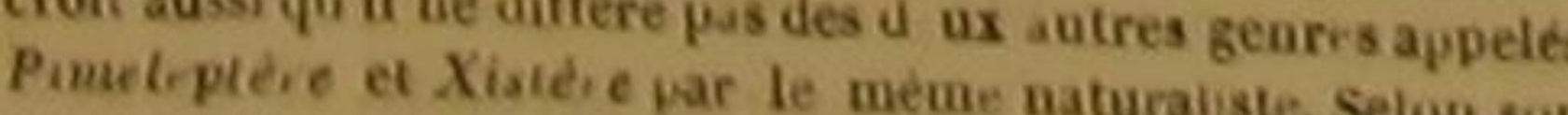
opiuton, il faudrait réduire ces yuatre getures en un seul. $D$. Nul. Le nowa generique syphose, krpuosts, que now avoss donné a ce possion, vient du mot kyphos, qui $+n$ grec fait deriver lo 'avons vo. nom spécifique, est conformée, à peu pres, comme la première, mais moins grande, et située entre les yeux. La ligne latérale suit la courbure du dos, dont elle est tres-voisine. Les nageoires pectorales sont allongées et terminées en pointe. La longueur de la nageoire de l'anus n'égale que la moitié, ou environ, de celle de la nageoire dorsale. La nageoire de la queue est rès-fourchue. Des écailles semblables à celles du dos recouvrent au moins une grande partie des opercules '.

\section{SOIXANTE-QUATORZIĖME GENRE.} LES OSPHRONÈMES ${ }^{2}$

Cinq ou six rayons à chaque nageoire thoracine: le premier de ces rayons aiguillonne et le second ter. mine par un filament tres-long.

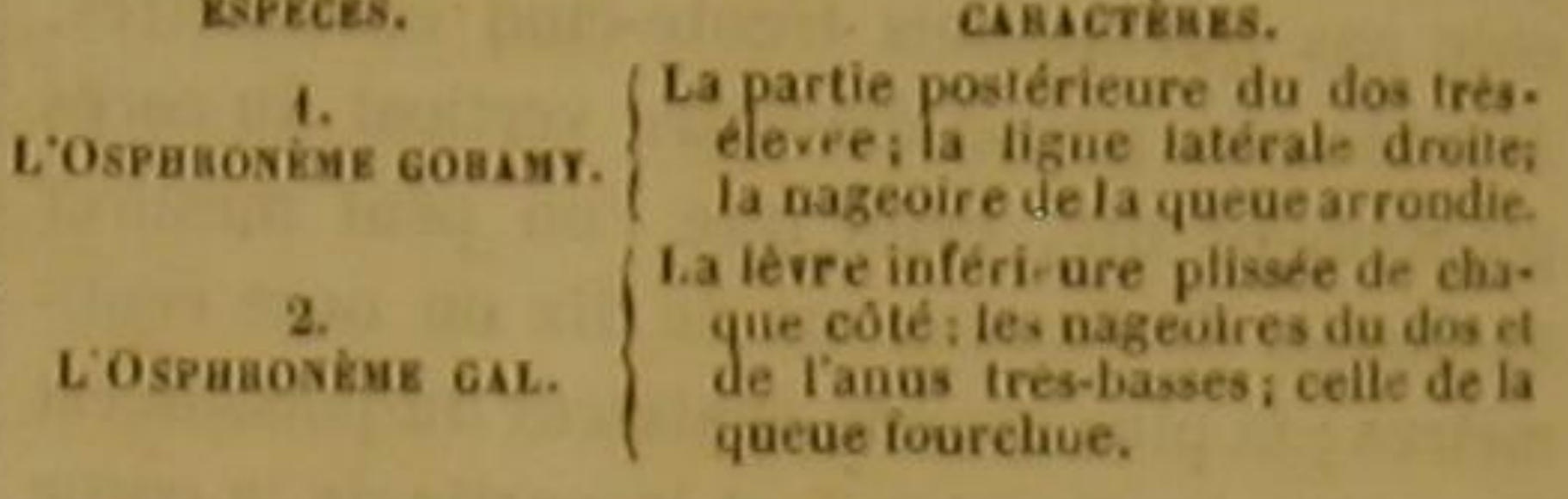
-

L'OSPHRONEME GORAMY ${ }^{3}$.

Ospuronemus Olfax, Comm., Cuv.; Ospbronemus Goramy, Lacep.

Nous conservons à ce poisson le nom générique qui lui a été donné par Commerson, dans les manuscrits duquel nous avons trouvé la description et la figure de ce thoracin.

Cet osphronème est remarquable par sa forme, par sa grandeur, et par la bonté de sa chair. Il peut parvenir jusqu'à la longueur de deux mètres; et comme sa hauteur est très. grande à proportion de ses autres dimensions, il fournit un aliment aussi copieux qu'agréable. Commerson l'a observé dans l'ile de France, en révrier 1770, par les soins de Seré, commandant des troupes royales. Ce poisson y avait été apporté de la Chine, où il est indigène, et de Batavia, où on le trouve aussi, selon l'estimais 15 aiguillons et 12 rayons articalés a la nageoire dorsale, is ou if rayons a chacune des pectorales, 5 ou 6 a chacure

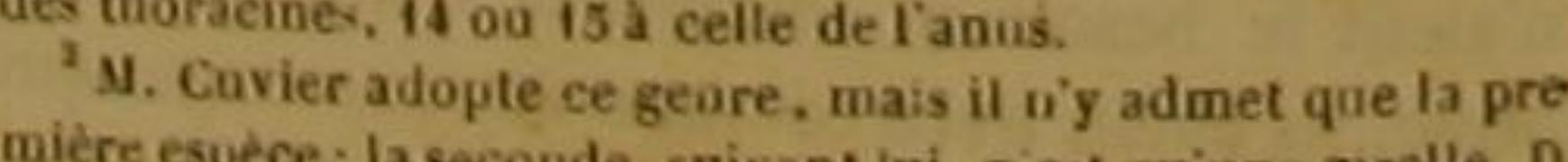
'Poisson gouramie, ou gouramy. (II funt une girelle ce nom de poisson gouramie, on gouramy, on goramy a été aussi donne, dans le grand océan, au trichopode mes-
tounier.)

DES POISSONS.

173

ble M. Cossigny '. On l'avait d'abord élevé dan des viviers; et il s'était ensuite répandu dans les rivieres, où il s'était multiplié avec une grande facilité, et où il avait assez conservé toutes ses qualités pour être, dit Commerson, le plus recherché des poissons d'eau douce. I serait bien à désirer que quelque ami des sciences naturelles, jaloux de favoriser l'aceroissement des objets véritablement utiles, se donnát le peu de soins nécessaires pour le faire arriver en vie en France, l'y acelimater dans nos rivières, et procurer ainsi à notre patrie une nourriture peu chère, exquise, salubre, et trèsabondante.

Voyons quelle est la conformation de cet osphronème goramy.

Le corps est très-comprimé et très-haut. $\mathrm{L}$. dessous du ventre et de la queue et la partie postérieure du dos présentent une carène aiguē. Cette même extrémité postérieure du dos montre une sorte d'échancrure, qui diminue beaucoup la hauteur de l'animal, a une petite distance de la nageoire caudale; et lorsqu'on n'a sous les yeux qu'un des cótés de cet osphronème, on voit facilement que sa partie inférieure est plus arrondie, et s'étend au-dessous du diamètre longitudinal qui va du bout du museau i la fin de la queue, beaucoup plus que sa partie supérieure ne s'élève au-dessus de ce même diamètre ${ }^{2}$.

De larges écailles couvrent le corps, la queue, les opercules et la téte; et d'autres écailles plus petites revêtent une portion assez considérable des nageoires du dos et de l'anus. Le dessus de la tête, incliné vers le museau, offre d ailleurs deux légers enfoncements. La mâchoire supérieure est extensible; l'inférieure plus avancée que celle d'en haut : toutes les deux sont garnies d'une double rangée de dents; le rang ex. térieur est composé de dents courtes et un peu recourbées en dedans; l'intérieur n'est formé que de dents plus petites et plus serrées.

$\because$ Devectus e sina, edueatus primùm in piscinis, etc., lanuscrits de Commerson, - I Le pois sin w'est pas extré. : dans le pays. On pourrait en former des viviers. diéta gsais - propos d'y transpisnter le Goramy, cet rycelent pois on - yue nous avons transporie de Batovia a I Ille de Prance, et "qui s'y est natural se. . Voyage au Bengole, etc., par 1. Charpeuter-Cissizuy, $t$. 1, p. 18

. nes pectorales, I aigailion et 5 rayons arlicales a chacine des thoraciues, 10 aiguilions et 20 rayons articolés it in mat seoire de I aums, 16 rayons a celle de la fucue.
On apercoit une callosite au palais: la langue est blanchătre, retirée, pour ainsi dire, dans le fond de la gueule, anquel elle est attachée; les oritices des narines sont doubles; chaque opercule est formé de deux lames, dont la premiere est excavée vers le bas par deux ou trois petites fossettes, et dont la seconde s'avance en pointe vers les nageoires pectorales, et de plus est bordée d'une membrane.

On aperçoit dans l'intérieur de la bouche, et au-dessus des branchies, une sorte d'os ethmoide, labyrinthiforme, pour employer l'expression de Commerson, et placé dans une cavité particulière. L'usage de cet os a paru au voyageur que nous venons de citer, très-digne d'étre recherché, et nous nous en occuperons de nouveau dans notre Discours sur les parties solides des poissons.

La nageoire du dos commence loin de la nuque, et s'élève ensuite à mesure qu'elle s'approche de la caudale, auprès de laquelle elle est très-arrondie.

Chaque nageoire thoracine renferme six rayons. Le premier est un aiguillon très-fort le second se termine par un filamentqui s'étend jusqu'á l'extrémité de la nageoire de la queue, ce qui donne à l'osphronème un rapport très. marqué avec les trichopodes : mais dans ces derniers ce filament est la continuation d'un rayon unique, au lieu que, dans l'osphronème chaque thoracine présente au moins cinq rayons.

L'anus est deux fois plus près de la gorge que de l'extrémité de la queue : la nageoíre qui le suit a une forme très-analogue à celle de la dorsale; mais, ce qui est particulierement à remarquer, elle est beaucoup plus étendue.

On ne compte au-dessus ni au-dessous de la caudale, qui est arrondie, aucun de ces rayons articulés, très-courts et inégaux, qu'on a nommés Faux rayons ou Rayons batards, et qui accompaguent la nageoire de la queue d'un si grand nombre de poissons.

Enfin la ligne latérale, plus voisine du dos que du ventre, n'offre pas de courbure trèsensible.

Au reste, le goramy est brun avec des teintes rougeâtres plus claires sur les nageoires que sur le dos ; et les écailles de ses cótés et de sa partie inférieure, qui sont argentées et bordées de brun, font paraitre ces mémes portions comme couvertes de mailles. 


\section{L'OSPHRONEMME GAL '.}

Labrus Gallus, Linn., Gmel.; Osphronemus Gallus,

Forskael a vu sur les côtes d'Arabie cet osphronème, qu'il a inscrit parmi les scares, et que le professeur Gmelin a ensuite transporté parmi les labres, mais dont la véritable place nous parait étre à côté du goramy. Ce poisson est regardé comme très-venimeux par les habitants des rivages qu'il fréquente; et dès lors on peut présumer qu'il se nourrit de mollusques, de vers, et d'autres animaux marins imprégnés de sucs malfaisants ou même délétères pour l'homme. Mais s'il est dangereux de manger de la chair du gal, il doit étre très-agréable de voir cet osphronème : il offre des nuances gracieuses, variées et brillantes; et ces humeurs funestes, dérobées aux regards par des écailles qui resplendissent des couleurs qui émaillent nos parterres, offrent une nouvelle image du poison que la nature a sí souvent placé sous des fleurs.

Le gal est d'un vert foncé; et chacune de ses écailles étant marquée d'une petite ligne transversale violette ou pourpre, l'osphronème paralt rayé de pourpre ou de violet sur presque toute sa surface. Deux bandes bleues règnent de plus sur son abdomen. Les nageoires du dos et de l'anus sont violettes à leur base, et bleues dan leur bord extérieur les pectore, et bleues dans leur bord extérieur; les pectorales bleues et violettes dans leur centre; les thoracines bleues. la caudale est jaune et aurore dans le milieu; violette sur les catés, bleue dans sa circonfe, rence; et l'iris est rouge autour de circonférence; et l'iris est rouge autour de la prunelle, et vert dans le reste de son disque.

Le rouge, l'orangé, le jaune, le vert, le bleu le pourpre et le violet, c'est-à-dire les sept couleurs que donne le prisme solaire, et que nouvoyons briller dans l'are-en-eiel, sont done distribuées sur le gal, qui les montre d'ailleurs disposées avec goût, et fondues les unes dans les autres par des nuances très-doun unes dans A joutons, pour achever de douces.

de cet osphrons, pour achever de donner une idée de cet osphronème, que sa lèvre inférieure est plissée de chaque coté ; que ses dents ne forment qu'une rangée; que celles de devant sorplus grandes que celles qui les suivent, sont peu écartées l'ue celles qui les suivent, et un peu écartées l'une de l'autre; que la ligne la'Scarus Gallus. Forskael, Faun. Arab., p. 26, n. 11. sous-geare Girelle, dans le grand geare des Labres. D.
I térale se courbe vers le bas, auprès de la fin de la nageoire dorsale; et que les écailles son striées, faiblement attachées à l'animal membraneuses dans une grande partie de lev contour' ${ }^{\prime}$.

\section{SOIXANTE-QUINZIĖME GENRE}

LES TRICHOPODES 2

Un senl rayon beaucoup plus long que le corps, $\dot{a}$ chocrne des nageoires thoraeines; ume seule nageoire dorsale.

EsPíces.

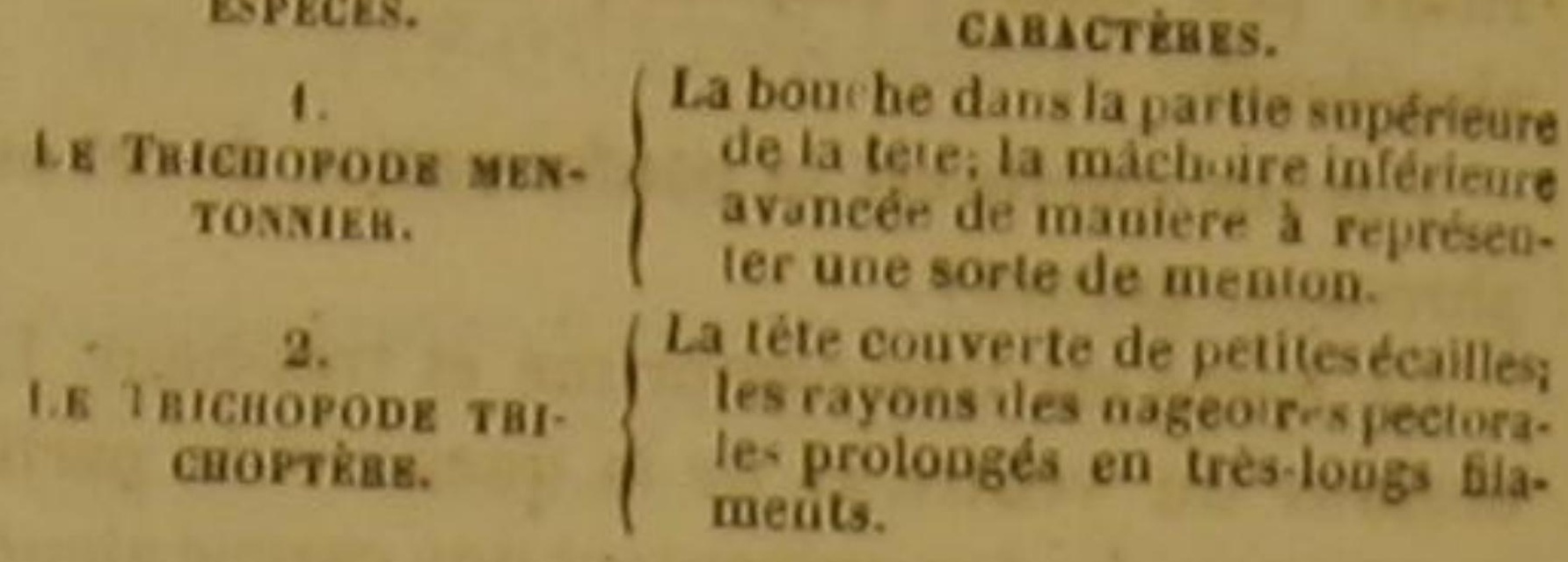

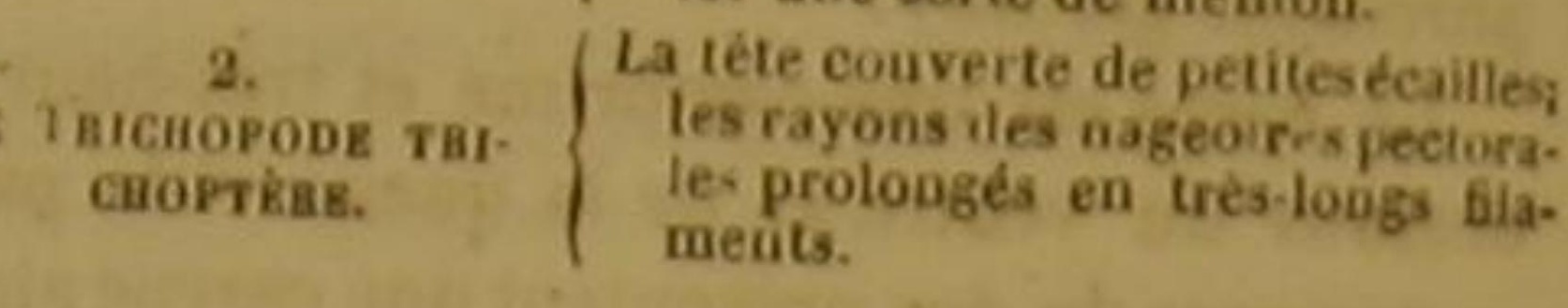

\section{LE TRICHOPODE MENTONNIER ${ }^{3}$,}

Trichopodus Mentum, Lacep. 4.

C'est eneore le savant Commerson qui a observé ce poisson, dont nous avons trouvé un essin fait avec beaucoup de soin et d'exaetiude dans ses précieux manuserits.

La téte de cet animal est extrêmement remarquable ; elle est le produit bien plutót singulier que bizarre d'une de ces combinaisons de formes plus rares qu'extraordinaires, que on est surpris de repcontrer mais que devrait être bien plus étonné de ne pas avoir fréquemment sous les yeux, et qui n'étant que de nouvelles preuves de ce grand principe que ous ne cessons de chercher a f́tablir, loul ui peut être, existe, méritent néanmoin otre examen le plus attentif et nos réflexion les plus profondes. Elle présente d'une manière rappante les principaux caractères de la plus noble des espèces, les traits les plus reconnaissables de la face auguste du suprême domina-

' 5 rayons a la membrane des branchies, 8 aiguillons et 1 des pectorales a la nageoire du dos, 14 rayons a chacune des thoracines, 5 aiguillon et 5 rayons articulés à chacune lanus, 15 rayons a celle de la M. Cuvier, en aloptant queve.

seconde espece seutement a genre, n'y comprend que I ne miavaise figure de tosphronemere ne repose yue su Gouramy, on gouramic.

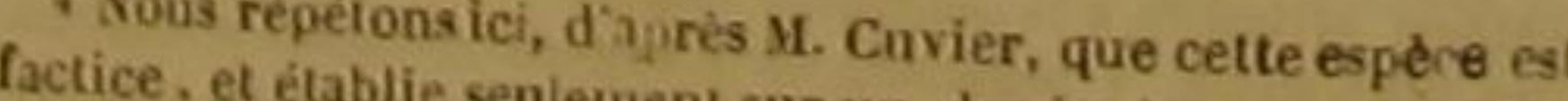
phronèmet établie seulement sur un dessin inexact de ro:

DES POISSONS

175

teur des ètres; elle rappelle le ehef-d'œuvre de la création; elle montre en quelque sorte un exemplaire de la figure humaine. La conformation de la mảchoire inférieure, qui s'avance, s'arrondit, se relève et se recourbe, pour représenter une sorte de menton; le léger enfoncement qui suit cette saillie; la position de la bouche, et ses dimensions; la forme des lèvres; la place des yeux, et leur diamètre; des opercules à deux lames, que l'on est tenté de comparer à des joues; la convexité du front l'absence de toute écaille proprement dite de dessus l'ensemble de la face, qui, revêtue uniquement de grandes lames, parait comme eouverte d'une peau; toutes les parties de la tête du mentonnier se réunissent pour produire cette image du visage de l'homme, aux yeux surtout qui regardent ce trichopode de profil. Mais cette image n'est pas complète. Les principaux linéaments sont tracés : mais leur ensemble n'a pas reçu de la justesse des proportions une véritable ressemblance; ils ne produisent qu'une copie grotesque, qu'un portrait chargé de détails exagérés. Ce n'est done pas une téte humaine que l'imagination place au bout du corps du poisson mentonnier; elle y suppose plutôt une tête de singe ou de paresseux ; et ce n'est mème qu'un instant qu'elle peut être séduite par un commencement d'illusion. Le défaut de jeu dans cette téte qui la frappe, l'absence de toute physionomie, la privation de toute expression sensible d'un mouvement intérieur, font bientôt disparaitre toute idée d'étre privilégié, et ne laissent voir qu'un animal dont quelques portions de la face ont dans leurs dimensions les rapports peu communs que nous venons d'indiquer. C'est le plus saillant de ces rapports que j'ai cru devoir désigner par le nom spécifique de Mentonnier, de mème que j'ai fait allusion par le mot Trichopode (pieds en forme de filaments) au caractère de la famille particulière dans laquelle j'ai pensé qu'il fallait l'inserire.

Chacune des nageoires thoracines des poissons de cette famille, et par conséquent du mentonnier, n'est composée en effet que d'un rayon ou filament tres-délié. Mais cette prolongation trèsnolle, au lieu d'ètre très-courte et à peine visible, comme dans les monodictyles, est si étendue, qu'elle surpasse ou du moins égale en longueur le corps et la queue réunis.

Le mentonnier a d'ailleurs ce corps et cette queue très-comprimés, assez hauts vers to milieu de la longueur totale de Panimal ; la nageoire dorsale et celle de l'anus, basses, et presque égales I'unea l'autre; la caudale rectiligne ; et les pectorales courtes, larges et arrondies '.

\section{LE TRICHOPODE TRICHOPTËRE 2 .}

Labrus trichopterus, Pall., Linn., Gmel.; Trichopterus Pallasii, Shaw; Trichogaster trichopterus, Bloch Pallasii, Shaw; Trichogaster trichopte
Triehopodus trichopterus, Lacep., Cuv.

Ce trichopode est distingué du précédent par plusieurs traits que I'on saisira avec facilité en lisant la deseription suivante. Il en differe surtout par la forme de sa téte, qui ne présente pas cette sorte de masque que nous avons vu sur le mentonnier. Cette partie de l'aaimal est petite et couverte d'écailles semblables à celles du dos. L'ouverture de la bouche est étroite, et située vers la portion supérieure du museau proprement dit.

Les lèvres sont extensibles. La nageoire du dos est courte, pointue, ne commence qu'à l'endroit où le corps a le plus de hauteur, et se termine à une grande distance de la nageoire de la queue. Il est a remarquer que celle de l'anus est, au contraire, très longue ; qu'elle renferme, a très-peu près, quatre fois plus de rayons que la dorsale, qu'elie touche presque la caudale; qu'elle s'étend beaucoup vers la tête, et que, par une suite de cette dísposition, l'orifice de I'anus, qui la précède, est très-près de la base des thoracines

Ces dernières nageoires ne consistent chacune que dans un rayon ou filament plus long que le corps et la queue considérés ensemble ${ }^{3}$; et de plus, chaque pectorale, qui est trés-étroite, se termine par un autre filament très-allongé, ce qui a fait donner au poisson dont nous parlons le nom de Trichoptère, ou d'Aile à filament. . Nous lui avons conservé ce nom spécifique; mais au lieu de le laisser dans le genre des labres ou des spares, nous avons cru, d'après les principes qui nous dirigent dans nos distributions méthodiques, devoir le comprendre dans

- A la nageoire du dos 18 rayons, a chacune des thoracines $C$. a la nagenire de l'anos 18.

Spirus, etc. Koelreuter, Nov. Comm. Petrop. 1X,p. 432 , 7, tab. 10. - Labre crin. Bounaterre, pl, de I'Ene neit. 4 agguillons et 7 rayons articutes a la nageoire ou dos, 9 rayons a chacune des pectorales. 1 rayon a cliacune vies thoranes, 4 rayons et 58 rayous articalés a la nageoire de $\mathrm{V}$. 
one petite famille particulière, et le placer dans nus est presque au-dessous des nageoires pece même genre que le mentonnier.

torales, qui sont pointues. La ligne latérale pec.

Le trichoptère est ondé de diverses nuances la courbure du dos, dont elle est peu eloignée. de brun. On voit de chaque cóté sur le corps et L'opercule des branchies est composé de deux la sur la queue, une tache ronde, noire et bordée mes, dont la postérieure parait irrégulièremen d une couleur plus claire. Des taches brunes festonnée. Les yeux sont gros. L'ouverture sont répandues sur la tête, dont la teinte est, la bouche est petite : la mâchoire supérieure prépour ainsi dire, livide; et la nageoire de la sente une forme demi-circulaire, et iles dents queue, ainsi que celle de l'anus, sont pointil- courtes, aiguès et serrées; elle est d'allleurs exlées de blanc.

Ce trichopode ne parvient guère qu'à un décimètre de longueur. On le trouve dans la mer qui baigne les grandes Indes.

\section{SOIXANTE-SEIZIEMME GENRE}

LES MONODACTYLES '

Un seul rayon très-court el à peine visible ù chaque nageoire thoracine; une seule nageoire dorsale.

ESPËct.

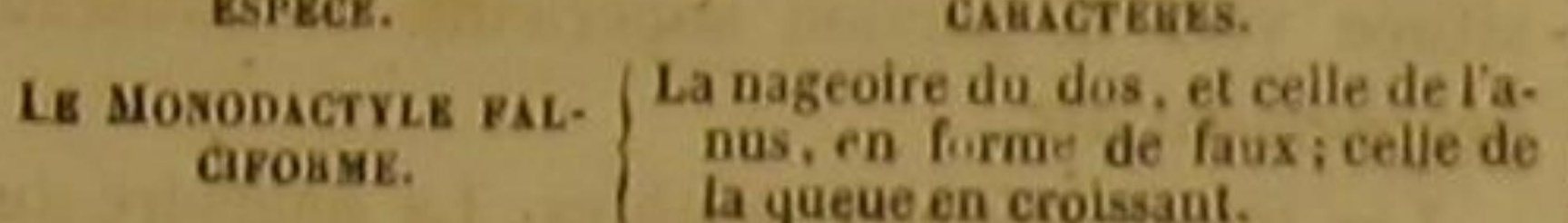

$$
\text { - }
$$

LE MONODACTYLE FALCIFORME 2

Monodactylus falciformis, Lacep.; Psettus CommersoDii. Cuv. ?

Nous donoons ce nom à une espèce de poisson dont nous avons trouvé la description et la figure, dans les manuserits de Commerson. Nous l'avons placé dans un genre particulier que nous avons appelé Monodactyle, c'est-â-dire, à un seul doigl, parce que chacune de ses nageoires thoracines, qui représentent en quelque sorte ses pieds, n'a qu'un rayon très-court et aiguillonné, ou pour parler le langage de plusieurs naturalistes, n'a qu'un doigt très-petit. Le nom spécifiqué par lequel nous avons cru de-

voir d'ailleurs distinguer cet animal, nous a été indique par la forme de ses nageoires du dos et de l'anus, dont la figure ressemble un peu à celle d'une fanx. Ces deux nageoires sont de plus assez égales en étendue, et touchent presque la nageoire de la queue, qui esten croissant. L'a-

a. Ce genre se rapporte a celui que M. Cuvier nomme
Pseltus, etdans lesuel il ou Centropome rhomboidal de Lactpede. Qmant , Furk. dactyle falciforme, it peuse que ce poissou pourrait bieno pas differer du Chatodon argenteus, Lina., ou Acantho$\therefore$. Psetlus spinis pele.

Commerson, masauscrits déja cités. tensible et embrasse linferieure. La langue est

large, arrondie à son extrémité, amincie dans ses bords, rude sur presque toute sa surface. On voit, de chaque cóté du museau, deux orifices de narines, dont l'antérieur est le plus petit et quelquefois le plus élevê.

La concavité des arcs osseux qui soutiennent les branchies, présente des protubérances semblables à des dents, et plus sensibles dans les trois anterieurs. Le corps et la queue sont trèscomprimés, couverts d'écailles petites, arrondies et lisses, que l'on retrouve avec des dimensions plus petites encore sur une partie des d'une couleur d'argent, mélée sur le dos avec des teintes brunes. Ces mèmes nuances obscures se montrent aussi sur la portion antérieure de la nageoire de l'anus et de celle du dos, ainsi que sur les pectorales, qui néanmoins offrent souvent une couleur incarnate. Le monodactyle falciforme ne parvient ordinairement qu'à une longueur de vingt-six centimètres '.

\section{SOIXANTE-DIX-SEPTIEME GENRE}

LES PLECTORHINQUES ${ }^{2}$.

Une seule nageoire dorsale; point d'aiguillons isoles au-devant de la nageoire du dos, de carine laterale, ni de petile nageoire au-devant de celle de l'anus; les de lopercule branchial dentelies. ESPËCE.

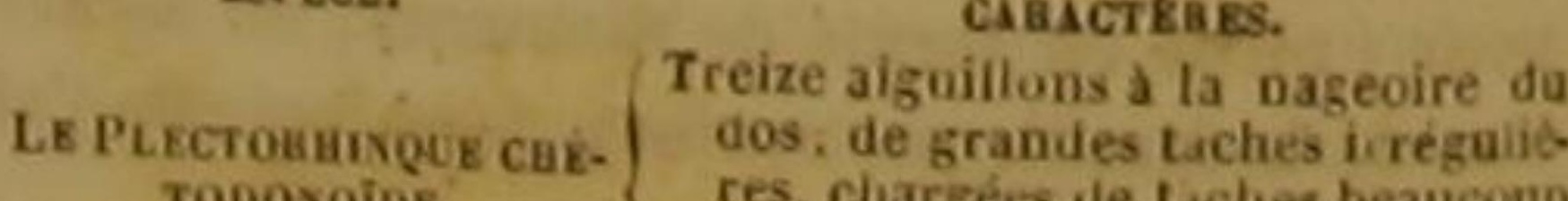
da dos, 17 a chacune des pectorales. 1 rayon aiguillonné a l'anus. is. giens scienoīdes. D.
Dans la familie des Acinthopléry nageoires du dos et de l'anus, et respleudissants

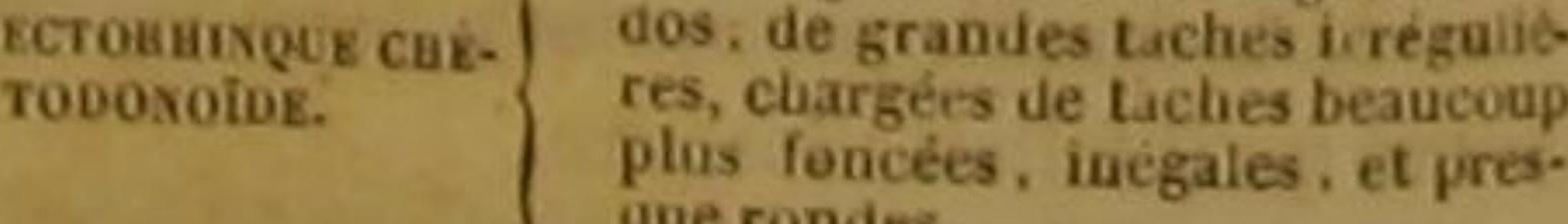
i 7 rayons a la membrane des branchies, 35 a la nageoire a son genre Diagramme, lis plectorhinques de $\mathbf{M}$. Je Lacépede

DES POISSONS.

LE PLECTORHINQUE CHÉTODONOHDE. Plectorbynchus chetodonoides, Lacep.; Diagramma
chetodonoides, Cur.

Le mot plectorhinque désigne les plis extraordinaires que présente le museau de ce poisson, et qui forment, avee la dentelure de ses opercules, un de ses principaux caractères génériques. Nous avons employé de plus, pour cet osseux, le nom spécifique de Chétodonoride, parce que l'ensemble de sa conformation lui donne de très-grands rapports avec les Chélodons, dont l'histoire ne sera pas très-éloignée de la description du plectorhinque. Ce dernier animal leur ressemble d'ailleurs par la beaute de sa parure. Sur un fond d'une couleur trèsfoncée, paraissent, en effet, de chaque côté, sept ou huit taches très-étendues, inégales, irrégulières, mais d'une nuance claire et trèséclatante, variées par leur contour, agréables par leur disposition, relevées par des taches plus petites, foncées, et presque toutes arrondies, qu'elles renferment en nombre plus ou moins grand. On peut voir aisément, par le moins grand. On peut voir aisément, par le
moyen du dessin que nous avons fait graver, le bel effet qui résulte de leur figore, de leur ton, de leur distribution, d'autant plus qu'on aperçoit des taches qui ont beaucoup d'analogie avee ces premières, à l'extrémité de toutes les nageoires, et surtout de la partie postérieure de la nageoire du dos.

Cette nageoire dorsale montre une sorte d'é. chancrure arrondie qui la divise en deux portions très-contigués, mais faciles à distinguer, dont l'une est soutenue par treize rayons a guillonnés, et l'autre par vingt rayons articalés '. Les thoracines et la nageoire de lanus présentent à peu pres la même surface l'une que l'autre : les deux premiers rayonsqu'elles com. prennent, sont aiguillonnés, et le second de ces deux piquants est très-long et tres-fort.

La nageoire caudale est rectiligne ou arrondie. Il n'y a pas de ligne latérale sensible. téte est grosse, comprimée comme le corps et la queue, et revétue, ainsi que ces derpi et parties, d'écailles petites et placées les unes au-dessus des autres. Des écailles semblables recouvrent des appendices charnus auxquels

i 15 rayons a chácune des nageoires pectorales, 2 rayons àgullonnes et 15 rayons articulés à celle de ranus, 18 rayons
a celle de la queue.

n. torales, et celle de looires thoraeines, les pecLes, et celle de l'anus.

L'oil est grand; l'ouverture de la bouche petite; le museau un peu avancé, et comme caehé dans les plis et les contours charnus ou membraneux des deux máchoires.

Nous avons décrit cette espèce encore inconnue des naturalistes, d'après un individu de la oolleetion hollandaise donnée à la France.

\section{SOIXANTE-DIX-HUITIEME GENRE.} LES POGONIAS '.

Une seule nageoire dorsale; point d'aiguillons isoles au-decant de la nageoire du dos, de carène laterale. mi de petite nageoire au-deoant de celle de l'anus ; un inferiend nombre de pelits barbillons à la mdechoir

Espìce.

cauctimes.

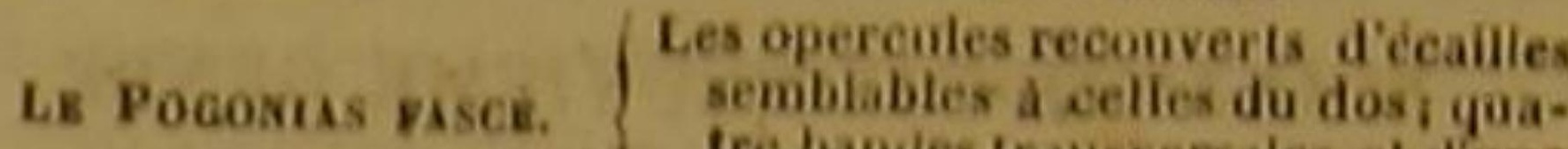
tro bandes tramsversales, el duae
couleur tres-foncee ou tres.vive.

\section{LE POgONIAS FAScé.}

Pogonias fascialus, Lacep., Cuy.

Nous donnons ce nom de Pogonias à un genre dont aucun individu n'a encore été connu des naturalistes.Cettedénomination signifie Barbu, et désigne le grand nombre de barbillons qui garnissent la mâchoire inférieure, et pour ainsi dire, le menton de l'animal. Nous avons décrit et fait ligurer l'espèce que nous distinguons par l'épithete de Fascé, d'après un poisson très-bien conservé, qui faisait partie de la collection du stathouder à La Haye, et qui se trouve maintenant dans celle du Muséum d'histoire naturelle.

Ce pogonias a la tête grosse; les yeux grands; la bouche large; Ies levres doubles; les dents des deux mâchoires aiguês, égales, et peu serrées; la mâchoire supérieure plus avancée que l'inférieure; I opercule composé de deux lames et recouvert d'écailles arrondies comme celles du dos, auxquelles elles ressemblent d'ailleurs en tout; la seconde lame de cet opercule branchial terminée en pointe; la nageoire du dos étendue de. puis l'endroit le plus haut du corps jusqu'à une distance assez petite de l'extrémité de la queue,

- Les Pogonias forment pour M. Cuvis le sous-geare Tambour (Pogonias) dass lo gaure Selene, de ta famille des Acanthoplérygiens sciéécoldes.
di. 
et presque partagée en deux portions inégale par une sorte d'échancrure cependant peu profoude; un aiguillon presque détaché au-devant de cette nageoire dorsale et de celle de l'anus; cette dernière nageoire très-petite et inférieure même en surface aux thoracines, qui néanmoin sont moins grandes que les pectorales; la caudale rectiligne ou arrondie; les côtés dénués de higne latérale; la mâchoire inférieure garnie de plus de vingt filaments déliés, assez courts, rapprochés deux à deux, ou trois à trois, et représentant assez bien une barbe naissante '

Quatre bandes foncées ou vives, étroites, mais très-distinctes, règnent de haut en bas de chaque côté du pogonias fascé; de petits points sont disséminés sur une grande partie de la surface de l'animal.

\section{SOIXANTE-DIX-NEUVIEME GENRE.} I.ES Bósthyches ${ }^{2}$

Le corps allonge et serpentiforme: deux nageoires dor-
sales: la seconde sizare de celle de le gueve ; sales: la seconde siparee de celle de la queue; deux barbillons à la mächoire superieure: les youx assez grands et sans roile.

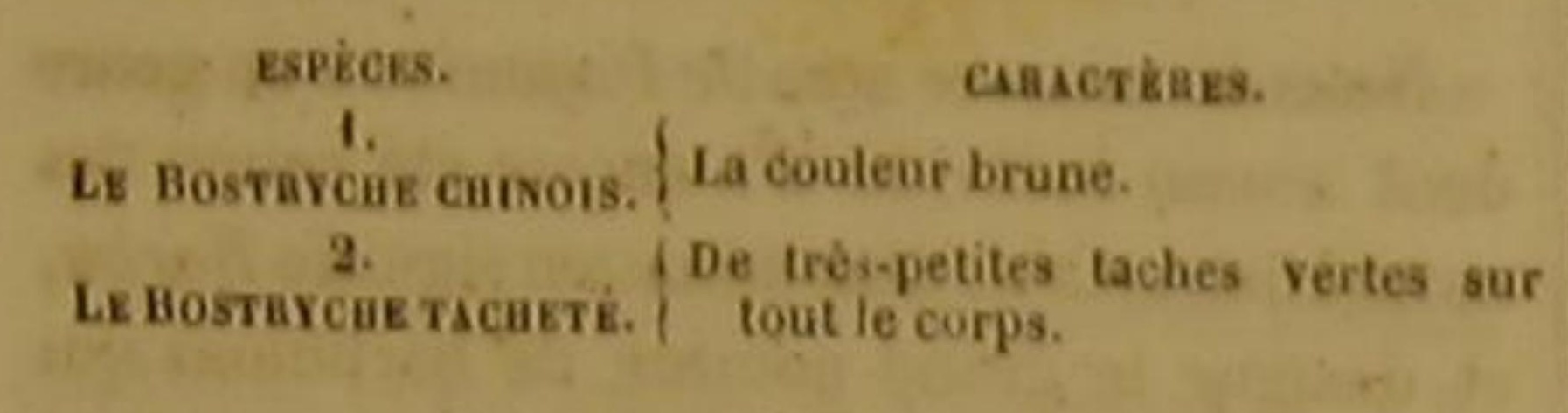

\section{LE BOSTRYCHE CHINOIS}

Bostrychus sinensis, Lacep.

C'est dans les dessins chinois dont nous avons déja parlé, que nous avons trouvé la figure de ce bostryche, ainsi que celle du bostryche tacheté. Les barbillons que ces poissons ont à la màchoire supérieure, et qui nous ont indiqué leur nom générique ${ }^{4}$, les distingueraient seuls des gobies, des gobioides, des gobiomores et des gobiomoroīdes, avee lesquels ils ont cependant beaucoup de rapports par leur conformation générale. Nous ne doutons pas que ces osseux n'aient des nageoires au-dessous du corps,

seux n aient des nageoires au-dessous du corps,

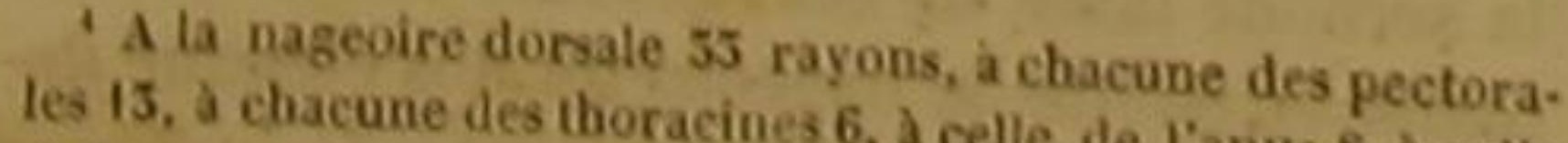

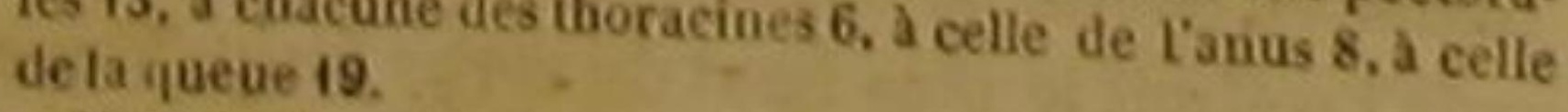
2M. Curier

se rapportant an senre Ostryches de M. de Lacépede comm giens labyriuthiformes dans tor ire des Acilite des Pbaryn-

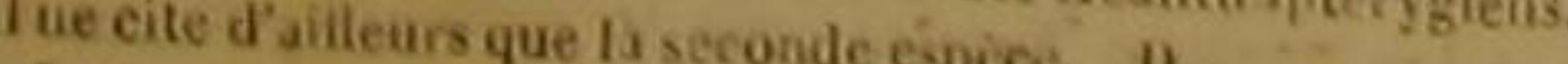
'Non mentionné par M. Eivier. D

"Do.then sou gree veut dire flumeul, barbillon, ete. et ne doivent ètre compris parmi les thoracins, quoique la position dans laquelle ils sont repré sentés ne permette pas de distinguer ces na. geoires. Au reste, si de nouvelles observations apprenaient que les bostryches n'ont pas de geoires inférieures, ils n'en devraient pas moins former un genre séparé des autrés genres déjä connus; il suffirait de les retrancher de la co. lonne des thoracins, et de les porter sur celle des apodes. On les y rapprocherait des myrènes, dont il serait néanmoins facile de les distinguer par la forme de leurs yeux et les di. mensions ainsi que la position de leurs na. geoires. Ajoutons que cette remarque relative à l'absence de nageoires inférieures et au deplacement qui en serait le seul résultat, s'applique au genre des bostrychoides dont nous allons parler

Le bostryche chinois est d'une couleu brune. On voit de chaque cóté de la queue, e auprès de la nageoire qui termine cette partie, une belle tache bleue, entourée d'un cercle aune vers le corps et rouge vers la nageoire. L'animal ne parait revêtu d'aucune ecaill facile à voir. Sa tête est grosse; l'ouverture de sa bouche arrondie; l'opereule branchial d'une seule pièce; la première nageoire dorsale très courte relativement à la seconde; celle de lanus, semblable et presque égale à la première dorsale, se montre au-dessous de la seconde nageoire du dos; celle de la queue est lancéolée. Les mouvements et les habitudes du bostryche chinois doivent ressembler beaucoup à ceux des murènes.

\section{LE BOSTRYCHE TACHETÉ}

Bostrychus maculatus, Lacep,; Ophicephalus macula tus, Cuv. :

Ce bostryche diffère du chinois par quelquesnes de ses proportions, par plusieurs de ees raits vagues de conformation que l'œil saisit et que la parole rend difficilement, et par les uances ainsique la disposition de ses couleurs. Il est, en effet, parsemé de très-petites taches vertes.

3. Cuvier fait remaryuer la ressemblance de ce poisso D. D.
D.
DES POISSONS.

QUATRE-VINGTIEME GENRE.

LES BOSTRYCHOİDES '.

Le corps allonge at sexpentiforme; une scule nageoire dorsate; celle de la queue siparce de celle du dos:

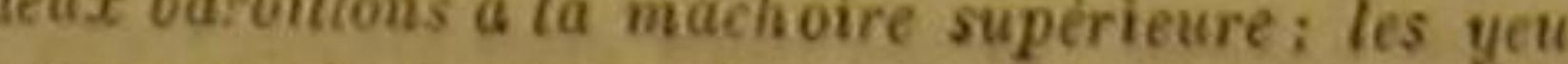
assez grands et saus coile.
ESPÉCE.

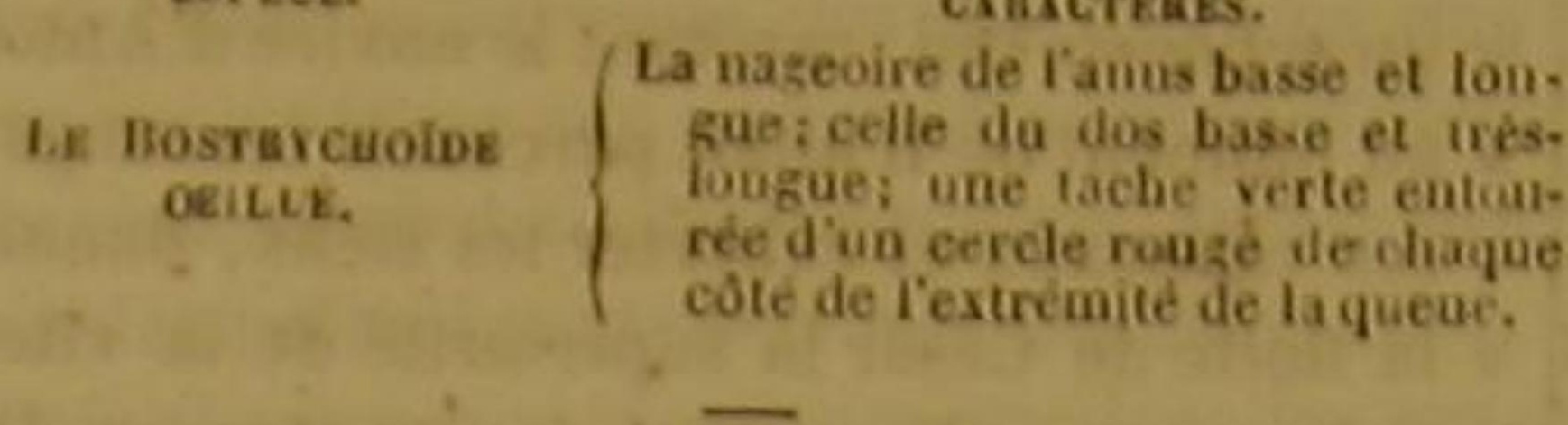

\section{LE BOSTRYCHOIDE OEILLE.}

Bostrychoides oculatus, Lacep. '

Ce poisson est figuré dans les dessins chinois arrivés par la Hollande au Muséum d'histoir naturelle de France. Sa téte, son corps et sa queue sont couverts de petites écailles; sa tète est moins grosse que la partie antérieure du corps. Les nageoires pectorales sont petites et arrondies; celle de la queue est lancéolée, La couleur de l'auimal est brune, avee des bandes ransversales plus foncées, et un très-ôrand nombre de petites taches vertes. Une tache verte plus grande, placée dans ui cercle rouge, et semblable a une prunelle entourée de son ris, parait de chaque cóté de l'extrèmité de la queue. La conformation générale de ce poisson doit faire présumer que sa manière de vivre, ainsi que celle des bostryches, a beaucoup de rapports avee les habitudes des murènes.

QUATRE-VINGT-UNIEME GENRE LES ÉCHÉNÉIS

Une plaque trìs-grande, orale, composce, de lames transtersales, el placie sur la tite pui est diprimic. Espices.

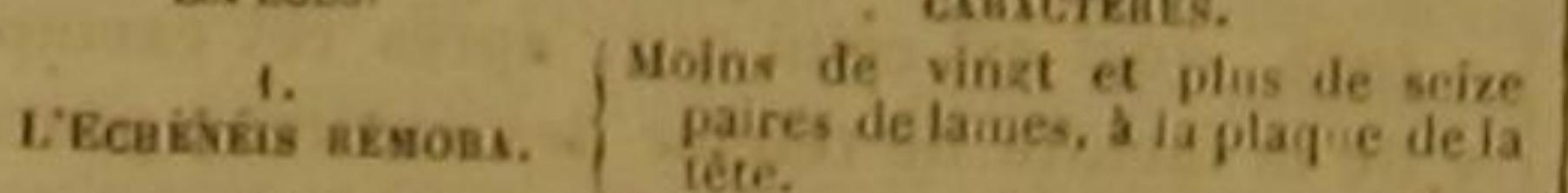

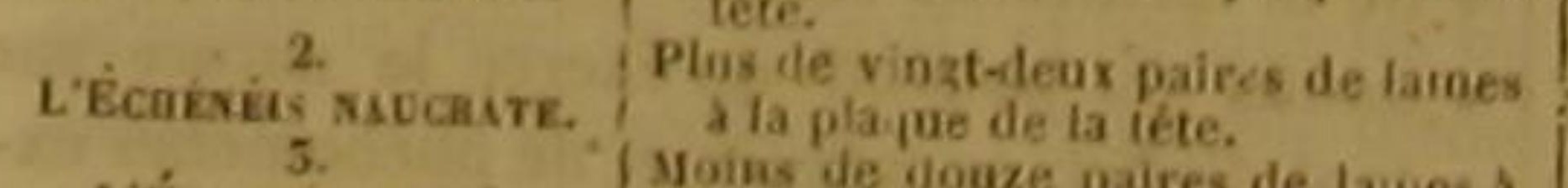
L’Échexis maré. $\quad \begin{gathered}\text { Moins de douze paires de lanes a } \\ \text { la plaque de la léte. }\end{gathered}$ - Ce genre de M, de Lacépède est, cornme te précédent, rapporté par M. Cuvier au geure Ophicéphale de Blo b qu" adopte. D.

- Cavier cite ce prisson it le considère comme étan - Ce genre träs-anciengergent tíbli de Buchanam. D.

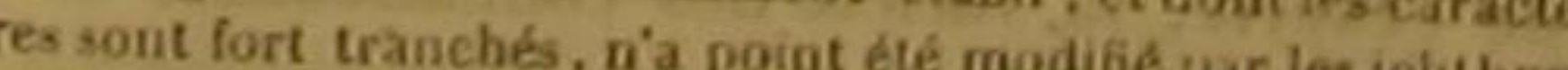
logistes modernes. D.

\section{L'ECHEN ĖIS REMORA '}

179
L'histoire de ce poisson présente un phénomène relatif à l'espèce humaine, et que la philosophie ne dédaignera pas.

Depuis le temps d'Aristote jusqu'à nos jours, cet animal a éte l'objet d'une attention constante; on l'a examiné dans ses formes, observo dans ses habitudes, considéré dans ses effets : on ne s'est pas contenté de lui ảttribuer des propriétés merveilleuses, des facultés absurdes, des forces ridicules; on l'a regardé comme un exemple frappant des qualités occultes départies par la nature à ses diverses productions ; il a paru une preuve convaincante de l'existence de ces qualités secrètes dans leur origine et in. connues dans leur essence. II a figuré aveo honneur dans les tableaux des poètes, dans les comparaisons des orateurs, dans les récits des voyageurs, dans les deseriptions des naturalistes; et cependant á peine, dans le moment ou nous ćcrivons, limage de ses traits, de ses mours, de ses effets, a-t-elle été tracée avec quelque fidélité. Ecoutons, par exemple, au sujet de ce rémora, l'un des plus beaux génies de lantiquité. "L'échénéis, dit Pline, est mn "petit poisson accoutumé à vívre au milieu des " rochers : on croit que lorsqu'il s'attache a la "carène des vaisseaux, il en retarde la mara che; et de là vient le nom qu'il porte, et qui

- Nómare. - Sucel, - Arrele-bouf. - Pilote, - Heme endroits de ta Heigique et de ta Hoth - Sugger, dans plas.

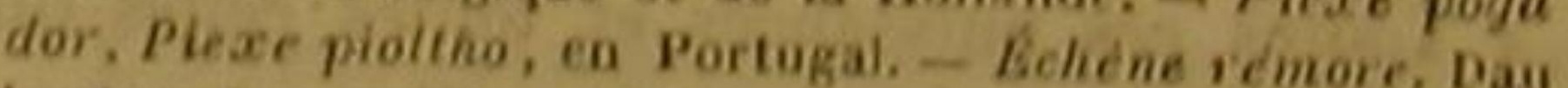
benton, Enc, meeth, - Id, Bonoaterre, pl, se l'kac méth Echeneis remora, Commerson, manuscrits ilejs cités. - Id . Forskae, Faun. Arabic, p. 19. - Ariedi, Gen. 15. syin. 28.

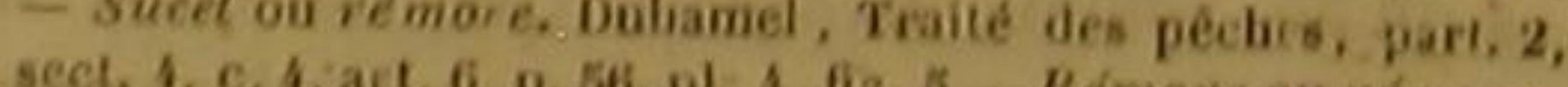

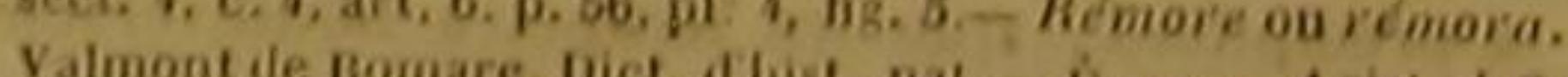

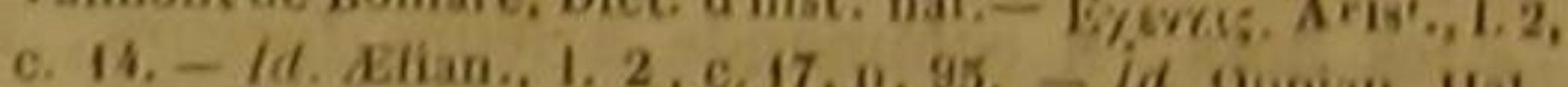

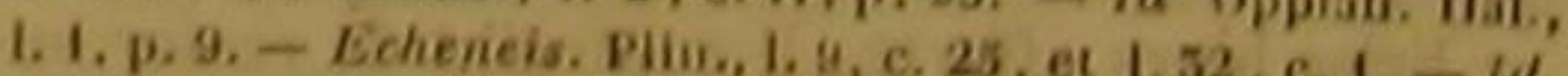
Wotton, I. 8, c. 166, fol. 169. a. - Echeneis. C. , c. 1. $-1 d$. - Achandes. Id., L. 5, e. 1, fol, 71, a. - Echeueis Gesner. Aqual.. p. 400. - Remora. Aldrovand, 1. 3, c. 22, p. 536. Id. Rai, p. 71. - Id. Hondelet, list. des poissons, part. i. is.c. W7. - Echenels remora. appenuix du Voyage a la

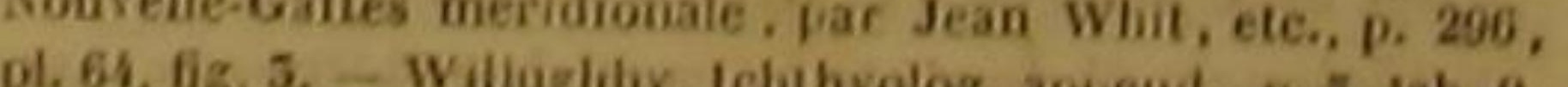
fig. 2. - Echeneis, Alweevis anolog. append., p. o. ab.

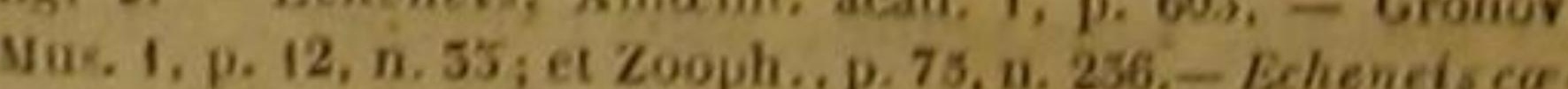

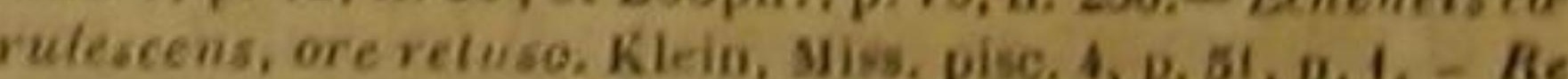

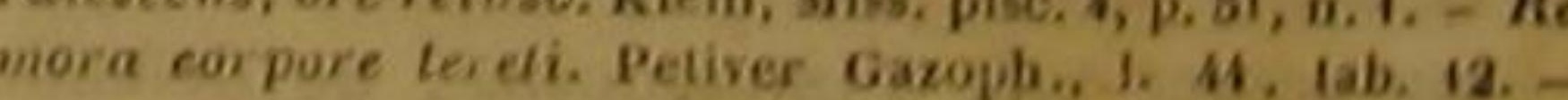
Adam Olearii, Gottorlische kun-tkammer, p. A2. tai, 23.Belon, Aquat., 1. M10. - Stom. Jamale, 1, 1.8 - Eateshy Carolin. 2, tab. 26. - Du Tertre, Antill. 2, p. 209, 222 - 
" est formé de deux mots grecs, dont l'un si- | " armées pour la guerre se chargent de tours - gnifie je retiens, et l'autre navire. Il sert à " de remparts qui s'élèvent pour que l'on com- composer des poisons capables d'amortir et "batte au milieu des mers comme du haut des " d'éteindre les feux de l'amour. Doué d'une a-murs. 0 vanité humaine! un poisson très. a puissance bien plus étonnante, agissant par a petit contient leurs éperons armés de fer et a une faculté morale, il arrête l'action de la u de bronze, et les tient enchainées! On rap. a justice et la marche des tribunaux : compen- "porte que, lors de la bataille d'Actium, ce fut a sant cependant ces qualités funestes par des a un échénéis qui, arrêtant le navire d'Antoine " propriétés utiles, it délivre les femmes en- " au moment ou il allait parcourir les rangs de " ceintes des accidents qui pourraient trop " ses váisseaux et exhorter les siens, donna à a hâter la naissance de leurs enfants; et lors- a la flotte de César la supériorité de la vitesse - qu'on le conserve dans du sel, son appro- "et l'avantige d'une attaque impétueuse. Plos " che seule suffit pour retirer du fond des " récemment, le bátiment monté par Caĩus, " puits les plus profonds l'or qui peut y être a lors de son retour d'Andura-à Antium, s'ar. a tombé '. .

Mais le naturaliste romain ajoute, avant la fin de la célebre histoire qu'il a écrite, une peinture bien plus étonnante des attributs du rémora; et voyons comment il s'exprime au commencement de son trente-deuxième livre.

a Nous voici parvenus au plus haut des a forces de la nature, au sommet de tous les a exemples de son pouvoir. Une immense " manifestation de sa puissance occulte se " présente d'elle-même; ne cherchons rien " au, delà, n'en espérons pas d'égale ni de " semblable : ici la nature se surmonte elle " méme, et le declare par des effets nombreux. " Qu'y a-t-il de plus violent que la mer, les - vents, les tourbillons et les tempétes? Quels " plus grands auxiliaires le génie de l'homme " s'est-il donnés que les voiles et les rames? - Ajoutez la force inexprimable des flux alter" natifs qui font un fleuve de tout l'Océan. "Toutes ces puissances et toutes celles qui - pourraient se réunir à leurs efforts, sont en- chainées par un seul et très-petit poisson " qu'on nomme Échènéis. Que les vents se "précipitent, que les tempètes bouleversent " les flots, il commande à leurs fureurs, il a brise leurs efforts, il contraint de rester im- mobiles des vaísseaux que u'aurait pu retenir a aucune chaine, aucune ancre précipitée dans - la mer, et assez pesante pour ne pouvoir pas " en être retirée. II donne ainsi un frein â I * violence, il dompte la rage des éléments, sans " travail, sans peine, sans chercher à retenir, " et seulement en adhérant : il lui suffit, pour " surmonter tant d'impétuosité, de défendre - aux navires d'avancer. Cependant les flottes

'Pline, L. 9, c. 2s $-$ beauté du talent, elles ont été presque univerde siècles. Mais l'on n'attend pas de nous une mythologie; e'est l'histoire de la nature que nous devons tâcher d'écrire. Cherehons done uniquement à faire connaitre les vêritables formes et les habitudes du rémora. Nous allons réunir, pour y parvenir, les observations que nous avons faites sur un grand nombre d'individus conservés dans des collections, avec celles dont des individus vivants avaient été l'objet, et que Commerson a eonsignées dans les manuscrits qui pous ont été confiés dans le temps par Buffon.

La longueur totale de l'animal égale très-rarement trois décimètres. Sa couleur est brune et sans tache; et ce qu'il faut remarquer avec soin, la teinte en est la mème sur la partie inférieure êt sur la partie supérieure de l'animal. Ce fait est une nouvelle preuve de ce que nous avons dit au sujet des couleurs des poissons, dans notre Discours sur la nature de ces animaux : en effet, nous allons voir, vers la fin de cet article, que, par une suite des habitudes du rếmora, et de la manière dont cet échénéis sattache aux rochers, aux vaisseaux' ou aux grands poissons, son ventre doit être aussi souvent exposé que son dos aux rayons de la lumière.

Les nageoires présentent quelques nuances de bleuátre. L'iris est brun, et montre d'ailleurs un cercle dore.

Une variété que l'on rencontre assez fréquemment, suivant Commerson, et que I'on voit souvent attachée au méme poisson, et, par exemple, au méme squale que les individus bruns, est distinguée par sa couleur blanchâtre.

Le corps et la queue sont couverts d'une peau molle et visqueuse, sur laquelle on ne peut apercevoir aucune parcelle écailleuse qu'après la mort de l'animal, et lorsque les tẻguments sont desséchés; et l'ensemble formé par la queue et le corps proprement dit, est d'ailleurs très-allongé et presque conique.

La tète est trés-volumineuse, très-aplatie, et chargée dans sa partie supérieure d'une sort de bouclier ou de grande plaque.

Cette plaque est allongée, ovale, amincie et membraneuse dans ses bords. Son disque est garni ou plutôt armé dé petites lames placées transversalement et attachées des deux cótés d'une aréte ou saillie longitudinale qui partage le disque en deux. Ces lames transversales et arrangées ainsi par paires sont ordinairement u nombre de trente-six, ou de dix-huit paires: leur longueur dimioue d'autant plus qu'elles sont situées plus près de l'une ou de l'autre des deux extrémités du bouclier ovale. De plus, ces lames sont solides, osseuses, presque parallèles les unes anx antres, très-aplaties, couchées obliquement, susceptibles d'ètre un peu relevees, hérissées, comme une seie, de très-petites dents, et retenues par une sorte de clou articulé.

Le museau est très-arrondi, et la máchoire inférieure beaucoup plus avancée que celle d'en haut, qui d'ailleurs est simple, et ne peut pas s'allonger à la volonté de l'animal: I'une et l'autre ressemblent à une lime, à cause d'un grand nombre de rangs de dents très-peites qui y sont attachées:

D'autres dents également très-petites sont placées autour du gosier, sur une éminence osseuse faite en forme de fer-a-cheval et attachée au palais, et sur la langue, qui est courte, large, arrondie par devant, dure, a demi cartilagineuse, et retenue en dessous par un frein assez court.

Au reste, I'intérieur de la bouche est d'un incarnat communément très-vif, et l'ouverture de cet organe a beaucoup de rapports, par sa forme et par sa grandeur proportionnelle, avec l'ouverture de la bouche de la lophie baudroie.

L'orifice des narines est double de chaque coté.

Les yeux, placés sur les cotés de la tête, et séparés par toute la largeur du bouclier, ne sont ni voilés ni très-saillants.

Deux lames composent chaque opercule des branchies, et une peau légère le recouvre.

La membrane branchiale est soutenue par neuf rayons '.

Les branchies sont au nombre de quatre de chaque côté, et la partie concave de leurs ares est denticulée.

Les nageoires thoracines offrent la même longueur, mais non pas la méme largeur, que les pectorales : elles comprennent chacune six rayons; le plus extérieur cependant touche de

'A la nageoire da dos 22 rayons, a chacune des pectora. de la queue 17. Veriebres dorsales 12, vertebres caudales is 
si près le rayon voisin, qu'il est très-difficile de l'apercevoir.

La nageoire du dos et celle de l'anus présentent à peu près la mème figure, la même étendue et le mème décroissement en hauteur, à mesure qu'elles sont plus près de celle de la queue, qui est fourehue.

L'orifice de l'ànus consiste dans une fente dont les bords sont blanchâtres.

La ligue latérale est composée d'une série de points saillants; elle part de la base des nageoires pectorales, s'élève vers le dos, descend auprès du milieu du corps, et tend ensuite direetement vers la nágeoire de la queue.

Telle est la figure du rémora, tracée d'après le vivant par Commerson, et dont j'ai pu vérifier les traits principaux, en examinant un grand nombre d'individus de cette espèce conservés avec soin dans diverses collections.

Ce poisson présente les mêmes formes dans les diverses parties, non-seulement de la Méditerranée, mais encore de l'Océan, soit qu'on l'observe à des latitudes élevées, ou dans les portions de cet Océan comprises entre les deux tropiques.

Il s'attãche souvent aux cétacées et aux poissons d'une très-grande taille, tels que les squales, et particulièrement le squale requin. II y adhère très-fortement par le moyen des lames de son bouelier, dont les petites dents lui servent comme autant de crochets, à se tenir cramponné. Ces dents, qui hérissent le tord de toutes les lames, sont si nombreuses, et multiplient à un tel degré les points de contact et d'adhésion du rémora, que toute la force d'un homm très-vigoureux nę peut pas suffire pour arracher ce petit poisson du cóté du squale sur lequel il s'est accroché, tant qu'on veut l'en séparer dan un sens opposé a la direetion des lames. Ce n'es que lorsqu'on cherehe à suivre cette direction et à s'aider de l'inelinaison de ces mèmes lames, qu'on parvient aisément à détacher l'échénéis du squale, ou plutôt à le faire clisser sur la surface du requin, et à l'en éearter ensuite.

Commerson rapporte ' qu'ayant vousuite. procher son pouce du bouclier d'un rémo apvant qu'il observait, il éprouva une force de cohésion si grande, qu'une stupeur remarqua ble et même une sorte de paralysie saisit son doigt, et ne se dissipa que longtemps après qu'il eut cessé de toucher l'échénéis.

'Hanuscrits dejit cites.
Le même naturaliste ajoute, avec raison, que, dans cette adhésion du rémora au squale, le premier de ces deux poissons n'opère aucune succion, comme on l'avait pensé; et la cob́t rence de l'échénéis ne lui sert pas immédiate ment à se nourrir, puisqu il n'y a aucune com munication proprement dite entre les lames la plaque ovale et l'intérieur de la bouche et d canal alimentaire, ainsi que je m'en suis as suré, après Commerson, par la dissection attentive de plusieurs individus. Le rémora ne s'attache, par le moyen des nombreux crochets qu hérissent son bouclier, que pour naviguer san peine, profiter, dans ses déplacements, de mo vements étrangers, et se nourrir des restes de proie du requin, comme presque tous les marin le disent, et comme Commerson lui-mème l'a cru vraisemblable. Au reste, il demeure colie avee tant de constance à son conducteur, que lorsque le requin est pris, et que ce squale avant d'étre jeté sur le pont, éprouve des frottements violents contre les bords du vaisseav, il arrive très-souvent que le rémora ne cherche pas a s'échapper, mais qu'il demeure cramponné au corps de son terrible compagnon jus. qu'à la mort de ce deruier et redoutable animal. Commerson dit aussi que lorsqu'on met un rémora dans un récipient rempli d'eau de mer, plusieurs fois renouvelée en tres-peu de temps, on peut le conserver en vie pendant quelques heures, et que l'on voit presque toujours cel échénéis, privé de soutien et de corps étranger auquel il puisse adhérer, se tenir renversé sur le dos, et ne nager que dans cette position très. extraordinaire. On doit eonclure de ce fait très. curieux, et qui a été observé par un naturaliste des plus habiles et des plus dignes de foi, que lorsque le rémora change de place au milieu de l'Océan par le seul effet de ses propres forces, qu'il se meut sans appui, qu'il n'est pas transporté par un squale, par un cétacée ou par tout autre moteur analogue, et qu'il nage véritablement, il s'avance le plus souvent couché sur son dos, et par conséquent dans une position contraire à celle que presque tous les poissons présentent dans leurs mouvements. L'inspection de la figure générale des rémora, et particuliement la considération de la grandeur, de la forme, de la nature et de la situation de leur bouclier, doivent faire présumer que leur centre de gravité est placé de felle sorte qu'il les détermine à voguer sur le dos plutót que sur le ven. tre; et c'est ainsi que leur partie inférieure étant trés-fréquemment exposée, pendant leur natation, à une quantité de lumière plus considérable que leur partie supérieure, et d'ailleurs recevant ègalement un très-grand nombre de rayons lumineux, lorsque l'animal est attaché par son bouclier à un squale ou à un cétacée, il n'est pas sorprenant que le dessous du corps de ces échénéis présente une nuance aussi foncée que le dessus de ces poissons.

Lorsque les rémora ne sont pas à portée de se coller contre quelque grand habitant deseaux, ils s'accrochent à la carène des vaisseaux; et c'est de cette habitude que sont nés tous les contes que l'antiquité a imaginés sur ces animaux et qui ont été transmis avee beaucoup de soin, ainsi que tant d'autres absurdités, au travers des siècles d'ignorance.

Dumilieu de cessuppositions ridicules, il jaillit cependant une vérité 4 e'est que daas les instants oủ la carène d un vaisseau est hérissée, pour ainsi dire, d'un très.grand nombre d'échènéis, elle éprouve en einglant au milieu des eaux, une résistance semblable à celle que feraient naitro des animaux à coquille très-nombreux et attachés également à sa surface, qu'elle glisse avee moins de facilité au travers d'un fluide que choquent des aspérités, et qu'elle ne présente plus la méme vitesse. Et il ne faut pas eroire que les eirconstances où les échénèis se trouvent ainsi accumulés contre la charpente extérieure d'un navire, soient extrêmement rares dans tous les parages : il est dés mers où l'on a vu ces poissons nager en grand nombre autour des vaisseaux, et les suivre ainsi en troupes pour saisir les matières animales que I on jette hors du batiment, pour se nourrir des substances corrompues dont on se débarrasse, ct même pour recueillir jusqu'aux excréments. C'est ce qu on a observé particulierement dans le golfe de Guinée; et voilà pourquoi, suivant Barbot ', les Hollandais, qui fréquentent la côte occidentale d'Afrique, ont nommé les rémora Poissons d'ordures. Des rassemblements semblables de ces échénéis ont été apercus quel. quefois autour des grands squales, et surtout des requins, qu'ils paraissent suivre, environner et précéder sans crainte et dont on dit qu'ils sont alors les pilotes; soit que ces poissons redoutables aient, ainsi qu'on I a écrit, une sorte d'an-

- Hisi. gea. des voyazes, liv, 5, p. 262. tipathie contre le goùt ou l'odeur de leur chair, et des lors ne cherchent pas à les dévorer; soit que les rémora aient assez d'agilité, dadresse ou de ruse, pour échapper aox dents meurtrières des squales, en cherchant, par exemple, un asile sur la surface mème de ces grands animaux, à laquelle ils peuvent se coller dans les instants de leur plus grand danger, aussi bien que dans les moments de leur plus grande fatique. Ce sont encore des réunions analogues et par conséquent nombreuses de ces écheneis, que l'on a remarquées sur des rochers auxquels ils adhéraient comme sur la carère d'un vaisseau, ou le corps d'un requin, surtout lorsque l'orage avait bouleversé la mer, quils craignaient de se livrer à la fureur des ondes, et que daillews la tempéte avait déjá brisé leurs forces.

\section{L'ÉCHÉNEIS NAUGRATE '.}

Eeheneis Naucrates, Linn., Bloch, Lacep., Cuv,

On trouve dans presque toutes les mers, et partieulièrement dans celles qui sont comprises entre les deux tropiques, cette espèce d'échénéis, qui ręssemble beaucoup au rémora, et qui en differe cependant non-seulement par sagrandeur, mais encore par le nombre de paires de lames que son bouclier comprend, et pav quelques antres traits de sa conformation. On lui a domné le nom de Nauvrate, ou de Naucrates, qui en gree signifie pilote; ou conducleur de vaisseau. Les individus qui la composent, parviennent quelquefois jusqu'à la longueur de vingt-trois décimètres, suivant des mémoires manuserits cités par le professeur Bloch, et rédigés par le prince Maurice de Nassau, qui avart fait quelque séjour dans plusieurs contrées maritimes de l'Amérique méridionale. Le bouclier placé au-dessus de leur tête présente toujours plus de vingt-deux et quelquefois vingt-six paires de lames transversales et dentelées. D'ail-

'Bchène suceel. Daubenton, $E n c$, métb.-Id. Bonnaterre. 1.. de l'Enc meth. - Echeneis cauda integra, otris capilis viginti-quateor, - Hasselqnist. It. Palest. 524, n. 68. - Gronov. Zooph., p. 75, 0. 252 fet Mus. 1, p. 15, n. 34. Echeneis fuscus, pinnis posierioribus albo margioatis.

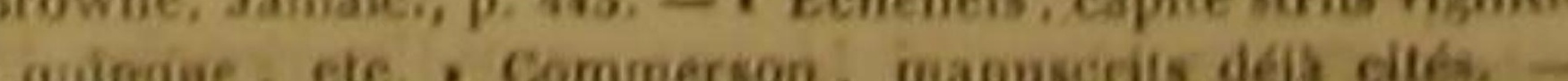
quinque, ete. Commerson, manuscrits deja cites.
Echeneis in estremo subrotanda. , séta, Mus. 3 , tab. 35 ,

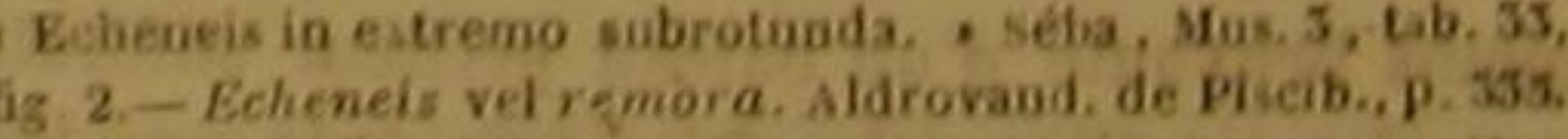
- Jonston. de Piscibus, p. 16. Iab. 4, fig.5. - tperewaikia, et piraquiba. Marezr. Brasil., p. 180. - Willughby, lehth.

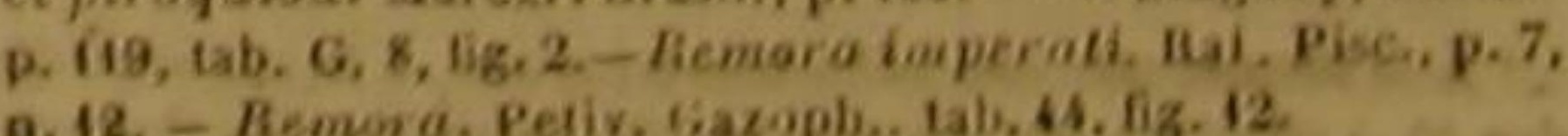


leurs la nageoire de la queue du naucrate, au jistances, ou plonger à de grandes profondeurs. lieu d'être fourchue comme celle du rémora, est Mais voici le piége que l'on tend de loin à la arrondie ou rectiligne. De plus, les nágeoires première tortue que l'on aperçoit endormie. la du dos et de l'anus, plus longues à propor- remet dans la mer le naucrate garni de sa lon. tion que sur le rémora, montrent un peu la gue corde: l'animal, délivré ên partie de sa forme d'une faux '.

La figure de l'une de ces deux nageoires est semblable à celle de l'autre. L'ouverture del'anus est allongée, et située à peu près vers le milieu de la longueur totale de l'échénéis; et la ligne latérale, composée de points très-peu sensibles, s'approche d'abord du dos, change ensuite de direction, et tend vers la queue à l'extrémité de laquelle elie parvient.

Le uaucrate offre des habitudes très-analogues á celles du rémora; on le rencontre de même en assez grand nombre autour des requins. Ses mouvements ne sont pas toujours faciles: mais comme il est plus grand et plus fort que le rémora, il se nourrit quelquefois d'animaux à coquille et de crabes; et lorsqu'il adhère à un corps vivant ou inanimé, il faut des efforts bien plus grands pour l'en détacher que pour séparer un rémora de son appui.

Commerson, qui l'a observé sur les rivages de l'lle de France, a éerit que ce poisson fréquentait très-souvent la cote de Mozambique, et qu'auprès de cette cotte on employait pour la pêche des tortues marines, et d'une manière bien remarquable, la facilité de se cramponner dont jouit cet échénéis. Nous cromponner dont jouit cet échénéis. Nous croyons devoir rapporter ici ce que Commerson a recueilli au sujet de ce fait très-curieux, le seul de mème genre que l'on ait encore observé.

On attache à la queue d'un naucrate vivant, un anneau d'un diamètre assez large pour ne pas incommoder le poisson, et assez étroit pou ètre retenu par la nageoire caudale. Une cord très-longue tient à cet anneau. Lorsque l'corde néis est ainsi prépat anneau. Lorsque l'échévase pleinsi préparé, on le renferme dans un vase plein d'eau salee, qu'on renouvelle trèssouvent; et les pécheurs mettent le vase dan leur barque. Ils voguent ensuite vers les dans ges fréquentés par les tortues mers les paratues ont l'habitude les tortues marines. Ces torface de l'habitude de dormir souvent à la surface de l'eau sur laquelle elles flottent; et leur sommeil est alors si léger, que l'approche moins bruyante d'un bateau pécheur suffirai pour les réveiller et les fairé fuir à de grandes 'A la membrane dés branchies 9 rayons, Det 4 ou 8 , I celle de ranus 40 , a celle, a chacuae des thoracicaptivité, tous les côtés. On lui lâche corde égale à la distar marine le la barque des pepare la tortue marine de la barque des pécheurs. Le naucrate, retenu par ce lien, fait d'abord de nouveaux ef. forts pour se soustraireà la main qui le maitrise; sentant bientót cependant qu'il s'agite en vain et qu'il ne peut se dégager, il parcourt tout le cercle dont la corde est en quelque sorte le rayon, pour rencontrer un point d'adhésion, et par conséquent un peu de repos, II trouve cette sorte d'asyle sous le plastron de fa tortue flot. tante, s'y attache fortement par le moyen de son bouclier, et donne ainsi aux pècheurs, aux quels il sert de crampon, le moyen de tirer eux la tortue en retirant la corde.

On voit tout de suite la différence remarqua ble qui sépare cet emploi du nauerate, de lí sage analogue auquel on fait servir plusieurs oiseaux d'eau ou de rivage, et particulièrement des cormorans, des hérons et des butors. Dan la peche des tortues faite par le moven d'u échénéis, on n'a sous les yeux qu'un poisson con traint dans ses mouvements, mais conservan la tendance, faisant les mémes efforts, répétan les mêmes actes que lorsqu'il nage en liberté, et n'étant qu'un prisonnier qui cherche a briser ses chaines, tandis que les oiseaux élevés pour la péche sont altérés dans leurs habitudes, et modifiés par l'art de I'homme, au point de servir en esclaves volontaires ses caprices et besoins. On a pu entrevoir dans deux de nos Discours géhéraux ', la cause de cette difference, qui mérite toute l'attention des physiciens.

\section{L'ÉCHÉNÉIS RAYÉ 2}

Echeneis lineata, Schn., Lacep., Cuv.

Le naturaliste anglais Archibald Menzies 2 donné, dans le premier volume des de la société linnéenne de Londres, la description de ce poisson, qui differe des deux éché-

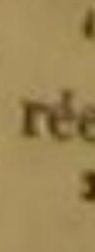

Arebibald Menzies. Trans. de la Soc. lion. de Londres.

nêis dont nous venons de parler, par le nombre des lames qui composent sa plaque ovale. En effet; cet osseux n'a que dix paires de stries transversales, dans l'espèce de bouclier dont sa tête est coúverte. D'ailleurs sa nageoire caudale, au lieu d'ètre fourchue comme celle du rémora, ou rectiligne ou arrondie comme celle du naucrate, se termine en pointe. Sa máchoire inférieure est plus longue que la supérieure. Les dents des deux mâchoires sont petites, ainsi que les écailles qui revêtent l'animal. La couleur génerale est d'un brun foncé, et relevée de chaque eòté par deux raies blanches qui s'étendent depuis les yeux jusque vers le bout de la queue. L'échénéis rayé se trouve dans le grand Océan, connu sous le nom de mer Pacifique ; on l'y a vu adhérer à des tortues. L'individu déeri par l'auteur anglais avait treize centimètres do long'.

\section{OUATRE-VINGT-DEUXIEMEE GENRE} LES MACHOURES ?.

Deux nageoires sur te dos: la queue deux fois phus longue que le corps.

esres. cascrikes.

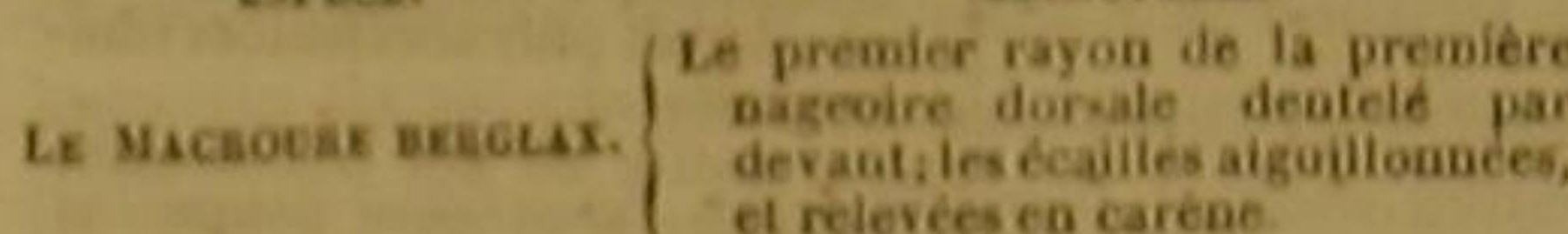
-

LE MACROURE BERGLAX ?

Macrourus rupestris, Bl., Cuv.; Macrourus Berglax, Lacep.; Lepidoleprus calorbynchus, Kisso.

Auprès des rivages du Groenland et de l'Islande, habite ce macroure que Bloch et Gunner ont cru, avec raison, devoir placer dans un genre particulier. La longueur de sa queue sépare sa forme de celle des autres poissons thoracins, et donne un caractère particulier à ses habitudes, en accroissant l'étendue de son principal instrument de natation, et en douant cet osseux d'une force particulière pour se mouvoir avec vitesse au milieu des mers hyperbo-

is la membrane branchiale 10 rayons, a la hageoire dorsale 35 , a chacune des peciorales is, a chacune des thoraci

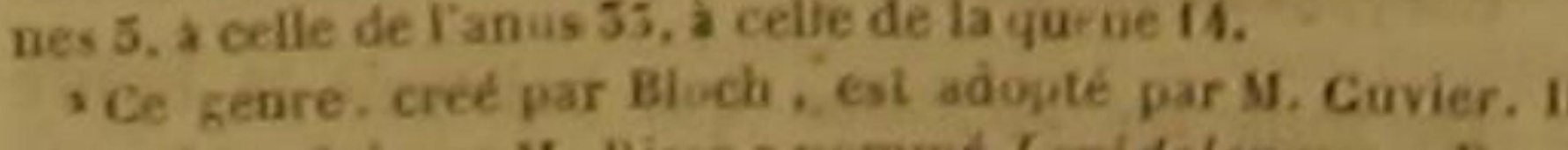
répond a celai que II. Hisso a nommé L-pidoleprus. D.

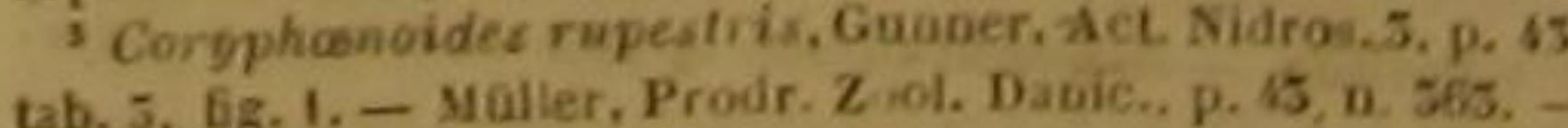

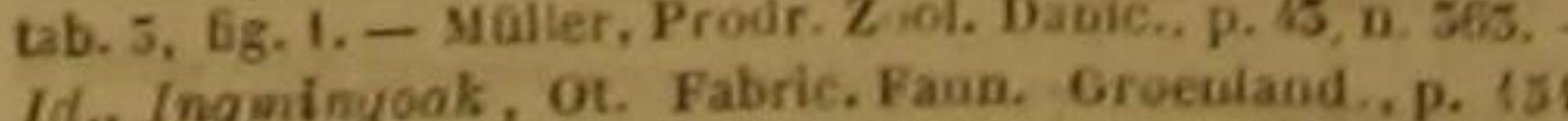
I., ii. - Fivkligen brosme. - Ingminaicel, Cranz, Groed

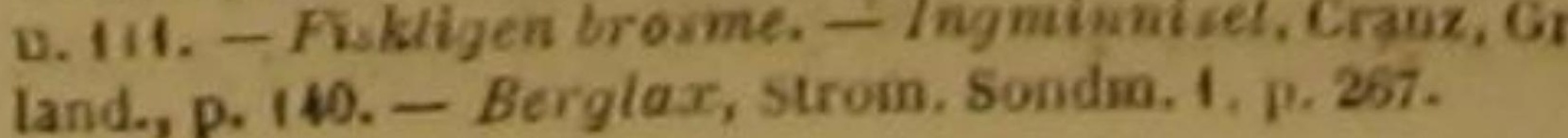

réennes. Long d'un mètre, ou environ, il four-
nit un aliment utile et quelquefois mème nit un aliment utile et quelquefois mème
abondant aux peuplades de ces cótes groenlandaisés et islandaises, si peu favorisées par la nature, et condamnées pendant une si grande partie de l'année à tous les effets funestes d'ùn froid excessif. Son nom de Berglax vient des rapports qu'il a paru présenter avec le saumon que I'on nomme Laehs ou Lax dans plusieurs langues du Nord, et des rochers au milieu desquels il séjourne fréquemment. Sa tète est grande et large; ses yeux sont ronds et saillants; les ouvertures des narines doubles de chaque coté; et les deux màchoires proprement dites, à peu près égales. Cependant le museau est trés-avancé au-dessus de la máchoire superieure, qui est armée ordínairement de cinq rangées de dents; et la máchoire inférieure, qui n'en montre que trois rangées, est garnie d'un filament ou barbillon semblable, par sa forme, sa nature et sa longueui, à celui de plusieurs gades. La langue est courte, épaisse, cartilagineuse, blanche, et lisse comme le palais. Un opereule d'une seule piece couvre une grande ouverture branchiale, L'anus est plus près de la tête que de l'extrémité de la queue. La ligue latérale se rapproche du haut du corps, dans une grande partie de sa direetion. Deux nageoires s'élèvent sur le dos; la seconde est réunie avee celle de la queue, quí touche aussi celle de l'anus '; et les écailles qui recouvrent ce Macroure, ou, ce qui est la mème chose, ce poisson à longue queue, sont relevées par une arète qui se termine en pointo ou en aiguillon.

Présentant d'ailleurs un éclat argentin, ces écailles donnent une teinte très-brillante au berglax, dont la partie supérieure montre uéanmoins une couleur plus foncée ou plus bleuâtre que l'inférieure; et les nageoires ajoutent quelquefois à la parure de l'animal, en offrant une nuance d'un assez beau jaune, et une bordure bleue qui fait ressortir ce fond presque doré.

Le berglax fraye assez tard. On te péche avec des lignes de fond ${ }^{2}$ : lorsqu'il est pris, il se débat violemment, agite àvec force sa lon-

'A la membrane des branchies 6 rayons, a la premiere na. geoire da dos 11 , a la ne onde 124 . a chacune des pe itora. les 19 , a chacune des thoracinas 7 , a celle de Yanus 1 is. ? Voyez ce que uous avous dit des ligues de foud, dan l'bisioire de la Murene congre. 
gue queue, anime ses gros yeux, et se gonfle d'une manière assez analogue à celle que nous a vons observée en parlant des tétrodons.

\section{QUATRE-VINGT-TROISIEMME GENRE} LES CORYPHĖNES'

Le sommel de la téte très-comprimé et comme tranchan por le haut, ou très-eleré et finissant sur le decant par un plan presque vertical, ou termine anteriewremen par un quart de cercle, ou garni d'ecailles semblables
$\dot{a}$ celles du dos; a celles du dos; une seule nageoire dorsule, et cette nageoire du dos presque aussi longue que le corps et
la queur.

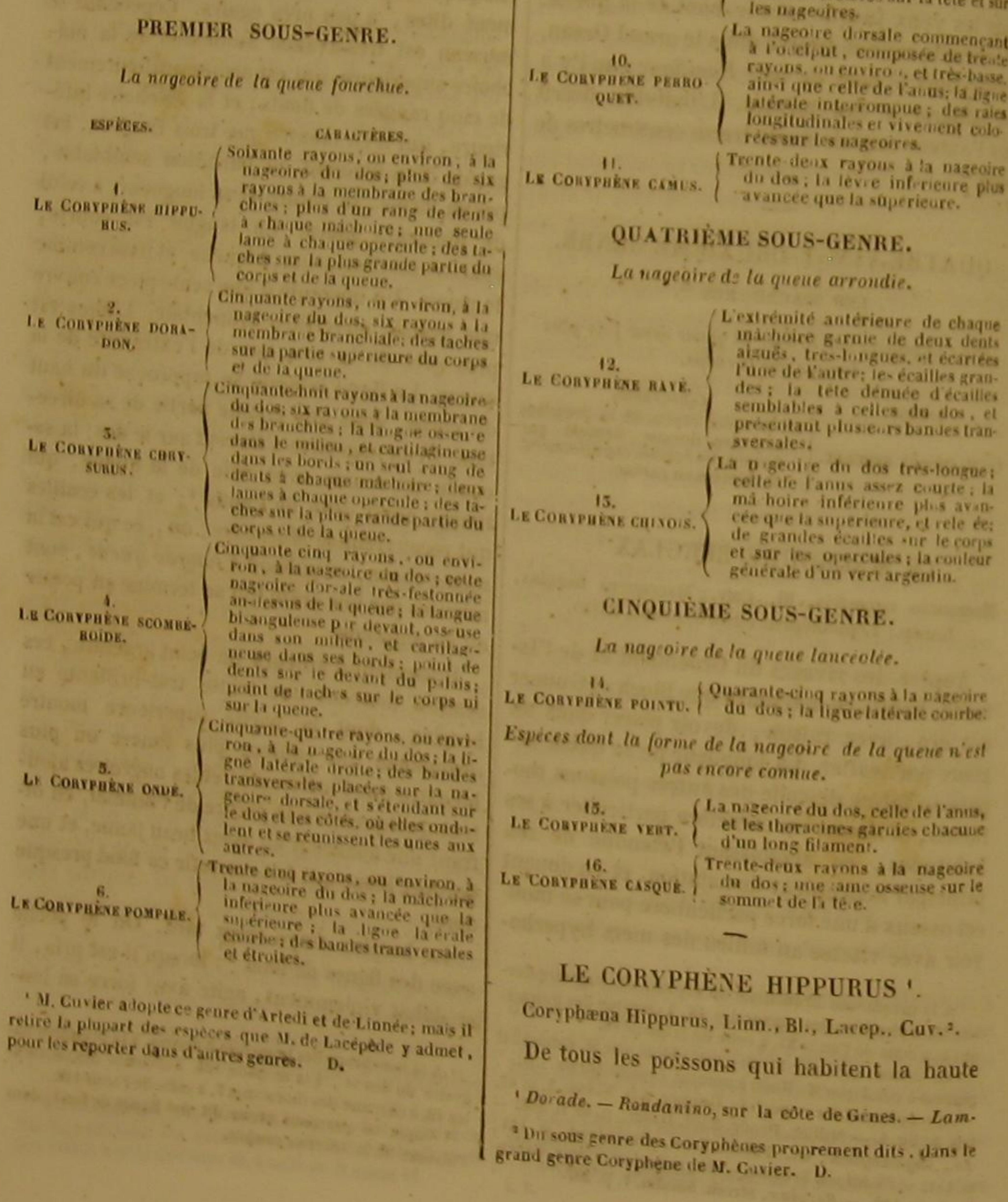

\section{DES POISSONS.}

mer, aucun ne parait avoir reçu de parure / ou de Queue de cheval, donné à l'une des plus plus magnifique que les coryphènes. Revètus belles espèces de coryphène, ne vienne de la d'écailles grandes et polies, réfléchissant avec conformation de cette mème nageoire dorsale, vivacité les rayons du soleil, brillant des cou- dont les rayons très-nombreux ont quelqués leurs les plus variées, converts d'or, pour ainsi dire, et resplendissant de tous les feux du diamant et des pierres orientales les plus préeieuses, ils ajoutent d'autant plus, ces coryphènes privilégiés, à la beauté du spectacle de l'Océan, lorsque, sous un ciel sans nuages, de légers zéphyrs commandent seuls aux ondes, qu'ils nagent fréquemment à la surface des eaux, qu'on les voit, en quelque sorte, sur le sommet des vagues, que leurs mouvements très-agiles et très-répétés multiplient sans cesse les aspects sous lesquels on les considère, ainsi que les reflets éclatants qui les décorent, et que, voraces et audacieux, ils entourent en grandes troupès les vaisseaux qu'ils rencontrent, et s'en approchent d'assez près pour ne rien dérober à l'cil du spectateur, de la variété ni de la richesse des nuances qu'ils étalent. C'est pour indiquer cette prééminence des coryphènes dans l'éelat et dans la diversité de leurs couleurs, ainsi que dans la vélocité de leur course et la rapidité de leurs évolutions, et pour faire allusion d'ailleurs à la hauteur à laquelle ils se plaisent à nager, que, suivant plusieurs écrivains, ils ont reçu le nom générique qu'ils portent, et qui vient de deux mots grees, dont l'un, roouphn, veut dire sommet, et l'autre, vis, signifie je nage. On a également prétenda que la dénomination de coryplène, employée dès le temps des anciens naturalistes, désignait une des formes les plus rémarquables des poissons dont nous parlons, c'est-à-dire ta. position de leur nageoire dorsale, qui commence très-près du haut de la téte. Ouelque opinion que l'on adopte áccet égard, on ne peut pas douter que le nom particulier d'Hippurus,

pugo, en Espazne. - Dolptín, eu Angleterre. - Dorado, dans pins. autres endroits de l'Earape. - Coryphiene dofin. Daubenton. Enc. meth. $-I$ d. Bonnaterre, pl. de I'Enc. méth, - osbeck, It. 507. - - Coryphas na cauda bifured, etc.,

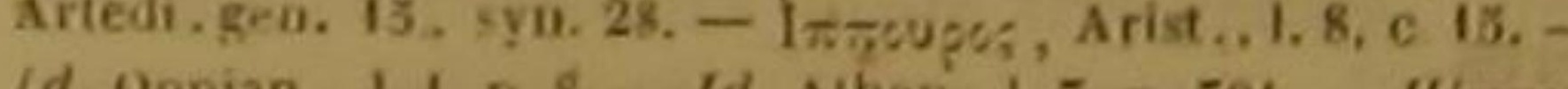
Id. Oppian., 1. 1. p. 8. -Id. Aiken., I. 7, p. 304,-Hippu-

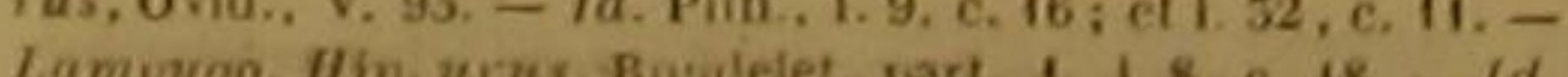

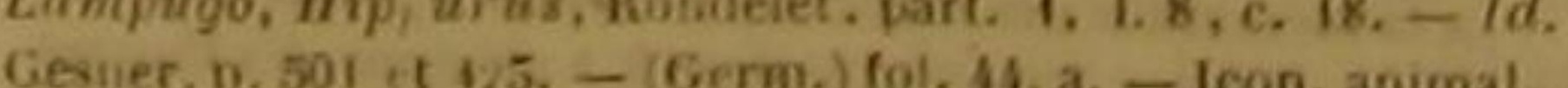

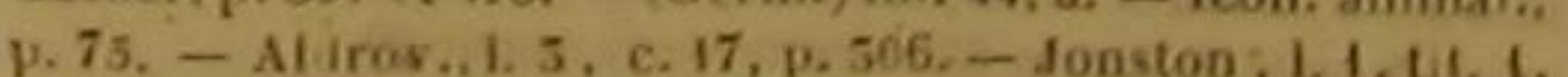
c. 1, a, 6. tab. 1. - Chariel, p. 124. - Willugbby, lehib," p. 215 , tab. O, 1, fig. 3. - Kai, p. 100, n. 1. - Equisele, Eiquiselis, Gaz. Arist., I. 4, c. 10; E1 1. 8, c. 15. - . Hippopise, $5,0,55$, 1 raichialibus deanratis, ele., Kiein, Miss. pise. 5, p. 53, n. 1,2 . rapports avec les crins du cheval. Cet hippurus, qui est l'objet de cet article, parvient quelque. fois jusqu'à la longueur d'un mètre et demi. Son corps est comprimé aussi bien que sa tète; l'ouverture de sa bouche très-grande; sa langue courte; ses lèvres sont épaisses; ses mâchoires garnies de quatre dents aiguës et recourbées en arrière. Un opercule composé d'une seule pièce couvre une large ouverture branchiale '; la ligne latérale est fléchie vers la poitrine, et droite ensuite jusqu'à la nageoire caudale, qui est fourchue; les écailles sont minces, mais fortement attachées.

A l'indication des formes ajoutons l'exposition des nuances, pour achever de donner une idée de ce superbe coryphène, Lorsqu'il est vivant, dans l'eau, et en mouvement, il brille sur le dos d'une couleur d'or très-éclatante, mélée à une belle teinte de bleu ou de vert de mer, que relèvent des taches dorées et le jaune doré de la ligne latérale. Le dessous du corps est argenté. Les nageoires pectorales et thoracines présentent un jaune très-vif, à la splendeur duquel ajoute la teinte brume de leur base; la nageoire caudale, qui offre la mème nuance de jaune, est d'ailleurs bordée de vert; celle de lanus est dorée; et une dorure des plus riches fait remarquer les nombreux rayons de la nageoire dorsale, au milicu de la membrane d'un bleu céleste qui les réunit.

C'est ce maguifique assortiment de couleurs d'or et d'azur qui trahit de loin le coryphène hippurus, lorsque, cédant à sa voracité naturelle, il poursuit sans relache les trigles et les exocets, dont il aime à se nourrir, contraint ces poissons volauts à s'élancer hors de l'eau, les suit d'un regard assuré, pendant que ces animaux effrayés parcourent dans Pair leur demi-cercle, et les reçoit, pour ainsi dire, dans sa gueule, à l'instant ou, fatigués d'agiter leurs nageoires pectorales, et ne pouvant plus soutenir dans l'atmosphère leur corps trop pesant, ils retombent au milieu de leur fluide natal sans pouvoir y trouver un asile. Non-seulement les hippurus cherchent ainsi 'A la membrane des branchies 10 rayons, a la nageoire da
dos 60 , a chacune des pectorales 20 , a chacune des thoraci. dos 6 , a chacune des pectorales 20 , a chiacuar der thoraci 
à satisfaire le besoin impérieux de la faim qui autres. Il en est séparé par le nombre des les presse, au milieu des bandes nombreuses rayons de la nageoire dorsale, qui n'en rende poissons moins orauds et plus faibles qu'eux; ferme que cinquante ou environ, par celui des mais encore, peu difficiles dans le ehoix de rayons de la membrane des branchies, qui n'en leurs aliments, ils voguent en grandes troupes comprend que six, pendant que la membrane autour des vaisseaux, les accompagnent avec branchiale de l'hippurus en présente sept et constance, et saisissent avec tant d'avidité tout quelquefois dix, et de plus par la disposition ce que les passagers jettent dans la mer, qu'on des taches couleur d'or qui ne sont disséminées a trouvé dans l'estomac d'un de ces poissons que sur la partie supérieure du corps et de la jusqu'à quatre clous de fer, dont un avait plus queue. D'ailleurs, en jetant les yeux sur ume de quinze centimètres de longueur.

On profite d'autant plus de leur gloutonnerie pour les prendre, que leur chair est ferme et tres-agréable au goút. Pendant le temps de leur frai, c'est-à-dire dans le printemps et dans l'automne, on les péche avec des filets aupres des rivages, vers lesquels ils vont déposer ou féconder leurs oufs; et dans les autres saisons où ils préferent la haute mer, on se sert de lignes de fond ', que la voracité de ces cory. phènes rend tres-dangereuses pour ces animaux. Ce qui fait d'ailleurs que leur recherche est facile et avantageuse, c'est qu'ils sont en tris-grand nombre dans les parties de la me qui leur conviennent, parce qu indépendam. ment de leur fécondité, ils croissent si vite, u'on les voit grandir d'une manière trésmompte dans les nasses ou on les renferme après les avoir pris en vie.

Ils vivent dans presque toutes les mers chaudes et même tempérées. On les trouve non-seulement dáns le grand Océan équatorial, improprement appelé mer Pacifique, mai encore dans une grande portion de l'Océan lantique, et jusque dans la Méditerranée.

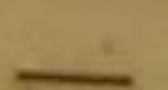

\section{LE CORYPHENE DORADON 2 .}

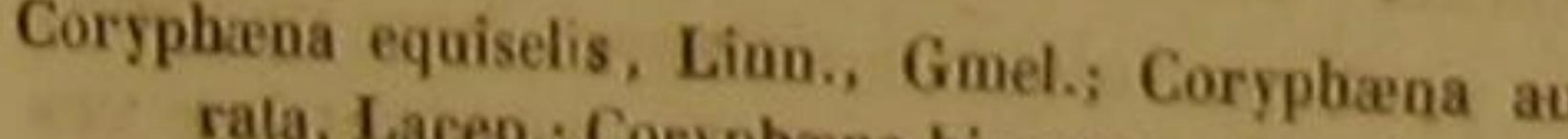
rata, Lacep; Corypheoa bippuras, Cuv. ${ }^{3}$.

Nous conservous ce nom de Doradon à un coryphene qui a plusieurs traits communs avec l'hippurus, mais qui en differe par plusieurs "Noyez, sur les tigues de foud, Iarticle de ta Raie bou.
dée, et celui de ta Murcine conyre.

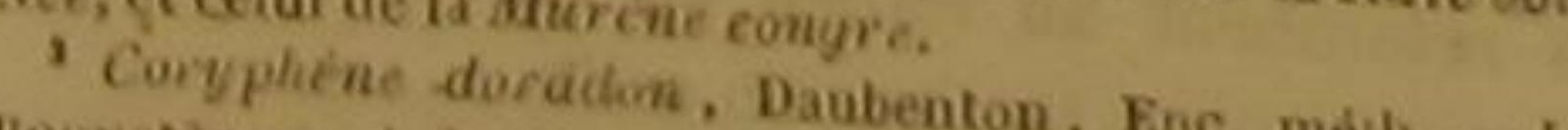
Hozusterre, pl. de I'kac, méth. - Dorado, Osbeck. - Id. tot, p. 160 - W Waregrav, Brasil., p. 160. - Id. Piso, p. 100, 160. - Williughby, Ichth., p. 24. . - Rai, Pisc.,
p. Uiffere specifitiner, il r'est pas bien constant que ce poisson viffere spéeifiquemeat du précédent. B. peinture exécutée d'apres les dessins coloriés et originaux du célebre Plumier, laquelle fai partie de la belle collection de peintures sur vélin déposées dans le Muséum d'histoire naturelle, et qui représente avec autant d'exactitude que de vivacité les brillantes nuances du doradon, on ne peut pas douter que ce dernie coryphène n'ait chacun des opercules de ses branchies composé de deux lames, pendan que l'opercule de l'hippurus est formé d'une seule pièce, On pourra s'en assurer, en examinant la copie de cette peinture, que nous avons eru devoir faire graver ${ }^{-}$. Au reste, l'agilité, I voracité et les autres qualités du doradon, ainsi que les diverses habitudes de ce poisson, sont à peu près les mèmes que celles de l'hippurus; et on le trouve également dans un grand nombre de mers chaudes ou tempérées.

\section{LE CORYPHENE CHRYSURUS}

$$
\text { Coryphæua chrysurus, Lacep. '. }
$$

C'est dans la mer Pacifique, ou plutót dans ryphène a été vu par Commerson, qui accompagnait alors notre célebre navigateur Bougainville. Il Ya observé sur la fin d'avril de 1768 , vers le $16^{\circ}$ degré de latitude australe, et le $170^{\circ}$ de longitude. Au premier coup d'ceil, on croirait devoir le rapporter à la mème espèce que l'hippurus; mais en le décrivant daprès Commerson, nous allons montrer aisement qu'il en différe par un grand nombre de caractères.

A A membrane des branchies 6 rayons, a la nazeoire dor. 4. 26 , a celle de ranus 25 a celte de la queue 20 . Cory his chry 25 a c.... Und queue 20. vescente, guttuksque lateralibus, caruleis, candá er ; dorso, de la mer d Commerson, manuscrits deja cites. - Doral le grand Océan équatorial, que ce superbe co-
Toute la surface de ce coryphène, et particulièrement sa queue, brillent d'une couleur d'or tres-éclataute. Quelques nuances d'argent sont seulement répandues sur la gorge et la poitrine; et quelques teintes d'un bleu cèleste jouent, pour ainsi dire, au milieu des reflets dorés du sommet du dos. Une belle couleu d'azur parait aussi sur les nageoires, principalement sur celle du dos et sur les pectorales elle ést relevée sur les thoracines par le jaune d'une partie des rayons, et sur celle de l'anus par les teintes dorées avee lesquelles elle y est mêlée; mais elle ne se montre sur la nageoire de la queue que paux y former un léger liséré, et pour y encadrer, en quelque sorte, l'or resplendissant qui la recouvre, et qui a indiqué le nom du coryphene '.

Ajoutons, pour achever de peindre la magniflque parure du chrysurus, que des taches bleues et lentieulaires sont répandues: sans ordre sur le dos, les cotés et la partie inférieure du poisson, et scintillent au milieu de l'or, comme autant de saphirs enchâssés dans le plus riche des mètaux

L'admirable vêtement que la nature a donné au chrysurus, est done assez différent de celui de l'hippurus, pour qu'on ne se presse pas de les confondre dans la même espèce. Nous ailons les voir séparés par des caractères encore plus constants et plus remarquables.

Le corps du chrysurus, très-allongé et trèscomprimê, est terminé dans le haut par une sorte de carène aigue qui s'étend depuis la tête jusqu'à la nageoire de la queue; et une semblable carène règne en dessous, depuis cette même nageoire caudale jusqu'à l'anus.

La partie antérieure et supérieure de la tête représente assez exactement un quart de cercle, et se termine dans le haut par une sorte d'aréte aiguê.

La mâchoire inférieure, qui se relève vers la supérieure, est un pen plus longue que cette derniere. Toutes les deux sont composées d'un os que hérissent des dents très-petites, trescourtes, très-aiguès, assez écartées I'une de l'autre, placees comme celles d'un peigne, et très-différentes, par leur forme, leur nombre et leur disposition, de celles de l'hippurus.

On voit d'ailleurs deax tubercules garnis de dents très-menues et très-serrées auprès de trois autres tubercules presque semblables vers le milieu du palais, et un sixieme tubercule très-analogue presque au-dessus du gosier.

La langue est large, courte, arrondie par de vant, osseuse dans son milieu, et eartilagineuse dans ses bords. L'ouverture de la bouche est peu étendue : on compte de chaque cóté deux orifices des narines; une sorte d'anneau membraneux entoure l'antérieur. Les opercules des branchies sont, comme la téte, dénués de petites écailles; ils sont de plus assez grands, et composés chacun de deux pièces, dont celle de devant est airondie vers la queue, et dont celle de derrière se prolonge également vers la queue, en appendice quelquefois un peu recourbè.

Six rayons aplatis soutiennent de ehaque côté une mémbrane branchiale, au-đessous de laquelle sont placées quatre branchies trésrouges, formées chacune de deux rangées de filaments allongés : la partie concave de l'are de cercle osseux de la premiere et de la seconde est garnie de longues dents arrangées comme celles d'un peigne; la concavité de l'are de la roisicme et de la quatrieme ne présente que des aspérités.

La nageoire du dos, qui commence au-dessus des yeux, et s'étend presque jusqu'á celle de la queue, comprend cinquante-huit rayons '

les huit premiers sont d'autant plus longs qu'ils sont situés plus loin de la téte, et la longueur des autres est au contraire d'autant moindre, quoique avec des differences peu sensibles, qu'ils sont plas prés de la nageoire caudale.

L'anus est placé vers le milieu de la longueur totale de l'animal ; et l'on voit, entre cet orifice et la base des nageoires thoracines, un petit sillon longitudinal.

La nageoire de la queue est fourchue, comme celle de tous les cory phenes du premier sous-genre; la ligne laterale serpente depuis le haut de l'ouverture branchiale, où elle prend son origine, jusqu auprès de l'extrémité des nageoires pectorales, et atteint ensuite la nageoire de la queue en ne se flechissant que par de légeres ondulations; et enfin les écailles qui recouvrent le poisson, sont allongées, arrondies 
a leur sommet, lisses, et fortement attachées. On a done pu remarquer sept traits principaux par lesquels le chrysurus differe de l'hippurus : premièrement, le nombre des rayons n'est pas le mème dans la plupart des nageoires
de ces deux coryphènes; secondement, la membrane branchiale du chrysurus ne renferme que six rayons, il y en a toujours depuis sept jusqu'ă dị à celle de l'hippurus; troisièmement, le dos du premier est caréné, celui du second est convexe; quatrièmement, l'ouverture de la bouche est peu ẻtendue dans le chrysurus, elle est très-grande dans I'hippurus; cinquièmement, les dents du chirysurus sont conformées et placées bien différemment que celles de I'hippurus; sixièmement, l'opercule branchial du chrysurus comprend deux lames, on ne voit qu'une pièce dans celui de I'hippurus; i et septièmement, nous avons déjà montré une distribution de couleurs bien peu semblabte sur l'un et sur l'autre de ces deux coryphènes. IIs doisent done constituer deux espèces differentes, dont une, e'est-à-dire celle que nous decrivons, est encore inconnue des naturalistes; car elle est aussi très-distiucte du coryphène doradon, ainsi qu'on peut facilement s'en convaincre en comparant les formes du doradon vaincre en compara
celles du chrysurus.

$\Lambda u$ reste, les habitudes du coryphène qui fait le sujet de cet article, doivent se rapprocher beaucoup de celles de Phippurus. En effet, Commerson ayant ouvert un chrysurus qui avait plus de sept décimètres de longrus qui trouva son estomac qui était allongé et membraneux, rempli de petits poissons volants, d'autres poissons tres-peu volumineux, II vitaussisons tres-peu volumineux.

Il vitaussi s'agiter au milieu de cet estomac, et dans une sorte de páte ou de chyme, plusieurs vers filiformes, et de la longueur de deux ou trois centimètres.

Ce voyageur rapporte d'ailleurs dans les ma auserits qui m'ont été confeús dans les mapar Buffon, que lorsque les mans le temps la pêche ont pris un chrysurus, ils exercés à a une corde, et lo chrysurus, il' l'attachent vaisseau, de et le suspendent à la proue du vaisseau, de manière que l'animal parait étre encore en vie et nager à la surface de la mer. Ils attirent et réunissent, par ce procédé, un assez grand nombre d'autres chrysurus, qu'ils peuvent alors percer facilement qu'ils fouine'.

'La fouine eat un peigue de fer allachée a un long manche.
Commerson ajoute que les chrysurus l'emportent sur presque tous les poissons de mer par le bon goút de leur chair, que l'on prépare de plusieurs manières, et particulièrement ave du beurre et des câpres.

\section{LE CORYPHÉNE SCOMBÉROIDE'}

Coryphæna scomberöides, Lacep. ${ }^{2}$.

Nous avons trouvé dans les manuscrits de Commerson la deseription de cette espèce de coryphène, que ce savant voyageur avait vue, au mois de mars 1768 , dans la mer du Sud, ou, poûr mieux dire, dans le grand Océan équatorial, vers le $18^{\circ}$ degré de latitude australe, et le $134^{e}$ degré de longitude, et par conséquent a une distance de la ligne trés-peu diffe. rente de celle où il observa, un ou deux mois après, le coryphène cbrysurus.

Le scombéroide est d'une longueur intermé. diaire entre celle du scombre maquereau et celle du hareng. Sa couleur totale est argentée et brillante; mais elle n'est pure que sur les côtés et sur le ventre. Une teinte brune mélée de bleu céleste est rêpandue sur le dos; cette teinte s'étend aussi sur le sommet de la téte, où elle est plus foncée, plus noirâtre, et mélée avee des reflets dorés que l'on voit également autour des yeux et sur les lames des opercules. Toutes les nageoires sont entierement brunes, excepté les thóracines, dont la partie extérieure est blanche, et les pectorales, qui sont un peu dorées.

La måchoire supérieure est plus courte que l'inférieure. Les os qui composent l'une et l'autre, sont hérissés d'un si grand nombre de pe-

On donne aussi ce nom, aiois que celui de forne et de on ajuste ensemble denx, troinée par un dard. Quelyedoas ames, pour former une fouonne, on grand nombre d autres fois on eaploie ces noms pour desizner ou powin. Furche. On attache finstrumeat au but d'une perm be, et fond de leen pour percer les poissons que lon apercoit a lond de leau, ou qui sont caches dans la vase, les enfiler et
les retirer. $\therefore$ Coryph

Clongissima radiongenteus. . - . Coryphus pinná dorsal tulo in media lingua. quinquaginta-yuinque, osse quadra. ccilatus, pinnis fu-cis, dorsali radio-um argentens, immaCarme, anali viginti quibyue, candar bifured fuscessente. glasse on lonanuscrits déja cités. - Osteoglossus, ostéo W.: ibid.
.

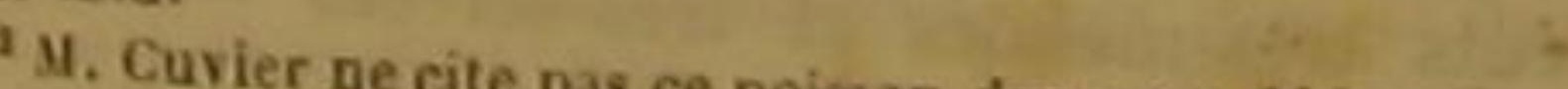
M. Cuvier ne cite pas ce poisson dans son Mémoire
les Coryphénes, ete. Mém. du Mus.. t. I, p. 524 et suir. tites dents tournées en arrière, qu'ils montrent la surface d'une lime, et qu'ils tiennent l'ani, mal facilement suspendu à un doigt, par exemple, que lon introduit dans la cavité de la bouche.

L.a langue a une figure remarquable; elle ressemble en quèlque sorte à un ongle humain: elle est large, un peu arrondie par devant, et néanmoins terminée par un angle à chaque bout de son are antérieur; de plus, elle présente dans son milieu un os presque earré, et couvert de petites aspérités dirigées vers le gosier; sa circonférence est formée par un cartilage qui s'amineit vers le bord; et un frein large et épais la retient par-dessous.

La voute du palais est entièrement lisse, excepté l'endroit le plus voisin du gosier, où l'on voit de petites élévations osseuses et dentieulées.

Deux lames arrondies par derrière, grandes et lisses, composent chaque opercule; six rayons soutienuent la membrane branchiale; et les branehies sont assez semblables, par leur nombre et par leur conformation, à celles du shrysurus.

La ligne latérale offre plusieurs sinuosités qui décroissent à mesure qu'elles sont plus voisines de la nngeoire eaudale.

Les nagcoires thoracines sont réunies $a$ leur base par une membrane qui tient aussi à un sillon longitudinal placé sous te ventre, et dans lequel le poisson peut coucher $a$ volonté ces mèmes nageoires. Elles renferment cbacune einq ou six rayons.

Le dessous de la queue est terminé par une carène très-aiguê.

La nageoire dorsale rigne depuis l'oceiput jusque vers l'extrémité de- la queue; elle est festonnée dans sa partie postérieure, de manière à imiter les très-petites nageoires que l'on voit sur la queue des scombres: la nageoire de l'anus offre une conformation analogue; et ces traits particuliers au poisson que nous décrivons, ne servant pas peu à le rapprocher des scombres, avec lesquels d'ailleurs on peut voir, dans cette histoire, que les coryphènes ont beaucoup de rapports, j'ai eru devoir nommer Scomberoide, l'espece que nous cherchons, dans cet article, à faire connaitre des naturalistes '.
Commerson vit des milliers de ces scombéroides suivre les vaisseaux français avee assiduité, et pendant plusieurs jours. Ils vivaient de très-jeunes ou très-petits poissons volants, qui, pendant ce temps, voltigeaient autour des navires comme des nuées de papillons, qu'ils ne surpassaíent guère en grosseur; et c'est à cause de la petitesse de leurs dimensions, qu'ils pouvaient servir de proie aux scombéroides, dont la bouche étroite n'aurait pas pu admettre des animaux plus gros. En effet, l'un des plus grands de ces coryphènes observés par Commerson n'avait qu'environ trois décimètres de longueur. Cet individu était cependant adulte et femelle.

Au reste, les ovaires de cette femelle, qui avaient une forme allongée, oceupaient la plus grande partie de l'intérieur du ventre, comme dans les cyprins, et contenaient une quantite innombrable d'oufs; ce qui prouve ce que nous avons déjá dit au sujet de la grande fécondité des coryphènes.

\section{IE CORYPHENE ONDÉ}

\section{Coryphæna fasciolata, Pallas, Linn., Gmel; Coryphena} undulata, Lacep. '

Pallas a décrit le premier cette espèce de coryphène. L'individu qu'il a observé et qui avait été péché dans les eaux de l'ile d'Amboine, Les formes et les couleurs de cet animal étaient élègantes : très-allongé et un peu comprimé, il montrait sur la plus grande partie de sa surface une teinte agréable qui réunissait la blancheur du lait a l'éclat de l'argent; une nuance grise variait son dos; la nageoire dorsale et celle de lanus étaient distinguées par de petites bandes transversales brunes; les bandelettes de la première de ces deux nazeoires s'étendaient sur la partie supérieure de l'animal, y ondulaient, pour ainsi dire, s'y réunissaient les unes aux autres, disparaissaient vers la partie inférieure du poisson; et la nageoire de la queue, qui était fourchue, présentait un croissant tresbrun.

dos 55 , a chacune des pectorales 48 , a chacune festhore el. nes 6, a celle de l anus 25 , 4 celle de la queue, qui eat faur chue, is. 'Coryphiene ondoyant. Bonnsterre, pl. de IEne, ineth. n'était long que de cinq centimètres ou environ. "sh. Cusier rapporie ce poison au pompile decrit ciapres, 
HISTOIRE NATURELLE

D'ailleurs ce coryphène avait des yeux assez grands; l'ouverture de sa bouche, étant trèslarge, laissait voir facilement une langue lisse, et arrondie par devant; un operçule compose de deux lames non découpées couvrait de chaque côté un grand orifice branchial ; la ligne latérale était droite et peu proéminente '.

\section{LE CORYPHÉNE POMPILE ${ }^{2}$.}

Coryphæna Pompilus, Linu., Gmel., Lacep.; Centrolophus Pompilus, Cuv: '.

De tous les coryphènes du premier sousgenre, le pompile est celui dont la nageoire caudale est la moins fourchue; et voilà pourquoi quelques naturalistes, et particulièrement Artedi , le comparant sans doute à l'hippurus, ont écrit que cette nageoire de la queue n'était pas échancrée. Cependant, lorsqu'on a sous les yeux un individu de cette espèce, non altéré, on s'aperçoit aisément que sa nageòire caudale présente à son extrémité un angle rentrant. Les anciens ont nommé Pompile lé coryphène dont nous traitons dans cet article, parce que, se rapprochant beaucoup par ses habitudes de I'hippurus et du doradon, on dirait qu'il se. plait à accompagner les vaisseaux, et que pompe signifie en gree pampe ou corlége. Au reste, il ne faut pas etre étonné qu ils aient assez bien conuu la manière de vivre de ce poisson osseux, puisqu il habite dans la Méditerranée, aussi bieu que dans plusieurs portions chaudes ou tempérées de l'Ocèaú Atlantique et du gran Océan.

L'ouverture de la bouche du pompile est très-grande; sa mâchoire inférieure plus avancée que la supérieure, et un peu relevée; les cótés de la tète présentent des dentelures et des

'A la membrane des branchies 6 rayons, a la nazeoire do dos 51 , a chacune des peetoraies 19 , a chacune des thong ves 5 , a celle de lanus 27 , a celle de la queue 17 ,

Bonnaterre, pit. de I'Enge. Daubeuton, Eoc. méth. - Id

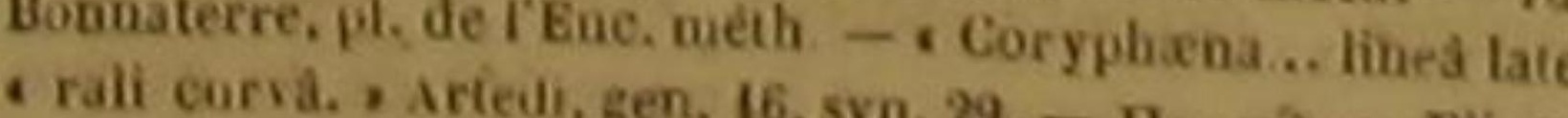

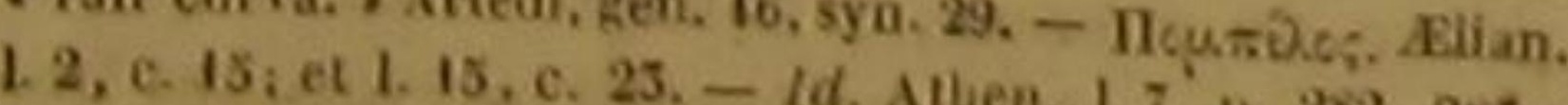
284. - Id. Oppian., Hat. I. I. p. 8. - Pomp. 2\$2, $2 \times 3$ et Pompilus. Plia. Hist, mundi, 1 32, e. 11 . - Pome. Ovid. delet, part, 1, 1, 8, e. 15. - Xpúreqpes, par plus. ancen auteurs - Gesner, p. 881, 75s; et (Germ, fut, 60, a, b. -

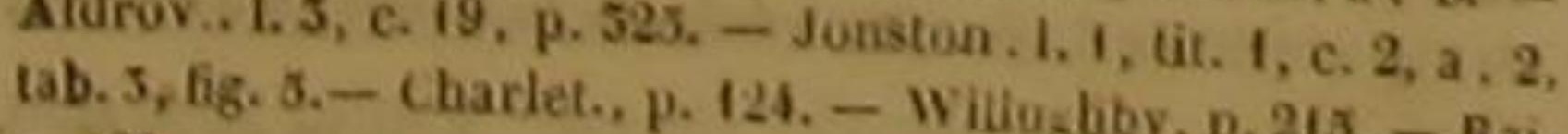
tab. 3, fig. 8. - Charlet., p. 124. - Willus biby, p. 213. - Rai,
p. 101. P. M. Cuvier place cette espece dans le sous.genre Cutro. lophe du graud geore Coryphene. $\quad$ D.
D. D. Iabre. Curier. enfoncements; la ligne latérale est courbe; les nageoires pectorales sont pointues '; des bandes ransversales, étroites, et communément jaunes, règnent sur les còtés. La dorure qui distingue un si grand nombre de coryphènes, se manifeste sur le pompile au-dessus de chaque œil; et voilà pourquoi on l'a nommé Sourcil d'or, en gree zouropous.

\section{LE CORYPHĖNE BLEU 2}

Coryphæna cærulea, Lino., Gmel., Lacep. ’.

L'or, l'argent et l'azur brillent sur les coryphènes que nous venons d'examiner; la parure de celui que nous déerivons est plus simple, mais élégante. II ne présente ni argent ni or; mais toute sa surface est d'un bleu nuancé par des teintes agréablement diversifiées, et fondues par de douces dégradations de elarté. On le trouve dans les mers tempérées ou chaudes qui baignent les rivages orientaux de l'Amérique. Ses écailles sont grandes; celles qui revêtent le dessus et les cótés de sa téte, sont assez semblables aux écailles du dos. Une seule lame compose l'opercule des branchies, dont l'ouverture est très-large; la ligne latérale est plus proche du dos que de la partie inferieure de l'animal; les yeux sont ronds et grands; et une rangée de dents fortes et pointues garnit chaque mâchoire 4

\section{LE CORYPHĖNE PLUMIER s.}

Corypbæna Plumieri, Blocb, Lacep. .

Ce coryphène, que le docteur Bloch a fait connaitre, et qu'il a déerit d'après un manuscrit de Plumier, habite á peu prês dans les mémes mers que le bleu : on le trouve particulièrement, ainsi que le bleu, dans le bassin des An-

'A la nageoire dorsale 35 rayons, à chacune des pectora les 14 , a chacune des thoracines 6 , a celle de 1 anus 24 , a

celle de la queue 16.
2 Bloch. pl. 176. - Novacula cerulea. Catesby, Carol, lab. 18. - Coryghìne rasoir bleu.

- Cavier rapporte cr polson a genre des Scares. D. a ves 5 , a c lle - e lanus 14 . a celle it, a chacune des thuraciCoryphene paon de mer. Bom lacue. I. Cuvier considère ce poisson commét ét D.

DES PUISSONS.

193

tilles. Mais combien il diffère de ce dernier poisson par la magnificence et la variété des couleurs dout il est revêtu! C'est un des plus beaux habitants de l'Oeéan. Tâchons de peindre son portrait avee fidélité.

Son dos est brun; et sur ce fond que la nature semble avoir préparé pour faire mieux ressortir les nuances qu'elle $y$ a distribuées, on voit un grand nombre de petites raies bleues serpenter, s'éloigner les unes des autres, et se réunir dans quelques points. Cette especee de dessin est comme encadré dans l'or qui resplendit sur les cótés du poisson, et qui se change en argent éclatant sur la partie inférieure du coryphène. La tête est brune; mais chaque œil est situé au-dessous d'une sorte de tache jaune, au-dessus d'une plaque urgentée, et au centre de pelits rayons d'azur. Une bordure grise fait ressortir le jaune des nageoires pectorales et thoracines; la nageoire de la queue, qui est jaune comme celle de l'anus, présente de plus des teintes rouges et un liséré bleu; et enfin une longue nageoire violette règne sur la partie supérieure du corps et de la queue '. Le coryphène plumier est d'ailleurs couvert de petites écailles; il n'a qu'une lame à chacun de ses opercules; il parvient ordinairement à la longueur d'un demi-metre; et sa nageoire caudale est en croissant, comme celle du bleu.

\section{LE CORYPHĖNE RASOIR ${ }^{2}$}

Coryphæna novacula, Linn., Gmel., Lacep.; Xirichthys novacula, Cuv.'.

Ce poisson a sa partie supérieure terminée par une arête assez aiguẽ, pour qu'on n'ait pas balancé a lui donner le nom que nous avons

- A la membrane des branchies 4 rayons, a la nageoire du dos 77 , a chacue des pectorales 11 , a chacome des thoractnes 6 , a celle de ranus 55 , a celle de la queue 16.

2 Pesce peltine, sur les côtes de la Ligarie. - Rason, sur plus. cótes d'Espagne. - Coryphiene rason. Daubenton, Lnc. métli. - Id. Bonnaterre, pl. de I'Enc. métb. - : Cory. - phrana palmaris pulcure varia, dorso acuto. A Arledi. gen. 15, syo. 29. - Noracu a prisels. . . D... Hist, mundi, 1. 32, Gisner, p. 628, 629 et 721 :e (Germ fol. 52 , a - Pescepet

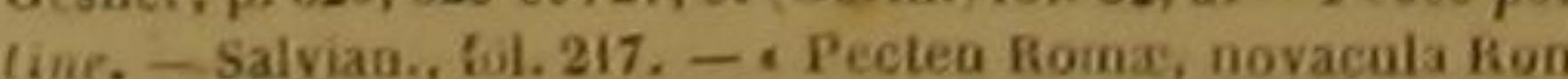
- deletii., Aldrov., 1. 2, c. 27, p. 205. - Peclen Romano. ruv. Jonston, I. 1. tit. 5 , cap. 4, a, 15. - . Pesce pettine - Sulviani . novacula Kondeiet, , Gesner. Paralipum., p. 24. - Willughby, Iclth., p. $214,-$ Mai, p. 101.
sil. Cuvier considere ce poisson comme formant te type Ton nouvean genre de la famille des Labroides, qü̆ nomme Jan nouvean genre de

11. cru devoir lui conserver. Il habite dans la Mé-
diterranée; et voila pourquoi il a été connu dest anciens, et particulièrement de Pline, II est très-beau; on voit sur sa tète et sur plusieurs de ses nageoires, des raiés qui se croisent en différents séns, et qui montrent cette couleur bleue que nous avons déja observée sur les coryphènes : mais il est le premier poisson de son genre qui nous présente des nuances rouges éclatantes, et relevées par des teintes dorées. Ce rouge resplendissant est répandu sur la plus grande partie de la surface de l'animal ; et il y est rétléchi par des écailles très-grandes. La chair du rasoir est tendre, délicate, et assez recherchée sur plusieurs rivages de la Méditerranée. Sa ligne latérale suit a peu près la courbure du dos, dont elle est trés-voisine; chacui de ses opercules est composé de deux lames; et sa nageoire eaudale étant reetiligne, nous l'avons placé dans le second sous-genre des coryphènes. Aa reste, l'histoire de ce poisson nous fournit un exemple remarquable de l'inGluence des mots. On l'a nommé Rasoir longtemps avant le siècle de Pline : à cette époque, où les sciences physiques étaient extrèmement peu avancées, cette dénomination a suffi pour faire attribuer à cet animal plusieurs des proprietés d'un véritable rasoir, et mème pour faire croire, ainsi que le rapporte le naturaliste romain, que ce coryphène donnait un goủt métallique, et particulièrement un goût de fer; a tout ce qu'il touchait.

LE CORYPHENE PERROQUET',

Coryphæna Psiltacus, Linn.,Gmel., Lacep.; Xiriclithy Psittacus, Cur,?

La forme rectiligne que présente la nageoire caudale de ce poisson, détermine sa place dans le rroisième sous-genre des coryphènes. Sa li. gne latérale est interrompue; et sa nageoire dorsale, assez básse et composée dé trente rayons ou environ, commence a l'occiput ${ }^{3}$.

Il a été observé par le doeteur Garden dans les eaux de la Caroline. La beauté des couleurs + Coryphéne perroquel. Daubenton, Ene. neeth - $/ d$. Bonnaterre, ph. de l'Ene. méth.

2M. Cuvier lase ce noisson, ainsi que le précédent, dan Xiri lithys de la fanilice iles Labruides. "D. 'A la nageoire du dos 50 rayoss a chacuue des pee ora.

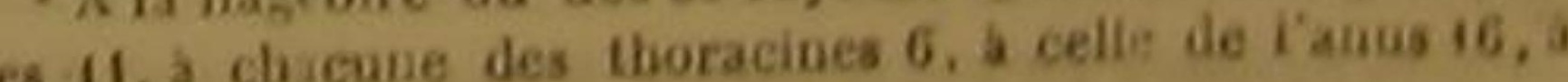
celle de la queve it. 
dont il brille lorsqu'il est animé paŕ la chaleur présente pas de semblables; elle n'est couscrte de la vie, ainsi que par les feux du soleil, a que de grandes lames. L'extrémité antérieure mérité qu'orr le comparât aux oiseaux les plus de chaque imâchoire est garnie de deux dents distingués par la variété de leưrs teintes, la vi- áiguês, très-longues, et écartées l'une de l'auvacitéde leurs nuances, la magnificence de leur tre: et la forme de la nageoire caudale, qui est parure, et particulièrement aux perroquets. Les arrondie, place le rayé dans le quatrième souslames qui recouvrent la tête montrent la diver- genre des coryphènes.

sité de reflets des métaux polis et des pierres précieuses ; son iris, couleur de feu, est bordé d'azur; des raies longitudinales relèvent le fond des nageoires; et l'on aperçoit vers le dos, au milieu du tronc, une tache remarquable par ses couleurs aussi bien que par sa forme, faite en losange, et présentant, en quelque sorte, toutes les teintes de l'are-en-ciel, puisqu'elle offre du rouge, du jaune, du vert, dubleu et du pourpre.

LE CORYPHENE CAMUS '

Coryphæna sima, Lìno., Gmelio, Licep. '.

Le nombre des rayons de la nageoire dorsale, et la prolongation de la mạchoire inférieure plus avanée que la supérieure, servent à distinguer ce coryphène, qui habite dans les mers de I A. sie, et yui, par la forme rectiligne de sa nageoire caudale, uppartient au troisieme sous-genre des poissons que nous considérons ${ }^{3}$.

IE CORYPHENE RAYE 4 . Goryphrona lineala, Lion., Gmel, Laeep.; Xirichthys
lineatus, Gur.?

\section{LE CORYPHENE CHINOIS.}

Coryphæna sinensis, Lacep.; Latilus argenteus, Cuv. ¿

Ce coryphènen'a pas encore été déerit. Nons en avons trouvé une figure coloriée et faite avec beaucoup de soin, dans ce reeueil de peintures chinoises qui fait partie des collections du Muséum d'histoire naturelle, et que nous avons déjá cité plusieurs fois. Nous lui avons donné le nom de Coryphène ehinois, pour désigner les rivages auprès desquels on le trouve, et l'ouvrage precieux auquel rous en devons la connaissance. Sa parure est riche, et en mème temps simple, élégante et gracieuse. Sa couleur est d'un vert plus ou moins elair, suivant les parties du corps sur lesquelles il parait; mais ces nuances agréables et douces sont mélées avec des reflets éelatants et argentins.

Au reste, il n'est pas inutile de remarquer qu'en rapprochant par la pensée les diverses peintures chinoises que l'on peut connaitre en Europe, de ce qu'on a appris au sujet des soins que les Chinois se donnent pour l'éducation des Le docteur Garden a fait connaitre ce poisson, | animaux, on se convainera aisément que ce qui habite dans les eaux de la Caroline. Ce cory- peuple n’a accordé une certaine attention, soit phène à la tête rayée transversalement de cou- dans ses oceupations économiques, soit dans leurs assez vives; d'autres raies trés-petites pa- les productions de ses beaux-arts , qu'aux raissent sur la nageoire du dos, ainsi que sur animaux utiles à la nourriture de l'homme, ou celle de l'anus ". Les écailles qui revêtent le le $\begin{aligned} & \text { animaux utiles a la nourriture de I homme, ou } \\ & \text { propres à charmer ses yeux par la beauté de }\end{aligned}$ corps et la queue sont très-grandes. La tête n'en $\begin{aligned} & \text { propres a charmer ses yeux par la beauté de } \\ & \text { leurs couleurs. Ce trait de caractère si digne de }\end{aligned}$ :Coryphène rechignce. Bonnaterre, pl. de I'Enc. métb. l'observation du philosophe ne devait-il pas 'Ce poisson tiest admis par $M$. Cusier nizlass le genere $C$. ryphètue, ni dans te genre Rasoas. C'est un de ceux quil n'oserait iutroduire dans le systeme ichthyologique, dans is crainte dy porter le désordre, en les y plaçant par conjec-

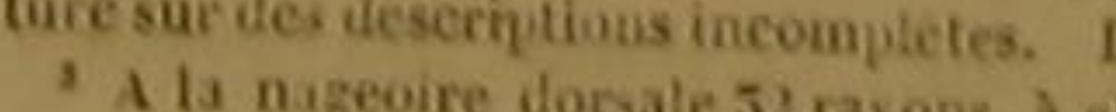
les 16 , a chacone des thoracines 6 , a celle de lianos pectorade liquieue 16.

'Coryphène rayce. Donnaterre, pl. ze réce. mét. 'Le poisson de cet article est rapporté par M. Cinvier sou zeare Rason, Xirenthys, de ta famille des Labroites.

i A ta rageoire du dos 21 rayons, a chacune dis rectora. les 11 , a chicune des thorachies 6 . A cetle te I amus is, a
oelle de L yueue 12 . Ce

Ce beau coryphène chinois montre une trèslongue nageoire dorsale; mais celle de l'anus est assez courte. La nageoire caudale est arrondie. De grandes écailles couvrent le corps, la queue et les opercules. La máchoire inférieure est relevée et plus avancée que la supérieure; cé qui ajoute aux rapports du chinois avec le coryphène camus.

- Du genre Latilus formé par M. Cuvier, dags la famille
des Acanthoptérygiens sciénoơdes.

\section{DES POISSONS}

Itii

\section{LE CORYPHÉNE POINTU '}

Coryphæna acuta, Lino., Gm., Lac. '.

Le nom de Pointu, que Linnée a donné à ce coryphène, vient de la forme lancéolée de la nageoire caudale déce poisson; et éest à cause de cette mème forme que nous avons placé cet osseux dans un cinquième sous-genre. Cet animal qui habite dans les mers de l'Asie, a quarante-cinq rayons à la nageoire du dos, et sa ligue latérale est courbe ${ }^{3}$.

\section{LE CORYPHÉNE VERT ,}

Coryphena vireus, Lino., Gmel.; Coryphæona viridis Lacep.

ET LE CORYPHENE CASQUÉ ?

Coryphæna clypeata, Linn., Gmel. , Coryphæna galeata, Lacep.'.

Nous avons divisé le genre que nous examinons, en cinq sous-genres; et nous avons placé les coryphènes dans l'un ou l'autre de ces groupès, suivant le degré d'étendue relative, et par conséquent de force proportionnelle, don née à leur nageoire caudale, ou, ce qui est la mème chose, à un de leurs principaux. instruments de natation, par la forme de cette méme nageoire, ou fourchue, ou en croissant, ou rectiligne, ou arrondie, ou pointue. Nous n'avons vu aucun individu de l'espèce du coryphène vert, ni de celle du coryphène casqué; aucun naturaliste n'a décrit ou figuré la forme de ia nageoire caudale de l'un ni de l'autre de ces deux poissons : nous avons done été obligés de les présenter séparés des cinq sous-genres que nous avons établis ; et de nouvelles observations pourront seules les faire rapporter à cellede ces petites sections à laquelle ils doivent appartenir. Tous les deux vivent dans fes mers de l'Asie; et tous les deux sont faciles à distinguer des autres coryphènes : le premier, par un long fila-

'Coryphène pointue. Bonnaterre, pl. de I'Eac. méth. 'Espece trop vagueneat décrite, pour qu'on puisse ladmettre soit dans le genre Ciryphène, soit dans lè genre Ra. son, selon M. Cuvier. D. A la nageoire da dos 43 rayons, a chacune des pectora-
les 16 , a chacune des thoracines 6 , a celle de l'anos 16 , d celle

- Coryphène verte. Bonnaterre, pl. de IEnc. méth.

- M. Cavier se refuse à admettre ces denx es méth. parmi les Coryphènes, scit parmi les Rasons, à cause so is brieveté de leur description, qui ne permet pas de s'ea for. ment que présente chacune des nageoires du dos et de l'anus, ainsi que des thoracines '; $\mathrm{ct}$ le second, par une lame osseuse située au-dessus des yeux, et que l'on a comparée à une sorte de bouclier ou plutot de easque. On ignore la couleur du casqué; celle du vert est indiquée par le nom de ce coryphène ${ }^{2}$.

\section{QUATRE-VINGT-QUATRIEME GENRE,} LES MÉMPTÉHONOTES 3 .

Le sommet de la the tris-comprime, et comme trancliant par le haut, ou tris-eleve at finissant sier le derant par un plan presque verlical, ou termise anterieurement par un quart de crecle, ou garni d'icailles semblables à celles do dos ; une seule nagcoire dorsale i lla longueur de cette nageoire du dos ne sur

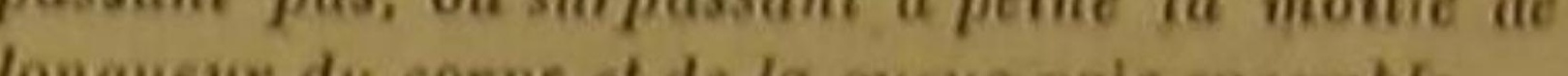
longueur du corps et de la queue pris ensemble.

EPREE - canseriknes.

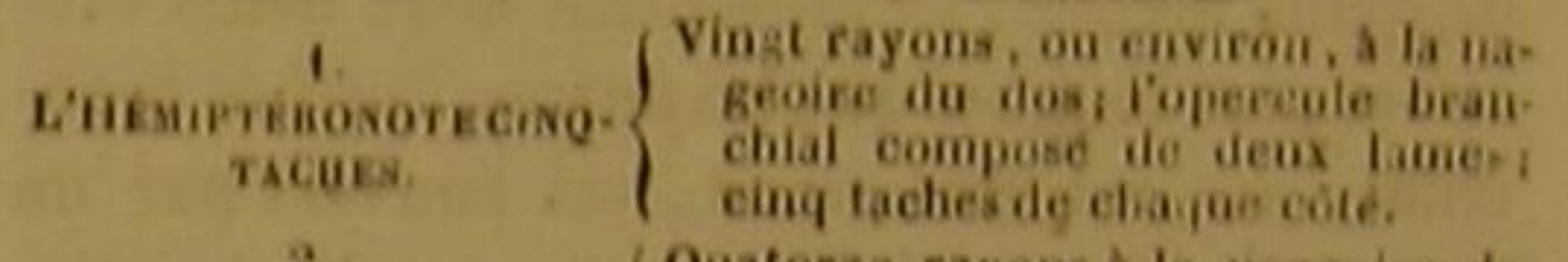

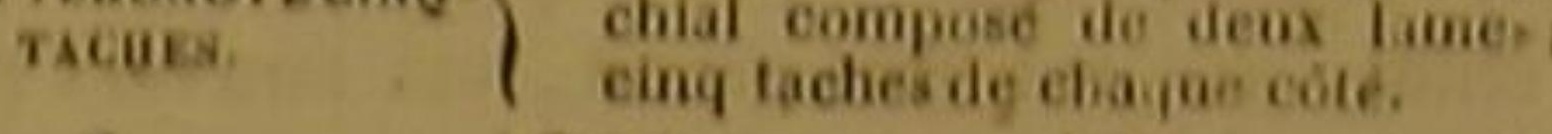

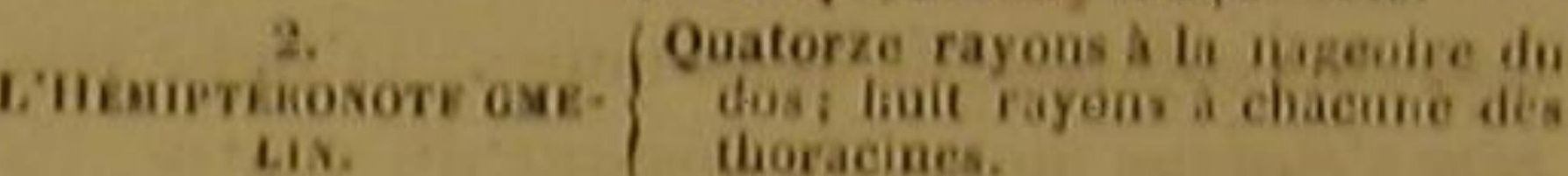
$-$

L'HEMIPTERONOTE CINQ-TACHES :

Coryptrana pentadactyla, Liun., Gmel.; Hemipteronotus quinque maculates, Lacep. '

La brièveté de la nageoire dorsale et sa position à une assez grande distance de l'oceiput, distinguent le einq-taches, et les autres poissons 'A A a rageoire an dos 20 rayous, a chacune des prectirales 15,4 chacune des thora ines 6 , a celle de 1 amos is, a celi de ta quese 16.

in nageoire da dos 32 rayoos, a chac ne despectora

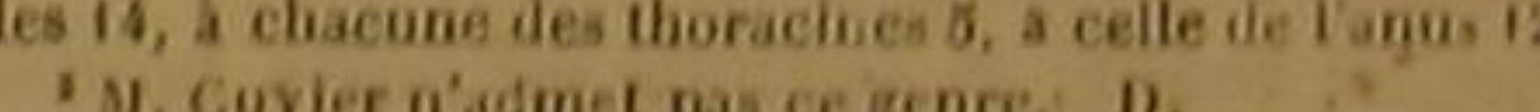

'Coryphene cinq-farhes, Daubentou, Kne, meili. - Id Bonesterre, pil. de I Euc. méth. - C Coryphisna cauda aymal, - puná dorsi, radiis uno et viginti. = Morth, pl. 173. ' Blennius, inaculis quinque utrinque ver as caput , igris. Act. Stockh. 1740, p. 460, lab, 5, fig, 2, - Ikan bandau jang

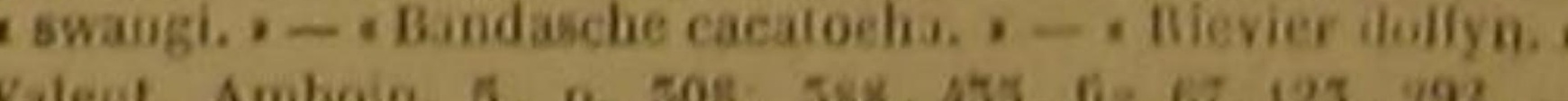
Oranje visch met vier vlakken.

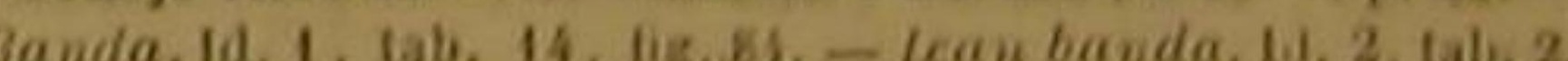
fig. 6. - Ican potou banda. 1d., tab. 25. Ifg. 112. - Ican

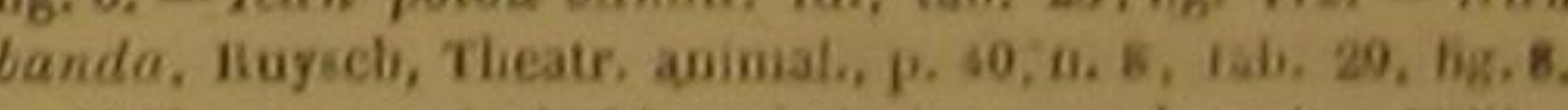
- Viil venjer viseh, id esi, piscis pentadaciylos. Willoghby, Ap; eud., p. 7, tab. 8, big. 2:- Maj, Pise, 150, B. 23. - Le Coryphena peritadactyta de BL. 175, et un Rason

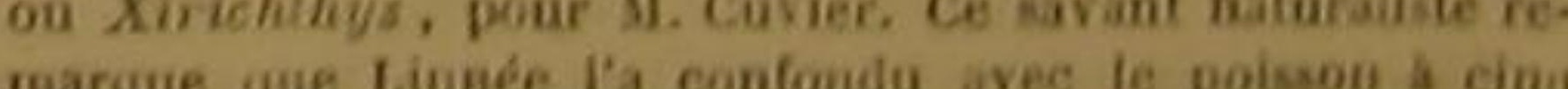

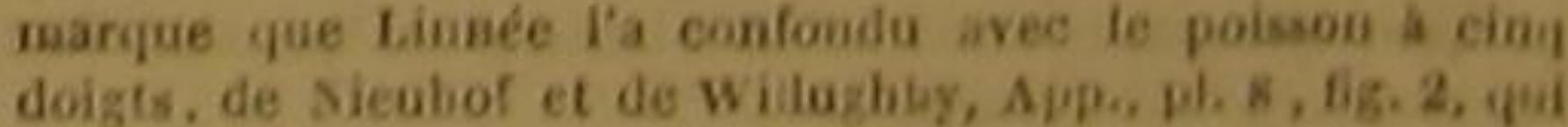
doigts, de sieubof et de Willughty, Aype, ph. 8 , fig. 2, qui son genre Hémi, iéroude, doat les curacterrs ne consien.

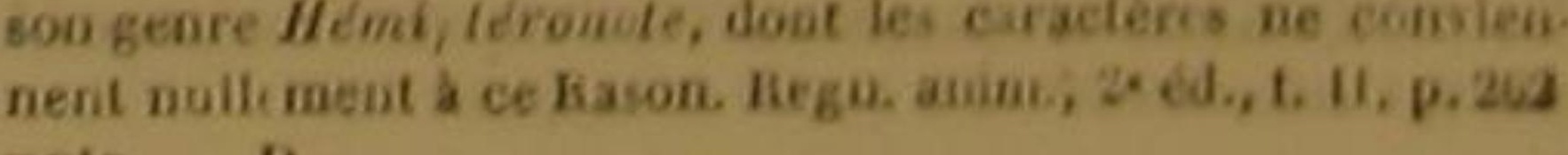
note. D. 
qui appartiennent au genre quenous décrivons, des coryphènes proprement dits. Le nom générique d'Hémiptéronole ' désigne ce peu de longueur de la nageoire dorsale, et son rapport avec la nageoire du dos des coryphènes, qui est presque toujours une fois plus étendue. Les osseux que nous examinons maintenant, ressemblent d'ailleurs, par beaucoup de formes et d'habitudes, à ces mèmes coryphènes avec lesquels on les a confondus jusquà présent. Le cinq-taches, le poisson le plus connu des hémiptéronotes, habite dans les fleaves de la Chine, des Moluques et de quelques autres iles de l'arehipel indien. Il y parvient communément a la longueur de six décimetres; sa téte est granće; ses yeux sont rapprochés l'un de l'autre, et par conséquent placés sur le sommet de la tête; l'ouverture de la bouche est médiocre; les deux mâchoires sont garnies d'une rangée de dents aigués, et présentent deux dents crochues plus longues que les autres; l'orifice branchial, qui est tres-grand, est couvert par un opercule composé de deux lames; la ligne latérale s'éloigne moins du dos que du ventre; i'anus est plus près de la gorge que de la nageoire caudale, qui est fourchue ${ }^{2}$; des écailles trespetites couvrent les jours, et d'autres écailles assez grandes revêtent presque tout le reste de la surface du cinq-taches

Voici maintenant les couleurs dont la nature a peint ces diverses formes.

La partie supérieure de l'animal est brune; les cotés sont blanes, ainsi que la partie infecieure ; une raie bleue règne sur la tête ; l'iris est jaune: des cinq tachesqui paraissent de chaque côté du corps, la première est noire, bordée de jaume, et ronde; la seconde est noire, bordée de jaune, et ovale; les trois autres sont bleues et plus petites. Une belle couleur d'azur distingue la nageoire caudale et celle du dos, qui d'ailleurs montre un liséré orangé; et deux taches blanches sont situées a la base des nageoires thoracines, lesquelles sont comme les pectorales et comme celle de l'anus, orangées, et bordées de violet ou de pourpre.

Du brun, du blane, du bleu, du jaune, du noir, de l'orangẻ, et du pourpre et du violet,

' Hémiptêronote vient de trois mots grecs qui signifien Moitie, nageoire, et dos.

J ues 6 , a celle de lasuus 15 , a celle de ia queue ia des thoraci- composent donel'assortiment de nuances qui caractérise le cinq-taches, et qui est d'autant plus brillant qu'il est animé par le poli et le luisant argentin des écailles. Mais cette espèce est aussi féconde que belle : aussi va-t-elle par très-grandes troupes; et comme dailleurs sa - char est agréable au goùt, on la pèche avee soin; on en prend mème un si grand nombre d'individus, qu'on ne peut pas les consommer tous aupres des eaux qu'ils habitent. On prépare de diversés manières ces individus surabondants; on les ait sécher ou saler; on les emporte au loin; et Is forment, dans plusieurs contrées orientales, une branche de commerce assez analogue celle que fournit le gade morue dans les régions septentrionales de I'Europe et de I'Amérique.

\section{L'HEMIPTÉRONOTE GMELIN '}

Coryphæua hemiptera, Lion., Gmel.; Hemipteronotus Gmelini, Lacep. .

Cet hémiptéronote à la nageoire dorsale encore plus courte que le cinq-taches; ses máchoires sont d'ailleurs à peu près également avancées. On le pêche dans les mers d'Asie, et nous avons cru devoir lui donner un nom qui rappelât la reconnaissance des nafuralistes envers le savant Gmelin, auquel ils ont obligation de la reizième édition du Syslème de la nature par Linnée.

\section{QUATRE-VINGT-CINQUIĖME GENRE ${ }^{3}$.} LES CORYPHÉNOIDDES.

Le sommet de la tète très-comprimé, et comme tran chant por le haut, ou trés-elecé et finissant sur le decant par un plan presque rertical, ou terminé anterieurement par un quart de cercle, ou garni d'tdorsale; lourerhire des branchies ne con ist int gue dans une fonte transcersale.

zspíč.

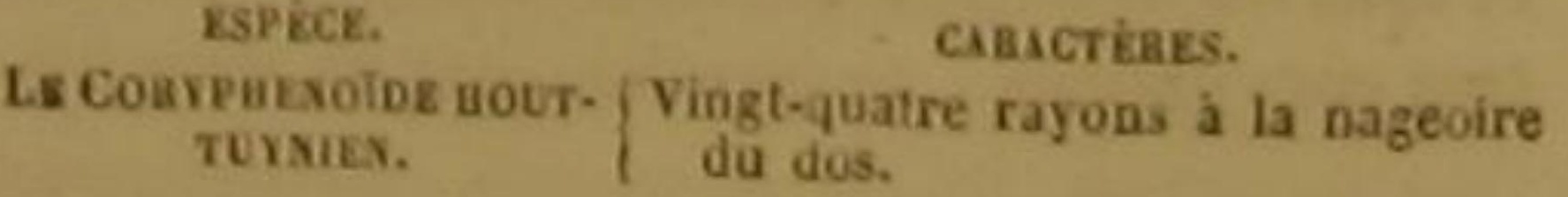

'Coryphine à demi-nageoire. Bonnaterre, pl. de IEnc. mélb.

'M. Cavier range ce polsson au nombre de ceux qui ont

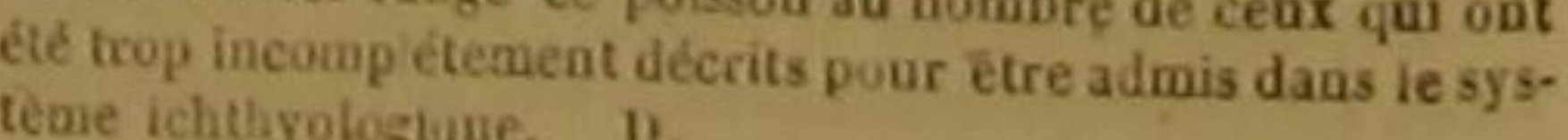
teme ichthyologlique. $\mathrm{b}$.

- Geare Lon adopté par M. Cuvier. D.

DES POISSONS.

IE CORYPHÉNOIDE HOUTTUYNIEN '.

Coryphizas branchiostega et Coryphæna japonica,

On trouve daus la mer du Japon, et dans d'autres mers de l'Asie, ce poisson que l'on a inscrit parmi les coryphènes, mais qu'il faut en séparer, à cause de plusieurs différences essentielles, et particulièrement à cause de la forme de ses ouvertures branchiales, qui ne consistent chacune que dans une fente transversale. Nous le nommons Coryphénoüde pour désigner les rapports de conformation qui cependant le lient avec les coryphènes proprement dits; et nous lui donnons le nom spéciflque d'Houttuynien, parce que le naturaliste Houttuyn n'a pas peu contribué à le faire connaitre. Il n'a communement que deux décimètres de longueur; les écailles qui le revétent sont minces; sa couleur tire sur le jaune ${ }^{3}$.

QUATRE-VINGT-SIXIEME GENRE. LES ASPIDOPHORES 4.

Le corps et la quene coureris d'une sorte de cuirasse ecailleuse : deux nageoires sur le dosi moins de quatr rayons aux nagcoires thoracines

PREMIER SOUS-GENRE,

Ún ou plusieurs barbi lons à la máchoire inférieure.

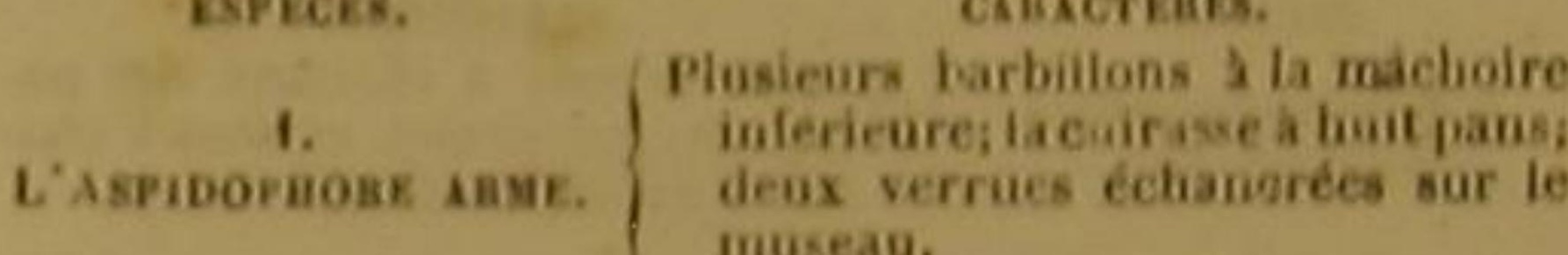
SECOND SOUS-GENRE. Point de barbillons à le machoire inferieure.

2. Aspiborione Lsiza. $\left\{\begin{array}{l}\text { Ca cuirase a Anit on plusieurspans, } \\ \text { el garnie d aiguillons. }\end{array}\right.$

L'ASPIDOPHORE ARMÉ 5

Cottus cataphractus, Limn., Gmel.; Aspidophorus armatus, Lacep.; Aspidoptorus europous, Cuv. `.

Nous avons séparé des cottes, les poissons

'Hontiuys, Acl. Ilasrl., 20, 2, p. 515 - Coryphiene bran chiostoge. Bunnaterre, ph, de l'Enc. méth.

20. Cuvier ne regarde pas I existen e de ce poisson comme certaiue. II venurait qu elle reposít sur une autorité meil-

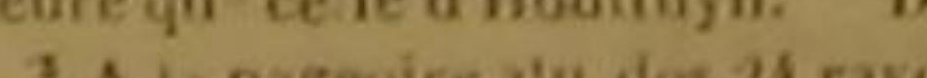
A a a ageoire du dos 24 rayons, a chacune des pectorade la queve 16.

-Ce genr: est ddopté, mais comme sous-geure, dans ceiu des Chisots, Coltus, par M. Cuvier. D. - A pogge, dans le nord de TAngie erre. - Cole arme. osseux et thoracins dont le corps et la queue sont couverts de plaques ou boucliers très-durs disposés de manière à former un grand nombre d'anneaux solides, et dont T'ensemble compose une sorte de cuirasse, ou de fourreau à plusieurs faces longitudinales. Nous leur avons donné le nom gẻnérique d'Aspidophore, qui veut dire porle-bouclier, et qui désigne leur conformation extérieure. Ils ont beaucoup de rapports, par les traits extérieurs qui les distinguent, avee les syngnathes et les pegases. Nous ne connaissons encore que deux espèces dans le genre qu ils forment; et la plus anciennement, ainsi que la plus généralement connue des deux, est celle à laquelle nous conservons le nom spécifique d'Armé, et qui se trouve dans 'Océan Atlantique, Elle y habite au milieu des rochers voisins des sables du rivage; elle y dépose ou féconde ses cuf́s vers le printemps; e c'est le plus souvent d'insectes marins, de mol'usques ou de vers, et particulierement de crabes, qu'elle cherche a finire sa nourriture. La couleur générale de l'armé est brune par-dessus et blanche par-dessous. On voit plusieurs tache noiratres sur le dos ou sur les côtés; d'autres taches noires et presque carrées sont répandues sur les deux nageoires du dos, dont le fond est gris; les nageoires pectorales sont blanchatres et tachetées de noir ; et cette mème teinte noire occupe la base de la nageoire de l'anus.

Une sorte de bouclier ou de casque très-solide, écailleux, et même presque osseux, creusé en petites cavités irrégulières et relevé par des pointes ou des tubereules, parantit le dessus de ia tête. Les deux máchoires et le palais sont hérissés de plusieurs rangs de dents petites et aigués; un grand nombre de barbillons garnissent le contour arrondi de la mâchoire inférieure, qui est plus courte que la supérieure; l'opercule branchial n'est composé que d'une seule lame

-Bloch, pl. 58 , fig. 3 et 4.- - Cotlus cirris plarimis, corpore - octogono. A Artedi, gen. 49, spec, 87, spu. 77,-Cillus co tab. 46, 6g. B et 6. - Ch iritet, Onom. p. 152. - IVillughby Ichth.. p. 211. - Kaj, p. 77, - Vaum. succic, 524, - Bronn. Pisc. Nassil., P. 51, n. 45. - Mail., Prodrom. Zool. Danic,

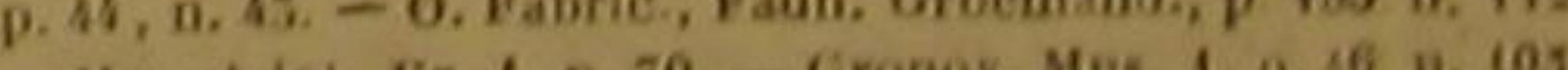
- Mas. Adol. Yr. 1, p. 70. - Gronov. Mus. A, p. 46, M.

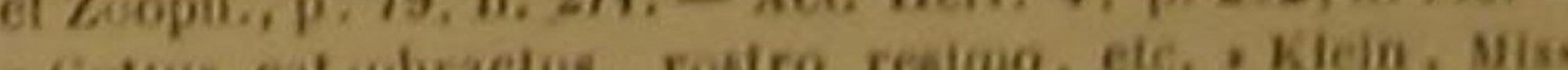

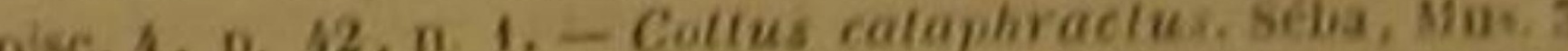

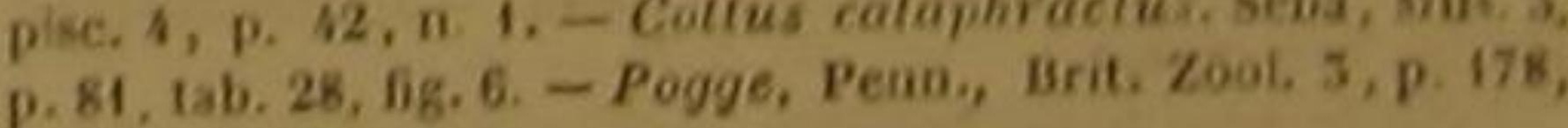
2, tab. 11 . Dspidophoras Europeus, Cav, Hist. des Poissons, $\mathrm{L}$ iv, - Aspidophoras D.
201. D. 
un pir ant recourbé termine chaque pièce des anneaux sont conformés de manière à donner à annacis solides dont se forme la cuirasse géné- la cuirasse ou à l'étui général une très-grande rale de l'animal; cette méme cuirasse présente ressemblance avec une pyramide à huit faces, huit pans longitudinaux, qui se réduisenta à six ou à un plus grand nombre de côtés, qui se autour de la partie postérieure de la queue; la réduisent à cinq, six ou sept, vers le sommet Ilone latérale est droite; l'anus situé a peu près de la pyramide.

all-dessous de la première nageoire du dos; la La premièrenageoire du dos correspond à peu nageoire caudale arrondie; les pectorales sont près aux pectorales et aux thoracines, et la segrandes, et les thoracines longues et étroites '. conde à celle de l'anus. Chacune des thoracines

L'aspidophore armé parvient communément ne comprend que deux rayons; ceux de toutes à une longueur de deux ou trois déeimètres. les nageoires sont, en général, forts et non ar-Nous pensons que l'on doit rapporter á cette ticulés; et l'orifice de l'anus est un peu plus ispèce le poisson auquel Olafsen et Müller ont près de la gorge que de la nageoire caudale.

donné le nom de Cotte Brodame ${ }^{2}$, et qui ne Le fond de la couleur de l'aspidophore que parait différer par aucun trait important, du nous déerivons est d'un blane jaunâtre; mais thoracin qui fait le sujet de cet article. le dos, plusieurs petites raies placées sur les nageoires ', une grande tache rayonnante située auprès de la nuque, et des bandes distribuées transversalement ou dans d'autres directions

L'ASPIDOPHORE LISIZA ${ }^{3}$

Coltus japonicus et Pbalangistes japoniens, Pallas; sur le corps ou sur la queue, offrent une teinte

Agonus japonicus, Bl., Sebo.; Aspidophorus Lisiza, brunâtre.
Lacep.; Aspidophorus supereiliosus, Cuv. 4.

Pallas a fait connaitre ce poisson, qui vit auprès du Japon et des iles Kuriles, et qui a beaucoup de rapports avec l'armé.

La tête de cet aspidophore est allongée, comprimée, et aplatie dans sa partie supérieure, quí présente d'ailleurs une sorte de gouttière longitudinale. De chaque coté du museau, qui est obtus, et partagé en deux lobes, on voit une lame à deux ou trois échancrures, et arnie sur le devant d'un petit barbillon. Les bords des màchoires sont hérissés d'un grand nombre de dents; les yeux situés assez près de l'extrémité du museau, et surmontés chacun par une sorte de petite corne ou de protubérance osseuse ; et les opercules dentelés ou découpés.

Une pointe ou épine releve presque toutes les pièces dont se composent les anneaux et par conséquent l'ensemble de la cuirasse, dans les. quels le corps et la queue sont renfermés. Ces pièces offrent d'ailleurs des stries disposées pieces offrent d'ailleurs des stries disposées
comme des rayons autour d'un centre; et les

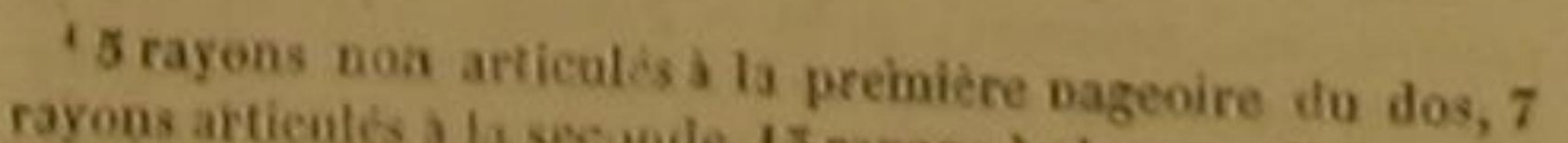
ryons artientes a la secsumile, 13 rayons a chacune des pect 7 celle de la puene, des thoracines, 6 a celle de lanus, 10 a ${ }^{2}$ Coltus bridi

Zool, Danic. Prodiom, OLfsen, Ish., 1. 1. p. 589. - Id. Moll., Ene. mell

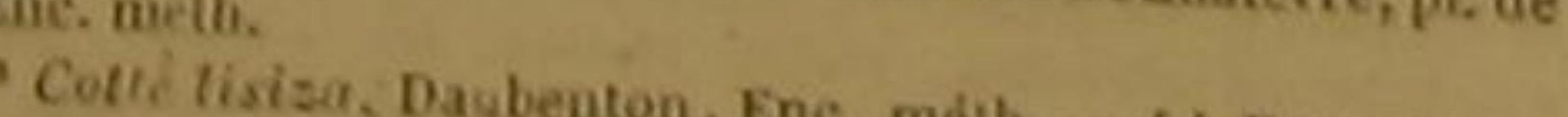
1. de r'Eue. méth.

itapidophore tiants-sourcils, Asp. superciliosus, Cav,

La longueur ordinaire du lisiza est de trois ou quatre decimètres.

\section{QUATRE-VINGT-SEPTIÉME GENRE.} LES ASPIDOPHOROIDES ${ }^{2}$.

Le corps et la quene courerls d'une sorle de cuirass ecaillense : ine senle nageoire sur le dos; moins de atre rayons an $x$ nageoires thoracines.

isprèce.

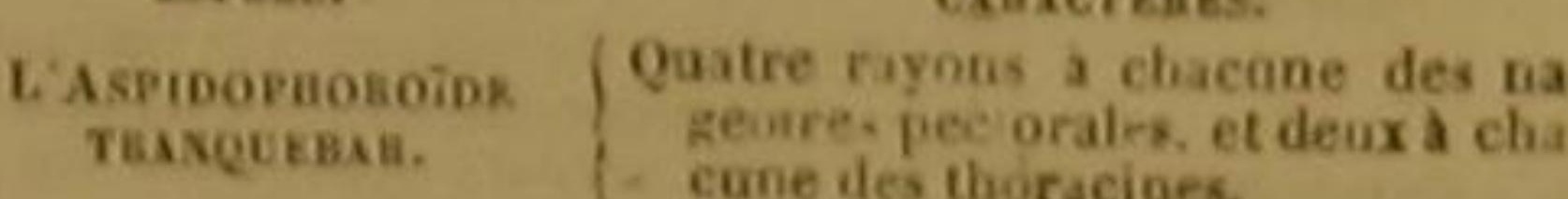

L'ASPIDOPHOROIDE TRANQUEBAR ${ }^{3}$

Agonus monopterygius; BI., Scho.; Aspidophoroides Tranquebar, Licep. ; Aspidophorus monopterygius. Cuv.

Les aspidophoroides sont séparés des aspidtophores par plusieurs caractères, et particnlie rement par l'unité de la nageoire dorsale. II ont cependant beaucoup de rapports avec ces derniers ; et ce sont ces ressemblances que leur

'Ala membrane des branchies 6 rayons, a la premicre nades nageoires pectorales 12 , a chasune des 1 thurachacanc 'ile de ranis 8 , a celle de la quene 12

'Ce geare est rémini, par M. Cavier, à celui des Aspidopho , qui consutue un sous-gene parmi les Colles. D Aspidophore a vue seove dorsatere, pl. de I'Enc. mètit gius, Cuv., Hist. nat des Poissons L. IV Aspid. moncrilery nom aénérique indique. Le tranquebar est d'ailleurs remarquable par le très-petit nombre de rayons que renferment ses diverses nageoires; ét ce trait de la conformation de ce poisson est si sensible, que tous les rayons de la naceoire du dos, de celle de l'auns, de celle de la queue, des deux pectorales et des deux thoracines ne montent ensemble qu'à trente-deux.

Cet aspidophoroìde vit dans les eaux de Tranquebar, ainsi que l'annonce son nom spécifique. Sa nourriture ordinaire est composée de jeunes cancres et de petits mollusques ou vers aquatiques. Il est brun par-dessus, gris sur les côtés; et l'on voit sur ces mèmes cótés des bandes transversales et des points bruns, ainsi que des taches blanches sur la partie inférieure de l'animal, et des taches brunes sur la nageoire de la queue et sur les pectorales '.

Sa cuirasse est à huit pans longitudinaux, qui se réunissent de manière à n'en former que six vers la nageoire caudale; les yeux sont rapprochés du sommet de la téte; la mâchoire supérieure, plus longue que l'inferieure, présente deux piquants recourbés en arrière; une seule lame compose l'opercule des branchies, dont l'ouverture est très-grande; on apercoit sur le dos une sorte de petite excavation longitudinale; la nageoire dorsale est au-dessus de celle de l'anus, et celle de la queue est arrondie.

\section{QUATRE-VINGT-HUITIEME GENRE.}

LES COTTES 2 .

Li tele plus targe que le corps: la forme generale un pen conique; deux nageoires sur le dos: des aigut desbranchies: plus de trois rayons anx nageoire Hharacines.

PREMIER SOUS-GENRE.

Des barbillons ù la máchoire inferieurc.

Espices.

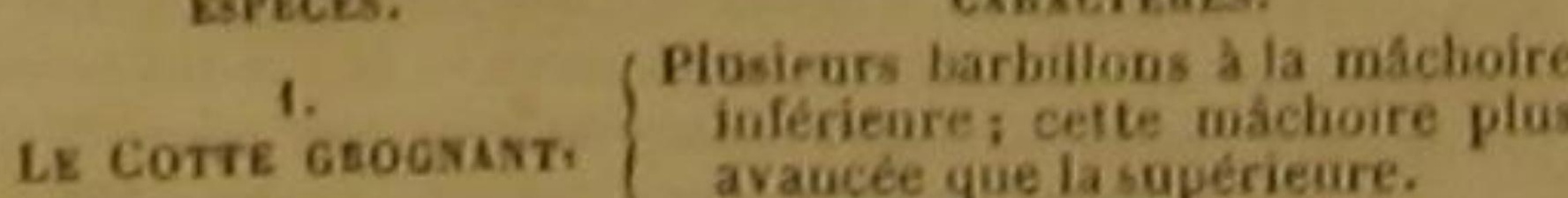

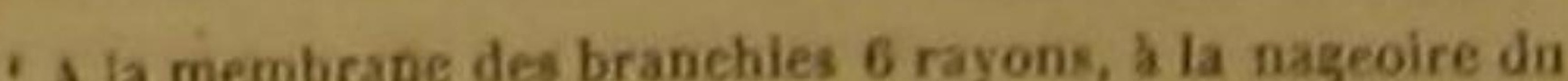

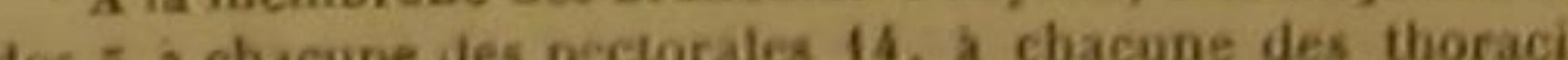
les 2 , a celle de l'anus 5 , a celle de ia queue 6 .

'Ce eenre est adopté par M. Cavier, qui le partage en deo sous-geures, 10 celui des Cottes proprement dits, et $2^{\circ}$ celor des Aspitophores. Quel jues especes se rapportent, suivant in, i d autres genres. tels que ceux des Butrachoides et des
SECOND SOUS-GENRE.

Point de barbillons à la mdchoire inferienre. espàcrs. crascrènes.

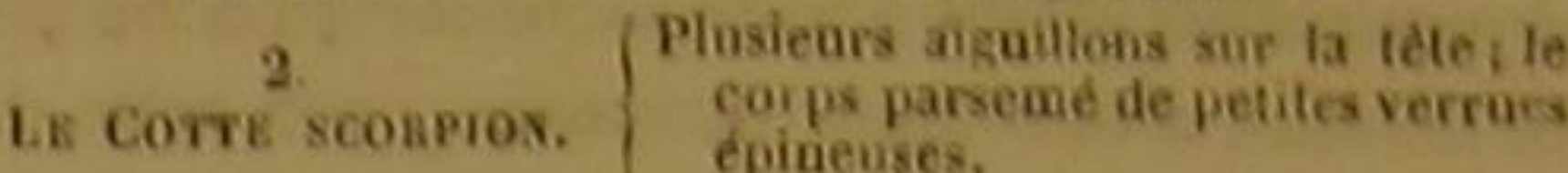

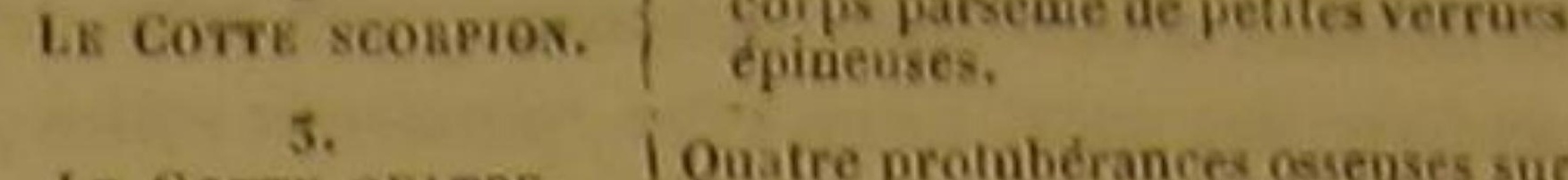
5.
I.E CoTtE oostak.
cokss.

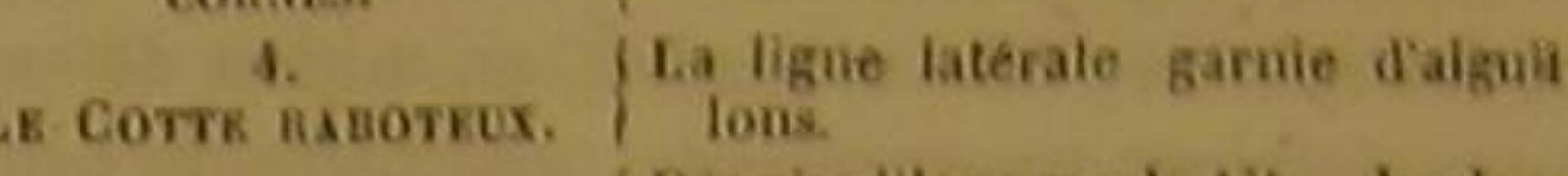
3.
ortr. Austax.

6.
issiduseun.

Deux aigniltons recourbós de bla.
que cote de la tétei mo sillon lon.

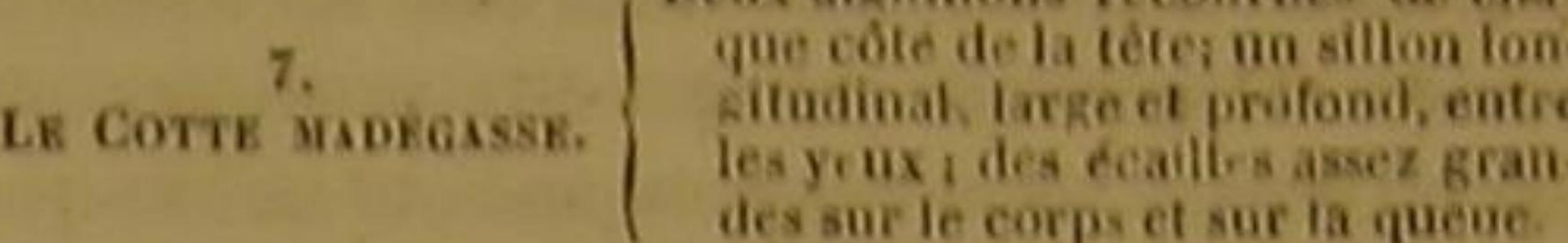
des sur le corps et sur a queve.
Wh aiguilton de chasque cotet de is

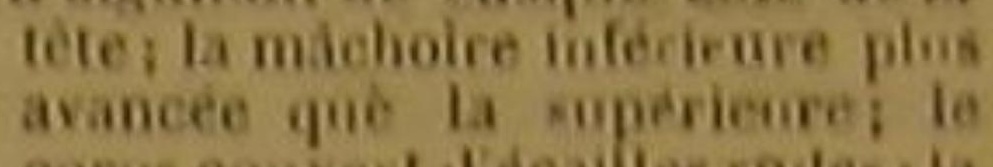
8.
9.

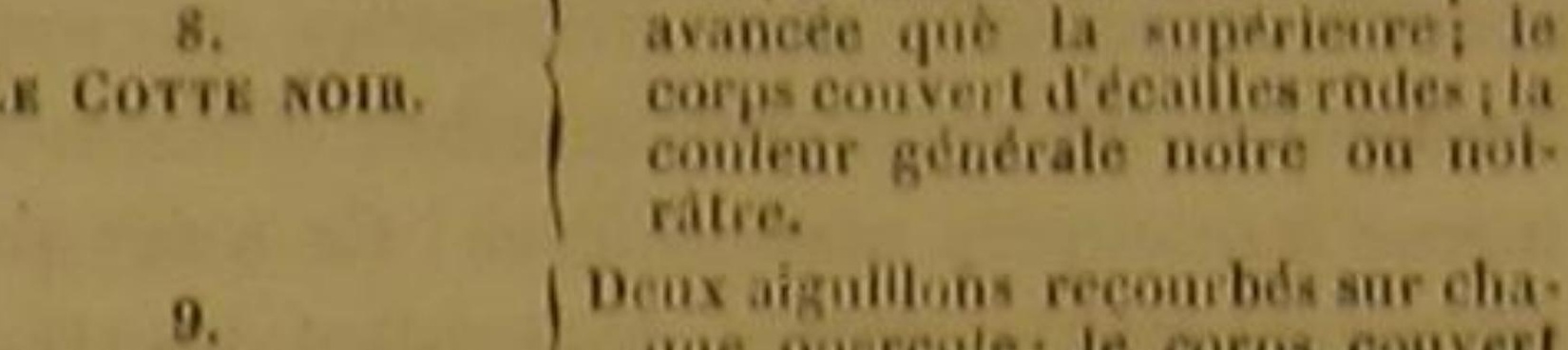

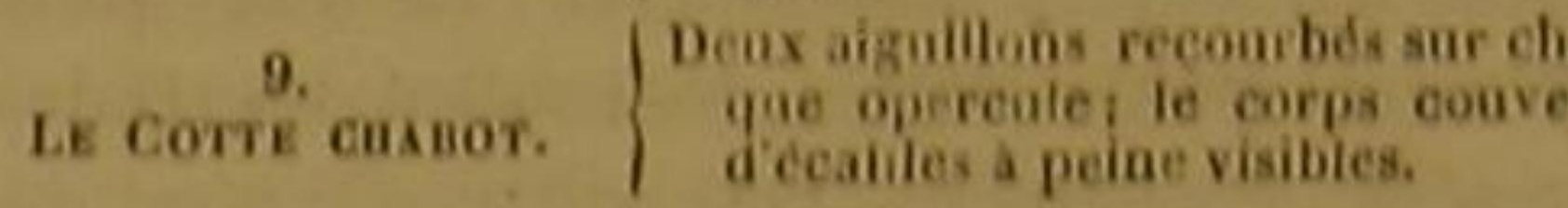

LE COTTE GROGNANT ' Cottus grunuiens, Lind.. Lacep.; Batrachus grunniens,
Cuv,?

Presque tous les cottes ne présentent que des couleurs ternes, des nuances obseures, des teintes monotones. Enduits d une liqueur onetueuse qui retient sur leur surface le sable et le limon, couverts le plus souvent de vase et de boue, défigurés par eette couche sale et irrégulière, aussi peu agréables par leurs proportions apparentes que par leurs téguments, qu'ils different, dans leurs attributs extérieurs, de ces magnifiques coryphenes sur lesquels les feux des diamants, de l'or, des rubis et des saphirs scintillent de toutes parts, et aupres desquels on dirait que la nature lés a placés, pour qu'ils fissent mieux ressortir l'éclatante parure de ces poissons privilégiés ! On pourrait être tenté de - Bloch, pl. 179. - Colle grognard. Dimbenton, Vuc. géth, - Id. Bonnaterre, pl. de I'sne, meth. - Mus. Adolph. Frid. 2. p. 6s. - Gronov, Mos. 1, 1. 46, n.

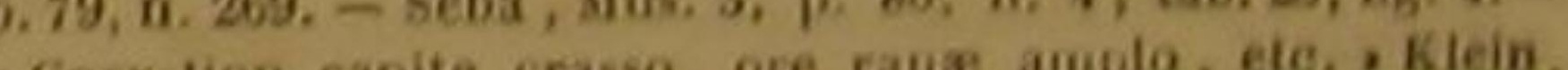

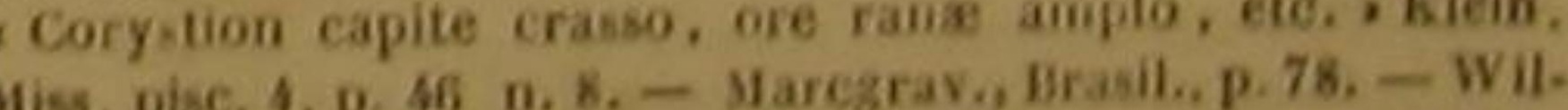
Igahby. Ichith, p. 289, tab. S. 11, tig 1; A ppend. p. 3, tab. 4 fig. 1.-Nigud, Hai, Pise, p. 92, n. 7 ; et p. 160, n. 7 . - Is. cuvier fait remarquer que pilusieurs poissoas qui avaient été plactes avec les cittes (et eutre aures ceini de cet article) ont dó en étre séparés et reportés dass lo geare Batrachuide. Batraclasa, parce qu is out ia tete apistie of non cuiraske :
les, etc D.. 
eroire que, s'ils ont été si peu favorisés lorsque cepté les pectorales et les thoracines, sur lesleur vêtement leur a été départi, ils en sont, quelles on aperęoit une teinte rougeâtre '. pour ainsi dire, dédommagés par une faculté La surface du grognant est parsemée de pores remarquable et qui n'a été accordée qu'à un pe- d'oủ découle cette humeur visqueuse et abontit nombre d'habitants des paux, par celle de dante dont il est enduit, comme presque tous proférer des sons. Et en effet, plusieurs cottes, les autres cottes. Malgré la quantité de cette comme quelques balistes, des zées, des trigles matière gluante dont il est imprégné, sa chair et des cobites, font entendre, au milieu de cer- est agréable au goût; on ne la dédaigne pas ; on tains de leurs mouvements, une sorte de bruit ne redoute que le foie, qui est regardé comme particulier. Qu'il y a loin cependant d'un sim- tres - malfaisant, que l'on considère méme ple bruissement assez faible, très-monotone, comme une espèce de poison; et n'est-il pas à très-court et fréquemment involontaire, non remarquer que, dans tous les poissons, ce visseulement à ces sons articulés dont les nuances cère est la portion de l'animal dans laquelle les variées et légèies ne peuvent être produites que substances huileuses abondent le plus ? par un organe vocal tres-composé, ni saisies que par une oreilic très-delicate, mais encore à ces accents expressifs et si diversifiés qui appartiennent à un si grand nombre doiseaux et même à quelques mammiferes! Ce n'est qu'un frolement que les cottes, les cobites, les trigles, les zées, les balistes, font naitre. Ce n'est que lorsque, saisis de crainte ou agités par quelque autre affection vive, ils se contractent avec force, resserrent subitement leurs cavités intérieures, chassent avec violence les différents gaz renfermés dans ces cavités, que ces vapeurs sortant avec vitesse, et s'échappant prineipalement par les ouvertures branchiales, en froissent les opercules élastiques, et, par ce frottement toujours peu soutenu, font naitre des sons, dont ledegréd'élévation estinappréciable, etqui par conséquent, n'étant pas une voix, et ne formant qu'un véritable bruit, sont mème audessous du sifflement des reptiles '.

Parmi les cottes, l'un de ceux qui jouissent le plus de cette faculté de frôler et de bruire, a êté nommé Grognanl, parce que l'envie de rapprocher des ètres sans discernement et d'après les rapports les plus vagues, qui l'a si souvent emporté sur l'utilité de comparer leurs proprié tés avec couvenance, a fait dire qu'il y avait quelque analogie entre le grognement du cocho et le bruissement un peu grave du cotte, poisson est celui que nous allons décrire dans cet article.

On le trouve dans les eaux de l'A mérique méridionale, ainsi que dans celles des Indes oriertales. Il est brun sur le dos, et mêlé de brun de blane sur les cótés. Des taches brunes sont répandues sur ses nageoires, qui sont grises, ex-
DES POISSONS.

que l'on trouve ce cotte remarquable par ses | résister pendant assez longtemps au défaut armes, par sa force, par son ag lité. Il poursuit d'eau, la nature el la conformation de ses operavec unegrande rapidité, et par conséquent avec eules et de ses membranes branchiales lui donun grand avautage, la proie qui fuit devant nant la faculté de clore presque entièrement les lui à la surface de la mer. Doué d'une vigueur orifices de ses organes respiratoires, d'en intertrès-digne d'attention dansses musclescaudaux, dire le contact à l'air de l'atmosphère, et de pourvu par cetattribut d'un excellentinstrument garantir ainsi ces organes essentiels et délicats de natation, s'élançant comme un trait, très- de l'influence trop aetive, trop desséchante, et vorace, hardi, audacieux mẻme, il attaque avec par conséquent trop dangereuse, de ce mème promptitude des blennies, des gades, des clu- fluide atmosphérique.

pées, des saumons; il les combat avee acharnement, les frappe vivement avee les piquants de sa tète, les aiguillons de ses nageoires, les tubercules aigus répandus sur son corps, et en triomphe le plus souvent avee d'autant plus de facilité, qu'il joint une assez grande taille a l'impétuosité de ses mouvements, au nombre de ses dards et a la supériorité de sa hardiesse. En effet, nous devons croire, en comparant tous les témoignages, et malgré l'opinion de plusieurs habiles naturalistes, que dans les mers où il est le plusa l'abri de ses ennemis, le cotte scorpion peut parvenir a une longueur de plus de deux mètres : ce n'est qu'auprès des côtes fréquentées par des animaux marins dangereux pour ce poisson, qu'il ne montre presque jamais des dimensions tres-copsidérables. L'homme ne nuit guère a son entier développement, en le faisant périr avant le terme naturel de sa vie. La chair de ce cotte, peu agréable au goût et à l'odorat, n'est pas recherchée par les pècheurs; ce ne sont que les habitants peu délicats du Groenland, ainsi que de quelques autres fioides et sauvages contrées du Nord, qui en font quelquefois leur nourriture; et tout au plus tire-t-on parti de son foie pour en faire de l'huile, dans les éndroits oú, comme en Norvège, par exemple, il est très-répandu.

Si d'ailleurs ce poisson est jeté par quelque accident sur la greve, et que le retour des vagues, le reflux de la marée ou ses propres efforts, ne le ramènent pas promptement au milieu du fluide nécessaire à son existence, il peut nev., p. 67. - Scorpius marinus, Jonston, tab, 47, fig. 4et 5. - . Cotus scorpanx B-lonis simils., I willu liby, p. 15\%, Rai, p. 145, N. 12; et 142, n. 5 - Aldrevand., 1 b. 2, cap. 27 (pro 2J) , y. 202. - Gronov, 3as, 1. p. 66, n. 104; Act, 161.

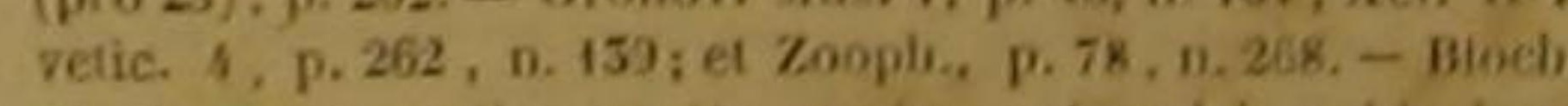
ph. 59. - reorystion capite masimo, et acul is vilde for- rids., Klein, Misce pisc. 4. p. 47, n. 11, Lab, 15, fig, 2 el 5 - Fisk sympen. Act. Nuros 2, p.585, Lab. 15 14. - Sea

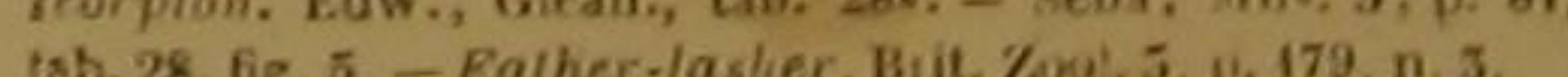

C'est pendant l'été que la plupart des cottes scorpions commencent a s'approcher des rivages de la mer; mais communement l hiver est dejà avancé, lorsqu'ils déposent léurs oufs, dont la couleur est rongeatre.

Tout leur corps est parsemé de petites verrues en quelque sorte épineuses, et beaucoup moins sensibles dans les femelles que dans les mâles.

La couleur de leur partie supérieure varie lle est ordinairement brune avec des raies et des points blanes: leur partie inférieure est aussi très-fréquemment mêlée de blane et de ches blanches; on distingue que quefois les fe melles par les nuances de ces mèmes nageoires, qui sont alors blanches et rayées de noir, et par le blanc assez pur du dessous de leur corps '.

La tête du scorpion est garnie de tubercules et d'aiguillons; les yeux sont grands, allongés, rapprochés l'un de l'autre, et placés sur le sommet de la tête; les màchoires sont extensibles, et hérissées comme le palais, de deuts aigués; la langue est épaisse, courte et dure; l'ouverture branchiale très-large ; I'opercule composé de deux lames; la iigne latérale droite, formée communément d'une suite de petits corps écailleux faciles a distinguer malgré la peau qui les recouvre, et placée le plus souvent au-dessous d'une seconde ligne produite par les pointes de die, et chacune des thoracines assez longue.

- A la premiere nag oire do dos 10 rayons. 3 la seconite 16 ,

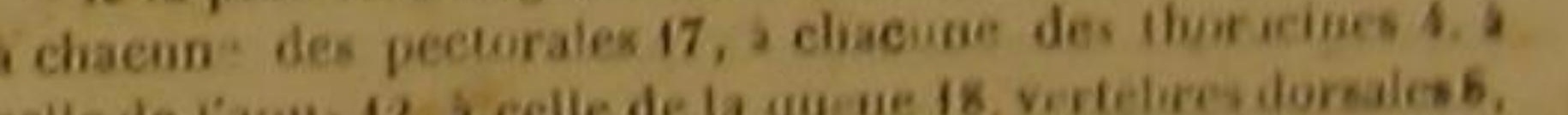
celle de rana-12, a celle de la quane is, in is. brun. Les nageoires sont rouges avec des ta. petites arêtes: la nageoire caudale est arron- 
LE COTTE QUATRE-CORNES '. Coltus quadricornis, Linn., Gmel., Lacep., Cuv.

Quatre tubercules osseux, rudes, poreux, s'élevent et forment un carré sur le sommet de la tête de ce cotte; ils y représentent, en quelque sorte, quatre cornes, dont les deux situées le plus pres du museau sont plus hautes et plus arrondies que les deux postêrieures.

Plus de vingt apophyses osseuses et piquantes, mais recouvertes par une légère pellicule se font aussi remarquer sur différentes portions de la tête ou du corps: on en distingue surtout deux au-dessus de la membrane des branehies, trois de chaque côté du carté formé par les cornes, deux auprès des narines, deux sur la nuque, et une au-dessus de chaque nageoire pectorale.

Le quatre-cornes ressemble d'ailleurs par un très-grand nombre de traits au cotte scorpion : il présente presque toutes les habitudes de dernier; il habite de mème dans l'Océan Atlantique septentrional, et particulierement dans la Baltique et auprès du Groenland; également armé, fort, vorace, audacieux, imprudent, il nage avec d'autant plus de rapidité, qu'il a de tres-grandes nageoires pectorales ${ }^{3}$, et qu'il les remue très-vivement : il se tient quelquefois en embuscade au milieu des fucus et des autres plantes marines, oú il dépose ses œưfs d'une couleur assez pâle; et dans certaines saisons il remonte les fleuves pour y trouver avee plus de facilité les vers, les insectes aquatiques et de jeunes poissons dont il aime à se nourrir.

On dit, au reste, que sa chair est plus agreable à manger que celle du scorpion; it ne parvient pas à une grandeur aussi considé nare dernier cotte; et les couleurs brunes eque geuses que présente le dos du quatre-cornes sont plus foncées, surtout lorsque l'animal est femelle, que les nuances distribué l'animal est tie supérieure du seores distribuées sur la parthe supérieure du scorpion. Le dessous du corps COllus quadricornis. - Horn simpa en Sutt

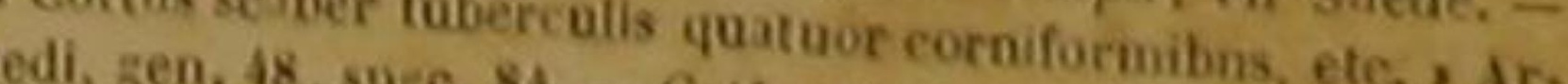
Enc. méth. - Id. Bonmate quntrecernes. Danbenton. Siecie, 521. - Mus, Adolut. Eid. de I Ene, mé h. - Fad

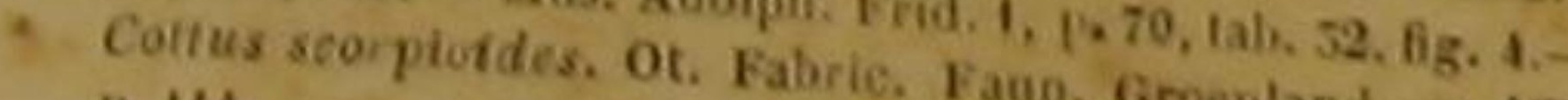
0. 114. "Chabois eau a quatre tubercutes, des mers sein p. i6s D quadricornis, Cav., Hist, nat. des toiss, I. p. $16 \mathrm{x}, \mathrm{D}$

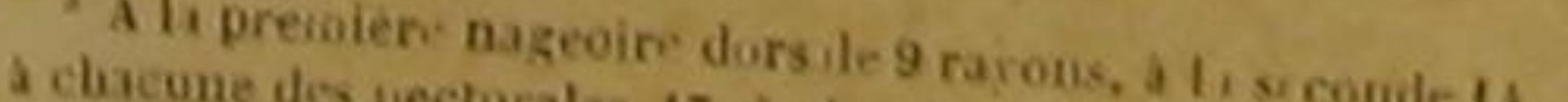

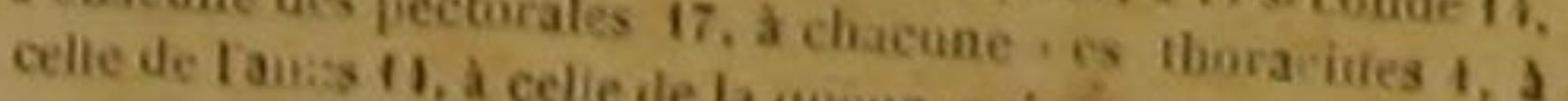

du cotte que nous déerivons, est d'un brun jaunátre.

Lorsqu'on ouvre un individu de cette espèce, on voit sept appendices ou cœecum auprès dupyore; quarante vertebres à l'épine dorsale; foie grand, jaunâtre, non divisé en lobes, situé du cêté gauche plus que du côté droit, et adherent à la vésicule du fiel qu'il recouvre; un canal intestinal recourbé deux fois; un péritoine noirâtre; et les poches membraneuses des œufs sont de la méme couleur.

\section{LE COTTE RABOTEUX '.}

Cottus scaber, Linn., Gmel., Lacep.; Platycephalus seaber, Guv, BI. " ?

Ce poisson habite dans le grand Océan, et particulièrement auprès des rivages des Indes orientales, ou il vit de mollusques et de crabes. C'est un des cottes dont les couleurs sont le moins obscures et le moins monotones : du bleuâtre regne sur son dos; ses côtés sont argentés; six ou sept bandes rougeátres forment comme autant de ceintures autour de son corps: ses nageoires sont bleues ${ }^{3}$; on voit trois bandes jaunes sur les thoracines; et les pectorales présentent à leur base la mème nuance jaune.

Les écailles sont petites, mais fortement attachées, dures et dentelées; la ligne latérale offre une rangée longitudinale d'aiguillons recour en arvière; quatre piquants également recourbés paraissent sur la tete, et indépendamment des rayons aiguillonnés ou non articntés des rayons aiguillonnés ou non articulés qui soutiennent la première nageoire dorsale, voila née au cotte qui fait le sujet de cet arux, donD'ailleurs la fête le sujet de cet article. D'ailleurs la téte est allongée, la mâchoire in. férieure plus a vancée que la supérieure, la lan. gue mince, l'ouverture de la bouche très-grande, t'orifice branchial très-large.

Collus scaber. - Colte rabotemx. Daubenton En 'Cette espiece est play ple de I Enc. méth. - Bloch, pl. I80. M. Cuvier. D.

angevire dic dos 8. a la secoode 12 rayons ", a la premiere les 18 , a chacune des thoracines 6 , a celle de Fanis I2 aetira de la quene 16.

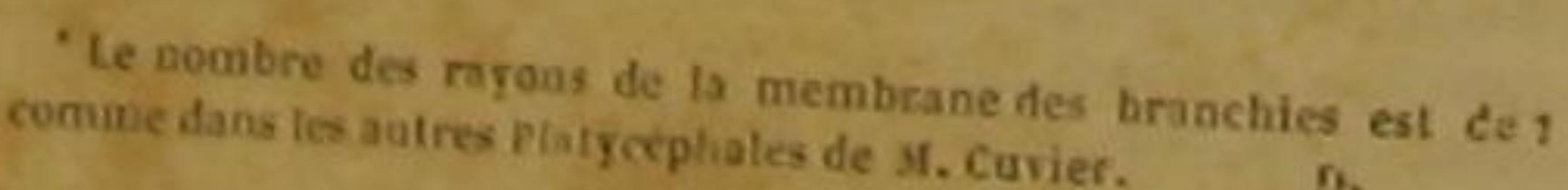

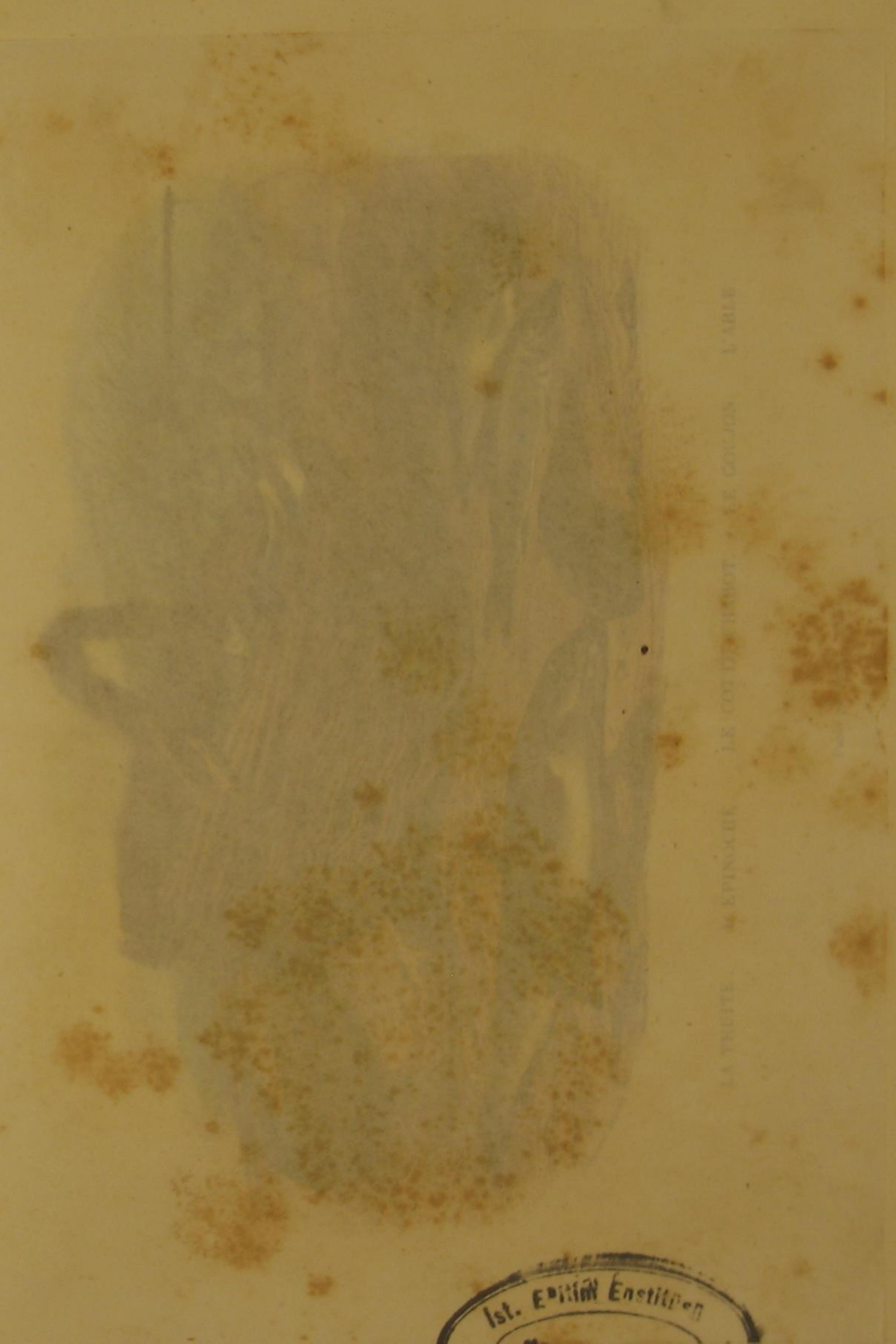



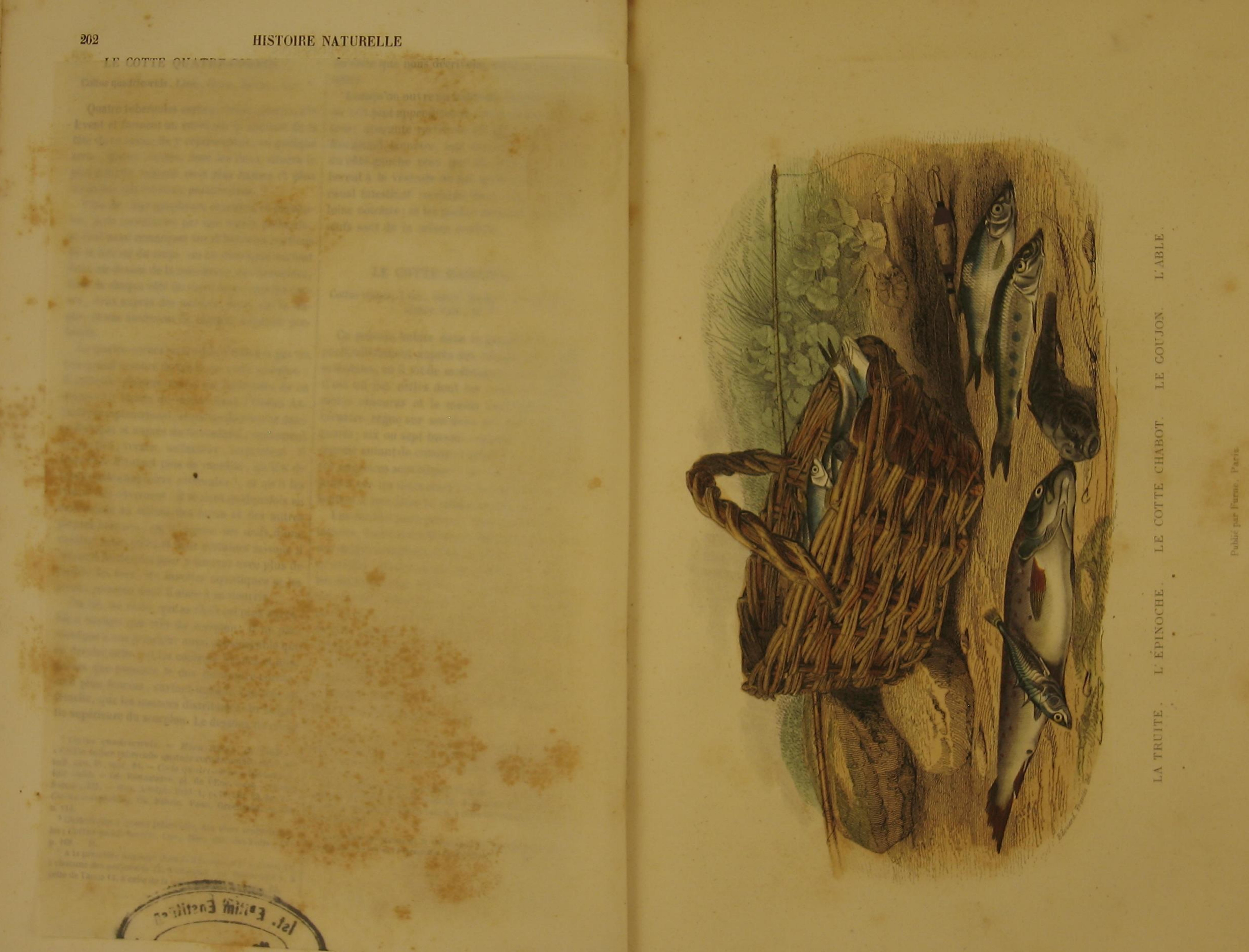
LE COTTE AUSTRAL '.

Cnttus australis, J. White, Lacep.; Apistes australis, Cuv, ${ }^{2}$.

Nous plaçons ici la notice d'un cotte observe dans le grand Océan équinoxial, et auquel nou conservons le nom spécifique d'Austral, qui lui a été donné dans l'Appendix du Voyage de l'Anglais Jean White à la Nouvelle-Galles méridionale. Ce poisson est blauchâtre; il présente de bandes transversales d'une couleur livide, et des raies longitudinales jaunâtres; sa tète est armé d'aiguillons. L'individu de cette espèce dont on a donné la figure dans le Voyage que nous venons de eiter, n'avait guère qu'un décimètre de longueur.

\section{LE COTTE INSIDIATEUR ${ }^{3}$.}

Coltus insidiator, Forsk., Linu., Lacep.; Coltus Spatula, Bl.; Batrachus indicus, ibid.; Platyceph? indicus, ibid.; Platyecphalus insidiator, Cuv. ‘

i Ce cotte se couche dans le sable; il s'y tient en embuscade pour saisir avée plus de facilite les poissons dont il veut faire sa proie; et de là vient le nom qu'il porte. On le trouve en Arabie; il y a été observé par Forskael, et il y parvient quelquefois jusqu'à la longueur de six ou sept décimetres Sa tête présente des stries relevées, et deux aiguillons de chaque coté. II est gris par-dessus et blanc par-dessous; la queue est blanche 5 : I'on voit dailleurs sur cette même portion de l'animal une tache jaune et échancrée, ainsi que deux raies inégales, obliques et noires; et de plus le dos est parsemé de taches et de points bruns.

- Cottus austratis. Appendix du Voyage à la Nouvelle

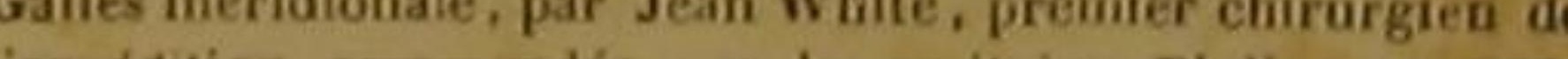
expédition commandée par te capitaine Phllipp, p. 263.

Cuvier retire ce poisson du genre des Cbabots, Collus pour les reporperler dan

'Forskael, Faun. Arab

naterre, pl. de l'Enc, méth. phale, fait remarguer quiil a été décrit trois fois par $\mathrm{M}$. de Lacepede, sous les divers aons de ro Cotle insidiateur, $2^{\circ} \mathrm{Cal}$ thomore indien (vayez p. ba), el so Colle madégasse (voyez 5 A b ?

5 . veue 13.
LE COTTE MADÉGASSE '. Cottus madagascariensis, Lacep,; Platycephalus insi-
diator, Cuv. ?

La description de ce cotte n'a point encore été publiée; nous en avons trouvé une courte notice dans les manuscrits de Commerson, qui l'a observé auprès du fort Dauphin de l'ile de

Madagascar, et qui nous en a laissé deux dessins très-exacts, l'un représentant l'animal vu par-dessus, et l'autre le montrant vu par-dessous.

Ce poisson, qui parvient à quatre décimètres ou environ de longueur, a la tête armée, de chaque côté, de deux aiguillons recourbés. De plus, cette tête, qui est aplatie de haut en bas, présente dans sa partie supérieure un sillon profondet très-large, qui s'étend longitudinalement entre les yeux, et continue de s'a vancer entre les deux opercules, en s'y rétrécissant cependant. Ce trait seul suffirait pour séparer le madégasse des autres cottes.

D'ailleurs son corps est couvert d'écailles assez grandes; son museau arrondi, et la máchoire inférieure plus avancée que la supérieure. Les yeux, très-rapprochésl'un de l'autre, sont situés dans la partie supérieure de la tête; les opercules sont pointillés; la première nageoire du dos est triangulaire ${ }^{3} ;$ l'anus plus proche de la gorge que de la nageoire caudale; et cette derniere nageoire parait, dans les deux figures du madégasse réuníes aux manuserits de Commerson, et que nous avons fait graver, parait, dis-je, doublement échancrée, c'est-a-dire divisée en trois lobes arrondis; ce qui donnerait une conformation extrêmement rare parmi celles des poissons non élevés en domesticité.

\section{LE COTTE NOIR}

Coltus niger, Lacep. '

Voici le précis de ce que nous avons trouvé . Coltus s $\mathrm{i}$ inis quatuor tateralibus retroversis, canda va. riegata, ori capite retrorsum tetracantho, sulco inter ocu- los longitudinali lato et profundo. , Commerson, manus. crits dejacites.

23. Guvier place le Cotte madegasse dans le genre Piaty ephate, et in prouve que ce poisson est, sinon le meme yn-

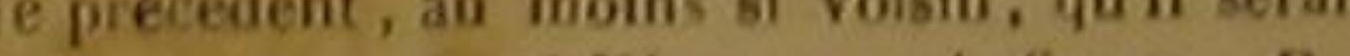

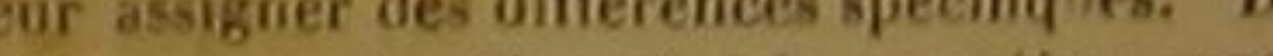
'S rayons aigunitonnes a la prem rayons artieulés a chieune iles pectorales, 5 ou 6 rayons articules a chacune des thora. cines, la nageoire de l'anus est trese-éroith.

Le petil cabol noir. -. Collos nigricans, squamosus, scaber, acoleo obscuro in capite utrinque. . Cammerson, manuscrits déja cités. 
dans les manuscrits de Commerson au sujet de septentrionale, dont le fond est pierreux ou sace cotte, qu'il a observé, et qu'il ne faut con- blonneux. Il y parvient jusquà la longueur de fondre avec aucune des espèces déjà connues deux décimètres '. Il s'y tient souvent caché des naturalistes.

La grandeur et le port de ce poisson sont assez semblables à ceux du gobie noir; sa longeur ne va pas à deux décimètres. La couleur générale est noire, ou d'un brun noirâtre; la seconde nageoire du dos, celle de l'anus et celle de la queue sont bordées d'un liséré plus foncé, ou pointillées de noir ; la première nageoire dorsale présente plusieurs nuances de jaune, et deux bandes longitudinales noirâtres; et le noir ou le noirâtre se retrouve encore sur l'iris.

La tète épaisse, plus large par derrière que la partie antérieure du corps, et armée d'un potit aiguillon de chaque côté, parait comme gonflée à cause des dimensions et de la figure des muscles situés sur les joues, c'est-à-dire au-dessus de la région des branchies. Le museau est arrondi; l'ouverture de la bouche trés-grande; la mâchoire inférieure plus avancée que la supérieure; celle-ci facilement extensible; chacune de ces deux máchoires garnie de dents courtes, serrées, et semblables à celles que l'on voit sur deux éminences osseuses placées auprès du gosier; le palais très-lisse, et tout le corps revêtu, de mème que la queue, d'écailles très-rudes au toucher.

\section{LE COTTE CHABOT'.}

Cottus Gobio, Lino., Gmel., Lacep., Bloch, Gav, ,

On trouve ce cotte dans presque tous les fletves et tous les ruisseaux de l'Europe et de l'A sie

genre Eleotris, ou au sous-genre Périophthalme, dans le genre
Gobie. D. 'Sten simpa, Sten lake, en Suede. - Bull-head, Millers conmb. en Angleterre. - Messore, Capo grosso, dans ptus. Cotle chabat. Dambenten ane, Ane, dans plus, dép, mér. -

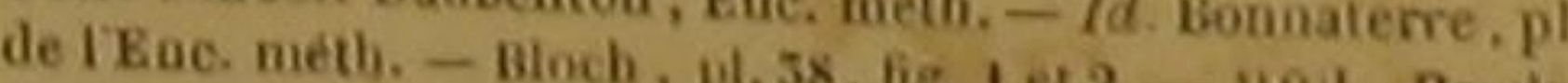
Zool. Danic., p. A4. o. 368. - Ot. Fabric Fan. - Grit, Prods p. 159. n. 115. - C Cottus alevidotos, elabere, capite diand

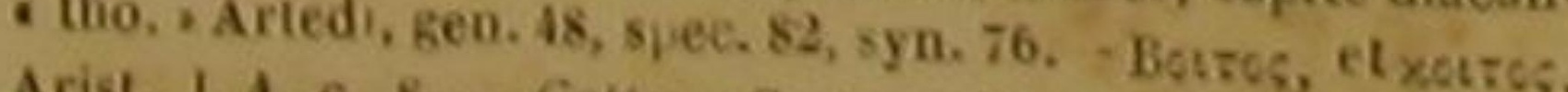
Arist, I. A, e. 8. - Cottus, Gaza, Arist. - Chabot. Ronde-

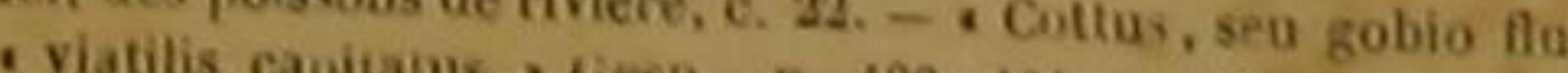

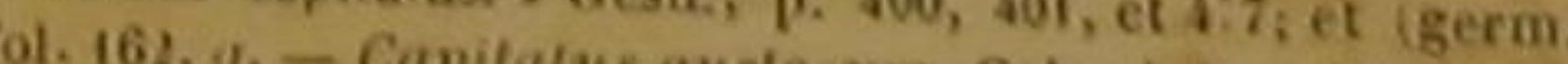

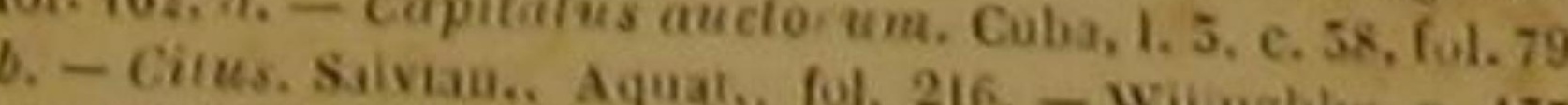
lab. II, 3, fig, 5. - - Gubius fluviatilis, sive copula, p. 157,

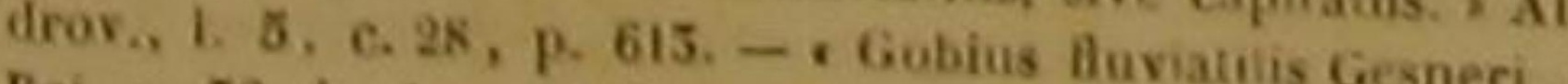

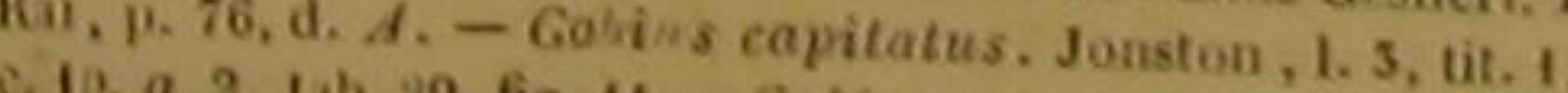
G, a. 2, tab. 29, fig. 11. - Gobio ca pilalus. Chäi.., p. 157, genre des Chabots ou Chaboisseanx proprener, type du sousBenre du même nom. $\mathrm{D}$.

deux décimetres '. Il s'y tient souvent caché
parmi les pierres, ou dans une espèce de petit terrier ; et lorsqu'il sort de cet asile ou de cette embuscade, c'est avec une très-grande rapidité qu'il nage, soit pour atteindre la petite proie qu'il préfere, soit pour échapperà ses nombreux ennemis. Il aime à se nourrir de très-jeunes poissons, ainsi que de vers et d'insectes aquatiques ; et lorsque cet aliment lui manque, il se jette sur les œufs des diverses espèces d'animaux qui habitent dans les eaux qu'il fréquente.

II est très-vorace : mais la vivacité de ses ap. pétits est trop éloignée de pouvoir compenser les effets de la petitesse de sa taille, de ses mauvaises armes et de son peu de force; et il succombe fréquemment sous la dent des per. ches, des saumons, et surtout des brochets. I bonté et la salubrité de sa chair, qui devien rouge par la cuisson comme celle du saumon et de plusieurs autres poissons délicats et agrẻables au goût, lui donnent aussi l'homme pour ennemi. Dès le temps d'Aristote, on savait que, pour le prendre avec plus de facilité, il fallai frapper sur les pierres qui lui servaient d'abri qu'à l'instant il sortait de sa retraite, et que souvent il venait, tout étourdi par le coup, se livrer lui-méme à la main ou au filet du pécheur. Le plus souvent ce dernier emploie la nasse ${ }^{2}$, pour être plus sûr d'empêcher le chabot de s'échapper. II faut saisir ce cotte avec précaution lorsqu'on veut le retenir avec la main : sa peau très-visqueuse lui donne en effet la faculté de glisser rapidement entre les doigts. Cependant, malgré tous les piéges qu'on lui tend, et le grand nombre dennemis qui le poursuivent, on le trouve fréquemment dans plusieurs rivières. Cette espèce est très-féconde. La femelle, plus grosse que le mâle, ainsi que celles de tant Chabot, Valmont de Bomare, Dict. dhist. nat. - , Cottus alepidotus, capile plagiop ateo. lat?, obtuso, etc., Gronov. Kle n. Mis. pisc., p. $45, \mathrm{n}, 17$, - G G bins, et brevis, etc. Bél nn, Aquat., p. 521. - Gobio fuviatils capitatos. Warsigi, Danub. 4, p. 75, tab. 24, fig. 2. - Bull-head, Brit lab. 12, p. 177, L. 11. - Rots kolbe, Meyer, Thierb. 2, p. A.

- A la memhrane des branchies 4 rayons, à la première na a chacune des thoracines de 17 , a cha une dis pecturates 14 queve 15 . "Voyez la description de la nasse dans larticle du Pélro.
myzon lamproie. 


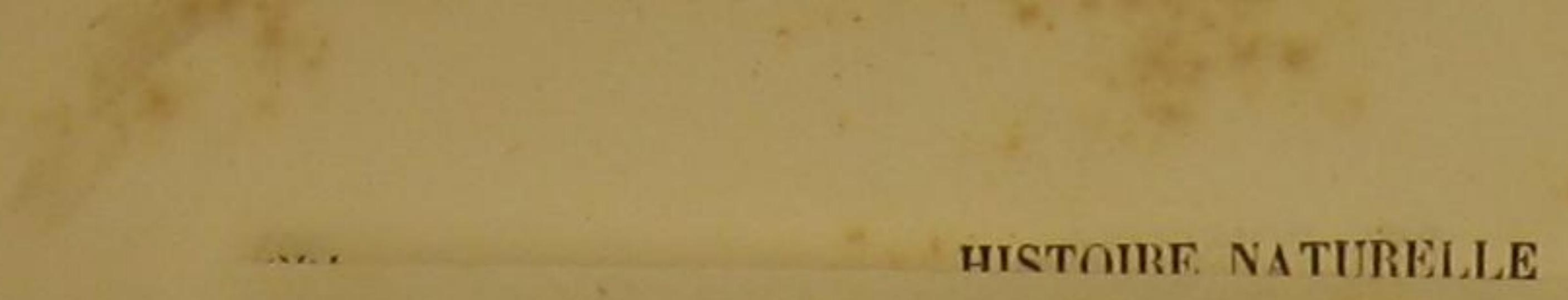




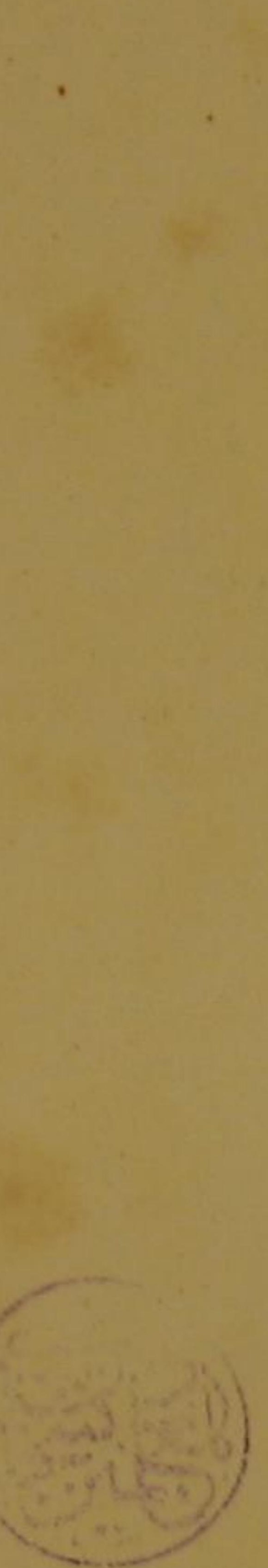

d'autres espèces de poissons, parait comme gonflée dans le temps où ses ceufs sont près d'être pondus. Les protubérances formées par les deux pondus. Les protuberancest, pour ainsi dire, à cette époque, en se remplissant d'un très-grand cette ế doús sont assez élevées et assez ar. nombre d au qu'on les ait comparées à des ma-

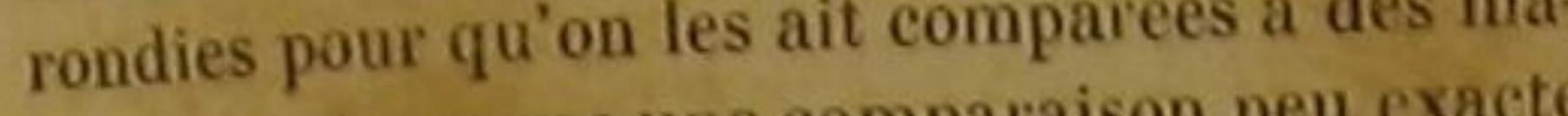
melles; et comme une comparaison peuc cacte conduit souvent à une idée exagérée, et une idée exagérée à une erreur, de célèbres naturalistes ont écrit que la femelle du chabot avait listes ont écrit que la femelie du chabot mais ennon-seulement un rapport de forme, mais encore un rapport d'habitude, avec les animaux à mamelles, qu'elle couvait ses øufs, et qu'elle perdait plutôt la vie que de les abandonner. Pour peu qu'on veuille rappeler ce que nou avons écrit' sur la manière dont les poissons se reproduisent, on verra aisément combien on s'est mépris sur le but de quelques actes aceidentels d'un petit nombre d'individus soumis à lentuence de circonstances passageres et trèsparticulières. On a pu observer des chabots femelles et même des chabots mâles se retirer, se presser, se cacher dans le mème endroit ou des press de leur espèce avaientété pondus, les coucuifs de lear espette attitude, et conserver leur posivrir dans cette attitude, et conserver tes pour la tion malgré un grand nombre d'efforts pour la leur faire quitter. Mais ces manœuvres n'ont point été des soins attentifs pour les embryons point été des soins attenire; elles se réduisent à qu'ils avaient pu produire; elles se reduns pour des signes de crainte, a des precautions pour leur súreté; et peut-étre meme ces individus auxquels on a cru devoir attribuer une tendresse constante et courageuse, n'ont-ils été surpris que prêts à dévorer ces mèmes œuf́s qu'ils paraissaient vouloir réchauffer, garantir qu'ils paraiss
et défendre.

Au reste, les écailles dont la peau muqueuse du chabot est revêtue, ne sont un peu sensibles du cha par moyen de quelques procédés ou dans que par le noynd de ed certaines circonstances : mais si la matiere ecailleusene s'étend pas sur son corps en lames brillantes et facilement visibles, elle s'y réunit en petits tubercules ou verrues arrondies. Le despetits tubercules ou veranc : le mâle est, dans sous de son corps est blanc: le male est, brusa partie supérieure, gris avec des taches brunes; et la femelle brune avec des taches noires. Les nageoires sont le plus souvent bleuâtres et tachetées de noir ; les thoracines de la femelle tache et de brun.

' Voyez le Discours suic ha nature dis poissone.
Les yeux sont très-rapprochès l'un de l'autre. Des dents ai uếs hérissent les máchoires, le palais et le cosier; mais la langue est lisse. Chaque opercule ne présente qu une seule pièce t deux aiguillons recourbés. La nageoire caudale est arrondie.

On voit de chaque cóté les deux branchies intermediairesgarnies, dansleur partie coneave, de deux rangs de tubercules. Le foie est grand, non divisó, jaunâtre, et situé en grande partie du côté gauche de l'animal; l'estomac est vaste. Auprès du pylore sont attachés quatre cacum ou appendices intestinaux; le canal intestinal n'est plié que deux fois; les deux laites des máles et les deux ovaires des femelles se réunissent vers l'anus, et sont contenus dans une membrane dont la couleur est très-noire, ainsi que celle du péritoine; les reins et la vessie quinaire sont très-étendus et situés dans le fond de l'abdomen.

On compte dans la charpente osseuse du chabot trente-une vertèbres; et il y a environ dix cotes de chaque côté.

\section{QUATRE-VINGT-NEUVIEME GENRE.}

LES sconpénes'.

La tete garnie d'aiguillons, ou de protuberances, ou de barbilions, et depoir

PREMIER SOUS-GENRE. point de barbillons. esPECES.

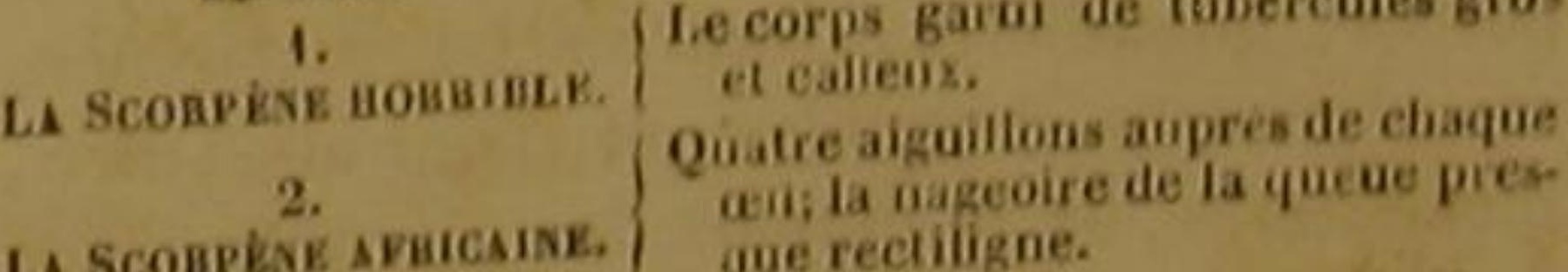 ua scomats s.

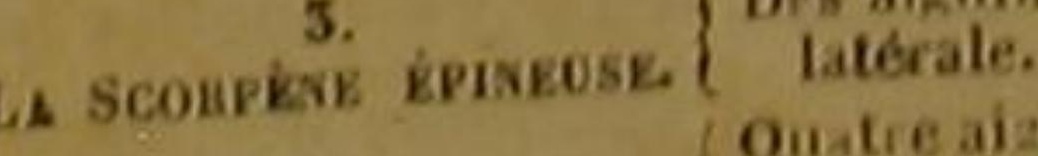 A.
LA Scospisk siout-
LoNsk.

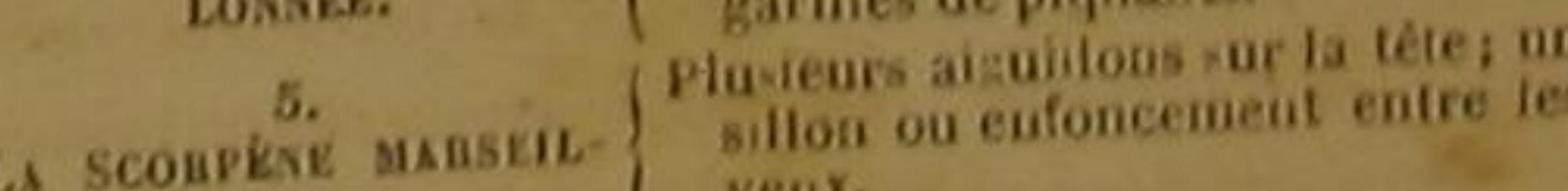 uA SCOMPESE MAISEL-
LAISE. 6.
LA SCOBRE DoveLE.
yLAMEST.
13. Cuvier admet le genre Seorpana de Linnée (dans sa

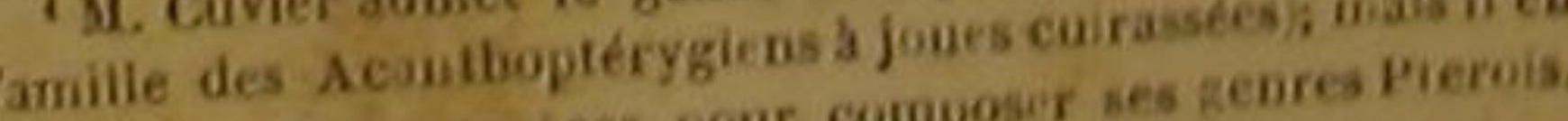 distrait eeria nes especes, pour composes synancée. 11 partage

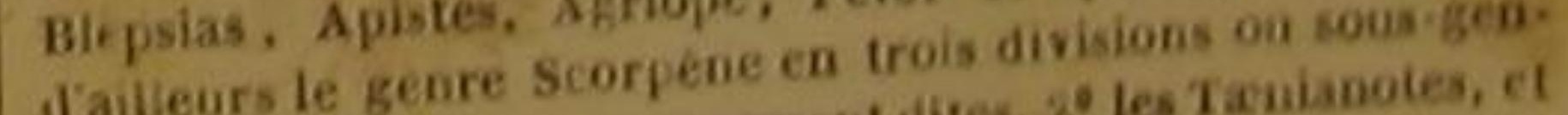 res, $1^{\circ}$ les Scoryenes proprencut dites, $2^{\circ}$ les res, fo les scorpenes
3o les 8 basies. D.

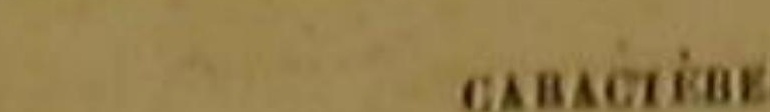




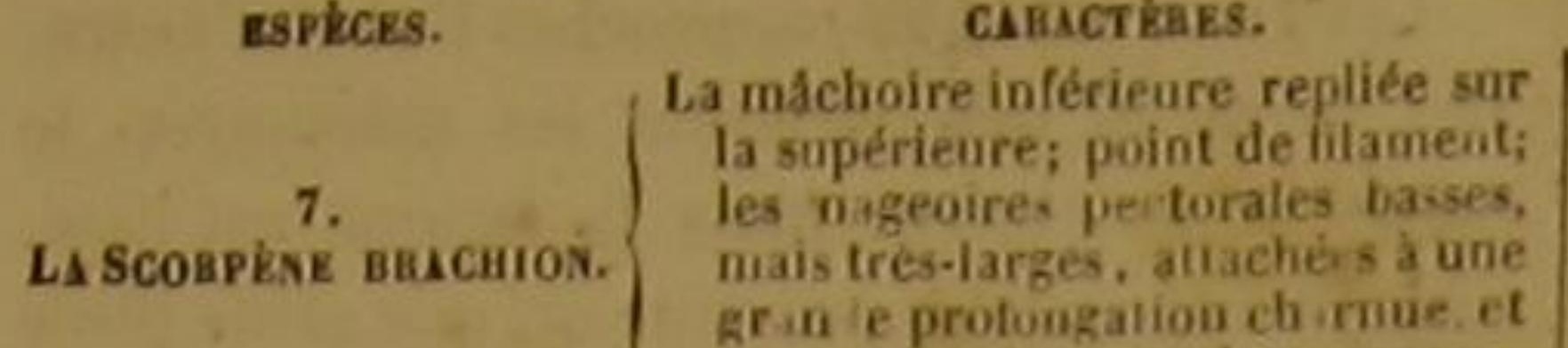 grin e protomgalion ch irmue. et
composesde vingt-deux rayons.}

SECOND SOUS-GENRE.

Des barbillons.

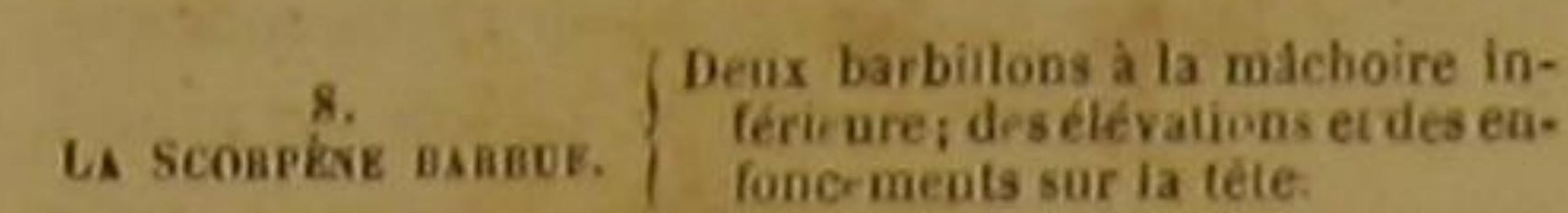

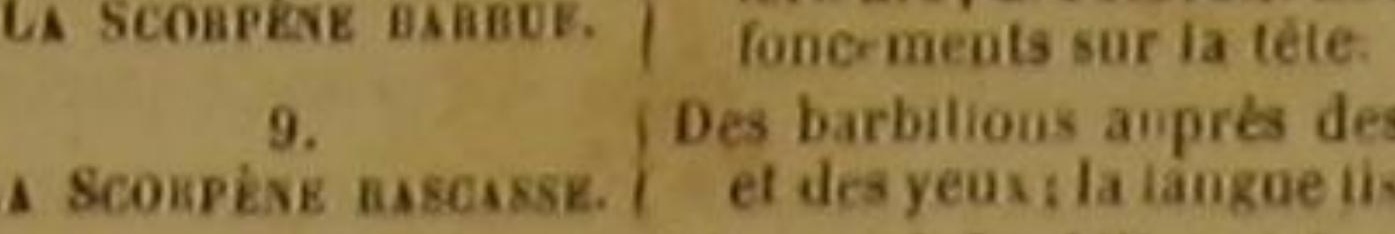

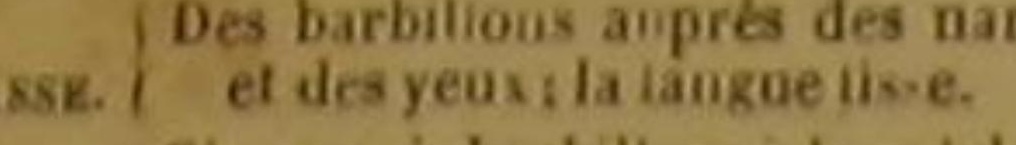

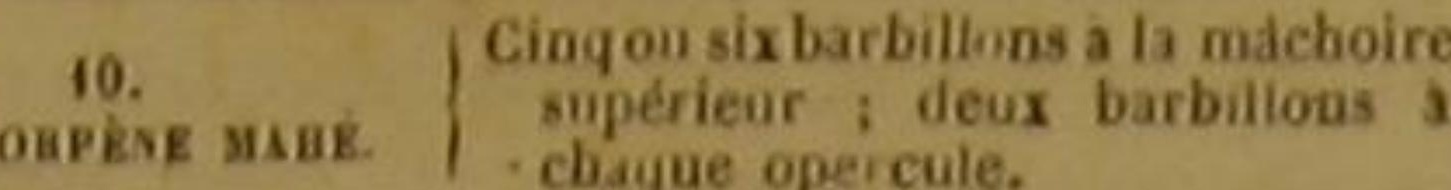
- chaque opercule.

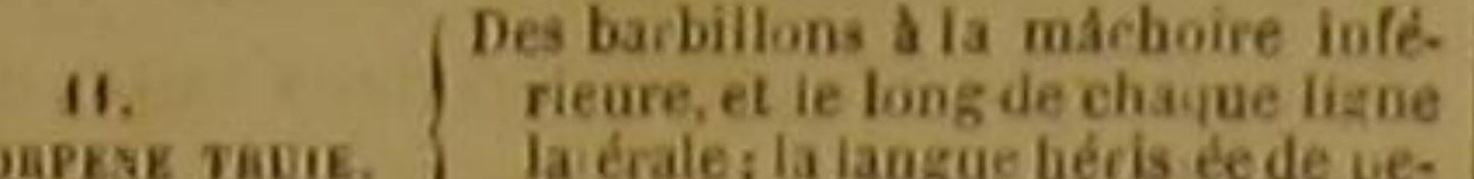
la crale;
tites dent.

Quatre barbilions frangés a la ma.

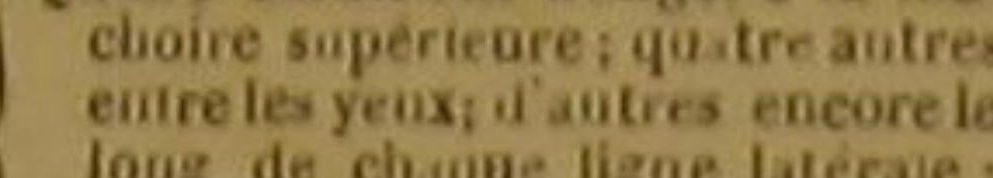
loug de chique ligne biterale :
despiquants trangulaires sur ia
test

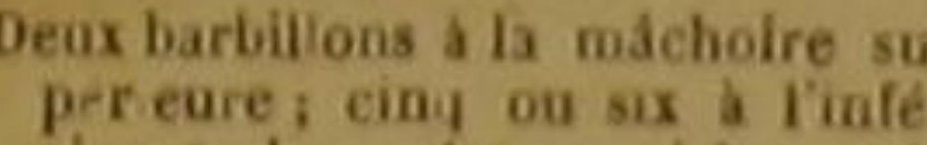

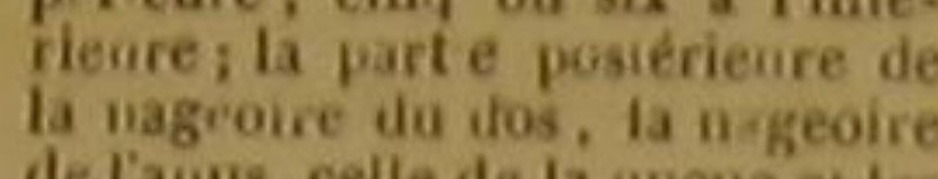
da nagroire du dos, ta ngeoire
de lauus, eclie de la queue et le
pectorales, tressarrondies.

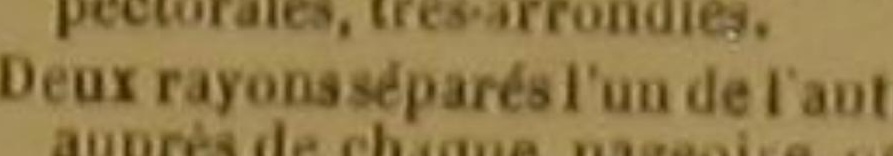
aupresons de chaques nazeoire pee
lorale. UA SCoRPERE DIDAC-
TMLE.

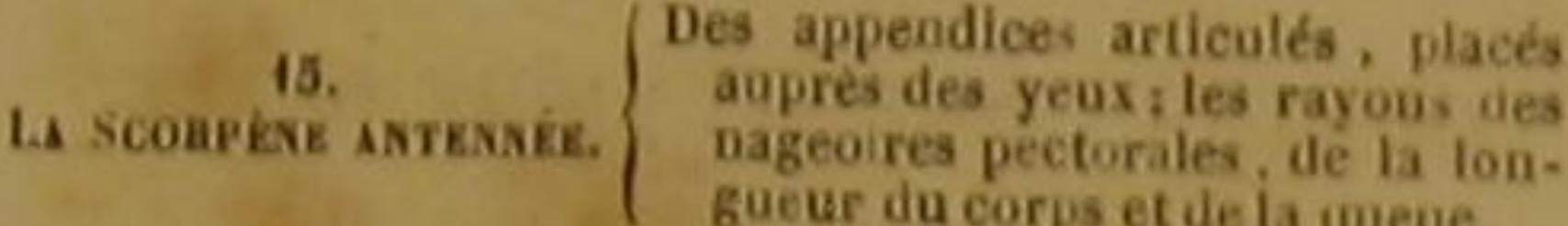
$16 . \quad$ Les nageoires pectorales plus ton-

LA SCORPENE HORRIBLE'

Scorpæena horrida, Linu, Gmel., Lacep., Bloch Synan eia horrida, Cuv. '?

On dirait que c'est dans les formes très composées, singulières, bizarres en apparence, monstrueuses, horribles, et, pour ainsi dire menaçantes, de la plupart des scorpènes, que les poètes, les romanciers, les mythologues et les peintres ont cherché les modeles des étres fantastiques, des larves, des ombres évoquées et des démous, dont ils ont environné leurs sages enchanteurs, leurs magiciens redontables et leurs sorciers ridicules; ce n'est mème qu'avee une sorte de peine que l'imagination parait

'Bloch. pl. 185. - Seorpene erapaud, Daubenton, Ene.

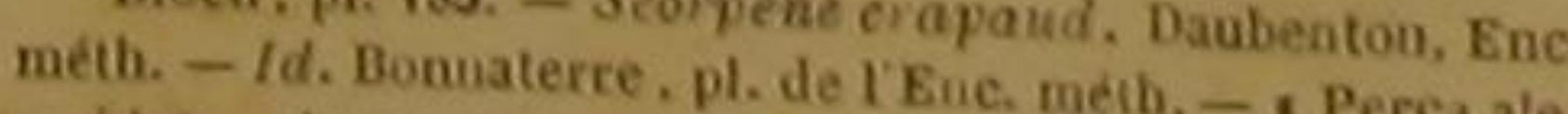
- pidota, dorso monopterygio, capite caremato Lato, etc. , Grou Zooph., p. 88, n. 292, tab, II, 12, is

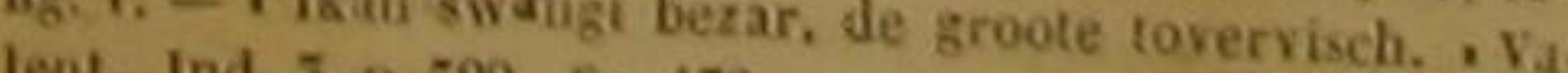

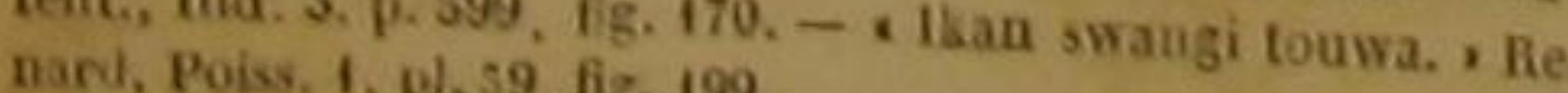
xee poisone est te type do crée par schneider pour placer direnoancée, Synanceio,

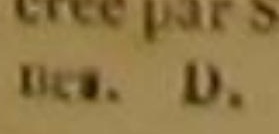

étre parvenue à surpasser ces modèles, à placer ses productions mensongères au-dessus de ces réalités, et à s'étonner encore plus des résultats de ses jeux que des combinaisons par lesquelles la nature a donné naissance au genre que nous examinons. Mais si en façonnant les scorpènes la nature a donné un exemple remarquable de l'infinie variété que ses ouvrages peuvent présenter, elle a montré d'une manière bien plus frappante combien sa manière de procéder est toujours supérieure à celle de l'art elle a imprimé d'une manière éclatante sur ces scorpènes, comme sur tant d'autres produits de sa puissance créatrice, le sceau de sa prééminence sur l'intelligence humaine : et cette considération n'est-elle pas d'une haute importanee pour le philosophe? le génie de I'homme rapproche ou sépare, réunit ou divise, anéan. tit, pour ainsi dire, ou reproduit tout ce qu'il conęoit : mais de quelque manière qu'il place à cóté les uns des autres ces êtres qu'il transporte à son gré, il ne peut pas les lier complétement par cette série infinie de nuances insensibles, analogues et intermédiaires, qui ne dépendent que de la nature; le grand art des transitions appartient par excellence à cette nature féconde et merveilleuse. Lors mème qu'elle associe les formes que la première vue considère comme les plus disparates, soit qu'elle en revète ees monstruosités passagères auxquelles elle refuse le droit de se reproduire, soit qu'elle les applique à des sujets constants qui se multiplient et se perpétuent sans manifester de changement sensible, elle les coordonne, les groupe et les modifie d'une telle manière, qu' elles montrent facilement à une attention peu soutenue une sorte d'air général de fảmille, et que d'habiles dégradations ne laissent que des rapports qui s'attirent, à la place de nombreuses disconvenances qui se repousseraient. La scorpène horrible offre une preuve de cette manière d'opérer, qui est un des grands secrets de la nature. On s'en convaincra aisément, en examinant la description et la figure de cet animal remarquable

Sa téte est très-grande et très-inégale dans sa surface : creusée par de profonds sinus, reievée en d'autres endroits par des protubérances très. saillantes, hérissée d'aiguillons, elle est d'ailleurs parsemée, sur les côtés, de tubercules ou de callosités un peu arrondies et cependant ir. régulières et très-inégales en grossendant ir-

DES POIS. 'ONS.

des plus grands enfoncements qu'elle présente sont séparés, par une cloison très-incliuée, en deux ureux inégaux et irréguliers, et sont placés au-dessous des yeux, qui d'aifleurs sont très-petits, et situés ehacun dans une proéminence très-relevée et un peu arrondie par le haut; sur la nuque s'élèvent deux autres protubérances comprimées dans leur partie supérieure, anguleuses, et qui montrent sur leur côté extérieur une cavité assez profonde; et ces deux éminences réunies avec celles des yeux forment, sur la grande tète de l'horrible, quatre sortes de cornes très-irrégulières, trèsfrappantes, et, pour ainsi dire, hidenses.

Les deux mâchoires sont articulées de manière que lorsque la bouche est fermée, elles s'élèvent presque verticalement, au lieu de s'etendre horizontalement : la måchoire inférieure ne peut clore la bouche qu'en se relevant comme un battant ou comme une sorte de pont-levis . et en dépassant mème quelquefois en arrière la ligne verticale, afin de s'appliquer plus exactement contre la mâchoire supérieure ; et quand elle est dans cette position, et qu'on la regarde par devant, elle ressemble assez à un fer a cheval : ces deux máchoires sont garnies d'un grand nombre de très-petites dents, ainsi que le gosier. Le palais et la langue sont lisses ; cette dernière est, de plus, large, arrondie, et assez libre. On la découvre aisément, pou peu que la scorpène rabatte sa mâchoire inférieure et ouvre sa grande gueule; l'orifice branchial est aussi trè-large.

Les trois ou quatre premiers rayons de la nageoire du dos, très-gros, très-difformes, trèsséparés l'un del'autre, très-inégaux, très-irréguliers, très-dénués d'une véritable membrane, ressemblent moins àdes piquants de nageoire qu'à des tubérosités branchues, dont le sommet néanmoins laisse dépasser la pointe de l'aiguillon '; la ligne latérale suit la courbure du dos.

Le corps et la queue, sont garnis de tubereules calleux semblables à ceux qui sont répandus sur la tête; et l'on en voít d'analogues, mais plus petits, non-seulement sur les nageoires pectorales qui sont très-longues, mais encore sur la membrane qui réunit les rayons de la nageoire dorsale.

' 3 rayons à la ménbrane des branchies, 15 rayons non art cules et sept rayons articules a la nageore dis dos. 16 rayons $\lambda$ chacune des pectorales, 6 a chacune des thoracines. 3 rayons non articulés et 6 . i a nageoire de la queue est arrondie et rayée : la c vleur générale de l'animal est variée de bru. $t$ de blanc; et c'est dans les Indes orientales que l'on rencontre cette espèce, qui se nourrit de crabes et de mollusques, sur laquelle, au milieu de rapprochements bizarres en apparence et cependant merveilleusement concertés, des formes très-disparates au premier coup d'wil se liant par des dégradations intermédiaires et bien ménagées, montrant des parties semblables où I'on n'avait d'abord soupçonne que des portions très-différentes, paraissent avoir été bien plutot préparées les unes pour les autres que placées de maniére à se heurter, pour ainsi dire, avee violence, mais dont l'ensemble, malgré ces sortes de précautions, repousse tellement le premier regard, qu'on n'a pas eru la dégrader en la nommant horrible, en l'appelant de plus Crapaud de mer, et en lui donnant ainsi le nom d'un des animaux les plus bideux.

\section{A SCORPENE AFRICAINE '.}

Srorpana capensis, Limu., Gmel.; Scorpena africana, Lacep.; Sebastes capensis, Cuv, "

On rencontre auprès du cap de Bomne-Espérance et de quelques autres contrées de l'Afrique, cette scorpene dont la longueur ordinaire est de quatre décimètres; elle est revêtue d'écailles petites, rudes, et placées les unes audessus des autres comme les ardoises des toits ${ }^{3}$.

Les yeux sont situés sur les cotés de la tète yui est prande et convexe : une prolongation de l'épiderme les couvre comme un voile transparent ; l'ouverture de la bouche est trés-large; les deux mâchoires sont également avancées; deux lames composent chaque opercule; quatre pointes garnissent la supèrieure; l'inferieure se termine en pointe du côté de la queue; et le dos est arqué ainsi que caréné.

'Gronov. Zooph., p. 88, n. 295.

iM. Covier place ce poisson dans le sous-genre sebaste, "un de ceux qui partagent son genre scorpéne. D. Gen Guleset 12 peyons articules a la uageoire du dos, 18 rayons chacune des pectorales, 1 rayon non articulé et 5 rayous articules a ciacene des thoracin:s, 3 rayońs non articules at G rayoi
quene. 
LA SCORPÉNE ÉPINEUSE '

Scorpæna spinosa, Linn., Gmel., Lacep. ; Apistes longispinis, Cuv. ${ }^{3}$.

Le corps de ce poisson est comprimé ; des aiguillons paraissent sur sa tête; sa ligne latérale est d'ailleurs hérissée de pointes; et sa nageoire dorsale, plus étendue encore que celle de la plupart des scorpènes, règne depuis l'entre-deux des yeux jusqu'a la nageoire caudale.

\section{LA SCORPÉNE AIGUILLONNÉE.} Scorpwena aculeata, Licep ; Premnas unicolor, Cuv.'.

La description de cette espèce n'a èncore été publiée par aucun auteur; nous en avons vu des individus dans la collection de poissons sees que renferme le Muséum d'histoire naturelle. Quatre aiguillons recourbés vers le bas et en arrière paraissent au-dessous des yeux ; ces pointes sont d'ailleurs très-fortes, surtout la première et la troisième; des piquants garnissent les deux lames de chaque opercule; la partie des nageoires du dos et de l'anus ${ }^{4}$, que des rayons articulés soutiennent, est plus élevée que l'autre portion ; elle est de plus arrondie comme tes pectorales, et comme la nageoire de la queue.

\section{LA SCORPÉNE MARSEILLAISE.}

Coltus massilliensis, Forsk., Linn, Gmel.; Seorpen massiliensis, Lacep. s.

Ce poisson a beaucoup de rapports avec les cottes, parmí lesquels il a mème été inscrit, quoiqu'il n'offre pas tous les caractères essentiels de ces derniers, et qu'il présente tous ceu qui servent à distinguer les scorpènes. Il res-

' Ind, Mus, Linek. f. p. 41.

'Il. Cuvier regarde ce posson comme appartenant da soo -M. Cusier retire ce potsonsons, t. IV, p. 408. D

re, orter dans celui quil a nommé Eremmade, weia, pour le

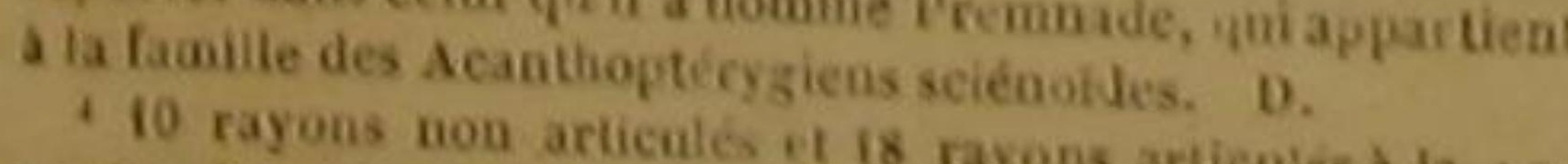

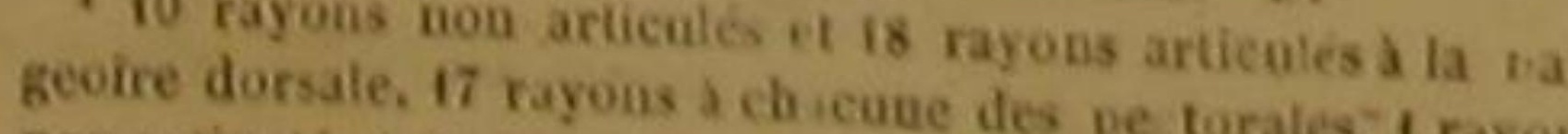

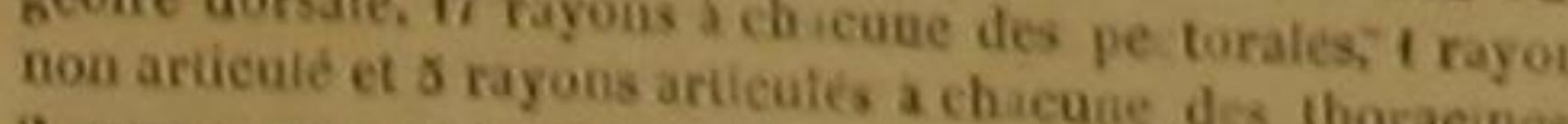
2 rayous non articults oft in ins a chicune des thoraenes,

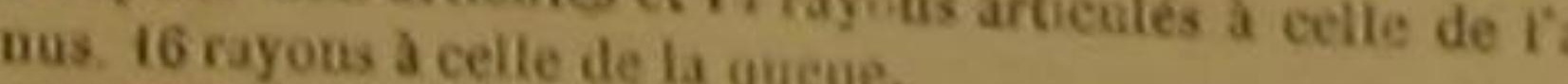

Bique. II la reconnati bien pour weee da système ichthyolo. Furt dectider, dapres ses caracteres. sit fant has ra il ne sa-

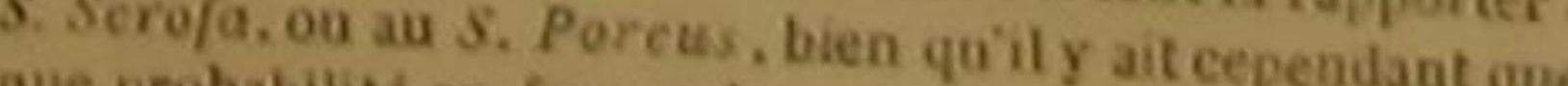

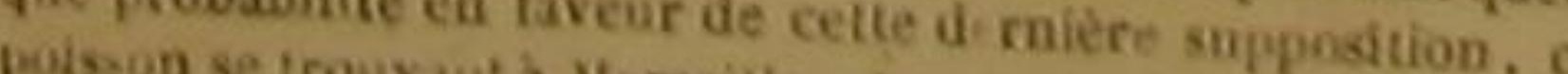
casae. D. pion

semble particulièrement au cotte scorpion, dont il differe néanmoins par plusieurs traits, et notamment par l'unité de la nageoire dorsale, qui est double au contraire sur le scor-

La tête du marseillais est armée de plusieurs piquants; un sillon est creusé entre ses deux yeux, et son nom indique la contrée arrosée par la mer dans laquelle on le trouve.

-

LA SCORPENE DOUBLE-FILAMENT.

Scorpæua bieirrata, Lacep.; Synaneeia bicapilla Cav.?

Nous devons la connaissance de ce poisson au voyageur Commerson, qui nous en a laissé ne figure très-exacte que nous avons eru devoir faire graver. Cet animal est couvert d'écailles si petites, que l'on ne peut les voir que trè-difícilement La téte est grosse, un peu platie par-dessus, garnie de protubérances; et a máchoire inferieure est tellement relevee, repliée et appliquée contre la supérieure, qu'elle dépasse beaucoup la ligne vertieale, et s'avance du cóté de la queue au delá de cette ligne, tors. que la bouche est fermée. Au reste, ces deux måchoires sont arrondies dans leur contour. Les yeux sont extrèmement petits et très-rapprochés; les nageoires pectorales très-larges et assez longues pour atteindre jusque vers I milieu de la longueur totale de la scorpène. La nageoire de la queue est arrondie; celle de I'anus l'est aussi, et d'ailleurs elle est à peu près semblable à la portion de la nageoire du dos au-dessous de laquelle elle est située, et qui est composée de rayons articulés. Les antres rayons de la nageoire dorsale-sont au nom bre de treize, et comme très-séparés les uns des autres, parce que la membrane qui les réunit est profondément échancrée entre chacun de ces aiguillons, qui, par une suite de cette conformation, paraissent lobés ou lancéolés. Au-dessus de la nuque on voit s'élever et partir du mème point deux flaments tris-de liés, d'une si grande Iongueur; qu'ils dé-

- 12 rayons non artientés el 10 rayons articulés a la na. geoire dorsale, 17 rayons à chicune des migeoires pectorales,

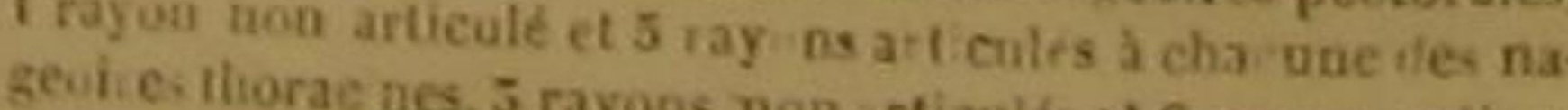
lés a cellè de 1 anus 1 ?

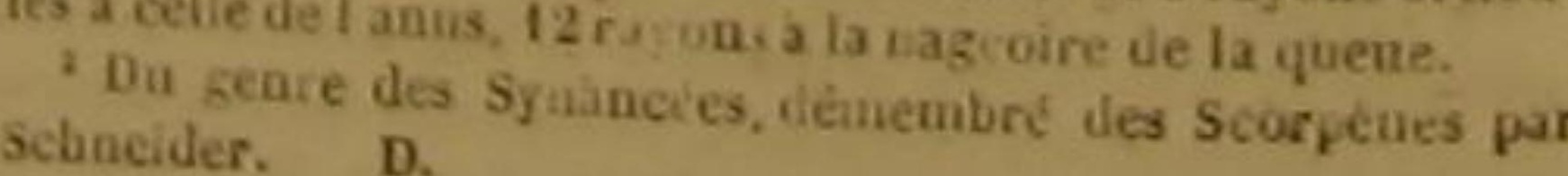

DES POISSONS

passent la nageoire caudale; et c'est de ce trait particulier que j'ai cru devoir tirer le nom spécilique de la scorpène que je viens de décrire 4

\section{LA SCORPĖNE BRACHION.}

Scorpæna Brachio, Lacep.; Synanceia Brachio, Cuv, 3.

Nous allons décrire cette scorpène d'aprè un dessin très-exact trouvé dans les papiers de Commerson, et que nous avons fait graver elle ressemble beaucoup à la scorpène doublefilament par la forme générale de la tète, la petitesse et la position des yeux, la conformation des máchoires, la place de l'ouverture de la bouche, la situation de la màchoire inférieure qui se relève et s'applique contre la supérieure de manière à dépasser du cóté de la queue la ligne verticale, la nature des téguments qui ne présentent pas d'écailles facilement visibles, et l'arrondissement de la nageoire caudale. Mais elle en differe par plusieurs caractères, et notamment par les traits suivants : premièrement, elle n'a sur la nuque aucune sorte de filament; secondement, l'échancrure que montre la membrane de la nageoire du dos, à côté de chacun des rayons aiguillonnés qui composent cette nageoire, est très-peu sensible relativement aux échancrures analogues que l'on voit sur la seorpene á laquelle nous comparons Io brachion; troisièmement, chacune des nageoires pectorales forme comme une bande qu s'étend depuis le dessous de la partie anterieure de l'opercule branchial jusqu'auprès de l'anus, et qui, de plus, est attachée à une prolongation charnue et longitudinale, assez sem blable à la prolongation qui soutient les nageoires pectorales de plusieurs gobies; et e'est de cette sorte de bras que nous avons tiré le nom spécifique du poisson qui fait le sujet de cet article ${ }^{3}$.

i 13 rayons aiguillonnes et 7 rayons articules a la nageoir du dos , 17 rayons a cbacune des pectorales, 7 a celie de $\mathrm{I}^{\prime}$ Lus, 14 a celle de la quene.

Ce poisson, qui est une Synancé, a reçu de Shaw le no de Scorpena brachiata: de Bloch et de Schueider, celur

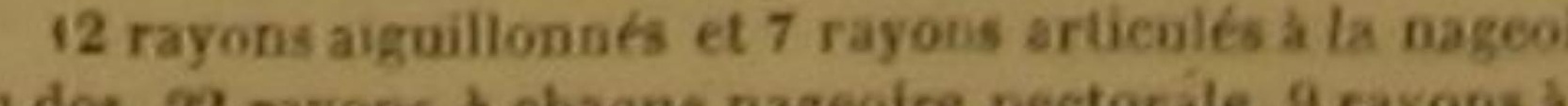
mageoire de 1 'anos.

I.
LA SCORPENE BARBUE ' Scorpæna barbata, Lacep.; Seorpena Serofa, Cus ,

La tête de ce poisson est relevée par des protubérances, et creusée dans d'autres endroits, de manière à présenter des cavités assez grandes. Deux barbillons garnissent la mâchoire inférieure; les nageoires thoracines sont réunies l'une à l'autre par une petite membrane; la nageoire caudale est presque rectiligne ${ }^{3}$.

\section{LA SCORPENE RASCASSE}

Scorpeua Porcus, Linu., Gmel. Lacep., Cur. ',

La raseasse habite dans la Méditerranée et dans plusieurs autres mers. On l'y trouve auprès des rivages, où elle se met en embuscade sous les fucus et les autres plantes marines, pour saisir avee plus de facilite les poissons plus faibles ou moins armés qu'elle; et lorsque sa ruse est inutile, que son attente est trom. pée, et que les poissons se dérobent à ses coups. elle se jette sur les cancres, qui ont bien moins de force, d'agilité et de vitesse, pour échapper a sa poursuite. Si dans ses attaques elle trouve

- Scorpene barbue, Bonnaterre, pl. de IEnc, meth. Ccorpana capite cavernoso, cirni gemini in - rore,, Gronov, Mus. Ichithyolog. I. p. 46 .

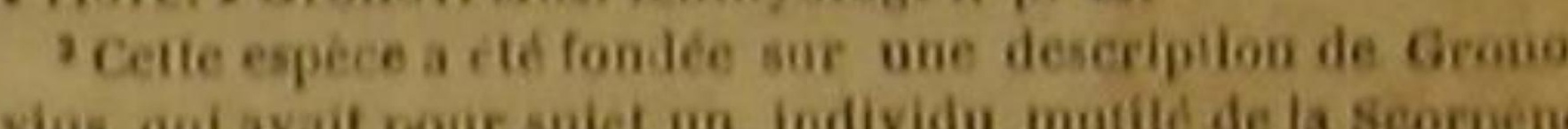

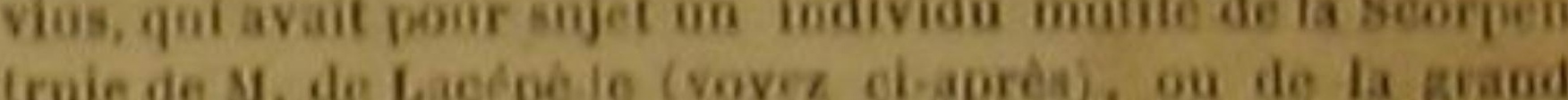
Scorpene rouge, Scorpena Serofa. Cuv, D. $\$ 2$ rayons signilionnés et 10 rayons articatés a ta nazeoir du dos, 15 rayous a chacune des pectorales , 6 rayons d celle de l'anns, 15 rayons a celic de la queue

- Scrofanello, dans plus, contries de I lialic, - Seorpén rascasse. Danbeaton, Kne, meti. - Id. Bonnaterie, ph. do

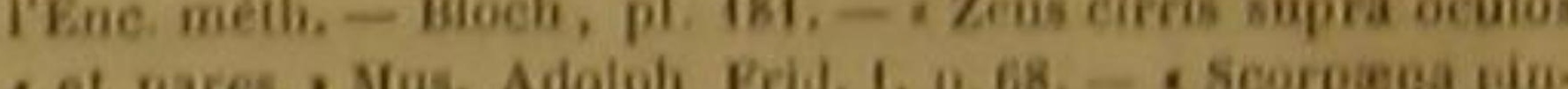

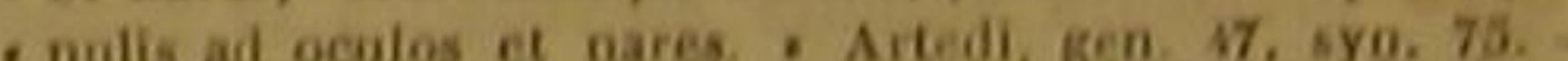

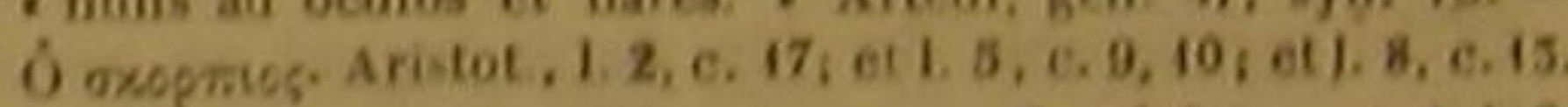
-1d. Athen. 1. 7, p. 320.-Scorpeno. Bondelet, part. 1,1.6. c. 19. - Scorpius Rondeleti. Aldrok, L. 2, C, 24, p. $10 \mathrm{~L}$ Scorpiur minor. Jonston, De piscibus. p. 71, tab. 19, fig. 10.

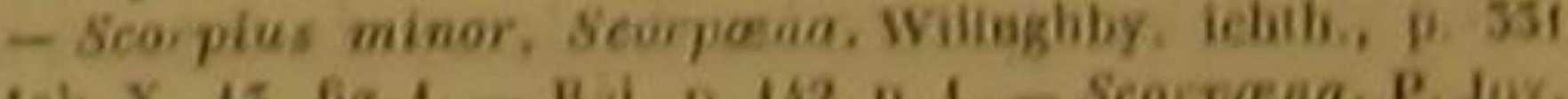

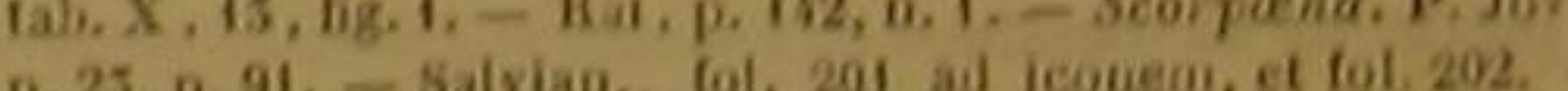

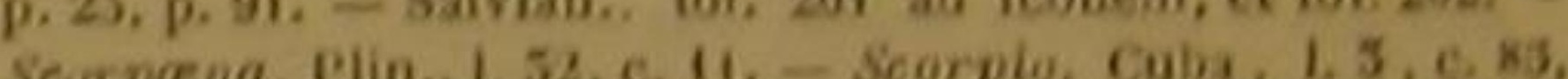
fol. 90, a, - Wotton, I. 8, c. 178, fol. 158, b. - Scarpio, vel scorpis, vel scorpana. id est; seorpius minor, Gesuer, p 857, 1018, et (germ.) tol, 43. - Scorpides, neu scorpana. Charlet., p. 142. - Scur pene, ou scourpion de mer, ou ma. canse. Va mont de Bomine, biel. a hist, nat. - Maselquis. It, 530. - \& Scoryana. eirris ad ocuios naresque, Brana.

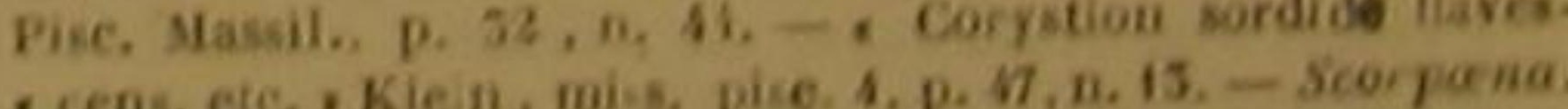
Belon, Aqual, p. 148. tCe poisson est nommé an fran ais, par M. Cuvier, pett scorpeue brune, oo rius specialement Rascasse. D. 
| de la résistance, si elle est obligée de se défendre contre un ennemi supérieur, si elle veut empêcher la main du pècheur de la retenir, elle se contracte, déploie et étend vivement ses nageoires, que de nombreux aiguillons rendent des armes un peu dangereuses, ajoute par ses efforts á l'énergie de ses muscles, présente ses dards, s'en hérisse, pour ainsi dire, et frappant avec rapidité, fait pénétrer ses piquants assez avant pour produire quelquefois des blessures fàcheuses, et du moins faire éprouver une douleur aiguê. Sa chair est agréable au goùt, mais ordinairement un peu dure. Sa longueur ne dépasse guère quatre décimètres. Les éeailles qui la recouvrent sont rudes et petites.

La couleur de sa partie supérieure est brune, avec quelques taches noires; du blanc mêlé de rougeâtre est répandu sur sa partie inférieure. Les nageoires sont d'un rouge ou d'un jaune faible et tacheté de brun, excepté les thoracines, qui ne présentent pas de taches, et les pectorales, qui sont grises.

La tête est grosse; les yeux sont grands et très-rapprochés; l'iris est doré et rouge; l'ouverture de la bouche très-large; chaque mâchoire hérissée, ainsi que le palais, de plusieurs rangs de dents petites et aiguês; la langue courte et lisse ; l'opercule branchial garni d'aiguillons et de filaments; et la partie antérieure de la nageoire dorsale, soutenue par douze piquants très-forts et courbés en arrière '.

Huit appendices intestinaux sont placés auprès du pylore; l'estomae est vaste; le foie blanc; la vésicule du fiel verte; le tube intestinal large.

Du temps de Rondelet, on croyait encore, avee plusieurs auteurs anciens, à la grande vertu médieinale du vin dans lequel on avait fait mourir une rascasse; et l'on ne paraissait pas douter que ce vin ne produisit des effet pierre de la vessie.

12 aiguillons et 9 rayons articulés ala nageoire da dos, 16
rayons a chacune des peetorates 1 rage rayous articulies s dacune des therayon aiguillomé et 5

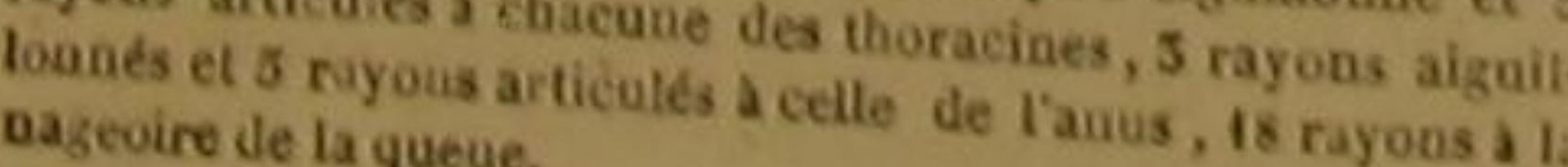

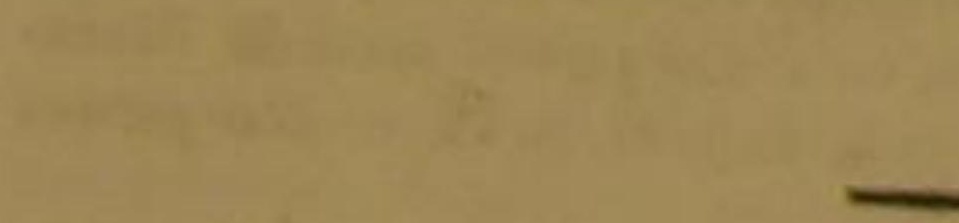
Scorpæna Mahe, Lacep.; Scorpæna volitaus, Lios.,
Gmel.; Pterois volitans, Cuv, ${ }^{2}$

Commerson a laissé dans ses manuscrits une description de ce poisson. Toutes les nageoires de cette scorpène sont variées de plusieurs nuances; et le corps ainsi que la queue présentent des bandes transversales, qui ont paru a Commerson jaunes et brunes sur l'individu que ce voyageur a observé. Mais cet individu était mort depuis trop longtemps pour que Commerson ait cru pouvoir déterminer avee précision les couleurs de ces bandes transver sales.

Le mahé est revêtu d'écailles petites, fine. ment dentelées du côté de la nageoire caudale, serrées et placées les unées au-dessus des autres, comme les ardoises qui recouvrent les toits. I téte est grande et garnie d'un grand nombre d'aiguillons. Les orbites relevées et dentelées forment comme deux crêtes au milieu des. quelles s'étend un sillon longitudinal assez profond

Les deux máchoires ne sont pas parfaitement égales; l'inférieure est plus avancée que la supérieure, qui est extensible à la volonté de l'animal, et de chaque côté de laquelle on voit pendre trois ou quatre barbillons ou tilaments mollasses.

Des dents très-petites et très-rapprochées les unes des autres donnent d'ailleurs aux deux mâchoires la forme d'une lime. Un filament marque, pour ainsi dire, la place de chaque narine.

L'opercule branchial est composé de deux lames : la première de ces deux pièces montre vers sa partie inferieure deux barbillons, et dans son bord postérieur, deux ou trois piquants; la seconde lame est triangulaire, et son angle postérieur est très-prolongé.

Le dos est arqué et caréné; la ligne latérale se courbe vers le bas.

La nageoire dorsale présente des largeurs très-inégales dans les diverses parties de sa - Ir Seorpena cirris pluribus ori circumpositis, corpore
sonsvensim fasciato, pinnis omnibus variegatis. . Commerson, manuscrits déja cités.

2II. Cuvier s'est assuré par une lecture attentive de Far.
ticle de Commerson, sur lop ticle de Commerson, sur lequel M. de Lacépede a établicelle espece, qu'elle a rapport à la Scorpène volante de Linnée un scourpereis de valtigeant, en sorte, dit-il, qu'on doit rayer ia
DES POI

longueur. Les pectorales sout assez longue pour atteindre jusqu'à l'extrémité de cette nageoire dorsale. Celle de la queue est arrondie '.

Commerson a vu cette scorpène dans les environs des iles Mahé, dont nous avons cru devoir donner le nom à ce poisson; et c'est ver la fin de 1768 qu'il l'a observée.

\section{LA SCORPÉNE TRUIE 3 .}

Scorpæua scrofa, Linn., Gmel., Bloch., Lacep., Cuv."

Cette scorpène est beaucoup plus grande que la rascasse; elle parvient quelquefois jusqu'b une longueur de plus de quatre mètres : aussi attaque-t-elle avee avantage non-seulement des poissons assez forts, mais des oiseaux d'eau faibles et jeunes, qu'elle saisit avec facilité par leurs pieds palmés, dans les moments ou ils nagent au-dessus de la surface des eaux qu'elle habite. On la trouve dans l'Océan Atlantique et dans d'autres mers, particulièrement dans la Méditerranée, sur les bords de laquelle elle est assez recherchée. Les écailles qui la couvrent sont assez grandes; elles présentent une couleur d'un rouge blanchátre, plus foncée et même presque brune sur le dos, et relevée d'ailleurs par des bandes brunes et transversales. La membrane des nageoires est bleue, et soutenue par des rayons jaunes et bruns.

La tête est grande; les yeux sont gros; l'ouverture de la bouche est très-large; des dents

' 7 rayons a la membrane des branchies, 15 rayons aiguil. chacune des pectorales, 1 aigeillion et 5 rayong arlicultes a chacone des thoracines, 5 aiguillons el 9 rayons articules a celle de Tanus, 12 ray ons a celle de la queve.

'Crabe de Biarits. - Besugo, Pesce cappone, dans Ligurie - Scrofano, dans dautres contrées de I litalie. Scorpéne truie, Danbenton, Enc. méth. - Id Bornaterre, pi. de rEnc, meth. - I Scorpzona tota ratens, cirris plurimis marinus. Salvian., fol. 197, $a$. ad iconem, et fol. 199, 200. - Scorpius major. Gesner (germ.) fol. usb.-ld. Willughby, p. 351 - Id. Rai, p. 142, n. 2. - Scorpio. Charlet, p. 162. - Autre scarpion de mer, etc. Valmont de Bomare, Dict. d'bist. nat. - Perca dorso monopterygio, eapite subca.

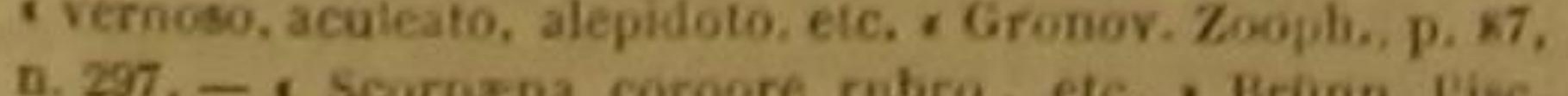
Massil., p. 52, n. $45,-$. Trigla subfivera nebulata, Ge. Browne, Jamaic., p. 456, n. $5 .-$. Coltes sebuamosos, var - rivs, ete, Séba, Slus, 5, p. 79. n. 2, Lab. 28, fiz. 2. - Scorpius major. Jonston, De piscibus, p. 71, tab. 19, fig. 9. 'M. Cuvier dóne a cetre espece le nom de grande scor. pene rouge, par opposition a la rascasse, que il appecle petite
211

petites, aiguēs et recourbées hérissent la langue, le palais, le gosier, et les deux máchoires, qui sont également avancées; des barbillons garnissent les environs des yeux, les joues, la måchoire inférieure, et la ligne latérale, qui suit la courbure du dos; deux grands aiguillons et plusieurs petits piquants arment, pour ainsi dire, chaque opercule; et l'anus est plus près de la nageoire caudale que de la gorge '.

LA SCORPÉNE PLUMIER 2 .

Seorpena Plumierii, Lac, Scorpena grandicornis. Cuv.

Les manuscrits de Plumier, que l'on conserve dans la Bibliothèque royale de France, renferment un dessin fait avee soin de cette scorpène, a laquelle j'ai cru devoir donner un nom spécifique qui rappelát celui du savant voyageur auquel on en devra la connaissanee. Le dessus et les cótés de la tête sont garnis, ainsi que les opercules, de piquants trianguaires, plats et aigus. Quatre barbillons ou appendices frangés s'élèvent entre les yeux; quatre autres barbillons d'une forme semblable, mais un peu plus petits, paraissent audessus de la lèvre supérieure: un grand nombre d'appendices également frangés sont placés le loug de la ligne latérale; les écailles ne présentent qu'une grandeur médiocre. La premlère partie de la nageoire dorsale est soutenue par des rayons non articulés, et un peu arrondie dans son contour supérieur; celle de la queue est aussi arrondie; on voit quelques taches petites et rondes sur les thoracines. La couleur générale est d'un brun presque noir, et dont la nuance est à peu pres la même sur tout l'animal 4 .

- 6 rayons a la membrane des branchies, 12 aiguillows et 10 rayons articules a la nageoire du dos, 19 rayons a chacune des pectorales. $f$ aguiflou et 5 rayous articules a chacune desthoracines, I aiguilons el s rayons articules a la mageoir

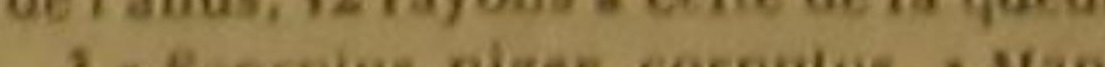
nuserits de Numier, de. - Do sous-genre des scorpenes proprement dites dans le Grand genre Scorpene, Conv. D.

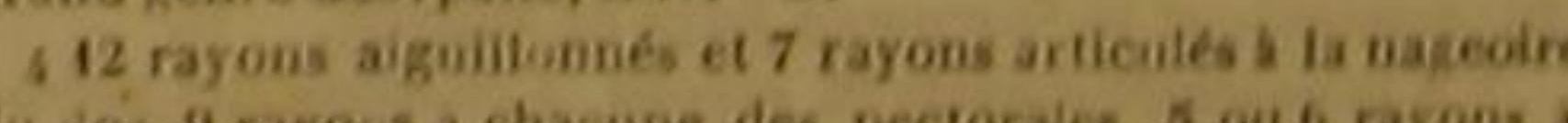
du dos, 9 rayous a chacune des pectorales, 5 ou 6 rayons:

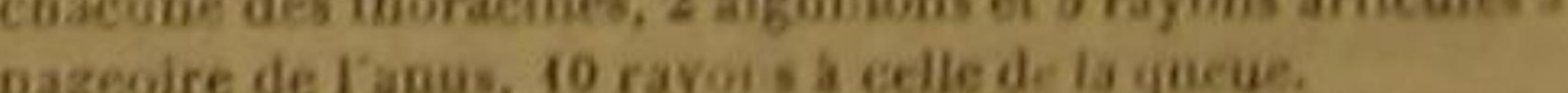


LA SCORPENE AMÉRICAINE '.

Scorpæna americana, Linn., Gmel., Lacep. '.

La tète de ce poisson présente des protubérances et des piquants; d'ailleurs on voit deux barbillons á la mâchoire supérieure, et cinq ou six à la mâchoire inférieure. Les quinze derniers rayons de la nageoire dorsale forment une portion plus élevée que la partie antérieure de cette même nageoire; cette portion est, de plus, très-arrondie, semblable par la figure ainsi qu'égale par l'étendue à la nageoire de l'anus, et située précisément au-dessus de ce dernier instrument de natation. Les nageoires pectorales et la caudale sont aussi très-arrondies $^{3}$. Lorsque la femelle est pleine, son ventre parait très-gros; et c'est une suite du grand nombre d'œufs que l'on compte dans cette espèce, qui est très-féconde, toutes les autres scorpènes.

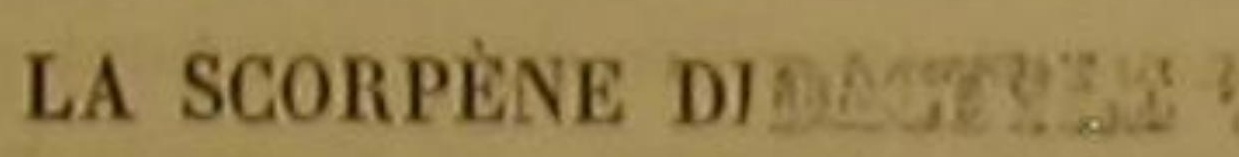
Scorpæna didactyla, Pallas, 1
scurum, $C$

La tête de cet animal, que Pallas a tres-bien décrit, présente les formes les plus singulières que l'on ait encore observées dans les poissons; elle ressemble bien plus à celle de ces animaux fantastiques dont l'image fait partie des déeorations bizarres auxquelles on a donné le nom d'arabesques, qu'à un ouvrage régulier de la sage nature. Les yeux gros, ovales et saillants, sont placés au sommet de deux protubérances très-rapprochées; on voit deux fossettes creusées entre ces éminences et le bout du museau; des rugosités anguleuses paraissent auprès de ce museau et de la base des opereules.

Des barbillons charnus, découpés, aplatis et assez larges, sont dispersés sur plusieurs point de la surface de cette tête, que l'on est tenté de

- Diable de mer. Duhamel, Trailté des péches, t. 5, part. 2 p. 99, n. 7 , pl. 2 , fig. 5

'C'est arec beaucoup de donte que M. Cuvier cite cette espece, comme pouvant se rapporter an poisson quili a appelé Clemitripterus americanus, et qui est le mème que 1 Bi. Selneid., et le Seorpennant, le Coltus tripterygius de - A la nazeoire dorsale 35 rayons a chair. D. les 15 , a celle de lánus 16 , a celle de la queve 15 . 4 Pallas, Spicileg. zuol. 7, p. 26, tab. 4, Eq. I. a deuse doigts. Bunnaterre, pl. de l'Ene, niél h.

- vi. Cinver che, comme syuonyme de cette espece de

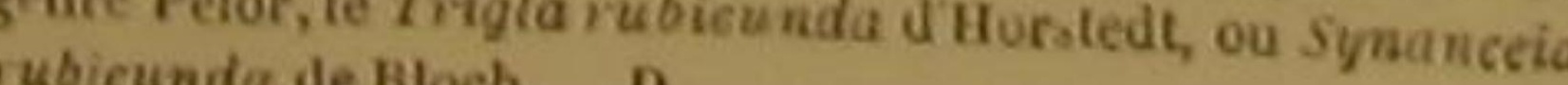

considérer comme un produit de l'art; deux de ces filaments, beaucoup plus grands que les autres, pendent, l'un à droite, et l'autre à gauche de la måchoire inférieure : cette måchoire est plus avancée que celle d'eu haut; l'une etl'autre sont garnies de dents, ainsi que le devant du palais et le fond du gosier; la langue montre des raies noires et de petits grains jaunes : on aperçoit de plus, auprès de chaque nageoire pee. torale, c'est-à-dire de chacune de ces nageoires que l'on a comparées à des bras, deux rayons articulés, trés-longs, dénués de membranes, dans lesquels on a trouvé quelque analogie avec des doigts; et voila pourquoi la scorpène dont nous parlons a été nommée à deux doigts, ou didactyle. La nageoire de la queue est arrondie; toutes les autres sont grandes; celle du dos règne le long d'une ligne très-étendue; plusieurs de ses rayons dépassent la membrane proprement dite, et sont garnis de lambeaux membraneux et déchirés ou découpés.

La peau de ce poisson, dénuće d'écailles facilement visibles, est enduite d'une humeur visqueuse. Cette scorpène parvient d'ailleurs à une longueur de trois ou quatre décimètres. Elle est brune avec des raies jaunes sur le dos, et des taches de la mème couleur sur les côtés, ainsi que sur sa partie inférieure. Des bandes noires sont distribuées sur la nageoire de la queue, ainsi que sur les pectorales. Cet animal remarquable habite dans la mer des Indes '.

\section{LA SCORPENNE ANTENNÉE 2}

Scorpæoa antennata, Bloch, Lacep.; Plerois antennata,

$$
\text { Cuv. '. }
$$

On pêche dans les eaux douces de l'ile d'Amboine une scorpène dont Bloch a publié la description, et dont voici les principaux caracteres.

La tète est hérissée de filaments et de piquants de diverses grandeurs; au-dessus des yeux, qui sont grandś et rapprochés, s'élèvent ' 16 rayons aiguillonnés el 8 rayons articulés a la nageoire
du dos. 10 rayous a d chacune des p ctoral-s, 6 a chacane des thorac nes. 12 a celle de 1 abus, 12 a celle de la queue. . Scorpéne ḋ antennes. Bonnaterre, ol. iDn ance

- Cavier. pour placer les torale tressallonges, et qui manquent de dents aux os palains. D. deux barbillons cylindriques, renflés dans quatre portions de leur longueur par une sorte de bourrelet tres-sensible, et qui, paraissant articulés et ayant beaucoup de rapports avec les antennes de plusieurs insectes, ont fait donner à l'animal dont nous parlons le nom de Scorpène antennée. Au-dessous de chacun des organes de la vue, on compte communément deux rangées de petits aiguillons. Chaque narine a rangées de petits aiguillons. Chè des yeux. Les deux ouvertures situées très-près des yeux. Les sont garnies de dents petites et aiguês. Des écailles semblables à celles du dos revétent les écailles semblables à celles du dos revetent les
opercules. Les onze ou douze premiers rayons de la nageoire du dos sont aiguillonnés, trèslongs, et réunis uniquement près de leur base, par une membrane très-basse, qui s'étend obliquement de l'un à l'autre, s'elève un peu contre la partie postérieure de ces grands aiguillons, et s'abaisse auprès de leur partie antérieure. La membrane des nageoires pectorales ne s'étend pas jusqu'au bord antérieur de la nageoire de l'anus; mais les rayons qui la soutiennent la dépassent, et se prolongent la plupart jusqu'à l'extrémité de la nageoire caudale, qui est arrondie.

Une raie très-foncée traverse obliquement le globe de l'oil. On voit d'ailleurs des taches assez grandes et irrégulières sur la tête, de petites taches sur les rayons des nageoires, et des bandes transversales sur le corps, ainsi que sur la queue.

La scorpène antennée vit communément de poissons jeunes ou faibles. Le goût de sa chair est exquis '.

\section{LA SCORPÉNE VOLANTE ${ }^{2}$.}

Scorpæna volitans, Linn., Gmel., Lacep.i Pterois volitans, Cuv. '.

Cette scorpène est presque le seul poisson d'eau douce qui ait des nageoires pectorale

- 6 rayons a ta membrane des branchies, 12 aiguillons et 12 rayons articulés a la nageoire du dos. 17 rayons a cliacune des pectorales, 6 a chacune des thoracines, 3 aiguillons
7 rayons articulés a la nageoire de l'anus, 12 rayons a la nageoire de la queue.

'Scorpéne colante. Bonnaterre, pl, de lEne. métb.-Gasterost us volitans. Linn. Syst. nat., XII, p 491, n, 9.-Bloch, pl. 184. - Gronov. Mus. 2. p. 55, n. 191; et Zoopht. 1, p. 89. n. 294-Pseudoplerus, eic. Kiein, Miss, pisc. 5, p.76, n. 1.tab. 28. lig. 1. - Ikan soangi. Raysch. Theatr. anatomic. 1, tues ou conformées de manieve a lui donla faculté de s'élever à quelques mètre dans l'atmosphère, à s'y soutenir pendant quelues instants, et à ne retomber dans son fluide natal qu'en parcourant une courbe très-longue. Ces nageoires pectorales sont assez grandes dans la scorpène volante pour dépasser la longueur du corps; et d'ailleurs la membrane qui en réunit les rayons est assez large et assez entre chacun de ces longs eylindres. pour qu'ils puissent étre écartés et rapprochés 'un de l'autre très-sensiblement; que l'ensem. ble de In naceoire qu'ils composent, s'etende ou se rétrécisse à la volonté de l'animal; que le poisson puisse agir sur l'air par une surface très-ample ou très-resserrée; qu'indépendamment de l'inégalité des efforts de ses muscles, a scorpène emploie une sorte d'aile plus développée, lorsqu'elle frappe en arrière contre les couches atmosphériques, que lorsque, ramenant en avant sa nageoire pour donner un nouveau coup d'aile ou de rame, elle comprime igalement en avant une partie des couches qu'elle traverse; qu'il y ait une supériorité très-marquée du point d'appui qu'elle trouve dans la première de ces deux mancuvres, a la résistance qu'elle éprouve dans la seconde; et qu'ainsi elle jouisse d'une des conditions les plus nécessaires au vol des animaux. Mais si la facilité de voltiger dont est douée la scorpene que nous décrivons, lui fait éviter quelquefois la dent meurtriere des gros poissons qui la poursuivent, elle ne peut pas la mettre a l'abri des pecheurs qui la recherchent, et qui s'efforcent d autant plus de la saisir, que sa chair est délicieuse; elle la livre mème quelquefois entre leurs mains, en la faisant donner dans leur piéges, ou tomber dans leurs filets, lorsque attaquée avec trop d'avantage, ou menacée de trop orands dangers au milieu de l'eau, elle s'élance du sein de ce fluide dans celui de l'atmosphère.

C'est dans les rivières du Japon et dans celles d'Amboine que l'on a particulierement observé ses précautions heureuses ou funestes, fig. 4t, p, 12: pl. 45, n. 215.-Kalkoeven viseli, Vatent. Ind. 3, p. 415, Kig. 215. - Amboynsche eisch. Nienth. Imi. 2, p. 20. Perer ambioinensis. Rui, Pise, p. 98, n. 28 .

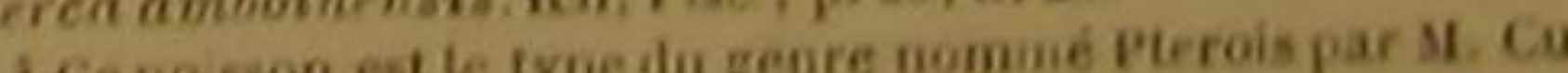
vier, if dopt nows avons indiqué les caracleres principan ans ta note que nous avoas ajontee a lespece precédenu, dans La note
p. $212 . \quad$ D. 
et ses autres habitudes. Il parait qu'elle ne se nourrit communément que de poissons trèsjeunes, ou peu redoutables pour elle.

Sa peau est revêtue de petites écailles placées avec ordre les unes au-dessus des autres. Elle présente, d'ailleurs, des bandes transversales alternativement orangées et blanches, et dont les unes sont larges et les autres étroites. Les rayons aiguillonnés de la nageoire dorsale sont variés de jaune et de brun; les autres rayons de la mème nageoire, noirs et tachés de jaune ${ }^{1}$. et les pectorales et les thoracines, violettes et tachetées de blanc. Des points blancs marquent le cours de la ligne latérale. L'iris présente des rayons bleus et des rayons noirs. Et quant aux formes de la scorpène volante, il suffira de remarquer que la tête, très-large par devant, est garnie de barbillons et d'aiguillons; que les deux màchoires, également avancées, sont armées de dents petites et aiguês; que les lèvres sont extensibles; que la langue est petite, pointue, et un peu libre dans ses mouvements ; que de petites écailles sont placées sur les opercules; et que la membrane qui réunit les rayons aiguillonnés de la nageoire du dos est très-basse, comme la membrane analogue de la scorpène antenuée.

\section{QUATRE-VINGT-DIXIEME GENRE.} LES SCOMBĖnOMORFs ${ }^{2}$.

Uhe sente nageoire dorsale ; de petiles nageoires au-des. sus et au-dessous de la queuei point d'aiguillons isoles -decant de la nageoire du do.

Espick.

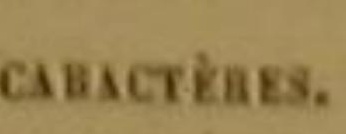

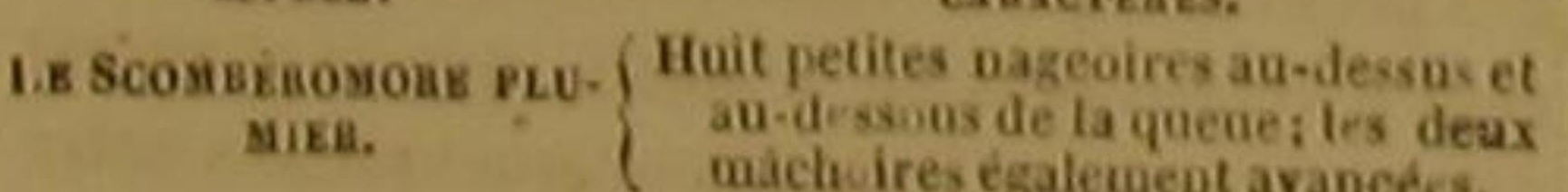
-

LE SCOMBÉROMORE PLUMIER 3.

\section{comberomorus Plumierii. Lacep.; Scomber regalis,} Bloch, pl. 535; Cybium regale, Cuv.

Les peintures sur vélin qui font partie de la collection du Muséum d'histoire naturelle ren‘ 6 rayons 3 la membrane des brancbies, 12 aiguidons et 12
rayons articulés a ta nazeoire dorat des pretorales 6 a chacune des thoracines, 3 rayons aiguil. lonn's et 7 rayons articules a la nage ire de I anus, 12 rayons I la nageoire de la queae, yui est arroudie.

Dissudu geuredes scombreset du qui est fonié sur un Cium, du mème naturaliste. D.

'Il nous parait que tion doit $\mathrm{r}$, de notre Stomberusiore pluaier, te poissoa yue Bloch a de a dous lo a fira de Scumber regahis ou Tassard, et dout il ferment la figure d'un poisson représenté d'après un dessin de Plumier, et qui parait avoir beancoup de rapports avec la bonite. Le savant voya geur que nous venons de citer, l'avait mème appelé Bonite ou Pélamis, petite et tachetée vulgairement Lezard. Mais les caracteres genériques que montrent les vrais scombres, et particulièrement la bonite, ne se retrouvant pas sur le poisson plumier, nous avons du le séparer de cette famille. Les principes de distribation méthodique que nous suivons nous ont même engagés à l'inscrire dans un genre particulier que nous avons nommé Seombéromore, pour désigner les ressemblances qui le lient avec celui des scombres, et dont nous aurions placé la notice à la suite de l'histoire de ces derniers, si quelques circonstances ne s'y étaient opposées.

Le scombéromore plumier vit daus les eaux de la Martinique. Sa nageoire dorsale présente deux portions si distinctes par leurs tigures, que on croirait avoir sous les yeux deux naceoires dorsales très-rapprochées. La premiere de ces portions est triangulaire, et composée de vingt rayons aiguillonnés; la seconde est placée audessus de celle de l'anus, a laquelle elle ressemble par son étendue, ainsi que par sa forme comparable à celle d'une faux. Huit petites nageoires paraissent au-dessus et au-dessous de la queue, Les couleurs de l'animal sont d'ailleurs magnifiques : l'azur de son dos et l'argenté de sa partie inférieure sont relevés par les teintes brillantes de ses nageoires, et par l'éclat d'une bande dorée qui s'étend le long de la ligne latérale, et règne entre deux rangées longitudinales de taches irrégulières et d'u jaune doré.

QUATRE-VINGT-ONZIEMME GENRE. LES gastérostéEs.

Une seule nageoire dorsale; des aiguillons isolés, on presque isoles, ali-decant de la nageoire dis dos: une carcine longitudinale de chaque cóle de la queue ; un doux rayons au plus a chaque nageoire thorecine; ce rayons aiguillonnes.$$
\text { ESPECES. }
$$

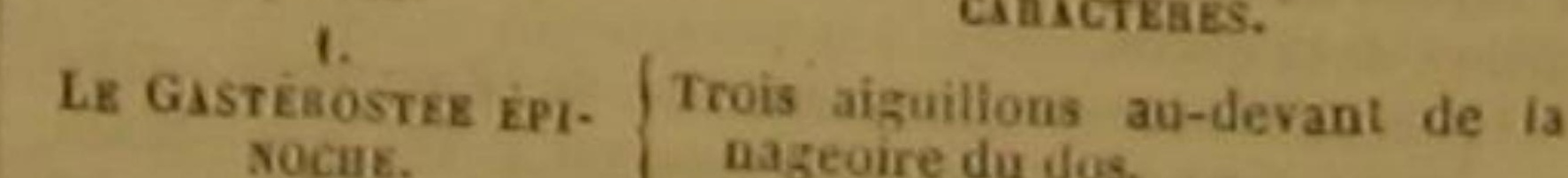

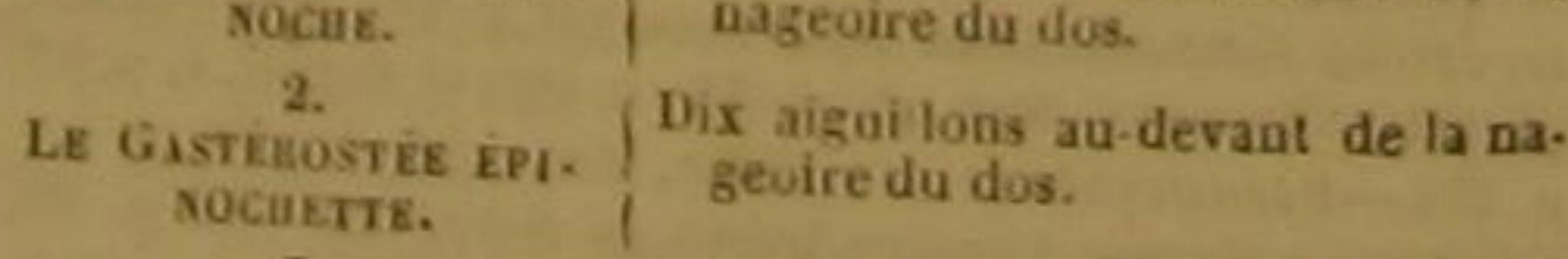
5
L.E Gistriostie sRe
NACUIE.
LE GASTÉROSTEE ÉPINOCHE ',

Gisterostens aculeatus, Lion., Gmel., Bl.; Gasterosteus teraculeatus, La

LE GASTÉROSTÉE ÉPINOCHETTE *, Gasterosteus Pungitius, Linn., Gmel., Lacep., Cuv. ‘.

LE GASTEROSTÉE SPINACHIE ${ }^{5}$.

Gasterostens Spinachia, Linn., Gmel., Cuv, •

C'est dans les eaux douces de l'Europe que vit l'épinoche. Ce gastérostée est un des plus

- skitspigg, Skiubär den större, en suede, - Steckle baek, Banslickle, Sharpling, en Ang leterre, - Spinarde,

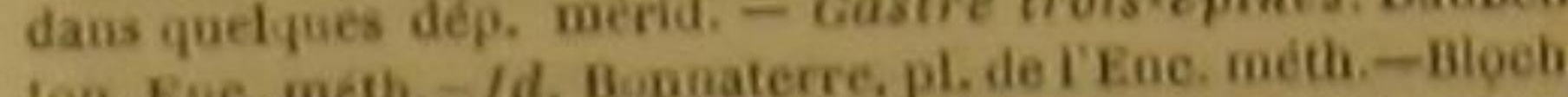
ton, Ene. meth. - Td. Bunnaterre, pl. do Gasterosteus in dorso Itrilus - Artedi, gen. 52 , spec, 26 , syn. 80, - Maller, Prodrom. Zool. Dames, p. A7, n. 5. - Gronov, Nus, 1, p. 49. n. 111; Zooph., p. 15t, n. 403. - C. Centriscus duobus ta dorso

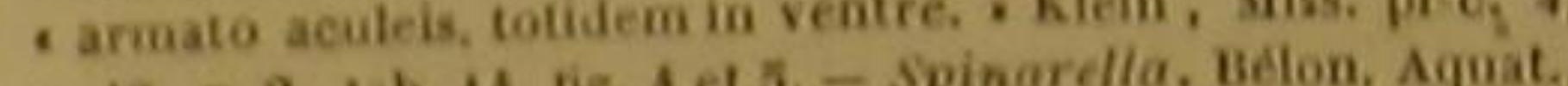

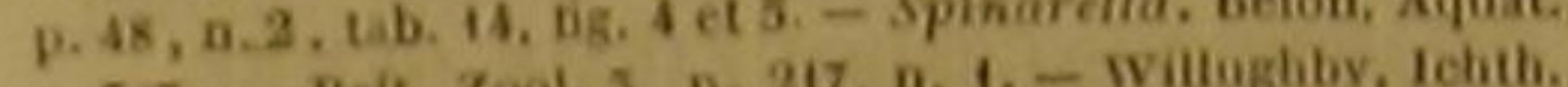
p. 5.7. - Brit. Zool. 3, P. 277, a. . - Wondelet, des Poisson

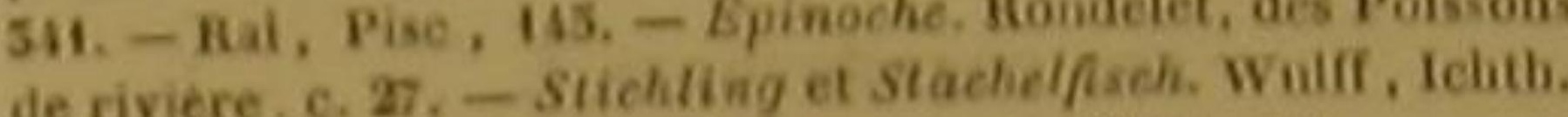
- Epinoche Valmont de Bomare, Diet. d'bist. nat. as. Cuvier a fat connaltre qu'en France it existe, dans le eaus douers, deax expéces a Épinoches qu'on a contondues sous le nom comman de Gaslerosteus aculealus on a troir aiguilloos. Liune de ces especess (Gast. Kracliarns, Cav.),

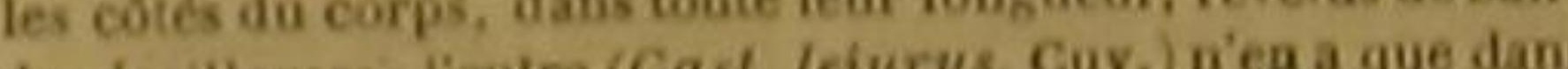
la région pectorale. $\mathrm{N}$.

a région pectorale. 1 .

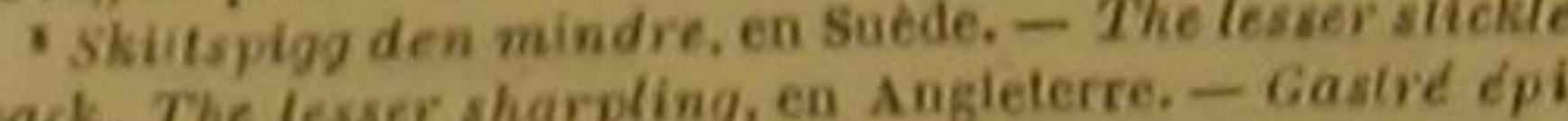
noche. Daubeaton. Enc. méti. - Bloch, pl. 53, fig. 4. - Faun. Suedic, 537. - . Gasterosteus aculeis in dorso tribus. . Ar ledi, gen. 52, spec. 97, syn. 80, - Gronov, Mus. 1, p. B0,

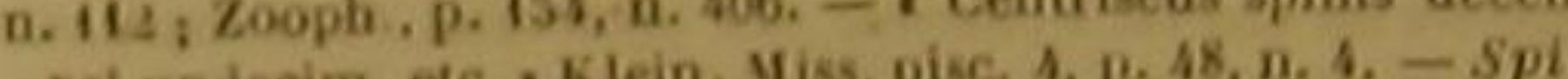

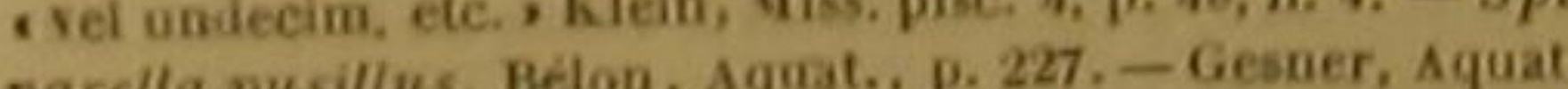
p. 8.

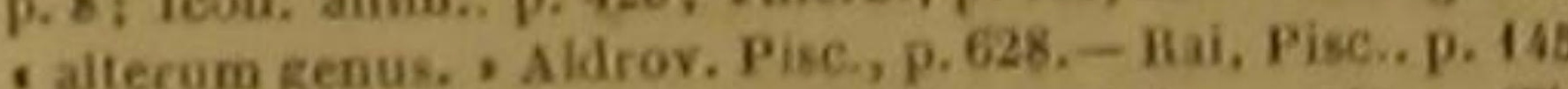
n. 4. - Lesser stickleback. Willoghby, Ichth., p. 342, - The pined stickeleback. Brit. Zool.5, p. 219, n. 2 .

'M. Cavier nomme ce petit poisson Épinochette, ou petit Épochetle d'Europe à neut épines. D.

steinticker, dans plus. contrées de l'Allemagne. Erakraper. dans plas. pays du Nord. - Gastre quinse-e, meth, - Fasp, snecic, 5s8. - Grooov. Mlas. 1, p. 50, n. 11 Zooph.. p. 15i, n. 407 - Bloch, pl, 55, fig. 1. - Gasterosteu pentagonus. Mus. Ad. Frid, p., 34. - . Centrisens aculei -quindecim in dorso. , Klein, Miss. pisc. 4, p. 48, n. 1.

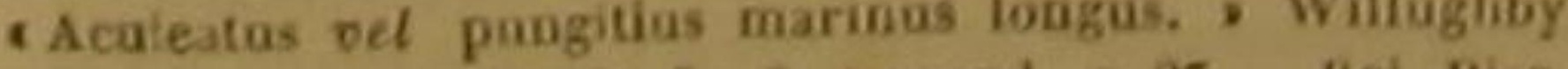
Ichitho, p. 510 , tab. X, 15, fig. 2; Append., p. 25, - ial, Pisc, p. 145, n. $15 .-$ Fifleen spined sliclileback. Bril. Zool. 5 ,
p. 220 , n. 5 .

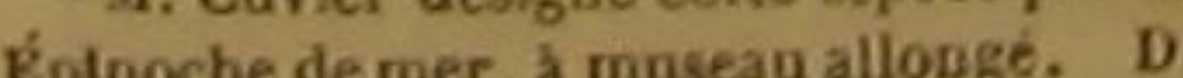

petits poissons que l'on connaisse; à peine parvient-il à la longueur d'un décimètre : aussi a-t-on voulu qu'il oceupât dans l'échelle de la durée une place aussi éloignée des poissons les plus favorisés, que sur celle des grandeurs. On a écrit qu'il ne vivait tout au plus que trois ans. Quelque sùres qu'aient pu paraitre les observations sur lesquelles on a fondé cette assertion, nous croyons qu'elles ont porté sur des accidents individuels plutot que sur des faits généraux; et nous regardons comme bien peu vraisemblable une aussi grande brièveté dans la vie d'un animal qui, dans ses formes, dans ses qualités, dans son séjour, dans ses mouyements, dans ses autres actes, dans sa nourriture, ne présente aucune différence très-marquée avec des poissons qui vivent pendant un très-grand nombre d'années. Et d'ailleurs ne reconnait-on pas dans l'épinoche la présence ou 'influence de toutes les causes que nous avons assignes à In longueur très-remarquable de vie des babitants des eaux, et particulièrement des poissons considérés en général? C'est dans le printemps que ce petit osseux. dépose ses coufs sur les plantes aquatiques, qui les maintiennent à une assez grande proximite de la surface des laes ou des rivières, pour que la chaleur du soleil favorise leur développe ment. II se nourrit de vers, de chrysalides, d'insectes que les bords des eaux peuvent lui présenter, d'œufs de poissons; et, malgré sa faiblesse, il attrape quelquefois des poissons à la vérité extrêmement jeunes, et venant, pour ainsi dire, d'éclore. Les ajguillons dont son dos est armé, et le bouclier ainsi que les lames dont son corps est revêtu, le défendent mieux qu'on ne le croirait au premier coup d'cil, de l'attaque de plusieurs des animaux qui vivent dans les mémes eaux que lui : mais ils ne le garantissent pas de vers intestinaux dont il est fréquèemment la victime; ils ne le préservent pas non plus de la recherche des pêcheurs. On ne le prend pas cependant, au moins le plus souvent, pour la nourriture de l'homme, parce que son goût est rarement très-agréable : mais comme cette espèce est grasse et féconde en individus, il est plusieurs contrées oú l'on répand les épinoches par milliers dans les champs, sur les. quels elles forment en se corrompant un excel. lent fumier; ou bien on les emploie a engraisser dans les basses-cours voisines des lacs qui leur ont servi d'habitation, des canards, des co- 
chons, et d'autres animaux utiles dans l'économie domestique.

On peut aussi exprimer de milliers d'épino. ches une assez grande quantité d'huile bonne à brủler; et nous ne devons pas oublier de faire remarquer qu'il est un grand nombre d'espèces de poissons, dédaignées à cause du goût peu agréable de leur chair, dont on pourrait tirer, comme de l'épinoche, un aliment convenable à plusieurs animaux, un engrais très-propre à fertiliser nos campagnes, ou une huile trèsutile à plusieurs arts.

Les yeux de l'épinoche sont saillants, et ses mâchoires presque aussi avancées l'une que I'autre : chaque ligne latérale est marquée ou recouverte par des plaques osseuses placées transversalement, plus petites vers la tête ainsi que vers la queue, et qui, au nombre de vingtcinq, de vingt-six ou de vingt-sept, forment une sorte de cuirasse assez solide '. Deux os allongés, durs, et affermis antérieurement par un troisième, couvrent le ventre comme un bouclier; et de là vient le nom générique de Gust rostee que porte l'épinoche. Chaque thoracine est composée de deux rayons : le premier, grand, pointu, et presque toujours dentelé, frappe aisément la vue; le second, blane, trèscourt, tres-mou, est difficilement aperçu.

Trois aiguillons allongés, et séparés l'un de l'autre, s'elèvent au-devant de la nageoire du dos: les deux premiers sont dentelés des deux côtés; le troisième l'est quelquefois, mais il est presque toujours moins haut que les deux pre-

On compte trois lobes au foie, qui est trèsétendu, et dont le lobe droit est particulièrement très-long. On ne voit pas de cœeum auprès du pylore; et le canal intestinal se recourbe à peine vers la tête, avant de s'avancer en ligne droite vers l'anus, ce qui doit faire présumer que les sues digestifs de l'épinoche sont tres-actifs.

La vésicule natatoire est épaisse, simple, grande, et attachéeà l'épine du dos, dont ceperdant on peut la séparer avec facilité.

Au reste, l'iris, l'opercule branchial et les côtés de l'épinoche brillent de l'éclat de l'argent; ses nageoires, de celui de l'or; et sa

' M. Cuvier fait remarquer que $\mathrm{M}$. de Lacépede a suivi Arteii, en indiquant le nombre de 26 ou 27 ecailles; mais $\mathrm{Ar}$ -

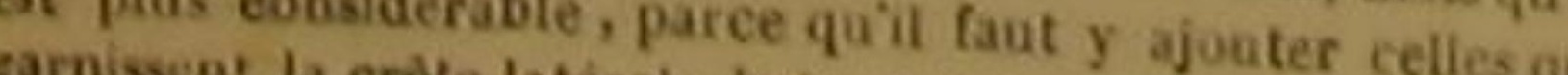
que les autres. D.
quaterale de la queue, qui sont plus serreee orge ainsi que sa poitrine, montrent souvent celui du rubis '.

L'épinochette vit en troupes nombreuses dans les lacs et dans les mers de l'Europe; on la voit pendant le printemps auprès des embouchures des fleuves; et, suivant M. Noèl, on la péche dans la Seine, jusqu'au-dessus de Quillebeuf. La spinachie ne se trouve ordinairement que dans la mer. Elle est plus grande du double, ou environ, que l'épinoche, pendant que l'épinochette ne parvient communément qu'à la longeur d'un demi-décimetre. Cette épinochette est d'ailleurs dénuée de lames osseuses et mème d'écailles facilement visibles, sa couleur est jaune sur son dos, et blanche ou argentée sur sa partie inférieure ${ }^{2}$.

La spinachie offre à peu près le même ton et la mème disposition dans ses nuances que l'épinochette; mais ses cotés sont garnis de lames dures. Elle a de plus le museau avancé en forme de tube, l'ouverture de la bouche petite, et l'opercule ciselé en rayons ${ }^{3}$.

QUATRE-VINGT-DOUZIEME GENRF LES CENTROPODES 4 .

Deux nageoires dorsales : un aiguillon et cinq ou six rayons articulés très-petits à chaque nageoire thoracime; point de piquants isoles au-decant des nageoires du dos, mais les rayons de la premieze dorsale á pein réunis par uae membrane : point de carine laterale à la queue.

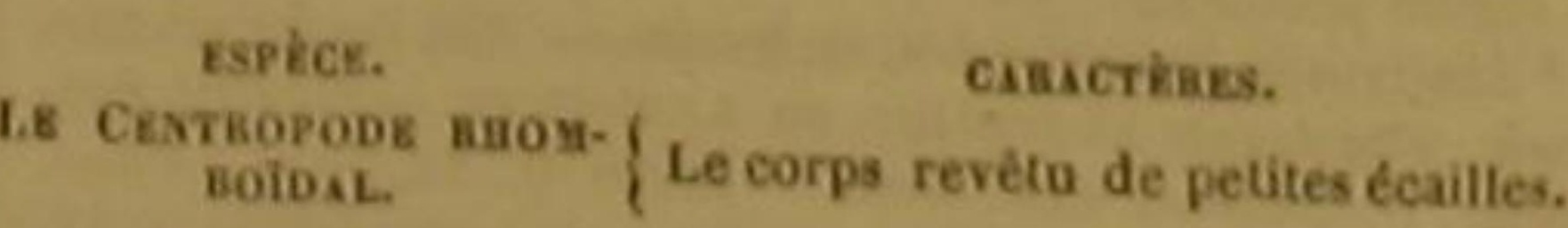
A la membrane des branchies de l'épinoche 3 rayons, a la ageoire da dos 12 , a chacune des pectorales 10 , a chacune
des thuracines 2 , a celle de l'anus 9 , a celle de la quece, yue est recti igne, 12 . - A la nageoire du dos de lépinochette 11 rayons, a cha. cune des pectorales $10, \mathrm{a}$ chacune des thoracines, dont 1 membrane est trés blancie, 2 , a celle de l'anus 11 , a celle de
la queve is. ta queve is.

'A la nazeoire da dos de la spinachie 6 ou 7 rayons, a de l'anos 6 ou 7 , a celle de chacune des thoracines 2 , a celle + M. Cuvier na cone de la queue, qui est arrondie, 12. Monodactyles ef aux Acanthopodes de. We réun ssant aus en compare celui quîil nomme Pseltus, da. de Lacépède, il et qu il place dins la famille des Acanthoptérygienmerson, mipenues. $\mathrm{D}$

DES POISSONS.

LE CENTROPODE RHOMBOIDAL '.

Scomber rhombens, Forsk.; Centrogaster rhombeus, Linn., Gmel.; Centropodus rhombeus, Lacep.; Psettus shombeus, Cuv. '.

La conformation de ce poisson nous oblige à le placer dans un genre particulier. Il a été observé par Forskael dans la mer Rouge. Les pe tites écailles dont il est revêtu brillent comme des lames d'argent. Les nageoires sont blanehes, excepté celle de la queue, qui est d'un vert bleuâtre; et la seconde dorsale est noire ans sa partie la plus élevée. Cette seconde nageoire du dos est d'ailleurs triangulaire et écailleuse dans sa partie antérieure, comme celle de l'anus, et basse, ainsi que transparente, dans Ie reste de son étendue, Les cinq rayons articuiés qui, réunis avee un aiguillon, composent chacune des nageoires thoracines, sont à peine visibles $^{3}$. Une membrane assez peu large soutient les quatre ou cinq piquants qui forment la première dorsale. Les dents sont deliées et nombreuses; et au-dessus du bout de la langue on voit une callosité ovale et rude. La queue proprement dite est très-courte; ce qui donne à chaque cóté de l'auimal une figure rhomboidale.

QUATRE-VINGT-TREIZIEME GENRE ^ LES CENTHOgastènes.

Quatre aiguillons et six rayous arlicules à chaque nageoire thoracine.

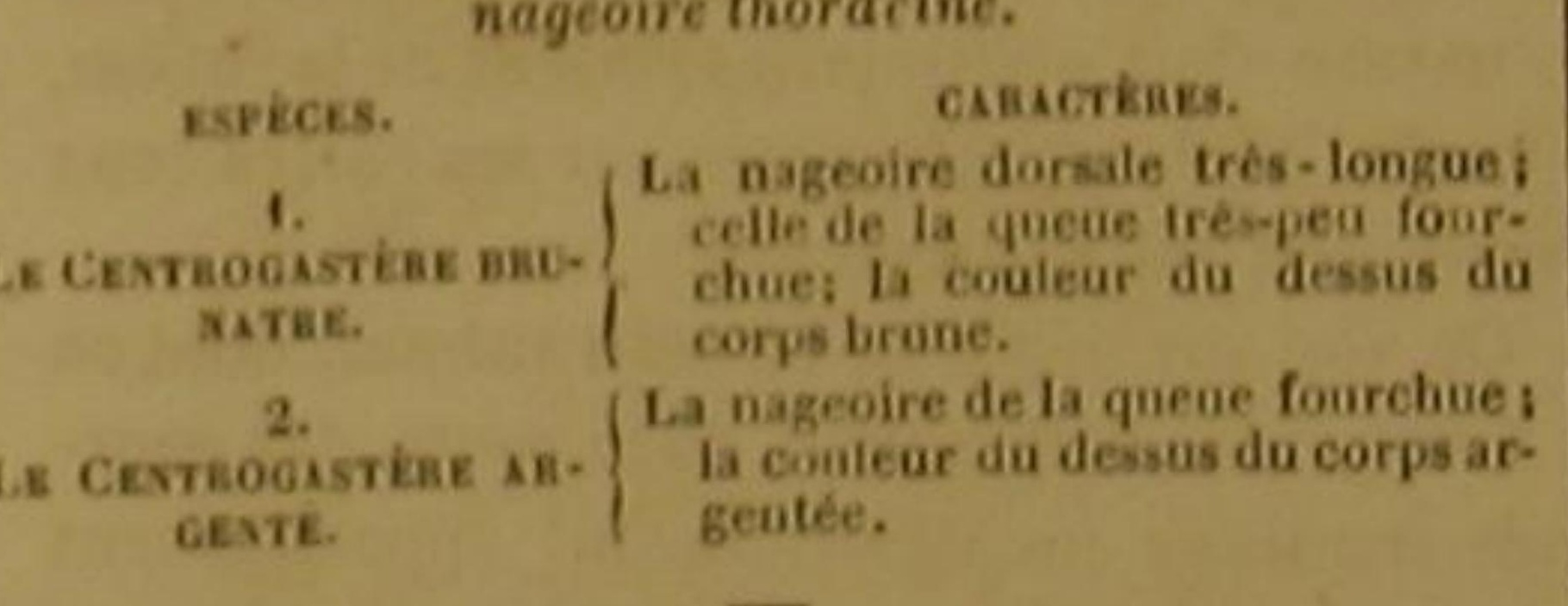

E CENTROgastéRE BRUNATRE ${ }^{s}$, Cen rogaster fusecens, Lin., Gmel., Lacep.; Sigano fuscescens, Cuv.'

LE CENTROGaStere ARGENTÉ ${ }^{7}$.

Getrotas, Lino., Gmel., Laccp.; Sig gas argenteus, Cuv.'

Les mers qui arrosent le Japon, nourrissent

' Forskael, Faun. Arab.. p. 58, n. 78. Scombre tabuk. Bonnaterre, pl. de I Ene. bielih.

2 Voyez la note 4 de la pase precedente. $\mathrm{D}$. Caire on dos 4 en 5 . a la seconde 32 . a chacune des pectorales 13 . a chacune des thoracines 6, a calle de lavus 54 , a celle a la quene, qui est un peu arrondie, 16.

w.1. Cavier n'admet pas ce genre, et en rapporte les es. Tes Teuthyes parmil. ces deux centrogastères dont on doit la connais sance au savant Houttuyn, et dont le nom gé. nérique vient des aiguillons que l'on voit audessous de leur corps, et qui composent une partie de leurs nageoires inférieures. Ces poissons ue parviennent qu'a une longueur très-peu considérable: le brunátie n'a pas ordinairement deux décimetres de long, et l'argenté n'en a qu'un. La máchoire supérieure du premier est garnie de dents aiguès; le second a sur la nuque un grande tache brune, et communément arrondie. Les notes suivantes ' et ${ }^{2}$, et le tableau de leur genre, indiquent leurs autres traits principaux.

OUATRE-VINGT-QUATORZIEME GENRE ${ }^{3}$. LES CBNTHONOTRS.

Une seule nageoire dorsale : quatre rayons au moins à chaque thoracine; des piquants isoles altilerant de la nageoire du dos ; the saillie longitudinale sur chaque colt de fo gueue, ou deur aiguillons au-decant de la nageoire de l'anus.

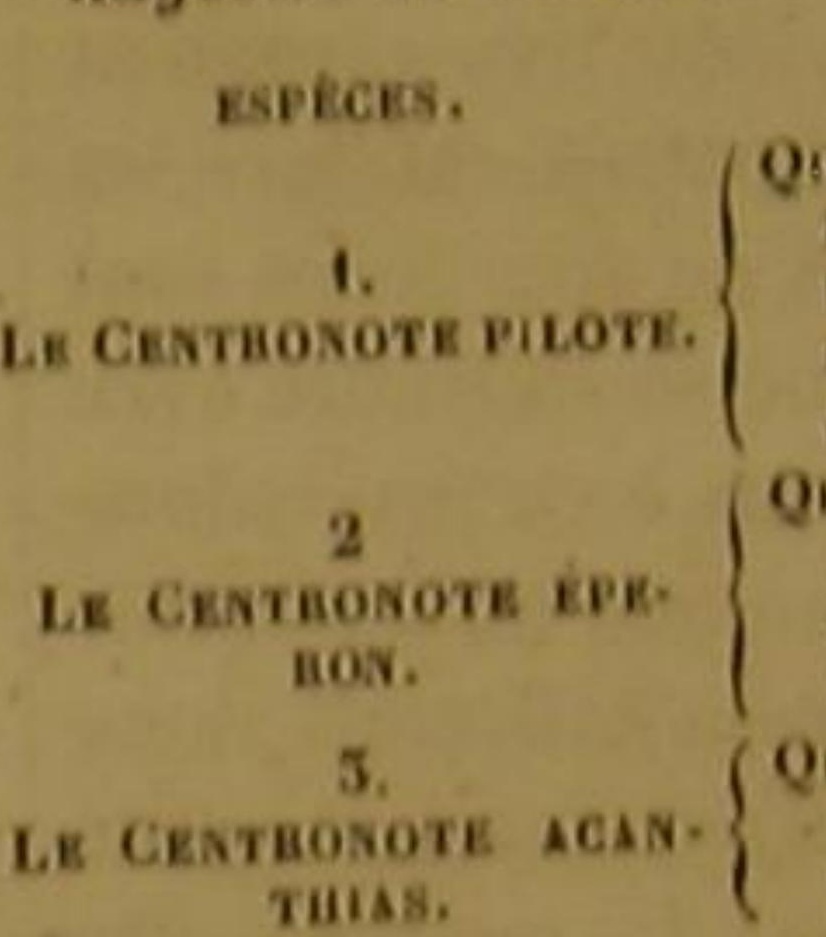

CARACTĖ⿴囗十

atre aigwillows au-devant de 1 in

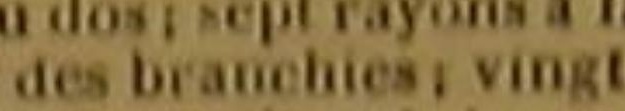

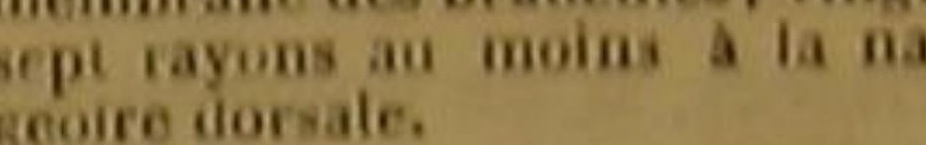

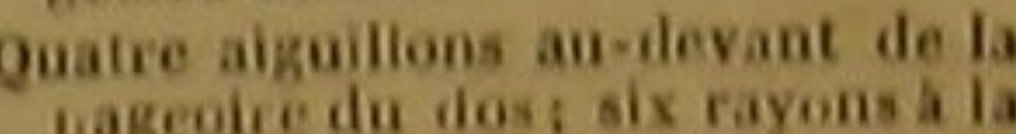

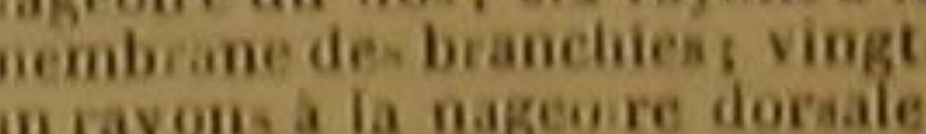
Qmatr. arguillons an devant de I

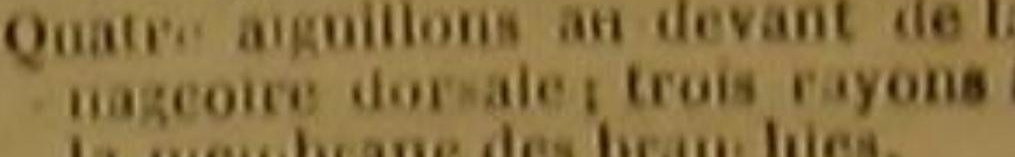
Cimy aiguiltons andevant de ta nageoire da dos: le premier

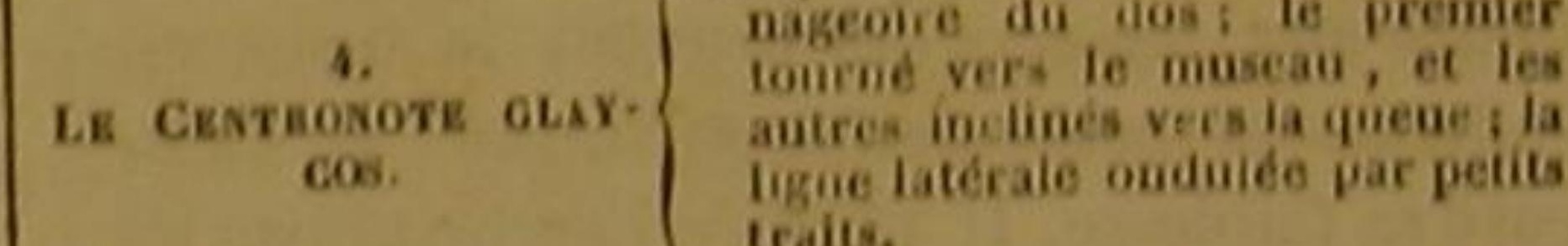

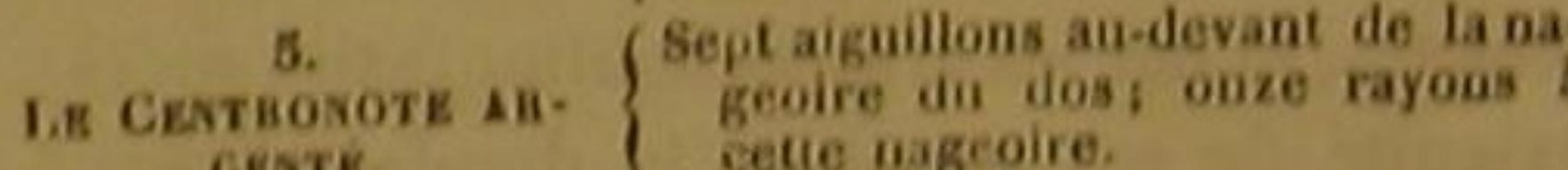

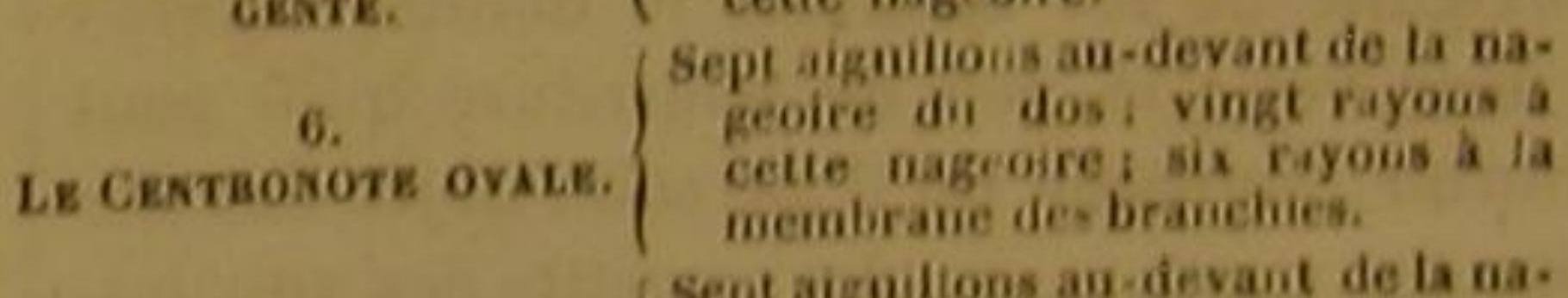

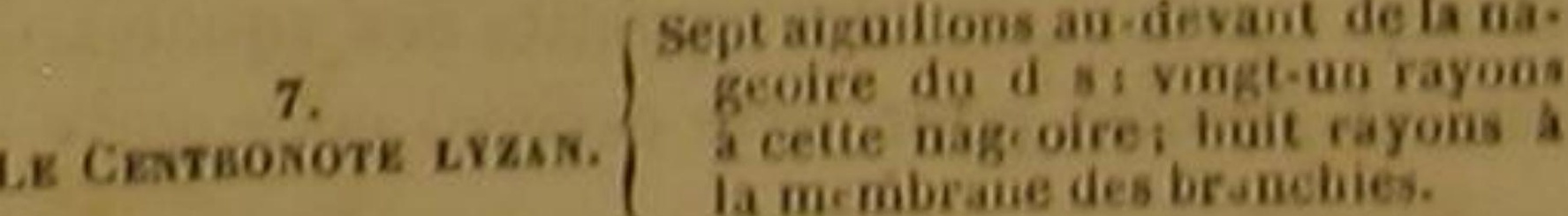
aus, de Porikael. les Buros de Commerson, les Centroga Ler diHowteyn, les Amphacanthus de Bloch. $\mathrm{D}$.

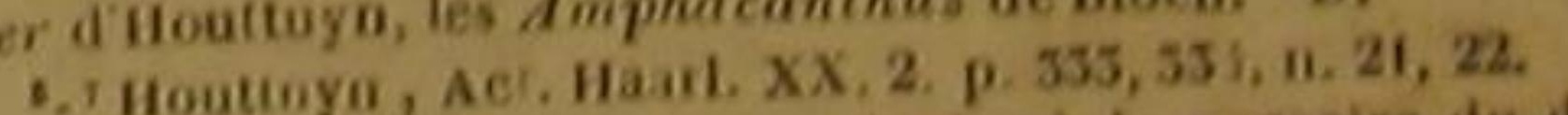
if a guillows et 11 rayons articules a la napeoire din des du brunatre, 16 rayons a chacune des pretorales, 7 aiguilion

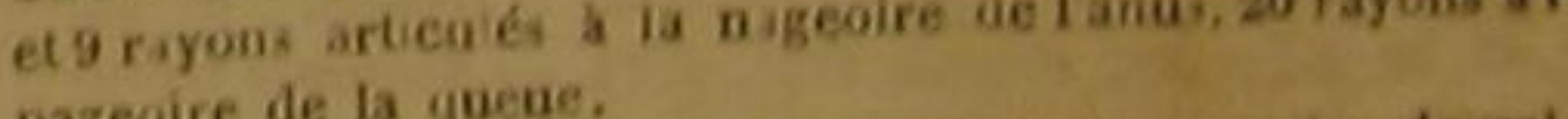
nageoire de la quene.
2x aizuiltons a la partic antérieure de la nageoire dorsal:

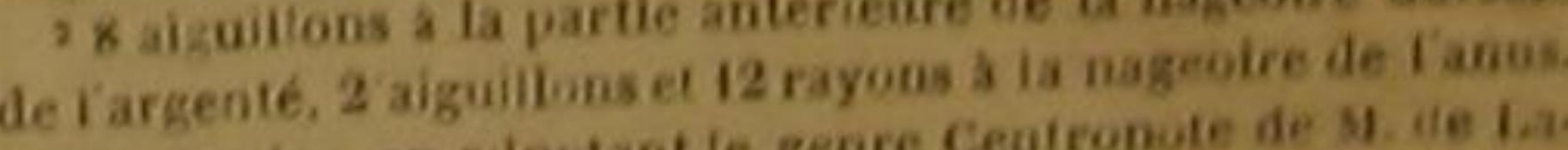

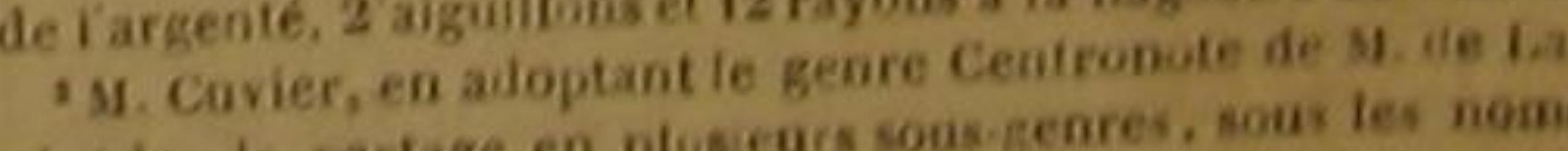
cépede, Le partage en plusears sous-genres, sous lices nou

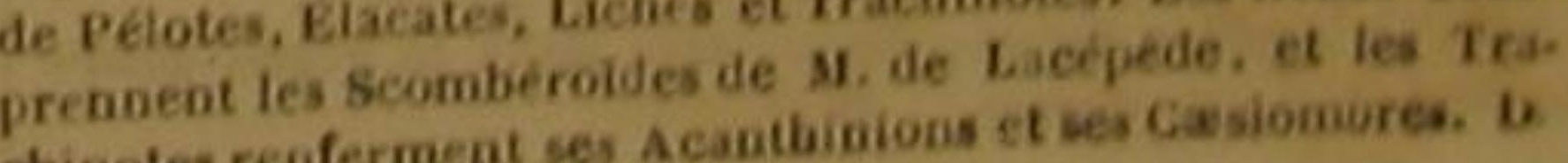




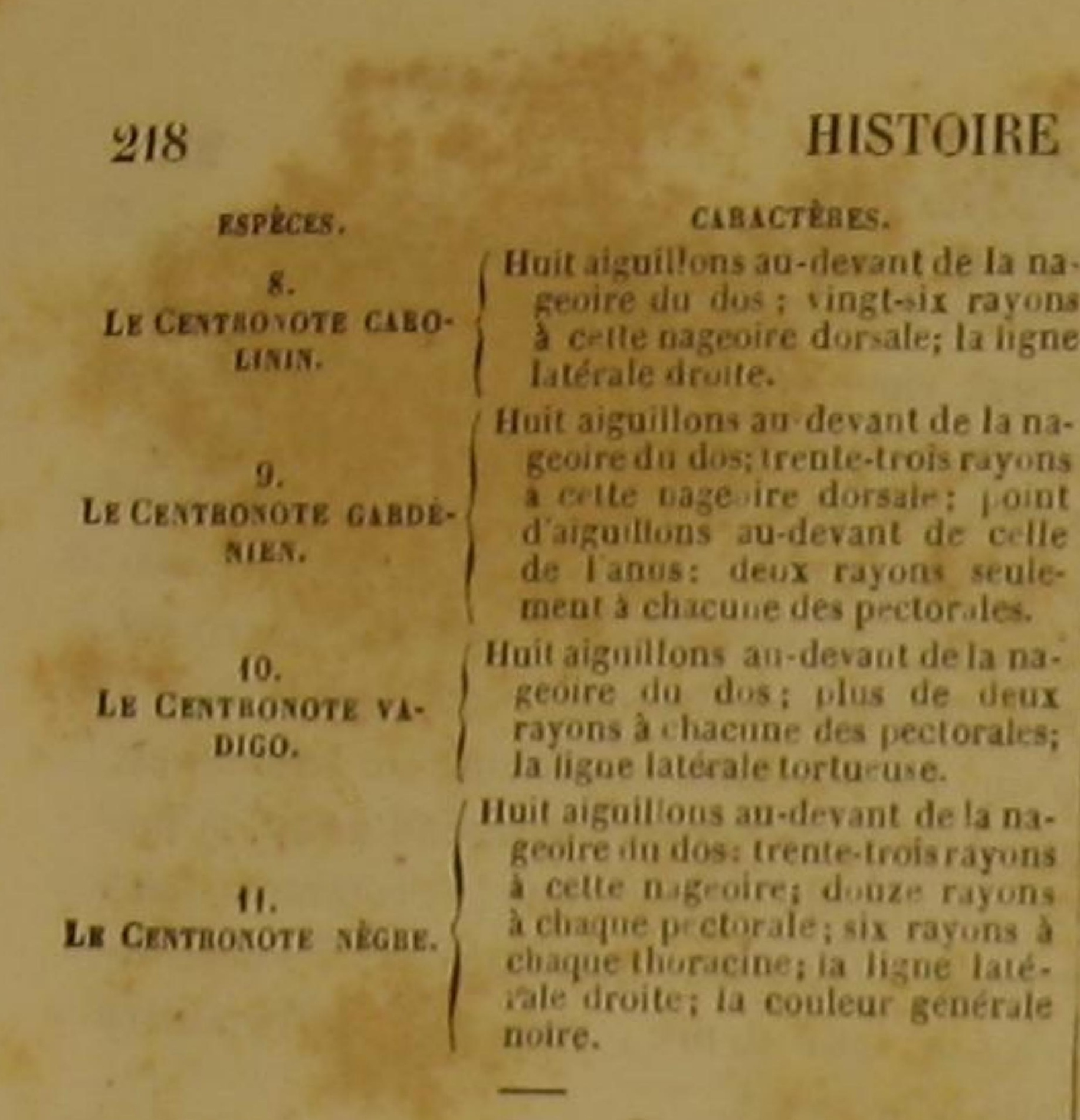

LE CENTRONOTE PILOTE '.

Gasterosteus Ductor, Linn,; Gmel.; Scomber Duetor, Bl.; Centronotus Conductor, Lacep.; Ceatronotus
Dnetor, Cur,

Presque toutes les espèces du genre des Centronotes, ainsi que celui des Gastérostées et celui des Centropodes, ne renferment que d'assez petits individus. Le centronote dont nous traitons dans cet article parvient très-rarement à la longueur de deux déeimètres. Malgré les dards dont quelques parties de son corps sont hérissées, il ne pourrait done se défendre avec succès que contre des ennemis bien peu redoutables, ni attaquer avee avantage qu'une proie presque invisible. Son espèce n'existerait don plus depuis longtemps, s'il n'avait reçu l'agilité en partage : il se soustrait par des mouvements rapides aux dangers qui peuvent le menacer. D'ailleurs sa petitesse fait sa sủreté, et compense sa faiblesse. II n'est recherché ni pompécheurs, ni par les grands habitants des mers; l'exiguité de ses membres le dérobe souvent à leur vue; le peu de nourriture qu'il peut fournir, empêche qu'il ne soit l'objet des désirs des marins, ou des appetits des squales. 11 en est résulté pour cette espèce, cette sorte

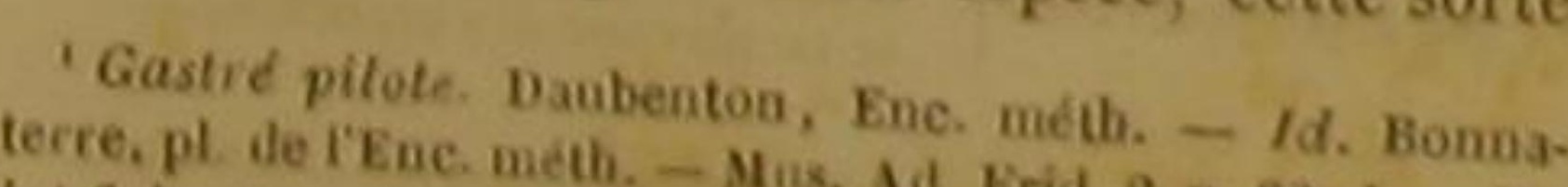

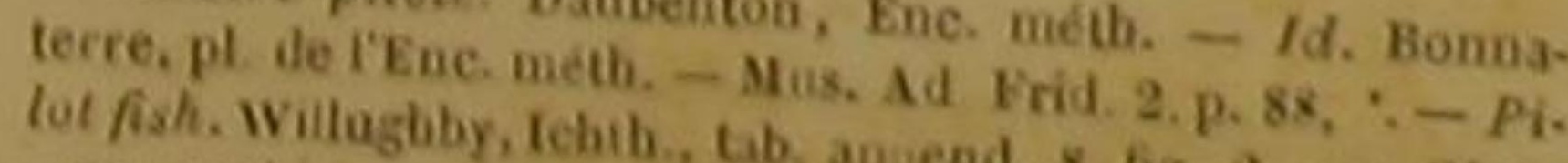

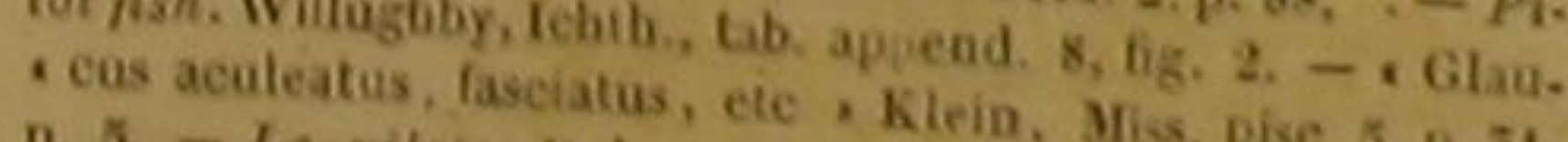

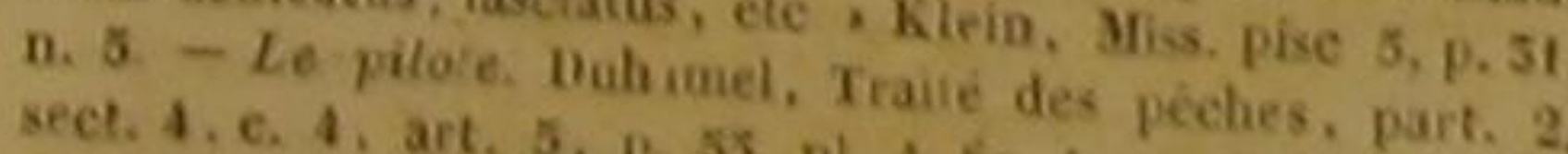

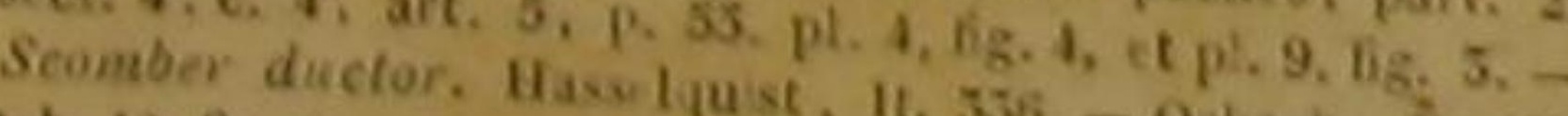
ab. 12, 6ig. 2 iet Aet. Stockb. 175s, p. $71,-$ Steck, it. 75 ,

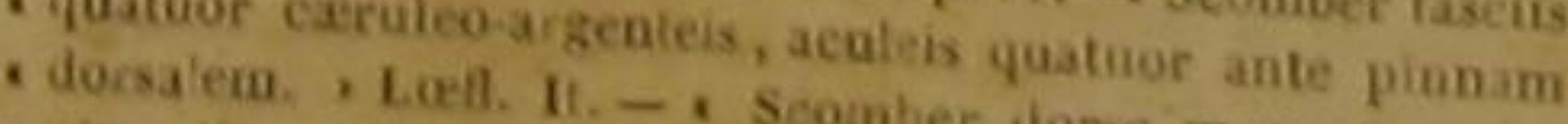
: pinnulis aultis, ete. , Gronov. Zioph dono minopterygio, Hai, Pise, 156, - Loolsmanuekens. Brann. It. 325 iste pisceis. -So wbre Pilote; Seomberiekens, Brann. It. 325 . Cu sous-geare Pilote, Noucratis, di.jo.

Ceatronote de II. Cuvier. Daucrales, dais le grand geare
D.
URELLE

de sécurité qui dédommage le faible de tant de privations. Pressée par la faim, ne trouvant pas facilement a certaines distances des rivages les œufs, les vers, les insectes, les mollusques qu'elle pourrait saisir, elle ne fuit ni le voisinage des vaisseaux, ni mème la présence des squales, ou des autres tyrans des mers; elle s'en approche sans défiance et sans crainte; elle joue au-devant des bâtiments, ou au milieu des terribles poissons qui la dédaignent; elle trouve dans les aliments corrompus que l'on rejette des navires ou dans les restes des victimes im. molées par le féroce requin, des fragments appropriés par leur ténuité à la petitesse de ses organes ; elle précède ou suit avec constance la proue qui fend les ondes, ou des troupes carnassières de grands squales; et frappant vivement l'imagination par la tranquillité avee laquelle elle habite son singulier asile, elle a été bientót donée, par les amis du merveilleux, d'une intelligence partieulière ; on lui a attribue un instinet éelairé, une prêvoyance remarquable, un attachement courageux ; on l'a revêtue de fonctions très-extraordinaires, et on ne s'est arrèté qu'après avoir voulu qu'elle partaged avee les échénéis, le titre de conducteur du requin, de pilote des vaisseaux. Nous avons été bien aises de rappeler cette opinion bizarre par le nom spécifique que nous avons conservé ce centronote avec le plus avand nombre des auteurs modernes. Celui qui écrit I'histoire de la nature doit marquer les écueils de la raison, comme l'hydrographe trace sur ses cartes ceux où out péri les navigateurs.

On voit sur le dos de ce petit animal, dont on a voulu faire le direeteur de la route des énormes requius, ces aiguillons qui appartiennent a tous les poissons compris dans le quatre-vingtonzième genre, et dont la présénce et la position sont indiquées par le nom de Centronole', que nous avons cru devoirleur donner : compte que quatre an-devant de la naged dorsale du Pilote. Les cótés de la queue de ce poisson sont relevés longitudinalement en carene. La ligne latérale est droite. Plusieurs bandes transversales et noires font ressortir la couleur de sa partie supérienre, qui prisente des teintes brunes et des reflets qui presente des le nom deflets dorés. Il paraít que le nombre de ces bandes varie depuis quatre 'Kivipov, en grec, signifle aiguillon; et véros signifie
dos.

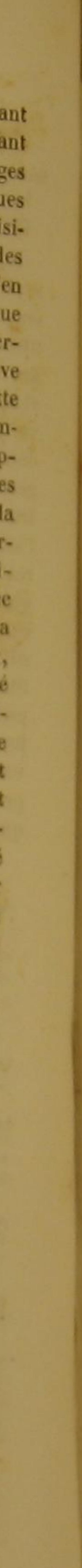




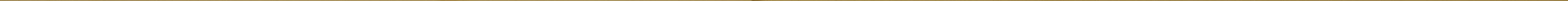


LE CEnTRonote ACANTHIAS ${ }^{2}$, Gasterosteus acanthias, Linn., Gmel, Lacep. "'

\section{LE CENTRONOTE GLAYCOS} Centronotus glaycos, Lacep., Risso; Lichia glauca, Cuv.

Les mers qui arrosent le Danemarck nourrissent, selon Pontoppidan, l'acanthias; et la Méditerranée est la patrie du glaycos. Nous avons conservé ce nom grec glaycos, qui veut dire glauque (d'un bleu de mer), à un ceptronote décrit et figuré par Rondelet, et auquel, suivant ce naturaliste, les anciens avaient donné cette dénomiuation. Cette espèce a le corps allongé, les dents très-pointues, la ligne latérale ondée à petits traits; la partie supérieure du corps d'un bleu obscur, l'inférieure très-blanche; la chair grasse, ferme et de bon goût.

LE CENTRONOTE ARGENTÉ , Gasterosteus ocçidentalis, Linn., Gmel;; Centronotus argenteus, Lacep.; Lichia occidentalis, Cuv. '

LE CENTRONOTE OVALE ${ }^{8}$ Gasterostens ovatus, Linn., Gmel.; Centronotus oralis, Lacep; ; Trachinotus ovatus, Cuv, ${ }^{3}$

ET LE CENTRONOTE LYZAN ${ }^{\circ}$.

Scomber Lyzan, Forsk.: Gasterosteus Lyzan, Linn. Gmel. Centronotos Lyzan, Lacep.; Lichia Lyzan, Cur.".

On pêche auprès des côtes de l'Amérique

- A la nazeoire do dos 28 rayons, a chacune des pector les 20 . a chacune des thoracines 6 , a celle de l'anus 17 .

2 Pontoppid. Naturg. Danaem.. p. 188, n. 5 .

' M. Cuvier ne fait pas meation de cette espece. D.

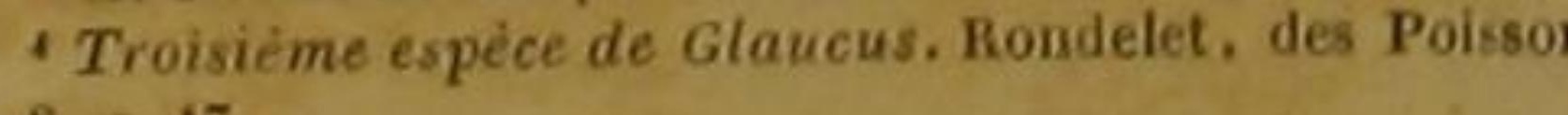

8, c. 17.

- Da centronote selon M Curier. D.

- Gastré saure, Danbenton, Knc. méth. - Id. Bonn 'erre, pl. de l'Enc. méth. - - Saurus argenteus candá ló- gitudinal ter striata, , Browne, Jam, 432, lab. 46, hig. 2. 'M. Cavier place ce poisson, qui se rappro.he des Seche

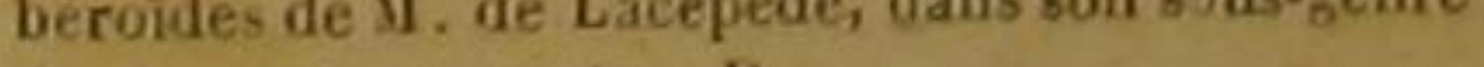
du genre Centronote.

pl. de l'Euc, méth.

Di Da sons genre Trachinote dans le genre Centrono Cuv. D.

10 Scombrelyzan. Bonaaterre, pl. de l'Enc, méth.

"Del, Faun. Arab., p. 54, u. of. équinoxiale, l'argenté, dont la couleur est désignée par le nom spécifique que nous arons eru devoir lui donner ', pendant que c'est dans les mers de l'Asie que vit l'ovale ${ }^{2}$, dont l'ajguillon dorsal le plus antérieur est couché vers la tète, dont les mâchoires sont hérissées de petites dents, et dont le corps très-comprimé, comme celui des chétodons, a indiqué par sa figure la dénomination spécifique de ce centronote.

Forskael a vu le lyzan sur les cótes de l'Arabie. Ce poisson est couvert d'écailles petites, lancéolees, et resplendissantes comme des lames d'argent; ses lignes latérales sont ondées vers l'opercule et droites auprès de la queue; son dos est d'un brun mêlé de bleu ${ }^{3}$.

\section{LE CENTRONOTE CAROLININ}

Gasterosteus carolinus, Linn., Gmel.; Centronotus carolinus, Lacep. ".

\section{LE CENTRONOTE GARDENIEN o}

Gasterosteus canadus, Linn., Gmel.; Centronotu Gardenii, Lacep, Elacates americana, Cuv. ${ }^{7}$.

\section{ET LE CENTRONOTE VADIGO *}

Scomber Amia, Linn., Gmel.; Centronotus Vadigo, Lacep.; Lichia Vadigo, Cuv. ’.

Le carolinin et le gardénien habitent la CaroM. Ouvier. Ce poisson a les caracteres des Scomberoídes de de Lacépede. D.

7 rayous a chacue des nageoires pectorales de largenté, 6 rayon à chacune des thoracines, 2 aiguilions au-devant de la nageoire de tanus, 1 aigution el 6 rayons articules a ta nageoire anate, 16 rayons a la nageoire de la quen.

- 46 rayons a chacune des nazeoires pectorales de l'ovate. 6 rayons a chachac d-s thoracines, 2 arguilions su-devant do

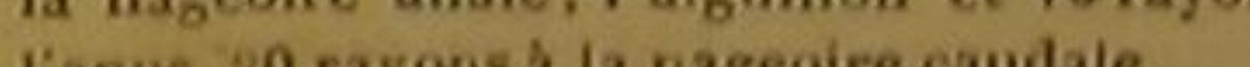
"17 ryyous à chacime des peciorales du Iyzan, 1 aignillon 5 rayons a chacune des thoracines, 2 aiguiltons au devant de ta nageoire de lanus, 1 aiguilton et 18 rayons a cello

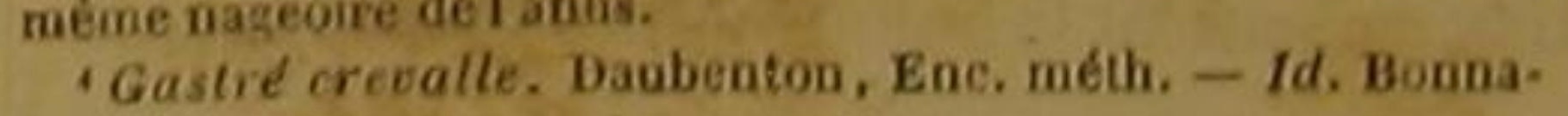
erre, pl de l'Enc. meth.

D.

- Gastré canade. Dav

'D Du sous-genre Balacate dans te geñre Centronote do M. Cuvier. C'est probablement ie Centronotus spinosus. Mitchill. D.

- Liche, Pelamide, dans plus. départ. mérid. - Liche, ou seconde espece de glaucus. Ronielet, des Poissons, Part. $1,1.8$, c.
BL, pl. 536, tig. 1

Ce puisson ai du sons-genre Liche dans le genre Ceniro. note de M. Cavier. Il est décrit par llondelet, p. 234, et par Salviani. p. 121. D. 
DES POISSONS.

line: le nom du premier indique leur pays; ce- reau ; et leur chair n'est pas désagréable a

lui du second, l'observateur qui les a fait con- goût.

naitre. C'est en effet le docteur Garden qui en envoya, dans le temps, la description à Linnée. Ces deux poissons, et le vadigo, qui se trouve dans la Méditerranée, se ressemblent par la forme de leurs nageoires du dos et de l'anus, qui présentent la figure d'une faux, et par celle de la nageoire de la queue, qui est fourchue: mais, indépendamment des dissemblances

que nous n'avons pas besoin d'énumérer, le carolinin n'a que vingt-six rayons à la nageoire du dos ', et le gardénien y en a trente-trois ${ }^{2}$; celui-ci n'a que deux rayons à chacune des pectorales, et le vadigo y en présente un nombre bien plus grand, pendant que ses lignes latérales sont tortueuses et courbées vers le bas, au lieu d'être droites comme celles du carolinin. Au reste, l'aiguillon dorsal le plus antérieur du vadigo est incliné vers le museau.

LE CENTRONOTE ÉPERON ${ }^{3}$ Scomber Calcar, Bl.; Centronotus Calear, Lac.; Lichia Calcar, Cuv. 4

LE CENTRONOTE NËGRE 5 . Scomber niger, BI.; Centronotus niger, Lacep.; Naucrates niger, Cuv, :

Le corps et la queue de l'éperon paraissent dénués d'écailles. La mâchoire inférieure de passe celle de dessus. La langue est mobile, lisse et large. Chaque uarine ne montre qu'un orifice. La ligne latérale est presque droite. Les thoracines peuvent être couchées dans une sorte sillon, La couleur générale est argentée: des teintes noires règnent sur le dos; les nageoires sont bleuâtres. On trouve une grande quantité de centronotes éperons sur la côte de Guinée. Ilsy présentent la grandeur du scombre maque-

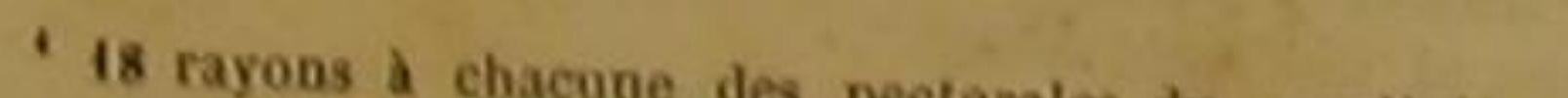
rayons a chacune des thoracines, 5 rales du carolinin, of articulés i ta nageoire de l'anus, 27 rayons et 24 rayon quene. 27 rayons a la membrane des branchies du gardénien, cines, 26 a i a nageoire de $t$ ectorales, 7 a chacune des thoraa seom ire ép ron, Scomber car a celle de la queue. 4 Du sous-genre Liete dans le genre Bl., pl. 356, fią. 2. - Seffer, sur les cotes d'Afrique. - Ceirunote. Cuv. D. - Slachicher blauling, par les Allemands - Nean Brésil. rel, par les Anglaic, - Scombre ne'gre. Bloch, pl. 557.
D. Du sous-gence des Pilotes dans le geare Ceatronote.
Le centronote nègre habite dans la partie de I'Océan Atlantique qui sépare l'A frique de l'A. mérique méridionale. Barbot l'a trouvé auprès de la côte d'Or; et Maregrave, Pison et le prince Maurice de Nassau l ont vu dans les eaux du Brésil. Il parvient à une longueur remarquable. Suivant Barbot, il a près de deux mètres de long; $e$ Maregrave lui attribue une longueur de plus de trois mètres. Sa chair est d'ailleurs grasse, blanche et ferme : aussi est-il très-recherché, et préparé pour être envoyé au loin. Lorsqu'il est frais, on compare son goût à celui de l'anguille, et lorsqu'il est séché, a celui du saumon fumé. il séjourne ordinairement dans la haute mer mais de temps en temps on voit des troupes nombreuses d'individus de cette espèce s'approcher des terres, préférer les fonds pierreux, et y chercher les crustacées et les animaux à coquille, qui doivent servir à leur nourriture. Les nègres les prennent sur ces bas-fonds, et les péchent à la lueur de brandons allumés ?

Le centronote nègre a la peau lisse, aplatie et dénuée de petites écailles; le museau arrondi; l'ouverture de la bouche assez grande; les dents petites; la langue large et mobile; deux orifices à chaque narine: les écailles qui revètent son corps et sa queue sont petites, lisses et minces. Sa couleur nớreest relevée par le gris de la base et du milieu de ses thoracines, ainsi que par les nuances blanches et argentées qui resplendissent sur ses cótés.

\section{QUATRE-VINGT-QUINZIËME GENRE ${ }^{2}$.} LES LÉPISACANTHES.

Les écailles du dos grandes, cilieses, et terminees par un aiguillon : les opercules denteles dans leur parlie posisolice, et demues de petites ecailles; des aiguillons isoles au-derant de la nageoire dorsale.

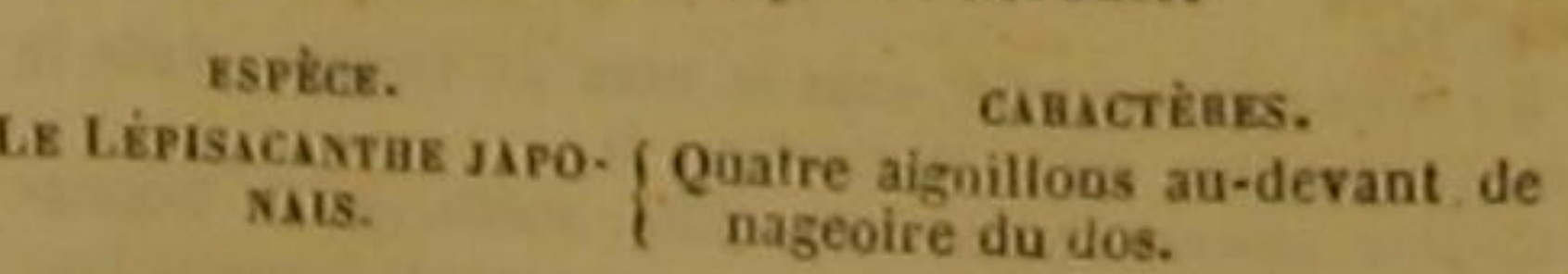

14 rayons a chaque pectorale du centronote éperon. 1 rayon aiguilonne et 3 rayons articulésà chaque thoracine, de hiquelle on voit deurayons articulés a l'anale, an devant is rayons \& la nageire de li ons réunis par une membratie. de lanus du centronote de la queue, 21 rayons a la nigeoire 'Le genre Lépisacanthe, Lacép. 17 ranons à la caudale. Schn., est adopté par M. Cavier, qui le place entre les Scorpènes et les Epinoches, dans sa familie des ace les Scorgiens a joues cuirassees. Ce genre ne renferme qu'une senle
espece. D.
EÉPISACANTHE JAPONAIS !

Gasterosteus japonicus, Hoult., Liun., Gmel.; Vouejaponicus, Lac. ${ }^{2}$.

Le nom génerique de cet animal désigne la forme particulière de ses écailles ${ }^{3}$; et sa dènomination spécifique, 'les mers dans lesquelles on l'a vu. Houttuyn l'a fait connaitre, et nous avons eru devoir le séparer des centronotes, et des autres poissonsavee lesquels on l'avait place dans le genre des centrogastères, atin d'étre fidèles aux principes de distribution methodique que nous avons préférés. Le museau de cet 0 seux est arrondi; ses mâchoires sont hérissées de petites aspérités, plutôt que garnies de dents proprement dites. Une fossette longitudinale recoit et cache, à la volonté de l'animal, les piquants épais, forts, inégaux et isolés, que l'on voit au-devant de la nageoire du dos. Les rayons de chacune des thoracines sont réunis et allongés de manière à former un aiguillon peu mobile, rude, et égal en longueur aux trois đixièmes, ou à peu près, de la longeur totale du poisson. Le japonais ne parvient d'ailieurs qu'à de très-petites dimensions, il n'a pas un double décimètre de long; et sa couleur est jaune 4.

QUATRE-VINGT-SEIZIEME GENRE LES CÉPHALACaNTHES.

Le derritre de la tete gami, de chaque côte, de deus piquauts denteles of tres-tongs; point d'aiguillons isoles au-derant de la nageoire du dos.

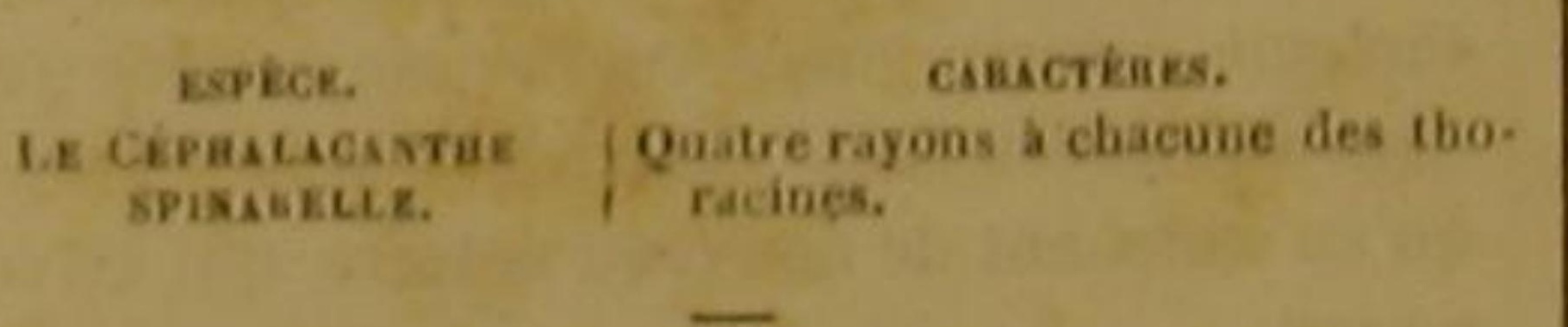

LE CÉPHALACANTHE SPINABELLE • Gasterosteus spinarella, Linn., Gmel.; Cephalacanthus spinarella, Cuv.

Ce céphalacanthe ne présente qu' une petite longueur. Sa tête, plus large quele corps, est striée - Gassée du Japon. Bonnaterre, pl, de I'Enc, méth, .. Houttuyn, ACl. Haart. XX, 2. p. 329.

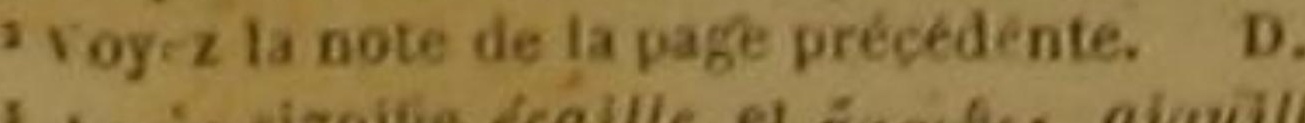

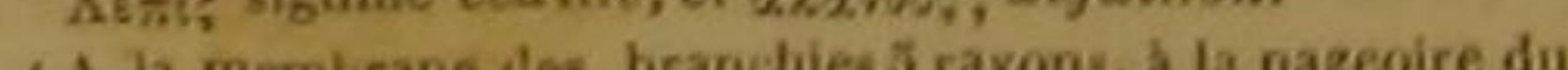
dos 10 . a chaeune des pectorales 12 , a celle de ranus 9 , a celle de la quene 22.

'Ce genre, dout on ne connait encore qu'une pelite es péce de la Guyane, a eté adoplé par M. Cuvier, et placé par loi dans sa famille des Acanthojićcygiens a joues cuirassees. sur toute sa surface, et garnie par derrière de quatre grands aiguillons. Les deux supérieurs sont plus dentelés, plus larges et plus courtsque les deux inférieurs. La spinarelle, qui vit dans I'Inde', a été placée dans le mẻme genre que les gastérostées et les centronotes: mais elle en differe par trop de traits pour que nous n'ayons pas dủ l'en séparer. L'absence d'aiguillons isolés audevant de la nageoire dorsale aurait suffi pour Véloigner de ces ossenx. Nous l'avons done inserite dans un genre particulier qui précède immédiatement celui des dactylopteres, parm lesquels on compte la pirapede dont la tete ressemble beaucoup à celle de la spinarelle ${ }^{2}$.

\section{QUATRE-VINGT-DIX-SEPTIEME GENRE 3} LES DACTVLOPTK̇⿴Es.

One petite nageoire campose de rayons soutenus par me membrone, aupres de la base de chaque nageoire pectorale.

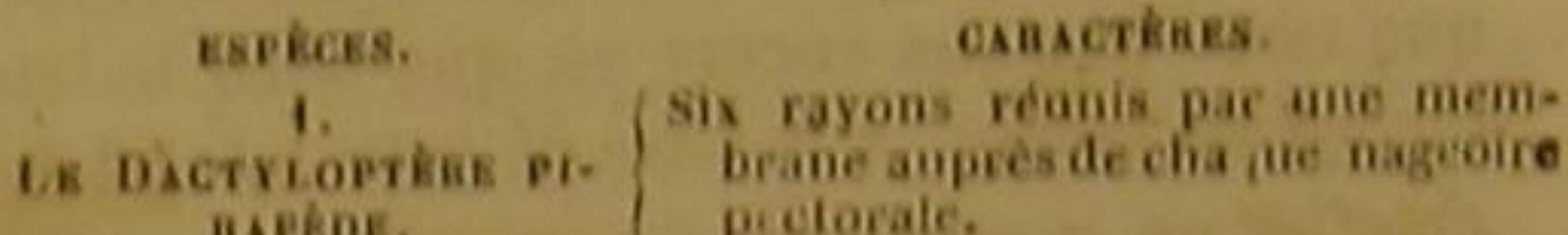

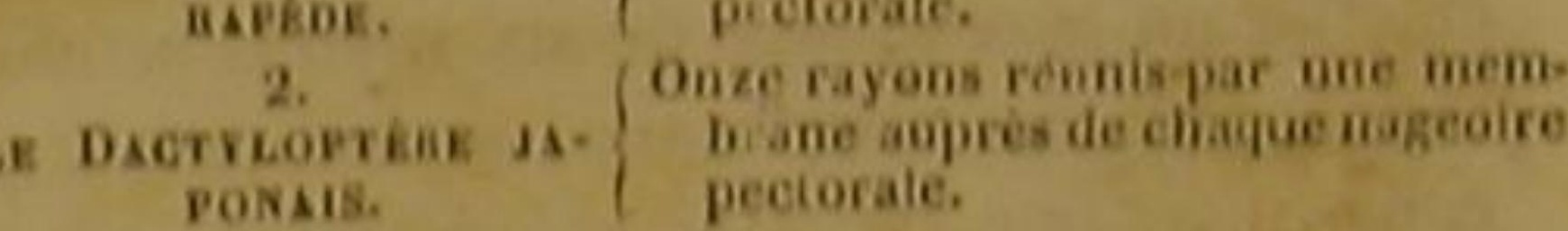

LE DACTYLOPTERE PIRAPEDE 4.

Trigla volitans, Linn., Gmel,; Dactylof terus Pirapeda. Lacep,; Dactylopterus commuais, Cur, s,

Parmi les traits remarquablesqui distinguent

piquant. - Pungitius pusillus. Mus, Adolpt. Erid. I, D.74, tab. 52. ig. B. - Gastrd spinarelle, 1

. Ce pots on est de la Guyanc, el non pasdes Indes, comme in l'a toujours dit. Cav. D.

a la nageoire di Jos 16 , a cliacune des pectorales 20 , a chacune des thoract etes, a celle de Tanus 8.

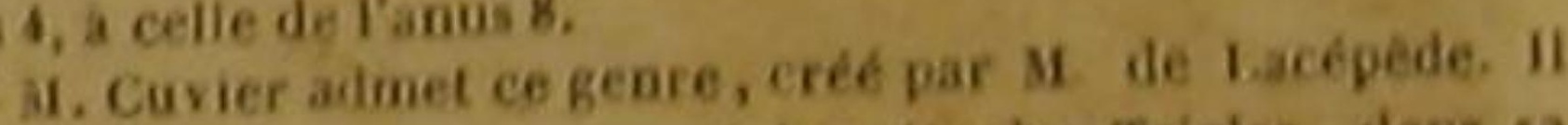
Is suite des Trigles, dans sa - Whe des Acanthopterygens a joues cuirassées. D. Palcone, a Nitte et en Sieile. - Flygande fisk, eu suede. Swahow fish, Kile fish, en Angletere. - Arondelle, Rondole, Chaude-sotris, halepenade, dams plus depart, mend

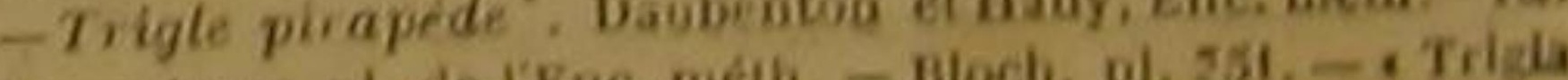

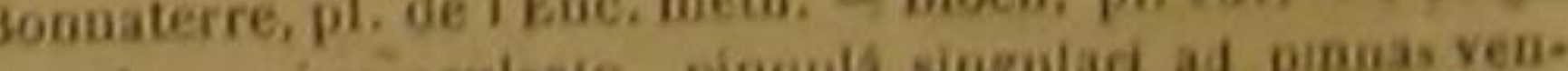

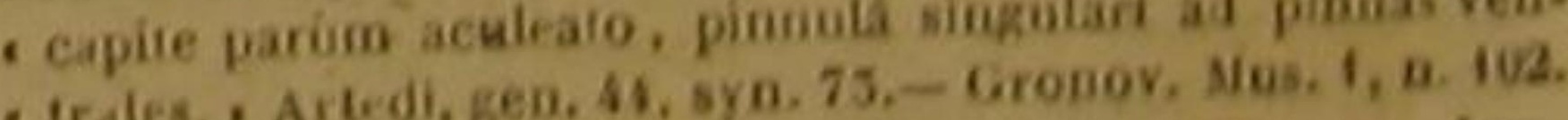

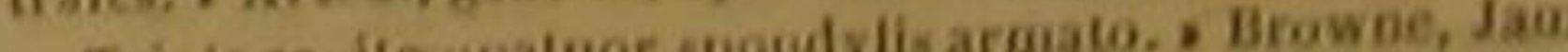

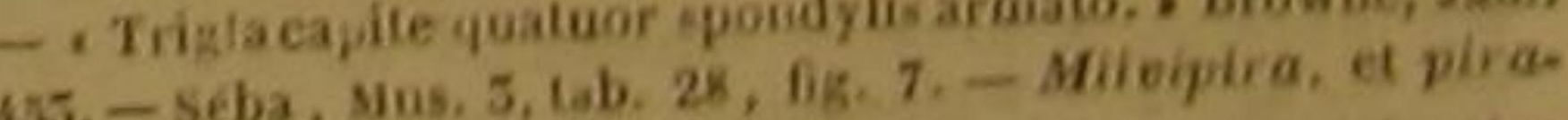
- U. Curier donne a ce polson le nom de Bacicoptore

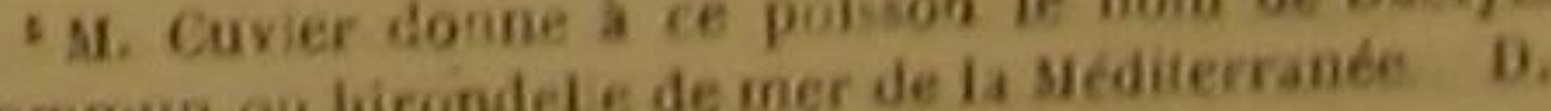

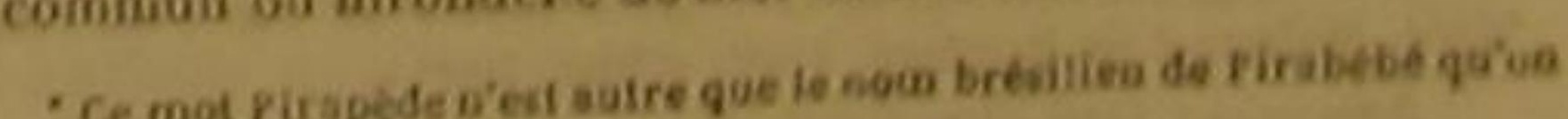




\section{HISTOIRE NATURELLE}

ce grand poisson volant et les autres osseux qui doivent appartenir au mème genre, il faut compter particulierement les dimensions de ses nageoires pectorales. Elles sont assez étendues pour qu'on ait dú les désigner par le nom d'aies; et ces instruments de natation, et principalement de vol, étant composés d'une largè membrane soutenue par de longs rayons articulés que l'on a comparés à des doigts comme les rayons des pectorales de tous les poissons, les ailes de la pirapéde ont beaucoup de rapports dans leur conformation avec celles des chauve-souris, dont on leur a donné le nom dans plusieurs contrées ; et nous avons cru devoir leur appliquer la dénomination générique de Dactyloptère, qui a été souvent employée pour ces chauves-souris, aussi bien que celle de Cheiroptere, et qui signifie aile attachée aux doigts, ou formée par les doigts'.

La pectorale des pirapèdes est d'ailleurs double, et présente par conséquent un caractère que nous n'avons encore vu que dans le lépadogastère gouan. $A$ la base de cette aile on voit en effet un assemblage de six rayons articulés réunis par une membrane, et composant par conséquent une véritable nageoire qu'il est impossible de ne pas considérer comme pectom-

De plus, l'aile des poissons nons offre une grande surface; elle montre lorsqu'elle est déployée une figure assez semblable à celle d'un disque, et elle atteint le piuouvent au delà de la nageoire de l'anus le plus près de celle de la queue. Les rayons qu'elle renferme étant assez écartés l'un de l'autre lorsqu'elle est étendue, et n'étant liés ensémble qupar une membre que par une membrane souple qui permet facilement leur rapprochement, il n'est pas surprenant que l'animal puisse donner aisément et rapidement à la surface de ses ailes, cette alternative d'épanouissement et de contraction,

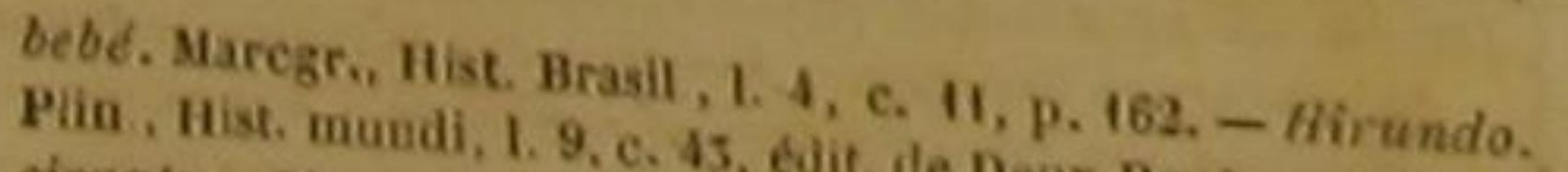
cirratus, Sloand, I. 9, c. 43, edit. de Deox-Ponts. - Miltous

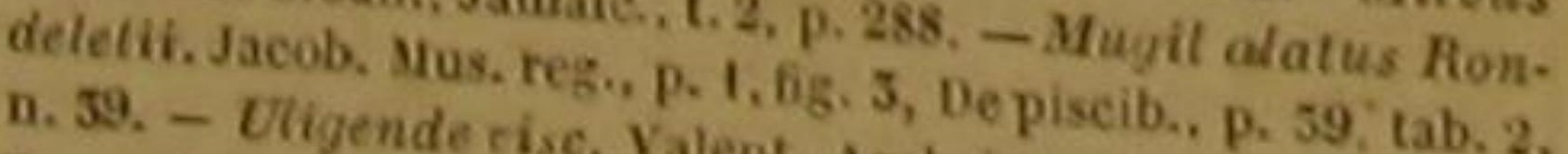

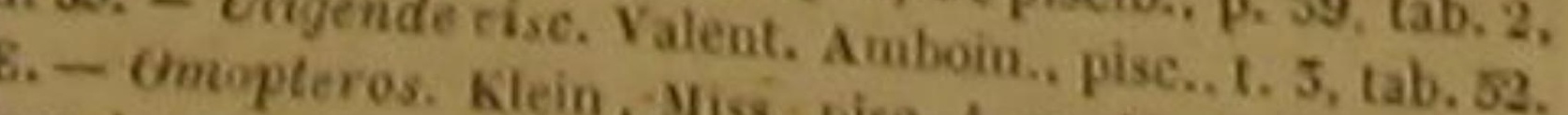
rundo aquatica. Bont. Ind. orieat., p. p. 78 - Hirindo - Hi.
wii. Mus. Worm.

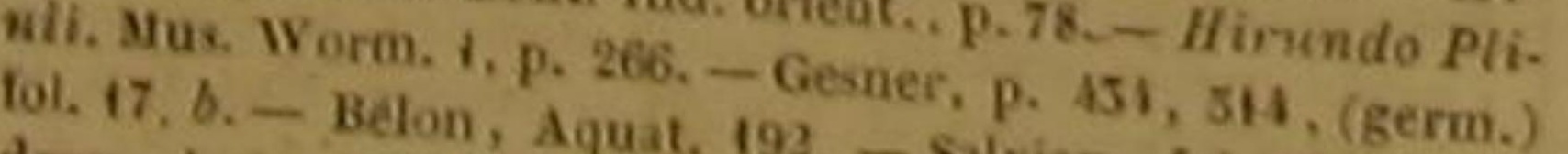

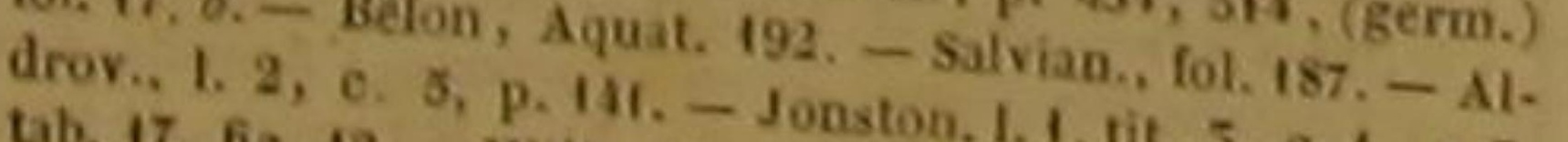

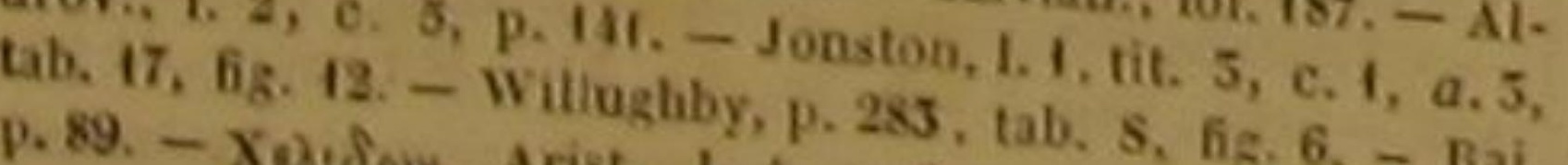
p. 89. - X Xoldor, Arist. I 4, c. 9. - Arondelle de $\mathrm{R}$

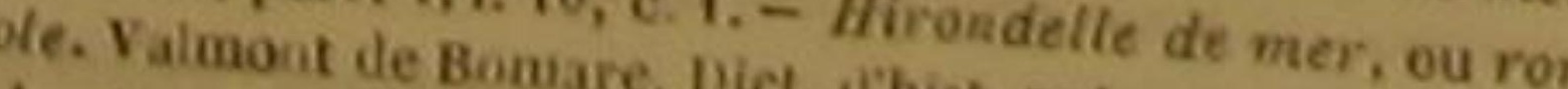
'Daxivides reut dire doigt, el maspoy, aile. inégalités successives, qui, produisant des forts alternativement inégaux contre l'air d l'atmosphère, et le frappant dans un sens plos violemment que dans un autre, font changer place a l'animal lancé et suspendu, pour ainsi dire, dans ce fluide, et le douent véritablement de la faculté de voler ' .

Voilà pourquol la pirapède peut s'élever andessus de la mer, à une assez grande hauteur pour que la courbe qu'elle décrit dans l'air ve la ramène dans les flots que lorsqu'elle a franchi un intervalle égal, suivant quelques observateurs, au moins à une trentaine de mètres et voilà pourquoi encore depuis Aristote jusqu'à nous elle a porté le nom de Faucon de la mer et surtout d'Hirondelle marine.

Elle traverserait au milieu de l'atmosphère des espaces bien plus grands encore, si la membrane de ses ailes pouvait conserver sa souplesse au milieu de l'air chaud et quelquefois mème brûlant des contrées où on la trouve: mais le fluide qu'elle frappe avee ses grandes nageoires, les a bientót desséchées, au point de rendre très-difficile le rapprochement et l'écarte. ment alternatifs des rayons; et alors le poisson que nous décrivons, perdant rapidement sa faculté distinctive, retombe vers les ondes audessus desquelles il s'était soutenu, et ne peut plus s'élancer de nouveau dans l'atmosphère que lorsqu'il a plongé ses ailes dans une eau réparatrice, et que, retrouvant ses attributs par son immersion dans son fluide natal, il offre une sorte de petite image de cet Antée que la mythologie grecque nous représente comme perlant ses forces dans l'air, et ne les retrouvant u'en touchant de nouveau la terre qui l'avait nourri.

Les pirapèdes usent d'autant plus souvent du pouvoir de voler qui leur a été départi, qu'elles , grand nombre d'ennemis. Plusieurs gros poissons, et partienlièrementles prors bres, cherchent i des scomheureuse dest a les dévorer, et telle est la malhes animaux qui, poissons toiseaux, sembleraient avoir un doubleasie quils ne trouvent de sùreté nulle part, qu'ils n'échappent aux périls dulle part, qu'ils exposés à ceux de l'a da mer que pour être tent la deux de l'atmosphere, et qu'ils n'éviétre da dent des habitants des eaux que pour etre saisis par le redoutable bee des frégates,

DES POISSONS.

des phaétons, des mauves, et de plusieurs autres oiseaux màrins.

Lorsque des circonstances favorables éloignent de la partie de l'atmosphère, qu'elles traversent des ennemis dangereux, on les voit offrir au-dessus de la mer un spectacle assez agréable. Ayant quelquefois un demi-mètre de longueur, agitant vivement dans l'air de larges et longues nageoires, elles attirent d'ailleurs l'attention par leur nombre, quisouvent est de plus de mille. Mues par la mème crainte, cédant au même besoin de se soustraire à une mort ìnévitable dans l'Océan, elles s'envolent en grandes troupes; et lorsqu'ellès se sont confiées ainsi à leurs ailes au milieu d'une nuit obseure, on les a vues briller d'une lumière phosphorique, semblable à celle dont resplendissent plusieurs autres poissons, et à l'éclat que jettent, pendant les belles nuits des pays meridionaux, les inseetes auxquels le vulgaire a donné le nom de Vers luisants. Si la mer est alors calme et silencieuse on entend le petit bruit que font naitre le mouvement rapide de leurs ailes et le choc de ces instruments contre les couches de I air; et on distingue aussi quelquefois un bruissement d uneautre nature, produit au travers des ouvertures branchiales par la sortie aceélérée du gaz que I animal exprime, pour ainsi dire, dediverses cavités intérieures de son corps, en rapprochant vivement leurs parois. Ce bruissement a lieu d'autant plus facilement, que ces ouvertures branchialesétant très-étroítes, donnent lieu à un frôlement plus considérable; et e'est parce que ces orifices sont très-petits, que les pirapèdes, moins exposées à un desséchement subit de leurs organes respiratoires, peuvent vivre assez longtemps hors de l'eau

On rencontre ces poissons dans la Méditerranée et dans presque toutes les mers des climats tempérés; mais c'est principalement auprès des tropiques qu'ils habitent. C'est surtout,auprès de ces tropiques qu'on a pu contempler leurs maucuvres et observer leurs évolutions. Aussi leur nom et leur histoire ne sont-ils jamais entendus avec indifférence par ces voyageurs courageux qui, loin de l'Europe, ont affronté les tempêtes de l'Océan, et ses calmes sonvent plus funestes encore. Ils retracent a leur souvenir leurs peines, leurs plaisirs, leurs dangers, leurs succès. Ils nous ramènent, nous qui tâchons de dessiner leurs traits, vers ces compagnons de ' Discours sur la nature des poissons. nos travaux, qui, dévoués à la gloire de leur pays, animés par un ardent amour de la science, dirigés par un chef habile, conduits par le brave navigateur Baudin, et réunis par les liens d une amitié touchante ainsi que d'une estime mutielle, quittent, dans le moment mème où mon cœur s'épanche vers eux, les rivages de leur patrie, se séparent de tout ce qu'ils ont de plus cher, et vont braver sur des mers lointaines la rigueur des elimats et la fureur des ondes, pour ajouter à la prospérité publique par l'accroissement des connaissances humaines. Noble dévouement, généreux sacrifices! la reconnaissance des hommes éclairés, les applaudissements de l'Europe, les lauriers de la gloire, les embrassements de l'amitié, seront leur douce et brillante récompense.

Cependant quelles sont les formes de ces poissons ailés dont l'image rappelle-des objets si chers, des entreprises si utiles, des efforts si dignes d'éloges?

La téte de la pirapede ressemble un peu à celle du céphalacanthe spinarelle. Elle est arrondie par devant, et comme renfermée dans me sorte de casque ou d'enveloppe osseuse à quatre fices, terminée par quatre aiguillons larges et allongés, et chargée de petits points arrondis et disposés en rayons. La mâchoire supérieure est plus avancée que l'inférieure. Plusieurs rangs de dents très-petites garnissent l'une et l'autre de ces deux màchoires; et l'ou. verture de la bouche est très-large, ce qui donne a la pirapède un rapport de plus avec une hirondelle. La langue est courte, épaisse, et lisse comme le palais. Le dessous du corps présente une surface presque plate. Les écailles qui couvrent le dos et les cótés, sont relevées par une arcte longitudinale.

Le rougeatre domine sur la partie supérieure de lanimal, le violet sur la tête, le bleu céleste sur la première nageoire du dos et sur celle de la queue, le vert sur la seconde nageoire dorsale; et pour ajouter à cet élégant assortiment de bleu très-clair, de violet, de vert et de rouge, les grandes ailes ou nageoires pectorales de la pirapède sont couleur d'olive, et parsemées de taches rondes et bleues, qui brillent, pour ainsi dire, comme autant de saphirs, lorsque les rayoons du soleil des tropiques sont vivement réfléchis par ces larges ailes étendues avee force et agitées avec vitesse '.

- A la membrane brancbiale 7 rayous, 8 is premiere $\mathrm{ma}$. 
in compte plusieurs appendices ou cœecums different assez les uns des autres pour que nous auprès du pylore; et les œufs que renferment ayons dủ les séparer; et cependant ils se resles doubles ovaires des femelles, sont ordinaire- semblent assez pour qu'on ait placé les prionoment très-rouges. Ia chair des pirapèdes est maigre; elle est gles dont nous allons nous occuper. Ils sont liés aussi un peu dure, à moins qu'on ne puisse la conserver pendant quelques jours.

LE DACTYLOPTĖRE JAPONAIS '. Trigla alata, Linn., Gmel.; Dactylopterus japonicus, Lac. '.

On trouve dans les mers du Japon ce dactyloptère, qui, de même que la pirapède, a été inscrit jusqu'à présent dans legenre des trigles. II a été décrit par Houttuyn. Il ne parvient guère qu'à la longueur d'un décimètre et demi. On voit deux aiguillons longs et aigus a sa machoire inférieure et au bord postérieur de ses opercules. On compte onze rayons à chacune de ses petites nageoires pectorales ${ }^{3}$.

$$
\text { - }
$$

QUATRE-VINGT-DIX-HUITIËME GENRE 4 LES PRIONOTES.

Des aiguillons denteles entre les deux nageoires dorsales: des rayons articules el non rèunis par une membrane. aupres de chacune des nageoires pectorales.

espeker. caliactiknes.

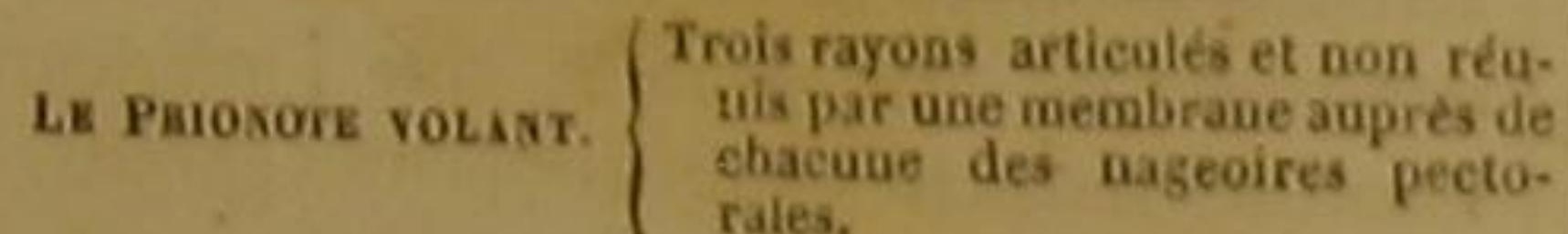
$-$

LE PRIONOTE VOLANT s

Trigla evolans? Linn., Gmel.; Prionotus evolans,Lae.•.

En comparant les caractères génériques des dactyloptères et des prionotes, on voit qu'ils geoire du dos 6 , a la seconde 8 , a chacune des grandes na-
geoires pectorales 20 . a chacured Choracines 6 , a celle de l'ânus 11 , a celle de 1 , a chacue des 'Houttuyn, Aet, Haarl, XX, 2, p. $556,0,23$ queue 12. 'Moutcuyn, Act, Haarl, XX, 2, p. 5s6, n. 2 . d'Houttuyn, où ce pois en tre trosant exactement le passage gle proprement dit, et non un Dactylopt que c'est un Triadique pas lespece. D. A la preatere nageoire du dos 7 rayons, a chacune des
petites nageoires perofores petites nageoires pectorales 11 , a chaeme des thoracines 6 . i Ce geore formé par Me de la queue 14.

snis-grure, dans le ar M, de Lacépede, a été adopté comme Fexistence des rayous articolsts non par M. Cuvien, qui gie dossales, ers rayons élant eompris dong th eutre les deux premiere de ces nageoires. D.
sTrigla volitans minor. B.

G.. 3. - Trigle rolant, Daubeoten, Jamaic. 455, Lb. 47 ,

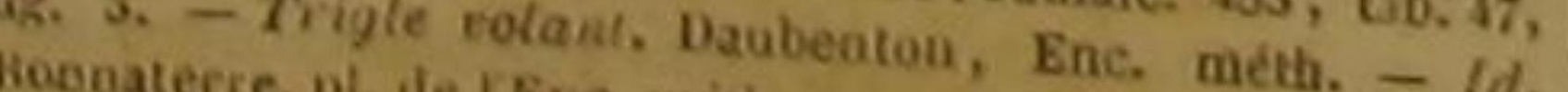
particulièrement par la forme de leur tète et par une habitude remarquable. Le prionote que nous décrivons, a la surface de sa tête ciselée de ma. nière à représenter des rayons ; et de plus il a la faculté de s'élever dans l'atmosphèrè, et de s'y soutenir pendant quelque temps, comme les dactylopteres. C'est cette dernière faculté qui lui a fait donner le nom spécifique de Volant; et nous avons eru d'autant plus devoir le désigner par le nom générique de Priono. $t e{ }^{4}$, qu'indépendamment de trois aiguillons dentelés qui s'élèvent entre les deux nageoires de son dos, le premier rayon de la seconde dorsale et les deux premiers de la première sont un peu dentelés par-devaut. Les pectorales sont assez longues pour attejndre à la moitié de la longueur du corps; et étant d'ailleurs très-lar. ges, elles forment des ailes un peu étendues, que leur couleur noire fait souvent distinguer à ane grande distance.

La nageoire de la queue est fourchue ${ }^{2}$.

$$
-
$$

QUATRE-VINGT-DIX-NEUVIEME GENRE: LES TRIGLES.

Point d'aiguillons denteles entre les deuxnageoires dor-

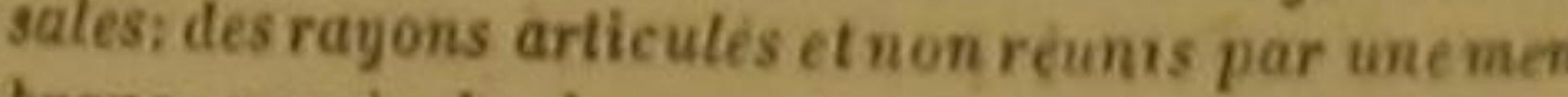

\section{PREMIER SOUS-GENRE.}

Plus de trois rayons articulès auprès de chaque nageoire pectorale.

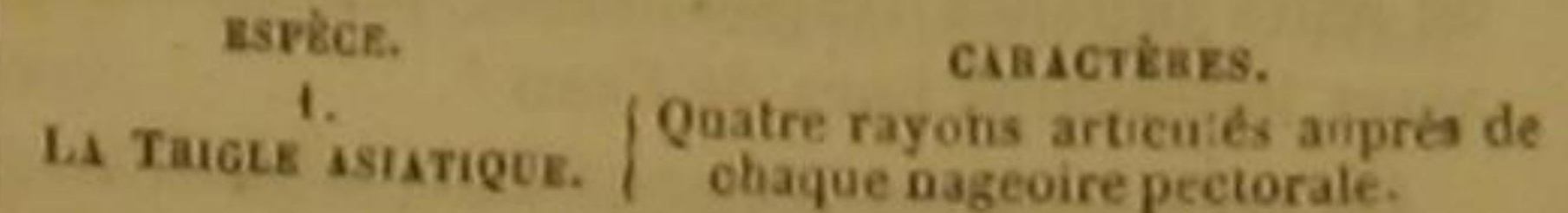

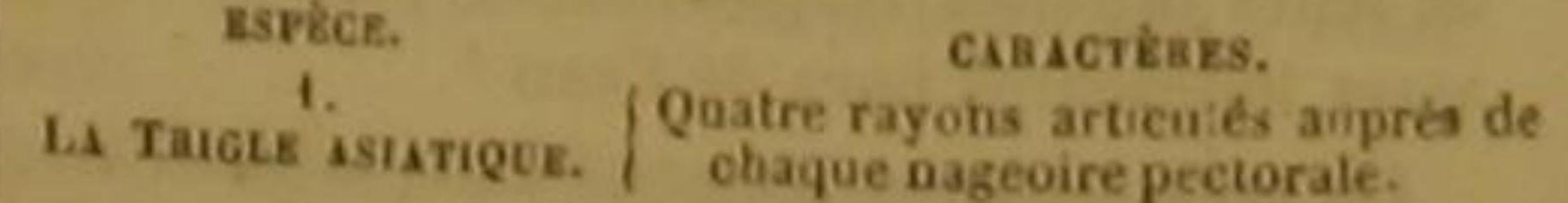
pose de quatre especes, et que la cilation ci-de sus donnée de fere pas se rapporte à son Primotus punctotus, qui ne dif-

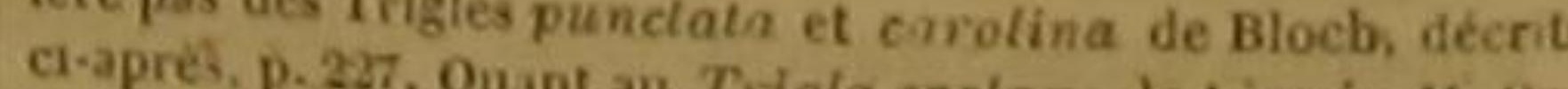
vier croitle retrouver dans son Prionota de Lionée, M. Cule Trigla lineata de Mitchill. Prionotus striga (us, qui eal 'Hicur sizoibe seic, triti. D. A la membrane des branchies 8 rare dos. nageoire da dos 8 , a la seconde 11 , a chans, à la première celle de la gacune des thoracines 6, a celle de l'anus 11 , 4 Ce la queue is.

qu iil est ici, par M. C Iun des plus naturels, est adopte ques espéces qui y ont été placées à tort, ou qui sont factices.
D.
SECOND SOUS-GENRE.

Trois rayons articules auprès de chaque nageoire pectorale.

\section{EsPÈces. \\ LA THGLE LYE.}

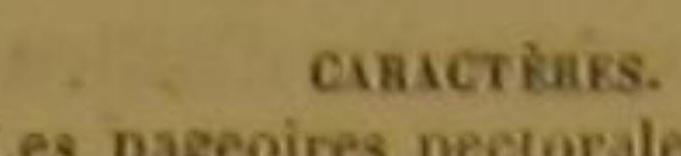
Les nazeoires pectorales longues
la máchoire superienre prolongee ea- leox lobes deateles; les
oritices des narines teluleur:

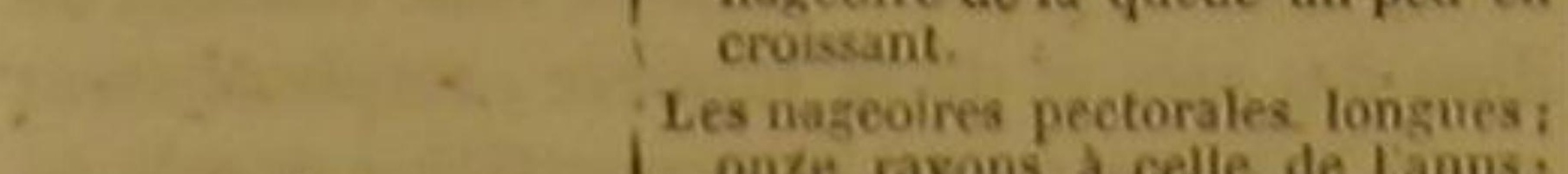

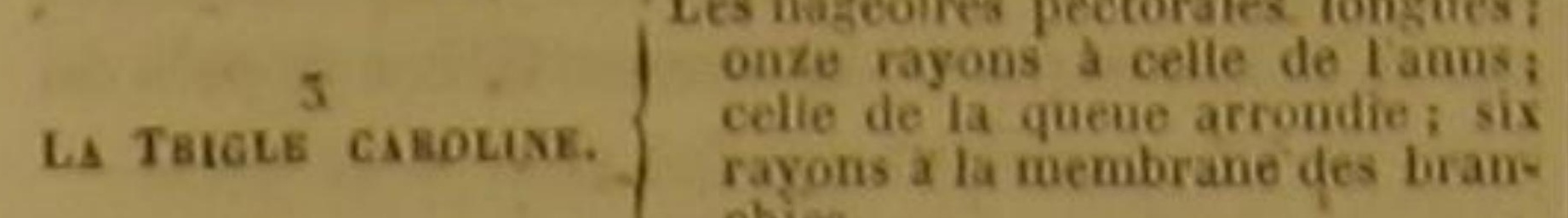

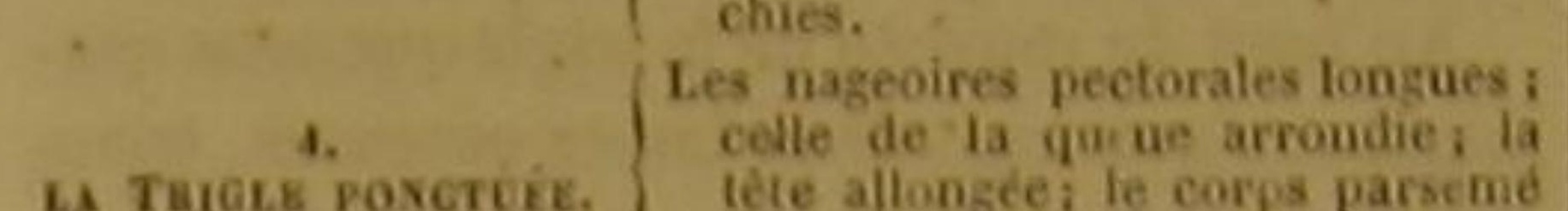

léte allongce le corps pa
de petites tachie rouges.

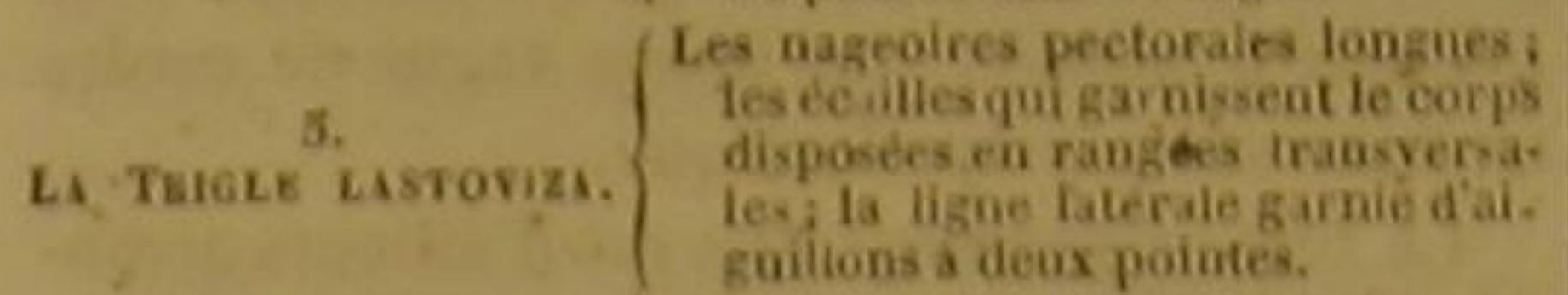

Li Taiger m.

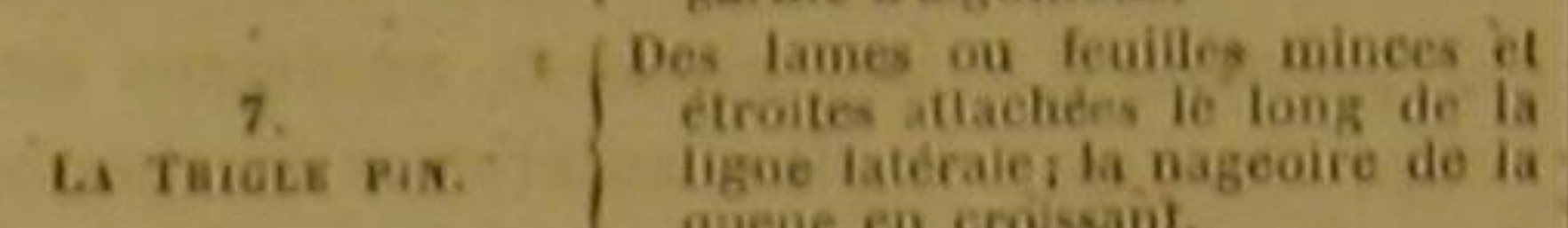

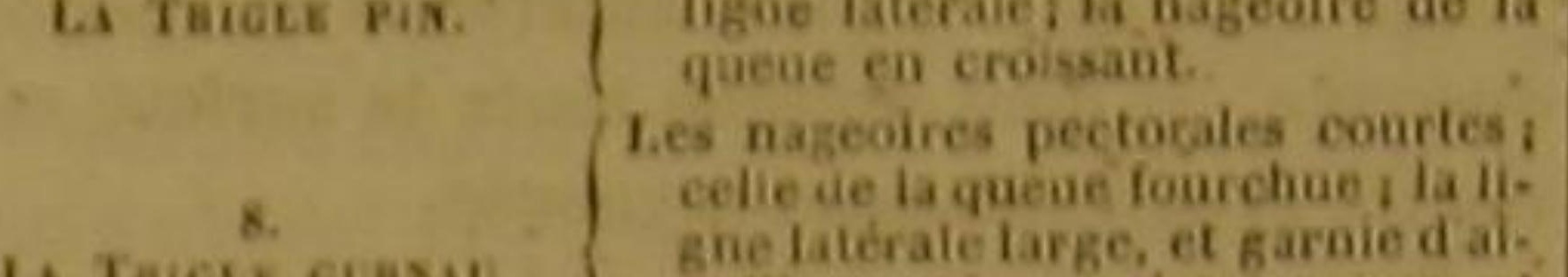

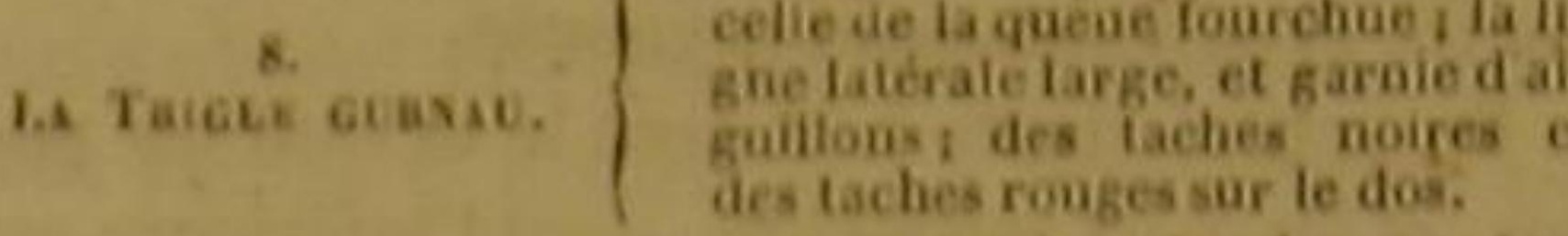

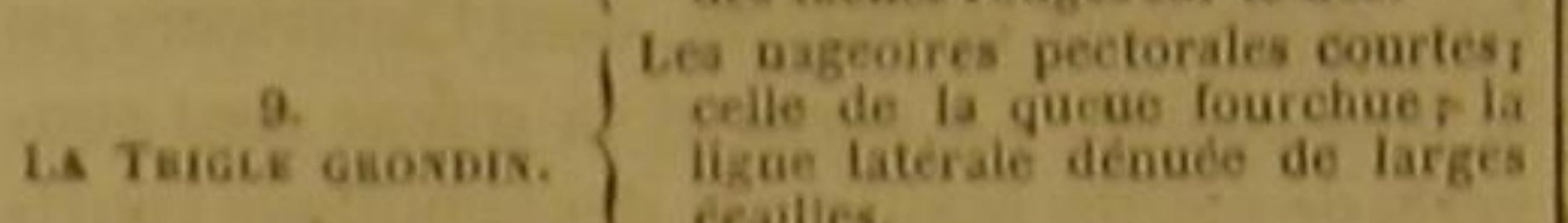

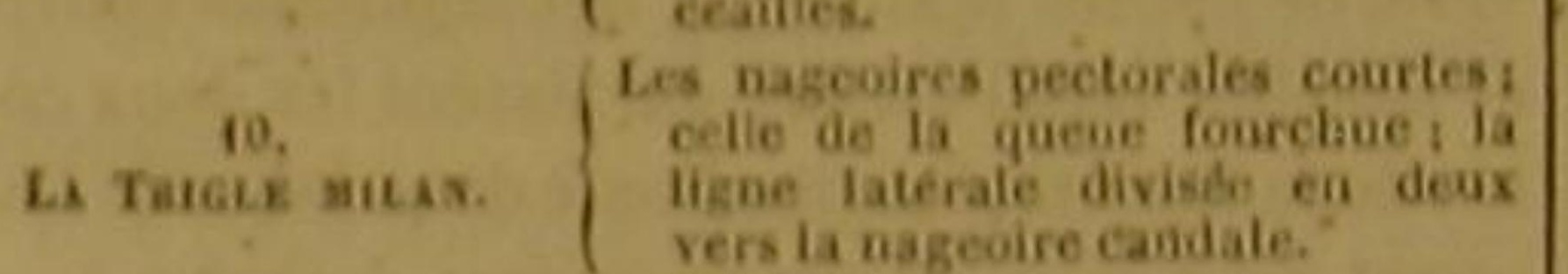

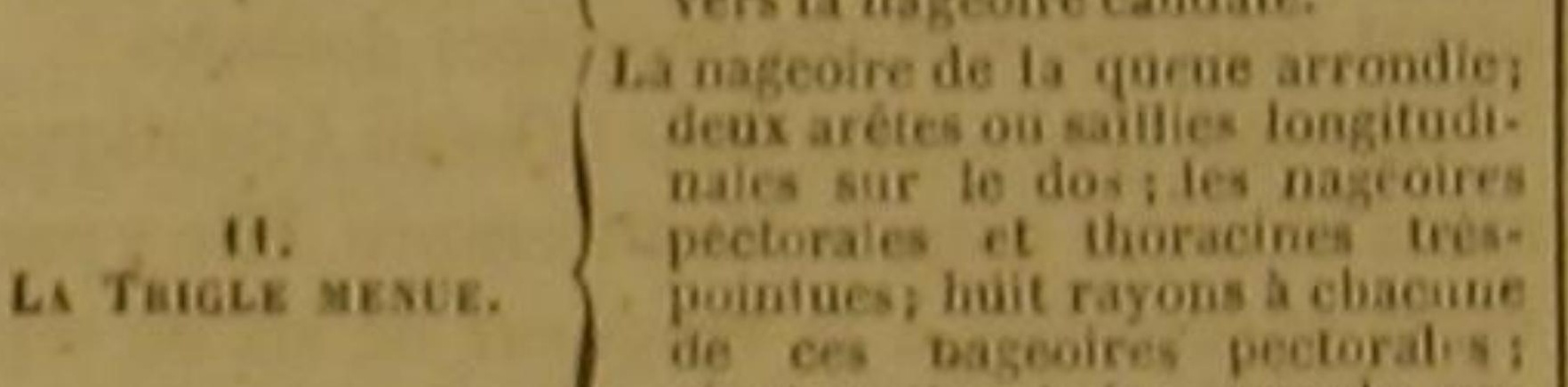

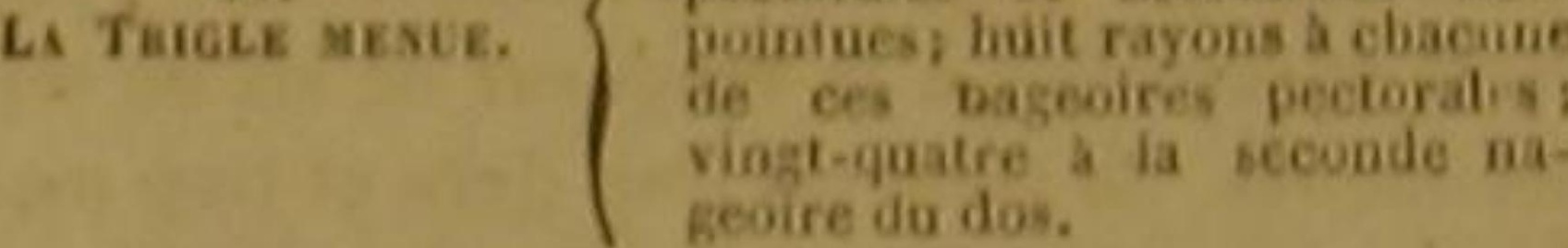
TROISIÉME SOES-GENRE.

Moins de trois rayons articules auprès de chaque nageoire pectorale.

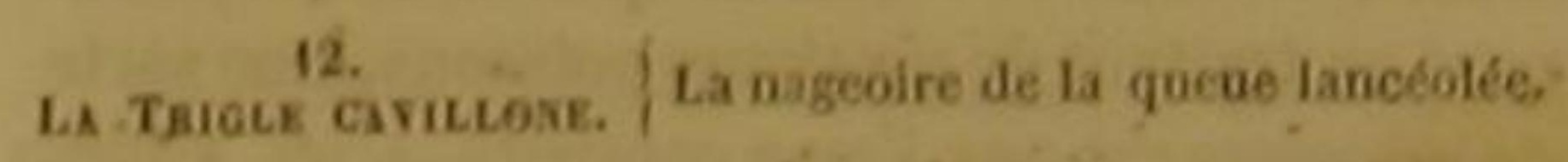

LA TRIGLE ASIATIQUE.

Trigla asiatica, Linn., Gmel., Lacep. '

Les tàbleaux génériques montrent les différences qui séparent les trigles dés prionotes et des dactyloptères. Mais si teurs formes extérieures ressemblent assez peu à celles de ces deux derniers genres, pour que nous ayons dú les en séparer, elles s'en rapprochent beaucoup par

'M. Cavier remaryue que cepoisson est bien sórement un Polynème, et mêrme quil ne paralt pas differer spécifique- leurs habitudes; et presque toutes ont, comme la pirapède, le pouvoir de voler dans l'atmosphère, lorsque la mer ne leur offre pas un asile assez sưr. Elles sont d'ailleurs, comme les dactyloptères et les prionotes, extrèmement fécondes; elles póndent souvent jusqu'à trois foisdans la même année; et c'est cette reproduction remarquable que plusieurs anciens Grees ont voulu

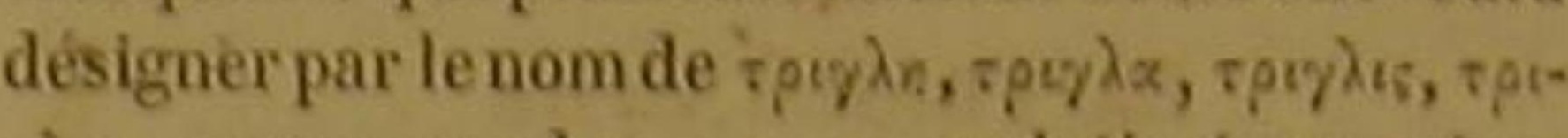
$\gamma^{\lambda}$ os, corrompu de rpryovos, en latin ter parien. (qui produit trois fois) ${ }^{f}$.De mèmeque les pirapèdes, elles volent et nagent en troupes nombreuses ; elles montrent une réunion constante; et quoique la simultanéité des mouvements et des manœuvres de milliers dindividus nè soit pour ces animaux que le produit d'un danger redouté à la fois par tous, ou d'un besoín agissant sur tous dans les mémes moments, elles n'en pré sentent pas moins rapparence de cette société touchante et fidèle qu'un sentiment mutuel fait naitre et conserve. Peintes d'ailleurs de couleurs très-vives, tròs-variées, très-agréables elles répandent souvent l'éclat du phosphore. Resplendissantes dans leurs téguments, brillantes dans leur parure, rapides dans leurnatation, agiles dans leur vol, vivant ensemble sans se combattre, pouvant s'aider sans se nuire, on croirait devoir les comprendre parmi les étres sur lesquels la nature a répandu le plus de faveurs, Mais les dons qu'elles ont reçus ne sont presque tous que des dons funestes; et comme si elles avaient été destinéesá donner à l'homme des lecons de sagesse et de modération, leur éclat les trahit et les perd; la magnificence de leur parure les empéche de se dérober à la recherche active de leurs ennemis; leur grand nombre les décèle lorsqu'elles fendént en troupes le sein des eaux salées; leur vol les livre plus facilement à l'oiseau de proie ; et leurs attributs les plus frappants auraient bientôt amené la destruction de leurs espèces, si une fécondité extraordinaire ne réparait sans cesse, par la production de nouveaux individus, la perte de ceux qui périssent victimes des tyrans deśs mers, ou de ceux de l'atmosphère,

La première de cés trigles condamnées par la nature a tant de périls, à tant d'agitations, á tant de traverses, est, dans Yordre que nous nous sommes preserit, celle à laquelle jai doane avec Linnée le nom d'Asialique. On la trouve en général dans l'Océan, wais

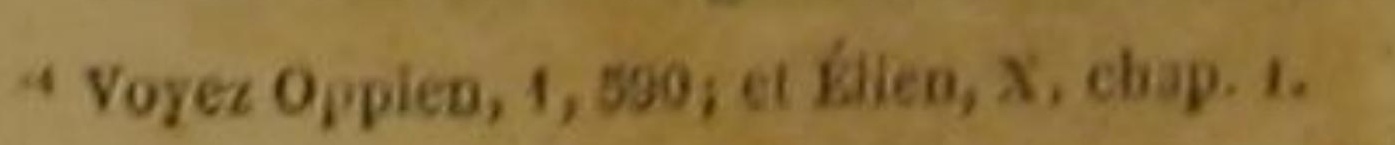


particulierement dans les mers de l'Asie. Son | ou argentées; la sorte de dorure qui distingue corps est mince; sa couleur argentée; son mu- les rayons par lesquels la membrane des nageojseau proéminent ; l'intérieur de sa bouche hé- res est soutenue, ajoute à l'éclat de ce rouge rissé d'aspérités; la première pièce de l'oper- que font réssortir d'ailleurs quelques nuances cule branchial, dentelée ; et chaque nageoire de vert ou de noir répandues sur ces mèmes napectorale conformée comme une sorte de faux '.

\section{LA TRIGLE LYRE ${ }^{2}$.}

Trigla Lyra, Linn., Gmel, Lacep., Bloch, Cuv. I.

Heureux nom que celui qui rappelle et le beau ciel et les beaux jours de la Grece, et sa riante mythologie, et sa poésie enchanteresse, et l'instrument favori du dieu du génie, et cet Homère a qui le dieu avait remis sa lyre pour chanter la nature! Non, je ne supprimerai pas ce nom magique, qui fait naitre tant d'idées élevées, qui retrace tant de doux souvenirs, pour le remplacer par un nom barbare. Le dieu qui inspire le poête est aussi celui des amants de la nature et son emblème ne peut jamais leur étre étranger. Une ressemblance bien faible, je lè sais, a déterminé les naturalistes grees à décorer de ce nom l'ètre que nous allons décrire; mais toutes les fois que la sévérité de l'histoire le permet, ne nous refusons pas au charme de leu imagination agréable et féconde. Et d'ailleurs le poisson que nous voulons continuer d'appeler Lyre, a été revêtu de nuances assez belles pour mériter de paraitre à jamais consacré, par sa dénomination, pour ainsi dire mythologique, au dispensateur de la lumière qui colore en mème temps qu'elle éclaire et vivilie.

Un rouge assez vif règne en effet sur tout le corps de la trigle que nous désirons de faire connaitre; il se diversifie dans la partie inferieure de l'animal, en se mèlant a des teintes blanches

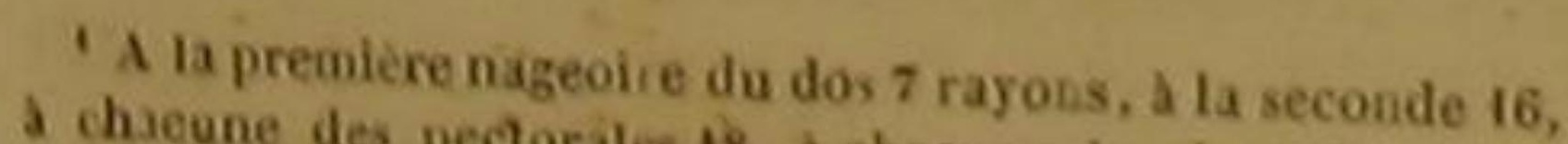
celle de Lanus it; a celle de 1 , a ehacune des thoracines 6 , 1 'Gronau, Rouget, dans plus. départ. - Boureall, sor tes nes. - Pesce argano a vecidentales. - Orga nie, a GềMeer leyer, ou see leyer, en Ail - Piper, en Angleterre. vaubeaton, Ene, méth. - Id. Bonnae.-Trigle gronai, méth. - I Trigla rostro longo dacanotho, naribus. de t'Eỏe. Atredi, gea. 46, gea. 7t. -Gronau et lyre. Bondelet, pasis,

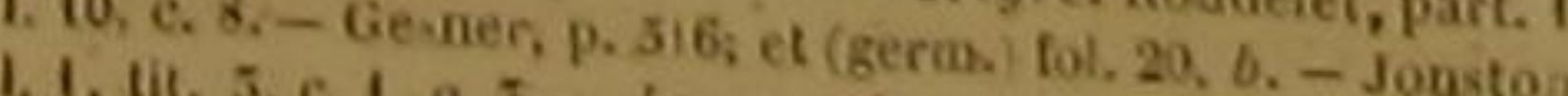
c. 7, p. 146- Piper. Lagre prior fiondelet. Aldror., I. 2

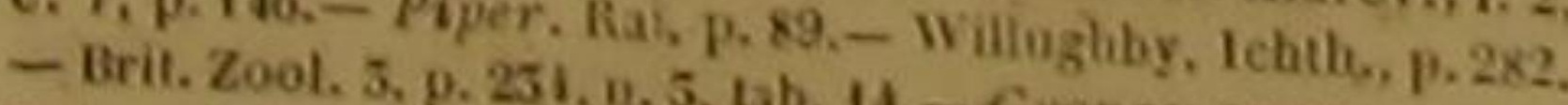
Valmont de Bomare, Dict. d'hist. nat. 'Al. Gavier décrit ce poinson sos tos geoires ; et ainsi les couleurs les plus brillantes, celles dont la poésie a orné le char radieux da dieu des arts et de la lumière, resplendissen sur le poisson que l'ingénieuse Grèce appela du nom de l'instrument qui fut cher à ce dieu.

Au bout du museau de la trigle quenous examinons, s'avancent deux lames osseuses, triangulaires et dentelées, ou plutôt découpées de manière à montrer une image vague de cordes tendues sur une lyre antique.

La tète proprement dite est d'ailleurs arroindie et comme emboitée dans une enveloppe lamelleuse, qui s̉e termine par derrière par quátre ou six aiguillons longs, pointus et très-forts, qui présente d'autres piquants au-dessus des yeux, ainsi qu'à la pièce antérieure de chaque opercule, et dont présque toute la surface est ciselée et agréablement rayonnée.

De petites dents hérissent le devant du palais, et les deux mâchoires, dont l'inférieure est la plus courte. Le corps et la queue sont couverts de petites écailles; et des aiguillons courts et courbés vers l'arrière garnissent les deux cótés de la fossette longitudinale dans laquelle l'animal peut coucher ses nageoires dorsales '.

La trigle lyre habite dans I'Océan Atlantique, aussi bien que dans la Méditerranée. Elle y parvient quelquefois à la longueur de six ou sept déeimètres. Sa chair est trop dure et trop maigre pour qu'elle soit très-recherchée. On la pêche cependant de temps en temps; et lorsqu'elle est prise, elle fait entendre, par un mécanisme semblable à celui que nous avons exposé en traitant de plusieurs poissons, une sorte debruissement que l'on a comparé à un sifflement proprement dit, et qui l a fait nommer dans plusieurs pays, et particulièrement sur quelques côtes d'Angleterre, Poisson siffleur (the piper, the fish piper $)^{2}$.

'A la nembrane des branchies 7 rayons, à la première cune des thoracines 6 , a celle de des pectorales 12 , a clas. queue 19 .
quat

ressie natatoire est longue et simple.
LA TRIGLE CAROLINE ',

Trigla caroliua , Lino., Gimel., Lacep, '. LA TRIGLE PONCTUEE ${ }^{3}$, Trigla punetata, Bloch, Lacep. + .

ET LA TRIGLE LASTOVIZA *, Trigla adriatica, Linn., Gmel.; Trigla Lastoviza,

Ces trois trigles ont les nageoires pectoral très-longues et assez-grandes pour s'élever audessús de la surface des eaux. Nous devons done les inserire parmi les véritables poissons volants. Voyons rapidement leurs traits principaux.

Dans ces trois espèces, la tête est comme ciselée, et parsemée de figures étoilées ou rayonnantes qui ont un peu de relief. L'enveloppe lamelleuse qui ta recouvre, montre, dans la caroline, deux petits piquants dentelés au-dessus'de chaque oil, deux plus grands à la nuque, trois ou quatre à chaque opercule, et un à chaque os elavieulaire. Les écailles qui revêtent le dos sont petites et dentelées. La ligne latéralé est droite et lisse; et le silion longitudinal dans lequel l'animal peut coucher ses nageoires dorsales, est bordé, de chaqué côté, d'aiguillons recourbés.

Une tache noiratre qui occupe la moitié supé rieure de l'óil, donne a cet organe une-apparence singulière. Une autre tache noirátre parait vers le haut de la prennière nageoire dorsale. Le corps et la quene sont jaunátres avee dé pe tites taches viólettés, et les nageoires pectoralés sont violettes avec quatre bandes transversales brunes et arquées ?

On trouve cette trigle, dont la chair est dure

- The smaller flying fish, dans quelyues contrees an Elaises. - Trigle ca coline. Bonnaterre, pl, de IEuc. méll - Trigle carolini, ou caroline. Bloch, wl. 552. pas des triales nopers ne differeot pas entre elles et ne son 8.0 prionolc

P. Rubio colador, en espagnol. - Lyra alota. Plomier, peintures sur vélin du Muséum dhist. nat.

Sruno. Pisc. Btassil, p. 99. - Trigle lastoviza. Bònìaterre, pl, de IEuc. méth. - Brit. Zool. 3., D. 236, U. 3. -

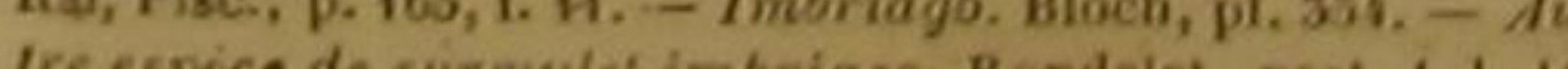
c. 4 . le oom de Rouget camard, Trigla lineala. D. A la membrane braschiale de la caroline 6 rayons, i la premiere nageoire du dos 9, a la seconde 12, a chacume des pecturaies 15, a chacuine des thoracines 6 , a celle de 1 aquas 11 , et maigre, et la longoueur d'un on deux décimètres, aux environs de la Caroline et des Antilles. C'est dans tes mèmes mers qu'habite la ponetuee, dont les couleurs sont plus vives, plus variées et plus gaies. Nous déerivons ces nuances d'après une peinture qui fait partie de celles du Muséum d'histoire naturelle, et dont on a dù a Plumier le dessin original I la partie supérieure de l'animal est d'un rougge elair, et la partie inférieure d'un beau jaune. Les cótés et le dos sont parsemés de taches rondes, petites, et 'un rouge foneé. Ces mèmes taches rouges se montrent sur les nageoires du dos et de l'anus, qui sont lilas; sur celle de la queue, qui est bleue à sa base et jaune à son extrémité; et sur les ailes, qui sont également jaunes à leur extrémité et bleues a leur base.

La téte de la ponetuée est plus allongée que celle de lá caroline '.

Quant a la trigle lastoviza, elle est rouge pardessus et blanchátre par-dessous, avec des tarches et des bandes couleur de sang, ou noiratres, placées sur le dos. Les ailes offrent-souvent par-dessus quelques taches brones, et pardessous ume bordure et des points bleus'sur un fond noir. Les thoracines et l'unale sont blanches, et quelquefois noires a leur sommet. Au reste, la ligne latérale de ce poisson est hérissće de piquants à deux pointes; la máehoire supérieure presque aussi avancée que linfévieure; le dessus des yeux garni de petites pointes, la nuque hérissée de deux aiguillons dentelés; ehaque opercule armé de deux aiguillops semblables; l'os claviculaire étendu, pour ains dire, en épine également dentelée, et, de plus, longue, aiguè a son sommet et large à sa base; et la fossette dorsale bordée, de chaque cóté, de piquants a trois ou quatre pointes.

Ce beau poisson parvient quelquefois a la tongueur d'un demi-mètre, et habitedans la Méditerrance et dans l'Ocean Atlantique ${ }^{2}$.

- A chacuoe des nageoires pectorales dé ta pónetuée. ryous, a chacue des thoracines6, a cille de la queue 12. 10-rayons aiguillonoés a la preniere uagroire dorsile 0 Ia trigle tastoviza, 17 rayons a ia seconde, 10 rayons i cha

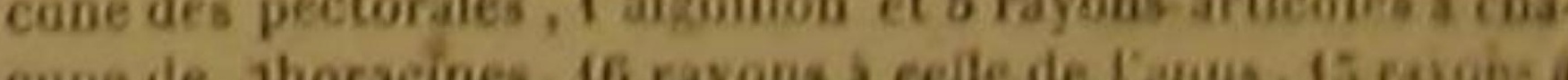
celle de la queue. 
LA TRIGLE HIRONDELLE ${ }^{-}$.

Trigla Hirundo, Lino,, Gmel., Bloch, Lacep., Cur. 2

La partie supérieure de ce poisson est d'un violet mèlé de bruh, et l'inférieure d'un blanc plus ou moins pur et argentin. Il vit dáns la Méditerranée, et dans les eaux de l'Océan. Il y devient assez grand, puisque sa longueur surpasse quelquefojs deùx tiers de mètre. H nage avec une grande rapidité, ses pectorales pouvant lui servir de rames puissantes. Comme il habite les fonds de la pleine mer pendant une grandé partie de l'année, on le prend ordinairement avec des'lignes de fond; et quoique sa chair soit duré, il est assez recherché danis plusieurs pays du nord, et particulièrement sur les rivages du Danemarek, où on le sale et le sèche a fair pour l'approvisionmement des vaisseaux ${ }^{3}$.

Le bruissement qu'il fait entendre lorsqu'on le touche, a paru aux anciens naturalistes grees et romains avoir quelque rapport avec le croassement des corbeaux ; et voila pourquo ils T'ont nommé Corbeau de mer.

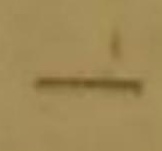

LA THIGLE PIN. Trigla Gueulus, Linn., Gmel.? Trigla Piul, Bl.,
Lacep.4.

Les lames ou feuilles minces, étroites, et semblables à des feuilles de pin, qui garnissent les

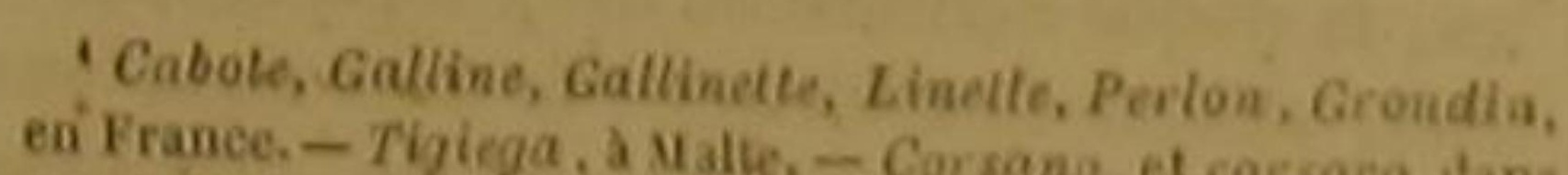
en Franee, - Tigiega, a Nalte. - Corsano, et corsaco, dans la Ligurie. - Capone, A Rome. - Tub fish, Sapphiriae
gurnard, en Angleterre, - Knurr-dahn, en Alemazne. Soe-hane, ou knurr-Aane, en Danemarek. - Riot, ouskar.

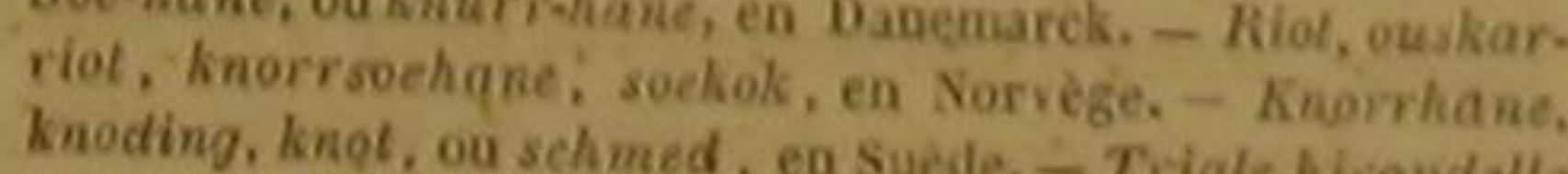
knoding, knot, ou sehmed, en Suede, - Trigle hirondelle

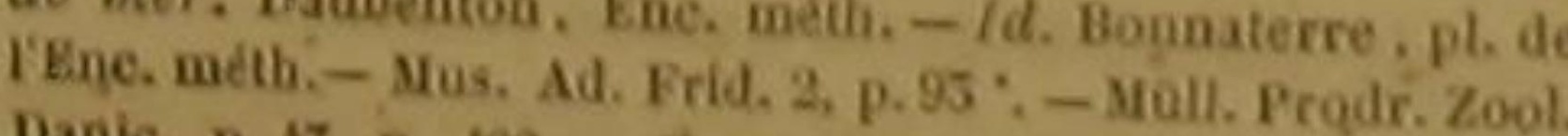

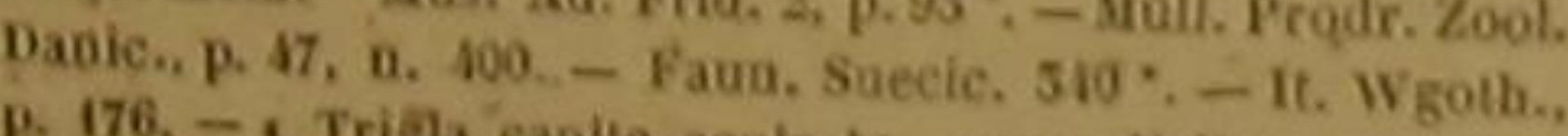
P. 176. - Trigla eapile aculeato, appendicibus utringue

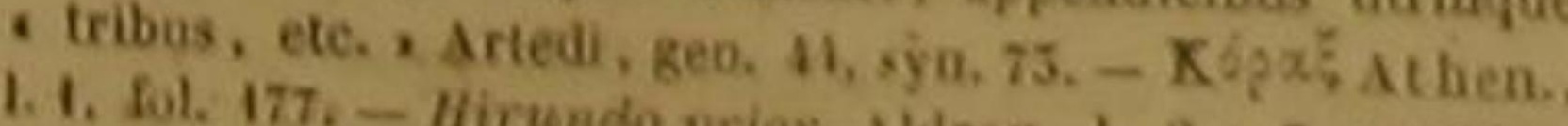

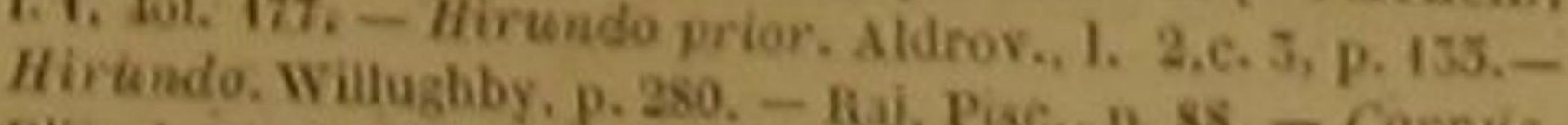

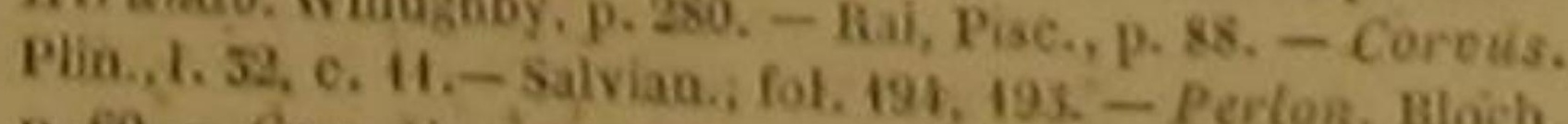
p. 60. - Corystion Eentivicosus. Klein, Miss. pisen. Bloch, n. $3,-$ Corax. Gesner, Aquat, p. 299; Thierb., p. 21, Brit. Zoot. 3, p. 25s, u. 4. - Corbeas de mer., Hondelet,
part. part. 4, 1. 10, e: 6

nom de Perlon, ou Rouget groadin. par if. Cuvier, sons le 'A ta membrane des branchies 7 ravo

geoire đu dos 8, a la secoude 15 , a chacune, a la premiêre na.

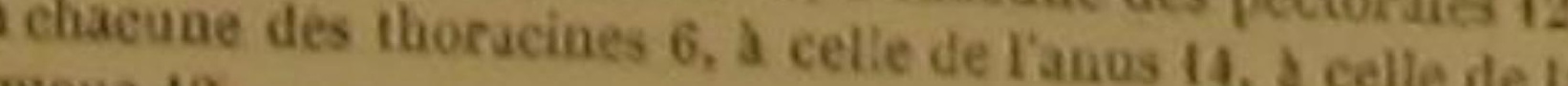
quene 19.

sous les nom par M. Cuvier, qui ladmet parmi ses Trigles, sous les nomas de Grondia rouge ou de Rouget commua de
Paria. D. deux côtés de chaque ligne latérale, ont suggéré à Bloch le nom spécifique qu'il a donne cette trigle, lorsqu'il l'a fait connaitre. Le museaú dé ce poisson est un peu échaneré et terminé par plusieurs aiguillons ordinairement au nombre de six ou de huit. De petites dents hérissent les mâchoires. On aperçoit un os trahsversal et rude sur le devant du palais, et quatre os rudes et ovales auprès du gosier. On voit un piquant au-dessus de chaque œil, ou à la pièce antérieure de chaque opercule, deux́ à la pièce postérieure, et un aiguillon presque triangulaire et dentelé à chaque os claviculaire. La fossette longitudinale du dos esf bordêe d'épines inclinées vers la queue '. Les écailles sont très-petites; et toute lả surface de l'animảl réfléchitun rouge un peu foncé, excepté le dessous du corps et de la queue, qui est jaunâtre, et les nageoires du dos, de la poitrine, de la queue et de l'a. aus, qui sont d'un vert tirant sur le bleu.

\section{LA. TRIGLE GU'RNAU "} Trigla Gurnardus, Limn., Gmel., BI., Cuv. ,

ET LA TRIGLE GRONDIN 4 .

Trigla euculus, 8f., Cuv.; Trigla grauniens, Lacep.'

La premiêre de ces trigles présente une faculté A la membrane des branchies 7 rayons, i ta premiere Ba rale 10,2 chacuae des thoraciues 6 , a celle de ranus 16 , celle de la queue 18

Bellicent, Goarneau, dans plus. contrées de France. -

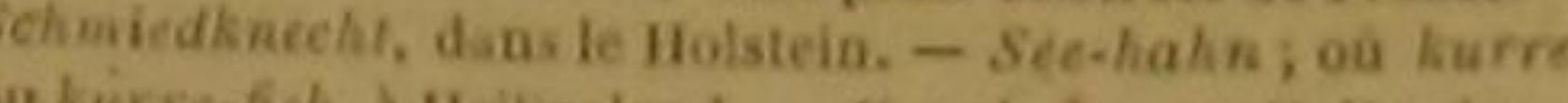

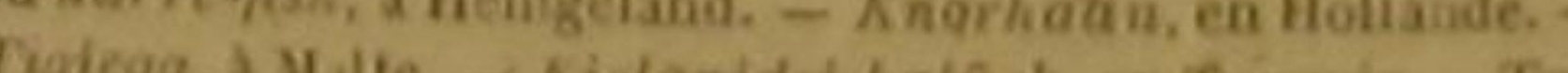

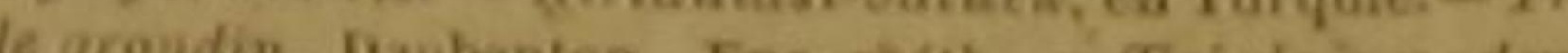
Ganaterre, pl. de lEne, Eúth. - Trial vigle grondenr.

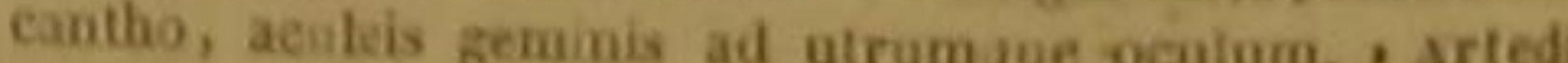
seu. 46, syn. 74. - Gronav, Mrs. I, p. 44, n. 101, Zooph. F.81, 0. 285. Bronn. Pisc. Massil., p. 74, n. 90 - Gurneau Whech, pi. 38. - Charlet. Onom., p. 159. - r Corystion gro. mard Brit.

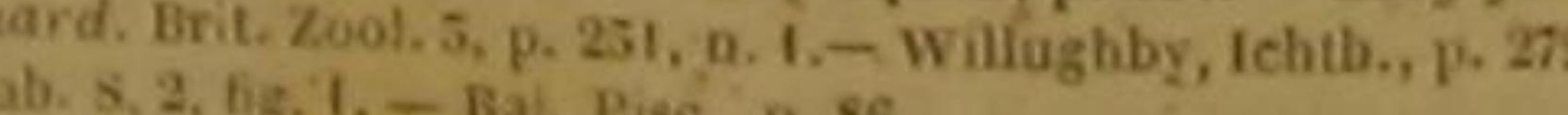

Groadin proprement nard des Anglais. $D$.

'Morrude, Rougel, Rouget grondin, Perlon, Galline. Frala, dans plins, depart. - Hunchem, dans le nord de "Europe. - The kagen, dans plus. contrées du nord de

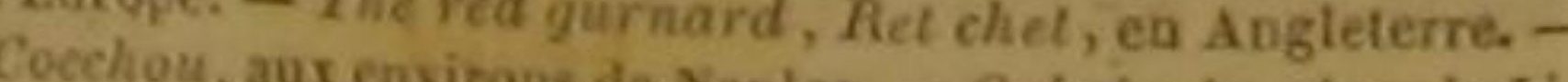
sucie, - Organt . sur plus, cotes, - Cabriggia, dans la Liperlon. Danbeaton, Enc. meth - Id. Bennate. - Trigle Enc. méth. - Mus. Adolph. Frid. 2, p. $95^{\circ}$ : - - Trigha lot ' ress, rostro parum bicoroi, opercolis branchiarum 3 Ce poisson, qui est quelquéfols appelé Rouget, est nonme
Grondin rouge, pars semblable à celle que nous avons remarquée dans la lyre. Elle peut faire entendre un bruissement très-sensible parle frolement de ses opercules, que les gaz de l'intérieur de son corps font, pour ainsi dire, vibrer, en s'échappant avee violence lorsque l'amimal comprime ses organes internes; et voilà d'ou lụi vient le nom de Gurnau qu'elle porte. Ce gurnau a d'ailleurs plusieurs rapports de conformation avee la lyre; et, de plus, il ressemble beaucoup au grondin, qui est doué, comme la lyre, de la faculté de siffler ou de bruire. Mais indépendamment des différences indiquées sur le tableaû du génre des trigles, et qui séparent le grondin du gurnau, le grondin a la tête et l'ouverture de la bouche plus petites que celles du gurnau : celui-ci peut parvenir à la longueur d'ün mètre '; celui-là n'atteint ordinairement qu'à celle de trois ouquatre décimètres ${ }^{2}$. Leséeailles qui revêtent le gurnau, sont blanches ou grises, et bordées de noir; des taches rouges et noires sont souvent répandues sur son dos; ses nageoires de la poitrine et de la queue offrent une teinte noirátre; celles de l'anus et du dos sont d'un gris rougeatre; la première dorsale est parsemée de taches blanches : les lames épaisseset largesqui recoùvient la ligne latérale sout noires et bordées de blanc. Le grondin a les lames de ses lignes latérales blanches et bordées de noir; la partie supéricure de son corps et de sa queue, rouge et pointitlée de blane; la partie inferieure argentée; les nagéoi res caudales et pectorales, rougeátres;-celle de l'anús, blanche; et les deux dorsales blanches et pointillées d'orangé.

Au reste, le gurnau et le grondin ont tous les deux les thoraeines blanches. Leur chair est trèsagréable au goùt : celle du grondin 'est mème quelquefois exquise. Ils habitent dans la Mé-

- striatis, Artedi, gen. 45, syn. 74. - Rougst, et rouget grondin. Bloch, pl. 59:- 0 xixwo k, Arit., 1. 4, c. 9; et L. 8,

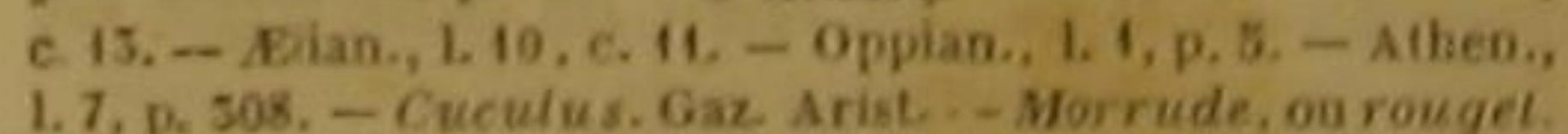
L. 7, p. $508 .-$ Cuculus. Gaz Arist.-Morrude, ou rouget.
Rondelet, part. 1, 1. 10, c. 2. - Gesner, p. 305 et 306 , et (gern.) fol. 17, b. - Aldrovand., 1. 2, c. 4, p. 159. - Jons ion, Pisc., p. 61, tab. 17, fig. 11. - Wiltighthy, p. 281. - Kai, . Ins lyre species. Schonev, p. 32.-Lyra. Charlet, p. 259. - - Corystion capite conico, ele,, Klein, Miss. pise 4, p. 46. n. 6, tab. 4, fig. 4. - Red gurnard. Brit. Zool. 5 , p. 253 , a. 2 . - A la premiére naizeoire dorsale da gurnau 7 rayons, ala seconde 19 , \& chacune des pectorales 10 , a clacune des thoracines 6 , b celle de l'anus 17 , a celle de la queue 9 .

A la premiere nageoire dorssle do grondin 10 rayons, a 1 cines 6 , a ceñe de l'anns 12 , a celle de la queue 15 . diterranée; on les trouve aussi dans l'Oeéan At. lantique, particulièrement auprès de l'Angle. terre; et e'est vers le commencement ou la fin du printemps que l'un et l'autre s'avancent et se pressent, pour ainsi dire, près des rivages pour y déposer leurs coufs, ou les arroser de la liqueur fécondante que la laite renferme :

\section{LA TRIGLE MILAN ? \\ Trigla Milvus, Lacep, ’}

Plusieurs trigles ont reçu des noms d'oiseaux on lesa àppelées Hirondelle, Coucou, Milan,ete, II était en effet assez naturel de donner à des poissons ailés qui s'élèvent dans l'atmosphère, des dénominatións qui rappèlassent les rapports de conformation, de fueultés et dhabitudes, qui les lientavee les habitants de l'air. Aussi ces noms spéciflques ont-ils été imposés par des obsecvateurs et adoptés assez généralement, mème dès le temps des anciens nàturalistes; et voilà pourquoi noús avons cru devoir en conserver deux. La trigle milan a été aussi uppelée, et mème par plusieurs célèbres naturalistes, Lanterne ou Fanal, parce qu'elle offre d'une manière assez remarquable la propriété de luire dans les ténébres, qui appartient nonseulement aux poissons morts dont les chairs commeneent à s'altérer et à se décomposer, mais encore a un nombre assez grand d'osseux et de cartilagineux vivants ' C'est principalement la tête du milan, et particulierement l'intérieur de sa bouche, et surtout son palais, qui brillent, dans I' obseurité, de l'ćclat doux et tranquille que répandent, pendant les belles nuits de l'été des contrées méridionales, tant de substan-

I On voit deux aignillons auprés de chaque ail du grondin.

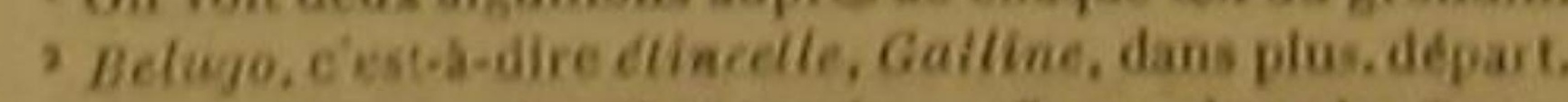
mérid. - Organo, dans La Ligurie, - Cocco, dans les Deus. Siciles. - Trigla lucerna. Linnee, ed. de Gmelin. - Trigle milan. Dantenton, Enc, meth. - - Id. Bonnaterre. ph, de Enc, meti. - Triga rostro parum bindo, lines baterali,

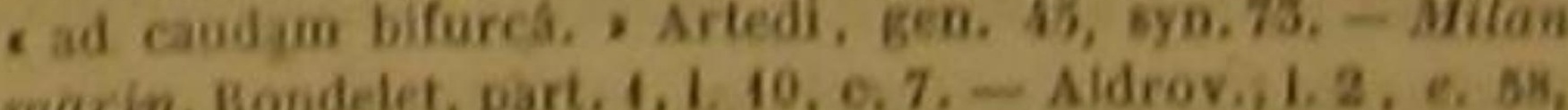

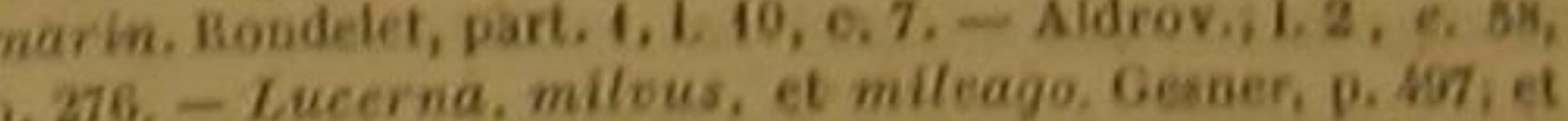
gerio.) fol. 17, $a_{.}-$Lucerna Venetorum. Willughby, p. 281. - Rai, p. 88. - Cuculus, Salvian.. fol. 190, 191. Gronov, Mus, 1, n. $100 ;$ Zooph., p. 84, n. 284 . 'M. de Lacépede rapporte a ce polson, dont ta synonymie est fort incertaine, le Trigla Lueerna de Limides mais M. Cuvier demontre que ce dernier est une eppece factice. Lo vrai $T$. Lucerna de Brumnich i morrude, orgue ou orzano, racterise par a lige taterale garnie d'ecailles ples tastes que Lareses, et par la deuvieme éplos dorale quiest proloa.

gete en filet. D.
. Voyez le Discours sur is nature des poisons. 
ces phosphoriques vivantes ou inanimées. Lors- $\mid$ sées et piquantés. Le museau est échancré ef que dans un temps calme, et aprèste coucher dentelé. On compte deux aiguillons au-dessus du soleil, plusieurs centaines de trigles milans, des, yeux ; deux autres aiguillons ', et deux exposées au mème danger, saisies du mème ef- piquants plus forts que ces quatre premiers, an. froi, emportées hors de leur fluide par la mème près de l'occiput; et une épine assez grande, à nécessité d'échapper à un ennemi rédontable, proportion des dimensions de l'animal, garnit s'élancent dans les couches les plus basses de la partie postérieure de chaque opereule.

l'air et s'y maintiennent pendant quelques instants, en agitant leurs ailes membraneuses, courtes à la vérité, mais mues par des muscles puissants, c'est un spectacle assez curieux que celui de ces lumieres paisibles qui montant avec vitesse au-dessus des ondes, s'avancant, retombant dans les flots, dessinant dans l'atmosphère des routes de feu qui se croisent, se séparent et se réunissent, ajoutent une illumination aérienne, mobile, et perpétuellement variée, à celle qui repose, pour ainsi dire, sur la surface phosphorique de la mer. Au reste, les milans volant ou nageant en troupes, offrent pendant le jour un coup d'œil moins singulier, mais cependant agréable par la vivacité, la disposition, et l'harmonie de leurs couleurs. Le rouge domine fréquemment sur leur partie supérieure; et l'on voit souvent de belles taches noires, bleuesou jaunes, sur leurs grandesnageoires pectorales. Leur ligne latéraleest garnie d'aiguillons, et divisée en deux vers la queue. On les trouve dans l'Océan Atlantique aussi bien que dans la Méditerranée. Leur chair est presque tonjours dure et sèche '; et il se pourrait que ces milans ne fussent qu'une variété des trigles hirondelles.

\section{LA TRIGLE MENUE a}

Trigla minuta, Lino., Gmel., Lacep. .

Le nom de cette trigle désigne sa petitesse : sa longueur n'égale ordinairement que celle du doigt. Les deux saillies longitudinates qui for ment la fossette propre à recevoir les nageoires du dos torsque l'animal les ineline et les plie, sont composées de petites lames un peu redres i A la premiere nazioire du dos 10 rayons, a la seconde 17 , 1 chacuse des pectorales 10 . 1 chaciune des thoracines 6 , a
elle de lanus 15 . 'La petile trigle. Bonaterre, pl. de I'Ene, meth. piract etre une rr ie trigle; twais ce que dit Linnée de seoires sout compis dive feces, et les rayons des pavoit dans les autres, yue of Coven si contraire a ce que liog

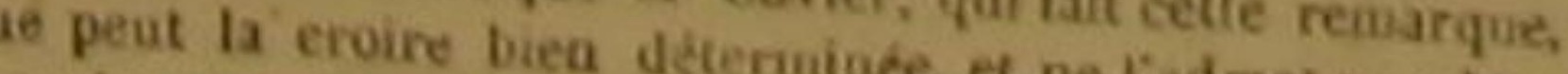

On trouve la trigle menue dans les mers de 'Inde.

\section{LA TRIGLE CAVILLONE 2} Trigla Cavillone, Lacep.; Trigla aspera, Viviani,
Cav. ?.

Rondelet a décrit cette trigle, dont il a aussi publié une figure gravée. N'ayant que deux rayons articulés et isolés à chaque nageoire pectorale, non-seulement elle est séparée des espèces que nouś venons de dècrire, mais elle ap. partient méme à un sous-genre particulier. 0 'a appelée Cavillone dans plusieurs départements français voisins de la Méditerranée, cause de sa ressemblance avee une cheville, ue l'on y nomme caville. L'animal est en effet beaucoup plus gros vers la téte que vers la na geoire de la queuè. Il eșt couvert d'écailles peites, mais dentelées, âpres et dures, La ligne latérale est très-droite et très-voisine du dos. On voit un piquant au-dessus de chaque cil, et six aiguillons très-grandś et un peu aplatis a la partie postérieure de cette sorte de casqué ou d'enveloppe famelleuse et ciselée, qui défend la tête.

La cavillone est d'un très-beau rouge, lequel fait ressortir la couleur de ses ailes, qui sont blanches par-dessus, et d'un vert noirâtre pardessous '. Ses dimensions sont ordinairement aussi petites que celles de la menue. Son foie est trè-long; mais son estomac est peu étendu, et sou pylore garni d'un petit nombre d'appen. dices ou ccecums. La chair de cette trigle est dure, et peu agréable au goút.

is rayons aiguillonnes a la première nageoire da dos, 25 des thoracines, it a celle de l'ae des pectorales, 6 a chacun "Autre espece de surmolet, dite cavillone, My llue. ie us. Rondeiet, part. 1, 1. 10, c. 5 .

- Du sous-genre des Trigles proprement dites, selon $M$. vier, D. 7 rayons aiguillonnes a la première nageoire du dos, qui
t triangulaire.

\section{DES POISSONS}

951

CENTIÈME GENRE : LES PÉRISTÉdIONS.

Des rayons articules et non réunis par uée membrane, aupees des nageoires pectorales; une seule nageoire plusieurs plapues ossenses adidess

$$
\begin{aligned}
& \text { espéces. }
\end{aligned}
$$

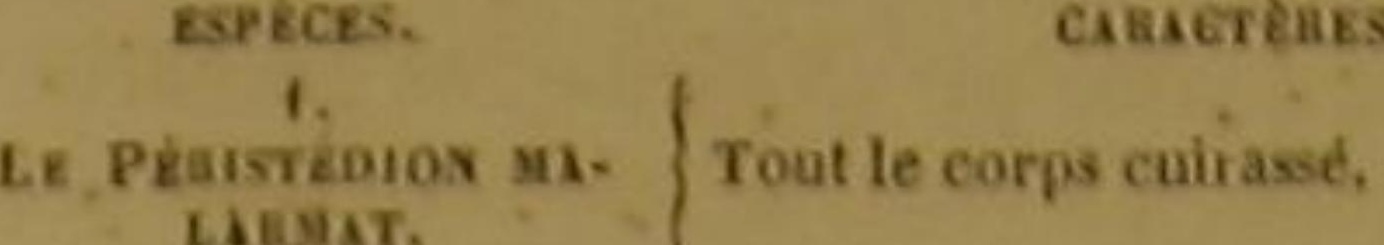

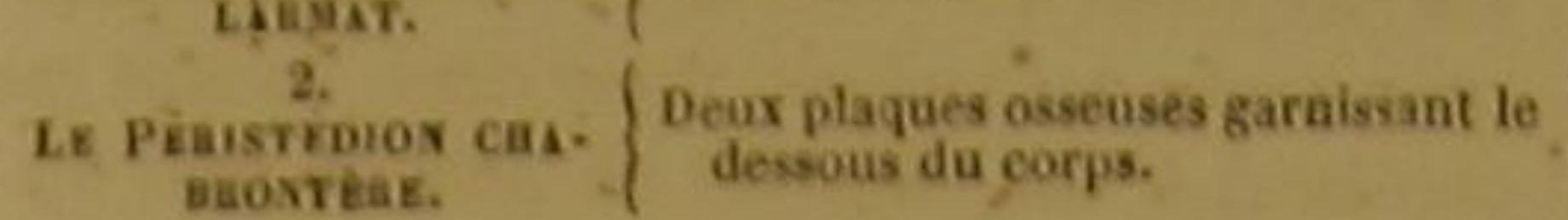$$
-
$$

\section{LE PÉRISTEDION MALARMAT ${ }^{2}$,}

Trigla cataphracta, Linn., Gmel.; Peristedion Malar- mat, Lacep., Cur.

-Les plaques osseuses qui garnissent le dessous du corps des péristedions, et y forment une sorte de plastron, séparent ces poissons des trigles proprement dites, et nous ont suggéré le nom genérique que nous leur donnons ${ }^{3}$. Cette euirasse est tres-êtendue sur la partie inférieure du malarmat; elle la cóuvé en entier; elle se réunitavec cellequi défend la partie supérieure: ou, pour mieux dire, fa totalité du corps et de la queve de cet osseux est renfermée dans une sorte de gaine composée de huit rangs de lames quila font paraitre octogone. Chacune de ces lames est plus large que longue, irréguliérement hexagone, et re'evée dans son milieu par un piquant recourbe vers Parriere. Ces plaques ou lames dures sont d'autant moíns grandes qu'elles sont placées plus près de la gueue, et I'on compte quelquefois plus de quarante pièces à chacune des rangées longitudinales de ces lames aiguillonnées.

La téte est renfermée, comme celle de pres-

4. Cavler considere les Malarmats on périsiédions com lormant un sous-genre dans son grand genre Trigle, 0 . 'Pesce capone, Prsce furca, Porchato, Pesce forcha, en
Italie. - Srala feno, dans la Ligurie - Gabel fisch, Panser. Iatie. - Srala feno, dans la Ligure- - Gabel hech, Panzer.

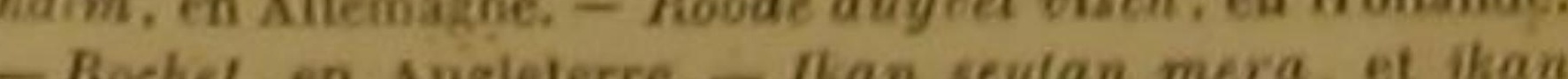

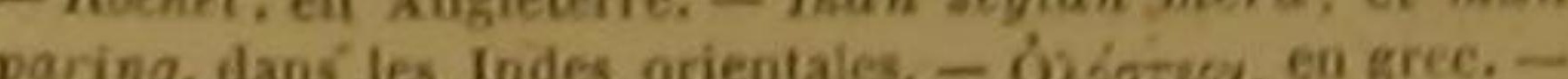
Bloch, pl. 349. - Trigle malarmat, - Daubenton, Ene. meth. - Id. Honniterre, pl de IEne. méth. - Mas. Adotph. Pr. 2, p. $92 \cdot$. - Trisla..... corpore octogono., Artedi, gen. 46.syo. 73 - . Lyra altera Rondeletii., Akirov. 1, 2, c. 7, p. 147. -Jd. Willeghby, p. 285. - 1d. Rai, p. 89. yra. Salvian. fol. 192, b. ad iconem, et 19s. - Malarmat. Rondelet, part. 1, I. 16, c. 9. Gener, p. 517, 610; el (gerro.)

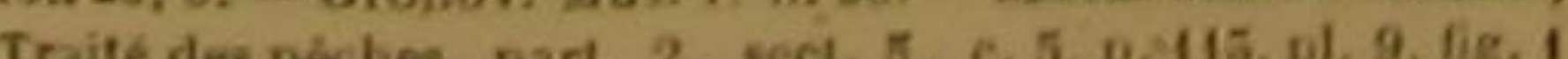

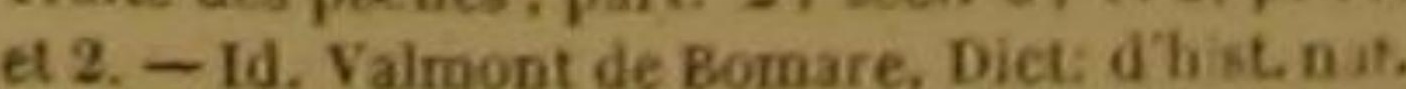

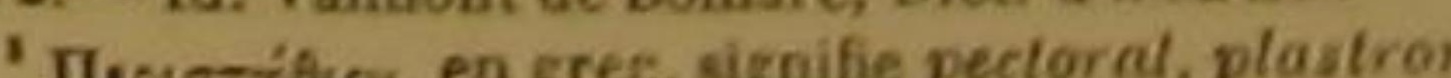

que toutes les trigles, dans une enveloppe à quatre faces, đure, un peu osseuse, relevée par des arètes longitudinales, et parsemée de piquants dans sa partie supérieure. Le museau se termine en deux os longs et plats, dont l'ensemble ressemble asseź à celui d'une fourehe. Les máchoires sont dépourvuesde dents proprement dites; le palais et la langue sont lisses. On voit à la màchoire inférieure plusieurs barbillons tres-courts, et deux autres barbillons longs et ramifiés.

Chaque opercule est composé d'une seule lame, et terminé en pointe. L'anus est plus près du museau que de la nageoire caudale, qui est en croissant; et on ne compte auprès de chaque nageoire pectorale que deux rayons articulés et libres; ce qui donne au malarmat un rapport de plus avee la trigle eavillone'

Presque tout l'animal est d'un rouge pale, comme plusieurs trigles; les thoracines sont griseş, et les pectorales noiràtres.

Le malarmat habite non-seulement dans la mer Méditerramée, maís encore dans celle qui baigne les Moluques: Il ne parvient guère qu'à la lôngueur de six ou sept décimètres. Et l'on doít croire que si le poisson nommé Cornuta par Pline est le malarmat, il faut lire dans cet auteur, et avec Rondelet, que les cornes ou appendices du museau de cetosseux ont un demipied (cornua semipedalia), et non pas un pied et demi (sesquipedalia). Nous devons mème ajouter qu'il y aurait encore de l'exagération dans cette évaluation des appendices du malarnat, et quedes cornes de deux décimètres de longueur supposeraient, dans les dimensions générales de ce poisson, une grandeur bien audessus de la réalité.

Le péristédion que nous décrivons se nourrit de mollusques, de vers marins et de plantes marines. Il se tient souvent au fond de la mer; $t$ quoique sa chair soit dure et maigre, on le pêche dâns beaucoup d'endroits pendant toute I'année, particulierement pendant le printemps. On le prend communément avee des filets. II nage avec beaucoup de rapidité; et comme il est très-vif dans ses mouvements, il brise fré- 
quemment ses appendices contre les rochers ou d'autrès corps durs.

La vessie nątatoire est grande, ce qui ajoute à la facilité avec laquelle le malarmat peut se soutenir dans l'eau, malgré la pesanteur de sạ cuirasse. Le pylore est entouré de six petits cœecums.

LE PÉRISTÉDION CHABRONTÉRE '.

Peristedion Chasbrontera. Lac. ; Trigla hamata, Bl., Schn. ${ }^{2}$.

La chabrontère n'a comme le malarmat, que deux rayons libres et articnlés, auprès de chaque nageoire pectorale; son museau est fourchu, comme celui du malarmat; mais elle n'est pas renfermée dans une gaine octogone. Deux plaques osseuses défendent cependant la partie inferieure de son corps : elles s'étendent depuis ta poitrine, jusqu'à l'anus. On compte plusieur aiguillons droits ou recourbés au-dessus du museau; et on en voit troís au-dessus et trois autres au-dessoús de la queue ${ }^{3}$. Toutes les nageoires, excepté la caudale, sont très-longués et d'un rouge éclatant.

On trouve la chabrontère dans la Méditerranée.

\section{CENT UNIÈME GENRE ^} LES ISTIOPHORES.

Point de rayons arliculés el libres auprés des nageoires péclorales, ni de plaques osseuses au-dessous du corps d'une houteur superieure à celle do corps sue rayons à chaque thoracine.

Espíce.

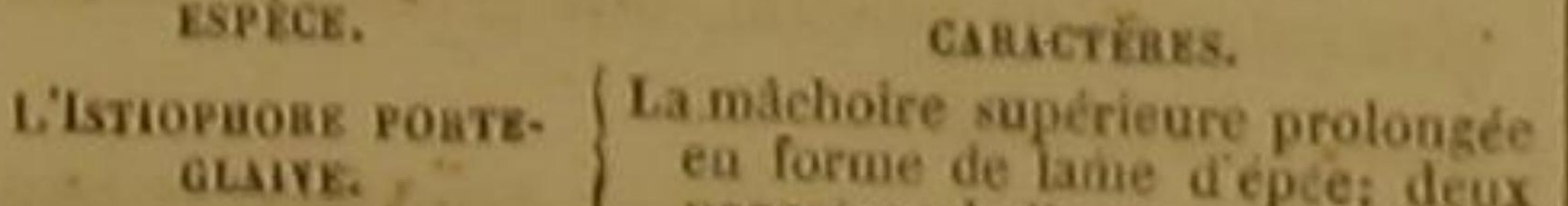
ea forme de lame depce; deux 'Osbeck, Fragm tére, Bomaterse, fi dehtlyol. Hisp. sil. Cuvier, e, a del'Enc, méth. qui te premier a tail conn de nouveau le texted o osbeck ne diftere pas spécilfiquement dn Périsisson, démontre qu i A la membraue des branchies 7 rayons, a ta mase. D. dos 26 , a clacune des thoracines, 6 , a celle de lasous 20 . 4hes istophores forment, pour M. Cuvier, un sous. de sa faimille des dans le grand geare Espadón, Xiphie mann avait crếé, pour ces poisyiens scombéroúdes. Her maan avait créé, pour ces poissons, La déaounination géné-
rique de Notistium. D.
L'ISTIOPHORE 'PORTE-GLAIVE '

Scomber Gladius, Broussoo.; Xiphiąs velifẹr., Bl. Scho.; Xiphias platysterus, Shaỵ.; ; Istiophorus gl difer, Lacep. ${ }^{2}$.

Marégrave, Pison, Willughby, Kai, Jonston, Ruysch, mon savant confere Broussonnet, et feu le célèbre Bloch, ont parlé de ce poisso très-remarquable par sa forme, sà grandeur $\mathrm{et}$ ses habitudes. En effet, sa tête ressemble beaucoup à celle des xiphias; il parvient, comme ces derniers, à une longueur de plus de trois metres : comme ces derniers encore, il jouit d'une grande force, d'une grande agilité, d'une grand audace; il attaque avee courage, et' souvent avec avantage, des ennemís très-dangereux. $\mathrm{Ce}_{\mathrm{e}}$ pendant les xiphias appartiennent à l'ordre des apodes de la cinquieme division; et le porteglaive doit être inserit dans la méme division, a lá vérité, mais dans l'ordre des thoracins.

La mâchoire supérieure de l'istiophore que noùs décrivons, est trois fois plus avancée que l'inférieure : très-étroite, très-longue, convexe par-dessus, et pointue, elle ressemble à une épée, et a indiqué le nom spécifíque de l'animal. Elle est garnie, ainsi que le palais et la màchoire inférieure, dé dents très-petites don on nè trouve aucun vestige sur la langue. $\mathrm{I}$ tête est menue; chaque opercule composé de deux lames ; to corps allongé, épais, et garni, ainsi que la queue, d'écailles difficiles à voir au-dessous de la membrane qui les couvre; I ligne latérale courbe, et-terminée par une saillie longue et dure; le dos noir; chaque cote bleu; le déssous du corps et dé la queue, argentin; la couleur des pectorales et de l'anale noire; et celle de la première nageoire dorsale, d'un bleu célesté parsemé de taches petites et d'un rouge brun ${ }^{3}$.

Les pectorales sont pointues; la caudale est fourchue; chaque nageoire thoracine ne présente que deux rayons longs, larges et un peu courbés; on compte deux nageoires de l'anus; elles sont toutes les deux triangulaires, et à peu

$\checkmark$ Voitier, Brochet volant, Becasse de nuer. pur plus ar teirs ou voyageurs français. - Schwerdt-makrebe, par les risch Loyds. - Ola , et sword-fish, par les Anglais. - Zeylorientales, - Zee-snipp, par les Hollandais des Indes orientales, - Loilier, sjabelang jang terbang," aux Inder 'Voyez la note $A$ de la colonne prizs. Bloch, pl. 315. 'A la membrave brancliane précédente. 7 . geoire dorsale 45 , à la seconde 7 , à chang a la première nachaque thoracione 2 , a la premiére de l'anuis pectorale 15,

DES POISSONS:

près de la mème surface que la seconde dorsale, au-dèssous de laquelle la seçonde nageoire de l'anus se trouve placée.

Quant à la première dorsale, sa forme et ses dimensions sont très-dignes d'attention. Elle s'étend depuis la nuque jusqu'ả une petite distance de l'extrémité de la queue; elle est done très-longùe: Elle est aussi très-haute, sa hauteur surpassant la moitié de sa longueur. Son contour est arrondi; et elle s'éleve comme un demi-disque, ou plutôt eomme une voile, qui a fait nommer Tanimal Voilier, et d'après laquelle nous lui avons donnể le nom générique de portevoile (istiophorus, istiophore ')

Le porte glaive nage souvent à la surface de l'eau, au-dessus de laquélle sa nageoire dorsale parait d'asséz loin, 'et présenté une surface de quinze ou seize décimétres de long, sur huit ou neuf de haut. II hàbife les mers chaudes des Indes orientales aussi bien que des oceidentales. Le célèbre cheválier Banks l'a vu à Madagascar et a I'lle-de-France. II a pris à Surate un individu de cette espèce, qui avait plas de trois mètres de longueur, dont te plus grand diamètre du corps était d'un quart de mètre, et qui pesait dix myriagrammes.

Dans sa natation rapide; l'istiophore porteglaive s'avance sans crainte, se jette sur de trèsgrós poissons, ne recule pas devant l'homme, et se précipite contre les vaisseaux, dans te bordage desquels il laisse quelquefois des troncons de son arme brisée par la violence du choc. Il lutte ayee facilité contre les ondes agitées, ne se cache pas à l'approche des orages, parait méme rechercher les tempêtès, pour saisir plus promptement une proie troublée, fatiguée, et, pour ainsi dire, a demi vaincue par le bouleversement des flots; et voila pourquoi'son apparition sứ l'Océan a été regardée par des navigateurs comme le présage d'un ouragan.

Il avale tout entiers des poissons longs de trois ou quatre décímètres. Lorsqué encore jeune il ne présente qu'une longueur d'un mètre ou environ, sa chair n'est pas assez imbibée de graisse pour étre indigeste; et de plus elle est trèsagréable au goût.

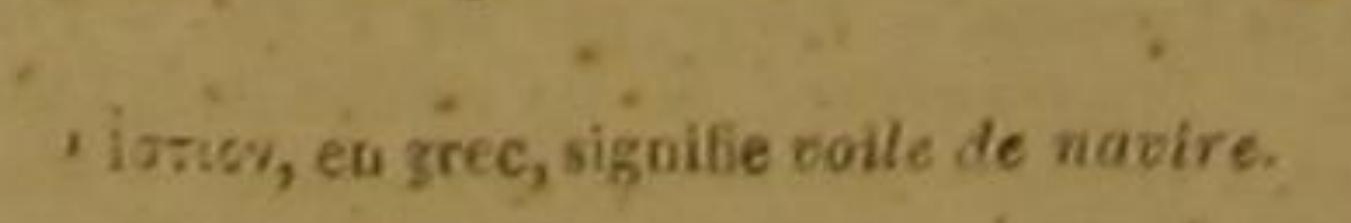

CENT DEUXIÈME GENRE

\section{LES GYMNETRES.} Point de nageoire de l'auss; une seule nagroire dorsale: Espéce.

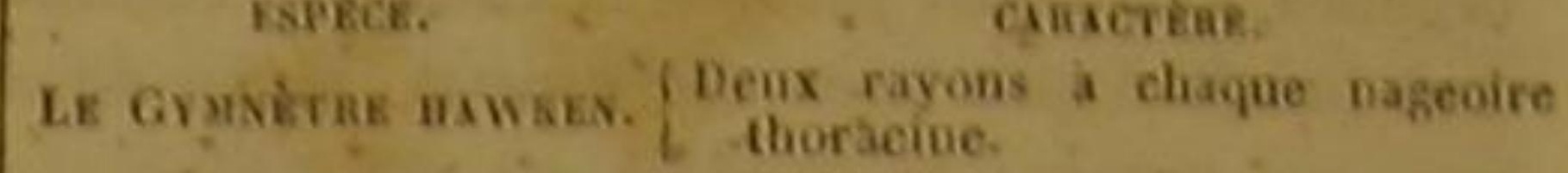

LE GYMNÉTRE HAWKEN ?

Gymnetrins Hankeuii, Bt., Lacep. '

Les poissons renfermés dans ce genre n'àyant pas de nageoire de lants, nous, aurions ipserit les gymnetres à la tête des thoracins de la cinquieme division, si l'esperance de recueillir de nouveaux renseìnèments au sujet de ces animaux ne m'avait fuit differer jusqu'a ce moment l'impression de cet article.

Les gymnètres ont beaucoup de rapports vee les réealees; mais indépendamment de plusieurs différenees qư il est aisé d'apercevoir, et sans considérer, par exemple, que les régaleés ont deux nageoires dorsales, et que les ymmetres n'en ont qu'une, ees derniers appartieunent à l'ordre des thoracins, et les régalees à celui des apodes.

Le fuiwken a été ainsí nommé par reconnaissance pour l'amí des sciences naturelles M. Hawken), qui a envoyé dans le témps un undividu de cette espece a Bloch de Berlin.

Chaque rageoire thoracine de ce poisson est composée de deux rayons séparés I'un de l'ạre, et prolongés en forme de filament jusque vers le milieu de la longueur totale de l'animal. A son extrémité, chacun de ces rayous s'épanouit, s'élargit, se divise en six ou sept petits rayons réanis par une membrane, et forme comme une petite palette arrondie.

L'ensemble du hawken est d'ailleurs serpentiforme, mais un peu comprimé; la mû-

- Le genre Gymnétre de Bloch, adopté par M. Cuvier. et place par loi dans sa tamille des Acanthopterygiens $\mathrm{T} x$ arojdes; et it y réunit les Hégatecr, Ces poissoos, done sructure tres-grete, font rarement trouves entien, ce qui a

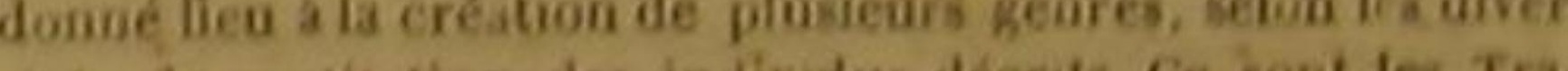

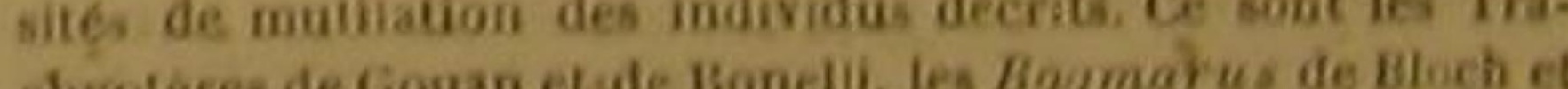

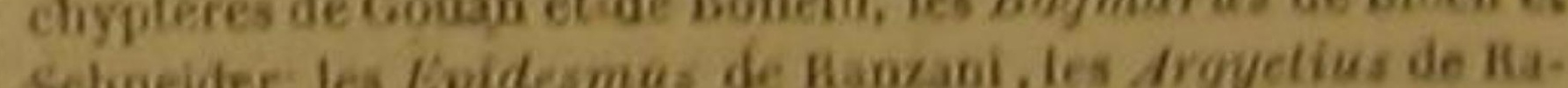

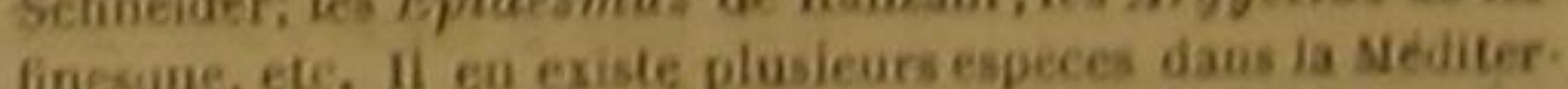
ranée, deux dars les mers du Sord, et une dans ta mer des Indes : celleci rat le sojet de Paricle suirant. D. B Blochi, vi. 423 S" Vayez la note précédente, $\mathrm{n}^{\circ}$ 4. M. Cuvier semble douter

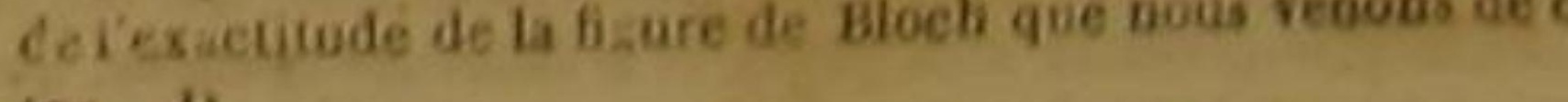


choire Inférieure dépasse la supérieure ; I'ouvertore branchiale est -grande; on voit un petit enfoncement au-devant des yeux; la nageoire dorsale commence au-dessus de ces derniers organes, et s'étend jusqu'à la caudale, comme une bande à peu près également êlevée dans tous ses points; la caudale est en croíssant; toutes les nageoíres sont couleur de sang; le corps et la queue sont d'un gris bleu avec des taches et de petites bandes brunes disposées assez régulièrement.

L'individu décrit par Bloch, avait été pris auprès de Goa. Il avait plus de huit décimètres de long, et pesait près de cinq kilogrammes. 
et c'est au sujet de cés animaux que Pline s'é- de la recherche prodigue et de la euriosité cruelle crie: "On s'est plaínt de voir des cuisiniers que noüs venons de retracer, et comme ces a évaltés à des sommes excessives. Maintenant deux osseux ont les mêmés habitudes, et assez " c'est au prix des triomphes qu'ọn achète et de formes et de qualités communés pour qu'or "- les cuisiniers et les poissons qu'ils doivent ait souvent appliqué les mêmes dénominations " préparer. "Et que ce luxe absurde, ces à Y'uu et à l'autre, on est tombé dans une telle plaisirs féroces, cette, prodigalité folle, ces confusion d'idées au sujet de-ces deux mullęs, abus sans reproduction, cette ostentation sans que d'illustres naturalistes très-récents les on goût, ces jouissances sanś délicatesse, cette rapportés à la méme espèce, saps supposer vile débauche, cette plate recherche, 'ces appé- mèmequ'ils formassent deux variétés distinctes. tits de brute, qui se sont engendrés mutuelle- . En comparant néanmoins cet article avec ment, qui n'existent presque jamais l'un sans celui qui suit, fl sera aisé de voir que le rouget l'autre, et que nous rappellent les traits, que et le-mulet sont différents l'un de l'aútre. nous venons de eiter, ne nous étonnent point. Le devant de la tète du rouget parait comme De Rome, républicaine il ne restait qué le n̂oh ; tronqué, op, poưr mieux dire, le sommet de la toute idée libérâle avait disparu; la servitude tète de cet osseux ẹst, très-ếévé Les deux màavait brisé tous les ressorts de lâme ; les senti- choires, également aváncées, sont, de plus, mentśgếnéreux s'étaient éteints; la vertu, qui garnies d'une gronde quantité de petites dents. n'ést que la force de làme, n'existait plus; lè De très-petites aspérités hérissent le devânt dn goủt, qui ne eonsiste que dans la pérception dé- palais' et quatre os placés auprès du gosier. licate de convenances que la tyrannie abhorre, Deux barbillons assez longs pour atteindre chaque jour se dépravait; les arts, qui ne pros- l'extrémité des operculés, pendent au-dessous pèrent que par l'élévation de la pensée, lã pu- du museau. Chaque narine n'a qu'une ouver. reté dú goủt, la chaleur du sentiment, étej- ture, Deux pièees composent chaque opercule, gnaient leứrs flambeaux; la seience ne conve- au-dessous duquel la membrane branchiale peut nait plus à des esclaves dont elle ne pouvait étre cachée presque en entier ' '. La ligne latéraéclairer que les ferś des joies fausses, mais le est voisinè du dos; l'anus plus éloigné de la bruyantes et qui étourdissent, des plaisírs tête quę de la nageoire de la queue, qui èst grossiers qui enivrent, des jouissancés sensuel- fourchiue; et tous les rayons de la première les qui amènent tout oubli du passé, toute con-- dorsale, ainsi que le premons de la première sidération du présent, toute crainte de l'aveni- dorsale, ainsi que le premier des péctorales, de sidération du présent, toute crainte de l'avenir, l'anale et des thoracines, sont aiguillonnés.
des représentations vaiues de ces trésors trom.

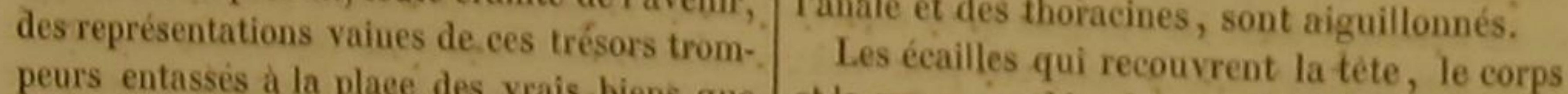
I'on avait perdus, plusienrs rech res, tristes sympto parbres, tristes symptómes - de la férocité, dernier terme d'un courage abåtardi, devaient donc convenir à des Romains avilis, à des citoyens dégradés, à des hommes abrutis. Queiques philosophes dignes des respeets de la postérité s'éservie : encore au milieu de cette tourbe asservie: mais plusieurs furent immolés par le despotisme; et dans leur lutte trop inégale contre une corruption trop générale, ils éternisèrent par leurs écrits la honte de leurs contemporains, saus pouvoir corriger leurs vices funestes et contagieux.

Les poissons dont le nom se trouve tié aro

l'histoire de ces Romains dé trouve lié avèec l'attention de plusieurs écrivains. Mais comme la plupart des ces autéurs étaient peu yersés dans les sciences naturelles, comme d'ailleurs le surmulet a été, ainsi que le rouget, l'objet
Le rouget vit souvent de crustacées. Il n'entre que rarement dans les rivieres; et il est des contrées oủ on le prend dans toutes les saisons. On le péche non-seulement à la ligne, mais encore au filet. Onne devine pas pourquoi un des plus célébres interprètes d'Aristote, Alexandre d'Aphrodisée, a écrit que ceux qui tenaient ce mulfe dans la main, étaient a l'abri de la secousse violente que la raie torpille peut faire éprouver ${ }^{3}$.

On trouve le rouget dans plusieurs mers, seoire du dos 7 , a h seconde 9 , a chacune dies pectorales is

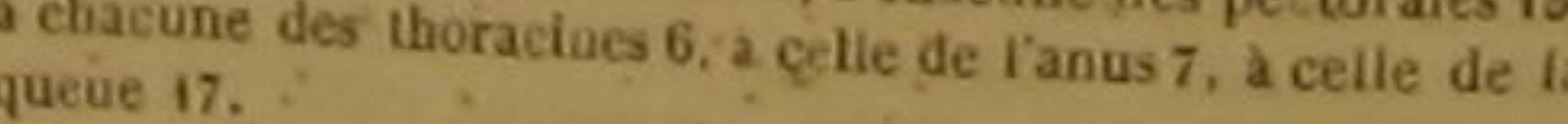

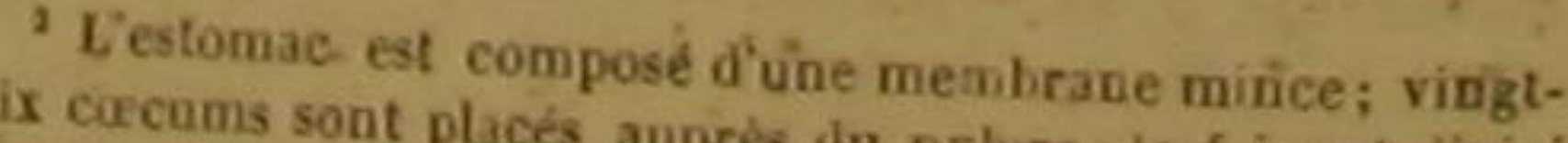
cí deux lobes; et laces aupress du pylore; le fuie est divise

"Voyez l'ilistoire naturelle et lititéraire des poissons, par
e savant professear Schneider,

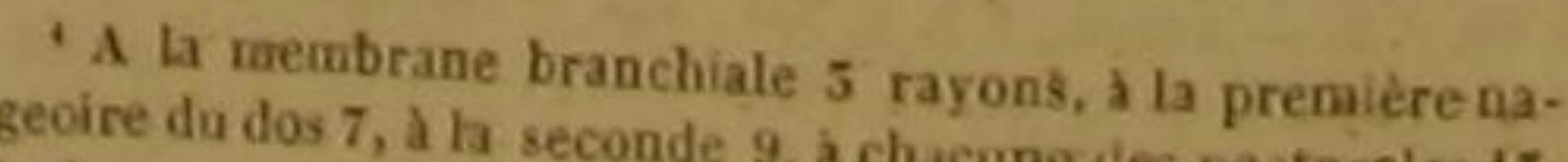

dans le eanal de la Manche, dans la Baltique près dụ Danemarck, dans la mer d'Allemagne vers la Hollande, dans l'Océan Atlantique auprès des cotes du Portugal, de l'Espagne, de la France, et particulièrement à une petite distance de l'embouchurè de la Giroirde, dans la Méditerranée, aux environs de la Sardaigne, de Malte, du Tibre et de l'Hellespont, et dans les eaux qui baignent les rivages des iles $\mathrm{Mo}^{-}$ luques.

Quoique nous ayons vu que l'empereur Tibère vendit un rouget du poids de deux kilogrammes, ce mulfe ne paryient ordinairement qu'à la longueur de trois décimètres. It a la chair blanche, ferme, et de très-bon goút, particulièrement lorsqu'il vit dans la partie de l'Océan quil reçoit les eáux réunies de la Granne et de la Dordoghe:

\section{LE MULLE SURMULET '.}

Mullus surmuletas, Lino., Gmel, Lacep., Bl., Cun ?.

Des raies dorées et loggitudinales servent à distinguer ce poisson du rouget. Elles s'étendent non-seulement sur le corps et sur la queue, mais encore sur la tête, oú elles se marient, d'une-manière très-agréable à l'cil, aveo le rouge argentin qui fait le fond de la couleur de cette partie. Il paraít que ces nuances disposées en raies appartiennent aux écailles, et par conséquent s'évanouissent par la chute de ces lames, tandis que le rouge sur lequel elles sont dessinées, provenant de la distribution des vaisseaux sanguins près de la surface de l'ani-
mal, subsiște' dans tout son éclat, lors méme que le poisson est entièrement dépouillé de son tégument écailleux. Le brillant de l'or resplen-

r. B...

'Barbarin, Rouget barbe, Mulet barbe, dans plus. contrées de France. - Tekyr, en Tarquie. - Rothbart, en

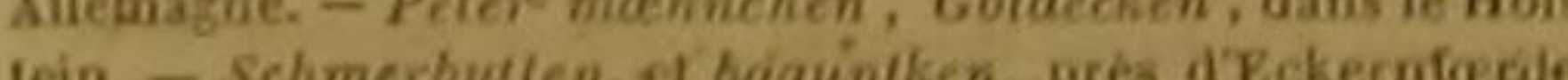
Konig tan de hagarisgi en Hollande. - Byenaneque eft Konig van de harisg, en Ho lande. - Byenaneque, et ta miar, a lachine. - Mulet surmulel. Bongaterie; pl. de IEne, méth. - Trigla capite glabro, nneis utrinque qua- taor lateis, etc. A Artedi, geo: 45, syn. 72, - Mullus ma jor. Salvian. - G Mollus major ex Hispania missus. x Aldroror. 1. 2.e. 1, p. 125. - stulius major noster el Salviani., whi. Pisc. Nassil., p. 71, n. 88. - Surmulet. Eéion. A quat. p. A76. - striped surmulet, Brit. Zool, 5 , pas. 229 , n., tab. 15.

${ }^{2}$ Du sóns-genre des mulles propremeat dits, daris le genire stolle, selon M. Cavier, qui le désigne par les dénominations de Surmulet, ou grand mulle raye de ja ne. D. dit d'ailleurs sur les nageoires; et c'est ànsi que les teintes les plus riches se réunissent sur le surmulet, comme sur le rouget, mais combinées dans d'autres proportions, et disposees d'après un dessin different.

L'ouverture de la bouche est petite; la machoire sứpérieure un peu plus àvancée que l'inférieure; et la ligne laterale parattele au dos, excepté vers la nageoire caudale, Les deux barbillons sont un peu plus longsà proportion que ceux du rouget ${ }^{\prime}$.

Le stimulet vit non-seulement danis la $\mathrm{Me}$ diterranée et dans-l'Océan Atlantique boréal mais encore dãis la Baltique, auprès des rivages des Antilles, et dans les eaux de la Chine. Il y varie dans sa longueur depuis deux jusqu'a cino déeimètres; et quoique Juvénal ait écrit qu'un mulle qui parait devoir etre rapporte a la mème espèce que notre surmulet, a pese trois kilogramines, on ne peut pas attribuer à un surmulet, ni à aucun autre mulle, le poids de quarante kilogrammes, assigné par Pline â un poisson de la mer Rouge, que ee grand ecrivain regarde comme un mulle, mais qu'il faut plutót inscrire parmi ces silures si communs dans les eaux de l'Egypte, dont plusieurs deviennent très-grands, et qui, de même que les mulles, ont leur museau garni de très-longs barbillons. Le mulle surmulet a lá chair blánche, un peu feuilletée, ferme, très-agréable au goùt, et malgré l'autoritê de Galien, facile a digérer, quand elle n' est pas trés-grasse. Nous avous vu dans l'article précédent, qu'il étaih comme lé rouget, poúr les Romains qui vivaient sous tes premiers empereurs, un objet de-recherche et de jouissance insensées. Aussi ce poisson avait il donné lieu au proverbe: Ne le mange pas qui le prend. Les morceaux que l'on en estimait le plus, étaient la téfe et le foie:

II se nourrit ordínairement de poissons tres. jeunes, de cancres, et d'animaux à coquille. Galien a écrit que l'ódeur de ce poisson étri désagréable, quand il avait mangé des cancres; et, suivant Pline, il répand cette mauvaise odeur, quard il a préféré des animaux a coquille. Aú reste, commé le surmulet est vorace, il se jette souvent sur des, cadavres, soit d'hommes, soit d'animaux. Les Grees croyaient is riyons a la membrane des branchlies, 7 rayons aigoll. Ionnés Y la premiere mageoire doraste, 9 rayons a la veonde. 15 a chacuinedés pectorales,
de l'anus, 22 a celle de la 
même qu'il poursuivait et parvenait à tuer des poissons dangereux; et le regardant comme une sorte de chasseur utile, ils l'avaient consacré à Diane.

Les surmulets vont par troupes, sortent, vers le commencement du printemps, des profondeurś de la mer, font alors leur première ponte auprès des embouchures des rivieres, et, selon Aristote, pondent trois fois dans la mème année, comme d'autres mulles, et de mẹmé que plusieurs trigles.

On les pêche avec dés filets, dés louves ', dès nasses, et surtout a l'hamecon; et dans plusieurs contrées, lorsqu'on veut pouvoir les envoyer au loin sans qu'ils se gâtent, on les fait bouillir dans de l'eau de mer aussitot aprè quils ont été pris, on les saupoudre de farine, et on les entoure d'une páte qui les garantit de tout contact de l'air.

Nous ne rapporterons pas le conte adopté par Athénée, au sujet de la prétendue stérilité des surmulets femelles, causée pâr de petits vers qui s'engendrent dans leur corps lorsqu'elles ont produit trois fois: Nous ne réfuterons pas I'opinion de quelques auteurs anciens qui ont écrit que du vin dans lequel on avait fait mourir des surmulels, rendait incapable d'engendrer, et que ces animaux attachés crus sur une partie du cerps, guérissajent de la jaunisse; et nous terminerons cet article en disant que ces poissons ont le canal intẹstinal assez court, $\mathrm{e}$ vingt-six cœcums auprès du pylore.

\section{LE MULLE JAPONAIS 2}

Mullus japonicus, Houtt., Línn., Gmel, Lacèp. Upeneus japonicus, Cur. s.

Ce poissou qu'Houttuyn a fait connaitre, semble beaucoup au rouget et au surmulet; mais il en differe par la petitesse des dents dont ses mảchoires sont garnies, si même elles n'en sont pas entièrement dénuées : et d'ailleurs il ne présente pas de raies longitudinales; et sa couleur est jaune, au lieu d'étre rouge. Il habite dans les eaux du Japon, ainsi qué l'indque son nom spécifique ?

'Voyez, relatirement i ta loure, I lart. du Pêromyzon
Lamproie. Lamproie.

Houthyo, Act, Haarl, XX, 2, p. 354, D. 25

A la pregenare Upénens dins le genre Mulle. Cuv, D.

LE MULLE AURIFLAMME '

Mallus Auriflamma, Forsk., Liun., Gmel., Lacep.; Upeneus Auriflamma, Cuv.

Mullus Aurillanma. Commers., Lacep.; Mullus macronemus, Lacep. ; Cpeneus lateristriga, Cuv. '.

Forskael a vú ce poisson dans la mer d'Arabie. Ajoutons à ce que nous en avons dit dans le tableau de son genre, que les côtés de sa tête sont tachés de jaune; que deux raies jaunes ou couleur d'or sont placées au-dessons de sa queue; que la mème nuance distingue ses dorsales; que ses pectorales ${ }^{3}$, son anale et ses thoraciues sont blanchătres; et enfin que les écailles dont il est revêtu, sont membraneuses dans une partie de leur circonférence.

Un des dessius de Commerson, que nous avons fait graver, présente une variété de l'au. riflamme.

\section{LE MULLE BAYÉ *}

Mullus yiltatas, Forsk., Linn., Gimel., Lacep.; Upeneus viltatus, Cur."

Les petites dents qui garnissent les mâchoi. res de ce mulle; sont serrées les unes contre les autres. Ses nageoires pectorales, thoracines, et anale, sont blanchâtres; les dorsales présentent deș raies noires sur un fond blane. On peut voir les autres traits du raýé, dans le tąbleau de son genre. Cé poìsson habite la mer d'Arabie $\%$ :

'Forskael, Eaun. Arab., p. 50, n. 19. - Mulet ambirir.

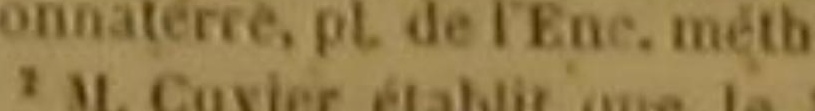

ici decrit, est une espece le Mfulle auriflamme deForskael,

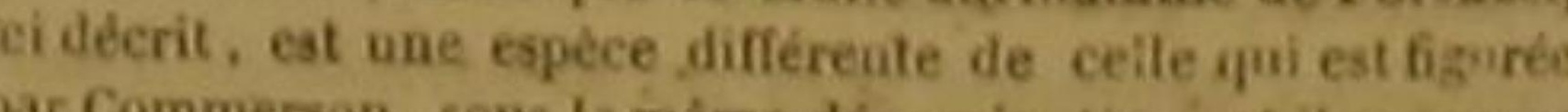

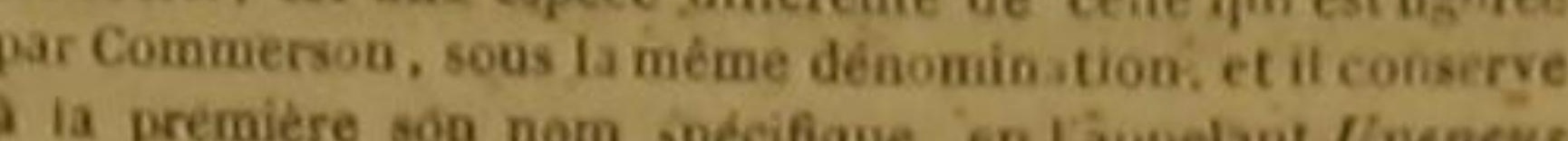
Juriftom Auriflamma. Quant au Mulle auriflamme du dessin de Commersop, i ne le trouve pas different du Mulle macro: péneus a trait biteral etif leur donne le nom commun d $\mathrm{U}$. I5 rayons a la membrane des branchiga. D. loniés a la premiére nazeoires de dranchi- $s, 7$ rayons aiguil. 3 rayónis articnéés a lá seconde dorsale. 17 raying a crazue pectocale, 6 a chaque thoracine, 2 rayois aiguiltoniés et 7 rayons articulésu célle de ranns, is rayons a celle de la qaeue.

Forskael, Fanin. Arabic., p. 51, n. 20. - Mulet raye.
Bonaterre, pla de IE - Du sons-pise lEnc. méth.

i5 rayous a la membrane des de genre Mulle. Cuv. D.

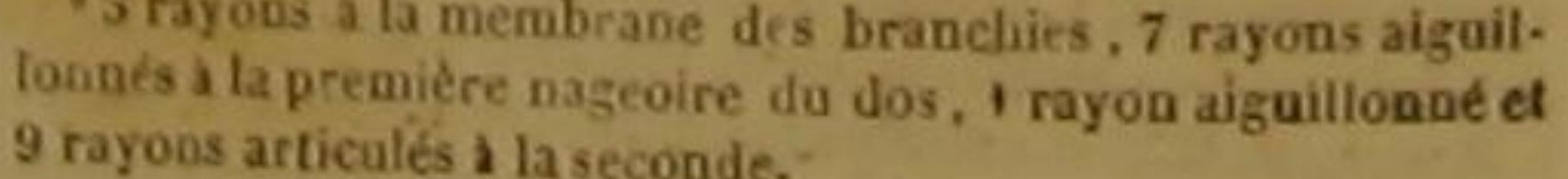

\section{DES POISSONS.}

LE MULLE TACHETÉ '

Mullus maculatus, Bi., Lacep.; Mullus Surmuletus, var. $\beta$, Linn., Gmel.; Úpeneus maeulatus, Guv. 3

Mareǵrave, Pison, Ruysch, Klein, et /e prince Maurice de Nassau, cité par Bloch, ont parlé de ce mulle, qué le professeur Gmelin ne regarde que comme une variété du surmulet. On trouve le tacheté dans la mer des Antilles; et on le péche aussi dans les lacs que fe Brésil renferme. Ce poisson a dans certaines eaux, et particulièrement dans celles qui sont peu agitées, la chair tendré, grasse et succulente. Les deux mâchoires sont également avancées ; l'ouverture de l'anus est placée vers le milieu de la longueur totale; une belle couleur rouge répandue sur presque tout l'animal est relevée par la teinte dorée ou jaune des barbillons, aunsi que du bord de la nageoire caudale, et par trois taches noires, presque rondes et assez grandes, que l'on voit de chaque cóté sur la ligne latérale ${ }^{3}$.

\section{LE MULLE DEUX-BANDES,} Mtullus bifasciatus, Lacep.; Upeneus bifasciatus, Cur,

LE MULLE CYCLOSTOME,

Mullus cyclostomus et Sciwna heptacantha, Lacep, : Upeneus ejclostomus, Cuv.

LE MULLE TROIS-BANDES, Mollus trifasciatus, Lacep.; Upeneus trifasciatus, Cuv. ET LE MULLE MACRONÈME.

Mullus macronemus, Lacep., ; et Mullus Aurillamma Comm., Lacep, ; Upeneus lateristriga Cuv. '

C'est d'après les observations -manuscrites de Commerson, qui mont été remises dans le temps par Bufion, que j'ai inscrit pármi les mulles ces quatre espècés encore inconnues des naturalistes, et dont j'ai fait graver les dessins exécutés sous les yeux de ce célèbre voyageur. Le tableau des mulles présente- les traits principaux de ces quatre poissons : disons uni- Salmoneta, en Espagne et en Portugal. - Pikametara, Wrésil - Marcgr. Brasil. 181. - Pison. Ind., p. 60. 'Du sous-genre Upéneus, sous le norn de Úpeneus Me.

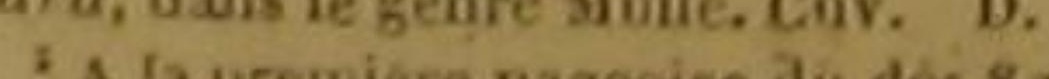
actis nos 10 , a celle de la quene 19.

'Ces quatre especes som do sous-genre Upénens de Y Cit" vier, dans le genre Mullé. A la dernière di faut rapporter le dessin de Commerson, cité ci-avant page 238, comme repré. Jentant une variété du nulle auriflammie de Fonkael, lequel Lastitucune erpece distincte. Le raulle cyclostofae de M. de suts le nom de Sciernt une seconde. fois par ce nataraliste, quement dans cet article, que le deux-bandes a les écailles de sa partie supérieure táchées vers leur base, et ses màchoires garnies de petites dents '; que le cyclostome 2 a sa nageoire caudale non-seulement fourchue comme celle de presque tous les mulles, mais encore trèsgrande, et de petites dents à ses deux máchoires $^{3}$; que les opereules du trois-bandes sont composés chacun de deux piếces; et ses deux nageoires dorsales très-rapprochées ${ }^{4}$; que le macronème 5 a les thoracines beaucoup plus petites que les pectorales, et une bande longitu. dinale et très-foncée sur la baséde la seconde dorsale ${ }^{0}$; et enfin que de petites dents arment les máchoires du macronème et du trois-bandes, qui l'un et l'nutre ont, comme le cyclostome, fa mâchoire inférieure plus avancée que la supérieure.

\section{LE MULLE BARBERIN ?}

Mullus Barberinus, Lac; Upeneus Barberiaus, Cuv.

LE MULLE ROUGEATRE: Mullus rubesceús, Lacep.

LE MULLE ROUGEOR ${ }^{\circ}$,

Mullus chryserydros et Seiwoa elliata, Lac.; Mullu radiatus, Staw.; Upencus deryserydros, Guv.

ET LE MULLE COBDON-JAUNE 10

Hulfus flavo-lineatus, Lacep; ; Multus auréo-vittatus, Staw, Upeneus flaro-lineatus, Gur, ".

Voici quatre autres espèces de mulles, en-

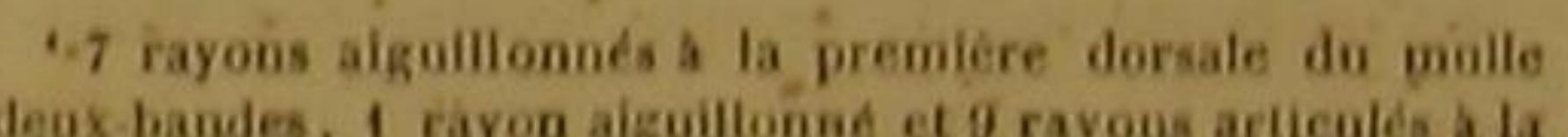
2. 6 ou 7 rayons a celle de $I$ an

'La déiomination de eyclosilome désigne la forme de la bouche : zóxhossignifie cercle et arsp. $x_{\text {, bouche. }}$

'8 rayons aguillonnés a la premere dorsale du cyclos. 7oine, rayon argationad el 8 rayous articulés a la second. 7 oil 8 rayons a celle de lanus.

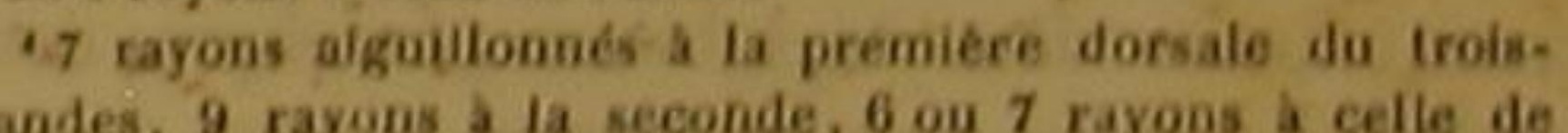
lanus.

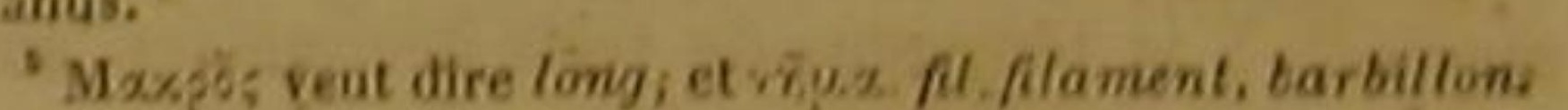
- 7 rayons aiguillonnes a th ireniere dorsale du microgeme, 8 ou 9 rayons a la seconde, 7 ou 8 rayons a celie do ranus. - Sullus binis in meñto cirris, ténia lóngitadinati nigra. - ocellogue cands utrint

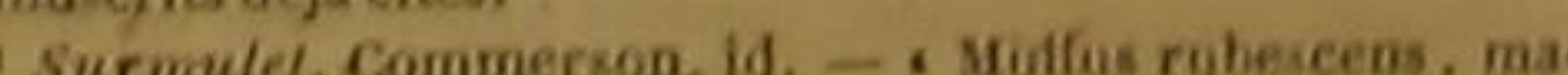
c culá supra caudx basio nigrá. pinná dorsi secunda. anali, - el cauda fuscá, lenticulatio, , Id.jibid.

' Mullus rubeins, dorso inter pionan cosnominem et a cuda basin tlavescente, lineis aureis circa ocolos radia-

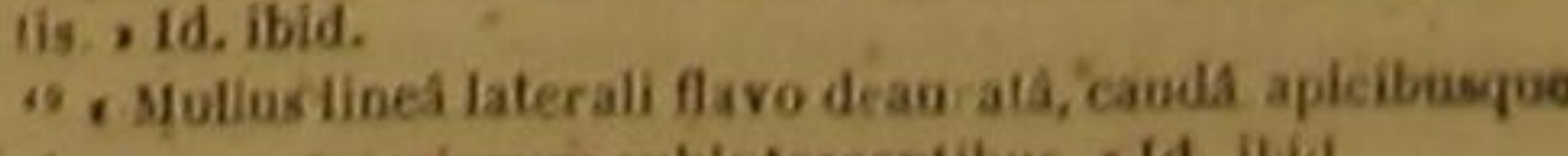

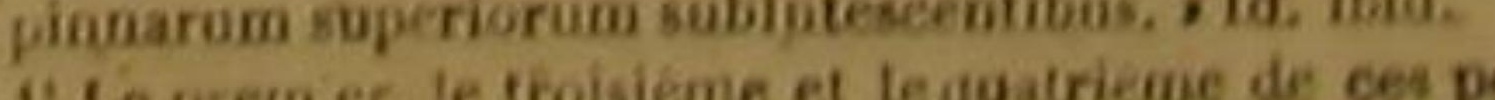


core inconnues des naturalistes, et dont nous celles du rougeâtre, et que sa longueur ne dédevons la description à Commerson.

Le barberin parvient jusqu’à la longueur de quatre ou cinq decimètres. Sa partie supérieure est d'un vert foncé, mélé de quelques teintes jaunes; du rougeâtre et du brun règnent sur la portion la plus élevée de la tête et du dos; une raie longitudinale et noire s'étend de chaque côté de l'amimal, dont la partie inférieure est blanchátre; une tache noire, presque ronde et assez grande, parait vers l'extrémité de chaque ligne latérale; et une couleur incarnate distingue les nageoires ${ }^{\prime}$.

La mâchoire supérieure extensible, et un peu plus avancée que l'inferríeure, est garnie, comme celle-ci, de dents afguês, très-courtes et clairsemées; la langue est cartilağineuise et dure; quelques écailles semblablés a celles du dos sont répandues sur. les opercules, au-dessous de chacan desquels Commerson a vu' le rudiment d'une cinquième branchie; la ligne latérale, qui suit la courbuire du dos, dont elle est voisine, est composée, comme celle de plusieurs mulles, d'une série de petits traits ramifiés du cóté du dos, et sémblables aux raies d'une demi-étoile; et enfin, leś écailles qui revêtent le corps et la queue, sont striées en rayons vers leur base, et finement dentelées à leur extrémité, de manière à donner la même sensation qu'une substance assez rudé, à ceux qui frottent le poisson avec la main, en la conduisant de la queue vers la tête.

Lę barberin habite la mer voisine des Moluques, dont les habitantš apportaient dans leurs barques un grand nombre d'individus de cett espéce au vaisseau sur lequel Commerson naviguait en septembre 1768

Le rougeâtre, dont les principaux earactères sont exposés dams le tableau générique, des mulles, parvient communément, selôr Commerson, à la longueur de trois décimètres ou

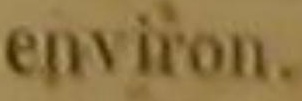

II parait que le rougeor ne présente pas ordimairement des dimensions aussi étendues que

oont décris, par M. Cuvier, comme appartenaut au sồns-

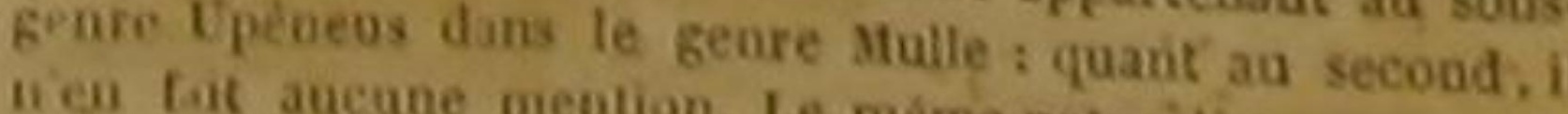

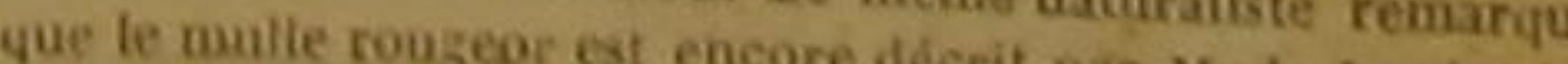

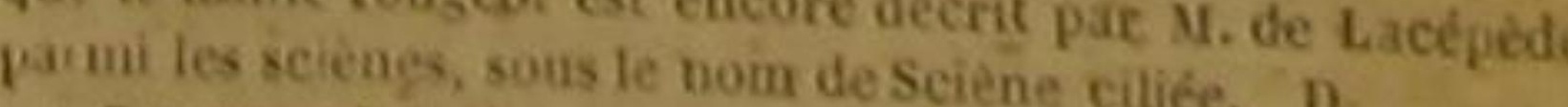
5 rayons a la membrave des branchice, 7 .

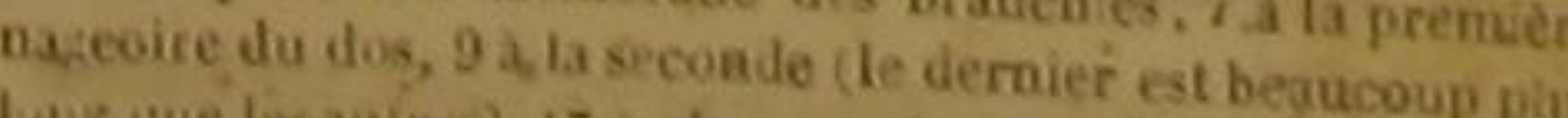

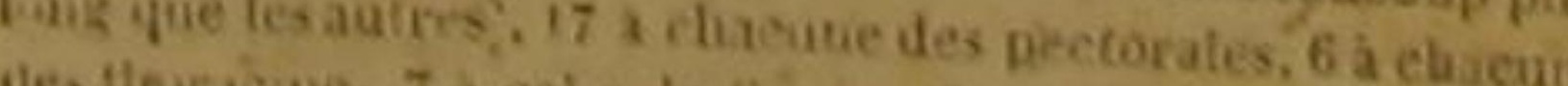

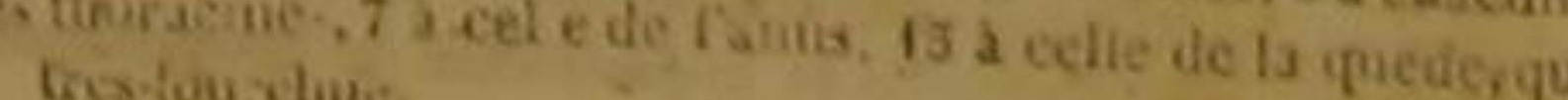
passe guère deux décînétres. On le trouve pendant presquie toutes les saisons, mais cependant assez rarement, auprès des rivages d Ille-de-France, où Commerson l'a observé e février 1770. Ses couleurs brillantes sont in diquées par son nom. Il resplendit de l'éclas de l'or, et de celui du rubis et de l'améthyste. Un rouge fóncé et assez sèmblable à celui dé la lie du vin parait sur presque toute sa surface. Une tache très-grande, très-remarquable, trèsdorée, s'étend entre les nageoires dorsales et celle de la queue, descend des deux cótés du mulle, et représente une sorte de selle magnifique placée sur la qúeue de l'animal. Les yeux sont d'ailleurs entourés dé rayons dorés et assez longs; et des raies jaunes ou-dorées 'sont situées obliquement sur la seconde dorsale et sur la nagéoire de l'anus '.

La mâchoire supérieure est èxtensible, et un peu plus longue que linférieure; leș deux machoires sont garnies de dents courtes, mousses, dispỏsées sur un seul rang, et séparées l'une de l'autre; la langue est attachée á la bonche dans tout sỏn contour; des dents semblables à celles d'un peigue garnissent le côté concave de l'are osseux de la première branchíe; à la place de ces dents, on voit des striés dans la concavite des ares osseux des autres trois organes respiratoires.

Sa chair est d'un goût agréable; mais celle du cordon-jàune est surtout très-recherchée.

Ce dernier mulle parait dans différentes saisons de l'année. Sa grandeur est à peu près égale à célle du rougeor. Sa partie supérieure est a'un bleu-mèlé de brun, sa partie inférieure d'un blanc argentio; et ces nuances sont animées par un cordon ou raie longitudinale d'un jaune doré, qui règne de chaque cóté de l'animal

Ajoutons que le sommet des deux nageoires dorsales présente des teintes jaunâtres; qu'on voit quelquefois au-devanit des yeux une ou deux raies obliques jaunes ou dorées; et que lorsque lés écailles ont été détachées du pois. son par quelque accident; Tes muscles montrent un rouge plus ou moins vif.

Les formes du cordon-jaune ont beaucoup

- 4 rayous a la membrane des branchies du rongeor (le

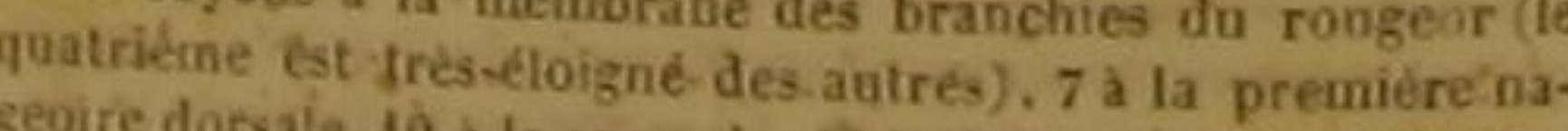
6 a chacune des thoracinosde, 16 a chacine des pectorales, la queue, qui ex trì' for 8 a ceile de lanus, 15 à celle de de rapports avec celles du rougeor; mais ses peine visibles '

\section{CENT QUATRIÈME GENRE ${ }^{2}$.} LẺS APOGONS.

Les écailles grandes et faciles à detacher; le sommet de la tete elere: deux nageoires dorsales; point de barEstlons atr-dessous.
Eš́c.

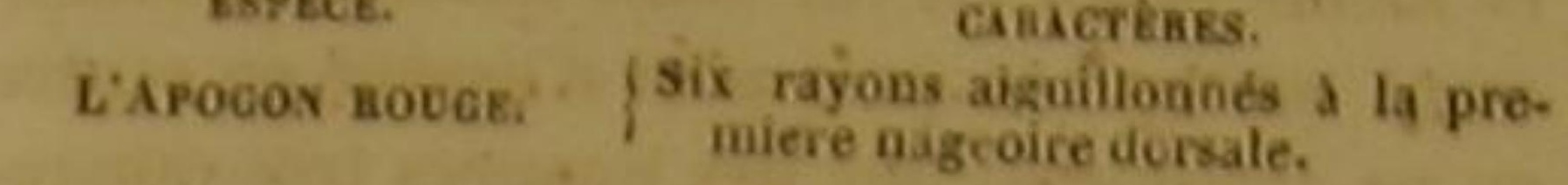

\section{L'APOGON ROUGE ${ }^{3}$.}

Mullus imberbis, Lino.. Gmel:; A pogon ruber, Lacep. Apogon Res Mullorum, Cuy,; Ceutropomus rubeas, Apogon Ker Mullorum, Cuv.; Ceutropomus rubeas,
Spinola.

Ce poisson vit dans les eaux qui baignent les rochers de Malte. Il est remarquable par sa belle couleur rouge. L'ouverture de sa bouche est grande; son palais et ses deux mảchoires sont hérissés d'aspérités ${ }^{4}$. On ignore pourquoi on l'a nommé Roi des mulles, des trigles, ou des rougets 5 .

\section{CENT CINQUTEME GENRE ? LES LONCHURES.}

La nageoire de la queue lanciolie : celle nagcoire et les pectorales aussi longues, au noins, que le quart de la tongueur totale de l'animal; la nageoire dorsale longue et profondement echancré ; deux barbillons à la
méchoire inferieure.

Ešré

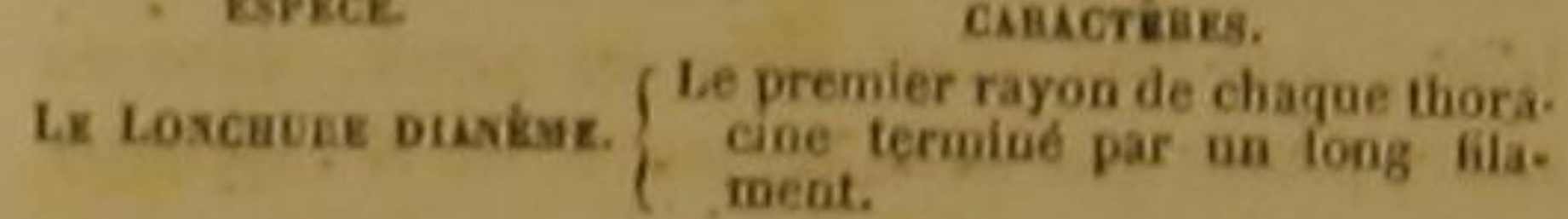

-A la membrane des branchies du cordon-jaune 4 rayons, Ia preapere nogeoire dorsaie 7 . a ia seconde 8 , a chaque de ta greve, avi est forachoe, a vi est fourchoe, 15

'Ce genre appartient \& la famille des Acanthoptérygiens percoides. Il renferme, selon M, Guvier, des poissons placés
din. d datres genres de rliynque Fieurien, le Dipterodon hexacantise le Cotopome doré, tous déc its plus loin dans cet ouvr ge. $\mathrm{D}$. 'Ae di trigtin, à Malte. - Malet, roi des rongets. Daibenton, Enci néth, - Id. Bonnaterge, pl. de YẼnc, méti. gen. 45,

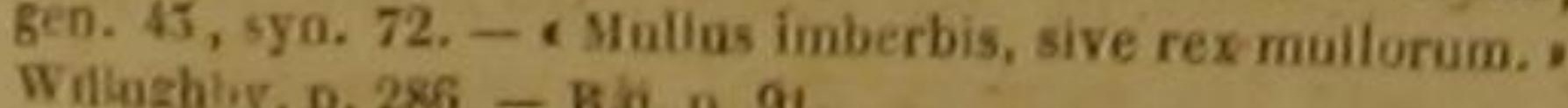

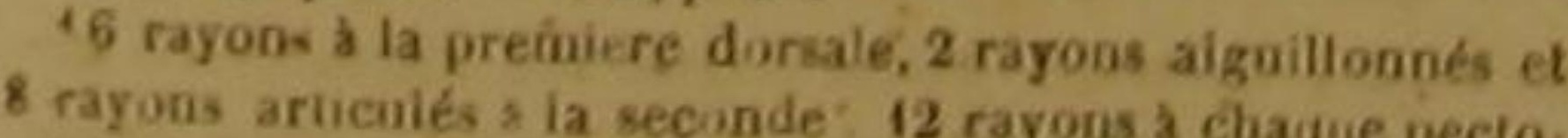
rale, 6 à chăque thoracine, 2 rayons aignifionnés et 8 rayon articules a la nazeoire de lánus; 20 rayous a celle de i quene, yui est échancré.

"A.
LE LONGHURE DIANEME. Lonchurus barbatus, Bt.; Louchorus dianema, Lae. C'est Bloch qui-a fait connaitre ce genre de poisson, auquel nous n'avons eu besoin que d'assignier des caractéres préeis, véritablement distinctifs, et anatogues à nos primcipes de dis. tribution méthodique. La seule espèce que l'on ait encore inscrite parmi ces lonchures, on pois sous á longue queue, est remarquable par la longueur du filament qui termine lé premier rayon de chaque thoracine '; et voila pourquo nous l'avons nommée Dianème, qui veut dire deux y Is ou deux filaments, L'individu que Bloch a vu, lui avait été envoyé de Surinam. Le museau était avancé au-dessus de la machoire - den haut; la tete comprimée et couverte en entier d'écailles semblables a celles du dos; la mâchoire supérieure égale à l'inférieure, et garnie, comme cette derniere, de dents petites et poiutues; l'os de chaque côté des lèvres, assez large; la pièce antérieure des opercules, comme dentelée; la ligne latérale, voisine du dos; et presque toute la surface de I'animal, d'une couleur brune mélée de rougeâtre.

\section{CENT SIXIEME GENRE 2} LES MACnOpODEs.

Les thoracines au moins de la longueur du corps propre ment dit: la nageoire caudale très-fourchue ồ à peu pres aussi longue que le terrs de la longueur totale de l'añmal; la tite proprement dite ot lesoper cules recelus d'ceailles semblables a celles du dos: t'ouverture de la bouclie très-petite.

espréc.

CALCTkass.

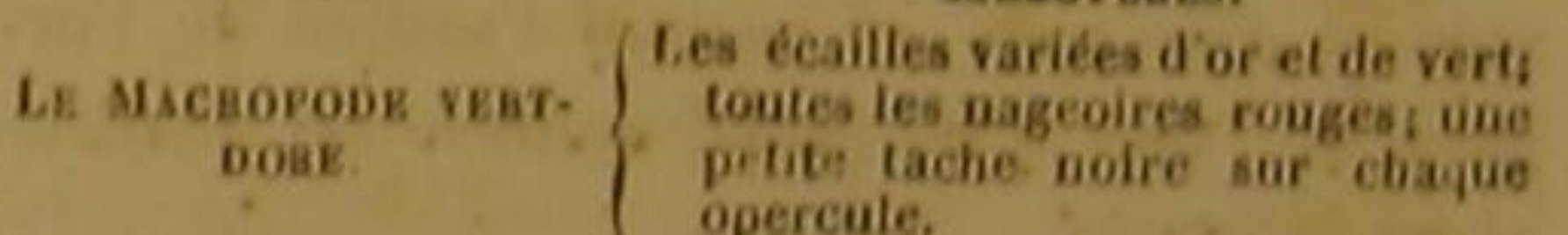

LE MACROPODE VERT-DORE

Macropodus viridiauratus, Lacep, Cuv.

Le vert-doré ne parvient qu'à de petites dimensions ; il n'a ordinairement qu'un ou deux décimetres de long : mais il est très-agréable a des ombrives. $I$ un de ceux guill établit dañs le grand g are des Scieties. D.

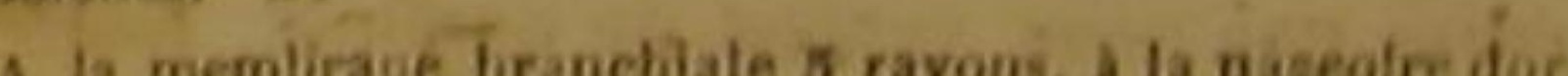
sale 46, a charme des pecturales 15 , t cheane des thors canes 6 a celle de l'anus 9 a ceile de la queue 18. - 31. Cuvier place ce gesre dans la famille des Acautbopte. rggiens jharyngiens-abyrimitiformes. D. 
voir ; ses couleurs sont magnifiques, ses mouvements légers, ses évolutions variées; il anime et pare d'une manière charmante. I'eau timpide des lacs; et il n'est pas surprenant que les Chinois, qui cultivent les beaux poissons comme les belles fleurs, et qui aiment, pour ainsi dire, à faire de leurs pièces d'eau, éclairées par un soleil brillant, autant de parterres vivants,

$\checkmark$ mobiles, et émaillés de toutes les nuances de Tiris, se plaisent a le nourrir, à le multiplier, et à multiplier aussi son image par une peinture fidèle.

Les petits tableaux ou peintures sur papier, exécutés à la Chine avec beaúcoup de soin, qui représentent la nature avec vérité, quí ont été cédés à la France par la Hollande, et que l'on conserve dans le Muséum d'histoire naturelle, renferment l'image du vert-doré vu dans quatre positions, ou plutot dans quatre mouvemients différents. Le nom spécifique de ee poisson indique l'or et le vert fondus sur sa surface et relevés par le rouge des nageoires. Ce rouge ajoute d'autant plus à la parure de l'animal, que ses instruments de natation présentent de graudes dimensions, particulièrement la nageoire caudale et les thoracines; et la longueur de ces thoracines, qui sont comme les pieds du poisson, est le trait qui nous a suggéré le nom générique de Macropode, lequel signifie long pied.

Au reste, le vert-doré n'a pas de dents, .ou n'a que des dents très-petites. Chaque opercule n'est composé que d'une plèce; et sur la surface de cette pièce on voit une tache petite, ronde, très-foncée, faisant de loin l'effet d'un vide ou d'un trou, et imitant l'orifice de l'organe de l'ouie d'un grand nombre de quadrupèdes ovipares.

\section{NOMENCLATURE}

Des Labres, Cheilines, Cheilodiptères; Ophicéptrales, Hologymooses, Scares, Ostorbinques, Spares, Dipnotes, Seiènes, Mieropteres, Hodians, Treaiasèques.

Les poissons renfermés dans les dix-sept geúres que nous venons de nommer, forment bien plus de deux cents espèces, et composent par leur réunion uné tribu, à l'ex composent par leur reunion une tribu, à l'examen, à ta
deseription, a l'histoire de laquelle nous avons dù apporter une attiention toute particulière. En effet, les caractères généraux par lesquels on pourrait chereher à la distinguer, se rapprochent beaucoup de ceux des tribus ou des genres vo. sins. De plus, les espèces qu'elle comprend ne sont séparées l'une de l'autre que par des traits peu prononcés, de manière que depuis le genre ui precéderait cette grande et nombreuse tribu en la tonehant immédiatement dáns l'ordre le plus naturel, jusqu'a celui qui la suivrait dans ce mème ordre en lui étant aussi immédiate. meñt contigu, on peut aller d'espèce en espèce en ne parcourant que des nuances très-rapprochées. Ét comment ne s'avancerait-on pas ainsi, en ne reneontrant que des différences très-peu sensibles, puisque les deux extrèmes de cette série se ressemblent beaucoup, sont placés, par conséquent, à une petite élévation Yun audessus de l'autre, et cependant communiquent ensemble, si je puis employer cette expresslon, par plus de deux cents degrés?

Les divisions que l'on peut former dans cette longue série ne peuvent done étre déterminées qu'après beaucoup de soins, de recherches et e comparaisons; et voilà pourquol presque ous les naturalistes, mème les plus habiles, uayant pas eu à leur disposition assez de emps, ou des collections assez nombreuses, ont établi pour cette tribu, des genres caractérisés d'une manière si faible, si vague, si peu constante, ou si terronée, que, malgré des efforts pénibles et une patience soutenue, il était quelquefois impossible, en adoptant leur méthode distributive, d'inserire un individu de cett tribu, que l'on avait sous les yeux, dans un genre plutot que dans un autre, de fe rapporter à sa véritable espèce, ou, ce qui-est la même chose, d'en reconnaitre la nature.

Bloch avait senti une partie des difficultés que je viens d'exposer; il a proposé, en consé quence, pour les espèces dé cette grande famille, plusieurs nouveaux genres, dont j'ai adopté quelques-uns : mais son travail à l'égard de ces animaux m'a paru d'autant plus insuflisant, qu'il n'a pas traité de toutes les espèces de cette tribu counues de son temps; qu il n'avait pas à classer les espèces dont je vais publier, te premier, la description; que lés caractères génériques qu'il a chôisis ne sont pas tous aussi importants qu'ils doive l'etre gour produire de bonves qu'ils doivent l'étre pour produire de bonies associations génériques; et enfin qu'ayant composé plusieurs genres pour la tribu qui nous oecupe, longtemps après avoir formé

DES POISSONS.

pour cette mème famille un assez grand nombre d autres geures, sans prévoir, en quelque sorte, le besoin d'un supplement de groupes, il avait déjà placé, dans ses anciens genres, des espèces qu'il devait rapporter aux nouveaux genres qu'il voulait fonder.

Profitant done des travaux de mes prédécesseurs, de l'avantage dé pouvoir examiner d'immenses collections, des observations nombreuses que plusieurs naturalistes ont bien voulu me communiquer, et de l'expérience que Iai aequise par plusieurs années d'étude et par les différents cours que j'ai donnés, j'ai considéré dans leur ensemble toutes les espèces de la tribu que nous avons dans ce moment sous es yeux; je l'ai distribuée en nouveaux groupés; et recevant certains genres de Linnée et de Bloch, moditiant les autres ou les rejetant, $y$ ajoutant de nouveaux genres, dont quelquesuns avaient été indiqués par moi dans mes cours et adoptés par mou savant ami et confrère M. Cuvier dans ses Eléments d'histoire naturelle, donnant entio à toutes ces sections des caractères précis, constants et distincts, j'ai terminé l'arrangement méthodique dont on va voir le résultat.

Jai employé et circonscrit d'une manière nouvelle et rigoureuse les genres des Labres, des Scares, des Spares, des Lutjans, des Bodians, des Holocentres, et des Persèques. J'ai introduit parmi ces associations particulieres le genre des Ophicéphales, proposé récemment par Bloch. Séparant dans chaque réunion lés poissons à deax nageoires dorsales, de ceux qui n'en offrent qu'une, j'ai fait naitre le genre des Cheilodiptères dans le voísinage des $\mathrm{La}$ bres, celui des Diptérodons auprès des Spares, celui des Centropomes à la suite des Lutjans, celui des véritables Sciènes, que l'on a eu jusqu'ici tant de peine à reconnaitre, à une petite distance des Bodians. J'ai placé entre ces Sciènes et-les Bodians, le nouveau genre des Taniunoles, qui forme un passage naturel des unes aùx autres; j'ai inscrit le nouveau groupe des Cheilines entre les Labres et les Cheilodip-. tères, celui des Hologymnoses entre les Ophicéphales et les Scares, celui des Ostorhinques entre les Scares et les Spares, celui des Micropteres entre Jes Sciènes et les Holocentres; et j'ai distribué parmi les Labres, parmi les Lutjans, ou parmi les Holocentres, les especes appliquées par Bloch à ses genres des Johnius, des Anthias, des Epinèphèles, et đes Gymnocéphales, qui m'ont paru caractérisés par des traits spécifiques plutót que par des caractères génériques, et que, par conséquent, je n'ai pas cru devoir admettre sur mon tableau général des poissons.

Toutes ces opérations ont produit les dixsept genres des Labres, des Cheilines, des Cheilodipteres, des Ophicéphales, des Hologymnoses, des Scares, des Ostorhinquies, des Spares, des Diptérodons, des Luljans, des Centropomes, des Bodians, des Tanianotes, des Seiènes, des Mieropières, des Holocentres, et des Perseques, dont nous allons tâcher de présenter les formes et les habitudes.

\section{CENT SEPTIÈME GENRE}

\section{LES LABHES,}

L lare superieare extensible ; point de dents incisices "1i molaires; les opercules des branchies denues de piThamis a de dentediro, une seule nageoire dorsale. cate nageovire da dos his-srparce de celle de la quene, ou tres-doignee de la nuque, ou composce de rayous
termines par un filament.

PREMTEI SOUS-GENRE.

La nagcoire de la queue fourchue ou en croissant.

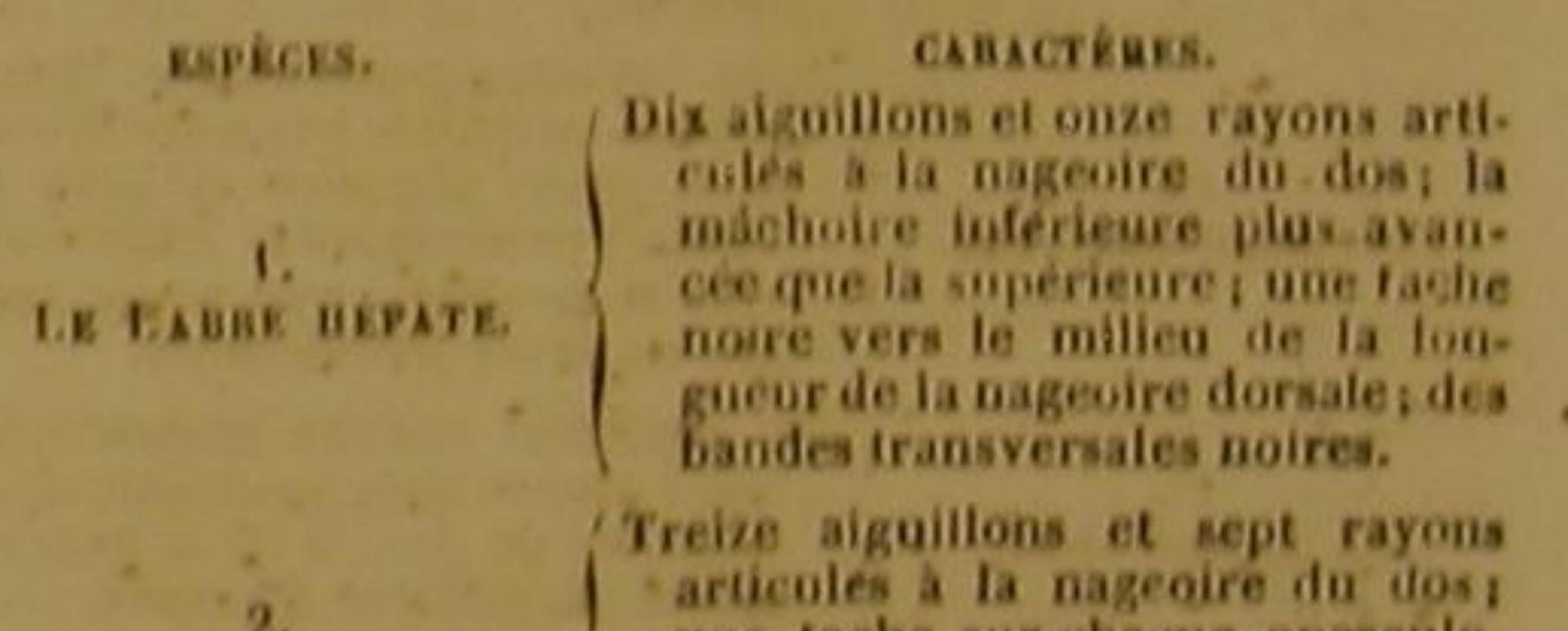

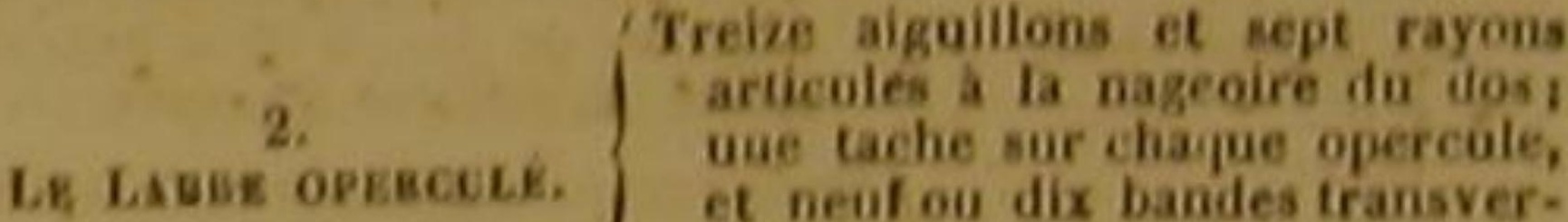

saies brenes.

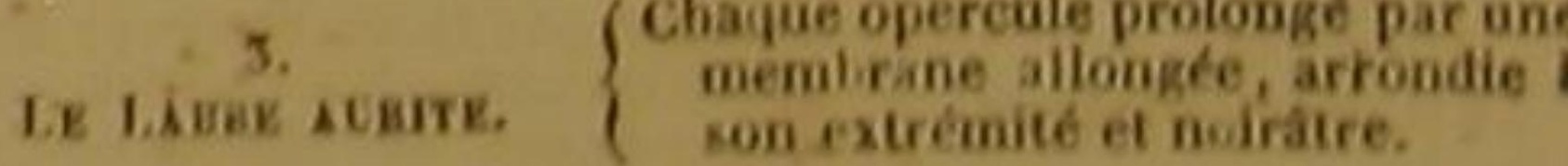

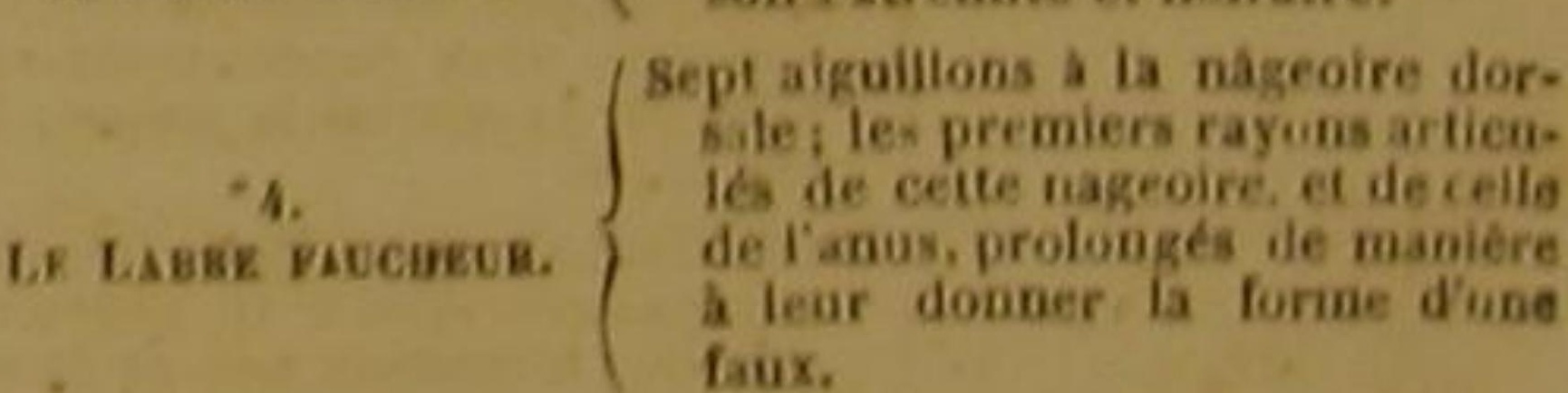

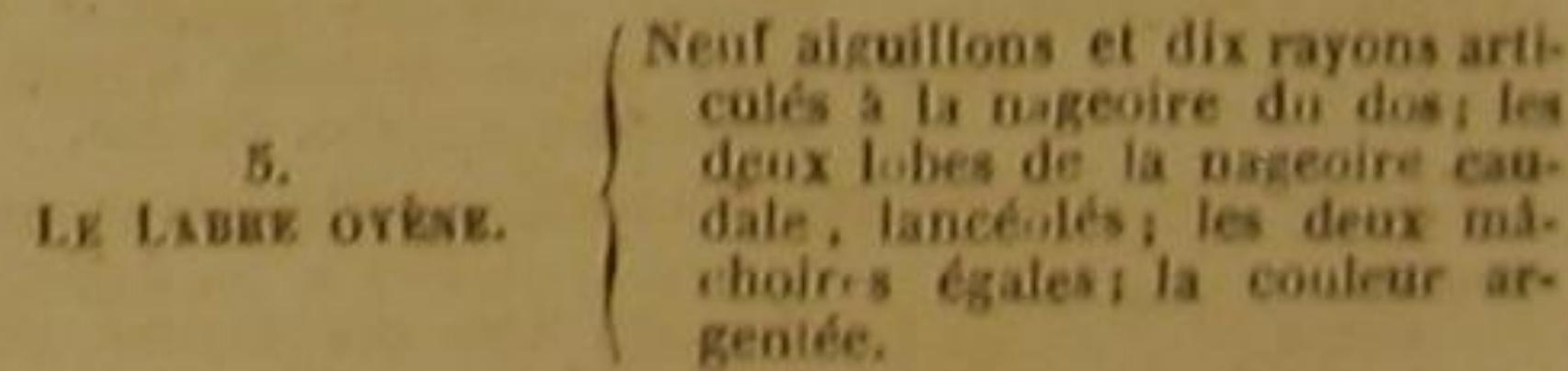

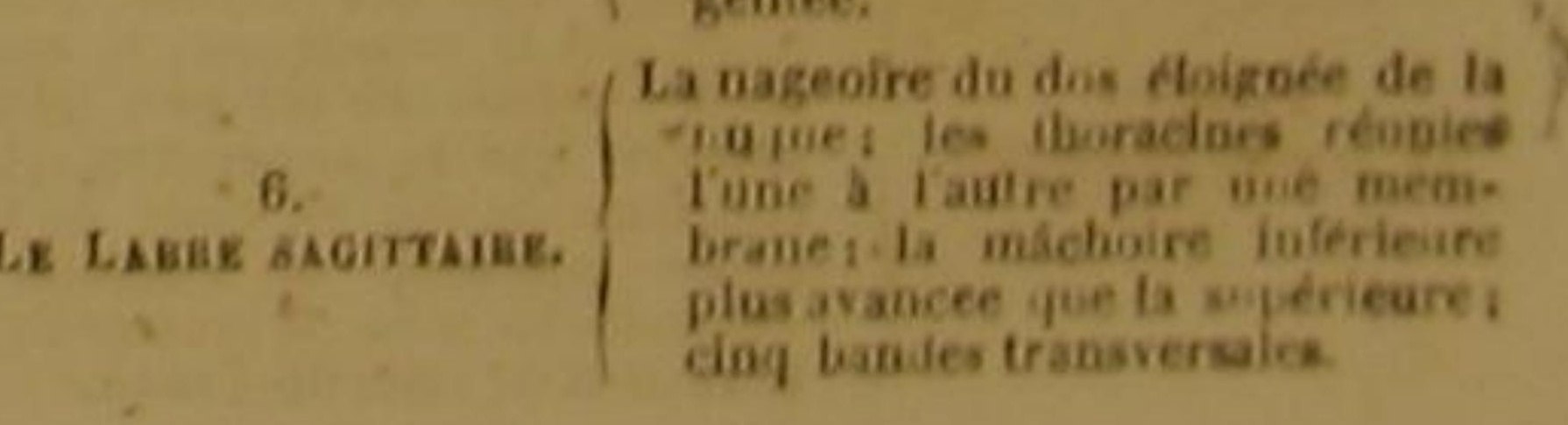


Espícrs. CARictìness.

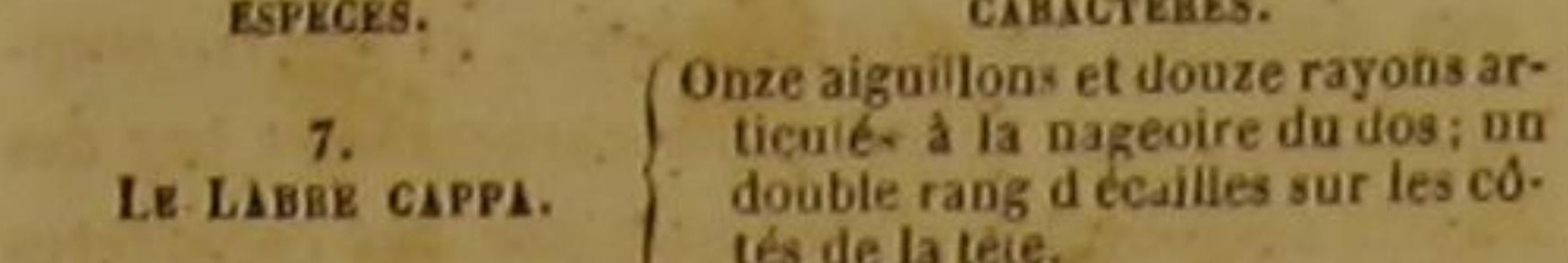

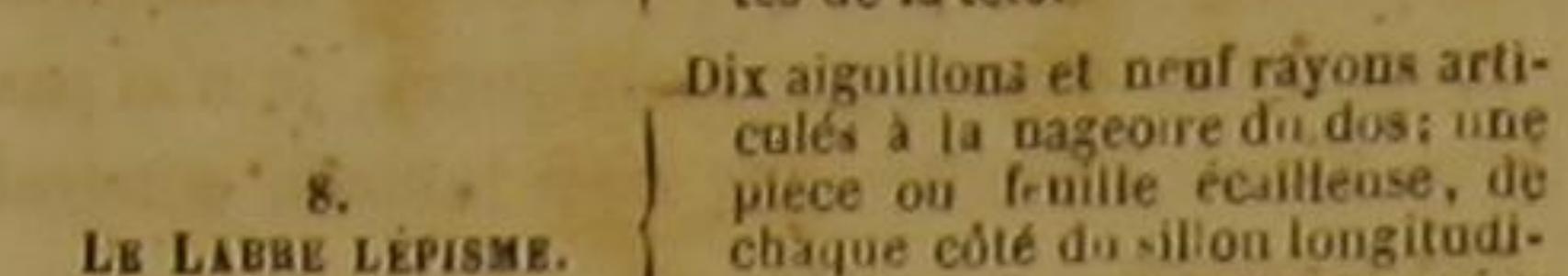

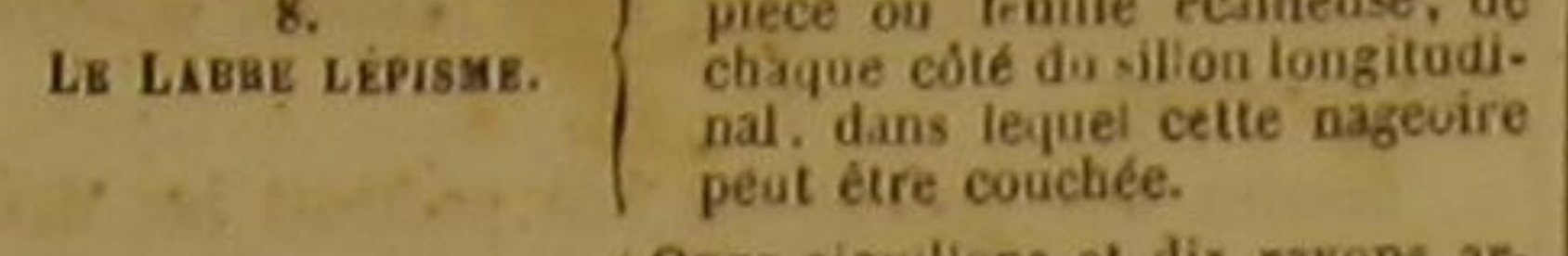

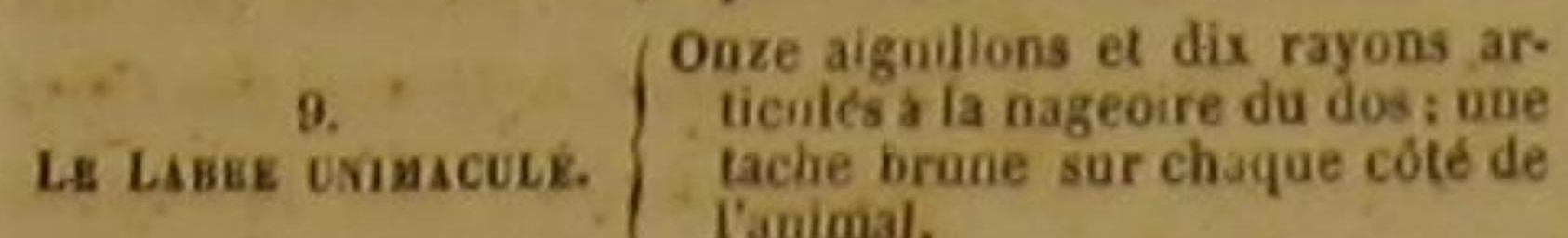

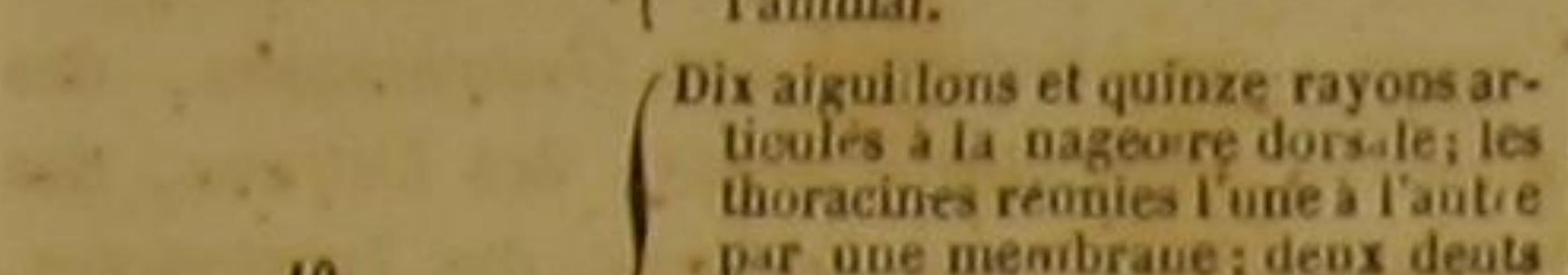

10.
LE LAUK kонав, longues pour dépasser linfe-
rieures lacouleur rougraitre arec
des raies et des taches irregu-
lieres blanchatres.

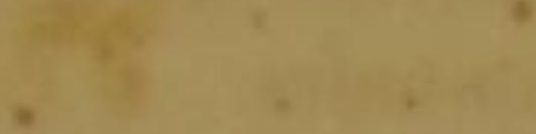

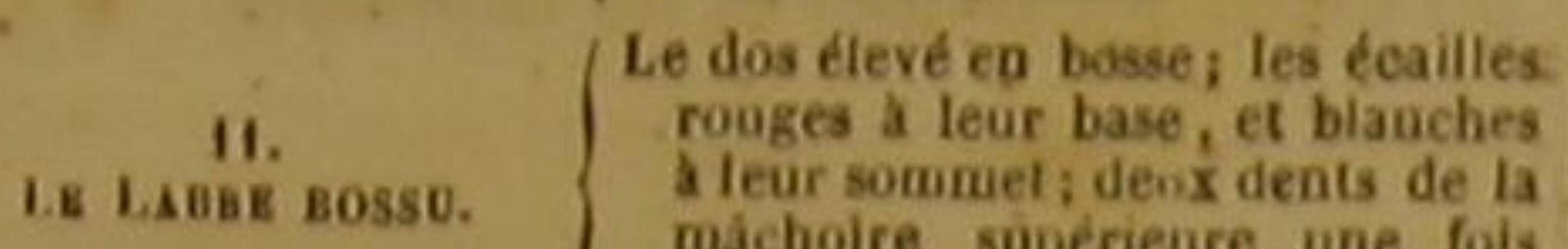

máchoire supérieure une fois
plas loogues que les autres.

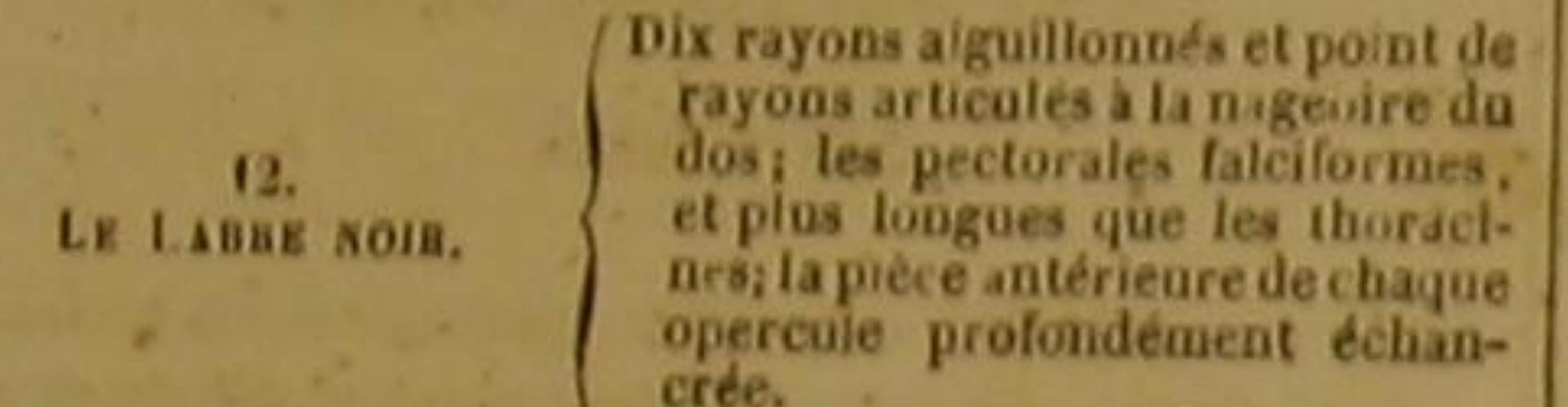

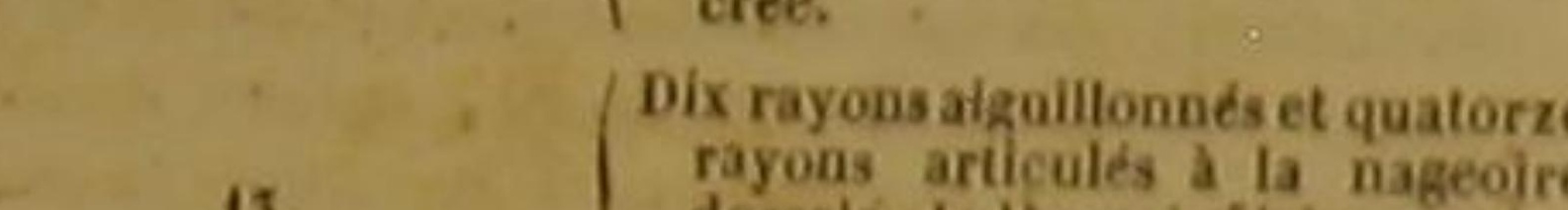

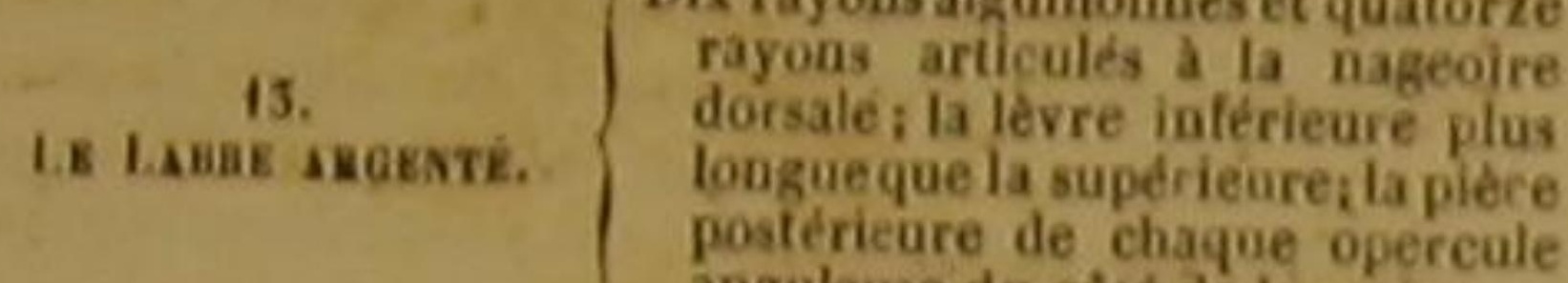

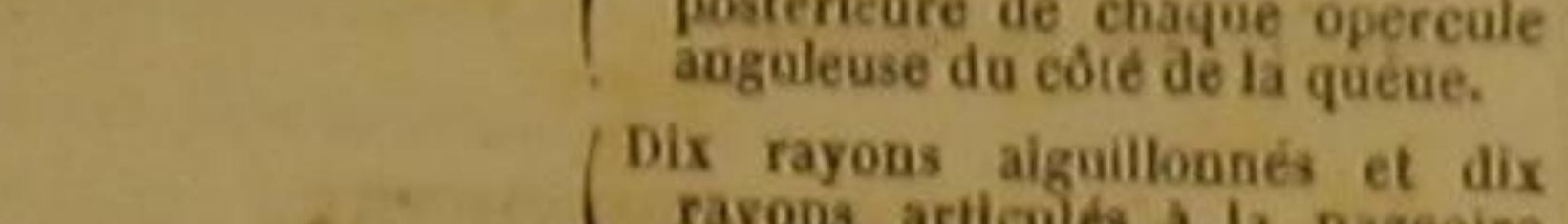

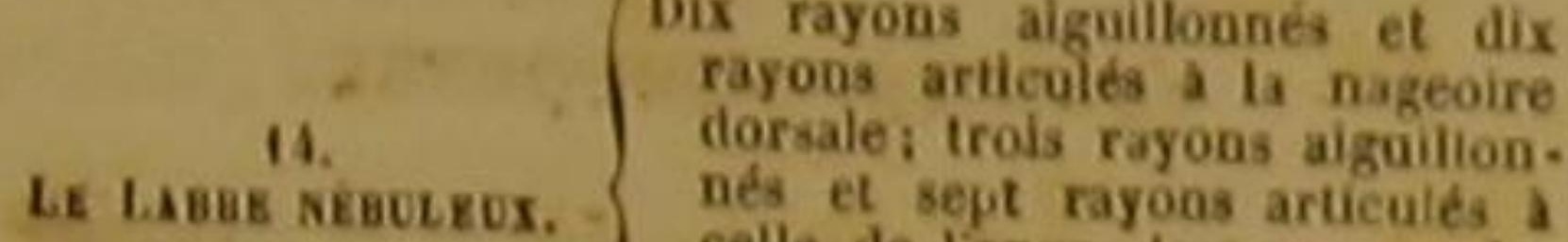
nés et sept rayons articulés a
celle de lanusi les rayous des
nageoires terminés par des fila.
ments.

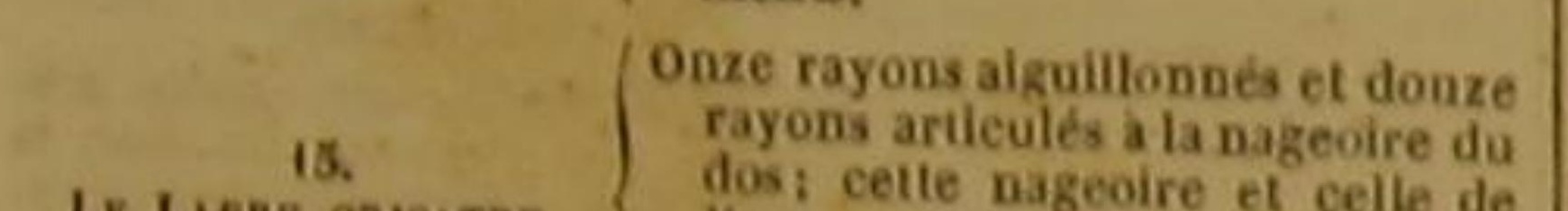

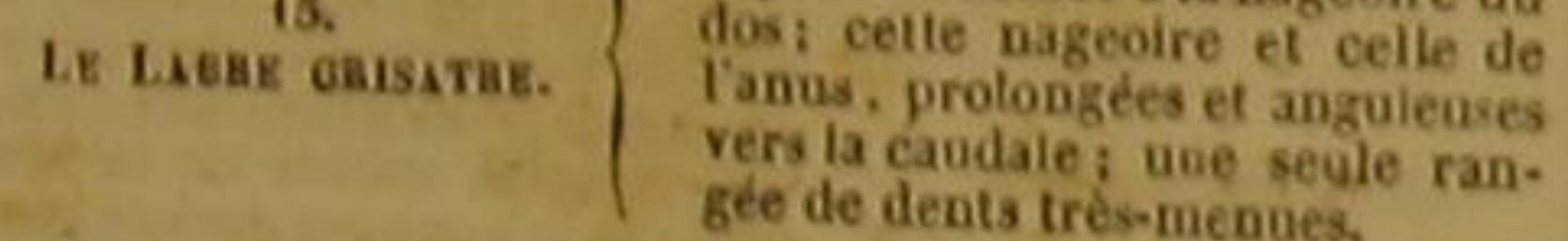

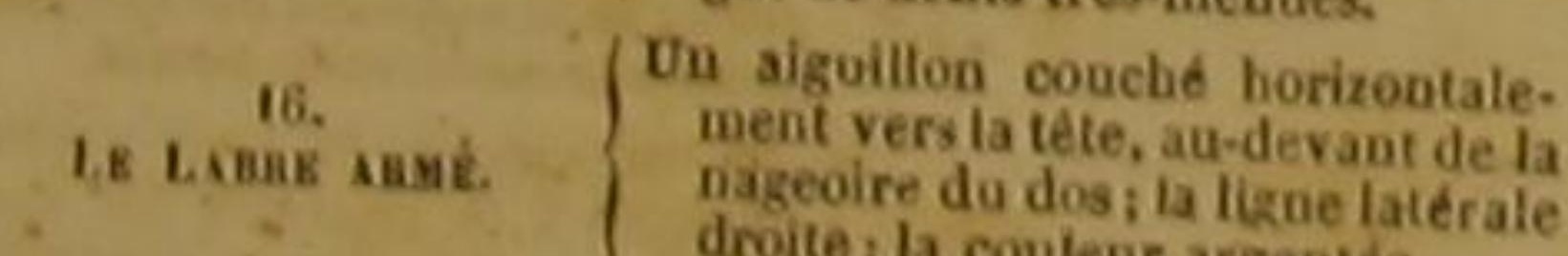

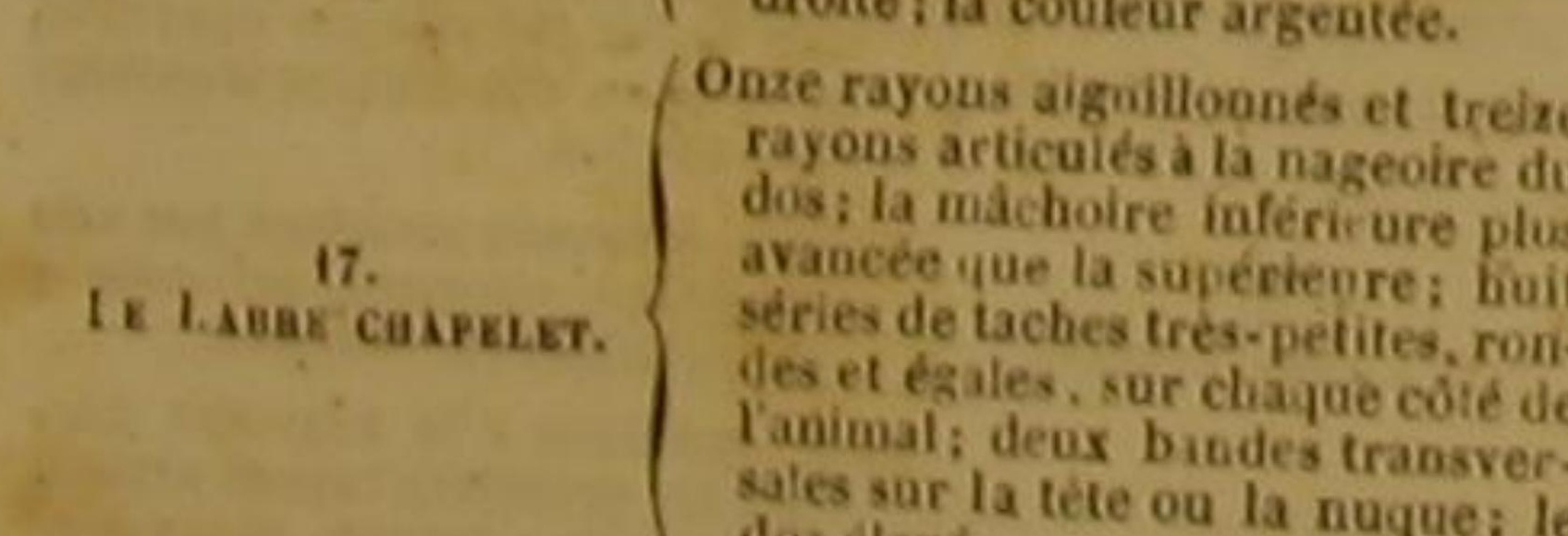

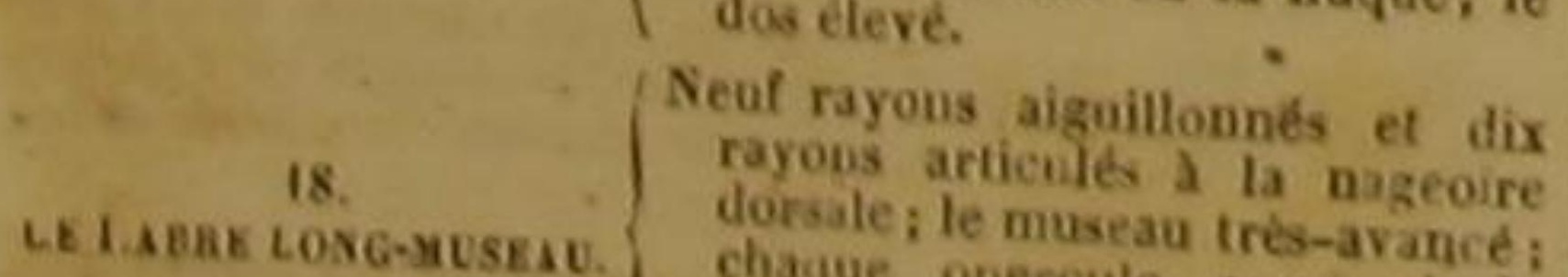

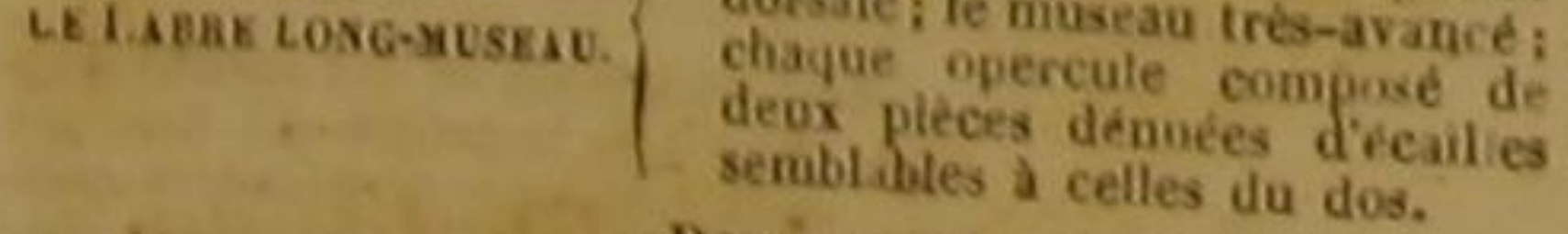

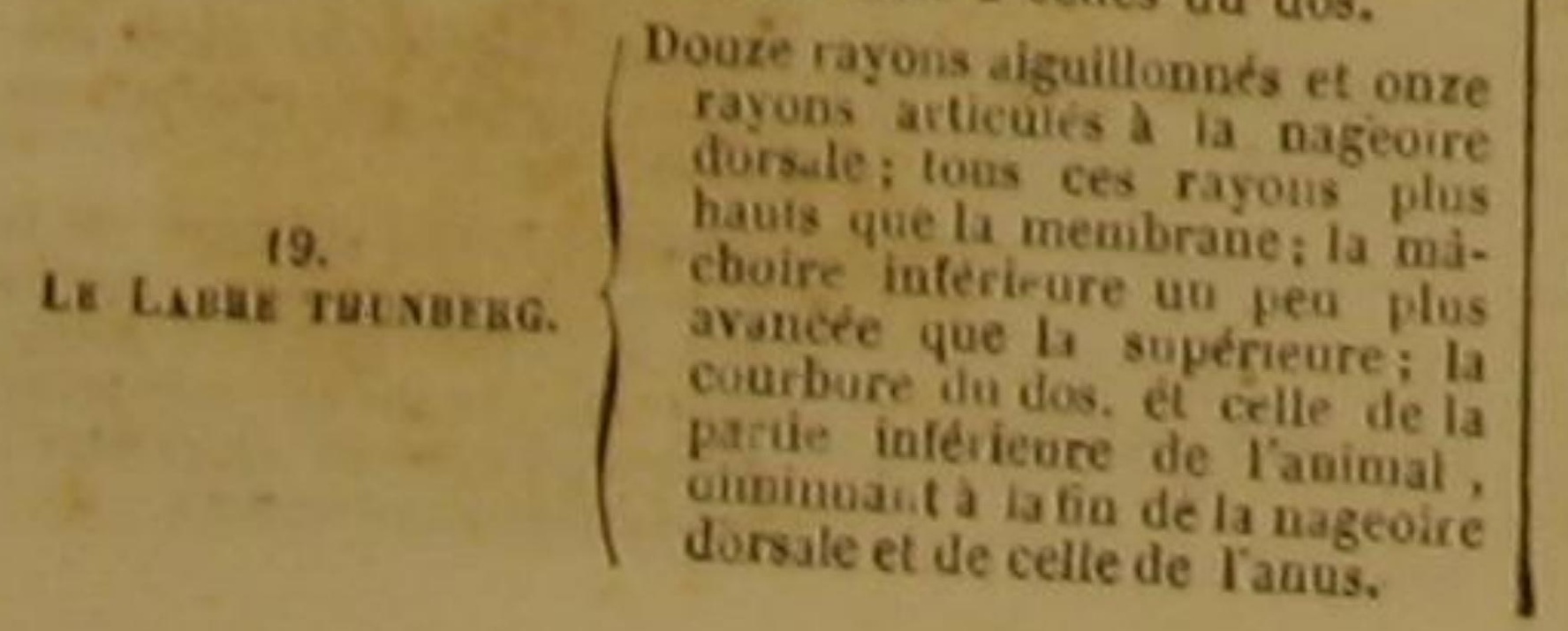

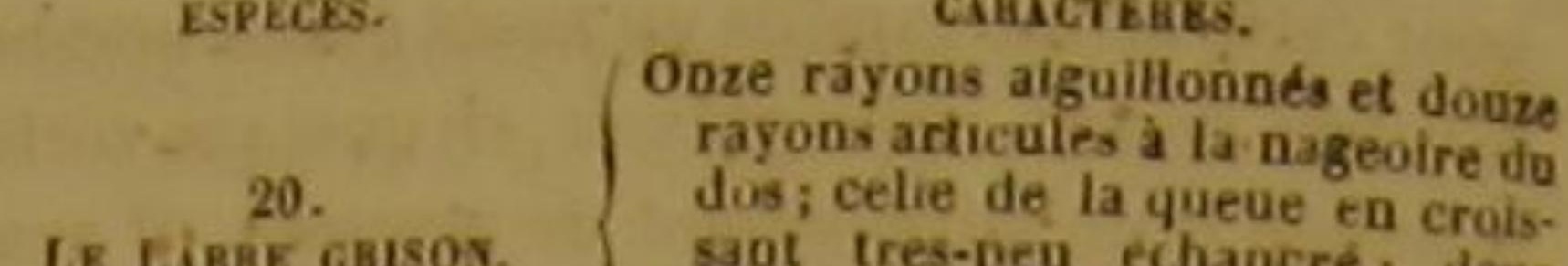

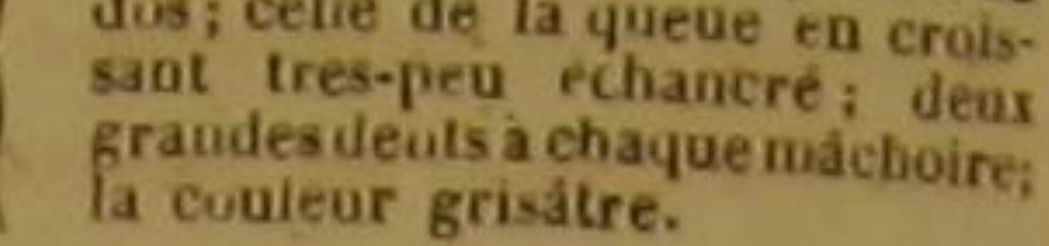

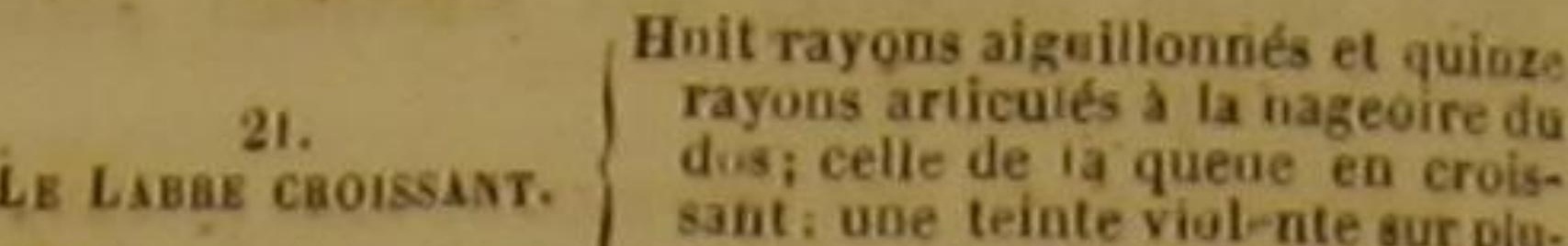
sant; une teinte viole-nte sur plu-
siears parties de lavimal.

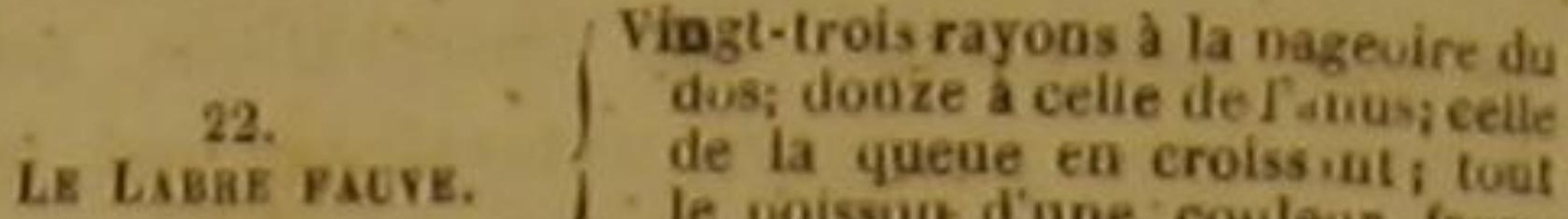
de la queue en crobssint i tout
le poissour diune couleur taure
ou jaune.

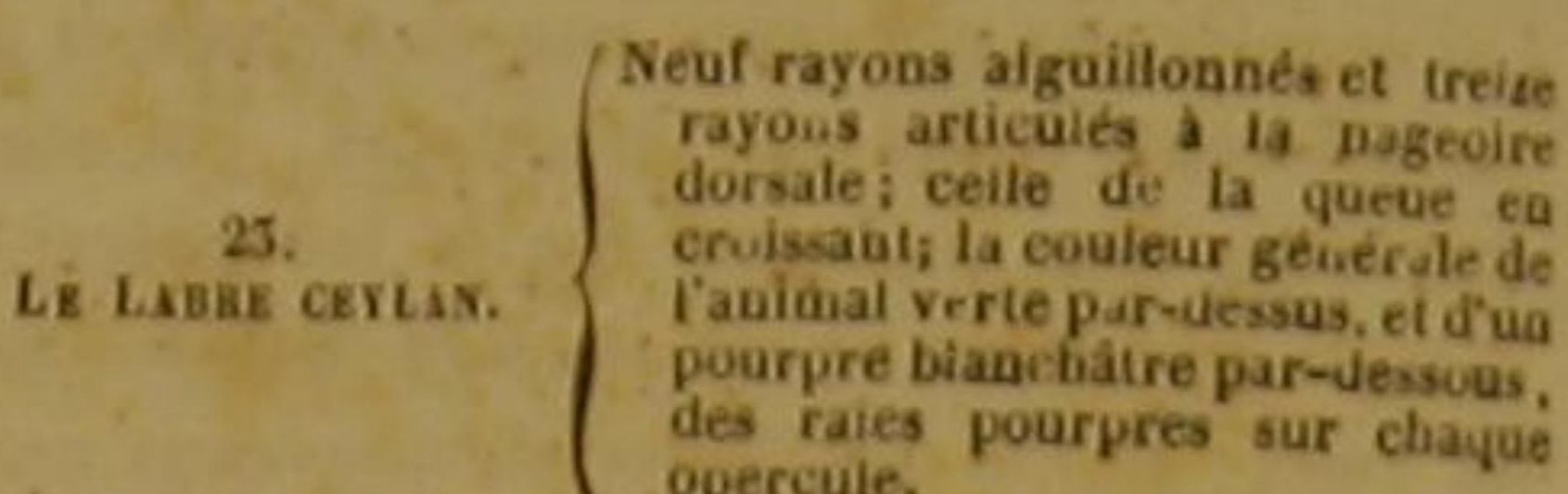

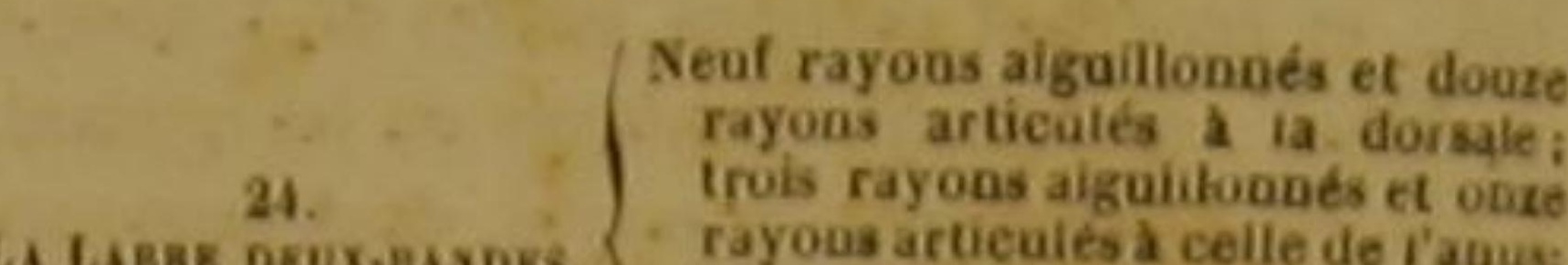
rayous arueuies a celle de l'anuss
la cancale eu croissaut deux
bandes brunes et trausversales barle corps propremeut dit.
sur

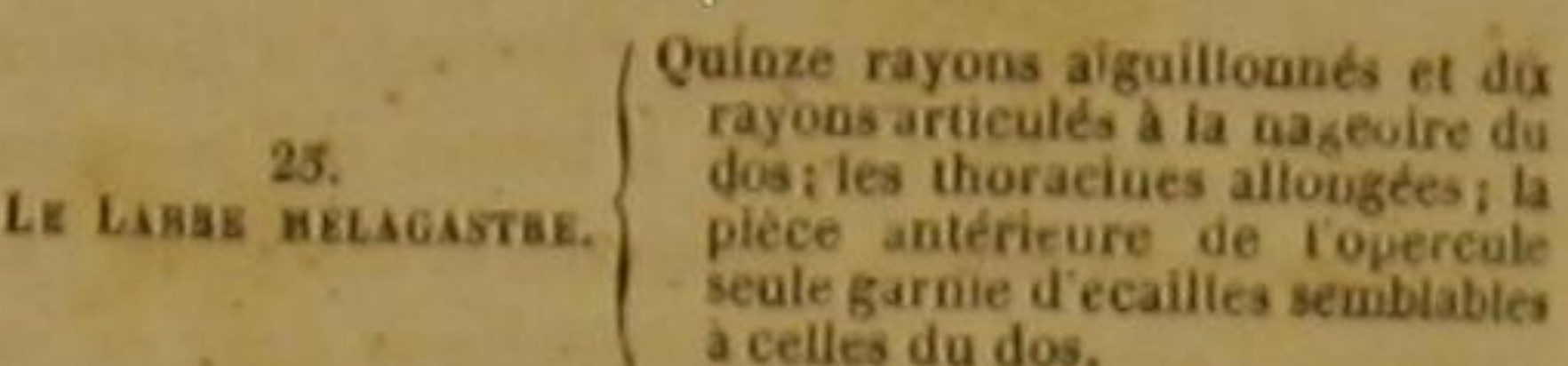

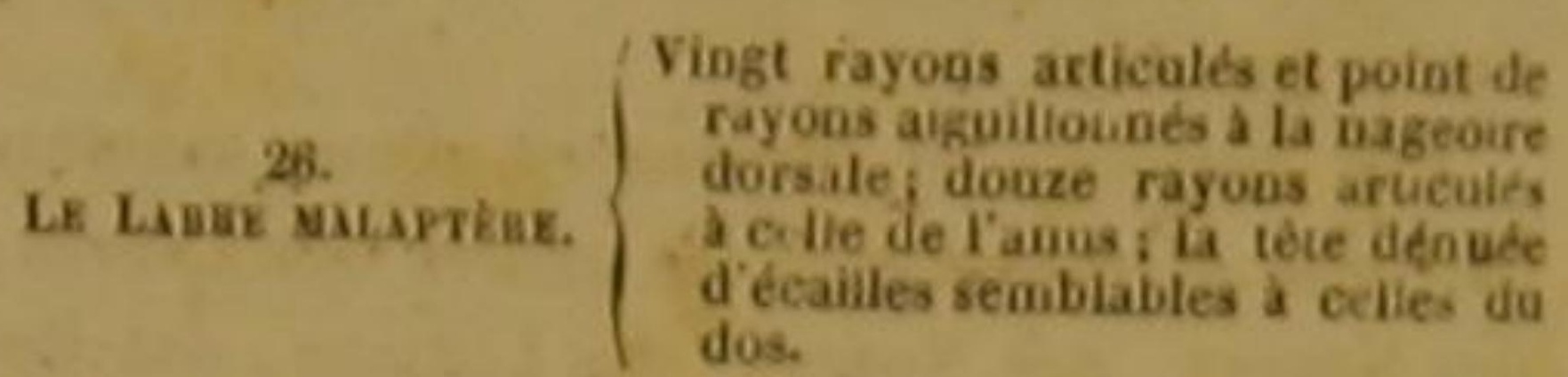

$\therefore \quad 27$.

Douze rayons aiguillonnes et ouze dos; le sixieme rayon articue de a dersale, beaucuup plus long
que les autres; la base de ia partie pastérieuro de la doreale. garnie decailles ; quatre deats plus grandes que les autres a ia
máchoire superieure; la partie autérieure de lanimal, rouge, $\mathrm{et}$
h posterieure janue.

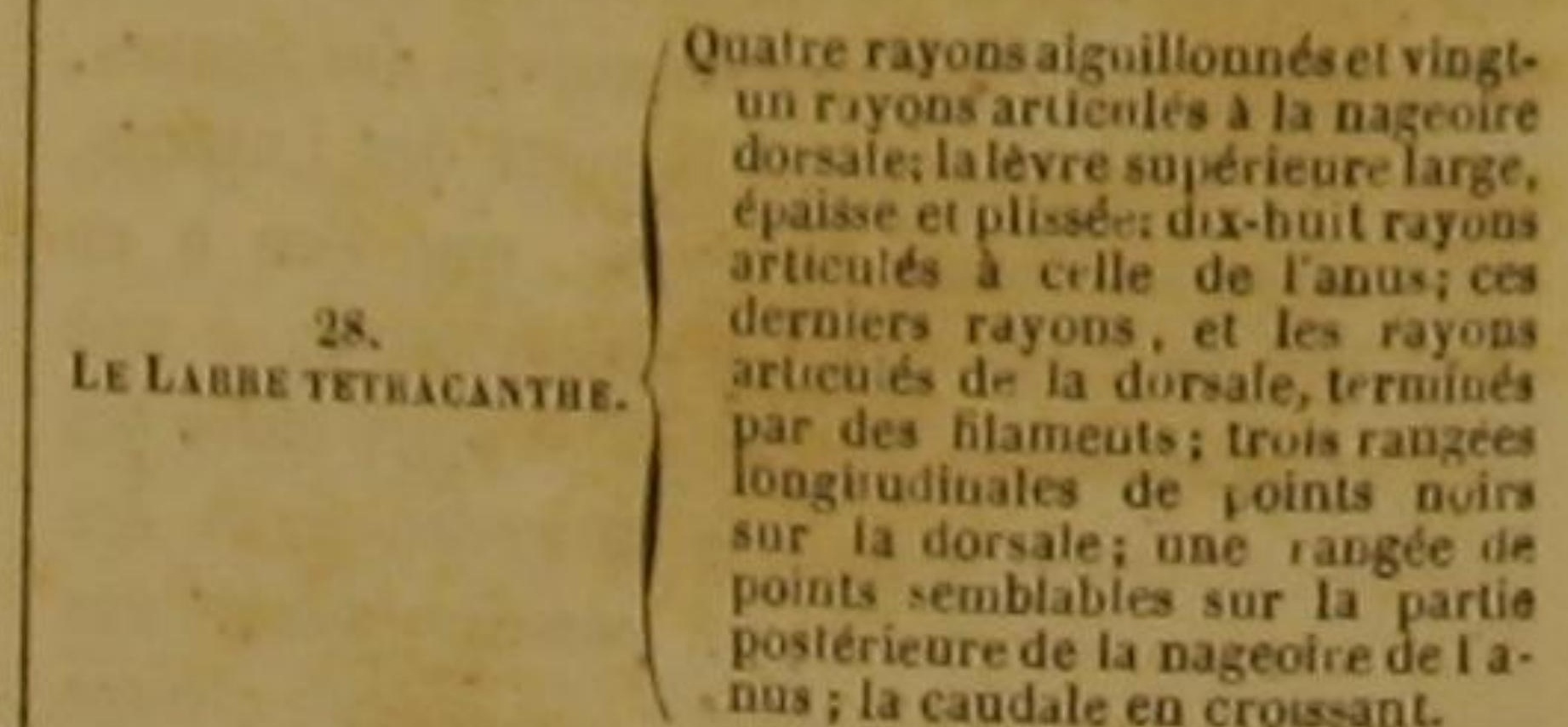

LE LABBE DEMII-DISOLE

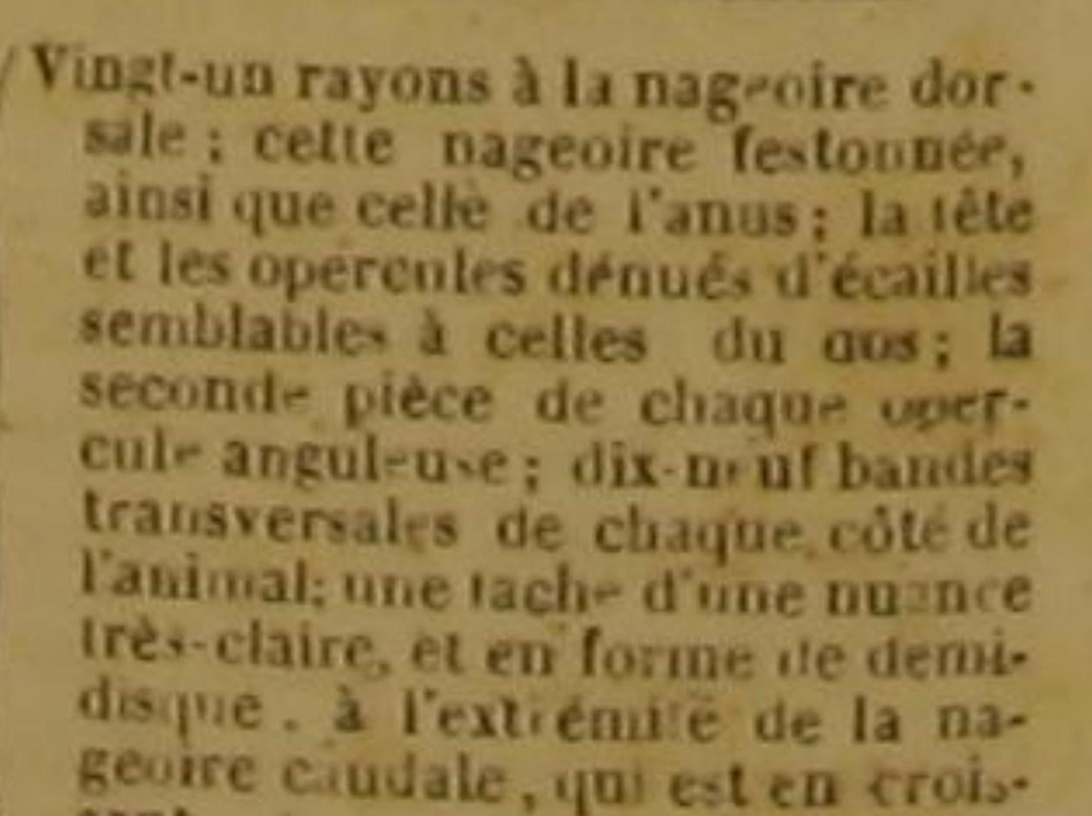

kSPECES. CAMACTÈRES.

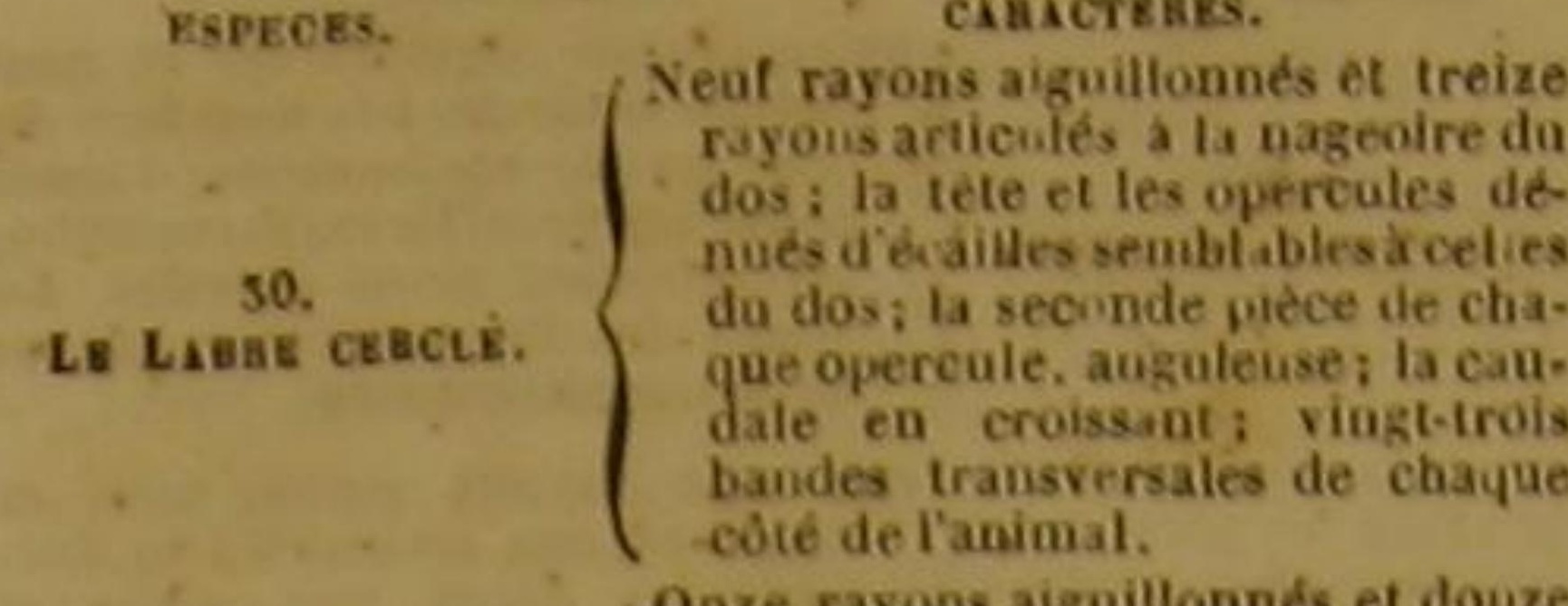

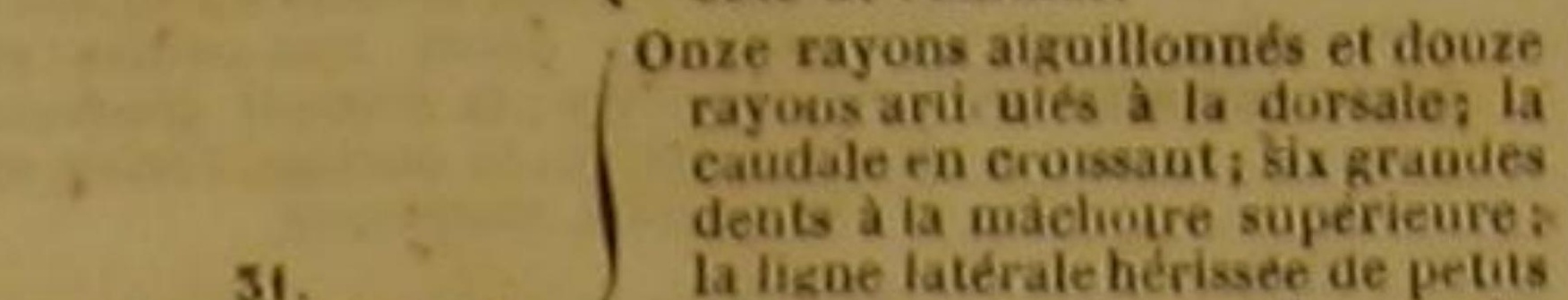

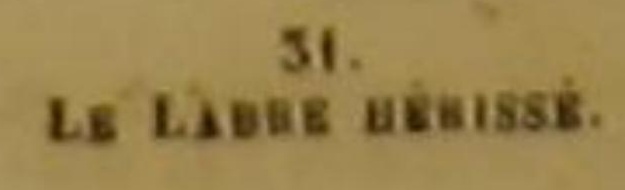
la lizae latérale bérissee de petuls
piyuants i douze raes longitudi-

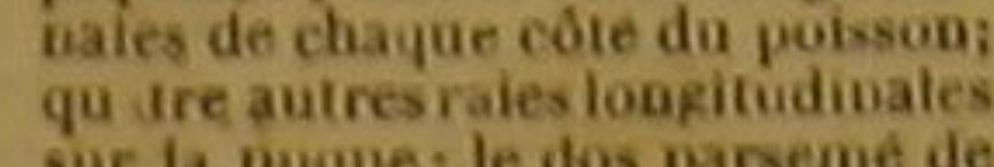

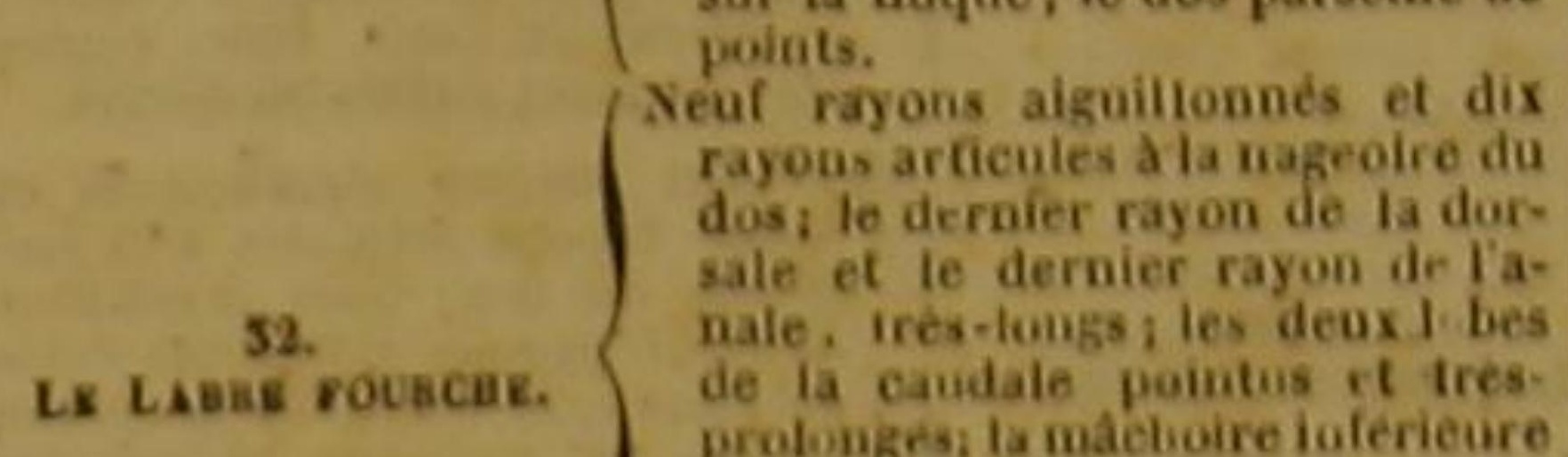

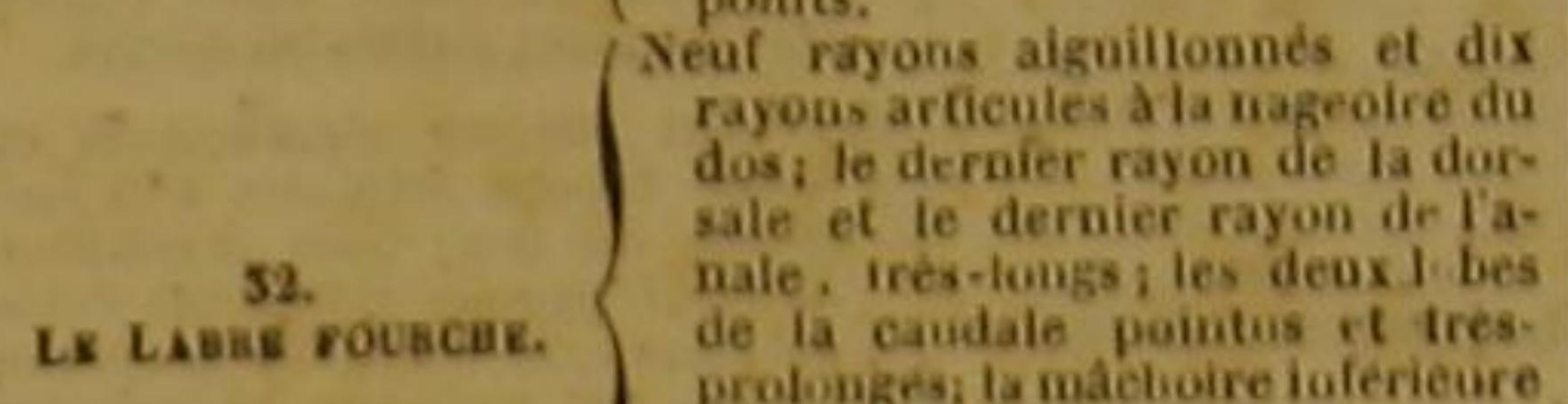

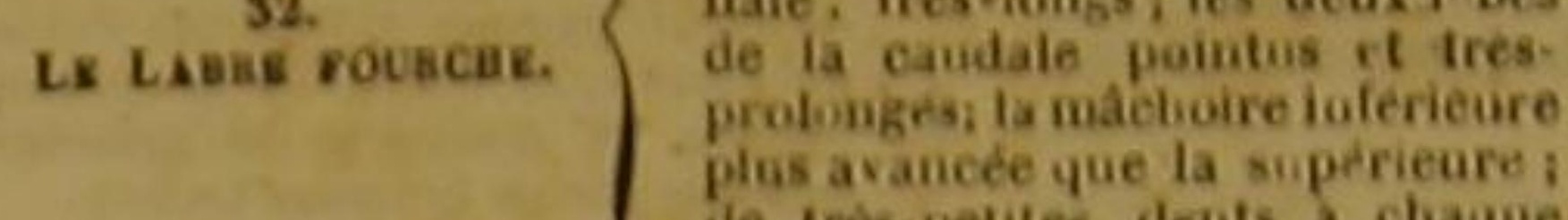

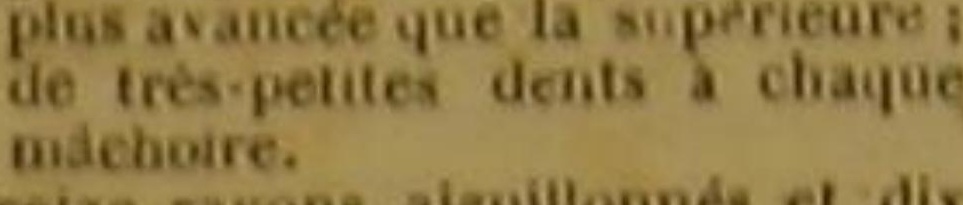

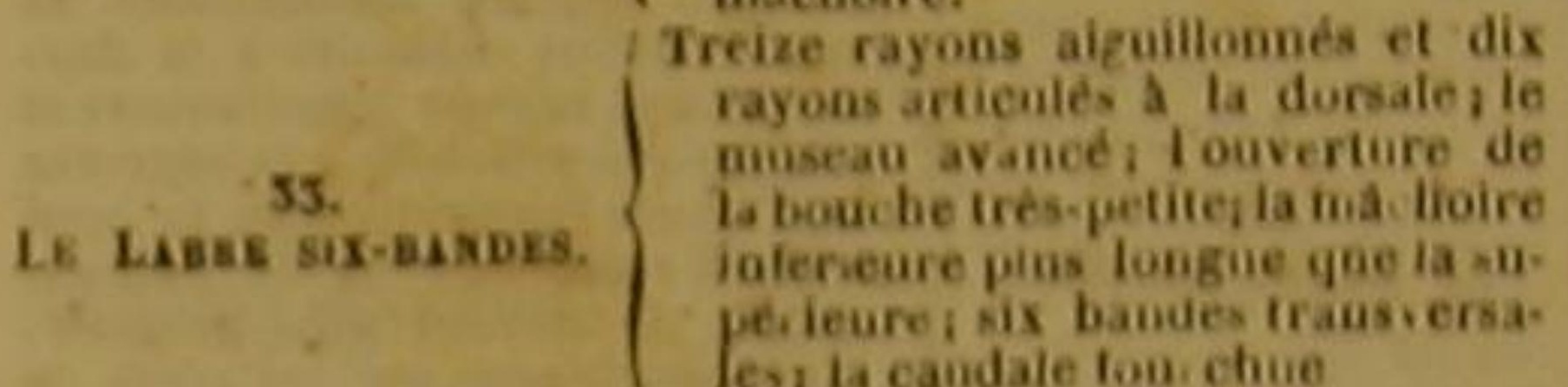

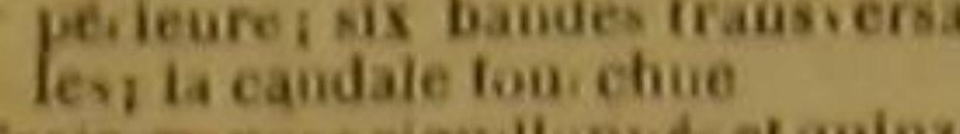

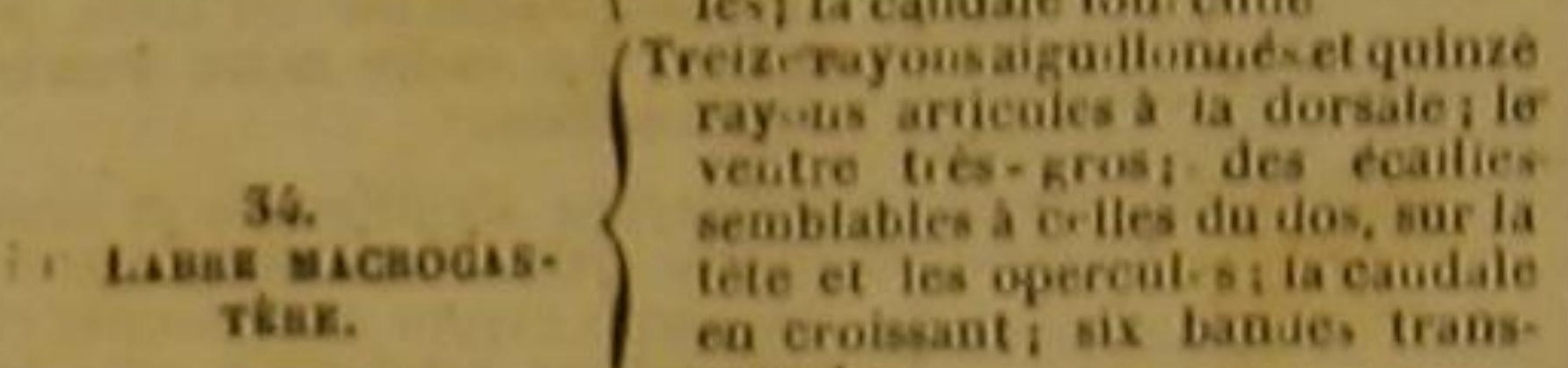

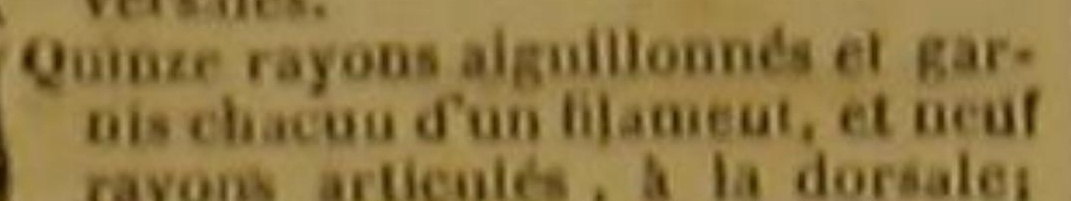

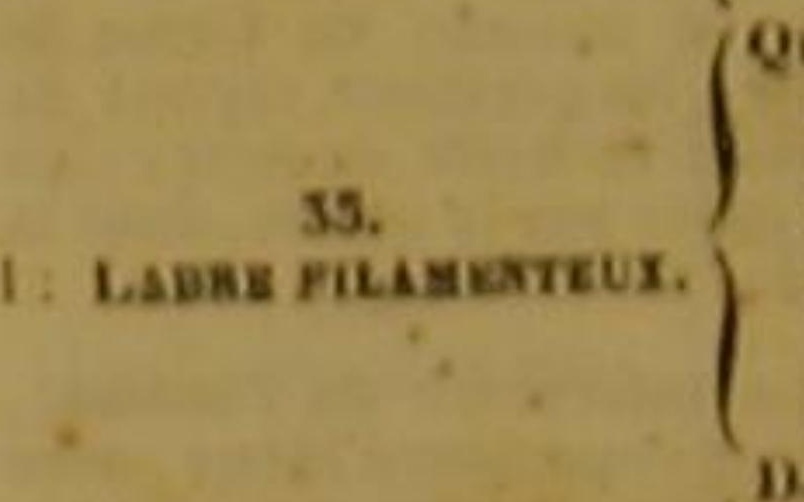

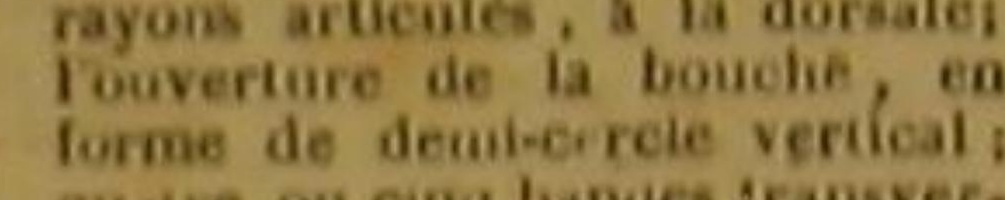

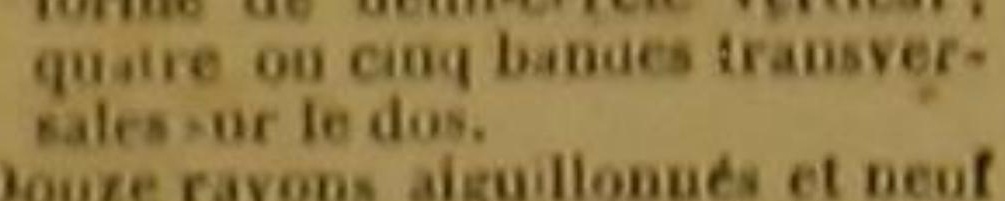

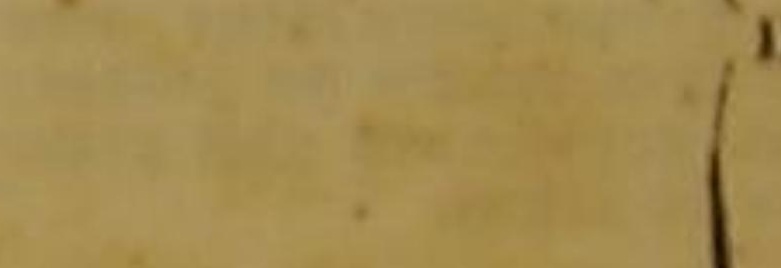
syous articules a la donales les
ayous articules de cette doraie beancoup plus lougs que les al.
guillounes de cerle méme na:

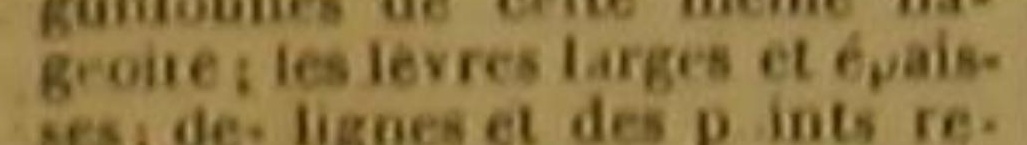

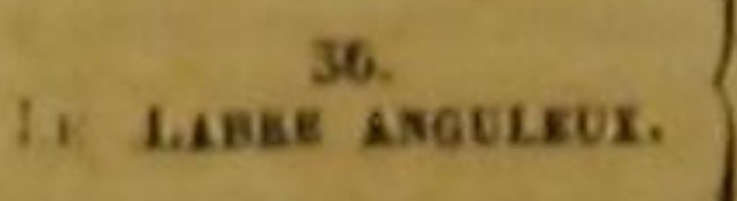

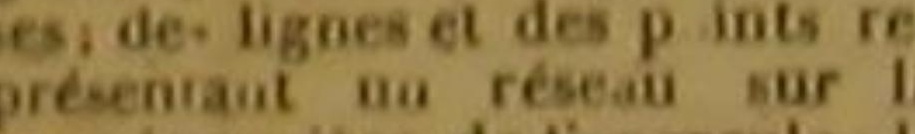

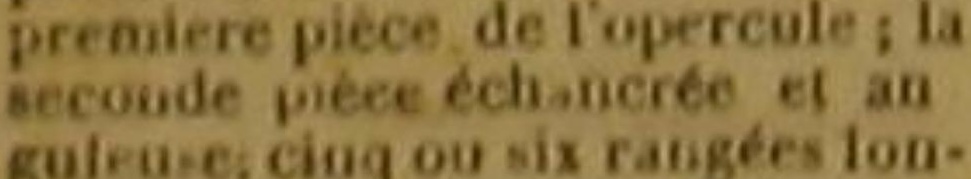
gulfare; cing ou six ratiges lon.
gitudinates de perits points de Chaque cote de ranimal.
onze rayons alguillonnés ot douze

\section{Espìces.}

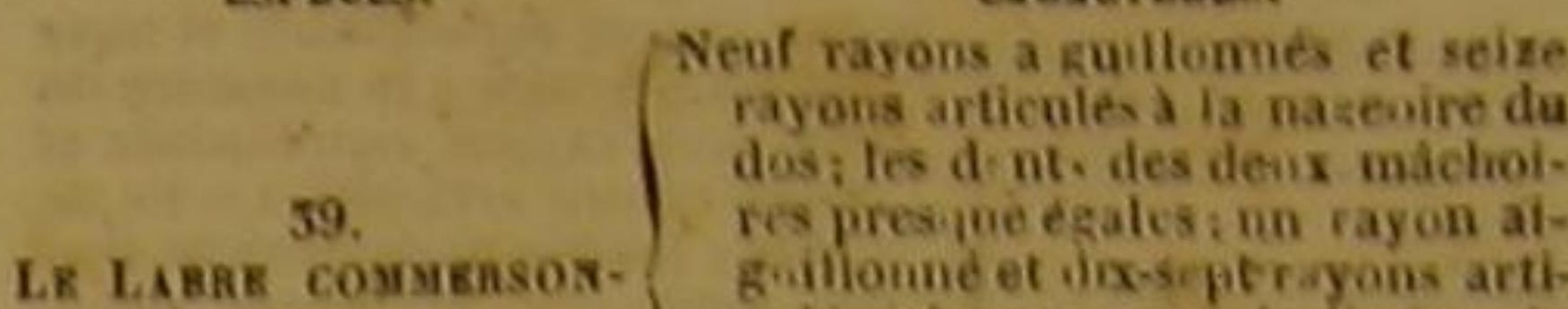
LR LABRE Conmensos-
NIEN.

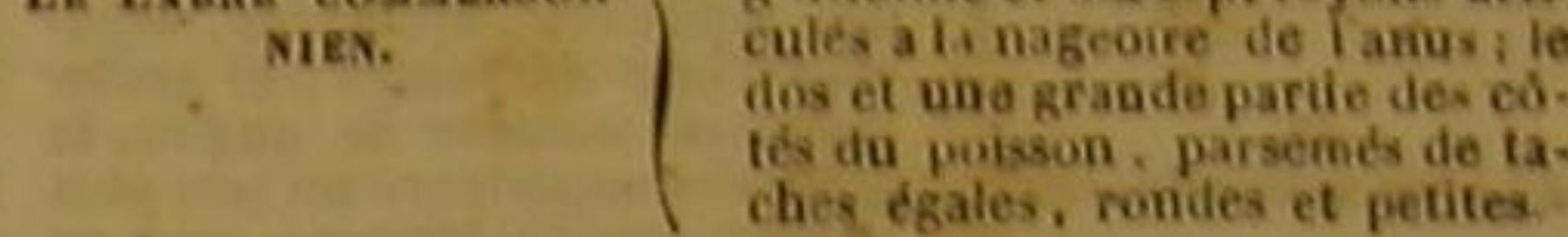

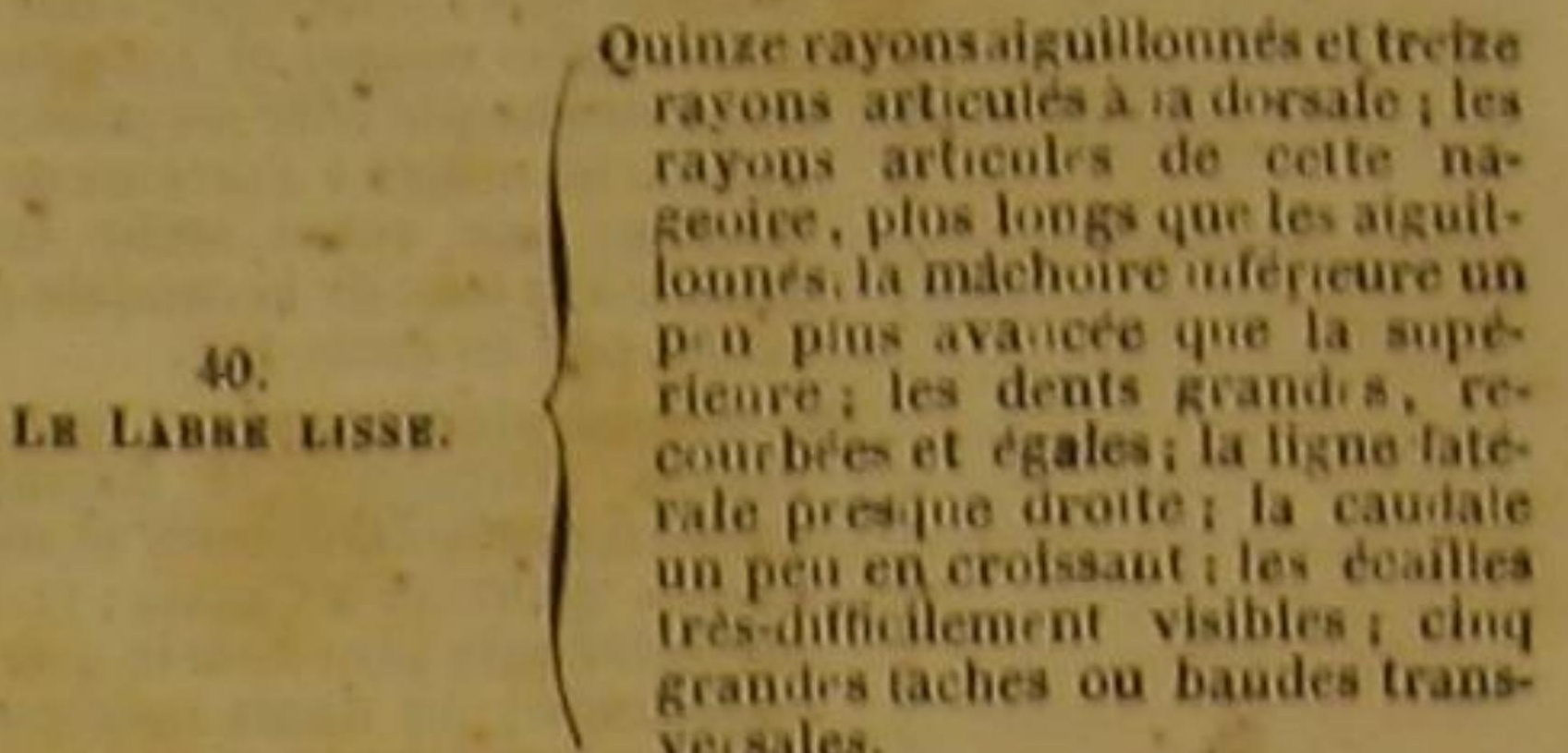

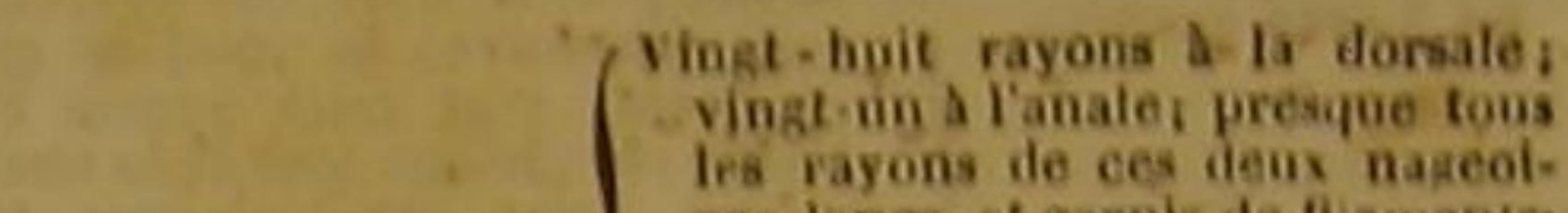
LE LA A1. 41.

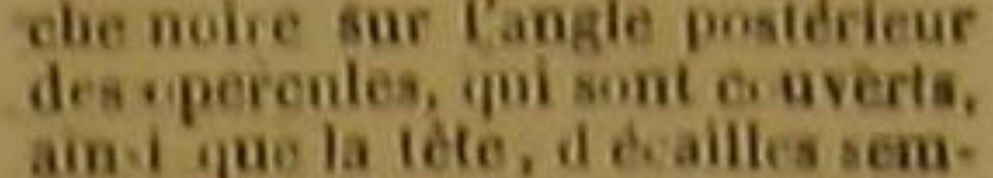
biables a celles du dos.
bits

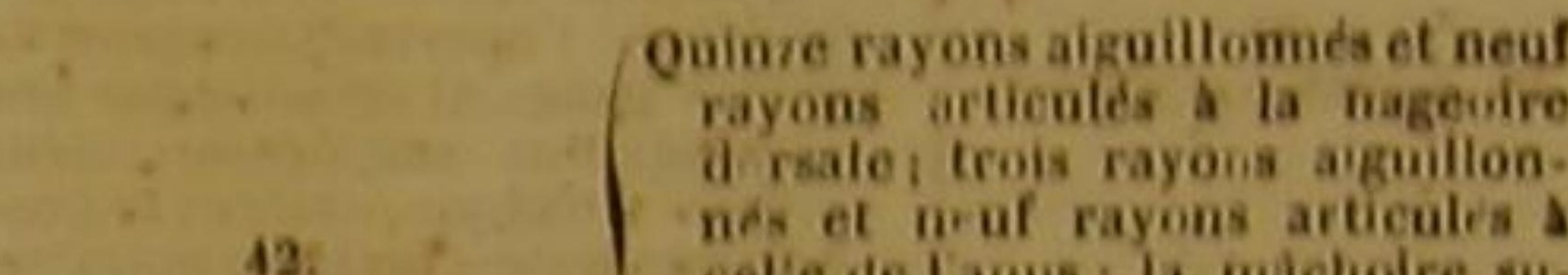

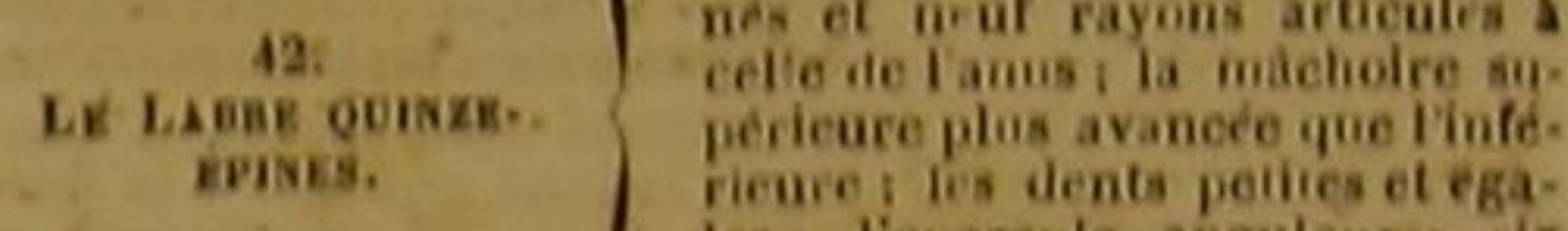

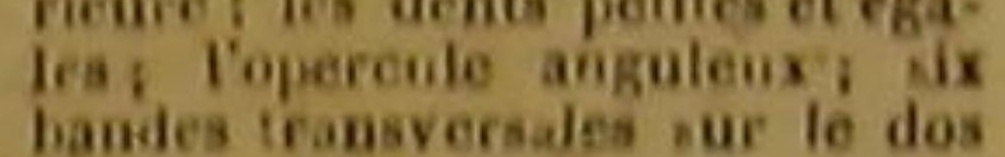
handes transversales sur lo dos
et la nuquo.

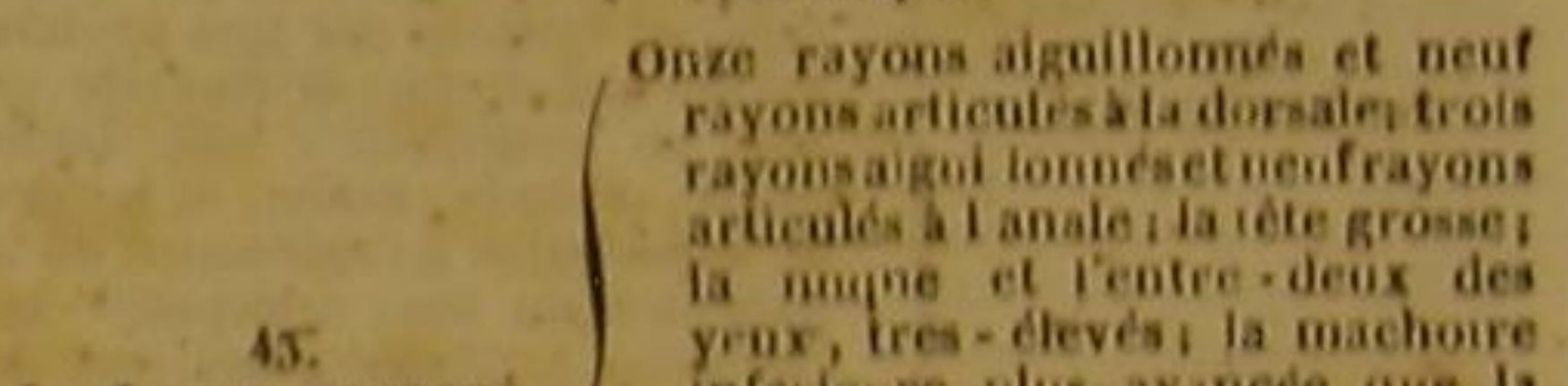

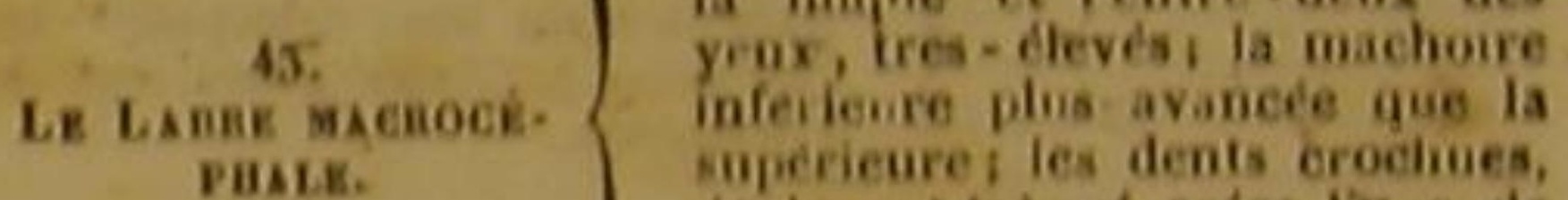

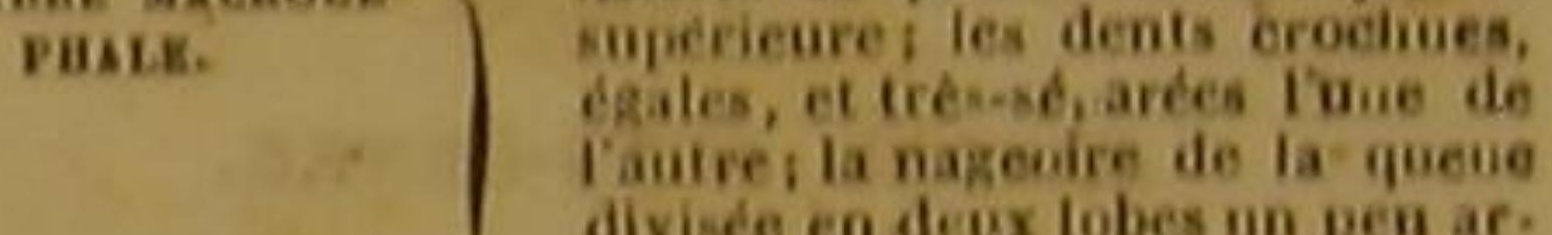

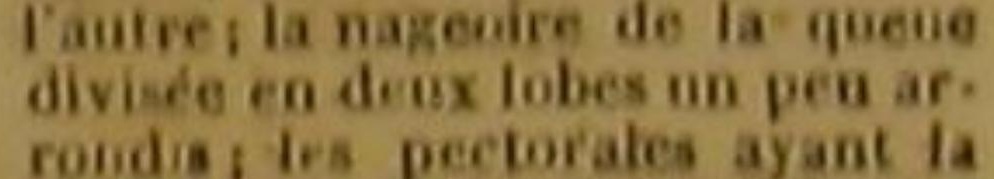

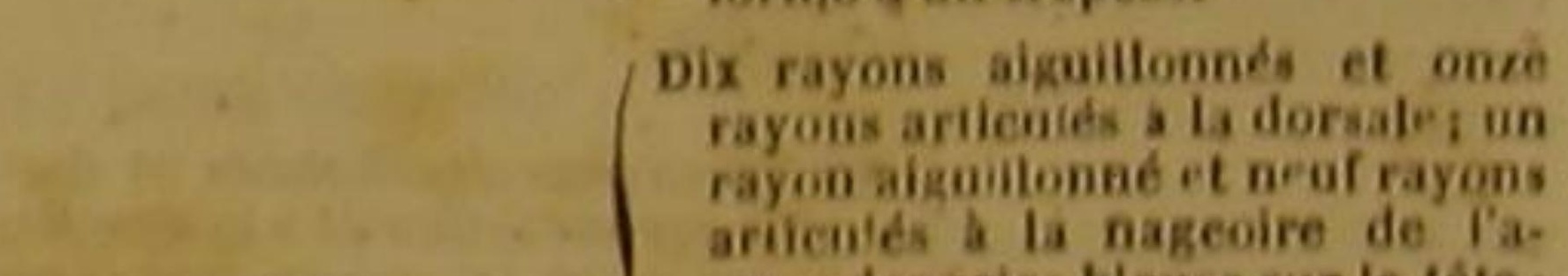

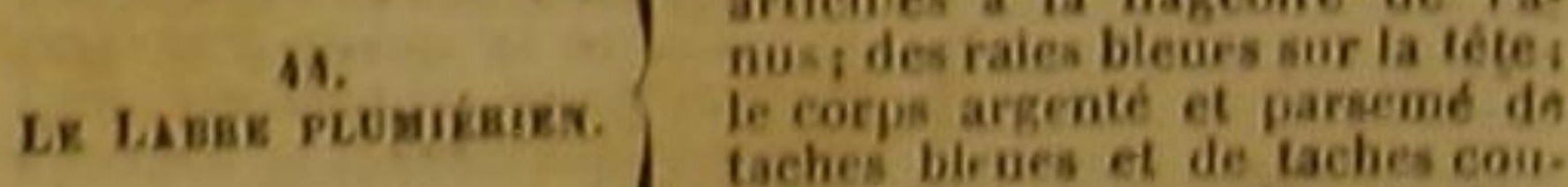

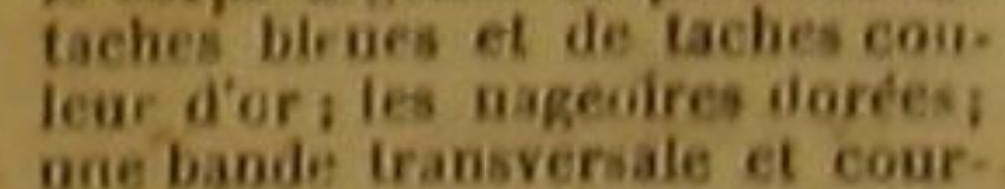

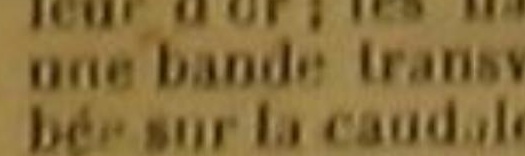

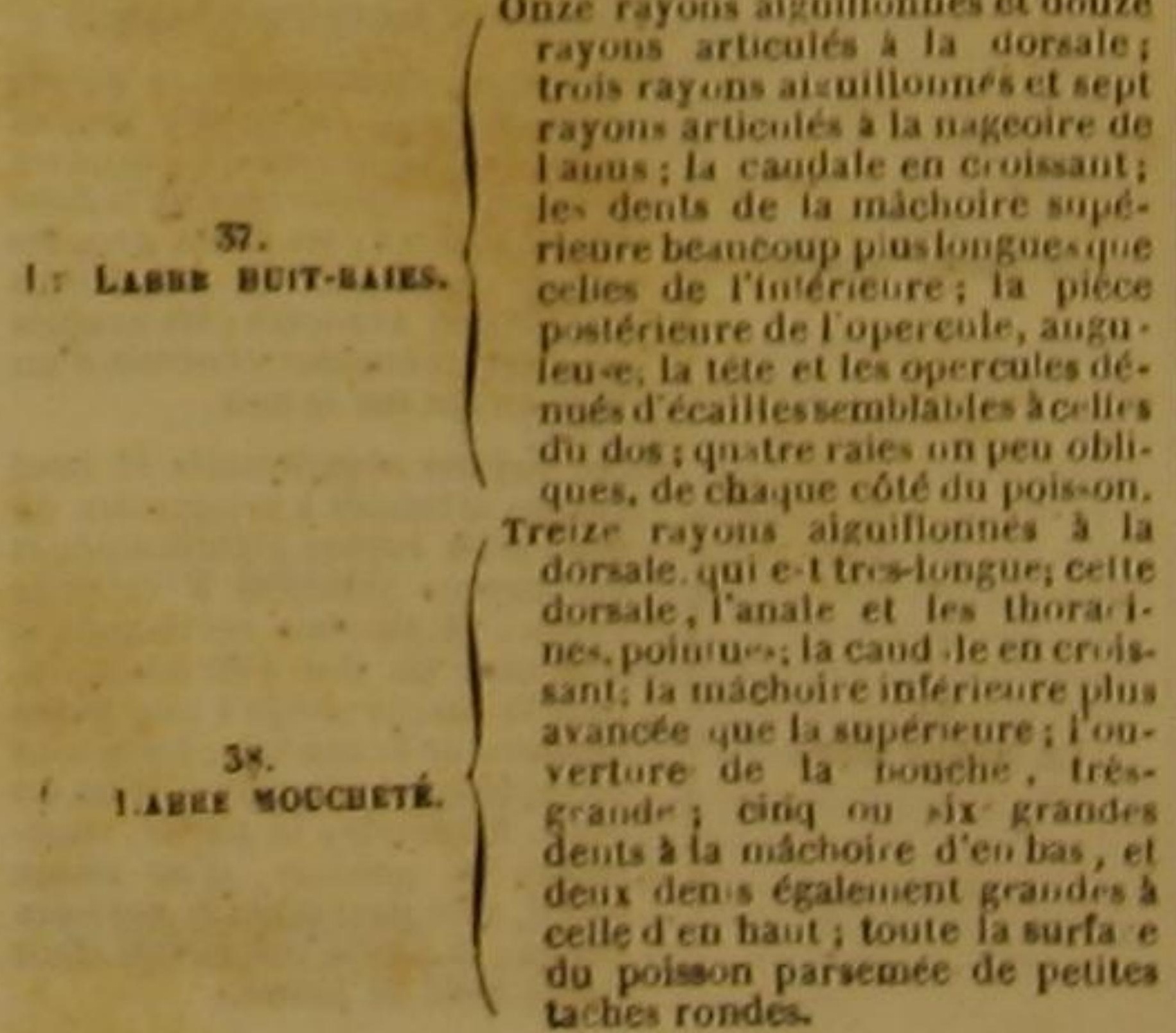
Hoit rayons arguilionnes et onze
rayons articules a ta dorsile : Iros rayonsaiguillonnes et treizo
rayons articules a la nageore de

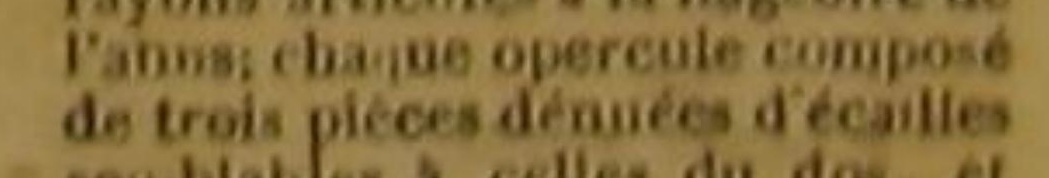
de trois pices celles du dos, et termine par me prolongation
larke et arrondie . Fi lisne bite. pointu entre les thoraciness is

Le Labak góess.

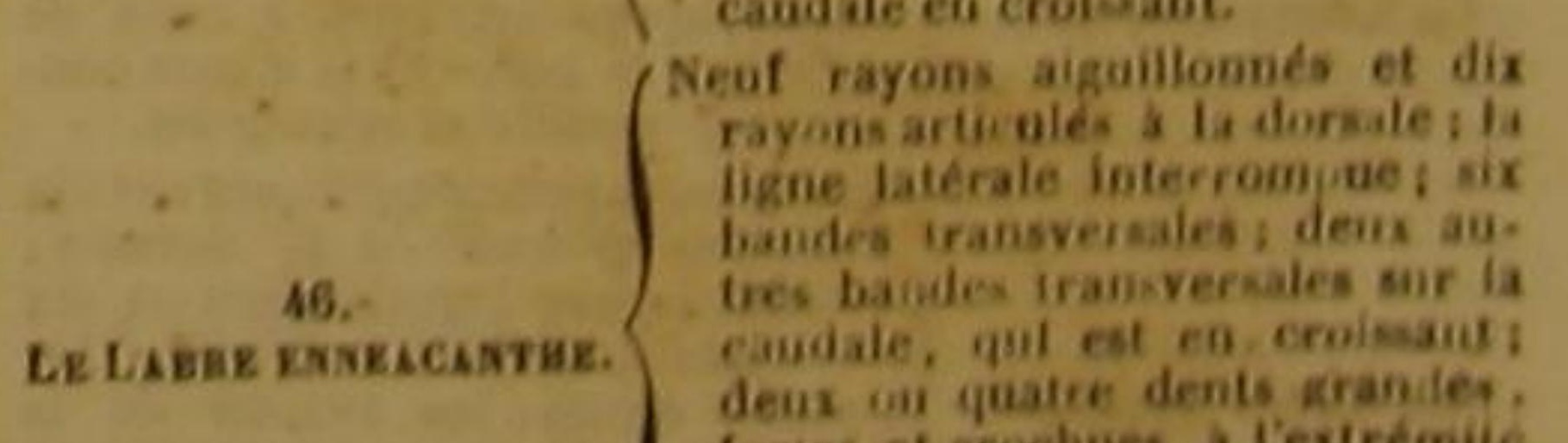



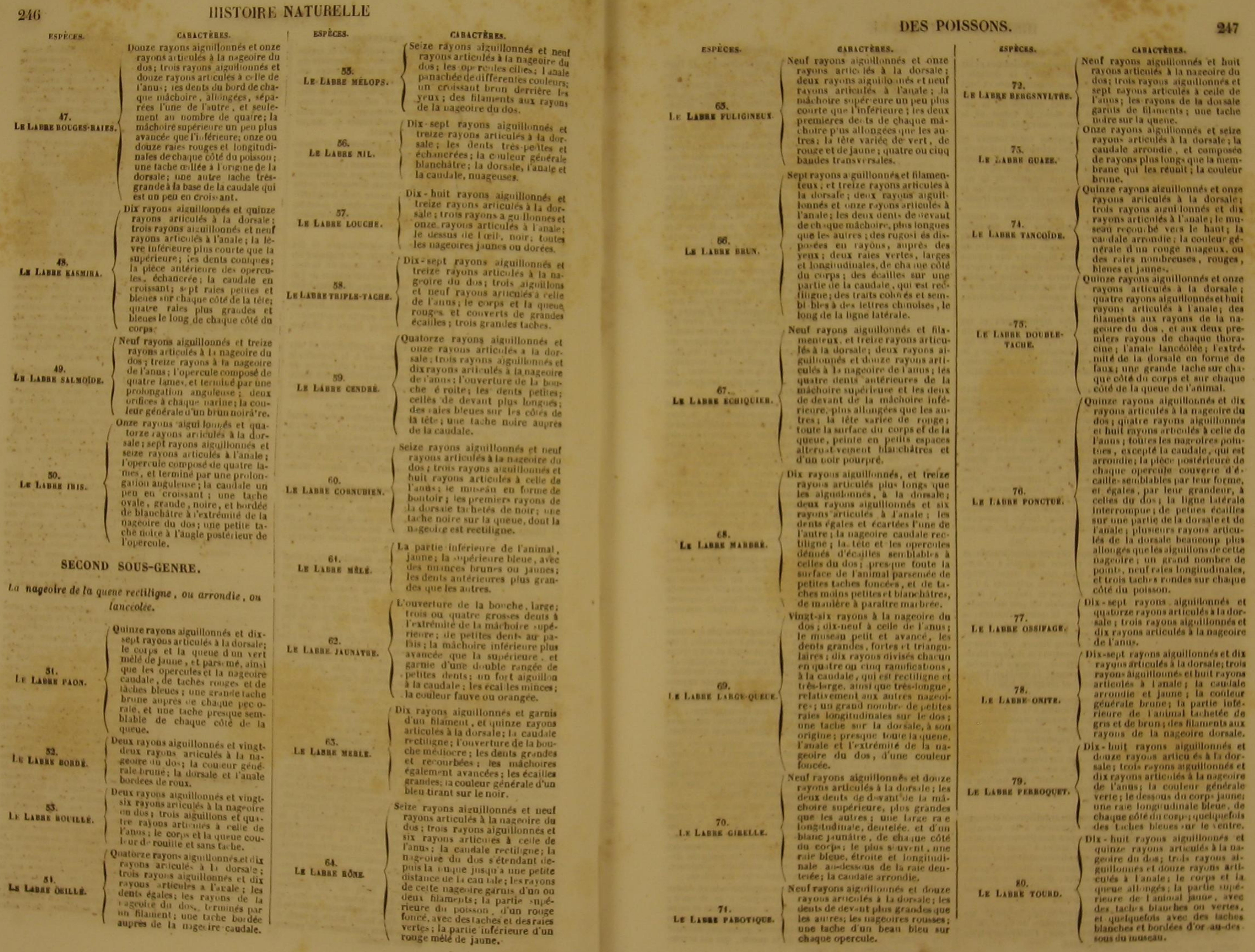
248

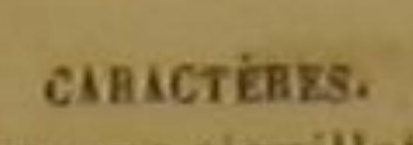
rSPĖCE:

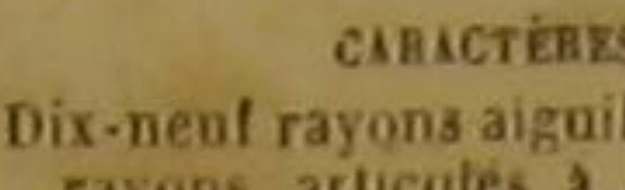

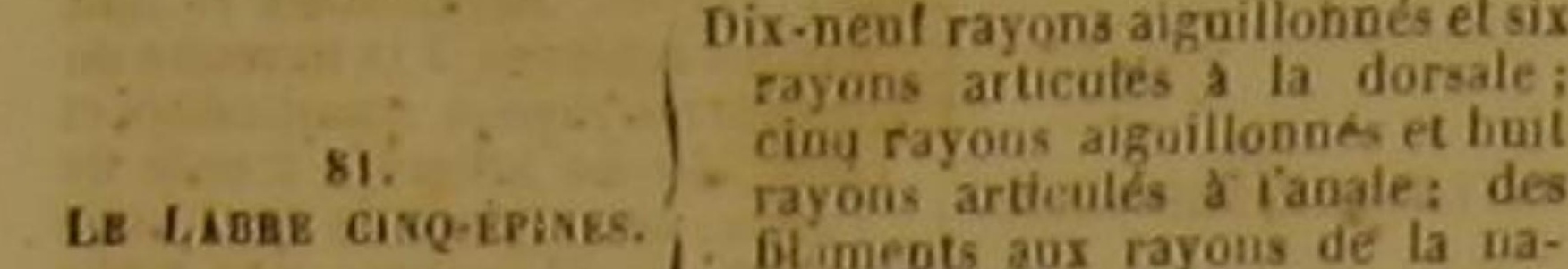
$\left\{\begin{array}{l}\text { fimeots aux rayons de la } \\ \text { genire du dos i le corps et } \\ \text { queue bleus, ou rayes de bleu. }\end{array}\right.$

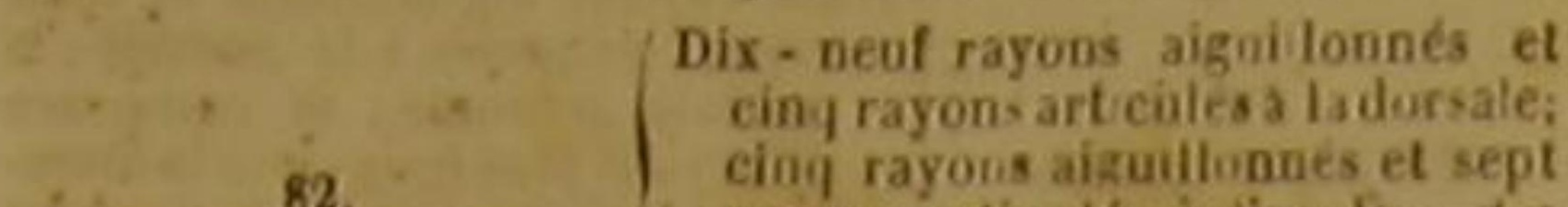

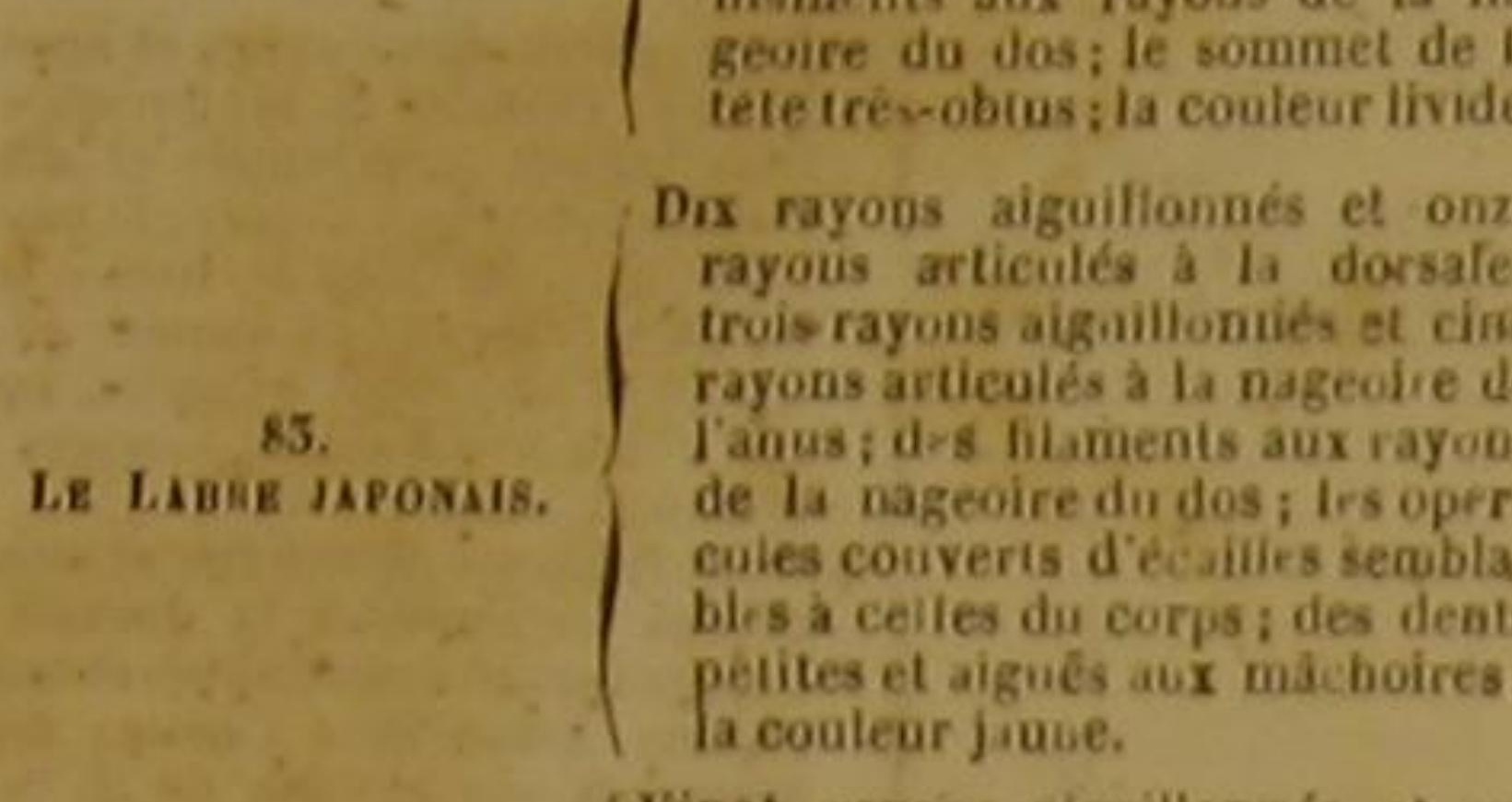

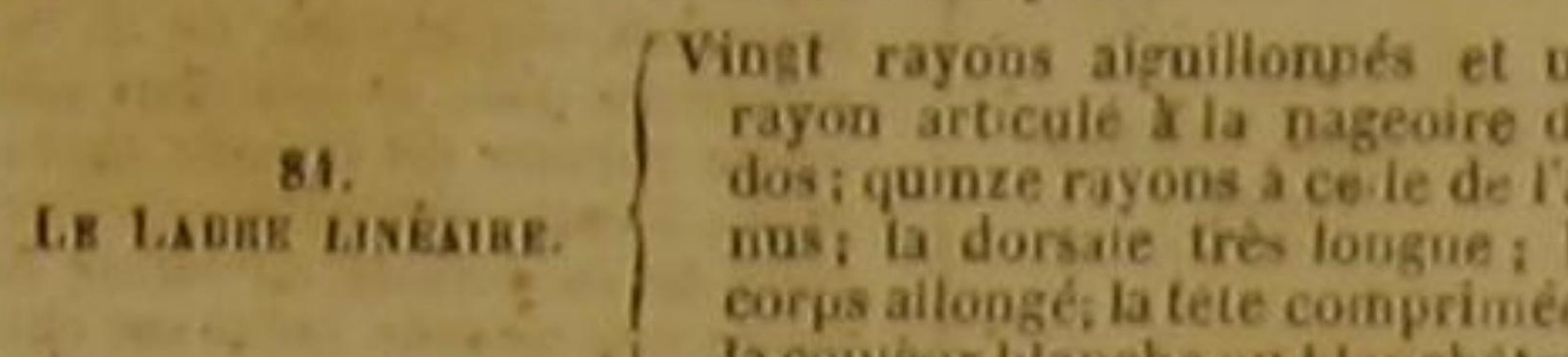

corps aillongés la tete comprimièe;
la couleur bianche ou blanchatre.

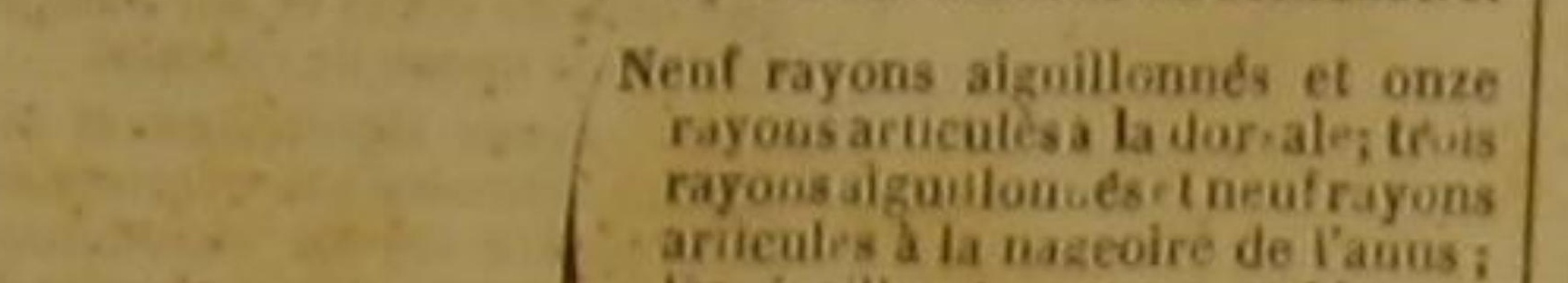

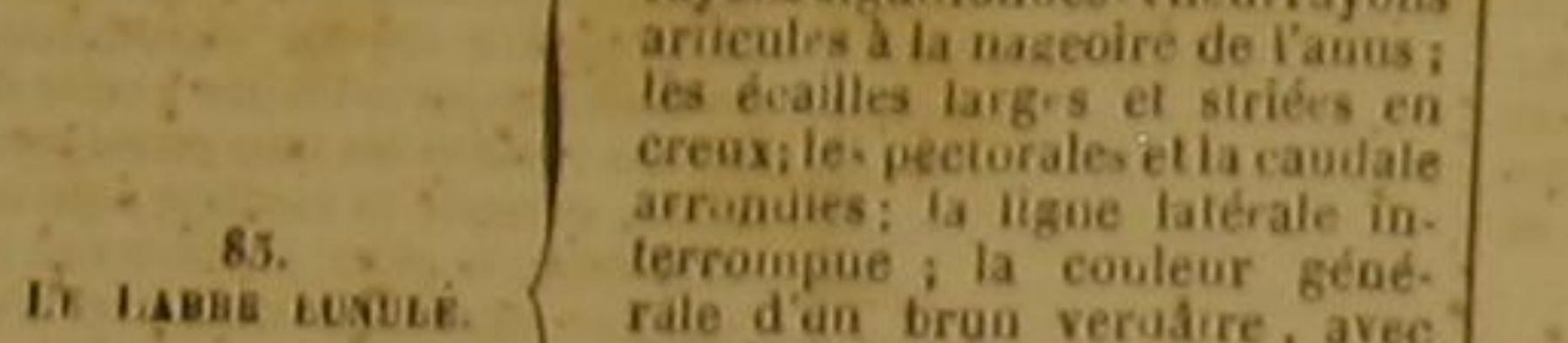

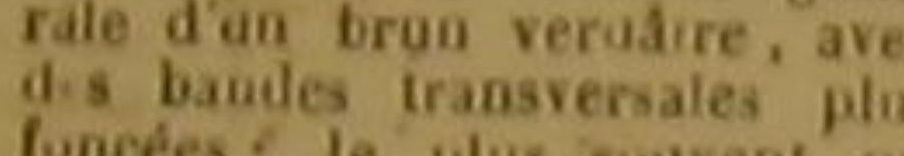

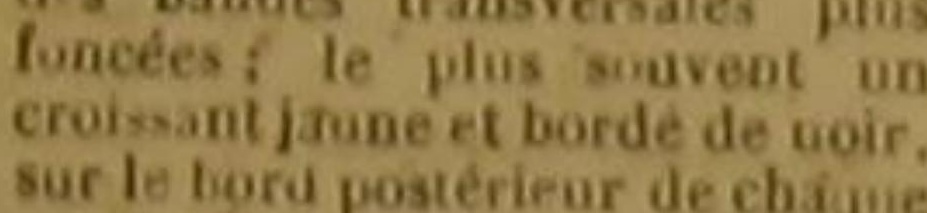
opercole; deux tache, juanessur
la menubrane brancbiale, yoi est
iete.

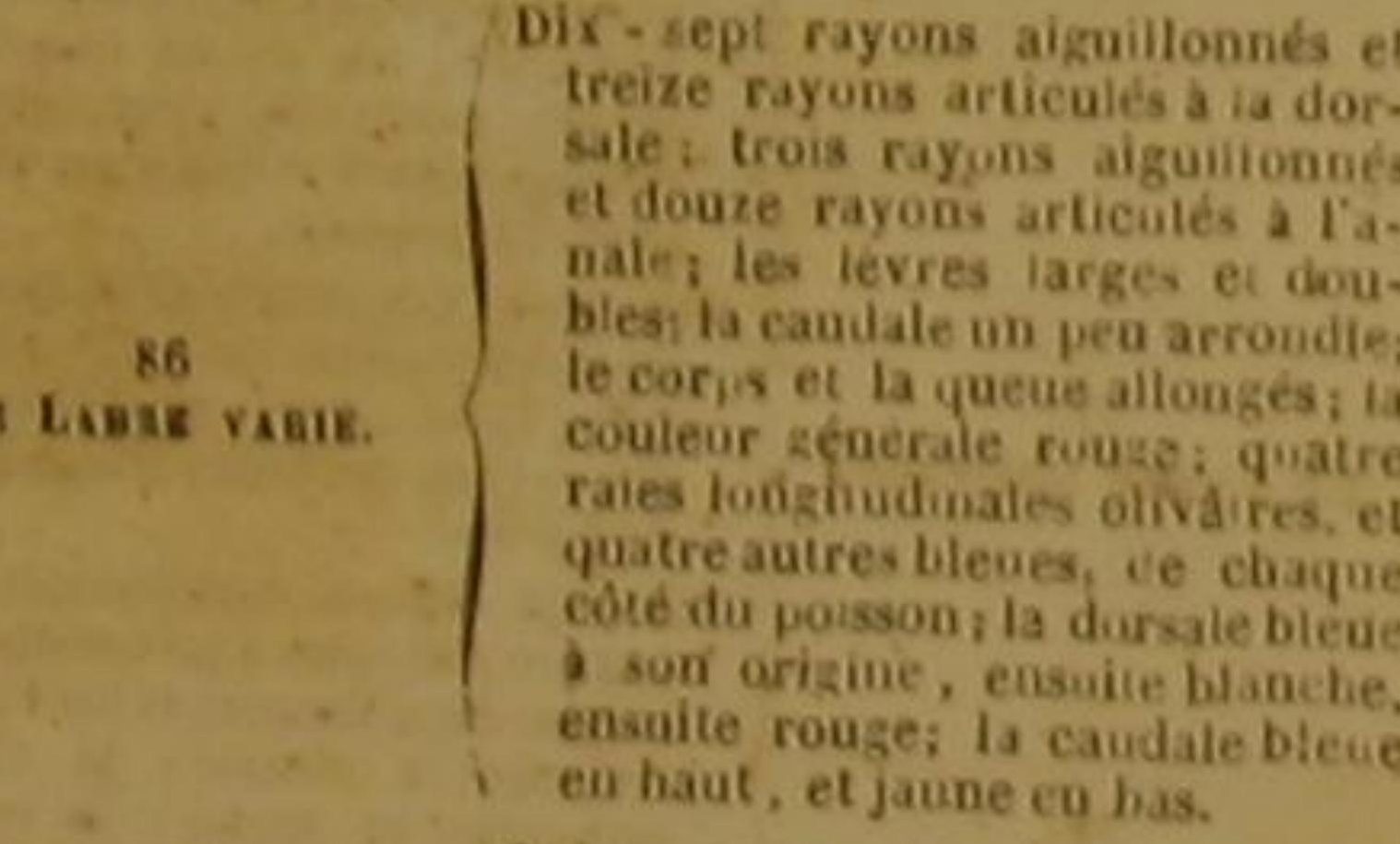

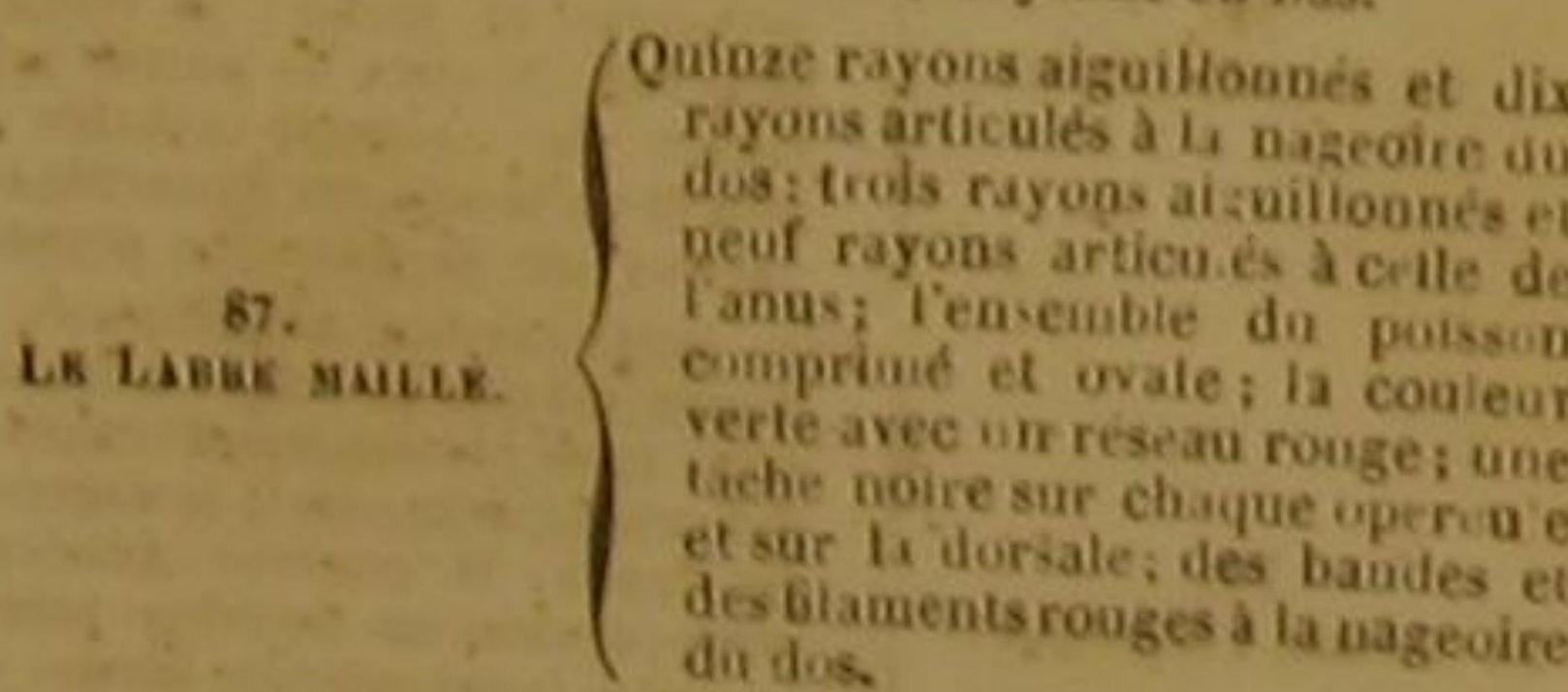

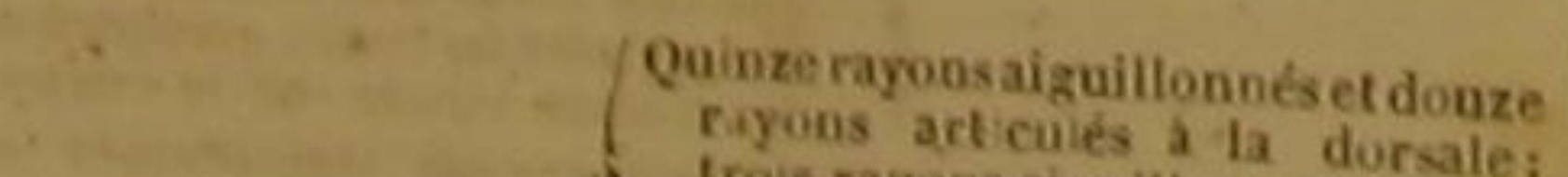

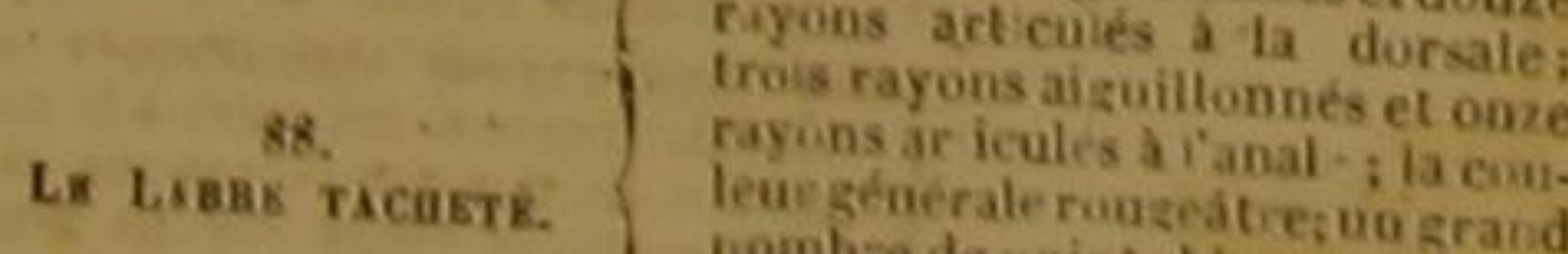

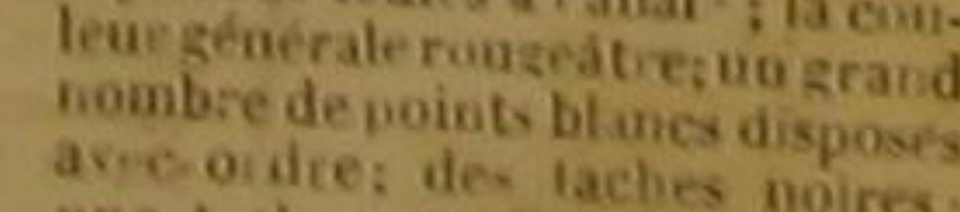
me tich-an ailieu de la base
ir la candate.

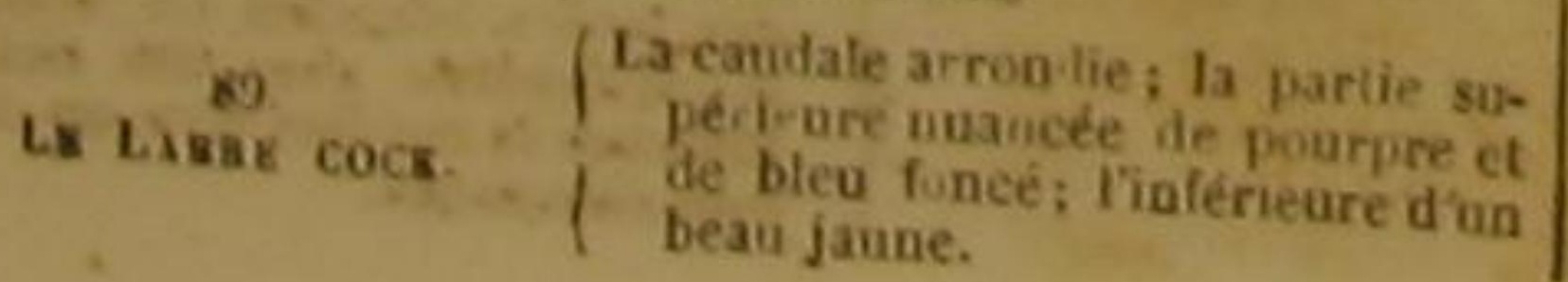

$$
\text { Le LARE CINEDE. }
$$

ARACTÈazs.

Des rayons aiguilionnés à la do
sale, yui séiend depuis la nity jusqua la caudale; la gueule pe
tite; les dents créurlées, ou

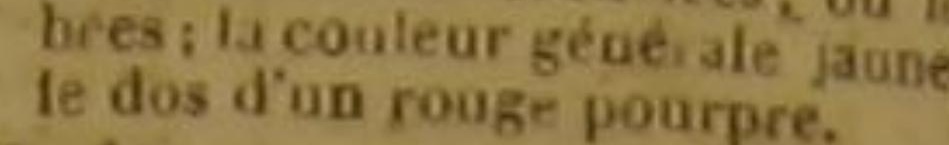
Neaf rayons aiguilloniés et one

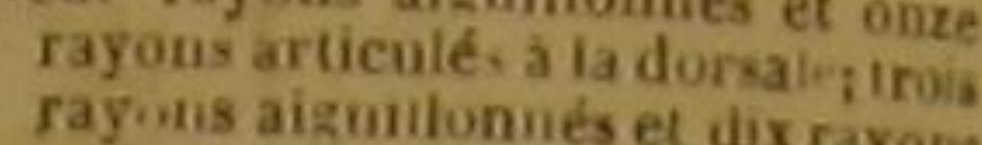

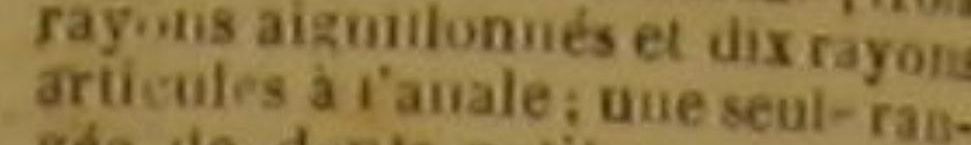

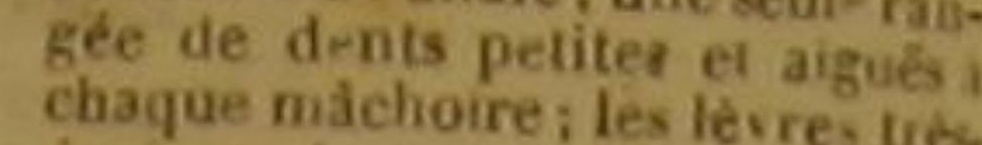
ises; le curys allonot; la co

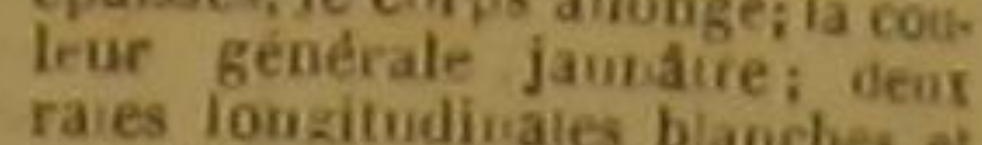
raies longitudinales blanches et
tres-longu-s, et une troisieme
raie.

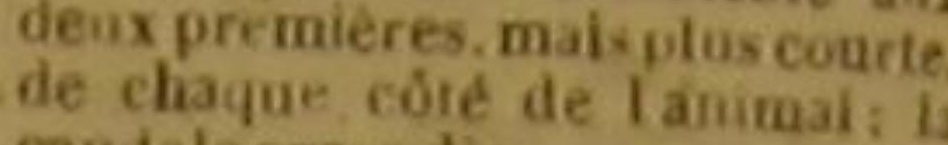

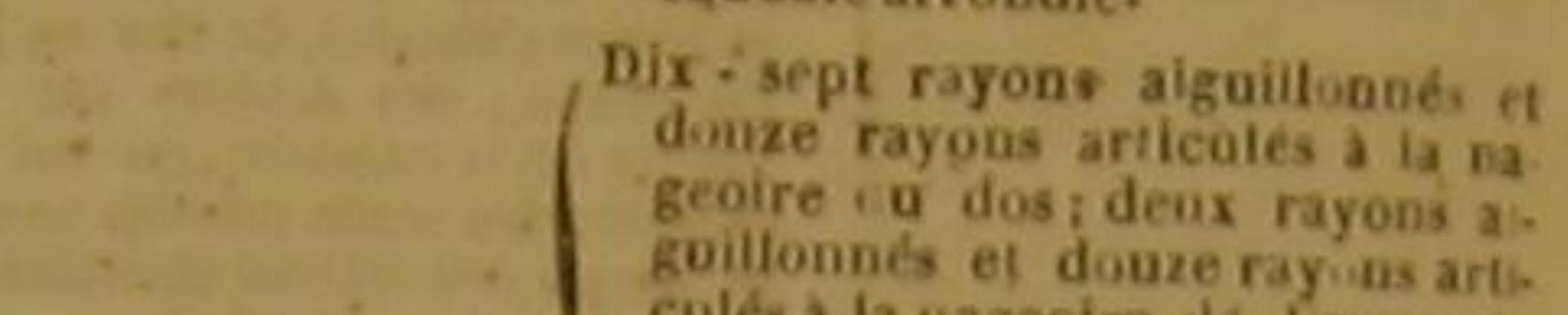

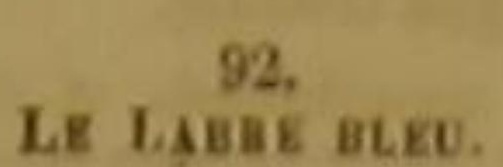
covieur a nazeoire de lanus; ia

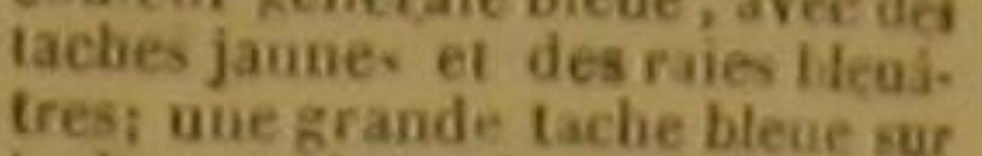

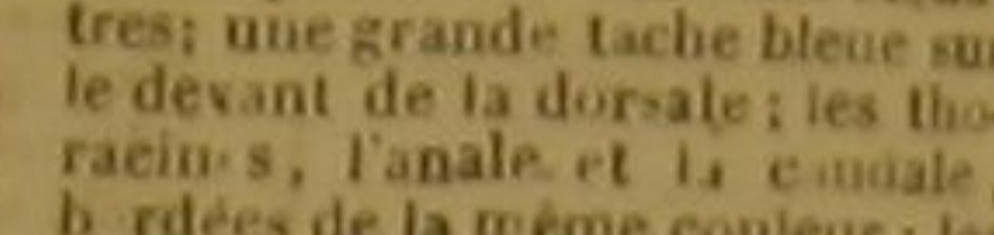

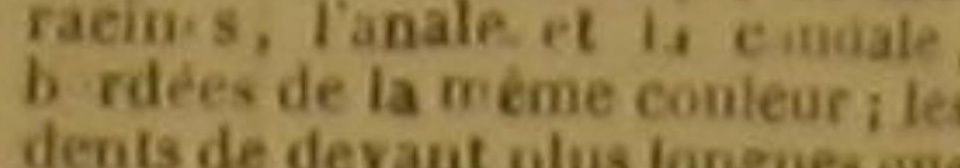

Dix - sept rayons aiguillonnés et
treize rayons articuies a ta dor.

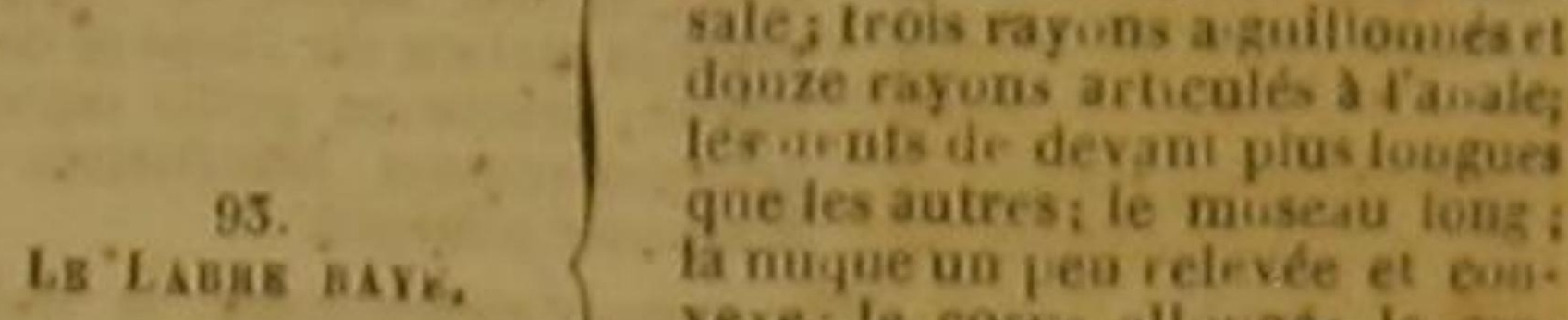

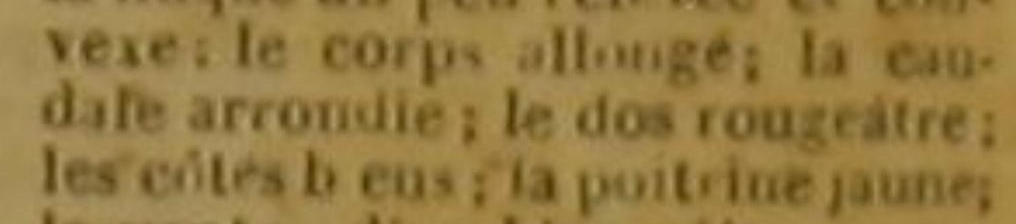

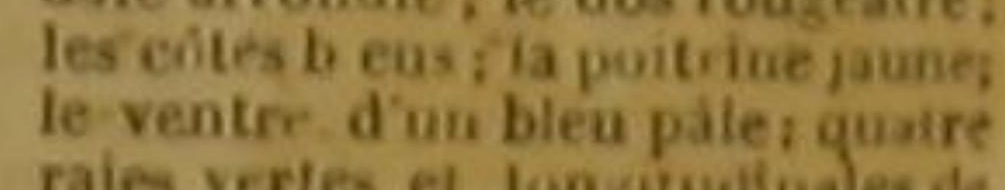
raie vertes et lonstudil.
chayue cóte du poisson.

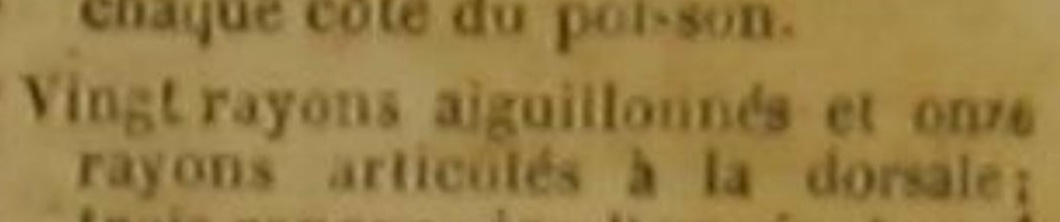

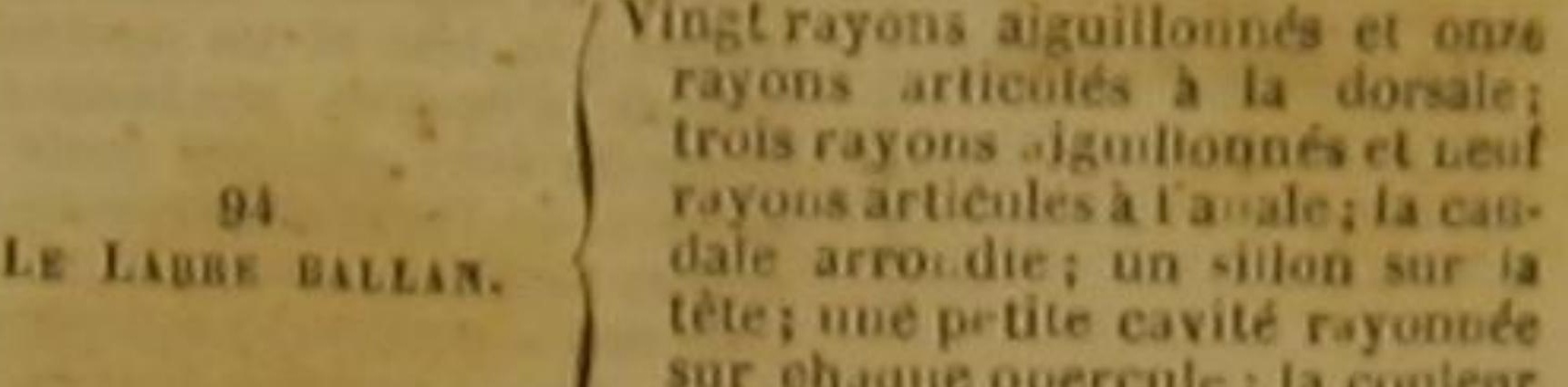

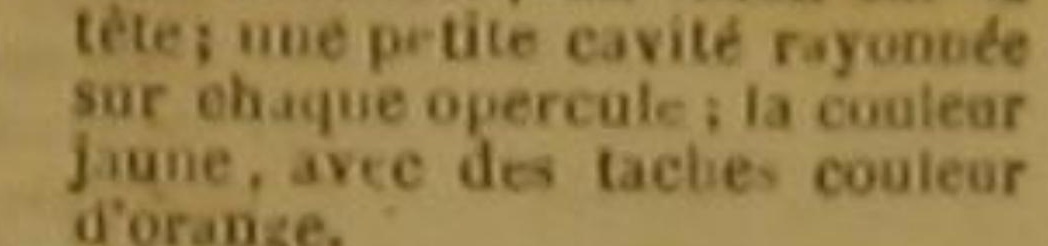

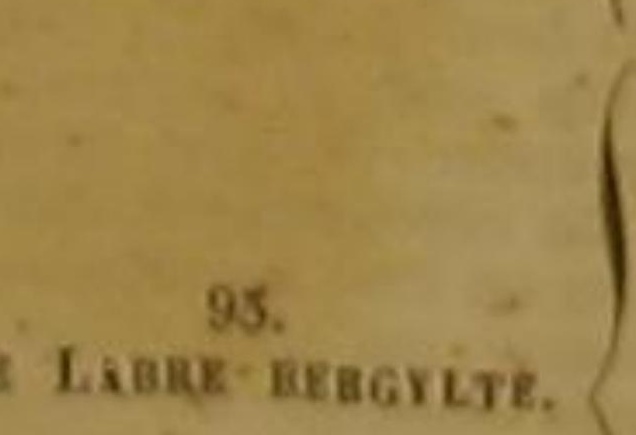

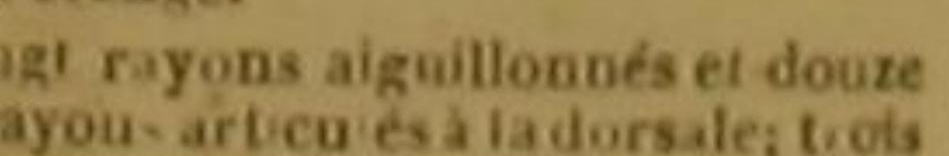
rayous aiguill manés et six riyong
riculés a tavale; la caudale ar.

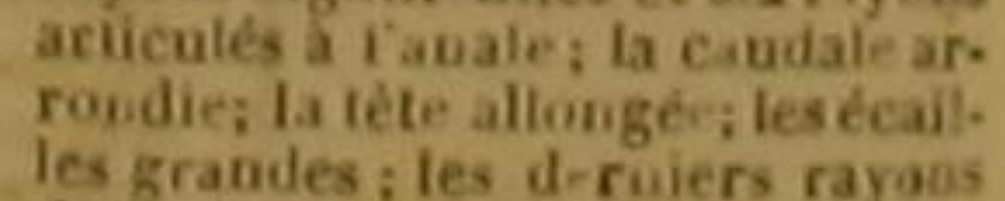
de $1 \mathrm{~d}$ dorsale e e de Tanale, heas.

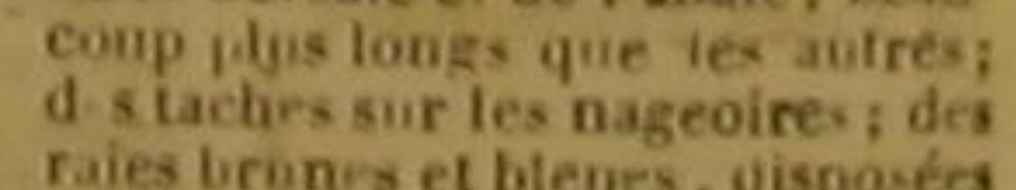
raies brunrs et bleurs. visposés
alternativemeut sur la poitriun.

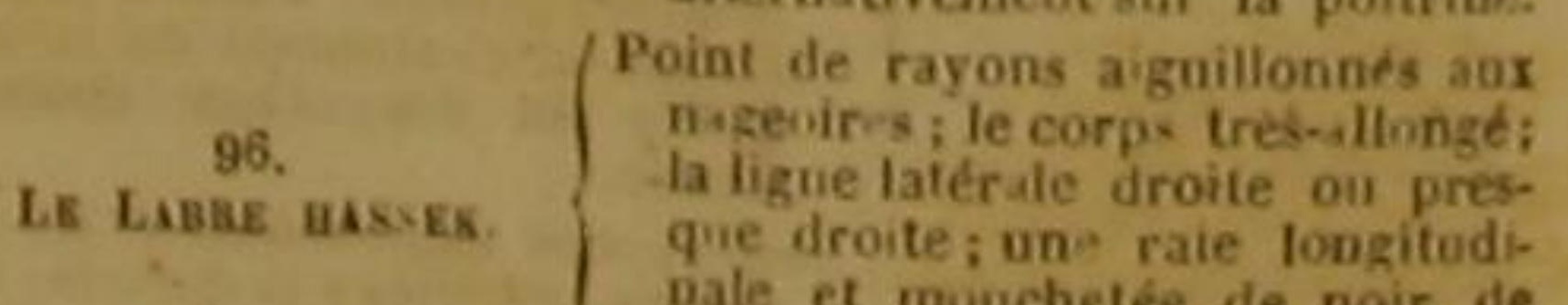

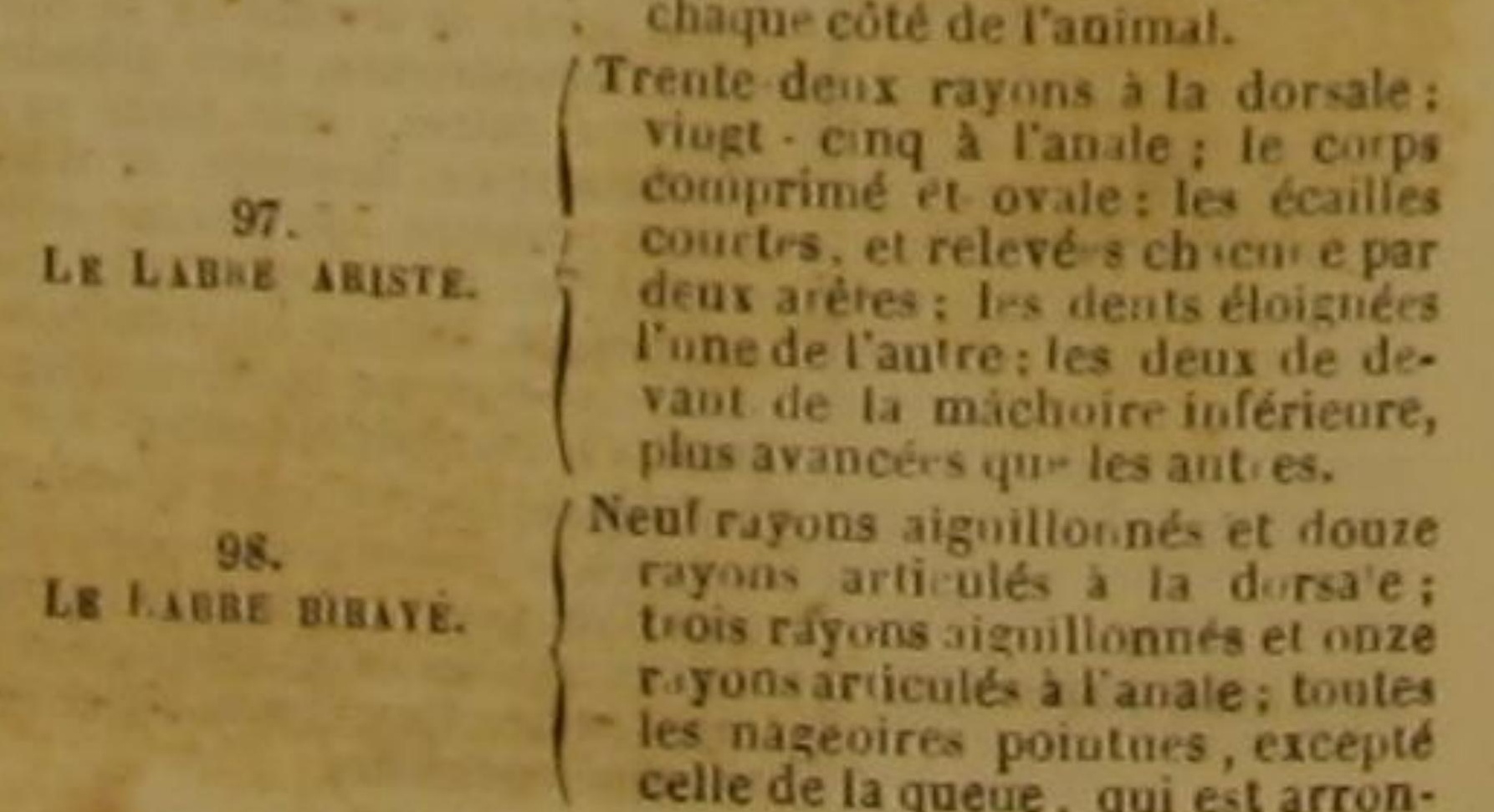

DES POISSONS.

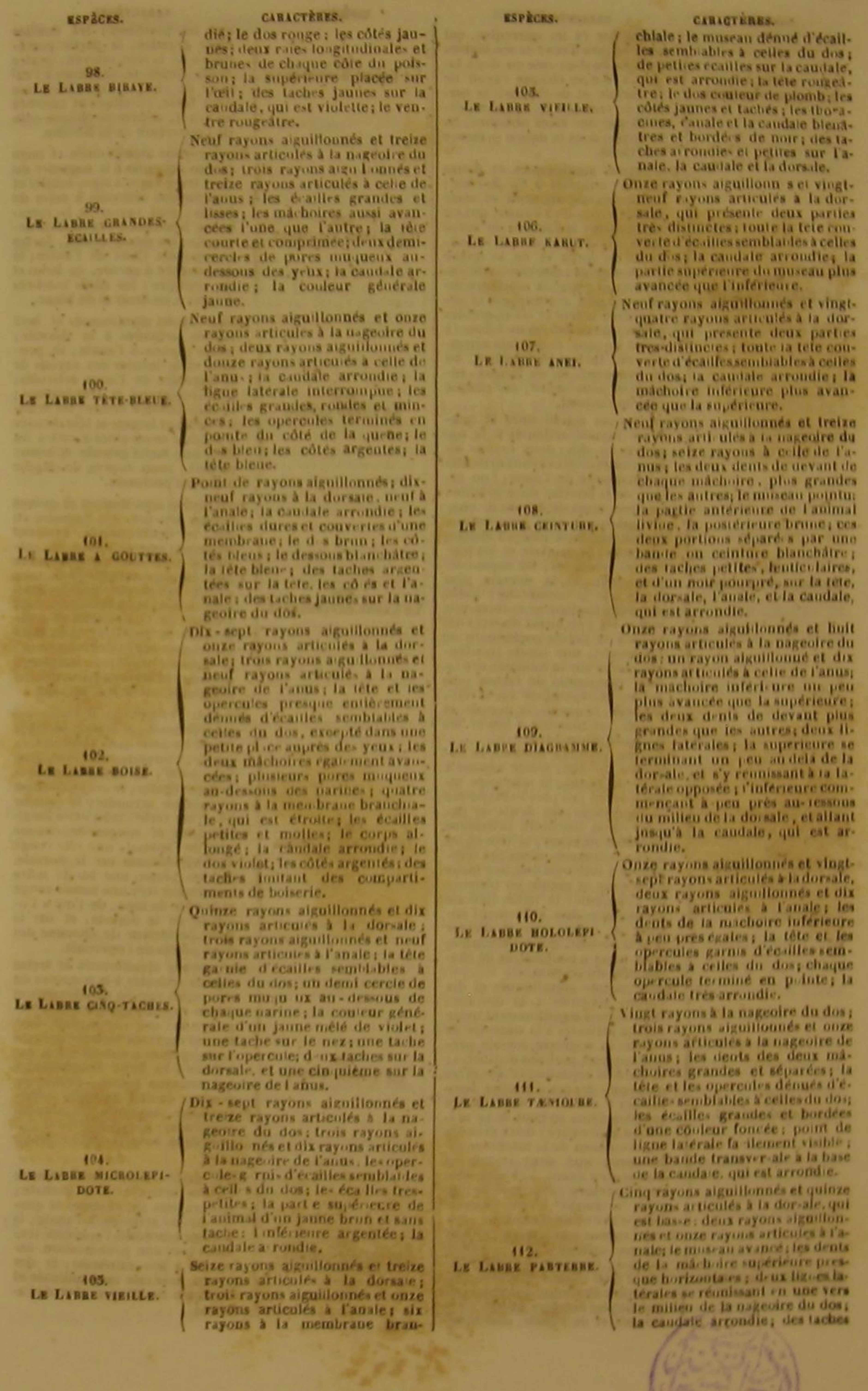




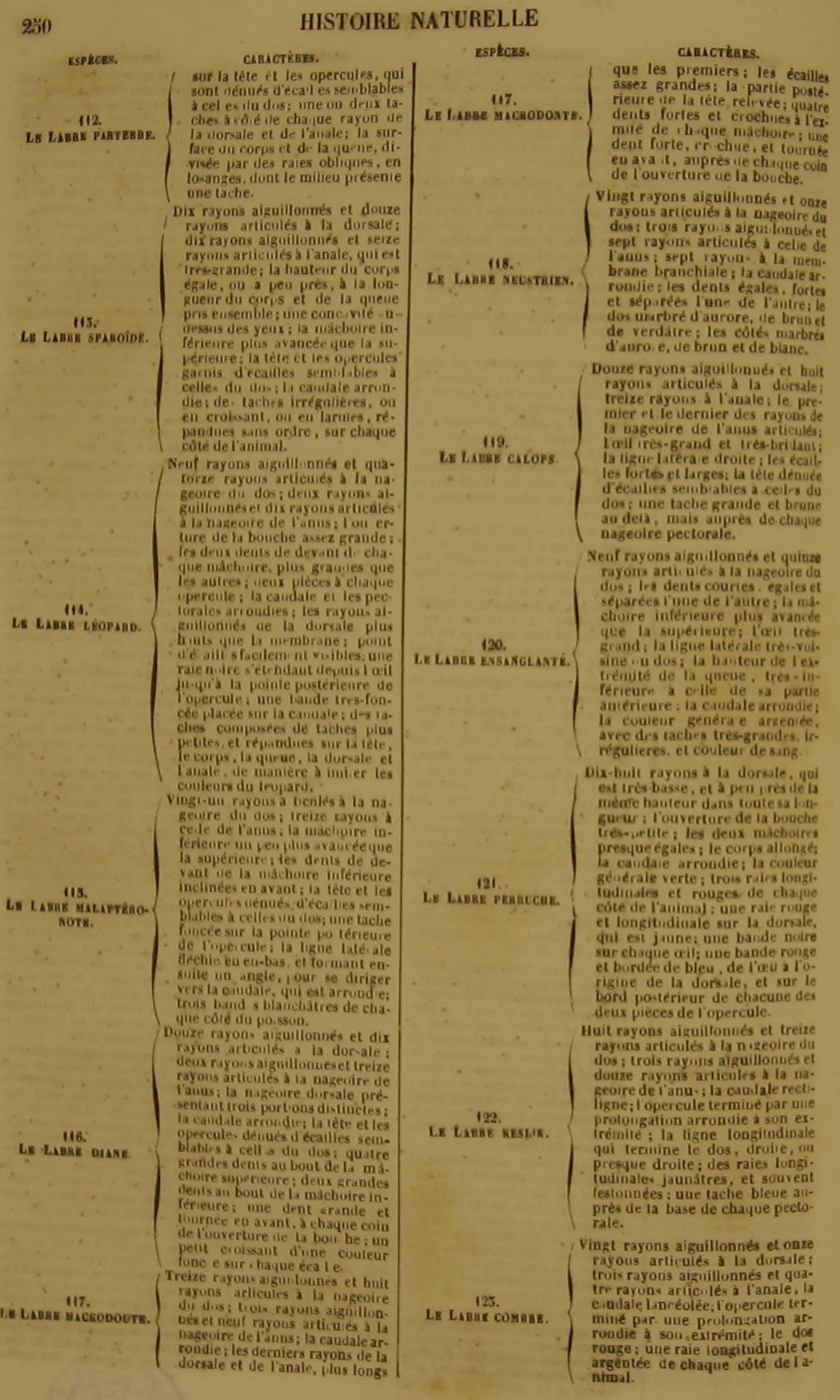

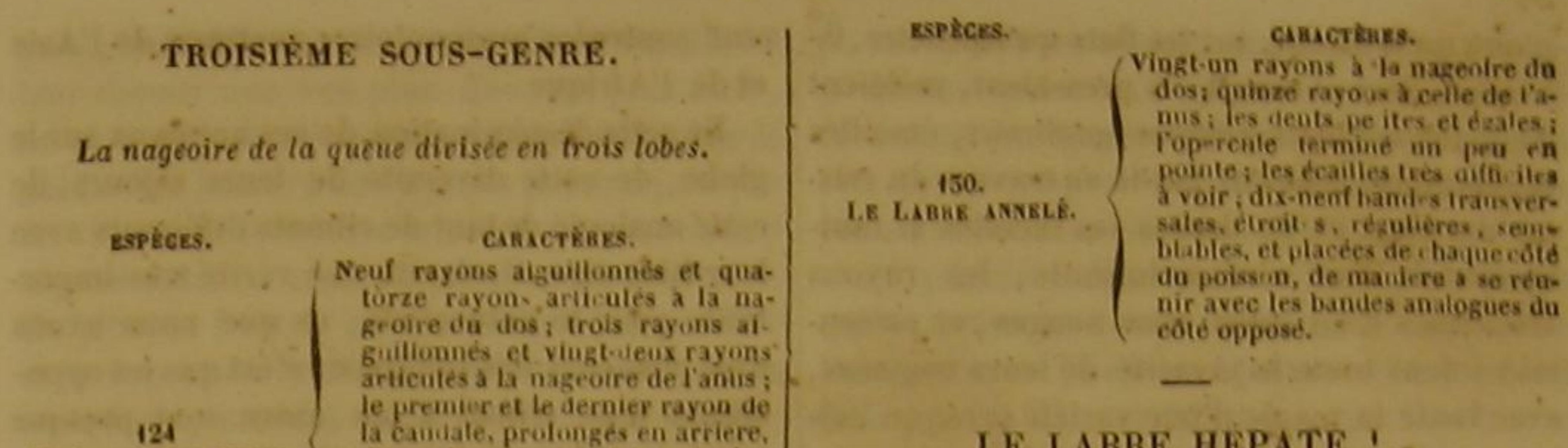

\section{LE LABRE HEPATE '.}

Labrus Hepatus, Linn., Gmel., Lacep.; Lutjanus adriaticus, Lacep, ; Labrus adriatious, Limn., Gmel.; Holocentrus triacanthus, Lacep ; Holocentrus stria-
tus, Bl.; Holocentrus siagonotus, Delaroetie ; Serratus, Bi.; Holocentrus si,
nus Hépatus, Guv.? rieure; deex on trois I goes 100 Ritud
bale.

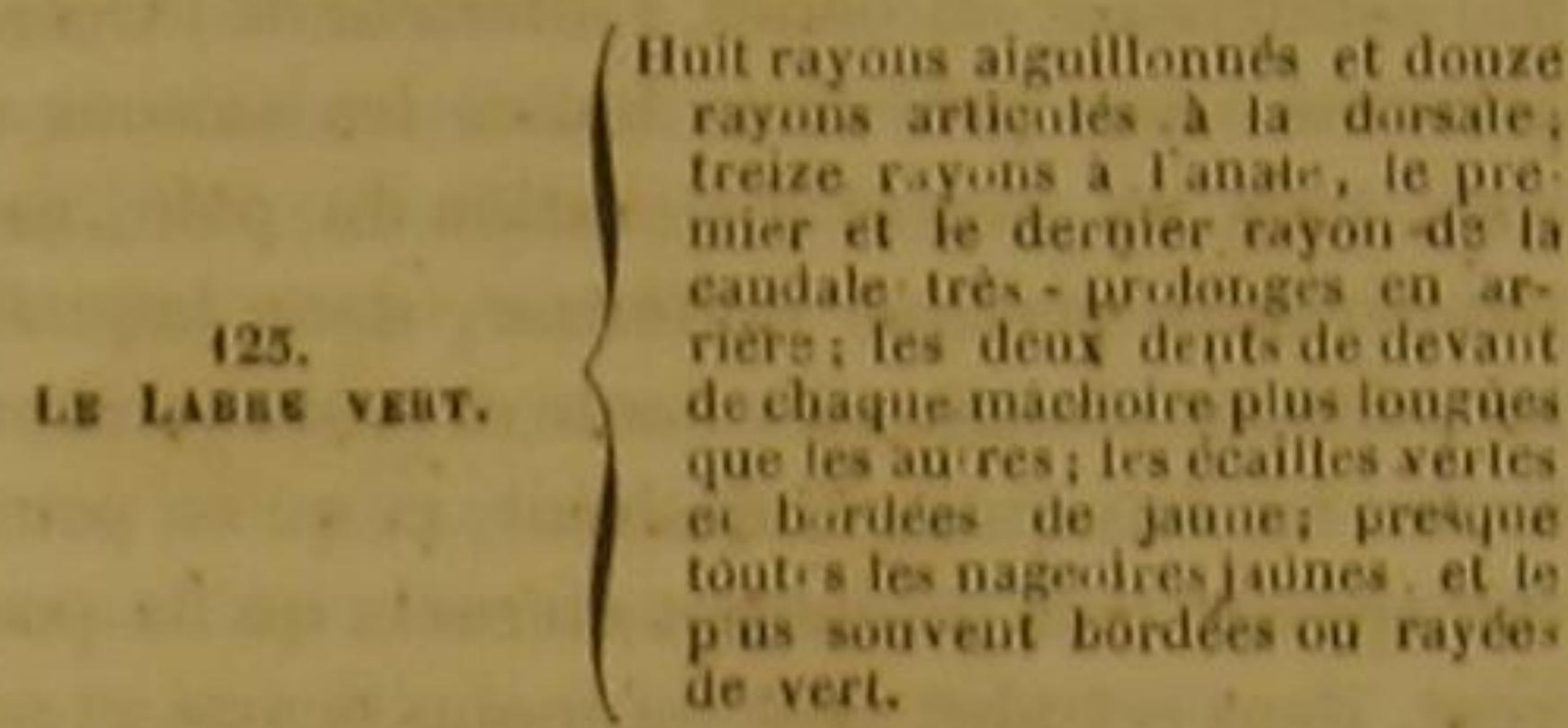

La nature n'a accordé aux labres ni la grandeur, ní la force, ni là puissance. Ils ne règnent pas au milieu des ondes en tyraus redoutables. Des formes singulieires, des habitudes extraordinaires, des facultés terribles, ou, pour ainsi dire, merveilleuses, un goùt exquís, une qualité particulière daus feur chair, in'ont point lié lité particulière daus feur chair, n'ont point lié
lêu fistoire avec celle des navigations lointaileur histoire avec celle des navigations lointal-
ues, des expéditions hardies, des péches fameu. ses, du commerce des peuples, des nsages et des mours des différents siécles. Ils n'ont point des mours des differents siecles. Iis no ont point
eu de fastueuse célébrité. Mais ils out recu des proportions agréables, des mouvements agiles, des rames rapides. Mais toutes les couleurs de I'are céleste leur ant été domées pôur leur paI'are céleste leur ont ete domees pour lecir pa-
rure. Les nuances les plus variés, Ies tons les rure. Les nuances les plus variees, les tons les
plus vifs leur ont été prodigués. Le feu du diamant, dư rubis; de la topaze, de Pémeraưde, du saphir, de l'améthyste, du grenat, scintille sur saphir, de l'amethyste, du grem lectles polies; il brille sur leurface en gouttes, en croissants, en raies, en bandes, en anneaux, en ceintures, en zones, en-ondes; il se mêleà l'éclat de l'or et de l'argentqui y resplendit sur de grandes places, ou il reléve les reflets plus doux, les teintes obscures, les aires pâles, et, pour-ainsi dire, décolorées. Quel

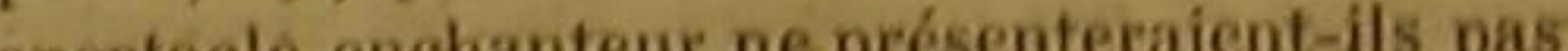
si appelés de toutes les mers qu'ils habitent, et

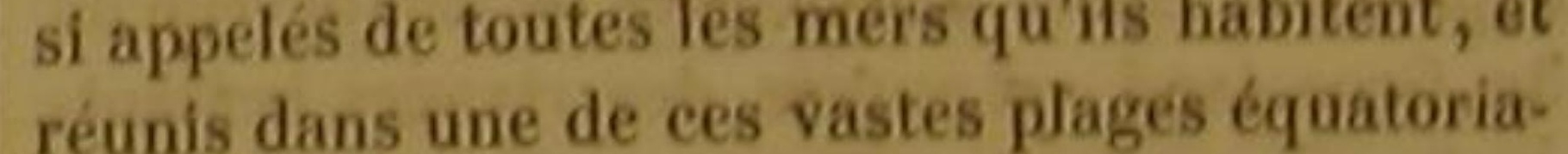
les, ôu un Océan de lumiére tombe de l'atmosin tres-vive, ainst youne buld tran-versilesi
que opercule.

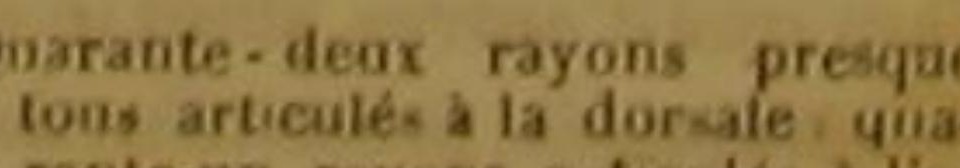

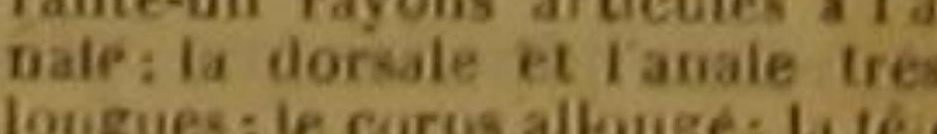

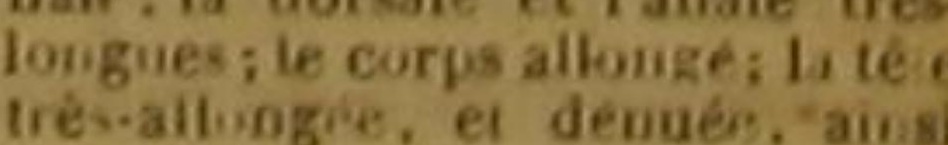

L8 LABEะ LigGe-aMe.

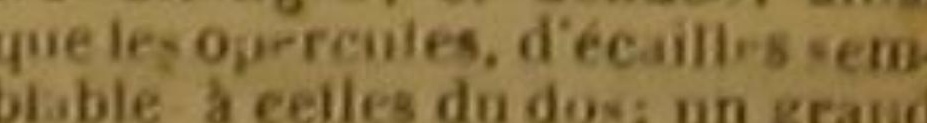

- Labre hépale, Daubenton et Haay, Ene. méth. - id.

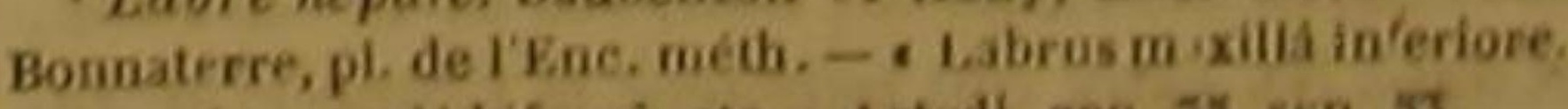

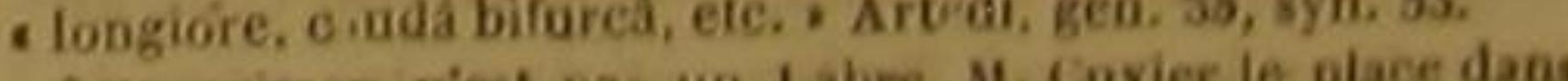

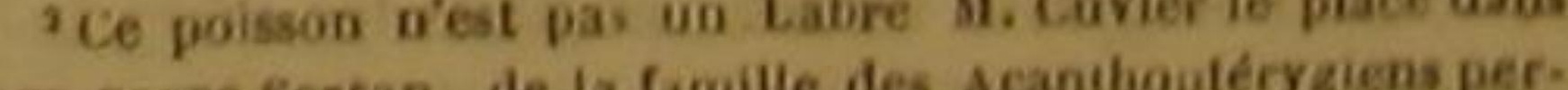

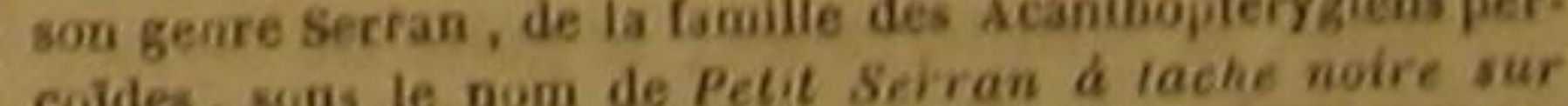

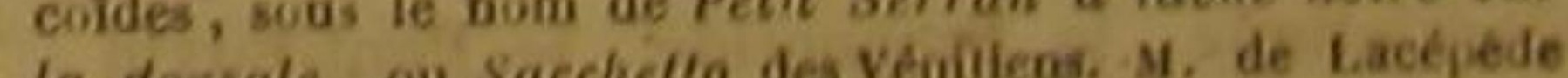

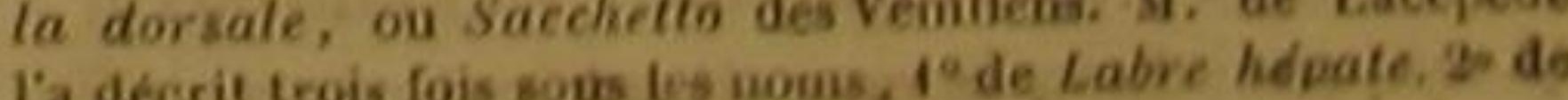
Lujan adriatique, t 1 so d'Holocentre triacanthe. D. 
phère qu'il inonde, sur les flots qu'il pénètre, il- jent contre les promontoires austraux de l'Asie lumine, dore et rougit, ils pressaient, mélaient et de l'Afrique.

confondaient leurs groupes nombreux, émaillés et éclatants, faisaiênt jaillir au travers du cristal des eaux et de dessus les facettes si multipliées de leur surface luisante, les rayons abondants d'un soleil sans nuages, et présentaient dans toute la vivacité de leurs couleurs, avec toute la magie d'une variété presque infinie, et par le pouvoir le plus étendu des contrastes, la richesse de leurs vètements, la magnificence de leurs décorations, et le charme de leur parure!

C'ésten les voyantainsi rassemblés, qué l'am de la nature, que le chantre des étres créés, rappelant dans son âme émue toutes les jouissances que peut faire naitre la contemplation des superbes habitants des eaux, et enviromné, par les prestiges d'une imagination animée, de toutes les images riantes que la mythologie répandit sur les bords fortunés de l'antique Grèce, voudrait entomer de nouveau un hymne à la beauté. Une philosophie plus calme et plos touchaite suspendrait cependant son essor poétique, Un présent bien plus précieux, dirait-elle à son cœur, a été fait par la bienfaisanté nature à ees animaux dont la splendeur et l'élégance plaisent à vos yeux. Ils ont plus.que de l'éclat, ils ont le repos ; l'homme du moins ne leur déclarepresquejamais laguerre; et si leur asile, où ils ont si peu souvent à craindre les filets ou les lignes des pècheurs, est quèlquefois troublé par la tempête, ils peuvent facilement échapper à l'agitation des vagues, et aller ehercher dans d'autres plages, des eaux plus tranguilles dans séjour plus paisible. Tous les climats et un en effet leur convenir. lobe oú on convenir. 11 n'est aucune partie du de labres: ils viveuve une ou plusieurs espèces rivières l'équateur et dans les fleuves voisins de léquateur et des tropiques. On les rèncontre auprès des glaces amoncelées de la Norvège ou du Groenland, et auprès des rivages brồ ou de Surinam ou des Indes orivages brûlants haute mer, ou des Indes orientales; dans la hatute mer, et à une petite distance des embouchures desrivières; non loin de la Caroline, et dans les eaux qui baignent la Chine et le Japon; dans le grand Océan, et dans le et le Jatérieures, la Méditerranée, le gans les mers inl'Adriatique, la Proponée, le golfe de Syrie, I'Arabique, la Propontide, le Pont-Euxin, I'Arabique; dans la mer si souvent courroucé d'Ecosse, et dans celle que les ouragans souce globe, de cette diversité de leurs séjours, de cette analogie de tant de climats différents avee leur bièn-être, il résulte une vérité très-impor. tante pour le naturaliste, et que nous avons déjà plusieurs fois indiquée: c'est que les oppositions d'un climat à un autre sont presque nulles pour les habitants des eaux; que l'in fluence de l'atmosphère s'arrête, pour ainsi dire, à la surface des mers; qu'à une très-petite distance de cette même surface et des rivages qui contiennent les ondes, l'intérieur de l'Océan présente à peu près dans toutes les saisons et sous tous les degrés d'élévation du pôle, une température presque uniforme, dans laquelle les poissons plongent à volonté et vont ehereher, toutes les fois qu'ils le désirent, ce qu'on pourrait appeler leur printemps éternel; qu'ils peu. vent, dans cet abri plus ou moins écarté et séparé de l'inconstante atmosphère, braver et les ardeurs du soleil des tropiques, et le froid rigoureux qui règne autour des montagnes congelées et entassées sur les Océans polaíres; quii est possible que les animaux marins aient de retraites tempérées au-dessous même de ces amas énormes de monts de glace flottants ou immobiles; et que les grandes diversités que les mers et les Alenves présentent relativement aux besoins des poissous, consistent principalement dans le défaut oú l'abondance d'une nourriture nécessaire, dans la convenance du fond, et dans les qualités de l'eau salée ou douce, trouble ou limpide, pesante ou légère, privée de sible ou fréquemment bouleversée par d'horr bles tempêtes.

Il ne faut pas conclure néanmoins de ce que nous venons de dire, que toutes les espèces de abres aient absolument la mème organisation : les unes ont le dos élevé, et une hauteur remarquable relativement à leur longueur, penant que d'autres, dont le corps et la queue son très-allongés, présentent dans cettemèmequeue ne rame plus longue, plus ́́tendue en surface, plus-susceptible de mouvements alternatifs et précipités. La longueur, la largeur et la figure es nageoires offrent aussi de grandes differences de labres. D'aitleurs plusieurs de ces poissons ont les yeux beaucoup plus gros que ceux
De cette dissémination de ces animiaux sur mouvement ou courante, presque toujours pais, lorsqu'on les considère dans diverses espè de leurs congẻnères, et conformés de mauière à leur donner une vue plus fine, ou plus forte, ou plus délicate, et plus exposée à être altérée par la vive lumière des régions polaires; ou par les rayons plus éblouissants encore que le solei répand dans les contrées voisines des tropiques. De plus, la forme, les dimensions, le nombre et la disposition des dents varient beaucoup dans les labres, suivant leurs différentes espèces. Ceux-ci ont des dents très-grandes, et ceux-lá des dents très-petites; dans quelques especes ces armes sont égales entre elles, et dans d'autres très-inégales; et enfin, lorsqu'on examine successivement tous les labres déjà connus, on voit ces mèmes dents tantôt presque droites et tantôt très-crochues, souvent implantées perpendiculairement dans les os des mâchoires, et souvent inclinées dans un sens très-oblique. II n'est done pas surprenant qu'il y wit aussi de la diversité dans les aliments desdifferentes espèces que nous allons déerire rapidement; et voila pourquoi, tandis que la plupart des labres se nourrissent d'ceufs, de vers, de mollusques, d'insectes marins, de poissons très-jeunes ou trèspetits, quelques-uns de ces osseux, et particulièrement le tancoide, qui vit dans la mer Britannique, préferènt des crustacées ou de animaux à coquille, dont ils peuvent briser la croûte, ou concasser l'écaille.

Au reste, si les naturalistes qui nous ont précédés ont bien observé les couleurs et les formes d'ur assez grand nombre de véritables labres, ils se sont peu attachés à connaitre léurs habitudes générales, qui ne présentant rien de différent de la manière de vivire de plusieurs gères de thoracins osseux n'ont piqué leur curiosité par aucun phénomèné particulier et remarquable. Nous n'avons done pu tirer de la diversité des mœurs de ces poíssons, qu'un petit nombre d'indications pour parvenir à distinguer les espèces auxquelles ils appartiennent. Mais en combinant les traits de la conformation extérieure avec les tons et les distributions des couleurs, nous avons obtenu des caractères spécifiques d'autant plus propres à faire éviter toute équivoque, que la nuance et surtout les-dispositions de ces mêmés conleurs mi ont paru constantes dans les diverses especies de labres, malgré les différences d'âge, de sexe et de pays natal, quê les individus mont présentées dans les nombreux examens que j'ai été à portée d'en faire; et c'estainsi que nous avons pu composer un tableau sur lequel on distinguera sans peine les signes caractéristiques des cent vingt-huit especes de veritables labres que I'on devra compter d'après les recherches que j'ai eu le bonheur de faire.

La première de ces cent vingthuit espèces qui se présente sur le tableau méthodique de leur genre, est Thépate, Ajoutons à ce que nous en avons dit dans ce tableau ', que l'on trouve ce poisson dans la Méditerranée, et dans quelques rivières qui portent leurs eanx au fond de I'Adriatique; que son museau est pointu; que son palais montre un espace triangulaire hérissé d'aspérités, et que ses mâchoires sont garnies de petites dents.

\section{LE LABRE OPERCULE ?}

Labrus operculatus, Linn, Gmel., Lacep. '.

Le Labre Aurite 4, L. auritus, Linno., Gm.; Pomotis vulga ris, Cuv." - $L$. Faucheur ', L. falcatos, Linn., Gm.

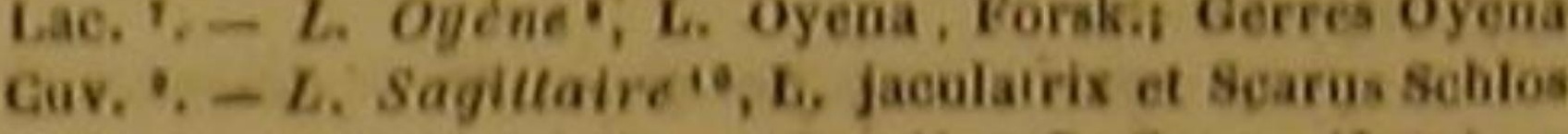
seri, Lac, Toxotes jacolator, Cuv.", - L. Cappa ", seizn Cappa, Linn., Gm. IL. Cappa, Lac, ",- L. Lépisme" " Scisna Lepisma, Linn., Gmel. L. Leplsma, Lac, ", $-L$ Unimacule ", Scixns unimaculata, Lino., Gme I, L. uni-
maculatus, Lac. ", - L. Buhar " ", Sciena Bohar, Korsk.,

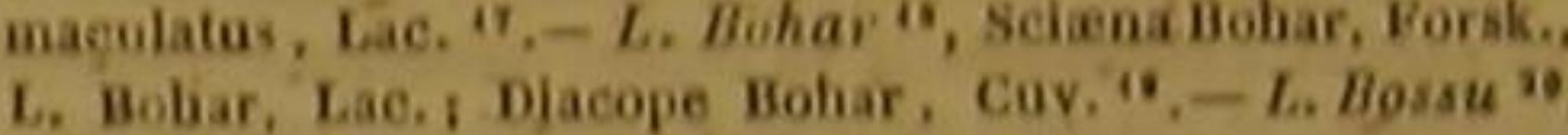

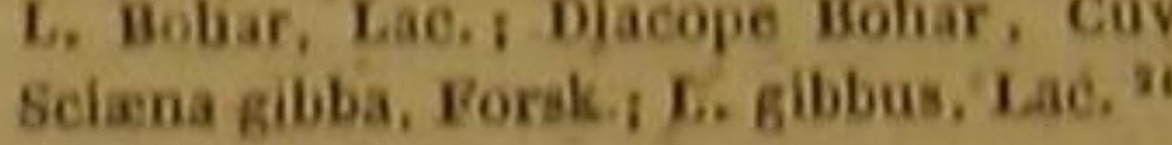

L'operculé et le sagittaire habitent les mers qui baignentl'Asie, et particulièrement legrand

is rayons \& chayue pectorale, 1 rayon algnillonne et o Jounéset 6 rayons articuiés a la nageoire de lanus. 'Amonit. academ. 4, p. 248. - Labie mouche. Danbenaeth.

Non mentionné par s. Cuvier. D.

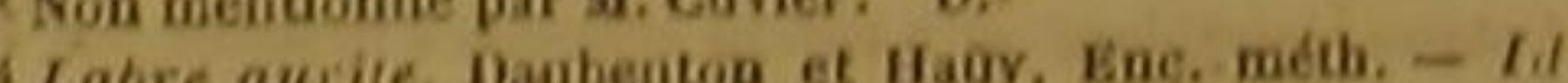
Dounaterre, pl de $Y$ Ene, meth. coides, Cuv., Hist des Poissons, L. III, p. 31 . D. - Labie faucheur, Dabbenton et Hady, Euc. méth. - Id Bannaterre, pl. de I'Euc, ineu.

?Non mentionné par A. Cuvier. D. 'Yorkael, Yaum. Arab., p

Gonaterre, pl. de I'Enie. méth.

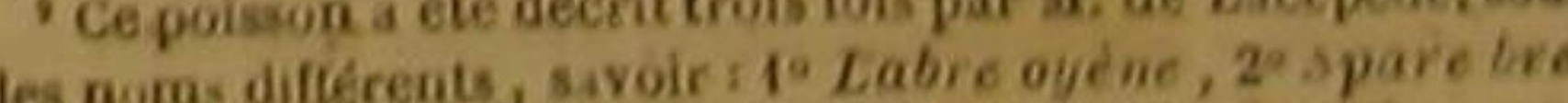
an, et $7^{\circ}$ Lutre long nuscau, A. Cuvier le place dans son genre Gerres, de la famille des Mevides, dass lordre des Acanthopterygiens. D. is Scine sagillaire. Bounaterre, pl. de IVue, méth Tranis. pbil., L. 56, p. 187

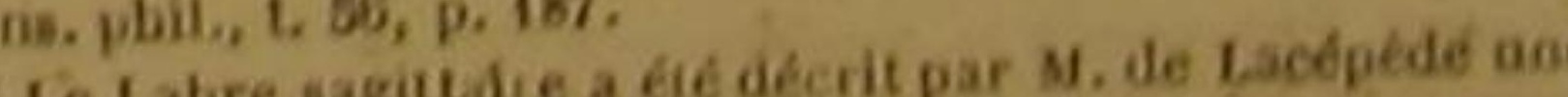

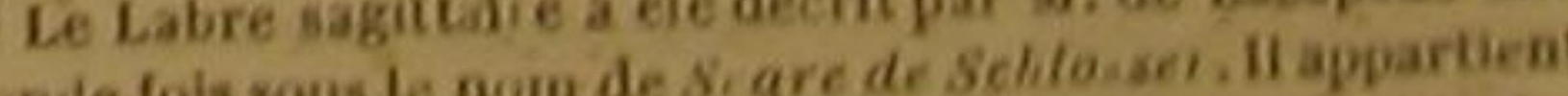
ag Genre Toutes que s. Cuvier rance dans a famble des au genre Tosoles. que di. Ces Acanthopterygieas, $\mathrm{D}$.

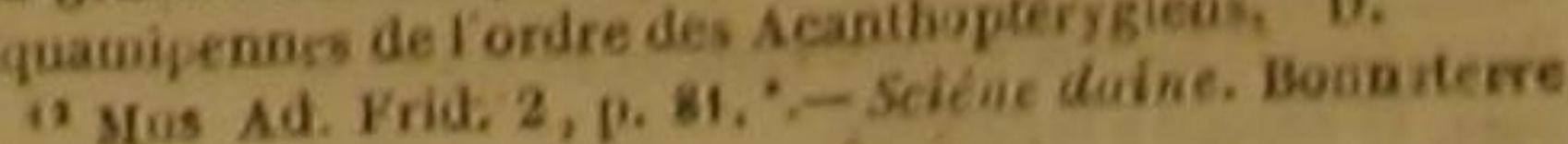




\section{HISTOIRE NATURELLE}

golfe de I'Inde; la mer d'Arabie nourrit l'oyène, le bohar et le bossu; ta Méditerranée est le séjour du cappa et de l'unimaculé; et c'est dans les eaux douces ou dans les eaux salées de l'Amérique septentrionale que vivent l'aurite et le faucheur. Les dents du faucheur sont aiguês; celles de l'oyène nombreuses et très-courtes I'unimaculé a quatre dents à la mâchoire d'en haut, et six dents un peu grandes, ainsi que quelques autres plas petites, a la mâehoire d'en bas. D'ailleurs l'operculé ' présente de

pl. de I'Enc. métb. - Id. Danbenton el Haay. Enc.méth "Non mentionné par M. Cuvier. D.

"Sciéne lépiıme. Bonbaterre, pl. de l'Eoe, méth. - Id. Daubentun et Haay, Enc. méth.
"Noos mentionné par. Curier.

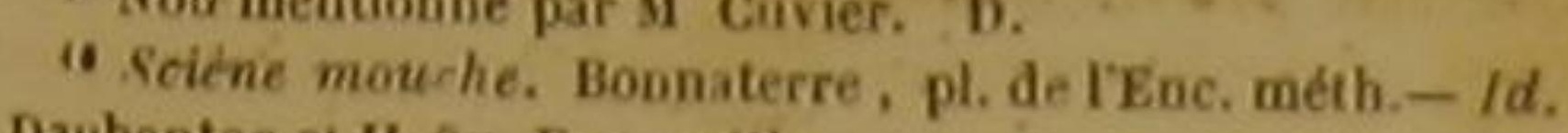
Daubentoo el H Hôy. Eno méth.

is. Cuvier remarque que ta dešcription du Labre nnimaculé est c lle d ua Picarel (Snaris), et que la figure de, M. de Lacépède se rapporte a ion Mesoprion astigmate, Mesoprion

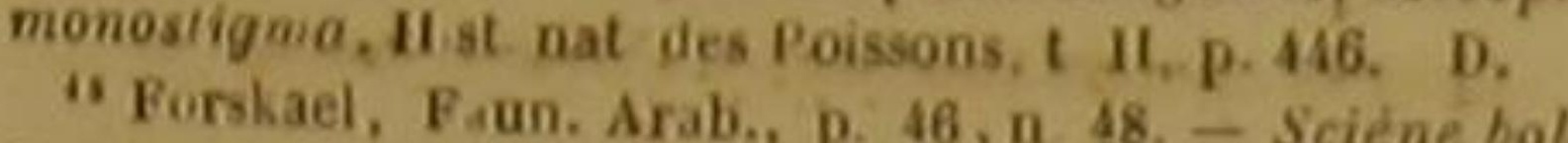

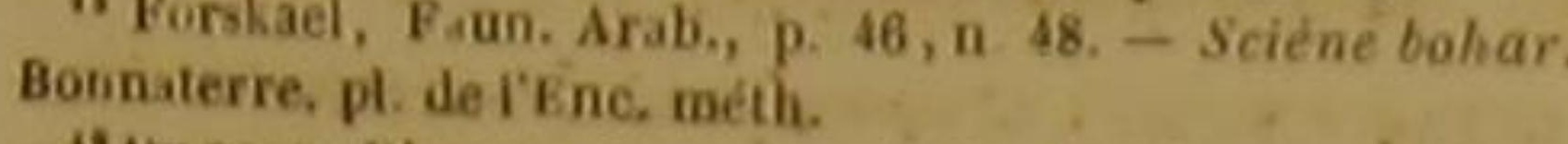
"Dugeare Discope, Car i d

rygiens percoíles. D.
D. Car, dans la lamille dea Acanthopté"Furskiel, Faun.

Bonnaterre, pl. de I'Ene, méth.

"Non mestionoé par M, Cuvier. D,

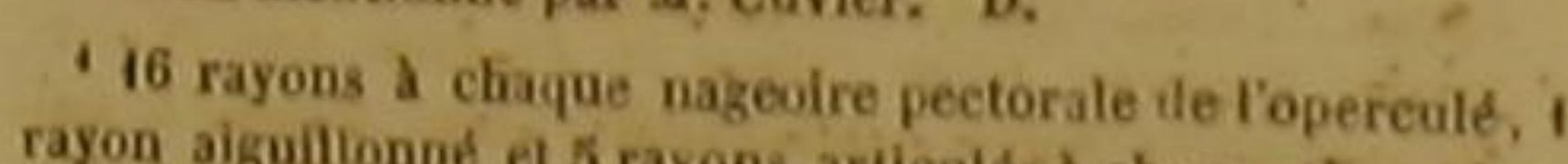
rayon aigultonné et 5 rayons articalés a chaque thoracine,

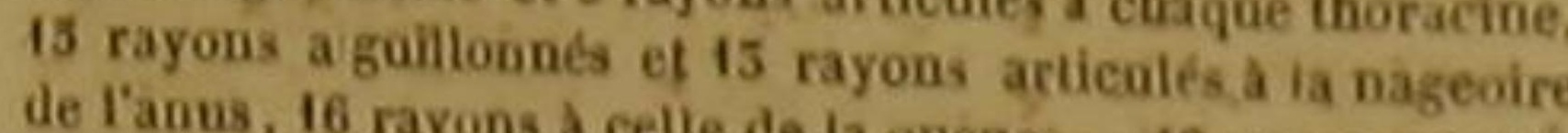
de ranus, 16 rayons a celle de la queue: - 10 rayonsaiguif.
loninés et 11 rayons articules a la pazeoire dorsale de I aurite, is rayons a chacune des pectorales, 6 a chacue des thoracis rayons a chacune des pectorales, 6 a chacuue des thora-
17 rayons ans alguilionnes el 10 eayons aricules a Fanale,

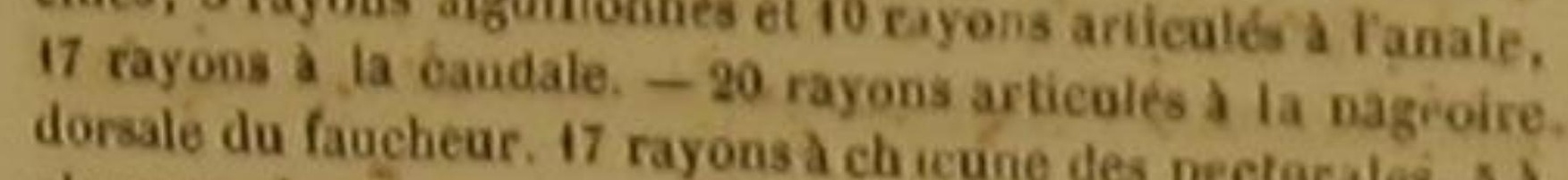
clacune des thoracines, 3 rayons aiguillonnés et 17 rayons

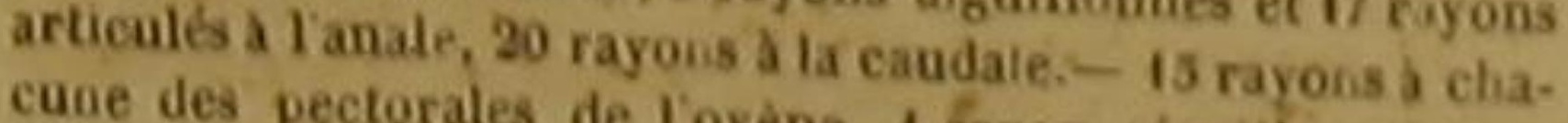
cune des pectorales de loyene, 1 fayon aiguiltonne et 5 tomós et 7 rayous articolés des thóracines, 3 rayon-aignil. -4 rayons aiguillomés et 11 rayong arlicons d tis caudiale. dorsale du sagittaire, 12 rayons a chacune des pectoraire

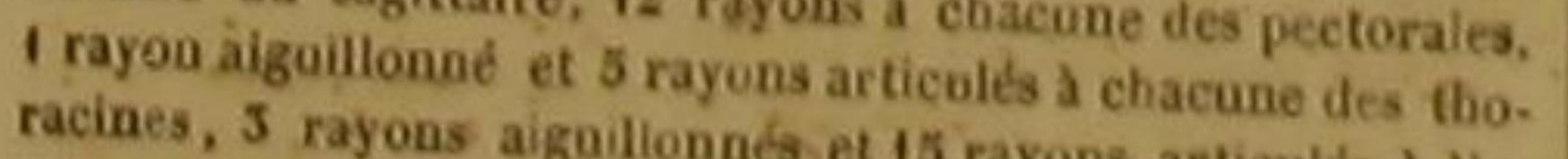

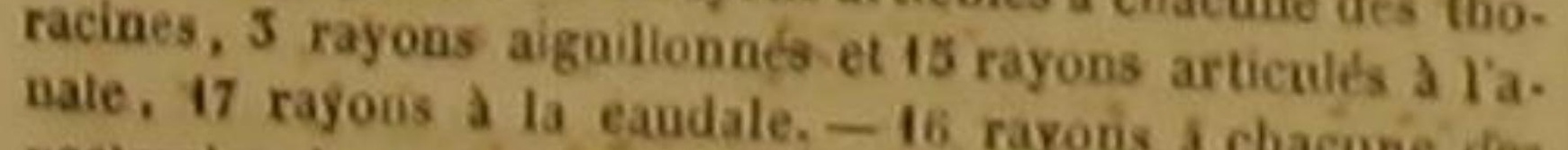

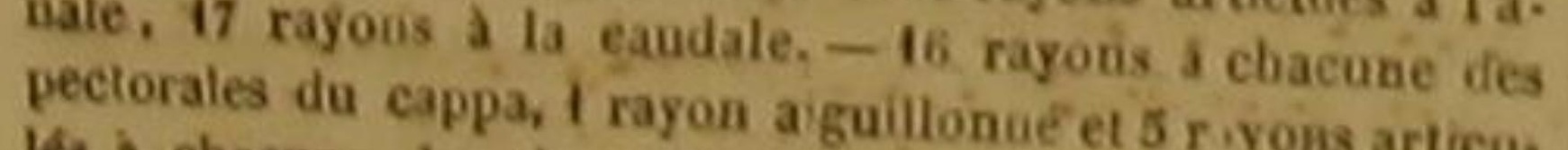
les a chacune des thoraciées, 3 rayons aiguillonads et to
rayons articulés a ranale, 10 ray a chaque nageoire pectorale rug lés a la candale. - 11 rayons

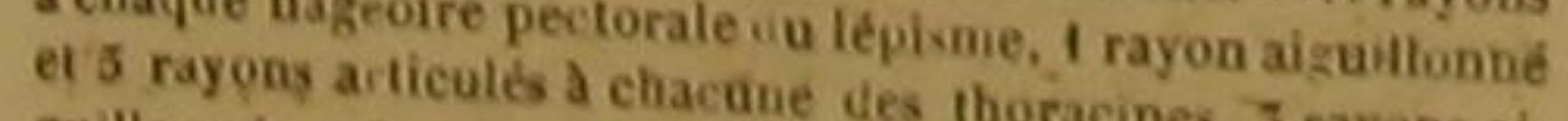
guillonués el 8 ray ons articulés a l'anale, 15 rayons a ha aldale. -15 rayons a chacune des nageo res pectorales de
Iunimacule, cune des thoracines 3 royone er 3 rayous articnies d cha cultes a tanale, 17 rayons as aiguillomós et 9 rayous artimembrane branchiale du bohar, 16 raugons. -7 rayonis 8 la

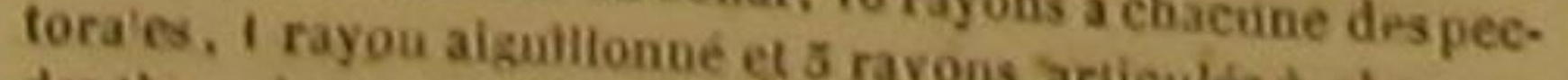
des thuraciars, 3 rayons aiguillonnets et 9 rayos a chacune Tanale, 17 rayons a la eaudale. -6 rayons a la mernies de culbs a is uagowa, 10 rayons algaillonnés et 3 rayonis artirales, 1 rayog aiguill ast, is raygns a chacune des pecio-

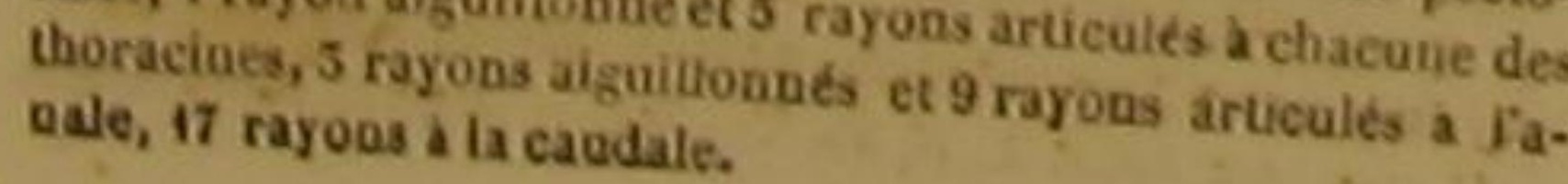

petites taches noires sur le derrière de la téte; le faucheur, une couleur argentée ; l'ovene, des nageoires d'un vert de mer, et quelquefois des raies rouges; et le sagittaire, des nuances d'v jaune doré.

\section{LE LABRE NOIR ',} Sciæna nigra, Forsk.; Lalırus niger, Linn., Gmel.,
Lacep.; Diacope nigra, Cuv. ?

Labre Argente", Sciæna argentata, Forsk.. Limn., Gmel.
L. argentatus,

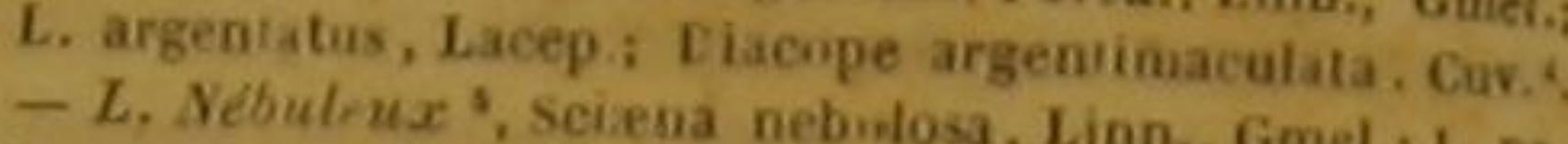

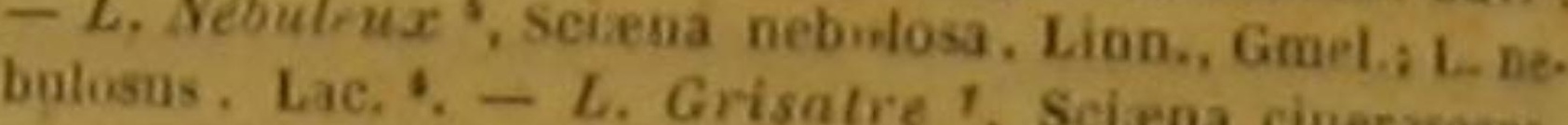
Lion., Gmel, i L. einerascens, Lae. ', Scizna cinerascens, armata, Forsk; $L$. armarus, Lacep. $0 .-L$. Chapelet, $L$.

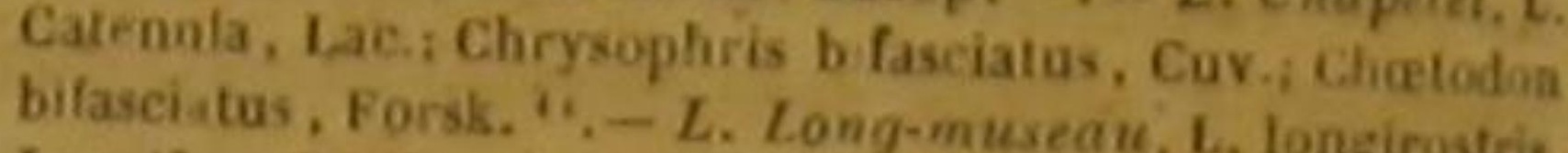

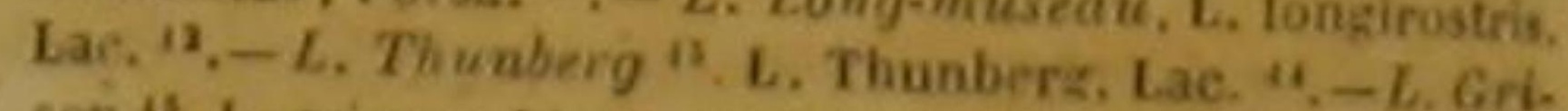
son ", L, griseus, Linn., Gmel., Lac, ", $-L$ Croissant", On peut remarquer aisément que l'extrémité de chaque mâchoire du labire noir est dépourvue de dents, et que son gosier est garni d'un très-grand nombre de dents petites et effilées; dans l'argenté, les dents sont d'autant plus grandes qu'elles sont plus éloignées du bout

'Porakael, Faud, Arab., p. 47, n. 49. - Sciene gatih.
Bonnaterre, pl. de IEne milh 'Du geure Djacope dans la famille des Acanthopterygient
percoides. D. percoides. D.

"Eorakael, Faun. A rab., p. 17, a. 50, - Sciene schaafen. "Do gerre, pl. de I'Eñe, métb.

crooldes de Diacope dans la famille des Aeanthopteryzien abre argrnté de M. dér. Selón ce naturaliste. la figure do - Porskal, Faun. Arab, p. 81, n, 61. - Sctene bonkose Bonnaterre, pl de I'Enc. méth.

- Non mentionné par M. Cuvier. D.

'Forkazel, Faun. Arab., p. 55, n, 66, - Sciéne tahmel,

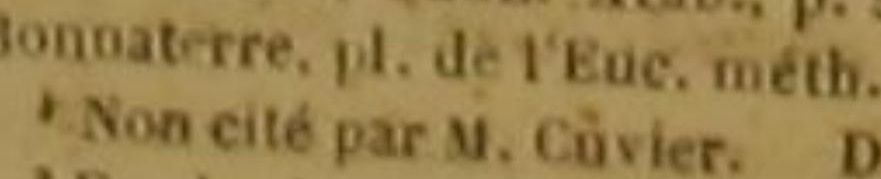

' Forskael. Faun, Arab., p. 53, n. 68. - Seléne galenfish.

Bonaterre, pl. de IEnc., métb.

"Ce poisson estat páccis mention de ce poisson, D. ?

les noms : to de Labre chapelet, 20 de Spare méde, sou

d'Hotocentre rabagi. M. Cuvier le place dans son genne

aurade de la tamilte des Acanithoptérygietis sparuides.

is Sun mentionné par M. Cuvier. D.

"Scicena fusca. Thunberg, voyaze au Japon

"Catesb. Canné par M. Cuvier. D.

bentoz et Hayy, Enc. méth. - Id. Bonnaterre, pl. de I'Eac.
méth
ONon

Gron iv. Mas. 2. nuvier. D

Daubentón et Hauy, Euc, métb:- fig. 2,-Labre croissant.

i" 10 Labris

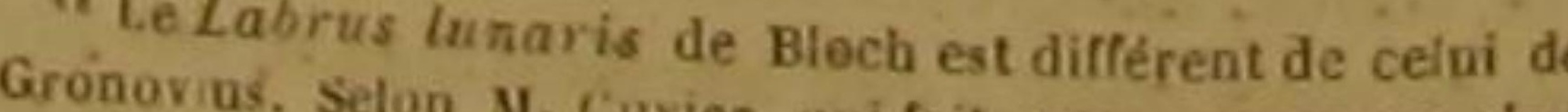
une Girelle mal cooservee, peut-être de l'espece de la Girelle

\section{DES POISSONS.}

du museau; six grandes dents arment la màehoire supérieure du chapelet; iet les deux machoires du thunberg en présentent chacune quatre plus grandes que les autres. La ligue latêrale du croissant n'est courbe que jusqu'à la fin de la nageoire du dos. L'armé montre un aiguillon presque horizontal, tourné en avant, et situé entrè la tête et la dorsale; ce qui lui donne un rapport assez grand avee les casiomores, dont il differe néanmoius par plusieurs traits, et avee lesquels il serait impossible de le confondre, par cela seul que les exsiomores ont au moins deux piquants entre la dorsale et le derrière de la téte '.

Au reste, complétons ce que nous avons à faire connaitre relativement aux couleurs des dix labres nommés dans cet article, en disant. que le noir tire son nom d'un noir ordinairement foncé qui règne sur sa partie supérieure, et dont on voit des teintes au milieu des nuances blanchátres et brunes de son ventre; que les écailles de l'argenté sont brunátres et bordées d'argent, et qu'une bandelette bleue parait au-dessous de chaque cil de ce poisson; que le nébuleux offre des taches nuageuses bleues et jaunatres, et quelquefois des raies longitudinales ínégales eu largeur, et de diverses nuances de rouge ou de violet; que le grisátre est d'un gris tirant sur le vert, avee des raies longitudinales jaunes, et un liséré blane autour des pectorales; que la dorsale et l'anale de l'arme sont blanches et bordèes de noir, pendant que sa caudale est brune et lisérée de blanc; que l'on peut compter, sur chaque côté du long-

7 nayons a la membrane branchiale du labre noir, if rayons i chaque nageoire pectorale, 1 rayon aiguillonné

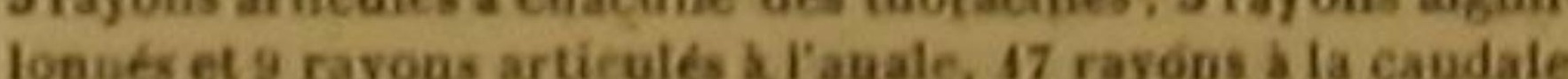
-7 rayons a la membrane branchiale de l'a a gente, 17 rayons a chaque nageoire pectorale, 1 ryyon aignillonné ets rayons 9 aricules a chacune des thoracines, 3 rayons aiguilloinés et 9 rayons articidés at Vauale, 18 rayona i ia caudale. -
is rayons a chaque nageoire pect rale wu nébulenx, 1 rayon 15 rayons a chaque nageoire pect rale wu nebulenx, 1 rayon
aiguilloane et 5 rayous articules a chacune des ithoraciues, aiguilosane et 5 rayous articulés a chacune des thoraciues
7 7rayons a da caudale, -7 rayous a Ia merobrane branchiale du grisitre. 18 rayous a chaque nazeoire pectorale. I rayo

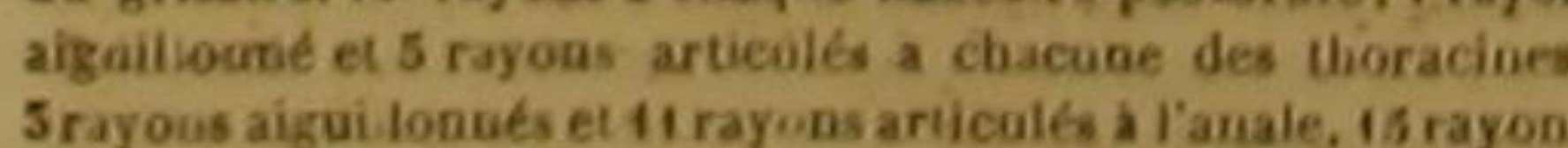
a la candale -5 rayons aigoillonoés et 7 rayons articules a la nagevire de lanus do loug-museau. -6 rayons a la membrane branchiale do thonberg. 15 rayons a chaqne nageoire pectorale, 1 rayon aizuilione et 5 rayons articules b chacun lanale, 19 rayons a la ciodale, 17 rayons a chagene rageuin pectorale du crossant, 6 à chacaúe des thor aciues, 3 rayóns aigullonoés et 14 rafóns anicules a lamale, 16 rayous a ia museau, quatre ou eing petites raies longitudi. ales, et trois ou quatre series de taches trèspetites et éloignées l'une de l'autre; et enfin, q'une couleur brune, ainsi qu'une bordure Distinguent les écailles du thunberg. De ces dix labres, il en est deux, le Chapelet et le Long-museau, qui ne sont pas encore connus des naturalistes, et dont nous avons fait graver la figure d'apres des dessins de Commerson. On les trouve dans le grand golfe de l'Inde et dans les mers voisines de ce golfe. C'est aussi dans ces mèmes mers, et particulièrement dass celle d'Arabie, qu'habitent le noir, l'argenté, le nébuleux, le grisátre et l'armé les eaux salées qui mugissent si souvent autour des rivages orageux du Japon, nourrissent le Thunberg, auquel nous avons cru devoir, par reconnaissance, donner le nom de I' habile voyageur qui l'a observé et déerit; le Grison vit dans l'Amérique septentrionale; et le Croissant préfére les eaux de l'Amérique méridionale, ainsi que celles des grandes Indes.

\section{LE LABRE FAUVE ',}

Labrus rufus, Linn., Gmel., Lacep. ',

Lo Labre de Ceylan ', L, xeylanieus, Limm, Gmeli, Lac, : -L. Deux-bandes', L. bifasciatus, Mlocb, Lac.4 Jnlis be fasciata, Cav,,- L. Melagastre ', L. melagaser, Bloch,

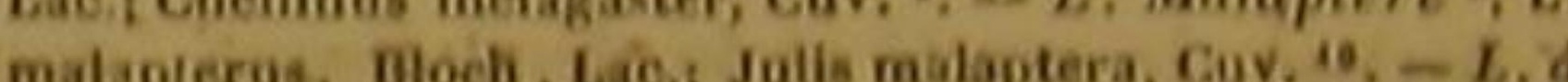

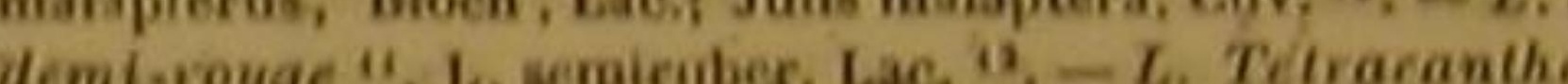
L. Ietracanthus, Lac, Percis cancellata, Cuv,", $-L$. Demi. disque, T. semidiseas, Lae, Julls semidisons, Cuv, 4,L. Cerole, Li doliatus, bae, Julis
rised, L hirsotos, Lae., Cuv, "10.

Le fauve, qui parvient communément a ta longueur de trois ou quatre décimètres, est, sur

A Catesby, Carol, 2, p. 11, tab, 11. - Labre fauce Dau.

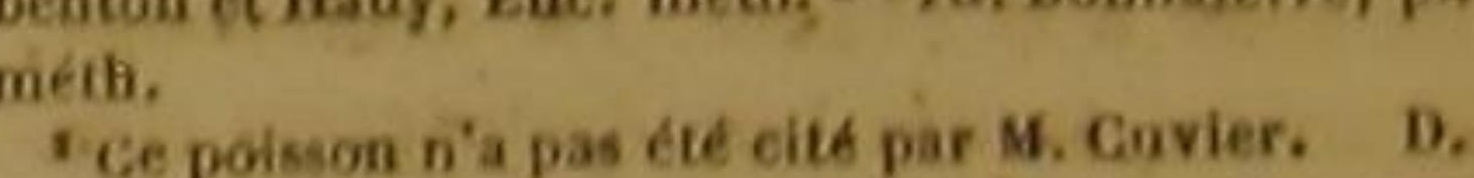
- Dschirau-malas par les Chinguiais,-Papegaay-iseh.

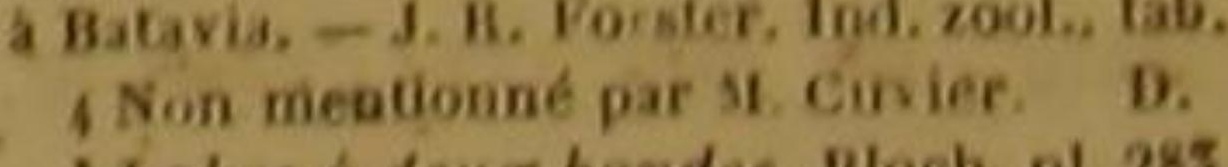
Labre á deux bandes. Bloch. pl. 285. - Da sous geare Girelle (Jufis) dans lo grand genre Labre de la fanilie des Acantioptérygiens labroides. D.

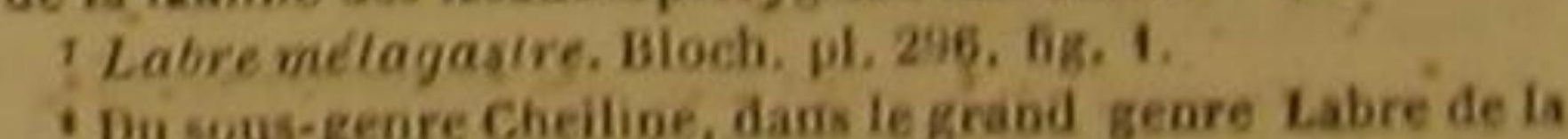
- Du suss-genre Cheiline, dans le grand geare Iamilie des Acanthopterygiens abroiders. D. 16 Dos sous-geure Girelle, dans le grand genre des Labres. seton M. Cuvier, qui remaryue que ce poisson parah tire le meme que le Coris angule de $\mathrm{M}$. de Lacépede les Coris de ce dernier naturaliste nétant que des Girelies a queue tronquée, dout on n'a que des fíures faulives ea
próopercule n'y eat pas séparé de I'opercule." D. 
toute sa surface, dun roux plus ou moins mêlé marehé aux poissons de la capitale du Brésil de jaune ou d'orangé. Le ceylan, dont les dimeusionšs sout ordinairement plus grandes que celles du fauve, a la tète bleue, la dorsale et l'anale viólettes et bordées de vert, et la caudale jaune, rayée de rouge, et bleue à la base. La partie supérieure du labre deux-bandes est grise; sa tête violette; sa poitrine blanche; dorsale rougeatre et bordée de bleu, ainsi que son anale; chacune de ses pectorales jaune, de mème que les thoracines; et la caudale brune avec une grande tache bleue. Les écailles qu recouvrent le mélagastre sont variées de brun et de noir, excepté celles qui revêtent le ventre, et qui sont noires comme les nageoires. La couleur générale du malaptère est d'un blanc bleuâtre, avec cinq taches noiratres de chaque cóté, et les nageoires nuancées de jaune et de bleu. Quatre rangées de taches presque rondes, à peu près égales.et très-rapprồchées l'une de l'autre, paraissent sur chaque, ôté dù tétraeanthe, qui d'ailleurs a des points noirs répandus sur sa caudale. Le hérissé montre sur sa queue une large bande transversale

Voilà ce que nous devions ajouter au tableau générique, pour bien faire reeonnaitre les couleurs des dix labres que nous considéronș maintenant.

Les trois derniers de ces labres, c'est-à-dire le hérissé, le cerelé et le demi-disque, dont nous avons fait graver la figure d'après les deśsins de Commerson, et dont la description n'avait pas encore été publiée, habitent dans le grand golfe de l'Inde ou dans les mers qui communiquent avec ce golfe. Nous ignorons la patrie du tétracanthe, que nous avons fait des. sinér d'après un individu conservé dans de Pal. cool, et qui faisait partie de la collection cédée par la Hollande a la France. Le demi-rouge, dont nous avons trouvé une description étendue dans les manuserits de Commerson, fut vu par ce voyageur, en juin 1767 , dans le "Labrus semiruber, semiaflavus: Labrushemichrysus.

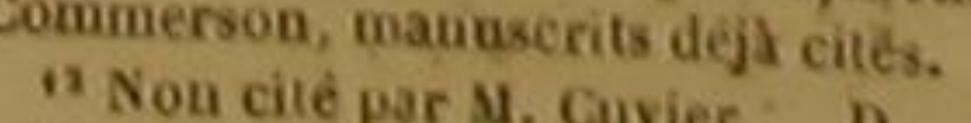

"Mis: Cuvier place ce poisson dans son genre Perclis, de la lamille des Ac.u⿰tiopterysiens percoides. II remarque que M. de Lacépede la decrit une seconde fois sons le nom de
Bodian tétracanthe. D.

Cur. D. D.

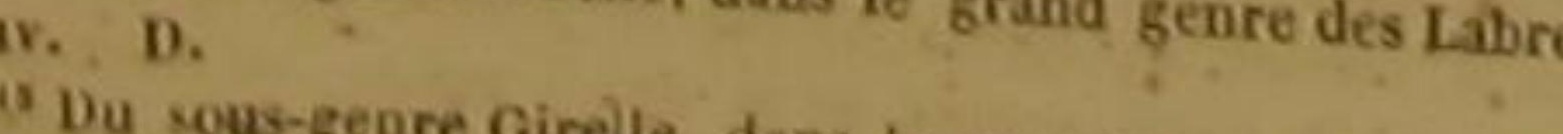
de la familie des Acanthoptérygiens grand genze des Labres, "Lè Labre bérissé est un labre propremient dit pour. D.
vier.
D. D.
Surinam est la patrie du mélagastre; la Caroline, et en général l'Amérique septentrionale, celle du fauve; Ceylan, celle du labre qui porte le nom de cette grande ile, et que l'on dit bon à manger; les eaux des grandes Indes nom. rissent le labre deux-bandes, et celles du Japon le malaptère '.

Finissons cet article en parlant de quèlques traits de la conformation de ces animaux, que nous n'avons pas encore indiqués.

La mâchoîre inférieure du fauve est plus longue que la supérieure; les dents antérieures de la måchoire d'en haut sont plus iongues que les autres, dans ce mème poisson, dans le deux-bandes, dans le malaptere; les dents des deux mâchoires sont presque égales les unes aux autres en longueur et en grosseur, dans le mélagastre, dans le demi-disque, dans le cerclé. La ligne latêrale du mélagastre est intercelle du cerclé très-droite pendant la plus grande partie de sa longueur; et la base de la nageoire de l'anus du labre à demí rouge est re vêtue d'écailles, comme uné partie de la base de la nageoire dú dos de ce méme poisson ${ }^{2}$.

6 17 rayons d chaque nageoire pectorale du labre faure 6 rayoas a chaque thoracine, 16 a la candale, -5 rayons a eoire peetorale, it ayu labre deox-bandes, 12 a chayue o. chaque thoraeive, it rayon aizulllonné et 5 rayons articalés nembrane branchiale in melsana cacdale. -5 rayons a

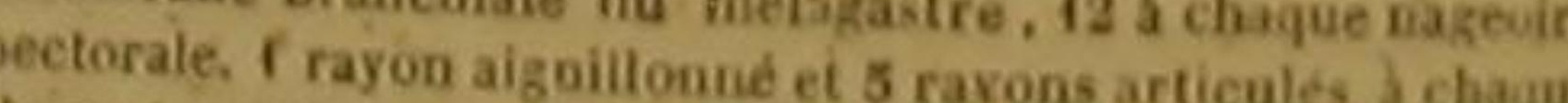

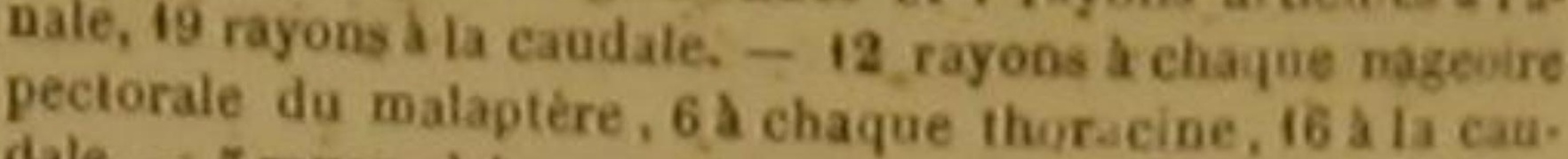
longe, 16 a chayue nageoire pectorale, I rayon aiguivillonites et is rayones a chaque thoracine, 5 rayous ai candale. - 18 rayons articulés a la pagale, 14 rayens i in Fracanthe, 14 rayous a la nageoire de I lanos de demi-disque II andale. - M rayons a la nageoire de l'anus da cer.

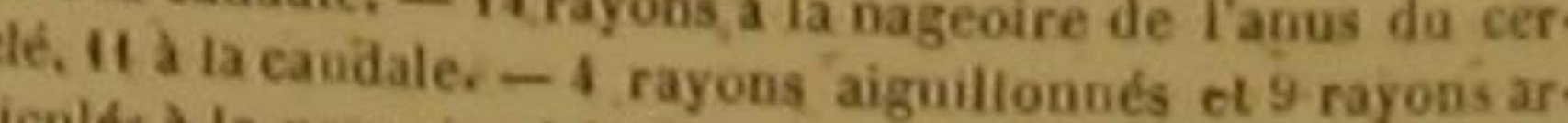
tholés a la nageoire dé l'anus du hérisse, 15 rayons à la cau.
dale.

Commerson, dans la description manascrite el latine que st composé de desyeux, dit que liopercule do dermi-rouge riécre est trè--légerenteses, et que le bord de la piéce ante sons que nous avons ét té a mếme Les différentes cômpara. les dessins executés suus sa direction, ou avec des individos des espetes quili avait décrites, nons ont portés a crôire que antérieure diste navait pas voulu indiquer antour de la lame prénent dite el tercule du demi-rouge, uné dentelure prolatjans. Si cependant des observaracterise le genre de nü reconnattre dans ce poisson mif pations ultérieures. faisaien une veritable deutelure operculaire, il serait focte de jaune rompue; celle du tétracanthe est peu sensible, horacine, 3 rayons aiguillonoes et 7 rayons articules a f pectorale du malaptère, 6 a chaque thoracine, 16 a la cau
dale. -5 rayooss a la membrane branchịale do labre a dem

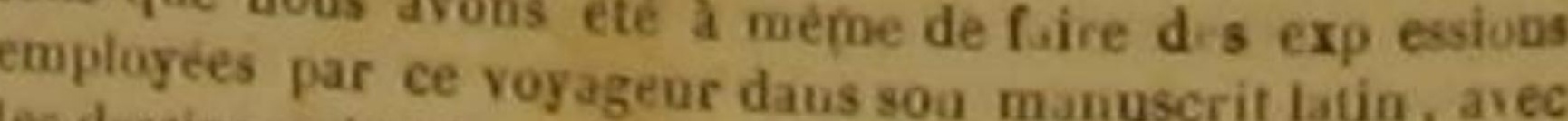

DES POISSONS.

\section{LE LABRE FOURCHE,}

Labrus Furca, Lacep. '?

Le Labre six-bandes, Labrus sexfasciatus, Lac,; Glyphiso-
don calestinus, Solander, Cuv.; Chatodon saxatitis, Bl. ? - L. Macrogastere, L. maerogaster, Lac, : Chatodo beogalensis, Bl.; Glyphisodon bengalenis, Cuv, $s,-L . F$ -

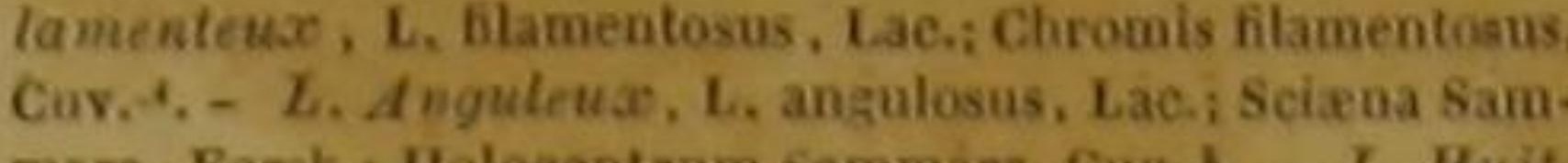
mara, Forsk,; Holocentram Sammara. Cuv, $4,-L$. Huit raies, L. octovituatus et L. Kasmira, Lac; Holocentrus bengaleusis et II. S-linestus, Bi.; Seirna Kasmira, Forsk,
Diacope 8 lineata, Cuv,,$-L$. Mouchete, L. punctulatus, Lac; serranus punet ulatus, Cuv. ', $-L$. Commersonien, L. Commersonii et Lutjanus microstomus, Lae, Scixna
Nageb, Forsk,; Pristipoma Commersonii Cuv,', - L. Lisse, Nageb, Forsk,; Pristipoma Commersonil Cuv,", - L. Lisse,
L. Ixvis, Lac,; Bodiauns eyclostomus et Bod, melanolea-

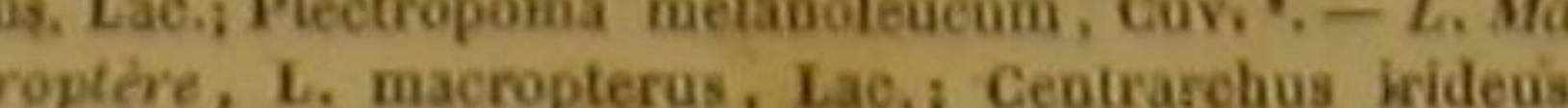
croptere, L. macropterus, Lae, Ceourarchus isideus
Cur. "..

Aucun de ces dix labres n'est encore connu des naturalistes; nous en avons fait graver Ia figure d'après les dessins trouvés parmi les manuscrits de Conmerson, que Buffon nous remit iorsqu'il nous engagea à continuer l'Histoire naturelle; et voilà pourquoi nous avons donne à l'un de ces poissoñs le nom de Labre Com. mersonien. La patrie de ces dix espèces est le grand golfe de. I'Inde; ot on peut aussi les trouver dans la partie du grand Océan qui est comprise entre la Nouvelle-Hollande et le continent de l'Amérique, ainsi que dans cette mer si souvent bouleversée par les tempêtes, et qui bat la cote sud-est de l'Afrique et les rives de Madagascar, Leur forme et leurs caractères

trancher do genre de nos labres, et de le transporter dans ce lai des lutjans dont nous nous oocuperons bieatót.

¿Non cité par M. Cavier. D
'Du gene Giyphisodon, dans la famille des Acanthoptéry.
giens sciénoîses, Cov, D. D. giens scelénoìdes, Cav. D.

"Du genre Glyphisodon, selón M. Cuvier. D. ¿ Da genre Cbromis, dans la familte des Acanthoptéryglen labroides, Cuv. D.

Sammer, ef de place ce poisson sous le nom diHolocentr percoides. D. D.

- Le Labre huit-raies ne differe pas specifiquement do Labre kasmira decrit ci-aprés. M. Cuvier le range dans son
geare Diacope de ia famille des Acasthoptérygiens percol. geare Diacope de la famille des Acasthoptérygiens percoi-
des. D. 'Le Labre moucheté est un Serran pour M. Cuvier. Conpercoides. D.

'Le Labre cormersonien est décrit une seconde fois par M. de Lactpede, sous le nom de Luljan mierostome. M. Ca. vier le range dans son genre Pristipome de la famille det Acanthopterygiens scienoides. D.

Le Labre lise ent dictit deax antres fois par M. de Lace-

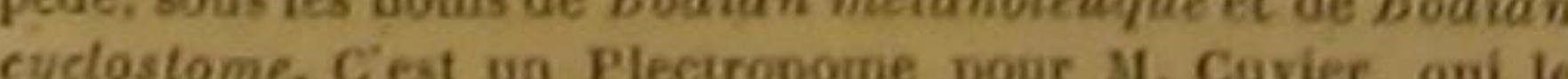
place dans la famille des Acsithopterygieris pereciles. D. "Du geare Centrarchus dans la famille des Açanthoplery.
giens percoides, Cuv. D.

II. distinctifs sont trop bien représentés dans les planches que nous joignons à cette Histoire, pour que nous ayons besoin d'ajouter beaucoup de détails à ceux que renferme le tableau générique, On peut voir aisément que le macroptère, qui tire son nom de la grandeur de ses nageoires du dos et de l'amus ', a la máchoire inférieure un peu plus avancée que la supérieure, et vraisemblablement garnie, ainsi qué cette dernière, de dents très-petites; que l'anguleux et le six-bandes doivent avoir des dents très-fines; que celles du filamenteux et du macrogastère sont trés-courtes et presque égales les unes aux autres; que la ligne latérale de ce mème macrogastère ? est interrompue; qu'une tache irrégulière et foncée, et cinq ou six petits points blanes, sont placés sur chaque coté de la nageoire ${ }^{3}$ dorsale de l'anguleux; ct que la dorsale du huit-raies est bordée de noir ou de brun.

LE LABRE QUINZE-EPINES,

Labrìus quinquedecim-aculealus, Lacep.; Chrómis 15-spinosus, Cur,.

Le Labre Macrocéphiale, Labros macrocephatus, Laci, Dentex macrocephalus, Cav, S, - L. Plumierien ', L. Plu-

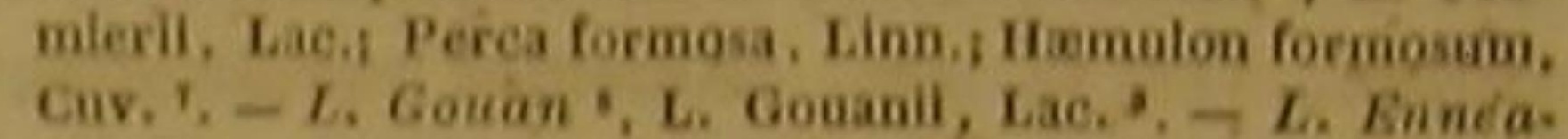
canthe, L. enneacanthus, Eac, isparas fasciatus, Bloch, Cheilinus fasciatus, Cuy,"1, - L. Kouges-raies ", L. rubro-

Ces six labres sont eneore inconnus des na-

'Maxpos veut dire long ou yrand; et жгеро, alle ou на. " Cagrì signifie ventre. on peut voir sur le tablean géneique, que le macrogastère a en effet lę ventro très-gros. 2 rayons aiguiltonnés et 10 rayons articulés a la nageoiro de l'anos du Labre fourche. -12 rayons a chaque pectorale du Wx-bandes, 10 a ranale. - 10 rayous a chaque nageoire pee. rayous a la nageoire cavdale du filamentenx, couda 7 rayong on pea eloigoés l'un de Fautre a claque nageoire pectorile Je laviguleux, 5 rayons aiguillonnés et 6 rayons articules s Panale, 14 rayons a la caudale. -16 rayous a la nageoire caudale du buitraies -12 ou 15 rayons a la nageoire caudal. da mouchete, -12 rayons a chaque mageoire pectorale du Du genre Chromis, dans la famille des Acanthopterygiens
sbroides, Cuv. D.

- Da peore Denté, Dentex, dans la famille des Acanthop. Érygiens sparoldes, Cuv. D.

- Tuxdus aureo ceruleus. Plumler, peintures sur velia

du Moseum d'istoire naturelle.
7 Da genre Goretfe, Hamulon, daas la famille des Acas. opterygiens scicuoides, Cuv. D.

' - Non mentionne par M. Cuvier. D. io Du sous geare Cheiline, dans le grand geare Labre, de la famille des Acautbopterygieas labroides, Cur. D. 
turalistes; le premier sous-genre de la famille des véritables labres en renferme donc, sur quarante-huit espèces, vingt-trois dont la description n'a pas encore été publiée. C'est une nouvelle preuve de ce que nous avons dit dans l'article intitulé: De la nomenclature des $\mathbf{L} a-$ bres, des Cheilines, des Cheilodipteres, ete.

Le rouges-raies que Commerson a décrit avec beaucoup de soin dans son reeueil latin et manuscrit, habite au milieu des syrtes et des ro. chers de corail qui environnent les iles de Madagascar et de Bourbon. Nous iguorons la patrie de l'ennéacanthe ' et du gouan, que nous faisons connaitre d'après des individus de la collection hollandaise cédée à la France. Le plumiérien vit en Amérique; et le macrocéphale ${ }^{2}$, ainsi que le quinze-épines, représentés dans nos planches d'après les dessins de Commerson, se trouvent vraisemblablement dans le grand golfe de l'Inde, et auprès des iles dites de la mer du Sud

Les dents du labre gouan sont erochues, et d'autant moins longues que leur:place est plus éloignée du bout du museau.

La ligne latérale est interrompue dans le quinze-épines ${ }^{3}$, dorée dans le plumiérien, et garnie, vers la tête, de petites ramifications dans le rouges-raies. Cé dernier labre a le fond de ses couleurs d'un brun plus ou moins foneć, et ses nageoires pectorales d'un rouge incarnat et la caudale du macrocéphale êst bordée, son extrémité, d'un lisêré d'une nuance vive ou très-claire.

" . Labrus linels lateratibus plurimls rubris variegatur acello pinne dorsalis, latissimeque ad hasin cauds, "Non cité par

'Tingar. Cavier. D.

Ennéacanthe désigne les neuf algullitons de la dorsale.
Luvia veut dire neuf. Lwida veut dire neuf.

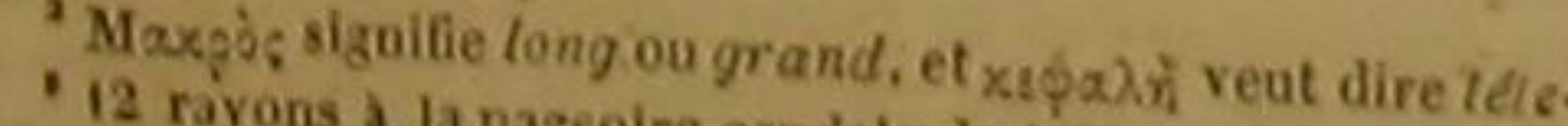
-8 rayons a cha caue nageoire pectorale du macrocetéphines.

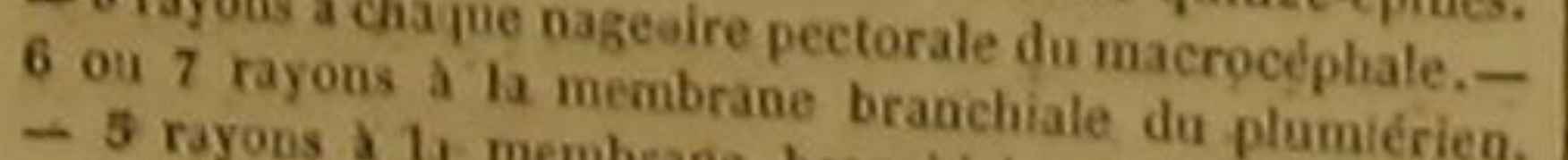
chaque nageoire pectorale, 1 rayon aigulu. gouan, 12 articutéts a chacune des thoracines. 14 rayons $\$$ iné et 5 rayon 15 rayons a chaque nageoire pectorale du labre ennésale. racines. 5 rayons siguilloy rans articulés a clacune des the 45 rayons a la caudie -6 rayong ayons articules a l'anale. Ju rouges -raies.
do -6 rayons a chacune des thoraeines

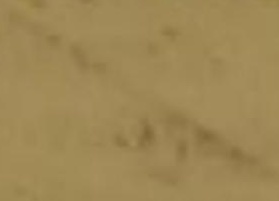

\section{Labrus Kasmira et Labrus octovittatus, Lacep.; Scirn} Kalnir , Forsk., Liun.; ; Holocentrus bengalenisis

Ce beau poisson a le sommet de la têtebla et la couleur gếnérale jaune. Quelquefois sa queue montre de chaque côté unẹ tache grande et brune. Il vit dans ia mer Rouge, aupres des rivages de l'Arabie ${ }^{3}$.

\section{LE LABRE PAON 4.}

Labrus Paro, Linn., Gmẹl, Lacep.

Ce labre habite dans la Méditerranée, et particulièrement auprès des cotes de Syrie. l'éporque oú on eommença à l'examiner, à le distinguer, à le désigner par un nom partiellier, l'histoire naturelie avait fait peu de progrès; le nombre des animaux déja connus n'était pas encore très-grand; on n'avait pas découvert la plupart de ces poissons richement colorés qui vivent dans les mers de l'Asie oude l'Amérique méridionale : le labre paon dut par conséquent fíapper lès observateurs par la ma gnificence de sa parure; et il n'est pas surprenant qu'on lui ait donné le nom de l'oiseau que l'on regardait comme émaillé des nuances les plus vivés et les flus variées. Ce labre présente en effet presqué toutes les couleurs de l'are-enciel, que l'on se plait à-retronver étalées avec tant de pompe sur la belle queue de I'oiseau paon; et d'ailleurs le poli de ses écailles; le contraste éclatant de plusieurs des tons dont il brille, et les dégradations multipliées par les-

'Forkael, Faun. Arab, p. 16, D. 46. - Sciene tirki. Hoo.
naterre, pl, del' naterre, pl. de l'Enc. métb.

nom de Labre' huif-jeja décrit par $\mathbf{M}$, de Lacépede, sous le de la famille des Acantiopterygiens prevfles de Cusies D.

7 rayons a la membrare branchlale, 16 a chaque nageoire pectorale, 1 rayon aiguillonné et 3 rayons arlicultes a char i Pagagallo, des, 17 rayons a ta candale. Danbenton et Hagy, plus, conir. de litalie. - Labre paon. I'Enc. méth.- I Labrus poteth. I Id. Bonnaterre, pl. de syo. 53. - Paro. Salvian, fol. 225 , etc., Artedi, gen. 31 ,

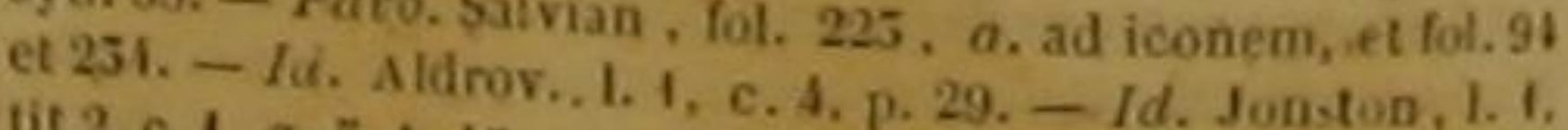

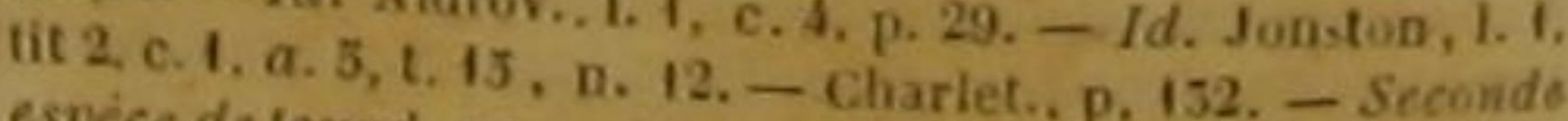
espece de tourd, nomme paon. Tiandelet, part. 1, 1. 6. c. 6 . ¿dus perbella detus pavo, ete, , Gesner, p, 1016. - - TurRai, p. 157, - Labtus, ete. I Willughby, Iclith., p. 522.'Ce poisson n'eat pas pavo. Hasselquist, It. 34, n, 77. dont lespécé n'est vaaisemblatalem. Cuvier. C'est un labre, Labre tácheté de ce naturalisto. pas dificreatedece quelles ses autres nuances s'éteignent les nnes dans les autres, ou s'animent pour se séparer et resplendir plus vivement, imitent les reflets rapides qui se jouent, pour ainsi dire, sur les plumes ehatoyantes du paon, et les feux que I'on croirait en voir jaillir. Lorsque le soleil éelaire et dore la surface de la Méditerránée, que les vents se taisent, que les ondes sont paisibles, et que le labre paon nàge sans s'agiter at-dessous d'une eouche d'eau mince et limpide, qui le revèt, pour ainsi dire, d'un vernis transparent, on admire le vert mêté de fiaune que montre sá surface supérieure, et au milieu duquel des taches rouges et des taches bleues scintillent, en quelque sorte, comme les rubis et les saphirs de l'oiseau de Junon. Des taches plus petites, mais également bleues ou rouges, sont répandues sur les opercules, sur la nngeoire de la queue, et sur celle de l'ànus, qu est violette ou indigo; et ún bleu mèlé de pourpre distingue le devant de la nageoire dorsale, pendant que deux belles taches brunes sont placées sur chaque côté du poisson, que les thoracines offrent uno rouge très-vif, et que des teintes d'or, d'argent, rouges; orang'es et jaunes, ébiouissantes ou gracieuses; constantes ou fugitives, étendues sur de grandes places, ou disséminées en traits lẻgers; - completent un des assortiments de couleurs les plus splendides et les plus agréables.

Aú reste, ces beaux reflets se déploient sur un corps et sur une quéue allongés et compri més; ill n'y a qu'un seul rang de depts aux máchoires; les nageoires pectorales sont arrondies ; les rayons de fa dorsalé et de Ja nageoire de l'anus ont vie longueur plus considérable, a mesure qu'ils sont placés plus loin de la tète; et communément le labre paon á trois ou quatre décimetres de longueur totale '.

\section{LE LABRE BORDÉ 2,}

Lsbrus marginalis, Lino., Gmel., Lacep.'

Le Labre roulile', Labrus ferrugineus, Lin n, Gm., Lac. s. - L. OBille', L. ocellaris, Linn., Gm. Lac. ', - L. Me. i 5 rayons a ia membrane branchiale du labre paon, 14 a chaque nageoire pectorale, $t$ rayon aiguilionné et 8 rayons itticules a chacume des thoracines, 5 rayons aigailtom
11 rayons articinles a fanale, 15 rayons a la candale.

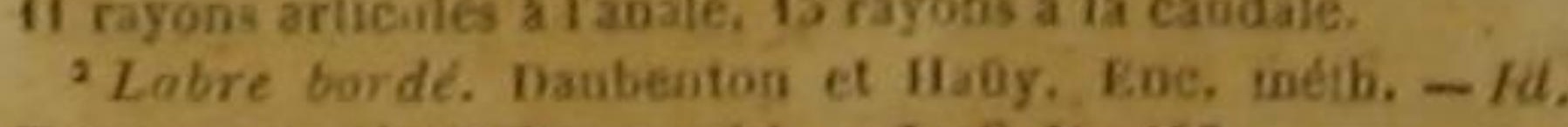
Bonniterre, pl. de l'Euc, méth. - Lafl. It., 103. ' Non cité par M. Cuvier. D. . Bonaterre, pl. de l'Esc métb.

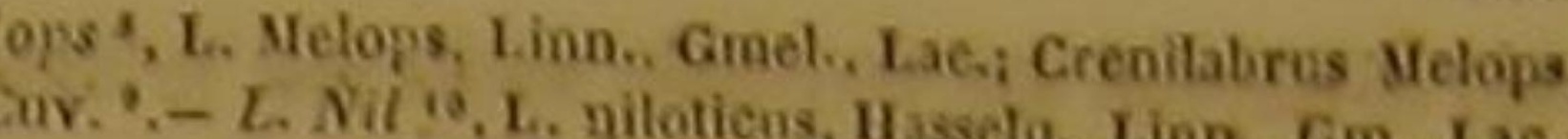

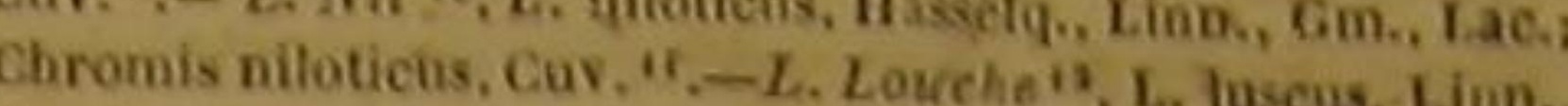

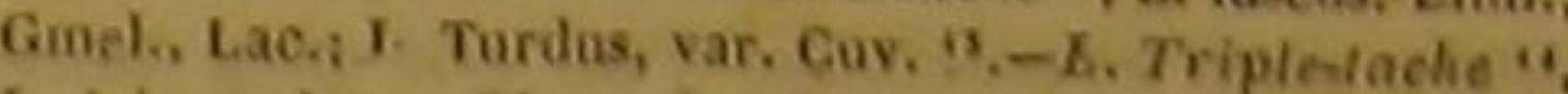
L. trimaculatus, Linn, Gmel., Lac, Bl.; L. carneos, Bi., Cuv, 13,- L. Cendere, L. cinerens, Laces L. griseus, Gm ",

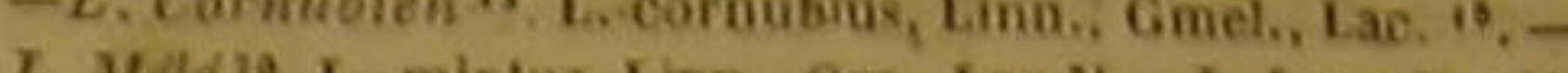

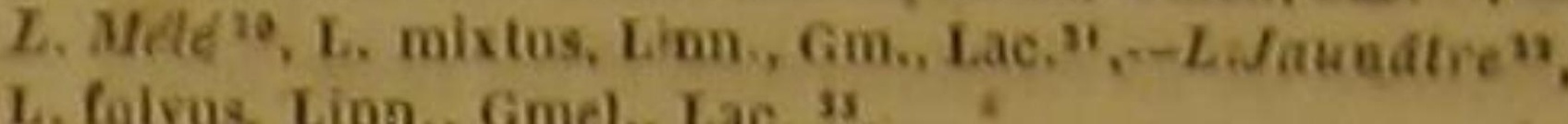

La coulêur générale du lóuche est jaunatre la dorsale, l'anale et la caudale du triple-tache sopt quelquefois lisérées de bleu. La nourriture osdinaire de ce dernier labre, dont les écailles rélléchissent différentes nuanees d'un beau rouge, consiste dans des animaux à coquille, dont il brise l'enveloppe calcaire par le moyen de ses-dents antérieurés, plus longués et plus fortes que les autres; nouvel exemple de ces rapports de la qualité des aliments avee la rivacité des couleurs, que nous avons fait remarquer dans notre Discours sur la nature des poissons, qu'il ne faut jamais négliger d'obser-

Son cild par M. Cavier. D

- Mus. Ad. Frid, 2, p. $78^{\circ}:$ - Laste aille, Dantenton et

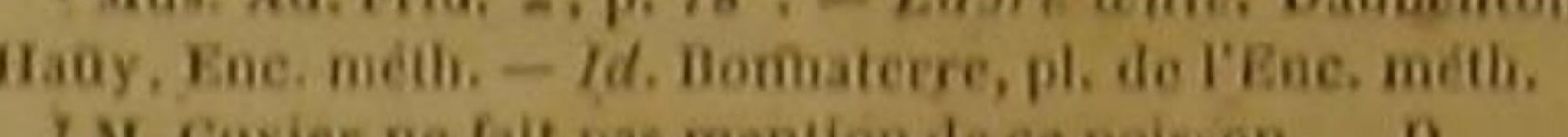

Mos. Ad, Erid. 2, p. 78: - Labre métope. Danbenton et Haog, Eno, meith. - Id, Donnatere, pl do I'Enc. méth.

- Da sous-genre Crétiltatire, dans le grand genre Labre de M: Cuvier, de la fomille des Acanthoptérygieus labroides. $\mathrm{D}$

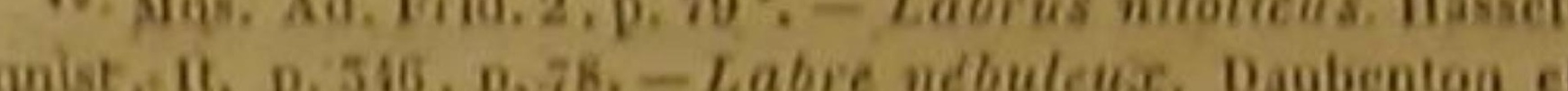

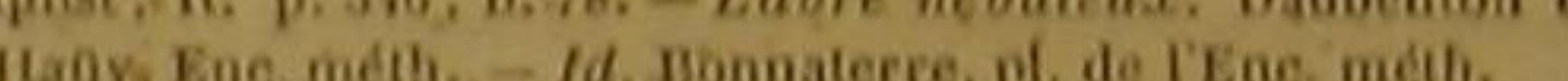
4 Du genere Clomonts, de la famille des Acallopitryejen

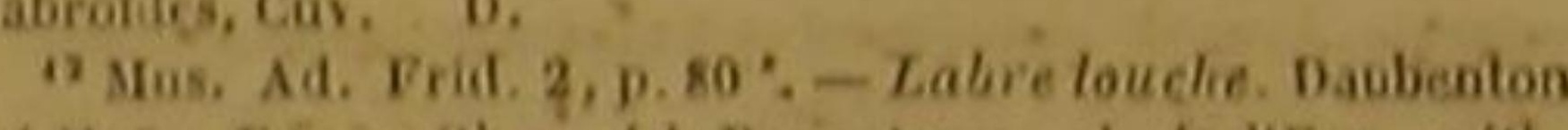

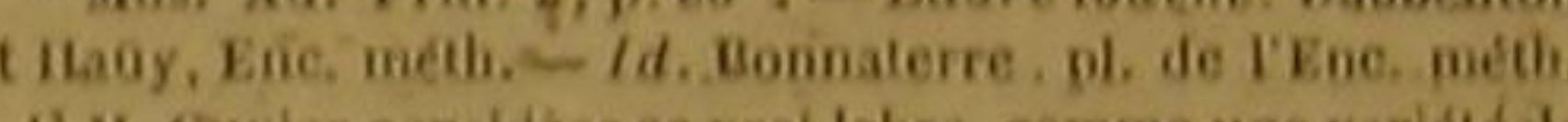
"M. Cuvier eonsidére ce vrai labre, comme une varicted respéce qui appelle Vieille noire. Labrus firrula. D,

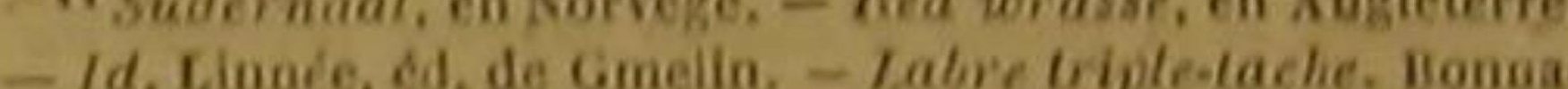
terre, pl. de f'Enc, méth- - Paon rouge, labrüs earneus.

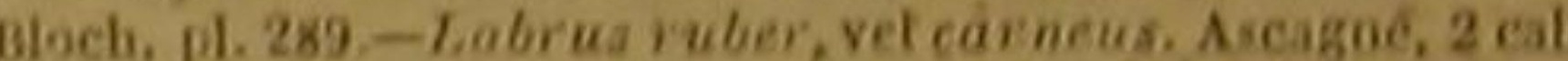
p. 6, pl. 15. - Trimaculated wrasse. Penoant, Brit. Zoci. 5. p. 206, n. 5 .

"Ce virai Labre, selon Mi Cuvier, ce rapporte a lesieco 4ail nomme Vieille coulear de chair, Labrus carneus.

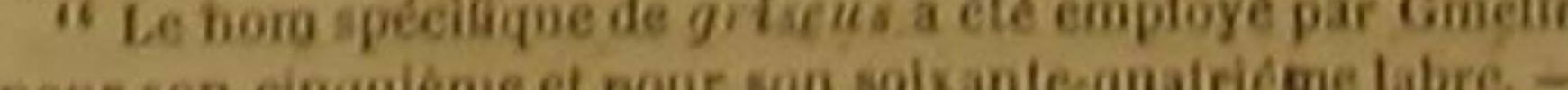

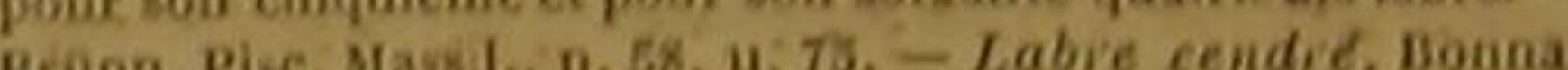
terre; ol. de I'Eac. inéth.

" Noa eite par $\mathrm{M}$. Cuvlér. D, "Labre goldsinny. Bonnaterie, pl. de I'Ene. métb.Goldsinny Cornubiensium. Peunant, Brit, Zool. 3, p. 203. n. 6. - Mal, Dise, p. 165, fig. 5 .

16. Labros ex flavo êt cerruleo varius, dentibus anteriori. Gus majoribus. A Artedi, gen. 51, ays. 57. - Turdus ma.

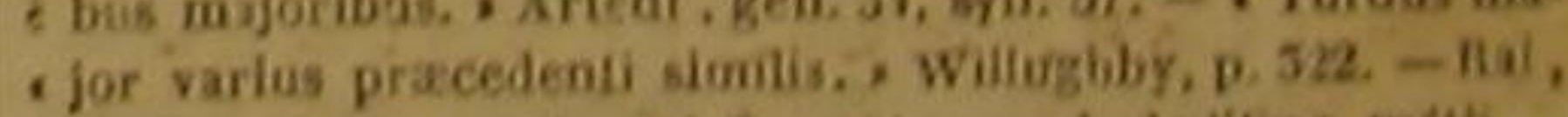
p. 157. - Labre mélange. Bonmaterre, pl. de íne, netti. - M. Cuvier ne cite pas ce polsson. D. " Catesby, Carol, 2, D. 10, tab. 10, fig. 2,-Labre jaynatire Navbenton et Hagy, Eoc, métb. - Id. Boncaterre, pli da "Enec, neéth. 
ver, et qui ont été très-bien saisis par le naturaliste Ascague. Le cendré a sa partie supérieure grise et pointillée d'un gris plus foncé, et les nagenires rôgeâtrès avec des taches d'un jaune obscur. La téte du mélé et la partie supérieure de sa caudale sont d'un beau bleu. Ce labre mêlé habite dans la Méditerranée, ainsi que le cendré; le jaunâtre vit dans I'Ámérique septentrionale; le rouillé, dans les Indes; le mélops, dans l'Europe australe; le nil, en Egypte; le triple-tache, en Norvège; le cornubien, dans la mer Britannique ' : on ignore la véritable patrié du bordé, de l'œillé et du louche.

Que devrions-nious ajouter maintenant à ce que nous disons dans les notes ou dans le ta. bleau générique, au sujet des onze labres renfermés dans cet article?

LE LABRE MERLE ?

Labrus Merula, Linn., Gmel., Lacep., B.., Cuv. '.

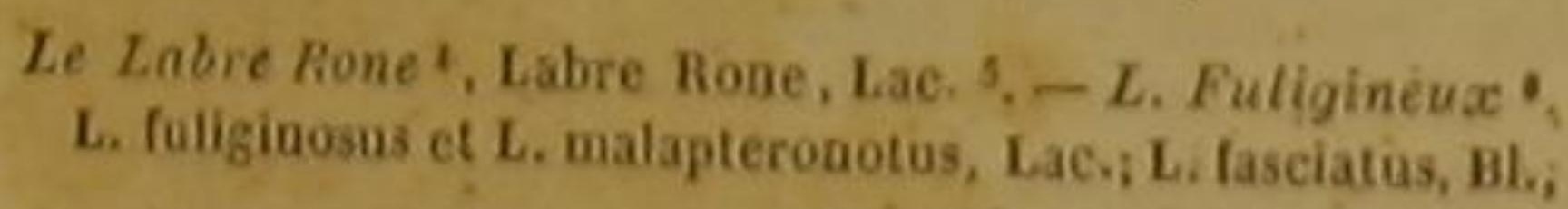

¿ 17 rayons a chaque nageofre pectorale da Jabre borde, 6 a chaque thoracine, 5 rayons algutlonnés et 9 rayons arelculés a lanale, 47 rayons a la caudale. -16 rayons a chaque

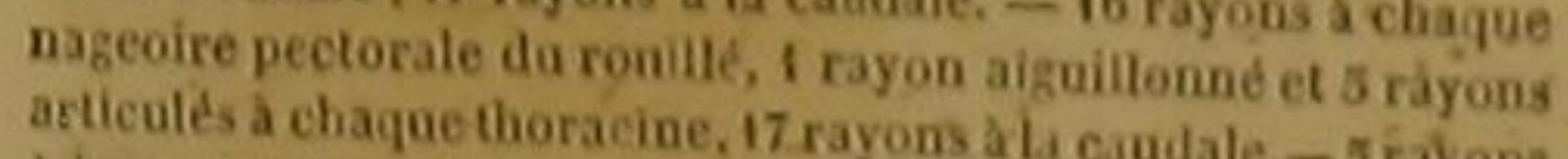

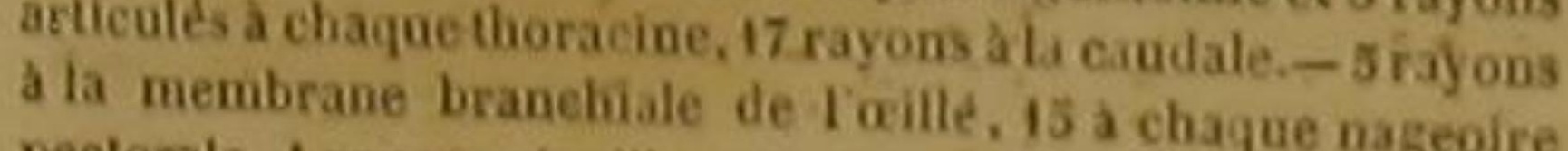

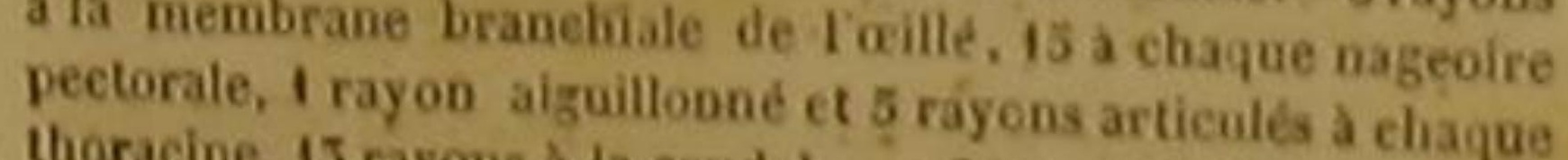
tharacine, 13 rayous a la caudale. -6 rayons a la membrave
branchiale du métops, 15 a chaque nageoise I rayon aiguilloneé et 5 rayons arlicut nageoire pectorale,

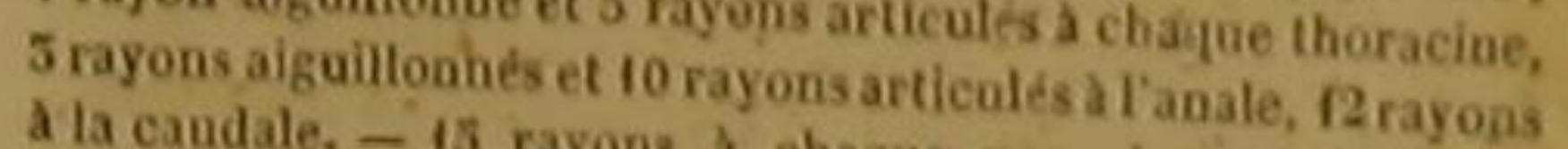
A la caudale. -15 rayons a chaque nageoire pectorale du
nif, 1 rayon aiguiltonné $\mathrm{et} 5$ rayons articulés a chave the

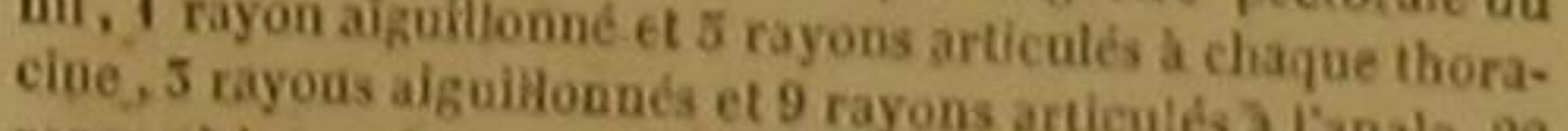
cine, 3 rayous aiguiltonnés et 9 rayons articulés a lanale, 20
rayons a la caudale -14 rayons a cha

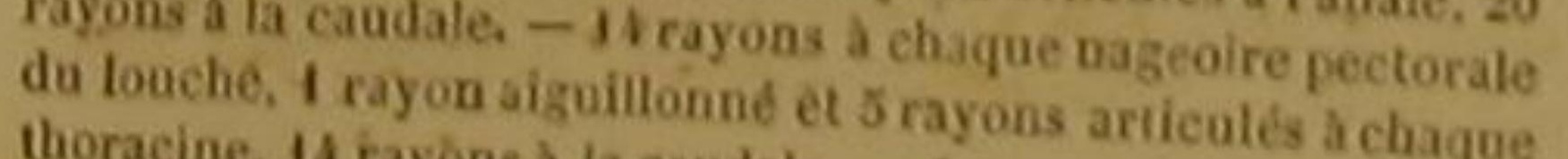
thoracioe, 14 rayouns a la caudale. -6 rayons a la la membrane
brancbiale do triple-tehe 1 rayon aiguillonoé et 5 rayons articultes a chare pectorale, -5 rayons a la membrane branchiale du cendré, 55 a chane.

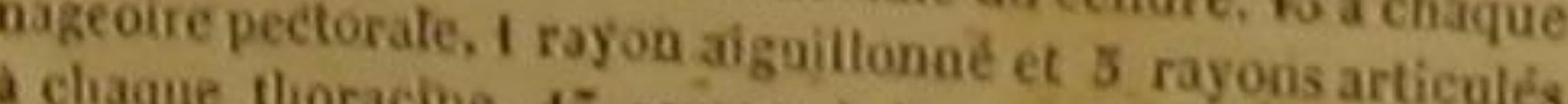
chaque nageoire pectorioyons a la caudale. -14 rayons

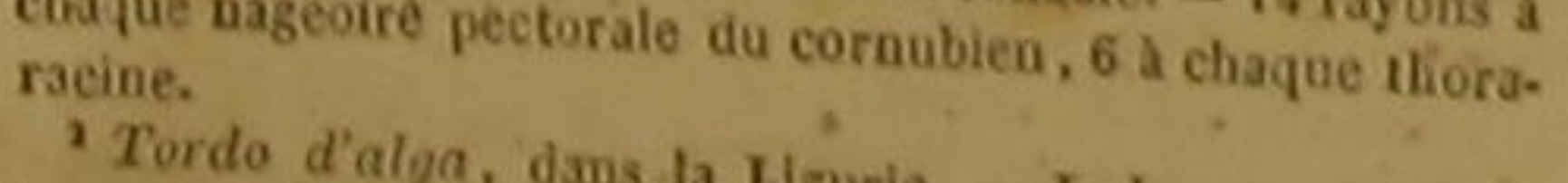
benton et Haay, Enc. méth - Ligurie. - Labre merle, Dau.

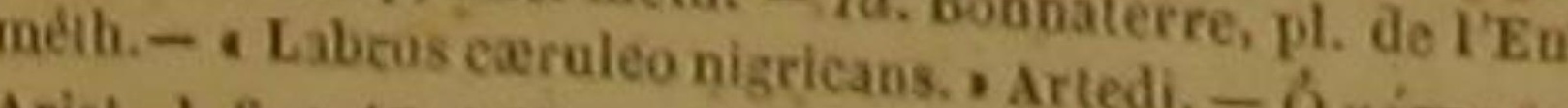

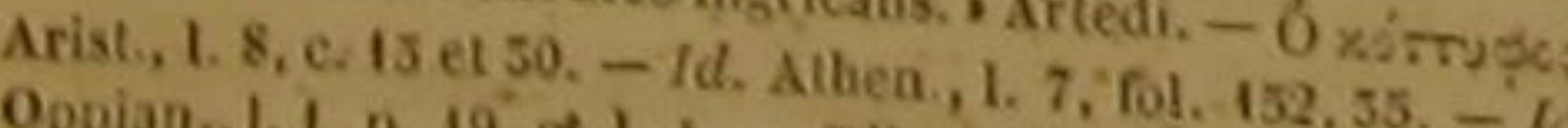

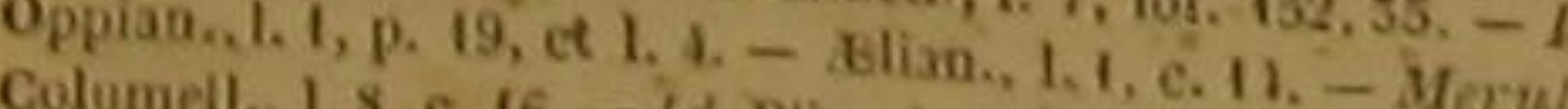
Id. Jov., c. 20 . . 57 . Id. Plio, 1. 9, c. 15; et L. 32, c. 4 . c. 3,-Merula. Salviom - Jerle, Rondelet, part. 1.1. 6 , $221 a_{i}-1 d$. Gesnér, p. 5is, et (germ) fonea, 87; et 2.5.

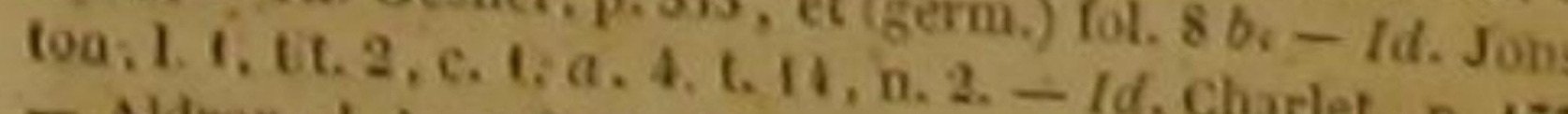
- Alfrov., L. 1. c. 6. p. 53. - Turdus niger .et, p. 135. Werle on Kondeletif., Willughby, p. 320. - Ral, p. I5 Galmont de Bomare, Diet, Rlist, p. IJt.
Cheilinus fasciatus, Cuv, T. - L. Brun '. L. fuscus, Lac,

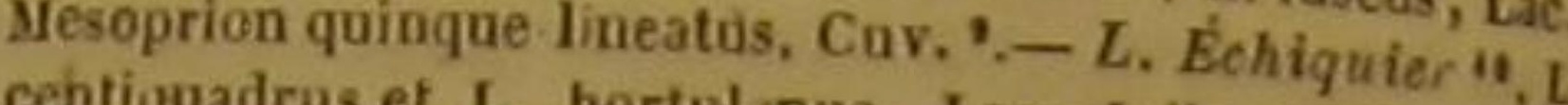

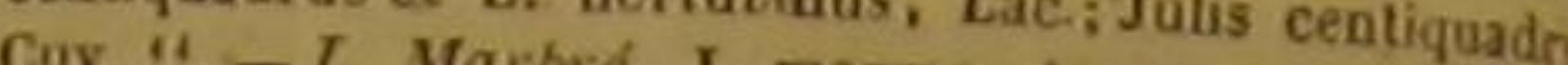
maculatns, Lac, Cuy, 12 - L. Large, Lac., et Cirrtile rus, Lac., Cuv, ", $-L$. Girelle" ", L Jolise, L. macree Bl., Lac.; Jullis mediterranea, Risso, Cuv, is.

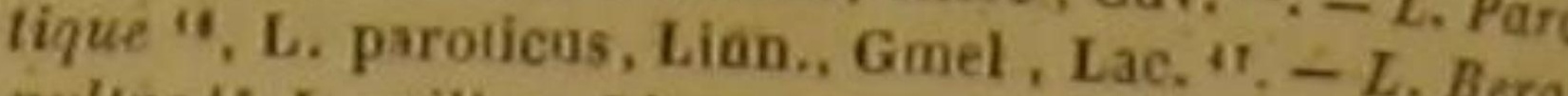
nyltre ", L. suillus, Linn., Gm.; L. Bergosnyliros, Berg.

Le noir bleuâtre que présente le labre merle, lui a fait donner, dès le temps d'Aristote, le D. 'Strand karasse, en Danemarck. - Ascagae, eaj. 2, p.6,
pl. 14. - Mall. Zool. Danic. Prodrom., p. 46. $\rightarrow$ Labre rdae. Eonnaterre, pl, de l'Enc. métb.

Non mentionné par M. Guvier. D.

- Labrus capite ex viridi, rubro, luteoque, variegato; tas - ciis transversis quatuor vel quinque, é fusco decoloribus., IM. Cuvier s'est assires

neux (non la figure)-doit étre rapportion du labre foligiplus loio, sous le nom de Labre malapteronote. Ouän tácrite igure, elle represente le Mesoprion uninotalus, Cov, $C$ labre fuligineux, selon ce naturaliste, se rapporte an soges genre Cheiline, dans le grand genre des Labres. D.

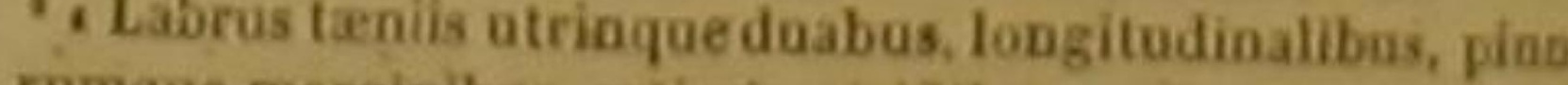
4rumque marginibus extimis viriaibus. , Commerson, ma. I I. Cuvier raver.

Iérygiens percoides, sous le poisson a la famille des Acanthop. . Mesoprion quinque. neatus., D.

toto corpore areolis atro posterioribus rubra variegatis, Commerson, manuscrits déj citc.

"Le Labire échiquier-de M. de Lacépède ne differe pas pecifiquement du babré parterce décrit ci-après. M. Cuvies e grand gente des appartenant au genre des Givelles, dans a Le Labre mastodest. D.

Léte marbré est une seconde fois décrit par M. de ans son genre Cirrbiter de la fate marbré. I Cuvier I admet percoides. D.

"Le large-queue est un vrai labre pour M. Cuṽier. D. "1) Donsella. Zigorella, dans la Ligariev - Jurella on

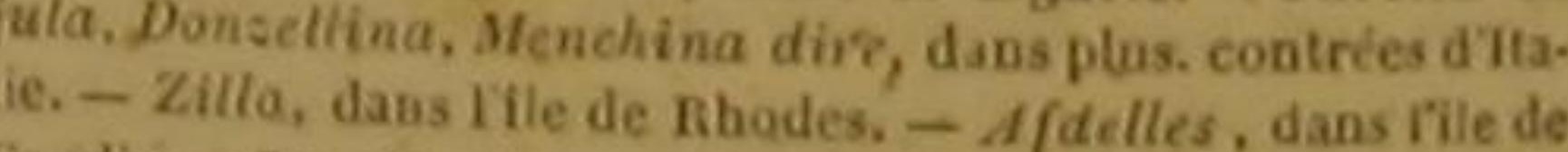
Walte, - Dorella, dans quelgues départ. mérid. - Haruza,

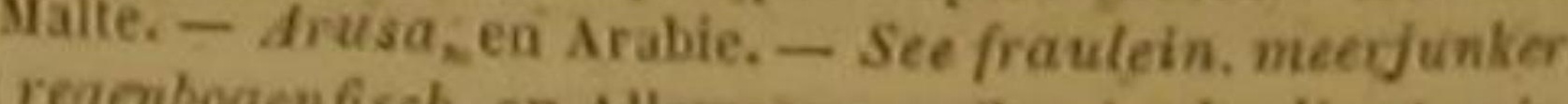
Cog fish en fisch, en Allemagne.- Sea junkerlin et rain us. Ad, Frid. 2, p. $75^{\circ}$ - Jonkerviseh, en Hollande. irelle. Daubenton et Haüy, Enc, peth. 287 , fig. I. - Labr 1. de I'Enc. méth - - Labrus palmaris yarips, denthos doo a bus majoribus maxillt superibris. , Art. gen. 51, syn. 55.

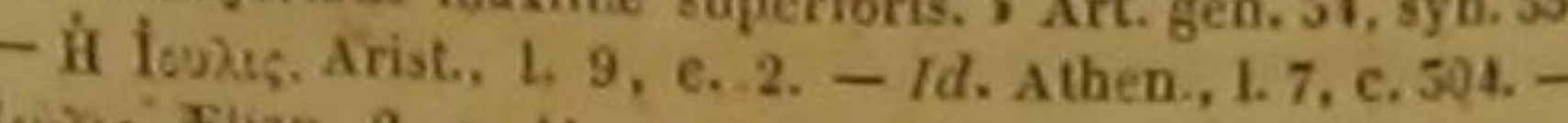

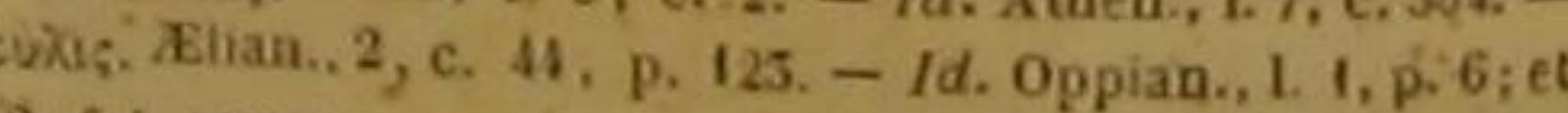
I., fol. 127, 56, $-I d$. Galen. elass, 2 , fol. $29, D, E .-J$ uli Plin, L, Salvian., fol. 217, ad iconem, et fol. 219. - Julis. Pulis, Ge, c. 9. - Girella. Koudelet, part. 2.1.6, c. 7. -

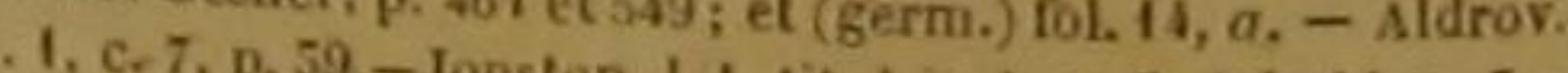
Willughby, I hth p. de Bomare, Dict. d hrist. nat. "La Girelle est le type d'un sond"ier, dans le grand genre des Labres de Linnnée. D. Enc. mét. Ad. Frid. 2, p. $76:$ - Labre parot. Danbentod, nom spécifique qu'il porte: Il offre en effet les mêmes nuances et fes mèmes reflets que l'orseau si commun en Europe et connu sous le nom de-Merle; et il n'est pas indifférent de faire remarquer que les premiers observateurs, frappés des grands rapports qu'ils trouvaient entre les écailles et les plumes, la parure des oiseaux et le vêtement des poissons, les ailes des premiers et les nageoires des seconds, le vol des habitants de l'atmosphère et la natation des habitants des eaux, aimaient à indiquerces ressemblances curieuses par des noms d'oiseaux donnés à des poissons. Cette intention adoptée par plusieurs naturalįstes moderneś, leur a fai employer les noms de Merle et de Tourd on de Grive, pour le genre des labres, dont cependant ils connaissaient á peine quelques espèces ; et comme, lorsqu'on a fait valoir une ressemblance, on aime à l'étendre de méme que si elle était devenue son propre ouvrage, on a voulu trouver des individus blanes parmi les merles labres, comme on en voit quelquefois parmi les merles oiseaux. On est ensuite allé plus loin. On a prétendu que ce passage du noir au blanc était régulier, périodique, annuel, et commiun à toute l'espèce pour le labre qui nous occupe, tandis que, pour le merle oiseau, il est irrégulier, fortuit, très-peu frêquent; et propre à quelques individus de la couvée dans laquelle on compte d'autres individus qui ne présentent en rien cette sorte de métamorphose. Aristote a écrit que les merles, ainsi que les tourds, se montraient au printemps, après avoir passé l'hỉver dans les profondeurs des rochers des rivages marins, qu'ils étaient alors revêtus de leur beau noir chatoyant en bleu, et que pendant le reste de l'année ils étaient blancs. I faut tout au plus croire que, dans certaines contrées, le défaut daliment, la qualité de la nourriture, la nature de l'eau, la température de ce fluide, ou toute autre cause semblable, affaiblissent l'éclat des écailles du labre merle, en ternissent les nuances, en alterent les tons au point de les rendre plutôt páles et un peo blanchâtres que d'un bleu foncé et presque noir. Quoi qu'il en soit, it ne faut pas passer sous silence une autre assertion d'Aristote, analogu à des idées que nous exposerons dans un des "Non mentionné par M. Covier. D. “- Labre bergsnyltre. Dáubeuton et Haay, Enc, méth. Id. Bonnaterre, pl. de I'Enc, meth. - Faun. Suecic. 350. Sparus bergsnyltra. It. Wgoth. 179
" Non cite par M. Cuvier. D. discours que doit offrir encore l'histoire que nous écrivons. Ce philosophe a dit que les merles poissons fécondaient les oúfs d'autres espèces de labres, et que ces autres labres rendaient féconds les cuf́s des poissons merles. Ce fait n'est pas impossible; mais il en a été de cette remarque comme de beaucoup d'aperçus d'hommes de génie : l'idée d'Aristote a été dénaturée, et Oppien, par oxemple, l'a altéreée jusqu'à écrire que les merles n'étaient que les mâles des tourds. Au reste, l'iris du merle labre est d'un beau rouge, comme celui de plusieurs oiseaux dont le plumage est d'un noir plus ou moins foncé.

L'iris n'est pas rouge dans le labre fuliginéux, mais d'un jaune doré. Ce fuligineux a d'ailleurs la dorsale d'un pourpre noír avee quelques points bleuatres; les pectorales rougeatres avee une tache noire à leur base; les thoraeines variées de bleu, de pourpre, de noi et de verdatre; lanale, d'un noir tirant sur lo bleu; la caudale, d'un vert mélé de brun; et une petite tache noire a l'extrémité de chaque ligue latérale.

Le nom du labre brun vient de la teinte de son dos et de sa tête, qui est brune; sa dorsale son anale et sa caudale sont bordées de vert, ses thoracines légèrement verdâtres, et ses pectorales faunes à leur base, et brunes à leur extrémité.

Nous n'avons besoin d'ajouter à ee que nou avons dit, dans le tableau générique, des couleurs du labre échiquier, que quelques mot relatifs aux nuances de ses nageoires. On voit des points et des lignes rouges sur la dorsale et sur l'anale; une tache noire parait sur chacune des pectorales; et la caudale est jaunatre.

Une couleur bleuâtre ou d'un-vert foncé, répandue sur la partie supérieure de la girelle, relève avec tant de grâce les raies larges et longitudinales que le tableau générique nou montre sur chacun des cotés de ce labre, qu'll r'est pas surprenant qu'on le reparde comme un des poissons de l'Europe dont la parurè est la plus bélle et la plus agréablé. La dorsale et lanale offrent une bande jaune, une bande rouge et une bande bleue plačées l'un au-dessus de l'autre, et l'on croit que les males sont distingués par deux taches, dont la supérieure est rouge et l'inférieure noire, et que l'on voit en effet ainsi disposées sur les preniers rayons de la nageoire du dos de plusieurs fipdividus. 
Une vàriété de cette espèce a sa partie supérieure rouge, l'inférieure blanche, la caudale verte, et le bout des opercules bleu. Des couleurs vives, gracieuses, bríllantes, variées, et distribuées de manière à se faire ressortir sans aucune dureté dans les tons, appartiennent donc à tous les individus que l'on peut compter dans cette espèce de la girelle.

Ce labre vit souvent par trompes, et se plaî parmi lès rớchers. Élien a écrit que ces troúpes nombreuses attaquaient quelquefois les hommes quí nageaient auprès d'elles, et les mordaient avec plus on moins de force. Il est possible que quelques accidents particuliers aient donné lieu à cette opinion, que Rondelet a confirmée par un témoignage formè ; mais lorsque Élien ajoute que leur bouche, plejne de venin, infecte toutes les substances alimentaires qu'elles reacontrent dans la mer, et les rend nuisibles à l'homme, il faut relézuer son-assertion parmi les erreurs de son siècle, et tout au plus doit-on croire que, dans quelques circonstances de temps ou de lieu, des girelles auront pu avaler des mollusques ou des vers márins vénéneux, et àvoir été ensuite funestes à ceux qui s'en seront nourris sans préeaution ', et peut-être sans les avoir vidées avee soin. Passons aux couleurs du parotique. Ce labre a le dos gris et le ventre blanchàtre.

Le violet parait être la couleur dominante du bergsnyltre, dont la màchoire inférieure et les pectorales sont quelquefois d'un beau jaune.

Quant aux formes principales des dix labres nommés dans cet article, nous ne pouvons que renvoyer au tableau générique. Le merle ${ }^{2}$, le

' Voyez le savaint ourrage de J. G. Schnelder, intitulé, Petri drtedi synonymia piscium, etc.. p. 80.

Trayon arailtonené et 5 rayons articulés a cbaque thoradu rone, 14 a cherie. -5 rayons a la membrane branchiale t 5 rayouns articules chane pectorale, 1 rayon aiguillonn dale. -14 rayons d chaque nageoire ine, 14 rayous a la cain-

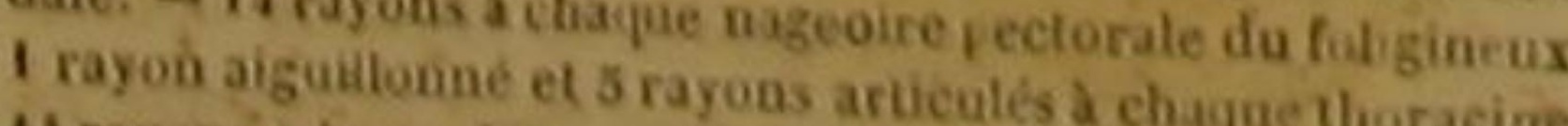

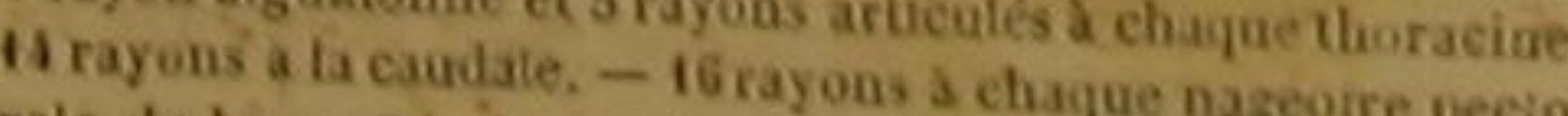
rale du brun, 6 a chaque thoracine, 12 ou 14 rayons a lacon

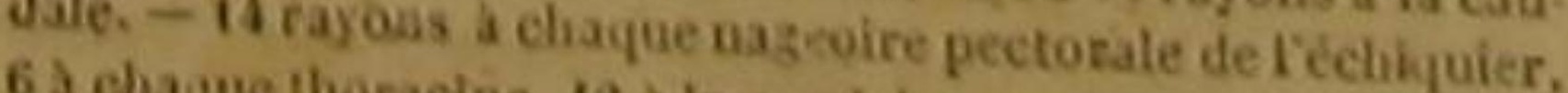
nageoire pectorale du a la cacdale: -13 rayons a claque cauda e. -14 rayous a chape, 6 a chaque thoracine, 15 a la queue. -6 rayons a la membrane branchiale do du large. is a cha pue nageoire pectorale, I rayon aign lloogicelle,

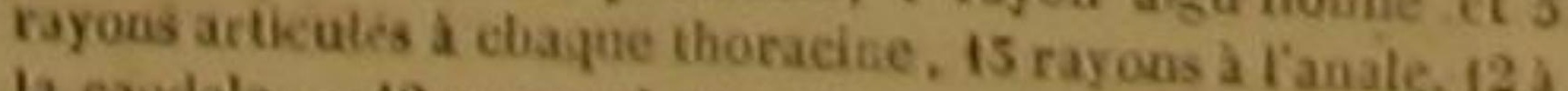

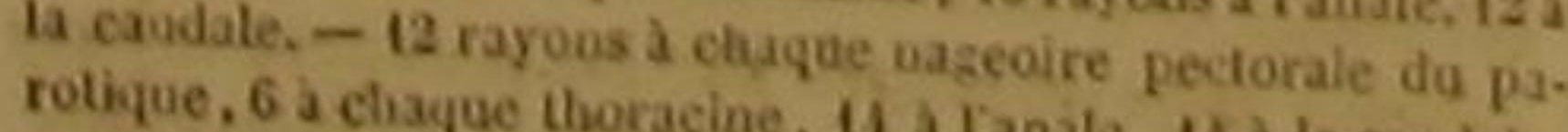

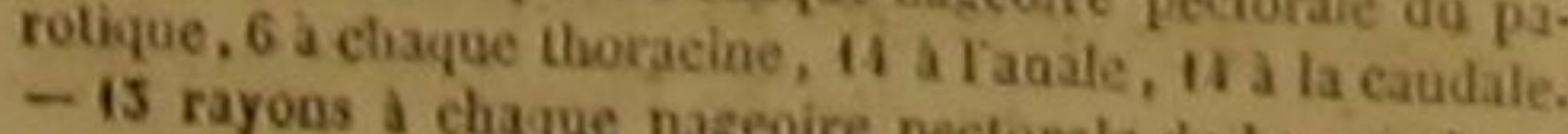

premier de ces dix labres, habite dans les mers de l'Europe; le rône se trouve particulièrement dans celle de Norvège; le fuligineux, le bru et l'échiquier vivent parmi les rochers qui environnent les iles de Madagasear, de France de Bourbon; le marbré et le large-quene a partiennent au grand Océan équatorial : ees cinq derniers-labres ont été observés par Com. merson, auquel nous devons les descriptions et les figures de ces animaux, que nous publions aujourd'hui ; et qui sont encore inconnues des vaturalistes. On pèche la girelle dans la Míditerranée, ainsi que dans la mer Rouge; les Indes sont la patrie du parotique, et le bergsnyitre panait préférer l'Océan Atlantique boréal.

\section{LE LABRE GUAZE ',}

Labrus Guaza, Linn., GmeL, Lacep., ,

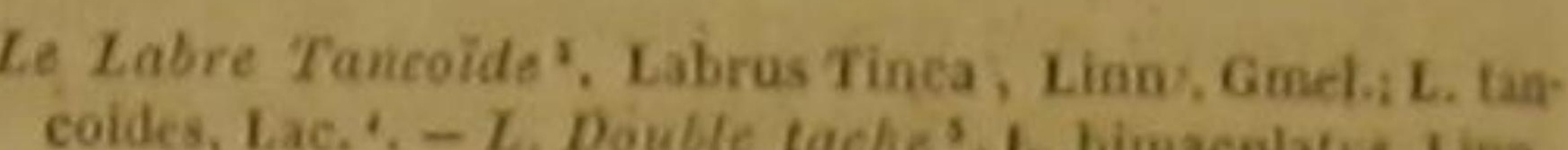

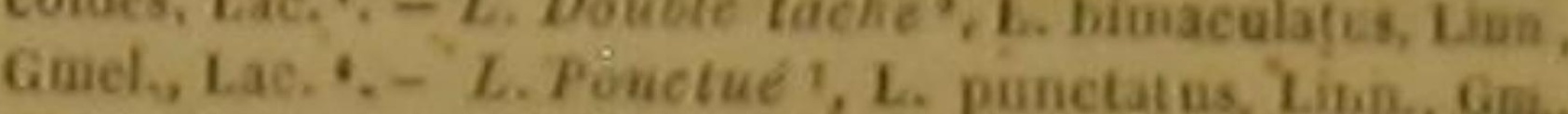

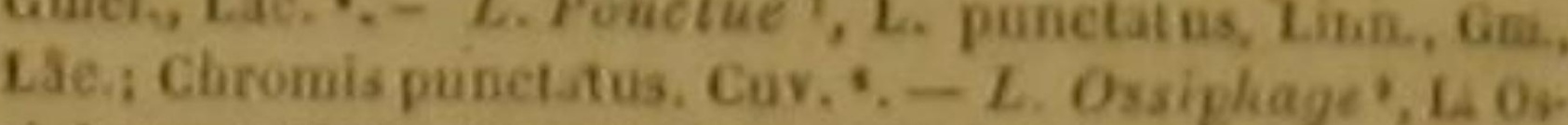

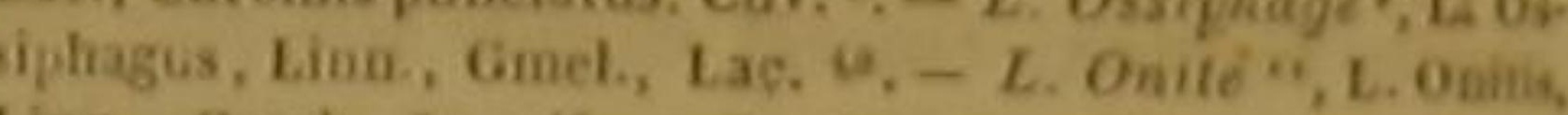
Aimn., Gimel., Lae, 13, $-L$. Perroquel ", I. Psittacess, Lac, L. viridis. Lion., Gmel.; L. Turdus, var, Cur. "4, L. Tourd ". . Turdus, Limn., Gm.. Lac, Cur." "., $-L$.

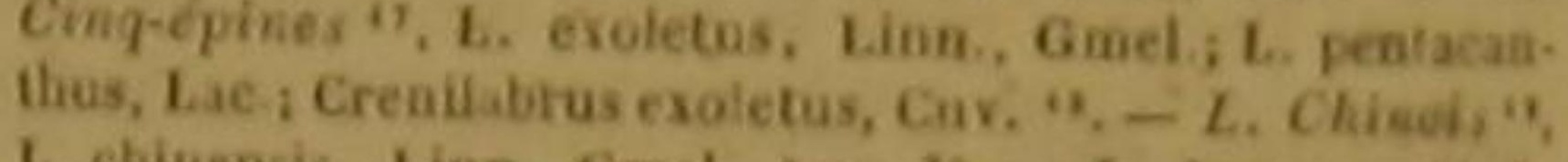

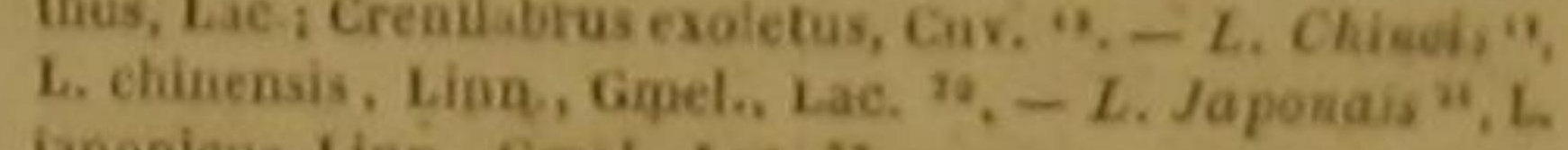
Japonicus, Lino., Gmel., Lae. ",

Le guaze et l'onite viveht dans les bautes mers; l'ossiphạge et le tourd, dans l'Océan At-

I rayou aiguillonné et 5 rayons artíenlés a chaque nugoine thoracine, 14 rayons a la candale.

'Latl, 11. 104. - Labre guase. Dambenton et Haby, Ene méth. - Id. Bonnaterre, pl. de l'Ene, méth. 1I. Cuvier ne cite pas cetle espece. II rapporte d son Me. Fou petil Zanana, Serranus Zananella, nee figure dongte

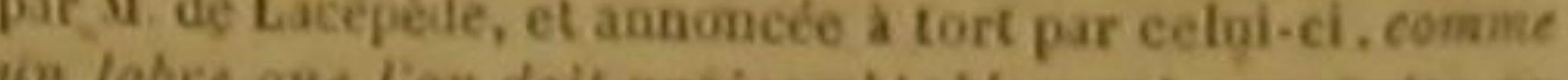
Guase. De fon doil vraisemblablement rapporter as

Frasse, old wife, et gurach, en Angleterre. - Labre a mer. Vaubenton ef Hady, Ene. meth. - Id. Hoa.

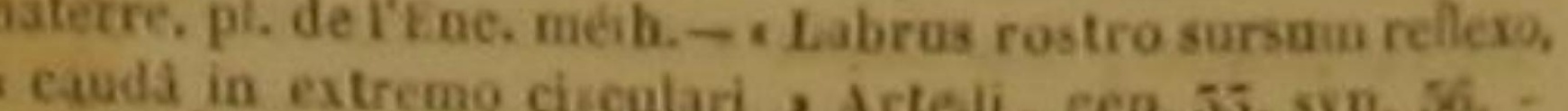
"Turdus vulgatissimus; tive marina Veneris. , Willughbj,

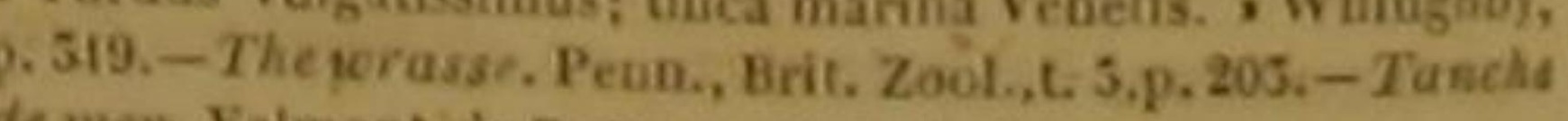
- Non cite par de Barmire, Dict. d'hist. uat.

- Labre doub M. Cuvier. D.

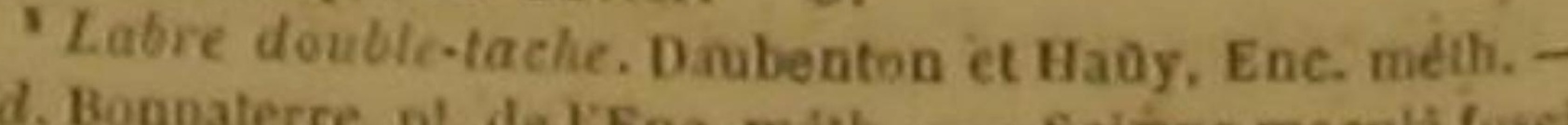
- in médio coryorisel supra bacim. - - Seix́na macolá fusced p. 66. - Brit. Zool. 5, p. 205. n. 2 .

Non cité par M. Gavier. D

'Prick mylta, en Suèle. - Labre ponctue. Daubenton - isciennal méth. $-I d$. Bonnaterre, pl. de l'Enc, néth. Mus. Ad. Frid, 1, p. 66. - Gronov. Mus, I, Ds 87. - Bloch,
Iantique ou dans la Méditerranée; le perroquet se trouve dans cette même Méditerranée, où l'on pèche également le labre double-tache, qu'on a observé aussi dans les eaux salées qui entourent la Grande-Bretagne; le tancoide habite pendant une graude partie de l'anuée dans les profondes anfractuosités des roehers qui ceignent les rivages britanhiques, ou qui sont peu éloignés de ces rivages; le cinq̨-épines a été rencontré dans cette mer si souvent hérissée de montagues de glace, et qui sépare la Norvège du Groenlànd; les eaux de. la mer équatoriale qui baigue Súfinam, paraissent au contraire préférées par le ponctué; le chinois a été vu près des côtes de la Chine; et Houttuyn a découvert le japonais auprès de celles du Japon.

Nous croyons que quelques naturalistes ont été induits en erreur par des accidents ou des altérations que leur ont présentês des individus de l'espèce du tancoide, lorsq̨u ils ont écrit que la lame supérieure de l opercule de ce labre était dentelée; nous pensons que la conformation qu'ils ont aperçue dains Fopercule de ces individus était une sorte d'érosion plus ou moins irrégulière, et bien differente de la véitable

- Do genre Chromis, dass la famille des Acanthoptérygiens labroides, Cuv. D.

'Labre ossifaye. Paubenton

"Noncié par M. Cuvier. D.

A. Mas, Ad. Fnd. 2, p. 29. - Labre onile, Dambenton a

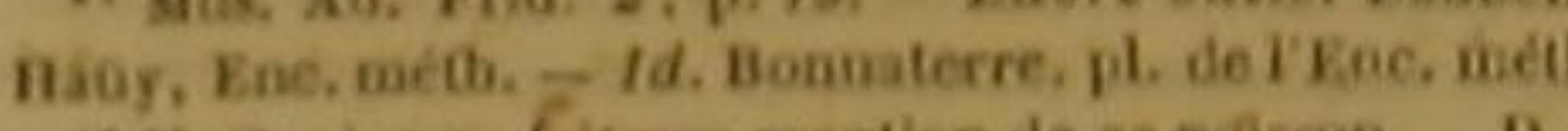

“M. Cavier ne fait pas mention de ce poisson. D.

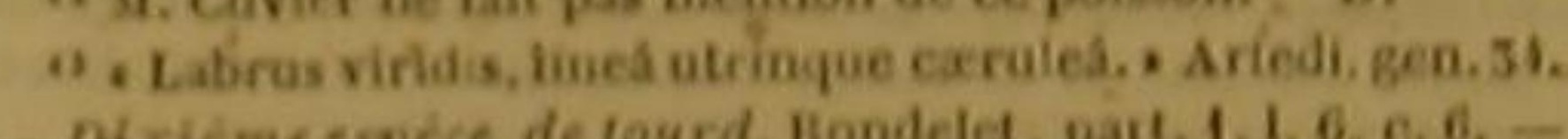
Turdus eiridiss seu decimus Rondeletii. Willoghby, Iclith., p. S20. - Labre perroguit, Daubenton et Haay, Eac, méth. p. Id. Bonnaterre, pl. de I'Ene méth.

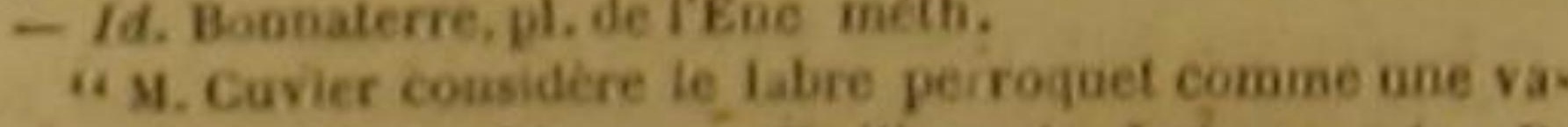
riete de Vespece quill nommie Vieille verte, Labre turdus D. ", Labrus oblongus viridis, iride lutes, , Artedi, gen. 34, syn. 57. - Turdus ciridis major. . Turdas oblowg as, fus.

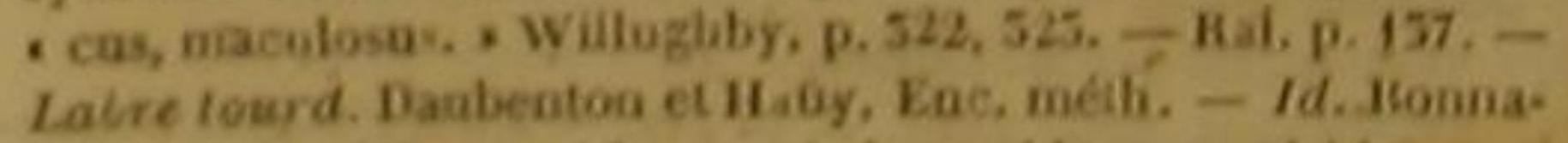
terre, pil. de IEnc, meth. - - Labrus oblongas, viridecicens, - maculatus, etc, , Brann. Pice, Missil., p. 3i. n. 67.

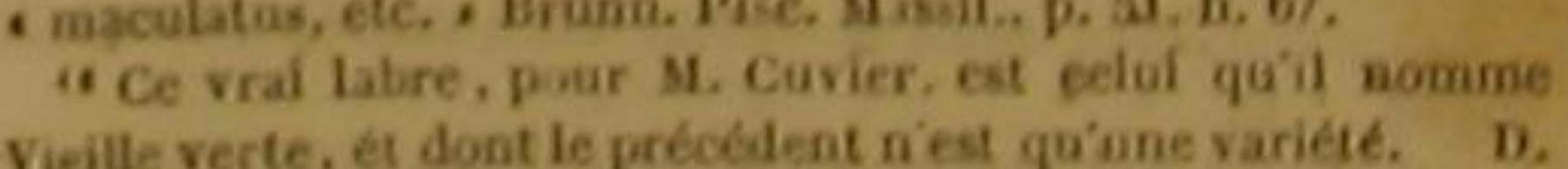

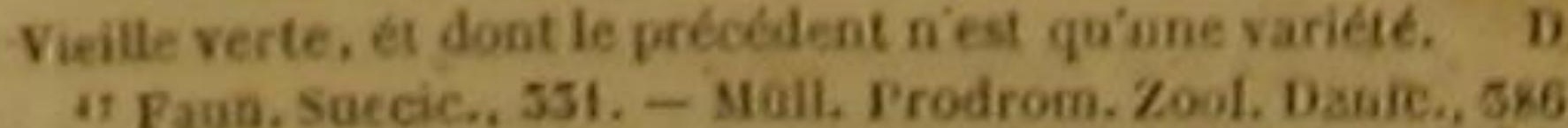
-OL. Fabric. Favo. Groenland., p. 165 , n. $120 .-$ strom. Son Im. 267, n. 3. - Labre cing-épines, Daubenton et Haay, Enc. inéth. - Id. Bonnaterre, pl, de IEnc. mét

una bródes. D.

"Labre lioide. Daubraton et Haay, Enc, meth. - Id Bonnaterre ph. de LEnc. meth.

"10 Non cile par M. Cavier. D.

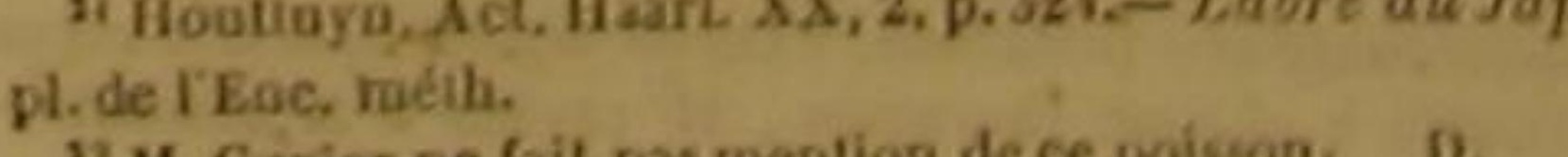

"We Civier ne fait pas meation de ce poisson. D. dentelure, que nous regardons comme un des principaux caractères du genre des lutjans: mais. si notre opinion se trouvait detruite par des observations constantes et nombreuses, il serait bien aisé de transporter le tancoide dans ce genre des lutjans, et de l'y inscrire dans le second sous-genre.

Les dents antérieures du tourd sont plus grandes que les autres. Il est facile de voic, èn parcourant le tableau génériquie, que ce labre tourd peut présenter, relativement à ses couleurs, trois variétés plus ou moins permanentes: Lorsqu it est jaune avee des taches blanehes, sa tête mòntre communément, et indépendamment des taches blanches, quelques taches noires vers son sommet, et quelques filets rouges sur ses cotés; son ventre est alors argenté avee des veines rouges, et ses nageoires dorsale; thoraeines, anale et caudale, sont rouges et tachées de blane. Si ce méme tourd a a couleur générale verte, ses pectorales sont 'un jaume pále, ses thoracines bleuátres, et sa longueur est un peu moins grande que lorsqu'il ofire une autre variété de nuances. Et enfin, quand il a des taches dorées ou bordées d'ov au-dessous du museau, avec la partie supérieure verte, il parvient aux dimensions ordinaires de son espece, il est long de trois décimètres ou environ; - il a le ventre jaunátre et parsemé de taches blanches, frrégulières, bordées de rouge; une raie formée de points blanes ct rougeátres règne avec la tigne latérale, et est placée aú-dessus de plusieurs autreś raies lonritudinales, composées de petites taclies blat. ches et vertes '.

- 16 rayons s chaque nogeo're pectorale du labre guaze, $6 \mathrm{i}$ chaque thoracine, 15 a ravale, 15 a ta caudale. - 6 rayons a a membrane branchiale do tancoide. 11 a claque nageoire la mentrane branchiale du donble-aclie, 15 a chaque na.

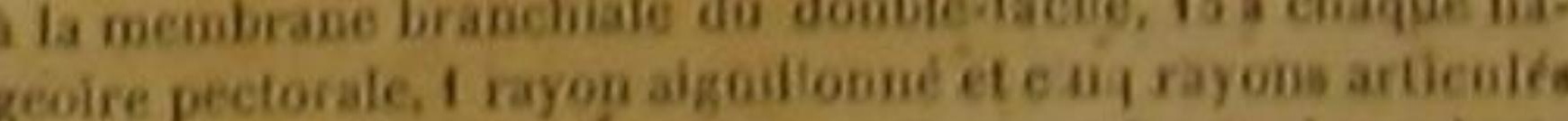

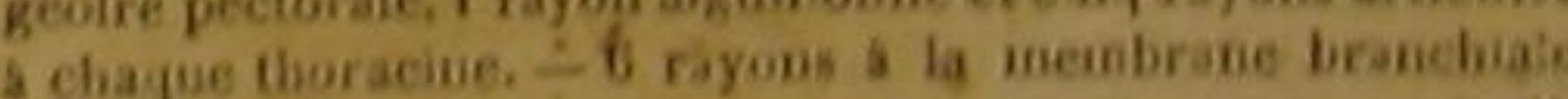
a pon toé, 15 a chaque mageoiré pectorale, I rayon alguit lonné et 5 rayous ardiculs a clasque thoeacine, 18 rayous a la candale, - 15 rayobsa chaque nazeire veciorale de losi-. hiage, Irayon aigoillonne et 5 rayons articules a chajue

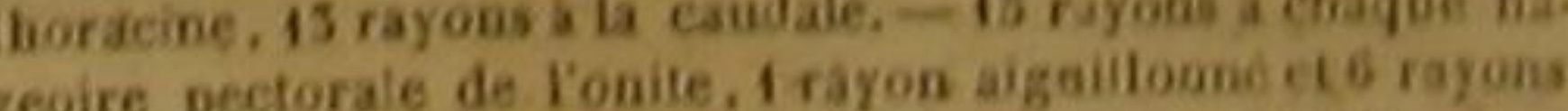

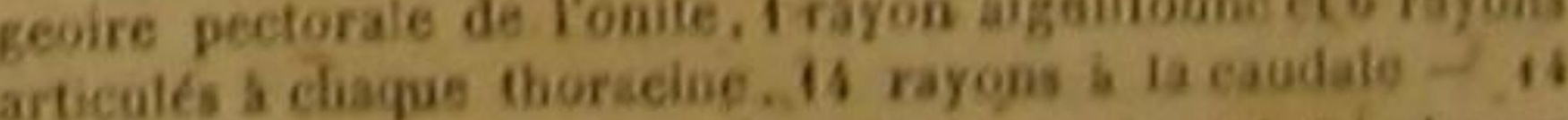
rayons a chaque nageoire peetorale da pecroguet, 6 i clague

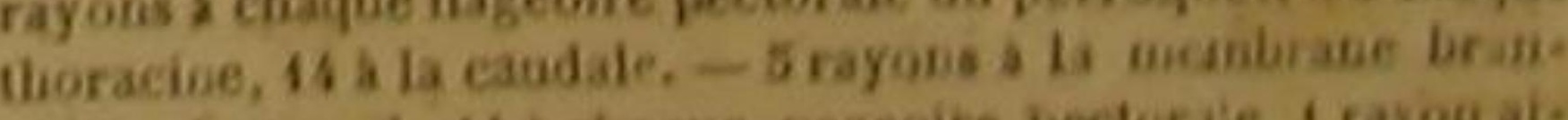

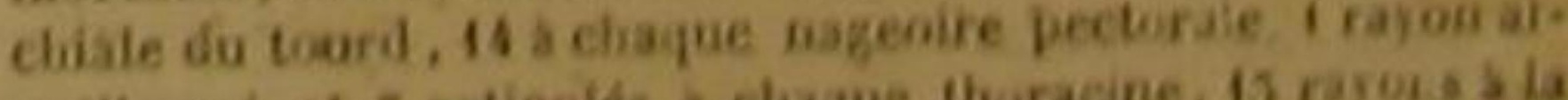

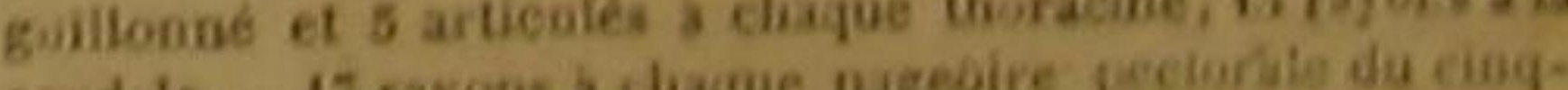

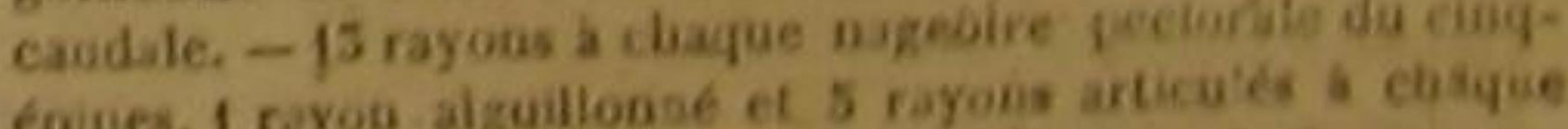

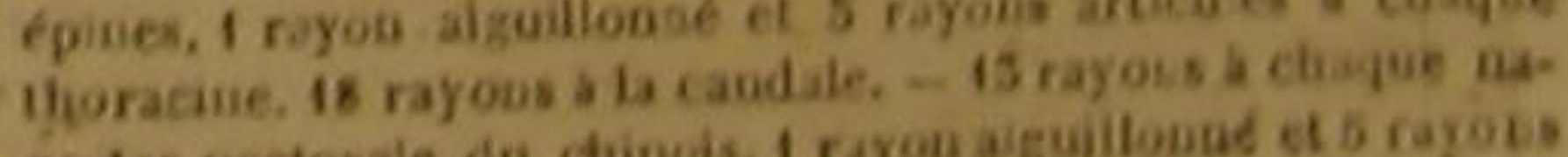


Quelle différence đe ces couleurs variées et les dents de devant plus grandes que les autres vives qui grivèlent, pour ainsi dire, le tourd, le lunulé a la tête et la poitrine parsemées de et Ini ont fait donner le nom spéeifique qu'il taches rouges, les pectorales jaunes, les antres breuses du ponctué! Ce dernier labre est brun, geâtres, et quelquefois des-rayons rouges auét cette teinte obscure n'est relevée que pàr des tour des yeux. Les opereules du varié sont gris points d'un gris très-foncé ou noiråtres, qưi et rayés de jaune; ses pectorales tachées d'olicomposent les raies longitudinales indiquées dans le tableau générique, êt par d'autres taches, ou points, ou petites raies transversales ou longitudinales, du même ton ou à peu près, et épars sur la quete ainsi que sur une partie de la dorsale et de la nageoire de l'anus.

LE LABRE LINÉAIRE ', Labrus linearis, Lịnn., Gmel.s Lacep. ?.

Le Labie Lunule-s, L. lunulatus, Forsk, Linn., Gm , Lac.:

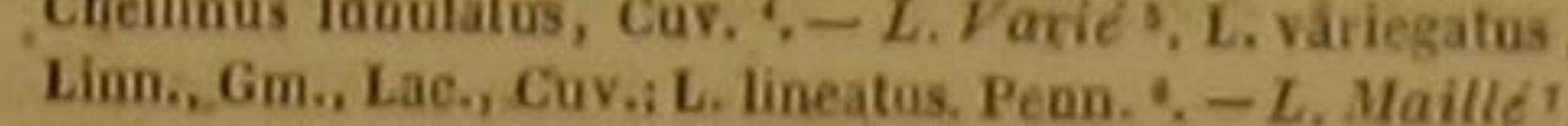
L, reticulatus, Lac; $L$. venosus, Brunn., Lino., Gm.; Gre

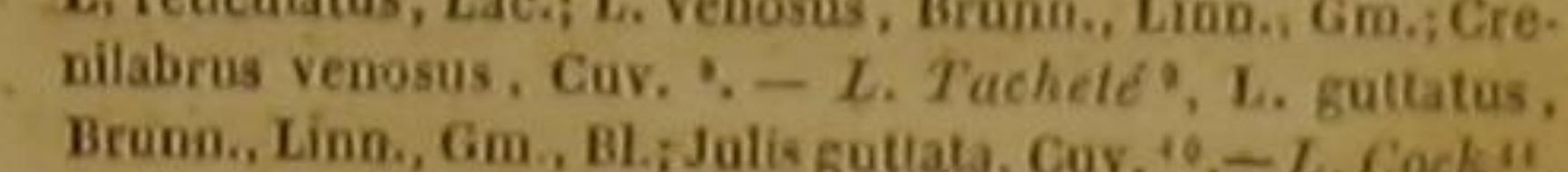

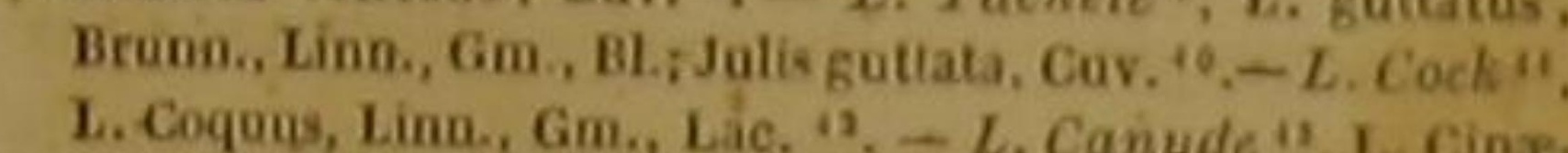

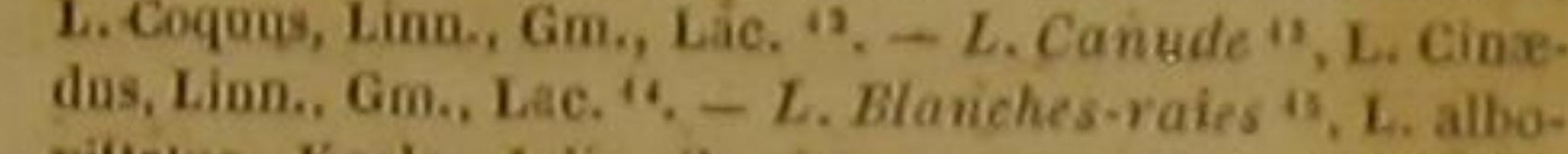
vitatus, Koelr, Julis albovittata, Cuv, "., $-L$. Bleit "

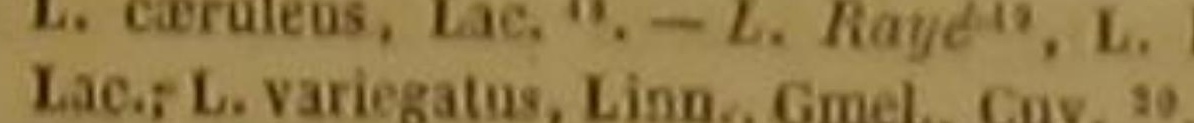

Le linéaire a; comme plusieurs autres labres, et particulièrement comme le bleu et le rayé,

articulés a chaque thoracine, 12 rayons a la caudale. -

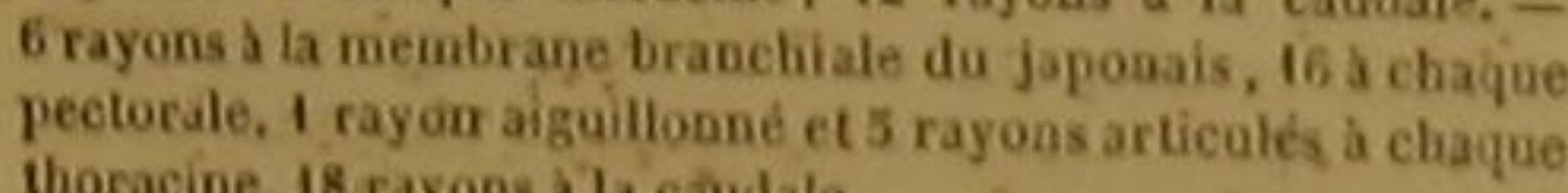
I Amon, academ i, paúdalo.

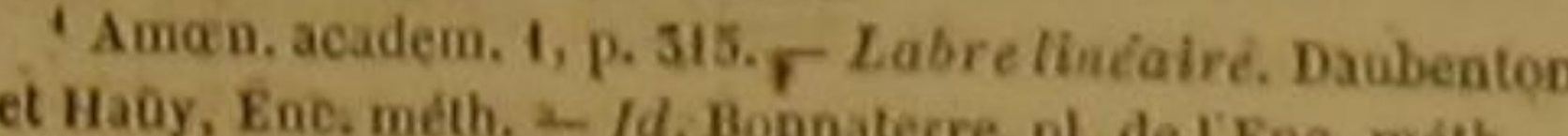
'Non cité par M. Cuvier. D. "Forskael, Faun. Arab., p. 57, n. 51. - Lasre lunule.
Bonnaterre, pl. de IEne, méih.

'Du sous-geare Cheidine, dans le grand genre Libre, de Ia Samille des Acanthoptérygiens labroider, Cuv. D.

- Cepod wrasse. Brit. Zool. 5, p. 207, n.

gé sous le nom de vieal Labre pour M. Cuvier, qui le dési-

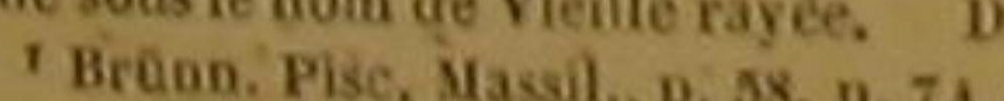

Daterre, pl. de I'Euc. méth.
pr, 0. 74. - Labre maille. Bon- Du sous.genre Crénilabre, dans te grand genre Labre, Cuv. Do

Bonnaterre. Pisc. Massill, p. 50, n. 76. - Labre tachete.

Cuv. D.

Aे Cosk Cost

Pisc., p. 165, f. 4.
(4) "Non cite par M. Cavior. D.

"hochau, Canus, Canudo, dans plos, départ. mérid.

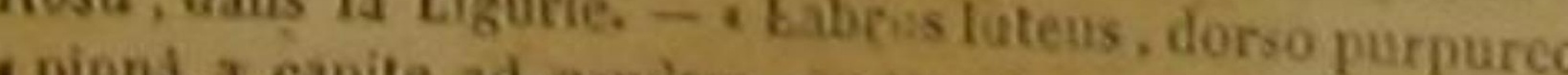

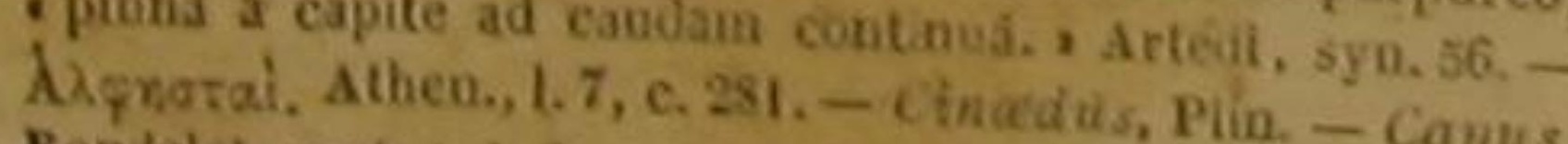

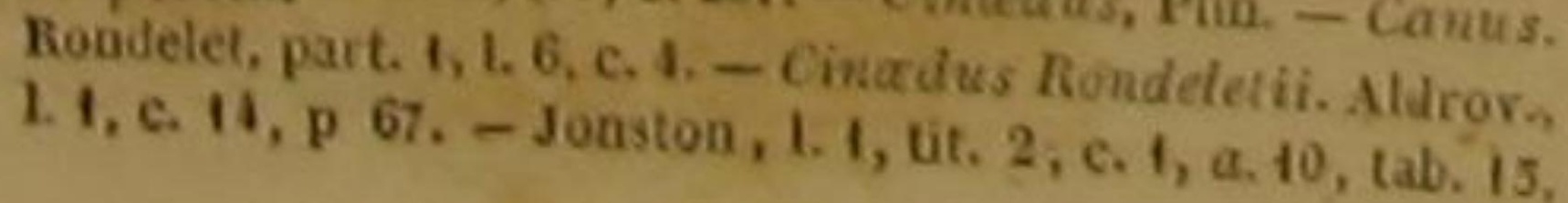

vâtre à lẹc base; et ses thoracines, ainsi que son anale, bleues à leur sommet. Le rayé pré. sente un liséré bleu au bout des thoracines, de I'anale et de la caudale; les rayons de cette dernière nageoire sont jaunes à leur base, $\mathrm{t}$ une tache bleue est placée sur la partie anté. rieure de la dorsale.

Ce labre rayé vit dans les mers de la Grande. Bretagne, ainsi que le bleu, qui fréquente aussi les riyes de la Norvège et du Danemarek, le cock et le varié, que l'on jencontre particulierement près des íles Skerry; le linéaire se trouve dans les Indes et près des rivages de l'Amérique méridionale; le lunulé, près des côtes de l'Arabie, et le maillé, le tachété et le canude sont pèchés dans la Méditerranée, où ce canude était cómnu dès le temps d'Athénée et mème de celui d'Aristote, et où on l'avait nommé Alpheslas et Cincedus, parce qu'on voyait presque toujours les individus de cette espèce, nager deux à deux à la-queue l'on de l'aùtre '. La chair de ces canudes présente les

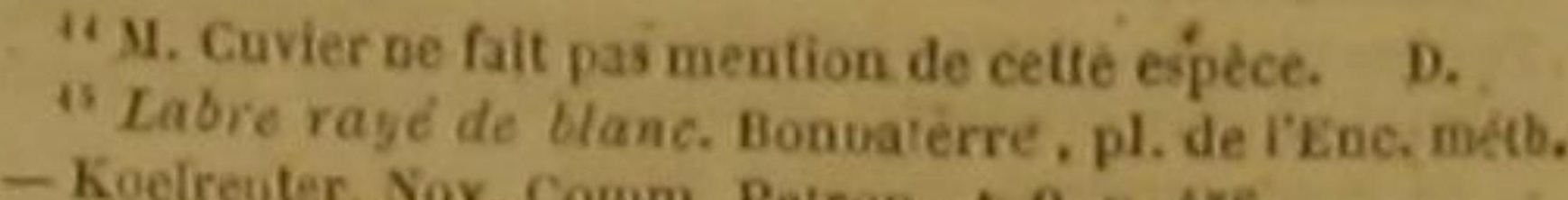

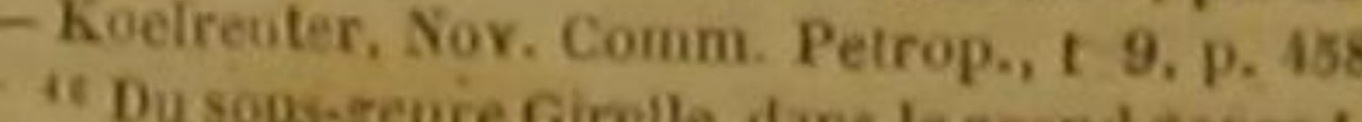

"Blaastaal et Blaustak, en Danemare Labre. Cur. D. deIEnc. méth.

"Non cité par M. Cuvier. D.

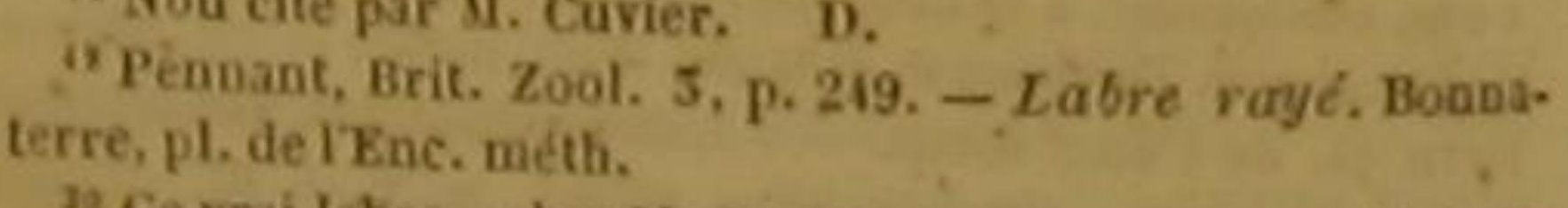

${ }^{3 a}$ Ce vrai labre, selon M. Cavier, est nommé par lai Vieille
rayée. D.

6 rayons a la membrane branchiale du labre linéaire, 12 A chaque nageoire pectorale, 6 a chaque thoraciñe, 12 a la
caudac. -5 rayons a la membrane branchiale do donite, 12 d chaque nageo re pectorale, 1 rayon aisuillond et 5 rijons articules à chaque thoracine, 15 rayons a la candale. cha pethale, 1 rayon aignilionné et 5 rayons articules d mailié, 15 a he. 5 rayons a la membrane branchiale da et 5 rayons articulés a chaire pectorale, 1 rayon aiguil onné dale. -5 rayons a la membrane branchiale ryons a la cav. chaque uageoire pectorale, $t$ rayon agrillog tachete, 17 a

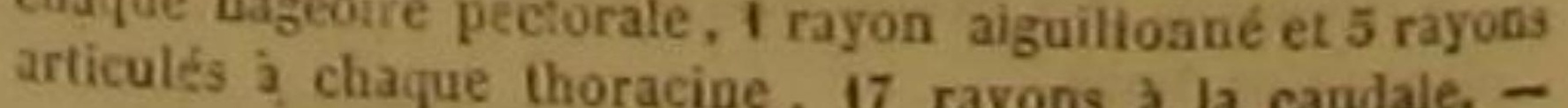

\section{n. I. - Alphestes, vel Cincodus. Gesner, p. $56.40 \mathrm{et}$ (gern.)
fol. 15. - Alphestes. Charlet., p. 135. - Alphestrs, tive} Cinedus, IViltughby, p. 525, - Rat, p. 157. - Labreca. aude. Danbenton et Haay, Enc. méth. - Id. Bonnaterre, Ascagoe, cah. 2, p. 5 , pl. 12, - Labre bleus. Boimaterre, ph . mémes qualités que celle de la plupart des autres poissons qui vivent au milieu des roehers, et qu'on a nommés Saxatiles; elle est, suivant Rondelet, molle, tendre, friable, ficile à digérer, et fournit une nourriture conve nable aux malades ou aux convaleseents.

\section{LE LABRE BALLAN '.}

Labrus Ballan, Penn; Lacep a L, Bergylla, Ascan; L. maculatus, Bl., Cuv, ?

Le Labie Bergylle s, Labrus Beraylta, Ase, I. Ballan Peno., Lac, L. maçulatus, Bl., Cur. ' $-L$, Hassek', L

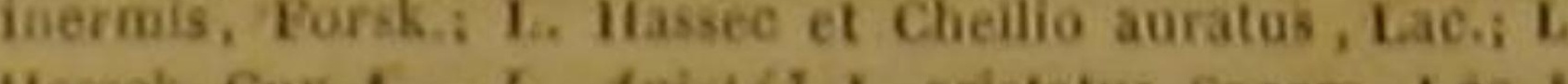
Hasses, Cav. "O L. Arisice, L. aristatus, sparm., Lae,"

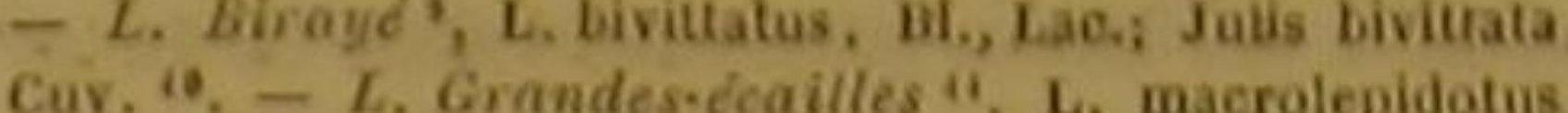

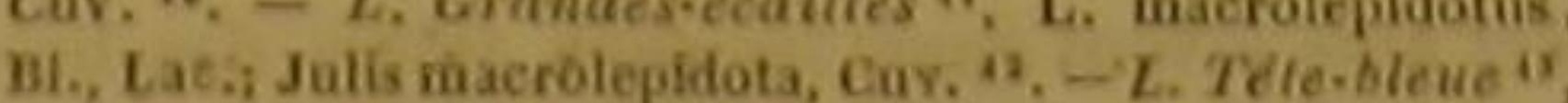
L. eyanocephalus, Bl, Lac.; Julis cyanocepbala, Cuv, "."

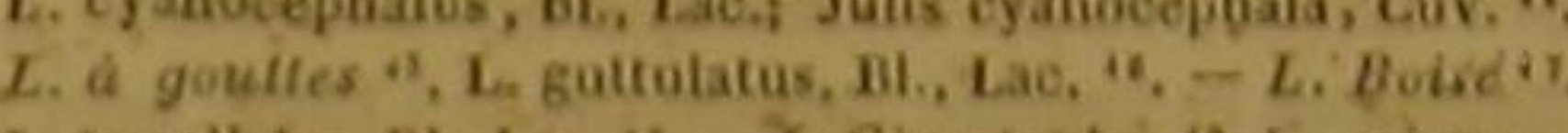
L. tessellatus, Bl., Lac, ", - X. Cinqtachés ", L. qujiquemaculatus, Bloch, Läceps Grenilabrus quipquè-maculatus,
Cüv. ${ }^{20}$.

Quelles nuances devons-nous décrire encore, pour compléter l'idée que nous dọnne le tableau générique des couleurs de ces labres? La teinte

15 rayons a chaque nageoire pectorale du blanches raics, $6 \mathrm{a}$ chaque thorecine, $12 \mathrm{a}$ la caudale, -5 rayons a ta membrane branchiale da bieu, 14 a chaque nageoire pectorale, $f$ rayon aisuillonue et 5 rayons aricales a chaque thoracine, 11

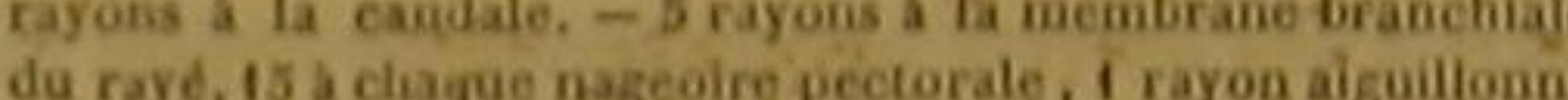
et 5 rayons arlicules a chave choracine.

- Pengant, Brit. Zool. 5, p. 2v6. - Labre bal̆an, B̂onna tére, pli. dé IEne math

'selon M. Cuvier, te Ballan, qû́ est un vrai labré, ne differe specifiquement pas da Bergylie. C'est une simple variéte du Labre tacheté. D.

- Berj-gall, Berg gylle, Sed-aborne, en Norvége. - See carpe (earpe de mer, ea Dald Ascagoe, pl. 4. - Labre tacieic. Bloca, pl. 294. - La

4 Voyez la note 2 précedente. D.

- Labrus hassek, Labre inermis. Bonaterre, pl. del'Enc. métb. - Fonkael, Descript. animal, p. 54. -M. de Lacépéde a décrit ume seconde fois le Labre tassek, sous la dénomination dé Cheilion doré. C'est un vrai labre, guivant s. Cpavier. D.

' Labre arific, Bonnaterre, pl, del'Enc, meth. - sparmann, Amoce. acad., vol. 7, p. 50.
: Non cité par M. Cuvier.

- Blocit, pl. 284, fig. 1 .

"Da sous-genre Girelle, dans le geare Labre, Cuv. . D

" Blocis, pl. 254. fig. 2.

12 Du sous genre Girelle de M. Cavier. D.

"Bloch, pl. 286.

" Du sous-geore Girelle, Cuv. D.

Bloch, ph. 287 , fig. 2.

D.

"Non cilé par 1 . Cuvier. D.

"Bioch, pl. 231, fig. 1 .

20 Du sous-gente Crén labre, dais le grand genré Labre,

selon M. Cuvier." D. eserale du bergylte est brune, et ce brun est mèlé de jaune sur les opereules; le hassek est vert, aveo le dos brun, et des taches blanchâtres sur les cótés; presque toutes les nageoires du birayé sont d'un vielet mèlé de jaune; le labre grandes-écailles présente des nageoires colorées de mème, des taches violettes sur ses opercules, et quelques taches bleues à l'origine de la dorsale; un gris tírant sur le vert distingue les nageoires du labre têtebleue; presque toutes Jes taches que $\Gamma$ on voit sur le labre a gouttes, sont ordinairement rondes comme des gouttes de pluie; le boisé a les thoracines noires, les pectorales et la caudale bleues, la dorsale et l'analé variées de bleu, de jaune et de brun; et le cinq-taches a les nageoires jaunes, bordées de violet. Nous devons a Bloch la comaissance des six derniers labres que nous venons denommer, et nous savons par ce naturaliste que le cinq-taches vit, ainsi que te boisé, dans la mer de Norvège, d'où. M. Spengler, de Stoekholm, avait reçu des individus de ces deux espèces. C'est dans les mers de la Grande-Bretagne, on à une distance asséz peu consídérable de la Norvège, que l'on trouve le bergylte et te ballan: On péche le hassok dans la mer d'Arabie; et M. Sparman dit que le labre aristé a pour patrie lés eaux de la Chine'

Les mâchoires du labre grandes-écailles n'offrent qu'un seul rang de dents, dont les antérieurés sont les plus longues; la ligne latérale de ce poisson est interrompue; une seule rangée de dents petites et aiguès garnit les deux machoires du labre boisé.

'4 rayons a la membrane branchiale du Labre ballam, 14 claque nageoire pectorale, 1 rayon aiguillonie et 5 rayons articales a cliaque thoracine, - B rayous a la membrapo
branchiate du bergyite, th a chaque nageoire pectorale. branchiate du bergyite, 14 a chaque nageoire pectorale,
t rayon aiguillowné et 4 rayons aricules a chaque thoraciae, I rayon aiguillonée et 4 rayons ariculés a chaque thoraciee,
is rayons a la candate. - 12 rayonis a chaque nageoire pecto-

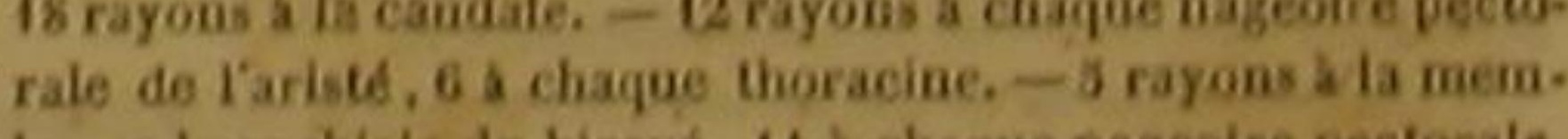
rale de lariste, 6 a chaque thoracine, -5 rayons a la mem.
brane branchiale du biraye, 14 a chaque nageoire pectorale,
i 1 rayon aignilloine et 5 rayous anticulés a chaque thoradie. is rayons a la caudale. -5 rayons a a membrahe brancliale

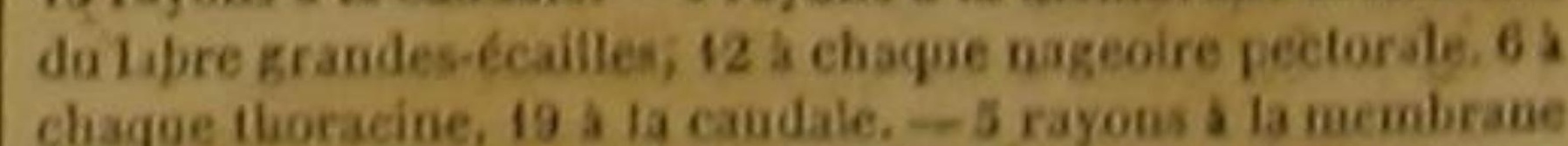
chaque thoracine, 19 a la caudale. - 5 rayous a la membirane
branchiale du tabre téte bieve, 12 a chaque nageoire peco.

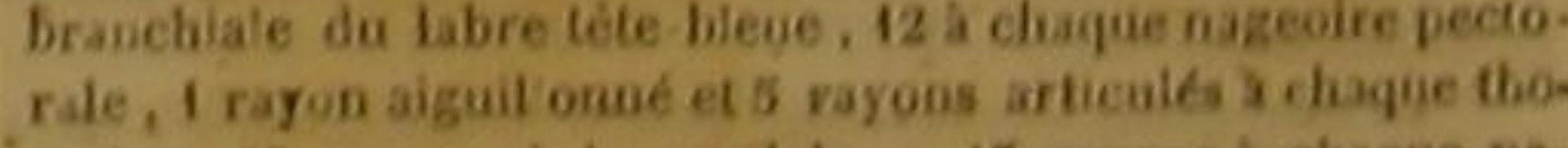
raciue, 12 rayons is is caudale. - 15 rayons a chaque na.

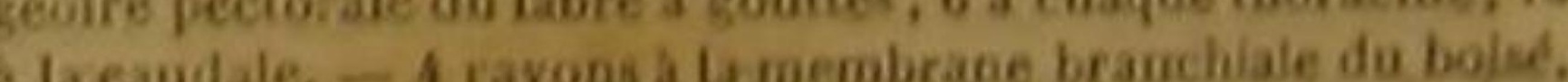
16 a claque nageoire pectorale, 1 rayon aiguillongef et so rayons aricules $i$ cha gue thoracine, 16 rayous i 1 caudale. 5 rayous a la meembrane bräuchiale du cinq acbes, 15 a cla. que nagecuire pectorale, 1 rayon aigoilloune et 5 rayous ard. 
LE LABRE MICROLÉPIDOTE '.

Labrus microlepidotus, Bloch, Lacep. ?

- Le Labre Vieille s, Labrus Vetnla, BL, Lacep.; L. limeatus.

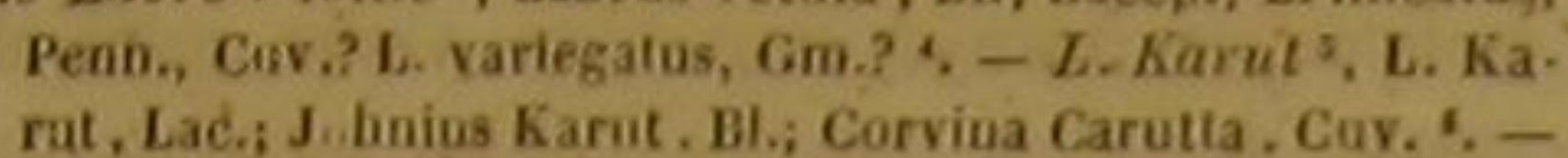
L. Anevi. L. Aneus, Lacep.; Johnius Aneus, Bl.; Corvina Anei, Cav, ', - L, Ceinture', L. Cinguluôn, Lac: Jalis Cingulum, Cuv, 10. - L. Digramme, L. Digramms, Lae.; Cleilïus Digramma, Cav, ". - - L. Hololépidofe, L. ho. tolepidotus; Lac,; Sciena hololepidota, Cav, 12, $-\boldsymbol{L}$. Tox nioure, L. Ixniourus, Sparnis Hemispherium et Sparus horislanus et. L. centiquadras, Lacep.i Jutis hortulana, Cav, U. - L. Sparoide", L. sparoides, Lice.; Centrarchus sparoites, Cuv. "1, $-L$. Leopard, L. Leopardes,
Lac,; Serranus Leopardus, Cav, "1, - L. Mala teronoté,

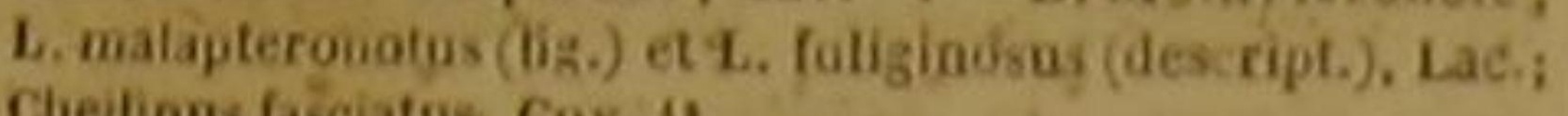

Bloch, qui le premier a publié la deseription du microlépidote, du labre vieille, du karut et de l'anéi, ignorait quelle est la patrie du mierolépidote. Le labre vieille est pêché près des

Hlocb, pl. 292.

"Non cite par M. Cuvier. D

"Carpe de me, sur queliques cotes occíleutales do France, - Bloch, pl. 29

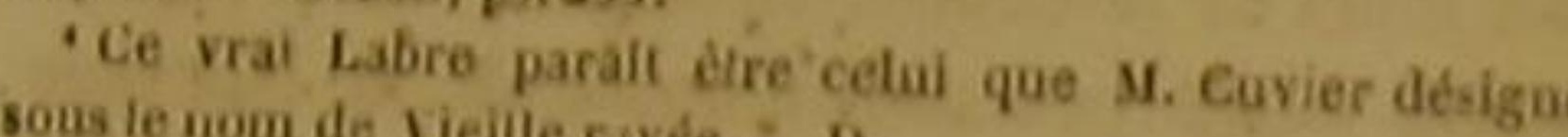
Sous le nom de lieille rayée." D.

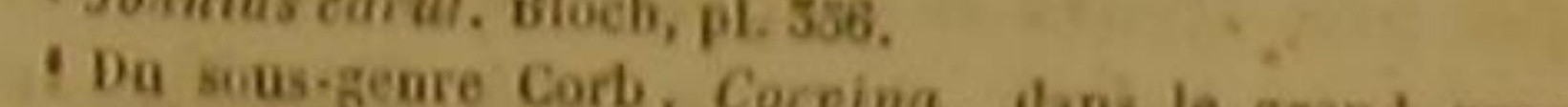

Sciene, de ta famille des Acanithopteryains le grand genre 'Anei katuatci, par les Malais. - Jobonius aneus. Bloeh,
pl. 5357 .

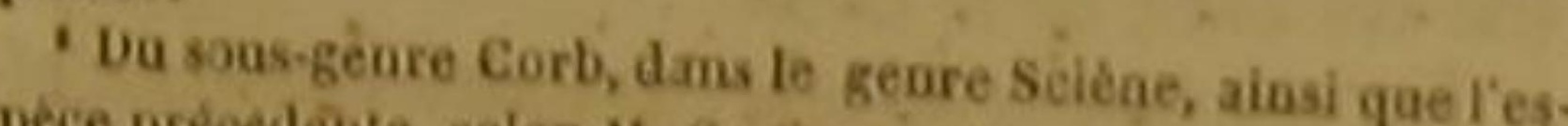
pece précedeute, selon N. Cuvier. - D,

'cus, cingulo intermedto menietate lividus, posticd fus. 4 eapiti iuspersis. . Commerson maguretis atro-purpurei 1" Du sous-genre Girelle, duns lé genre Leja cites. Acanthoptérygiens labroiles, Cuv. D, Labre,famille des

Cur. D. dans le grand geare Sciéne (tamille des Acantb optérygies. "Ce poisour. D

refie, du genre des Labres, place dans te sous.genre GiLacépede, sous tes noms, th de L dite thois fois par M.

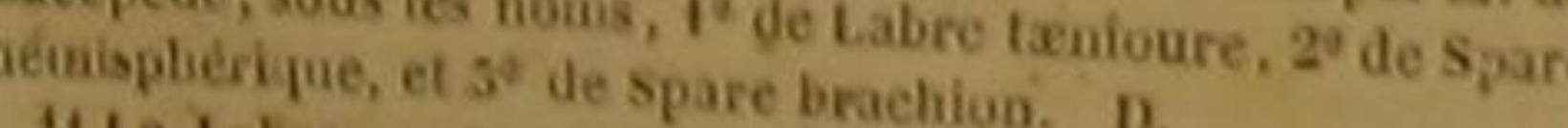

espéce que son Labre échiquier (voyez ci-avant de la mème Mous du geare Latre.
D 11. Perca notata. Buse. " Dugeare Ceatrarehives inuscrits commmniques. siens pereoiles, Cav. D. forille sous-gente des Merous, daus le genre sernan "Du sous-geure Gerygiens pereoldes, Cuv. D.

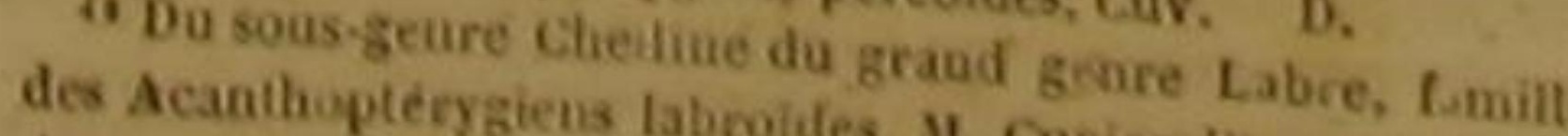
de ce poissou, domée par II. de L. Cuvier dit que la kggure ter a la description du Libre futigineus (voti se rapporp. 260), mais non a is fízure de ce dernier, gì ciavant,

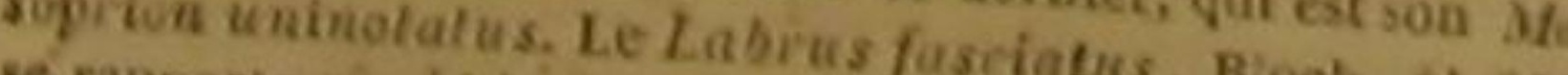

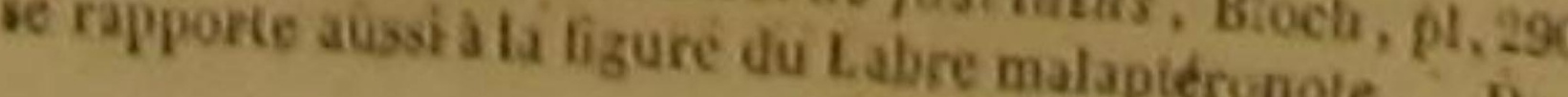

còtesde Norvège, d'où on avait fait parvenirdes individus de cette espèce à M. Spengler ; on trouve aussi auprès des rivages occidentaux de France. Le karut et l'anéi 2 que Bloeh avait cru pouvoir comprendre dans un genre particulier, qu'il avait consacré à son ami John, voyage et missionnaire dans les Indes, en donnant a ce groupe le nom de Johnius, nous, ont paru de voir ètre inserits avec les véritables labres, d'après, les prineipes de dístribution méthod. que que nous suivons; et, en effet, ils n'of. frent aucun caractère qu'on ne retrouve dan une ou plusieurs éspèces, considérèes, par presque tous les naturalistes et par Bloch lui-mémé, comme des labres proprement dits. Ce karut cet anếi vivent dans. les eaux salées des Indes orientales, et particulièrement dans-celles qui baignent la grande presquile de I Inde, tant au levant qu'au couchant de cette immense péninsule.

Quant aux autres huit labres nommés daus cet article, nous en donnons les premiers la deseription, daprès les manuserits de Commerson ou les dessins qui faisaiènt partie de ces manus. crits, et que nous avons fait graver. Ces huit labres habitent le grand Océán équaforial, ou les mers quì eu sont voisinines; et le labre ceinture a êté observé particulièrement auprès de l'lle-de-France.

Les deux mâchoirts du microlépidote et du labre vieille sout aussi longues I'une que l'autre ; elles sont de plus garnies de dents pointues et peu serrées; et le karut et l'anéi n'offrent que des dents petites et pointues.

Disons encore quelques mots des couleurs des douze labres que nous examinons.

La dorsale du microlépidete ${ }^{\prime}$ est presque entièrement brune; ses autres nageoires sont blan châtres. Le dos et les flanes du karut réfléchis. sent un blen dacier; une nuance d'un beau jaune distingue son vèntre et ses lignes latérales; ses nageoires offrent un brun rongeătre, excepté la dorsale et la caindale, qui sont bleues. L'anéi a le dos noirâtre, les côtés blanes; les

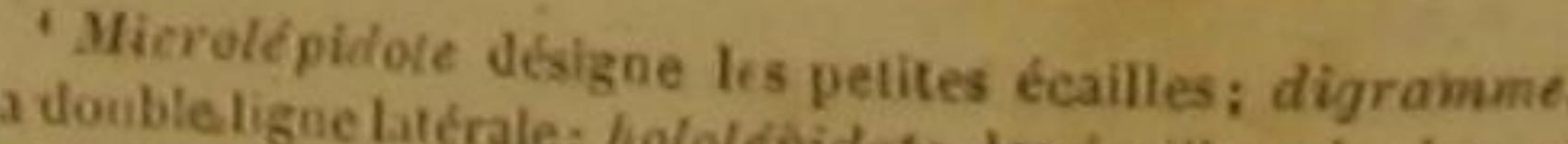
loute la surace de linimal, ternion, les écailles plactes sur que l' on voil sur la nazevise caudale, et ruban ou la bande rayuns mobs qui composent secels ia nagroire dorsale. Maper

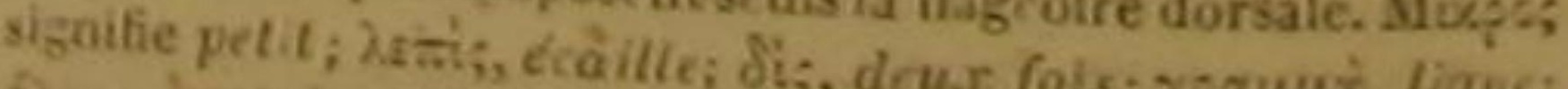

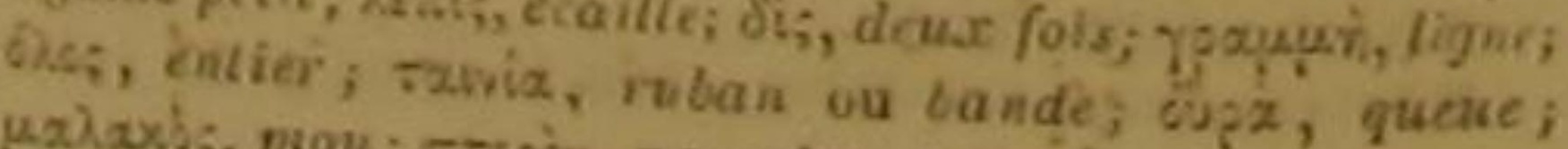

pectorales et les thoracines rougeátres; la partie postérieure de la dorsalé, l'anale et la caudal rouges a leur base et bleuátres à leur sommet. Le bord de la dorsale et de lianale du labre ceinture est souvent blanchàtre ', et l'on voit ordinairement sur l'angle posterieur de l'opercule de ce póisson une tache noìre, remarquable par un point blane ou blanchàtre, qui lui donne rapparence d'un iris avee sa prunelle.

\section{$+$}

LE LABRE SALMOIDE.

Labrus Salmoides, Lae, ; Perea Trutta, Bose, mss. Cyela variabilis, Lesueur; Gristes Salmoides, Cur. '.

\section{IE LABRE IRIS.}

Labrus irideus et L. macropterus, Lacep.; Perea in dea, Bose, mss.; Centrarchus irideus, Cuv. .'

On devra à M. Bose la connaissance du labre salmoide et du labre iris, qui tous les deux habitent dans les eaux de la Caroline.

Lesalmoidea une petite éévation sur le nez; l'ouverture de la bouche fort large; la máchoire inférieure un peu pius longue que la supérieure; l'une et l'autré garnies d'une grande quantite de dents tres-menues; la langue charnue; le palajs hérissé de petites dents que l'on voit disposees sur deux rangées et sur une plaque triangulaire; le gosier situé au-dessus ot audessous de-deux autres plaques égálement hé-

1 12 rayons a chaque nageoiro pectorale du tabre mierole. pidote, 1 rayon aguilloniee et 5 rayons articules a claque thuracine, is rayons s is caudale. - 14 rayons a çhaque na. geoire pectorale du tabre vieille, 1 rayon aiguiltonné els
rayons artica.és a cha cue thoraeine, 16 rayous a la caudale. rayous articué a a cha pue thoraeine, 16 rayous a la caudale.
-5 rayous a la membrane branchiale du karut, 16 a chaque -5 rayous a la membrane branchiale du karut, 16 a chaques
nageoire prectorale, 1 rayon aiguilionué et 5 rayons aricicules

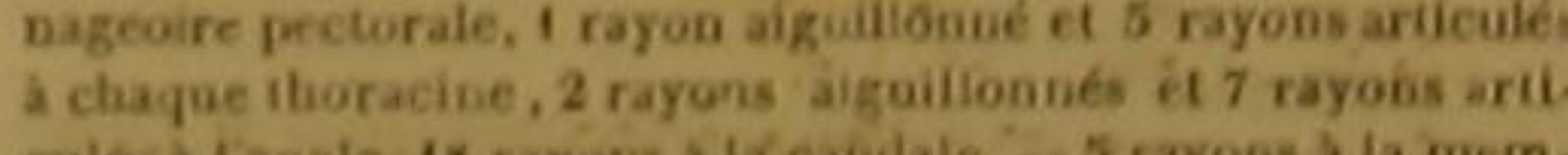
brane branchale de lanés, 14 a clague nageoirê pectorale, Irigon aiguillonue et 5 rayơns articulís a chaque thoracine, 2 rayons aiguilloneses et 7 rayous articules a lanale, to ragons a la can Laie. - 15 rayous a chaquetagevire pectorale du iz bre ceinture, 6 2 chaque thoracine, 14 a La caudale, - 11 rayons a chaque nagcoire vectorale du digramme. 6 a chaque

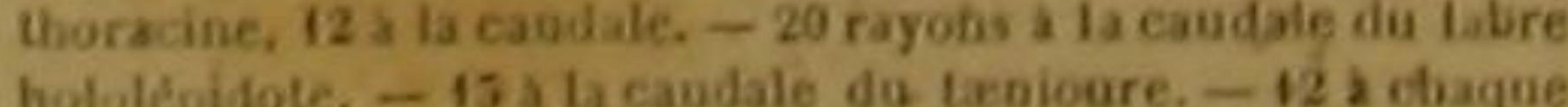
nageoire pectorale du Labre parterre, 16 a la caudale. - 17 rayons a la candale da sparoide. -12 rayons a ja caudale do leupard. - 11 rayons a ia nageoire candale du malaptero. note.

'Da grné Growier, Gristes, Cav, dass la tagrille de Acaniliopterygieas percoides. D.

- Ce pulava , de, a decrit par si. de Lictpede, sous le ion 4 Cuvier, tamille des Acanthoptery giens perevides. D. D. rissees; l'ceil mrand: les cótés de la tête revêtus de petites écailles; la ligne latérale parallèle an dos; une fossette propre a recevoir la partie antérieure de la dorsale; les deux thoracines rèunies par une membrane; l'iris jaune, et le ventre blane.

On trouve un très-grand nombre d'individus decette éspèce dans toutes les rivières de la $\mathrm{Ca}$ roline; on leur donne le nom de Traut ou Truile. On les prend à Phamecon; on les attire par lo moyen de moreeaux de eyprin. Ils parviennent à la longueur de six ou sept décimètres; leu chair est fermé, et d'un goùt très-agréable.

Le labre iris montre un aplatissement et une petite rainure sur la tête, au-devant des yeux ; des dents extrèmement petites; une membrane placée de maniere ă réunir les thoracines l'une à l'autre; une longueur d'un à deux décimetres; une couleur générale, d'un gris brun ponetué et taché d'un brun plus foncé; une raie jaune et très-peu sensible sur presque toutes les écailles; et deux raies obliques, ainsi que plusieurs taclies rouges et petites sur la nageolre du dos. Les individus de cette espèce vivent en très-grand nombre dans les eaux douces do In Caroline, comme les labres sparoides. On les y recherche particulièrement au printemps '.

LE LABRE DIANE,

Labrus Diana, Lacep., Cuv.'

Le Labre Maerodonte, Lairus macrodontus, Lac,,$-L$. Neustcien ', L. Neustria ef L. Bergylla, Lacs L. macula. tus, var, Cuves L. BergyiL, Ascan. '- L. Calops ', L. ca. tops, Lacep. ${ }^{3},-$ L. Ensanglante', L. cruentatus, Lac,

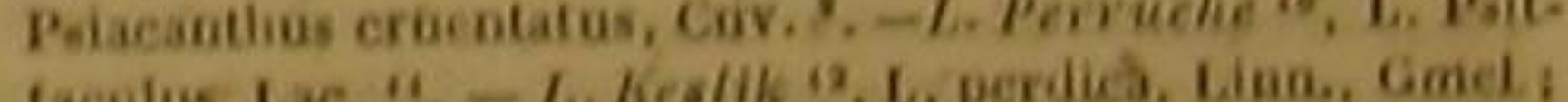

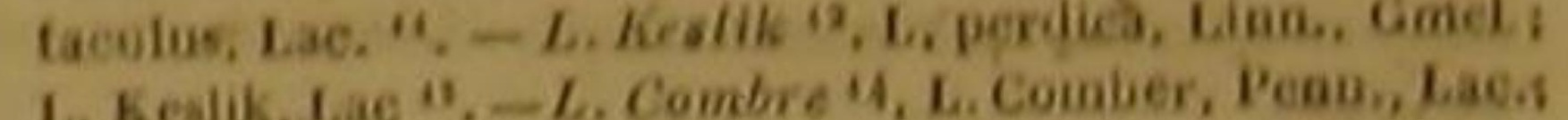

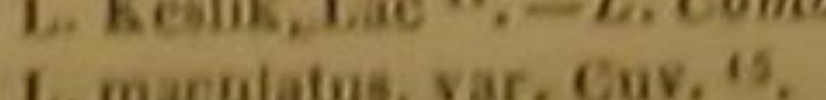

La description comparée des six premiers do ces huit labres n'a encore été publiée par au-

16 rayons a la membrane des pranchies da tabre ralmuide, is a chaque pectorale, 6 rayous a chaquie thoracine, is ata nageoire de la queue. - 9 rayons a claque pectorale da Lbre
rite iris, I rayou aiguillonné el f rayons articules s chaque tho. racine, 24 rayons ala candale.
is Covirr admet cette espece parimi les labres propre. inent dits. D.

' Non eté par sl. Cuvier. D.

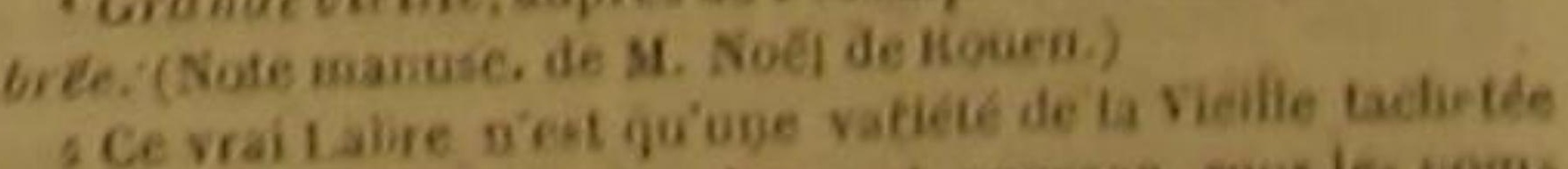
de M. Cavierideja decrite dans eet aavrage, nous les noms de Labre ballan ef de Labreterafle, V. p. 25s. D. 
HISTOIRE NATURELLE

cun nataraliste. Suivant M. Noẻl, qui nous a |Constantinople; les beaux labres ensanglantéet fait parvenir des notes manuscrites au sujet du perruche vivent dans l'Amérique, où ils ont labre neustrien et du calops, ce dernier poisson été dessinés et observés avec soin par Plumier; a les deux mâchoires garnies d'une rangée de le neustrien et le calops, près des riveș de l'andents doubles et pointues. La dorsale du neus- cienne Neustrie; et le labre diane .', dont nous trien présente des nuances et une disposition de devons la figure à Commerson, se trouve dans couleurs assez semblables à celles que l'on voit le grand Océan équatorial : quant au macrosur les cótés de cet animal, et les péctorales; donte, quée nous avons décrit d'après des indiles thoracines, lanale et la caudale, offrent des vidus de la collection cédée à la France par la tons et une distribution de teintes pareils à ceux Hollande, nous ignorons sa patrie.

que montre le dos. L'iris du càlops, qui est très-grand, ainsi que l'œil considéré dans son ensemble, est d'un noir si éclatánt, que j'ai cru devoir tirer de ce trait de la physionomie de ce labre le nom spécifique de Calops que jai donné à ce poisson, et qui signifie bel ail'. Le dos du labre calops est brunátre; mais cet osseux est revêtu sur toute sa surface, excepté celle de sa tête, d'écailles fortes ; larges et trés-brillantes ${ }^{2}$. L'éclat des diamants et des rubis, qui charme les yeux des observateurs sur l'ensanglanté, est relevé par les nuances des nageoires, qui sont toutes dorées. L'anale da labre perruche est jaune avee une bordure rouge, et sa caudale est également jaune, avec quatre ou cinq bandes courbes, concentriques, inëgales. en largeur, et alternativement rouges et bleues. Le keslik a la tête brune, et la dorsale, ainsi que l'anale, rouges. Le combre a souvent le ventre d'un jaune clair, et les nageoires rougeátres: il habite dans les mers britanniques; le keslik, dans celle qui baigne les murs de

- La brune, par les jécheurs de Dieppe, - Bandoulière brune, (Note man. de B. Noēıde Honen.)

'Non cite par M. Cuvier. D,

A tus. I Peintures sur, velin fait, maculis parpureis tessella.

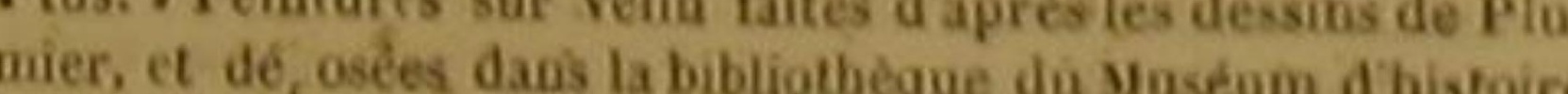
naturelle.

- Da genre Priacanthe, dans la famille des Acauthoptéry giens percoides, Cuv. D.

(ures sur vélin d"spies varius, vulgò petit perroquet. \& Pein"Non eite par M. Cuvier. D. Plamier.

12 Forkael, Descript, anim, p. 34, n. 26. - Labre keslis. Bomnaterre, pi. de l'Enes meth.

"M. Cuvier he cite point ce poisson. D.

Ger. Babie combre. Bonnaterre, pl. de l'Ene, méth. - Com

6. Brit. Zool, 3, p. 210, n, 7. - Rai, Pisc., p. 165, fig. 5 . rieté du vrai Labre quäl nomme Vieille tachetée.

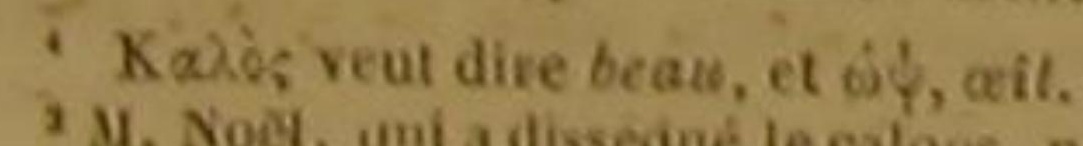

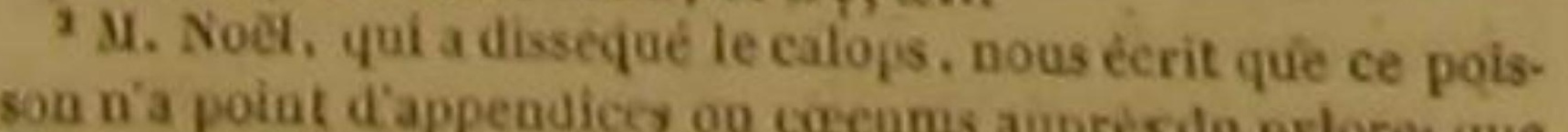
la vessie natatoire est t'une grande capacitéf qu'elle est siluée au-dessous de l'épine dorsale: que cette épine est com poste de vingl-deus vertebres, dont dix réppondent a la capaferme comrae celle d'une jeuné morue.
mal est blanche, et 4. Chacune des ithoracines, 14 rayons a ia caudaie, -7 rayuges Ia membrane branchisle du aeustrien, is a chacune des pectorales, 1 rayoa aiguilioune ets rayous articules a dia. chembrane branchiale do calops, 17 a ch cune jes pectora. es, I rayon aguilloune et 5 rayons ari cules a chacune des horaciges, 2 rayous a la caudale. - te rayons a la nageoine de 1 anus de la perruche, 12 a la ciudale. - 14 rayous a cha. cune des pectorales du kesik, 1 rayon aiguillonne et 5 rayuas articples a chacune des tporaciues, 14 rayons a 1 a caudile. 4 rayons-a chacuue des pectorales du combre, 5 a chacune des thoracines.

- Du sous-genre Girelle, daps le grand genre Labré de
M. Cuyier. D,

Da sous-geure des Labres appelés Girelles par M. Cuvier. - Da sous -genre Gifelle, Cur. D. Dẹ la division des vrals Cobres, dans le grand geare Labre, elon M. Cuvier. D.

- Le labire largeraie a été décrit une seconde fois par M. dé Laépéde, suus te nom de Teuianote large-raie. II. Cis. vier le place dans le genre Malacanthe, qu il a étabi dans la Gamile des deanthopterygiens labroiles. D.

Da sous-genre des Girelles, dans le grand genre Labre, veion M. Cuvier. D.

dans l'ourrage de Bloch, me para du brasilién, que Ton trouve ta caudale de ce poisson, en ne la représentant pan conne trilobé, si mon opiniou a cet ́égard n'etait pas fondee, il taudrait Oter le brasilien du troisieme sous-genre des labres.
DES POISSONS. vive ou foncée, Le brasilien brille, sur presque toute sa surface, de T'éelat de l'or; et cette do-

- 12 rayons a la caudale du labre diane, - 5 rayous a la etle placer daas le premier. connaitre les cinq autres, dont nous avons trouvé des dessins parmi les manuserits de Commerson. La ligne latérale des deux derniers de ces cinq labres, c'est-à-dire du labre largeraie et de P'annelé, est courbe à son origine, et droite vers la nageoire caudale : une grande tache, ayant à peu près la forme d'un eroissant, est d'ailleurs placée sur la base de fa caudale de cé labre annelé, et occupe presque toute ln surface de cette nageoire; on voit de plus une ou deux raies longitudinales sur l'anale de ce même poisson, et une raie oblique passe audessus de chacun de ses yeux. La dorsale et l'anale du trìlobé sont bordées d'une couleu rure est relevée par quelques traits bleuś, par le bleu des raies longitudinales qui s'étendent sur la dorsale et'sur l'aniale', et par la couleu également bleue des peetorales, des thoracine et de la caudale :- ce beau poisson vit dans les eaux du Brésil; il est recherché à cause de I bonté de sa chair, et sa longueur excède quel quefois un tiers de mètre. Le vert habite dans les eaux du Japon; le trilobé, te deux-croissants, l'hébraiqque, le large-raie et l'annelé on été vus dans le grand Océan équatorial.

\section{LE CHEILINE SGARE}

Cheilinus Scarus, Lacep. '

Il y a peu de poissons, et même d'animaux, qui aient été, pour les premiers peuples civilisés de I'Europe, l'objet de plus de recherches, d'attention et d'éloges, que le scare dont nous allons parler. Nous avons eru devoir le séparer des labres proprement dits, et le mettre à la tête d'un ǵgenre particulier dont le nom Cheiline indique la conformation des lèvres, qui rapproche des labres cette petite famille, pendant qu'elle s'en éloigne par d'autres caractères. Mais il ne faut pas surtout le confondre ayee les osseux connus des naturalistes modernes sous le nom de Scares, qui forment un genre très-distinct de tous les autres, êt quoi different de notre cheiline par des traits très-remarquables, quoiqué plusieurs de ces animaux habitent dans la Méditerranée, comme lé poisson dont nous éerivons l'histoire. La dénomination de Scare est générique pour tous ces osseux qui composent une famille particulière ; il est spécifique pour celui que nous décrivọns. Nous aurions cependant, pour éviter toute équivoque, supprimé ou ce nom générique ou ce nom spécilique, si le premier n'avait été généralement adopté par tous les naturalistes récents, et sil le second n'avait été consacré et par tous lés éerivains anciens, et par tous les auteurs modernes qui ont traité du cheiline que nous examinons.
CENT HUITIEME GENRE. LEŚ CHEILINES ${ }^{2}$.

La lecre supérieure extensible; tes opercules des branchies denues de piquants el de dentelures: une seut nageoire dorsale: celle nagcoire du dos très-sèpare de celle de la queue, ou tris-eloignie dela nuque, on compose de rayons terminis par, un flamnt: de composee de rayons terminis par, un flamnt: de grandes ceai les ou des appendices placees sur la bas: espices, canctiones.

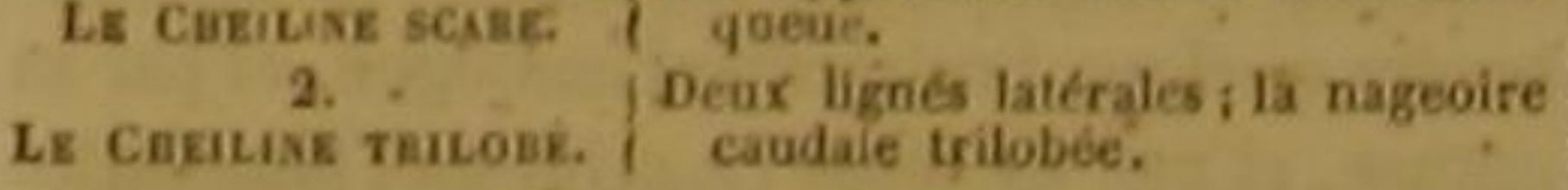
411 rayonsa chacine des nageoires pectorales du labré brasilien, I rayon aigoillonné et 5 rayons articolés a chacun des thoracines, 18 rayons a la caudale. - 12 rayons a cha cune des pectoraled du labre vert, 6 a chacune des tho-
racines, 11 a la caudale. -15 rayons a chacune des pecracines, 11 a la caudale. -15 rayons a chacune des pec-
torales du trilobé, 15 a ir candale. -15 rayons a chacune des, pectorales da labre deyx-croissan's, is a Vanale, 9 a la caudale. - 10 rayobs a chacane des pectorales da habre
bebraíque. 16 a la caudale- -11 rayons a la caudale da largeraie, 7 a chacune des pectorales ce lannelé, 15 a la caudsile. 2M. Cuvier admet les Cheilines comme sons-genre das le grand genre des Labres. If en disfrait le Chelline scare digramme. (Voyez ci-avant) D.

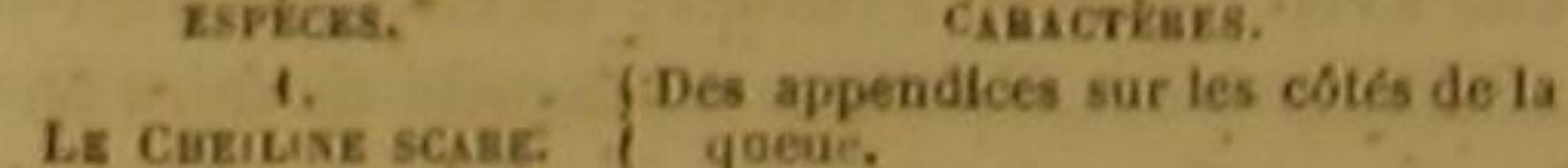

Ce poisson non-seulement habite dans la Méditerranée, ainsi que nous venons de le dire, mais eneore vit dans les eaux qui baignent et

- Sargo, Cantheno, dans le midi de lEurope, - Dente, ans quelques départ. mérid, - Labre scare, Daubenton et

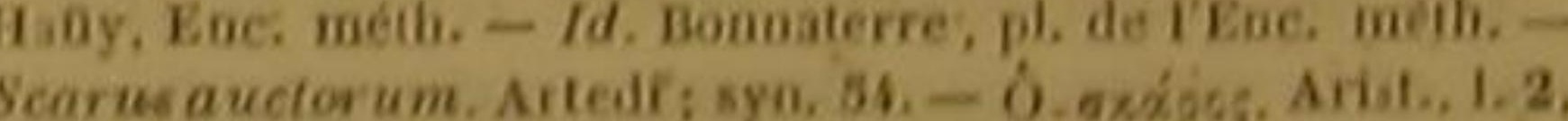

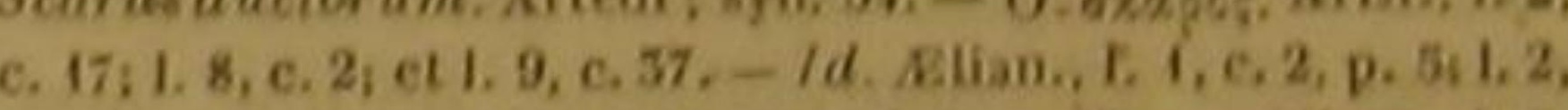
c. 54. - Opplan., 1. 1, p. 3,6i \& 1.2, p. 85, - Allien., I. 7 , p. 319. - Scarus. Plin., L. 9, c. 17, - Aldrov, 1, 1, c. 2, p. 7 , - Scare Rondelet part. 1, 1. 6, c. 2. - Jonston, L. 1, wit. 2.

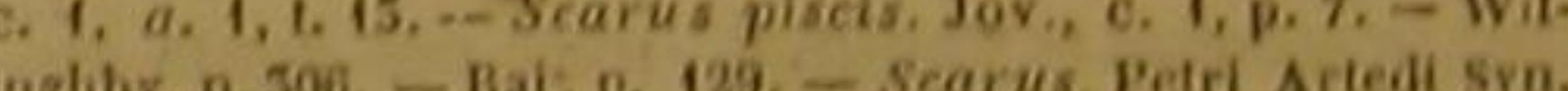

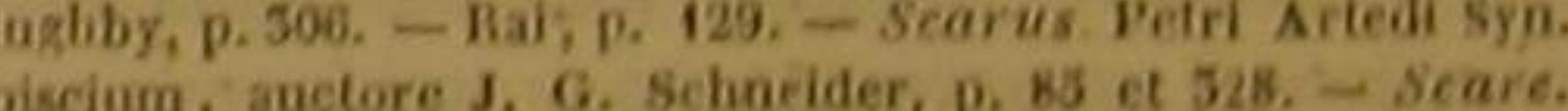
Valmoot de Bomare, Dict. d hist. nat.

2-st. Cavier, dans ti deuxieme édition du Regne animal. ajoute ta vote suivante : Le Labrus Scarus L. C. Cheiline "seare, Lae.), navait été établi par Artedi et Limnäus, que sur une description equivoque de Belon. Aqualil., edit Lat. p. 259, et Obs., p. 21, ou l'on ne péut pas mêne voir de

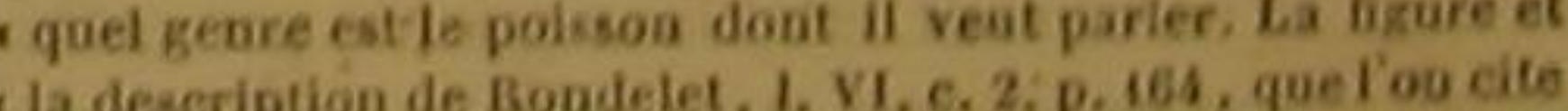
"dordinaire avec celle de belon appartiennent a un poissos , fout different, et do genere des Spares. Le rrai Scarus des - Grecsest un tout autre polison. Dares. 'Xeibos sigaifie 
HISTOIRE NATURELLE

la Sicile, et la Grèce, et les íles répandues au- les accourant vers une femelle retenue dans une près des rivages fortunés de cette Grèce si fa- nasse ou par un hameçon, et s'exposant, pour meuse. Il n'est donc pas surprenant que les l'amour d'elle, à tous les dangers dont les pépremiers naturalistes grees aient pu observer cheurs les menacent. Mais je n'ai pas besoin de cet osséux avec facilité. Ce cheiline est d'une faire remarquer que c'est un poète qui parle; it couleur blanchâtre ou livide, mélée de rouge. combien le naturaliste, plus sévèré que le poête, Il-ne parvient guère quà la longueur de deux n'est-il pas forcé de réduire à quelques faits peu ou trois décimètres. Les écailles qui le recou- extraordinaires, des habitudes si touchantes, et vrent sont grandes et transparentes. Il montre, que la senșibilité voudrait conserver comme sur les cotés de sa queue, des appendices trans-. autant d'exemples utiles et d'heureux souvenirs! versales, dont la forme et la position ont frappé . Le seare s'avançait, lors des prèmièr's siècles les observateurs. La conformation de ses dents de l'ère vulgaire, dans l'Archipel et dans la mer n’a pas été moins remarquée: elles sont émons- dite alors de Carpathie, jusqu'au premier prosées, au lieu d'être pointues, et par conséquent montoire de la Troade. C'est de ces parages que, très-propres à couper ou arracher les algues et sous l'empire de Tibère Claude, le commandant les autres plantes marines que le seare trouve d'une flotte romaine; nommé Optatus Elipertius sur les rochers qu'il fréquente. Ces végétaux ou Elipartius, apporta plusieurs seares vivants marins paraissent être l'aliment préféré par ce qu'il répandit le long du rivage d'Ostie et de la cheilipe, et cette singularité n'a pas échappé Campanie. Pendant énq ans; on eut le soin de aux naturalistes d'Europe les plus anciens. Mais rendre à la mer ceux de ces poissons que lés pêils ne se sont pas contentés de rechereher les cheurs prenaient avec leurs lignes ou dans leurs rapports que présente le scare entre la forme filets; et pâr cette attention brien faeile et bien de ses dents, les dimensions de son eanal intes:-, simple, mais soutenue, les seares multiplierent tinal, la qualité de ses sues digestifs, et la na- promptement et devinrent très-communs auprès ture de sa nourriture très-différente de celle qui des côtes italiquues, dans le voisinage desquelles eonvient au plus grand nombre de poissons : on n'en avait jamais vu auparavant. Ce fait est ils ont considéré le scare comme occupant parmi plus important qu'on' ne le croit, et pourrait ces poissons caroassiers la même place que les nous servirà prouver ce que nous dirons, avant animaux ruminants qui ne vivent que de plan- de terminer cette histoire, ap sojet de lacelimates, parmi les mammifères qủi ne se nourrissent tation des poíssons, à ceux qui s'intéressent à que de proie; exagérant ce parallèle, étendant la prospérité deś peuples.

les ressemblances, et tombant dans une erreur Le commentatear d'Aristote, I'Égyptien Phiqu'il aurait été cependant facile d'éviter, ils loponus, a éerit vers la fin du sixième siècle, ou voilà pousqu a dire que le scare ruminait; et au commencement du septième, que les scares Aristote, plusieurs Grees

Les individus de cette espèce vivent en troupes; et le poête grec Oppien, qui a eru devoir chanter leur affection -mutuelle, dit que, lorsqu'un seare a été pris à l'hameçon, un de ses compagions accourt, et coupe la corde qui retient le cróchet et P'animal, avec ces dents ob-
tuses dont il est accoutumé à se servir pour artuses dont il est aceoutumé à se servir pour arracher ou scier l'herbe qui tapisse le fond des mers; il ajouteque si un seare enfermé dans une nasse cherche à en sortir la queue la première,
ces mémes compagnous l'aident dans ses efforts en le saisissant avee leur gueule par cette. queue qui se présente à eux, et en la tirant avec force et constance; et entin, pour ne refuser à l'espéce dont nous nous oceupons, aucune nuance d'attachement, il nous montre les masurface de la mer, et élevant la tête au-dessus des ondes, ils faisaient jaillir l'eau de leur bouche avee rảpidité. Peut-être en effet faudra-t-il attribuer à ces cheilines la faeculté de faire entendre quelque bruissement analogue, et par' sa nature, et par sa cause, à celui que font naitrè plusieurs trigles et d'autres espèces de poissons cartilagineux ou osseux, dont nous avons dẹja parlé '.

Dans le temps du grand luxe des Romains, le scare était très-recherehé. Le poéte latin Martial nous apprend que ce poisson faísait les délices des tables les plus délicates et les plus somptueuses; que son foie était la partie de ce poisson que l'on -préférait; et que mème l'on
DES POISSONS.

.271

mangeait ses intestios sans les vider; ce qui doit f. d'une cảrpe ordinaire. La couleur générale de moins étonner lorsqu'on pense que cet osseux / ce poisson est d'm brun bleuãtre relevé sur la ne vit que de végétạu, que de voir nos gour- tête, la nuque et les operenles, par des traits, mets modernes manger également, sans les vi- des taches ou des points rouges, blanes et jauder, des oiseaux dont l'aliment composé de nes. Ses pectorales sont jaunes, particulièresubstances animales est sujet à une véritable ment à leur base; et ses thoracines, variées de corruption. Dans le siècle de Rondelet, ce goùt rouge. La tété et le corps du trilobé sont d'ailpour le scare, et même pour ses intestios, était leurs hauts et épais. Presque toute sa surfice encore très-vif: ce naturaliste a écrit que cét os- est revêtue d'écailles arrondies, grandes et seux devait êtrẻ regardé comme le premier en- lisses. Les deux dents antérieures de chaque tre les poissons qui vivent au milieu des rochers, mâchoire sont plus longues que les autres. Deux que sa chair était légère, fríable, facilè à digé- lames composent chaque opercule. Indépenrer, très-agréable, et que ses bovaux, qu'il ne damment de la forme trilobée et de la surface fallait pas jeter, sentaient la violette. Mais le très-étendue dela caudale, cette nageoire est reprix que l'on donnait au seare, à l'époque où couverteà sa base etde chaque coté par trois ou Rondelet a publié son Histoire des poissons; quatre appendices presque membraneuses, sem. était bieñ inférieur à celui qu'on en offrait à blables par leur forme á des éeailles longues, Rome quelque temps avant que Pline ne mit aú larges et pointues, et qui flottent, pour ainsi jour son immortel ouvrage. Ce poisson entrait dire, sur cette méme base, à laquelle elles ne dans la composition de ces mets fameux pour tiennent que par une petite portion de leur conlesquiels on réunissait les objets les plus rares, et tour. La dorsaleet l'analese prolongent en pointe quę l'on servait à Vitellius dans un p̉lat qui, a vers ta caudále. Les deux lignes latérales sont cause de sa grandeur, avant été appelé le Bou- très-droites: Ia supérieure régne depuis l'operchier de Minerve. Les entrailles du seare parais- cule jusque vers la fin de la dorsale; la seconde saient dans ce plat avec des cervelles de faisans . va depuis le point corréspondant au milieu de et de paons, des langues de phénicoptèes, et lá longueur de l'anale, jusqu'aux appendices de des laites du poisson que les anciens appelaient la nageoire de la 'queue'; et chacune parait Murène, et que nous nommons Murénophis. composée de,petites raies qui, par leur tigure et Au reste, ce ne sont pas seulement les plan- lear position, imitent une suite de caracteres tes marines qui convienhent au seare: il senour- chinois. Coimmerson a observé le trilobé, en rit aussi de végétaux terrestres; et voilà pour- 1769 , dans la mer qui baigne les cótes de l'íle quoj, lorsqu'on a voulu le péchier, on a souvent Bourbon, de celle de France, et de celle de Maemployé avée succès, pour amorce, dés feuilles dagascar.

de pois, de feves, oud'autres plantes analogoes à ces derniéres .

\section{CENT NEUVIEMME GENRE.}

LEs CHELODIPTĖmes ?

\section{LE CHEILINE TRILOBÉ 2}

Chei inus trilobatus, Lac,, Cuv.; Sparus cblórurus BI. ':

Suivant Commerson, danś les papiers đưquel nous avons trouvé une note trèsétendue sur ce cheiline encore inconmu des naturalistes, le trilobé a la grandeur ét une partíe des proportions 'Le scare a le conr anguleux, fe foie divicé en trois lobes,
Iestomac pelit, le pylore entouré de quatre ou cinq cacouns, et le canal intestinal courbé plos doune fors.

$\therefore$ Labrus capite gatlato, canis tricuspidata, squamis - membranaceis ad basim imbriçtis. : Commerson, manuscrits déja cites.

13. Cuvier fait de ce poisson le type da sonis-genre cheiline, quili aumet dans le grand genre des Labres, de sa fa-
ville des Acanthoptérygiens labroides.
La livere superieure extensible ; point de dents incisires ni moluires: les opercules des branchies denues de piquants et de dentelues : deux nageoires dorsales.

- PREMIER SOUS-GenRE.

La nageoire de la queue fourcliue, ou en croissant.

espices. csiscrimes.

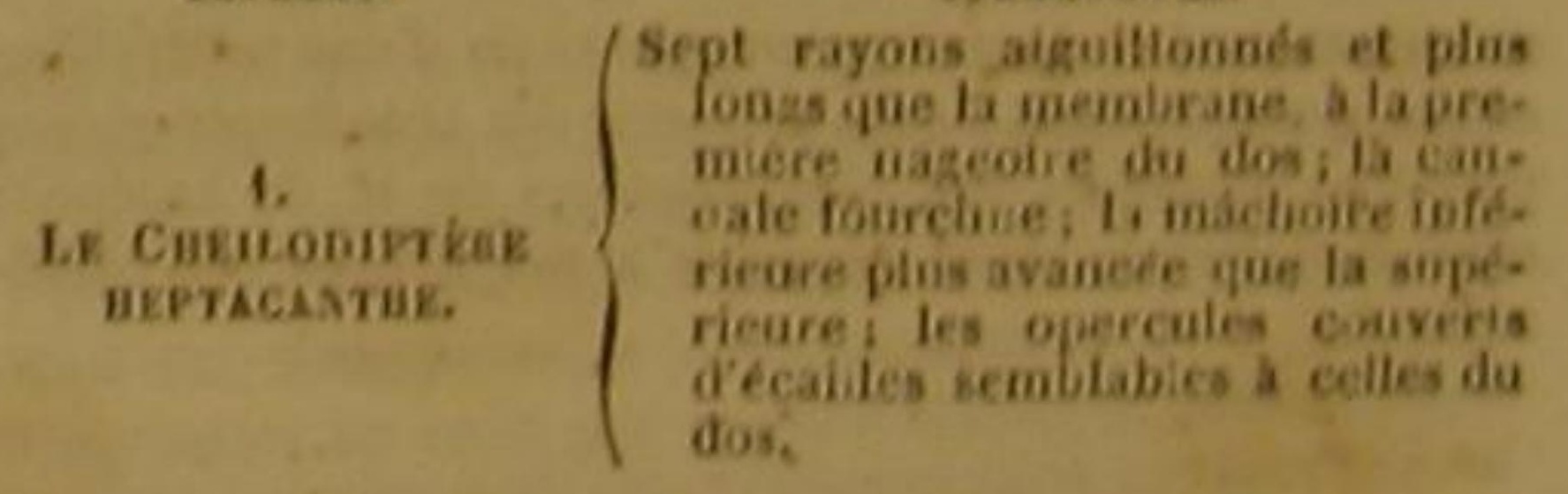

9 rayons aiguillonnés et 10 rayons articules s ta nageoire da dos, 12 a chacune des peciorales, 6 a chacune der thoracines 5 rayous aiguillonnese et orayous articales a To male, 12 rayons a la nageoire de la queue.
i is. Covier conserve le genre Cheilodip'ere, mais il be to 


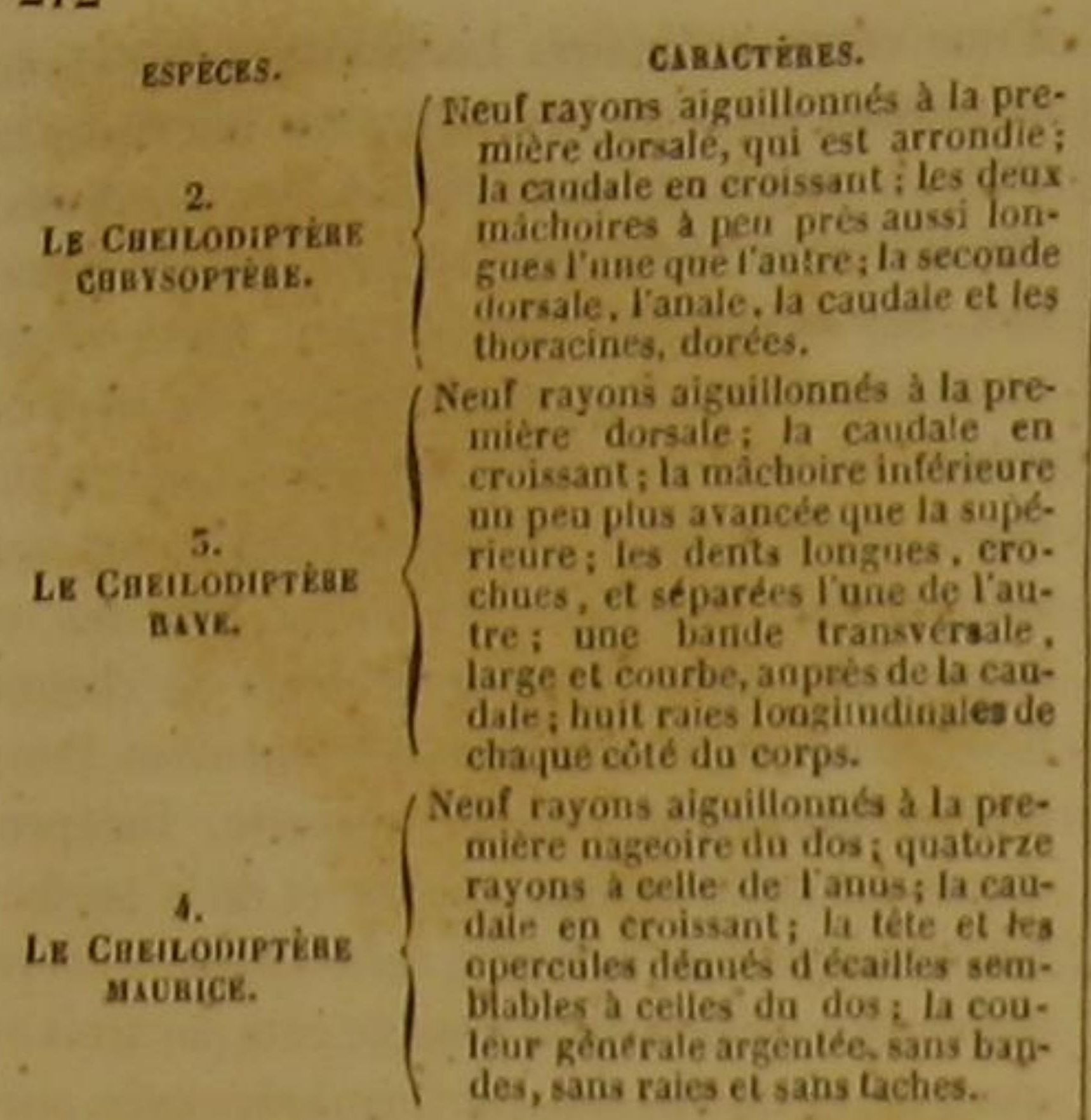

SECOND SOUS-GENRE.

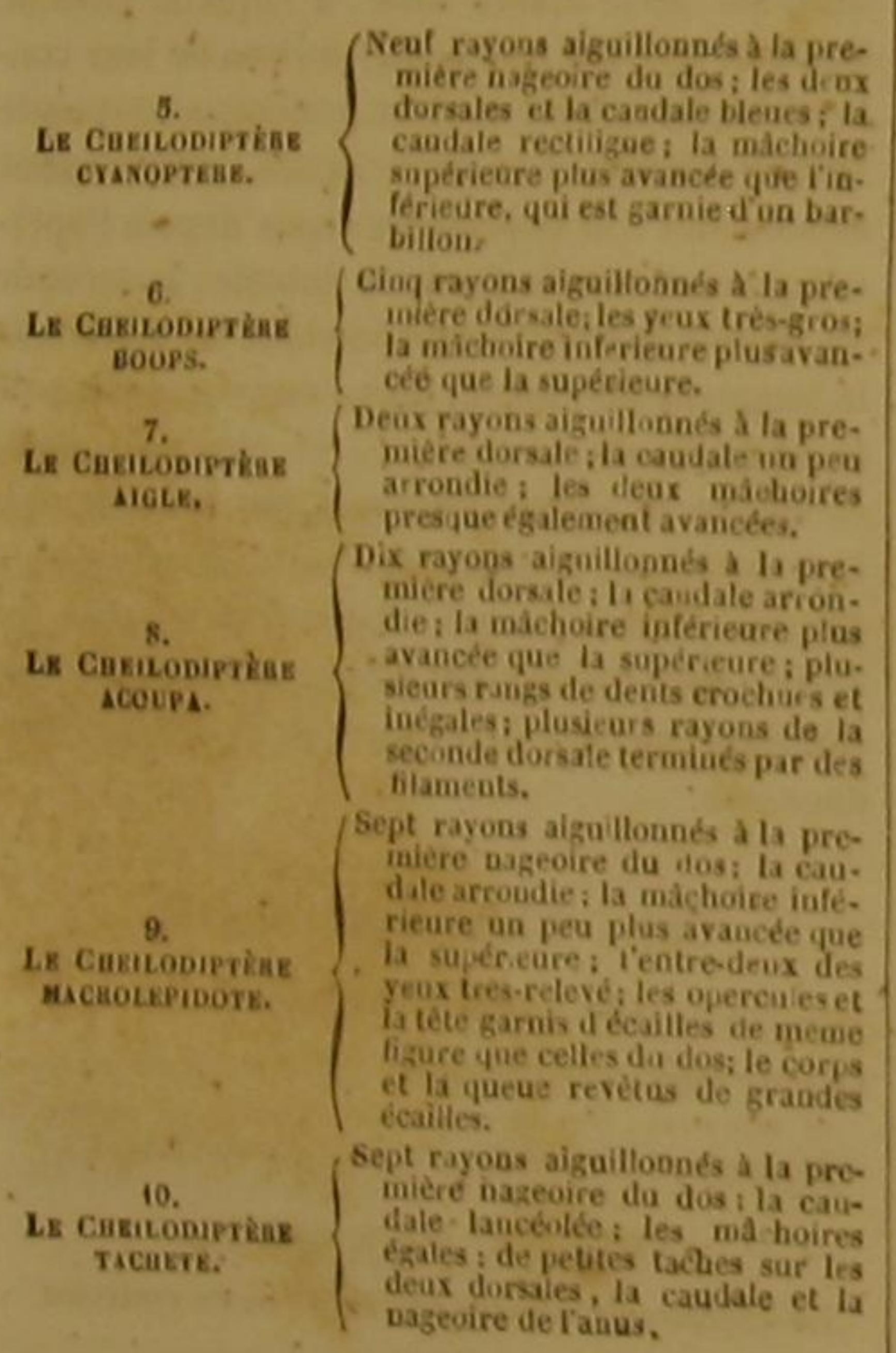

reconnait que I valeur d un sous-geare ou d'une sublivlion

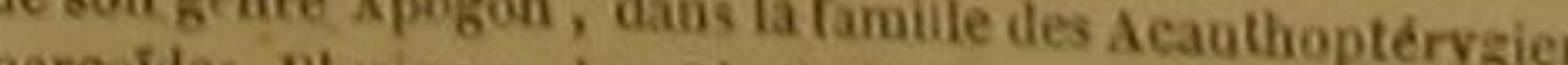
percides. Museurs des Cheilodiptères de M. de Lacépès reats. D.
LE CHEILODIPTERE HEPTACANTHE,

Cheilodipterus beptacanthus, Lacep.; Temnodon hepaeapthus, Cuv. $\because$.

\section{TSERE ${ }^{2}$} Cheilodipterus chrysopterus, Lac.; Perea Plumieri,
Cav. ?

\section{ET LE CHEILODIPTĖRE RAYE}

Cheilodipterus limeatus et Centropoma maerodoa, Lacep.; Cheillodipterus oetovittatus, Cuv. 4 .

Le premier de ees trois cheilodiptères a été dessiné sous leś yeux de Commerson, qui l'a v dans le grand Océan équatorial. Nous luỉ àvons donné le nom d'Heptacanthe ${ }^{5}$, pour indiquer les sept rayons aiguillonnés, forts et lóngs, qu présente la première nageoire du dos, et à la suite desquels on apereoit un huitième rayon très-petit. La seconde dorsale est un peu en forme de faux ${ }^{\circ}$. Nous n'avons pas besoin de faire observer que le nom générique Cheilodiplère désigne la forme des lèvres, semblable a celle que présentent les lèvres des labres, et les deux nageoires que l'on voit sur le dos de l'heptacanthe et des autres poissons compris dans le genre que nous examinons.

La seconde éspèce de ce genre, celle que nous appelons le Chrysoptère ${ }^{-1}$, est encore inconnue des naturalistes; de même que l'lieptacanthe, le rayé, le cyanoptère et l'acoupa. Cet osseux chrysoptére vit dans les eaux de l'Amérique méridionale, où Plumier I'a dessiné. Ses couleurs sont très-belles. Indépendamment de celle qu'indique le tableau générique, il pré-

'M. Cuvier place le Cheilodiptère heptacanthe de Lactpede dans soa geore Temaodon, de la famille des Acan. thoptérygiens scombéroídes. II le considere aussi comme ne différant pas, mème spécifiquement to du Pomatome skis. de Lacépède, d'aprés Bose et $2^{\circ}$ du Labre sauteor, ausid de trouvede. Entin, c'est le Perca saltatrix de Limnée on l trouve presque sans aucune différence sur les côtes d Égypte,
des Étaț-Enis, du Brésil, du Cap de Bonne-Espérance et de la Noüvelle-Hollande.

- Cheloniger ex auro et argenteo virgatus. , Peintures r vélio, daprès les dessins de Plang vir.

'M. Cuvier place dans le genre des Perches proprement dites le Cheilodiptère chrysoptère de Lacépesde, lequel ne differe pas da Centropome Plumier du mème naturaliste, ou Sciana Plupuerii de Bloch. D.

ie le genre Apogou de M. Cuvier. M. de Lacépéde l'a décril i - -2 signifi, sous le nom de Centropome macrodon. D. ' 21 rayons a la seconde dorsale de Theptacathe, 15 a l'anale, 15 à la caudale.

'Xpuoòs veot dire or, et magiz nageoire.

DES POISSONS.

sente le ton et r'eclat de l'argent sur une tresgrande partie de sa surface. Une nuance d'un noir rougeâtre ou violet est répandue sur le dos, sur les cótés, où elle forme, à la droite ainsi qu'à la gauche de l'animal, neuf grandes taches ou bandes transversales, un peu triangulaires et inégales, sur le premier rayou de l'anale, et sur le premier et le dernier rayon de la nageoire de la queue. Quatre rales longitudinales et dorées règnent d'ailleur's de ehaque cóté du chrysoptère, dont l'îris brille comme une topaze '.

Le raye ${ }^{2}$, dont nous avous fait graver la figure d'après un dêssin trouvé dans les papiers de Commerson, habite, comme I'heptacanthe, dans le grand Océan équatorial. Ses yeux sont gros, très-brillants, et eufourés d'un cercle dont la nuauce est très-éclatante.

\section{-}

LE CHEILODIPTERE MAURICE ${ }^{3}$

Cheilodipterus Mauritii, Làcep.; Eléotris Mauritii, Cur. :

Nous rapportons au premier sous-genre des cheilodipteres cé poisson que Bloch a compris parmi les thoracins auxquels il a donué le nom de Sciènes. Mais nous avons déja vu les raisons d'après lesquelles nous avons dù adopter une distribution inéthodique différente de celle de ce célèbre ichthyologiste, Cet habíle naturaliste a décrit cette espéce d'âprés un dessin et un manuscrit du prince 3. Maurice de Nassau-Siegen, qui, dans le commencement du dix-septieme siécle; gouverna une partie du Brésil, ct dont il a donné le nom a ce thorącin, pour rendre durable le témoignage de la reconnaissance des hommes instruits cnvers un ami éclairé des sciences et des arts. Le chéilodiptere Maurice vit dans les eaux du Brísil, ou il parvient a la grandeur de-la perche. Sa ligne tatérale est dorée; sés nageoires présentent des teintes coulear d'or mélées à des nuances bleuâtres ; et ce méme bleu règne sur le dos du poisson ".

- 19 rayons a la seconde dossale du chirysoptere, 11 o flo

" 10 rayons a la seconde donsale du rayé, 8 a chaque pectorale, 12 a l anale, 15 a sa cadale.
"Guaru, au Bresil. - Scicena Mauritii. Bloch, pl. 507, lig.t. 1. Cavier (Hist. nat: des Poiss, L. 1I, p. 16i) indique eo poisson comme đevant étre placé dans soi geure Kileotris, de anthopterygiens gobioides. D.

Gorasle 10 aguillonnés et 15 rayons articulés i la reconide u.
IE CHEILODIPTERE CYANOPTÉRE ', Cheilodipterus eyanoplerus, Lacep. ; Sciana cirrhoss,

Lìno., Umbrina vulgaris, Cur, '

LE CHEILODHPTERE BOOPS 3 ,

Cheilodipterus Boops, Lacep.; Labrus boops, Houtt., Lion, Gmel., Lacep.

\section{ET LE CHEHLODIPTĖRE ACOUPA.}

Cheilodipterus Acoupa, Lacep, ; Bodianus Stellifer? Bl. ; Corrima trispinosa, Cuv, s.

Le cyanoptère et l'acoupa n'ont pas encore áté déerits. Nous faisous connaitre le premier d'après un -dessin de Plumier, et lo second daprès un individu femelle qui m'a été adresse desenvirons de Cayenne par M. Leblond, que jai dejà eu oceasion de citer avee gratitude dans cet ouvage. Ces deux especes vivent dans l'Amérique méridionale, ou dans la' partie de I'Amerique comprise entre les tropiques. Quant au boops, il se trouve dans les caux du Japon. Lenom spécilique de cé dernier, qui veut dire cil de breuf, désigne la crandeur du diametre de sos yeus, qui, par une suite de leur's dimensons, sont tiès-rapprochés l'un de l'autre, et occipent presique ta totalité de la partie supécicure de la tete. Sés opercules sont garnis J'écailles semblables à celles du dos. Ceux de l'acoupa sout composés chacun de deux pièces. On comple une piéce de plus dans l'opereule du cyanoptère; et cette troisiême pièce est échancrée du coté de la queue, assez profondément pour y présenter deux saillies ou prolongations, dont la supérieure a le bout un peu arrondi, ef l'inférieure l'extrémité très-aiguè, L'acoupa montre une ligne latérale prolongée jusqu'à ta fin de la nageoire caudale. La ligne latérale du lonné é r rayans artientés a clacune destliogracines, 5 rayon Gevillopnes ct 14 rayons articulés a la nageoire de fanas, aiguillonnes ct 11 rayons ant

'Gry ary - Gro gro. - C Giromis, seu tembra aurce ccreroles, inturis fuscis variegati. Peintues sur vélin d'après les destios de Plumier.

"Ce puisson se rapporte, seton M. Cuvier, A l'espéce de 1 Perséque umbre de Lacépéde. It appartient conséquenmpei au sons-geure Ombrine, dans le grand beare bcisae, eto N. Cuvier. Pamilte des Acantiopterygenas sciénoides. Lab - Houltayn, Mea. de Ml de I'Ence meth. ty. Cuvier ne croit pas pouvoir classec ce poison, faut

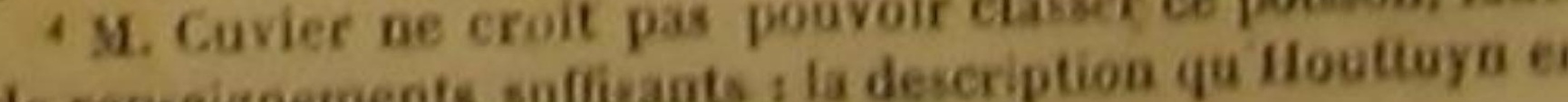
a domife étant tres-incomplete. D.
s placé dans le sous-geure Corb. du grand genre dea Scle. ness, par M. Covier, ce poisson parist tetre le méme que le B. dian étoile de Lacépede, on Bodianucstellsfer, BL. D. 


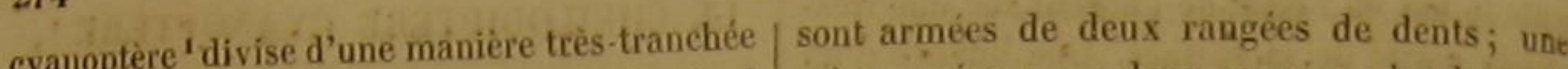
cyanoptere divise d une supérieure de I animal rainure sépare ces deux rangées : les dents de les colles de la partie inférieure ${ }^{2}$ : Au-dessus-de la première sont fortes; celles de la seconde et varié de nuances sont plas petites. La lève supérieure

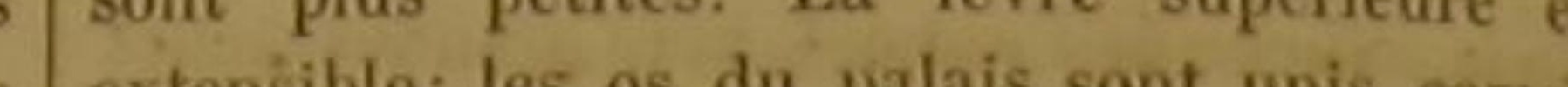
cont unis comme átroites, inégales, ondulées, et f́nclinées vers la langue, qui d'ailleurs est courte et cartilagila caudale, tandis qu'au-dessous de cette mème neuse. On peut voir au fond de la bouche deur ligne latérale on voit des bandes plus irrégu- éminences hérissées d'aiguillons. L'ouvertur lières, plus sinueuses, plus inclinées, et qqui n'offrent guère quie des teintes vertes et brunes. Au reste, lés pectorales, les thorąeines et I'anale du cyanoptère réfléchissent l'éclat de l'or.

la gueule est large; deux orifices appartiennent a chaque narine; l'œil est un peu allongi et incliné vers le bout du museau. Deux pièces composent chaque opercule; la seconde est terminée par une sorte d'appendice. Les deux nzgeoires du dos ont peu d'élévation '. Des ècaille grandes, un peu ovales, minces, très-serrée l'une contre l'autre, et fortement attachées

\section{LE CHELLODIPTERE AIGLE ${ }^{3}$}

Gheilodipteras Aqu Ia, Lacep.; Perca Vauloo, Riss. Icht. I" edit.; Scjona Aguila, Cuv d.

Nous allons décrire ce poisson, que lès naturatistes ne paraissent pas counnaitre encore, d'apres des notes manuserites que M. Noél dé Rouen, et M. Mesaize, pharmacien de la mōne ville, ont bien voulu nous envoyer.

Dans le mois de septembre 1802 , deš pècheurs de Dieppe et de Fecamp ont pris neuf ou dix individus d'une grande espece de poisson qui leur était inconnue, et à laquellè ils ont donné le nom d'Aigle de mer. Le plus grand de ces individus avait au moins un metre et deux tiers de longueur, et pesait trente-cinq $\mathrm{ki}$ logrammes. La longueur de la tète était le cinquième de la longueur totale.

Les máchoires de cet Aigle de mer, que nous avons dú rapporter au genre des cheilodiptères ikosir

'Koג̇uses siguifie blecu; et cya noptere désigue ta couteu theue des dorsiles et de la caudale du poisson auquel nou avous cru devoir donner ce nom spéclíque.

14 rayou atguilloane et 18 rayons articules a ta seconde lorales, 1 rayou aiguilloone et 6 rayours a chacune des pec. des thoraches, 12 rayous 1 la caudale -12 rayous 1 tase eonde dorsale du boops. 14 a chacune des pectoralés, I rayoo aiguillonee el 8 rayons artieulés a cbacune des thoracines,

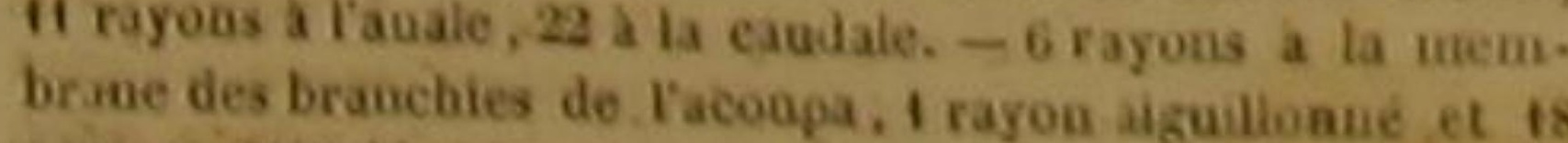

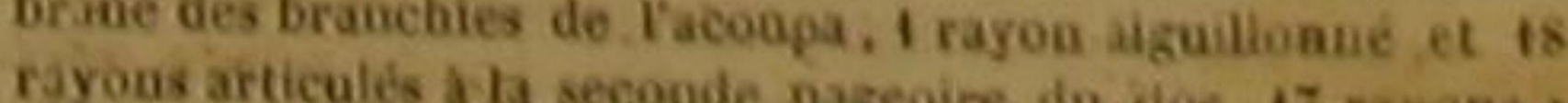
chacune des pectorales, 1 rayon ajgere du dos, 17 rayons culés $a$ chacune des thoracines, 1 rayne et 5 rayons art sayons articultes a fanale, 20 rayons a la caudale. Aigle de mes.

- Ce poison est tres-ancienuement cóqnu ea France sons le nom do Maigre. M. Curvier, qui ea a donné 1 histoire avec

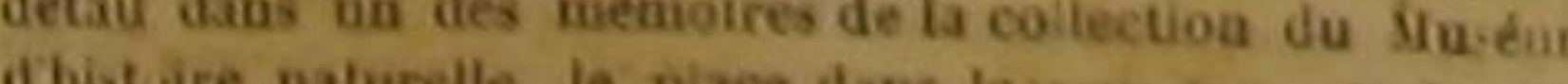

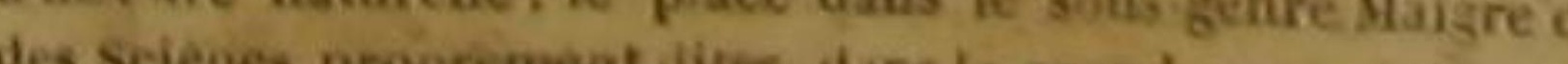

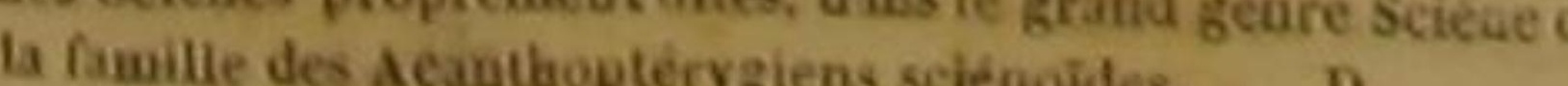

la pean, revitent le lout du musean, le tou des yeux, une portion des opercules, le corp et la queue. La couleur génécale est blanchâtre.

LE CHEILODIPTERE 2 MACROLEPIDOTE, Cheilodipterus macrotepidotas, Lacep.; Sciana ma erolepidota, BI.; Éleotris maerolepidota, Cur.

\section{ET LE CHEILODIPTÉRE TACHETE ?}

Cheilodipterus maculatus, Lacep.; Seiana maculata Guv, '?

Le macrolépidote et le tacheté ont été déerits par Bloeh. Le premier vit dans les Indes, sujvant cet ichthyologister. Les deux mâchoires de ce cheilodiptère sout hérissées de deats petites, aiguès et égales. Ses écailles sont grandes, mais umies et tendres. Sa couleur générale est d'u jưne doré avee six ou sept bandes transver. sales violettes. Les pectorales sont d'un jaune clair; les thoracineś, d'un rouge couleur de brique; les dorsales, l'anale, et la hageoire de la queue, jaumes dans la plus grande partie de leur surface, bleuatres à leur base, et marquees

i 7 rayogs a a membrane branchiale do cheilodiptere air gle, 2 rayous aiguilloanés et 7 rayons articules à la premiere aagécire du dos, 29 rayons ála seconde dorsale, 17 a chajse peciorale, 6 .
de ta queue.

- Sciene a grandes cecailles. Bloch, pl. 298. 'Lej deux poissons decrits dans cet article avaient tet considécés par $\mathbf{M}$. Cuvier, comme devant former nn eroupe particulier, anquel il doònat le nom de Prochilus. Dans la dernière elition de son Regne hnimal, il les rapporte a. genre Éféotrís quîl admet dans la famille des Acauttoptery.

DES POISSONS.

$27 \mathrm{a}$

de plusieurs rangs de taches petites, arrondies et brunes '.

Les taches que l'on voit sur la caudale, fianale et les dorsales du cheilodiptère tacheté, sont d'une nuance plus foncée; mais d'ailleurs presque semblables à celles du maerolépidote, et disposées de nième. Les nageoires đu tacheté présentent aussi des couleurs générales de la même teinte que celles de ce dernier cheilodiptère : mais ses thoracines sont jaunes, et non pas rouges; et de plus, au lieu de bandes violettes sur un fond d'un jaune dore, le corps et la queue offrent des taches brunes, grandes et irrégulières, placées sur un fond jaune, Le devant de la tête est, en outre, dénué d'écailles semblables a celles du dos; la langue lisse et un peu libre; et chaque máchoire garnie de dents courtes, pointues, et séparées les unes de autrés ${ }^{2}$.

\section{CENT DIXIEME GENRE}

LES OPHEEPHALES ${ }^{3}$.

Point de dents incisiees ni molaires: les opercules des branchies denues de piquants of de dentelures: une seule nagroire dorsale : la tice aplatie, arronitie par

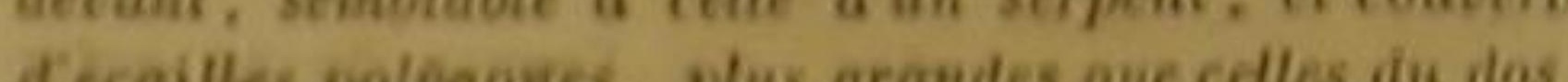
decaities poiggones, plus grandes que cedles dur dos. et aisposes a peu pres comme celles que fon a ill sor des negroires arliculis.

exikes.

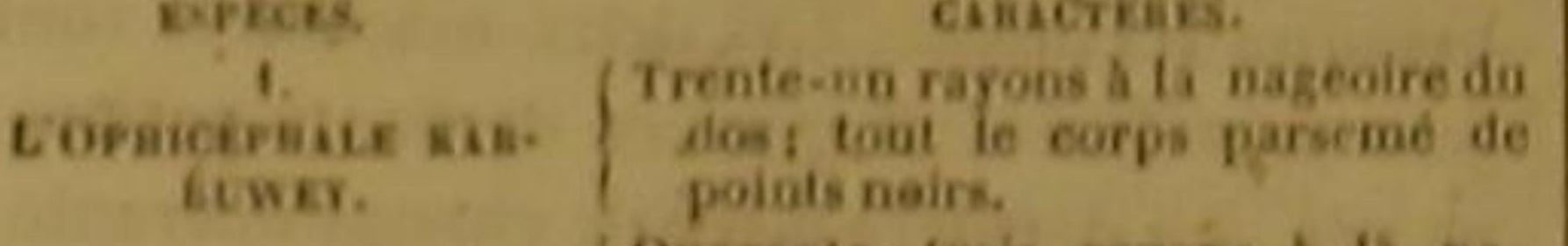
EิพพE.

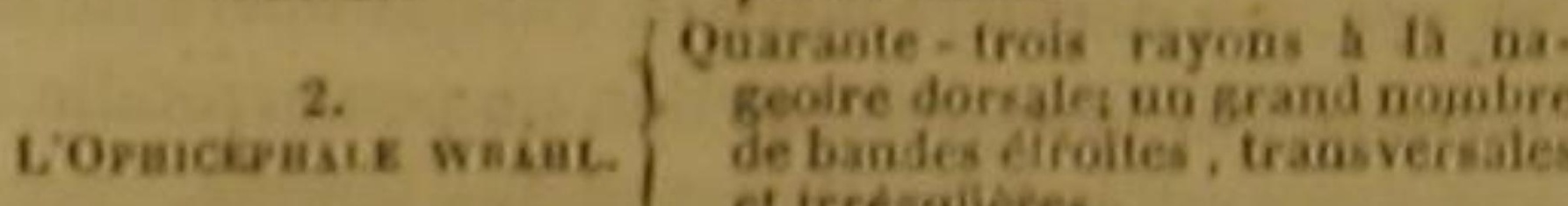

-10 rayons $\mathrm{k}$ la seconde dorsale do macrolépidote, 15 chaque pectorale, 6 s chaque thoracine, I rayor aiguillowin et 10 rayons articules a la nageoire de lanos, 18 rayons a 1

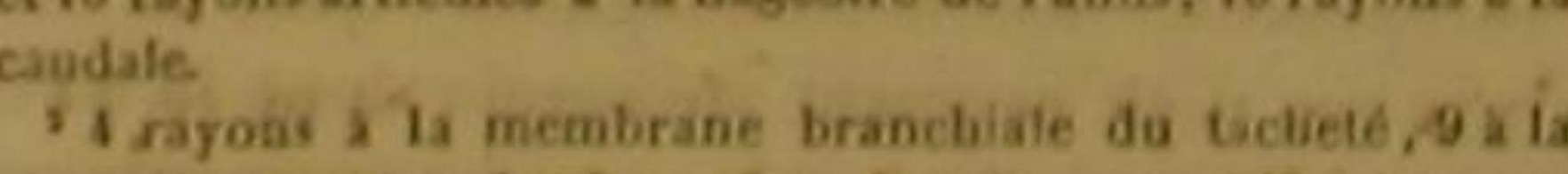
reconde nageoire da dos, 12 i daque pecior lé, I rayou

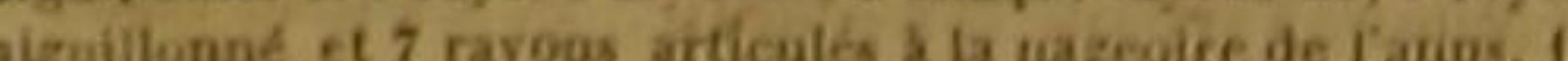

rayons a celle de la quene. lans a tamille des Acantisiopterygieas pharyngiens-labyriothiformics. D
L'OPHICÉPHALE KARRUWEY ',

Ophicephalus punctatus, Bt., Cur.; Opbiceptalus

\section{ET L'OPHICEPHALE WRAHL ${ }^{2}$.}

Ophicephatus striatus, BI., Guv., Lacep,; Opticephalus Cheoa? Buch. ?

Le naturaliste Bloch a fait connaitre le premier ce genre de poissons, qui mérite l'atteation des physiciens et par ses formes et par se habitudes. Indépendamment de la conformation particuliere de leur tete, que nous yenon de décrire dans le tableau générique, et qu leur a fait donner par Bloch le'nom d'Ophicephale, lequel vent dire tete de serpent ', les osseux compris daus cette petite famille sont remarquables pá la forme des écailles qui recouvrent leurs oporenles, leur corps it leu queue. Ces éeailles, au lieu d'être ou lisses, ou rayounées, ou relevées par une aréte, sont parsemées, daus la portion de leur surface qui est découverte, de petits grains ou de petites éévations arrondies qui les rendent rudes an toneher. Les eaux des rivieres et des laes de In cote de Coromandel, et particulierement do Tranquebar, nourrissent ces animaux; ils s'y tiennent dans ta vase, et fls peuvent même s'enfoncer dams le limon d'autant plus profondément, que la piéce postérieure de chacun de leurs opercules est garnie intérieurement d'une sorte de lame osseuse, perpendiculaire a ce méme opercule, et quí, en se rapprochant de la lame opposée, ne laisse pas de passage á la bourbe ou terre délayée, et ne s'oppose pas cependant à l'entrée de l'eau nécessaire à la respiration de l'ophicéphale. Le coté coneave des ares des branchies est d'ailleurs garní d'un grand nombre de petites élévations hérissées de pointes, et qui contribnent a arrêter le limoi que l'eau entrainerait dans la cavité branchiale, lorsque l'animal souleve ses opereules pou faire arriver aupres de sés organes respiratoires le fluide sans lequel il cesserait de vivre. On ne compte encore que deux espèces d'ophicéphales : le Karruwey, auquel nous avons conservé le nom que lui donnent les Tamules: et le Wrahl, auquel nous avons cru devoir

COphicephalus punclaius. Btocti. of. 588 . "Ophiec phatus striatus. Bloch, pl. 350 .

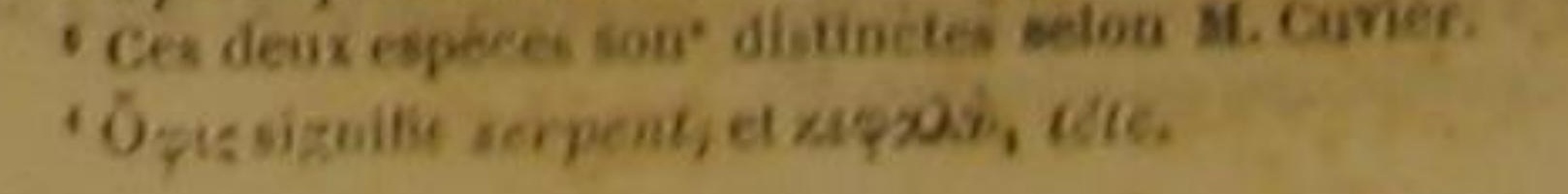


lalsser la dénomination employée par les Malais pour le désigner. Le premier de ces ophicephales a Touverture de la bouche médiocre, les deux mâchoires aussi longues l'une que l'autre et garniés de dents petites et pointues, le palais rude, la langue lisse, l'orifice branchial assez large, la membrane branchiale cachée sous l'opereule, le ventre court, la ligne latérale droite, le corps et la quene allongés, la caudale arrondie, la couleur générale d'un blanc sale, l'extrémité des nageoires noire, et presque toute la surface parsemée de points noirs '. C'est un de ces poissons que l'on trouve dans les rivières de la partie orientale de la presqu'ile de l'Inde, et partieulièrement du Kaiveri, lorsque; vers le commencement de l'été et dans la saison des pluies, les eaux découlant abondamment des montagnes de Gate, les fleuves et les lacs sont gonflés, et les campagnes arrosées ou inondées. II présente communément une longueur de deux ou trois decimètres, est recherché à cause de la salubrité et du bon goût de sa chair, se nourrit de racines d'algue, et fraie dans les lacs vers la fin du printemps, ou le milieu de Fété. Le missionnaire John avaic envoyé des renseignements sur cette espèce à son ami Bloch, en lui faisant parvenir aussi u individu de l'espece du Wrahl.

Ce second ophicéphale a sa partie supérieur d'un vert noiratre, sa partie inferieure d'u jaune blanchàtre, et ses bandes transyersales jaunes et brunes. II parvient quelquefois à Ia longueur de douze ou treize decimètres. Sa chair est agréable et saine; et comme il se tient le plus souvent dans la vase, on ne cherche pas a le prendre avee des filets, mais avee des bires ou paniers d'osier, rouds, hauts de six ou sept décimètres, larges vers le bas de quarante-eing ou cinquaute centimètres, plus étroits vers le haut, et ouverts dans leur partie supérieure. 0 enfonce ces paniers en différents endroits plus óu moins limoneux; on sonde, pour ainsi dire; et le mouvement du poisson avertit de sa presence dans la bire le pècheur attentif de sa prepresse de passer son bras par l'orifice supérieur du paoier, et de saisir l'ophicéphale ?

1A ha membrane branchiale du karruwey 5 rayoos, a chaeune de ses pectorales 16 , a cha que thoracine 6 , a Fanale 22 ,
in mageoire de la quene ii - A la membrane branch.

pectorale 17 , a elayue thoracine un wrahil 5 rayons, a chaq 2 la caudale, qui cst arrondie, iz, a la dageoire de Tanus 26,

\section{CENT ONZIÈME GENRE}

LES HOLOG YMNOSES '.

Toute la surface de lanimal dinuée d'écailles fucil ment risibles : ta queue representant deux cônes trô. ques, appliques le sommet de $I$ un contre le soms de lautre, et inegaux en longueur; la caudale tres courte : chaque thoracine compoşee d'un ou plusiears rayonis mous et reumis ou enreloppés de maniére à im fer un barbillon charnu.

Espice.

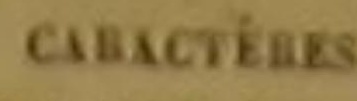

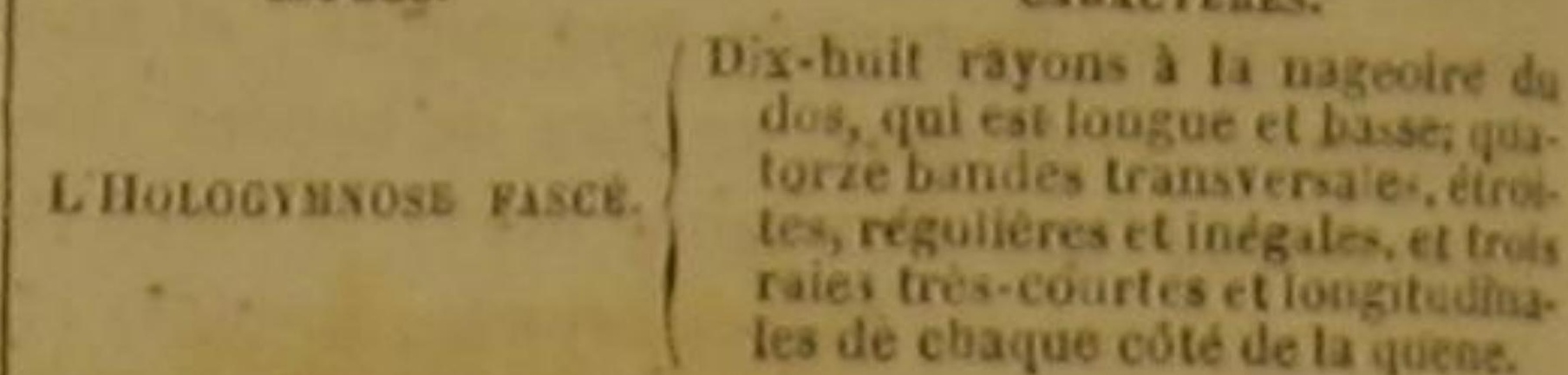

L'HOLOGYMNOSE FASCE.

Hologymnosus faseiatus, Laeep. ; Julis fascista, Cuv. ?

Aucun auteur n'a encore parlé de ce genre dout le nom Hologymnose (entièrement nu ) désigne l'un de ses. prineipaux earaetères dis. tinctifs, son dénuement de toute écaille facilement visible. Nous ne comptons encore dans e genre particulier qu'une espèce, dont nous avons fait graver la figure d'aprês un dessin de Commerson, et que nous avons nommée Hologymnose fasce, a cause du grand nombre de ses bandes transversales. La forme de sa queue, qui va en s'élargissant à une certaine distane de la nageoire caudale, est très-remarquable, aínsi que la brièveté de cette caudale, qui est presque rectiligne. Les deux mâcboires sont peu près égales et garnies de dents petites et aiguès. La dernière piècè de chaque opereule se termine par une prolongation un peu arrondie a son extrémité. L'anale est moins longũe, mais aussi étroite que la dorsale. Cette derniere offre avant chacun des dix derniers rayons qui la composent, une tache singulière qui, en imitant un petit segment de cercle dont la corde s'appuierait sur le dos du poisson, présente une couleur vive ou très-claire, et montre dans sa partie supérieure une première bordure foncée,

' M. Cuvier remaryue que le genre Hologymnose de La. cépède se compose de Girelles (Julis), dont les écailles du corps, plus petites que de coutume, soat cachées, dans l'état
de vie, par un épiderme épais, mais deviennent apparentes de vie, par un épiderme épais, mais
aprés ha mort par la dessiccation. D.

"Du sous-geirre Girelle, dass le grand genre Labre, de L tumile des Acauthoptérygiens labroídes, selon $\mathrm{N}$, Cuvier. I

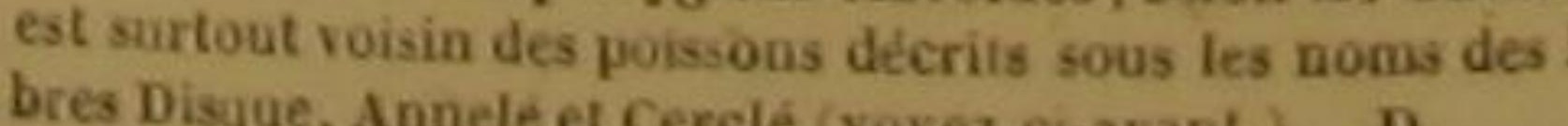
'Oles rent dire culier, et (vojez ci-aract.)

DES POISSONS.

977

t une seconde bordure plus foncée encore. Les quatorze bandes que l'on voit sur ohaque coté de la queue, n'aboutissent ni au bord supérieur ni au bord inférieur du poisson. Les trois raies qui les suivent ne touchent pas non plus à la caudale. On distingue une raie étróite et quelques taches irrégulières sur l'anale, et d'autres taches nuageuses paraissent sur la tête et sur les opercules '. L'hologymmose fascé vit dans le arand Océan équátorial. Nous ignorons quelles sont les qualités de sa chair.

\section{CENT DOUZIĖME GENRE.} LES SCARES ${ }^{2}$

Les mdehoires osseuses, tris-aranceles, et tenant liei de reritables dents: me snde nag coire torsale.

PREMIER SOUS-GENRE.

La nageoire de la quene, fourchue, on en croissant.

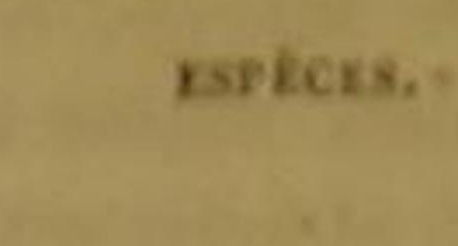

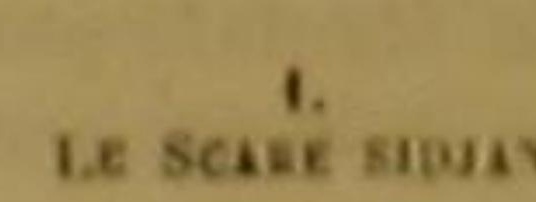

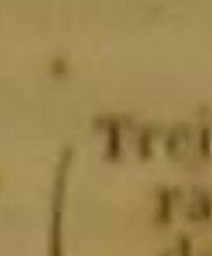
canscriass,
ixe rayons aiguillonnés et dix illoned et dix

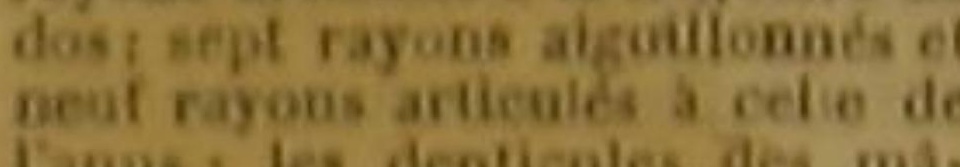

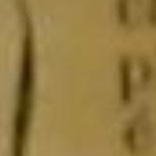
chaires bifforaes, of dantan
plus couries quelies sont plus

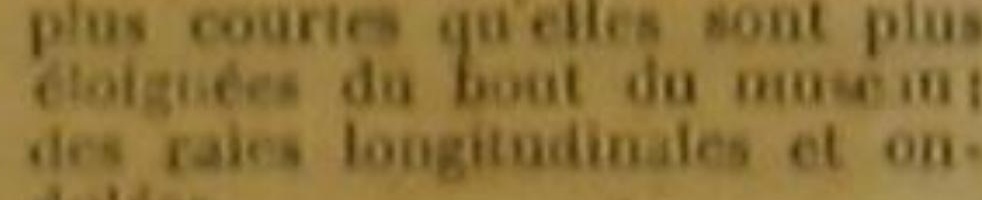
descresic

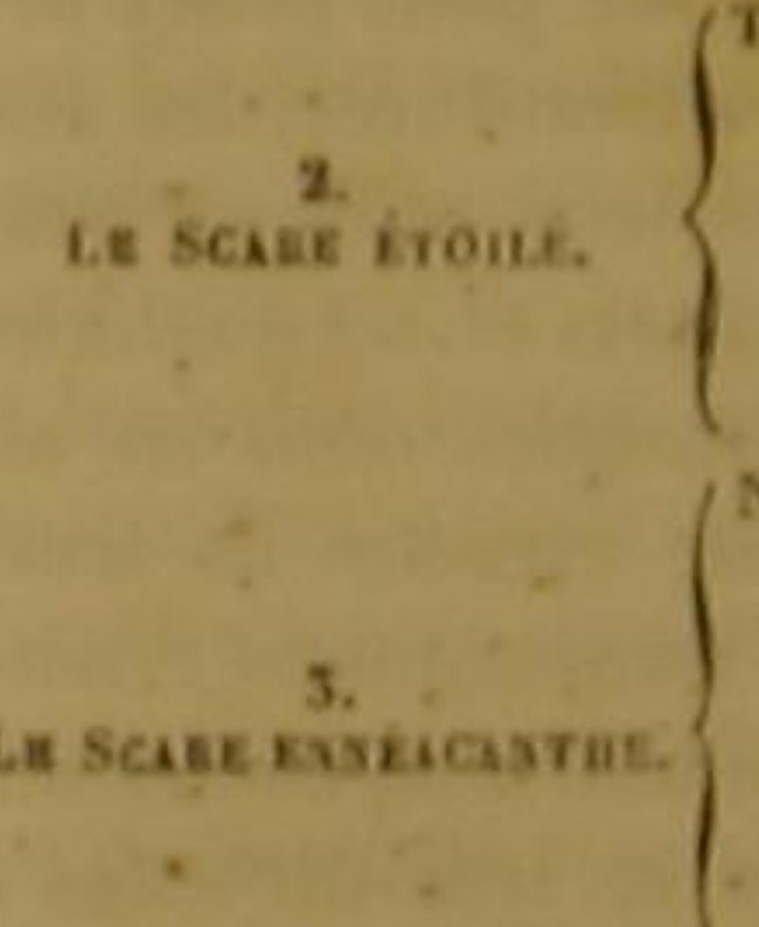

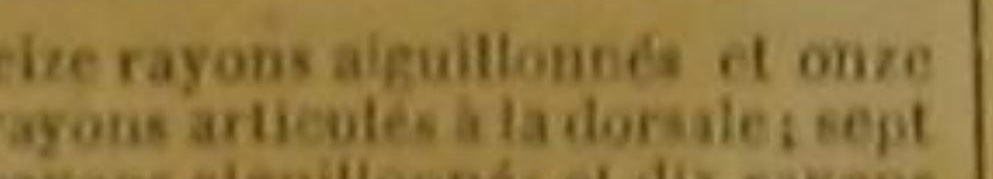

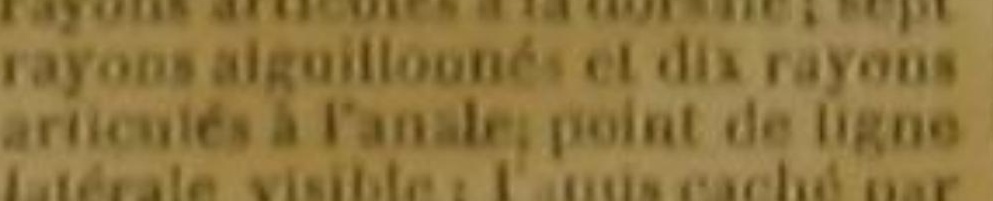

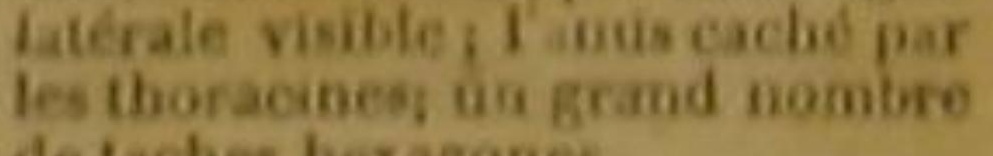

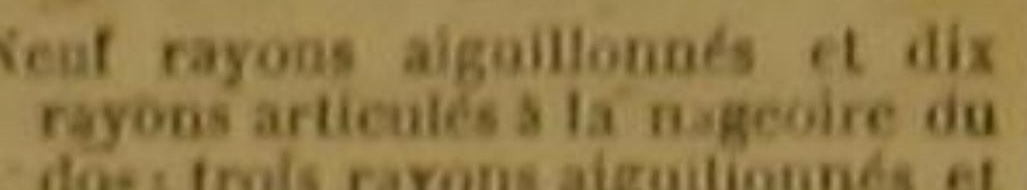
(n) dost trols rayons aiguiliomes et
neut rayous arricules a celle de Fiene tatérate interrompue is anticules des mácbires tres

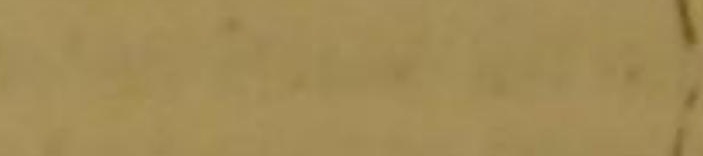

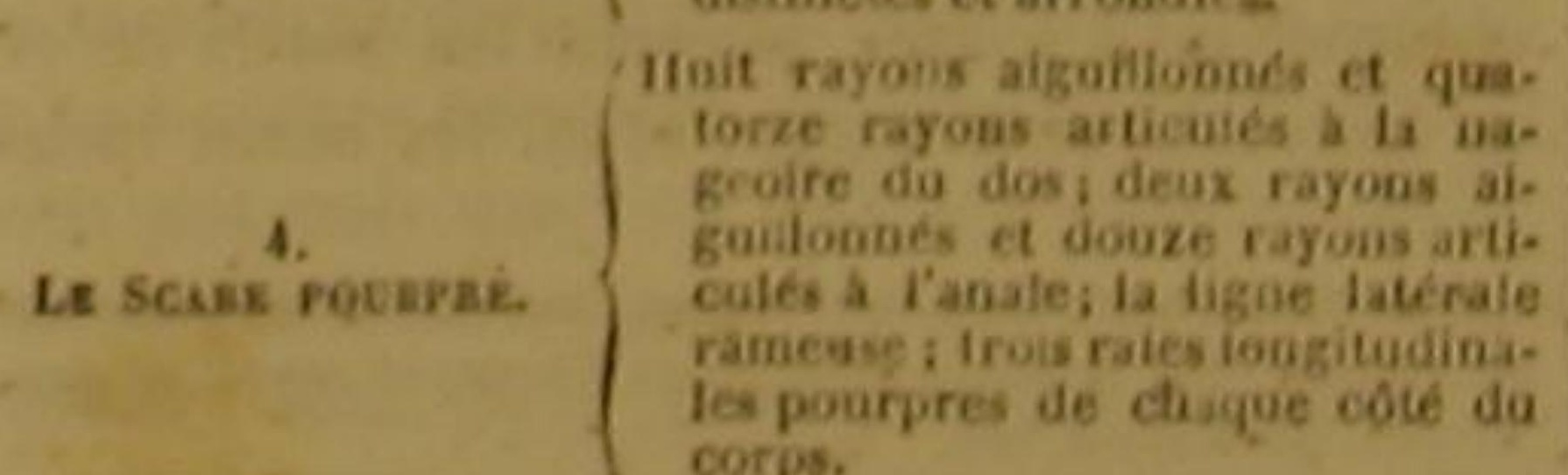
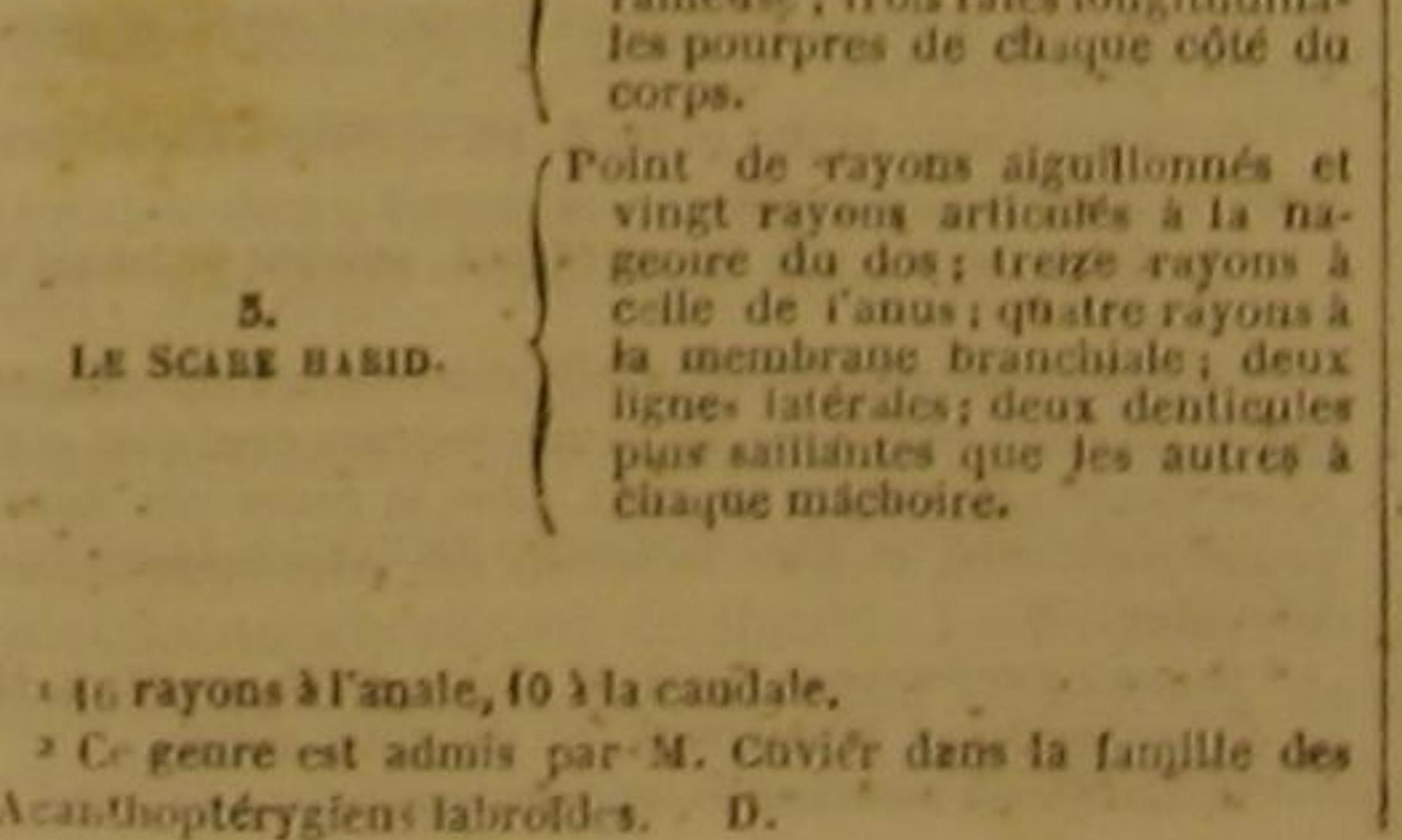

Espices.

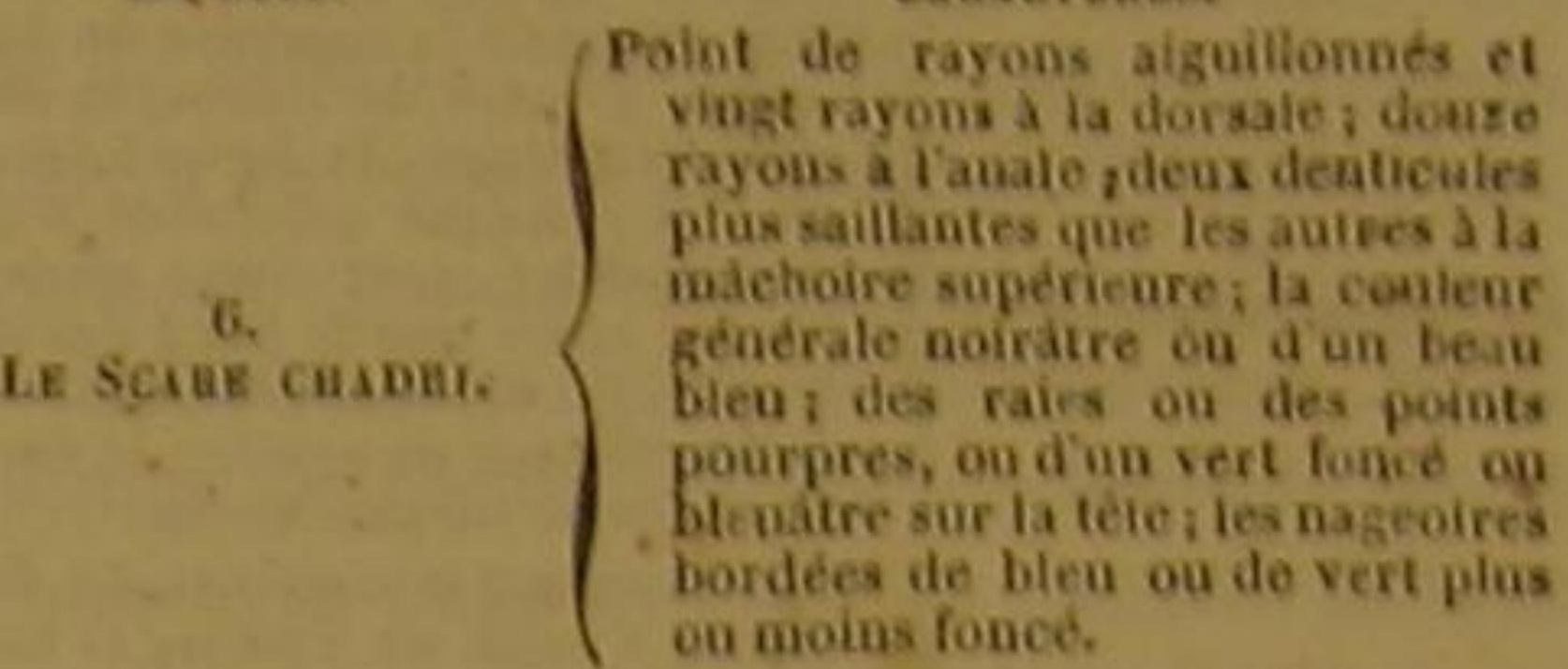

Peint de rayons aiguillones et Pe onze rayons a celle cing rayons a la membrane birat-
chiale, deux Lignes laterales i ces

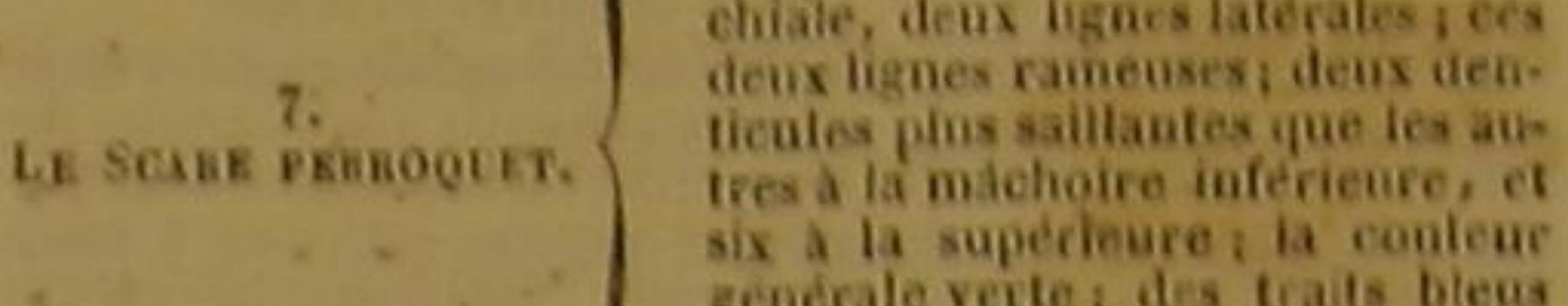

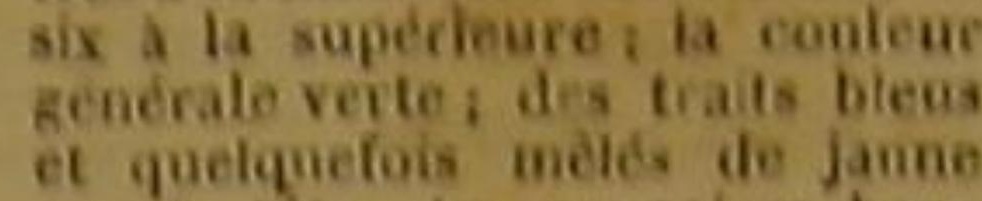
et quetquetoss meis de jamne
sur ta tetei les nageoires bor.

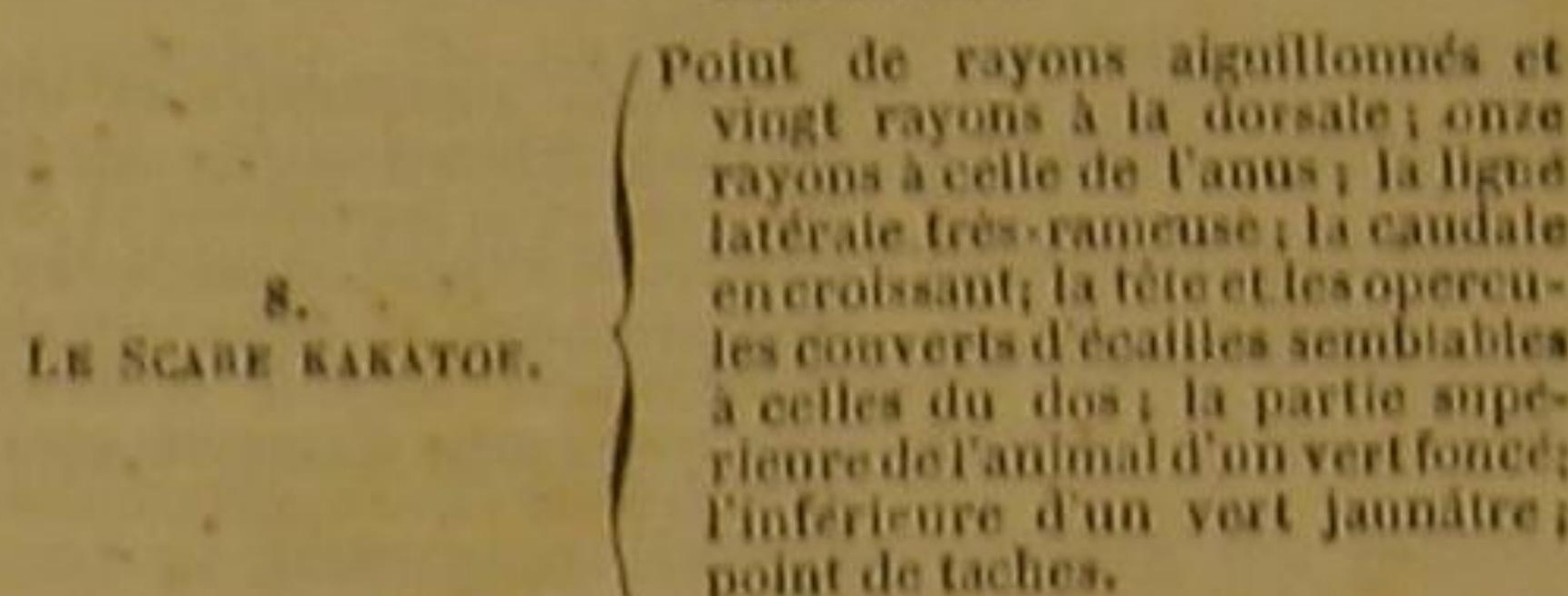

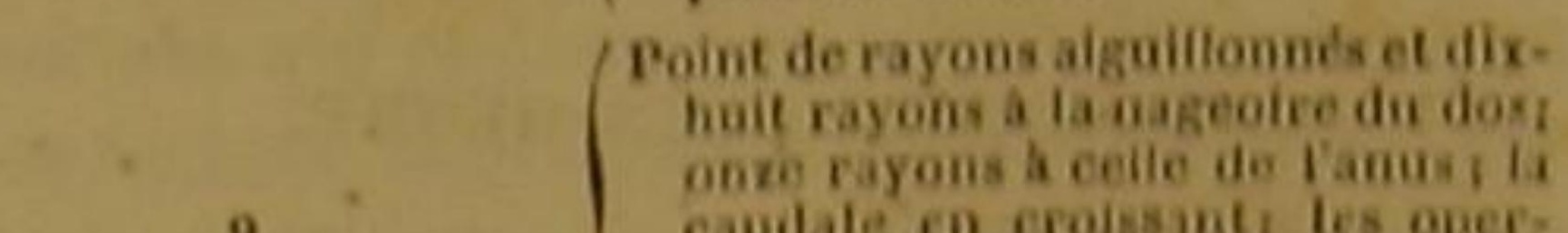

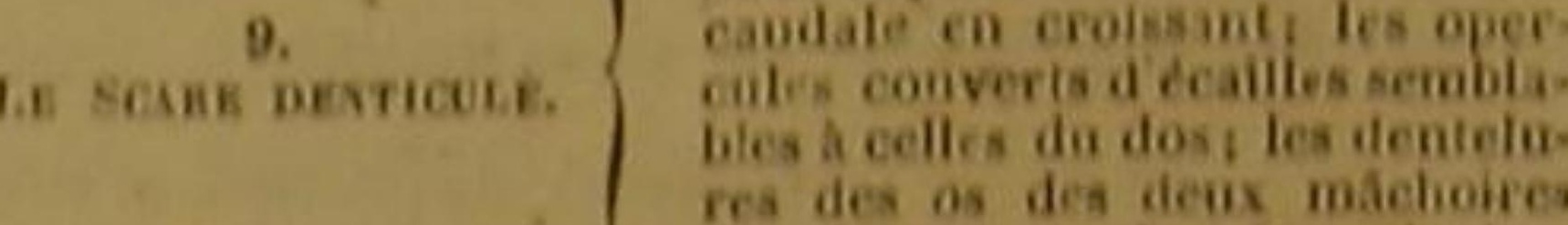
tross-fincs, tress-sedparieset égales.

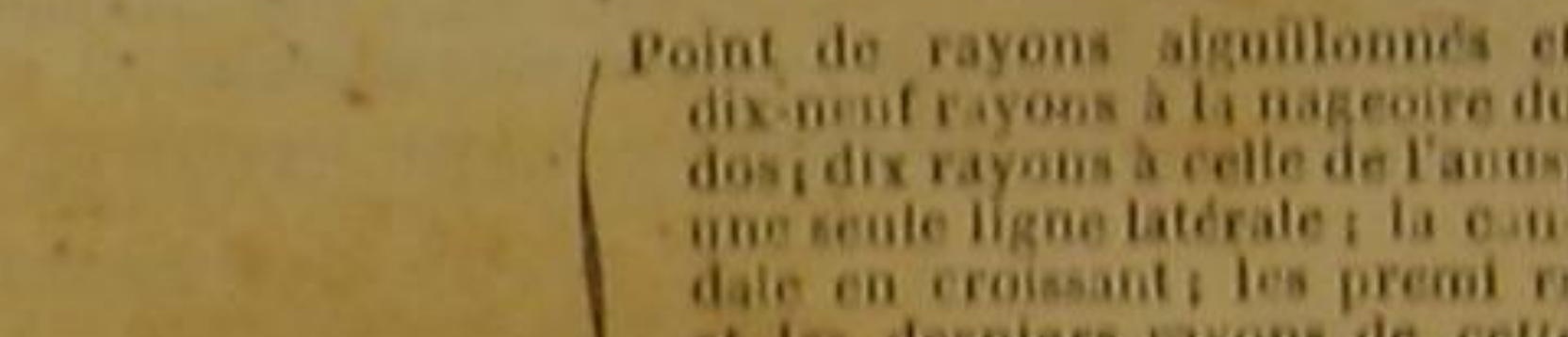

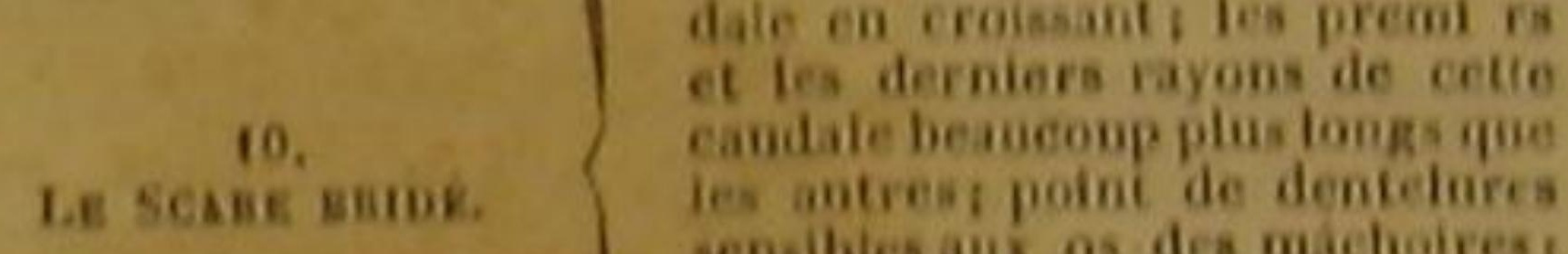

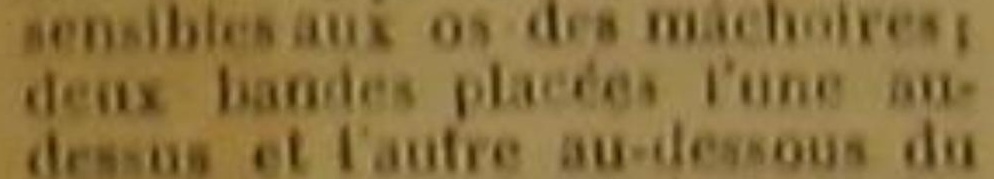

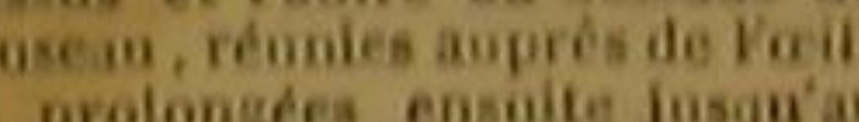
hord postevieur do lopereule.

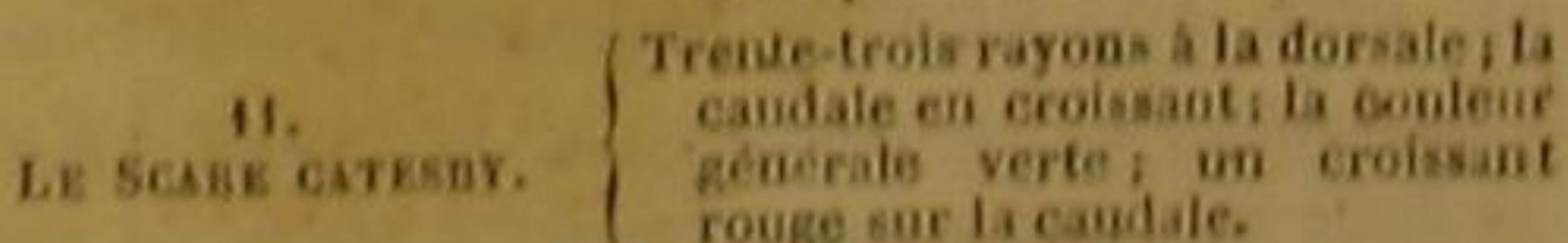

DEUXIÈME SOUS-GENRE.

La nagcoire de ta quéue, rectiligne, ou arrondie.

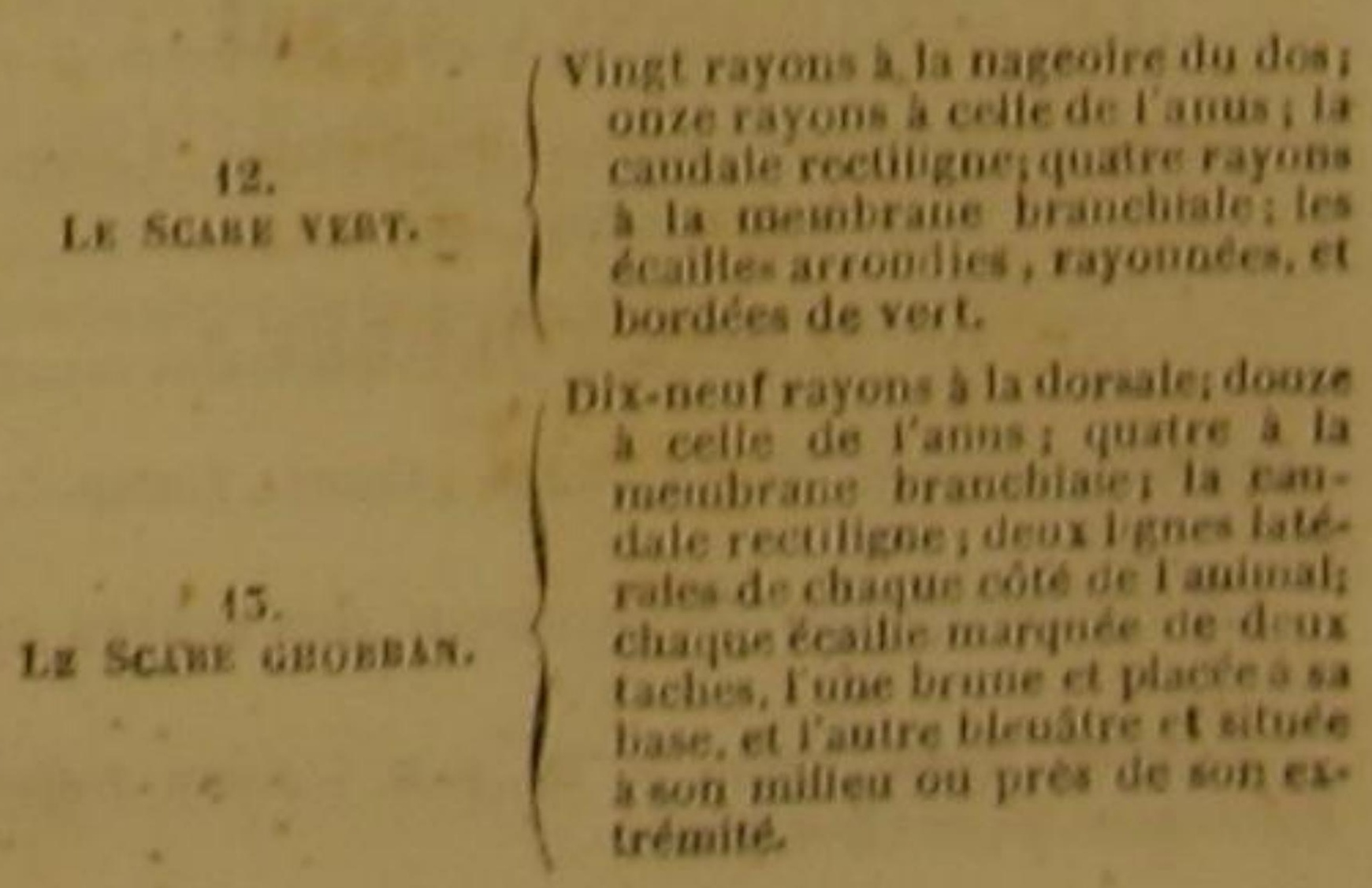




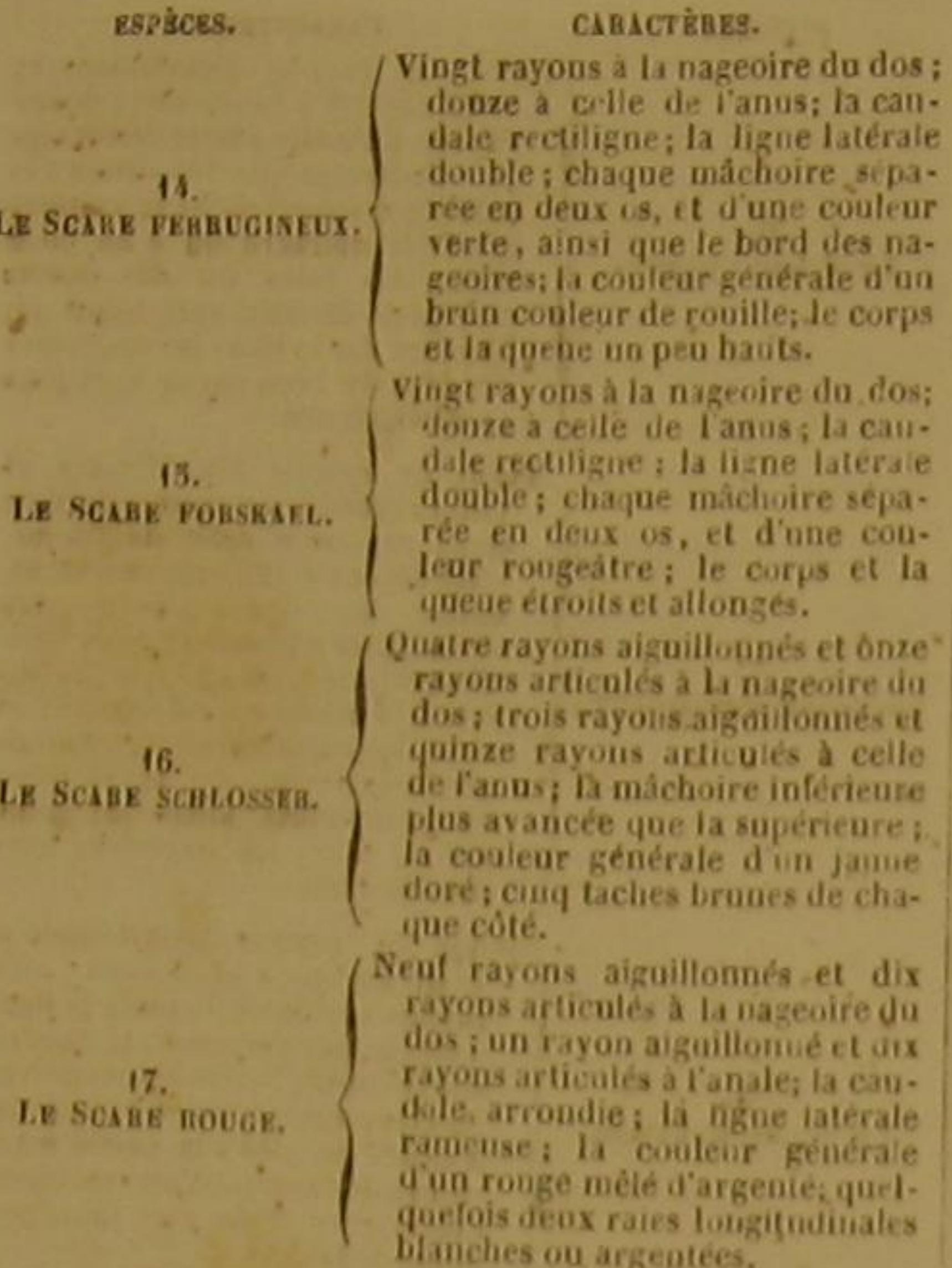

TROISHĖME SOUS-GENRE.

La nageoire de la queue trilobee.

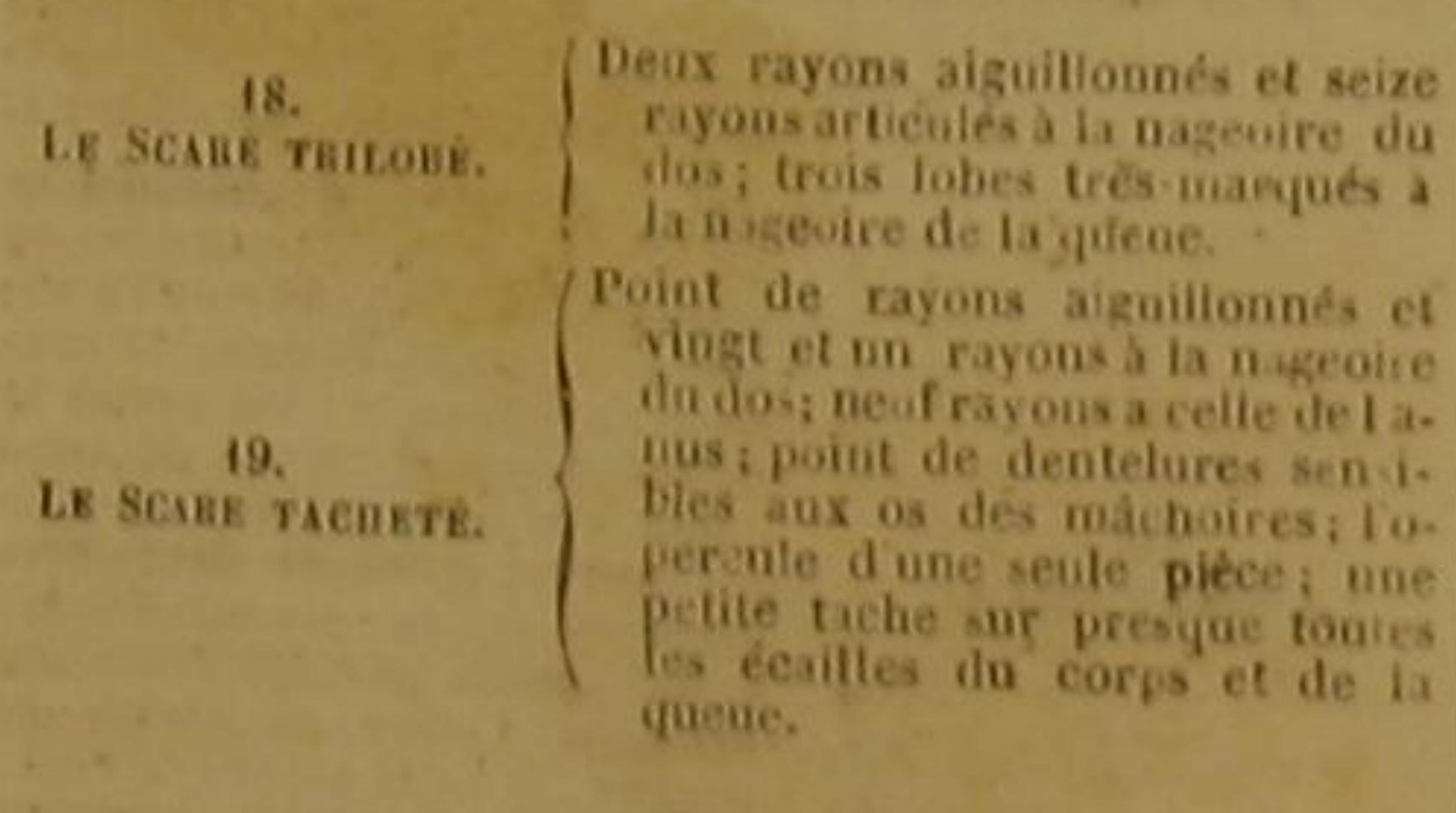

LE SGABE SIDJAN ',

Scarus Sidjan, Lacep. ; Scarus rivulatus, Linn., Gmel.

Siganus rivilatue, Forsk, Cues,"

LE SCARE ÉTOILE ${ }^{3}$,

Siganus steliatus, Forsk., Cuv.; Scarus stellatus, Linn. Gmel., Laeep. :

LE SCARE ENNEACANTHE,

Scarus enneacanthus et Searus denticulatus, Lacep.;
Searus eapitaneus, Cuv. s.

ET LE SCARE POURPRE ${ }^{\circ}$. Searus purpureus, Forsk., Linn, Gmel., Lacep. '

La conformation du museau des scares est 'Forskael, Faun. Arab., p. 25, n. 9. - Sccore Sidjan.
Bonnaterre, pl. de IEnc, métb,

très-remarquable. Elle suffirait seule pour les istinguer des autres póissons osseux; et ell eur donne de si grands rapports avee les didons, les ovoides et tes tétrodons, que l'on pent les considérer comme étant, dans leur sous. classe, les représentants de ces cartilagineux. Leurs màchoires sont en effet ossepses, tris. dures, très-saillantes au dełà des lèvres, a moins à leur volonté, convexes à l'extérieur, concaves à l'intérieur, 'quelquefois lisses su leurs bords, quelquefois erénelées ou dentelies comme une lame de scie, composées chacune, suivant quelques observateurs, d'une senl pièce dans eertaines espèces, formée de deux portions très-distinctes dans lés autres, et presque toujours dénuées de dents proprement dites, c'est-à-dire de corps particuliers, solides ou flexibles, pointus ou arrondis, recourbés et en chássés en partie dans des cavités ošsenses on membranenses. Ce museau, dont l'ensemble offie souventl'extérieur d'une portion de sphère creuse, a été comparé non-seulèment à celü des tortues, qui sont, comme les scares, dépouryues de véritables dents, mais méme an bee de quelques oiseaaux - et particulièrement a celui des perroquets. On a saisi d'autant plus cette analogie, que les màchoires du seare sont fortes, et piopres à couper, trancher et écraser, comme celles des perroquets; et que si ces oiseaux se servent de leur bee pour briser des os ou concasser des graines très-dures, les sci. res emploient avec succès leur museau pour réduire en pièees.les petits têts et les coquilles des crustacées et des mollusques dont-ils aiment a se nourrir. Un long exercice de leurs mâchoires et une pression fréquemment renouvelée de ces instruments de nutrition contre des substances très-compactes et très-difficiles à entamer ou à casser, altèront les bords de ces os convexes et avaneés, et en les usant inéga.

- Ge poisson est du genre Sidjan, que 3. Covier place tans Hinres, les Nasoms etceptérygiens Thentyes, avec les Acaa'Fo skael, Gaun Arab,

materre, pl. qe l'Enc. méth.
" 26, n. 10. - Searétoile. Boo. ' if M. de Lacenéaesnthe est décrit deux autres fois ci-apres care Chadñ. Ml. Cuvier les nonis de Scare denticulé et de fruprèment dits, et dans la famille de genre des Scres labroides. D.

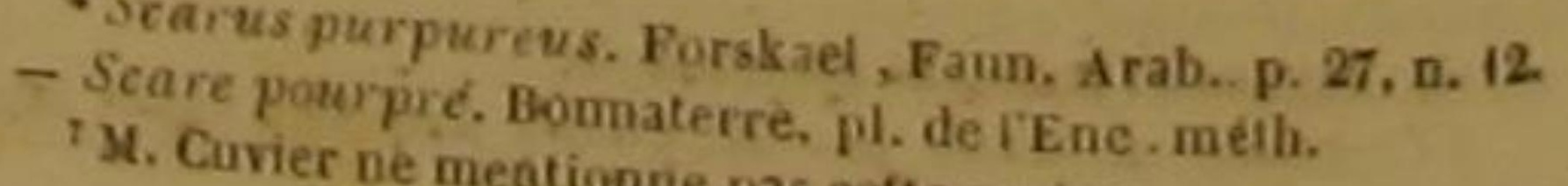

DES POISSONS.

lement, $\mathbf{y}$ produisent souvent des saillies et de petits enfoneements irréguliers. Mais il est toujours aisé de distinguer ces effets aceidentels que le temps amène, d'avee les formes constantes que présentent ces mèmes mảehoires dans certaines espèces, mèmé au moment où l'individu vient de sortir de l'œuf, et qui, consistant dans des denticules plus ou moins sensibles, ont toujours une disposition symétrique, signe non équivoque de leur origine naturelle.

Les scares se nourrissant de crustacées, d'animaux à coquille, ou de plantes marines qu'ils peuvent couper et brouter, pour ainsi dire, avee autant de faeilité qu'ils ont de force pour écraser des euveloppes épaisses, tous ceux de nos lecteurs qui se rappelleront ce que nous avons dit de l'influence des aliments des poissons sur la richesse de leur parure, s'attendront à voir les osseux de la famille que nous examinons, parés de couleurs variées, ou resplendissants de nuances très-vives. Leur attente ne sera pas trompée : les scares sont de très-beaux poissons. Le sidjan, par exemple, est d'un bleuátre trèsagréable a la vue, et relevé par des taches noires, ainsi que par le jaune clair ou doré de sês raies longitudinales. L'étoilése montre couver presque en entier de taches hexagones ou de petites étoiles blanches ou. jaunes, ou d'ui beau noir, disséminées sur un fond noirátre qui les fait ressortir, et accompagneat d'une manière trés-gracieuse le jaunatre des pectoriles, le jaune de la dorsale ainsi que de l'anale, et les raies dorées que l'on voit sur la caudale de quelques individus. Les raies pourpres, et longitudinalés du pourpré se marient, par une sorte de chatoiement tres-varié, avec le verdatre de la partie supérieure de ce poisson, le bleu de sa partie inférieure, la tache noire et carrée et la bordure pourprée de chaque opereule, te croissant noir que l'on voit sur chaque pectorale et sur la dốrsale, le vert de ces mèmes nageoires, celui de la caudale qui d'ailleurs est tachée de pourpre, et te bleu de l'anale ainsi que des deux thoracines. Ces tons si diversifiés cont, au reste, l'attribut bien naturet d'animanx qui, en 's'approchant de la surface des maux qui, en s'approchant de la surface des
mers, peuvent facilement, dans le elimat qu'ils babitent, être fréquemment imprégnés đe rayons solaires nombreux et éclatants. Le sidjan; l'étoilé et le pourpré vivent près des eôtes de l'Àrabie, où ils ont été observés par Forskael.
L'ennéacanthe se trouve dans une mer voisine de celle de l'Arabie. Un individu de cette espèce a été apporté au Mnséum d’histoìre naturelle, du grand Océan équinoxial, où it avait été pèché sous les yeux de Commerson. Nous ignorons de qnelle couleur co thoracin a ete peint par la nature; mais ses nuances doivent étre vives, puisque ses éeailles sont très-granđes. Comme le sidjan, létoilé et le pourpré, il a des rayons aiguillonnés à la nageoire dorsale. Mais au milieu de la petite famille que composent ees quatre seares, le sidjan, qui parvient jusqu'à une longueur de onze ou douze décimètres, et l'étoilé, qui ordinairement n'a que deux déeimètres de longueur, forment un groupe particulier. Ils ont l'un et l'autre, au-devant de la nageolre da dos, un aiguillon communé ment tourné vers la tête, et cachó sous la peau au moins en très-grande partie. Les éeailles qu revêtent ces poissons sont petites; et ils paraissent préférer pour leur nourriture les plantes marines qui croissent au milieu des coraux ou des rochers, auprès des rivages arabiques: Leu chair, au moins celle du sidjan, est agréable au goùt; cependant, comme des blessures faites par les aiguillons de leurs nageoires ont souven été douloureuses et ont causé des inflammations assez vives, on les a regardés comme venimeux '.

Le pourpré est bon à manger, de même que le sidjan : mais ses éeailles, au lieu d'étre petites comme celles de ce dernier seare, sont très-largés: elles ont de plus une forme rhomboidale, montrent une ciselure en rayons, et ne sont attachées que faiblement a la peau. On voit au-devant de ses narines un petit trou et une sorte de bapbillon; ses opercules sont denués d'ceailles semblables à eelies du dos.

is rafons a chaque pectorale du sidjan , 2 rayons aiguit lonnés (ie premier $1 t$ le dervier) et 2 ou 5 rayous articuies chaque dioraciue, fir rayons a la caudale fo fayons a ch que pectorale de

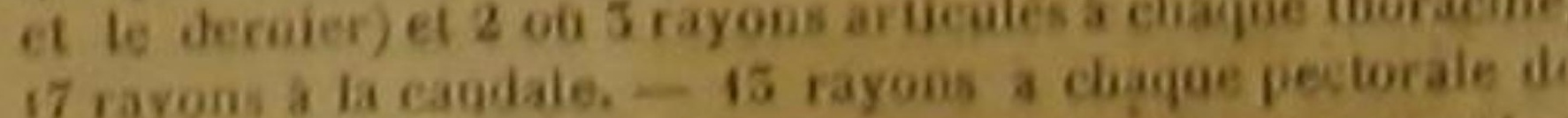

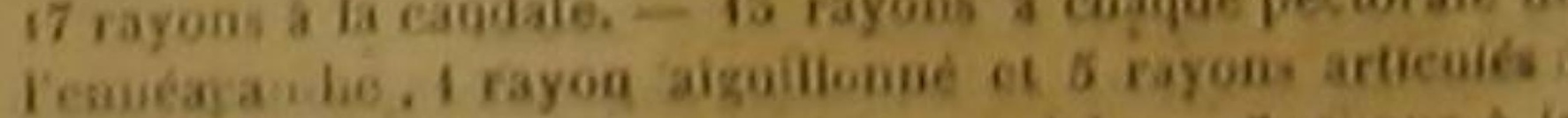
chaque thoracias, 22 rayous is ta caudale, - 6 rayous 3 is membranofiranchiale da pourpre, 15 a elaque pecturate, 6 i chaque thoracine 12 \& 1 
LE SCARE HARID '

Scarus Harid, Forsk., Linn., Gmel, Lacep. ’.

Le Scare Chadri s, Scarus̀ niger, Forsk.; Labrus niger,

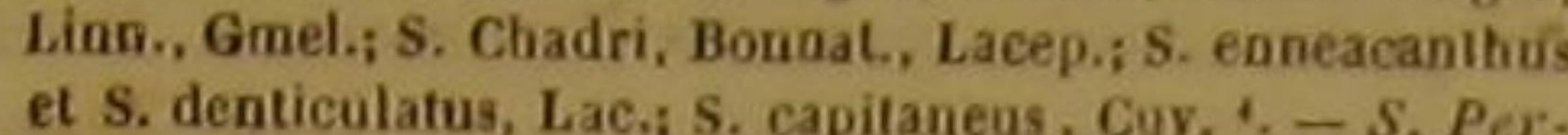

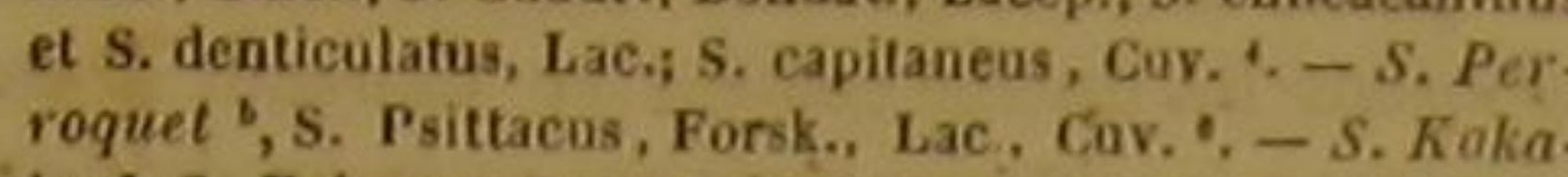
toe ', S. Kakatoe, Lac.; Labrus cretensis, Linn... Gmel. S. Denticule, S. denticulatus, S. enneacanthuset S. Cha-

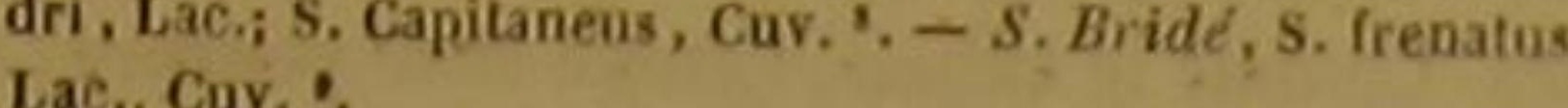

C'est dans les eaux de la mer Arabique que Forskael a vu le harid, le chadri, le perroquet. Le kakatoe, auquel nous avons dù d'autant plus conserver le nom qu'il porte dans lés Indes, où il est très-commun, que cette dénomination indique les rapports que loi donne la forme de son museau avee les Kakatoes, ou perroquets huppés, vit non-seulement dans plusieurs mers asjatiques, mais encore dans celle qui baigne et les rivages de Crète, et les cótes de Syrie, et les bords septentrionaux de I'Egypte.

Le denticulé et le bridé ont été observés dans le grand Océan équinóxial par Commerson, qui en a laissé des dessins parmi ses marruserits, et qui a trouvé le chadri dans cette même grand bande marine située entre les deux tropiques.

'Forkael, Faun. A f́ab., p. 50, n. 1\%, - Scare Harid. 'Non cite, pl, de I'Ene, méth.

'Non cité par M, Guvier. D.

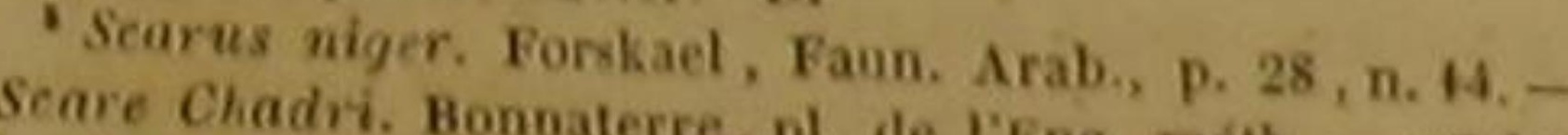
- odon, odax, toto corpore cererite de l'Enc, méth. - - Odax - purpureo, , Commerson, manuscrits défj citís. 'La description du seare chausi ser rajaja cités. res espices do seare enneacanthe et du scare dent denx anontété a tort distinguées par M. de Lacépéde. M, Cuviér adinet ce poisson dansson genre Scares D.

Seare bee de perroquel, Bunvalerp. Arab., p. 29, n. 16. - Ce poissoz est admis par $\mathbf{M}$. Cuverer de I Inec, méth. seare de la famille des Acanthoptérygiens tabs le vrai genr ' Kakatoeka, capitano, dans les Indes, - Labro. D,

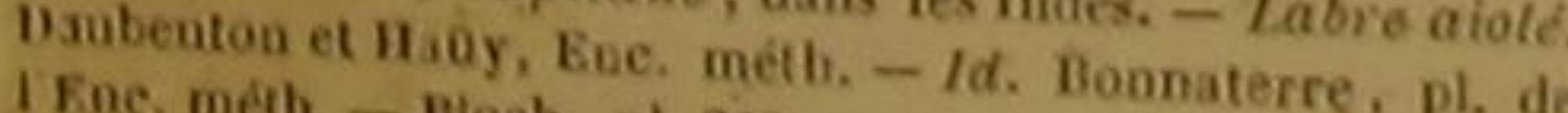
- cens, call - Bloch, pl. 220. - - Labrus tetraodon viree

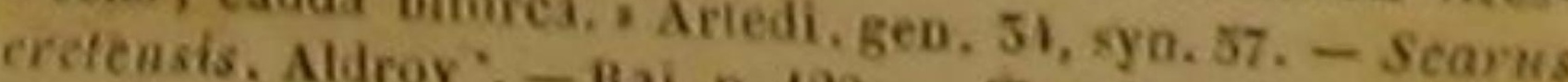
cus. Lister. App. Willoghby, p. 29, -Turdas viridis indi- Le Seare denticulé et le se. 23 , tab. X.

11. Cuvier, qu' une méme espéce. a a laquéntbe ne sont, selon apporter la description du Scare chadri de cet farticte encor Capitaneus. Dugenre des

thoptérygiens labrois Seares de M. Cavier, famille des Acan-
D'après ce célèbre voyageur, le chadri, presente de chaque côté deux lignes latéral composées de traits petits et rameux, est vert d ecailles tres-grandes et entieux, est cor. les opercules présentent des écailles sem bs a celles du dos; et l'on voit dans l'intérieur de a bouche deux plaques osseurses, que plusiens rangs d'élévations ou-de très-petites dets h. rissent ou font paraitre comme ehagrinées, qui sont très-propres à écraser les tiges des eoraux et les fragments des madrépores. C'est, en effet, suivant ce mème naturaliste, des anmaux marins qui construisent ces tiges et ces fragmients calcaires, que le harid aime à s nourrir. Il parvient à les saisir en corrodant avee ses máchoires osseuses la substance cretacée dans laquelle ils se renferment; et d'après la nature de ses aliments ordinaires, il n'es pas surprenant qu'il ne soit pas recherché l'lle de France, ou Commerson l'a déerit, qu'il y soit regardé comme malfaísant, et que ce savant auteur adopte I'opinion de ceux qui l'y croient venimeux. Commerson a remarquè que ce scare avait autour des yeux un anneau ou cercle coloré en pourpre. Quant aux couleurs des autres cinq seares nommés dåns cet artiele le tableau générique indique les principales de celles qui sont répandues sur quelques-uns de ces animaux. Disons de plus, que le harid a les pectorales jaunâtres, et le dessous du corps violet, ainsi que la dorsale, la candale, et la nageoire de l'anns; que le perroquet a la base de ses nageoires pourprée; que le kakatoe a les cótés d'un vert clair, et les nageoires jaunes a leur base et rertes a leur extrémité que la plus grande partie de la queue du bridé est d'une teinte plus elaire que le reste de la sur. face de l'animal '; que la ligne qui sépare les deux nuances génêrales de ce thoracin est courbe; et que la dorsale ainsi que l'anale de ce poisson présentent, à leur base et a leur bord extérieur, une raie longitudinale très-étroite, et d'une couleur foncée en très-vive.

ine, 11 rayons a claque pectorale da harid, 6 à chaque thoradiue, fra a la caudale. -5 rayons a la membrame branchiale du chadri, 15 a chaque pectorale, 7 a chaque thoracine, 15 i perroquet de a quene. -15 rayons à cbaque pectorale du -4 rayong i ha mae thoracine, 12 a la nageoire de la qu me. que pectorale, 6 t chane branchiale du kakatoe, 16 à chr. - 14 dachaque pectorale do dentine, 18 a celle de la qưne. rayons à chaque pectorale da bride, 10 a la candale.

\section{IE SCARE CATESBY $\bullet$ \\ Searus Catesby, Lacep., Cur.?}

Catesby a observé ce seare, qui vit dans les eaux de la mer voisine de la Caroline; et voilà pourquoi nous avons donnéa ce poisson un nom spécifique qui rappelát les grands services rendus aux sciences physiqués par ce voyageur. La dorsale de ce thoraein est très-longue, et sa caudale très-haute; les denticules de ses deux mâchoires sont très-grandes, très-fortes et égales. L'ensemble formé par son corps et sa queue est très-élevé; il pourrait done fournir une nourriture assez abondante: il n'est cependant pas recherehé pour la délicatesse de sa chair, mais il plait par sa beauté. Le vert dont brillent ses écailles est relevé par le brun du dessus de la tête, de Ia dorsale, des pectorales et des thorieines; ees thoracines et ces pectorales sont d'ailleurs bordées de bleu. L'opercule est bleu, bordé de rouge du cóté de la queue et marqué, sur sa piéce postérieure, d'une tache jaune et éclatante; et enfin une rale rouge rège sur toute la Jongueur de la nageoire de l'anus.

IE SCARE VEITT 3

Searus viridis, Blocb, Lacep., Cus. '.

Le Scare Ghobban s, Scarus Ghobhan, Forsks, Linn., Gmet., Lac, - - S. Ferrugineux ', s. Ferrugineus, Forkk, Lion,,

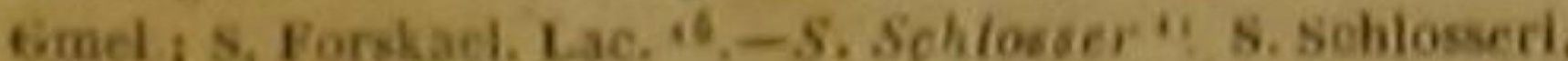
Linn., Gmel. Lac, Toxotes jacoiator, Cuvis Labrus sagittarius, Lace ", - S. Nouge ", S. rober, Lacep. "."

Dans plusieurs individus de f'espèce du scare vert, on voit, de chaque côté, ta dernière den-

'Catesb. Carolin. 2, p. 29. tab. 29. - Scare, poisson vert. Donasterre, phe de l'Enc mith.

'Du vrai genre des scares, dans la famille des Acanthopté. giens tabroides, Cuv. D

'Du vrai geure Scare de $\mathbf{M}$. Cuvier, dans la tamille des Acanthoptérygiens labroides. D.

'Forisael, Faun. Arab., p. 28, n. 15. - Scare ghobban.

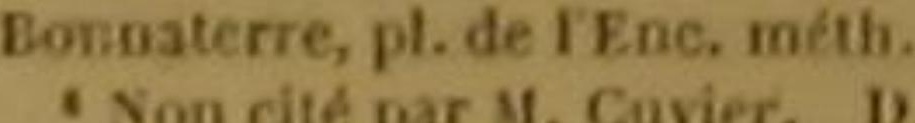

Turskael, Faun. Arab. 10. 29 , n. 15. - Scare ferrugt

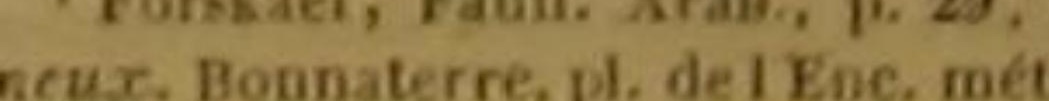

- Non cite par 4 Cavier. D.

naterre, pl. de l'Enc, méth.

"Non cite par M. Cuvier.

"Pallas, spie. zool. 8, p. 41 .

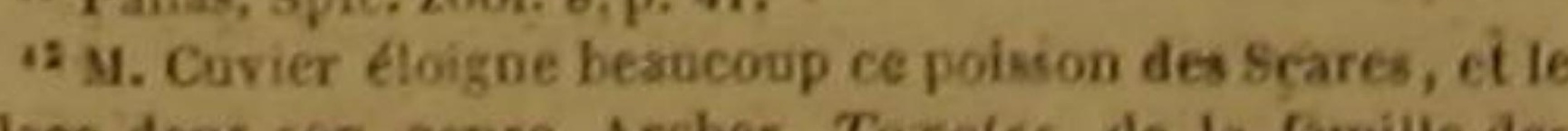

Acanthopterygiens squamipernes, $11 \mathrm{Te}$ regarde comme ne telure de I'une et l'autre des deux máchoires recourbée en arrière comme une sorte de crochet, et beaucoup plus longue que les autres. Ilne parait pas qu'un trait semblable ait été remarque par aucun naturaliste sur le ghobban. Ce dernier scare a d'ailleurs deux lignes latérales rameuses, dont l'inférieure commence avant la fin de la supérieure. Ces différences, ré unies à quelques autres, que l'on saisira sans peine, et particulterement à celle des couleurs du seare vert, et des nuances qui distinguent lo ghobban, nous ont déterminés, au moins jus qu'au moment où nous aurons recueilli un plus grand nombre d'observations, a considérer ces deux poissons comme appartenant à deux espèces diștinetes, malgré les très-grands rapports qui les rapprochent.

Le rouge a, sur la partiessupérieure de son museau, un grand nombre de pores très-sensibles; on voit deux petits barbillons auprès de chacune de ses narines, et cinq ou six denticules plus grosses et plus longues que les autres à la màchoire supérieure '

On doit le compter parmi les poissons dont la parure est la plus riche et la plus élégante. L'éclat de l'argent et la vivacité du rouge lo p'us agréable sont réunis pour former ce qu'on est tenté de nommer on assortiment de couleurs da meilleur goùt. I a partie inférieure de 'animal est argentée; deux larges bandes arrentées aussi s'étendent de chaque cóté de plusieurs individus, depuis les yeux jusqu'à l'oxtrémité ou auprès de l'extrémité de la queue; et la base des pectorales, des thoracines et de la caudale, est dorée.

Ies couleurs qui distinguent le forskael, sont bien moins brillantess. A la vérité, ses pectorales et sa caudale sont jaunâtres : mais ses thoracines sont violettes, sa dorsale est brune, et sa partie supérieure d'un brun foncé, ou gris-derer.

Lo méme gris-de-fer, ou un brun presque semblable, mélé de teintes couleur de rouille, compose la couleur générale du ferrugineux, dont la dorsa le et la caudale sont jaunatres, et

difterant pas specifiguement da Labre sagittaire de tace pede, (dérit eiarant) du Sciana jaculatixix de "1) Mloch, pl, 221 .

"1" Non cite par M. Cavier. D.

- Une sorte d'aiguilton tourne vers la queve est plack as coré exterieur de chaque thoracine. 
les thoracines, ainsi que l'anale, d'un rouge violet.

Le rouge violet caractérise aussi les nageoires du ghobban, dont la dorsale et l'anale sont bơrdées, à l'intérieur ou à l'extérieur, et quelquefois en haut et en bas, d'un vert tirant suir le bleu; dont la caudale, et souvent les pectorales et les thoracines, sont lisérées de verdâre ; et dont la tête montre des raies du même ton, ou à peu près.

Ce ghobban vit dans la mer d'Arabie, ainsi que le ferrugineux et le forskael, auquel j'ai donné un nom spécifique qui rappelle le voyageur célèbre dont les recherches nous ont pro. curé la description de oes trois seares '.

Le vert habite dans les eaux du Japon; le schlosser, à Java; et le rouge, dans la mer de Antilles, aussi bien que dans celle des Indes orientales.

\section{LE SCARE TRILOBE ${ }^{2}$,}

Searus trilobatus, Lacep. $\rightarrow$.

\section{ET LE SCARE TACHETÉ.}

Scarus maculosus, Lacep. 4 .

Nous avons trouvé dans les manuserits de Plumier le dessin du seare trilobé. Nous nous empressons de publier la description de ce poisson, auquel nous avons donnè un nom spécifque qui indique ta forme trilobée, très-remarquable, ou le double croissant très-mårqué, que présente sa nageoire caudale. La mâchoire superieure de ce thoraein est plus longue que l'inférieure; et de plus, son museau s'avance eu s'arrondissant au-dessus et au delà de la mâ choire d'en haut. Ses couleurs sont diversifiées. II habite daus les eaux de l'Amérique méridionale ${ }^{5}$.

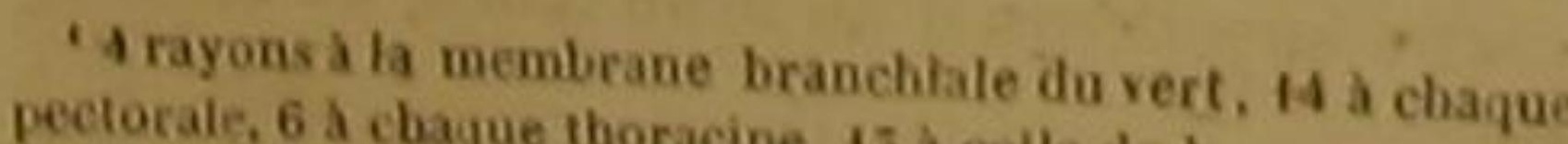

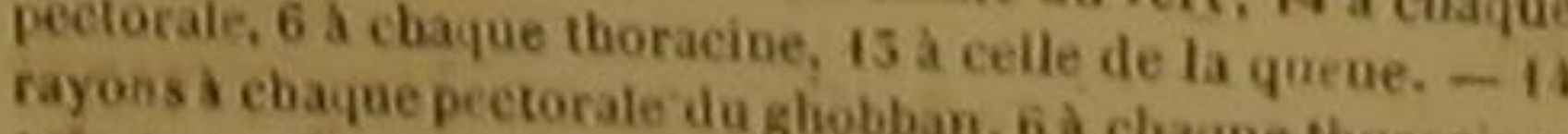

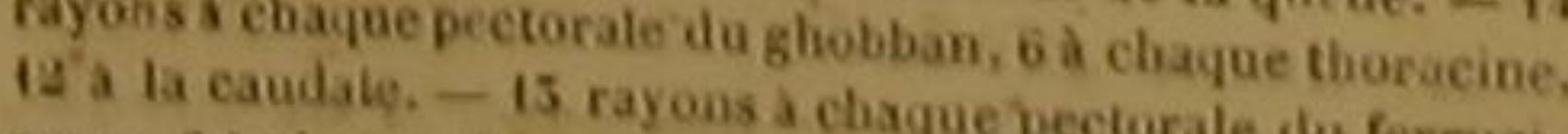
neux, 6 a chaque thoracine, is a d a candale. - 14 rayonschaque pectorale du forskael, 6 a elaque tioraeine, 12 \& I

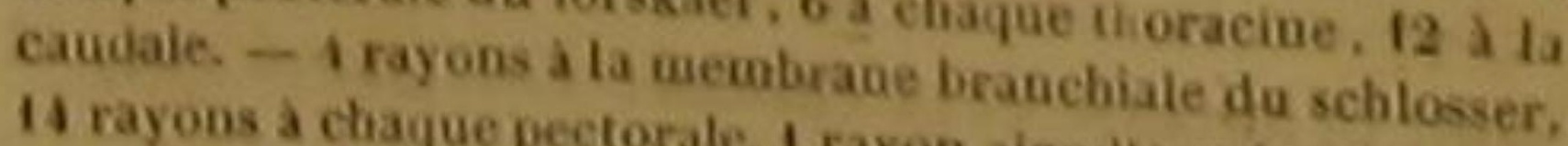
A rayous a chaque pectorale, 1 rayon aigutlouné et 5 rayon:
articules a chaque thoracine, 17 rayons ' I I articulés a chaque thoracine, 17 rayons 'd la caudale. -
rayons a la membrane branchiale du rouge, 12 rayons a cha que pectorale, 1 rayon alguillonne et 5 rayons articult's a $\because$ Turdus varims, riche a la candale.

nascrits de Plumier, déposés a la Biblioda fuscinulata. , I 'Non cité par M. Curier. D. 'Non cite par M. Cuvier. D,
Le tacheté a étévu dans le grand Océan équ noxial par Commerson, qui en a laissé une figure parmi les manuscrits que Buffon m'a remi dans le temps. L'anale de ce seare offre dem raies longitudinales très-petites, et situées I première au bord extérieur et la seconde au bord intérieur de cette nageoire.

Les autres traits de ce poisson et du trilob sont indiqués dans les notes de cet article, sur le tableau générique

\section{CENT TREIZIEMME GENRE.} LES OSTORHINQUES ?

Les mâchoires asseuses très-arancées, et tenant lieud téritables dents; deux nageoires dorsales. ESPìcB.

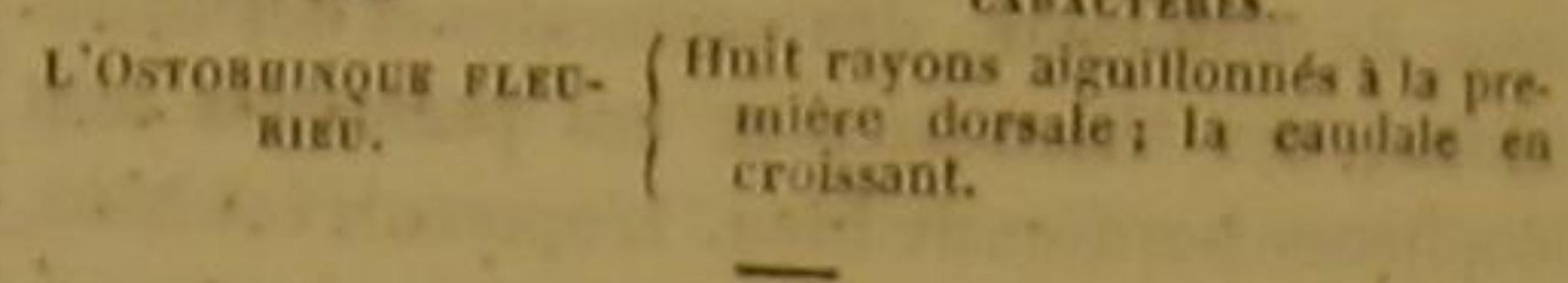

\section{L'OSTORHINQUE FLEURIEU}

Ostorhiñehus Flearieu, Dipterodon hexacanthus el Centropomus auratus, Lacep.; - Mullus imberbis, Critrepomus auratus, Lacep.; Mtul
Lint.; Apogon Rexmullorum, Cuv. :

Les ostorhinques ne different des seares que parce qu'ils ont deux nageoires sur le dos, au lieu de ne présenter qu'une seule nageoire dorsale; et leur museau, composé de deux máhoires osseuses et très-avanicées, ressemble, comme celui des scares, au devant de ta bouche des diodons, des ovoídes, des tétrodons, des tortues, et mème au bec des perroquets. Ils ne composent encore qu'une espèce, dont nous publions la description d'après les manuserits de Commerson, qui en a dessiné les traits. J'ai pensé qu'ún poisson découvert dans le grand Océan équinoxiał par un habile observateur, et pendant le fameux voyage de notre Bougainville, devait être choisi pour rappeler par a dénomination spécifique la reconnaissance ceux qui s'intéressent aux progrès des sciences, nvers mon célèbré confrère et ami M. Fleu-

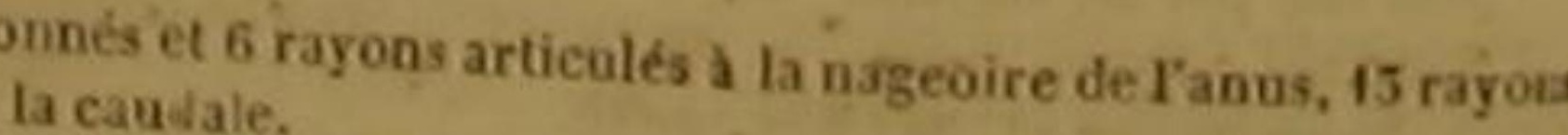

15 rayons à chaque pectorale do tácheté. 'Ce poisson doit étre geare de M. de Lacépéde. D.

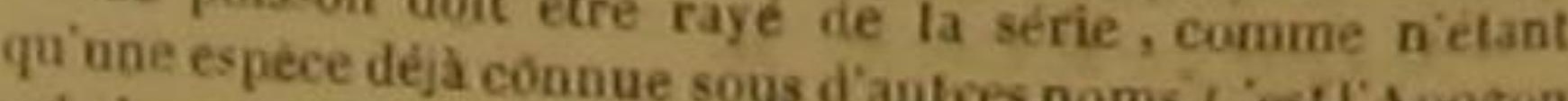
rol des rougets. de M. Cuvier. ou Mullus ims bit Apogom If: de Lacépéde l'a déccít deox antres fois, sons las, Lin. Wiptérodon hexacanthe et de Centropoine dore. M. Spiools rieu, de l'Institut de France, pour tous les ouvrages dont il a enrichi les navigateurs, les géographes et les naturalistes; et particulièrement pour la belle nomenelature hydrographique qu'il vient de publier.

L'ostorhinque que nous examinons, a la mâchoire inféríeure un peu plus avancée que la supérieure, les yeux gros, la téte dénuée d'écailles semblables à celles du dos, les nageoires dorsales et de l'anus assez courtes, la caudale trèsgrande, et une bande transversale d'une couleur vive ou foncée auprès de cette nageoire de la quene. La ligne laterale n'est pas sensible '

\section{CENT QUATORZIEME GENRE.} ĹS SPABES ?

Les lecres supérieures pert extensibles ou non extensibles, on des dents incisizes, ou des dents molaires, disposees sur un ou plusieurs rangs : point de piquants $11 \mathrm{i}$ de dentelures aux opereules; rme seule nageoire dorde dentetures aux opercules; nue seule nageoire dor-
sale; celle nageoire eloignce de celle de la queue; ou sale : cilte nagcoire eloignce de celle de la queue, ou
la plus grande hauteur du corps proprement dit, sipe ptus grande hauteur da corps propreme, ou cgale, ou presque egale a In longueur de ee meme corps.

\section{PIEMIER SOUS-GENRE.}

La nagcoire de lá gumene, fourchue, ou cu croissant.

$$
\text { espices. }
$$
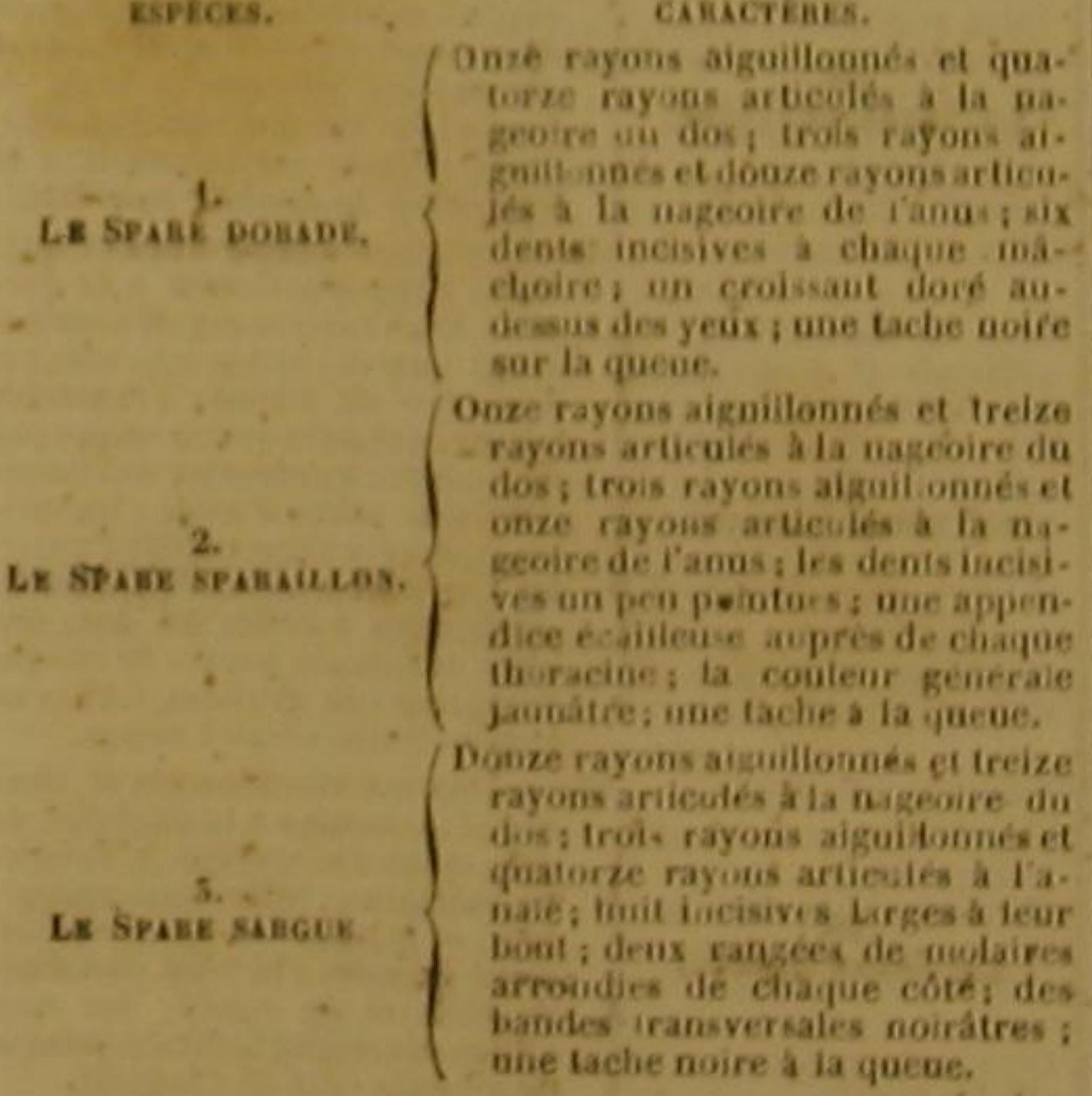

I 14 rayons a la secionde doregle, 8 y chayne pectorate, 9 a la mageoire de $\mathrm{T}$ anus, 18 a celle de la quevie.

"Ce Reare correspond, pour le plas grand nombre te ses especes, aux lamilles des Acantioptérygiens sparoides et menides de $\mathrm{M}$. Cuvier. Cependant beaucoup des poissons qu elle comprend dotvent etre renvoyes a dautres familien tres-tioignees, telles que celles des Acanthopterygiens per-

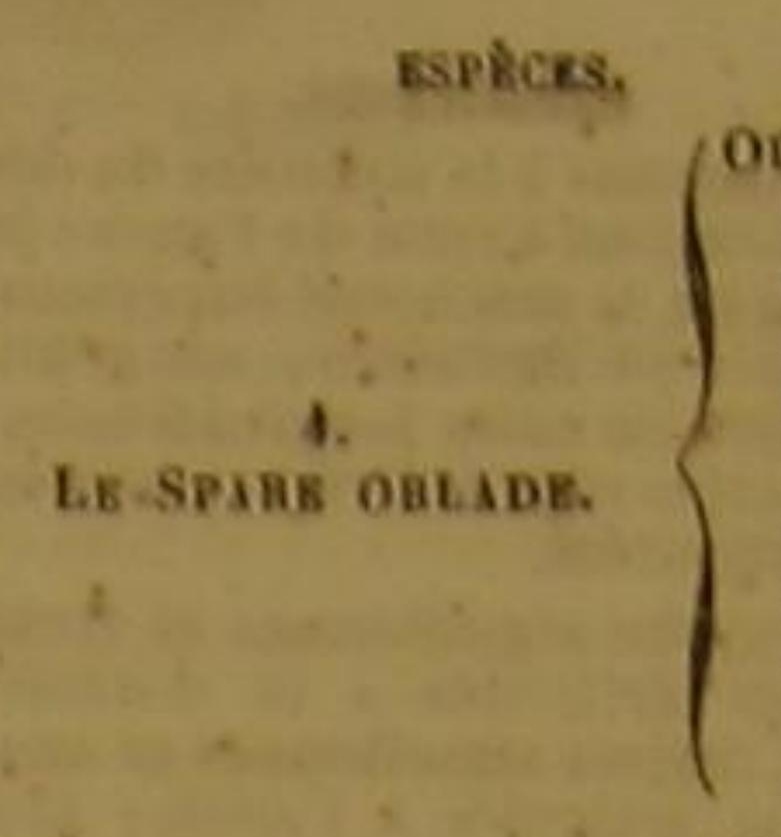

CABActḱars

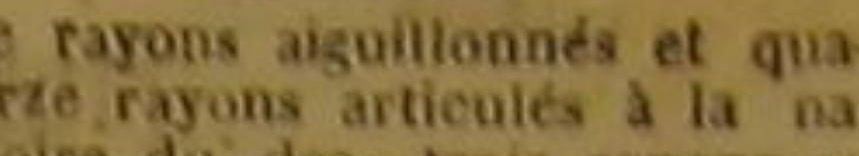

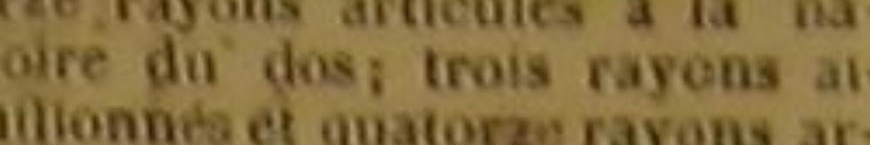

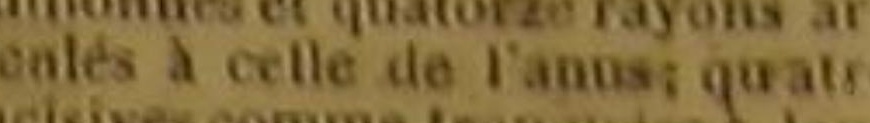

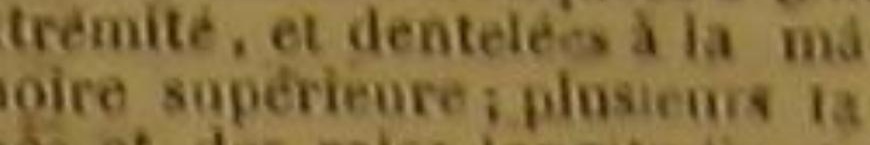
iechaque colie de tranimaliti an

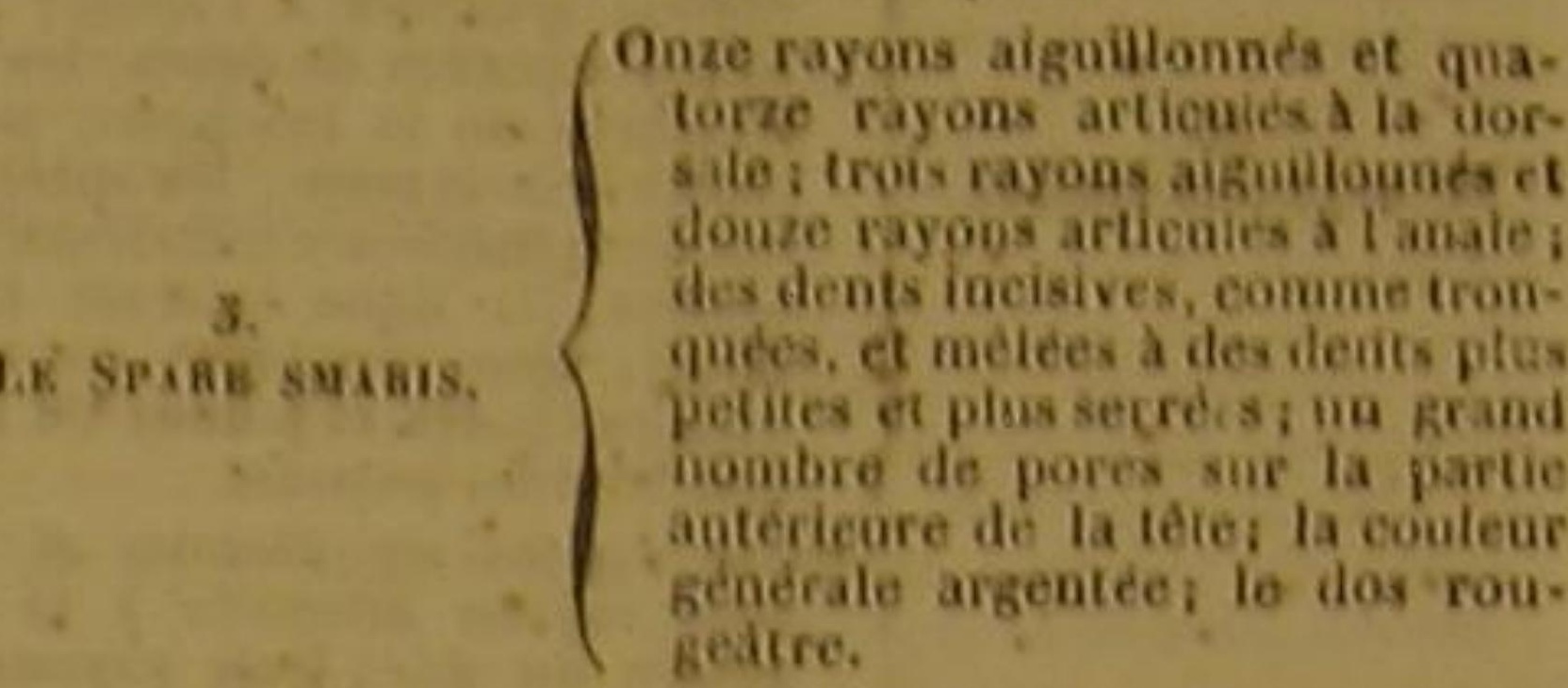

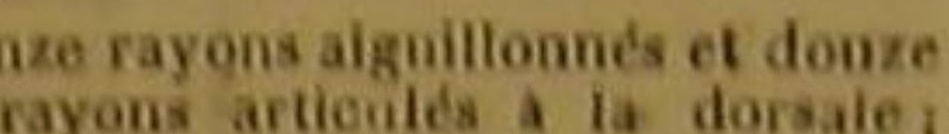

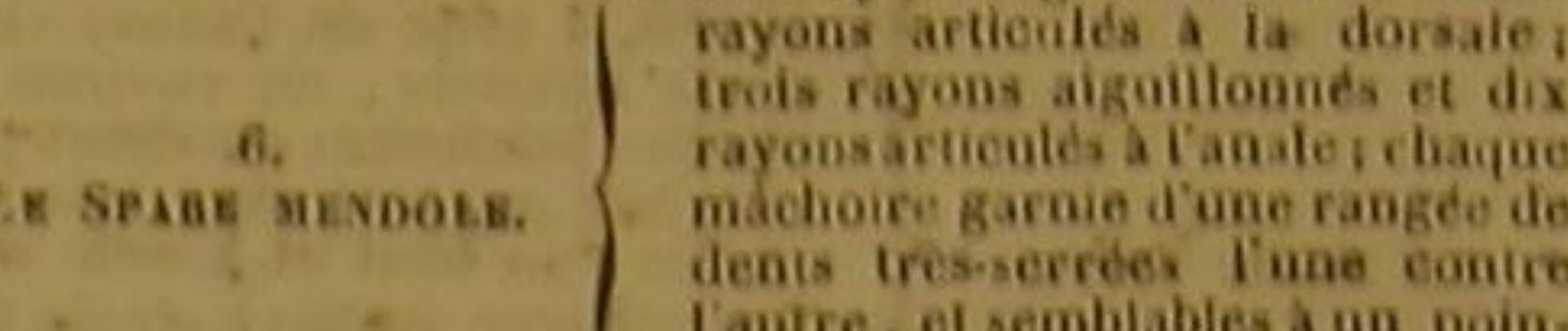
$\because \cdots+1$ of rayons alguillonnes et vingt-

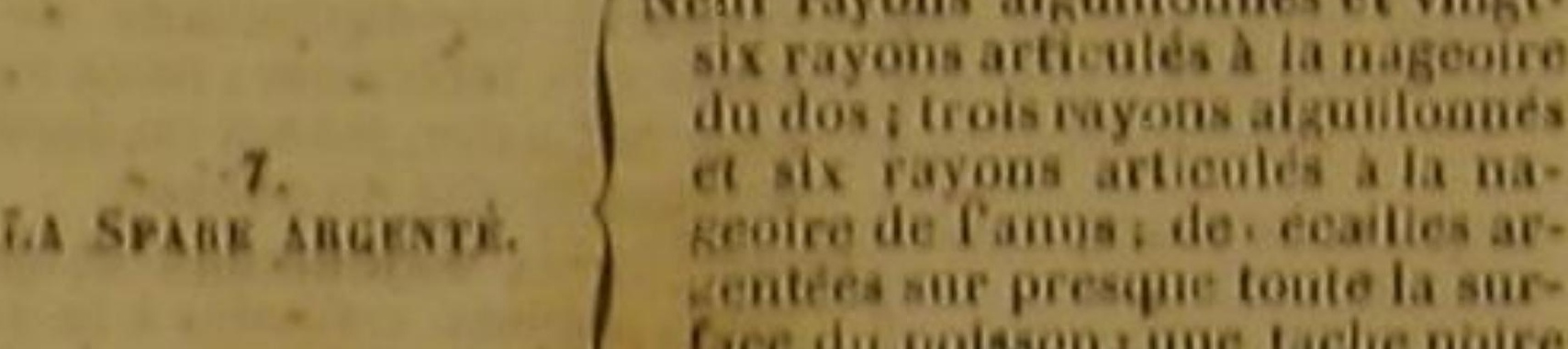
Des
pres des brauchics. Cre ryyom aisuillonnis et douze

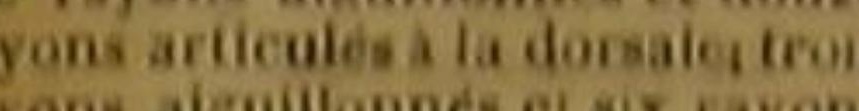
articulén a la nageotie de tranus

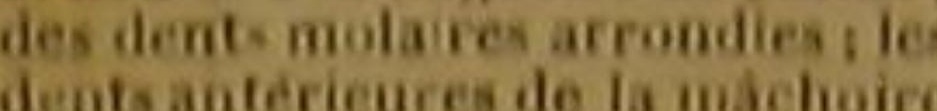

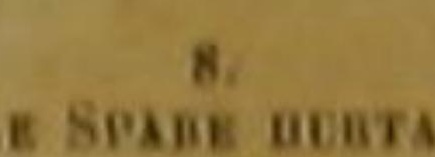

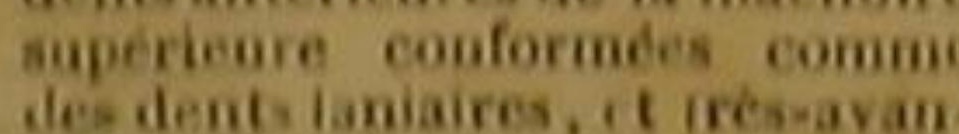
con des landes transiceralio

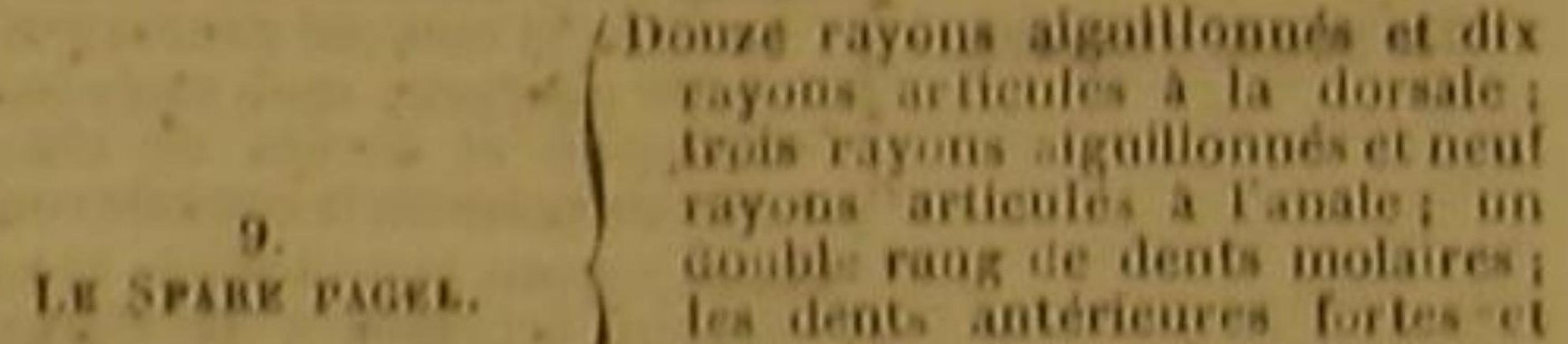

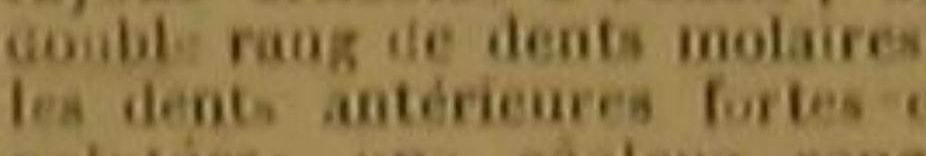

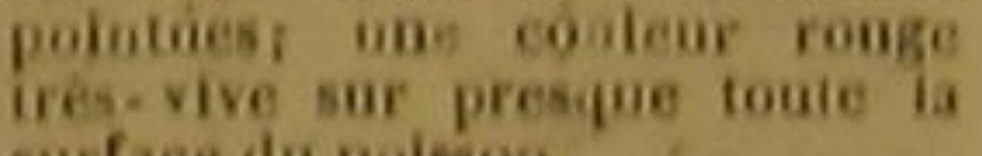
iufface du poisson iguilionnes et dix

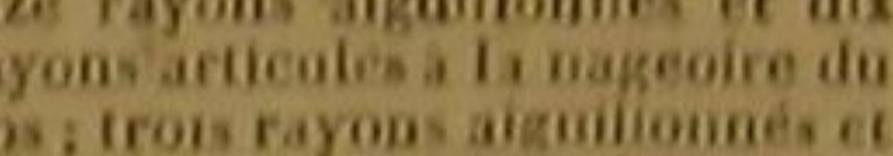
teut rayons articules of tomale: une membirane placeis an-dessus
de la base des rayous articuiés de

20. du d ruier rayon de chicuies de

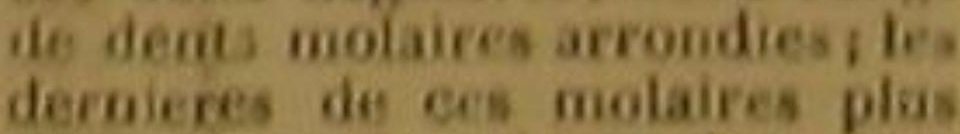

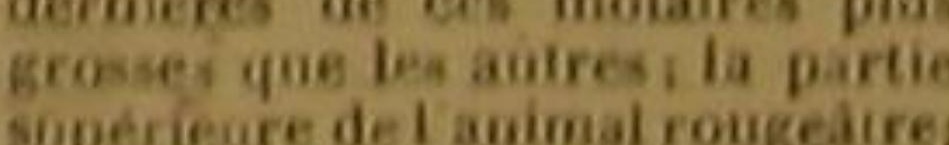
作 Die: les seus premiers rayous

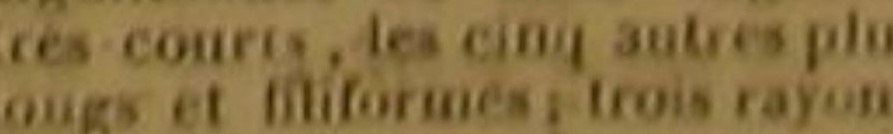

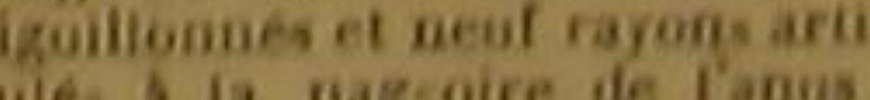
ix SPAgE "I.

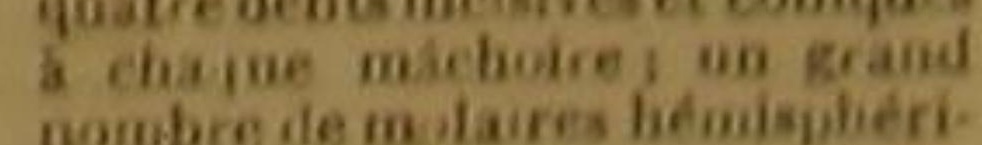

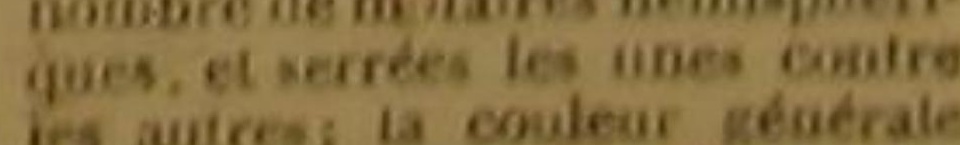

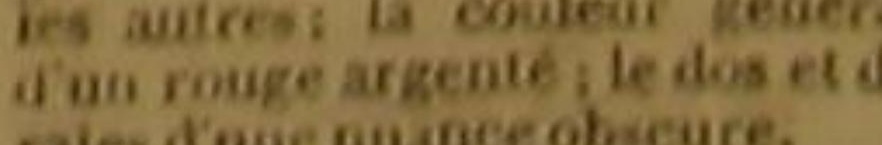




\section{HISTOIRE NATURELLE}

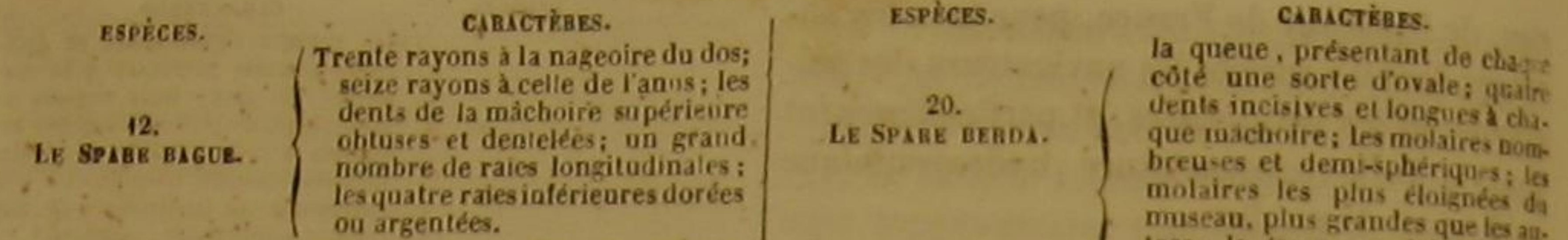

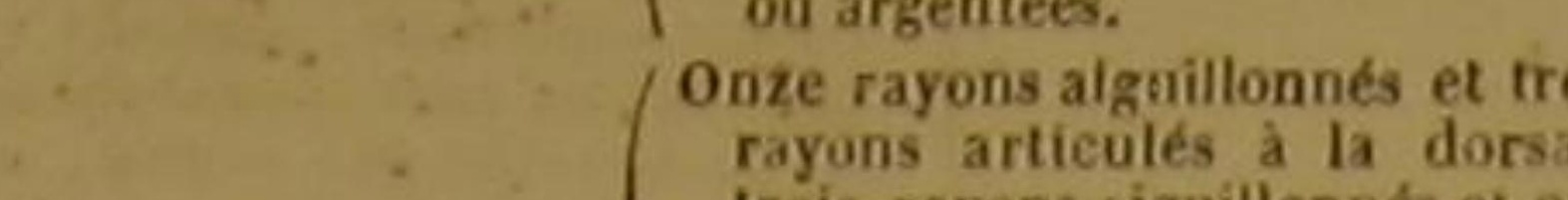

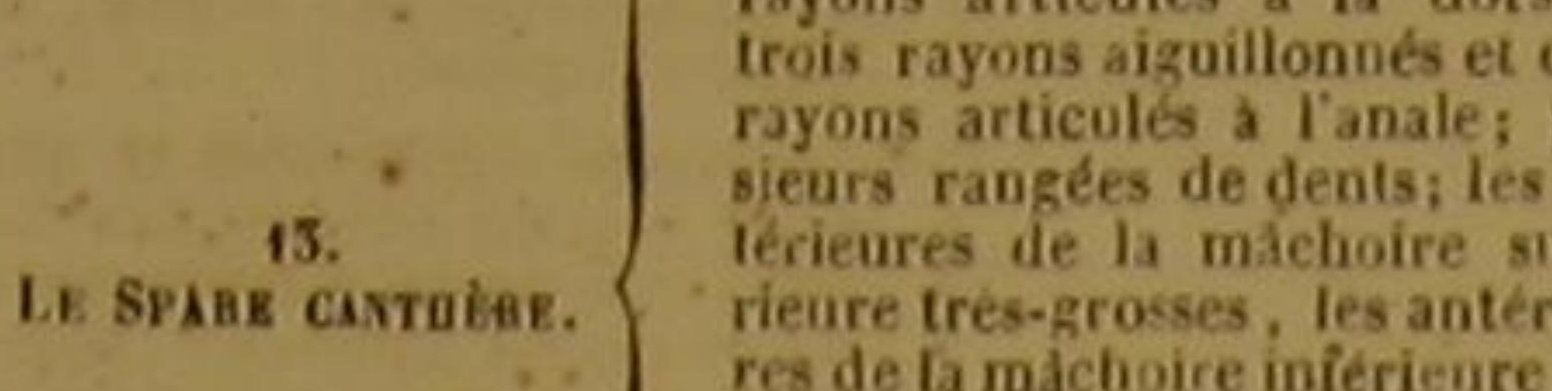

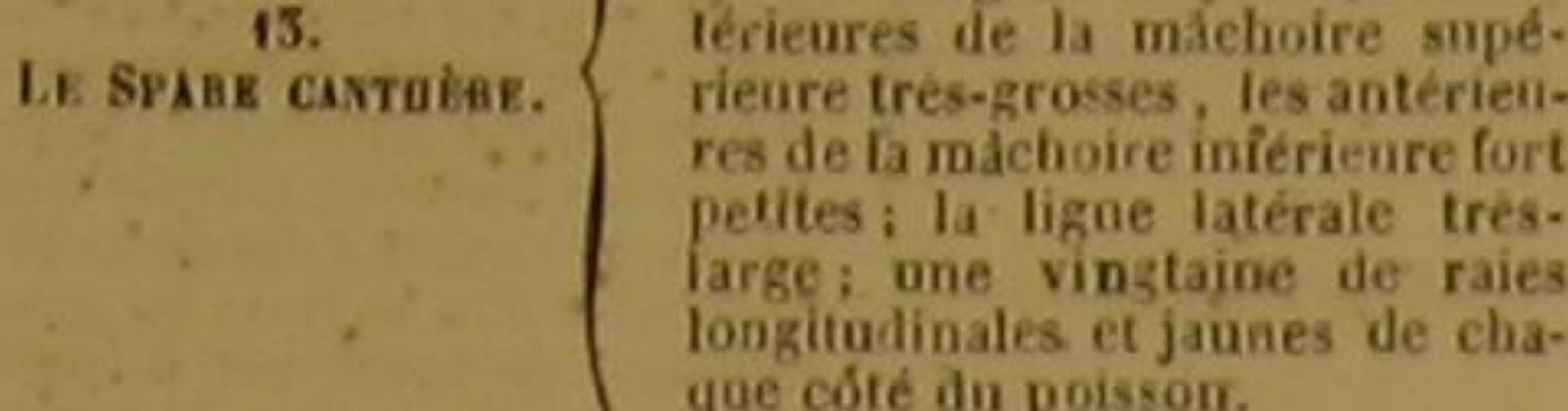

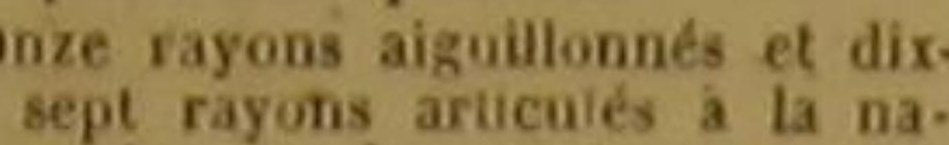

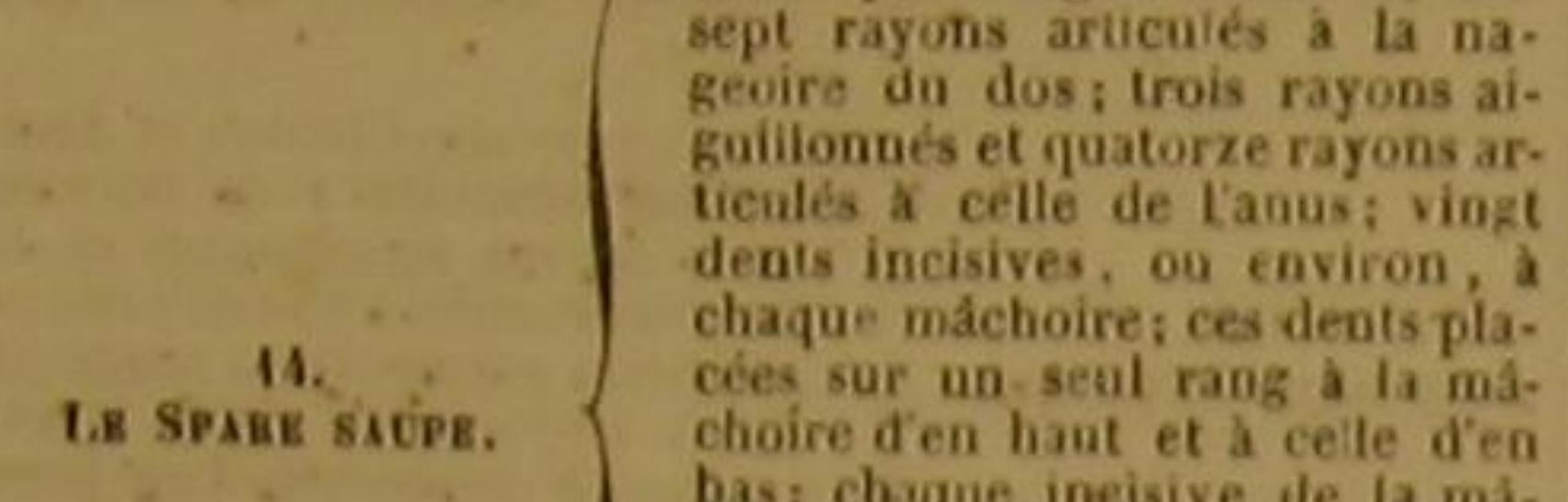

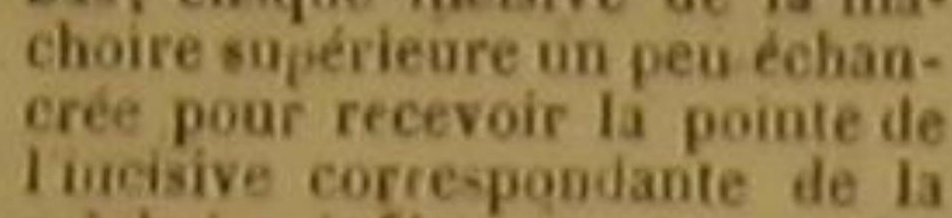

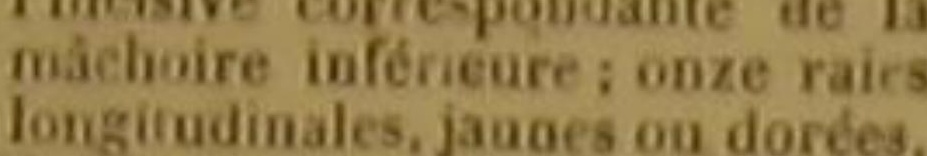
longitudinales, jauees ou doré,
de chaque coté du poisson

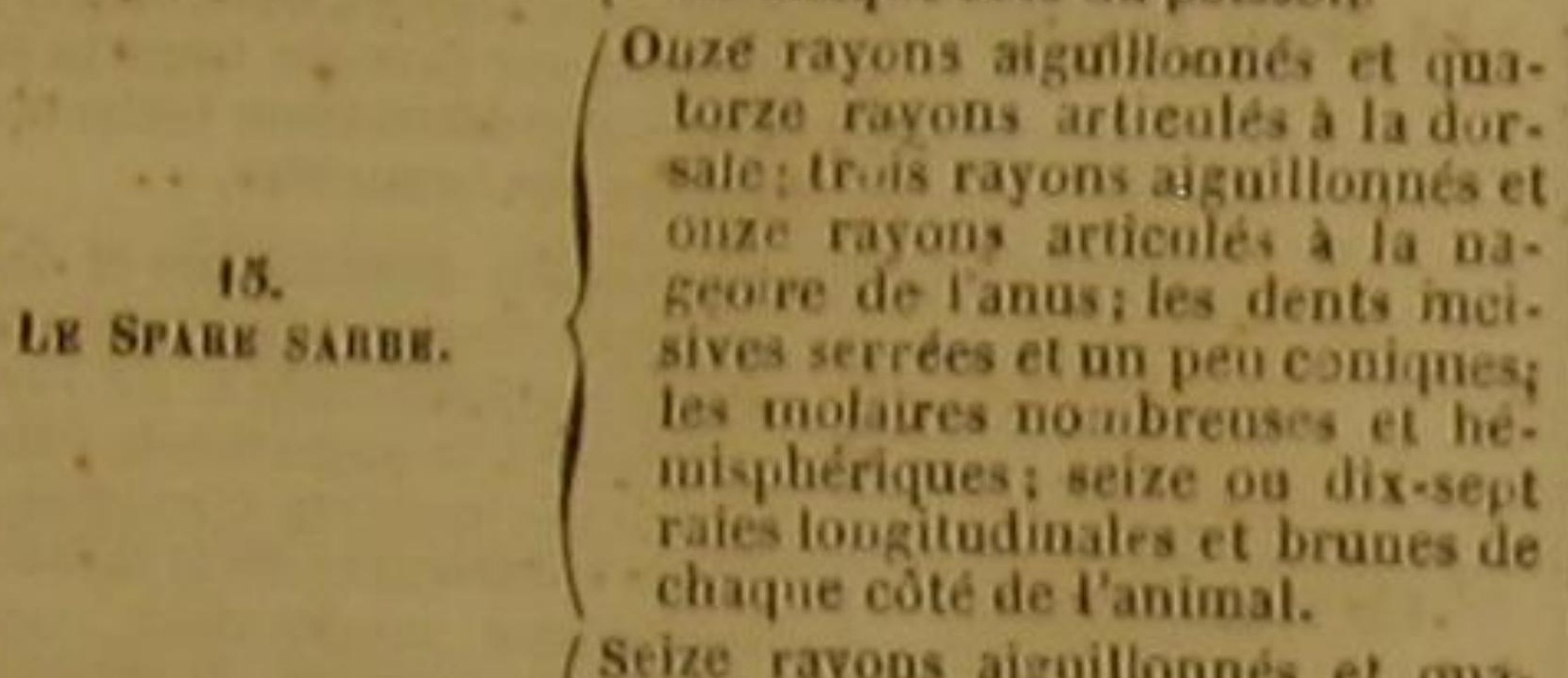

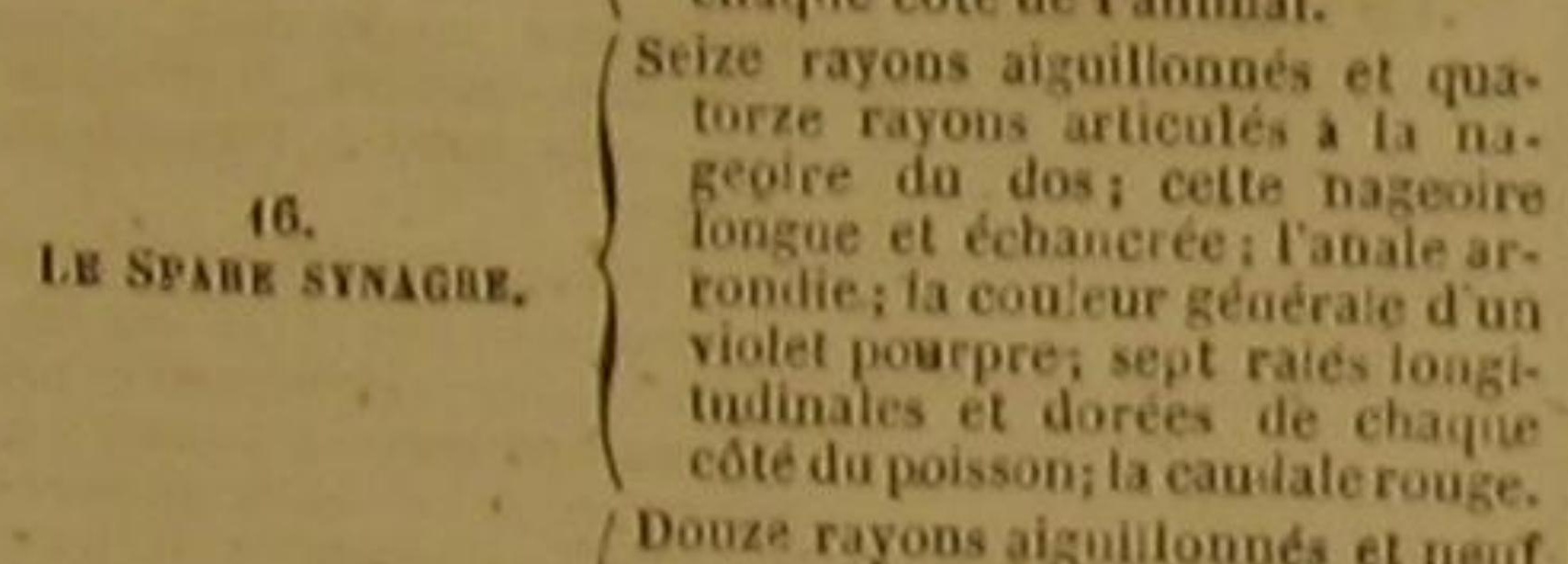

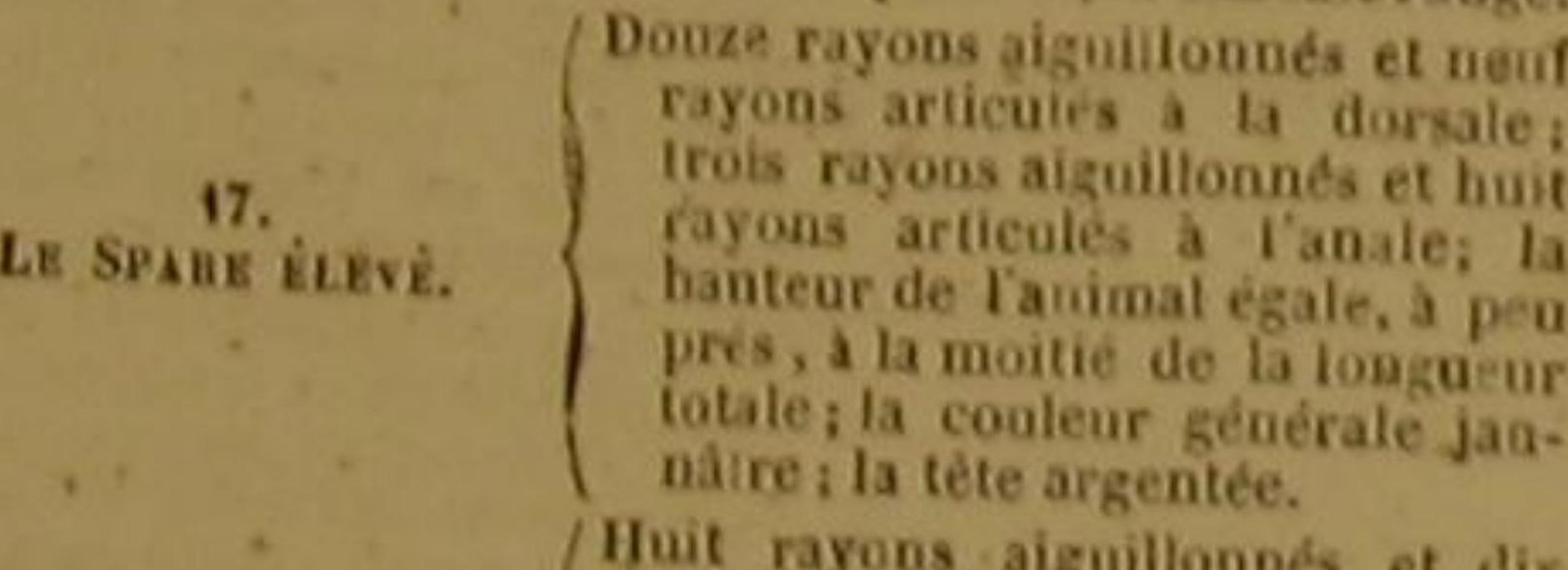

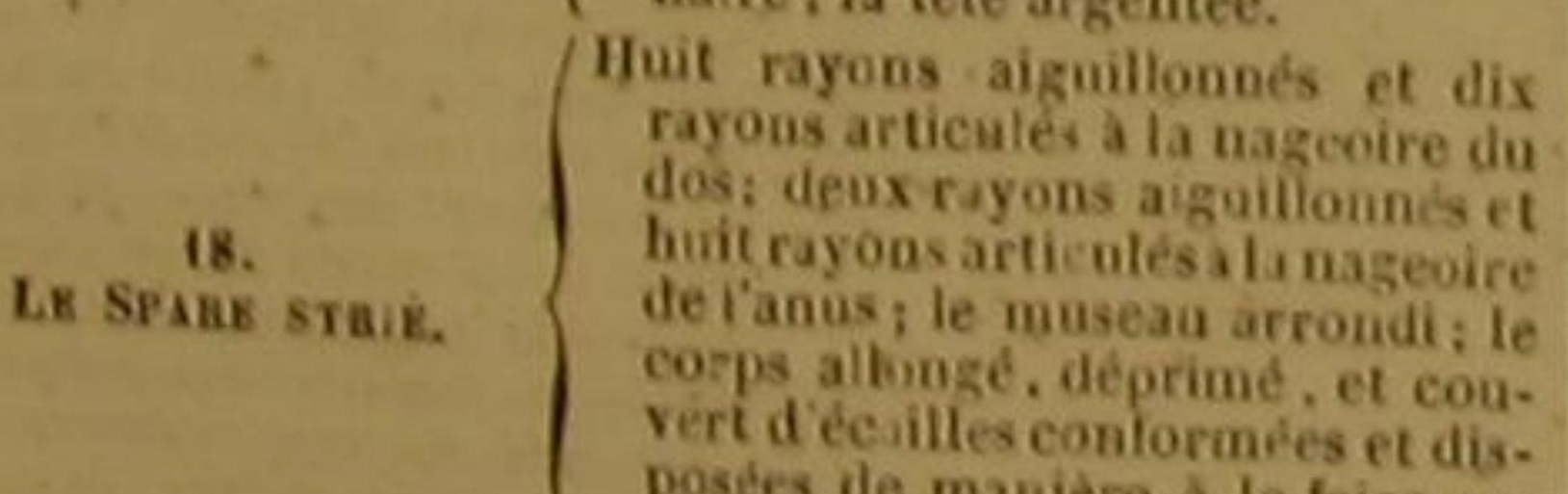

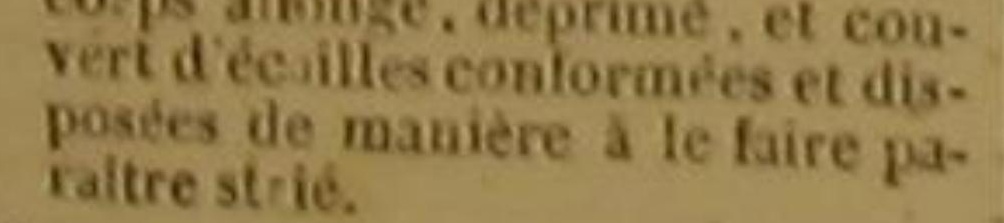

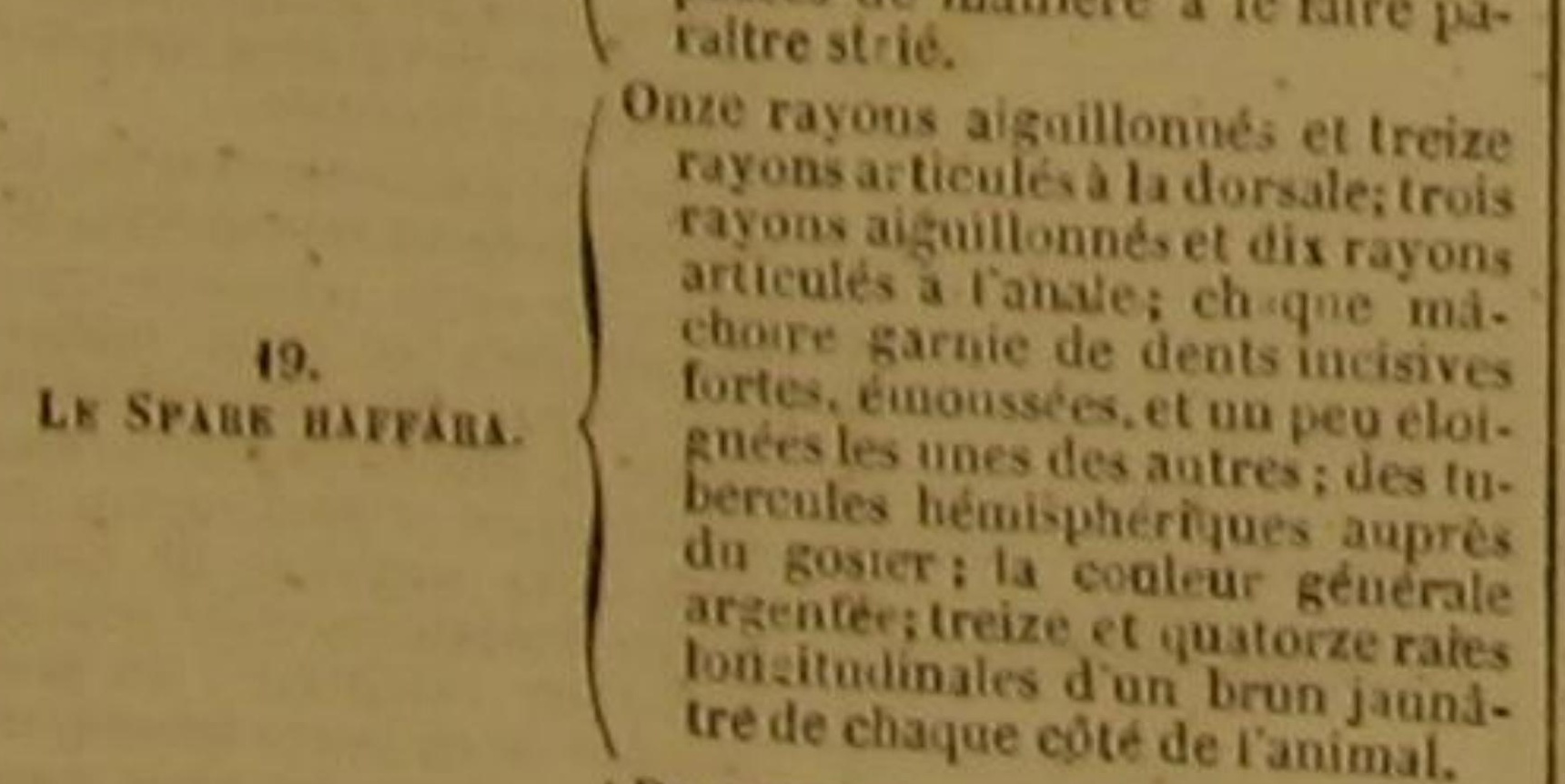

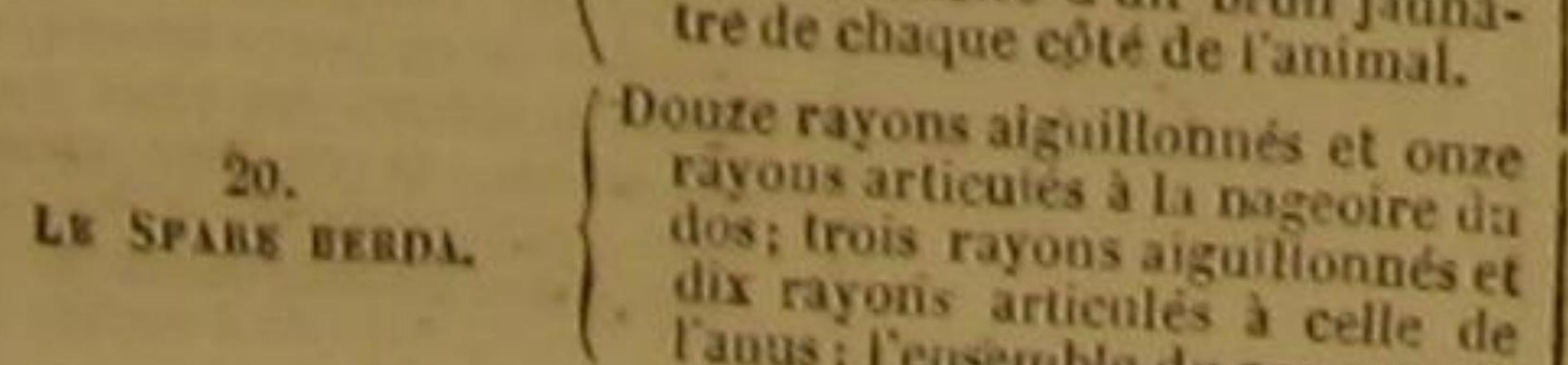

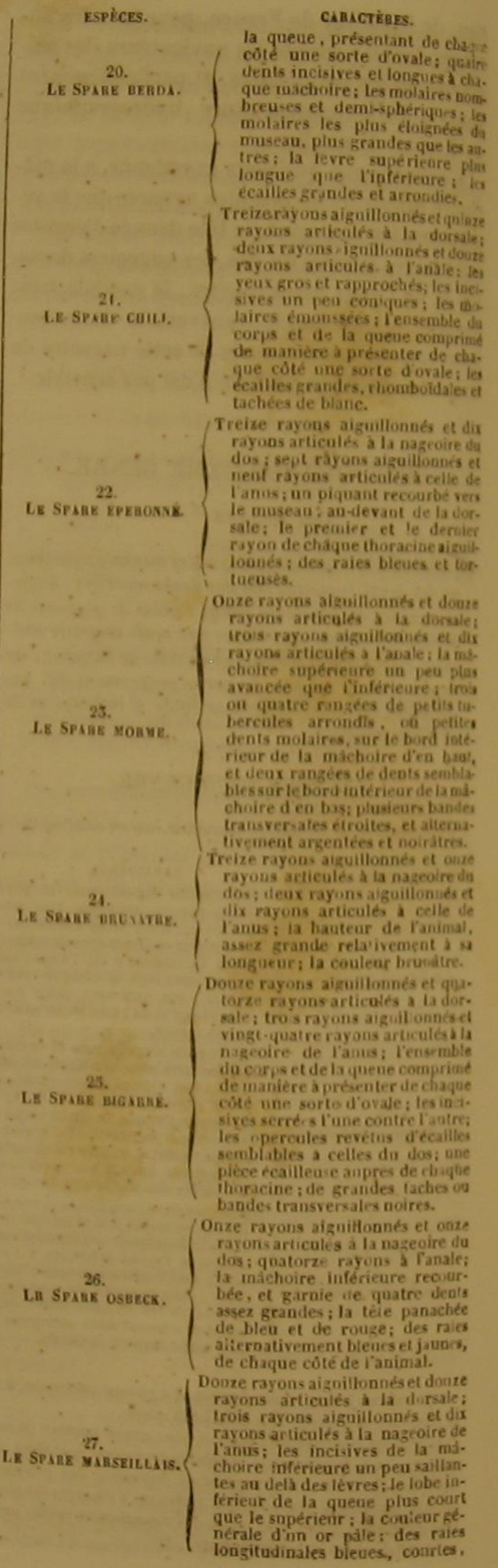

DES POISSONS.

985
CARACTíass.

Espicks.

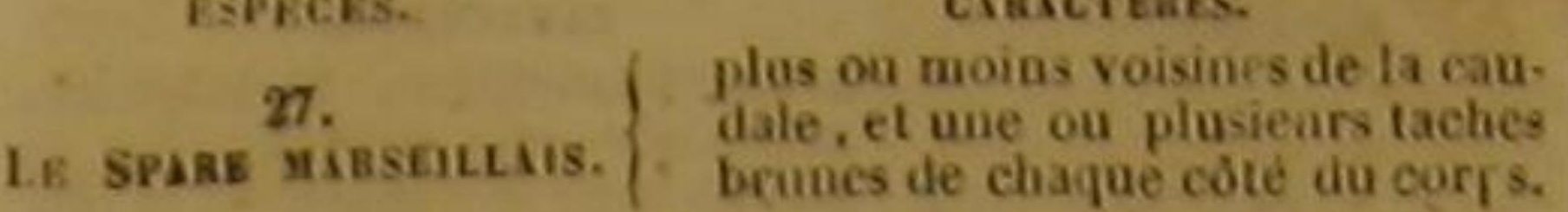

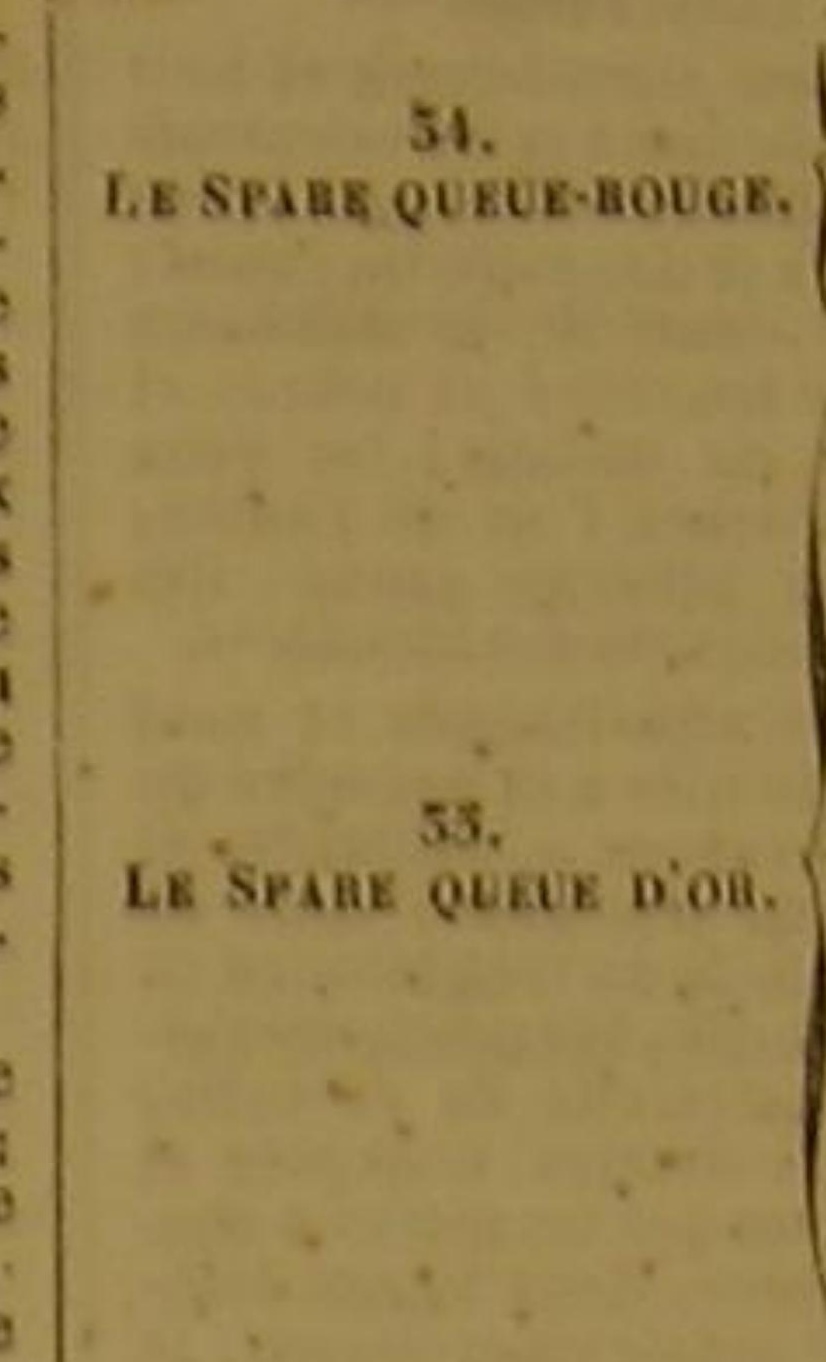

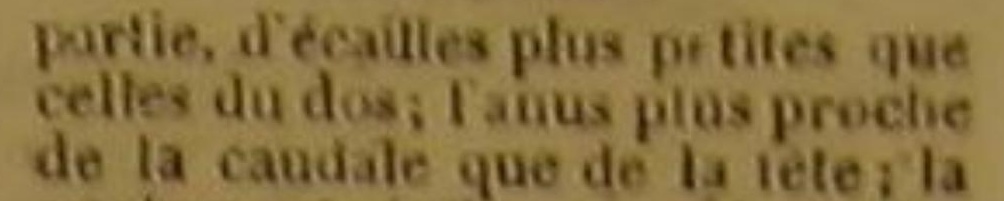

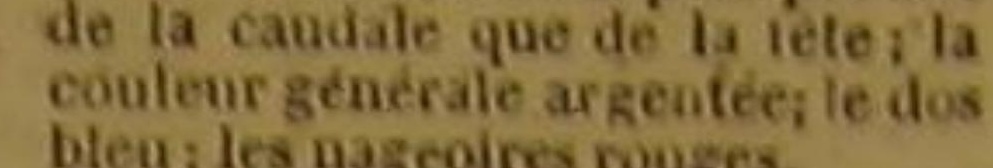

rayons articules $\mathrm{a}$ ta nazeoure dil

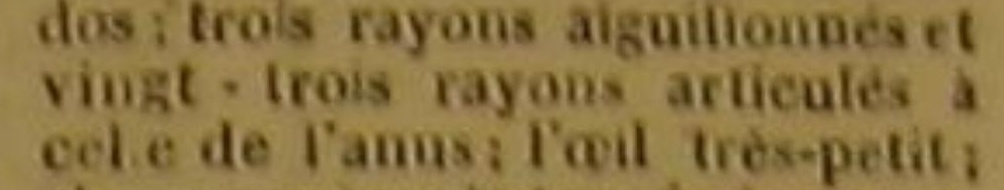

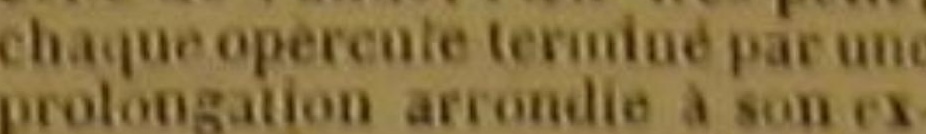
iremite; Panms phis pres de ta générale d' un violet argentés inin

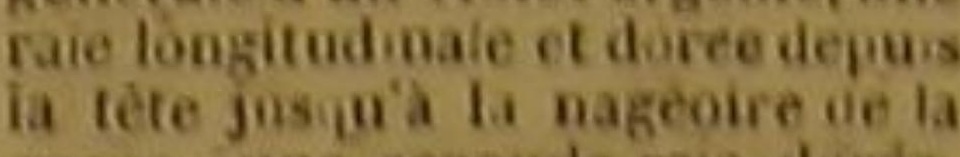

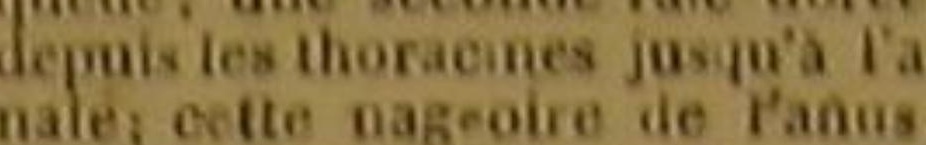

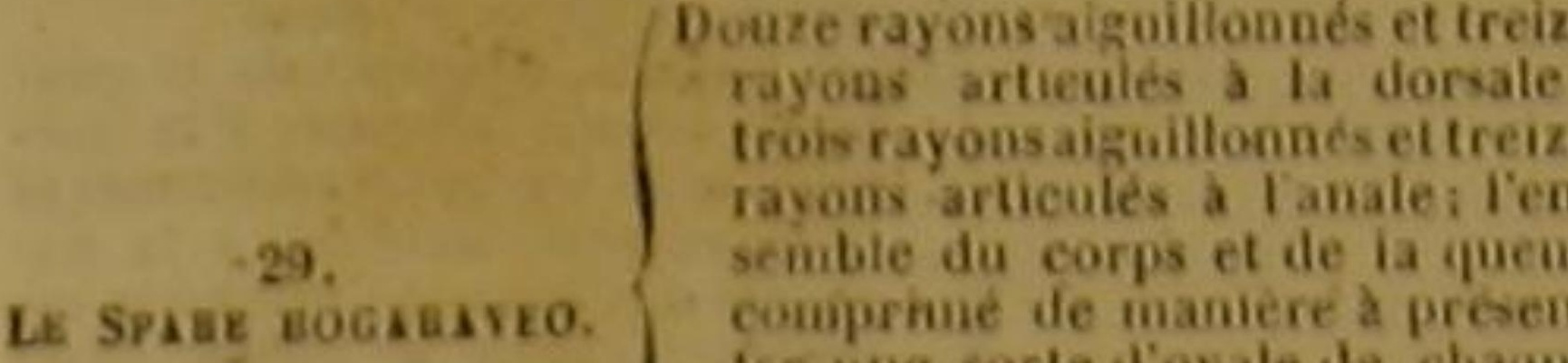

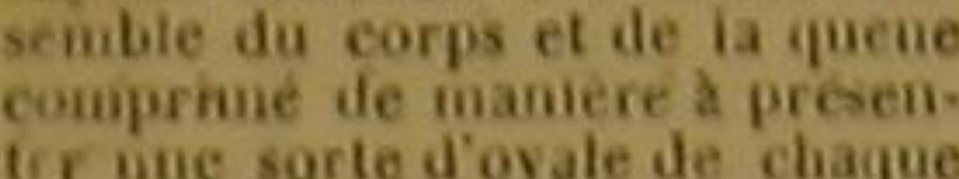

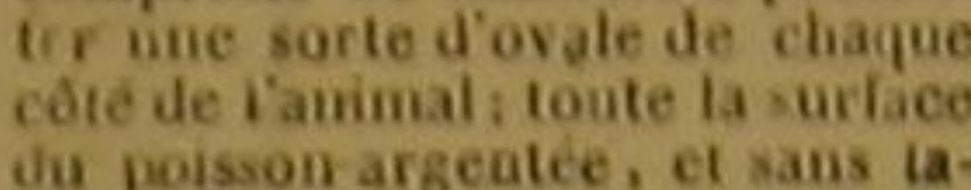
Ju poison argeatce, et xans la-
chece

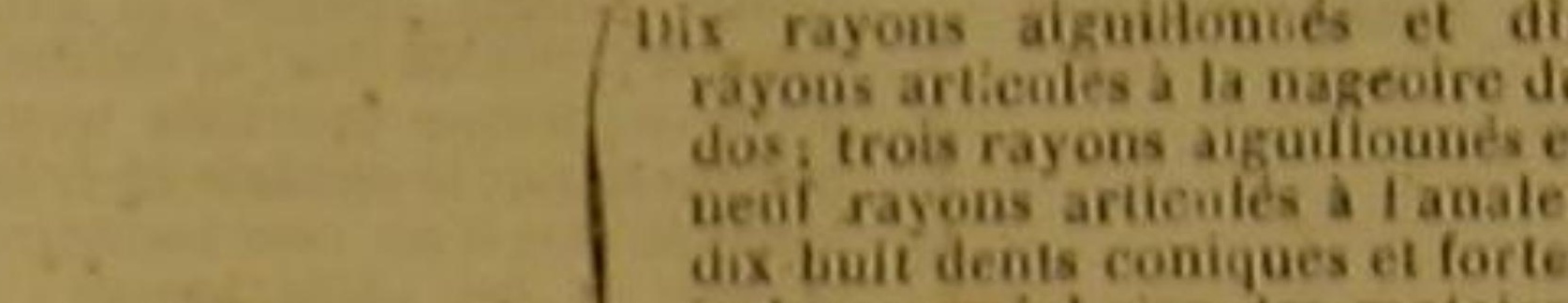

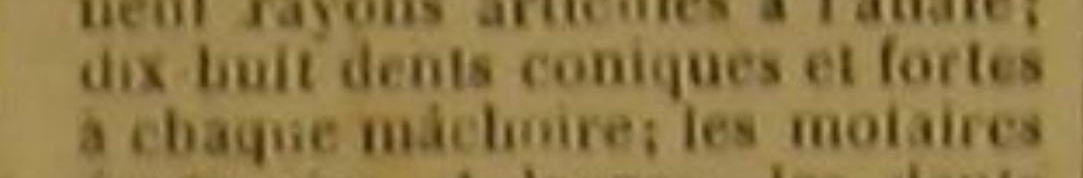

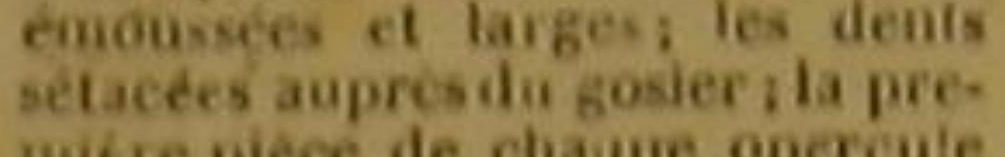

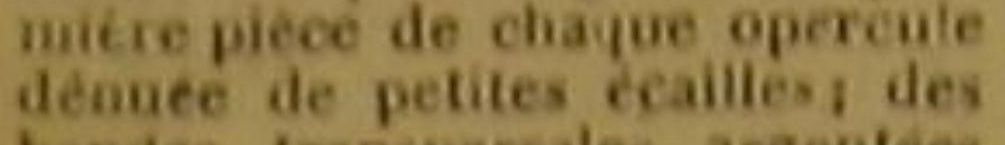
bindes transversales argentecs nix rayons aiguillonnes et treire

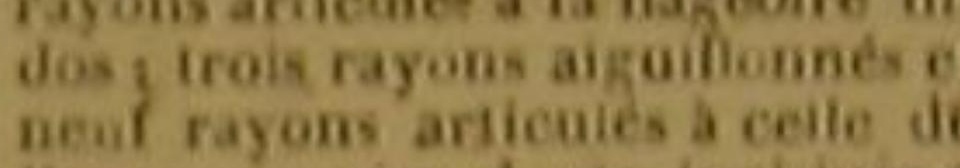

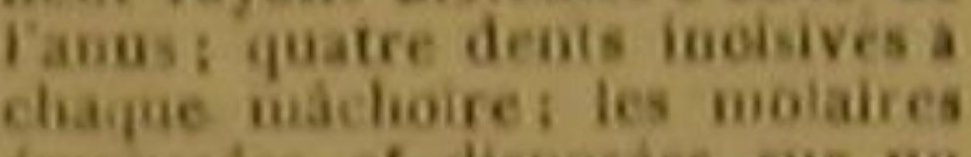

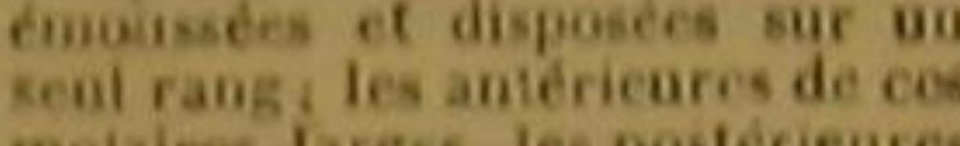

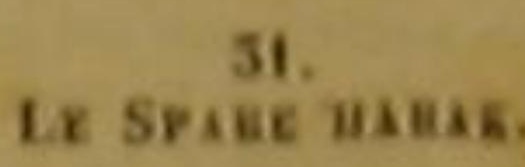
liemispherigues ides dents setad-riberesi it premiere piece de

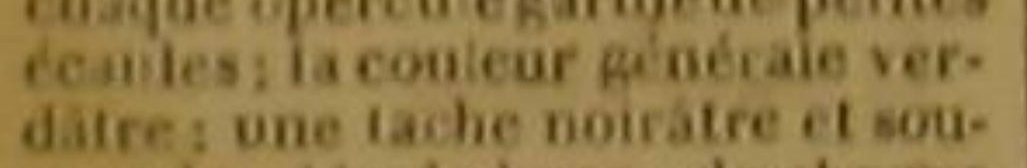
vent bordié de brua, de claque

Dix rayons aigniflonnes et neut

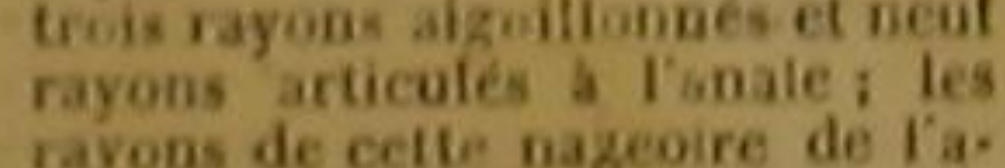

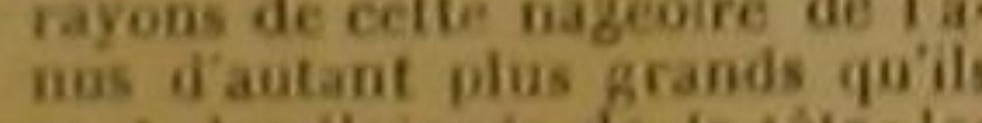

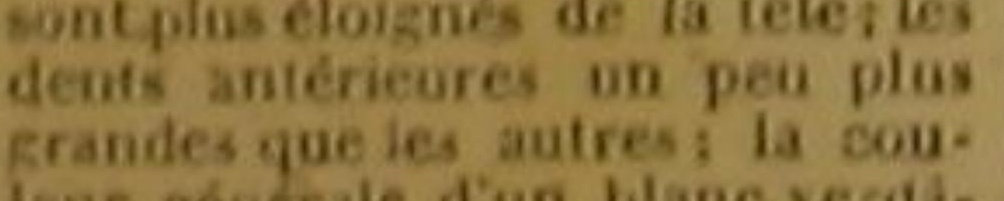

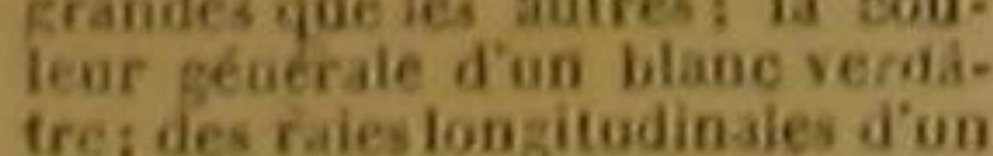
jaqne violet.

Le $\operatorname{sen} 52 \sin$

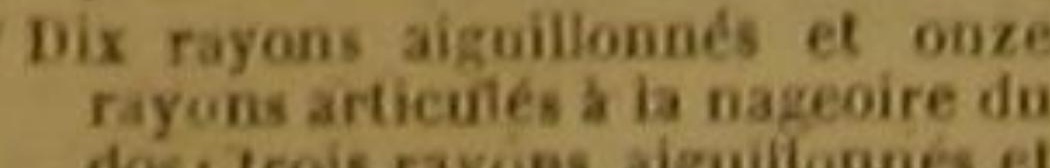

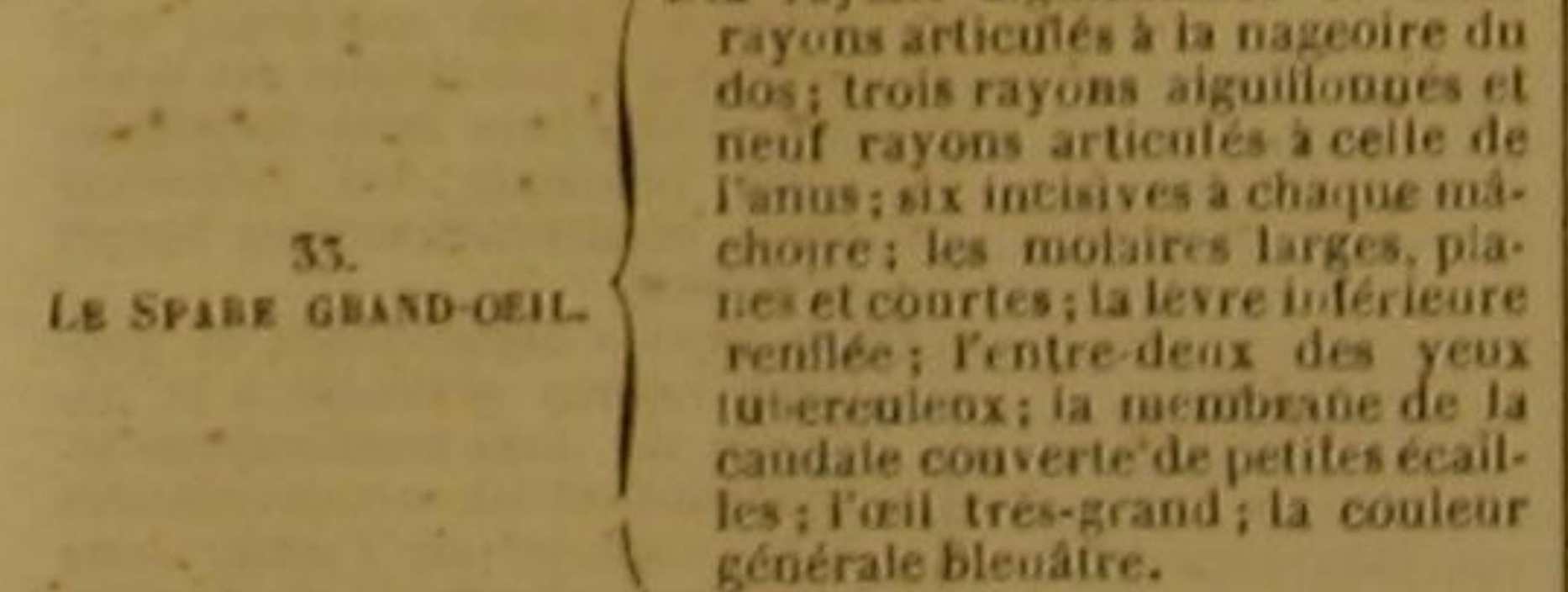

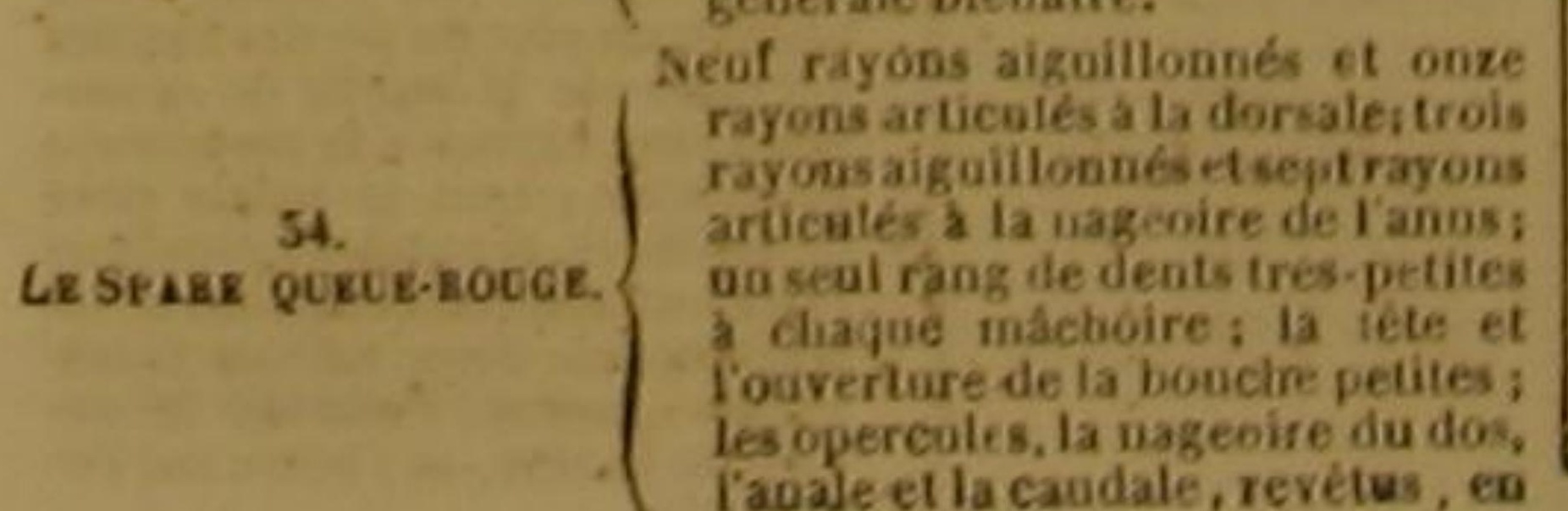

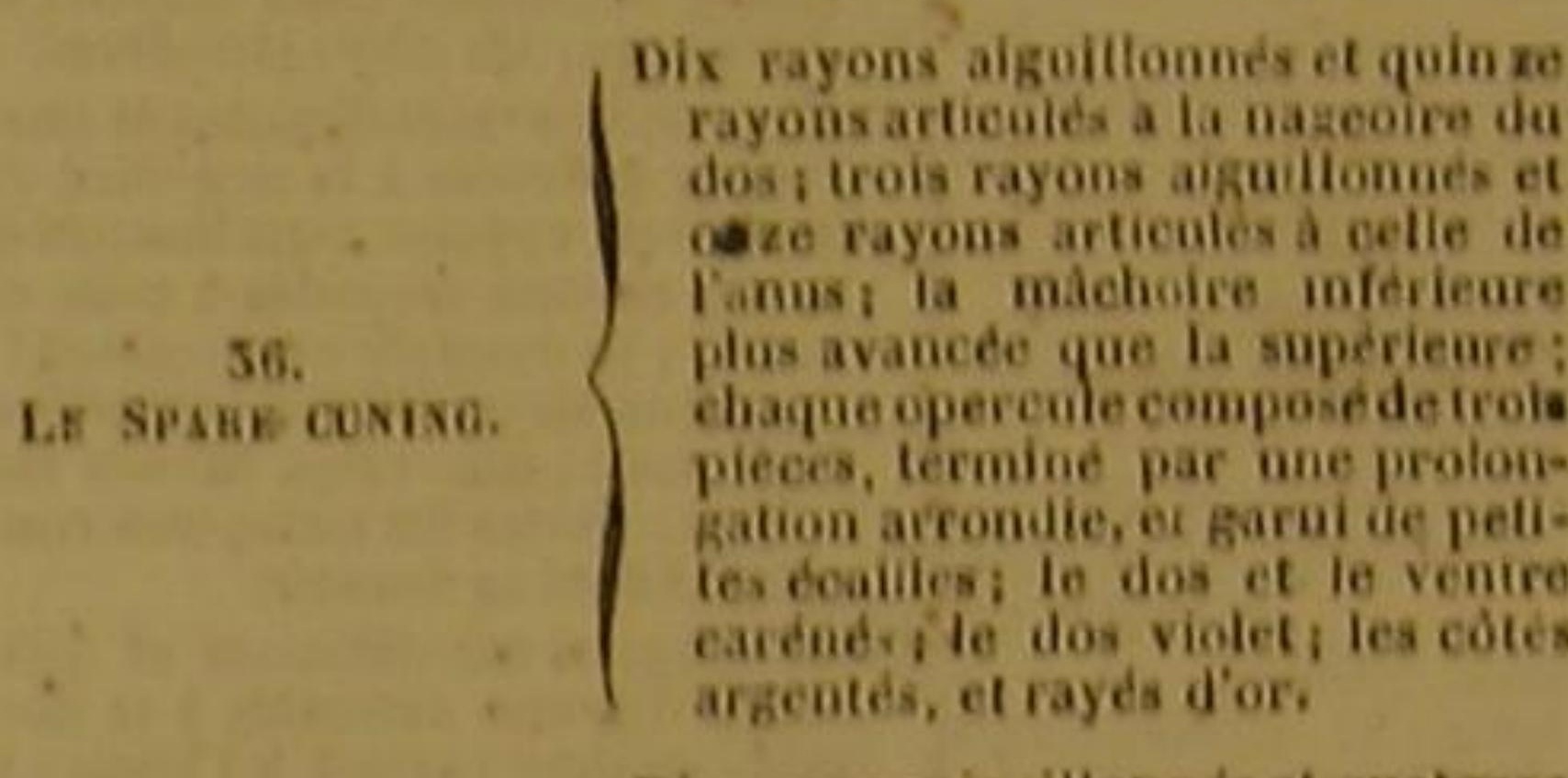

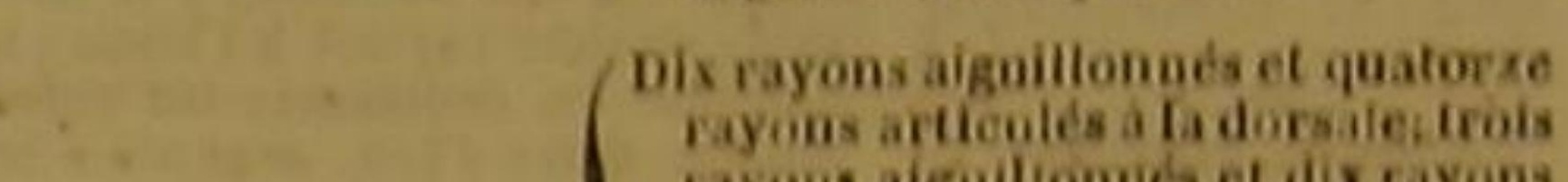

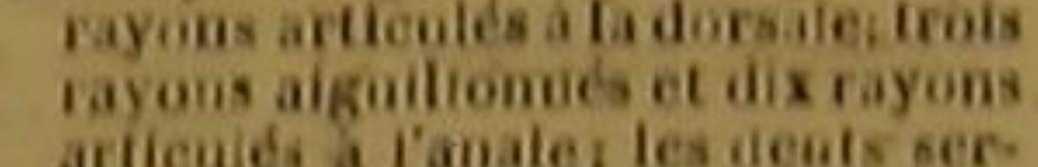

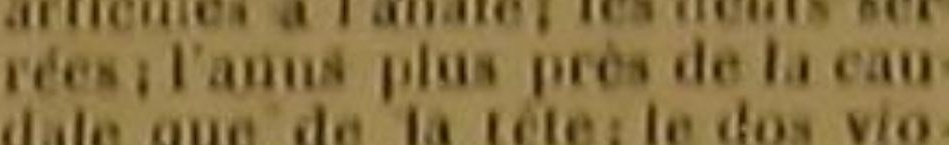

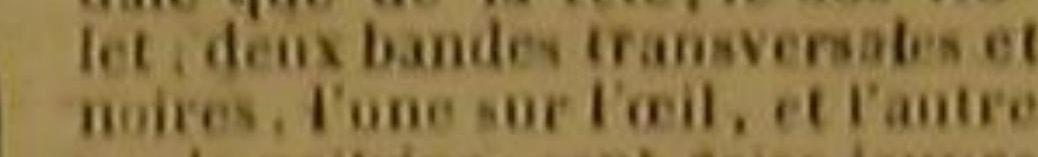

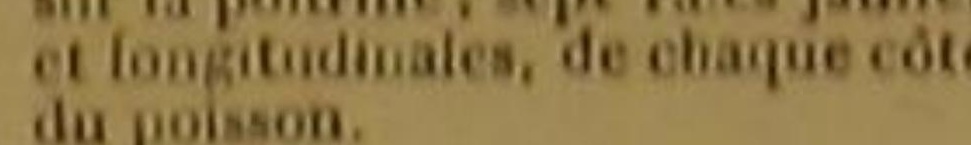
Sil rayons aiguilloneds et douz dix rayousariciculés a la nagrooire clioire superieure plus larkes pitus serreses que ceiles de tintecomitere diabord vers le hamt, en

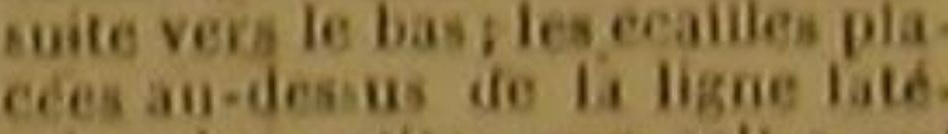
rale, plos petiten et les autres rudes an toucher : $\mathrm{l}$. melé de dorés le ventre blainc.

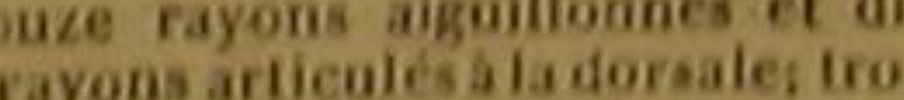

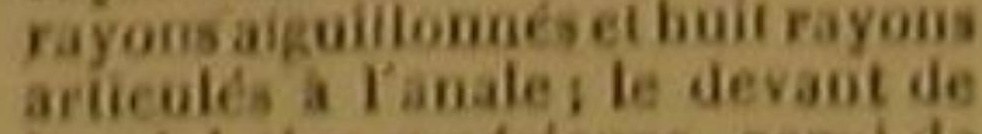
la máchoire superieure, garui a
pitusieurs rangs de dentsis les liuii

39.2

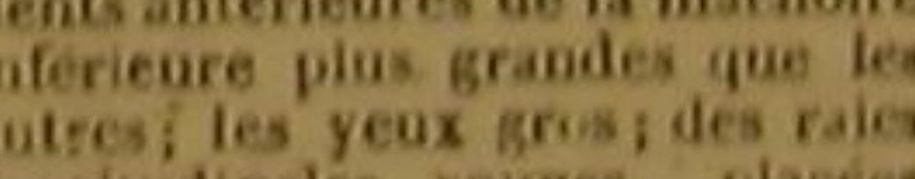

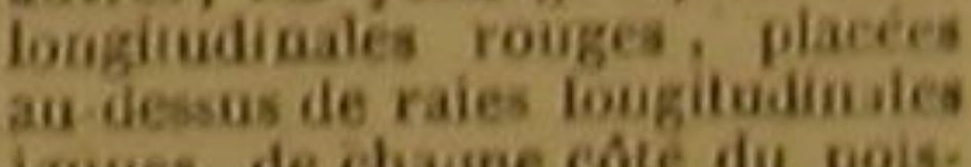
Onze rayons al ailloneés et fuil

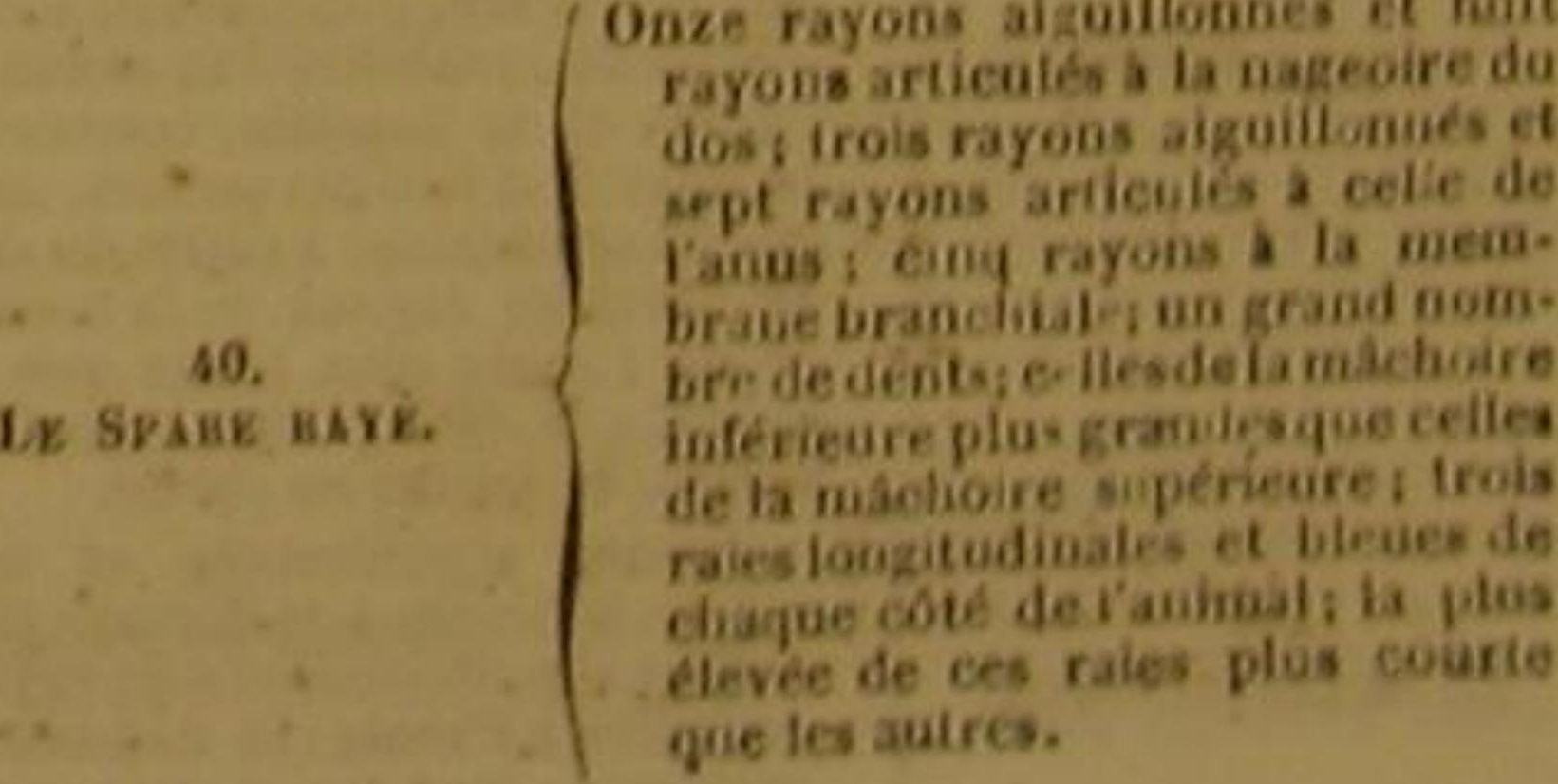


ISPÉCES.
LE SPAEE AXCRE.

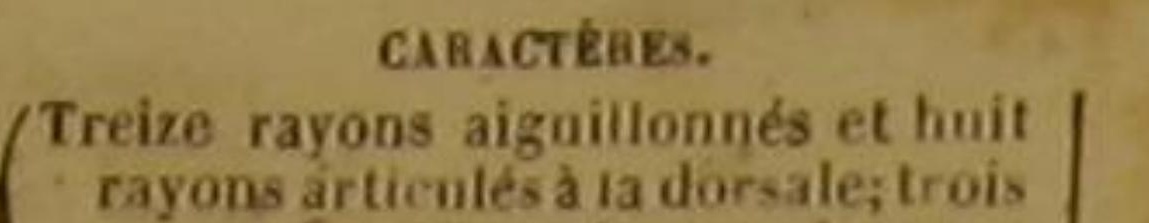
comberes en deitans les yeux
tres-rapporochés l'un de lautre:

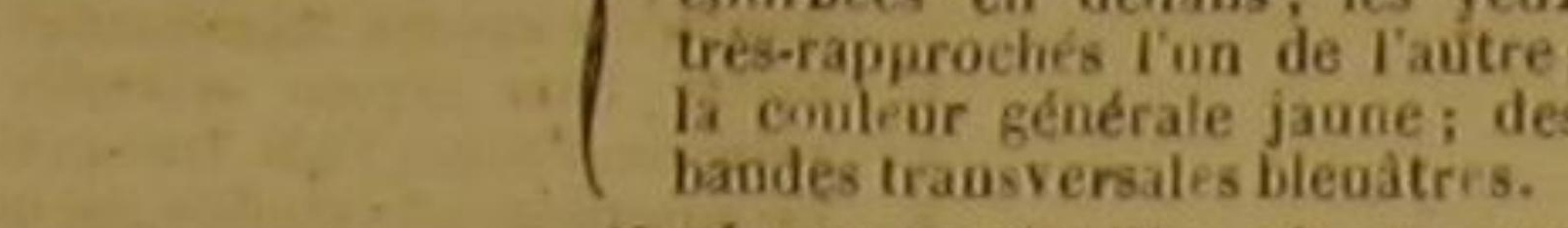

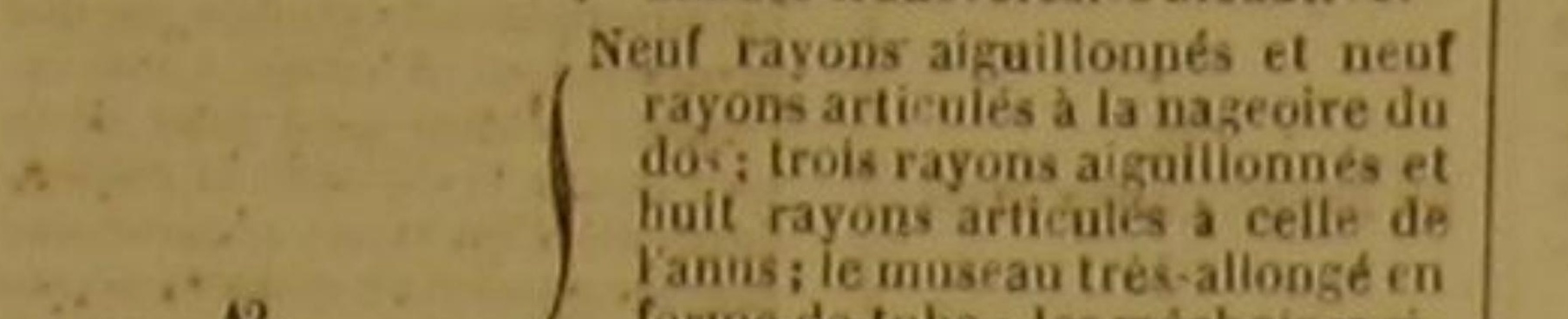

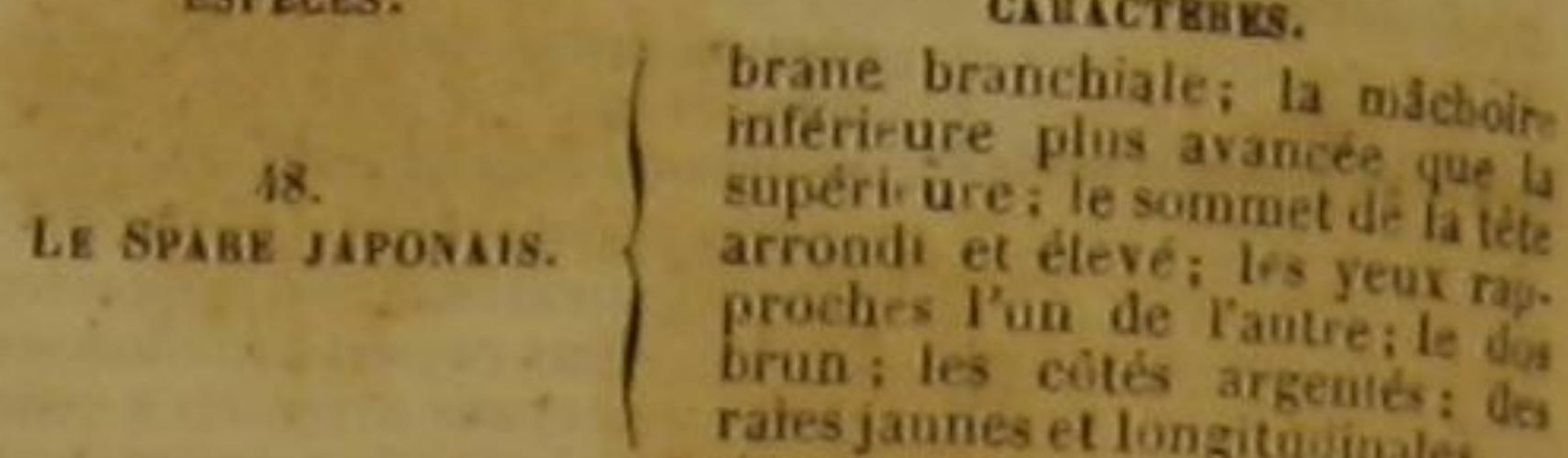
Le SPALE TROMPELE Whents droites. coniques et plus grandes que les autres a cha-
que machoire; deux lignes laté. rales; la caudale en croissant; ie
dos rouge; les cótés jaunátres.

LE SPABE YOBGS. tanns; la candale en eroissant; liri- dore; des raies bleues sur
la tete; tontes les nazeoires rou. lé la dorsile.

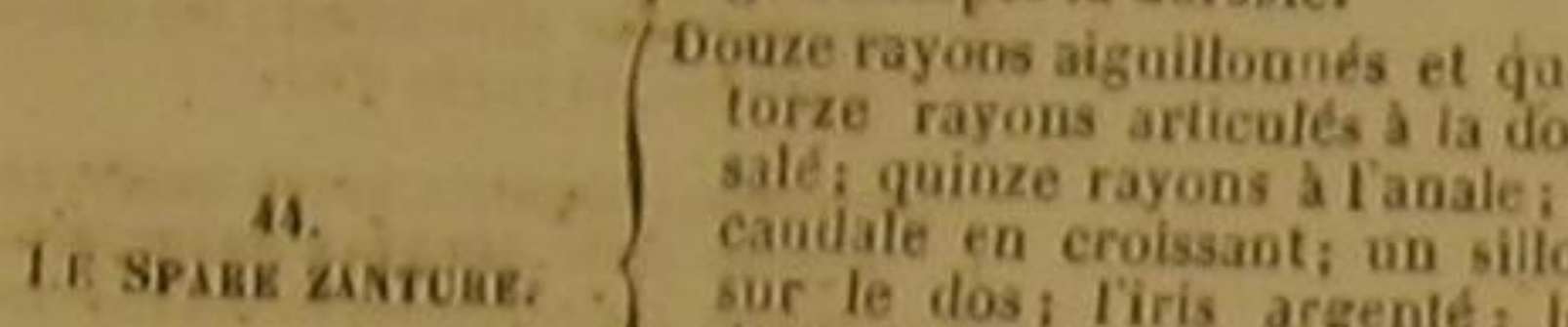

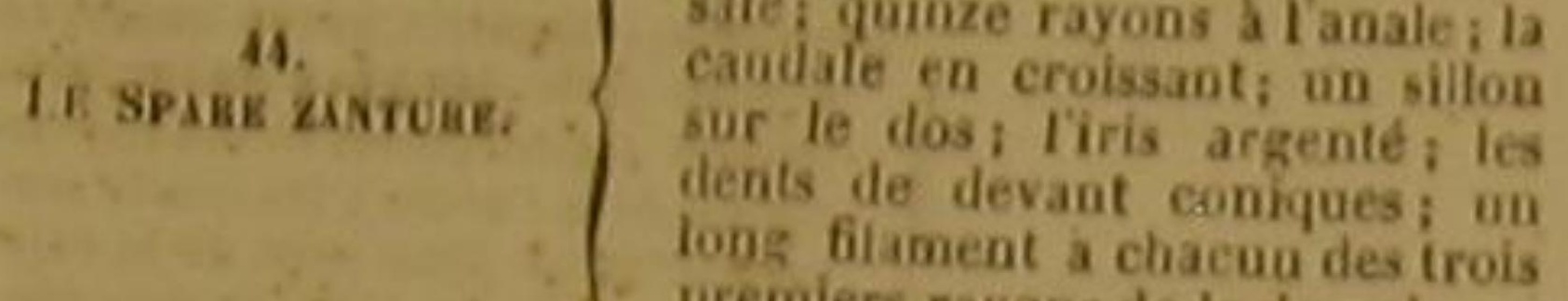

LE SPAITE DEงTE.

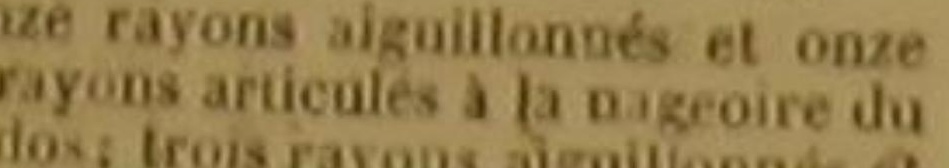

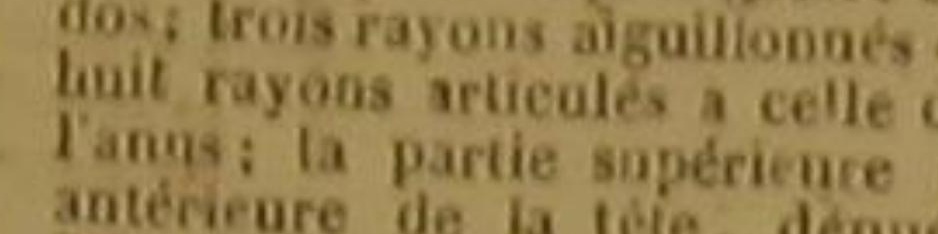

Thate DENTE.

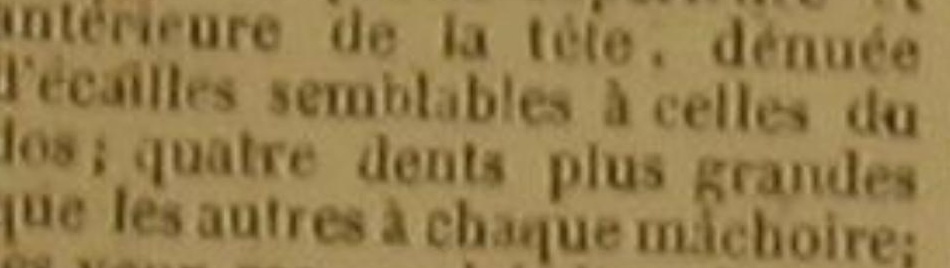
lre; la dorsale, les pectorales,
lanale et la caudale, parnies, en
partie. de petités écailiess lacos artie, de petites ceaillies; la cou
leur genérale ou blanche. leur genérale ou blanche, ou
pourpre, ou d'un jaune argente.

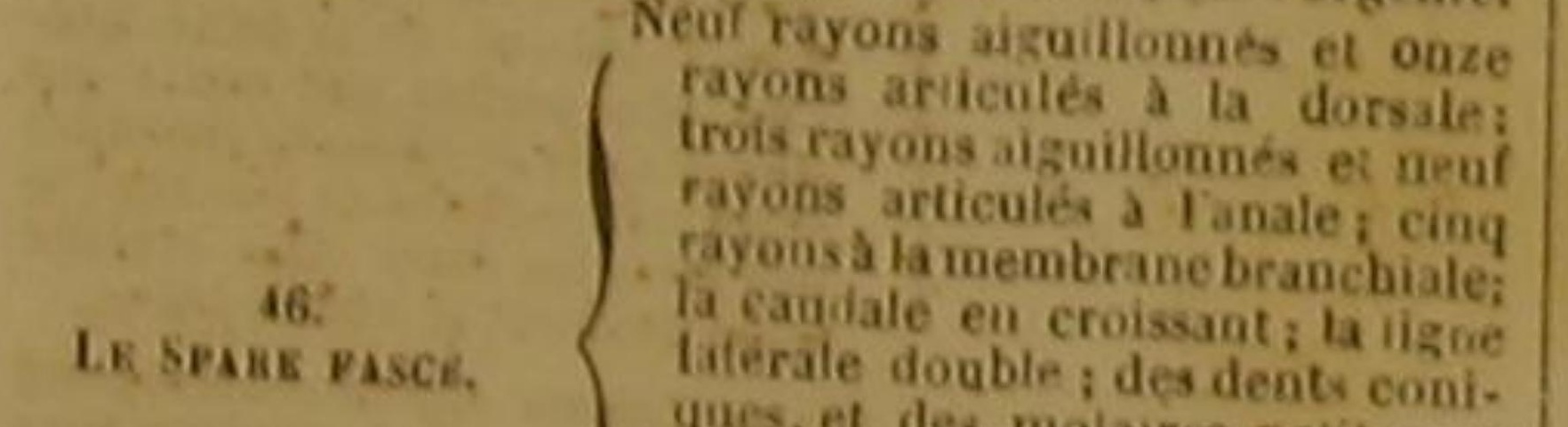
ques, et des molares petites et
arrondies, ta dorsale, Tanaie et
la ceudale, garnies, en partie, de
pelites de

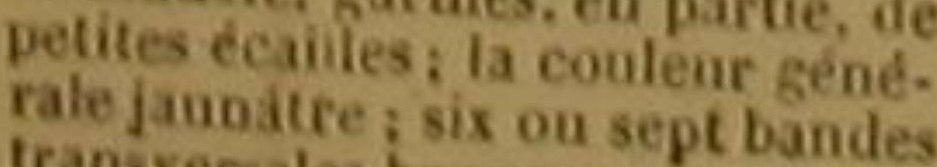
transversales brunes.
tix ou bandes septrayonysertic aignillonnes et

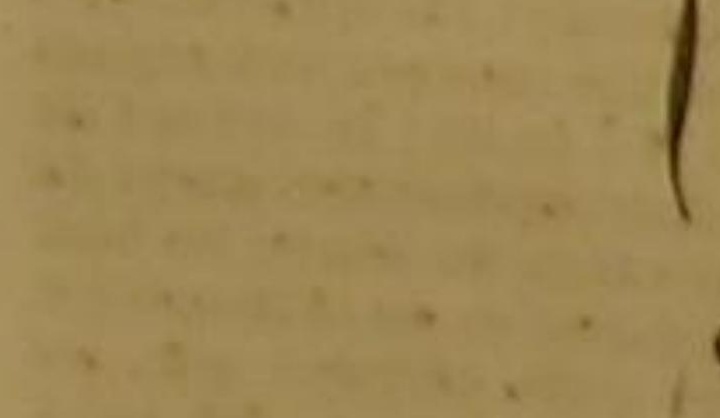

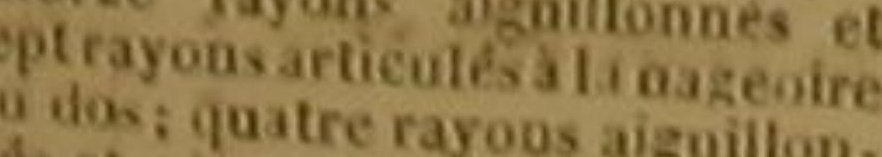
et recourb quatre dents grandes

Lí SPAME PALCiLL.

S0.

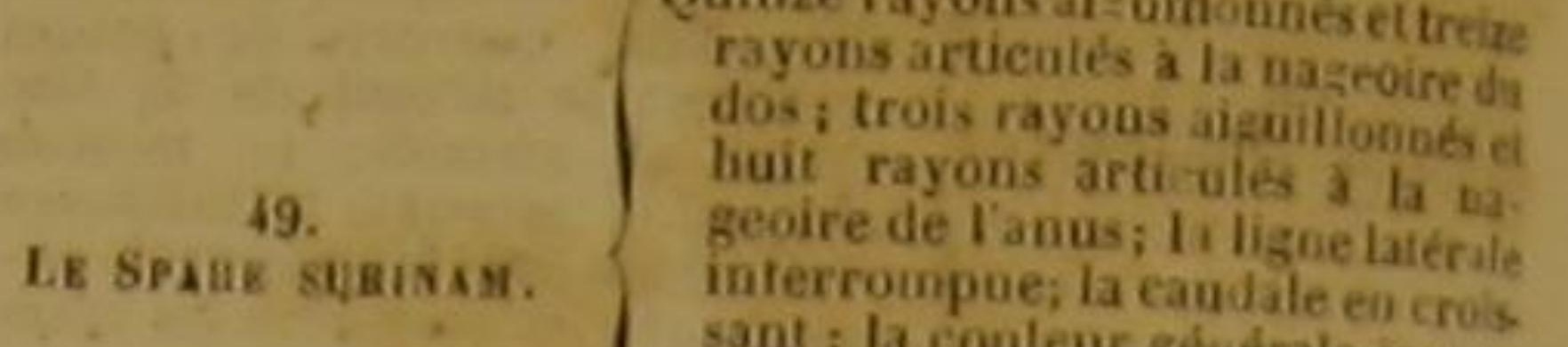

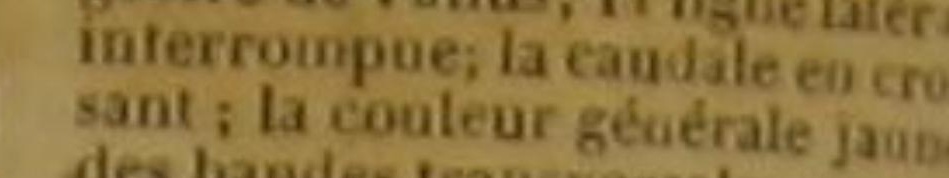
des bandes transversarales jauge,
trois taches grandes et noires onze rayons adguillonnés et qu
torze rayons articules a la orze rayons articules a la dor.
sale; trois rayous aizuilloonto onze rayons articules a la as perienare gande de quatre dena comme celles du dosi i la deriue pléce de chaque opereule ternil.
nee en anzie; la eaudale en crovis sant; le dos d'un vert bruadtre rentre diun jaune argeate ; eaudale rouges. Onze rayons aiguillonnés et regt
rayons articulés d la nageoire de rayons articuless a la nageodre du
doฯ: quatre rayons aigullonna et sept rayons articuets i celle
de Ianns; un rayon aiguillonot

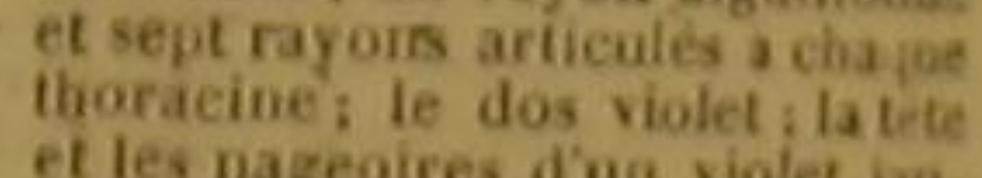
et les nageoires dua violet jouTreize rayons aiguillonelís et qua torze rayonsarticuless a i dorsate,
dout la partie antérieure est ar.

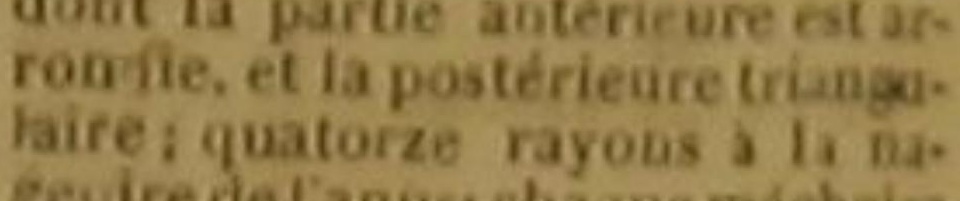
geviredelianosichaque máchoire
garnie de dents inclisives quis garnie de dents incsives quise
lowehent: ia scconde lame de chaque opereule terminee par une ou denx petites prolonga.
tions arrondies a leur bout; cing rayons a la membrane des bran.
chies; la couleur genereale doríe et mécé de veri et de brun: eing
bandes transsersales un peu larges et noires.

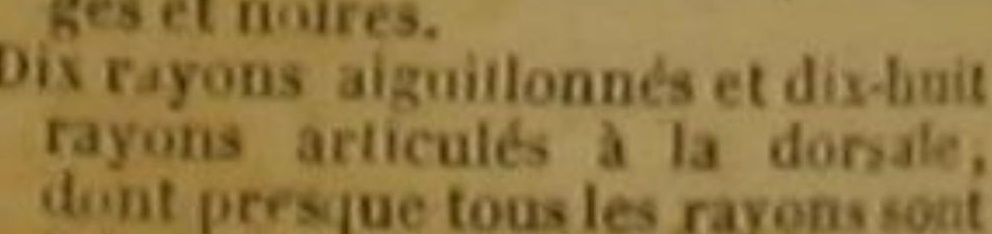

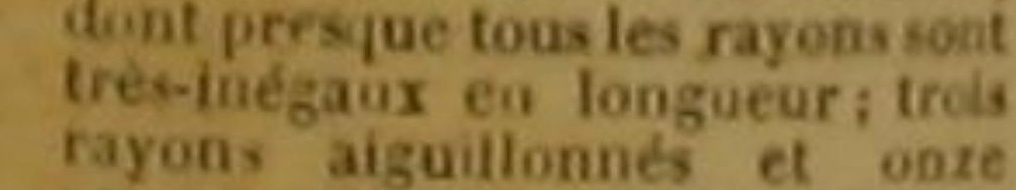
rayons aiguillonnds et onze
rayons articules a la nageoire de ranus: lacumdale an peuen croite 55.
LE SPAHE MILOSTOME. ant; le sommet de la tére et lé
los trés relevés; le fond da palís

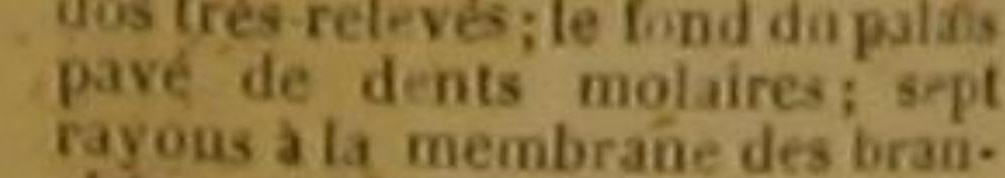
clres; plnsterns raies loogitindi-
nales plasieurs fois interrompues, et alteruativement blená
et dorées.

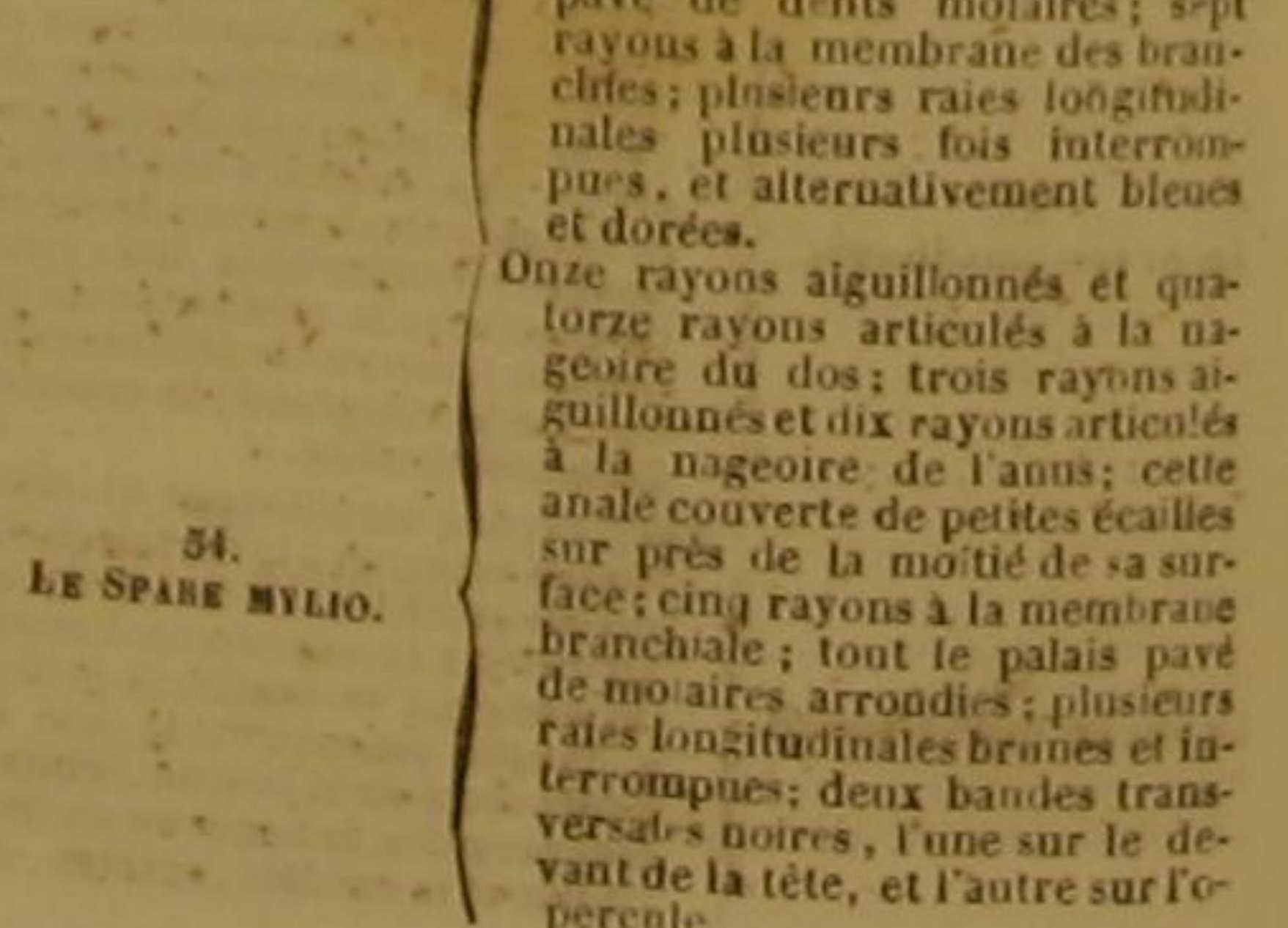
et de laniers rayon plus tonga torsale

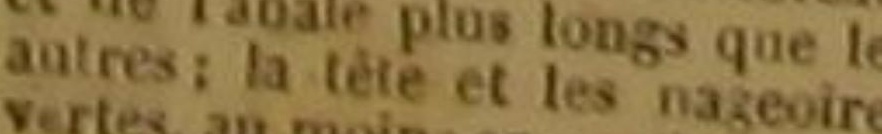

Le STAEx isposis.

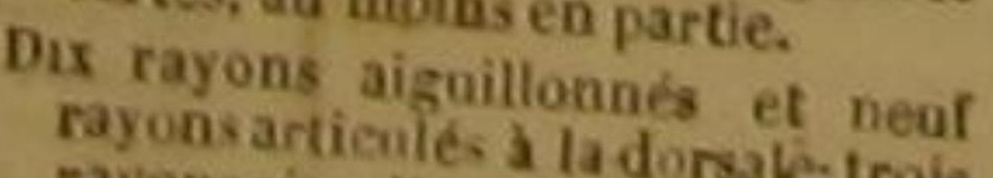

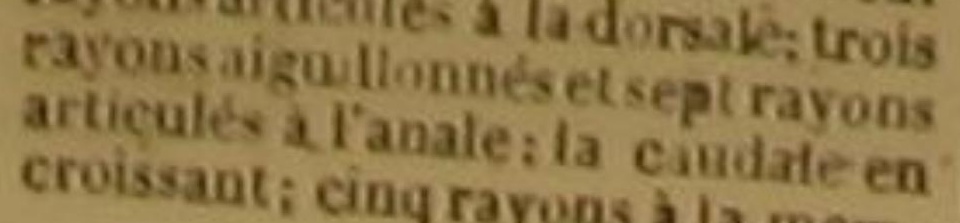

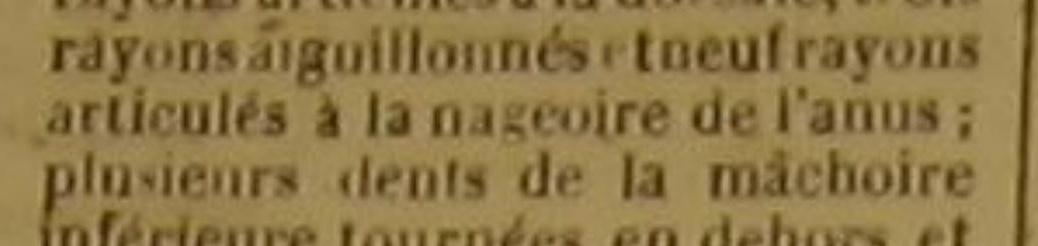

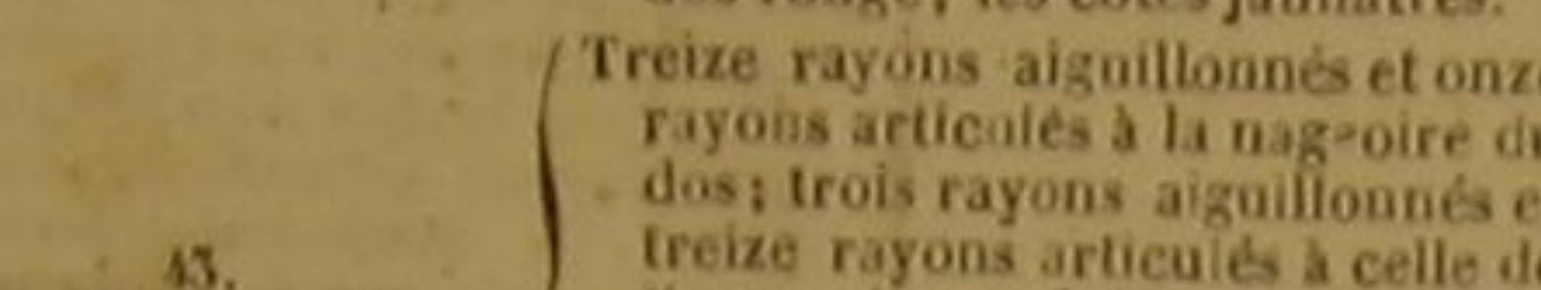

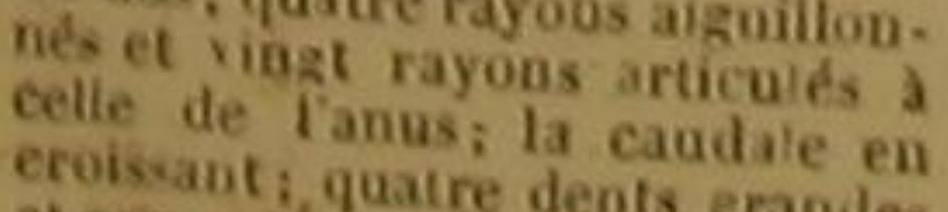

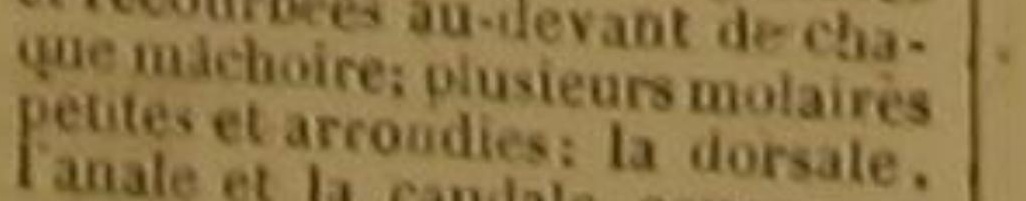
geoire de lanus : la máchoire si.

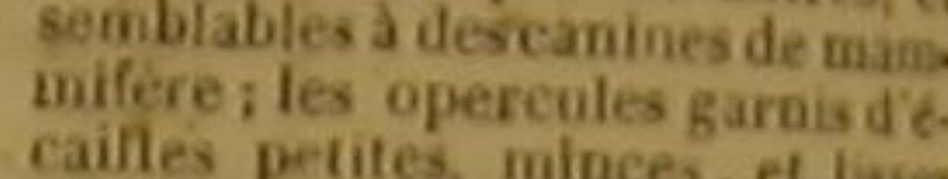

ESPĖCES.

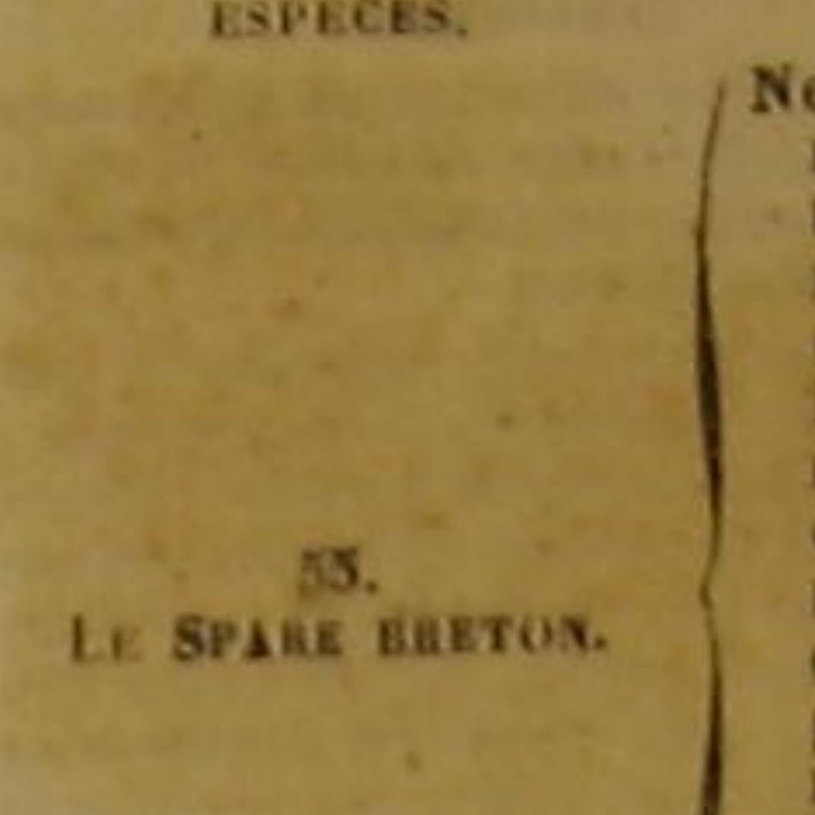
CARAcrèses.
a

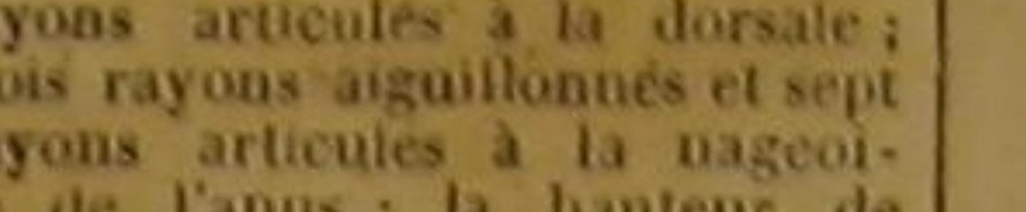
animal tres-grande relative-
eat a $\mathrm{t}$ longueur totale, doni tiersicing chies; les plus longs rayons des nageoire de tainusi la couleur

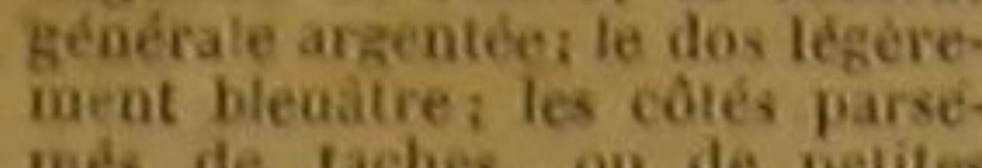
raies tongitudinales ioterrompues

et bruues.

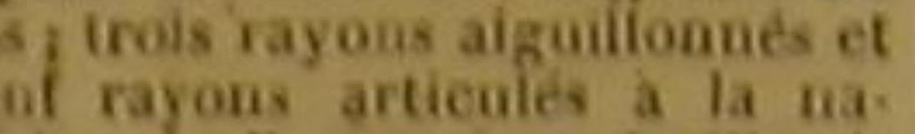
keoire de lanus sue ecaille ai-
lougee en forme daguillou, auFres tu bout exterieur de la baso decha un des o,ercules, yinit sont

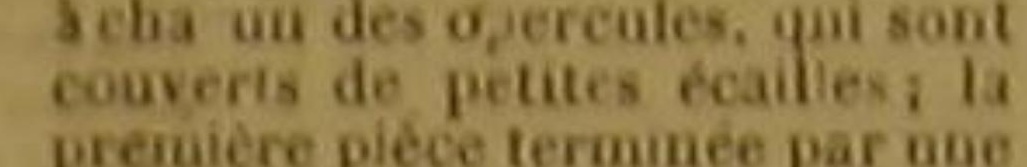

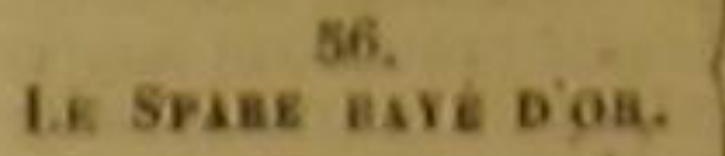

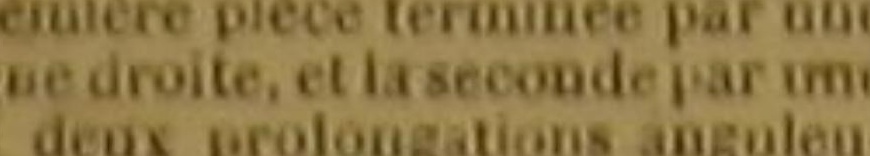
ses: des rale longitudinales of
fories: ume tacie allongeo. sous de festremite de fa doraale flowze rayons alguiltoneds et dix thons articules a la dorsal

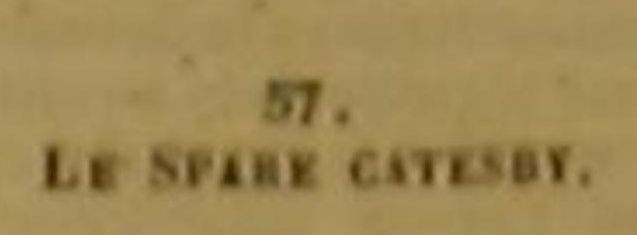

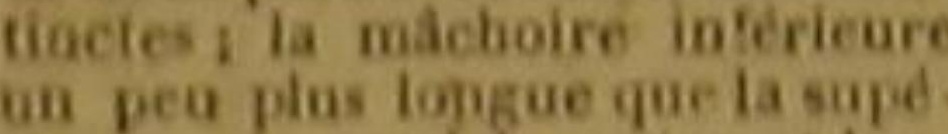
rifure, la caudale noire ei bo la tete s des raies longitudiosies
c jaunes de claque cóte du poisson

rayom aiguillonosect dix doss trois rayons aiguillounes $t$

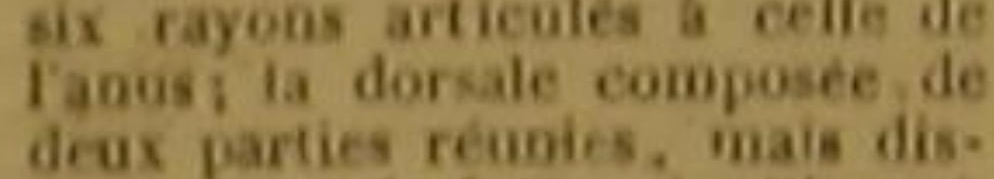

Le SPAE SAOTER. nootes trois forts aiguilions a

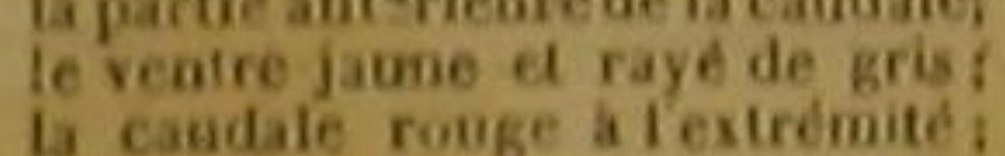
graades taches d an jaune
tosmor, au-dessis de la lighe ia térale.

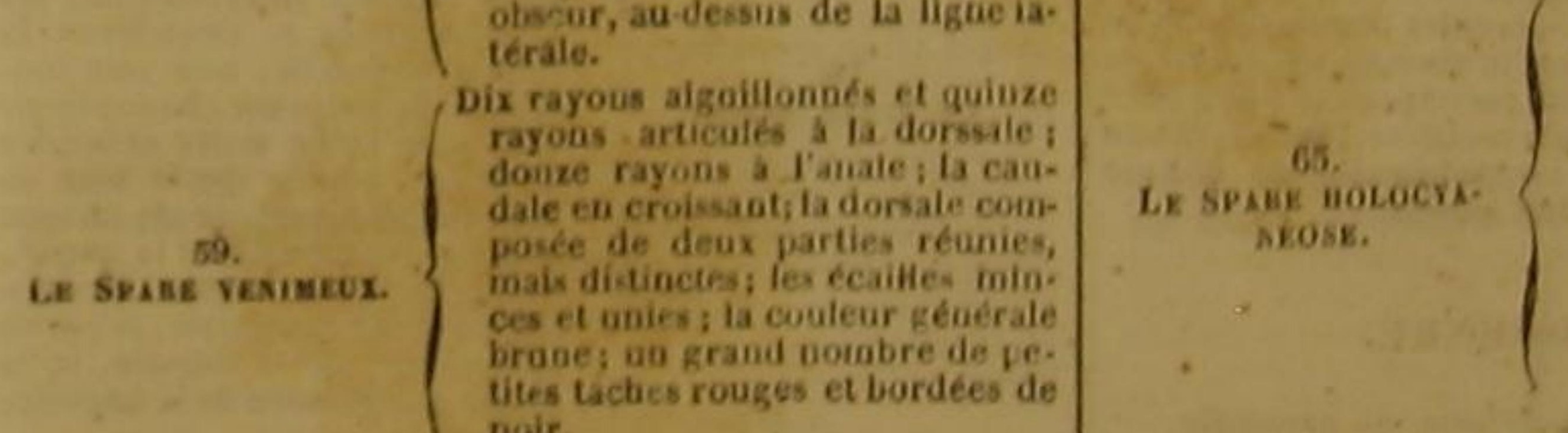
r. lactes rouges et bordees de

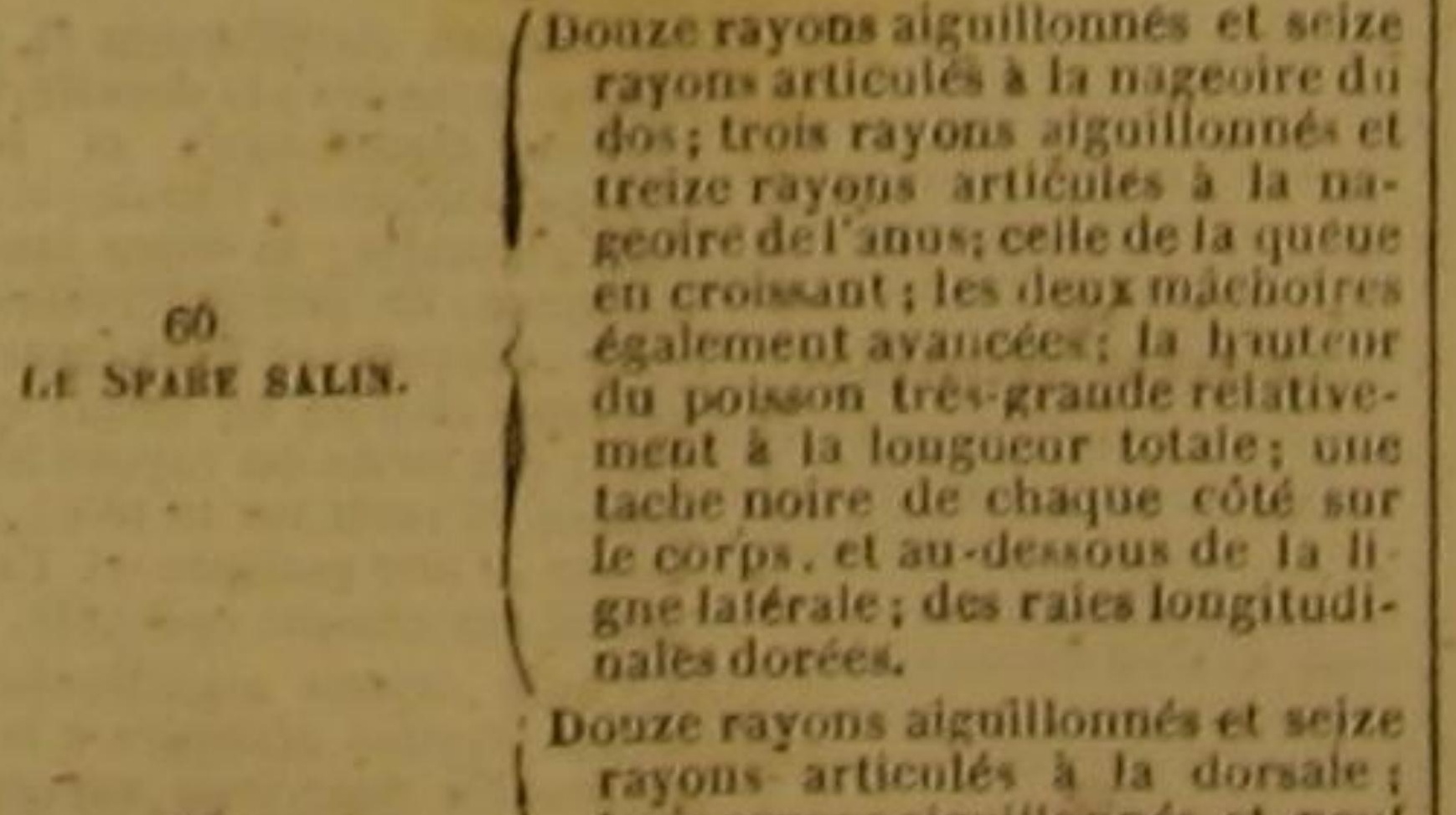

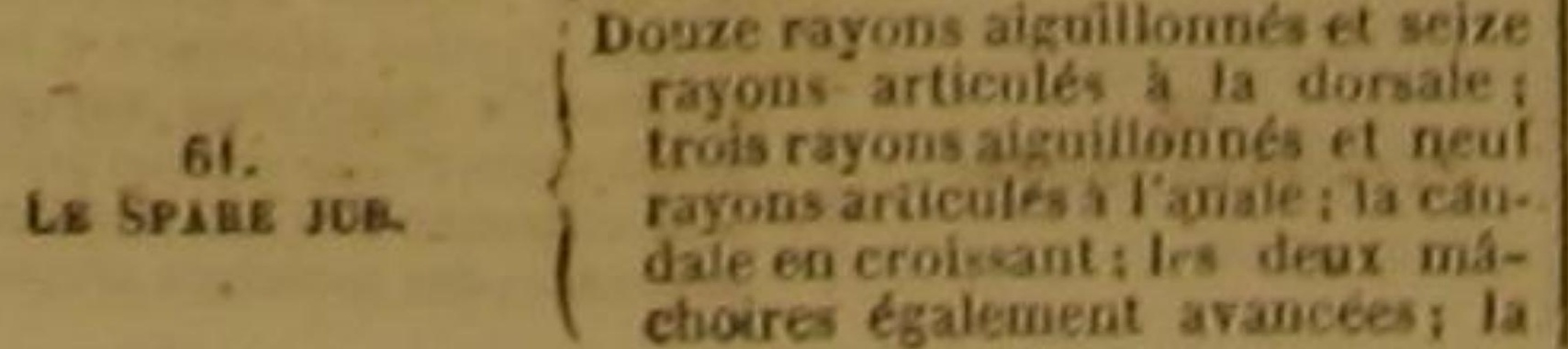
Le SPAGE DEMLUNY. dalo en croisant iles deux má-
choires egalement avances; ia

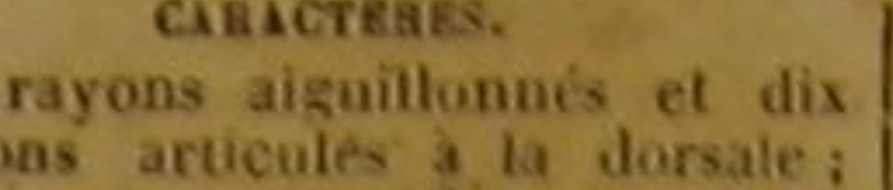

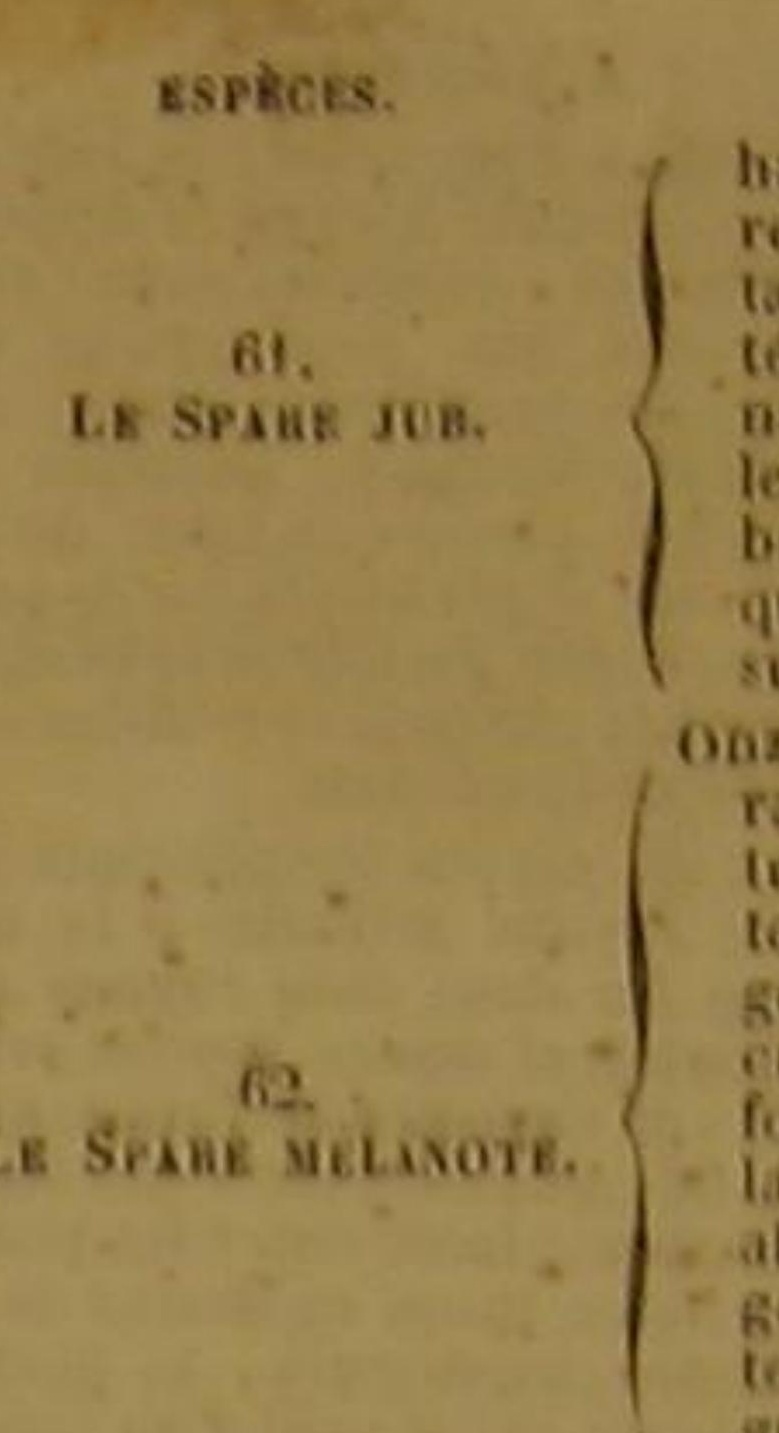
calacisiass.
teur da poisson trese-grande

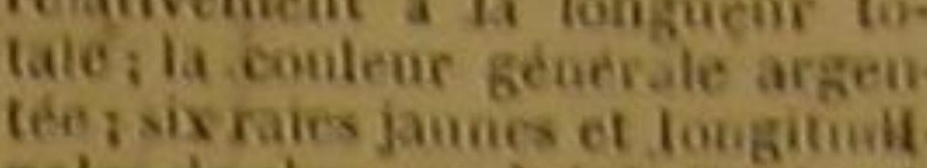

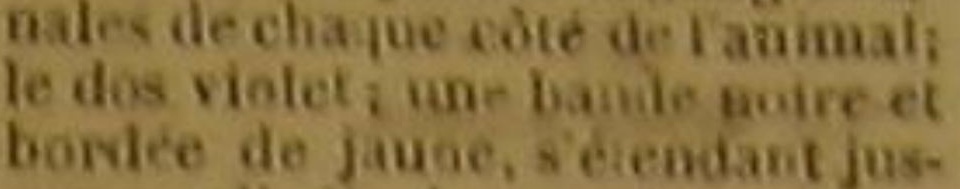
bordee de jaune, s eendait jus-
que sur livil deus taches brumes

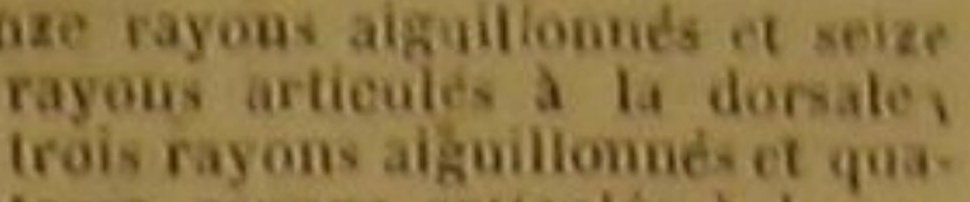
torze rayons arteales a h $\mathrm{na}$.
geoire de lamisf la caudale en

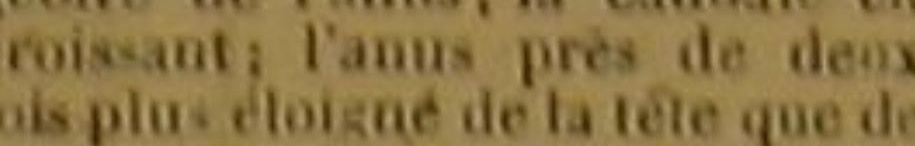

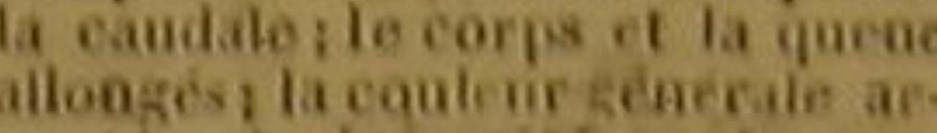
lorales, les thoracines ef Tanale grios, aree la baso rougeatre

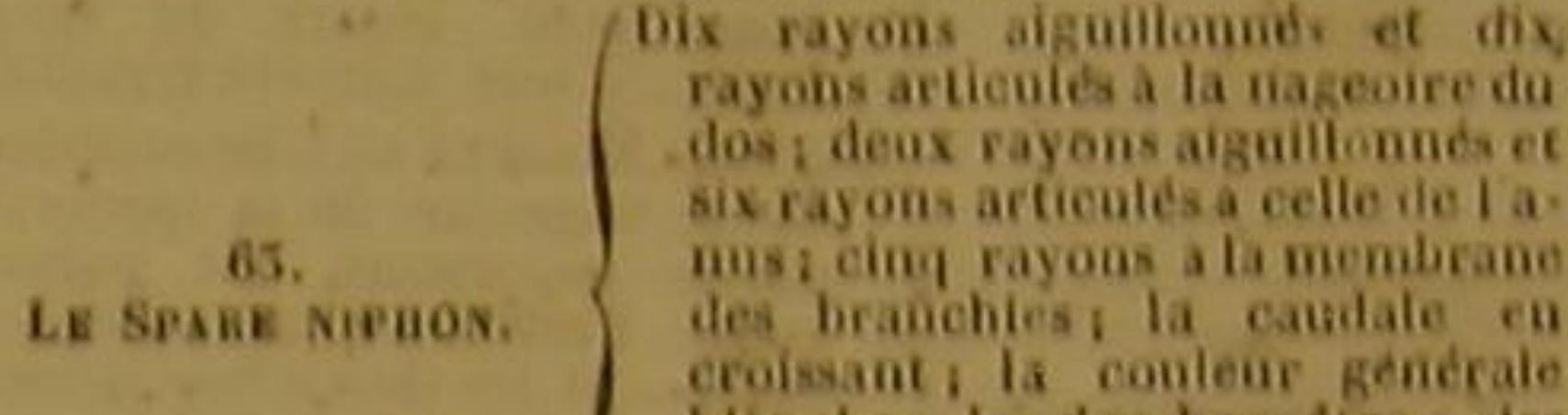

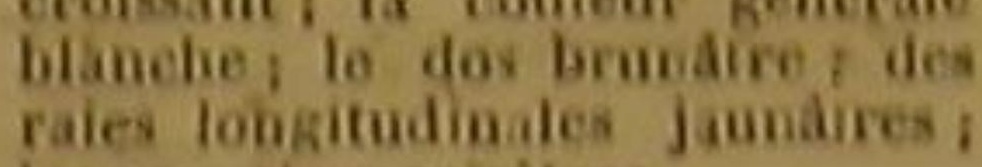

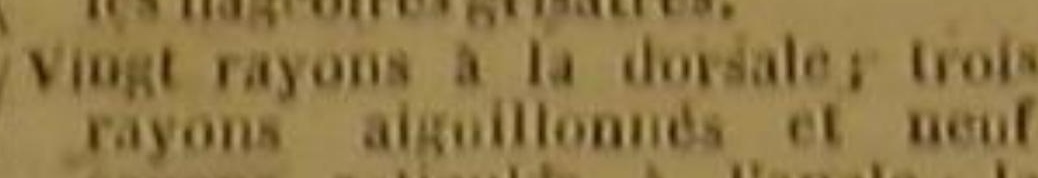
rayons articules a Tanaie i cornes do ciorsant ires-allon. gecsi a hauteur de Tanimal si.

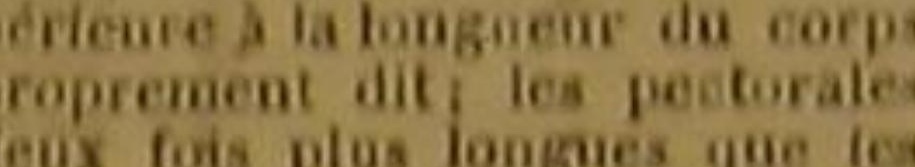

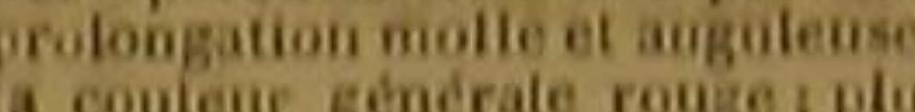
ieurs taches doreses at Irrego leces sur la partio superieure des
cotes, et sur le dos qui est blea;

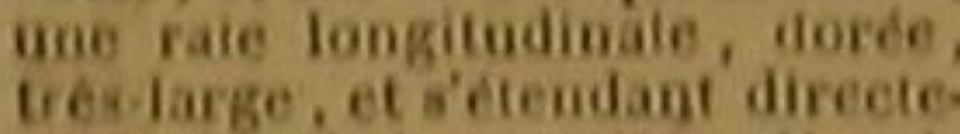
ment de puis la premiere plece de doré, avec une raie lodgitud Onze rayous aiguillonnés ef neut

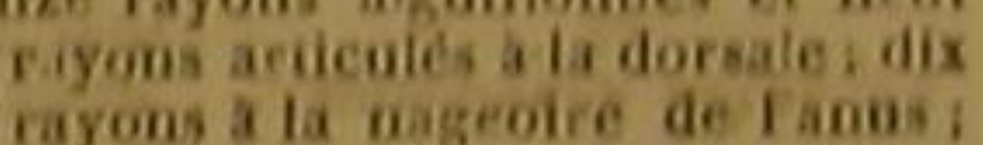
. cornes de ce crosssat trese eloi rales Giciformes: les madchires

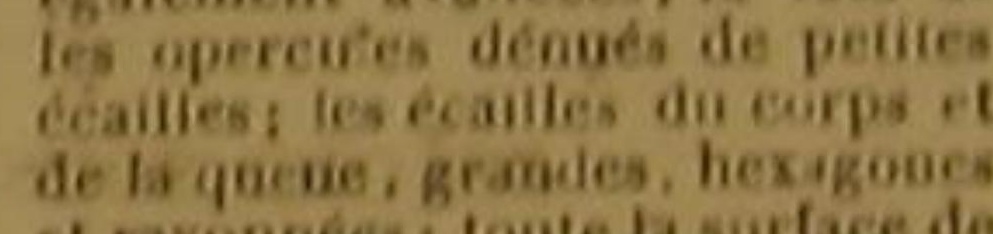
A rayonnés, toute ta surface de
I'soimal, bleue, sans taches. Dis rayous aiguillonaeset quatorze

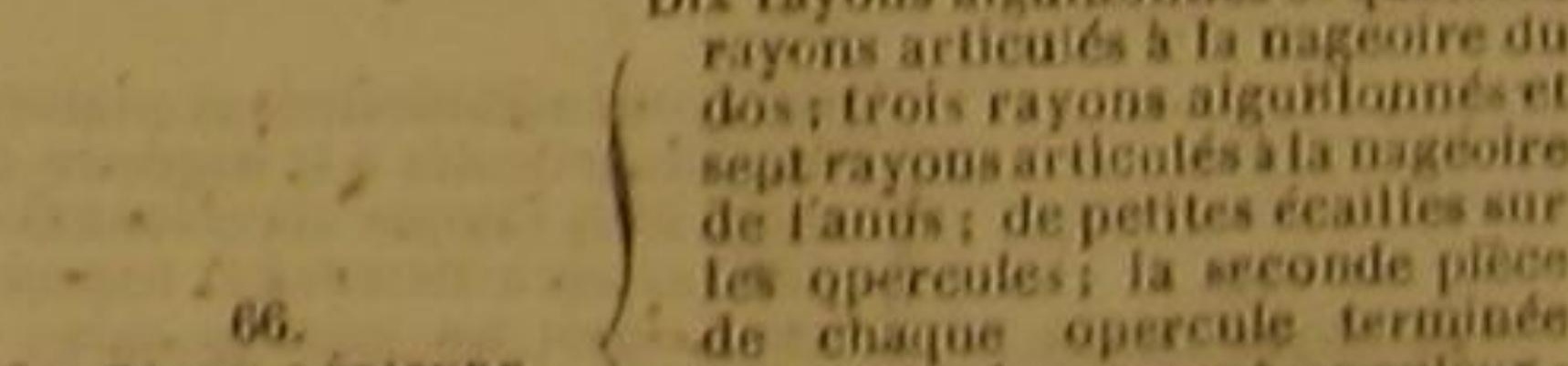

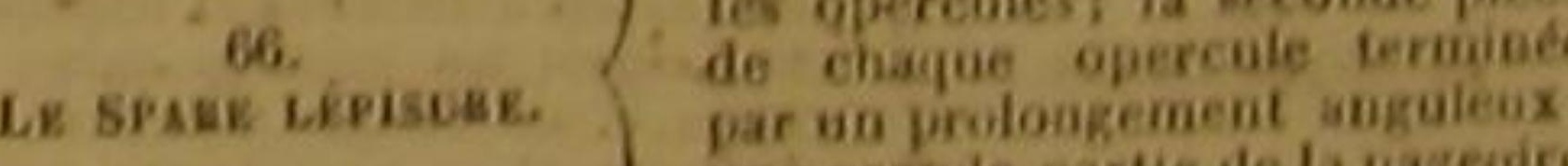

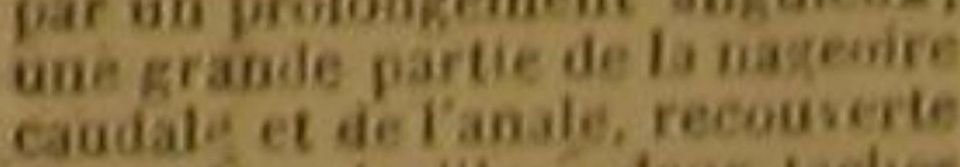
de peities ceaillesi denx becie
ronides, ou ovales, sur le dos, et

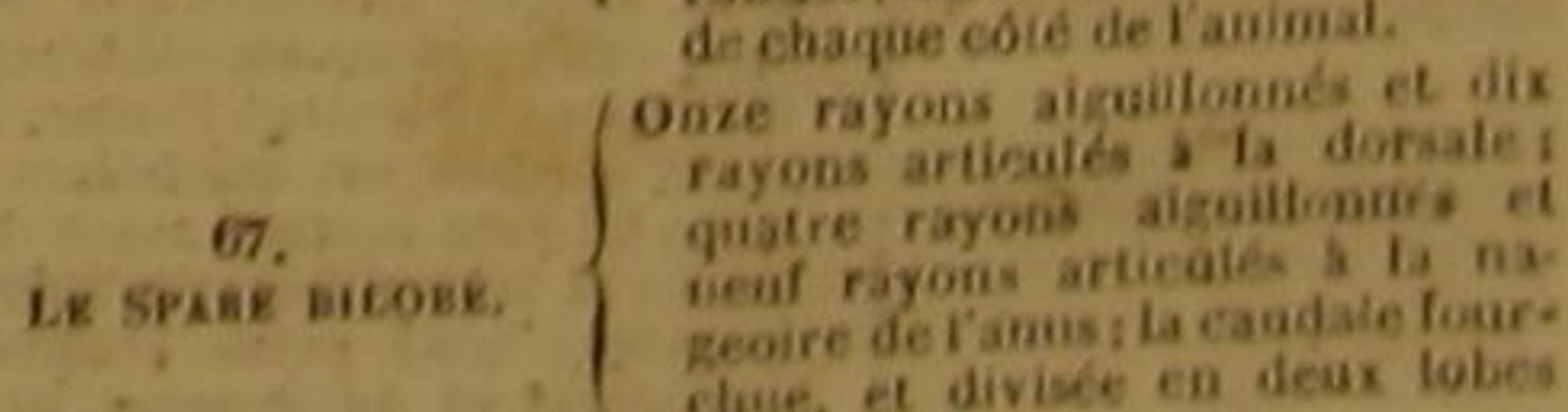


288

ESPĖCES

$-1$

casictéarss,

$-1$

opscules garnis d décailles
embliables a celles da dos; i lea-

tre - ileax des yeux relevé en
bosse; les yeux gros: quatre ou

ix deats lonzues, pontues et
crochues, placées au bout de la

dinne rangee de molairires béminis.
hériques de petites érsilles sur

LE SPALE CABDISAL.

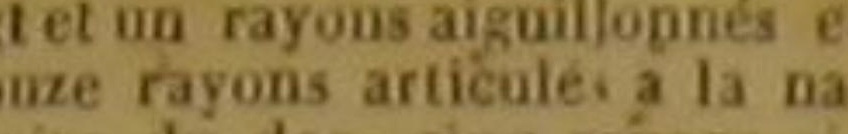
geoire dii dos; cinq rayous a
giillonnes et douze rayors ari.

colés a tá nageoire de ranusi une

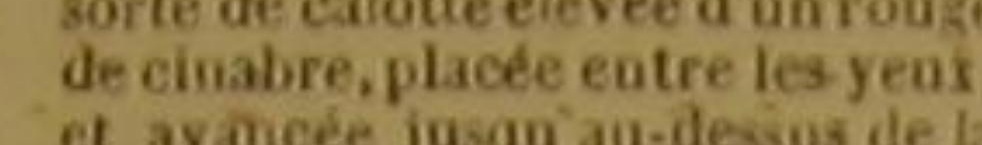

máchoire soperieure: la parti
sitiérieure del animald'un roou

fonce: la partie intérieure dun
rouge clas, separe du ronge
fonce, dune mawiere trancliee,

$3=2+2,+2$

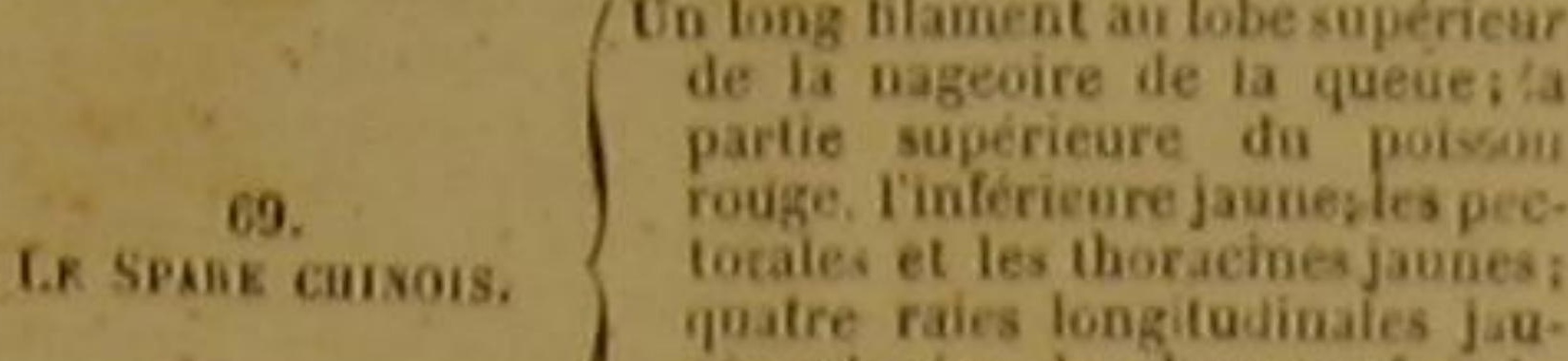

quatre raies long todinales jau.
nes, placées de chaque óte du
corps, et protongees jusyuat lex

tremile de la caudale.
Onze rayons aizullonnés et treize

naze rayons aiguillonoés el treize
rayous articulét a la nageoire du dos i quinze rayons a la nageoire
delaniuss la caudale en crobsar

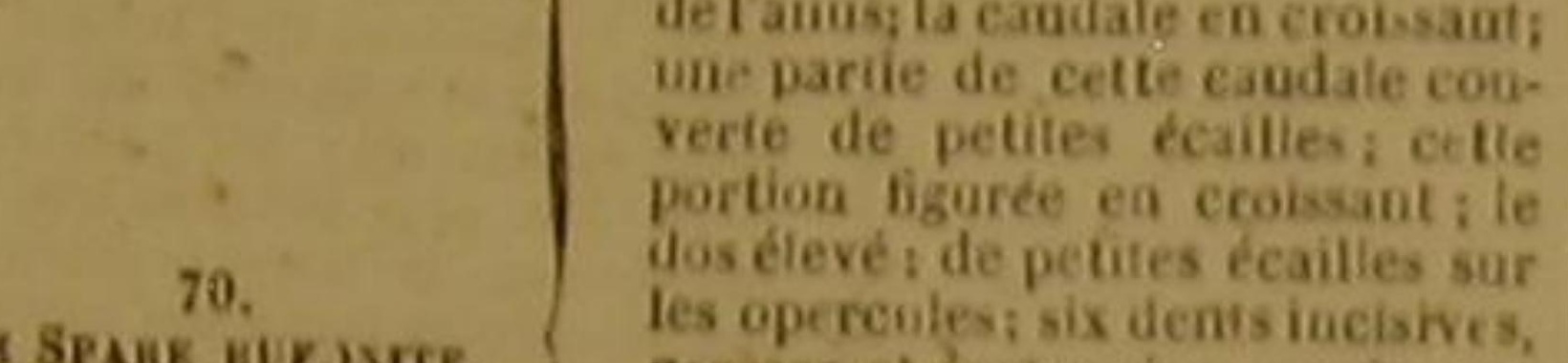

LE SPAIE LiUJSTE.

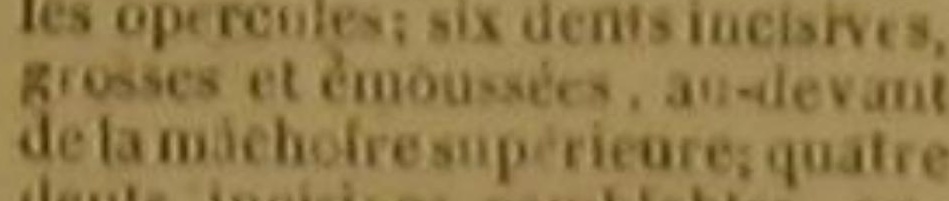

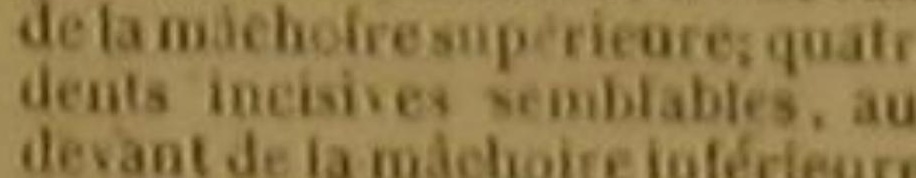

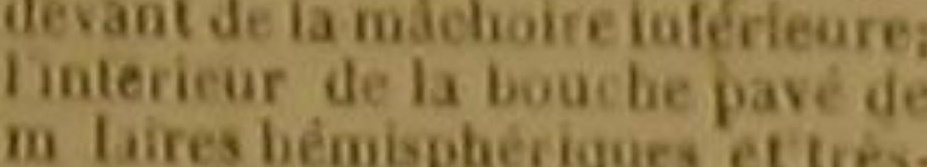
imégales en granideñ , onse on
douze raieslongituainales de cha-

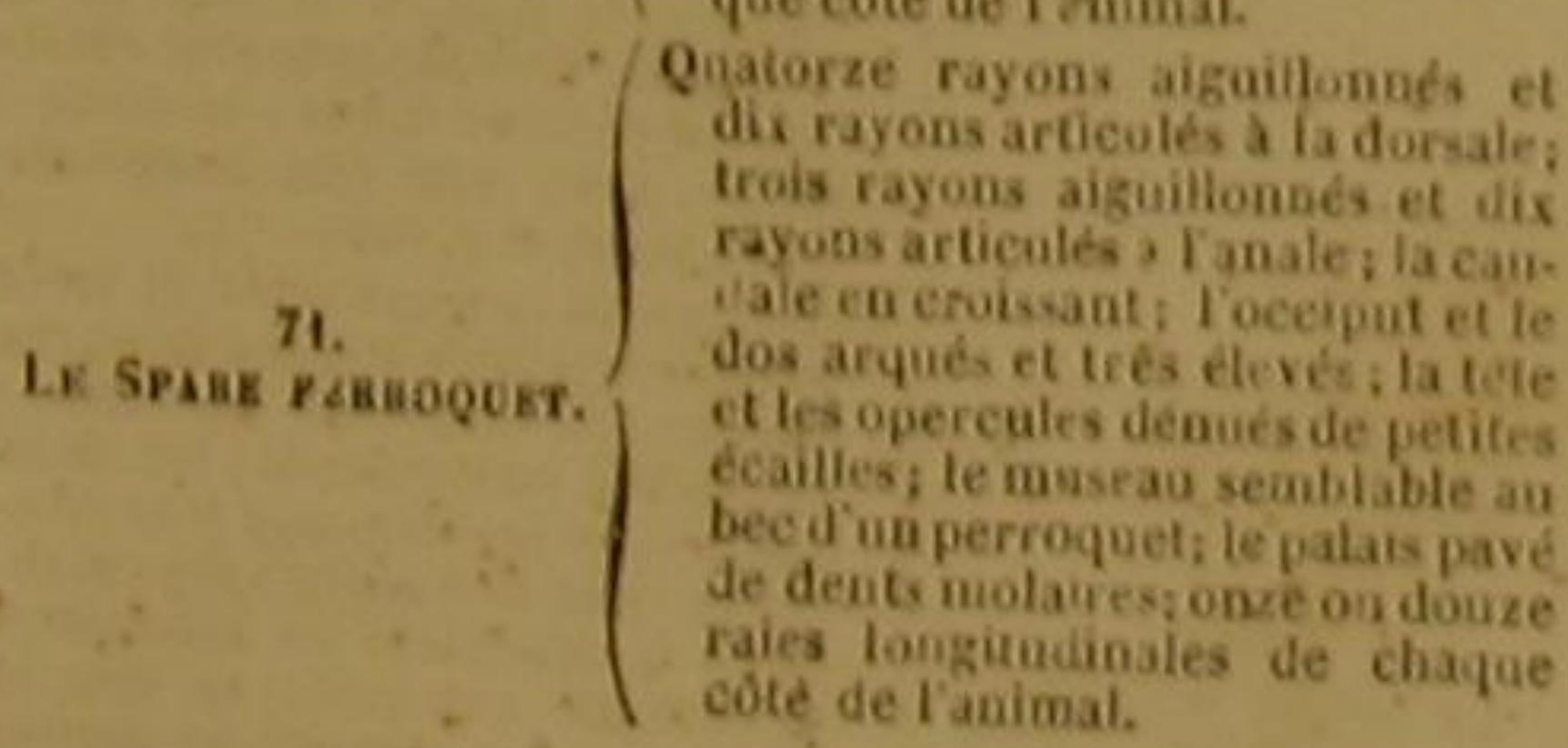

SECOND SOUS-GENRE.

La nageoire de la quess, reclligne, ou arrondie.

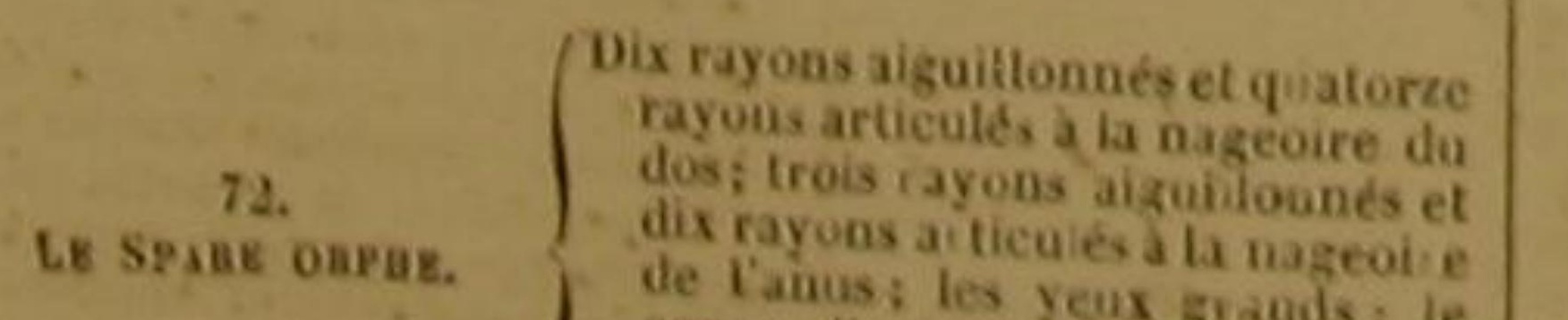

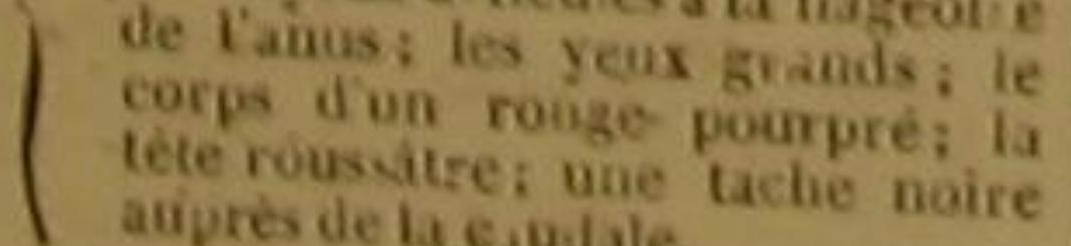

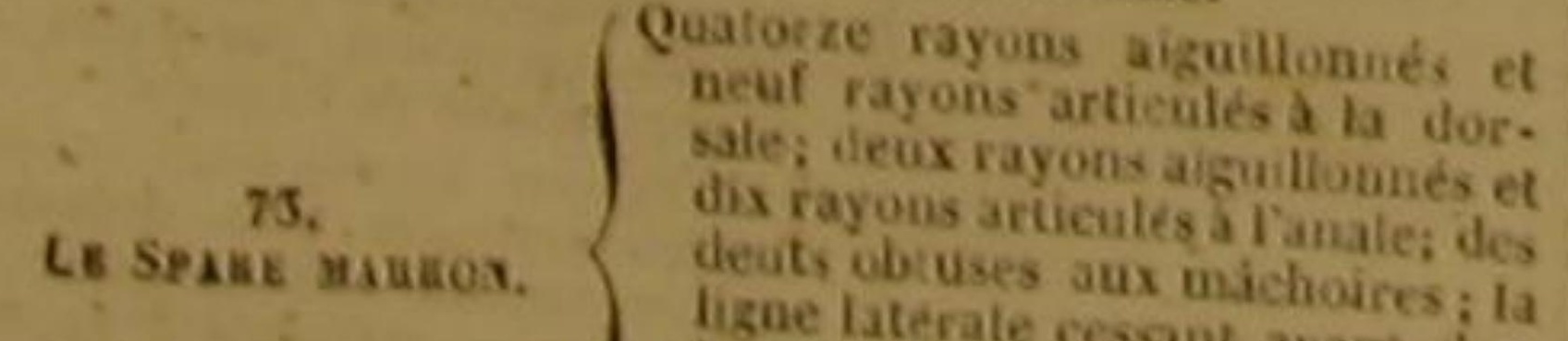

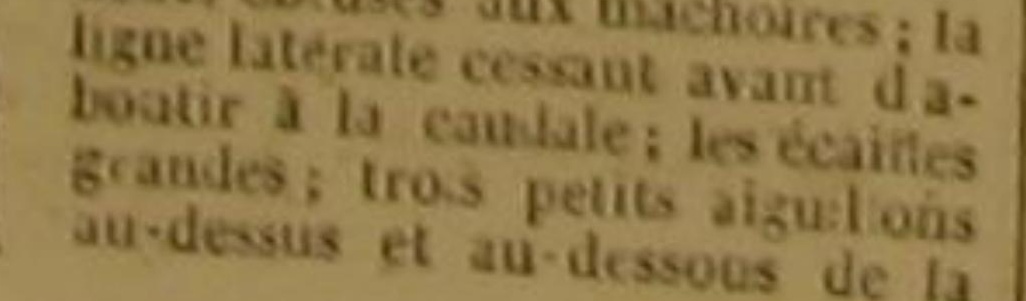

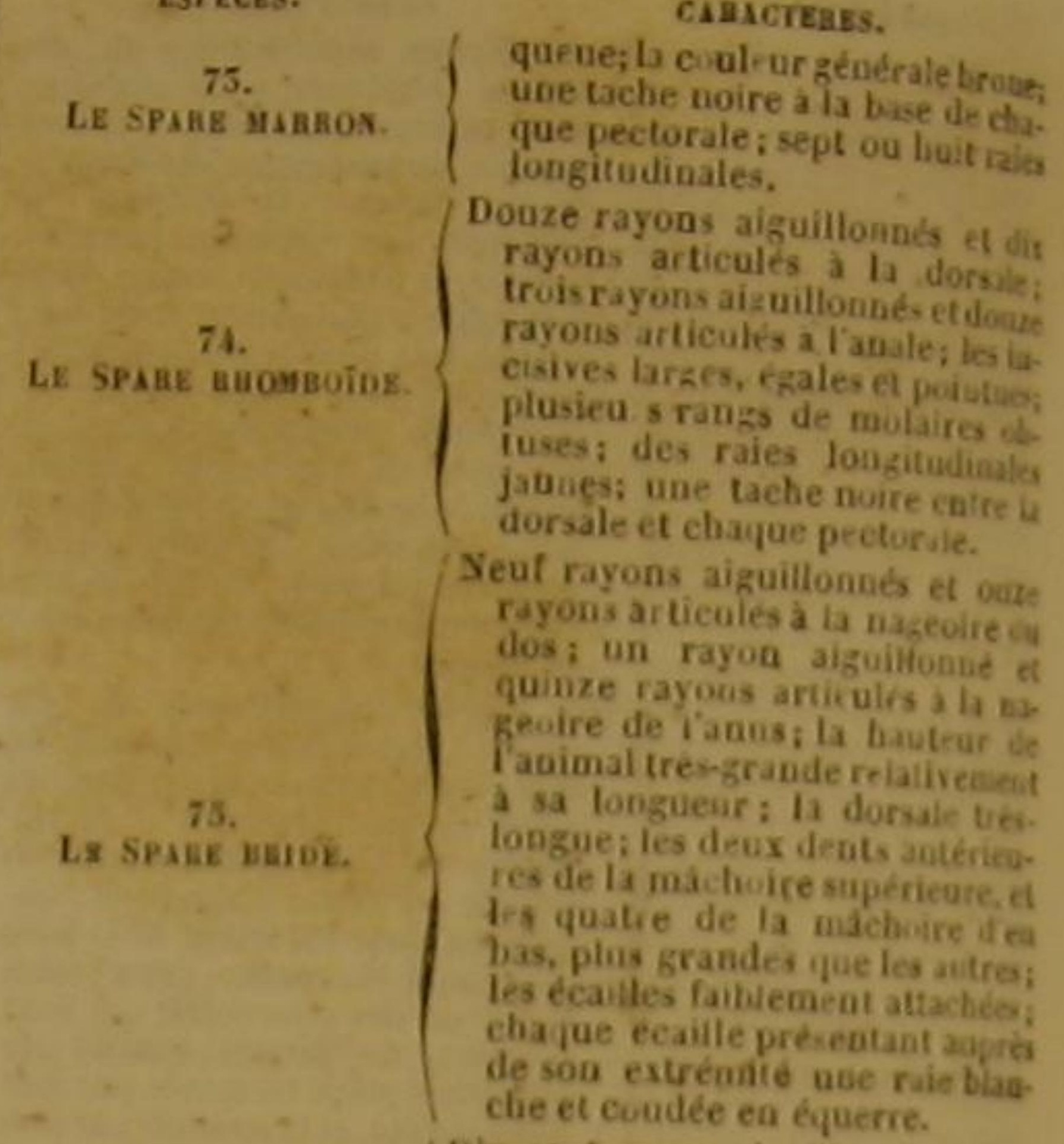

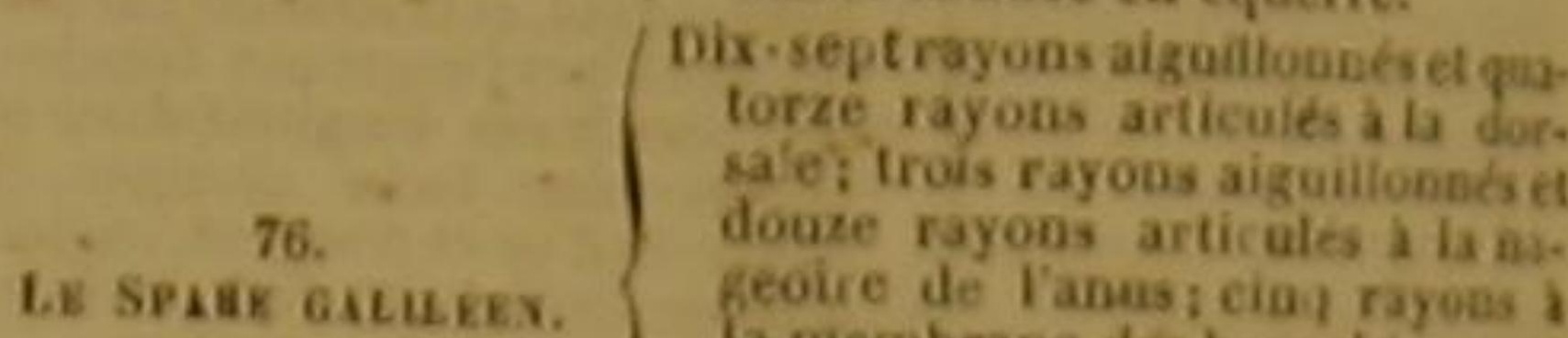

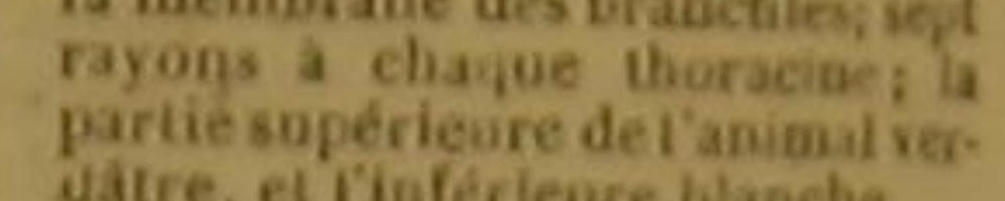

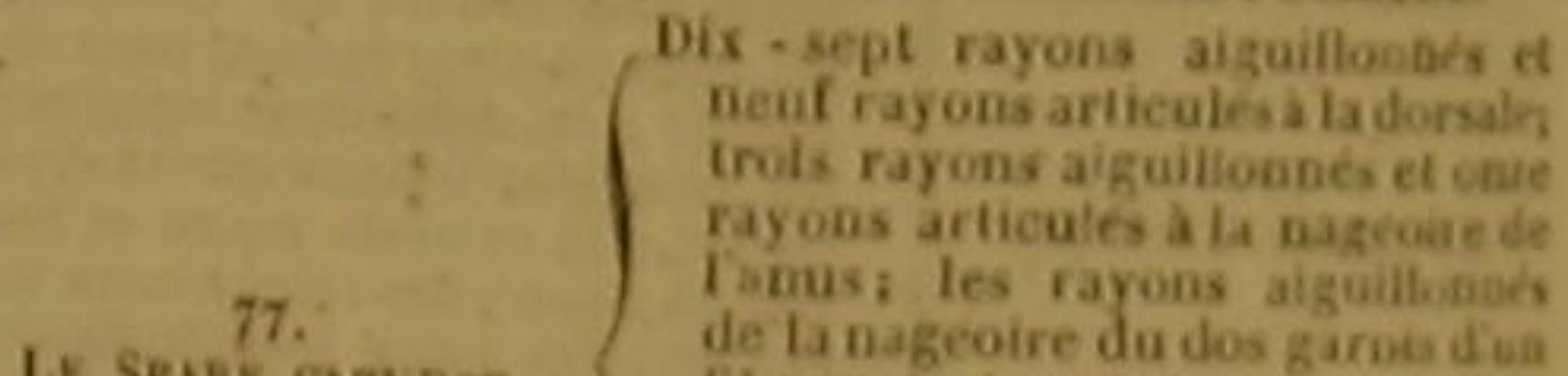

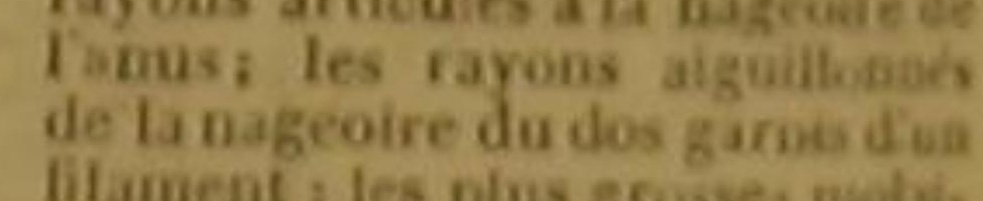

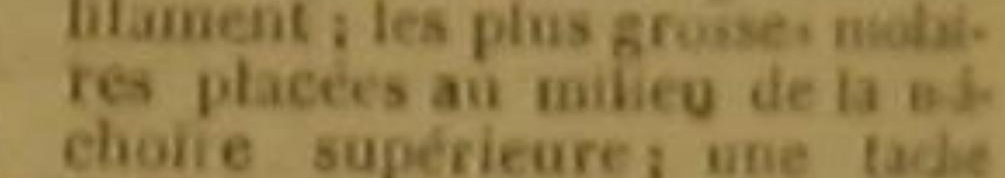
choile superieure, mine bade
Lrumesur le bord superieur det anterieure de la dorsale.

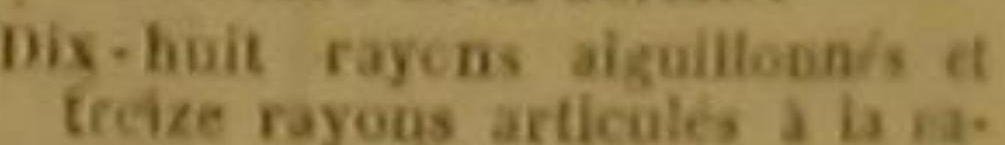
treze rayous articules a is a.
govire du dos: trols rajoos ai Ginillonn's et necut zayons action. is a colle de lasiss les royos
aiguillono's de ia dorste garo din ou ptusieurs filaments ib

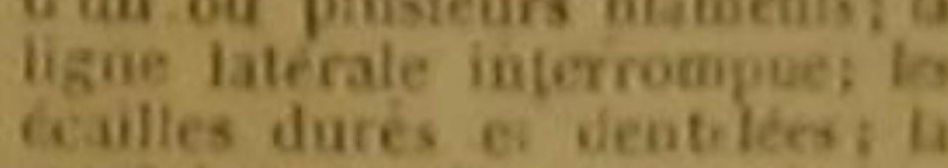

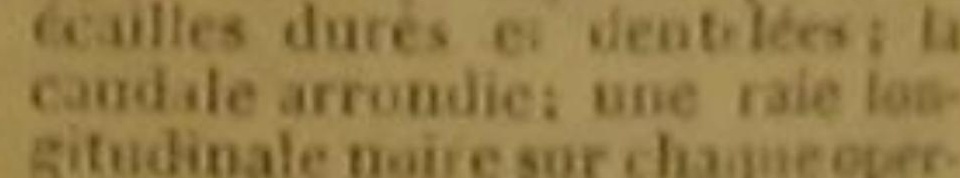
ale: ane tache noire et bood de blane aupres do la base
cha gue pectorale. et de chape

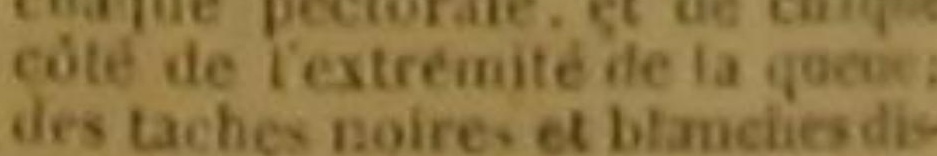
tribuées sur la cardate, la partic

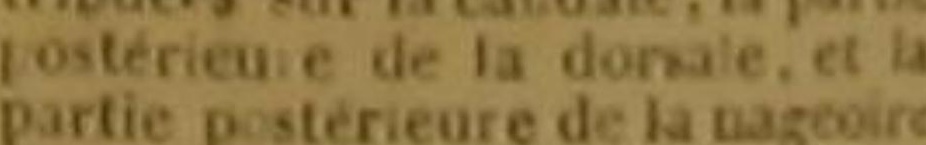
partie pos.
de Tanus.

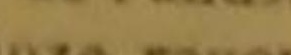 \\ rayons aiguillonnes $C \mathrm{C}$ oove}

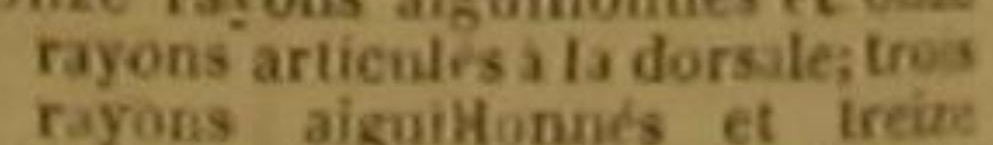
ravonsarticulés a Tranale; la cas dale arrondie; la ligne lateralo
composion de perites tesilles di-

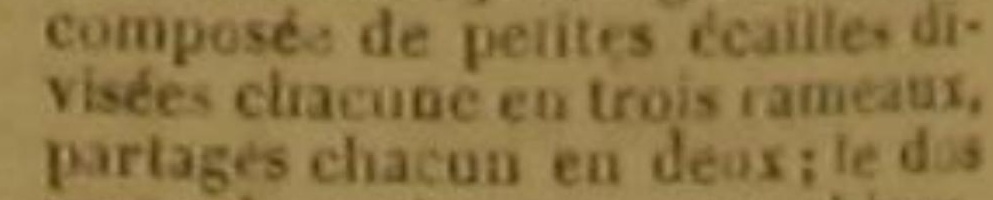

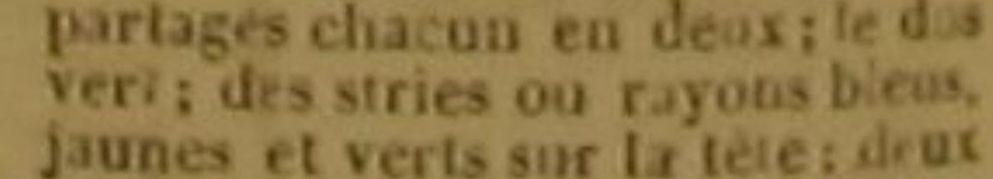
jaunes et verts sur la tele: ideux
taclies, I vne pourpre et Tautre jauae, sur claque opercule. la membrane des branchions in

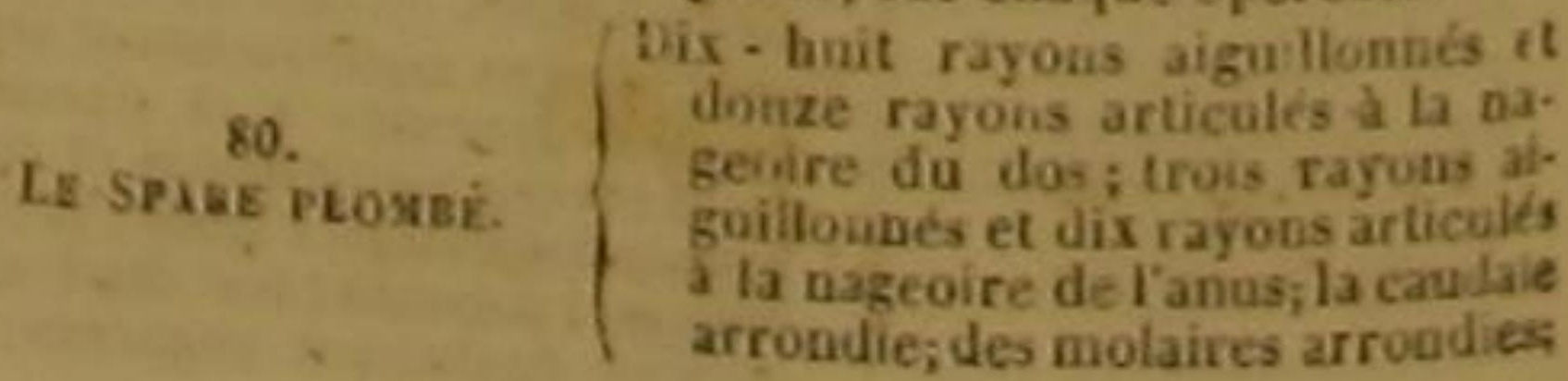

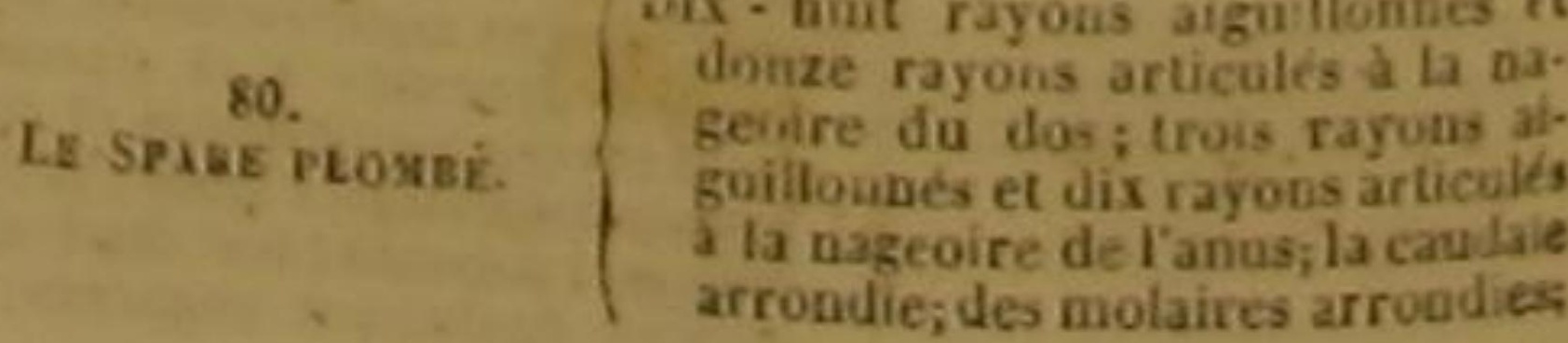

DES POISSONS.

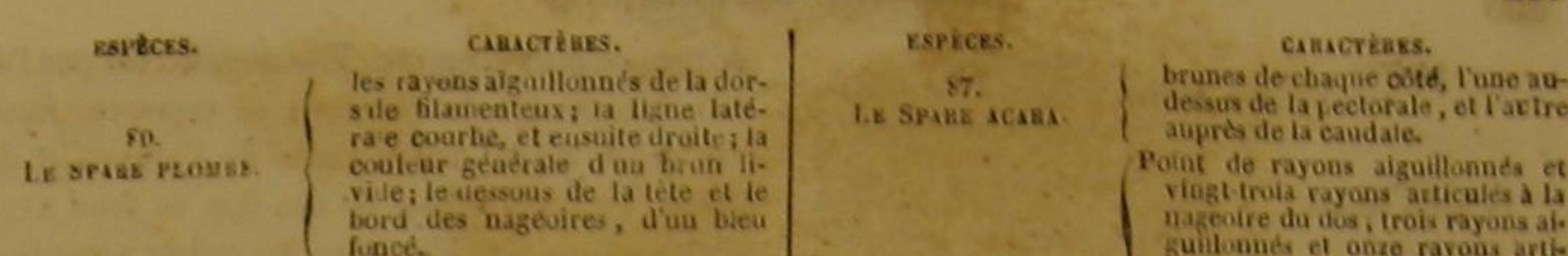

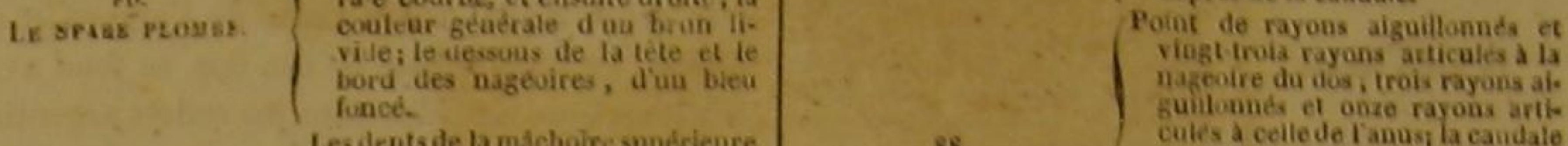

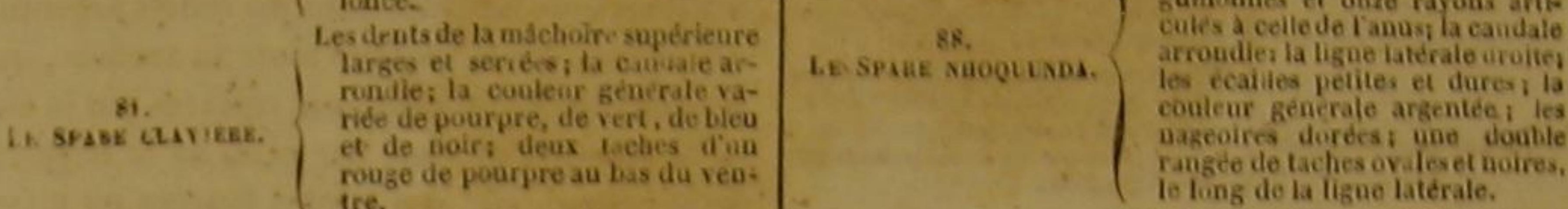

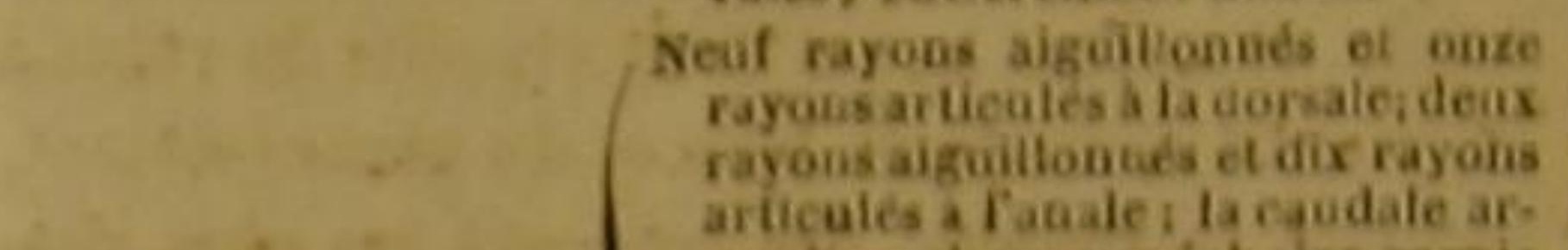

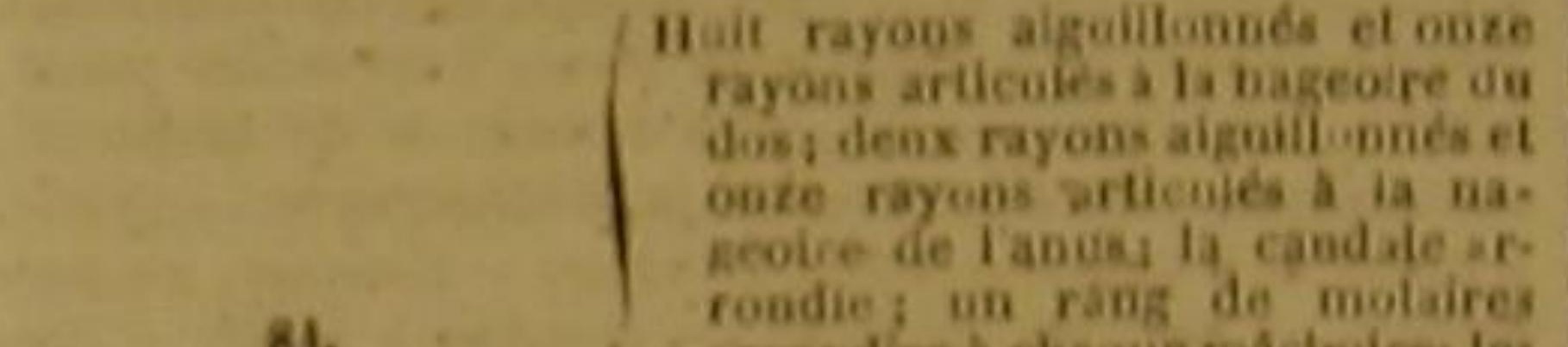
wit rayons aiguilloseng of onze dos; trous rayons aiguiltounés
dix rayons articules a celle de Tanus; la caudale arrondiej une
nangede de molaires arrondies niaires a la màchoire su deux autres touruees ei detiors a la máchoure deu basi les yeux

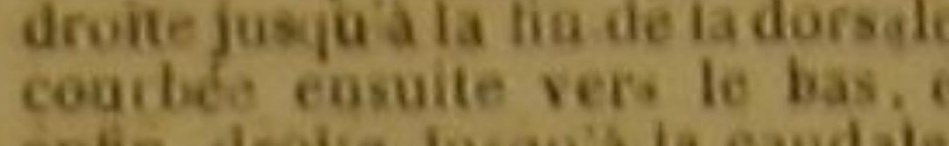
les nagroires, excepte los pecio rales, eutierement butres. rondies chayue machoire gan taats et phocessule devinit, et

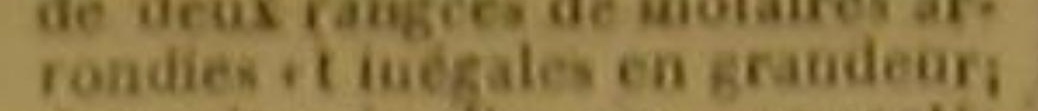

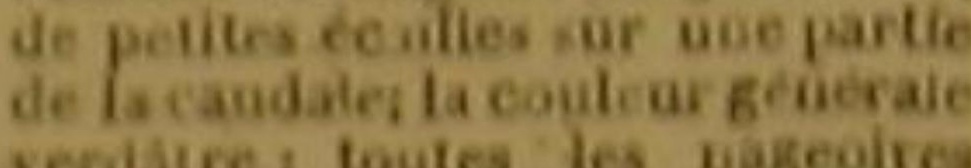
vertes ; toules is pagcoires

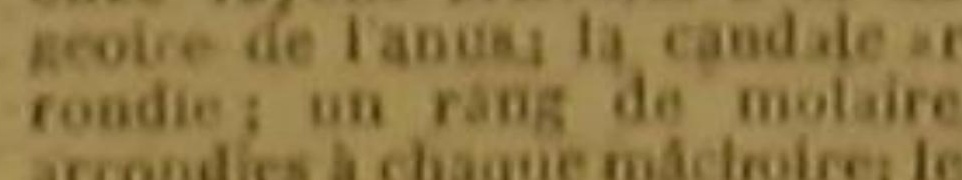
levres tres-frostest tes ecalles gravdes et lisess de peiten cait
ies sur h premiere piteo de cha-

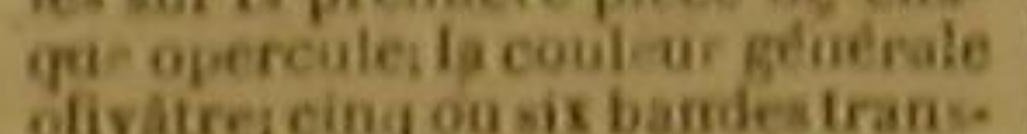

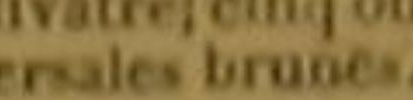

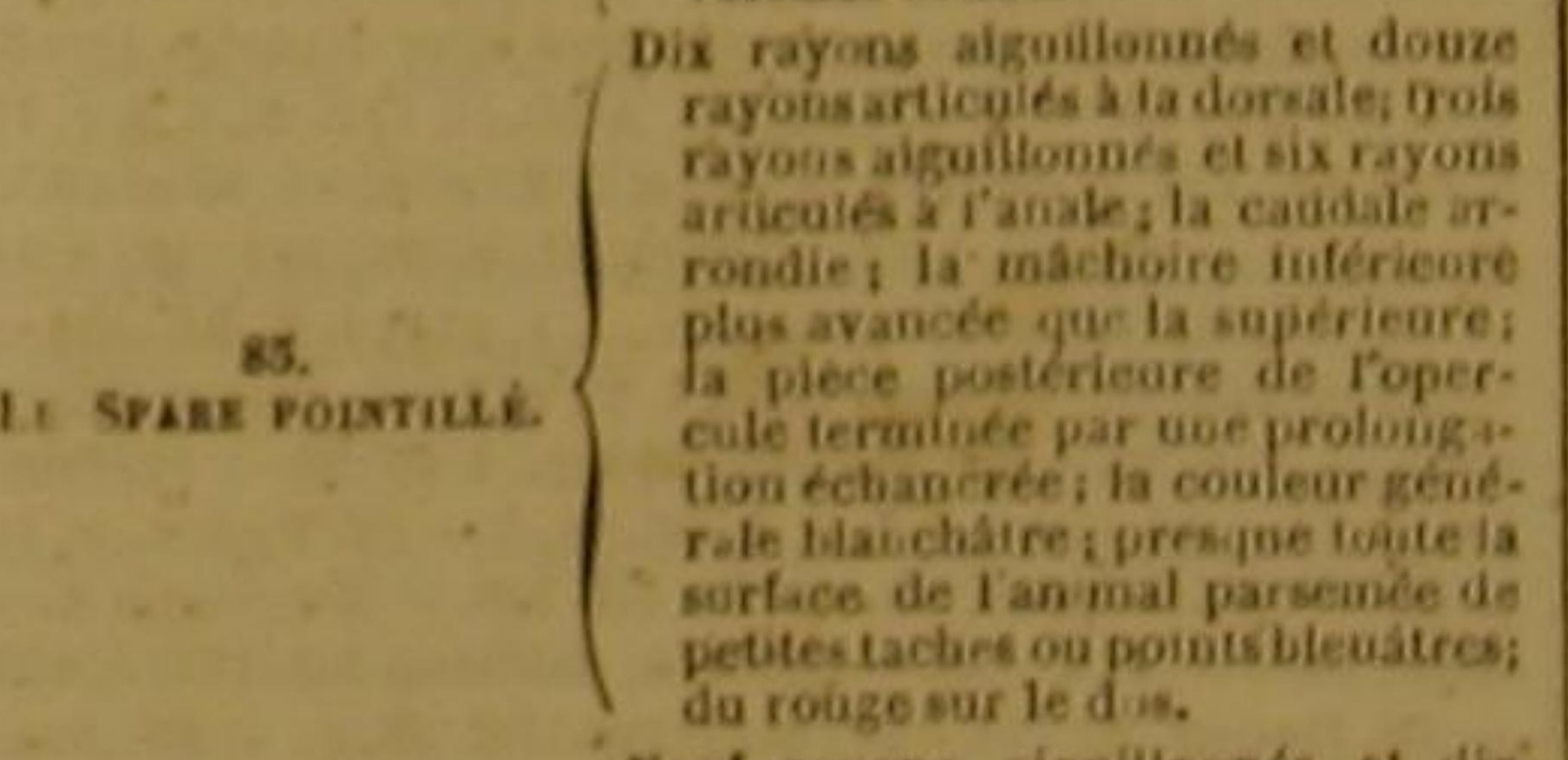

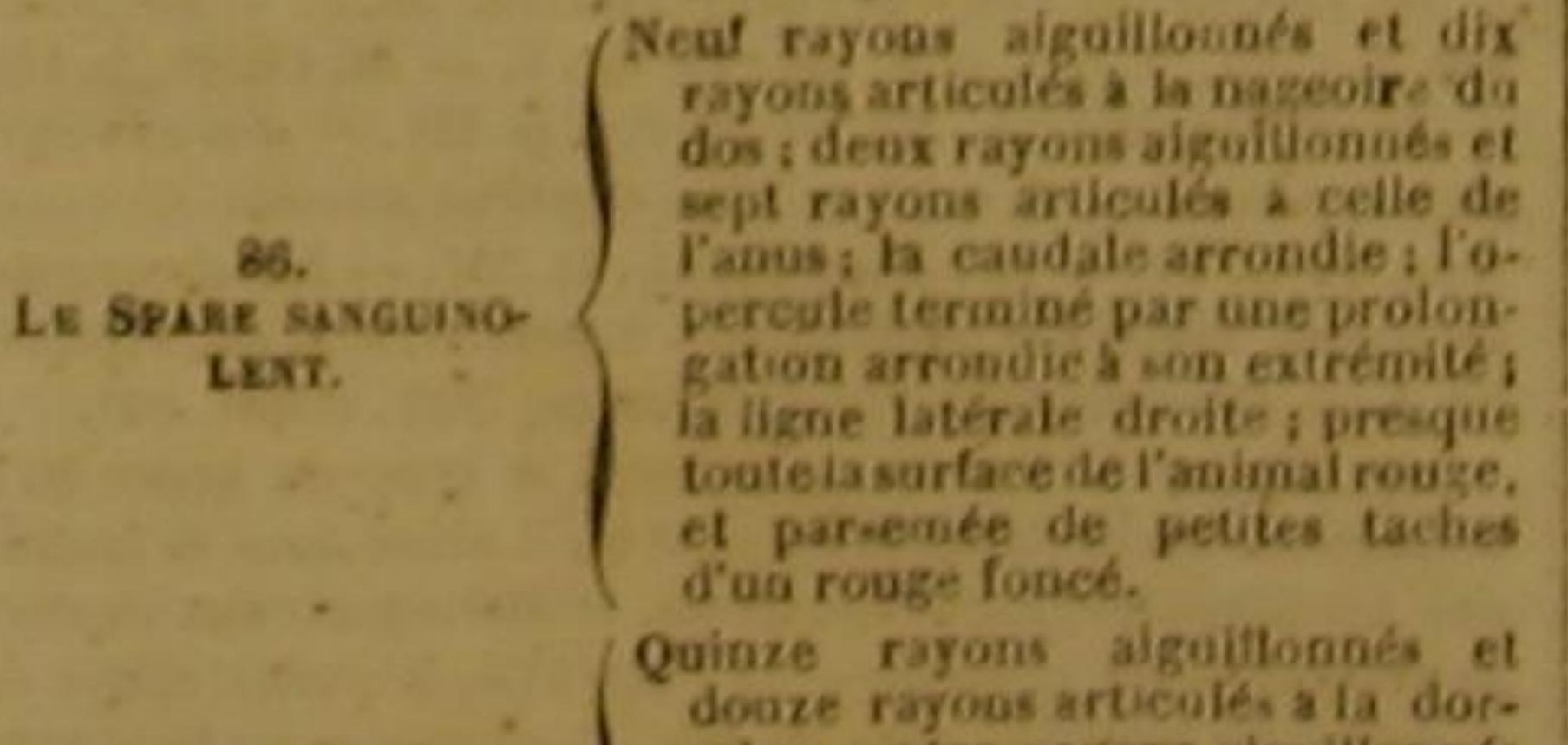

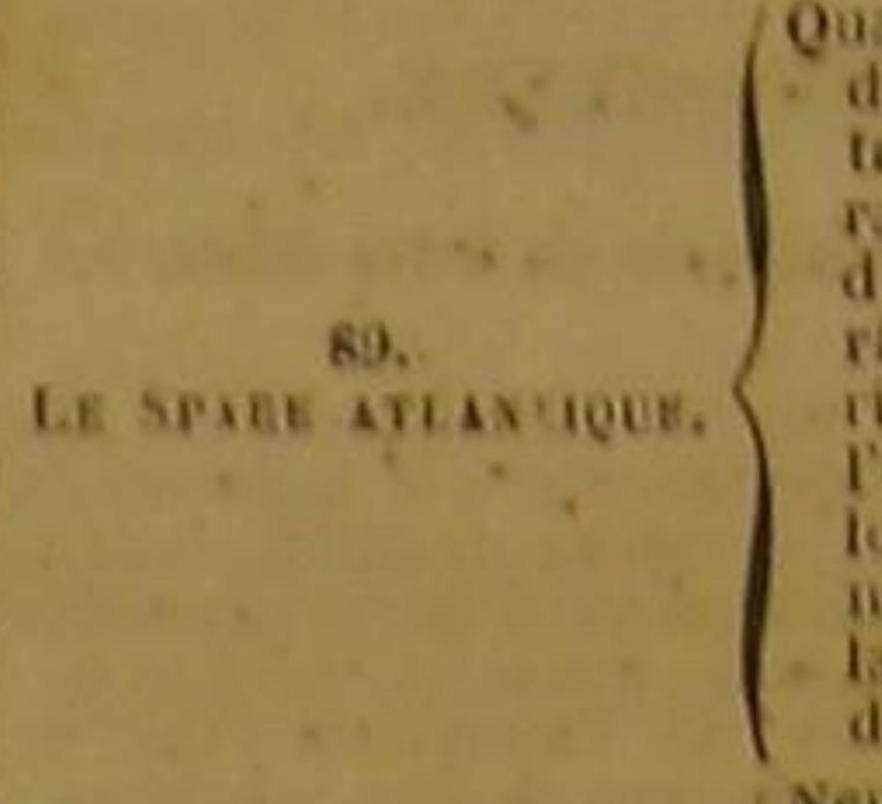

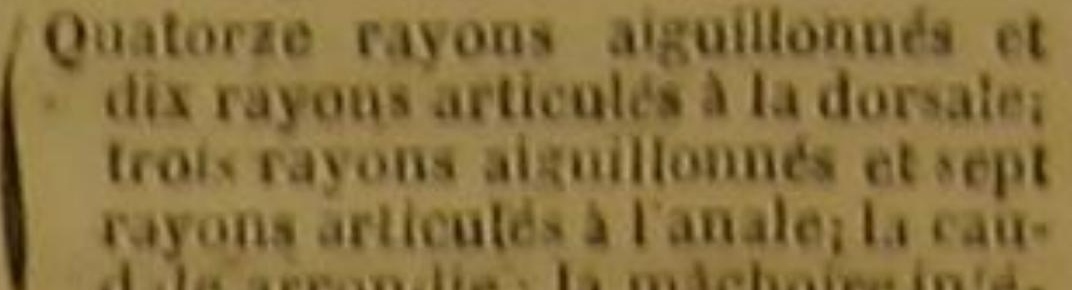
(de arrondie; la machoire in'?

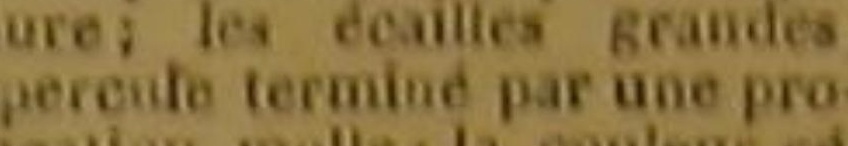
erale blanchatres presque toute surfice do T'animal pa.
petites taches rouges. fray us almillonnes et treiz

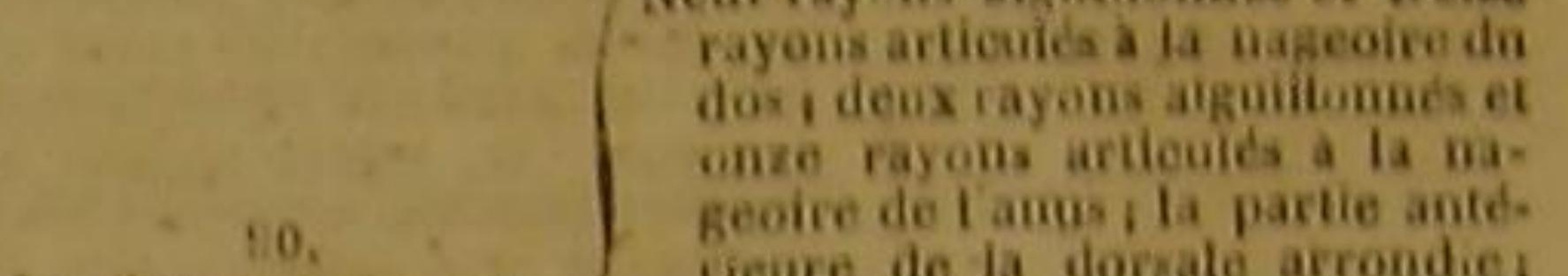

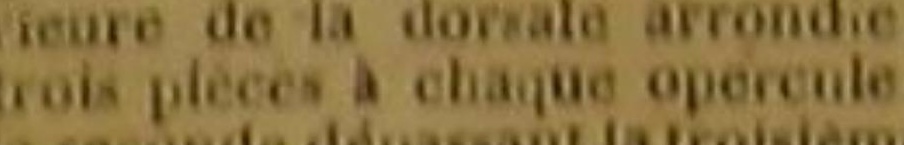
par unc prolongat an arrondice

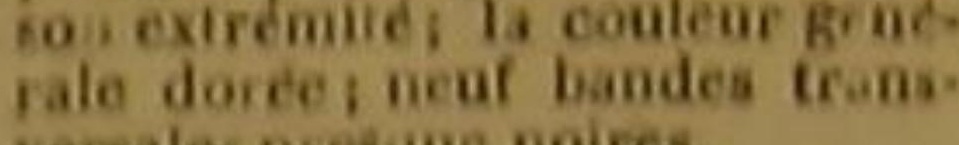
Illonanes et doure at douze
dorsele 作 la tôte arrondio en demi-sijhere,

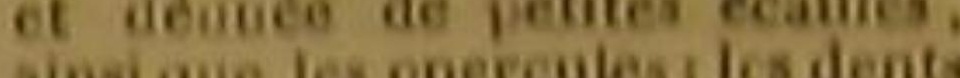
antericurea de la máchoires supe. rieore plus lomguen que les au elaque cóte; ta candale arrondie; nee bande transveraile et coube, nakeoire f une tache noire it base de chaque pectorale, eta ia pax rayons aiguilonnes et one nestruit rayon ariculer a anale; la camdiace as rondie ide petites écallies sur i

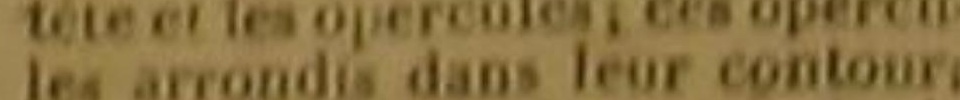
is michoire inferieure parnie do quatre dents plus grandes que les antres, et sembamiteres celte méme mâchoire relevée contre

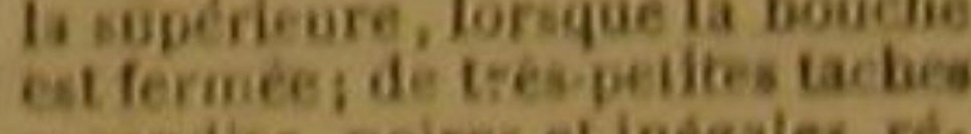

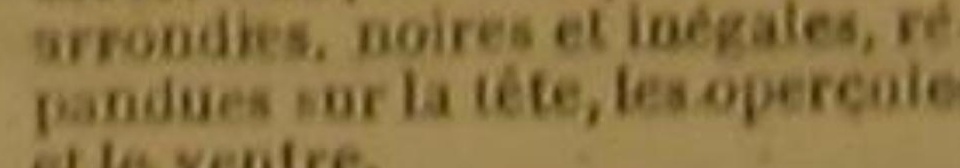
Vingt rayons a la nageoire doratei

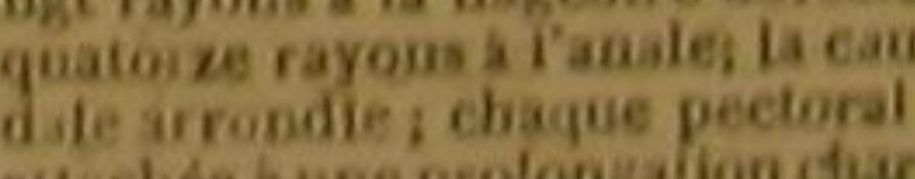

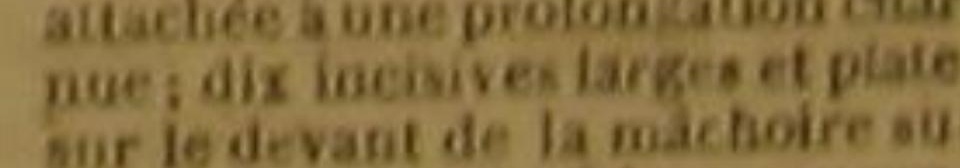

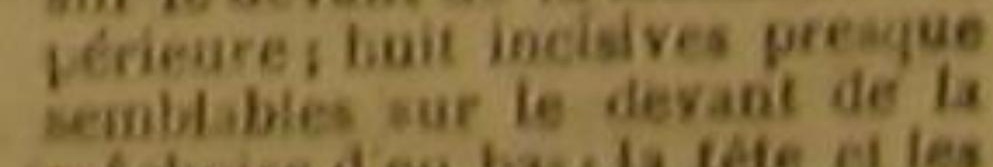

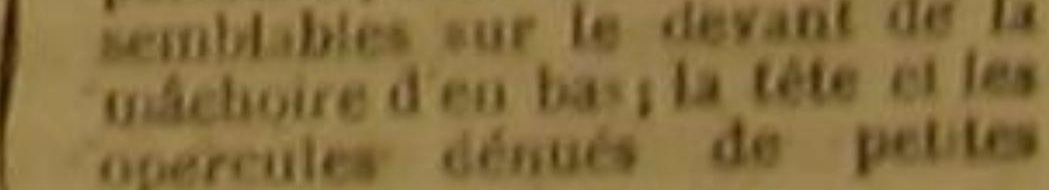
opercules
easiles.

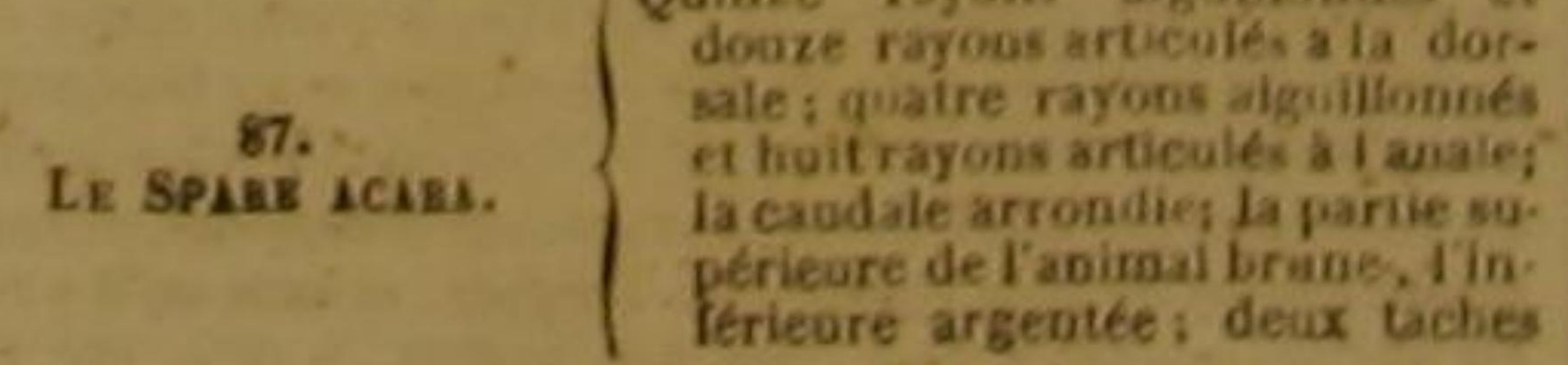

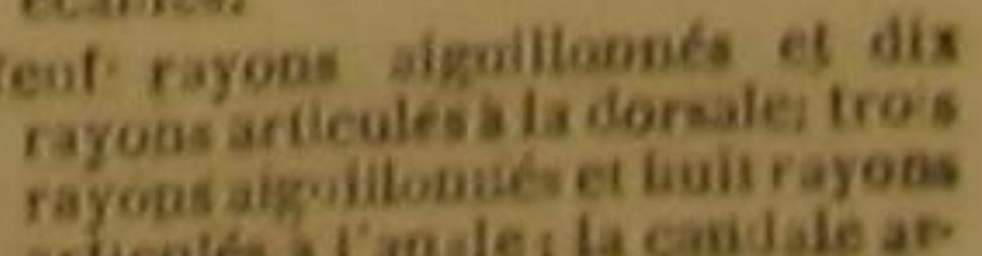


LE SPABE MÉ̇̇CO. Vingl-trois rayons a la nageoire du
dos; onze rayons a celle de la.
nas; une ta the noire sur la par.
ine tiesspetieure d
de loperteule.

TROISIẺME SOUS-GENRE.

La nageoire de la queire ditisée én trois lobes.

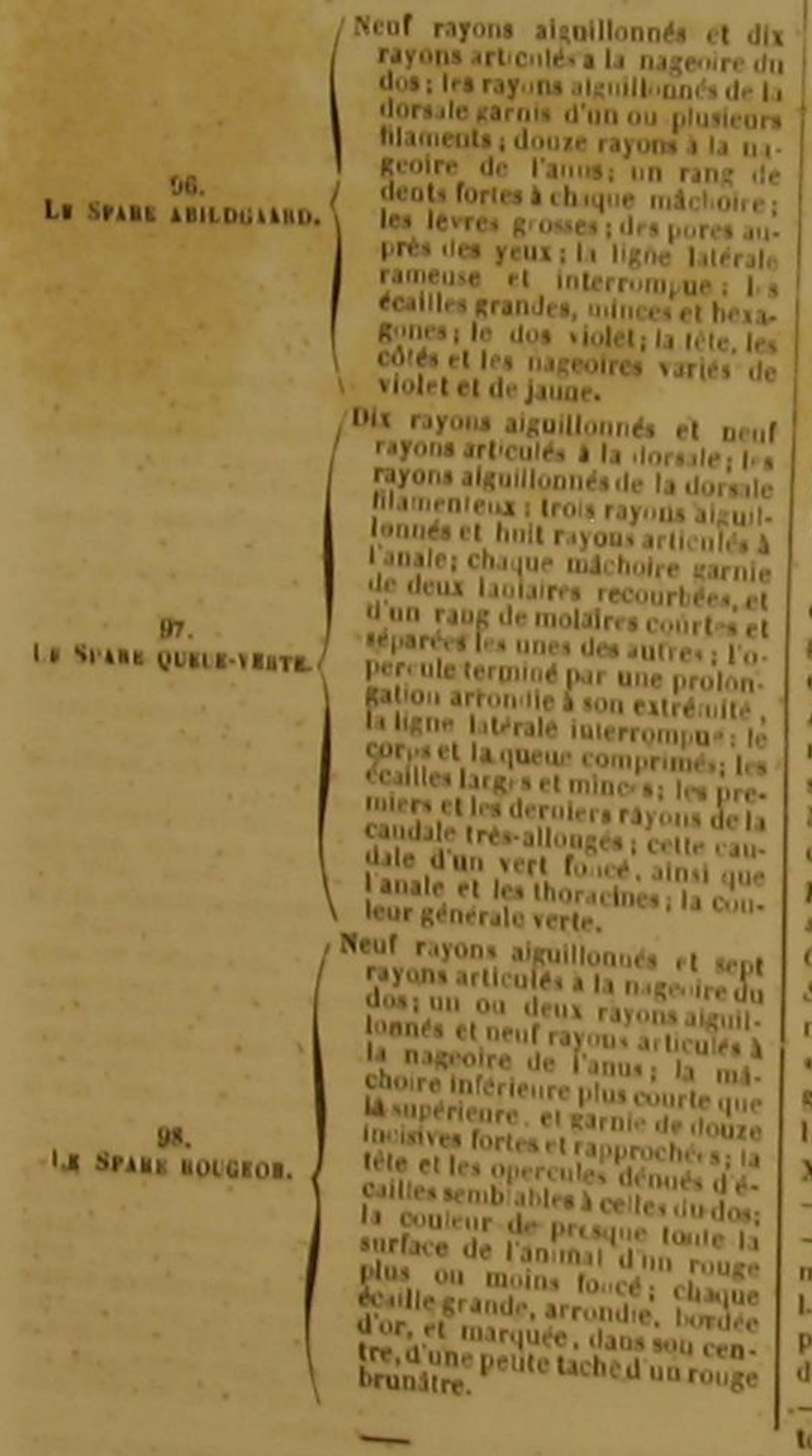

LE SPARE DORADE ।

Sparus aurata, Lino., Gmel., Lacep.; Chrysophris

Plusieurs poissons pur.

aurata, Cuv. 3 .
issons présentent un vêtement

plus magnifique que la dorade; aucun n’a reçu

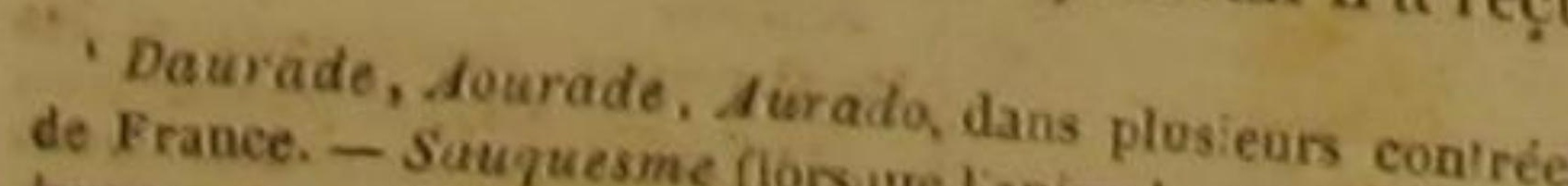

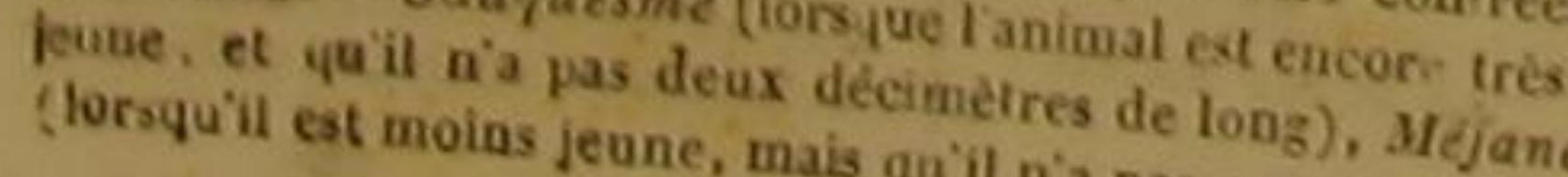

\section{NATURELLE}

de parure plus élégante. Elle ne réfléchit pas l'é et élouissant de Vor et de pourpre; lle brille de la douce clarté de l'argent azur. Le bleu céleste de son dos se fond are d'autant plus de grâce dans les reflets argentins qui se jouent sur presque toute sa surface ces deux belles nuances sont relevées par le noir de la nageoire du dos, par celui de la nageoir de la queue, par des teintes foncées ou grises des autres nageoires, et par des raies longitudinales brunes qui s'étendent comme autant d'or. nements de bon goùt sur lé corps argenté du poisson. Un croissant d'or forme une sorte de sourcil remarquable au-dessus de chaque ail; une tache d'un noir luisant contraste, sur queue et sur l'opercule, avec l'argent dés écailles ; et une troisième tache d'un beau rouge, se montrant de chaque cóté au-dessus de la peetorale, et mélant le ton et la vivacité du rubis a I'heureux mélange du bleu et du blanc éclatant, termine la réunion des couleurs les plus sim. ples, et en même temps les mienx ménagées, les plas riches, et cependant les plus agréables.

Gecimètres de lo gueur), Subre daurade (lorbquill est trón

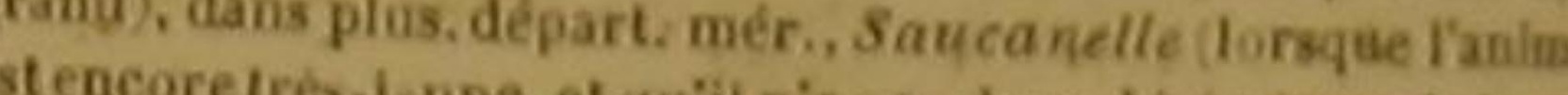
Poumerengue, ou paumergrae dorsmill ateitres de long,

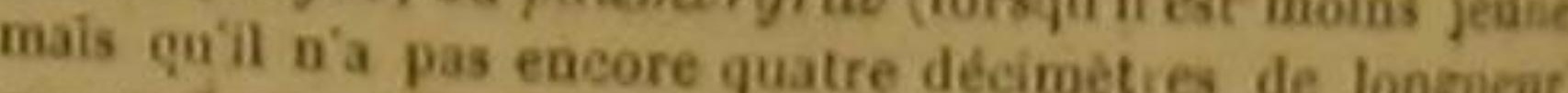

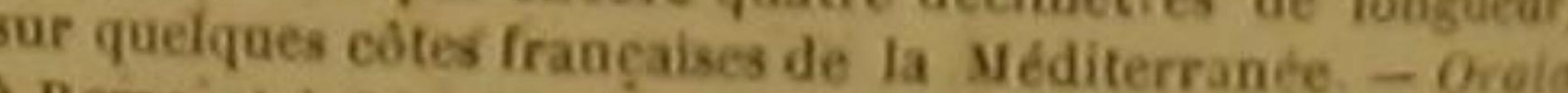
drome el a Geaes. - Ora, á Venise. - Canina, en str digne. - Aurada, a Malte, - Orada a Alzer. - Sip puris, par les Grees moderose. - Vergulde, Goud braa Cold brabe. - Gilt hend, Gilt poll, en Analeterre. Spare dorade. Da Allemagne. - Sus. Ad. Prid. 2, p. 72. naterre, pl. de T'Ene mé et Haay, Enc. méth. - Id. Bon - dorso acutissimo, lined arcuats apred inter oco. - ' Spara

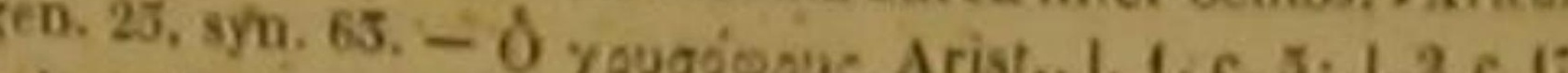

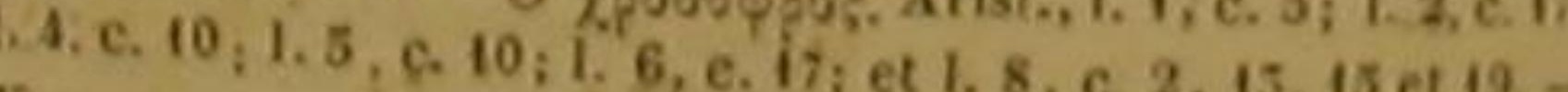

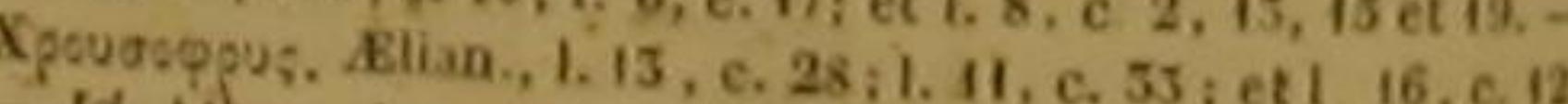
Id, Atien., 1.7 et 8. - Oppisn Chrysophlirys. Varron, Rnst. I. 5, , . . 5. - Aurata. Co's 1. 9, c. I6 C. 16. - Id. Martial, Epigr. 1. 15, 90. - Id. Pin. p. 68. - Id. Wotton, I. ., c. 4. fol. 71, b.: Id. P. Jov., c. II, delet. part. 1, I. 5, c. 2. - c. 174, fol. 156. - Daurade. Ron. Id. Gesner, p. 110, i28, et (Germ. Salvian., fol. 174, b. 175

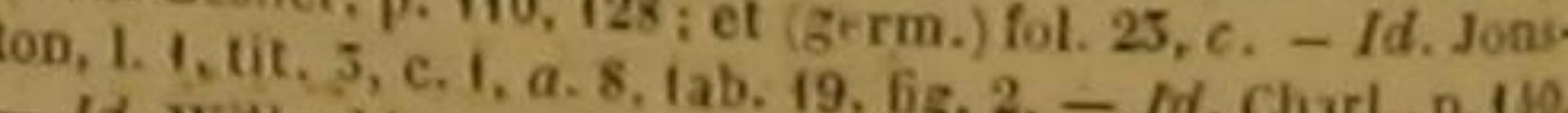
Id. Willughby, p. 507:- Id. Rai, p. - Ist - Charl., p.14 gavis. Aldrov.. 1. 2, c. 15, p. 171. - Sparus aurata. Gronor. Mus, I, n. 90. - Id. Hasselyuist, If. 357 . La daurade. ig 1. - Dorade des péches, part. 2, sect. A, c. 2, art, 1, pl.11. 'M. Cuvier forme dent de Bomare, Dict. d hist. nat. nomme Daurade $C$ de ce poissun le type du genre quil des Acanthoptéryziens sparis, et quil place dans la famille de Duurades: 10 ia valgaire, $e$. aurats istingue deux especer phoses en haut, et cinz en bas a dint a quatre rangs de $C$. mierod que les autres; et $2^{\circ} \mathrm{O}$ ia Daurade a petites ients toufes autont a deux rangs de molaires seulement ea bas,

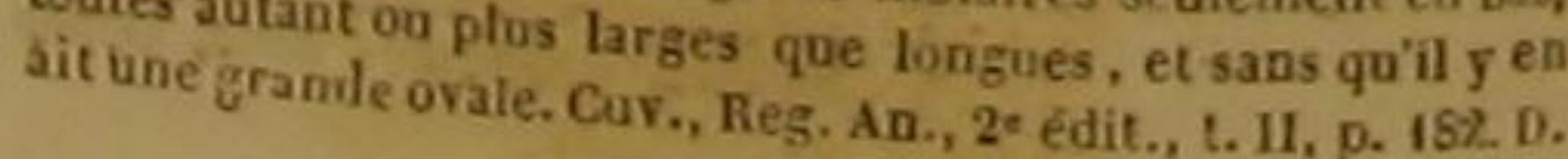

DES POISSONS.

491

Les Grees, qui ont admiré avee complaisanee ce charmant assortiment, et qui cherehaient dains la nature la rècle de lenr goût, le type de leurs arts, et mème lorigine de leurs modes, l'ont choisi sans doute plús d'une fois pour le modele des nuances destincés à parer la jeune épouse, a moment où s'allumait pour elle le flambeau de I'hyménée. Ils avaient du moíns consácré la doradeà Vénus. Elle était poư eux l'emblème de la beauté féconide : elle êtait done celle de la nature; elle était le symbòle de cette puissance admírable et vivifiante, quỉ crée et qui coordonne, quì anime êt qui embellit, qu enflamme et quĩ enchame, et qu'un des plus célèbres poêtes de I'antíque Rome, pénétré de l'esprit my thologique qu'il cherchait cependant à détruire, et lui rendant hommage même en le combattant, invoquait soùs le nom de la déesse des graces et de la reproduction, dans un des plus beaúx poêmes que les anciens nous aient transmis. Mais cette idée tenait, sans doute, à une iđée plus élevée encore. Cette sorte d'hiéroglyphe de la beauté céleste n'avát pas été empruntée sans intention du sein des éaux. Ce n'était pas seulement la nature créatrice et ré paratrice qui devait indiquer cetté consécration de la dorade. Les idées religieuses des Grees n'étaient qu'une traduction poétíque des dogmes sacrés des premiers Égyptiéns. L'origin des mystères de Thèbes, liée avec la doctriue sacerdotale de l'Asie, remonte, comme ectt doctrine, aux derniers grands bouleversemenis que le globe a éprouvés. Ils ne sont que lé réei allégorique des phếnómènes qui ont distingue les differents âges de la terrè et des cieux. Cette histoire des dieux de l'Orient et du Midi est tracée sur un voile sacré, derrière lequel la vérité a gravé les fastes de la nature. Et cet emblème, qui n'était pour les Grecs que le signe de la beauté productive, doit avoir été, pour les anciens habitants de IInde, de la Perse et de l'Égypte, le symbole de fa-terresortant du milieu des flots ef recevant sur sa surface vivifiée par les rayons du dieu de la lumière, tous les germes de la fécondité et tous les traits de la beauté parfaite. Cette époque où la mer a cessé de couvrir nos íles et nos continents, pouvait d'autant plus être rappelée à l'imagination, dans une langue mythologique, par l'habitant de l'Océan dont nous tâchons de dessiner l'image, que des dépouilles très-reconnaissables d'un grand nombre d'indi- vidus de l'espece de la dorade gisent th dim rentes profondeurs àu milieu des couches du globe, où les courants et les autrés différenté agitations des ondes les ont aecnmulées avant que les eaux ne se retirassent de dessus ces couehes maintenant plus exhaussées que les rivages marins, et où elles se trouvent, pour aínsi dire, déposées comme autant de médailles propres à constater l'important événement de la derniere formation des continents et des lles. Cétte espece était done contemporaine de l'apparition des montagnes et des plateaux élevés autdessus de la surface de l'Océan; elle existai même longtemps avant, pussque des débris de plusieurs des individus qu'elle renfermait font partie des couches de ces plateaux et de ces montagues. Il faut done la compter parmi celles qui habitaient I'antique Océan, lorsqu au molns une grande portion de l'Europe, et méme de l'Afrique et de I'Asie, n'était que le fond de celte mer dont les marées, les courants et les tempétes elaboraient les grandes inégalités de la surface actuelle du globe. Elle appartient done à dés périodes de tempś bien plus reculées que les terribles catastrophies qui out successivement " gite et bouléversé les continents, depuis que les eaux de la mer se sont éloignées de leurs sommets; elle est done bien plus agée que l'espéce humaine; et, ce qui est bien plus remarquable, elle a traversé et les orages de destruetion qui ont laíssé sur le globe de si funestes empreintes, et les siècles de réparation et de reproduction qui ont rempli les intervalles de cesconvulsion. horribles, sans éprouver aucune grande alteration, sans perdre les principaux traits qui la distinguent : les fragments de dorade que l'on rencontre dans l'intérieur des montagnes, sont entierement semblables a ceux quel'on voitdan des alluvions plus récentes ', et mème aux parties analogues des individus qui vivent dans $c e$ moment auprès de nos rivages. Des milliers d'années n'ont pu agir que superficiellement sur l'espèce que nous examinons; elle jouit, pour ainsi dire, d'une jeùnessé éternelle; et pendant que te temps moissonne par myriades les individus qu'elle a compris ou qu'elle renferme, pendant qu'ils tombent dans la mort comme les - Il rest presque aucun ouvrage de gelologie ou d'oryctologie, qui ne refferme quelque preuve de cetee aseriou, on

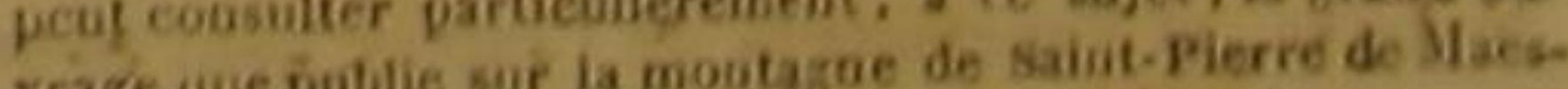

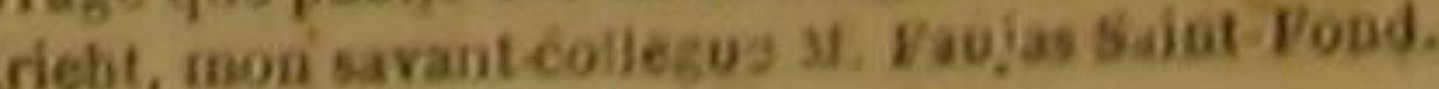


I feuilles sèches sur la surface de la terre vers la breux et les mieux conservés appartienneot i fin de l'automne, elle reste à l'abri de la destruction, et brave la puissance des siècles, comme un témoin de cette merveilleuse force de la nature, qui partout mêle l'image consolante de la durée aux dégradations du dépérissement, et élève les signes brillants de l'immortalité sur les bords du néant.

Cette antiquité de l'espèce de la dorade doit, au reste, d'autant moins étomer, qu'on aurait dû la deviner par une observation un peu attentive de ses habitudes actuelles. Elle vit dans tous les climats. Toutes les eaux lui conviennent : les flots des rivières, les ondes de la mer, les lacs, les viviers, l'eau douce, l'eau salée, l'eau trouble et épaisse, I'eau claire et légère, entretiennent son existeuce et conservent ses propriétés, sans les modifier, au moins profondement. La diversité de température parait n’altérer non plus, ni ses qualités, ni ses formes: elle supporte le fond du voisinage des glaces flottantes, des rivages neigeux et congelés, et de la croûteendurcie de la merdu Nord; elle n'y succombe pas du moins, lorsqu'il n'est pas excessif. Elle résiste à la chaleur des mers des tropiques; et nous verrons en parcouran l'bistoire des animaux de sa famille, qui peutetre sont des races plus ou moins anciennes, lesquelles lui doivent leur origine, que le spare auquel nous avons donné le nom de notre savant ami Desfontaines, se plait au milieu saeaux thermales de la Barbaríe. Cette analogie avec les eaux thermales ne pourrait-elle pas être considérée d'ailleurs comme un reste pas cette convenance de f'organisatio un reste de et des habitudes de f'organisation, des besoins et des habitudes avee des fluides plus échauffè que l'eau des fleuves ou des mers de nos jours quia dù exister dans les espèces contemporaines chés sous les nos continents étaient encore cachers sous les eaux, au moins si nous devons penseravec les Leibuitz, les Buffonet les Laplace, que la température générale de notre planète, et par cónséquent cellè des mers de notre globète, ment de l'ère plus élevée avant le commencement de l'ère de l'existence de nos continents que dans les siècles qui viennent de s'écouler Quoí qu'il en soit de cette dernière conjecture faisons remarquer que parmi ces déponjecture, dorade, qui attestent en mém ces dépouilles de sieurs des révolutiont en méme temps et plu. sieurs des révolutions qui ont changé la face de la terre, et l'ancienneté de l'espéce dont nons icriıons l'histoire, les fragments les plus nous ces portions des animaux, dont la conform tion toujours la mème prouve le mieux la dori des principaux caractères de l'espèce, parce de la constance de leur manière d'étre on de conclure la permanence de la manière de vira de l'animal, et de ses autres principales habi tudes, toujours liées avee les formes extérien. res et les organes intérieurs les plus importants. Cês restes d'anciennes dorades qui habitaientl'0. céan it y a des milliers d'années, sont des portions de máchoire, ou des màehoires entières garnies de leurs dents ineisives et de leurs rab. gées nombreuses de dents molaires. Pour eom. parer avec soin ces antiques dépouilles avec les dents des dorades actuellement vivantes, il ne faut pas perdre de vue qu'indépendamment de six incisives arrondies et séparées les unes des autres, que l'on trouve sur le devant de chaque mâchoire de ces spares, la mâchoire supérieure est armée ordinairement de trois rangs de mo. laires. Le premier de ces rangs coutient dix ma. chelières de chaque cóté, Le second et le troksième n'en comprennent pas un aussi grand particulièrement les plus éloiguées du bout du museau, sont plus grandes et plus fortes que les autres. On remarque le plus souvent, dans la máchoire inférieure, des linêaments d'u quatrième rang de molaires, ou une qua trième rangée intérieure très-bien conformée; en général, la quantité de rangées et de molalres parait augmenter avec la grandeur et par conséquent avee l'áge du poisson. La configuatiou de ces máchelières varie aussi vraisem hablement avee les dimensions de l'animal: mais le fond de cette configuration reste, et ces dents destinées à broyer ont le plus fréquemment une forme ovale ou demi-sphérique, plus ou moins régulière, convexe ou aplatie, et même quelquefois un peu concave, peut-être suivant le nombre et la résistance des corps durs que le spare a été contraint d'écraser, et qui, par leur réaction, ont usé cés instruments de nutrition ou de défense journalières.

Ce sont ces molaires fossiles, ou arrachées à pare dorade morte depuis peu de temps, mais particulièrement les fossiles les plus grandes et les plus régulières, que l'on a nommées $C r a-$ paudines ou Bufonites, de mème que les máchelieres de l'Anarhique Loup, et celles de quelques autres poissolis, parce qu'on les a nombre; mais celles de la troisième rangée, et crues, comme ces dernières, des pierres produites dans la tête d'un erapaud. On les a recherchées, achetées assez cher, enchåssées dans des métaux préeieux; êt conservées avee soin, soit comme de petits objets d'un luxe particulier, soit comme douées de qualités médicinales utiles. On a surtout attaché un assez grand prix, au moins à certaines époques, aux molaires de dorade que l'on trouve dans l'intérieur des couches de la terre, et qui, plus ou moins altérées dans leur couleur par leur séjour dans ces couches, offrent différentes nuances de gris, de brun, de roux, de rouge brunâtre, On a estimé encore dâvantage ces mâchelières dont on Iguorait la véritable nature, lorsque leurs teintés, distribuées par zones, ont montré dans leur centre une tache presque ronde et noiratre. On a comparé cette taché foícée à une prunelle; on a vu dans ces molaires ainsi colorées une grande ressemblanee avee un wil; on leur a donné le nom d'OEil de Serpent; on les a supposées des yeux de serpent pétrifiés; on leur a dès lors attribué des vertus plus puissantes; on les a vendues plus cher ; et, en conséquence, on les a contrefoites dans quelques endroits voisins des parages fréquentés par les dorades, et particalièrenent dans l'ile de Malte, en faisant avec de l'acide nitreux une marque noire au centre des molaires de spare dorade non fossiles, et prisés sur un individu récemment expiré.

prises sur un individu recemment expire.
Les máchoires qui sont garnies de ces dent molaires ou ineisives dont nous venous de parler, n'avancent pas l'une plus que l'autre. Chaque lève est charnue; l'ouverture de la bouche que lèvre est péu étroite; la téte comprimée, très-relevée à l'endroit des yeux, et dénuée de petites écailles sur le devant; la langue épaísse, courte et lisse; l'espace compris entre les deux orifices de chaque narine, marqué par un sillon; l'opercule revêtu d'éeailles semblables à celles du dos, et arrondi dans son contour; le corps élevé; le dos caréné ; le ventre convexe; l'anus plus voisin de la caudale que de la tête; et l'ensemble du corps et de la queue, couvert d'écailles tendres et lisses, qui s'étendent sur une portion de la dorsale et de la nageoire de l'anus.

Telles sont les formes principales de la dorade. Sa grandeur est ordinairement considérable. Si elle ne pèse communément que einq ou six kilogrammes dans certains parages, elle en pése jusqu'à dix dans d'autres, particulière ment aupres Jes rivages de la Sardaigne; et te
Veygeur suedois Hasselquist en a vu dans I'Archipel, et notamment auprès de Smyrne, qui avaient plus de donze déeimètres de longueur. Ce spare, suivant son âge et sa grandeur, re coit des pécheurs de quelques cotes maritimes, des noms différents que l'on trouvera dans la synonymie placée au commencement de cet artiele, et qui seuls prouveraient combien on s'est oceupé de ce poisson, et combien on a cherché a reconnaitre et à distinguer ses diverses manières d'être.

L'estomac de la dorade est long; le pylore garni de trois appendices ou coeums; le canal intestinal proprement dit, trois fois sibueux ; ie péritoine noir ; et la vessie natatoire placée audessous du dos.

Indépendamment du secours que ce spare ire de cette vessie pour nager avec facilite, il recoit de la force de ses muscles, et de la vitesse avee laquelle il agite ses nageoires, une grande légèreté dans ses mouvements, et une grande rapidité dans ses évolutions : aussi peut. II, dans un grand nombre de eirconstances, satisfaire la voracité qui le distingue; it le peut d'autant plus, que la proie qu'il préfere ne lui échappe ni par la fuite, ni par la nature de l'abri dans lequel elle se renferme. La dorade aime th se nourrir de crustacées et d'animaux à coquille, dont les uns sont constamment attachés i la rive ou au bane de sable sur lequel ils sont nés; et dont les autres ne semeuvent qu'avec une lenteur assez grande. D'ailleurs, ni le tét des crustacées, ni même l'enveloppe dure et calcaire des animaux à coquille, ne peuvent les garantir de la dent de la dorade : ses máchoire sont si fortes, qu'elles plient les crochets des haims lorsque le fer en est doux, et les cassent s'ils ont été fabriqués avee du fer aigre; elle écrase avee ses molaires les coquilles les plus épaisses; elle les brise assez bruyamment pour que les pécheurs reconnaissent sa présence aux petits éclats de ces enveloppes concassées avec violence; et afin qu'elle ne manque d'aueun moyen d'apaiser sa faim, on prétend qu'elle est assez industrieuse pour découvrir, en agitant vivement sa queue, les coquillages enfouis dans le sable ou dans la vase.

Ce goút pour les crustacées et les animaux a coquille détermine la dorade à fréquenter souvent les rivages comme les lieux ou les coquillages et les crabes abondent le plus. Cependant II parait que, sous plusieurs elimats, I'habita- 
tion de ce spare varie avec les saisons : il craint le trés-grand froid; et lorsque I'hiver est trèsrigoureux, il se retire dans les eaux profondes, ou il peut assez s'éloigner de la surface, au moins de temps en temps, pour échapper à l'influence des gelées très-fortes.

Les dorades ne sont pas les seuls poissons qui passent la saison du froid dans les profondeurs de la mer, qu'ils ne paraissent quitier, pour venir à la surface de l'eau, que lorsque la chaleur du printemps a commencé de se faire sentir, et qui bien loin d'y être engourdis, $\dot{y}$ poursuivent leur proie, s'y agitenten différents sens, y conservent presque toutes leurs habitudes ordinaires, quoique séparés, par des couches d'eau très-épaisses, de l'air de l'atmosphère, et mème de la lumière, qui ne peut du moins parveni jusqu'à leurs yeux qu'extrêmement affaiblie. Si ce grand phénomène était entièrement constaté, il donnerait l'explication des observations particulières, en apparence, contraires a ce fait très-remarquable, et qui ont été publiées par des physiciens très-estimables. Il montrerait peut-être que si quelques espèces de poissons, soumises à des circonstances extraordinaires, et placées, par exemple, dans de trèspetits volumes d'eau, paraissent forcées, pour conserver leur vie, de venir de tempsen temps a la surface du fluide dans lequel elles se trouvent plongées, elles y sont quelquefois moins contraintes par le besoin de respirer l'air de l'atmosphère, que par la nécessité d'échapper à des emanations delétères produites dans le petit es. pace qui les reuferme et les retient captives.

On a éerit que la dorade eraignait le chaud aussi bien que le très-grand froid. Cette assertion ne nous parait fondee en aucune maserà moins qu' on n'ait vouln en aucune manière ; très elevée, on n'ait voulu parler d'une chaleur qués elevée, et, par exemple, supérieure à celle qui parait très-bien convenir au Spare Desfonlaines. Si en général une température chaude etait contraire à la dorade, on ne trouverait ce poisson dans des mers très-voisines de la ligae ou des tropiques. En effet, quoique la dorade habite dans la mer du Nord, et dans toute la partie de la mer Atlantique qui sépare l'A toute rique de l'Europe, on la pèche aussi dans !a Mediterranée, non-seulement auprès des cótes de France, mais encore aupres de celles de Ia campagne de Rome, de Naples, de la Sarda Burbarie. Sicile, de Malte, de la Syrie, de la

des Grandes Indes, mers du Japon, dans celle a commes exemple, auprès des rochers que l'on voit sou une grande étendue des bords de la Méditern née, la dorade passe une partie assez consid rable du jour dans les creux et les divers asil que ces rochèrs peuvent lui présenter, ce n'es pas, au moins le plus souvent, pour éviter un chaleur trop importune produite par la présene du soleil sur l'horizon, mais pour se livrer are plus de calme au sommeil, auquel elle aime s'abandonner pendant que le jour Juit encore, et qui, suivant Rondelet, est quelquefois si profond quand la nuit, préférée presque toujours par la dorade pour la recherche de sa proie, n'a pas commencé de réguer, qu'on peut alors pres. dre facilement ce spare en le harponnant, on le perçant avec une fourche attachée à une longue perche.

Dansle temps du frai, et par conséquent dans le printemps, lesdorades s'approchent non-seg. lement des rivages, mais encore des embouch. res des rivières, dont l'eau douce parait alors leur étre au moins très-agréable. Elles s'engagênt souvent à cétte époque, ainsi que vers d'autres mois, dans ies étangs ou petits laes sa. lés qui communiquent avee la mer : elles s'y nourrissent des coquillages qui y abondent; elles y grandissent au point qu'un seul été suffit pour que leur poids y devienne trois fois plus considérable qu'auparavant; elles y parviennent a des dimensions telles, qu'elles pesent neuf ou dix kilogrammes ; et en y engraissant elles acquièrent des qualités qui les ont toujours fait rechercher beaucoup plus que celles qui vivent dans la mer proprement dite. On a préféré sur tout, dans les départements méridionaux de France, celles qui avaient vécu dans les étangs d'Hyères, de Martigues et de Latte, près du cap de Cette. Les anciens Romains les plus diffieiles dans le choix des objets du luxe des tables, estimaient aussi les dorades des etangs beaucoup plus que celles de la Méditerranée: voila pourquoi ils en faisaient transporter dans les ress intérieurs qu'ils possédaient, et particulièrement dans le fameux lac Lucrin. Columelle mẻme, dans sés ouvrages sur l'économie rurale, couseillait de peupler les viviers de ces spares: céqui prouve qu'il n' les viviers de ces spares laquelle on peut acour à vivre dans l'eau douce, et les y faire multi- plier. Cette convenance des eaux des lacs non salés des riviereset des fleuves, aveel'organisation des spares dorades, et la supériorité de goùt que leur chair contracte au milieu de ces rivières, de ces lacs et des viviers, n'ont pas échappé à Duhamel; et nous partageons bieu vivement ledesir que Bloch a expriméen conséquence, de voir l'industrie de ceux qui aiment les entreprises utiles, se porter yers l'acelimatation ou plutót le transport et la multiplication des dorades an milieu de ces eaux douces qui perfectionnent leurs qualités.

Au reste, lorsqu'on veut jouir de ce goùt agréable de la chair des dorades, il ne suffit pas de préférer celles de certaines mers, et particulièrement de la Méditerranée, à celles de I'Océan, comme Rondelet et d'autres écrivains l'ont recommandé, de rechercher plutót celles des étangs salés que celles qui n'ont pas quitte la Méditerranée, et d'estimer, avaut toutes les autres, les dorades qui vivent dans de l'eau douce : il faut eneore avoir l'attention de rejeter ceux de ces spares qui ont été péchés dans des eaux trop bourbeuses et sales, les dorades trop grandes, et par conséquent trop vieilles et trop dures; et enfin d'attendre, pour s'en nourrir, l'automne, qui est la saison ou les propriétés de ces poissons ne sont alterées par aucune eirconstance. C'est pour n'avoir pas usé de cette précaution, que l'on a souvent trouvé des dozades difficiles à digérer, ainsi que Celse l'a éerit; et e'est au contraire paree que les anciens Romains ne la négligeaient pas, qu'ils avaient des dorades d'un goùt exquis, et d'une chair légère et trèssalubre : aưssi en ont-ils donné de très-grands prix, et un Romain nommé Sérge attachait-il une sorte d'honneur à étre surnommé Orala , a cause de sa passion pour ces spares.

Les qualités médicinales qu'on a attribuées à ees poissons, et particulièremént la vertu purgative, et la faculté de guérir de certaines indigestions, ainsi que de préserver des mauvais effets de quelques substances vénéneuses, ont de mème, pendant quelques siècles, fait rechereher ces osseux. Du temps d'Elien, on les prenait, en formant sur la grèse que la haute mer devait couvrir, une sorte d'enceinte composée de rameaux plantés dans la vase ou dans le sable. Les dorades arrivaient avee te flux; $e t$ arrétées par les rameaux lorsque la mer baissait et qu'elles voulaient suivre te reflux, elles étaient retenues dans l'enceinte, ou mème des femmes et des enfants les saisissaient avee facilite. Bondelet dit qu'on employait, à l'époque où il éerivait, un moyen à peu près semblable pour se procurer des dorades dans l'etang de Latte, sur les bords duquel on se servait aussi de filets pour les pècher; et il y a peu d'añées qu'on usait dans différentes mers, pour la pé che des dorades, du bregin ', du verveu, ${ }^{2}$, du tremail ${ }^{3}$, et des haims garnis de chair de scombre, et de crustacées, ou d'animaux a coquille. Lorsqu'on prend une très grande quantité de dorades, on en fait saler, pour pouvoir a envoyer au loin; et lorsqu'on a voulu les manger fraiches, on les a préparées d'un très-grand nombre de manières, que Rondelet a eu l'attention de décrire avee beaucoup d'exactitude. Mais comme l'histoire de la nature n'est pas celle de l'art de la cuisine, passons aux differenices qui distinguent des dorades les autres espèces de spares, soit que nous considérion les formes, ou que nous examinions les couleurs, ou que nous observions les habitudes de ces poissons 4 .

LE SPARE SPARAILLON Sparns annularis, Linn., Gmel. S Sparus Sparulus, Lacep. i Sargus anublaris, Cuy, ‘

LE SPARE SARGUE ${ }^{\top}$,

Sparus Sargus, Linh., Gmel., Lacep., Sargus vulgaris, Guv, i et Sargus raueus, Geof, Cuv, ',

LE SPARE OBLADE ${ }^{\circ}$

Sparus Oblada, Lacep.; Sparus melauurus, Liou., Gmel, ; Oblada melauura, Cur." ". VT LE SPARE SMARIS " Sparus Smaris, Linn., Gmel., Lae ; Smaris vulgaris,
Cur."

On trouvé ces quatre poissons dans la Méditerranée.

- On pomme bregin ou buurgin, a Marseille, un filst qui resembile beaucoup au pelit bo

parté a Tarticte da Srombre thon.

2.) Voyrz larticle du Gade collin.

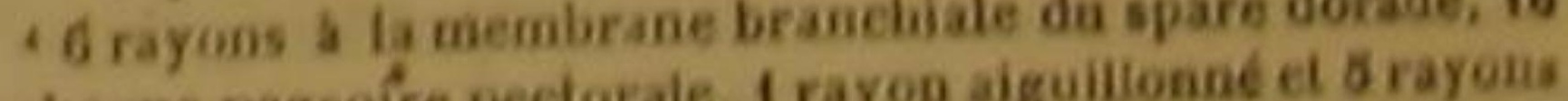
a chaque nageoire pectorale, 1 rayou aigo la eadale.

articules a chaque ibrius, - Raspailtion, Cante, dans quel. (joes depart mérid, - sparlo, Carlino, Carlinoto, ea lis. le. - Pisi, en Dalmatie - Smind, en Turquie - Spargu,

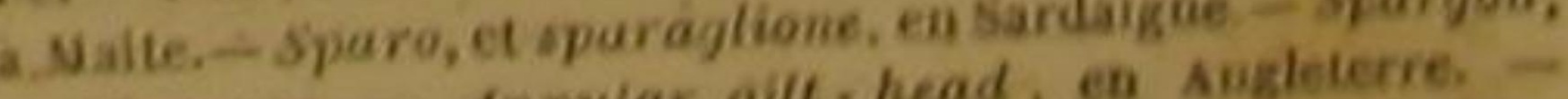
en Espagne. - Annular gut head, a traseen, en Alle. Schuarts ringel. Ringel.brassem, Sparbrasem, co Alic.

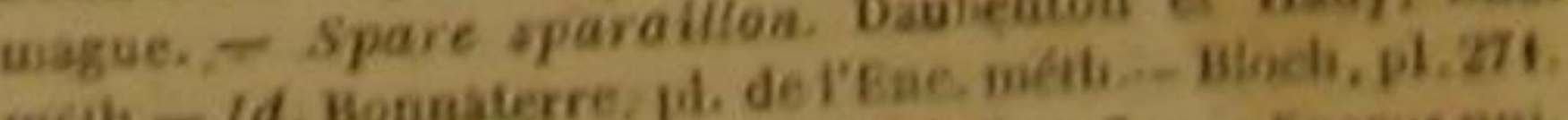

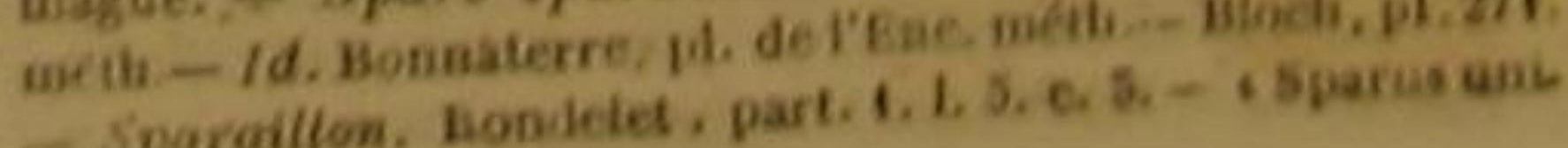


HISTOIRE NATURELLE

Le sparaillon a la tête petite; les deux mâchoires également avancées; celle d'en haut garnie de quatre rangs de molaires arrondies; celle d'en bas armée de deux rangées de molaires semblables; la langue libre; de petites

- color flavescens, maculá nigrá annulari ad caudam. , Ar-

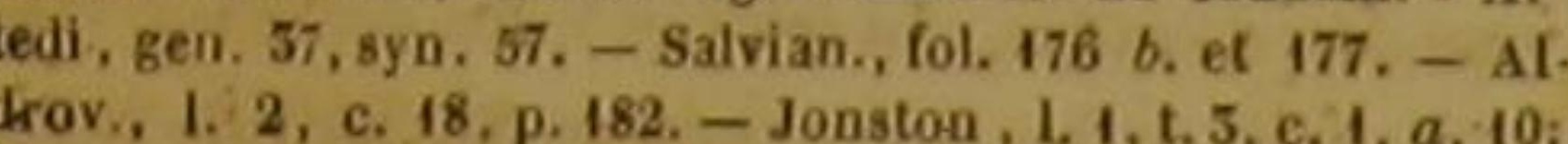
L. 18, n. 11. - Charlet., p. 14. - Wvillughby, p. 308. - Ra p. 129.-Sparus marinus. Gesner, p. $880 \mathrm{et} 1036$; el (germ.) ol. 25. b. - Dohamei, Traite des péches, part 2, sect. 4, c. 2 . p. 15, pl. 1, fig. 3.

parołtes. Cav. M. de Lacépéde a figuré dasanthoptéry gien in-40, sous le nom de Variélé du Sparaillon son ourrage, éd. fig. I, un poisson despeces différente, le ply hisodon sp. rolde, Cuv., de la fapuilte des Acanthoptérygieas labroides.

' Sargo, Sar, Sarg, dans plus. départ., et en Italie. Pagaro, en Dalmatie. - Base, en Angleterre. - Geissbras gem, et Crandirte-brassem, en Allemagne. - Spare sar de l'Enc. méth. - Bloch, puc, méth. - Id. Bonuaterre, pl. - Sparus linei, transversis rarius, - Mus. Ad. Frid. 2, p. 73 .

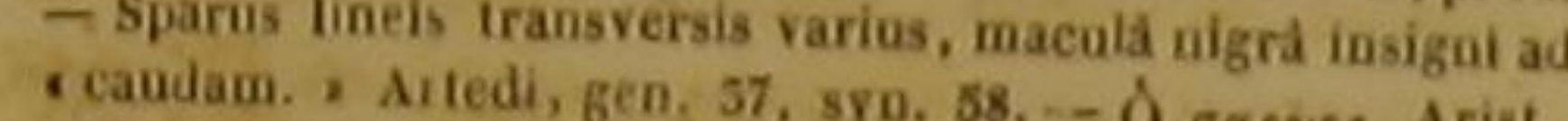

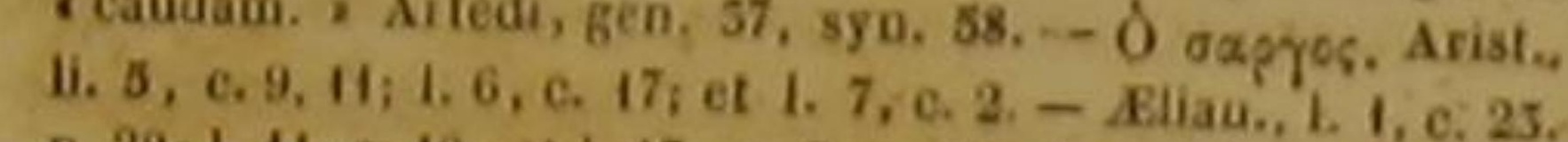

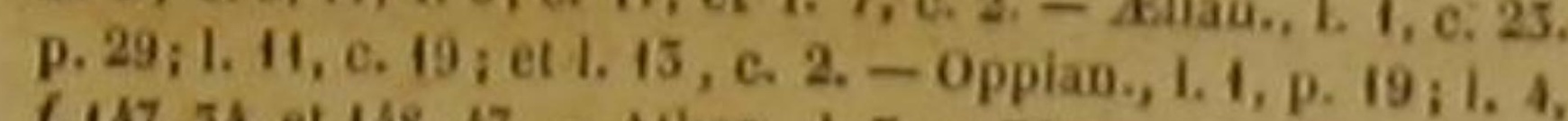
f. 147, 54, et 148, 47. - Altien., I. 7, p. 341. - Sargus. Plip 1.9, c. 17, 51, 59. - Jov, p. 74. - Sargo. Rondelet, part. ., L. 5, c. 5. - Salvian, fol, 178, b. 179 et 183 - Gesner, p. 823
et 993 , et et 993 , et (germ.) fol. 24, b. - Aldrov, 1. 2, c. 16, p. 176. Willoghby, p. 509. - c. 1, a, 9. 1. 19. - Charlet., p. 141. ovato tato, cauda bifurca, ete. $150,-$ Gronov. Cinædus corpore Type du geure Sargue, dans la famille des Acant nop. 219. giens sparoides. MM. Geoffroy et Cuvier en distingentéry. Sapeces; le sargue de Hondelet, $S$. raucus, et le sar doe do Salviani, $S$. vulyaris. D.

plus, contrées de littalie départ. mérid. - Oehiado, dans Haay, Enc. méth. - Id. Bonpare oblade. Daubenton et - Sparus lineis longiudinalibus variog, de I'Enc. méth. -

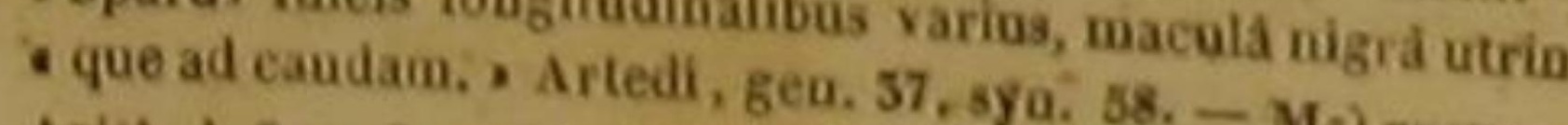
Arist, 1. 8, c. 2, Id, Blian,., 1. 1, c. 41, p. 48; I. 12, e. 17,
Id, Oppian., I. 1

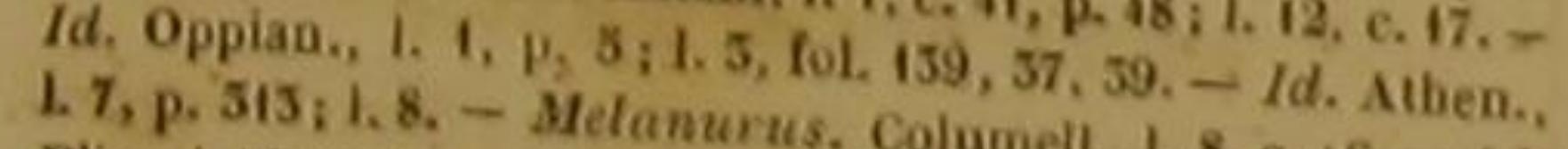

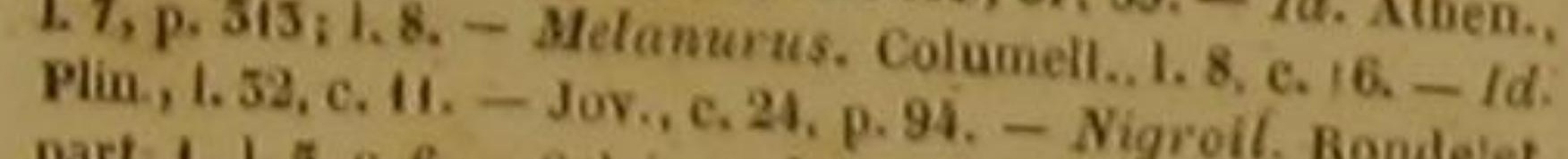
part, 1, 1.5, c. 6. - Salviau., fol. 181, 182 , - Gesner, p. 540 . n. 15. - Uharlet., p. 154, Jonston, 1. 1, t. 2, c. 1, a. 10, 1. 14, Aldrov, 1.1, c. 15, p.64. Willugbby, p. 310.- Rai, p. 13i, "Type du genre Obis

Aeanthopterygiens sparoides. D. Cuvier, dans la famille des
" Marsi-C

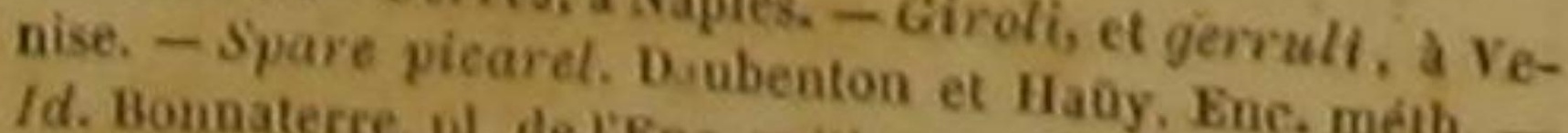

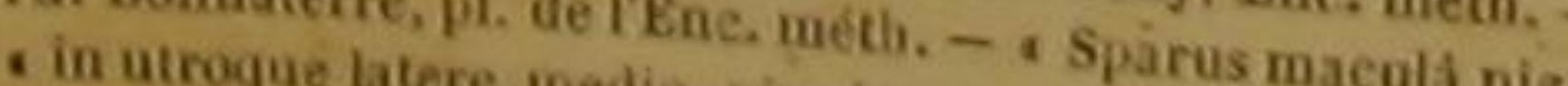

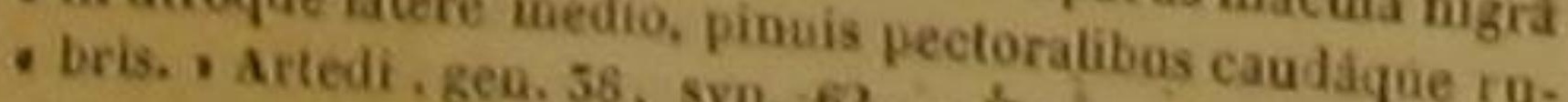

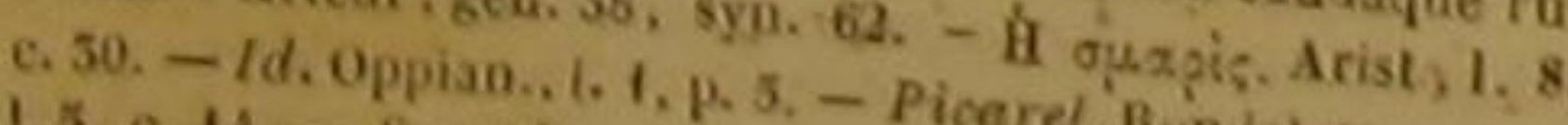

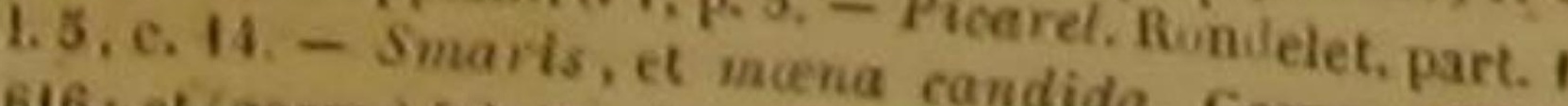
616 ; et (germ.) fol. 55, b. - Aldrov, 1.2. Gesner, 526 et

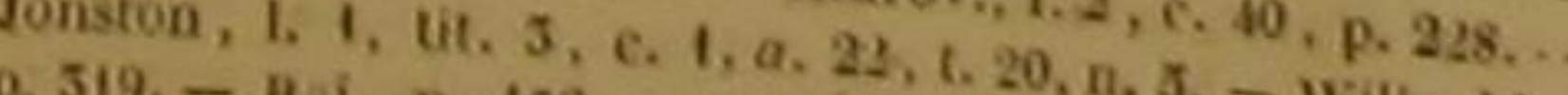

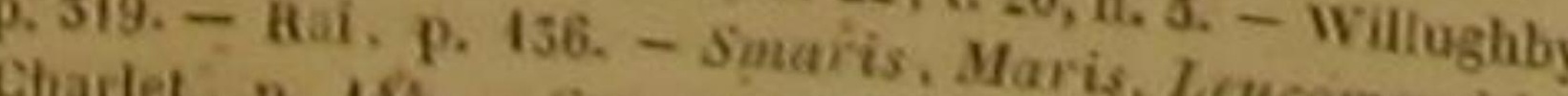
Martial. - Picarel. Velimont de Bomare, Dich. - Gerres. aLe spare Smaris ou Picarel, et quelques a d hist. nat.
furment

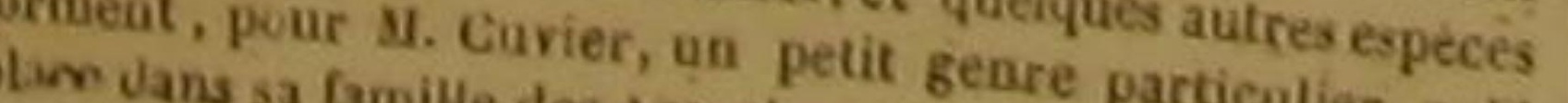
Dhim uans sa lamille des Acanilheptérygieas mesides. quili écailles sur la base de la nageoire de l'anus et sur celle de la caudale; le dos, les thoracines I'anale, et le bord de la caudale, noiràtres; des bandes transversales d'un noir brun; cin pendices auprès du pylore; le canal intestip long et très-sinueux; le péritoine noir. Sa ton gueur n'excède guère trois décimètres. Il est des parages où sa chair est trop molle pour soit recherché. Il fraie vers l'équinoxe du pul temps, se tient en grandes troupes près des rivages, entre, comme la dorade, dans les laes salés; suit la marée dans les rivières, fait quel. quefois des voyages très-longs, se cache peadant l'hiver dans les profondeurs de la mer, en sort très-maigre vers le milieu ou le commen. cement du printemps, s'il a éprouvé un froid assez vif pour tomber dans une sorte d'engon. dissement, multiplie beaucoup, se nourrit par préférence de moules et de petits crabes, et se laisse prendre facilement à un hameeon d'un morceau de crustacée. On le pêche particulièrement dans l'Adriatique, dans les eaux de la Toscane, et dans le lac de Cagliari.

It ressemble beaucoup à la dorade et at sargue.

Ce dernier spare, indépendamment de ses larges incisives et de la double rangée de molaires arrondies que l'on voit à chaque mâchoire a la partie de l'intérieur de la bouche, qui es située derrière les incisives d'en haut et derrière celles den bas, pavée de dents courtes et aplaties : aussi écrase-t-il avec facilité des corp très-durs, et se nourrit-il des polypes des coraux; et des mollusques des coquilles. Sa langue néanmoins est lisse. Les écailles qui recouvrent les opercules sont plus écailles qui recoudu du dos. La partie supérieure du eorps est comme carénée. Trois appendices ou çecums sont situés auprès du pylore. La couleur générale parait argéntée. Un très-grand nombre de raies longitudinales dorées, ou jaumes, ou couleur d'orange, la relèvent, ainsi que la ligne latérale, qui est composée de petits traits noirs, les: bandes étroites et transversales que le tableau générique indique, et la nuance noiratre de la nuque, du dos, des thoracines, d'une par. tie de la queue, et du bord de la caudale. Le sargue ne vit pas seulement dans la Me diterranee : on le tronve aussi dans l'Océan au moins auprès de plusieus cotans l'Océan, dans la mer Rouge et dans le Nil, ou l'on péche pèce pour en transporter jusqu'au mont Sinaĩ ; et il y parvient quelquefois à la longueur de six ou sept décimètres.

Aristote a eu raison de compter le sairguie parmi les poissons qui se réunissent en troupes et qui fréquentent les rivages. Peut-être ce grand naturaliste n'a-t-il pas eu autant de raison de dire que ce spare frayait deux fois par an, dans le printemps et dans l'automne.

Comme dans presque toutes les espèces de poissons, on trouve dans celle du sargue plus de femelles que de mâles.

Lorsque ce spare a passé l'été dans une sorte d'abondance, et qu'il a vécu dans des endroits rocailleux, sa chair est tendre et délicate.

A l'égard de l'amour merveilleux qu'Élien et Oppien ont attribué à ce thoraeín pour les chèvres, et de la propriété qu'on a supposée dans les ineisives ou les molaires de ce spare, qui, portées avec soin, préservent, dit-on, de tout mal aux dents, nous ne ferons pas à nos lecteurs le tort de les prémunir contre des assertions dont l'état actuel de la science ne permet pas de craindre la répétition.

Je crois que nous devons regarder comme une variété du sargue un poisson que le naturaliste Cetti a fait connaitre dans son histoire intéressante des amphibies et des poissons de la Sardaigne, et que le professeur Gmelin a inserit parmi les spares sous le nom spécifique de Puntazzo, dans la treizième édition de Linnée, qu'il a donnée au public. Ce puntazzo ne nous a paru, en effet, différer du sargue, que par des traits très-peu nombreux ou trèspeu essentiels, à moins que la forme de la caudale de l'un ne soít aussi peu semblable à la forme de la caudale de l'autre que la phrase du professeur Gmelin parait I'indiquer; ce dont nous doutons cependant dautant plus que ce savant lui-mème fait remarquer de très-grands rapports de conformation, de grandeur et de couleur, entre le sargue et le puntazzo.

Loblade a la mâchoire inférieure hérissée de dents petites, aiguès et nombreuses. Son dos est d'un bleu noirâtre. Plusieurs raies longitudinales brunes s'étendent sur les cotés, qui sont argentés, et sur lesquels on voit aussi quelques taches grandes, le plus souvent trèsirrégulières et d'une nuance obscure. Une de ces taches, placée près de la caudale, y repré-

ces taches, placée près de la
sente une bande transversale.

Ce spare ne pèse communément que cinq hectogrammes. Mais si les individus de cette espèce sont faibles, leur instinet leur donne les petites man̋uvres de la ruse. il est assez difficile de les prendre dans une nasse, au tilet, et surtout à l'hamecon; on dirait que l'habitude de n'être poursuivis par les pécheurs que pendant le beau temps, leur a donné celle de se tenir tranquilles et cachés dans le sable ou dans le limon lorsque le ciel est serein et que la mer est ealme. Mais si les ondes sont bouleversées par les vents déchainés, ils parcourent en grandes troupes de très-grands espaces marins ils vont au loin chercher l'aliment qu'ils préférent, sans être retenus par les flots agités qu'ils sont obligés de traverser, et s'approchent sans crainte des rochers des rivages, si ces rive battues par la mer courroucée leur présentent une nourriture qui leur convienne. Des pécheurs industrieux ont souvent choisi ces temps de tempette pour jeter dans l'eau de petites masses dé pain et de fromage pétris ensemble, que les oblades avalaient sans danger, dont ces spares pouvaient revoir l'image sans méflance, et au. pres desquelles on plongeait bientot des hamecons garnis d'une composition semblable, dont les précautions ordinaires de ces thoracins ne les éloignaient plus. Duhamel nous apprend que les habitants de la cote voisine d'Alicante en Espagne attirent ces animaux avee de petites boules de soufre; et nous trouvons dans Pline, qu'auprès d'Herculanum et de Stabia les oblades s'approchaient assez de la rive pour prendre le pain qu'on leur jetait, mais qu'elles avaient assez d'attention et d'expérience pour distinruer l'appát perfide qui tenait à un hameçon. Le smaris a les nageoires pectorales et thoracines terminées en pointe. Une belle tache noire relève la blancheur ou la couleur argentée de ses cotés. Du temps de Rondelet, on prenait sur plusieurs cótes de la Méditerranée, et particulierrement sur les rivages septentrionaux de cette mer, une grande quantité de smaris. Les pécheurs les exposaient a l'air pour les faire sécher, ou les conservaient en les imbibant de sel, ce qui donnait à ces poissons un goût trèspiquant et les faisait nommer Picarels dan plusieurs contrées de France, ou les laissaient tremper et fondre, pour ainsí dire, dans de l'eau salée, pour obtenír cette composition nommée Garum, dont les anciens étaient si avides, et qu'ils appelaient une liqueur exquise' '.

qu'ils appelaient une liqueur exquise'. 
LE SPARE MENDOLE', Sparus Mæna, Linn., Gmel.: Sparus Mendola , Lacep.;
Mæna volgaris, Cuv.?

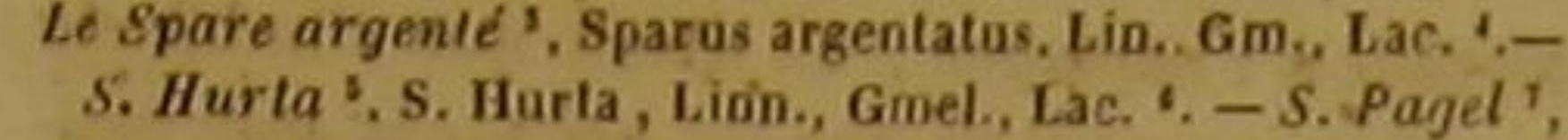
S. erythrinos, Línn., Gmel.; S. Pagel, Lac.; Pagelus vulgaris'. - S. Pagre ', S. Pagrus, Lion., Gmel., Lacep.;

La mendole, le hurta et le pagre habitent dans la Méditerranée; le pagel se trouve dans

chacune des pectorales, 1 rayon aigullionné et 5 rayons articules a chaque thoracine, 20 rayons a la caruale. -6 rayons

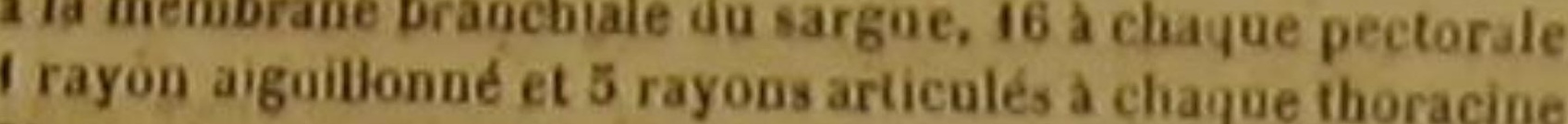
22 rayons a la nageoire de la queue. -6 rayons a la mem

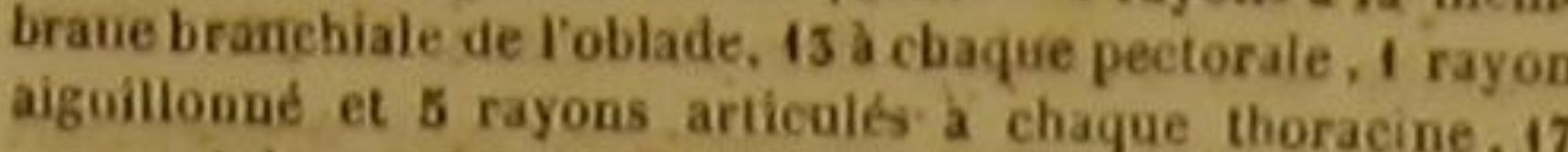
rayous a la ciudde. -6 rayons a la membrane branehiale do stmaris, 14 a chaque pectorate, 1 rayon aiguillowiné et de la quene. Cagarel

contrees merid. de France, - Mundoure, dans quelques la Ligurie el a Houre. - Minula a Malle. - Maris, Serola, par les Grecs modernes. - Menela, a Venise. - Sclave, par Laxir.fisch ier Adratique. - Scheisser, Scheepserling laude. - Cackerel, en Angleterse - Zeessoliyter, en Hö hienton et Haay, Ene. méth. - Id, Bopare mendole: Dauméih. - Hloch, pl. 270 - - Sparus varins, were, pl, de I'Ene.

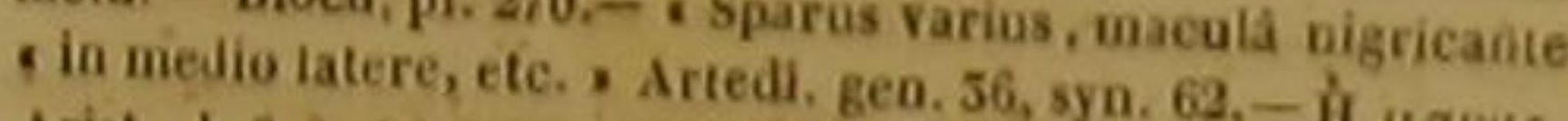
Arist., L. 6, C. 15, 17; 1. 8, c. 30; L. 9, c 2-0 - opian, L Lativis. - Attien, 1. 7. p. 515, - Mena. Plin.. 1:9, e. 26, dote. Rondelet, part, 1. I. 5, c. 15, - Mendole. Valmont

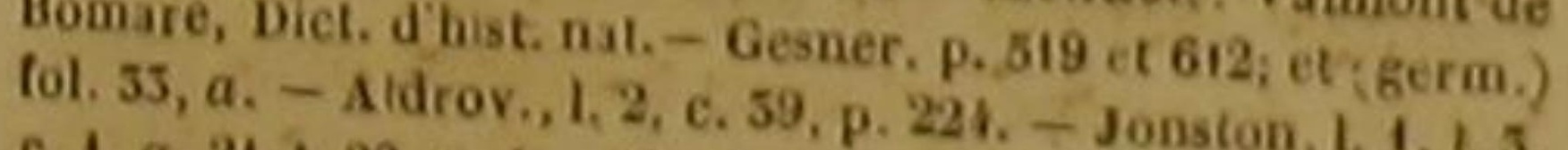

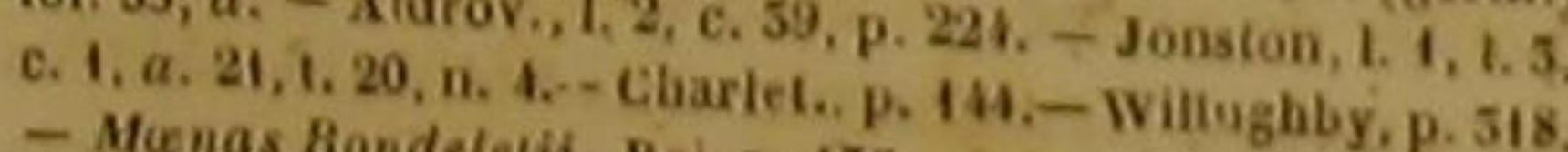
- Munas Rondeletii, Rai, p. 155 ,

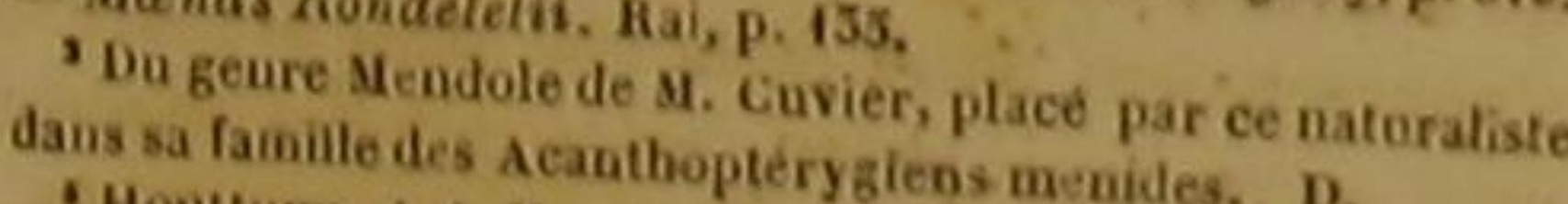

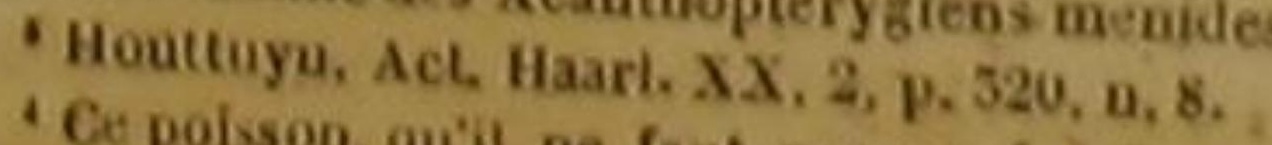

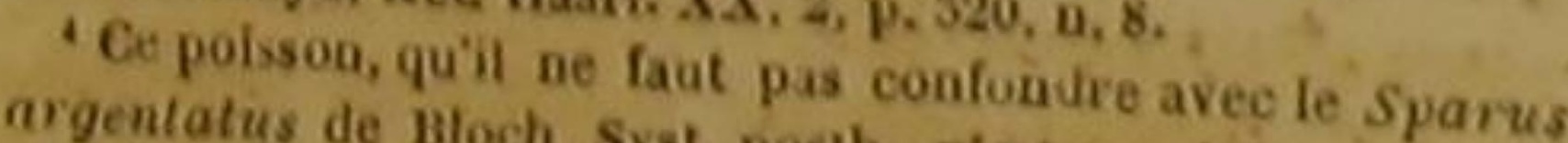
vien. D.
ves de Bloch, Syst. posth., n'est pas cité par $M$. Cu-

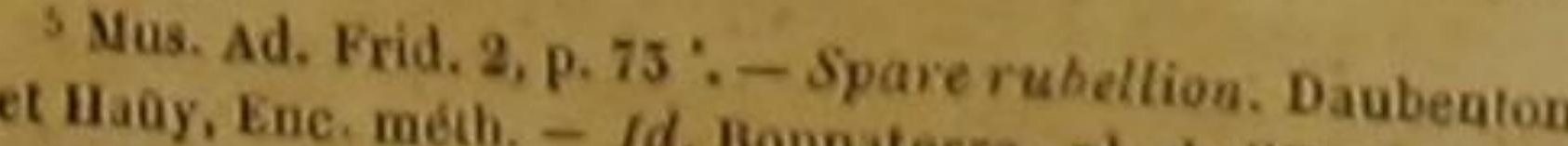
'M. Cuvier ne cite pas ce poisong. p. de l'Enc. méth. Pageur, Pageau, Pageu, dems

Rauce, - Pegel, eu Espagne, - Pagestlog passda midi de la Alboro, a Matte. - Frangolino et fragolino a A Ro gee. - Koode bro, a Venise. - Koth-schuppe, an Alle. lerre. - Bouccanégre, aur ande. - Sea rough, eu Angleentou et Haúy, Eue, thétb. - Id B - spare pagel. Dan-

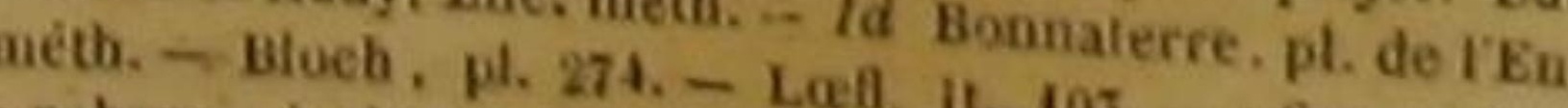

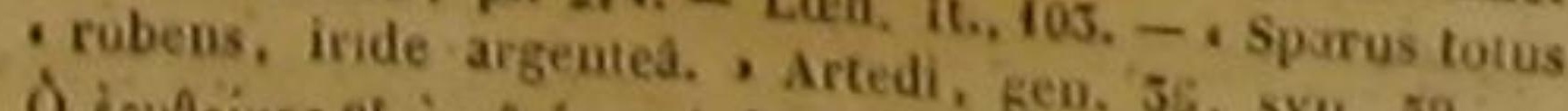

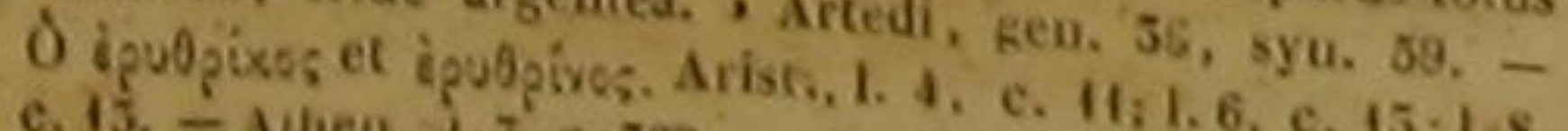

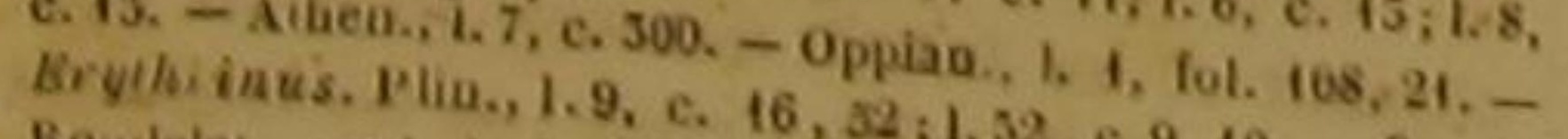

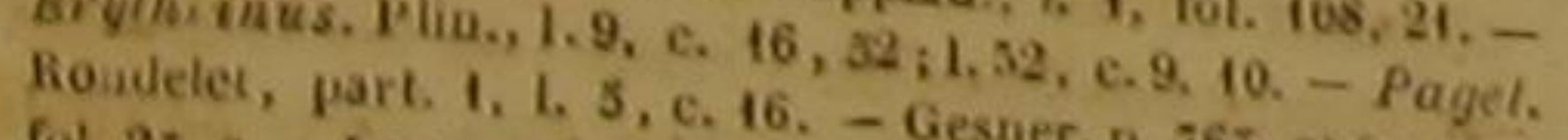

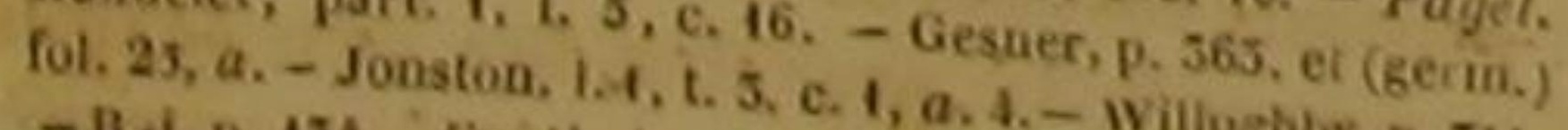
- Ris, p. 134.-Bryethrinus, sive rubellio. Salviany, p. S11.

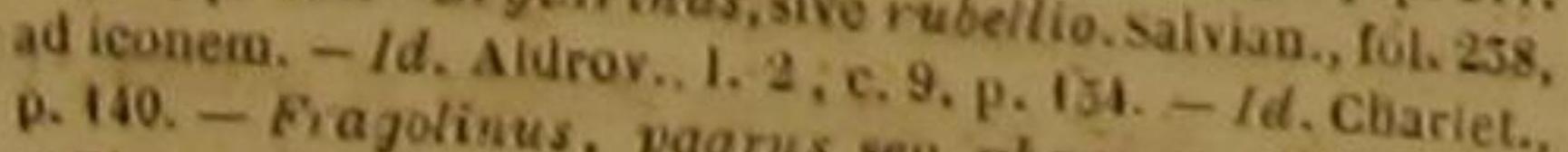
p.71. - Eritrinus primus seu major, vulgó boucandigne

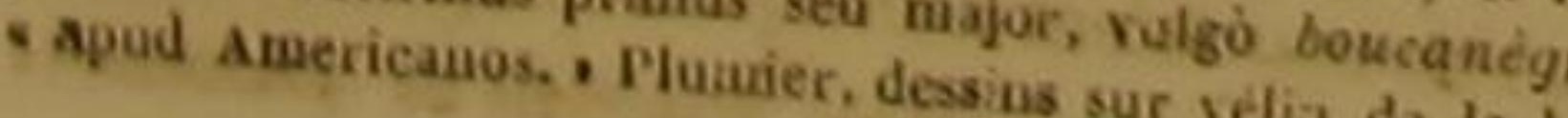

la Méditerranée, dans l'Océan Atlantique, dan grand Océan équinosial, dans la mer Japon ; et c'est cette dernière mer, si fertile tempêtes et dont les flots agités font retenti les rivages romantiques des iles japonaise qui nourrit l'argenté. Jetons un coup d'enis es formes et les habitudes de ces diat sur

La mendole a les deux mâchoires garnies d'un grand nombre de dents petites, pointues et placées derrière celles que nous avons con parées à des poinçons dans te tableau générique. La langue est lisse; le palais rude; la máchoire supérieure aussi avancée que l'inférieure; l'opercule garai de petites écailles, et composéde plusieurs pièces.

La couleur générale de cet osseux est blanchâtre, avec des raies longitudinales très nombreuses, étroites et bleues, toutes les nageoires rouges, et une grande tache noire de chaque cóté, à peu près au-dessus de l'anus. Mais la menidole offre un exemple remarqu ble des changements de couleurs auxquels plusieurs poissons sont sujets. Les nuances que nous venons d'indiquer ne sont communémeut vives et très-distinctes que dans les parties de la Méditerranée les plus rapprochées de la cote Afrique, et vers le milieu de l'été; elles se ternissent lorsque l'animal fait quelque séjour vers des plages moins méridionales; elles s'effacent entièrement et se changent en une teinte blanche, lorsque I'hiver a remplacé l'été : et

Hiotheque do Musium d'histoire naturelle :- - Pagel, Val. Hont de Bomare, Dict. d hist. nat. a famille de Acan genre Pagel, formé par M. Cuvier, das 'Phagros, en Portugat - Pavpalides. D.

- Pagra, en Sardaigne. - Pagru a Besoge, en Espagne. Ligurie. - Phagorio, dans plus astres con - Pagaro, Arborcllo, a Ancóne; - Aroum, en Dalmatie, - Mertsen, Turyure. - Rothe brassem, et sock flosser, en Allems et red - Lach brassem, en Hollande. - llacke, sea brean, tou, - Spare paca d weterre. - Arropuero, au cap Bre. Bounaterre, pl. Jele. Baubenton et Hauy, Enc. méth. - Id - rubescens, cute ad rafín - Blocil, pi. 267. - r Span. - producta. . Artedi, gen, 36 , syoum dorsi et ani in simia. 8, c. 15. - Id . Elian., I. 9, c. 7 p. 517, ó páyocs, Arist,

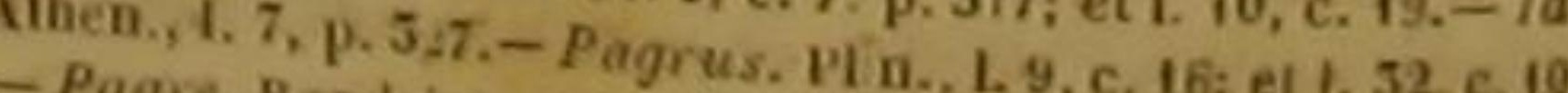

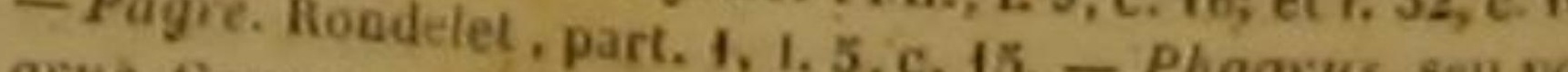
grus. Gesner, p. 656 ; et (germ.) fol $25, b$. Aldrov., L. 2
c. 8, p. 131.- W

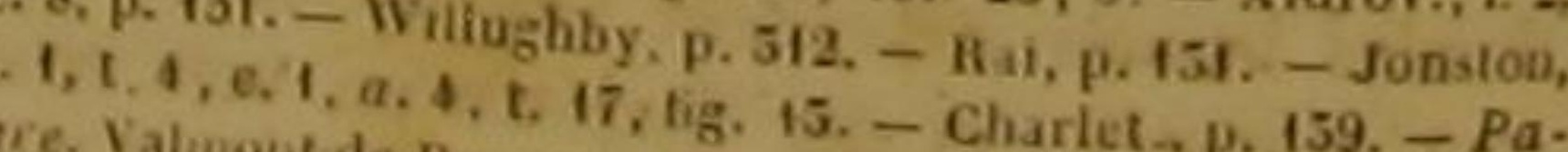

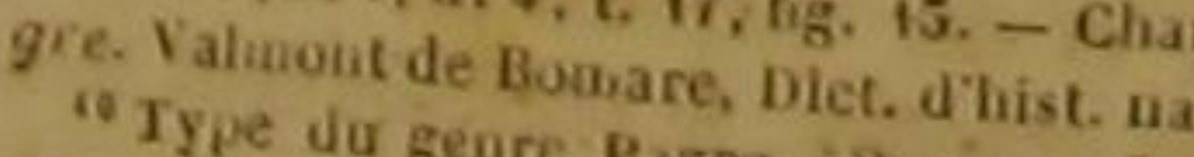
dans sa familine des deagihopt Pagrus, fonde par M.

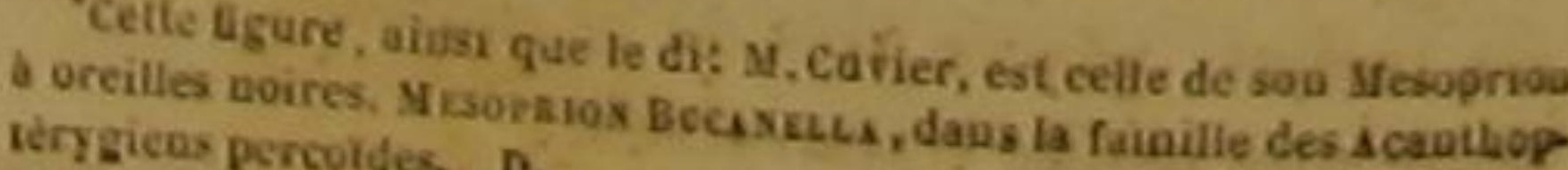

n'oublions pas de remarquer, en rappelant ce que nous avons dit de la coloration des poissons dans notre Discours sur la nature de ces animaux, que les couleurs des mendoles sont d'autant plus variées, qu'une habitation moins septentrionale et une saison moins froide les soumettent à l'intluence d'une chaleur plus intense, d'une lumière plus abondante, et d'un plus long séjour du soleil sur l'horizon.

Les mendoles sont très-fécondes : on les voit se rassembler en foule près des rivages sablonneux ou pierreux. Comme ces thoracins aiment à se nourrir de jeunes poissons, ils nuisem beaucoup au suecès de plusî́eurs péches, Leu chair est souvent maigre, coriace et insipide. Cependant, lorsque les mendoles se sont engraissées, leur goût n'est pas désagréable; et I'on dit que les femelles remplies d' $\propto$ ufs sont, dans certaines circonstances, assez bonnes à manger. Il est des endroits dans la mer Adristique, et partieulièrement auprès de Venise, ou l'on en prend a la ligne, ou au fllet, une si grande quantité, qu'on les vend par moncèaux t qu'on en fait saler un très-graud nombre. Dioscoride a prétendu que la sauce et la saumure de la mendole, prises intérleurement oo seulement appliquées sur le ventre, avaient une vertu purgative; et de cette assertion viennent quelques dénominations bizarres rapportées dans la première note de cet article, et employées, pour désigner les mendoles, pa les Allemands, les Hollandais et les Anglais.

Au reste, ces sparesn'ont ordinairement que deux décimétres de longueur Leur péritoine est noir, leur pilore garni de quatre coecums, et leur vésicule natatoire attachée aux côtes. Ajoutons que les mâtes de l'espèce que nous examinons présentent fréquemment desnuances ou reflets zoirâtres, surtout sur les nageoires et les opercules, pendant que les femelles sont encore pleines, et que, dès le temps d'Aristote, ils recevaient des Grès, à cette époque, de l'altération de leurs couleurs en noirâtre ou en noir, le nom de boucs (* $\left.\alpha_{\alpha} \times \circ\right)$. Nous avons vu, dans l'article du sargue, qu'Elien a parlé d'un prétendu amour de ces dẹniers poissons pour les chèvres. On pourrait trouver l'origine de cett croyance ridicule dans quelques contes absurdes substitués maladroitement par l'ignorance a une opinion peut-être fausse, mas que l'o. ne pourrait pas regarder au moins comme tresinvraisemblable. L'espéee du sargue et celle de la mendole ont tant de rapports l'une avee l'autre, que des mâles de la première peuvent très-bien, dans la saison du frai, rechercher les œufs pondus par les femelles de la seconde, et ces femelles elles-mèmes. Cette habitude aura été observée par les anciens Grees, qui dèslors auront parlé de Paffection des sargues pour les mendoles femelles. Ces mendoles femelles auront été désignées par eux sous le nom de Chìves, eomme les mendoles males létaient sous celui de Boucs; et dans un pays amidu merveilleux, et où l'histoire de la nature était perpétuellement melée avec les création de la mythologie et les inventions des poebtes, on aura bientot dit et répété que les sargues avaient une sorte d'amour assez violent, non pas pour des mendoles appelées Chèvres, mais pour les véritables chèvres que l'on conduisai dans les gras páturages arrosés par la mer.

Le spare argenté, que Houttuyn a fait conaaitre, n'est ordinairement long que de deux décimètres; et son épaisseur est à proportion plus considérable que celle de la dorade, à laquelle on l'a comparé.

Le corps ét la queue du hurta sont hauts et comprimés; sa dorsale est reçue dans un sillon longitudinal, lorsque l'animal I'incline et la couche en arriere.

Le pagel a deux rangées de dents petites et pointues placées dericière les dents antérieures. La langue et le palais de ce spare sont lisses. Chaque opercule est composé de trois lames; le dos caréné, et le ventre arrondi. La grande variété de nuances rouges dont brillent se écailles a teintes argentines, devrait le faire mulfiplier dans nos étangs et dans nos petíts laes d'eau douce, où il serait très-facile de le transporter et de l'acelimater et ou la vivacit de ses couleurs charmerait les yeux, en contrastant avec le bleu céleste ou le blanc un peo azuré d'une eau pure et tranquille. D'ailleursil est des saisons et des parages oú une nourriture convenable donne a la chair de ce spare une couleur blanche, une graisse abondante, et une saveur très-délicate. Pendant l'hiver, le pagel se rêfugie dans la haute mer; mais il vient, au printemps, déposer ou féconder ses aufs près des rivages, qu if n abandonne pas pendant l'été, pariee que sa veracité le porte à se nourrir des paree que sa voracite le pole a so nour ains dire, jeunes poissons qui pullulent, pour ainsi dire, auprès des cotes, pendant la belle saison, auss bien quà rechercher les moules, leb autres tes- 
tacées et les crabes, dont il écrase facilement I croúte ou les coquilles entre ses molaires nom breuses, fortes et arrondies.

A mesure que le pagel vieillit, la beautédesa parure diminue; l'ćclat de ses couleurs s'efface; ses teintes deviennent plus blanchâtres ou plus grises; et comme, daus cet état de dépérissement intérieur et d'altération extérieure, il a une plus grande ressemblance avec plusieurs espèces de son geñe, il n'est pas surprenant que des pêcheurs peu instruits aient cru ainsi que le rapporte Rondelet, que ces pagels devenus très-vieux s'étaient mêtamorphosés en d'autres spares, et particulièrement en Dentés ou Synagres, ete. Mais il est bién plus étonnant qu'un aussi grand philosophe qu'Aristote ait écrit que dans le temps du frai on trouvait que des pagels pleins d'œufs, et que, par conséquent, il n'y avait pas de mảles parm ces spares. Quoique cette erreur d'Aristote ait été adoptée par Pline et par d'autres auteurs anciens, nous ne la réfuterons pas; mais nous ferons remarquer qu'elle doit être fondée sur ce que, daus l'espèce du pagel, comme dans plusieurs autres espècesde poissons, le nombre des mâles èst inférieur à celuí des femelles, et que d'ailleurs ces mèmes femelles sont contraintes pour réussir dans toutes les petites opérations, sans lesquelles elles ne pourraient pas toujours se débarrasser de leurs œufs, de s'approcher des rivages plutot que lés mâles, et de sejourner aupres des terres plus constamment que ces derniers.

Au reste, le pagel parvient à la longueur de quatre décimètres.

Le pagre pèse quelquefois ciuq kilogrammes. Indépendamment des dents molaires indiqu dans le tableau, il a le devant de chiquées choire garni de dents petites, pointues, un perecourbées, serrées l'une contre l'autre; et de riere ces sortes d'incisives, l'on voit plusievrs rangées de dents bien plus petites, plus cosieu plus serrées, et émoussées. La langue est lisse les yeux sont gros; la nuque est large et lisse die; chaque opereule compose de deux piècenla couleur générale diun rouge de deux pièces le ventre argente; la teinte mêlé de jaune geátre; chaque cóté du poisson rayé longitudnalement de jaune ; et la base de ehaque pectorale, marquée d'une tache no de ehaque pecvoisinage de chaque opercule.

le paye reque opercule. raconte que, de son temps, Papparition de et osseux dans le Nil causait une joie général parmi la multitude, parce que l'arrivée de a spare ne précédait que de peu de jours le débor dement du fleuve.

Ainsi qué dans beaucoup d'autres cireonstaj. ces, ce qui d'abord n'avait paru qu'un signe agréable, avait été métamorphosé ensuite en une cause utile : on ětait allé jusqu'à attribver I'heureux évênement dé l'inondation fécondante a la présence du poissen; et bien loin de le pour. suivre pòur s'en nourrir, on l'avait placé parmi les animaux sacrés, et on lui rendait les hon neurs divins.

La chair du pagre est moins délicate pendant la saison où il vit dans les eaux douces des fleu. ves, que pendant le temps qu'il passe au milieu des flots salés de la Méditerranée ou de l'Océan. Cette différence doit venir de la plus grande difficulté qu'il éprouve pour se procurer dans les riviêres l'aliment qui lui convient le mieur. Il parait préférer, en effet, des crustacées, des nimaux à coquille, et le frai des sèches o. d'autres sépíés que l'on ne rencontre point dan 'eau douce ${ }^{-1}$. Quoi qu'il en soit; il abandone les rivières et les fleuves, lorsque l'hiver approhe; il se retire alors dans la haute mer et s'y enfonce dans des profondeurs oủ la températur de l'atmosphère n'exeree presque aucune in fluence. Pline pensait que si quelque obstaele empéchait le pagre d'user de ce moyen de se soustraire à la rigueur de l'hiyer, et le laissail exposé à l'action d'un très-grand froid, ce spare perdait bientôt la vue. En rappelant ce que nons avons dit dans plusieurs endroits de cette his. toire, et notamment dans l'article du scombre maquereau, on verra aisément qu'un affaiblissement daus l'organe de la vue, et une sorte de cécité passagère, doivent étre comptés parmi les principaux et les premiers effets de l'engourdissement des poissons, produit par un froid très-intense ou très-long.

C 6 rayons a ta membrane branchiale do spare mendole, is t chuquectorale 1 rayon aiguillonné et 5 rayons articulé chaque pectorale, 19 rayous a la caudale. -16 rayons i - 5 rayons a la de Targenté, 18 a la nageoire de la queue. cliaque pectorale 6 t dabe branchiale da spare harts, 16 dule, -5 rayons a la chaque thor-cise, 17 rayons a la can chaque pectorale, 1 rayon arane branchiale du pagel, $17 \mathrm{j}$ 6 rayo thoracine, 20 rayons à la nageoire de la guene. 6 rayons a la membrane branchiale du pagre 15 a chaque

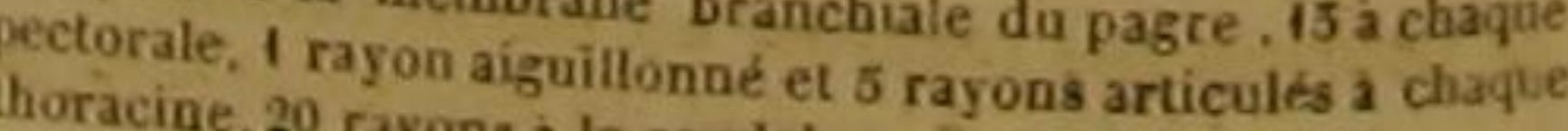

DES POISSONS.

Willughby, qui a observé le pagre sur la côte de Gènes, parait être le premier qui ait remarqué dans cet animal cette qualité phosphorique, commune à un grand nombre de poissons vivants, surtout dans les contrẻes chaudes ou tem. pérées, et par une suite de laquelle ils resplen. dissent quelquefois avee tant d'éelat au milieu des ténèbres '

Le pylore du pagre est garní de deux coecums longs et de deux cœeums courts ; son canal intestinal ne présente qu'une sinuosité, et sa vessie natatoire est attachée aux cótes.

LE SPARE PORTE-ÉPINE ${ }^{2}$,

Sparus spinifer, Forsk., Linu., Gmel., Lae.; Pagros spinifer, Cur. '.

Le Spare Bogue', Sparas Boops, Linó., Gmei, Lae ; Boops vulgaris, Cuv, s. - S. Canthere, S. Cantharus, Limn. Gmel., Lac ; Cantharus vulgaris, Cur, ', $-S$. Saupe 's S. Sarba, Forkik, Lina., Gmel., Lacep.; Chrysophiris Sarba Sur.".

Le porte-épine vit dans les endroits vaseux et profonds de la mer d'Arabie, oú Forskael l'a

' Voyez le Discours suir la nature des poissons.

Forkkael, Faun. Arab., P. 32, n. 25.-Square poit epine. Boneaterre, pi. de ITne, meti.

- Du geare Pagre, Cav, dans la famille des Acanthoptery giens sparoides. D.

Boope, sur quelques ootes de la mer Adriatique. - Boga dans la Ligurie. - Spare begue. Danbenton CI Haay, Enc. meth. - Id. Bonnaterre, pl. de IEvc., meth. - I Sparus it. - parallelis. . Artedi, gen. 56, syo. 61. - Baxa, Arist., 1.8,

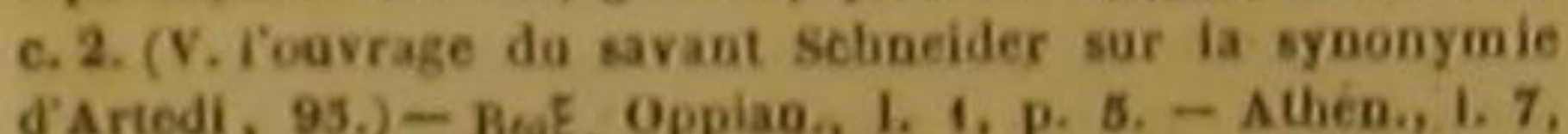
d'Ariodi, 93.) - Bę, Oppiano, L. 1, p. B. - Athen., L. 7 p. $286,-$ Box. Plis, L. 32 , c. M, p. $89 .-$ Boca. Jov., c. 21 . - Bogue. Rondelet, part. 1, 1. 14. - Boops. Gesner, p. 127, \$7, a (Germ.) fol, 33, 6. - Boops Bellonii, Boca specied, Venetiis picta. Aldrov., 1.2, c. 41, p. 231.-Boops, Charlet.

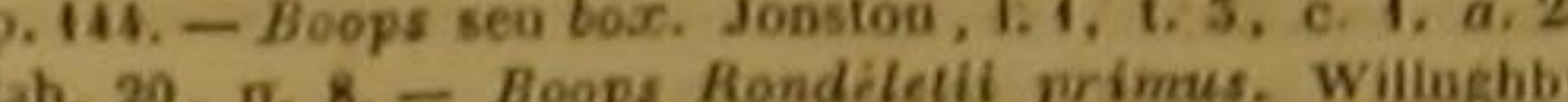

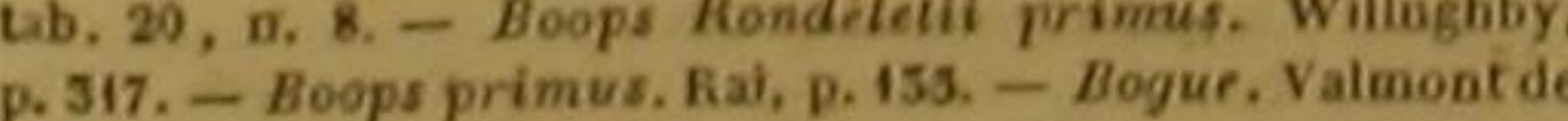
Bomare, Dict. d hist. mat.

'Type du genre Bogue, Boops, Cuv., dansta lamille des Acantbopterygiens sparoldes.

- Cantheno, z Genes. - Lucerna da scóglio, dans la Ligurie. - Spare canthere. Dánbeaton et Haay, Enc. méth.
- Spare canthere. Bonnaterre, pl. de I'Enc. mettb.-, Spa- Spare canthere. Bonnaterre, pl. de I Ene. metib.-, Spa argeoted. 3 Artedi, gen. 36, sya. 58. - Kav0apos. Aristot,

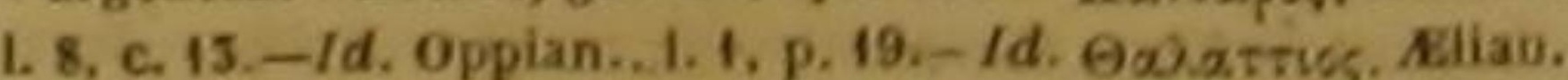
L., c. 26, p. 30. - Cantharus. Plin., 1. 32, e. 11. - Can theno. Rondelet, part. 1. 1. 5, c. 4. - Gesner, p. 178. 211, et (geri.), fol. 22, b. - Aldroy...1. 2, c. 20, p. 186. - Cantia. rus. Charlet, p. 14

' C'est le type du-geore Canthère, Cantharus de M. Cre vier, qui le
ruldes. $D$.

- Vergadelle (lorspue le poisson est jeune), Sopi, dass plus. départ mérid - Salpa en italie. - Sarpa, a Génes. - Scilpo, a Malte. -Goldstrich, en Alemagne.-Goldstro- observé. Il ne s'approche que très-rarement des rivages. Le dessus de sa téte est bombé, dénuéde petites écailles, et ponctué. La lèvre supérleure sétend, à la volonté de l'animal, beaucoup plus avant que I'inférieure. Les écailles qui couvrent le corps et la queue, sont larges et striées, et le bord postérieur de la caudale est rouge.

Le bogue, qui se trouve dans la mer du Japon, habite aussi dans la Méditerranée. Les anciens Grees l'ont bien connu ; ils ont remarqué la grosseur de ses yeux, qui sont très-grands relativement aux dimensions générales de ce spare; ils ont trouvé des rapports entre ces organes et les yeux d'un bouf ou d'un veau, et ils ont nommé cet osseux Boou, qui veut díre aeil de bouf. Cette expression grecque, Bosw, a été bientót métamorphosée, par erreur, par inadvertance, ou par quelque faute de copiste, en celle de $B \omega \xi ̧$, ou de Boxğ. On a cru que cette derniere dénomination Box̌̆, venait de Boxas, je crie; et en conséquence, des poêtes se sont empressés d'écrire que le bogue fuisait entendre une sorte de cri, quoiqu'aucun véritable poisson ne puisse avoir de voix proprement dite, et que le spare dont nous parlons, ne paraisse mème pas jouir de la faculté de produire un bruissement semblable à celui que font nai tre les opercules vivement froissés de quelques trigles, d'autres osseux, et de certains eartilagineux'.

L'ensemble du bogue est long, et un peu cyindrique. La couleur générale de son dos varie depuis l'olivâtre jusqu'au jaune brillant, selon 'aspect sous lequel on le regarde. Son ventre est argenté; ses pectorales sont rougeátres. Plusieurs cœeums sont placés auprès du pylore. mer, é Hollande. - Goldilin, en Angleterre. - Spare saupe, Daubenton et Haay, Ene. méth. - Id, Bonnaterre
Wh. de l'Enc, métb. - Bloch, ol. 265. - - Sparus linei a. de

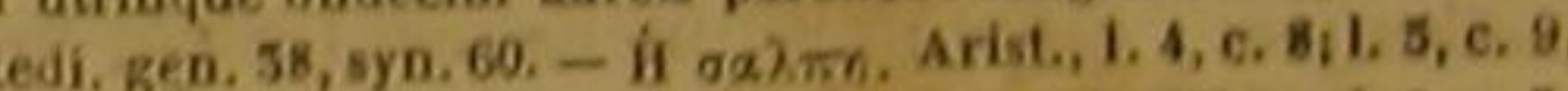

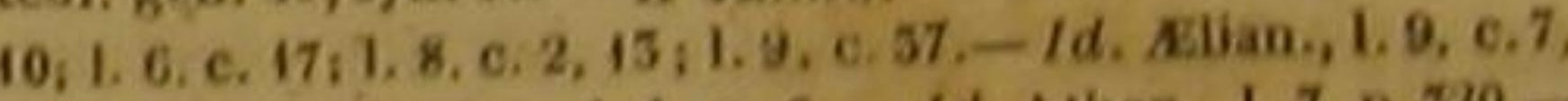
p. 516. - Id. Oppian... L. p. 6. - Id. Athen, L. 7. p. 320 Salpa. Plin., 1. 9, c. 57: - Id. Jov., c. 14, p. 73. - Saupe

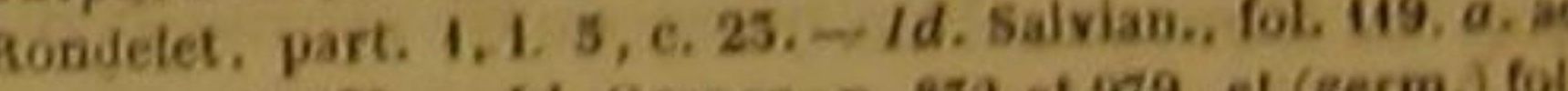
conem, et 120. - Id. Gesper, D. 832 et v79, et (germa.) for 34, b. - Id. Aldrov, 1.2, c. 21, p. 189. - Id. Jouston, if

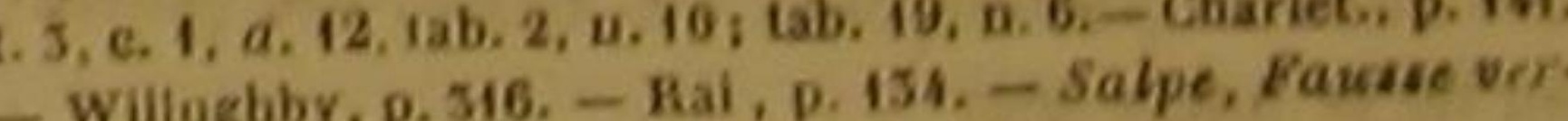
gadelle. Valmoat de Bomare, Dict. d'hist. nat. grziens sparoides. 1 .

" Forkael, Paun. Arab., p. 3t, D. 22

“" M. Cuvier place ce poisson dasts wa geure Dorade, Chry.

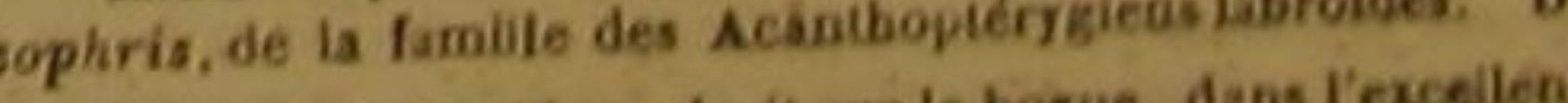
' $v$. ce que Schneider a terit sur le bogue, dans fecteilen 
Sa chair est ordinairement succulente et facile à digérer; et la nourriture qu'il préfère consiste en algues, en très-petits poissons, et en débris de corps organisés qu'il cherche dans la vase. Le canthère, que l'on pèche dans la Méditerranée, présente dans la partie supérieure un fond noirâtre, qui faitparaitre plus agréables les raiés jaunes dont nous avons parlé dans le tableau générique des spares. II se plait dans les ports aux embouchures des rivières, et dans toutes les parties de la mer voisines des rivages, où les fots apportent du limon; et oú les fleuves et les eaux de pluie entrainent de la vase. Sa chair est ordinairement peu recherchée, commen'étantni assez succulente, ni assez sèche, ni assez ferme.

Celle de la saupe est peut-être moins estimée encore, parce qu'elle est molle et difficile à digérer, et parce que, de plus, elle répand souvent une mauvaise odeur Ce spare saupe a l'ouverture de la bouche petite; les máchoires egales; la langue lisse; l'opercule composé de trois lames, et garni de très-petites éeailles; la ligne latérale presque droite; les écailles du dos et de la queue, grandes et unies; le dos noiratre; les côtés et le ventre argentés; les nageoi. res grises et bordées de- argentés; les nageoires grises et bordées de brunâtre; le péritoine noir; la vésicule du fiel très-longue; l'estomac grand ; le pylore entouré de quatre çeums ; et le canal intestinal trois ou quatre fois plus long que la tête, le corps, la queue et la plus long que la tète, le
dale pris ensemble.

dale pris ensemble.

Au reste, les dimensions de la saupe varient suivant son sêjour. Or en a pêché de plus de troìs décimètres de longueur, ếché de plus de gramme de poids.

Ce spare fraie communément en automne. On le trouve fréquemment sur les bas-fonds, où il est attiré par les plantes marines donds, aime à se nourrîr, et vraisestes marines dont it aime à se nourrîr, et vraisemblablement par les mollusques, qui doivent lui donner l'odeur fétide quil exhale. Il mange aussi des végétaux terrestres; et on le prend facilement en garnis. saut un hameçon d'un morceau de eitrouille ou d'autré cucurbitacée. Pendant de eitrouille ou tire dans les profondeurs des baies, des golfes, ou de la haute mer '.

46 rayons a la membrane branchiale lu port chaque nageoire pectorale, 1 rayon aignillonné et 5 . 16 a articués a chaque thorieine, 16 rayous a ta caudale. -6 rayonis a la membrane branchiale do bogue, 9 a chaque na.

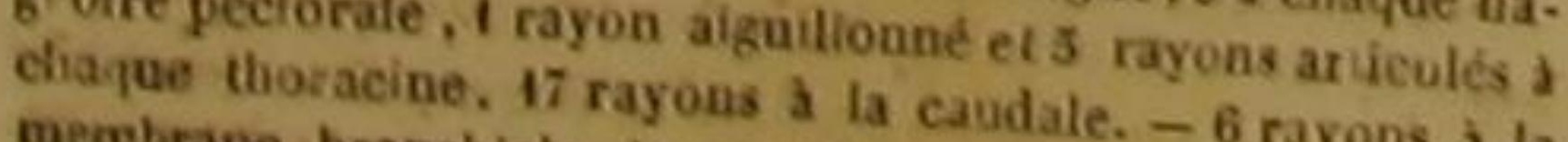

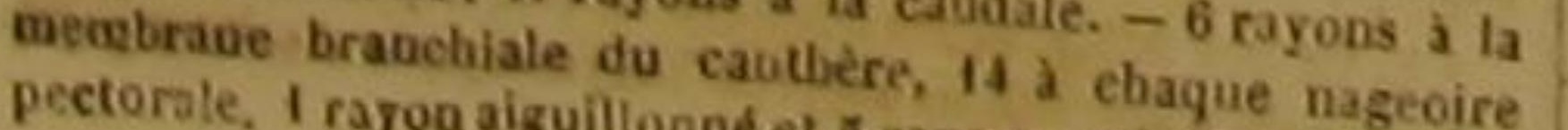

Le spare sarbe, dont la chair est agréable à goùt, et qui se plait auprès des côtes de la mer d'Arabie, dans les endroits vaseux et tapissés de coraux ou de plantes marines, est conses d'écailles larges et argentées. Ses peetorales sont blanchátres, lancéolées et beaucoup plus longues que les thoracines. Une nuance plus beau jaune parait sur ces thoracines, sur l'anale, et sur la partie inférieure de la caudale.

\section{LE SPARE SYNAGRE ',} Sparus Synagris, Lion., Gmel., Lacep ?.

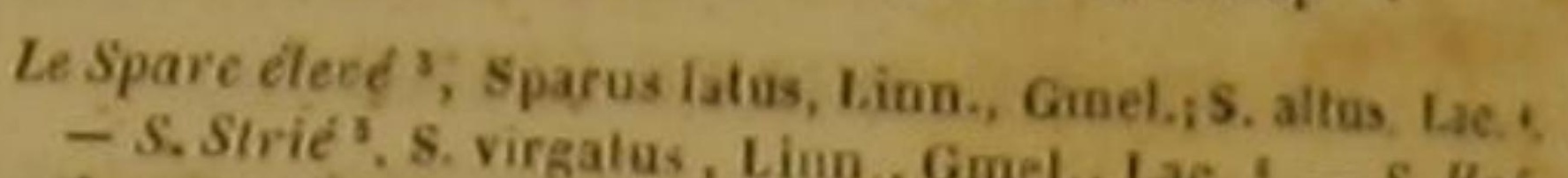
fara ', s. Haffara. Fursk., Linn., Gmel, Chrysop. Haf.

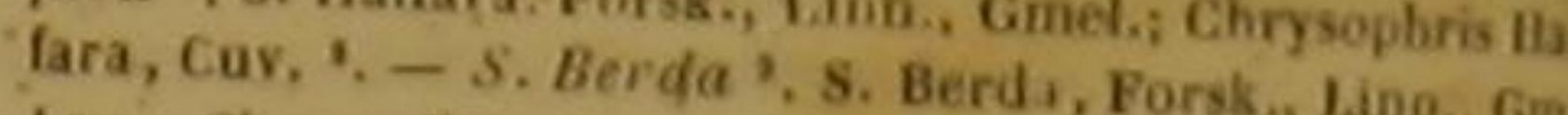

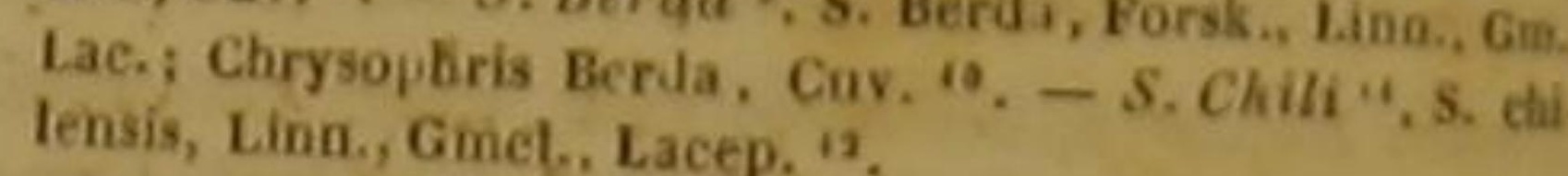

Le synagre vit dans les eaux de l'Amérique septentrionale; le spare élevé et le strié habitent dans celles qui arrosent les rivages du pon; le haffara et le berda sont péchés dans I ner d'Arabie, et l'on trouve le spare chili dans a mer qui baigne la grande contrée de l'Amé. rquẽ méridionale, dont il porte le nom.

Le synagre, qu'il ue faut pas confondre are le spare auquel les anciens Gíecs ont donné ee nom, puisqu'il parait n'avoir été observé que daus l'Amérique septentrionale, où Catesby l'a décrit, a les yeux grands, l'iris rouge, la dor. sale longue et échancrée.

thoracine, 17 rayous a $\mathrm{l}$ a nageoire de $\mathrm{L}, \mathrm{quecue},-6 \mathrm{a}$ la ment rate I ranchiale de la sampe, 16 a claque nagholre peeto racine, 20 payons anone et 5 rayois arueulés a elayue tho branehise do 20 a a la caudae. -6 rayous a la membram I rayon aiguillomué ets rayogs 13 chaque nagevire pectorale, rayons a la nageoire de la queve.

spare synagre. Daubeuton et Haay, Enc. méth. - 10 . Ganaterre, pl. de i Enc. méth. - Salpa purpurascens taI Non cilesby, Carol. 2, p. 17, tab. 17.

Nod cité par M. Cuvier. D.

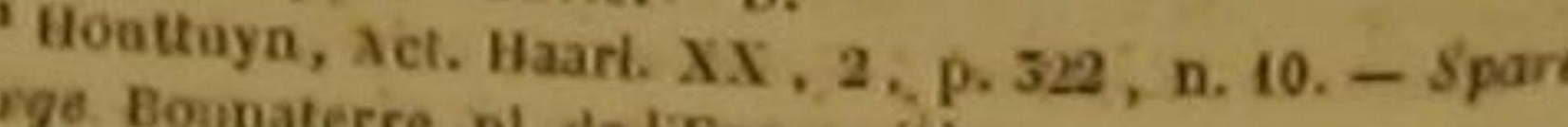
Non citét pre, pl. de I Enc.

Mou tiyn, Act. Gavier.

Non cié, par M. Cnvier. D., p. 325, n. 11.

spare haffare. Bonnaterre,

' Faun. Arabic., p. 33, n. 25. pl, de IEne. méth, - Forb Du genre Daurade, Chrysophris, dans is famille de 'Forskael, Faun. Arab., p. 52, n. 24. - Spare berde. Dure, pl. de l'Eac méti.

Dille des Acanrade. Chrysophris, de M. Cavier, dans la Mlolina, Hiss naterygiens sparoĩdes. D.

"Nou cité par M. Cuvier.
"Nón. crues, comme ces dernières, des pierres produites dans la tète d'un crapaud. On lés a recherchées, achetées assez cher, enchảssées dans des métaux préeieux, et conservées avec soin, soit comme de petits objets d'un luxe particulier, soit comme douées de qualités médicinales utiles. On a surtout attaché un assez grand prix, au moins à certaines époques, aux molaires de dorade que l'on trouve dans l'intérieur des couches de la terre, et qui, plus ou moins altérées dans leur couleur par leur sèjour dans ces couches, ofirent différentes nuances de gris, de brun, de roux, de rougé brunâtre. On a estimé encore davantage ces mạchelières dont on ignorait la véritable nature, lorsque leurs telintes, distribuées par zones, ont montre dans leur centre une tache presque ronde et noiratre, On a comparé cette tache foncée à une prunelle; on a vu dans ces molairis ainsi colorẻes une grande ressemblanee avee un œil; on lêur a donné le nom d'OEil de Serpent; on les a supposées des yeux de serpent pétrifiés; on leur a dès lors attribué des vertus plus puissantes; on les a vendues plus eher; et, en conséquence, on les a eontrefaites dans quelques endroits voisins des parages fréquentés par les dorades, et particulièremient dans líle de Malte, en faisant avec de l'àcide nitreux une marque noire au centre des mólaires de spare dorade non fossiles, et prises sur un individu récemment expiré.

Les mâehoires qui sont garnies de ces dents molaires ou incisives dont nous venons de parler, n'avancent pas l'une plus que l'autre. Chaque lèvre est charnue; l'ouverture de la bouche est peu étroite; la tête comprimée, très-rélevéeà l'endroit des yeux, et dénuée de petites écailles sưr le devant; la langue épaisse, courte et lisse; lespace compris entre les deux orifices de chaque narine, marqué par un sillon; l'opercule revêtu d'écailles semblables à celles du dos, et arrondi dans son contour; le corps élevé; le dos caréné ; le ventre convexe; l'anus plus voisin de la caudale que de la tete; et l'ensemble du corps et de la queue, couvert d'écailles tendres et lisses, qui s'étendent sur une portion de la dorsale et de la nageoire de l'anus.

Telles sont les formes principales de la dorade. Sa grandeur est ordinairement considérable. Si elle ne pèse communément que cinq ou six kilogrammes dans certains parages, elle en pèse jusqu'à dix dans d'iutres, particulièrement aupres des rivages de la Sardaigne; voyageur suédois Hasselquist en a vu dans I'Archipel, et notamment auprès de Smyrne, qui avaient plus de douze déeimètres de longueur. Ce spare, suivant son àge et sa grandeur, reçoit des pècheurs de quelques cótes maritimes, des noms différents que l'on trouvera dans la synonymie placée au commencement de cet article, et qui seuls prou veraient combien on s'est occupé de ce poisson, et combien on a cherché à reconnaitre et à distinguer ses diverses manières d'étre.

L'estomac de la dorade est long; le pylore garni de trois appendices ou cocums; le canal intestinal proprement dit, trois fois sibueux ; le péritoine noir ; et la vessie natatoire placée audessous du dos.

Indépendamment da secours que ce spare tire de cette vessie pour nager avee facilité, il reçoit de la force de ses muscles, et de la vitesse avee laquelle il agite ses nageoires, une grande légèreté dans ses mouvemeńts, et une grande rapidité dans ses évolutions : aussi peut. ii, dans un grand nombre de circonstances, satisfuire la voracité qui le distingue; il le peut d'autant plus, que la proie qu'il préfere ne lui échappe ni par la fuite, ni par la nature de l'abri dans lequel elle se renferme. La dorade aime a se nourrir de erustacées et d'animaux à coquille, dont les uns sont constamment at tachés a la rive ou au bane de sable sur lequel ils sont nés, et dontlesautres ne semeuventqu avec une lenteur assez grande. D'ailleurs, ni le tèt des crustacées, ni mème l'enveloppe dure et calcaire des animaux à coquille, ne peuvent les garantir de la dent de la dorade: ses máchoires sont si fortes, qu'elles plient les crochets des haims lorsque le fer en est doux, et les cassent s'ils ont été fabriqués avec du fer aigre; clle écrase avec ses molaires lés coquilles les plus épaisses; elle les brise assez bruyamment pour que les pécheurs reconnaissent sa présence aux petits éclats de ces enveloppes concassées avec violence; et afin qu'elle ne manque d'aucun moyen d'apaiser sa faim, on prétend qu'elle est assez industrieuse pour découvrir, en agitant vivement sa queue, les coquillages enfouis dans le sable ou dans la vase.

Ce goût pour les crustacées et les animaux a coquille détermine la dorade à fréquenter sottvent les rivages comme les lieux ou les coquillages et les crabes abondent le plus. Cependant il paraft que, sous plusieurs elimats, l'babita- 
dorée qui se mêle aux nuances brunes de sa couleur générale, de manière à donner une parure sombre, mais riche, à cet animal.

Celles du bigarré, au lieu de réfléchir l'éclat de l'or, brillent de celui de l'argent, et relèvent par cette teinte d'un blanc resplendissant les bandes et les taches noires que l'on voit sur les côtés de ce spare, ainsi que le noir de ses thoracines, et la bordure noire de sa caudale. II vit dans la Méditerranée comme l'Osbeck et le marseillais, auquel nous avons voulu donner un nom spécifique qui indiquât la partic de cette mer dans laquelle il parait avoir été particulièrement rencontré. Quant à l'Osbeck, nous l'avons ainsi nommé pour éviter la confusion qu'aurait pu introduire dans la nomenclature la conservation de son nom de Spare rayé, et pour témoiguer la reconnaissance des amis de l'histoire naturelle envers le savant Osbeck, qui l'a fait connaitre.

Ce spare Osbeck présente de chaque côté une tache noire située au-desșus de la ligne latérale ${ }^{\prime}$ Le marseillais montre deux croissants sur la partie supérieure de sa tête, l'un placé entre lés yeux, et l'autre au-dessous du premier. La dorsale est bleue avec du vert à sa base ; les thoracines sont bleuâtres; l'anale et la caudale sont d'un vert pâle. La longueur ordinaire de ee spare est de trois ou quatre décimètres.$$
-
$$

LE SPARE CASTAGNOLE .

Brama Castəōeola, Cuv.; Sparus Castaneola, BI., Lac. r.

Le Spare Bogaravéo ‘, Pägellus Bogaraveo, Cir.; Sparo

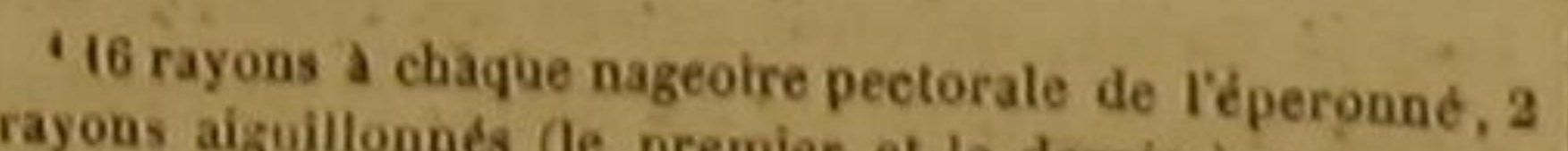
articul's rayons a chaque nageoire pectorale du a a caudale, - Is guillionne eq 5 rayons articulés a chaque thoracine, 1 rayon a 2. la nazeoire de la queue. -16 rayons a chaque nayens pectorale du spare brunśtre, $t$ rayon aiguillonité et $a$ rayots articules a chaque thoracine. $-\delta$ rayons \& la membran I rayou aiguillooné et 5 ra, 16 à chaque nageoire pectorale cive, 17 rayons a la cardale -6 roves a chayue thorabranebiale de l'Osbeck, 6 a chaque nagens a la membrane rayons a la membrane branchiale do spare pectorate. - 6 casque nageoire pectorate, 6 a chaque thoracine, 44 a a na seoire de la queue.

Bonnaterce, pl. de I'Enc, món, pl. 275. - Spare bréme denté, 4. 243. 'Du genre Castaguole ( $B$ rama), daos la famille des Acan-

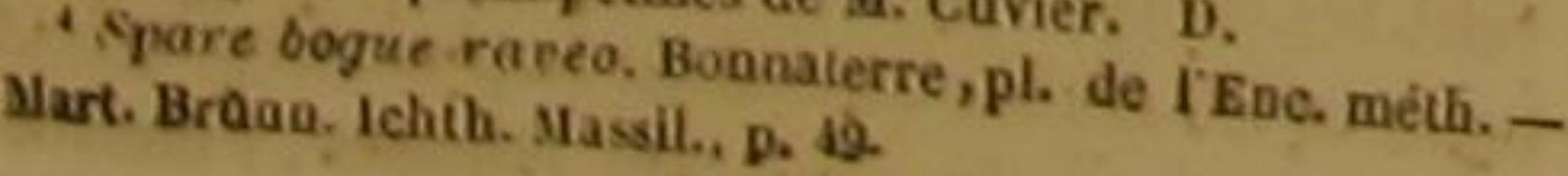

Bogaraveo, Brunn., Lac. s. - Spare Mahséna 4, Lethr. (n) Scizoa Harak, For-l, Linn, Ga, Lethrious Harak? Lu - Spare Ramak to, Sciæna Ramak, Porsk, Larak. Lac. Sparus Ramak, Lac. " 4 . - S S pare Grand. OFil ' 2 , Gmel, phrys grandoculis, Cuv.; Scizna grandocellis, Cbrp. Línn., Gmel.; Sparus grandoculis, Lac. ".

C'est dans l'Océan Atlantique que l'on a ol. servé la castagnole. Ce spare a la mâchoire ínférieure garnie de deux rangées de dents mires, recourbées et inégales : un rang de dents emblables parait â la mâchoire supérieure. I corps est plus haut dans sa partie antérieur que dans sa partie postérieure; les écailles sont molles et lisses; l'anus est plus près de la tèt que de la caudale. En général, la forme de I castaguole est facile à distinguer de celle desau. res poissons. Ses nageoires sont bleues, excepti les pectorales et les thoracines, dont la coulem est jaune.

Le bogaravéo, qui a été vu par Brūnnich daus la Méditerranée, a la ligne latérale brune une longueur d'un décimètre ou environ.

Le mahséna, le harak, le ramak et le grand. ceil, habitent dans la mer d'Arabie. Ils ont éte déerits par Forskael, à l'exemple duquel Gme lin et le professeur Bonnaterre les ont inscrits parmi les sciênes. Mais les principes d'aprè lesquels j'ai cru que l'on devait classer les pois sons, m'ont obligé à les comprendre parmi les véritables spares.

Des mollusques proprement dits et des animaux à coquille servent de nourriture au mabséna, qui fréquente beaucoup les rivages. II le sommet de la téte èlevé, le corps peu allongé, et les nageoires garnies de filaments.

- Du genre Pagel, dans la famille des Acanthopterrygieu sparoides, Cuv. D.

Bonnaterre, pl. de I. Linn., ed. de Gmelin.-Scičnehosny. p. 52. n. E. . Pl. de l'Euc, méth. - Forskael, Faan. Arab. Du gen

genre Léthripus, daus la famille des Acanthoptery

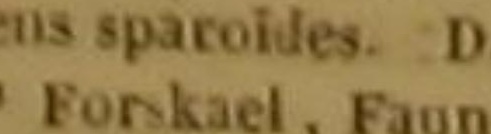

'Vonkael, Faun. Arab., p. 52, n. 65. - Sciène harak '

.

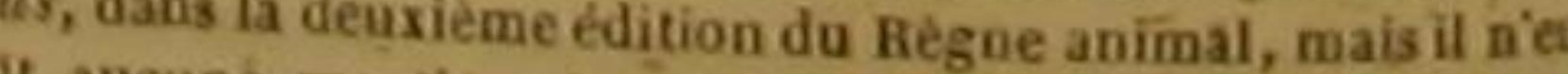
sons, t. VI. D.

"Forskael, Faun. Arab., p. 52, n. 64. - Sciène ramak. "Non mentione l'Euc. méth.

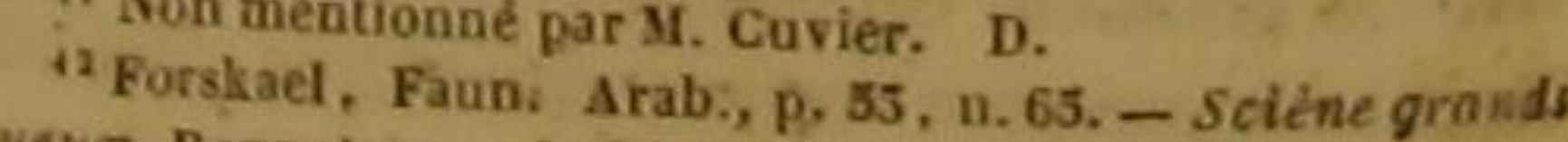

yeux, Bonnaterre, pl. de IEnce, més

" "Du genre Daurade, Chrysophirys, de M. Cavier, dans ls Gamille des Acanthoplérygiens sparoìtes. D.
Le harak, dont les nageoires sont rougeàtres, Japon, a les yeux grands et presque verticaux montre d'ailleurs dans sa conformation, ainsi et le corps très-élevé au-devant de la nageoire que dans ses habitudes, beaucoup de rapports dorsale

avec le mahsénả.

Le ramak a les nageoires de la mème couleur que le harak, et, comme ce dernier spare, ressemble beaucoup au mahséna. Au reste, nous pensons avee Gmelin et le professeur Bonnaterre, que la sciène Dib de Forskael ' n'est qu'une variété du ramak ${ }^{2}$

La nageoire du dos et l'anale du spare grandœil sont terminées, du côté de la caudale, par une sorte de lobe. Sa couleur générale est relevée par des raies; et ses naǵeoires sont violettes, ou d'un rouge pále.

LE SPARE QUEUE-ROUGE ${ }^{3}$,

Gerres Oyena, Cur.; Labrus Orena, Forsk., Lacep. Labrus longirostris, Sparus erythrurus, et Sparu Brilannus, Lac, ‘.

Le Spare quetue-d or s, Mesoprion chrysurus, Cuv,; Sparu

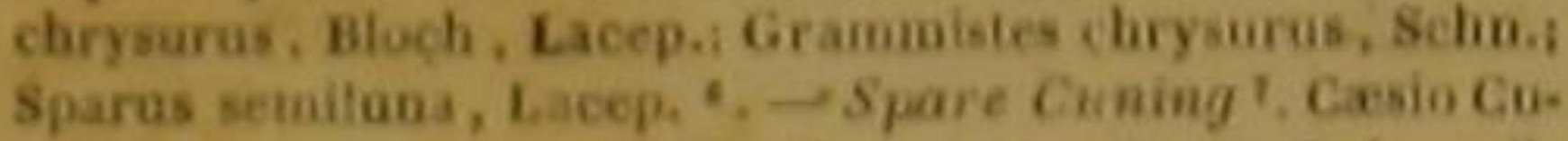

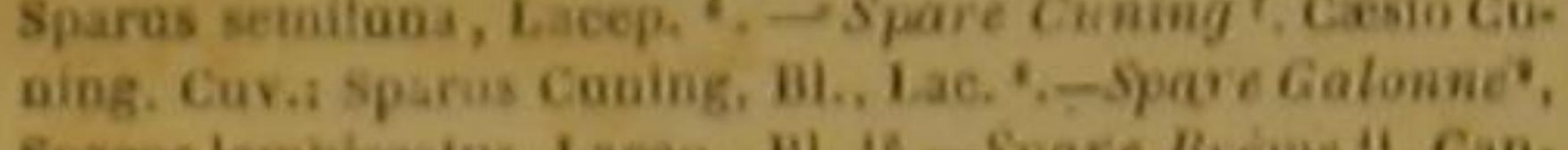

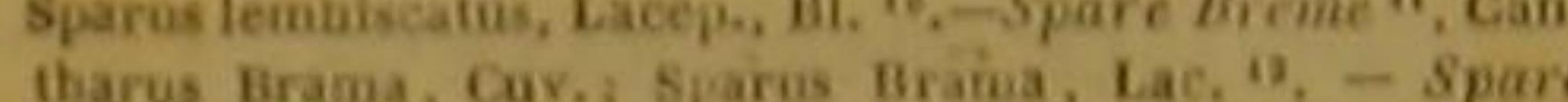
Gros OEl ", Dentex macropthalmus, Cav, sis sarus macropthaimus, BL., Lacep," ".

Nous devons à Hloch la connaissance de ces six spares. Le premier, qui fiabite la mer du

1. Sclana lamina tr

कs. 'S rayons a la menbrane branchiale de la castagnole, 20 i articoles a chaque thoracine, 22 rayoos a la nageoire de $\mathrm{L}$. quene, -6 rayous a la membrane branchiale du bogaravéo, is a chaque nageoire pectorale, 1 rayou aiguillomé et so rayons arientés a claque thoracine. 17 rayous a la caudale. -6 rayon a la membrane brauclisile du mahsens, 15 a chapee vageoire pectorsie, 1 rayon agguilioune et 5 rayons ariiquene. -6 rayous a la membraue branchisle du harak, is a chaque hageoire pectorale, 1 rayon aignillonné et 5 rayon urticules a chaque thoracine, 17 rayons a la cayjale. - 6 rayons a la membrane brauchiaie du ramak, 15 a chaque nageoire pectorale, 1 rayon alguillonne et 5 rayons articuies a chaque thoracibe, it rayuss a la nageore de la quede. -

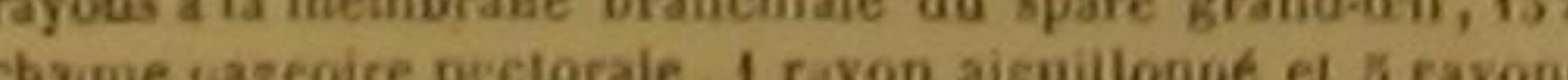
articoles a chague thoracine, 17 rayons a la caudale.

'Bloeb, pl. 261.

Du =enre Geakes; Gerres, Cav. Dans ta tamille des Acar. thoptérygieus m- Dides, Selon M. Covier, N. de La épede a

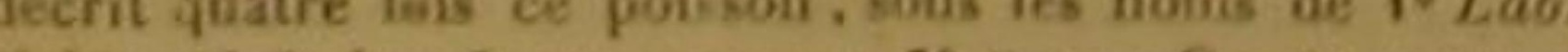
Oyène, $2^{0}$ Labre Long-muscau, so Spare Queve rouge, et
5o spare Brdon. D.

Acara pitanga, Acara pilamba, an Bresilh, - Mabir-

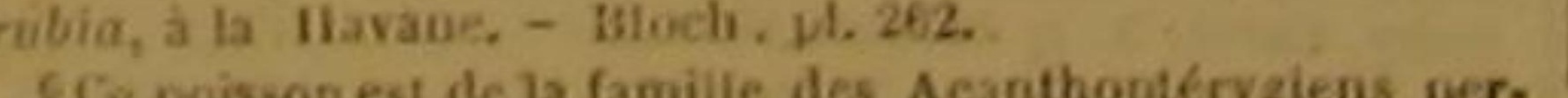

Le spare queue-d'or vit dans la mer qui baigne les côtes du Brésil. Ses couleurs sont régulières, brillantes et magnifiques : le tableau géaérique en indique les nuances et la disposition. Quelques individus, au lieu d'un violet argenté, présentent sur uné grande partie de leur surface un rouge clair, ou couleur de rose animé; mais les tons dont ce spare resplendit, sont en général si éclatants, que Pison a cru devoir attribuer à leur vivacité la phosphorescence dont jouissent les spares queue-d'or, indépendamment de toute rêflexion de lumière due à leurs écailles luisantes et colorées. Copendant cette qualité phosphorique est élevée dans ces animaux, ainsi que dans plusieurs autres poissons, á un degre assez haut pour que la réunion d'mu très-grand nombre de ces osseux répande une clarté à l'aide de faquelle on peut lire au milieu d'une, nuit rès-obscure. Le spare queue-d'or a recu dans cette propriété phosphorique un présent funeste: on le peche avec bien plus de facilité que s'il on était privé. La lumière qu'il produit, quelquie douce ou faible qu'elle puisse être, le trahit, lors mème que son instinct I'entraine dans la mer a quelque profondeur, comme dans un asile assuré ; et on le recherche d'autant plus des plus agréables une grandeur considérable.

Maregrave l'a vu offrir une longueur de six ou sept déc mètres. Le prince Maurice de Nassau a laissé un très-beau dessin de ce spare, dont Maregrave, et d'apres lui, Joaston, Willughby et Ruysch, ont aussi donné la figure.

Les Indes orientales nourrissent le cuning. spare Queued or et de Spare Demi-Lune. D, iental s. - Blocis, pl. 263 , fig. 1 .

eure Casso de Al. Cuvier, dans ta famille des Acan. rygiens mésides. D.

Spare raye. Bloch, pl, 205, fig. 2.

"Breme de mer, Carpe de mer, sur pius. cotes de Prance. - Bloch, pl. 269. - Brème de ner. Duham I. Traité des péchies.

3. Cuvier plice ce poisson dans son genre Casmikay, de la famite des Acauthopterygens sparoidee, La ngure yue

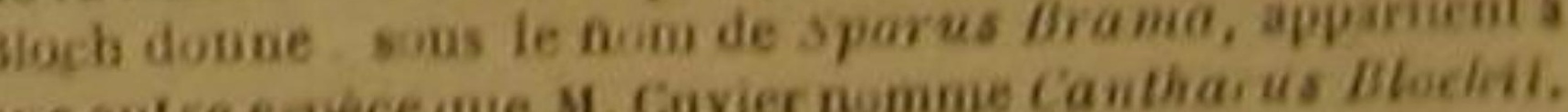
"s spare cill de beuf. Bloch, pl. 272. ¿1) Du genre besre, Dentrx, dans is famille des Aean. ithoptérygieassparoides de 31, Cavier. D. qu'il réunit à une chair des plus délicates et 
La tête de ce spare est petite et comprimée. Un rang de petites dents garnit l'une et l'aubtre des deux mâchoires: La languc et le palais sont lis. ses. La ligue latérale est. presque droite. Un sillon longitudinal recoit la nageoire du dos à la volonté de l'animal. Les nageoires sont jaunes.

Le spare galonné a le corps beaucoup plus élevé que le cuning. Il préfere la mer du Brésil, comme la queue d'or. Toutes ses uageoires sont jaunes ou dorées, ainsi que les galons ou raies longitudinales dont il est paré. Il ne parvient ordinairement qu'à la longueur de deux décimètres. Il séjourne auprès des rivages rocailleux où l'eau est pure, et oùil peut trouver pour sa nourriture une grande quantité d'cufs' de poisson. D'après cette habitude, il n'est pas surprenant que Maregrave et Pişon, qui ont donné la figure de cet osseux, ainsi que le prinee Maurice, Jonston et Ruysch, et d'apres lesquels Klein et Willughby en ont parlé, lui aient at tribué une saveur des plus agréables, et supérieure mème à celle de la carpe.

Le spare brème a la téte comprimée ét petite la langue et le palais lissès; les deux máchoies également avancées; les opercules couvèit de très-petites écailles, et composés chacun de trois piêces; le corps et la queue très-élevés; le ventre arrondi; la ligue Fatérale bordée de points noirs, eu haut et en bas; et toutes les nageoires d'un rouge de brique, exceptéla dorsale, qui est rougeâtre à sa base, d'un vert bleuâtre sur la plus grande partie de sa surface, et lisérée de noir '

Ce spare brème se trouve dans le canal qui aussi la France de l'Angleterre. On le voit aussi auprès de presque toutes les eotes occinage dutales de France, et même dans le voisinage du eap de Bonne-Espérance. II détruit

48 rayons a chaque

rouge, 1 rayou aiguilloone et pectorale du spare queo a chaque, 20 rayons a la nageoire de la artieulés a chacue aiguillonne et 5 rectorale du spare queue-d or, I rays rayousa la cadade. -6 raticalés a chaque thoracioe du cuning 18 a chaque nagors a la membrane branchiale loné et 3 rayons ariecules i chavectorale, 1 rayon aiguilla nagevire de la queve. -12 rayous a'chacine, 19 rayons a torale du galooné, $t$ rayon aiguillouné et 5 ravongevire rec. membrane bracine, 16 rayons a ta eaudale -6 payticnlés pectorate, 1 rayon a dig svare breme, 15 a ehaque naseoine

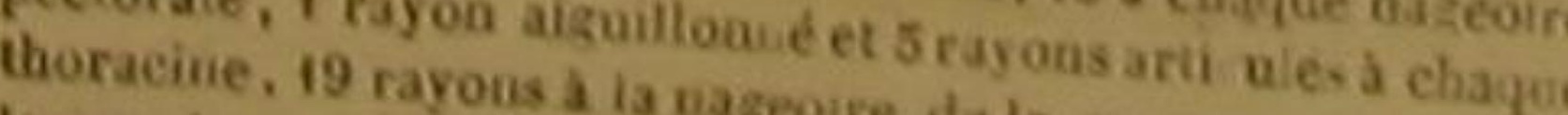
la membrawe biauchiale du spare arona queue, -6 rayons

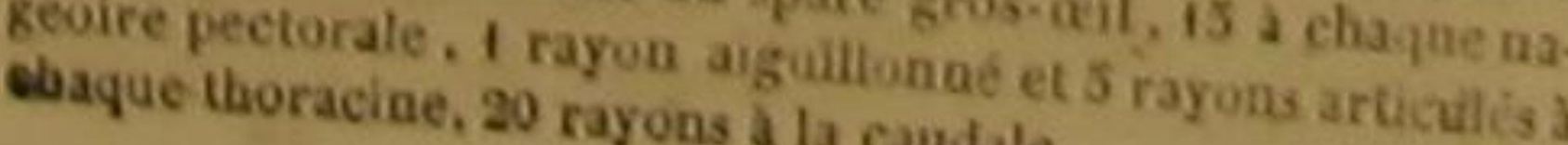

une grande quantité, de frai èt de jeunes pois sons. Il a la chair blanche, mais mole: pois. dant il est assez bon a manger lore; ceper. grand et qu'il a vécu dans des endroits is reux. On le prend pendant l'ete avee de pierou des ligate pret l'on profice sovee dilkto ou des ligues ; et l'on profite souvent, pour pècher, des temps d'orage et de tempéte, per. dant lesquels il se réfugie pris des rivages et sur les bas-forids.

Le spare gros-cil a, en effet, l'ceil très-gme ainsi que le montre le tableau genérique : diamètre del orbite est à peu près éal a la mol tiê du grand diametre de f'ouverture de la boo. che. Les mảchòires sont aussi avaucées l'me que l'autre; la langue est lisse, l'extrémité de est queaucoup moins haute que le corps et la partie antérieure de cette mème queue. Les couleurs sont très-riches; les raies longitudius les rouges ou jaunes, que le tableau générique indique, regnent sur un fond d un jaune doré; les nageoires sont variées de jaune et de rouge; la caudale est jaune à sa base et grise à sonex trémité.

\section{LE SPARE RAYE',}

Pentapus viltatus, Cuv,; Sparus viltatus, Bl., Lacep Bodianus decaeanthus, Lacep? ?

Le Spare Ancres, Cheilinus Anchorago, Cavris Spares A. chorago, BL., Lae. 4- - Spare Trompeurs, Epitalus is sidiator, Cav, i Sparns insidiator, Linn., Gmel, Lace,
- Spare Pory

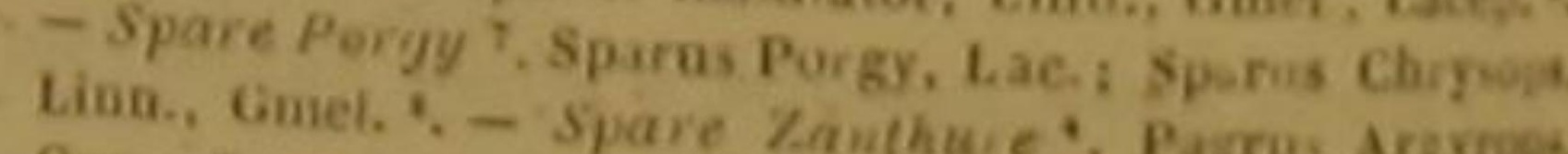
Cuv,; Sparus Argyrops, Lion, Gaiel.i S Sarus Zanition Dentex, Lino, Gene "., Dentex valgaris, Cuvis Spent

Leseaux du Japon nourrissent, suivant Blocb

'Bloch, pl. 278.

Da geare Pkntapodz, Pentapus; dans la familie de poisson a éré décrit une seconde fois. Cavier dit que ce us te now de Bodian decacanthe fois par M. de Lactyid 'Bloep, pl. 276 Ues Labres, tans la famille des Acanthoptérygiens iabroìlea.
D.

- Spare flout. Bonaterre, pl de IEnc, méth. - I spars p. 41, tab. 3. Gig. 1. - Glotsmael. Va Pallas, Spic. zool.

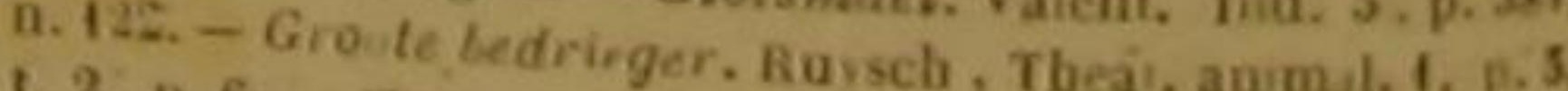
4. 2. B. 6. - Trompeur ou filou. Renard, Poiss. I. f. A3. - Da 010,$2 ; f .4,0.15 ;$ et f. 17 , 0. 15

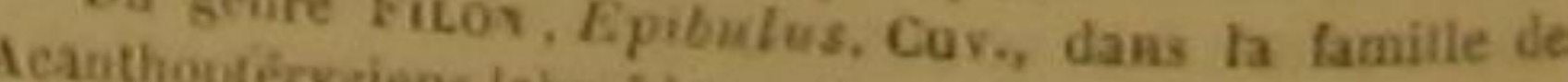
S Spare porgy. Dasofes.

Bonnaterre, pl. de IEnce, melo. et Hauy, Ene, méb, - Id. tesby, Carol. 2, p. 16, tab, 16

DES POISSONS

le spare raye. Chaque narine de ce spare n'a qu'un orifice. Les mâchoires sont à peu près aussi avancées l'uné que l'autre. I.e devant de chacune de ces máchoires presente des dents pluslongues que celles des côtés. Les tiois raies larges et bleues que l'ou voit régner sur le corps et la queue de l'animal, sont relevées par l'éelat des écailles, qui sont dorées sur la partie supérieure du poisson, et argentées sur l'inférieure, Les nageoires pectorales et les thoraci. nes montrent des nuances rougeátres : les antres nageoires sont variées de bleu et de jaune.

Le nom d'Anere, donné par Bloch, au second des spares déerits dans cet article, vient. de la forme de plusieurs dents de la mảohoire inférieure de cet osseux, lesquelles sont courbées en deux sens. La téte de ce poisson est grande et comprimée. Une dent plus grande que les voisines, et tournée en avant, se montre à la máchoire supérieure, auprès de l'angl des deux måchoires. On ne voit qu'un oritic pour chaque narine, Les écailles sont grandes et lisses. Bes teintes rougeâtres paraissent sur la tête et sur les nageoires, exeepté sur la dorsale, qui est bleuâtre et tachetée de brun.

Le spare trompeur est très-remarquable par sa forme, ainsi que par les habitudes qui en decoulent, et qui lui ont fait donner le nom qu'il

- Spare santure, Daabenton et Haby, Ene, métb. - Id Bonasterre, pl, de IEne, méth. - - Sparos iride argented

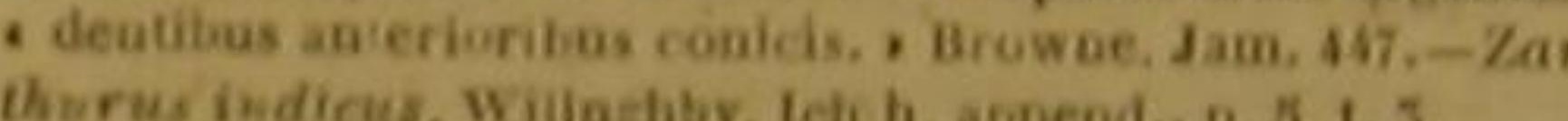

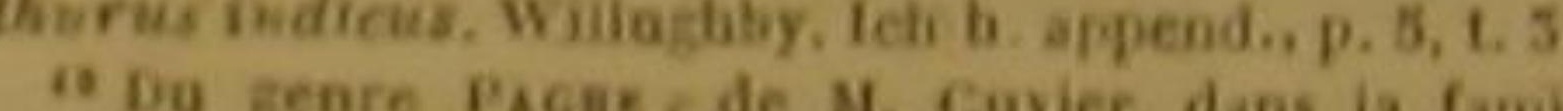
Acanibopterygieas sparvides. D

"Dritale, dans queliges depart. - Dentultac, Marmo, daus quelques départ. mér. - Dentice, dass la Lizarie. Id.ea Sandaigae. - Dénici, a stalte, - Dentrke, dans plos. partis de ritalie. - Synagrida, par les Grecs moderness. Whan brachsem, os zahn brasem, ex Allenagne - Taa Spare denis Dasbentoge' Aea rosgh, en Anigletere terre, pil. de IE

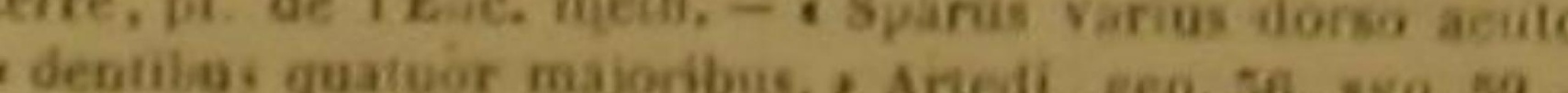

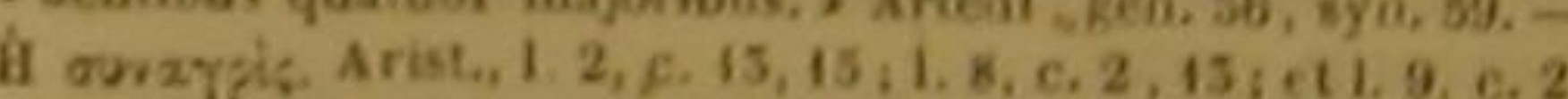

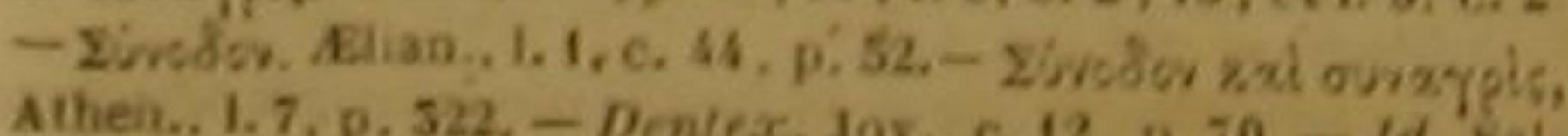

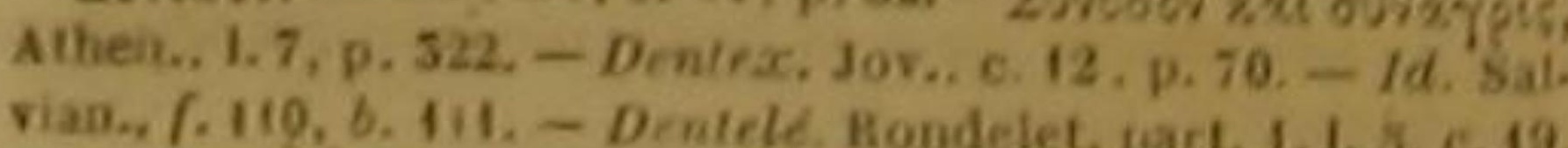

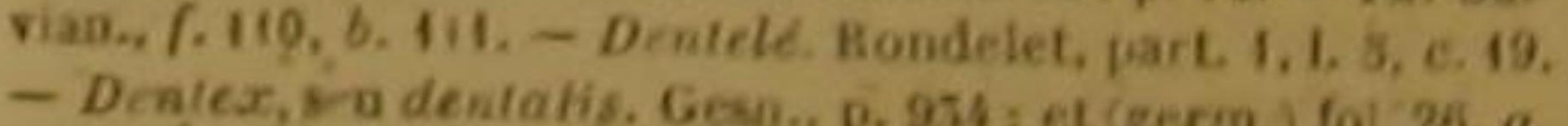

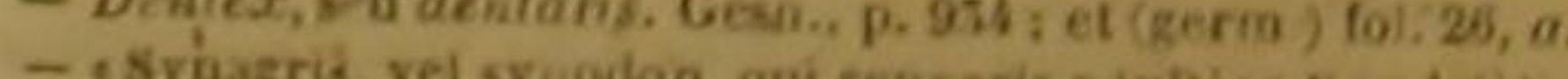
- videtor Denlex. Aldrov. Os. - Synagris Bilomit. 10. p. 958 .

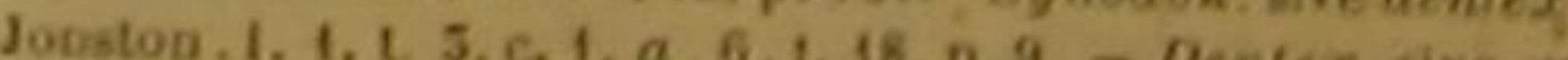
nodon Aldrovandi, Wiloghby, D. $512,-1 \mathrm{i} i \mathrm{i}, \mathrm{p}=15 \mathrm{t}$ -

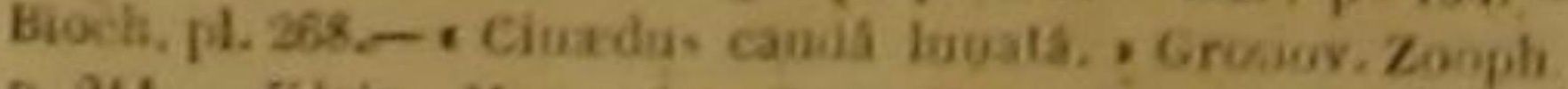
a. 214. - Klevin, Miss, pise. 5, p. 49. A.t. - Dente Butia pi. 8. Gg. 9. - Dentale. Valmont de Bomare, Diet ort. 3 , aat. ag. o. - Denjale. Valmont de Bomare, Diet. dihist. 'Type du genre Deuté, Dentex, Car. dans la $\mathrm{t}$ mift des Acauthopicry giens sparoides. De, porte. Son museau, très-allongé, semblable a un tube, et terminé par la petite ouverture de sa bouche, lui sert d'instrument de projection, pour lancer en petites gouttes l'ean qu'il introduit dans le fond de sa gueule par les orifices des branchies. C'est avec ees petits projectiles fluides uqu'il attaque les insectes qui voltigent au-dessus de la surface de la mer, dans l'endroit ou il se tient en embuseade; qu'il les tue, ou les étourdit, on les mouille, et les met toujours hors d'état de s'envoler et d'échapper à sa poursuite. II est lui-mème très-recherché dans les grandes Indes, qu'il habite; et sa proie est vengée par les pécheurs de ces belles contrées, oú l'on aime beaucoup à se nourrir de poisson. Sa chair est; en effet, très-agréable au goút : mais son volumeest peu considérable; il ne parvient ordiuairement qu'à la longueur de trois décimetres. Des deux lignes latérales qu'il présente, la supérieure suit, à peu près, la courbure du dos ; l'inférieure est droite. Les éenilles sont grandes et boidées de verdátre; les nageoires; jaụnes; et la dorsale et Panale, ornées de bandelettes vertes.

La couleur générale du porgy est bleuâtre; son séjour, la Caroline. Catesby et Garden l'ont fait connaitre.

Le zanture, que l'on trouve dans les mers voisines de la Caroline et de la Jamaique, a de tres-grands rapports avee le porgy.

Le denté en a d'assez remarquables avec Io hurta ; et de plus, pour éviter toute équivoque, il est bon d'observer qu'il parait que ce spare n'a pas reçu des anciens nataralistes grees le mème nom à tout âge. Dans sa jeunesse, if a ét nommé par eux Synagris; et dans un äge plus avancé, Synoden. Mais it ne faut pas le confondre avec le spare auquel nous avons conserve la dénomination de Synagre, d'après Linnée, Daubenton, Bonnaterre, etc., et qui a été vu par Catesby dans les eaux de la Caroline, ni avec celui que nous nommons, ainsí que Bloch, Cynodon ou Dent de chien.

Au reste, le denté a la tête comprimée; les deux mâchoires également avancées, et garnies chacune d'une rangée de dents pointues et re. courbées; la langue et le palais lisses; l'ouver. ture de chaque narine double; la tete variée de doré, d'argent et de vert; des points bleus plus ou moins apparents sur les côtés; la nageoire dorsale et la eaudale, jaunes a leur baseet bleues à leur extrémité; les pectorales rougeâtres; les 
thoracines et l'anale d'un jaune foncé; quatre
cœecums auprès du pylore, et la vessie natatoire cœcums auprès du pylore, et la vessie natatoire $x$ portions.

Ce poisson change de couleur avec l'âge : il devient pourpre lorsqu'il est vieux; ce qui a dû porter les anciens a donner ä ce- spare, suivant le nombre de ses années, le nom de Synagre ou celui de Synodon. On dit que ses teintes varient aussi avec les saisons, et qu'il est blanc ou presque blanc en hiver.

Le denté habite non-seulement dañs la Méditerranée, où il a été observé par les anciens naturalistes grees, mais dans la mer d'Arabie et dans celle de la Jamaique '. Il est très-commun auprès de l'ile de Sardaigne, de la Campague de Rome, de Venise, de la Dalmatie, et des côtes de l'Archipel et de Syrie, ou du temps de Jove, on prenait une assez grande quantíté d'individus de cette espéce pour en faire mariner un nombre considérable, que l'on transportait dans des contrées très-éloignées du lieu où on les avait péchés. II pèsé communément de deux à cinq myriagrammes, quelquefois de onze douze; et Duhamel rapporte qu'un de ses correspondants en avait vu un du poids de trente-huit. On le prend à la ligne, et avec toute sorte de filets. Au printemps, on le trouve dans les basfonds voisins des rivages; et il se réfugie dans les profondeurs de la mer, seit pendant l'hiver pour échapper à un froid trop rigoureur, soit pendant l'été pour se dérober à l'influence funeste des rayons du soleil.

45 rayons a la membraine branchiale - du spore rayd, 10 a chaque nageoire pectorale, 1 rayon aiguillannè et 5 rayons
articulís a chaque thoracine, I8 ray

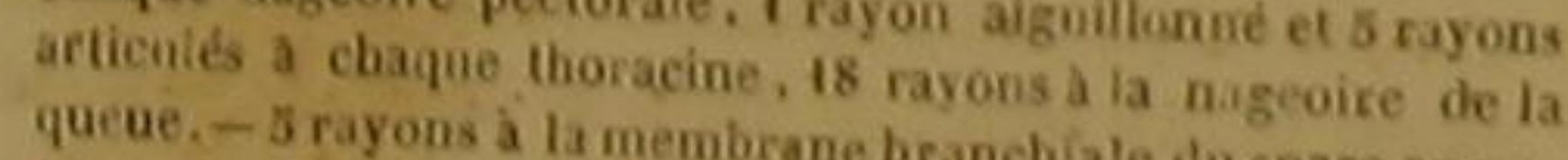
queue. -5 rayons à la membrane branchiale du spare ancre,
15 a - chaque nageoire pretorale, 1 rayon aizoullongé et

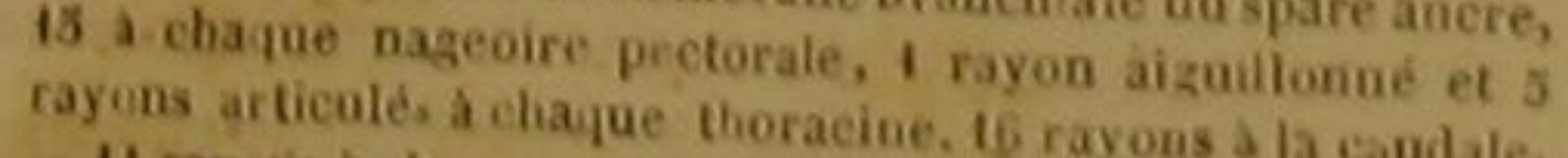
rayons articolé a claque thoracine, 6 rayons a a caudale.
-11 rayonis a chaque nagenire pe torale dn spare trompeur, - If rayons a chaque nagenire pe torale dn spare trompeur,
6 h chaque thoracine, 11 a la caudale. -6 rayons a la mem.
brane branchiale dn

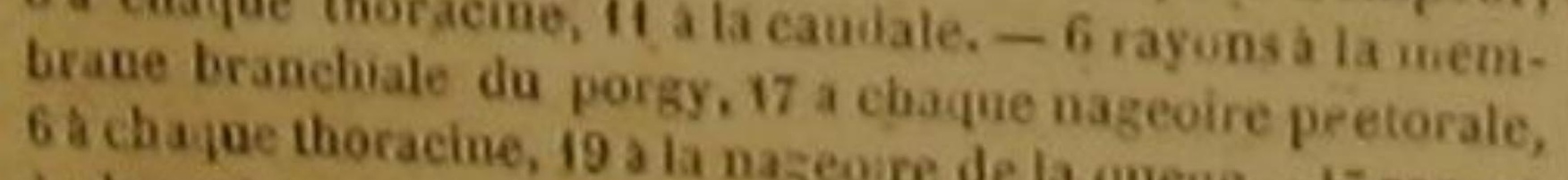

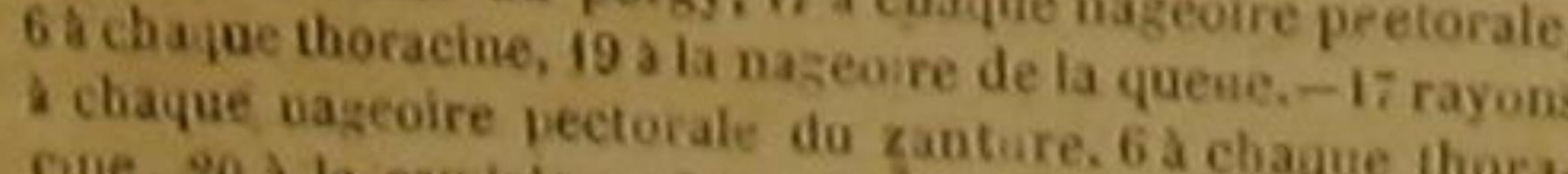

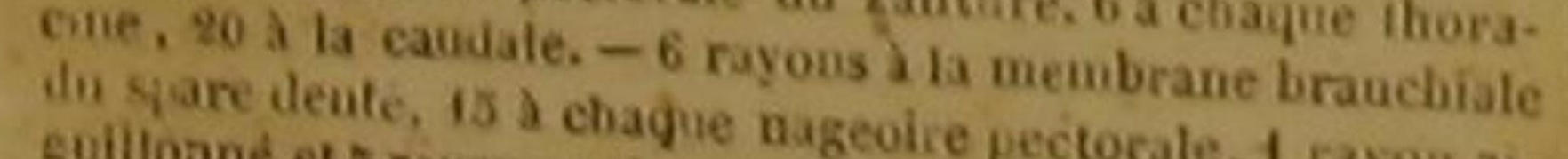

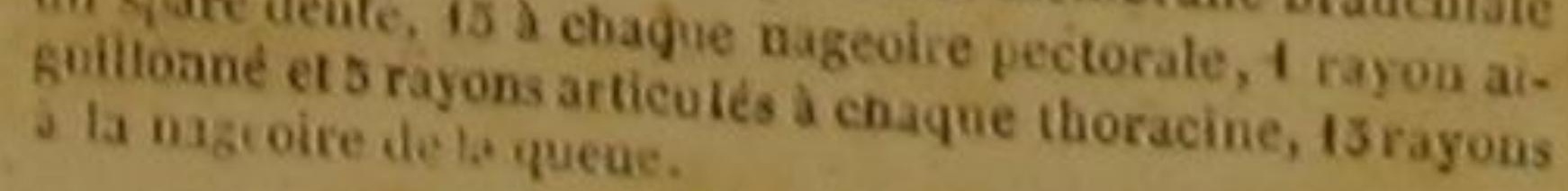

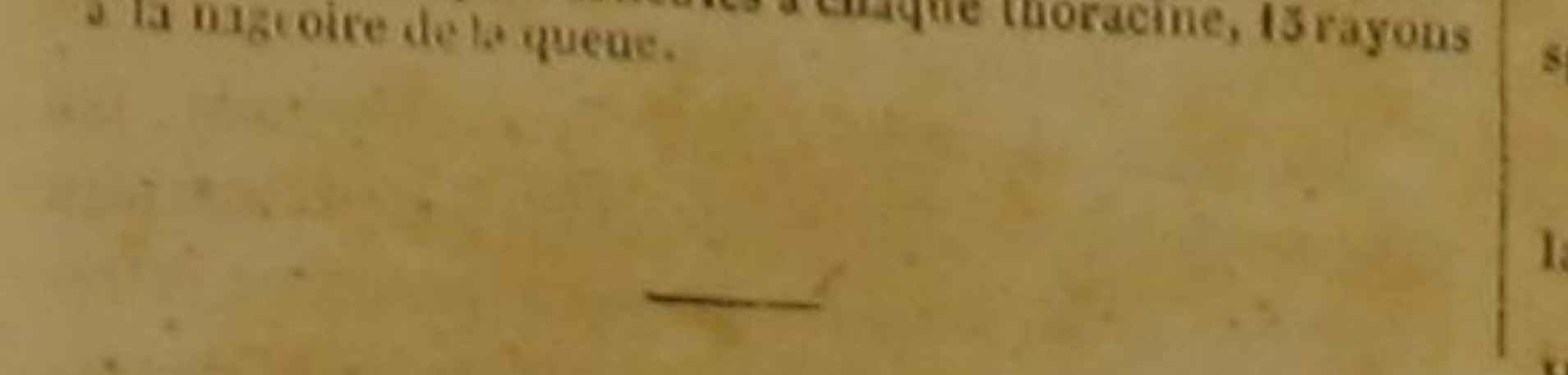

LE SPARE FASCE ', Labruatus, Cuv.; Sparus fasciatus, BI., Laecp.i
Lacanthus, Lac. ${ }^{2}$

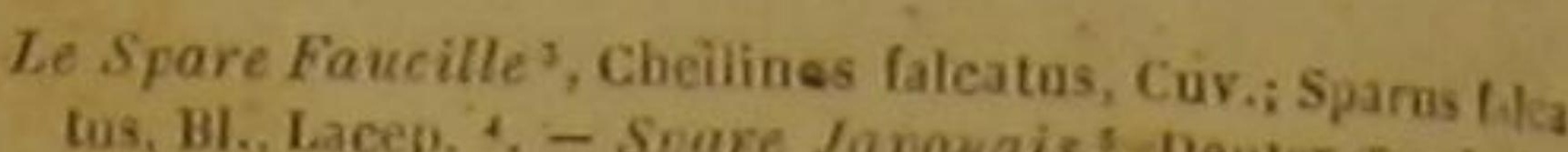
Cuv,: Sparus japopicus, Bl Lacep. - - Deutes Tambina Chromis surimamensis. Guv,; Sparus sí inarenesis , Lac. '- S Spare 'ynod in', Deñex Cynojon, Cuy . 5 ,

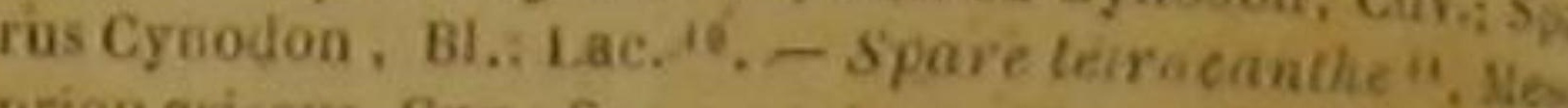
priongriseas, Cuv.; Sparus teira arithus Bl., Lae, Crebl

Bloch a publié, le premier, la description de ces six espêces de poissous.

Le fascé a la tète comprimée : l'ouverture de la bouehe assez grande; les mâchoires d'égale longueur; Ja langue et le palais lisses ; chaque narine indiquée par un seul orifice; les éeailles larges, lisses et minees ; une bande noire sur caudale, dont l'extrémité est d'ailleurs tresbrune, et de petites taches sur un liseré trés. brun qui garnit la dorsale et la nageoire de l'a nus.

II se trouve au Japon.

Le spare faucille habite dans la mer des Antilles, et a été dessiné par Plumier. Ce beau spare est couvert d'écailles brillantes de l'éclat de l'or, et du vert de l'émeraude. Sa tête est grande. Deux deuts fortes et recourbées garnis. sent, des deux cotés, la partie postérieure de chaque måchoiré. Chaque narine a un oritice double. Les opercules sont revétus' de petites écailles. Le ventre est court, gros et arrondi.

Le nom du spare japonais apprend quelle est sa pátrie. On doit remarquer la langue et le palais de ce poisson, qui sont lisses, I'orifice uni'Bloch, pl. 257

Acanthout geare Cheiline, dans le genre labre, fanille da Lacépede a décrit denx fous Cuv. - Selon M. Cuvier, M. de Labre eanéacanihe, et $2^{\circ}$ de Se poisson, sous les noust $1^{\circ}$ de 'Bloch. pl. 258. Da sons-geure Cheiline, dacis le grand genre des Labres. Sivant M. Cavier.

'Block, pl. 277, fig. 1.

apaides denente, daus la famille des Acautboptérygleas Bloch, Ml, 271, for. D.

'Du geare i hromis, dans L familiè des Acanthoptérygient

abroídes de M. Cur er. D.

- lean cacaloea ija, an Janon. - Papageifish, par iea

Hollandais du Japon. - Bloch, pl. 278 .
10 Du

Dy genre Denté, dans la fomille des Acanthoptérygien

"Bloch, Cuv. O27.

"1 Du genre

Sers vercoiles, Mesoprion, de la farnille des Aconthoptery

M. de Lacépéte, Curv. Ce poisson a eté décrit deux fois par

sous celui de Bodian vicaver de que de chacune de ses narines, la compression de son corps, la largeur et la surface mie de ses écailles, le jaune de ses opercules et la couleur de ses nageoires, qui sont variées de rouge et de gris.

Nous n'avons pas besoin de dire que les eaux de Surinam sont celles que préfère le spare qui porte le nom de cette contrée. Ce poisson a l'ouverture de la bouche petite. On né voit qu' un orifice à chacune de ses narines. Les écailles sont lisses et minces; des raies brunes règnent sur les nageoires qui sont jaunes '.

On a observé dans la mer du Japon le cynodon, dont les yeux sont ovales et tres-grands, les narines percees ehacune d'un seut oritice, les deux máchoires d'égale longueur, les écailles lisses et petites, la dorsale ainsi que l'anale variées de jauné et de rouge.

Et enfin Plumier a dessiné dans les Antilies le tétracanthe, qui se plait dans les eaux de ces iles, parvient à une grandeur considérable, et réunit aux traits présentés par le tableau générique un orifice double pour chaque narine, de petites écailles sur les opercules, un trone elevé, et une tache presque ronde, argenté, d'autant plus éelatanté qu'elle est bordée de noir, et placée a l'origine de la lígne latérale.

\section{LE SPARE VERTOR ${ }^{2}$}

Sparus viridi-aureus, Lacep. :

Le Spare Mylostome 4, Sparus Sylostomus, Lac, 1,- Spare

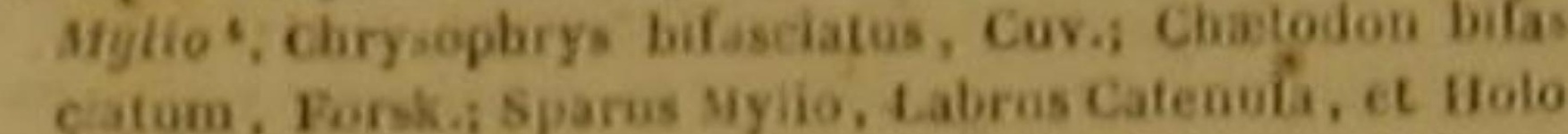
centrus Rabaji, Lac. 1-Spare breton ', Gerres oyena,

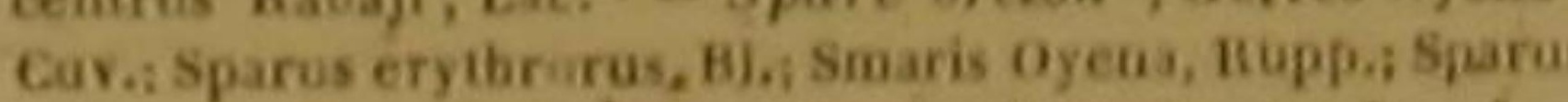
Britanuus, Labrus iongirosiris, et Latrus Oyena, Lac., '. Spare raye d or 16 , Pentapus auroliuealtus, Cuv; spartu surolineatus, Zac." ".

Nous avons trouvé dans les manuscrits de Commerson la description de ces cinq spares.

is rayons a la membrane branchisle du' spare fasce, 12 a chaque pectorale, 1 rayon aiguillondé et 5 riyons articolés a chaque thoracine, 15 rayons a la nageoire de la quene. chayue pectorale, 6 a chaq ie thoracine. 10 a la candale. 5 rayous a la membrane bran hiale do yare japosais, is chaque pectorale, $1 \mathrm{r}$ yon alguillonié et 5 ou 6 rayous ari. cules a chaque thoracue

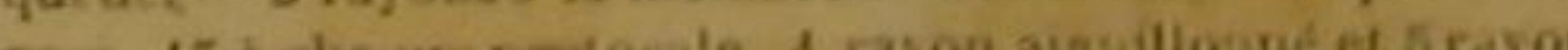
arricules a chanue thoracine, 16 nyons a la caudale rayons a t membrane branchisle do cyoodon, 15 s chaque fectorsle, 6 a das gue thoracine, 20 a ta nagenire de ba qu we is sayons a cha que nageoire pectorale du teiracanthe, 22

a la caudale.
Le vertor habite dańs le grand Océan auprès dés cótes de la Nourelle-Guinée, ou Commerson a vu des myriades d'individus de cette es* pèce, et oú il n'en a remarqué aucunqui eùt plus d'un demi-décimètre de long. Son dos est caréné et son ventre arondi, comme le dos et le ventre de plusieurs spares. Les deux máchoires présentent à peu près la mème longueur. La tèvie supérieure est extensible. De petites écailles couvrent toute la sufface de l'animal. On voit a l'angle extérieur de chaque thoracine une lame écailleuse allongée et aiguillonnée, que Commerson regardait comme un caractere distinctif de tous les spares; mais ce naturafiste n'avait pas observé un grand nombre de cesos. seux. Les vertors suivaient en troupes si considérables le vaisseau de ce voyageur, au milieu du mois d'aỏut 1768 , lorsqu'il allait vers les rivages de la Nouvelle-Guinée, qu'on ne pouvait pas enfoncer un seau dans la mer pour y puiser de l'eau, sans en retirer plusieurs de ces petits poissons, distingués par la beauté de leurs nuances que le bleu noiratre de la base des pectorales fait ressortir avec encore plus d'éclat.

Le mylostome a êté pèché sous les yeux de Commerson, auprès des côtes des iles Praslin, au mois de juillet i768. Le goút de ce thoracin estassez agréable. Ce poisson a beaucoup de rap.

Iranaversis, tel sparus of fusco viridi ioauratus, fascis quinque annutan us nigris, basi- pinuarum pectoraitim iNon mentioume far M. Cuvier. D.

' Gueute payde Commerson. - . Myllo lineis fractis ef , refractis, atteruatim aureiset ceroleis, longindinaliter va. Criegatus: macula in pôstremo otrimque dor o migra. Commer on; manuscrits deja cites.

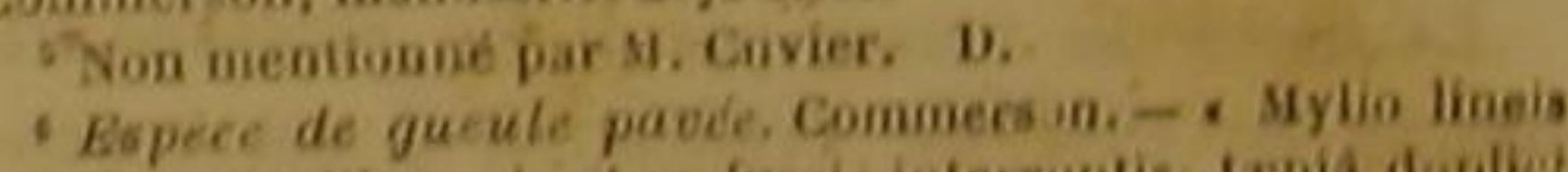

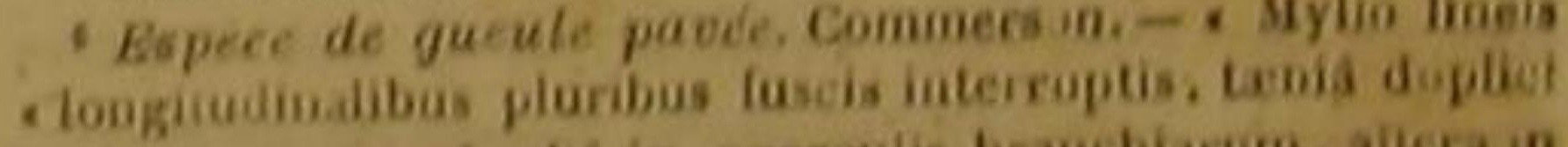
- nigra transveos, alia in operculis branchiarum, alkra in - capiléanteriore , Commerson, manuscris deja cies. I Da geure Denté de M. Cavier, dans La familie des Acan thopteryge us spuroides. M. de Lacépede a décrit ce poisoin trostois sous les noms, $1^{9}$ de spare.Mglio, $2^{\circ}$ de Latre cha

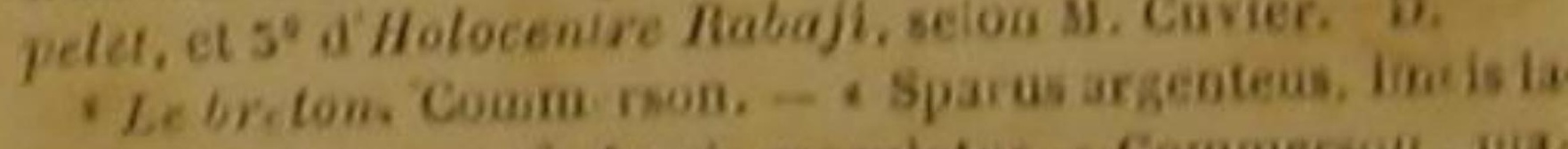

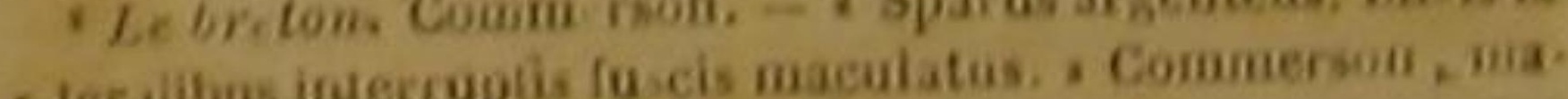

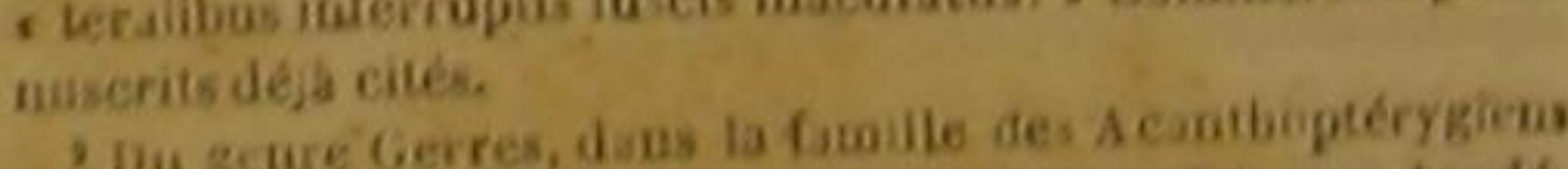

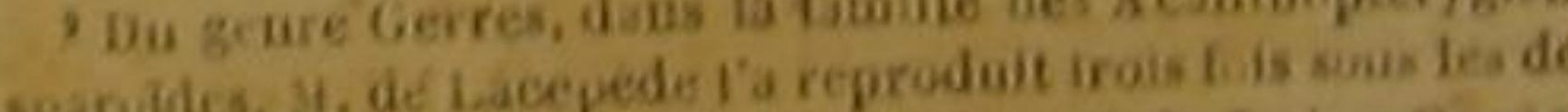
nominaconsi, 10 de Labre long-museau, $2^{2}$ de Labre Oyena 5o de sparebrelon. D.

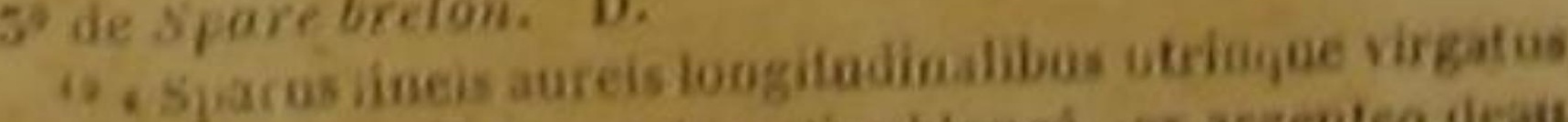
- msenta a tergo pious dorsalis oblonga, ex argenteo deat

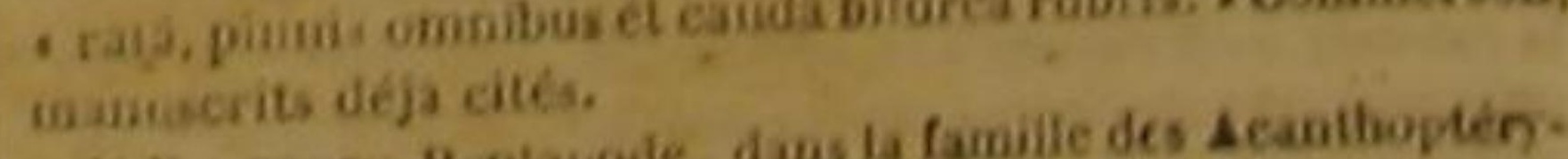
"Da geare Penta. 


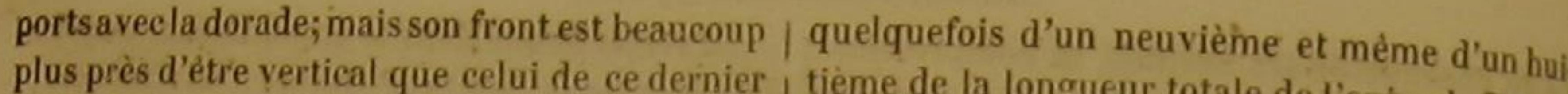
ple la longueur totale de !'animal. Chaque \begin{tabular}{l|l} 
spare. Les deux máchoires sont également avan- & mâchoire est garnie de très-petites dents. \\
cées, et hérissées de dents trés-petites et ser. & Le spare rayé d'or a deux ou trois dé
\end{tabular} rées, comme celles d'une lime, La langue est courte, large, pointue et cartilagineuse. Deux orifices appartiennent à chaquenarine. Les yeux sont très-gros et saillants. Les ècailles qui recouvrent les opereules, le corps et la queue, sont rayonnées, et un per crénelées dans len bord postérieur. La couleur générale est d'un jaune foncé, plus clair sur les pectorales, mèlé avee du vert sur une grande partie de la dorsate et de la caudale, et qui s'etend jusqu'an bord intérieur de la máchoire inféricure, a la langue, au palais et au gosier. Denx taches noirâtres sont placées sur l'extrèmité de la queue, de manière à se réunir et a y representer, suivant les expressions de Commerson, whe paire

La mer yoisine de l'lle de France nourrit le mylio, qui ressemble beaucoup au mylostome, et qui parvient a la grandeur d'un cyprin de taille moyenne. Les écailles qui revètent ses opercules, son corps et sa queue, sont larges, lisses et brillantes. Six dents saillantes en avant nissent l'extrémité des dẹux màchoires, clont l'inférieure est la plus courte; la lèvre supérieure est extensible.

Le fond de la couleur de ce mylio est argenté les pectorales, une portion de la dorsale caudale sont jaunes; les thoracines, la plus grande partie de l'anale, le bord supérieur de la dorsale, et l'extrémité de la caudale, offrent une teinte noiratre; et chaque joue présente unt tache trés-dorée '.

Le breton se trouve parmi les poissons tittoraux de l'Tle de France: il y est cependant assez rare. On vante la bonté de sa chnir, mais il ne parvient ordinairement qu'a la longueur de deux ou trois décimètres. La lèvé supérieure est si extensible, qu'elle. s'allonge

' 18 rayons a chaque nageoire pectorale du vertor, irayin

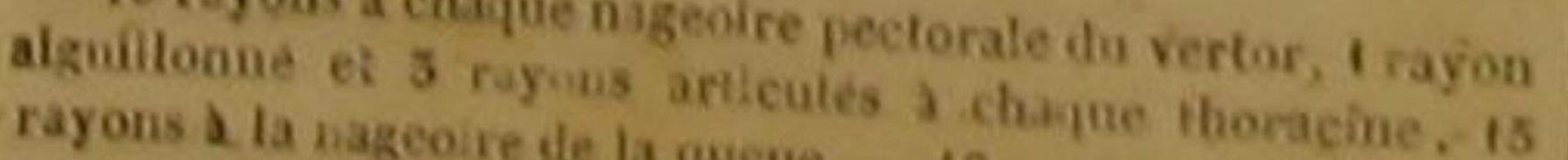
geoire pectorale du miglostome, -1 ray rayons a chaque aarayons articulds a chaque thoracine, 18 rayons it to coné ef 5 - Is rayons a chaque uazeoire pectorale itu mylio, 1 rage. rayons $\dot{y}$ ta et 5 ravons artenles a cbaque thoraeine: it geoire pector de du spare brecue. -17 rayons i chaque nala caudale. -6 rayons a b a men, 6 j chayue thoracine, 17 ; rayes doc, 15 a chayue mageoire pectorale, I rayon aiguilloore el 6 rayus articultes i chaque thoracine, 17 rayons a la na.
keoire de la quecue.
Le spare rayé d'or a deux ou trois décimètres de longueur, les deux mâchoires presque également avancées, le doş brun, et les cótés argéntés.

\section{LE SPARE CATESBY ।}

Hæmulon ....., Cuv.; Perca melanura, Linn., Gmel,
Sparus Catesby, Le Spare Saufeur's, Temnodon saltator, Cuv. Percambe trix, Lino : Gruel, Sparu saltator, Cheilodi, Ferea solta. canthas, el Poniatoma Skib, Lac. 4. - Spare Veaimess Serans....., Cuv,; Perca veneriosa, Liun. Gmel, Spare

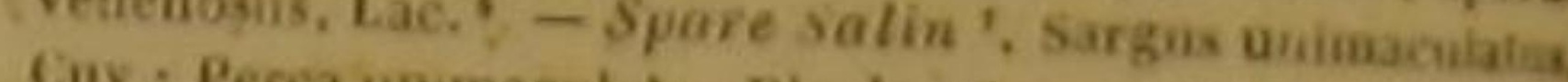

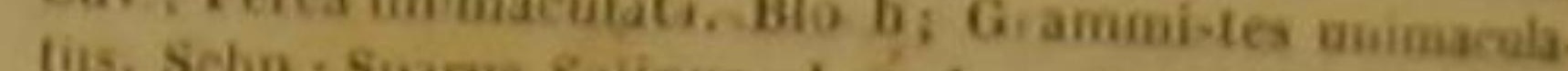
poma Nodo. Cuv.; Perea Juta, et Sppare Jub ', Prisi. sparus Jub, et Lutjanes vieginicus iasus vitatus, Blu bi

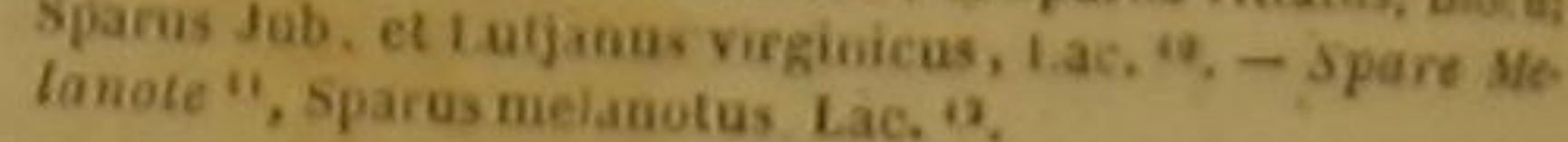

Nous devons â Catesby la connaissance đu sparé auquel nous avons donné le nom de ce

1. Perea marica, eandá nigra. . Catesby, Carot. 2, p.7.

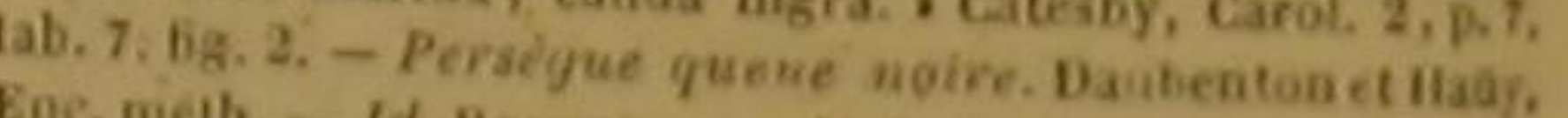

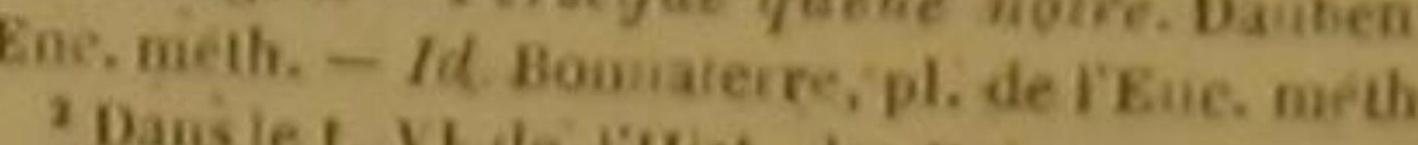

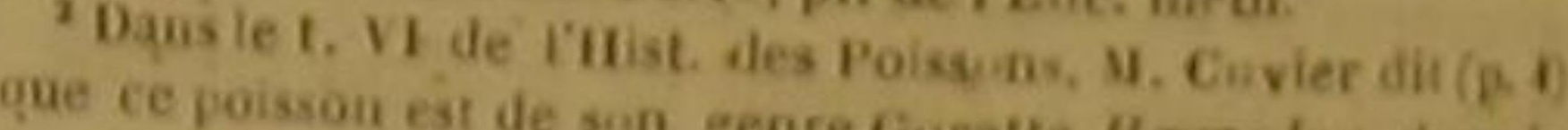
fue ce poisson est de san geare Gurette Homilon, dans ia

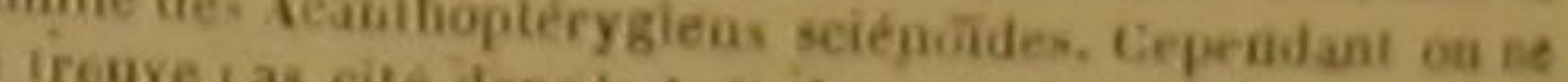

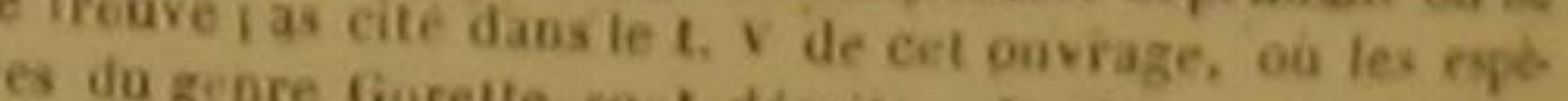

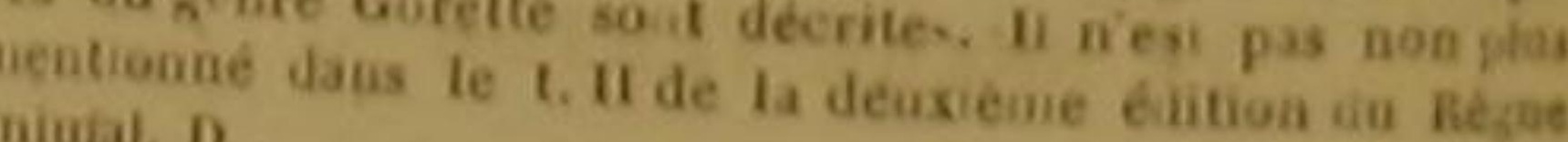
mimal, D

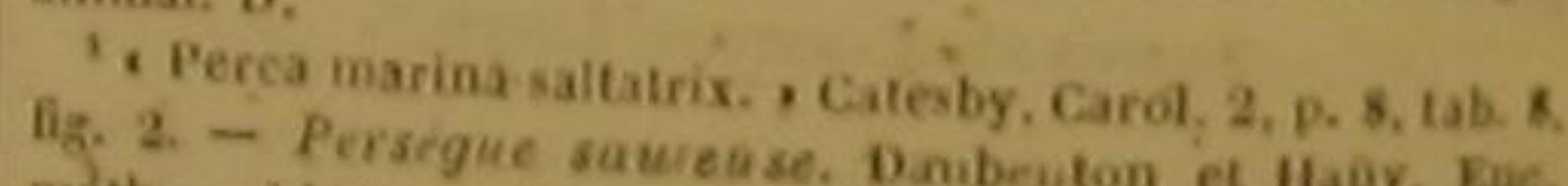
il -ld, Bunaterw, pl de IEnc, meib.

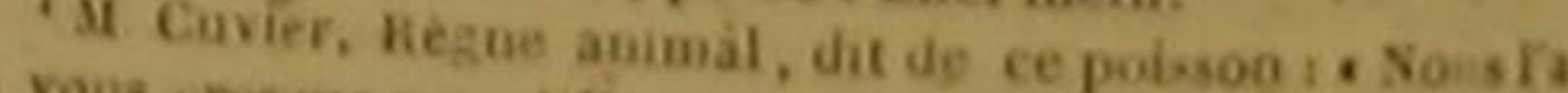

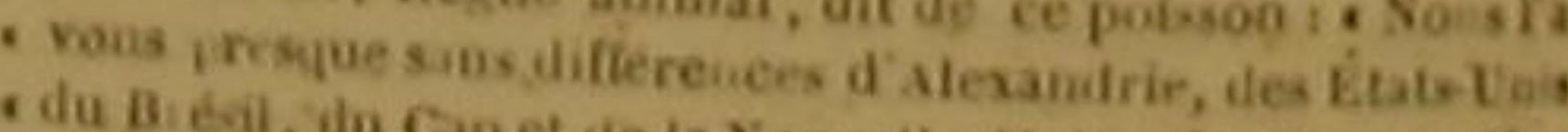
- lodintere heptap et de la Noureile-Hobande. Cot le CbeSon Pomatome Slab de Lacépede. d apres Commernob, ef

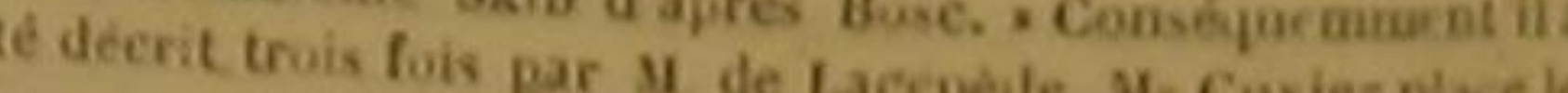
Biensseomberioides. D.

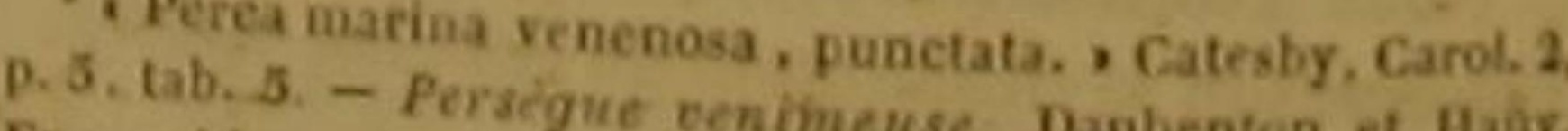
- Id.Bunnaterre, pl, de IFuc, méth. et Haũy,

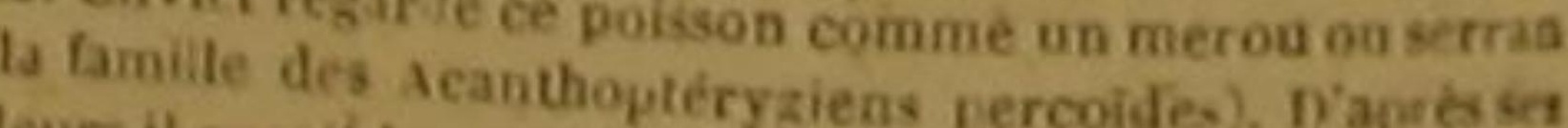

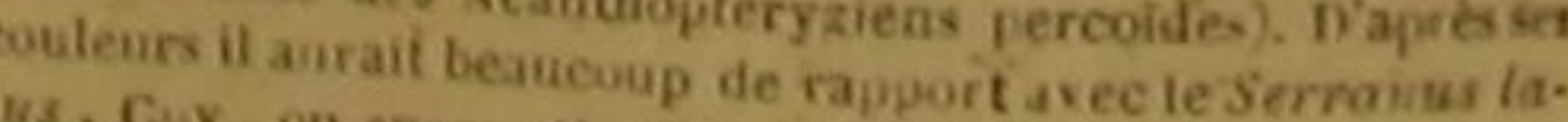
de ce dernier spare atlantique de Lacé, e ie: mais la querie comme on les voit das la figure de Catso sale n. Ins Poen, Selumixira, an Bresit, - Selle D. Selim par , Doto h, pl. 308, fig. I.

span ides de II Cuvier. dans la famille des Acarithoptérygiens 'Gua umapa juba, an Brat

ig. 2.

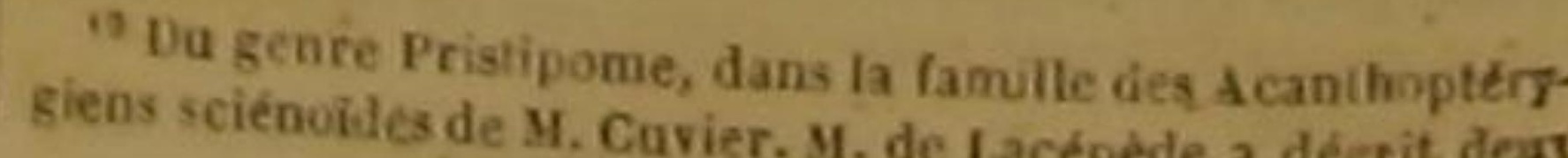
geore auquel it appartient dans lac fuevilte Ma Cavier place

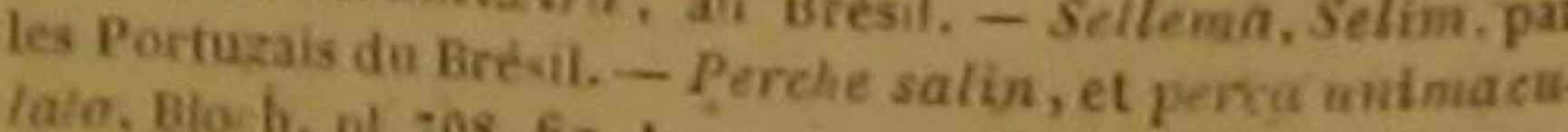

voyageur, ainsi que celle du sauteur et du venimeux. Ces trois espèees habirent dans les eaux de l'Amérique septentrionale un peu voisines des tropiques, et particulièrement dans celles de fa Caroline. Le premier de ces trois spares a ordinairement trois ou quatre decimetres de longueur. Sa gueule est grande et rougeal'interieur; et les écailles qui recouvrent son corps et sa queue sont larges, brunes, et hordées de jaune.

L.e sauteur, qui doit son nom spécifique à la facilité avec laquelle il s'élance, comme plusieurs autres poissons, au dessus de la surface de l'eau, présente sur ses opercules un melange de blane, de rouge et de jaune. La couleur générale de sa partie supérieure est brune. II se plait dans les climats ehauds. II n'a souvent que deur décimetres de longueur. Mais la rapidité et la force avec. lesquelles il agite sa queue, lui donnent, indépendamment de la faculté de sauter et de s'elever presque verticalement à une hauteur plus ou moins remarquable, celle de nager avee vitesse, et de suivre les vaisseaux mème lorsque leurs voiles sont en: flées par le vent le plus favorable.

La longueur ordinaire du venimeux est depuis six jusqu'à dix décimètres, et par conséquent très-considérable. II a été xegardé comme renfermant un poison dangereux ; et de lá vient le nom spècilfque qu'il porte, Mais il parait qu'il n'est pas venimeux ou malfaisant dans toutes les contrées ni dans toutes les saisonscoù on le pèche, et par conséquent qu'il ne doit ses qualités funestes qu'a la nature des aliments qu'i préfere dans certaines circônstances, et qui, innocents pour ce thoracin, sont mortels pour I'bomme ou pour plusieurs animaux. Cet osseux est des lors un nouvel exemple de ce que nous avons dit dans notre Discours sur la nature des poissons, de l'essence et de l'origine de leurs sues vénéneux; mais il n'en doit pás moins êtrę l'ohjet de l'examen le plus attentif, ou plutôt des épreuves les plus rigoureuses, avant qu'oh ne puisse avec prudence se nourrir de sa chair, dont il sera toujours bien plus sùr de se priver.

La patrie du salin est le Brésil. Ce spare, dont Maregrave et le prince Maurice de Nassau

Cols ce poisson, sous les noms de Spare jub, et de Luijan eirginien, - D.

"Perche orgentée. Bloch, pl. s11, fig. ont laissé chacun un dessin, a la tête petite, la couleur générale d'un bleu argenté, toutes les nageoires jaunes ou dorees, des intestins trèslarges, un ovaire très-grand, et une longueur de trois ou quatre décimètres. II quitte la mer au printemps pour remonter dans les riviéres, et ne revient dans l'Océan que vers la fin de T'automne.

Le jub habite le Brésil comme le salin. La nuque de ce poisson est très-relevée : son dos d'un violet noirátre; et chacune de ses nageobres variée de jaune et d'orangé. Ce spare devient deux fois plus grand que le salin ; mais il ne monte pas, comme ce dernier, dans les rivieres. Il s'arrete entre les rochers voisins des embouchures des fleuves; il y passe méme très. souventl'hiver; et on y péche un nombre d'autant plus grand d'individus de cette espèce, que la chair du jub est très-bonne à manger, et que celle des joues de cet osseux, ainsi que de sa langue, a été regardé comme une nourriture des plus délieates. Le prince Maurice a fait un dessin de ce spare; on en trouve un autre, mais mauvais, dans Marcgrave, qui en a donné aussi une description. Le dessin de Maregrave a étó copié par Pison; sa description par Willughby: l'un et l'autre l'ont été par Jonston et par Ruysch. Bloch a publie le dessin du prince Maurice.

C'est dars te Japon que vit le mélanote. Ce thoracin a les dents petites; et chacune de sea arriges n'a qu'un orifice. Ses autres traits sont indiqués dans le tableau générique, ou dans cette note ${ }^{4}$.

\section{LE SPABE NIPHON 2 ,}

Sparus Niphon, Lacep. '

Le spare demi-lune ', Mesoprion chrysurus, Cuy ispacis

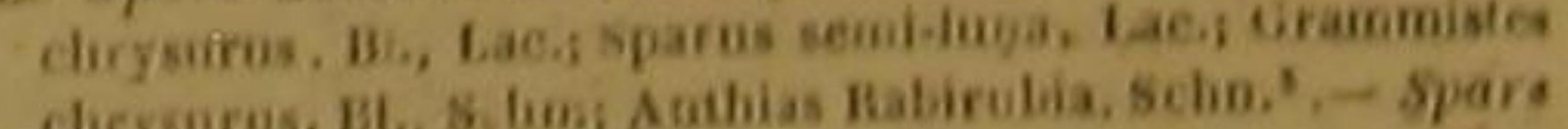

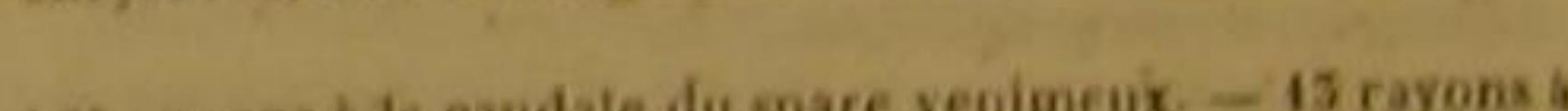

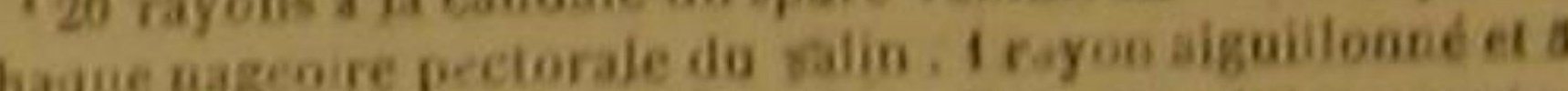
chaque nageo re pectorale do pain. Irayou angat is nazeoiro

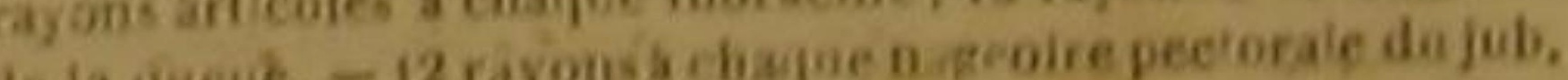

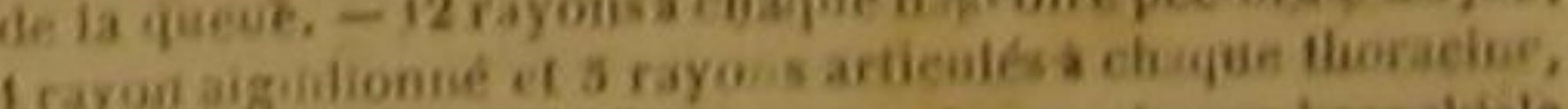
17 royoins 3 be caudite -5 raycus a ta membirase brancliale

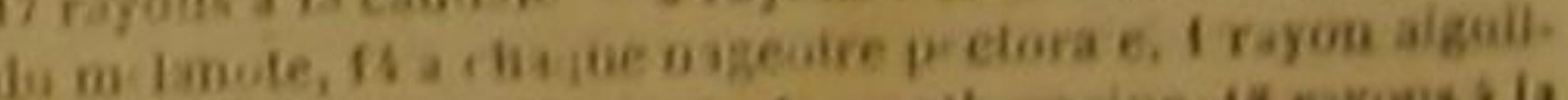

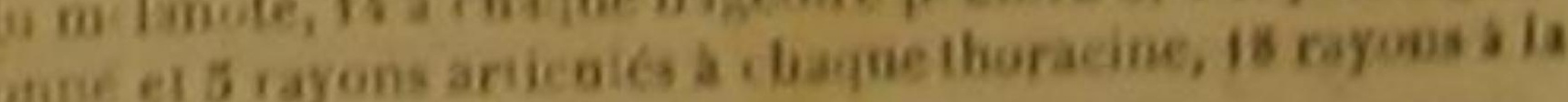
ageoire de la quecue.

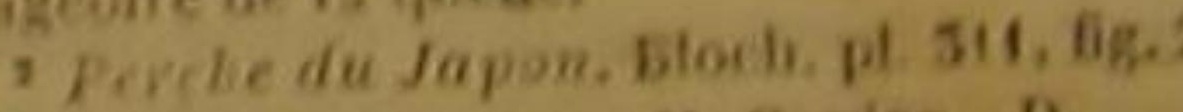

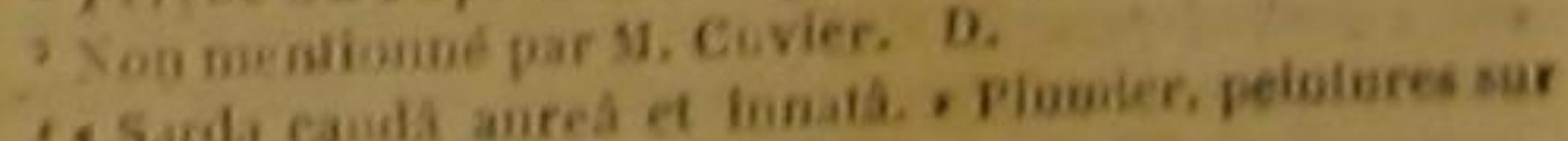

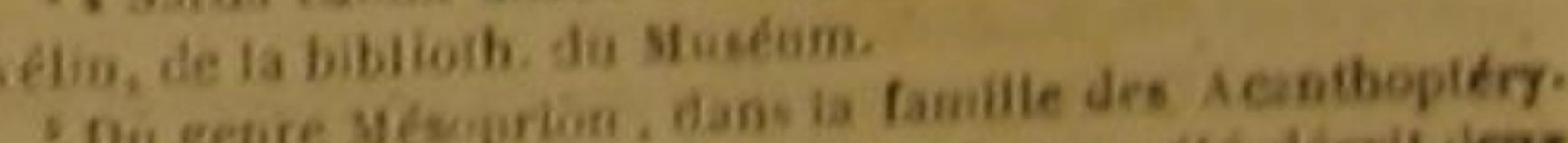

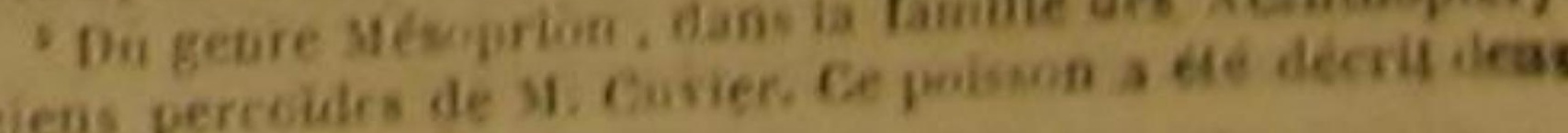


Holocyanose', Scarus cæruleus, Cuv, Bl; Coryphæna
cæralea, Bl.; Sparus holocyaneos, Lacep. ${ }^{2}$. - Spare Lepicærulea, Bl; ; Sparus holocyaneos, Lacep. ${ }^{2}$. - Spare Lepisure, Diacope quadriguttata Cus,; Sparus lepisurus, Lac.
- Spare bilobe 4 , Chrysophrys bilobata, Cuv,; Spärus bilobatus, Lac. ". - Spare cardinal, Chrysophrys Cardina-

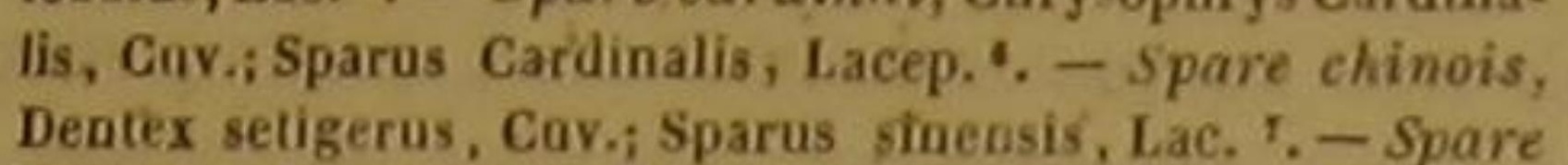
Dentex setigerus, Cav,; Sparus stinensis, Lac, r. - Spare Bufonile; Chrysophrys Sarba, Cav.; Sparus Sarba, Forsk.,
Lipn., Gm., Lac,; Sparus Psittacus, Lac. '. - Spare Perroquet, Chrysophrys Sarba, Cuv.; Sparus Psittacus, Sarba t Bufonites, Lac. '.

teintes douces et agréables du bleu qui règne seul sur teute sa surface.

Le lépisure ', qui appartient au grand 0 cè équinoxial, a l'ouverture de la bouche tres grande, les dents petites, et le bord supérie de la partie de la nageoire dorsale qui n'est tenue que par des rayons aiguillonnés, d'une nuance beaucoup plus claire que le reste de cette nageoire.

Le bilobé vit dans le grand Océan équinoxia

Le nom de Niphon indique que le premier des neuf spares dont nous allons parler vit dans les eaux du Japon, dont cette grande ile de Niphon fait partie. Bloch a fait connaitre ce poisson. La tête de ce spare est petite; sa mâchoire supérieure égale en longueur ả l'inférieure, et hérissée, comme cette derniere, de dents semblables à celles d'une lime; chacune de ses narines garnie d'un seul orifice.

Le tableau générique montre les prineipale formes et les couleurs les plus riehes du superb spare auquel nous avoñs donné le nom de DemiLune, et dont nous avons trouvé une peinture parmi celles que l'on a exécutées sur. vélin d'après les dessins de Plumier, et que l'on conserve dans le Muséum national d'histoire nàturelle. Nous n'avons rien à ajouter maintenant au sujet de cet osseux, si ce n'est que ce beat poisson a les deux máchoires aussi avancées l'une que l'autre, que ses pectorales, ses tho. racines et son anale sont grises et qu'il habite V'Amérique méridionale.

C'est la mer de cette mème partie de l'A mérique qui nourrit l'holocyanéose to dont nous devons la connaissance à Plumier, et qui n’éblouit pas l'ceil de l'observateor par la mu réficence de sa parure, mais le char la magni-

fois par M. de Lacépede, sous les nows de $S$ pare demi-lun
et de $S$ pare ¿t de Spare queue-d"or. D.

2 Du genre Scares, selus cerulens. Plumièr, ibid.

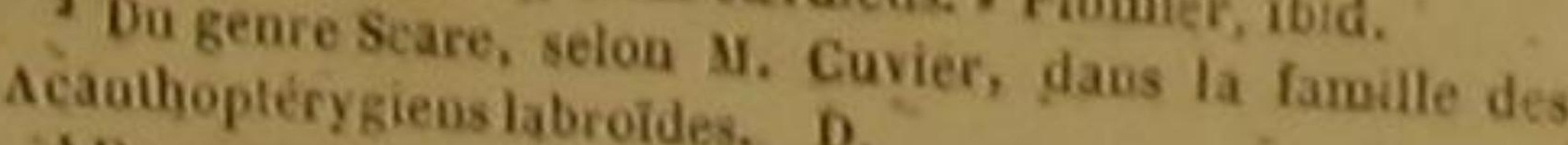

"Du geare Diacope de M. Cuvier, dans la famille des Acau-
thoptérygieas pereoides. D.

'Capizaine Blane, J. Wy

'Du geure Dsurade, Chry yop narys sateurs.

- Du genre Dansparoídes de M. Cuvier. D.

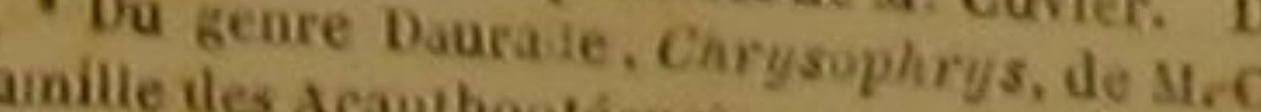

¿ Du genre Deuté, $D$-neex.

des Acanithoptéryglenas sparoides, de M. Cuvier, danis la famile

des Acinthophiryde, Chrysophrys, de M. Cuvier Ine

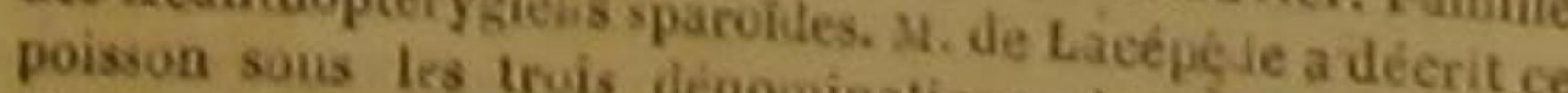
Spare Bufonite et S Sore Painations de Spare Sarbe 'Ce spare Perroquet na difruquet. D.

du spare sarbe, décrit dans le ro pas du précédent, et aussi

"Ôhos veut dire tout, et xúgruses articie. comme le lépisure; et c'est parmi les manus-

crits de Commerson que nous avons trouvé les desșins de ces deux spares.

Les merš ou les rivières et les lacs de la Chine sont la patrie du spare cardinal et du spare chihier de manuscrits chinoois cédés à la France pai la Hollande, et déposés maintenant dans is bibliothèque du Muséum national d' histoire naturelle ${ }^{2}$

Le spare bufonite et le spare perroquet out été péchés dans le grand Océan équinoxial, et tigures par les soins de Commerson, qui en transmit dans le temps a Buffor, les dessins que j'ai fait graver. Les dents incisives et molaires qui garnissent la bouchè du premier de ces spares, et dont on peut voir la forme représentée sur fa méme planche que ce bufonite, ont tant de ressemblance avec celles de ia vraie dorade, qu'il ne m'a pas paru invraisemblable que dans quelques circonstances on ait pris, ou l'on prit à l'avenir, des dents fossiles de bu. fonite pour des dents de dorade; et comme cette erreur peut étre de quelque importance relativement aux conséquences que le géologue tire quand il compare la patrie actuelle d'une espece de poisson avec les pays ou il trouve des dépouilles de cette méme espece, $\mathrm{j}$ 'ai désiré que le nom du spare dont la conformation pouvait entrainer une méprise fâchreuse, indiquảt l'attention avee laquelle on doit observer tous ses traits $^{3}$; et je l'ai appeté $B$ ufonite par allusion à

'Le mot lépisure désigue les écailles qui sont sur la cas.

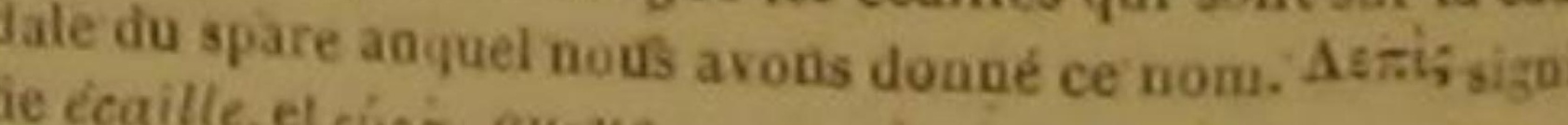
' voyille, el cospá, qurue.

cuté en Chine; et pour le spinois, la page 23 de ce cahier, ex ' 5 rayons a la membrane brare cardimal, les piges 46 et rayons a chaque peciorale du spare demi-ture - 10 rayons a chaque pectorale da sparé holocyanéose, 12 a la nageoire do

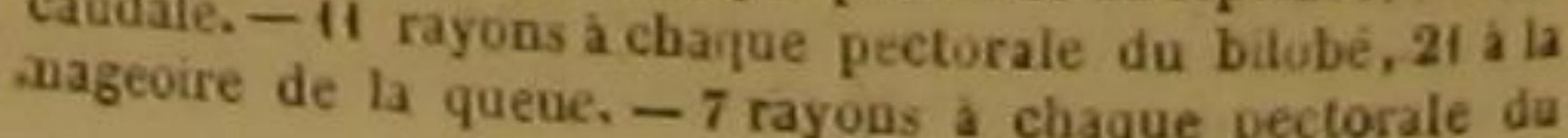
nois, dont nous avons vu la figure dans un ca. que pectoraie, 6 a chaque thoracine, 16 i ia candase -13 la querue. - 15 rayons a chaque pectorale du lépisure, 17 a i un des noms donnés à ces molaires fossilès de la véritable dołade, qui different à peine de celles du spare dont je publie le premier la description.

Au reste, les pectorales du bufonite sont allongécs et très-pointues; et chacune de ses narines a deux orifices inégaux en grandeur.

Le perroquet $a$, comme le bufonite, les pectorales pointues; sa dorsale est d'ailleurs basse et allongée.

\section{LE SPARE ORPHE :}

Pagellus centrolontus, Cav, ; Sparus ceutrodontus. La roche; Sparus Orphus, Laeep. 3

Le Spare marron s, Chromis vulgaris, Cuvis Sparus Chromis, Lim., Gmel, Lacep. 4,- Spare rhomboide', Sargus rhomboides, Cur, Sparus shomboides, Lino., Gmel., Lac, - spare Eride', Sparus capistratus, Limn., Gme,

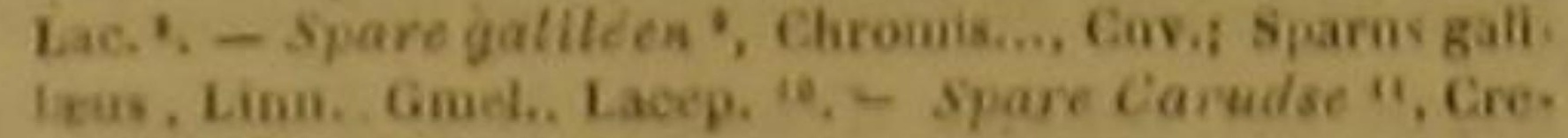
nilabrus rupestris, Cur., Labrus rupestris, Limo, Gmel. Lutjanus rupestris, Bioch ; Sparus Carudse, Lac.

L'orphe vit dans la Méditerranée, ou il a été bien observé, mèmedè le temps d'Aristote. II

spare eardinal, 6 a chaque thoracieé, is a ta Eandale -

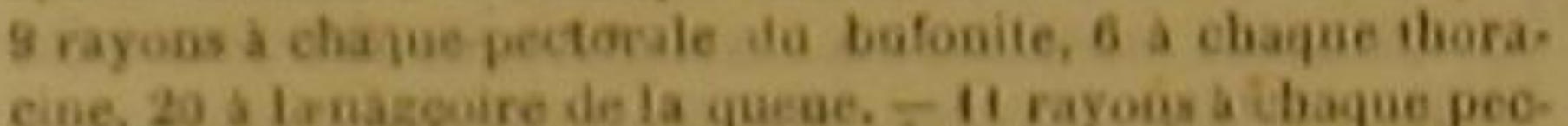
cine, 20 a lonageure de la queve. -11 .

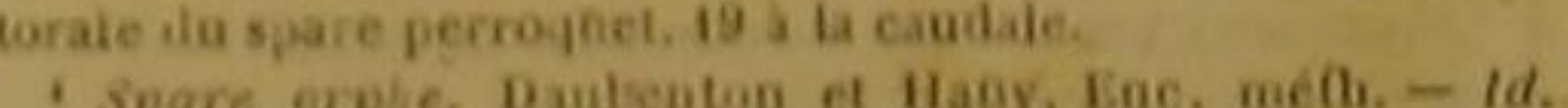

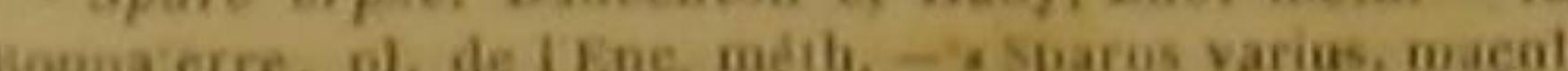
coigra ad candam in estremo wqualem, , Ariedi, , gen. 57,

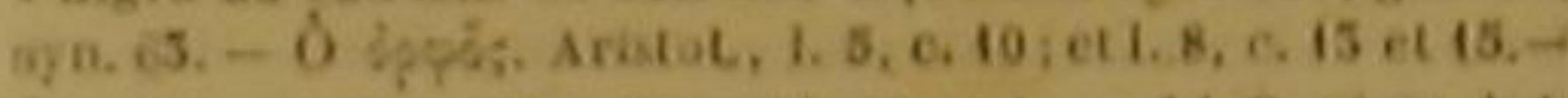

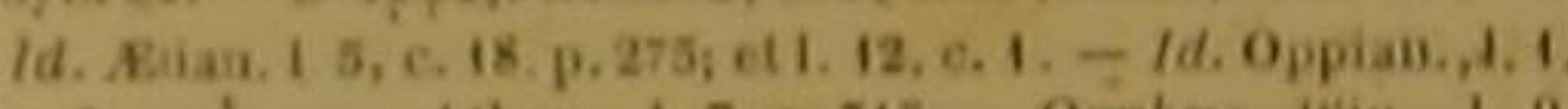
p. 6. - Operos. Athen, 1. 7. 1. 315, - Orphas. Min., 1. 9, c. 16. - Orphe. Noudelet, part. I, I. 5, c. 2s - Orplus, Aldrovand, 1, 2, cap. 11, 1., 158, - Joñston, 1, 1, L,5, 6., a 5 , tab. 18, , . 8. - Corphas alius velerum. 6 Grsuer, p. 658

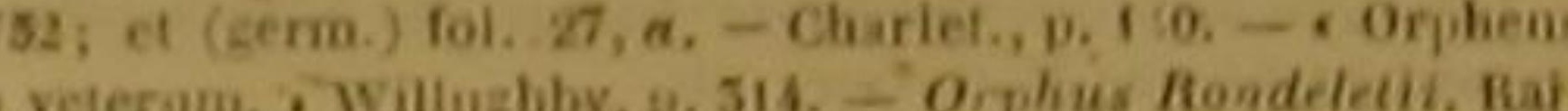
p. 135, - Cernuo, Gaz, in Aristot.

a Da geore Pagel, daus la fanille des Acanthopterygien sparoides, Cav, - Selon 3. Cuvier, ce poisson est 1 Orphius de Rondelet, d' Aldrovande et de Willoghby, dout M. de La. épele a tradpiit la description. Mais Artedi, en réubisson les artieles de ces anciens auteurs sous un catactere qui aj

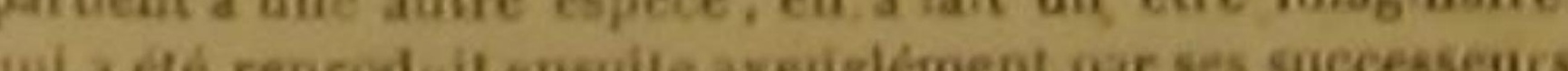
Liunée, Gmelin, etc. $\boldsymbol{b}$.

'Castagnol, en Ligurie et en Toscane. - Monachelle, en Sicile, - Spare marror. Danbenton et Hay, Ene, méth.Id. Bonnaterre, pl. de l'Ené méth - isparus ossiculó ter cundo pinnarum ventralium in tongam setam quasi pro - ducto. . Arted., gen. 57, syn. 62 - $\delta$ ypipu, zpopis, wxi xeopis, Arist., 1. 4, c. 8, 9; 1, 5, c. 9; et i. 8, c. 19.-X X p'jus

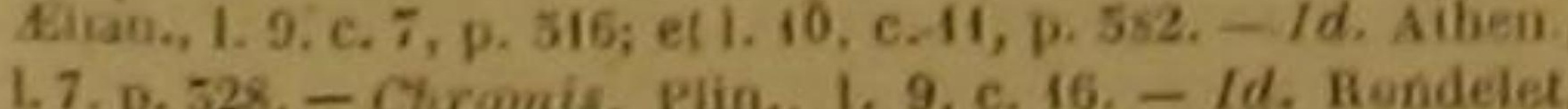

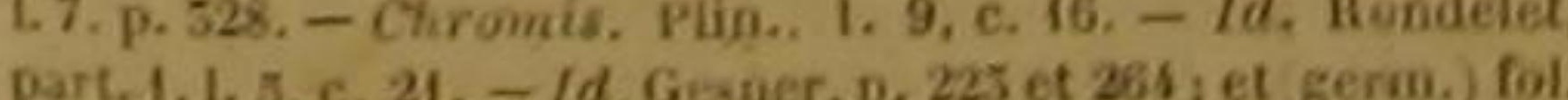
26, b. - Id. Aldrov, 1. 2, e. 14, D, 168. - Id. Jon ton, I. A, t.5, c. I. a. .7, t. 17, n. 14 . - Id. W willughthy, p. $550-1 d$. Rai, p.14. 'Type du geare Chromis, dans'a famille des Acanthoyte-
rggiens a aboides, CuY, D. roit avee beaucoup de vitesse, pendant qu'il est jeune. II fréquente les riyages lorsque la belle saison règue: mais il se retire pendant Phiver dans les profondeurs de la mer; et l'on a éerit que son instinct le portait à choisir pour le lieu de sa retraite les cavérnes sous-marines où abondaient les animaux à coquille, L'orphe perd difficilement la vie; ses mouvements vitaux sont mème assez intenses pour que son irritabilite subsiste quelque temps après sa mort, et que ses membres palpitent fortement après qu'il a étédissequé.

La Méditerranée est la patrie du spare marron, comme de l'orplie. Ce spare marron a la tête petite, le museau court, le second rayon de chaque thoracine termine ordinairement par un filament, une épaisseur un peu considerable, et une longueur d'un ou deux déeimetres: Les rajes longitudinales qu'it présente sont d'une teinte plus claire que la couleur générale brune qui le distingue, et que rappelle son nom spécifiaùe, Les individus de cette espèce vont sou. vent par troupes nombreuses, On prétend que, comme plusicurs autres poissons dont uous avons déja parlé, ils peuvent produire un bruisement tress-sensible, on faisant siffler contre les opercules de leurs branchies les gaz qui sortent avee rapidité de leur estomac et de leurs intestins, lorsque ees animaux compriment vivement ces derniers organes. On a aussi éerit, at cette opinion parait venir-d'Aristote, que le

- Spare brème de mer, Baubeuton et Hây, Kac. méth,-

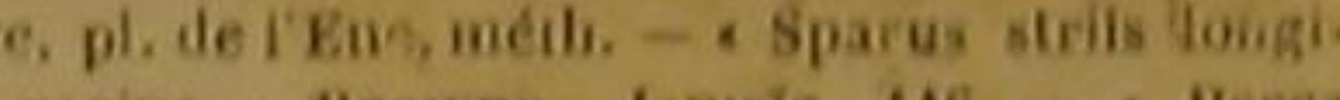

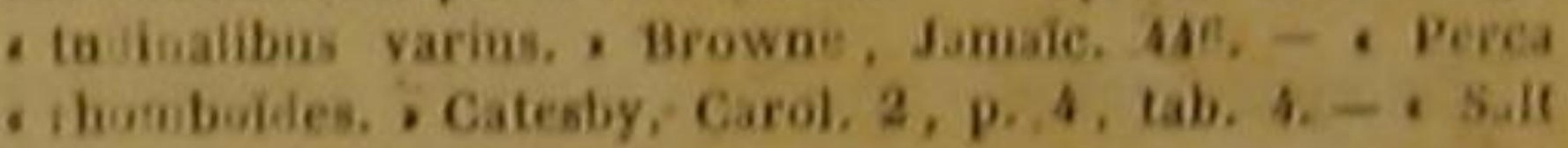
water bream. D. Garden.

- Du senre Ssigue de M. Cuvier, dans la famille des Acanhopteryg ens sparoties II ne bogit ici que du polsson en. roye a himee par Garden, nous le noan do sall water.

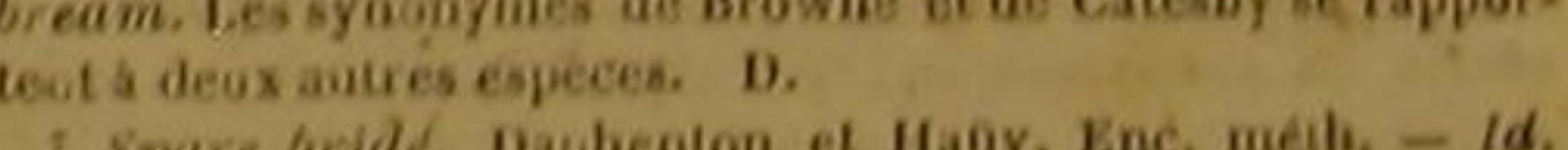
Bonaterre, ph. de I'Enc, méth.

- Son mentioned par M, Cavier. D.

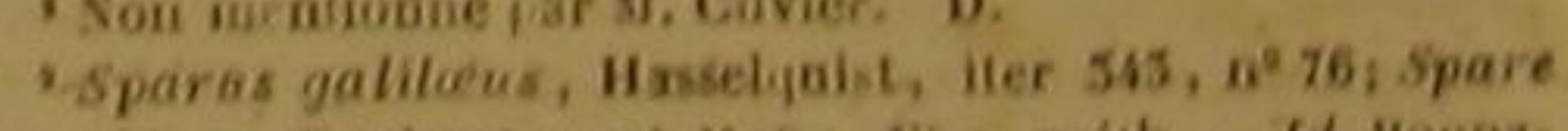

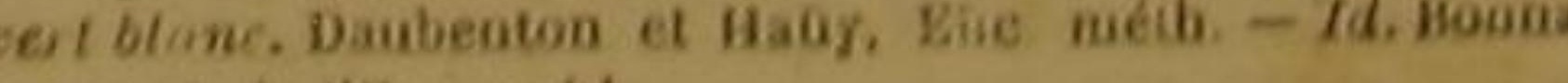
ierre, pl. de i'Ese. méth.

Wh. Cavier soupgoune que ce poison doit étre plact kiens labroides. D.

"Laje car ude, Darubenton et Hagy, Lue, wált. - Id.

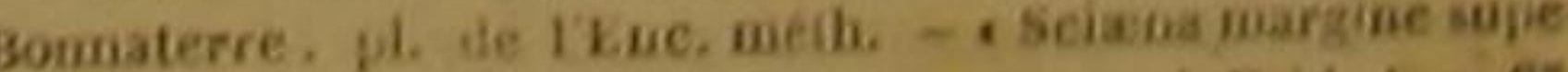
- riore cande macula fus d notato. . Mus, Ad, Vrid. L, p. 65. -Carudse. Sirom. sondm. 291. - + Lutjanas rupestris, es - rassin de mer. Blocli, pl. 250 . "Du sous-geare Crénilatere, daus le grand genre labr de H. Cuint 
spare marron devait étre compté parmi les poissons dont l'ouie est la plús fine.

C'est-dans les mers de l'Amérique septentrionale que l'on trouve le rhomboìde et le bridé:

Le galileen est du petit nombre des thoracins qui ont plus de six rayons à chaque thoracine. Son nom spécifique annonce qu'il habite dans la Galilée: on l'y a vu dans le lac de Gẻhézareth; et quelques auteurs se sont plu à écrire que l'on devaít rapporter à cette espèce les poissons pris en si grand nombre dans le lac de Galilée, lors d'une fameuse péche dont saint Lue a' parlé '.

Le carudse, que l'on a observé dans la me qui bangne- les côtes de la Norvège, a les opercules garnis de petites écailles; et sa coùleu générale est grise. Si les opercules dé ce poisso sont dentelés, ainsi que Bloch l'a ecrit, et ainsi que le montre la figure publiée par ce naturaliste, it faudra placer ce earudse parmi-les lutjans, dans le genre desquels il a été inserit pa le célèbre ichthyologiste de Berlin.

\section{LE SPARE PAON ${ }^{2}$}

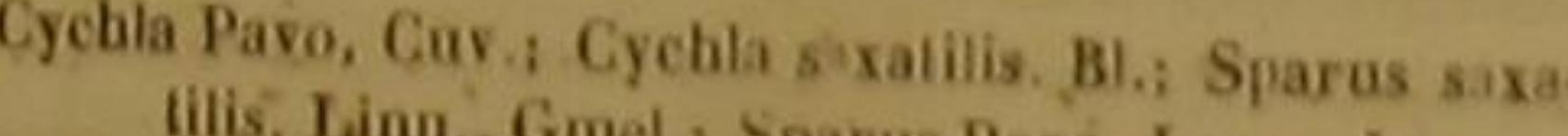
tilis, Linn,, Gmel, sparus Paro, Lacep, ".

Le Spare rayoniè, Sparus radi fuí, Limn., Gmel., Lac. :
- S, are plombe:

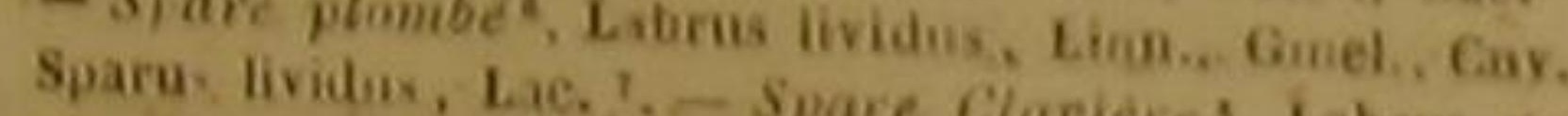
rius, Lion., Gmel., Cuv ; Sparns Clavie a S ', Labrus va

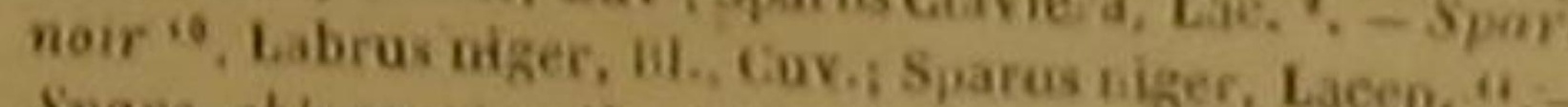

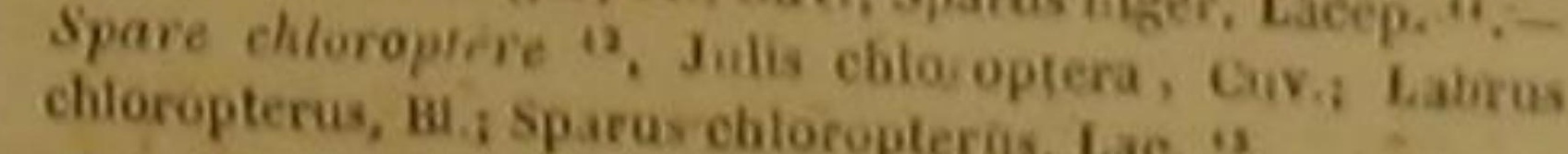

Le spare paon, que l'on a pêché auprès des rivages pierreux de Surinam, présente un corps

46 rayons a chaque peeforale de lorphe, 6 a chasue the

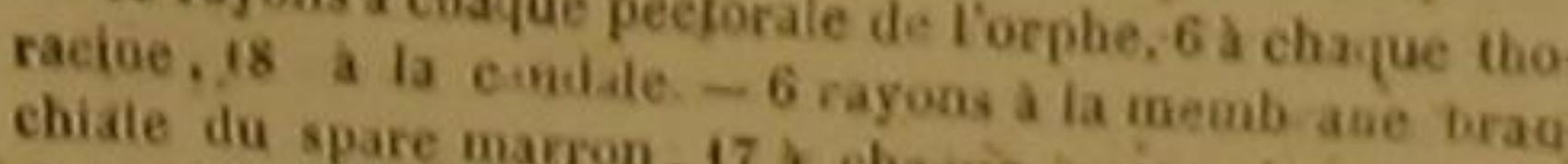
siguillowe of of marron, 17 \& chaque peciorale, 1 rayo rayous a la nagevire de la quevés a chaquê thoracise, 15 branchiale, du spa e rlouboide, 16 a chajue m. mbrime

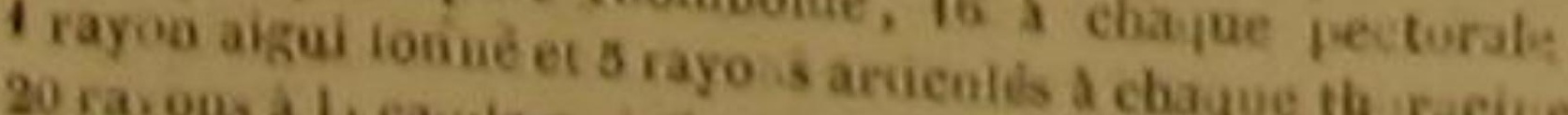

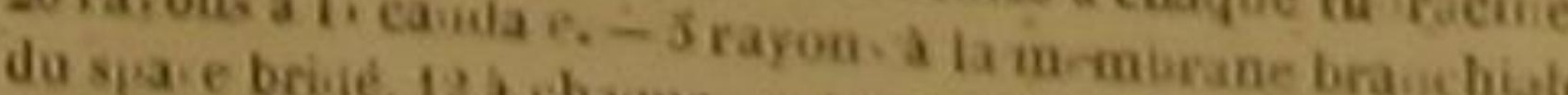

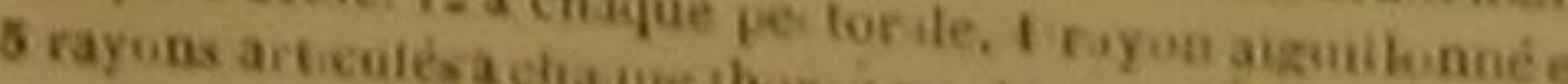

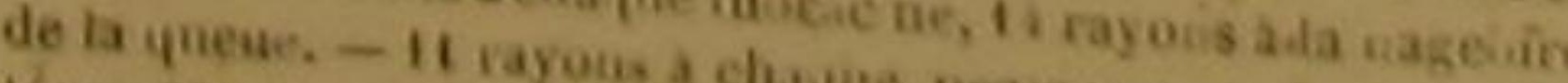
leen, 20 a la caucaie. -5 cayons s bec ocate do 'spa-e gati-

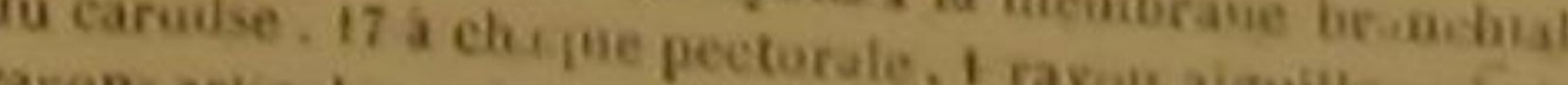

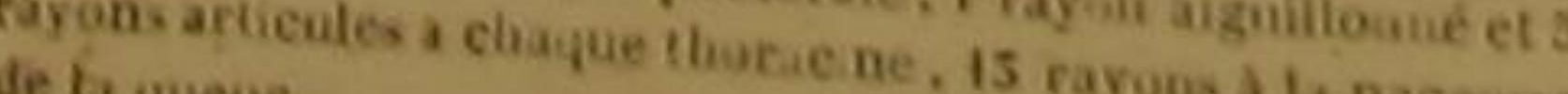
siome

bracksem, eu Aliem Anzleterre. - Stein berseh, Sicin

Hany, Ene. meth $=$ id

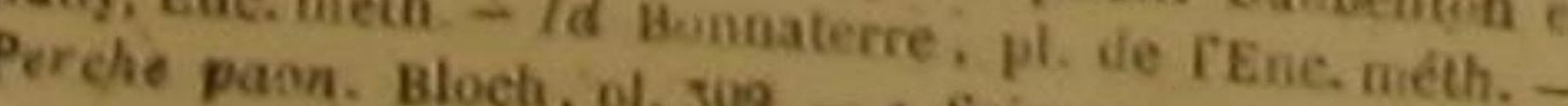

gros et allongé, -une tète étroite par devant et arge par derrière, une bouche assez grande. et des dents pointues. Sa míchoire inférieure est plus longue que la supérieure. Chacune de so narines n'a qu'un orifice. Son ventre est très. long, sa couleur générale est brune, et sa cha blanche, grasse et succulente.

Le spare rayomé vit dans tes eaux de la c. rolîne. Il a la lève supérieure extensible; les deux dénts de devant plus grandes que les an. tres; les côtés pourpres, et le ventre roux.

Le plombé appartient à la Méditerranée. sa longueur n'est le plus souvent que de trois ou, quatre déeimètres.

Il est dificile dé voir un plus beau poisson que la elavière. Ce spare brille de tous les relets de l'émeraude et du saphir, fondus dans des nuances noires ou brunes, et daus fes teintes les plus agréables de l'amethyste et du grenat. $\mathrm{s}_{\mathrm{a}}$ queue est couleur d'iudigo. II a d'ailleurs chair tendre, délicate et salubre. Il était très. commun auprès de Marseille et d'Antibes, do temps dé Riondelet.

La tète et les opercules du spare noir sont dé.

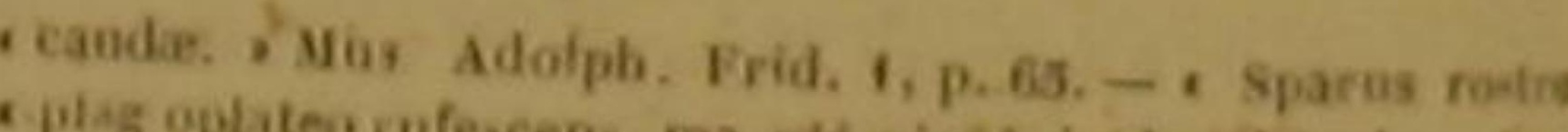

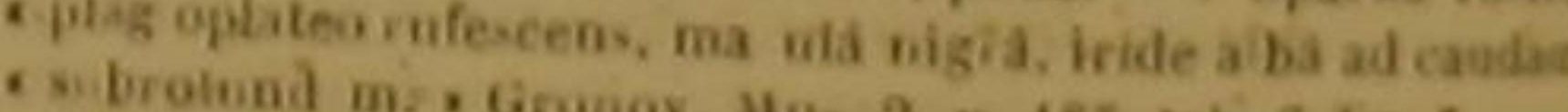

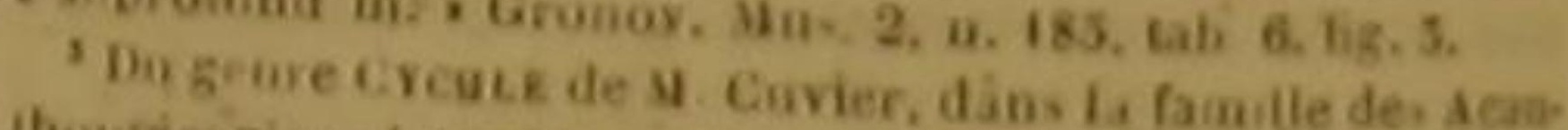
itoprerygiens latiroldes. D.

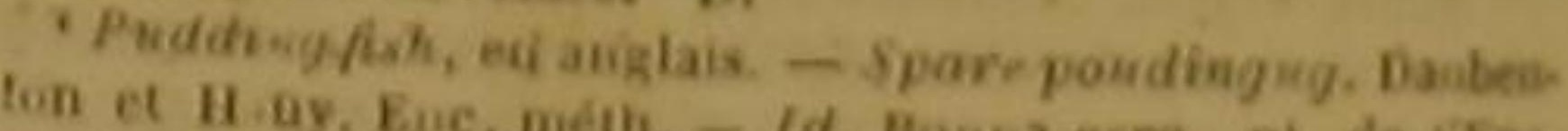

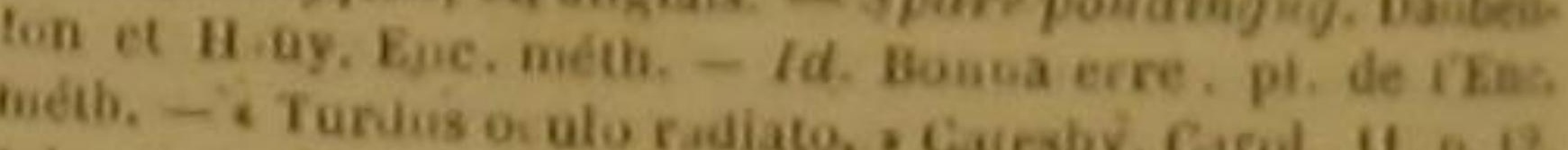
tab, 12, fic, I.
"Nün ment ongé par M. Cuvier.

- Labre plongé par M. Cuvier.

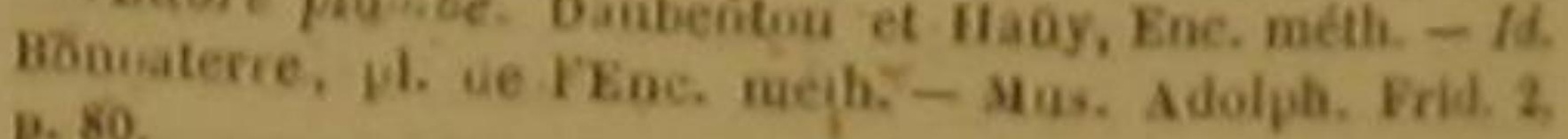
p. 80.

geus iabrua es un vrai Labre (famille des Acanthopiter - Aistes, en gree, suivans Bond, D.

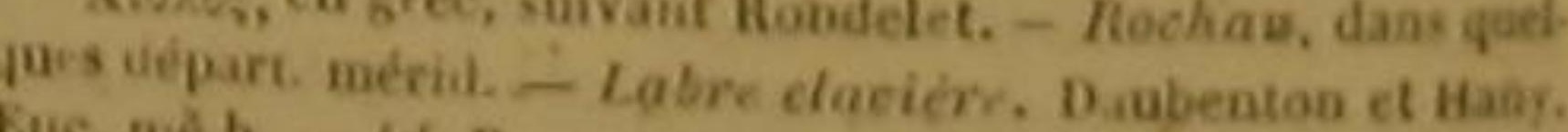

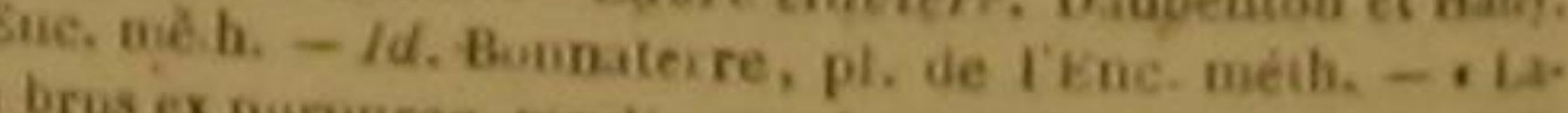
ea. 35 . syo , s. part $4,1,6 ; \mathrm{e}, 5$. Sreunde espece de scare. Rondeles.

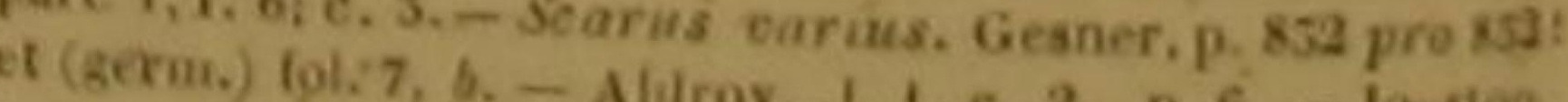

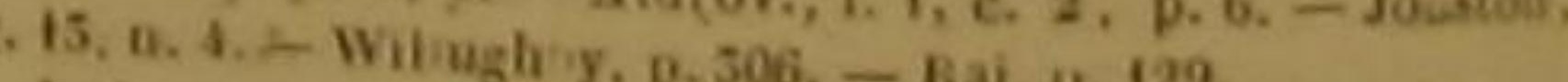
abire pour M. Euvier.

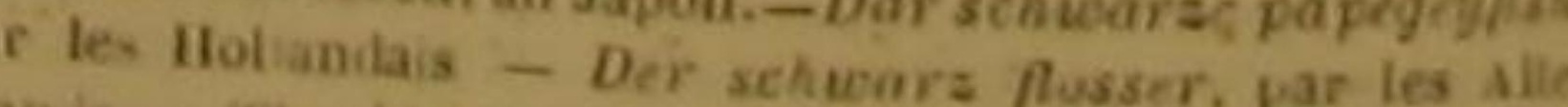

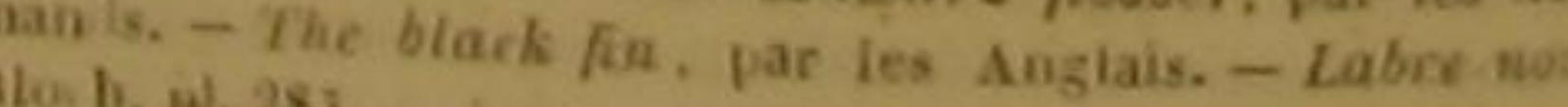

De greene pon M. Cavier. D.

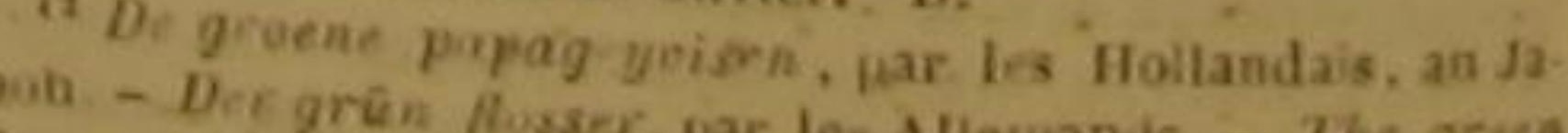
in, par les Augliss, - Labré à negroures reries. Bioth. Me

Wu sons geare Girelle, Julis, dansle graad genre Labre.
Le Lamille des Acanthopterygiens labroides de $\$$. Cuvier. nués de petites éailies; la piece posterieure de chaque opercule presente une prolongation qui parait commé tronquée; cbaque narine n'a qu'un orifice; des conduits terminés chacun par un pore, et destinés à répandre sur la surface de lanimal cette humeur huileuse et gluante dont nous avons parlé si souvent, sont disposés en rayons autour de chaque œil. Ces canaux, les opercules, le ventre et la queue, sont verts; Is partie supérieure de l'animal est d'un rou brun; les pectorales sont jaunes ou brunes.

Ce spare est du Japon, ainsi que le chloroptère '

Ce dernier a la tête comprimée, brune, et rayée de bleu ; les deux máchoires également avancées ; une dent saillante et recqurbee a chaque angle de la bouche; deux orifices à chaque narine; les opercules dénués décailles semblables à eelles du dos; et l'anus plus proche de la téte que de la caudale.

\section{LE SPARE ZONEPHORE ${ }^{2}$}

Cheilinus fascialus, Cuv., Labrus fasciatus, Bl.; Libris malapieronotus, et Sparus zoneptiorus, Lacep. '.

Le Spare ' pointule, Serranus ..... Car i Perca punetulats. Lian, Gmel; S, aras punetuiatus, Lae 1, - Spare son-

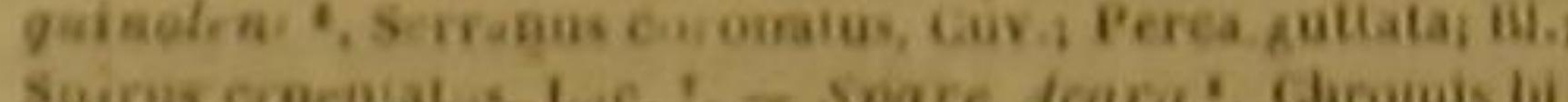

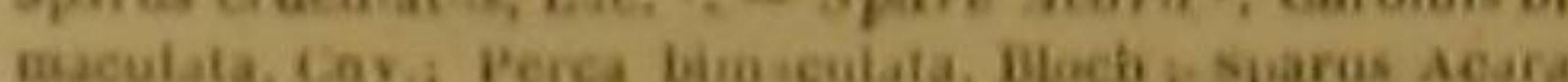
Lac :- Syare Nhogubeda", Cychia brasiliensis, CuY,

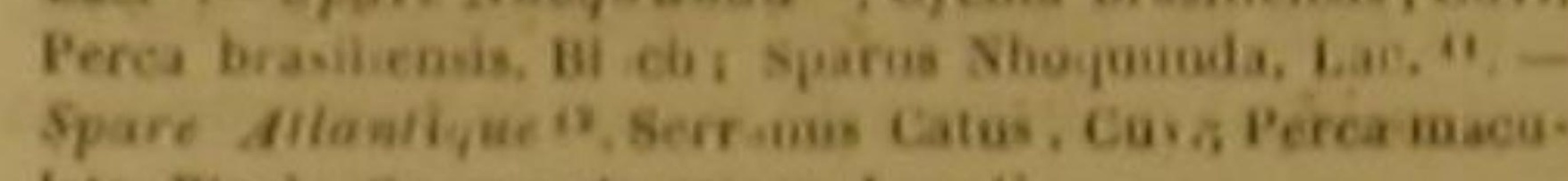
Lata, Bloch i Sparus atianteas, Lac.

Nous avons donné le nom dẻ Zonéphore, ou de Porte-ceinlure, au premier deces six spares,

16 rayons a L meimbrane branchiale du spare paon, 17 \& haque pecturale, 1 ray un aiguillanné ets rayuas articule 6 rayobs a ia membrane bra chiae do sparr fayonie., 12 a caque prectorale, 6 a chayue thoracine, 17 a ia nageoire de la quene. -5 rayous a la membranie brancháe un $\rightarrow$ pare plo be, 14 s clayur pectorale, 1 rayou aiga liusinée 15 rayon aiticules a chapue thoracine, if rayous a lis ciadal. - of

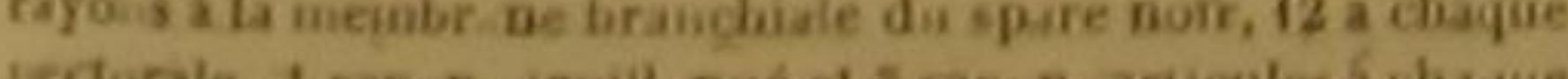

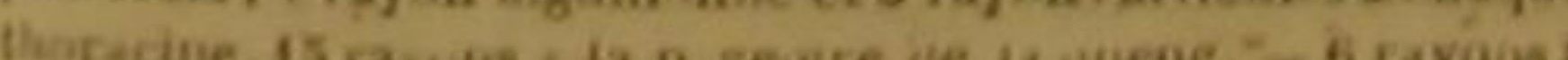

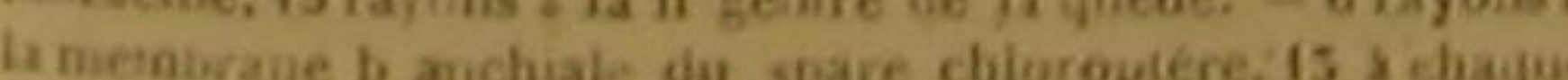
pecturale, 1 rag all a

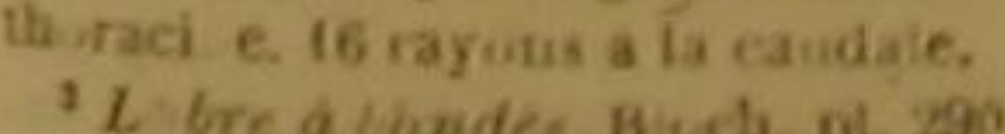

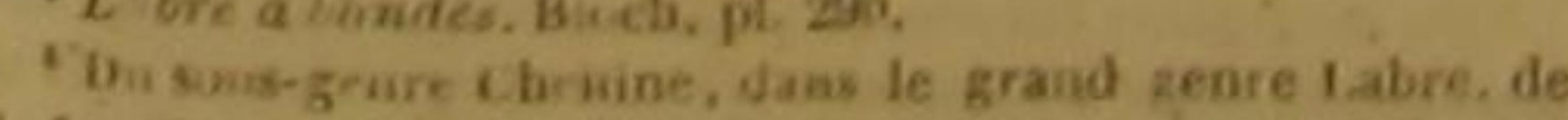

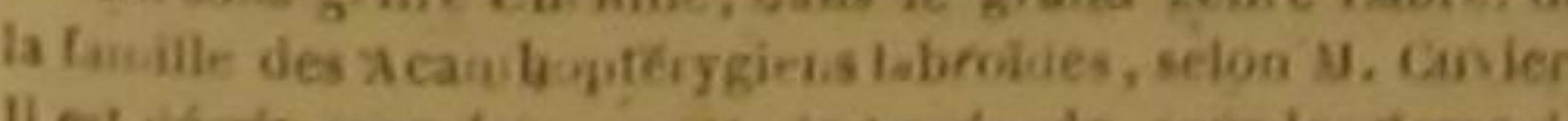
Labre malapux fois yar M, de Lacéprede, sous les ni

- Ifan a pieronole el de Spare sonephore. D.

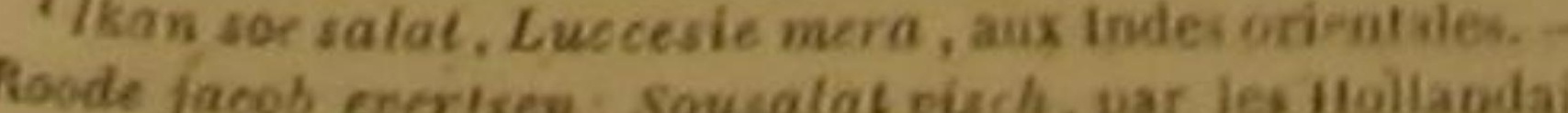
ies grandes Irides. - Negrofish, par les Auglais. - Perche pour designer les cinq ou six bandes qui forment comme autant de ceintures autour du corps de ce poisson. Le Japon est la patrie de cet os. seux. La grosseur des levres de ce spare lai donne quelques rapports particuliers avee les abres, Les deux máchoires sont egalement avancées, et armées, chacune dans leur partic autérieure, de deux dents très-allongées. Chaque rarine a deux orifices. La ligne laterale est interrompue; le dos earéné, le ventre arrondi; et toutes les nageoires sont brunes, excepte la dorsale et l'anale, dont la couleur est noirátre. Le pointille habite non-seulement dans la mer des Moluques, ou il a été observé par Valentyn, mais encore dans celle des Antillés, ou Plumier l'a trouvé, et dans les eaux de la Caroline, ou Catesby l'a vu.

Il parvient à la grandeur de quatre ou eínq decimètres; et P'éclat de l'argent mèlé a celui du rubis, au milieu duquel on croirait voir briller un grand nombre de petits saphirs, le rend un des plus beaux poissons des mers voisines des tropiques.

Sa chair est de bon goòt. Les écailles dont il est revêtu sont grandes; ses nageoires sont arrondies; et sa ligne laterale est presque droite. Le spare sanguinolent, dont le nom amonce la vivacité des nuances rouges qui scintillent seules sur sa surface, habite dans les deux Indes; Plumier l'a vu auprès des Antilles, et Catesby auprés dés iles Bahama : on le trouve souvent dans les bas-fondś voisins des rivages. Sa

ponclude, Danbenton et Hagy, Enc, méth. $-I d$. Bonnaterre, ph, de LEne, meth. - . Perca marina pun tala, C. Ca.

A. 3is.
saus te sixiéme volume de I'Histoire des Poiśons, M. Cu, ver rapporie celle esiece an gence Mseov, Serranus, de it - Iaes Acanthopterygiess i ercuides. D. mands. - The hind, par les Anglais, - Poision couronne, i la Martinique, saivant Plomier, - Perche sanguinoiente.

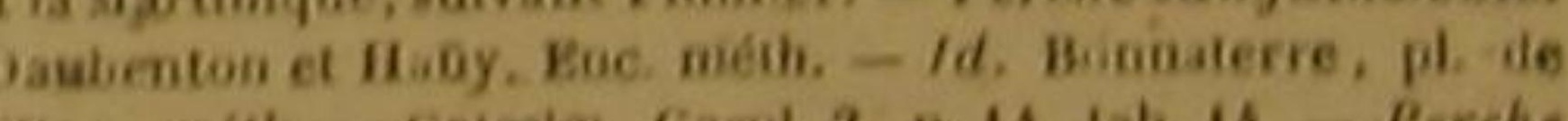
Lac, méth. - Catesiv, Carol 2, p. 14, Lab, 14. - Perche a anguinolente. Bloch, pl. 312. - . Turdas bitis parpureus,

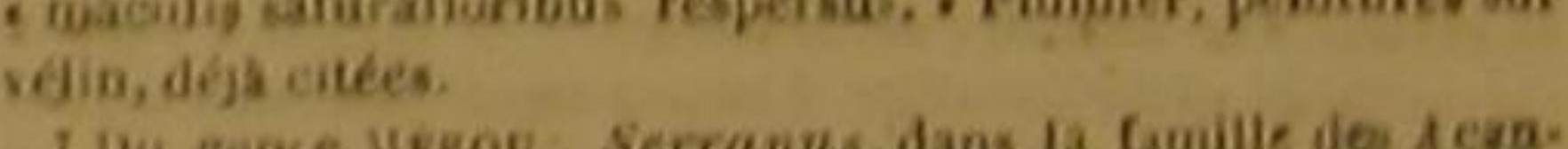

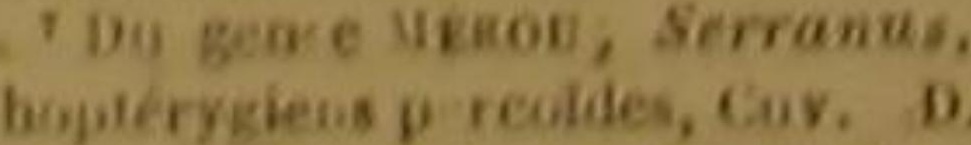

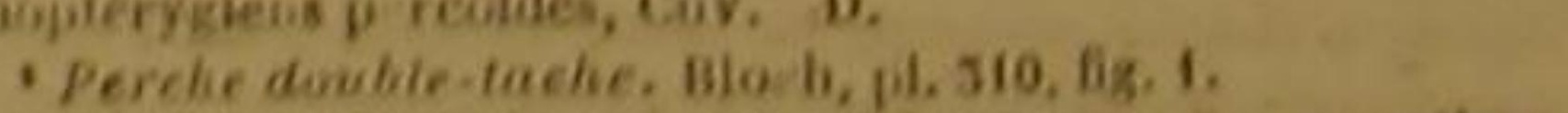
- Da geure cusovis. Cuv., dans la lamilie des Acanthog.

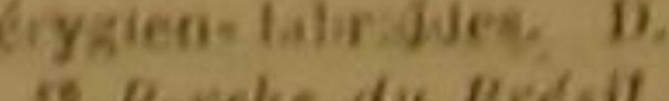

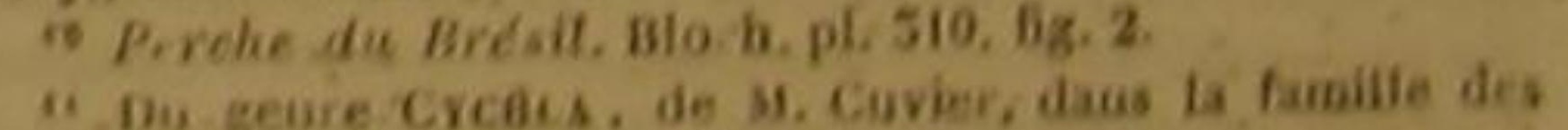

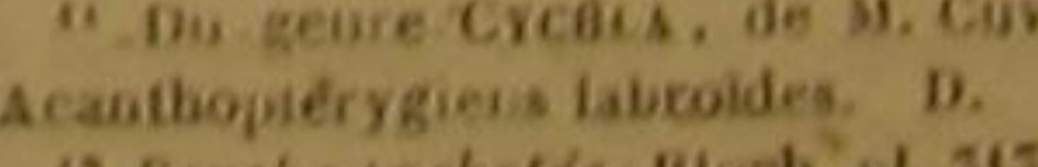

"D Da genre Menov. Scrranus, Cuv, dam la fanile des 
chair n'est pas désagréable à manger ; et sa longueur est quelquefois de seṕt ou huit décimètres.

\section{LE SPARE CHRYSOMELANE ',}

Serranus striatus, Cuv.; Anthias striatus et Cbers Bl.; Sparus chrysomelanus, et Lutjanus striatus, La
cep. ${ }^{2}$.

a tete et l'ouverture de la bouche son des; les deux máchoires aussi avancées l'une que l'autre; les yeux rapprochés du sommet de la tête; êt les éeailles assez larges.

L'acara est péché dans lés rivières du Brésíl. II est gros, mais sa longueur n'excède guère deux ou trois déeimètres. Sa chair est bonne à manger. Le prince Maurice de Nasșau en a laissé un dessin; celui que Marcğrave en a donné, a été copié par. Willughby, Jonston et Ruysch. Les nageoires de ce poisson sont d'une couleur brune metée de jaune.

Le nhoquuunda vit dans les mèmes rivières, parvient à la mème longueur, a la même saveur, et a été dessiné ou figuré par les mèmes auteurs que lacara. Les deus rangs de taches ovales, dont l'un est situé sur un cóté, et l'autie sur le côté opposé de l'animal, ne servent pas pen a distinguer ce spare, dont la tête, le corps et la queue sont allongés, les màchoires également avancées, et les narines percées chacune de deux ouverturés; I'anus est deux fois aussi élóigné de lả tête que de la caudale '.

A l'égard du spare atlantique, son nom spécifique indique la mer dans laquelie on te trou. ve; mais c'est le plus souvent le voisinage des Antilles qu'il préfère. Son corps est allongé, et l'orifice de chaque narine est donble.

Nous avons trouvé dans les peintures sur vélin du Muséum, exécutées d'après les dessins de Plumier, la figure d'un spare que nous regardons comme une variété de l'atlantique. La couleur générale de ce poisson est mélée de brun ou de noir; et chacune de ses taches rouges est chargée, dans le centre, d'un point plus rouge encore. Plumier l'a nommé turdus vtius niger, maculis purpureis oculatus.

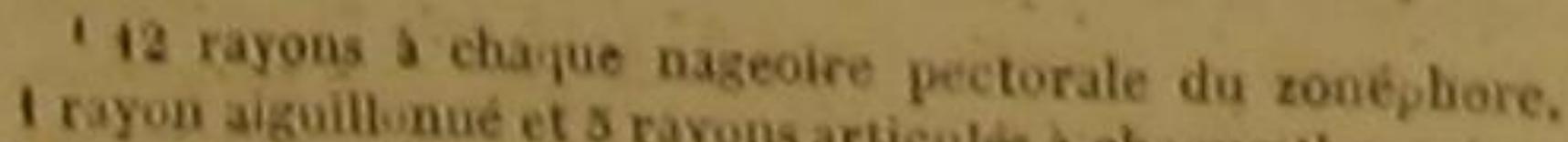
it ray ous a la nageoire de la queveue. - 10 rayous a chace. arienilés a chase pointillé, 1 rayon aiguillouné et a rayous rayons a chaque peelorate dia soyeus $x$ la eatuale -10

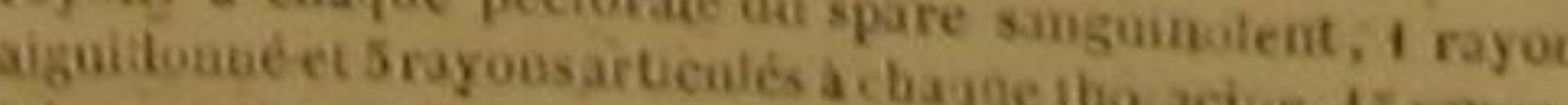
a la bagroire ie li queae - 11 rayoos a day aciere, 15 rayou

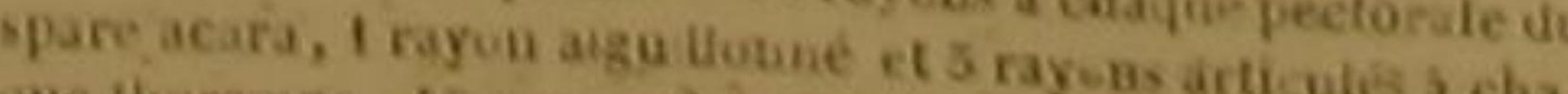
pe torate

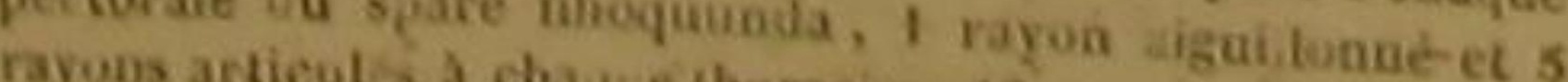
de la quever - 13 rayousa cho

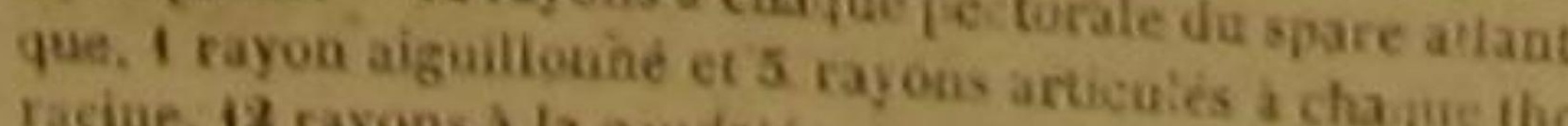

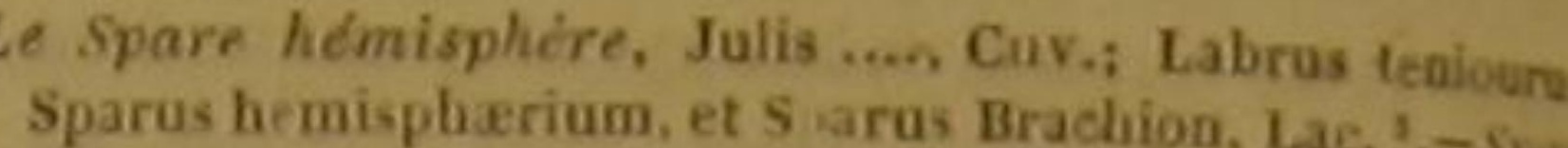

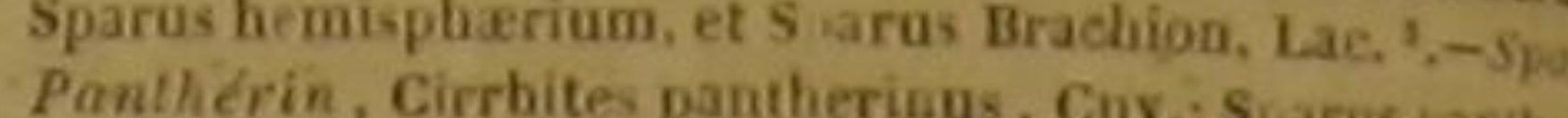
nus, Lacep. - - Spare Brachion, Julis...... Cus ; Sa

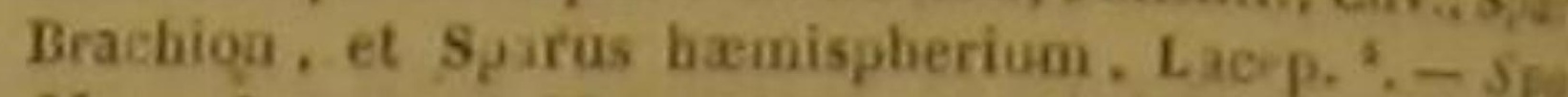
Meaco", Apogou Meaco, Cuv,; Sparis Meueo, Lacep. :Spare Desfomtaines; Clromis Desfontaiuiu, Cuv;; Span

Nous devons à Plumier un dessio du Chryo mélane, qui, dans les eaux de l'Amérique equi noxiale, parvient à une longueur de quatre os cinq décimetres. La máchoire inferieure de at poisson est plus avancée que la supérieure; les levres sont grosses, l'ceil est grand; et tout les nageoires sont comme marbrées de couleu de chair et de gris ou de bleu.

Le spare hemisphere habite dans le grand Océan équinoxial, où il a étẻ observẻ par Commerson, qui en a transmis une figure dans ses manuserits, avec un dessin du panthérin, et u. dessin du brachion, que l'on trouve l'un et l'au re dans les eaux oư l'on péche le spare hèmi. sphere. Ce dernier thoraein a la dorsale et l' nale très-longues et très-larges ou très-hautes cette nageoire de l'anus est d'ailleurs parsemex de petites taches.

La tète du méaco est comprimée; et ses D. lui avonis donné rappelle- une grande ville du Japon, et indique qu'on le pêche daus les eaux de cette contree, ou Thunberg l'a observé. Quant au spàre Desfontaines, nous le dedions, par la dénomination que nous lui don-

deji cited

Du geure Mlkov, Serranus, Cav., dans la farailie da A

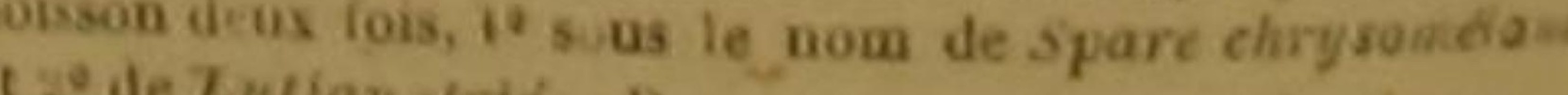

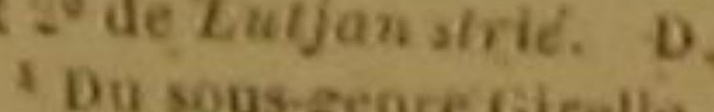

Gywite dess-geare Girelle, dans le grand geore Labre. de lu

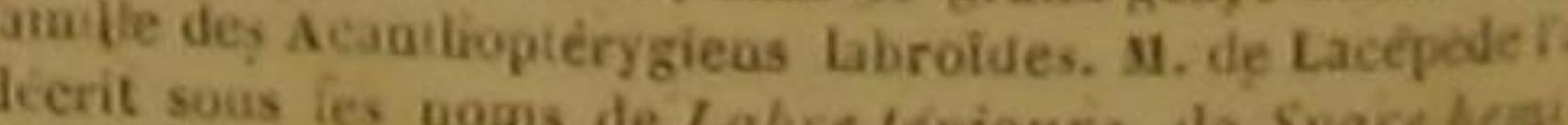
perterdes, Cuv. D.

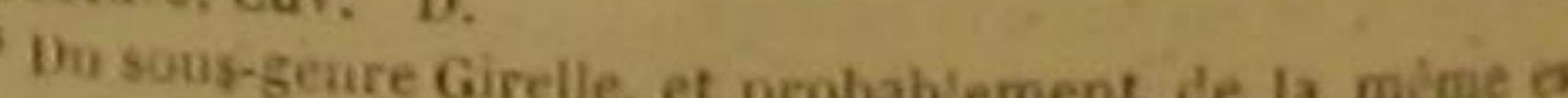

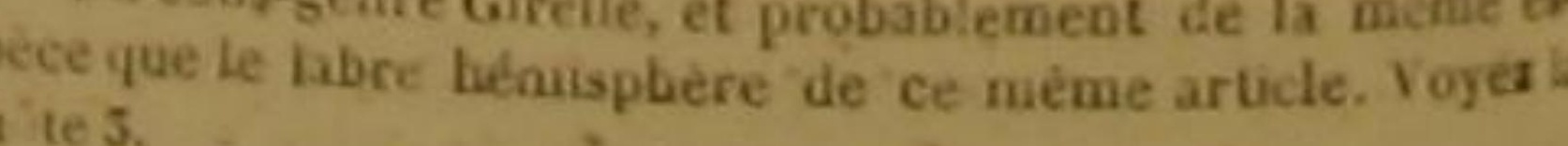
geoires sont tachetées de brun; le nom que nous

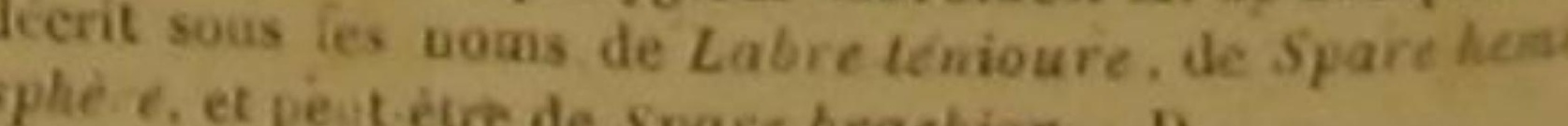

\section{DES POISSONS.}

nons, à notre célebre et excellent ami Desfontaines, notre confrere à l'Institut, et notre collègue au Muséum d'hịstoire naturelle, qui l'a trouvé dans les eaux thermales, pendant son intéressant voyage en Barbarie. M. Desfontaines a vu ce poisson dans les eaux chaudes des deux fontaines de la ville de Cafsa au royaume de Tunis. Ces eaux firent monter le thermomètre de Réaumur à teente degrés au-dessus de la glace, dans le mois de jaovier, saison où, daus eette partie de I Afrique, la température de l'atmosphère varie, pendant le jour, de dix à quinze degrés. Ceseaux chaudes sont fumantes, mais elles n'ont pas paru minérales à M.' Desfontaines ; lorsqu'on les a laisséés se refro dir, elles sont bonnes, tres-limpides, et les seules dont fassent usage pour leur bojsson les habitants de la ville de Cafsa et des environs. Nous conslgnons ce fait important ' avec d'autant plus' de soin dans cette histoire, que M. Desfontaínes a trouvé la mème espèce de spare ${ }^{2}$ dạns les ruisseaux deau froide et saumâtre qui arrosent les plantations de dattiers Tozzer $^{3}$.

LE SPABE ABILDGAARD 4, Searus coccioeus, Bl., Cur; Sparus Abildgaardi, et Sparus aureo-ruber, Lic, ",

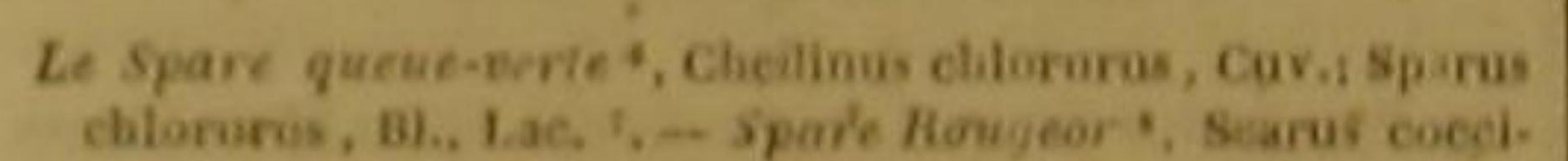

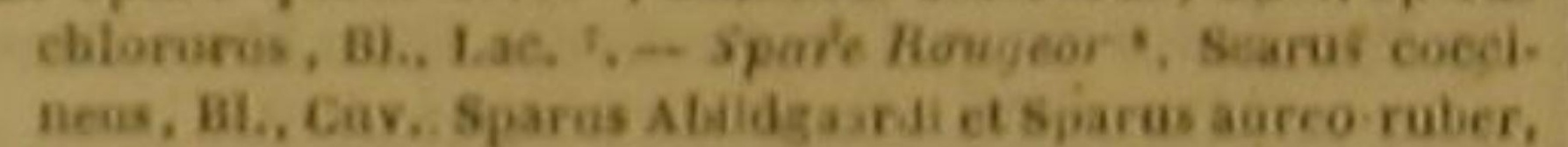
Lacen:

Le premier de ces spares habite aupres de Sainte-Croix en Amérique. La tête de ce poisson

'Vogea le Discours sir ha nature des poissous, ei Vart. du spare dorade.

Pote mannserite communiquée par M. Destontaines.

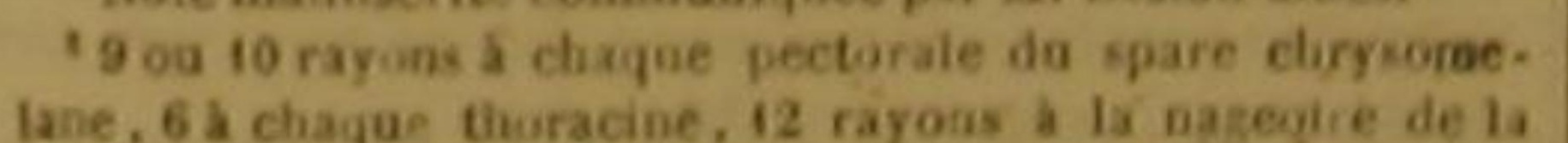
lane, 6 a claque duracine, 12 rayons a ia nageguic de 19 sphicre, 6 s chayne itoracioe, is a la caudale. -12 rayogs a chaque pectoraie dn spare pauthérin, 11 ou 12 rayons a ia nazeoire dế is qurae. - 11 rayons a chaque pectorale da spare bráchion, 10 \& la caudale. - 9 rayons a claque pectorale du meaco. I riyon aigui ione et s rayons articanles a cha pue thoracine, 15 rayons a is nag-oire de la quen. - I5 rayons a chaque pectora e da spare Destoutaives, 62 it Bloch, pl. 259 .

s Du genre Scine, dans la fanille des, Acanthoptérygien Labruides, Cuv. - Cepoinon a été décrit par M. de Lactpéde sous ies deux n ms de Sjare Abildgaard et de $S_{t}$ are roy. geor. D.

\section{'Bioch. pl. 200.}

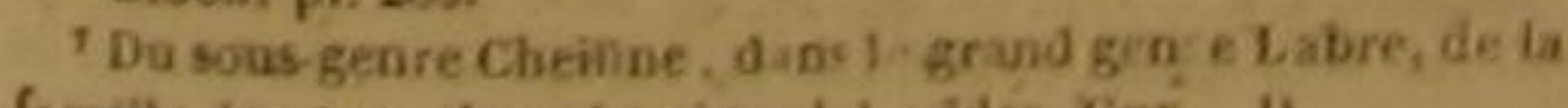

est grande, large et comprimée; ses lèvres sont grosses; l'orifice de ehacune de ses narines est double. Un individa de cette espèce avait eté adressé au professeur Abildgaard, anide Bloch, à qui nous devons la connaissance du spare qu'il a dédié à son ami, ainsi que celle du spare queue-verte.

Ce dernier ossenx se trouve et dans les eaux des Antilles, et dans celles du Japon. Il a Ia tête étroite; l'ouverture de la bouche petite; les deux mâchoires également avàncées; un seul orifice à chaque narine; une partie de l'anale garnie d'écailles; les thoracines pointues; de petites taches d'une nuance pâle auprès du museau; les máchoires et presque tous les os d'une couleur verte?

Plumier a laissé dans ses manuscrits un dessin du rougeor, que nous avons nommé ainsi a cause de ses belles teintes, et qui vit dans l'A mérique équinoxiale, ou dans lés environs de cette partie du Nonveau-Monde.

Ce spare devient assez grand ; son iris est doré; ses pectorales sont nuancées d'or et de brun, et ses autres nageoires variees d'or, de brun et de rouge.

CENT QUINZIEME GENIE.

LES DIPTinODONS ${ }^{2}$.

Tes ticres superidires peu extensibles ou non exiensibtes ou des dents incisires, on der dents motares, disposes sur ton ou pl-sicar's rangsi point de pisquats $n$ de dentelures aux opercules i deux nag oìes doriales la seçonde nigeoire du dos exigmee de relle de la queue, ou la plus grante hauleur di corps propre ment dit, superieure, eqale, ou presque igale a la lougueur de ce méme corps.

PREMIER SOUS-GENRE.

La nagroire de la queite, fourchiue, ou en croissant.

exkcis емвстикеs.

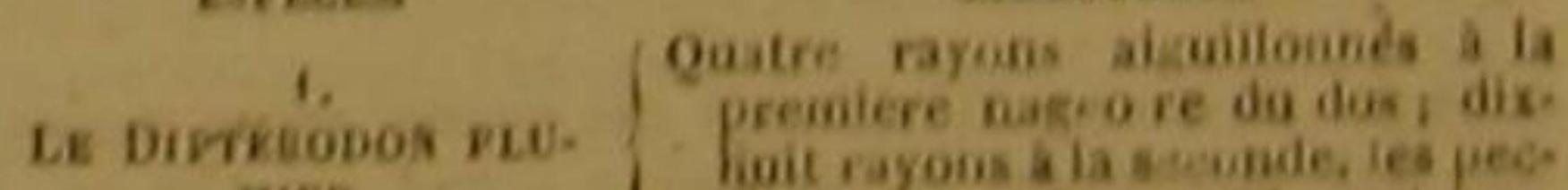
- Aper seu turius erythrinus. equamis amplis. Pio.

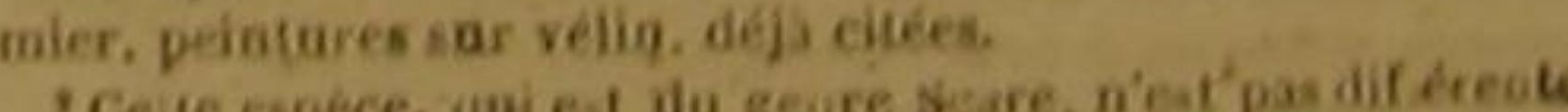

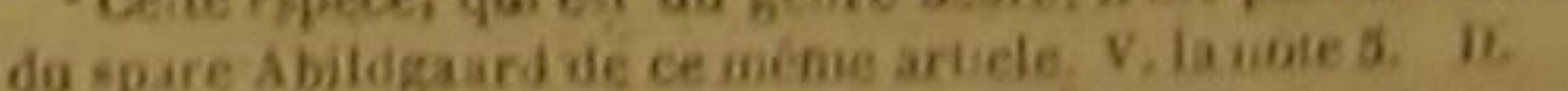
' 12 rayoris a chaque pee osale do pare ah Ligard, 1 rayon aicuilloyné et 5 rayons art ceiles s ciague tioracine, 17 ray ns a la caudales - 5 rayons a ia mentirne troneliale du spare queue serie. 12 a ch que pectirais, 1 ryoy algois. loivé el 3 rayons articules a cliague than

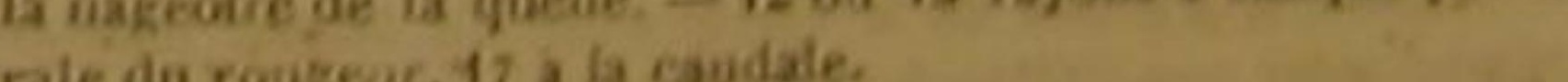

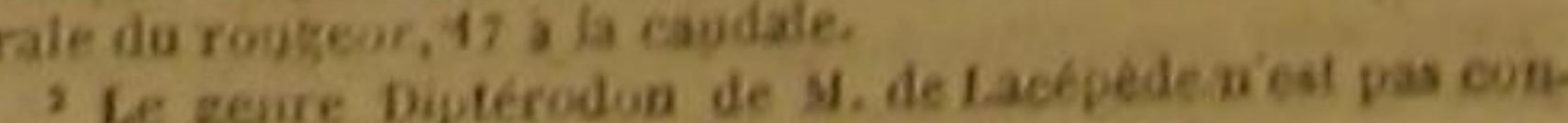


ESPÉCES:

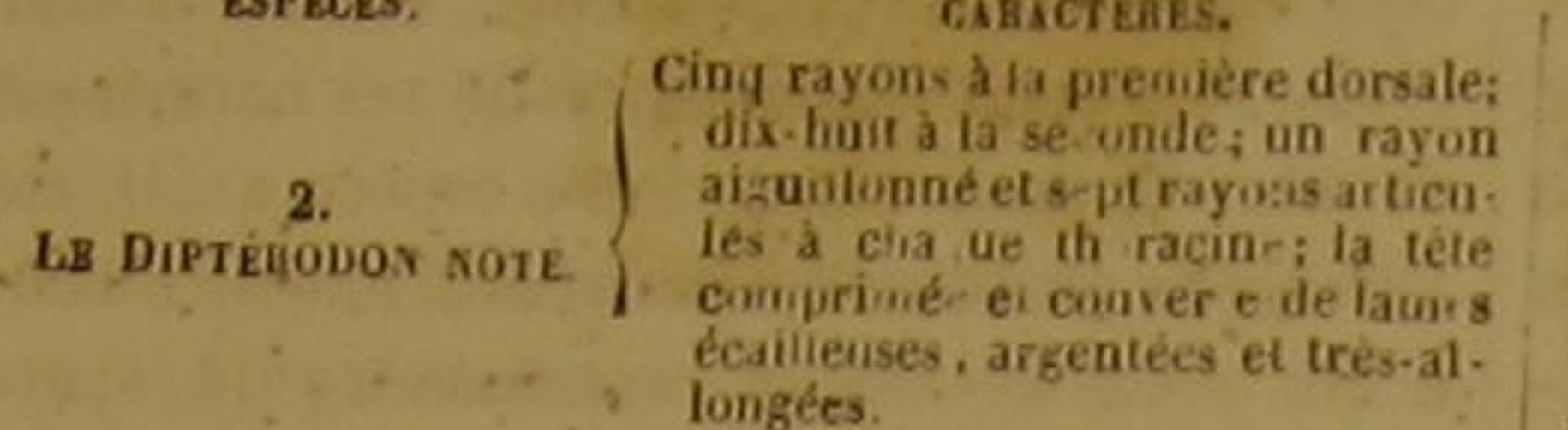

ecallenses, argentées et trés-al
longées.
Six rayous aiguillonnés à ta pre.
mierre dorsile:

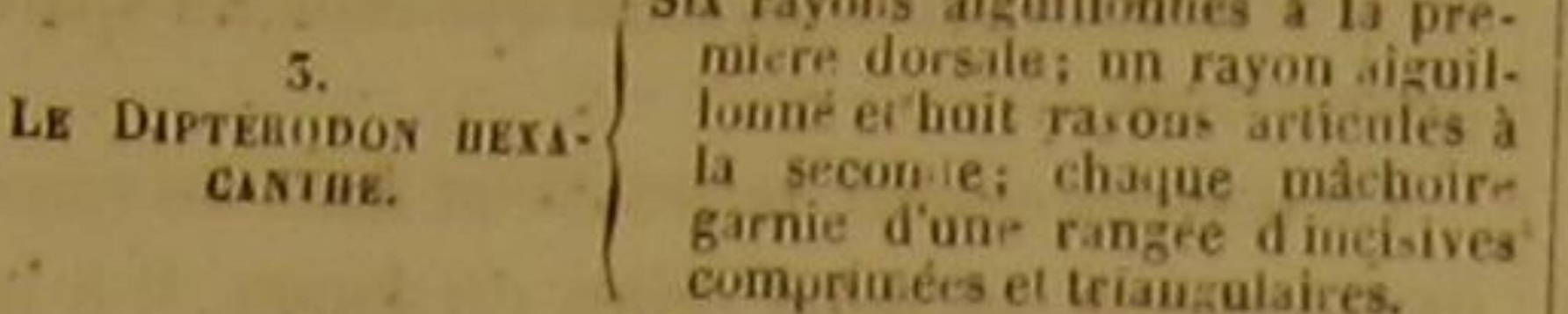

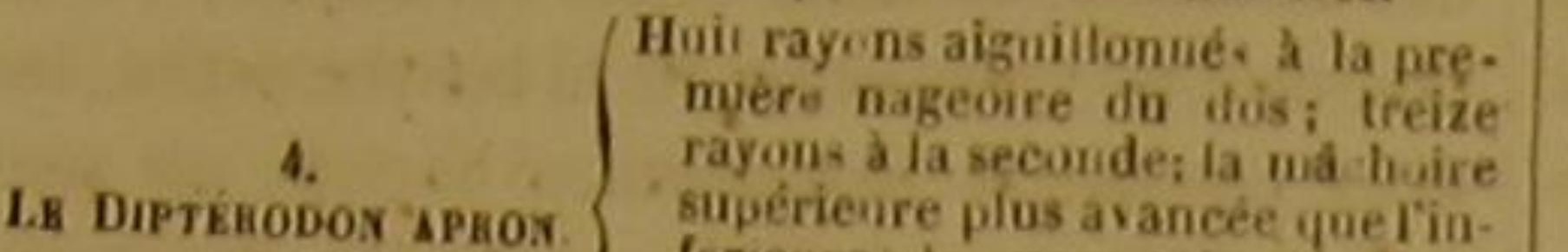

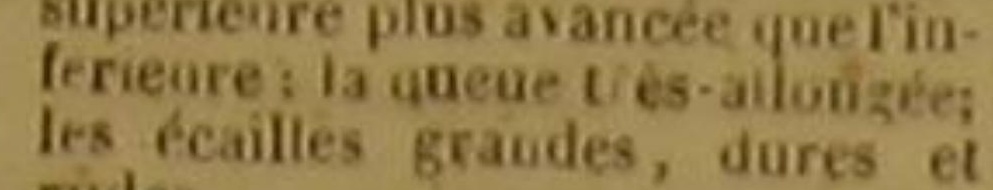

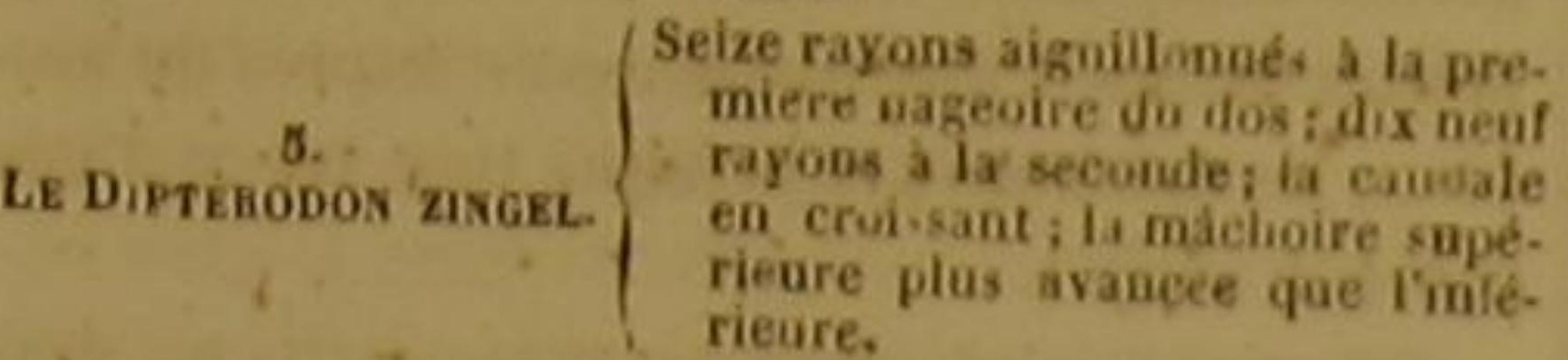

SECOND SOUS-GENRE.

I. nageoire de la queue, rectiligié, ou arrondie.

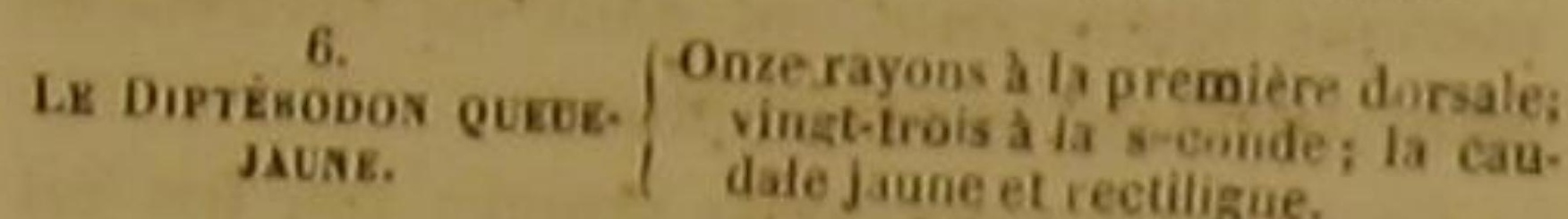

LE DIPTERODON PLUMIER ',

Mesoprion uninotatus, Cuv,; Lutjanus Aubrietii, Desm. Diplerodon Plumieri, Lacep. "'

Lo Diptérodon note' ', A pogon...... Gív.; Sparus notatus.
Linn., Gmel.; i iplerodon hexacrunthe, A pogoo......., Câv.; Dipterodon bexacantbus,
Lac, 3 .

On trouve parmi les manuscrits de Plumier la figure du diptérodon auquel nous avons er devoir douner le nom du voyageur naturaliste qui l'avait découvert. Ce poisson a l'ceil la machoire inférieure plus avantée que la supérieure; des incisives comprimées, pointues triangulaires, et placées à des distances évales 'une de l'autre; ehaque opercule composé deux pièces, dont la seconde se termine de

serve par M. Cuvier. 11 reaterme des

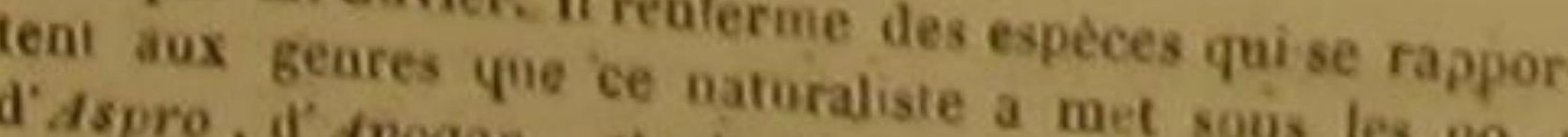
Dipterodon apogon, et de M-soprion. Is cus les vo at quil plave usere quill compose d'une es tce nomm

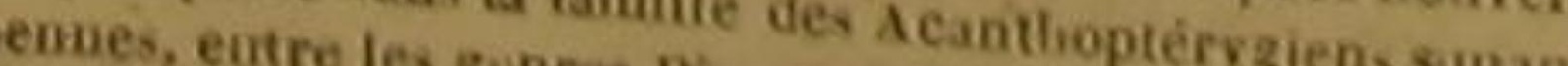

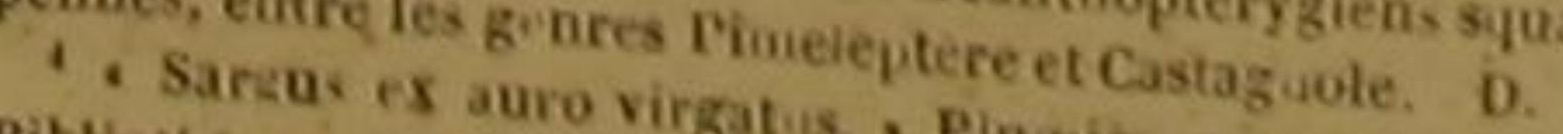

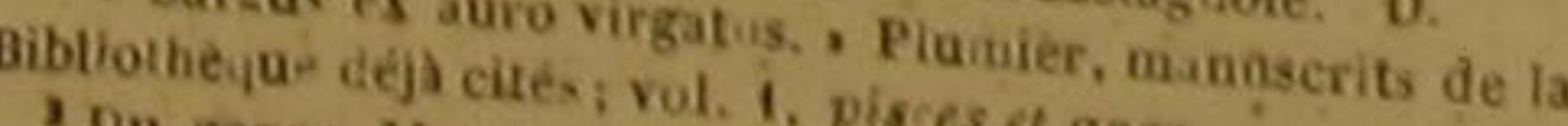
Da geare Mesoprion de i Curctares.

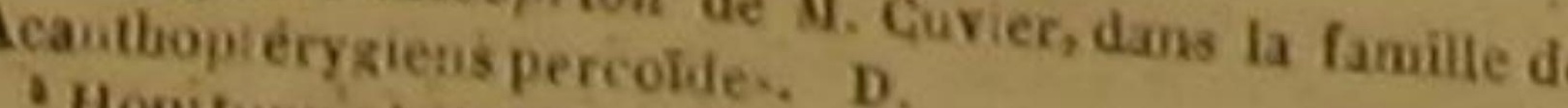

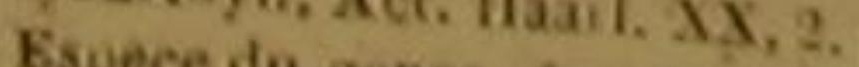

par ce naturaliste. A pogun de M. Cuvier, no

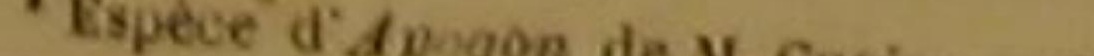
Mace, ainsi que l'Ostorhingurerer qui l'a Lissée indéter

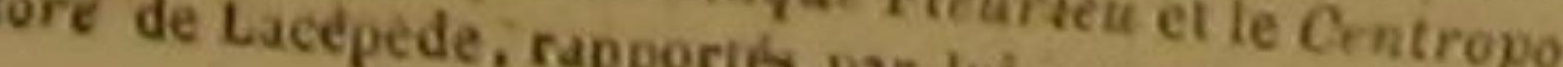

pointe, et dénue, ainsi que la tête proprem dite, d ecailies semblables à celles du dos; des raies longitudinales sur les joues; des goutt iregulieres sur les opercules, et des taches gurees comme de petites raies longitudinales, le corps et sur la queue.

La patrie du diptérodon plumier est l'Amí rique; celle du noté est la mer qui baigne le pon. Les opereules et la queue de ce diptérodo ponais sont tachetés de nŏoir.

L'hexacanthe ' habite dans le grand Océan équinoxial, où il a été vu par Commer en a laissé un dessin dans ses manuserts. naturalistes n'ont encore publié aucune descrip ion de cet hexacanthe, non plus que du dipterodon plumier.

Deux ou trois pièces composent chaque opercule de I hexacanthe; la dernière de ces pieces est terminée par une petite prolongation arrondie, et de petites écailles les recouvrent machoire inférieure est un peu plus longue que la supérieure; une bande transversale d'uoe couleur foncée est située très-pres de la nageoirt de la queue ?

\section{LE DIPTÉRODON APRON}

Aspro rulgaris, Cuv,; Perca asper, Lino., Gmel., BI. Dipterodon Apron, Lacep. :

14. Diplétodon Zingel ', Aspro Zingel, Cuv,i Perea Zingel Linn., Gmel.; Dipterudun Zingel, Lac.`.

L'apron a la tête large; l'ouverture de la bouche est placée au-dessous du museau, petite, et

'Le mot hexacanthe (six aiguillons) désigne le nombre

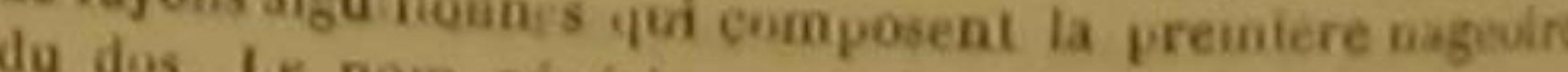
nagenires du dos génériyne intétedon rappeile les dus

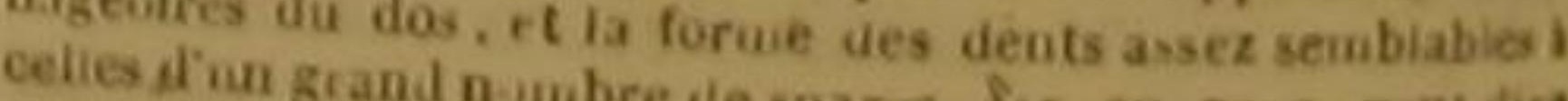

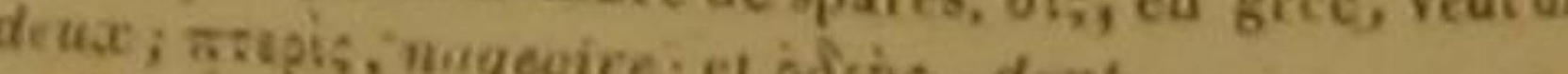
24 rayonis aiswill

de ranus du dipterodon plumier, is a la ia la nageotre

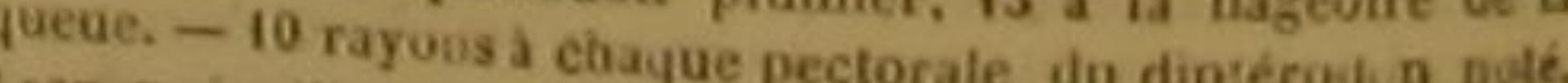

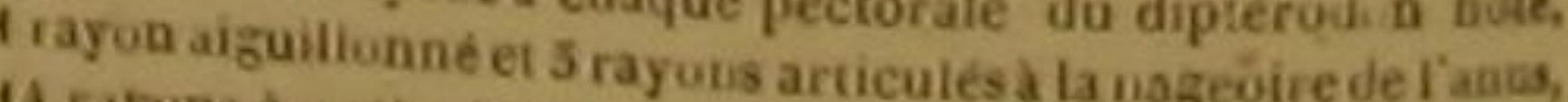
rale du dipteirode la yneue -7 rayons a chaque pecto. aazeoire sie liodou hexacuntlee, 6 à chaque thoracine, 9 aL 'Zivdel, en Surve a la caudale.

en Allemazue. - Slabe. - Straberr, Straber bach. Pfeiferi, les Calmouques. - Persegue aprone. - Berschis, da Euc. m-th. - rd. Boimaterre, pl. de I Enc. méth et Perche pron. Bluch, pL. 107, fig.1, 2. - I Perca lineis ot rin peocto

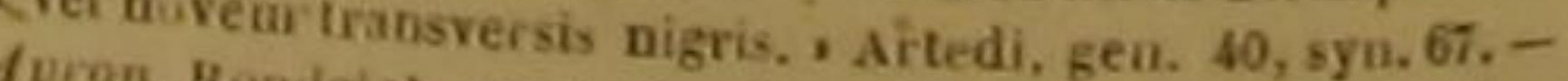
J onston. Rondeiet, part. 2 , chap. 29. - Asper pisciculus. -Id. Willingbby, p. H, tab. 26, 5g 18. - Id. Cbarlel., p. 155.

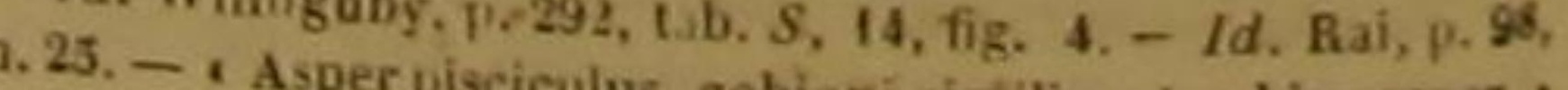

\section{DES POISSONS.}

en forme de croissant; chaque narine a un double orifice; une seule plaque ou lame compose chaque opereule; I'anus est plus pres de la tète que de la candale, qui est fourchue. La couleur générale est jaunátre, le dos noir, le ventre blane; trois ou quatre bandes transversales et noires relèvent le ton de la couleur générale, et les nageoires sont jaunes.

L'apron babite dans le Rhône et dans d'autres rivières de France, en Allemagne, et partsculierement dans quelques laes et dans plusieurs rivières de la Bavière, dans le Volga $e$ dans le Jaĩk, qui portent leurs eaux à la mer Caspienne. Il parvient a la longueur de deux ou trois déeimètres. Ses aéufs sont petits et blanchatres ; il les dépose ou tes féconde au commencement du printemps, et c'est alors qu'on le péche avee des filets ou à l'hamegon, parce que, dans toute autre saison, il se tient presque toujours au fond de l'eau. On le prend cepen. dant quelquefois pendant l'hiver, au-dessous des glaces. Il se nourrit d'insectes et de iers Il arrive souvent qu'en les cherchant dans la vase, il avale un peu de limon, et comme ce limon est mélé avee des paillettes dor dans quelques-unes des rivières qu'il babite, on a trouve dansson estomac de ces paillettes métalliques et e'est cequi a fait dire au vulgaire des pêcheurs dans certaines contrées, qu'il se nourrissait de molécules dor. Sa chair est saine et de bon goùt. Il perd difficitement la vie lorsqu'il est retenu hors de Peau, et voila pourquoi on peut facilement le transporter d'une rivière ou d'un étang dans un autre sans le faire pérír, surtout lorsque la température de l'atr.osphère n'est ni trop froide, ni trop chaude.

Le zingel a la téte grosse et aplatie de haut en bas : l'ouverture de la bouche large et placée au-dessous du museau; le palais garni, comm les mâchoires, de dents pointues; la langue dure et un peu libre dans ses mouvements

Gesner, p 405, 478, paralip. 19; ét (germ.) 162, b. - Aldrov. 1. 3, c. 2s, p. 6i6. - P Perca dorso dipt-ryg D, ete. , Gronov.

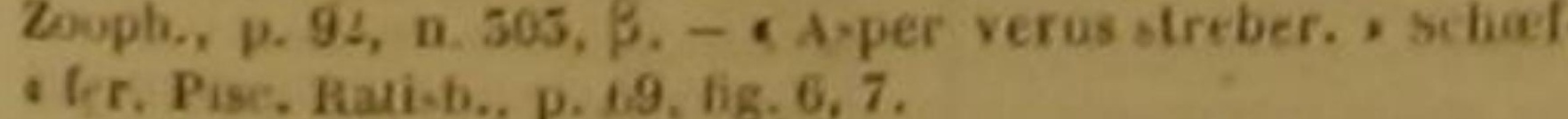

thoyiterysiens percoides, D.

'Ci.gl, dins quet yues contrbes de Brance. - Kotez, en

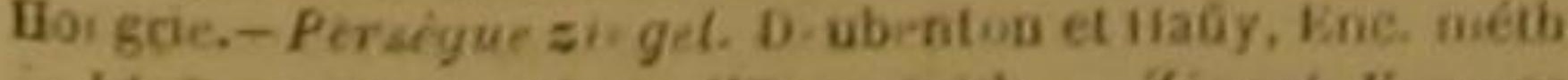

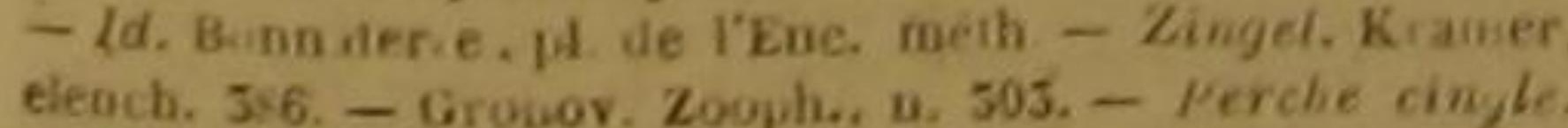
eieach. 3:6. - Growav. Zooph., u. 503. - Perche cinjle. Bluch, p1. 106.

- Du mé. chaque narine garnie de deux orifices; ces orlfices et les yeux situés dans la partie superieure de la tête; l'opercule formé d une seule pièce; les écailles dures, dentelees, et fortement attachées a la peau; la couleur générale jaune, avec le ventre blanchatre, des taches et des bandes transversales brunes.

On voit le ziogel dans l'Allemagne méridionale, particulierement dans te Danube et dans d'autres rivières, ainsi que dans plusieurs lacs de la Baviere et del'Autriche. Il presente souvent une longueur de quatre ou cinq décimétres, et son poids est alors d'm ou deux kilogrammes, Sa chair est blanche, ferme, agreable au goùt, facile à digérer. Ses habitudes ressemblent beaucoúp à celles de l'apron. Il est nèanmoinis vorace; et, excepté le brochet, presque tous les poissons qui vivent dans les mémes eaux que ce diptérodon craignent de l'attaquer à eause de lá force de ses piquants et de la rudesse de ses ecailles : aussi multiplie-t-il beaucoup malgré la guerre que les pécheurs lui font 1 .

Lé canal intestinal du zingel offre troís cacums ou appendices, et trois sinuosités. Ses oufs sont jaunes et de la grosseur des graines de pavot. La vessie natatoire est blanche, mais pointillée de noir.

\section{LE DIPTERODON QUEUE-JAUNE ${ }^{3}$.}

Corvina argyroleuca, Cuv; Bodianus argyrolencus, Miteb:- Dipterodon chrysouru, Lae.'

Ce diptérodon a été observé daus les mers voisines de la Caroline. II a la téte argentée, et le corps parsemé de traits et de points noirs ${ }^{4}$.

17 rayons a la membiane branchiale de Iaprob. 11 a clia. ine peclorile. 6 a chavie tharache, 9 a la nageoure de Ta. de chaque cóte de La culon evertibraie. - 14 rayous a cla que pietorale dy zimel. 6 a chaque thorac ne; is a la na.

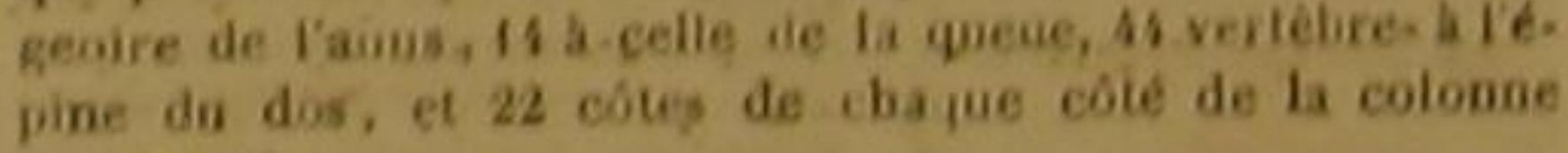
vertélirite.

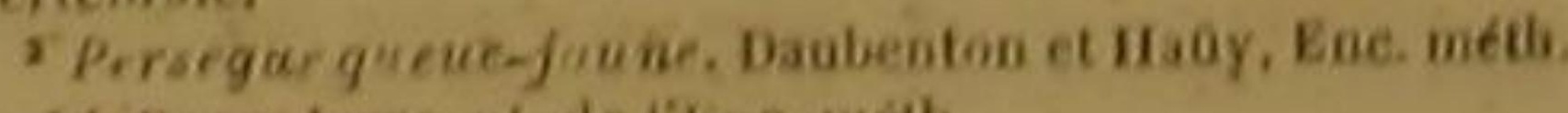
c. mét

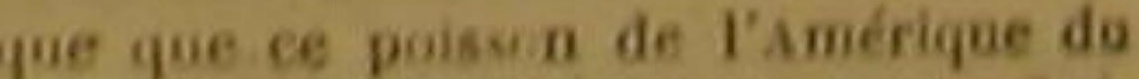
vord cat le perca punetata de Gimelio sedit. 12), dout lar.

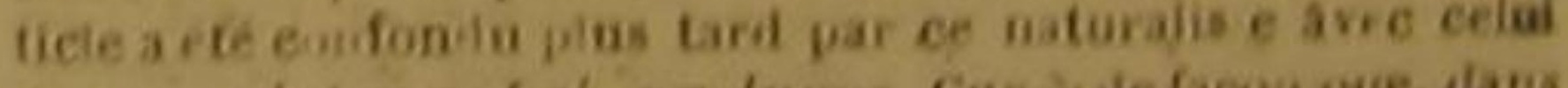

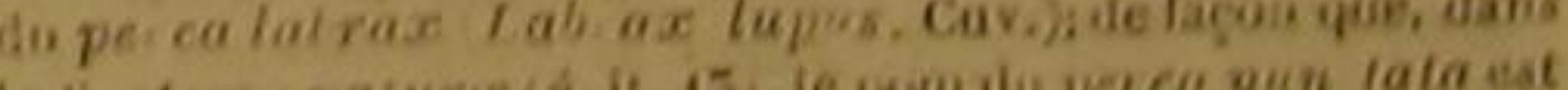

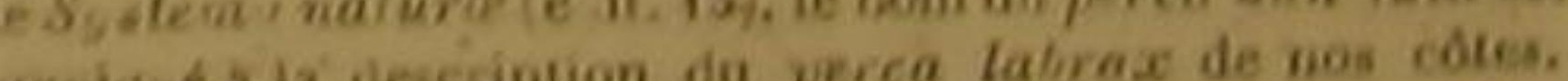

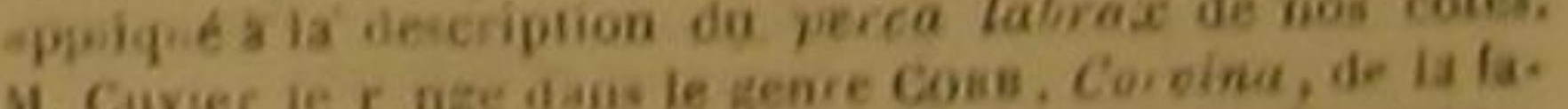

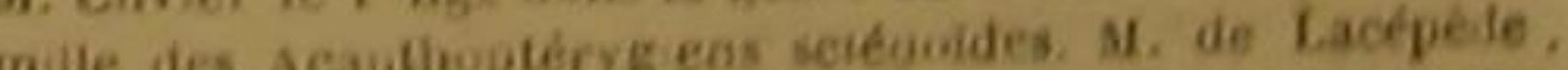
comme Gipelio ra ponte a tost a synouycuie a celle da Har

d'Euroje Latrax lapué. Cav
1. rayous a is membrane branchiale du diptiorodos 
CENT SEIZIEME GENRE.

\section{LES LUTJANS.}

Une dentelure à une ou plusierrs pices de chaque opercule; poìt de piquants a ces pieces; une seule nageoire dorsale; un seul baruillon ou point de barbilion aux madchoires.

PREMIER SOUS-GENRE.

La nageoire de la quene fourclue, ou en croissant.

espréces.

CABsctè̀izs.

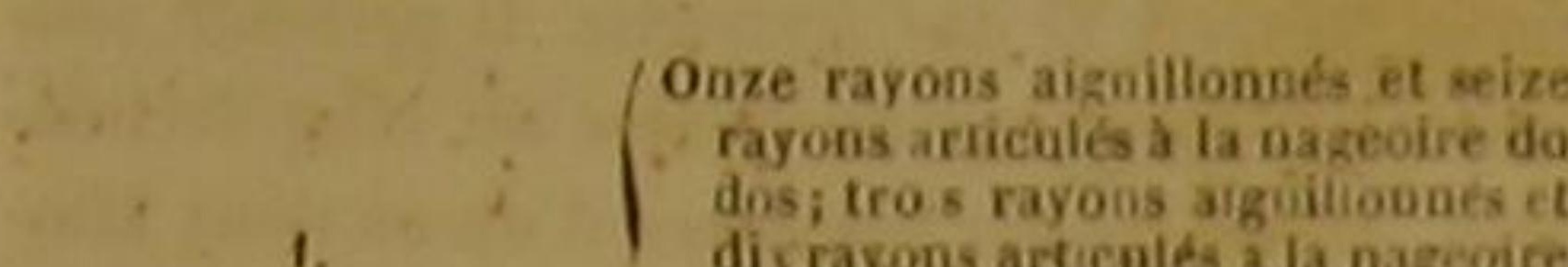

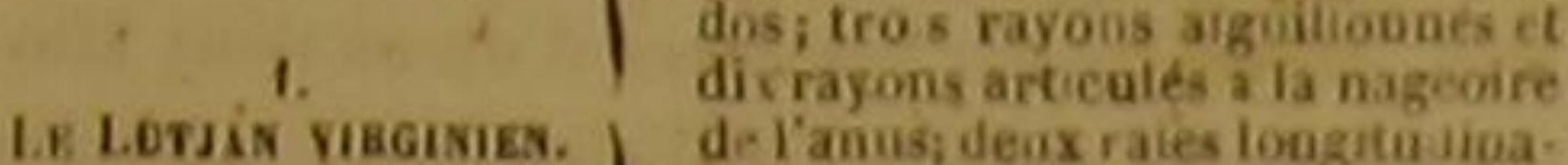

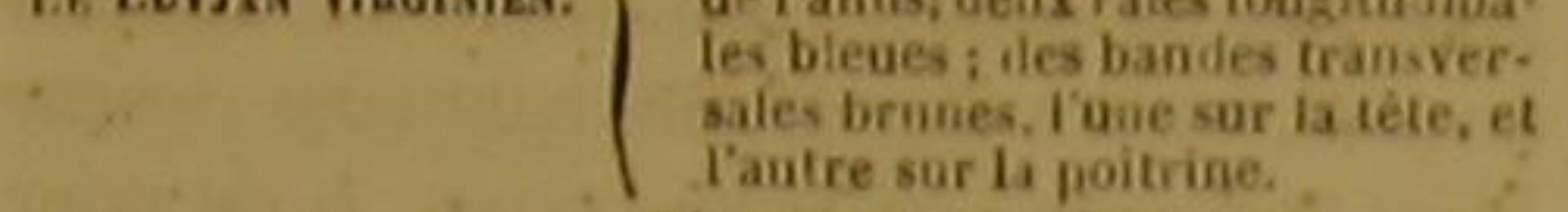

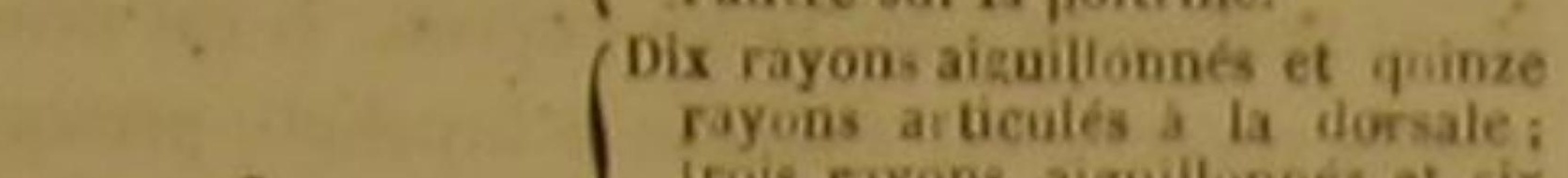

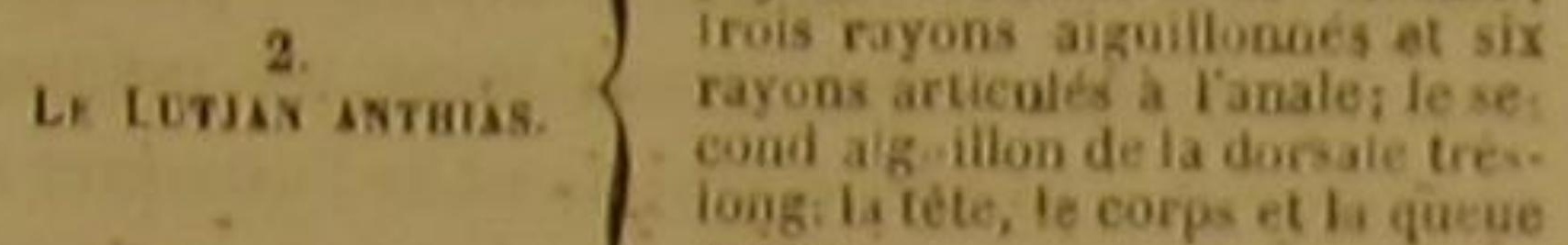

- ( rouges.

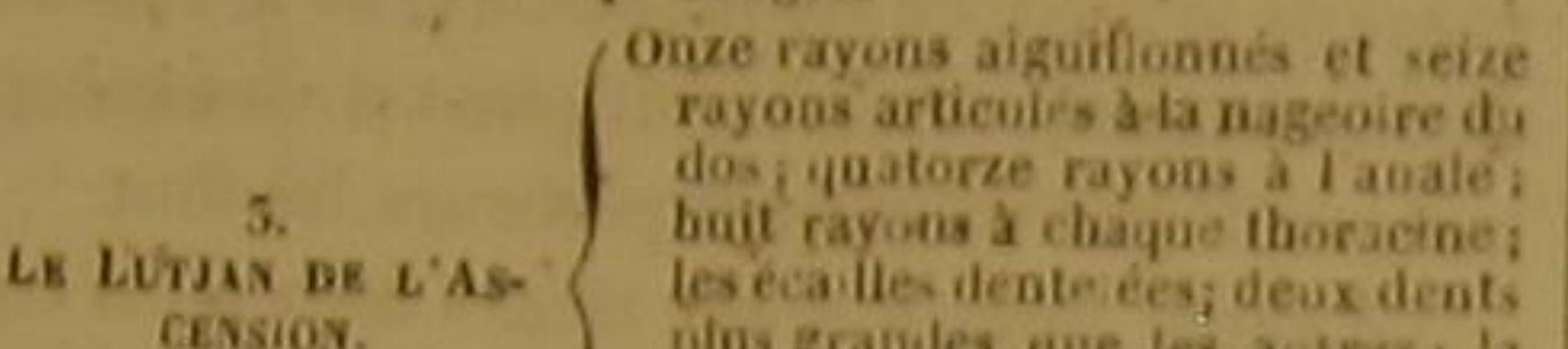

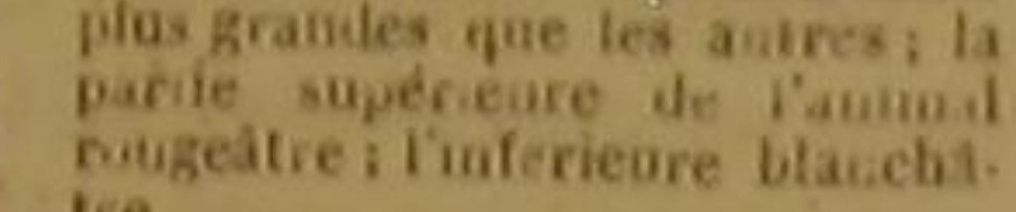

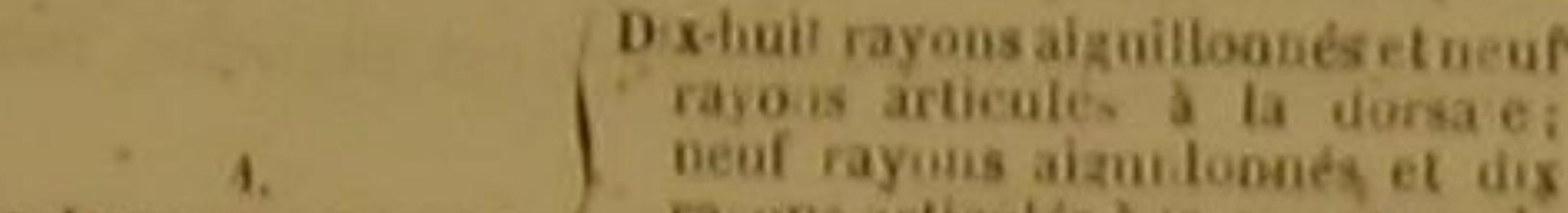

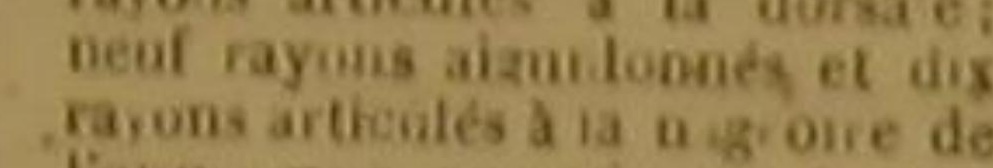

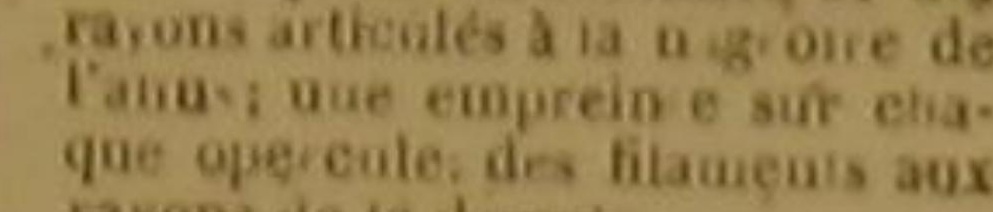
Tremos ile la doral

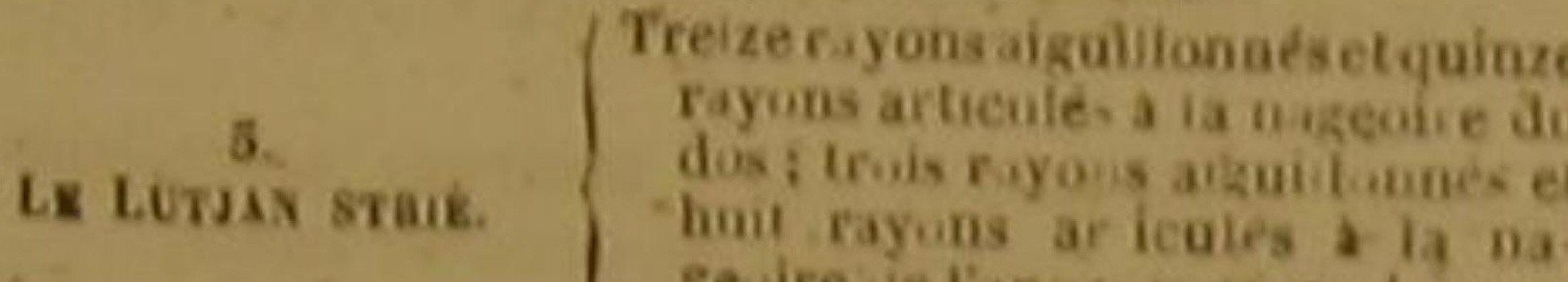

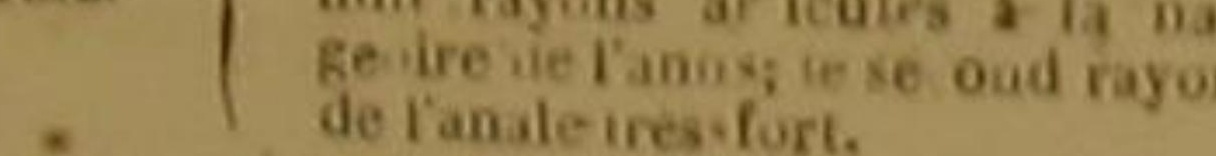

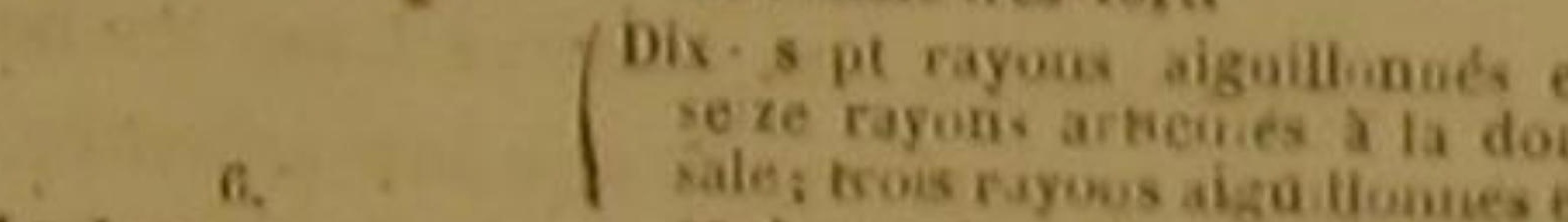

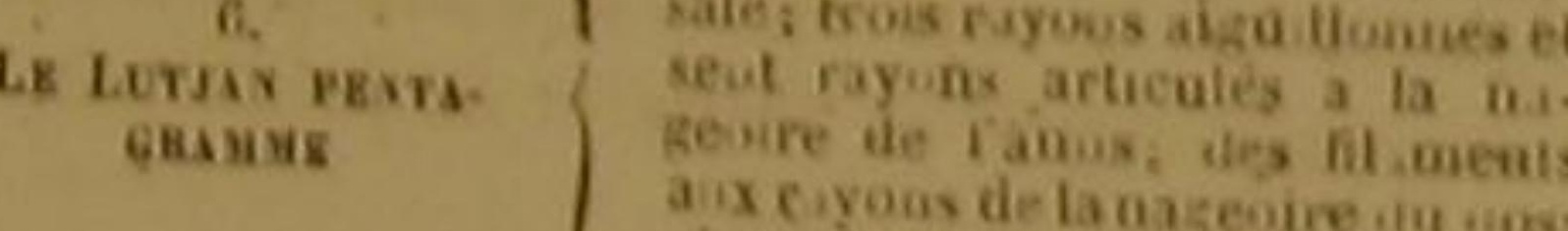

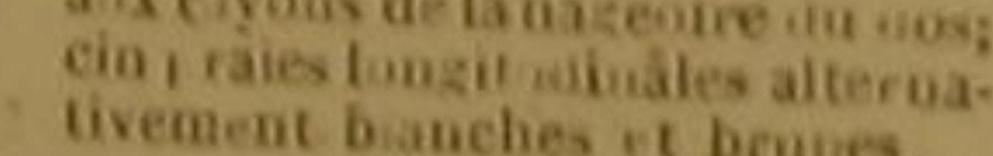

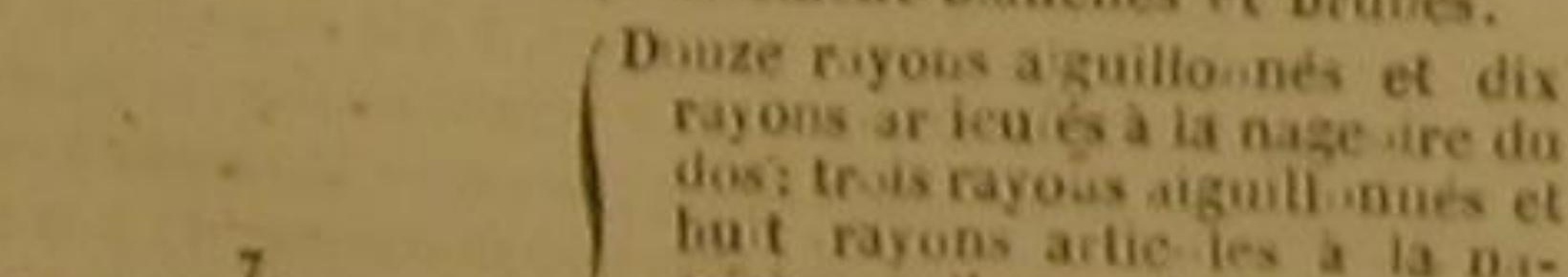

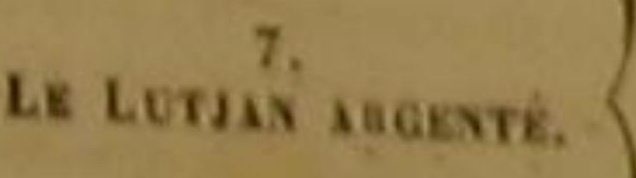

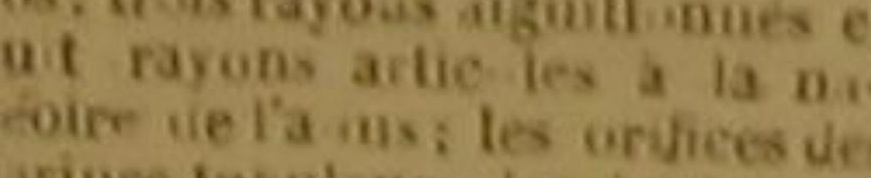

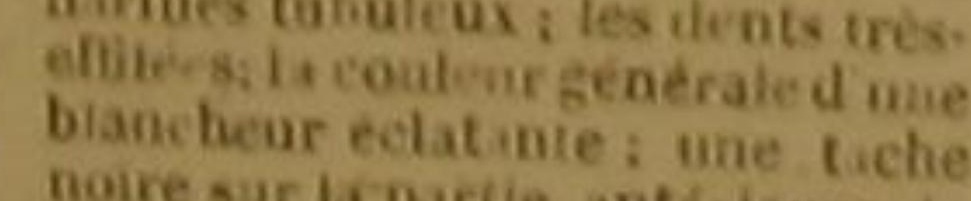
noire sur las partie anténieure de
La nageoire du das

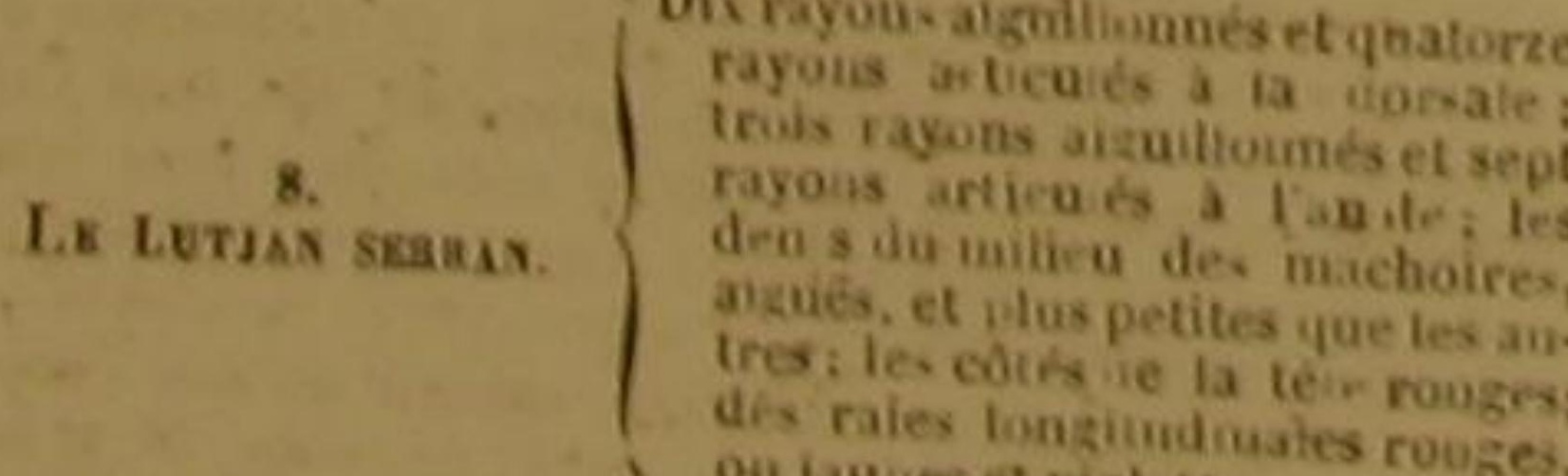

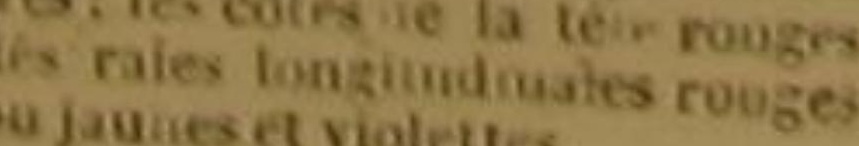

qucue-jaune, 16 a chaque vectorale, 1 rayon aign illond

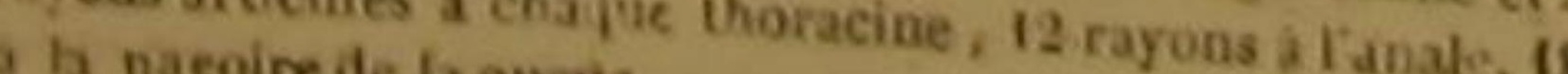

\section{espéces.}

-risictèress.

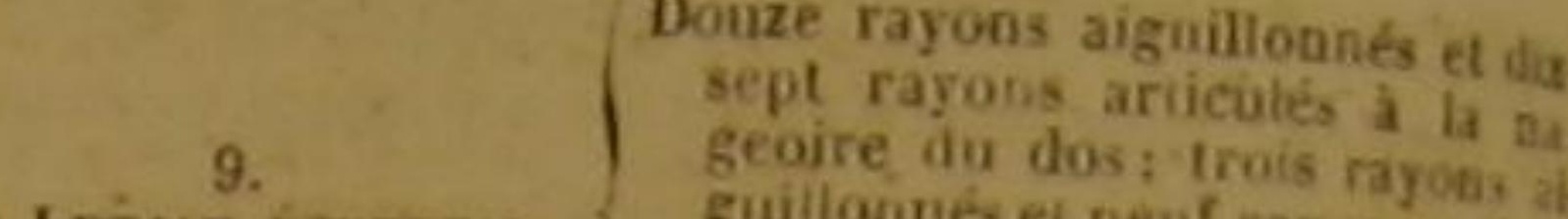

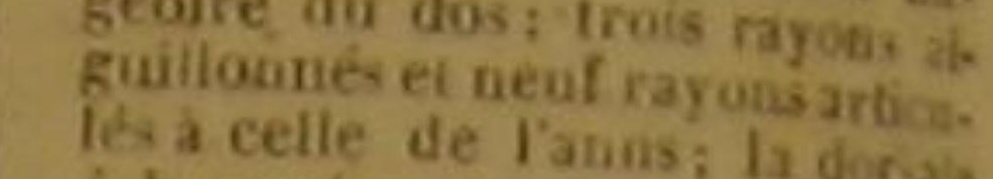
échunerée; des raies bleuess sal
la tétle.

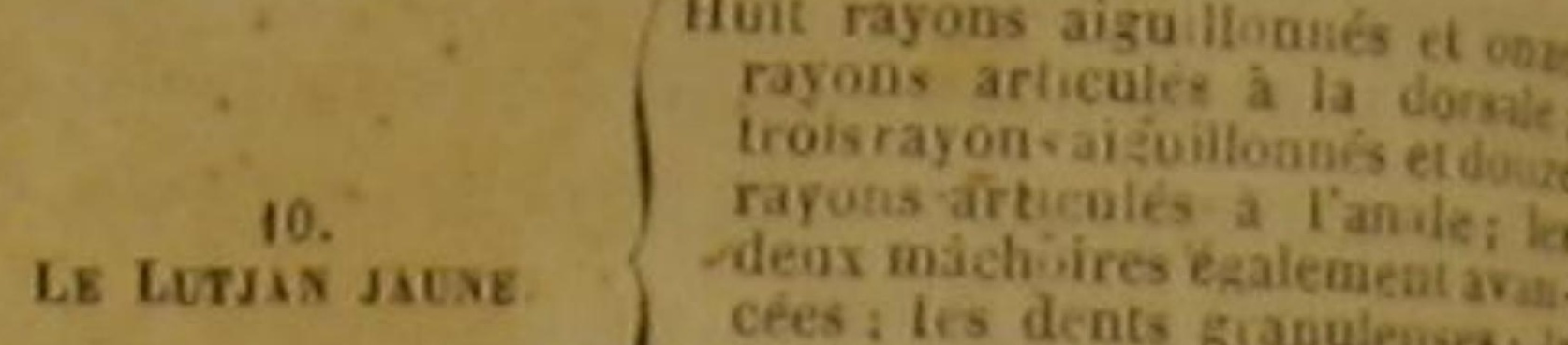

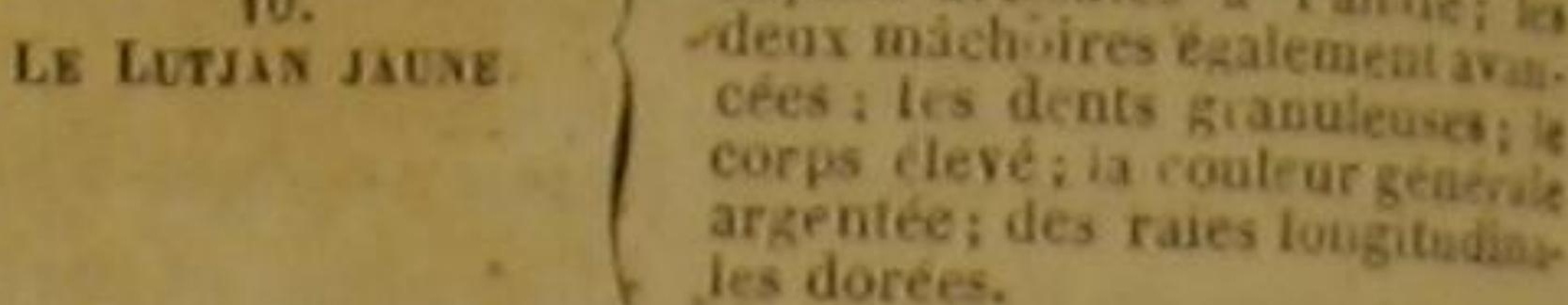

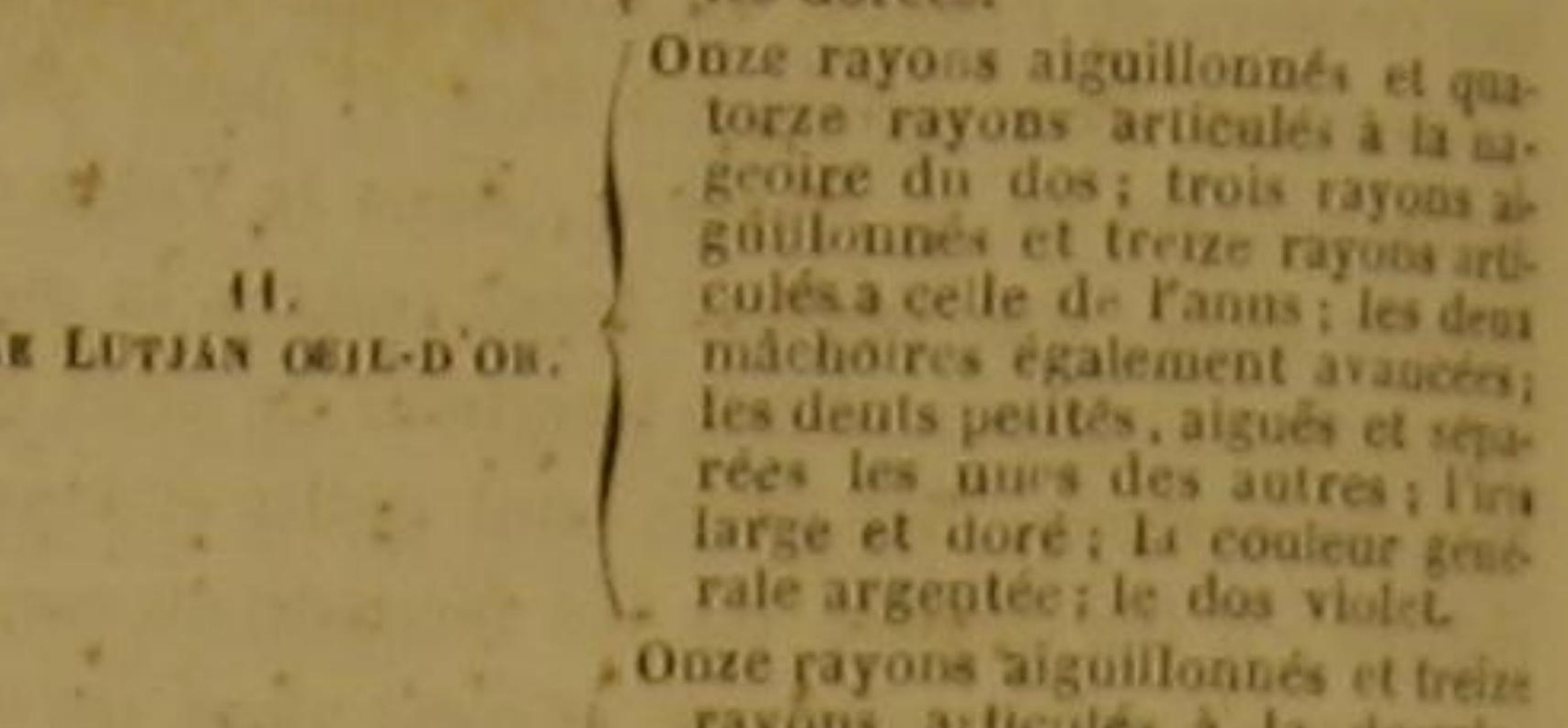

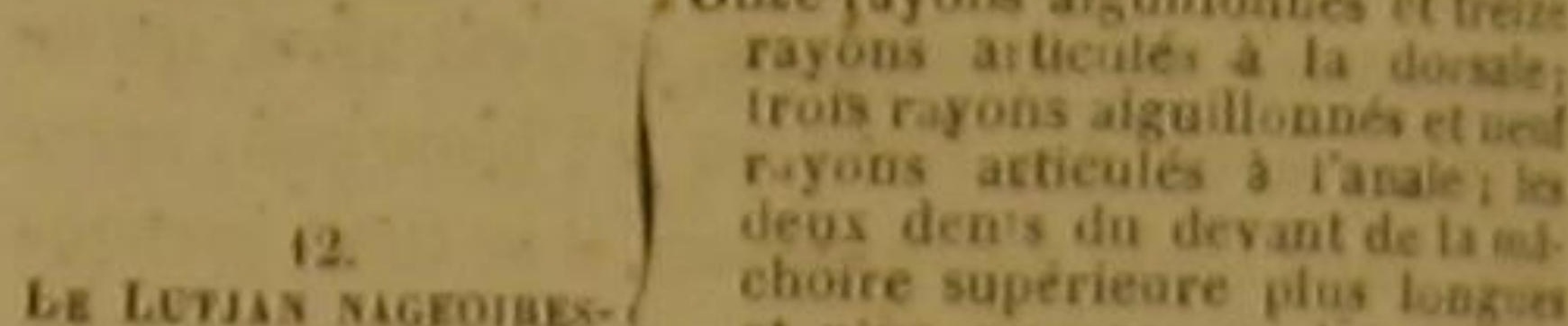

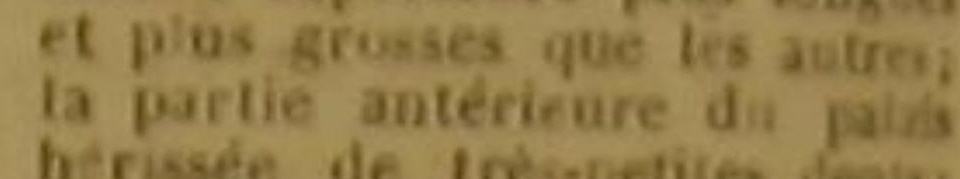

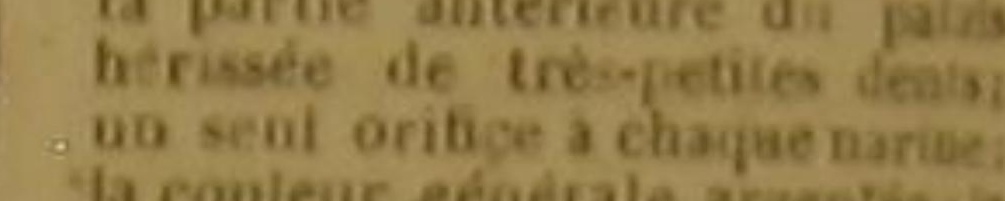

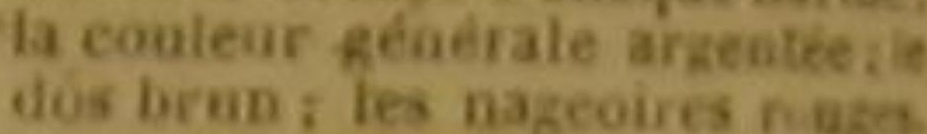

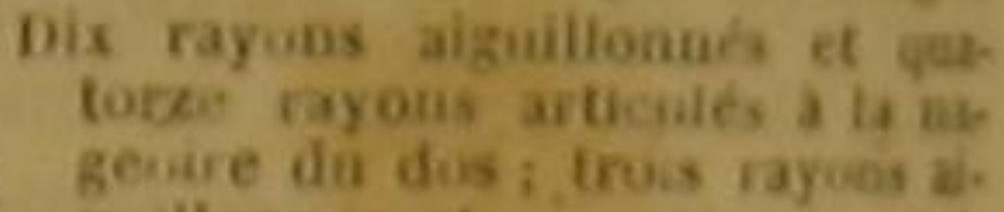

Le Lับ15.

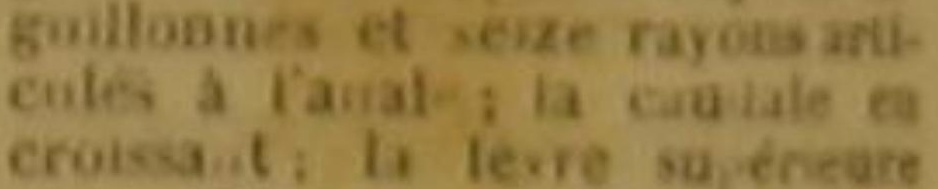

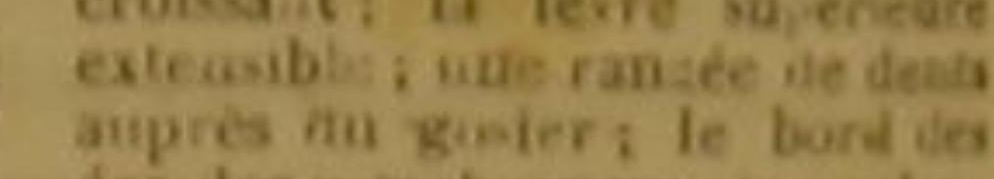
eca les nembrancus: la couler

LE Lusur.

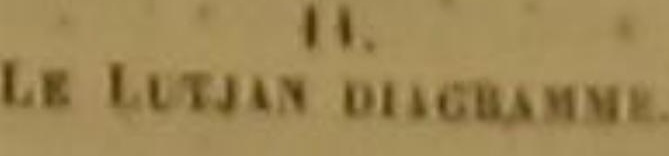

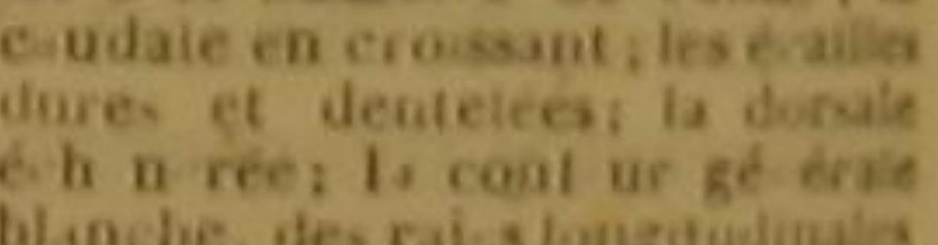

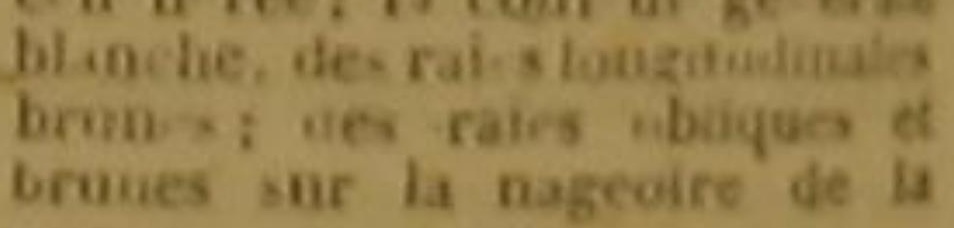

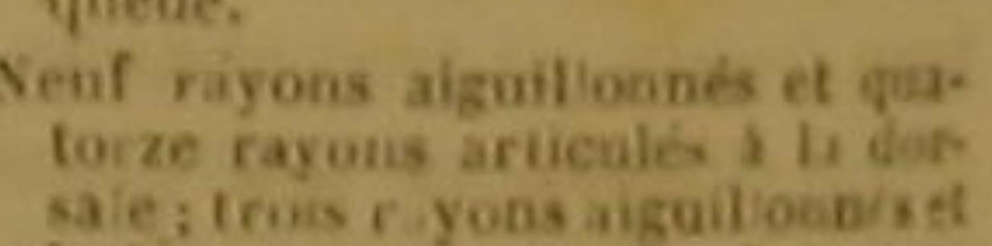

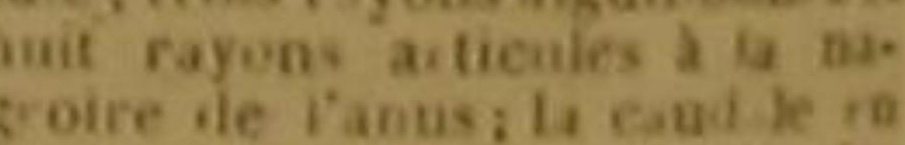
croissant; le devant de la tete
denoe vie peties eceillesi la lests derif ax michoirs, sear. LE LTIN. anx intervalles de celes dis
bas; le dus arrondis le veatre caremé i la coulear genern
b anche: le dow jaunatie: des baides eiroites, transerensies a

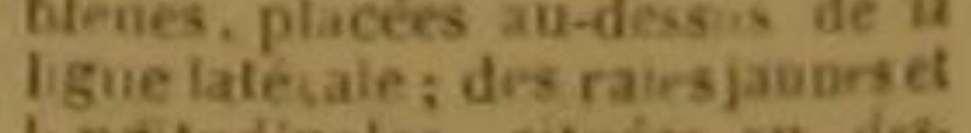
lingitudinales, situécs au -de sons de celte mème ligne.

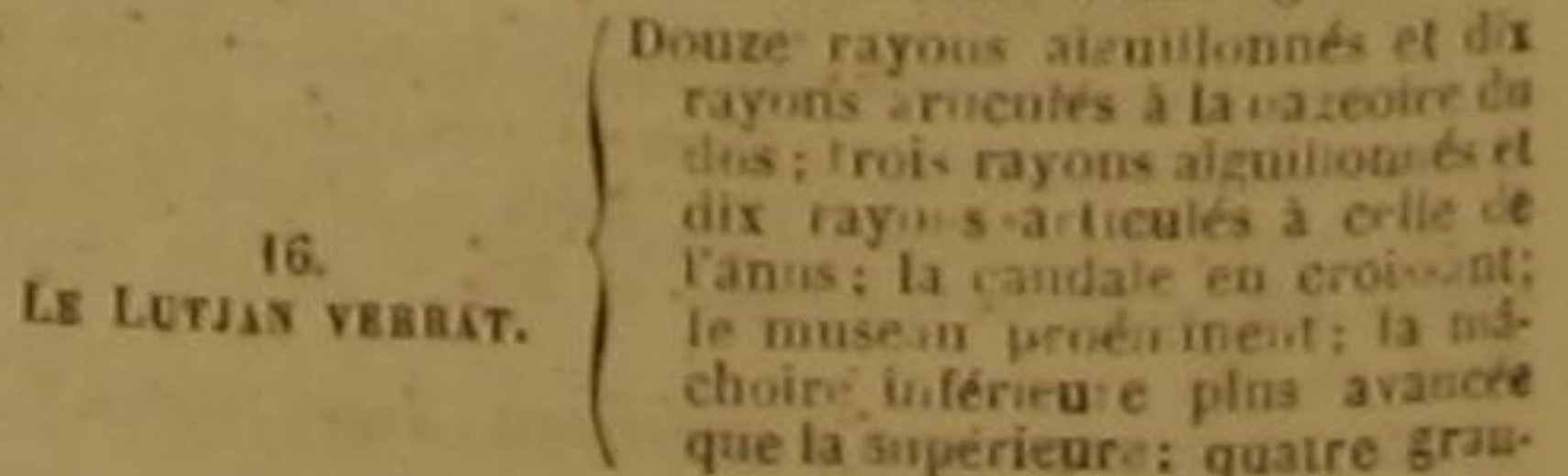
ta sinperieure: quatre gra
DES POISSONS.

3ะ่

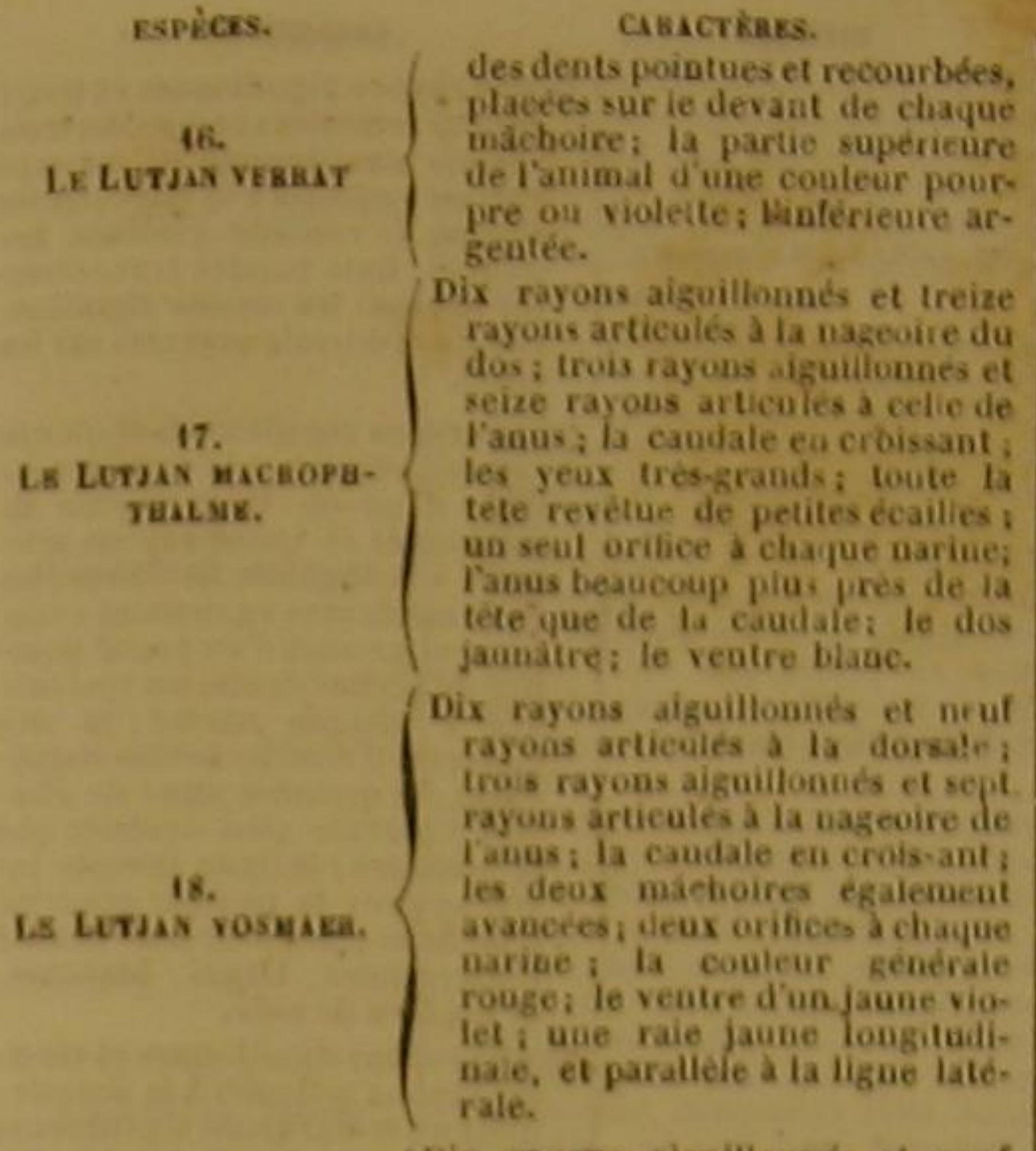

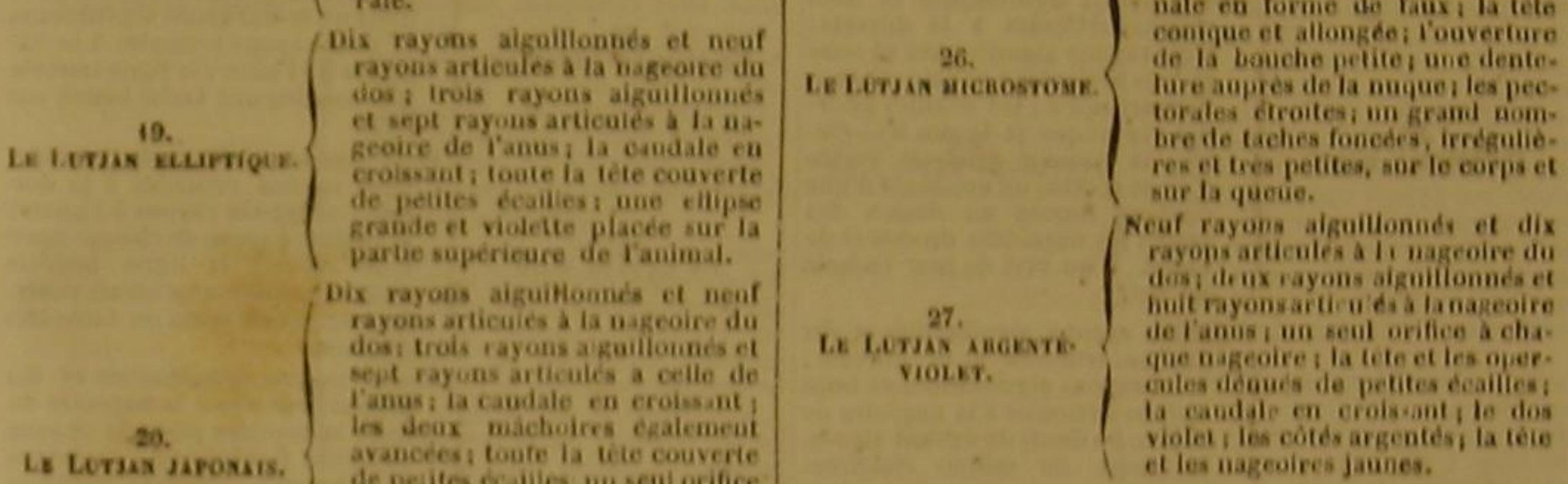
de peites calles un secul oritice

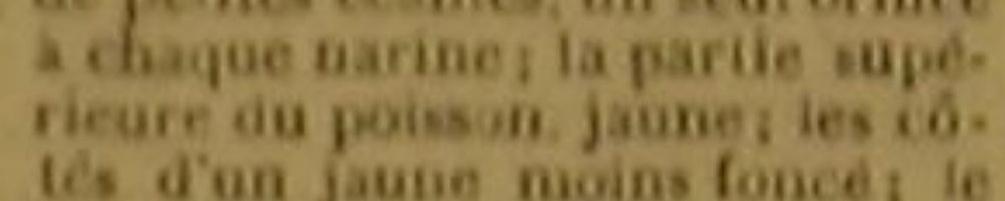
rentre rougeatre; presque

SECOND SOUS-GENIE.

Le Lotisx 21. Onze rayons aigaillonnes of qua.
torze rayona ariculís i i i va.

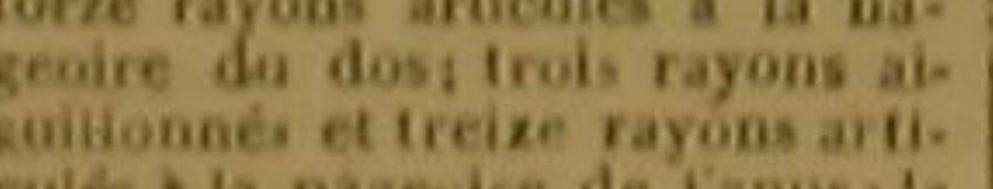

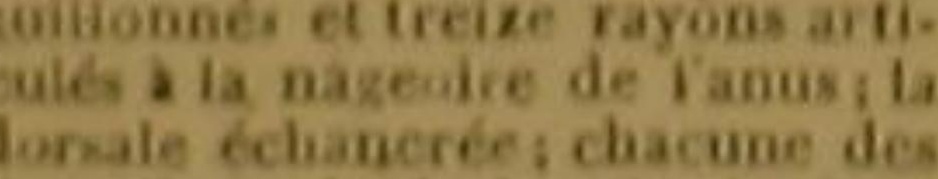
deux taces latérales de f animal Bé; tontrs ies pieces de cliaque opercule denteléns des lames
dentelés autour des yeax s ylu. sieurs rmzade deuts mouses a chaque máchoir: Mix rayons aiguillotines el quatorze

Le Lovus césissint. as; trois rayons aiguilonnés t neaf rayous articules a celie de lanus: sept rayons a chaque
horaceine; les deox máchoiress cgales : des dents crochues el commet de la tete denué de letus do docailles semblables a celtorme.
dale.

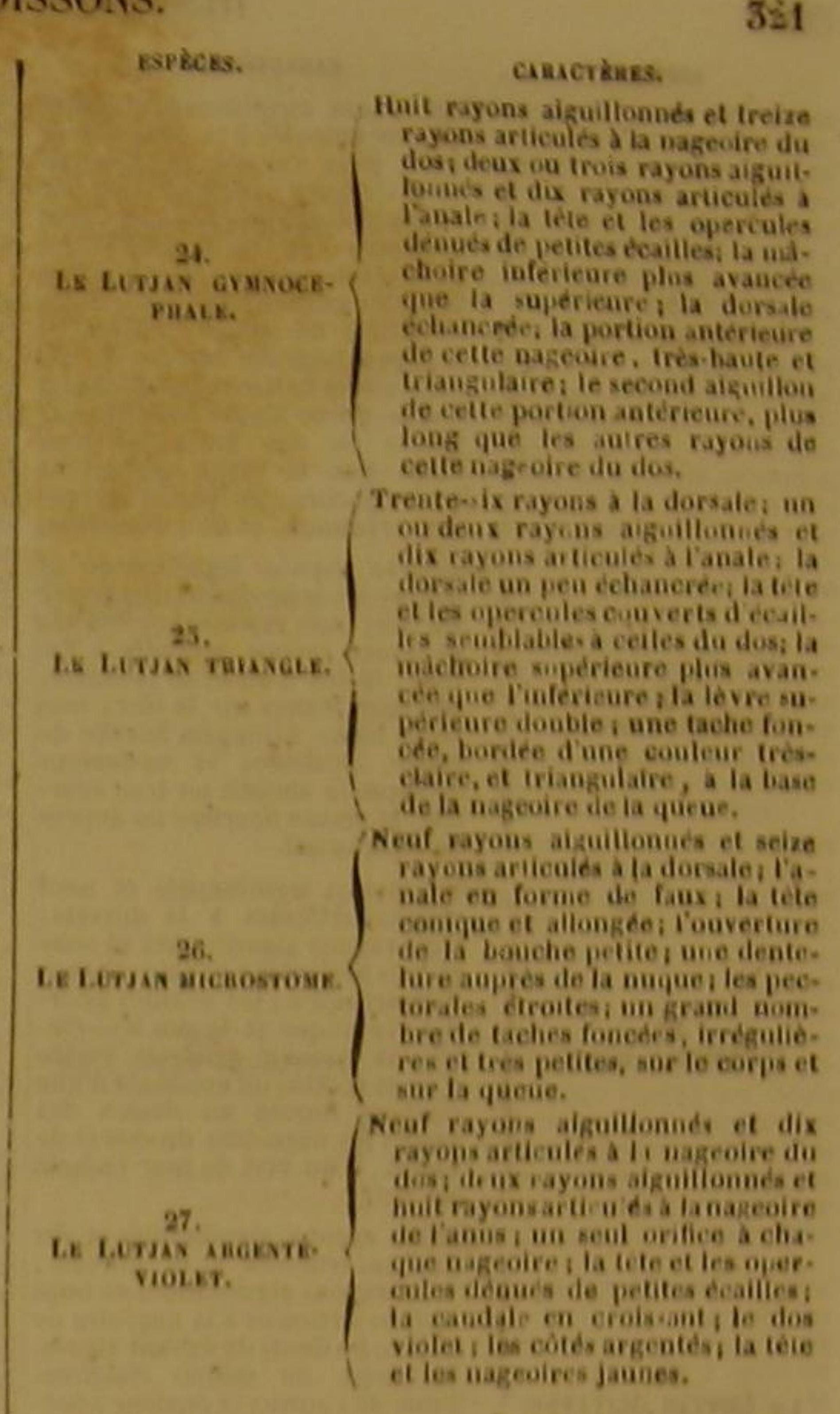

ta nageoire de, la queuc, ou terminie par une ligne droite, ou arroudic.

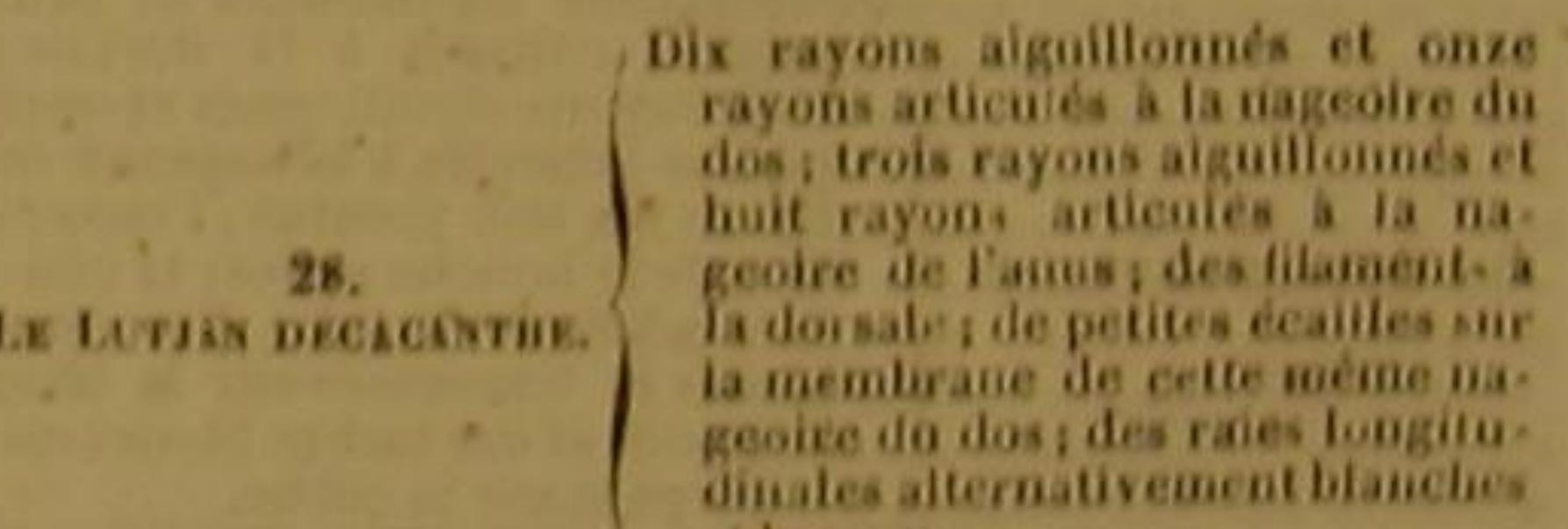
et bromes.

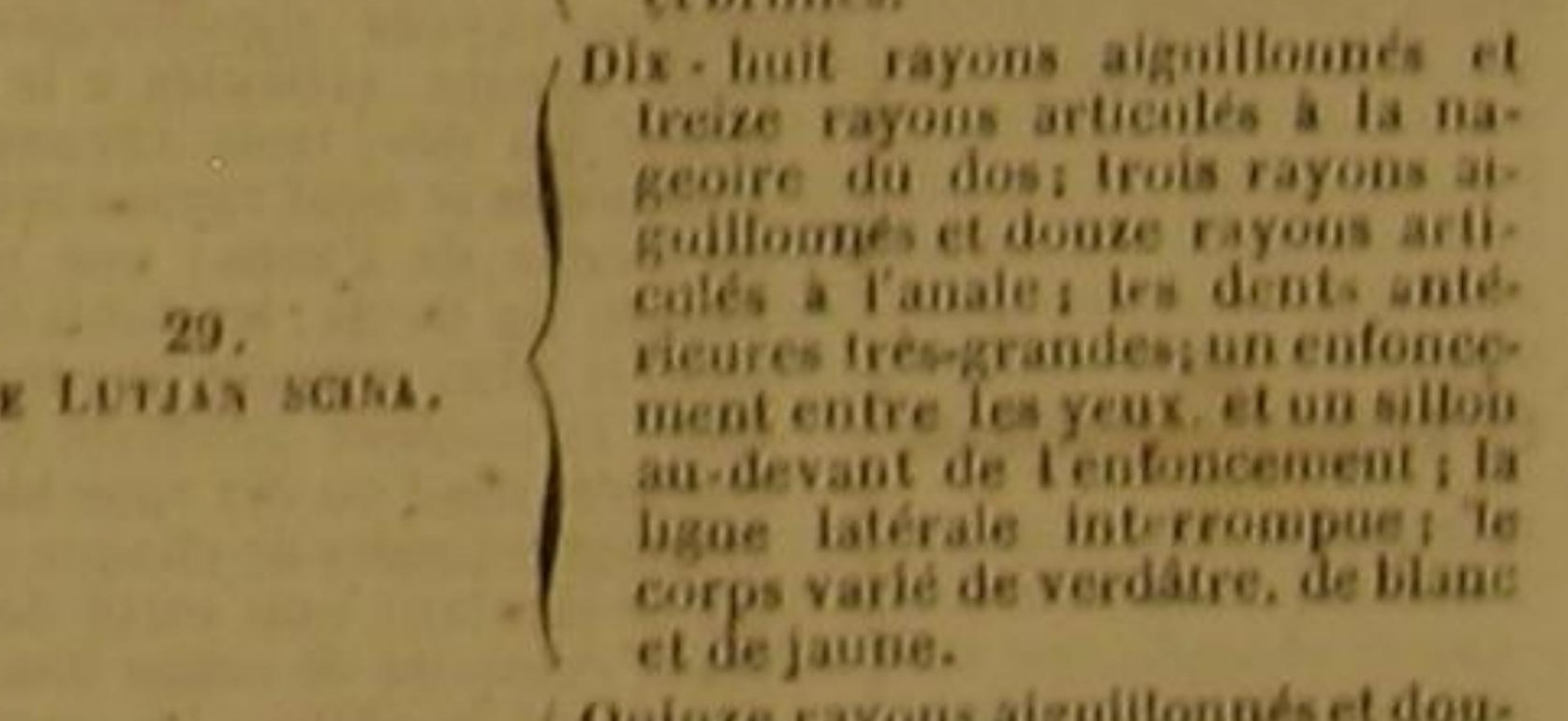
Quinze rayous aigullionneset dou-
ze rayous aricules a la dorale;

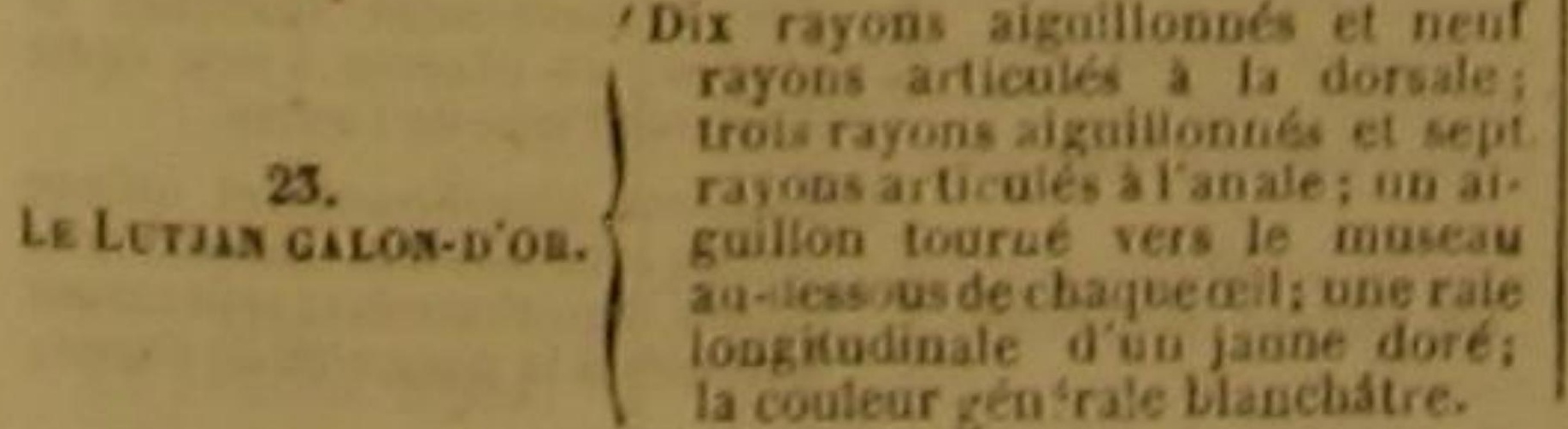
rayons articoles a $1 \mathrm{~b}$ nazeoire de

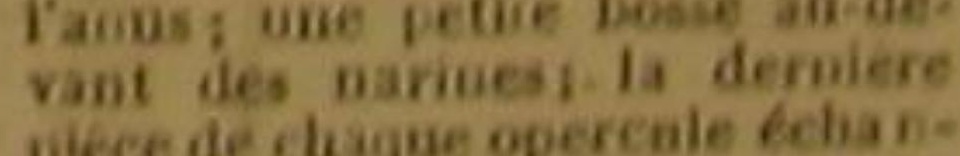

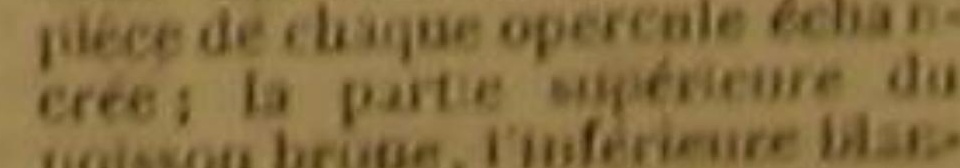

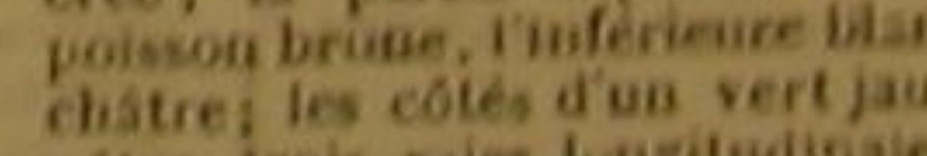

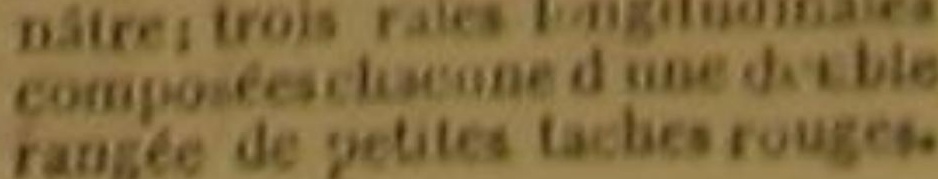




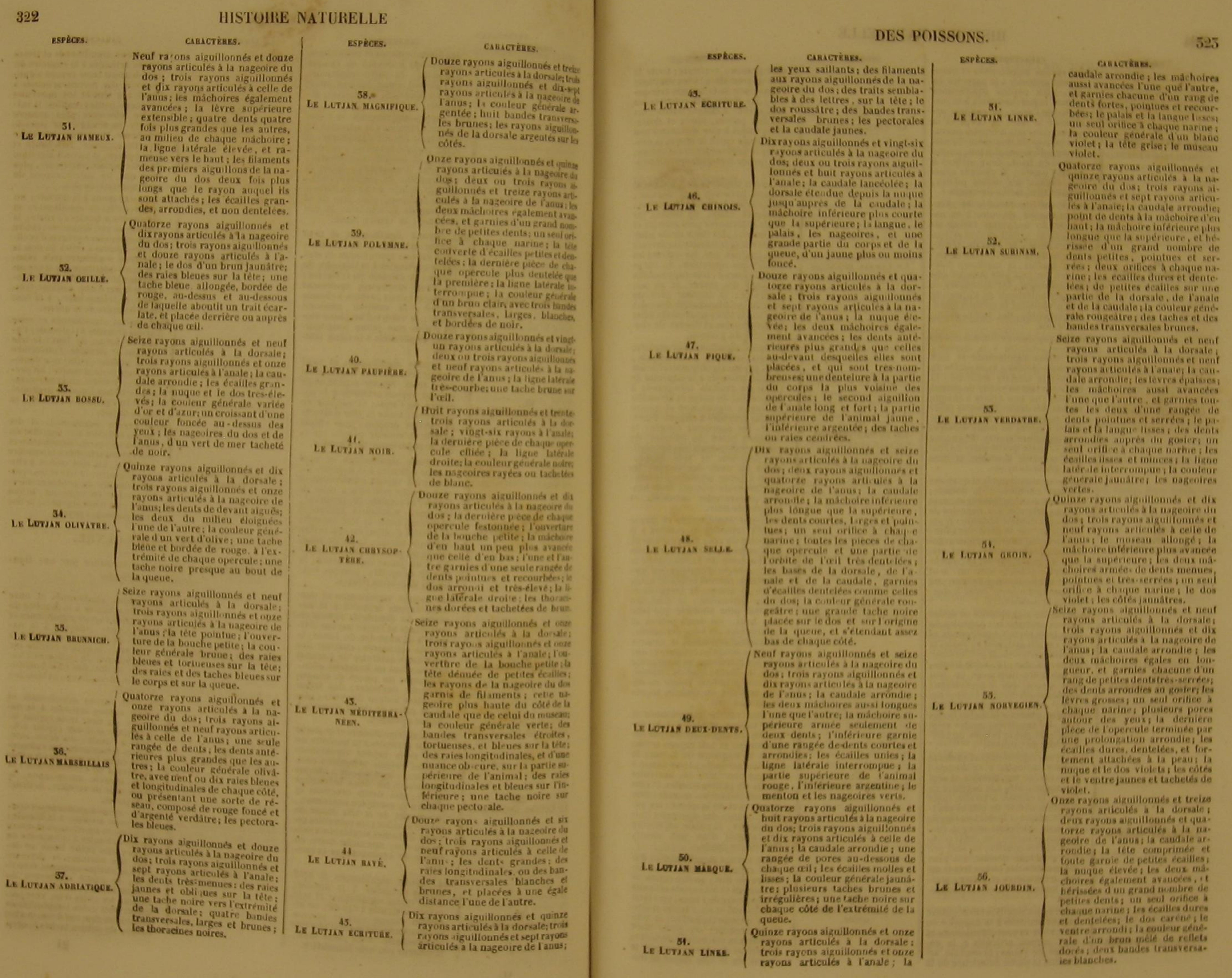


324

HISTOIRE NATURELLE

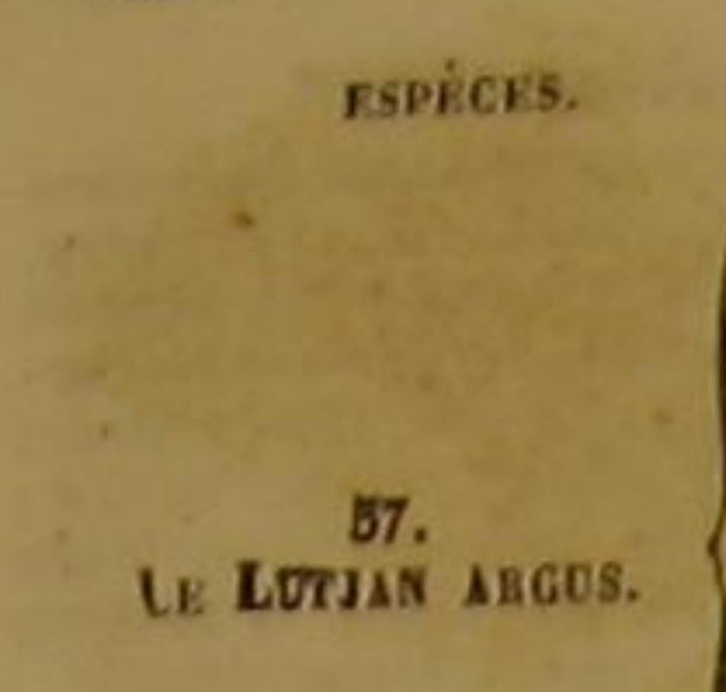

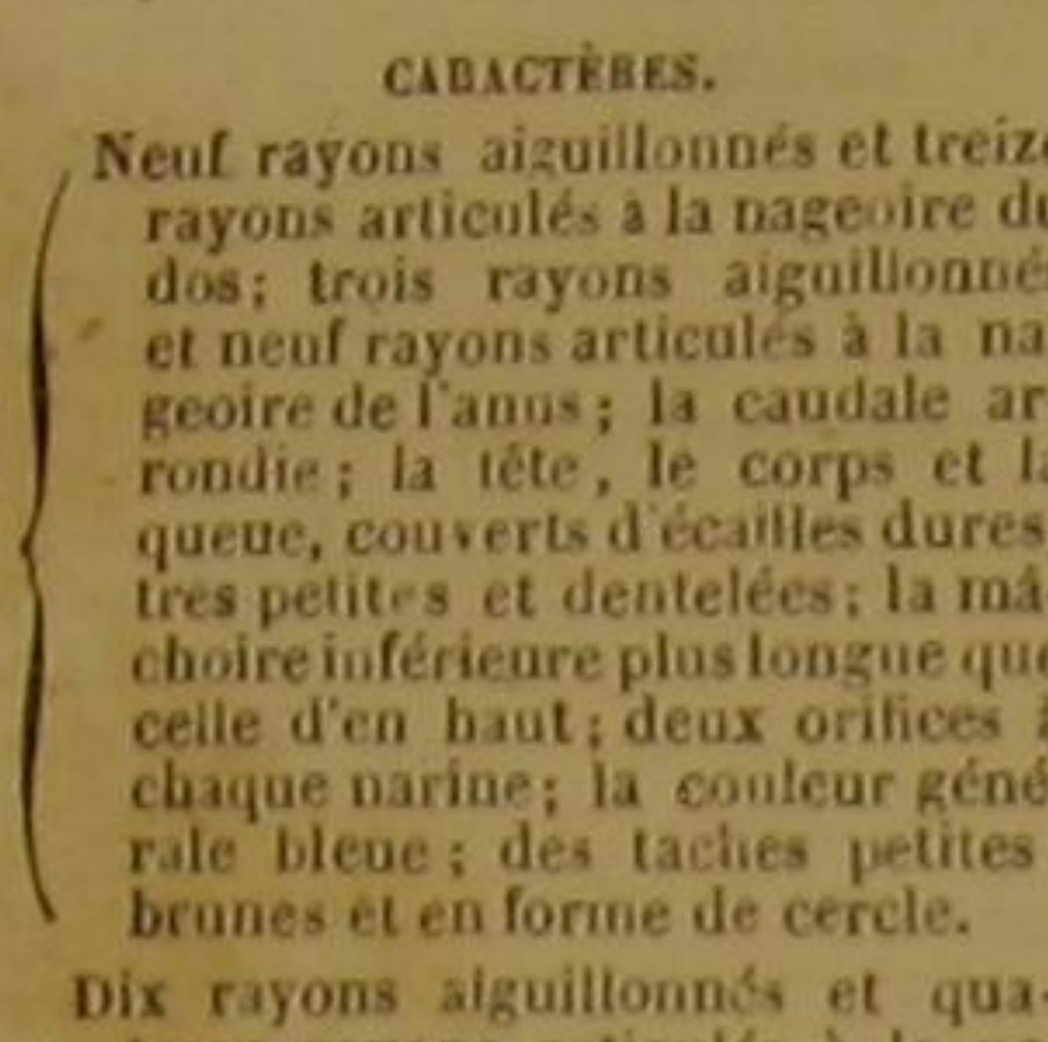
Dix rayons siguiltonn's et qua-
torze rayong articules a ta na-

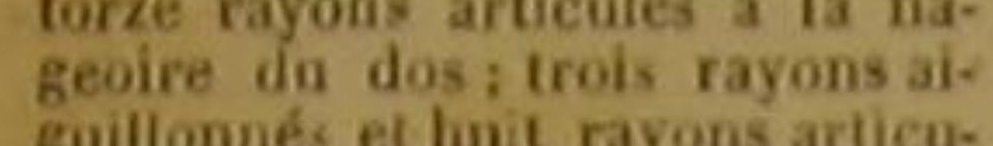

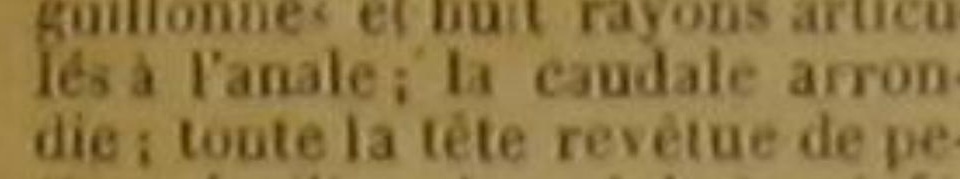

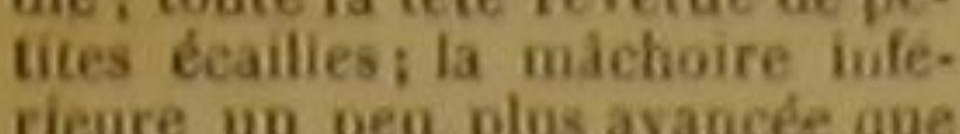

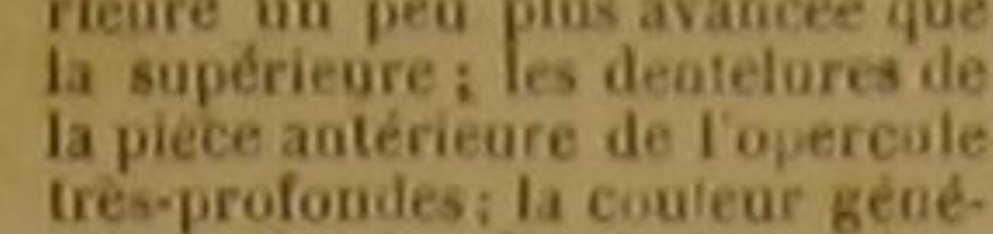

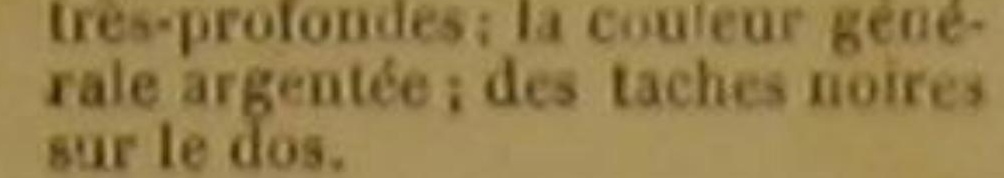
Dix-kuit rayonsaiaguillonnéset neut
rayons articules a ta dorsale dix rayons aignillomenés et bu
rayons articules a La nageonire

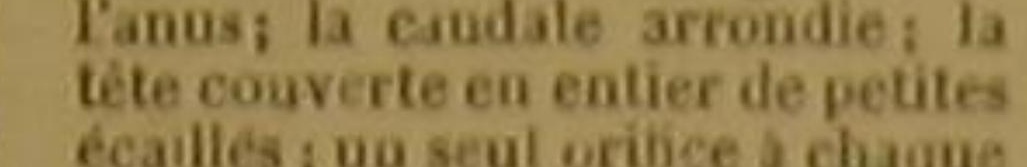
narine iles deux maichoires pros-
que éfalement avancés i plu-

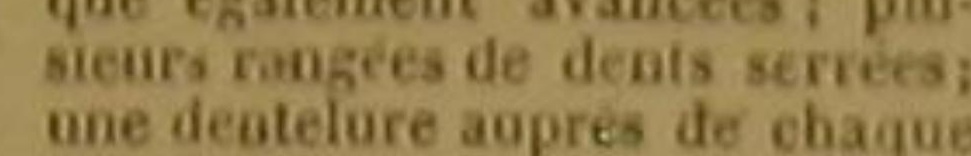

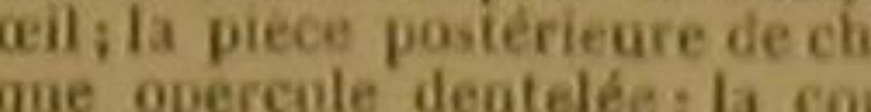
leur generale brune.

LE Lotini rontug. tlounés et quatorze

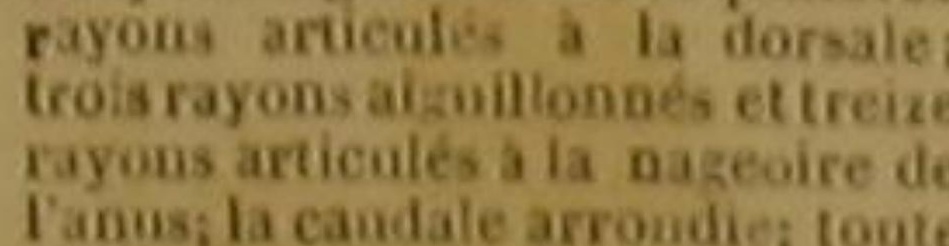

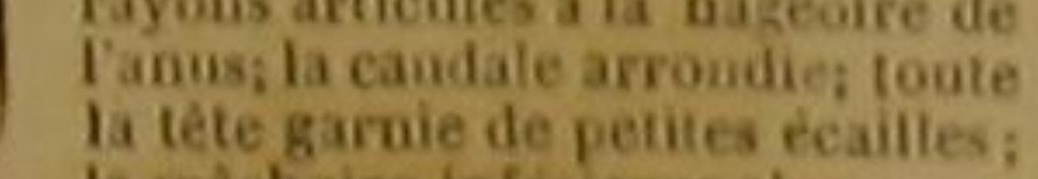

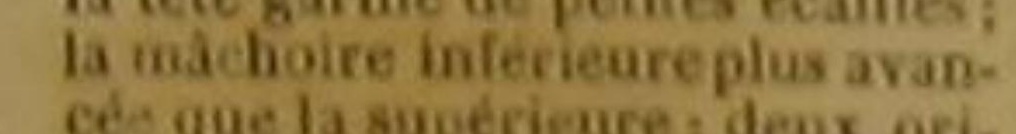

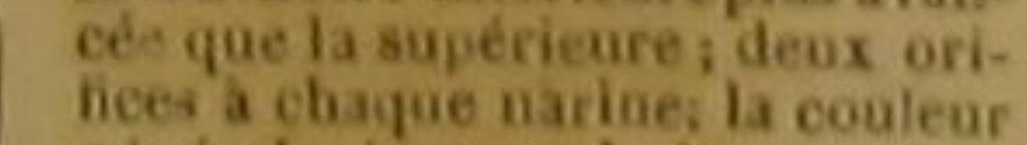

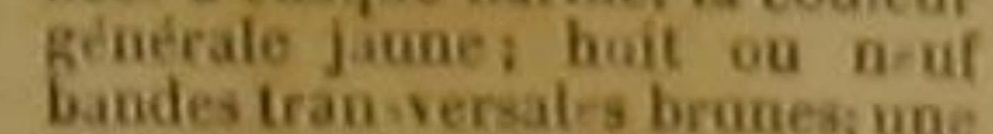

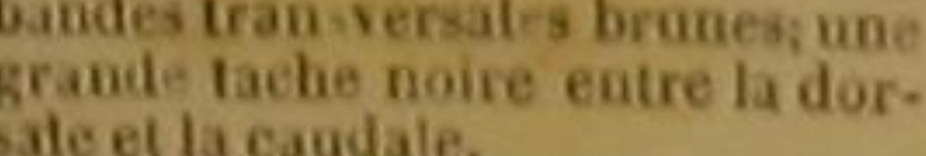
Onze rayons aiguillomedés et donze

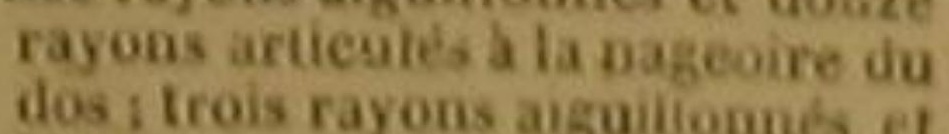

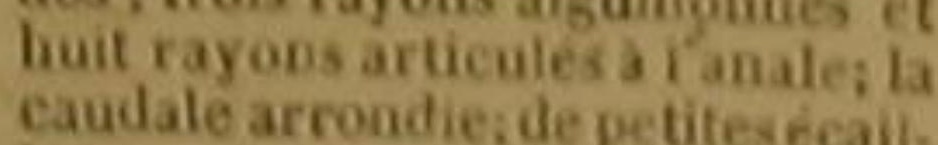

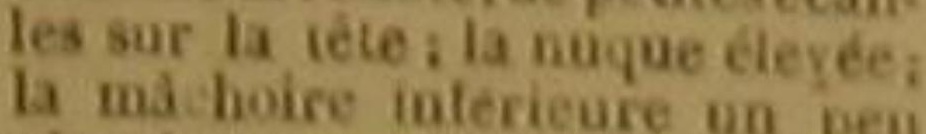
pilus longe que la superieure

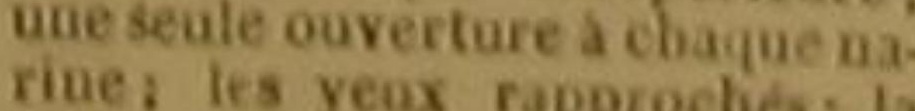

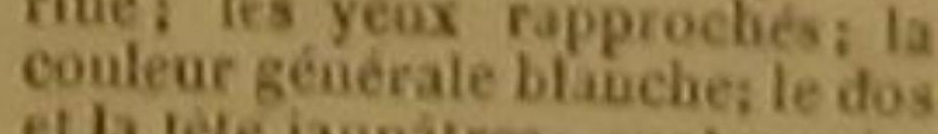

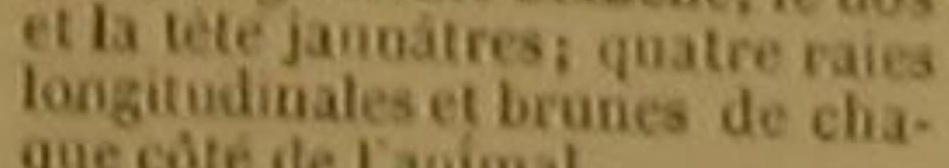
Dix rayous siguilloanés et guatorze
rayous aricieulés a ta dorsale

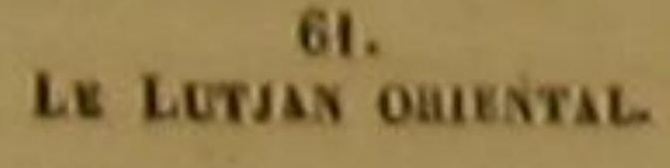
$\left.\right|_{10} ^{1}$

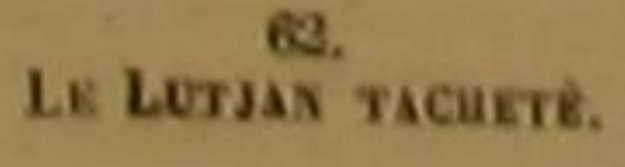
rayonsariculés a lanase el sepi

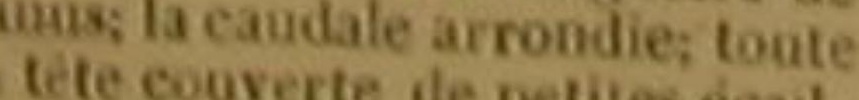

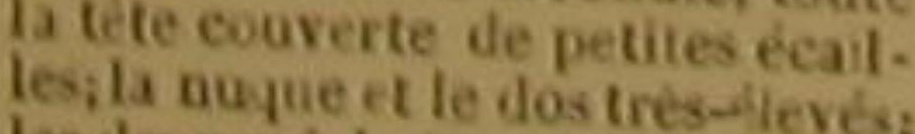
les deux wajhoires presque és;
lement

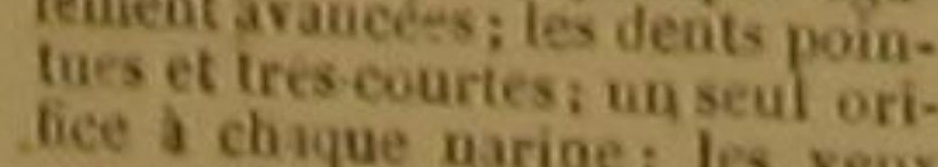

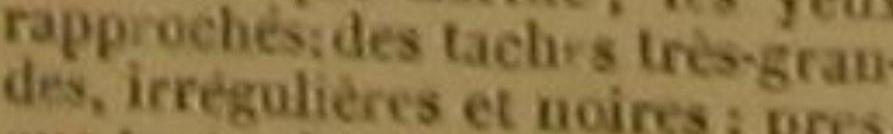

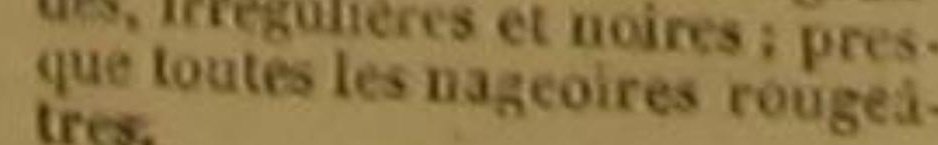

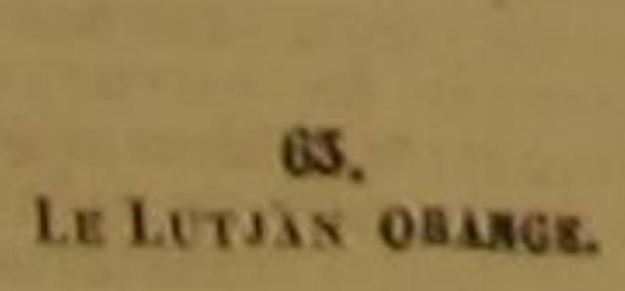

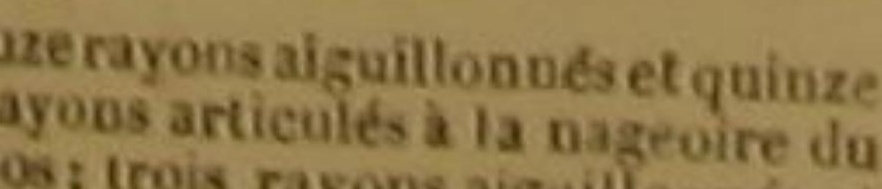

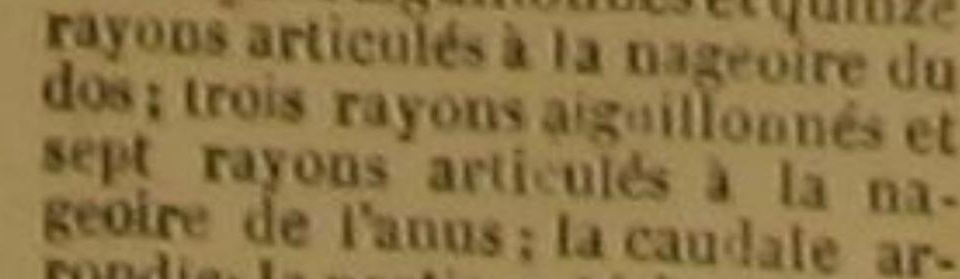

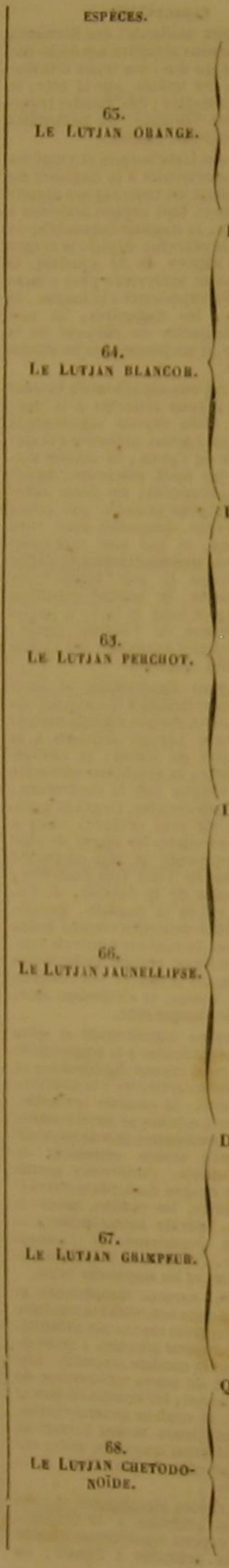

санастіkes.

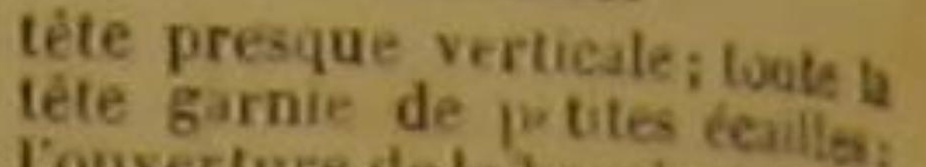

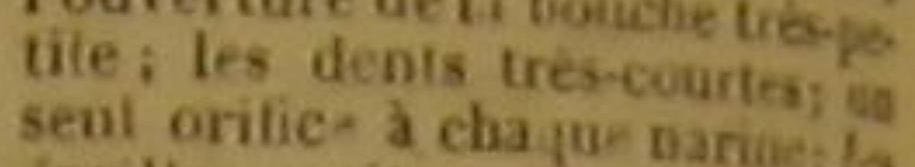

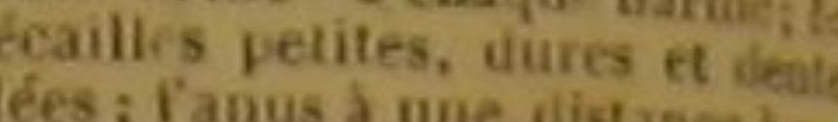

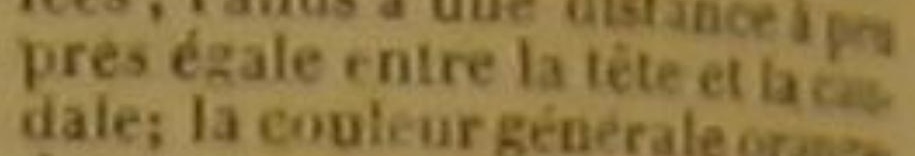

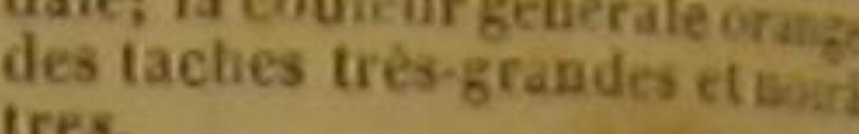

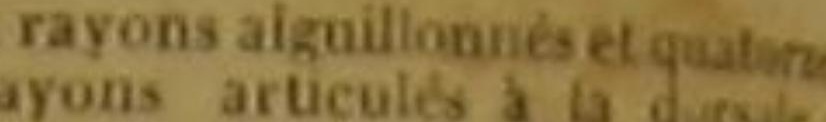

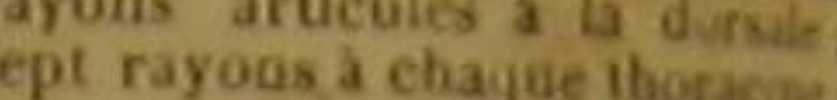

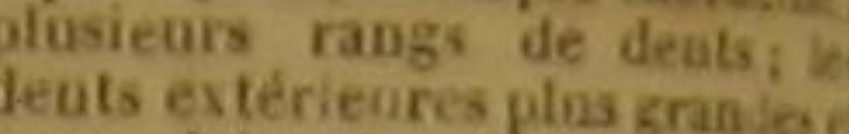

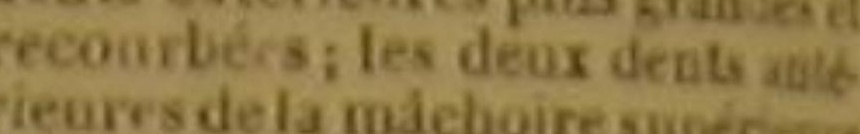

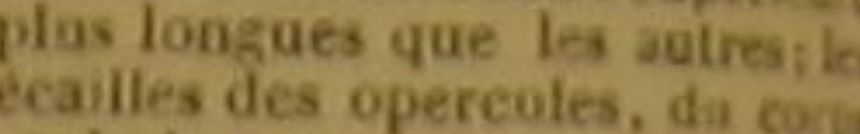

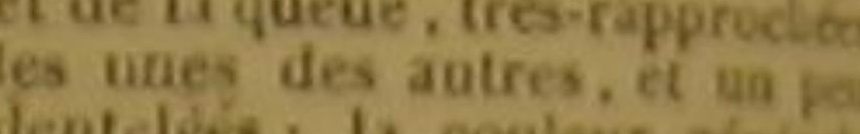

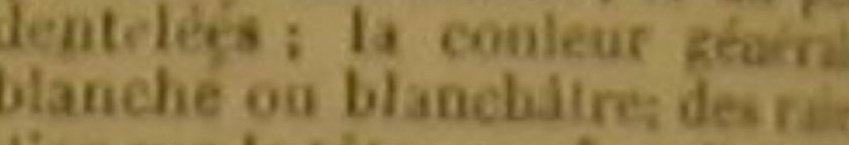

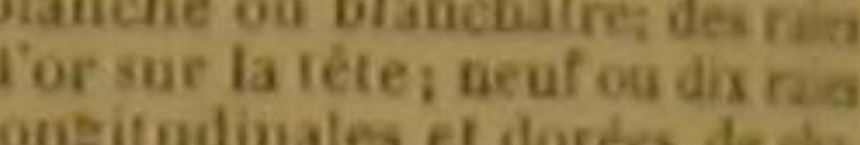
que eote da poissoo.

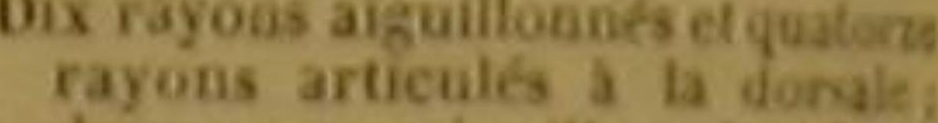

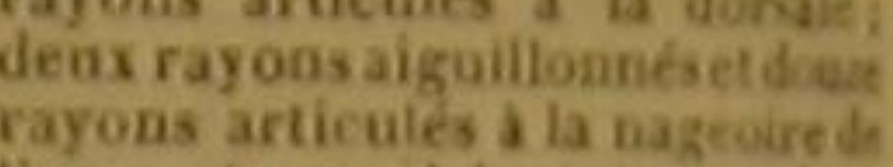

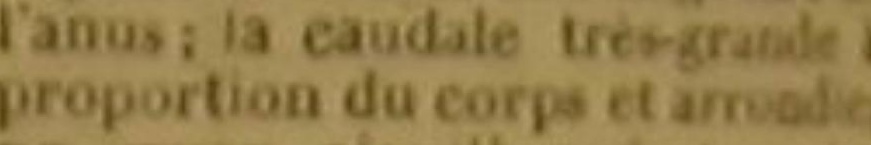

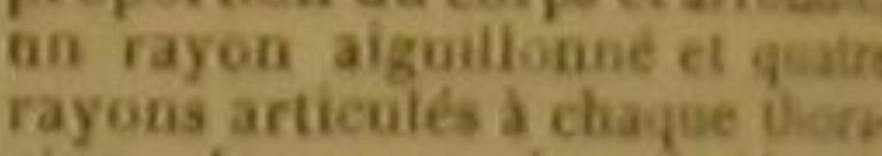

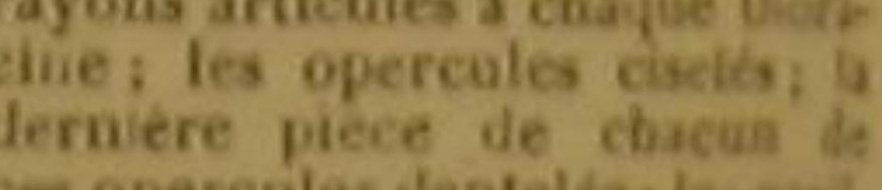

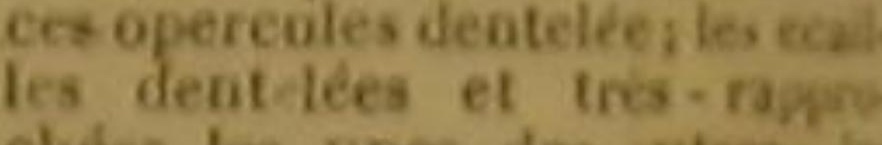
leats a perine sersibies ilaco.

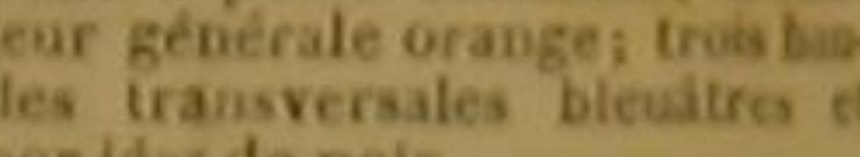
wix rayons aiguillomens et doent
rayons articults et rameensit

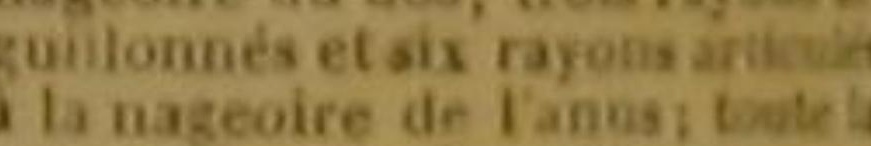
te esiverte decailis on pre

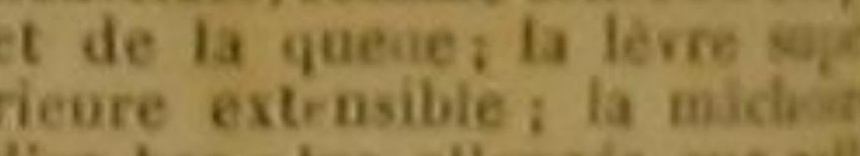

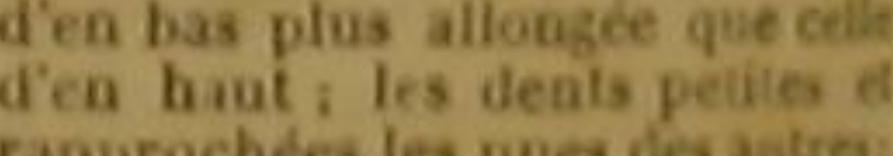

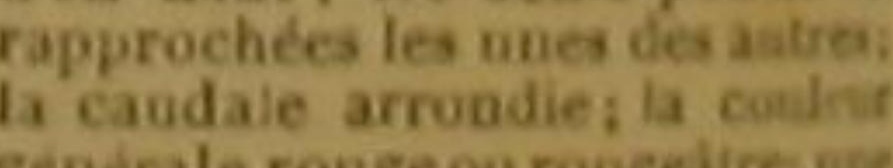

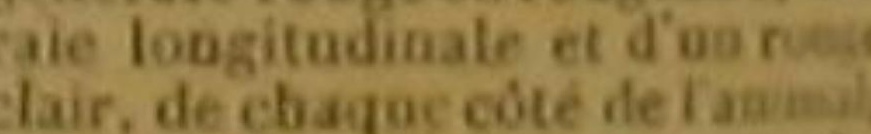

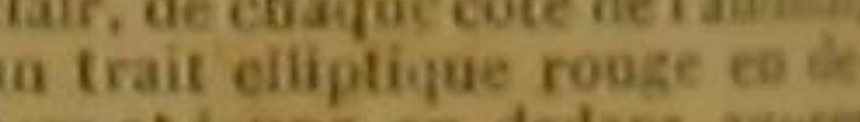
hive et juane e Dix - sept rayous aiguillononde

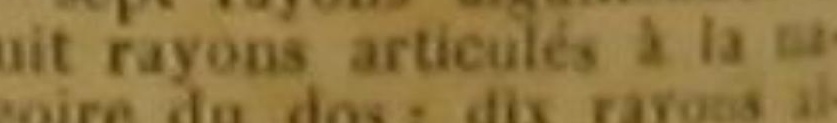
fuillonies et huit rayons ariou audale arrondie; ; tros picied

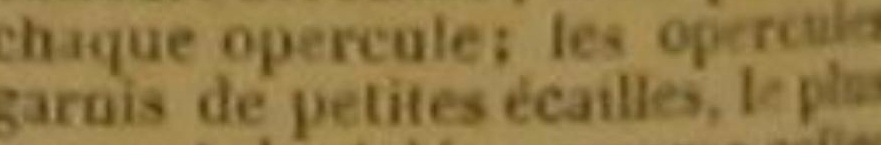

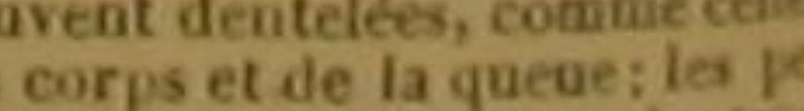
ints piquants des operculs tror.

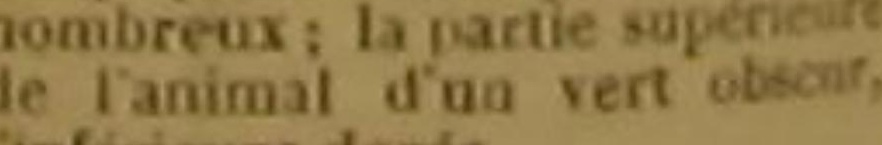
inferieure dorte. Qunze rayons aiguillonnés et dx
veuf rayons articul's i la an. vilomnés et six rayons articules la hageoire de lanous; ua ravon lés à chané et six rayous arrices dale arrondie: six pores ast
grands a la machoire intenteure; hintérienr des levres granudic le
lessus de la téte relevé de tos

DES POISSONS.

523

cinkockass.
sspicks
Gs. sa partie autérieure, par une li-.
gne e rointe.

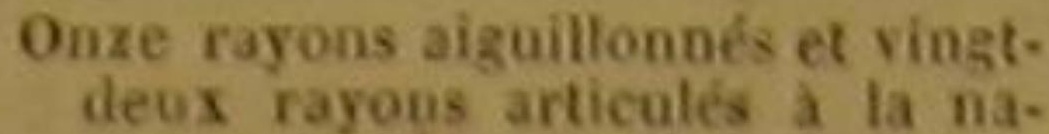
Reoire du dos; deux rayons at-

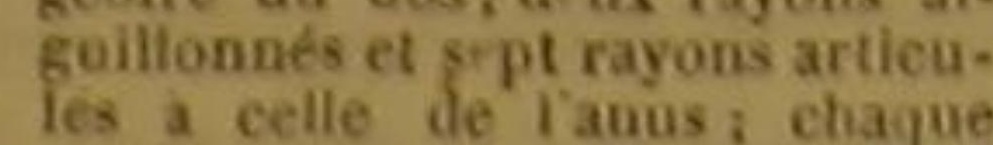
les a celle de Tauus : chaqu
máchoire granie dua rang do

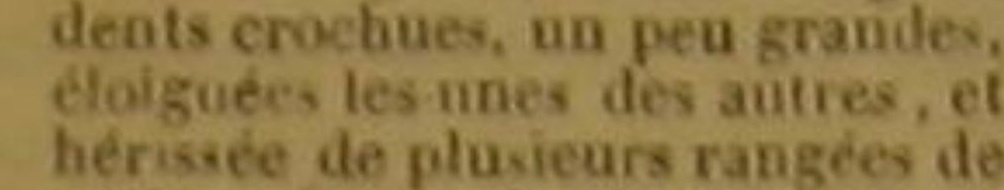
petites dents ia ligue atcicate
courbite vers le dos, et ensuile

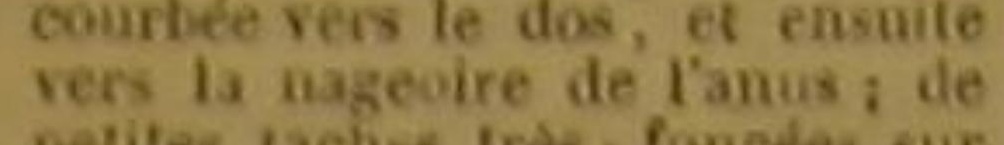
les côtés de l'animal et surle nageoures

L3 Lักง 69. rayons aizuillonnéset vinat-mo

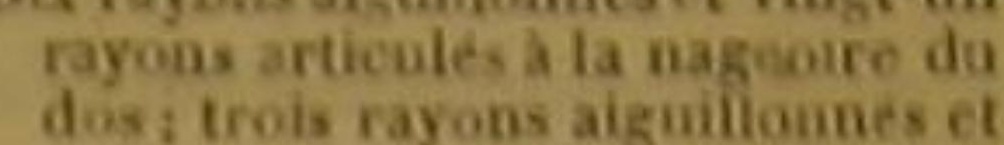

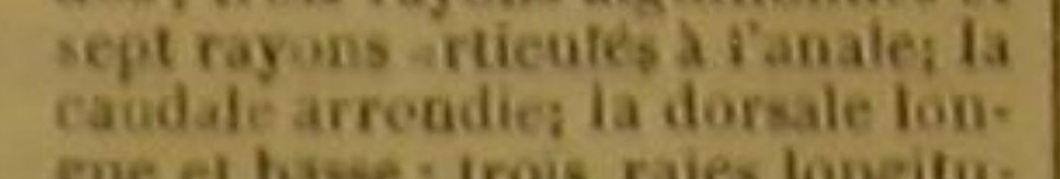

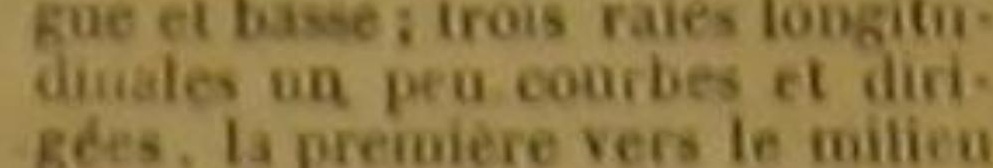

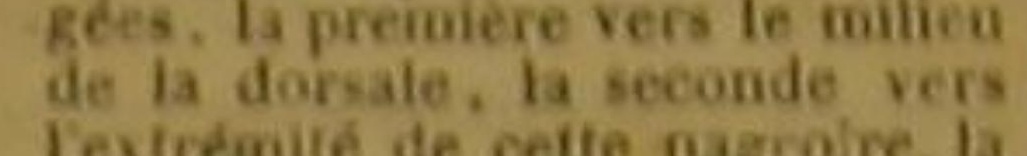
lestremilie de cette nagro
troisteme vers la eaudale.

LE tữix peis.

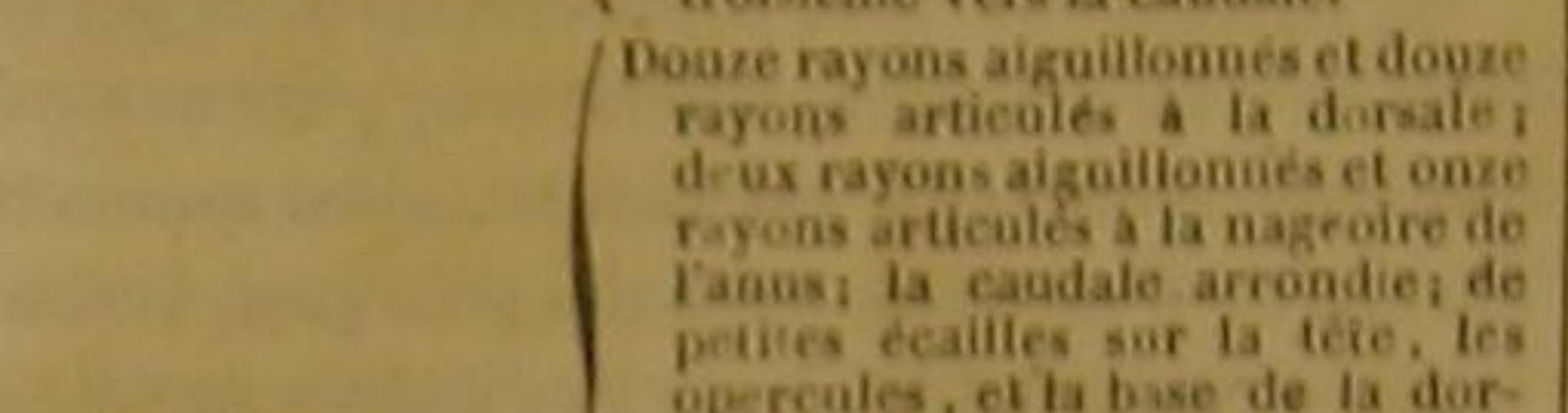

LE Lenix Ansers.

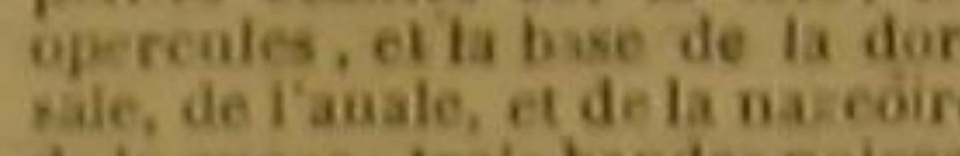
de la queces i trols bandes noires:

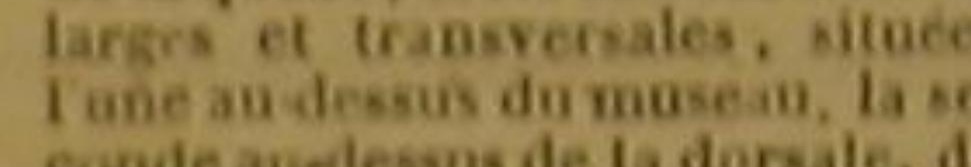

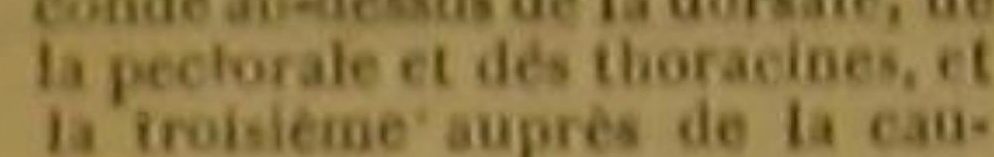
la pee
a
dile.
dile.

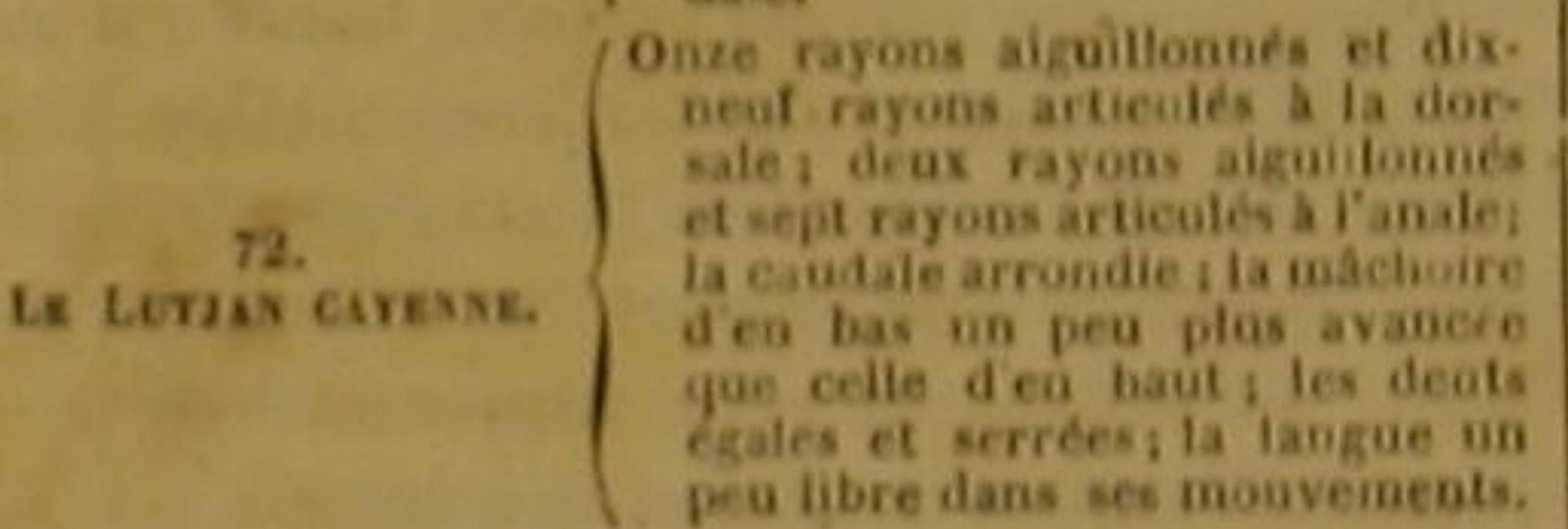

TROISIĖME SOUS-GENRE.

La nageoire de ia queac dirisic en trois lobes.

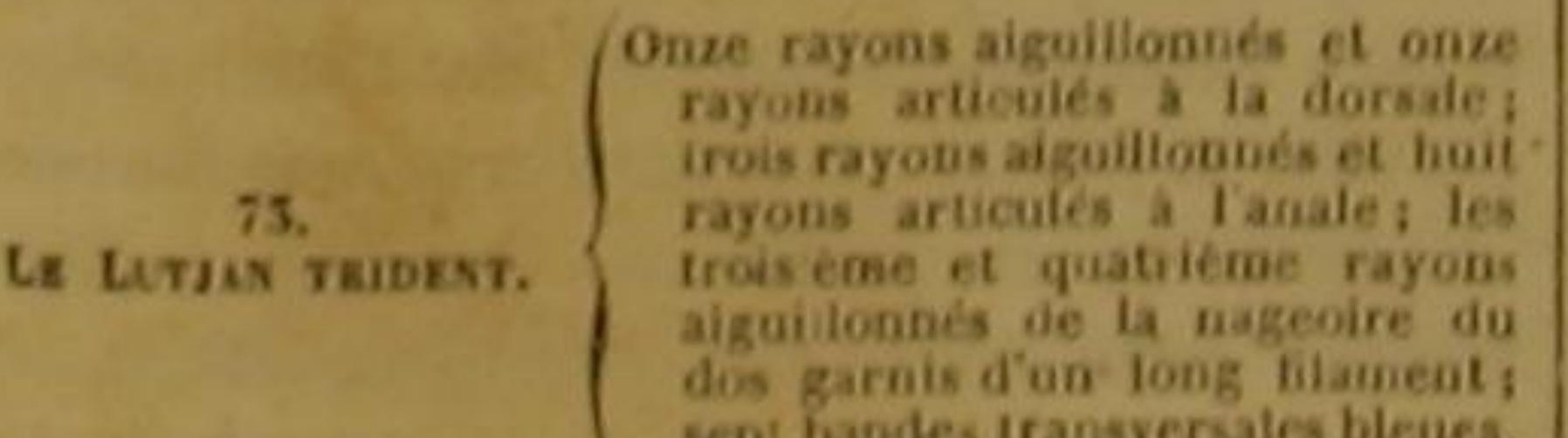
six rayons aiguilloonés et size hyous an

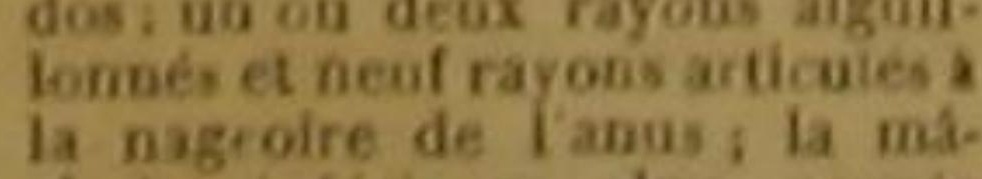
gue la superieure: deax orifices a chajue narine; toute ta tele

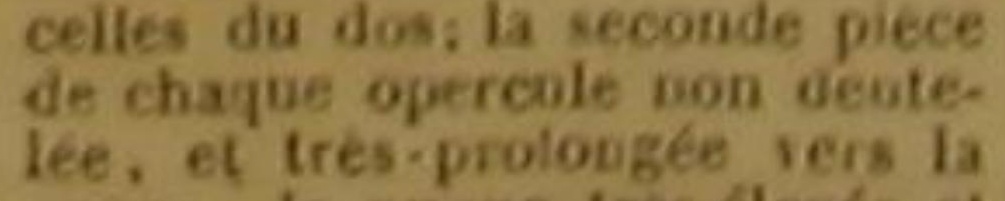

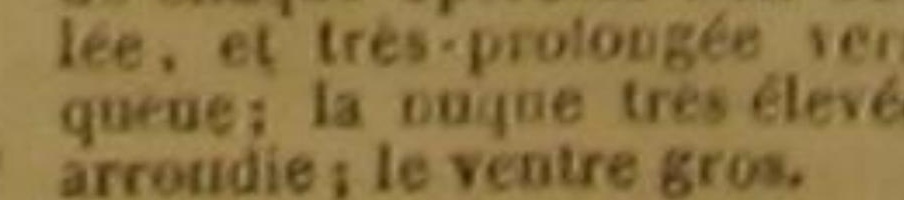

Pristipoma Rodo, Cuvi, Sparus virginieus, Lina., Jub, ef Lutjanus virginims, Laces. ? inicus, Lacep. ?

Le Labre Anthias s, Serrauns Antbias, Cav, Labrus An. thias, Einn, Anthias sacer, Bl; Latjanus Anthias, Lace, it. Cuv, Perea Ascensionis, Linn., Gimel,; Amphreanthu Ascensionis, Bt.; Luyamus Ascensionis, Lae, 4, - Lutjan Shigmate, Perea stigma, Lino., Ginel, Latjamus stigma,

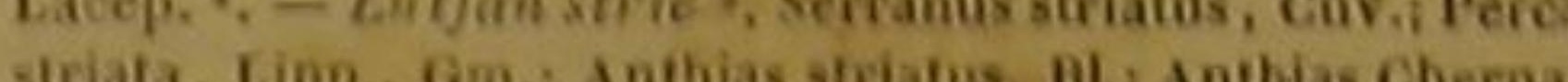
Bloch, Setrin Sparus etrysome lanus, et Luyjanus striatus, Lae, 10 .

Les lutjans ont beaucoup de rapports avec les spares; ils ont recu, comme ces derniers, des armes remarquables, au moins relativement à leur force et à leur grandeur. Mais celles des spares, consistant dans plusieurs rangées de dents propres à déchirer une victime, ou a écraser de dures enveloppes sous lesquelles leur proie táche en vain de trouver un abri paraissent destinées pour l'attaque plutót que pour la défense, pendant que les latjans, n'ayant ordinairement à la place de ces instruments

ispare rhomboildal, Daubenton et Haay, Enc. méth. -

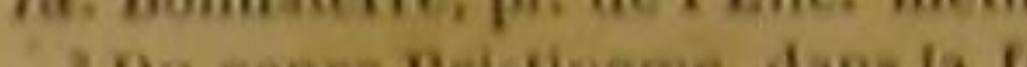

Camille des Acanthoptery. crit par s. de Lacépede, rous les noma i" de spare jub, 20 de Lutjan viryinien. D.

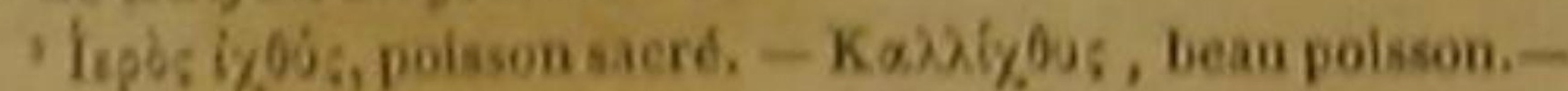

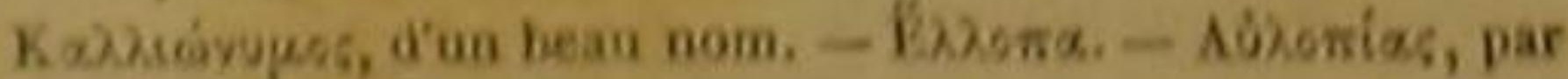

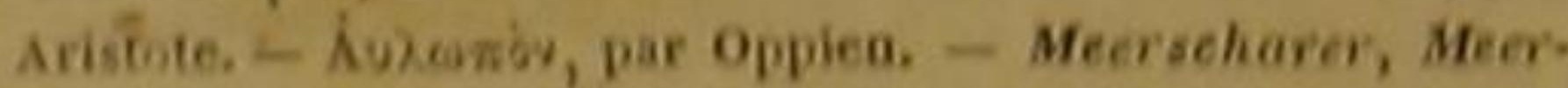
heiliger, Rundkopf. Rothing, par les Allemands.-The red gunt, par les Aoglais, - Labre barbier. Davienton at Hiay, Enc, méth. - Id, Bonnaterre, pl. de IEnc, méth, Anthias barbter. Bloch, pi. 5t5-C Labrus totus rubescen,

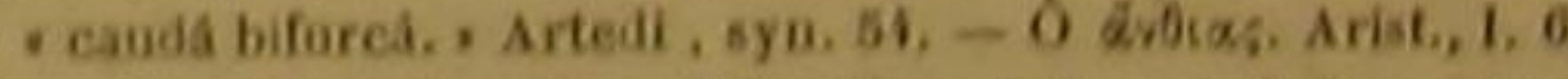

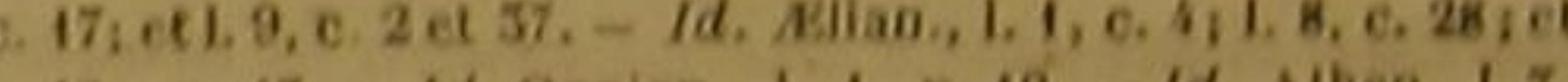
$12, c, 47,-1 d$, eppian.. I. A, p. 10. - Id. Achen., 1.7.

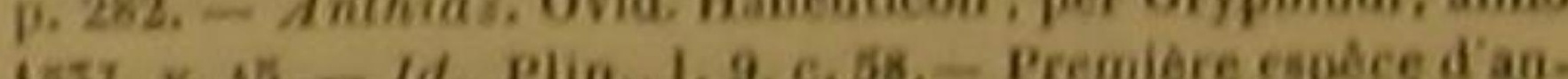
Gos, v. An thie primu species. Gener, 10. 85, 6t, et (germ.) 15. Anthias primas Rondeitti, , WVillughby, p. 325. - Id. inal, p. 158, - Catesby, Carol, 2, p. 23, Gab. 25,

tDa genre Neno0, Serranus de A. Cavier, dans La famillo des Acanthopterygiens percoldes. ID.

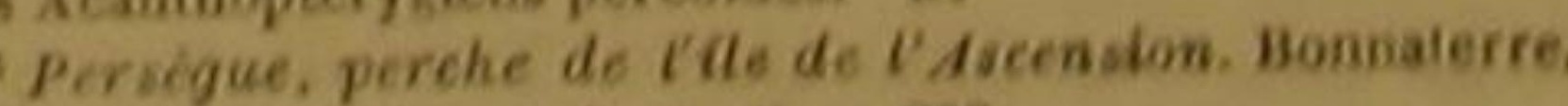

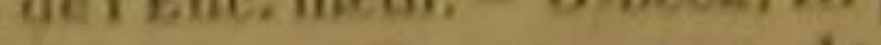

vier, dans ta famille

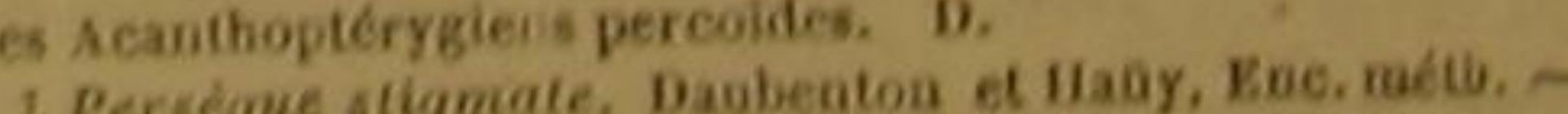
d. Bonnaterre, pl de I Bac, meth.

Son mentioné par M. Cuvier. D. - Persiegue striéc. Daubenton a

Gonnaterre, pi. de I Zue, meth. 4 Da genre Mrsov, Serranus, Cav., dass a fascite des

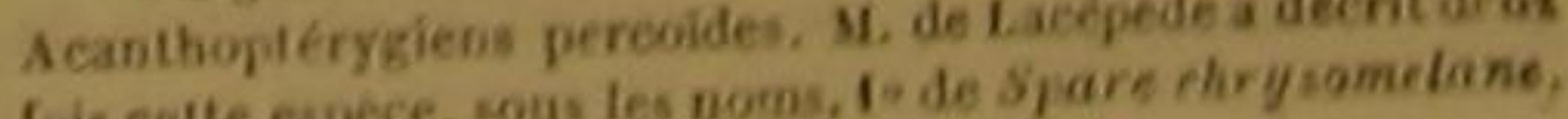
et Tride Luijan atrie. D. 
puissants que les piquants de leurs nageoires et ceux de leurs opercules, nc pouvant user avec avantage de ces aiguillons que contre l'ennemi qui les atteint et les saisit, ne semblent armés que pour se garantir des efforts d'un dangereux adversaire, arréter son attaque, et le contraindre a cesser sa poursuite et ses combats. Les spares provoquent et les lutjans attendent les habitants des eaux qui leur font la guerre : tel est du moins le premier aperçu qui se présente lorsqu'on les compare. On se presse d'en conclure que les lutjans sont moins voraces, moins agités, plus pacifiques, plus sociables que les spares; et la philosophie se plait d'autant plus a embrasser cette idée de paix, à la produire, a l'embellir, à la métamorphoser, pour ainsi dire, en une lecon heureuse donnée par la nature elle-mème, que les lutjans montrent presque tous une parure agréable et riante. Et que charme secret n'eprouve-t-on pas toutes les foi qu'on voit l'image du bon goút, la convenance daus les assortiments, l'élegance daus les ornements, et la belle distribution des coufeurs éelatantes ou suaves, réunies a vec la douceur des meurs et la bonté des habitudes?

Parmi ces intéressants lutjans, le premier qui s'offre ò nous, et auquel on a donné le nom de Virginien, habite non-seulement dans la Virginie, mais dans plusieurs autres contrées de l'Amérique septentrionale.

L'anthias, qui suit, vit dans la Méditerranée Son nom doit venir de $\alpha$ vos, qui en gree signifie fleur; et cette dénomination, ainsi que celles de beau poisson et de poisson d'un beou nom ', par lesquelles le désignait ce peupl spirituel et sensible à tóus les genrés de beaute, qui habitait la Grèce, indique le charmant assemblage des nuances variéeset des couleurs rivales de celles des fleurs, qui chatoient sur les éeailles de l'anthias êt le rayon allongé de s nageoire dorsale, qui s'élève au milieu de ces rellets agréables comme une anthère ou un pistil au sein d'un beau calice. Tous les tons que le rouge peut présenter depuis l'éclat du rubi ou celui du grenat jusqu'aux demi-teintes du rose le plus tendre, se mélent en effet sur surface de l'anthias avee le brillaht de l'argent; et la vivacité scintillante ou la douce fusion de ces nuances toutes gracieuses plaisent d'autant plus á l'œil , qu'elles se marient avec le feu

- Voyez la troisième note de cet articl. la topaze qui resplendit par reflets fugitifs sur les grandes nageoires de ce poisson favorisé par la nature.

Peut-être sa parure n'a-t-elle pas peu contribué à le faire regarder comme sacré 4 par on peuple qui avait divinisé la beauté, et qui nepouvait voir qu'avec enthousiasme les emblemes de sa divinitè chérie; et e'est vraisemblable ment par une suite de cette espèce de conscration, que les anciens Grecs pensaient qu'arcun animal dangereux ne pouvait habiter dan les mêmes eaux que l'anthias, et que les plongeurs pouvaient descendre sans crainte jusqu'a fond des mers, dans tous les endroits où ils rencontraient ce luțan privilégié.

Quoi qu'il' en 'soit, voyons rapidement les formes principales de ce poisson.

Sa téte est courte et toute couverte de petites écailles ; sa måchoire inférieure, plus avancée que celle d'en haut, est garnie, ainsi que cette dèrnière, d'un rang de dents pointues, recour. bées, ot séparées les unes des autres par dau. tres dents plus petites, serrées et trés-aigues; ta 解 ne présente aucune aspérité; chaque ba. rine n'a qu'un orifice, et la ligne latérale est interrompue.

Plusieurs des auteurs grees et latins qui on: parlé de l'anthias, et particulièrement Oppienet Pline, se sont occupés de la manière de le pécher. Selon ce que rapporte le naturaliste ro main, les lutjans de cette espèce étaient tres. communs auprès desiles et des écueils voisias des côtes de l'Asie mineure. Un pécheur, toujours vêtu du mème habit, se promenait dans une petite barque pendant plusieurs jours de suite ; et chaque jour à la même heure, dans un espace déterminé auprès de ces écueils ou de ces iles, il jetait aux anthias quelques-uns des aliments quils préferent. Pendant quelque temps, cetle nourriture était suspecte à des animaux qui, armés pour se défendre bien plotôt que pour attaquer, doivent étre plus timides, plus réservés, plus précautionnés, plus rusés que plusieurs autres habitants des mers. Cependant, au bout de quelques jours, un de ces poissons se hasardait à saisir quelques parcelles de la pâture qui lui était offerte : le pécheur l'examinait avec attention, comme l'auteur de son espoir et de ses sucees, et l'observait assez pour le reconnaitre facilement. L'exemple de

DES POISSONS

lindividu plus hardi-que les autres n'avait pas

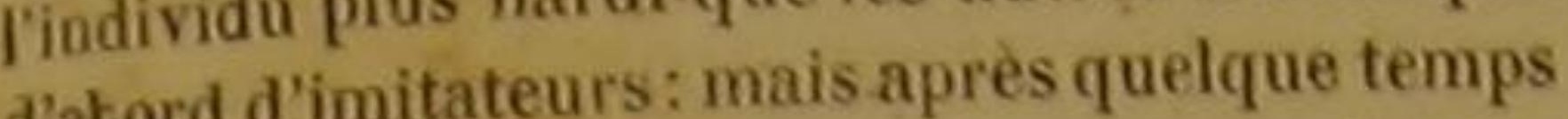
d abord dimitateu'see des compagnons dont le it ne gare angmentait peu à peu; et enfin il ne se nombre au'avee une troupe nombreuse d'aumontrait qu avec une familiarisaient bientot avec tres anthias qui se familiarisaient bientot avec le pècheur, et s'accoutumaíent à recevoir leur nonrriture de sa main. Ce méme pécheur, canow alors un hamecon dans l'aliment qu'il chant alors un hameçoux trompés, les retenait, présentait à ces animaux trompes, les retenait, les enlevait, les jetait avec vitesse et facili dans son petit bátiment, mais avait un grand soin de ne pas saisir l'anthias imprudent ausoin de ne pas saisir la de sa pèche, et dont la pre fuite tous ceux qui ne s'étaient avancés vers le navire qu'en qui ne setaient avíe, et en se mettant, en quelque sorte, sous sa conduite.

Oppien raconte que lorsque, dans d'autres irconstamees, un anthias est pris a I'hameçon, es compagnons s'empressent de l'aider à le détacherdu fatal crochet, ou de la ligne, en le poussant avec leur dos ; et que même, quelquefois f'individu retenu par la corde la coupe avec l'aiguillon long et dentelé de sa mageoire dorsale. Si ce dernier fait est vrai, il faudrait l'attribuer a un autre poisson que l'anthias, et peut-être à quelques grands silures; car le long aiguillon de la dorsale du lutjan dont nous nous oceupons, quoique fort, et en quelque sorte un peu tranchant ' , ne présente aucune dentelure. C'est aussi à des espèces différentes de celle que nou décrivons, qu'il faut rapporter ce qu'Elien et d'antres anciens ont écrit des couleurs, de queld'autres anciens ont écrit des couleurs, des ques desquels ils ont dit que si la taille de ces animaux était inférieure à celle des thons, ils l'emportaient par leur force sur ces derniers osseux ${ }^{2}$ taient par leur force sur ces derniers osse de luAu reste, on pourra recueillir beaucoup de lumières a ce sujet dans l'ouvrage de l habile pro-

'Cest cet aiguillon qu'on a comparé a un rasoir, et qui tait donver, par
notre anthias.

218 rayons a chaque pectorale du latjan virginien, 4 rayo aiguillonené et 5 rayons artientés a chaque thoracine, 18 rayons a la caudale. -5 rayons à la membrave branchial du lotjan anthias, 14 a chague pectorale, 16 ayos as $x$ la $\mathrm{na}$ et 5 rayons articules a chaque thoracine, 6 rayous a la nal

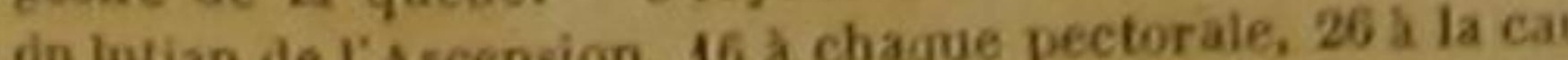
dale, -13 rayons a chaque pectorale da lotjan stigmate, 1 rayon aignillonnéet 5 rayons articales à ch que thoracine, 17 rayons a la nageoire de la queue. - 15 rayons a chaque pectoraie du latjan strié, 1 rayon aiguitionne el s rager fesseur Schncider, intitulé - Synonymie des poissons d'Arledi, ete, p. 81 .

N'oublions pas de dire que l'anthias vit depetits erustacees et de jeunes poissons.

Le Intjan de l'Ascension se trouve auprès de l'íle du même nom, dans I'Océan Atlantique. Les deux pièces dé chacun de ses opereules sont dentelees, et le second niguillon de sa dorsale prèsente aussi une dentelure.

Les Indes sont les contrées préférées par le Iotjan stigmate. L'empreinte que montre ce poisson ressemble à celle qu'aurait laissée un fer chaud.

Le lutjan strié présente sur son corps plasieurs petit traits; et e'est dans l'A mérique septentrionale qu'il a êté pèché.

LE LUTJAN PENTAgRAMME ',

Perea lineata, Limo, Gmel.; Lutjonus pentagramma, Lac, ,

Le Luljan argente', Perca argentea, Limn, Gmels Luljau arene Holocentrus Chant, Bodi. nus Liatula, et Lutjanus serran, Lac. \%. - Lutjan Beu reuil f, Hexwotum formosum, Cuv,s Perca formoss, Lims. Gro.s Labrus Plumieri, et Lujgaus Scimos, Lae, s, - Lat. jan jaune ", Diagramma cavifrons, Cav.; Laijanus lu-

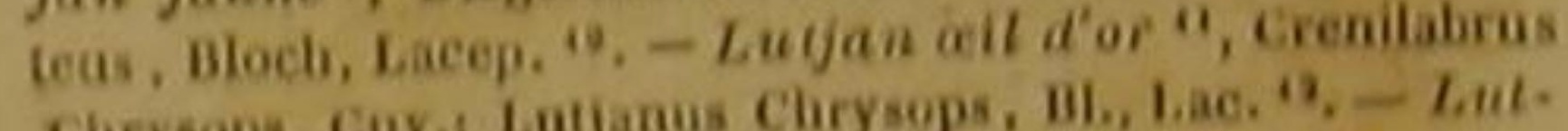

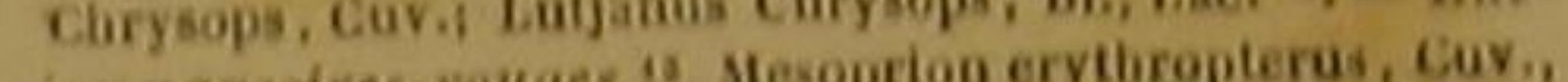
jan nageoires-rouges ", Mesoption an

Nous ne connaissons pas la patrie du pentaramme; l'argenté, dont la partie antérieure du

1. Persigue eirq-lignes. Dambentou et Haay, Kac, méth.

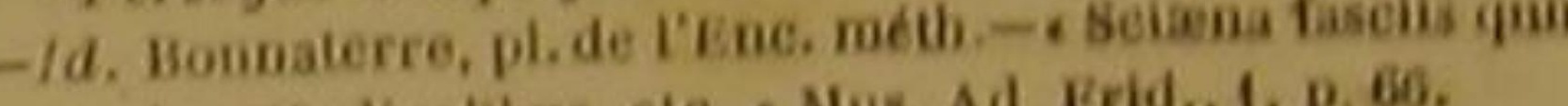
- que longitudinalibus, etc, A Aus, Ad

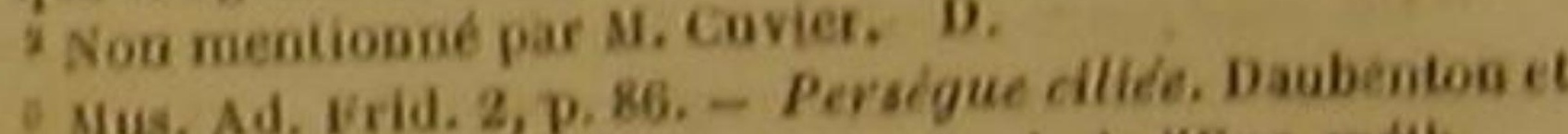
Mus. Ad, Vrid. 2, p. 86. - Persegue pl de I'Enc, méth. 'Non mentionné par \$1, Cuvier.' D. Derca lituris llavis, eic., Mus. Ad. Erid 2, p. b7. Persigas serran. Baubenton at

Bonnaterre, pi. de I Kne, meth. Car, dans la familte des - va geare shov, Seres. M. de Lacépede a reprodui

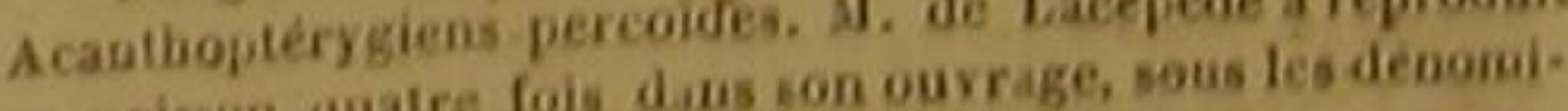
ce poiswon quatre fois diusendere, $2^{\circ}$ de Luljan serran,

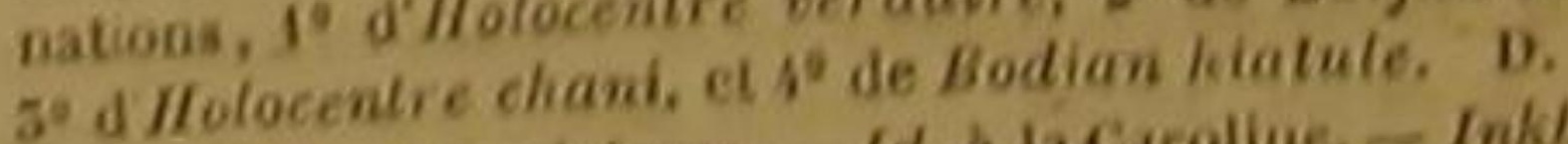
${ }^{2}$ Grunt, en Anglelerre. - Id a laciaroline, - Inkhioorn visch, en Hollande, - Squirrel-fisch, en suede. - Blau. Kopf, Eichitorn-Ash, Rothmund, eu Allemagne. - Perie. gue ceureuil. Daubestos at Hay, a marina capite striato. naterre, pl, de IEnc, me ia 6. fig. 1. - Anthias ccureuil.

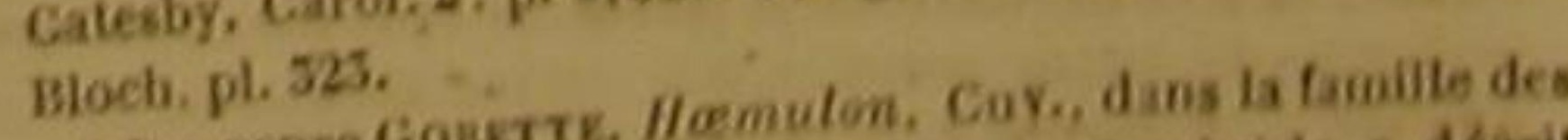

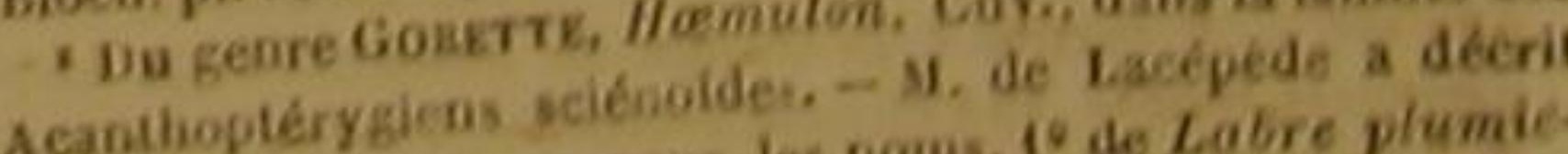
acantioptérygiens scienolder. II. 10 de Labre plumie

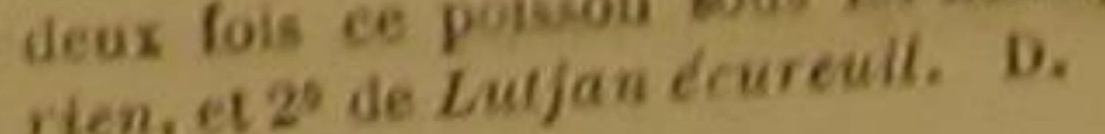


IISTOIRE NATURELLE

dos est carénée, vit dans les eaux de l'Amérique; on pèche dans la Méditerranée le serran, qui présente souvent un filament derrière chaque rayon aiguillonné de sa dorsale; et l'on trouve aux Moluques, dans phusieurs autres contrées orientales, dans les iles de Bahama et dans les Antilles, le lutjan écureuil, que Linnée avait nommé le Beau, à cause des nuances et de la distribution de ses couleurs, et qui en effet charme l'œil par la dorure de ses écailles qu'une bordure brune rend plus éclatantes dans leur centre par le bleu de plusieurs raies qui règnent de chaque cóté du corps et de la queue, et se marient très-bien avec celles de la tête, et par le jaune doré de toutes les nageoires. La tête de ce lutjan est couverte de petites écailles dures et souvent dentelées, comme celles du dos. La langue est large et lisse; les deux mâchoires sont aussi avancées l'une que l'autre; l'on voit deux orifices à chaque narine.

Le lutjan jaune, qui se plait dans les eaux des Antilles, a aussi deux orifices à chaque narine: il a de plus lés yeux très-grands; la dernière pièce de chaque opercule terminée par une pointe molle; de petites écailles sur une portion de l'anale, ainsi que de la caudale, et toutes les nageoires d'un jaune couleur d'or'.

Bloch a fait connaitre le lutjan oil d'or, d'après un individu de la collection de M. Linke de Leipsick. La tète de ce poisson est allongée chacune de ses narines a deux orifices; sa li-

'Lutjanjaune. Bloch, pl. 247.

Diagramme é front concare, poison a l'espèce qu'il nomme des Acanthopterygiens sciénoides." D.
". place dans la famill "Bloch, pl. 248.

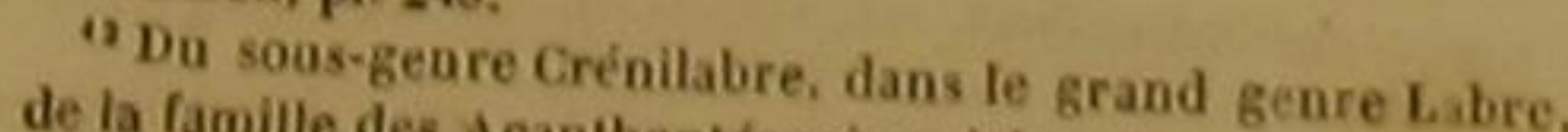
" Bloch, pl. 249.

"Doptérygiens percoprion, Cur., daus la famille des Acan.
D.

I rayon ayons a chaque pectorale du lutjan pentagranme. cine, 16 rayons i la nazeoire de articulés a chaque thoranembrane branchiale du lotijn argente, 12 . chayons a la rale, 1 rayon aiguiltonoé et 3 rayous articules a d chae pectoracioe, 17 rayons a la caudale, -16 rayons a chague pectorale du lujjan serran, 1 rayon aiguillononé et 5 rayon.
articolés a chape queue. -5 raque thoracine, 17 rayons a la mageoire de 1 a reuil, 16 a chaque pectorate, 1 rae branchiale du latjan écuarticulés a chaque pectorale, 1 rayon aigultonné et 5 rayons rayons a chaque pectorale du lutjan jaune, 6 a dale. -17 raciee, 16 a la nageoire de la queue. -14 rayons a charopectorale du lutjan oil-d or, 6 a cha que thoracine. 18 a i razeoires. 6 rayous a ta membrane branchiale du $\ln$ ijon et 5 ari icol's a ch inge chaque pectorale, 1 rayon aignillognes b queue. gue laterale est interrompue; ses pectorales, ses thoracines et son anale sont d'un jaune mèlé de violet, et sa dorsale, ainsi que sa candale, d'une nuance brune.

Au Jieu de cette teinte obscure, les nageoires du lutjan nageoires-rouges brillent d'une belle couleur de vermillon. Bloch avait recu de pon un individu de cette espéce. Les deux ma. choires de ce poisson sont également avaneió. sa langue est lisse; ses yeux sont gros; un sil. lon longitudinal peut recevoir la nageoire dor. sale; de petites écailles sont placées sur la base de la caudale, et sur celle de la nageoire de l'anus.

\section{IE LUTJAN HAMRUR ',}

Priacanthes Hamrur, Cuv, Sciena Hamrur, Forik Anthias Hamrur, Bl.; Lutjanus Hamrur, Lac. :

Le Luljan Diagramme s, Dảgramma lineatum, Cur.

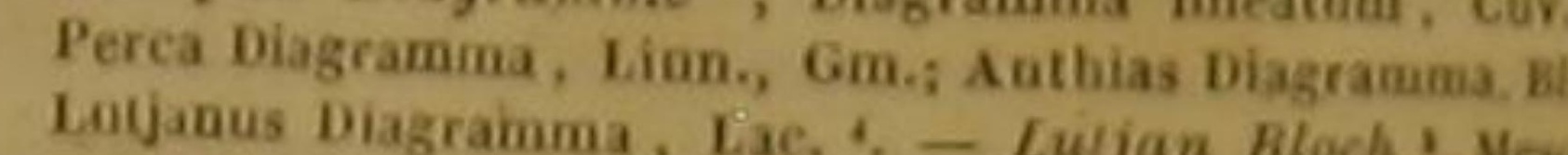
prion Lutjanas, Cuv; Lutjanus Lutjanus, BL. L Lujaga Blochii, Lac. ‘. - Lu'jun Verrat', Grenilabrus..... Cor. Bodianus Bodianns, Bi ; Lutjanus Verres, Bl., Lacep, B Bo dianus Blochii, Lacep. :- - Lutjan Macrophthalad mus, Bl.; Lutjacrophthalmus, Cuv.; Anthias

Le hamrur, que Forskael a vu auprès des rivages de I'Arabie, a les dents des deux mâchoires petites, égales, fortes, renfléez et un pet eloignées les unes des autres; la dernière pièce

'Forskael, Faun. Arab., p. 45, D. 41. - Sciène hosroen Bonnaterre, pl, de I'Enc., méth

Du Beore Priacanihe, de la famille des Acanthoptery giens percoides, selon $M$. Cuvier. D.

Ikan warna, Warna ruepanja, dans les Indes crien. Garje

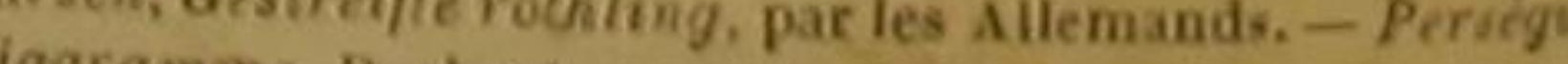
lerre, pl. de IEncenton et Haay, Enc. méth. $-1 d$. Bonn

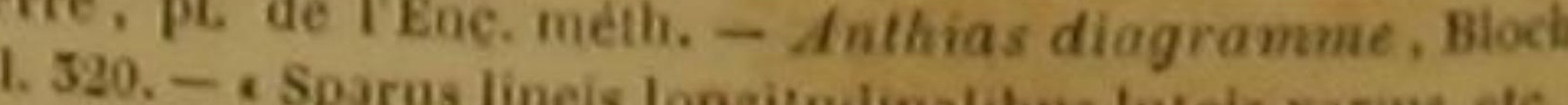

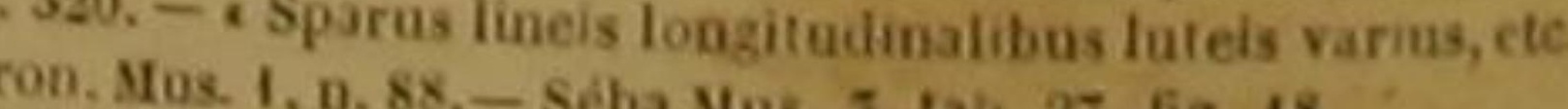

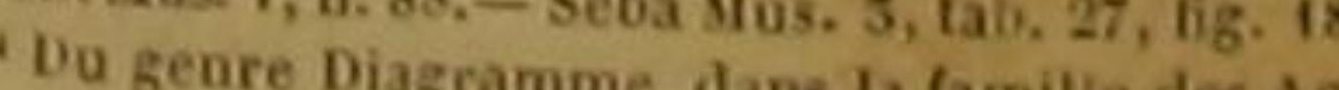
Shens scienoides, suivant M. Cuvier. D. 'Ikan lutjang, au Japon. - Lutian Ititian. Bloch, ' Du genre Mtesoprion, dans la famille des Acanthoptery 'Perro colos de M. Cuvier. D.

1. 253.

'Du soins genre Crénilabre d to Lamille des Acanthoptérygiens labroides. Ce poisson a tee incrit deax fois par Bloch, sous les noms de Lutjanus rerins. el de Bodianus bedia nus. M. de l.acépéde a commis l Bodianu, senlement, au genre Bodian, il a changé le now - Anthias macrophs, en celui de Bodiants 10 Du genre Priacasthe, dans loch, pl. 519. giens percoides, Civr. D. dans la famille des Acanthoptéry-

\section{DES POISSONS.}

de ses opercules est terminée en pointe; et ses pectorales, dont la couleur est rougeâtre, sont plus courtes de la moitié que ses thoracines.

Le diagramme habite les eaux des grandes Indes ; sa chair est ferme, grasse et de très-bon goùt; il parvient à une longueur de trois ou quatre décimètres, et il est assez courageux pour attaquer des poissons plus grands que lui. Sa tête est entièrement couverte de petites éeailles; les deux máchoires sont aussi avancées l'une que l'autre; les dents petites et nombreuses; le palais et la langue lisses; les narines percées chacune de deux orifices, et les yeux gros et un peu rapprochés.

Le lutjan Bloch a la máchoire inférieure plus avancée que la supérieure; le palais hérissé de dents très-petites; deux orifices à chaque narine; la dernière pièce de chaque opercule terminée par une prolongation un peu membraneuse; le nageoires rougeâtres; la partie antérieure de l. dorsale d'un blèu clair ou grisatre.

Ce poisson a été observé dans le Japon, et e'est le nom de Lutjang quil y porte, que Bloch a attribué à un genre particulier, et que nous avons donné au genre dont nous nous oceupons,

Le Japon est aussi la patrie du verrat.

Ce dernier lutjan a le palais revétu de dents petites et arrondies; on ne compte qu' un orifice à chaque narine. Les écailles sont fortes et dentelées; ou en voit de semblables à celles du dos, sur une partie de la dorsale, de l'anale et de la caudale. Cette nageoire de la quene, la base des pectorales, et la dernière portion de la nageoire du dos, ainsi que celle de l'anus, brillent d'un beau rouge : on remarque des teintes dorées sur la partie inférieure de l'animal '.

C'est encore au Japon que l'ou trouve le macrophthalme, dont le nom indique la grosseur très-remarquable des yeux ${ }^{2}$. Ses deux mâchoi. 6 rayons a la membrane branchiale du lutjan hamrur, 18 a chaque pectorale, 1 rayon aiguilionné et 5 rayons articu. la membrane branchiale do lotjan disgramme, 16 a chaque pectorale, trayon aiguillonne et 5 rayons articulés a chaque thoracine, 19 rayons à la nageoire de la quene. - 6 rayois a la membrane branchiale da iarjan bloch, if a chague pecto-

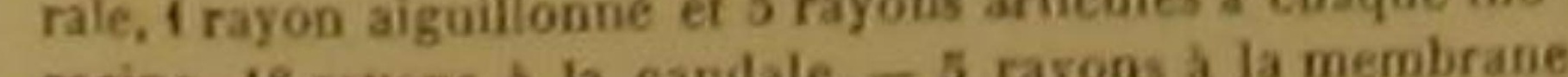
racine, 18 rayous 1 ti cast 16 a chaque pectorale, 1 rayon aigrillonvé 415 rayons articulés à chaque thoracine, 15 rayons a la nageoire de la quene. -5 rayons a ia membrane branchiale do lotjan macrophthalme, 16 a chaque pectorale, 1 rayon aiguillonne et 5 rayons ar icules a chaque tho-

racine, 18 rayons à la candale. res sont d'une longueur égale; ses dents trèspetites; les écailles dentelées et dures; les pectorales et les thoracines rouges; ot la base de la dorsale, celle de l'anale, et l'extrémité de la eaudale, d'un jaune ou d'un gris mèlé de bleu.

\section{LE LUTJAN VOSMAER,}

Scolopsides Vosmaeri, Cur,; Scolopsis argyrosomus. Kubl; Anthias Vosmaer, Bi. ; Lutjanus Vosmaeri, et Lutjanus aureo-rittatus, Lac, ‘

Le Lutjan elliptique , Scolopsides bilineatus, Cav, AnLet

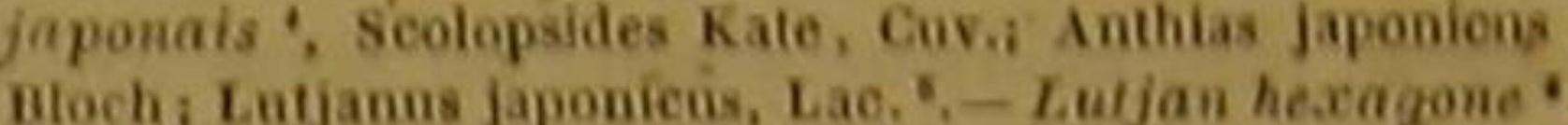
Myripristis hexagonns, Cuv, Lutjanms hexagomms, Lae. Lutjan croissant 4, Mesoprion lunolatus, Cuv,i Perca tonulata, Mungo-Park; Latjanus lunulatus, Lac, "

Les trois premiers de ces Lutjans sont du Japon. Nons en devons la connaissance à Bloch, quil les a placés dans le genre particulier auque il a douné le nom d'Anthias, parce que leur tête est entièrement couverte de petites écailles. Mais les principes de distribution méthodique que nous avons eru devoir: suivre, ne nous ont pas permis d'adopter ce genre d'anthias, et nous avons inscrit parmi les vrais lutjans les troi poissonis japonais dont nous parlons dans eet article.

Le vosmaer a de très-petites dents ; les pectorales, les thoracines et la caudale, rouges; Ia dorsale ef l'anale bleues, avee des teintes rougeâtres sur quelques rayons.

Le lutjan elliptique présente un rang de dents courtes et pointues a chacune de ses máchoires qui sont égales en longueur. On ne compte qu'un orifice à chaque narine. L'ellipse violette que

que la distance qui sépare la ligne latérale de ce lutyan, de sa nagesire du dos.

'Du fenre scolopside, dans ia famitie des Acantioptery 'ens sciénoldes de M. Cuvier. M. de Lacépéde a décrit deux his ce poisson, sous les noms $1^{\circ}$ de Luljan vosmaer, at de Luijan galon d'or. D. - Du gevee scolopside, dans la famille des Acanthoptery. (1)

:Anthas japonais. Bloch, pl. 525, fig. 2 . dentes, selou M. Cuvier. D.

- Bollok in dsoud water, par les shollandais. 'Du geare Mrsipussis, Car., dans la familte des tean

thoptérygieus percoldes. D.
-Prea lun lata. Descripton des poisons de Sumatra. par Mungo-pa 1. pu genre Misopaos, dass la famille des Acanthoptery.

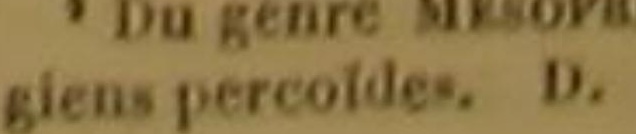


I'on voit sur le dos de l'animal est le plus souvent double; la partie supérieure du poisson est d'un vert jaunâtre, plus ou moins mêlé de brun la dorsale, les pectorales et la caudale sont violettes; les thoracines'sont variées de jaune et de violet; l'anale est noire dans sa partíe antérieure, et jaune dans l'autre.

Des raies étroites, obliques et verdâtres, règnent fréquemment sur le dos du japonais ; et le devant de sa dorsale est d'un violet mêlé de gris ou de blanc'

L'hexagone a l'cil très-grand; les écailles fortement striées; le diamètre vertical de la queue bien inférieur à celui du corps. On n'a poińt encore publié de deseription de cette espèce, dont nous avons tronvé un individu parmi les poissons desséchés qui font partie de la belle collection donnée par la Hollande à la Franee.

Les nageoires du lutjan croissant sont rougeâtres, excepté les thoracines, qui offrent une couleur d'or ou d'orange. La patrie de ce deraier poisson est l'ile de Sumatra.

$$
\text { - }
$$

\section{LE LUTJAN GALON-D'OR ?,}

Scolopsides Vosmaeri, Cuv.; Scolopsis argyrosonnus, Kuhl; Anthias Vosmaer, B1 ; Lutjanus aureo-vittatas,

Le Lutjan Gymnocéphale, Ambassis Commersonii, Cuv, Lutjanus gymnocephalus, et Centropomus Ambassis, La-
cep. 4 - Luljan triangle, Corvina imberbis, Mitch.; Perea ocellata, Linn.; Lntjanss Trim tum, et Centropowus ocellatus, Lac, s. - Lutjan micresmus, et Laphe Cownersomil, Cur,; Luljanus microsto-

Les eaux de Sumatra nourrissent le lutia galon-d'or. Indépendamment du ruban doré qui Ifrayons a la membrane branchialedu lntjan vosmaer, 16 a
chaque pectorale, 1 rayon aiguillonnd et chaque pectorale, $t$ rayon aiguillonné et $\sigma$ rayons articntés a at ta membrane branchiate nageoire de la queue, -3 rayons pectorale, 1 rayon arsoillo du turjan elliptique, 14 a chaque thoracine, 20 rayons a la caudale -6 rays articules a chaque branchiale du tutjan japonais. 14 a chaque pect la membrane rayons $\Delta$ ine et 8 rayons artieules a chague thoracis rayon torale du lotjoire de la queue. - 16 rayons a chagve, 16

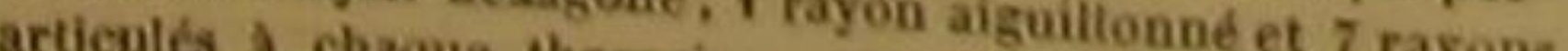
7 rayons a la membrane branchia rayons a la candale. chaque pectorde, 17 a la nageoire de ta pan croissant, 16 a Perea aurata. Description de la queuc.

par Mrungo-Park (Actes de la société Lianéenne de Sumatra, s. p.

Lacépede, dans l'artiele précéścelelui déja décrit par M. de

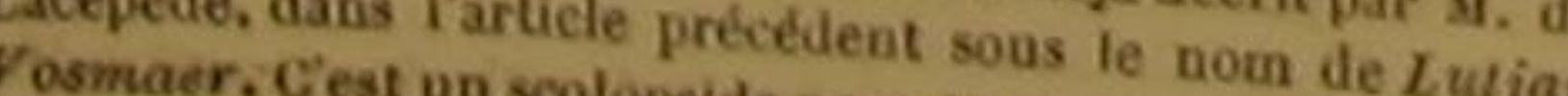
- Du genre AMBa sss, dans la famille durier. D. nous a indiqué son nom spécifique, sa couleur blanchâtre est relevée par le beau jaune de ses pectoraleset de sa nageoire de la queve; la dos sale et les thoracines sont d'un brun me blane.

Aucun naturaliste n'a encore publié la des. cription du gymnocéphale, du triangle, ni du microstome, dont nous avons vu des dessins parmi les manuscrits de Commerson, et qui vivent dans le grand Océan équinoxial, ou dans les parties de ce grand Océan voisines des tro piques.

Le gymnocéphale a les dents égales et poln tues: les deux premières pièces de chaque opercule dentelées, et les narines percées chacur d'un seul orifice.

On doit remarquer sur le lutjan triangle forme de sa caudale qui est en croissant, la dorble ouverture de chacune de ses narines, l'e chancrure de la derniere pièce de l'opereulequl, au-dessous de cette sorte d'entaille, montre un prolongation arrondie, et les petites taches don sont marquées presque toutes les écailles de 1 partie supérieure du poisson.

Les dents du microstome ' sont petites et do liées, et son anus est plus près de la tète que de la nageoire de la queue ${ }^{2}$.

Hens percoídes, selon M. Cavier. M. de Lacépede a decrite poisson denx fois, 10 sous le nom de Lutjan gymnociphol. 20 sous celui de Centropome ambasse. D. 'Du genre Jouxils corvina, dans la famille des Acanthop Urygiens sciénoides de M. Cavier. M. de Lacépede a decri tor fois celle espece, sons les nonis $\mathrm{I}^{\circ}$ de Lutjan triangle, ide Centropome cille. D.

giens scitoltes, sorr, dans la famille des Acanthoptery.

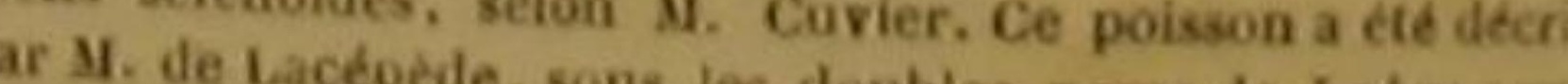

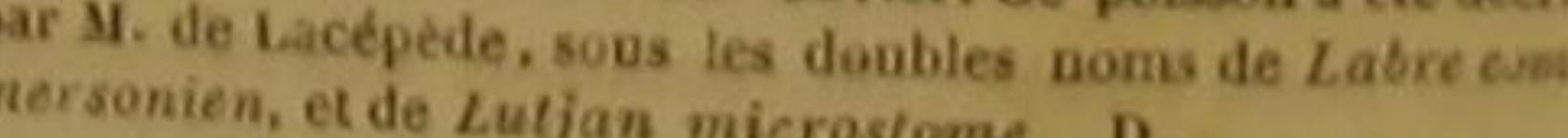

Micrs

Microslome signifie petite bouche, et gymnociphlale, re nue, ou dénuée de petites écallies. Muxpos, cn eflet, veut dire, en gree, petit: aróm $x$, bouche; puuvos, nu, a aepalar, tele.

5 rayons a la inembrane branchiale du lutjan galon-d or, is a chąque pectorale, 6 à chaque thoracine, 18 a la nageoire Je ia queue. -7 rayons a chaque nageoire thoracine da lutfran kymnocéphale. -8 ou 9 à chaque pectorale du lutian triangle, 17 à la caudale, -9 ou 10 rayons a chaque pecto-
rale du lotjan microstome.

\section{DES POISSONS.}

551

LE LUTJAN ARGENTÉ-VIOLET '.

Gyunocephalus argenteus, Bl.; Lutjanus argenteoviolaceus, Lacep. ?

Les Grandes-Indes sont la patrie de ce pois-

Les dents de I'argenté sont à peine visibles. La dernière pièce de chaque opercule ne présente pas ordinairement de dentelures. L'anus est plus éloigué de la gorge que de la caudale ${ }^{3}$.

LE LUTJAN DÉCACANTHE A, Labrus striatos, Lino.. Gmel.; Laljauus decacanthus, Lao

Le Luljan Scines, Labrus Scina, Limn., Gmel.; Lutjano Scina. Lac, - Luijan Lapine ', Grehiliberus Lapioa, Car Lutjan rameux ?', Labrus ramentosus, Linn., Gmel. L.int. janus rameotusus, Lace- Lutjan ceille", Crenilabrus.. Cur.; Labrus oceliatus, Liun., Gmel, L Lutjanus o. ellatis,

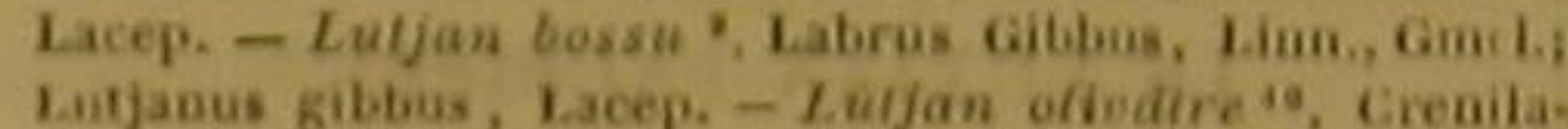
Luifjans gibbus, Lacep. - Luijan ofivdire
bros., Crenita olivaceus, Laes "

On a observé en Amérique le lutjan déencanthe, dont la couleur générale est d'un brun jaunâtre.

Le lutjan scina et le lutjan lapine habitent dans la Propontide, et particulièrement auprès de Constantinople, Le scina a le dessous du corps et de la queue blane, avec des raies jaunes et un peu tortueuses; les pectorales jaunes et sans taches; les autres nageoires jaunatres et tachées de bleu. La tête du lutjan lapine pré-

:Gymnoce phale argente. Blocb, pl. 5s2, fig. 2 . 'M. Cavier ne fait pas meation de ce poisson. D. "S rayous a la menbrae brachiale da intan argente, 12 articalés a chaque thoracine, 14 rayons a ia nageoire de ta queue.

'Mlos. Ad. Frid, 2, p. 77 : - Labre strie. Daubenton Iláy, Enc. méth. - Id. Bonnaterre, pi. de I Eac. méth. - Forskaci, faun. Arab., p. 36, 0. 30. - Labre Kiclia. Donuaterre, pl. de I Enc. melh.

- Forskael, Faun. Arab., p. 36, n. 31. - Labre Tapine. Donaterre, pi. de iknc, meth.

'Pinte rameu 'Forskact, Faun. Arab., ,

Sale. Bonnaterre, pl. de IEnc. méth. GGobous wrasse. Peunant, Brit. Zool. 5, p. 208, n. 5. Labre bossu. Bonnaterre, pl. de I'Enc. méth.

19 Bruun. Pisc. Massil, D. 56, n. 71. - Labre olicatre. Bomnaterre, pi. de I"Eoc. méth.

M. Cavier ne mentionne que trois de ces sept expeces de genre Crénilalure, dans le grand genre des Labres, et seion lui, le Lutjan aililé de cet article ne differe pas spécifiquement du Latjan olivătre. D. sente des taches rouges sur le cóté, et une raie petite, ondée, et bleue au-dessous de l'oil; ses pectorales sont jaunes; les thoracines bleues; et ses autres nageoires violettes avee des taches bleues. Forskael a le premier publié la description de ces deux lutjans, ainsi que du rameux et de l'eillé, dont l'un vit dans la mee d'Arabie, et l'autre dans celle de Syrie. Le rameux est d'un vert mélé de brun; il a des taches violettes sur le sommet de la tête, au-dessous des yeux, et sur les nageoires. L'aillé, qui préfère les eaux de la Syrio, montre auprès de chaque œil une tache ronde et couleur d'écarlate, qui se marie très-bien avee la tache bleue et bordée dé rouge qu'indique pour ce poisson te tableau générique des lutjans.

On a péché le bossu auprès des cotes d'Angleterre. Les pectorales de ce thoracin sont jan nes; la base de ces pectorales offre des bande étroites, transversales et rouges; les thoraciues et la nageoire de la queue sont verdâtres '.

A l'égard de l'olivatre, que l'on rencontre dans la Méditerranée, comptons parmi ses príncipaux attributs les teintes argentées desa téte, celles de sa caudale, qui est roussátre, et la couleur de ses autres nageoires, qui est semblable a celle du corps.

LE LUJAN BRUNNICH ${ }^{2}$, Grenilabrus fuscus, Car,; Labrus fuscus, Linn., Gmel. Latjanus Brunnichii, Lacep, '

Le Luljan marselllais 4, Grenitabrus unimaculates, Cuv, ; Labrus unimaculatus, Linn., GmeL Luțasus mosillensis,

1 6 rayos a la membrane branchiale da lotjan décacanthe, 17 a chaque pectorale, 1 rayou alguitionne et s rayons ariculés a chaque thoracine, 12 rayons a L caudale. - 14 rayoi

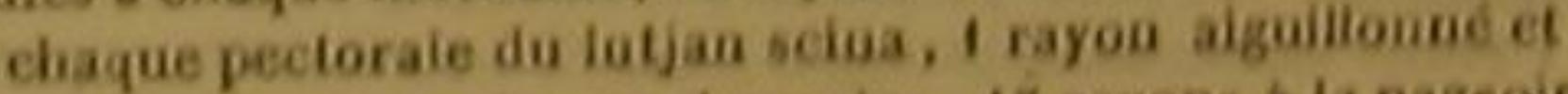

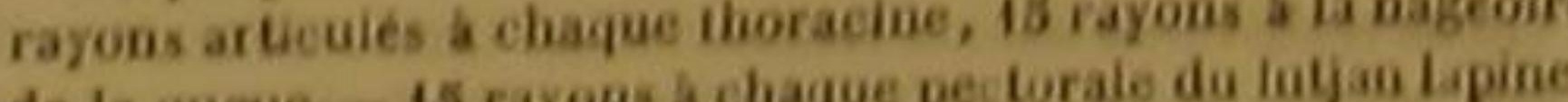

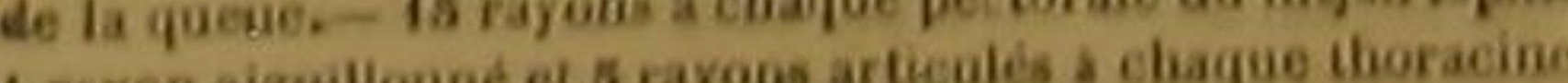
Go rayons i la candale. -5 rayous a la membrase branchia Uo injag rameux, is a chaque pectorale, 1 rayon aigoilionn is rayons articulés a chaque thoracine, 12 rayons a ta $\mathrm{ha}$. geoire de la queue. - 11 rayons a chaque pectorale da latj. eille, 1 rayou aiguillonne et 5 rayous aricuies a canque thoracine, 15 rayons a ia caudale. - 15 rayosa a chaqu pecto rale da lutau bosso, 4 rayon as a la membrane branchiale do

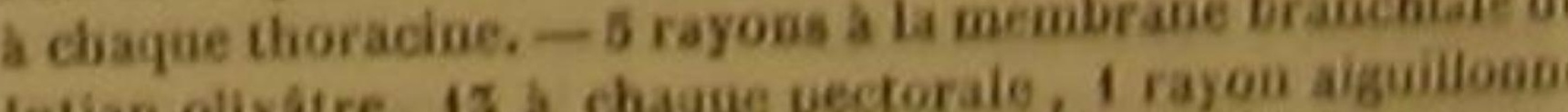
I 5 rayons articules a chaque thoraeine, 12 rayous a i a $\mathrm{a}$ geoire de la queue.

2 Brunn. Pise, Massil., p. 56, n. 72. - Labre serpenitin. Eonnaterre, ple de I'Ene, méth.

- Gu soussgeare Creatlabre, dasa le grand geare Labre de familie des Aeanthopterygiens salroides, Cur, D, - Brunn. Pise Massil., p. 57, a. 75 i et p. 97 . 


\section{HISTOIRE NATURELLE}

Lac. '.- Lutjan adriatique 2, Serranus Hepatus, Cuv. Labrus adriaticus, Lion., Gmel, Luljanus adriaticus, Lac, Holocentrus striatus, Bl.; Hol, siagonotus, Larochie 3. -
Luijan magnifique, Perca nobilis, Limo. Gmel; ;utjanus Imons, Bl, Schn, Cov, Anthias Polymnos, Bl.; Lutjang Polymous, Lac. 1

Le brunnich ne parvient ordinairement qu'à la longueur d'un décimètre; il est allongé et un peu comprimé : sa dorsale, son anale et sa caudale sont brunes ou rousses à leur base, et tachées de bleu; les pectorales rousses à leur base t bleues à leur sommet; les thoracines rouges et sans taches. Il a été observé par Brunnieh dans la Méditerranée, ainsique le marseillais. Ce dernier lutjan est aussi petit et aussi comprime que le premier, mais sa forme générale est moins allongée. On voit souvent une tache noire vers l'extrémité postérieure de sa nageoire du dos.

C'est encore le savant Brunnich qui a décrit e premier le lutjan adriatique. II l'a vu dans Ia mer de ce nom auprès de Spalatro. La longueur ordinaire de ce poisson est à peu-près égale à celle du marseillais et du brunnich. Sa nageoire de l'anus est noire a la base et jaune à son bord extérieur ${ }^{7}$

L'éclat de l'argent dont brille le magnifique ' Da sous-genre Grénilabre, de M, Cuvier, eomme ie prếcédent. D

"Labre rayé de brun. Bonnaterré, pl, de I Enc. méth, Brunn. Pisc. Massil., p. 98, 0. 11

'Du genre Miknoo, Serranus, dans la famille des Acar

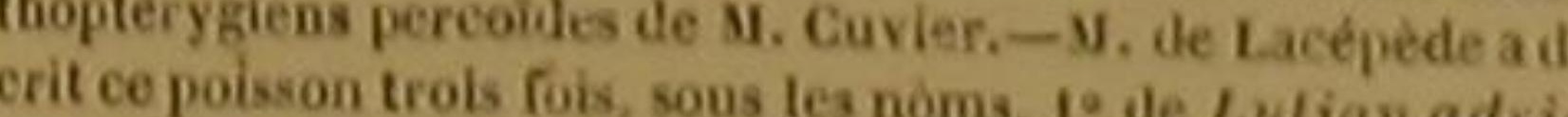
tique, 2* de Labre hicpale, et $3^{\circ}$ de Holocentre tringan the. D.

: Non mentlonne par M. Cuvier. D.

Tontelfon, dans les grandes Indes. - Id. en Angieterr

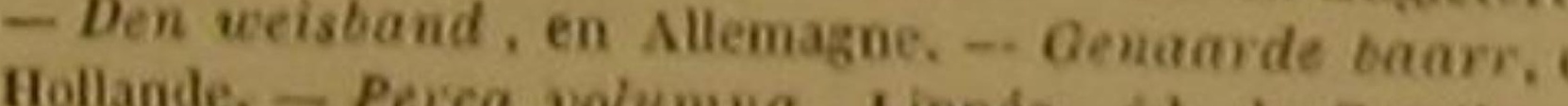
- Perca dorso monopterygio, Lannée, él, de Gimelin. tascis transversis alb s. . Gronov. Mus, 190, - Stho, Mnor tab. 26, fig. 20, - Perselgue polymme, Daut - Seba, Mas. kne, méth - Id. Bonnaterre, pl. de IEne, meth.-- Luhlias polymne. Bloch, pl. 316, fig. 1.

- Du genre Amphiprion, dans la fanille des Acanthoptér siens sciénoởdes, Cur. D.

12 a chaque pectorale, 4 rayon branchiale du tutjan brunnich cules a chaque thoraeine, 13 rayons a $\mathrm{t}$ t cand et 3 rayons art A la membrane branchiate du taijsn marseillais, is -5 rayon pectorale, 1 ryon aiguillonne et 5 rayons articulés a chaqu ti membrane branchiale do int de la queue. -6 rayons pectorale, 1 rayon aizuillonne et 5 arriatique, 14 a chaque thoracine, 17 rayons i ta candale 3 rayons articult's a chaque torale da latjan magnifique, 1 rayon aizuillonné et et 3 rave pec articules a chaque thoracine, 17 rayons a la nazeoire do I lyune, 16 \& chaque pectorale, 1 rayon aizoillonné latjan polywne, 16 a chaque pectorale, 1 rayon aigullonné et 5 rayons
articultes a chaque thoracine, 14 rayons $\mathrm{a}$ la caudate. m'a indiqué le nom spécifique que j'ai cru de voir lui donner. Ce lutjan habite dans les esu del'Amérique; et les orifices de ses narines so placés comme au bout d'un très-petit tube ' Les Grandes-Indes sont la patrie du polymne. La tête de ce poisson est petite; la nuque ète. vée; la langue lisse, ainsi que le palais; le dos caréné, le ventre arrondi.

Bloch a déerit une variété de ce beau ly. jan $^{2}$. Elle differe du polymne que nous tâchon de faire connaitre par les quatre caracteres st vants : premièrement, le corps et la queue son plus allongés que ceux de ce mème polymne secondement, toutes les nageoires sont bordés de noir ; troisièmement, la partie postérieure d a dorsale, les pectorales, les thoracines, l'anal et la caudale sont cendrées; et quatrièmemen la ligne latérale n'est pas interrompue.

\section{LE LUTJAN PAUPIERE ,}

Perca paipebrosa, Linn, Gmel.; Lutjanus palpebratus Lacep.

Le Luljan noir s, Perea airaria, Linn., Gmel.; Lotjona

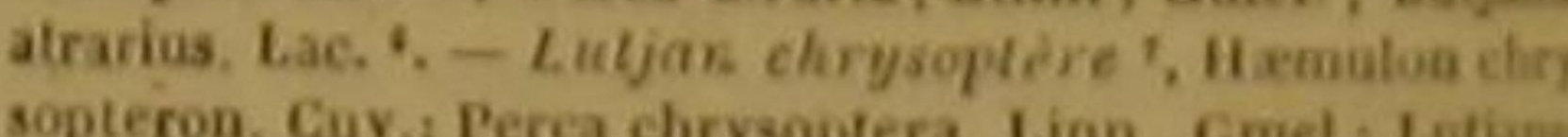
chrysopterus, Lac. :, - Luijan médilerranden', Creal. janus mediterranems, Lac, 10 - Luyan raye ", Pera vil lats, Linn., Gmel.s I utjongs

Le lutjan paupière, qui habite en Amérique, ne présente jamais que de petites dimensions.

- Je n'al pas vo dinidivida de lespéce da magnifique :i ce Iutjan, contre mon opinion, rivatit pas de dentelure an opercules, il faudrait le placer parmi les labres ou parmi la
ares, suivant les caracteres que Iobservation ferait reóno-

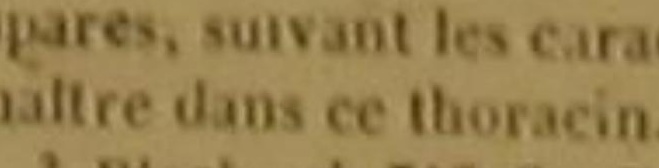

' Bloch, pl. 516, fig.

Persegue paupiere, Daubenton et Haoy, Enc. méth.- Non mentionné de l'Enc, méth.

Black fish, dans ia Camedine, ov. D.

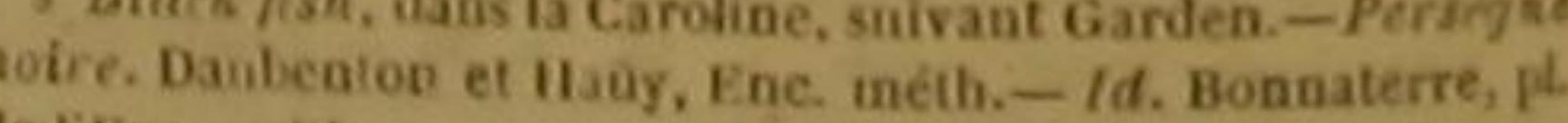
te l'Enc, méth.

'. Non mentionné par M. Cuvier. D.

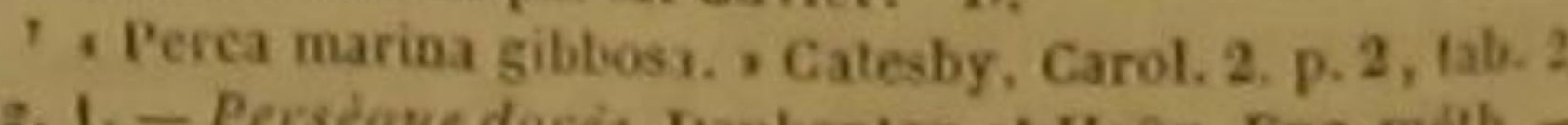
. Bonnaterre, pl. del'Enc, méht.

'Da genre Gonetre, Homulon, Cav., dans la lamille de

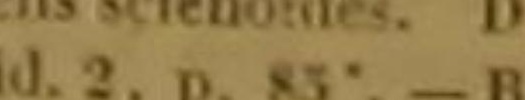

82. - Persegue thelice. Danbenton et Pisc. Massil, p. 66. Bonuaterre, pl.de IEnc. méth.

"Indiqué eomme se rapportant an sons-genré Crénilabre.

"

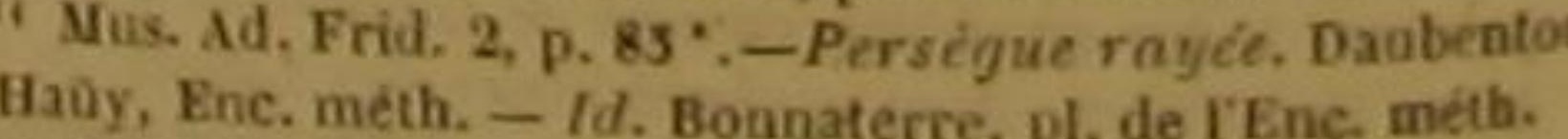
"Nón eité par M. Cuvier. D."
DES POISSONS.

355

Le noir et le chrysoptère ont été vus partieulièrement dans les eaux de la Caroline, l'un par Garden, et l'autre par ce mème observateur et par Casteby. Le second de ces lutjans a la téte allongée, et couverte en entierde petites écailles, et I'auale aiusi que la caudale tachetées de brun '.

Nous n'avons pas besoin de dire que le méditerranéen vit dans la Méditerranée. Il n’a point de petites écailles sur la partie supérieure de la téte; et ses peetorales, ses thoracines, son anale et sa caudale sont rousses ou jaunes.

Le lutjan rayé a été pêché en Amérique. On a remarqué la foree du second rayon aiguillonné de sa nageoire de l'anus. II nous semble que c'est avec raison que les professeurs Gmelin et Bonnaterre ont rapporté à cette especce le poisson du Japon, déerit par le savant Houttuyn, dans les Memoires de Harlem, tome $X X$, p. 326 , et qui avait un peu plus de deux décimètres de longueur.

\section{LE LUTJAN ECRTTURE ?}

Serranus Seriba, Cur,j Perea Scriba, Linn., Gmel Latjanus Scriptura, Holocentrus marious, et Holo
centrus fasciatus, Lac. ?

Le Lutjan chinois', Peras sineasis, Lion., Gmel, Lutjänus

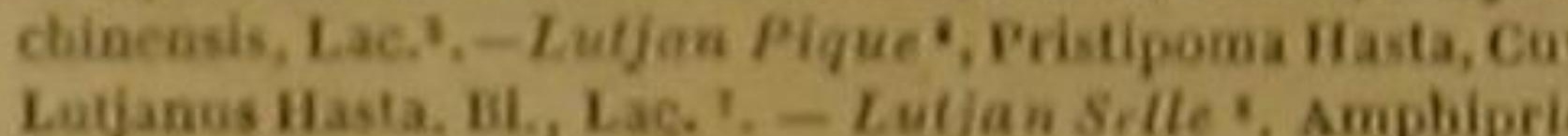

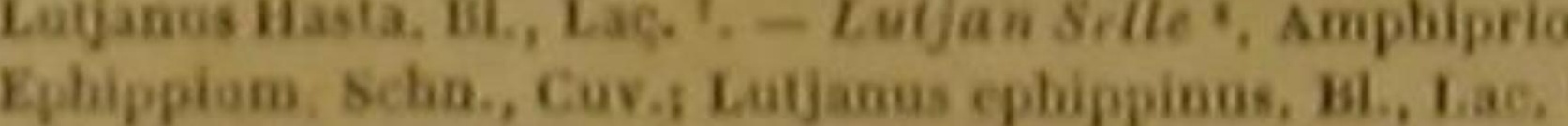

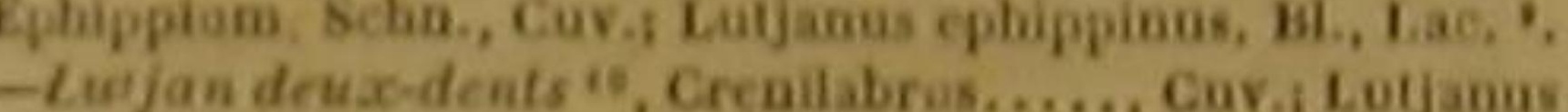
Uidens, Bl., Lac,".

On ne connait pas la patrie du lutjanécriture;

i 15 rayons a chaque pectorale da lutjan paupiére, 1 rayou aiguilionene et 5 rayons articules a chaque thoracine, 17 rayons I la nageoire de la queue. - 7 rayons a la membrave branchisle du latjan noir, 203 chaque pectorale, $7 \mathrm{~b}$ chaque tho. racine, 20 a la caudale. -5 rayons a la membrane branchiale du laljan mediterraneen. 14 i diaque pectorale, 1 rayon aipuilloned et 5 rayons articules a chaque thoracine, 15 rayons
it a nigeoire de la queue. -6 ou 7 rayons \& ia membrane Ita nigeoire de ia queue. -6 ou 7 rayons $\&$ la membrane
branchiale du latjan rayé, 18 a chaque pectorale, 1 rayon aiguillowie et 5 rayons articules a chaque thoracine, 17 rayons ila eavdile.

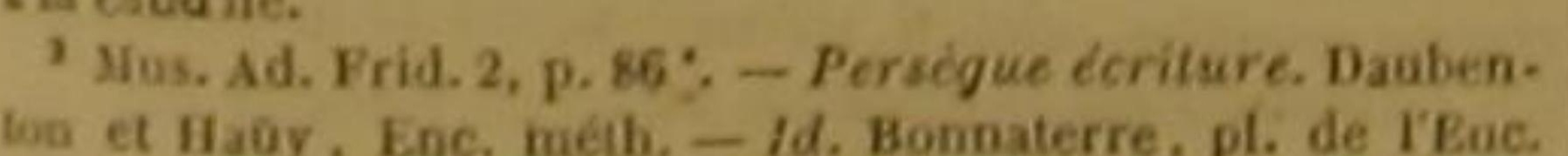
átib.

'Du geare Mḱzoo, Serranus, Cuv.. dans la famille des

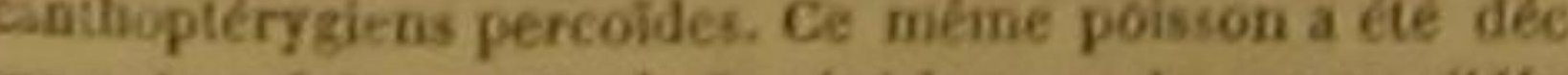
centre fascé et d Holocenire marin, D.

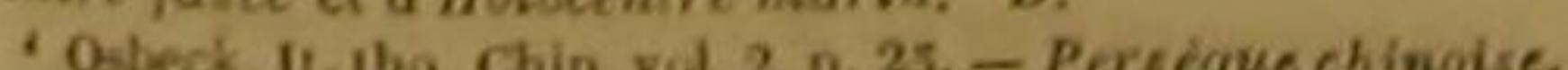
Boonaterre, pi. de IEoc, méth.

: Non mentionné par M. Cuvier. D. 'Lutjan broche. Bloch, pl. 215, 6z. A.

' Du geare Pastipoye, Car.
Il serait superflu de dire quelle est celle du chinois. Ce dernier poisson a de petites dents aux deux màchoires, et la nageoire du dos échancrée 1

On tiouve au Japon le lutjan pique, dont le nom a été imaginé pour désigner la longueu et la forme du second aiguillon de son anale, lequel a paru présenter une petite image du fer d'une pique. Le palais de co thoracin est revetu de' dents très-petites; ses yeux sont un peu saillants; la nageoire du dos est tachetée de dale sont rouges: l'anale est bleuảtre.

La langue du lutjan selle est courte, épaisse t lisse, de mème que son palais; la nuque est relevée; la grande tache noire placée sur le dos, t descendant des deux cótés de l'animal, comme ûne selle, s'étend d'autant plus, àproportion des dimensions du poisson, que l'individu est moins jeune et plus grand. Toutes les nageoires de ce thoracin sont d'un gris bleuátre. On a péché cet osseux dans les Indes orientales.

Le lutjan deux-dents habite dans l'Océan Atlantique boreal, et par conséquent dans une mer bien éloignée de celle dans laquelle on a observé le lutjan selle. Il n'y a qu'un seul orifice à cha. que narine du premier de ces deux poissons : cette ouverture est très-proche de l'wil. Une tache noire marque la base de chaque pectorale; chaque écaille montre une petite raie longitudinale, et d'un jaune pâte.

- Luljan selle. Bloch, pl. 250, fig. 2

- Do genre Aurmpaov, Cuv, dans la famille des Acantho

10 Luljan dent-double, Bloch, pl, 25I, fig.t.

i 7 rayons a la membrane branchiale du liwjan ecriture, 13 a chaque thoracine, 13 rayous a la caudale - 18 rayens chaque pectorale du tujan chiaois, 1 rayou aigutionné et

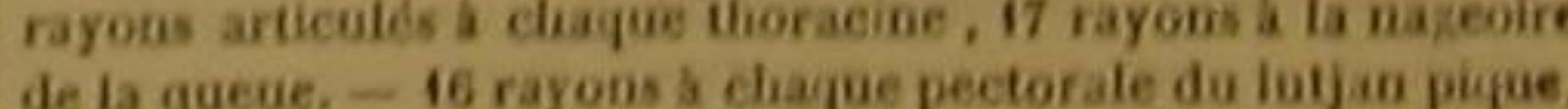
I rayon aizuillonné et s rayons articulés a chaque thoracine. 18 rayons a la candale. -6 rayous a la membrane branchial. du lajjan selle, 19 a chaque pectorale, 1 rayon aiguilloune ef 5 rayous articolés a chaque thoracine, 16 rayous a is nageoire de la queue, -5 rayons a la membrane branchiale du letja

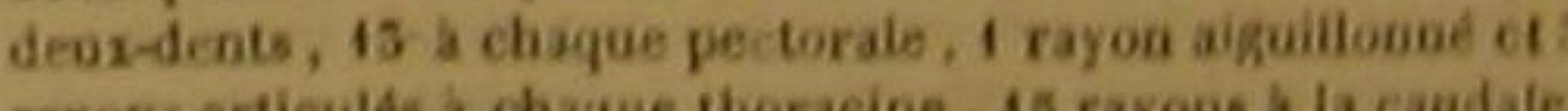
brun; les peetorales, les thoracines et la cauachaque pectorile, 1 rayon aguitionie et 5 rayons articule 
LE LUTJAN MARQUE '

Crenilabrus notatus, Cav.; Lutjanus notatus, Bl., Lac. ?

Le Luljan Linke ', Creailabrus Linkii, Cav,; Lafjanus Linkii, Bl., Lac, 4. - Luljan Surinam ', Pristipoma surina-

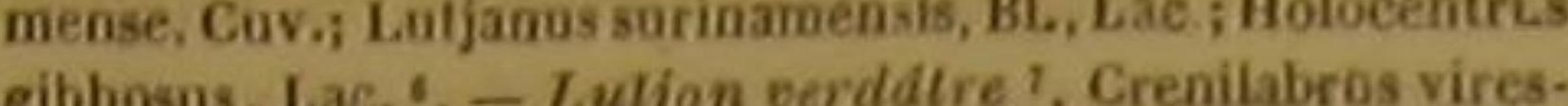
cens, CoY, i Lotjons virescens, BL, , Lac. 's, - Lutjan ceus, Cav.; Lutjanus virescens, Bi, Lac, - Luljan
Groin', Crenilabrus Verres, Cuv.; Laljanus Verres, et Bodianus Bodianns, Bl: Latjanus rostratus, Lac. 19,- Lutjan norvégien ", Crenilabrus norvegicus, Cuv.; Latjanus norvegicus, Bl., Lac.

Le marqué n'a qu'une rangée de dents serrées et pointues à chacune de ses mâchoires; sa langue et son palais sont lisses; ehaque narine n'a qu'un orifice; les Indes orientales sont sa patrie.

Bloch, qui a déerit le premier le lutjan linke, a donné à ce poisson le nom de M. Linke son ami, de quili avait reçu un individu de cette espèce, mais il ignorait dans quelles eaux cet individu avait été pêché.

Le lutjan surinam, dont la patrie est indiquée par le nom que porte ce thoracin, a la fangue lisse, mais le palais rude au toucher; chaque opercule composé de trois pièces; les nageoires bleues; et la caudale rouge dans sa partie supérieure ${ }^{13}$

'Luljan marqué, Bloch, pi. 251, fig. 2

(c) grand fence Labre,

Selon M. Cuvier. D.

- Autre espece dis. Bloch, p. 252.

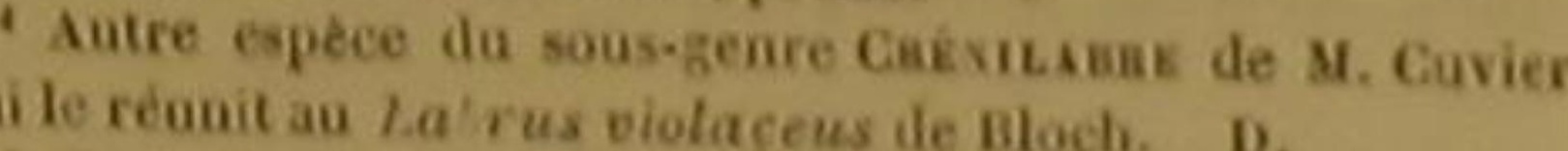

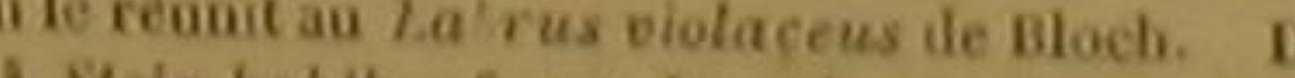

par les Hollontak, par les Alitemands. - Steen kaal kop - Du geure Passuposs an de Surinam. Blocb, pl. $2 x 3$. giens sciénoides, Cuy, it de ha famille des Aeanthoptéry. deus fuis, I'sous le nom de Lutjan Surlngecrit ce poisson

centrebossu, D.

Lutian verdatre. Blocb, pl. 2su, fi. I

- Da sous-genre CuksiLsanar, dans le grand genre des

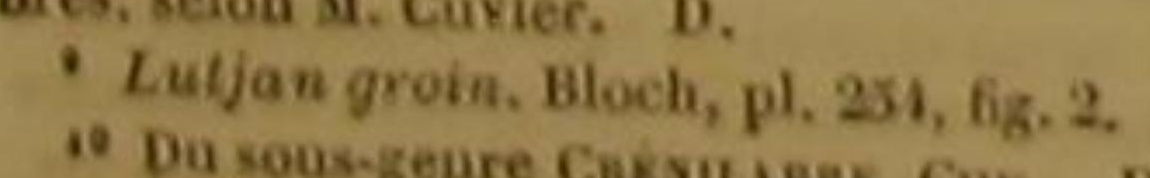

"Du sous-geure Caksulane, Cuv, D

as Du sous-geare Cuisus ass, pi. 256.

de M. Cavier. D.

"I rayous a la membrane branchiale du lutjan maryué 11

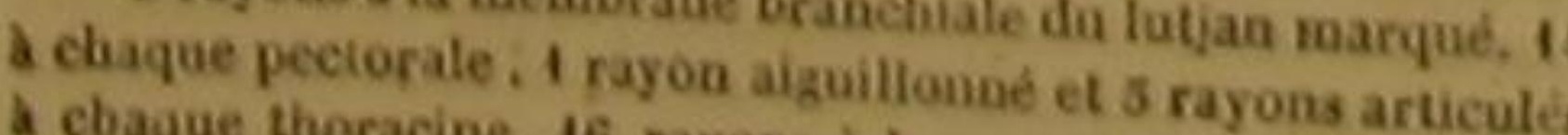

it rayons a chague, 16 rayous a la nageoire de la queue.

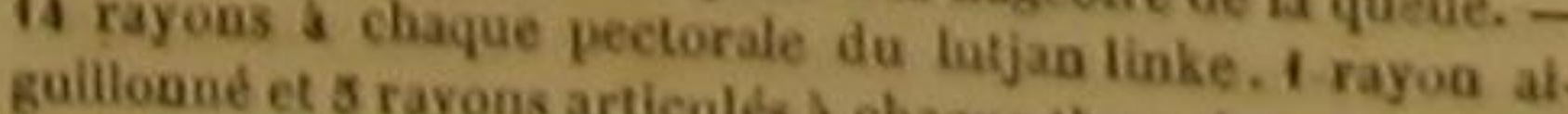

a La caudale. -6 rayous a la membrue thoracine, 15 rayoos

surinam, 16 a chaque pectorale, 1 rayon aigailenone lu et 5

de la queue. - s rayous a la la membrane branehiale duageoire

rerdátre, 12 a chaque pectorale, 1 rayon aiguillonné et

s rayons a la mes a chaque thoracine, 16 rayons à lacaudaé et

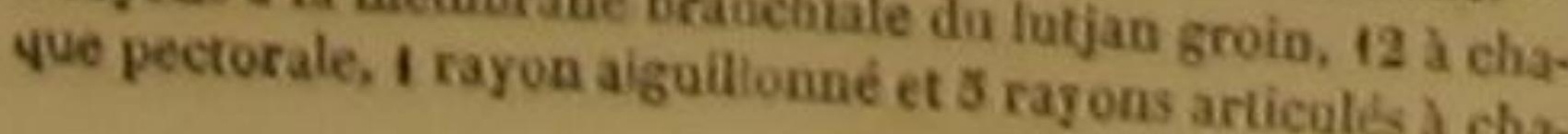

On ne doit pas oublier de remarquer, sur le lutjan verdâtre, la forme de la dernière pièce de chaque opercule, qui se termine en pointe les raies violettes qui règnent sur la tête, les côtés, la dorsale et l'anale; ni les deux bandes transversales, étroites, courbes, et d'un viole plus ou moins foncé, que l'on peut voir sur la caudale.

Le palais et la langue du lutjan groin sont doux au toucher, et ses nageoires courtes.

Le lutjan norvégien a aussi sa langue et son palais très-lisses; une petite membranes'avaner un peu au-dessus de chaque ail de ce poisson; une humeur gluante sort des pores que l'o peut compter auprès de cet organe; les ravons aguillonnés de la dorsale sont garnis ehacun d'un filament; une nuance bleue distingue les pectorales et les thoracines; l'anale et la caudale sont violettes à leur extrémité.

\section{LE LUTJAN JOURDIN '}

Amphiprion bifasciatus, Bl., Seho., Cuv.; Anthias bifas ciatus, Bl.; Holocentrus bifasciatus, Schneid.; Lutpr uus Jourdin, Lae. ${ }^{3}$

Le Lutjan Argus ", Anthias Argus, Bl, Latjaus Argis

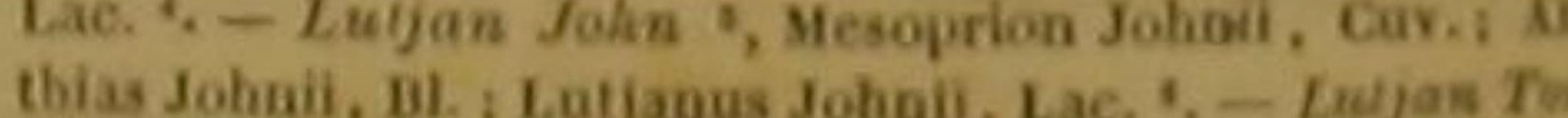
tue ', Anabas testudineus, Cuv. i Anthias testrdineus, E. Latjanus testadineus, Lac. ', - Lutjan Plumier ', Serranus striatus, Cuv,; Anthis striatus, Bl.; Anthias Clerbi

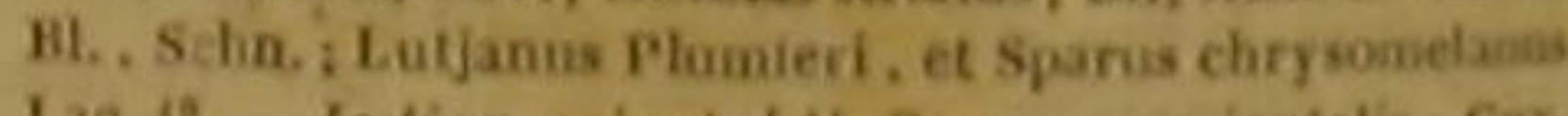
Antias orientalis, Briental ", Serranus orientalis, Cav. Anibias orientalis, Bl, Lutjanus orientalis, et Loijjmis an
rantius, Lac, 19.

Le lutjan jourdin à beaucoup de rapports avec le lutjan polymne. Son palais et sa langue

que thoracine, is rayons a la nageoire de la queue. - 5 rayons a la membrane branchiale du lutjan norvegien, if chaque pectoraie. I rayog aiguillonne et 5 rayons artical Jiaque thoracine, 16 rayons a la caudale.

- Doppel tand, par les Allemands. - - Anthias fourdio, ho biss iatus, , Bloch, pt. 316, 6ig. 2.

Da geare Ampurasor, dans ta famille des Acanthopte-

gicus sparoiles, selon M. Cuvier. D.

I Non mentiones , Bloch, p. अ7.

$\because$ Anthias Johnil., Bloch, pl. 318 .

Du genre MEcoparor, dans la fimille des scanthoptirn.

'ins percoides de M. Cuvier. D.

- Ce poisson est place par $\mathbf{M}$. Cuvier Gans le genre Asins. dormes. Ciest des Acanthoptérygiens pharynziens labyriuth. 'A Anthas striatus, , Bloch, pl. s2l.

to Da gense Misioes Serran, pl. 52. .

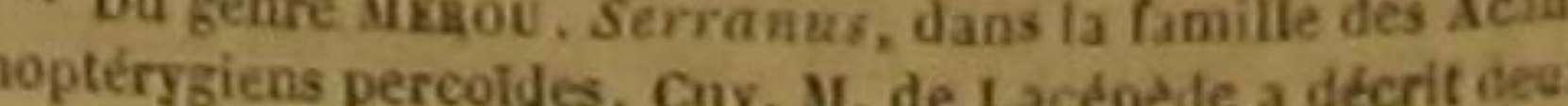

DES POISSONS.

535

sont dénués de petites dents; mais son gosier , voir désigner la manière d'étre de cette boite osen est entouré. Les deux pièces de chaque opereule sont dentelées, et la postérieure l'est profondément. Les deux cótés de la caudale sont blanes, de manière à faire présenter par la couleur brune du milieu de cette nageoire, la figure d'un fer de lance. On voit aussi sur le haut de la partie postérieure de la dorsale une teinte blanche qui se réunit et se confond avee la seconde bande transversale. Valentyn, qui a donué le premier un dessin de ee beau poisson, que l'on trouve dans les eaux de l'ile d'Amboine, dit que ce thoracin parvient à la longueur de deux ou trois décimètres, et que les reflets dorés dont it brille jettent un tel éelat, que, lorsqu'on voit plusieurs individus de cette espece nager ensemble, ils offrent un petit spectacle des plus agréables.

L'argus est remarquable par ses taches brunes en forme de cerele ou d'anneau, et par conséquent un peu semblables à une prunelle entourée de son iris; il a d'ailleurs sur la téte et sur les nageoires d'autres taches de la méme eouleur, rondes, mais plus petites, et non pereées dans leur centre. Les deux máchoires de ce poisson sont garnies de dents aiguès et égales.

Le lutjan John a reçu de Bloch le nom qu'il porte; et ce savant naturaliste le lui a donne pour exprimer sa reconnaissance envers son ami, le missionnaire John, qui lui avait envoyé un individu de cette espèce, Ce thoracin vit a Tranquebar. II a la chaic blanche et de bon goùt. La mâchoire supérieure est garnie de dents aigués et séparées les unes des autres, parmi lesquelles deux attirent l'ail par leur longueur. L'orifice de chaque narine est double. Chaque opercule est terminé par une prolongation pointue. Une partie de la caudale est couverte de petites écailles. Cette même caudale, les pectorales et les thoracines sont rouges, pendant que le bleu et Lorangé distinguent la dorsale et la nageoire de l'anus.

On trouve dans le Japon, aussi bien que sur la cote de Coromandel, le lutjan tortue. Ses écailles sont grandes; et son cràne a paru assez dur au naturaliste Bloch pour qu'il ait cru delois ce poisson, sous les noms,

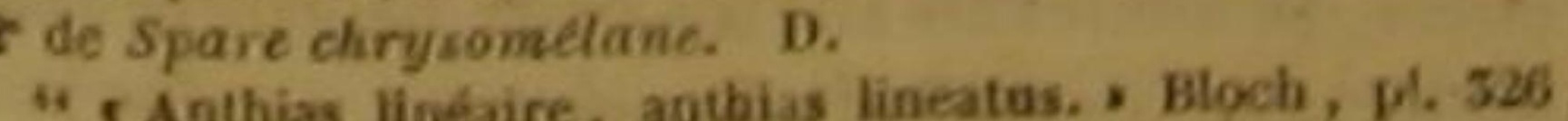
ig. I. "Du geure Minov, Serranus, Cav, M. de Lacépede seuse, par le nom de Tortue qu'il a dónné a l'animal.

Les nageoires du lutjan Plumier sont rouged. tres; et, suivant le célebre voyageur dont nous avons eru devoir lui faire porter le nom, sa chai est dẻ bon goùt et facile à digérer. On le pèche dans la partie de l'Océan Atlantique qui entoure les Antilles '.

L'oriental, dont la dénomination annonce qu il habite les Indes orientales, a chaque opercule terminé par une prolongation anguleuse; les peetorales, les thoracines et la caudale, rouges ou rougeátres; la dorsale et l'anale rouges du cóté de la tête et jaunes vers la nageoire de la queue, sur laquelle on voit des taches noires et petites, ainsi que sur la nageoire du dos.

Bloch a publie le premier la description des six lutjans dont nous venons de parler.

LE LUTJAN TACHETÉ ${ }^{2}$

Pristipoma Caripa, Cav, $q_{\text {; Anthias macolatus it. }}$ Lutjanus maculatus, Lac, '.

Le Luyan Orange 4, Serranus orientalis, Cav. Anthias oricutalis, Bl, Lutjanus aurantims, et L, orientalis, Lac, ", - Lutjan Blane-or ", Mesoprion albo-surens, Cuvis Lut. janas albo-aureus, Lao, ', - Lujan Perchot , Amphi.

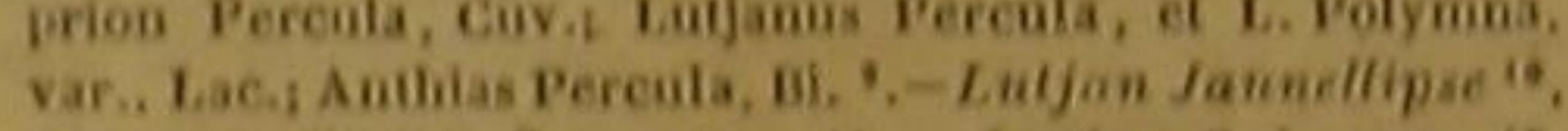
Lutjanes elliptico-flavus, Lae, ", - Lutjan Grimpear ".", Schins, Perca scandens, Dildorff, Lutjasmes scandens, Lacep. ", - Lutjan Chelodonode, Diagramma PlectoHiynchus, Cuv.s Plectorynchus chatodonolies, et Latja. nus chatodonoides, Lac, ", - Lutjan Diacanthe, Cor vina Catalea, Cuv, Lutjanos Diacsothus, Lacep. "., Lujjan Cayenne, Otolitbus Toe-toe, Cuv.i Latjanu

Le tacheté se trouve dans les Indes orientales, et a les écailles dures et argentées.

i 6 rayong a L membraue branchiale du futjan joordin, 14 chaque peetorale, 1 rayou aiguillonné et 5 rayous articules a chajue thoracine, 14 rayous a ta eadale. - 16 rayons a

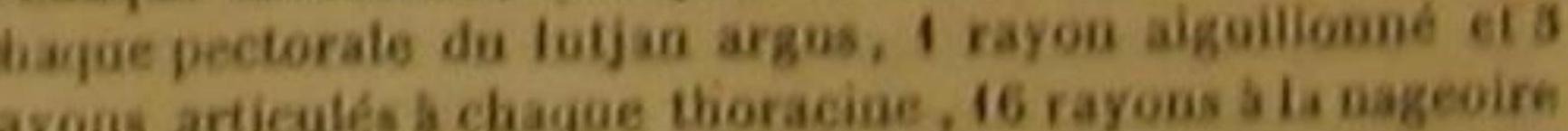
de la queue, - 6 rayose a la memirane branchiale da lat. jan Jobn, 16 a chaque pectorale, 1 rayon aiguillonie 6 s rayons arvicules a ehaque thoraciae, , is rayons a la caudiste:

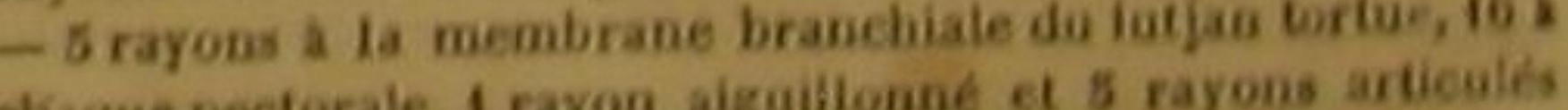
chaque pecharale, 6 rayon alous a la nageoire de ia queue.it ravons a chaque peetorale du latjas plomier, I rayon alpillonne et 5 rayons aricules a chaque thoracine, 18 rayous ala caudale. - 5 rayous a la mewbrane branchiale da latjan oriental, 16 a chaque pectorale, 1 rayon aiguilonas en a rayons articul
de la queve.

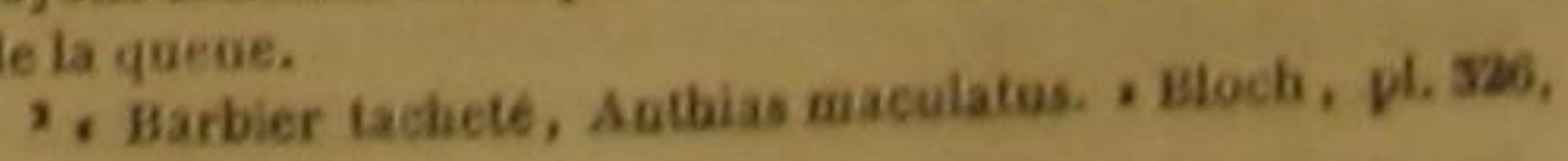


HISTOIRE NATURELLE

L orange habite dans les eaux du Japon.

Le blanc-or a été vu par Commerson auprès des rivages de la Nouvelle-France, pendant l'éte de cette contrée. Il parvient à deux ou trois décimètres de longueur. Le dessus de la tête et du dos de ce poisson est brunátre; ses nageoires sont jaunes, excepté la caudale, qui est noire et terminée par une raie blanche, le haut de Ia partie antérieure de la dorsale, qui est rouge, et le haut de la partie postérieure de cette mème nageoire, qui est noir. Ce lutjan a des écailles allongées auprès de ses thoracines, Commerson a écrit que la chair de ce poisson n'était ní mal saime ni désagréable au goùt.

Le perchot habite auprès des rivages de Ia Nouvelle-Bretagne, et particulierement dans le port Praslin, ou Commerson jeta l'ancre avee notre célèbre Bougainville, en juillet 1768. Ce poisson, qui parvient à peine à la longueur d un décimètre, et qui ne peut pas être recherché pour la table à cause de sa petitesse, vit au milieu des rochers, ou il se cache parmi les coraux.

'M. Guvier rapporte, presque sans doute, le lutjan tachele, Lac, a son Pristipome Caripe, de la femille des Acanthoptérygiens sciénoides. D.

- Mougrel, par les Anglais. - . Mulot, Anthias orieata His, , Bloch, pl. 526, fig. 5 .

"Du genre Mriou, dans la famille des Aeanthoptérygiens

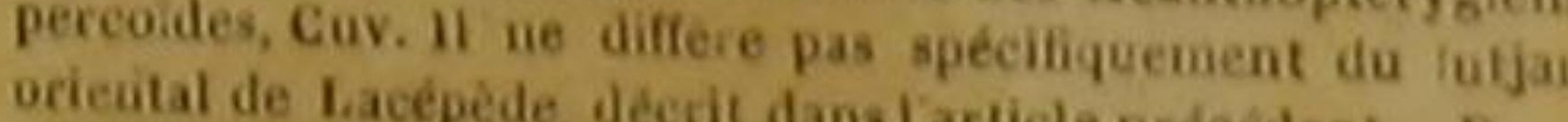
- Aspro linels aureis (circiter deceme précédent. D. - naliter virgatus, pinnæ dorsalis posterioris Lue) longitudi- nigris, a Commenson, manuscrits déja cités.
'Du geare Mrsoparo

gilens percơdes, Cuv. D.

- Perchot de la Nouvelle-Bretagne. - - Aspro ex auran- ginatis, eapiti postremo, ne - circumfusis. s Commerson, masio corpori, cauteque ba - Du genre Anpuiparor, manuscrits deja cite.

percoides. II. Cuvier lui rapporte la varieté do Ltérygiens lyme, décrite par M. de Lacepede. D.

${ }^{40}$ A A spro subrabeas, teaia elliptici ocalis pone contigua. "Non mentionserits déja cités.

"' Nou mentiouné par M. Cavier.

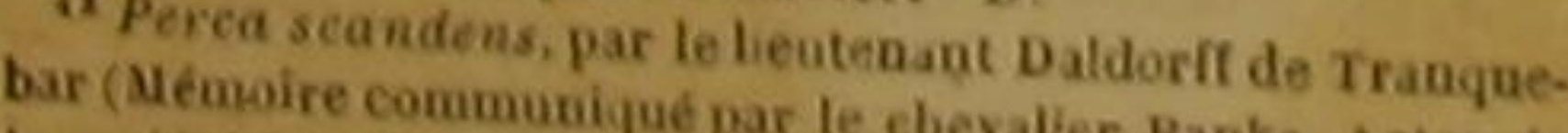
la société Lionéeune de Londres, elevalter Banks, Actes do

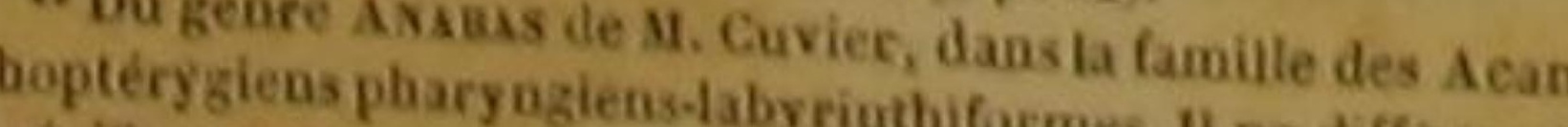
specifityuement du Luljan toriue, décrit dans farticle prét.
dent. D. dent. D.

es belles couleurs orange et bleue non-sente. ment se font ressortir mutuellement d'une me nière très-gracieuse par leurs nuances et par lear distribution, mais encore sont relevées par le liséré noir des trois bandes transversales, par une bordure noire que l'on voit à l'exthe mité de chaque nageoire. L'iris brille de l'éclat d'un petit rubis.

La tête est un peu épaisse; le museau ar. rondi ; la mâchoire supérieure extensible, moins a vancée que l'inferieure; la langue courte, dure, et à demi-cartilagineuse; le dos élevé et caréné.

On peut croire, d'après les manuscrits de Commerson, que le lutjan auquel nous avons donné le nom de Jaunellipse, et que ce voya. geur a vu près des cótes de I'lle-de-France, en décembre 1769 , est très-rare auprès de ces ri: vages, puisque notre naturaliste ne l'y a observé qu'une fois. Ce poisson est moins petit que le perchot; mais sa longueur ordinaire ne paraít pas aller jusqu'à deux déeimètres. Il al nageoire du dos et celle de la queue d'un rouge brillant; les pectorales et les thoracines sont Yun rouge pále; des nuances brunes sont répandues sur l'anale; des taches noires parais. sent sur la membrane de la partie de la bageoire du dos, qui n'est soutenue que par des rayons articulés, une ligne noire règne au-des. sous de la gorge; et cing ou six taches rouges sont placées sur chaque opercule.

Les petites dents qui hérissent chaque michoire, sont situées derrière d'autres dents w peu plus grandes, et séparées les unes des autres. Chaque opercule se termine par une prolongation anguleuse.

Le grimpeur a été vu à Tranquebar, en no vembre 1791. Le lieutenant anglais Daldorffa observé la faculté remarquable qui a fait donner a ce lutjan le nom scientifique que nous lui avons conservé. Un individu de cette espèce, surpris dans une fente de l'écorce d'un palmier érentail, à deux mètres, ou environ, au-dessus de la surface d'un étang, s'efforeait de monter. Sus. pendu à droite et à gauche par la dentelure de ses opercules, il agitait sa quene, saccrochait avee les rayons aiguillonnés de la nageoire do dos et celle de l'anus, détachait alors ses opereules, se soulevait sur ses deux nageoires anale et dorsale, s'attachait de nouveau, et plus haut que la premiere fois, avec les dentelures des opercules de ses branchies, et, par la répétition

DES POISSONE.

de ces mouvements alternatifs, grimpait avec assez de facilité. Il employa les mèmes manœuvres pour ramper sur le sable où on le plaça, et où il véeut hors de l'eau pendant plus de quatre heures.

Cette manière de se mouvoir est curieuse : elle est uné nouvelle preuve du grand usage que les poissons peuvent faire de leur queue. Cet instrument de natation, qui, devenant quelquefois une arme funeste a leurs ennemis, leur sert souvent pour s'élancer' , et dans certaines eirconstances pour ramper ${ }^{2}$, peut donic aussi étre employé par ces animaux pour gìmper à sne bauteur assez grande

Les habitants de Trauquebar eroient que les petits piquants dont la réunion forme la dentelure des opercules, sont venimeux. On ne pourrait le supposer qu'en regardant ces pointes comme propres à faire entrer dans les petites plaies que Pon doit leur rapporter, quelques gouttes de l'humeur visqueuse et noiratre dont le grimpeur est enduit, qui est plus abondante auprès des opercules que sur plusieurs autres portions de la surface de l'animal, paree queles pores d'où elle coule sont plus gros et plus nombreux sur la tête que sur le corps et sur in queve, et qui pourrait contracter de temps en temps une qualité vẻnéneuse ${ }^{3}$.

La longueur ordinaire du lutjan grimpeur est d'un palme. II peut coucher sa dorsale et son anale dans un sillon longitudinal '

Le chétodonoide it les lèvres charnues et extensibles. Il présente sur presque toute sa surface des taches blanches très-grandes, et char-

'Voyez Lart, du Saumon. ' Voyez Iart.de I'Anguille. - Voyez le Discours sur la natare des poisons.

'T rayons a i membrane braschiale da lotjan tachete, is thayge pectorale, I rayon aiguillonné et 5 rayons articuié detayue thoracine, 16 rayons a pa caudaie: -5 rayons a 1 membrasé branctisle du lutjan orange, 12 a claque pecto raciece, is rayous a la nazeoire de ta queue. -7 rayous a is

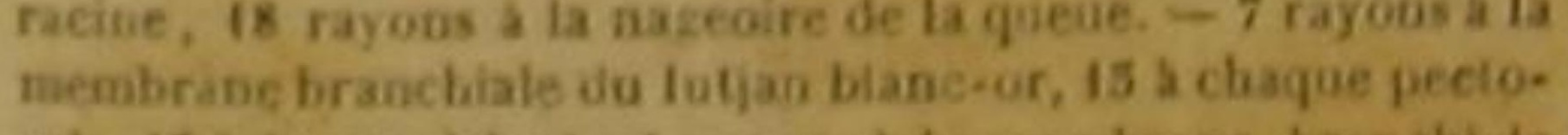
rale, 15 a la ciadale. -4 rayois a Li membraae liranchiste da latjan perchot, 14 a chaque pectorace, 15 \& la nageoire do la queve. -5 rayons a la inembrane branchiale du latjan

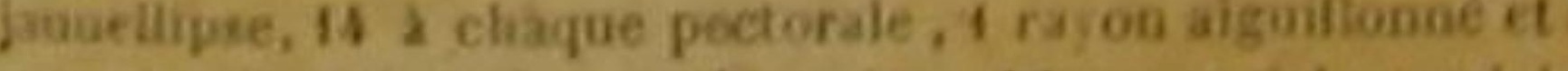
rayoos articulés a chaque tiosaciae, if rayom a la cavialo -12 rayons à chaque pectorale dia lujas grimpror, 1 rayo

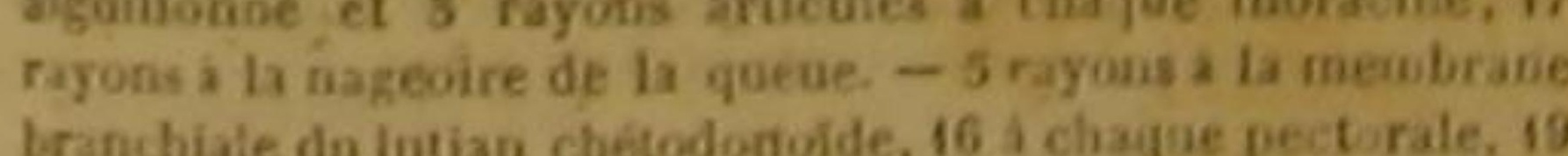
a la condale - 19 rayons a chaque pe clurale du lu jarr da canthe, I rayoh aiguillowne et 5 rayous atticulée a chą̧u Uhoracise; 18 rayons a ia nag oire de la queie. - I rayou a guilloane et 5 rayous articules a chaque thoracine du lotjy. cyenie. gées d'une ou de plusieurs petites taches foncées. La collection du Musẽum d histoire naturelle renferme un indiviäu de cette espèce, dont on a pas ençore publié de description.

La première pièce de l opercule du diacanthe est la seule dentelée, Nous avons décrit ce thoracin d'après un individu desséché, mais trèsbien conservé de la collection hollandaise cédée à la France.

Le nom du Luljan Cayenze indique la patrie de cette espèce, dont un individu a été envoyé au Muséum par le naturaliste Leblond.

\section{LE LUTJAN PEINT.}

Diagramma pictum, Cur.; Perca picta, Thuaberg, I.utjanus pietus. Lac, 1 .

La couleur générale de ce lutjan est blanche la partie supérieure de la dorsale, pointillée de blane et de brun; I'anale blanche; I'extrémite de cette nageoire noiratre; la caudale blanche et rayée de elaque cóté.

Thunberg a vu ce lutjan dans la mer qui bai. gue les iles du Japon ${ }^{2}$.

\section{LE LUTJAN AIAUNA}

Dascyllos Aruanus, Cuv., Chotodon Aruanus, Lion., Gmel.; Lutjanus Aruamus, Lac. ‘.

L'arauna a été placé parmi les chétodons; mais it n'en'a pas les caracteres, ce que Bloch avait tres-bien remarqué; ct il offre ceux des lutjans. De petites dents coniques et aigués garnissent ses deu $x$ máchoires, qui sont aussi avancées l'une que l'autre Le dos est jaunatre; les cotés sont argentins; l'anale est jaune; les pectorales sont transparentes; la caudale est grise : les thoracines sont longues et noires.

' Uu genre Dngasink, dans la familte des Acantioptéry. giens sciénodides, selon M. Cuvier. D. "14 rayons a chaque pectorale du latjan peint, 1 rayou ai. goiltomé et s rayons articules s claque thoracine, 16 rayon

A la uageoire de la queue.
Abu-dasur, en Arabie. - Buyl-Klippare, par les sue.
A dois.-Bourgonjese Klipuanna, par les Hollasdais. -

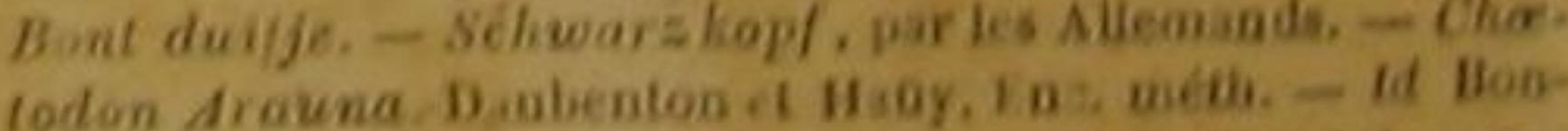
aaterre, fi. de l'Euc, meth. - Bandouillere a trois banases.

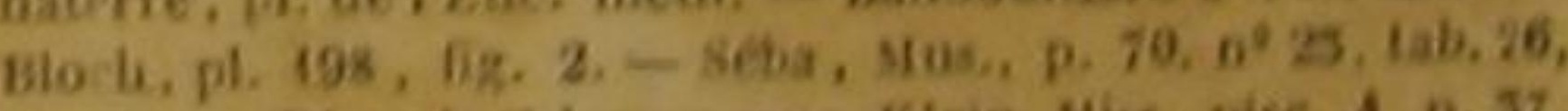
fig. 25. - Ahombolides parous. Kleis, Miss, pise. 4, p. 37,

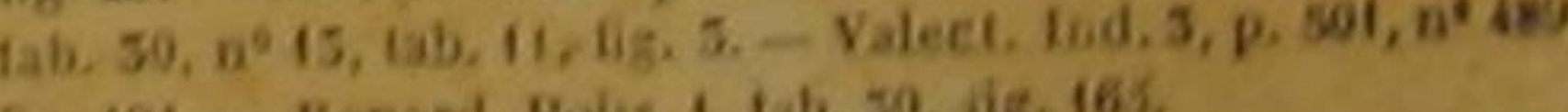
fig. 491. - Henard, Polis. 1, Lb. 50, ags. 1 s.

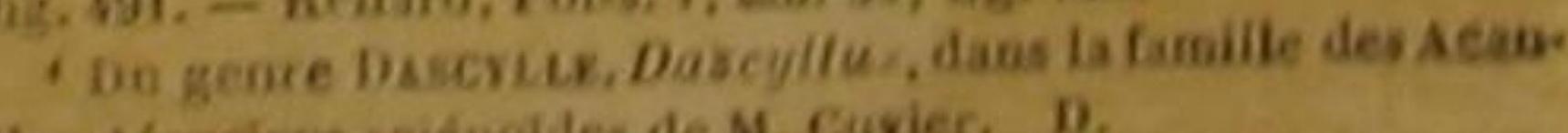
. 
HISTOIRE NATURELLE

L'arauna se plaíi au milieu des coraux. Il se nourrit de vers et d'autres petits animaux marins. On le preud au filet et à l'bameçon; mais sa chair est peu agréable au goût '. . .

\section{LE LUTJAN TRIDENT ${ }^{2}$;}

Centropristes trifurcatus, Cuv.; Perca trifurca, Lino. Gmel.; Luljanus Tridens, Lac. '.

\section{ET LE LUTJAN TRILOBE.}

Centropristes nigricans, Cur.; Coryphæna nigrescens,

Bl.; Perca varia, Mitcbill ; Lutjanus. Trilobus, Lac,

Le trident et le trilobé appartiennent au troisième sous-genre des lutjans, dout le caráctère distinctif consiste dans les trois lobes ou dans la double échanerure de la nageoire de la queue, qui, par cette conformation, ressemble un peu à un trident, ou à une fourehe à trois pointes. Le premier de ces deux thoracins a la téte peinte de couleurs variées et agréables; il vit dans la mer qui baigue la Caroline, "et a été observé par le docteur Garden. Nous ne comnaissons pas la patrie du second, que nous avons dif pas la près un bel individu de la collection du Muséum d'histoire natùrelle, Les dents qui garnissent ses máchoires sont très-petites et égales. garnissent perçoit pas de ligne latérale. La nageoire dorsale présente un grand nombre de taches ou plutôt de raies inégales, irrégulières, et placées entre les rayons ${ }^{4}$

, 17 rayons a elaque pectorale du Jutian arama, in aiguillonóe et 4 rayons articulés a chaque thoracine, 16
rayons a ta caudale.

Bonnaterre, pl. de l'.

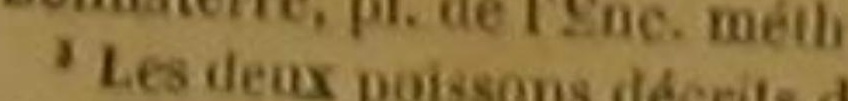

M. Cuvier, dans le geare CEsis deet article sont placés. par Acanthoptérygiens pereoides. D.

aguillonué et 5 rayons articulés. A chaque thon, 1 rayon

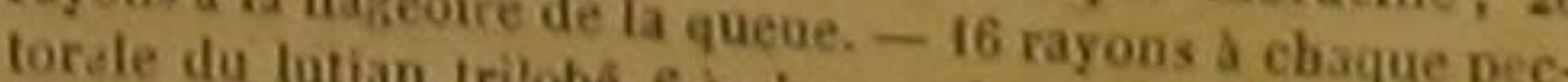
cauda'e.

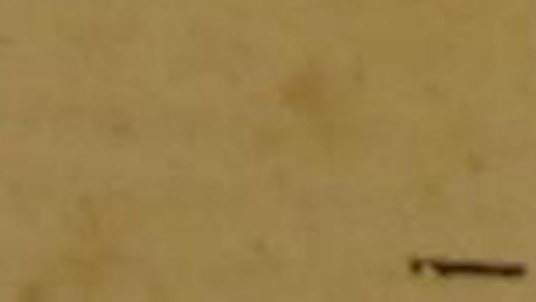

CENT DIX-SEPTIEME GENRE.

LES CENTROPOMES '.

Une dentelure à une ou plusieurs pices de chaque poen cule: pojnt d'aiguillon à ces pièces; un seul barli lon, ou point de barbillon aux machoires; deus nageoires dorsales.

PREMIER SOUS-GENRE,

La nágeoire de la queue fourchue, ou en croissant.

Espices.

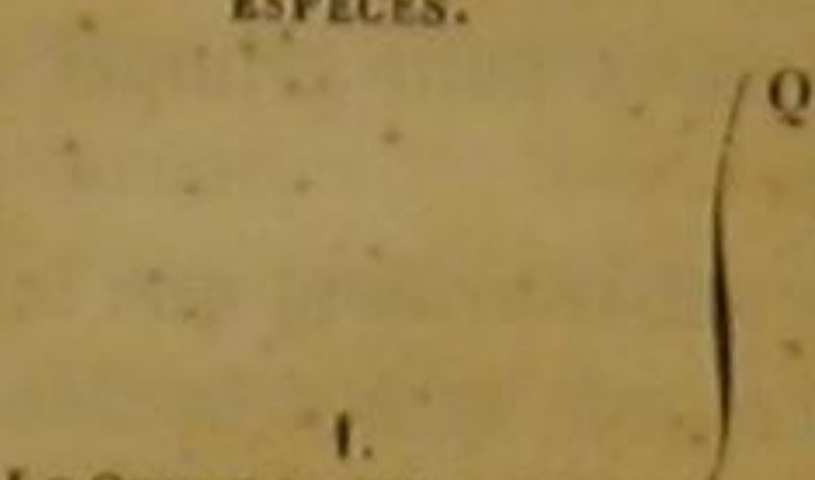

$$
\text { сансотівеs: }
$$

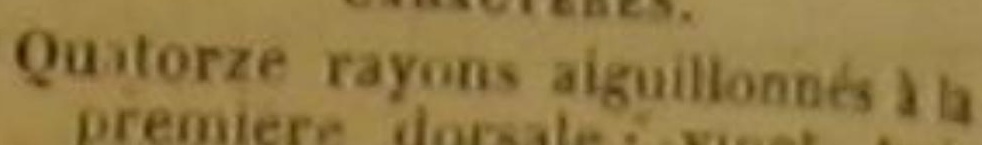

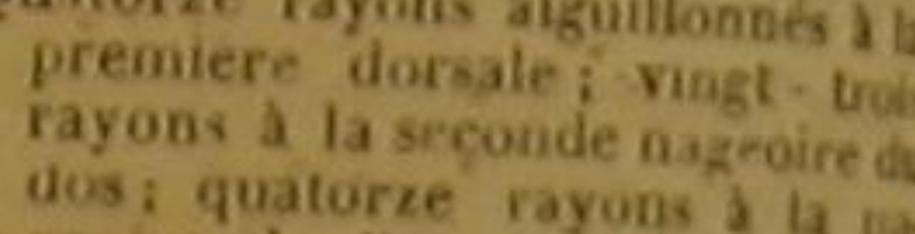

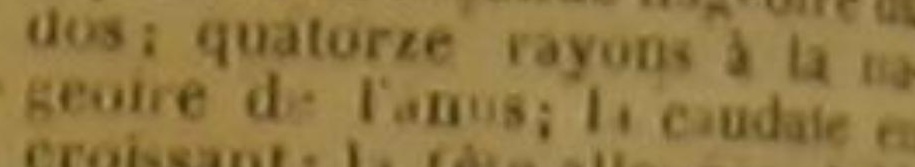

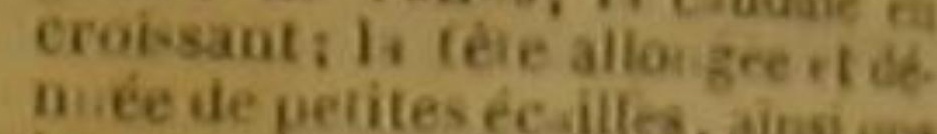

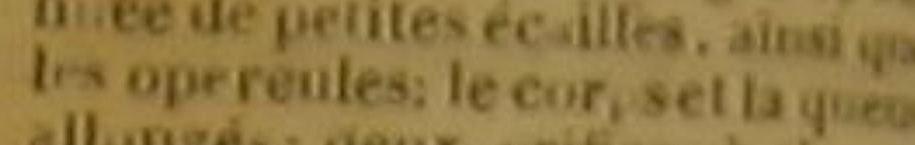

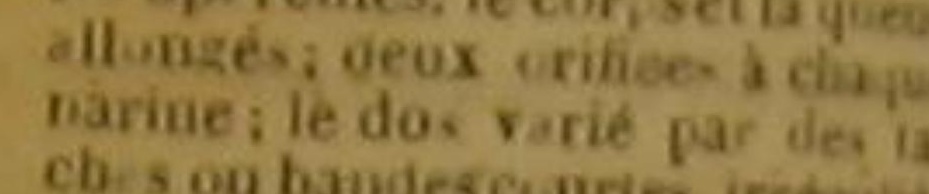

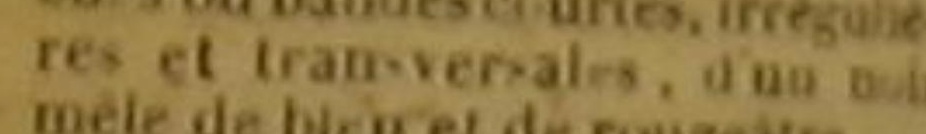
mele de biru et de rougeatre. trayous aiguiltomes sta per aiguillomié et quatorze rayousar izuillonnes et ar uf rayons at

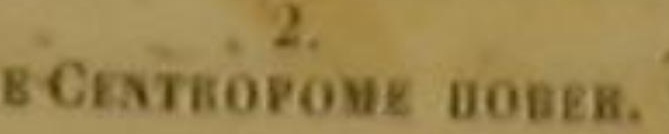

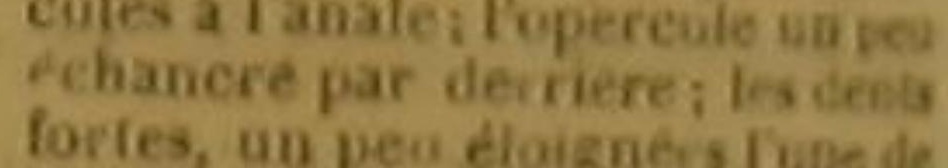

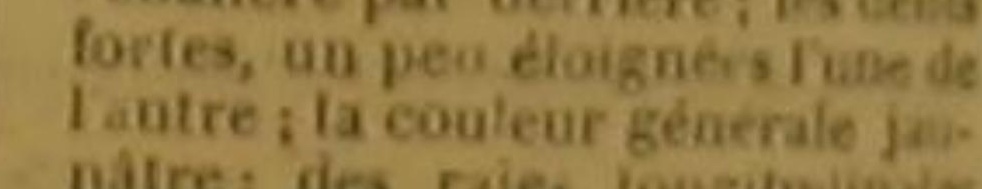

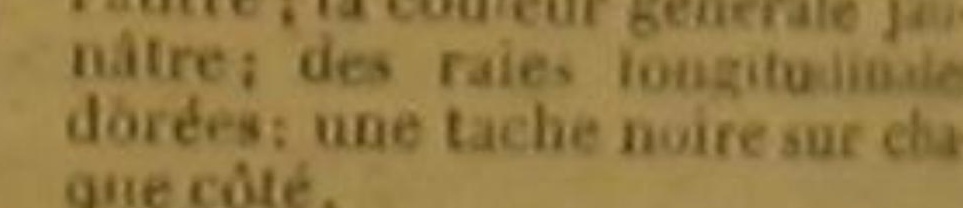

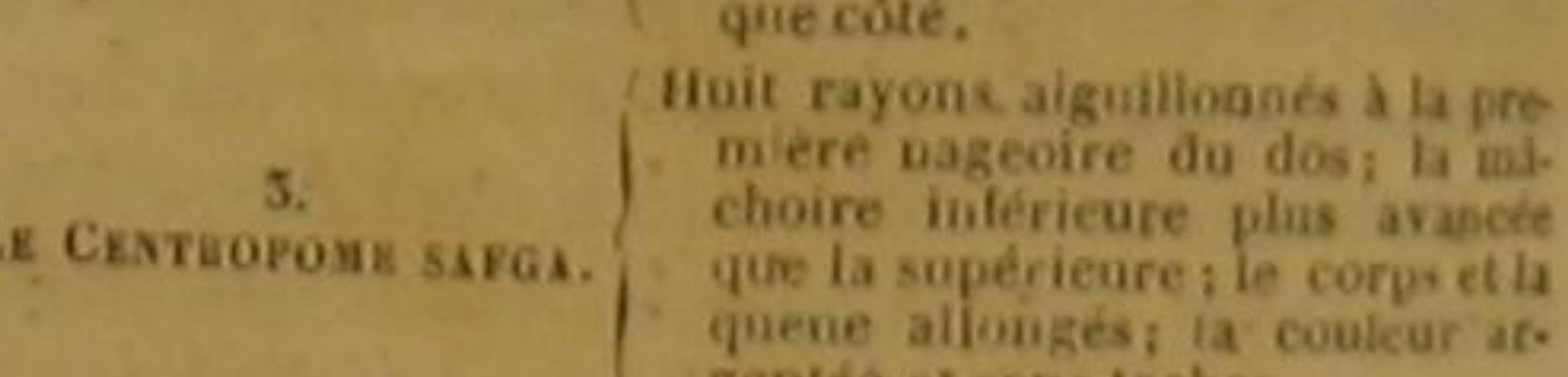
gentée et sans taches.

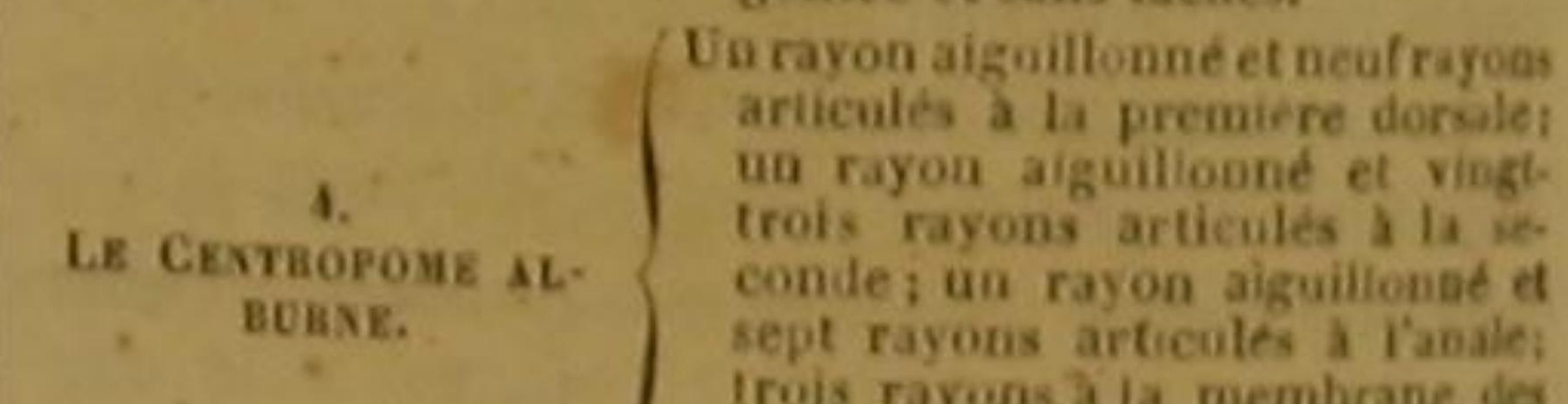
fois rayons a la membrane del
ranchies; plusicurs bandes oblit

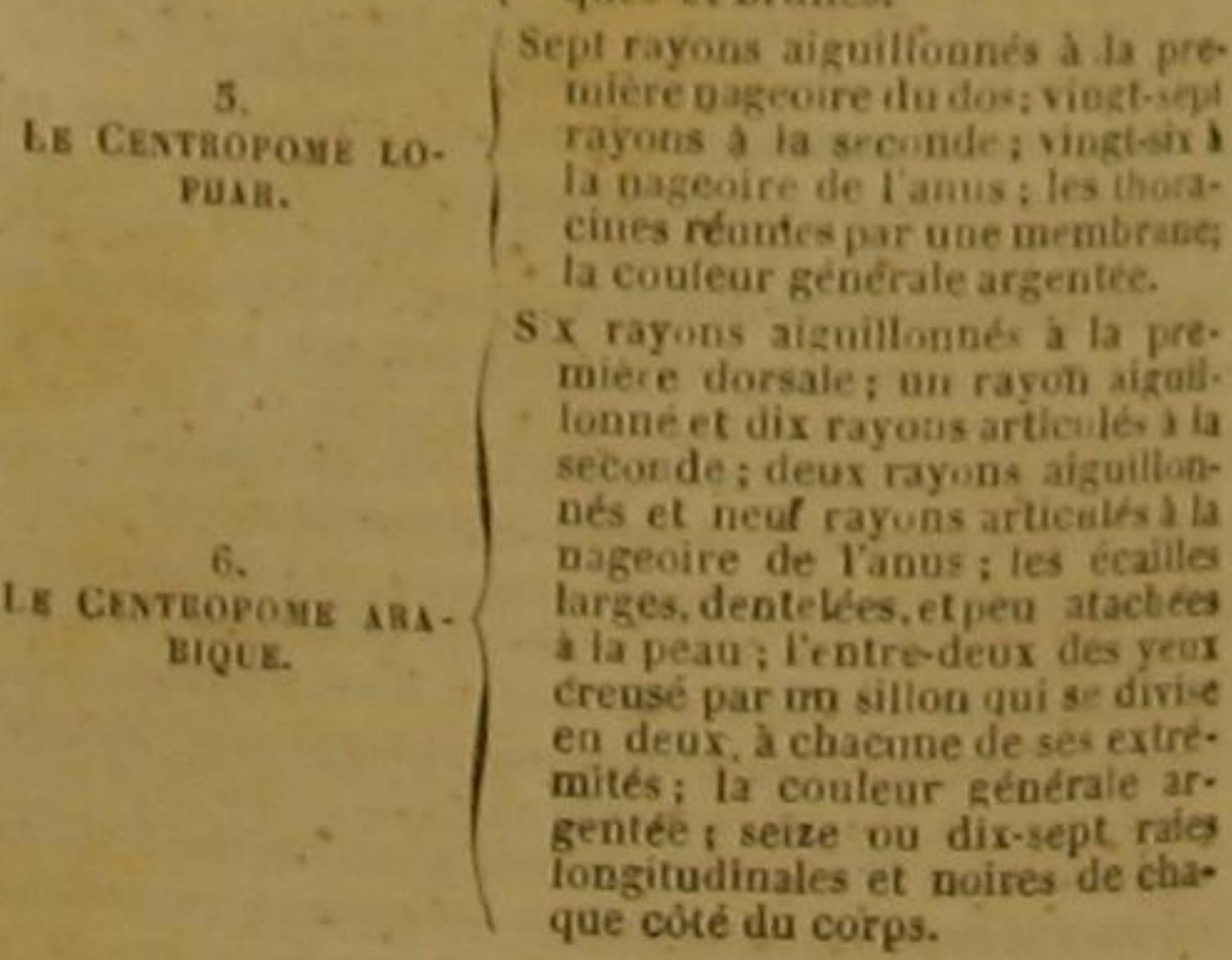

'M. Cavier ne conserve qu'uné senle espèce dans ce geore, le Centropome onze-rayons. Toutes les antrés sont réparities dans ditferents geores, tels que ceux qu'il nomme PercaLabrax, Lucioperca, Cheilodipterus, Diagramma. Dia.
cope, M Mripristis, Ambassis, Apogon, ete. D.
DES POISSONS.

559 seacrias.

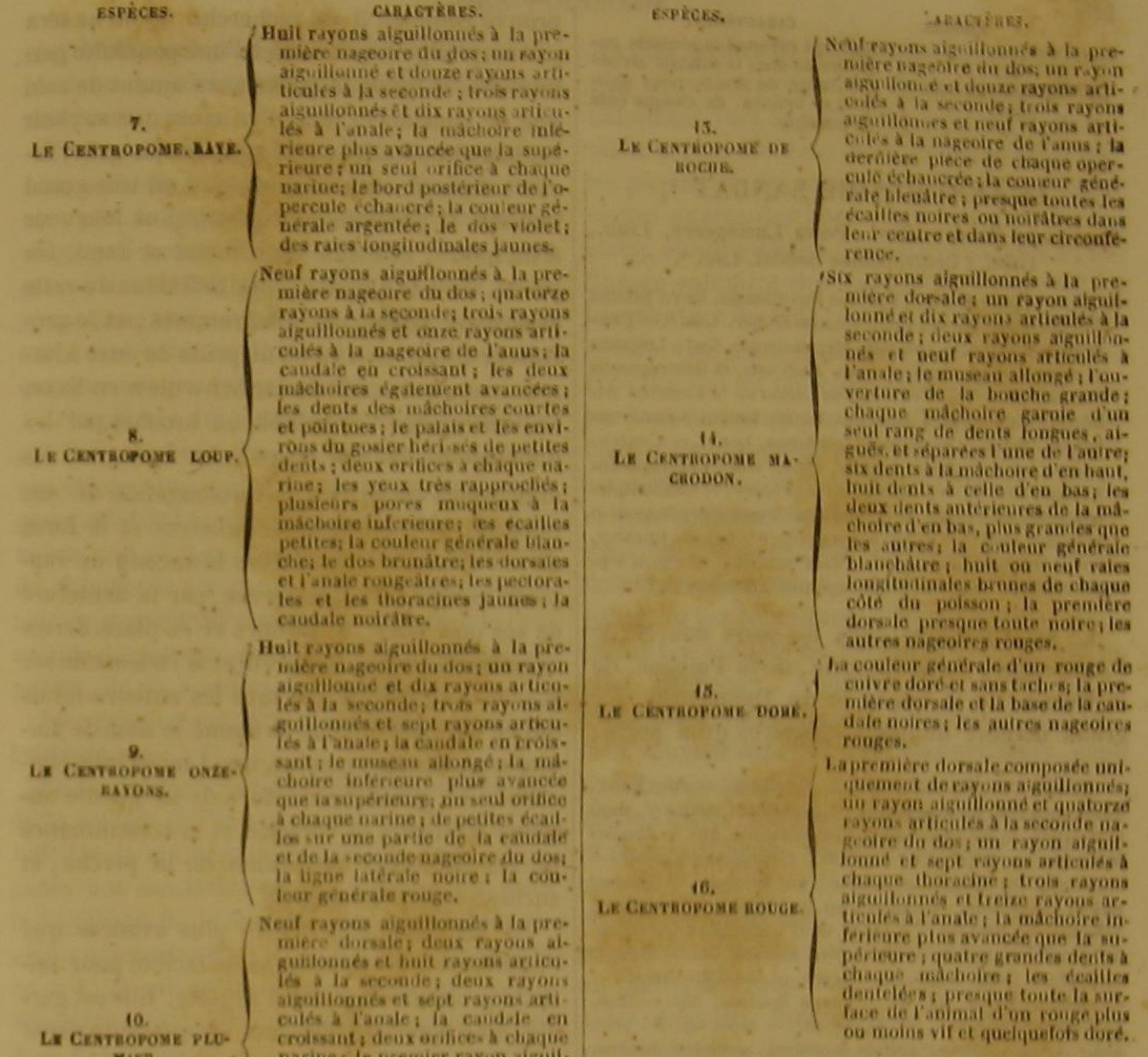

SECOND SOUS-GENRE.

La nageoire de la queue, rectiligne, ou arrondie, et non

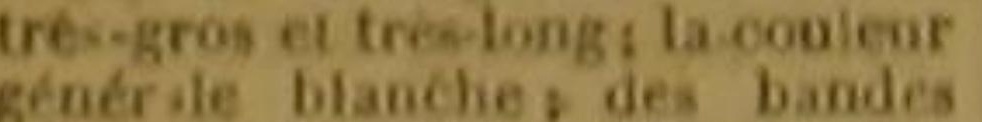
iransversales browes, des rale

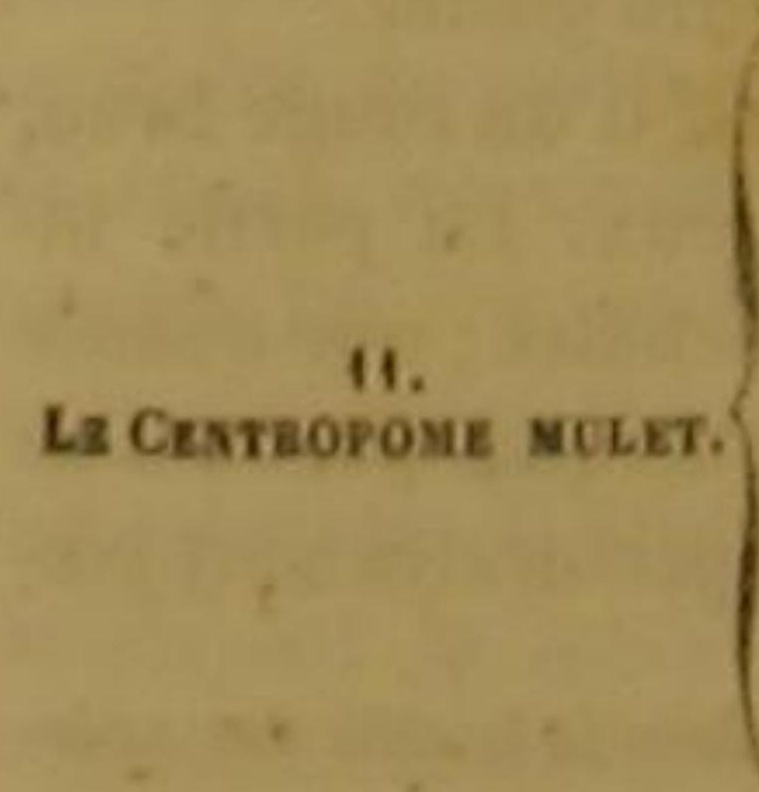

rayons aizwillonots a la pre. mice nageoire du dos: treze
rayons a la nazeoire de lanoss rayons a la nageoire de lanos:
seot rayons a ia membranebran-

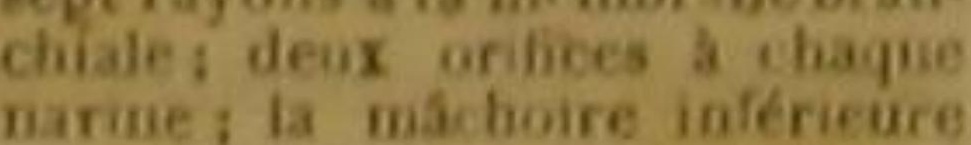

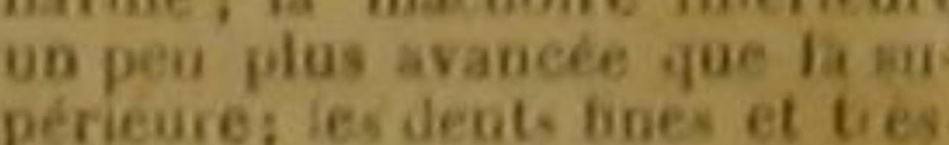

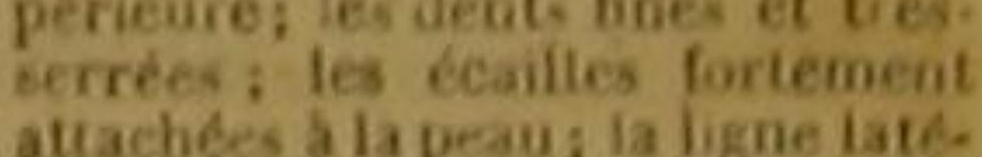

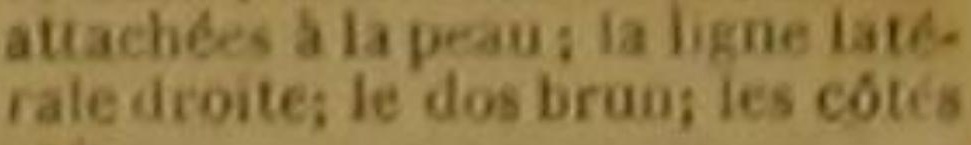

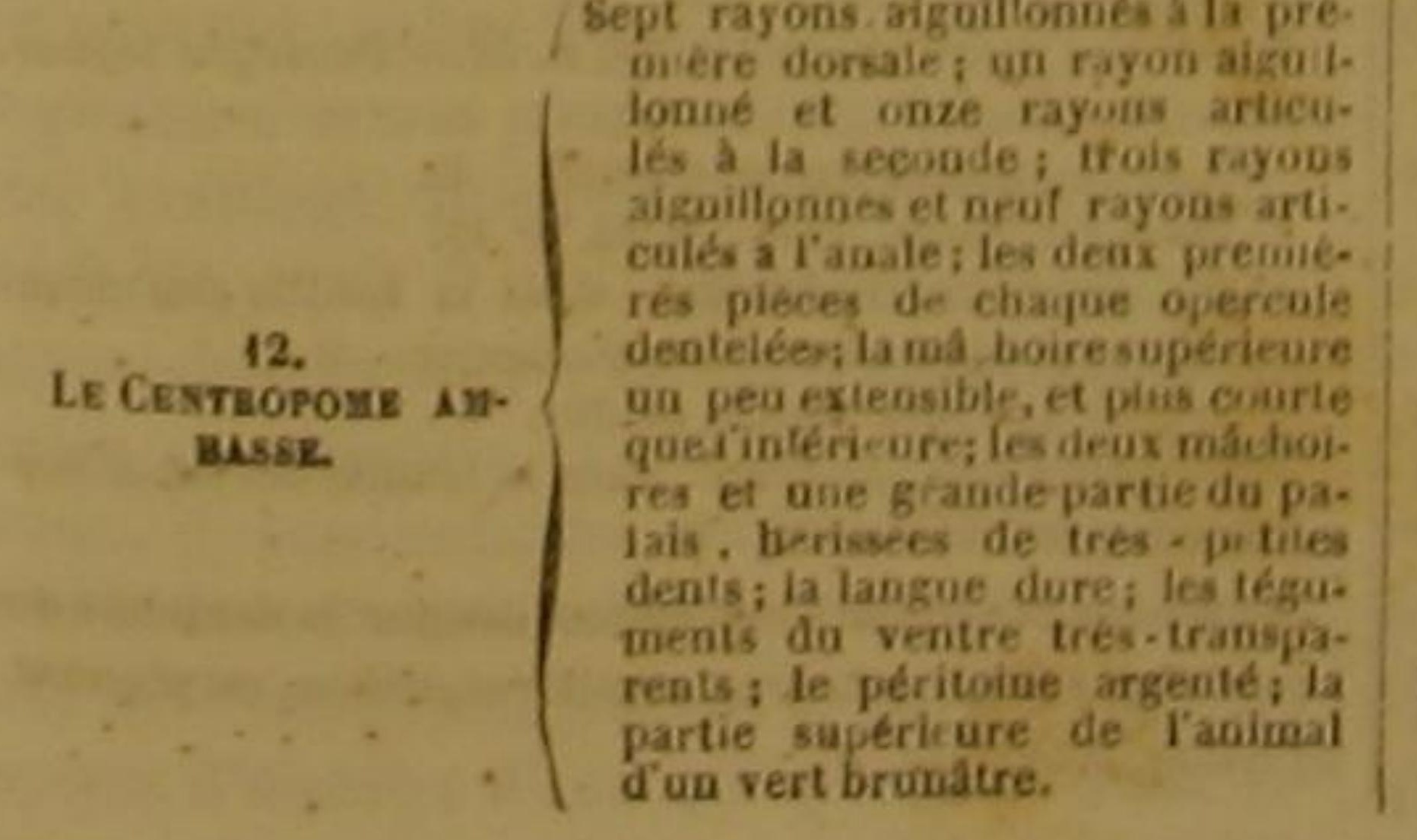
echancrie.

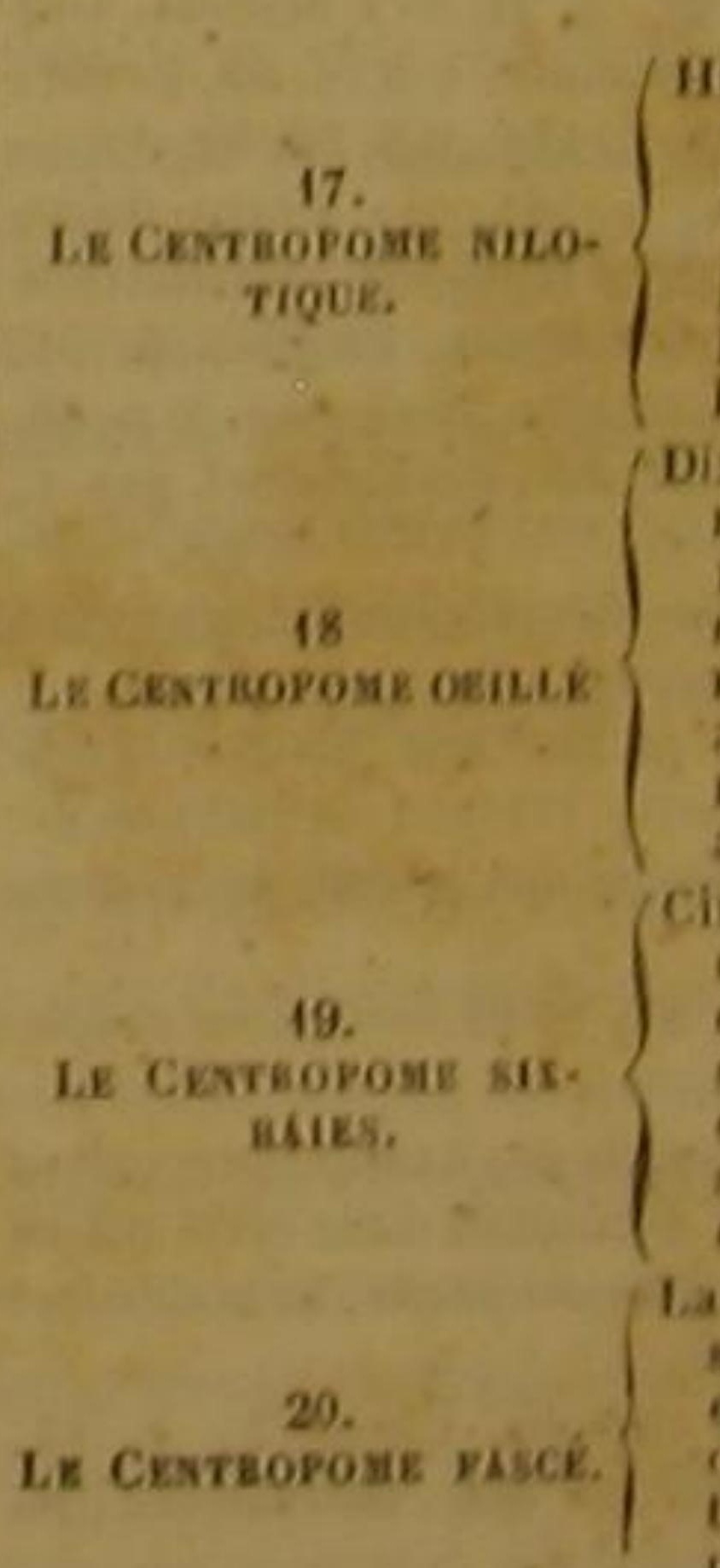

Hoit rayons alzwillonnes a ta pre-

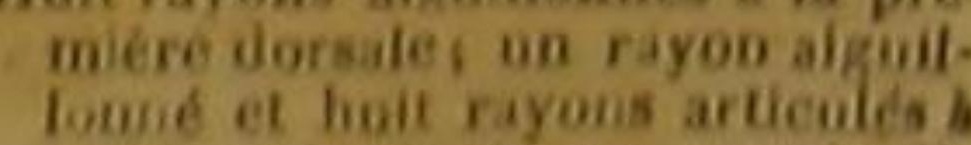
is seconde trois rayons siguil-
hones et dix rayons articiles a anale i la coulear generale Jix rayons a'guilionnés a to pre. riyon aiguillowind t tvingt ingation ayoos articutés a la secindes yo

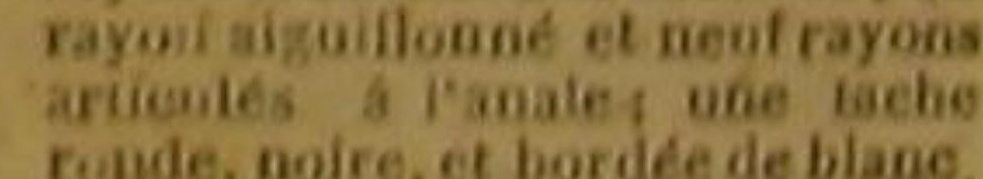
rayons aizullioniess la pre.

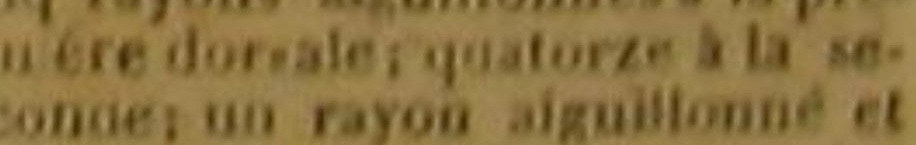
disrayonsaricules la nageoire
de Lrams la candide arrundiei

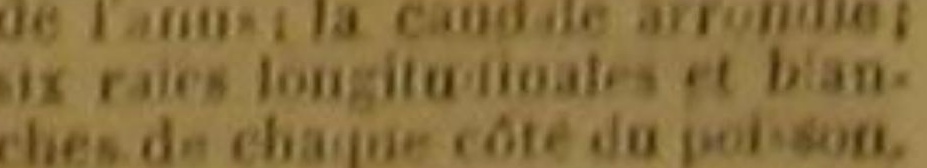

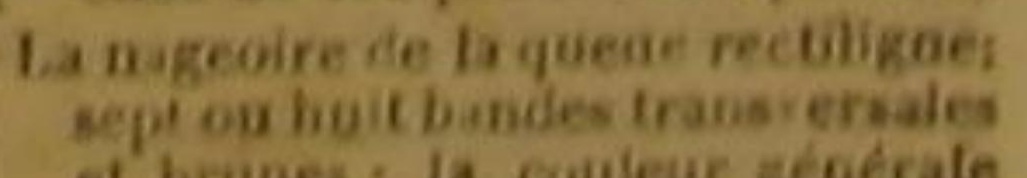

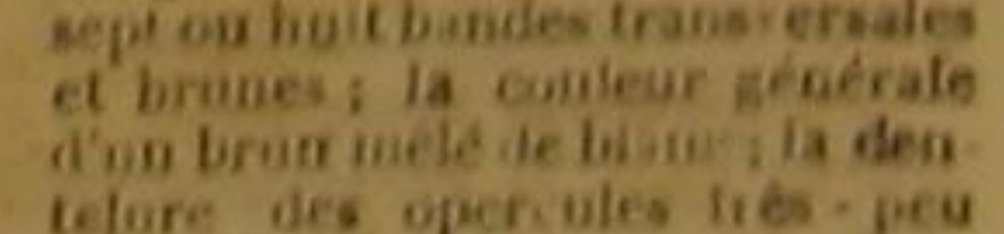




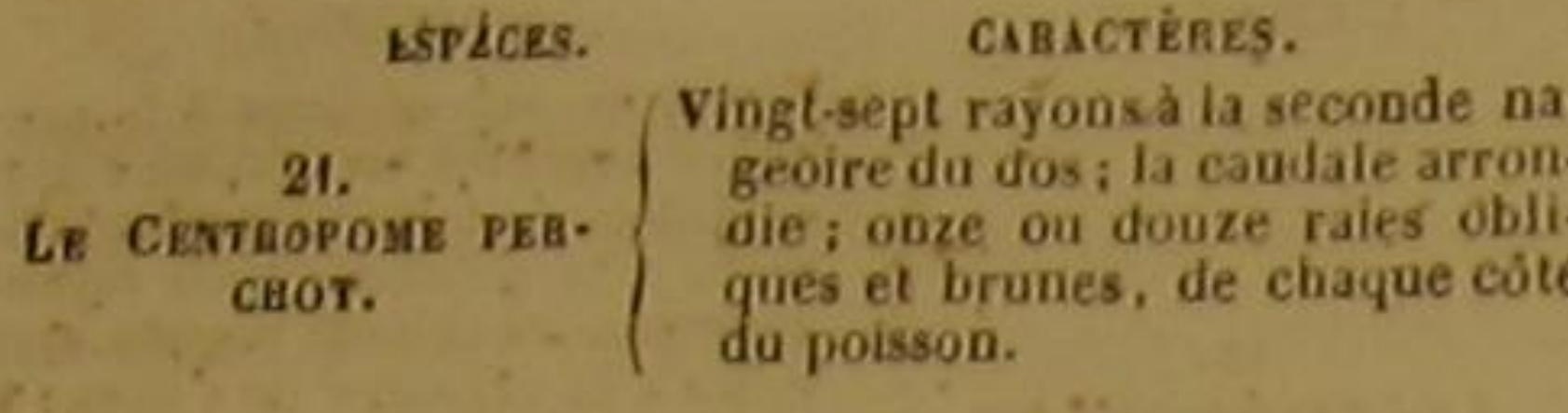

LE CENTROPOME SANDAT ',

Lucioperca Sandra, Cuv,; Perca Lucioperca, Lino. Gmel.; Centropomus Sandat, Lac. '.

Le Centropiome Ulober 1 , Diacope fulvillamma, Cav.; Scixna fulvilamma, Forsk, Centroponus Hober, Lac, 4, - Cen-

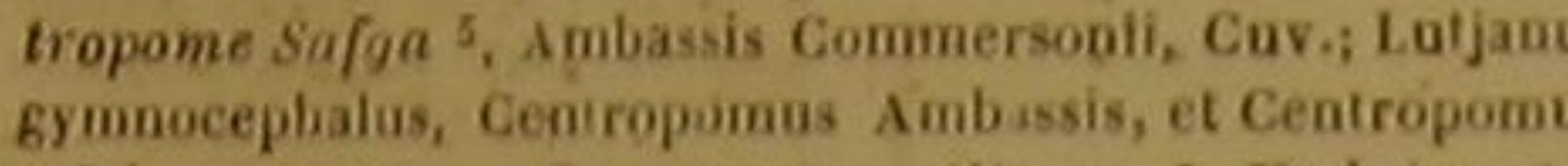
Salgha, Lac. '. - Centropome Alburne ', Umbrina Al-

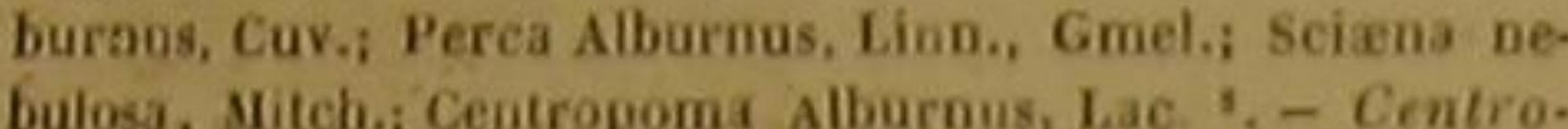
Galosa, Alich,; Centropoma Alburnus, hac. ',- CentroLophar, Lac. "10. - Centropome arabique ", Cheilodiple. arabicus, Lac, "3. - Centropome raye ", Labrax lineatus, Covv; Scizoa lineatas, Bl; Perca'sasatilis, et Perca s,

Le sam habite dais les eaux douces a

Le saudat habite danis les caux douces de l'Allemagne, de la Hongrie, de la Pologne, de
la Russie, de la Suéde et du Danemarck. Le. graud nombre de noms vulgaires qu'il porte,

'Zander, dans plos, contrées de Prusse. - Id., Xant, Sand baarsch, en Poméranie. - Sandalet sandarl, dan Aolstein, lo deckiembourg. la Pounéranie, ete. - Sanda Sudacki, en Russie. - Sedox, en Pologes - Zent a sahnt, en Silesie. - Schiel, en Autriche, - Nagmant. Schindel, en Baviere. - Sa ntor, dans te Danemarek.-Gio , ou gioes, en Suede. - Persecyue sandat. Daubenten e Haay, Enc. meth. - Id. Bonnaterre, pl. de I'Ene, méth. Le sandre. Bloch, pl. 51. - Fauna Suecica, 332. - Mull.

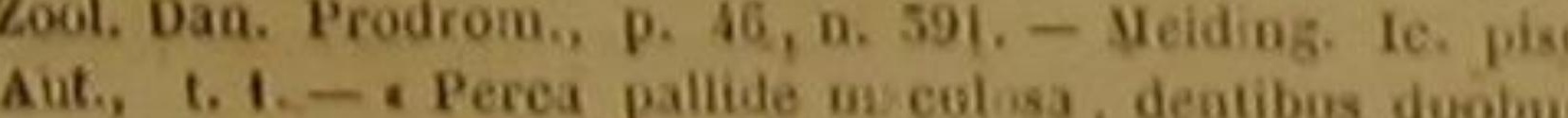
; utriaque majoribus, , Attedi, geu. 39, ,yn. 67, spec, 76, 'Lucioperea et piscis quem schilnum Germani vecant, al

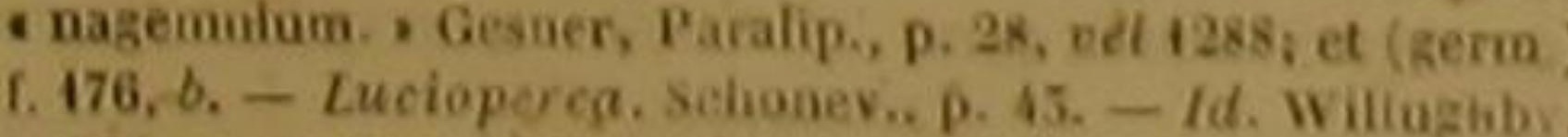

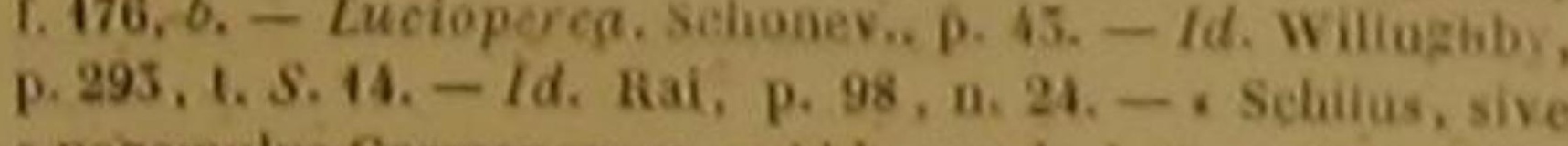

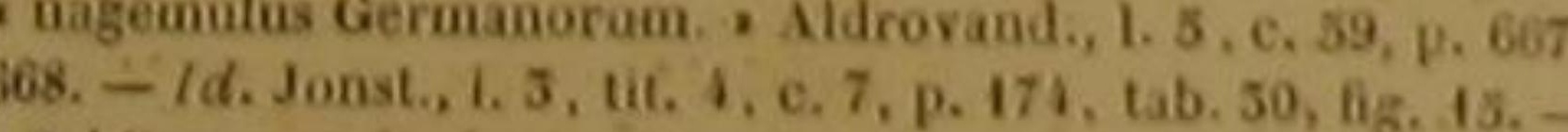
- Sctúlus nageunulus, , Charlet., p. 164, -- Perca dorso - dipterygio, capite levi alepidota, dentibus maxillaribus
- duobus, utriuque majoribus, O Gronor. Zoogh., p.

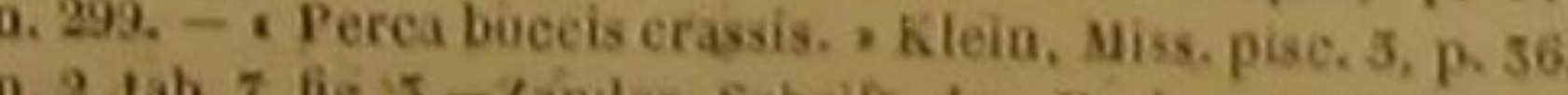

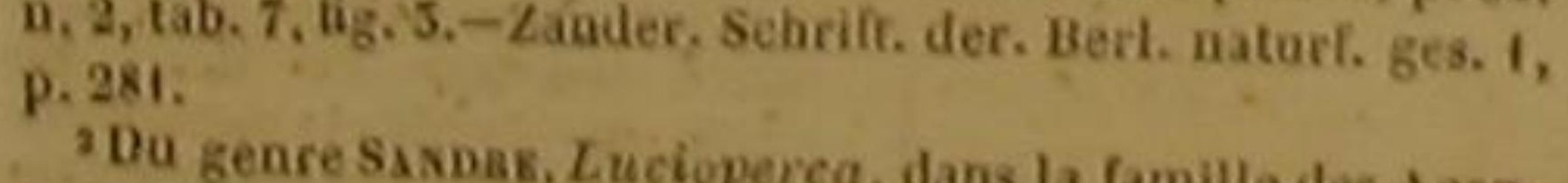
thoptérygiens percouldes de di. Cuvier. D.
- Damille des AeanSclene hober. Boanaterre, ph. deI kael, Faur. Arab., p, 45, n. 45. perevides, Cur. D.

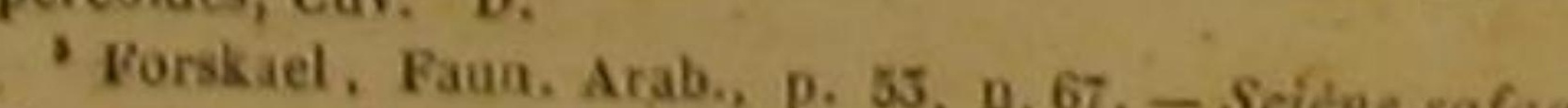
"Wonaterre, pl. del Ene. méth.

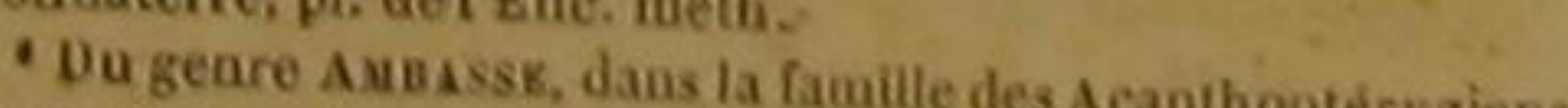
percoides, seton M. Cuvier, yui reconnalt dans cette minge copece de poissoa, ie Lutjan gymanociphale, et le Centro-

Y Alburnous americade.

lab. 12. fig. 2. - Persiguce a Catesby, Carol. 2, p. 12

di Ikite méts.
derséyue ableile de mer. Bonusterre, pt. prouve combien il est recherché : et on ne sera pas surpris qu'il soit l'objet d'une poursuite particuliêre, et qu'on le péche avee autant de soin que de constance, lorsqu'on saura que sa chair est blanche, tendre, très-agréable au goût, facile à digérer, et qu il parvient à un très-grand volume. Il présente quelquefois une longueur d'un mètre, et mème d'un mètre et demi. On prend, dans le Danube, des individus de cette espece qui pèsent dix kilogrammes, et le professeur Bloch en a vu un du poids de onze kilo. grammes, qui venait du iac Schwulow en Saxe. Ce centropome 'ressemble au brochet par les dimensions de son corps, la forme et les dimensions de sa tête, la prolongation de son museau, la disposition, la grosseur et la force de ses dents. Il a d'ailleurs beaucoup de rapports avee la perseque perche, par la dentelure de ses opercules, le nombre et ia place de ses nageoires dorsales, la duretê et la rudesse de ses écailles : aussi-presque tous les auteurs latins qui en ont parlé lui ont-ís donné le nom de $L u$ ciaperca (brochet perche), que Linnée lui a conservé. La grande ouverture de sa gueule annonce d'ailiéurs sa voracité, et la ressemblance de ses habitudes avee celles de la perche, et surtout celles du brochet.

Sa mâchoire supérieure, plus avancée que I'inférieure, lui donne plus de facilité pour saisir la proie sur laquelle il se jette. Elle est garnie, ainsi que cette dernière, de quarante dents ou environ; ces dents sont inégales et très-propres à percer, retenir et déchirer une victime. On voit aussi de petites dents dans quelques endroits du palais et auprès du gosier.

L'iris de ce centropome est d'un rouge brun, et son œil parait très-nebuleux. La partie inférieure, du poisson est blanchátre; une nuanće verdâtre est répandue sur quelques portions de la téte et des opercules; les pectorales sont jau-

'Du genre OMasss, Umbrina, dans la famille des Acan-

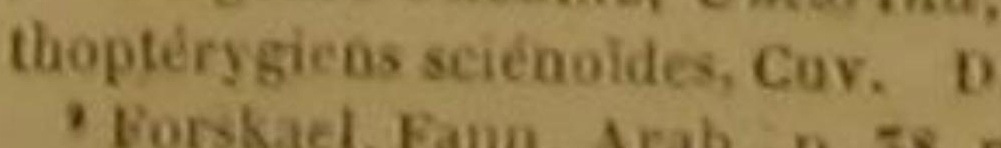

Pl. de I'Eve, Fano. Arab., p. 58, n. 55.-Perségue lophar.

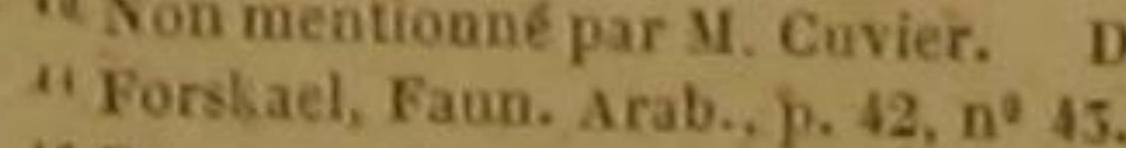

a Du genre Cazilodiftikar, dans la fanille des dean ist Srygiens pereordes, selon M. Cuvier. D.

"Derene a lijmes. Bloch, pl. 501.

uérygiens pereol, Labrax, aans ha famille des Acun thop.

- Le nom générique Centropome désigne la dentelure der

opercules. Kivrposv, en gree, signitie aiguillon, ou piquant nes; les thoracines, l'anale et la caudale grises; les deux dorsales grises et tachetées d'un brun très-foncé.

Nous suivons pour le sandat la règle que nous nous sommes imposée pour tant d'autres espèces, afin de nepas allonger sans nécessité l'onvrage que nous offrons au public. Nous avons cru ne devoir pas répéter dans l'histoire de ces animaux ce que nous dirons de leurs caractères extérieurs dans les tables génériques sur lesquelles nous les avons imscrits.

L'cesophage du sandat est grand, ainsi que son éstomac; son foie, et sa vésicule du fiel, qui est de plus jauuie et transparente. Les organes relatifs à la digestion sont done ceux d'un animal qui peut beaucoup détruire à proportiou du volume de son corps; i t si son canal intestinal proprement dit n'est pas aussi long que l'ensemble du poisson, ce tube est garni, auprès du pylore, de six coeums ou appendices.

Le péritojne est d'une couleur argentée et brillante.

Le sandat ne vient pas fréquemment auprès de la surface de l'eau: peut-être l'apparènce nébuleuse de ses yeux indique-t-elle dans ces organes une sensibilité ou une faiblesse qui rend le voisinage de la lumière plus incommode ou moins nécessaire pour cé centropome. Quoi qu'i en soit, il vit ordinairement dans les profondeurs des lacs qu'il habite; et comme il a besoin d'un fluide assez pur, on ne le trouve communément que dans les lacs qui renferment beaucoup d'eau, dont te fond est' de sable ou de glaise, et qui reçoivent de petites rivières, ou au moins de petits ruisseaux. II se plait dans les étangs ou vivent les poissons qui aiment, comme lui, à se temir au fond de l'eau; et voilà pourquoi il préfere ceux quí nourrissent des éperlans. Il croit trés-vite, lorsqu'il trouve facilement la quantité de nourriture dont il a besoin. Il dévore un grand nombre de petits poissons, mème de ceux qui ont de la force et quelques armes pour se défendre. II attaque avec avantage quelques perches et quelques brochets; mais il n'est pour ces animaux un ennemi dangereux que lorsqu il jouit de presque toutes ses facultés. Pendant qu'il est encore jeune, il succombe au contraire très-souvent sous la dent du brochet et de la perche, comme sous celle des silures, et sous le bec de plusieurs espèces d'oiseaux d'eau qui plongent avec vitesse, et le poursuivent jusque dans ses asiles les plus reculés. Il abandonne ces retraites écartées dans le temps de son frai, qử a lieu ordinairement vers le milieu du printemps. Sa femelle dépose alers ses ócuifs sur les broussailles, les pierres, ou les autres corps durs qu'elle rencontre auprès des bords de son lae ou de son étang, et qui peuvent soumettre ces oufs à l'influence salutaire des rayons du soleil, de la température de l'air, ou des fluides de l'atmosphere. Ces oufs sont d'un jaune blanchátre. L'ovaire qui les renferme est composé de deux portions distinctes par le haut, et réunies par le bas. Le conduit par lequel ils en sortent, aboutit à un orifice particulier situé au delà de l'anus, et cette conformation que l'on ne peut observer dans un grand nombre d'espèces de poissons doit étre remarquée. Ces mèmes aufs sont trèspetits, et par conséquent très-nombreux; néanmoins les sandats ne paraissent pas se multiplier beaucoup, apparemment parce qu'ils s'attaquent mutuellement, et parce qu'ils tombent souvent dans les fllets des pécheurs, particulièrement dans la saison du frai, où les sensations qu'ils éprouvent les rendent plus hardis et plus vagabonds. Ils ont cependant un grand moyen d'échapper à la poursuite des pécheurs ou des animaux qui leur font la guerre: ils nagent avec facilité, et s'èèvent ou s'abaissent au milieu des eaux avec promptitude, Ils sont addés, dans leur fuite du fond des eaux vers la surface des lacs, par une vessie natatoire placée. près du dos, qui égale presque toute la longueur du corps proprement dit, dont I'enveloppe consistedansune peau très-dure, et qui se sépare, du côté de la tête, en deux portions ou appendices, lesquels luidonnent la forme d'un cour tel que celui que les peintres représentent. Le canal pneumatique de cette vessie est situé vers le haut de la partie antérieure de cet organe, que I'on ne peut détacher que difficilement des parties de Vanimal àuxquelles il tient, parceque sa derniere membrane appartient aussi au péritoine. Le sandat meurt promptement, lorsqu'on le tire du lac ou de l'étangqui l'a nourri, et qu'on le met dans un vase rempli d'eao. Il expire sur. tout très-vite, si on le retient hors de l'eau, principalement lorsqu'une température chaude hato lê desséchement si funeste aux poissons, dont nous avons déja parlé plusieurs fois dans cet ou vrage. On ne peut donc le transporter en vie qu'a de petites distances, avec beaucoup de précautions, et lorsque la saison est froide; $e t$ 
(endant, comme le sandat est un des poissons . Les deux dents de devant de la mâchoire inféles plus précieux pour l'économie publique et rieurè surpassent les autres dénts en grandeur. privée, et de ceux qu'il faut le plus chereherà Ce poisson vit dans le Volga et dans d'autres introduire deproche en proche dans tous les lacs fleuves du bassin de la Caspienne :

etdanstous lésétangs. nousnedevons pas négli- "Le hober, que l'on trouve dans la mer d'Arager de recommander, avec Bloch, de se servir bie, a été bien moins observé que lé sandat. On

des cufs fécondés de ce centropome, pour ré- en doit la connaissance à Forskael. Ce poisson pandre cette espèce.

Immédiatement àprès l'époque oủ les mâles se seront débarrassés de leur laite, on prendra de petites branches sur lesquelles on découvrira des œufs de sandat; on les mettra dans un vase plein d'eau, et on les transportera dans l'étane ou dans le lac que Fon voudra peupler d'individus de l'espèce dont nous nous occupons, et où l'on ne manquera pas de fournir aux jeunes poissons qui seront sortis de ces $\alpha u f$ s de petit éperlans, des goujons, ou d'autres cyprins à petites dimensions, dont ils puissent se nourri sans peine.

On péche les sandats non-seulemeńt avec des filets, et notamment avec des collerets ou petites seines ', mais encore avec des hameçons et des lignes de fond. Il ne faut pas les garder longtemps dans des réservoirs, ou dans des bannetons, parce que, ne voulant pas manger dans ces enceintes ou prisons résserrées, il y perdent bientot de leur graisse et du bou goût de leur chair.

Lorsqu'ils sont morts, on les envoie au loin salés ou fumés, ou empaquetés dans des herbes ou de la neige.

- Nous croyous devoir rapporter à une variété du sandat, le poisson décrit par le célèbre Pallas dans le premier volume de ses Voyages, et inscrit parmi les persèques ou perches dans l'édition de Linnée, que nous devons au professeur Gmelin ${ }^{2}$.

Ce thoracin a tant de rapports avec le sandat et la perehe ordinaire, ou la perche d'eau douce, qu'on l'a regardé comme un métis provenant du mélange de ces deux espèces. Sa couleur á́nérale est d'un vert doré, relevé par des bandes transversales ou places noires, au nombre de einq ou six. On remarque aussi cinq bandes sur les dorsales, qui sont soutenues par des rayons très-forts. Les écailles sont grandes et rudes.

V. La description de la seine, t. 1 ; p. 551 . 'Pallas, It. 1, p. 461, D. 21 . - Percu colgensis. Linne, a reconde 6 melia. -15 rayons a la premiere dorsole, 25 la seconde, 6 chaque thoracine, is a la nageoire de la
queue. a les deux dorsales arrondies; le premier de ces deux instruments de natation, brunâtre, le second jaune, et toutes les autres nageoires jaunâtres.

Le safga habiteles mémes eaux que le hober On pèche dans la mer qui arrose la Caroline, l'alburne, que Catesby et Garden ont observé. Ce poisson est remârquable par la conformation de sa première dorsale, qui ne présente qu'un rayon aiguillonné, ainsi qu'on peut le voir dans le tableau générique des centropomes. II monsances. L'échancrure de sa eaudale est peu profonde. Sa couleur généralé est d'un brun clair; et sa longueur, de trois ou quatre décimètres. Le lophar a été péché dans la Propontide, auprès de Constantinople. II a beaucoup de rapports avec-le háreng, et par sa conformation générale, et pay ses dimensions. Des sillons longitudinaux sont tracés dans l'entre-deux de ses yeux: La base de la seeonde dorsale et celle de l'anale sont charnues, ou plutót adipeuses.

Le dos est d'un vert brun; et l'extrémité de la eaudale, noirâtre ${ }^{2}$.

Il est superllu de dire que l'arabique vit près des rivages de I'Arabie. On voit derrière ses yeux trois stries relevées et osseuses. La mâchoire supérieure est armée de six dents longues, droites et écartées l'une de l'autre. On en compte huitd'analoguesà la mâchoire inférieure.

M. Cuvier considère ce poisson comme une espèce dis.

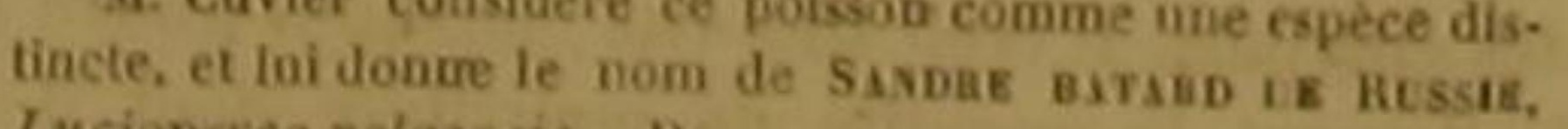
Lucioperea volgensis. D.

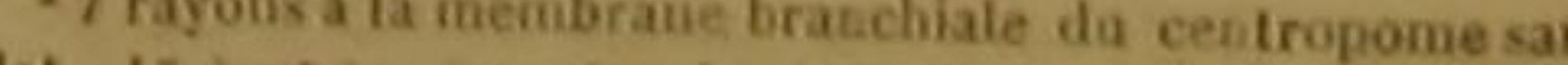
dat, 15 a cha jue pectorale, 7 a chaque thoracine, 22 a a pome biser 15 a cha a membrane branebiale da cenirorayons articates a chague thore, frayon aigutitonne et geoire de la quene. -22 rayous a ebaque pecturale du na. I6 rayous a dha pae pectorale di centropome lophar, I ravon - Fayons a la nageoire de la quene. - I 14 rayons à chaque pec-

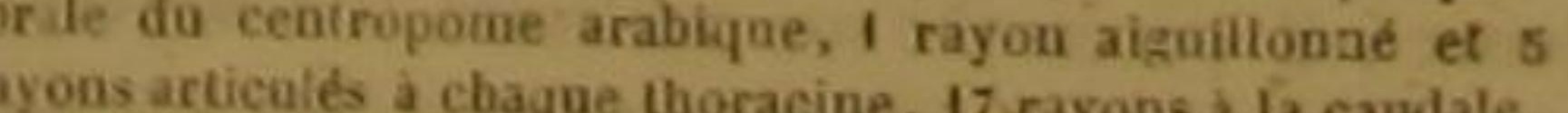
-5 rayons a la membrane liranchiale du ous a fi caciale. 16 a chaque jectorale, 1 rayó aiguillonné et 5 rayens aye. cutes a chaque thocacine, 16 rayous à la nageoire de la tre à sa máchioire inférieure einq ou six excroisiropome alburne, 6 a chaque thoraciue, $19 \mathrm{a} \mathrm{la} \mathrm{candte-}$ aizuillonoé of 5 rayons arliculés a chaque thoraciae, 17
La langue est lisse; mais le palais est hérisse de dents petites, déliées et très-nombreuses. Les deux segments de la caudale ont la forme d'un fer de lance, de mểme que lés pectorales. Les dorsales, les thoracines et l'anale sont triangulaires. Toutes les nageoires offrent d'ailleurs un brun mèlé de jaune, excepté la première dorsale, qui est brune; et une tache noire, bordée d'or, brille sur le milieu de ta queue.

La Méditerranée est la patrie du centropome rayé. Une petite pièce dentelée est placée audessus de l'extrémité de chaque opereule de ce poisson. La plus grande partie de la tete et lés nageoires sont jaunes ou couleur d'or.

\section{LE CENTROPOME LOUP',}

Labrax Lapus, Cur.; Perea Labrax, Lina.; Perea panctata, Gmel.; Sciana Labrax, BI., Centropomo Lupus, et Centroporaus Mfullus, Lac,

Le Centropome onse- rayons', Centroponus un lecimalis, Cuva, Centropoinas undecimqadiatus, Perea Loubina, ef

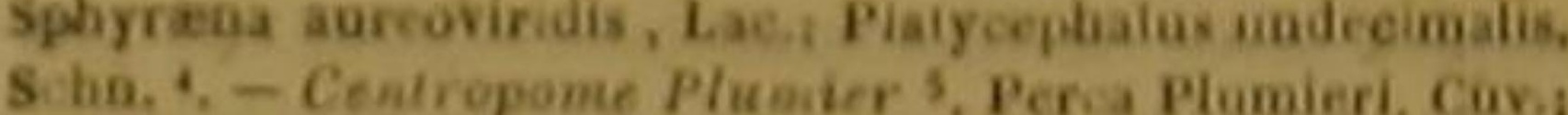
seiena Plumieri, Bta Centropomus Plumieri, et Cheilo. dipterus chryopterus, Lac 4. - Centropome Mula, La. brax Lupus, Cav, Centropomus Mullas, et Centropomu Lupus, Lac,

On trouve le loup non-seulement dans I'Adriatique et dans toute la Méditerranée, mais encore dans les eaux de l'Océan qui arrosent les

'Bar, Loubine, Brigne, sur les cátes do France voisines. de LOcéan ou de la Medilerranee. - Dreligny, Loupasson, Lubin ou lupin, dans plas. départ, merid.-Lapo, en Es: pagne. - Louvasso, dass la Ligarie. - Arañco, en Tos. cane. - Spigola, Lupasso, par les Romsios. - Bronchini. Varolo, a Venise, - Cavalla. a Bpalatro. - Salmbarach, Lachsumber. par ies Ailemands. - Basse, Bosse, par les An
glais. - Zee snoeck, par les Holl sndais. - Persegue loup. giais. - Zee snoeck, par les Hoilsudais. - Persegue loup.
Vaubeaton et Hany, Ene, meth. - Id. Bonnaterre, pl. de IEuc, meth. - Mos. Ad. Frid. 2, p. $82 \%$ - Gronov, Act. Upsal. 1750, p. 39, L. 4. - . Perca rafís pinnze doralis seCundx 15, ani 14. Artedi, gen. 41, syn. 69.-Sciéne loup. Bloch, pl. 501. - A a.6pass. Aristot., L. 1, c.5: 1. 4, c. 8 ; et I. 5, e. 9 et 10. -Id. slian. 1. A, e. 50, p. 56; I. 9. c. 7; 1. 10,

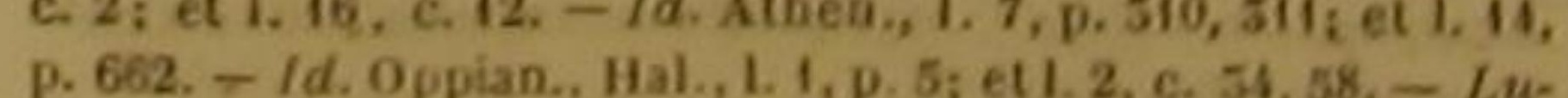
pus. Ovid. Hal, v. $25,58.112$. - Id. Varro, Rustic, L 3 , c, 5. - Id. Prín., 1. 9. c. 16, 17, 51, 54; et I. 32, c. 2. - Wot. ton, I. 8, C 77 , fol: 155 . - Loup. Bondelet. part 1. I. 9 , c. 6. - Salvian., fol. 107. 6. 108, 109.-Gesner. p. 506, et (germ.) fol. 57, b. - Aldroc,., 1. 4. c. 2, p. 491, 492. - Jons. hai, p. 85 - S pigolg, sive lupus. P. Jov caby, p. 274 . - Dn genre BAB, Labrax, CaY, dons la fonfle des. thoptéryg:ens percoides. IL. de Lactpede a séparé a tort do ce poisson, le centroporue mal à qua décrit dians le mérne
artiele. D. cotes de l'Europe, particulièrement dans le golfe de Gascogne, dans la Manehe on canal de France et d'Angleterre, et dans le golfe Britannique, Il devient grand; et, selon Duhamel, on en prend quelquefois auprès de l'embouchure de la Loire qui pèsent jusqu'á quinze kilo. grammes. Il se plait dans le voisinage des fleu ves et des grandes rivieres; mais il ne s'engage que rarement dans leur lit. Il a la chair trèsdélicate et par conséquent il doit étre très-recherché. Les anciens Romains le payaient trèscher; ils le comptaient, avee la murénophis hélène, le mulle rouget, l'acipensère esturgeon, et le muge, qu'ils nommaient Myxo, parmi les poissons les plus précieux. Ils désiraient surfout de montrer sur leurs tables, et dans leurs festins les plus splendides; les loups que l'on prenait dans le Tibre, entre les deux ponts de Rome: Cependant on a toujours dỏ préférer, suivant Rondelet, ceux de ces poissons qui viventauprès de l'embouchure des fleuves à ceux qui remontent dans les rivieres, ceux que l'ontrouve dans les étangs salés à ceux que l'on prend aupres de l'embouchure des fleuves, et ceux que l'on rencontre dans ia baute merà ceux qui ne quittent pas les étangs salés. Au reste, Pline nous apprend que les anciens gourmets de Romé et d'Italie attachuient moins de prix aux loups ordinaires qu'â ceux 'qu'ils nommaient laineux (lanati), à cause de leur blancheur, de la mollesse, et vraisemblablement de la graisse de leur chair.

C'est auprès des endroits oủ les rivières se jettent dans la mer que le loup dépose ses aufs, quelquefois deux fois par an. Ces oufs ont ét souvent employés, comme ceux d'autres poissons, à faire cette préparation que l'on nomme boutargue ou botargo.

Ce centropome est très-hardi : il est de plus très-vorace ; et voila pourquoi on lui a douné le nom de Loup. Il nage fréquemment très-près

$\because$ Seimas undecimalis. , Bloch, pli 305

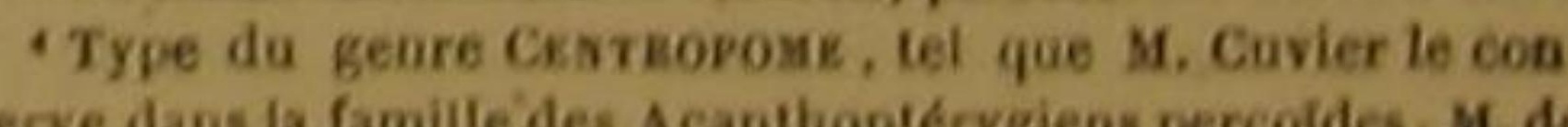
ackpede a decrit ce poisson trois fols sons les nomes de Centropome onse-rayons, de Peraique loubine, et de Sphy. réne oreerd. $\mathrm{D}$.

s. Sciene sirié, scima Plumierii, , Bloch, pl 306. - Da geare Pescas, type de la familte des Aesatbopitery. gieus percoldes, seion a. Cuvier. Ma, de Lacepede a decril deux fois ce poisson, sous ies noms de Centropome Plumier,

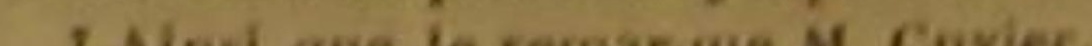
Le Lacépede est manifestement de la méme enpece que lo centropome bap, décrit daus le méme article. D. 
344

HISTOIRE NATURELLE

de la surface de la mer. Plusieurs auteurs anciens se sont plu à lui attribuer la finesse de l'instinct, aussi bien que le courage de la force; et ils ont écrit que lorsqu'on voulait le prendre avec des filets, il savait creuser dans le sable, en agitant vivement sa queue, une sorte de sillon dans lequel il s'enfonçait pour laiśser passe au-dessus de lui la nappe verticale dans laquelle on cherchait à l'envelopper.

On le pêche pendant toute l'année, et avec plusieurs sortes de filets; mais la saison la plus favorable pour le prendre est communément la fin de l'été.

Nous avons exposé ses principaux caractère extérieurs dans le tableau générique. Nous aurione pu y parler encore d'une tache noire que l'or yoit à la pointe postérieure de chaque opercule de ce centropome.

On compte six ceecums auprès de son pylore; son foie prèsente deux lobes ; sa vésicule du fiel est grande; et sa vessie natatoire, qu n'offre aucune division intérieure, est attachée aux cótes.

La Jamaique est la patrie du centropom onze-rayons, qui y vit auprès des fonds pierreux. Ce poisson a la nuque très-relevée; les dent très-petites, nombreuses et serrées ; l'opercule terminé par une prolongation un peu arrondie, et surmonté par derrière d'une petite pièe écailleuse et dentelée; le corps gros ; le vent rond; le dos arrondi et bleuảtre; les cótés argentés; les pectorales et les thoracines d'un rouge brun; la caudale grise ou bleue à son extrémité.

La mer des Antilles nourrit le centropome plumier, qui, par conséquent, habite très-près du onze-rayons. Bloch en a publié la description d'après un dessin de Plumier, le célèbre voyageur et l'habile naturaliste. Les deux mâchoires de ce thoracin sont aussi avancées l'une que l'autre; le dos est brun; les nageoires sont jaunes; la première dorsale est bordée de brü ou de noir?

Is rayons a la membrané branchiale du centropome loup. 18 a chaque pectorale, 1 rayou aiguillonoé et 5 rayons artien. ba meirtrane branchiale du cens a b caudale. -5 rayous a chaque pectorale, 1 rayon aiguiltomene et 5 rayerayons, 15 i chaque thoracine, 18 rayons a ta nagenire de ia minenes is rayons a chaque pretorale da centropome plumier. rayon ajguillonné et $\delta$ rayous articulés á chaque thoracine, rayons a la caudale. -15 rayons a claque pectorale du geoire de la queue, 21 rertebres.
J'ai reçu de MM. Noēl de Rouen et Métaihe, la description du poisson auquel j'ai conservé le nom de Mulet, qui lui avait étè donné par ces observateurs, et que j'ai dú placer dans le genre des centropomes d'après sa conformation. Ce thoracin abandonne la mer pour remonter dảnś les rivières, lorsque l'été succède au printemps: Le temps le plus chaud parait étre celui qu'il préfere pour ce voyage annuel, qu'il termine lorsque l'automne arrive. Il est très-commun dans laSeine, dèpuis le solstice de l'été jusqu'à l'équinoxé de l'automne. Sa chair est excellente un mois après son entrée dans l'eau donce. Il se nourrit de débris ou de résidus de corps organisés. Il va par troupes très-nombreuses : aussi en prend-on quelquefois quatre ou cinq cents d'un seul coup de filet. Ses mouvements sout très-vif́s; et les sauts elevés et fréquents qu'il fait au-dessus de la surface de la rivière, l'annoncent de loin aux pècheurs. Lorsqu'on le trouve dans une eau bourbeuse, on le pêche avec la sèine; mais lorsqu'il est dans des eaux très - claires, on cherche plutôt à le prendre avee le filet nommé vergaut. Il parvient souvent à la longueur de six décimètres; et alors il a plus de trois déeimetres de tour dans la partie la plus grosse de son corps. Chacun de ses opereules est composé de trois piècés. Sa langue est large, et son palais lisse dans presque toute sa surface. Six appendices sont placés auprès de son pylore. Sa vessie natatoire a près de deux décimètres de longueur.

\section{LE CENTROPOME AMBASSE, ';}

Ambassis Commersonii, Cuv.; Lufjanus gymnocephaLass, Centropomus Ambassis, et Centropomus Safga,

Ceniropome de Roche', Dules rupestris, Cur.; Cantropomus ropestris, Lac. 4. - Centropome Macrodon ", tws, et Cerus octovituatus, Cav.; Cheilodipterus lineadore'? Apogon Centropome rouge ' Myripristis trens aurens, Lac. " tropomus ruber, Lae io

Les cinq centropomes dont nous allons parler ontété observés, par Commerson, dans les eaux 1. Aspro ambassis (le deux sons) Tambasse du Goll) dorso : primx, feré obsoletá, ventre per transpice pinne dorsalis c argenté albicinte, , Commerson, manuscrits deja citone ${ }^{2}$ Du genre Aubusse, dans lik famille des Acanthoptéry-

DES POISSONS.

545

douces des iles de France et de Bourbon, ou dans la mer qui en baigne les rivages. La description n'en a encore été publiée par aucur naturaliste.

L'ambasse se trouve dans rétang de lille Bourbon sur le bord duquel on voyait, du temps de Commerson, un château nommé Gol. On pèchait dans cet étang un grand nombre d'individus de cette espèce. Leur longueur était presque toujours au-dessous de deux décimètres; mais ils étaient cependant très-recherchés par les habitants de l'ile, qui les préparaient d'une manière analogue à celle dont on prépare les anchois en Europe, les employaient également à relever le gont des mets; et les trouvaient méme d'une saveur plus agréable et plus appetissante que ces derniers poissons.

L'ámbasse a deux callosités sur la partie antérieure du palais, et une tache noire, quelquefois très-faible, au plus haut de la première dorsale, qui est triangulaire.

Le centropome de roche parvient a des dimensions plus considérables que l'ambasse : il est souvent long de quatro ou cinq decimetres. Il se tient dans les eaux douces, ou auprés des embouchures des rivieres. Commerson l'a vu particulierement dans la ravine du Got de I'ile Bourbon. Sa chair est de très-bon goùt. De

siens percoides, Cav, M. de Lactpede a décrit ce poisson. 10 sous te nom de Luijan gymnocephale, $2 \%$ sous reloi de Centropome anbasse, et $3^{\circ}$ probabiement cacure, sous $\mathrm{A}$ denomination de Centropome safga. S Vuyex ci-dessus
page 540). D. page 5to). D. Aspro domat

- Aspro dorso dipterygio cerrulescente, kquamis laterum, 'capile utrinque majoribus et frequentioribus., Idem, itid. Dir geore borces, Dutes, dans la famille des Acanthop.

- Aspro dorso dipterygio, dentibus raris at longis et : exertis, corpore fatilis f
:que lineato. I Idem, ibid.

- Da genre Carilopiptiaz de M. Cuvier, dars la famille des Acanthopterygiens percoides. M. de Lacépéde a décrit ce poisson deux fois, sous les nams, IT de Cheilodjptére raye, et $2^{*}$ de Centropome macrodon. D.

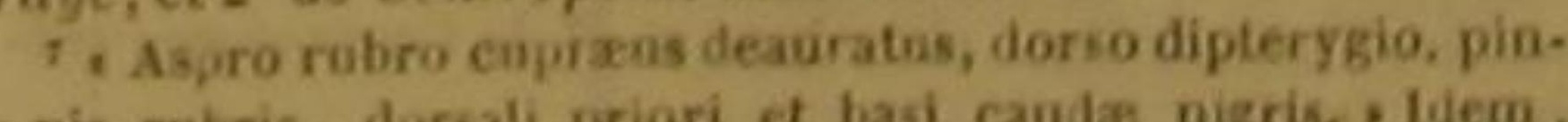
ibis rubris, dorsali priori et basi cauda nigris., luem. - Du geore Apocos, dans la famille des Acantlopterygiens pércoídes, selon M. Cuvier, qui n'en détermine pas liespice. $\because$ Aspro totus rubens, pinnarum posteriorum marginibus albis, postioo operculorum branchialium limbo atrato. Idem, itid.

(Acanth. percoides). et crovit qu'elle est ideiti jue avec son Myripristis becazone. si cela est, ce poisson a elé décrit une seconde fois par M. de Laópede, sous le nom de Lutjan seconge fois pas
hexagons. D petites taches noires sont répandues sur lés opereules; les éeailles qui garnissent le dessous de la poitrine ne sont noires qu'à leur base; une nuance brune, plus ou moins foncée, est répandue sur les nageoires et sur la membrane des branchies; et la caudale ne présente qu'une légère échanerure.

Le maerodon n'a pas ordinairement trois de. cimètres de longueur. Plusienrs dents très-petites sont placées dans les intervalles qui sépa rent les grandes dents de la máchoire inferieure. La lève d'en haut pent s'étendre a la volonté de l'animal. Le palais est relevé par deux bosses, dont la postérieure est hérissée de petites dents : on n'en voit pas sur la langue, qui s'arrondit et s'élargit un peu par devant. Les yeux sont tres-grands; les écailles larges, et faiblement attachées à la peau; les secondes pieces des opercules anguleuses do cóté de la queue le péritoine est argenté.

Le centropome doré ne parvient qu'à de pe tites dimensions: Il a été vu très-souvent par Commerson, qui cependant ne lui a jamais trouvé nò longueur égale à deux décimètres. Le centropome rouge est long de plus de trois décimètres. Sa saveur est très-agréable au goùt, et sa parure des plus riches; toute sa surface présente un melange de rose, de rouge et de doré, relevé par une trés-grande variété de reflets, par un liséré blane qui borde une grande partie du contour de la seconde dorsale, des pectorales, de l'anale et de la caudale, et par une superbe tache noire placée a l'extrémité de l'opercule et a la base de chaque pectorale. Les nuances de ce beau centropome brillent d'au. tant plus, que les écailles qui en réfléchissent l'éclat offrent une grande targeur '. La dentelure de ces écailles est d'ailleurs si forte, que l'on ne peut toucher le poisson sans étre blessé, a moins que la main n'aille dans le sens de la tête à la queue. Toutes les lames qui revétent la téte, sont aussi très-dentelées, dans leur circonférence, La mâchoire superieure, dont le poisson peut étendre la levve, parait comme

- 6 rayons a la membriane branchiale du centropome am. bass, is a chaque pectorale, 1 rayon ajguilonae et 5 raygus becterale. I rayon aignillonné et s rayons articulés claque thàrae ne. 17 rayonis a la caudale, -7 rayons 2 la wembrabe branchial du centropome macrodon, 12 a chaque pectorale, 6 a cluyge thoracine, 17 a la aageoire de la que ue. -7 ayons it 1

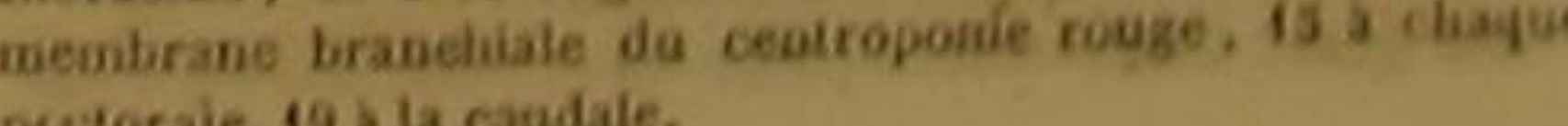


tronquée lorsque l'animal ne meut pas cette orientales, ce centropome dont la mâenoire inIère d'en haut. Ontre les huit grandes dents férieure est plus avancée qué la supérieure, et indiquées par le tableau générique, le centro- dont la tête, le corps et la queue présentent six pome rouge a un grand nombre de petites dents raies blanches de chaque côté.

à chaque máchoire et auprès du gosier; mais M. Noēl nous a envoyé une description et son palais est lisse. Les yeux très-grands relati- un dessin de cé poisson '

vement au volume de la tête, ont de diamètre le neuvième, ou a peu près, de la longueur totale du poisson. Deux plaques écailleuses et dentelées sont situées de chaque côté, au-dessus de l'ouverturé branchiale; et la ligne laterale est composée d'une série de tres-petites lignes.

LE CENTROPOME NILOTIQUE ',

Lates niloticus, Cur.; Perea nilotica, Lino., Gmel. Centropomus uiloficus, Lac. ${ }^{3}$

ET LE CENTROPOME OEILLE் 3.

Corvina ocellata, Cur.; Perca ocellata, Limo., Gmel.; Sciæna imberbis, Mitch.; Latjanus tráagulum, e Centropomus ocellatus, Lac. ‘.

Le nilotique habite dans le Nil ; mais on I trouve aussi dans la mer Caspienne. Ses deux nageoires dorsales sont très-rapprochées l'une de l'autre.

L'aeillé a été observé dans la Caroline par le docteur Garden. Le premier rayon de la premièredorsale et celui de chaque thorasine sont rès-courts. On ne voit qu'un petit intervalle entre les deux nageoires du dos ${ }^{5}$.

\section{LE CENTROPOME SIX-RAIES.}

Grammistes orientalis, BI., Cuv.; Seiæna vittata, Perea triacautba, Perca peatacantha, Bodianùs sex-linéatus, et Centropomus sex-lineatus, Lac. '.

On a péché daus la mer qui baigne les Indes 'Mus, Ad: Frid? 2, p. 8s:- - s. G. Gmelin, H. 5. p. su. - Persegue brune. Daphenton et Hagy, Bn.. H. 359, n.8 Bonnaterre, pl. de l'Euc. meth.

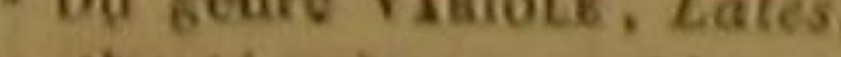

Acantapherys cas percordes, Cur. D. Hay, Enc. méth. - Id. Berersyue basse. Daubentón

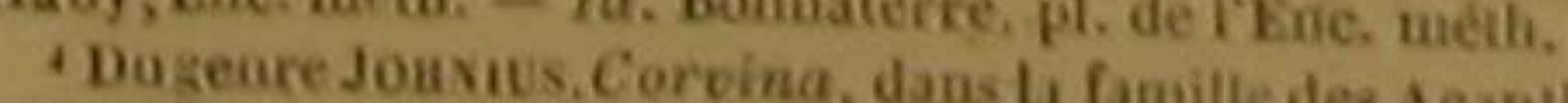
téryziens sciénoldes, Cur. M. de Lacépede a décrit déns fors

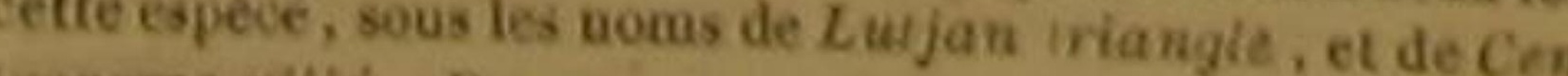
ropome cillie. D.

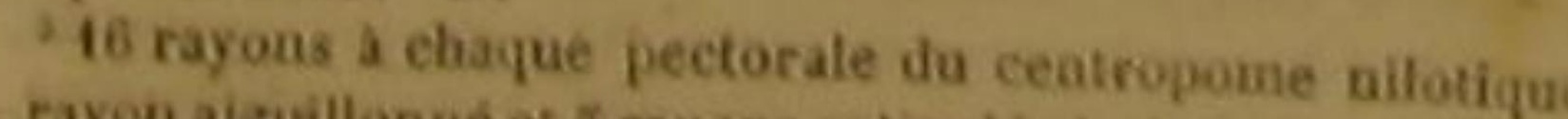

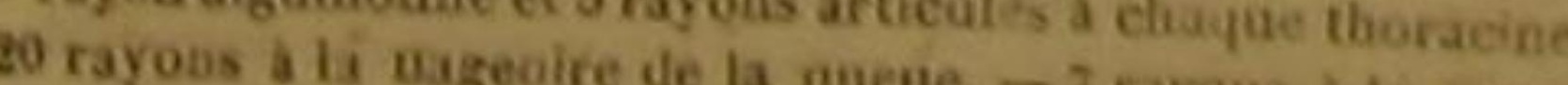

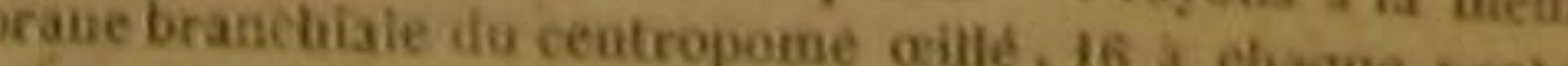

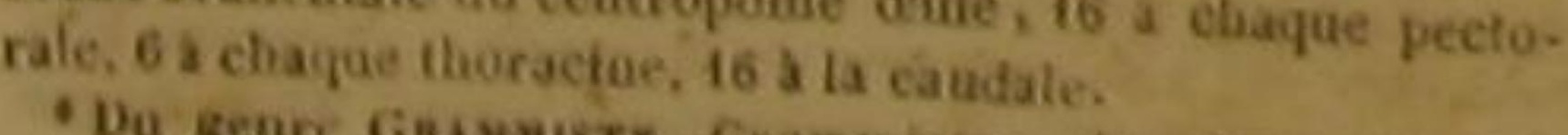

\section{LE CENTROPOME FASCÉ ${ }^{2}$,}

Centropomus fasciatus, Lacep. "

ET LE CENTROPOME PERCHÓT

Centropomus Perculus, Lacep. ?

Nous avons trouvé dans les manuserits de Commerson, la description de ces deux centropomes que les naturalistes ne connaissent pas encore.

La couleur générale du perchot est d'un gris brun qui se méle sur le ventre avee des teintes blanches; les thoracines sont jaunattres; I'anale et les pectorales sont variées de jaune et de brun; Piris est brun dans sa partie superieure,

et argenté ou doré dans le reste de sa surface.

\section{CENT DIX-HUITIEME GENRE.}

$$
\text { LES BODLANs * }
$$

Un ou plusieurs aiguillons et point de dentehre aux PREMIER SOUS-GENRE.

La nageoire dela quewe fourchue ou en croissan. sspecces. cassctèuss.

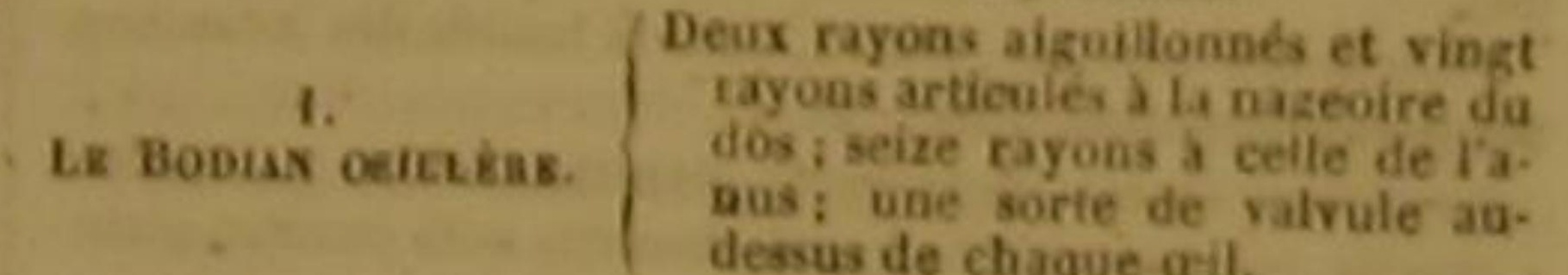
Acanthoptings

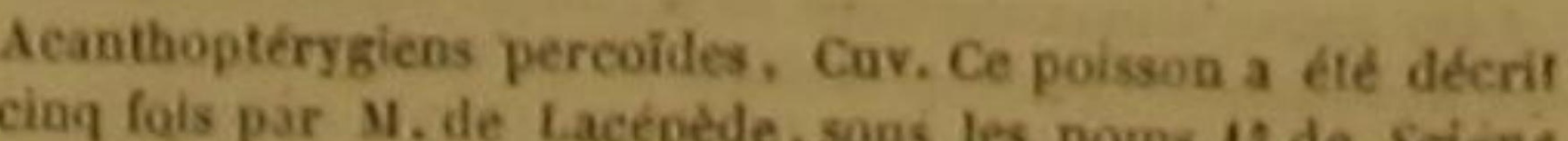
rayce, $2^{2}$ de Perségue triaconthe les noms 10 de Scine ranthe, $4^{\circ}$ de Bodian six-raies, et $5^{\circ}$ de Centropomenta. aies. D.

- 6 rayous a ia membrane branchiale du centropome six. raies, 15 a chaque pectorale, 1 rayon aiguillonné et 5 rayons

$\because$ Perea dorso đipterygio, ete. , Commerson, man. deja 'Non mentionne par s. Curier. D. ¿ Perca donso dipterygio, cauda medio productiori, etc., Commersoa, man. deja cittes. - Cuvier ne cite pas ce poisson. D. opercules; un seul barbillon, ou point de barbillon
DES POISSONS.

347

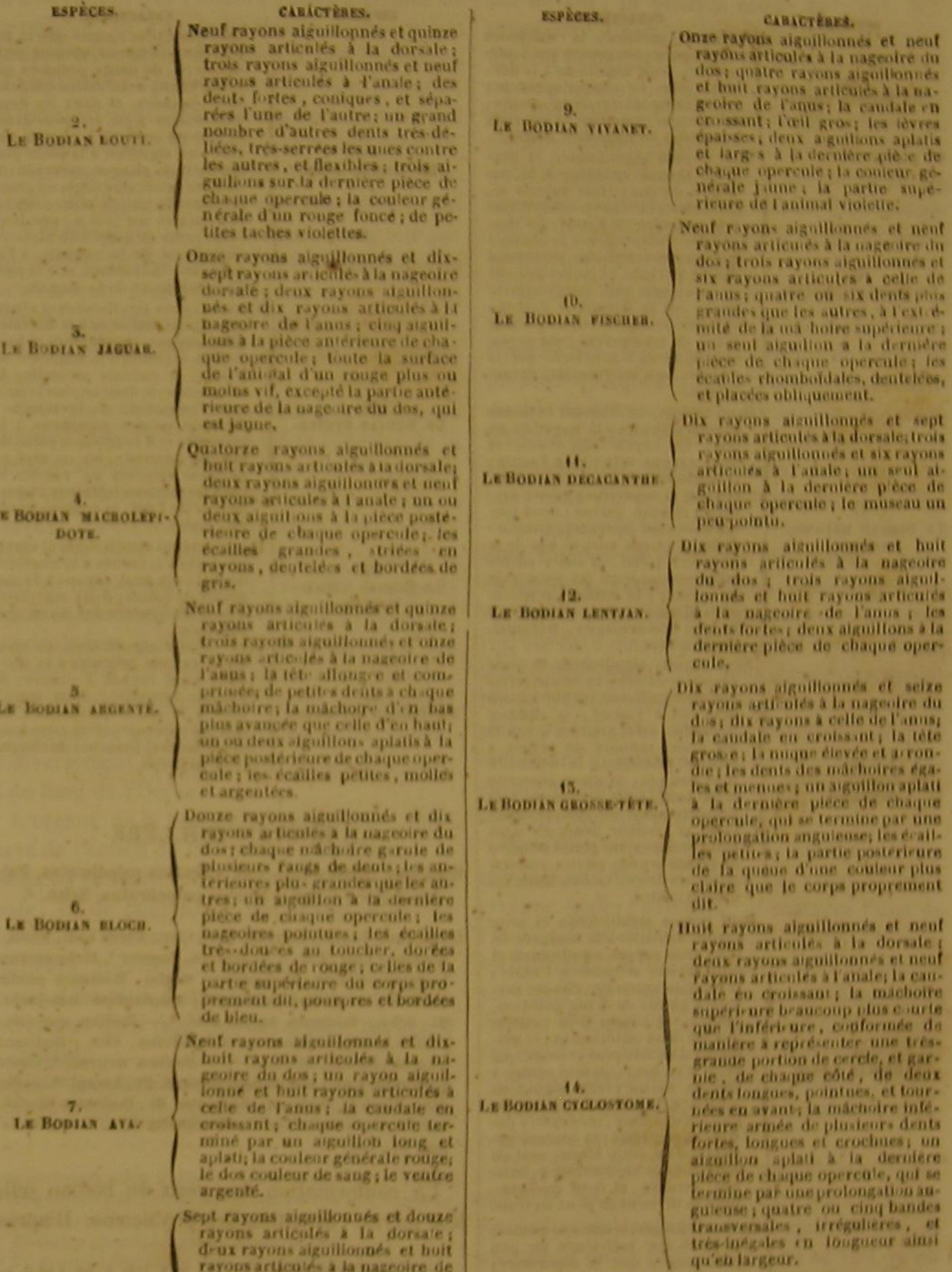
DEUXIĖME SOUS-GENRE.

Le Bobus xicatete.

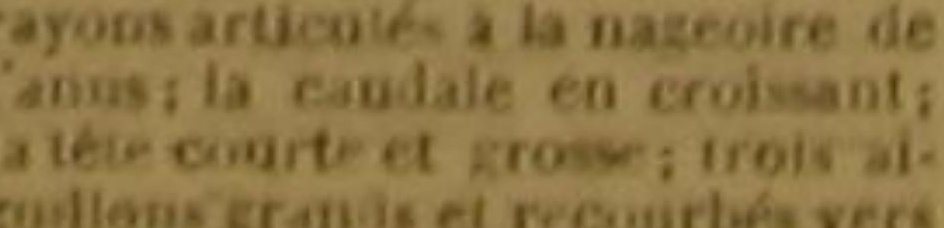

La nageoire de la queue rectiligne ou arrondie, a non 
HISTOIRE NATURELLE

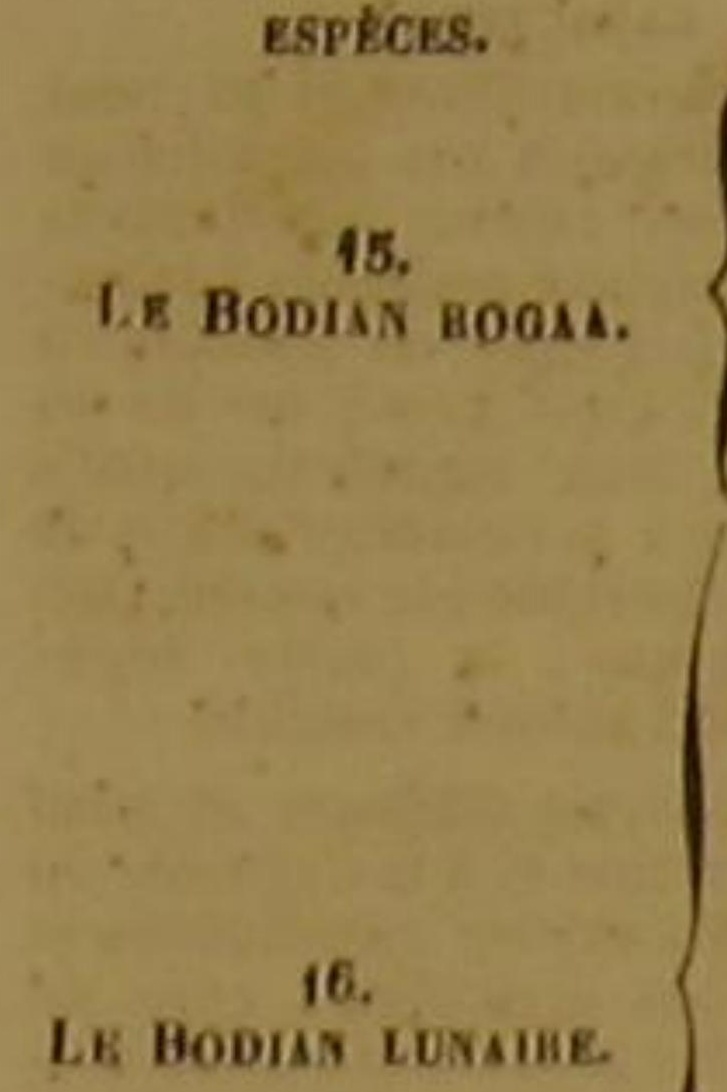

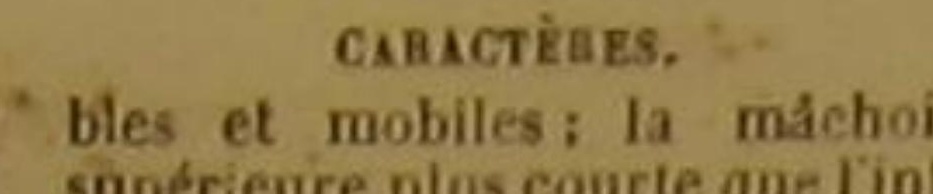

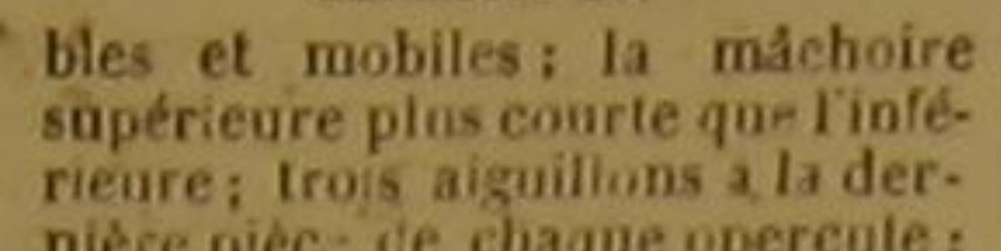

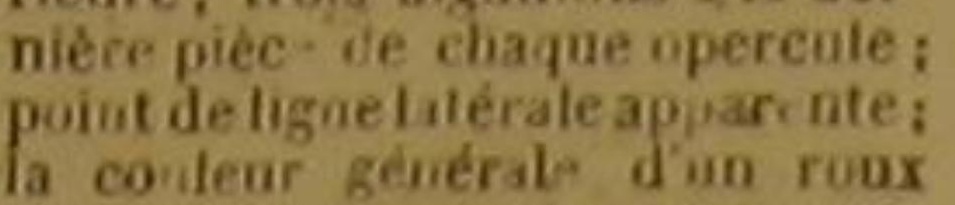

Neuf rayons aiguiloones et et dix-
neat rayons articoles a la na-

neat rayons articules a la
ecoire dn dos; Irois rayons

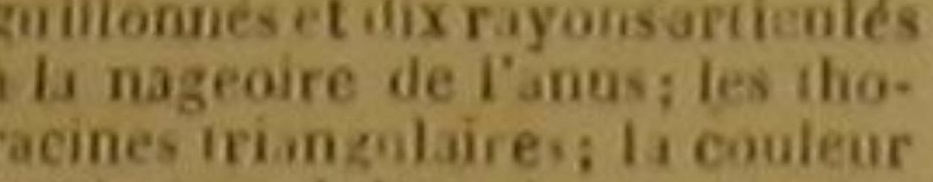

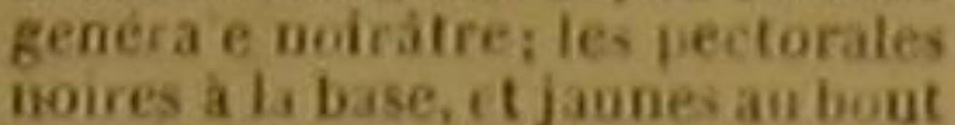

oppose; une raie longitidina
rouge sur ta dorsale ei I Imale

bane et tranaparent; nit crois
sant blanc et transparent sur caudale, qui est roussitre etrec

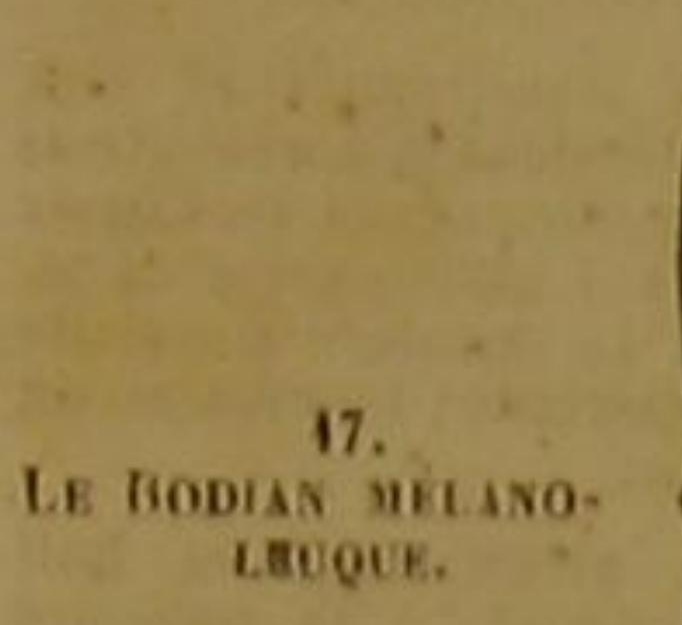
rat rayons aiguillonnés el douze
rayourticuiés a la nageore du dos, un rayon aigugeome

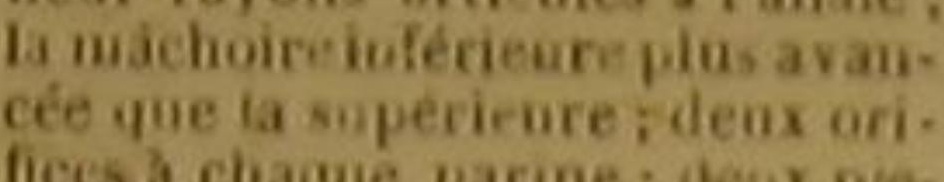
ces a cha pue opercele; i troos al.

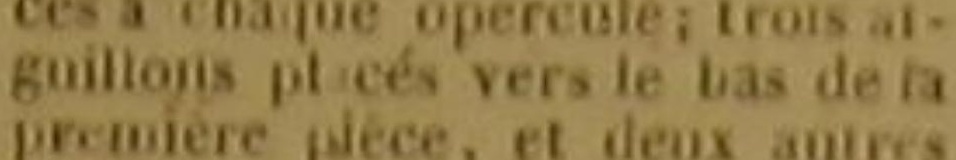

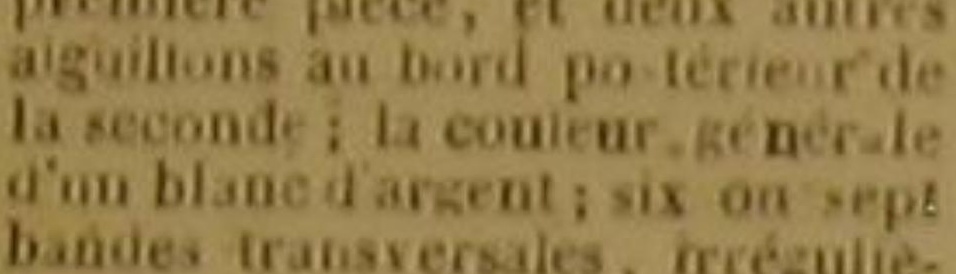
bandes train
res et noires.

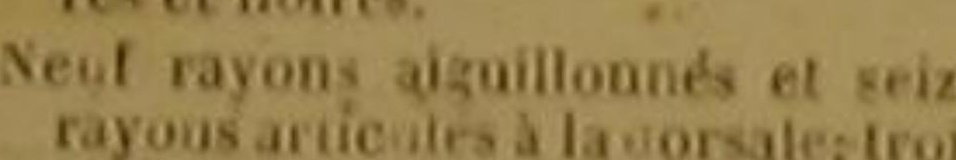

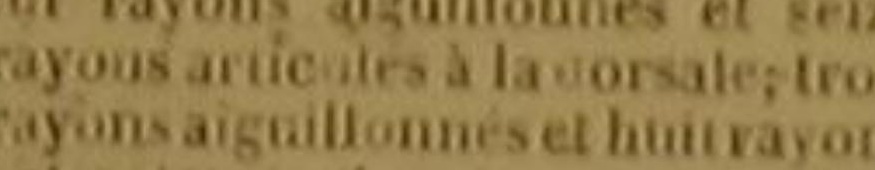

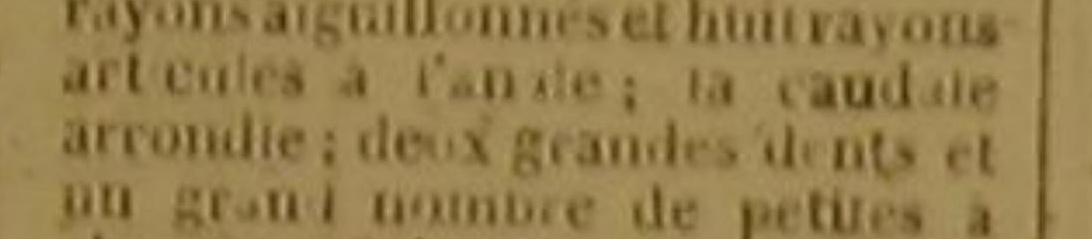

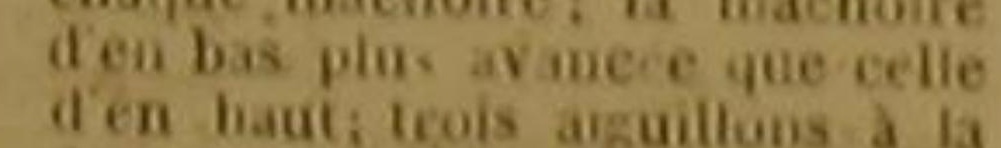
dermero piece de chaque oper-
utes la coud

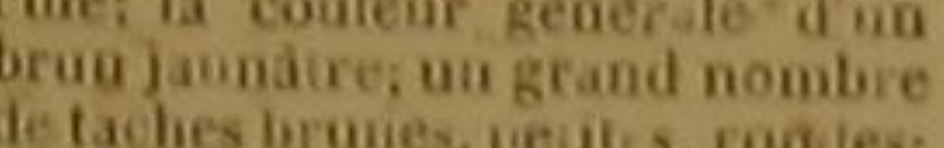
plosiens de ces taches boaces
dang le centre.

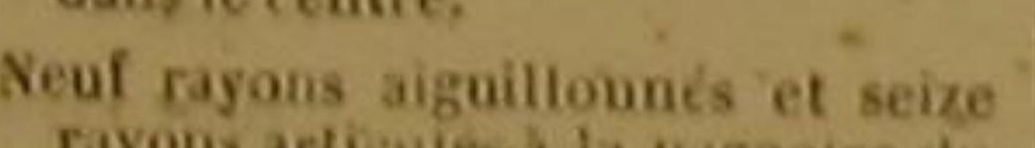

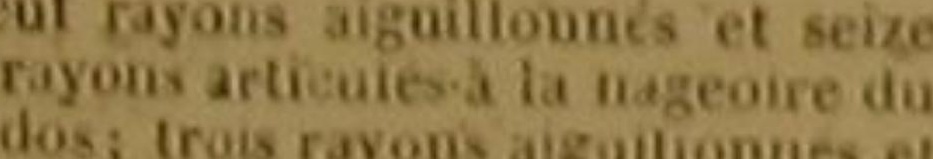

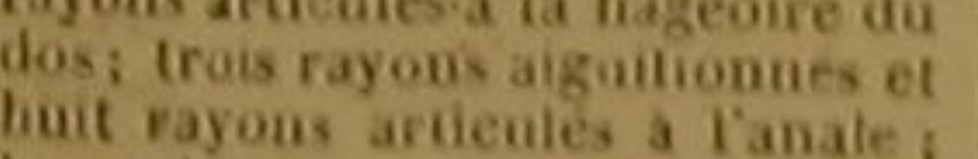

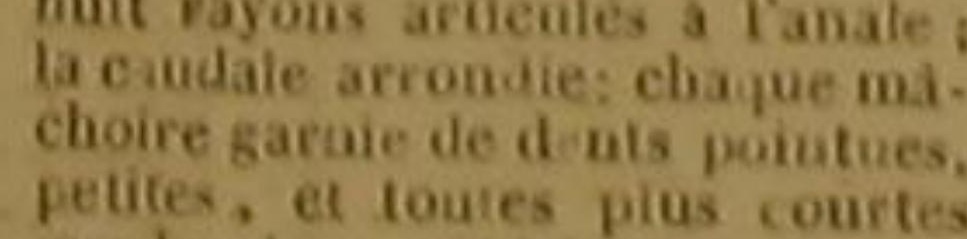

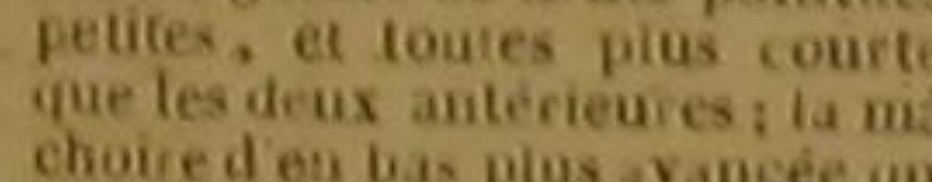

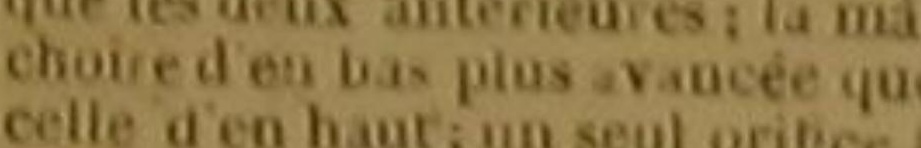

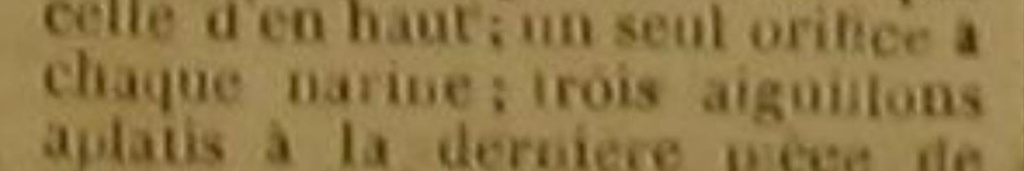

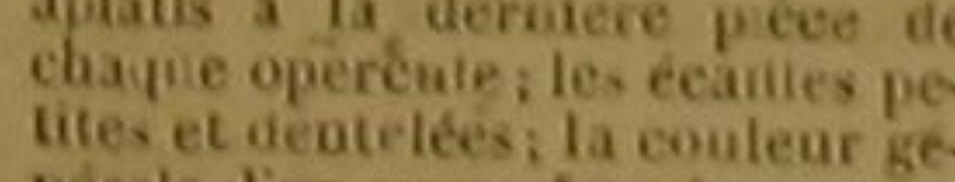

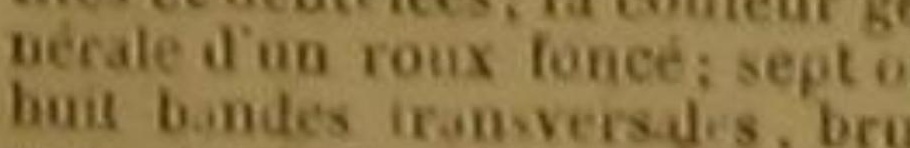
nes, éroites, et dont queique
unes se divisent en deux ou rois.

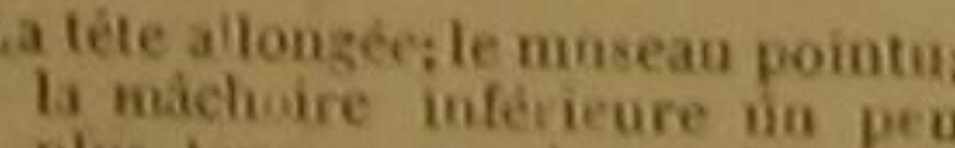

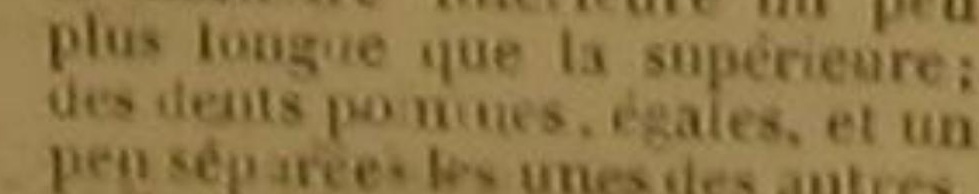

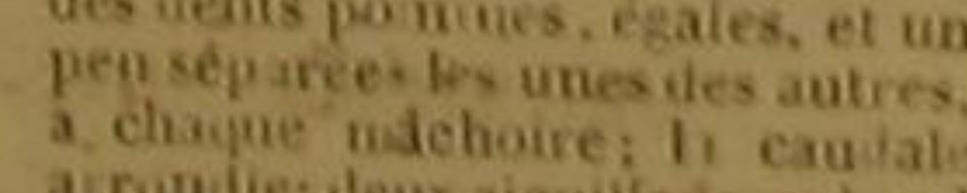

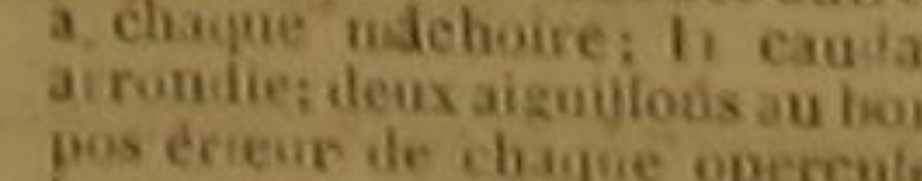

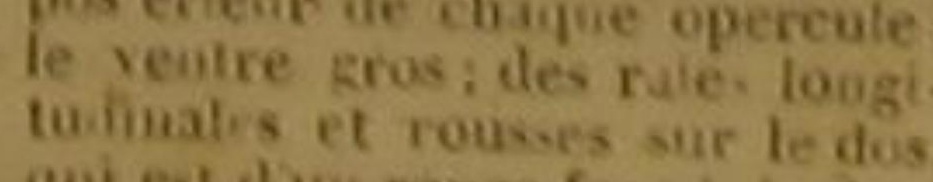

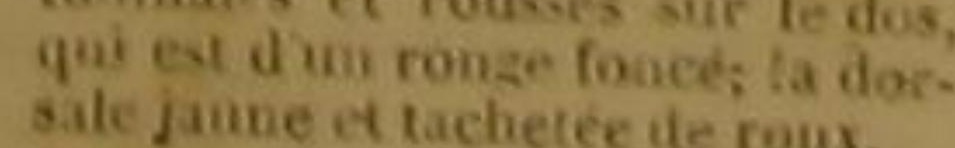

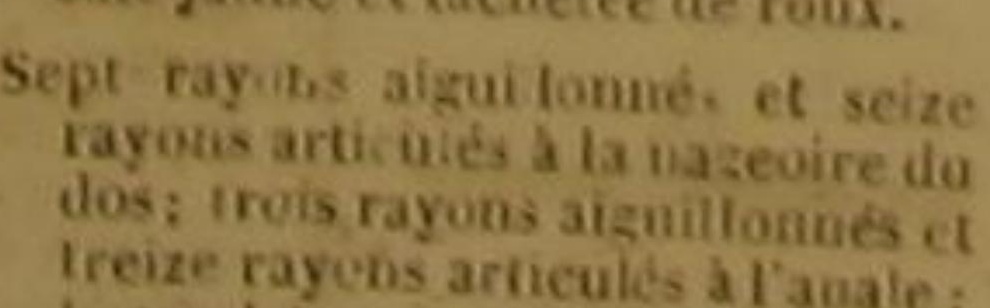

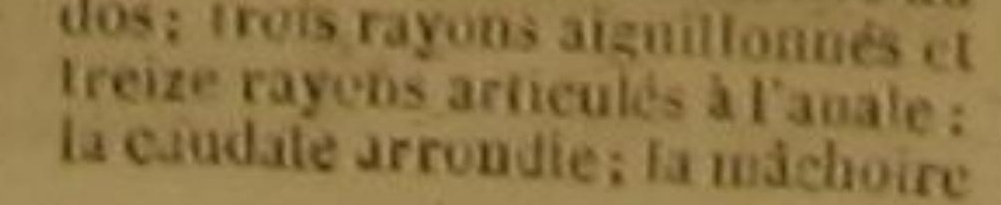

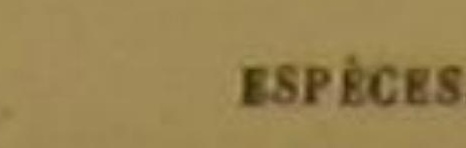

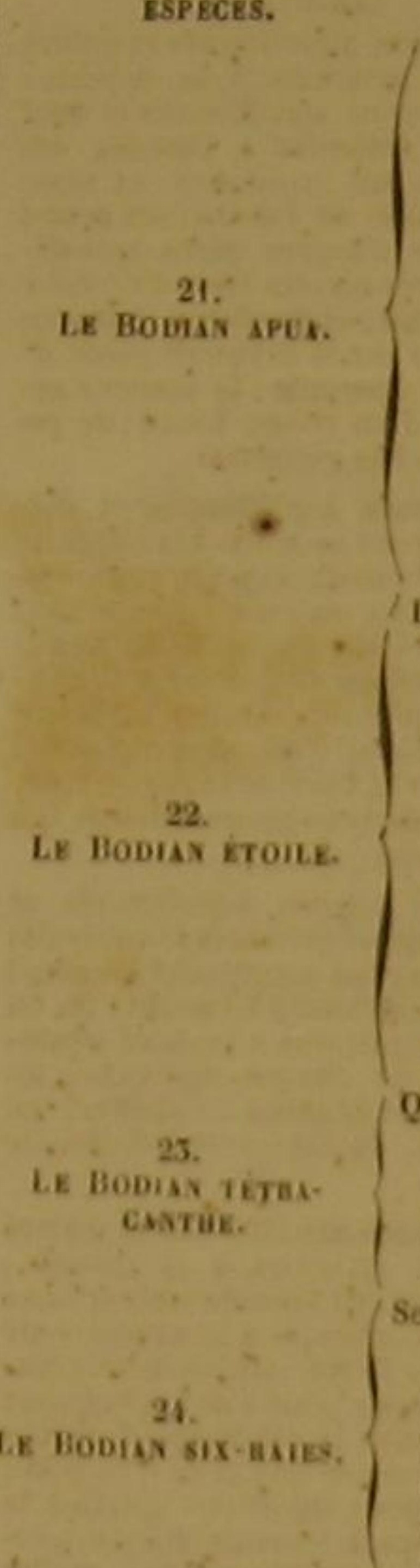

CABsctikses.

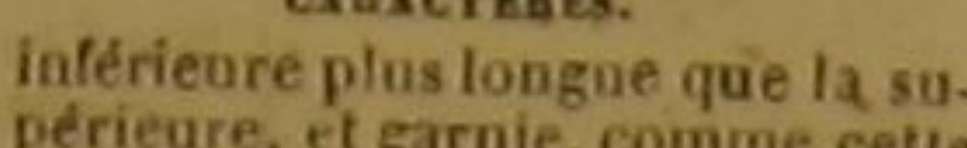

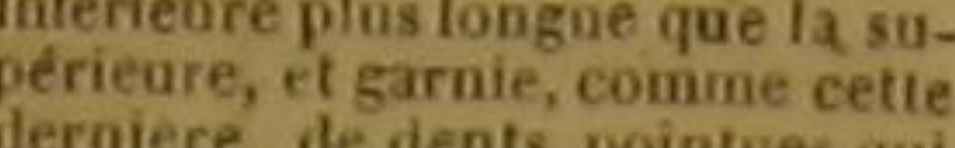

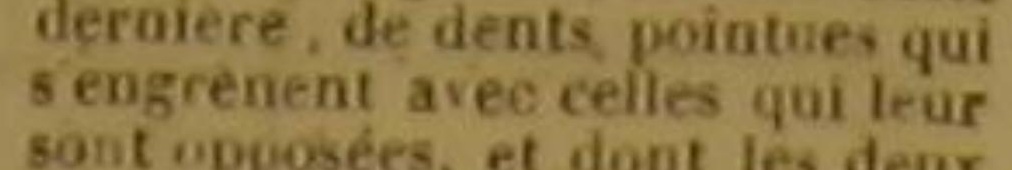
sont upposées, et dont les deux
antérieires sint les plus gran.
des; deux orifices a a chayue na. rime; un aiguillon a la piece pos:
téreure do chaqne opprcule ila coulear générale rouge; un grand nombre de points noirs; des tadure noire et lisérre de blane,
lestrénilé de la coudale. a Faale, anx thoracines, et a la par-
lie posterieure do la dorsale.

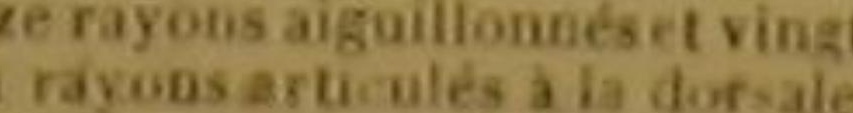
cyyous articulés a la nazeset benit anus; la cauiale arrondie; ia Tue louverture do la bouche trois on quatre aiguilions a premiere et a laseconie piece de
chague operent

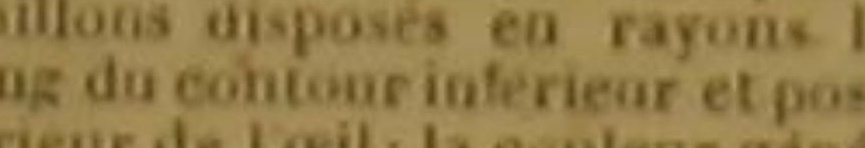

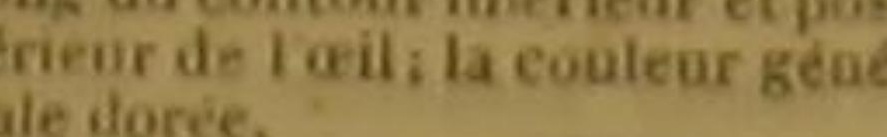
Quatre rayons aiguillonnés et vingt.
Wid ravons articolés a la nageoir-

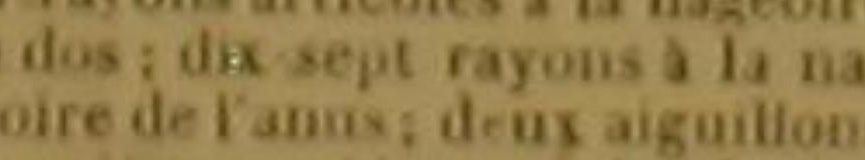
ath piece posterieure de clisque orze rayous artieniess a is gor. cie: neut rayous i ranale; ia

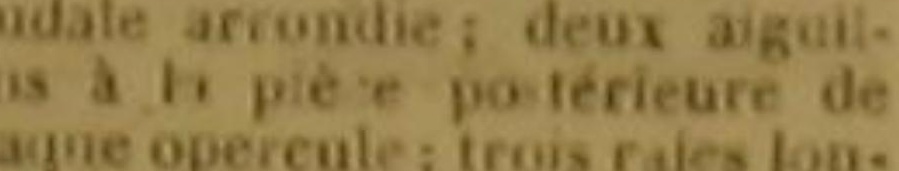
gitudinales et bianches de chaque

LE BODIAN OEHLERE '

Bodianus palpebratus. Lac,; Sparus palpebratus, Pallas,Linn.; Gmel.; Kurtus palpebratus, Schn. ?.

Le Bodian Louti ', Serranus Luti, Cuy,; Perca Luti, Forsk. Longipinue, Cav,; Hofocentras sogho, Bodiagnes pentacanthus et Seizna rubra, B1.; Amphiprion Matejuelo, Bl.. Schn.; Bodianus Jaguar Lac, '- - Bodian mgerole.

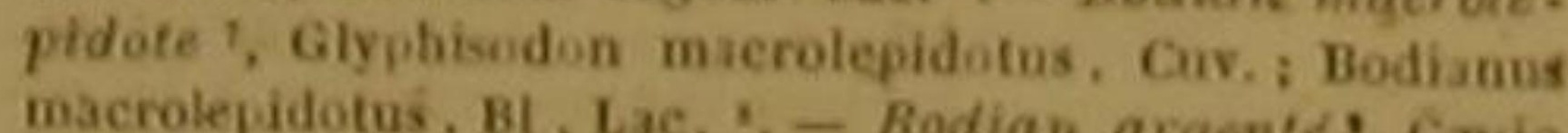
argentens, Cuv.: Bodianos argentews. Bi, argente ", Cresto dim Bloch ", Bodianas Bodianus, Bl.; Bodian. "O, - Bo. Lac. '2. - Bodian Aya ", Mesoprion Aya, Cuv,; Bodis. nus, BI, Lac, "4.

La conformation des yeux du bodian oillère mérite l'attention des physiciens. D'après

. Pallas. n. Nord. Beytr. 2, p. 55, n. 1, tab. 4, tig. 1 et 2.spare aillère. Bonnaterre, pl. de rEnc., méth. selon M. Cuvier, on ue peut encore, faute d'observation, placer le bodian aillere de cet article, poisson trés-singu'Forskacl, Fauo. Arab., p. 40, D. 40, - Persigue louti.

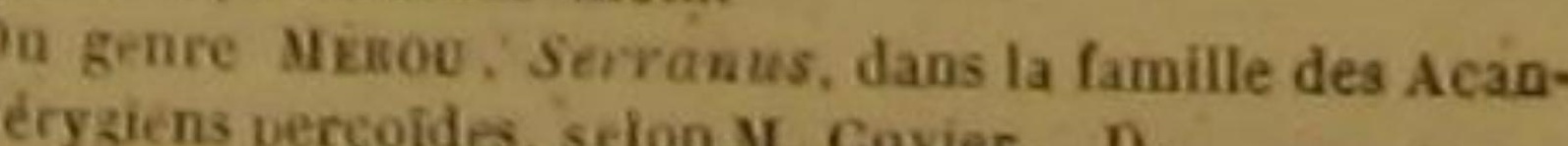

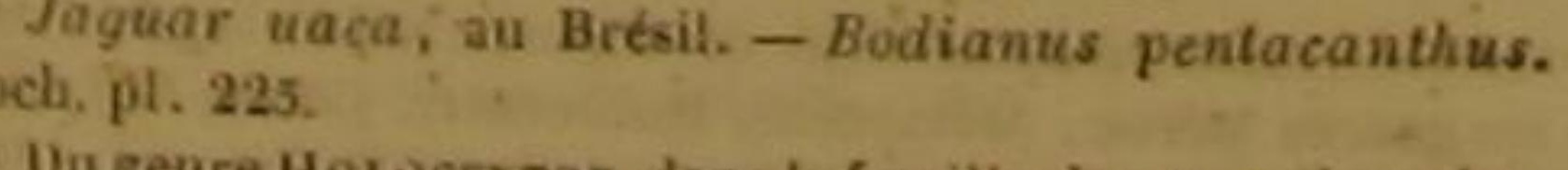

\section{DES POISSONS.}

la description que l'illustre Pailas a donnée de ce poisson, et d'aprěs un dessin colorié que te célèbre naturaliste Boddạert a fait lui-mème, et qu'il a bien voulu m'envoyer dans le temps, ce thoracin présente au-dessus de chàque oxil une pièce membraneuse un peu ovale, qui n'est attachée que par son extrémité antérieure, sur laquelle elle joue comme sur une charaière, et qui en s'écartant ou se rapprochant de la tète par son extrémité postérieure, et en s'abaissant ou en s'élevant, déeouvre l'organe de la vue, ou le cache en entier, et fait l'office des ceilleres dont on couvre les yeux des chevaux ombrageux.

Cette sorte de paupière mobile à la volonté de l'animal garantit l'ceil des effets funestes de la lumière éblouissante que répand sứ la surface de la mer le soleil de la zone torride, et qui est souvent d'autant plus vive autour dú bodian dont nous nous occupons, qué ce poisson se plait au milieu des rochers, sur des bas-fonds pierreux, et daus les endroits oú les rayons solaires n'ayant a traverser, pour arriver à ses organes, que des couches deau assez minces sont réfléchis, rapprochés et réunis en différents foyers, par les surfaces blanches, unies, polies, et diversement concaves, des roches du rivage et du fond de l'Océan.

L'organe de la vue du bodian ceillère, préservé de l'action de la lumière pendant tout le temps où ce thoracin u'a besoin ni.de diriger sa route, ni de poursuivre une petite proie, ni d'éviter un ennemi, doit done être, tout éga d'ailleurs, très-délicat; et il est d'autant plus propre à lui faire distinguer les objets qu'il recherche ou qu'il fuit, que cet organe est grand et saillant.

Cétte paupière membraneuse présente une couleur d'un beau jaune; la tête est arrondie

siens percoides, selon M. Cuvier, qui a reconon que Fesperce lu Bodian jaguar de Lacépede, est toodée sur une bgurede Marcegrave, aliéree par Bloch, D.

'Bodian á grandes ceailles, Rloch. pl. 250 - Da genre Guspusodor dans la famille des Acanthopte. rygiens scienoides, selon $\mathrm{M}$. Cuvier. D.

'Bloch. pl. 251, ig. 2. "Da genre CEsio, dans la famille des Acanthopterygien méoides de M. Cuvier.

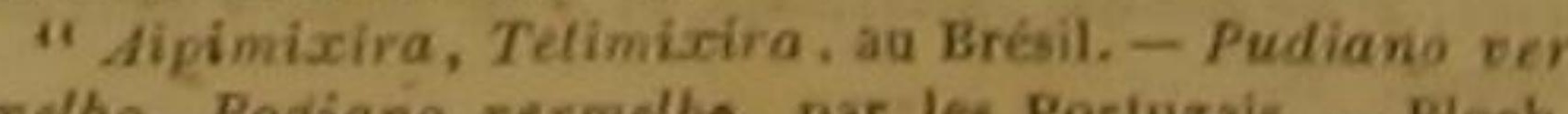
pl. 223 . Soumeationé par M. Cavier, D. Aeara ayn, Garanka, an birail. - Bloch. pl. 2.7. "Du geare MEsopaioy, dabs la famille des Aesmithoptéry par devant, et presque noire; le queue sont d'un brun jaunátre; decx arment la dernière piece de chaque opercule un ou plusieurs petits sillons règnent sur le des sus de la tête; la ligne latérale, blanche ou argentée, commence paì quatre ou cinq papilles ou tubereules; les nageoires sont noiratres. La longueur ordinaire de l'animal est d'undécimé tre; et c'est particulierement a Amboine que le bodian cillêre a été pèché:

Le louti vit dans la mer d'Arabie, où il se plait parmi les madrépores et tes coraux. Chacune de ses nageoires est bordée de jaune. II parvient quelquefois jusqu'à la longueur remarquable de douze ou treize décimètres. Ses écailles sont petites, arrondies et striées. La lèvre opérieure est moins avancée que celle d'en bas ; mais elle peut êtré étendue par le bodian. Le jaguar habite dans la mer du Brésil ; it aime à demeurè au milieu des écueils, et par conséquent, auprès des côtes. II parait préférer surtout le voisinage de l'embouchure des rivières; ete'est dans ce voisinage qu'il s'engraisse, et que sa chair acquiert un goút encore plus agréable qu'à l'ordinaire, lorsqué, dans la saison des pluies, les fleuves débordes entrainent jusqu'à la mer une grande quantité de substances organiques et nutritives, dont le jaguar retire un aliment salutaire et abondant.

Ce bodian a la mâchoire d'en haut plus avancée que celle d'en bas ; plusieurs rảngs de dents presque égales, pointues, et séparées l'une de Vautre; deux oríices a chaque narine; les écallles dentelées; et le lobe susuérieur de sa caùdale plus long que l'inferieur. Le prince Maurice de Nassau a laissé de ce poisson un dessin quí a été copié par Bloch, et qứ l'avait été auparavant par Maregrave, d'apres lequel Pison, Willughby, Jonston et Ruysch paraissent avoir représenté ce bodian.

On peut croire que le macrolépidote a été péché dans les grandes Indés. Leś deux mácholres sont aussi avancées l'une que l'autre, et garnies de dents très-serrées; on ne voit qu'un orifice à ehaque narine; la ligne latérale est droite, et aboutit á la fin de la dorsale, oú elle se perd. On apercoit du rougeatre sur la tête et sur le dos de l'animal; les pectorales et les thoracines sont jaunes; la dorsale et Yanale sont brunes; et ia caudale est brune comme la dorsale, maí jaune dans son milieu. L'argenté a la langue et le palais tres-lisses; 
un seul -orifice à chaque nariné; les nageoires L L'aya a l'ouverture de la bouche assezgrande; jaunâtres; et la caudale bordée de bleu ou de la mâchoire supérieure un peu plus avancée que cramoisi. Il parait qu'on l'a observé dans la l'inférieure; les deux mâchoires garnies d'un Mẻditerranée.

Le prince Maurice de Nassau, Marcgrave, rieures sont les plus grosses; et deux orifices à Pison, Willughby, Jonston, Kuysch et Bloch, chaque narine.

ont fait dessiner le poisson auquel j'ai donné un nom spécifique qui rappelle celui du savant ichthyologiste de Berlin. J'ai voulu, par cette nouvelle marque d'estime pour ce naturaliste, indiquer l'espèce dont le nom vulgaire a été employé par lui pour désigner le genre entier des bodians, 'qu'il a proposé le premier, et que j'ai adopté après avoir lait subir quelques modifications à cette partie de sa classification.

- Le bodian blơch a été vu dans la mer du Brésil; il y parvient à la grandeur du eyprin earpe, et y a été très-recherché à cause de la bonté de sa chair. Chaque narine de ce poisson ne présente qu'un orifice; du pourpre, du rouge et du jaune doré, resplendissent sur ses nageoires.

La figure de l'aya a été donnée par Maregrave, Pison, Willughby Jonston, Ruysch, le prince de Nassan et Bloch, qui a fait copier le dessin du prince Maurice '. On le trouve dans les lacs du Brésil, Il y parvient fréquemment à la longueur d'un mètre; et il y multiplie si fort, qu'on envoie au loin un grand nombre d'individus de cette espèce, salés ou séchés au soleil: Il serait très-utile et peut-être assez faeile d'acelimater ce grand et beau bodian, dont la chair est très-agréable au goút, dans les eaux douces de l'Europe, et particulièrement dans les laes et les étangs de cette partie du globe. Au reste, nous n'avons pas besoin de répéter ici ce que nous avons déjà écrit sur l'acclimatation des poissons, dans plus d un endroit de l'histoire de ces auimaux.

' 16 rayons a chaque pectorale du bodian ceillerè, 6 a cha que thoracine, 20 i la caudale. -7 rayons a la membran aiguillonoue et 8 rayons arlicules a d da pectorale, 1 rayos rayoos a la mageoire de ta queue - 15 rayons a chaque, ise torale du bodian jaguar, 1 rayon aizuillonné et 5 rayons articulés a cha que thoracioe, 18 rayons a la caudale. - 4 rayoo chayue peetorale $t$ ragonate du bodian macrolépidote, is a chaque thoracine, 22 rayong bi a na 7 rayons a la membrane branchiale du bodian argenté chaque pectorale, $t$ rayon aiguillonné et 5 rayons artientés a

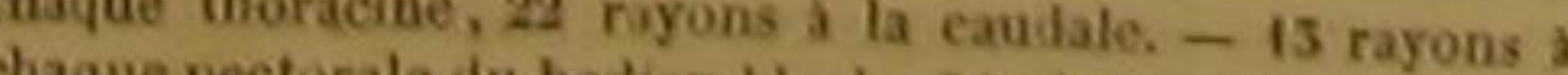
ta nageoire de la guedian bloch, 6 a chaque thoracine, 15

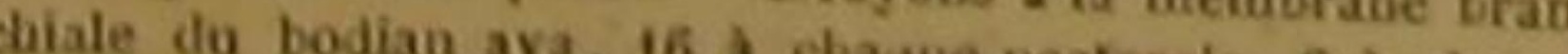
thoracine, 15 a la candale
Plectropoma maculatum, Cuv,; Bodianus maculatus, B1., Lac. ${ }^{2}$.

Bodian Vivanet s, Mesoprion griseus, Cav.; Sparus tetracanthus, Bl; Cichla tetracaniha. Schn.; Bodianis Viva-

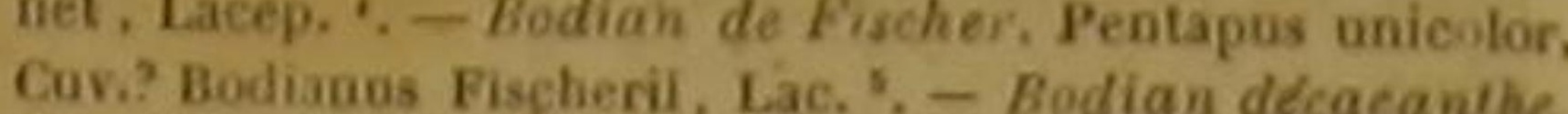
Pentapus viltatus, Cuv? Sparus viltatus, BI , Botligne decaçiothus, Lac. 1- Bodian Lenfjan, Lethrinus LeatJanas Civ,; Bodianus Leatjan, Lac. 1, - Bodian grossetéle, Serrañus Davo exrolens, Cuv.; Holocentros flavoceroleus, Holocentrus gymoosus, et Bodiasnus macroce phalos, Lae. : - Bodian cyclostome. Plectropoma me lanoleacum, Cavi: Labris levis, B dianus melanoleucas
et Bodianos eyclostomus, L.ae. ?

Le tacheté a été vu dans le Japon. Ses deux måchoires sont également avancées. Lęs dents antérieures surpassent les autres en longueur. II n'y a qu'un orifice à cháque narine. Les écailles sont petites, dures et dentelées; les pectorales, les thoracines et la caudale, d'un rouge brun; la dorsale et l'anale bleues, et bordées d'un brun rougeatre ${ }^{10}$.

; Bloch, pl. 228

2. Du genre Pucriopong, dans la famille des Acanthopte. rygiens percoldes. D.

- cam, A Plumier, peintures spr vétinet gris, apud Martini- Du genre siesoparox, dans la Gumille des Acanthoptéry. Biens percoides. D,

oM Cuvier rapporte, mais avee un peu de donte, ce pois. son a lespéce quil nomme Peniápede unicolor (famille des
Acanthopiérygiens sparoiles)

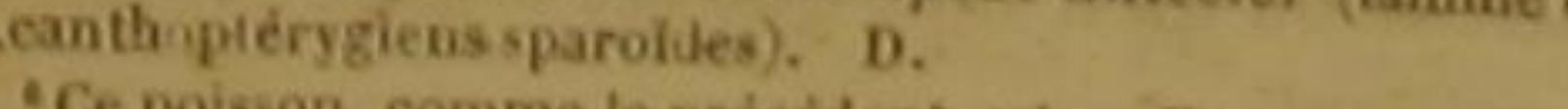
Lapis, pour M. Cuvier, dans la famille des Arsapode, Pen-

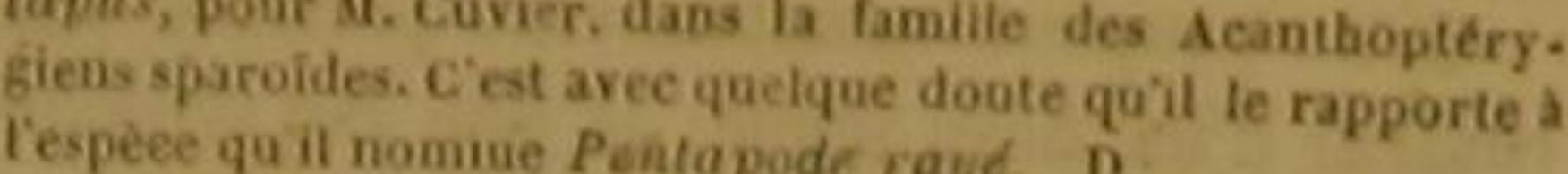
Du genre Letruasers, dans la famille des Acanthoptéry. gien sparoites. D.

Wopterygiens pereov, Seranus, dans la tamille des Acangrosse-lete, $2^{\circ}$ d'Holocentre joune el llev, 1 de Bodia centre gymnose. D.

'Du genre PLectropong, dans la famille des Acanithoptérgiens percoídes, selon M. Cuvier. Ce poisson a été décrit lisse, $2^{\circ}$ de $B$. de Lacepede, sous les noms. $1^{\circ}$ de Labre huque. D. (isuque. D.

is a chaque pectorase, I branchiale du bodian ticheté, culés a chaque thoracine, 9 r rayon aiguillonene et 5 rayons arti-12 rayons a chaque peetorile du budian vivanet 6 a
claque thoracine 1400 is a la candale. -16 rayms a cha.

\section{LE BODIAN TACHETÉ ',} Hécrit trois fols ce poiscon M. Cuvier. M. de Lacepede a
Le vivanet vit dans les eaux de la Martinique. Ses pectorales et sa caudale sont trèsgrandes, et doivent lui donner une natation rapide; les premières sont, de plus, triangulaires; deux raies longitudinales, assez larges, dorées, et dont la supérieure offre souvent des nuances très-faibles, accompagnent la ligne latérale; les nageoires sont variées de jaune et de violet,

Aucun naturaliste n'a encore publié la dessription du Fischer, ni des autres quatre bodians dont la notice suit celle de ce thoracin. Nous avous désiré quéle nom spécíique de ce poisson fùt un témoignage de notre estime et de notre attachement pour le naturaliste - Fischer, bibliothécaire de Mayence, qui chaque four acquiert, par son zèle et par ses ouvrages, de nouveaux droits à la reconnaissance des amis des sciences, et s'efforce de donner une nouvelle activité au noble et si utile commerce des lumières entre la France et I'Allemagne.

Le bodian fischer a le corps et la queue allongés, et les rayonsaiguillonnés desa dorsale trèséloignés I'un de l'autre. Nous faisons' connaitre ce poisson d'après un individu de cette espèce compris dans la belle collection zoologique cédée par la Hollande à. la France.

Cête méme collection renfermait des individus de l'espèce que nous avons nommée. Décacanthe, et de celle que nous appelons Lentjan, parce qu'une note manuscrite nous a appris qu'elle avait reçu ce nom de Lentjan dans le pays qu'elle habite.

A l'égard du Bodian grosse-téte et du Cyclostome, nous en avons trouvé des dessins parmi les manuscrits de Commerson.

que pectorale da bodian fiscber, 1 rayon aiguillonné et 5 rayoms ardicaics a chaque tionacine, 17 rayoos a la nageoire de ia queue. - -66 rayons a chaque pectorale du bo. dian decacanche, 1 rayon a aguitionne et 5 rayons articulés 15 rayons a chayue pectorale du bodian lentian, $t$ rayon at guilloqné et 5 rayous articulés a chaque thoracine 17 rayons a la can iale. -9 ou to rayons a chaque pectorale da bodian grosectéte, 14 ou is a la nageoire de la queve. -14 ou 12 rayors a chaque pecturate du bodian cyclostome, 12 ou is

\section{LE BODIAN ROGAA ,}

Serranus Rogaa, Cuv,; Perca Rogaa, Forsk., Linn., Gmel.; Bodianus Rogaa, Cuv. ",

Bodian lunaire ', Perca lunaria, Linn, Gmel., Bodianas tuararius, Lac, 4, - Bodian mélanolengue ', Plectronolencus, et Bodianus cyclostomus, Lacep. $5 .-$ Modian

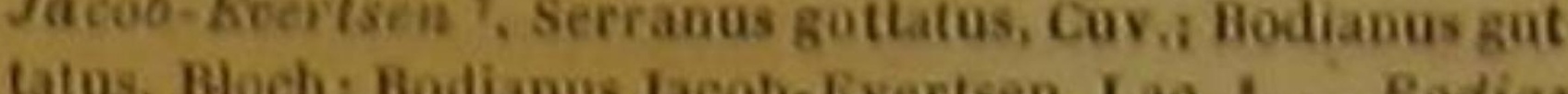

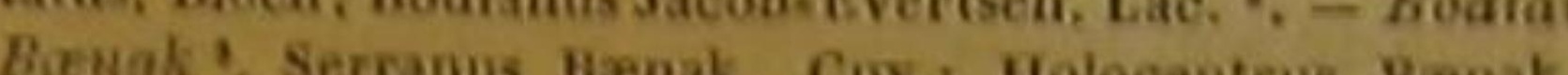

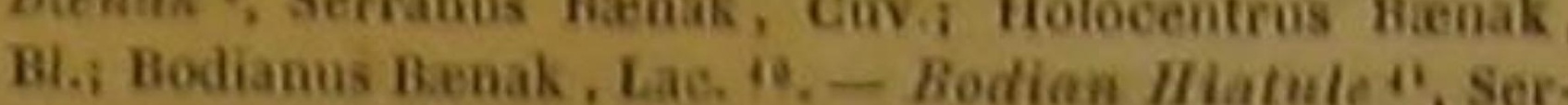
ranus Cabrilla, Cuv, Peres Catrilla, Limn fllotocentris Chani, Holocentrus virescens, Lutjanus Serran, et Hodia nus Hiatula, Lacep. "3, - Bodian Apue "s, serranus s pua, Car.s Bodianos A pua, Bl., Lacep. ",- Bodian Eloile", dipteris Acouna, Euv,i Bodians stellifer, Bl.z Cheilo-

La mer d'Arabie nourrit le rogaa et le lunaire.

Le rogaa a les lèvres très-grosses, et la supérieure extensible; le devant de ses máchoires présente sóuvent deux dents fortes et un peu coniques; sa longueur est ordinairement de six

'Fonkaei, Faun. Arab., P. 38, n. 30. - Pesedgue rogaa, sonuaterre, pl de l'Enc, mét

Du genre Minoo, Serranus, dans la famille des Acan-

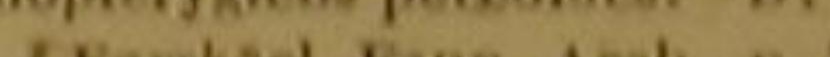

'Forskacl, Faun, Arab, p. 59, n. 57,-Persigue lunaire. t Nen mentionne par M. Cavier.

- Aspro piunis dorsalibus umitis, radis octo spinosis, - duodecm muticis, colpore argenteo, maculis sex septemve

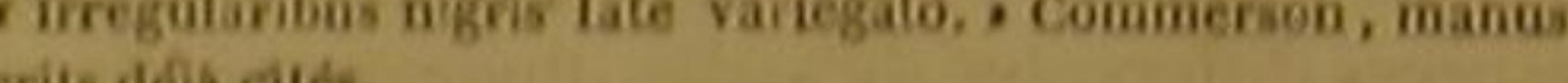
crits dẹja cités.

A. Luvier regarde ce poisson comme étant de la méme
apéce que le Bonlan cyclostome, décrit dans lartiele púcé dent. Cette copece appartient an genre Pascruopoure, dans a famille des Acanthopterygiens percoides. M. de lacépede fait un triple emploi de ce polson, sous les noms de Labie lisse, de Bodian cyelosiome, et de Bodian melanoteuque.

The jew-fish, par les Anglais, - Ican ocara, au Japon. pl. 222.

- Du genre Mksov, Serranus, dans ta faimille des Acan-

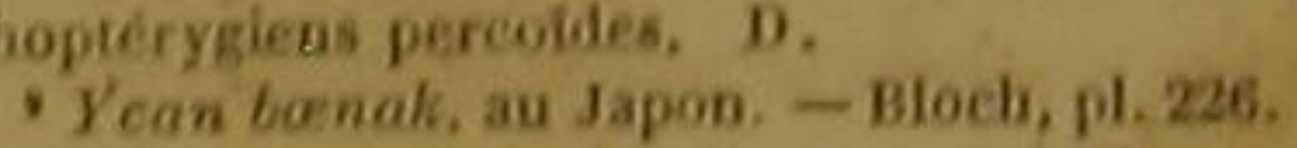
10 Du méme geure que fépéce précédente (Mörou), selon I. Cuvier. D

Core hiatule Bonnaterre, pl. de ITEne, méth. - Salv.

is Du genre Mkeov, Serranus, Cuv.. dans la famille des

Acasuthoptérygiens percoldes. M. de Lacépéde le déerit qua cre fois, et dans trois genres differents, sous les noms soivants. $1^{\circ}$ Lutjan Serran, $2^{\circ}$ Bodian Hiatule, $5^{\circ}$ Holocentro

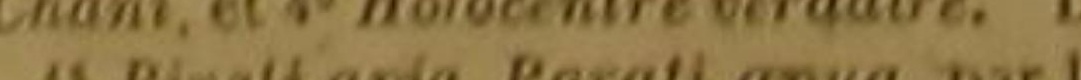
Brasiliens. - Bloch, pl. 220.

"Avioch, pli. 25s, Eg. I.

19a geare cone, Coreina, Cur, dans la familie des Acanthopleryg ens scienoldes. M. Cavier lai rapporto, mais en conservant quelques doules, te Chentodaciyle acoupa de 
on sept décimètres; il se plait au milieu des coraux et des madrípores.

Le mélanoleuque a été vu par Commerson près des rivages de l'Ille-de-France. Ses couleurs blanche et noire m'ont indiqué le nom spécifique que j'ai cru devoir lui donner '. Ses nageoires sont jaunátres; ses pectorales et ses thoracines offrent à leur base une tache noire; le bout de son museau brille d'un beau jaune. Le corps et la queue sont allongés; la lèvre supérieure est extensible; les mâchoires sont garnies de plusieurs rangs de dents inégales; on voit de petites dents sur une partie ảu palais; et la longueur ordinaire de l'animal est de quatreou cinq décimètres

Le Jacob-Evertsen a deux orifices à chaque narine; la ligne latérale estlarge. La dorsale, la caudale, et la nageoire de l'anus, sont couvertes en partie de petites écailles; elles sont d'ailleurs jaunes et bordées de violet : une nuance jaune distingue les pectorales et les thoracines.

Le nom que porte ce bodian est celui d'un mátelot de Hollande, dont le visage gâté par la petite vérole présentait des taehes semblables à celles de ce poisson, et que d'autres marins hollandais avaient sous les yeux, lorsqu'ils dé. couvtirent l'espèce dont nous nous occupons ; ce nom de Jacob-Evertsen a même été donné depuis par plusieurs navigateurs bataves à dẹs espèces différentes du bodiandont nous parlons, mais qui montraient sur leur surface un grand nombre de petites taches.

On trouve les Jacob - Evertsens auprès de l'ile de Sainte-Héléne, ou l'on en péche beaucoup; dans les grandes Indes, et dans la mer du Japon. Ils vivent de proie, sont très-goulus, se jettent imprudemment sur les lignes, et sont pris facilement dans toutes les saisons. Ils remontentles fleuves dans le temps dela ponte des œuf́s, qu'ilsdéposent par préférencesur les fonds pierreux. Ils parviennent souvent dans l'Asie à la longueur de treize ou quatorze décimètres: ils y sont très-gras, très-agréables au goùt, et très-recherchés surtout par les Européens. Bloch pense que l'on doit les regarder comme de même espèce que le Jeujish, dont Browne a parlé, qui, suivant ce dernier auteur, vit dans les eaux de la Jamaique, et qui y pèse quelquefois cent cinquante kilogrammes. Le prince Maurice de Nassau, Bontius, Renard et Nieu- hof, ont laissé des dessins de ces poissons, dont Willughby et Seba ont fait copier la figure'.

Le banak a la tête étroite et allongée; l'onverture de la bouche petite; les yeux rapprochés du sommet; les nageoires dun jaune plus ou moins mélé de brun; la dorsale et les pectorales relevées par des prolongations de quelquesunes des bandes transversales que le tableau générique indique; et une bande transversale et courbe placée sur la caudale.

Il a été envoyé du Japón à Bloch, qui a reç aussi du même pays une variété de ce bodian distinguée des autres individus de cette especé par des raies d'une nuance claire, que l'on aperçoit très-difficilement.

L'hiatule se trouve dans-la Méditerranée. Nous n'avons pas besoin de faire observer que ce bodian' est d'une espèce bien différente de celle que nous avons déerite sous le nom de Hiatule gardéniehne.

On voit l'apue dans le Brésil : ce thoracin y rècherehe pendant l'été l'eau salée qui baigne les rivageś et les écueils de la mer, et pendant l'hiver leau douce des rivières. Sa chair est grasse, et d'un goùt exquis. Sa pèche est trèsabondante, et d'aatant plus utile que son poids ordinaire est de deux ou trois kilogrammes ${ }^{2}$.

Le prince Maurice, Maregrave, Pison; Willughby, Jooston, Ruysch et Bloch, ont fait faire des dešsins de ce poisson, dont Klein s'est aussi occupé.

C'est du cap de Bonne-Espérance qu'on a apporté en Europe l'étoilé. Ses dents sont très-petites; sa langue et son palais très-lisses; ses narines percées chäune d'une seule ouverture.

' Les dessins de Bontios, de Renard et de Vienthot, sint

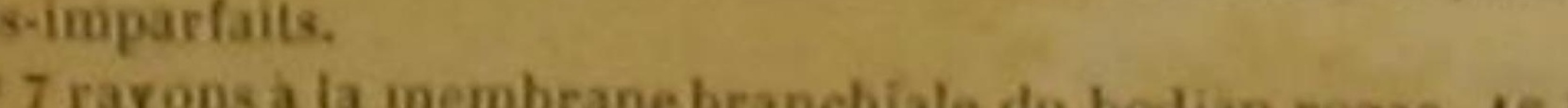
chaque pectorale, 1 rayon aiguillonne et 5 rayours articul's i Caque thoracine, 14 rayons a ia eaudale. -7 rayons a 1 membrane branchiale do boutan inasire, 18 a chaque pecto-

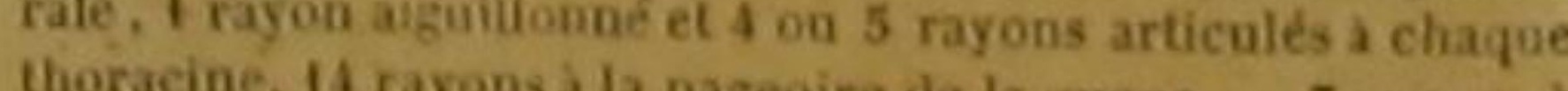
la membrame branchiale du botian ma queue. -7 rayous que pectorale, 1 rayour aiguilionné et 5 rayonse, arrientés a chaque thoracine, 15 rayons a ta caudale. -5 rayons a di membrane branchiale du bodian jacob-évertsen, 14 a chaque pectorale, 1 rayon siguillone et $\widetilde{5}$ rayons articulés a chaque a la menbrame brans a nageoire de la queve. - 7 rayon pectorale, $f$ rayon aiguale da hodian brenak, 15 a chaque thoracibe, 17 rayons a la caudale. - -15 rayoncies a chaque turale du bodian apus. 1 rayon aignillonné et 5 rayons articulés à chaque thoracine, 17 rayons a la nageoire de 1 a queue. -4 rayuns a la membrane branchiale da bodian etoile, 14 a chayue pectorale, 1 rayou aiguillonné ef 3 rayon

DES POISSONS.

LE BODIAN TÉTRACANTHE,

Percis eaneellata, Cuv.; Labrus tetracanthus, et Bodianus tetracanthus, Lacep. '

\section{ET LE BODIAN SIX-RAIES.}

Grammistes orientalis, Cur,; Centropomus ser-lineatus, Seizna viltata, Perca triacantha, Perea pentacantha, et Bodianus ser-lineatus, Lac. ?

On n'a pas èncore publiéde description de cés leux bodians; nous avons vu un individu de chacune de ces espèces dans la collection du Muséum national d'histoire naturelle. La première a la tẻte un peu déprimée et plus large que le corps ; la lèvre supérieure épaisse et extensible; les dents aiguês, crochues et inćgales. La seconde a l'ouverture de la bouche trèsgrande, et la mâchoire ìnérieure plus avancé que la supérieure ${ }^{3}$.

\section{CENT DIX-NEUVIEME GENRE.} LES TANIANOTES.

Un ou plusieurs aiguillons, $t$ point de dentelure aur epereutes; un seul barbilfon, on point de barbillons aux maichoires : tme nagcoire dorsale itendue demis l'ent e-deux des yeux jusqu'a la nagéoire de ta quere, ou tès-longue at composce de plus de quarante rayous:

PREMIER SOUS-GENRE.

La nageaire de la queue, fourchue, ou en croissant. especess. cascrìnes.

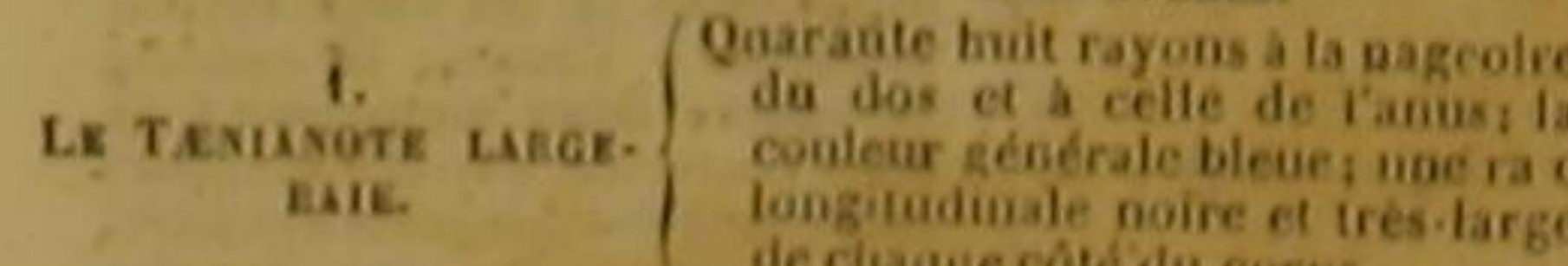
SECOND SOUS-GENRE.

La nageoire de la queue, rectiligne, ou arrondie, at non chancree.

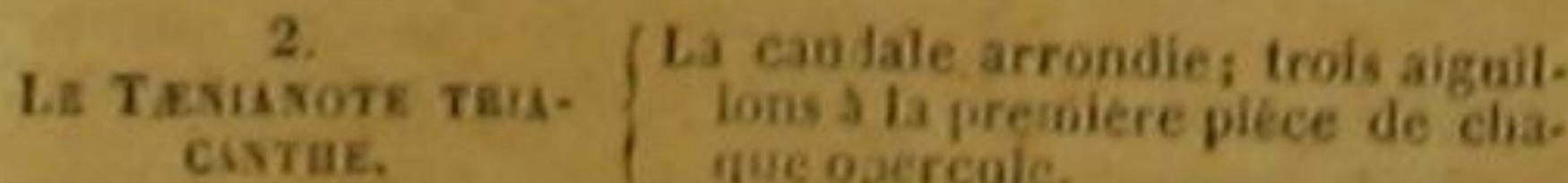

- Du genre Pescis, Percis, Cav., dans is fomille dis Acanthoptérygens percoiles. Ce poiston a eté dimille des fois par s. de tacepése, sous les noms to de Labre deúta canthe, et $2^{2}$ de Bodian telraconthe. D.

? Da geare Gassisase, de M. Cuvier, dans la famille des Acantboptérygiens perooides. II est décrit eing fois par

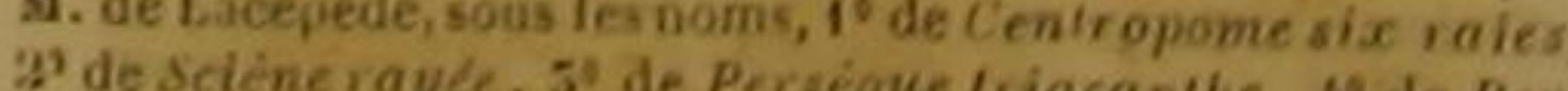
séque pentacanthe, et $5^{\circ}$ de Bodian six raies. D. 8 rayons à la meinbrane branchiale du bodign ifling the, 17 a chaque pectora.e. 6 a chaque thoracine, ix a Ia ma geoire de ia queuc. -8 rayons a la menbrane brinchiste dy

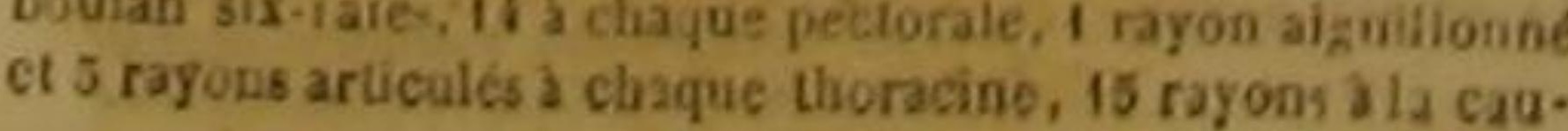

LE TANIANOTE LARGE-RAIE.

Malacanthus...... Gur.; Tænianotos lato-vittatus, Lac.; Labrus lato-vittatus, (fg.), Lae.

Les tænianotes n'ont encore été décrits par ueun anteur; je les ai compris dans un genre particulier, auquel j'ai donné le nom de Tanianote pour désigner la très-grande longueur de leur nageoire dorsale, dont l'étendue forme un des caractères distinctifs de ce groupe ${ }^{2}$. Commerson a vu, dans le marché au poisson de I'lle-de-France, des individus de l'espèce que je nomme Large-raie, Leur longueur était de quatre à cinq décimètres; leur saveur pen agréable; et l'on trouvait, dans leur estomaé, des débris de coraux, et des fragments de coquilles. Les dents du tenianote que nous decrivons, sont cependant très-petites; et sa langue ainsi que son palais, n'offrent ni dents ni aspérités : lá dureté des máchoires, la constance des efforts et le nombre des dents suppléent, dans ce thoracin, à la grandeur de ces derniers instruments, et sont une nouvelle preuve de la réserve avec laquelle on doit, dans l'étude de I'histoire naturelle, conelure l'existence des habitudes de celle des formes dont elles paraissent le plus dépendre, ou T'existence de ces formes, de celle de ces habitudes.

Le large-raie a deux oriflees à chaque narine, les yeux un péu rapprochés I'un de I'autre; les écailles très-petites, mais rudes et dentelées; un aiguillon á la pièce postérieure de chaque opercule, qui d'ailleurs se termine en pointe; leventre argenté; la nageoire du dos et les pectorales variées de brun et de bleu; les thoracines et l'anale blanchâties; la caudale distinguée par la prolongation de la raic longitudinale large et noire quí règne sur le corps et sur la queue, et par une tache blanche et grande, placée sur le lobe inferieur ${ }^{3}$.

13. Cuvier rapporte la description de ce polsson an genrs

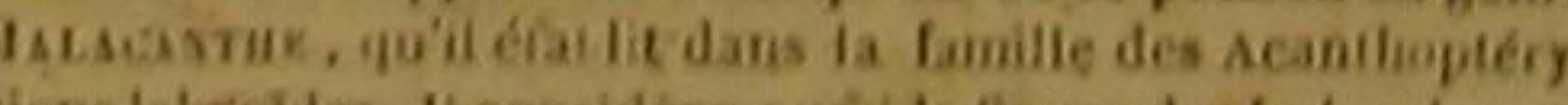

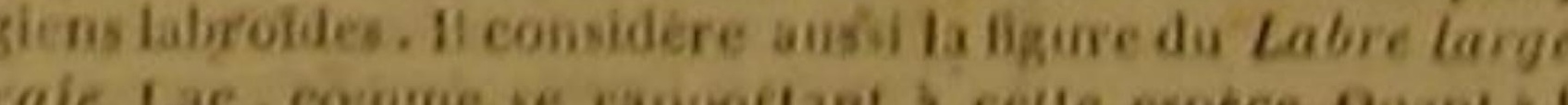

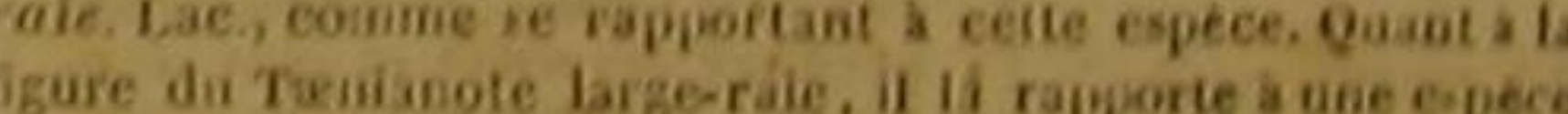
de songenre Apistes, Aphotus iceniznolus, daes la famillo des Acautboptérygiens a jouer cuirassées. D.

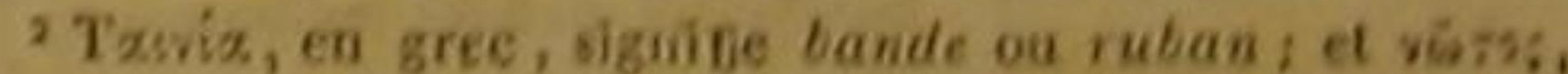
'6 rayons a la membrane brancliate, 17 s chaque pecto.

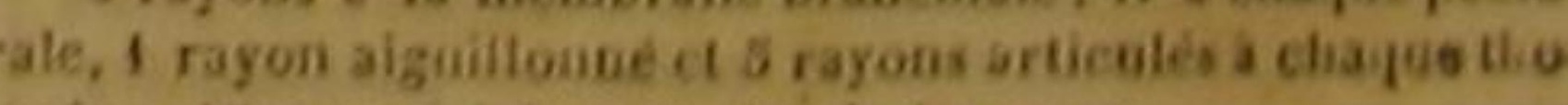
racine, 15 rayous a la nageoire de la quese. 


\section{LE TANLANOTE TRIACANTHE.}

Tænianotus triacanthus, Gav.? Lac. '.

Cette espèce a le corps allongé et très-comprimé. Sa nageoire du dos ressemble à une longue bande, plus élevée vers le crâne et la nuque que vers la lin du corps et au-dessus de la queue. La partie antérieure de ce remarquable instrument de natation est arrondie; et les premiers rayons qui la soutiennent sont un peu séparés l'un de l'autre. L'ouverture de la bouche et les dents sont très-petites. La mâchoire inférieure avance plus que celle d'en haut.

Un tænianote triacanthe était conservé dans de l'alcool, parmi les poissons qui faisaient partie de la nombreuse collection d'histoire naturelle donnéce par la Hollande à la France ${ }^{2}$

\section{CENT VINGTIEMME GENRE.} LFS SCIĖNES.

Un ou plusieurs aiguillons et point de dentelure aux opereutes: in sent barbillon, ou point de burbillons an $x$ máchoires; deux nageoires dorsales.

PREMIER SOUS-GENRE.

La nageoire de la queue, fourchue, ou en croissanf.

Espìces.

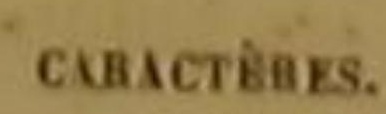

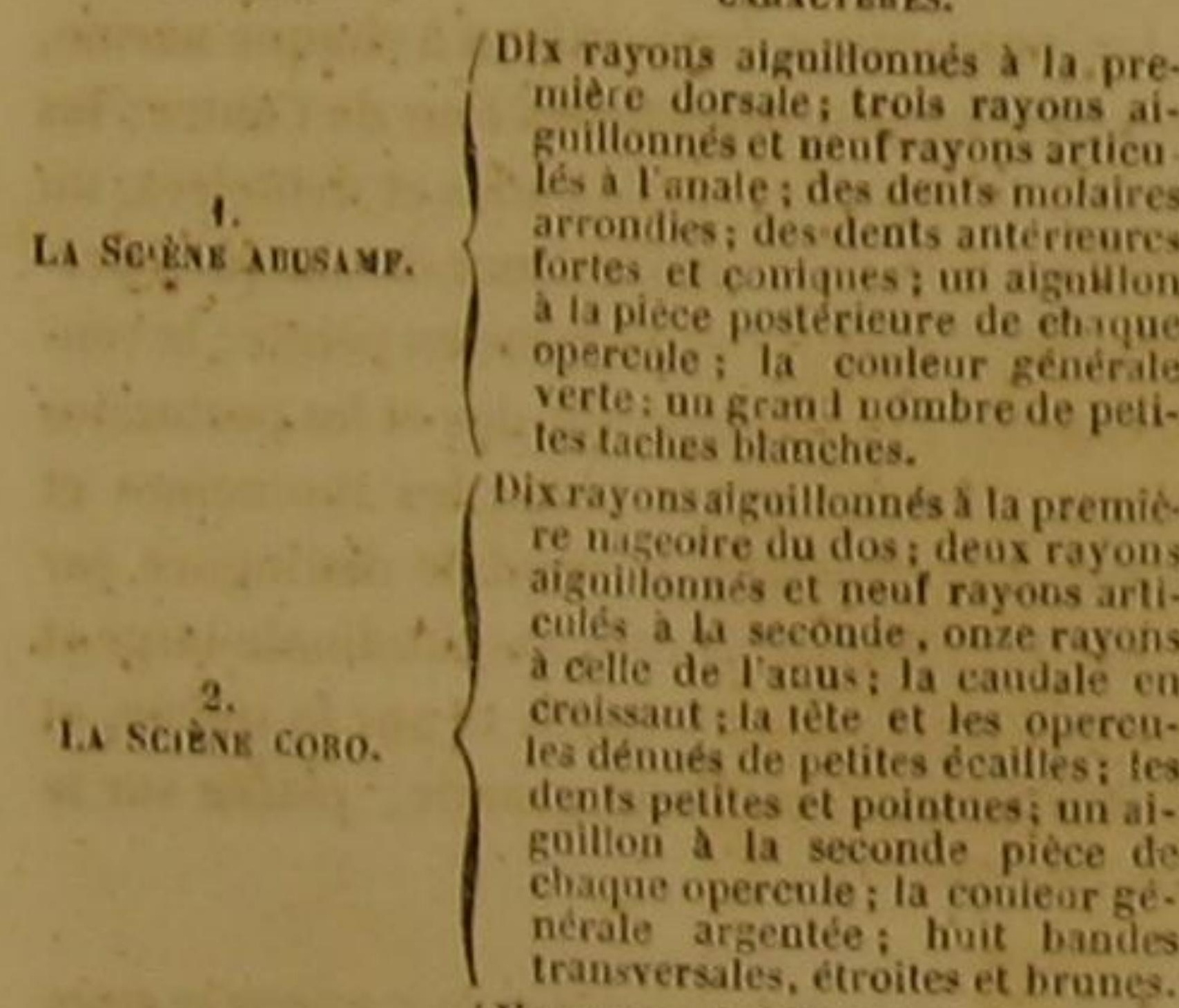

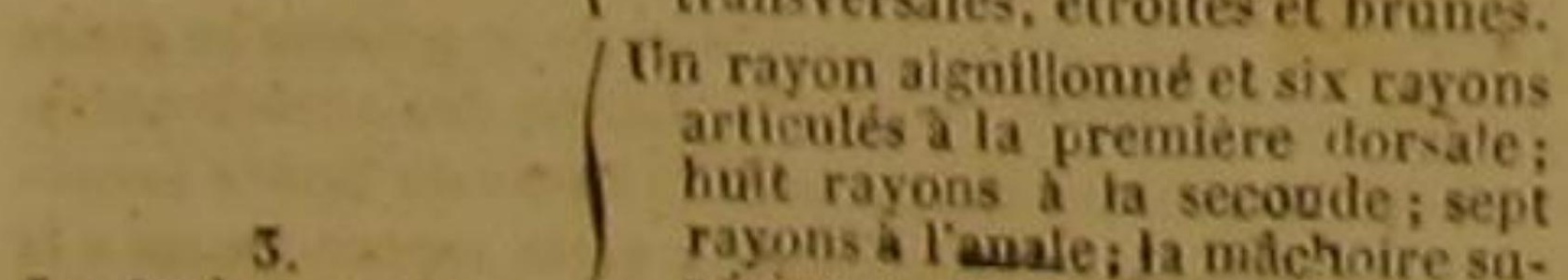

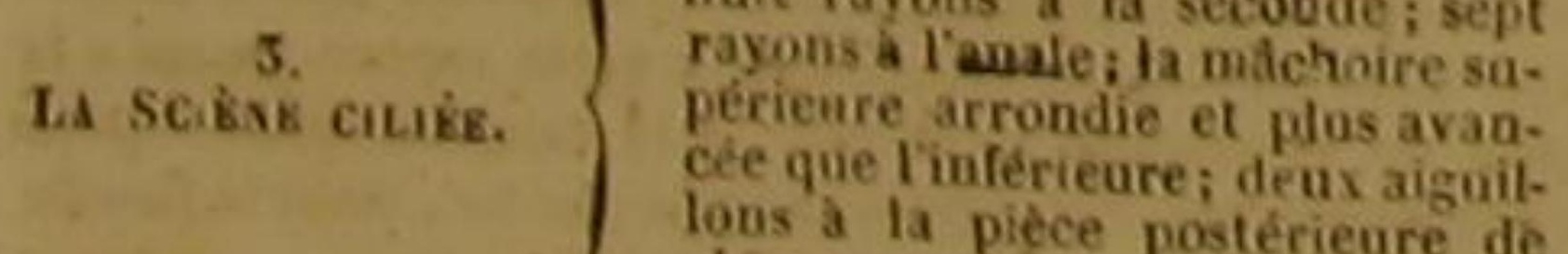
lons a la piece postérieure de
chaque opercale; prescue toutes
les ecailles divisés en deur por 'Ce n'est qn'avec donte que M. Cuvier rapporte la des.
cription du Tornianote triacanthe de Tacidede, Truxots, quil admet dans la famille des Acanthoptérsots rayons a lasees, près uiu genre Scorpène. D.

8 rayons articultés à chaque thoracine, 1 rayon aiguillonné et
de fayons à la nageoire

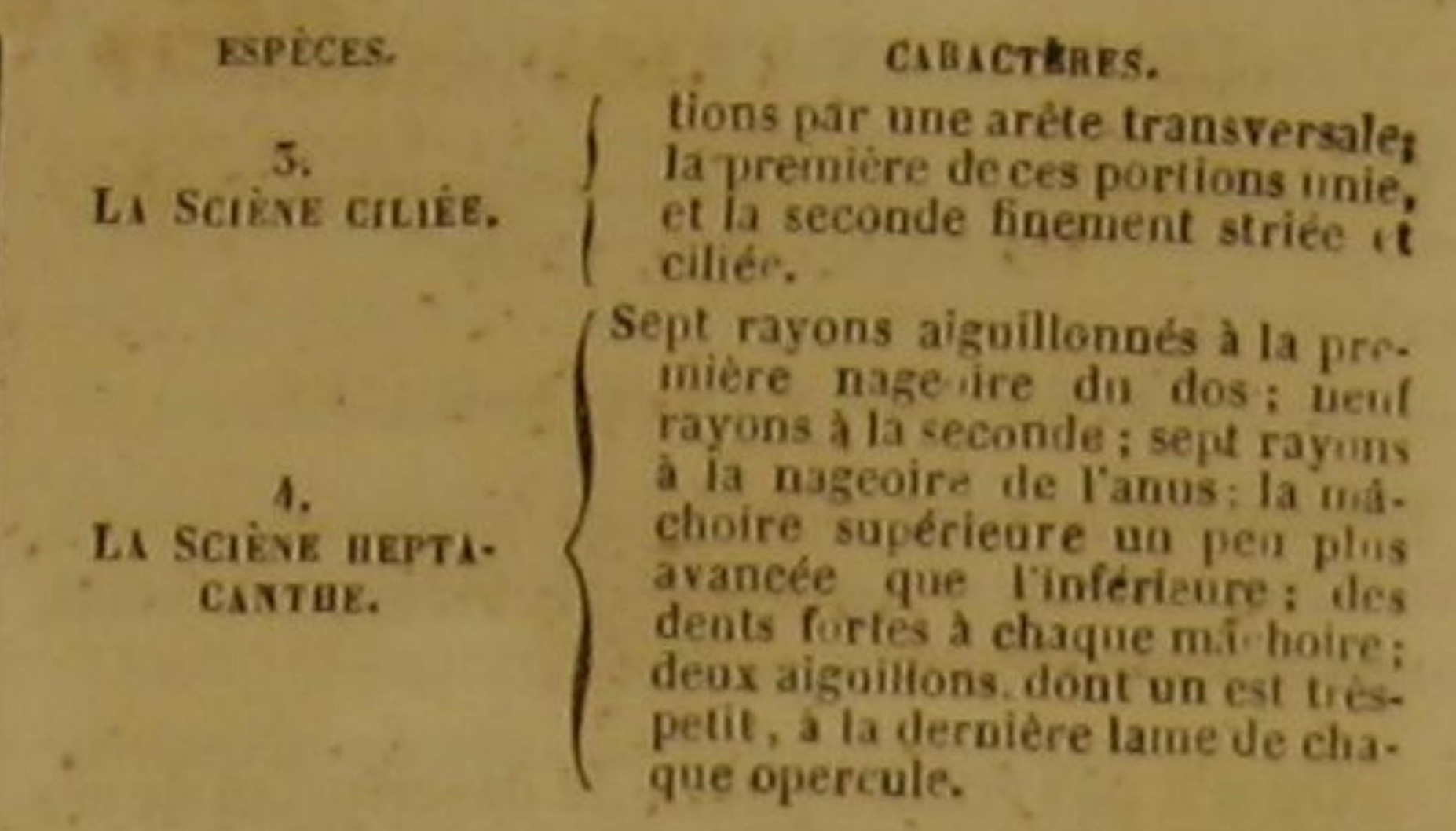

SECOND SOUS-GENRE.

ta nageoire de la queue, rectiligne, ou arrondie, et non echancrée.

$\therefore \quad$ Dix rayons a la premlère dersale; $\quad$ Les sciènes ne diffèrent des bodiansque par le nombre de leurs nageoires dorsates; elles en ont deux, pendant que l'on n'en voit qu'une sur les bodians; elles ont done avee ces derniers le même degré d'afìnité que les cheilodiptères avec les labres, les ostorhinqùes avee les scares, les diptérodońs avec les spares, les centropomes avec les lutjans, et les persèques avec lẹs holocentres.

Les habitudes de la sciène umbre, dont nous tâcherons de présenter quelques traitș, noiıs donneront une idée de celles des autres seiènes. Mais l'umbre n'appartient qu'au second sousgenre de ces thoracins : avant de nous en oceuper, jetons un coup d'ail sur les sciènes du premier sous-gènre.

L'abuisamf vit dansla mer d'Arabie, et le coro dans celle du Brésil.

Ce dernier poisson parvient a la longueur de quatre ou einq décimétres; les deux mâchoires sont aussi avancées l'une-que l'autre; la caudale brille de l'éclat de l'or. On pêche cette scièue dans toutes les saisons; mais elle est peu recherchée, parce que sa chair est dure et sèche, Le prince Maurice de Nassau, Marcgrave,

'Forkkael, Fann. Arab., p. 49, n. 55. -Scirne abu-samf varieté de la sciéne murdjan. Bonnaterre, pl. de I Euc. méth. 'M. Cuvier remarque (Hist. des polss, tome III) que ce ne peut étre que par errear que ie Seicena abusamf de Forsce serait platôt me pagre (dans la famille des Acanthopterygiens sparoìies). Néanmoins, dans le tome IV du mèmé ourrage, qui contient la deseription des Pagres, it n'en est fail aulle mention. D.

Corocoro, Corocoraca, au Brésil. - Bloch, pl. 507, fiz.2. - Du genre Paistipone, dans la famille des Acanthoptery'Ds sciénoídes. D.

"Da genre Upeseos, I'un de cenx que M. Cuvier range, des. II. de Lacepede a décrit deux fois ce poisson, $10^{\circ}$ sous ie nom de Mulle rougeor, et $2^{\circ}$ de Sciéne cilice. D. Du mème genre (Uraseus) que l'espece prècédente. Voyez
OISSONS.

Pison, Willughby, Jonston, Ruysch, Klein et Bloch, ont déerit ou fait dessiner le coro. La ciliée et l'heptacanthe n'ont pas encore été décrites. Nous avons trouvé un individu de chacune de ces deux espèces parmi les poissons desséchés qui font partie de la collection hollandaise donnée á la France, Le tableau génériquue indique la forme remarquable des écailles de la ciliée. Disons de plus que ces écailles présentent la figure d'un trapéze : celles qui garnissent la ligne latérale offrent des arêtes disposées comme des rayons divergents; a'antres écailles plus petites couvrent la base de la nageoire de la queve '.

LA SCHENE CHROMIS *

Pogonias Chromis, Guv,; Labrus Clromis, Lino. Gmel.; Pogonias fasciatus, Sciana Chromis, et Pogonathus Courbina, Lac, ; Sciena Furea, el Stian Gigas, Mitcb."

La Sciène Croker ', Mlicropogon undulatus, Caven Perca

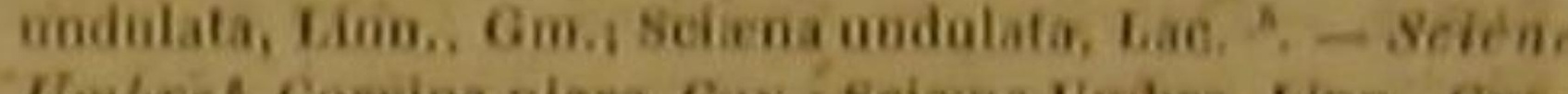

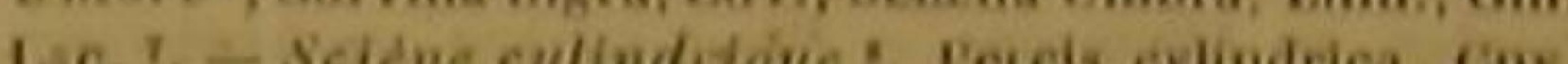

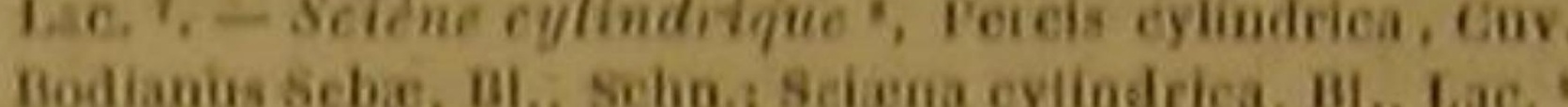

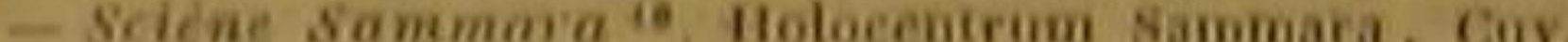
Sciena Sammara, Forkk., Límn., Gm., Lac:s Labirns amenlosus, Lac. .". - Sciene pentadactyle, seimma pentada.

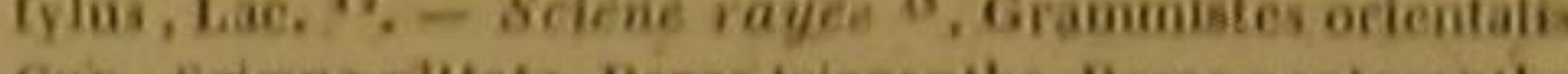

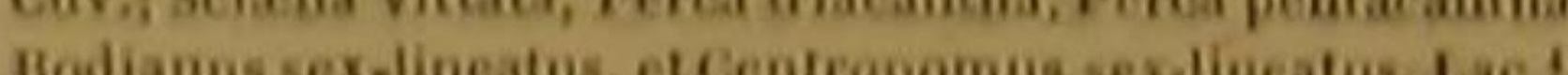

On peut voir dans Schneider ${ }^{5}$ combien it est difficile de déterminer à quels poissons les au-

18 rayons a la membrane branchiale de la seiêne abisamt. is a chaque pectorale, 1 rayon aiguitionae et o rayons art.

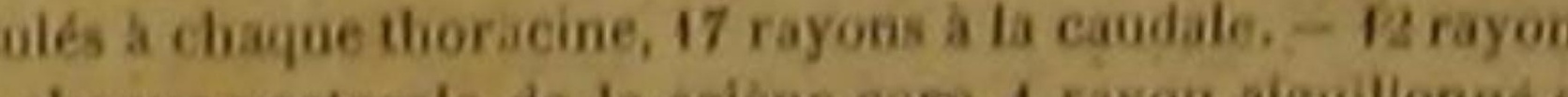

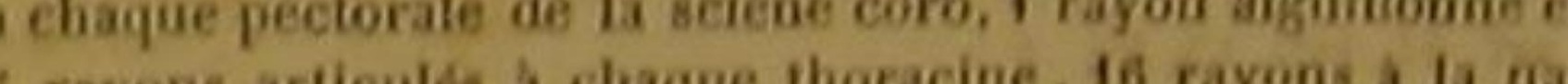

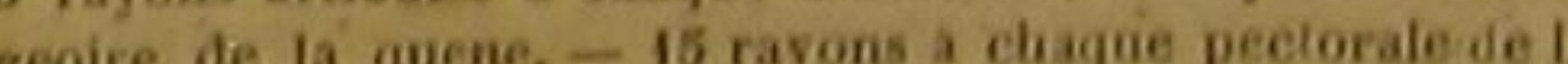
ciene cilié, 1 rayon aiguillonné et 5 rayons articulés a chaque thoracine, 16 rayous a la candate, - -16 rayons a chaque pectorale de ta sciene heptacanthe, 1 rayou aigniltonne ef rayons articules a chaque thoracine, 19 rayons a a nageoir

"Drum, dans la Caroline. - C Chromls sulargenteus.

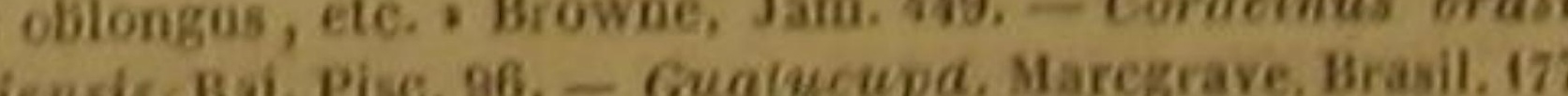
- Labre lambour. Daubenton et Haay, Enc, intb. - Id

Bonnaterre, pl. de IEnc. métb.
'Da geare Pocosiss, dans la famille des Acanthoptery giens sciénoides, Cuv. Ce poisson a eé décrit trois fois par

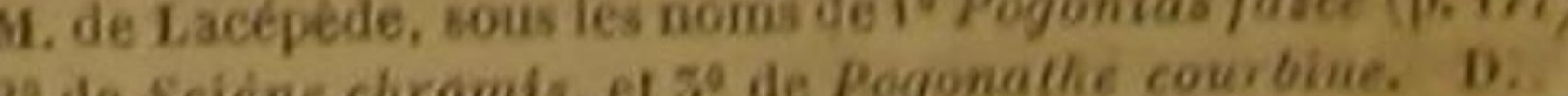
Ae perea marios pinna dorsi divisa, , Cateshy, Garol. 2

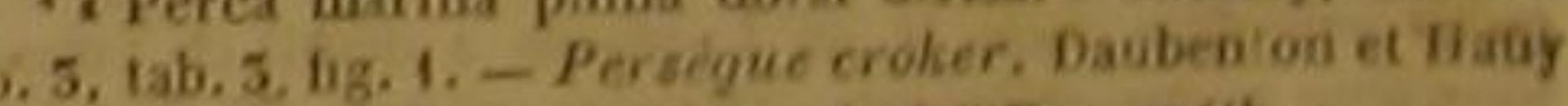

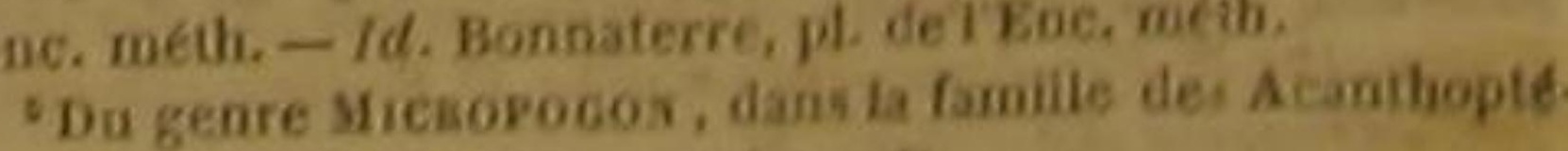
Tiens sciénolides de 3 . Cuvier. 
ciens auteurs grecs et latins ont donné le nom |choires hérissees de plusieurs rangees de tresJeromis, ou Cromis. II nous semble quils petites dents; une tache brune auprès des nal'ont attribué à plus d'une espèce de ces ani- geoires pectorales; et sa tongueur est souvent maux; mais, quoi qu'il en soit, Linnée s'en est de près d'un mètre.

servi pour désigner un thoracin auquel noús La sciène umbre a été souvent confondue avons cru devoir le conserver, quoique ce tho- avec notre persèque umbre. II est cependant dans la Méditerranée, que les anciens ont pa de l'autre. Indépendamment de plusieurs autres connaitre. Cette application que le grand natu- différences, la sciène umbre a les deux mâchoires raliste de Suède a faite du nom de Chromis ä un également avancées, et la persèque umbre a la osseux de l'Amérique, est venue de ce que ce mâchoire d'en haut plus longue que celle a'en poisson fait entendre une sorte de bruissement, bas. On ne voit aucun bạrbillon auprès de l'ouqui a rappelé un prétendu son produit par le verture de la bouche de la première: la ma chromis des Grees; et c'est ce même bruisse- choire inférieure de la seconde est garnie d'un ment qui a fait nommer Tambour cette sciène barbillon. D'ailleurs la sciène umbre a des piquants sans dentelure aux opercules de line et dans celles du Brésil. Ses mâchoires sont branchies; la persèque umbre présente dans armées de petites dents; et sa couleur géné- ses opercules comme la perche et toutes les vérirale est argentée.

La Caroline est aussi la patrie de la sciène croker. Ce poisson a la gueule large; les mâ-

France. - Umbrina, en Sardaigne. - Corvo di fortiera, Curvo, en Halie. - Figaro, dans la Ligurie. - Sehwarts-

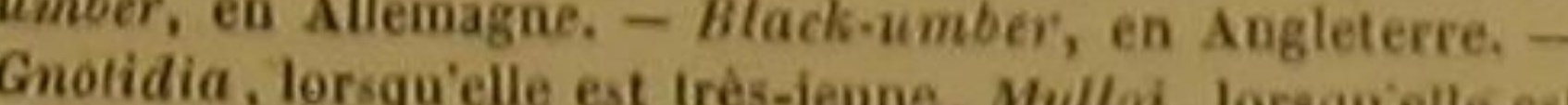
Gnotidia, lorsqu'elle est très-jeune, Mylloi, lorsque elle ent de la Gréce, sulvant Roudelet. - Mus. Ad. Frid. 2, posts.

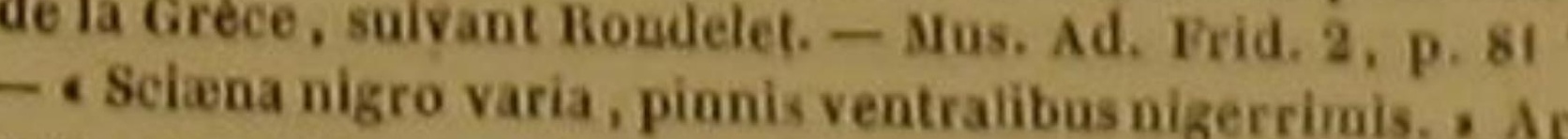
tedi, gen. 59, syo. 65, - Kopáxivos. Arist., 1. 5, c. $10 ; 1.5$. c. 17, 1. 8, e, 15, 19. 30; et 1. 9, c. 2.-Id. Flian., I. 14. 25 p. 855 . Id. Athen.. 1. 7, p. 308. - Id. Oppian., Hal., I. I p. 6. - Coracinus. Plio., 1. 9, c. 16 et 18 ; 1. 5, c. 9; et1. 32 Coracinus. Peteri noire corbeau de mer: Bloch, pl, 297.

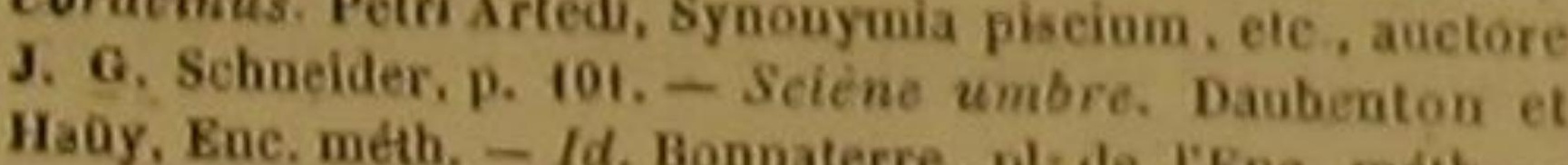
Corp. Kondelet, part. I, I. z, e. \&. - Gesner Franeth. (604) , p. 291. - ' Coraciaus niger Salviani. A Aldeov. (B. logue, 1658) lib. 1, cap. 15, p. 75. - Caracimus Gesneri. Id art, 11, tab, 15, fig Joaston (Ams. 1637) lib. 1, tit, 2, cap. I, iCe poison, dont ingy

du Maigre d' Europe (Seiena dquile a été confondue avec cell geare Cons. Cest le Corvina nigra, que M. Cuvier place dans la famille des Áanthoptérygieas sciéno:Ides. D. :Seicena cylindrica. Bloch, pl. 299, fig.1. percớdes, Cur. D. "OForskael, Faun.

i" Du genre Holockerye, , 48, n. 55. inopterygiens percoides. Ce poisson a etét deterit des Acan政 is Non mentiounée par M. Cuvier. D. "A. Aspro niger lipeis M. Cuvier. Merson, manuserits dés ája cités.
. " Du gene Gasmiste, dans 政

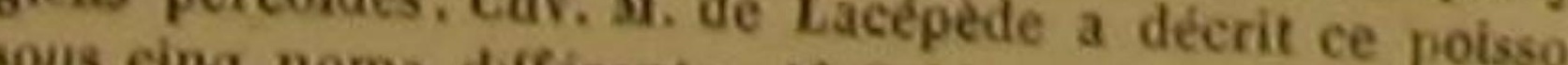
triacanthe, $5^{\circ}$ Persetgents, 10 Sciène rayce, $2^{\circ}$ Persegune se Centropome six.race D. tables perséques, une dentelure etdes piquants. Elles appartiénnent done non-seulement á deux espèces distinctes, mais mème à deux genres différents.

Nous n'avons pas cru cependant qu'il nous suffit de montrer les grandes dissemblances qui separent ces deux thoracins: nous avons voulu rapporter à chacun de ces animaux les passages des auteurs qui ont trait à ses formes ou a ses habitudes, et qui ont été eités par les principaux naturalistes modernes; nous avonis tiché de rectifier les erreurs qui se sont glissées dans ces eitations, particulièrement dans celles qui ont été faites par Artédi et par les naturalistes qui l'ont copié. Les notes de cet ourrage qui presentent la synonymie relative acettescienect a cette perseque, offrent le résultat de notre travail à cet égard. La sciène umbre est le poisson Corbeau, le Coracin des Grees, des Latins, et des naturalistes des derniers siècles : la persèque umbre est la véritable $U$ mbre dẻ ces mêmes auteurs: La première est aussi le Corp de Rondelet, et de plusieurs autres éerivains; et il au. kait été à désirer que dans des ouvrages d'histoire naturelle très-recommandables, on n'eùt pas appliqué á la perseqque umbre cette dénomination de Corp, qui n'aurait dù appartenir qu' la sciène dont nous écrivons I'histoire. Cette sciène a la tète courte, et toute cou. verte, ainsi que la base de la seconde dorsale, de l'anale et de la caudale, d'écailles semblables a celles du dos; chaque narine percée de deux orifices; deux rangs de dents petites et pointues à la mâchoire d'eu haut, un frond nombre de dents plus petites à celle d'en bas; les écailles finement dentelées; les thoracines très-noires; les autres nageoires noires avec un peu de jaune à leur base; les cótés du corps et de la queue parsemés d'une très-grande quantité de points noirs presque imperceptibles; et des reflets dorés qui brillent au milieu des differentes nuances noirâtres dont elle est varièe.

C'est le beau noir dont l'umbre est parée, qui l'a fait, dit-on, comparer au corbeau, corax en ree, et l'a fait nommer Coracinus. Le poète gree Marcellus, de Séide en Pamphylie, lui donné le nom d'Argiodonte ', à cause de la blancheur des dents de ce poisson, que l'on avait d'autant plus observée, que la couleur générale de l'animal est noire.

Elle parvienta la longueur de trois ou quatric décimetres. Son canạl intestiual n'est pas long mais son estomae est grand, le foie volumineux, et le pylore entouré de sept ou huit coecums.

Elle habite dans la Méditerranée, et notamment dans I Adriatique; elle remonte aussi daus les fleuves. On la trouve particulierement dans le Nil, et il parait qu'elle se plait au milieu des algues ou d'autres plantes aquatiques.

Aristote la regardait comme un des poisson qui eroissent le plus vite.

Les individus de cette espece vivent en troupes. Les femelles portent leurs aufs pendant longtemps; elles aiment à les déposer près de rivages ombragés, et sur les bas-fonds tapissés de végétaux ou garnis d'éponges; elles s'en débarrassent pendant l'été ou au commencement de l'automne, suivant le climat dont elles subisent l'influence; et e'est pendant qư elles sont encore pleines que leur chair ést ordinairement le plus agréable au goút

Plus l'eau de la mer ou celle des rivieres est échauffée par les rayons du soleil, et plus elle convient aux umbres; aussi ces sciènes, plu sensibles au froid que beaucoup d'autres poissons, s'enfoncent-elles dans lés profondeurs de la mer ou des grands fleuves, des les premieres gelées de l'hiver. On ne peut alors les prendre que rarement et difficilement; et on ne peut mème y parvenir dans ce temps de leur retraite que lorsque leur asile n'est pas inaccessible ì la traine ${ }^{2}$ ou au boulier ${ }^{3}$. 'Argos, en grec, signifie blanc.
? Traine est un des norus du filet appelé seine. Voyer tart de la Raie bouclée,

Le boulier est un filet dont on peut voir la description
Dans les autres saisons, on les prend avee plusieurs sortes de filets, ou on les pèche avec des ligues que I'on garnit souvent de portions de crustacee. Elles aiment en effet à se nourrir de cancres, aussi bien que d'animaux à coquille, et d'autres habitants des eaux, faibles et petits.

Dès le temps de Pline, les umbres du Nil etaient recherchees, comme l'emportant sur les autres par la bonté de leur goùt. Toutes celles que l'on trouvait dans les fleuves, les rivières ou les laes, étaient en général, préférées á celles que l'on prenait dans la mer; et les jeunes étaient plus estimées que les plus agées.

Dans tous les pays où l'on en péchait une très-grande quantité, on les conservait pour les transporter au loin, en les imprégnant de sel. Celles que I'on avaít ainsi préparées en Egypte, recevaleut des anciens Grees, suivant le fameux philosophe Xénocrate, le nom particulier de Coraxidia; et ces mèmes Grees nommaient Tarichion conaxinibos le garum que l'on faisait avec ces sciènes imbibées de sèl. La variété de la sciene umbre, dont plusieurs auteurs ont parlé, et quí est distinguée par ses nuances blanches, était moins recherchée que les umbres ordinaires ou umbres noires. Au reste, it est bon de remarquer que l'on a vu dans l'espèce de poisson noir dont nous nous occupons, une variété plus ou moins blanche, de mème que l'on voit des hidividus blanes dans les espèces de mammiferes et d'oiseaux dont le noir est la couleur générale.

Suivant Bloch, on emploie maintenant, pour conserver les umbres que l'on a prises, une autre préparation : on les grille et on les met dans du vinaigre épicé.

Indépendamment du goût agréable des sciénes umbres, les anciens avaient un motif trèspuissant pour les pécher; ils s'étaient persuadés que ces poissons jouissaient de facultés très-extraordinaires; ils ont écrit que des frictions faites avec ces scienes salées etaient un excellent remede contre la morsure du scorpion, et méme contre lecharbon pestilentiel et quele foie de ces osseux éclaircíssait ou améliorait la vue. La sciène cylindrique a la partie antérieure de la tête dénuée de petites écailles; la bouche grande; les lèvres grosses; la máchoire infé. rieure plus longue que la supérieure, et garnie, comme cette dernière, de dents petites et pointues; un seul orifice a chaque narine; les 


\section{IISTOIRE NAIURELLE}

écailles dures et dentelées; la ligne latérale celles d'une lime. Les écailles sont très-lisses droite; l'anus plus proche de la tète que de la et très-petites. Cette sciène offre des dimensions caudale; la première dorsale noire; les pecto- à peu pres semblables à celles de la pentadacrales et les thoracines jaunes; la seconde nageoire du dos, l'anale et la caudale jaunâtres, et pointillées de noir.

La mer d'Arabie est la patrie de la sciène sammara. Ses còtés sont argentés, et présentent chacun dix petites raies longitudinales. Lespectorales sont roússes; les thoracines blanches; la seconde nageoire du dos, l'inale et la caudale transparentes. De plus, les deux cótés de la caudale, le premier et le dernier rayon de lanale, ainsi que le second et le troisième de la seconde dorsale, brillent d'un beau rouge '.

Commerson a vu dans les embouchures timeneuses des petites rivières de l'lle de Franeê, qui se jettent daus la mer et recoivent un peu d'eau salée, la sciène a laquelle nous avons donné le nom de Pentaduclyle, ou de poisson a cinq doigts, pour designer les einiq ray ons de ses thoracines. On sait que les thoracines ont èté, en effet, comparees à des pieds, et.leurs rayons a des doigts, La langue de cette sciène est lisse ${ }^{2}$; l'aiguillon de l'opereule tres-petit dans les jeunes individus; et la longueur ordinaire de l'animal, de quinze ou vingt centimetres.

Commerson a trouvé dans les mềmes caux, ou à peu près, la sciène rayée. On voit une tache blanche sur la premiere dorsale et sur les thoracines de ce poisson. La mâchoire supérieure est extensible, et plus courte que l'infésieure, au-dessous de laquelle on aperçoit un tres-petit barbillon. Les deux mâchoires sout garnies de dents tres-courtes, et pressèes comn

- Nous navons pas vu dindividus de lespecee die la sammara. St, contre notre opinion, ce poisson avait les opercules 2 18 rayons a chaque pectorale de ia sciènes

cha que thoraeine, 19 a la nageoire de la queue. -6 rayons la menbraue branchiate de la seiene croker, is a chaque pectorale, 1 rayon aiguillouné et 5 rayons ar tieulés a chaque

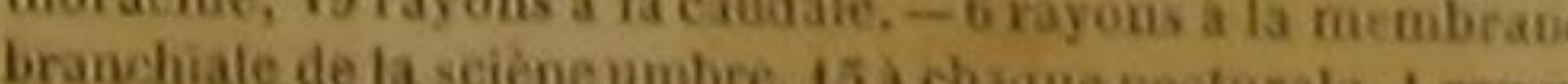
aiguillónoné el 5 rayous articulés a charpe thoracine, ig rayons a la nageoire die la queue, -5 rayons d la mene, 19 branchiale de la sciene cyliaurique, 12 a chaque pectorale, I rayou aiguilloané et 5 rayons arliculés a chaque thoradive, is rayous a la caudaie. -8 rayons a la membrane

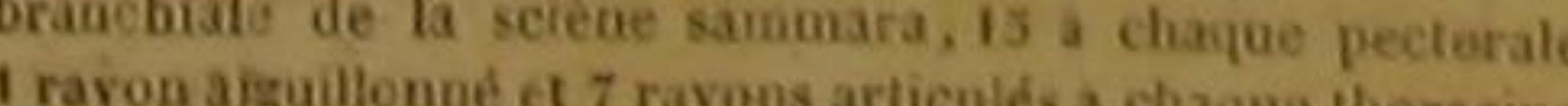
20 rayons a la vageoire de la queue. -6 rayons a 3 is mene. brane brancbiale de la seiène pentadactyle, í a cha anentorale, 16 a la caudale: -15 rayons a chaque pectorale ie seiebe rayée, 1 rayou aigullonné et 5 rayons articultés a cha-
que thoractoe, 15 rayons a la nageoire de la queue. tyle.

\section{CENT VINGT-UNIEME GENRE.}

LES MICROPTĘ̇:ES .'

Un ou plusiews aiguailons, et point de dentelure aus opergutes; un barbillow, ou point de barbillon aumächoires: deux nageoires dorsales : la seconde trèsbasse, tres-coturte, el comprenant as ptus cing rajois.

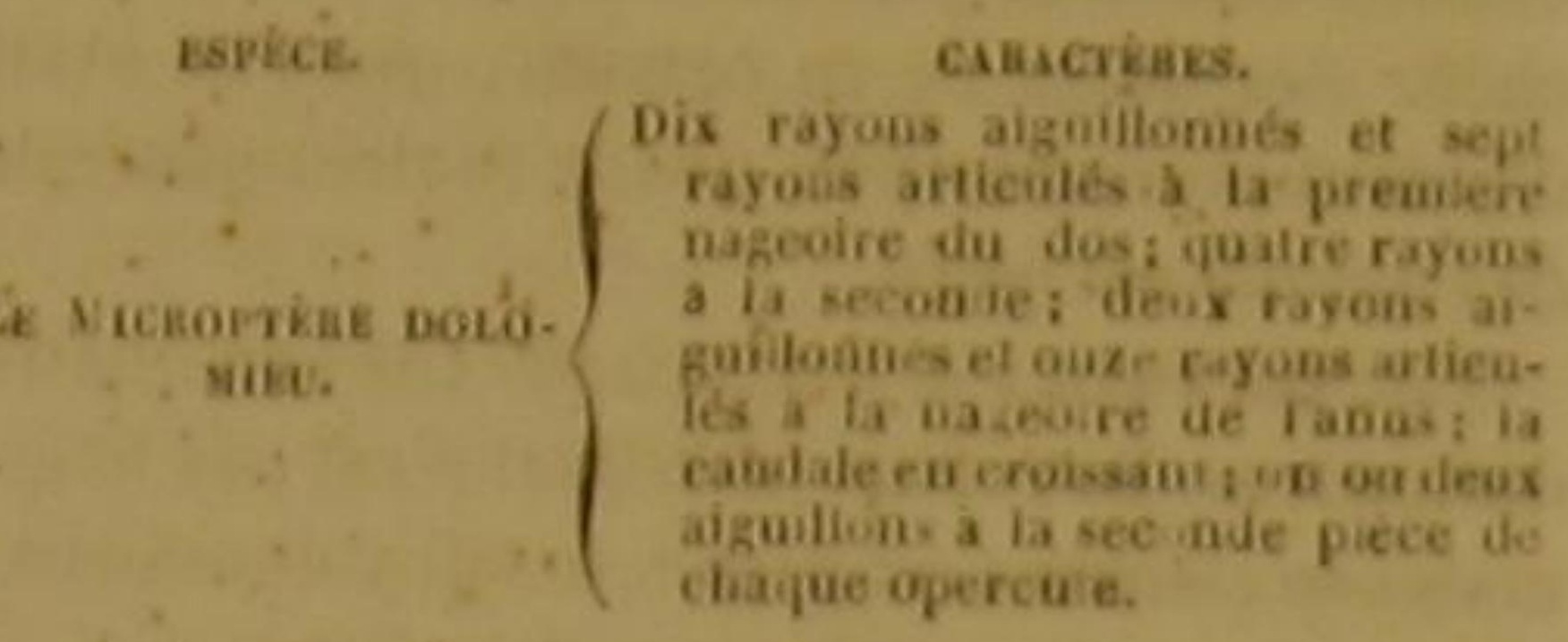

IE MGROPTERE DOLOMIET Nicrồpterus Dolowieu et Labrus Salmoides, Lacèp. ?. Je désire que le nom de ce poisson, qu'aucun naturaliste n'a encore décrit, rappelle ma tendre amitie et ma profonde estime pour l'illustre Dolomieu, dont la vistoire vient de briser les fers ${ }^{3}$. En écrivant mon Discours sur la duree des especes, $j$ 'ai exprime la vive douleur que m'inpirait son affreuse captivite, et l'admiration pour sa constance héroique, que l'Europe mehait à ses veux pour lui. Qu'il m'est doux de ne pas terniner l'immense tableau que je tàche d'esquisser, sans avoir senti le bouheur de le serrer de nouveau dans mes bras!

Les mieroptères ressemblent beaucoup aux sciènes: mais la petitesse très-remarquable de eur seconde nageoire dorsale les en sépare;

4.2 Dans le t. II de la 20 edit. dù Regne animal, M. Cavier place le geare MicioptènE dans la farnille des Acanthopterydes pourvises et dans L division qui renfermè les sciénoidesterale continge tels quageoire dorsale et diune ligne

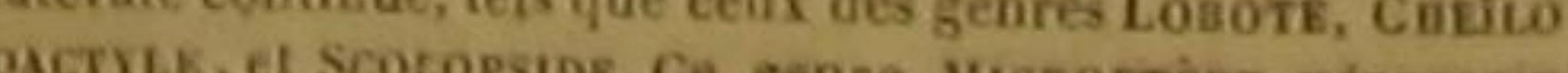
riest pas compris dans la description déaillée des Scibmi. des qui compose le tome $\mathbf{V}$ de I Histoire naturelle des Poissons, et dans la preflace de ce volume M. Cuvier fait comai. ure quion nouvel examen qu il a tait de I exemplaire anique qui a servi a la description de M. de Lacépéde. lai a démon-

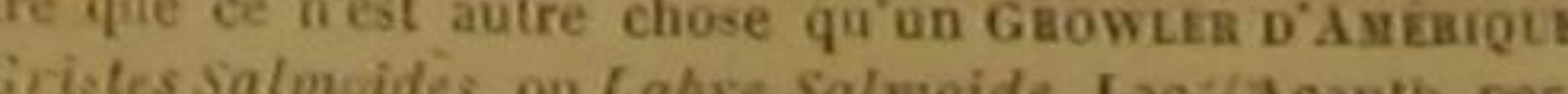
coiles), dans lequel Labre Salmoide, Lac: (Acanth. permous de la dorsale, en sorte que les rayons git surajon "enblent former ure petite nageoire particuliére. $\mathbf{D}$.

DES POISSONS

359

et c'est cette petitesse que désigne le nom générique que je leur ai donné '

La collection du Museum national d'histoire naturelle renferme un bel individu de l'espece que nous décrivons dans cet article. Cette espece, qui est encore la seule inserite dans le nouveau genre des microptères, que nous avons cru devoir établir, a les deux máchoires, le palais et la langue, garnis d'un tres-grand nombre de rangées de dents petites, crochues et serrées; la langue est d'ailleurs très-libre dans ses mouvements; et la máchoire inférieure plus avancée que celle d'en haut. La membrane branchiale disparait entierement sous l'opercule qui présente deux pièces, dont la première est arrondie dans son contour, et la seconde anguleuse. Cet operoule est couvert de plusieurs écailles ; celles du dos sont assez grandes et airondies. La hauteur du corps proprement dit excède de beaucoup celle de l'origine de fa queue. La ligne laterale se plie d'abord vers to bas, et se releve ensuite pour suivre la courbure du dos. Les nageoires pectorales et celle de l'anus sont très-arrondies: la première du dos ne commence qu'a une assez grande distancé de la queue. Elle cesse d'être attachée au dos de l'animal, à l'endroit où elle parvient audessus de l'anale: mais elle se prolonge en bande pointue et flottante jusquau-dessus de la seconde nageoire dorsale, qui-est très-basse et très-petite, ainsi que nous venous de le dire, et que l'on éroirait au premier coup d'cill entierement adipeuse ${ }^{2}$.

\section{CENT VINGT-DEUXIEME GENRE.} LES HOLOCENTHES ?

Un ou plusieurs aiguillons et me dentelure aux operlous aux michoires; tane seule nogeoire dorsale.

PREMIER SOUS-GENRE.

La nageoire de la queue fourchue, ou echancrie en crois

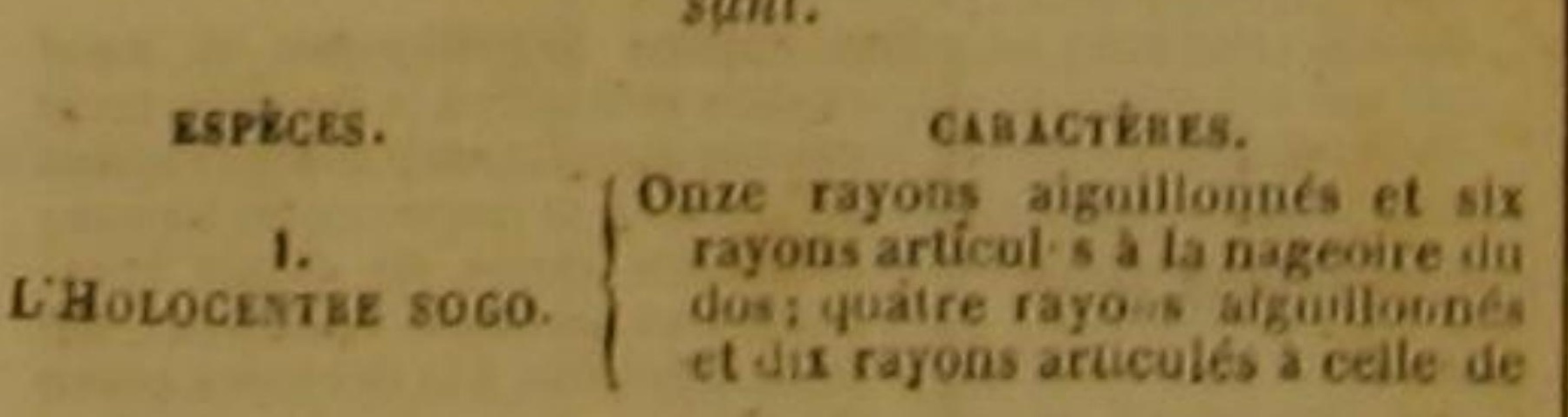
- Mupos, en greć, signifie petil.

Mcxpos, en grec, signifie petil. rale. I rayos a membrone branchiale. 16 a chaque pectoracine, 17 rajons à la nageoire de la queue.

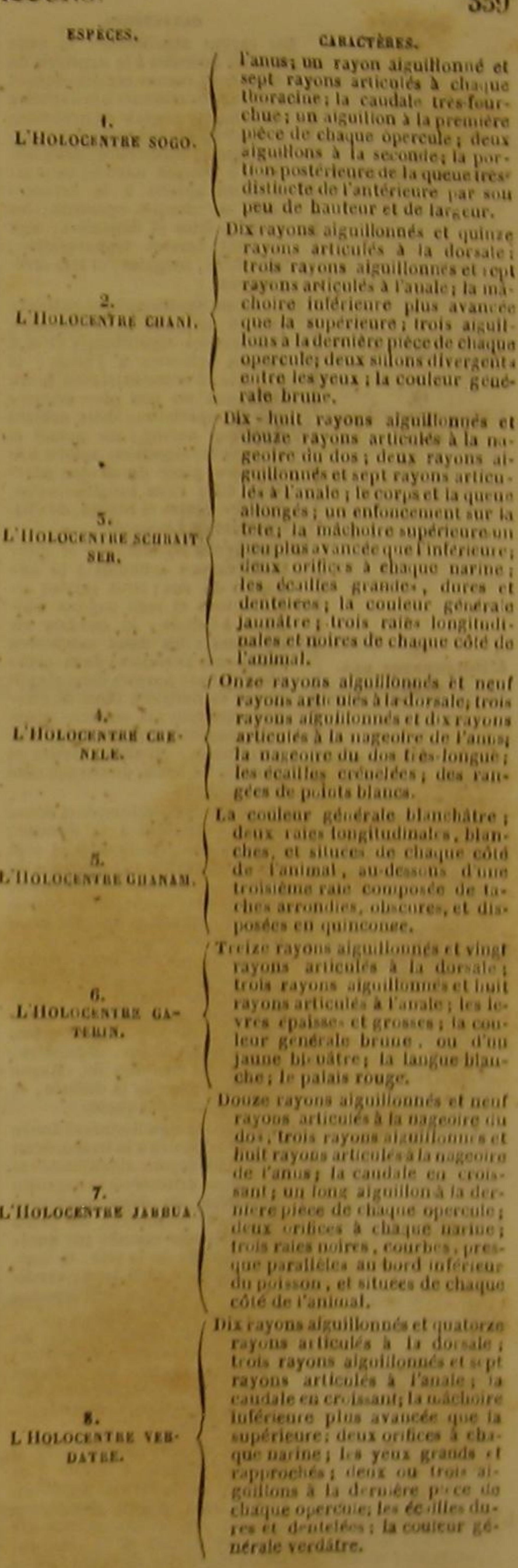

qưun petit nombre des eapeces de $\mathrm{A}$ de Lactpete. Il rabige

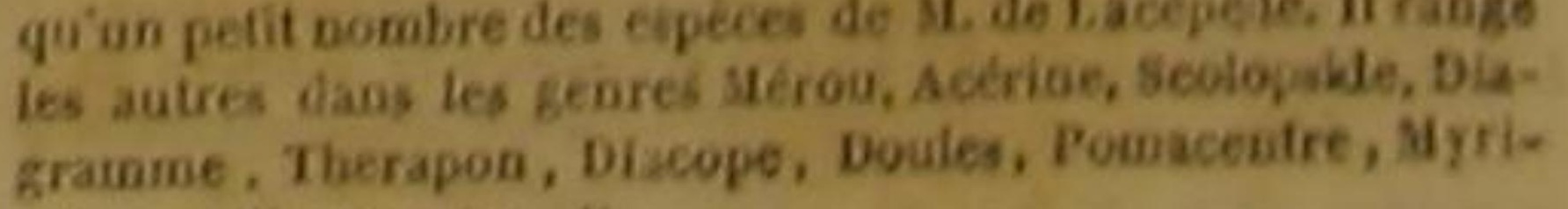
gramme, Therapon, Dizop
pristis, Sebaste, ete. D. 


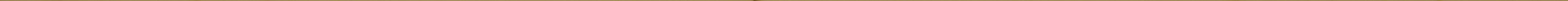


HISTOIRE NATURELLE

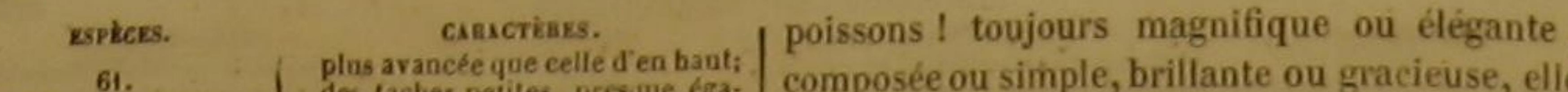
les et rondes, sur ia ticitic corps est si diversifiée, cette parure remarquable, ou par les nuances qui la composent, ou par la

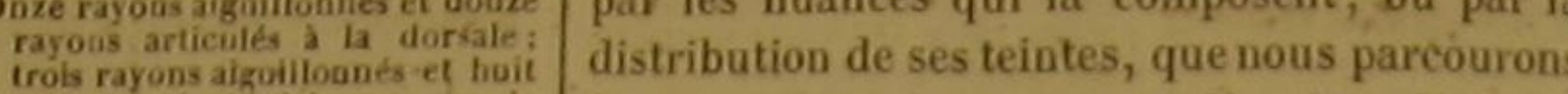
rayons articules a la nazcoire de en vain un nombre immense d'espèces differen-
lanus: la caurdale arroudie: deux aiguilions à la derniere pieee de tes; nous avons toujours sous les yeux un as. chaque opercule, quil hinit en
pointe; la máchoire inferieure

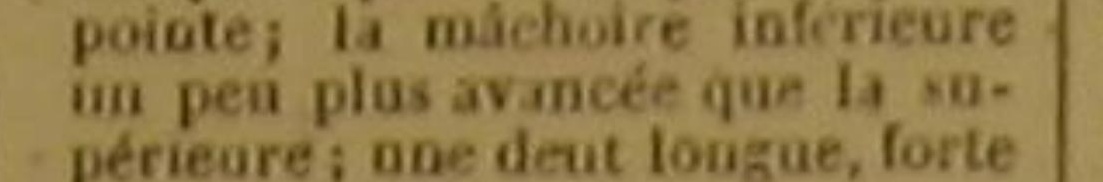
sortiment nouveau de couleurs et de tons. Aucune espèee ne ressemble à urie autre par la disposition, par les reflets, par l'éclat de ses nuances, Et que l'oir ne soit pas étonné que les sept couleurs du prisme suffisent pour produire, entre les mains de la nature, cette merveilleuse diversité. Lorsqu'on rappelle la quantité prodigieuse de dégradations que chaque couleur peut présenter, toutes les combinaisons qui proviennent des mélanges de ces dégradations, employées deux á deux, trois à trois, quatre à quatre, et fondues successivement les unes qui se termine en pointe; cin
bandes transversales, courtes et
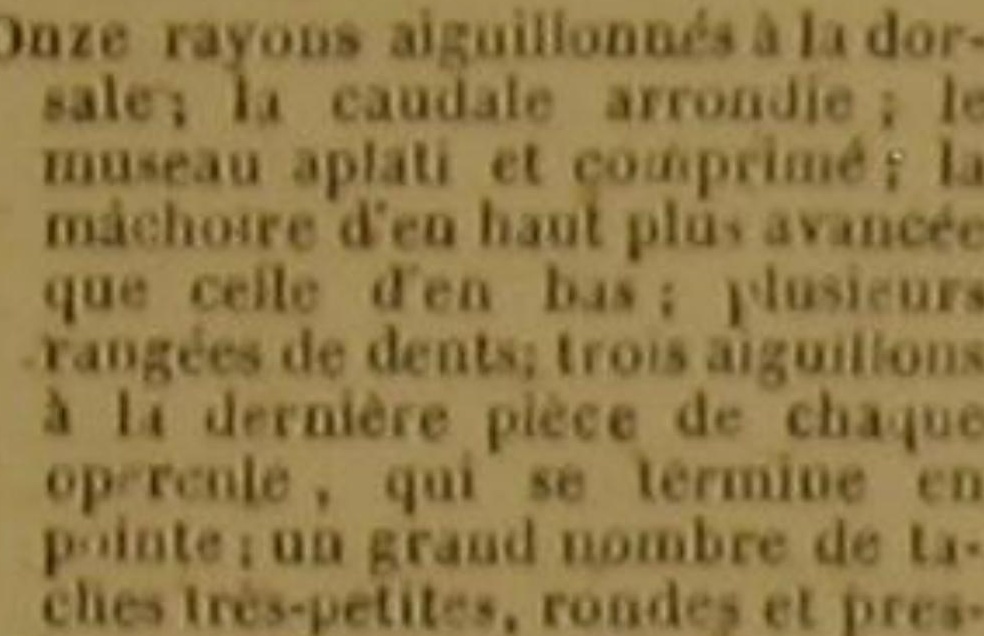

ches tres-petites, roodeg et pres.
que egates sur ia téte, le corps,
la quene et les nazeoires.

Lales. - The wetahinan, par les Anglais de la Jamailuue. The squirrel, par les Anglais de la Caroline. - Marignau.

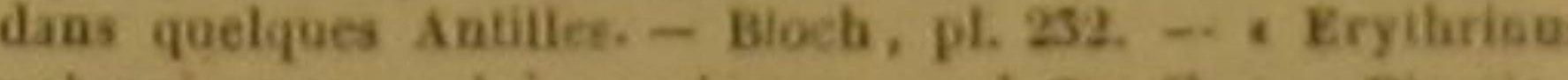
polygrammos, valgo unarignan apud Caralbas. P Piumier,

a Da geore HoLocastas de M. Cuvier, dass ta famille des
A - Labre chani. Bonnaterce, pl, de IFnc, méth.-Forikael, Faun. Arab., p. 36, D. 32.

1. Da gène Minoo, Serranus, dans la fumille des AemIt opterygiens percoides de il. Cuvier, al, de Lacípede a decrit ee polson quatre fois dans soa ourrage, sous les bomis do et i Hol centre Chaial.

IS Seiralsel, Serafen, Schrasen, Schrans, dans plas.
eoutrées de 1 Allemague. - Persegue sehraiser. Daubento

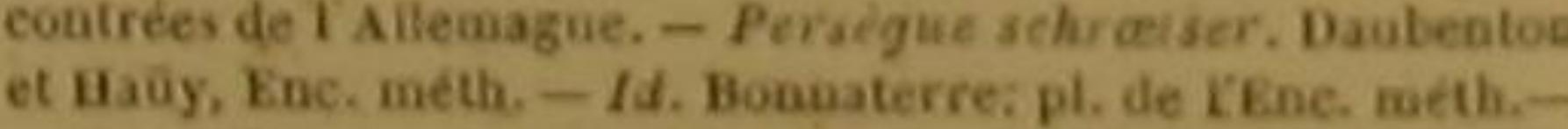
- Perea dorso monopterygio, lieeis utrinque longitudinati-

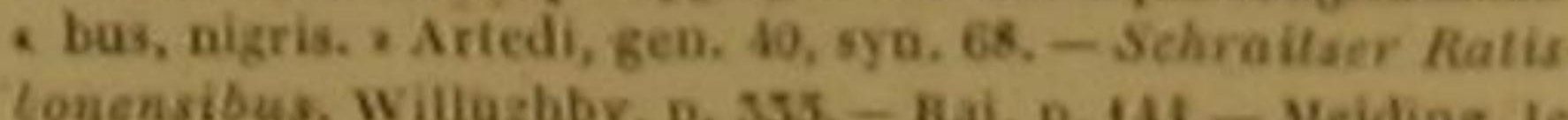

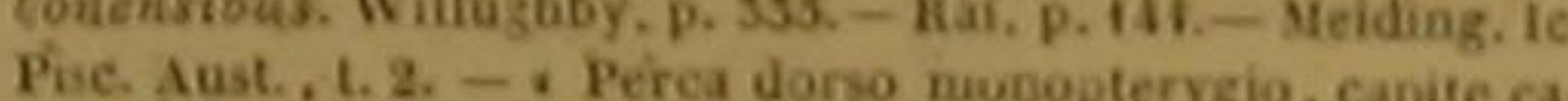
- vernoso alepidoto aculeato, caujás sublunatí, carpor tineari. . Gronov, Zooph. 289. - Kram. Elench., p. 387, u. 5. - Schraitser. Schofl. Pisc. Ratisb. 48, tab. 2, fig. 2. -

Du geare Garmiler, Acerina , Cur., dans la famille des Acunthoptérygiens percoildes. D.

Id. Bonosterse pl, de IEnce menton et Hany, Eoc, meth. -

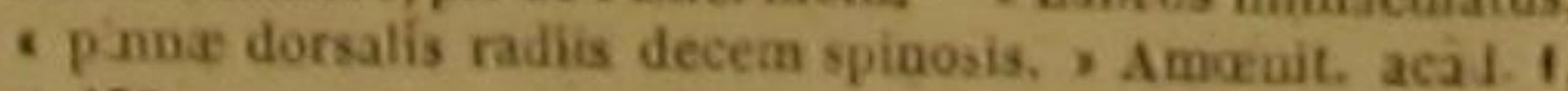
p. 153.

: Non mentionné par M. Cuvier. D.

. Sorkael, Faun. Arab., p. 50, n. 56. - Sciène ghanam. Honnaterre, pl. de IEnc. mieth.

rygens ucieofdes, Coys. D. dans la tamille des Acantbopte"Forskael, Faun. Arab.

. Du genre Dugasme, Cuv., dans la famille des Acan"He Hieces scienoides, D.

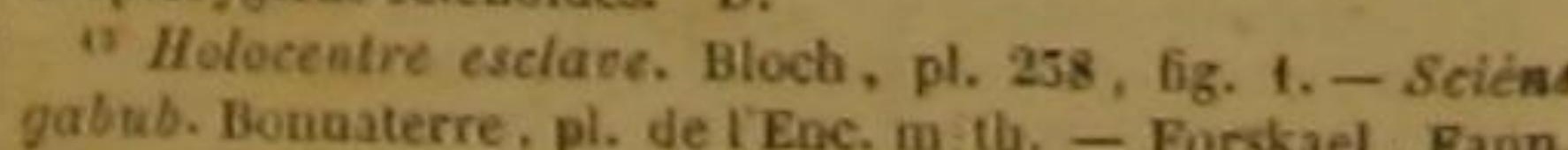

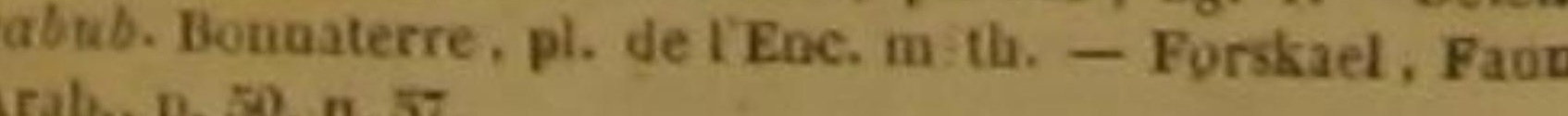
Arab., p. 30.

" Da genre Tukapos; Cuv., dans la famille des Acan-
Chopterygiens percoildes. D.

DES POISSONS.

dans les autres, juśqu'à ce qu'on ait épuisé toutes les différences que ces rapprochements peuvent faire naitre; lorsque enfin on multiplie tons ces produits par des quantités bien plus grandes encore, par toutes les sortes de distributions de nuances qui peuvent étre réalisêes, on parvient à des nombres que l'esprit ne peut saisir dans leur ensemble, dont I'imagination la plus vive ne découvre qu'une pórtion de la série presque infinie, et dont on ne détermine toute l'étendue qu'en usant de toutes les ressources que l'on peut devoir à la science du caleul.

Le genre des Holocentres va nous fournir d nouveaux exemples de l'emploi qu'a fait la nature, de ces combinaisons de distributions uniformes ou differentes avee des nuances diverses ou semblables. Le sogo est un de ces exemples les plus frappants. Nous avons déjà vu un bien grand nombre de poissons briller de l'éelat de l'or, des diamants et des rubis; nous allons encore voir sur le sogo les feux des rubis, des diamants ou de l'or. Mais quelle nouvelle disposition de nuanees animées ou radoucies ! Ie rouge le plus vif se fond dans le blane pur da diamant, en descendant de chaque cóté de l'animal, depuis le haut du dos jusqu'au-dessous du corps et de la quẹe, et en se dégradant par une suecession insensible de teintes amies et de reflets assortis. Au milieu de ce fond nuaneé s'étendent, sur chaque face latérale du poisson, six ou sept raies longitudinales et dorées ; la couleur de l'or se méle encore au rouge de la tête et des nageoires, particulièrement a celui qui -colore la dorsale, l'anale et la caudale; $\mathrm{et}$ son cil très-saillant montre un iris argentin entouré d'un cercle d'or.

Ce beau sogo doit charmer d'autant plus les regards lorsqu'il nage dans une eau limpide, pendant que le soleil brille dans toute sa splendeur au milieú d'un ciel azuré, que ses nageoires sont longues, que les mouvements en sont plus rapides, et que, réfléchissant plus fréquemment, et par des surfaces plus étendues, les rayons de l'astre de la lumiere, elles scintillent plus vivement, et efiacent avec plus d'avantage l'éclat des métaux polis et des pierres orientales les plus précieuses.

On devrait le multiplier dans ces lacs charmants qu'un art enchanteur contourne mainte. nant avec tant de goût au milieu d'une prairie émaillée, et â cóté d'arbres et touffus et fleuris, dans ces jardins avoués par la nature et parés de toutes ses grâces, d'où le sentiment n'est jamais exilé par une froide monotonie, et qui eutives, il y a trois mille ans, dans la Grece heroique, conservés jusqu'à nos jours dans l'industrieuse Chine, et adoptés par l'Europe civilisée, ont mérité d'étre chantes par flomère et Delille. Se livrant à ses mouvements aqrèables au milieu des eaux de ces lacs paisibles, il y ondulerait, pour ainsi dire, comme l'image d'une belle fleur agitée par un doux zéphyr; il completerait le tableau riant d'un Eden où les caux, ta verdure et le ciel marieraient et leurs brillants ornements et leurs nuances touchantes. II s'accoutumerait d'autant plus facilement a sa nouvelle demeure, que la nature l'a placé non-seulement aux Indes orientales, en Afrique, aux Antiiles, a la Jamaique, mais encore dans les eaux de l'Europe.

Et d'ailleurs il réunit a la magnificenee de ses vétements une chair tres-blanche et d'un goùt exquis.

Au reste, sa langue est lisse ; le sommet de la tête sillonné é dénué de petites écailles. On ne compte qu'un orifice à chaque narine; les ecailles du corps et de la queue sont dentelies; et les deux máchoires garnies, ainsi que le paais; de dents petités, pointues et semblables a celles d'une lime.

Bloch a va une variété. đu sogo, qui differe des autres individus de cette espece par les. traits suivants. Le museau est obtus au lieu d'ctre pointu; la téte n'est armée que d'un aiguillon de chaque côté; les proportions des rayons de la dorsale et de la nageoire de l'anus ne sont pas tout a fait semblables a celles que montre le sogo proprement dit; on compte a l'anale deux rayons articulés de plus qu'à celle de ce dernier poisson : les raies longitudinales et jaunes sont si-faibles, quion a de la peine a les apercevoir; quełquefois même elles disparaissent en entier.

II ne faut pas confondre l'holocentre Chani, que Forskael a découvert, qui habite dans la Propontide, et qui vit particulierement auprès de Constantinople, avec le lutjan serran, que les Grees on nommé et nomment encore Chan no', et sur lequel on trouve des observationa précieuses dans un nouvel ouvrage très-important du savant naturaliste et célebre voyageur M. de Sonnini ${ }^{2}$.

: v. I'Hist des polsons du profesear sebiaeider, p. 80. 
L'holocentre chani a trois petites raies bleuâ- | ordinairement jaunes; il est souvent tacheté de che tache bleue et carrée au-dessous de l'oil ; les décimètres ; mais on compte dans cette espèce
pectorales, les thoracines et l'anale jaunes; la trois variétés assez remarquables pour qu'elles pectorales, les thoracines et l'anale jaunes; la trois varietés assez renarquables pour qu' elles

C'est dans le Danube et dans les rivières qui mière, que l'on nomme Abu-mgaterin, n'a mèlent leurs eaux à celles de ce grand fleuve, qu'un décimètre de longueur; et chacun de ses qu'on pèche l'holocentre schraitser. Ce poisson eótés présenté quatre raies longitudinales bruparvient à la longueur de trois ou quatre déci- nes et mouchetées de noir: les pécheurs de la metres. Sa chair est blanche, ferme, saine, et mer d'Arabie disent, et leur opinion me parait d'un goùt agréible. Il se nourrit de ver̉s, d'in- trè-vraisemblable, que l'abu-mgaterin n'est sectes, et de très-petits poissons; il fraie dans qu'un gaterin très-jeune, qui perd en grandisle printemps, cherelie les eaux limpides, et perd saut ses raies mouchetées et brunes. La seeonde difficilemènt la vie. Les inondations du fleuve variété est appelée.Sofat; sa longueur est de ou desrivières qu'il habite, le transportent quel- douze déeimètres; ses nageoires sont noires au quefois au-dessns des bords de ces rivières, lieu d'ètre rouges; èt son goủt est très-agréajusque dans des laes assez éloignés, dont le sé- ble. La troisième variété, a laquelle on a donné jour ne parait pas lui nuire.

Sa tête ni ses opereules ne présentent pas de petites écailles; la langue est lisse; le palai rude ; chaque mâchoire garnie de petites dent semblables à cellesd'une lime; l'estomac allonge et membraneux; le pylore entouré de trois ap pendices; le canal intestinal recourbé deux fois; e foie grand et divisé en trois lobes; la vésicule du fiel pleine d'un fluide jaune et très-amer l'ovaire simple; la vessie batatoire longue et attachée aux côtes, qui, de chaque cóté, sont au nombre de neuf, et l'epine dorsale composée de trente-neuf vertèbres.

Le péritoine est aroenté ; les onfs sont jannes et de la grosseur d'un grain de millet; les nageoires bleuátres; la partie antérieure de la dorsale est tachetee de noir ; et de très-petits points noirs sont répandus sur la téte.

Nous devons faire remarquer comme une preuve de ce que nous avons dit dans le Discours sur la nature des poissons, au sujet des couleurs de ces animanx, que, lorsqu'on a enlevé les écailles du schraitser, sa peau offre encore les trois ou quatre raies longitudinales et noires qui règuent sur chacun de ses cótés, et que nous avons indiquées dans le tableau générique des holocentres.

Le crénelé vit dans l'Inde; et le ghanam, dansla mer d'Arabie. Comme nous n'avons pas vud'individu de cette dernière espèce, nous ne pouvons pas assurer que la nageoire de la queue de ce thoracin soit fourchue ou en erossant ; mais plusieurs raisons nous le font présumer.

L'holocentre gaterin a la mer d'Arabie pour patrie, comme le ghauam; ses nageoires sont le nóm de Folela, est aussi d'une saveur trèsrecherchée: mais elle parvient à des dimensions bien plus grandes que la seconde; elle est quelquefois longue de trois ou quatre mètres. Sa grandeưr, son poids, et la bonté de sa cbair, doivent la rendre l'objet d'une péche assidue; et comme elle a de plus que les autres varietes, et mèmeque le gaterin proprement dit, des ramifieations très-sensibles aux cayons aiguillonnés de la dorsale, ét qu'elle offre ainsi un trait d'un développement plus étenda et d'une conforma. fon plus complète, ne pourrait-on pas croire que la Fetela n'est que la sofat.parvenue à un áge plus avancé et à un plus grand aceroissement; que la sofat n'est qu un gaterin plus agé: et que par consequent, a mesure que I holocentre dont nous parlons grandit en aequérant des années, il s'appelle.d'abord $A b u$-mgaterin, ensuite Gaterin, ensuite Sofat, et enfin Fotela? Au reste, le gaterin se plait au milieu des coraux et près des rivages.

Ces mêmes rivages arabiques servent d'asile au jarbua, que l'on trouve aussi dans le grand Oeéan, aux environs des tropiques, où Commerson en a fait faire un dessin que nous avons fait graver: On pêche également cet holocentre dans les eaux du Japon: mais comme il y èst très-abondant et qu'il a la chair maigre, il y est dédaigné par les gens riches, qui l'abandonnent pour la nourriture de leurs eselaves; et éest ce qui a fait donner á ce poissón, par les Hollandais des grandes Indes, le nom d'Esclave, que Bloch lui a conservé'

if a chaque pectorale, 20 à la caudale. de 1 holocentré sogo
Ce jarbua a la tête courte et comprimée; des dents petites et séparées l une de l'autre, à chaque máchoire; la langue lisse; le palais rude; chaque opercule garni de très-petites écailles ; la couleur générale argentée ; les pectorales et les thoracines jaunâtres; une raie longitudinale et deux raies noires et obliques sur la caudale, dont les deux pointes sont de la méme nuance que ces raies; et plusieurs taches noires et irrégulières sủr la nageoire du dos.

L'HOLOCENTRE V̀ERDATRE ',

Serrauus Cabrilla; var., Cur.; Bodianus Hatula, LutJanus Serran, Holoeentrus Chanos, et Holocentros virescens, Lacep, ',

L'Holocentre tigred', Secranus tigrinus, Cur., Holocentrus Ugrinus, Bl, Lac, 4. - Holocentre cinq-raies ', Diacope octolineata, Cuvi y Grammistes S-lineatus, BL., Schin. Holoceatrus stlineatus, Bi., Lae; Labrus octolineatus, et Labrus Kamira, Lae, i Holocentrus bengalensis, B1, Lac, 4, - Hoto centre Bengale, Diacope octolineata, Cav. (voy. I i kyno.

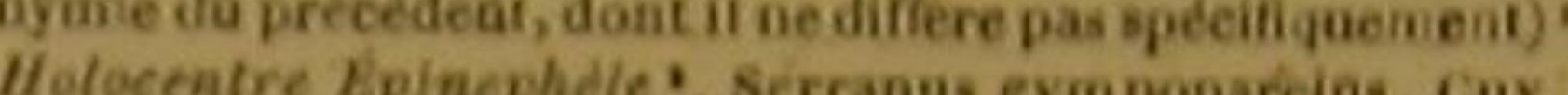

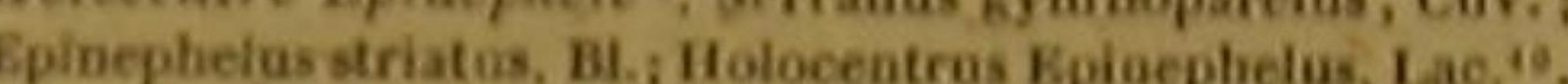
- Holocentre Post "u, Acerina valgaris, Cuvis Perea Cernoa, Lion., Gmel., Bl.s Gymnoerphalus Cernus, Bl., Schn. Uolocentrus Post, Lac, ",- Molocentre noir" ", Coryphena Pomp los, Lion ; Centrotophrus niger, et Holocentrus niger, Peres Acerins, Geldenst. Lign ", Acerina rossica, Cav. rina, Lace".

Il parait que le verdatre se trouve dans les

pectorale de Pholoceatre chant, I rayon aiguillonine et is rayons acticulés a chaque thoracine, 17 rayons at la nazeotio de la queue, -6 rayons a a membrave branchialo de 1 holo. centre schraitser, 14 a chaque pectorale, 1 rayon aiguilloned As rayons articuies a chaque thoracine, 15 rayons a la cau. ele. I rayous a ta membrane branchiale de Tholocentre articulét I chapue pectorate, 1 rayon aiguillowné et 5 rayons

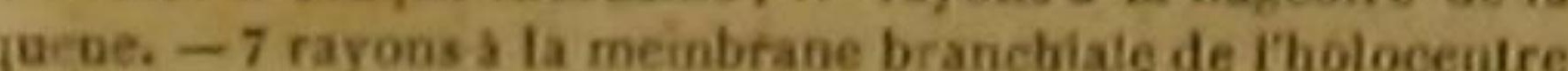
gaterin, 17 a chaque pectorale, 1 rayon aiguilitonné et 5 rayons articulés i chaque thoracine, 17 rayons \& la candale. -6 ayons a i membrane branchiale de I holocentre jarbua, 15 . isloch, pl. 255.

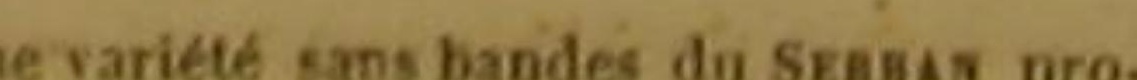
prement dit, on Mesoo Szanas de M. Cuvier. A cette mime espece e rapporteat encore trois autres poissons décrits par A. de Lacepede, sous les noms de Lutjan Serran, Holocen. tre Chani, et Bodian Hiatule. D.

- Ikan makekae, aux indes orientales. - Marquille, par - Da genre ME thoptérygiens percoiles. $\mathrm{D}$.

s. B oche, pl. 259.

- Ce poisson eas regardé par M. Cuvier comme une variété

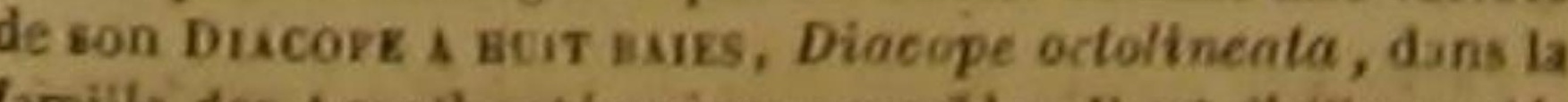
famille des Acanthopterygiens percớldes. II est d'ailieurs dé. garnies de dents pointues, dont les deux ante rieures sont les plus grandes; la ligne latérale est hérissée d'écailles petites et aignēs; des raies jaunâtres rènent sur les opercules; le dos présente des taches ou bandes tiansversales et irgulières d'un vert foncé ; on voit des teintes jaunes à la bąse des nageoires, particulièrement a celles des pectorales et des thoracines.

Valentyn, Renard, Klein, Séba et Bloch; ont

Labre d hail raies, Labre Kasmira, et Holocentre benali. D

loch, pli, 248, fig. 2

'Ce poisson n'est qu'une simple variete de l'espece pried- Thye stive Bloch pli so

Selsia de son de la mème espàce (famille des Acanthoptéryeiens pereot des ). D.

Perehe goujonniere, Gremillat, par les pécheurs de is Seine iolerieure, - Gremille, sur les bords de la Moselle ei

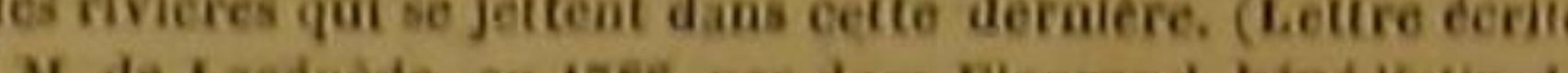
Ay, de Lactpede, ea 7785 , par dom Fleurand, benedetin do

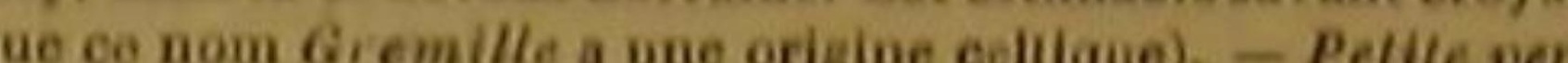
The, dans plus. eontrées de France - Cerna, i MalteAllemagne, - Pfaflentaus, hotswoli, e Autriche, - Sechroll, en Haviere, - Stuer, Stuer bass, A Hambourg. - Kaulaarsch, en Livonie, - Rissis, Ullis,

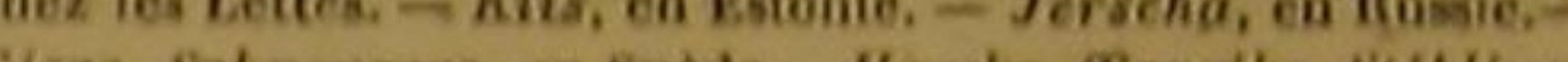
en Danemargers, en Suede, - Horcke, Tarrike, sibling. Post, Posch ou posehje, ea Hollande, - Pope, Kuffe ou Bauleaton et Hany, Enc, meth:- $-I d$. Hounaterre, pl. de Wac, meth. - Vaun. Suecic. 385. - Mull. Prodrom. Zoolog. Pere p. $46, \mathrm{n}, 392$. - Meiding, Icon. Piso. Austr., L. 3.

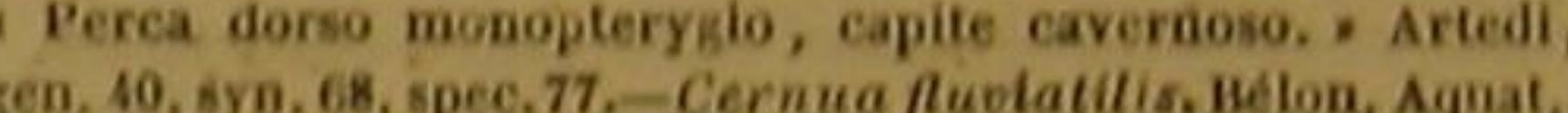
291. - Id. et peree fusialilis genus minus, Gesner, 1. 191, 701; et (germ.) fol. 160 a. - Id. Willoghby, D. 55 , ab. X, 14, fig, 2, - Id. Ra, p. 144, n. 10.-, Cernua fluviatiiis allis perca minor., Charlet, p. 158 et $161 .-\sim$ Perca mi.

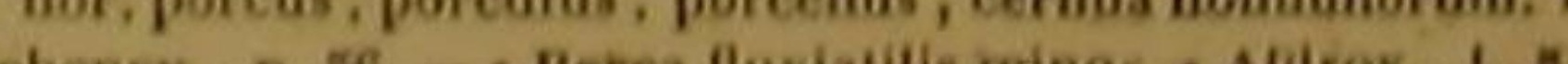

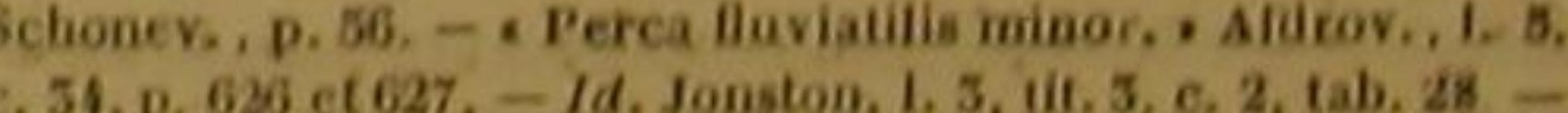

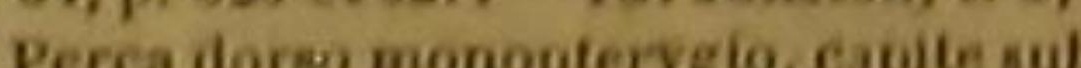
- aculeato. ete. , Gronov, Mas. 1, p. A1, 0. 94; Znoph... p. 85 a. 288. - Kram. Elench. 586. - Cernua. Schaffer, Pise. Ha

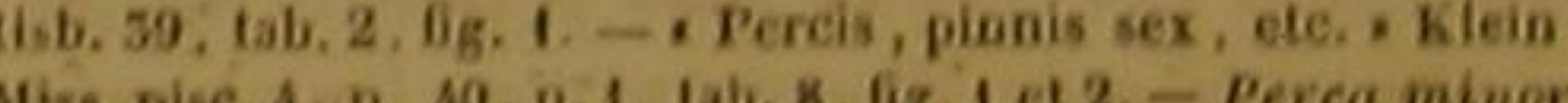

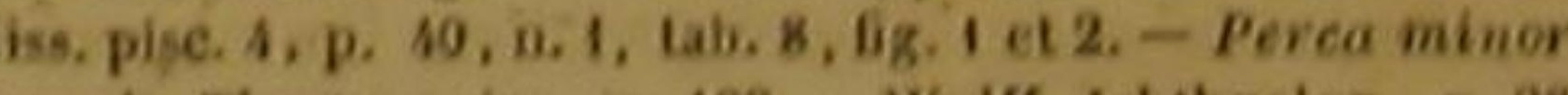
aysch, Theatr, anim., p. 108, - Woifr, Ichthyolog., p. 28 Marsigli, Danub. 4, p. 67, lab. 23, lig. 2.

"a Cest la grémilte commune ou perche goujonniere de nos pays, type da genre GasmiLle, Acerina, Cuv., dans la t. gaille des scanthopterygiens percoldes. $D$. "Blaufish. Brit, Zool. 3, p. 216, o. A.-Id. Borlase Cornwall, p. 274, abo, 25, ag. .

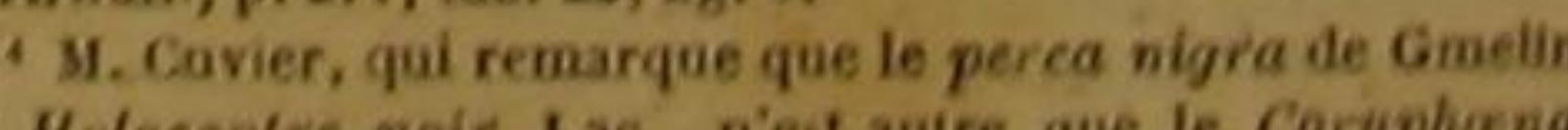
pompilus, Lion., ou ce qui est la méme chose, que le Cin.

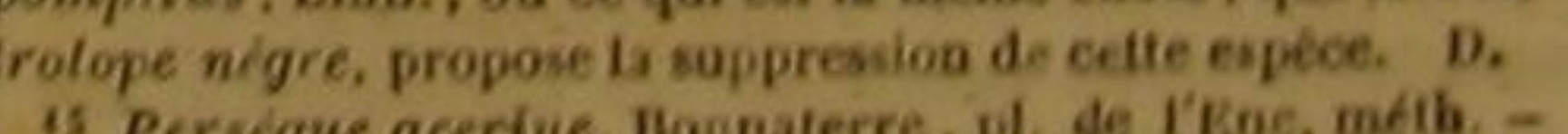
is Perisgue acerine. Bonnaterre, ph. de I'Ene.
Caidenstaedt, Nov. Comm. Petropolit, 19, p. 45 .

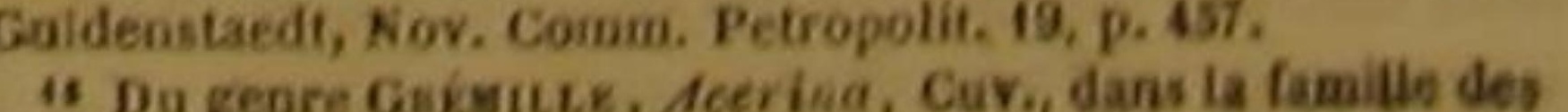
Acanthopterygiens percoldes. D. 
donné chacun une figure de l'holocentre tigré. | donnant le nom générique de eette petíte faCe poisson des Indes orientales a la chair déli- mille à la première espece de ce groupe qui se cate. Sa téte ést longue êt comprimée; les dents présente à nous dans l'examen que nous faisons sont pointues et irrégales ; la langue est lisse, et des divers holocentres. L'épinéphèle a le palais le palais rude; la couleur générale est bleuâtre; hérissé de petites dents; la langue lisse ; les on voit une raie brune passer an-dessus de cha- deux máchoires garnies de dents assez courtes; que oil, et s'avancer vers le museau. Indépen- le ventre arrondi; l'anus plus voisin de la tête damment des bandes transversales qu'indique que de la caudale. Deux raies longitudinales le tableau générique, la tête, le corps, la queue et brunes s'étendent sur chaque côté de l'aet les nageoires sont parsemés de taches bru- nimal, dont la couleur générale est blanchâtre. nes, presque toutes arrondies.

Le Japen est la patrie de l'holocentre cinq. raies. Il a la tête courte et comprimée ; un rang de dents séparées l'une de l'autre, à chaque machoire; un grand nombre d'autres dents serrées et placées sans ordre, à la mảehoire supérieure, ainsi qưau palais; ta première pièce de chaque opercule, échançée de manière à recevơir une sorte d'aiguillon tourné vers le museau, et attaché à la seconde pièce, laquelle d'ailleurs se termine en pointe membraneuse. La nuance générale du poisson est jaunàtre ; et un rouge foncé colore les nageoires.

Le nom du bengali annonce fe pays dans lequel on l'a pèché. Sa langue est lisse; mais sou palais est hérissé de dents coưtes et menues. On trouve des dents semblables à la máchoire supérieure, à la suite d'une rangée dautres dents plus longues et recoubées que l'on voit également à la máchoire d'en bas, La premièré pièce de chaque opereule reģoit dans une échancrure, et comme celle de l'holocentre cint-raies, une sorte de erochet ou d'aiguillon qui tient à la seconde pièce. Par le moyen de ce mécanis. me, l'animal, en ouvrant la bouche, presse cette seconde pièce contre son corps, de manière à clore très-exactement Y'ouverture branchiale. Une plaque dentelée est d'ailleurs placée au-dessus de l'échancrure de cette piece postérieure. Les écailles sont petites et dente lées. Le jaune et le bleu règnent sur les nageores.

L'épinéphèle habite dans les eaux de la Jamaique. Ses yeux et ceux de quelques autres holocentres sont voilés par une membrane tran sparente comme ceux des muremes et de plusparente comme ceux des murènes et de plusieurs autres poissons. Cette conformation dans l'organe de la vue de ces holocentres, avait engage Bloch à les comprendre dans un genre particulier. Nos principes de distribution ne nous ont pas permis d'admettre ce genre; mais nous avons été bien aises de le rappeler, en -...
On voit des teintes jaunes sur la tête et sur les nageoires.

Le post se trouve dans la plupart des conles rivières et dans lés lacs dont le fond est de sable ou de glaise, et dont les eaux sont elaires et pures. Il est surtout très-multiplié dans la Prusșe. Il ne parvient ordinairement qu'a la longueur de deux ou trois décimètrés; mais cependant il y a, auprès de Prenzlow, des lacs ou on a pris des individus de cette espèce, d'une graneur bien supérieure.

Les ennemis dont il est le plus souvent oblige d'éviter la poursuite, surtout lorsqu'il ne présente que de petites dimensions, sont' le broehet, la perche, la lote, l'anguille, et les grand oiseaux d'eau. Il se nourrit de vers, d'insectes aquatiques, et de poissons très-jeunes, et par conséquent très-petits. C'est au printemps qu'il quitte les lacs pour remonter dans les riviêres au sêjour desquelles il préfere de nouveau celui des lacs, lorsque l'hiver approche. C'est auss dans le printemps qu'il fraie. Il dépose ses cuîs sur des banes de sable, ou sur les corps durs qu'il trouve dans les eanx qu'il habile, et il les place a une profondeur telle, qu'ils ne soient communémeut urau-dessuśd un ou deux mètres de profondeur, ni au-dessous de trois ou quatre. Ces cuf́s sont petits et d'un blane mélé de jaune. Bloch err a compté soixante-quinze mille six cents dans un ovaire qui ne pesait pas tont à fait quatre grammes. On a écrit que le post ne croissaitque lentement; et comme d'ailleurs les individus de cette espèce sont tris-richerchés, on pourrait croire que c'est à cause de Ia lenteur de leur développement, qu'on n'en trouve que très-rarement de parvenus à des On prend le post à l'hameçon et au filet, particulièrement au trémail '. Mais c'est princi' Voyez une courte description do trémall a larcicle do trées septentrionales de l'Europe. II y vit dans dimensions et à un poids considẻrables. palement pendant l'hiver, et par conséquent lorsqü il est descendu dans les lacs, qu'on le recherche avee le plus d'avantage. On le pèche. avee beaucoup de succès sous la croùte glacée de ces lacs d'eau douce. On le poursuit avee d'autant plus de constance et de soin, que sa chair est tendre, de bon goút, et facile à digérer : elle devient mème exquise dans certaiucs eaux; et l'on cite en Allemagne, comme excellents à manger, les posts des laes Golis et Wandelitz.

M. Noēl de Rouen nous écrit que, dans la Seine, dont les pécheurs nomment le post Perche goujonniere, parce que sa longueur excède rarement celle du plus grand goujon, on ne prend guère eet holocentre qu'auprès de l'embouchure de l'Eure, ou on le trouve au milieu de petits barbeaux et de jeunes cyprins brèmes.

La bonté de l'aliment que donne le post, la salubrité de sa chair, et sa petitesse, ainsi que sa faiblesse ordinaire, le font preferer à beaucoup d'autres poissons par ceux quí cherchent à peapler un étang de la manière la plus conveuable. En l'y renfermant, on n'y introduit pas un ennemi dévastateur. C'est pendant te printemps ou l'automne qu'on le transporte communément des laçs ou des rivieres dans les étangs où l'on veut le voir multiplier. On le prènd pour cet objet dans les lacs peu profonds, plutot que dans ceux dont le fond est trés-éloigné de la surface de l'eau, parce que les tilets dont on est le plus souvent obligé de sé servir pour le pécher dans ces derniers, le fatiguent au point de lui óter la faculté de vivere, méme pendant quelques heures, hors de son fluide natal. Le post ccpendant, lorsqu'il n'a pas été tourmenté par la manière dont on l'a péché, perd diffieilement la vie: On peut, pendant l'hiver, le faire parvenir vivant a d'assez grandes distances : un froid très-rigoureux ne suffit pas pour le faire périr; et on l'a vu souvent privé de tout mouvement et entièrement gelé en apparence, retrouver promptement la vie et son agilité, après avoir été plongé pendant quelques moments dans de l'eau froide, mais liquide ?

- 6 rayons à la membrabe branchisle de Iliolocentre verdátre, 14 a chaque pectorale, 1 rayorr aiguillonate et 5 ray

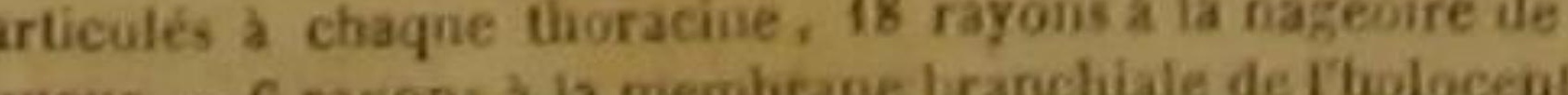

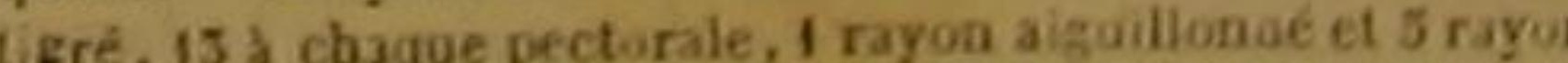
sutcul's a chaque thoracine, 13 rayons a la caudale. -6
rayons a la membrane branchiale de Thooloecentre cing-raies, ss.
Le corps et la queue du post sont allongés et visqueux. J'ai voulu, pendant quelque temps lacer ce thoracin parmi les lutjans, parce qu'on ourrait à la rigueur ne vouloirreconnaitre dans ses opereules qu une simple dentelure; je l'a inserit cependant parmi les véritables holocen tres; non-seulement parce qu'un grand nombre de traits de sa conformation le rapprochient, aussi bien que plusieurs de ses habitudes, de cęs holocentres, ainsi que des vaies persèques, mais encore parce que, dans la plupart des inlividus de cette espèce, plusicurs des pointes le la dentelure sont assez grandes pour être regardées conme de véritables aiguillons. Au reste, la tête de ce poisson est un peu dèprimée. Le palais et le gosier sont garnis, comme les mâchoires, de dents petites et trés-pointues. Le dos est noirâtre, Le pylore n'est entouré que de trois cocums. On compte quinze cótes de chaque coté de l'épine dorsale, qui comprend trente vertebres.

Le noir est ordimirement long de quatre on cinq décimetres, et par conséquent plus grand que les individus de l'espèce du post, que l'on rencontre lé plus souvent.

On trouve l'acerine dans la mer Noire, et pendant l'cé, dans les grands fleuves qui y ont lèur embouchure. Sa tête est plus allongée que celle du post; mais elle a de grands rapports avec cette espece, qu elle devrait suivie, ains que le noir, dans le genre des lutjans, si on al mait mieux comprendre lo post dans cette fa. mille que dans celle des holocentres.

L'HOLOCENTRE BOUTTON. ',

Diacope bottoniensis, Cuv.; Helocentrus Boutton, Lac. 3 . IIolocentre Jaune el bleu s, Serranus flavo caruleus, Cuv.,
Bodianus macrocephalus, Holo, eatrus gymnosus, ci Holo.

16 diague pectorale, 1 rayon a' guiltonde et 8 rayous ari. - Tha a chaque thoracine, 20 rayous a la mageoire de la quene.

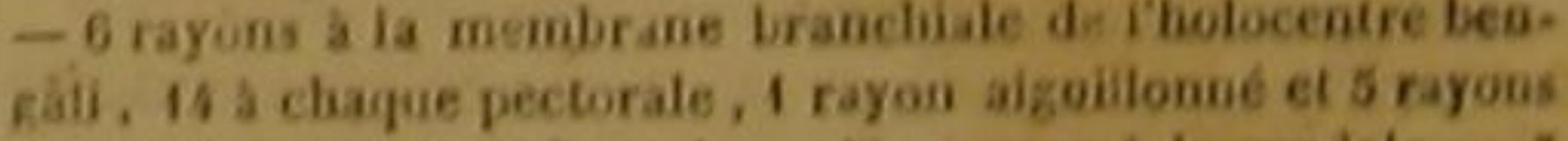
articules a cliaque thoracine, is rayour a ta caudale. - 8 rayons a ta membrane brascbiale de libolocentre epinejhele,

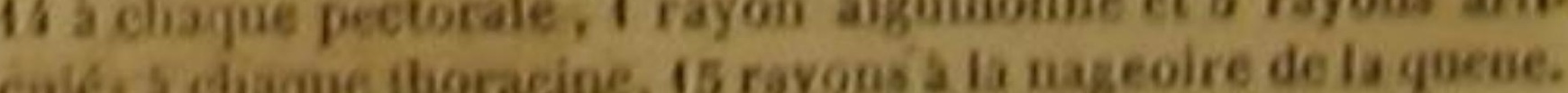
- 7 xuyons a ta membrane branchiale de liboloceatre post, Whichayne pectorate, I rayou oiguillenne et 5 rayous arti. coles a chaque tioracine, 17 rayous a i eadale. -7 rayon.

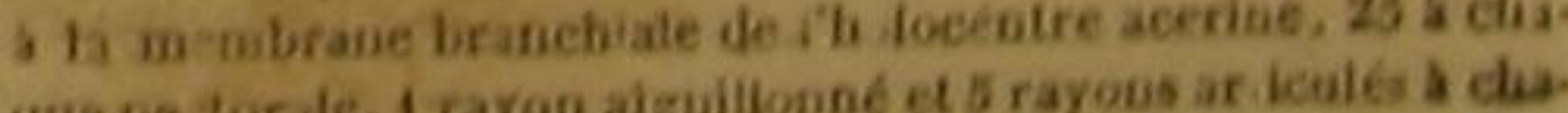

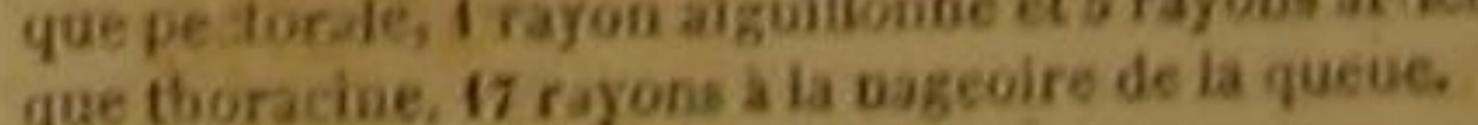

. Asper antrorsom sabteriasque rubens, sursuin et tate- 
HISTOIRE NATURELLE

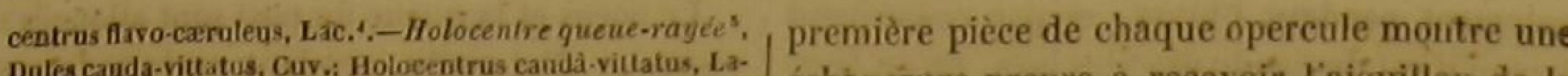

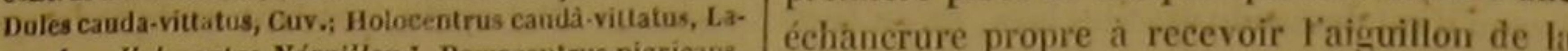

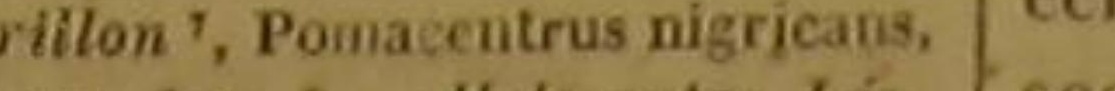
pard, Plectropoma Leopardinus, Cavv ; Holecentrus Leo- Les Indiens des Moluques apportèrent plusieurs Cave; Lycogenis argyrosomi, Kulhl.; Holocentrus ciliatus, individus de cette espèce au vaisseau sur lequel Cav,; Lycogenis argyrosoma, Kuli,
Lac. 10. - Holocentre Thunberg ", Myripristis .......... Commerson parcourait le grand Océan, avee Cuv.; Sciæna loricala, Thunb.; Holocentras Thubberz, notre Bougainville, -en 1768; et ee voyageu Lac. ${ }^{23}$. dit dans ses manuserits, que ces individus

C'est dans les manuscrits dé Commerson qué étaient mélés avec plusieurs autres poissons sénous avons trouvé la description des quatre pre- chés, très-bien prèparés, et étendus entre deux miers de ces holocentres : aucun auteur n'en a bâtons qui les fixaient.

encore parlé. Le Boulton, dont le nom spécifique indique le pays natal, a deux ou trois décimetres de longueur. Sa caudalè est jaunâtre. Ses thoracines et son anale présentent la mème couleur que la nageoire de la queue; mais leurs premiers rayóns sont rougeâtres. Cette nuance rouge parait sur la base des pectorales, que distingue de plus une petite tache d'un pourpre foncé; le reste de la surface de ces organes estjaune, de mème que le bord supérieur de la dorsale, qui d'ailleurs est transparente. Les dents antérieures sont un peu longues; les áutres très-petites, et serrées les unes contre les autres, comme celles d'une lime. On voit aussi de très-petites dents au fond du palais et du gosier: mais la langue est lisse ; elle est en outre courte, un peu large et très-blanche. La

- railiter flavescens, opercullis branchiarum in angulo aste: riore spinà ad caput rellexa notatis, - Perche du détroit do - Boutton. $\times$ Commerson, manuseris défa cités.

percoides. $\mathrm{D}$.

¿Asper carulescens, pinais omnibus et cauda, etiam- Ium basi, lateis. $x$ Comemerson, manuscrits deja cités.

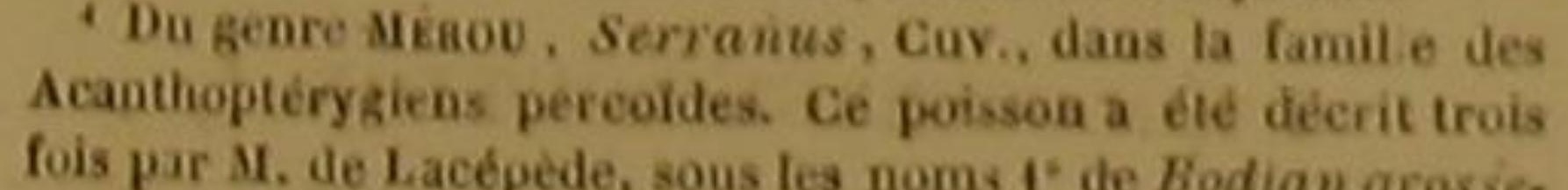

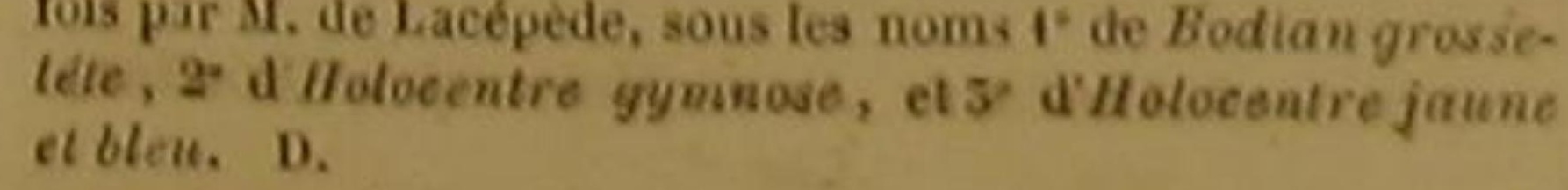

S. Aspro dorso carulescente, lateribus argenteis, cauda - lituris albis et nigris alteruis. , Commerson, manuserits dẹja cités.

ha geare Douless, Dules, dans la famille des Acanthopte-
rygiens pereoídes. D. I. Aspro tótus atrat

'Lerson, manuserits déja cités.
.

- Du geare Powackstak.

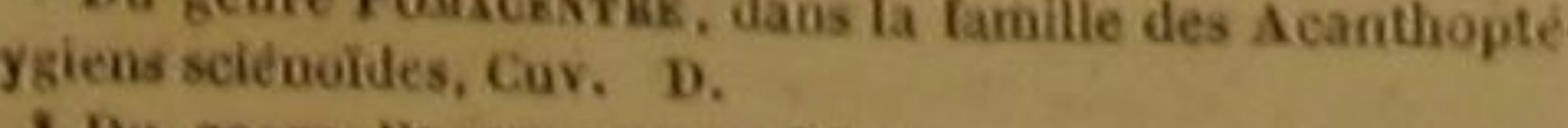

familte des Acauthopterrgis, Plectropoma, Cuv., dags La 10 Da genre ScozopsioE, dans la famille des Aeanthoptérygiens scieuoudes, Cav. D.

berg, Voyage au Japou, ete.

"a Ce poisson est bien certaipement do genre Mrkipasti

mais ce naturaliste ne te rapporte propterygiens percoides; pece, tout eu remarynant quil se rapproctie surtout du $M y$.
ripristis hexagoum.

Le jaune et bleu habite dans les eaux qui baignent l'Isle de France. II est ordinairement plus grand que le boutton. Quelquefois l'extrêmité de ses pectorales est noire; le bord de la máchoire supérieure jaunatre ; l'entre-deux des yeux peint de la même couleur, et une tache ovale de la mème teinte placée sur le derrière de l'oceiput : mais il n'offre d'ailleurs que les deux nuances indiquées par le nom spécifique que je lui ai donné.

Les deux mâchoires sont hérissées de dents très-menues, très-courtes, très-serrees, an-devant desquelles la máchoire d'en haut en présente quatre plus épaisses et un peu plas longues. Des éminences osseuses situées sur le palais, et la circonférence du gosier, sont également garnies de dents très-petites et très-fines mais on n'en voit pas sur la langue, qui est courte, large à son extrémité, un peu cartilagineuse, assez libre dans ses mouvements, et blanchâtre. Les premiers rayons de la dorsale sont garnis chacuu d'un filament. Le péritoine est blane; le canal intestinal trois fois recourbé la vessie natatoire adhérente au dos. L'animal vit de petits crabes et de jeunes poissons qu'il vale tout entiers. Sa chair est agréable et saine.

L'holocentre queue rayée est communèment moins grand que le boutton. Les raies longitudinales blanches et noires qu'il a sur la queue, varient pour le nombre depuis trois jusqu'à dix. La mâchoire supérieure est extensible et un pen plus courte que celle d'en bas: l'une et l'autre présentent, ainsi que le devant du palais, un grand nombre de petites dents semblables a celles d'une seie. La langue est lisse. L'Isle de France est sa patrie.

Le négrillon a la tête petite; le dos très-élevé, les dents menues, blanchâtres, rapprochées et arrangées comme eelles d'un peigne; Ia langue et le palais sans aspérités; et la ligne latérale si

DES POISSON:

371

courte, qu'elle se termiue à l'extrémité de la nagenire du dos '.

Aucun naturaliste n'a encore rien publié au sujet du léopard et du eilié. Le premier de ces deux holocentres a la lèvre supérieure double; la mâchoire d'en haut, qui est un peu moins ayancée que celle d'en bas, montre, áinsi que cette dernière, six dents fortes, grandes et crochues, et plusieurs rangs de dents plus petites. Le corps et la queue du cilié sont allongès.

Le thunberg, auquel nous avons donné le nom du savant voyageur qui l'a fait connaitre, n'a qu'une nageoire dorsale, quoiqu'il paraisse en avoir deux. Sa lèvre supérieure est double on voit au moins trois dents mousses de chaque côté de la mâchoire d'en bas; le dos est élevé:

Cet holocentre vit dans la mer da Japon.

LHOLOCENTRE BLANC-ROUGE, Holoceatram orieatale, Cur, ; Hotocentrus albo-ruber,
Lae, ?

WHoloceutre baude-blanche, Sebartes a botasciatus, Guv.;

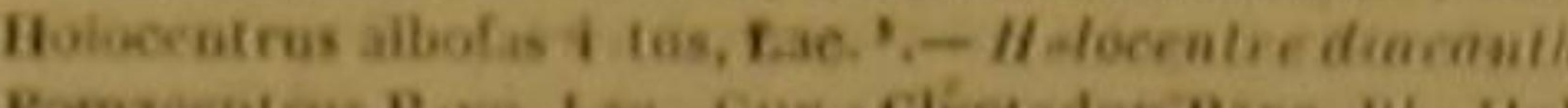

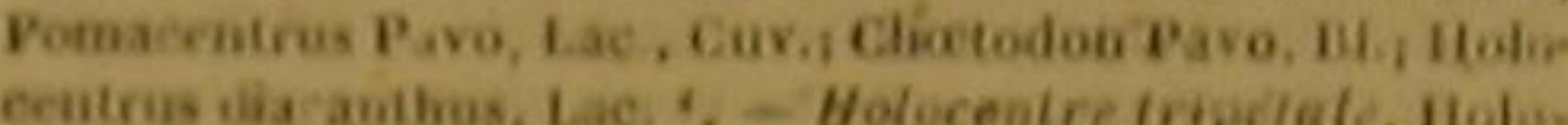

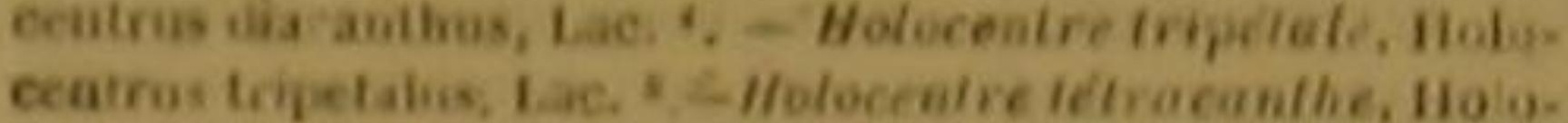

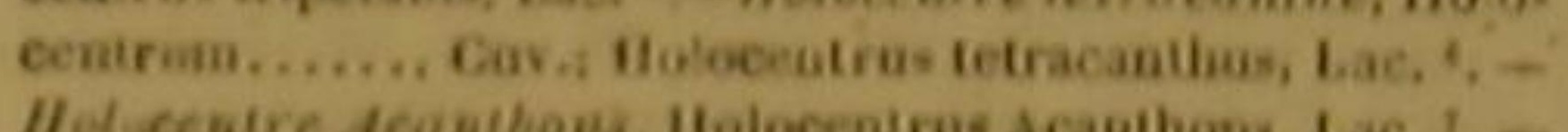

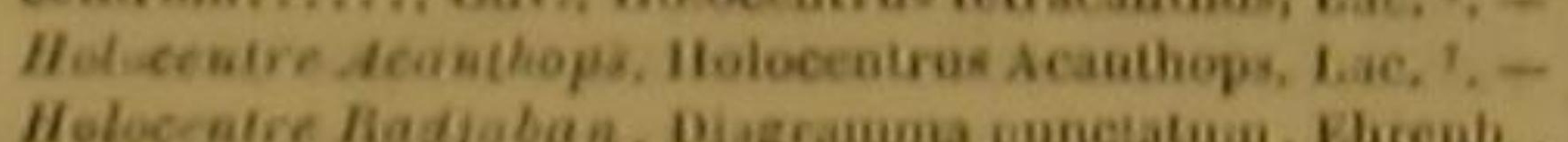

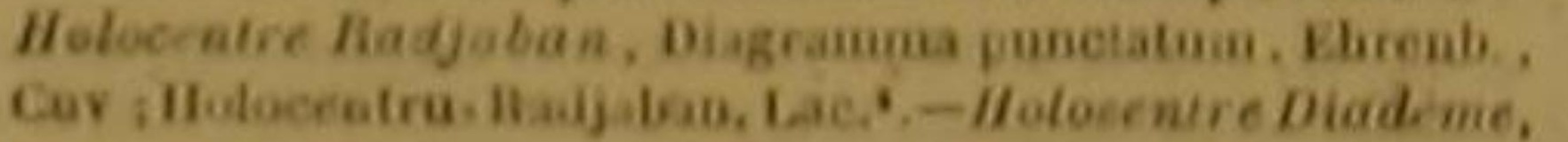

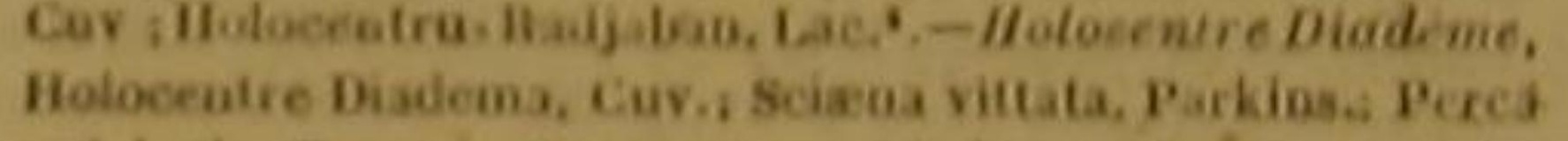

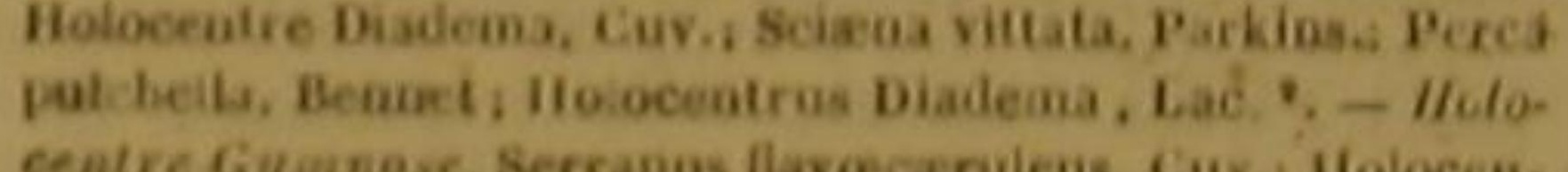
tous Havo-exralias, Holocentrus gywuosus, ef Boulison. macrocephalus, Lac, "0.

Ces neuf especes sont encore incomues des naturalistes. Nous avons trouvé une figure de

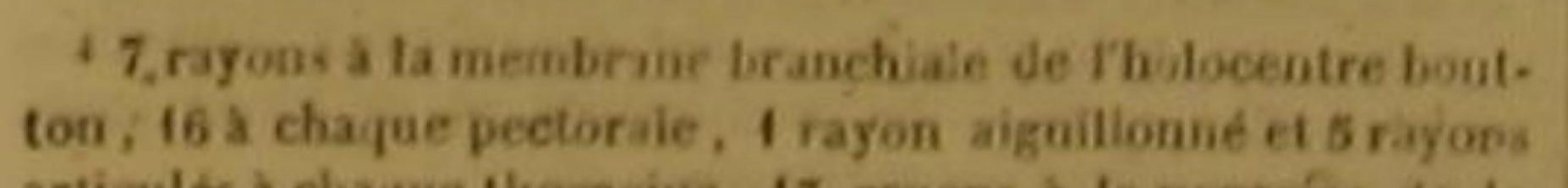

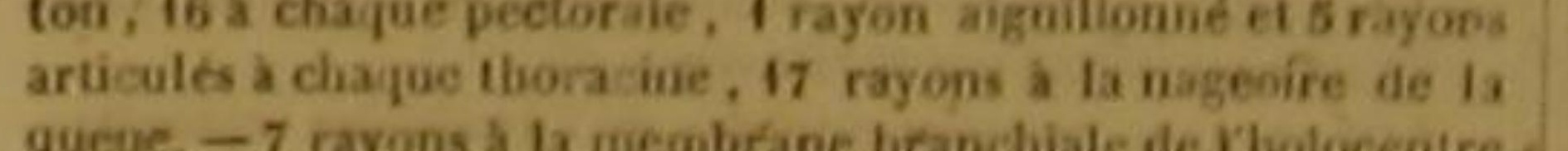
queve, -7 rayons a la miembrane branchiale de Yholocentre rayous articules a chaque thoracine, 15 rayons a ia eaudafe.6 rayons a la membrane branchiste de l'holocentre queue rayee, 16 a chaque peciorale, 15 a la nageoire de la quese.

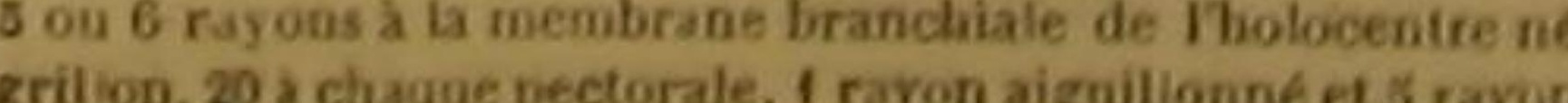
articules a i haque thoracine, 13 rayons a la ceaviales - It rayois a chaque pectorale de tholocentre leopard, in a la nageoire de la queae. - 17 rayons a chaque peetorale de Tholocentre cilié, 1 ryyon aignillowe et 5 rayons articules a chayee thoracine. 19 rayous à la caudale. -7 rayous a i i

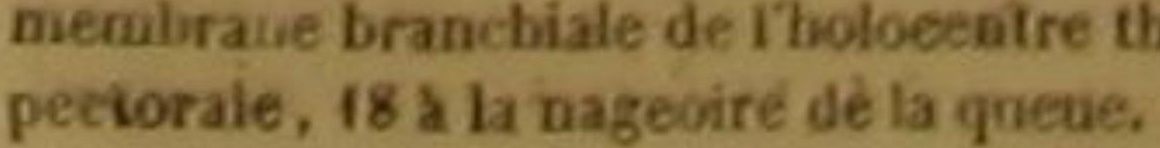

2M. Cuvier rapporte celle espèce a son HoLocestee dre la première à la page 25 d'un cahier de manuscrits chinois, déposé dans la bibliothéque du Museum d'histoire naturelle, et que nous avons đejă eitể à l'article du Spare chinois et à celui du Spare cardinal. La page 112 de ce mème manuscrit présente l'image de la seconde de ces neuf espèces. Nous avons vn des individus des oinq especes suivantes daus la collection d'objets d'histoire naturelle donnée à la France par la Hollande; et les manuserits de Commerson renfermaient deux dessins quí représentaient les deux dernières.

Le blanc-rouge et I' holocentre bande-blanche vivent done dans les eaux de la Chine.

L'holocentre diacanthe, que nous avons ainsi noṁné a cause des deux rayons aignillonnés de sa nageoire de l'anus, a deux pieces à chacuı de ses opercules.

Le tripétale, dont te nom spécilique désigne les trois pieces de son opercule, montre pla sieurs rangs de petites dents, et de plus nident assez grosse auprès de chacune des deu. extrémités de la mấchoire inférieure, opposées au museau.

Le tetracanthe, dont le nom indique les quatre rayons aiguillomes de sa nageoire de l'a uứs, a la mächoire d'en bas plus avancée que celle d'en haut; ses dents sont petites; des la. mes écailleuses etzont la sumface offre desstries disposées en rayons, couvient le dessus des yeux ; une grande partie de la portion de la dorsale, que soutienent des rayons aiguillonnés, est trés-distincte du reste de cette nageoire.

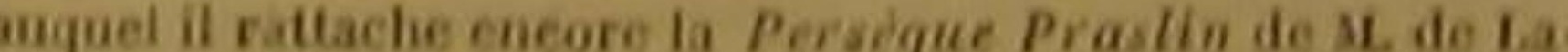

cepele.

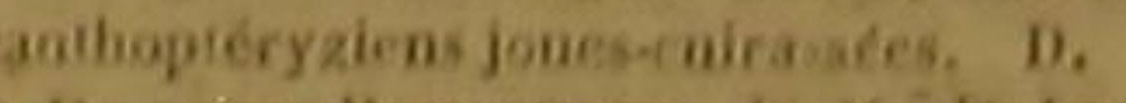

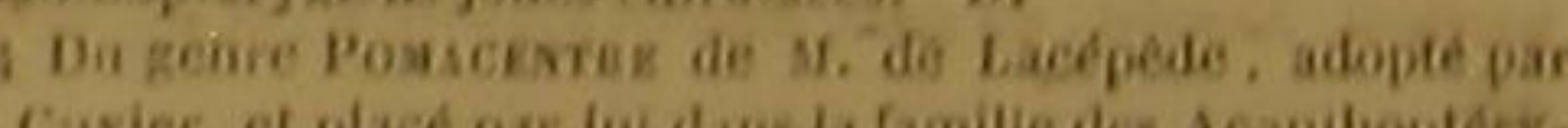

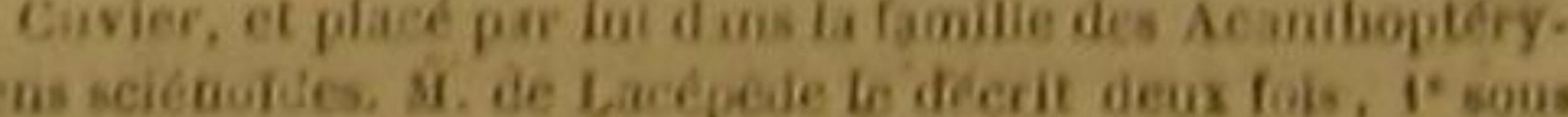
nom de Pomacentre paon, a 2 d'Hotocentre diacanthe. s Non mentionoé par M. Cavier. D.

4. Cuvier reconnait daus ce poison les earaeteres de sot . giens percoides :
qnil adrec. $1 \mathrm{D}$.

Non mentionné par M. Cuvier. D. Le Radjaban, qui porte ce nom aux Indes orientiles, est placé par M. Cuvier, dans son gene Bugausme, de la familie des Acanthoptérysieus sciénoldes. D. - Da geore HoLocestae, Holocentrum, Cav. (tamille de

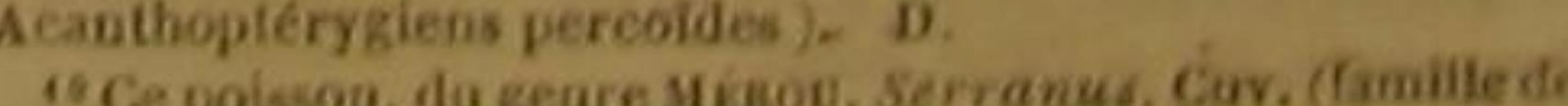
Acanhoptérysiens percolies), a ere decrit trois fois pas

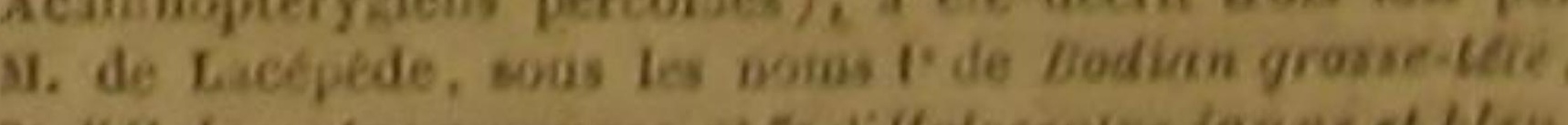

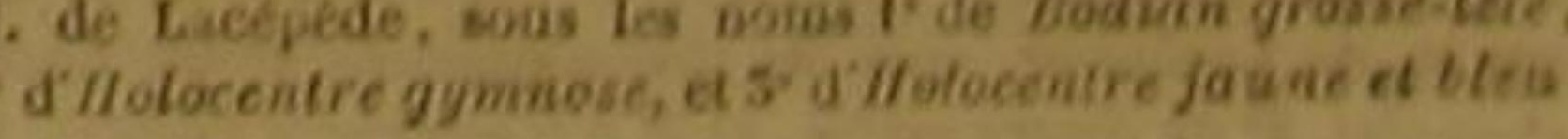


HISTOIRE NATURELLE

L'œil de l'acanthops est gros; sa ligne la- | de dents molaires hémisphêilques, fortes et sertéraie et très-marquée '

Les deux mâchoires du radjaban sont garnies de plusieurs rangs de dents serrées et presque égales les unes aux autres; la grosseur des yeux est remarquable ; on voit une lame écailleuse et dentelée au-dessus de la dernière pièce de chaque opercule ; et la ligne latérale est presque droite.

Six ou sept raies étroites et longitudinales parent chaque côté de l'holocentre diadème. Les bandes noires et blanches qui décorent la partie antérieure de sa nageoire dorsale, représentent le bandeau auquel les anciens donnaient le nom de diadème; et les rayons aiguillonnés qui s'élèvent dans cette méme partie au-dessus de la membrane, rappellent les pointes dont ce bandeau était quelquefois orné ${ }^{2}$.

Les dents du gymnose sont petites et aiguềs; l'extrémité antérieure de la mâchoire d'en haut en présente de plus grandes que les autres.

\section{L'HOLOCENTRE RABAJI ${ }^{3}$}

Chrysophrys bifasciata, Cuv.; Chatodon bifasciatus, Forsk.: Labrus Catenula, Sparus Mylio, et Holocentrus Rabaji, Lac. 4.

La couleur générale dé cet holocentre es brillante et argentée. La dorsale et l'anaie sout jaunes; les thoracines noires; les peetorales jaunes sur une partie de leur surfacé, et blanches sur l'autre. On aperçoit des rugosités sur le sommet de la tète. Chaque mâchoire est garnie

- La dénominatiou d'Acanthops désigne les aignilloris

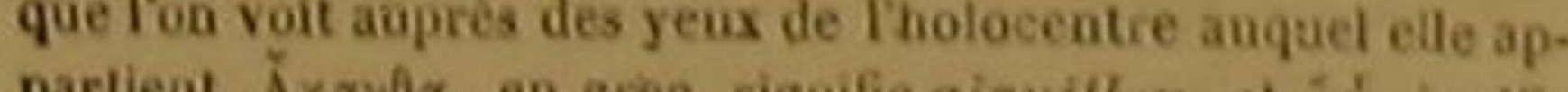
ail. I5 rayons a la membrane branchiale de Tholocentre diacan. the, 16 a chaque pectorale, 6 a chaque thoracine, 16 a la uagevire
de la queue, -16 rayous a chaque peetorale de l'holocentre ripetale, 1 rayon aigullomé et 5 rayons artieul's à cbaque hioracine, 18 rayons a la caudale, -12 rayobs a chaque pee. - 14 rayons a cbaque peclorile de l'bolocentre e la que I rayon aiguilloané et 5 rayous articules a chiqque thoracine, 9 rayous a ta caudale. - 16 rayous a chaque peetorale de foolucentre radjaban, 1 rayon aigullomeé et 5 rayons arti- 15 rayons a cloracine, 16 rayous a la mageoire de la queue. A chaque thoracine, 18 a ta caudale. 'Forskael, Faua. Arab., p. 64, Bonnaterre, pl, de l'Enc, méth.

'Du geare Dsunade, Chrysophirys, Cuv., daus la famille par Acauthopterybiens sparolves. II a été décrit tocis folls chapelet, 20 de Spare mylie, et $3^{\circ}$ dillolocentre rabaji. D. rées, et de cinq incisives dures et coniques 1.

\section{L'HOLOCENTRE MARIN 2 ,}

Serranus Scriba, Cuv.; Perca Seriba, Línn.; Perc marina, Bruno.; Holocentrus máriuus, Lac, $L$ róche; Holocentrus Argus, Spin. : Holocentrus fasciatus, et Hol. maroecanus, Bl.; Lutjanus Seriptura Lac.

Holocentre Telard ", Perea Cottoides, Linn., Gimel.; Holocentrus Gyrinus, Lae ', - Holocentre philadelphien

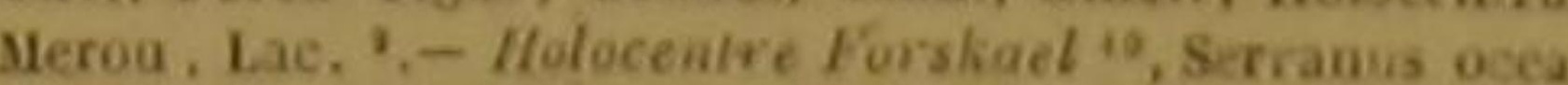
nícus, Cav,; Perea fasciata, Forsk.. Limm., Gmel.; Hoto eentras oceaniens, et Hofocentrus Forskael, Lae. ". Molocentre tric can the ", serrainus bepatus, Cur.; Latiras hiepatus, Lion, Gimel., Lac,; Lutjanus adi iaticus, et HoloSerranus argentious, Cur, Holceentrus argeatimins, BL., Lac.

On pêche I'holocentre marin dans la Méditerranée, et peut-être dans la partie de l'Océan

if rayons a la membrine branchiale de f tholocentre rabaji,

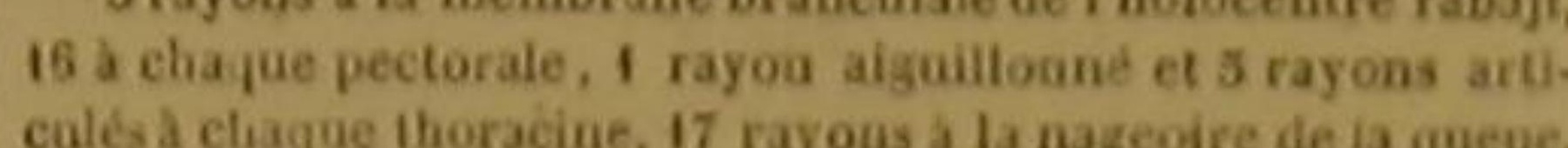

2Percia; dins les environs de Rome, - Pcrselyue perchie pi. de l'Ene, méth. - Perca tine s utrieque septem trans- anties veutris. Artedi. geb. 50, syn. 68. - Mus. Ad

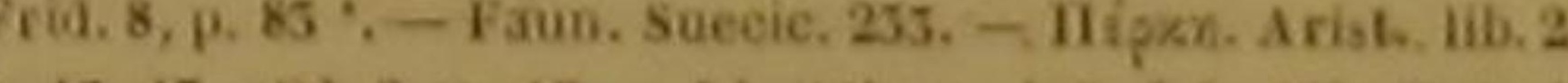
13. 17, et 1. 8, e. 15. - /d. Athen.. 1. 7, fol. 159, 29 (ed Palderi).-Id. oppian., 1. 1, p. 6. - Perea. Plia., 1. 9, c. I6 Perva gelagia. Jov., c. 21, p. 12. - Priche. Hondelet, A. 1, 1. 6, c. 8. - Salvian, fol. 221, b. ad icoì m. - Peree

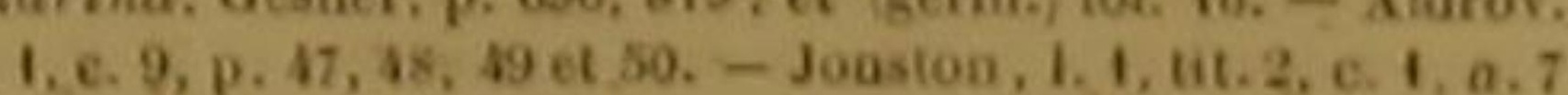
14, fig. 8. - Charieton, p. 154. - Wilughthy, p. 3ar. ai, p. 110

Da geare Mh̀rope, Serranis, Car., dans la famille des

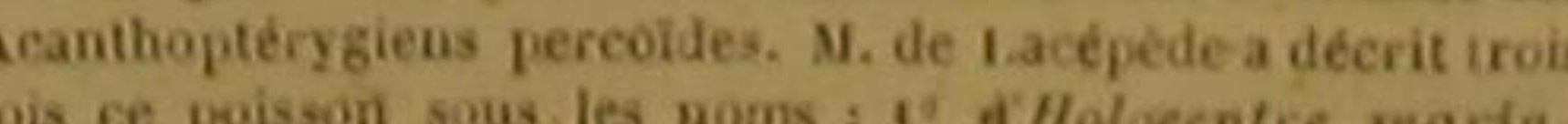

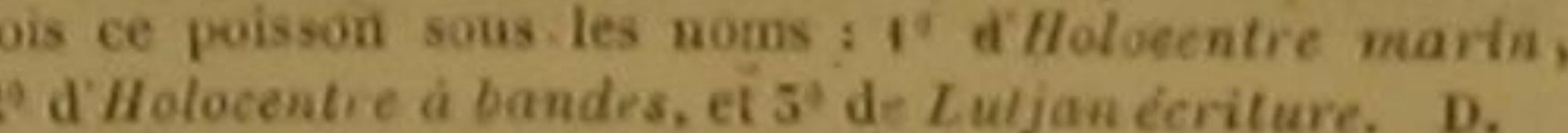
- Mus. AJ. Frid. 2, p.8i. - Persegue tétard Da D. Hauy, Euc. méth, - Id. Bonaaterre, pl. de ITne, inél sNou mentioné par M. Cuvier. D.

- Chab. dans quelques contrées de l'Amérique septentrioate. - Persegue meunier de mer. Daubenton et Haoy,

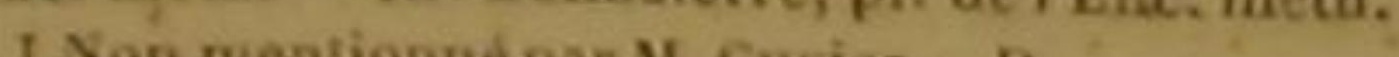
'Pa par M. Cavier. O.

1. - Persiguse meros.

Ce poisson est le Mkaou proprement dit, on Gasn

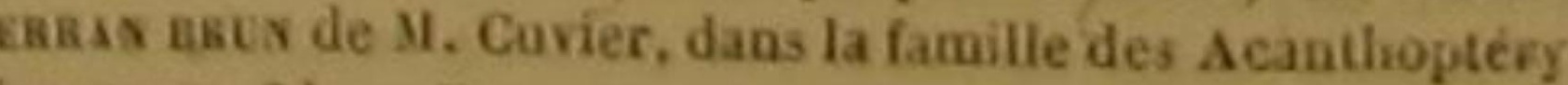
giens percuides. D.

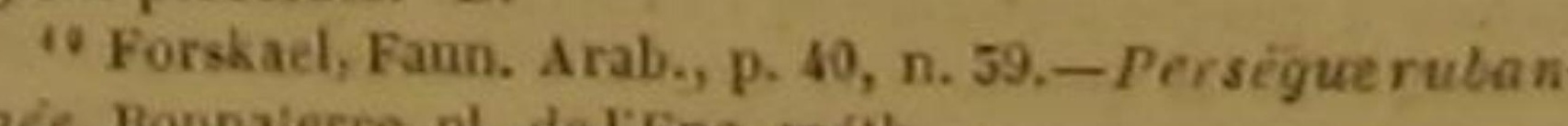

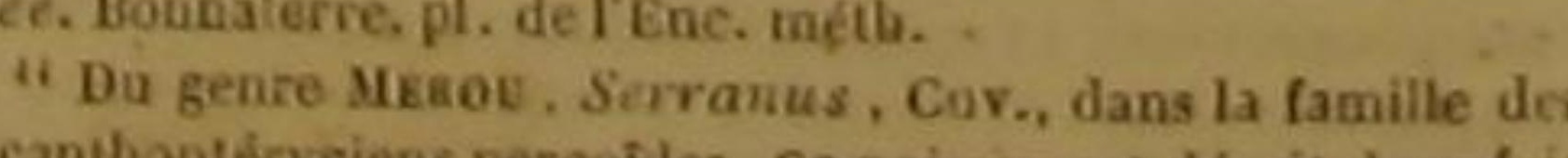

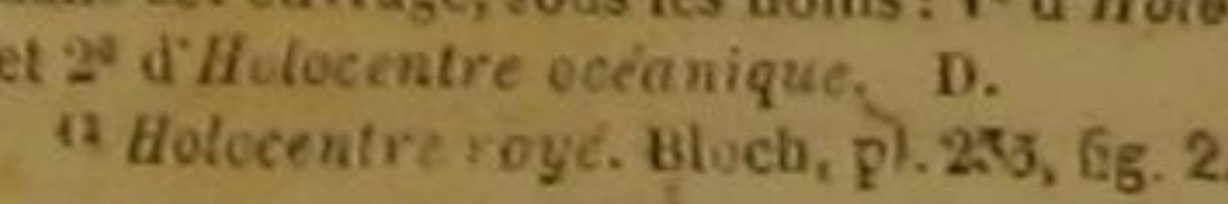

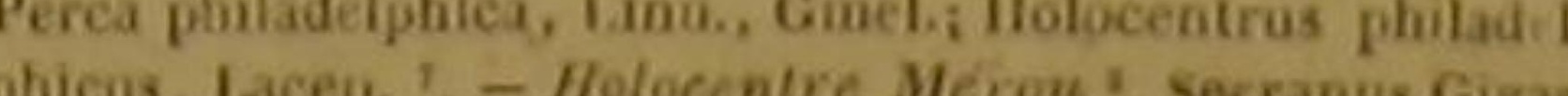
Cuv:: Perea Gigas, brund., Linn., Gmel.; Hobeenire - versis nigris, duetihus miniaceis ceruleisque in eapite ef

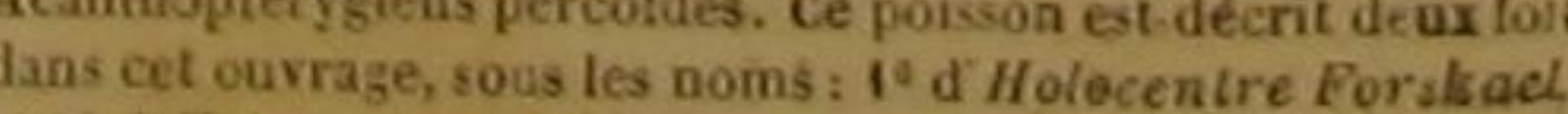

DES POISSONS.

qui baigne la Norvège, ainsi que dans plusieurs, le long de chaque mâchoire; la langue est lisse, autres portions de cet Océan Atlantique, Son et le palais rude.

museau est allongé et poìntu; sa dorsale, son anale et sa caudale sent souvent jaunes et monchetées d'unjaune plus foncé; l'on voit quelquefois des raies rouges sur ses pectorales. Sa longueur ordinaire est de trois ou quatre déeimètres

Le tétard habite dans I'Inde; sa tête, son corps et sa queue sont parsemés de taches brunes et presque rondes.

Le philadelphien vit dans L'Amérique septentrionale

On a pêché le mérou dans la Méditerranée. Cet holocentre est lons d'un mètre : aussi lu a-t-on donné le nom de Géant. Le dessous de sa tête est rouge; louverture de sa bouche, grande; sa langue lísse; son palais hérissé depetites dents, ainsi que son gosier; chacune deses mâchoires garnies de plusieurs rangées de dent aiguês; le devant de sa mâchoire supérieure, armé de quatre dents coniques et plus longues que les autres; sa dorsale bordée de filaments.

Le forskael est encore plus grand que le merou : sa longueur surpasse douze decimètres. Les deux máchoires sout.égatement avancées, et présentent chacune deux dents coniques; on voit de plus á la mâchoire supérieure plusieurs rangs de dents flexibles et très-fines; la mâchoire d'en bas montre un rang de ces dents trés-déliées. Ce poisson a été observé dans la mer d'Arabie.

Le triacanthe a la langue lisse; le palais et les mâchoires hérissés de dents petites et communément très-serićes; les thoracines d'une couleur foncée; les autres nageoires d'une nuane plus claire.

L'or et l'argent brillent sur les écailles de l'argenté; d'ailleurs le dessus de la tête est violet; la dorsale, l'anale et la caudale sont d'un bleu clair; les pectorales, ainsi que les thoracines jaunes '; des dents petites et aiguês distribuées

"Du geare Mesoo, Serranus, Cuv, dans ta famille des Acan thopiteryg ens percoídes. - Ce poisson est dégrit deux lique, et $2^{\circ}$ d Holorentrel, iacanthe. D,

is Da genre MEeov, Serranus, Cav. (lamille des Acanthoptérýgiens percoides). D.

I 7 rayons à la membrane brauch ale Je Tholoceutre mário, 19 a chaque pectorale, 1 rayon aiguillonné et 5 rayouis articules a chaque thoracine, 14 rayons a la nageoire de la queve: -8 rayons a la membrabe branchiale de libolocentre $t e$.

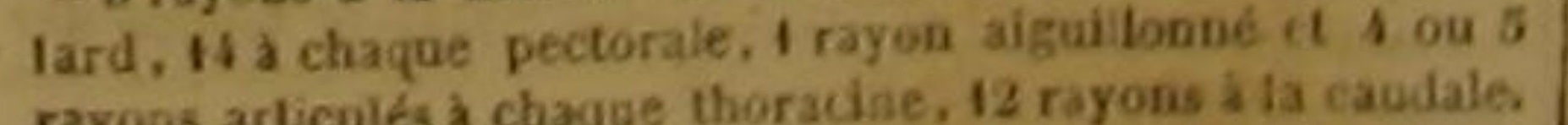
rayons articules à chaque thoracise, 12 rayons a ia caudale.

\section{L'HOLOCENTRE TAUVIN ',}

Serranus Merra, Cuv.; Epinephelus Merva, Bl, ; Pere Tauvina, Forsk., Holoceotrus Merra, et Helocentro Tausious, Larep, ?

L'Holocentre Ongo ', Serranus dehropterus, Cuv.; HoloCentrus ongus, Lac, 4, - Holocentre dore ', Serranus auHe quatre-reies', Therapon quadrilineatus, Cuv,; Holo.

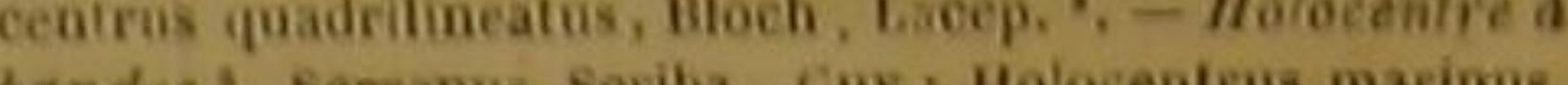

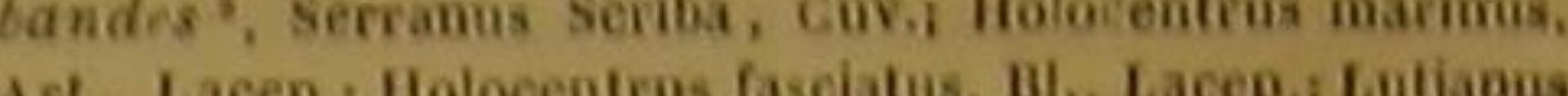
Acripturs, Lac, 10, - Holocentre Piva-p Lronga " ", Ser. ranus Pixanga, Cur, Holocentros punctatus, M. Holocentrus Pira-pixanga, Lae, "1, - Holoeentre lancedold ", Serranus tanceolatus, Cuv, Holocentrus tanceolatus,' tac."

Les rivages couverts de coraux et de madrépores, de la mer d'Arabie, nourrissent to

Ielphien, 16 a chaque pectorale, 1 rayon aboulfound ets de lia quewe, -7 rayons a la membrane branchiale de i holo.

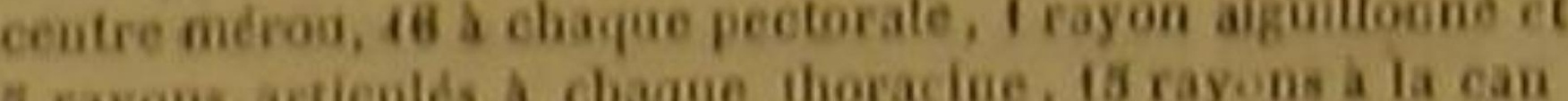

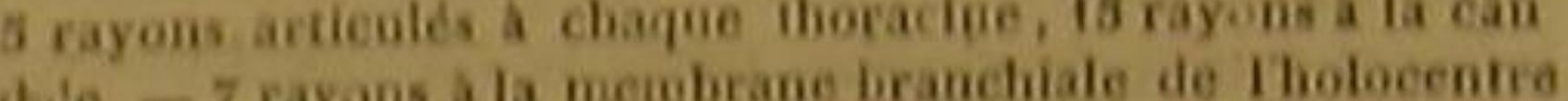
forikael, 17 a claque pectorale, 1 rayon aljoiltonnd et s rayons articules a chaque thoracine, 17 rayous a L magcolro de la queue, - I rayons a la membrane branchiale de 1 tiolo. centre triacenthe, 15 a chaque pectorale, 1 rayon alguilionod et 8 rayons articules a claque thoracioe, 16 rayons a la cau.

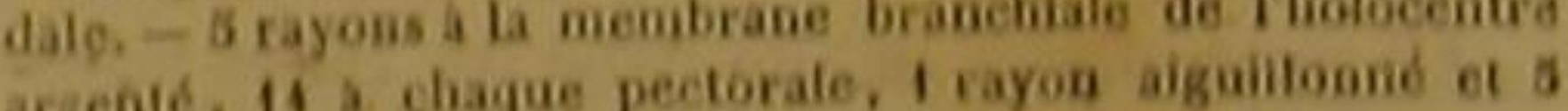
riyons articulés a chaque thoracine, 15 rayons a la nageoire de la queue.

Perea tausina, Linnée, edd, de Gmelin. - Vorikael,

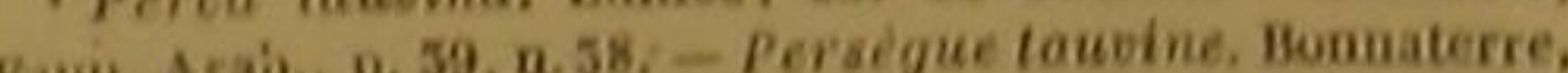
Yamu. Arajo, p.
ph. del'Bue, mét

Du geare Mkoov, Serranus, Cav, dans la famille des Aenthoptérygiens pereoldes. st. de hacepede a decrit co

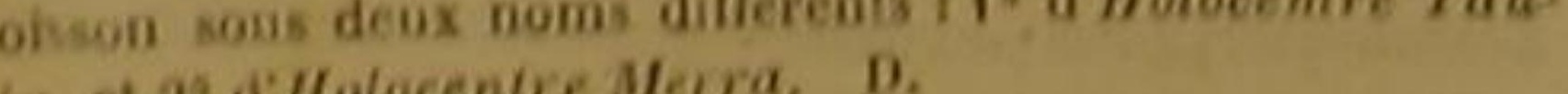

g. Bloch.

'Du geare Méroo, Sient

Hotocentre dorf. Bt cli, pl. 330 .

- Du genre Misou, Car. (tamilie des Acanthopterygiens perceviles). M. Cuvier remarque les rapports qui existent

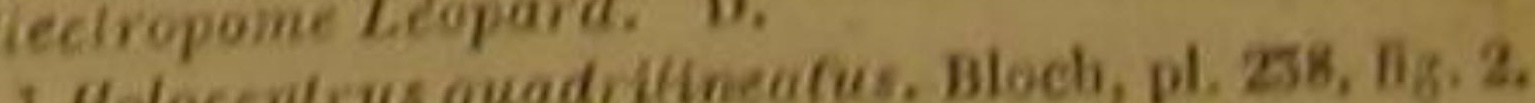

- Iin geare TuEsapor, dass la famille des Acantioptery.

gens pereulds de s. Cuvier. D.

it ba genre Menov, Serranus (tamile des Acanthoptery-

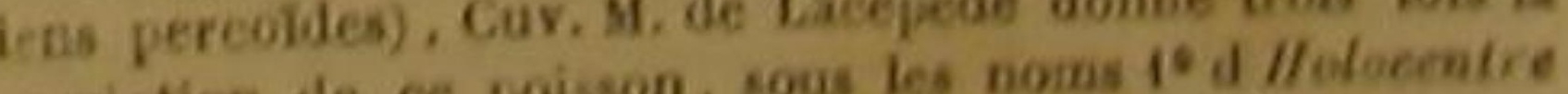

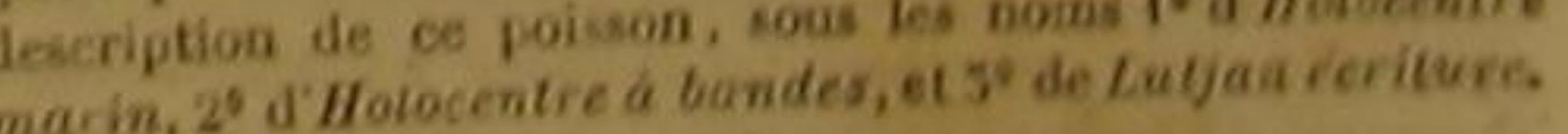

"i Gall-visch, par les Holliandais. - Peselie gatto, pas len

Portugals. - Holocontre pointe. Bloch, pl. $2 \mathrm{wi}$ rayons arilcoles a chaque thoracine, 11 rayons a th nagreire

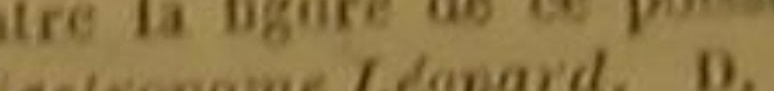

- Holocrntrus facialus. Bloch. pl. 240. 
tauvin, dont la chair est'peu agréable au gon̂t, , dans une sorte de sillon longitudinal; et sa liet dont toutes les écailles sont petites et dente- gne latérale est tortueuse.

lées. La base de la laugue et le gosier sont garnis de dents menues et llexibles. La lèvre supérieure est extensible. On voit trois aiguillon sur la partie postérieure de chaque opereule. La couleur brune de l'animal est relevée par des taches arrondies et noirătres; et ces taches sont boidées de blane, dans une partie de leur circonférence, au-dessus de presque toutes les nageoires.

L.es six autres espéces d'holocentres dont nous parlons dans cet article, ont été déerites pour la première fois par. Bloch.

L'Ongo vit dans les eaux du Japon. Chacune de ses máchoires présente un ramg de dents courtes et pojntues; le palais est lisse; chaque narine a deux orifices; l'iris, les pectorales et les thoracines brillent de la couleur de l'or'

Le doré des Indes orientales a les écailles très-petites, mais plus éelatantes encore que les thoracines et les pectorales de l'ongo. Les dents des deux màchoires sont petites, pointues et presque toutes d'une longueur égale; le palais est garni de dents, comme les mâchoires : ume belle couleur d'écarlate borde les nageoires du dos, de l'anus et de la queue; les pectorales sont d'un violet pále, et les thoracines d'un rouge foncé.

Le quatre-raies habite dans les Indes orientales, comme le doré; mais sa. parure n'est pas aussi magnifique. Sa dorsale peut être couchée

"2 Du genre Mǩnou, Serranus, Cuv., dans la famille des Acanthoptérygiens percoĩdes. D.

"Drectire lancette, B'och, pl. 242, fiz. I. Acanthoptérygiens perooĩcs.' D.
A. Cav, dans ia famille des

47 rayons a la nembrane bramchiale de libolocentre tau. artieulés a chaque thoraciene, 17 royonouiltonné et 5 rajons queue. - 5 rayons a la membrane branchiale de fholoeentre ongo, 12 a chaque pectorale, 1 rayon aiguillonué et 5 rayoa arteules a ehaque tharacine, 18 rayons à la candale. S diague fa membrane branchisle de Iholoceutre dore, 16 a chaque thoracine, 20 lay angultonné et 8 ray ons articulés 6 rayons a la membrane branchiale de l'holoceptre guatreraies, 15 a chaqne pectorale, 1 rayos aiguilonné et 5 rayon articules-a chaque thoraciue, 16 royons a ia caudale. is ayons a ta membrame branchiale de 1 holocentre a bandes, culés a chapue thoricine 15 rajollonoé et 5 rayons arti.

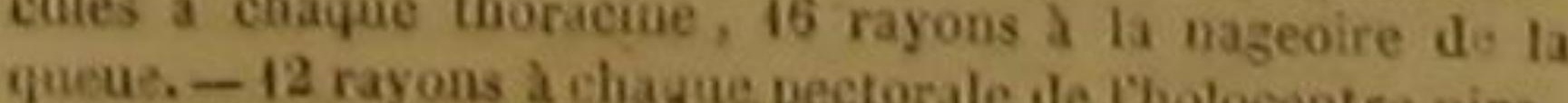

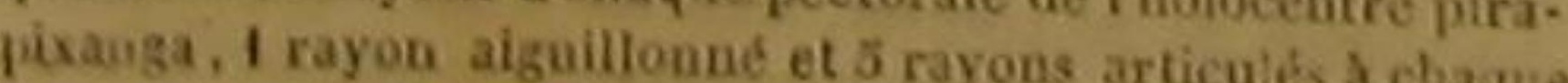
thoraciue, 17 rayons a la caudale. -6 rayons a la meinbirane branchiale de Itholocentre laneéolé, 16 a chaque pectorale. it rayou aguilionee et 5 rayons articulles a cha que thoracine,
is rayons a ta nageolre de la queue.

\section{L'holocentre ả bandes a le museau avancé, le} palais garni de petites dents, et la langue lisse. Le pira-pixanga est un poisson du Brésil : il vit dans la mer et-au milieu des éeueils; et voila pourquoi les Hollaudais et les Portugais l'ont nommé Poisson de roche. Il ne parvient pasá de très-grandes dimensions; mais sa chair. est blanche, ferme, de bon goủt, et tres-saine : aussí le pêche-t-ố dans toutes les saisons; on le prend avec des filets. Pison dit que cet animal perd difficilement la vię; qu'il a trouvé un pira-pixanga qui n’avait pas cessé de vivre trois heures après avoir été tiré de l'eau; qu'ill'a ouvert au bout de deux heures, et que le cour de ce poisson palpitait eneore. Maregrave en a donné une figure qui a été copiée par-Pison, Willughby, Jonston et Ruyseh. Klein et Gronou en ont parlé ; et lê prince Maurice de Nas. sau en a laissé, dans ses mamuscrits, un dessin qui a été publié par Bloch. Ses éeailles, sont dures et dentelées; son dos est élevé et arrondi la tête, le corps et la queue sont allongés.

Les Inides orientales sont la patrie du lancéolé. Plusieurs rangées de dents petites et pointues garnissent les mâchoires; le palais est rude; la langue est lisse et un peu libre dans ses mouvements.

\section{L'HOLOCENTRE POINTS BLEUS ',} Serranus caruleo-punctatus, Cuv.; Holocentrus edroleo-punetalus, Bof, to

C'Holocentre blane ef brun', Hel icentrus alto - fiscus Lac. ‘. - Holoeentre Syrimam ', Lobotes surioamensis,

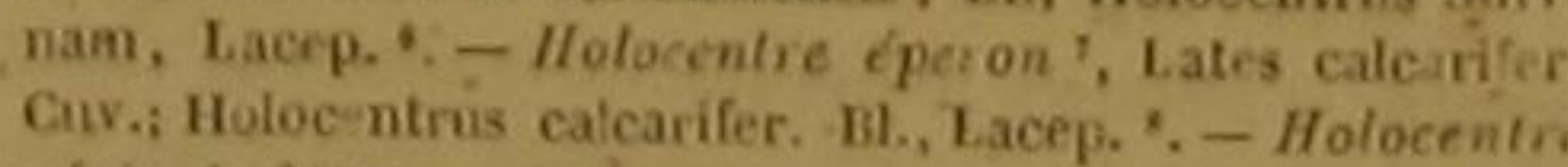
ufricain ', Serranus alexan Irinus. Cuv.? Epinephelus Afer. Sertanus mareinalis, Cavp. ". - Holocentre borde" Holocentrus Rosmarns, Lacep. 12 - Ho/ocemire brent, Epinephelus fusens, Bl.; Holocentrus fuscus, Lacep. " ". Holocentie Merra ", Serranus Merra, Cuv.; Epineph las Merra, Bl.; Perca Tanvina. Forskael; Holocentrus Tau-

Bloch a fait connaitre tes neuf holocentres dont cet article renferme la notice. Celui de ces

'Bioch, pl. 222, fig. 2. - Holocentre tacheré. Bloch. D. Cuv; Holoceutrus surinamensis, BL; Holocentros Sur-
nam, Lacep. - - Holocentre éperon , Lates calcriter rouge "t, Serrocentrus Merra, Lacep. ". - Hotocentie Holocentros ruber, L..., Cuv.; Epinephelus riber, Bicedi:

"Du genere Mínou, Serramus, Cav,; dans la fanille des poissons auquel il a donné le nom de Pointsbieus, a des dents très-fines aux mâchoires, la langue lisse, le palais rude, les écailles extrêmementpetites, et les nageoires très-brunes, Le blane et brun se trouve dans tes Indes orientales. Les dents qui garnissent les máchoires sont égales et pointues; la langue est lisse ; le palais parait rude au toucher; les couleurs sont remarquables par leur distribution, et par les eontrastes que forment leurs nuances.

Le surinam parvient à la grandeur de la perche d'Europe; sa chair est grasse et très-agréable au goùt: son nom annonce le pays qu'il habite. Les deux mâchoires sont garnies de dents courtes, grosses et recourbées; $\mathrm{e}^{2}$ de plus la máchoire supérieure est hérissée de dents trèsfines, placées derrière les premières; le palais et la langue sont lisses. On voit de petites écailles sur la base des nageoireś du dos, de l'anus et de la quęue ; ces nageoires sont, ainsi que les autres, variées de jaune, de brun et de violet; une bande brune transversale et figurée en portion de cercle, est placée sur la caudale

Le Japon est la patris de l'éperon. Indépendamment des aignillons dont la position et lã forme lū̉ ont fait donher le nom qu'il porte, et sont exposées dans le tableau générique, it présente une tête un peu aplatie et comprimée; des dents très-fines, mème à peine visibles, et

Son mentionne par U, Cavier, D

'Non meationn

'Bloch, pl, 215.
Da genre Lonores, daisis a famille des Acanthoptérygiens selénoides. 0 .

'Bloch, pl. 24.

- Du genre Vasiole, La les, dans la famille des A canthopérygieus percoìdes.

Epinéphele africain. Bloch, pl. 527. 10 N. Cuvier croit pouvoir, sas trop de doute, rappote ter folocenire africain, Lacp., a Tesuece de polsson qu (dans la familie des'Acanthoptírygiens percoides). D.

"Epinéphiele borde. Bloch, pl. 528 , tig. 1.

a va genre Bizkoo, Serranas, Cav., dans la famille de Acanthopterygiens percondes. M. de Lacepède a déerit deus fois ce poisson, sous les noms
20 d'Holocentre Rosmare. D.

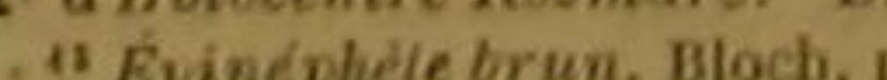

As son mentipgé par Y. Ceviers, fig. 2.

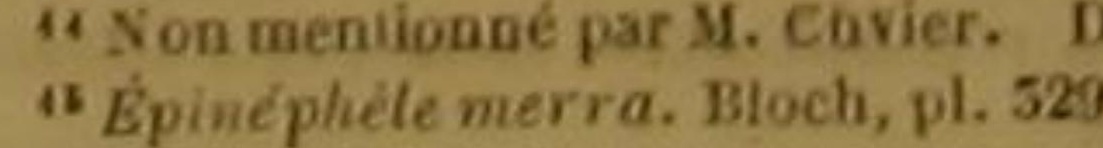

"Du genre Mízou, Serranus, Cuv., famille des Acanthoptérygiens pereoídes. M. de Lacépede a fait in double empici en décrivant deux fols ce poisson sous les noms

centre Tauvin, etze difolocentre stor.

"1) De genre Mrgov, Serranus, dans la famille des Acanthoptérygiens pereoides. $\mathbf{V}$. Cuvier dit quil ne différe de son Serranus aurantius que parce que Bloch fui comple deur rayons caineux de plos a la dorsale, et an rayon mo de moins. D. tres-nombreuses, distribuées sur lo palgis at le long des deux máchoires; une strie longitudinale sur chaque écaille; ur mélange de violet et de jaune sur les nageoires; deux raies longitudinales ou deux bandes transversales brunes sur ces mèmes nageoires, excepté la eaudale, sur laquelle regnent trois de ces bandes trans. versales.

L'holocentre africain parvient à une grandeu considérable. Bloch l'a compris avee le bordé, le. brun, le merra et le rouge, daus le genre particulier qu il a proposé de nommer Épinephèle, ou Taie, mais que nous n'avons pas cru devoir adopter. L'africain vit pres des rivages oecidentaux d'Afrique voisins de la zone torride ; il se plait dans les bas-fonds; on l'a pèche particulierement à Acara, sur la cote de Guinée. II se noourrit de mollusques et d'écevisses et sa chair est blanche, délicate et saine. On doit observer, indépendamment des traits indiqués dans le tableau générique, les dents de chaque máchoire, qui sont très-petites; celles qui forment $\mathrm{mi}$ are suir le palais; la langue, qui est lisse; la partie anterieure de la queue, qui est très-haute; les petites écailles placées ur les nageoires du dos, de la poitrine, de I'aaus et de la queue; la couleur des thoraeines, qui est orangée ; et celle des pectorales, qui est d'un jaune de soufre.

Le bordé a quatre grandes dents à la partie antérieure de chaque màchoire.

Les eaux de la Norvège nourrissent le brun. Cet holocentre montre des dents petites et égales, et cinq ou six raies bleues disposćes sur chaque opercule, de manière à tendre vers l'oil, comme vers un centre'.

12 rayons a chague pectorale de libolocentre pointsbleus. 1 rayon aiguillosn et 3 rayous aricules a chaque thioracing, is rayons a la caudale. - 6rayons a ia menabaio Grachiale de nuolocenté biance et bron, 15 a chaque pectoraciue, 15 rayons a la nageoire de ta queue. -6 rayons al suembrane branchiale de fbolocentre surinam, 14 is chaqu pectorale, 1 rayon aigeitionee et 6 rayons articuica a chaqu Lhoracise, 17 rayens a la caudale. -6 rayons a la menbrang branchiale do l'bolocentre épron, is a chaque pectorate,

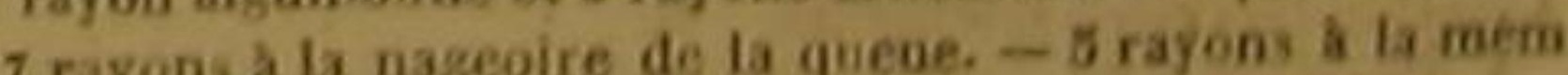

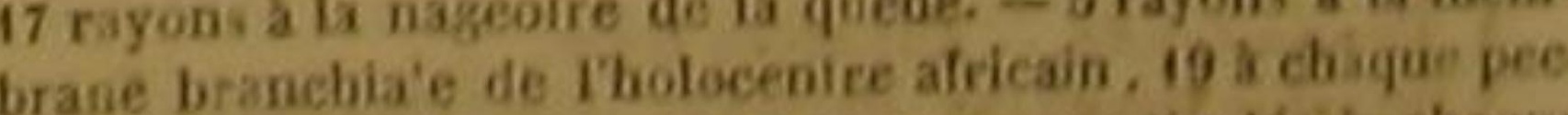

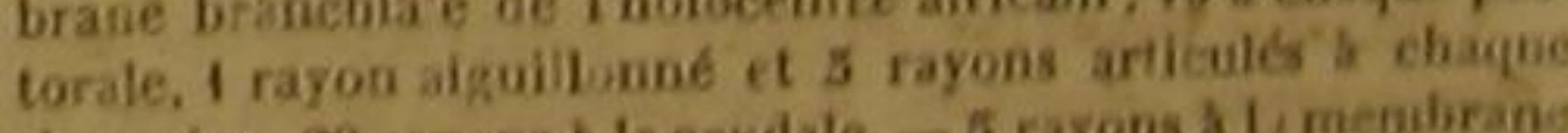
thoracine, 29 rayons a la caudale. -5 rayons a L menairan

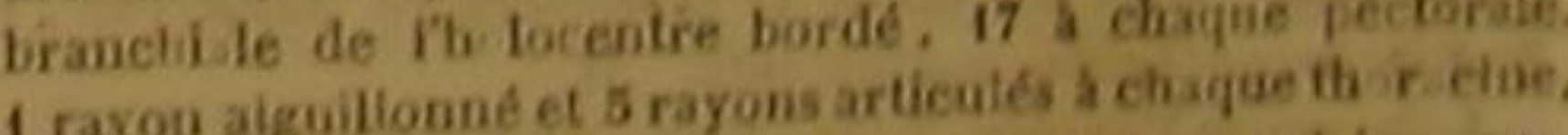

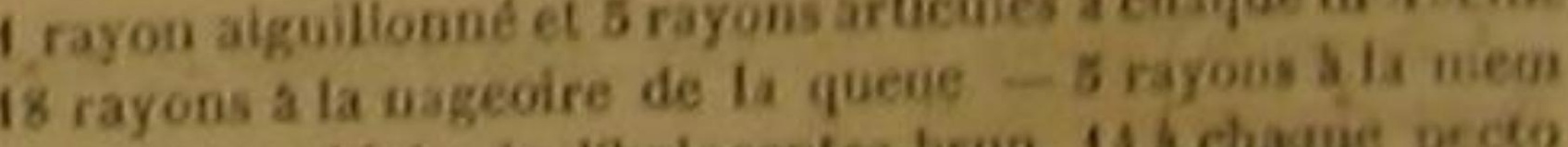

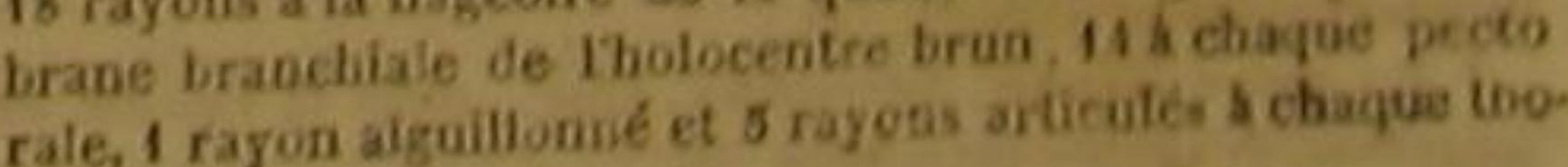


La langue du merra est lisse; son palais hé- | dont mous allons parler, n'a encore été publié rissé de petites dents; et chacune de ses mâ- par aucun auteứ. J'ai décrit le rouge-brun d'a choires garnie de dents courtes et pointues. près les manuscrits du célèbre Commerson,

Séba et Klein ont donné chaeun une figure de qui l'a observé, en octobre 1769, dans les mers cet holocentre, que l'oin a vu dans les iaux du Japon.

C'est dans ces mèmes eaux que se trouve le rouge. Ce poisson n'a que de petites dents à chaque machoire; la base de sa dorsale, de sa caudale, et de sa nageoire de l'anus, est couverte de petites écailles; et l'iris est jaune du cóté de la prunelle, et bleu dans sa circonférence.

L'HOLOCENTRE ROUGE-BRUN ', Holocentrus rubro-fuscus, Lac '

L'llolecentre Soldado ', Cosvina Miles, Cuv, i Holoceutros Soldado, Lae, 4.- Hotocentre bossu, Pristipoma surina-

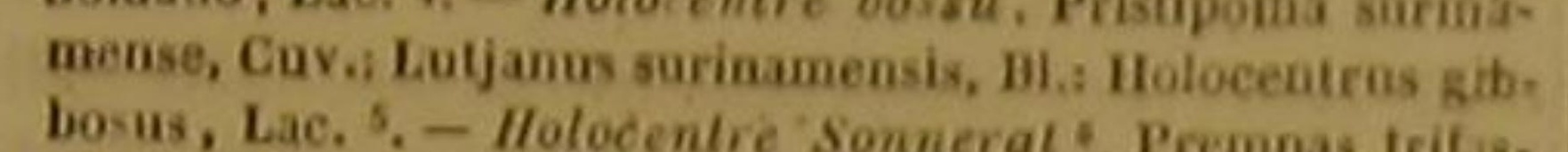
clatus, Cuv, i Luyanus teifasciatus, Bl., Schro, ; Chatodo bisculeatus, Bl.; Holacanthus biaculeatus, et Holocentrus Sonnerat, Lac, 1. - Holocentre hepladactyle, Lates nobi-

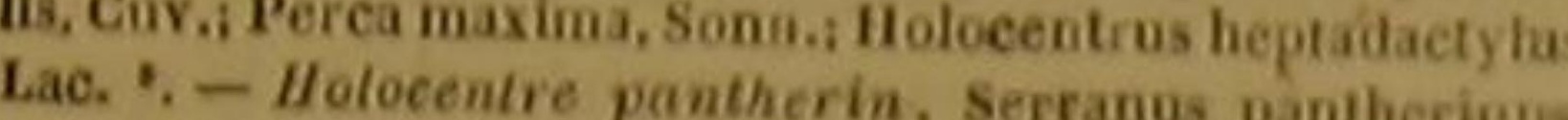

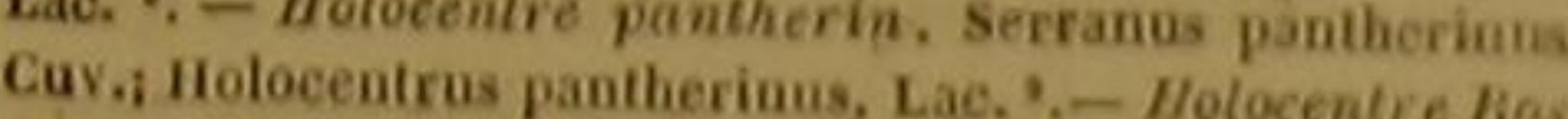
wave, Serranus marginalis, Guv.; Holocentrus marginate et Holocentrus Rosmaras, Lac. 10 . - Holocentre océanique, Serranus oceanicus, Cuv,; Perca fasciata, Forsk. Holocentre Salmoide, Serranus silmoides, Cuv,; Holocen-

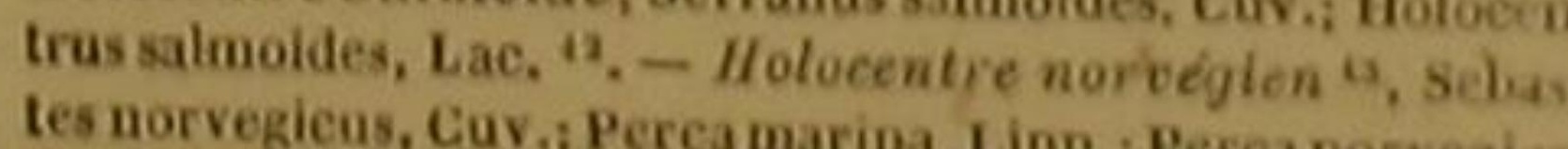

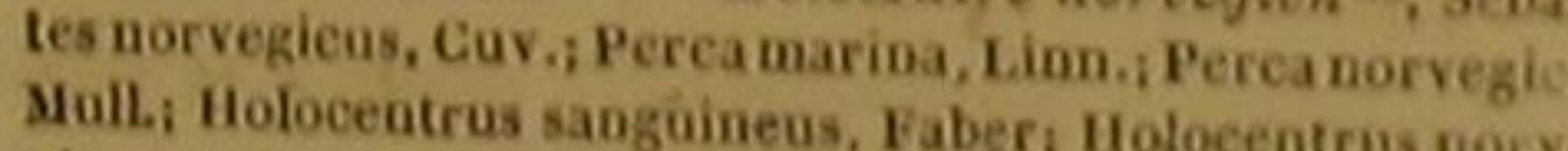
Mulli, Holoceatrus sanguineus, Faber; Holocentrus norn
gleus, Lac. "4.

La description des neuf premiers holocentres

rache, 18 rayons a la caudale. -5 rayons a $\mathrm{L}$ membranc I rayon aiguiltonoé et s rayens ant is a chaque pectorale, 16 rayons a la nazeoire de la queve -5 raque thoricine, brane branchiale de 1 tho ocenire reuge, 12 a ch 19 ment rale, 1 rayon aiguillonoé et 5 rayons articulés à chaque racine, 20 rayons a la eandale.

¿Aspró subrubens, macula ponè pinnaun dossaleun nig a a

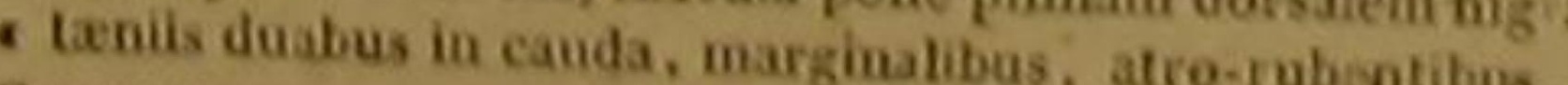
Cominerson, manuscrits deja cités.
isou mentiouné par M. Cuvier. D. S Nou mentio

4 Du geure Cous, Corvina, Cur., dans la familte des Acan

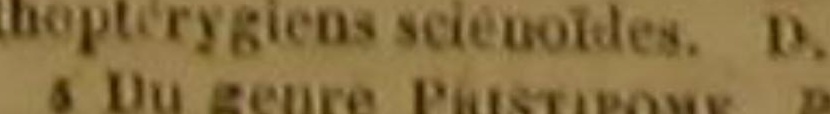

Acanthoptérygiens sciénooides. Pristipoma, dans la fatritle des
D. : Tanda-tanda, - Kakatora itam.

- Dugenre Pasarade, Premáas, dans la familte des Acin-

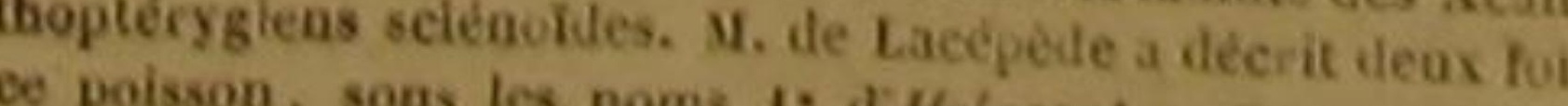
of poisson, sous les noms 1. dHotocentre Sonnerat - et - Du genre VamoLs, Lates, Cur.,dans ta fumile de i Acan. thopterggicas percoides. D. Acanthopterygiens percoider. D
Dur., dins ta familte des voisines de I'Ile-de-France. Ce poisson y est quelquefois assez rare. Sa chair est de bon goùt et facile à digérer. Sa plus grande longueur n'excède guère deux déeimètres. On voit, auprès de chaque $\alpha i l$ de cet animal, une tache noirâtre et un pẹu vague. Sa dorsale et so: anale sont rayées, tachées et bordées de rouge; ses thoracines présentent une couleur de minium; et ses pectorales sont jaunătres, avee de petites taches rouges a leur base. Des dents déliées, recourbées et très-serrées, garnissent ses mảchoires. D'autres dents plus petites hérissent une sorte de tubérosité placée au milieu du palais, et fes environs du gosier. La langue est blanchâtre et lisse, on à peu près. La ligne latérale parait composée de petites ligues qui ne se touchent pas; et les écailles sont petites et rudes.

Des deux soldados que nous avons examinés, lection donnce par la Hollande à la France, et l'aútre nous avait été envoyé de Cayenne par M. Leblond. La máchoire inferieure de ces holocentres était plus avaneée que la supérieure; on comptait-sur ces màchoires tin grand nombre de dents inégales, fortes, pointues, assez grandes surtout vers le bout du museau, et distribuées en plusieurs rangs à la mảchioire d'en haut, où les intẻrieures étaient très-pressées; des écailles très-argentées rendaient très-brillants les opercules, la máchoire d'en bas, la ligne latérale, et la partie de la membrane branchiale que l'opereule ne recouvraitpas.

L.e bossu a les dents petites, serrées et égales. Nous avons vu des individus de cette espèce et des deux suivantes, parmi les poissons de la belle collection hollandaise.

"Du genre MÉaoc, Serranus, Cav. (Lmille des A camtho-

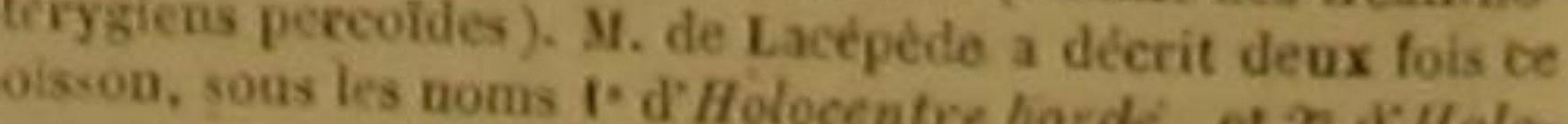
centre Rosmare. D.

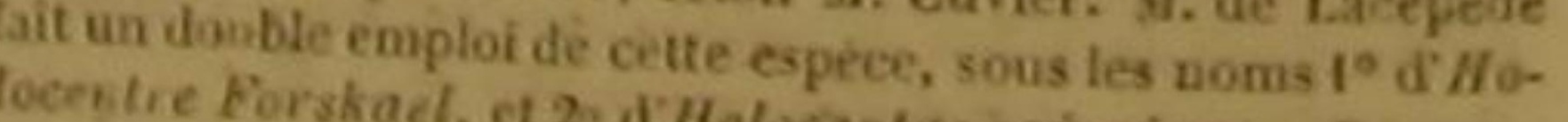
"a Du genre Mkiso, Serranus, Cuv. (fanilte des Acan-
thoptérygiens percoldes). D. Persegue norrógienne. D. - Otho Fabric. Fanu. Groenland., p. 457, pl. de IEnc, meth. "'Du geure Sebuste, Sebastes., Cuv., dans la farille des un avait fait partie des poissons sees de la col.

i" Ga genre Mrisou, Serrants, dans la famille des Aeanthopl rygiens percoides, selon II. Cavier. M. de Lacépede
Le sonnerat, auquel nous avons donnéle nom d'uu voyageardont les observations, les ouvrages et les envois ont enriehi la science et lé Muséum $d$ 'histoire naturelle, a le corps long et comprimé, la couleur générale jaunátre, et ses bandes transversales d'un blane ou d'un argenté très-éelatant. Il nous a été envoyé de I'Ile-de-France.

L'heptadactyle ', dent le nom indique que les rayons de ses thoracines, ces rayons analogues aux doigts des pieds, sont au nombre de sept, a au palais, ainsi qu'aux déux mảehoires, plusieurs rangs de dents petites et égales. Sa dorsale est divišée en deux parties presque assez distinctes pour représenter deux nageoires contiguês. Et comme nous avons été à même d'examiner plusieurs de ces heptadactyles, nous avons pu nous assurer d'un fait curieux, et qui pourrait étre de quelque utilité pour l'auteur d'une méthode ichthyologique : e'est que dans les deux lames dentelées que l'on voit auprés de chaque opereule, le nombre des dents ou pointes augmente avee I'âge. Nous n'en avous, par exemple, compté que six daus la lame la plus voisine de la pectorale; sur un jeune hep. tadactyle dont la longueur n'égalait pas encore deux déeimetres, et nous n'en avons trouvé que trois dans la seconde lame, pendant que sur un individu plus ágé et long de plusdequatre décimètres, la lame situce auprès de la pectorale nous en a présenté dix, et l'autre lame nous en a offert cing

Commerson nous a laissé une figure du panthérin, d'aprés laquelle on doit croire que les écailles de ce poisson sont tres-difficiles à voir. La disposition des taches de cet osseux nous a suggéré le nồn que nous luí àons donné, de mème que nous avons eru devoir employer ce. lui de Rosmare pour l'espece suivante, afin d'indiquer le rapport que dohnent à ce dernier holocentre la figure et la disposition de ses deux dents supérieures, avec le Morse rosmarus ou Vache marine, dont les laniaires supérieures sont longues, tournées vers le bas, et au nombre de deux ${ }^{2}$.

1. Hepta signife sept, et dactylos signifie doigt. 7 rayons a la reenibrane bramchiale de I'tholocentre rouge-

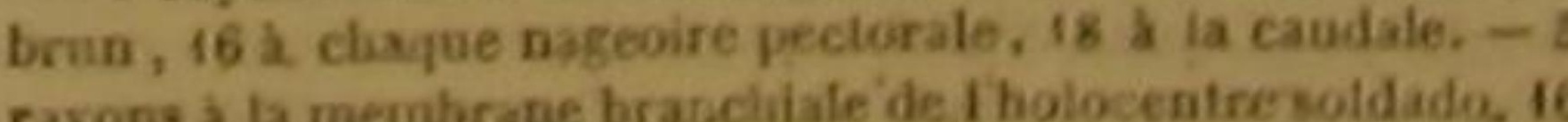
rayons a la membrane brascinale dei i holocentresoldada, 16 a chaque thorscine, 17 rayons a ta nazeoire de is quese. -

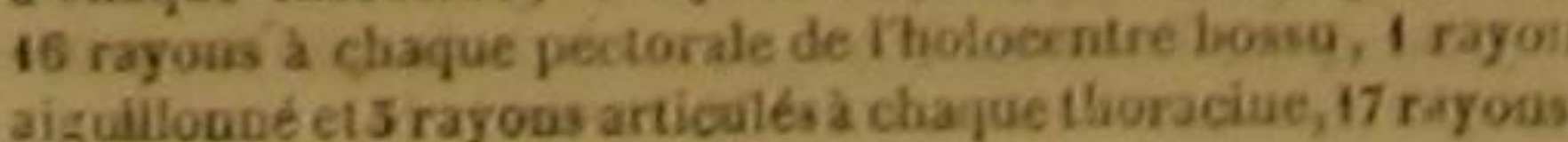

La première partie de la dorsale de eet holocentre rosmare est plus basse que la seconde, et raisemblablement bordée de brun ou de noir. C'est encore Commerson qui nons a transmis un dessín de ce rosmare, de l'océanique, et du salmoide.

L'océanique a, eomme le rosmare, la prenière partie de la nageoire du dos moins haute que la seconde, et bordée d'une couleur foncée. Il vit dans le grand Océan, auprès de la ligne ou des tropiques; et e'est aussi dans ce grand Ocean, que lon a rencontré le salmoide, dont nous avons tiré le nom spécilique de la ressemblance de sa tête aveo celle du saumon. Une mer bien plus rapproehée du pôle est la patrie du norvégien : il habite dans celle qu sépare le Groenland de la Norvège, Son opercule se termine par une longue epine. Les ouvertures de ses narines sont doubles; et on a mème écrit qu'elles étaient triples, ce qui nous paraltrait extraordinaire. L'ereur de ceux qui auront eru voir trois oriflees pour chaque narine, sera venue de I'altération de I'individu qu'ils aoront examiné, Les ceailles sont arrondies, grandes, et fortement attachées ; les peetorales allongées; et la dorsale s'étend depuis le sommet de la téte jusqu'a la queue.

\section{CENT VINGT-TROISIEME GENRF.}

LES RERSÉOUS '

Un ou plusicurs aiguillons el une dentelure aus opercutes; un barbillon, ou point de barbillons aus machoires; deus nageoires doriales.

PREMER SOUS-GENHE.

Ia nageoire de la queue fourchue, ou tehanerde en croissant.

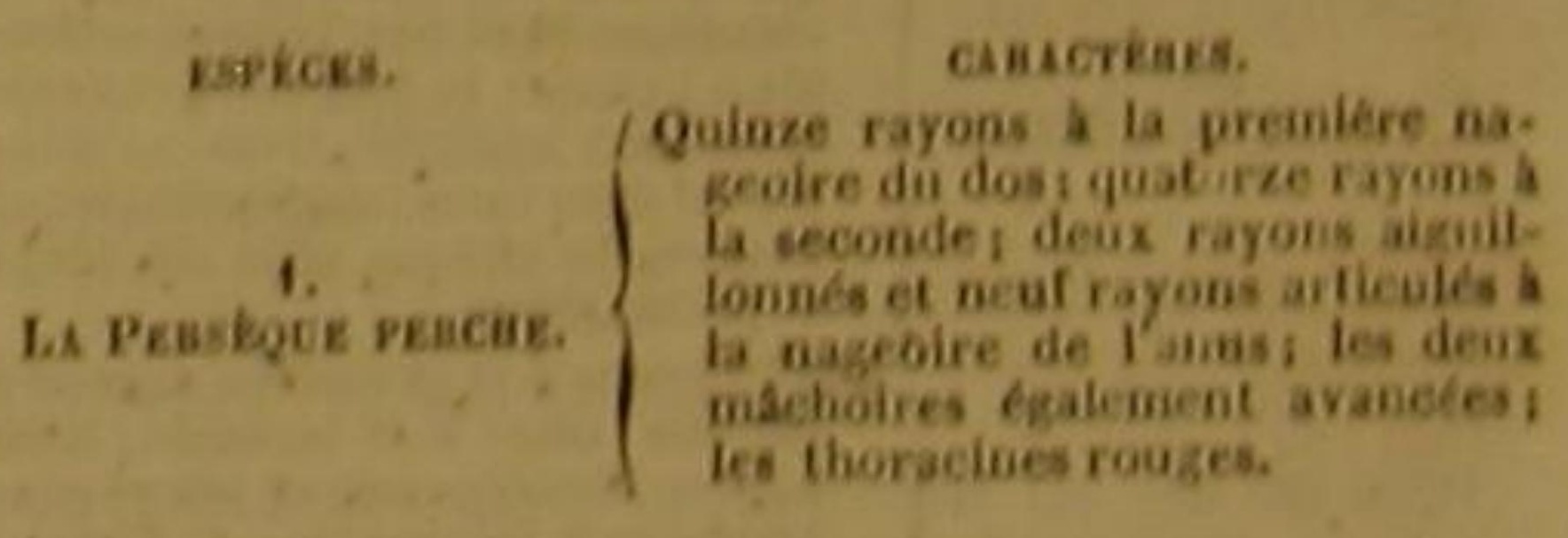

a la candale. -6 rayons a la membrane branchisile de tholo centre soninerat, 17 b chaque peetorale, 1 rayou aiguiliona

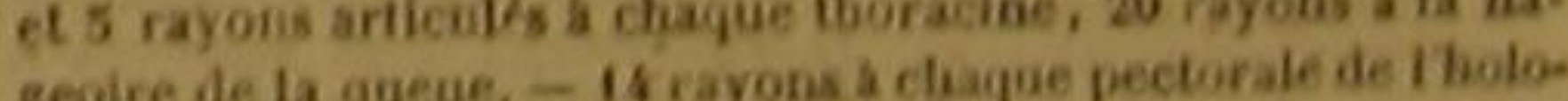
centre beptadactyle, 17 i la caudale. - II rayous a chaque pectorale de tholoecntre pambéria. - 10 rayons a claquo pectorale de I huloeentre rosmare. -14 rayons a chaque pre corale de I toboentre cecauique, 16 a la nageoire de la qaeue.

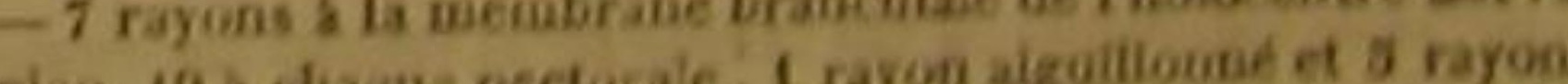

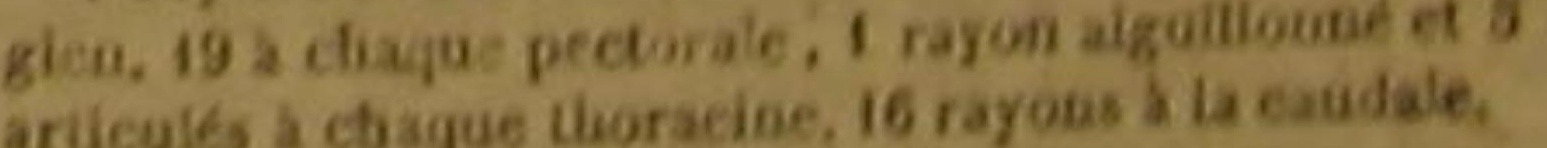

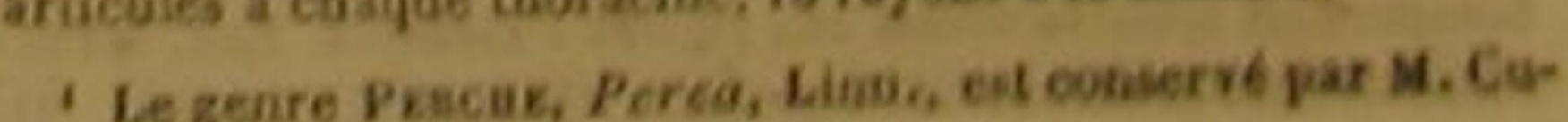


erpkes. eABuctìnes.

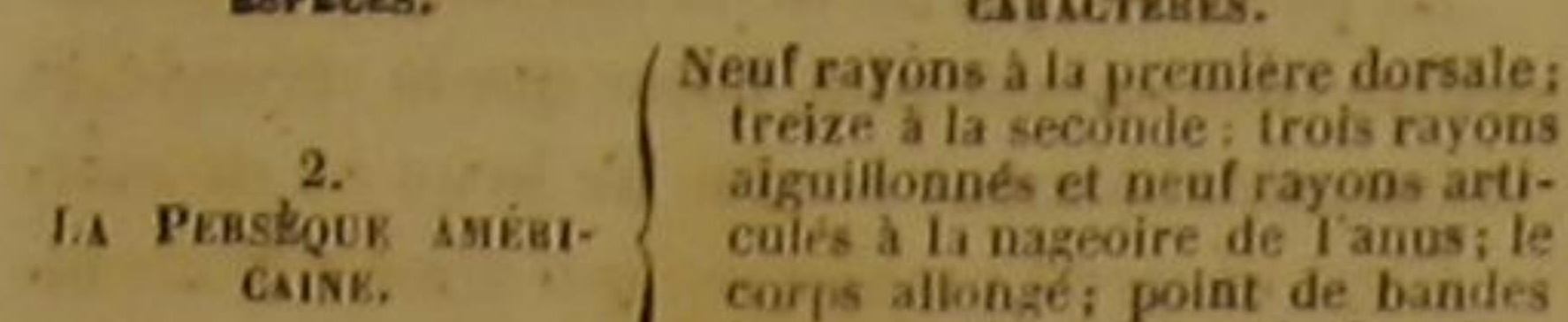

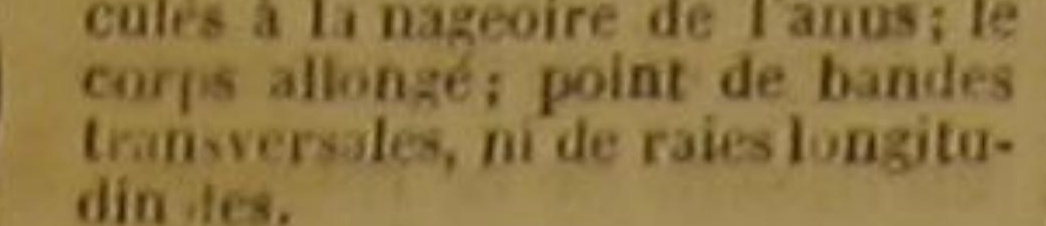

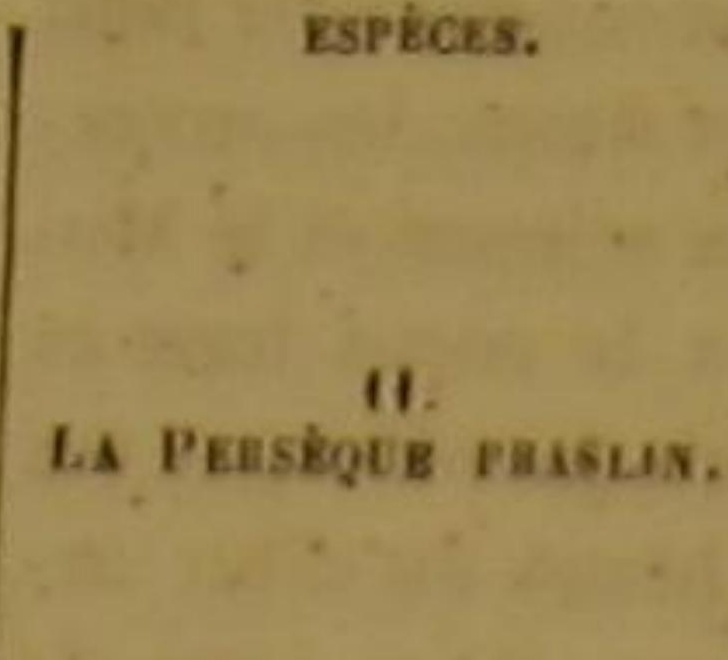

crictikas.

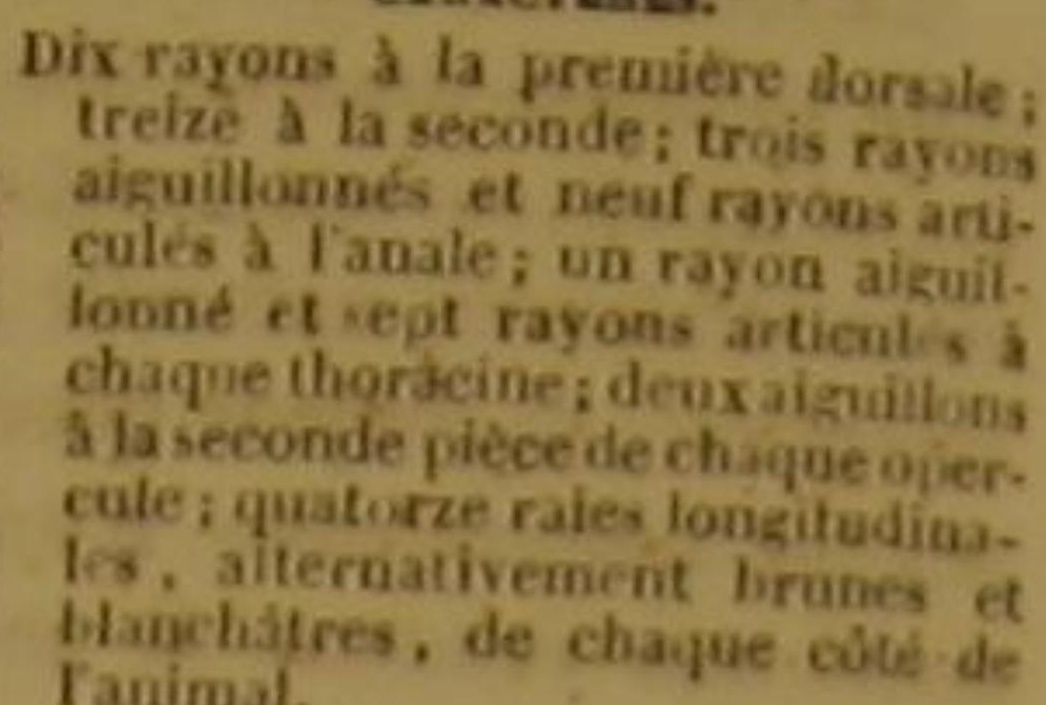

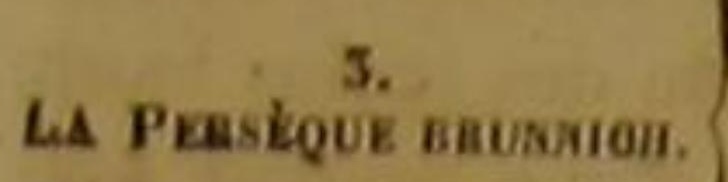

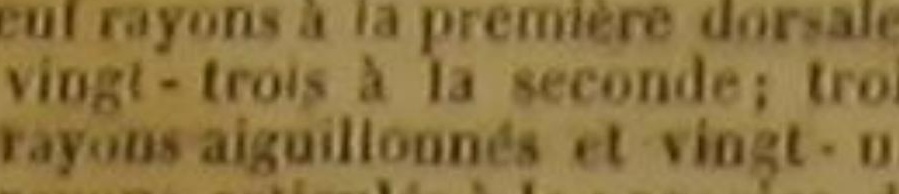

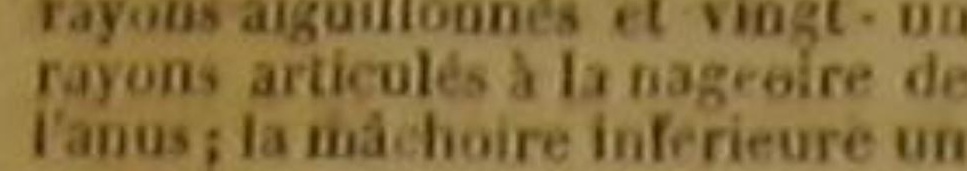
peu plos avancie que la supe
rieure; te rayon aiguillonie di chaque thoracine, dentele sur soo
bord anterieur.

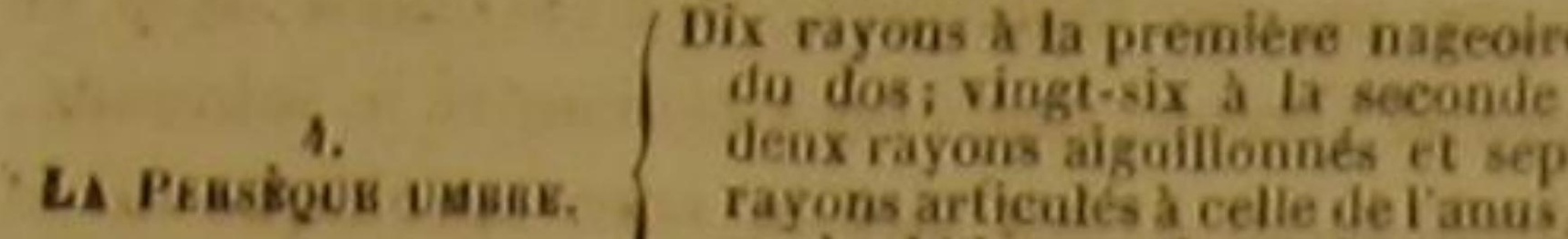

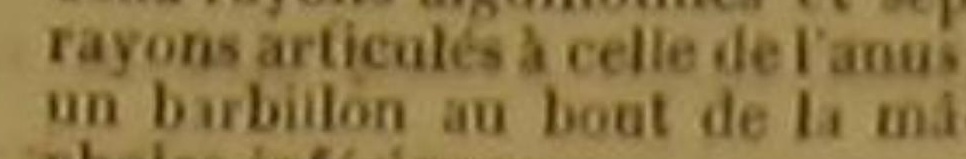
thelrẹ inferieure.

4. 5. Nent rayons a la premiere dorsale
treize a ta seconde ; rools rayon

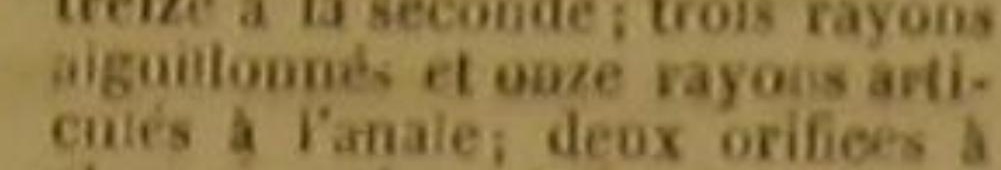
chaque opercules an argailfons nom

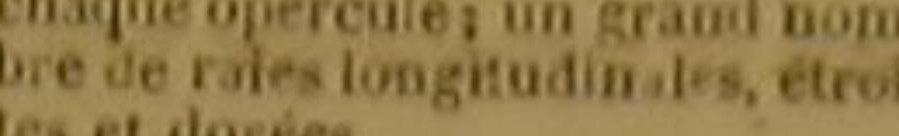

L1 Prasige pois

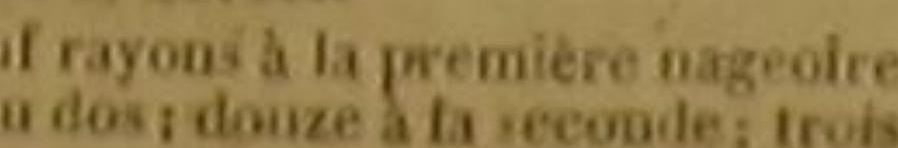

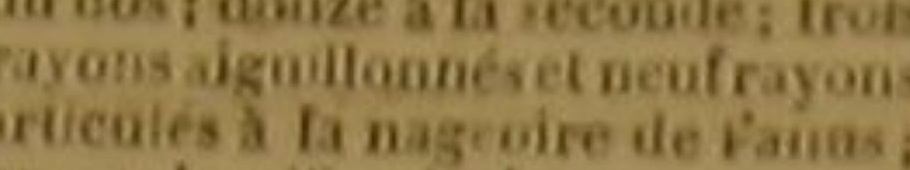
iucuies a fa nagcoire de tainas;
ux on orihice a chaque narine;

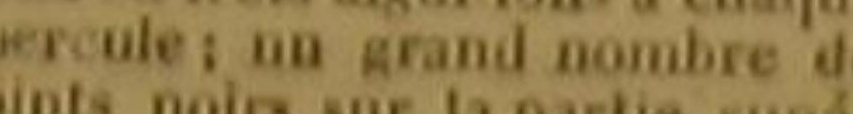
points nois sur
rieure de tamima

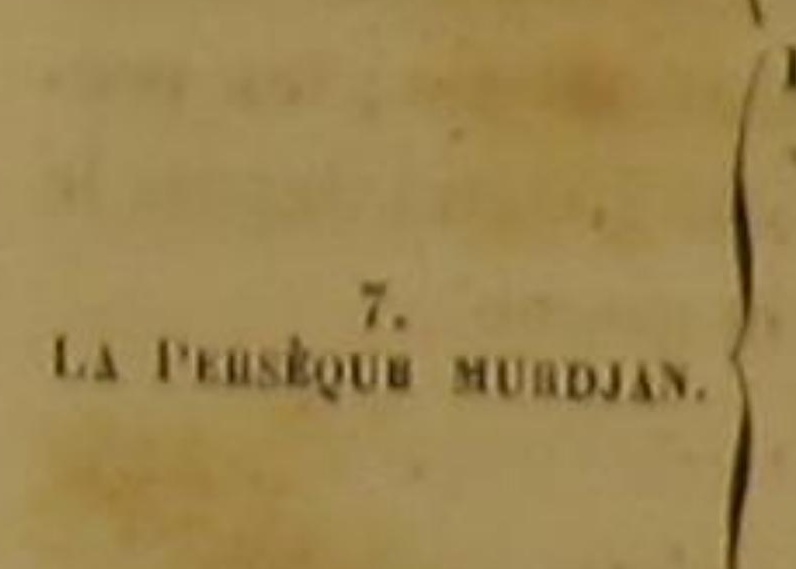

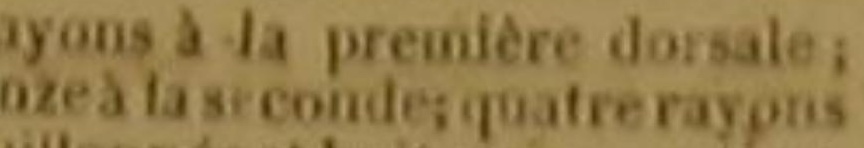

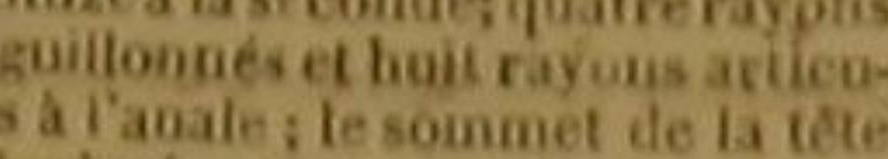

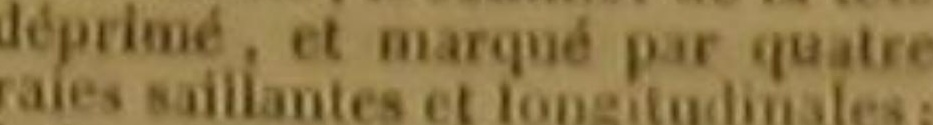
havre superieure extens bie, es

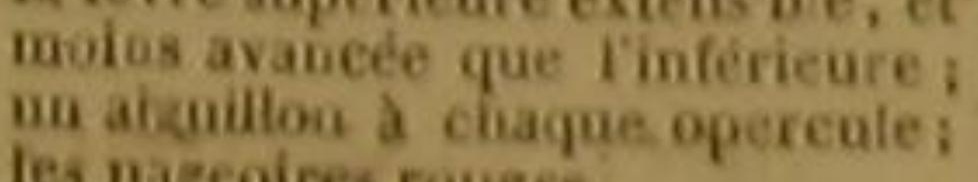
dis rayons d ta $p$

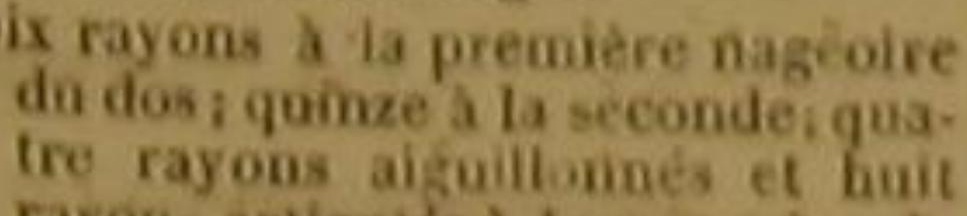
8.
LA PEasigur posite.
EFine.

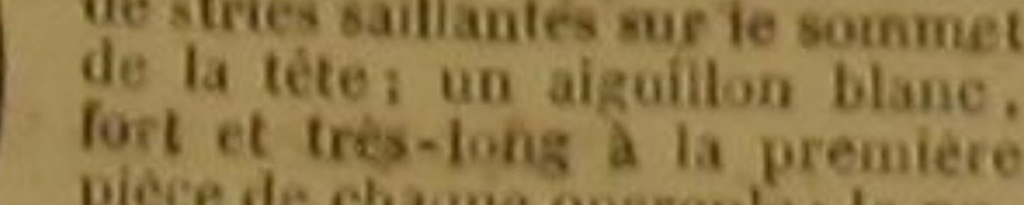
lort et tres-long a la premiere
piece de chaque opercule; th ag-
que relevee en bosse. Ouze rayons a la prem.

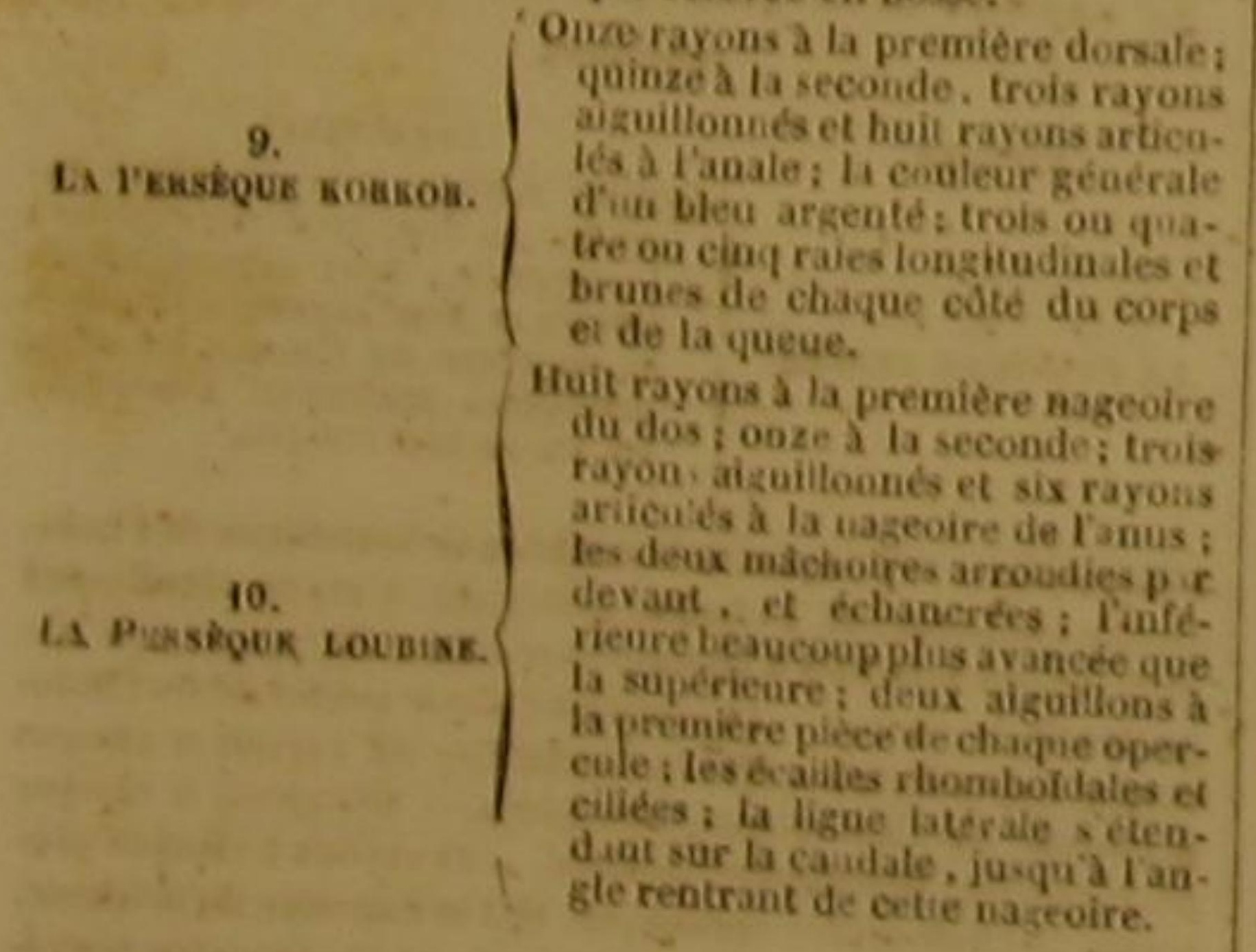
Ner, et ce uaturaliste en fait le type de sa Fumille is so

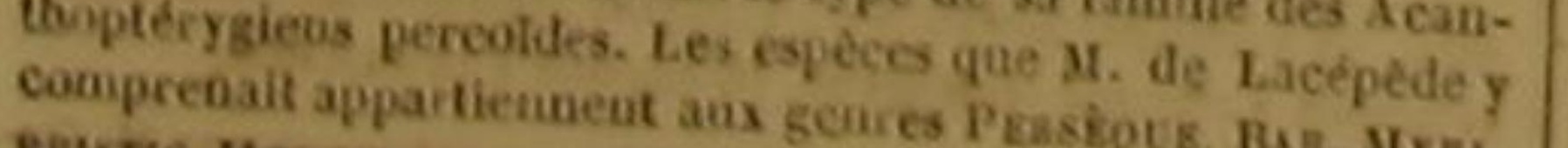

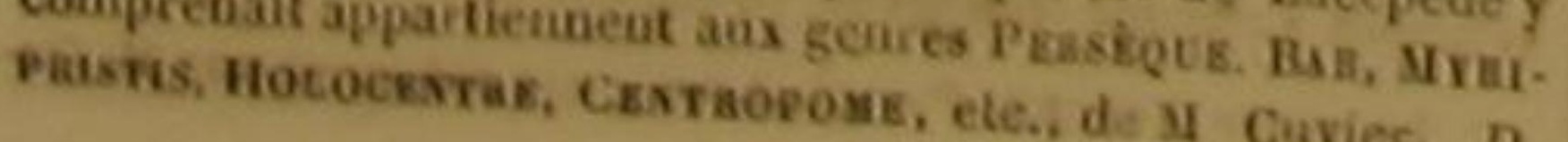

SECOND SOUS-GENRE.

La nageoire de la queue rectiligne, ou arrondie, et non. échanerée.

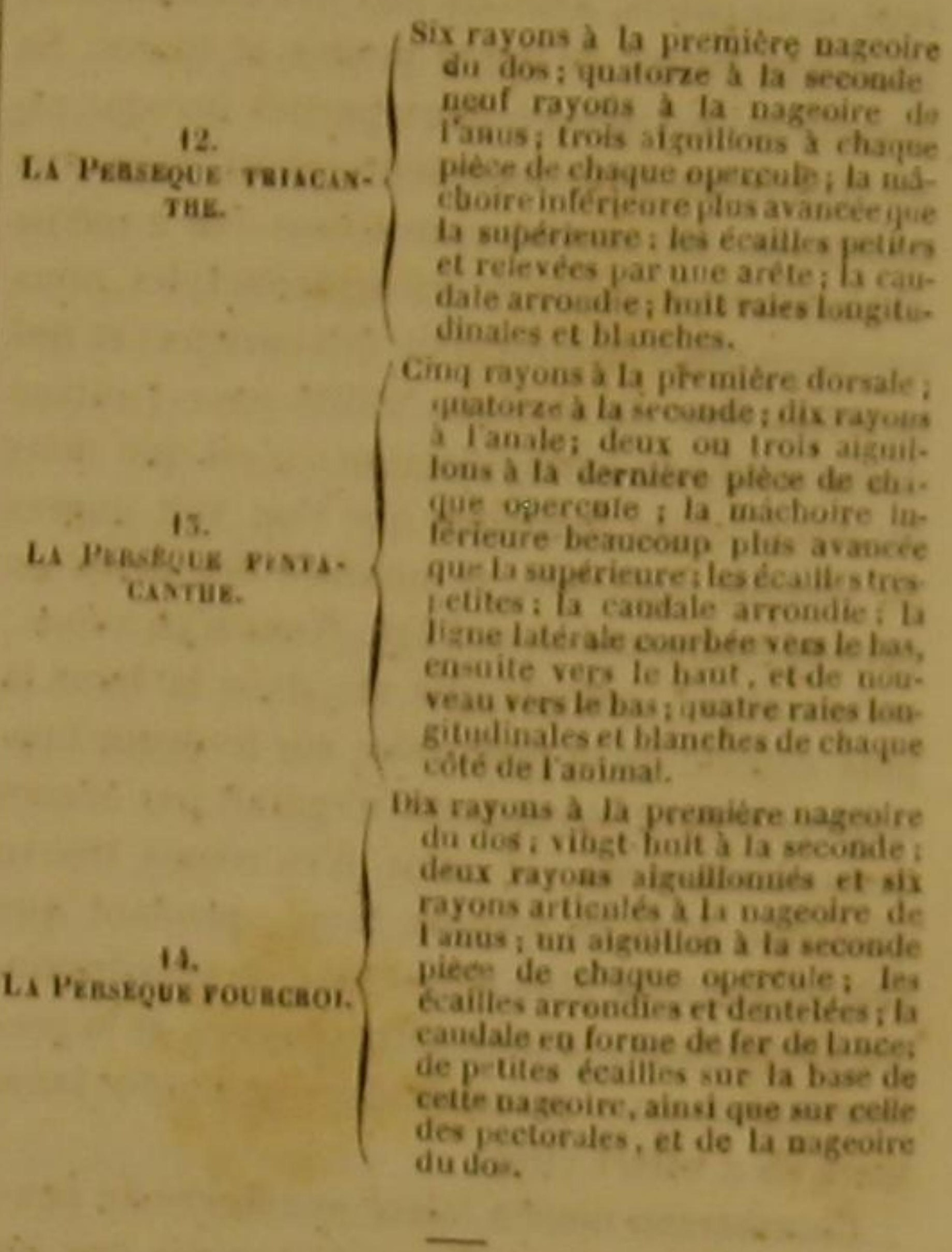

LA PERSEQUie PERCHe ; Perca fluriatilis, Lino., Gmel., Car., BI., Lac. . La Nature nous a environnés de merveilles. Est-il autour de nous un de ses ouvrages dont

- Peísiga, en tialie. - Pesce parsieo, dans quel quars fles eqlen, I Pige de. - Hereeling, a räge d'un an, Egle, ou

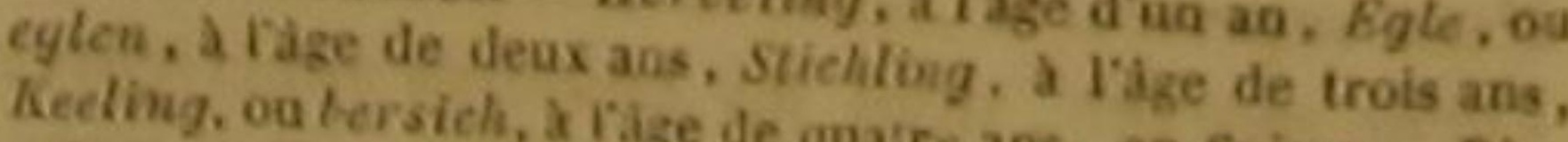
yel-persing, Bunt baarses quatre ans, en Suisse. - Rin. Baviêre.-Berslling, Perschling. Warschiegrintel, en Assure, on as, Bearsch, Stockbaarseh, en Poméravie. - Ovinum, en Pologive - O Lettes, - Ahwen, en Estonie. Suede. - Tryde, Skybbo, en Noryezse. - Aborre, en aborre, $\boldsymbol{A}$ torn, en Danemarck. - Bears, - Eersk - vands Perch, en Angieterre. - Persegue perche. Baubento. -

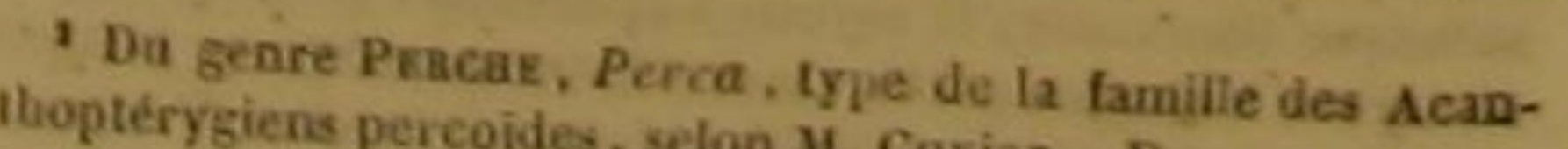
Prusse, - Mars. Ba, en Hongrie. - Barsch, Perseke, en l'observation attentive ne puisse nous dévoiler un phénomène curieux et nous donner un plaisir et bien vif et bien doux ? et cependant combien peu d'objets nous, connaissons eneore, parmi ces productions si intéressantes qui se présentent sans cesse à nos regards ! quel grand nombre de preuves ne pourrions-nous pas offrir de cette vérité, qui, n'accusant que notre indifference, la changera par cela seut in zèle courageux, et nous promet pour Paveuír dés jouissances si variéés et des connaissances si utites!

Contentons-nous de faire remarquer celle que nous fournit le sujet de cet article.

La perche habite piarmi nous; elle people nos laeset nos rivières; elle est servie sur toutes nos tables: qu'if est neanmoins bien peu d hommes, même parmi les naturalistes instruits, qui en aient étudié l'intéressante histoire!

Táchons d’en présenter les faits les plus dignes de l'attention des physiciens; mais jetons auparavant les yeux sur quelques-uns des organes principaux de cet animal remarçuable

La perehe attire les regards par la nature et par la disposition de ses couleurs, surtout lorsqu'elle vit au milieu d'une onde pure. Klle brille d'une couleur d'or mélée de jaune et de vert, que rendent plus agreable a voir, et le rouge répandu sur toutes les nageoires, excepté sur celle du dos, et des bandes transversales larges et noirâtres. Ces bandes sont inégales en longueur, ordinairement au nombre de six; et ressemblant le plus sóuvent à des reflets qui ne paraissent que sous certains aspects, plutót qu'à des couleurs fortement prononcées, elles

Hay, Eac. meth. - Id. Honnaterre, pL de IEne méth. Faun. Suedc. 332 - Moll Prodrom. Zoolog, Banic. p. As,

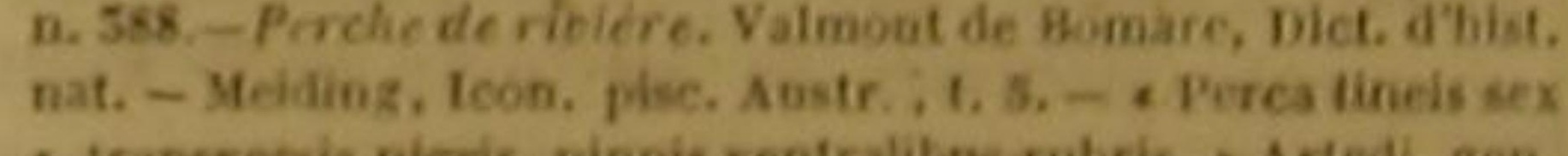

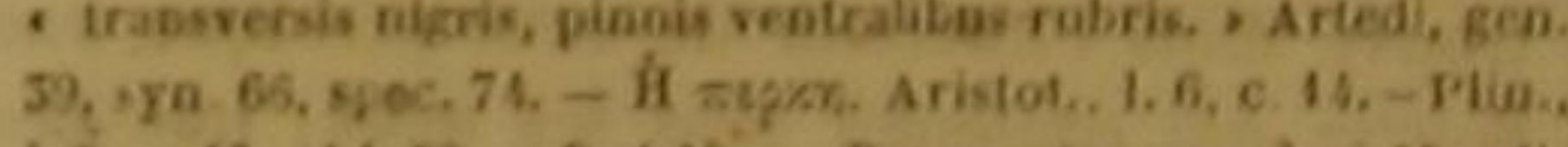

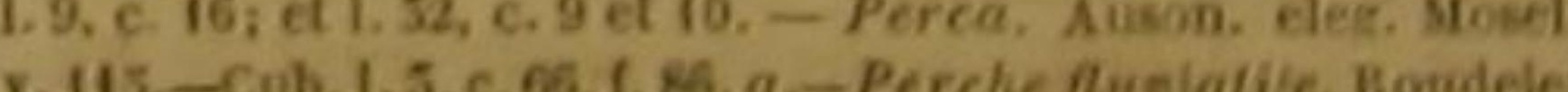
part. 2, e, 13,- Perca flueialilis, Wotton, 1. 8, 1. 157. - Id Saivias, I. 22A, b. et 266. - Ld. Gesner, p. 698, Icon. animal p. 302; et (germ.) ). 168, b. - Id. willoghtly, p. 291. - hai.

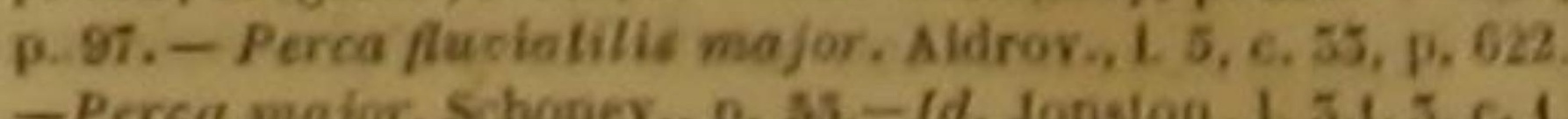

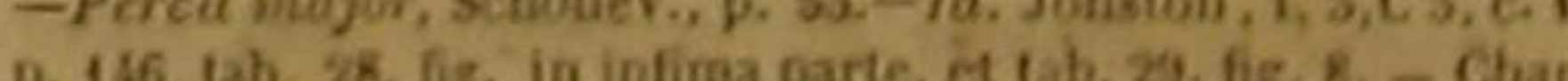
leton, p. 161 - Perca. Petri ariedi synonymia piesdum, ele auctare J. G. Schneider, p. 105. - $\rightarrow$ Perca dorso dipteryzio, - lineis utrinque sex, He., Gronov, Mus, 4. p. 22, n-96, Zooph., p. 91, 0. 501.-Bloch, Dh, 52- - Perca pianis dua

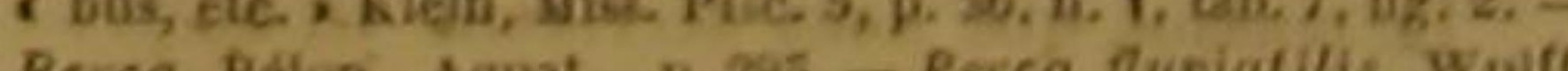
Perca. Belon, Aquat., p. 255. - Paca hueiatilis. Wi

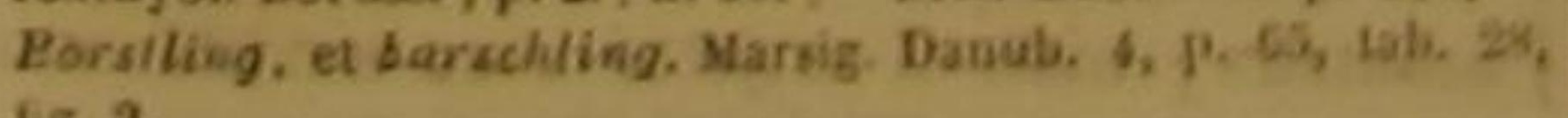

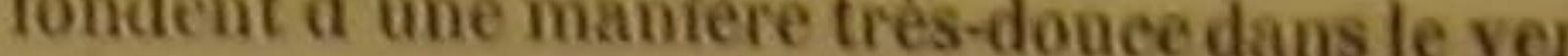
doré du dos et des cótés do l'animal. L'iris est bleu à l'extérieur et jaune à l'intérieur. I.es deux dorsales sont violettes; et la première de ces deux nageoires montre une tache noire à son extrèmité postérieure

Les dents qui carnissent les deux máchoires sont petites, mais pointues; d'antres dents sont repandues ser le palais et autour du gosier; la langue seule est tisse. On compte deux orilice à chaque narine: l'on voit, de chaque cóté, aupres de ees orifices, entre l'wil et lo bout du museau, trois ou quatre pores assez grands destinés à tiftrer une humeur visqueuse. La première piéce de chaque opereule est dentelée, et de plus garnie, vers le bas, de six ou sept aiguillons; la seconde ou troisteme plèce se termine en une sorte de pointe ou d'apophyse ai. gué; et tout lopersule est couvert de petites écailles, La partie osseuse de chaque branchi presente, dans sa coneavite, un double rang de tubereules presque égaux et semblables les uns aux autres, excepté ceux de la première, dont les extérieus sont aigus et trois ou quatre foi plus longs que les autres, Des cenilles dures, dentelées, et fortement attinchées a la peau, recouvrent le corps et la queue.

L'estomac est assez grand; le capal intestinal qui le suit est deux fois recourbé; trois appendices ofi coecums sont placés un peu au dela do pylore; la vessie est cylindrique et composee d'une membrane tres-mince; le fole se partage en deux lobes, dont lé gauche est le plus grand. et entre lesquels on distingue une vésicule du fiel, transparente et jaunatre, La laite de mâles est double; mais lovaire des remeite n'est composé que d'un sae membraneux. L'épine dorsale comprend quarante ou quarante et une vertebres, et soutient dix-neuf cotes de chaque côté.

La perche ne parvient guère dans les contrées tempérées, et particuliérement dans celles que gous habitons, qu'a la longueur de six ou sept décimetres, et elle pòse alors deux kilogrammes, ou à peu pres: mais, dans les pays plus rapprochés du nord, elle présente des dimenjons bien plus considérables. On en a péchéen Angleterre, du poids de quatre ou cinq kilogrammés. On en trouve en Sibérie et daus la Laponie, d'une grandeur tulle, que plusieurs Gerivains les ont nommées monstrueuses. Sufvant Bloch, on conserve, dans une église de 
Laponie, une tête de perche de plus de trois déci- l'incommode, doit ètre rapportée. Elle se frotte metres de longueur ; et l'on peut d'autant plus, contre des roseaux, ou d'autres corps aigus ; on d'apris ces faits, cioire que les eaur des climats les plus froids sont celles qui, tout égal d'ailleurs, conviennent le mieux à l'espèce dont nous parlons, qu'on ne peut pas dire que la grandeur des perches du nord de l'Europe dépende des soins que les Lapons ou les habitants de la Sibérie se sont donnés pour améliorer les poissons de lear patrie.

Les perches se plaisent beaucoup dans les lacs. Elles les quittent néanmoins pour remonter dans les rivières et dans les ruisseaux, lorsqu'elles doivent frayer. On ne lés voit guère que dans les eaux douces. Cependant nous lisons dans l'édition de Linnée donnée par le professeur Gmelin, qu'on les rencontre aussi dans la mer Caspienne. Peut-être les individus qu'on $y$ a pèchés n'étaient-ils que par accident dans cette mer, où ils avaient pu être entrainés, par exemple, lors de quelque grande inondotión, par le courant rapide des fleuves qui s'y jettent.

Au reste, la perche habite dans presque toute I'Europe; et si elle est assez rare vers l'embouchure des rivières, et notamment vers celle de la Seine ', ou d'autres fleuves de France, elle est commune auprés de leurs sources, dans les lacs dont ellès tirent leur origine, particulièrement dans celuii de Zurich ${ }^{2}$.

II n'est donč pas surprenant qu'elle ait été bien connue des anciens Grees et des anciens Romains.

Elle nage avec beaucoup de rapidité, et se tient habituellement assez près de la surface. La vessie natatoire qui l'aide dans ses mouvements et dans sa suspension au milieu des eaux, est grande, mais conformée d'une manière particulière; elle est eomposée d'une membrane qui, dans toute la longueur de l'abdomen, est placée contre le dos, et attachée par ses deux bords.

La perche ne fraie qu'a l'àge de trois ans. C'est au printemps qu'elle eherche à déposer ou à féconder ses cufs ; mais ce temps est toujours retardé lorsqu'elle vit dans des eaux profondes qui ne reçoivent que lentement l'influence de la chaleur de l'atmosphère. La maniere dont la femelle se débarrasse des oufs dont le poids corps jusqu'au sac qui forme sou ovaire, et que c'est en accrochant a cette pointe cette enveloppe membraneuse, en s'écartant un peu ensuite, et en se contournant eu différents sens, que, dans plusieurs circonstances, elle se délivre de son faix. Maịs quoi qu il en soit à cel égard, cette peau très-souple qui reuferme les œufs a quelquefois une longueur de deux ou trois mètres; et dès le temps d'Aristote, ou savait que les rufs de la perche, retenus les uns contre les autres, soit par une membrane commune, soit par une grande viscosité, formaien lans l'eau une sorte de chaine semblable à celle des ceufs des grenouilles, et pouvaient être facilement rapprochés, réunis, et retirés de l'ean par le moyen d'un baton, ou d'une branche d'arbre.

Ces cufs sont souvent de la grosseur des graines de pavot; mais lorsqu'ils sont eneor renfermés dans le corps de la femelle, ils n'on que le très-petit volume de la poudre fine a tirer. Le nombre de ces oufs varie snivant les individus, et mème selen quelques - circonstances particulières et passageres. Harmer, Bloch et Gmelin ont écrit que l'on devait à peine supposer trois cent mille cufs dans une perche de vingt-cinq décagrammes (ou une demilivre) de foids. Mais voici une observation d'après laquelle nous devons eroire qu'en géné. ral les perches femelles pondent un plus grand nombre d'œuf́s qu'on ne l'a pensé. Monsieur Picot de Genève, le digne ami de feú l'illustre Saussure, m'écrivait en floréal de Van 6, qu'il venait d ouvrir une perche du lac sur les bords duquel il habite; que ce poisson pesait six cent trouvé dans l'intérieur de cette persèque une bourse qui contenait tous les æûfs; que ces cufs pesaient le quart du poids total de l'animal, et que leur nombre était de neuf cent quatre-vingt douze mille.

Communément les œufs de perche éelosen quoique la chaleur du printemps soit encore très-faible; et n'est-ce pas une nouvelle preove de la convenance de l'espèce avéc les climuts très-froids?

Le poisson que nous décrivons vit de proie. Il ne peut attaquer avec avantage que de petits I animaux; mais il se jette avec-avidité nos-

\section{DES POISSONS.}

seulement sur des poissons très-jeunes ou très- 'd'ui autre corps pesant; et lorsqu'une ébullifaibles, mais encore sur des campagnols aquatiques, des salamandies, des grenouilles, des couleuvres encore peu développées. II se nourrit aussi quelquefois d'insectes; et lorsqu'il fait très-chaud, on le voit s'élever à la surface des lacs ou des rivières, et s'elancer avec agilite pour saisir les cousins qui se pressent par milliers au-dessus de ces rivières ou de ces lacs.

La perche est même si vorace, qu'elle se précipite fréquemment et sans précaution sur des ennemis dangereux pour elle par leurs armes, s'ils ne le sont pas par leur force. Elle veut souvent dévorer des épinoches: mais ces deroiers poissons s'agitant avec vitesse, font pénétrer leurs piquants dans le palais de la perehe, qui dès lors ne pouvant ni les avaler, ni les rejeter, ni fermer sa bouche, est contrainte de mourir de faim.

Lorsqu'elle peut se procurer facilement la nourriture qui lui est nécessaire, et qu'elle vit dans les eaux qui lui sont le plus favorables, elle est d'un gout exquis. Sa chair est d'ailleurs blanche, ferme, et tres-salubre. Les fiomains I recherchaient dans te temps ou le luxe de leur table étaît porté au plus haut degré; et le consul Ausone, dans son poême sur la Moselle, la compare au mulle rouget, et la nomme Delices des festins.

Les perches du Rhin sont particulièrement très-estimées '. Un ancien proverbe très-répandu en Suisse prouve la bonne idée qu'on a toujours eue de leurs qualités agréables et salutaires, et on a fait pendant longtemps à Genève un mets très-délicat de tres-petites perches du lac Léman, que l'on appelait Mille-canton lorsqu'on les avait ainsi préparées.

Les Lapons, dont le pays nourrit un trèsgrand nombre de grandes perches, ainsi que noos venons de le dire, se servent de la peau de ces animaux pour faire une colle qui leur est très-utile. Ils commencent par faire sécher cette peau; ils la ramollissent ensuite dans de l'eau froide, jusqu'au point nécessaire pour en détacher les écailles; ils la renferment dans une vessie de renne, ou l'enveloppent dans un morceau d"ccorce de bouleau; ils la placent dans un vase rempli d'eau bouillante, au fond de laquelle ils la maintiennent par le moyen d'une pierre ou tion d'une heure l'a pénétrée et ramollie de nouveau, elle est devenue assez visqueuse pour etre employée à la place de la colle ordinairo d'acipensère huso. Ciest par le moven de cedte substance que les Lapons donnent particulierement beaucoup de durée à leurs ares, qu'ils font de bouleau ou d'épine: Bloch, qui rapporte les manipulations dont nous venons de parler, ajoute, aveo raison, qu'on devrait, à l'imitation des habitants de la Laponie, faire une colle utile de la peau des perches, dans toutes les circonstances où, à cause de la chaleur, d'autres accidents de l'atmosphère, ou de la distance du lieu de la peehe à des endroits peuplés, on ne peut pas vendre dune maniere avantageuse ceux de ces animaux que l'on a pris. II eroit aussi, avee toute raison, qu'en variant les procédes, on ferait avee cette peau une colle aussi bonne que celle que donne la vessie natatoire des acipenseres; et voila une nouvelle preuve de ce que nous avons dit au commencement de cet ouvrage ', sur la facilité avec laquelle on peut convertir en excellente colle non-seulement la vessie natatoire mais tontes les membranes de tous les poissons tant de mer que d'eau douce.

On prend les perches de plusieurs manieres. On les péche peadant l'hiver, au colerel ${ }^{2}$; et pendant l'eté, avec un autre filet qui ressemble beaucoup au tramail ${ }^{3}$, et que l'ou nomme $\mathrm{Fi}$. let à perches. Ona remarqué dans beaucoup de pays que, lorsque ces poissons entrent dans le filet, ils nagent quelquefois si rapidement, qu'ils se doment des coups violents contre les mailles, s'étourdissent, se renversent sur le dos, et flottent comme morts. Mais I'hamegou est lintrument le plus favorable à la péche de ees animaus : on le garnit ordinairement d'un très-petit poisson, ou d'un lombric, ou d'une patte d'écrevisse.

Les pêcheurs cependant ne sont pas les seuls comis que la perche doive redouter ; elle est la proie, non-seulement des grands poissons, et

- Article de l'Acipensére huso. Dapres Iinsileation qual avait t en voula me demander, mon confrere $\mathrm{M}$. Hochon, de

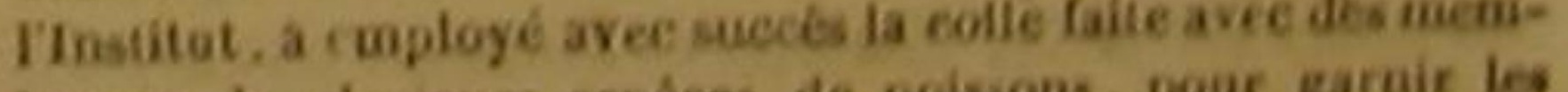
branes de plose curs copeces de poisions, pour garnir les des vaissaux. 
particulièrement desgrosses anguilles, mais en² Aldrovande, Willughby, Klein_et Gronou, core des canąrds, et d autres oiseaux d'eau. De avec neuf; Schæffer, avèc huit; j'en ai compté petits animaux, et notamment des cloportes, sept sur un individu de l'espèce que nous décris'attachent quelquefois a ses branchies, et, vons; Pennant a vu des perches quí n'en déchirant, malgré tous ses efforts, son organe avaient que quatre; et Richter, Maŕsigli et respiratoire, lui donnent bientôt la mort.

Parmi les différentes maladies auxquelles elle est aussi exposée, de même que presque toutes les autres espèces de poissons, il en est une qui produit un effet singulier. Elle gagne cette maladie lorsqu'elle séjourne pendant long-temps dans une eau dont la surface est gelée, et dont, par conséquent, les miasmes retenus par la glace ne peuvent pas se dissiper dans l'atmosphère '. Elle devient alors enflée à un tel degré, que la peau del'intérieur de sa bouehe se gonfle, et sort en forme de sac. Un gonflement semblable a aussi lieu quelquefois à l'extrémité de son rectum ; et e'est l'espèce de poche que produit a l'extérieur la tension et la sortie de la membrane intestinale qui a été prise par des pécheurs pour la vessie natatoire de l'animat que la maladie aurait détaçhée et poussée en dehors.

De plus, quelques aceidents particuliers peuvent agir sur les parties osseuses, ou pluto sur les muscles de la perche, de manière fléchir et courber son épine du dos. Elle est alors non pas bossue, ainsi qu'on l'a écrit, mais contrefaite.

Elle peut néanmoins résister avee plas de faeilité que plusieurs autres poissons, í beas de coup de maladies et d'ennemis. Elle a la vie dure; et lorsque, dans un temps frais, on l'a mise dans de l'herbe, on peut la transporte vivante à plusieurs kilomètres.
vive

On a eu tort de regarder comme différentes les unes des autres, les perches des laes ot eentiles des rivières, puisque les mêmes indivilus bitent, suivant les saisons, dans lividus hadans les lacs; tes saisons, dans les rivieres et dans les lacs; mais on peut distinguer plusieurs variétés de perches plus ou moins passagères, d'après la couleur, le nombre ou l'absience des bandes transversales. On a vu ces bandes, au lieu de montrer la couleur noiratre qu'elles présentent le plus souvent, offrir une nuance blanche, ou d'un vert foncé, ou d'un bleu mélé de noir. De plus, Blasius et Jonston ont trouvé des perches avec douze bandes transversales; bande '

\section{LA PERSĖQUE AMĖRICAINE ?} Labrax ....., Cuv, ; Perca americana, Sehepet,

\section{ET LA PERSEQUE BRUNNICH 4,}

\section{Capros Aper, Lioz., Lae.; Perea Bruonich, Lie.}

Le nom de l'américaine indique sa patrie. Elle vit dans les eanx à demi salées du nouveau coutinent, e'est-à-dire dans la partie des fleuves la plus voisine de leur embouchure et oủ parviennent les hautes marées, ou dans les lacs qui reçoivent des rivières, et qui cependant communiquent avee la mer. Elle a beaueoup de rapports avee la perche : mais indépendamment de plusieurs de ses proportions qui sont différentes, et particulierement du peu d'élé vation de son dos, indépendamment encore de l'absence de toute bande transversale, elle ne montre aucune tache à l'extrémité de la première nageoire du dos, et elle a la lèvre inférieure, le dessous de la gorge, la membrane branchiale et Popercule, d'une belle couleur rouge. On ne compte qu'un rayon aiguillonné à la seconde dorsale ${ }^{6}$.

147 rayons a la membrane branchisle de la persidque percte. geoire de la queve.

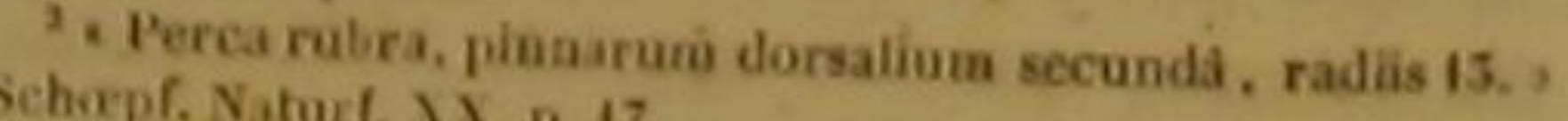

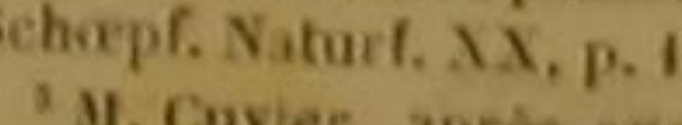

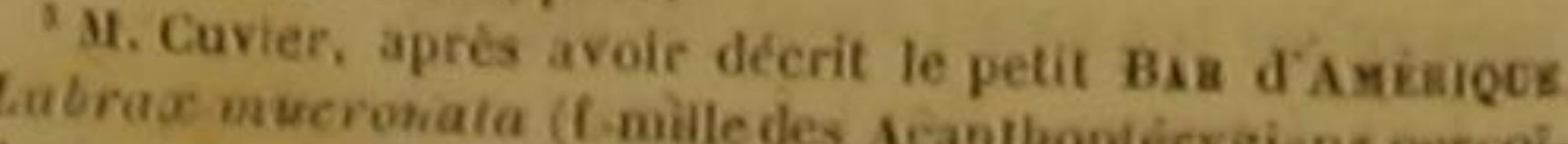

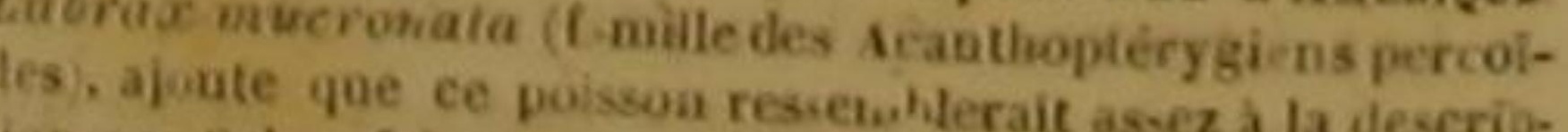
tou que Schopt dume de son Pera american, si ce n'et

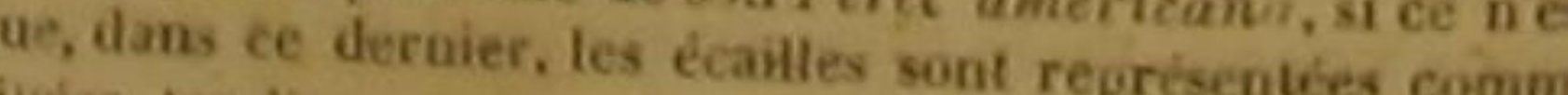
'ities, landis que, dans le pelit Bar d'Anuériqne, it y a précit Mart. Brunenich. Ichth.

verséque. Bonnaterre, pl. de I Insc. méth. 62 , n. 79. - Petite

In Capros sangtier de M. de Lacépéde. Aine differe pas lérents. D.
loux fois par ce naturaliste, sous deux nomis dif-

I rayon aizuillowné et 5 rayons articnlers a chéque amérisaine, is rayous a la candale. -6 rayons a la a chaque theraciue. de la persèque brunnich, 14 à chaque pectorale 1 rauchiale Guillonné et 5 rayons articutés a chaque thoracine, 14 rayon ai14 a chaque pectorale, 5 ou 6 a chaque thoracipe, 23 a la maespeces dn méme geare. D. D. s ba Persèque Bronnich, selon. méth.
La persèque brunnich, qui a été déerite pour la première fois par le naturaliste dont je lui ai donué le nom, habite dans la Méditerrauée. Elle brille de l'éelat de fargent et de celui du rubis, toute sa surface réfléchissant diverses nuances variées de rouge et de blanc argentin. Son corps et sa queue sont très-comprimés; le dos est élevé; les écailles sont très-petites, mais très-pointues, et par conséquent très-rudes au toucher; le museau est pointu; l'íris blane et la longueur totale de l'animal n'excède pas communément cinq centimètros

\section{LA PERSEQUE UMBRE',}

Umbrina vulgaris, Cuv.; Sciæna cirrhosa, Linn.,
Gmel, J Johnius cirrhosus, BI., Sehn.; Perca umbra Gmel.; Johnius cirrhosas, Bl., Schn.; Perca umbr. Lae, ?.

Nous avons déjà dit, à l'article de la Sciène umbre, combien cette sciène et la persèquedont nous allons parler, ont été fréquemment confondues, et quel soin nous avons cru devoir nous donner, non-seulement pour reconnaitre et indiquer leurs veritables caractères distinctifs, mais encore pour rapporter à chacune de ces deux espèces les passages dans lesquels les naturalistes tant anciens que modernes les ont

mière dorsale sout aiguillonnes, et tous ceux de la seconde mière dor
articults.
Oambro,

Ombre, dans plas. contries de Prance. - Daine, dans
Conse ples. départ, mérid. - Umbrino, sur plus. cótes septent, de a Mediterranée. - Corvo, Corvetto, a Bome. - Nota. Ces noms de Corro el de Corvello oat elé ansei donnés a nol sciene unabre). - Millocono, eu Grece. - Schilpech, par ic

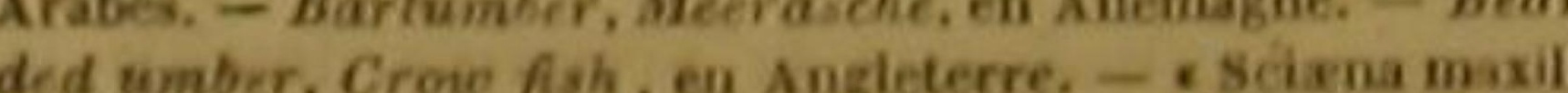
asuperiore longiore, cirrou in interiore. P Artedi, gen. 38 ,

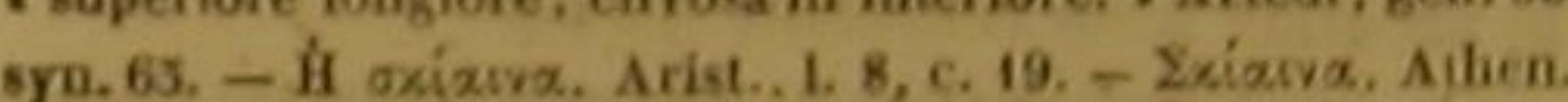
L. 7. p. sz. - Chromis, Umbra marina, Glaveus, Belon - Scicena et ymbra auctorum. - Vimbra. Varron. - Id Colsmeit. - Id. Ennius poeta. - Id. Wotton, L. 8, c. 175 1. 156. - Umbre Hondelet, part, L. L. 5, c. 9. - Umbra

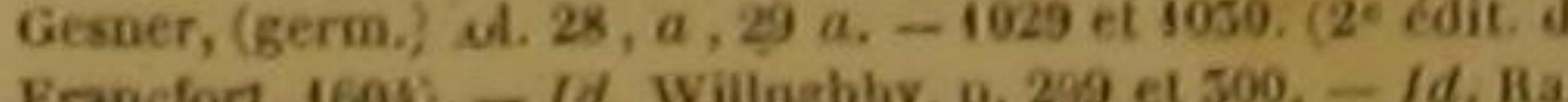

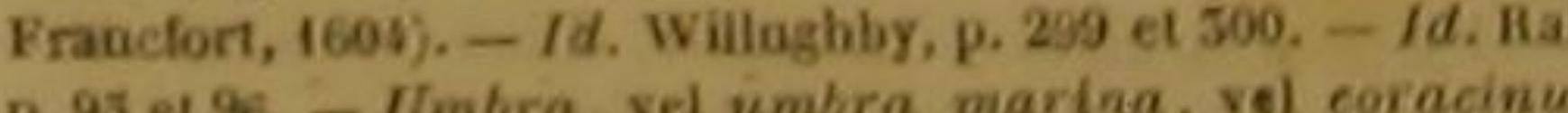
Saloiani, vel glaucus Balonit. Aldrov. (Bolon. 1658), I. I c. 15, p. 72; et c. 18, p. 84. - Umbra, vel coracinus, vel coracinus niger. Salvian., fol. $115 a, 116 b, 117 a, 117 b, 118 a_{*}$ et 118 b. - Umbra, seu sciena, sea glaucus. Jonston. I. 1 . tit. 2, cap. 1, a. 13, tab. 15, Eg. 10. (Amsterd. 1657), - Sciana Plin., 1.9. c. 16. - Umbra. Peiri Artedi Synon, visc., etc, auctore J. G. Schneider, p. 101. - Scic ne barbue. Bloch. Id. Bonaterre, pl. de IEne, mélb. - (Nola. Nous avons déja va que ce nơm de Corp avait été donisé dans vlas. départ. meridionaux, et appligué par Rondelet ì notre s. ambre,.- Sciana umbra. Haselquist, it. 352, n. 80. 2.Du genre Onsaise, umbrina, dans la famille des Acanthopiérygiens sciénôt eues en vue. La ressemblance des noms donnés à cette persèque et à cette sciène a introduit la confusion que nous avons voulu dissiper. II resulte de nos recherches, ainsi qu'on a dejä pn le voir, que notre sciène umbre est le Corbeas marin, ou le Poisson corbeau de la plupart des auteurs, et que la persèque déerite dans cet article est la véritable Dmbre de ces mèmes auteurs, et mème leur vaie Seiène, au moins si on ne prend ce dernier mot que pour une dénomination spécifique. Mais cette Sciène ou Unbre des auteurs ne peut pas être inserite dans un gemre différent de celui des vaies Persèques, auxquelles elle ressemble par tous les traits génériques que tout bon méthodiste admettrait comme tels. Nous n'avons done pas pu la comprendre dans le groupe de thoraeins auquel nous avons réservé le nom générique de Sciène; et ciest a ta suite de la perche, de la persèque américaine, et de la persèque brunnich, que nous avons dú placer sa notice. Notre perséque umbre, T'umbre dés auteurs, vit dans la Méditerranée, où elle a été observée des le temps d'Aristote: mais on la trouve aussi dans la mer des Antilles, ou Plumier en a fait un dessiu que Bloch a copié. Elle parvient quelquefois, suivant Hasselquist, qui l'a vue en Egypte, jusqu'à la longueur de six ou sept décimetres.

Sa tete est comprimée et toute couverte de petites écailles: Les deux mâchoires, dont l'inférieure est la plas courte, sont garnies de dents très-petites et semblablesa celles d'une lime. Chaque narine a deux orifices. Le barbillon qui pend au-dessous du museau est gros, mais tres-court. Un aiguillon arme la derniere piece de chaque opereule. Le dos et le ventre sont arrondis. La hauteur de l'animal est assez grande. Le corps et la quúeue sont comprimés; les écailles farges, rhomboidales et un peu dentelées: les rayons de la premiere nageoire du dos águillonnés; ceux de la seconde articulés, excepté le premier. La coulear générale de l'animal est faune. Des raies bleues vers le haut, et argentées vers le bas, s'étendent obliquement sur chaque cóté du poisson. Une tache noire parait à l'éxtrémité de chaque opercule. Les pectorales, les thoracines et la caudale sont noiratres; l'anale est rougeátre; les dorsales sont brunes ; et denx raies longitudinales et

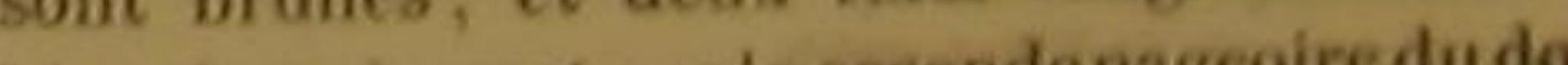
blanches règnent sur la secondenageoire dudos.
L'umbre a d'ailleurs le péritoine fort et ar- 
genté; l'estomac allóngé; six appendices auprès et étendues jusque sur la base de la caudale, et du pylore; le canal intestinal proprement dit sur celle dela secondé nageoire du dos; lé corpset ecourbé trois fois; le foie divisé en deux lobes, la queue comprimés et allongés. On ne voit que a plus long desquels la vésicule du fiel est at- des ravons aiguillonnés à la première dorsate;

tachée; l'ovaire ou la laite double; et la vessie on n'en compte qu'un à la seconde. Ces ma natatoire large, simple, et formée par une membrane épaisse.

Cette perseque se plait dans les endroits pierreux, et se retire pendant I'hiver dans les profondeurs voisines des rivages. Il arrive souvent qu'elle ne fraie qu'en automne. Eile aime à déposer ses ceufs sur les éponges qui éroissent près des còtes. Elle se nourrit d'algues et de vers, Vraisemblablement elle mange aussi de petits poissons. Sa chair est ferme, mais facile à digérer; et il parait que sa tète était, très-recherchée par les anciens Romains '.

\section{LA PERSEQUUE DIACANTHE ?,}

Labrax Lupus, Cav.; Scizna diacantha, Bl., Lac. Centropoma Lupus, Lacep. "

La Perseque pointillé 4, Labrax Lupus, Cuv.; Scixns punctulata, et scirna diacantia. Bloch. Lac.; Centropoma Lupus, Lacep, s. - Persequo Murdjon ", Myripristis....

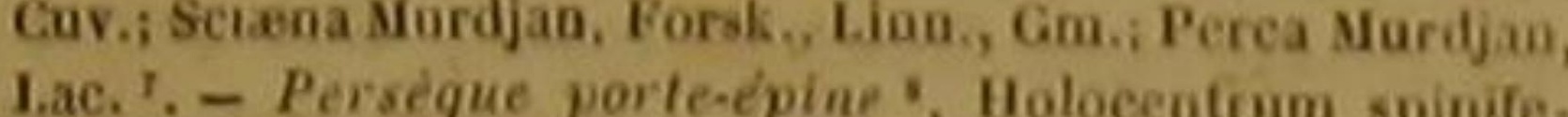
rom, Cuv; Scisna spinifera. Forsk. Limn. Geme spinifo-

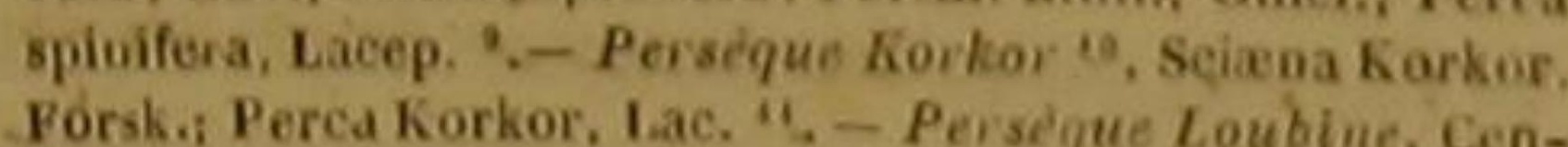
tropomus undecimalis, Cuv., lacep.; Sciena undecimalis, Mloch ; Sphyrena auroviridis, et Perea Loubina, Lac. 12.

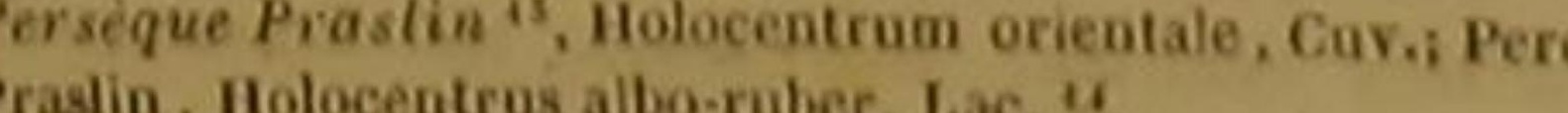

La diacanthe a les deux màchoires aussiavancèes l'une que l'autre ; les dents qưi les garnissent sont petites; les écailles dures, dentelées,

Is rayóns a la mermbrane branchiale de la persèue umbre,
i7 a chaque peetorale, 1 rayon aiguillonné et 5 rayung arth17 à chaque pectorale, 1 rayon aiguillonnę et 5 rayuns arti-

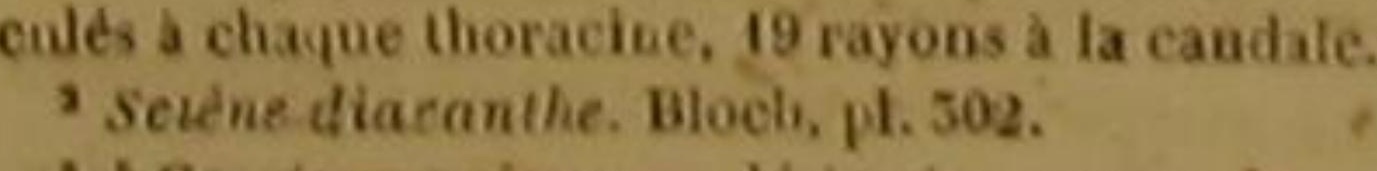

isces ceus poissons, désignés comme des épéces différentes de solènes par Bloch et Lacépède, doivent ére rénnis

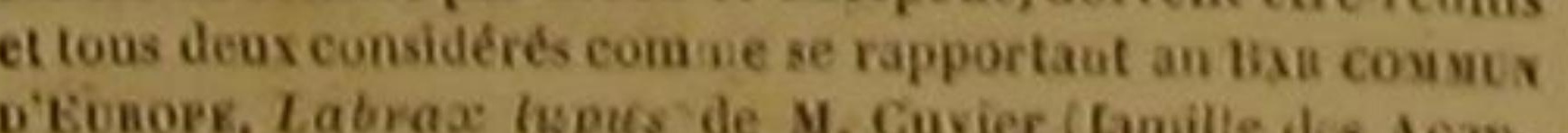

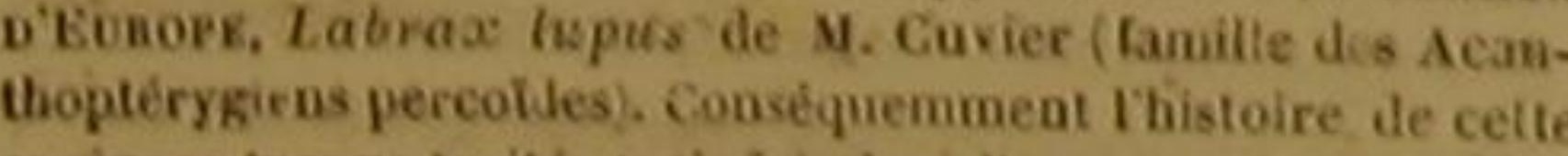
specese trouve traitte trois gis dans Tourrage de M. de La-

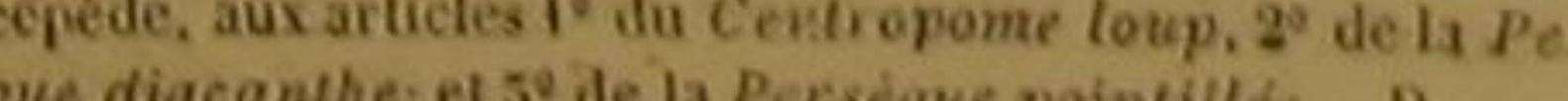
4 Seiene pointece. Bloct. pl. sos. - Forskael, Faud. Arab., p. 18, n. 52 - - Seiène murdjon. Bonnaterre, pi de i'Euc, welt. 'Ce poissous st pour U. Cuvier une espèce ladéterwinèce de soa genre sistaras - Forskael, Fum. geoires sont bleuâtres; les pectorales, les thoracines, l'anale et la caudale offrent la même teinte; mais leur hase est rougeatre. La coulen générale de l'animal est d'un argentin plus ou moins mèlé de bleu.

La diacanthe habite la Méditerranée, comime sur le dos, de l'argenté sur les côtés, du rougéatre sur les peetorales et sur les thoracines, ainsi que sur l'anale et la caudale, dont l'extrémité est bleuâtre, et un mélange de jaune et de bleu sur les deux dorsales. Tous les rayons de la première de ces deux nageoíres du dos, et le premier de la seconde, sont aiguillonnés; les dents petites et nombreuses; et les deux máchoires égales en longueur.

Les trois persèques suivantés ont été observées par Forskael dans la mer d'Arabie, dont une grande partie de l'aumée.

La murdjon est revềtue d'écailles larges, brillantes et dentelées; ses thoracines sont bordées de blane; les raies saillantes et longitudinales du sommet de sa tète se ramifient par deriere; on voit autour de chaque ail une sorte d'auneau osseux, festouné et même dentelé par le bas; les dents sont petites, nombreuses et serrées; la langue est rouge et tres-rude; le corps est élevé et comprímé ; il n'y a que des rayons aiguillonnés à la première dorsale, et la seconde n'en renferme qu'un

On peut remarquer la méme nature de rayons dans les dorsales de la perséque porte-épine. Ce thoracin présente une couleur générale diun

10 Sciana stridens. - Forskael, Faun. Ar b. p. 50, Sciene Korkor. Bonnaterre, pl. de i'Enc. meth

"Non mentionné par M. Cuvier. D.

"2 Du genre Cestuopous, Lac., Cuv., dans la famille des Acautiopterygiens percoides. Ce poisson a été décrit troi

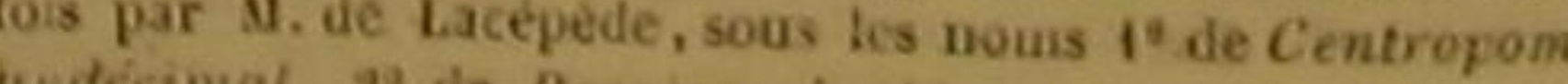
orcert. D. de Perseque loubine, et $5^{\circ}$ de Sphiyren Commerson, manuscrits déjà cites. Da geure Holockstaz, Holocenirum, Cuv., dans la fa. prait avoie décrit une seconde fides, Cuv. M. de Lactpetuo pistenom la pointillée. Cette dernière montre du bleuátre elles fréquentent les rivages, au moins pendant

"Perche dUtopie et de I Nouvelie-Bretagne. - A Aspro

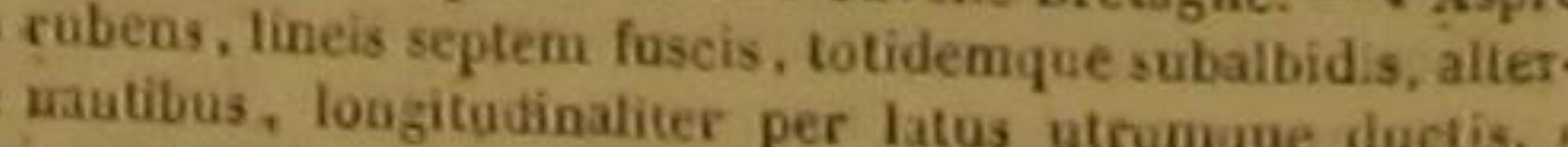

rouge plus ou movins vif; des ecailles grandes et denteléts; un cercle osseux et garni de petits piquants autour de chaque œil ; une queue trèsallongee.

La korkor a beaucoup de rapports avec la persèque porte-épine, ainsi qu'avec la murdjan; de même que ces deux poissons, elle ne monre que. des rayons aiguillonnés dans sa preni ère dorsale, et n'en a qu'un dans la seconde. Elle se nourrit de plantes marines; et lorsqu' on la tire de l'eau, elle fait entendre un petit bruis. sement semblable à celui dont nous avons dejà parlé plusieurs fois, en traitant, par exemple, des balistes, des trigles, et d'autres poissons osseux ou eartilagineux. Nous n'avons pas vu d individu de l'espéce de la korkor; et nous n'avons pas besoin dé dire quée si, contre notre opinion, cette persèque n'avait pas la eaudale échanerée, it faudrait la placer dans le second sous-genre, tout comme il faudrait la retrancher du genre des persèques, et la trausporter dans celui des cheilodiptères, ou des centropomes, ou des sciènes, si ses opereules no présentaient pas la dentelure et les aiguillon que nous avons dû supposer dans les lames qui les composent '.

M. Leblond nous a envoyé de Cayenne de individus mâles de l'espece que l'on y notrm Loubine, et dont la description n'a encore ete publiée par aucun naturaliste. La premiere dorsale ne comprend que des rayons aiguilionnés la seconde n'en contientqu un. La troisième piece de chaque opercule est terminée par un appendice membraneux et allongé. Les mảchoire ne sont point armées de dents, danis lendroit. ou elles sont échancrées; mais sur leurs autres

Is rayons a la membrane branchiafe de la perséque diacanthe, 16 a chaque pectorale, 1 rayon aigoillonné et 5 rayón articules a chayue thoracioe, 20 rayons a la mageoire de is que ae. -5 rayons a la membrane branchiale de ia perséque

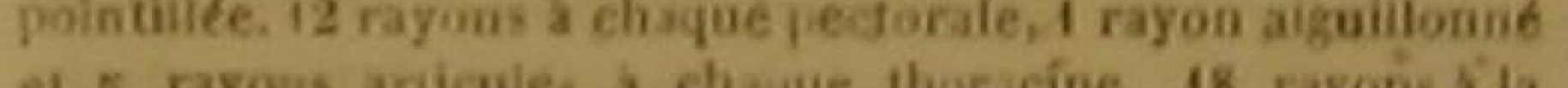
caudalé, -7 sayo on la memibrane branchiale de $L$ on perta

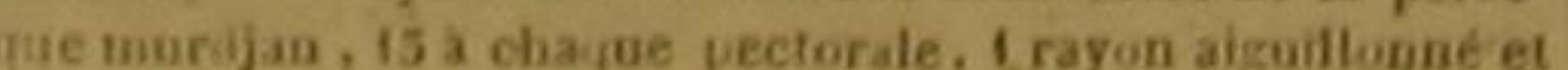
r yons articules a chaque thoracine, 19 rayons $X$ ba na. ctaire de la quence. -8 rayoos a la meinbrane branchiale de a perscyue porie-eyane, 14 ì chaque peciorale, 1 rayon a milouse e 7 ravons aricules a chaque thorarine, 20 rayous

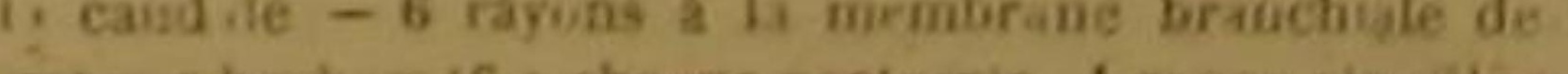

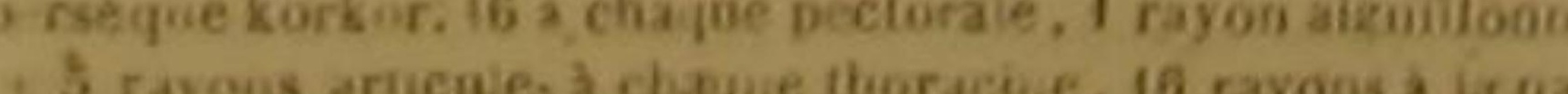

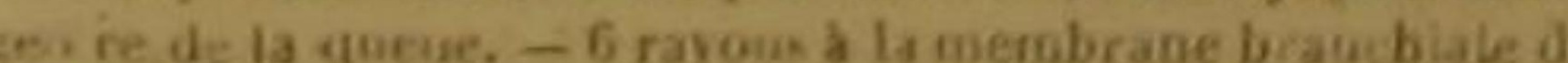
a, ervy e thiobine, 16 s cha pie precturale, 1 ray in aiguit-

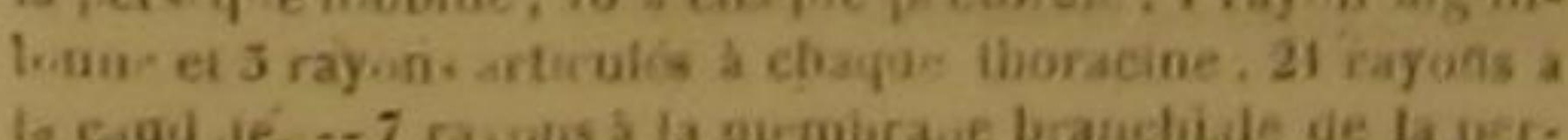

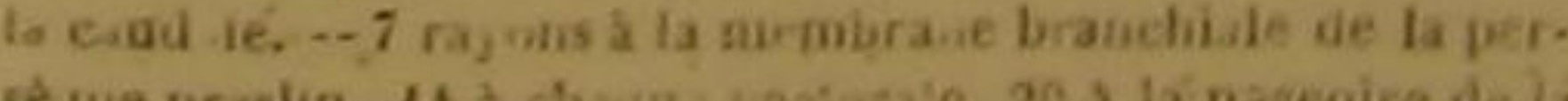

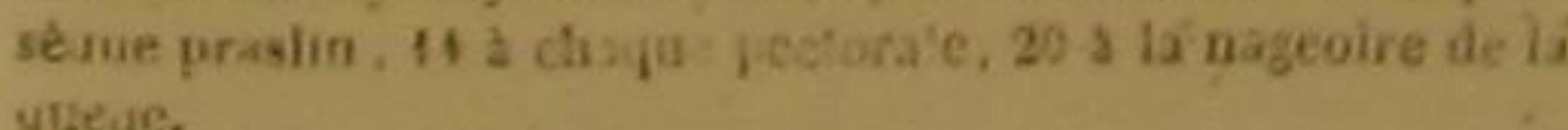

ent hèrissées de dents égales, trespetites, très-nombreuses, et semblables à d'autres deuts qui garnissent une eminence de ta partie antéieure du palais, La téte, le corps e a queue sont allonges et comprimes.

La persèque que nous nommons Praslin a été observée pour la première fois, et dans le port de ce nom, par Commerson, en juillet1768, ors de la célebre expédition de notre Bougainville. Nous en avons trouvé la description dans les manuscrits du voyageur naturaliste qui accompagnait notre collègue.

Ce thoracin parvient à la longueur de trois dé imètres; il se plait au milieu des coraux et des madrépores qui bordent les rivages de la Nouvelle-Bretagne. Le goùt de sa chair est trèsagréable. Toutes ses nageoires sont d'un jaune mélé de rouge. Des sillons et des stries relevées font paraitre sa têle comme ciselée. La levre supérieure est estensible. Des dents petites, serrees et semblables a celles d'une lime, garnissent les deux máchoires. Une lame osseuse, dentelée et demi-circulaire, est placée au-dessous de chaque ail. Tous les rayons de la premiere dorsale, et te premier de la seconde, sont aiguillonnés. La premiere de ces déux nayeoires du dos est bordée vers le haut de pourpre, et vers le bas, de rouge. La couleur générale de l'animal est rougedtre; une tache pourpre distingue la nageoire de l'auus.

\section{LA PERSEQUE TRIAGANTHE,}

Grammistes orientalis, Cuv.; Scinna vituata, Centropomus sex-lineatus, Bo lianus sex-lineatus, Rerca

La Peridque pentacanthe, Grammites orientals, Cur

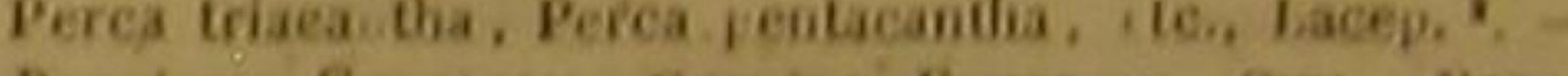
Perselque Pourcroy, Corying Modr Pace

Aucune de ces trois persèques n'est encore connue des naturalistes: nous en avons trouvé des individus trés-bien conservés dans la collection cédée à la France par la Hollande; et

1.2 us deux poisons appartiennenta une mème eipece. I

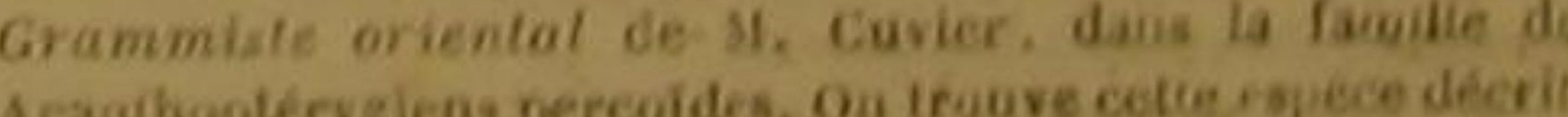
Gan fois par M. de Laecpede, sons ins natus 19 de Scion rayce. $2^{\circ} \mathrm{d}$ - Centropome ixeraves, so de Bodias vid. raies, to de Persecque triaconthes ei so de Persique penta.

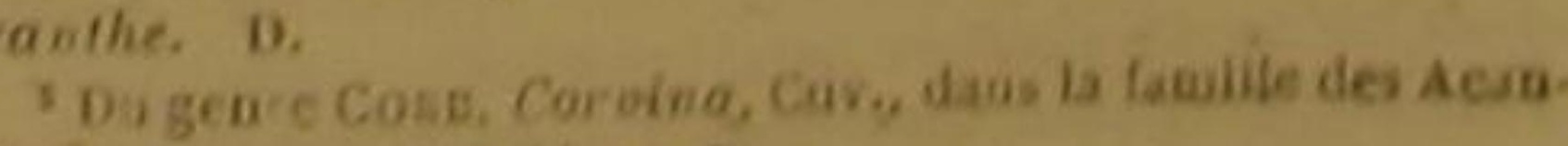


nous avons dédié ta plus belle de ces trois espèces à notre célebre confrère Fourcroi, qui nes'est pas contenté de faire faire de très-grands progrès à la chimie, et d'elever un beau monument en l'honneur de cette science, mais qui a rendu de nombreux services à l'histoire naturelle, et auquel nous sommes bien aises de donner un témoignage public de notre baute estime et de notre ancienne amitié.

La persèque triacanthe a la lèvre supérieure double; les dents petites, aiğuếs, et distribuées en plusieurs rangs, le long des mâchoirés, sur la langue, an palais; auprès du gosier; et la couleur générale plus ou moins foncée.

La pentacanthe présente une lèvre supérieure extensible, des dênts très-petites, et uné raie longitudinale et blanche sur le dos.

La perséque fourcroi a le museau avancé; lá levre supérieure double et extensible; un sillon longitudinal sur la tête; les yeux gros; les dent très-menues; i les écailles dentelées '.

CENT VINGT - QUATRIÈME GENRE LES HARPÉS ${ }^{2}$

Plusieurs dents très-longues. fortes at recourbees, au sonmet et aupres de l'articulation de chaque màchoire; des dents petiles, comprimees et, triang ilaires de chaque côte de la máchoire superieure, entre les grandes dents roisines de tarticulation et relles du sommet; un barbilton romprime et triangulare de chaque rate el aupres de la commissure des letres; ies thoracines. ha dorsale et l'anate, trés-grandes, el en forme ic faux; la caudale convexe dans son th haul at dendue en forme de faick ir s-allongee dans

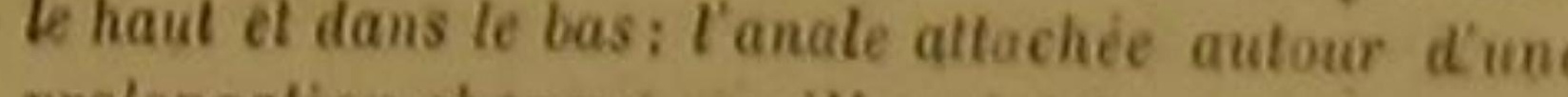
prolongalion chantic, ceailleuse, très-grande, comprimee et triangulair.

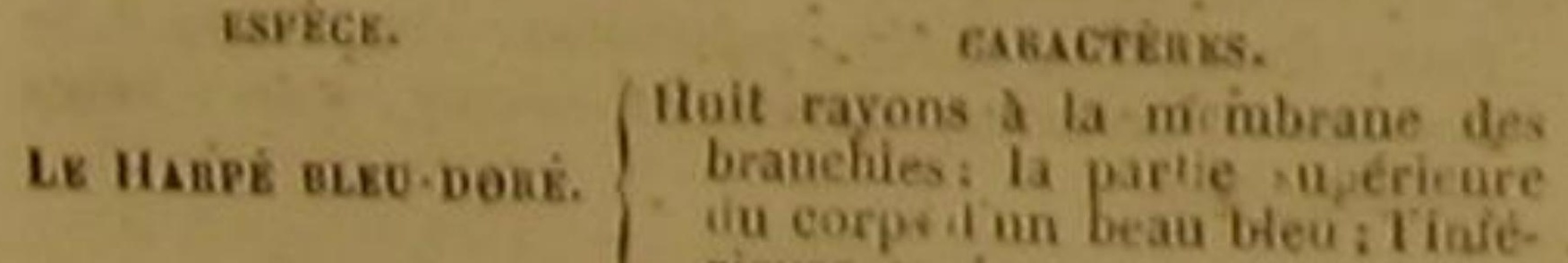

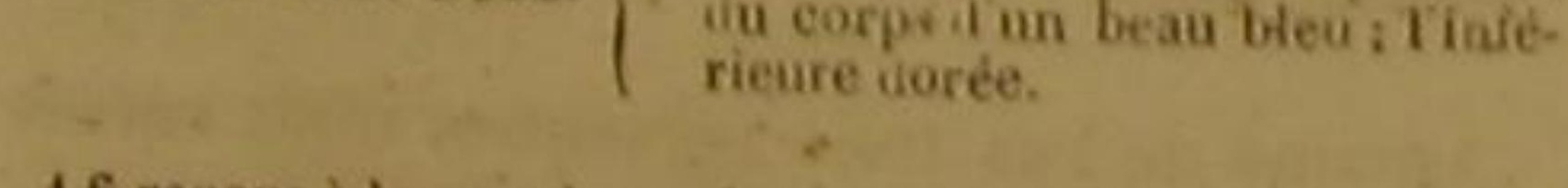

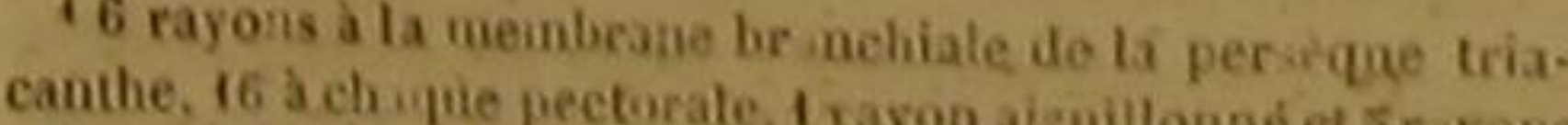

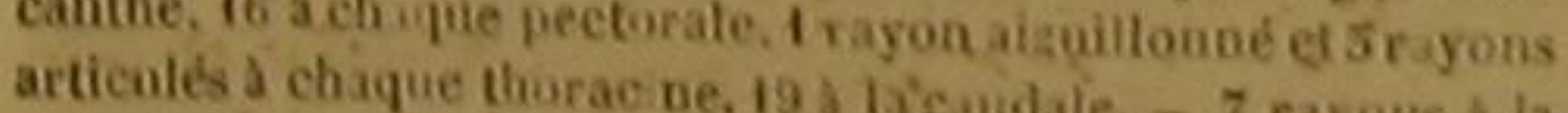
membrane bras hisie de la perseture penlacanithe, 14 a dha que peetosale, 15 a la uageoire de ta queue. -6 rayons a i membraae branchiale de la per seque four 1 roi, 17 a cha pue pectorale, 1 rayon aiznillonné et 5 roy

- M Cur er ne cons rve pas ce.

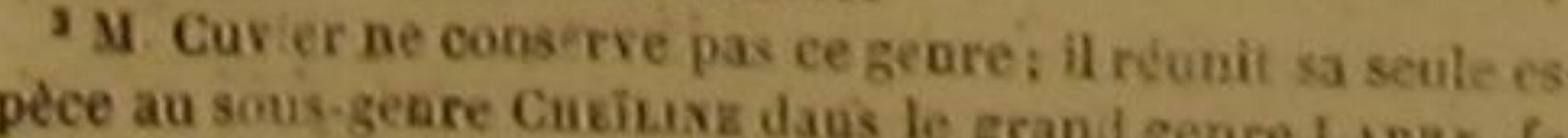
puilte des acuathoptécygiens labroldés. D.
reare Lavax, fa-

\section{LE HARPÉ BLEU-DORÉ ',} Cheiliaus . . . . Cuv.; Harpe cœruleo-aureus, Lac."

Nous cessons de nous occuper des dix-sept genres sur la compoșition et 'la nomenclature desquels nous avons fait quelques réllexions particulières dans l'article qui précède le ta. bleau methodique du genre des labres.

Ces dix-sept genres comprennent quatre cent soixante-onze especes, parmi lesquelles il en est cent quarante-trois dont nous aurons les premiers publié la description.

Le harpé-bleu-doré devra aussi ètre compté parmi les espéces de poissons que nous aurons fait connaitre aux naturalistes.

Ce superbe thoracin est très-bien représenté dans les peintures sur vélín qui sont déposées au Muséum d'histoire naturelle, et qui ont été exécutées avec beaucoup de soin d'après les dessins du célèbre Plámjer.

Ce magñifique harpê ne montre que deux couleurs; mais ces couleurs sont celles de l'or et du-sapliir le plus pur. Elles sont d'ailleurs d'uutant plus éclatantes, que les écailles qui les refléchissent offrent une surface large et polie.

La première de ces deux bellés nuances resplen. dit sur les lèvres, sưr l'iris, sur les côtés, sur la partie inférieure du corps et de la queue, sur le haut dè la dorsale, et à l'extrémité de la prolongation en forme de faux qui termine cette mème dorsale, les thoracines, l'anale et les deux bouts de la nageoire de la queue. Le reste de la surface de l'animal est peint d'un azur que des rellets dorés animent et varient ${ }^{3}$

Il n'y a qu'un orifíce pour chaque narine. La tête et les' deux-premieres pièces de chaque opercule sont-dénuées de petites éeailles ; mais ou en voit plusieurs rangs sur la base de la nageoire du dos. Le diametre vertical de la queue va en augmentant depuis le second tiers de la longueur de cette partie, jusqu'à la base de la caudale.

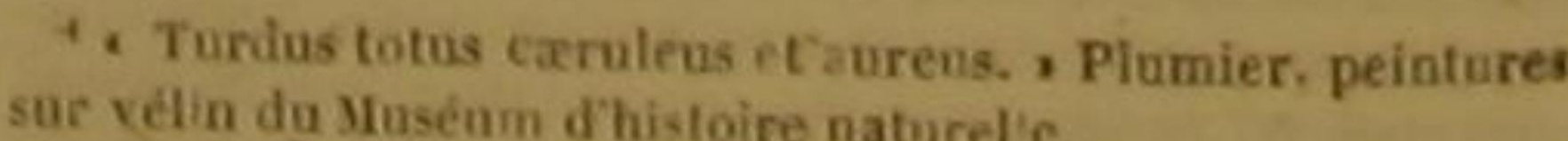
2 vein du sfusenm dhistoire naturel'c.

210 rayons aisuillannés et 8 rayerés ente. D.

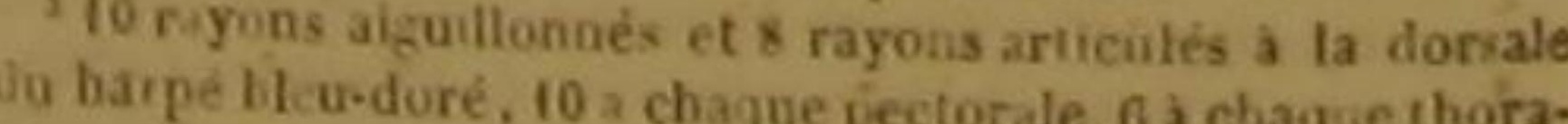
cine, 2 ou 5 rayons aizuillomés et 15 ragons articolde $\$ \mathrm{I}^{2}$ nale, 15 rayons a la nageoire de la queue.

DES POISSONS.

CENT VINGT - CINQUIEME GENRE.

LES PIMÉLEPTÈRES ।

La totalite ou une grende partie de la dorsale, de lianale et de la nageare de la quew, adipeuse, ou presg de la gorge que les peçorales.

EsPéce.

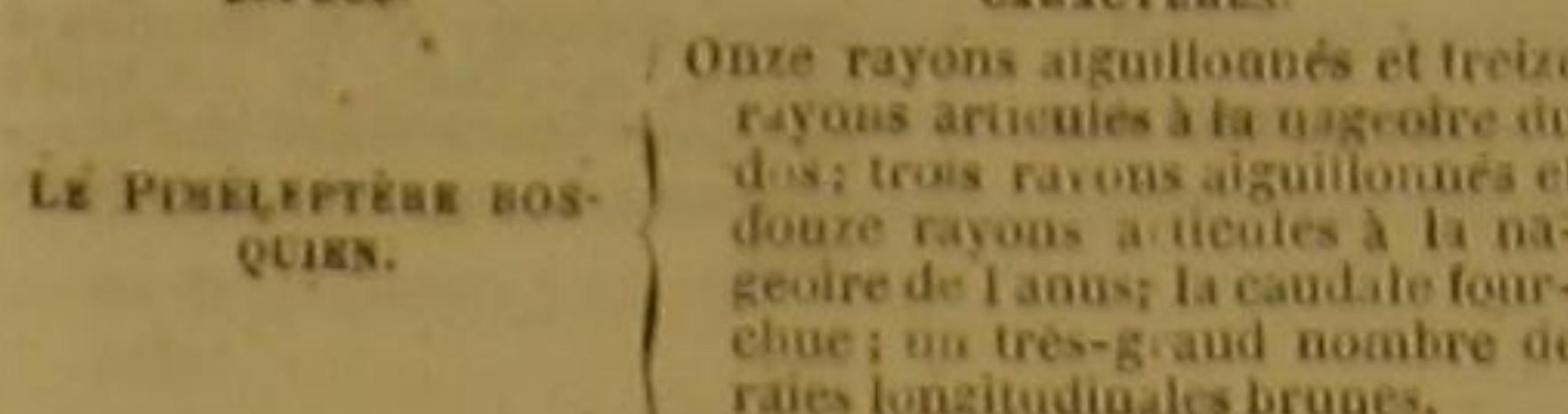
s.

LE PIMÉLEPTEKRE ${ }^{2}$ BOSQUIEN 3 , Pimelepterus Boscii, Lac., Cur, ‘

La position des nageoires inférieures de cet osseux est remarquable. Elles sont en effet plus eloignees de la.gorge que dans les autres thoracins. Mon savant confrere, M. Bose, auquel nous devons la connaissance de ce poísson, lo a donné le nom génériqué de Gasterrosté; mais il a remarqué, avee son babileté ordinaire, et indiqué dans son manuscrít les caractéres qui éloiguent cet osseux des véritables gastérostées et marquent la place de cette espece dans un genre particulier.

II l'a vu et dessiné dans I'Amérique septentrionale. II nous a apprisque les habitudes de ce pimeleptère avaient beaucoup d'analogie ave celles du Centronote pilote, que les uaturalistes nommaient, avant moi, Gastérostée condurteur. Le piméleptère bosquien suit en effet les vaisseanx qui traversent l'Océan Atlantique boréal. Il se tieńt particulierement auprès du gouvernait, où il saisit avec avidité les fragments de substances nutritives que l'ón jette dans la mer. Il est difficile de le prendre a l'hameçon, parce qu'il a l'adresse d'emporter l'appât, sans être retenu par le erochet, Les Anglais, suivant

AM. Cavier remarque que ce genre de $\mathrm{H}$. de Lackétede, fait

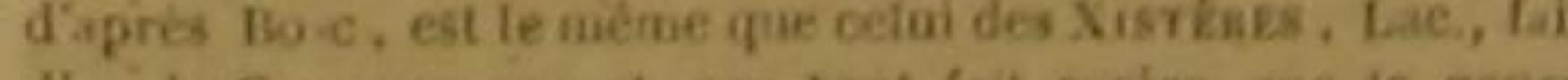

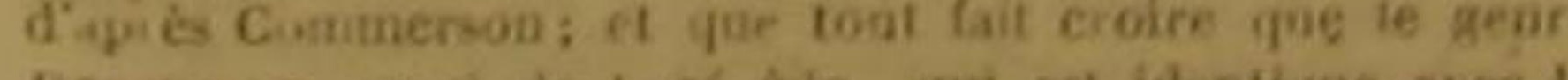

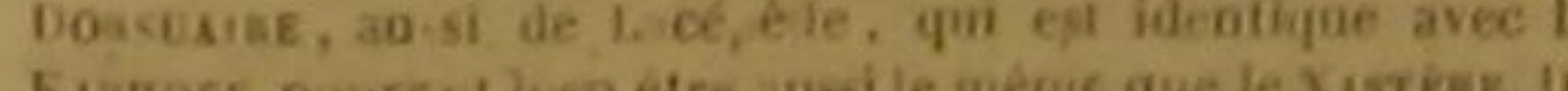

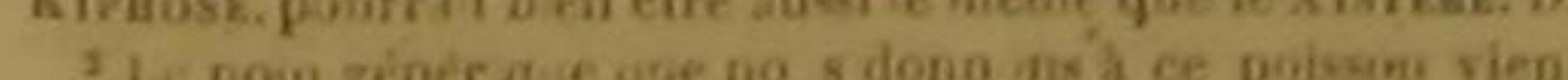
de pimile, qui, en grec, signifiegraisse, ei de plecron-qui siznifi-nag-vire. "Giaster steus ath rinis, pivis donal bys indivicks....

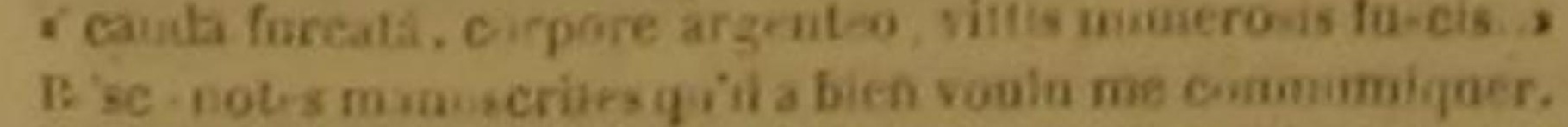

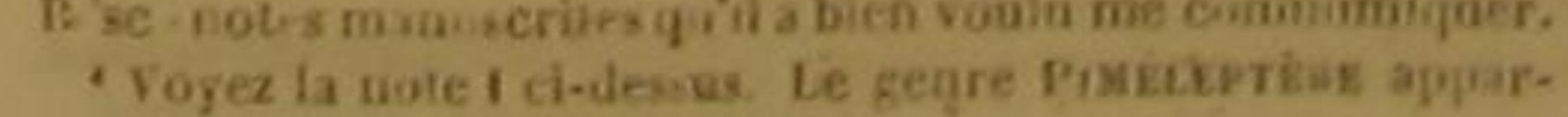

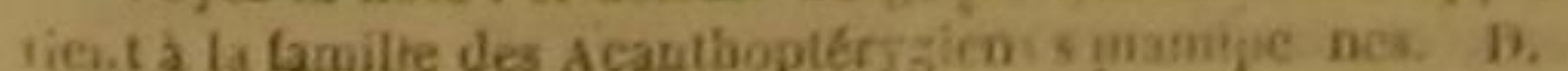

mon confrère, n'aiment pas à s'en nourrix; mais les Français le recherchent.

La tete du bosquien est petite; il peut allon. ger ses lèvres; ses dents sont petites et obtuses ; sa langue est ovale; liris présente une couleur brune mèlée de blanc; on voit une petite raie argentée au-dessous; les écailles qui recouvrent le corps et la queue sont arrondies, larges, ar. gentines, brunes sur les cótés: et ce sont les séries de ces places brunes qui forment les raies longitudinalés indiquées sur le tableau genérique. La partie postérieure de la nageoire du dos, presque toute l'anale, et la eaudale, sont adipeuses. La longueur ordinaire de I'animal est de près de vingt centimetres, sa hauteur de six ou sept; et sa largeur de deux ou trois'.

\section{CENT VINGT-SIXIEME GENHE.}

LEs CIRHLions ?

Le corps at la ẹueu très-allongis: le bout du musean aplati; la tele el les opercules denues de petiles centi. less: les opercules sans demirlure el sans aigulthons, maiscieles testerres, et sirtout celle de la madhofie - inferieme, tris-pindantesi les dents tris petitesi la dersale basse el tris-tongue; les rayons aiquillonmes ou non articules de chaque nageoire aussi mous ou presque ausi mous que les arlicules : ume seule dorsale : les thoracines tris petites.

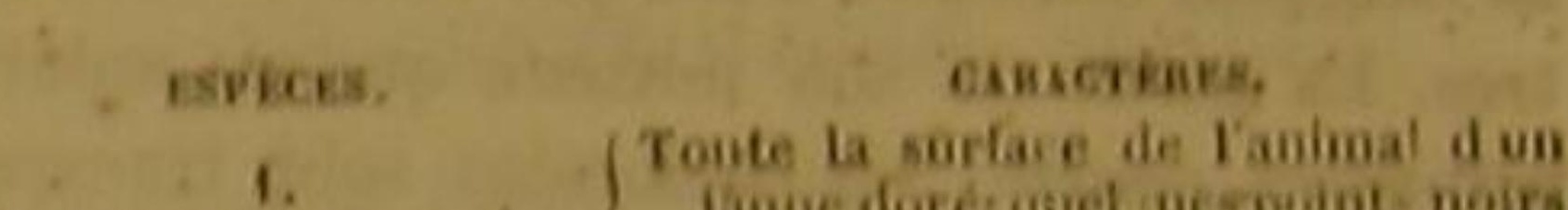

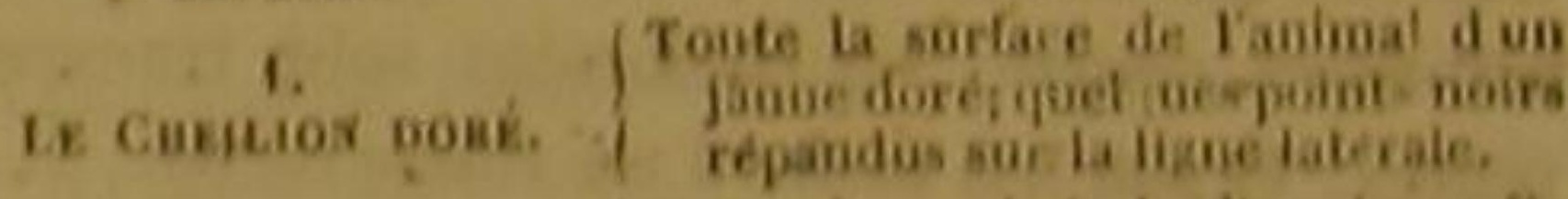

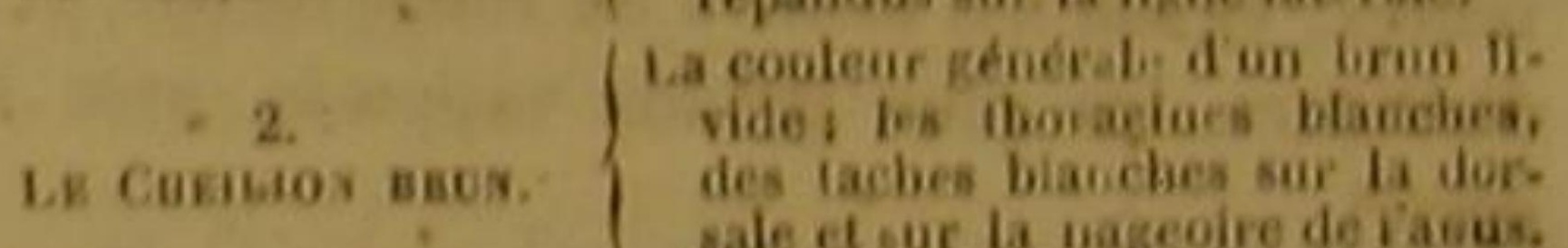

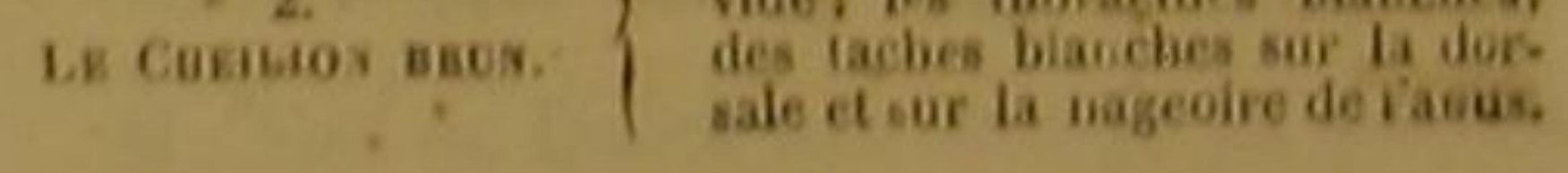

LE CHEILION DORÉ,

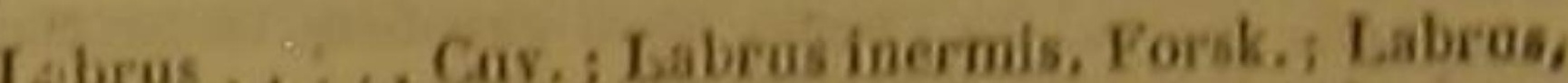
Hassel; el Cheilio auratus, Lac. :

ET LE CHEILION BRUN",

$$
\text { Cheilio fuscus, Lac." }
$$

C'est dans les manuserits de Commerson que nous avons trouvé la description de ces deux I 4 rayons a ta membrane branchiale do piméteptere tos. quien 15 a chayue pectorate, 6 a chaque thoracine, 16 a i

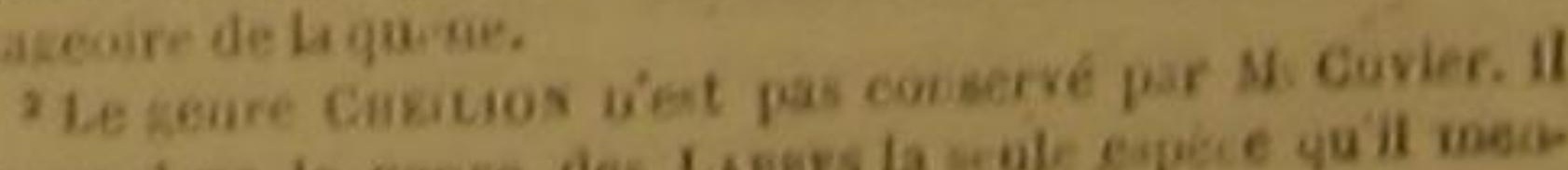
ranze dins
igune, $\mathrm{D}$.

Le jaunel. - Chelinus che io. - Tolus Plarus, vei clary.

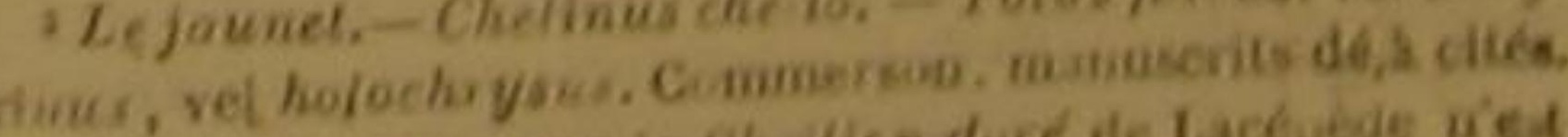

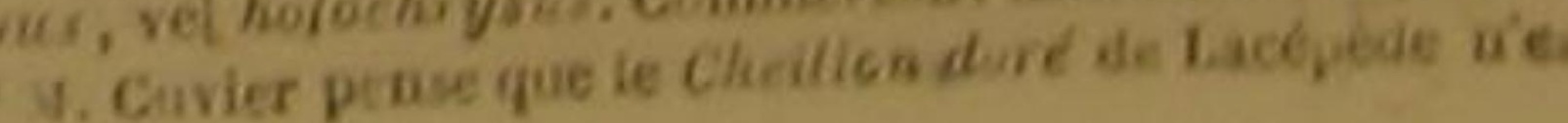


tes naturalistes ignorent encore l'existence, et pour lesquelles nous avons dủ etablir un geure particulier.

Commerson en a vu des individus dans te marché au poisson ou dans les barques des pécheurs de l'ile Maurice.

La chair du cheilion ' doré est blanche et agréable au goût, mais peu recherchée, parcee que ce poisson est très-commun. La longueur ordinaire de l'animal est de quatre décimètres, ou environ. La mâchoire supériéure est plus avancée que l'inférieure; ét la lèvre d'en-haut extensible. On ne voit qu'une rangée de dents à chaque máchoire; il n'y en a pas au palais. La langue est à demi cartilagineuse, et nn peu libre dans ses mouvements; mais la pointe en est cachée au-dessous d'uue petite membrane tendue à l'angle formé vers le bout do musea par les deux cotés de la máchoire d'en-bas. Les yeux sont rapprochés I'un de l'autre; les écailles qui recouvrent le corps et la queue lisses, et arrondies dans leur contour; les opereules composés de deux pièces et terminés par un appendice membraneux; les rayons de la dorsal dénués de filaments. La caudale est arrondie et la membrane, qui forme la vessie natatoire, est attachée au-dessous de l'épine dorsale.

Le cheiliou brun est moins grand qque le doré : sa longueur ordinaire n'est que de trois décimetres. La partie de son museau qui est aplatie est assez courte. Ses pectorales sont transparentes; et son iris brille d un rouge de feu. It a d'ailleurs les plus grands rapports avec le doré 2 .

\section{CENT VINGT -SEPTIÈME GENRE.}

LES POMATOMES '.

$L$ opercule entaille dans le hant de son bord postiriear. el courert d'ecailles sembtables à rellés du dos, le corps et ta queue allonges : deux nageoires dorsales. la nageoire de $l$ anus tres-adipeuse.

Espèce. 'санастеввs.

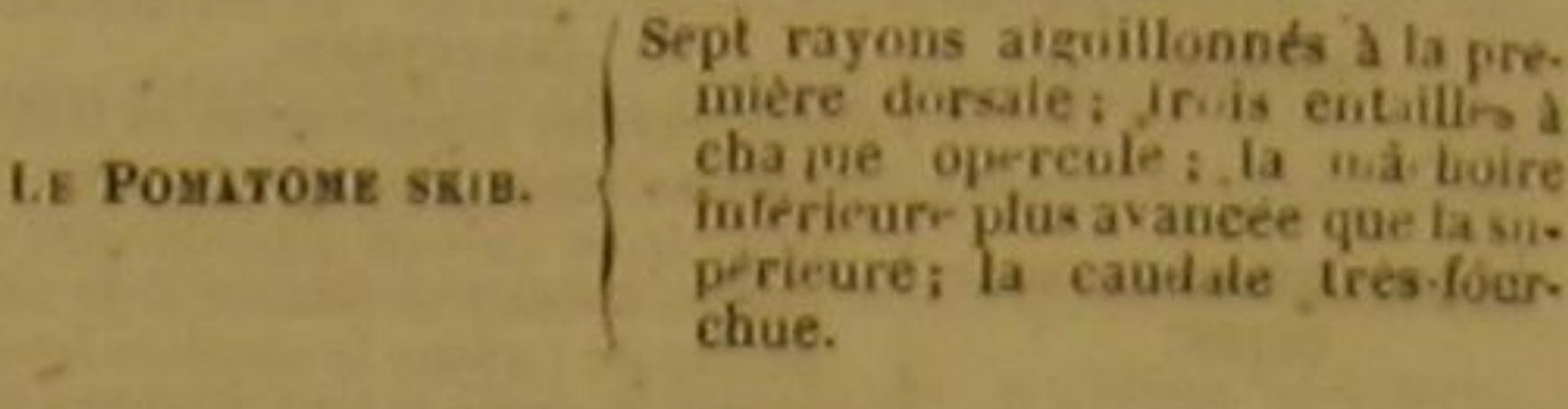

LE POMATOME SKIB ${ }^{2}$,

Temnodon saltator, Cuv.; Perca saltatrix, Linn.; Cheilodipterus heptacantbus, Sparus saltator, et Poina.
tomus Skib, Lac. '

Nous devons la connaissance de ce poisson à notre savant confrère $\mathbf{M}$ : Bose, qui a bien voulo nous communiquer un dessin et une deseription de cette espeeee, dont il a observé les formes et les babitudes, avec son habilete ordinaire; pendant le sejour qu'il a fait dans les Etats-Unis.

Ce pomatome thabite dans les baies et vers les embouchures des rivières de la Caroline. On ne l'y trouve cependant qu'assez rarement. II sante et s'élance fréquemment à une distance plus ou moins grande; et cette faculté ne doit pas surpiendre dans un poisson dont la quene est conformée de manière a pouvoir être agitée avec rapidité. La chaị du skib est très-agreable au gout

Les mâchoires sont garnies chacune d'une qu'un labre trés-gréle, dont les épines dorsales sont tiexibies. rangée de dents aplaties, presqué égales, et un M. de Laćpède a décrit deux fois ce poisson, sous les coọ peu séparées les unes des autres. La seconde
To de Labre hassek, 20 de Cheilion dore D. s. Chelio fuscus. - - Chieilio fuscu-plumbeus immacola. dorsale est plus longue que la première, et - tusis c Commerson, manuserits déja ciltes. iNon tuentioonè par $\$$. Cuvier. D.

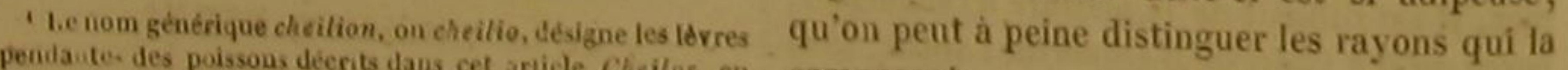
pendainter des poisso
grec, siguilie litre.

${ }^{2} 6$ rayous a la membrane branchiale du cheilion dored dn cheilion brun, 23 a la nigreoire du dos, 11 à chanue veré rile, 6 a chaque thoreciue, is a tangle, 12 a la magevire de

L'animal est verdâtre dans sa partie supé.

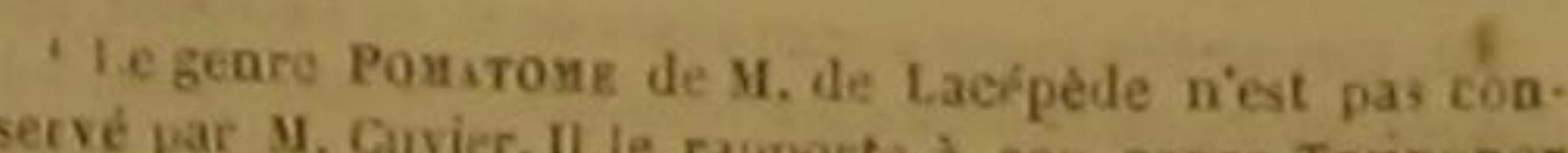
de ha femille des Acanthopterygiens à sou geare Trisod

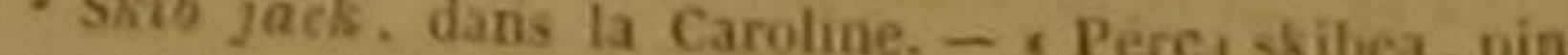
"Corsalbus distinceis, secundá viginti-quatnor radis, cor'pore arseutea, cau á bifurci. ,

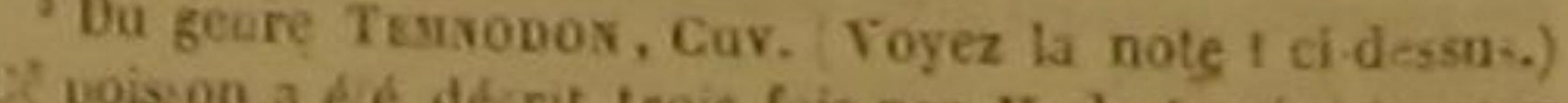
its noms $1^{0}$ de Cheilodiptive hept 31 . de Lacépele, sons auteur, et 50 de Pompatome slib D. eo grec, signifie opercule, et tome, incicion. rieure, et argenté dans sa partie inférieure. L'iris est jaune; et l'on voit une tache noire sur la base des pectorales, qui sont jaunåtres '.

CENT VINGT-HUITIEME GENRE. LES LEIOSTOMES ${ }^{2}$.

Les machoires denuees de dents, et entierrment caches sous les lecres; ces memes levres extensibles; la bonehe placee au-dessous du musean : point de dentelure ni de piquants aux opercules: deux nageoires dorsales.

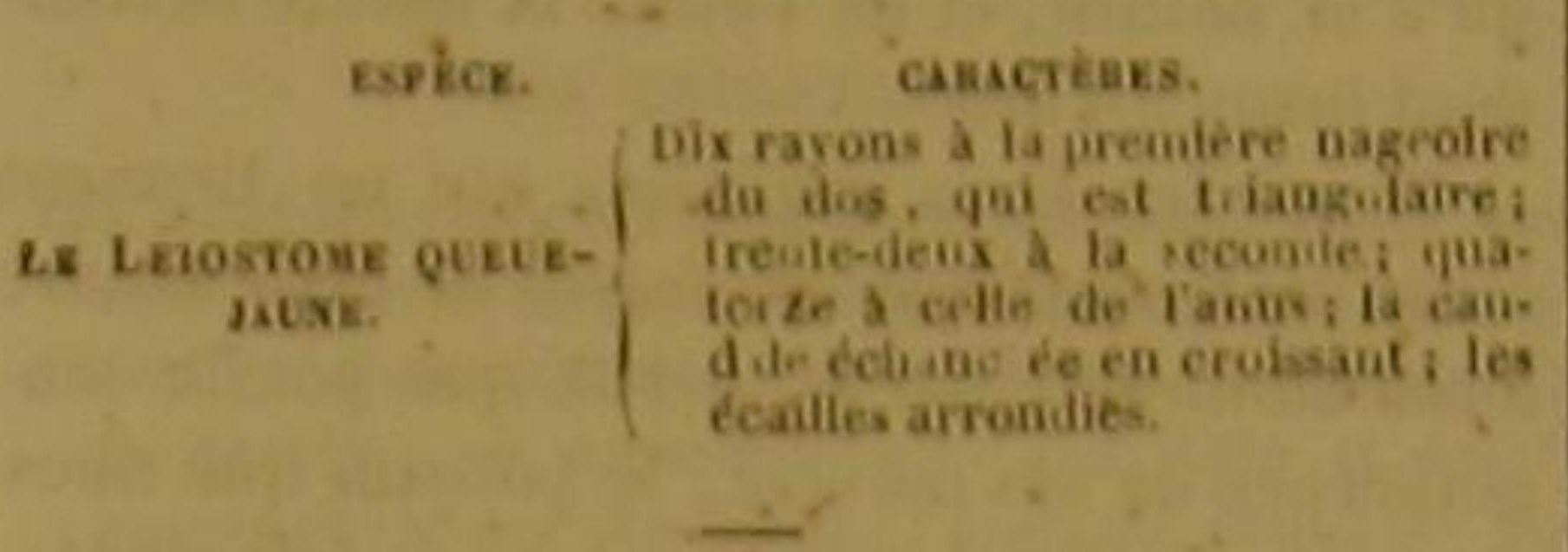

\section{LE LEIOSTOME QUEUE-JAUNE ,}

Leiostomus santhurus, Lac., Cur. ${ }^{2}$

C'est encore à mon confrère M. Bose que nous devons la connaissance de ce thoracin Cet habile naturaliste lui a donné, dans ses notes manuserites, le nom de Perche ou Persèque; mais il y a témoigné le désir de le voir placé dans un genre particulier, a cause des traits remarquables qui séparent ce poisson des perseques on perches, et que personne ne pouvait mieux saisir que ce savant. Le défaut de vait mieux saisir que ce savant. Le defaut de
dents aux mâchioires ét de dentelure aux operdents aux mâchoires ét de dentelure aux oper-
cules, est celui de ces traits distinctís qu'il a principalement indiqué, comme devant séparer le poisson décrit dans cet article, des véritables perches ou perseques; et e'est aussí a cause de perches ou perseques; et e'est aussi a cause de ce défaut de dents que nous avons donne a cet osseux le nom générique de Letostome . Nous jaune qu'il porte a la Caroline, ou M. Bose l'a observe. Il a en effet la nageoire de la queue, observe. Il a en effet la nageoire de la quese,

if ryons a la membrane bran hiale do pomatomie skib. 24 a ha seconde dorsile, 15 a chayue peciorale, 6 a chajue thoracene. 26 a la nagroire de lamis, is a cete de $h$ a quene. 2.t Le genre Leiostone de M, de Lacriede a ele adopte

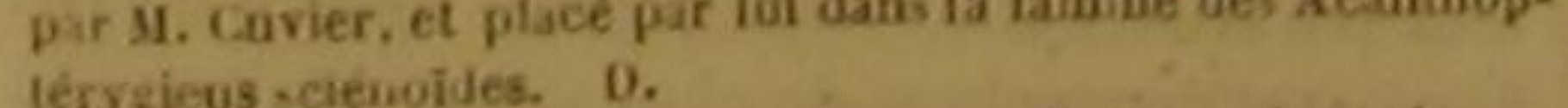
lerysieus scienoides.

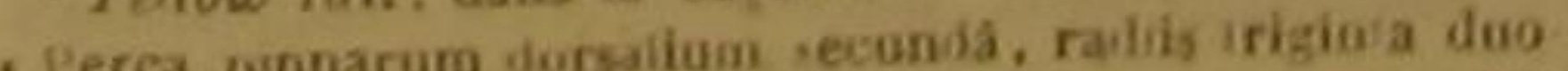

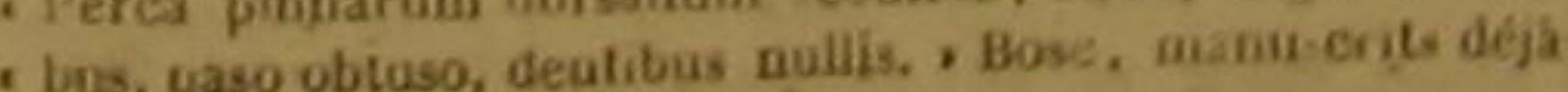
citcs.

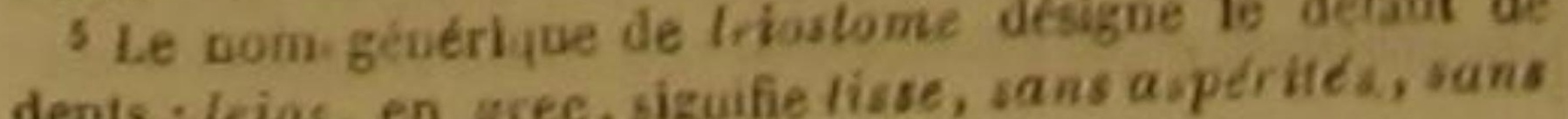
dents : Leios, en gree, siguifie timar nảtres; elles sont d'ailleurs pointillées de noir. Une couleur brune argentine règne sur la partie supérieure de l animal, et un blane argenté sur l'inférieure. L'iris est jaune, Les yeux sont gros. Chaque narine a un oritice double. Le bout dn museau est mousse. La tête, le corps et la queue sont comprimés.

Le leiostomé queue-jaune n'a souvent qu'un décimètre, ou environ, de longueur; et alors sn plus gránde-hauteur est cependant de près de quatre centimetres. Ce poisson, dont la chair est agréable au goùt, vit dans les eaux douces de la Caroline ${ }^{\text {. }}$.

\section{CENT VINGT-NEUVIEME GENRE} LES CENTHOLOPHES ?

Dne crite longitudinale, at un rang longitudinat de piquants très-scpares les uns des autres a caches en partie sous la peau au-dessus de la nuque : une scule

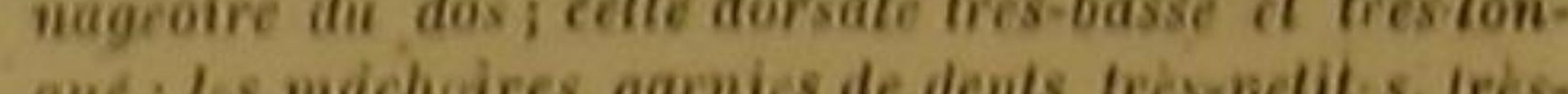

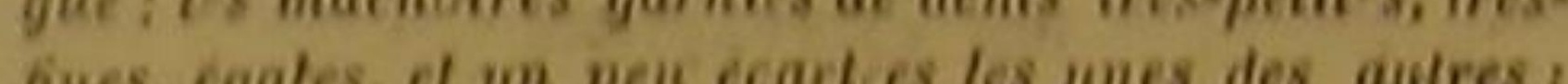
. a membrane braichiale.

ispece. anscrias.

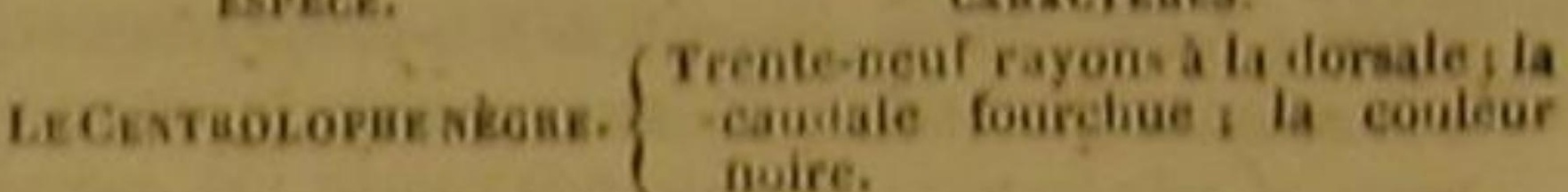

LE CENTROLOPHE NËGRE,

Centrolophus Pompilus, Cuv.; Coryphasua Pompitus et Perea uigra, Limo.. Gmel., Bociase; Centroloptua niger, el Holocentrus niger, Lacep. '

M. Noél de Rouen ma envoyé un individu 位. alistes ne connaissent pas encore, et que sa conformation singulièrem'a fait inserire dans un genre particulier. Ce poisson venait d'étre pèché Fécamp, ou personne ne s'est souvenu d'en aroir va de semblable. les pécheurs l'ont ammé le Nère, à cause de sa couleur noire; et nous avons cru devoir adopter cette dénomination spécifique.

I rayons a la membrane branchiale du teioscome queae. ame. 18 a chayue

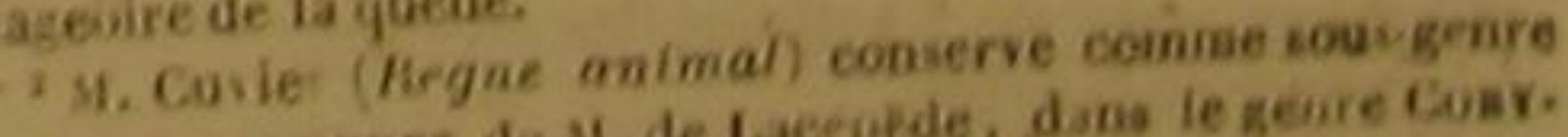

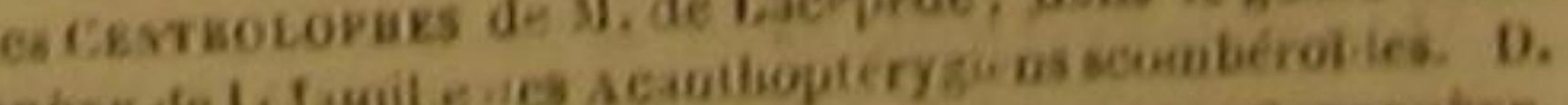
- Du sus-genr cesteolopas, dass le geare Cunsuras,

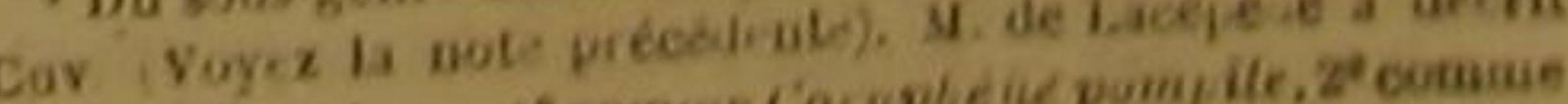

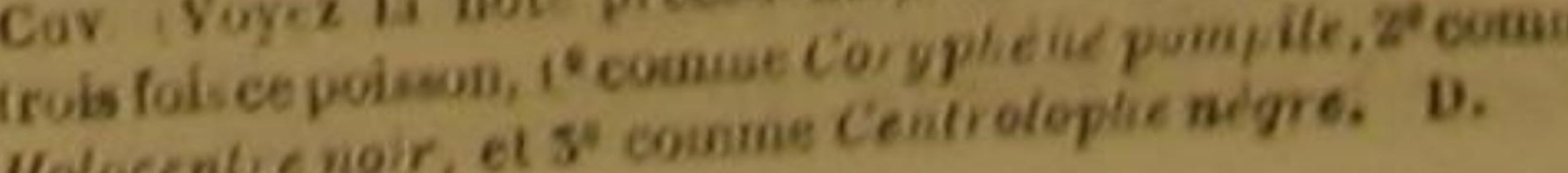


Ce centrolophe ' parvient au moins à la lon- nature, de mème nous recevons souvent queur de trois décimetres. Son museau est ar- plaisir particulier des ouvrages de la nature rondi; sa mâchoire inférieure plus avancẻe que qui nous offrent ces sortes de singularité rela supérieure; l'orifice de chaque narine double; marquable, de contraste frappant, de régularité le palais lisse, ainsi que la langue, qui est recherchée, de symétrie rigoureuse, que nous libre dans ses mouvements, blanche et lẻgère- présentent un si grảnd nombre de produetions ment pointillée de noir. Les yeux sout très- delart. Cette metamorphose, si je puis parlêr gros; les piquants placés entrę la petite erète ainsi, ce déguisement, ou cet échange de quaet la nageoire dorsale, sont au nombre de trois, lités, nous donnent une satisfaction assez vive; et situés verticalement, ou dirigẹs en avant. et l'on dirait que notre amour-propre se comDes écailles très-petites, rhomboïdales et for- ṕlait, en les considerant, dans cette illusion tement attachées, couvient la têté, les oper- qui lui montrerait d'un côté l'art s'élevant juscules, le corps et la queue; mais celles qui qu'a la nature, et de l'autre la nature descenrevêtent la tète ont des dimensions encore dant jusqu'a l'art.

moins considérables que les autres; et une figure peu déterminée. L'auale est très-basse comme la dorsale. La ligne latérale est fléchie vers l'anus, au lieu de suivre la courbure du $\operatorname{dos}^{2}$.

\section{CENT TRENTIEME GENRE,} LES CHEVALIERS

Plusieurs rangs de dents á chaque mächoire; deux na geoires dorsales: la premiere presque aussi haute qu lecorps, Iriangulare, el garnie de très-longs filaments a lextremite de chacun de ses rayons: la s cond basse et trìslongue: lanale tris-courte, et moins grande que chacune des thoracines: celte anale, les
deux nageoires un dos el celle de la queue courertes presque en entier de petites ecalles; l'operente san presque en entier de petites ecaulles : l'opercule sans
piquanis ni dentelure i les ccailles grandes ef denteles.

Espíce. cascrikas

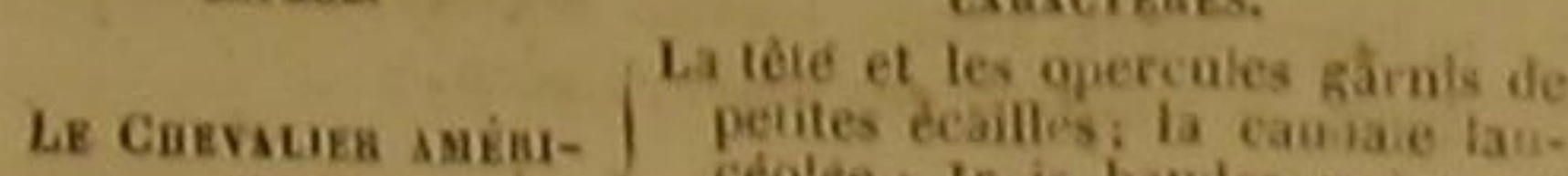

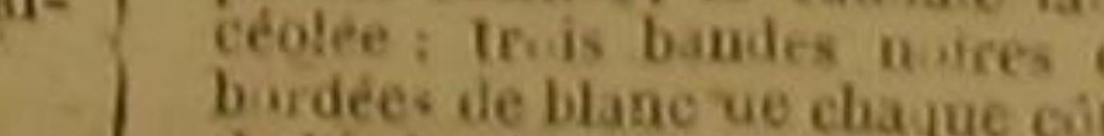

$$
\text { - }
$$

LE CHEVALIER AMÉRICAIN ', Eques balteatus, Cuv.; Èques americanus, Bl., Lac. Chatodon lanceolatus, Linn. s.

De même que te plus grand charme de l'ar vient de la perfection avee laquelle il imite la 'Le mot centrolophe désigne les piquants et it crête do crête.

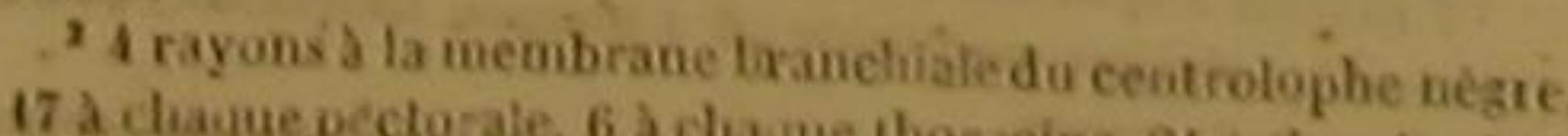
17. a chayue pectorate, 6 a cla gue thoracine, 21 a lanate, 23 ) la nigesre ile la quece.

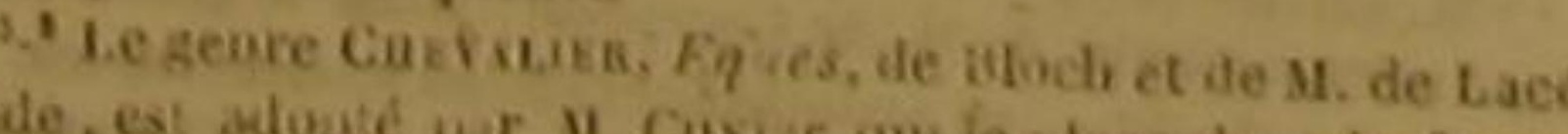

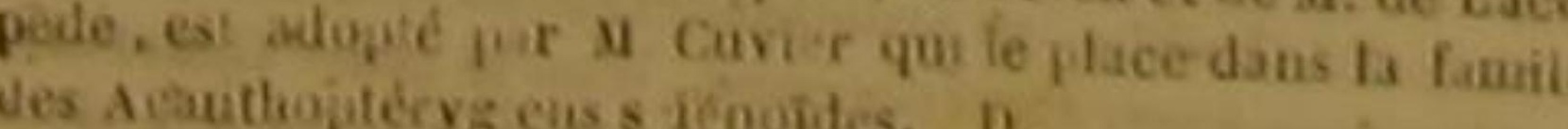

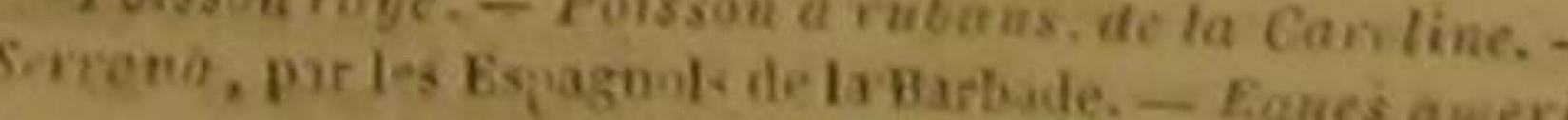

tienent leurs ornements que des mains de cette nature aussi admirable par la variété que par la magnilicence de ses cuvres, le poisson que nous décrivons doit principalement attirer les regards, comme ayant reçu pour sa parure des nuances et une distribution de couleurs, qu'on ne croiralt pouvoir rapporter qu'au caprice, ou, si on l'aime mieux, au goùt recherché de l'art. En effet, au-dessus de la couleur d'or diversifiée dans ses tons, dont brille presque toute sa surface, on voit de chaque côté trois bandes d'un beau noir, lisérées de blane, et quí, par cette bordure tranchante, se detachent davan. tage du riche fond qui les entoure. La premiere et la moins large de ces bandes est transversale, un peu courbe, et passe au-dessus du globe de l'ceil; la seeonde s'etend, en serpenant un peu, depuis le sommet de la tète jus. qu'aupres de la bấse des thoracines; la troisieme, qui est la plus large, commence á l'extremité superieure de la première nageoire dorsale, descend obliquement vers la tête, se reeourbe de l'animal, s a avancé ensuite longitudinalement jusqu'a la caudale, au bout de laquelle elle parvient sans s'affaiblir. Six autres bandes brunes et inégales relèvent le jaune doré de Ia nageoire du dos, et se repandent de chaque cóté sur le dos du poisson. L'iris est orangé. Cet assortiment de couleurs, et surtout les trois longues bandes noires et bordées de blane, font paraitre l'ainéricain comme décoré de rubans, ou de cordous de chevalerie; et c'est apcamirs. Bloch, pl. 5n. - Guaperog. Edw. Av. tab. $210-$

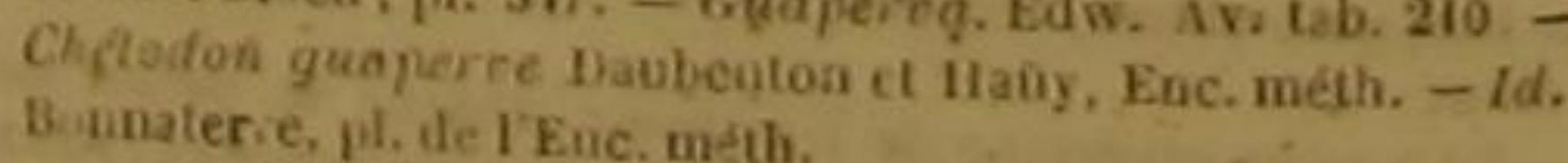
vers la queue lorsqu'elle est parvenue au dos paremment cette disposition de nuances qui a suggéré à Bloch le nom génèrique de ce thoracin.

La tête est petite et comprimée; le museau arrondi; l'orifice de chaque narine double; le corps élevé, la queue beaucoup moins haute; la ligné latérale droite.

Ce beau poisson vit dans les eaux de la Caroline, de la Havane, de la Guadeloupe, et d'autres pays du nouveau continent '.

\section{CENT TRENTE ÉT UNIEME GENRE.} LES LÉIOGNATHES ${ }^{2}$

Les mächoires denuess de denits proprement dites; 10 sinte nageoire du dos : un aiguillon recospré at trit fort des deux côtis de chacium des rayons articules it la dorsale ; un appendice ecail eux, long of aplat aupres de ch que thoracine; I'opercule denne de petites eraillss, it un peu e sele: la hauteur du corp cgale ou presque sgale à la moitie de la longueur totale du poisson.

rspicx.

LE Leioesuras AI.
Gevie. -

LE LEIOGNATHE ARGENTE ${ }^{2}$

Equula ensifera, Cuv.; Scomber edentulus, Bl.; Leia goasthus argenteus, Lac. ‘.

Bloch a décrit le premier ce poisson, qu'il a inserit parmi les seombies. Ce thoracin, en effet, a beaucoup de rapports avec ces poissons: et c'est cé qui nous aurait dêterminés à lui donner le nom spécifique de Scombéroìde, si nous n'avions pas employé déjà cetté dénomination pour désigner un genre voisin de celui des scombres : mais il differe de ces añimaux par trop de traits remarquables, pour que nous n'ayons pas dú, d'apres nos principes de distribution méthodique, le placer dans un genre

is rayons a la membrane branchisle do chevalier ameri. eain, 11 a la premiere dorsile, 50 a la seconde. 16 a chaque prectorale, 1 rayon a guilloniné et 5 rayons articulés a chaque

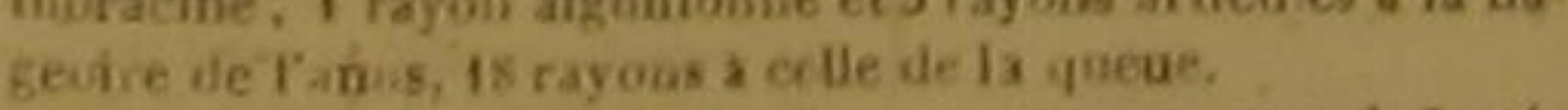
2 M. Cuvi-r n-conerve pas le gene Leiocsitue de Lacepède, doug le type rst le Scomber Equula de Firskati. II forme de ce poisson, et de plasiears autres, soa sons-graze Eqcols, dans lé grand zeure Boukz. Zeus, de ta Gamilie dex

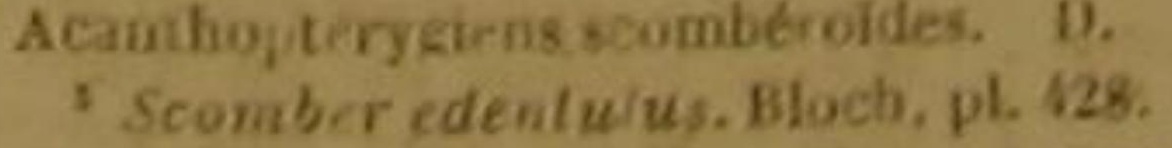

Scomber edenturus. Bloct, pl. 128.

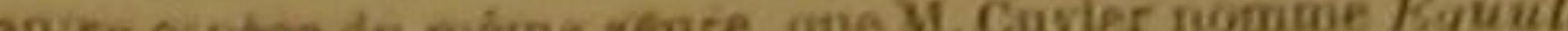
cabaila. D.
Un seul de ces traits, le défint absolu de dents, aurait suffí pour rendre cette séparation nécessaire; et voilà pourquoi nous avons choisi pour l'argenté, dont nous traitons dans cet article, le nom générique de Lèiognathe, qui indique des máchoires lisses ou non ar mees de dents ',

L'argentéa d'ailleurs l'ouverture dela botich petite; la tète, le corps et la queue, très comprimés; deux orifices à chaque narine; l'anus une distance à peu près égale du bout du musean et de l'extrémité supérieure ou inférieure de la caudale; les écailles minces et argentées; la nageoire de la queue violette, en tout ou en partie; les autres nageoires, les opercules te dessous de la poitrine, dorés; te dos violet; plusieurs bandes transversales, brunes, et souvent rapprochées deux à deux ${ }^{2}$.

Le lélognathe parvient à la longueur de trois ou quatre décimetres, II vit auprés de Tranquebar, il n'entre que rarement dans les ri vieres. On le prend dans toutes les saisons; mais il est surtout très-aisé de le pécher pendant l'hiver. Sa chair est grasse et de bou goût; et comme les individus de cette espèce sont très-nombreux, la péche de ce thoracin est trèsutile aux habitants des rivages dont il s'approche.

\section{CENT TRENTE-DEUXIÉME GENRE.}

LES CHĖTodons

Les dents petiles, fexibles at mobites: le corps at la queue tris comprimes i de petiles ceailles sur la dor sale ou sur a a itres nagcoires, ou la hauteur du corp sapé

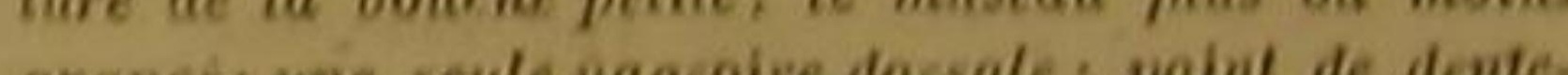
lure ni de piquants a ax opercules.

PREMIER SOUS-GENRE.

a nageoire de la queue fourchue, on echanerie en

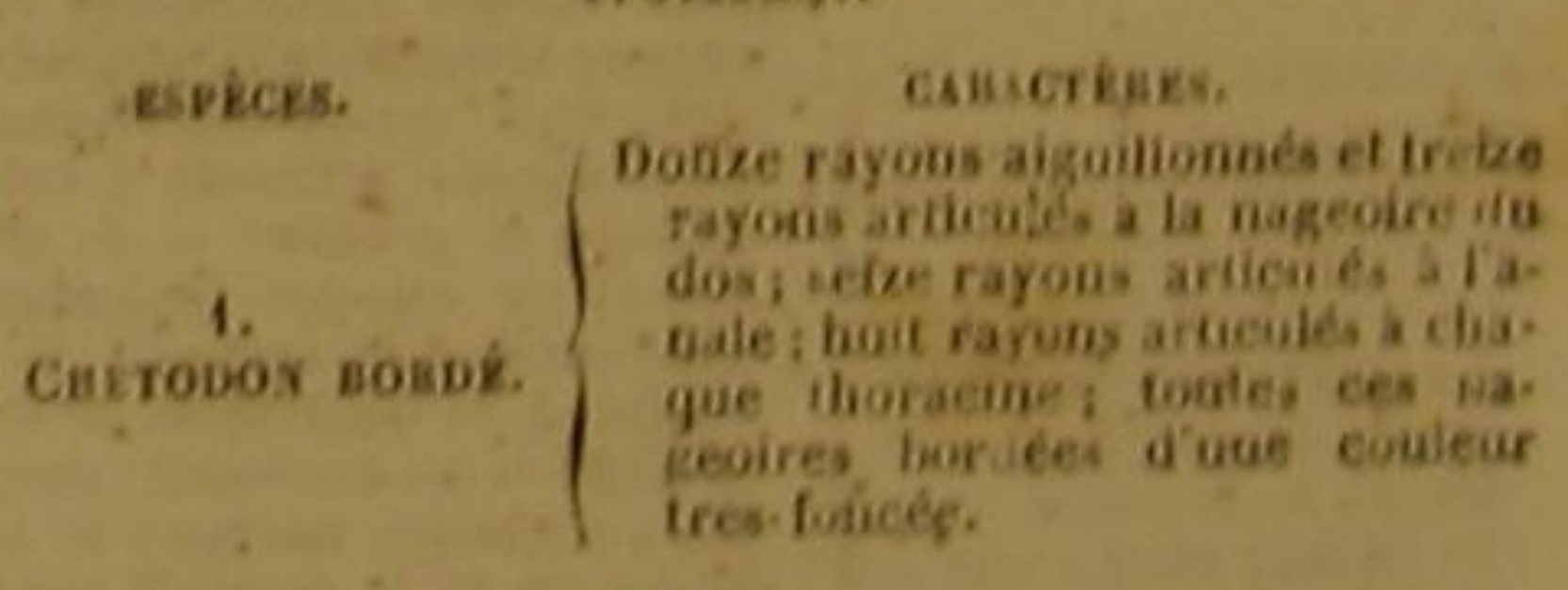

Leios, en grec, reat dire tiese, et gnatios, michoire.

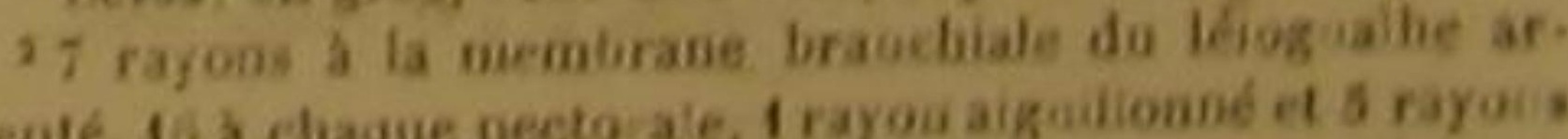

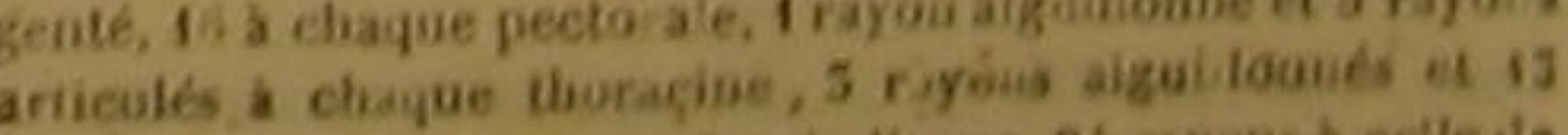

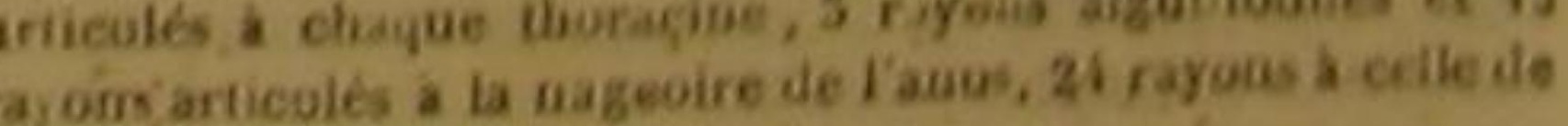

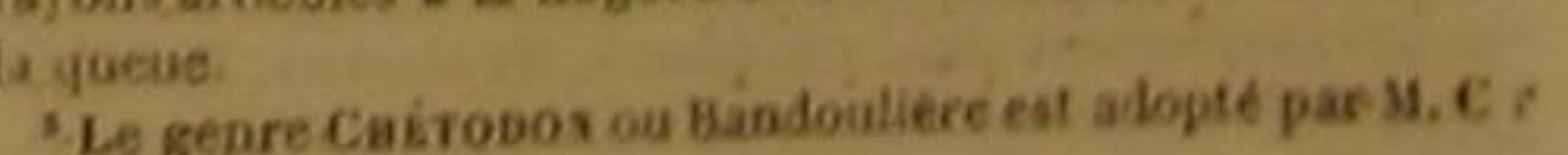



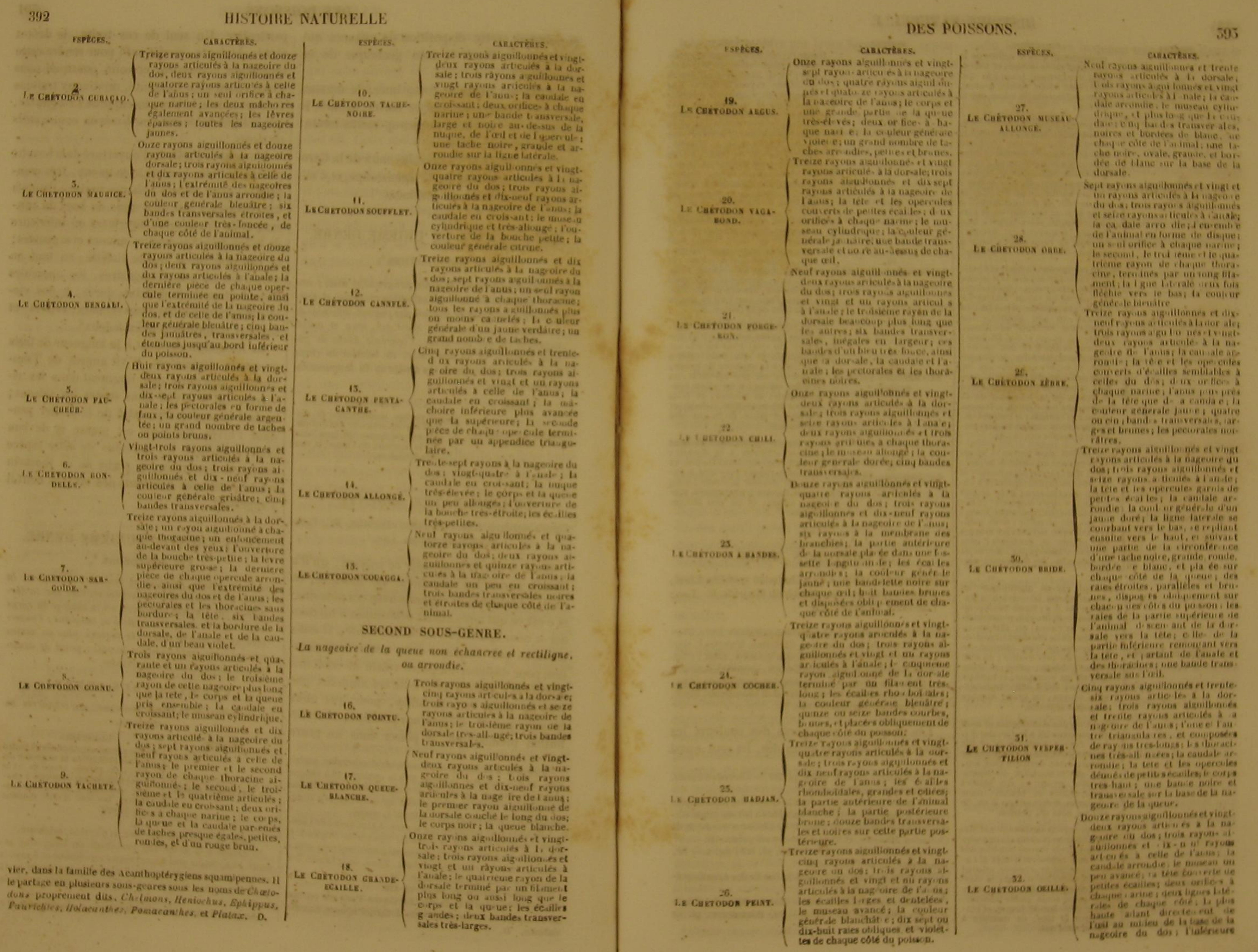
esprecrs.

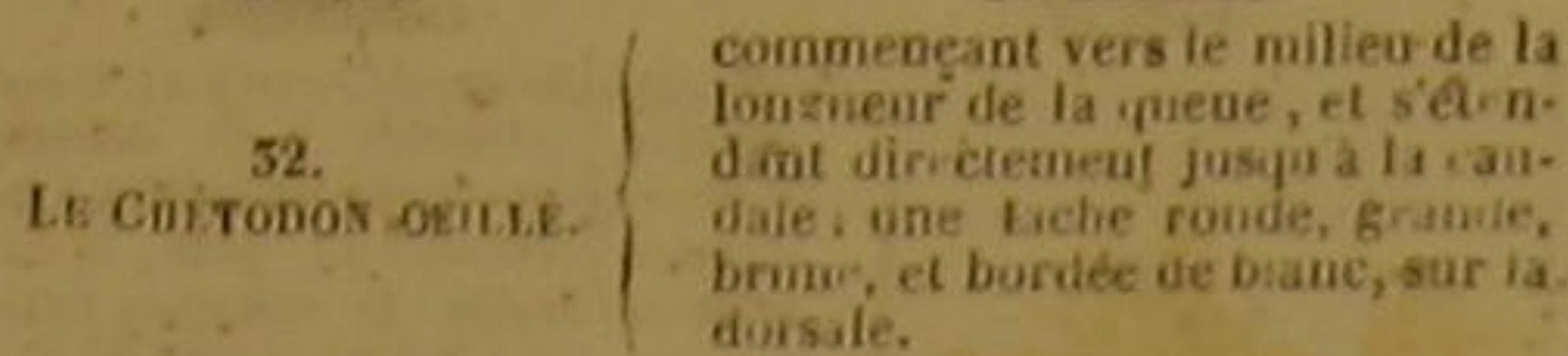

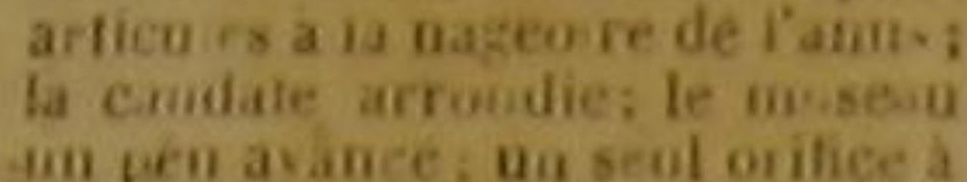

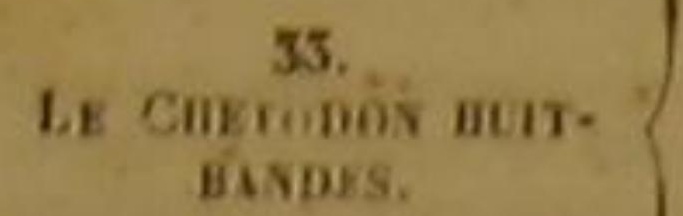

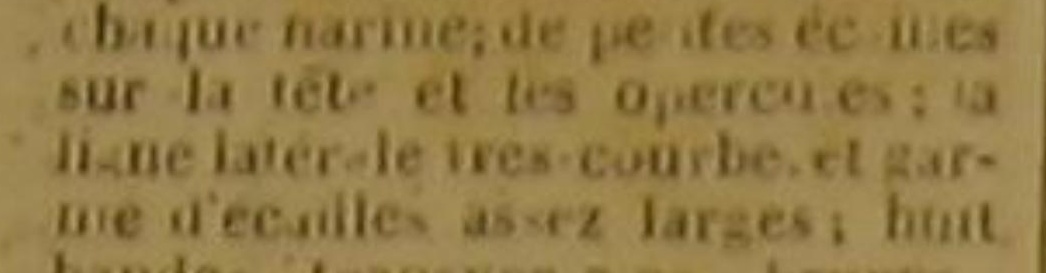

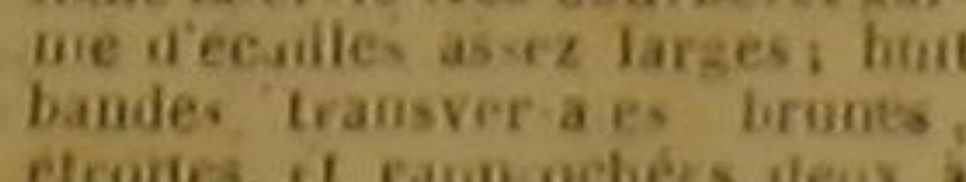
denx de chaque cote do posson

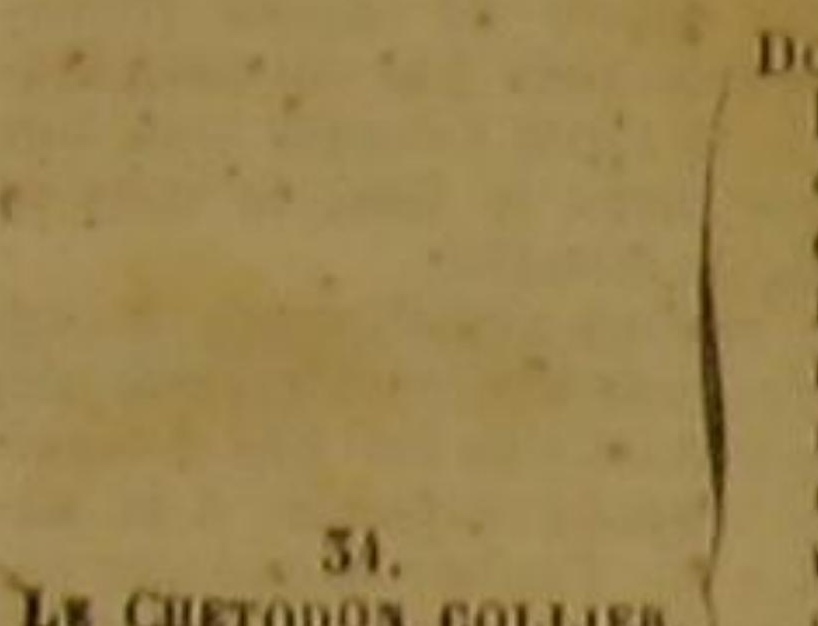

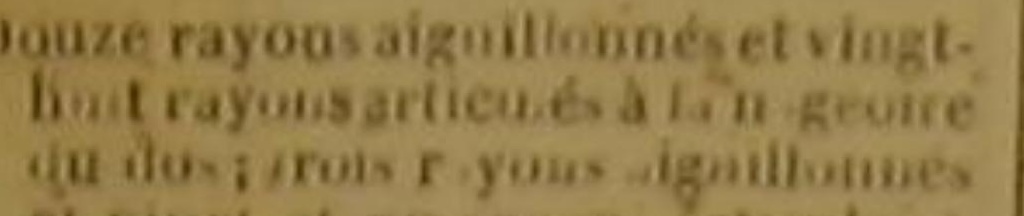

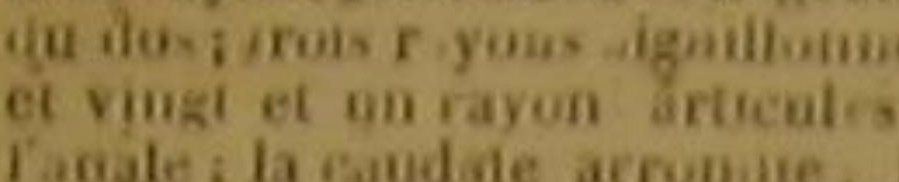

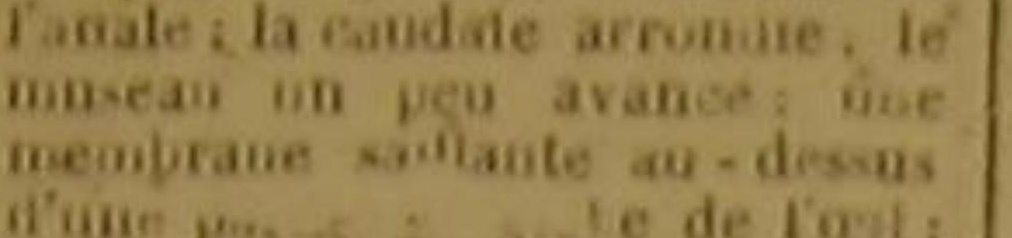

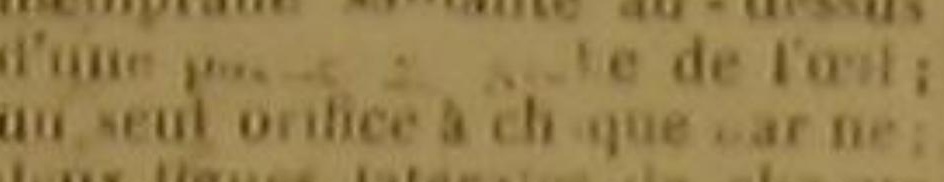

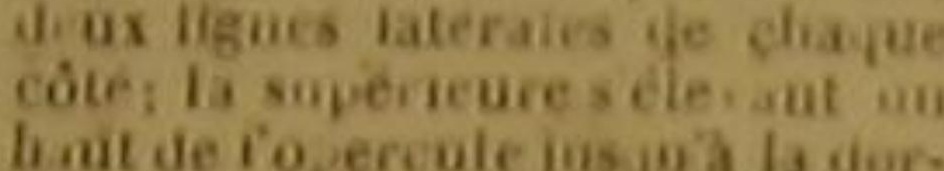

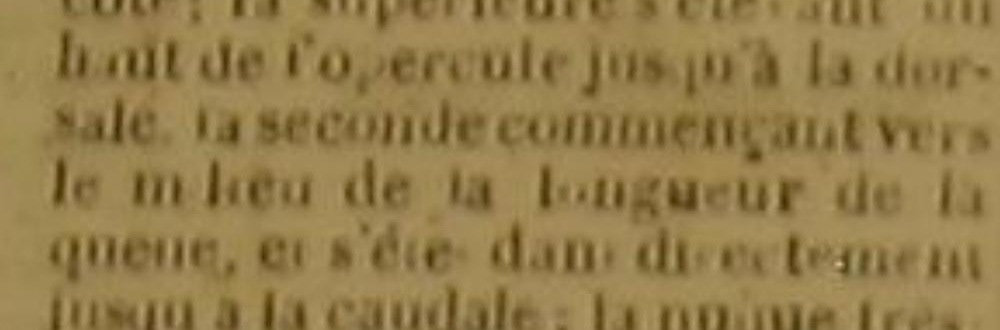

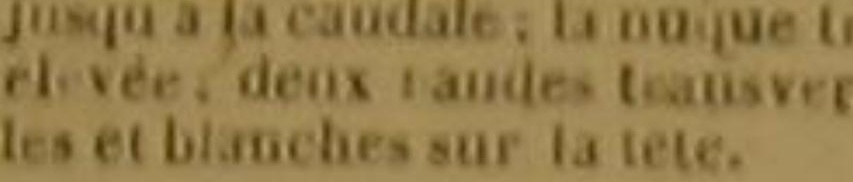
Coq rayous aigui lonnés et vingat.

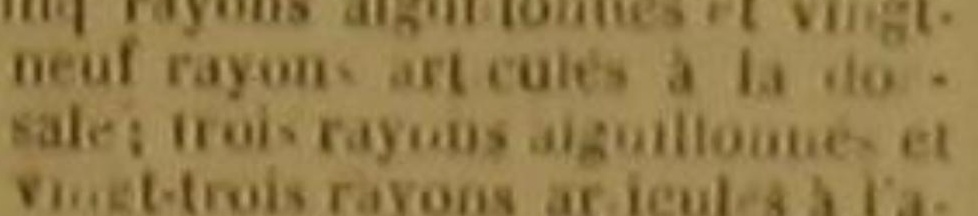

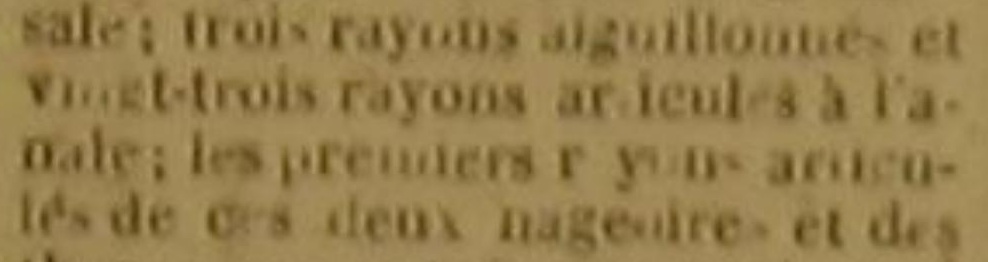

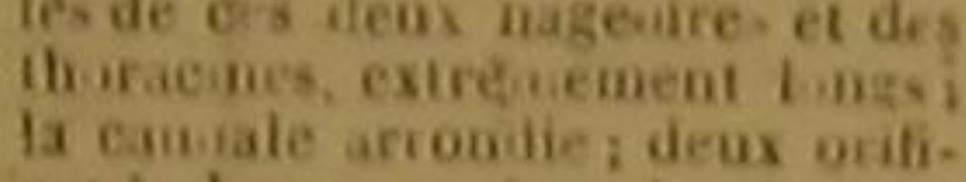

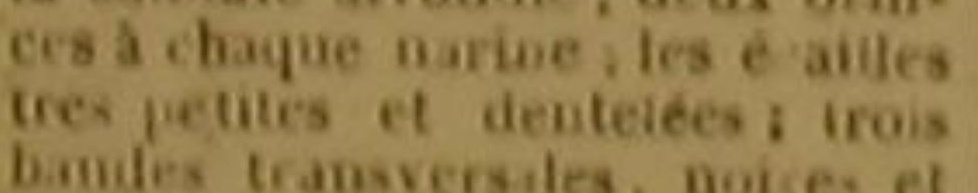
Ozze rayons aignilloniés très-forts,

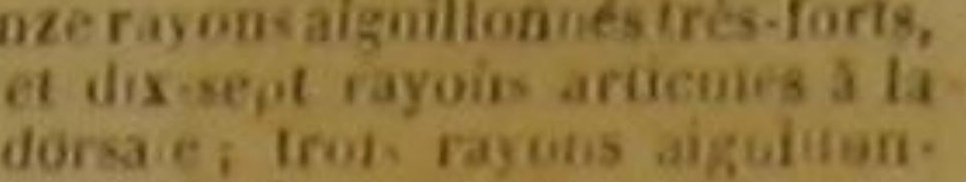

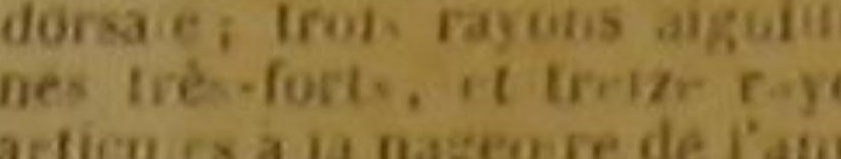
bandes transversiles. noi e- et
trés hongues; leg thuracines noi-

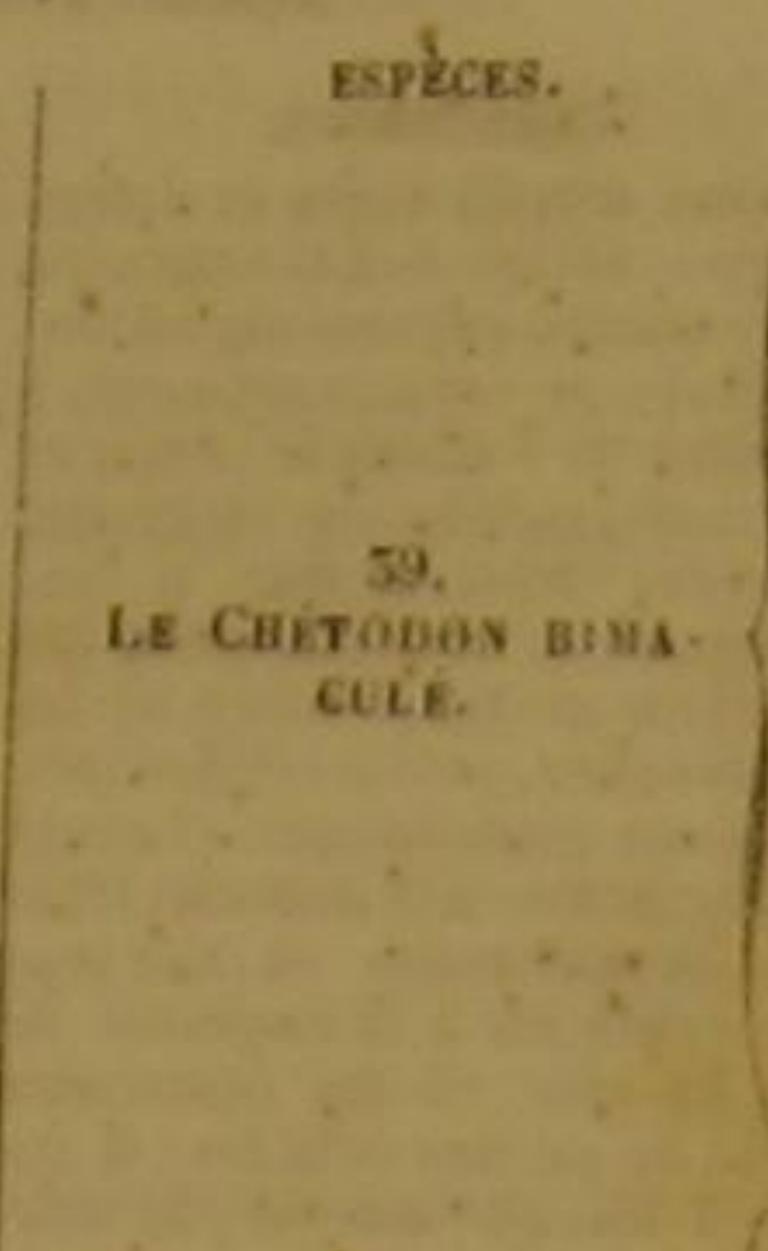

CABsctènes.

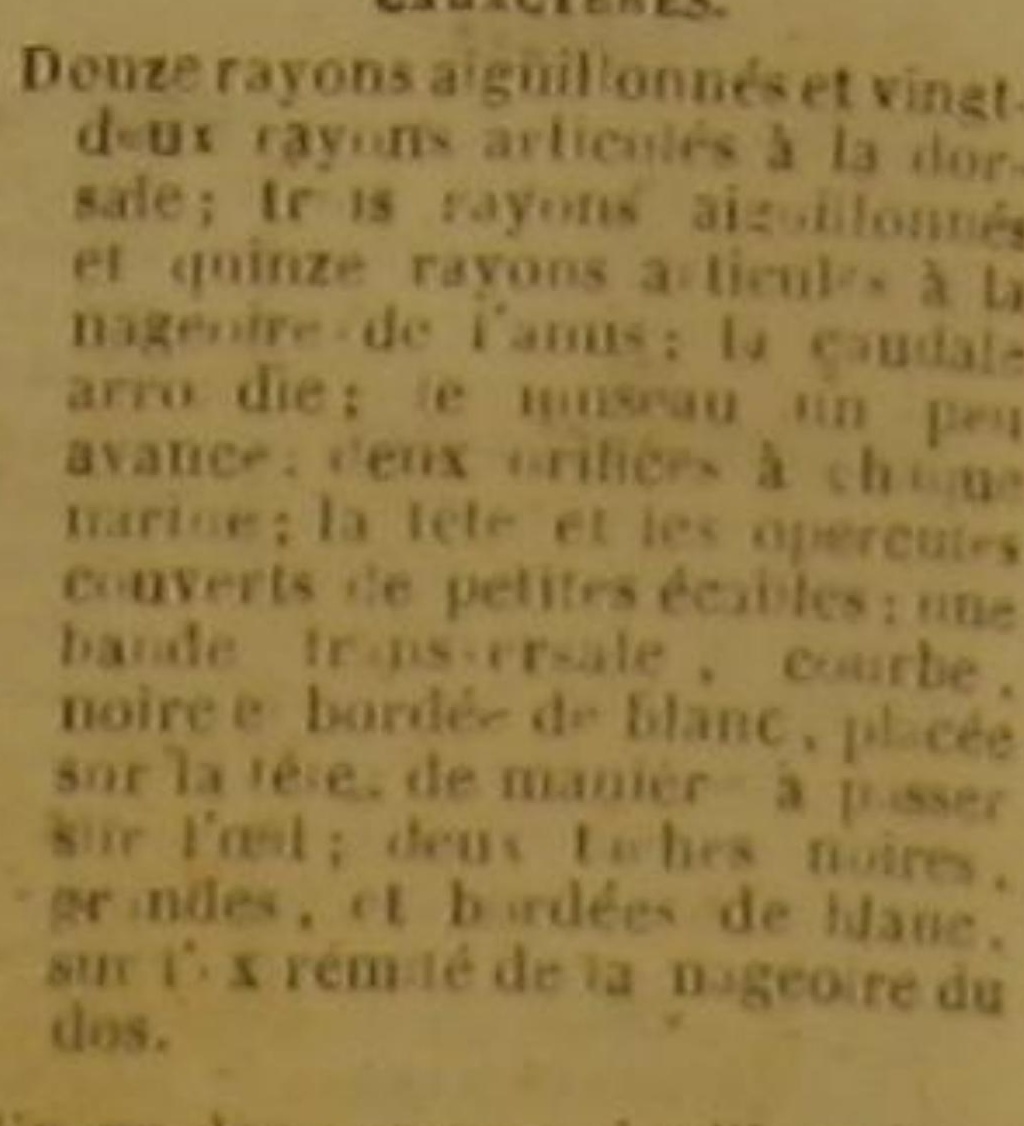

$\therefore \quad \therefore$

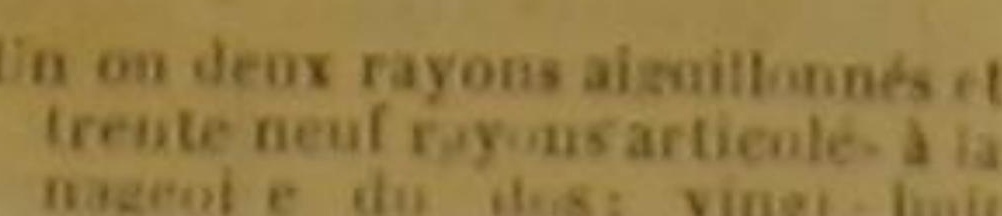

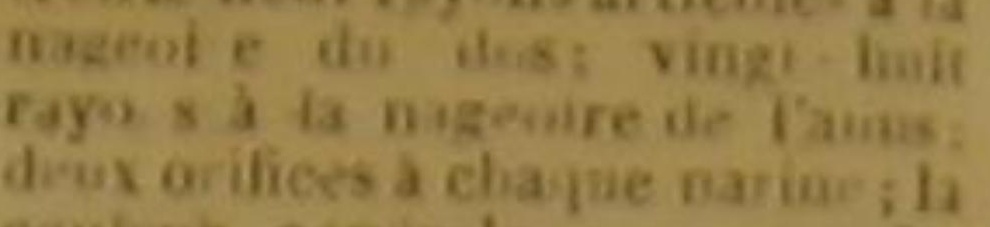

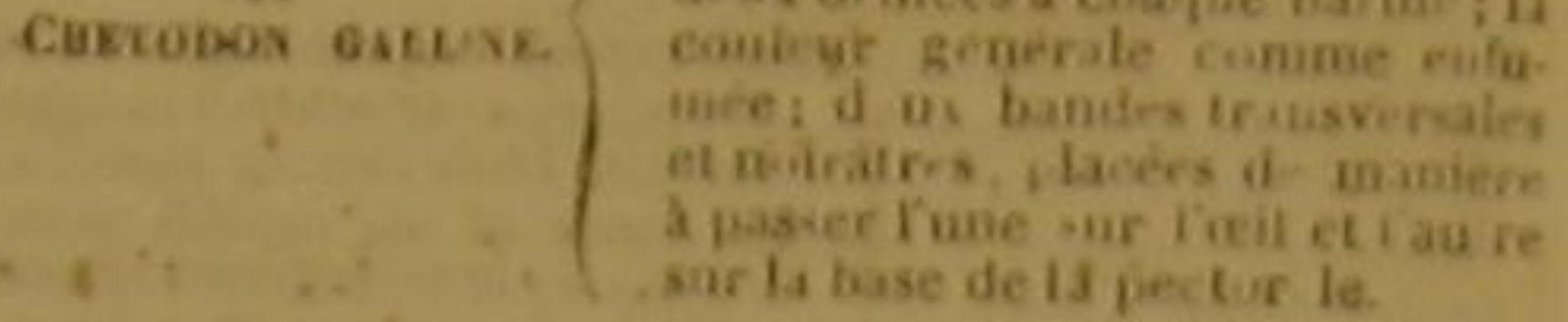

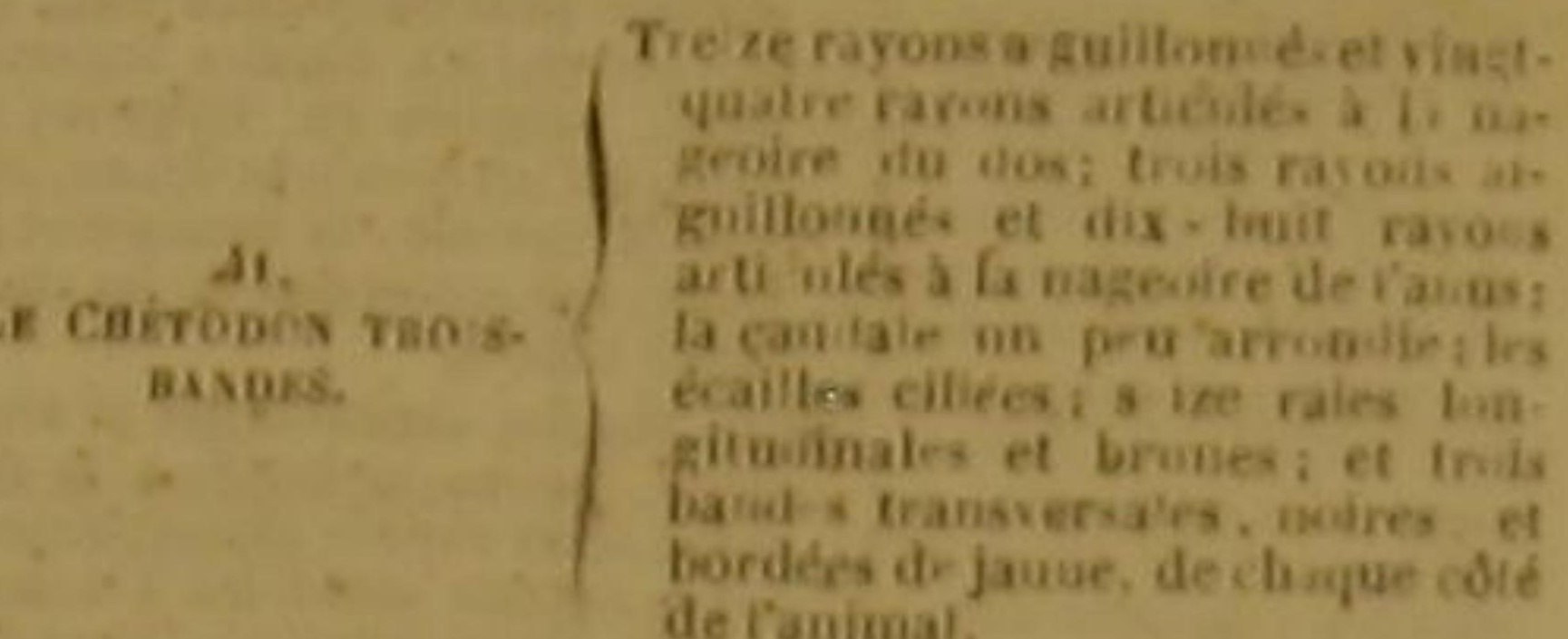

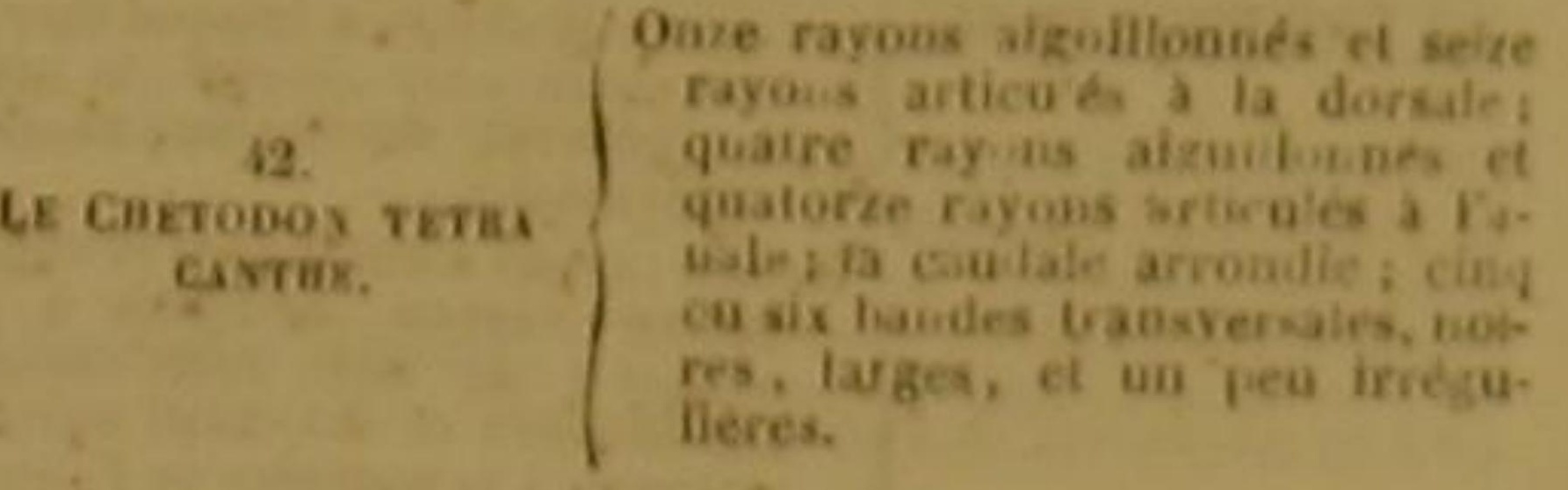

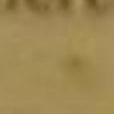

IE CHÉTODON BORDÉ ',

Glyphisodon saxatilis, Cuv. Chetodon saxatitis, Lino. Chatodon marginatus, Chatodon Mauruili, Bi., Lac. Chatodon sargo des, Lac, 2

Le Cheiedon Curacae ', Glephisodon Curassao, Cuy a Cha.

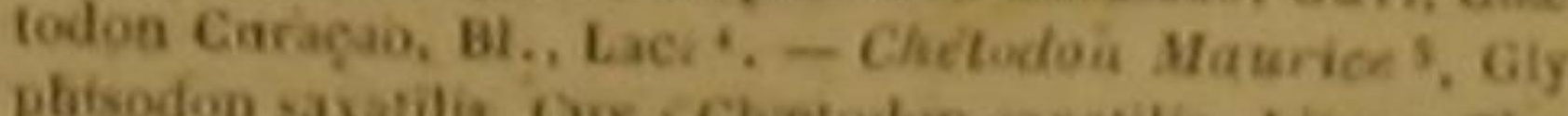

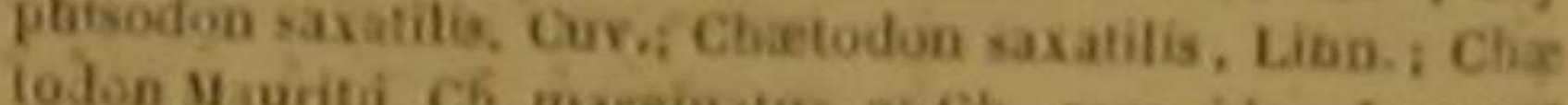

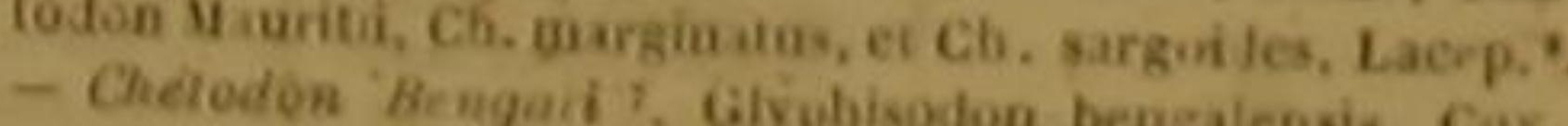

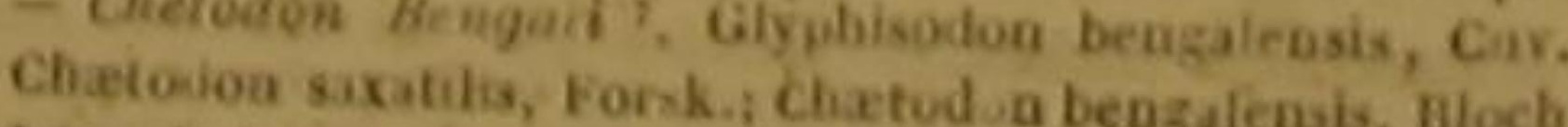
Lic, ; Labrus maerogaster, Lac. ,

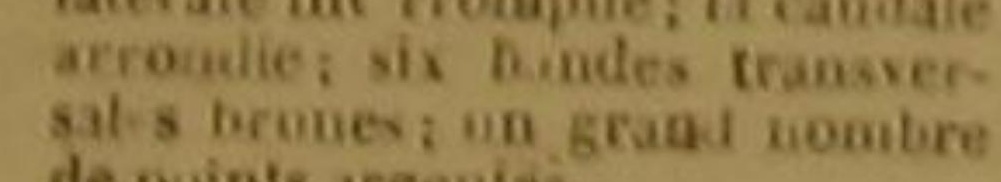
de puints argentes.

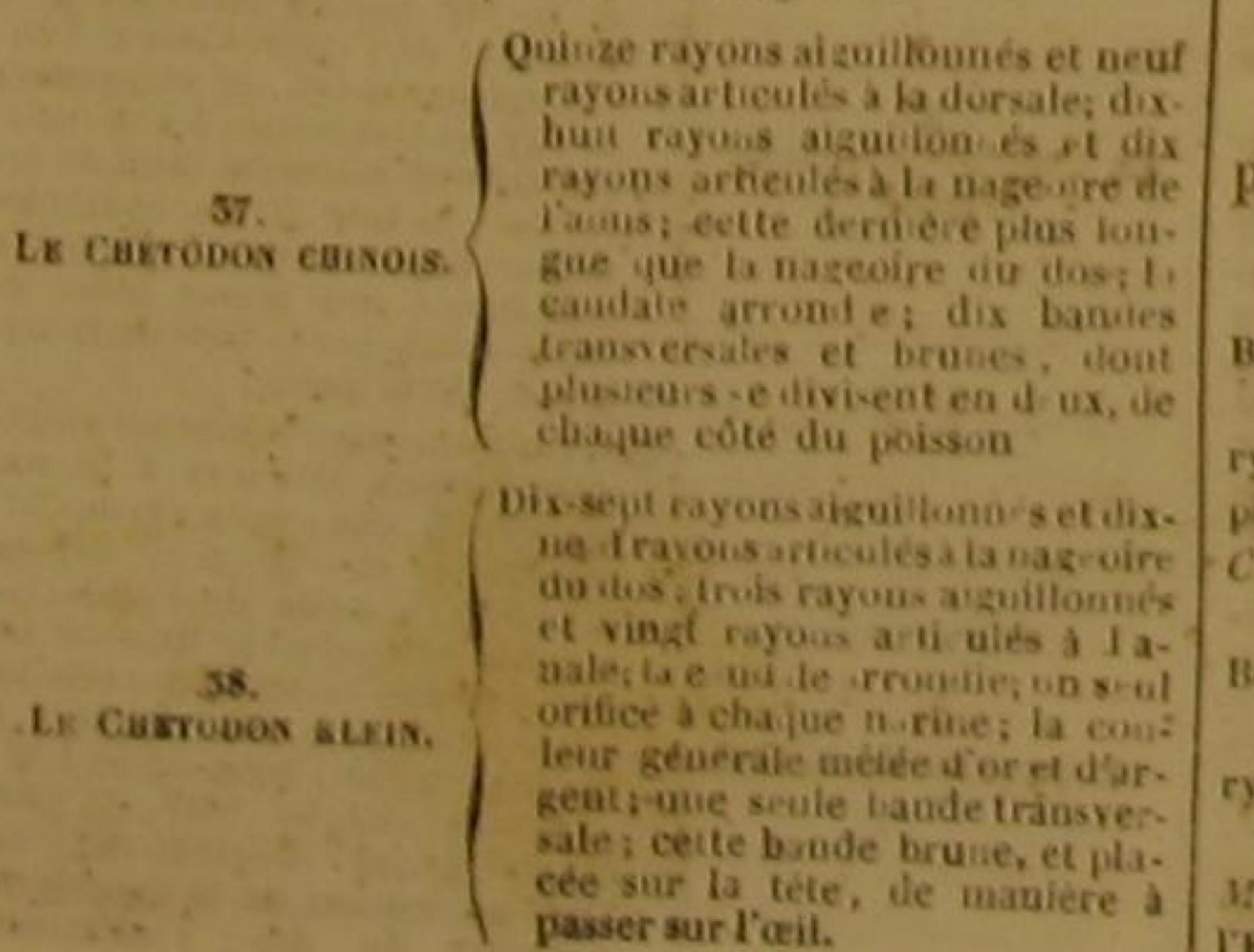

Les chétodons sont parés des couleurs les plus vives et les pluś agréables. Ils sont aussi

- Zandoutiere tordee. Bloch, pl.207.-Chelodon borde Wauterre, pl. de I'Ene, méh.

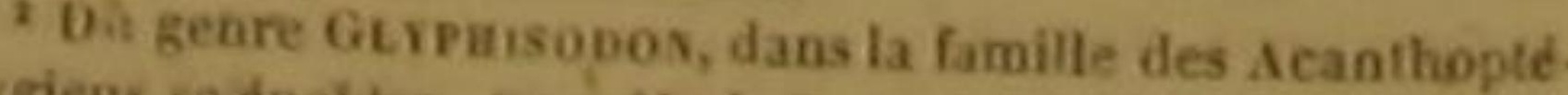

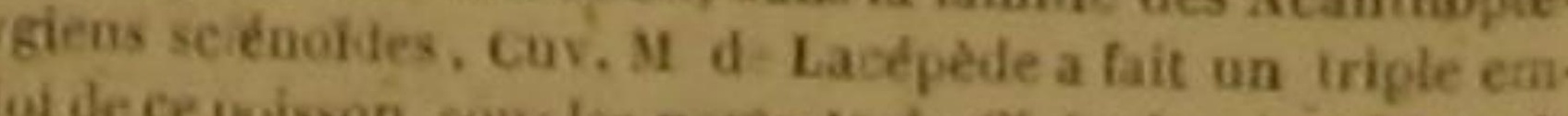
Cheitodon Maurthe, et $5^{\circ}$ de Cicote Chelodon borde, 20 de

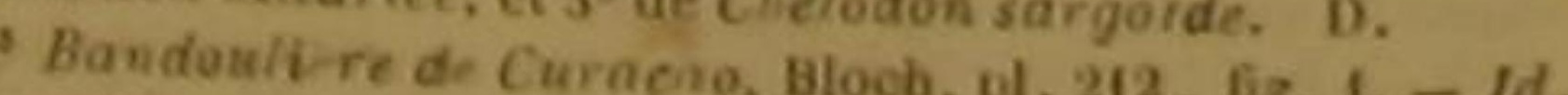
Sunatecre, pt. de TEne, meth.

"Nu genre GLYFaisodox, dans la fam lle des Acanthoptérygiens scểenoídes. Cav.

5 Jrgua caguare, au Brésil. - Bandouliere du prince
Movice. Bloch, pl. 215, fig. I. - Id. Bonnaterre, phe de
DES POISSONS.

595

très-remarquables par leurs formes; et, cepen- enfin lo corps et la queue très-aplatis dans dant on n’a éncore détermiue leurs caractères sens de leur Jargeur.

distinctif́s que d'une manière vagiue. On a laissé . Nous avons retranché de leur genre, et placé dans le geare qu'ils composent, des poissons qui, malgré leurs grands rapports avee ces chétodons, doivent cependant en être écartés dans une distribution véritablement méthodique et réguliêre; et on a mème placé, parmi ces animaux, des espèces qui présentent des traits opposés à ceux que l'on indique cormme devant servir à caractériser ces thoracins.

Il est résulté de cette néuligence, non-seulement une confusion que l'on ne doit plus laisser subsister en histoire naturelle, mais encore de grandes diffeultés poùr reconnaitre le génr et pour séparer avec netteté les espéces I une đe l'autre. Cés difficultès on été d'ailleursd'autant plus embarrassantes, que le groupe forme par les vrais chétodons est tres-nombreux.

Nous avons done cru devoir chercher avee beaucoup dé soin à rectifier la nomenclature et par conséquent la distribution des chétndons, et des poissons que l'on avait mètés á tort ave ees animaux, comme nous avons táché de rec tifier Yarrangement et les dénominations des labres, des spares, dessciènés, des persèques et d'autres osseax voisins de cés deeniers. Nous avons eu recours, pour la réforme de l'ordre établi parmi les chétodons, aux moyes que nous avons employés pour distribuer convenablement les persêques, les holocentres, les sciènes, les bodias; les spares, lés Inbres, ete, et voici le résultat de notre travail ce sujet.

Le mot chétodon' désignant des dents plus ou moins détiées et semblables a des soies ou poils flexibles, mobiles et élastiques, j'ai eru ne -devoir laisser dans le gènre, des véritables chétodons, que les poissons qui offraient ce caractère remarquable et facile a saisir, et qui montraient de plus on museau au moins un peu avancé, une ouverture très-etroite á leur bouche, de petites écailles sur une ou plusieurs de leurs nageoires, ou un corps tres-élevé, et -Ce poisson ne differe pas siécifiquement de cèluí qui eat

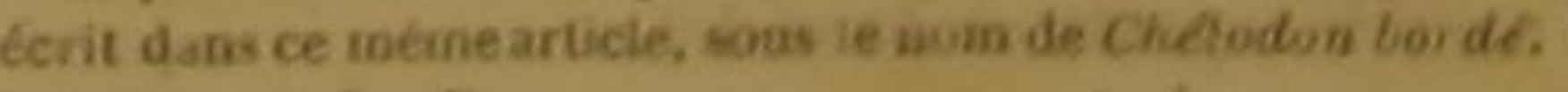

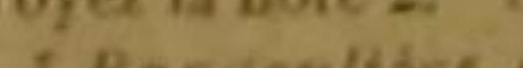

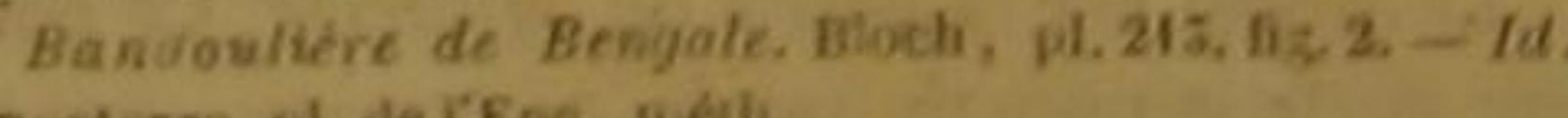

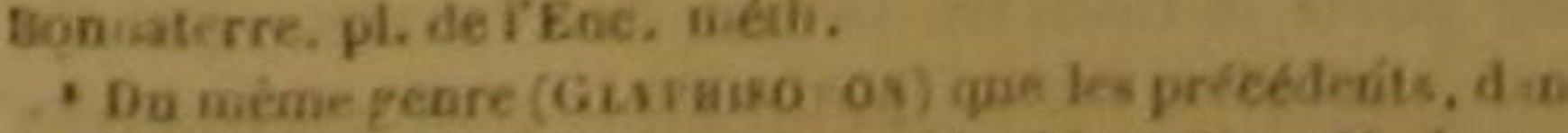

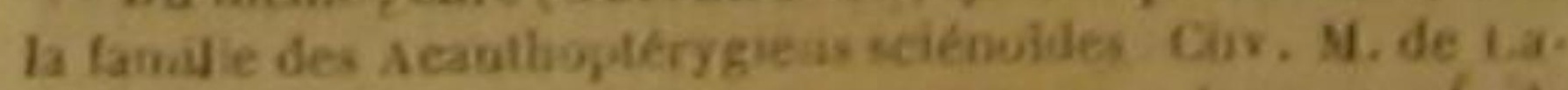

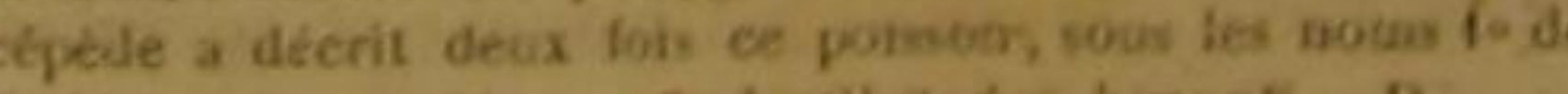
tChoile, en srec, sigrofie des poils ow soiles.
Premièrement, les poissons qui different de ces véritables chetodons par des aiguillons entierement ou presque entièrement dénués de membrané, et placés isolément an-devant de is nageoire du dos; nous les avous nommés Acan thinions;

Secondement, ceux qui ont reçu deux nageoi. res dorsales, et que nous appellerons Chętodip. teres

Troisièmement, ceux dont I'opercule est dengénérique sera Pomacentre;

Ouatrièmement, ceux que nous appelons Pómadasys, dont le dos est garni de deux uageoires, et l'opereule dentelé :

Cinquièmemènt, ceux qui ont leurs opercules armés de piquants, et que nous distínguons par la dénomination de Pomacanthes ;

Sixiemement, ceux dont les opercules dentelés sout aussi hérissés de pointes ou aiguillons, et que le nom d'llolacanthes distinguera; Et septiemement, ceux qui ont une dente lure, des aiguillons, deux nageoires du dos, et

Les espèces renfermées dans les sept genres que nous verions de désignex, ont d'ailleurs des dents sétacees comme les especes pour lesquelles nons avons réservé le nom générique de Chetodon. Mais nous avons séparé de nos chétodons. par des motifs bien plus grands, les Glyphisodons, qui ont les dents crénelées; les Acarithures, dont les cotés de la queue sont armés d'un ou de plusicurs aiguillons, dont les dents n'ont pas la flexibilite et la mobilité des poils ou des soles; les Aspisures, dont une sorte de bouclier revêt les cotés de la queue; et les Acanthopodes, dont les nagegires thoracínes ne sont composées que d'une ou dè deux épines.

Nous avons done réparti en douze genres lés thoracins que l'on n'ayait encore inscrits que dans un ou deux genres, et que Ion n'avait nommés que Caélodons ou Acanthures.

Le genre-auquel nous ayous conservé exclusivement te nom de Chelodon, reuferme cepan. daot quarante especes.

Quels sont les traits qui leur appartiennent? telé, qui n'ont qu'une dorsale, et dont le nom auxquels le nom d'Énoploses appartiendra. Nous venons d'indiquer la graude compres. 
sion de leur corps et de leur queue, les tégu- | auprès de Vérone, ou l'on a découvert, sous les ments éeailleux deleurs nageoires, la petitessede couches de lave du mont Bolen, dous les leur bouche, la nature de leursdents. Cesdents, quelquefois disposées sur une seule rangée, le plus souvent composent plusieurs rangs trèsserrés. Les opercules sont tantôt couverts et tantòt dénửes décailles semblablesà celles du dos. Ges dernières, arrondies ou rhomboìdales, grandes ou petites, sont unies ou ciliéés, ou dentelées dans leur circonférence. Nous verrons, dans un de nos Discours généraux, ce quie l'on doit principalement observer dans la conformation intérieure de nos chétodons : mais disons que leurs couleurs sont presque toujours brilantes et contrastées; que l'or, l'argent, le rouge, le bleu, le beau noir, le blane de lait sont répandus avec éclat sur leur surface, en raies longitudinales, en bandes transversales peu nombreuses ou très-multipliées, en lignes courbées en différents séns, en rubans déployés particuliêrement sur l'œil ou sur l'opercule, en taches larges et irrégulières, en taches régulières et moins étendues, en taches rondes, colorées et bordées de manière à imiter une pronelle entouréc de son iris.

De si beaux assortiments charment $d$ autant plus les yeux, que les chétódons nagent aveć vitesse. Leur queue n'est pas longue, mais elle est très-haute; et d'ailleurs étant terminée par une large nageoire, elle peut frapper l'eau avec force, et communiquer a l'ahimal des mouvements rapides.

Cette vivacité dans les évolutions des chétodons, n'est cependant pas la seule cause qui ajoute à l'agrément de leur parure. Leursécailles out une surface très-polie; 'et ils n'habitent que dans des eaux assez voisinés de l'équateur, que qu'ils ne puissent s'approclier des rivages, ou de la surface des mers, qu'en réfléchissant un très-grand nombre de rayous lumineux.

On n'a rencontré, en effet, de chetodons vivants que sous la zone torride, ou á une distance très-petite des tropiques', soit dams l'ancien, soit dans le nouveau continent; et voilá pourquoi ces animaux ne sont conuus que depuis la decouverte du Nouveau-Monde et l'arrivée des Portugais dans les Grandes-Indes ; et néanmoins il n'est presque aureune contree ou l'on u'ait trouvé des poissons fossiles ou des empreintes de poissons, et ou l'on n'ait vu des restes ou des images de quelque espèce dé véritable chétodon. Ce fait, digne de l'attention des géologues, a été particulièrement véritié trés-bien co Ia Grandes-Indes, ou dans celle d'Arabie.

Nous avons done une grande raison de plus, de déterminer avec précision les caractères dis. tinctifs des espèces de chétodons. Parcourons ces caractères, et exposons ceux que nous n'avons pas décrits dàns le tableau générique qui
précède cet article.

Le bordé n’a de rayons aiguillonnés quu’a la nageoire dorsale. Toutes les nageoires se terminent en pointe très-avancée. Les thoracines sont de plus en forme de faux. La partie de la dorsale qui n'est soutenue que pardes rayons articulés, est presque entièrement semblableà celle de l'anus par sa figure et par ses dimensions; et elle présente l'image d'une sorte de fer de lance. Les écailles sont grandes. L'anus est trèsapproché de la caudale. Le tour des yeux est ovale, au lieu d'ètre rond. On ne voit qu'u orifice à chaque narine. La couleur générale est jaunâtre, et relevée par sept ou huit bandes transversales brunes, et placées de chaque côté sur la téte, le corps, la queue, ou la caudale. Ce sont ces bandes transversales et des bandes analogues observées sur plusieurs chétodons, qui ont fait donner à ces poissons le nom de Bandoulière.

Le bordé ne parvient ordinairement qu'à la longueur de deux ou trois décimètres. Il se plai dans lés endroits pierreux, et auprès des embouchures des rivières. II se nourrit de trèspetits poissons; et sa chair est agréable au goút. Le chétodon curaçao tire son nom de l'ile de Curaçao, dont il habite les environs. Sa chair est grasse et de bon goùt. Il a de petites écailles sur la tête, les opercules, la base de la dorsale, de la caudale, et de la nageoire de l'anus. La ligne latérale est interrompue; l'iris blane, bordé de jaune; et la couleur générale, d'un bleu mélé d'argenté et de violet.

Le Brèsil est la patrie du Maurice. Ce poisson porte le nom du prince de Nassau, qui I'a fait connaitre. II a quelquefois sept décimetres de fongueur. Sa chair est blanche et agrẻable au goùt. Il a le corps et la queue plus allongés qu'un très-grand nombre d'antres chétoôngés la mer du Japon, que lon ne péche que dans dans la mer qui baigne les Antilles. II y vit

DES POISSONS.

ies thoracinès jaunes; les pectorales d un bleu foncé, et les autres nageoires d'un bleu clair mêlẻ de rouge à leur base.

Le bengali, doit le nom indique l'habitation, montre de petites écailles sur la téte, les opercules, la base de l'anale, de la caudale et de la nageoire du dos; une ligne latérale interrompue; un brun mélé de bleu sur le bord des nageoires; et un jaune foncé sur la base de ces organes de mouvement '.

\section{LE CHÉTODON FAUCHEUR ?}

Ephippus falcatus, Cus.; Chatódon punctatus, Lion Gmel.; Chætodon falcatus, Lao. ',

Le Cheliodon Rundelle i, Giyuhisodon ..... Cur.; Chrotodon rotundes. Liun., Gmel.; Chatodon rotundates, Lac, ,- -

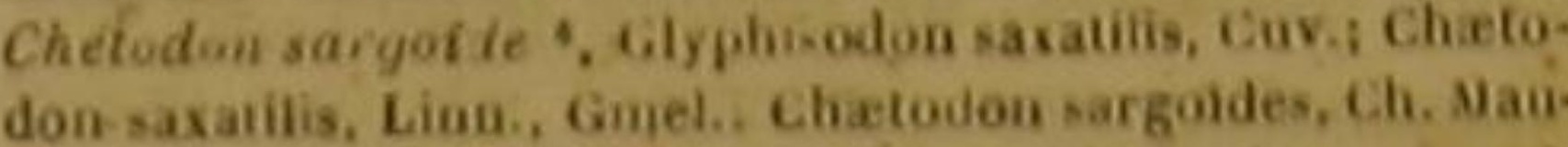
ricii, et Ch marsiuasus, Lacep. 1, - Chetodon coin nu"

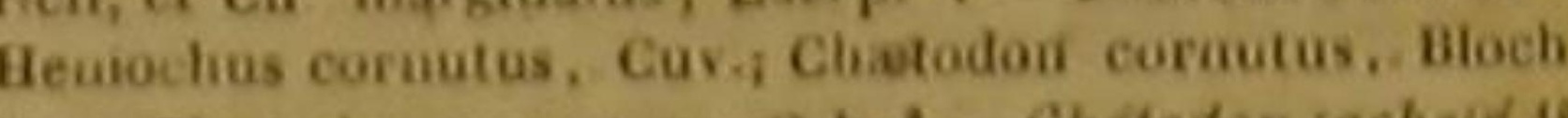

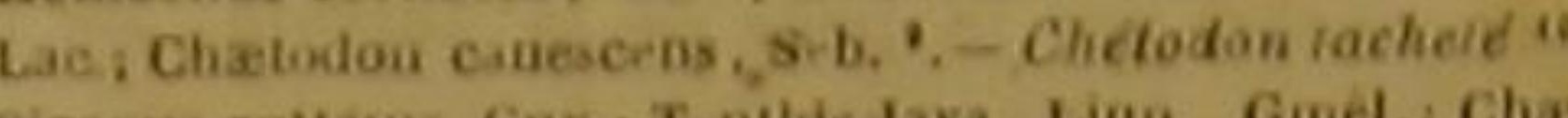
siganus guttaius. Cuv ; T. uthis Java, Lian, Gme., Cha Chatodon uni-maculates, Bloch, Cuv.. Chetodoo uigro maculatus, Lac, ", - Cheledon souffet ", Cheimon longirostris, Cur.j Chxtodon longirostris, Brouss., Lim. Gmel, Lac. ", - Cheiodon cannele ", Chetodon caualculatos, Lac, ". - Chelodon pentacanthe, Fitas penta canthus, Cave; Chatoson orbicalaris. lina, et Acumbinion orbicalaris, Lacep. "...-Chétodo lina, et Acumihioton orbicularis, Lacep,
allonge, Chastodou elougatus, Lic. "."

On trouve en Asie le Faucheur, dont les yeux sont grands et rouges; et dans L'Ámérique mò

I 12 rayons a chaque pectorale da chétodon bordé, $20 \mathrm{a} \mathrm{b}$ nagepoire de la queue, -12 rayons a chaqué pectorale do chélodon enraçao, frayon aiguillonne el 5 rayons atucukes a cha jue thoracine, 6 rayons a la cadale. - IA rayons chaque pectorale du chétodon maurice, 6 a chasque thora cine, 18 a la nageojre de la quarue. - 4 rayons a ia menrale, 6 a ch ugue thoracine, is a la cauda "Chétodon faucheur, Daubenton et Haay, Eno, méth. fd. Bonnaterre: pl. de l' Koć, méth.

'Du soll-genre CAvsuer, Ephippus. dans le grand genro D. Acanthoptérygiens squamipenues, selon is. Cuvier. D.

¿ Chatodon rotundatus cinereus, etc. a Mus. Ad. Frid 1

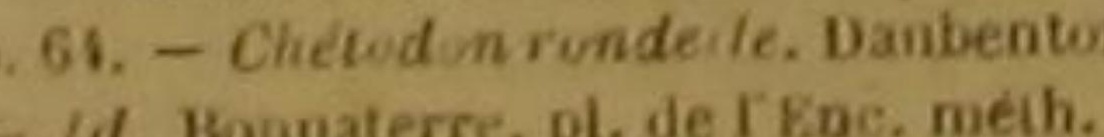

s. cuvier croit pouvoir rapporter ce poisson an gen LyP ws sopos, dans la famille des Acanthoptérygiens sciéno dirs. D.

Cyargns sobrotundus et fosciatus. = Plumier, peintures sur velino, déja citérs.

Cuv., dans la famillé des Acanhroptéryziens scéénidds, Cuv. Ce poisson a été décrit trois

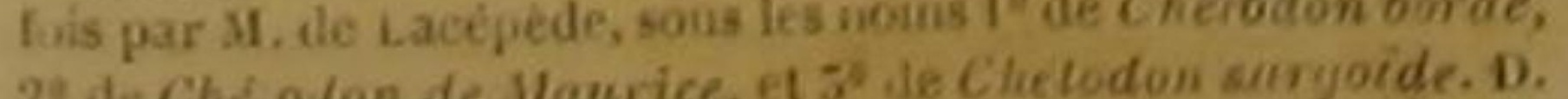
24 de Che a ton de Maurice, et $3^{\circ}$ de Chelodon suryoide.

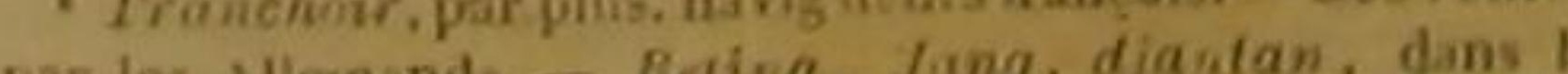
par les Allenands. - Beina, Jing. djantan, dans

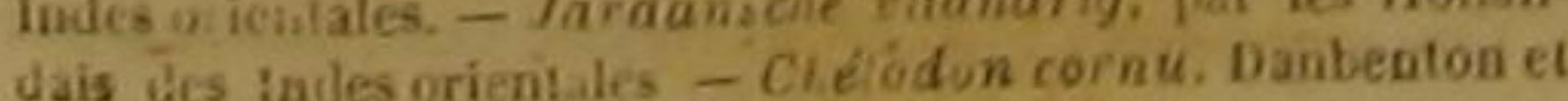

ridionale, ainsi que dans les Grandes-Indes, le chetodon rondelle, dont le nom indique sa hauteur, sa compression, et la courbure de sa ligne dorsale :.

Aucun naturaliste n'a éncore publié la des. ription du sargoide, dont Plumiera laissé un tres-beau dessin; la couleur génerale de ce poisson est d'ur jaune dore ; et on voit une tache bleue au-dessous de chaque cil.

- Le cornu tire son nom de deux aiguillons qu'il a ordinairement au-dessus dés yeux, et qui représentent deux petites cornes. Des écailles très-petites; deux rangées de dents à chaque máchoire ; les deux mảchoires également avancees: deux orifices a chaque narine; le dos très-élevé; l'opercule arrondi, et couvert, ainsi

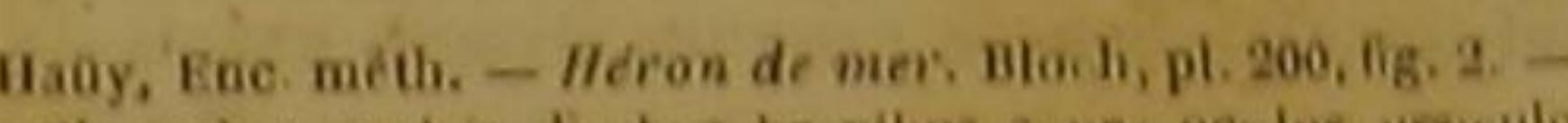
- Chaskodon aculeis diubus brevibus s. pr. ocitos, ussiento

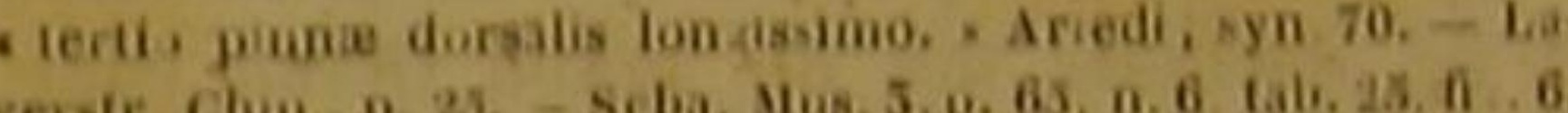

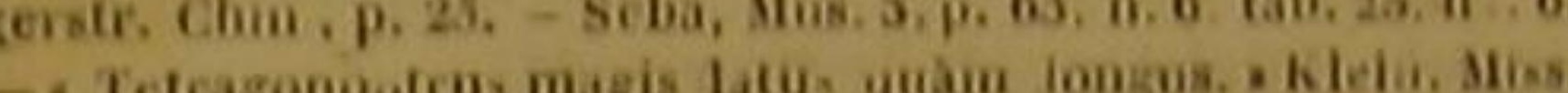

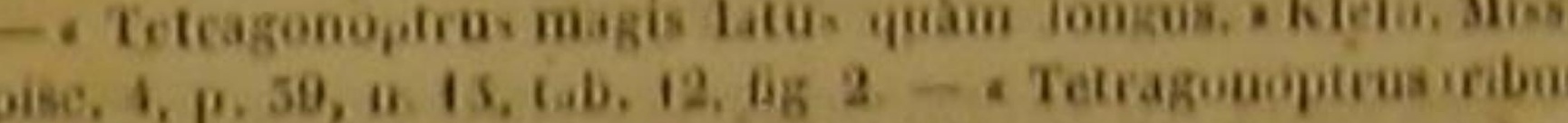

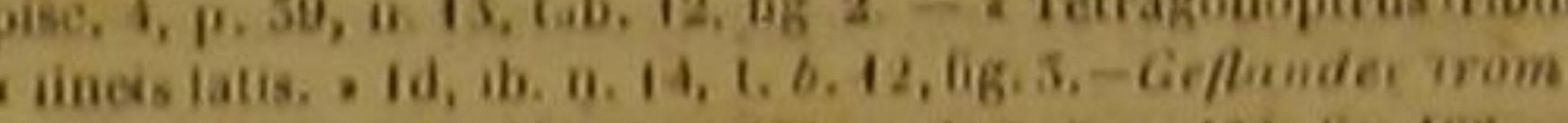

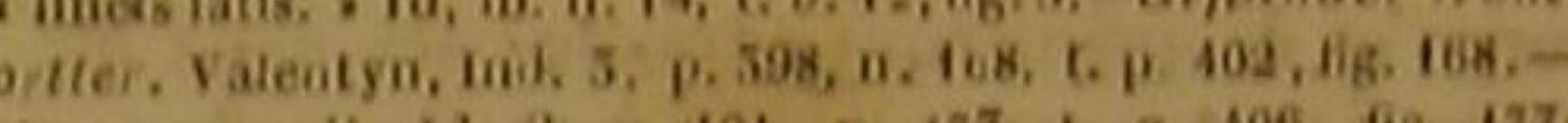
kan paroolt. Id. ib. p. 101, n. .177, L. p. 406, 18. 177 1. p. 410, n. 201, Hig. 201. - Alferes djuea. Id. Ib. p. 498,

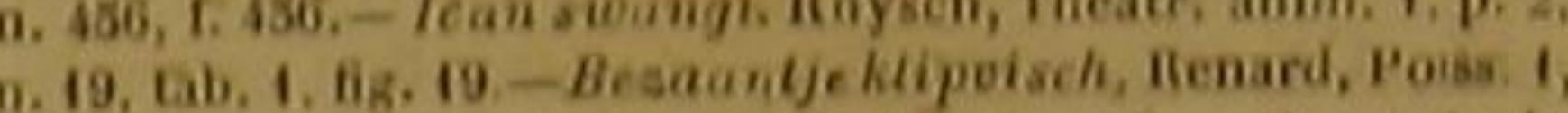

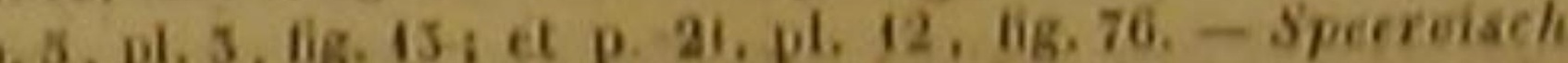
moorsche ofyodi. Id. it. 2, pli. 39 , Hig. 173 . - . Zauchos - transverse faccialus, radio pinas dura.ilis... lougisime re troducto, Comumersin, manuscrits deja citen.-. Chasedon nigro, lavo, exabido, transversim fasciatus, aculeo

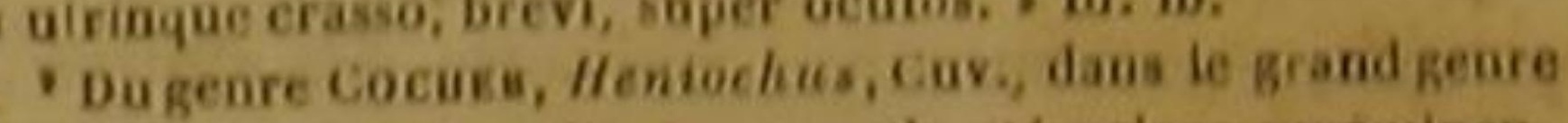
Cukтodor, de ta famille des Acanthopterygiens squàipenCиктоD
nes. D
$10 \mathrm{Ba}$

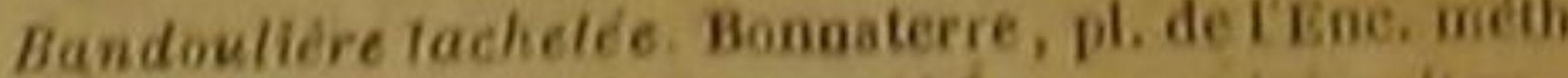

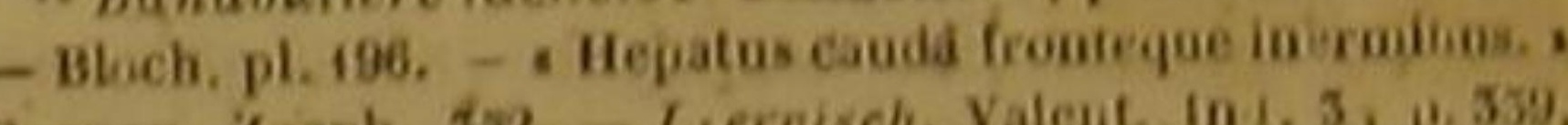
Gronov. Zooph. 352. - Leeroisch, Valcul. in 1. 3 , p. 35 ,

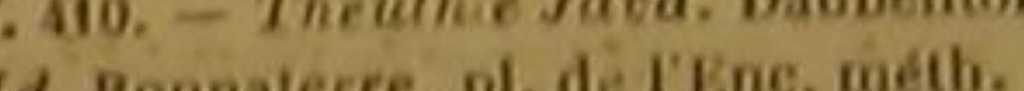

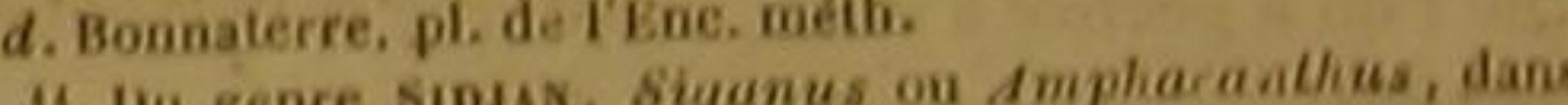

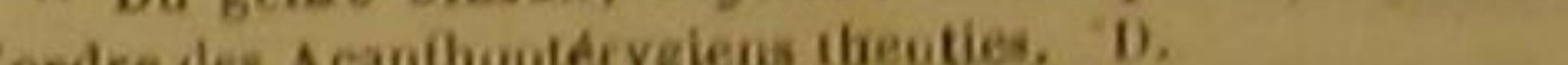
13. Chatodon unimacniatus. Handouliere a tache, , Bloch, pl. 201, fig. 1. - Chetodon tache noire, Bomaterre, pl, do i'Enc, métb. " Du soll-genre CuExồos, dans le grand geure desché"uroussonnt, Ich hyol.dec, 1, i. 6, tab.7. - Chelodon

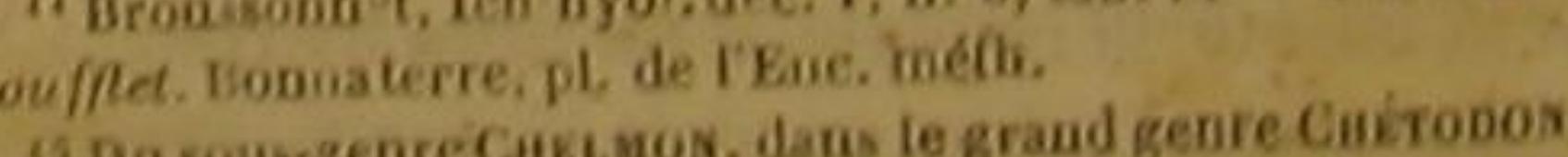
sebo H. Cavier. D. "Chatodin can

dre, L. 3, p. 55 .

16 Da soubgene PLATax, dans ie genregrand Cairobos,

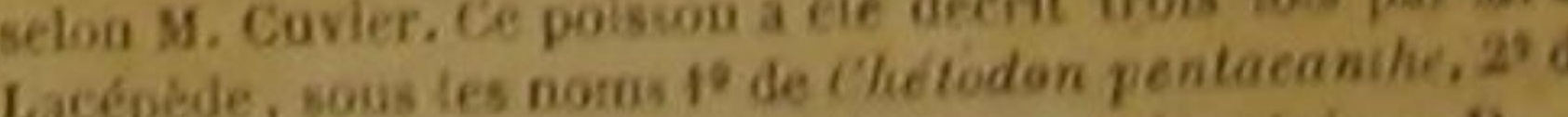
Chelodon galline, et $5^{\circ}$ of Aegnthinion urbiculair. $\mathrm{D}$. " san mentioné par 1. Cuvier. D.

- si, contre mon oginion, le fau benir et a rondeile n'oat la cavdale ni fourchive, ni en croissant, il faudra lis plaeer 
que la tête et même le museau, d'éeailles sem- raje blanche bordent l'extrémité de la dorsaie blables à celles qui revètent le corps la couleur et de la nageoire de l'anus, sur laquelle on genérale argentee; une bande transversate, yoit dailes une tache large, noire, quelquefois divisie en deix, passant au-dessus de l'œil, et s'éterrdant depuis les premiers rayons aiguillonnés de la dorsale jus- qu'aux thoracines; une seconde bande transversale, de la mèrne couleur, et quîi règne depuisl'extrémité du plus long rayon de la nageoire du dos, jusqu'au bout du rayon le plus allonge de l'anale; unc troisieme bande noire, terminee par un croissant gris, et située sur la caudale; tels sont les principaux caracteres que montre le cornu, indépendamment de ceux qui sońt jndiqués pour ce chétodon, sur le tableau de son genre, On le trouve dans les Grandes-Indes, et, suivant Commerson, sur les rivagés garnis de coraux ou de madrépores de la Nouvelle-France et de quelques iles du grand Océan- équinoxial. Sa chair est de bon goủt.

Les eaux du Japon nourrissent le tacheté. Son corps et sa queue sont allongés; ses deux màchoires également avancées; ses lèvres fortes ; celle de dessus peut-êtré un peu étendue, à la volonté de l'animal. Chaque opercule n'est comvolonté de l'animal. Chaque opercule n'est comrise.

Linnée a établi un genre particulier de poissons osseux sous le nom de Teuthis. IIl'a placé parmí ses abdominaux, à la suite des silures; et ill'a composé de deux espèces. Nous crovons devoir supprimer co genre, dont la première espèce est un véritable acanthure, ainsi qu'on le verra dans cette Histoire, et dont la seconde que l'on a pèchée à Java, n'est que le chétodon tacheté. caudale et les'pectorales sont d'un vert de mer relevé par le jaunâtre de la base de ces nageoires.

Le cannelé, que le célèbre Mungo Park a déerit dans les Acles de la Société linnéenne de Londres, et que ron a vu à Sumatra, a beaucoup de rapports avec le tacheté. Chacuu de ses opercules eśt composé de deux pièces; ses écailles sont très-petites, et sa chair est agréa. ble au goút' '.

Commerson a laissé dans-ses manuşerits des dessins du pentacanthe et de l'allongé, qu'il a observés danis le grand Océan. Le pentacanthe a le dos très-élevé, les écailles petites, serrées, et répandues non-seulement sur une grande partie de la téte, sur le corps et sur la queue, mais encore sur la base de la dorsale, de la caudale, et de la nageoire de l'anus, qui est presque triangulaire

L.a dorsale de l'allonge commence au-dessus des yeux; et ses deux mâchoires sont à pel près aussi avancées l'une que l'autre.

\section{LE CHETODON COUAGGA, Chætodon Couagga, Lae.}

\section{ET LE CHÉTODON TÉTRÅCANTHE.}

Ephippus tetracanthus, Cur.; Chætodou tetracanthus, Lac. :

Nous avons trouvé dans les dessins de Commerson ta figure de ces deux chétodons, dont

14 rayous a la membrane branchiale dù chétodon far cheur, 17. a chajpe pectorale, 1 rayou aiguillonnet et 5 rayoos ariealés schaque thoracine, 17 rayons a la niageoire de 13

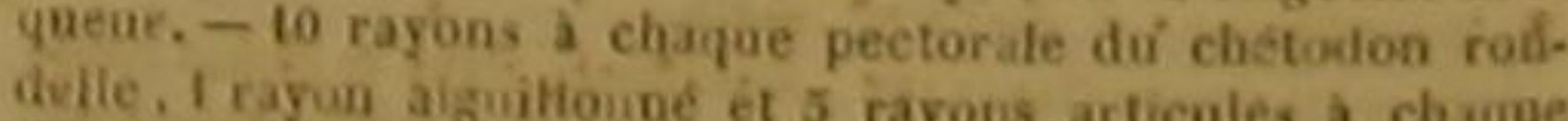

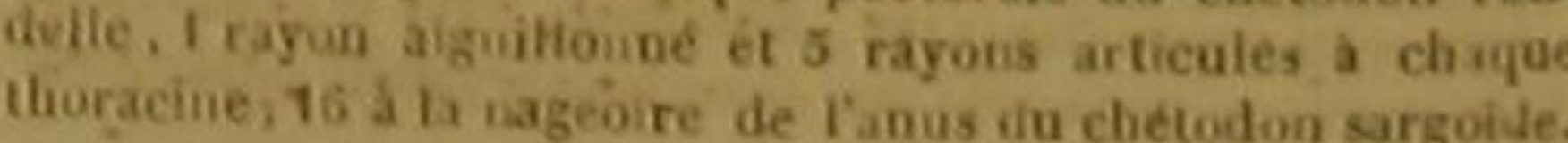

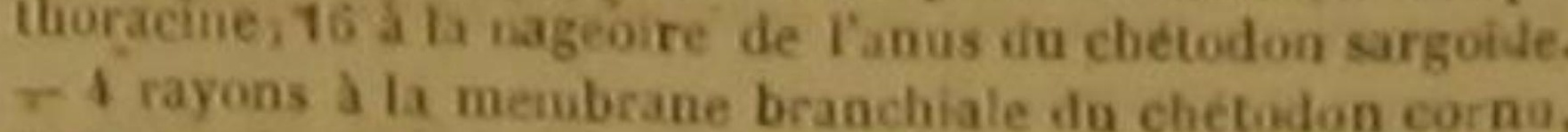

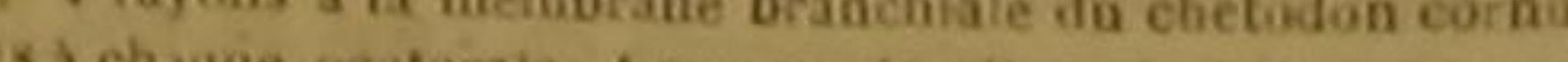
liculés a chaque thoracine 5 rayon sigmillonné et 5 rayons at articulés a ranale, 16 rayos s s i nas at-uillonnes et 29 rayon rayon-a chaque pertorale du chétodon tachere 16 a la canda.e. - trayuns al membrane braru hiale du chétndon $1^{3}$ che-noire, it a chajue pectorale, 1 rayon aiguiliumé et s rayous articulés a chaque thoracine, 15 rayonsa ia nazeoir lo is quene. -5 rayuns a la membrune brischiale da chétoravons articulés a cha pectorace, I rayon aiguiltonne et 5 rayous articu ies a cha fue thoracine. 25 a la candale. - I ciaque pectirale, 1 rayon aisuiltonné et 3 rayous arciculés a chayue thoracine, is rayous a la nageoire de la queue. Yoa meationié par $\mathrm{M}$. Cuvier.
DES POISSONS.

la description n'a pas encore été publiée par les | en disant qque fe pointu des deux Indes à le munaturalistes. Nous avons donné au premier le nom de Couagga, à cause de quelque analogie. que l'on peut remarquer entre la distribution de ses couleurs et la disposition des bandes qui ornent le couagga de l'Áfrique méridionale. Indépendamment de trois bandes dont nous venons de parler dans le supplément au tableau de son geure, on voit une tache noire sursa quene, une autre tache de la mème nuauce, mais plus petite, sur chacun des cótés de cette même partie du poisson, et une raie noire et oblique qui s'étend depuis l'œil jusque auprès de l'ouverture de la bouche. La partie inférieure de l'animal est d'une teinte beaurcoup plus claire que ses cótés et sa partie supérieure. Les ècailles qui le revetent sout très-petites.

Le tétracanthe a les deux máchoires égale ment avancées : l'opercule dénué de petites écail. les; et la partie de la dorsale, que des rayons aiguillonnés fortilient, très-arrondie et très-distinete de l'autre portion.

\section{LE CHETODON POINTU ',}

Heniochus macrolepídotus, Cuv.; Ghatodon macrolepidotus, Lino.. BI.; Lac.; Chætodon acuminatus, Linn., Lac, ?

Le Chetodon queme-Hanche', Chefodon leucurus, I.inn. Gimel. Lic. 4. - Chefodon grandedsailles, Henjoctus macrolepidotes Cuv; Chatodon macrolepidotus, Lino.

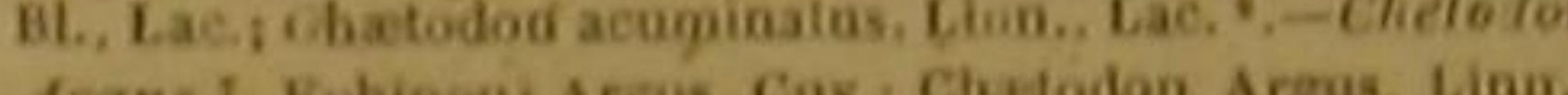
Argus ', Ephippou Arsus Cav, Chatodon Argus, Linn.
Gmel, Lac. - Chelodon ragationd ', Clioto ion vage bundus, Cuv.., Bloch, Lacep. " ". - Cheto ton Forgerinn", Chatodou Faber, Limn, Ginei, Cur., Hloch, Lacep, ', Gmèt, Lacep, ". - Chirodon a bandes is, Clisiodon fa. ciatas, Forsk, Linn., Gmel. Lac; Chetodon flaves, BI. scho."

Le tableau générique présente les principaux traits de ces chétodons : achevons leurs portraits

genre Caḱtodos, de la famille des Acantboptécygiens squamipeunes. D.

- Mns, Ad. Frid. 1. p. 65, tab. 5s, fig. 5. - Chetodon poiniu, Daubenton et Haay, Enc. méth. - Id. Bonnaterre.
jh, derEnc, méth. pl. der 'Eac, meth

- Du sous genre Cocien, Heniochus, dans le grand genre CHETodor, de la tamille des Acanthopterygiens squamipen. une simple varieté de Tesuece quíesi comprise daus ce même arciele, sous le nom de Chelodon grande eccaille. Ains $\mathrm{M}$. do Lacépede l'a decrit deux fois, 10 sois le nom de Chetedon

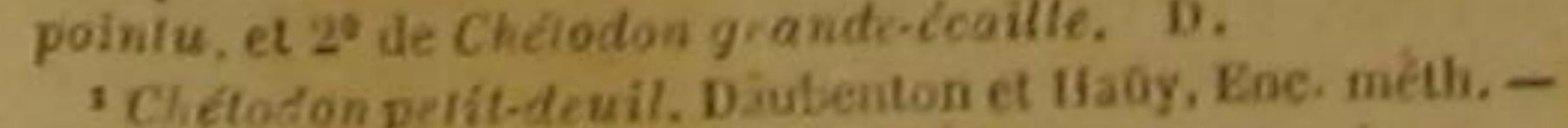
'Cl,etodon perit-deuil. Dasubenton ct1

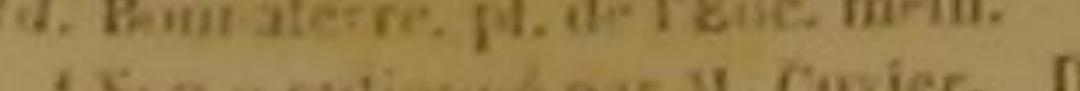

seau avancé, la couleur générale blanchảtre, et des bandes tiausversales brunes ;

Le chétodon quene-blanche d'Amérique, des dimensions très-petites, et les thoracines pointues ;

Le chétodon grande-écaille, des Indes orien-

${ }^{3}$ Tafel visch, Groote tafal fisch, Bragante Kligifisch, Moorse afgoth. Speer visch, Panpus visch, Vaandrager, nar les Hohlsadis, - lean pampis, Trieloc, ans todes Grinates. - Hoch, pl, 100, Nig. 1, - Chectodon grande-

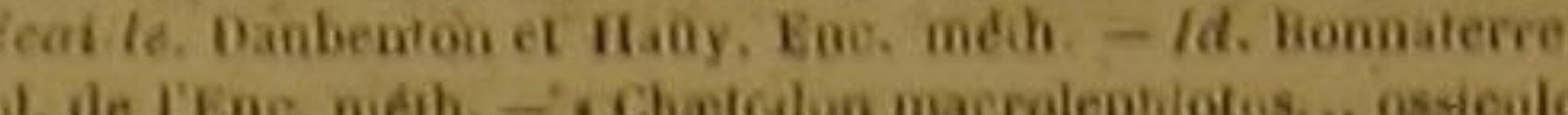
- Gronoy, Mis 2, p 2\%, n, i91; et Zooph., p. 69, n. 254. -

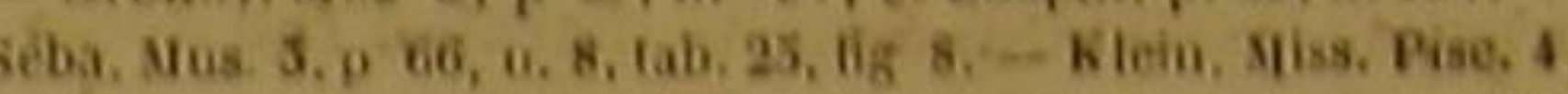

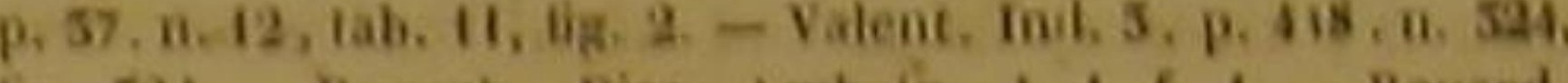

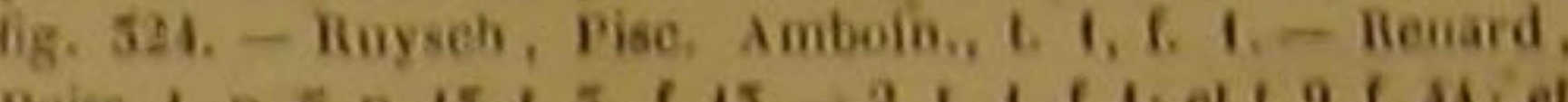

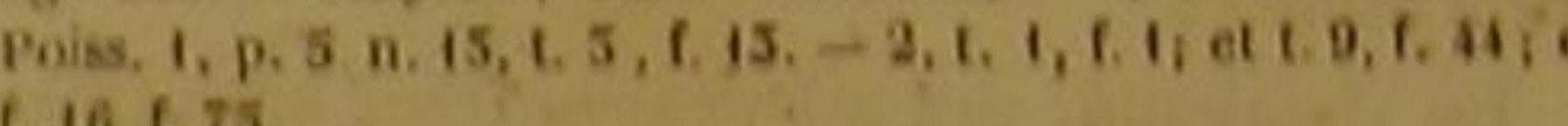

C. Mème espèton que ha première ie cet article, ou In Chíd.

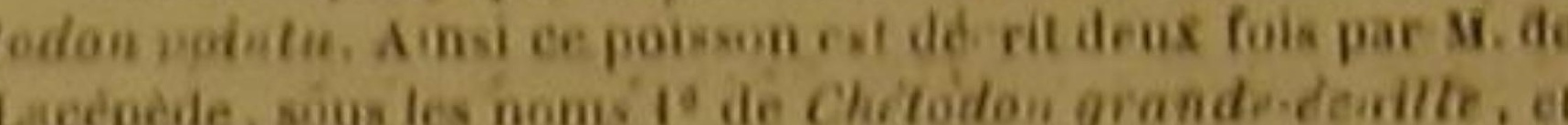

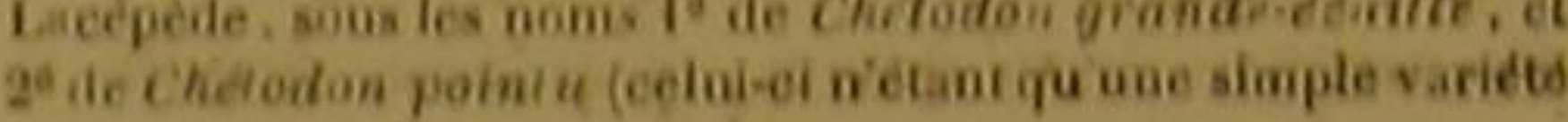
du premicer). D.

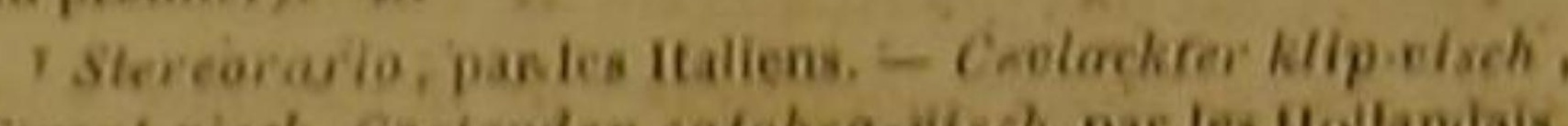
$\rightarrow$ Ican taki, Jcan foy, Cacatoetia babinang. Icau cát. hea babintang. par les ladigeuca dos Grandes-smdes. Btoch, ph. 204, fig. I, - Chetodon argus. Daubenton -

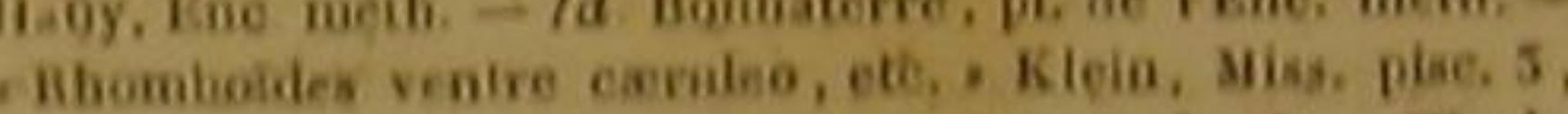

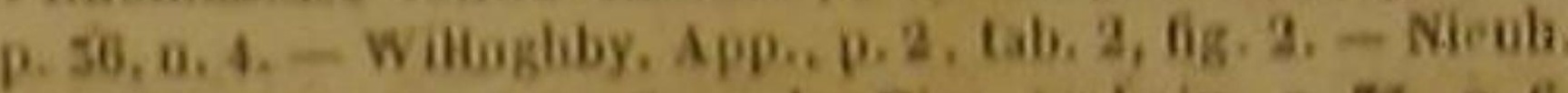
ind. 2, p. 269, Fig. 6 - Muysch, Pigc, Ambioin, p. 53, n. 6

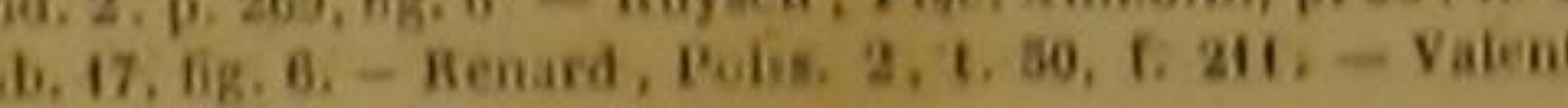
rid. 3. p. $403.0 \mathrm{lg}, 180$

- Da sous gonire Cavsues, Ephippus, dans le grand genre nes. D.

Selwaner par Ls Allemands. - Douwing prins, pae les indigenes dies Grandes-Indes. - Chetodon sown. Dasubenton of Hany, Enc. méf. - Id. Bonnatere, pl.de

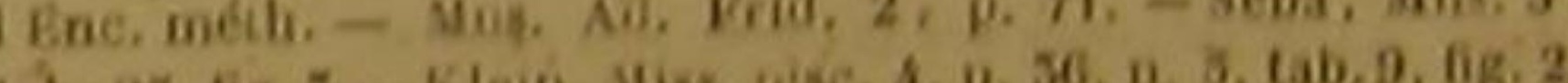

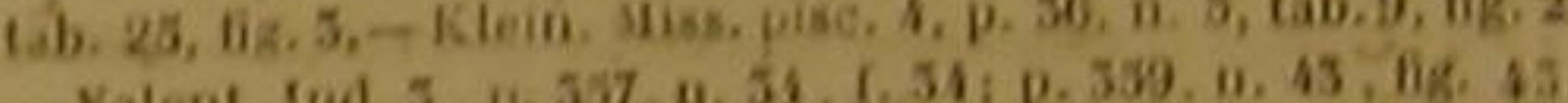

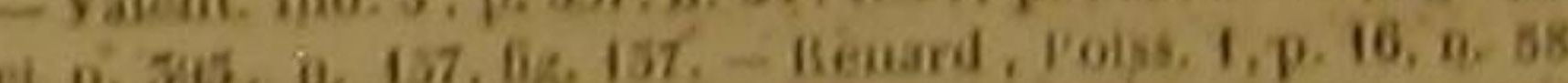

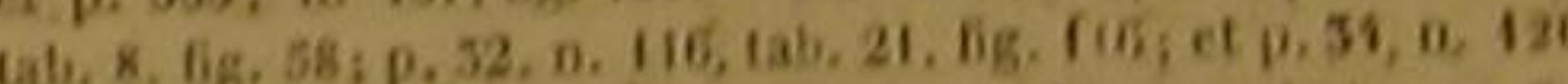

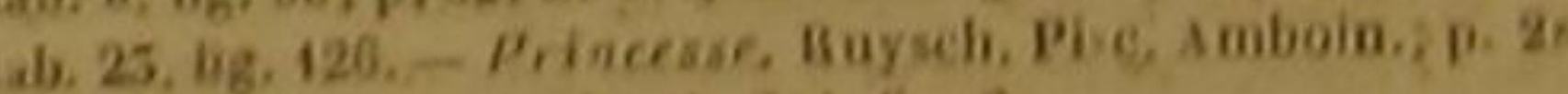
1ab. 14. 1ig. 17, - Bloch, pl. 204. ig. 2 . des Acanthopterygien ugamipenes).

1. Cherodon forgeron B och, pl, 212, Kg, 2. - Brouson-

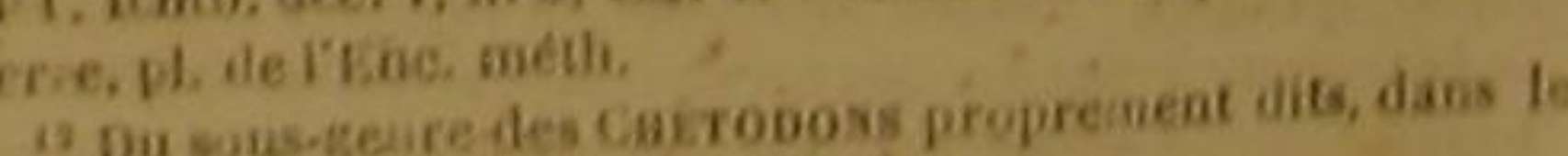

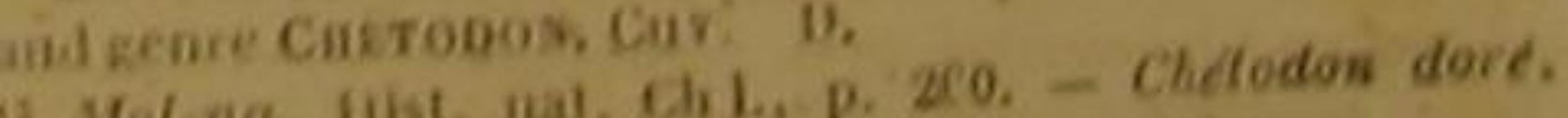

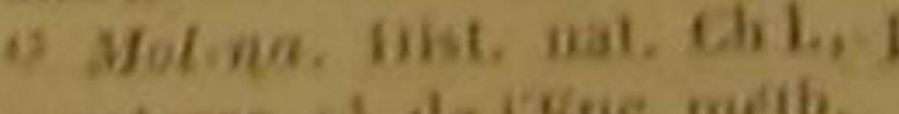

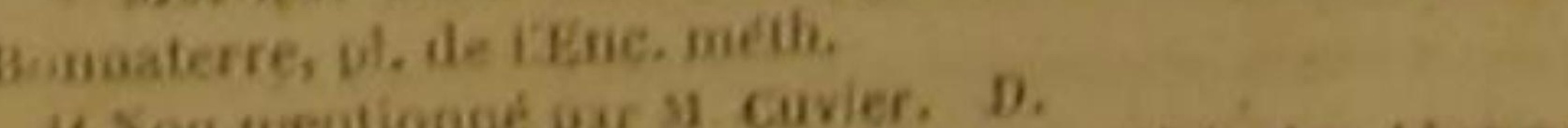

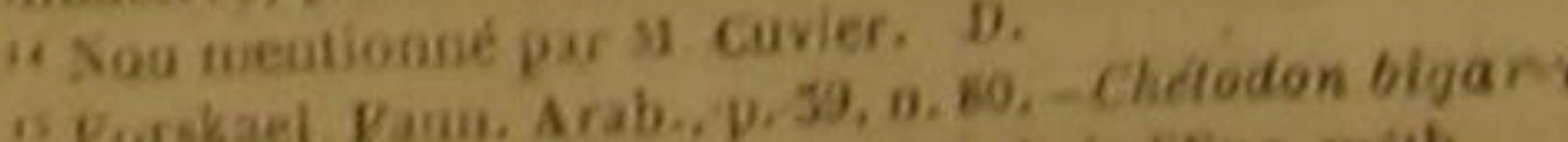
Now - Da nous-zeare des Curtoposs proprement dits, dan

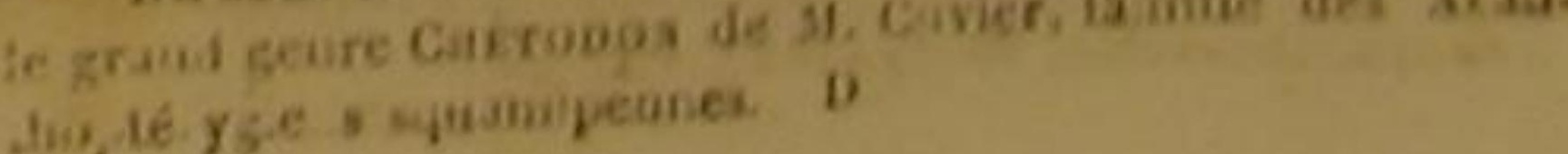

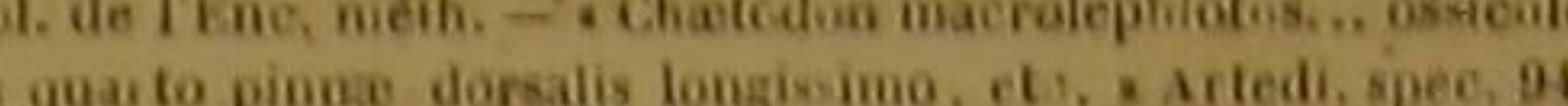
Siront-visch, Gesicrden catohra-visch, par les ilotandais.

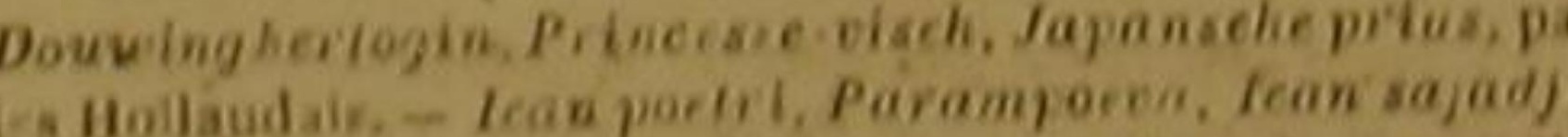


IISTOHL NATURLLL

tales, les deux mâchoires aussi avancées I'une que lautre, la tête couverte de petites écailles, la couleur generale argentine, deux bandes transversalis brunes, deux taches de la meme couleur sur la téte, la chair grasse et d'une saveur délicate qu'on a comparée à celle de la sole, et une grandeur telle que sa hauteur est très-considerable, et son poids de douze ou treize kilogrammes;

L'argus, de la partie de l'Asie voisine des tropiques; les máchoires égales, les nageoires courtes et jaunes, l'habitude de suivre les vaisseaux, et de se nourrir des restes de table qui sont jetés dans la mer, ou celle de pénétrer par les rivieres dans les marais d'eau douce, afin d y trouver un grand nombre des insectes qu'il aime ';

Le vagabond, des mèmes contrées orientales que l'argus, deux pièces a chaque opercule, une bande noire, fléchie en crochet, placée vers l'extrémité de la queue, et étendue depuis la nageoire du des jusqu'a celle de l'anus, l'extremité de ces deux nageoires et de la caudale bordée de noir, un eroissant noir sur cette mème nageoire de la queue, une chair grasse, ferme, et d'un goût agréable :

Le forgeron, qui vit dans l'Amérique méridionale, et que mon confrère, M. Broussonnet, a déerit le premier, la tête revétue de petites écailles, la couleur générale argentine, et la dorsale, la caudaleet l'anale d'un bleu fonce ${ }^{2}$, Le chêtodon chili, qui porte le nom du pays

'Liargus appartient anx eaux de la partie méridionale de CAsie, et neanmoins on a su des restes diun individu cette cspece parmi les poissons fossites du mont Bolea pres de Vérone. IChthyolithologia Veronensis, ete. Voyez, a co sujec, notre Discours sur la durée des espéces.

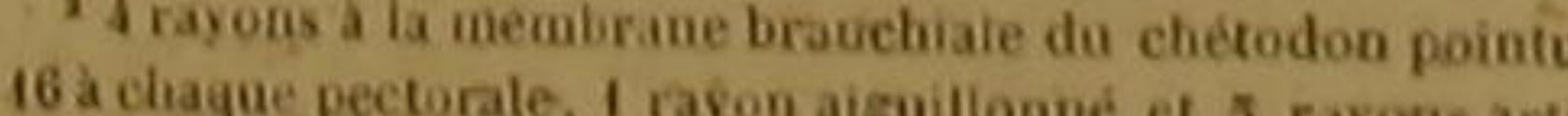
culcsa clusyue thoracine, 17 rayons a la nageoire de la quene. -10 rayons a chaque pectorale du chérodon queve-blito. che, 1 rayon aiguitlonné et 5 rayons articnlés d chaque thoracue, 26 ryons a la candale. - 16 rar ons a chaque peetorayons urienton grande-ecaille, 1 rayon aguitlonné et de la yueue, -4 rayons a la membeane branch a la nageore

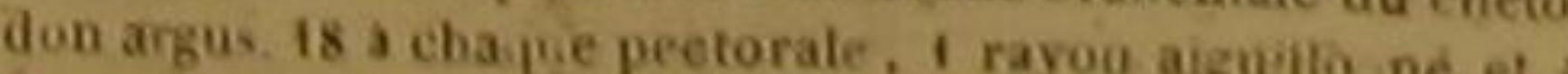
rayous articutés i chaque tharacine, 14 rayius a ta caé et - 18 rayons a chayue pectorale du chétodou vagabonis. It rayou asantonne et 5 rayous art culés d chaq ie thoracine,

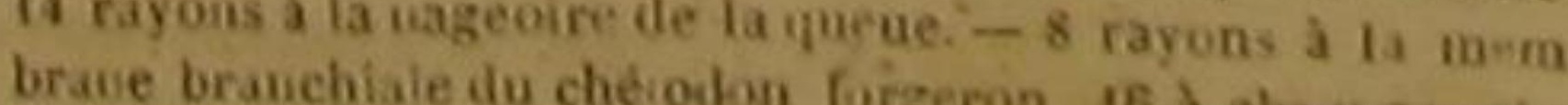

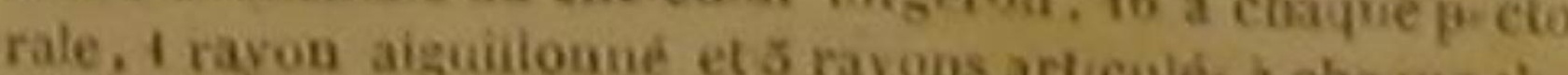

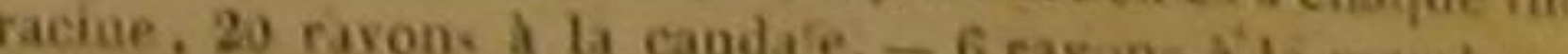
branchiale dn chétodon chiti, 2 a chajue pectirale, is is

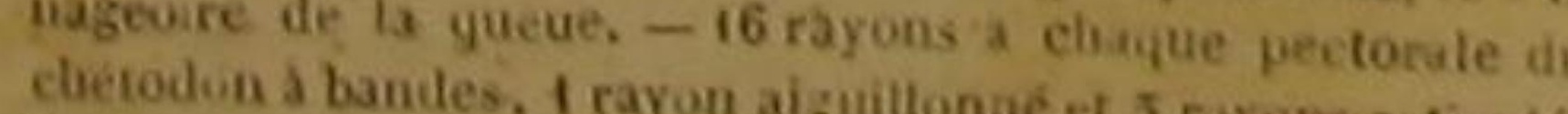

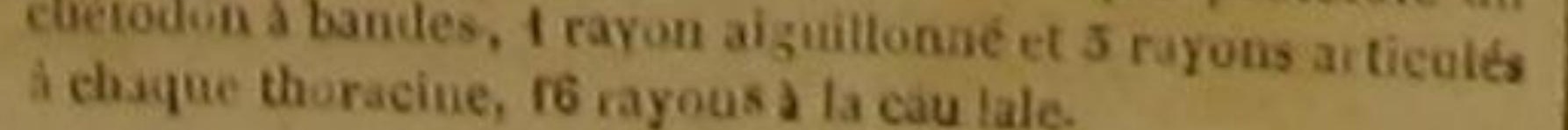

ou il a ete découvert, trois lames à chaqu opercule, des écailles très-petites, sa premiè bande noire, la seconde et la troisieme grises, la quatrieme et la ciuquième grises et noires, unetache grande, ovale et noire sur la queue, dorsale jaune, la nageoire de la queue argentée t bordee de jaune

Et enfin le chétodon a bandes, que Forskae a vu en Arabie, la lèvre supêrieure extensible la dorsale rayêe de roux, de noir, de jaunatre et de jaune, les pectorales verdatres, les thoracines jaunes, la caudale jaunàtre et chargée d'une bande brune.

\section{LE CHETODON COCHER ',}

Chætodon Auriga, Forsk, Lín , Gmel., Cuy., Lac, ,

Le Chetodon Hadjan ', Chrtodon mie ò̀tencos, Lìnn, Gm.

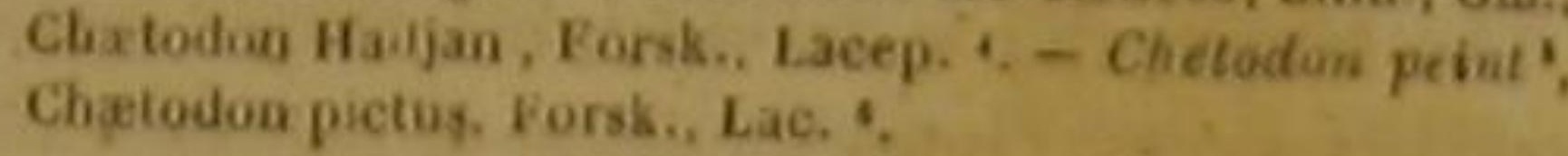
Les eaux de l'A rabie nourrissent ces troisché todons. On doit remarquer les quatre bandes transversales et rousses qui s'étendent sur lo téte du premier, la bande noire qui passe sur ses yeux, la bordure noire de l'extremité de sa dorsale, les raies blanches, jaunâtres et noires de sa nageolre de l'anus, ef les nuances rousses de sa caudale ${ }^{7}$;

La bande noirâtre qui s'étend sur l'œil de I'hadjan, la couleur verdâtre de ses pectorales, le blane de ses thoracinés, le brun de ses nageoires de fanus et du dos, ainsi que le noir de sa caudale dont l'extrềmité est tres-trans. parente ${ }^{8}$;

' Forskael, Faun. Arab., p. 60, D. 81. - Chelodon eocher. Bounatesre, pl. de IEnc. méth. (Nota. Lo nom de Coeher donné a ce chetoton vient du flament trés-long et sem-
brable a nn fonet delic, blabte a no fonet delie, que Pon voit a sa dorsale). alictoden a tergo flavas, torque nigro, fasciis albis obli"trorsum filo tos rectos concideatibus, pienàdorali re. crits déja cités. ${ }^{2}$ Da sous-geare des Cukionoss proprement dits dme le grind geure Cirtooor de la famille des A canthopterge eng squamipeutes. D.

Borkiel, Fáun. Arab., p. 61, n. 85.-Cheiodon hadjan. Bounerre, pl. Le i'Enc. meth.
'Non mentiongé par,

'Forsk-1, Fauu. Arab., p. 65, n.92. - Cheliodon ruban. Bonnatere, ph de l'Enc. $p$. hlo.

- Son meatiouné par M. Cuvier. D.

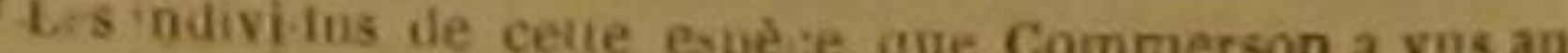
milien dis rochers de liile de France, differaient pea de ceus que Furssael a ubiervés en Arabie.

16 a chay e ve turale 1 rane branchiale du chétoilon encher. cules debayue thoracine, 17 rayons $₫$ tanne et 5 rayons arti-6 rayous a la membrase prano a la nageoire de la quene.
DES POISSONS.

Et enfin les einq bandes transversales et $\mid$ face de la mer pour pouvoir se jeter sur lui, il jaunes du chétodon peint, la bande noire, le eroissant doré et la bordure brune de sa nageoire de la queue, l'autre bande également nojre qui passe sur chaeun de ses yeux, et le noir de sa nageoire du dos.

LE CHÉTODON MUSEAU-ALLONGE'. Chelmon rostratus, Cur.; Chatodon rostratus, Linn., Gmel., Bl., Lac. '.

Ce poisson est d'autant plus beau à voir, que ses bandes et sa grande tache bordée de blanc sont placées sur un fond mélé d'or et d'argent, dont les nuances se marient avec plus de vingt raies longitudinales très-étroites et brunes, qui rendent leurs reflets encore plus brillants : mais il est encore plus curieux à observer 'lorsqu'il vit sans contrainte et sans crainte, dans les mers de l'Inde, qu'il parait préférer. Il se tient le plus souvent auprès de l'embouchure des rivieres, ou à une petite distance des rivages, et particulièrement dans les endroits où l'eau n'est pas profonde. II se nourrit d'insectes, et surtout de ceux que l'on peut trouver sur les plantes marines qui s'élèvent au-dessus de la surface de la mer. It emploie, pour les saisir, une manœuvre remarquable qui dépend de la forme très-allongée de son museau, et qu'au reste on retrouve, avee plus ou mojns de dif. férences, parmi les habitudes du spare insidiateur, du chétodon soufflet, et de quelques autres poissons dont le museau est trés-long, très-étroit, et presque cylindrique, comme celui de l'animal que nous décrivons. Lorsqu'il aperçoit un insecte dont-il désire de faire sa proie, etqu'il le voit trop haut au-dessus de la sur-

163 cha juepectorale, Irayon aiguillonné et 5 rayons articulés a chaque thoracine, 17 rayons \& la crudale. - Grayons ali membrane branchiale du chetodon peial,
torale, 1 rayon aiguilionné et 5 rayons articutes a chaque thoracine, 17 rayous a la bageoire de la queue.

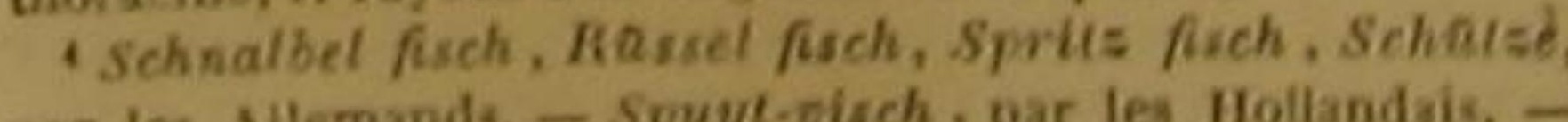
par les Alles. pas les soestois - Bandouliere à bec, Bloch. pl. 202, fig. 1. - - Chatodon rostratus, elc. , Mus. Ad. Frid. 1. p. 61. tab .35, fig. 2. - - Chxtodon., . . rostro longisr simo osseo, ete, Jron. 3rss. A, p. 48. n. 609; et Zooph. p. 69, n. 205. - Jaculator. Schioser, Act. Anglice 1765 ,

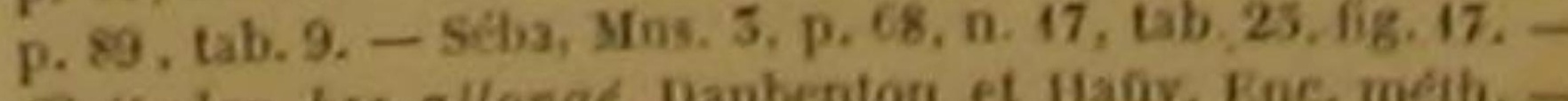
Chetodon bec allonge. Bonnaterre, pi.delEnc meth.

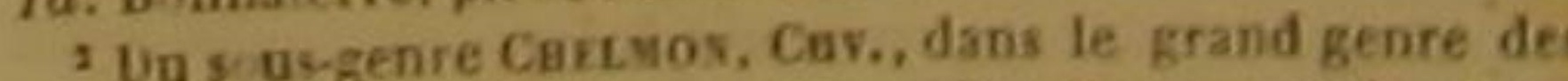
Crisodoss, famille des Acanthoptérygiens squamipennes. sen approehele plus possible; il remplitensuite a bouche deau de mer, ferme ses ouvertures branchiales, comprime avee vitesse sa petite gueule, et contraignant le fluide salé à s'échapper avec rapidité par le tube très-étroit que forme son museau, le lance quelquefois à deux mètres de distance avec tant de force, que l'inseete est étourdi, et précipité dans la mer. Cette chasse est un petit spectacle assez amusant pour que les gens riches de la plupart des iles des Indes orientales se plaisent à nourrir dans de grands vases, des chétodons à museau allongé. Bloch a cité dans son grand envrage ' M. Hommel, inspecteur des hópitaux de Batavia, qui avait fait mettre quelques uns de ces poisson's dans un vaisseau très-large et remplid'eau demer. Ilavait faitattacher une mouche sur le bord du vase, et il avait eu le plaisir de voir ces thoracins s'empresser a l'envi de s'emparer de la mouche, et ne cesser de lancer avee vitesse contre elle des gouttes d'eau qui atteimaient toujours le but. D'apres ces faits, it n'est pas surprenant que ce soit avec des insectes qu'on amorce les hameģons dont on se sert pour prendre les chétodons à museau allongé, lorsqu'on ne les péche pas avee des filets. joutons qu'ils seraient très-recherchés, quand mème ils ne seraient pas des chasseurs adroits, parce que leur chair est agréable et salubre ${ }^{2}$.

\section{LE CHETODON ORBE ${ }^{3}$}

Ephippus Orbis, Cay, , Cliatodon Orbis, Linn., Gmcl. Bi., Lacep. 4.

Le Cheitodon Zibre ", Chwtodon striatus, Cuv, Ml, Limn., Gmel:; Chatodon Zebra, Lacep. '. - Chétodon Lride', Chetodon Vespertilion ", Platax Vespertilio, Cuval Clis.

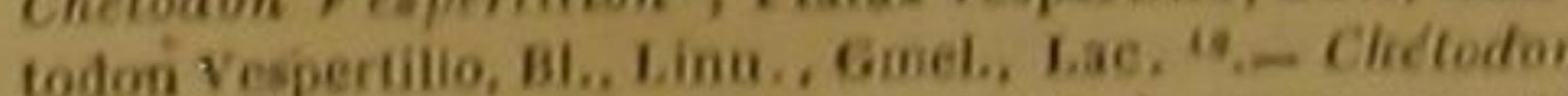
aille $"$, Chasto ion ocellatus, Cav, Bloch, Lion., Gmel. Lace, 13, - Chetodon huit-bandes", Chastodon octofas-

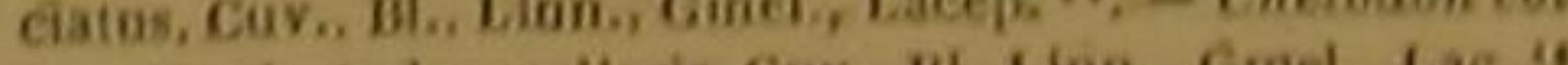

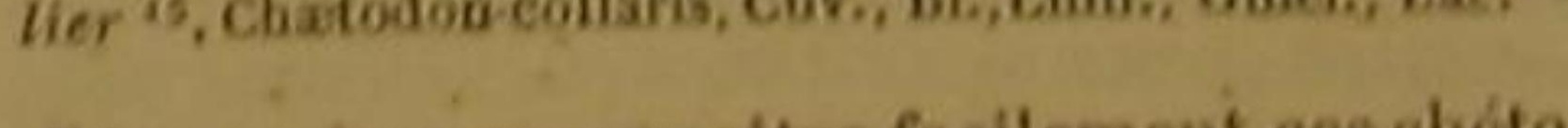

L'on poùrra reeonnaitre facilement ces cbétodons, d'après ce que nous a vons exposé de leurs formes dans te tableau générique : mais, pour - Artiele de la Bandouliere á bec.

Dranchies, 12 s claque pec. torale, 1 rayon siguillonné et $s$ rayons articules $\$$ chaque Choracine, 15 rayons a la nageoire de la quecue - Nota.Liorifiee de chaque narine est simple.
' Bloch, pl. 202, fig. 2 - Chelodon orber. Bonnatere, pl.

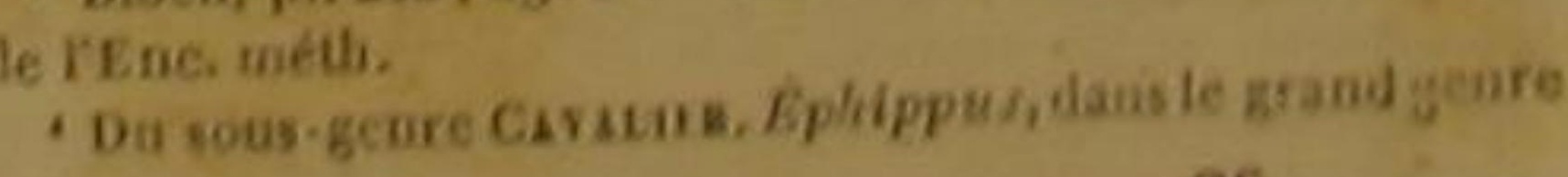


en donnèr une idée presque complète, il faut de la caudale et de l'anale, l'iris blanc et bordé que nous indiquions encore l'égale longueur des à l'intérieur de jaune, et le brun foncé ou I máchoires, la petitesse de la bouche, les noir de l'extrémité de toutes les nageoires du écailles placées au-dessus de la tête et des oper- zèbre que l'on trouve dans les Indes orientales, cules, et la couleur jaune des nageoires de que Duhamel a reçu d'Amérique, et dont la l'orbe qui appartient jux Indes orientales;

Les deux pièces de chaque opercule, les écailles distribuées sur la base de la dorsale,

CuÉrobov; de la famille des Acanthoptérysiens squamiDenines. D.

- Bandirter Blip-fisch, Strim-klippare, par les Ailemands. - Heer lykhe hlipp-visch, par les Hollandais. -

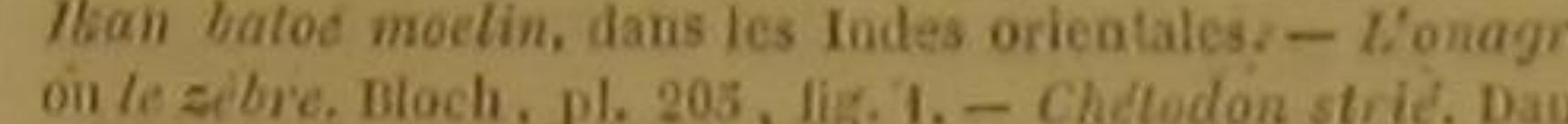
benton ot Haây, Enc, méth. - Id. Bonnaterre, p. de i'znc méth, - Mas. Ad. Frid. 1, p, 62, tab. 55, lig. 7. - a Labre "rostro reflexo, fasciis lateralibns tribas fascis., Amonit. acad, 1, p.515. - . Cha todon macroblepidotos, lineis utrin-
a que tribus nigris, latis, ete, A Areati, spec, 95, - Groriov.

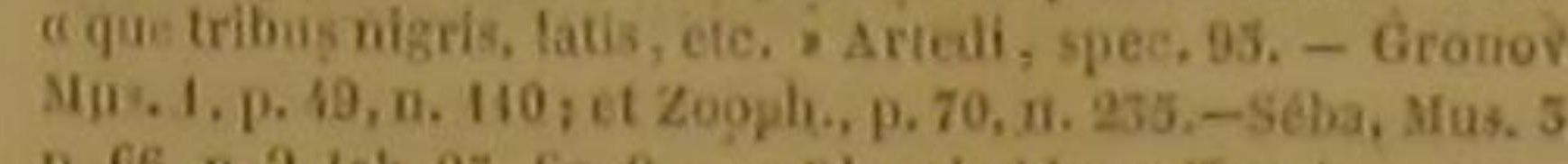

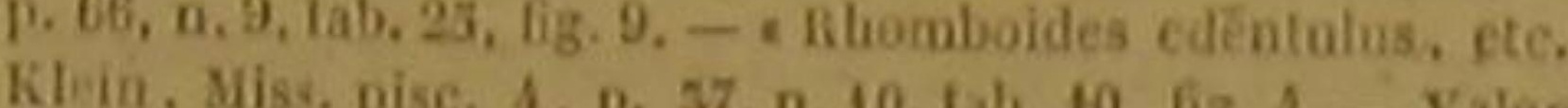
Ind. 3, p. 3.37, fig: 185

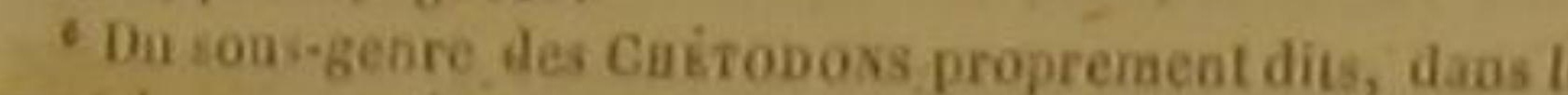
grand geare CukTonox, de la famille des Acanthoptérygiens

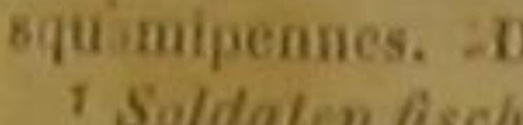

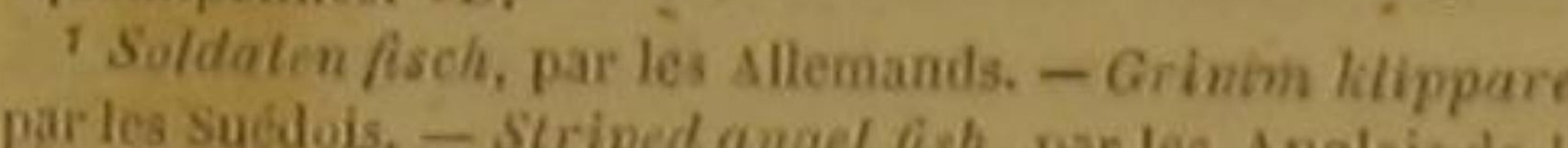
parles Sucdois, - Striped angel fish, par les Auglais de I

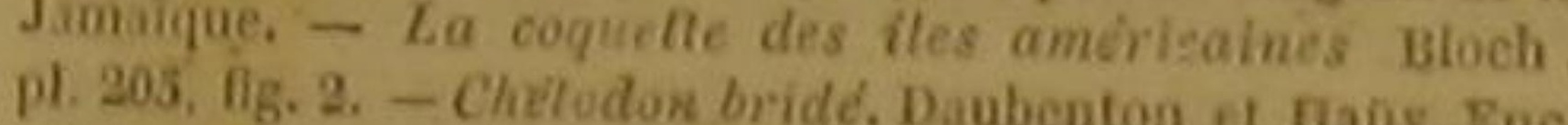
méth. -1 Id. Bonnaterre, pl. de l'Ene, méth. - Mlis. Ad.
Frid. 1 , p. 63, tab. 35 , fig. 4. - ocello porpureoiride alba. joxta candam. A Amenit, acad, p. 514. - Gronov. Mus. 2, p. 57, n. 193 ; el Zoophi, p. 70 10.207, - Séba, Mus, 5, p. 68, u. 16, 1ab. 25, fig. 16. - - Ten, 2, tab. 11, fis. 15, is:

- Da sous genre ide.

grand geare Cintodos. D - Btach, pl. 189, fig. 2. $-c$

Bonnaferre. pl. le I'Tie. - Chétodon à larges vageoires. 10. Da sous-genre Pusax, Platax, Cuv., dans le grané

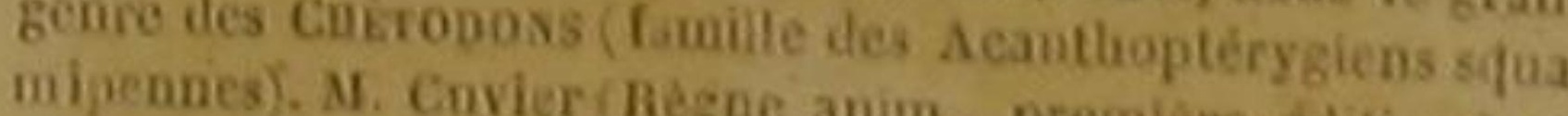
marque que le Chictodon vespertition pourrait bition) $\mathrm{ro}$ que ta femelle da Chétodon feira. 11 appule cette oping sur I'observation que l'enlumiaure de Rloch est souvent fantive pour les poissons étrangers. D.
" $L$ wil de paon.

paon. Bonnaterre, Ploch, p. 211, fig. 2.- Chétqdorit ail do

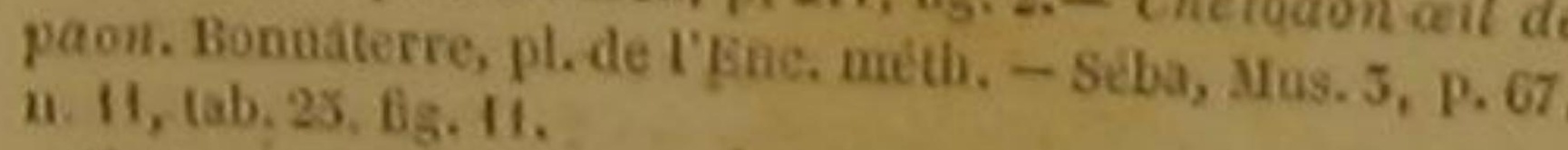

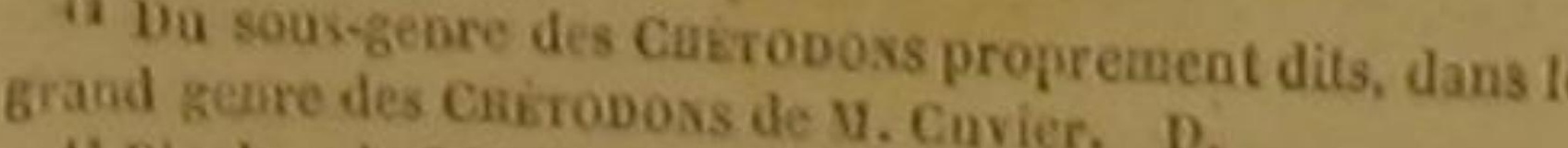
"Bloch, pl. 215, fig. 1. - Chedodon argen

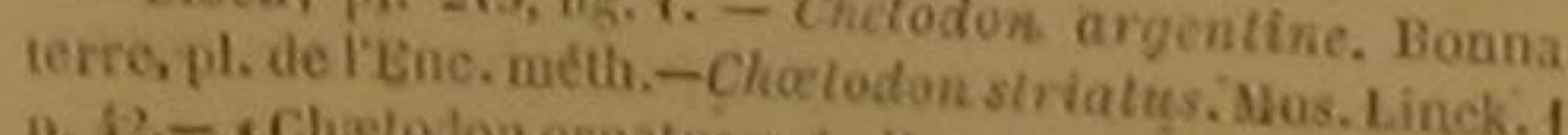

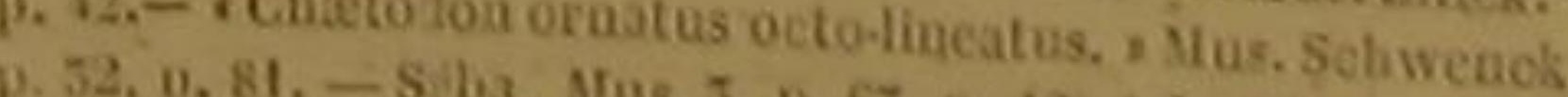

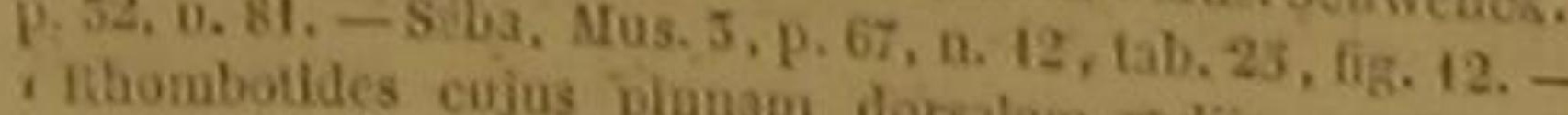
Cinermbus, etc. + Klein, Miss. pisc. 4 , p. 56 , b. 6 , tab. 9 ,
O.g. 5 . “ Du sous-genre des CuÉtonoss proprement dits, dime

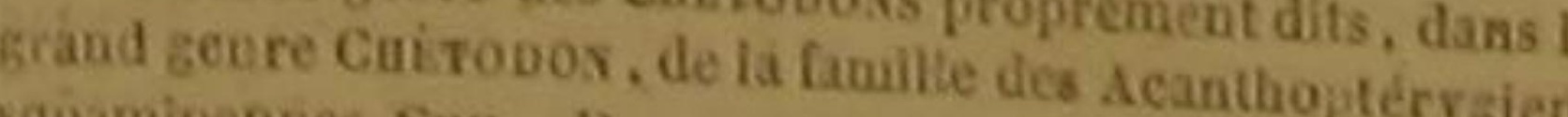
is Bloch, pir, Cur. D.

bl. de IEno. méth, - S - Chétodon collier. Bonnaterre, Ho 10 .

grand geure Cuito desor de $\mathrm{M}$. Cuvier. D.
D. chair est très-aqréable au goût; de la queue, l'extrémité noirátre de la dorsale et de l'anale, et le vert des opercules, ainsi que des rayons aiguillonmés de la nageoire du dos, des thoracines et de la nageoire de l'anus du chétodon bridé qui vit dans la mer de la Jamaĩque, dont le corps et la queue sont trèscomprimés, qui, parvenant à peine à la longueur d'un décimètre, est fréquemment la proie des poissons grands et voraces, et dont Séba, Linnée, Duhamel et Bloch nous ont transmis la figure !; queue, la base de la dorsale, de la caudale et de l'anale, et la couleur verdátre du vespertilion et dōnt on a reconnu cependant un individu parmi les poissons fossiles du mont Bolca près de Vérone²;

Les écailles de la base, et la couleur jaunâtre des nageoires dorsale, caudale et anale, la bande transversale étroite et noire que l'on voit sur la tète, et les teintes dorées et argentées du chétodou atillé des Grandes-Indes

Les écailles qui revêtent la plus grande partie des nageoires du dos, de la queue et de anus, la bordure brune de l'anale et de I

' 18 rayons a chaque pectorale du chétodou orbe, 4 rayon rayons a la nageoire dens articulés á chaque thoracioe, 16 branchiale du clétodon zébre, 10 a layons a la membran iguillonné et 5 rayons articulés a cha pue tharacine, 1 rayou rayons a ta ciudale. -8 rayons a la membrane branehine ch chetodon bride, 14 a chaque pectorale, 1 rayon aiguilloor chétedon vespeue - $\sigma$ rayons à la membrane branchiale da bonné et 5 rayons articel ca d chue pectorale, 1 rayon aiguilla candale. -5 rayons a la a chaque thoracine, 17 rayons : don aillé, 16 a chaque pectorale, 1 rayon aiguilto daétorayons articules a chaque thoracine, is ray ons à la naseoire luit-bandes, 1 rayon aiguillonné et 5 rayons articulés à cha. brane bra rale; 1 rayon aiguillotodon collier, 14 à chaque pectothozacine, 20 rayons a la nage 5 rayons articulés à claque 2 Consultez roumsage nageoire de la queue.

conte de Gazola, et qui est intitolé Ievons aux lumières do nensis, etc. Consultez aussi notre Discogral sur la durte des
La bande transversale et brune de la nageoire

L'orifice unique de chaque narine, la petitesse des écailles répandues sur. le corps, la quet on a envoyé du Japon an professeur Bloch, Ceoire de barticulés à chaque thoraeine, 16 rayons a la nade la queue. -16 rayons à chaque pectorale du chétodon dorsale, et les nuances violettes du chétodon huit-bandes, dont les - Indes orientales sont la patrie;

Et enfin le tégument écailleux d'une trèsgrande portion de la nageoire du dos, de celle de l'anus et de celle de la queue, le bleu du dos, le brun de la tête, le jaunátre de presque toutes les nageoires, lare foncé de la caudale et la bordure jaune de la dorsale du ehétodorrcollier que l'on a péché au Japon.

\section{LE CHÉTODON TEIRA ',}

Platax Teira, Cuv.; Chefodon Teira, et Chetodon Patax Teira, Cuv.; Chefodon Teira, et Chetodo
pingatus, Liono.. Gmel.; Chatodon Teira, Lac,?

Le Chetodon Surate'; Etroptus Melesgris, Cuv,i Chatodon

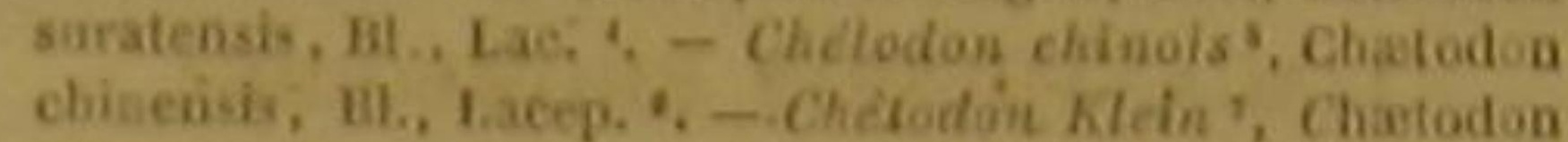

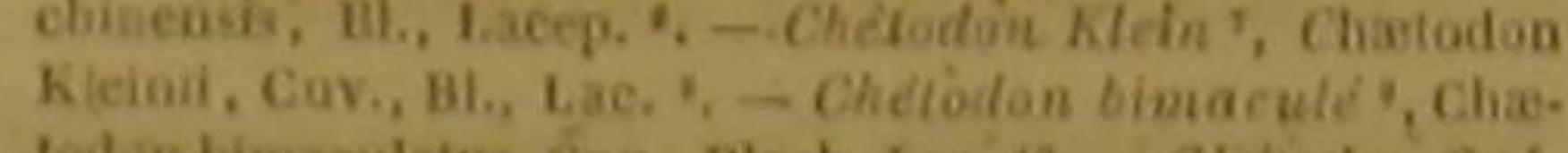

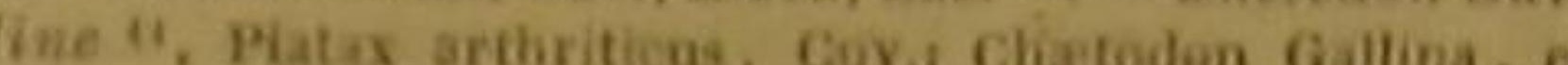

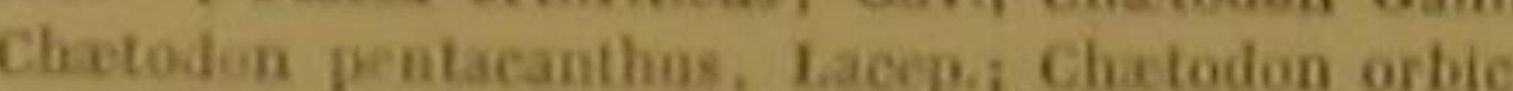
Forsk.; Acanthinion orbicalaris; Lacep, 19, - Chétodon trois-bandes ", Chatodon tritasciatus, Mugo-Park,

Le teira est nommé Daakar par leśs Arabes, lorsqu'il est grand et vieux; et e'est ce qui a fait naitre l'erreur d'un savant baturaliste qui a fait deux especes distinctes du daakar et du teira. Le teira dẹ Gmelin, et le chétodon à grandes - Schicars Rosser, par les Allemands. - Drecd.tinnige whipluch, zae dotje, prom ic bing, dans les Indes ofteotates, - Tring, in A - Man cam

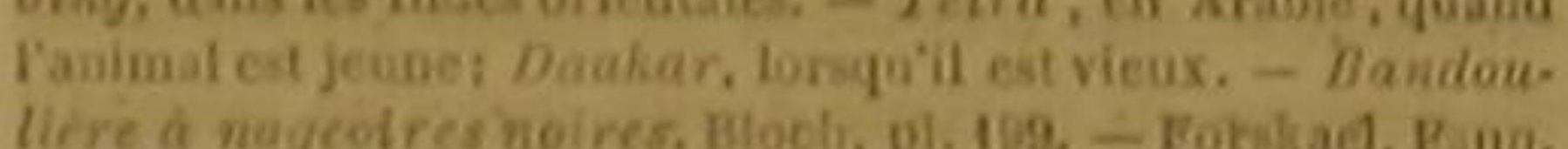

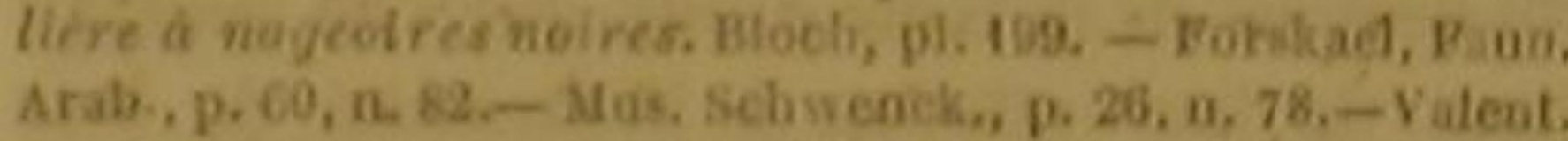

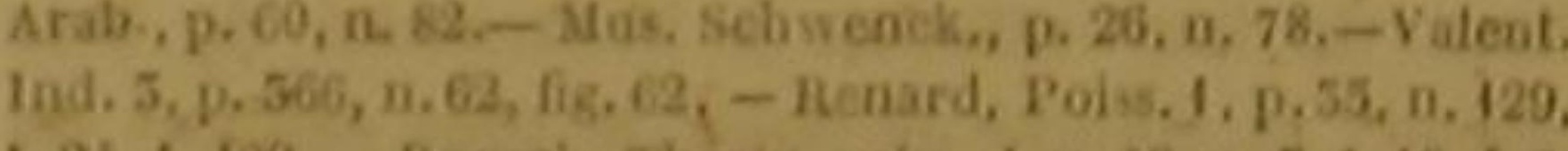

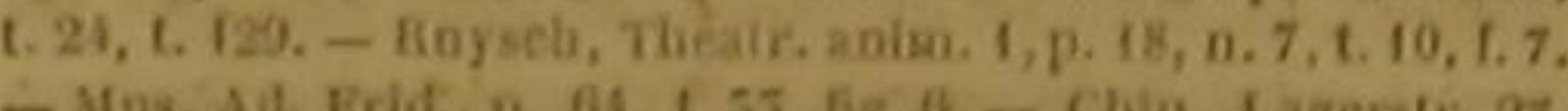

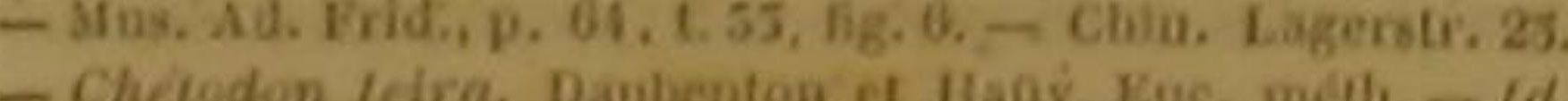
chétodon daakar. Bounat rre, pl. de l'Lne, méth. 2 Da sous-genre PLixax, Cuv., dans to grand genre des Critoposs, famille des Acanthoptérygiens squamipeanes. M. Cuvier soupconne que ce poisson cst le mále d'une espéce dont le Cheiodoa respertilion (voyez ci-avant p. 402) seciait Landoulingen

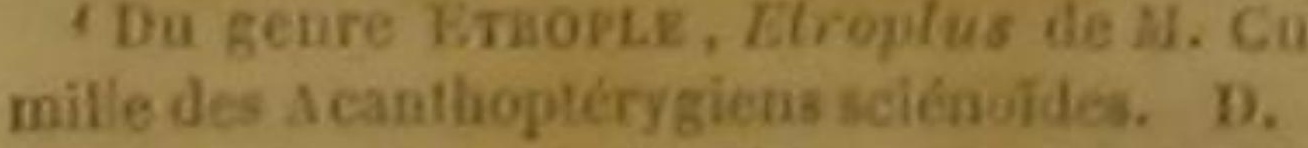

'Bandouliere de la Chine. Bloch, pil. 218 . fig. 6.

Non mentioné par M. Cuvie.

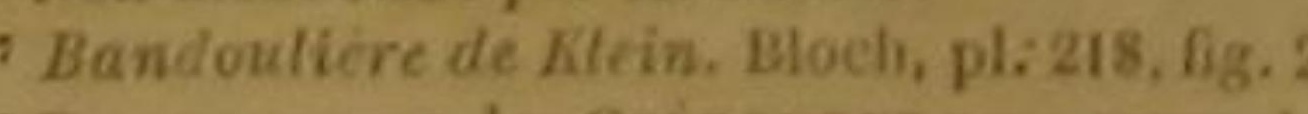

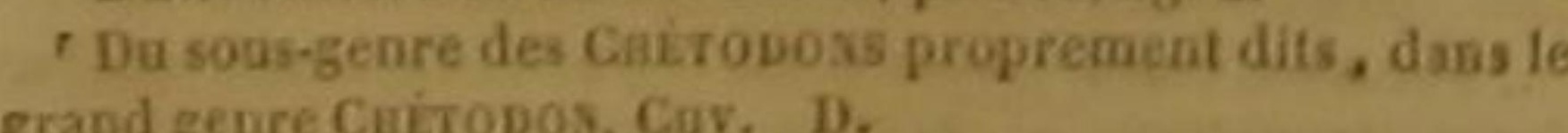

'Bandoulière á devar-taclies. Bloch, p1. 219, fig. 1.

10 Du sons genre des Caḱrodoss proprement dits, dans le

grand genre CukтoDos, Cur. D

" Poule de mer. - - Chàtodon fuscus, tenlâ poné oculos

arzenteá, superoculari nigriore. . Cominerson, masuscrits
deja cités.

da cua ciles. nageoires déerit par cet habile professeur, ne for ment noí plus qu'un mème poisson. Ce thoracin vit dans les eaux des Grandes-Indes et dans celles d'Arabie. Il y parvient, suivant Forskael, a la grandeur de plus d'un mètre et un quart; il $y$ vit des petits animaux qui construisent les coraux ou les madrépores, ou de ceux qui habitent les coquilles. Sa chair est très-bonne à manger; et on le prend non-seulement au filet, mais encore à l'hameçon.

Le corps du teîra est très-mince et très-élevé; la ligne latérale très-courbée; la couleur générale blanchátre; la caudale blanche; et la dorsale jaunătre, ainsi que le rayon aiguillonné de chaque thoracine.

M. de Gazola a vu un individu de cette espèce parmi les poissons fossiles du Véronals, qu'il a observés et déerits.

Le chétodon surate, dont la couleur générale est nuancée de blane et de violet, a une tache noire au-dessous de chaque pectorale, les thoracines noires avec le rayon aiguillonné d'un beau blane, les pectorales jaunes, et la dorsale, I'anale et la caudale variées de violet et de jaune, et revétues a leur base d'un grand nombro e petites écailles '.

Le corps et la queue du chinois sont pius allongés que ceux de presque tous les autres chétodons; chaque opercule présente une tache noirátre, ovale, et bordée de blanc; deux raies l'es-courtes et très-brunes paraissent entre l'oil et cette tache; la couleur générale est Doxs, Cuv. M. de Lacépéde a décrit ce polisson trois fois sous
les noms $1^{\circ}$ de Chétodon pentacantie, $2^{\circ}$ de Chétodon gal19 Mungo Park, Act. de La Soc. Linâ, de Londres, L. 3, p. 35. u Non mentionné par M. Cavier. D.

17 rayons a la membrane branchiale du chétodon teira. if a chaque pectorale, I rayon aiguillonoe et 8 rayon aticules a chaque thoraciue, 17 rajona a la cadale. rayons a La membrsne bracilale da chetodon surate, 10 à chaque thoracine, 16 rayons a la nageoire de la quene. 5 rayous a la membrame branchiale du chétodon chinois, 0 o chaque pectorale, 1 rayon aiguillonné et o rayons articulés i chaque thoracine, 16 rayons a ta caudale. -5 rayons a $\mathrm{L}$ membrane braschiale du chectodoa kien, is a chaque pec. Grale, 1 rayon aiguillonne et 5 rayons artieutes a chaque la memblrane tranchiale da chétodon bimacule. 14 s claque pectorale, 1 rayon aigullionné et 5 rayons articules a chaque thoracine, 17 rayons a la caudale. - 5 rayons a ta membrane uranchiale du chítodon galline, 18 rayous a chaque pectorale. 7a chaque thoracine, 16 d la nageoire de la queue. -4

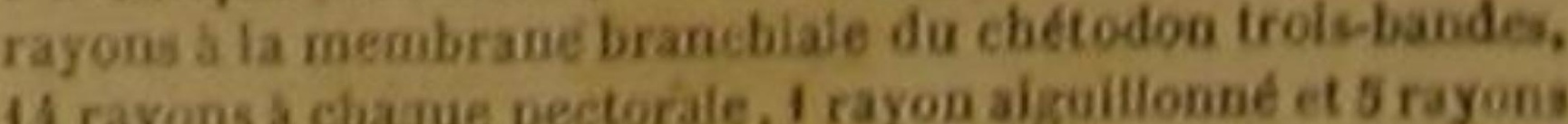
Ir rayons a chaque pectorale, 1 rayon aigaitlonne et 5 ray
articutés a chasque theracise, 16 ray ons a la caudale. 
blanchâtre; et un violet mêlé de gris et de jaune s'étend sur les nageoires.

Le klein des Indes orientales a les nageoires d'un jaune doré, et couvertes, en partie, d'écailles très-petítes.

La couleur générale du bimaculé est d'un blanc qui tire sur le gris; les pectorales et les thoracines sont rouges; les autres nageoires sont jaunes; leur extrémité est grise; et une lame triangulaire et écailleuse est située sur la base de chaque thoracine.

La galline a été observée par Commerson, quil'a vue, en septembre 1769 , dans lê marché de l'ile Manrice ou on la comptait parmi les poissons les plus agréables au goût. Sa longueur ordinaire est d'un demi-metre; la nuque est très-élevée; les dents menues, flexibles et mobiles, qui garnissent les deux mâchoires, sont très-nombreuses et placées sur plusieurs rangs; le palais est lisse; la mâchoire supérieure moins avancée que l'inférieure, mais un peu extensible. On n'aperçoit point de petites écailles sur les pièces qui composent chaque opercule; mais on en voit sur une grande partie de la surface des nageoires du dos, de la queue et de l'anus. L'intérieur de la bouche est trèsnoir.

Le célèbre Mungo Park a fait connaitre le chétodon trois-bandes. Ce poisson, de Sumatra, ne parvient ordinairement qu'à la longueur d'un déeimètre; l'ouverture de sa bouche est trèspetite; deux pièces forment chaque opercule; la ligne latérale est interrompue; ses nageoires sont jaunes; il se plait parmi les coraux.

CENT TRENTE-TROISIÈME GENRE. LES ACANTHINIONS.' Les dents petiles, pexibles et mobiles: le corps et la leurs est très-comprimé, chacun de ses cótés queue très-comprimés : de petites écailles sur la dorsale, ou sur d'autres nageoires, ou la hauteur du corps Sture eure on du moins egale à sa longueur; louverlure de la bouche pelite: le nuseau plus ou moins atance; une seule nageoire dorsale; plus de deur ués de membrane

EsPEers.

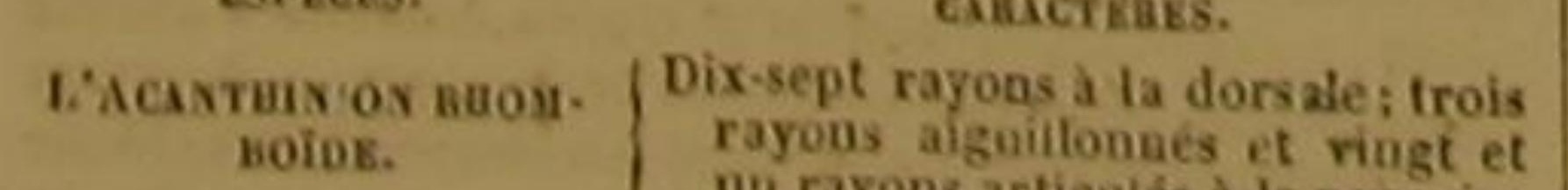

Cuvier, en adoptant le genre Tuscurote de $\mathrm{N}$ de Lreepede, en fait un simple saus-genre parmi les CEvTso-

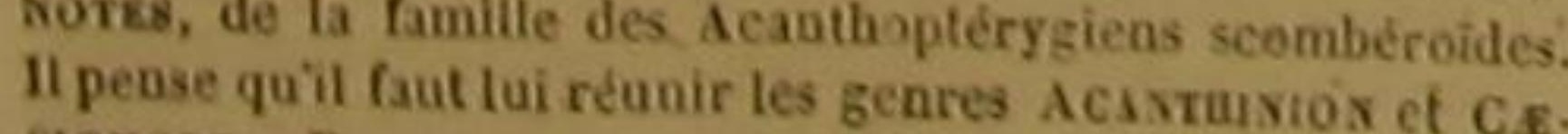
sionose. D.
ESPECKS.

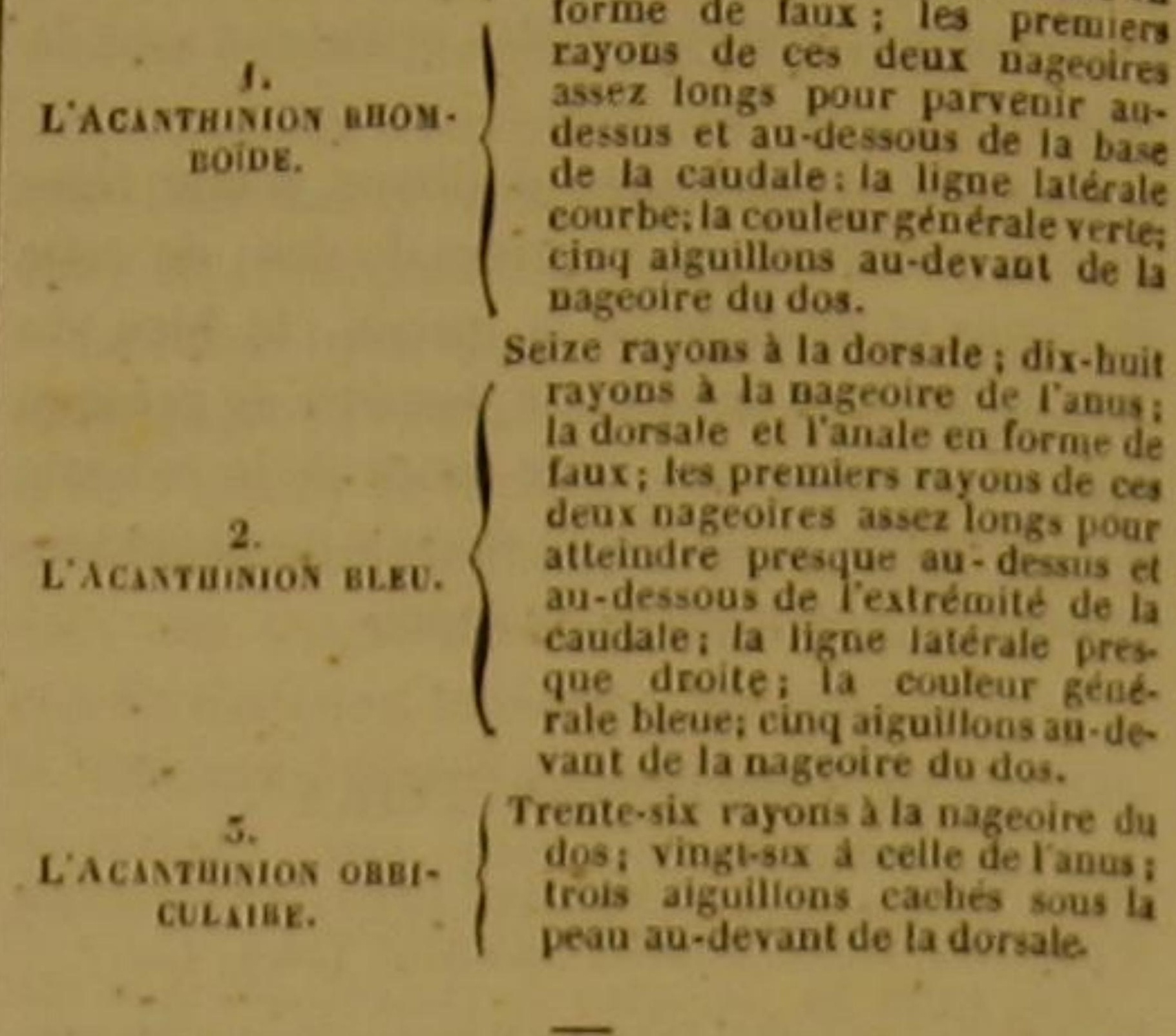

L'ACANTHINION RHOMBOIDE',

Trachinotus rhomboides, Cuv.; Chætodon rhomboides, Bl., Linn., Gmel. ; Aeanthinion rhomboides, Lae. ?. L'Acanthinion Bleu', Trachinotos glaucus, Cuv,; Chatodon glaucus. Lion., Gmel.; Acanthinion glancus, Lacep.4.-
Acanthinion orbiculaire s, Platax aribriticas, Cur., Chrtodon orbicularis, Forsk., Limo., Gmel.: Chatodoa peotacanthus, Chætodon Gallina , et Acantbinion orbiegpentacanthus, Lac, 9

Le nom d'Acanthinion ${ }^{7}$ désigne le principal caractère qui sépare des chétodons proprement dits, les trois poissons dont nous allons parler : cette dénomination indique les aiguillons placés sur le derrière de leur téte, et par conséquent au-devant de leur nageoire dorsale. Ces thoracins ont le dos très-élevé et l'anus très-abaissé au-dessous de la ligne droite que l'on pourrait tirer de leur museau à l'extrémité de leur quieue; et commie le point le plus saillant du I Bandouliere rhomboide. Bloch, pl. 209. - Chelodon rhomboide. Bonnaterre, pl. de I Enc. méth. 'Da sous-genre Tascarvote, Cuv., dans le grand genre roides. D.

Bonnaterre, pl. de lewe. Bloch, pl. 210. - Chetodon glaucus. 'Da sous-geore Tascigisote.

C. (tamille des Acanthoptére, dans le genre Cexriosote, Forskael, Faun. Arab., p. 59, D. 79. Chédedon. D. D.

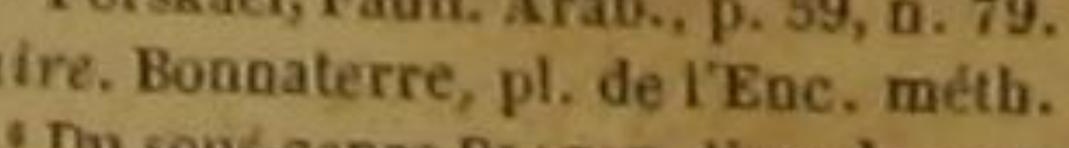
Cour qui divisent le genre squamipennes. - It. de la famille des Acanthopterygiens fois sous les noms 10 de Chéépedon a décrit ce poisson trols todon galline, et $5^{\circ} \mathrm{d}^{\mathrm{A}}$ Acanthinion orbiculare. $\mathrm{D}$. 'Acantha, en grec, signifie aiguillon, et inion, occiput CENThoxote, de la famille des Aeanthopterygiens scombé.

DES POISSONS.

ressemble à un grand losange; et de cette tigure vient le nom spécifique de Rhomboïde, qui lui a été donné par Bloch.

Ce poisson est très-beau à voir : un vert trèsgai règne sur sa partie supérieure, une couleur d'argent très-éclatante sur ses cótés, et une couleur d'or très-brillante sur son ventre et le dessous de sa queue; cet or et cet argent sont relevés par trois bandes transversales, vertes, triangulaires, et qui se réunissent par le haut avec le vert du dos et de la nuque; les pectorales et les thoracines sont jaunes à leur base, et violettes à leur extrémité; le vert domine sur la dorsale, la caudale et l'anale, dont la base est peinte en jaune on en blane.

La grandeur de cet acanthinion est souvent considérable; chacune de ses narines a deux orifices; sa caudale est très-étendue et trèsfourchue. C'est daus les eaux de l'Amérique qu'il vit et qu'il a été observé par Plumier.

Ce même naturaliste a aussi décrit le premier l'acanthinion bleu, qui habite, comme le rhomboide, dans les eaux américaines, et qui y parvient à une longueur dè douze décimetres. La chair de ce poisson étant blanché et très-bonne au goút, ce thoracin peut fournir unenourriture aussi agréable qu'abondante.

Chacune de ses narines a deux or̂ifices. Ses thoracines sont très-petites; mais sa dorsale, son anale, et sa caudale quoique très-fourcbue, présentent une grande surface. L'anale ne renferme aucun rayon aiguillonné. Toutes sont d'un bleu plus ou moiñs foncé, et, excepté la caudale, ont du jaune à la base. Chaque coté de l'animal, dont la partie inférieure est argentée, montre cinq ou six bandes transversales noires, courtes, inégales et très-étroites.

Les dents flexibles, mobiles et très-petites de l'orbiculaire sont placées sur plusieurs rangs, et celles du rang extérieur sont divisées en trois à leur sommet. De petites écailles recouvrent les opercules et la base de la dorsale, de l'anale et de la caudale, qui sont épaisses et charnues; celles qui revétent le corps et la queue sont lisses et arrondjes. La couleur générale de l'orbiculaire est brune; 1 ll est parsemé de points noirs; des teintes jaunâtres paraissent sur la ou elles se mélent à des nuances vertes. Les rivages garnis de rochers, de l'Arabie, sont la patrie de cet acanthinion

's rate cet accathicion

CENT TRENTE-QUATRIEME GENRF.

EES CHÉTODIPTÈrRES '

Les dents petiles, Pexibles at mobiles; le corps et le queve Ires-comprimes; de petites ecailles sur la dor-

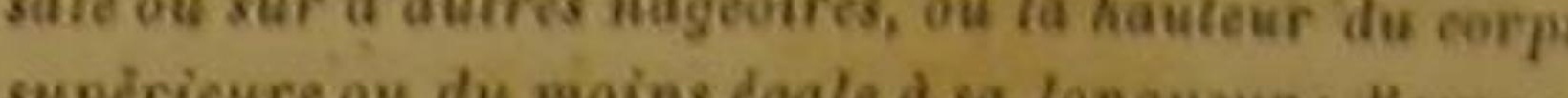
Sure de lure dę la botehe pelite; to museau plus ou moins avaned; point de dentelure ni de piquants aus opercules; denx nagcoires dorsales.

Espics cAMcrìnes.

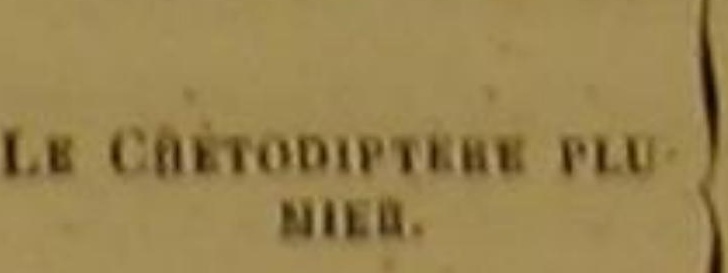
Cing rayons aigiillionés a ta pre-

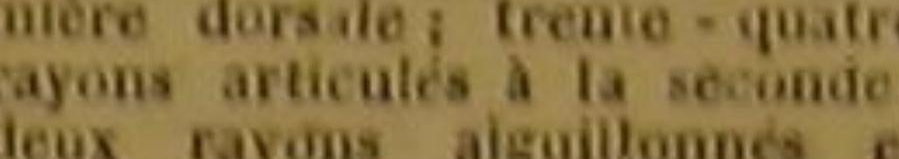

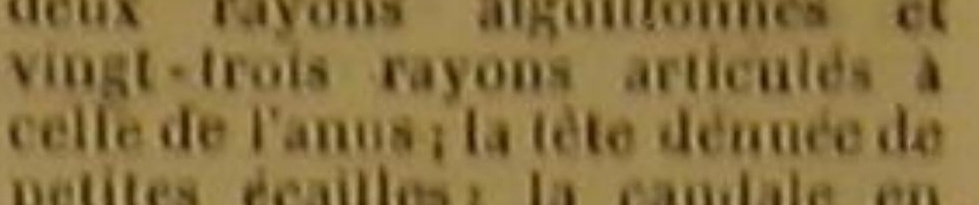
perites reaillosi la caudale en
colssant.

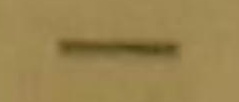

LE CHÉTODIPTĖRE PLUMIER ${ }^{3}$.

Platax Faber \& Cur.; Chatodon Plumieri, Bl, Limn., Gmel.; Chetodipterus Plumierii, Lac. '.

La hauteur de ce poisson est presque égale a sa longueur totale; et chacun de ses cótés présente la figure d'un losange. Chaque narine n'a qu'un oriflec. La seconde nageoire du dos t celle de l'anus sont conformées comme une faux, d'une maniêre d'autant plus remarquable, que leurs premiers rayons sont assez longs pour dépasser la caudale. La couleur générale de l'animal est d'un vert mété de jaune, sur lequel s'étendent, à droite et à gauche, six bandes ransversales, étroilas, régulières, presque égales les unes aux autres, et d'un vert assez foncé. Plumier a va ce chétodiptere 4 dans les caux des Indes occidentales, où il aime à se tenir au-dessus des fonds pierreux ${ }^{3}$.

6 a chaque thoracine, 26 rayons a la nageoire de La quene. -12 rayons a chaque pectorale de racaithinion bleu, 6 a chaque tioracine, 20 a la cad ate, -6 rayous a la membrane branchiale de lacabithinioi orbiculaire, 16 a chaque prelo

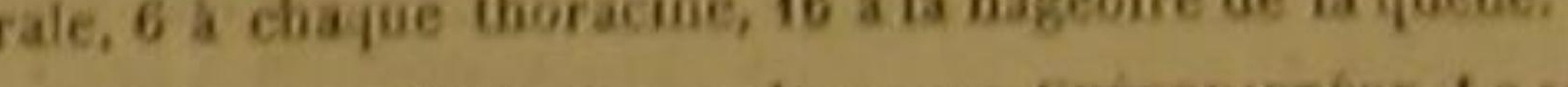

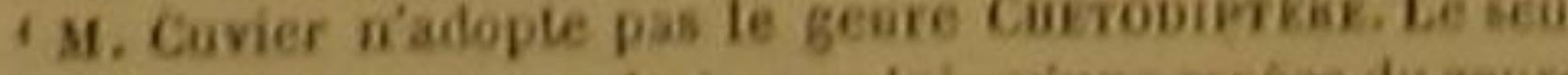
poisson qui le compose n'ent pour lai qu'une espece du geure

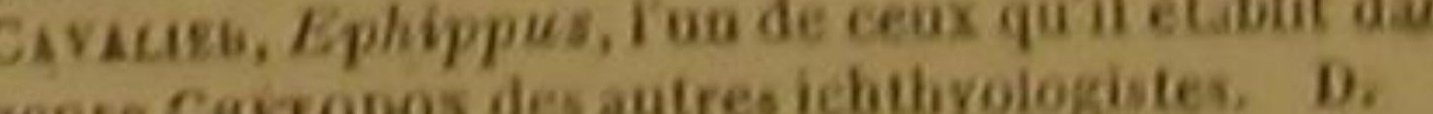
senre Condoultere de Plumier. Bloch, pl. 214, fig. 1. - Chedon bandouliere de Plumier. Bonuaterre, pi. de YEnc. wetti. 'M. Cuvier considere ce poisson comme trés-visin de son Platax Faber, si méme if uappartieat a la méme espece. Voyez la note 1.) D. - Le nóm gécériqu é chetodiptére est compose, par con. traction, de chetion
nageoires da dos.

is rayous a la membrans branchiale du chétudiptére plaaier 11 s chaque pectorale, 1 rayoa aiguilibade el 5 rayou 
CENT TRENTE-CINQUHEE GENRE.

LES POMACENTHES ${ }^{\prime}$.

dents petiles, fexibles et mobiles; le corps et ta

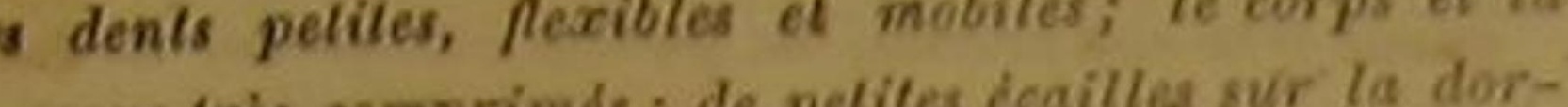

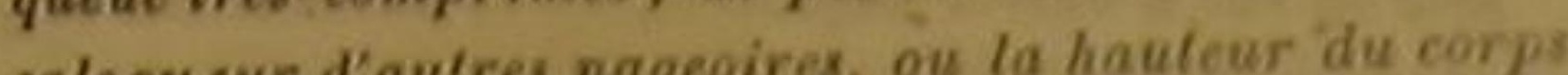
ele

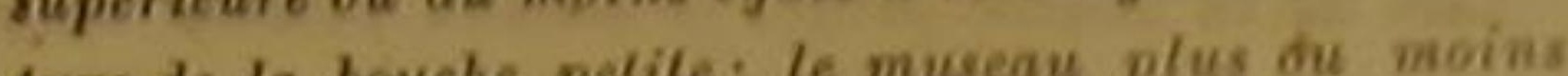

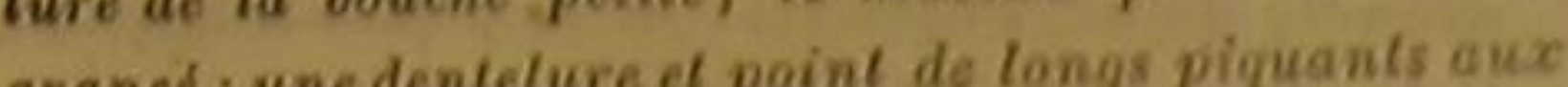
apance; ine dentelure et point de longs piquants aux opercules; une seule nageoire dorsale.

PREmier sous-genRe.

La nageoire de la queue, fourchue, ois tehanerie en croissant.

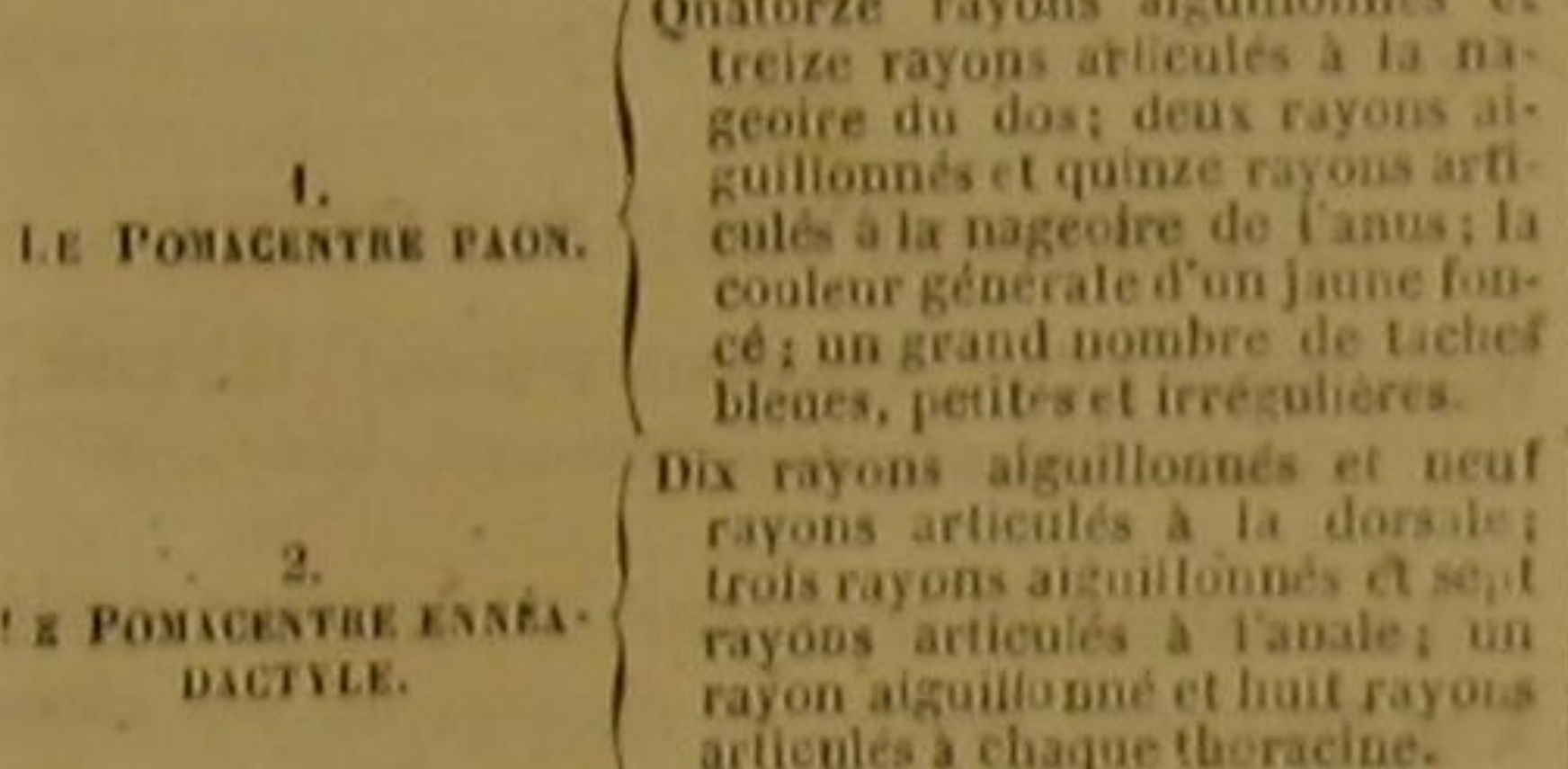

SECOND SOUS-GENRE.

La nageoire de la queue, rectiligne, ou arrondie, at sans ichanerure.

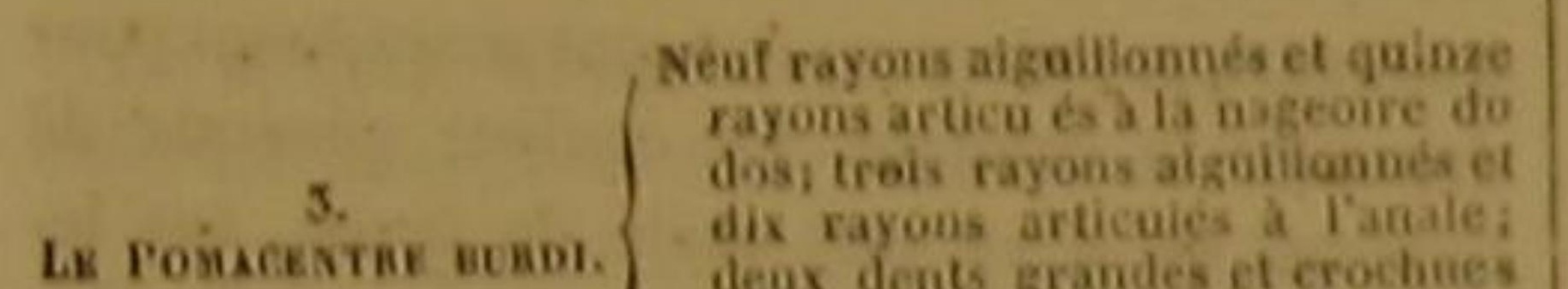

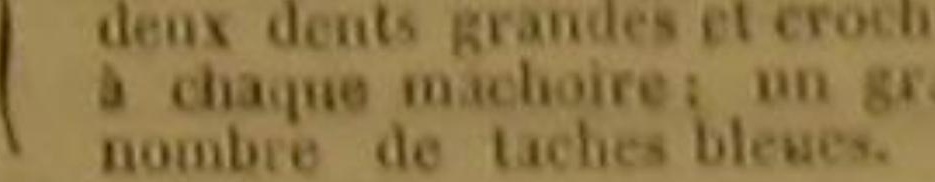
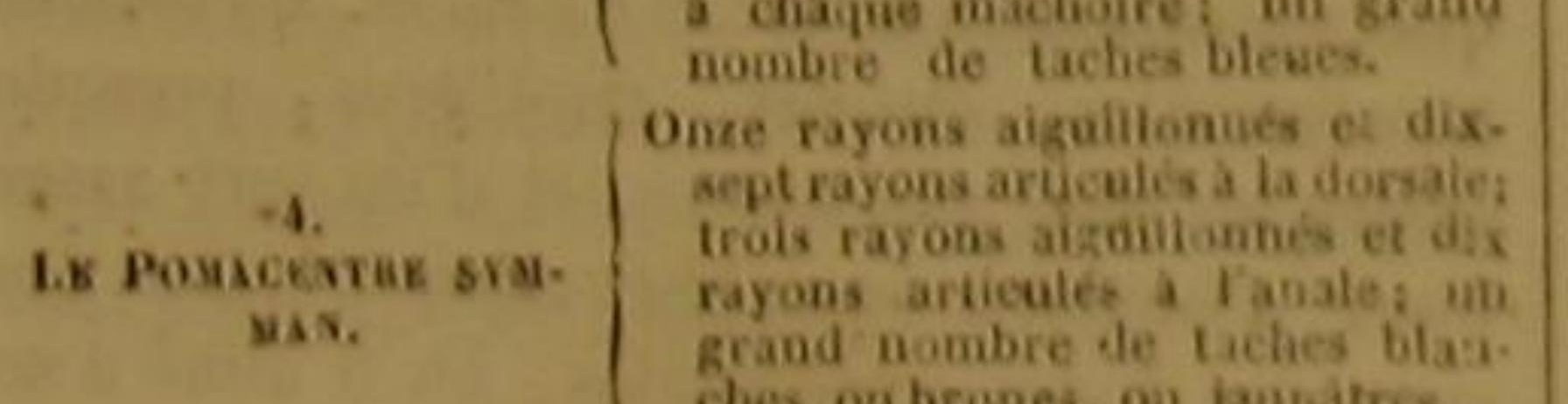
enayons aizoillonnés et vin
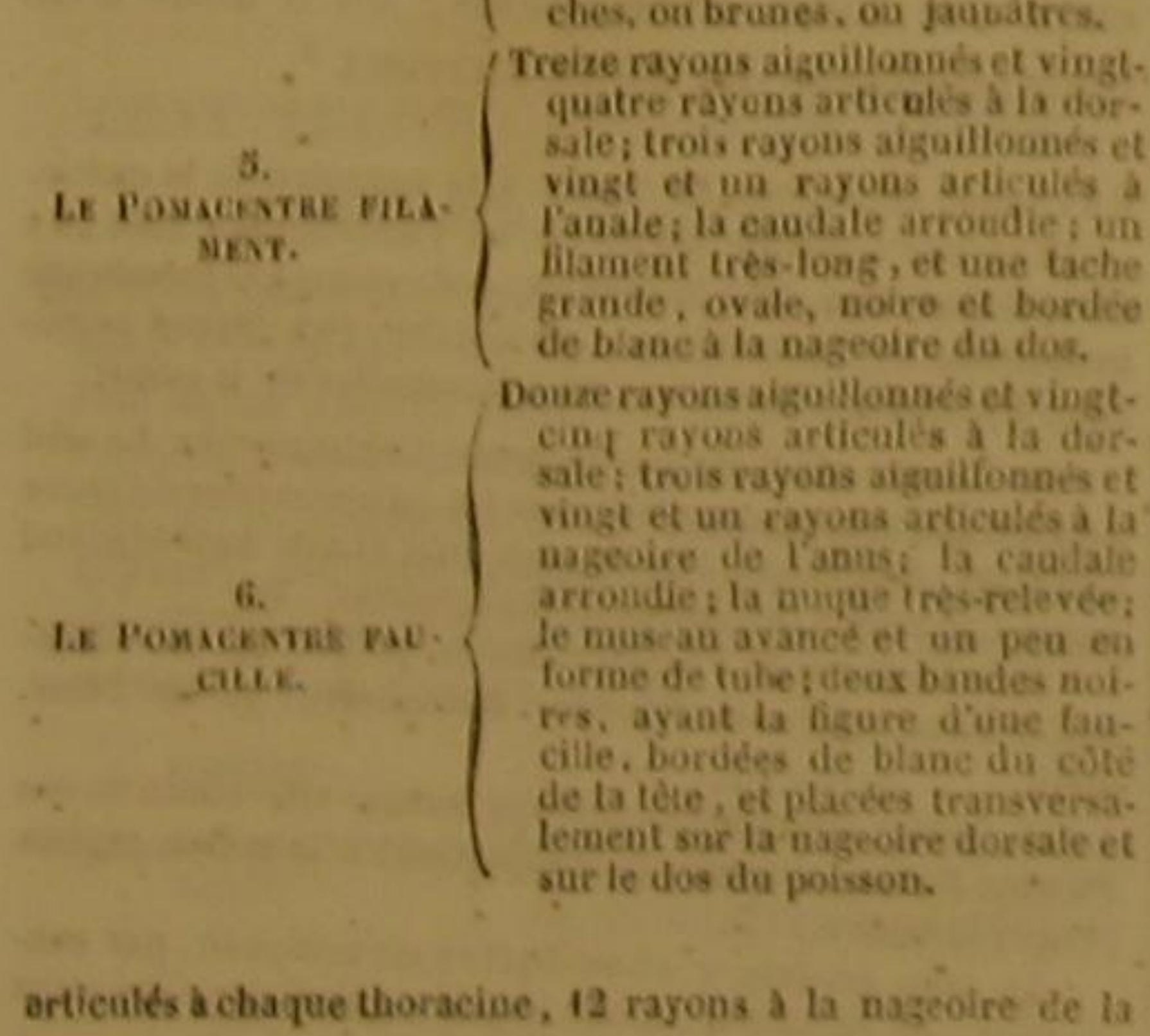

1. spricrs. Le rogaccsine caots

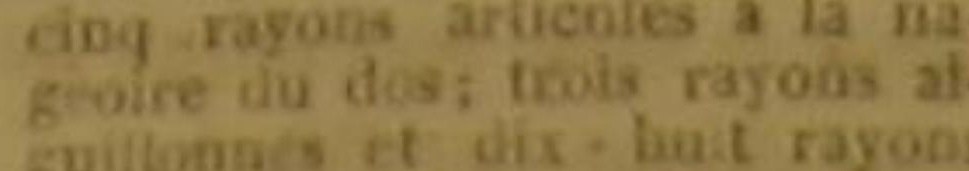

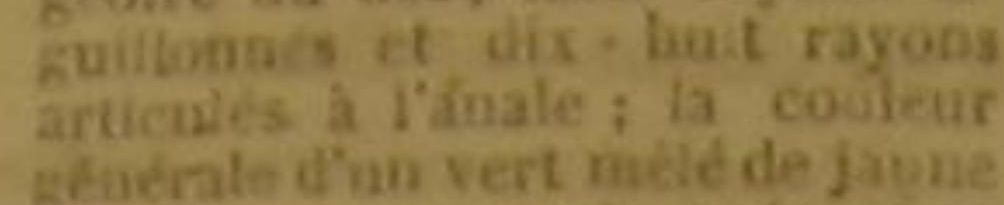

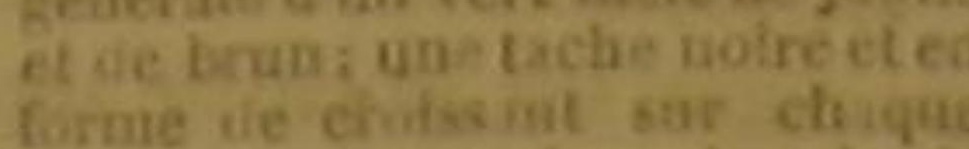
aliz ine autre tab- woirs ylace Touvertare brachialejus ine ver

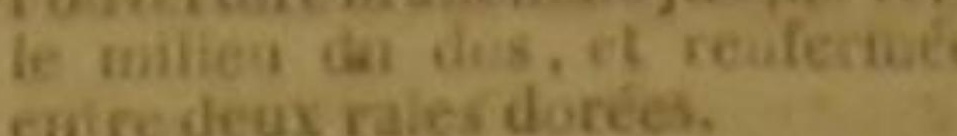
-

LE POMACENTRE PAON ' Pomacentrus Pavo, Lae., Cuv.; Chatodon Pavo, Lino, Gmel.; Holocentras dilacanthus, Lac." ET LE POMACENTRE ENNÉADACTYLE . Şcolopsides Vosmeri? Cuv.; Pomacentrus ennendaeTylus, Lae.

Ce nom de $P$ aqon, en rappelant les belies contrées des Indes orientales, dou les voyaceurs ont apporté dans I'Asie-Mineure et ensuite dans la Grece I'oiseau que la mythologic consacra it Junon, et dont la philosophie fit l'emblème de la vanite, retrace aussi les eouleurs brillanfes contrastées ou fondués avee tant de varieté $\mathrm{et}$ de magnifience sur les plumes soyeuses de cet oiseau privilégié. Ce double sonvenir a engagé, sans doute, le eélèbre Bloch à donner an poisson que nous allons décrire, le nom de Paon que nous lúf conservons. Ce pomacentre vit en effet dans les eaux desGrandes-Indes, et ses nuancessont dignes d'étre comparées à celles de l'oiseau que les poéfes ont attelé au char de la reine des cieux. Ce n'est pas que ses teinte soient aussi divérsifnées qu'on pourrait le croire d'après le nom de Paon. En effet, elles se ré duisent à un jaune plus otr-moins foncé qui fait le fond, et a des raies ou taches bleues qui composent la brodecie : mais ce jaune a par lui-mêmel'éclat de l'or; et ce bleu, distribué en petits rubans transversaux on en gouttes irrégulières sur la tête, le corps, la quene et les

tre pan); toutes les autves se rapportent a ses genres Sro-

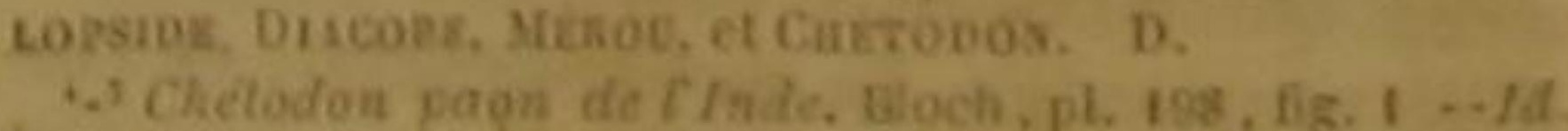

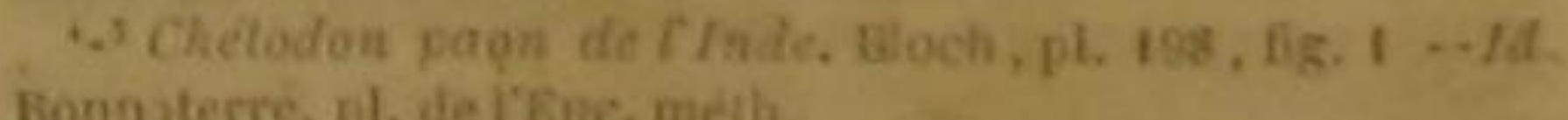
bonaterre, pis de inge, meih.

Oa geare Ponscentes, Cur., dans la famille des icin

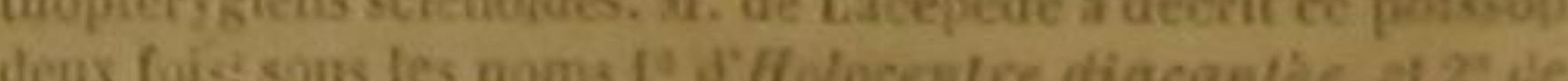
Poinacentre Paen. D.

Selon 1. Cuvier, des indtiditis secs de la Seotopside de Vosmarr ou Lutjan gaton dor de M. de Lacéptie ont vraisenblab ement s svi a établir lespece du Pornaceutre

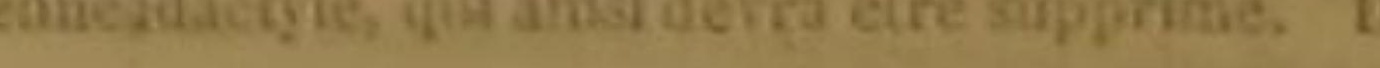

DES POISSONS.

nageoires de l'animal, offre des compartiments des plus gracieux, ar milieu desquels on croit apercevoir un grand nombre de petits yeux analogues à ceux de la quene du paon. D'ailleurs toutes ces couleurs sont très-mobiles; et pour peu que le poisson se livre à quelques évolutions auprès de la surface des eaux et sous un soleil sans nuages, on les voit se meler à des reflets qui, paraissant et disparaissant avee la rapidité de l'éclair, dont ils ont, pour ainsi dire, P'éclat éblouissant, réfléchissent tous les tons de l'iris, chatoient avee une merveillense variété, et ne laissent đésirer dans la parure du pomacentre, ni la magniflence que donne un grand nombre de couleurs, ni le charme qué peut faire naitre la diversité des images successives.

Au reste, l'ensemble du paon est plus allongè que celui de presque tous les poissons de son genre; chacune de ses narines u'a qu' un oriflee; sa ligne latérále est interrompue; et un appendice très-dur, triangulaire et allongé, est placé à eóté de chaque thoracine.

Le pomacentre ' ennéadactyle a le corps al. longé ; la mâchoire supérièure un peu plus avancèe que l'inférieure; la ligne latérale très-courbe jusque vers l'extrémité de la quèue, où elle est très-droite; uñe rangée d'écailles plus petites que celles da dos, le long de cette mème ligae latérale ; les écailles du dos et des cótés, gran. des, arrondies et eiliées; presquetous les rayons aiguillonnés de la dorsale et de la nageoire de I'anus, aplatis, longs et tres-forts. L'individu de cette espèce que nous avons décrit, faisait partie de la collection de poissons sees donnée à la France, avec d'autres collections d'histoire naturelle, par la Holfande ${ }^{2}$.

- Pomacentre designe la deatélure de fopertaule, poma. en gree, signifiant opereale, et centroa, pointe ou piquant. it ragoas a la memirane brancliaie du powaconire paon.

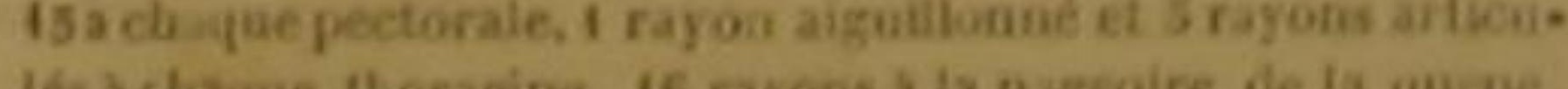
lesactasue boracine, 16 rayons a ia njgeoire de ia quace. tole, 17 ragons a to condete.

\section{LE POMACRNTIE BURDI ',}

Diacopo miniata, Cuv, ; Perce miniata, Forsk, Linn Gmel.; Pomacentrus Rurdi, Lic, ?

Le Pomacentre Symman \&, Serrabus Susmena, Cav.,

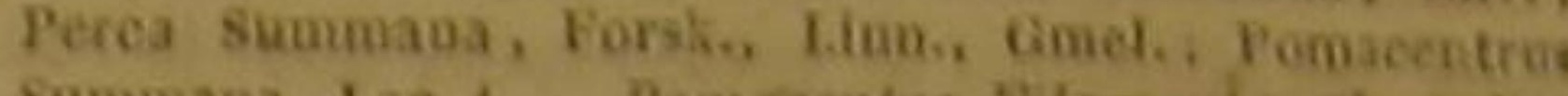
summana, Lac,,- Pomadentre Nhanents, Chatodon

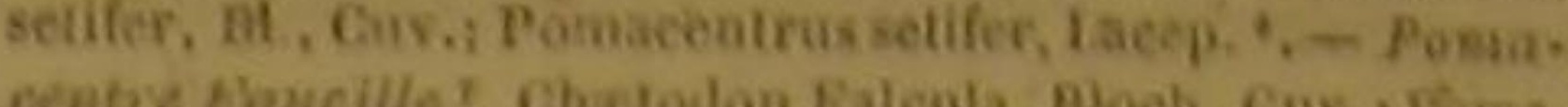

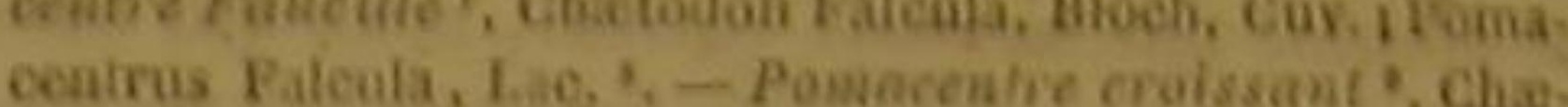
todoa froviatis, Cov, Pomacentrus Lunuta, Lac, ic,

Nous allons indiquer quelques particularités relatives à ces cinq pomacentres,

Les eaux de la mer d'Arable nourrissent les deus premiers, que Forskael a vus parmi les coraux qui bordent les rivages de cette mer.

La couleur générale du burdi est écarlate. mais, dans plusieurs individus de cette espece, elle est brune ou d'un rouge vif; et cette differencé a paru assez constante a Forskacl, pour qu'il admit dans l'espèce du burdi deux variétés permanentes reconnues d'alliteurs par les Arabes, qui nomment la première Belah, et la seconde Nagen. Lés taches bleues de l'une ou de I'autre de ces deux variétés sont bordées quel. quefofs d'un brun foncé; ce qui teur donnequelue ressemblanee avec une prand to entourée e son iris.

Les burdis ont presque tôus au-dessas des yux une tache composée de deux liznes qui, par leur position, représentent la lettre V. L éws levres sont épaisses; la supérieure est' extensi. ble, mais plus courte que l'inféricure. Chaque narine n'a qu'un oriflee, et cette ouverture est tubulée; les écailles sont petites, striéeset ar.

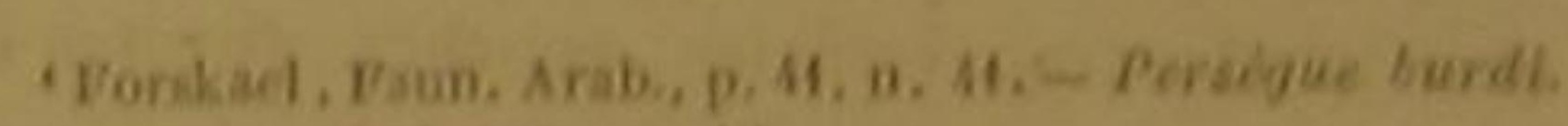

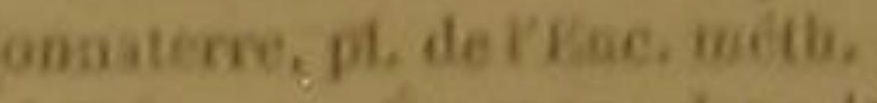

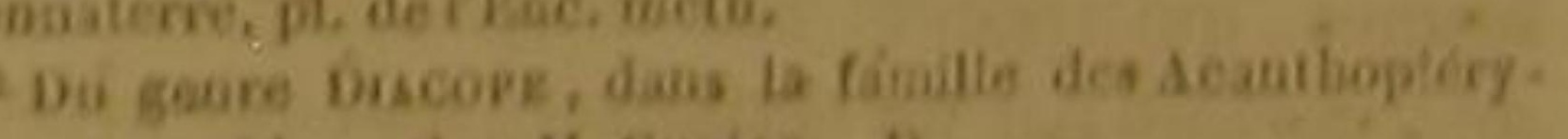

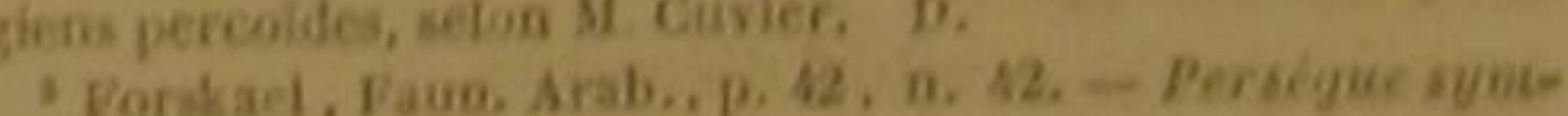

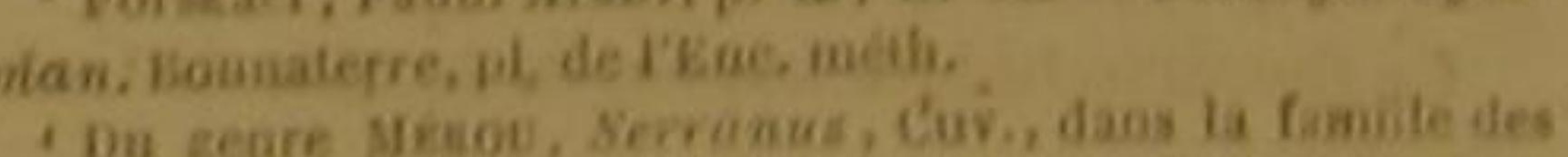
eanthopterygiens vercoides. D.

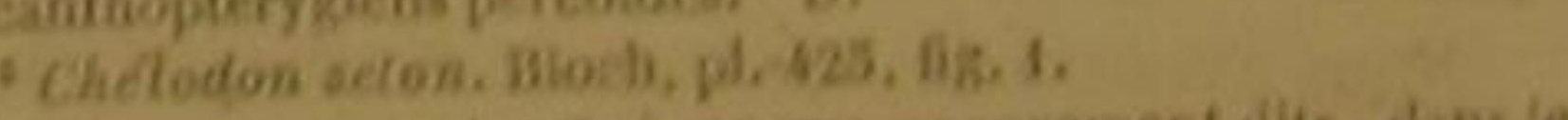

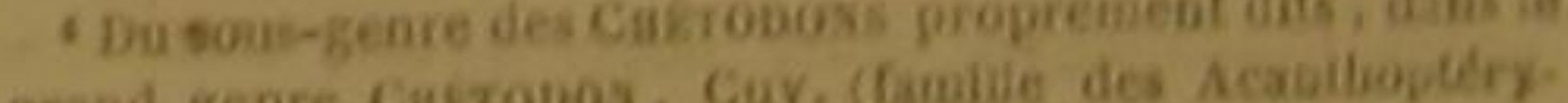
grand genre cansos). D.
giens squarmipenses).

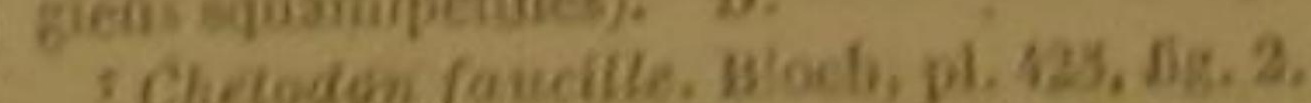
- Da sous-geare des Caizoposs proprement dits, dias le geare Cuiтonos. D.

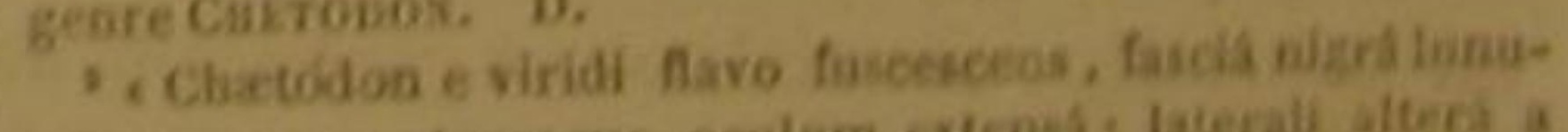

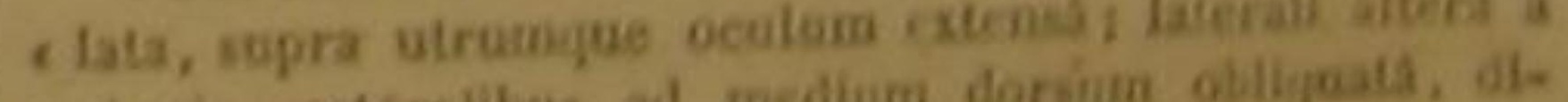
- piacis petorasibus al me manoserits defs eltio.

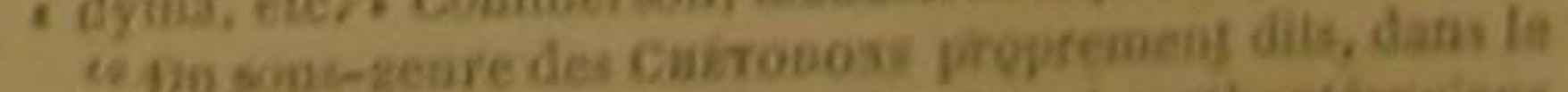

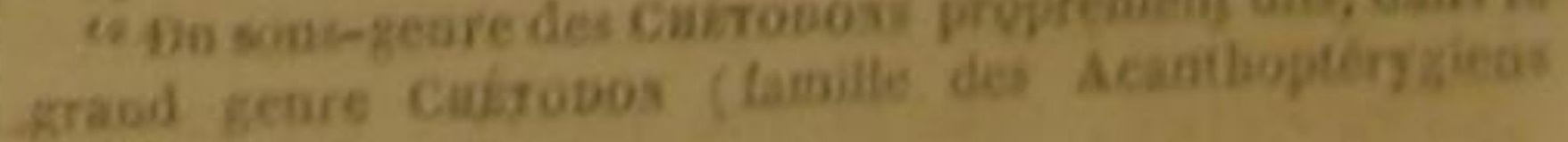
(squaripences). 
DES POISSONS.

rondies. La chair de ces poissons est agréable | courte que l'inférieure, une langue très-petite, au goủt.

Le symman a de très-grands rapports avec le burdi : il est ordinairement d'un gris-brun; Forskael a regardé comme une variété constante, les individus de cette espèce dont la couleurgénérale est bleuâtre avec des taches bleues, et comme une seconde variété, ceux qui montrent des taches d'un brun jaunậtre sur un fond d'un gris blanchàtre.

Une sorte de bandeau noir bordé de blanc décore la tête du pomacentre filament, et passe-sur chaque œil : des raies rouges traversent en différents sens les cótés de l'animal, dont la couleur générale est jaune; une raie noire borde l'extrémité de la caudale, de la nageoire du dos, et de celle de Tanus, qui sont couvertes presque en entier de petites écailles; le corps et la queue sont garnis d'écailles un peu plus grandes que ces dernières, et, de plus, dentelées et très-fortes.

La faucille n'a qu'un orifice à chaque narine. Sa tête, ses opercules, et ses nageoires du dos, de la queue et de l'anus, sont revètas de petites écailles; celles qui couvrent le corps et la queue sont grandes, dures, dentelées, et fortement attachées à la peau. Un appendice écailleux, allongé et triangulaire, est placé auprès de chaque thoracine, ainsi que sur le poisson précédent. La couleur générale est blanchàtre, et diversiliée par une bande noire et bordée de blanc qui passe sur chaque cil, par une bande semblable qui traverse la queue par une raie noire, large ou étroite, qui termine la caudale, la dorsale, l'anale et les opercules, par dix ou onze bandes transversales, courbes, étroites et brunes, qui règnent sur chaque cóté de l'animal, et enlin par un petit liséré noir que présentent un grand nombre d'écailles.

Ce thoracin habite auprès de la côte de Coromandel.

Nous avons donné le nom de Croissant, à un autre pomacentre dont nous avons trouvé deseription dans les manuserits de Commerson. Il montre une tache noire de chaque cote de la queue, une bande transversale noire sur la caudale, une raie noire à l'extrémité de la dorsale et de l'anale, quelques raies lonoitudinales pourprées et placées sur le ventre, un iris verdátre bordé de noir à l'extérieur et d'o à l'iutérieur, une nuque élevée, un musean avancé, une levre supérieure extensible et plus un appendice membraneux et pointu a la seconde pièce de chaque opercule, et un autre appendice écailleux et allongé à côté de chaque thoracine '. Nous n'avons rien trouvé, dans les manuscrits de Commerson, de relatif à la forme de la caudale. $\mathrm{Si}$, contre notre présomption, cette nageoire est échancrée, le Croissant doit tre placé dans le premier sous-genre des $P_{0}$ macentres.

\section{CENT TRENTE-SIXIÈME GENRE.} LES POMADASTS ?

Les dents petites, Rexibles et mobiles; le corps et la quew sur d'autres nageoires, ou la hauteur du corpo ingtrieure ou du moins égale de sa longueur; Pourertirs de la bouche petite; le museau plus on ming a une dentelure et point de longs pipunts aur apercules; dever nageoires dorsales.

EsPkCE. CABActKRES.

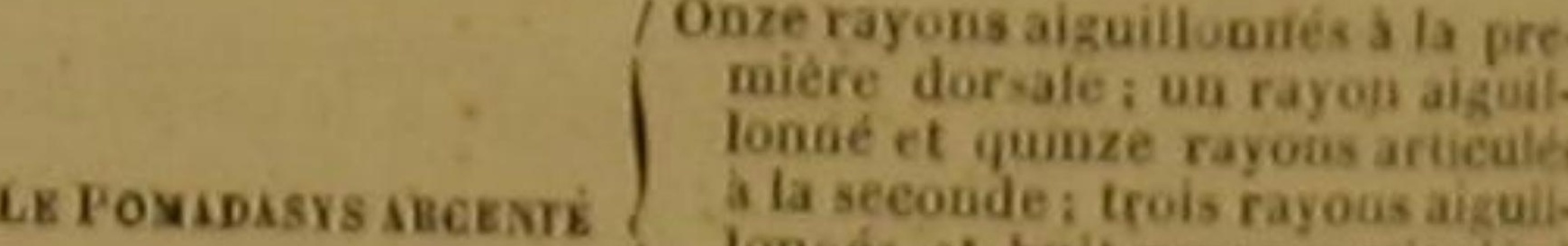

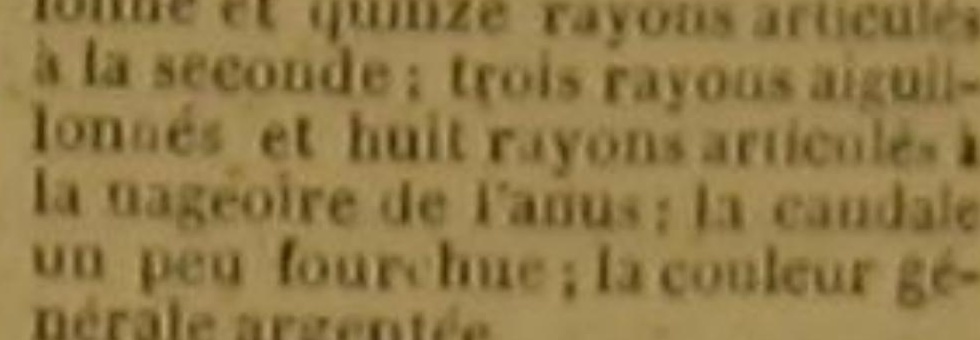

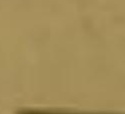

LE POMADASYS ABGENTE 3

Pristipoma argenteum, Cuv.; Sciæna argentea, Forsk., Linn., Gmel.; Pomadasys argenteus, Lac. ‘. Ajoutez aux traits présentés daus le tableau générique, deux raies elevées entre les narines,

177 rayons a la membrane branchiale do pomacentre burdi. 17 a cecaque pectorale, 1 rayon aiguillonné et 5 rayons arti-7 rayous a la membrane branchiale da pomacéntre symman, is a chaque pectorale, 1 rayon aiguillonné et 5 rayons articulés a chaque thoracine, 18 rayons a la caudale. 65 a chas a membrane braochiale du pomacentre filament,

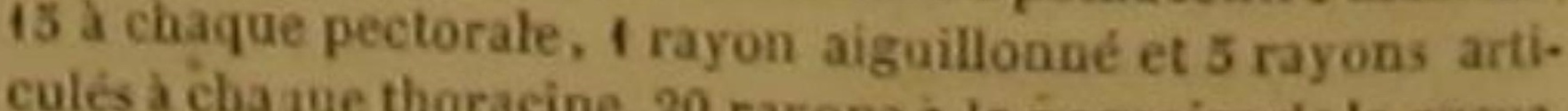
culc a cha que thoracine, 20 rayons a is nageoire de la queve.
-6 rayons a la membrane brancliale du porgcentre fagcille, 15 a chaque pectorale, 1 rayon aiguillonnáé et 5 rayons articulés à chaque thoracine, 20 à la caudale. -5 rayons à la membrane branchiale du pomacentre croissint, 16 a clia. que pectorale, 1 rayon aiguillonné et 5 rayons articulés à
chaque thoracine. 2.4

de, et le rapporte à sone genre Poisadsrs de M. de Lacte-

Acanthojtérygiens sciénooiles. D. Forstact, Paun. Arab., p. 51,

"Forsbacl, Paun. Arab., p. 51, n. 60. - Seiene najeb. tres-comprimes; de petites écailles sur la doryale oo une première dorsale arrondie, une secondé al. longée, desécailles ciliees, des taches noires sur le dos, des nuanees rousses sur les thoracines ainsi que sur l'anale, et vous aurez une idèe assez complète du pomadasys ' argenté, que Forskael a vu auprès des rivages de la mer d'Arabie, et que nous avons eru devoir placer dans un genre particulier ${ }^{2}$.

\section{CENT TRENTE-SEPTIEME GENRE.} LES POMACANTHES ${ }^{3}$.

Les dents petites, Rexibles el mobiles; lecorps el la queue tres-comprimes; de petiles écailles sur la dorsale on sur dautres nageofres, ou la hauteur du corpssupdrieure ou du moins egale d sa longueur; louverture
de la bouchepetite; le muscau plus ou moins aeand; de la bouche petite; le muscau plus ou moins aeance;
un ou plusieurs longs piquants et point de dentelur un ou plusieurs longs piquants et point de
aux opereules; une seule nayeoire dorsale.

PREMIER SOUS-GENRE.

La nageoire de la queúe fourehue, ou dehanerde en croissant.

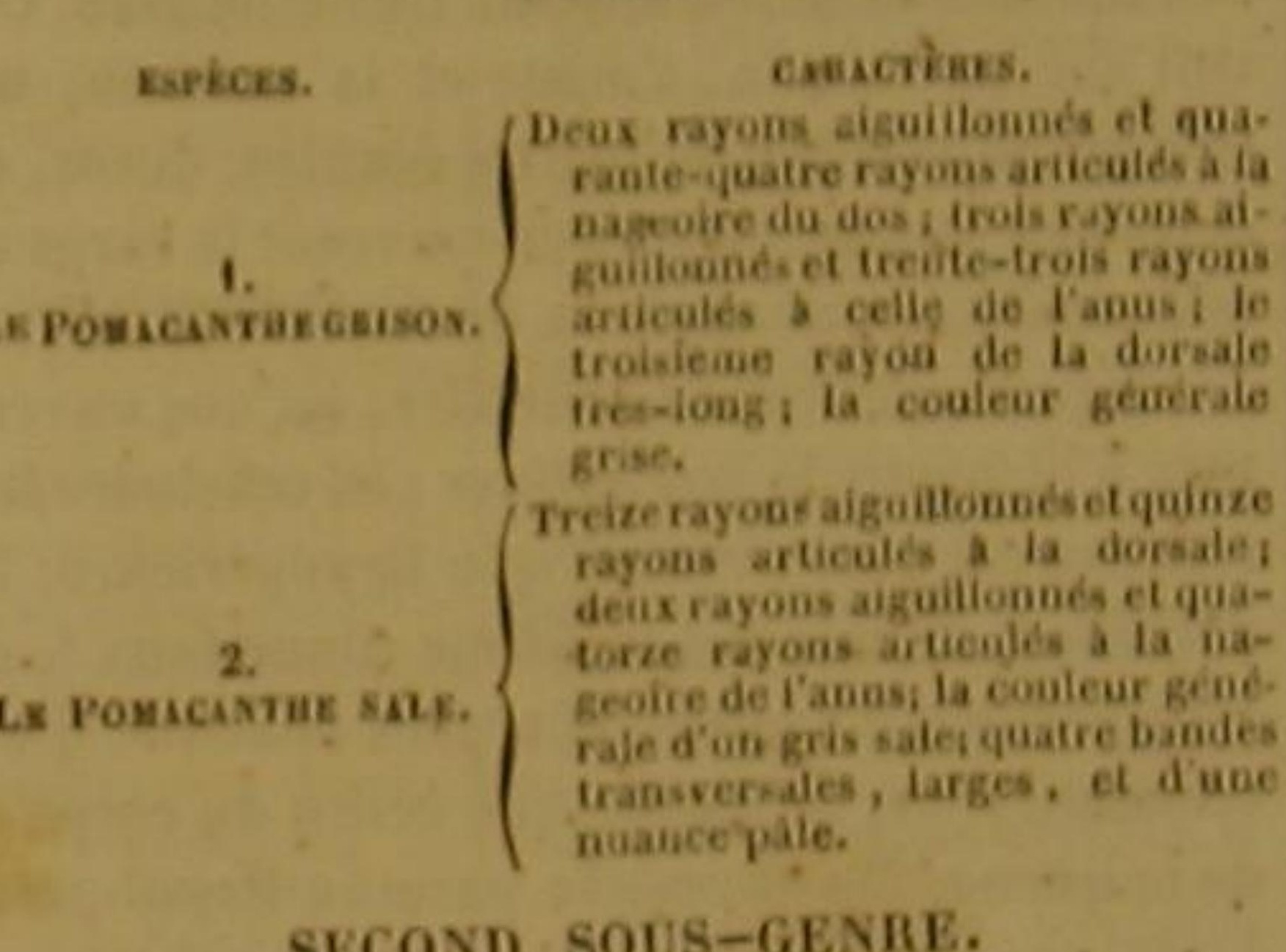
SECOND SOUS-GENRE.

La nageoire de la queue recliligne, ou arrondie sans ethancrure:

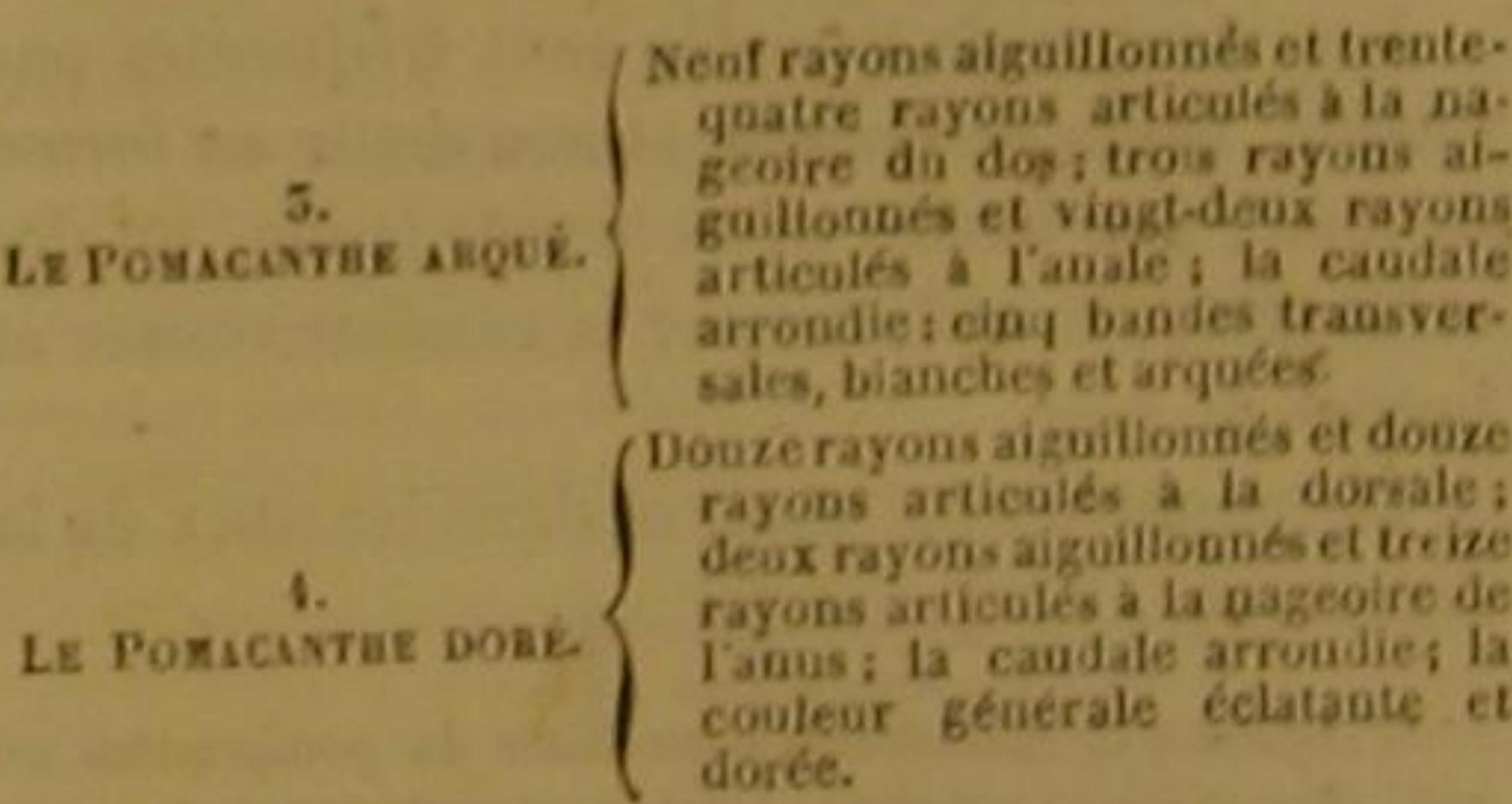

'Dasys, en grec, signifie bérisé, et poma, opercule. 27 rayoos a la membrane branchiale du pomadasys argenté, 16 a chaque pechrale, 1 rayons a la nageoire de ta queve.

13. Cuvier conserve les Posacurrazs, mais comme sousgenre, dans le grand genre des Cakzodoss, de la familie des Acanthopterygieas squamipeanes. D.

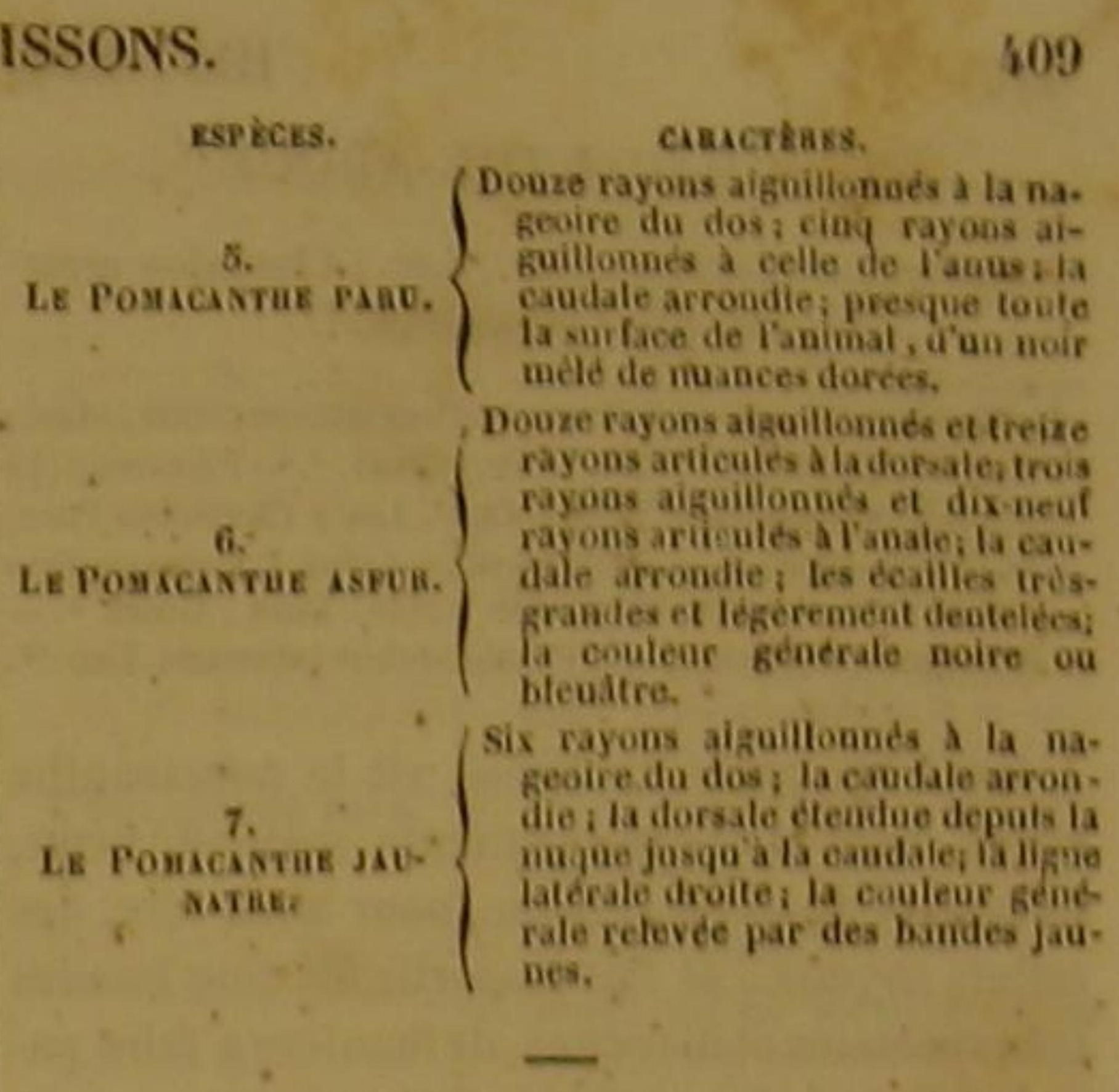

LE POMACANTHE GRISON ', Heniochus cornutus junior, Cuv, Chatodon canescens, Linn., Gmel. ; Pomaeanthus canescens, Lao, '? Le Pumacanthe sale ', Glyphisodon sordidus, Cuy, Che didus, Lac, 4.

Une double dentelure a la base des deux longs piquants du grison, et quelques raies noiraities sur chaque cote de ce poisson, qui vit dans l'A mérique méridionale :

Deux piquants a chaque opereule du pomacanthe sale; des écailles larges, membraneuses i léur bord, et un peu erénetées; la dorsale et l'anale arondies du côté de la caudale qui est jaunátre et distinguée par une tache noire; la couleur brune ou grisátre des autres nageoires de ce thoracin, que Forskael a vu parmi les coraux des rivages de l'Arabie, et dont la chai est trés-agréable au goût.

Tels sont les traits nécessaires pour compléter la description des deux premieres especes du genre que nous examinons ${ }^{5}$.

'Chétodon grison. Daubenton et Hậ, Ene, méth.-Id Bonnaterre, pl, de IEne. meth. - C Chatodon canescens, aculeo utriaque ad

M. Cuvier regarde le Pomacantle grison de M. de Lace de comme un jeune individu décoloré du Chetodon corna du méme auteur, qui pour lai est une espece du nous geas

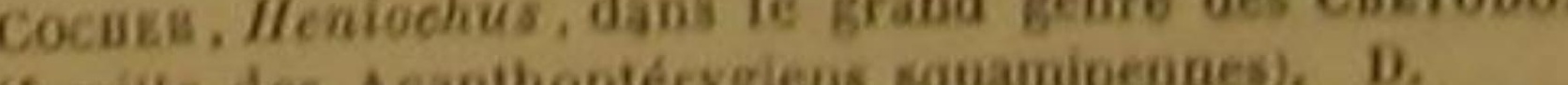

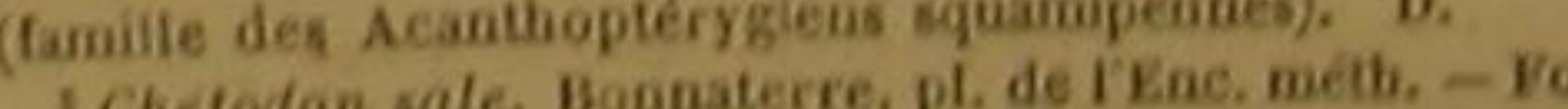
Gave. Arab., p. 62, 0. 87.

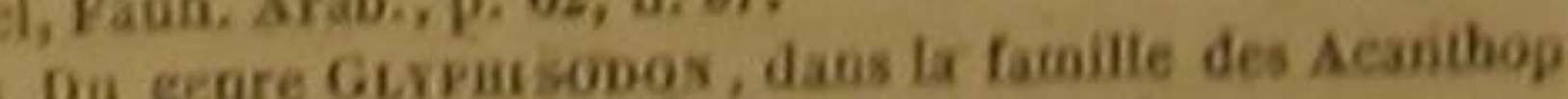
Gryieas sciérioildes. $D$.

i 17 rayops a chaque pectorale du pormacantibe gribon,

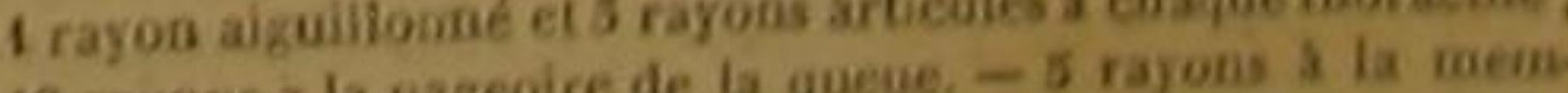

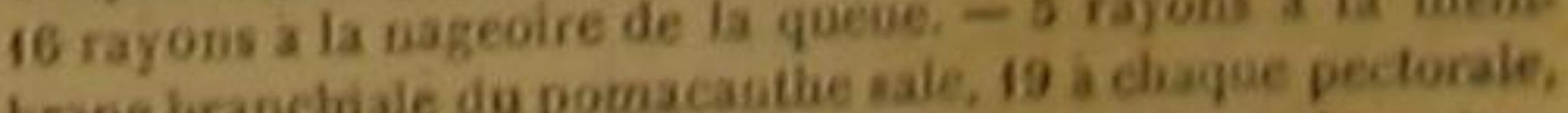

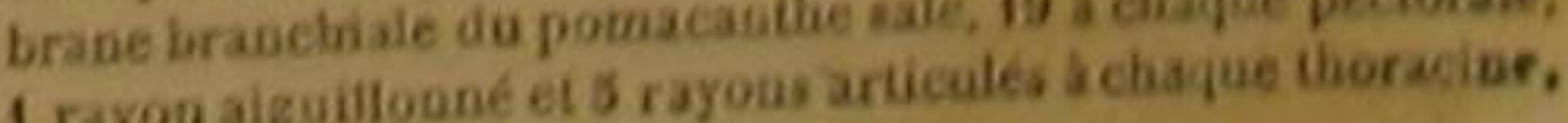

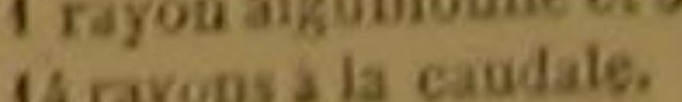


LE POMACANTHE ARQUÉ ,

Pomacanthus armatus, Cuv., Lac.; Chætodon armatus, Bl., Linn., Gmel. ?

Le Pomacanthe dore's, Pomacanthus aureus, Cuv., Lac, Gratndon adreas, Bloch, Linn., Gmel. - - Pomaeanthe Bl., Linn Grathus Parn, Cuv., Lac,; Chætodon Paro,

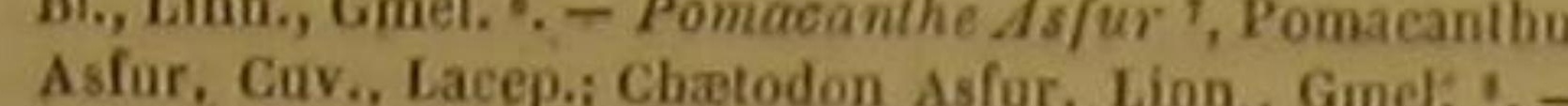

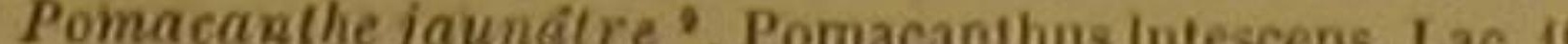

Dans les mers du Brésil vit le pomacanthe arqué, dont la couleur générale, mêlèe de brun de noir-et de dorê, renvoie, pour ainsi dire, des reflets soyeux, et fait ressortir les cinq bandes transversales et blanches, de manière à faire paraitre l'animal revêtu de velours et orné de lames d'argent. La première de ces bandes éclatantes et arquées entoure l'ouverture dé la bou-

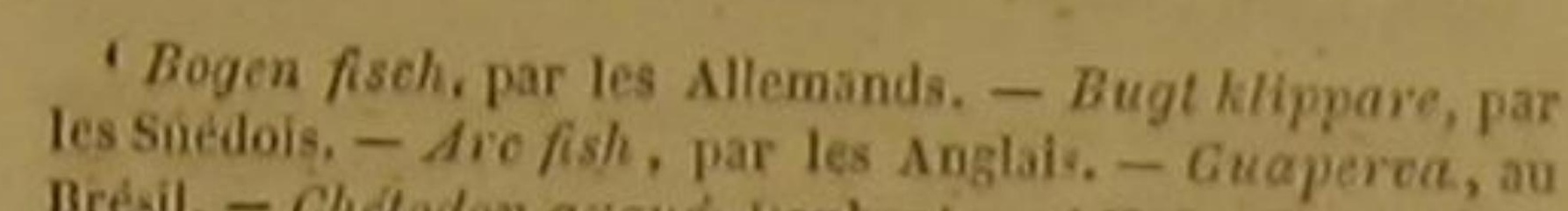
Bresil. - Chetodon ar'qué, Vaubenton et Hañy, Enc. métio are. Bloch, pl. 201, fis. 2, - Mus. Ad. Bri - Bandoufiche

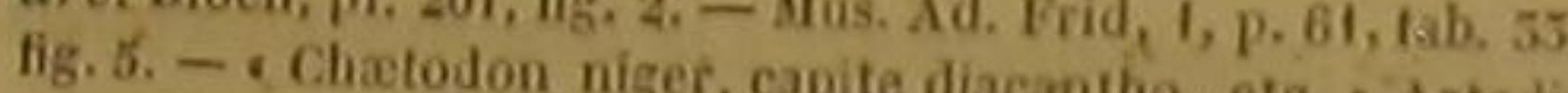
syn. 79, spec, 91. - - Chatodon nizer, ete , Sćs. Arted,

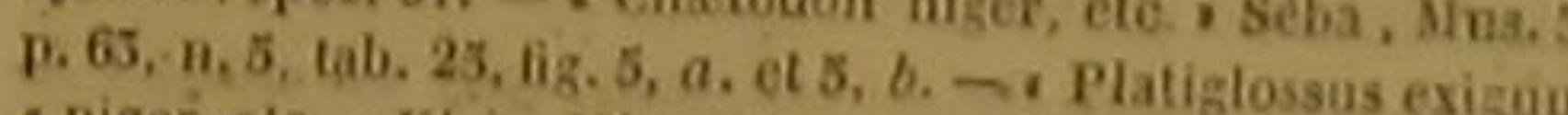
- niger, elc, , Klein, Miss. pisc, 4, p. 41, D. 5. - Guaperod Marcge. Brasil., p. 178. - Rai, Pisc, p. 105, A. 12. - Acap. $25, \mathrm{t}, 0,5$, fig. 5. - Chelodon aureus. Linnée, ed. Gimelin.

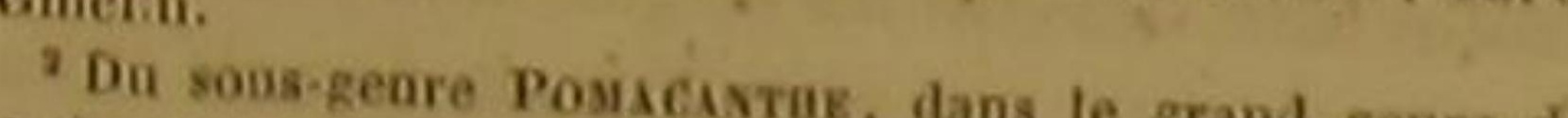
Cuikonors (fámille des Acanthoptírygiens grand geure de Cuv. D,

:Dorade de Plumier. Bloch, pt, 195,fig. I. - \& Seserinin tures sur velin dét) alins, pinnis coroutis, s' Plumier, peinB nnaterre, pli. de l'Ene. mell. + Dat sous-gene Ponsecisr.

Cürodose, comme le précíder, dans lo-grand genre de

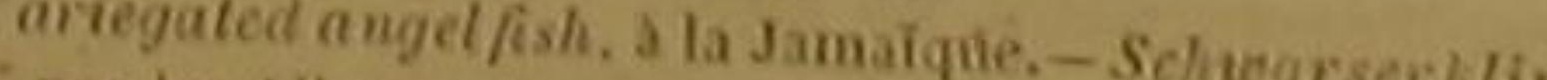

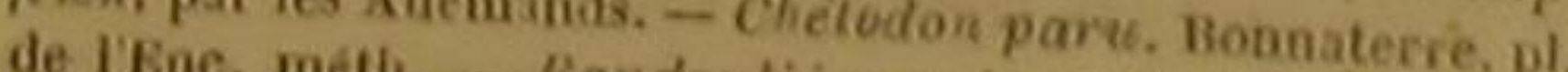
- Chatodon niger, Bandouticre noire, Bloch, pl. 197.-

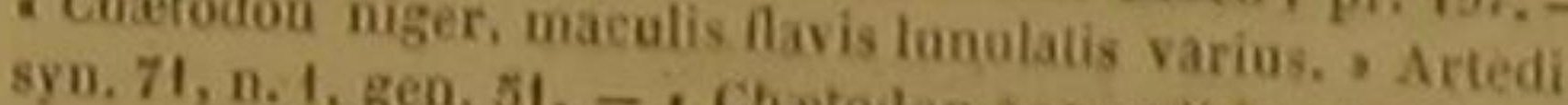
- siculis pinnæ dorsi, anique, interme opercutis acuteatis, osGronov. Zooph., p. 68, u 25i. - . Bhom intermitus, ete. cante corpore, squamis flavis quasi tornolatis. Whigr Miss. pise. 4, p. 36, a. 5, $\rightarrow$ chetodon minge " Klein p. 114 - - Piso. Ind Jamaic., p. 45i, n. 5. - Maregr. Brasil. fig. 2. - Ruysch, Th. 35. Jonston, Pise, p. 177, tab. 53 ,

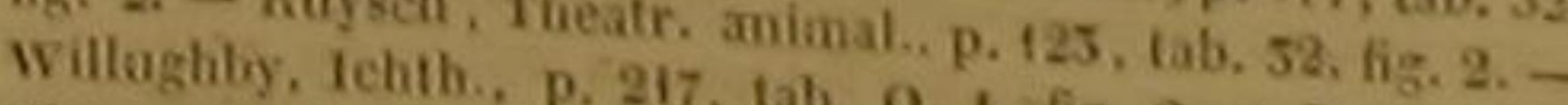
ris., p. 102, n. 7. Cinu sous-genre $\mathrm{P}$

'Chetod in as. Forskael, Faun a frar, Bonnaterre, pl. de l'Ene, méth.

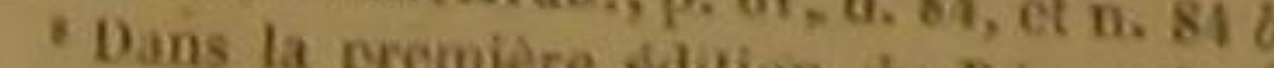

cite ce poissoa comme apparteang antmal, ML. Cuvier

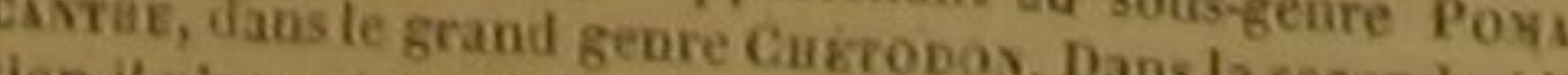
a it n'en est pas fait miention. D. Browne, Jamaje., p. 434, Bonnaterre, pl. de l'Fne. méth. 10 Non mention. p. 43, n. che; et l'extrémité de la caudale, qui est aussi d'un blanc très-pur, représente comme un sixfème ruban argenté. Des points blanes mar. quent la ligne latérale. Les yeux sont placés très-près du commiencement de la nageoire du dos, qui est uu peu triangulaire, ainsi que celle de l'anus. Une partie de la circonférence de cha. que écaille montre une dentelure profonde.

La patrie de ce beaú poisson est très-voisin de celle du doré, quet'on trouve dạns la mer des Antilles, et dont la parure est encore plus magnifique que celle de l'arqué. L'extrémité de outes les nageoires du pomacanthe doré resplendit d'un vert d'émeraude, qui se fond par des teintes très-variées avee l'or dont brille par des toute ia surface du poisson; et ce mélange est d’autant plus agréable a l'œil, que ces nageoires sont très-grandes, surtout celles du dos et de lanus, qui de plus se prolongènt en forme de faux, et doñt les premiers rayons articulés s'étendent bien au dela de la nageoire de la quene. Les thoracines sont d'ailleurs très-allongées. 0 in voit sur la dorsale, l'anale et la caudale, un très-grand nombre de petites écailles, dures, et dentelées comme celles qui couvrent le corps et la queue. Chaque narine a deux orifices.

Le paru n'offre, au contraire, qu'une ouverture à chacune de ses narines; sa mâchoire in. férieure est plus avancée que la supérienre la dorsale et l'anale ont la forme d'une faux ' ${ }^{\prime}$,et sont ganies d'écailles chargées chacune d'un croissant d'or, de méme que celles du corps et de la queue. On trouve le paru au Brésil, à la Jamaique, et dans d'autrès contrées de l'Amé. rique. Il $\mathrm{y}$ est bon à manger; et on l'y pèche ạu filet aussi bien qu'à l'hamecon.

Les rivages de l'Arabie sont fréquentés par I'asfur, qui a sa dorsale et son anale en forme de faux, une bande transversale jaune, ou de raies obliques violettes, et la caudale rousse bordée de noir.

Le jaunậtre a été observé dans les eaux de la Jamaique.

- 6 rayons à la nembrane branchiale du pomacanthe ar-

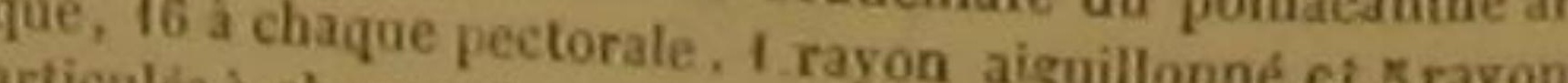
12 rayons daque thoracine, 14 à la nageoire de la queneque thoracine is a to torale da pomacaalhe doré, 6 à chapectorale du 75 à la nageoire de la que para, 6 a chaque thoracine. branchiale du pomacanthe asfor, 16 rayons à la membrane 1 rayon aiguillonné et 5 rayons articulés àue pectorale, racine, 16 rayons a ta caudale. -4 on 5 on 6 rayons at

CENT TRENTE-HUITIEME GENRE. LES HoLACANTHES '

Les dents petites, Rexiblesel mobiles; le corps et la queue ris-comprimés; de petites deailles sur la dorsale on sur d'autres nageoires ou la hauleur du corps supdreure au du noins igale d sa longueur; l laueerlure de la bouche petite; le museau plus ou moins acance; une dentelure et un ou plusieurs longs piquants d ehaque epercule; une semle nágeoire dorsale.

PREMER SOUS-GENRE.

La nageoire de la queus fourchue, ou ichancrie en

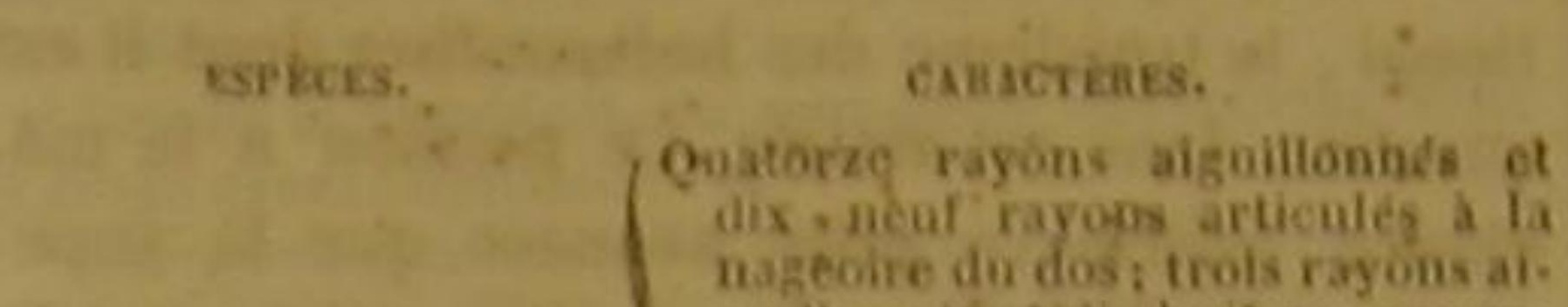

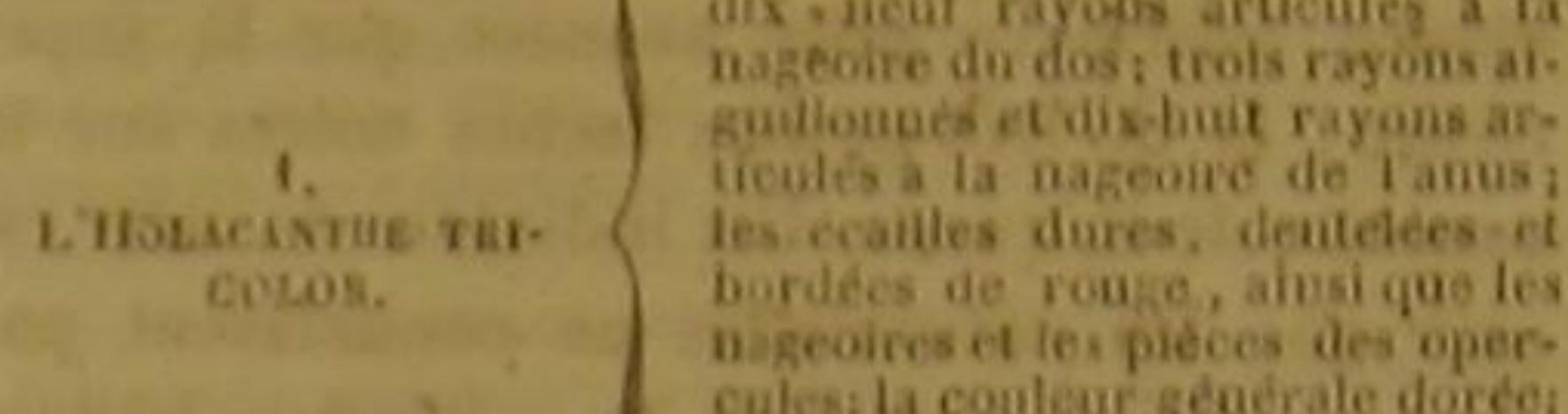
nieure de Tanimai ana noir forrce. Uwit rayons aiguillonnés a la dor-
sale i trois rayons aignillomnos

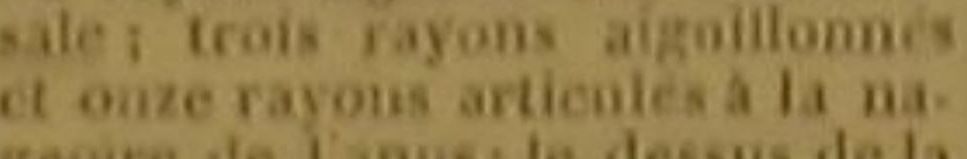
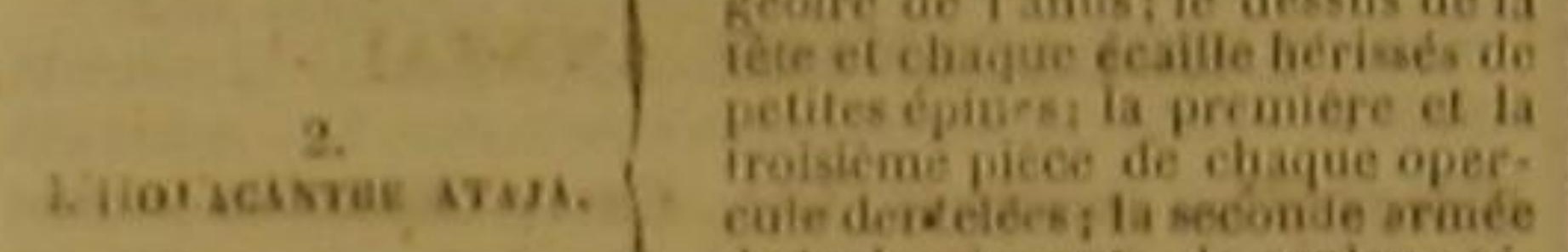

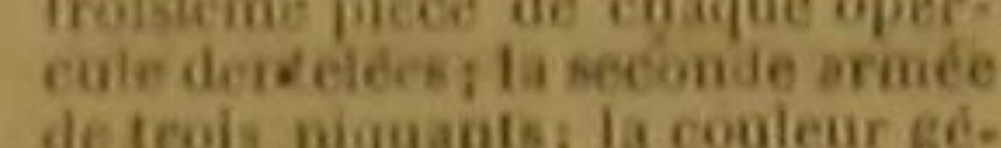

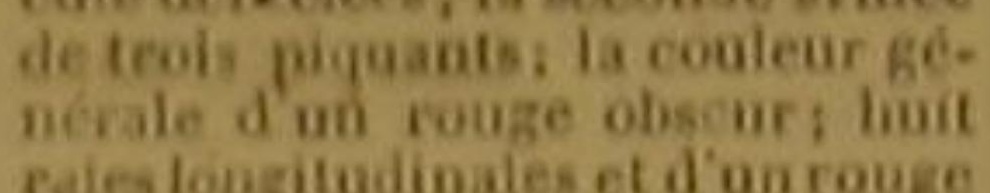

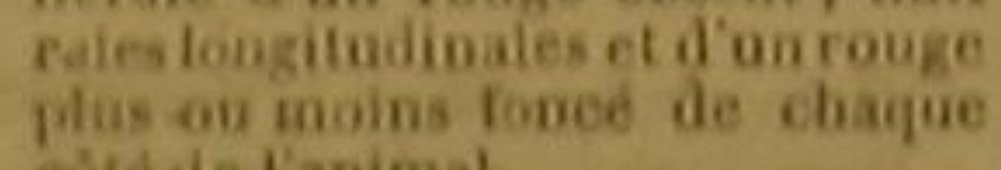
Guinze rayons aigullilonnés et scize

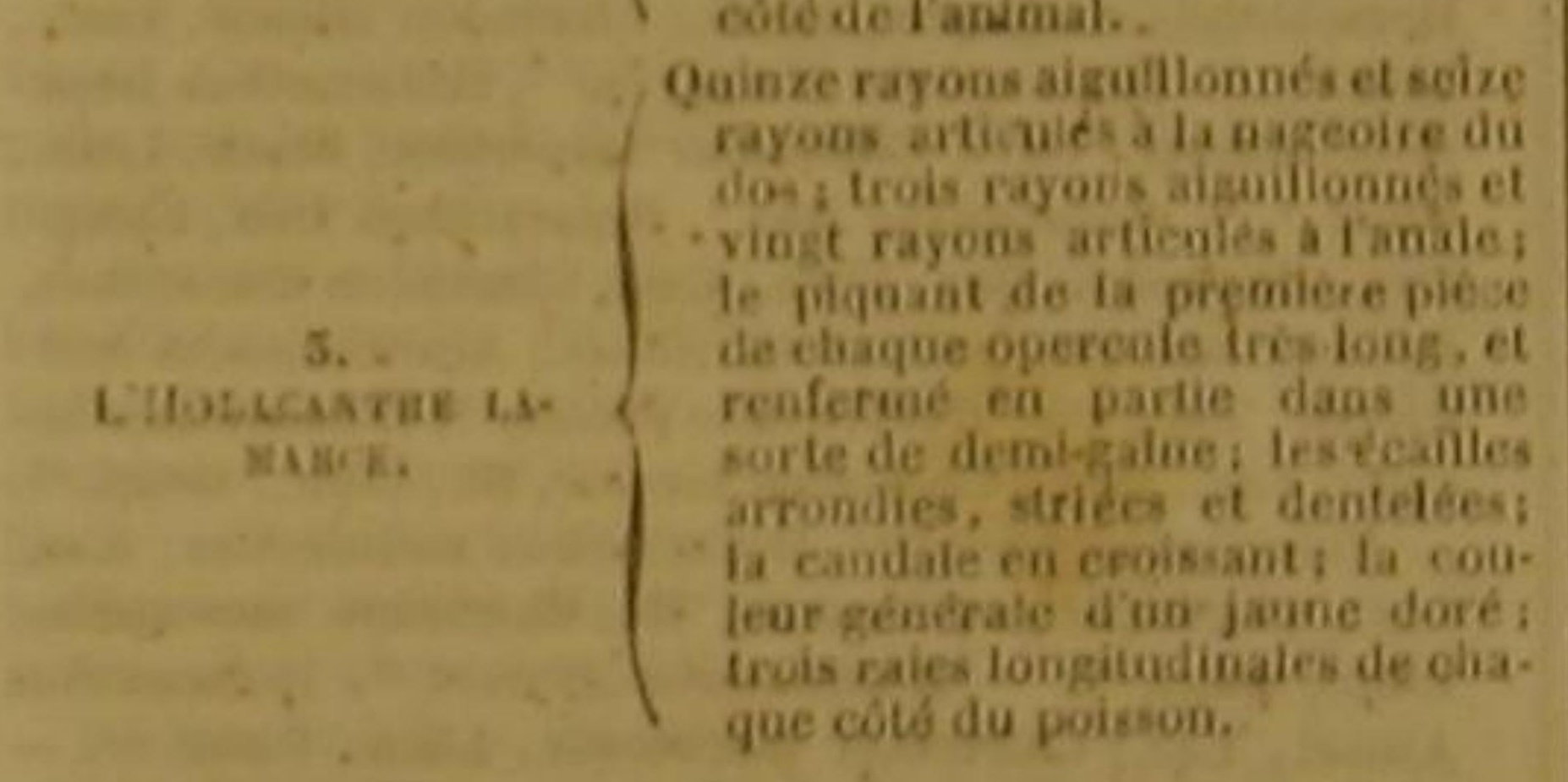

SECOND. SOUS-GENRE:

In nageoire de la queue rectiligne ou arrondie, sains echancrure.

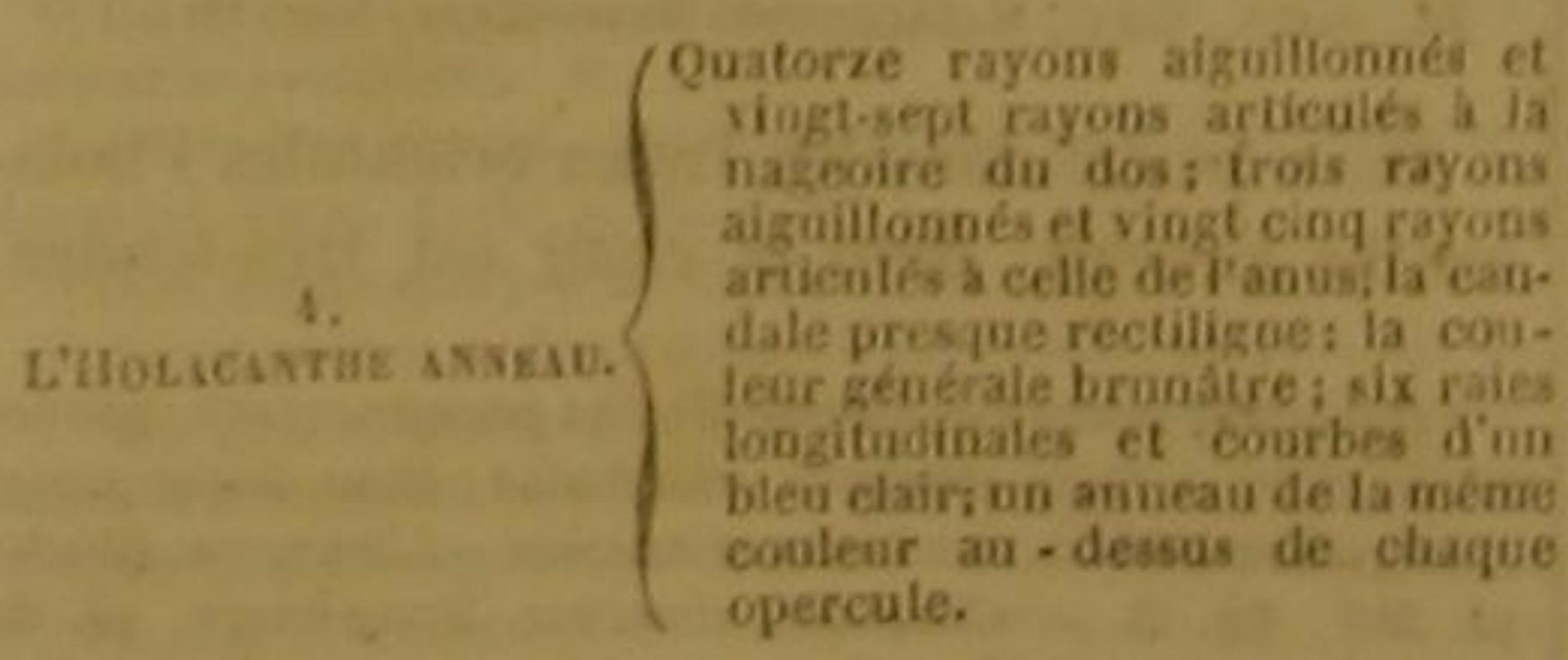

' H. Cavier conerve les HoLicisuás, de S. de Lackpede. wais comme sons-genre, dans le grand genre CaEToDos, de ta famille des àcantboptérygiens squamigennej. D.

\section{Epices.}

Cüscrìns.

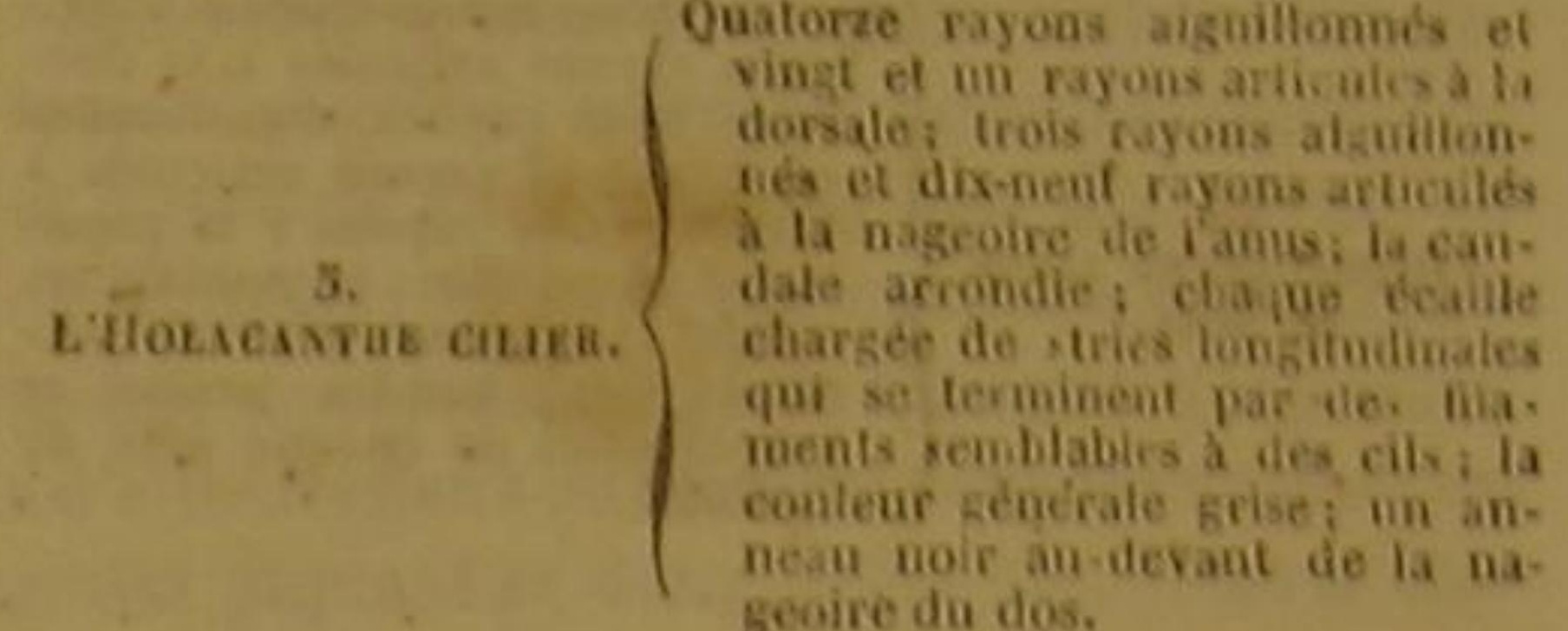
nean uor an derant de la na.
geoire da dos. Ouatorze rayons aiguillommis at

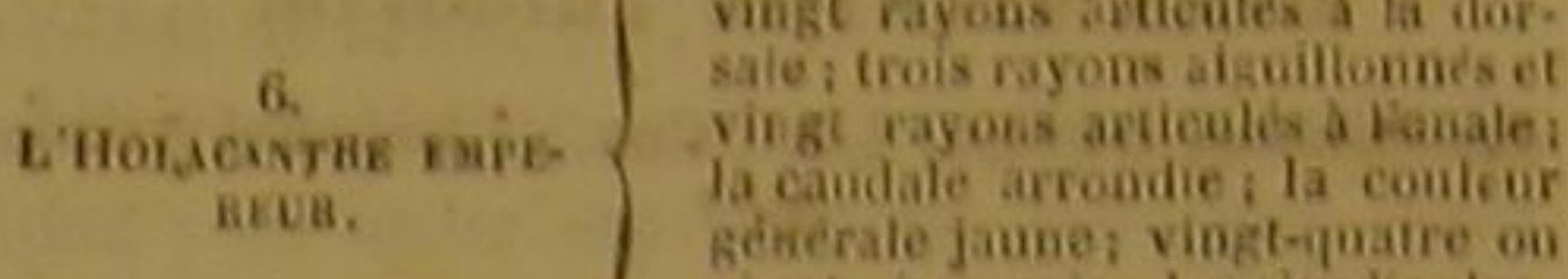

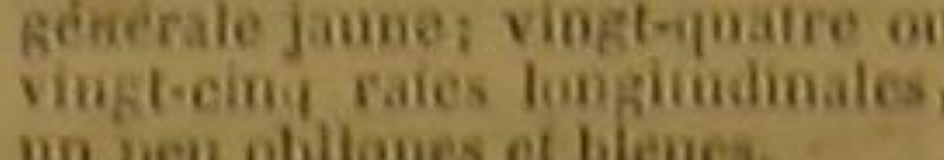

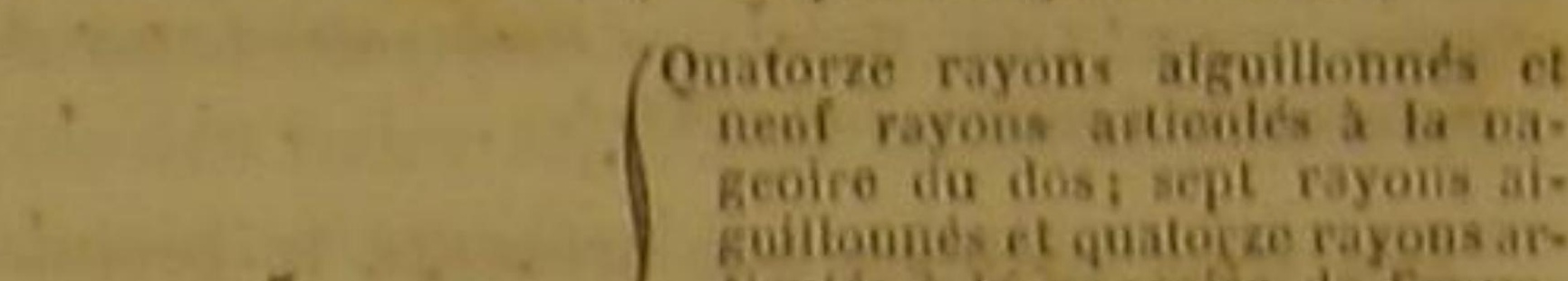

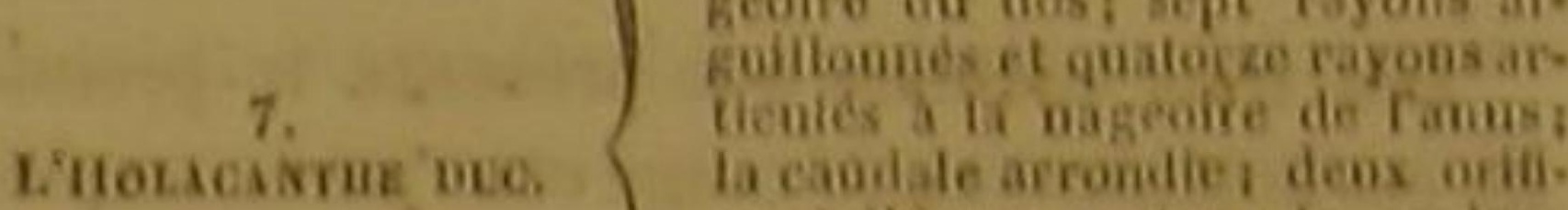

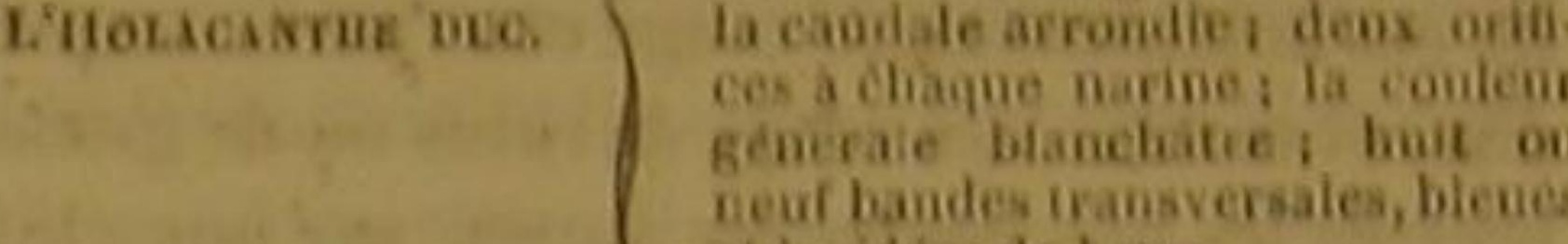
neur bandes yansversales, bieue
cenders de brews

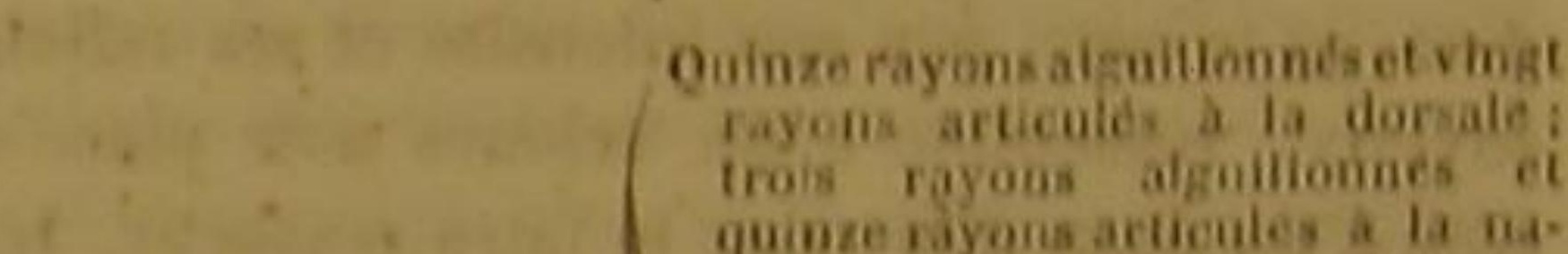
S. $\begin{gathered}\text { s. } \\ \text { CoLsesmus meron. }\end{gathered}$

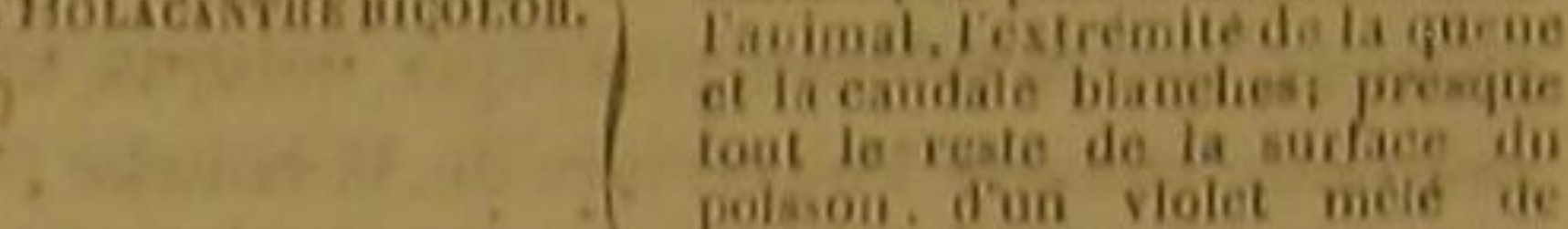

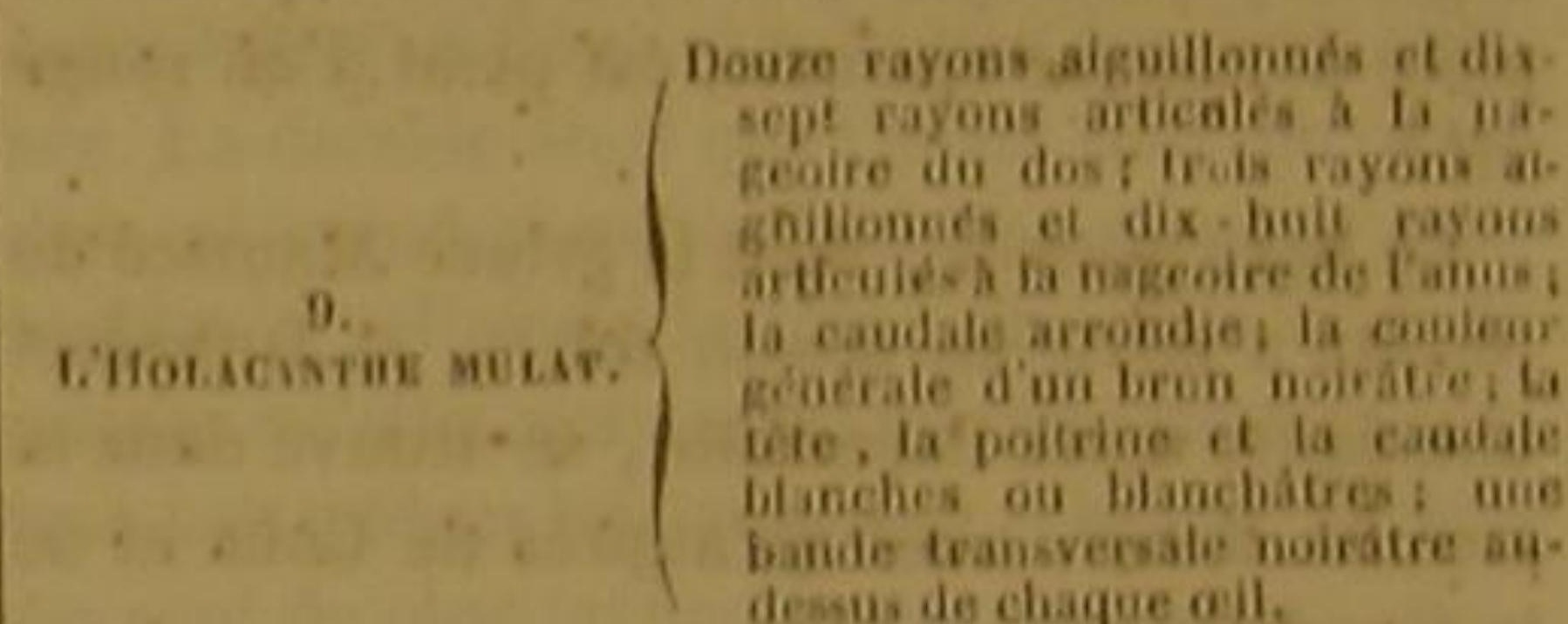

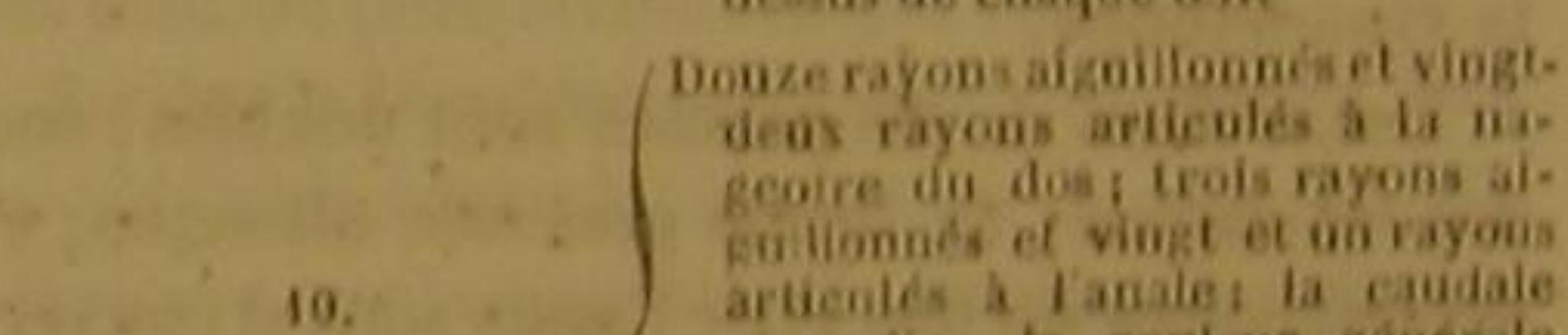

LHoLscastus anisex.

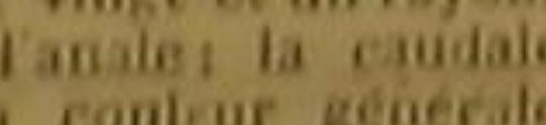

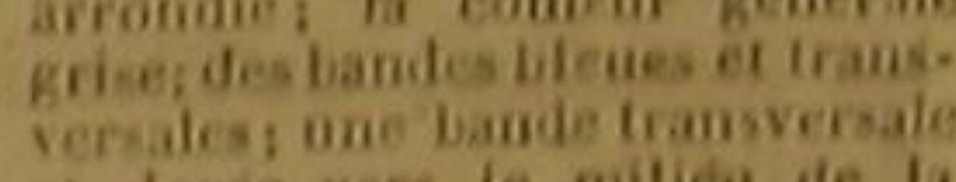

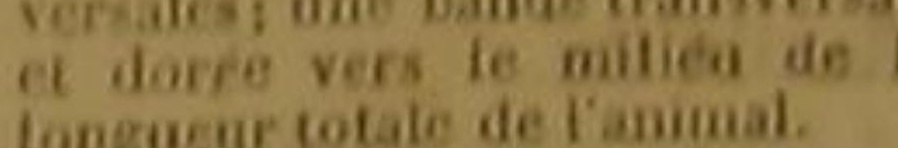
longueur totale de Tammal.

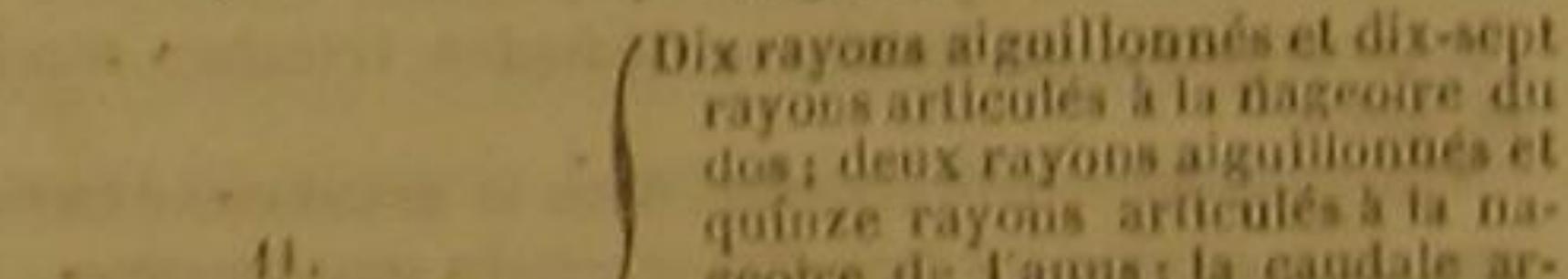

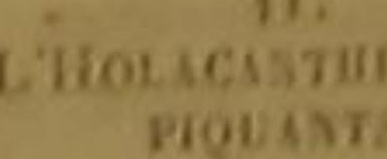
i

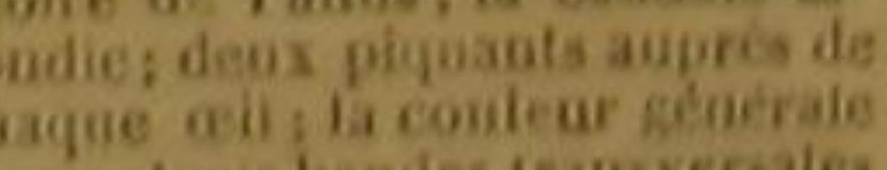

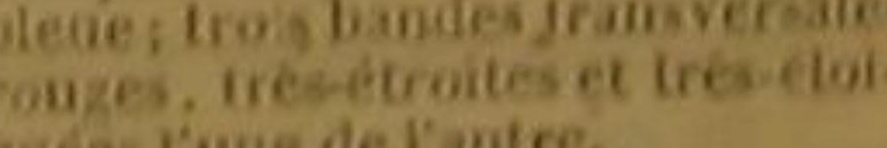
torze rayons aiguillonnds ot
vat et ui rayous artieales a i

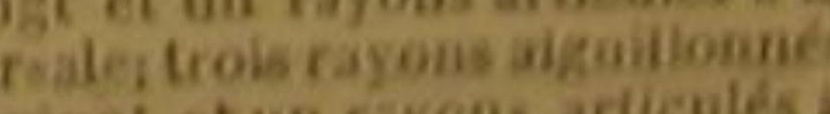

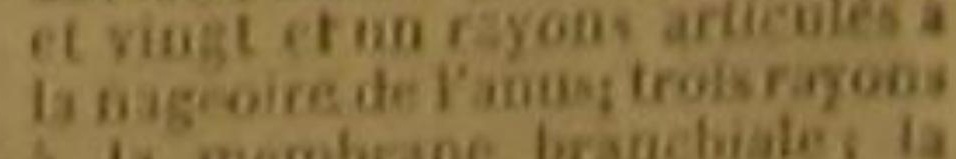

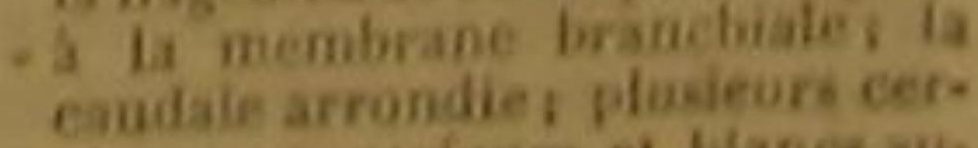

12

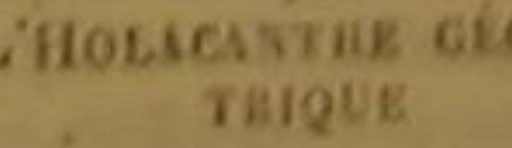

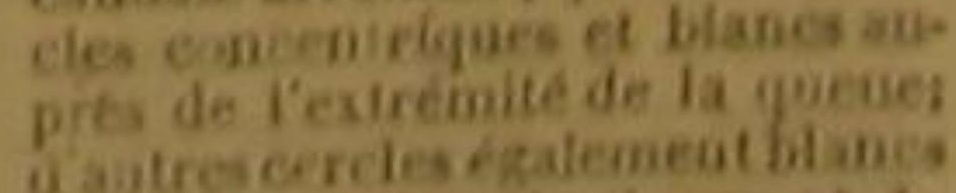

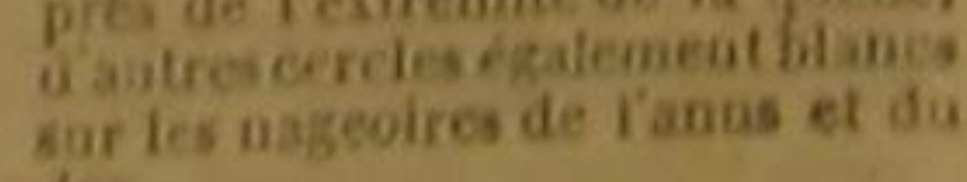




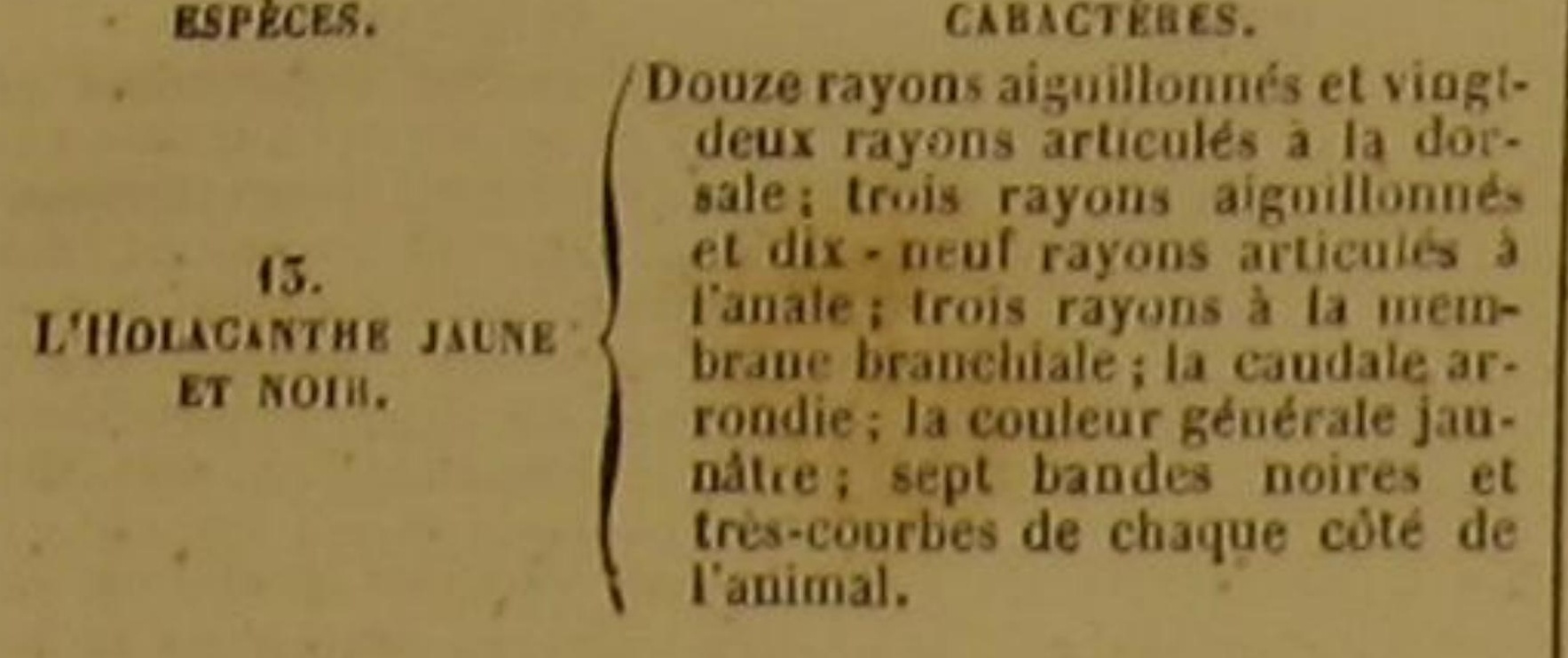

$\longrightarrow$

L'HOLACANTHE TRICOLOR ', Holacanthus tricolor, Lac., Guv.; Chætodon tricolor.
Bl.'?

L'Holacanthe Ataja ', Holacanthus Ataja, Lacep, Scime rubra, Forsk., Lino., Gmel. 4.-- Holacanthe Lamarek
Holacanthus Lamarck, Lac., Cav, 5 .

Des trois couleurs que présente le premier de ces holacanthes, le rouge et le jaune resplendissent comme des rangs de rubis ou de grenats pressés les uns contre les autres sur une étofi d'or; et le noir, par son intensité et ses reflets soyeux, ressemble à un velours noir placé à cóté d'un drap d'or pour le faire ressortir. Indépendamment des distributions de ces trois nuances, que le tableau générique indique, une raie noire entoure l'ouverture de la bouche; $\mathrm{et}$ le grand piquant que l'on remarque á la première pièce de chaque opercule, est peint d'un rouge vif ${ }^{\circ}$.

Ce beau poisson, dont le prince Maurice de Nassau a laissé un dessin fidèle, et Duhame une figure assez imparfaite, se trouve dans la mer du Brésil, ainsi qu'auprès de Cuba et de la Guadeloupe.

Les orifices de ses naxines sout doubles; son dos est caréné; sa forme générale allongée; $\mathrm{e}$ ses nageoires du dos et de l'anus sont si couvertes d'éeailles, qu'elles n'ont presque pas de flexibilité.

1. Acaraune, au Brésil. - Chétodon tricolor. Bloch,
pl. 426. , Dus

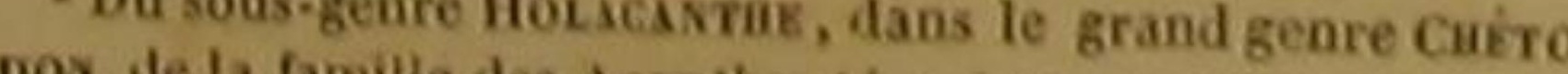
'Forskael, Faud. Arab., p. 18, D. D1.-Seiene ataja. Bon"Non mentionné par lh.

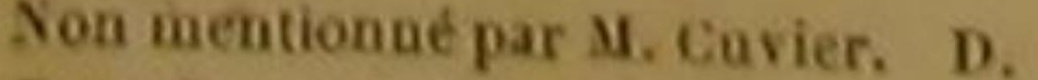
Du sous-genre HoLcistuk, dans le grand genre Cukto-
Dox, Cur. D. 6 rayons a la membrane branchiale de l'bolacanthe tricearticulés a chae pectorale, 1 rayou aiguillonné et $\delta$ rayons queaé. -8 rayons a la inembrane brans a la nageoire de $1 \mathrm{a}$

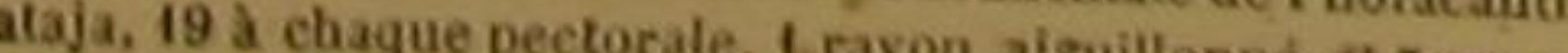
articules a chaque thoracinę, 15 rayons a la cand rayoes rayons a ia membrane branchiale de l'holacanthe lamarch culés a chaque thoracine, 17 rayonis a premiler et le deraier rayon sont tres-allongés.
L'ataja, dont la mer d'Arabie est la patrie, a chacun de ses yeux entouré d'une sorte de cercle de substance dure, dentelée, et garni d'aiguillons; sa levre supérieure est extensible deux raies rouges s'étendent sur sa dorsale; ses thoracines sont blanches sur leur bord extérie et noires sur leur bord intérieur. La caudale jaunâtre dauss son milieu ; peut-être ne présente-t-elle pas d'échancrure: si cette nageoire n'en montre pas, l'ataja devrait être inscrit parmi les holacanthes du second sous-genre.

Nous dédions à notre savant confrère $\mathrm{M}$. de Lamarck, professeur d'histoire naturelle au Jardin des plantes, et membre de l'Institut national, le troisième des holacanthes dont il est question dans cet artiele. Ce poisson a la má. choire inférieure plus avancée que la supé. rieure, et de très-petites taches noires sur la nageoire de la queue. Un individu de cette espece que les naturalistes ne. connaissent pas encore, faisait partie de la collection hollandaise, acquise par la France.

\section{L'HOLACANTHE ANNEAU ',} Holacanttis annularis, Lac., Cuv.; Chatodon annu-
laris, Bl., Lion., Gmel, ?.

L. Holacanthe cilier ', Holacanthus elliaris, Lacep., Cuv.i Holacanthus corvnatus, Desm.; Chxtodon ciliaris, Linn. rator, - Holacanthe Empereur s, Holacanthus Impe.

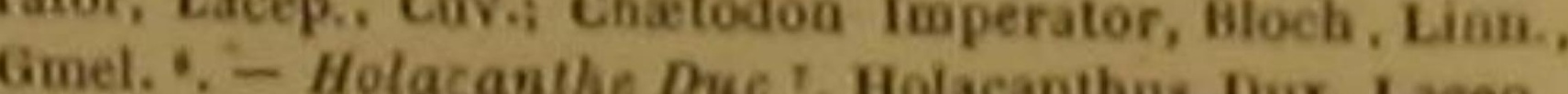
Cur,i Chatodon Dux, Linn., Gm: Chathodon diacsathus, Bodd, Chetodon Boddaeriii, Gmel.; Acanhhopodos Boddaertii, Lac, '- - Holacanthe bicolor '. Holacanthus bi. - Holacanthe Mulat"., Holseotor, BI., Lion., Gmel. "e. Cuv.; Chatodon mesolencus, Blanthus mesoleueus, Lae., Limn., Gmel. 13, - Holacanthe Arused 1", Hosomelas, Aruset, Lac,; Chretodon maculosus, Linn., Gmel, "., Holacanthe deux - piquants ". Premnas trifasciatus. Cuv.; Chærodon biaculestus, Bl.; Holacanthus biaculea. lus, et Holocentrus Sonnerat, Lac.; Lutjanus trifasciatus, Geometricus, Licep., Cuv , Chertodrique ", Holacanthus

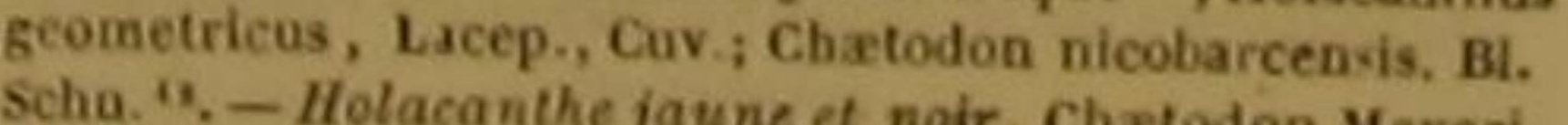
Bi., Schn., Cuv.; Holacanthus Aavo-niger, Lac, " Meyeri,

On a pêché dans les Indes orientales I'holacanthe anneau, dont la chair est très-tendre.

Douving marquis, Cambodische pampusvisch, par les Hollandais. - lkan pampus cambodia, Ikan batoe jang, Aboe, Aboe betina, aux Indes orientales. - L'anneau. Bloch.
pl. 215, fig. 2. - Chétodon anneau. Bonnaterre, pl, de PI.
IEnc. méth. - - Chetodon anneau. Bonnaterre, pl. de cus, ete, s Schwenck, p. 51 , u. 20; et p, 52 , n. 84 . Valent.

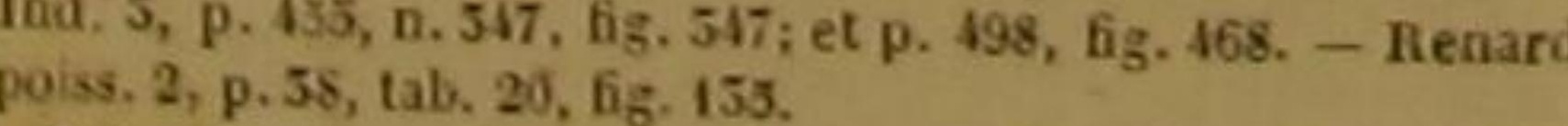

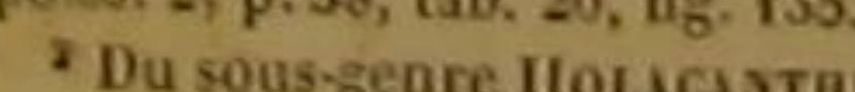

\section{DES POISSONS.}

Cnacune de ses narines a deux orifices, Ses pectorales, ses thoracines et sa caudale sont blanches; sa dorsale est noirâtre; et son anale noire avec une bordure bleue.

vox, de la famille des Acanthopterygiens squamipeone. 4. Cuvier, dans la premiere édition du Règne animal, le

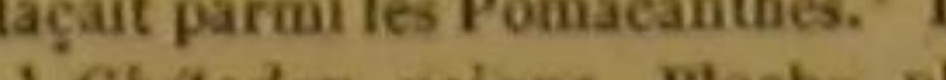

Danbeoton et Hagy, Ene, méth. - Id. - Bonoaterse, il. de IEne. meth. - Mus. Ad. Frid. 4, p. 62, tab. 53, 6ig. 1. - Sparus saxatilis. Osbeck, It. 275. - , Chixtodon mierolepido - tus, ete, 9 Groiov, Nus. 2, p. 36, D. 152, - , Platigloss - qui acarauaa altera major Listeri. , Kiein. Alss pisc. A,

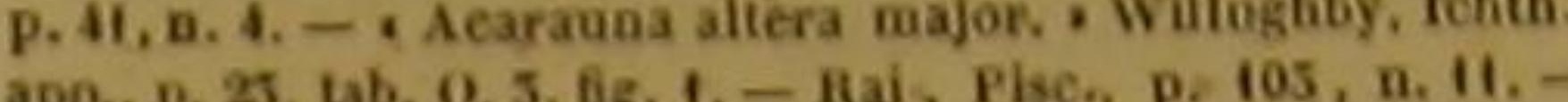
app., p. 25, ab. 0,3, ag.
Edw. Gleani., t: 283, fig. 4 . 4 Comme le precideot.

le grand geare Cuitiodos. D.

Guingam, dans les lodes orientales, - Chétodon empe reur du Japon. Bloch, pl. 194. - Id. Bonnaterre, pl. de TEnce, méth. - - Chastodon digro-ceraleus. liveis obliquatis

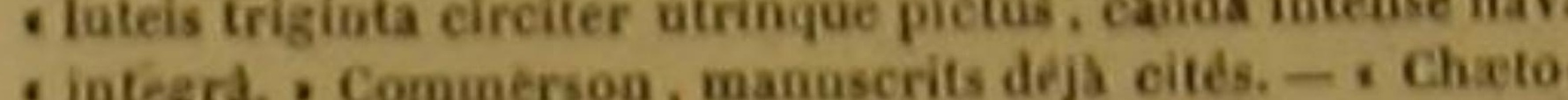
- dos eximix maznitudinis ei raritatis, slod. Mus, Schweeck, p. 32, n. 82. - Ruyseb, Theatr, anim. 1, p. 57, D. 1, tabe 10, lig. 1. - Renard, Polss. 2. pl. 56, fig. 238.

- Du méme sous-geare HoLscistee, dens le grand genr Cakiodor, Cur. B.

'Ikan sengadji molukko, dans les Indes orientates:Mroluksche herlog, dams ies colowiles hollandasises des Grannaterre, ph. de YEne. méth. - Valent, ind. 5, p. 504, D. 507, 6ig. s07, - Duchesse, et douwing batard a haroke, ehietsevisech. Heasrd, Polss. 1, p. 22, ph. 11, fig. Bti, et 2 , pl. 16, fig. M7, et pl. 58, fig. 169.

- Da sous-genre HoLsastax, dass le grand genre Cuirobos, Cur. Ce poisson est deccrit deux fois par M. de Lack pede, sous les noms to

- Acarauna du Bresil, par des Frabcals. - Groene koe. lar, Twre klenrige klipvisch, Color sousounam, par les Hollandais. - Ikan koelar, Ekorhouning, dans les Indes orientales.-L'auraune, et la griselle. Bloch, pl. 206

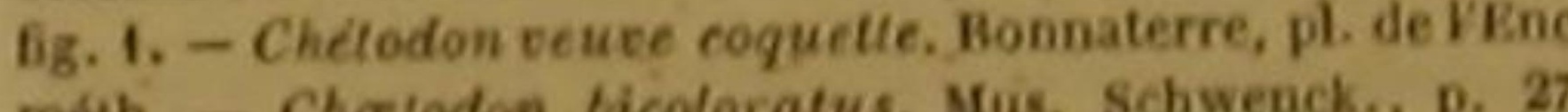
méth. - Chatodon bicoloratus. Mus. Schwenck., p. 27,

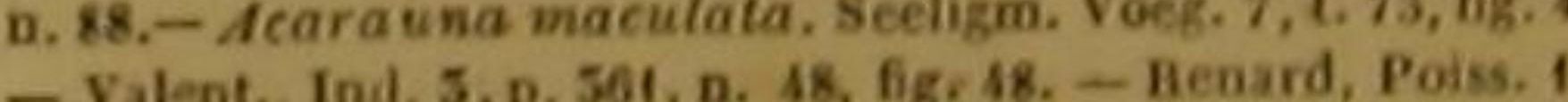
p. 10, L . ., fig. 53 ; p. 19, n. 106, L. 19, L. 106; et p. 35, n. 121. i. 22 , fig. 121 .

it Du sous-zenre HoLcicastae, dans le grand genre de Cuktodoss. selon M. Cuvier. D

"Chelodon mulat. Bloch, pl. 216, fig. 2. - Id. Bonn lerre, pl. de I Enc, meth.

"Du sous-gence Holucastue, daos le genre Cuítodos,

"Che precedent. D.

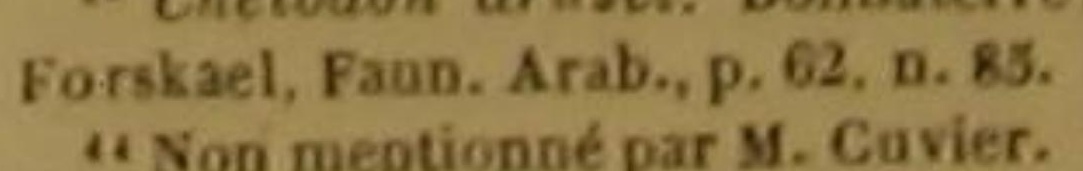

"Bandouliere a deux a aiguillons. Bloch, pl. 219. fig. 2. - Du genre Pagussog, Premnas, dans la familie des Acanthoplerybiens cile cons les noms 10 d'Holocentre Son nerat, et 2。 d Holacanthe deux-piquauls. D. "Douwing formose. Renard, A, pl. 5. fig. 34 . " Da sous-genre Holscistaz, dans le grand genre CatTobox. D. " Du sous-genre des Crítodoss proprement dits, dans Ie grand genre Cakitodos, de la famille des Acanthopterygien
squanipennes. D.
Le cilier se nourrit de petits crabes; son estomac est grand; son canal intestinal très-long, et plasieurs fois recourbé; son foie divisé en deux lobes; et sa vessie natatoire forte, et attachée aux deux cótés de l'animal. Ce poisson a d'ailleurs deux ouvertures à chaque narine; un grand piquant et deux petits aiguillons à cbaque opercule; et presque toutes les nageoires bordées de brun.

L holaeanthe empereur vit dans la mer du Japon; sa chair est souvent beaucoup plus grasse que celle de nos saumons; son gout est très-agréable; les habitants de plusieurs contrées des Indes orientales assurent mème que sa saveur est préférable à celle de tous les poissoñs que l'on trouve dans les mèmes eaux que cet holacanthe; et il se vend d'autant plus cher qu'il est très-rare. Il est d'ailleurs remarquable par la vivacite de ses couleurs et la beaute de leurs distributions. On croirait voir de beaux saphirs arrangés avee goủt et brillant d'un doux éclat, sur des lames d'or très-polies; une teinte d'azur entoure chaque $\alpha i l$, borde chaque pièce des opercules, et colore le long piquant dont chacun de ces opercules est armé. On compte deux orifices a l'une et $a$ l'autre des deux narines. La dorsale ainsi que l'anale sont couvertes d'un si grand nombre d'écailles presque semblables a celles de la tête, du corps et de la queve, qu'elles présentent une épaisseur et surtout une roideur très-grandes; ces deux nageolres sont de plus arrondies par derrière.

Le due a la même patrieque l'empereur. Des reses bleues sont placées autour de chaque oil, ansi que sur la nageoire de l'anus; et une bordure azurée parait a l'extrémité de la nageoire du dos.

Les deux Indes nourrissent le bicolor, dont le nom indique le nombre des couleurs qui composent sa parure. L'argent et le pourpre le décorent; et ces deux nuances, distribuées par grandes places, et opposées l'une á l'autre, pres que sans tons intermédiaires, donient beaucoup d'éclat à sa surface.

Les eaux du Japon sont celles dans lesquelles on a découvert le mulat, qui n'a qu'un orifice la dorsale, l'anale, les opercules et la tête sont revêtus de petites écailles.

On doit remarquer sur l'aruset de la mer d'A. rabie les écailles striées et dentelées, la dorsale, qui se termine en forme de faux, et la caudale, à chaque narine, non plus que le bicolor, et dont 
dont la couleur grise est relevée par des taches aunes et arrondies.

L'holacanthe deux piquants a le corps plus allongé que la plupart des autres poissons de son genre; chaque narine ne présente qu'un orifice; la dorsale est échancrée; les nageoires sont, en général, d'un gris mêlé de jaune. On l'a vu dañs les Indes orientales.

Nous avons tiré le nom du géométrique, de la régularité des figures blanches répandués sur sa surface. On peut compter quelquefóis, de chaque côté de l'animal, jusqu'à huit cereles concentriques, dont les quatre intérieurs sontentiers; six ou sept bandes blanehes et sinueuses paraissent d'aillèurs au-dessus de la tête et des opereules; de petites écailles couvrent les nageoires du dos, de la queue et de l'anus; et une demi-gaine membraneuse garnit le dessous du piquant allongé de l'opercule '

Le jaune et noir a la base de sa dorsale, de sa caudale et de son anale, chargée de petites éeailles, et la mâchoire inférieure plus avancée que celle d'en haut.

\section{$-$}

CENT TRENTE-NEUVIEME GENRE. LES ÉNOPLOSES ${ }^{2}$.

Les dents petites, faxibles el mobiles; le corps et la punu tris-comprimés; de très-petites écailles sur la dorsale

i 66 rayous a chrque pectorale de l'holacanthe arinesm, I rayon aiguilloune et 8 rayous ariculés d chaque thoracine 16 rayoas a la caudale, -6 rayous a la membrane branchial fonné et 5 rayous articulés a chaque thorac, 1 rayon aiguit la nageoire de la gueue, -5 rayous a la membre, 16 rayons a de litolacanthe empereor, is a chaque pectorate, 1 ravon at guithonné et 8 rayous articulés a chaque thoracine, 16 rayorom canthe dac - -16 rayons a ta membrane branchiale de l'bolaque thoracine, 14 rayons a a is et 3 rayons articulés a charayons à chaque pectorate de liboore de ta quacue, -1 aiguillomed et 3 rayons articules a chaque thore 1 rayo rayons a ta caudale. -16 rayons a claque pectorale in a chacune thonulat, 1 rayoo aigulltonné et 5 rayons artienk 5 rayons a la memb ta rayons a la nageoire de ta queue. chaque pectorale, 1 royon if ailt Indacanthe aruset, 1 lés à chaque thoraciue, 16 rayobos a la caudale. 5 riyons articu a la membrane branchiale de 1 bolzesnthe deus-piguante is a chaque pectorale, 1 rayon aiguillompe et 5 rayons a:ticalis

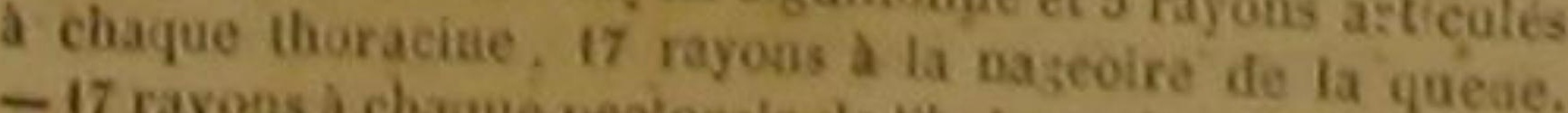

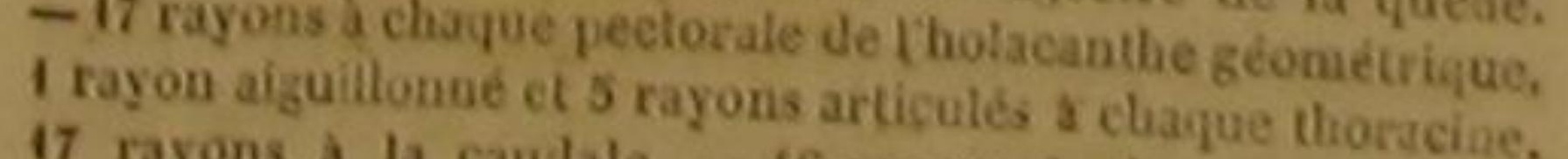

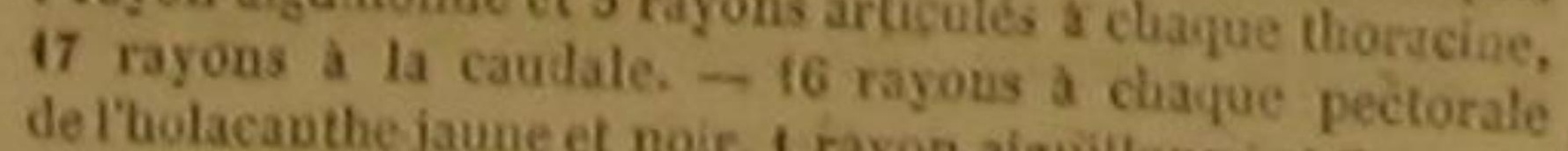
de l'bolacanthe jaune et noir, I rayou aiguillonne et 3 rayons articulés a ebaque thorecine, 17 rayous a la u a geoire de la
cueue. çueue. efpede, ue le consiletant le genre Exoplose de M. de La. efpede, ue le considêre néamoins que comme un sous.

Thires nageoires, ou la hauleur du corpssuperieure oudu moins igale de sa lonigueur; l'ouverture une dentelure et un ou plusieurs piquants acance, opercule; deux nageoires dorsales. EsPÈce. CARsctèaEs.

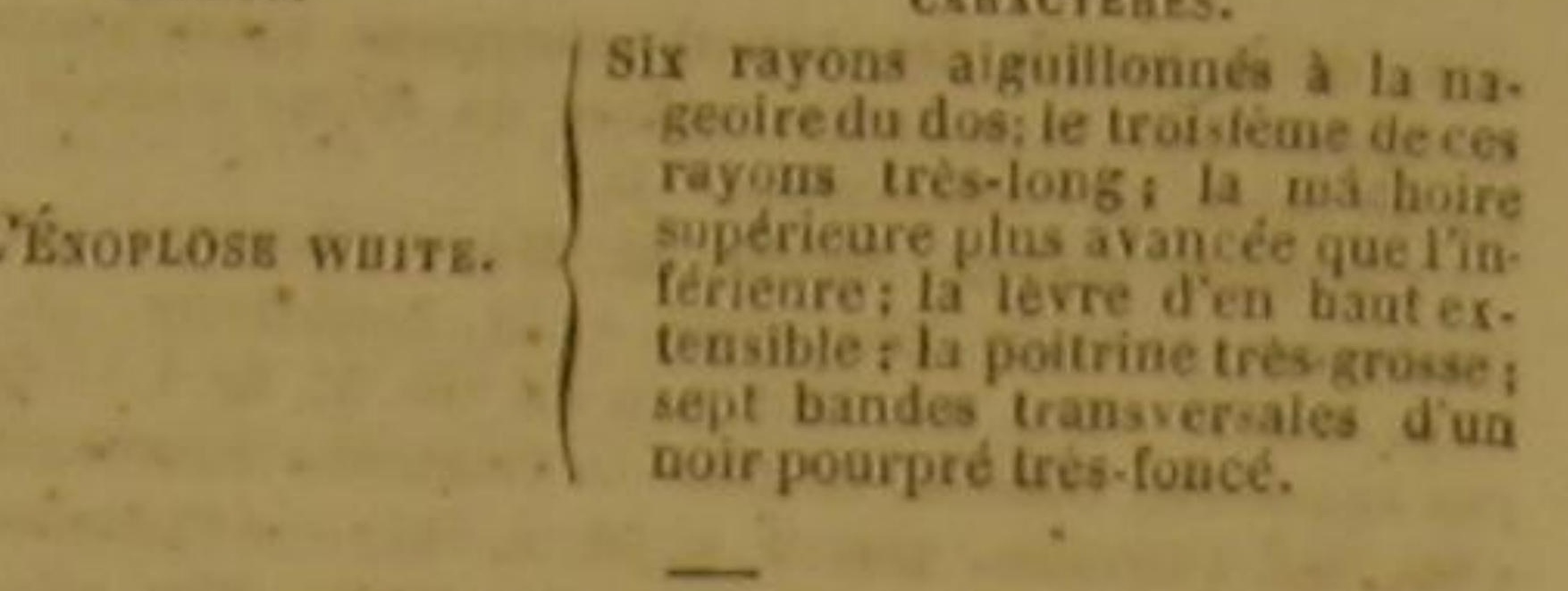

L'ENOPLOSE WHITE. '

Eooplosus armatus, Lac,, Cuv.; Chetodon armatus, John White, ?.

Nous dédions à M White, chirurgien anglais, ce poisson, déerit dans la relation du voyage de cet observateur dans la Nouvelle-Gälles méridionale. Le nom générique d' Enoplose, que nous donnons à ce thoracin, et qui vient du mot gree žozlos (armé), désigne la dentelure et les piquants de ses opercules, ainsi que les rayons aiguillonnés de sa première dorsale. La couleur générale de cet osseux est d'un blane bleuâtre et argenté, ses nageoires sont presque toutes d'un brun pâle; et la longineur de l'individu, dont on voit la figure dans l'ourrage de M. White, était d'un décimètre ou environ.

\section{CENT QUARANTIEME GENßE.} LES GLYPHISODONS ${ }^{3}$.

Les dents críneléas ou decouples; le corpa al la quene

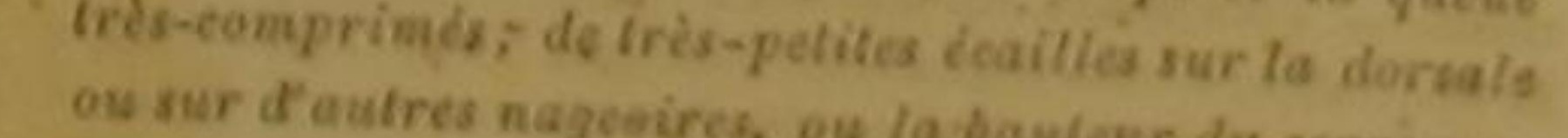

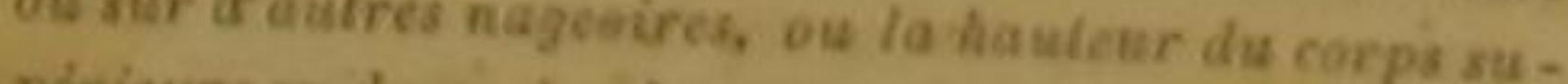
pericure ou du moins tgale d sa lenguerir; Powerture de fa bouche pehte; le museau plus ou moins avaned una nageoire dorsale.

\section{Espíces.}

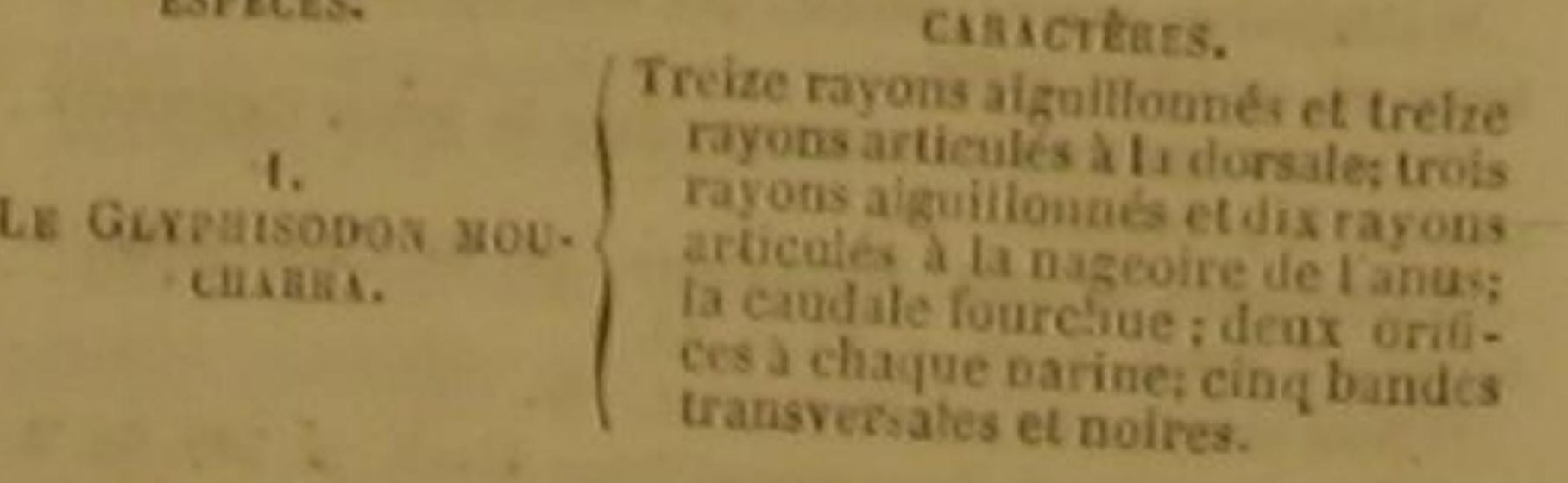

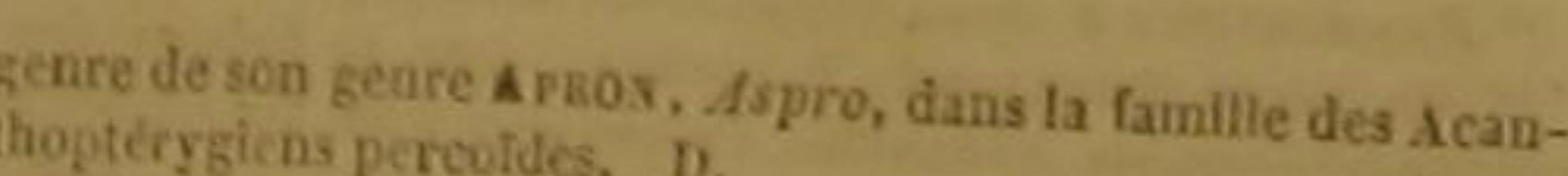
'Chátodon armalus. A Galles méridionale, par $J$, White, du Voyage a la Nourelle-

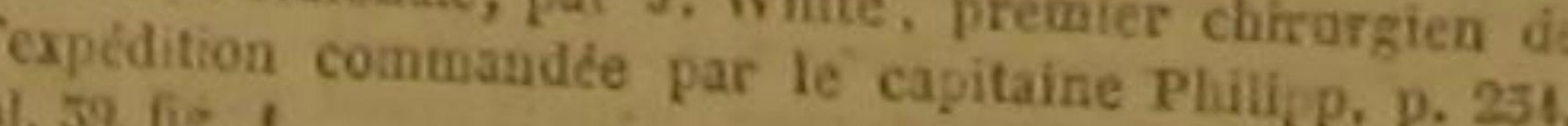
i Voir

"II. Cuvier adopte le genne précétente. D.

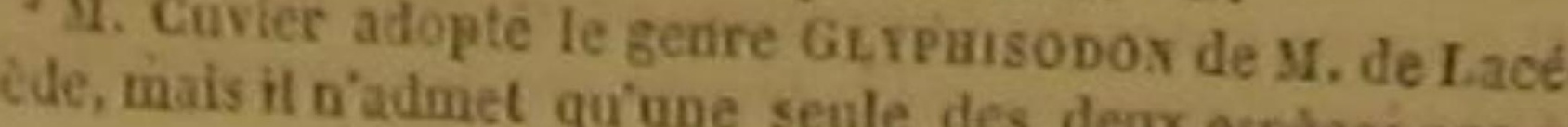

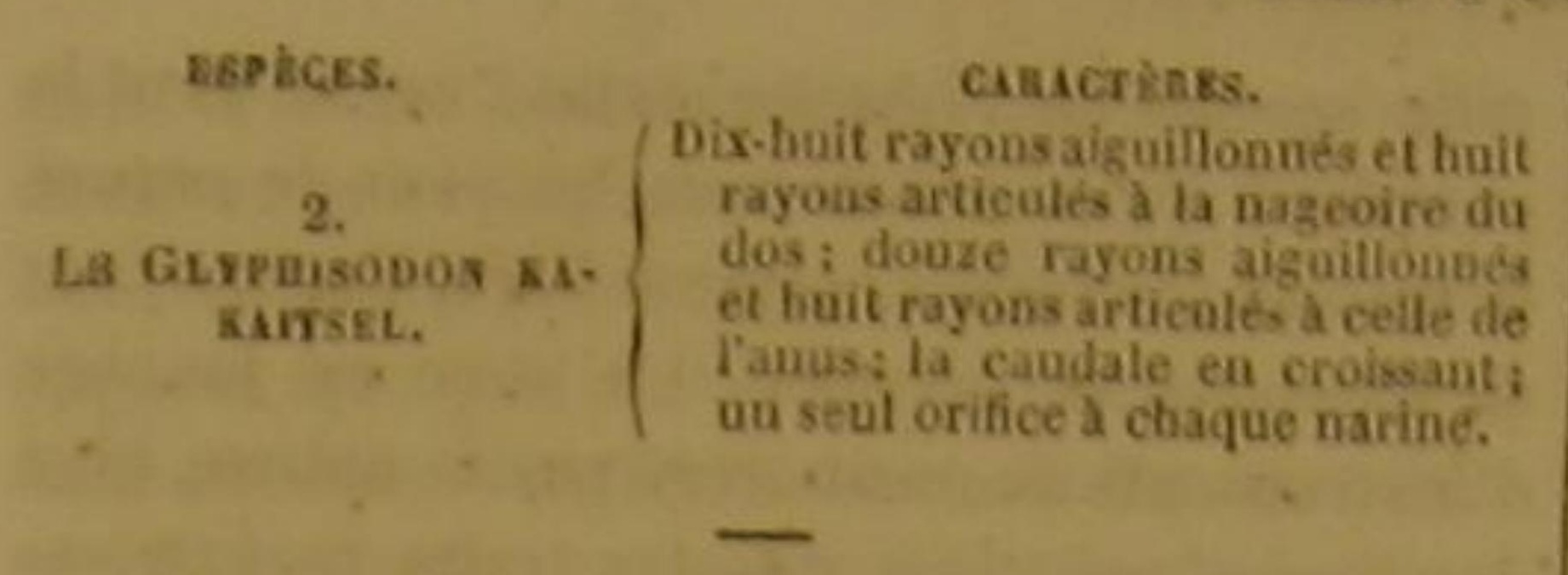

LE GLYPHISODON MOUCHARRA',

Glyphisodon saxatilis, Cur.; Glyphisodou Moucharra, Lac.; Chrtodon saxatitis, Líno., Gmel.; Chietodon marginatus, et Chætodon Sauritii, Bl, Lae.; Chatodon sargoides, Lacep. 2.

Lo Glyphis dun Kakaitset s, Etroplns maculatus, Cuv.

Le moucharra vit dans l'ancien ot dans Io nouveau continent. On le trouve dans les eaux du Brésil, de l'Arabie et des Indes' orientales. II ne quitte guere le fond de la mer. II y habite au milieu des coraux, et s'y nourrit de petits polypes. Comme il ne parvient ordinairement qu'a une longueur de deux décimètres, qu'il est très-dificile de le prendreà cause de la profondeu de son asile, et que sa chair est dore, coriace,

naturaliste y á plactes. D'ailleurs in fait voir que les caractó. res de ce genre se rapporteat a des polssous que N. de Laced. péde a rangés avec les Chétodons, tels que fes $\mathrm{C}$, sordidus,
narginatus, Ma uritii. bengalensis el suratensis. Il decri narginatus, Mauriti, bengalensis el suratemia, II decrit
beacooap d'especes nourclles dans lo geure GLspasovos,

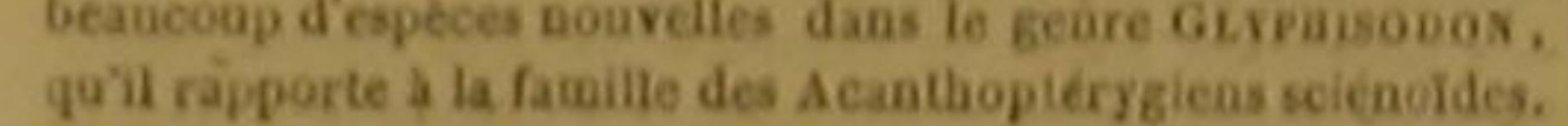
go. D. Gabel sehuans, par les Allemands. - Osr Mippare, par les Sued dols. - Siamase eivech, Loots moanetje, Loot masn des hayen, Groene lootsmann, par le Hollandalis -
Jaguaca guar, au Breil. - Jagueta, par les Portog als du

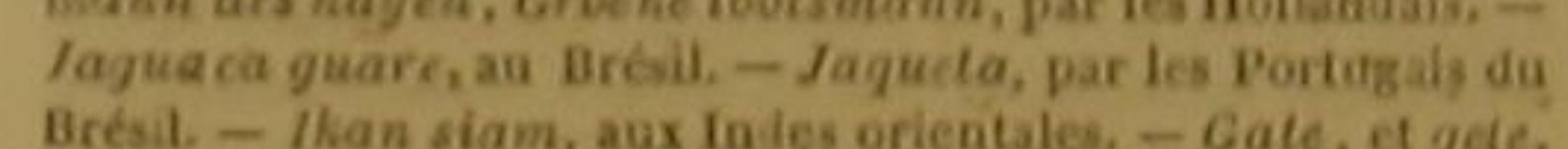
Brésil. - Man siam, aux In ies orientales. - Gate, et gede,
et gatyadt, en Arable. - Id. Bloch, pl. 206, rig. $2^{2}$ - Cheto.

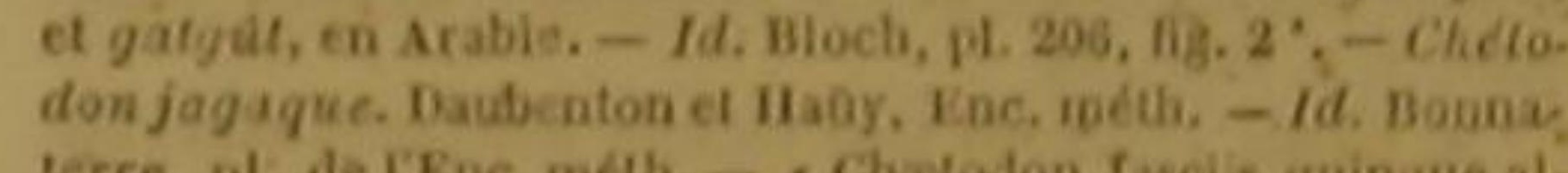

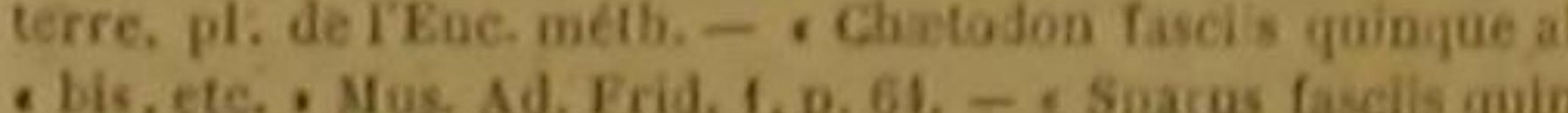
Eque transverais foris etc. Amonit. acad, A, a. 312 ispirus latissimus, ele. G Grobov, Ma* 1., D. 89, et Zooph.

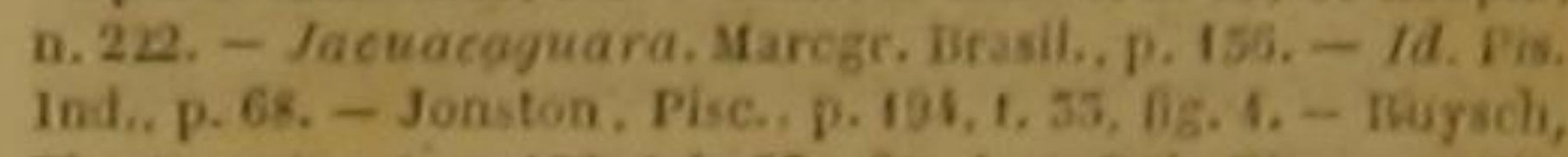

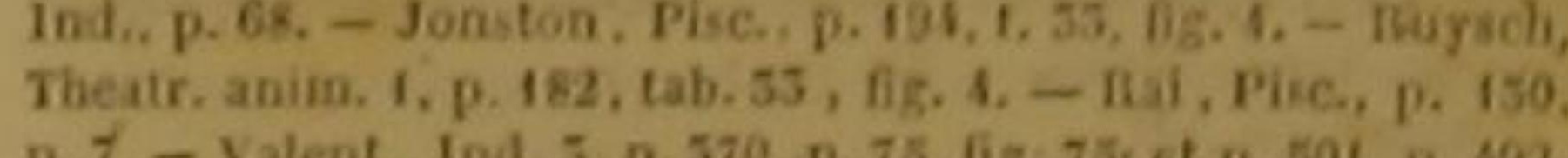
n. $7 .-1$ fig. $492 ;$ et p.
fig. $176 \mathrm{et} 177$

23. Cuvier fit dabord remarguer que le nom de Mou charra est a tort donné a ce poisson sil appartient a une ss péce de sargue. Co glyphisodon auquel il fant rapporter priacipalement le Chatodon-saxatilis de Linnee, a eté de crit quatre fois par $\mathrm{M}$. de Lacepede, sous les noms $10^{\circ}$ deGly-

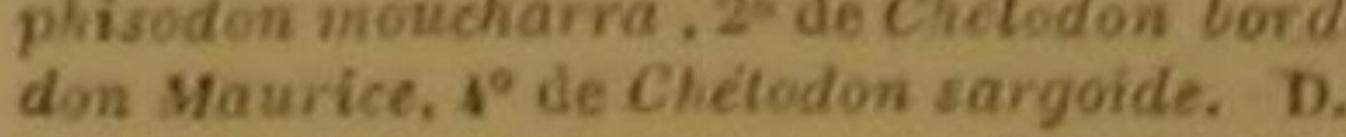
' Kakait-sellei, au Malabar. - Bandoulicre kakaitsel, el Chatodon maculatus. Sloch, pl. 427, fig. 2. 'Du genire Énopls, Etroplus, dans la tamille des Acan-
thopterygiens sciénoldes. D.

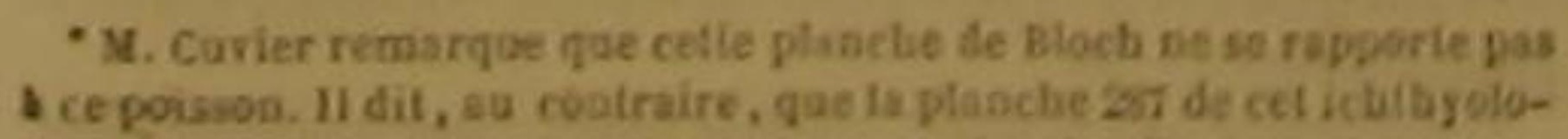

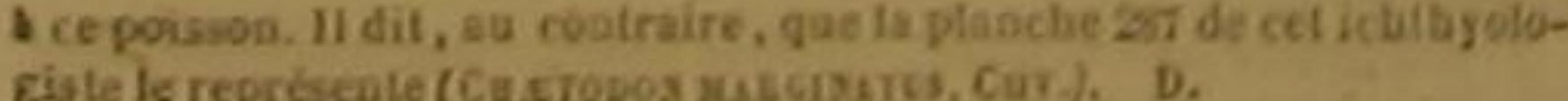

et peu agréable an goùt, qnoique très-blanche, il est peu recheiché par les pècheurs.

Sa parure n'attire pas d’ailleurs les regiards. Sa couleur générale est blanchàtre et terne; et toutes ses nageoires sont d'un gris noirâtre, II a le corps un peu allongé et épais, P'extrémitê de la queue très-basse, la ligne latérale interrompue, de petites écailles sur la base de la caudale, de la dorsále, et de la nageoire de l'anus'.

Le glyphisodon ${ }^{2}$ kakaitsel ne se plait pas au milieu de la mer; mais Il est, comme le moucharra, commun aux deux continents. On le péche daus les eaux douces de Surinam, aussi bien que dans les étangs de la cóte de Coromandel: II y multiplie beaucoup; mais comme il renferme une grande quantité d'arétes, on dít qu'il n'y a que les nègres qui en mangent. Chacane de ses écailles brille comme une lame d'or'. Une tache grande, ronde, noire, et einq ou six autres taches très-foncées, sont placées sur chacun de sés côtés.

\section{CENT QUARANTE-UNHEME GENIE.}

LES ACANTHUMEs

Is corpis at ta queue-tris-comprimds; do trit-petites deailles sur la dorsale ou sur d'autres nagroweses, on a hauteur du corps supéricure ou du moins égale d sa longueur ; Pouverture de lá bouche petito; le museau plus ou moins arand; uno nagcoire dorsale; un on plusicurs piquants de chaque cóte de la queue.

$$
\text { Espless. }
$$
cascrikas.

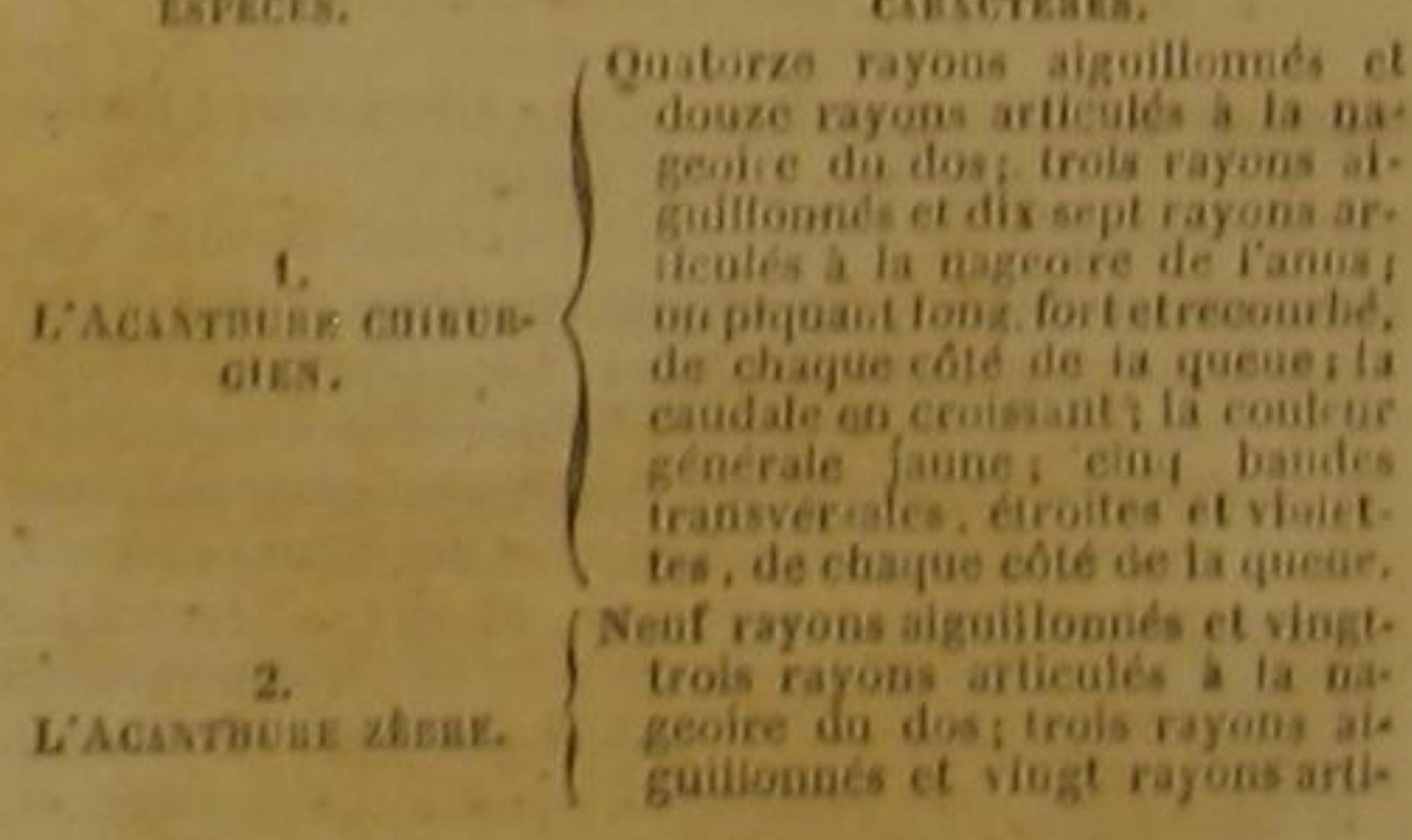

1 6 rayons a la membrane branchiste dn glyphilisodoa mont. charra, 18 a chayue pectorate, 4 rayon aiguilisine ets rayos. -6 rayons a ta membrane branchiste du Blyplisodon ka. kaitsel, 15 a chague pectorste 1 rayon aiguiltonse ef so rayons articules a clisgue thoracine, 20 rayons a ba cadate. 2. Glyphis, en gree, sgnilie incision, dentehue, erene. Iure. genre Acustause et adopte par M. Cuvier, el place
tLe

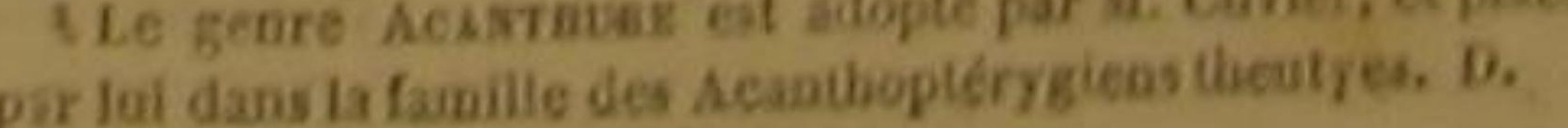


essekes.

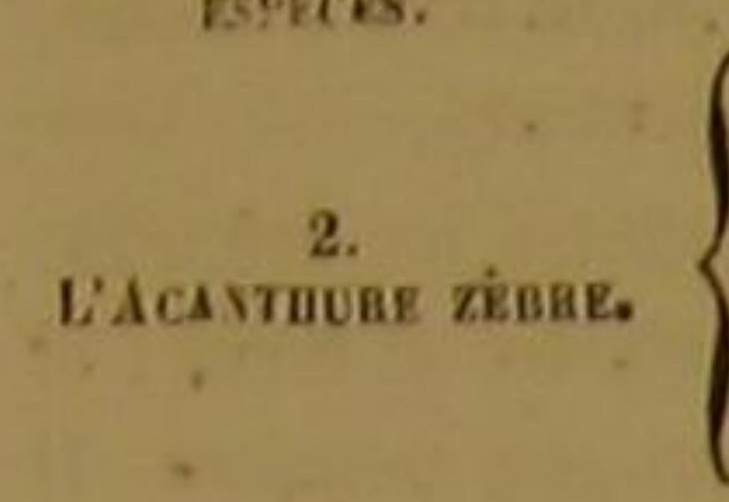

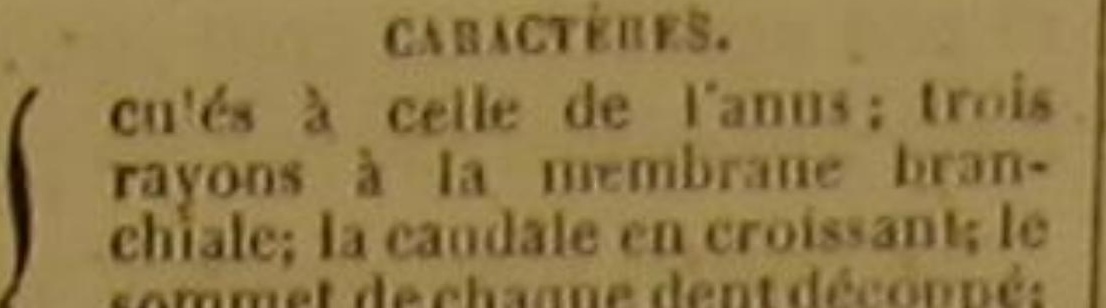

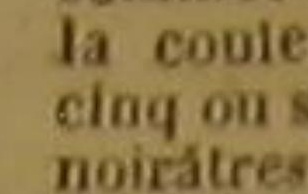

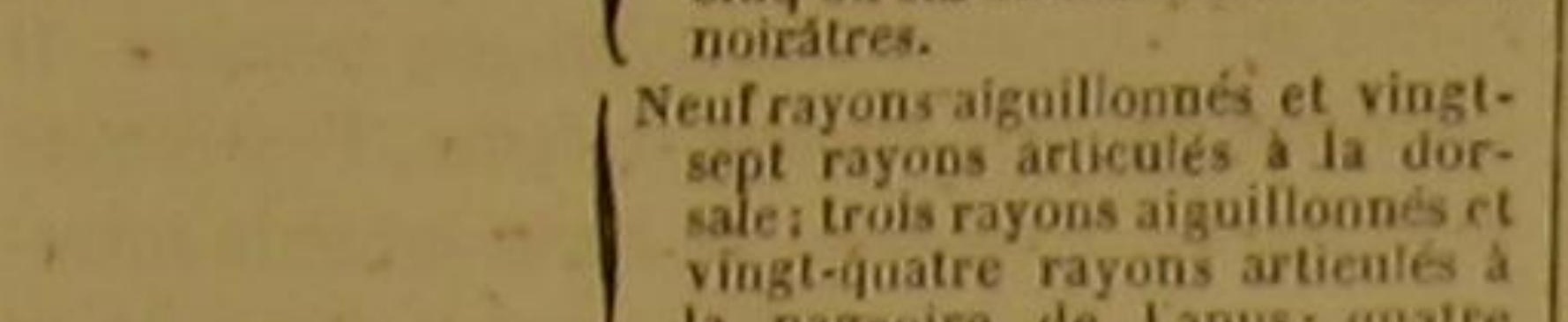

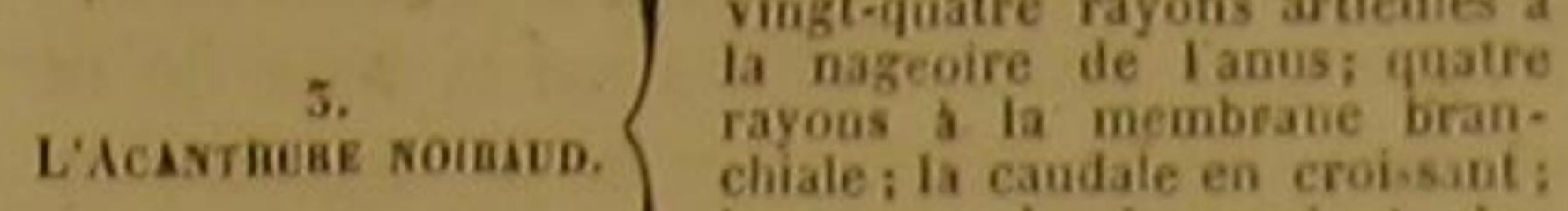
le sommet de chaque dent, plas
large que la base, et denteleita
coser de taches, de bandes, ni de rales. huit riyons articules a la na-

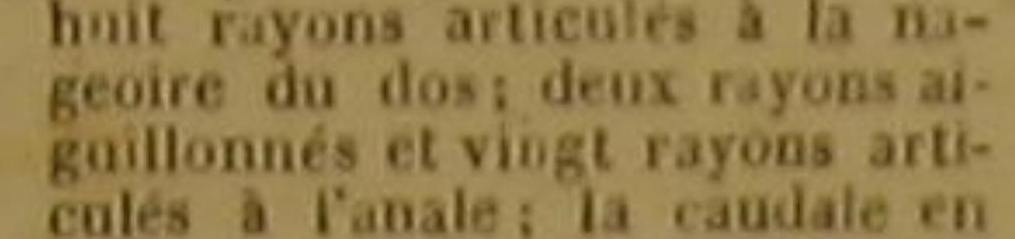

U. coles à l'ana
croissant; la geoire de Tanus tre-grandes et
arrondies par derriere; ta coulear générale d'un brun mélé de rougeatre; plusieurs rangeesion-
fitndinales do points blens, sur
lamale et sur la nazeoire dud dos. Quatre rayons aigoilloumés et
trente rayons arliculés a ta dor-

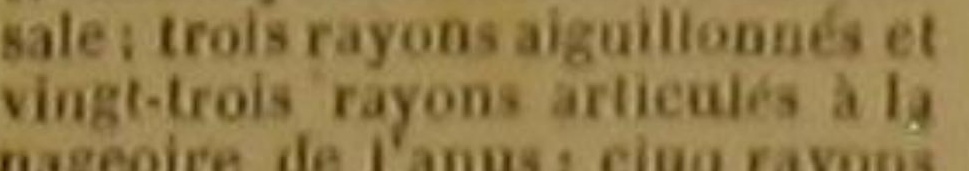
5. $\begin{gathered}\text { 5. } \\ \text { LAcastmuk raeutais. }\end{gathered}$

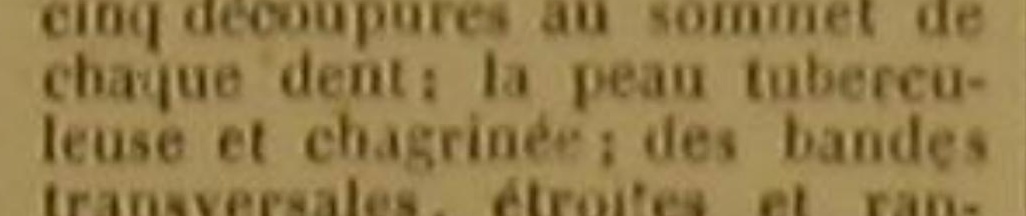
trasavere
prochées. of rayuns aiguillonés et ving

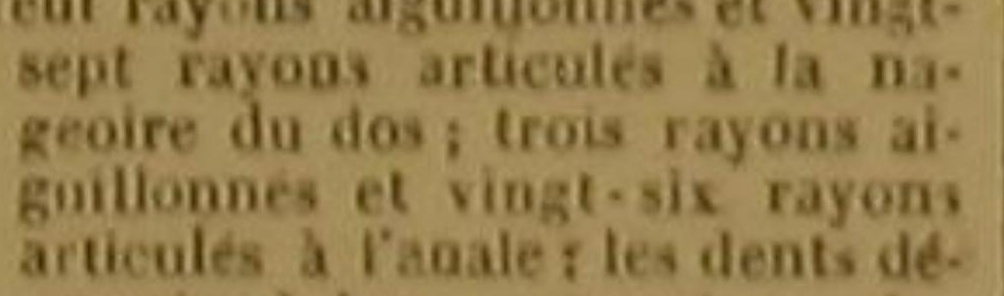

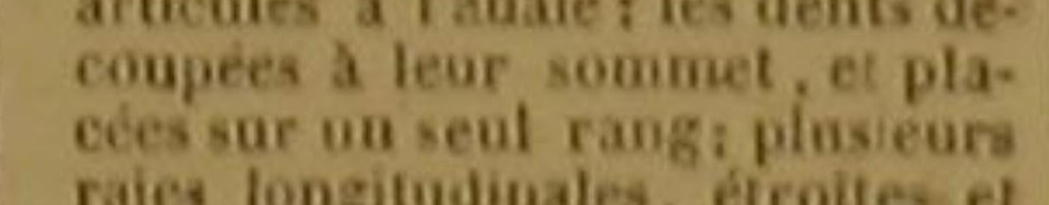
raies longitudinales, éroiltes et
bianches, de chaque coté de $\mathrm{I}$ a-
nimal.

L'ACANTHURE CHIRURGIEN ', Aeanthurus Chirurgus, Lac., Cur.; Chætodon Chirurgus, Bl., Lina., Gmel. ?.

L'Acanthure Zibres, Acanthurus triostegus, Cavis Acan-

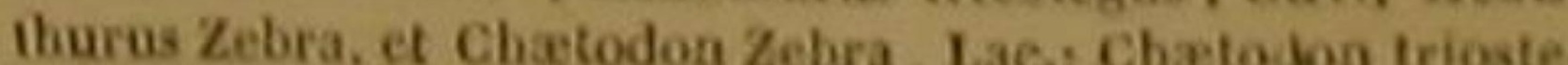
gus, Brouss, Linn., Gmel. 4. - Acanthure noiraud s,

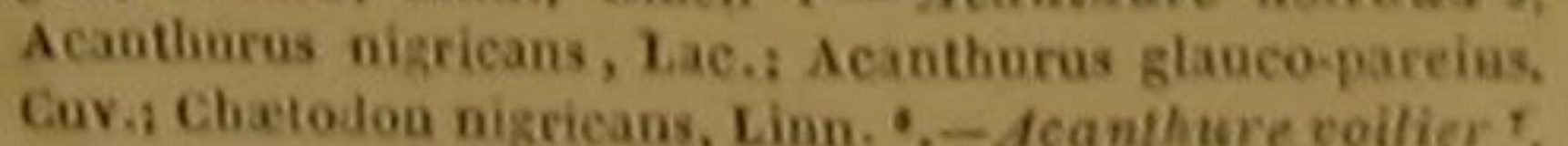

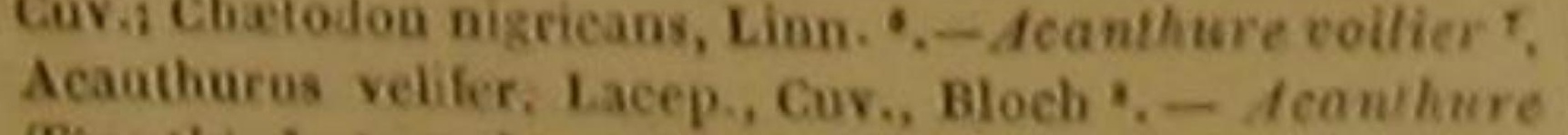

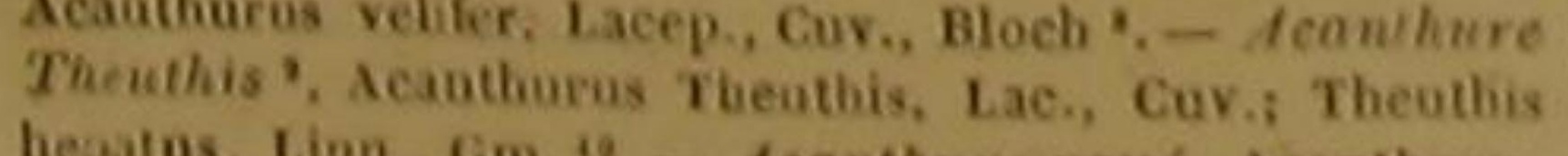
hejatos, Lian., Gm, ${ }^{10},-$ - Acanthave raye. Acuntburos

Eneore des poissons armés d'une manière remarquable! II en est done de l'histoire natu-

'Chclodon êirurgien. Bloch, pl, $208 .-1 d$. Bonnaterre,
i. de IEne, méth. Me isne, meth.

giens theutyes. D. bre. Dasbeaton et Hany, Ene. meth. - Id. Bomnaterre, pl.

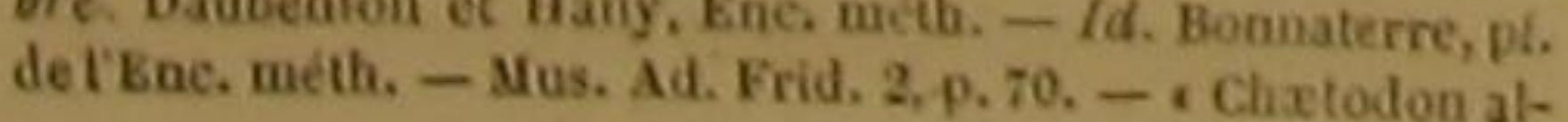

relle comme de l'histoire civile : on ne peut la parcourir qu'en ayant sous les yeux la nature inventant sanscesse, comme l'art, des moyens de blesser et de détruire. La terre est jonchie d'instruments de mort créés par la nature, plus mbreux peut-être que les traits meurtriers forgés par l'homme. Mais, à la honte de l'espèee humaine, des passions furieuses et implacables ont, sans nécessité, armé pour l'attaque . des armes défensives, et que des qraines substantielles et des fruits savoureu xauraient rendu plus sain, plus fort et plus heureux, tandis que, dans la nature, le fort n'est condamné à la guerre offensive que pour satisfaire des besoins impérieux imposés par son organisation, et le faible n'est jamais sans asile, sans ruse, ou

4 . De genre Acastuear, famille des Acanthop'érygien

- Cuantje of cerkenstopf, Oesier è eter, boanos klip

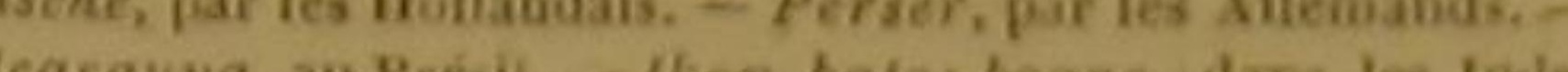
crientales. - Andre, Act, Anglie, 1784, 2, 278, ab 13.

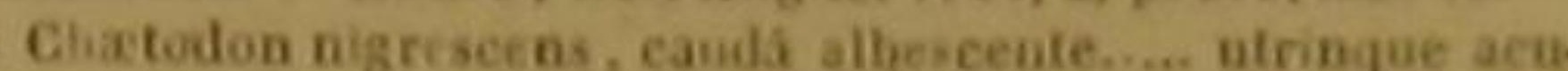
Ieati. A Artedi, spee, 90, - Clétodon noiraud. Danbentont Allaoy, Eue, meth. $-1 d$. Bonasterre, pl. de I'Ene. meth. Chelodon persien. Chatodon nigricans. Bloch, pl. .05, - Chatodon Gahm, $t$ chixtodou ex afro fuscus, ete.,

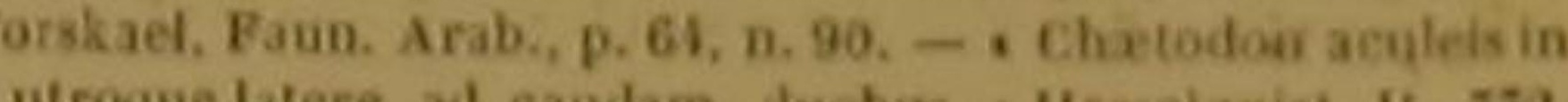

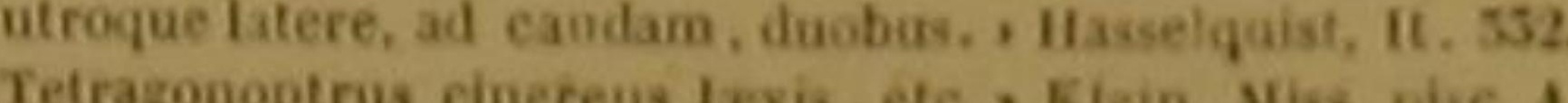

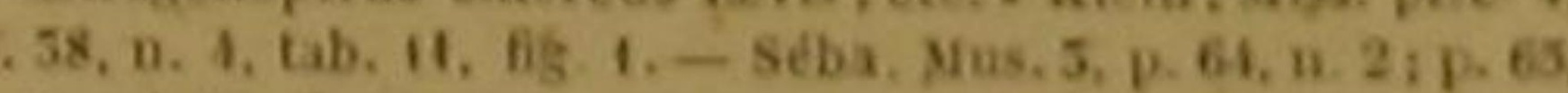
D. 5; pl. 23, fig. 2 et 3. - - Acarauna. Marezr, Brasil in -

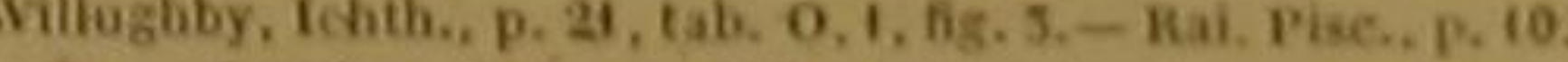
a. 8. - Jonston, Pisc., p. 177, 178, t. 32 . - Buyseh, Theatr. mim. 1. p. 123, 1. 32.

M. Cuvier reconmatt trois especes differeates dans ihis.

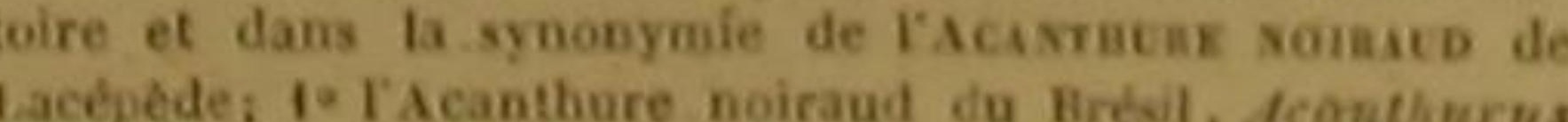
lauco-pareius, Cuv.: Séba, III, Xxv, 5, Chatodo igrieons, Linn. $2^{\circ}$ le Chatodon nigricans. B1., pl. 203 so le Chatodon atro-fuscus, Forsk., Chatodon nigroTreseus, Limn., Grmel. D.

'Blocb, pl. 427.

'

'Theuthis parou, Danbenton et Hany, Enc. méth. - Id. tlexo ntringue prope candam. Grons. Z Thenthis fusea reruleo nitens, etc. , Browne, Jama? is - Chaxiodon carulescens, dorso nigro, ete., Seba. Mus. 1. To4, tab. 35 , fig. 5. - - Turdus rhombioides. . Catesby, Chel. 2. p. 10, tab. 1, fig. 1. - Valent. Ind. 5. 1. 77. 38s, 104 Bonnaterne, pl. de IEne. mo et Hauy. Enc. meth. $-I d$. - tudinalibos yarims andi bifurci ntrincton lineis longiicli, spec, 89. - Seba, Mus. 2, tab. 25 , fig I. in thentyes. D.

"Du genre Acisticar, dans la famille des Acanthoptéry

\section{DES POISSONS}

sans defense. Les aeanthures sont un exemple de ce secours compensateur donné à la faiblesse. Leur taille est petite; leurs muscles ne peuvent opposer que peu d'efforts; ils succomberaient dans presque tous les combats qu'ils sont obligés de soutenir : mais plusieurs dards leur ont été donnés; ces aiguillons sont longs, gros et crochus; ils sont placés sur le coté de la queue ; et comme cette queue est très-mobile, ils ont, lorsqu'ils frappent, toute la force qu'une grande vitesse peut donner à une petite masse. It percent par leur pointe, ils coupent par leu tranehant, ils dechirent par leur crochet; et ee tranchant, ce erochet et cette pointe sont toujours d'autant plus aigus ou acérés, qu'aueu frottement inutile ne les use, qu'ils ne sont redressés que lorsqu'ils doivent protéger la vie du poisson, et que l'animal, qu'aucun danger u'efraie, les tient inclinès vers la tête, et couches dans une fossette longitudinale, de manière qu'ils n'en dépassent pas les bords.

Indépendamment de cés piquants redoutables pour leurs ennemis, presque tous les acanthures ont une ou plusieurs rangées de dents fortes, solides, élargies à leur sommet, et découpées dans leur partie supérieure, au point de lime les corps durs et de déchirer facilement le substances molles.

Leurs aiguillons pénètrent d'ailleurs trèsavant à cause de leur longueur; ils parviennen jusqu'aux vaisseaux veineux et méme quelque fois jusqu'aux arteriels; ils font couler le șange abondance; et e'est ee qui a engagé à nommer le Chirurgien l'une de ces especes le plus anciennement connues.

Ce chirurgien, que les naturalistes ont inscrít jusqu'a présent parmi les chétodons, àvee presque tous les autres acanthures, mais qu differe beaucoup, ainsi que ces derniers animaux, des véritables chétodons, vit dans la mer des Antilles, ou sa ehair est recherchée cause de son bon goút. Sa mâchoire supérieure est un peu plus avancée que l'inférieure, Chaque narine n'a qu'un orifice. La tête est variée de violet et de noir; le ventre bleuatre; l'anale violette comme les pectorales et les thoracines, et de plus rayée de jauue; l'extrémité de la audale violette; et la dorsalé marbrée de jaune et de violet.

Le zèbre, qu'il ne faut pas confondre avec un cnetodion du mème nom, vit dans le grand Océan équinoxial, ainsi que dans l'archipel des
Grandes Indes; il a les écailles petites, la langue et le palais lisses, le gosier entonne dio trois osselets hérissés de petits dents, l'opervule composé de deux pièces, et les thoracines blanchătres.

On trouve le noiraud au Brésil, dans la mer d'Arabie, et dans les Indes orientales: il y crolt jusqu'à la longueur de six ou sept déeimetres; on le pèche au fllet et a l'hameçon; it se nourrit de petits crabes, ainsi que d'animaux à coquille; et sa chair est ferme et agréable au gout.

Son foie est jaune, long et gros; l'estomac très-allongé; le canal intestinal large, très-recourbé, et composé d'une membrane épaisse; la cavité de l'abdomen assez grande pour parvenir jusque vers le milieu de la nageoire de I'anus; l'ovaire formé par une sorte de sae unique et courbé; et la vessienatatoire attachée au dos.

Plusieurs individus de cette espèce n'ont montré qu'un piquant de chaque cóté de la queue; mais Hasselquist at quelques autres observateurs en ont compté deux sur chaque face latérale de la queue d'autres individus. Ce second piquant est peut-être une marque du sexe, ou un aitribut de I'ảge; ou pent-étre faut-it dire que l'aiguillon de chaque coté de la queue tombe á certainés époques, et ne se détache quelquefois de la peau de l'animal, que lorsque le dard qui doit le rempiacer est presque entierement développé.

Chaque narine n'a qu'un orifice; Ies ćcailles sont petites; on apercoit des nuances blanehes ou grises sur plusieurs nageoires '.

On doit remarquer sur l'acanthure voilier, les petites taches irrégulières et roussátrés du museau et des environs de la base des pectorales; les deux bandes tranversales foncées, les deux bandes plus étroites et jaunes, et les - 16 rayons a claque pectorate de Pacanthure chinugion. is rayon aiguilione el s rayous aricules a chaque thoracine, pectorale de Vise mithure zebre, 1 rayon aiguiltome at rayons articulés s chàiue thoracine, 22 rayous s is eamiah.

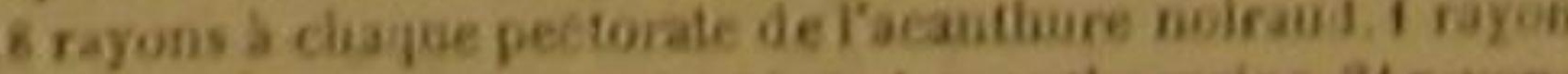
uggoilbumet 5 rayons arileules a chaque thoradie. 21 rayon

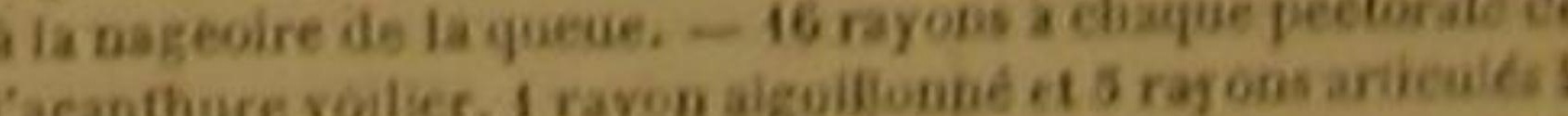

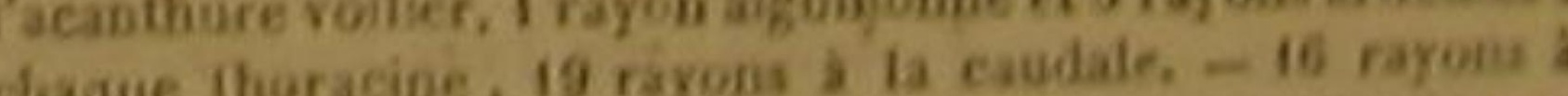
daque iburate de lacasthure theuthis, 1 rayon aiguil onne

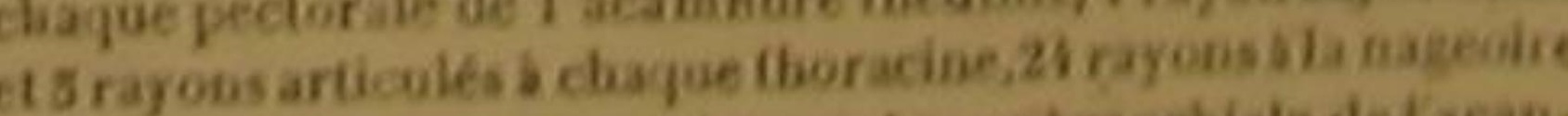

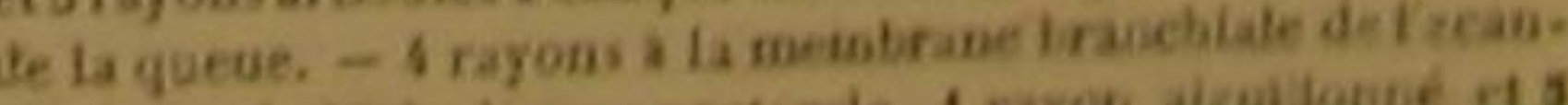

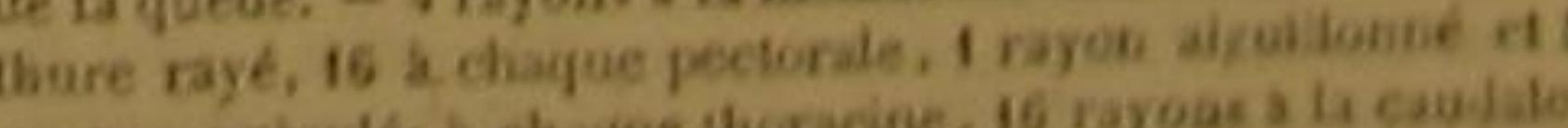
rayons anicules a chayue thoracine, 16 rayoas a $4 \mathrm{c}$ 
dix ou onze bandes violettes qui s'étendent sur chaque côté de l'animal; les taches noires qui forment trois ares sur la caudale; la bordure blanche de cette nageoire; et la couleur jaune des thoracines et des pectorales,

Nous avons déja dit' ${ }^{\prime}$ que nous ne pouvions pas admettre le genre Theulhis, quoique établi par Linnée. Des deux espéces que l'on avait inscrites dans ce genre, la seconde est notre chétodon tacheté; la première est un véritable aćanthure, auquel nous donnons le nom spécifique de Theuthis, pour changer le moins possible sa dénomination. Lorsque nous avons eu le plaisir de voir à Paris feu le célèbre professeur Bloch de Berlin, et qu'en lui montrant la riche collection de poissons du Muséum national, nous lui avons fait part de quelquesunes de nos idées sur lichthyologie, il a été entièrement de notre avis relativement à la suppression de ce genre Theuthis, qu'il n'avait, me dit-il; jamais voulu comprendre dans sa classification.

L'acanthure qui portera le nom que l'on avait donné à ce genre, est pêché dans les eaux d'Amboine, ainsi qu'à la Caroline. Son museau est avancé; ses dents sont fortes, et placées sur un seul rang; la hauteur de la dorsale égale la longueur du front.

Les écailles du rayé sont raboteuses; il habite dans les Indes orientales et dans l'Amérique méridionale.

\section{CENT QUARANTE-DEUXIĖE GENRE.} LES ASPISUnEs ${ }^{2}$

Le corps et la queue tris-comprimes; de très-petites écailles sur la dorsale ou sur d'autres nageoires, ou la hauleur du corps supérieure ou du moins egale d'sa longueur; l'oukeriure de la bouche pelite; le museau plus ou moins avance; une nageoire dorsale; uno plaque duro en forme de petil beuclier, de ehaque cole de la quene.
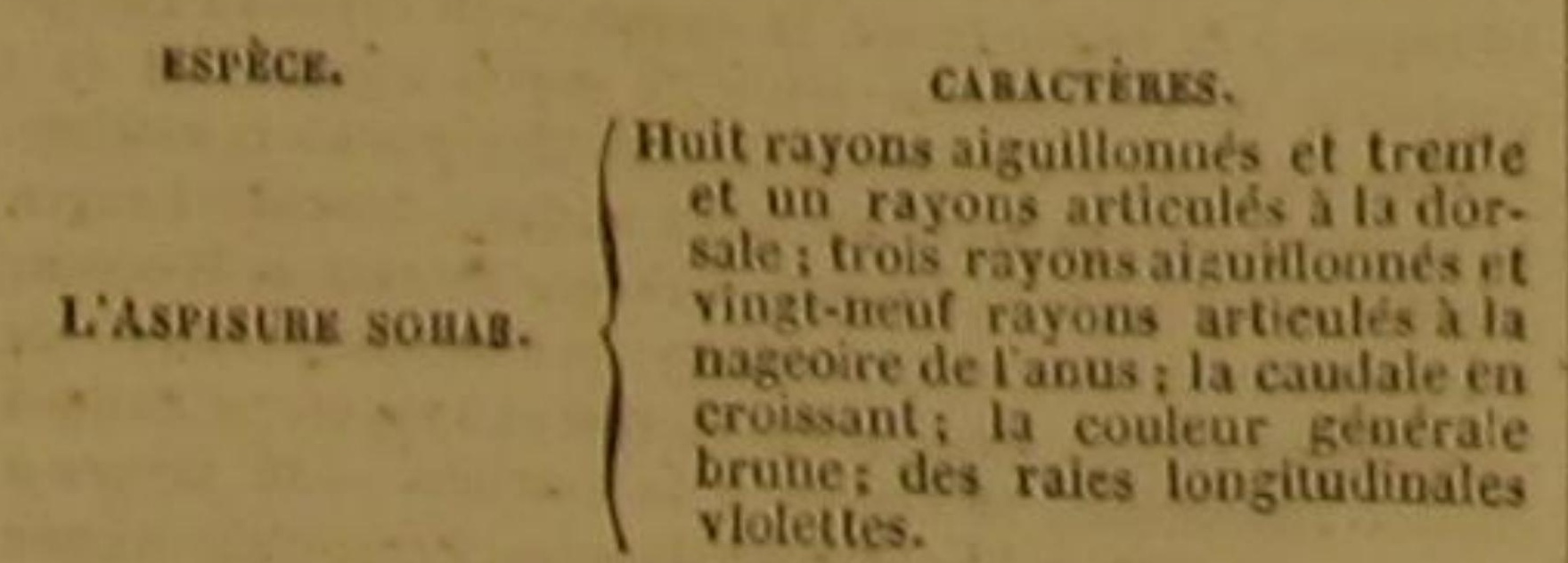

'Article du Chétodon tashete.

'M. Cuvier n'adopte pas ce genres il le réunit s celoi des Acastauks, de la fusille des Acanthoptérygiens theuires.
D.

\section{L'ASPISURE' SOHAR ${ }^{2}$}

Acanthurus Sohal, Cuv.; Chætodon Sohar, Forsk., Linn., Gmel.; Aspisurus Sohar, Lae. '.

Ce poisson vit dans la mer d'Arabie; il s'y tient auprès des rivages, et se nourrit, dit-on, des débris de eorps organisés qu'il trouve dans la vase déposée au fond des eaux. Ses dents sont cependant festonnées à leur sommet; et sa longueur est ordinairement assez considerable.

L'espèce de fossette dans laquelle on voit, de chaque cóté de la queue, une sorte de plaque ou de bouclier osseux, brille souvent d'une belle couleur rouge; les nageoires sont épaisses et violettes; une tache jaune est placée sur chaque pectorale ${ }^{4}$

CENT QUARANTETROISIÈME GENRE. LES ACANTHOPODES ${ }^{3}$.

Le corps ef la queue très-eomprimes; de tria-petites écailles sur la dorsale ou sur d'autres nageoires, ou Ia hauteur du corps superieure ou du moins dgale d so longueur; Pouverlure de la bouche petite; le museau plus ou moins avaned; une nageoire dorsale; un ou deux piquants d la place de ehaque theracine.

Ešìces. cansciknes.

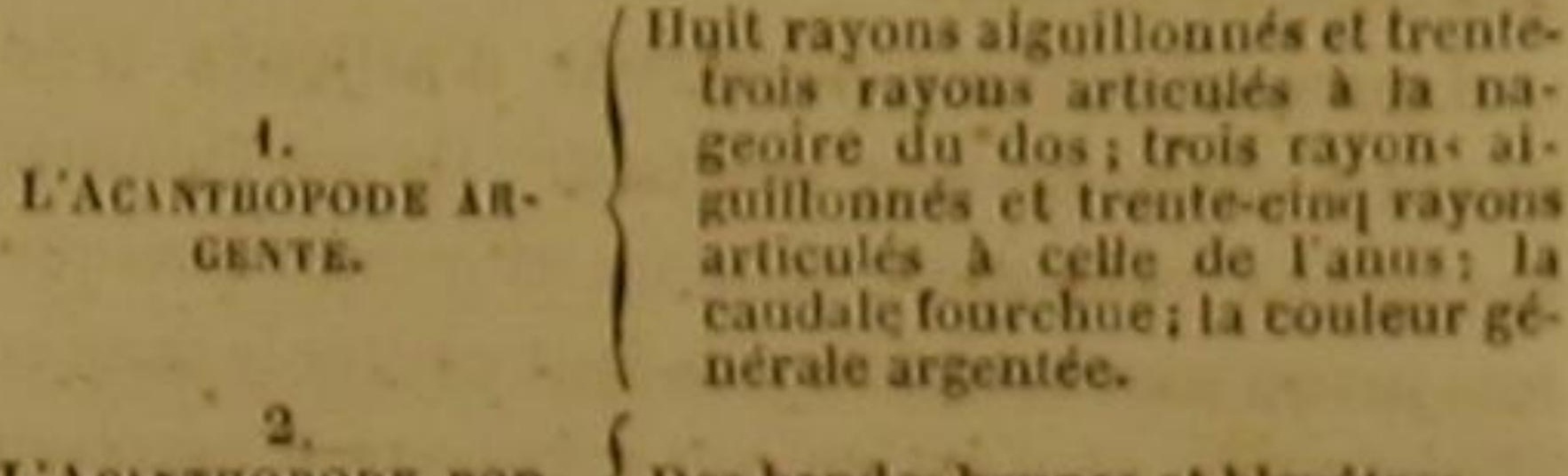

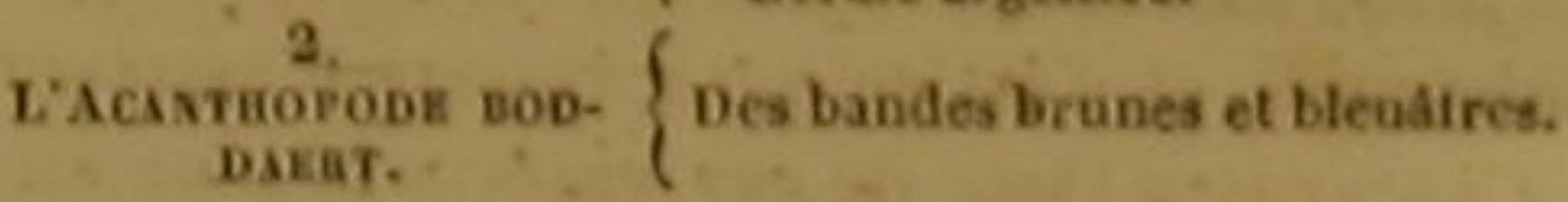

'Aspis, en grec, signifie bouclier, et ura, queue. Fonkael, Faun. Arabic., p. 65, n. 89.

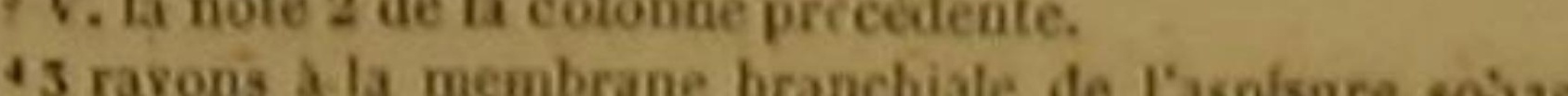
77 a chayue pectorale, 1 rayon aiguillonné et 5 rayong soitian, It a chaque thoracine, 16 rayons a la pageoire de la quene. - M. Cuvier croit pouvoir réunir sois le nom de PsEites, cree par Conmerson, les Acanthopodes, les Monodactyles. les Gentropodes de Lacepede, et quelques Centrogasteres Acanthoptérygiens spe ce geare Pserrts dans la famille de oat le corps beaucoup plis elevé que lons Ex. I Psellus Seba, Cur,; Chat. rhombeus, BI., schn, Séb. III, Sxyı, 21. - Ps. rhombeus. Cux.; Scomber rhombeus, Forsk, Centrogaster rhombeus, Gmel.; Centropode rhomboidal. Co. Les a tres sont de forme ronde ou ovale. Ex. : Pseltus bien ne pas diftirer donodactyie falciforme, qui pourrail bien ne pas differer du Cholodon argenteus ou Acantho
pode falciforme, Lac. D.
L'ACANTHOPODE ARGENTÉ ',

Psetlus Commersonii, Cur.; Acanthopodus argenteus, Lac.; Chætodon argen-

ET L'ACANTHOPODE BODDAERT. ${ }^{3}$

Holacanthus Dux, Lacep., Cuv.; Chatodon faseiatus, B1.; Chrtodon Dux, et Chatodon Boddaertii, Liuo., Gmel :

On trouve, dans la mer des Indes, largente décrit par Linnée, et eusuite par le professeu Bonnaterre, qui en a vu un individu dans le cabinet de mon célèbre collègue M. de Jussieu. Les écailles dont ce poisson est revêtu sont lisses et brillantes; la dorsale ainsi que l'anale échancrées en forme de faux; les trois premiers rayons de la nageoire du dos beaucoup plus courts que les autres; et les yeux couleur de sang.

Le boddaert porte le nom du savant natura'liste qui l'a fait connaitres.

CENT QUARANTE-QUATRIEME GENRE. LES SÉLĖEES

Eensemble da poissen tris-eomprime, et prisentant do ehaque celd la forne d'un pentagone ou d'un litragone; la ligne du froni presque verilicale; la distanee du plus haul do la viuque au-dessus du museau, digolo au moins d celle de la gorge d la nageoire de l'ánus, deux 'nageoires dorsales: un ou plusieurs piquants entre les deur doriales les premiers rayons de io is

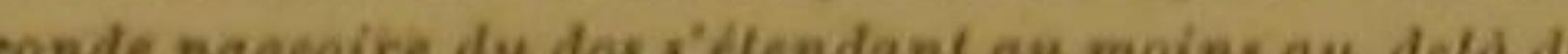
texiremité de la queue.

PREMIER SOUS-GENRE.

La nageoire de la queue, fourchue, ou echanerie on

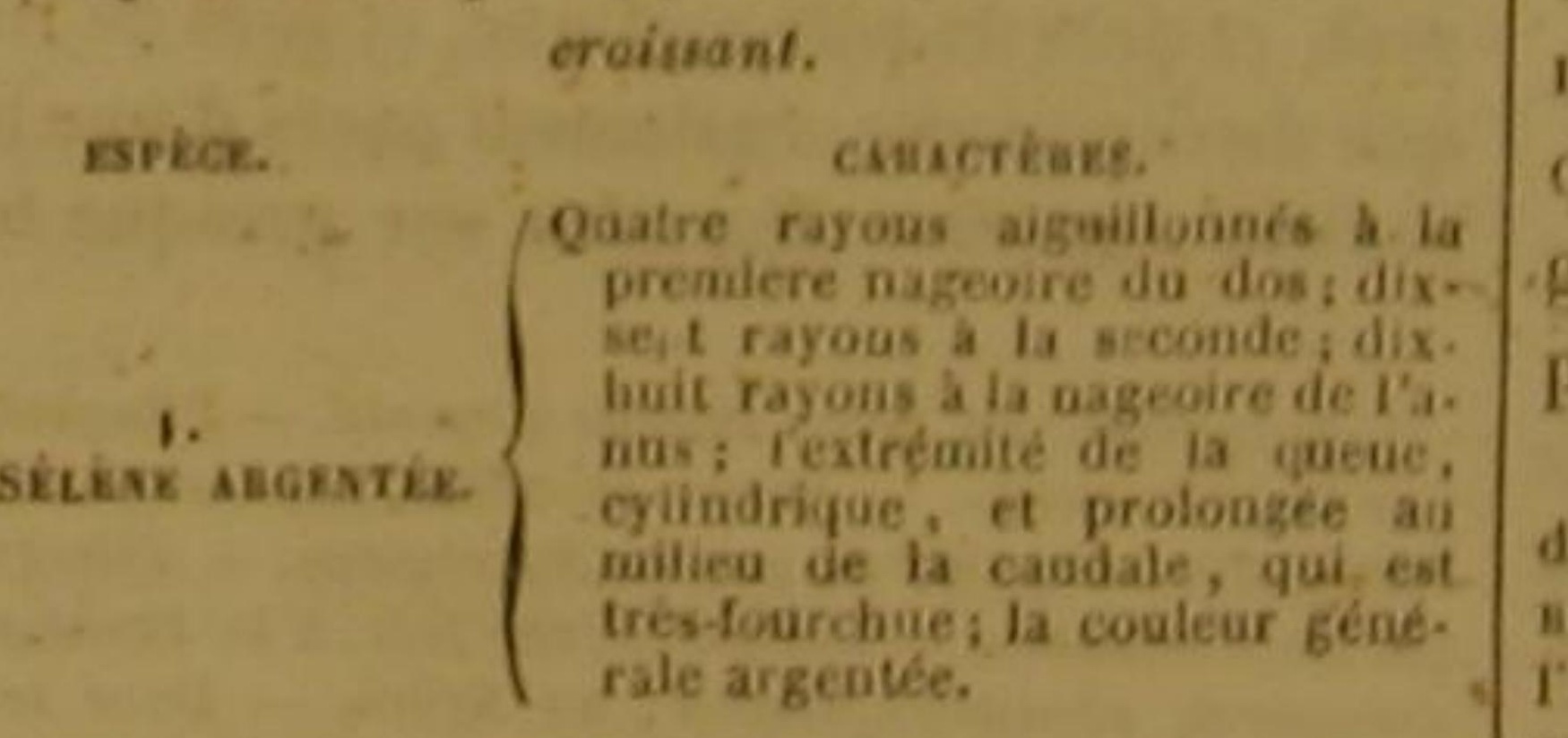

Amanit. Acad. A, p. 2 9. - Chelodon argente. Bouna

1 Amenit. Acad. 4, p.

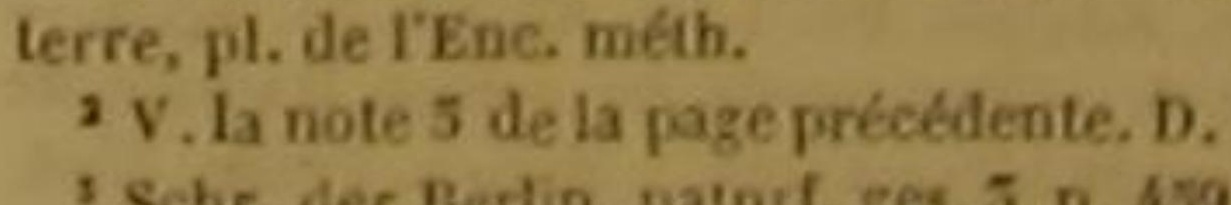

' 'Schr. der Berin. natarf. ges. 5, p. 45.

Dos, Cuv, (famille des Acanthoptérygiens squamipeane). M. de Lacképéde a décrit deus fois ce poisson, 10 sous le nom d'Holacanthe duc ; 2" sous celui d'Acanthopode Boddaert. ${ }_{5} 6$ rayons à la membrane branchiale de Pacanthopode ar.
genté, 14 a chaque pectorale, 16 rayons a la naseoire de is quene.

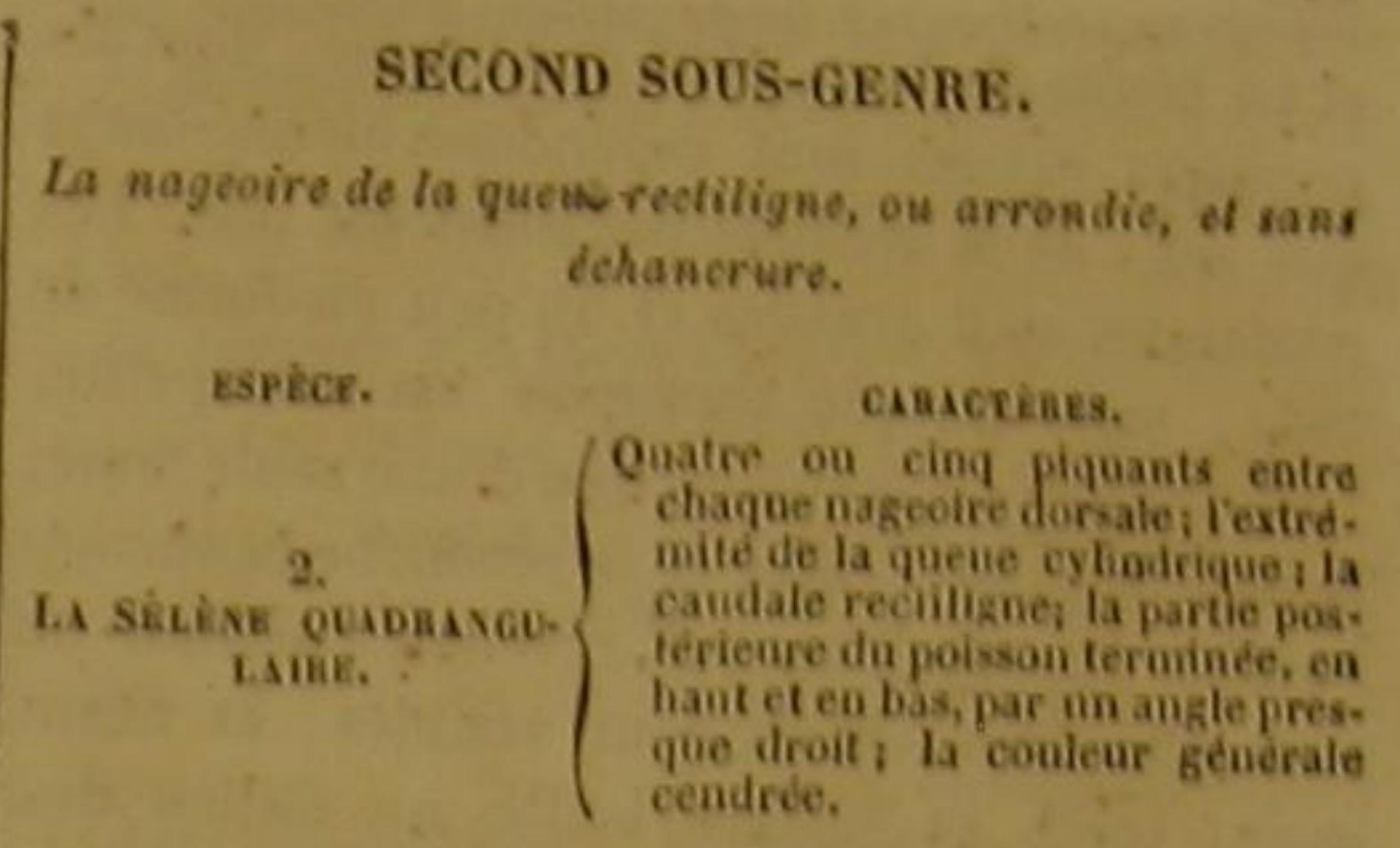

LA SELÈnE ARGENTÉE '.

Argyreyosus Vomer, Cuv, Abacatuia, Marcgr, Selene argentea, Lacep. ",

Plúmier a laissé un beau dessin de ce poisson dont aucun naturaliste n'a encore publié la description, et dont la figure se trouve dans les peintures sur vélin du Muséum d'histoire naturelle. On a comparé sa forme générale à celle d'un disque ou de la lune; et voila pourquoi on lui a donné, dans l'Amérique méridionale, $\mathrm{et}$ dans quelques autres contrées du nouveau continent, le nom de Lune que rappelle la dénomination générique de Sélìne ${ }^{3}$, par laquelle nous le désignons. Néanmoins cette forme générale n'est pas celle d'un disque; elle ne ressemble a celle de la lune que lorsque l'animal est vu de loin : elle est celle d'un veritable pentagone; et cette figure est d'autant plus remarquable, qu'un des côtés de ce pentagone termine la partie antérieure du dos, qui dés lors est rectiligne, au lieu d'être plús ou moins courbé dans le sens de la téte à la queue, comme le dos de presque tous les poissons. L'ouverture de la bouche n'est pas grande; on ne voit à chaque narine qu'un orifice, lequel est très-allongé; l'wil est gros, et la prunelle large; la premiere dorsale petite et triangulaire; la seconde très-étendue

deux expeces, dout il ratlactie I'une au sous-genre Augr.

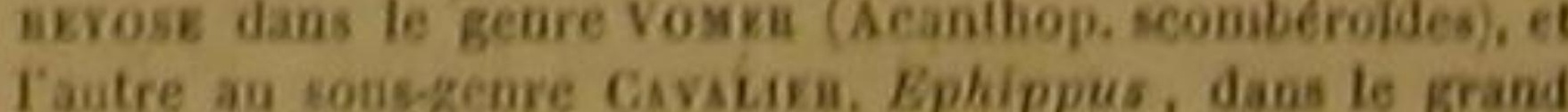

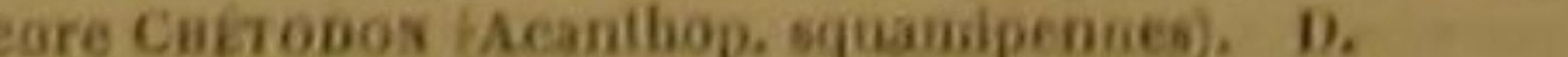
- Guaperta Maregravil, valgo la lune. Plumier, peintures sur velin, deja citées. - Nota. Oa verra hacilement com. When ce nom voigaire de Guaperva a ee applique a plasieun

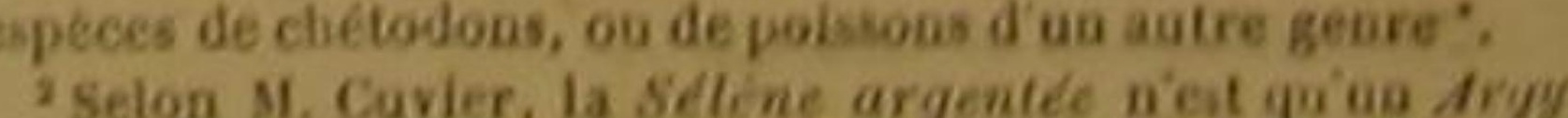
reyose vomer, ou Abacaluia de Marcerave, dont la premiere dorsale et les veatrales etaieot uses. Voyer la nute 6 diavant. D. - selene, eo grec, vignifie lune.

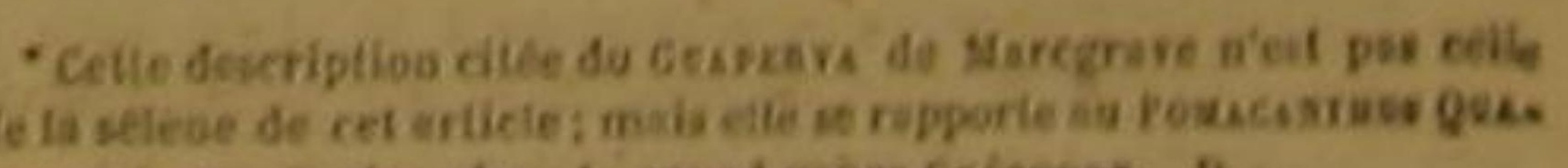


et en forme de faux, ainsi que l'anale, dont les premiers rayons sont cependant moins longs que ceux de la seconde nageoire du dos. Les pectorales sont grandes et un peu en forme de faux; mais chaque thoracine est très-petite. L'opercule n'est composé que d'une seule lame; la ligne latérale s'élève et se recourbe beaucoup ensuite. Les écailles qui revètent Yanimal ne sont que très-dificilement visibles; et néanmoins toute sa surface brille, au milieu des eaux, d'un éclat argenté et doux, assez semblable à celui de la lune dont il porte le nom. - L'iris resplendit comme une belle topaze, des reflets verdatres et violets paraissent sur toutes les nageoires.

LA SÉLÈNE QUADRANGULAIRE'

Ephippus Faber, Cuv.; Chætodon Faber, Brouss,, Bi., Lac.; Chatodon Plumieri, Bl.? Zeas quadrat Linu., Gmel, Selene quadrangularis, Lac. ?.

Sloane a déerit et fait représenter ce poisson dans I'Histoire nalurelle de la Jamaĩque. Ce thoracin a été inscrit jusqu'à présent dans le genre des Zées; mais il est évident qu'il appartient à celui des Sélènes que nous avons cru devoir établir, et qu'il ne présente pas les earacteres qui doivent distinguer les veritables zées.

La longueur de la sélène quadrangulaire est de cinq pouces anglais, et sa hauteur de quatre; la figure que chacun de ses côtés présente, est bien indiquée par le nom spécilique qu'elle porte. Vouverture de sa bouche est très-petite la machoire inférieure plus avancée que la supérieure, et garnie, comme cette dernière, d'une rangée de dents courtes et menues ; la langue arrondie dans une partie de son contour, et cartilagineuse; la première dorsale très-étroite et longue d'un pouce et demi anglais ; la seconde trangulaire; la nageoire de l'anus égale par son etendue, semblable par sa forme, et analogue par sa position, à cette seeonde nageoire du dos; la ligne latérale très-courbée; et I couleur générale relevée par trois ou quatre bandes obliques et noires.

'Pilot.fish. - C Faber marinus fêrè quadratus. S Stoane J.m. 2, p. 250, .1. 3. lab. 251, fig. 4-Dore quadrangulairc. Honmatere, pl. de l'Enc. métb. - Rai, Pisc., p. 160.

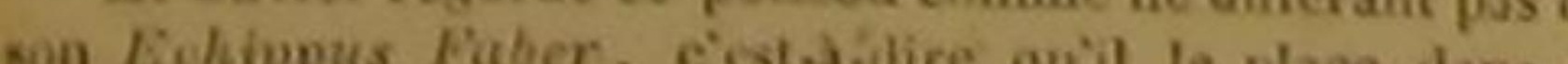

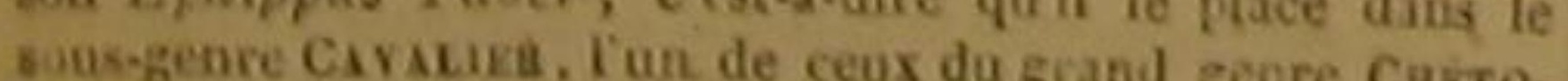

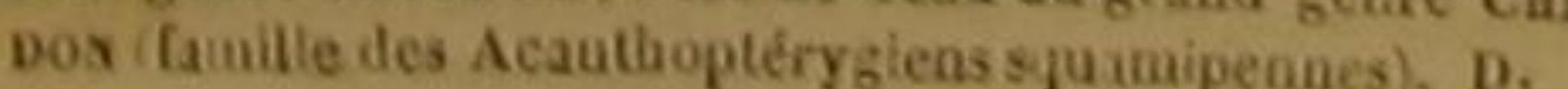

\section{CENT QUABANTE-CINQUIĖME GENRE.}

LES ARGYRÉIOSES.

Le corps el la queue très-comprimés; une seule nageoire Liorsale; plusieurs rayons de celle nageoire terminés par des flaments très-longs, ou plusieurs piquanis lo long de chaque colt de la nageoire du dos a une lo long de chaque coll de la angeoire da dos; une membrane verticale placee iransoersalement au-dessous de if licro saperieure; les deailles tris-pelites; les theracines ires-allongers; des aigwillons an-de vant de ta nageoire du dos el de celle de l'anus.

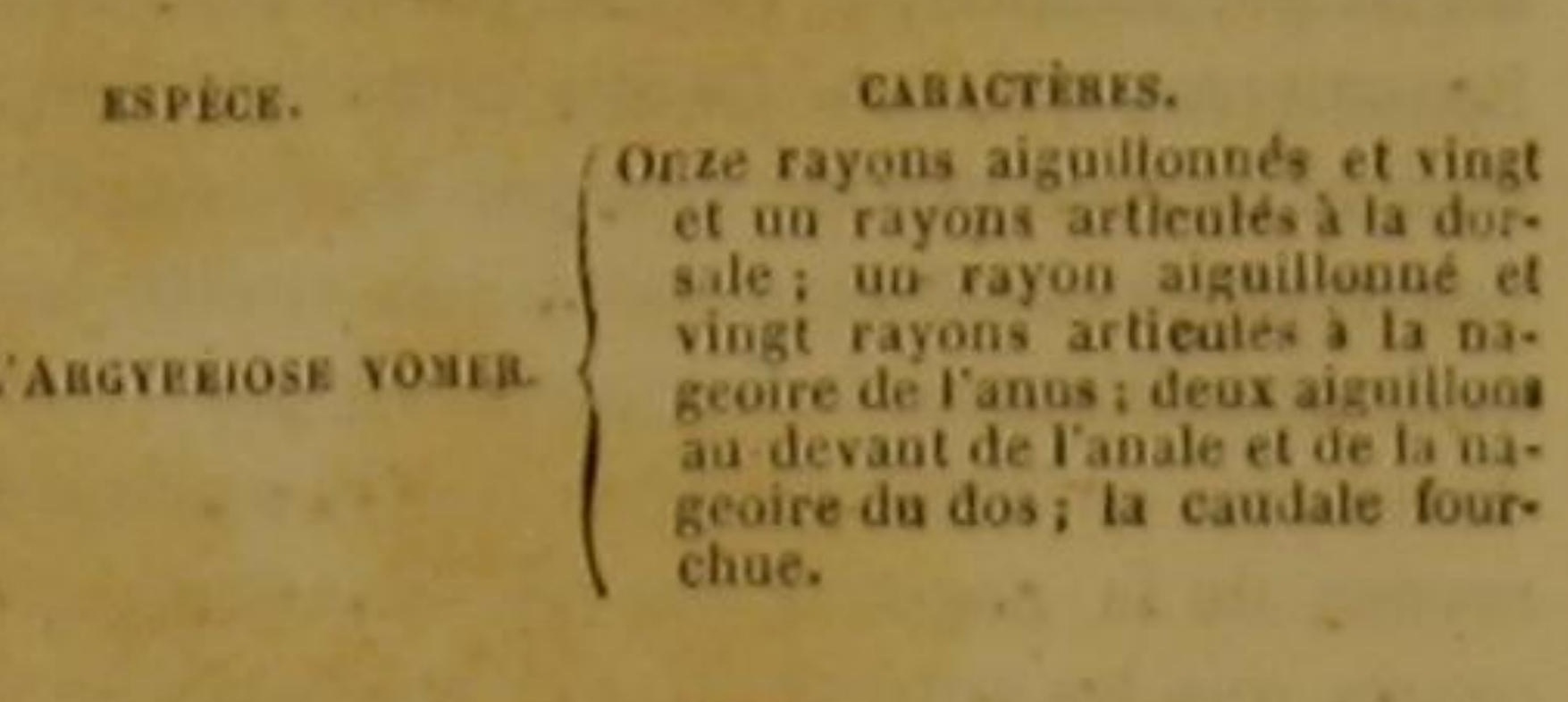

L'ARGYRÉIOSE VOMER '.

Argyreiosus Vomer, Lae., Cuv.; Abacaluia, Mareg.; Zeus Vomer, Ling, ’.

Les eaux chaudes du Brèsil, et les eaux froides qui baignent la Norvége, nourrissent également cet argyréiose; et c'est une nouvelle preuve de ce que nous avons dit, forsque nous avons exposé, dans un Discours particulier, les effets de l'art de l'homme sur la nature des poissons. Lagrandedifférence qui sépare le clímat glacial de la Norvége et le elimat brùlant du Brésil, n'influe pas mème d'une manière très-sensible sur les individus de cette espèce d'argyréiose vomer. Leurs formes sont semblables dans l'hémisphère nord et dans l'hémisphère austral. Ils sont, et près du póle arctique, et près du tropique du capricorne, également parés d'une belle couleur argentine répandue sur presque toute

- irgyrelos, en gree, signifie argenté. - Pflugschaar, par les Alemands. - Sileer skrabha, par les Suedois. par les nollandais, - Lorger silker fish, - Z Zileerfisch, Gunperva abacatrajarana, au Brésil, - Doré le con. Dautenton et llaay, Ene. méth. - Id. Bonnaterre, pl, de IEnc. méth. - Mus, Adolpb. Fr. 1, p. 67, tab. 51, fig. 2. Bloch, pl, 195, fig. 2. - Mannscrits da prince Maurice de Nassau, - Z Zeus cauda bifured, ete. , Muller. Prodr. Zool. Banic, p. A, a. J70. - Tetragonoptrus squamulis pinnisgue tab. 12 , fig. 1. - - Khomboida mass pisc. 4 , p. 38, n. 7,8 , J.m., p. 453, n. 2, - Marce. Brasil., p. 145. - Willnghby. ichuthyol., t. 0, I, fig. 4. - Jonst., de Piscib., p. 178, tab. 52 , Gig. 5. - Ruyssb, Theat, anim. 1, p. 121, tab. 52, fig. 5. de M. Cuvier. Farnille des Acase, dans le grand genre Vorka

DIS POISSONS.

leur surface, et rendue plus agréable par un beau bleu étendu sur toutes leurs nageoires; seulement des reflets d'azur ondulent au milieu des teintes d'argent des vomers du Brésil, pendant que des tons de pourpre distinguent ceux de la Norvége.

Les uns et les autres se nourrissent de crabes et d'animaux à coquilles; et comme ils trouvent en très-grande abondance de ces crustacés et de ces mollusques sur les rives de la Norvége, aussi bien que sur celles du Brésil, ils vivent avee une égale facilité dans les mers de ces deux contrées. Ils y parviennent à la mème longueur, qui est celle de quinze ou seize centimètres. Leurs museles sont peu volumineux; leur chair est de bon goủt en Europe et en Améri. que ; et leurs habitudes étant semblables daus I'ancien et dans le nouveau continent, on y emploie les mèmes procédés pour les pèeher: on les prend non-seulement au filet, mais encore à I hameçon.

Au reste, tous les vomers ont la dorsale deux fois découpée, et l'anale une fois échancrée en forme de faux; le second rayon de l'anale, et surtout le second et le troisieme rayons de la nageoire du dos, assez prólongés pour dépasser les pointes de la caudale; des thoracines dont la longueur égale celle du eorps et de la queue pris ensemble; des éeailles très-difficilement visibles; la nuque et le dos très-élevés ; ta mâchoire inférieure plus longue que celle d'en haut, et garnie, comme celte dermiere, de dents petites et pointues; un seul orifice à chaque narine; et la ligne latérale très-courbée.

On remarquera aisément les rapports qui lient le vomer avec la sélène argentée, et d'après lesquels les habitants du Brésil ont donné le nom vulgaire de Guaperva à ces deux animaux '.

\section{CENT QUARANTE-SIXIEME GENRE}

LES ZÉES.

Le corps et la queue très-comprimés; des dents aux ma chirce; ine seule nageoire dorsale; plusicurs rayo de celle nageoire lerminés par des flaments tritlongs, on plosicurs piquants le long de chaque cólé de longs, ou pla dos une membrane verlicale placte la nageoirs dus do ; desous de la lecre supérieure;

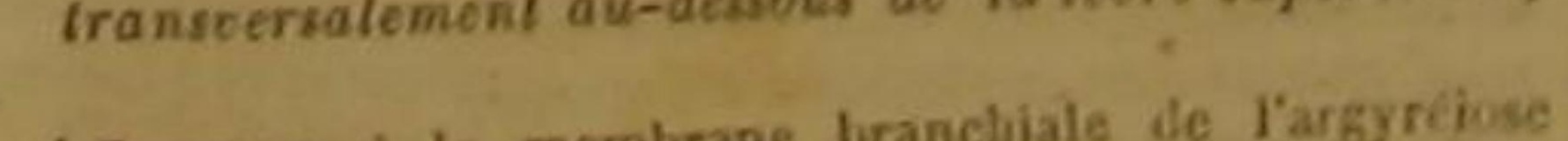

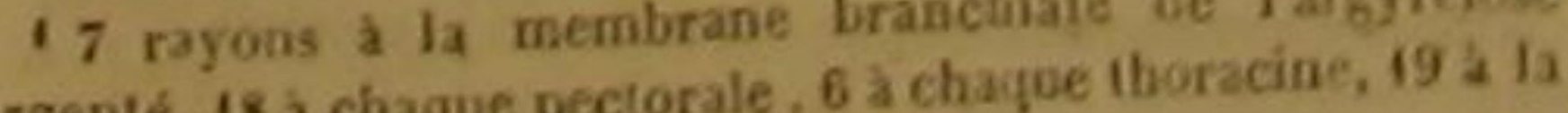
nageoire de la queve.

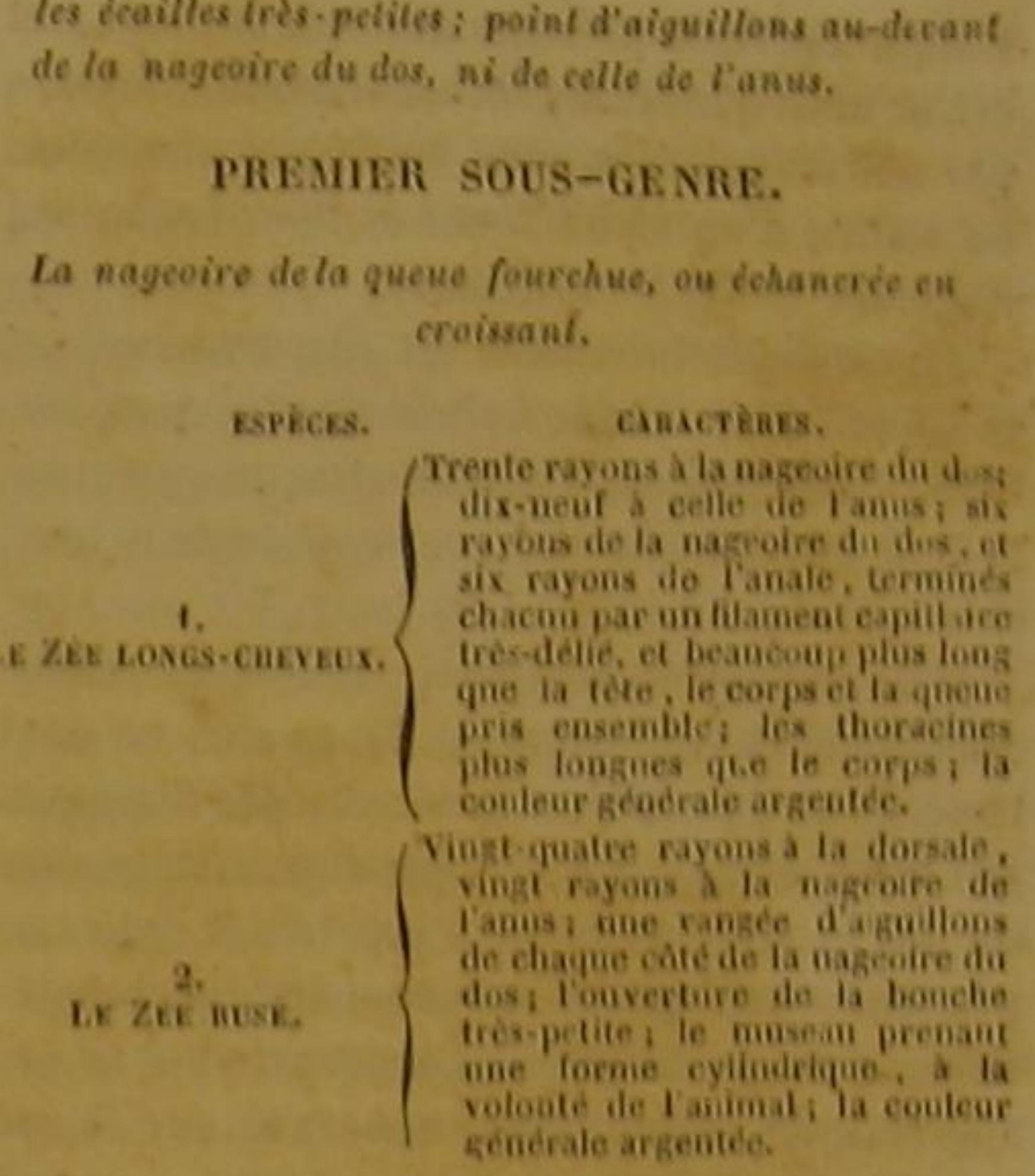

SECOND SOUS-GENIE.

La nageoire de la queue, rectiligne, ou arrondie, et rans ichanerure,

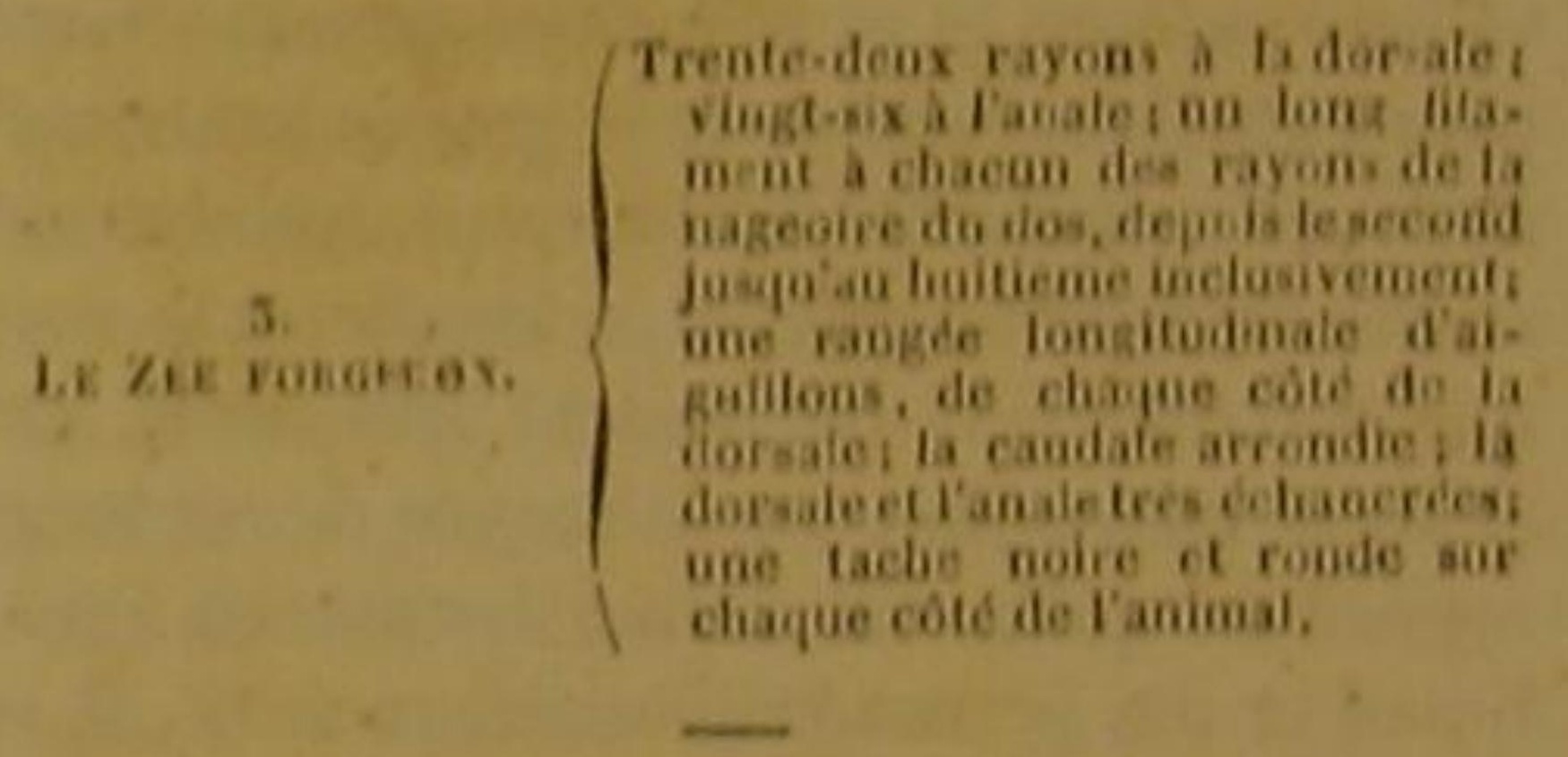

LE ZEE LONGS-CHEVEUX ',

Blepharis ciliaris, Car, ; Zeus ciliaris, Linn, Bi. Lae, '.

ET LE ZEE RUSE ".

Equala insidiatrix, Cuv.; Zeus insidiator, Lion. Bl., Lac. '

L'éclat que répand le zée longs-cheveux est trés-doux à l'oeil, parce que les écailles qui revêtent ce poisson ne pouvant étre vues que difficilement, ses nuances argentées ne sont pas ré. flechies par des lames dures, larges et polies, qui renvoient avec vivacité et les couleurs et la lumiere : mais ses teintes sout belles et riches;

Dorégal à longs cheveux, Bonnaterre, ph. de tKac eit. - Bloch, pl. Ivi.

To

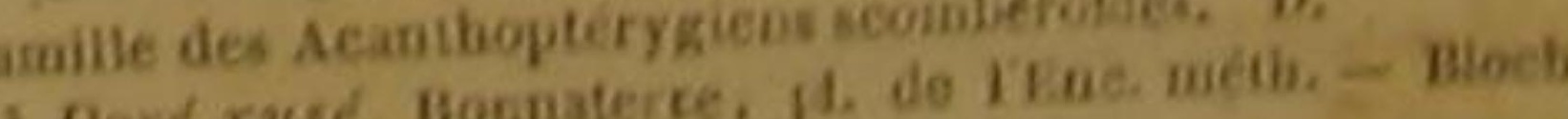
Dore rus.
i. 192 . ig. 2 .

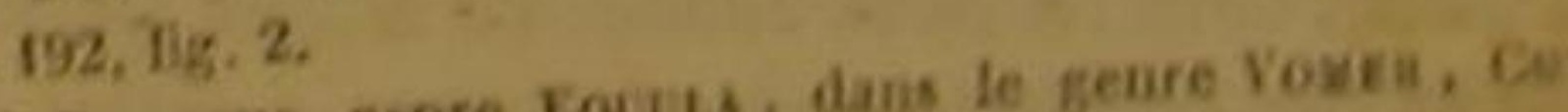
Vamille des Acanthopteryziens voubiéroiles. D. 
chaque opercule présente des reflets dorés; et / don soufflet, et du chétodon museau-allongé ; cet or ainsi que cet argent sont comme encadrés par une distribution aussi noble que gracieuse, au milieu d'un violet foncé et bien fondu qui règne sur toutes les nageoires.

La mâchoire inférieure est plus avancée que la supérieure; chaque narine montre deux orifices; deux plaques forment chaque opereule; la ligne latérale est très-courbe près de la tète, et ensuite très-droite.

Mais ce que l'on doit particulièrement remarquer dans la conformation de ce zée, ce sont l'excessive longueur et la ténuité des filaments qui terminent plusieurs rayons de ses nageoire du dos et de l'anus. Ces filaments si déliés ne peuvent servir ni à ses mouvements, ni à sa défense; mais je ne serais pas surpris quand on apprendrait, par quelque voyageur, qu'ils ont influé sur les habitudes de ce poisson, au point de rendre ses maurs très-dignes de l'observation du physicien. Il est probable que ce zée, qui ne peut pas employer beaucoup de force pou vaincre sa proie, ni peut-être une grande vitess pour l'atteindre, à cause de la grande hauteur et de la petite épaisseur de son corps, qui doivent rendre sa natation pénible, a recours à la ruse que ses filaments lui rendent trés-facile. On pourrait croire que, par le moyen de ces longs appendices qu'il roule autour des plantes aquatiques et des petites saillies des rochers, il se maintient daus un état de repos qui lui perme de dérober aisément sa présence à de petits poissons, surtout lorsqu'il est à demi caché par le végétaux ou Jes différents corps derrière lesquels il se place, et que, posté ainsi en embuscade, il emploie une partie de ces mèmes filaments comme plusieurs osseux ou cartilagineux se servent des leurs, à tromper les poissons trop jeunes et trop imprudents, qui, prenant ces fils agités en différents sens pour des vers marins ou fluviatiles, se jettent surces prolongationsanimées, et se précipitent, pour ainsi dire, dans la gueule de leur ennemi.

Cette conjecture est en quelque sorte confirmée par ce que nous savous déjà de la maniěre de vivre du zée rusé, que l'on trouve à Surate, comme le longs-cheveux.

Le rusé mérite en effet, par ses petites manøuvres, le nom spécifique qui lui a été donné. II offre, dans les eaux douces de le cotte de Malabar, des habitudes très-analogues à celles du cotte iusidiateur, du spare trompeur, du chéto- et cette ressemblance provient de la conformation particulière de son museau, laquelle a beaucoup de rapports avec celle de la bouche des quatre poissons chasseurs que nous venons de nommer.

La mâchoire inférieure du zée rusé s'élève dans une direetion presque droite; lorsque l'animal la baisse pour ouvrir la bouche, elle entraine en en-bas la mâchoire supérieure, et le museau est changé en une sorte de long cylindre, à l'extrémité duquel parait l'ouverture de la bouche; qui est très-petite, et qui par $\mathrm{c}$ mouvement se trouve descendue au-dessous du point qu'elle occupait. Cette ouverture reprend sa première place, lorsque l'animal, retirant vers le haut sa màchoire supérieure, relève l'inférieure, l'applique contre celle d'en haut, fait disparaitre la forme cylindrique du museau, et ferme entièrement sa bouche. Ce cylindre allongé, que l'animal forme toutes les fois et aussi vitequ'il le veut, lui sert de petit instrument pour jeter de petites gouttes d'eau sur les insectes qui volent auprès de la surface des lacs on des rivières, et qui, ne pouvant plus se soutenir sur des ailes mouillées, tombent et deviennent sa proie 4.

Chacun des̀ opereules du rusé est d'ailleurs composé de deux pièces; sa dorsale peut étre pliée et cachée dans une fossette longitudinale, que bordent les deux rangées d'aiguillons indiquées sur le tableau du genre. Ce zée paraít revêtu, sur toute sa surface, d'ume feuille d'argent qui présente des taches noires et irrégulières sur le dos, et de petits points noirs sur les côtés; sa cbair est grasse ainsi qu agréable au gout ; et lorsqu'on veut le prendre à l'hameçon, on garnit cet instrument d'insectes ailés. Les peintures ehinoises que l'on conserve dans la bibliothèque du Muséum national d'histoire naturelle, offrent la figure d'un zée qui peut-être forme une espèce particulière, et peutètre n'est qu'une variétê du rusé. Il parait en différer par trois caractères : une anale beaucoup plus fongue; un rayon de chaque thoracine très. allongé; et une ligue latérale non interrompue.

'7 rayons a la membra e branchiale du zée longs-chevenx, de la qu Le. -7 rayons a la meewbrane branchiale du zée rusé, 16 à chinue pectorale, I rayon aignillonné et 5 rayons articulís a claque thoracine, 18 rayons a la crudale 5 rayons

DES PUISSONS.

LE ZEE FORGERON '.

Zeus Faber, Liun. Bl., Lae, Guv. ${ }^{3}$.

Ce zée se trouve dans l'Océan atlantique et dans la Méditerranée. Dès le temps d'Ovide, il avait été observé dans cette dernière mer; Pline savait que, très-recherehé par les pécheurs de l'Océan, ce poisson était depuis très-longtemps préféré à presque tous les autres par les ci toyens de Cadix; et Columelle, qui était de cette ville, et qui a écrit avant Pline, indique le uom de Zèe comme donné très-aneiennement à ce thorain. Cet auteur connaissait, ainsi que Pline, le nom de Forgeron, que l'on avait employé pour cet osseux, particulièrement sur le rivage de la mer Atlantique, et que nous lu avons conservé avee Línée, et plusieurs autres naturalistes modernes.

Dans des temps bien postérieurs à ceux d'o vide, de Columelle et de Pline, des idées trèsdifférentes de celles qui occupaient ces illustres Romains, firent imaginer aux habitants de Rome, que le zée, dont nous donnons une notice, était le même animal qu'un poisson fameux dans I'histoire de Pierre, le premier apotre de Jésus, et que tous les individus de cette espèce n'avaient sur chacun de leurs cótés une tache ronde et noire que parceque les doigts da prince

- Doree, Poule de mer, en France. - Coq, Lau, sur quelques cotes tranģ, de Foctan, - Troueie, Saint- Pierre, hode, dans quelques depart. mérid. - Gat, en Espague,
Ul pesce fabro, en Sardajgae. - Laurata, a Malte. - Vabro, en Dalmatie. - Christophoron, par des Grees moderines. -
Pesee san-piedro, Citula, Rotula, en Italie. - Saint-petêr fisch, Sonnen fisch, Mecrschmid, en Aliemagne. - Iferingskenig, ca roi des harengs, aupres de nambourg el do Heiligeland. - Skrabba, en suede, - Sonneneis, en Hor

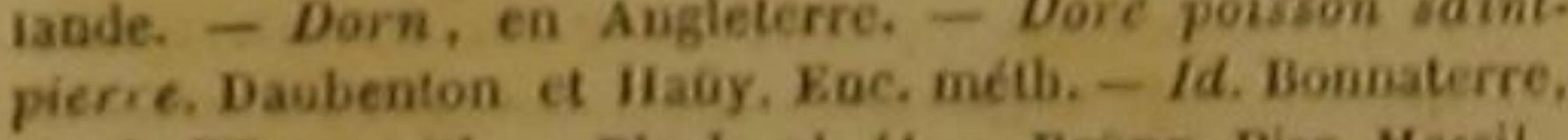
pl. de YEno, metb. - Bloch, pl. 44. - Brän. Pisc. Massil. p. $35, \mathrm{n}^{2}$ 46. - Mus. Ad. Fria, 1, D., 67, tab. 51, 6g. 2. - Zeus ventre aculeato, cauda in extremo circinats., Artedi, vald. - Oppian. 1. 1, fol, 6. 17. - , Zeus, id faber, , Plio., 19. 9. c. 18, et 1. 52, eap. 11. - Ovid. Halieutic, versu III.

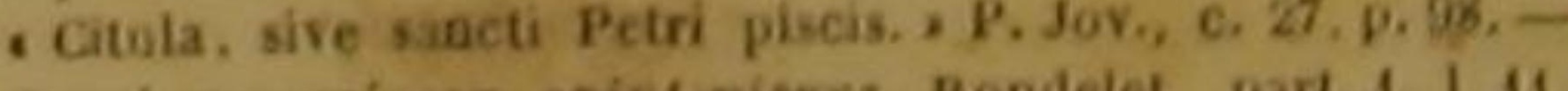

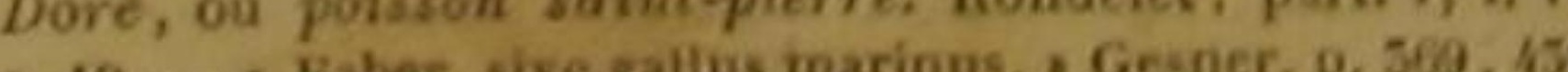

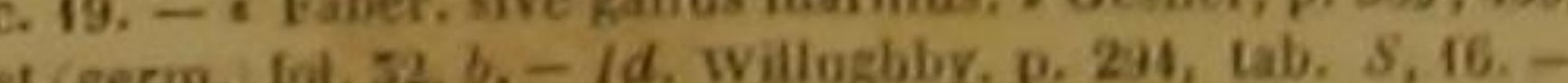
Id. Rai, p.99.- Faber. Columel., 1. 8, e, 16. - Id. Wotton I. 8 , c. 181, fol. 160. b. - Id. Salvian.. fol. 203, 20s, 205. Id. Aldrov, I, 1. c. 23, p. 112.-Id. Jonston, 1. 1, L. 2, c. 1, a 18, lab. 17, fig. 1, 2. Id. Charlet., p. 156. - Xavasus, id ent faber. Schn., Petri artedi Syoonymia piscium, etc, p. 14\%, -Grouor. Mus. I, p. 47, n. 107; Zooph, p. 95, N.. 31.

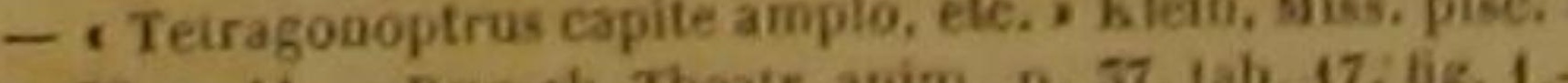

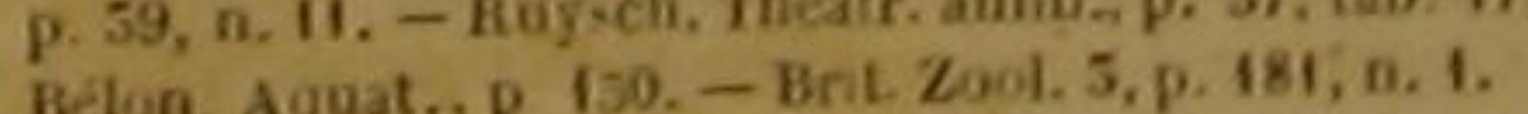
'Du sous-genre Doaik, Zeus, dans le graud genre Vousp, apotres s'etaient appliqués sur un endroit analogue, lorsqu'il avait pris un de ces zées pour obéir aux ordres de son maitre; ot comme les opinions les plus extraordinaires sont celles qui se répandent le plus vite et qui durent pendant le plus de temps, on donne encore de nos jours, surplusieurs cotes de la Méditerranée, le nom de Poisson de saint Pierre au zée forgeron. Les Grees modernes I'appellent aussi Poisson de saint Christophe, à eause d'une de leurs lé gendes pieuses, que l'on ne doit pas s'attendro à trouverdans un ourrage sur les seiences naturelles. Mais il est résulté de cette sorte de dé. dieace, que le forgeron a été observé avee plus de soin, et beaucoup plus tót connu que plasieurs autres poissons. Il parvient communement à la longueur de quatre ou einq décimé tres; et il pèse alors cing ou six kilogrammes. II se nourrit des poissons timides qu'il poursuit auprès des rivages, lorsqu'ils viennent y pondre ou y féconder leurs oufs. II est si vorace, qu'il se jetteavec avidité et sans aucun discernement sur toutes sortes d'appáts; et l'espèce d'audace qui accompague cette voracité ne doit pas étonaer daus un zée qui, indépendamment des dimensions de sa bouche, et du nombre ainsi que de la force de ses dents, a une rangée longitu dinale de piquants non-seulement de chaque côté de la dorsale, mais encore à droite et à gauche de la nageoire de I'anus. D'ailleurs ces águillons sont très-durs, et les sept ou huit derniers sont doubles. Les huit ou neuf premiers piquants de la nageoire du dos peuvent être considérés de chaque côté comme des apophyses de rayons aiguillonnés de cette nageoire; et les deux rangs d'aiguillons recourbés et contigus qui accompagnent la partie antéricure del'anale, se prolongent jusqu'a la gorge en garnissant le dessous du corps, de deux lames dentelée comme celle d'une scie. A toutes ces armes to forgeron réunit encore deux pointes dures et ai gués, qui partent de la base de chaque peetorale, et se dirigent verticalement, la plus courte vers le dos, et la plus longue vers l'anus.

La mâchoire supérieure est plus avancée que a supérieure; celle-ci peut s'étendre à la volonté de l'animal. Lés yeux sont gros et rapproches ; les narines ont de grands orifices, les branchies une large ouvertare, et les opercules chacu deux lames; les écailles sont trok-minces.

L'ensemble du poisson ressemblant un peu à un disque, au moins si fon en retranchaic le 
museau et la caudale, il n'est pas surprenant

qu'on l'ait comparé à une roue, et qu'on ait donné le nom de Roñdelle à l'animal. Sa couleur générale est mêfée de peu de vert et de beaucoup d'or, et voila pourquoi il a été appelé Doré ; mais sa parure, quoique très-riche, paraít enfumée; des teintes noires occupent le dos, la partie antérieure de la nageoire de l'anus; ainsi que de la dorsale, le museau, quelques portions de la tète; et e'est ce qui a fait nommer ce zée Forgeron.

Ses pectorales, ses thoracines, la partie postérieure de la nageoire du dos, et celle de l'ánale, sont grises; et la caudale est grise ave des raies jaunes ou dorées.

L'estomac est petit, le canal intestinal trèssinueux, l'ovaire double, ainsi que la laite. On compte trente et une vertèbres à l'épine du dos. La charpente osseuse, excepté les parties solides de la tête, a les plus grands rapports avec celle des pleuronectes, dont nous allons nou occuper; et cette analogie a été particulièrement remarquée par le savant professeur Schneider.

De mème que quelques balistes, quelques cottes, quelques trigles et d'autres poissons, le Forgeron peut comprimer assez rapidement sés organes intérieurs, pour que des gaz violemment pressés sortent par les ouvertures branchiales, froissent les opercules, et produisent un léger bruissement. Cette sorte de bruit a été comparée à un grognement, et a fait donner le nom de Truie au zée dont nous parlons '.

\section{CENT QUARANTE-SEPTIEME GENRE.} LES GALS

corps et la queue tris-comprimis, des donts aur maChoires; deux nageoires dorsales; plusienrs max ma-

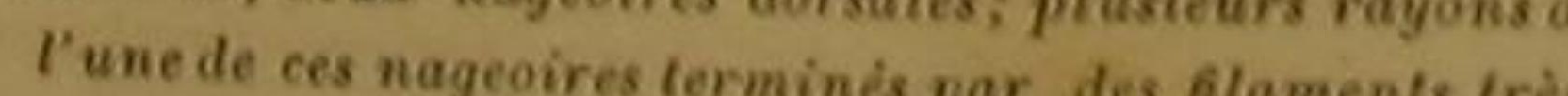
longs, ou plusieurs piquants to tong ite chapuse

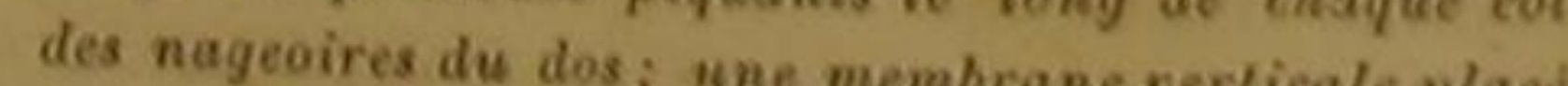
transcersalement ou-dessous de to iterticale placio

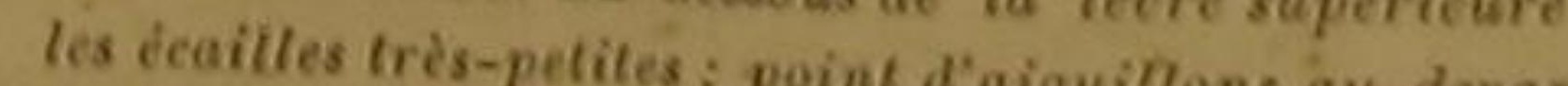
do la première ni de la seconde dom geoire de l'a

ESpice.

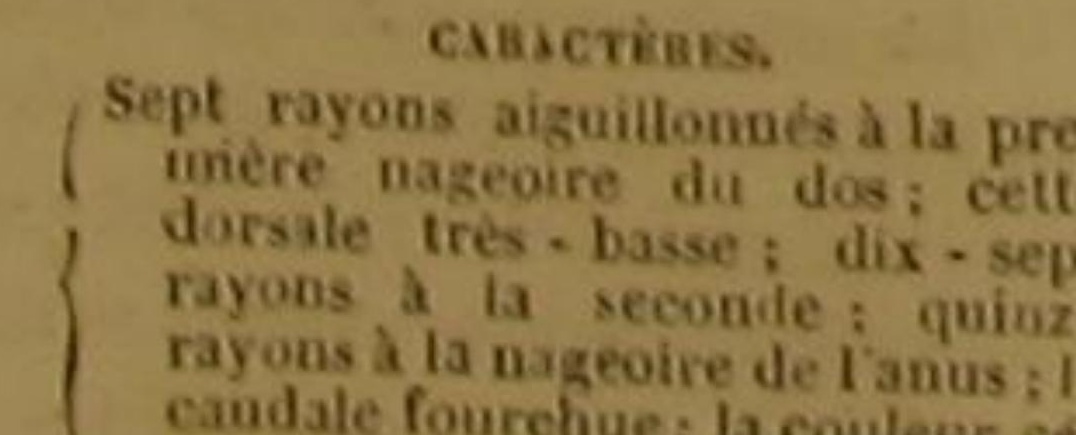

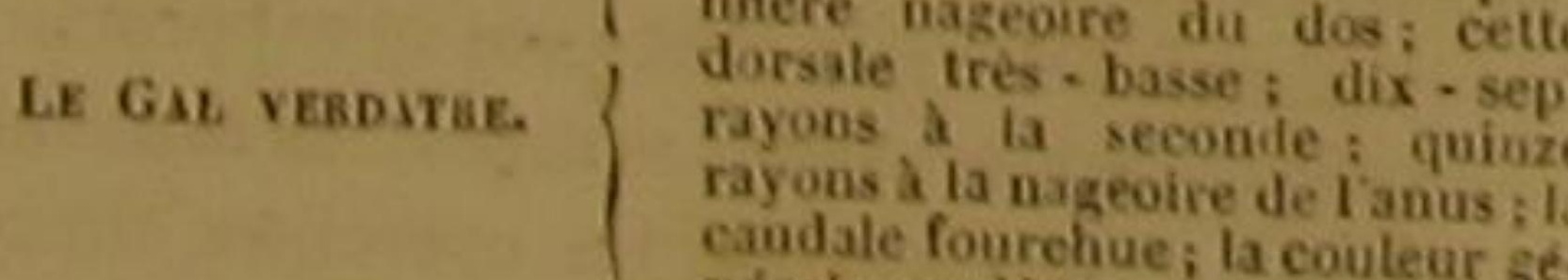
nérale verdát

' 7 rayons a la membrane branchiale du zée forgeron, 12 elaque pectorale, 9 a chaque thoracine, is a la bageoire de la
queue.
LE GAL VERDATRE '

Gallus virescens, Lac., Cuv. ; Zeus Gallus, Limn. , Bl. 2

Dans quelles mers ne se trouve pas ce ga verdâtre? On l'a vu aa Brèsil, à la Jamaĩque, aux Antilles, auprès du Groenland, dans les Indes orientales, dans la Méditerranée. Sous tous ces climats si différents, et même si opposés, il présente les mèmes habitudes, les mê mes formes, les mèmes couleurs, les mêmes dimensions. Il offre ordinairement, dans toutes les eaux salées qui le nourrissent, une longueur de près de deux déeimètres. Il recherche les très-petits poissons, et les vers ou les insectes qui habitent au fõnd ou a la surface de l'Océan. Il fait entendre, suivant Pison, un bruissement semblable à celui du zée forgeron, Sa chair est de bongoût. Ses éeailles ne peuvent ètre vues que très-difficilement, tant elles sont petites. Chaque narine a deux orifices. La nuque est très. relevée et un peu bombée. La ligne latérale s'élève, se courbe, descend, se recourbe de nouveau, et va ensuite très-directement jusqu'a la nageoire de la queue. Les nageoires sont d'un beau vert; et les cótés, d'un argenté brillant ${ }^{3}$.

\section{CENT QUARANTE-HUITIEME GENRE} LeS CHRYsotoses.

Le corps el la queue tris-comprimés; la plus grando hauteur de fanimal, egale ou presque egale d la longueur du corps et de la qurue pris ensemble; point de dents ause mathoirs, une seule nageoire dorale; les

- Cog de mer, Lune, par les Français. - Serduk, a Malte. a Groeoland - Merrhahn, Bonle fartije, en Hollornak. Larger silver fish, a la Jamaique. - Abrcoluaja, an Brtai - Peixe gallo, par les Portugais fu Bresil:- Ilkan kapelle. - Dores orientales.-Zée coy de mer. Bloch. pl. 192, fig. I. naterre, pt. Daubenton et Haay, Enc. méth. - Id. BonZooph., p. 96 , n. 312 . - Tetragonovis Mlus. 1, n. 105 : - levissimus, etc., Klein, Miss. pisc. 4, p. $58,0.8$ anteus - Zeus cauda bifund. A Artedi, pen. 33, syn, 78 - 8 el 9. Mus. 5, p. 72, n. 54. tab. 26, fig. 54.- Marcgr. Brasil. p. 161 , fig. 2. - Kai, Pisc, - Willughtly, Ichth., p. 295, tab. $5,18$.

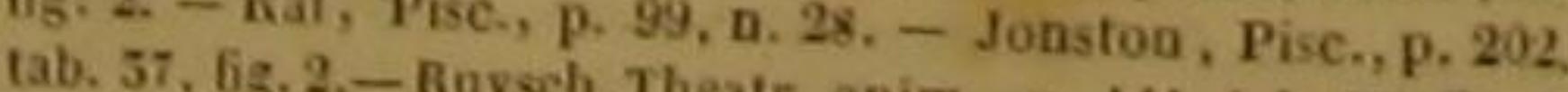
Meerhachn. Nieub Ind. 1 , p. azo anim., p. 141, t.b. 57, fig. 2 2. p. 215. - Rameur. Renard, Poiss. 2, tab. Te, fise, antill. Du sous genre Gst, dans le grand 2, lab. 26, fig. 12s. vier. Famille des Acanthoptérygiens scombéroides. Trayons a la membrane branchiale du gal verisistre, 16 a chaque pectorate, 1 rayon aiguillonné et 5 rayons articitiés ges, 21 rayons à la nageoire de la giers rayons sont trés-allon-

DE.S IOISSONS.

195

deailles tres-petites; point d'aiguillons au-devant de hait nageoire du dos, ni de cello

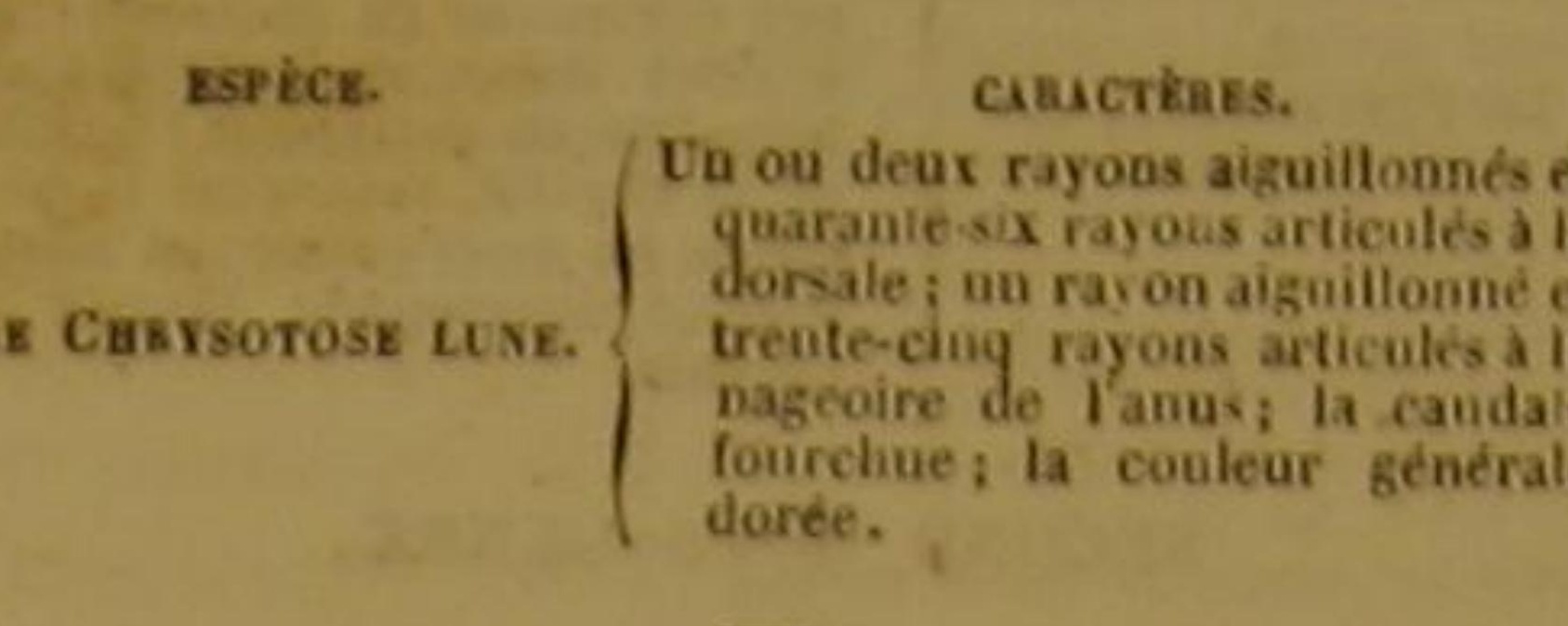

LE CHRYSOTOSE ' LUNE 2 .

Lampris gullatus, Betzius, Cur ; Chrysotosus Luna, Lae.; Zeus Luna, Linn., Gmel. ; Zeus regius, Bon-

C'est un grand et magnifique poisson que ce chrysotose, que Duhamel et Pennaut ont déerit, et que le professeur Gmelin, ainsi que le professeur Bonnaterre, ont inserit dans le genre des zées, mais qui n’apṕartient pas à ce genre, et qui n'est eneore qu'impariaitement conno. Un individu de cette superbe espèce, très-bien conservé dauis le Muséum d'histoire naturelle, et qui pourrait bien être celui sur lequel Duhamel a fait sa deseription, nous a présenté tous les traits distinetifs de ce beau chrysotose. Ce poisson osseux a beaucoup de rapports avec le cartilagineux auquel nous avons conservé le nom de Diodon Lune; mais, indépendamment d'autres grandes différences qui l'en séparent, il ne réfléchit pas les mémes nuances. Lorsqu'i resplendit auprès de la surface de la mer, il ne renvoie pas une lumière argentine comme celle de la lune; il brille de l'éclat de l'or: et e'est au disque solaire plutót qu'à celui de l'astre des nuits, qu'il aurait fallu comparer la surface richement décorće qu'offre chacun de ses cotés. Plusieurs reflets d'azur, d'un vert clair et d'arzent, se jouent sur ce fond doré, au milieu d'un grand nombre de taches couleur de perle ou de saphir; les nageoires sont du rouge le plus vif, et éest cequi a fait dire à un observateur, que l'on devrait regarder ce chrysotose comme in seigneur de lu cour de Neptune, en habit te gala ${ }^{4}$.

+ Le nom gtnérique de Chrysotore vieat da mot grec y jüsores, qui siguifie dore.

2 Poisson lune. Duhamel, des Péches, 3, pi. 15. - Poisson royal. Bonnalerre, pli. de FEnc, métb. - Pennant, Zool. Brit,., vol. 5, a. 101.

3 Da sous-geore Limpas, dans le grand genre VoMes, Cuv. Familie des Acan thopterygiens scomber Gides. D. "Sote manuscrite caterea remise, m'a donnee dans le temps.
Lorsque ce poisson lune parvient a des dimensions très-êtendues, et par exemple lorsqu'il a soixante-six centimetres de hauteur ( sans y comprendre les nageoires du dos et de l'anus ) sur dix ou onze déeimètres de longueur totale, ainsi que l'individu du Museum d'histoire naturelle, il pèse près de vingt kilogrammes. On ne distingue pas, sur cet individu du Muséam, de ligne latérale; la lèvre supérieure était extensible; la màchoire inférieure est plus longue que la supérieure; la dorsale est en forme de faux ; l'extrémité de la queue, trìs-basse et cylindrique, s'avance au milieu de la base de la caudale; les écailles sont unies; on n'en voit pas sur les opercules; les yeux sont ronds, gros et saillants '.

On ne rencontre que très-rarement les chrysotoses lunes. Lorsqu'on en montra un á Dieppe, it y a plusieurs années, les plus anciens pécheurs voyaient cette espèce pour la première fois. Les individus que les naturalistes ont observés, avaient été pris sur les cótes françaises ou anglaises de l'Océan Atlantique, II parait cependant que le chrysotose que nous décrivons habite aussi dans les mers de la Chine; nous avons eru en effet reconnaitre une variété de cette Lune, dans une des peintures chinoises qui font partie de la colleetion du Muséum d'histoire naturelle.

\section{CENT QUARANTE-NEUVIEME GENRE.}

LES CAPROS.

Le corps el la queue tris-comprimés el iris-hauls i point de dents aux mdehoires; deux nageoires dorsates; les ecailles très-petites; point d'aiguillons au-devand is la première ni de la eceonde doraale, ni de la nageoire de l'anus.

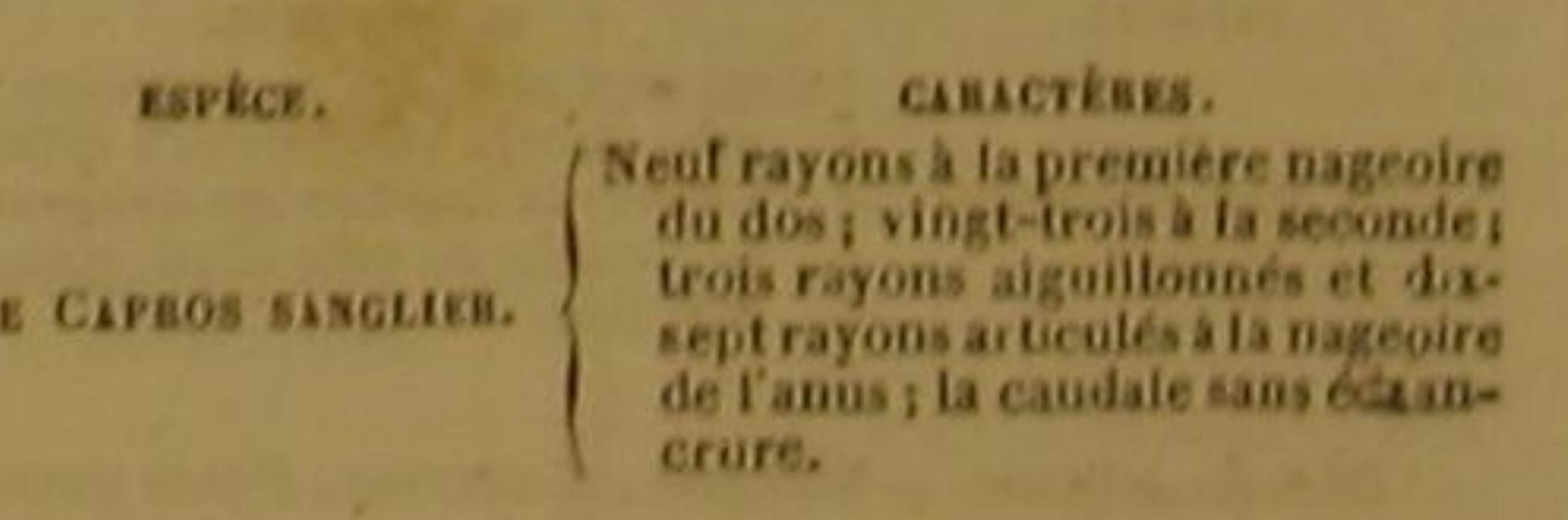

' 20 rayons a chaque pectorale du chryotose lune, I rayon

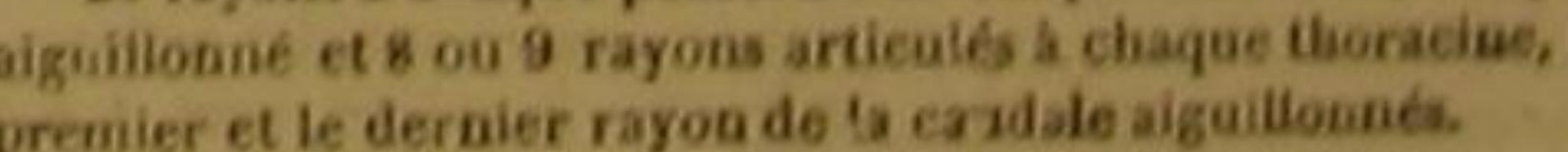




\section{LE GAPROS SANGLIER '}

Capros Aper, Lac., Cuv.; Zeus Aper, Linn., Bloch. ².

La mer qui baigne les rivages de la Ligurie et ceux de la campagne de Rome, nourrit ce poisson, que l'on n'y pêchait cependant que très-rarement du temps de Rondelet. Ce thoracin a le museau avancé, un peu cylindrique, terminé par une ouverture assez petite et par une levre supérieure facile à étendre, ce qui donne à cette partie de la tête quelque ressemblance avec le groin d'un cochon ou d'un sanglier; et cette analogie l'a fait désigner par le nom spécifique que nous avons conservé, ainsi que par celui de Capros, qui, en gree, signifie sanglier ou verrat, et dont nous a vons fait son nom générique. D'ailleurs les écailles dont ce poisson est revêtu, sont frangées sur leurs bords; et l'on n'a pas manqué de trouver un assez grand rapport entre les brins écailleux de ces franges et les soies du cochon.

La ligne latérale de ce capros est très-courbée

et mẻme ondulée; sa couleur générale parait

rougeâtre; l'extrémité de sa caudale est peinte

d'us rouge de minium.

Au reste, on le recherche d'autant moins, que sa chair est dure, et répand quelquefois une inauvaise odeur ${ }^{3}$.

CENT CINQUANTIEMEE GENRE. LES PLEURONECTES.

Les deux yeux du meme colé de la lote.

PREMIER SOUS-GENRE.

Les deux yeux d droite; la caudale fourchue, ou échanerée en croissant.

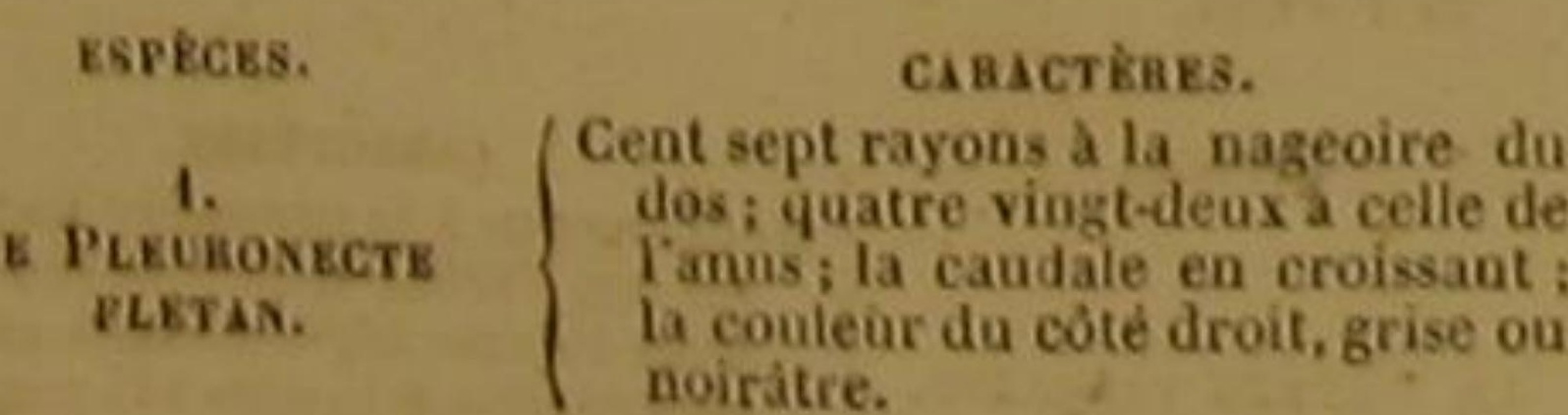

'Riondo, a Rome. - Strivale, Lucerna , Pesce pavotto, aux environs de Gènes. - Doré sanglier. Daubenton et

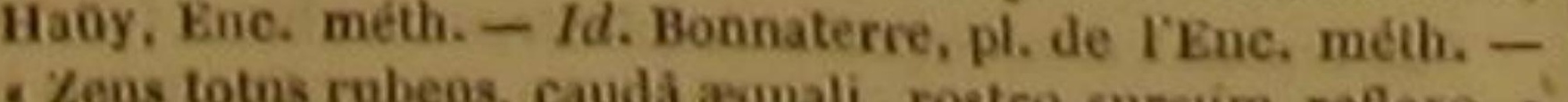
Artedi, gea. 50, syo. 78. - Sanglier. Rondele', part. 1, , c. 27. - Charl., p. 125. - Gesner, p. 61, 70; et (germ.) fol, 50 , b. - Aldrov., 1. 5, c. 12, p. 297. - Jonston, 1. 1, L. I, c. 1, $a_{\text {, }}$ 4. - Willughiby, p. 296. - Rai, p. 90.

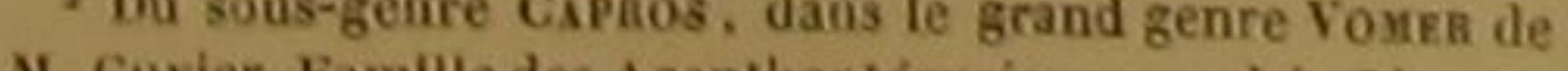
i 7 rayons a la membrane branchisle du copros sandes. D. a claque pectorale, $f$ rayou aiguillonne et 5 rayons articules
a claque thoracine.

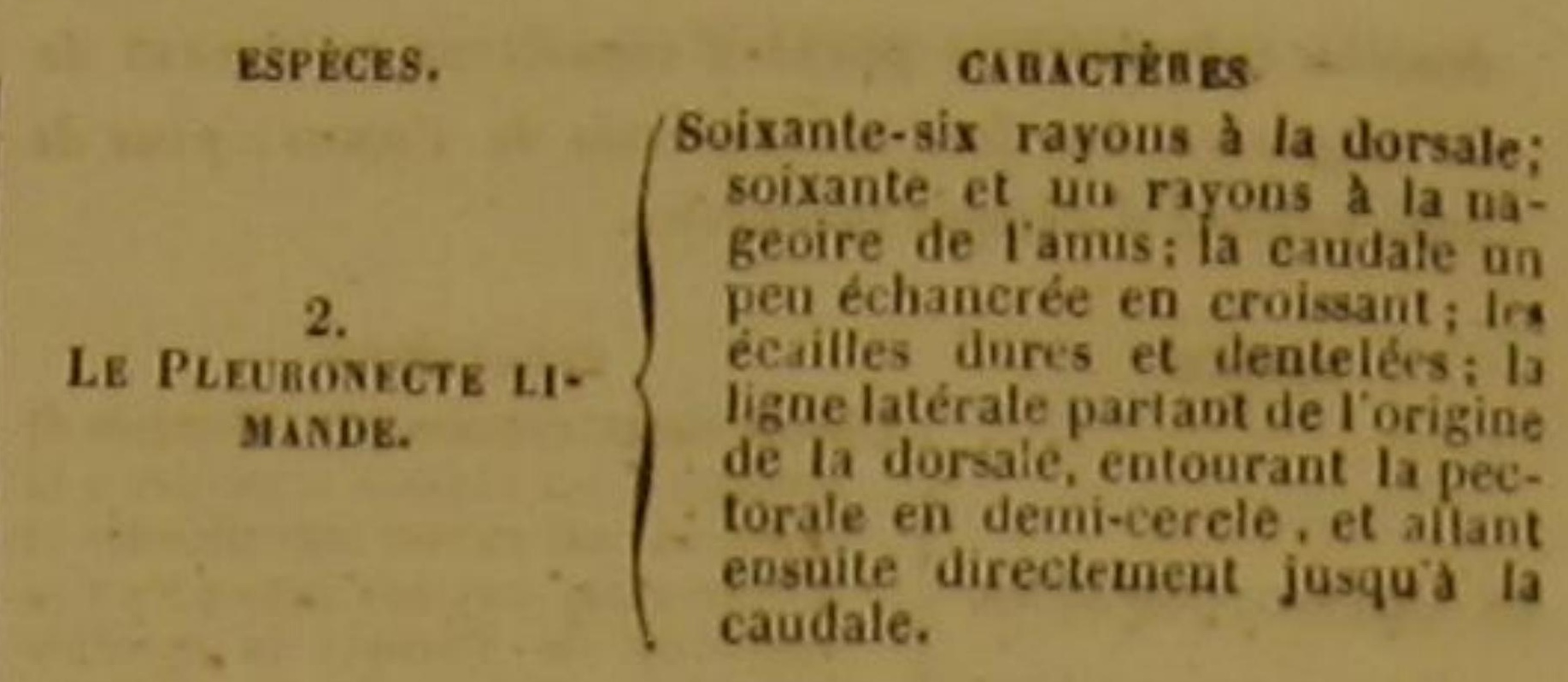

SECOND SOUS-GENRE.

Les deux yeux à droite; la caudale recliligne ou arrondie, et non échancré.

(Quatre-vingthon rayons a la na-

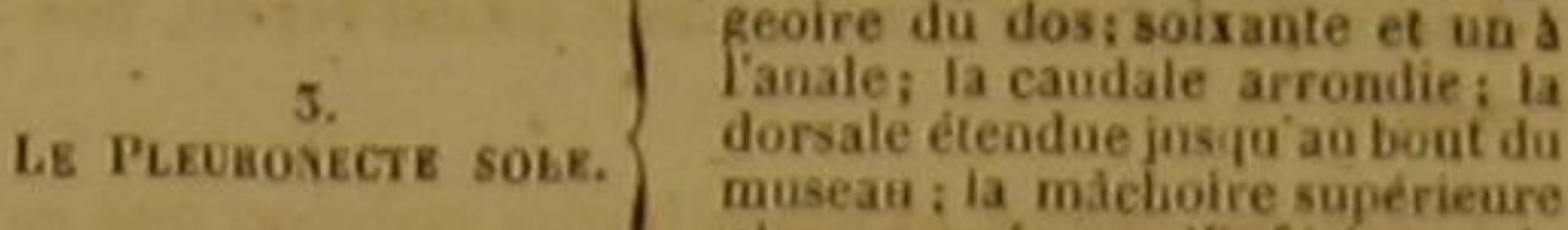
plas avancée que linférieure : lo

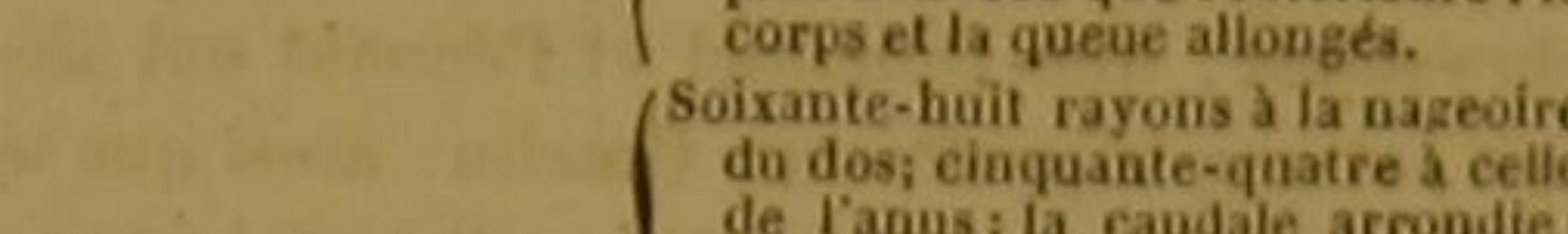
de lanus i la caudale arrondie
clng ou six eminences sur it

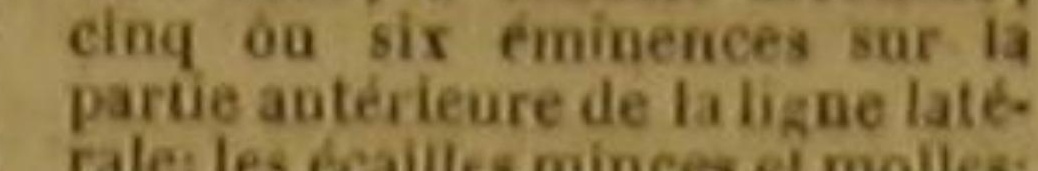
le colé drouit marbrés de brun et
de gris, avee des taches orantes.

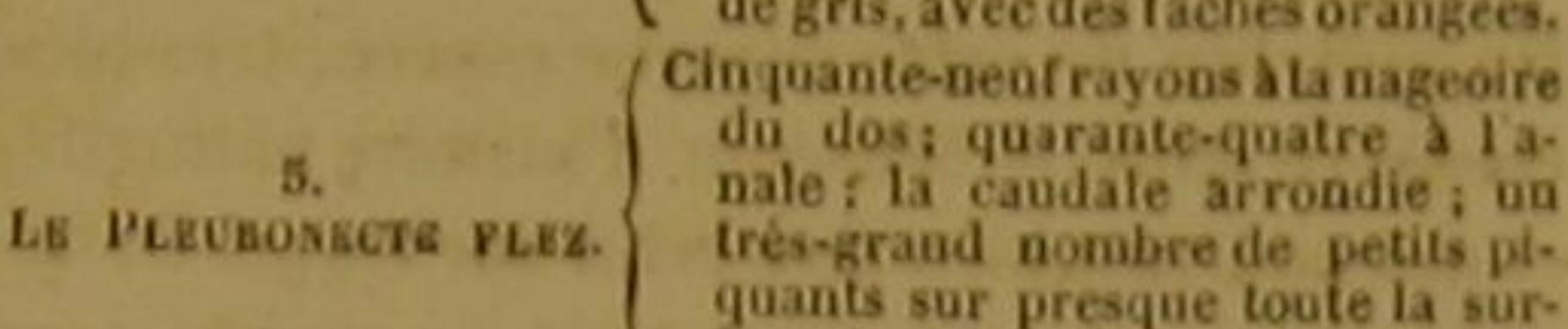

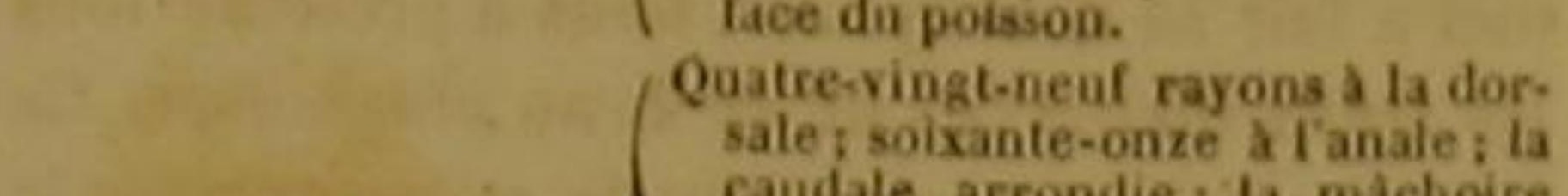

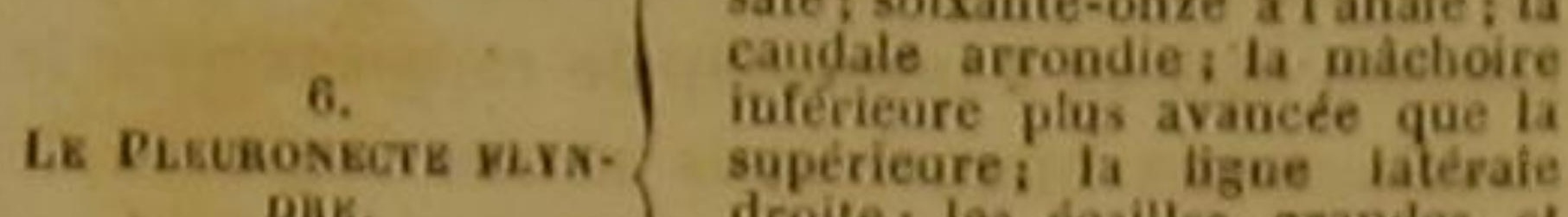

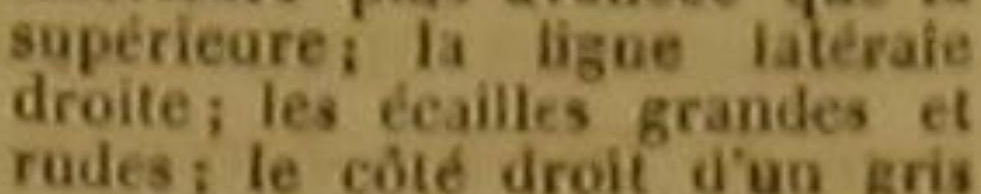
cendre, avec des taches brunes
ou rougeatres.

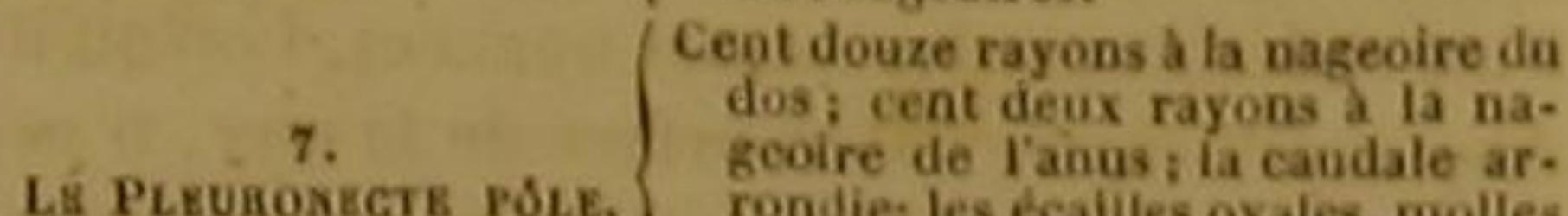
geoire de Tanus; ia caudale ar.
rondiei ies écalles ovales, molles
I lisses; les dents obtuses; le

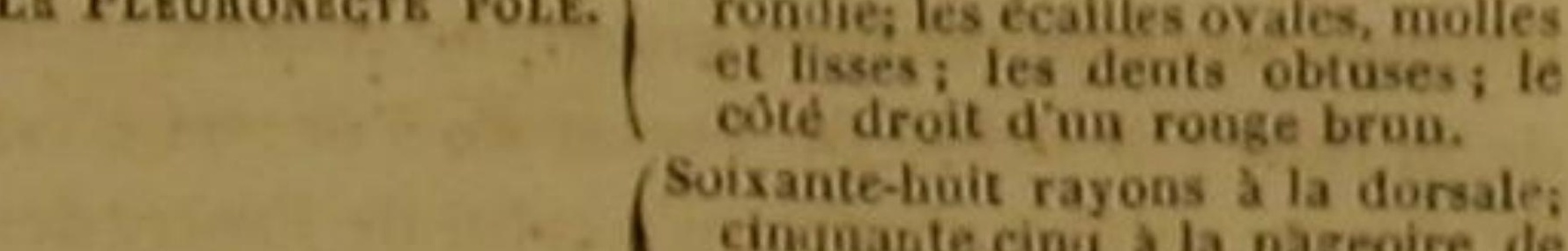

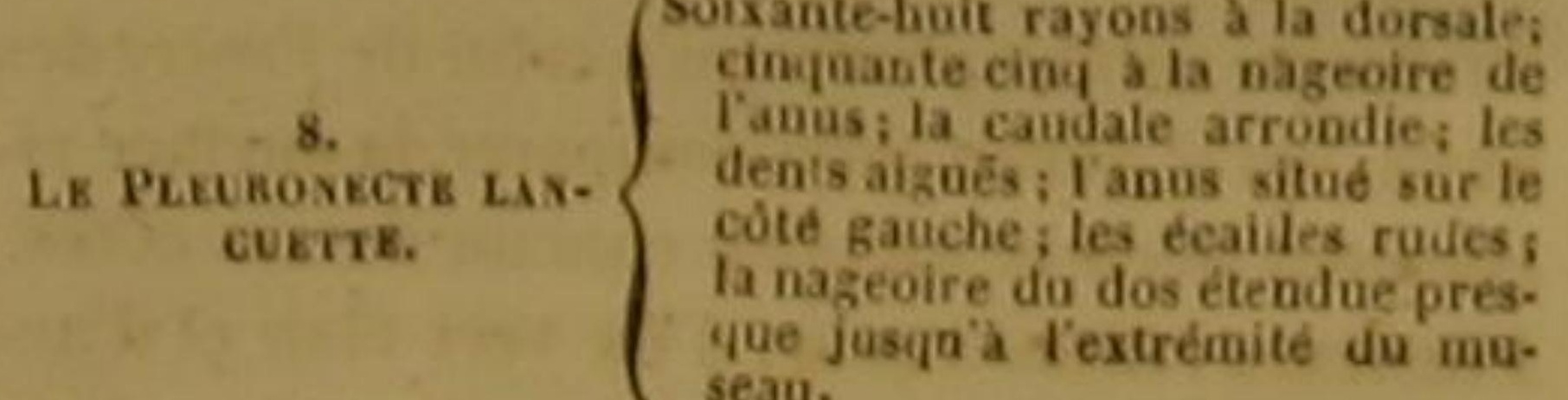

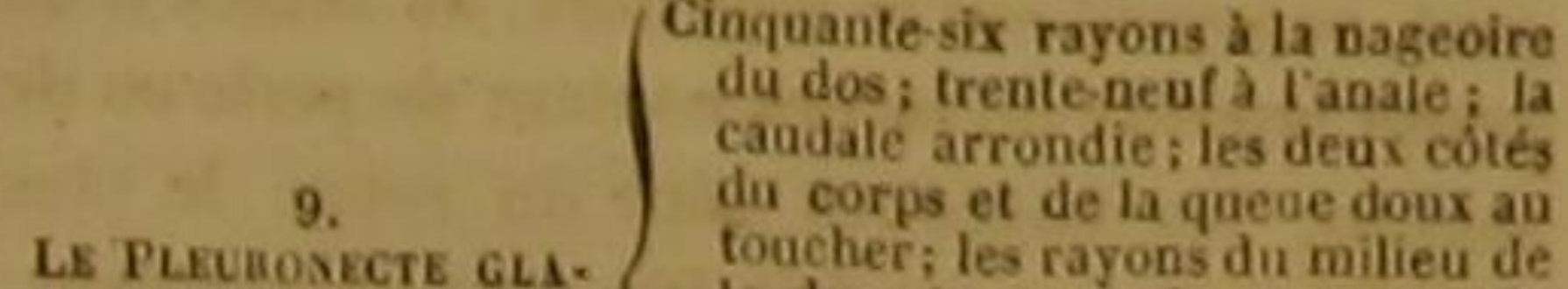
LE PLEunonecte GLA.
CAAL. -quants; une proéminence os-
seue et rude aupres des yeux;
locite dout bo seucet
lecoted d

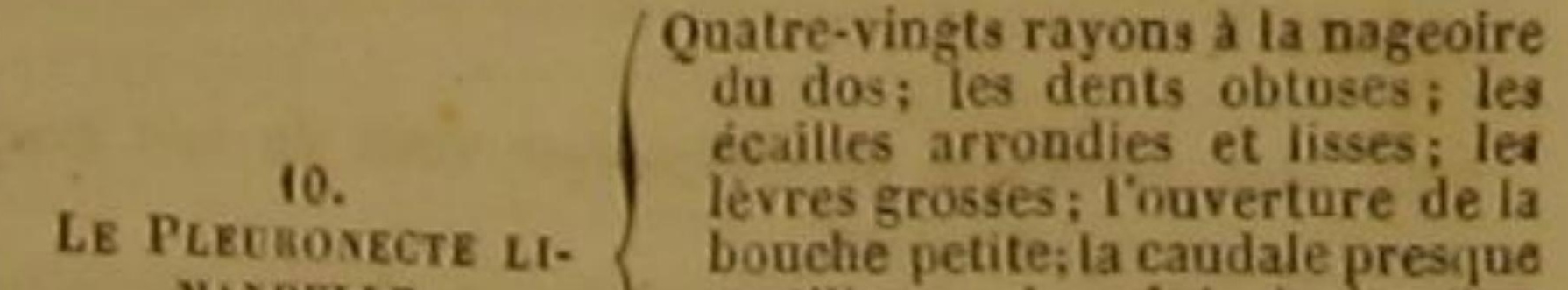
ma NDELLE.
H. chrs, et des taches d'un brun
fonce. II.
LE PLERonecte Cal-
kOIS.
DES POISSONS.

427

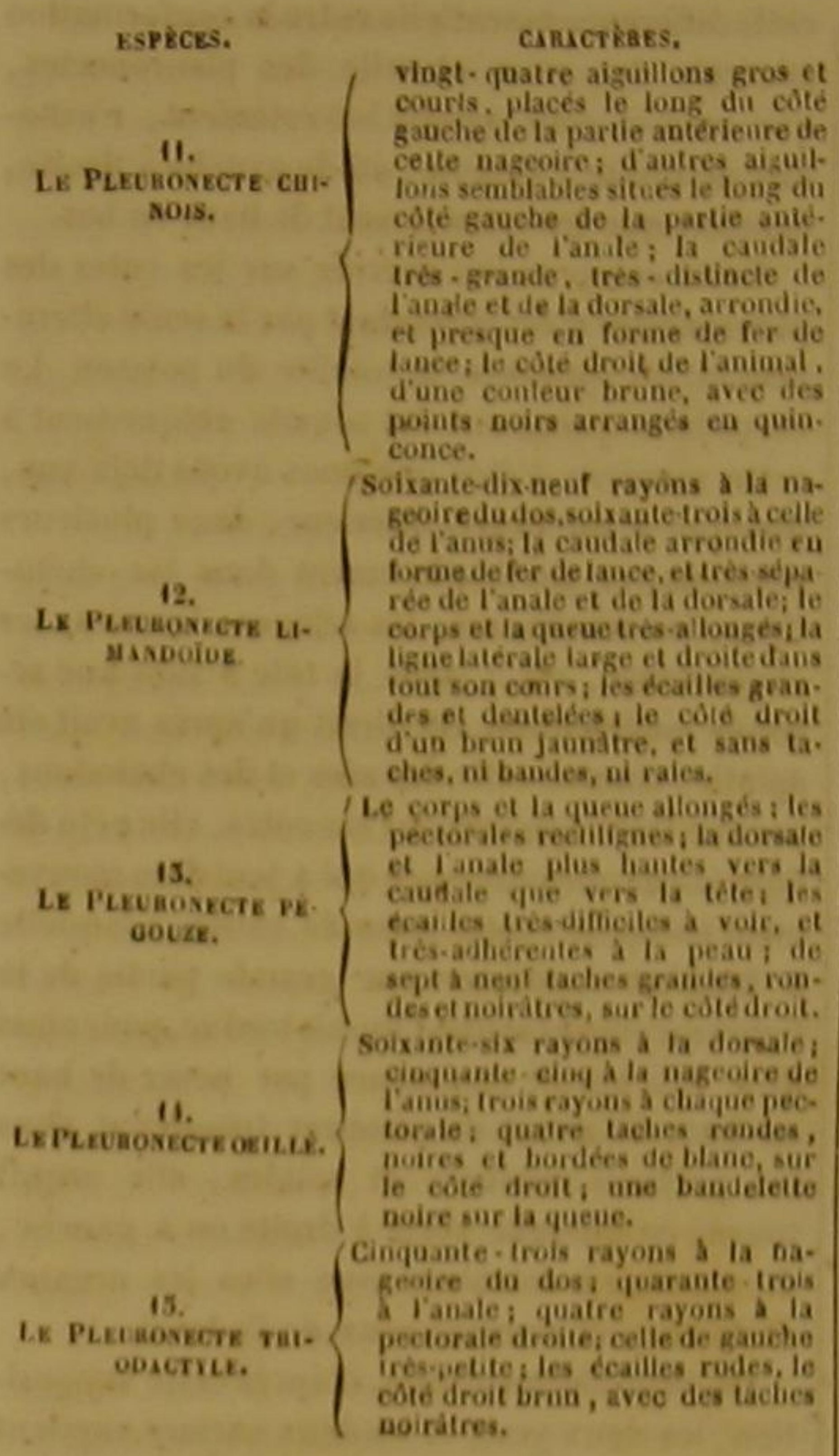

TROISIĖME SOUS-GENRE.

Les deux yeux d droilo; la caudale pointue, at réunio avec la nageoire du dos el celle de l'anus.

$\left(\begin{array}{c}\text { Quatre- viogt-un rayons a la dor- } \\ \text { sale: quarante-huiti a la nageoire } \\ \text { The }\end{array}\right)$

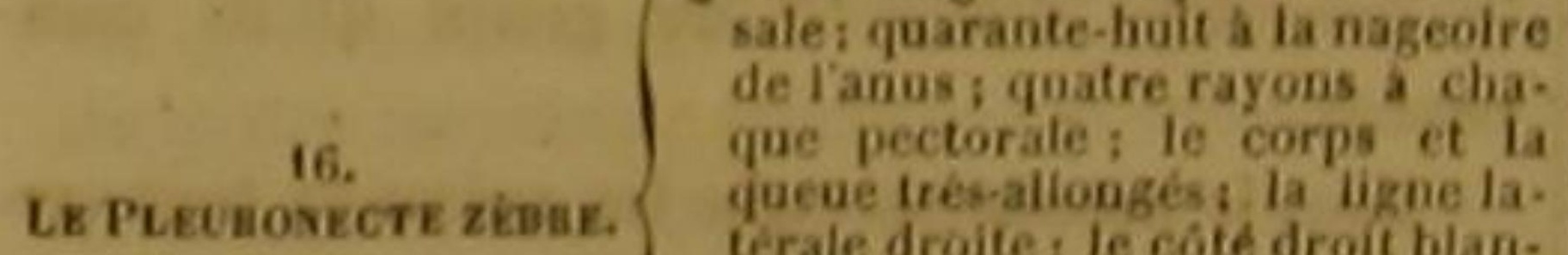

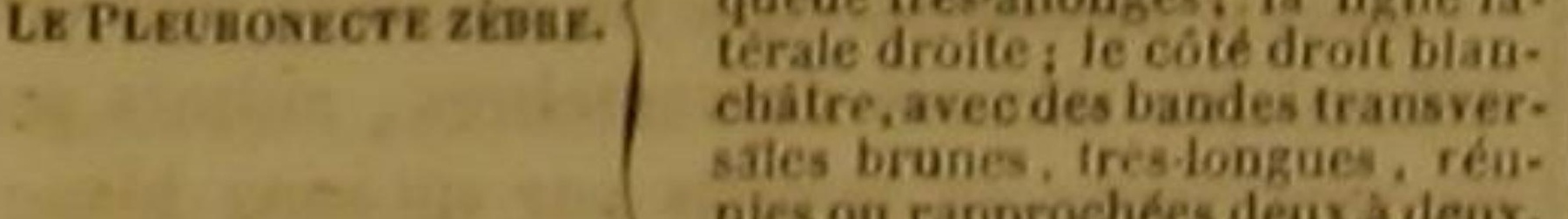
17.
LE PLEnovicte PLL-
cievse.

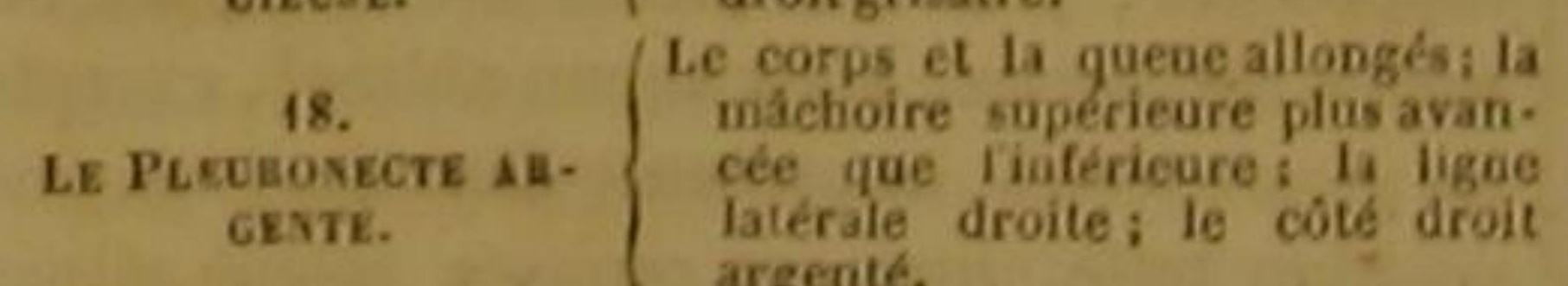
QUATRIĖME SOUS-GENRE.

Les deux yeux à gauche; la caudale rectiligne, ou arrondie, et sans échancrure.

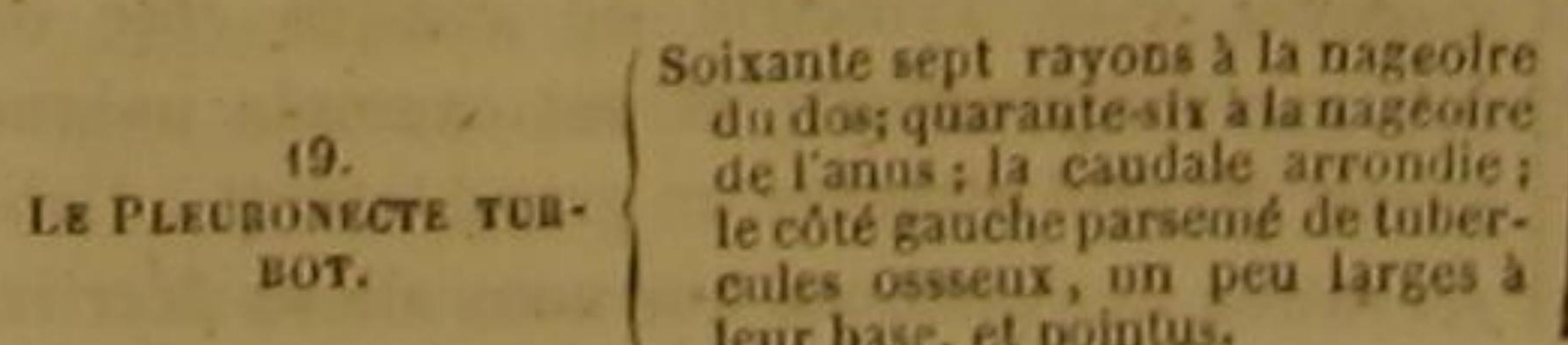

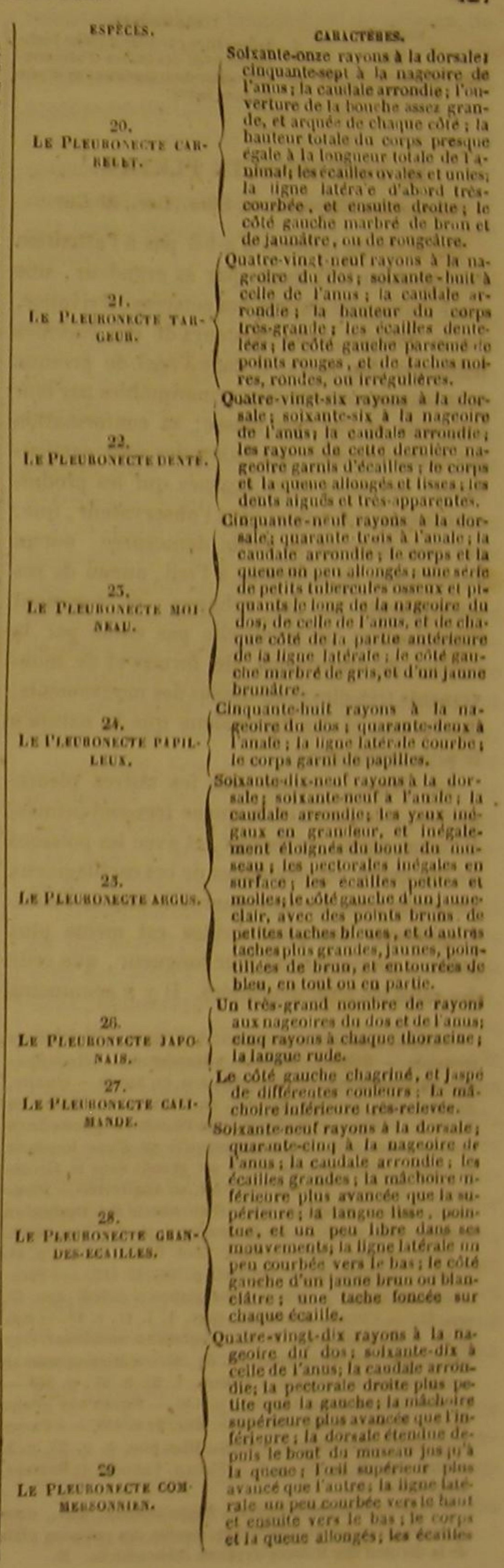




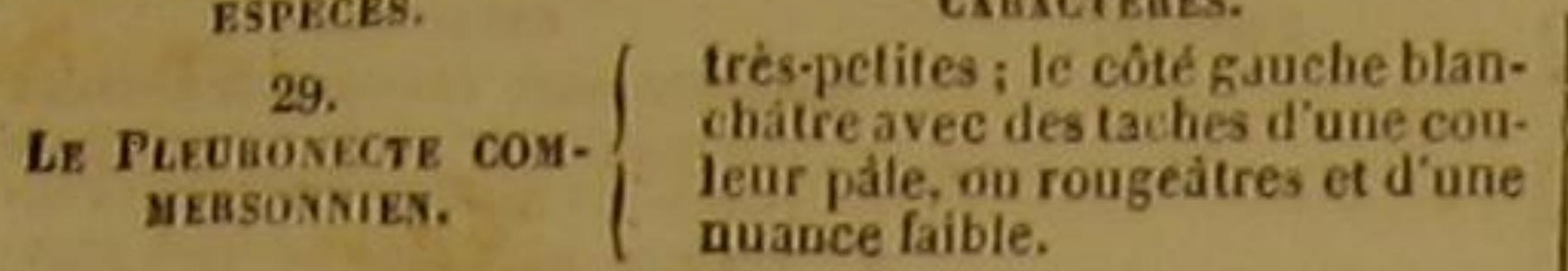

LE PLEURONECTE FLÉTAN.'

Pleuronectes Hippoglossus, Linn., Lac., BI. Cuv,4.

Quels droits le flétan n'a-t-il pas à l'attention du physicien! Il tient, par sa grandeur, une place distinguée auprès des cétacées; il rivalise, par le volume, avec plusieurs de ces énorme habitants des mers; il nage l'égal de presque tous les poissons les plus remarquables par leu longueur et par leur masse; sa conformation est extraordinaire; ses habitudes sont particulières; ses actes et les organes qui les produisent frappent d'autant plus l'observateur, que par une suite de sa taille démesurée, aucu de ses traits ne se dérobe à l'œil, aucun de ses mouvements ne lui échappe : et comment l'imagination ne serait-elle pas émue par la réunion de dimensions, de formes et de mouvements très-élevés au-dessus des mouvements, des formes et des dimensions que la nature a le plus multipliés?

Le flétan, comme tous les autres pleuronectes, a le corps et la queue tres-comprimés Il forme parmi les osseux, et avec les poissons de son genre, les analogues de ces cartilagineux auxquels nous avons conservé le nom de Raies. L'épaisseur des pleuronectes est mème plus petite à proportion de leur longueur, que celle des raies les plus déprimées. Il y a néanmoins

AFailan, dans quelques deparl. de France. - Heilbot, en Hollande. - Heilbut, Hilibut, a Hambours. - Helleflyn. der, en Danemarek. - Haelgflundra, en Suede. - Queite, Sandskiebbe, Skrobbe flynder, ea Norrége, - Baldes, en laponie. - Fydra, Heilop fish, ea Islande. - Queile-bam (lorsquil est pelit), Styoing (lorsquili est d'une lonzueur layenene), Netarnak (lorsyuil est grand), dans to Groenronecle fétan. Bloch, pl. 47. - Pleuronecle Ret. Dawbentet Haay, Euc, méth. - Id. Bonnaterre, pl. de l'Enc. méth. - Faun. Suecic. 529. - Moller, Zool. Danic. Prodr., p. 41 ronectes oculis a destroent., p. 161, n. 117. - - Pleusyn. 51. - Flétan, Rondelet, giaber. Artedi, gen. 17 , p. 5s. - Hippoglossus, id est, buglossus, C. 15. - Ra', ner, p. 669, 787; et (germ.), fol. 5t, b. - . Hippogus. Ge A Adrovando observatus. A Aldrok, 1. 2, c. 45 , p. 238 . majus. Schon pus. Charlet., p. 146, - Passerum genus - quatuor cubitos longus, - Klein. Mus. 2; n. 158. - - Passer - Brit. Zool. 5. p. 181, n. 1. - F'tetan, Yisc. 4. p. 35, D. 2 Diet. d hist. nat. cette différence essentielle entre la conformation générale des raies et celle des pleuronectes, que ceux-ci sont aplatis latéralement, c'est-ádire de droite à gauche, ou de gauche à droite pendant que les raies le sont de haut en bas.

Cette compression exercée sur les cótés des pleuronectes n'est cependant pas la seule altérotion qu'ait éprouvée la totalité du poisson. Le corps et la queue ont été soumis uniquement cette manière d'ètre que nous avons déjà vue, quoique à un degré inférieur, dans plusieurs poissons, et particulièrement dans les ehétodons, les acanthures, les sélènes, les zées, les chrysotoses, etc.; mais la tête a subi une seconde modification. On dirait qu'après avait été aplatie, comme celle des zées et des chétodons par une force agissant sur ses cótés, elle a été dé figurée par une puissance qui a joui d'un mouve. ment composé ; cette seconde cause, à laquelle il faudrait rapporter une grande partie de la figurequ'elle présente, l'aurait tordue, pourainsi dire. Elle aurait commencé par peser de haut en bas; et avant de pénétrer très-avant dans les portions osseuses et solides, elle auraít tourné en quelque sorte à droite ou à gauche, de manière à entrainer avee elles les organes de la vue, et souvent ceux de l'odorat.

On sent aisément que, d'après cette supposiion, les deux yeux et les deux narines auraient dû, à la fin de l'action de la force comprimante, se trouver situés ou à droite ou à gauche, suivant le côté vers lequel la puissance aurait fléchi sa direction, et c'est en effet ce qu'on observe dans les pleuronectes, et ce qui forme le caractère distinctif du genre qu'ils composent.

Tout le monde sait que les animaux tant vertébrés que dénués de vertèbres, animés par un sang rouge ou nourris par un sang blane, ont des yeux plus ou moins gros, plus on moins rapproches, plus ou moins élevés, plus ou moins nombreux; mais aucun aninal, excepte les pleuronectes, me prísente position position telle, que ces organes soient situés uniquement à droite où à gauche de I'axe qui va de la tête à l'extrémité opposée. Nous ne connaissons, du moins dans ce moment, que les pleuronectes qui n'aient pas leurs yeux disposes avec symétrie de chaque côté de cet axe longitudinal; et cet exemple unique aurait dủ seul attacher un grand intéret a l'observation des poissons que nous allons décrire.
De la conformation que nous venons d'exposer, il est résulté nécessairement, que les deux nerfs olfaetifs aboutissent non pas à l'extrémité supérieure du museau, mais à un des cótés de la tête. C'est aussí à un seul côté de cette même partie de l'animal que se rendent les deux nerfs optiques, quoique croisés l'un par l'autre, ainsi que dans tous les autres poissons, et dans tous les animaux vertébrés et à sang rouge.

Nous avons déjà vu ' que le cerveau, cet organe dont les nerfs tirent leur origine, était plus petit dans les pleuronectes que dans presque tous les poissons cartilagineux, et mème que dans tous les osseux. La cavité qui contient eette source du système nerveux n'a-t-elle pas dû, en effet, être plus petite dans une tête qui a subi une double et plus grande compression? L'os intermaxillaire est moins développédans le côté qui a porté l'effort de la seconde aussi bien que de la première force comprimante et altératrice.

Les cótes qui servent à consolider les parois de l'abdomen, et à donner un peu plus de largeurau corps, sont cependant si courtes, que plusieurs auteurs ont nié leur existence.

La eavité du ventre est fermée du coté de la queue, par l'apophyse inférieure de la premiere vertebre caudale; et cette apophyse est très-longue, assez grosse, arrondie en avant, et terminée en bas par un piquant ordinairement très-fort.

L'estomac contenu dans cette cavité parait comme un renflement du canal alimentaire. Le pylore est souvent dénué d'appendices ou de petits cœecums; quelquefois néanmoins on le voit garni de deux ou trois de ces poches ou tuyaux membraneux; le foie est sans division et peu étendu; l'abdomen se prolonge des deux cótés des apophyses inférieures des vertebres de la queue; une partie des intestins est placée dans ces extensions abdominales, ainsi que la laite ou les ovaires.

Sans ces deux prolongations, la cavité générale de l'abdomen aurait eu des dimensions trop resserrées pour le nombre et la grandeur des organes intérieurs qu'elle doit renfermer.

Nous venons de dire que les deux yeux sont situés du mème côté de la tête; mais indépendamment de ce défaut remarquable de symétrie,

cours sur la nature des poissons. elativement à l'axe longitudinal du poisson, ils en presentent frequemment un second par une inégalité frappante dans leur volume, Ces deux organes ne sont pas toujours aussi gros l'un que 'autre; et lorsqu'ils offrent cette inégalité si extraordinaire, e'est quelquefois l'ail supérieur qui l'emporte surl'œil inférieur, et d'autres fois l'oil inférieur qui surpasse le premier en grandeur.

Ces yeux, au reste, peuvent être placés de trois manieres differentes : dans plusieurs pleuronectes, ils sont situes sur la mème igne verticale; mais, dans quelques-ums de ees poissons, l'ceil d'en-haut est plus rapproché du museau que celui d'en-bas; et, dans quelques autres, l'ail d'en-bas est au contraire plus avancé que celui d'en-haut.

II est aussi des espèces de pleuronectes dans lesquelles la nageoire pectorale, attachée au cote sur lequel on voit les yeux, est plus étendue que celle de l'autre cote; et l'on serait tent de croire que la petitesse de la pectorale opposée provient de ce que cette sorte debras ou de main appartenant a la surface de l'animal, qui repose très-souvent sur la vase ou sur le sable, a été arrêtée, dans son developpement, par les frottements qu'elle a du eprouver contre te fond des mers, et par la compression que lu a fait subir le poids du corps, qu'elle a dù supporter en très-grande partie.

La position des pleuronectes qui se reposent ou qui nagent, est en effet bien differente de celle des autres poissons osseux ou cartilagineux, cylindriques ou aplatis, qui pareourent dans le sein des eaux, un espace plus ou moins étendu, ou appuient sur les rochers ou sur le limon leur corps plus ou moins fatigué. Dans l'inaction, de méme que daus le mouvement, les pleuronectes sont toujours renversés sur le côté; et nous n'avons pas besoin de faire remarquer que le coté tourné vers le fond de la me est, dans tous les moments de leur existence, celui qui est dénué d'yeux : lorsque leurs yeux sont à droite, le côté gauche est l'inférieur; et ils voguent ou s'arrètent, le côté gauche tuurn vers la surface de l'eau, lorsque leurs yeux sout à gauche.

C'est de cette manière très-particuliêre de Clest de ceur est venu le nom de Pleuronectes' 1 : elle est une dépendance du déplace. - Pleuroncele vient de plearon, qui, en gree, veat dire 
ment de leurs yeux, soit que l'on veuille croire très-étendues, et par conséquent comme deux que cette réunion des deux yeux sur une seule ramesqui seraient très-puissantes, siellesétaient face de la tête les ait forcés à ne se mouvoir mueslibrementetpardesmuselestrés-vigoureux. qu'en tournant vers le bas le côté opposé à Et c'est précisément parce qu'elles influent cette face, afin de tenir les organes de la vue beaucoup sur la natation des pleuronectes, que dans la position la plus favorable à la vision; la différence ou l'égalité de grandeur entre cette soit que l'on préfere de penser qu'un très-grand dorsale et cette anale se font sentir dans la siaplatissement latéral ne leur a pas permis de tuation de ces osseux; ils ne présentent un tenir leur corps ct leur queue dans un sens ver- plan véritablement horizontal que lorsque ces tical, comme les autres poissons; que les efforts deux rames ont une force égale; et on les voit de leurs pectorales, très-petites et très-faibles, un peu inclinés vers la nageoire de l'anus, n'ont pas pu maintenir en équilibre une lame lorsque cette dernière est moins puissante que très-étroite, très-haute, et très-exposée, par conséquent, à l'agitation tumultueuse des flots; que renversés bientot sur un de leurs côtés, forcés de conserver cette position, et obligés de nager dans cette posture, ils ont commencé une suite de tentatives perpétuellement renouvelées, pour ne pas perdre tout à fait l'usage de l'œil attaché au côté inférieur; qu'après un très-long temps, et même après une très-grande série de générations, des altérations successives dansl'organisation extérieure et intérieure de la tête auront amené l'œil inférieur, de proche en proche, jusque sur le côté supérieur, et par ce transport auront produit, sans doute, une position des organes de la vue bien extraordinaire, mais néanmoins auront fait naitre, dans la structure de la tête, des changements bien moins grands et bien moins profonds que les modifications apportées par le temps et par une contrainte permanente dans les parties molles ou solides de plusieurs autres animaux. En considérant la manière de nager qui appartient aux pleuronectes, il est facile de voir que leurs pectorales très-peu étendues, et situées l'ume au-dessus et l'autre au-dessous du corps, ne peuvent pas servir d'une manière sensible à diriger ou accroitre les mouvements de ces poissons. Leurs thoracines étant aussi extrêmement petites, sont de mème inutiles à leur natation. Mais l'anale et la dorsale peuvent servir beaucoup à accélérer la vítesse de ces animaux, et à leur imprimer les véritables directions qui leur sont nécessaires; elles sont très-longues et assez hautes; elles s'etendent le plus souvent depuis la tête jusqu'à la queue; elles présentent done une grande surface : d'ailleurs dans la position habituelle des pleuronectes, elles sont situées horizontalement, puisque l'animal est, pour aiusi dire, couché sur un cóté. Dès est, on peut les considérer commie deux pectorales

\section{a nageoire du dos.}

Cependant l'instrument le plus énergique de la natation des pleuronectes est leur nageoire caudale, et par-là ils se rapprochent de tous les habitants des eaux; mais ils se distinguent des autres poissons par la manière dont ils emploient cet organe.

Les pleuronectes étant renversés sur un côté, leur caudale n'est point verticale, mais horizontale : elle frappe done l'eau de la mer de haut en baset de bas en haut; ce qui donne aux pleuronectes des rapports de plus avec les cétacées. Il est facile néanmoins de comprendre que le mouvement rapide et alternatif duquel dépend la progression en avant de I'animal, peut offrir le mème degré de force et de fréquence dans une rame horizontale que dans une rame verticale. Les pleuronectes peuvent done, tout égal d'ailleurs, s'avancer aussí vite que les autres poissons. Ils ne tournent pas à droite ou à gauche avec la même facilité, parce que, n'ayant dans leur situation ordinaire aucune grande surface verticale dont ils puissent se servir pour frapper l'eau à gauche nombre des opérations motrices, et d'incliner leur corps avant de le dévier d'un côté ou de I'autre; mais ils compensent cet avantage par celui de monter ou de descendre avec plus de promptitude.

Et cette faeulté de s'élever on de s'abaisser facilement et rapidement dans le sein de l'Océan leur est d'autant plus utile, qu'ils passent une grande partie de leur vie dans les profondeurs des mers les plus hantes.

Cet éloignement de la surface des eaux, et labri densequent de l'atmosphère, les met à parce qu'ils trouvent d'un froid excessif; et c'est les effets des climent facilement un asile contre les effets des climats les pitus âpres, en se préou a droite, ils sont contraints d'augmenter le cipitant dans les abìmes de l'Océan, qu'ils habitent auprès du pôle, de même que dans la Méditerranée, et daus les environs de l'équateur et des tropiques. Ils sejournent d'autant plus long-temps dans ces retraites écartées, que, dénués de vessie natatoire, et prives par conséquent d'un grand moyen de s'élever, ils sont tentés moins fréquemment de se rapprocher de l'air atmosphérique, Ils se trainent sur la vase plus souvent qu'ils ne nagent véritablement; ils y tracent, pour ainsi dire, des sillons, et s'y cachent presque en entier sous le sable, pour dérober plus facilement leur présence ou à la proie qu'ils recherchent, ou à l'ennemi qu'ils redoutent.

Aristote, qui connaissait bien presque tous ceux que l'on pêche dans la Méditerranée, dit que lorsqu'ils se sontmis en embuseade ou renfermés sous le limon à une petite distance du rivage, on les découvre par le moyen de l'élévation que leur corps donne au sable ou à la vase, et qu'alors on les harponne et les enlève '. Du temps de ce grand philosophe, on pensait que les pleuronectes, que l'on nommait Bothes, Peiynes, Rhombes, Lyres, Soles, eto., engraissaient beaucoup plus dans le méme lieu et pendant la méme saison, lorsque le vent du midi souflait quoique les poissons allongés ou eylindriques acquissent, au contraire, plus de graisse lorsque le vent du nord régnait sur la mer.

Columelle ${ }^{2}$ nous apprend que les étangs marins, que l'on formait aux environs de Rome pour y élever des poissons, convenaient trèsbien aux pleuronectes, lorsqu'ils étaient limoneux et vaseux; qu'il sufisait de creuser, pour ces animaux très-plats, des piscines de soixante ou soixante-dix centimetres de profondew (dixhuit pouces à deux pieds), pourvu que, situées très-près de la côte, elles fussent toujours remplies d'une certaine quantité d'eau, que l'on devait leur donner une nourriture plus molle qu'à vait leur donner une nourriture plus molle qu'a
plusieurs autres habitants des eaux parce qu'ils ne pouvaient mâcher que très-peu, et qu'un aliment salé et odorant leur convenait micux que tout autre, parce que, couchés sur un côté, et ayant leurs deux yeux tournés vers le haut, ils cherchaient plus souvent leur nourriture par le moyen de leur odorat qu'avec le secours de leur vue.

Il faut observer que le côté supérieur de ces poissons, celui, par conséquent, qui, tourné vers l'atmosphère, reçoit, pendant les mouve. ments ainsi que pendant le repos de l'animal, l'influence de toute la lumière qui peut pénétrer jusqu'à ces osseux, présente souvent des couleurs vives, des taches brillantes et reanlières, des raies ou des bandes varićes dans leurs nuances, pendant que le coté infèrieur, auquel it ne parvient que des rayons réfléchis, n'offre qu'une teinte pảle et uniforme. Cette diversité est mème moins superfleielle qu'on ne le croirait au premier coup d'ail ; et les écailles d'un eóté sont quelquefois très-différentes de celles de l'autre, non-seulement par leur grandeur, mais encore par leur forme et par la nature de la matière quil les compose. Ces faitsne sont-ils pas des preuves remarquables des principes que nous avons cherehé a établir, en traitant de la coloration des poissons, dans notre premier Discours sur ces animaux?

Pour mieux ordonner nos idées au sujet des pleuronectes, et pour les distribuer dans l'ordre qui nous a paru le plus convenable, nous en avons d'abord séparé les espèces qui sont entierement dénuées de nageoires pectorales, et par conséquent privées des organes que l'on a comparés à des bras. Nous avons formé de ces especes un genre particulier, et nous leur avons conservé le nom collectif d'Achire, qui signifie sans main.

Nous avons ensuite placé dans deux groupes différents les pleuronectes qui ont leurs deux yeux à droite, et ceux qui les ont à gauche; et nous avons suivi, en adoptant cette division, non-seulement les idées des naturalistes modernes, mais encore celles des anciens, et particulièrement de Pline ', qui ont très-bien distingué les pleuronectes dont les yeux sont à gauche, d'avec ceux dont les yeux sont à droite.

Passant ensuite à la considération particulière de chacun de ces groupes, nous avous réparti en différentes sections les espèces à caudale fourchue ou échancrée en croissant, celles dont la nageoire de la queue est rectiligne ou arroudie sans échancrure, et enfin celles dont la caudale, plus ou moins pointue, touche à la dorsale et à la nageoire de l'anus.

Nous aurions pu, par conséquent, former six sous-genres ou sections dans le genre qu nous décrivons; mais, parmi les pleuronectes 
qui ont les yeux à gauche, nous n'avons vu ni | aient cessé de se débattre; ils les élèvent aior caudale pointue et confondue avec celles de l'a- et les assomment à coups de massue.

nus et du dos, ni caudale fourchue ou découpée en croissant.

Nous ne proposons done, quant à présent, que quatre sous-genres, dont on a pu voir les caractères distinctifs sur le tableau du genre qui nous occupe.

A la tête du premier de ces quatre sous-genres est le Flélan ou Hippoglosse, que ses grandes dimensions rendent encore plus comparable aux cétacées que tous les autres pleuronectes. On péché en Angleterre des individus de cette espèce qui pesaient trois cents livres; on en a pris en Islande qui pesaient quarante livres; Olafsen en a vu de pres de dix-huit pieds de longueur. et l'on en trouve en Norvége qui sont assegrands pour couvrir toute une nacelle.

On trouve les flétans dans tout l'Océan Atlantique septentrional. Les peuples du Nord les recherchent beaucoup. Les Anglais en tirent une assez grande quantité des environs de New foundland; et les Français en ont pêché auprès de Terre-Neuve.

On se sert communément, pour les prendie, d'un grand instrument que les pécheurs nomment Gangvaden, ou Ganywad. Cet instrument est composé d'une grosse corde de quinze ou dix-huit cents pieds de longueur, à laquelle on attache trente cordes moins grosses, et garnies chacune à son extrémité d'un crochet très-

fort. On emploie pour appât des cottes ou des gades. Des planches qui flottent à la surface de la mer, mais qui tiennent à la grosse corde par des liens très-longs, indiquent la place de cet instrument lorsqu'on l'a jeté dans l'eau. Èn le construisant, les Groenlandais remplacent ordinairement les cordes de chanvre par des lanieres ou portions de fanon de baleine, et par des bandes étroites de peau de squale. On retire les cordes au bout de vingt-quatre heures; et il n'est pas rare de trouver quatre ou cinq flétans Iris aux crochets.

On tue aussi les hippoglosses à coups de ja(lot, lorsqu'on les surprend couchés, pendant 1 chaleur, sur des banes de sable, ou sur des fouds de la mer, très-rapprochés de la surface : mais lorsque les pêcheurs les ont ainsi percés de leurs dards, ils se gardent bien de les tirer it eux, pendant que ces pleuroniectes jouiraient encore d'assez de force pour renverser leur barque; ils attendent que ces poissons très-affaiblis

Vers les rivages de la Norvège, on ne poursui les flétans que lorsque le printemps est déjà assez avancé pour que les nuits soient claires, et que l'on puisse les découvrir facilement sur les bas-fonds. Pendant l'été on interrompt la pẻche de ces auimaux, parce que, extrémement gras lorsque cette saison régne, ils ne pourraient pas être séchés convenablement, et que les préparations que l'on donnerait à leur chair ne l'empécheraient pas de se corrompre mème très. promptement.

On donne le nom de raff aux nageoires du flétan, et à la peau grasse à laquelle elles sont attachées; on appelle rackiel, des morceaux de la chair grasse de ce pleuronecte, coupée en long; et on distingue par la dénomination de skure flog, ou de square queite, des lanières de la chair maigre de ce thoracin.

Ces différents morceaux sont salés, exposés a l'air sur des bâtons, séchés et emballés pour être envoyés au loin. On les sale aussi par un procédé semblable à celui que nous décrirons en parlant des Clupées harengs. On a écrit que le meilleur rafj et le meilleur rackel venaient de Samosé, près de Berghen en Norvége. Mais ces sortes d'aliments ne conviennent guère, dit-on, qu'aux gens de mer et aux habitants des campagnes, qui ont un estomac fort et un tempérament robuste. Auprès de Hambourg et en Hollande, la tète fraiche du flétan a èté regardée comme un mets un peu délicat. Les Groenlandais ne se contentent pas de manger la chair de ce poisson, soit fraiche, soit secher ; ils mettent aussi au nombre de leurs comestibles le foie et mème la peau de ce pleuronecte. Ils préparent la membrane de son estomae, de manière qu'elle drasparente pour remplacer le verre des fenètres.

Quelque grand que soit le flétan, il a dans les dauphins des ennemis dangereux, qui l'attaquent avee d'autant plus de hardiesse, qu'il ne peut leur opposer, avee beaucoup d'avantage, que son volume, sa masse et ses mouvements, t qui employant contre lui leurs dents grosses, solides et crochues, le déchirent, emportent des morceaux de sa chair, lorsqu'ils sont contraints de renoncer à une victoire complète, et le laissent, ainsi mutilé, trainer en quelque sorte une miserable existence. Quand il est très-jeune, il est aussi la proie des squales, des raies, et des

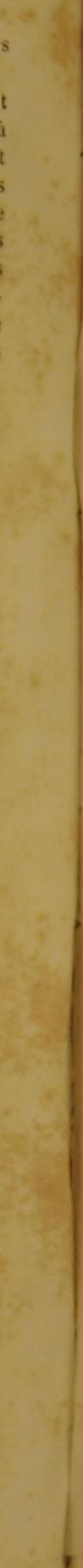


IIISTOIRE NATLREIIE

qui ont les yeux à gauche, nous caudale pointue et confondu.

nus et du dos, ni caur

en croissant.

Nous -

(a)

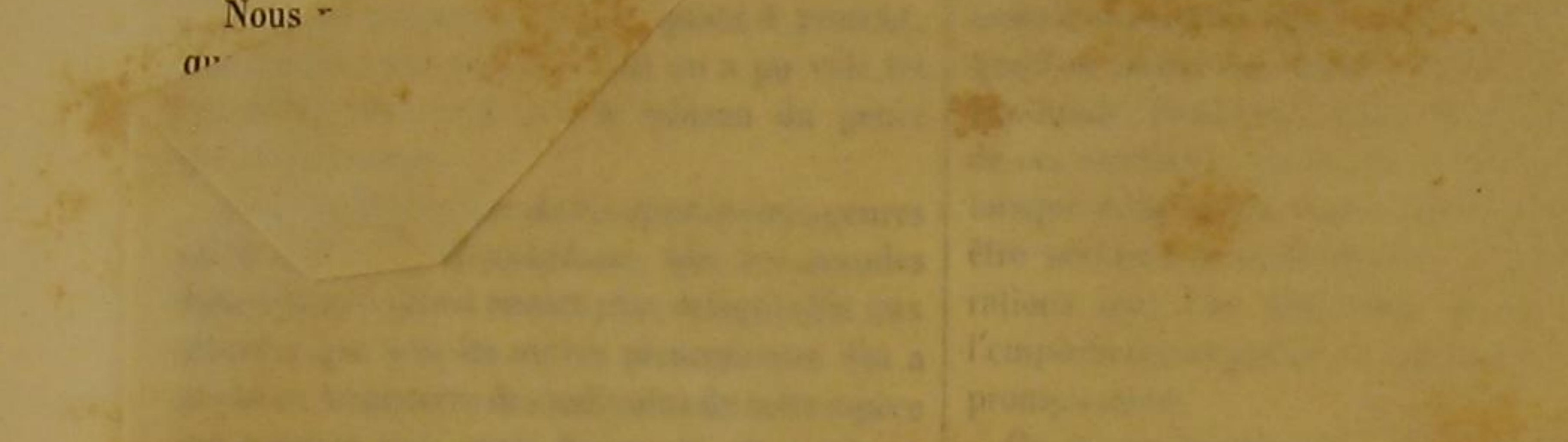

iis.
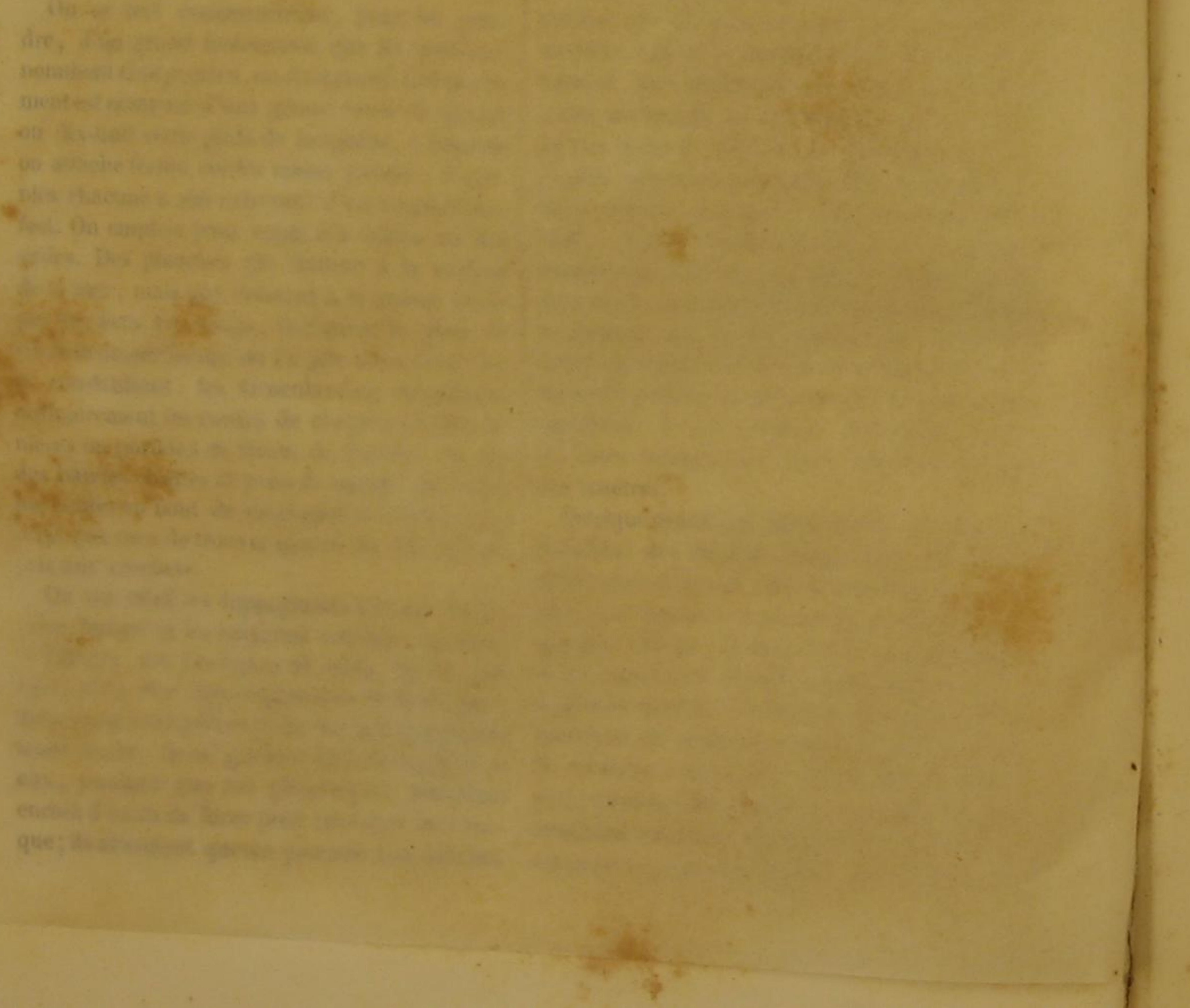
DES POISSONS.

autres habitants de la mer, remarquables par leurs armes ou par leur force.

Les oiseaux de proie qui vivent sur les rivages de la mer et se nourrissent de poissons le poursuivent avec acharnement, lorsqu'ils le découvrent auprès de la surface de l'Océan. Mais lorsque le flétan est groset fort, l'oiseau de proie périt souvent victime de son audace: le poisson plonge avec rapidité à l'instant où il sent la serre eruelle qui le saisit; et l'oiseau, dont les ongles crochus sont embarrassés sous la peau et les écailles du pleuronecte, fait en vain des efforts violents pour se dégager; le flétan l'entraine; ses cris sont bientôt étouffés par l'onde, et il est précipité jusque dans les abìmes de l'Océan, asile ordinaire de l'hippoglosse.

Il parait que, dans les différentes circonstances où le flétan se montre couvert d'insectes ou de vers marins attachés à sa peau, il éprouve une maladie qui influe sur le goût de sa chair ainsi que sur la quantité de sa graisse.

Il fraie au printemps; et c'est ordinairement entre les pierres qu'il dépose, près du rivage, des œufs dont la couleur est d'un rouge pale.

Tous les individus de cette espèce sont trèsTores; ils dévorent non-seulement les crabes, et mène des gades, mais encore des raies. Il paraissent très-friands des cycloptères lompes qu'ils trouvent attachés aux rochers. Ils se tiennent plusieurs ensemble dans le fond des mer qu'ils fréquentent; ils y forment quelquefois qu ils frequentét; ils y attendent, la gueule plusieurs rangées; ils y attendent, la guésisouverte, les poissons qui ne peuvent leur resister, et qu'ils engloutissent avec vitesse; et lorsqu'ils sont très-affamés, ils s'attaquent les uns les autres, et se mangent les nageoires ou la les aut

Leur canal intestinal présente deux sinuosités; un long appendice est situé auprès de leu tes, un long avaire est double; et soixanteestomac; lemir ópine du dos.

cinq vertebres compos recouvrent sont arrondies leur extrémité, molles, fortement attachées, enduites d'une liqueur visqueuse, et très-difficile à voir avant que le poisson ne soit mort et mème

desséché.

Le corps et la queue sont allongés. La tête n'est pas grande à proportion de l'énorme étendue des autres portions de ces pleuronecies : mais l'ouverture de la bouche est large; et les deux machoires sont garnies de plusieurs dents longues, pointues, courbees, et un peu séparées les unes des autres. La lèvre supérieure peut étre étendue en avant. Les yeux sont gros, et aussi rapprochés du museau l'un que l'autre. Trois lames composent l'opercule, qui cependant ne cache pas en entier la membrane branchiale. Un piquant tourné vers la gorge est placé au-devant de l'anale. L'anus est aussi éloigné de la tête que de la pectorale. La ligne latérale se courbe d'abord vers le haut, et s'étend ensuite directement jusqu'à la nageoire de la queue.

Le côté gauche du flétan, celui sur lequel i nage ou se íepose, est blanc ou blanchâtre : le côté droit parait d'autant plus foncé, que l'animal est plus maigre. L'iris est blane; la dorsale et l'anale sont jaunátres; chaque pectorale est jaunâtre ou jaune, avec une bordure foncée les thoracines et la caudale sont brunes '.

\section{LE PLEURONECTE LIMANDE} Pleuronectes Limanda, Linu., Lac, Bl. ; Pleuronecte (Platessa) Limanda, Cuv."

Ce poisson, très-commun sur nos tables, se trouve non-seulement dans l'Océan Atlantique, mais encore dáns la Baltique et dans la Méditerranée. Le temps de l'année où il est le plus agréable au goût, au moins dans les contrées du nord de l'Europe, est la fin de l'hiver ou le commencement du printemps. Il fraie ensuite; et alors sa chair est moins savoureuse et plus molle. Elle est cependant, dans les autres saisons, plus ferme que celle de plusieurs pleuronectes; mais comme elle est aussi moins suc-

i 7 rayons à la membrane branchisle du pleuronecte flétan,

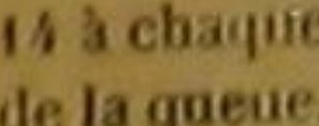

de la queue. Kletische, Kliesche, a Hambourg. - Skrubbe, en Dane sarck. - Gretle, en Hollande- - Dab, Brut, en Angleterre.

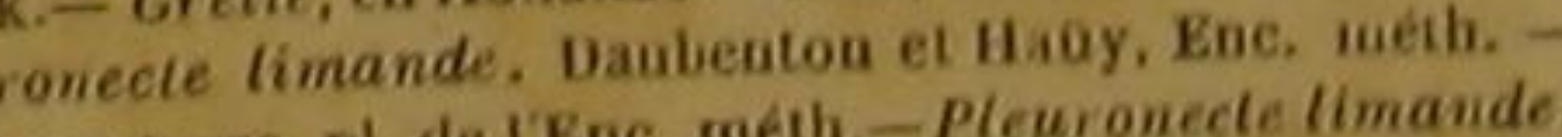
Id. Bonnaterre, pl. de IEnc, méth. - Pleuronecte Bimr. Zool

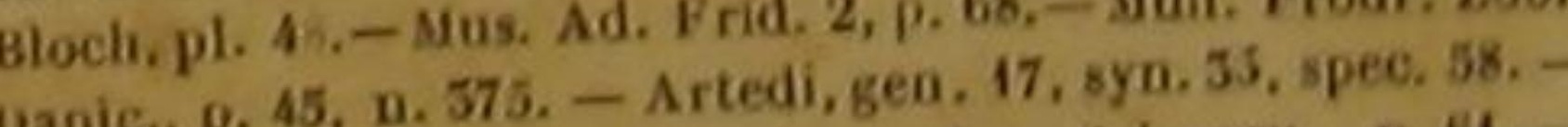
Limande. Hondelet, part, 1, c. 8. - Schonev., p. 6t. Aidrov, 1. 2. c. 46, p. 222. - willogibly, telith., p. 97. Rai, Pisc. p. 32. - Limanda, etc. Charlet., p. 145 - Belon, (gero.). .oi. 52, a. Cimanda, Jouston, Pisc., p. 90. - Bric Aquat, 5. 185. - 5. - Limande, Valmont de Bomare, Die d hist, nat.

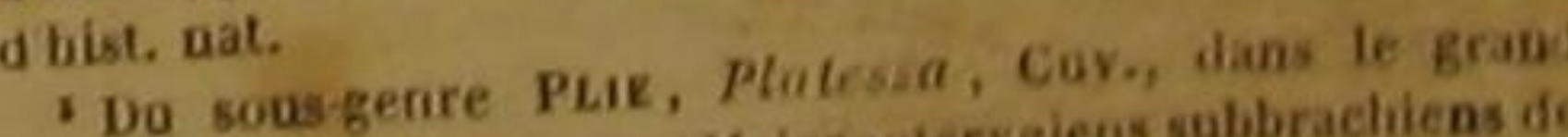
geare des PLEvBosectes ; Malacop a 
culente et moins délicate, on la fait sécher sur plusieurs côtes de l'Angleterre et de la Hollande.

La timande vit de vers ou d'insectes marins, et très-souvent de petits crabes.

Son épine dorsale ne comprend que cinquante et une vertèbres.

L'ouverture de sa bouche est étroite. Les deux mâchoires sont d'égale longueur ; mais on compte plus de dents à la supérieure qu'à l'inférieure. L'œil supérieur est placé au sommet de la tête. On aperçit au-devant de la nageoire de l'anus un piquant tourné vers la gorge. Le côté droit est jaune; le gauche est blane; l'iris couleur d'or, et la caudale brune'.

Le rhomboìde de Rondelet me parait être un variété de la limande ${ }^{2}$.

\section{-}

\section{LE PLEURONECTE SOIE ${ }^{3}$.}

Pleuronectes Solea, Liun., Gmel., Bl., Lac., Cur.

Ce poisson est recherché, même pour les tables les plus somptueuses. Sa chair est si tendre, si délicate et si agréable au goût, qu'on l'a

' 6 rayons a la membrane branchiale du pleuronecte li. mande, 14 a chaque pectorale, 6 a chaque thoracine, 15 a in nageoire de la queue.

"Rondelet, part. 1, I. 11, c. 5.

'Boyglatlon, boglosson, boglossa, boglotta, boglossos, mer, dans plis. départ. de France. - grecs. - Perdrix de gne. - Sagliotn en Surdaigne. - Linguata, en Italie. Sfoia, dans les environs de Veuise. - Dil baluek, en $Y$. quie. - Samamkusi, en Arabie. - Zange, See rephuhn, en Allemagne. - Tunge, Hunde tunge, Tunge pledder, Hav Tonge, ea Norrége et en Hollame, - Sola, en Suede. terre. - Zeetong, Bot, par tes Bollo - Sol, Soul, en Ang Pleuronecles Solea. Faun. Suec, 526 . - Moll. Prodr. Zo Dauic, p. 43. n. 376. - Pleuronecles tunga, It, Wgoth 178 - Pleuronectes maxilla superiore lougiore, corpor syo. 32, spee, 60 - Plewingue asperis. Artedi, geo, 18 , Enc. méth. - Id Bonnaterre ite sole, Daubenton et Haay. pl. 45. - Boglossos. Athen.. I. 7, p. 28s, - Sotta. - Bloch, lieut., v. 124. - Id. Plin, L. 9, c. 16. 20. - Id. Crbs. I. J,

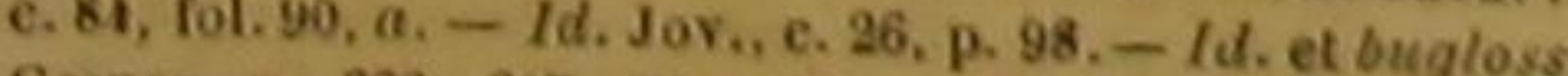
Gesner, p. 666, 667, 67t, 785, et (germ.), fol, $35,6.35$. p. $14 x$ - Buglos, . 2, a. 2, punct. 1, p. 82, - Solea. Charl. Bondelet, part. 1, 1. 11, . 10, 8, 167, fol, 150, - Sole. Willugbby, p. 100, tab. $P, 7,-B$ guglosso, vel oo, tive sole

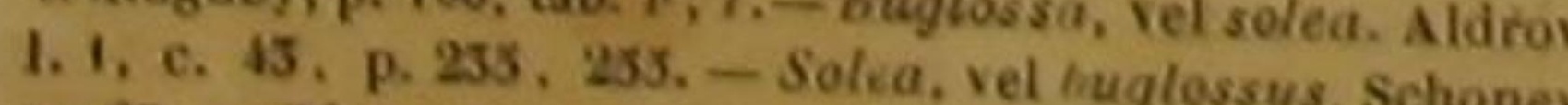
p. 65. - Pleuronectes solea. Brôno. Ithith. Mas il. p. n. 47. - Gronov. Mus. 1, p. 14, n. 37; Zooph., p. 74, p. 251 .

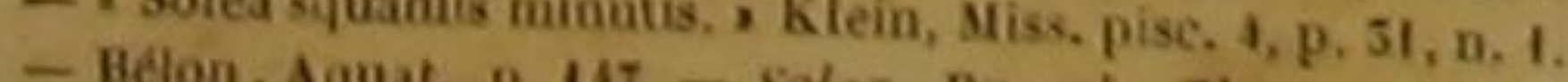

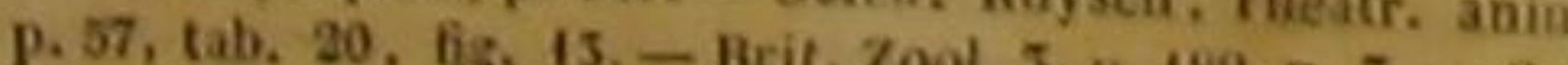

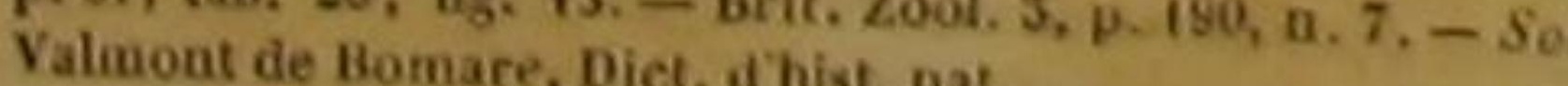
'Type da sous-genre

PLevioxecte, Cay. D surnonımé la Perdrix de mer. On le trouve aon-seulement dans la Baltique et dans l'Océan Atlantique boréal, mais encore dans les environs de Surinam et dans la mer Méditerranée, où l'on en fait particulièrement une pèche abondante auprès d'Orytana et de Saint-Antioche de Sardaigne. Il parait que sa grandeur varie suivant les côtes qu'il fréquente, et vraisemblable ment suivant la nourriture qu'il peut avoir à sa portée. On en prend quelquefois auprès de l'embouchure de la Seine, qui ont un pied et demi ou deux pieds de longueur. Il se nourrit d'œufs ou de très-petits individus de quelques espèces de poissons; mais lorsqu'il est encore très-jeune, il est la proie des grands crabes, qui le déchirent, le dépècent et le dévorent. On le voit quelquefois entrer dans les rivières. M. Noè de Rouen nous a écrit qu'on a pêché ce pleuronecte dans les guideaux de la Seine, auprès de Tancarville; et il ajoute que, pendant l'été, le flot peut l'apporter jusque dans le lae de Tôt mais pendant l'hiver il se tient dans les profondeurs de l'Océan. Il quitte le fond de la mer lorsque la belle saison arrive; il va cherehe alors les endroits voisins des rivages ou des embouchures des fleuves, ou les rayons du soleil peuvent parvenir assez facilement pou faciliter l'aceroissement de ses $\propto u f s$ et la sortie des foetus.

On le prend de plusieurs manières. On empioie, pour y parvenir, des hamecons dormants auxquels on attache pour appát des fragments de petits poissons. On peut aussi, lorsqu'une lumière très-vive est répandue dans l'atmosphère, chercher auprès des cótes et des banes de sable des fonds unis sur lesquels rien ne dérobe les soles à la vue du pecheur; à peine ce dernier en a-t-il découvert une, qu'il lance contre ce pleuronecte un plomb attaché à l'extrémité d'une petite corde, et garni de plusieurs crochets qui penetrant assez avant dans le dos forts qu'il fait pour échapper à la mort qui le menace. S'il n'y a même que deux ou trois brasses d'eau au-dessus du poisson, on le harponne, pour ainsi dire, par le moyen d'une perche dont le bout est armé de pointes recourbées. Il est aisé de voir que, pour avoir recours avec avantage à ces deux dernieres sortes de péche, il ne suffit pas que le soleil brille sans nuages; il faut eneore que la mer ne soit agitée par aucune vague autour du bateau pêcheur.

DES POISSONS

L'illustre Franklin nous a fait connaitre le procédé employé avec succès, pour maintenir pendant longtemps un calme presque parfait à une certaine distance autour de la barque. Une petite quantité d'huile que P'on répand sur la surface de la mer, et qui surnage autour du bátiment, rend cette surface unie, presque immobile, et très-propre à laisser parvenir les rayons de la lumière jusqu'au pleuronecte que l'on désire de distinguer.

On a d'autant plus de motifs de pécher In sole, qu'une saveur exquise n'est pas la senle qualité précieuse de la chair de ce poisson. Cette mème chair présente aussi la propriété de pouvoir être gardée pendant plusieurs jours, non-seulement sans se corrompre, mais encore sans cesser d'acquérir un goùt plus fin. Voilà pourquoi, tout égal d'ailleurs, les soles de l'Océan sont meilleures à Paris qu'auprès du Havre, et celles de la Méditerranée à Lyon, par exemple, qu'à Toulon ou à Montpellier.

Les écailles de la sole sont dures, raboteuses, dentelées, et fortement attachées à la peau, sur le cóté gauche, comme sur le cotté droit. L'ouverture de la bouche représente un croissant. On voit plusieurs rangs de dents petites et pointues à la máchoire inférieure, et des barbillons blancs et très-courts au cóté gauche des deu mâchoires. Deux os arrondis et.deux os allongés, tous les quatre hérissés de petites dents sont placés autour du gósier. La ligne latérale est droite. Un piquant assez fort parait auprè de l'anus, qui est très-près de la gorge. De petites écailles garnissent la base des longues nageoires de l'anus et du dos. Le côté droit est olivâtre; et le gauche, plus ou moins blane.

Le canal intestinal offre plusieurs sinuosités il n'y a point de coecums auprès du pylore; la colonne vertébrale est composée de quarantehuit vertèbres.

D'après une note que $\mathrm{M}$. Noēl a bien voulu nous faire parvenir, on doit regarder comme une variété de la sole un pleuronecte que l'on pêche auprès de l'embouchure de l'Orne, et que l'on nomme Cardine. La tête de cette cardine est beaucoup plus grande et plus allongée que celle de la sole; le côté droit de ce thoracin est d'un fauve roux assez clair; et sa chair est moins recherchée que celle du poisson que nous venons de décrire

46 rayons a la membrane branchiale du pleuronecte sole,

\section{LE PLEURONECTE PIIE'}

Pleuronectes Platessa, Lino, Gmel., Bl., Lac., Cuv, '

La plie est bonne à manger; mais, moins agréable au goût, moins tendre et moins déticate que la sole, elle est moins recherchée. Flle habite dans la Baltique, dans rOcéan Atlantique boréal, et dans plusieurs autres mers. Le cóté gauche dece thoracin est d'un blanc bleuă tre pendant la jeunesse du poisson, et rou. geátre lorsqu'il est plus âgé; l'ouverture de la bouche petite; In mâchoire inférieure plus avancée que la supérieure, et garnie, comme cette dernière, d'une rangée de dents petites et mousses; le gosier défendu, pour ainsi dire, par deux os très-rudes; la langue lisse; le palais dénué de dents; I ligne latérale presque droite; la base des nageoires du dos, de l'anus et de la queue, couverte de petites écailles; l'anale précédée d'un aiguillon assez fort; la hauteur de Panimal plus grande que celle de la sole, a proportion de la longueur totale; T'estomac allongé; te canal intestinal très-sinueux; to pylore voisin de deux ou quatre coceums ou appendices; et l'épine dorsale composée de quaranterois vertebres,

La plie pèse quelquefois quinze ou seize lives. Plusieurs de ses habitudes, et les differentes manières de la pecher, ressemblent beaucoup à celles que nous avons déerites en parlant

10 a chaque pectorale, 7 a chaque thoracine, 17 i a nageotre de la queve.

quelques dépirt de Prance pleis, plaethis, - Plye, dans 4. Duthrouil, officier de sante. - Plaise, en Angleterre. Karkole, en Isande. - Hellebuit, Sondmeer kong.

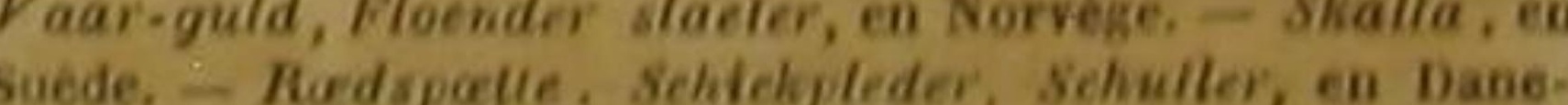
marik, Schulle, auprés de Hismbourz, - Platteis, Pladise, Scholle, en Allemagne. - Scholle, en Hollande. - Come, Jei, au Japon. - Hot, aux Solsques. - Pleuronecte plie. Gabbenton et Haby, Ence, méth. - Id. Bonnaterre, pli. de Enc. méth. - Bloch, pl. 12 - Pieuronecies tuberculia 7. 575. - If. Wgoth. 179. - Pleuronecles slaetrar. it con. 325 - . Plearonectes tubereults sex in deatra capi tis.. . Artedi, gen. 17 syu. 50, - Plie. Rondelet, part. I. i. 1. c. 6. - Passer, vel platessa. Gesser, p. Ge ei Grus.t

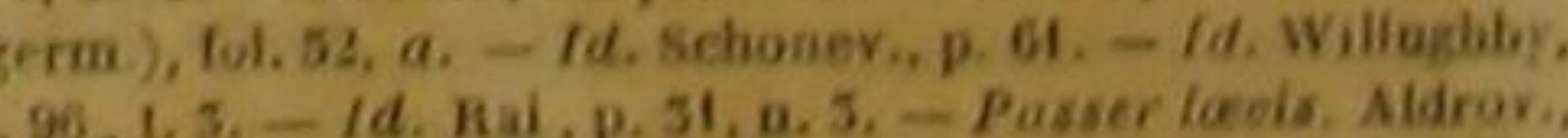

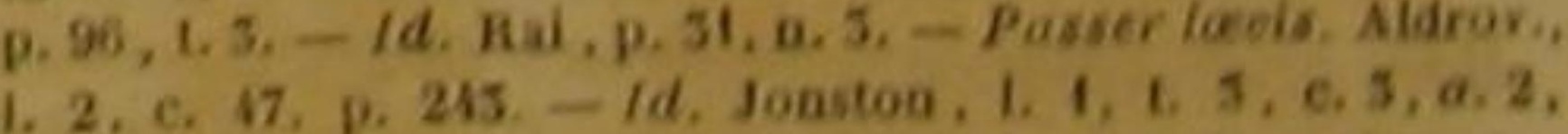

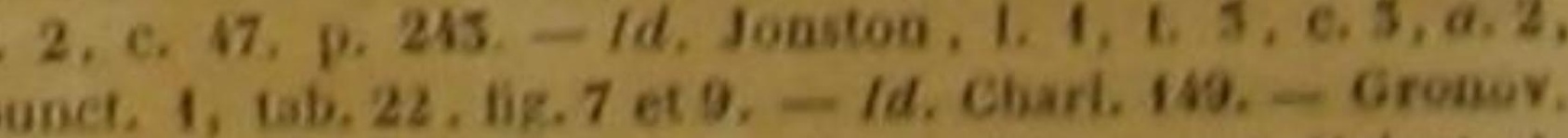

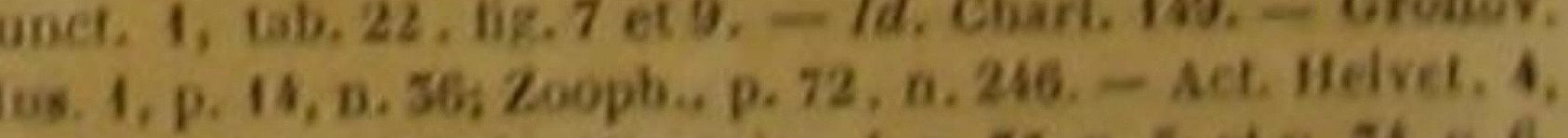

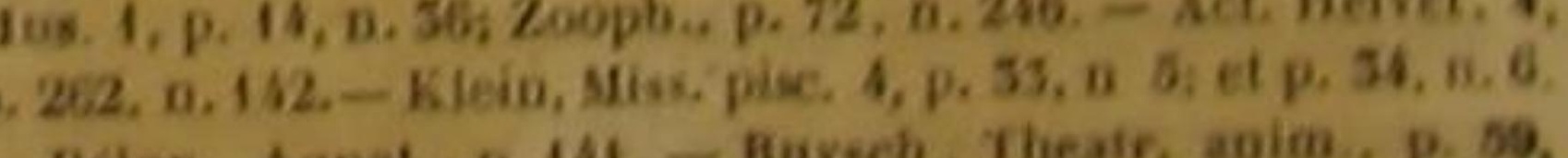
- Beloo, Aquat., p. 14t. - Ruyceh, Thears. anim., p. 59. 66, tab. 22. fig. 7 et 9. - Brit, Zool. 3, D. 186, a. 5. - Plie.
Valmont de Bomare, Dict. d' bist. mat.

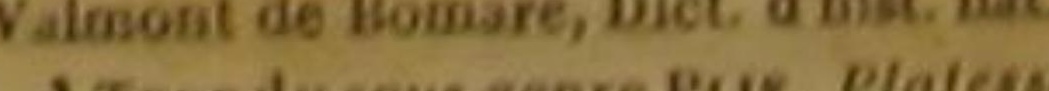
'Type du sous genre Puk, Platera de M. Cuvier, dass lo 
de la soln l'air

On a cru pendant longtemps, sur quelques côtes de France ou d'Angleterre, que la plie était engendrée par un petit crustacée nomme Chevrelle. Le physicien Deslandes chercha, il y a déjà un très-grand nombre d'années, à découvrir l'origine de cette opinion qui maintenant serait absurde. Il fit plusieurs observations à ce sujet. Il mit des chevrettes dans un vase de trois mètres de circonférence, et rempli d'eau de mer. Au bout de douze ou treize jours, il aperçut huit ou neuf petites plies, qui grandirent insensiblement; et cette expérience lu réussit toutes les fois qu'il la tenta. Dans le printemps suivant, il placa dans un vase des plies, et dans un second des plies et des chevrettes. Il parait que, parmi les plies des deux vases, il y avait des femelles qui pondirent leurs œufs, et cependant aucun jeune pleuronecte ne parut que dans celui des vaisseaux qui contenait des chevrettes. Deslandes examina alors ces crustacées, et il vit de véritables œufs de plies attachés sous le ventre de ces crabes. II les ouvrit, et s'aperçut non-seulement qu'ils avaient été fécondés, mais encore qu'ils renfermaient des embryons déjà un peu développés Il conclut de tout ce qu'il avait vu, que les œufs des plies ne pouvaient se développer que couvés, pour ainsi dire, sous le ventre des chevrettes. Au lieu d'admettre cette opinion que rien ne peut soutenir, ce physicien aurait dù penser que les plies écloses dans ces vases provenaient d'œufs pondus et fécondés près d'un livage fréquenté par des chevrettes, qui aiinent beaucoup à se nourrir du fra des poissons, et particulièrement de celui des pleurorectes. Ces œufs enduits d'une humeur trèsvisqueuse, au moment de leur fécondation, 'omme ceux de presque tous les habitants des eaux douces ou salées, s'étaient collés facilement contre le ventre des chevrettes qu'il avait prises pour en faire les sujets de ses expé riences.

Avant de terminer cet article, nous devons faire remarquer que plusieurs auteurs, et notamment Bélon, Rondelet, Gesner et Aldrovande, out fait représenter la plie avec les deux yeux placés au côté gauche. Cette faute est venue vraisemblablement de ce qu'ils n'ont pas eu le soin de diriger leurs artistes, qui auraien dù dessiner le poissonà rebours. Mais, quoi qu'il

DES POISSONS.

Il pénètre même dans les rivières : on le voit remonter très-avant dans celles d'Angleterre; et M. Noêl nous a écrit qu'on le pèchait souvent dans la Seine, jusqu'auprès de Tournedos, quelques myriamètres au-dessus du Pont-de-l'Arche, où on le nomme Flondre et Flondre d'eau douce ou de rivière. Les individus de cette espèce que l'on prend dans l'eau douce ont la couleur plus claire et la chair plus molle que ceux que l'on trouve dans la mer. On pèche le flez pendant la belle saison, parce qu alors il est plus charnu et plus gros. La bonté de sa chair varie d'ailleurs suivant la nourriture qui est a sa portée, et par conséquent suivant le pays qu'il habite. On prétend qu'aux environs de Memel, sa saveur est plus agréable que dans les autres parties de la Baltique. On peut le transporter facilement dans des vases et à une distance assez grande de son sèjour ordinaire, sans lui faire perdre la vie; et on a profite de cette facilité, ainsi que de celle avec laquelle il s'accoutume à toute sorte d'eau, pour l'acelimater et le multiplier dans plusieurs étangs de la Frise '. II ne.pese pas ordinairement plus de six livres. Deux petits cœeums sont placés au-

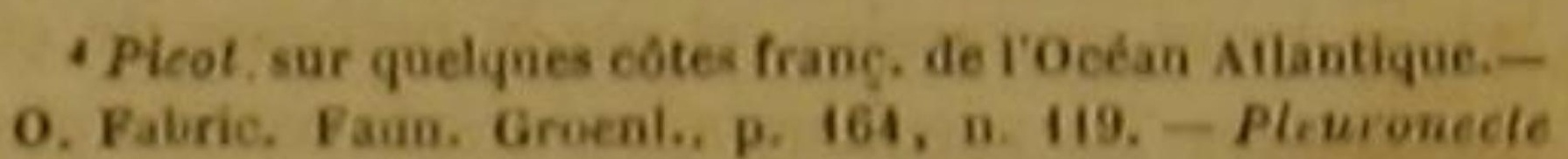

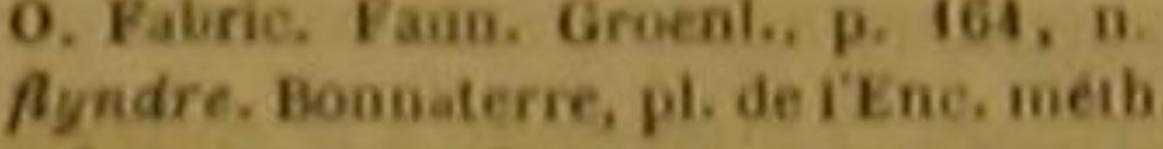

"Crite espece de pleuronecte n'est pas citce par M. Covier: mais il est probable qu'eile se rapporte an sous-geire des Pliks, Platessa. D,

- Gronor. Mus, 1, p. 14, n. 59 ; Zooph., p. 13, n. 247. o. Fabric. Faun, Groonl., p. 162,

' Du sove gence PUS, Plalessa, dans le graud genro PLEUROAKCTE, Civ. D

.. Pleuronectes... ano ad latussinistrum, dentbus acutis. Artedi, gen. 17, sya 31. - Pleuronede languelle, Daubenton et Haay, Eoc. meth. - Id, Bonnaterre, pl. de I Enc. meih. - Ce plenronecie nest pas cite par si. Cavier. sil se zapporte au $P$. linguatala, ho

10 Pallas, It. 5, p. 706, n. 18. - Pleuronecte glacial. Bontaterre, pl. de PÉnc, mét i.

"Ce poisson, du genre Plearonecte, d'est pas cite par M. Cuvier. D.

Cle I'Ene meith.

"Noocite par M. Cavier. D.

"Espece non in ationuée par M. Convier. D.

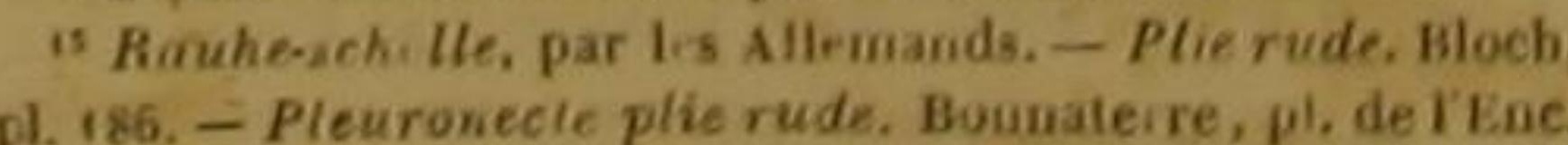
néth.

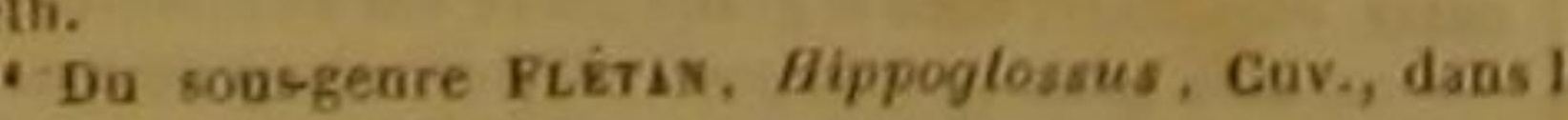
genr- Pleurouecte, D.

"Pleuronecle péyouse. Rondelet. part. 1. I. II. c. II. PLBU ROXECTE: D.

'Voyez ie Discours aztule Des effets de l'ari de l'homm sur la nature des poissons. rès de son pylore. Sa colonne dorsale comprend ente-cinq vertèbres. Les piquants dont sa surface est hérissée sont très-petits, mais parais. sent crochus, excepté ceux qui garnissent, du côté droit, la ligne latérale ou la base de la na. geoire de l'anus et de celle du dos. Cesdernier sont droits et forment de petits groupes; on en voit de semblatles sur la iigne latérale du cóte gauche, et sur le bord gauche de la base des nageoires du dos et de l'anus. Ce cóté gauche ou inférieur, et par conséquent presque toujours dérobé à l'influence de la lumière, est blane avec quelques nuages bruns et dés taches noirátres, vagues, très-peu foncéês, très-peu nombreuses et petites, tandis que le cóté droit est d'un brun foncé, relevé par des taches olivâtres, ou d'un vert jaune et noir. Au reste, indépendamment des piquants dont nous venons de parter, les deux cótés du flez sont couverts d'écailles minces, allongées, fortement attachées a la peau, et très-dificieiles à voir. La máchoire inferieure dépasse celle d'en haut i la taugue est courte et étroite; deux os ronds et rudes sont situés auprès du gosier. La ligne latérale se courbe vers le bas après s'être avancée vers la nageoire de la queue, jusqu'au delà de la pectorale, Un aiguillon assez fort parait au-devant de la nageoire de l'anus.

La Baltique n'est pas la seule mer où se plaise le flez; il est aussi très-répandu dans l'Océan Atlantique boréal, uinsi que le flyndre, qui fréquente particulièrement les embouchures des rivieres du Groenland. Ce dernier poisson est un des pleuronectes les moins grands et les moins agréables au goût. II ne parvient ordinairement qu'à la longueur d'un pied; et on ne lé mange elus souvent que séché. II se plait sur les fonds sablonneux, ou il se nourrit de vers marins et de petits poissons, et ou il dépose ses coufs vers le commencement de l'été. Sa forme générale est un peu semblable à celle d'une navette. Le coté gavche est blane et doux au tou-

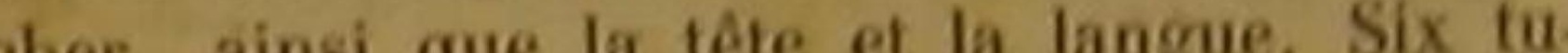
bereules garnis de petites dents entourent it gosier. Les pectorales sont courtes. Le flyndre est fréquemment tourmenté par des Gurdius, ou par d'autres vers intestinaux.

Le pole habite dans la partie de l'Océan At. lantique qui baigne la Belgique, et dans celle qui avoisine fe Groenland. On le trouve pendant I'hiver dans ies enfoncements littoraux donI les eaux sont profondes. Sa ligne latérale est $p$ Diet. dhist. nat.
Detelel, et $A=$. Vaimont de Bomare,

-Du sousgenre PLIE, Platessa, dans le graed perre Pleugonecte, Cuv. D. 


\section{HISTOIRE NATURELLE}

droite; sa dorsale s'étend depuis les yeux jusqu'à la nageoire de la queue. Son côté gauche est blanc. Il a beaucoup de rapports avec le flétan, mais sa chair est plus délicate; et il n'a communément que deux pieds ou deux pieds et demi de longueur '

Les mers de l'Europe sont la patrie du pleuronecte languette; et l'Océan Glacial arctique est celle du pleuronecte glacial, dont le nom indique le séjour, et qui en fréquente les côtes sablonneuses,

Les yeux de la limandelle sont ovales et trèsrapprochés; sa ligne latérale est d'abord courbée et ensuite droite; son côté gauche est blanc; ses pectorales et ses thoracines sont jaunes. Elle est quelquefois longue d'un pied et demi.

Le pleuronecte chinois est encore inconnu des naturalistes. Nous en avons trouvé une image très-bien faite parmi les peintures chinoises que la Hollande a cédées à la France, avec plusieurs belles collections d'histoire naturelle; et nous luí avons donné un nom spécifique qui indique le pays où il a été observé et peint avec beaucoup de soin. Trois ou quatre pièces composent chaque opercule. La hauteur de l'animal surpasse la moitié de sa longueur totale. Des taches brunes, irrégulières, assez grandes et nuageuses, sont répandues sur le coté droit, et varient le fond qui fait ressortir des points noirs arrangés en quinconce. Le côté gauche est d'un blanc-rose; et l'iris est un peu gauche
doré.

On pêche dans l'Océan Atlantique septentrienal, et particulièrement aux environs de Heiligeland, le pleuronecte auquel nous conservons le nom de Limandoide. Ce thoracin habite sur les sables du fond de la mer; il vit de jeunes crabes; il se prend à l'hameçon; sa chair est blanche et d'un bon goût; il a deux laites ou deux ovaires; son foie n'est pas divisé en lobes; deux ou trois ou quatre coecums sont placés auprès du pylore; plusieurs rangées de dents 1 6 raynns a la membrane branchiale du pleuronecte flez,
12 a ch aque peetorale, 6 a elaque thoracine, 16 a la nageoire de Ia queue, -8 rayons a la membrane branchiale du plen-

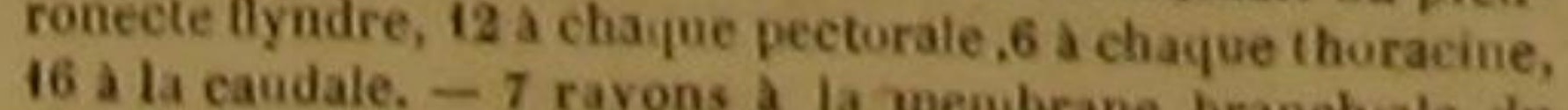
pleuronecte pole, 44 a chaque pecturale, 6 a change thora cine. 17 a la nageoire de ta queue. -9 rayons a chayue pec torale da pleuronecte languelte, $7 \mathrm{a}$ chaque thoracive. $19 \mathrm{a}$ a caudale. -9 rayons a cbaque pectirale du pleuronecte -11 a chaque pectorale da pleuronecte limandoide, 6 a
ehaque thoraeine, 15 a ta caodale. pointues arment chaque máchoire; deux os rudes sont voisins du gosier; la langue et le palais sont lisses; les deux ouvertures des narines paraissent dans une sorte de petite fossette; des écailles semblables à celles du dos revêtent la tête et les opercules; le côté gauche est blane. La pégouze vit dans la Méditerranée, où on lui a donné, suivant Rondelet, le nom qu'elle porte, parce que ses écailles sont adhérentes à la peau comme de la poix, et ne peuvent être détachées facilement qu'après avoir été trempées dans l'eau chaude. On l'a prise aussi dans les environs de Caen, selon M. Noel '; mais elle y est très-raré. Les belles taches de son côté droit sont placées sur un fond d'un roux sale, et souvent entourées d'une bordure très-foncée.

\section{LE PLEURONECTE ÓELLÉ ${ }^{3}$,}

Pleuronectes ocellatus, Lion., Gmel., Lacep. ‘.

\section{ET LE PLEURONECTE TRICHODACTYLE`}

Pleuronectes trichodactylus, Linn., Gmel., Lae. s.

Ces deux espèces ont beaucoup de ressemblance avec les achires. Elles s'en rapprochent par le petit nombre de rayons que l'on trouve dans leurs pectorales, et par la petitesse de ces nageoires. La première a la dorsale comme plissée, et vit à Surinam. La seconde a le côté gauche blanchátre; de très-grands rapports avee la sole; la ligne latérale droite; les dents si menues, qu'on a de la peine à les distinguer; la pectorale gauche si réduite dans ses dimensions, qu'elle ne montre ordinairement qu'un rayon; et une longueur totale presque toujours au-dessous de quatre pouces. On péche le trichodactyle ${ }^{6}$ dans les eaux d'Amboine ${ }^{7}$.

'Mus. Ad. Frid. communiquée par M. Noé de Ronen.

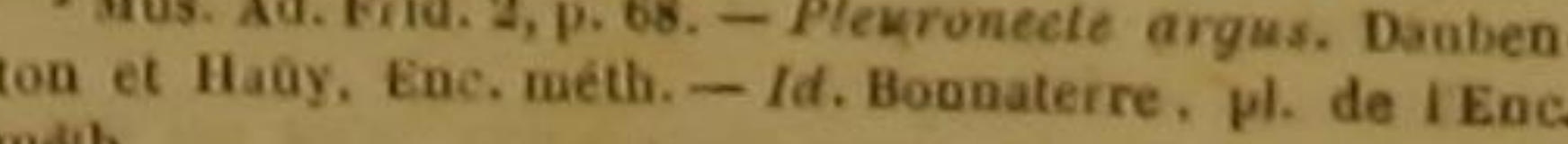
meth. M. Cuvier ne fait pas mention de celte espece de Pleu-
necte. D.

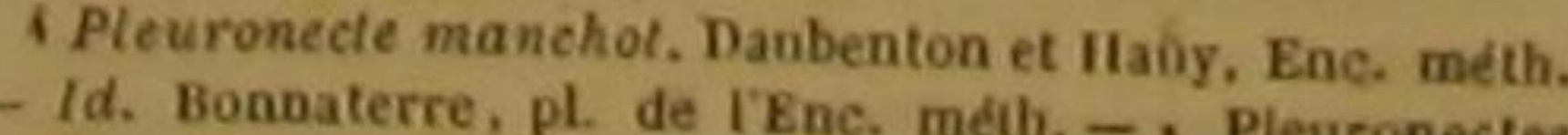
" pinnis lateralibus vix conspicuis. = Artedi, gen. 18, spec, 61. yn. 35.

M. Cuvier rapporte ce poisson à son sous-genre Moso"Le mot grec et la grand genre des PLFtaonectes. D.

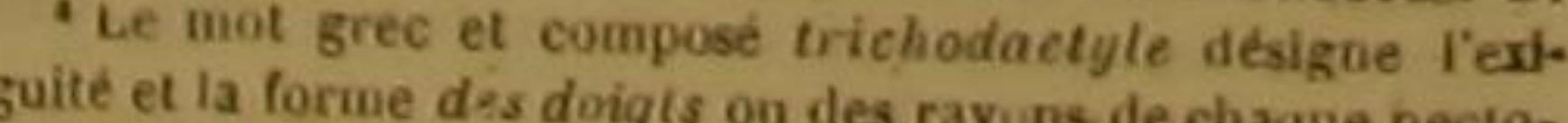
rele, qui sont deliess comigue des fes ray ns de chaque pecto-

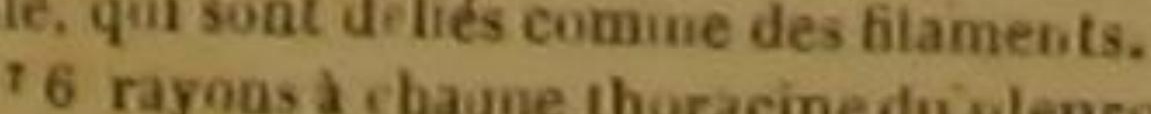

geoire de la queve - 6 rayung aleuronecte cille, 14 a du pleurouecte trichodactyle, 5 a a chaque thoracine, 16 a la

\section{DES POISSONS.}

459

LE PLEURONECTE ZÈBRE ',

Pleuronectes Zebra, Lino.., Gmel., Lac. ${ }^{2}$; Solea Zebra, Cuv.

LE PLEURONEGTE PLAGIEUSE ?, Pleuroneetes Plagiusa, Linn., Gmel., Lac.; Solea
Plagusia, Cur. 4

\section{ET LE PLEURONECTE ARGENTÉ s.}

Pleuronectes argenleus, I.ac. •.

La forme pointue de la caudale, et la réu. nion de cette nageoire avec eelles du dos et de l'anus, donnent une conformation générale assez remarquable aux trois poissons qui composent le troisième sous-genre des pleuronectes. Le premier de ces trois, celui qui a recu le nom de Zebre, et qui est originaire des Indes orientales, présente d'ailleurs une máchoire inférieure moins avancée que celle d'en haut; des dents menues et pointues, placies le long de chaque máchoire; des yeux très-petits et inégaux; un seul orifice à chaque narine; des écailles dentelées et très-rudes au toucher; un anus situé au-dessous des pectorales.

Le pleuronecte plagieuse a été observé dans les eaux de la Caroline, par le docteur Garden. L'argenté a le cóté gauche d'une couleur brune et terne, pendant que son côté droit resplendit de l'éclat de l'argent. On le trouve dans ia mer des Indes ?

\section{LE PLEURONECTE TURBOT s}

Pleuronectes maximus, Liun., Gmel., Bl., Lac. ; Rhombus maximus, Cuv.

Ce poisson est très-recherché, et doit l'être. II réunit, en effet, la grandeur à un goût ex-

- Die bavidirle zunge, par les Allemands. - Zébre de mer. Bloch, pl. 187. - Pieuronede sébre de mer. Bonnaterre, pl. de ítac méth

"Espece da sous-genre SoLe, Solea de M. Cuvier, dans le genre des PLecinosecres. B. - Id. Bonnaterre, pl. de iEnc, méth. vier. $D$.

Plécuron cle argenté, Bonoaterre, pl. de TÉne. méth. Prtiv. Gazophyl., H. 10, tab. 26.

Esvece non mentiounfe par M. Covier. Tha re iburacine, 10 a la cavidale.

- Paisan deau. - Bertonneau, sur quelipues oótes du cord-onest de la France. - Breel, en Angleterre. - Tarboil,

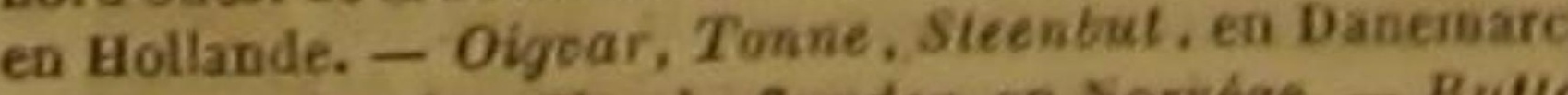

quis, ainsi qu'à une chair ferme; et voilà pourquol on l'a nommé Faisan d'eau ou Faisan de mer, pendant qu'on a donné à la sole le nom de Perdrix marine. Le turbot habite non-seulement dans la mer du Nord et dans la Baltique, mais encore dans la Méditerranée. Rondelet dit avoir vu dans cette dernière mer un individu de cette espèce quí avait einq coudèes de long, quatre coudees de large et un pied d's paisseur. Des furbots de cette taille sont très. rares : mais on en prend quelquefois sur les $\mathrm{co}-$ tes de France ou d'Angleterre, qui pèsent de vingt à trente livres ; et $\mathrm{M}$. Noël a bien voulu nous écrire que, dảns le mois d'avril 4801 , on avait vendu dans le marché de Rouen un turbot du poids de plus de vingt-six livres.

Le pleuronecte que nous décrivons est très. goulu; sa voracité le porte souvent à se tenir auprès de l'embouchure des fleuves, ou de l'entrée des étangs qui communiquent avee la mer, pour trouver un plus grand nombre des jeunes poissons dont il se nourrit, et pour les saisir avee plus de facilité lorsqu'ils pénètrent dans ces étangs et dans ces fleuves, ou lorsqu'ils en sortent pour revenir dans la mer. Quoique trèsgrand, il ne se contente pas d'employer sa foree contre sa proie; il a recours a la ruse. II se pré cipite au fond de l'Océan ou des Méditerranées applique son large corps contre le sable, se cou vre en partie de limon, trouble l'eau autour d lui, et, se tenant en embuscade au milieu de cette eau agitcé, vaseuse et peu transparente, trompe ses vietimes, et les dévore.

Au reste, les turbots sont très-difficiles dans le choix de leur nourriture; ils ne touchent guère

on Suede. - Botle, Stein bolte, en Prusse, - Stein buit, dans plise. contrees d'Allemagoe, - Ahombo, en traile. Rombi aspri, en Sardaigne, - Rhomb, dans plus. depart.

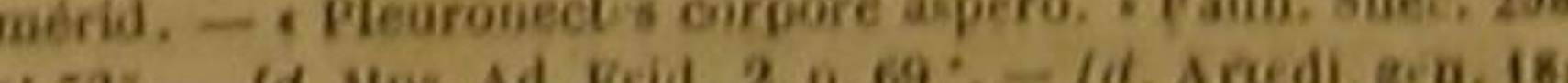

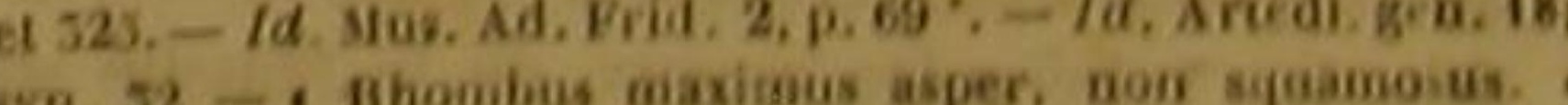
willuzhby, p. 03, tab, F, 8, Gig. 3, et p, 94 , tab. F, 2, - Mai

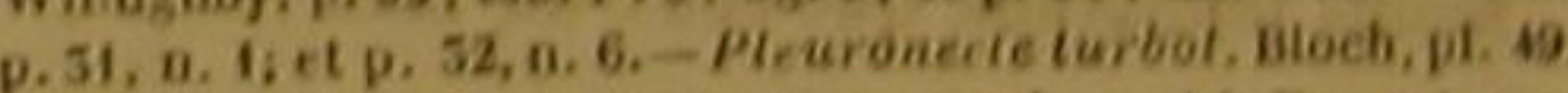
- Id. Dasenton et Hagy, Ene, meti. - 1d. Bounatere,

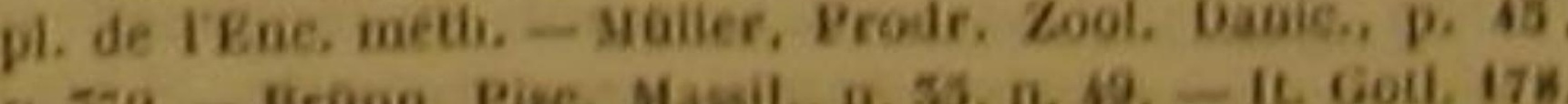

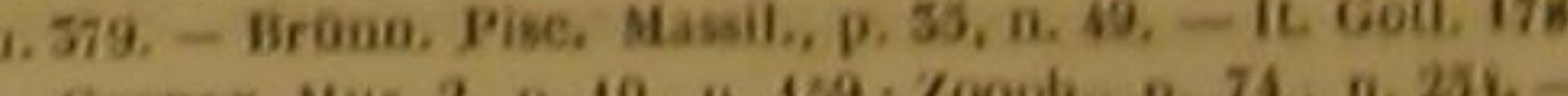

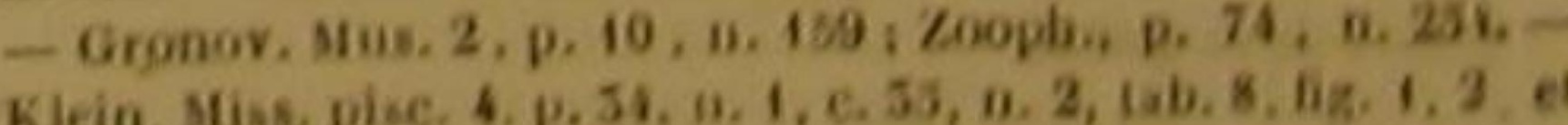

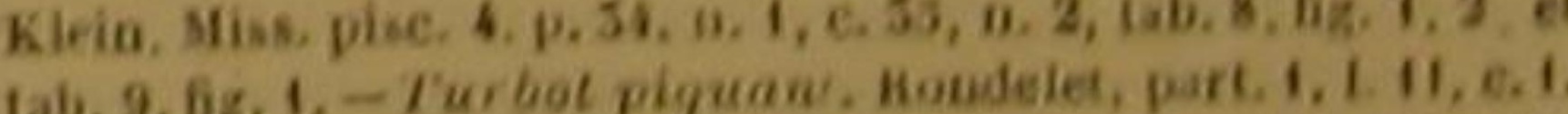

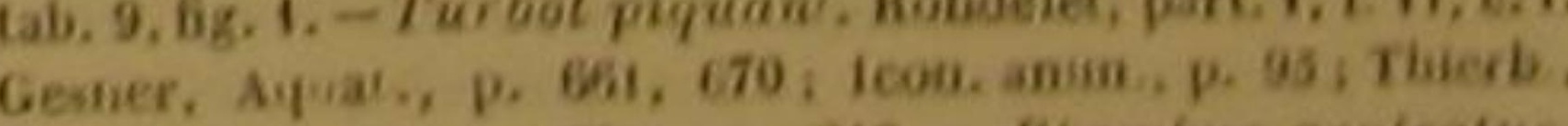
D. 50, b. - Aidrov Pice, p. 248. - Rhombus acsieatie. Jonton, Fise, p. 89, tab. 20, 6ig. 15, p. 99, tab. 22. if., 12 .

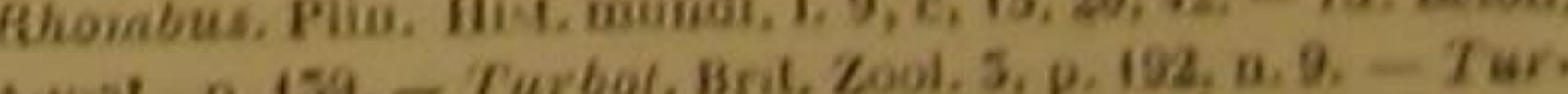

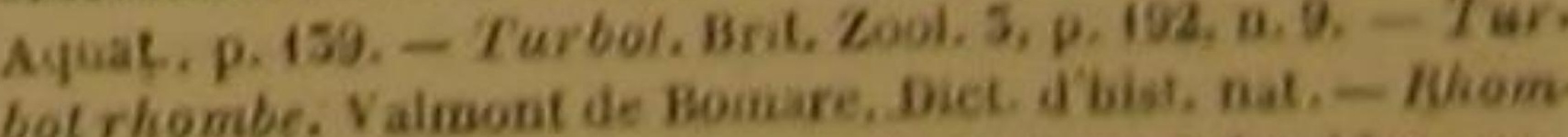

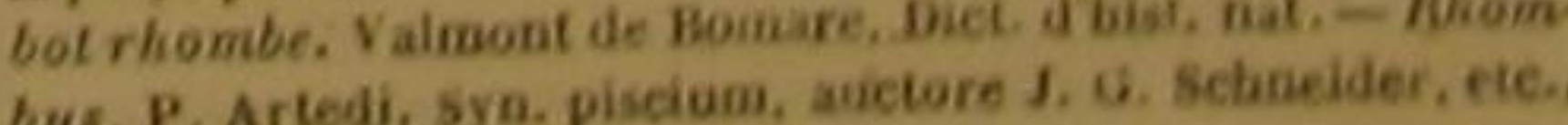
p.si. 


\section{HISTOIRE NATURELLE}

qu'à des poissons vivants ou très-frais. Aussi, au lieu de garnir uniquement de morceaux de gade, ou de clupée, et particulièrement de hareng, les hameçons avec lesquels on veut prendre ces pleuronectes, les Anglais ont-ils imaginé d'employer pour appât de petits poissons encore en vie, et surtout de jeunes pétromyzons pricka, qu'ils ont achetés de pêcheurs hollandais. On prétend mème que les turbots ne sont point attirés par des amorces auxquelles d'autres poissons ont mordu. Quoi qu'il en soit, ils sont trèsabondants sur les cotes de Suède, d'Angleterre et de France. On en trouve notamment un trèsgrand nombre entre Honfleur et l'embouchure de l'Orne, où on péche ceux que l'on vend dans les marchés du Havre, de Rouen et de Paris.

Les pêcheurs d'Angleterre, suivant le naturaliste Bloch, vont à la recherche des turbots, dans des canots qui portent trois hommes. Chacun d'eux a trois cordes ou lignes de trois milles anglais de longueur; on attache à chaque corde, de six pieds en six pieds, un crochet retenu par une ficelle de crin; des plombs maintiennent les lignes dans le fond de la mer; des morceaux de liége en indiquent la place, et on se règle sur les marées pour jeter ou relever les cordes.

La forme générale du turbot est un losange; et c'est de cette figure qu'est venu le nom de Rhombe, que tant d'auteurs anciens et modernes lui ont donné. La máchoire inférieure, plus avancée que la supérieure est garnie, comme cette dernière, de plusieurs rangées de petites dents. La ligne latérale descend pour se courber autou de la pectorale, et tend ensuite directement vers la nageoire de la queue, sans présenter aucun tubercule. Les nageoires sont jaunâtres, avec des taches et des points bruns; le côté gauche est marbré de brun et de jaune; le côté droit, qui est l'inférieur, est blanc avec des taches brunes; les tubercules osseux de la femelle son moins nombịeux que ceux du mâle '.

' 7 rayons a ta menbrane branchiale du pleuronecle tur601, to a chaque pecioraie, 6 a chaque thoracine, 16 a la na geoire de la queue.

\section{LE PLEURONECTE CARRELET '}

\section{Pleuronectes Rhombus, Linn., Gmel., BI., Lac., Curv.}

Le carrelet est très-commun. On le trouve dans I'Océan Atlantique boréal, ainsi que dans la Méditerrànée. Il se plait particulièrement dans cett e dernière mer, auprès des cótes de la Sardaigne il pénètre quelquefois dans les fleuves; il entr. notamment dans l'Elbe; et M. Noēl a appri: d'un pêcheur, qu'on avait pris un individu dc cette espèce dans la Seine, auprès de Quevill: a une petite distance de Rouen. On ne doit dor pas être étonné qu'on ait vu des empreintes o des dépouilles de cet osseux dans la carrièr d'OEningen, auprès du Rhin et du lac de Constance ${ }^{3}$.

Ce thoracin et le turbot sont les pleuronectes qui présentent le plus de largeur ou plutót de hauteur. Ils l'emportent même sur le flez par la grandeur relative de cette dimension; mais ils sont bien èloignés d'atteindre à la longueur de ce flez. On ne doit done donner aucune confiance à ce qu'on a écrit d'un carrelet pris sous Domitien, et qui aurait été d'une longueur si démesurée, qu’elle aurait égalé soixante-six ou soixante-neuf pieds.

Le pleuronecte dont nous nous occupons l'asophage large, la membrane de l'estomac épaisse, et deux coecums ou appendices auprès du pylore, On doit remarquer d'ailleurs sa máchoire inférieure un peu plus avancée que la supérieure, les différentes rangées de dents peti-

'Barbue, Rhombofle, dans plus. départ de Fraoce. Ghombo, en lialie. - Scallo, Songia, aupres de Venise. Hambourg. - Slaelwar, en Danemarck. Pigghars, Suede. - Sand-Aynder, eu Norrege. - Peari, a Londres. - Lug-aleaf, daus le comté de Cornouailles. - Grict, en Holiande. - Pleurnectes corpore giabro., Nus. Ad. Frid. 2 , p. $69^{*}$ - $-I d$. Artedi, geu. 18, sya. 31. - Pleuro-

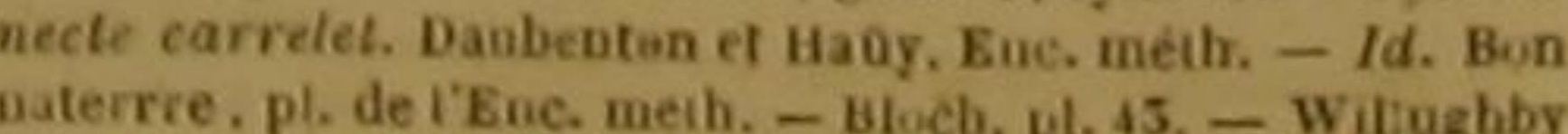
p. 96. - Hai, p. 52, n. 7. - Moiler, Prodr, 45 - Wiliughby, a. 578. - Bruunich, Pisc. Massil, p. 55, D.48 - Pleuronect piggearf. It. Wgoth. 178. - Pleuronecles arenarius. Strom. Subdm.-Gronov. Mus. 1. p. 23, n. 45; Zooph., p. 74, n. 253. - Turbol sans piquants. Rondeiet, part. 1, 1. 11, c. 2 . Gesner, A yuat., p. 865 - Ald. ov. Pisc., p. 249. - Jonston, Pisc., p. 99, 1. 22, hig. 15. - - Rhombus alter gallicus. Artedi Syo piscimm, anctore J. G. Schnetide, etc. p. 51

"Type du sous-genre Tuввот, Rhomibus, dans le grand genre PLetionetro, selun M. Cuvier. Ce poison est celu que Ton connait dans nos ports de la Nanche sous le nom de Basbue. D.

Voyage dans les alpen, di Horace-Bénédict de Sansecese.

DES POISSONS.

411

tes, inégales et pointues, qui arment les deux mâchoires, la saillie arrondie de la partie postérieure de chaque opercule, et la couleur blanche du côté droit de l'animal '

LE PLEURONECTE TARGEUR 2 Pleuronectes punctatus, Lina., Gmel, Bl.; Khombus
punctatus, Car. ? Le Pleuronecte dente 4, Pleuronecles dentatus . Linn., Gm. Lae, 5. - Pleuronecle Moincau 4, Pleuronecles Passer,

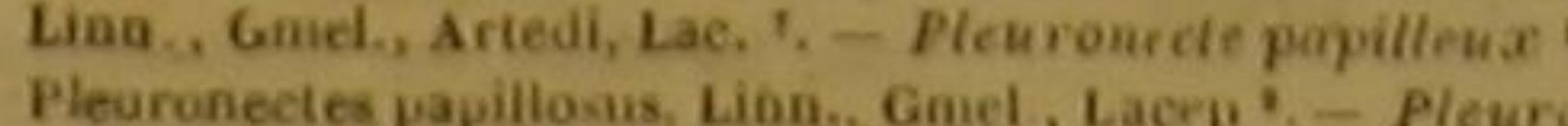

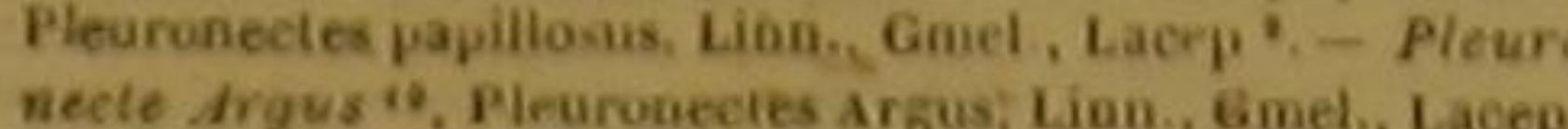

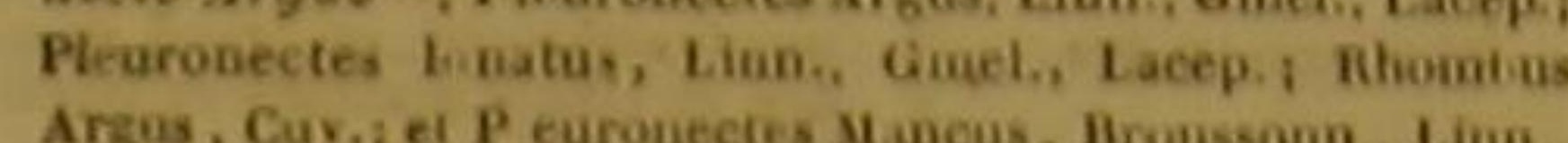

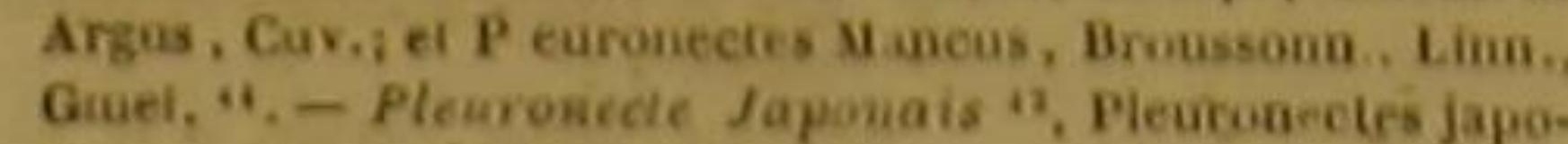

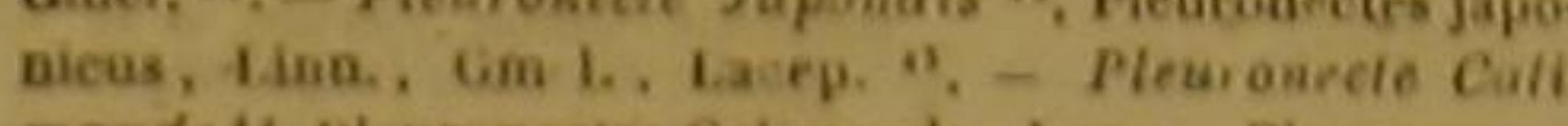
mande '., Me uroneetes Calimanda, Lacep i Pleuronecic

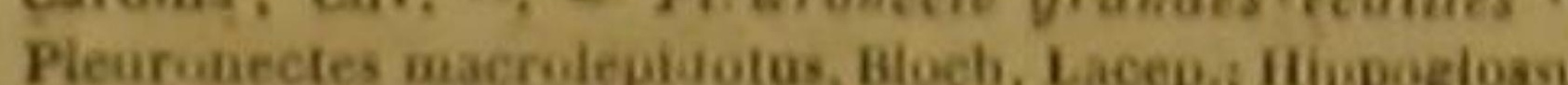
macrutepidetus, Cuv. ",- - Pleuronecle Commersennien ", Plearonectes Çolimersonuili, Lac, Cuv, ".,

Lorsqu'on aura jeté les yeux sur le tableau générique des pleuronectes, on complétera faci-

6 rayons a la membrane branchia e du pleuronecte car relet, a a chaque pectorale, 6 a chaque thoracine, 16 at caudiste.

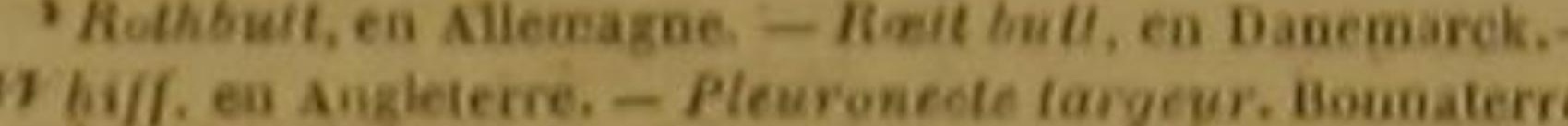
pl. de IEnc meth, $\rightarrow$ Bloch, pl. $189 .-$ - Passer alter, cut - dura et asperd, ele, - Kieis, Miss. pisc. 4. p. 5i, n. 9. Brit. Zoul. 3, p. 186, n. 2. - Hai, Pisc, p. 165, o. 2, 18b. 1 , 6g. 2. 'Da sous geure Tunor, Miombus, Cur., dans le gran

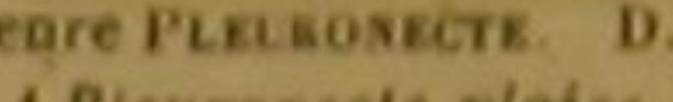

1d. Bunaterce, pl. de IEnce néti.

'M. Cuvier ne fait pas mentiou de celle espece de pleuroarcte. D.

- Passere, en Sardaigne. - Struff bull, allambourg.

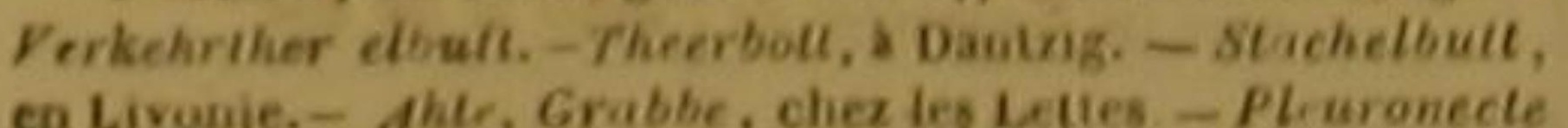
co Livanie.- Ahl, Grabbe, chea les Lelles - Pl-uronecl ph. de KEnc. meib-Bloch, ph. 50. - Gronov: Zooph., p. 73, n. 24k. - Kieis, Miss, pisc. 4, p. 35, B. 3. I Le Pl uroneries passer d Ariedi et de Linuee n'e point d fféreat du Turbot; celai de Bloch, pi. 50, a'est qu'un iveux fet, costourue a gancie, Cav. D

- Pleuronecte aramaque. Daubeuton et Haay, Eac meth. Id. Bosuaters, pi. de i Euc. me

i. Sichilchicariz, en-Allemagne. - Tunge, en Hollande. Lingnada, Cubricunka, en Portagal. - Aramaca, av Bresil. - Bade, dans The de Roiteriam, ou Anamoka. Pathi-miure, dars File ditatite - Pleurnecte lunule,

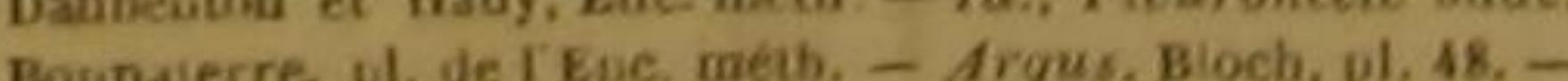
Bronssonuet, Ichth dec. 1, n. 3. Lab. 3, 4.-Catesty, Carol. 2 , p. 27, tab. 27 .

" Do soos genre TusBot, Rhombus, de M. Cavier, dans le grand genre PL8ukOsect. - Nota. Le pleurouecte Bad ou Manchot de Broussonacl, Phuronectes mancus, est une

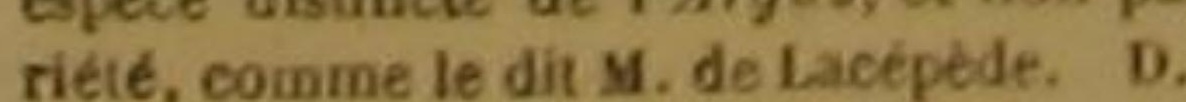

a Houttoyn, Act. Haarl. XX, 2, p. 317 lement l'idée générale des neuf espèces dont nous faisons mention dans cet article, en réunissant dans sa pensée les détails suivants.

Le targeur montre de petites écailles sur sa tête et sur les rayons de ses nageoires; un grand nombre de dents recourbées et très-serrées, in chaque mảchoire; une lèvre supérieure extensible; une ligne latérale courbe au-dessus de la pectorale, et ensuite drojte; un blane rougeâtre répandu sur'son cóté dioit; et des nuances grises distribuées sur les nageoires du dos et de l'anus. II habite dans la mer qui baigne les cotes d'Angleterre et celles du Danemarck; il parvient à la longueur d'un pied et demi.

Les eaux de la Carolíne sont la patrie du denté.

Le moinean se trouve dans la Baltique, ains que dạns I'Océan Atlantique septentrional. I pèse quelquefois plus de huit livres. Sa chair est agréable au goût. La máchoire inférieure dépasse celle de dessus. La ligne latérale est presque droite. Le côte droit est blane; les nageoires sont jaunátrés avec des taches brunes. On voit un piquant aupress de l'anus.

LAmerique nourrit le papilleux, dont le cote droit est blanc, et le coté gaveche grisatre.

L'argus, dont le badé ou le manchot de Broussonnetr' est qu' une variété, est souvent long d'un pied et demi à deux pieds. On la péché dans la mer des Antilles, dans celie de la Caroline, et dans les eaux des ifes du grand Océan equinoxial, improprement appelées iles de la mer du Sud. Pendant I'hiver, il se tient au fond de ia mer, mais lorsque l'été approche, il rèmonte

Ce plearonecte n'est pas cité par M. Cuvier. D atruronectios regias, calimasde royale, Bounaterre. pl de t kne, meth. gere PLenosecte. 1).

Wroas achuppigte cholle, par les Alemands - Tonge. Portogais-Aramara, au BrésilBloch, pl. 190. - Id. Bonaterre, pt. de I Eve, mé.h. Kiein, silss, pisc. 4, p. 52, n: .

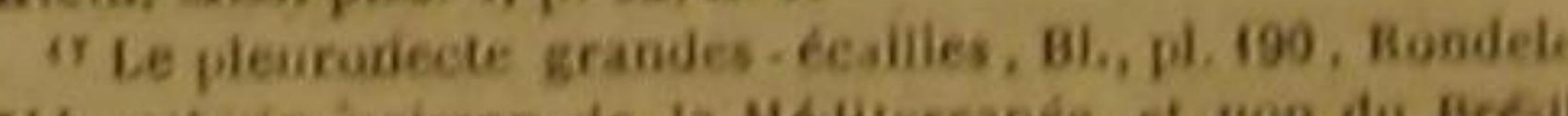

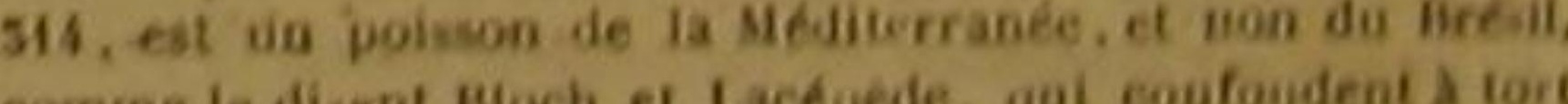

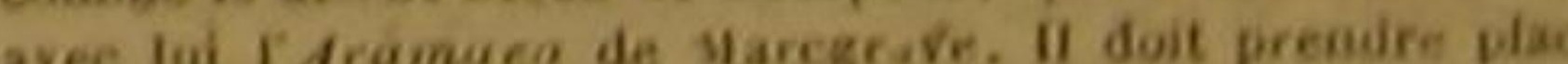

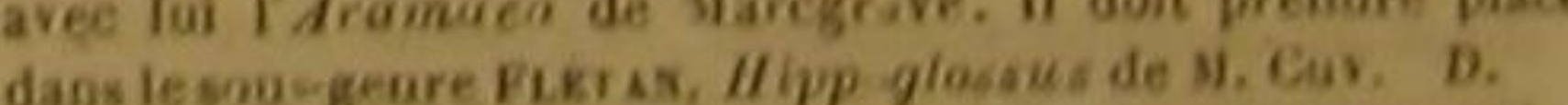
"sole de l fle de France. - Pieuraarctes ocutis a tibi- Iri, corpore pellucido, sordide exaibido gutis pallitifion. Gus subse
afjectios. Teion a Cavier, la figure du plearasecte eammersou

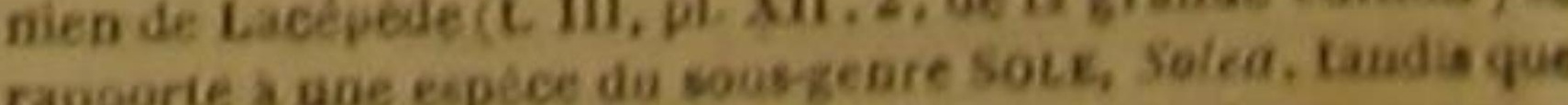
la description est celle d'uas autre espece da souscenare Tuseor. Rhombus. D. 
dans les fleuves, où sa chair devient tendre et d'un goût exquis. Sa parure est très-belle. Les taches dont il est peint ont paru avoir assez de rapports avec une prunelle entourée de son iris, pour que le nom d'Argus lui ait été donné. La membrane des nageoires est jaunâtre; les rayons qui la soutiennent sont bruns; et elles sont d'ailleurs ornées de petites taches bleues.

Le coté droit de l'animal est d'un gris cendré.

L'ceil supérieur est plus grand et plus recule que l'autre. La ligne latérale fait le tour de la pectorale avant de s'avancer directement vers l'extrémité de la queue. Plúsieurs rayons de la pectorale gaúche sont très-prolongés au delà de la membrane.

Le japonais est long de huit pouces, et blanchâtre sur son côté droit.

Le pleuronecte calimandren'a que huit à douze pouces de longueur; les couleurs dont il est jaspé sont ordinairement le rougeâtre, le marron, le gris-de-perle foncé. Plusieurs individus de cette espèce ont sur la queue une tache dorée entourée d'un cerele très-brun; les pêcheurs disent que les mâles ont une seconde tache audessus de la première, et une troisième auprès de l'opercule. Nous devons à Duhamel la description de ce thoracin, qui se plait dans l'Océan. Le pleuronecte grandes-écailles a le corps et la queue très-allongés; la tête et les opercules dénués d'éeailles semblables à celles du dos : les dents coniques très-longues; les nageoires brunes; une chair de bon goùt; une longueur de plus de deux pieds; et la mer du Brésil pour patrie ${ }^{-1}$.

Le commersonnien est à peine de la longueur de la main. Ses thoracines sont placées l'une devant l'autre; c'est la gauehe qui est la plus avancée. Il vit dans les eaux salées qui baignen I'lle-de-France; il est encore plus délicat que la sole. Nous en donnons la deseription d'après les manuscrits de Commerson, qui l'a fait dessiner.

11 rayons a chaque pectorale du pleuroneele targeur, 6 a chaque thoracine, 11 a la nageoire de la que ur. -7 rayons pectorale, 17 a la cau tale. -6 rayons a la membrane bragehible du pleurunerte moinean, 12 a elaque peet irale, 6 a chaque tauraciue. 16 a ia nageoire ve la queue. -12 rayon A chaque pectorale diu plearonecte papileas, 6 a chayue thoa-ete arzus, 8 a chayce thoracine, it a ia maeere de

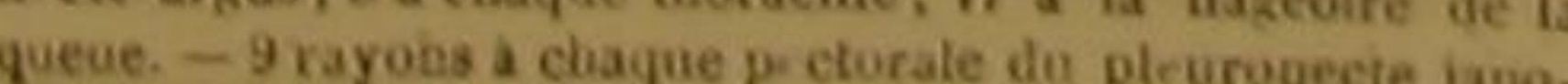
nas, 16 a la candale. - 14 ragons a ehaque pectorale du piraroaccie granues ecailites, 6 a chaque thoraciee, 17 a

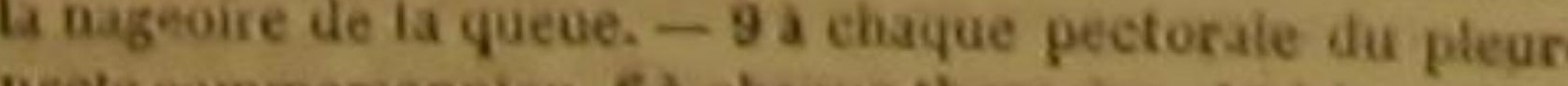

CENT CINQUANTE-UNIEME GENRE. LES ACHIRES.

La lete, le corps el la queue tris-comprimés; les doux yeux du meme cole de la lele; point de nageoires peccorates.

PREMIER SOUS-GENRE.

Les deux yeux d droilfe; la nageoire de la queue fourchue, ou echancrie en croissant, ou arrondie sant ehancrure.
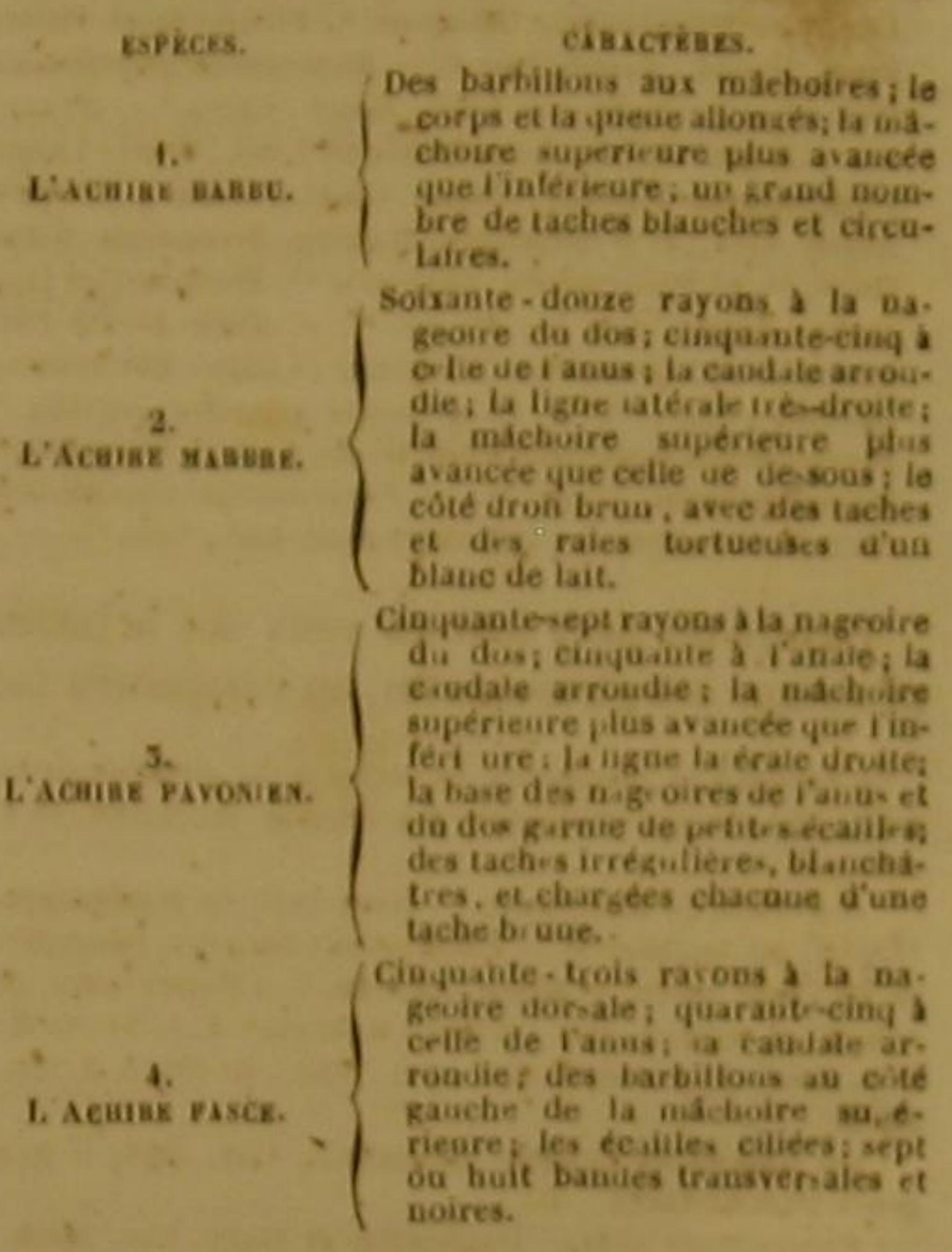

SECOND SOUS-GENRE.

Les deux yeux d gavehe; la caudale pointue ef réunie acee les nageoires de l'anus el dis dos.

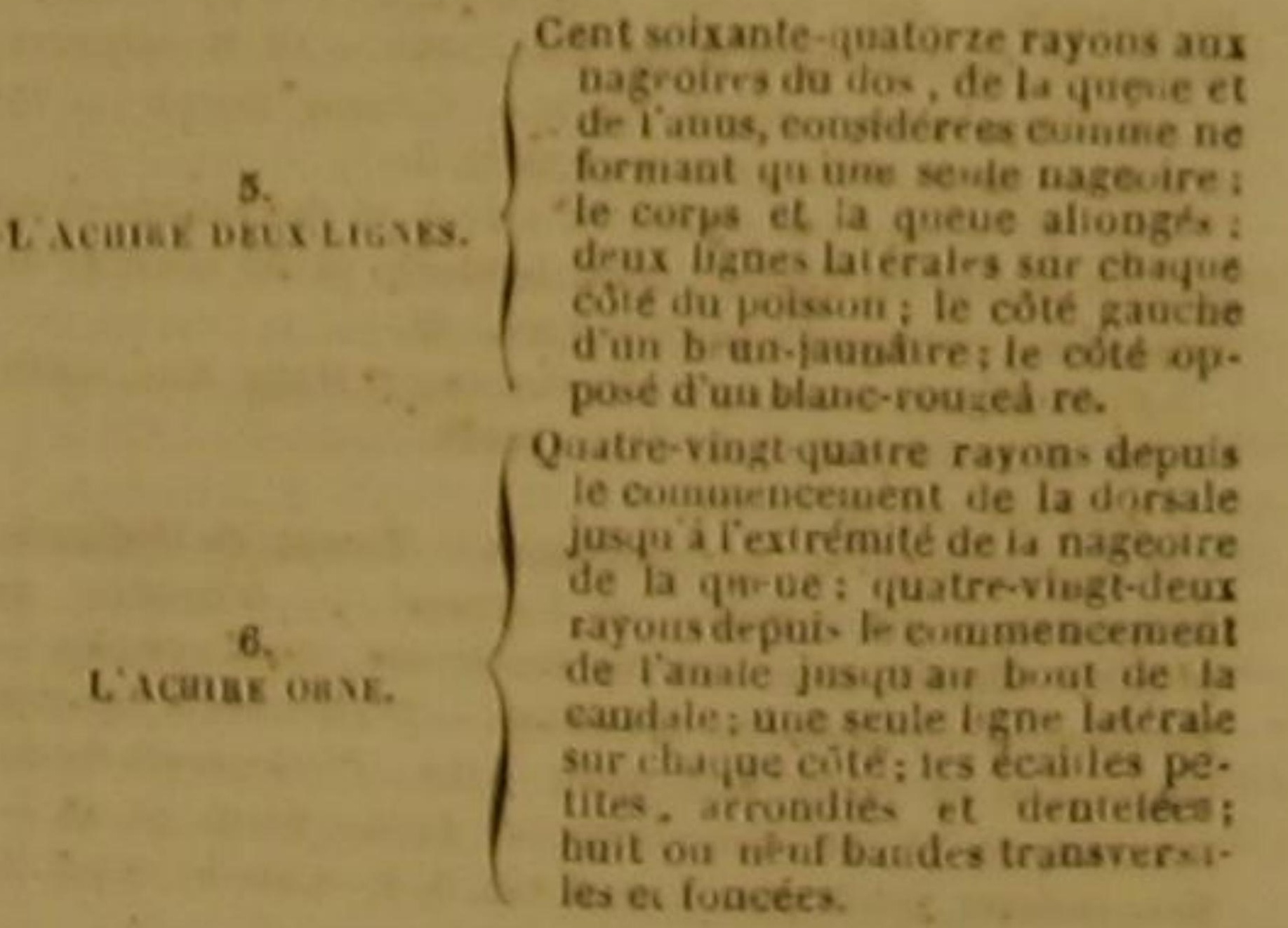

L'ACHIRE BARBU ', Aebirus barbalas, Lac., Cur, '.

L'ACIIIRE MARBRE ${ }^{3}$, Achirus marmoratus, Lac., Cuv. 4. ET L'ACHIRE PAVONIEN.

tehirus paroninus, Lac. s.

Les achires " ne different des pleuronectes que parce qu'ils sont entièrement privés de bras et de mains, ou, ce qui est la meeme chose, de nageoires pectorales. Leurs habitudes sont cependant semblables à celles des pleuroneetes, dont les pectorales sont trop petites, et placees tropdésavantageusement pour influer d'une manière sensible sur leurs mouvements et leur évolutions.

On ignore dans quelle mer habite le barbu

Le marbré est beau à voir. On le péche dan la partie de l'Océan qui arrose I'lle-de-France. Le goút desa chair y est excellent, et il y a éte observé en 1769 par Commerson. Lés naturalistes ne connaissent pas encore ce poisson. Ses nageoires, d'un blane mélé de gris et de bleu, sont parsemées de points noirs. On ne voit que difficilement ses écailles. La dorsale s'étend depuis le bout du museau jusqu'à la nageoire de la queue.

Commerson a fait une remarque curieuse sur cet achire. II a vu le long de la base des nageoires du dos et de l'anus, autant de pore que de rayons ; et lorsqu'on pressait les environ de ces petits orifices, il en sortait une mucosité laiteuse.

Nous avons trouvé un indivídu de cette espèce dans la collection de Hollande, cédée à In France.

Nous avons vu, dans la même collection, un individu d'une autre espèce d'achiré encore inconnue des naturalistes, et à laquelle nous avon donné le nom de Pavonien, à cause des taches

Gronov. Zoophin, a. 25s. - Pleuronecle barbue. BoDesterre, pl. de I Ene. méth.

"LC, re Acasak, que M. Cavier

- Pieurotectás oculis a dextra; corpore brupseo, rriezato ; pinnis omnibus exalididis nigro punctatis. 2 Commerson, manuscris ufja cites.

Du mèar som-geare ACans, selon M. Cavier. D.

-Acheires, ea grec, signifie manchot, qui manque de un peu semblables à des yeux de paon, dont elle est couverte.

La dorsale de cet achire pavonien règne depuis le dessus du museau jusqu'à la caudale, dont cependant elle est très-distincte, ainsi que la nageoire de l'anus '.

\section{L'ACHIRE FASCE ?}

Achirus faseiatus, Lao., Cur.; Pleuronectes fasciatus, Lina, Gmel, ?

Cet achire a été pêché dans les eaux de l'A. merique septentrionale, Son coté droit est brun ; son côté gauche blanchátre ‘.

L'ACHIRE DEUX-LIGNES ",

Achirus bilineatus, Lac, Cuv, '

\section{ET I'ACHIRE ORNE.}

Achirus oroatus, Lac, Gur, ',

Le premier de ces deux achires babite dans les eaux de la Chine et dans celles des Indes orientales. II se nourrit de petits crabes et d'animaux à coquille. Son foie n'a qu'un seul lobe; la membrane de son estomac est mince te canal intestinal se recourbe plusieurs fois les deux máchoires sont garnies dedents courte

et obtuses ; chaque narine a deux orifices, dont l'un est en forme de tubé; une seule plaque compose chaque opercule; les écailles qui recouvrent la tête, le corps et la queue, sont potites, presque rondes et dentelées; les deux lignes latérales, que l'on voit sur chaque coté de T'animal ; sont droites et presque parallèles; une I 5 ou 6 rayonis a la membrane branchiale de lachire mar-

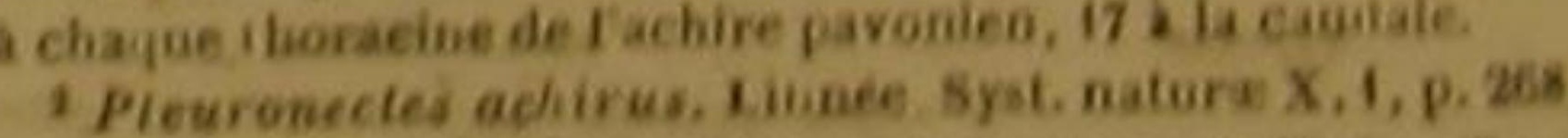
a. 1, 3. - Pleuronecte achire, Daubentou et Hady, En. meth. - Gronov, Mus, 1, n. n2. - Pleuronecies fiscas.... c lineis reptems nigris, ele., Browne, Jain. 4is - Sloane,

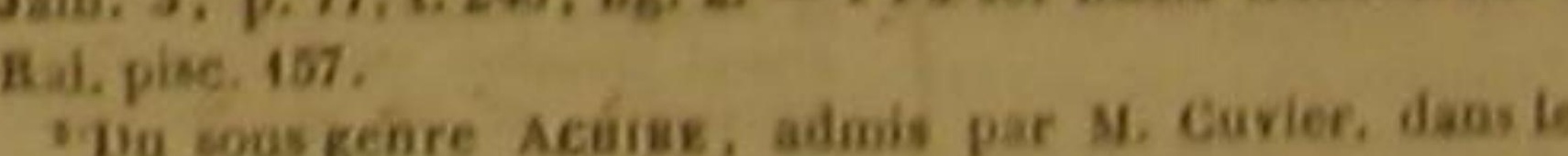
Tha 5 rayons a chayue thoracine de lachire tacé, 16 la nageoire de ta quene.

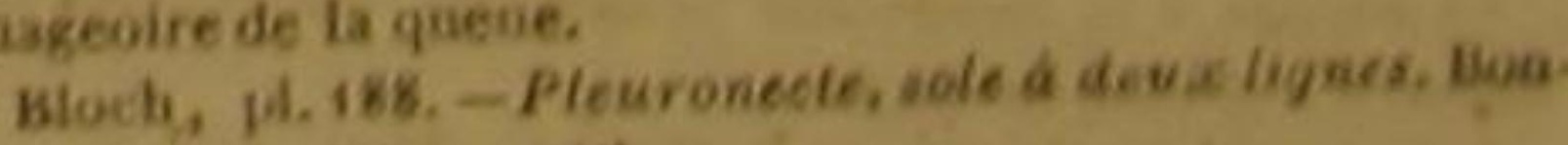

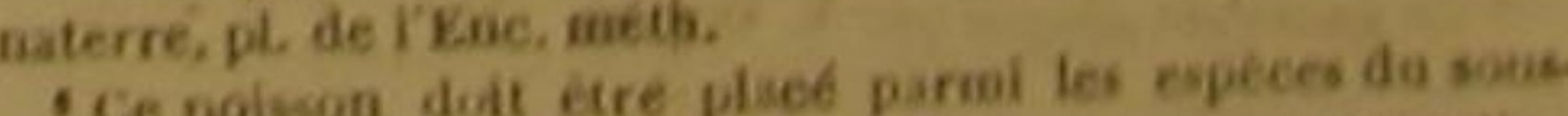
genre Acans. dout Browbe avait tait un geare paricalier, cous le nom de PLacusa. D. I L Achire orne cat de is otne division du vargeare scume gus le precedent. 
couleur brune, mélée de gris ou de verdâtre, distingue les nageoires.

Personne n'a encore publié la description de l'orné. Nous avons vu un individu de cette derniere espèce dans la collection hollandaise donnée à la France. La ligne latérale se relève au delà de l'opercule, pour suivre à peu près la direction du dos '

SECONDE SOUS-CLASSE polssons osseux.

Les parties solides de lintérieur du corps osseuses. -

PREMHERE DIVISION.

Poissons qui ont un opercule et une membrane des branchies.$$
-
$$

VINGTIEME ORDRE

DE LA CLASSE ENTIEEEE DÉS POISSONS,

QUATREEME ORDHE

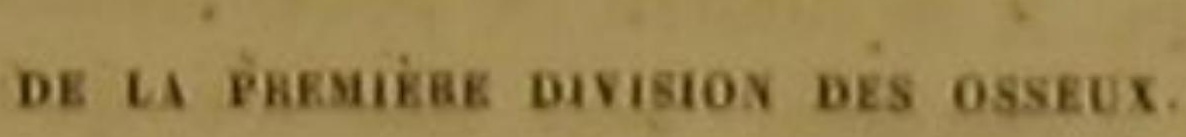

Poissons abdominaux, ou qui ont des nageoires inftrieures places sur l'abdomen, au deld des pectorates, el en depa de la nageoire de l'anus.

$$
\text { - }
$$

CENT CINQUANTE-DEUXIÈME GENRE. LES CIRRHTES ${ }^{2}$.

Sopt rayons d la membrane des branchies; le dernier Irès-iloigné des cutres; des barbilloñs réunis par une membrane, et placés cauprès de la pectorale, de manière d $r$ priter

ssrick

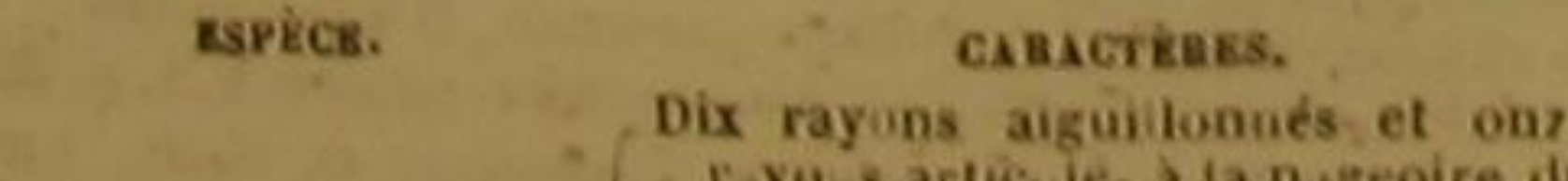

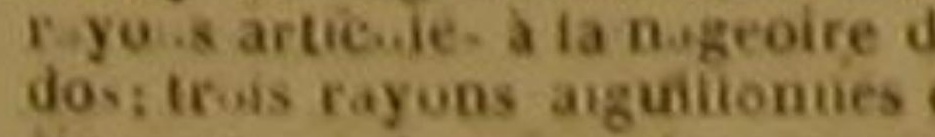

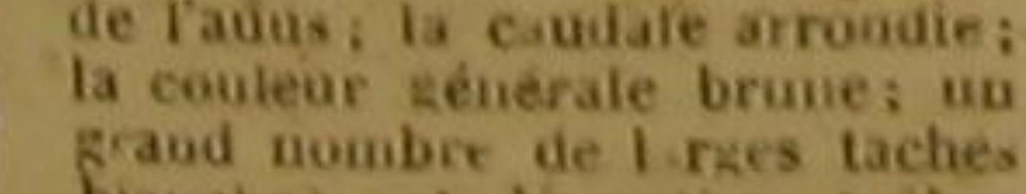

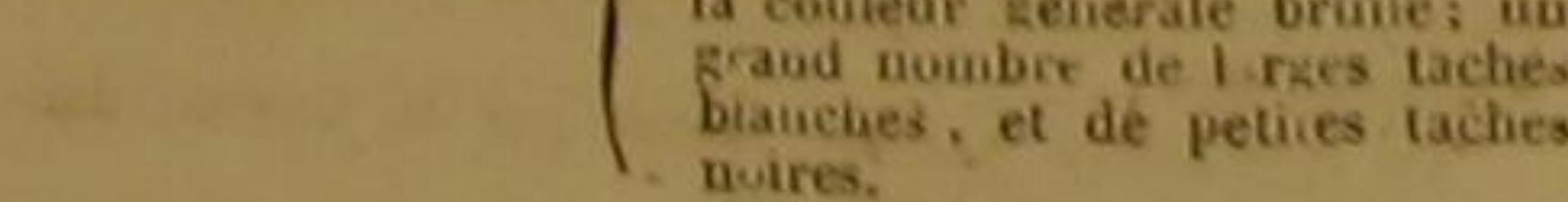
1 rayons a la membrane branchiale de lachire deux-

lignes, 1 a cha que thoraciue.
I Ce geure est adopte par Il. Curier. D.

\section{LE CIRRHITE TACHETE '.}

Cirrhites maculatus, Cuv., Lac. ?.

Ce poisson, dont on devra la connaissance à Commerson, est véritablement de l'ordre des abdominaux ; mais il doit être placé à la tête-de cet ordre, comme se rapprochant beaucoup de celui des thoracins, avec lesquels il a de grands rapports. Il ressemble surtout aux holocentres ou aux persèques. Il a, comme ces osseux, la première lame de son opercule dentelée, et la seconde ārmée d'un aiguillon.

Sa partie supérieure sé relève en are de cercle, sịtué dans le sens de sa longueur totale. On ne voit pas de petitè écarlles sur sa tête; mais son corps, saqueue, et une partie de ses opercules, en sont revêtus. II peut étendre ou retirer sa mâchoire supérieure ${ }^{3}$.

On divise facilement les dents de ses deux mâchoires en extérieures et en intérieures. Les premières sont écartées les unes des autres; les secondes, sont très-petites, et serrées comme celles d'une lime. La partie supérieure de l'orbite est relevée; et les yeux sont placés assez haut. Sept barbillons très-allongés et réunis par une membrane commune forment cette sorte de fausse nageoire que nous venons de faire remarquer dans le tableau générique, qui paraít, au prèmier coup d'cil, une seconde pectorale, et qui, donnant à l'animal un organe singulier, le rapproche des lépadogastères, des dactyloptères, des prionotes, des trigles et des polynèmes, sans cependant le confondre avee aucun de ces derniers. La ligne latérale suit la courbure du dos. Les nageoires sont brunes; des taches noires sont répandues sur la dorsale; une tache plus grande, mais de la même couleur, parait soụs la máchoire inférieure ${ }^{4}$.

-Cirronius. - Coneirrus. - Cincirous. - - Aspro fas.

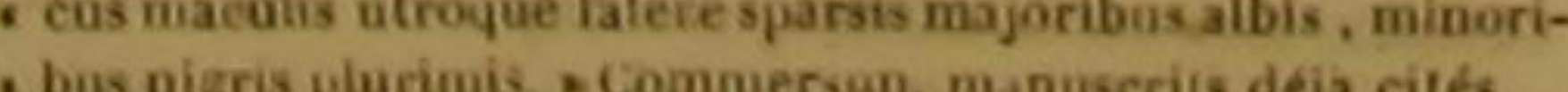
2M. Covier piace ce poisson dans son genre Cuasuirs, de la famille des Acintboptérygiens pereoices. M. de Lacépede Ia d-crit deur fois sous les noms $1^{\circ}$ de Labre marbre, et 29 de Cirrhite fachete. D.

'7 rayoas a cha que pecturale du cirrbite tacheté, 6 a chaque rentrale, 15 a la migeoire de la queve. ve Spare panthérin de nom de Cirrhites pantherinus. D

DES POISSONS.

CENT CINQUANTE-TROISIEME GENRE.

LES CHEILODACTYLES '

Lecorps et la queue iris-copiprimes; ta livie supdrieur double et exlensible; la partie awlerieure el supdrieure de la lele lerminee par wae ligne prespue droil et qui ne s'eloigne de la verticale que de 40 d 50 degres; les derniers rayous de chaque pectorale, trisallonges au dela de la membrane qui Les reiunit; na seule nayeoire dorsale.

esrece.

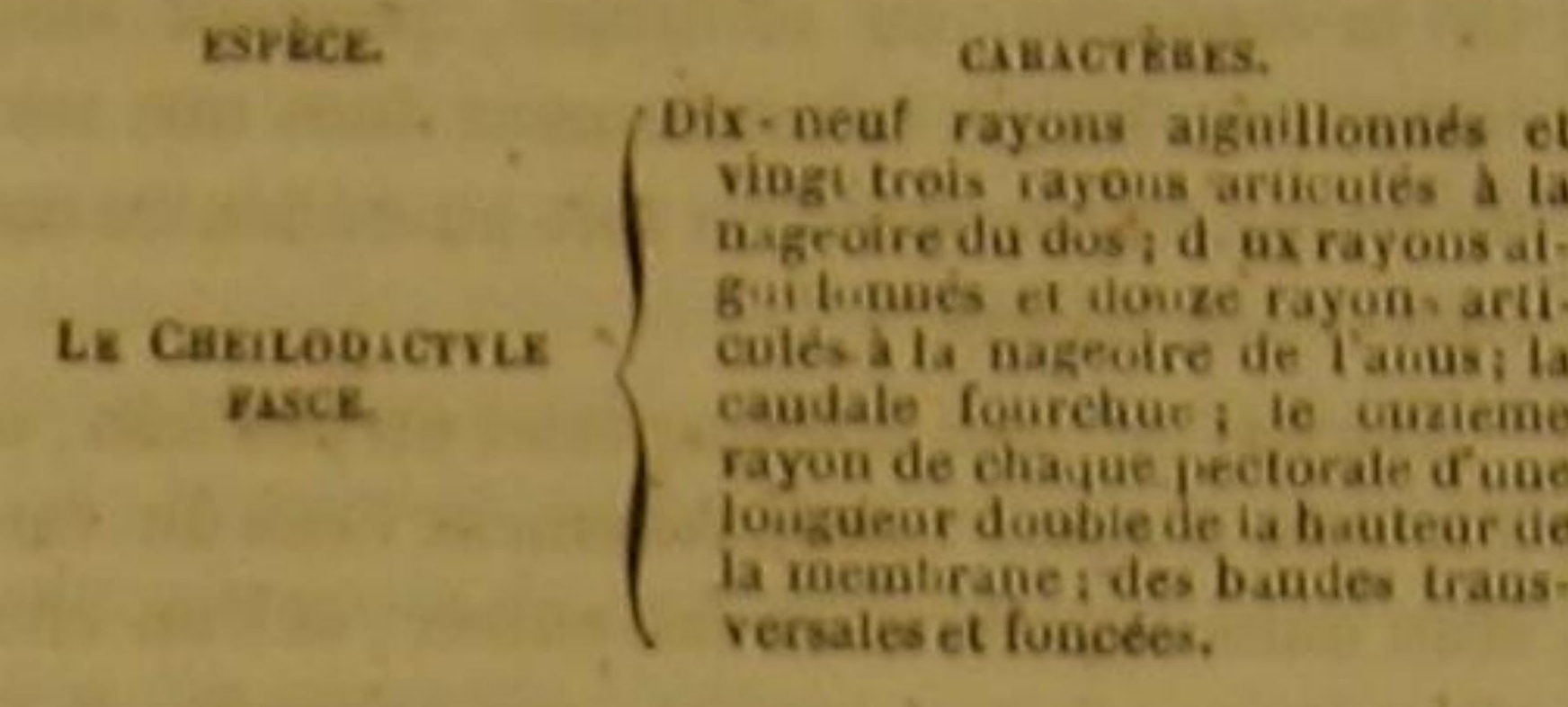
-

\section{LE CHELLODACTYLE FASCE ?}

Cheilodactylus fasciatus, Lac., Cur. '

Nous avons vu, dans la belle collection hollandaise cédée à la France, un individu très-bien conservé de cette espèce d'abdominal éncore inconnue des naturalistes, et que nous avons du inscrire dans un genre particulier, dont te nom indique et la forme de ses lèvres, et celle de ses doigts, ou des rayons de ses pectorales. La nageoire dorsale de ce cheilodactyle s'étend depuis une partie du dos très-voisine de la nuque, jusqu'à une très-petite distance de la nageoire de la queue. La portion dé cette nageoire, que soutiennent des rayons aiguillonnés, est plus basse que l'autre portion. Le quatorzième ou dernier rayon de chaque pectorale, quoique très-allongé au delà de la membrane, est moin long que le treizième, le treizième que le douzième, et le douzième que le onzième. L'anale présente un peu la forme d'une faux. On voit des taches foncées sur la nageoire du dos et sur celle de la queue 4 .

:Ce geáre est adopte par M. Cavier. D. "M bandes, du Cap, et le place dans la famille des Acactylét rygiens scienoides. D.

IA rayons a chaque pectorale du cheilodactyle fasce. I rayou aiguillonné et 5 rayons articulés a chaque ventrale, 17 rayon ila nageoire de la queue. ANTE-QUATRIËME GIRNRE. LES COBITES !

La tete, le corps et la queve cylindriques; les yeure trèsrapprochis du somamed de la tate; point de dents, el des barbilitons aus mdetoires; une seule nageoiro du des; la peau gluante, el recellue d'ecailles irès-difipeiles d voir.

ESPECE:

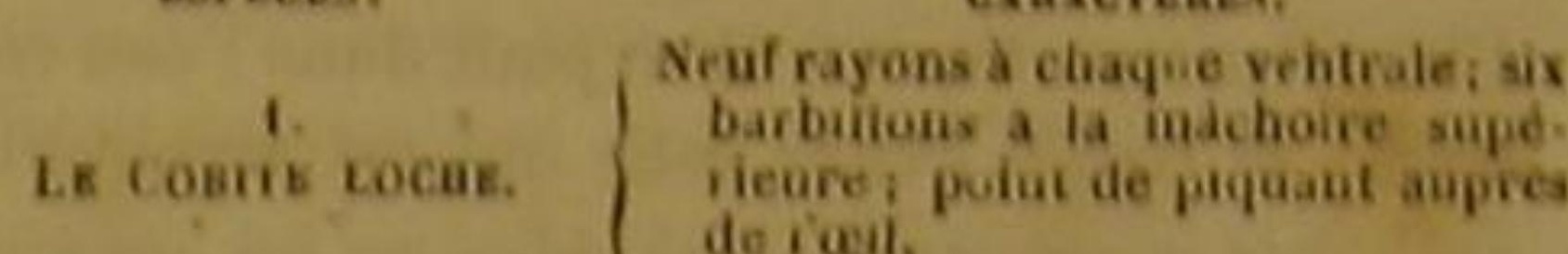

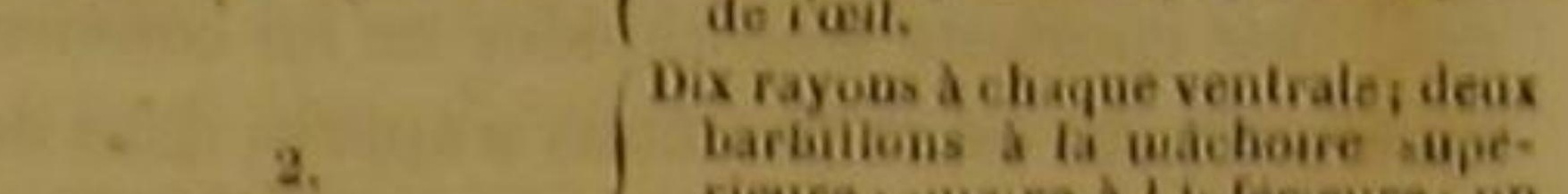

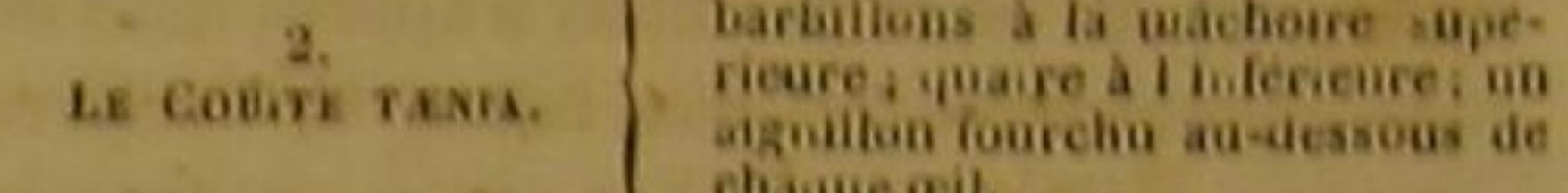

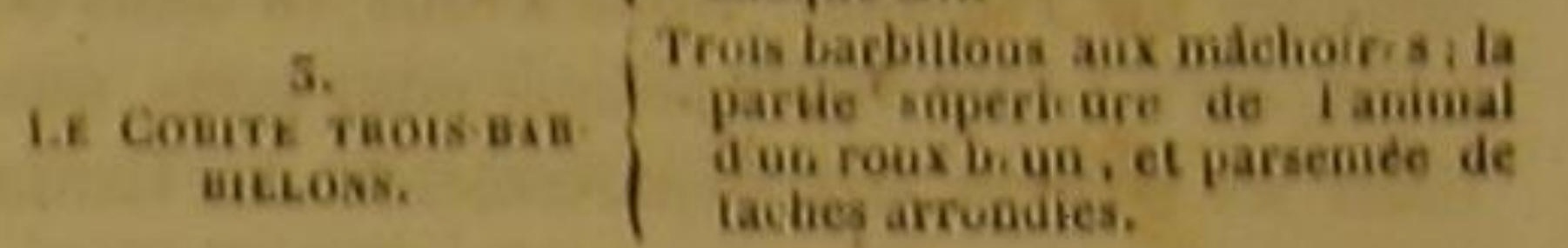

Cobitis Bariatula, Linn., Gmel, Lac. Cur. '.

LE COBITE TANIA ,

Cobitis Twoias Lino', Gmel, Lac, Cur. '

ET LE COBITE TROIS-BARBLLONS.

Cobitis Tricirrhata, Lac *

Le cobite loche est trés-petit; il ne parvient guère qu'à la longueur de quatre ou cinq pou-

- M. Cuvier conserve le geare Loche, ou Dornilte Cobitis, Linn., et le place dans fordre des Ma acopterygiens abdo:
minamx, el daus la tamilte des cyprinoides. II lui réuit ie genre, Misgurne de Lacépede. D.

'Pelit barbot, Loche franche, en 'France - Schmert, dans pius. cascona d Alemagne, - Schmering, sehmer-

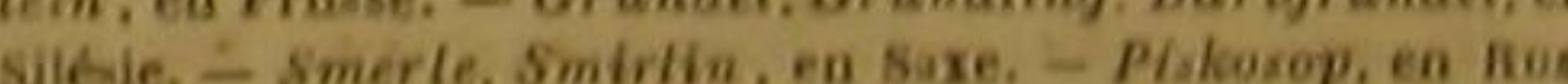
je... Gronling es suesie. - Smeeling en Danemarck. Hoogkyner, en Hollande. - Groundilin, ea Angletere. Cobilie fraviche barbotte. Dasbenton et liagy, Kne, weth.d. Boanaterre, pl. de I'Ene, meth - Bloch, pl. 31, fig. 3. - Mas. Ad. Vrid. 2, p. 95: - V Vun. Suee s4t. - Matler,

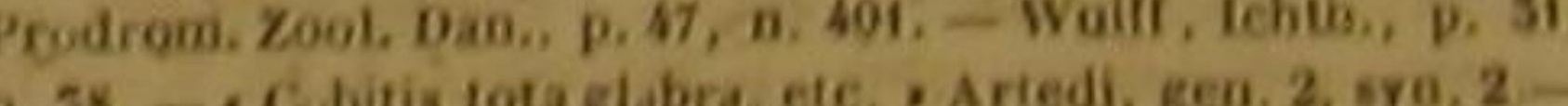
Cobitis barbatola. , Gesner, d. 40t; et (germ.) tot. 165, b.

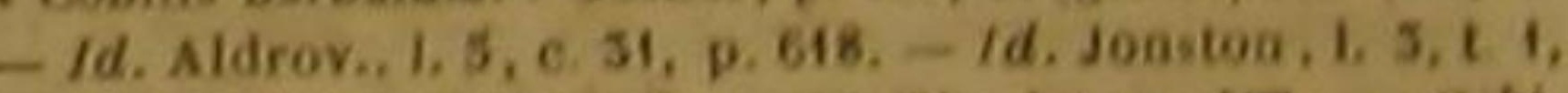
c. 12, art 5, tab. 20. fig. 22. - Id. Eharlet.. p 157. - . Cobi.

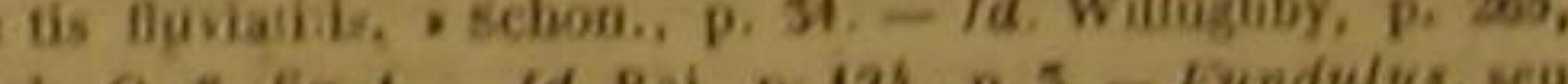
lab. Q 8, tig. 1. - Id. Rai, p. 121, D. S. - Fundala, se

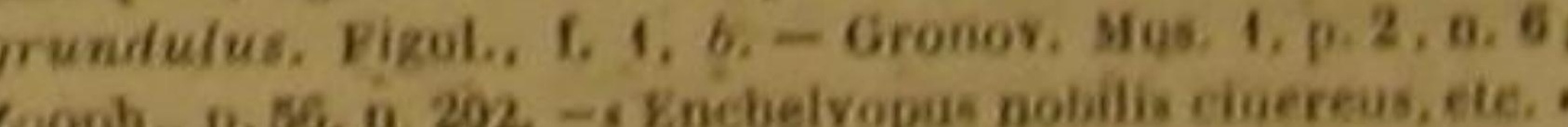

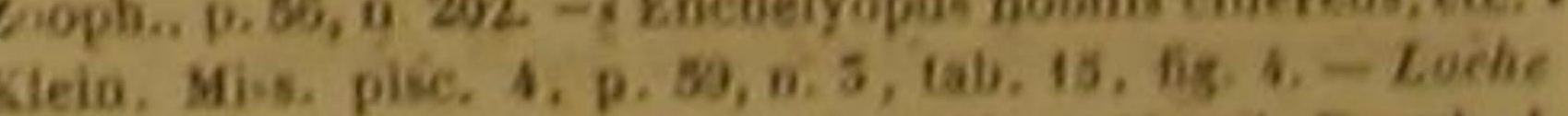
poudriet, part, 2, c. 28. - Vundulus Marsil Dasub, 4. p. 74. tob, 23, 6g. 1, - Loche, Bric Zoot. 3, p. 257, U. .

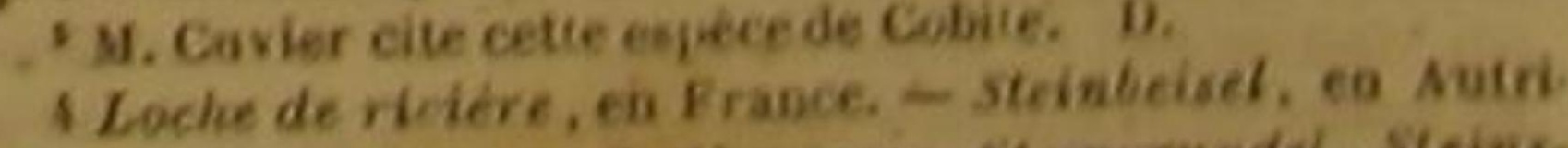

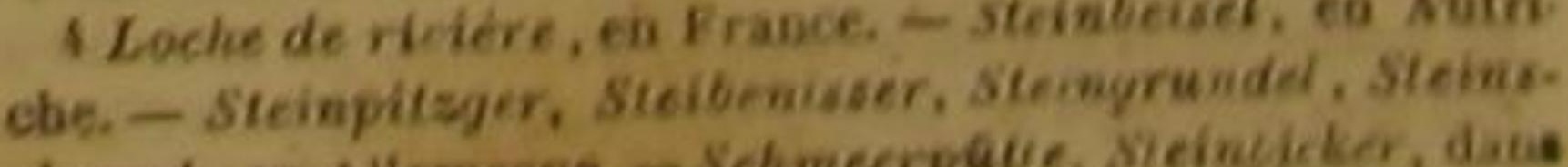

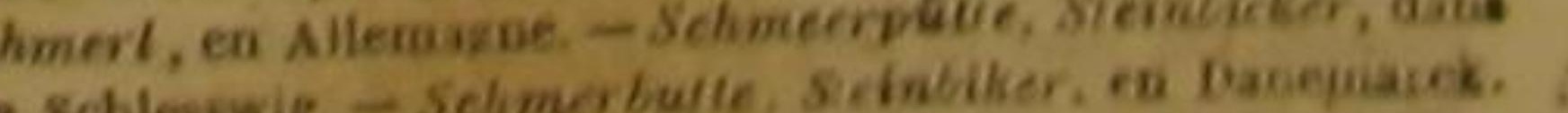

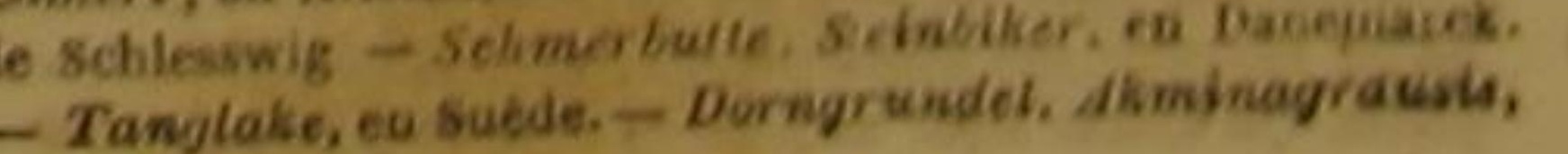


ces : mais le goût de sa chair est très-agréable; deux époques, sa chair est sí délicate, qu'on la thes de l'Europe, on a prefere a celle de presque tous les autres dorné beaucoup d'attention, et des soins très- tants des eaux, surtout, disent dans certain multipliés à ce poisson. On le trouve le plus pays les hommes occupés des recherches les plus souvent dans les ruisseaux et dans les petítes minutieuses relatives à la bonne chère, lorsrivières qui coulent sur un fond de pierres ou qu'elle a expiré dans du vin ou dans du lait. de cailloux, et particulièrement dans ceux qui Elle meurt trì-vite dès qu'elle est sortie de arrosent les pays montagneux. Il vit de vers et l'eau, et mème dès qu'on l'a placée dans queld'insectes aquatiques. Il se plât dans l'eau cou- que vase dont l'eau est dans un repos absolu. rante, et parait éviter celle qui est tranquille : On la conserve, au contraire, pendant longmais des courants trop rapides ne lui convien- temps en vie, en la renfermant dans une sorte nent pas; et c'est ce que nous a appris, dans des de huche trouée que l'on met au milieu du counotes manuscítes très-bien faites, $\mathbf{M}$. Pénières, rant d'une rivière. membre du Tribunat. Nous avons vu dans ces notes, qu'il a bien voulu rédiger pour nous, que, dans les rivières des départements du Cantal et de la Corrèze, la loche préfére les eaux profondes, et même quelquefois les eaux dormantes, à celles qui sont très-agitées et très-battues. Elle change rarement de place dans ces portions de rivière dont lé courant est moins fort; elle s'y tient comme collée contre le sable ou le gravier, et semble s'y nourrir de ce que l'eau y dépose.

Elle est la victime d'un très-grand nombre de poissons contre lesquels sa petitesse ne lui permet pas de se défendre; et malgré cette mème petitessequi devrait lui faire trouver si facilement des asiles impénétrables, elle est la proie des pécheurs, qui la prennent avee le carrelet, avee la louve et avec la nasse '. On la recherche surtout vers la fin de l'automne, et pendant le printemps, qui est la saison de sa ponte. A ces

en Livonie. - Cobitie loche. Daubenton et Haay, Enc., méth.

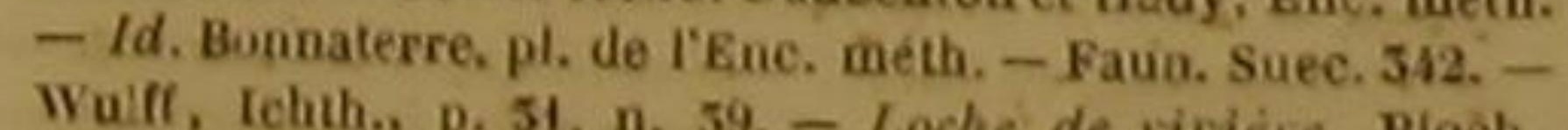

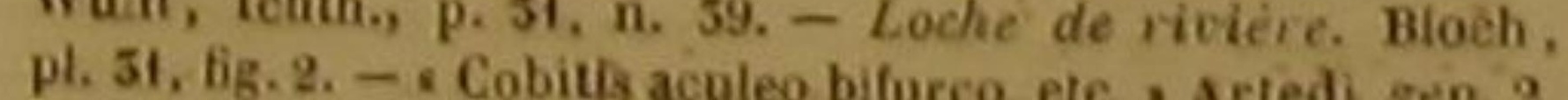

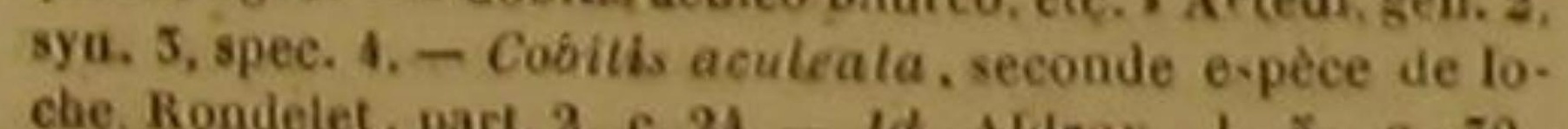

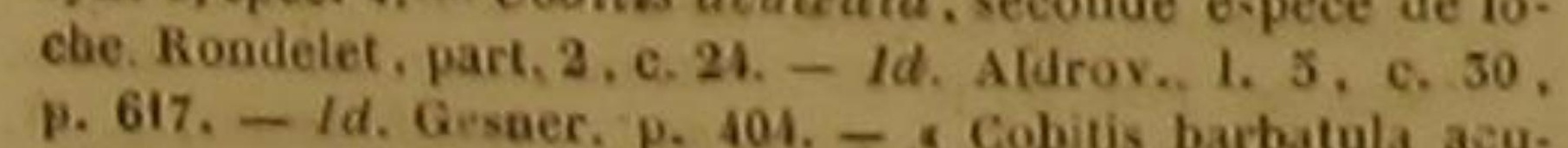

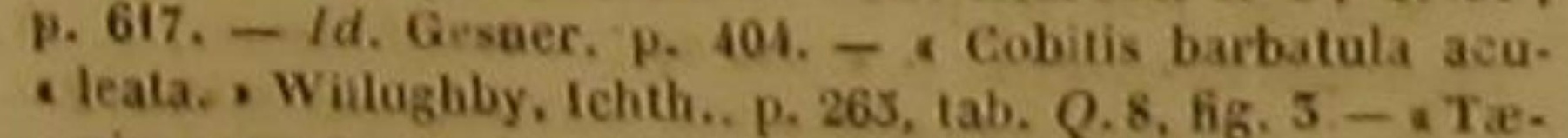

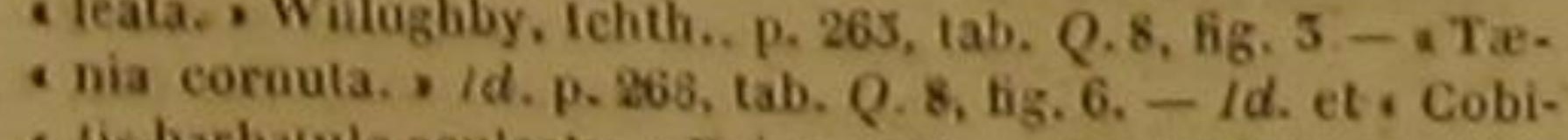

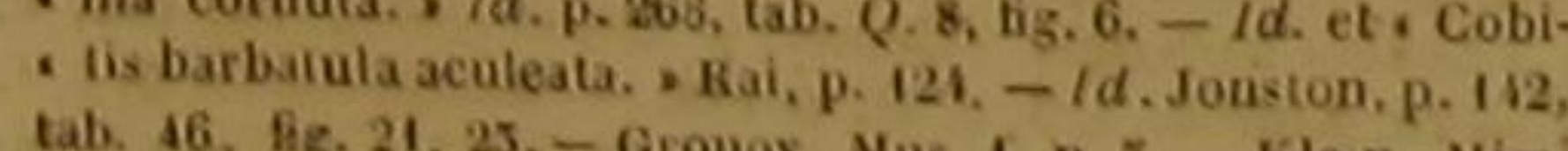

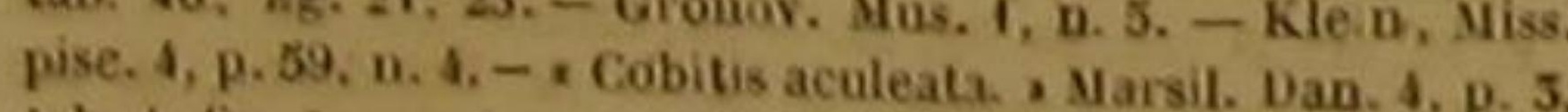
tab. 1, tig. 2. - - Lampetra, et cublitis pungews., Frisch.

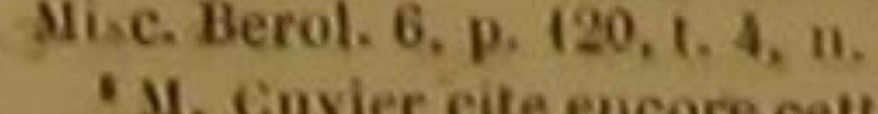
. Cuvier eite evcore cette espece.

diquee par M. Cuvier. D. ivasez, a farticle da Petromyson timproie, ce que

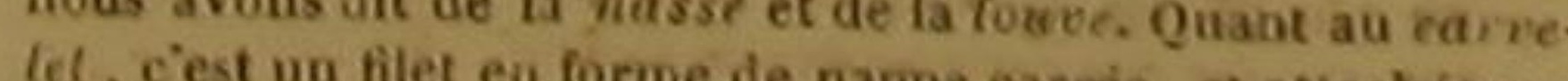
le. quatre coins aux estremitits de deuir are, et attachée par

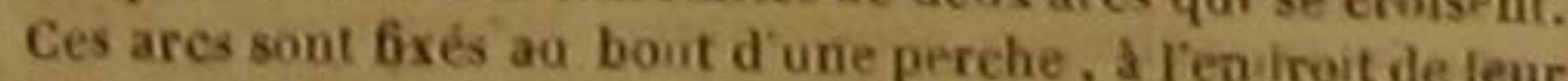
réuoium. On tend ce filet sur le tond des rivières; et dias Qu on appreroir des poissons au-cessus, an le releve avec rapionte. On donne aussi au currefer les noms de calen, de
Lorsqu'on veut la transporter un peu loin, on a le soin d'agiter continuellement l'eau du vaissit un temps frais, comme, par exemple, la fin de l'automne. C'est avec cette double précaution que Frédéric I"r, roi de Suède, fit venir d'Allemagne des lochés qu'il parvint à naturaliser dans son pays '.

Quand on veut faire réussir ces cobites dans une rivière ou dans un ruisseau, on pratique une fosse dans un endroit qui ait un fond de ailloux, ou qui reçoive l'eau d'une source. On donne à cette fosse deux pieds ou deux pieds et demi de profondeur, huit pieds de longueur et quatre de largeur. On la revêt de claies ou planches percées, qu'on établit cependant à une petite distance des cótés de la fosse. L'intervall compris entre ces cótés et les planches ou les claies, est rempli de fumier, et, quand on le peut, de fumier de brebis. On ménage deux ouvertures, l'une pour l'entrée de T'eau, et l'autre pour la sortie du courant. On garnit ces deux ouvertures d'une plaque de métal percée de plusieurs trous, qui laisse passer l'eau courante, mais fermel'entrée de la fosse à tout corpsétranger nuisible et à tout animal destructeur. On place dansle fond dela fosse, des cailloux ou des pierre usqu'à la hauteur de six ou huit pouces, afin de faciliter la ponte et la fécondation des œufs. Les loches qu'on introduit dans la fosse s'y nourrissent des sucs du fumier et des vers qui s'y engendrent. On leur donne néanmoins du pain de chènevis ou de la graine de pavot. Flles multiplient quelquefois à un si hant aegré das leur demeure artificielle, qu'on est obligé de construire trois fosses, une pour le frai, une seconde 'Voyez le Discours intitulé Des effels de lart de Phommo
sur la nature des poissons. seau dans lequel on la fait entrer, et l'on choi-
DES POISSONS.

447

pour l'alevin ou les jeunes loches, et une troisième pour les loches parvenuesà leur développement ordinaire.

Au reste, on peut conserver longtemps ces cobites et les envoyer au loin, après leur mort, en les faisant mariner.

La loche a la máchoire supérieure plus avanéé que l'inférieure; l'ouverture de la bouche, petite; la ligne latérale droite; la nageoire du dos très-courte et placée, à peu près, an-dessus des ventrales; le corps et la queue marbrés de gris et de blanc; les nageoires grises; la dorsale et la caudale pointillées et rayées ou fascées de bruo; le foie grand, ainsi que la vésicule du fiel; le canal intestinal assez court; Y'épine dorsale composée de quarante vertèbres, et fortiflée par quarante cótes.

Parmi les poissons d'eau douce ou de mer dont on a reconnu des empreintes dans la carrière d'OEningen, près du lac de Constance.' on doit compter le cobite Ioche: On doit comprendre aussi au nombre de ces poissons le cobite trenia.

Ce dernier cobite se trouve dans les rivières comme la loche; il s'y tient entre les pierres. II se nourrit de vers, d'insectes aquatiques, d'cufs, et mème quelquefois de très-jeunesindividus de quelques petites espèces de poissons. II perd la vie plus difficilement que la loche; et quand on le prend, il fait entendre une espèce de bruissement semblable à celui des balistes, des trigles, des cottes, des zées; ete. Bloch ayant mis deux tænias dans un vase plein d'eau de rivière etdanis le fond duquel il avait étendu du sable, les vit s'agiter sans cesse et remuer perpé tuellement leurs lèvres.

La chair des tænias est maigre et coriace; et d'ailleurs, ils sont d'autant moins recherchés que l'on ne peut guère les saisir sans être piqué par les petits aiguillons situés auprès de leurs yeux. Mais s'ils ont moins à eraindre des pêeheurs que les loches, ils sont la proie des persèques, des brochets, et des oiseaux d'eau.

Leur ligne latérale est à peine sensible; ils n'atteignent qu'à la longueur de quatre à huit pouces. Leur dos est brun; leurs cótés sont jaunâtres, avec quatre rangées de taches brunes, inégales, et irrégulières; les pectorales et l'anale sont grises; une nuance jaune distingue les ventrales; la dorsale est jaune et ornée de

- Voyage dans les Alpes, par Saussure, s 1535. cinq rangs de points bruns; la caudale montre sur un fond gris quatre ou cinq rangées transversales de points; le fole est long; la vésicule du fiel, petite; le canal intestinal sans sinùosités; l'épine du dos formée de quarante vertè bres; et le nombre total des cốtes, de cinquantesix.

Nous devons à M. Noëlla deseription du eobite trois-barbillons, qui se plait dans les ruisseaux d'eau courante et vive des environs de Rouen, et quel'on trouve, vers l'équinoxe du printemps, gras et plein d'ceufs ou de laite. Sa partie supérieureest d'un roux brun, et parsemée de taches arrondies ; l'inférieure est d'un fauve clair, ainsi que les nageoires. La dorsale et la nageoire de la queue sont pointillées de noirátre le long de leurs rayons '

\section{CENT CINQUANTE-CINQUIEME GENRE.} LES MISGURNES ${ }^{2}$.

Lo eorps et la queue eylindriques; la peau gluante, et dénuto d'ecailles facilement visibles; les yeux writsPillons aux machoires; une seulo dorvale; cellio nageoire trid-courle.

šikex.

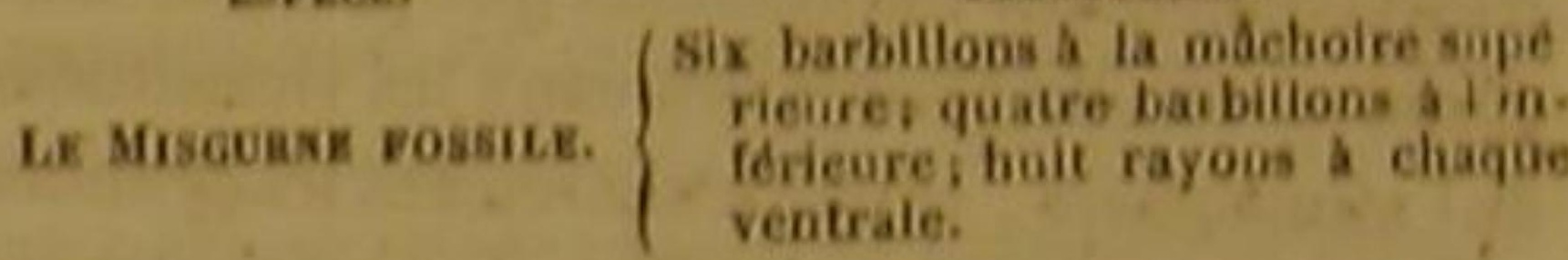

LE MISGURNE FOSSILE ${ }^{3}$.

Cobitis fossilis, Linn., Gmel., Guv, ; Misgurnus fossilis, Lac."

Ce poisson habite dans les étangs; on ne le voit du moins dans les laes et dans les rivieres,

If rayons a la membrane branchiale du cobite loche, 100 chaque pectorale, 9 a la nageoire da dos, 8 a celle de fanos,
it a is nageoire de la queue. -5 rayons a ta membraos

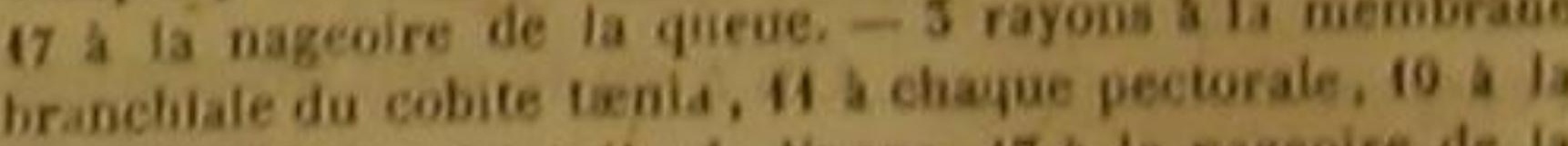
Gageoire da dos, 9 a ceille de Yaass, 17 a la nageoire de in

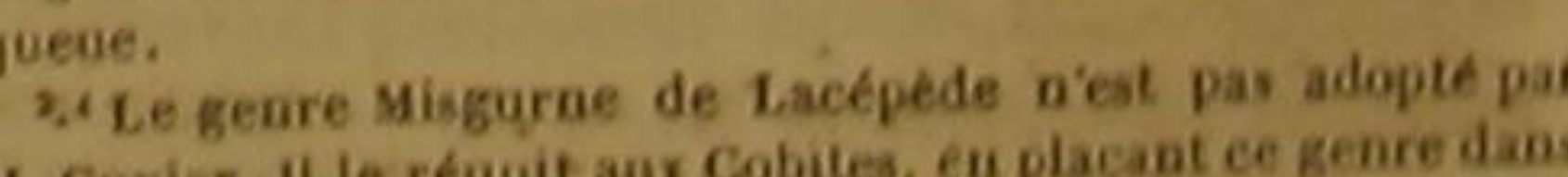
3. Cuvier. Il le réauit aux Cobites, en placant ce genre dan la famille des Cy
dominaux, D.

"Loche de elang, en Prance. - Fisgurn, Schlammpilsger.

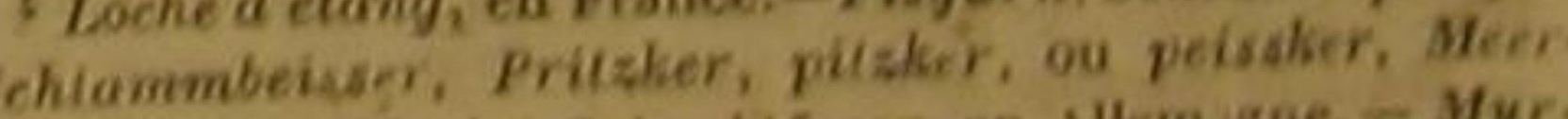
trusche, Pfulfasch, Schachifegen ea Allew gae, - Mur dal, en Boliéne. - Prisker, Plikste, en Liv nusie. - Mis.

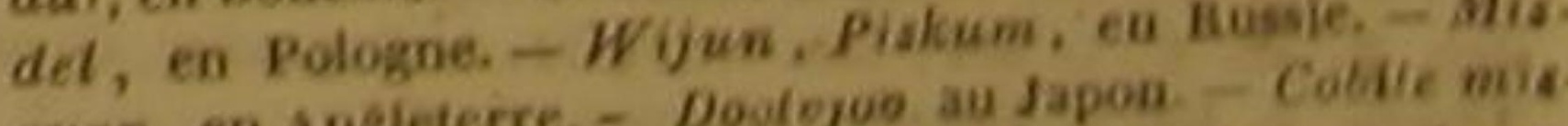
gurn, en Angieterre. - Doulogoo au Japon.-Cokive mis

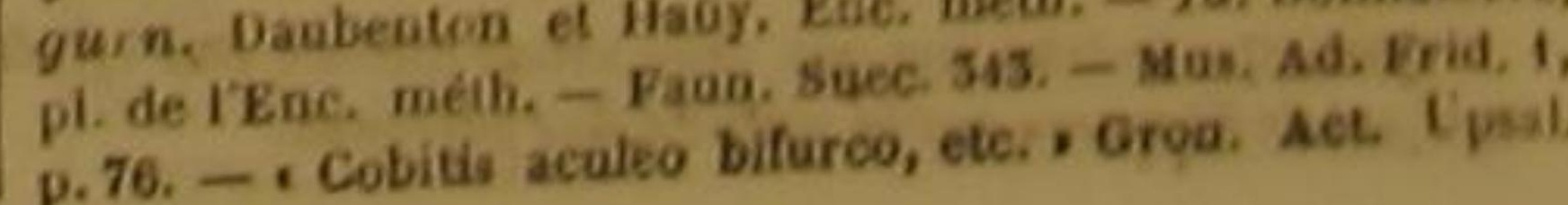
rapproehes du sommet de la lete; des dents el des bar 
HISTOIRE NATURELLE

que lorsque le fond en est vaseux. Il perd difficilement la vie. Il ne périt pas sous la glace, pour peu qu'il reste de l'eau fluide au-dessous de celle qui est gelée. Il ne meurt pas non plus lorsqu'il se trouve dans un marais que l'art ou la nature dessèchent, pourvu qu'il y reste quelque portion d'eau, quelque bourbeuse qu'elle puisse être : il se cache alors dans les trous qu'il creuse au milieu de la fange. On le rencontr sóuvent dans les cavités dè la terre humide qui faisait le fond d'un marais oud'un étang dont on vient de iaire écouler l'eau. C'est ce qui a fai croire à quelques auteurs qu'il s'engendrait dans la terre, et qu'il n'allait dans les rivière ou les lacs, que lorsque les inondations l'attejgnaient dans son asile et l'entrainaient ensuite Mais au lieu de cette fable qui a èté un pèu accréditée et qui lui a fait donner le nom de Fo. sile, il aurait fallu dire que, d'après tous ce faits, il paraissait que le misgurne dont nou parlons est beaucoup moins sensible que presque tous les autres poissons, aux effets funestes les gaz qui se forment au-dessous de la glace, u que produisent lesmarais qui, au lieu d'eau courante ou tranquille, ne présentent qu'une sorte de boue délayée et d'humidité fétide'.

Cependant cet abdominal semble ressentir très-vivement les impressions que peuvent fair eprouver aux habitants des eaux les vicissitade de l'atmosphère, et particulièrement les grandes variations que montre dans certains temps l'électricité de l'air et de la terre. On a remarqué que lorsque l'orage menace, ce misgurn quitte le fond des étangs pour venir à leur surface, et s'y agite, comme tourmenté par une gène fatigante, ou par une sorte de vive inquiétude. Cette habitude l'a fait garder avee soin dans des vases par plusieurs observateurs. On l'a piacé dans un vaisseau rempli d'eau de pluie ou de rivière, et garni, dans le bas, d'unecouche de terre grasse. $0 \mathrm{n}$ a eu le soin de change la terre et l'eau tous les trois ou quatre jour

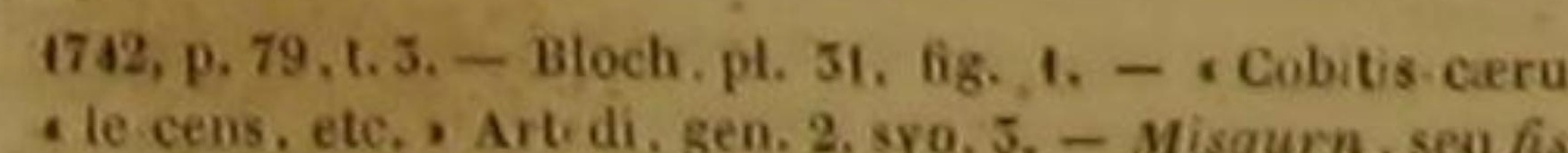
A le cens, ete,, Art di, gen. 2, syo. 5. - Misgurn, sea fis-

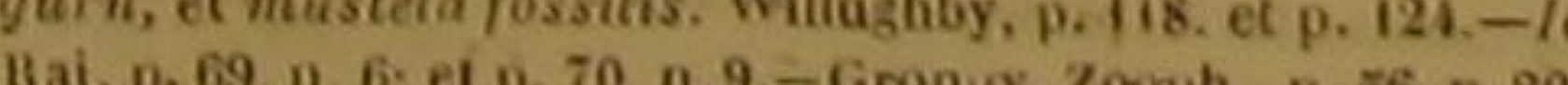
Mus, p. 69, 1. 6; et p. 70, n.9.-Groniv. Zooph., p. 56, n. 20 -Mustela fossilis. Alirov. Pise, p. 579. - Jon, 15, fig. p. 15i, tab. 28, fig. 8. - Marsil. Dasub. 4, p. 59, tab, 15, fig . Thermometrum rioum. Clauder, Ephem. nat, curios.
dec. 2, an. 6, p. 351 , ubs. 175, L. 71. - Beysaker. Gesn.
Thierb., p. 160. - Pacilia. Schonev., p. 56. thierb., p. 160. - Pcenila. schonev., p. 56. 'Consultez le Discours que nous avons intitulé Des effets
de lart del'homme surla nature des poissons.

pendant l'été, et tous les sept jours pendant l'hiver. On l'a mis pendant les froids dans un chambre chaude, auprès de la fenêtre. On l'a gardé ainsi pendant plus d'un an. On l'a vu rester tranquille pendant le calme, sur la terre humectée, mais se remuer fortement pendant la tempête, même vingt-quatre heures avant que l'orage n'êclatât, monter, descendre, remonter, parcourir l'intérieur du vase en différents sens, et -en troubler le fluide. C'est d'après cette observation qu'il a été comparé à un baromètre, et qu'il a été nommé baromètre vivant.

Il parvient à la longueur d'un pied ou un pied et demi, et quelquefois il a montré celle de trois ou quatre pieds. Ayant beaucoup de rapports par sa conformation extérieure avec la murène anguille, il n'est pas surprenant qu'il puisse facilement, comme cette dernière, s'insinuer dans la terre molle, et y pratiquer des cavités proportionnées à son volume; et c'est ce qui fait qu'il se retire dans la fange ou dans la vase, non-seulement lorsque le dessèchement des étangs ne lui permet pas de demeurer audessus de leur fond privé d'eau presque en entier, máis encore lorsqu'il veut éviter une action trop vive du froid qui parait l'incommoder. Cette précaution qu'il prend dese renfermer sous terre lorsque la température est moins chaude, l'a' fait appeler Thermomètre vivant, comme les mouvements qu'il se donne lorsque le temps est orageux, l'ont fait désigner par le nom de Baromètre vivant ou animé.

Le misgurne fossile sort de son habitation souterraine lorsque le printemps est de retour. Il va alors déposer ses œufs ou sa Iaite sur les herbages de son marais.

Il se nourrit de vers, d'insectes, de très-petits poissons, et de résidus de substances organisées qu'il trouve dans la vase. Il multiplie beaucoup; et néanmoins il a bien des ennemis à craindre. Les grenouillesl'attaquentavec succès, lorsqu'il est encore jeune, les écrevisses le saisissent avec leurs pattes, et le pressent assez fortement pour lui donner la mort; les persèques, les brochets, le dévorent; les pécheurs le poursuivent. Ils le prennent rarement à l'hamecon, auquel il ne se détermine pas facilement à mordre; mais ils le pêchent avec des nasses garnies d'herbes, avec des filets et particulièrement avec la truble'.
DES POISSONS.

Il n'est cependant pas très-recherché, parce | noires surun fond jaune; les ventrales et l'anale que sa chair est molle, imprégnée d'un goùt de sont jaunes ou jaunàtres.

marécàge, et enduite d'un suc visculux. On lui ote cette substance gluante, en le plongeant dans un vase dont l'eau contient du sel marin, ou des eendres. L'animal s'y remue, s'y contourne, s'y tourmente, s'y purifie, pour ainsi dire; et on le lave ensuite dans dé l'eau douce. Cette matière gluante dont le misgurne fossile est couvert, aussi bien que pénétrě, influe sur ses couleurs; elle en détermine plusieurs nuances ; suivant qu' elle est plus ou moins abondante, elle en fait varier quelques tons; et comme les différentes eaux peuvent, suivant leur pureté ou leur mélange avec des substances étrangères, agir diversement sur. cette liqueur visqueuse, en dissoudre ou en emporter plus ou moins, en diminuer plus ou moins la qualité et l'influence, les eouleurs du fossile varient suivant la nature des eaux qu'il habite. Ce qui lo prouve d'ailleurs, e'est que lorsqu'on nettoi avee de l'alcool, ou de toute autre manière, le ventre de ce misgurne, la belle couleur jaune de cette partie disparait entièrement.

Voici cependant quelles sont les couleurs les plus ordinaires de cet abdominal. Son dos est noirâtre; il est orné de raies longitudinales jaunes et brunes sur lesquelles on apercoit quelques taches. Son ventre brille d'une teinte orangée que relèvent des points noirs. Les joues et les membranes branchiales sont jâunç et parsemées de taches brunes. La dorsale, les pectorales et la caudale montrent des tąches

dont les bords sont altachés a la circonférence d' un cercle de bois ct de fer, auquel on ajuste un manche. Un pécheur qui passe le truble pardessous ces animaux, et le reléve a lins. last, de maniêre quilis se trouvent pris danis la poche. Oa ise sert aussi du truble poor s'emparer des poissons pris dans les bourdigues, ou pour enlever ceax qui ont morda a thamecon, mais qui par leur poids pourraient rompre les lignes. des pienx ou des fitetsices cloisons convergent vers le ciecte rant. Oa les éleve dans les canaua qui communiguent des tangs dans la mer, pour prendre les poisons goi vepient regagner l'eau salée. 11 y a des $t$ rubles carrés qui sont plin conmodes pour preadre les polssons reniernes dans des it servoirs particulicrs. Ceux que ton nomme dans queliques Care de cette sorte de capuchon est allarbe a an. L ouverture quatrè bátons suspendus au bout d'une perche. On amorce cet instrument avec des vers de terre, qu'on enfile par I milieu du corps, et qu on attache de maniere qu: lorsque it

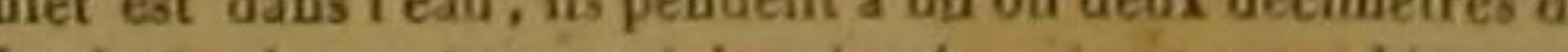
lond. On s ea sert pour pecher des ecrevisses, aussi bien que ane petile trable. Poissor. Le irublean est and peut or
Le museau du misgurne fossile est un peu pointu ; l'orifice de sa bouche allongé; chacune de ses mâchoires garnie de douze petites dents; sa langue menue et pointue; l'orifice de ses nalínes placé auprès d'un piquant; sa nuq̣ue large; sa caudale arrondie; sa dorsale courte, tête.

Ses écailles minces, légèrement rayées, demitransparentes, paraissent transmettre uniquement les numces de la peau produites ou modifiées par la substance visqueuse qui l'arrose'. L'estomac est petit; lo canal intestinal court et aans sinuosités; le foie long; la vésicule du fiel grande; l'ovaire double ainsi que la laite. Les aufs sont brunâties, et de la grosseur d'une graine de pavot.

Bloch a éerit que le fossile ne rejetait pas de bulles d'air ou de gaz par la bouche; qu'il en rendait par l'anus, et que cette différence venait de ce que ce poisson manquait de vessie aérienne ou natatoire. Il a pensé aussi que cet abdomina! avait auprès de la nuque deux vésicules remplies d'une substancelaiteuse. Maisle profes. seur' Sclneider ayant disséqué plusieurs individus de l'espece de misgurne que nous décrivons, a montré que ce poisson n'avait auprès de la nuque qu'une seule vésicule; que cette vésicule tait ossćuse, déprimée dans le milieu et arrondie dans les deux bouts, de manière à paraitre double; qu'elle était attachée à la troisieme et à la quatrieme vertébre; que ses apophyses ou ses appèndiees latérau x servaient de point d'attache aux muscles des nageoires pectorales; que cette sorte de boíte osseuse contenait une véritable vessie aérienne; que cette vessie aérienne ou natatoíre était peu volumineuse, simple, membraneuse, blanche; et qu'elle communiquait avec l'osophage par un conduit tres-petit et très-court ${ }^{2}$.

Ce savant proiesseur ajoute, dans son excellent ouvrage, qu'il n'a jamais vu le misgurne fossile rendre des bulles d'air par lanus, mais que cet abdominal en rejette trés-souvent par la bouche ${ }^{3}$, en faisant entendre un bruissement très-sensible 4

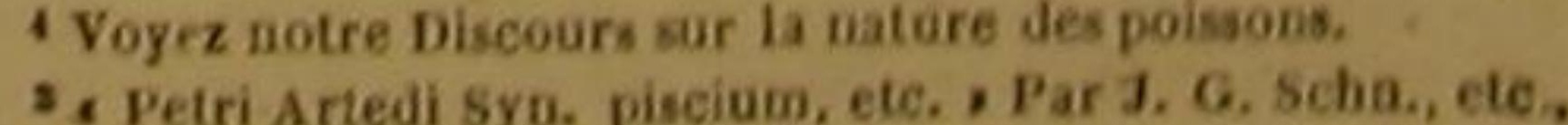

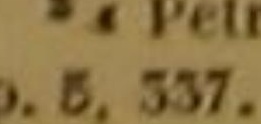

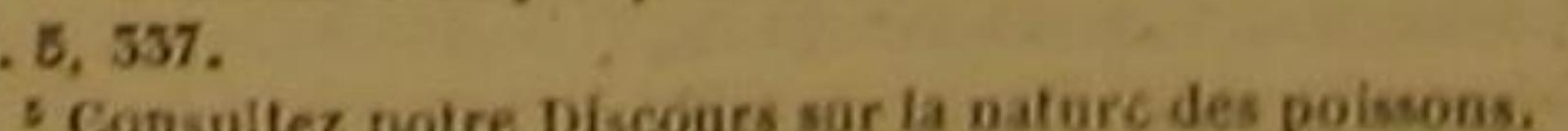

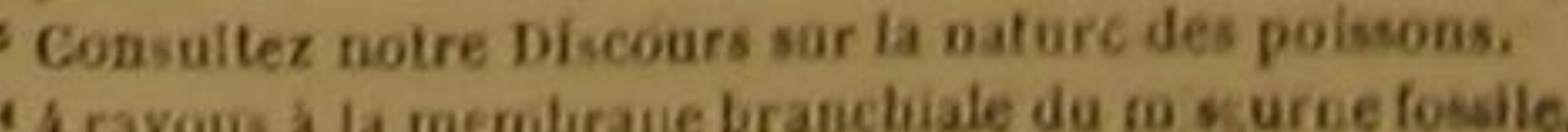
et plus près de la nageoire de la queue que de la 


\section{CENT CINQUANTE-SIXIÈME GENRE}

LES ANABLEPS '.

Lo corps el la queue presque cylindriques, des barbillons des dents aux machoires; une seulo nageoire du chaque ceil.

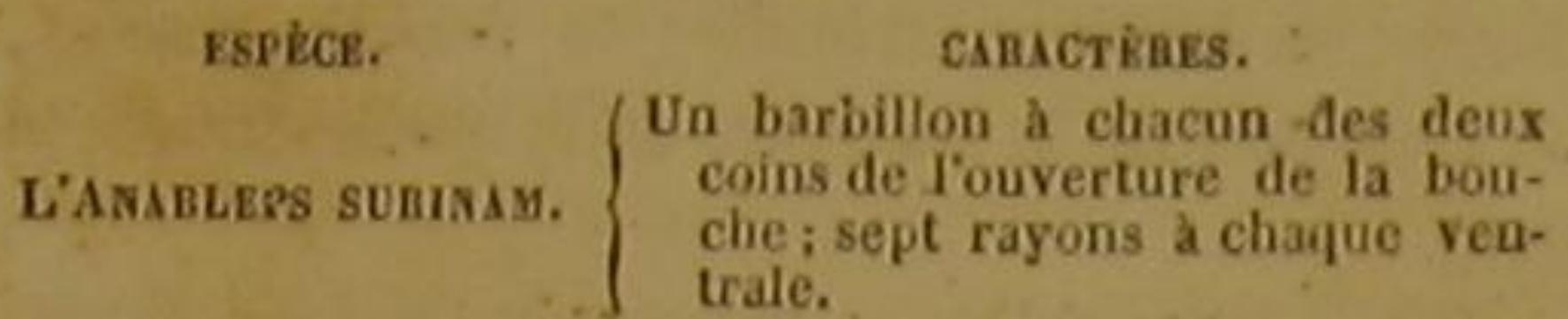

L'ANABLEPS SURINAM ${ }^{2}$

Anableps tetrophthalmus, Bl. ; Anableps surinamensis, Lac.; Cobitis Anableps, Gmel.?.

On trouve à Surinam, dans les rivières, et près des rivages de la mer; ce poisson très-digne de l'attention des physiciens par les singularités de sa conformation. On peut voir dans lesecond volume des Mémoires de la classe des sciences physiques et mathématiques de l' Instilyt national, une notice que nous avons lue devant nos confrères en juillet 1797, sur ce poisson-remarquableet particulièrement sur la strùcture extraordinaire de son organe de la vue. Nous allons réunir iei à ce que nous avions découvert dans la conformation de cet animal, lors de cette époque, ce que nous avons appris depuis sur le même sujet.

La tête de l'mableps surinam est couverte de petites écailles, plus large que haute, et comme trònquée et même échancrée par devant. La máchoire supérieure, plus ảvancée que l'inférieure, s'allonge et se replie vers le bas. Ces deux mâehoires, la langue et le palais sont hérissés de petites dents. On ne compte qu'un orifice à chaque narine.

Mais l'œil de cet anableps est l'orwane de ce poisson qui mérite le plus l'examen de l'observa-

A la dorsale, 11 a chaque pectorale, 8 a la nageoire de lanus, 4 a ceile de la queue, 48 vertebres a lépine da dos, 50 cótes de chaque cóte de l'épine dorsale.

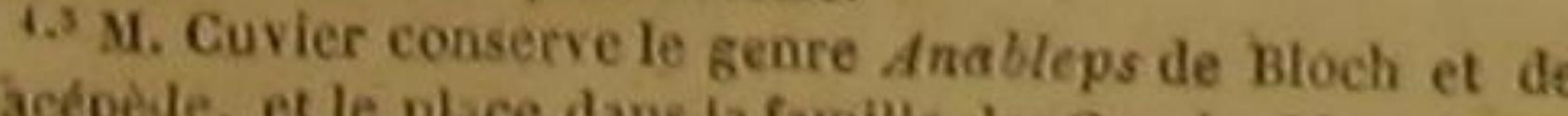
des Salacoptếrygícns abdominaux. D. Gros-yeux, par plus, Francis, Memands. - Four-eye, par les Anglais. - Hooe, par les

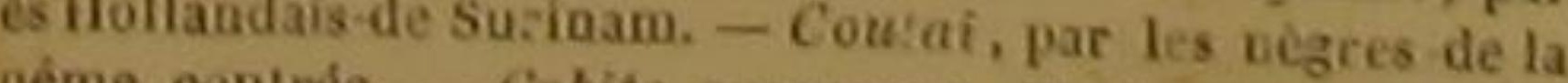

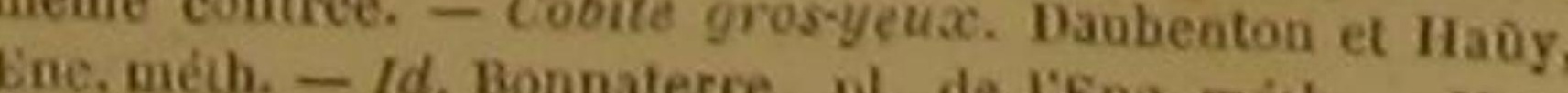
Ad. Frid. 2, p. 93, - Anableps. Ar IEne, méth. - Mus. d. Seba, Mus. 5, p. 108, tab. 54, As 7.

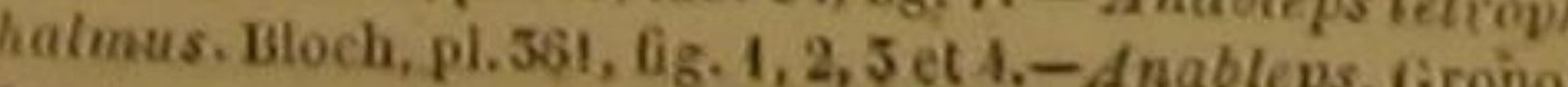
Mue. 1, n. 52, tab. 1, fig. 1.5. teur. Voici ce que nous en avons publié dans l'ouvrage que nous venons de citer:

" L'cil de l'anableps est placé dans une orbite dont le bord supérieur est très-relevé; mais il est très-gros et très-saillant.

- Si l'on regarde la cornée avec atténtion, on “ voit qu'elle est divisée en deux portions très" distinctes, à peu près égales en surface, fai" sant partie chacune d'une sphère particulière, a placées l'une en haut et l'autre en bas, et réu" nies par une pétife bande étroite, membra" neuse, peu transparente, et quiest à peu près “ dans un plan horizontal, lorsque le poisson est dans sa position naturelle.

a'Sil'on considèreensuite la cornée inférieure, on apercevra aisément au travers de cette cornée un iris et une prunelle assez grande, au delà de laquelle on voit très-facilement le " cristallin. Cet iris est incliné de dedans en dehors, et il va s'attacher à la bande courbe et horizontale qui réunit les deux cornées.

" Il a été vu par Artédi, ainsi que les deux cornées; maís là cesse la justesse des observations de cet habile naturaliste, qui n'a eu apparemment à sa disposition que des individus ma conservés. S'il avait examiné des amableps moins altérés, il aurait aperçu un second iri percé d'une seconde prunelle, placé derrière la cornée supérieure, comme le premier iris est situé derrière la cornéé d'en bas, et aboutissant également à la bandelette córbe et horizontale qui lie les deux cornées '.

" Les deux iris se touchent dans plusieurs points derrière cette bandelette. Ils sont les deux plans qui soutiennent les deux petite calottes formées par les deux cornées, et sont inclinés l'un sur l'autre, de manière à produire un angle très-ouvert.

« Danstous lesindividus que j'ai examinés, la prunelle de l'iris superieur m'a paru plus grande que celle de l'inférieur; et, d'après la difference de leurs diamètres, il n'est pas surprenant que l'on voie le cristallin encore mieux au travers de cette ouverture qu'au travers de la seconde. Il semble même quelquefois qu'on apercoive deux cristallins; et c'est ce qui justifie, jusqu'à un certain point,

' Depuis la lecture de ce Mémoire à la classe des sciences physiques et mathématiques de Tinstitur, nons a arons rences France la pariie de l'Ichithyologie de Bloch dans lagnelle savant a donné une description très détaillée de loxil de l's.
nableps surinam.
" était double. Mais ce n'est qu'une illusion a d'optique, dont je-me suis assuré en dissé" quant plusieurs yeux d'anableps; et qu'il est " aisé d'expliquer.

a En effet, la réfraction produite par la difference de densité qui se trouve entre les humeurs intérieures de l'ceil et le fluide extériem qui le baigne, doit faire que ceux qui exami- nent l'wil de l'anableps sous un certain angle, a voient le cristallin plus élevé qu'il né l'est réellement, s'ils le considêrent par f'ouver- ture de l'iris supérieur, et plus abaissé, au - contraire, s'ils le regardent par l'ouverture de l'iris inférieur. Lorsqu'ils l'observènt en même temps par les deux ouvertures, ils l'apercoivent à la fois plus haut et plus bas qu'il ne - l'est dans la réalité; et ils le volent en haut et en bas à une assez grande distance de sa véri" table place, pour que les deux images se séparent, et que le cristallin paraisse double. Il n'y a done qu'uñ seul organe dé la vue de chaque cóté ; car chaque wil n'a qu'un cristal" lin, qu'une humeur vitrée, et qu'une rétine: - mais chaque ail a plusteurs parties princi" pales doubles, une double cornée, une double a cavité pour l'humeur aqueuse, un double iris, - une double prunelle; et c'est ce que personne " n’avait encore vérillé ni même indiqué, et a qu'on ne retrouve dans atcune classe d'anj- maux vertébrés et à sang rouge.

" Chaque cornće appartenant à une sphère a- particulière, le centre de leurs courbures n'est a pas le mème; et comme le cristallin est sensi« blement sphérique, ainsi que dans presque " tous les poissons, il n'y a pas, dans ce dernier - corps, deux réfractions différentes, l'une pour " les rayonis qui ont traversé la première cornée, a et l'autre pour ceux qui ont passé au travers - de la seconde. Il doit done y avoir sur la rétine a deux foyers principaux, à l'un desquels ara rivent les rayons qui viennent de la cornée " supérieure, et dont l'autre recoit ceux qu'a a laissé passer la cornée inférieure. Voilà donc " encore un foyer double à ajouter à la double * cornée, à la double cavité, au double iris, à a la double prunelle; mais ce foyer et ces autres " parties doubles appartiennent au même or" gane, et il faut toujours dire que l'animal n'a - qu'un œil de chaque côté.

a Les iris de plusieurs espèces de poissons * paraissent ne pouvoir pas se dilater, ni dimi-
" nuer par leur extension l'ouverture à laquelie le nom de prunelle a été donné : mais je me is suis convaincu que ceux de plusieurs autres " espèces de ces animaux s'étendent et raccour" cissent les dimensions de la prunelle. Le plus a souvent mème ces derniers iris sont organisés " de manière que la prunelle, comme celle de ^ plusieurs quadrupèdes ovipares, de plusieurs a serpents, de plusieurs oiseaux, et de quelques “ quadrupedes à mamelles, diminue au point de a ne laisser passer qu'un très-petit nombre de " rayons de lumière, en se changeant en une " fente très-peu visible, verticale ou horizontale, a et cette organisation peut, dans certains pois" sons, compenser jusqu'à un certain degré le " défaut de vérítables paupières et de vraies a membranes clignotantes, que de savants na" turálistes ont cru voir sur plusteurs de ces a animaux, mais qui ne se trouvent cependant " peut-êtresur aucune de leurs espèces.

" Je ne puis pas dire positivement que les íris « de l'anableps soient donés de cette extensibilité. " Néanmoins une comparaison attentive, et a I'habitude que m'ont donnće plusieurs années a d'observations ichthyologiques, de distinguer "dans les parties des poissons, des traits assez " déliés, me font eroire que les dimensions des " prunelles de l'anableps peuvent aisément ètre a diminuées.

a Il faut remarquer que cetabdominal passe - une partie de sa vie caché presque en entier " dans la vase, comme les poissons de sa famille, a. et que, dans cette position, il ne peut aperce" voír que des objets situés au-dessus de sa tete; a mais qu'assez souvent cependant il nage près a de la surfaee des eaux, et doit alors chereher a à voir, au-dessous du plan qu'il occupe, les " petits vers dont il se nourrit, et les grand poissons dont il eraint de devenir la proie.

- Si l'on était assuré de la dilatabilitéde ses "iris, on pourrait done croire que, lorsqu'il est très-voisin de la surface des eaux, l'iris " supérieur, exposé à une lumière plus vive, se "dilate au point de réduire la prunelle supé- rieure à une petite fente, et que le poisson * voit nettement alors, par la prunelle inférieure “ beaucoup moinsresserrée, les corps placés aua dessous du plan dans lequel il se meut, les " images de ces corps ne se confondant plus - avec des fimpressions de rayong Inmineux "que ne laisse plus passer la prunelle supérieure. 
" On pourrait penser de même que, lors- 1 Le corps du surinam est un peu aplati par“ qu'au contraire l'anableps est caché en partie - dans le limon du fond des eaux, son iris su" périeur, très-peu éclairé, se contracte, sa pru" nelle supérieure s'agrandit en s'arrondissant, " et le poisson discerne les objets flottants au" dessus de lui, sans que sa vision soit troublée a par les effets de la prunelle inférieure, placée " alors, pour ainsi dire, contre la vase, et

" privée, par sa position, de presque toute a clarté.

"Au reste, on doit étre d'autant plus porté à " attribuer aux iris de l'anablèps la propriété de " se dilater, que, sảns cette faculté, les deux " foyers du fond de l'eil de cet animal seraient " souvent simultanémentébranlés par desrayons " lumineux très-nombreux. Mais comment alors " la vision ne serait-elle pas très-troublée, et " comment pourrait-il distinguer les objets qu'il " redoute, ou ceux qu' il recherche?

“D'ailleurs, sans cette mème extensibilité " des iris, la prunelle supérieure serait, pendant " la vie de l'animal, presque aussi grande que "dans les individus conservés après leur mort a dans de l'alcool affaibli : dès lors, non-seule" ment il y aurait souvent deux foyers simulta" nément en grande activité, et par conséquent une source de confusion dans la vision; mais " encore il est aiséde se convaincre, par l'obser" vation de quelques-uns de ces individus con" servés dans de l'aleool, qu'une assez grande " quantité de lumière, passant par la prunelle " supérieure, arriverait souvent jusqu'au fond " de l'oeil et jusqu'à la rétine sans traverser le " eristallin, pendant que ce cristallin serait tra" versé par d'autres rayons lumineux transmis " par cette mème prunelle supérieure; et la vi" sion de l'anableps ne serait-elle pas soumise à "une cause perturbatrice de plus?

" Mais la plupart de ces dernières idées ne " sont que des conjectures; et je regarde uni" quement comme prouvé, que si l'anableps n'a "pas deux yeux de chaque coté, il a dans " chaque oil deux cornées, deux cavités pour - l'humeur aqueuse, deux iris, deux prunelles, - et deux foyers de rayons lo deux pruar

Bloch a examiné des foetus d'anableps; et il a vu que, dans ces embryons, les deux prolongations de la choroïde ne se réunissant pas, et la bande transversale n'étant pas encore sensible, on ne distinguait pas les déux prunelles comme dans l'animal plus avancé en àge. dessus; mais sa queue est presque entièrement cylindrique. On aperçoit à peine la lígne latérale; l'anus est plus près de la caudale que de la tête; la dorsale est encore plus voisine de cette caudale qui est arrondie: ces deux nageoires, ainsi que celle de l'anus et les pectorales, sont revêtues en partie de petites écailles. dans le vèntre de la mère, comme ceux des raies, des squales, de quelques blennies, ete. ; l'ovaire consiste dans deux sacs inégaux, assez grands et membraneux, dans lesquels on a trouvé de jeunes individứs non encore éclos, renfermés dans une membrane très-fine et transparente qui forme l'enveloppe de leur ouf, et placés audessus d'un globule jaunâtre.

La nageoire de l'anus du mâle offre une conformation que nous ne devons pas passer sous silence. Elle est composée de neuf rayons : mais on n'en voit bien distinctement que les trois ou quatre derniers; les autres sont réunis au moins à demi avee un appendice conique couvert de petites écailles, et placé au-devant de la nageoire. Cet appendice est creux, percé par le bout, et communique avee les conduits de la laite et de la vessie urinaire. C'est par l'orifice que l'on voit à l'extrémité de ce tuyau dont la longueur égale la hauteur de l'anale, que l'anableps surínam rend son urine, et laisse échapper sa liqueur séminale, au lieu de faire sortir l'une et l'autre par l'anus, comme un si grand nombre de poissons.

Les jeunes anableps éclosant dans le ventre de la mère, il est évident que les œufs sont fê. condés dans l'ovaire, et par conséquent qu'il y a un véritable accouplement du mâle et de la femelle. Cette union doit être même plus intime que celle des raies, des squales, de quelques blennies, de quelques silures, parce que le mâle de l'anableps surinam a un organe génital extérieur dont il parait que l'extrémité, malgré la position de cet appendice contre l'anale, peut étre un peu introduite dans l'anus de la femelle.

La laite est double, mais petite à proportion de la grandeur du mâle. En général, les poissons qui s'accouplent et qui ne fécondent que les œufs renfermés dans les ovaires de la femelle, paraissent avoir une laite moins volumineuse que ceux qui ne s'accouplent pas, et qui parcourent les rivages pour répandre leur liqueur pro-
Les petits de cet anableps sortent de l'wuf lifique sur des tas d'œufs pondus depuis un temps plus ou moins long.

L'estomac est composé d'une membrane mince; le canal intestinal montre quelques sinuosités; et le foie a deux lobes.

De chaque côté de l'animal, on compte cinc raies longitudinales noirâtres qui se réunissent souvent vers la uageoire de la queue.

L'anableps surinam multiplie beaucoup; et les habitants du pays où on le trouve, aiment à s'en nourrir.

vit dans la mer. II s'y tient souvent is in surface, et la tête hors de l'eau. Il se plaít aussi à s'élancer sur la grève, d'où il revient en sautillant, lorsqu'il est effrayé par quelque objet '.

\section{GENT CINQUANTE-SEPTIEME GENRE.} LES FUNDULES ${ }^{2}$.

$L$ corps et ta queme praque cylindriques; des dents et poiat de barbillons aux mdehoires; une seule nageoir du des. esréces.

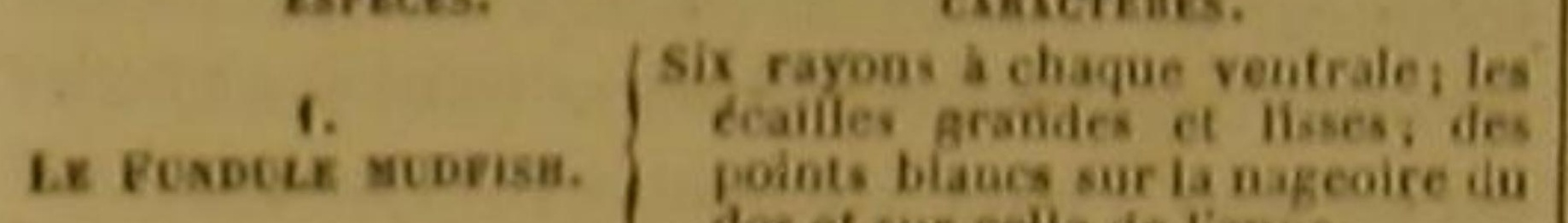
LE FosduL s. arosas. Fuit rayons a chaque ventrale. -

LE FUNDULE MUDFISH ${ }^{3}$, Fundulas Mudfish, Lae; Fundules canicolus, Val. Gur. ${ }^{4}$

\section{ET LE FUNDULE JAPONAIS s.}

Fundulus japonicus, Lac. '

La Caroline est la patrie du mudfish. Sa tête, garmie de petites écailles, est un peu aplatic. La nageoire dorsale est à peu près aussi reculée que celle de l'anus. Les taches rondes et blanchátres que l'on voit sur cès deux nageoires, sont transparentes. La caudale est aussi très-diaphane sur ses bords : elle est d'ailleurs arrondie, et pré-

15 rayons a la membrane branchiale de l'anableps surinam, 7 a la dorsale. 22 a chaque pectorale, 9 a la nageoire de l'anus, 19 a celle de la queue.

ar. 31 . Civier adopte le genre Fundale et le plisee dans la minaile des Cyprinoides, ordre des Malacopterygitns abdo. genre. $\mathrm{D}$.

'Cobite limoneux. Danbenton et Hây, Enc, méth.

Houttayn, Acl. Haarl. XY, 2, p. 337, n. 26,

Nen cité par M. Cuvier. sente non-seulement des taches blanches, mais encore des bandes transversales noires. Le dessous de l'animal montre une nuance jatuastre. Le japonais, qui a été décrit par le savant Houttuyn, n'a pas huit pouces de longueur. Sa grosseur est très-peu considérable, ainsi que celle du mudfish '.

\section{CENT CINQUANTE-HUITIÈME GENRE.}

LES COLUHMNES ?

La lele tris-allongde; sa partio supérieure revelne d'tcailles conformes at disposies commo celles qui recouvent le dessus de la the des couleuvres; lo corps très-allongd; point de nageoire dorsale.

sspice. camscrìnes.

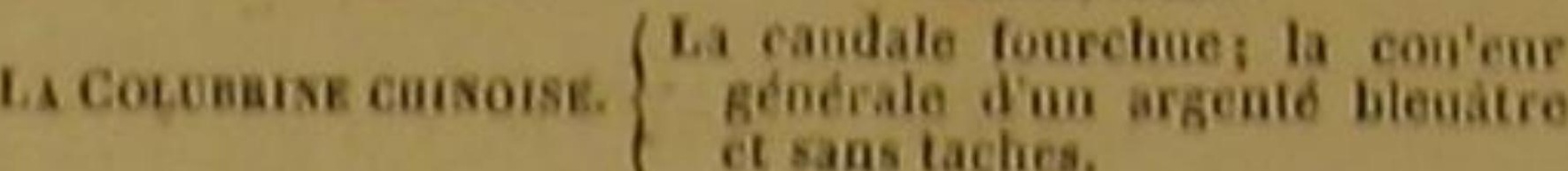

LA COLUBRINE CHINOISE.

Colubrina chinensis, Lác, :

La collection des belles peintures exécutées à la Chine et cédées à la France par la Hollande, renferme une image très-bien faite dô cette espèce pour laquelle nous avons dú former un genre particulier. Ses caractères génériques et ses principaux traits spécifiques sont indiqués sur le tableau de son genre. II montre, ce tableau, combien la colubrine chinoise a de rapports avec les couleuvres. Le défaut de la nageoire du dos, la couverture de la tête, I'allongement de la tête et-du corps, lui donnent surtout beaucoup de ressemblance avec les serpents; et par conséquent ses habitudes doivent se rapprocher beaucoup de celles des cobites, des cépoles, des murènes, des murénophis, et des autres poissons que l'on désigne par l'épithète de Serpentifor. mes.

Les nageoires ventrales de la chinoise sont três-près de I'anus; cet orifice est trois fois plus éloigné de la tête que de la caudale; elle a une nageoire au dela de cette ouverture; et les séparations de ses petits muscles obliques sont

is rayons s la membrane brancbiale du fundale mudfiso 2 a la nageoire do dos, 16 a chaque pectorale, 10 a ta na geoire de lanus, 25 a ia nageoire de is queue, -12 it la nageoire de Yamus, 20 a celle de la queve. 2.3 $\mathrm{sl}$. Cuvier ne fait aurane meation de ce genre, uniquement fonde sur une figare chinoise, qui ne se rapporte hau- 
tres-sensibles sur la partie supérieure de son corps et de sa queue.

CENT CINQUANTE-NEUVIEME GENRE. LES AMIES '.

La lete dénuée de petiles écailles, rude, recopurerte do grandes lames pue rábnizent des sutures trìt-miorgudes; des dents aux machoires et are palais ; des barbillons do machoire supérienre; lo dorsatio lon-

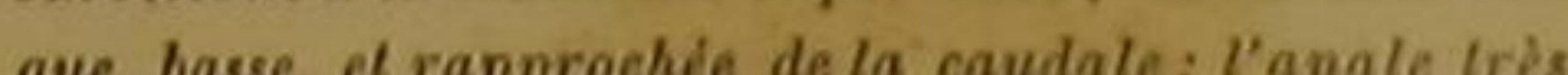

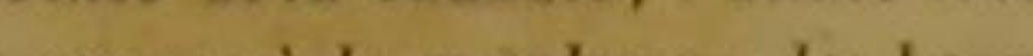
courle; plus de dix rayons d la membrane des bran-

ESPíker. cansctímes. L'A Ame cusure. $\quad\left\{\begin{array}{c}\text { La ligne latérále droite; la caudale } \\ \text { arrondie. }\end{array}\right.$

L'AMIE CHAUVE ${ }^{2}$.

Amia calva , Linn., Gmel.,Lac. , Cuv, 3.

Cette amie vit dans les eaux douces de la Cároline. Elle doit y préférer les fonds limoneux, fish). De petites écailles recouvrent son corps et sa queue : mais sa tête parait comme écorchée, et montrer à découvert les os qui la composent. Les opercules sont arrondis dans leur contour, et presque osseux. On peut voir, auprès de la gorge, deux petites plaques osseuse et striées du centre à la circonférence. Les pectorales et l'anate ne sont guère plus grandes que les ventrales. Ces dernières nageoires sont ì une distance presque égate de la tête et de la nageoire de la queue.

La mâchoire inférieure est un peu plus avancée que la supérieure, au-dessus de laquelle on compte deux barbillons.

L'amie chauve parvient à une longuieur un pen considérable. Mais il paraít qque le goût de sa chair n'est pas assez agréable pour qu'elle soit très-recherchée 4 .

6. M. Cuvier adople le genre Amle et terange dans l'ordr des Malacoptérygiens abdominanx et dans ti famitle de

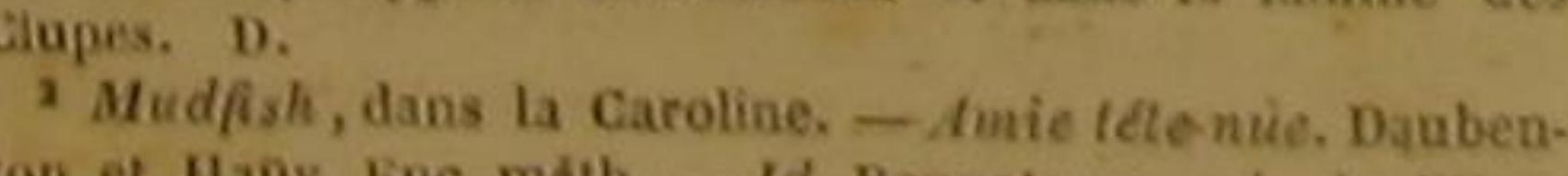
ton et the
mésb.

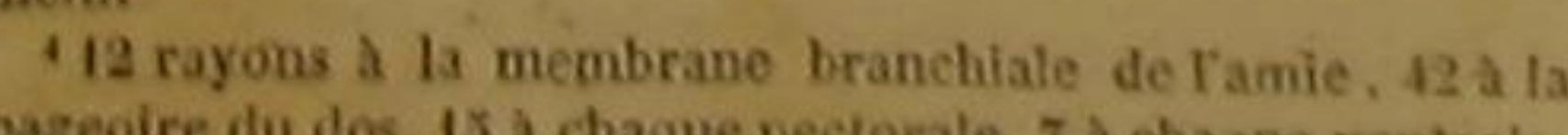

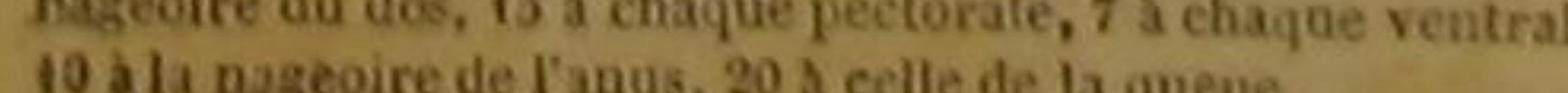

GENT SOIXANTIEME GKNRE.

LES BUTYRINS '.

La lele dénuéo de petiles ecailles, et ayant do longseur a peu près le quart de la longueur tolale de l'animal. une seple nageoire sur le dos.

espice.

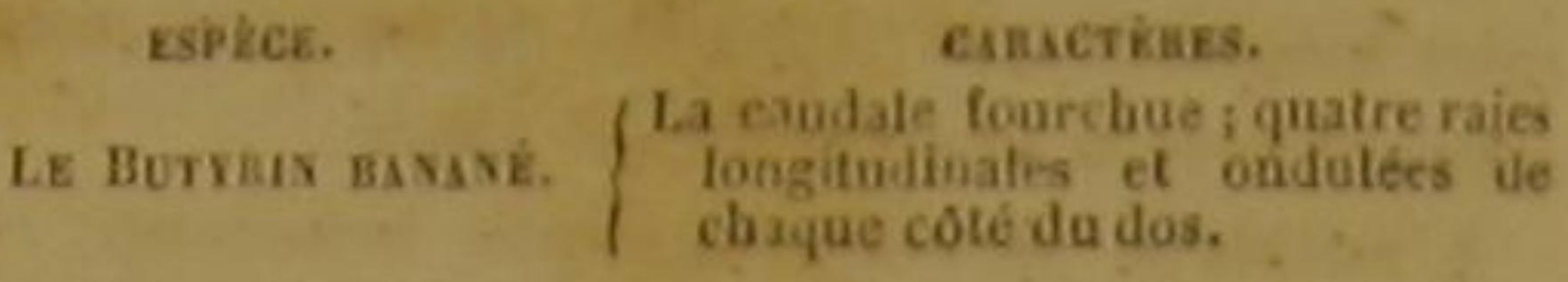

LE BUTYRIN BANANÉ ?

Batyrinus Bananas, Comm., Lac., Cuv.; Esox Vulpes, Lino.; Clupea brasiliensis, Albala gonorynchus ef Amia inimmeulata, Bl., Scb.; Clapea macrọeephala, Lac. :

Nous avons trouvé dans les manuscrits de Commerson une description courte, mais précise, de ce poisson, que les naturalistes ne connaissent pas encore. Nous avons dủ inscrire ce butyrin dans un 'genre particulier que nous avons placé à la suite des amies, parce que ce banané a beaucoup đe rapports avee ces abdominaux par la nudité de sa tête, pendant que la longueur de cette mème partie l'en sépare d'une manière très-distincte. Nous ne pouvons ajouter qu'un trait à ceux que nous avons indiqués sur le tableau générique, c'est que le butyrin banané a une ligne latérale presqué droite.

CENT SOIXANTE-UNIËME GENRE. LES TRIPTÉrosotes 4

Trois nageoires dorsales; wne seule nageoiré de l'anus. Espìce.

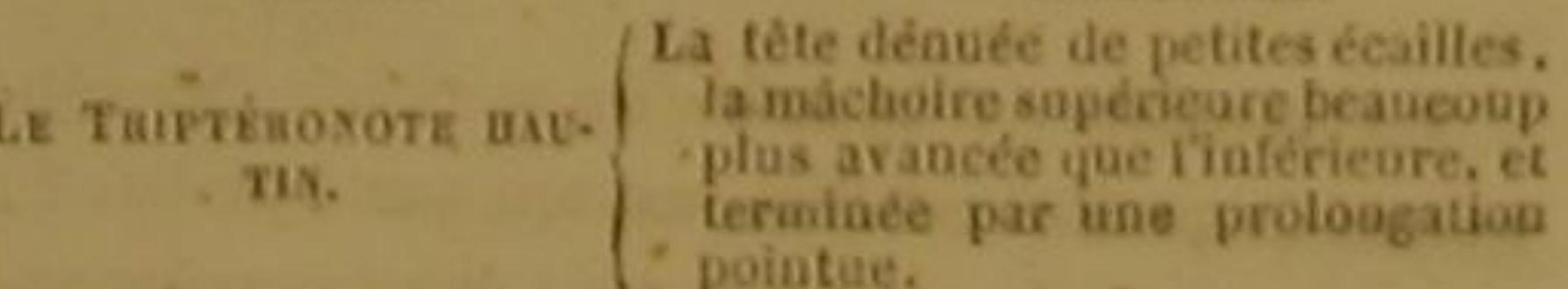
'Genre de Cònmerson alopté par $\$$. Cavier, et placé par lai dans ta famille des Clupes, orure des Malacopterygiens blominans. D.

putyrinus, poisson banané. Commerson, manuscrits (lejs cites.

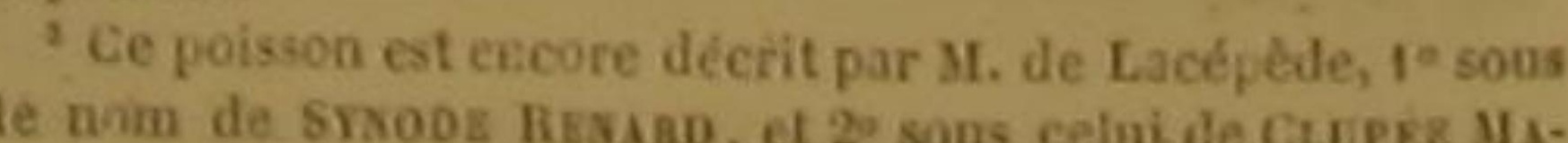
сRосїрแลLE. D.

$4 \mathrm{M}$. Cuvier fait remarquer que ce genre est fondês sur une mauvalse figure de Ron Jeiet qui se rapporte an Salmo oxy. rainchus de Linnée, Ce poisson est du sóñsgenre Lavaret. dasste grand genre Sarmon, de la famille des Saltmones, dans
l'ordre des Malacopteryziens abdominaux, D.

\section{LE TRIPTÉRONOTE HAUTIN '.}

Tripteronus Hautịn, Lac, ?

Rondelet a donné un dessin de cette espèce de poisson, dont il avait vu un individu à Anvers. Nous avons mis cet abdominal dans un genre particulier, et nous avons désigné ce genre par le nom de Tripléronote, pour indiquer le caractère remarquable que lui donne le nombre de ses nageoires du dos. On ne connait en effet que trè̀s-peu de poissons qui aient trois nageoires dorsales; le hautin est le seul des abdominaux qui en ait montré trois aux naturalistes; et málgré la présence de ce triple instrument de natation, il n'a qu'une nageoire de l'anus, pendant qu'on compte ordinairement deux anales, lorsqu'il y a trois nageoires du dos.

Toutes les dorsales et l'anale du hautin sonit triangulaires, et à peu près de la même grandeur. Sa eaudale est grande et fourchue. Les ventrales sout plus rapprochées de cette nageoire de la queue que de la tête. Le corps est recouvert, ainsi que la queue, d'écailles assez petites. L'opereule est arrondi; l'ail gros; le museau très-long, menu, pointu, noir et mou; l'ourerture de la bouche assez étroite.

\section{CENT SOIXANTE-DEUXIEME GENRE.} LES osroks "

Des barbillons et des dents aux machoires; point de nageoires dorsales; une longue nageoire de l'anus.

$$
\text { sspick. }
$$

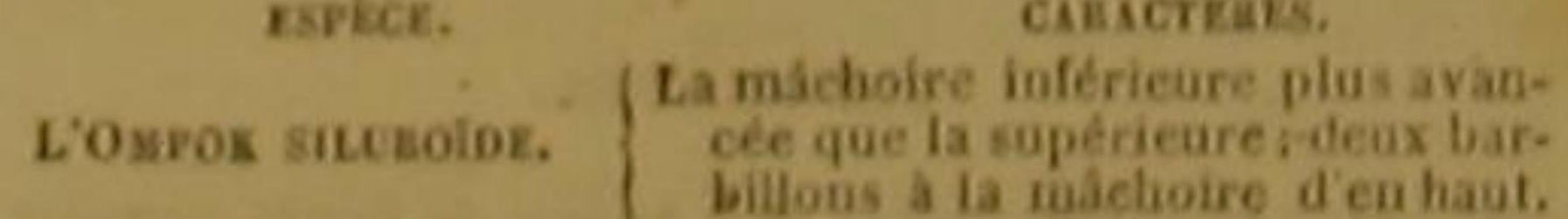

\section{L'OMPOK SILUROIDE. \\ Ompok siluroides, Lac. 4 .}

Nousavons trouvé un individu de cette espèce parmi les poissons desséchés de la collection donnée à-la France paŕ la Hollande. Une inseription attachée à cet individu indiquait que. le nom donné à cette espèce dans le pays cqu'elle habite, était $O \mathrm{mpok}$; nous en avons fait son nom générique, et nous avons tiré son nom propre de ses rapports avec les silures. Sa description

'Uautin. Rondelet, seconde partie, chap. 17. 2 Voyez la note i de la page 451, $2^{\circ} \mathrm{col}$. 4. M. Cuvier n'admet pas ce getre. D apres sne inspection de hiouivida destecue, qui a servi a Melablir, il a reconta que c'était un silare dont la
par le dessinateur. D. n'a encore été publiće par aueun naturaliste. Plusieurs rangs de dents grandes, acérées, mais iné gales, garnissent ses deux mathoires '. Les deu barbillons que l'on voit auprès des narines ont une longueur à peu près égale à celle de la tête. L'anale est assez longue pour s'étendre jusqu la nageoire de la quèe; mais elle ne se confond pas avec cette dernière.

\section{NOMENCLATURE}

Des Silures, des Maeroptéronotes, des Malaptérures, des Pimelodes, des Doras, des Pogonathes, des Cataphractes, des Plotoses, des Agénéioses, des Maćroramphoses, et des Ceatranodens:

On a décrit jusqu'à présent, sous le nom de Silures, un très-grand nombre de poissons de l'ancien ou du nouveau continent, très-propres à exciter la curiosité des physiciens par leurs formes et par leurs habitudes: mais plusieurs de cos animaux different trop do ceux avec lesquel on les a réunis, pour que nous ayons dù laisser subsister une association qui aurait jeté de l'obseurité dans la partie de l'histoire naturelle dont nous nous occupons, et donné des idées fausses sur les rapports qui lient les objets de notre étude. Bloch avait déjầ senti qu'il fallai diviser le genre des silures établi par les naturalistes qui l'avaient précédé, et il avait séparéde vrais silures les abdominaux qu'il a nommés Plalystes, et ceux qu'il a áppetés Cataphracles. Cependant, pour peu qu'on lise avec attention l'ouvrage de Bloch, et qu'on réfléchisse aux principes qui noús ont dirigés dans nos distributions méthodiques, on verra afsément que nous n'avons pu nous contenter de ces deux sections formées par Bloch, ni même les adopter sans quelques modifications. D'un autre eoté, nous avions à classer des espèces que l'on n'avait pas encore décrites, et qui sont plus ou moins voisines des véritables silures. D'apres ces considérations, nous avons cru devolr distribuer ces différents animaux dans onze genres différents. Tous ces poissons ont la tête couverte de lames grandes et dures, ou revétue d'une peau visqueuse. Leur bouche est situce a l'extrémité de leur museau. Dés barbillons garnissent leurs mâchoires, ou le premier rayon de leurs pectorales et celul de la nageoire de leur dos sont durs, forts, et souvent dentelés,

I 9 rayons a la membrane branchisie de fompok silurcade, 1 rayon aiguilionne ell rayoss articales a chaque pectoral 
ou du moins le premier rayon de l'une de ces les espèces qui ont deux nageoires dorsales fortinageoires présente cette dureté, cette force, fiées l'une et l'autre par des rayons, le premier et quelquefois une dentelure. Leur corps est rayon de la première de ces dorsales, très-long, gros; une mucosité abondante enduit et pénètre très-fort et dentelé, le museau très-allongé relapresque tous leurs téguments. Mais nous ne re- tivement à leurs dimensions générales, et les gardons comme de véritables silures que ceux måchoires sans barbillons. On-trouvera enfin, dont la dorsale est très-courte et unique, et qui dans le onzième, les espèces qui n'ayant pas par ce trait de conformation, ainsi que par plu- reçu de barbillons, élèvent sur leur dos deux sieurs autres caractères, ont de très-grands rap- nageoires maỉntenues par des rayons plus ou ports avec le Glanis, que tant d'auteurs n'ont moins nombreux, n'ont pas de dents à leurs mádésigné pendant longtemps que par le nom de choires, et closent les cavités de leurs branchies Silure. Nous plaçons dans un second genre avec des opercules armés d'un ou de plusieurs ceux qui, de même que la Charmulh du Nil, ont piquants.

une dorsale unique, mais très-longue. Nous ré- Nous conservons ou nous donnons à ces gen-

servons pour un troisième, l'espèce que les na- res les noms suivants.

turalistes appellent encore Silure electrique, qui ne montre qu'une nageoire du dos, mais sur laquelle cette dorsale n'est qu'une sorte d'excroissance adipeuse et s'élève très-près de la caudale. Un quatrième genre renfermera le Bagre et les autres espèces voisines de ce dernier, qui ont, comme ce poisson, une nageoire du dós soutenue par des rayons, et upe seconde dorsale uniquement adipeuse. Noús formons le cinquième de ceux qui, indépendamment d'une dorsale rayonnée et d'une seconde dorsale simplement adipeuse, ont une portion plus ou moins considérable de leurs côtés garnie d'une sorte de cuirasse que forment des lames larges, dure et souvent hérissées de petits dards. Nous avons inscrit dans le sixième genre les espèces dont on devra la connaissance à Commerson, et qui, présentant deux nageoires dorsales soutenues par des rayons, ont dé plus leurs côtés relevés longitudinalement par des lames ou des écailles particulières. On verra, dans le septième, e callichte et tous ceux des poissons dont nous nous occupons qui ont de grandes lames sur leurs cotés, deux nageoires sur le dos, des rayons à chacune de ces nageoires, et qui n'offrent qu'un seul rayon dans leur séconde dorsale. Le huitième renfermera ceux dont la queue très-longue est bordée d'une seconde dorsale, et d'une anale confondues l'une et l'autre avec la eaudale, lls ont un instrument de natation d'une grande énergie, et une rame puissante leur imprime des mouvements plus rapides que ceux de leurs analogues qui ont recu la même force et le même volume. Danș le neuvième se. ront rangés ceux qui ont deux nageoires dorsales dont la seconde est adipeuse, et qui sont dénués de barbillons. Au dixième appartiendront
Nous nommons le premier, Silure '; le second, Maeroptéronote ${ }^{2}$; le troisième, Malaptérure ${ }^{3}$; le quatrième, Pimelode ${ }^{4}$; le cinquième, Doras $^{5}$; le sixième, Pogonathe ${ }^{6}$; le septième, Cataphracte ; le huitième, Plotose ${ }^{7}$; le neuvième, Agénéiose ${ }^{8}$; le dixième, Macroramphose $^{9}$; et le onzième, Centranodon ${ }^{10}$.

Voyons de près ces onze groupes. En suivant les limites que nous venons de tracer autour d'eux, nous recevrons et nous conserverons sans peine des idées distinctes de leurs attributs; et nous reconnaitrons clairement, dans les differentes espèces de ces genres, les formes, les organes, les dimensions, les facultés, les habitudes qui leur ont été départis par la nature.

\section{CENT SOIXANTE-TROISIĖME GENRE.} LES SILURES.

La tele large, déprimide, et couverte de lames grandes at dures, ou d'une peau visqueuse; ta bouche d l'extrimited du museau; des barbillons aux mdehoirm;

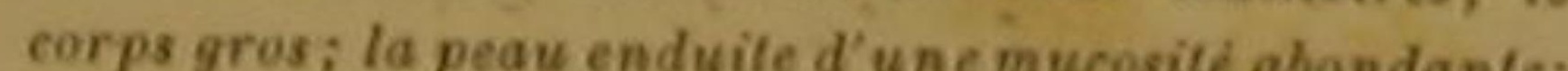
courle.

- Le mot gree silouros indique la rapidité avec laquelle les silures peavent aziter lear queve.
a Le mot macropteronote- exprime la longueur de la na. Le mot macropteronote- exprime la longueur de la na-
geoire da dos. geoire du dos.

Dou, pterons tiré te nom de malapterure de malacos. 'Pimelodes, en grec, st u'a, queue.

${ }^{5}$ Doras vent dire cuirasse.

'Pogonathe vient de pogon, barhe, et de gnathos, ma. choire.

Plotos veat dire qui nage aveo facilite.

: Ageneios signifie sans barbe.

insem.

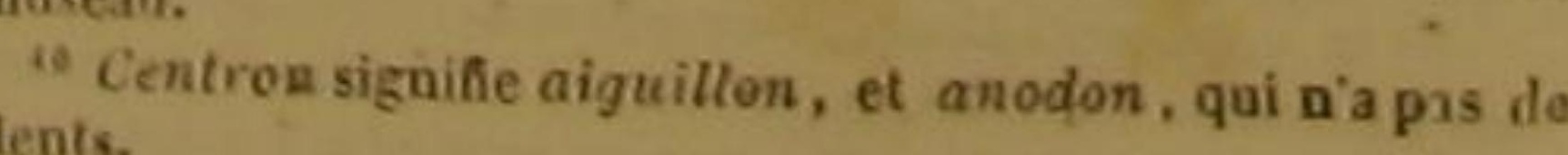
une seule nageoine dorole; celle nageino lite;

DES POISSONS.

PREMIER SOUS-GENRE.

La nageoire de la queue rectiligne, ou arrondie, et sans echanerure.

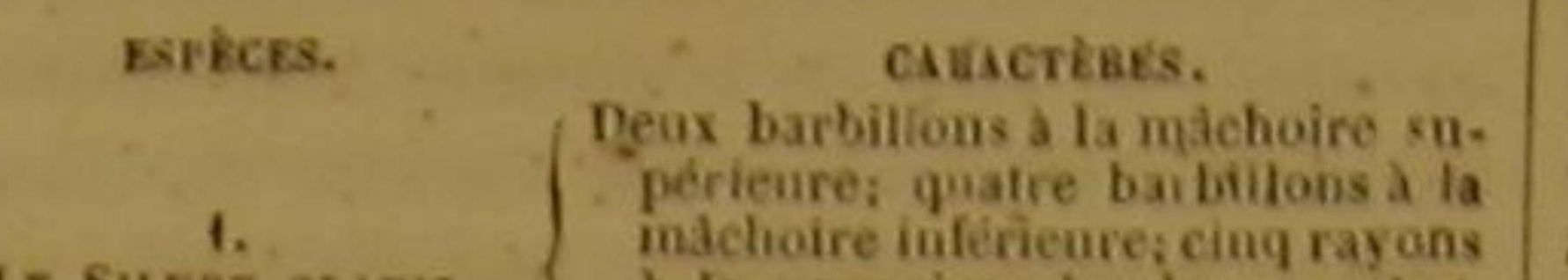

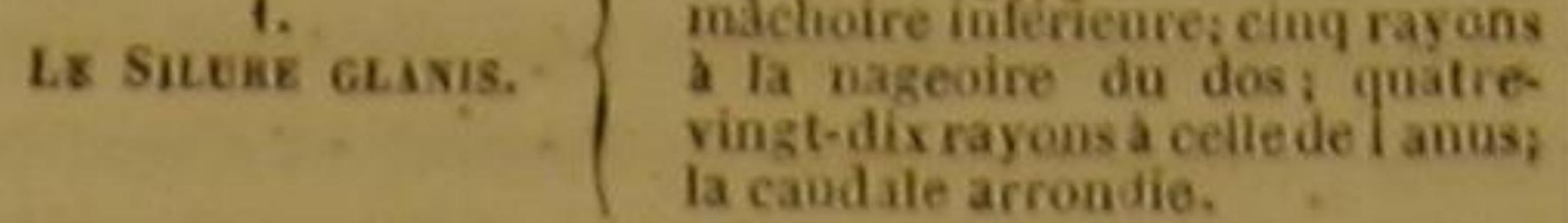
Un targe harbillon a chaque angle

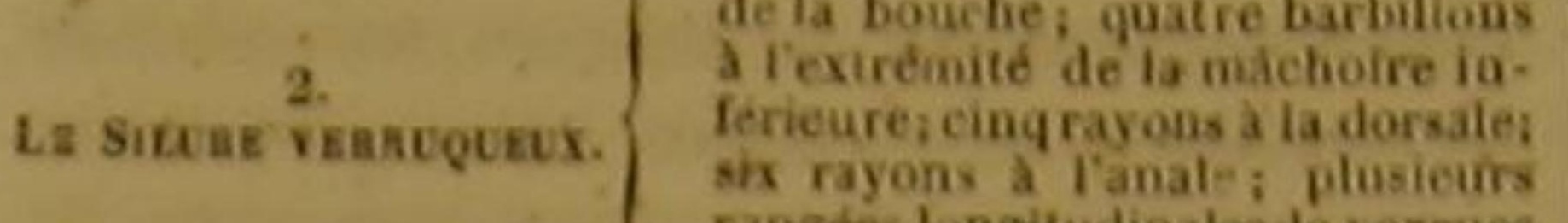
ranges lopgitudinales de verries

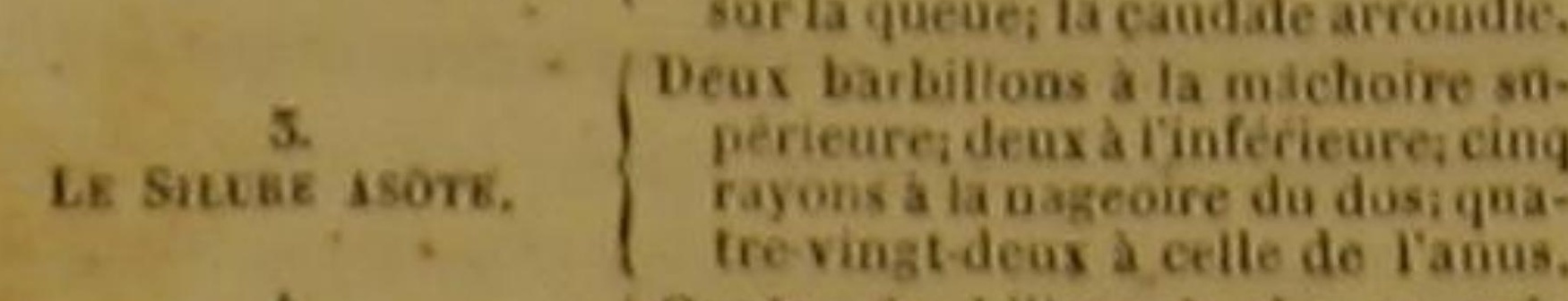

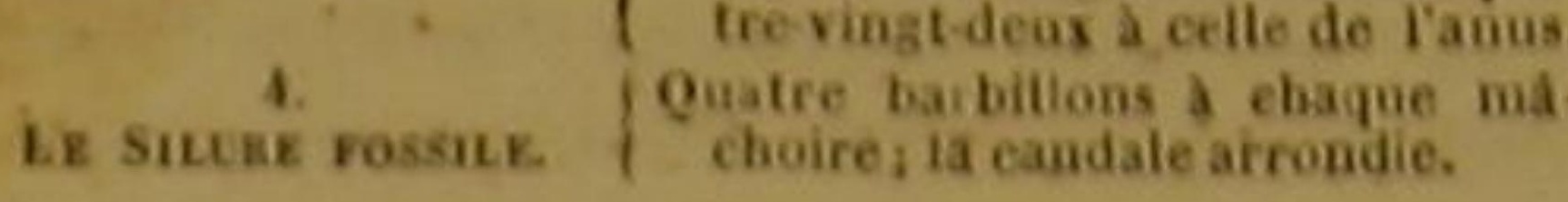
SECOND SOUS-GENRE.

La nageoire de la quene fourehue, ou tehanerdo en croissant.

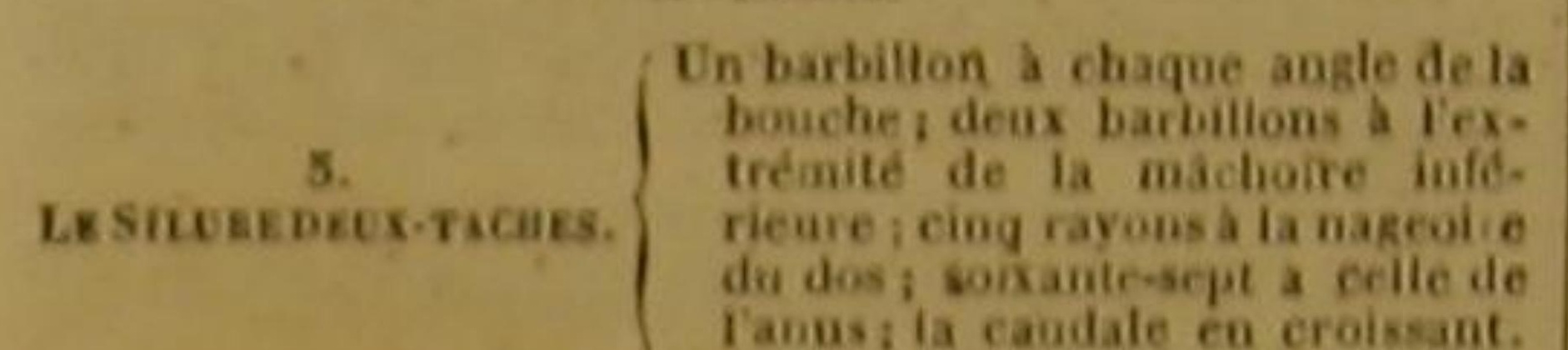

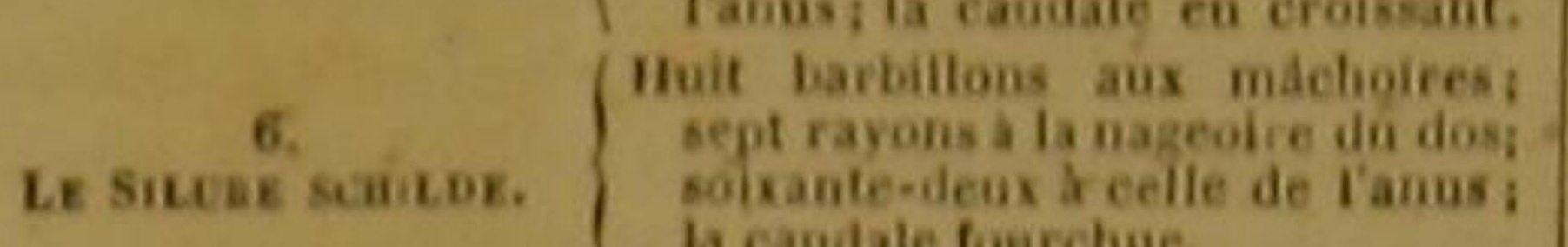
soixante-deux zeef
la caudale fourchue

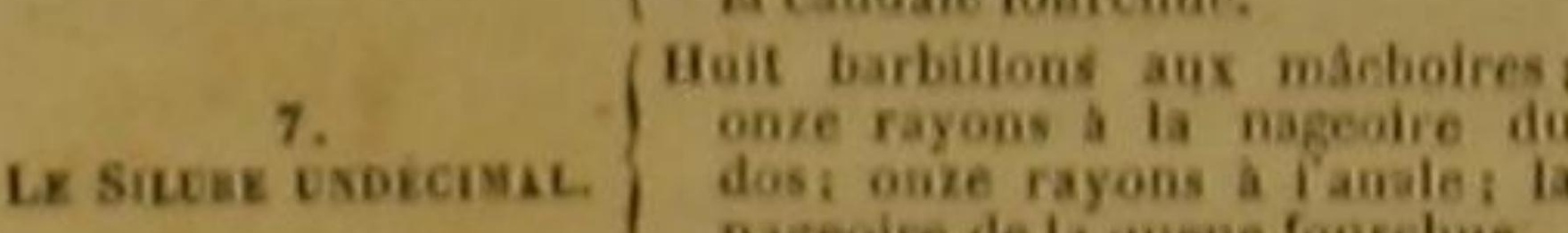
mageoire de La quecue fourchie.

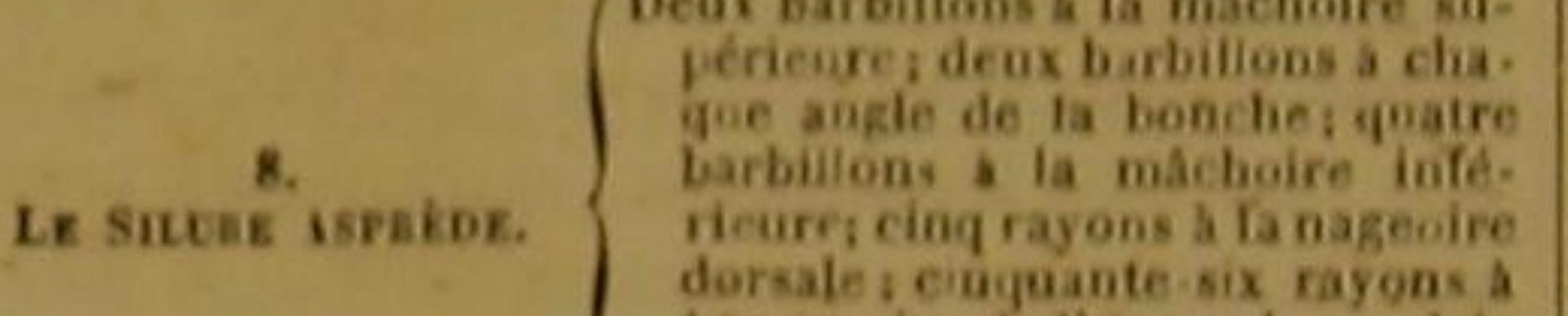

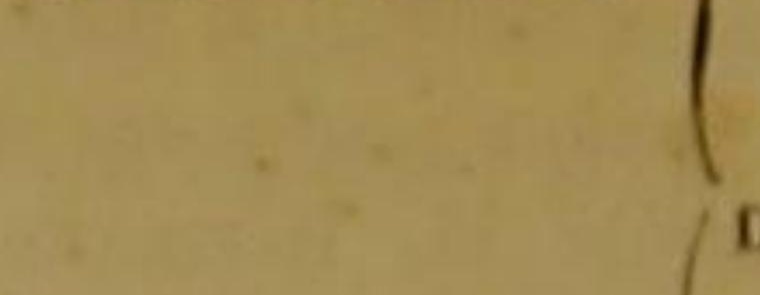
Deux barbillons a la machoiresu:
périenre: quatre burbilitons à Pénicure: quatre burbilitons à

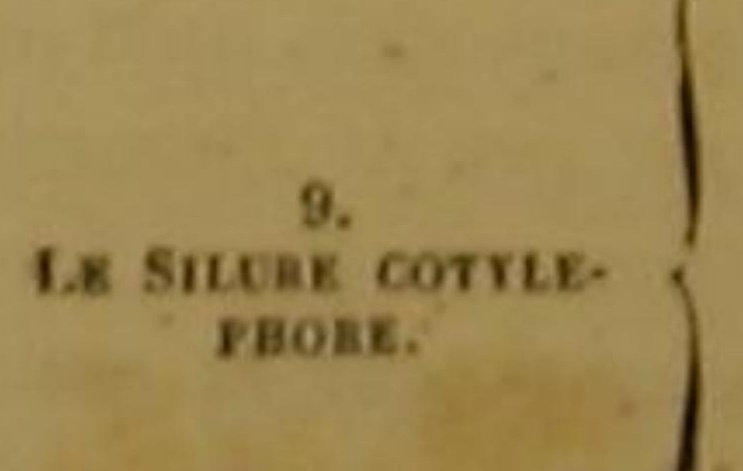

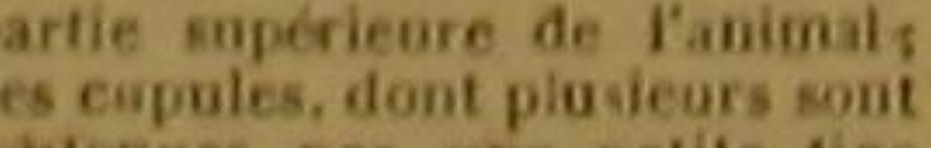
soitenines par une pelite big
flexible, sur la purtie infériens

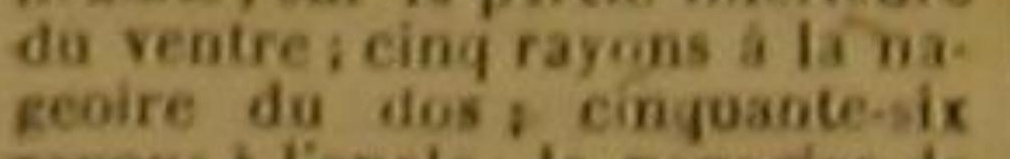
gecore du dos cinguane.
Tayous a lamale; ta nageoire de la quenefourchie,

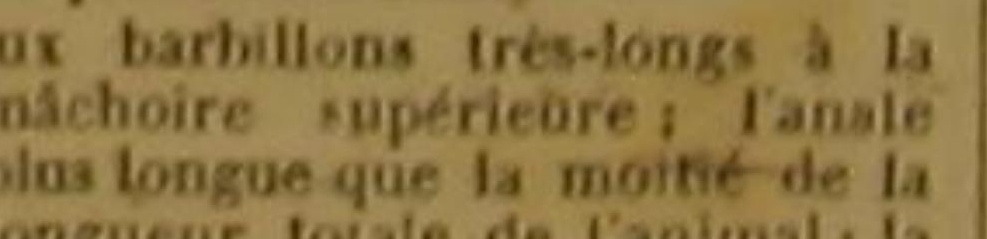

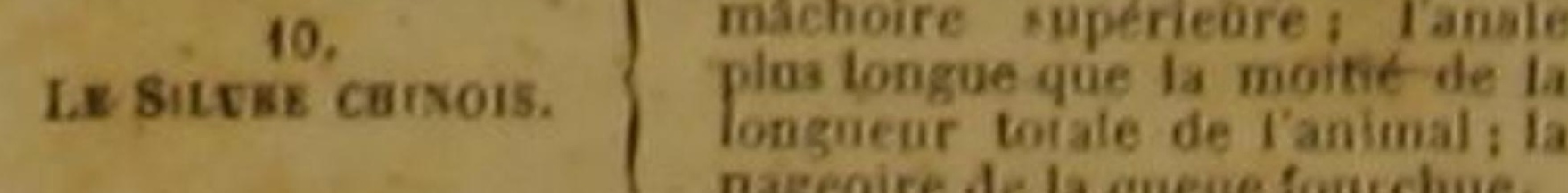

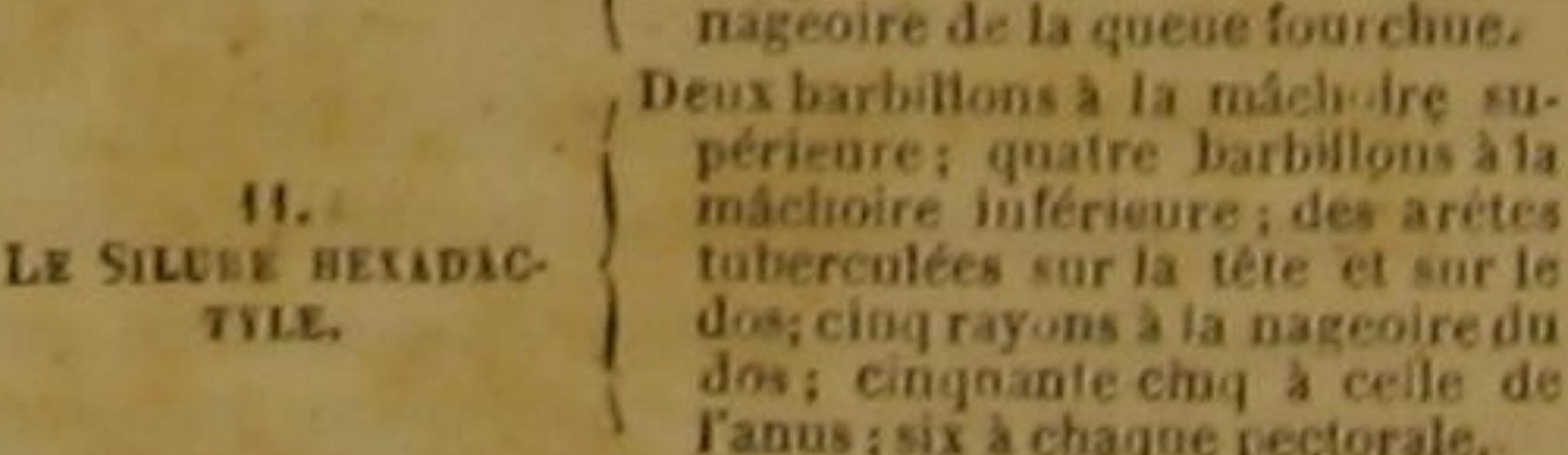

LE SILURE GLANIS '.

Silurus Glanis, Linn., Gmel., Lac., Cuv̌? Le glanis est un des plus grands habitants 'Lotie de Hongrie, aux environs de Strasbourg. - Har. des fleuves et des lacs. On l'a comparé à d'énormes cétacées; on l'a nommé la baleine des eaux douces. On s'est plu à dire qu'il régnait sur ces lics et sur ces fleures, comme la baleine sur l'Océan. Ce privilége de la grandeur aurait seul attiré les regards vers ce silure. Ce qui est grand fait toujours naitre l'étonnement, la curiosité, l'admiration, les sentiments élevés, les idées sublimes, A sa vue, le vulgaire surpris et d'abord accablé comme sous le poids d'une supériorité qui lui est étrangère, se familiarise cependant bientôt avec des sensations fortes, dont il jouit d'autant plus vivement qu'elles lui étaient inconnues; l'homme éclairé en recherehe, en mesure, en compare les rapports, les causes, les effets; le philosophe, découvrant dans cette sorte d'exemplaire dont toutes les parties ontété, pour ainsi dire, grossies, le nombre, les qualités, In disposition des ressortsou des élémentsqui échappent par leur ténuité dans des copies plus circonscrites, en contemple l'enchaínement dans une sorte de recuellement religieux; le poète, dont l'imagination obéit si facilement aux impressions inattendues ou extraordinaires, éprouve ces affeetions vives, ces mouvements soudains ces transports irrésistibles dont se compose un noble enthousiasme; et le génie, pour qui toute limite est importune, et qui veut commander à l'espace comme au temps, se plait à reconnaitre son empreinte dans le sujet de son examen, à trouver une masse très-étendue soumise à des lois, et à pouvoir considérer l'objet qui l'occupe, sans cesser de tenir ses idées à sa propre bauteur.

Lecaractere de la grandeur est d'inspirer tous ces sentiments, soit qu elle appartienne aux ouvrages de l'art, soit qu'elle distingue les próduetions de la nature; qu'elle ait été départie à la matière brute, ou accordée aux substances organisées, et qu'on la compte parmi les attributs

cha, en Italie, - Mardscha, en Hongrie, - Glano, danster environs de Constantinople, - Schaden, en Autriche.in as, Wr atler, Scheid, Schoiden, en Allenagne, - Szum, wels, en Livonie. - Som, en Busie. - Darhium, en Tarts rie. - Zolbarle, clez les Calmougues. - Mal, en Suede. Mall et Malle, en Danemar k. - Meerval, en Hollande The seat fish, en Angleterre, - Bloch, pl.5i. - Sihure mal. Dauhenton et Gay, Eve. meth. $-T d$. Bonnaterre, pl. de I'Euc. meth. - Faun. Suec, 516. - Meid ng. Ie, pise. Austr. p. 54, 1. 3. - Esiturus cirris quatoor in mento. A Artedi, 4ea. K2, syn. 110:- Grongr, \$us. 1, B. 23, L 6, fig. 1. 2 Da sous-genre Silcok, dans te grand geare suwn, ta.

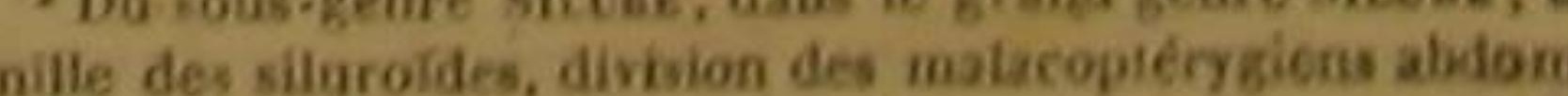


des êtres vivants et sensibles. On a dû également les éprouver et devant les jardins suspendus de Babylone, les antiques pagodes de l'Inde, les temples de Thèbes, les pyramides de Memphis, et devant ces énormes masses de rochers amoncelés qui composent les sommets des Andes, et devant l'immense baleine qui sillonne la surface des mers polaires, l'éléphant, le rhinocéros et l'hippopotame, qui fréquentent les rivages des contrées torridess, les serpents démesurés qui infestent les sables brûlants de l'Asie, de l'A. frique et de l'Amérique, les poissons gigantesques qui voguent dans l' Océan ou dominent dans les fleuves.

Et quoique tous les êtres qui présentent des dimensions supérieures à celles de leurs analogues, arrêtent nos regards et nos pensées, notre imagination est surtout émue par la vue des objets qui, l'emportant en étendue sur ceux auxquels ils ressemblent le plus, surpassent de beaucoup la mesure que la nature a donnée a l'homme pour juger du volume de ce qui l'entoure; cette mesure dont il ne cesse de se servir, quoiqu'il ignore souvent l'usage qu'il en fait, qui consiste dans sa propre hauteur. Un ciron de deux ou trois décimètres de longueur serait bien plus extraordinaire qu'un éléphant long de dix mètres, un squale de vingt, un serpent de cinquante, et une baleine de plus de cent, et pendant il nous frapperait beaucoup moins; il surprendrait davantage notre raison, mais il agirait moins vivement sur nos sens; il s'emparerait moins àe notre imagination; il imprimerait bien moins à notre ame ces sensations profondes, et à notre esprit ces conceptions sublimes que font naitre les dimensions incomparablement plus grandes que notre propre stature.

Ces dimensions très-rares dans les êtres vivants et sensibles sont celles du glanis.

Un individu de cette espèce, vu près de Limritz dans la Poméranie, avait la gueule assez grande pour qu'on pût $y$ faire entrer facilement un enfant de six ou sept ans. On trouve Volga des glanis de douze on trouve dans longueur. On prit, il y a quelques années, dans était du poids de cent vingt livres silures, qui tre de ces poissons, péchéa Writzen sur l'Oder, en pesait huit cents.

Le glanis a la tête grosse et très-aplatie de haut en bas; le museau très-arrondi par-devant; la máchoire inférieure un peu plus avancése quet; celle d'en haut, ces deux mâchoires garnies d'un très-grand nombre de dents petites et recourbées ; quatre os ovales, hérissés de dents aiguês, et situés au fond de la gueule; l'ouverture de la bouche très-large; une fossette de chaque côté de la lèvre inférieure; les yeux ronds, saillants, très-écartés l'un de l'autre, et d'une petitesse d'autant plus remarquable que les plus rands des animaux, les balejnes, les cachalots, les éléphants, les crocodiles, les serpents dimesurés, ont les yeux très-petits à proportion des énormes dimensions de leurs autres organes.

Le dos du glanis est épais; son ventre trèsgros; son anale très-longue; sa ligne latérale droite; sa peau enduite d'une humeur gluante laquelle s'attache une assez grande quantité de la vase limoneuse surlaquelle il aime à se reposer. Le premier rayon de chaque pectorale est osseux, très-fort et dentelé sur son bord intérieur '

Les ventrales sont plus éloignées de la tếte que la nageoire du dos.

La couleur générale de l'animal est d'un vert mêlé de noir, qui s'éclaircit sur les côtés et encore plus sur la partie inférieure du poisson, et sur lequel sont distribuées des taches noirâtres irrégulières. Les peetorales sont jaunes, ainsi que la dorsale et les ventrales; ces dernières ont leur extrémité bleuâtre; et l'extrémité de même que la base des peetorales présentent la méme nuance de bleu foncé. Le savant professeur de Strasbourg, feu mon confrère M. Hermann, rapporte, dans des notes manuscrites qu'il eut la bonté de me faire parvenir peu de moments avant sa mort, et auxquelles son digne frère M. Frédéric Hermann, ex-législateur et maire de Strasbourg, a bien voulu ajouter quelques observations, que les silures glanis un peu avancés en âge qu'il avait examinés dans les viviers de M. Hirschel, avaient le bord des pectorales peint d'une nuance rouge que l'on ne voyait pas sur eelles des individus plus jeunes.

L'anale et la nageoire de la queue du glanis ' Plusieurs poissons compris dans le genre silure, étabt
par Linnée, et qui ont à chaque pectorale un rayon dur et ce rayon une firsqu ils etendent cette mageoire, donner tournant. La base de ce rayon eseut vaincre que en le déphyses, Lorsque la pectorale est éterminee par denx aporieure entre dans un trou de la clavicole; le rapyse antéa pensar soa axe; lapophyse, qui est recourbée, son tourne gil ne du tron; et le rayon ne peut plus étre tiéchi, à moins du premisse sur son axe un mouvement en sens contraire sont eommunément d'un gris mêlé de jaune, et bordées d'une bande violette.

Le silure que nous venons de décrire habite non-seulement dans les eaux douces del'Europe, majs encore dans celles de l'Asie et de l'Afrique. On ne l'a trouvé que très-rarement dans la mer; et il parait qu'on nel'y a vu qu'auprès des rivages voisins de l'embouchure des grands neuves, hors desquels des accidents particuliers ou des circonstances extraordinaires peuventl'avoirquelquefois entrainé. Le professeur Kolpin; de Stettin, éerivait à Bloch, en 1766, qu'on avait pêché un siluré de l'espèce que nous examinons, auprès de l'ile de Rügen dậs la Baltique.

Comme les baleines, les éléphants, les crocodiles, les serpents de quarante ou soixante pleds, et tous les grands animaux, le glanisne parvient qu'après une longue suite d'années à son entier développement. On pourrait croire cependant, d'après les notes manuiscrites de M. Hermann, que, pendant la première jeunesse de ce silure, ce poisson croit avee vitesse, et que ce n'est qu'après avoir atteint à une longueur considérable, qu'il grandit avec beaucoup de lenteur, et que son développement s'opère pau des degrés trèspeu sensibles.

On a écrit qu'il en était đes mouvements du glanis comme de son accroissement; qu'il né nageait qu'avee peine, et qu'il ne paraissait remuer sa grande masse qu'avee difficulté. $\mathrm{La}$ queue de ce silure, et l'anale qui en augmenté la surface, sont trop longues et conformées d'une manière trop favorable à une natation rapide, pour qu'on puisse le croire réduit à une manière de s'avancer très-embarrassée et très-lente. Il faudrait, pour admettre cette sorte de nonchalance et de paresse forcées; supposer que les muscles de cet animal sont extrèmement faibles, et que s'il a reeu une rame trés-étendue, it est privé de la force nécessaire pour la remuer avec vitesse, et pour l'ágiter dans le-sens le plus propre à faciliter ses évolutions. La dissection des muscles du glanis n'indique aucune raison d'admettre cette organisation vicieuse. C'est dans son instinct qu'il faut chercher la cause du peu de mouvement qu'il se dome. S'il ne change pas fréquemment et promptement de place, il n'en a pas moins reçu les organes nécessaires pour se transporter avec célérité d'un endroit à un autre; mais il n'a ni le besoin, ni par coniséquent la volonté, de faire usage de sa vigueur et de ses instruments de natation. II vit de proie; mais il ne poursuit pas ses victimes. Il préfere ln ruse is in violence; il se place en embuse mbuscade, des creux, au-dessous des planches, des poteaux et des autres bois pourris qui peuvent border les rivages des fleuves qu'il fréquente; il se couvre de limon; il épie avee patience les poissons dont il veut se nourrir. I couleur obscure de sa peau empêche qu'on ne le distingue aisément au milleu de la vase dans laquelle il se couche, Ses longs barbillons, auxquels il donne des mouvements semblables a ceux des vers, attirent les animaux imprudents qu'il cherche à dévorer, et qu'il engloutit d'autant plus aisément qu'il tient presque toujours sa bouche béante, et quel'ouverture de sa gueule est tournée vers le haut.

It ne quitte que pendant un mois ou deux le fond des rivières ou il a établi sa péche: o'est ordinairement vers le printemps qu'il se montre de temps en temps à la surfuce de l'eau ; et e'est dans eette même saison qu'il dépose près des ives, ou sés cufs, ou lo sue proliffque qui doit les féconder. On a remarqué qu'il n'allai pondre ou arroser ses dufs que vers le milieu de la nuit, soit que cette habitude dépende du soin d'êviter lés embûches qu'on lui tend, ou de la délicatesse de ses yeux, que la lumièredu soleil blesserait, pour peu qu'elle fút trop abondante. Cetto seconde cause pourrait être d'autant plus la véri table, que presque tous les animaux qui passent la plus grande partie de leur vie dans des asiles écartés et dans des cavités obscures, ont l'organe de la vue très-sensible à l'action de la lumière.

Les membres du glanis étant arrosés, imbuset profondément pénétrés d'une humeur gluante, peuvent résister plus facilement quẹ ceux de plusieurs autres babitants des eaux, aux coups qui brisent, aux accidents qui écrasent, aux causes qui desséchent; et dès-lors on doit voir pourquoi il est plus difficile de lui faire perdre la vie qu'à beaucoup d'autres poissons '.

On a pensé que-sa sensibilité était extrêmement émoussće ; on Va concla du peu d'agitation qư il éprouvait lorsqu'il était pris, et de l'espece d'immobilité qu'il montrait souvent dans toutes ses parties, excepté dans ses barbillons. On aurait dû cependant se souvenir que, malgré le besoin qu'il a dese nourir de substances animales, il parait aveir l'instinet soeial. On voit 
presque toujours deux glanis ensemble; et c'est $\mid$ bords du Danube, la peau du glanis, séchée au ordinairement un mâle et une femelle qui vivent ainsi l'un auprès de l'autre.

Malgré sa grandeur, le glanis femelle ne contient qu'un très-petit nombre d'œufs, suivant plusieurs naturalistes; et si ce fait est bien constaté, il méritera d'autant plus l'attention des physiciens, qu'il sera une exception à la proportion que la nature semble avoir établie entre la grosseur des poissons et le nombre de leurs cufs '. Bloch rapporte qu'une femelle, qui pesait déjà une livre et demie, n'avait dans ses deux ovaires que dix-sept mille trois cents œufs. Lorsque les tempêtes sont assez violentes pour bouleverser toute la masse des eaux dans lesquelles vit le glanis, il quitte sa retraite limoneuse, et se montre à la surface des fleuves ; néanmoins, comme ces orages sont rares, et que d'ailleurs le temps pendant lequel il est attir vers les rivages est d'une durée assez courte, $i$ est exposé bien peu souvent à se défendre contre des poissons voraces assez forts pour oser l'attaquer. Mais les anguilles, les lotes, et d'autres poissons beaucoup plus petits, se nourrissent de sesœufs; et quand il est encore très-jeune, il est quelquefois la proie des grandes grenouilles.

Son osophage et son estomac présentent, dans leur intérieur, des plis assez profonds; et feu Hartmann ${ }^{2}$ ainsi que le professeur Schneider ${ }^{3}$. ont remarqué que cet estomac jouissait d'une irritabilité assez grande, même après la díssection de l'animal, pour offrir pendant longtemps des contractions et des dilatations alternatives.

Le canal intestinal est court et replié une seule fois; le foie gros, la vésicule du fiel longue et remplie d'une liqueur jaune; la vessie natatoire courte, large, et divisée longitudinalement en deux. Vingt côtes sont placées de chaque cóté de l'épine du dos, qui est composée de cent dix vertèbres.

La chair du glamis est blanche, grasse, douce, agréable au goût, mais mollasse ; visqueuse et difficile à digérer. Dans les environs du Volga, dont les eaux noưrrissent un très-grand nombre d'individus de cette espèce, on fait avec leur vessie natatoire une colle assez bonne, mais à laquelle on préfere cependant celle que donne la vessie natatoire de l'acipensère huso. Sur les 'Ditscours sur la nature des polssons. '. Mél. de l'acad. des curieux de la nature, déc. 2 , an 7 ,
p. 80 . p. 80.

Synonymie des poissons d'Artedi, etc., p. 170. soleil, a servi, pendant longtemps, de lard aux habitants peu fortunés ; et du temps de Bélon, cette mème peau avait été employée à couvrir des instruments de musique.

Les notes manuscrites du professeur Herman et de son frère le maire de Strasbourg, nous on appris que MM. Durr, l'oncle et le neveu, marchands poissonniers de cette ville, avaient tâché de naturaliser le glanis dans l'ancienne Alsace. Ils avaient d'abord fait à grands frais plusieurs voyages en Hongrie, pour y chereher dans le Danube plusieurs silures de cette espèce; ils avaient appris ensuite que des glanis habitent un lac de deux lieues de tour; situé dans la Souabe, à quelques milles de Doneschingen, à trente ou trente-cinq lieves de Strasbourg, et par conséquent beaucoup plus près des bords du Rhin que les rives hongroises du Danube. Ce lac se nomme en allemand, Feder-see; en latin, La. cus plumarius; en français, lac aux Plumes. Ils en avaient apporté plusieurs de ces silures, qu'on avait déjà multipliés dans les étangs de feu le respectable et malheureux Dietrich, au point qu'on y en comptait plus de cinq cents ; mais il y a une douzaine d'années que, lors d'un événement extraordinaire, ces poissons furent enlevés. et il n'en reste plus dans les étangs du département du Bas-Rhin. M. Durr le neveu, et son beau-frère M. Hirschel, font toujours venir du Feder-see des glanis, qu'ils vendent à Strasbourg, ou qu'ils envoient plus loin, et dont les plus petits pèsent ordinairement douze livres '.

LE SILURE VERRUQUEUX 2 , Aspredo verrucosus, Cuv.; Platystacus yerrucosus,
BI.; Silurus verrucosus, Lac. '.

ETT LE SILURE ASOTE +

Silurus Asotus, Palias, Lac., Cuv.

La tête du verruqueux présente, dans sa partie supérieure, un sillon longitudinal, à la suite 1 16 rayons a la membrane branchiale dn silure glanis. 18 chaque pectorale, 15 à chaque ventrale, 17 a $\mathrm{L}$ nageofire de $1 \mathrm{a}$
queue. ${ }_{2}^{2} \mathrm{Pl}$ Gi.5. Du genre ASPRÈDE on PLATSTE, famille des Siluroĩdes, dans la division des malacoptérygiens abdominaux. Cuv. D. Bonnaterre, pl. de Danbenton et Hañy, Enc. mélh. - Id. Bonnaterre, pl. de IEnc. méth.
- Du sous genre SILuge, dous. nom, sous genre SiLtie, dans le grand genre du méme
abdominanx, Cuv. D. D. duquel on voit sur le dos une saillie également longitudinale. Il n'y a qu'un orifice à chaque narine. Le premier rayon de chaque pectorale est très-dur, très-fort et dentelé.

On trouve dans l'Asie l'asote, qui, de mème que le verruqueux, a dans le premier rayon de chaque pectorale une sorte de dard dentelé, et dangereux, par sa dureté et sa grosseur, pour les animaux que ce silure attaque, ou qu'il táche de repousser. Les dents de ce poisson sont très-nombreuses, et sa nageoire de l'anus s'étend jusqu'à celle de la queue '.

\section{LE SILURE FOSSILE 2}

Silurus fossitis, Linn., Gmel., Bloch, Lac., Cur. ‘.

Bloch avait reçu de Tranquebar un individu de cette espèce. Le dessus de la tête de ce poisson montrait une fossette longitudinale. La couverture osseuse, qui revêtait cette même partie, était terminée par trois pointes. On voyait de petites dents à la partie antérieure du palais, ainsi qu'aux deux mâchoires, qui étaient auss avancées l'une que l'autre. La langue était courte, épaisse et lisse. La ligue latérale descendait jusque vers les ventrales, et s'étendait ensuite directement jusqu'à la nageoire de la queue, dont l'anus était une fois plus éloigné que de la tête. Le premier rayon de chaque pectorale paraissait très-fort. On pouvait distinguer les museles de l'animal au travers de sa peau. Sa couleur générale était celle du chocolat; les nageoires offraient une teinte d'un brún un peu clair, excepté l'anale qui était grise.

15 rayous a la membrane branchiale du silqre verruqueux 8 a chaque pectorale, 6 a chaque ventrale, 10 a la vageoire de

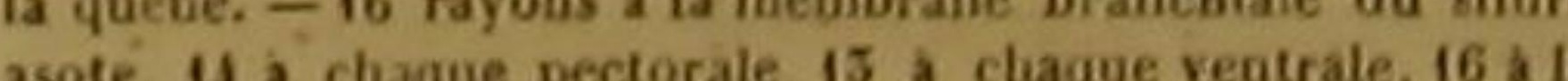
caudale.
Schlammwels, en allemand. - Muddy silure, eu an. glais. - Silure d'elang. Bloch, pl. 370. fig. 2 - Du sous-genre Silcaz, dans le grand genre Siluaz, famille des sives dacopterygien aldominanx. D.
LE SHURE DEUX-TACHES :

Silurus bimaculatus, Bloch, Lac, Cur.?.

LE SILURE SCHIDEE ${ }^{3}$, Sehilbe mystus, Cuv.; Silurus mystus, Lima., Gmel.,
Lae. ‘.

ET LE SILURE UNDÉCIMAL 5 .

Silurus undecimalis, Lac, 4 .

Le violet, le jaune et l'argenté concourent ì la parure du silure deux-taches. Sa partie supérieure est d'un violet clair; ses côtés brillent de l'éclat de l'argent; sá caudale est jaune, avec les deux extrémités du croissant qu'elle forme d'un violet foncé; les autres nageoires sont communément variées de jaune et de violet.

Ce beau poisson vit dans les lacs et dans les rivières de la cóte de Malabar; il fraie pendant l'été ; sa chair est d'un goût agréable.

Sa tête a moins de lárgeur que celle de la plupart des autres silures. Ses dents sont très-fortes; on en voit un grand nombre de petites'sur le palais : mais la langue est lisse. Il y a deux orifices à chaque narine. Les barbillons supérieurs sont longs, les inferieurs très-courts et d'une couleur blanchatre. Le premier rayon de chaque pectorale est dur, gros, et dentelé du côté opposé à la tête. La ligne latérale ne montre que de très-légères courbures.

Le schilde se plait dans les eaux du Nil. Quatre de ses barbillons tiennent à la máchoire supérieure; les autres quatre sont attachés à celle de dessous. Le premier rayon de ehaque pectorale est distingué par sa grosseur, par sa force et par sa dentelure.

Le silure undécimal, qui habite dans les vivières de Surinam, a onzể rayons à sa dorsale, à sa naceoire de l'anus et à chacune de ses peetorales; et ces trois nombres semblables ont indiqué le nom qu'on lui a donné. Uné dentelure garnit $\because$

Sewalti, chez les Tamules. - Silure à deux laches. Bloch, pl. 564.

"Du genre et du sous-genre des Silouss, Cuv. D." - Schilde ou schibe, sur les bords da Nit. - Silur pit. de IEnce, méth. $\rightarrow$ Mus, Ad. Frid. 2, p. 96. - - S silurus ischilde niloticus., Hisselquist, it, 576 ,

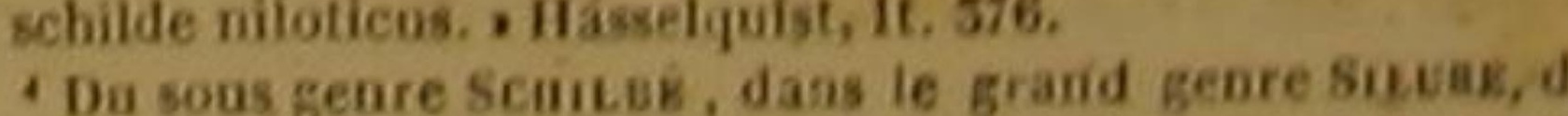
ta famille des Silarchues, division der Malseoptérygiens al deminaux. D.

S Silure ondecimal. Daubenton et Hay, Kne. méth.P. 97. 
chacun des côtés du premier rayon de l'une et | très-állongée et tres-mobile, est comprimée par de l'autre de ses pectorales; ses barbillons exté- les côtés, de manière à présenter une sorte de rieurs ònt une longueur égale à celle de son tranchant ou de earène longitudingle dans corps '. partie supérieure. La couleur générale est d'un brun mêlé de violet.

\section{LE SILURE ASPRĖDE ${ }^{2}$,}

Aspredo lævis, Cuv.; Silurus Aspredo, Linn., Gmel., Lac.; Platystacus lævis, BI. 3.

ET LE SILURE COTYLÉPHORE ${ }^{-1}$. Aspredo cotylephorus, Cuv.; Platystacus colylephiorus,
Bi.; Silurus cotylephoras, Lac. ?.

On pêche dans les fleuves del'Amérique, et peut-être dans ceux des grandes Indes, le silure asprède, dont la tête plate, osseuse et couvert d'une membrane, s'élargit beaucoup aúprès des pectorales, et présente, dans sa partie supérieure, une cavité longitudinale et triangulaire, qui se termine par une sorte de tube solide, prolongé jusqu’à la dorsale. On apercoit quelques verrues ou petits tubercules sur la tête et sur la poitrine. La mâchoire supérieure est plus avancée que celle de dessous; la langue et le palais sont lisses; chaque narine a deux orifces ; l'ouverture branchiale est courte et étroiteLes branchies sont petites; ; elles sont d'illewr garnies de filaments très-peu allongés et distribués par touffes très-séparées les unes des autres. Une dentelure hérisse chacun des côtés du premier rayon de chaque pectorale, qui, de plus, réunit beaucoup de force à une grosseur considérable. Le corps proprement dit étant courtet l'anale très-longue, l'anus est beaucoup plus près de la tête que de la caudale. Au delà de cet orifice, on voit une ouverture placée à l'extrémité d'une sorte de petit cylindre. La quéue $1 / 2$ rayons a la membrane branchiale do silure deux-ta.
ches, 14 a chaque pectorale, 6 a chaque ventrale, 16 a $a$. seire de la queve. -10 a la membrare des branchies do la caudale. - II rayue pectorale, 6 a chaque ventrale, 20 cimal, 6 a chaque ventrale, 17 aque pectorale da silure undé'Glattleib, par les Allemands nageoire de la queue. Suédols. - Silure aspréde. Daubenton et eggen, par les

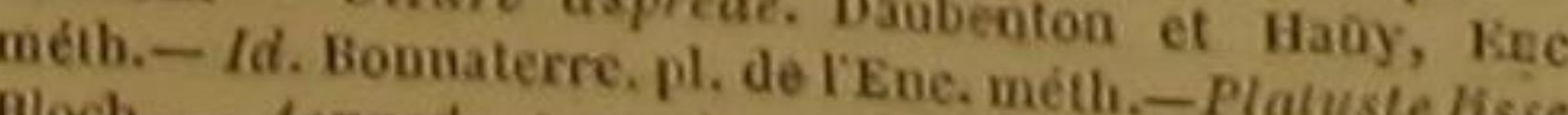
Och. - Aspredo. Amenit. acad. 1, p. 511, tak, 14 , fig. - Aspredo cirris 8. Gron.
. rốdes, division des Masacoptéryziens a Cur. Faznille des Silu- Silurils cotylephorus, - Telles trager, Rax. $\mathrm{D}$. par les Aliemands. - Runwe meireal, par les Holl wels, Plalyste cotyléphore. Bloch, pl. 572 .

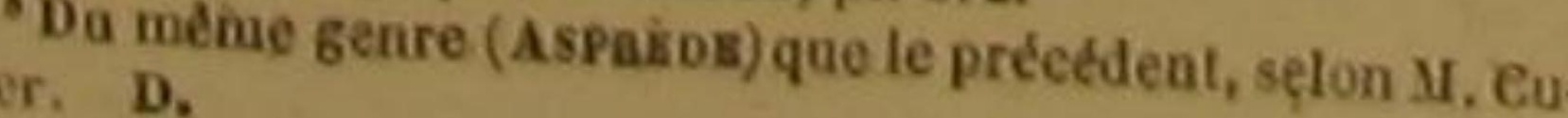

Le cotyléphore diffère de l'asprède parles traits suivants, dont le dernier est très-remarquable, et consiste dans une conformation que l'on n'a encore observée sur aucune autre espèce. Premièrement, il n'a que six barbillons a lieu de huit. que celles de l'asprède.

Troisièmement, toute sa partie supérieure est garnie de petits tubercules qui forment sur la queue huit rangées longitudinales.

Quatrièmement, l'os quide chaque cóté représente une clavicule, est divisé en deux par un intervalle que des muscles remplissent.

Cinquièmement, le dessous de la gorce, du ventre et d'une portion des nageoires ventrales, est garni de petits corps d'un diamètre à peu près égal à celui des tubercules du dos, arrondisdans leur contour, convexes du côté par lequel ils tiennent au poisson, concaves de l'autre, et assez semblables à une sorte d'entonnoir ou de petite coupe. Presque tous ces petits corps sont suspendus à une tige déliée, flexible, et d'autant plus courte que l'entonnoir est moins développé : les autres sont attachés sans aucun pédoncule au ventre, ou à la gorge, ou aux ventrales de l'animal '. Il est bon d'observer que ces appendices ne sont ainsi conformés que dins les cotyléphores adultes ou presque a dules : dans des individus moins ágés, ils sont appliqués immédiutement à la peau, de maniêre à ressembler à des taches, ou tout au plus a de légères élévations; et dans des silures de la mẹme espèce plus jeunes encore, on n'en apercolt aucun rudiment. On pourrait croire ces entonnoirs susceptibles de se coller, pour ainsi dire, contre differentes substances, et propres, par consequent, a donner à l'animal un moyen cattacher an fond des fleures, ou dans diverses positions fónd des fleuves, ou dans diverpositions nécessaires à ses besoins. Le silure cotyléphore habite dans les eaux des Indes orientales.

"4 rayons à la membrane branchiale du silure asprède, 8 z) chrque pectorale, 6 à chaque ventrale, 11 à la nageooire de
la queue. -8 rayose a che phore, 6 a chayons a chaque pectorale da silure cotyle
Deuxièmement, ses dents sont moins fortes
LE SILURE CHINOIS,

Silurus sinensis, Lac., Cuv. '

ET LE SILURE HEXADACTYLE.

Aspredo hexadaetylus, Cuv.; Silurus hexadaetylus,$$
\text { Cus:; }
$$

Les naturalistes n'ont pas encore publié de description de ces deux silures.

Nous avons vu une peinture très-fidèle et trèsbien faite du premier, dans la collection de peintures chinoises que nous avons souvent citée dans cet ouvrage.

La couleur de sa partie supérieure est d'un verdátre marbré de vert; les côtés et la partie inférieure sont d'un argenté mêlé de nuances vertes. Chaque opercule est composé de deux ou trois pièces presque ovales. Les deux barbillons ont une lóngueur à peu près égale à celle de la tête. La mâchoire inférieure est plus avancée que la supérieure. Aueune nageoire ne présente de rayon fort et dentelé.

La collection hollandaise déposée dans le $\mathrm{Mu}$ séum d'histoire naturelle renferme un individu très-bien conservé de l'espèce du silure hexadactyle. Nous avons tiré le nom spécilique de ce poisson, du nombre de rayons ou doigts de ses mains, ou nageoires pectorales, lesquels sont au nombre de six, ainsi que ceux de ses nageoires ventrales, ou de ses pieds.

Les quatre barbillons de la mâchoire d'en bas sont plus courts que les deux de la mâchoire d'en haut. L'ouverture de chaque narine est double. Les yeux sont petits et rapprochés I'un de Yautre. Indépendamment de plusieurs arêtes ou saillies tuberculées que l'on voit sur la tête et sur le corps, une saillie semblable part de chaque oil ; et ces deux arêtes sẹ réunissent au-dessus de la partie supérieure du dos. La tête et le corps sont très-aplatis; la longueur de ces deux parties n'est que le tiers, ou environ, de celle de la queue, qui réunit à cette dimension une conformation analogue à celle d'une pyramide à dix faces. Le premier rayon de chaque pectorale est large, aplati et dentelé sur ses deux bords de telle sorte que les pointes du bord externe sont tournées vers la queue, et celles du bord intérieur dirigées vers la tête.

- Du geore et du sous-genre Siture, dans la famille des Siluroides; division des Malacoptérygiens abdominaux. D. ${ }^{2}$ Da genre Aspaéde ou PLatrste, dans la fawille des.
Le dessus de la tete et du corps est blane avec des taches noires; presque tout le reste de la surface de l'animal est noir avee des taches blanches, excepté la partio inférieure de la tête, de la queue et du corps, qui est blanchátre.

\section{CENT SOIXANTE-QUATRIĖME GENRE.} LES MACROPTÉRONOTES '

La tele large, deprimee, el couverte de lames grandes el dures, ou d'une peau visqueuse; la bouche d lextremite du museau; des barbillons aux mdehoires; 10 corps gros; la peau enduite d'une mucositd abondante; une seule nageoire dorsate; celle nageoire ireslongue.

espekcrs. comscrimes.

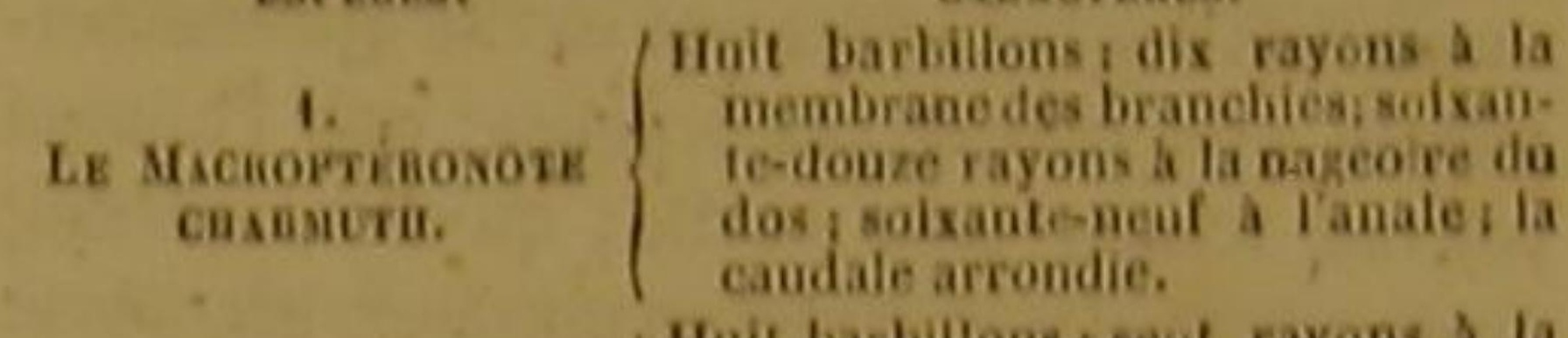

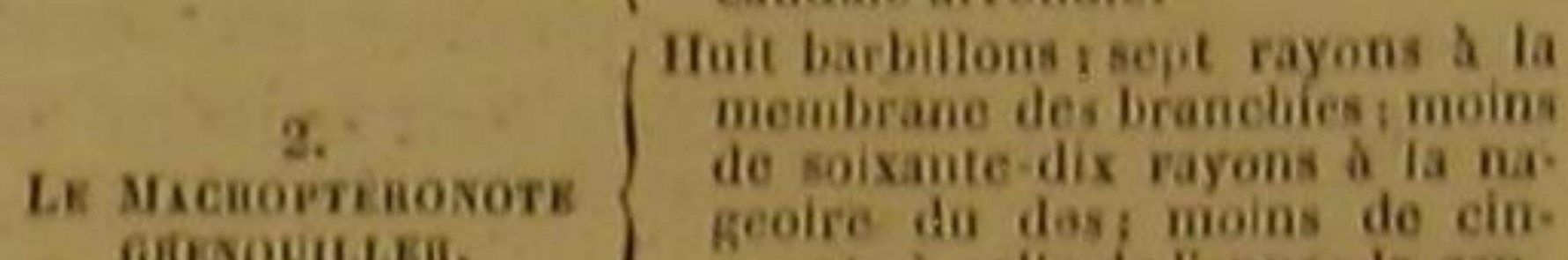

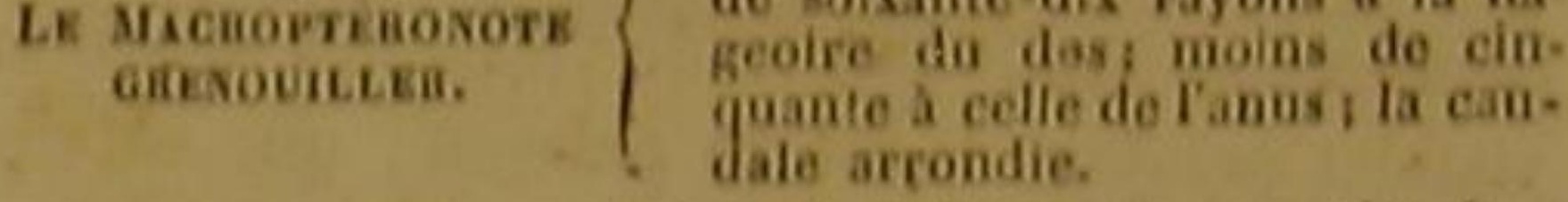

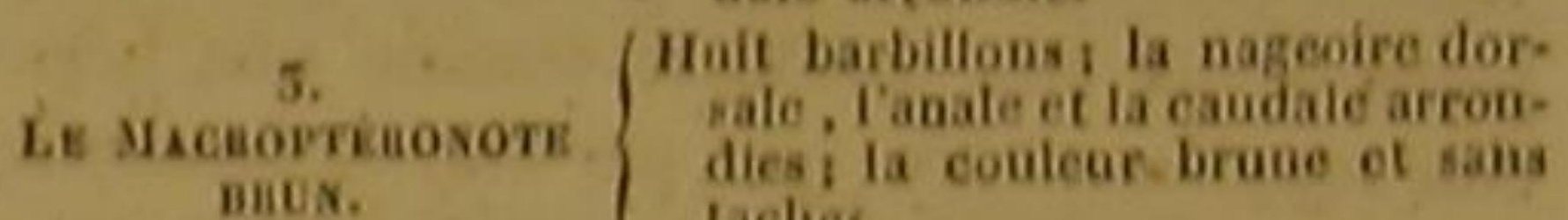

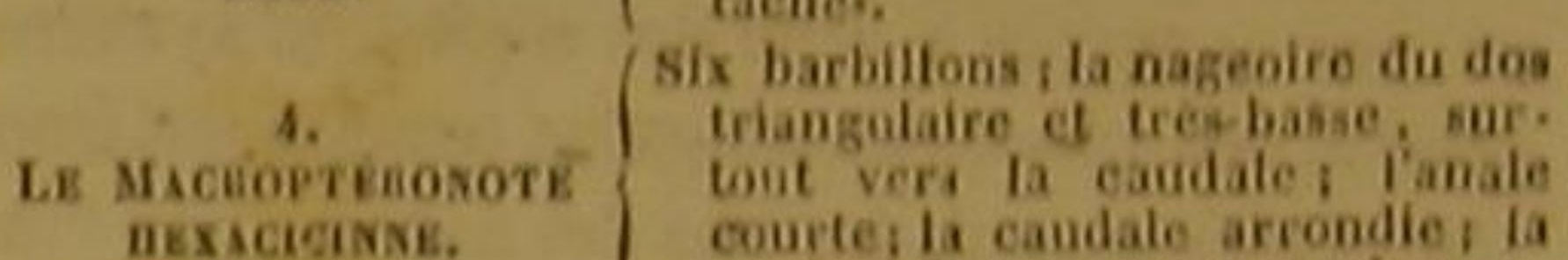

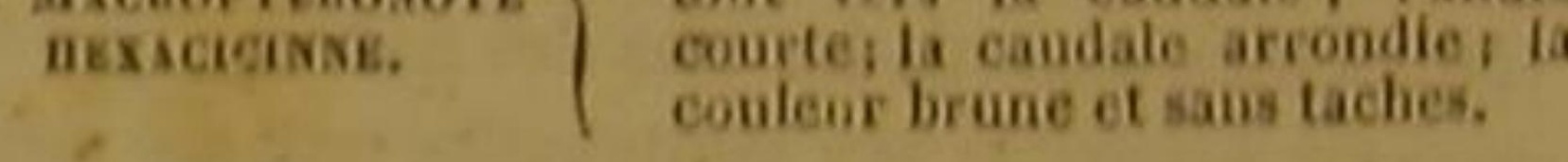

LE MACROPTÉRONOTE GHARMUTH ${ }^{2}$,

Heterobranchus Sharmuth, Geoff., Cuv.; Mačropteronotus Charmuth, Lac,; Silurus Anguillaris, Hasselq. '.

LE MACROPTÉRONOTE GRENOUILLER 4 .

Heterobranchus Bàtrachus Geoff, Cuv.; Macropteronotus Ba

Dans le genre dont nous nous occupons, la nageoire du dos s'étend jusqu'auprès de la cau-

A. Covier admet ce groupe, sous te nom d'tikriso

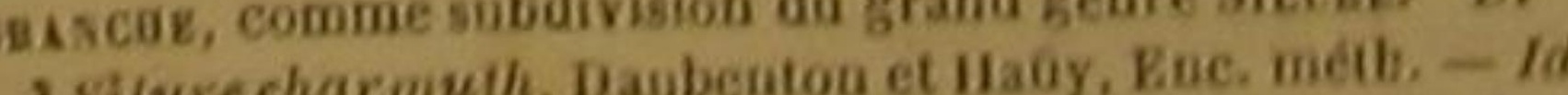

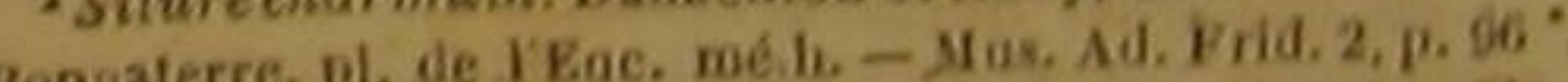
-. Silurus charmuth nilisticus, Illasselquist, It. 571 - Cla. rias. Gron. Zooph. 322, tab. 8, Gg. 3 et 4. - Blackfish, Hus-

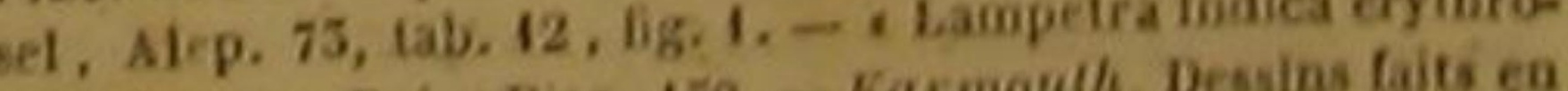
fithalmos, , Rai, Pisc, 150. - Karmoulh. Dessins taits e0 Egypte par $\mathrm{s}$. Cloquet, qui a bien voulu me ies com ont berit quer: - Aluby, par plusieurs anciens auteurs qui ont beril 
dale, augmente la surface de la qúeue, et donne |rayon de chaque pectorale fort et dentelé; la par conséquent plus de force à l'instrument couleur générale d'un brun mẻlé de jaune '. principal de la natation de l'animal : il n'est done pas surprenant qu'on ait remarqué beaucoup de rapidité dans les mouvements du charmuth. Le dessus de la tête de ce macroptéronote présente une multitude de pețits mamelons. De huit barbillons dont il est pourvu, les deux plus longs sont placés chacun à un des angles de la bouche, les deux plus courts auprès des narines, et les autres quatre sur les bords de la lèvre inférieure. La partie supérieure du poisson est d'un brun obscur, et la partie inférieure d'un blanc mêlé de gris. M. Geoffroy écrivait d'Égypte, le 16 août 1799 , à mon savant confrère $\mathrm{M}$. Cuvier, qu'il avait disséqué le charmuth ; qu'il avait vu au delà des branchies une cavité qui communiquait avec celle de ces org̉anes; que l'animal pouvait fermer cette cavité; qu'elle contenait un cartilage plat et divisé en plusieurs branches; que la surface de ce cartilage était couverte de nombreuses ramifications de vaìsseaux sanguins visibles pendant la vie du poisson; que cet appareil devait être considéré comme une branchie supplémentaire; que, par une conformation un peu analogue à celle des sépies, le système genéral des vaisseaux sanguins comprenait trois ventricules séparés les uns des autres, que l'on pouvait regarder ces ventricules comme autant de cours, ete. : mais tous ces détails vont être eclaireis par la publication des utiles travaux de M. Geoffroy, rendu, après quatre ans d'absence, à sa patrie, à ses amis, à sa famille ef à ses collègues.

Le charmuth habite dans le Nil ; on trouve le grenouiller dans l'Asie et dans I'Afrique.

La calotte osseuse qui revêt le dessus de tète du grenouiller se termine en pointe par derrière, et montre deux enfoncements. L'antérieur est allongé, et l'autre presque rond. Autour de chaque angle de la bouche sont distribués quatio barbillons longs et inégaux. Le palais est rude, la ligne latérale presque droite; le premier froy, professeur au Muséum đathistoire naturelle, a eu la bonte de nifecrire du Caire.)

geare SuLres, famille des Silvascue, Cuv, dans le grand rygiens abdominaux. D

- Froschwels, par les Allemands. - Toeli, par les Tamules. - Silure grenouiller. Bloch, pl. 570 , fig. 1. - Id. Da benton é. Hauy, Enc. 'métb. I Id. Boonaterre, pl. de l'Ence.

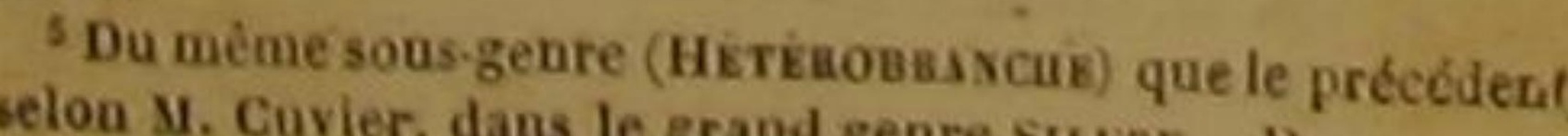

\section{LE MACROPTÉRONOTE BRUN,}

Heterobranchus Balrachus, Cuv, ; Macropteronotus fuscus, Lacep.".

\section{LE MACROPTÉRONOTE HEXACICINNE}

Heterobranchus hexacicinnus, Cuv.; Macropteronotus hexacicinuus, Lac. '.

Nous publions les premiers la description de ces deux espèces, dont fes peintures chinoises déposées đans la bibliothèque du Muséum d'hispour les formes que pour les couleurs.

Ces deux macroptéronotes vivent dans les eaux de la Chỉne. Le dessus de la tête du brun est couvert d'une enveloppe dure qui montre par derrière deux échancrures, et se termine en pointe. Le premier rayon de chaque pectorale st long, dur, un peu gros, mais sans dentèlure. On distingue une partie des muscles du corps el de la queue, au travers de la peau. Les ventrale sont petites et arrondies. Un grand barbillon est attaché à chaque angle de la bouche; les autres six sont moins longs, et situés deux auprès des narines, et quatre sur la mâchoire inférieure. L'iris est couleur d'or.

Le nom de l'hexacicinne désigne les six barbillons du second de ces macroptéronotes chinois. Ce poisson ne differe du premier que pau les traits indiqués sur le tableau générique, $\mathrm{e}$ vraisemblablement par ses dimensions que nous croyons inférieures à celles du brun.

1 10 rayons a chaque pectorale du macroptéronote charqueve -8 ou 7 a claque ventrale, 21 a la nageoire de la grenouiller. 67 a la naseoire du dos, 6 a chaque veutéronote a la nageoire de Tanus, 16 a la caudale. 2.) Ces deux poissons appartieuneut aú sous-genre Hétkioninscuk de M. Cuvier, dans le grand genre SILUBE. Le premier ne parait étre qu'une variété du Macroptéronote gré
nouiller de I larticle précedent. D.

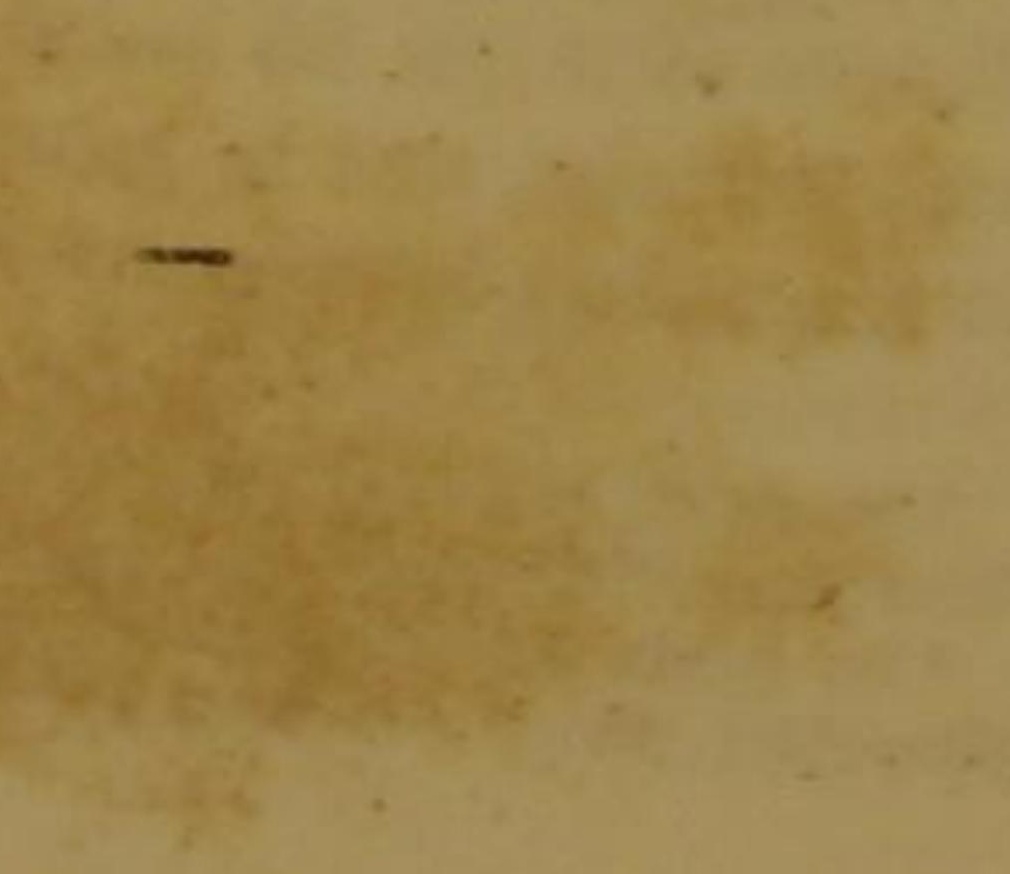
toire naturelle présentent une image aussi exacte

CENT SOIXANTE-CINQUIÈME GENRE. Les malaptériures '.

La tele déprímée et couverte de lames grandes el dures, ou d'une peau visqueuse; la bouche d' l'exirémité du museau; des barbillons aux machoires; le corps gros; la peau du corps et de la queue enduite d'une mucosite abondante; une seule nageoire dorsale; - cello nageoire adipeuse, et placée asses prìs de la caudale.

Espéck.

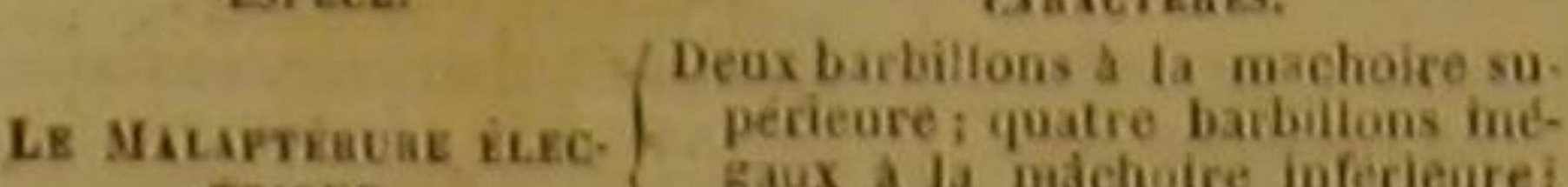

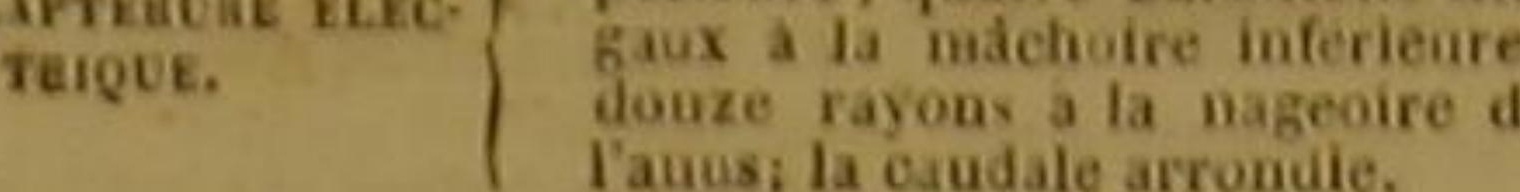

LE MALAPTÉRURE ÉLECTRIQUE ${ }^{2}$.

Malapterurus electricus, Lae., Cuv.; Silurus electricus Limn, Gmel. '.

Ce nom d'Électrique rappelle la propriété remarquable que nous avons déjà reconnue dans les quatre espêces de poissons, dảns lá raie torpille et dans le tétrodon, le gymnote et le trichiure, désignés par la même dénomination spéeifique que le malaptérure de cet article. Cetto propriété, observée avee soin dans ces différents animaux, pourra servir beaucoup aux progrès đe la théorie des phénomènes galvaniques, auxquels elle appartient de très-près; nous ne saurions assez inviter les voyageurs instruits à s'occuper de l'examen de cette force départie aux cinq poissons électriques, et qui parait si différente de la plupart de celles que possèdent les êtres organisés et vivants; et nous attendons avec beaucoup d'impatience la publication des recherches faites en Egypte par M. Geoffroy, sur le malaptérure que nous décrivons. Nous savons déjà par ce professeur ${ }^{4}$ que ce malaptérure est recouvert d'une couche épaisse de graisse. Ce fait doit être rapproché de ce que nous avons indiqué au sujet des poissons qui ont la faculté d'engourdir, dans le premier Discours sur cette Histoire, dans l'article de la torpille, et dans celui du gymnote électrique.

1. M. Cuvier conserve ce genre ef le place dans la famille des Siluroídes, qui appartieut a la division des Malacoptéry. giens abdominaux. $\mathbf{D}$.

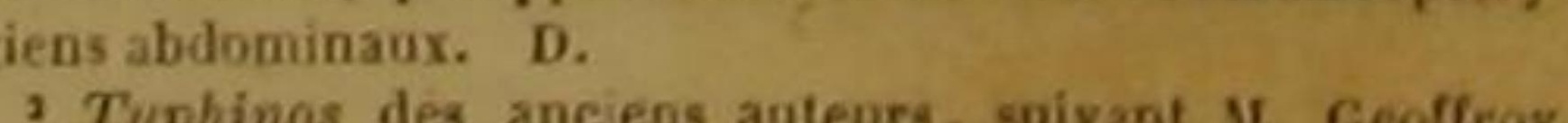
Leture adressée du Caire a M. Lacépéde. - Forskael, Fann. Arab., p. 15, n. 1. - Broussonnet, Acad. des sce, 1782,

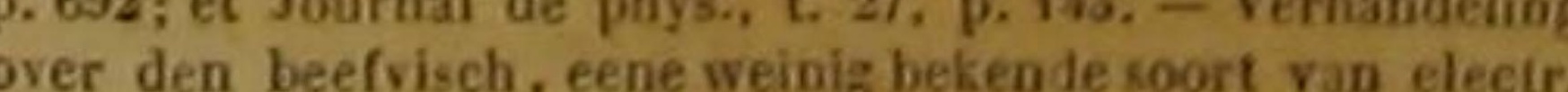
visch. - Algen, Geneesk. jaarboek, t. 4, D. 2t. - Silure trembleur. Bonaterre, pl. de l'Eoc, méth. 4 Lettre écrite do Caire, le 29 thermidor de l'an 7 (16 sepII.
Le malaptérure dont nous traitons ne se trouve pas seulement dans le Nil : il vit aussi dans d'autres fleures d'Afrique. 11 y représente le tétrodon et le trichure engourdissant de l'A. sie, le gymnote torporifique de l'Amérique, et la torpille de l'Europe. II y parrient à une longueur de plus d'un pied et demi. Son corps est aplati comme sa tête. Ses yeux, très-peu gros, sont recouverts par la membrane la plus extérieure de son tégument général, laquelle s'étend comme un voile transparent an-dessus de ces organes. Chaque narine a deux orifices. Sa couleur grisátre est relevée par quelques taches noires ou foncées que l'on voit sur sa queue '.

\section{CENT SOIXANTE-SIXIÈME GENRE.} LFS PIMÉLODEs ${ }^{2}$.

La tete diprime et couverto de lames grandes of dures, ou d'ane peau visqueuse; la boucho d l'extrdmitd du museau; des barbillons aux mdehoires; le corps gras. ta peau-du corps et ta queue onduito d'uno mucosite abondante; deux nageoires dorsales; la seconde adi-
peuse.

PREMIÉn SOUS-GENRE.

La nageoire de la queue fourchue, ou dehanerlo en ergitssant.

espices,

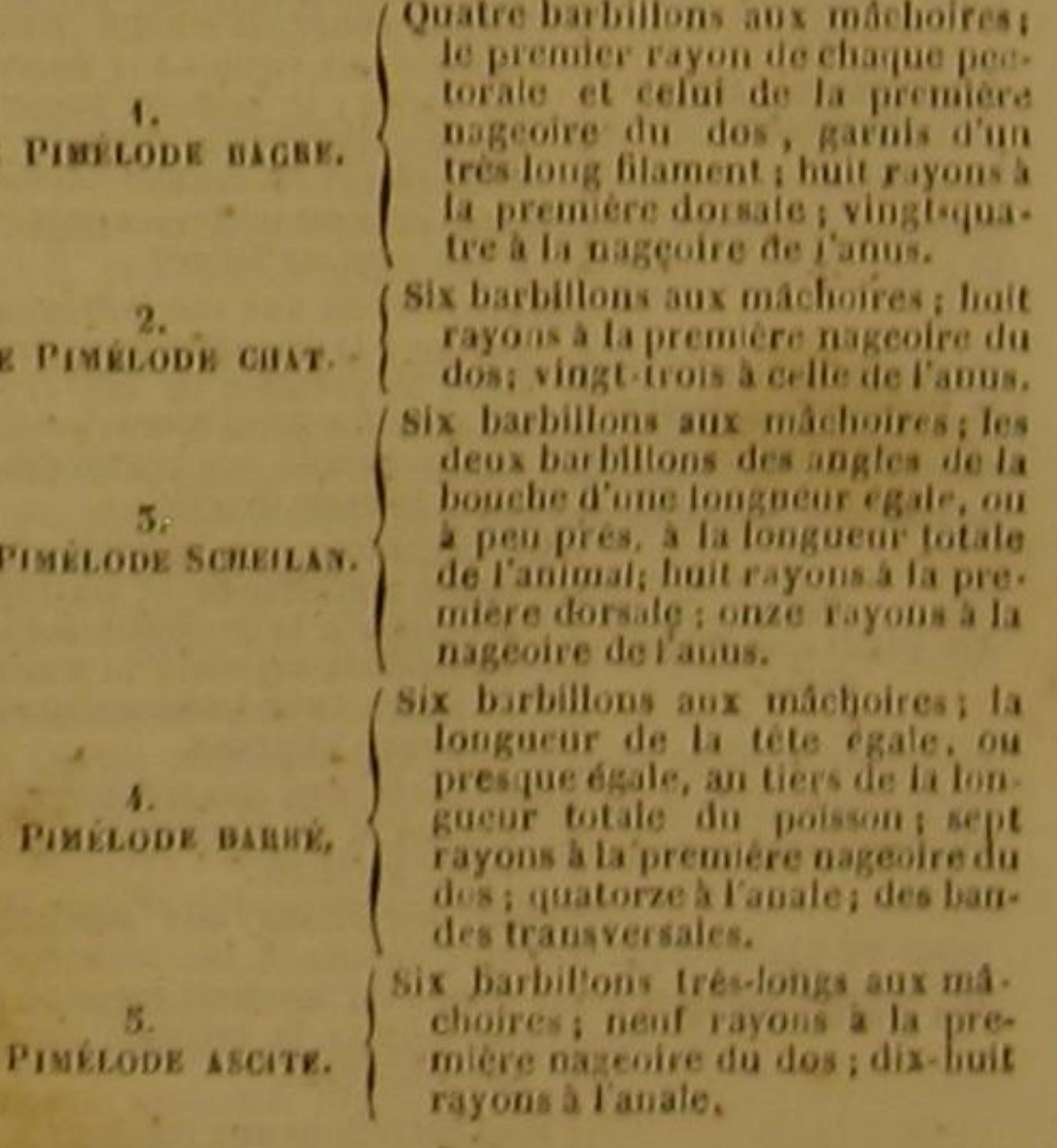

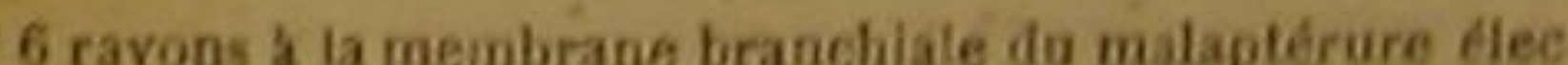
irique, 9 a chaque pectorale, 6 s chaque ventra'e, is a is Irique, g a chaque pecior
mageoire de la queue.

2M. Cavier admet, sous le nom de Micionass (Mystus), un grand sousgenre de Silures, qui comprebd les Pinétodes t les Doras de M. de Lacépéde. Nous cousidecrons ies Nime lodes comme formant un sous-gene particulier. 

CABACTÉ

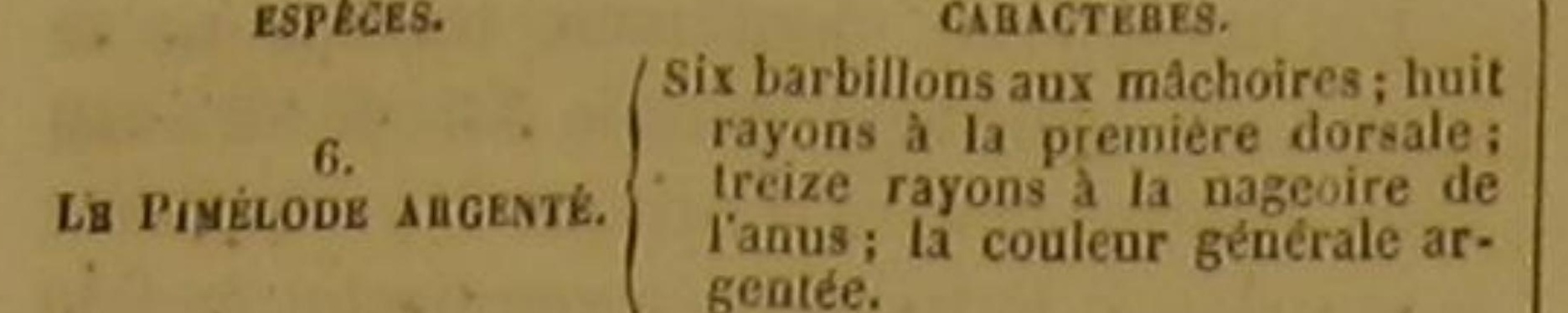

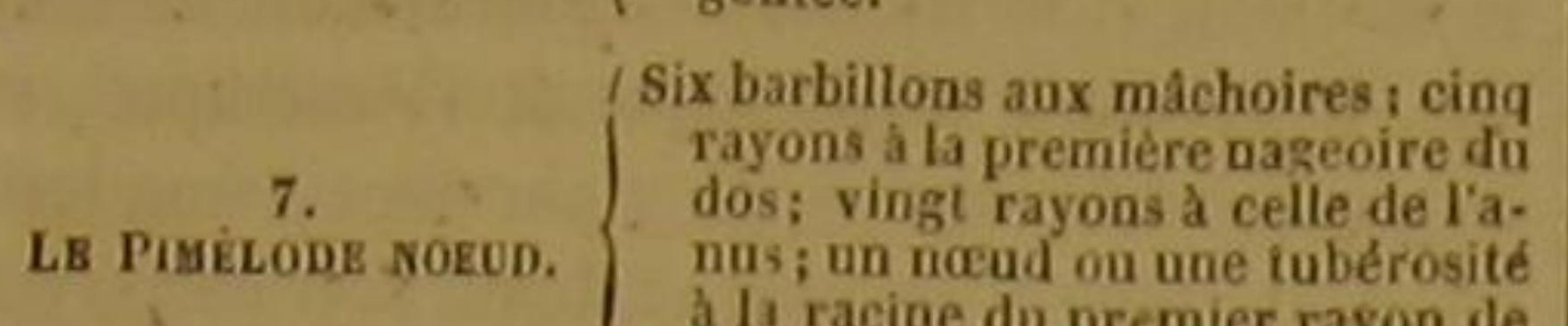

7.
a la racine du premier rayon de
la dorsale.

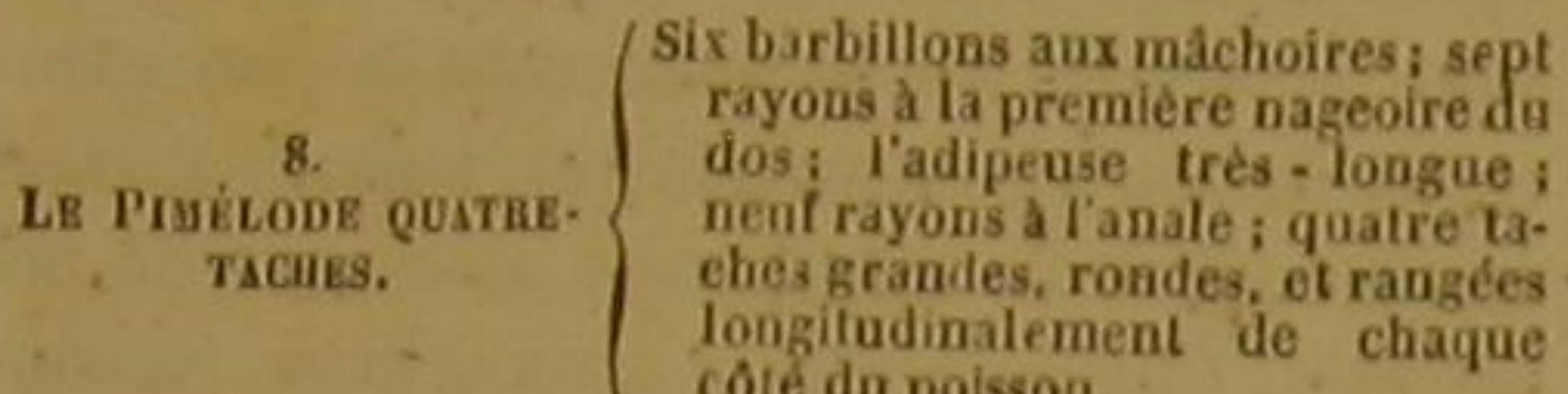

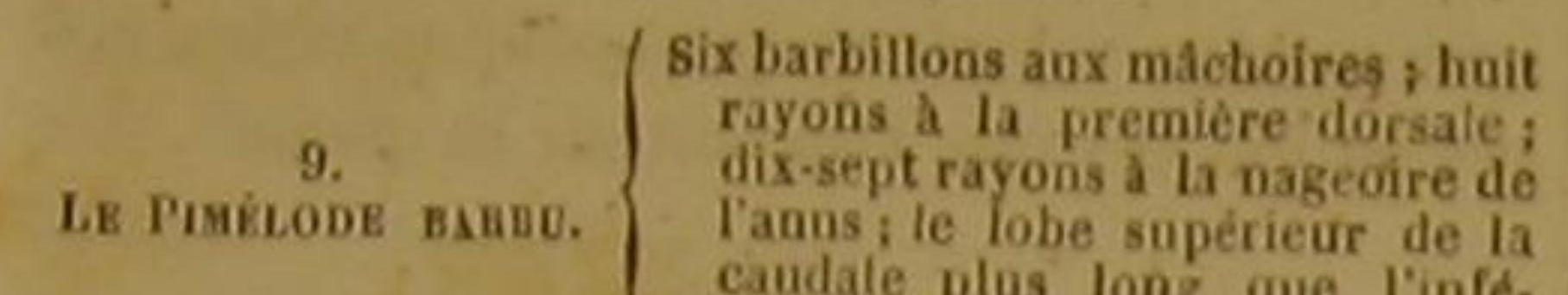

caudale plus long que l'infé-
rieur.

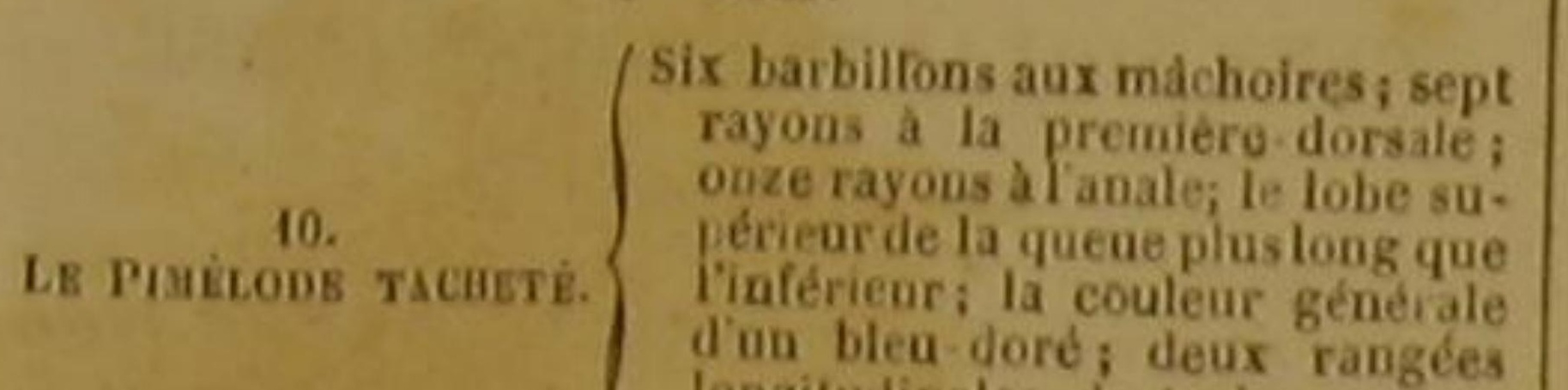

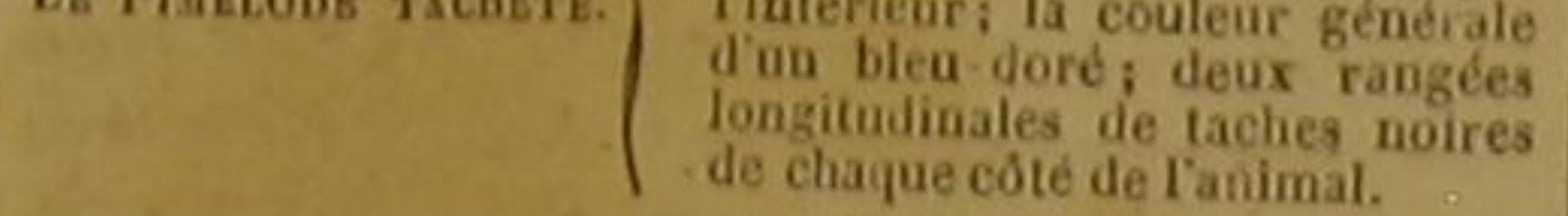

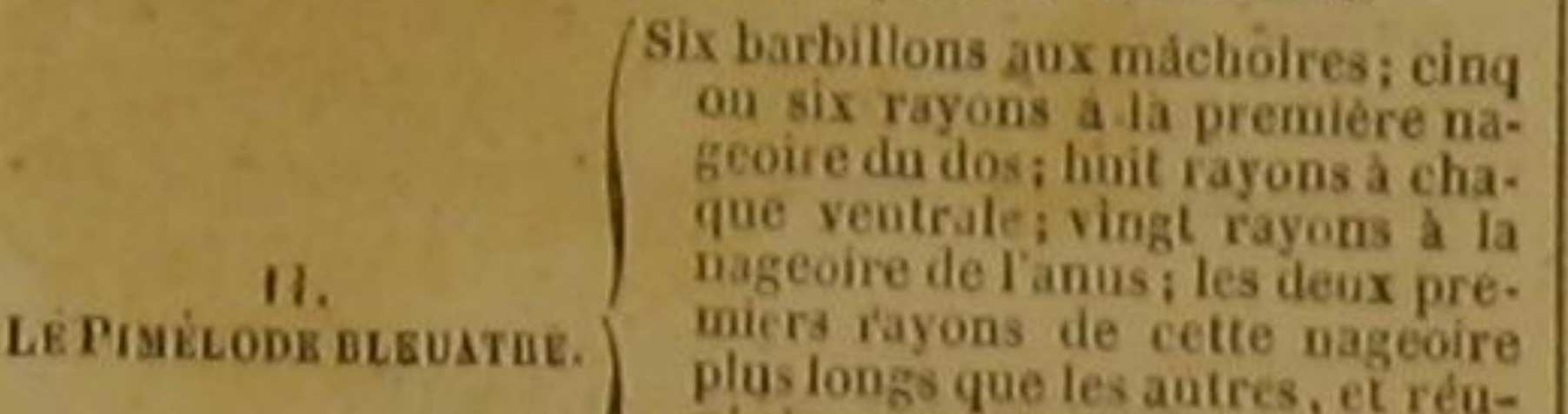
nis a un appendice membraneux,
filiforme, ep plus allongé que ces
rayous; la couleur géeerale bieual-
tre.

LE PIMĖODE DOIGT-
DE NEGGR, barbillons aux máchoires; huit
rayons a la premiere nageoire du tort
dent
dent e lanusis le premier rayon de

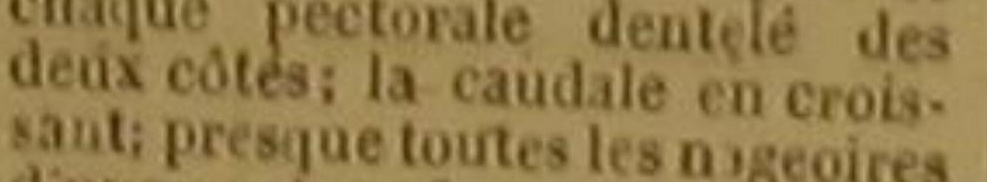

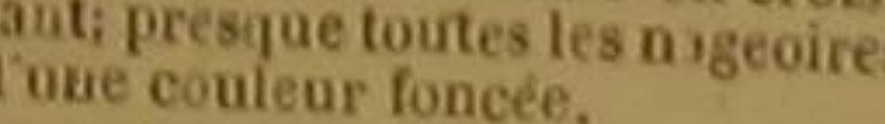
15.
LE PINLODE cosmen.
SONXIE. Six barbillons aux má hoires; sept
rayons a la premiere nageoire du
doy dos; le premier de ces rayons
deatele des dear cotés point de
rayon dentelé aux pectorales; is Six barbiltons droite.

LE PMELODE THOX.
BKBG.

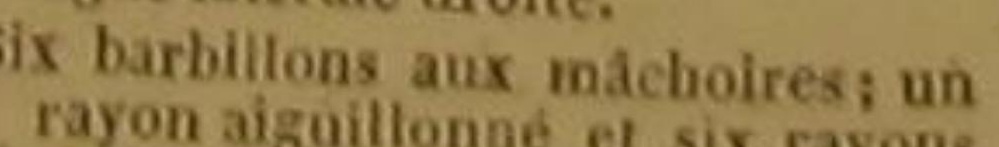

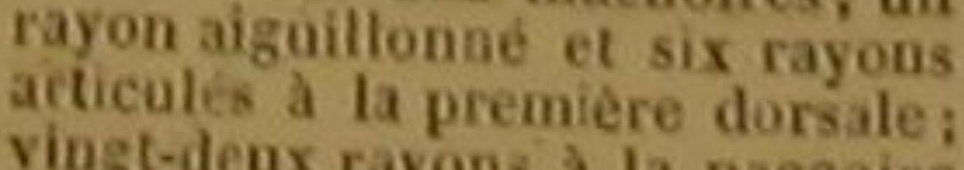
lagt-deux rayons a la nageoire
de laaus; mune tache noire sur la
nageoire adipeac.

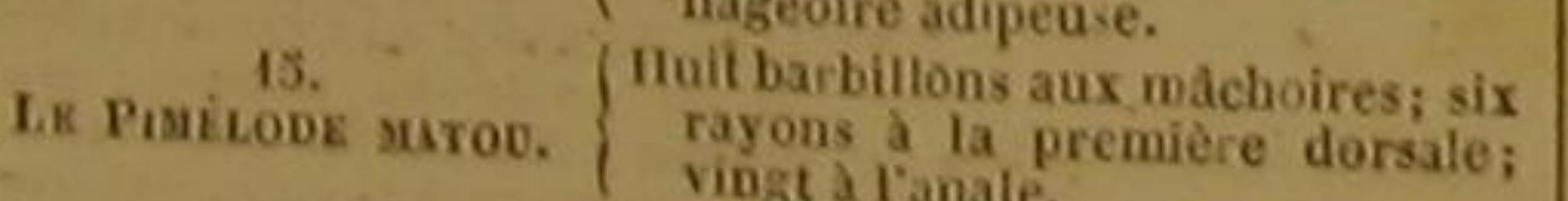

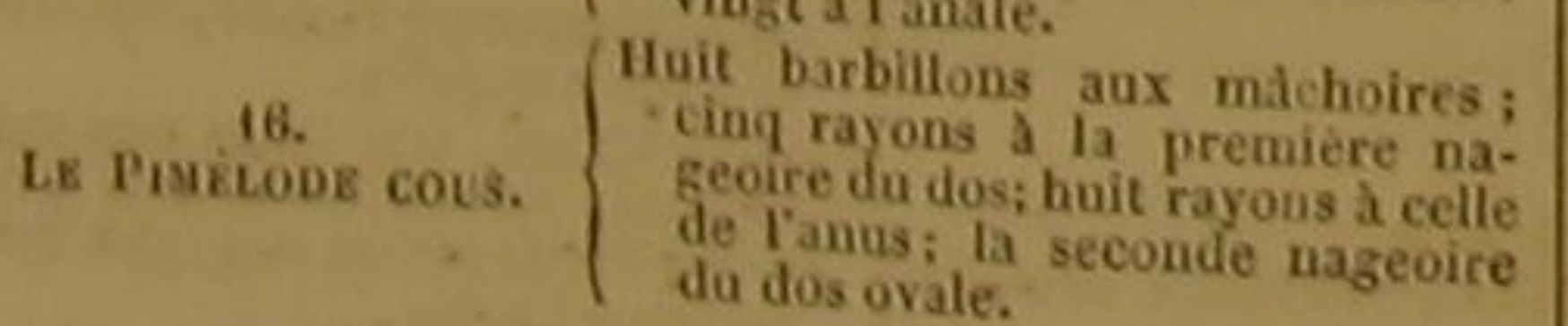

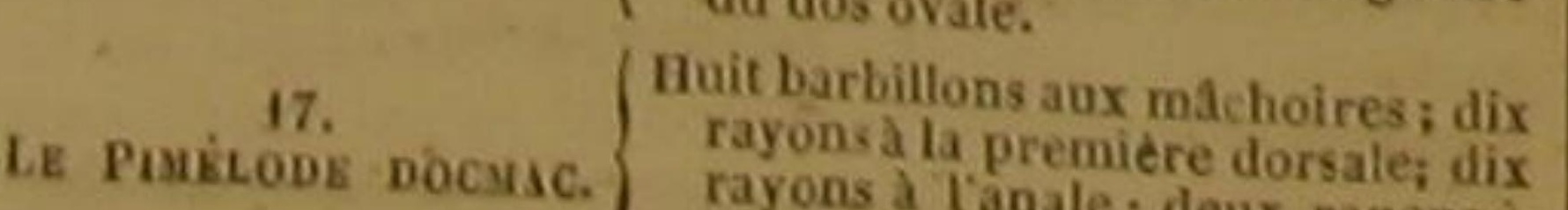

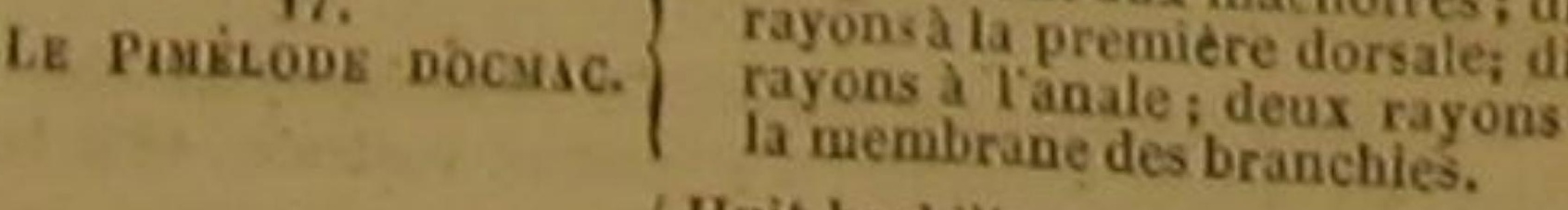

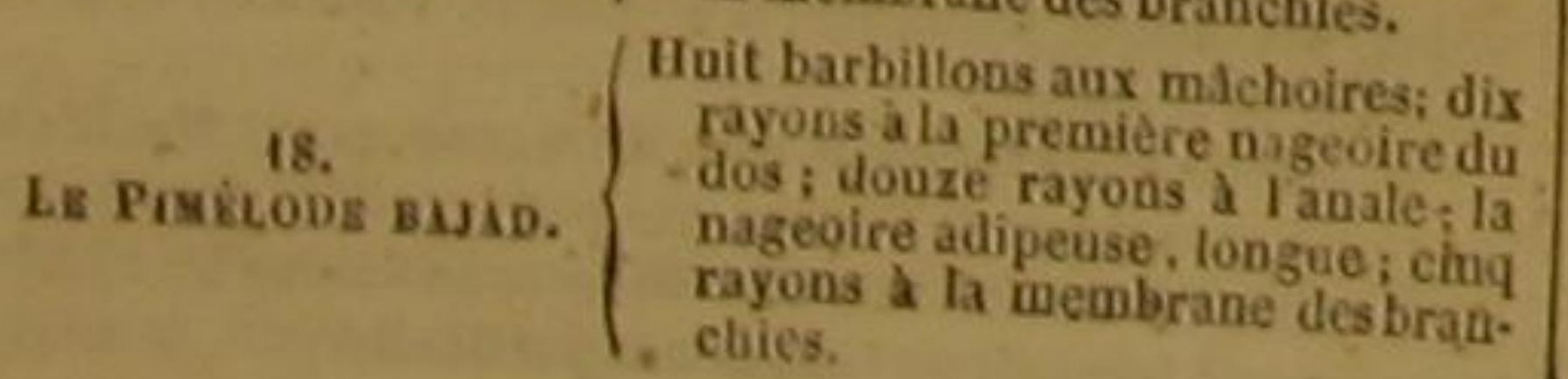

ESPĖCES.
19.
LE PIILEDE ĖHY-
TUROPTËIE. CAHGTÈ⿴囗十S.

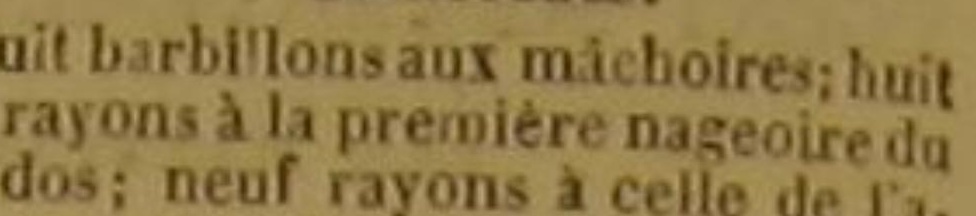
nus; la nageoire adipeuse, lon:
guee les deux lobes de la candale
trés-allongés; les pageoires rous ges. 20.
LE PRELLDE BAIE
D'ARGEST. Tait barbillons anx machoires: cipg

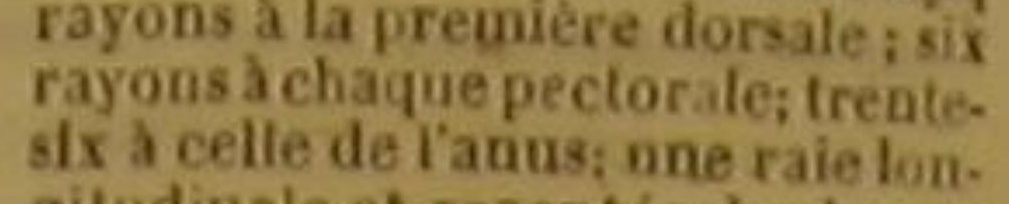
gitudinale et argentée de cha que
coté du poisson.

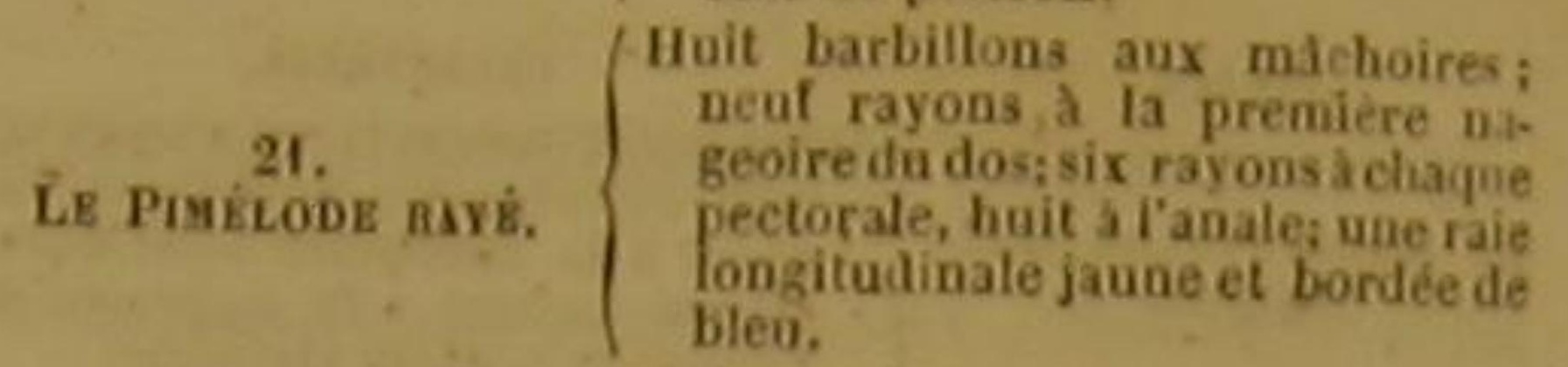

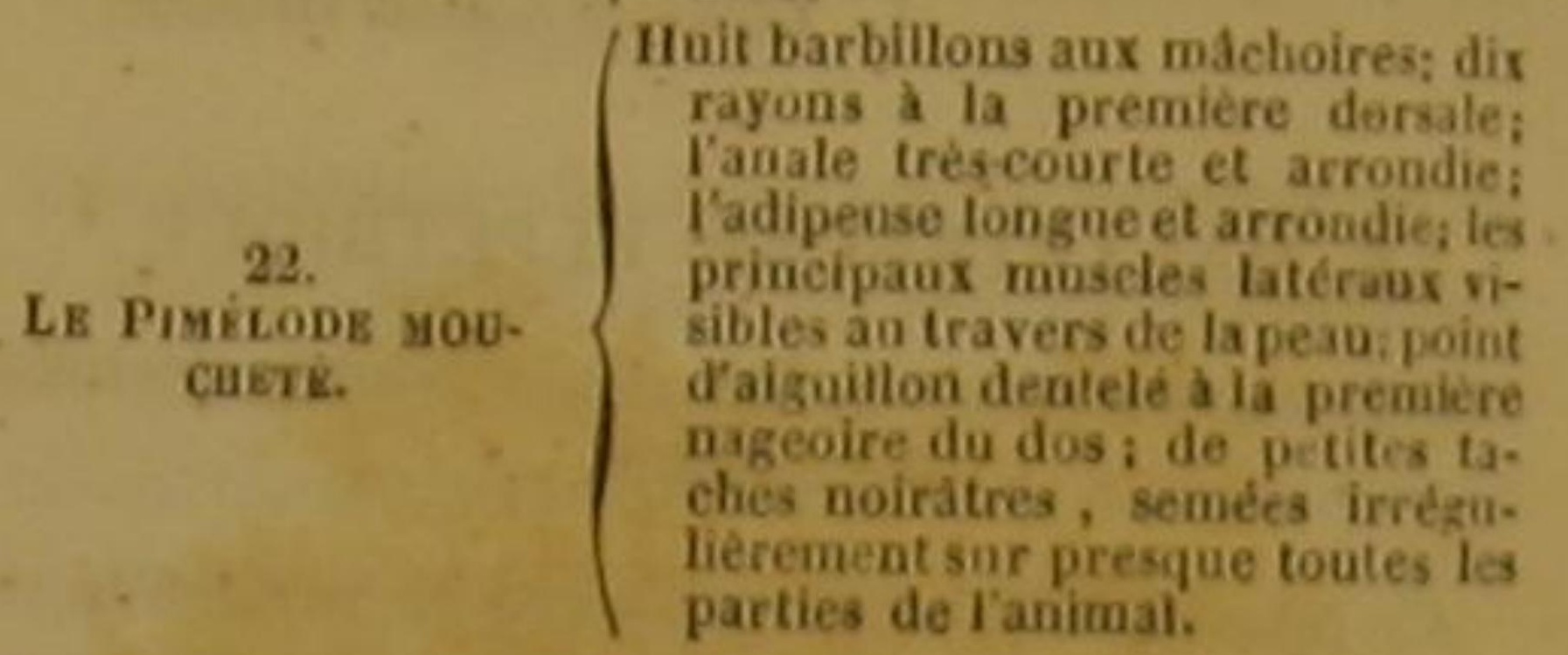
SECOND SOUS-GENRE.

$L_{a}$ nageoire de la queue terminée par une ligne droite, ou arrondie el sans fehancrure.

- Six barbillons aux máchoires: six

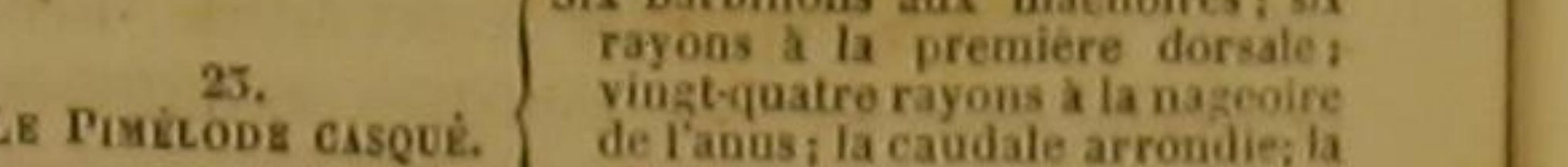
que et le devant du dos, couverts de plaques très-dures et osseuses; la ligne latérale courbée vers le bas; l'os qui représente la clavicule, soutenu par une pièce osseuse et triangulaire; le premier rayon de chaque pectorale, de la première nageoire du dos, et quelquefois de chaque ventrale, osseux, très-fort, dentelé d'un ou de deux côtés, et propre à faire des blessures dangereuses à caúse des déchirements qu'il peut produire dans les muscles et jusque dans le périoste; l'anale et la nageoire adipeuse échan-

composition
Stutiv. D - Silure chat Dane, Passani, Pelite gueule, ar Cayenne. naterre pi do linbentor at

- Espéce non mentionnée par 11, Cuvier. D." - Langbard, en Allemagne. - Langstrimad laudjagy. é Suède. - Silure scheilan. Daubenton et Hany, Enc.
méth. - Id. Bonnaterre, pl. de I'Enc, méth.- Mus. Ad Frid. I, p. 73; et 2. p. 98 :- - It. Scan. 82 - Grobor. Mos. 1 . n. 85, p, 51; Zooph., n, 384, p. 125. - Hasselquist, It 569. Barbarin. Bloch, pl. 35, fig. 1 :

- Dè la subdivision des Pimelodes appelées schals (Syno-

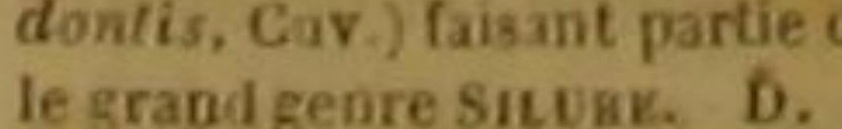

is Silure barré. Dasbenton et Hady, Ene, méth. - Id. Bonnaterre, pl. de l'Enc. méth. - Bloch, pl. 366. - Séba, Mns. 5, p. 84, tab. 19, fig. 6. - Gronov. Zooph. 586. 'Le Pimeloda barre, Lae., est de ia subuivision des Pimelodes nonmés Eagces par ML. Cavier. II appartient constquimment an sous-geare suctuonds, dans le grand gent

Celle agure eat cilte ici a tort ; elle se rapporle a un autre Pime-
lode. I.
P(ISSONS.

467

crées du cóté de la caudale, dont la pointe supérieure est plus longue que l'inférieure; le couleur générale d'un gris noir; le ventre d'un gris blane '.

Le barré vit à Surinam, comme le scheilan. Le haut dela tête sillonné; la máehoire supérieuro plus allongée que celle d'en bas; la langue lisse et courte; le palais rude; l'oriflce unique de chaque narine; les bandes transversales grises, jaunes et brunes; la blancheur du ventre, le rougeátre des pectorales, le bleuátre et les taches brunes des autres nageoires; tels sont les traits du pimélode barré, qu'il ne faut pas négliger de connaitre ${ }^{2}$.

\section{LE PIMÉLODE ASCITE ${ }^{3}$}

Silurus Ascila, Linn., Gmel; Pimelodus Ascita, Lac. ‘

Le Pimelode argentes, Pimelodus argehteus, Lao, Silturu

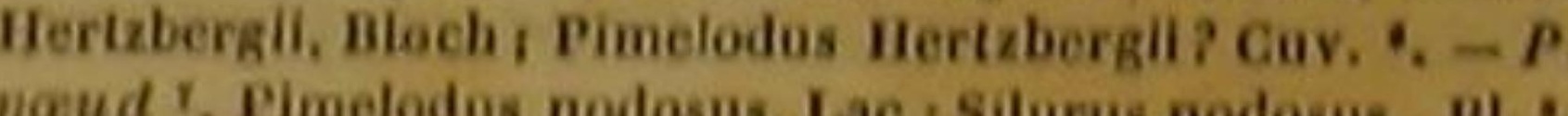
$-P$. quatretaches ${ }^{\circ}$, Dimelodus quadrimacolats , is,

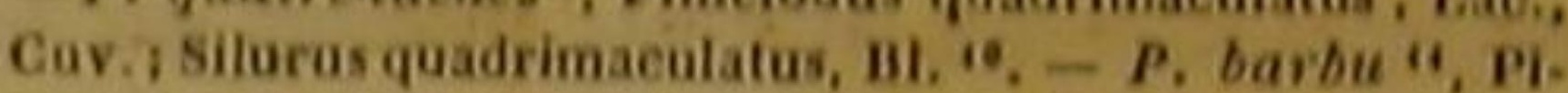
melodus Barbus, Lac, "1, - P, tacheld ", Pimelodus ma. colatus, Lacep, Cuv, "., - P. Bleudire, Pimelodus caralescens, Lac, ", - P, doigl-de-ndgre, Pimelodus nigrodi-

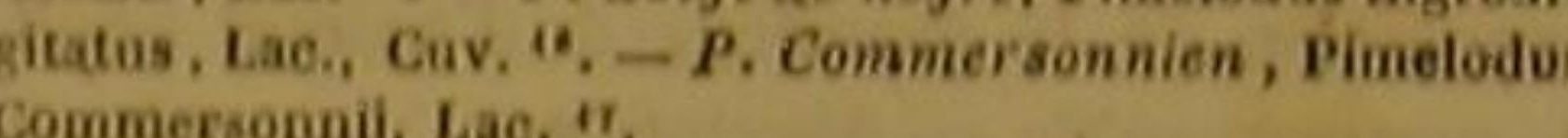

Nous avons déjà observé très-souvent que plusieurs poissons cartilagineux ou osseux, tels

- 6 rayons a la membrane des branchies du pimélode bagre, is a chaque pectorale, 8 a cliaque ventrale, 18 a la mageodre do la queue. -5 rayons a la membrane des biranchiea du pimecaudale. - 6 rayons a ta membrane des branchies du pimélode scheilan, 7 a chaque pectorale, 7 a chaque ventrale, is a la nazeoire de la queue. -12 rayons a la membrane des bran.
chies da pimétode barré, 12 i chaque pectorale, 6 a chaque cbies an pimétode barró, 12 a chaque pectorale, a a claque

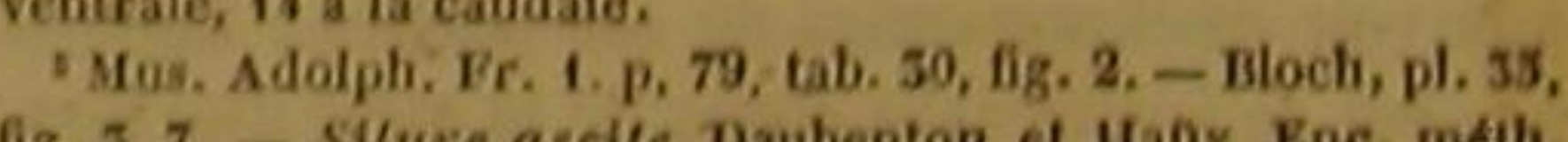

- Id. Bonnaterre, pl de I'Enc. métb.

S. Cuvier remarque qué le Pimélode ascite n'est qu'us Pimélode ordinaire, sortant de l'auf, et dont le jaune n'est pas encore tout a fait rentre dans Tabdomeu. D.

Silurus Hertzbergii. Bloch, pl, 367.

- Mentione par M. Culer, codine appartenant au sous. acoptérygiens abdominaux silturoides. D, ' Non mentionné par BI. Cuvier. D. Silurus quadrimaculatus. Bloch, pl. 5e8, fig. 2.

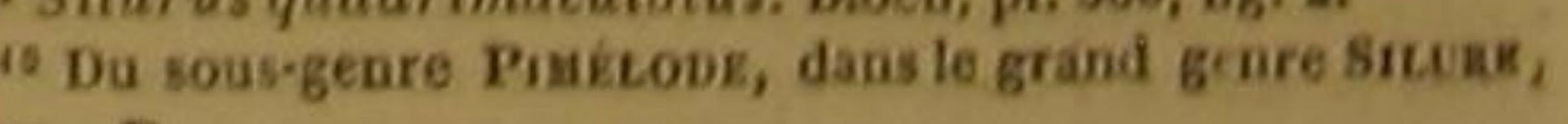
v. D.

Barbue, par les matelots français. - - Silurususpinna - dorsi prima ossiculorum octo, diris iabialibus sex, cauda déja cit's.s. 
que les raies, les squales, les blennies, etc. étaient ovovivipares, c'est-à-dire, provenaien d'un œuf éelos dans le ventre de la mère. Nous avons remarqué aussi que les syngnathes se développaiént d'une manière intermédiaire entre celle des ovovivipares et celle des ovipares. Leurs œufs, en effet, n'éclosent pas dans le ventre de la femelle; mais lorsque les petits syngnathes en sortent, ces œufs sont encore dansune sorte de rainure longitudinale qui se forme audessous de la queue de la mère, et où ils sont retenus par une membrane que les fotus déchirent pour venir à la lumière. Une génération différente, à plusieurs égards, de celle des syngnathes, mais qui s'en rappróche néanmoins, et qui tient également le milieu entre celle des ovovivipares et celle des ovipares, a été observée dans les ascites. Leurs oufs n'éclosent, pour ainsi dire, ni tout à fait dans le corps, ni tout à fait hors du corps de la femelle; et nous allons voir comment se passe ce phénomène remarquable qui confirme plusieurs des idées exposées dans nos différents Discours sur les poissons.

Les oufs de l'ascite deviennent très-gros d proportion de la grandeur de l'animal adulte. A mesure qu'ils se développent, le ventre se gonfle; la peau qui recouvre cet organe s'étend, s'amincit, et enfin se déchire longitudinalement. Les aufs détachés de l'ovaire parviennent jusqu'à l'ouverture du ventre; le plus avancé de ces œufs se fend à l'endroit qui répond à la tête de l'embryon; la membrane qui en forme l'enveloppe se retire; et l'on apercoit le jeune animal recourbé et attaché sur le jaune par une sorte de cordon ombilical, composé de plúsieurs vaisseaux. Dans cette position, l'embryon peut mouvoir quelques-unes de ses parties : mais il ne peut se séparer du corps de la mère que lorsque le jaune, dont il tire sa nourriture, est assez diminué pour passer au travers de la déchirure longitudinale du ventre; le jeune poisson s'éloigne alors, entrainant le jeune poisson reste de jouns, entrainant avec lui ce qui reste de jaune, et s'en nourrissant encore pendant un temps plus ou moins long. Un nouvel

13 Silurus corpore maculoso, cirris quatuor in mandibula
- inferiore : duobus in superiore, inferiore: duobus in superiore, ultra pinnam dorsi secen “" Dusous Cav. D.$$
{ }^{4} \text { Non mentionné par M. Cuvier. D. }
$$

Cur. 11 .

cuf prend la place de celui qui vient de sortir; lorsque tous les œufs se sont ainsi succédé, et que tous les petits sont éclos, le ventre se referme, les deux côtés de la fente se réunissent, et cette sorte de blessure disparait jusqu'à la ponte suivante.

Des six barbillons que présente l'ascite, deux sont placés à la màchoire supérieure, et quatre à l'inférieure. Le premier rayon de la première nageoire du dos et celui de chaque pectorale sont durs et pointus.

Il parait que l'ascite a été pèché dans les deux Indes.

A l'égard de l'Argenté, on l'a recu de Surinam. Ce pimélode a l'ouverture de la bouche petite; les mâchoires aussi longues l'une que l'autre, et hérissées de très-petites dents, comme le palais; la langue lisse et courte; un senl orifice à chaque narine; quatre barbillons à l'extrémité de la mâchoire inférieure; un barbillon à chaque coin de la gueule; la ligne latérale pres. que droite, et garnie, sur chacun de ses cótés, de plusieurs petites lignes tortueuses; le premier rayon de la première dorsale dentelé à son bord extérieur; le premier rayon de chaque pectorale dentelé sur ses deux bords; le dos brunâtre; et les nageoires variées de jaune.

Les eaux de Tranquebar nourrissent le pimé. lode Noud. Nous devons indiquer les petits sillons qui divisent en lames la couverture osseuse de sa tête, le double orifice de chacune de ses aarines, T'appendice triangulaire qui termine chaque clavicule, la dentelure que montre le bord intérieur du premier rayon de chaque pectorale et de la première nageoire du dos, la direction de la ligne latéralequi éstondée, le bleu du dos et de la nageoire de l'anus, la couleurbrune des utresnageoires, l'argenté des côtés et du ventre. Que l'on remarque dans le pimélode QuatreTaches, qui vit en Amérique, l'égal avancement des deux mâchoires; le nombre et la petitesse des dents qui les hérissent et qui garnissent le palais; la langue lisse; l'orifice unique de chaque narine; la longueur des barbillons placés au coin de la bouche; la dentelure du premier rayon de chaqué pectorale; le brun nuancé de violet qui règne sur le dos; le gris du ventre; le jaunâtre des nageoires; les taches de la première dorsale, dont la base est jaune, l'extrémité bleuâtre.

Les cinq pimélodes dont nous allons parler

DES POISSONS.

aucun ouvrage d histoire naturelle. Nous avons trouvé dans les manuserits de Commerson une notice très-étendue sur les deux premiers de ces quatre poissons, et un dessin du cinquième.

La couleur générale du Barbu est d'un bleu plus ou moins foncé ou plus ou moins semblable à la couleur du plomb; la partie inférieure de l'animal est d'un blane argenté; les côtés réfléchissent quelquefois l'éclat de l'or, quelques nageoires présentent des teintes d'incarnat. La couverture osseuse de la tête est comme ciselée, et relevée par des raies distribuées en rayons; la máchoire supérieure dépasse et embrassel'inférieure; de petitesdents hérissent l'une et l'autre, âinsi que deux croissants osseux situés dans la partie antérieure du palais, et deux tubercules placés auprès du gosier; la langue est très-large, unie, cartilagineuse, dure, et attachée dans tout son contour; chaque narine a deux orifices, et l'orifice postérieur, quí est le plus grand, est fermé par une petite valvule que le barbu peut relever à volonté; une carène osseuse et aiguë s'étend depuis l'occiput jusqu'à la première dorsale; la ligne latérale est à peỉne visible; te ventre est gros, et devient très-gonflé et comme pendant, lorsque l'animal a pris une quantité de nourriture un peu considérable. Le premier rayon de chaque pectorale et de la première nageoire du dos est dentelé de deux côtés, très-fort, et assez piquant pour faire des blessures très-douloureuses, graves et si profondes, qu'clles présentent des phénomènes semblables à ceux des plaies empoisonnées. La nageoire adipeuse est plus ferme que son nom ne I'indique, et sa nature est à demi cartilagineuse. On aperçoit au delà de l'ouverture de l'anus un second orifice destiné vraisemblablement à la sortie de la laite ou des aufs. Le foie est rougeátre; très-grand, et divisé en plusieurs lobes; l'estomac dénué de cocums ou d'àppendices; le canal intestinal replié plusieurs fois; la vessie natatoire attachée au-dessous du dos, entourée de graisse, et séparée en quatre loges.

Le goût de la chair du barbu est exquis; on le prend à la ligne ainsi qu'au filet. Lorsqu'on le tourmente ou l'effraie, il fait entendre une sorte de murmure, ou plutôt de bruissement. Il habite dans les eaux de l'Amérique méridionale.

Le pimélode tacheté a été vu dans les mêmes contrées. II vit particulièrement dans le grand fleuve de la Plata, et il a été observéa à BuénosAyres, ainsi qu'à la Encénada. Le téoument osseux de sa tête est relevé par des points et des ciselures, il montre un petit sillon entre les yeux et s'étend par un appendice jusqu'à la première nageoire du dos. La mâchoire supérieure est plus longue que celle de dessous. Les deux barbillons attachés à cette mème mảchoire d'en hau sont beaucoup plus longs que les autres. Derrière chacun des opercules, qui sont rayonnés, deux prolongations osseuses s'étendent vers In quene. Le premier rayon de chaque pectorale de la première nageoire du dos, et la nageoire adipeuse, ressemblent beaucoup à ceux du barbu. La ligne latérale suit la courbure du dos.

Le bleuâtre, dont M. Leblond nousà envoyé un individu de Cayenne, a beaucoup de rapports avee le pimélode chat. De ses six barbillons deux appartiennent à la máchoire d'en haut, et deux à celle d'en bas. Le premier rayon de la première dorsale et celui de chacune des pectorales sont dentelés.

Le Doigl-de-nègre tire son nom de la couleur des rayons de ses pectorales et de ses ventrales, rayons que l'on a pu comparer ì des doigts. Le premier rayon de chaque pectorale a ses deux dentelures dirigées en sens contraire l'une de l'autre. Plusieurs plaques osseuses garantissent le dessus de la tête. Celle qui couvre l'oceiput est carénée, pointue par derrière, et se réunit avec la pointe d'une autre plaque triangulaire, composée de plusieurs pièces, et dont la base embrasse l'aiguillon dentelé du dos. II paraít que le Doigl-de-nègre parvient ä une grandeur considérable. La collection du Muséum d’histoire naturelle en renferme un individu '.

Le commersonnien a deux orifices a chaque narine, et les deux dorsales triangulaires. Le dessus de sa tête est dénué de grandes plaques

15 rayons a chaque pectorale du pimélode ascite, 6 a chaque ventrate, 18 a la nageoire de la quene, -6 a la mem. brane branchialedu pimelode argente, 10 i chaque pectorale. des branchies du pimélode suend 7 a chaque peetorale, 8 s cague ventrale, 20 a la nageoire de la quene, -5 rayons 3 ia membrane des branchies da pimelode quatre taches, 72 chaque pectorale, $k$ a chaque veotrale, 19 a la caudale, á rayons a la membrane branchiale do pisélode barbu, 12 a chaque pectorale, 6 a chaque ventrale, is a la nageoire de 4 queue, -6 rayons a la membrane branchiale da pimélode laclieté, 9 a claque pectorale, 6 a chaque ventrale, 16 a L
caudale. -7 rayons a claque pectorate du pimélode blena re, 17 a la nageoire de la quecue. -10 rayous a chaque pecfre, 17 a la nageoire de la queue. -10 rayous a chaque pec-
corale du pimélode doigt-denegre, 6 a chaque ventrale, 20 is

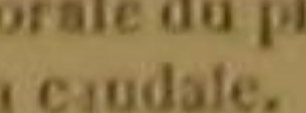


osseuses. Il ne montre ni taches, ni bandes, ni raies.

\section{LE PIMÉLODE THUNBERG '.}

Pimelodus Thunberg, Lacep. '.

La mâchoire supérieure de ce pimélode es plus avancée que l'inférieure; elle montre deux barbillons, et l'inférieurequatre : l'une etl'autre sont garnies de dents nombreuses, mais plus petites que celles qui hérissent le palais. Chaque opercule présente un aiguillon. Le premie rayon de la première dorsale, et celui de chaque pectorale, sont forts et dentelés.

Thunberg a vu ce pimélode dans les mers des Indes orientales ${ }^{3}$.

\section{LE PIMÉLODE MATOU ',}

Pimelodus Catus, Lac., Cuv.; Silurus Catus, Linn.s.

Le Pimelode Cous ', Pimelodus Cous, Lacep, silurus Cous,
Linn. ', - P. Docmae 4, Pimelodos Doemao, Silurus Doemao, Linn, ? - P. Bajad '0, Pimelodus Ba Jad., Lac., Cuv; ; Silurus Bajad, Lino, Gmel. " . - P. Brythroptère '12, Pimelodus ery thropteris, Lac., Cuv.; Silaris erythropterus, Bloch "s, $-P$, raie d' argenl " ", Pimelodu

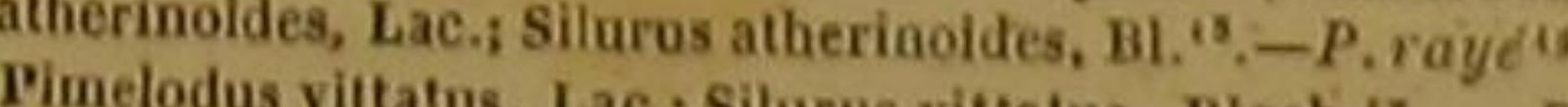
mouchete, Pimelodus gutlatus, Lac, “4,

L'Amérique et l'Asie nourrissent le matou,

Silurus maculatus. Thunberg.

M. Euvier ne cite pas cette espece. . D.

I rayon aiguillonné et 5 rayons articulés a chaque pec-

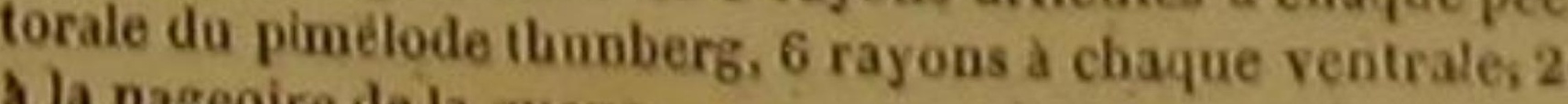

a la nageoire de la queue.

Bonnaterre, pl. de l'ibenton et Haũy, Enc. métb. - ld. Mareg. Brasil,, p. 175. - Catesthy, Carol Bagre spec. see:

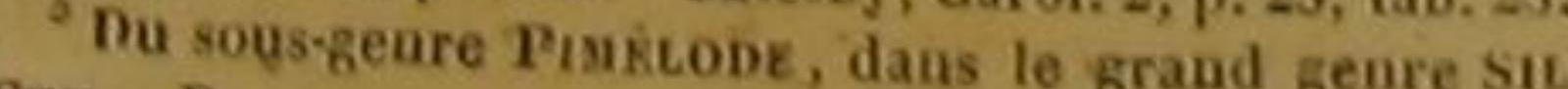

Cuv, D.

'Silure cous. Darbenton et Iraũy, Euc. méth. - Id. Bon fig. 7. - Wyst Rne. méth. - Gronor, Zoojh., p. 587, tib. 8 'Non mentionne par is Clep. 76, tab, 15, tig. 2.

- Yorskael, Faun Arab, pro,

Dilure dogmal.

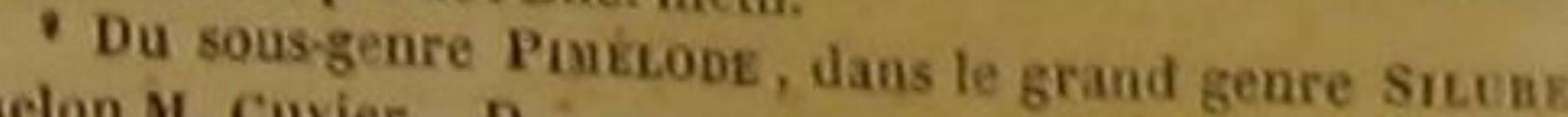

"OBayarte, en Égypte, soivant M. Cloquet.-Silwe onjac. p. 66, u. 95. "Bu so

Guiv, D.

"Bloch, pl. 569, big. 2.

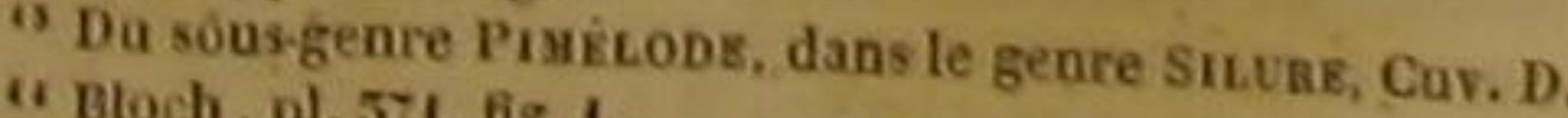

"Bloch, pl, 571, fig. I,

" Bloch, pl. 571, fig. 2 . Cuvier. D.

'Non cité par M. Cavier.

"Nou mentionue par M, Cuvier. D. et qui parre coune cur obscure et noirat tre, qui parvient souvent à la longueur de troi pieds ou trois pieds et demi. La Syrie est la patrie du cous, qui y vit dans l'eau douce, qui a la mâchoire inférieure plus courte que celle d'e haut, des dents très-petites, un orifice double chaque narine, et dont le dos est d'un blanc ar. gentin marbré de taches cendrées.

On trouve dans le $\mathrm{Nil}$, et particulièrement auprès du Delta, le docmac et le bajad. Le premier est grisâtre par-dessus, blanchâtre par-dessous, et quelquefois long de plus de quatre pieds. Ses barbillons sont inégaux et très-allongés; sa ligne latérale est droite; le premier rayon de chaque pectorale et de la première nageoire du dos, est osseux et dentelé par deirière.

Le bajad est bleuâtre ou d'un vert de mer. II a une fossette au-devant de chaque oil; la madchoire supérieure plus longue que l'inférieure, et armée d'un are double de dents très-serrées; les barbilions extérieurs de la-lèvre d'en hant très-allongés; la ligne latérale courbée vers le bas, auprès de son origine, et ensuite tres. droite; un aiguillon très-fort caché sous la peau, et placé auprès de chaque pectorale, qui présente une nuance rousse, ainsi que toutes les autres nageoires, excepté l'adipeuse.

Observez dans l'érythroptère d'Amérique l'égale prolongation des deux mâchoires; la grande longueur des barbillons des coins de la bouche; la rudesse du palais; la brièveté de la langue, qui est cartilagineuse et lisse; la direction de la ligne latérale, qui est ordinairement droite; la dentelure du borgd intérieur du premier rayon de claque pectorale et de la première dorsale; le brunátre du dos ainsì que des cotés, et la couleur grise du ventre;

Dans le pimélode raie d'argent, que l'on a découvert dans les eaux drouces de Malabar, l'égal longueur des deux mâchoires; la petitesse de leurs dents; les dimensions de celles du palais ; le double orilice de chaque narine; la position de lanus plus rapproché de la tête que de la caudale; le rayon dentelé dans son côté intérieur, que l'on voit à la première, dorsale et à chaque pectorale; la couleur générale qui est d'un brun clair; l'éclat argentin du dessous du corps de l'animal;

Dans le rayé de Tranquebar, le châtain de sa couleur générale, le cendré du ventre, les six pointes qui terminent la couverture osseuse de la tête, la longueur égale des deux màchoires, les dents arquées du palais, la surface unie de la langue, les deux orifices de chaque narine, la dentelure intérieure du premier rayon de chaque pectorale et de la première nageoir du dos, la direction très-droite de la ligne latérale '.

A l'égard du moucheté, dont on peut voir une figure très-exacte dans la collection de peintures chinoises dont nous avons parlé très-souvent, ajoutons à ce qu'indique de ce pimélode le tableau générique, que sa máchoire d'en haut est plus avancée que celle d'en bas, et que chaque pectorale a son premier rayon dentelé du eóté intérieur.

LE PIMÉLODE CASQUÉ ${ }^{2}$, Pinelodus galealus, Lac.; Silurus galeatus, Linn. '.

ET LE PIMÉLODE CHILI 4 .

Pimelodas ebileusis, Lae., Silurus chilensis, Lìno. s.

De petits dents semblables à celles d'une lime arment les deux mâchoires du casqué, dont la patrie est l'Amérique méridionale, La mâchoire inférieure avance un peu plus que celle d'en haut. Le palais est rude; la langue lisse; l'orifice de chaque narine double; le premier rayon de chaque pectorale dentelé sur ses deux bords; la ligne latérale ondulée, le dos bleuâtre; le ventre gris; et la couleur des nageoires, d'un brun foncé.

Le chili vit, comme le casqué, dans l'Amé rique méridionale, et particulièrement dans les eaux douces du pays dont il porte le nom. II y parvient à la longueur d'un pied ou quinze pouces. Sa tête est grande; ; sa partie supérieure,

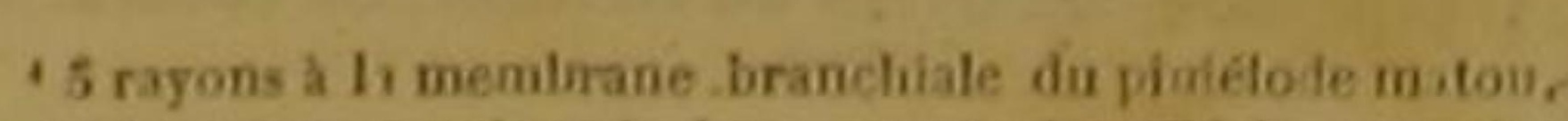
it a claque pectorale, 8 a chaque ventrale, 17 a la na eoir con-, 6 a chaque ventrale. -2 rayons a la membrane bran. chiale da pînélode docmac, 11 a chàque pectorale, 6 a cha. que ventrale. 18 a la candale. -11 rayons a chaque fectorale du p mélode baj id, 6 a chaque vẹntrale, 20 s la n igesire de la queue. -5 rayons a la menbrane des branchies du pimé 19 la car mélole raie d'argent, 6 d charge venteale, 20 a la mage de la queve. -5 rayons a la mendbrane branchiale do pímé. lode rayé, 6 a chaque ventrale, 20 a la candaic

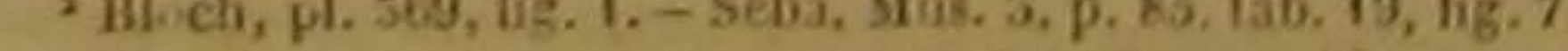
- Silure casque. Daubenton et Haúy, Ene. méth. - Id Bonnaterre, pl. del Enc. meth

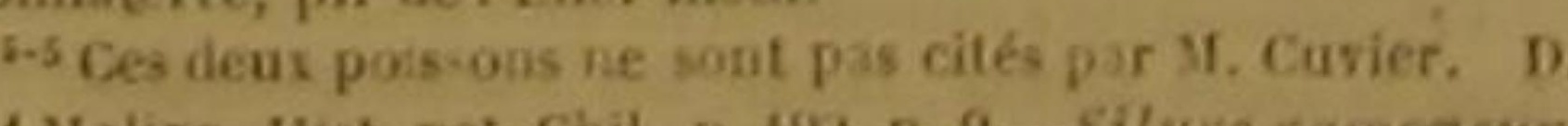
Bonnaterre, pl. de l'Enc, méth. brune ou noire; sa partie inférieure, blanche; et sa chair très-agréable au gout '

\section{GENT SOLXANTE-SEPTIÈME GENRE.}

LES DORAS ${ }^{2}$.

La tete diprimée et converle de lames grandes et dures on d'une peau visqueuse; la boucho d' l'extrémited du museav; des barbillons aux midehoires; lo corps gros; $l$ a peau du corps et do la queuo enduile d'une muensiti abondante; deux nageơizes dorsales; la seconde adipeuse ; des lapis longus at dumes rangies londe adipeuse; des lames larges a dures, rangies longitudi-
nalément de chaque cotd du poisson.

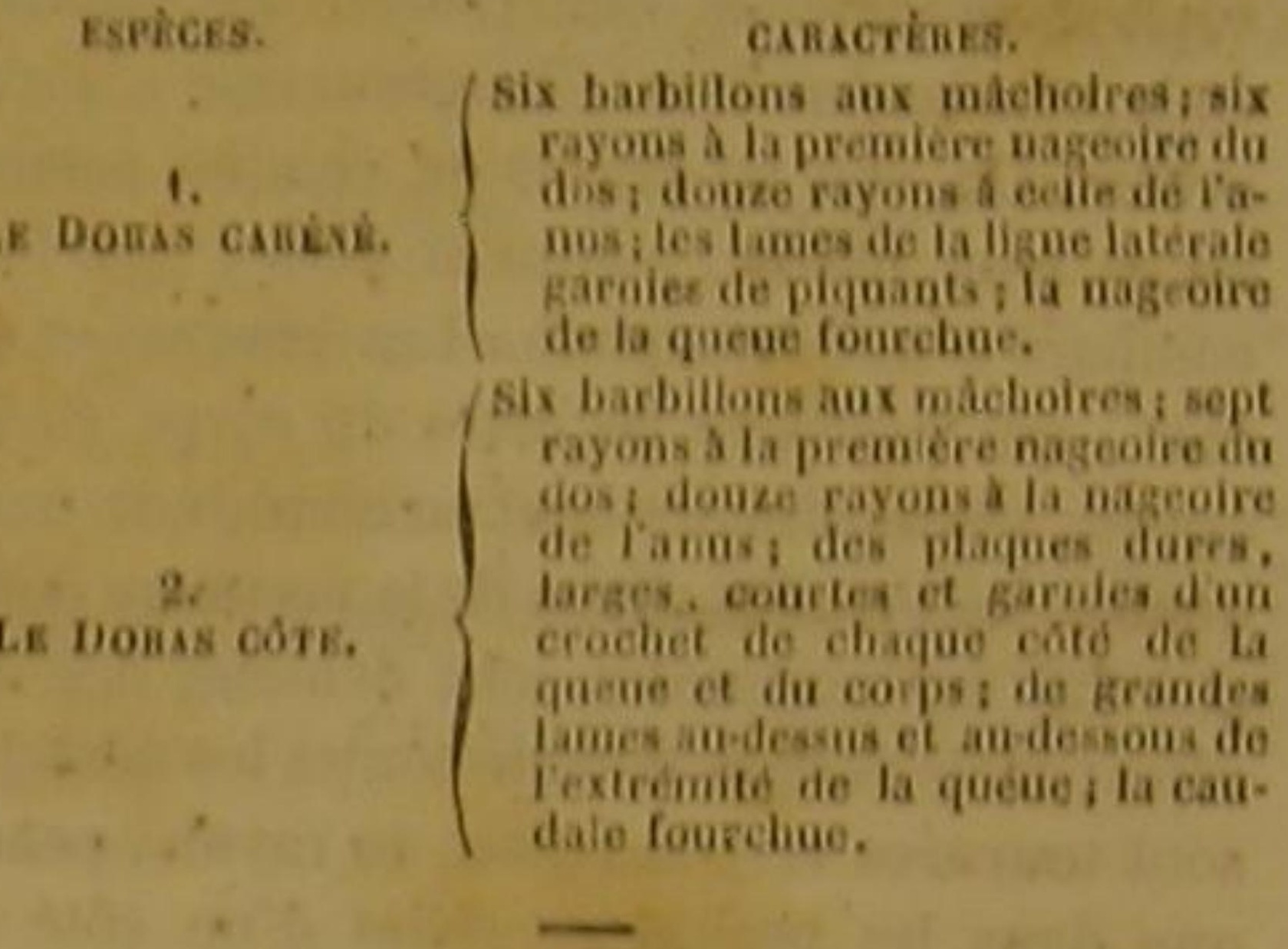

LE DORAS CARENÉ ${ }^{3}$

Doras carimatus, Lac., Cuv, 4 .

ET LE DORAS COTE:

Doras cosiatus, Lac, Cuv,

Les deux barbillons situés au coin de la beuche du caréné sont comme élargis par une

12 rayens a la membrane branchiale du pimálode cas jue, 7 a chaque pectora'c, 6 s echeque ventrate, 21 i is nageoire

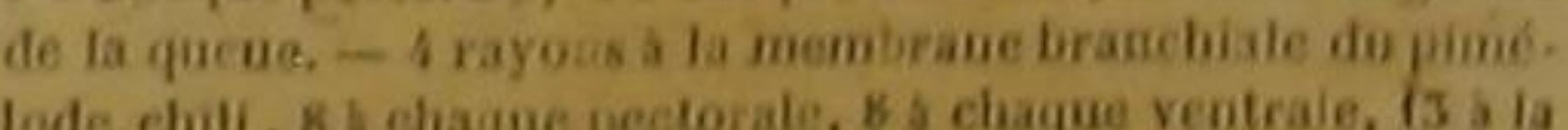
lode chill, 8 b ebaque pectorale, 8 s chaque ventrale, 13 a la
casuale.

ler alopte to gecore Doras, mis te cósidere - Silure caréne, Davlienton et Hany, Bnc, métb. - Id.

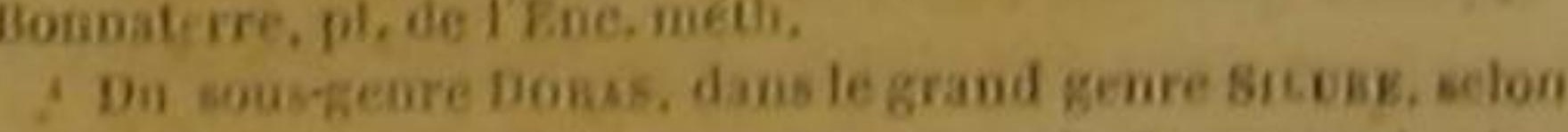
s. Cavier. Co matualiste remarque que lo Dor as carinatus

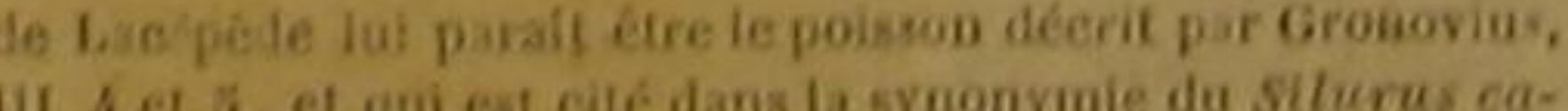

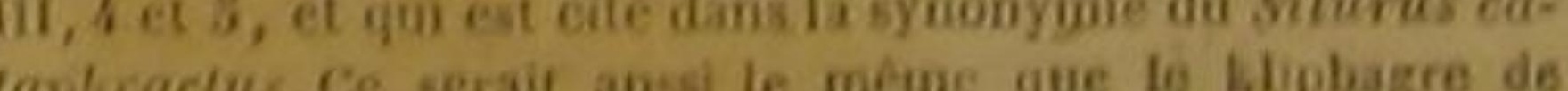
Marcerave 174 . Le pere du silurus catapheractus se trou.

verait ainsireduite a rien. D,
Urulu, an Bresil, - Gerilide meirnal, par les Hollan. dầs de l'Amérique mérid. - Silure cóle, Dankentos et Haby, Ene. méth. - Id. Bonmaterre, pi. de Fine meth.Cataphiractus costatus. n. 177, Lik. 5, fig. 1 cis. v. Cirvier, hni remsinge que le Siturus costalus; Bi., 576 . Gronov. v. 1 2, eit aussi le Cataphractus americanus, 
membrane dans leur cóté inférieur, et les quatre , suites d'un poison qu'ils ne distillent pas, mais de la mâchoire d'en bas paraissent garnis de par celles des déchirures profondes que fon petites papilles. Le premier rayon de la première souvent les dentelures de ces armes violemment dorsale est dentelé vers le haut; celui des pec- agitées '.

torales l'est des deux côtés. Ce doras habite à Surinam. L'espèce suivante se trouve également dans l'Amérique méridionale; mais elle vitaussi dans les Indes orientales.

La tète de ce second doras est revêtue d'une enveloppe osseuse qui s'étend jusque vers le milieu de la première nageoire du dos, et sur laquelle on voit plusieurs petites éminences rondes et sémblables à des perles. La mâchoire supéricure dépasse l'inférieure. Le palais est rude, et la langue lisse. Chaque narine n'a qu'un orifice. On voit au-déssus de chaque pectorale un os long, étroit, pointu et perlé, que l'on a comparé à une omoplate. Les plaques à crochet, qui hérissent les côtés du corps et de la queue, sont ordinairement au nombre de trentequatre. Le premier rayon de la première dorsale et celui des pectorales sont dentelés des deux cotés; mais dans la dorsale toutes les dentelures sont tournées vers la pointe du rayoh, pendant que dans les pectorales celles d'un côté sont dirigées vers la pointe, et celles de l'autre vers la base du rayon auquel elles appartiennent. La pártie supérieure de l'animal eșt d'un brun mêlé

Maregrave dit que sa chair est de mauvais goût : aussi ce poisson est-il peu recherché. doras cote a d'ailleurs des armes offensives et défensives à opposer à ses ennemis : presque toutes les parties de son corps sont cachées sous un casque ou sous une forte cuirasse; un dard dentelé arme son dos et chacun de ses bras. Pison rapporte même que les pècheurs de l'Amérique méridionale le redoutaient d'autant plus, et cherchaient à en débarrasser leurs filets avec d'autant plus de soin, qu'ils étaient persuadés quue les aiguillons dentelés de cet osseux reufermaient un venin qui donsait lo mort au bout de vingt-quatre heures, et dont ils ne pouvaient arrêter les effets funestes qu'en versant vaient arréter les effets funestes qu'en versant sur la plaie une grande quantité de l'huile de son foie, dont ils portaient toujours avec eux. Nous u'avons pas besoin de faire remarquer que cette erreur des pécheurs brasiliens venait de blessures dangereuses que peuvent produire en effet les dards de ce doras, non pas par les Catesby, suppl. IX, cite d'ordinaire comme Silurus cato-
thraclus, $\mathbf{D}_{\epsilon}$

\section{CENT SOIXANTE-HUITIÈME GENRE.} LES POGONATHES ${ }^{2}$.

La tele déprimée el couverte de lames grandes el dures, ou d'une peau visqueuse; la bouche d' lextrémité du museau; des barbillons aux machoires; le corps gros; la peau du corps et de la qreue enduite d'une mucosilé abondonte; deux nageoires dorsales, soutenues l'une es l'autre par des rayons; des lames larges of dures, rangées longiludinalement de chaque cold du poisson.

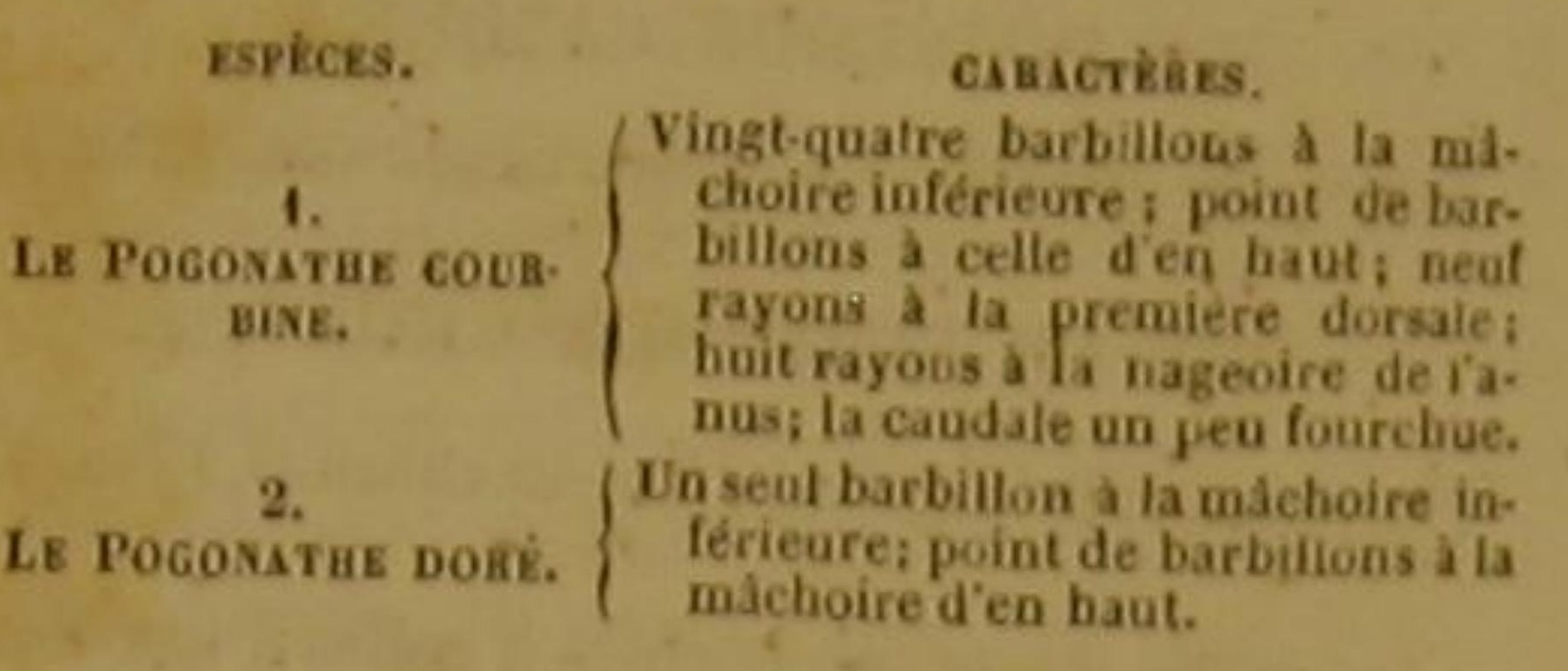

LE POGONATHE COURBINE ${ }^{3}$, Pogonias fasciatus, Lac., Cuv.; Pogonathus Courbina,
Lac. ‘

ET LE POGONATHE DORE 5 . Unbrina........, Cuv.; Pogonathus aurolus, Lac. . Ces deux poissons sont encore inconnus des naturalistes. Nous en avons trouvé la deseription dans les manuscrits de notre Commerson.

Le pogonathe courbine présente ordinairemen une longueur de deux pieds ou deux pieds trois pouces, sur une hauteur de quatreou six pouces Il pèse alors six livres ou environ. La couleur de 18 rayons a cbaque pectora'e, 8 a chaque ventrale, 24 a 1 .
nageoire de la queue. -5 rayons a la mat du dơras cote, 8 à chaque pectorale, 8 a chiaque ventrale, 21 a la caudal.

M. Cuvier n adopte pas ce genre. D. - menti viginti quatuodos. . - Pogonathus... silurus cirris merson, manuscrits dieja cit's.

et par conséquent il appartient an sons décrit p. 177 de ce vol., gonias, dans le genre Scí̌xe de M Cavier, fanilte des, $P$ thoptérygiens sciénoĩdes. D.

- Pogonathus cirro menti unico brevi, porulis qualuor - Ce poisson est éviderson, manuscrits déja cités. dans le genre Scrésk, famille des Acaothoptérygiens scié-
noilles, Cuv. D. son dos et de ses côtés est d'un bleu mêlé de brun et relevé par des reflets dorés; l'éclat de l'argent brille sur sa partie inférieure. Les écailles dont il est revêtu sont assez grandes. La måchoire supérieure, quel'animal peut avancer et retirer d volonté, est un peu plus longue quel'inférieure. L'une et l'autre sont garnies de dents petites, nombreuses et serrees comme celles d'une lime. La langue, le palais et les environs du gosier n'ont pas d'aspérités. Les vingt-quatre barbillons attachés à la máchoire d'en bas sont blancs, courts, très-mous, et disposés sur trois rangs transversaux. Le dos forme une earène aigue jusqu'à la première des deux nageoires qu'ii soutient, se courbe ensuite vers le bas jusqu' la seconde, et se relève au delà de cette seconde nageoire en se courbant de nouveau. Chaque rayon de la première dorsale est un aiguillon sans articulation, et part d'une sorte de tubercule placé sous la peau; mais ni cette nageoire, ni les pectorales, ne présentent de rayon dentelé. Les lames éeailleuses dont on voit une rangée longitudinale de chaque côté du poisson, sont striées et argentées. Le canal intestinal est plusieurs fois repliê; le foie petit et rouge; chaque ovaire long et jaune '.

Ce pogonathe est grand et beau; mais sa chair est mollasse, et son goût fade. Commerson l'a vu pêcher dans le flenve de la Plata, au mois d'avril 1767 .

Le doré ressemble beaucoup par ses couleurs à la courbine : mais ses écailles resplenidissent davantage de l'éclat de l'or. Ses ventrales et son anale sont d'un jaune blanchâtre; ses autres nageoires offrent des nuances brunâtres. II devient moins grand que la courbine. Quatre pores sont placés autour du seul barbillon que montrent les mâehoires de ce pogonathe.

CENT SOIXANTE-NEUVIĖME GENRE. LES CATAPHRACTES ${ }^{2}$.

La lete déprimée el couverle de lamex grandes el dures ou d'une peau visqueuse; la bouche à V'exirémilé du mureau; des barbillons aux machoires; le corps gros; lo peau du corps el de la queue enduile d'une mucosil

17 rayons a la membrane lranchiale du pogonathe cour bine, 18 a chaque pectorale. 1 rayon angulinone el s rayon nageoire de la queue.
a Le genre Catapunetr de Lacépéde est adopté, par abondante; deux nageoires dorsales; la secondesourenue par un seul rayon; des larmes larges el durn, rangés longitudinalement de chaque colle du poisson. PREMER SOUS-GENRE.

La nageoire de la queue arrondic ou terminée par une ligne droite et sans cehanerure.

Esríc

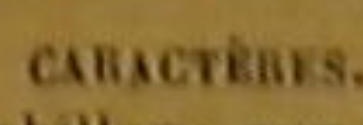

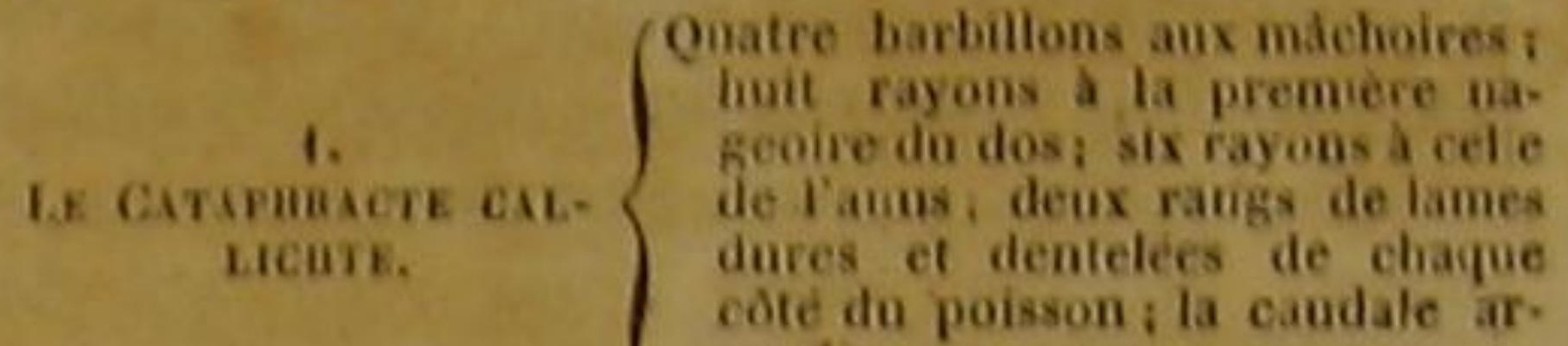
нсите. rondie.

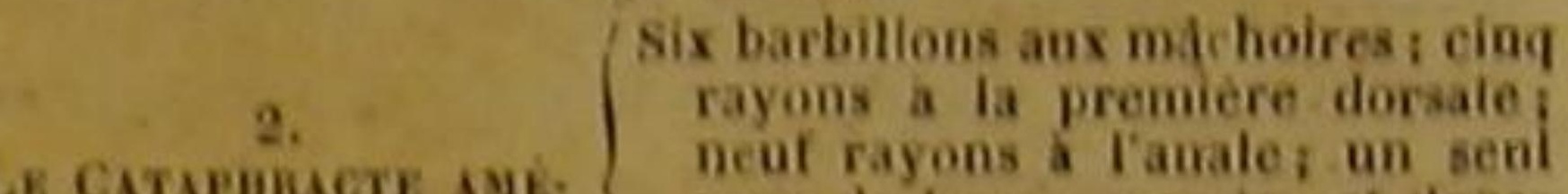
micsis.
mese SECOND SOUS-GENRE.

La nageoiro de la queiue fourchue ou dehancríe en croissant.

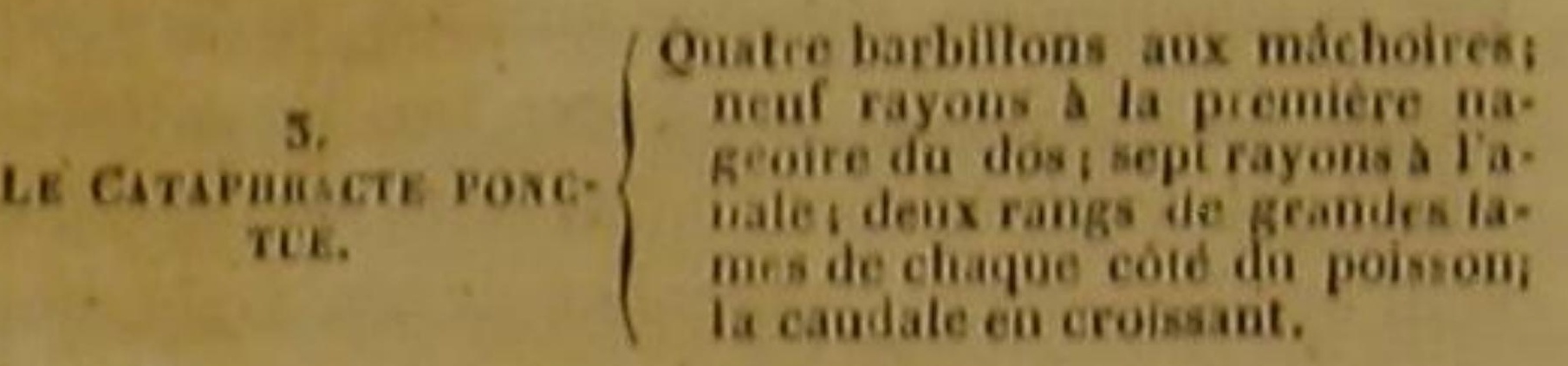

LE CATAPHRACTE GALLICHTE ', Callicitys....., Cur.; Cataphraetus Callicthys, Lac, Silurus Callichtys, BI. ?.

LE CATAPHRACTE AMÉRICAIN ${ }^{3}$, Doras costatus, Lac., Cuv.; Cataphratus americanus, Lac.; Silurus costatus, Linn., BI. '.

\section{ET LE CATAPHRAGTE PONCTUÉ s.}

Cataptractus punctatus, Lac. ‘.

Le callichte se trouve dans les deux Indes; il aime les eaux courantes et limpides. On a écrit 4. Cuvier, comme sous genre du grand genre silure : mas tous le nom de Catichite, deja employe par Linnee. Le cataphracte callichte est ta seule espéce qu'il y conserve; les deux autres sont fictives. D. - Soldat, par les Allemands. - Kripring-ming, par les Suedois. - Tomoate, par les Anglais. - Soldido, par te
Pertugais du Bresil. - Tamoata, par les Brasiliens. - Out Pui, a surinam. - Dieg dolfin, par les Hollandals des Indes

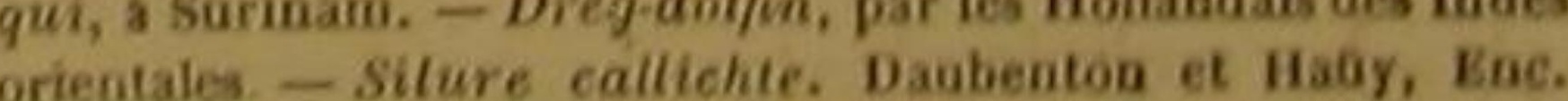
meth. - Id Ronnaterre, pl. de LEne, meth. - Cataphracto alliche Bloch, pl. 577 , tig. 1. - Amenit. acad, 1, p. 317 ,

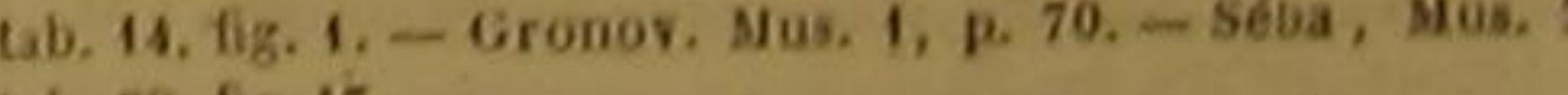
ab. 29 . fig. 45.

${ }^{2}$ Ce poisson est le scul que M. Cavier admet dans le wous

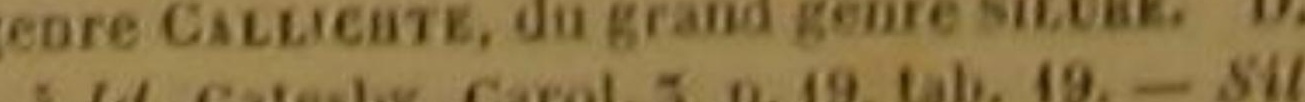
-Id. Catesiby, Carol. 5, p. 19, tab. 19. - Silure cuirase.

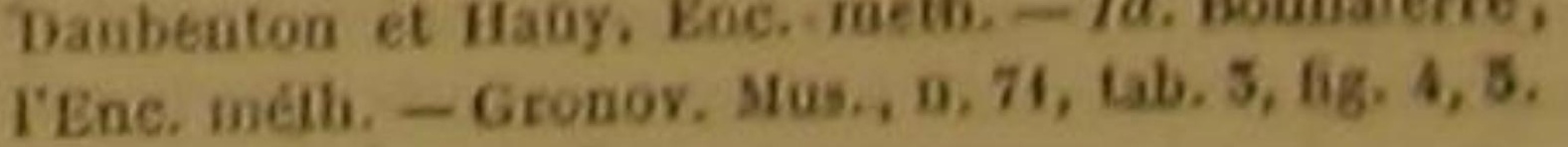


HISTOIRE NATURELLE

qu'il pouvait, comme l'anguille et quelques autres poissons, s'éloigner en rampant ou en sautillant, jusqu'à une distance assez grande des fleuves qu'il habite, et se creuser dans la vase, ou dans la terre humide, des trous assez profonds : mais voilà à quoi il faut réduire les habitudes et les facultés extraordinaires qu'on a voulu attribuer à cet animal. Il ne parvient que rarement à la longueur d'un pied ou quinze pouces. Sa chair est très-agréable au goût. Sa couleur générale paraít brune : on voit des taches brunatres et des nuances jaunes sur la nageoire de la queue. La tête est revêtue d'une couverture osseuse, dure et terminće de chaque côté par une portion allongée et triangulaire. La mâchoire supérieure avance plus que celle d'en bas; la langue est lisse; le fond de gueule rude; l'orifice de chaque narine double; l'cil petit; le premier rayon de chaque nageoire, fort et aiguillonné. Presque tous les rayons sont garnis de très-petits piquants. Les lames dentelées qui revêtent chacun des côtés du callichte, sont ordinairement au nombre de vingt-six des chaque rangée; et elles ont assez de largeur pour que les quatre rangs qu'elles forment soient continus de manière à produire un sillon longitudinal sur le dos et sur chaque côté du poisson.

Le nom de l'américain indique sa patrie. Il a été observé particulièrement dans la Caroline. On péche le ponctué dans les rivières poissonneuses de Surinam. Il a la tête comprimée; un casque osseux; la mâchoire d'en haut plus avancéeque celle d'en bas; deux orifices à cháque narine; l'œil voilé par une membrane; l'opercue composé de deux pièces; la clavicule large; les grandes lamès de chaque cóté, dentelées', les cées les unes au-dessus des autres, et formant des rangées de vingt-quatre; le premier rayon de l'anale, des pectorales, de la première nageoire du dos, et le rayon unique de la seconde, roides et aiguillonnés; la couleur générale jaune; une tache noire et irrégulière sur. la première dorsale; des points sur la tête, sur le dos et sur plusieurs nageoires '.

Ce poisson ne differe pas de celui que M. de Lacépede a décrit eiavant, page 771 , sous le nom de Doras ce lacépéde 'Bloch, pl. 377, fig. 22

- M. Cuvier ne cite pas ce poisson: D.

'5 rayons a la membrane branchiale du cataphracte cal.
lichte, 7 a chaque pectorale, 8 a cliane vent ceoire $r$ a chaque pectorale, 8 a cliaque ventrale, 14 a le $n$.

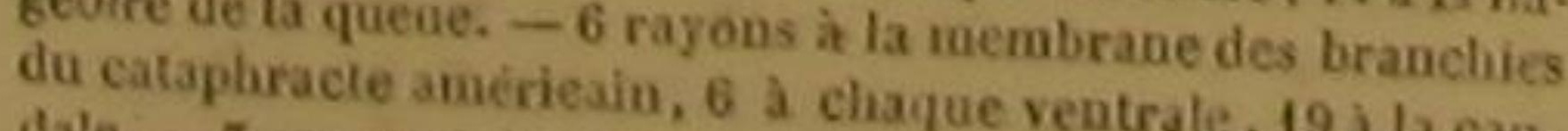
dale. -5 rayons a $\mathrm{L}$ membraue branchiale du cataphracte

\section{CENT SOIXANTE-DIXIÈME GENRE,} LES PLOTOSES '

La tele deprimée el couverte de lames grandes et dures o dune peau risqueuse; la bouche à l'extrèmité du mipeain du corps ans arc machoires; le corps gros: Ia pear du corps el de la quelle enduite d'une mucosit celle de l'anus rin nageoires dorsales; la seconde .l celle de l'anus reunies avec la nageoire de la quen.

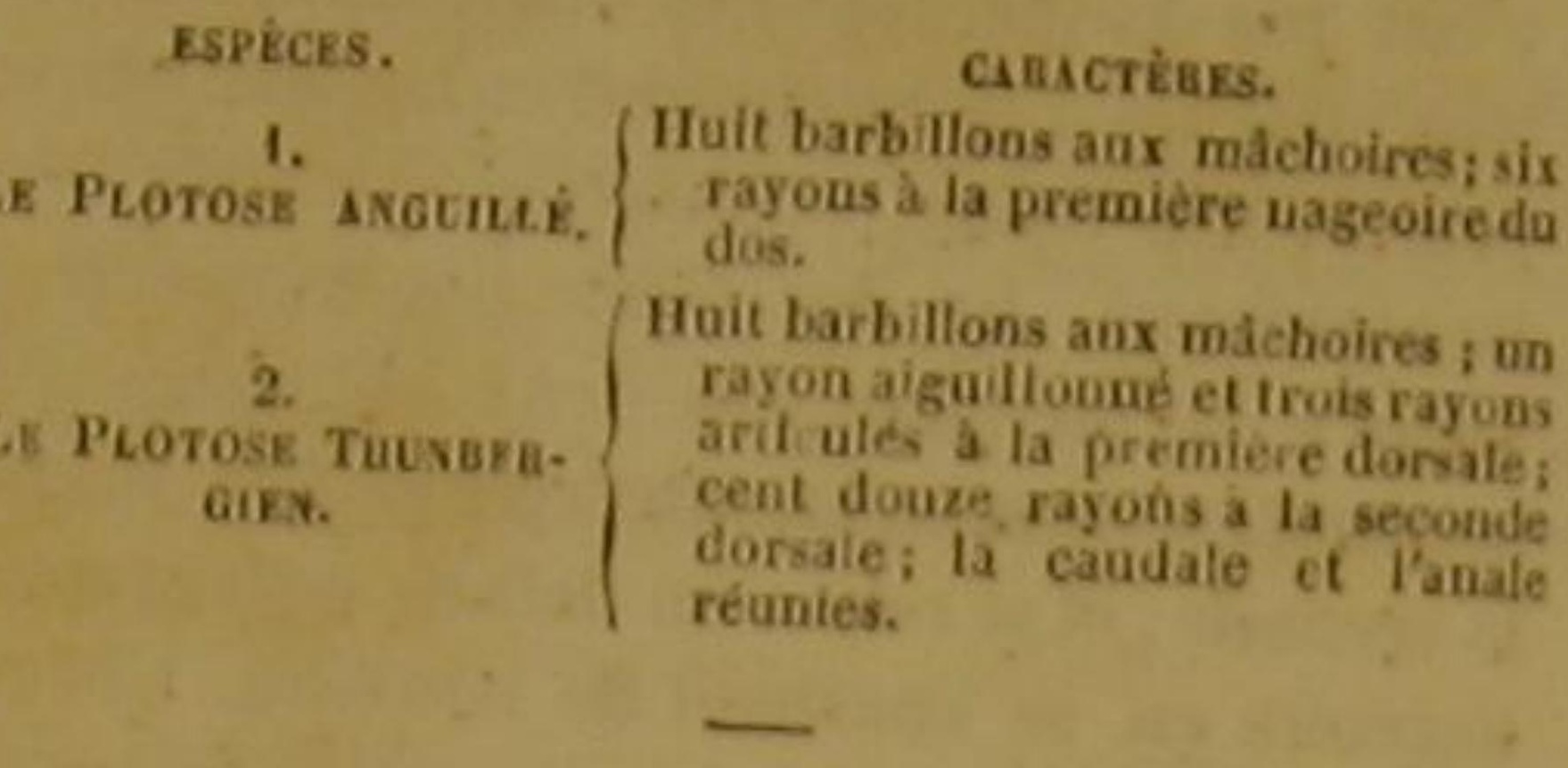

LE PLOTOSE ANGUILLÉ 2 Plotosus anguillaris, Lae., Cuv.; Piatystacus anguilla-
ris, Bl. 3 .

Pour peu que l'on jette les yeux sur ce poisson, on verra que sa queue longue et délice, la viscosité de sa peau, la position et la figure le ses nageoires, ainsi que la conformation de presque toutes les autres parties de son corps, doivent donner à ses habitudes une grande ressem. blance avec celles de la murène anguille. II vit dans les Grandes-Indes ; et Commerson en avait rencontré une variété dans un des parages qu'il a parcourus lors de son fameux voyage avec nore célèbre Bougainville.

Il a plusieurs rangs de dents coniques aux deux mâchoires; des dents globuleuses au palais d'autres dents pointues auprès du gosier; la langue lisse; la mảehoire supérieure plus avancée que l'inférieure; un seul orifice à chaque narine; le premier rayon de la première dorsa court, gros et dur; le second long plus osseux, aiguillonné et déné de de comme le premier. Ie prentelure peetora le premier; le premier rayon de chaque pectorale, également osseux, fort et allongé et d'ailleurs dentelé des deux cótés; la ligne , et rale garnie de petits tubercules; la couleur géponctué, 6 à chaquée pectorale, 6 à ch aque ventrale, 17 à la
nageoire de la queue. 'A. Cuvier admet ce
grand Benre Silore. D. ate comme sous-genre dans le ang'ais, - Aalforng, dans les grandès Indes. - Flateel, en ang'ais, - Aal formigen platt leib, en allemand, - Platys"Des deax especes. Bloch, pl. 575, fig. 1. né cite que celle-ci. D.
D.
DES POISSONS.

475

nérale d'un violet mêlé de brun ; le dessous du corps, blanchâtre; et einq raies blanches et longitudinales '.

J'ai vu, sur un individu de cette espèce, un orifice situé au delà de l'añus; par cet orifice sortait comme un organe sexuel, qui se divisait en deux coupes ou entonnoirs membraneux. Audevant de cet organe était un pédoncule ou appendice conique. L'état de l'individu ne me permit pas de savoir s'il était mále ou femelle. Bloch a fait une observation analogue sur l'individu qu'il a décrit.

\section{LE PLOTOSE THUNBERGIEN ${ }^{2}$.}

Plotosus thunbergianus, Lac. :

La couleur générale de ce poisson est d'un blane jaunâtre. Deux raies longitudinales et blanches paraissent de ehaque côté de - In tête, du corps et de la queue. Quatre barbillons garnissent chaque mâchoire. La ligne latérale est droite, $O n$ voit une dentelure au premier rayon des pectorales et de la première nageoire du dos. Ce plotose, dont on doit la connaissance au savant voyageur Thunberg, habite la partie orientale de la mer des grandes Indes ${ }^{4}$.

\section{CENT SOIXANTE-ONZIÈME GENRE.} LES AGÉNÉIOSES ${ }^{5}$.

La tele deprime el courerte de lames grandes at dures ou d'une peau visqueuse; la bouche à l'extrinité du muscau; point de barbillons; - te corps gros: la peau dante; denx nageoires dorsales i la seconde adipense. dailc; deux negeoires dorsales ; la seconde adipeuse.

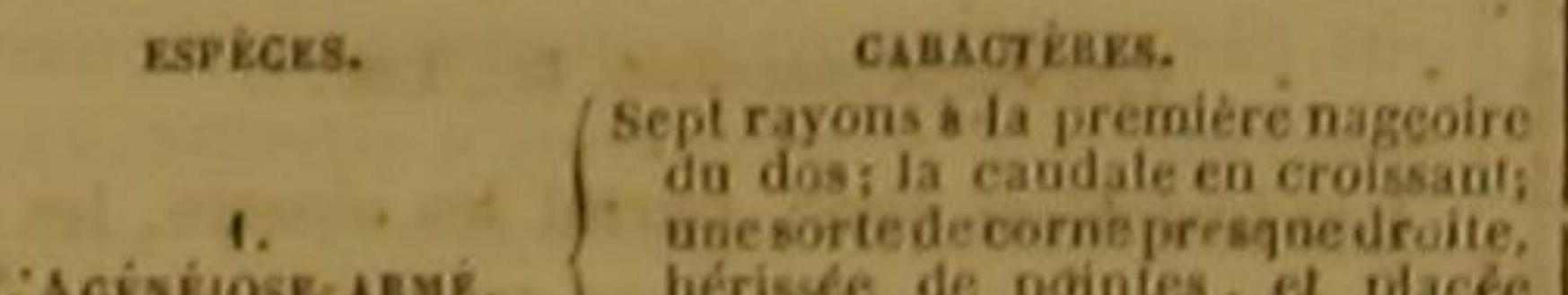

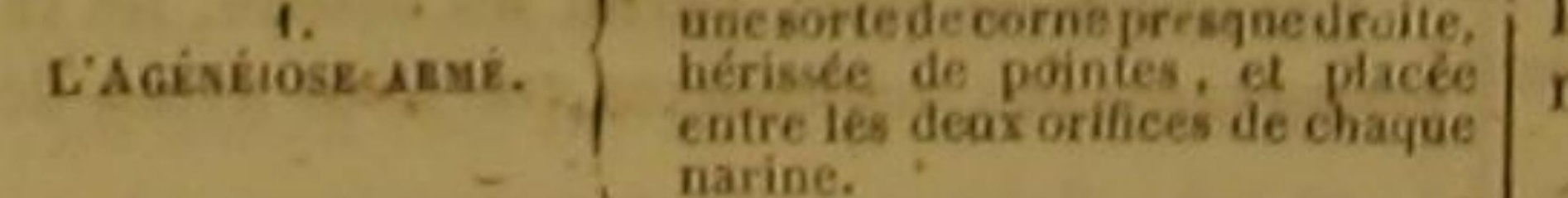

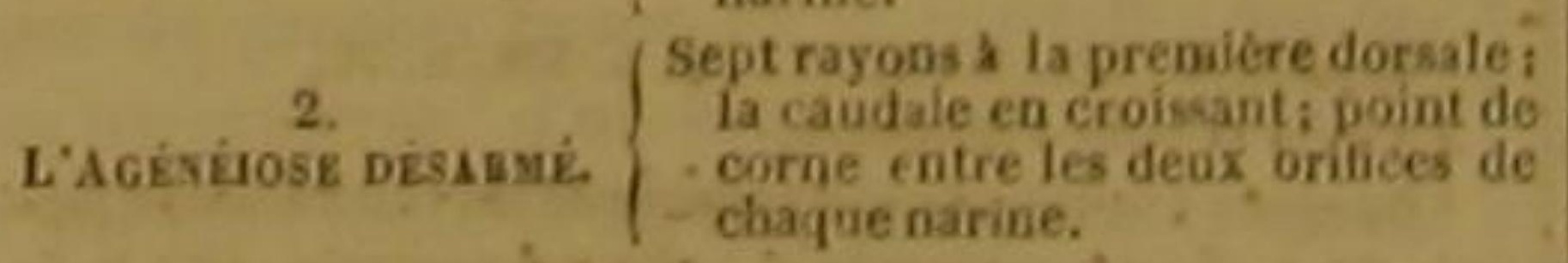
II rayons a la menibrane branchiale du plotose anguille, 111 rayons a la menbibrane branchiale du plotose anguille,
10 i chayue pectorale, 12 a chaque ventrale, 268 dans l'en10 a chayue pectorale, 12 a chaque ventrale, 268 dans i en-
semble formé par la réunion de la seconde dorsale, de la nageoire de I anus, et de celle de la queue.

2 silurus linealus. Thunberg.

' Non cité par M. Cavier. D.

1 I rayon aigaillonéé el 12 rayons articulés à chaque pec. torale do plotose thumbergien, 12 rayons a chaque ventrale. 'Les Agénetioses formeat, pour M. Cuvier, un sous genre
L'AGÉNÉIOSE ARME ' Igeneiosus militaris, Cuv,; Ageneiosus armatus, Lac, Silurus militaris, Linn., Gmel., BI. .

ET L'AGÉNÉIOSE DÉSARMÉ s. Ageneiosus inermis, Lac., Guv.; Siturus inermis, Linn., Gmel. :

Ces deux poissons vivent dans les eaux de Surinam, et peut-être dans celles des Grandes-Indes. Quels traits devons-nous ajouter à ceux que présente le tableau générique, pour terminer le portrait de ces deux agénéioses?

Pour le premier, la largeur et le grand aplatissement de la tête; lés dents petites et nombreuses des deux máchoires; In brièveté et la surface unie de la lanque; I'are hérissé de dents, placé sur le palais; in distance qui sépare les yeux; le rouge de la prunelle; la peau qui resé tout I'animal; la longueur et la dureté du premier rayon de la première dorsale, lequel est d'ailleurs garni d'un double rang de crochet: pointus, vers le milieu et à son extrémité ; la grosseur du ventre; les sinuosités et les ramificouleur générale; les dimensions étendues du poisson; le mauvais goût de sa chair.

Pour le second, tous ceux que nous venons d'ènoncer, excepté la couleur de la prunelle, qu est noire; la nature de la peau, qui est moins épaisse; la longueur et les crochets du premier rayon de la première dorsale, lequel est dur et aiguillonné, mais sans dentelure; et peut-être la grandeur des dimensions, ainsi que le goût peu agréable de la chair.

Le désarmé a de plus une prolongation triamgulaire et très-pointue à l'extrémité postéricure de la couverture osseuse de sa tête; des taches brunes et irrégulières; la première dorsale, les pectorales, les ventrales brunes, et les autres nageoires d'un gris quelquefois meté de violet ${ }^{5}$.

isteifbart, Gehornter vels, en allemand, - Horned of lure, en anglain. - Silure arme. Danbentonet inay, kac. pl. 562.

-4 Yoyez la note Bs cl-contre.

SSilure désarmé. Danbenton et Haoy, Ene. méth. - Id. Donnaterre, pl. de I'Euc. méth. - Bloch, pli, 565. - 9 rayous a la menbrane des branchies de l'agentiose arme. 6 a chague pectorase, 8 a chaque veatrale, 55 a la nageoir

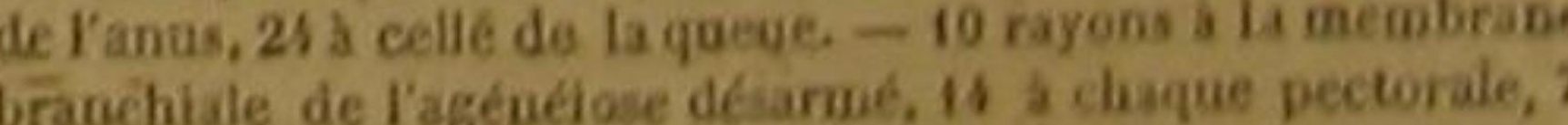

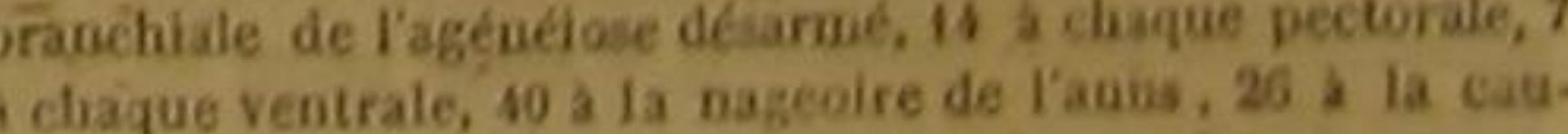
eations de la ligne latérale; le vert foncé de la 
CENT SOIXANTE-DOUZIÈME GENRE.

LES MACRORAMPHOSES '.

La lele déprimée el couverte de lames grandes et dures ou d'une peau visqueuse; la bouche d̀ l'extrémilé du museau; point de barbillons aux machoires; le corps gros; la peau du corps el de la queue enduile d'une mucosite abondante; deux nageoires dorsales; l'une et lautre soulenues par des rayons; le premier rayon de la première nageoire dorsale fort, trèslong el dentelé; le museau très-allongé.

FSPËCE.

CABActènes.

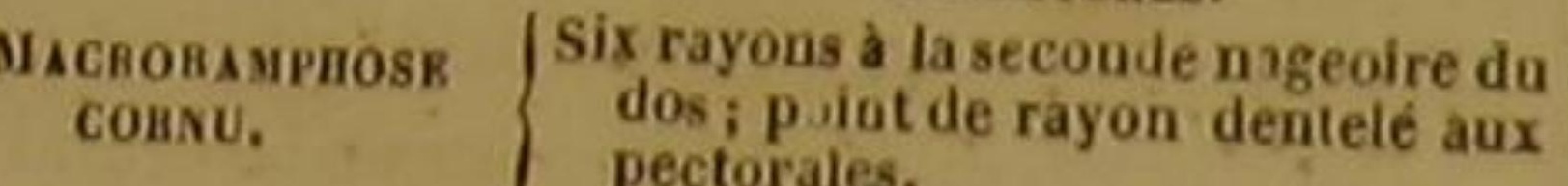

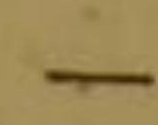

LE MACRORAMPHOSE CORNU 2 . Macroramphosus cornutus, Lac, ; Silurus cornutus,
Linn. ?.

La longueur du museau égale la moitié de la longueur du coips. Son extrémité est un peu recourbée. Le premier rayon de la premiêre nageoire du dos a deux rangs de petites dents sur la moìtié de son bord inférieur, et peut s'étendre jusqu'au-dessus de la nageoire de la queneOn compte neuf rayons à cette dernière na-
geoire.

\section{CENT SOIXANTE-TREIZIÈME GENRE.} LES CENTRANODONS 4 .

La tele déprimée et couverte de lames grandes ot dures ou d'une peau visqueuse; la bouche à l'extremite du museau; point de barbiltons ni de dents avx ma choires; le corps gros; la peau du corps el de la queue enduite d'une mucosité abondante; deux nageoires dorsales; l'une et l'autre soutenues par des rayons;

un ou phusieurs piquants d ehaque opercule.

EsPéce.

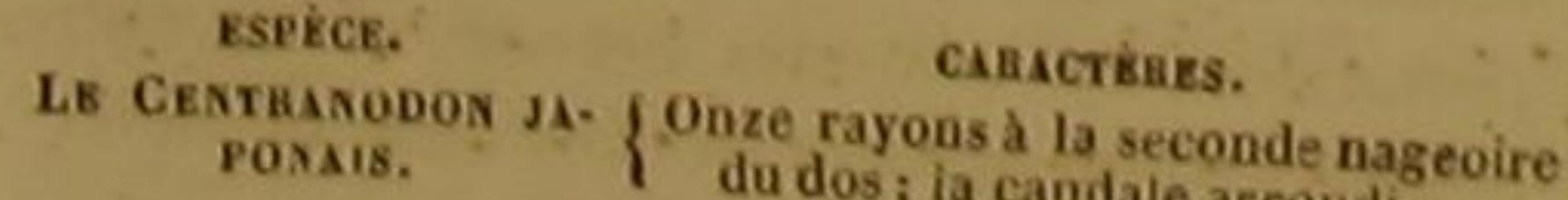

'. M. Cuvier a reconnu que ce genre est factice, et quii

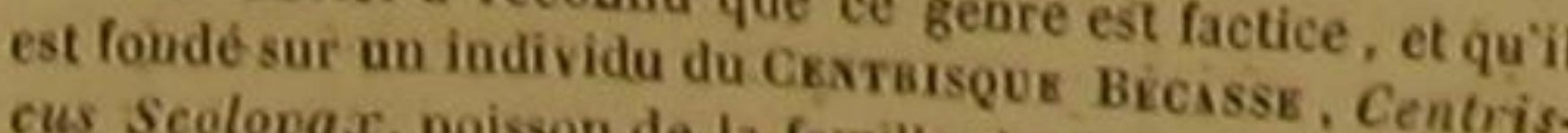
cus Scolopax, poisson de la familte des. Acasthoptérygiens
bouche en-late. D. Wouche en-flote. D.

nerel. Bongaterne, At de o. p. 66, n. 96. - Silure chardot-

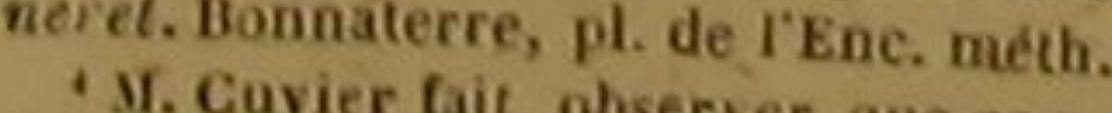

tenir a la famille des Siluroides ce poisson ne peat apparaiguillons aux opercules, la premiere dora des écalltes, des II le croit voisin des Perches, et remarque yue épineuse, etc. tuitement que Bloch (Schneider) le range parmi les gra-
LE CENTRANODON JAPONAIS '. Centranodon japonicus, Lac.; Silurus imberbis, Liun

Ce poisson a les yẹux gros et rapprochés l'u de l'autre. On compte deux piquants vers bord postérieur de chaque opercule. Le eorps et la queue sont très-allongés; ils sont couvert d'écailles très - faciles ì voir. Ce centraner parvient à la longueur de huit pouces. Sa couleur générale est rougeátre. Ses nageoires sont variées de blanc et de noir. Le Japon est sa patrie ${ }^{3}$.

\section{CENT SOIXANTE-QUATORZIÈME GENRE.} LES LORICAIRES 4.

Lo corps el la queue couverls en entier d'une sorle do euirasse d lames; la bouche au-dessous du niuseau;

EsPices. CARActènass.

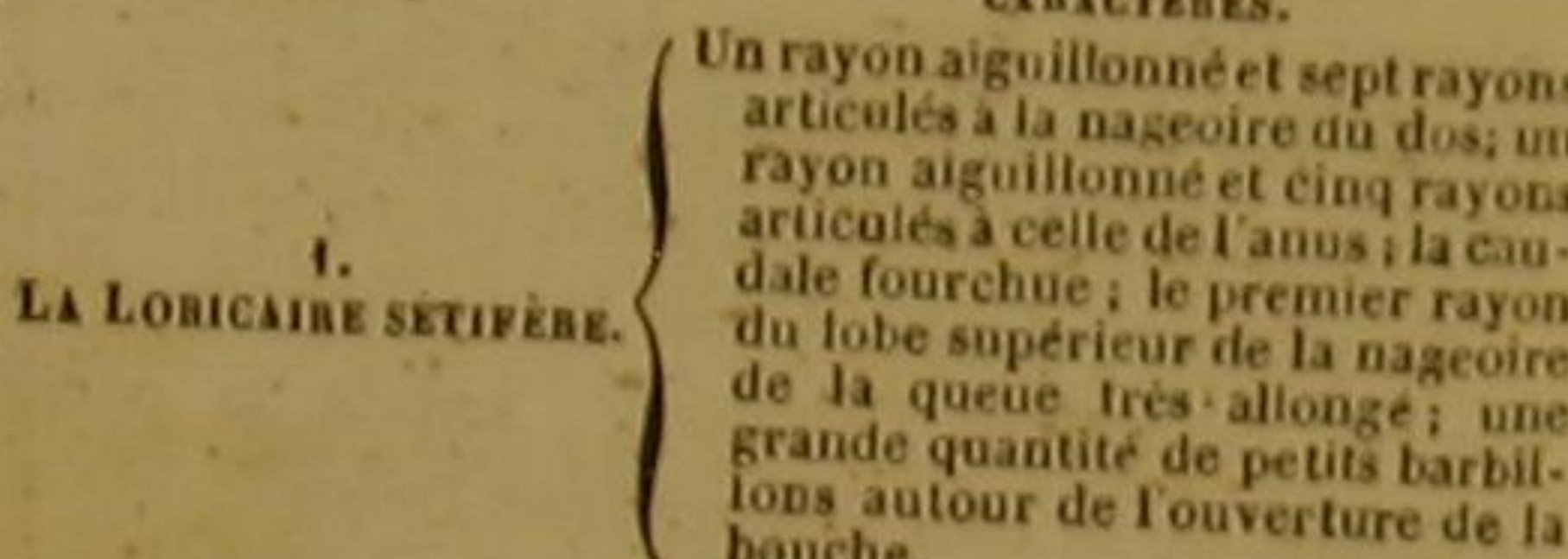

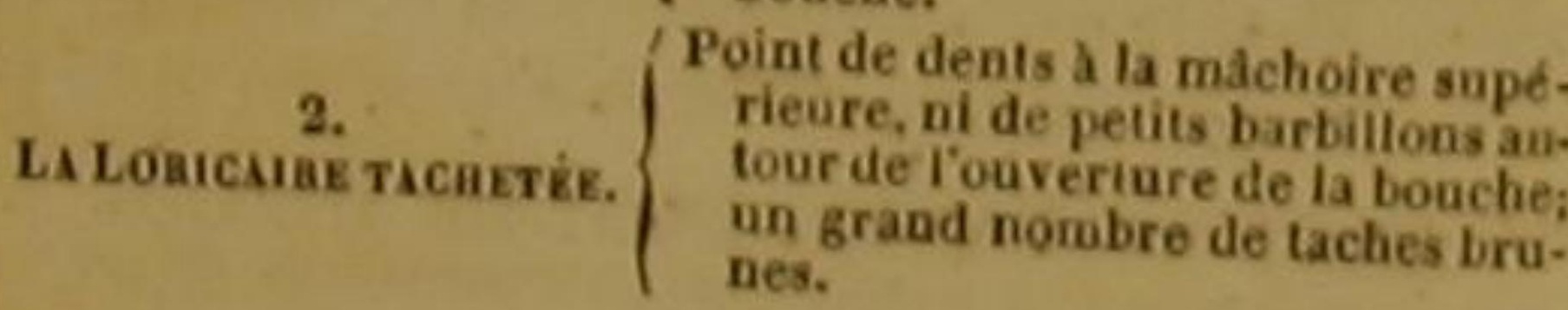

LA LORICAIRE SÉTIFĖRE s Loricaria catapbracta, Linn., Gmel., Loricaria cirrhosa, Bl., Schn.; Loricaria setigera, Lac. ‘

ET LA LORICAIRE TACHETÉE ? Loricaria maculata, BI., Lac. :

Les loricaires sont, parmi les osseux, les représentants des acipensères que nous avons dé-

Houttuyn, Act. Haarl. XX, 2. p. 558, n. 27 ? 6 razez la note 4 ci-contre.

nais, 20 a chaque pectorale, 6 àchiale du centranodon japo. eoire de $r a q u e$ pectorale, 6 à chaquè ventrale, 10 à la 4 M. Cuvier, en adoptont la quene.

Hypostome) et le place dans fordre, loi réunit le suivant dodomioaux, famille des Siluroides. Hes dialacoptérygien 5 Plecostestome et Loricaire. D. harnasman, - Panserfisch, en Allemagne. - Gercapende taphract, par Hollande. - Benfiaelling, en Suède. - Ca-

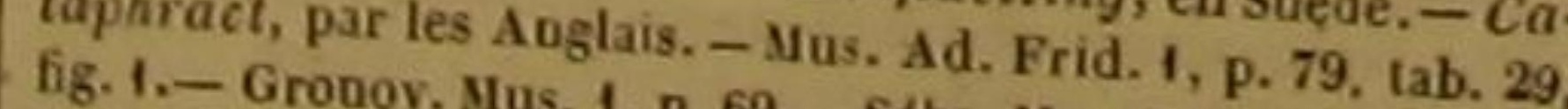
- Loricaire plécoste, D. 69. - Séba, Mus. J, tab. 29. fig. 14 ,
DES POISSONS.

17:

crits en traitant des cartilagineux. Elles ont / tache noire que l'on voit au bout du lobe infe avec cespoissons des rapports très-marqués par rieur de la nageoire de la queue.

leur conformation générale, par la position de la bouche au-dessous du museau, par leurs barbillons, par les plaques dures qui les revêtent; et si elles n'offrent pas des dimensions aussi grandes, une force aussi remarquable, des moyens d'attaque aussi redoutables pour leurs ennemis, elles ont des armes défensives à proportion plus sûres, parce que les pièces de leur cuirasse, placées sans intervalle les unes auprès des autres, ne laissent, pour ainsi dire, aucune de leurs parties sans abri.

La sétifere a les mâchoires garnies de dents petites, flexibles, et semblables à des soies; l'ouverture des branehies, très-étroite ; le premier rayon de ehaque pecto:ale, dentelé sur deux bords; celui des ventrales, dentelé ; celui de Panale et de la nageoire du dos, dur, gros et rude; le corps couvert de lames fortes, presque toutes losangées, et dont plusieurs sont garnies d'un aiguillon; la queue renfermée dans un étui composé d'anneaux situés les uns au-dessus des autres; ces anneaux découpés, comprimés, et formant souventen haut et en bas une arete ou carène dentelée; le premier rayon du lobe supérieur de la queue, quelquefois plus long que tout le corps; la couleur génírale d'un jaune brunâtre '.

Elle habite dans I'Amérique méridionale, ain que la tachetée, que nous regardons comme un espèce différente de la sétifêre, mais qui cependant pourrait n'en être qu'une variété distinguée par l'arondissement de la partie antérieure et inférieure de sa tête; le nombre de ses barbillons, qui n'excède pas deux; le défaut de dent sélacées; la présence de deux pointes, a la vérité très-difficiles à reconnaitre, à la mâchoir inférieure; de grandes lames placées sur le ventre, les unes à côté des autres; la moindre longueur du premier rayon de la caudale; des taches irrégulières, d'un brun foncé, distribuées sur presque toute la surface du poisson; et une

Id. Bonnaterre, pl. de l'Enc. métb. - Cuirassier plècoste. Bloch, pl. 375, fig. 5 . - Du sous genre Losicina, dans le geare du même nom, Dille des Malacoptérygiens abdominaux siluroídes, Cuy. D.

- M. Cuvier ne cite pas celle espece. D.

I 4 rayons a la mombrane branchiale de la loricaire setifere et de ta loricaire tachetée, 7 a chaque pectorale, 6 a chaque ventrale, 12 a la caudale.

\section{CENT SOIXANTE-QUINZIĖME GENRE.} LES HYPOSTOMES '

Le carpset la queue couverls en entier d'uno sorle de cuileveres exlensibles; deux nageoires dorsales.

EsPìce. canacrèns.

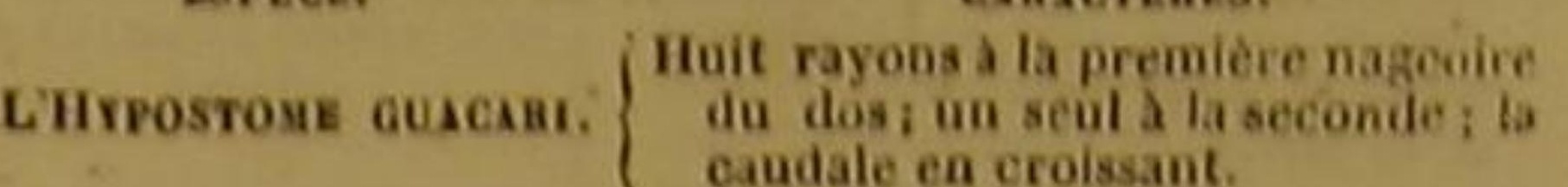

\section{L'HYPOSTOME GUACARI ${ }^{2}$}

Loricaria (Hypostoma) plecostomus, Cuv,; Loricaria plecostomus, Lion., Bl.; Hypostomus Guacari, Lac. ',

Le nom générique de ce poisson indique la position de sa bouche. Il montre une couverture osseuse et découpée par derrière sur sa téte ; une ouverture étroite et transversale, à sa bouche : des dents très-petites et comme sélacées, à ses máchoires; des verrues et deux barbillons à la lèvre inférieure ; une membrane lisse, sur la langue et le pálais; un seul oriflce à chaque narine quatre rangées longitudinales de lames de chaque coté de l'étui solide qui renferme son corps et sa queue; une arête terminée par une pointe, à ehacune de ces lames; un premier rayon trèsdur, à chaque ventrale; un premier rayon dentelé et très - fort, aux pectorales ainsi qu'à la première nageoire du dos; des taches inégales, arrondies, brunes ou noires; et différentes nuances d'orangé. dans sa couleur qénérale.

Le canal intestinal est six fois plus long que le poisson. La ehair est de bon goût. Les rivières de. I'Amérique méridionale sont le séjour ordinaire du guacari 4.

-s Ce genre est considérécomme sousgenre par $\mathrm{M}$. Cuvicr et reuni au précétent (coricaire) pour former le genre foet reuni au précédent (Loricaire) pour former le genre fo.
uICAIBE quíli admet dans la famille des Salacoptérygieas ab.

? Gore, aupres de Cayenne, -. Steveraglige plooy beeh, en Hollande, - Indian ialistox, en Suede. - Runselmaut, en meth. - Id. Bonnaterre, pl. de IEac. meth. - Loricaire plecosiome.

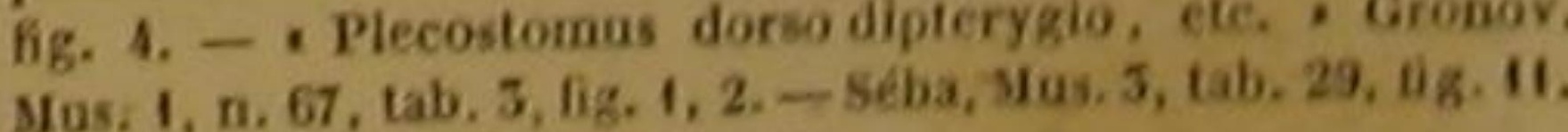
- Guacari. Marcg. Brasil, ife. A A rayons a la membrane branchiste de libyostome gua-

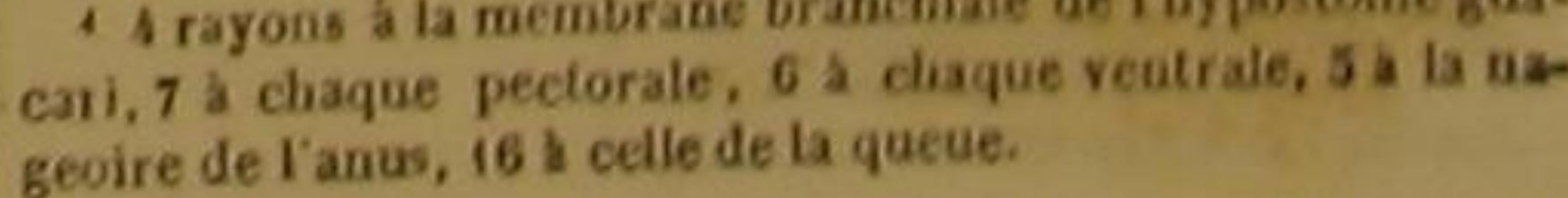
rasse d lames; la bouche au-dessous du museau; 1 dominanx siluroides. - $\mathbf{D}$. Allemagne. - Loricaire guacari, Dasubenon el Haay, En: 
CENT SOIXANTE-SEIZIÈME GENRE.

LES CORYDORAS '.

De grandes lames de chaque colé du corps el de la queu la tele couverle de pièces larges el dures; la bouche i l'extrémité du museau; point de barbillons; deux nageoires dorsales; plus d'un rayon d chaque napeoire $d u$ dos.

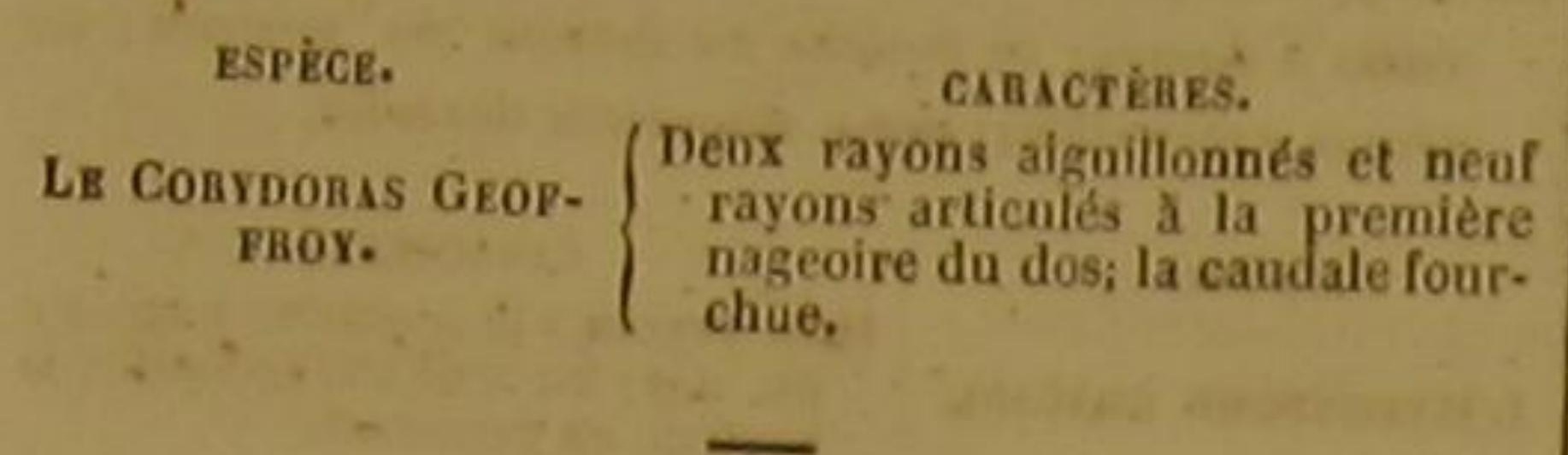

\section{LE CORYDORAS GEOFFROY.}

Corydoras Geoffroy, Lac, ?:

Nous avons trouvé, dans la collection donnée par la Hollande à la France, un individu de cette espèce encore inconnue des naturalistes. Le nom générique par lequel nous avons cru devoir la distinguer, indique la cuirasse et casque qu'elle a recus de la nature ${ }^{3}$; et nous si bien mérité à notre collègue Geoffroy, qui a si bien mérité la reconnaissance de tous ceux qui cultivent l'histoire naturelle, par les observations qu'il a faites en Egypte sur les divers animaux de cette contrée, et particulièrement sur les poissons du Nil.

Les lames qui garantissent chaque côté de cet osseux sont disposées sur deux rangs; elles brane asse tres-larges et hexagones. Une memsoutiennent la sue sépare les deux rayons qui mier rayont la seconde nageoire du dos. Le premier rayon de chaque pectorale est hérissé de très-petites pointes. Le second rayon de la première nageoíre du dos est dentelé d'ium sent côté. Le premier dé cette mème dentelé d'ùn seul pas de dentelure; il ette mème nageoire n'offre on peut remare; il est même très-court: mais deux orifices. Oner sa force. Chaque narine a sus de chaque poct une grande lame au-des-

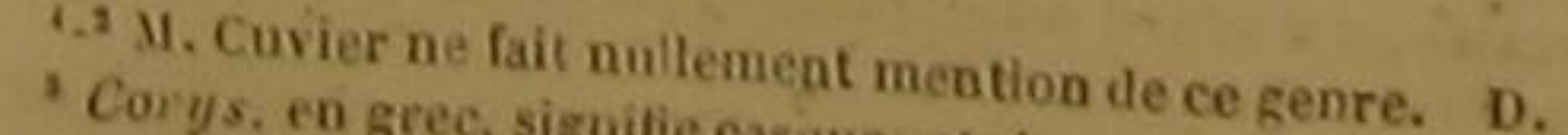
- II rayons à chaque pectorale in coras, euirasse. a scconde dorsale, 6 à chaque ventarydoras geuffroy, 2 anis, il a celle de 1 i queue.
| GENT SOIXANTE-DIX-SEPTIÈME GENRE.

Les tachysunes '

La bouche d l'extrémilé du museau; des barbillons au. machoires; le corps el la queue très-allongés et revell d'une peau visqueuse; le premier rayon de la pr miere nageoire du dos et de chaque pectorale frès-fort, deus nageoires dorsales, liune et l'aulre soulenu par plus d'un rayon.

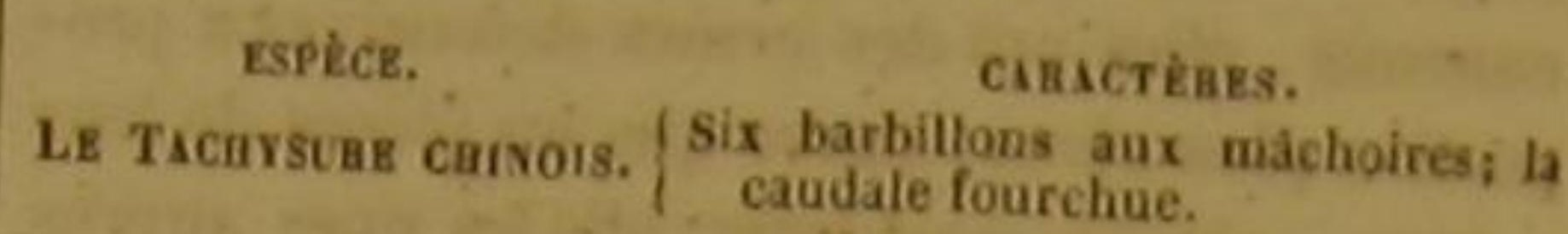

\section{LE TACHYSURE CHINOIS.}

Tachysurus sinensis, Lac. ?

Parmi les peintures chinoises déposées au Muséum d'histoire naturelle, on voit une figure de cette belle espèce, dont les formes et par conséquent les habitudes ont beaucoup de rapports avec celles des silures, des pimélodes, des pogonathes, ete.

Ce poisson vit dans l'eau douce. Son nom générique exprime l'agilité de sa queue longue ế déliée ${ }^{3}$, et son nom spécifique indique son pays.

La mâchoire supérieure est un peu plus avancée que l'inférieure; elle présente deux barbillons : on en compte quatre à la máchoire d'en bas. Chaque narine n'a qu'un orifice. Le dessus de la tête est aplati; le museau arrondi; le dos très-relevé et anguleux; la ligne latérale droite, 'opercule composé de trois pièces; la seconde nageoire du dos un peu ovale, et semblable, pour la forme ainsi que pour les dimensions, a celle del'anus, au-dessus de laquelle elle est situéo; la couleur générale verte, avee des taches d'un vert plus foncé. Des teintes rouges paraissent sur les ventrales et sur les nageoires de l'anus et de la quieue.

\section{CENT SOIXANTE-DIX-HUITIÈME GENRE}

$$
\text { LES SALMONES } 4 \text {. }
$$

des éce dillextrémìte du museau; la tele comprimée; queue; point de grat visibles sur le corps et sur la rasse, de piquontsandes lames sur les coltes, de cui-

rese diquants aux opercules, de rayons denteles,

4.2 M. Cuvier n'admet et ne cile pas ce Benre. D. - Tachys, en gree, signifie rapide.

- Ce genre de Lacépéde se rapporte en of des Salmones, dans l'ordre des Malacoptérygiens abdomizaux
de M. Cuvier. D.

DES POISSONS.

179

ni de barbillons; deux nageoires dorsales; la seconda I. ESPÈ

adipeuse et aénuée de rayons; la première plus près ou aussi prés de la tete que les ventrales; plus de quatre rayons d la membrane des oranchies; des dents forles auv maehoires.

espểers.

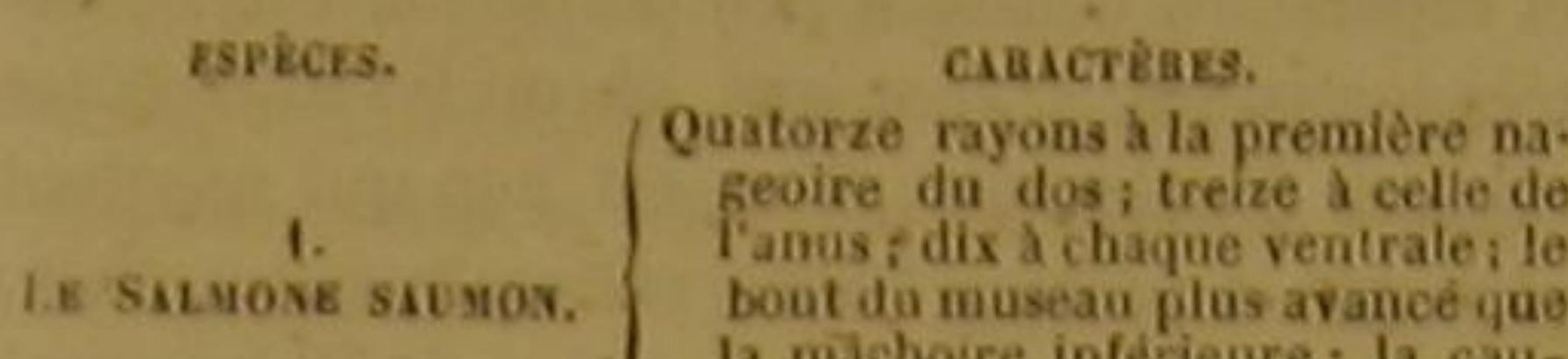
LE SILAONE CABPION.

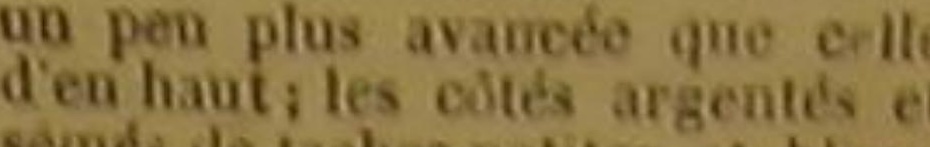
ches; du noir e e tut rouge sur les nageoires inferiences.
notis the rayons a la premiere na-
feorro do dos; donze a lanale; LE SALYONR SALVELINE.

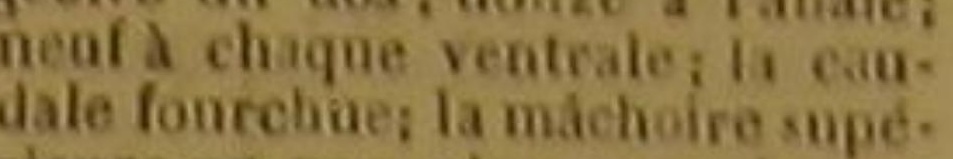

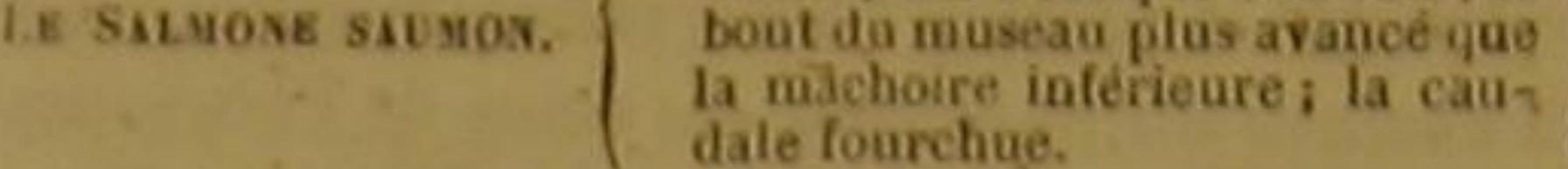

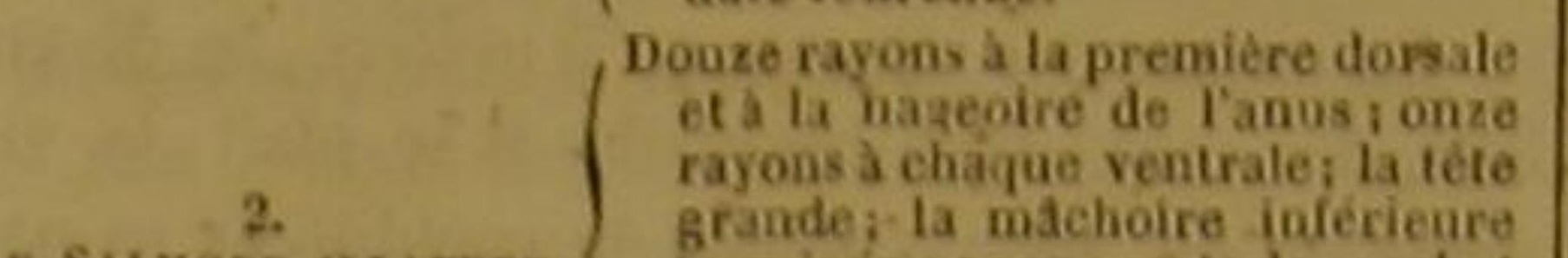

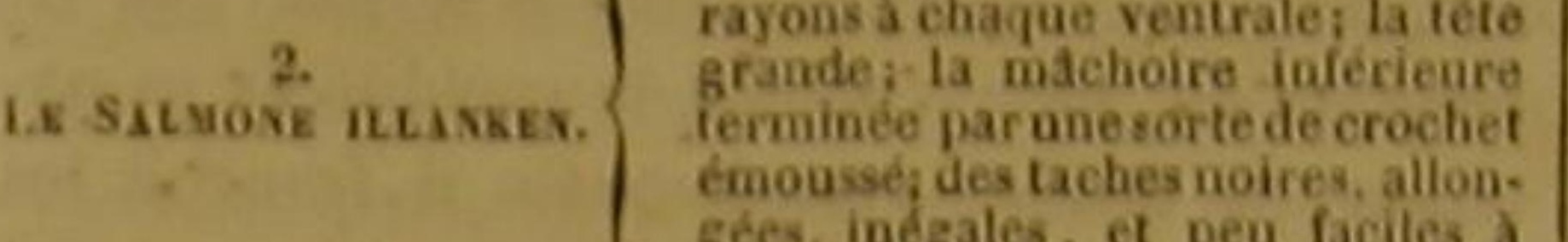
( tes, inég.
istuguer.

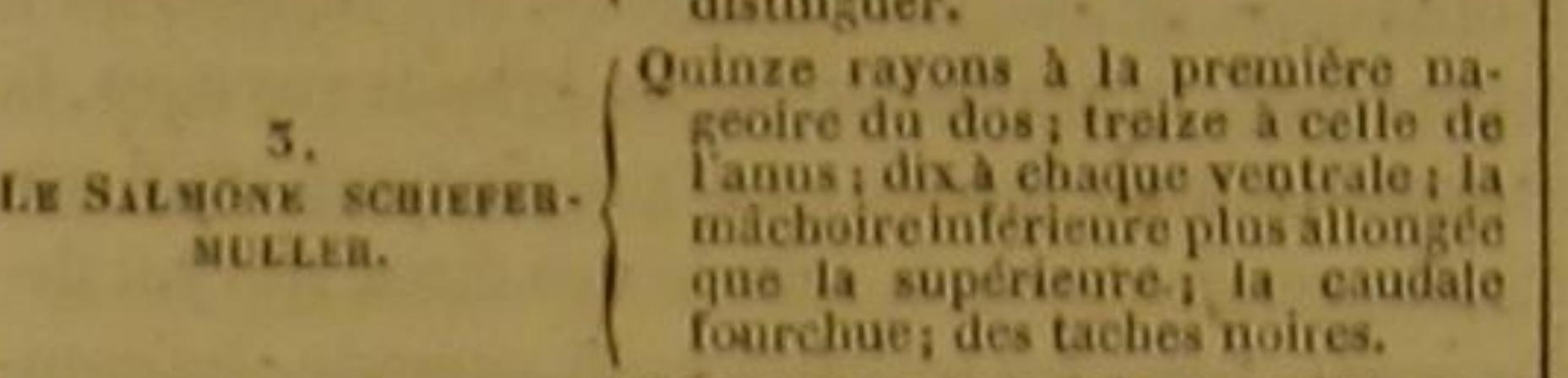

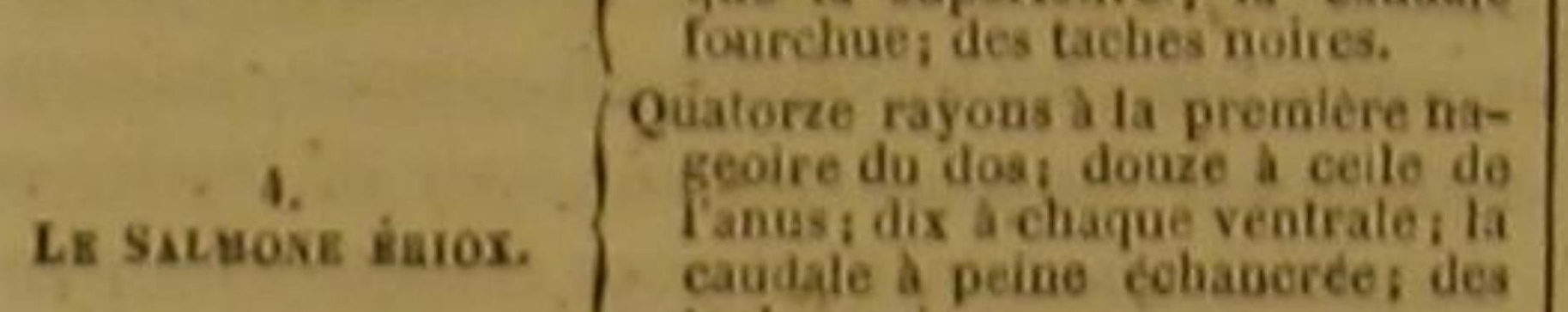
caudale a pesi
tactios grises.

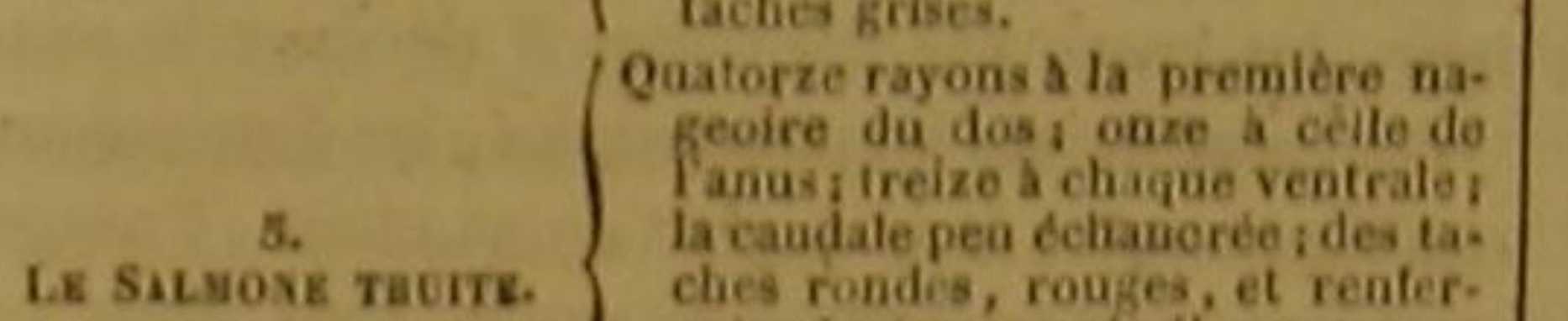

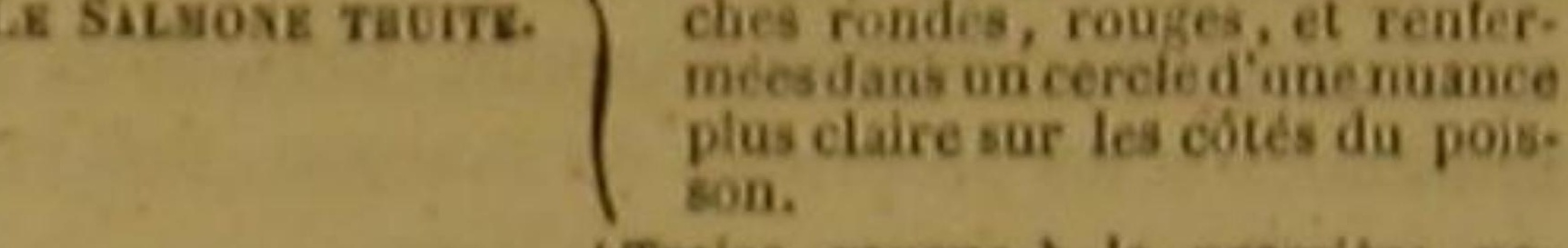

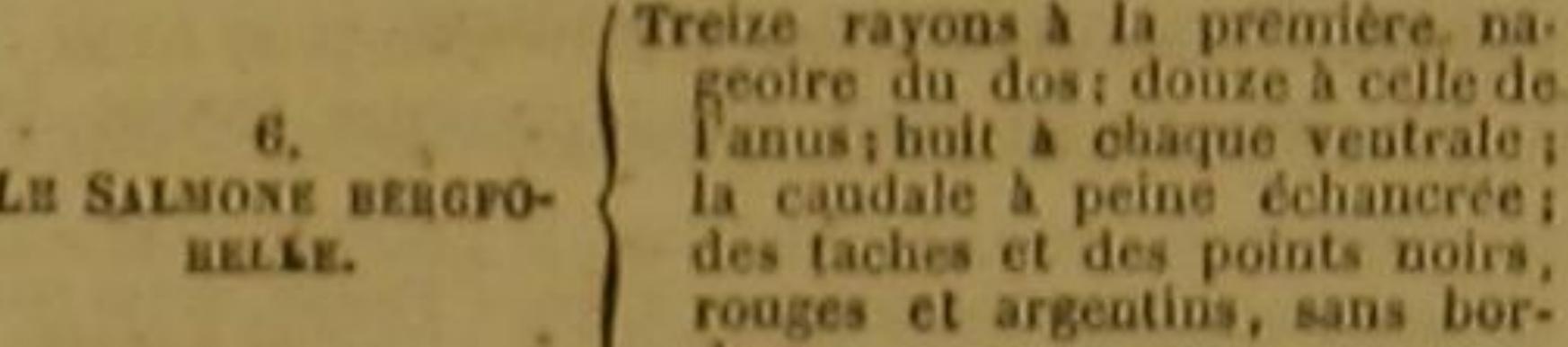
rouge:

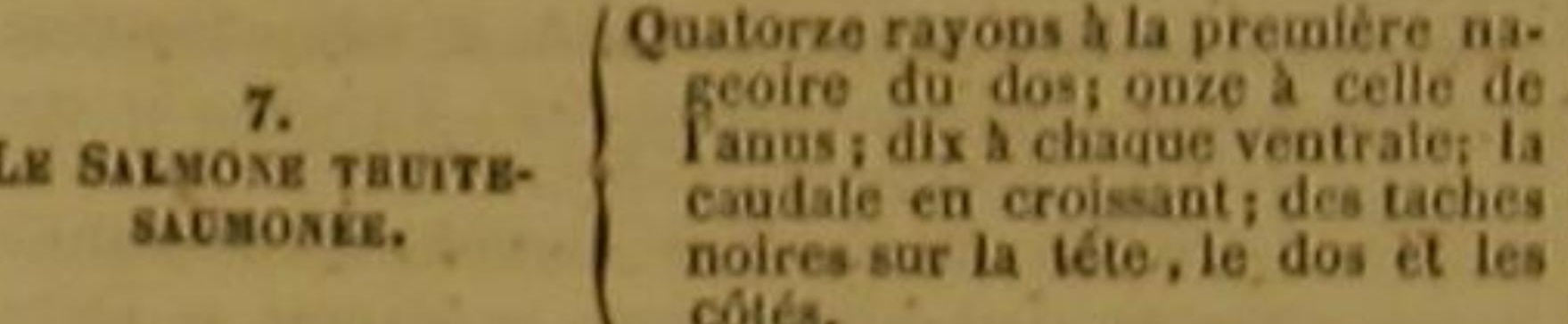<smiles>C1[C@H]2[C@@H]3C[C@H]3[C@@H]12</smiles>
Douze rayons a la premiére dorDouze rayons a a premicre do
sale; onze a la nageoire de i.
nus; dix a chaque veotrale, le

Le sacso

8. :

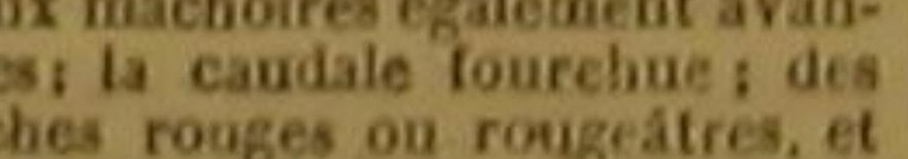
tre nuasces dun cercle dine aitgeoires de la queue, de I'ans na da ventre, et sur la partie infe-

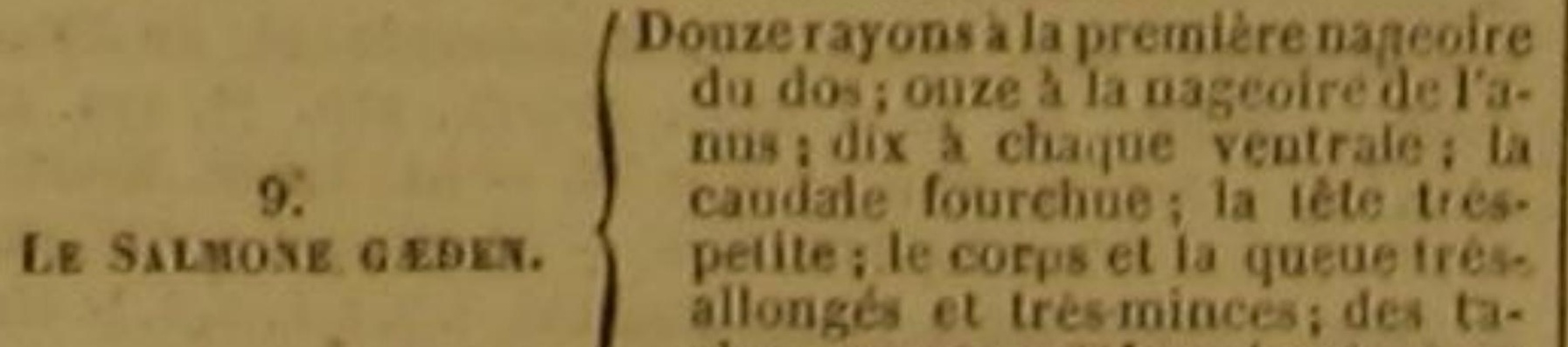
allonges et trésminces; des $\mathrm{t}$ -
clies rouges rentermées dans un

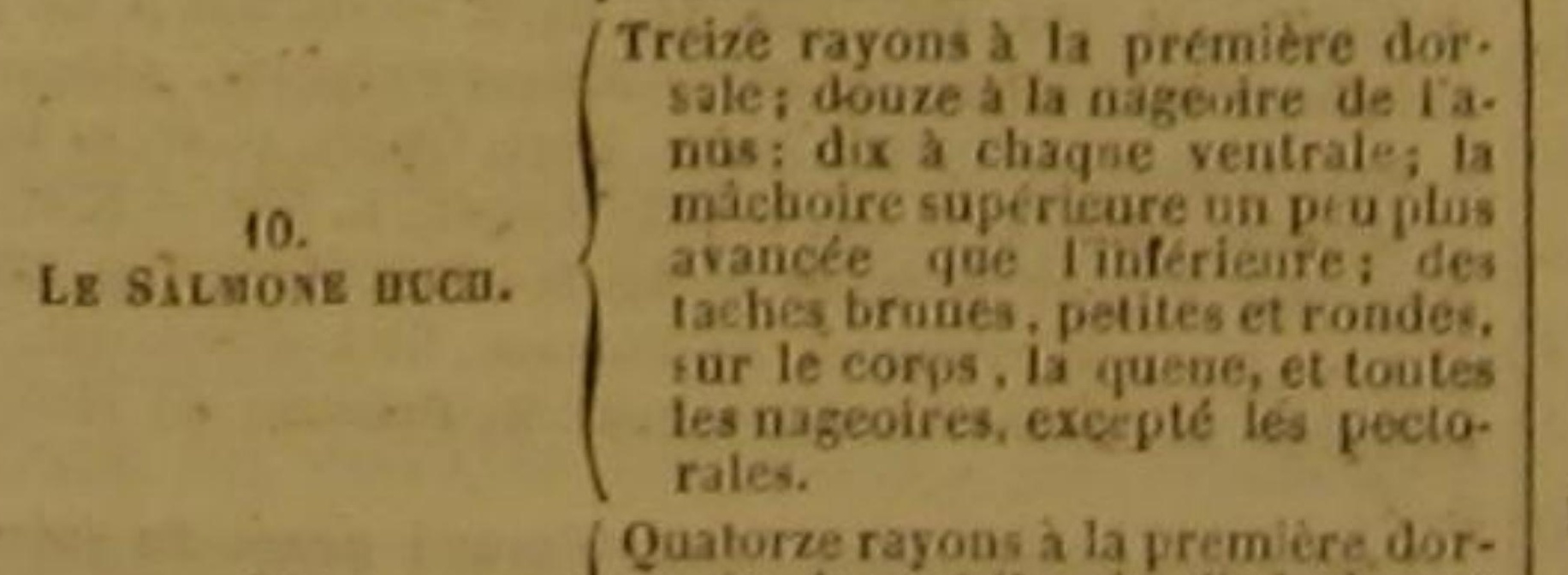

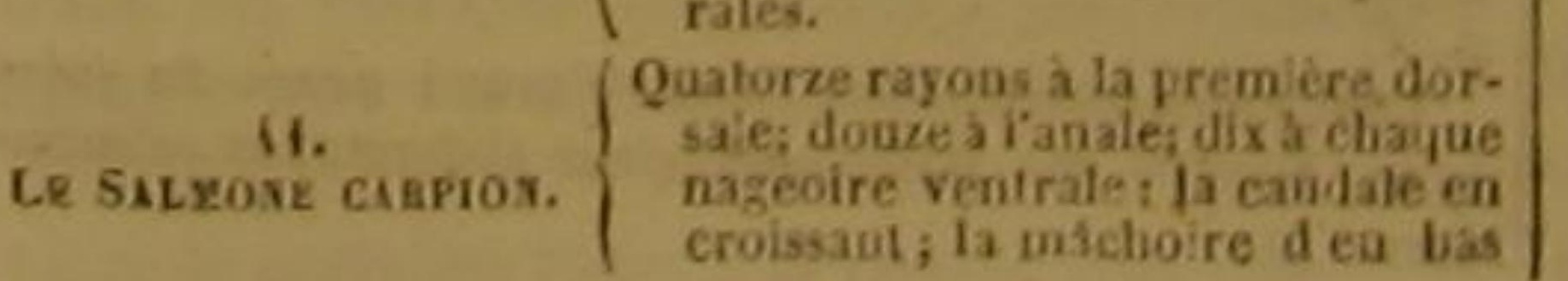

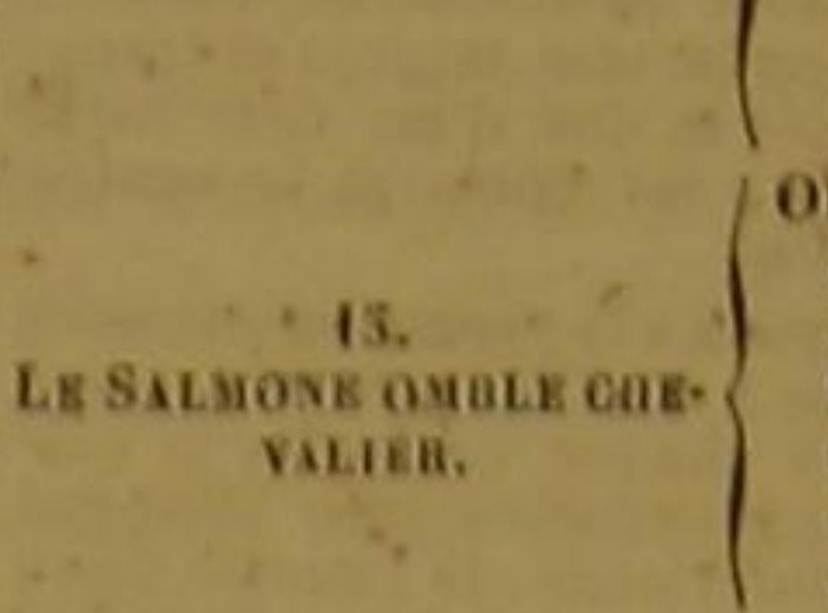
reset et de celle de lanus fortet
banc, Onze rayons a la premiere nageoire
du dos et a celle de laniss neut

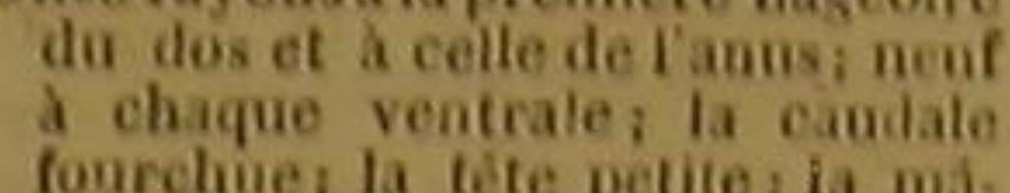

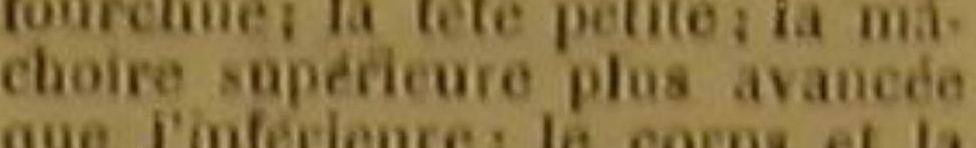
queue sams taches.

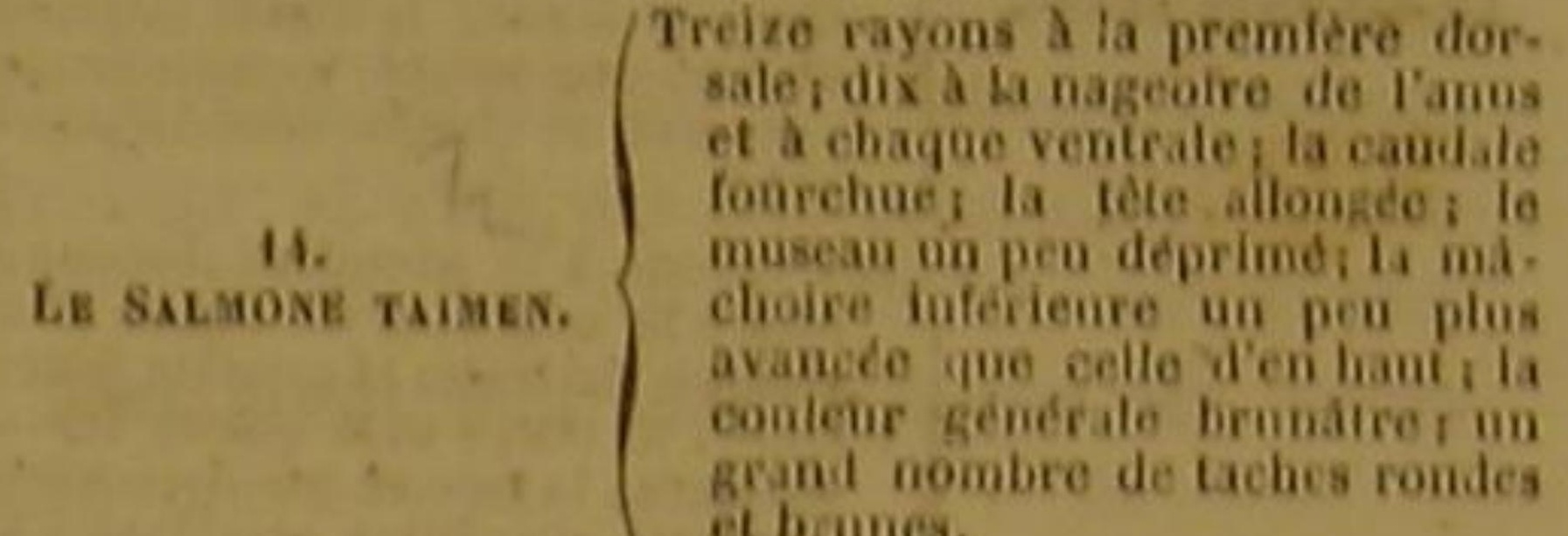

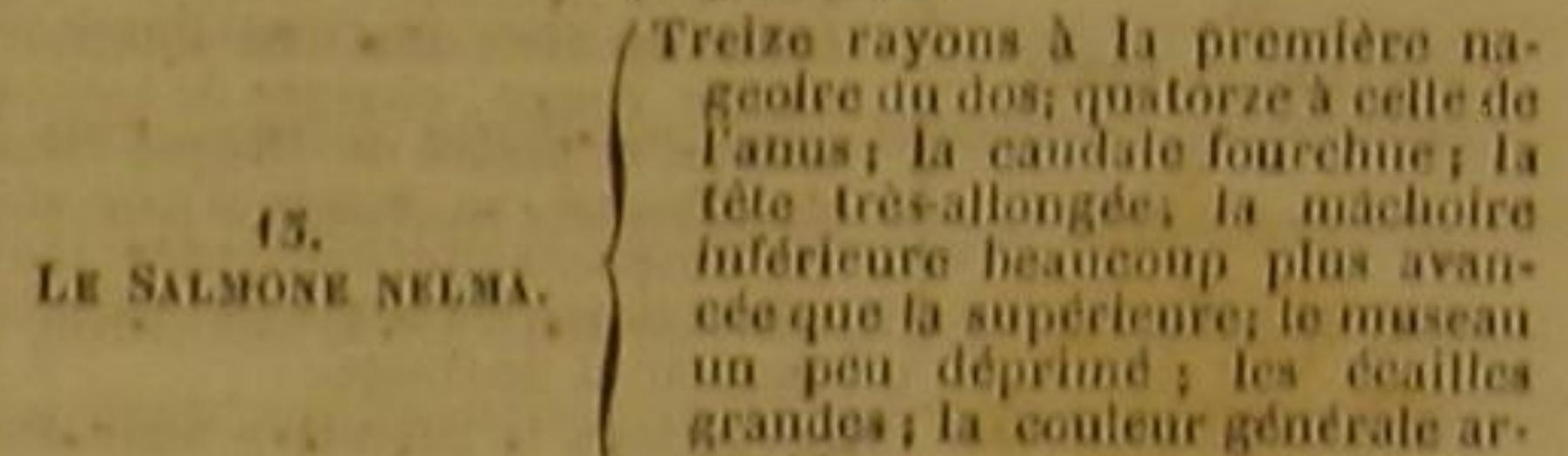

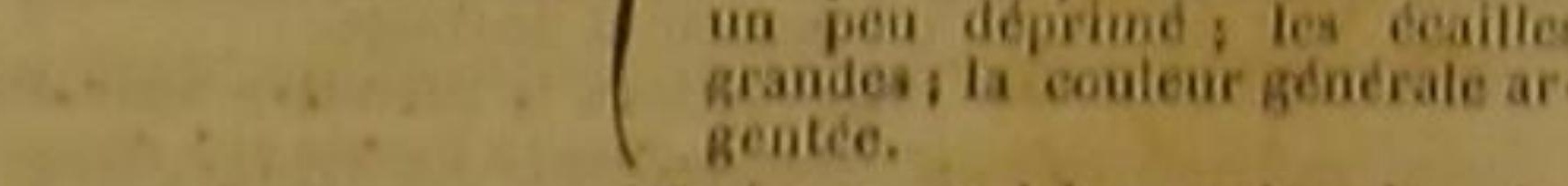

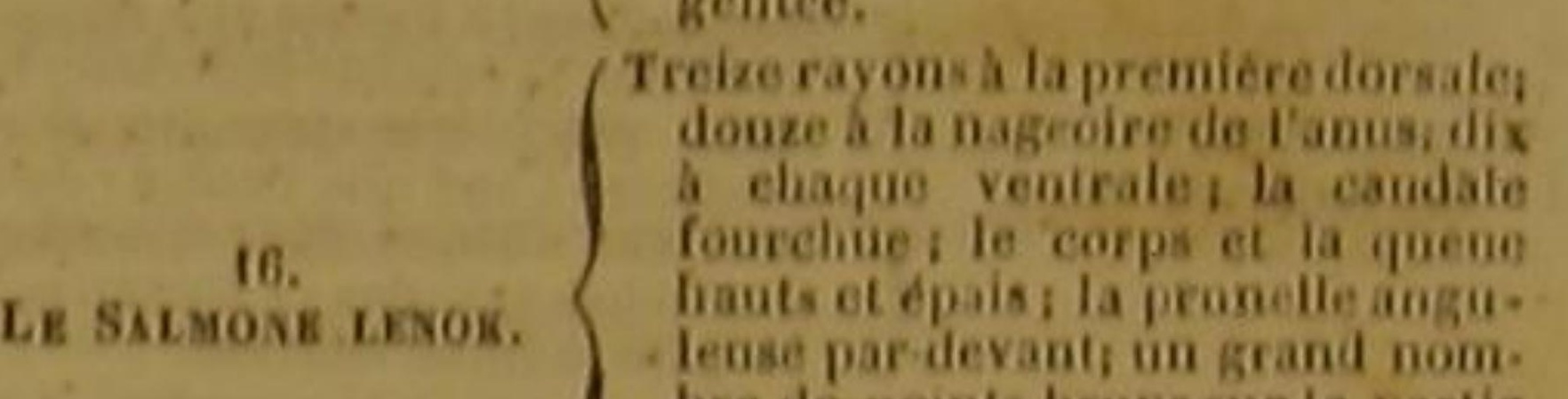

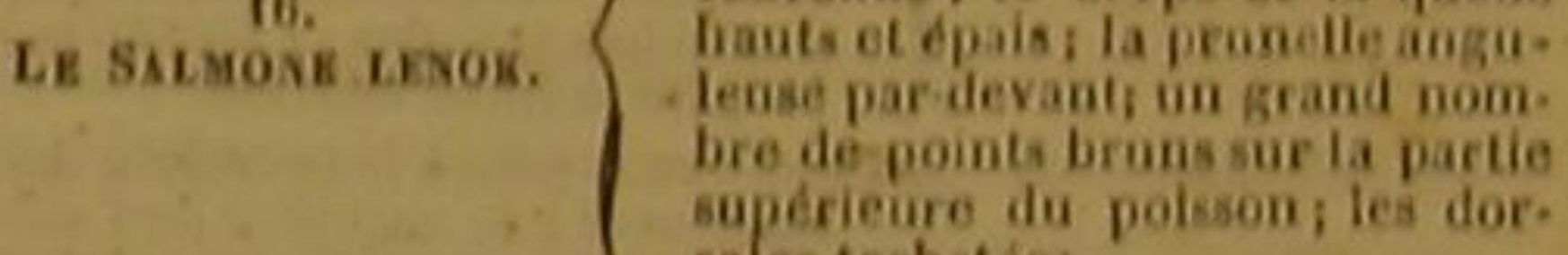

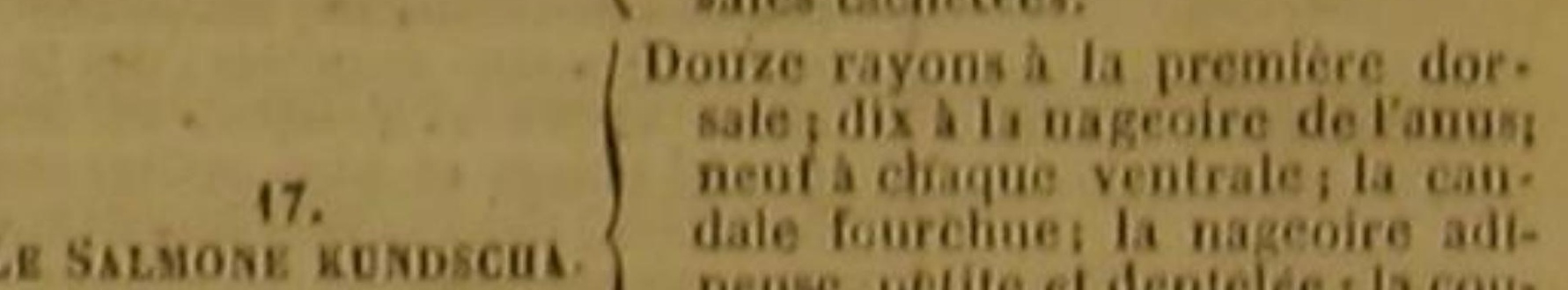

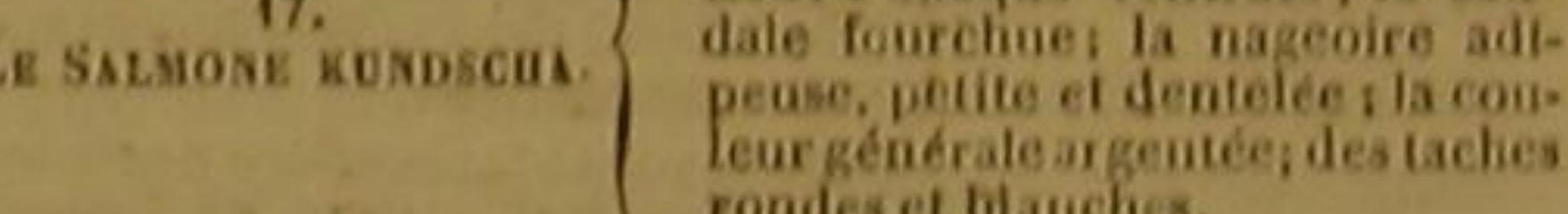

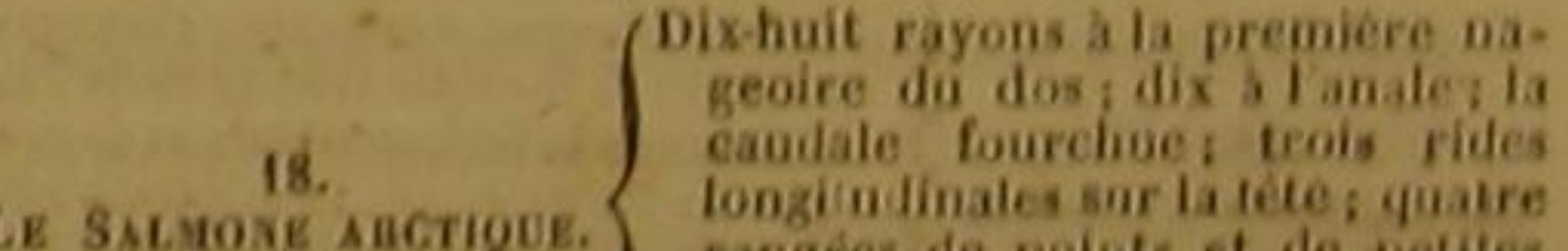

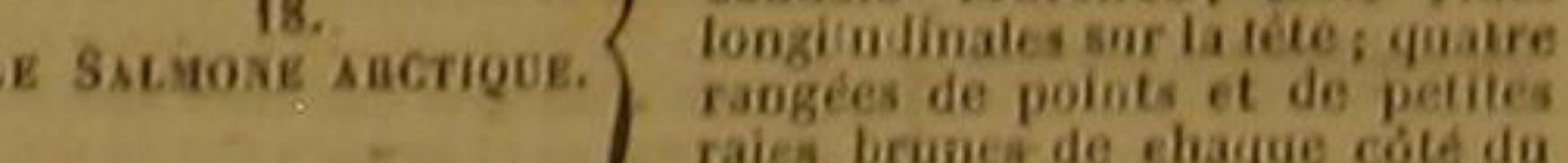
$\left(\begin{array}{l}\text { raies } \\ \text { poisson. } \\ \text { dols }\end{array}\right.$ L. SALON 19. et a chaque veatrales la candale un peu fourchue; ; adipeuse ea
forme de faux; la máchioire superieure plas longue que linte.
rieure; la coulene generale bra-
nattre; point de tiches.

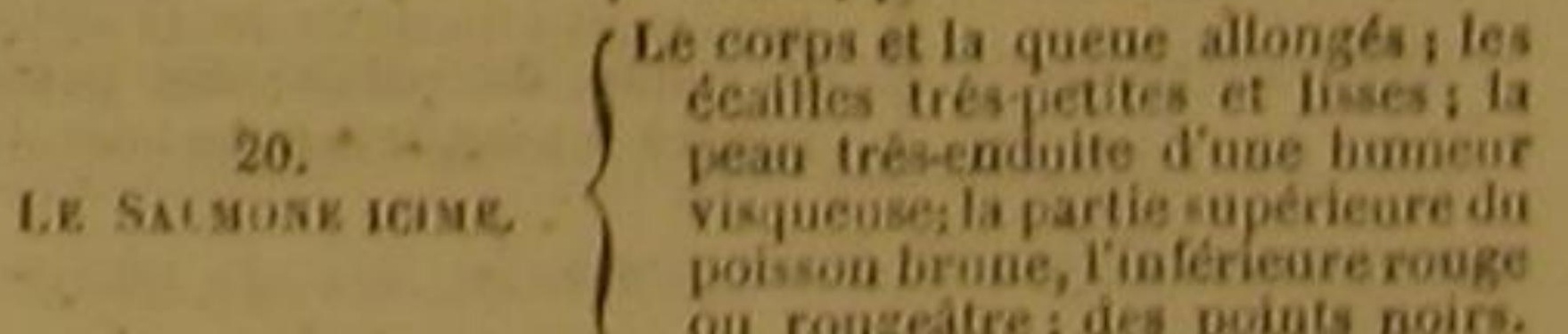

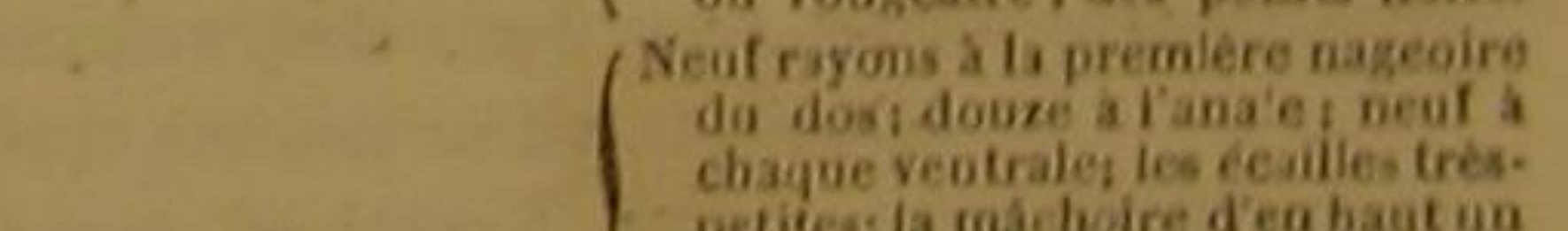

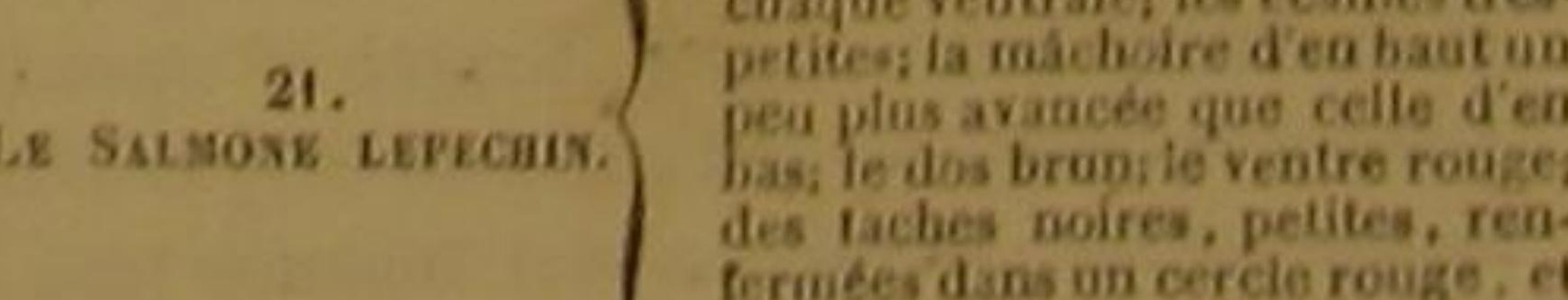




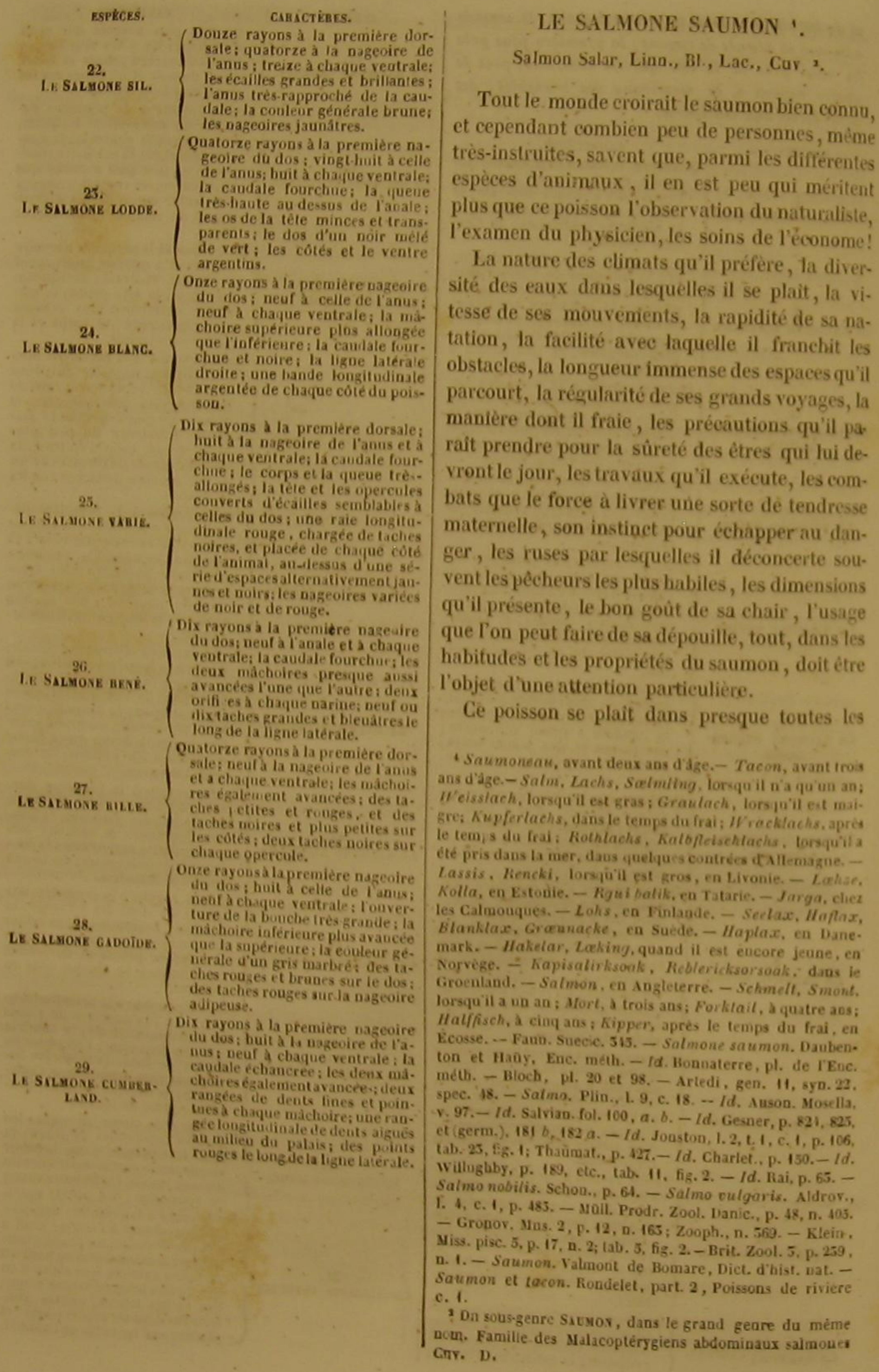

DES POISSONS.

mers; dans celles qui se rapprochent le plus du temps; et dans les régions moins éloimenées du pole, et danscelles qui sont le plus voisines de l'é- eercle polaire, ilsentrent das lesfeurges du quateur. On le trouve sur les côtes occidentales les glaces commencent à fondre sur les côtes de l'Europe; dans la Grande-Bretagne; auprès de l'Océan. Ils partent avee le flux, surtout lorsde tous les rivages de la Baltique, particulière- que les flots de la mer sont poussés contre le ment dans le golfe de Riga; au Spitzberg; au courant des rivières par un vent assez fort que Groenland; dans le nord de l'Amérique; dans l'on nomme, dans plusieurs pays, vent du saul'Amérique méridionale; dans la Nouvelle-Hol- mon. Ils préfèrent se jeter dans celles qu'ils lande, au fond de la Manche de Tatarie; au trouvent le plus débarrassées de glaçons, ou Kamtschatka, ete. II préfère partout le voisi- dans lesquelles ils sont entrafinés par la marée nage des grands fleuves et des rivièrés, dont laplushaute et la plus favorisée par le vent.Si les les eaux douces et rapides lui servent d'habita- chaleurs de l'été deviennnent trop fortes, ils se tion pendant une très-grande partie de l'année. réfugient dans les endroits les plus profonds, Il n'est point étranger aux lacs immenses ou aux où ils peuvent jouir, à une grande distance de la mers intérieures qui ne paraissent avoir aucune surface de la rivière de la fraicheur qu'ils recommunication avee l'Océan. On le compte cherchent; et e'est par une suite de ce besoin parmi les poissons de la Caspienne; et cepen- de la frafeheur, qu'ils aiment les enux douces dant on assurequ'on ne l'a point vu dans la Mé- dont les bords sont ombragés par des arbres diterranée, Aristote ne l'a pas connu. Pline ne touffus:

parle que des individus de cette espèce que l'on avait prís dans les Gaules; et le savant professeur Pietet conjecture qu'on ne l'a jảmaís observé dans le lae de Genève, parce qu'il n'entre pas dans la Méditerranée, ou du moins paree qu'il y est très-rare '.

II tient le milieu entre les poissons marins et ceux des rivières. S'il croit dans la mer, il naít dans l'eau douce; si pendant I'hiver, il se réfugie dans l'Océan, il passe la belle saison dans les fleuves. II en recherche les eaux les plus pares; il ne supporte qu'avec peinece qui peut en troubler la limpidité; et c'est presque toujours dans ces eaux claires qui coulent sur un fond de gravier, que l'on rencontre les troupes les plusnombreuses des saumons les plus beaux. II parcourt'avec facilité toute la longueur des plus grands fleuves. II parvient jusqu'en Bohêmepar l'Elbe, en Suisseparle Rhin, et auprès des hautes Cordilières de l'Amérique méridionale par l'immense Maragnon, dont le cours est de mille lieues. On a même écrit qu'il n'était ni effrayé ni rebutê par une grande étendue de trajet souterrain ; et on a prétendu qu' on ayait retrouvé, dans la mer Caspienne, des saumons du golfe Persique, qu'on avait reconnus aux anneaux d'or ou d'argent que de riches habitants des rives de ce golfe s'étaient plu à leur faire attacher.

Dans les contrées-tempérées, les saumons quittent la mér vers le commencement du pria-
Uls redescendent dans la mer vers In fin de l'autómne, pour remonter de nouveau dans les fleuves à l'approche du printemps. Plusieurs de ces poissons restent cependant, pendunt I'hiver dans les rivieres qu' ils ont parcourues. Plusieurs circonstances peuvent les y déterminer; ot ils y sont forcés quelquefois par les glaces qui se forment à l'embouchure, avant qu'ils ne solent arrivés pour la franchir.

Ils s'éloignent de la - mer en troupes nombreuses, et présentent souvent, dans l'arrangement de celles qu' ils forment, autant de régularité que les époques de lears grands voyages. Le plus gros de ces poissons, qui est ordinairement une femelle, s'avance le premier; à sa suite viennentles autres femelles deux à deux, etchacune à la distance de trois à six pieds de celle qui la précède; les mâles les plus grands paraissent ensuite, observent le même ordre que les femelles, ét sont suivis des plus jeunes. On peut croire que cette disposition est rêglée par l'iné. galité de la hardiesse de ces différents individus, de l'eau.

S'ils donnent coñtre un filet, ils le déchirent, ou cherchent à s'échapper par-dessous ou par les côtés de cet obstacle; et dés qu'un de ces poissonsatrouvé une issue, les autres le suivent, et leur premier ordre se rétablit.

Losqu'ils nagent, il se tierinent au milieu du fleuve et près de la surface de l'eau; ct comme ils sont souvent très-nombreux, qu'ils sgitent l'eau violemment, et qu'ils font beaucoup de ou de la force qu'ils peuvent opposer à l'action 
bruit, on les entend de loin, comme le murmure sourd d'un orage lointain. Lorsque la tempète menace, que le soleil lance des rayons très-ardents, et que l'atmosphère est très-échauffée, ils remontent les fleuves sans s'éloigner du fond de la riyière. Des tonneaux, des bois, et principalement des planches luisantes, flottant sur l'eau, les corps rouges, les couleurs très-vives, des bruits inconnus, peuvent lés effrayer au point de les détourner de leur direction, de les arrêter même dans leur voyage, et quelquefois de les obliger à retourner vers la mer.

Si la température de la rivière, la nature de la lumière du soleil, la vitesse et les qualités de l'eau leur conviennent, ils voyagent lentement. ils jouent à la surface du fleuve; ils s'écartent de leur route; ils reviennent plusieurs fois sur l'espace qu'ils ont déjà parcouru. Mais s'ils veulent se dérober à quelque sensation incommode, éviter un danger, échapper à un piége, ils s'élancent avec tant de rapidité, que l'œil a de la peine à les suivre. On peut d'ailleurs démontrer que ceux de ces poissons qui n'emploient que trois mois à remonter jusque vers les sources d'un fleuve tel que le Maragnon, dont le cours est de mille lieues, et dont le courant est remarquable par sa vitesse, sont obligés de déployar. pendant près de la moitié dé chaque jour, une force de natation telle qu'elle leur ferait parcourir, dans un lac tranquille, dix ou douze lieues par heure, et l'on a éprouvé de plus, que lorsqu'ils ne sont pas contraints à exécuter des mouvements aussi prolongés, ils franchissent par seconde une étendue de vingt-quatre pied ou environ '

On ne sera pas surpris de cette célérité, si l'on des poll ce que nous avons dit de la natation des poissons dans notre premier Discours sur Ges saumons ont dens leur quax. une rame très-puissante. I s muscles de partie de leur corps jouis Les muscles de cette grande énergie, jueuissent même d'une si sont pas pour que des cataractes élevées ne montable. Ilss' ces poissons un obstacle insurmontable. Ils s'appuient contre degrosses pierres rapprocheñt de leur bouche l'extrémité de leur queue, en serrent le bout avec les dents; en font par là une sorte de resșort fortement tendu, lu donnentavee promptitude sa première position debandent avec vivacité l'are qu'elle forme, frappent a vec violence contre l'eau, s'élancent à

' Voyez le Discours sur la nature dieso

ne hauteur de plus de douze ou quinze pleds, franchissent la cataracte'. Ils retombent quelquefois sans avoir pu s'élancer au dela do roches, ou l'emporter sur la chute de l'ean : mais ils recommencent bientôt leurs manœurres, ne cessent-de redoubler d'efforts qu'après des tentatives très-multipliées; et c'est surtout lorsque le plus gros de leur troupe, celui que l'on nommé leur conducteur, a sauté avec succès, qu'ils s'élancent avec une nouvelle ardeur.

Après toutes ces fatigues, ils ont souvent be soin de se reposer. Ils se placent alors sur quelque corps solide. Ils cherchent la position la plu favorable au délassement de leur queue, celui de leurs organes qui a le plus agi; et pour être toujours prêts à continuer leur route, ou poo recevoir plus facilement les émanations odorantes qui peuvent les avertir du voisinage des objets qu'ils désirent ou qu'ils craignent, ils tiennent la tête dirigée contre le courant.

Inđépendamment de leur queue longue, agile et vigoureuse, ils ont; pour attaquer ou pou se défendre, des dents nombreuses et trèspointues qui garnissent les deux mâchoires, et palais, sur chacun des côtés duquel elles forment une ou deux rangées.

On trouve aussi, des deux côtés du gosies, un os hérissé de dents aiguës et recourbées. Six ou huit dents semblables à ces dernières sont pla cées sui la langue; et, parmi celles que mon. trent les máchoires, il y én a de petites qui son mobiles. Les écailles qui recouvrent le corps et la queue sont d'une grandeur moyenne : la tête ni les opercules n'en présentent pas de semblables. Au côté extérieur de chaque ventrale paraít un appendice triangulaire, aplati, allongé, pointu, garni de petites écailles, couché le long du corps, et dirigé en arrière. Au reste, cet appendice n'est pas particulier au saumon : nous n'avons guère vu de salmone qui n'en eût un semblable ou analogue.

La ligue latérale est dròite; le foie rouge, gros et huileux; l'estomac allongé; le canal intestinal garni, auprès du pylore, de soixante-dix appendices ou cœeums réunis par une membrane; la vessie natatoire simple, et située trèsprès de l'épine du dos; cette épine composée de trenté-six vertèbres, et fortifiée de chaque côté

'Consultez particuliérement le Voyage de Twiss en Ir-
Iarde.
$2^{2}$ On trouve souvent dans
DES POISSONS.

485

Le front, la nuque, les joures et le dos sont noirs; les cótés bleuâtres ou verdâtres dans leur partie supérieure, et argentés dans l'inférieure; la gorge et le ventre d'un rouge jaune; les membranes branchiales jaunatres; lespectorales jaunes à leur base; et bleuâtres à leur extrémité ; les ventrales et l'anale d'un jaune dorè. La premiére nageoire du dos est grise et tachetée; l'adipeuse noire; et la caudale blene.

Quelquefois on voit sur la tête, les côtés et le dos, des tachés noires et irrégulières, plus grandes et plus clair-semées sur la femelle.

Les males, que l'on dit beaucoup moins nombreux que les femelles, offient d'ailleurs, dans quelques rivières, et particulièrement dans celle de Spal en Écosse, plus de nuances rouges, moins d'épásseur dans le corps, et plus de grosseur dans la tête.

Dans toutes les eaux, leur mâchoíre supérieure non-seulement est plus avancée que celle d'en bas, mais encore, lorsqu'ils sont parvenus à leur troisième année, elle devient plus longue et se recourbe vers Finférieure; son allongement et sa courbure augmentent $\mathbf{a}$ mesure qu' ils grandissent; elle a bientôt la forme d'un crochet émousséqui entre dans un enfoncement de la mâchoire d'en bas; et cette conformation, qui leưr a fait donner le nom de Bécard, ou Becquet, les avait fait regarder, par quelques naturalistes, comme d'une espèce différente de celle que nouis déerivons.

Leur laite est entièrement formée, et le tèmps du frai commence à une époque plus ou moin avancée de chaque printemps ou de chaque été, suivant qu'ils habitent dans des eaux plus ou moins éloignées dela zone glaciale. Les femelle cherchent alors un endroit commode pour leur ponte. Quelquefois elles aimeñt mieux déposer leurs œufs dans de petits ruisseaux que dansles grandes rivières auxquelles ils se réunissent '; et elles paraissent chercher le plus souvent à déposer leurs œufs dans un courant peu rapide, et sur du sable ou du gravier.

On a écrit que, dans plusieurs rivières de la Grande-Bretagne, la femelle ne se contentait-pas de choisir le lieu le plus favorable à la ponte; qu'elle travaillait à la rendre plus commode encore; qu'elle creusait dans l'endroit préféré un

dont la longueur est de près de trois pieds, et dont la tête est dans un des appendices.

- Notes manuscrites et tres intéressantes commimiquée par M. Pénières. trou allongé, et de quinze ou dix-huit pouces de profondeur, quelle s'y déchargeait de ses œufs , et qu'avee sa queue elle les recouvrait ensuite de sable. Peut-être peut-on douter de cette dernière précaution; mais les autres opérations on lieu dans presque tous les endroits où les saumons ont été bien observés. Le docteur Grant nous apprend, dans les Mémoires de Stockholm, que, lorsque les femelles travaillent à donner les dimensions nécessaires á la fosse qu'elles préparent, elles s'agitent à droite et à gauche, au point d'user leurs nageoires inférieures, et en laissant ordinairement leur tête immobile. On en vu se frotter si vivement contre te terrain, qu'elles en détachaient avee violence In terre et les petites plerres, et qu'en répétant les mêmes mouvements de cinc en cinc minutes; ou d peu près, elles parvenaient, au bout de deux heures, à creuser un enfoncement de trois pieds de long, de deux pieds de profondeur, et de six à huit pouces de rebord.

Lorsque la femelle a terminé ce travail, dont la principale cause est sans doute le besoin qu'elle a de frotter son ventre contre des corps durs, pour se débarrasser d'un poids qui la fatigue et la fait souffrir, et lorsque les oufs sont tombés dans le fond de la cavité qu'elle a creusée, et que l'on nomme frayère dans quelques-uns de nos départements, le mâle vient les féconder en les arrosant de sa liqueur vivifiante. Il peut se faire qu'alors il frotte le dessous de son corps contre le fond de la fosse, pour faire sortir plus facilement la substance liquide que sa laite contient: mais on lui a attribué une opération qui supposerait une sensibilité d'un ordre bien supérieur, et un instinct bien plus relevé; on a prétendu qu'il aidait la femelle à faire la fosse destinée à recevoir les cufs.

$\Lambda u$ reste, si nous ne devons pas admettre cette dernière assertion, nous devons croire que le mâle est entraíné à la fécondation des ocufs par une affection plus vive, ou d'une nature différente, que celle qui y porte la plupart des autre poissons. Lorsqual trouve un autre male auprès des cưfs déja déposés dans la frayère, ou auprès de la femelle pondant encore, il l'attaque avec courage, et le poursuit avec acharnement, ou ne lui cède la place qu'après l'avoir disputée avec obstination '. Les saumons ne fréqquentent ordinairement la 


\section{HISTOIRE NATURELLE}

frayère que pendaut la nuit. Néanmoins, lorsque des brouillards épais sont répandus dans l'atmosphère, ils profitent de l'obscurité que donnent ces brouillards pour se rendre dans leur fosse, et ils y accourent aussi comme pressés par de nouveaux besoins, lorsqu'i is sont exposés à l'influence d'un vent très-chaud '.

II arrive quelquefois cependant que les œufs pondus par les femelles, et la liqueur séminale des mâles, se mêlent uniquement par l'effet des courants.

Après le frai, les saumons, devenus mous, maigres et faibles, se laissent entrainer par les eaux, ou vont d'eux-mèmes reprendre dans l'eau salée une force nouvelle. Des taches brunes et de petites excroissances répandues sur leurs écailles sont quelquefois alors la marque de leur épuisement et du malaise qu'ils éprouvent.

Les œufs qu'ils ont pondus ou fécondés, se développent plus ou moins vite, suivant la température du climat, la chaleur de la saison, les qualités de l'eau dans laquelle ils ont été déposés. Le jeune saumon ne conserve ordinairement que pendant un mois ou environ, la bourse qui pend au-dessous de son estomac, et qui renferme la substance nécessaire à sa nourriture pendant les premiers jours de son existence. I grandit ensuite assez rapidement; et parvient bientôt à la taille de quatre ou cing pouces. Lorsqu'il a acquis une longueur de huit à dix pouces, il jouit d'assez de force pour quitter le haut des rivières, et pour en suivre le courant qui le conduit vers la mer, mais souvent, avant cetle époque, une inondation l'entraune vers l'embouchure du fleuve.

Les jeunes saumons qui ont atteint une longueur de quinze ou dix-huit pouces, quittent la mer pour remonter dans tes rivières : mais ils partent le plus souvent beaucoup plus tard que les gros saumons; ils attendent communément le commencement de l'été.

On les suppose âgés de deux ans, lớsqu'ils pèsent de six à huit livres. M. Pénières assure que, mème dans les con̂trées tempérées, ils ne fraient que vers leur quatrième ou cinquième année ${ }^{2}$.

Agés de cinq ou six ans, ils pèsent dix ou douze livres, et parviénnent bientôt à un développement très-considérable. Ce développement peut être d'autant plus grand, qu'on pè 'he fré-

1.2 Notes manuseriles de M. Pénières, quemment, en Écosse et en Suède, des saumon du poids de quatre-vingts livres, et que le très-grands individus de l'espèce que nous décrivons présentent une Jongueur de six pieds.

Les.saumons vivent d'insectes, de vers, et d jeunes poissons. Ils saisissent leur proie avec beaucoup d'agilité; et, par exemple, on les voi s'élancer, avec la rapidité de l'éclair, sur les moucherons, les papillons, les sauterelles, et les autres insectes que les courants eharrient, ou qu voltigent à quelquẹs pouces au-dessus de la surface des eaux.

Mais s'ils sont à eraindre pour un grand nombre de petits animaux, ils ont à redouter des ennemis bien puissants et bien nombreux. Ils sont poursuivis par les grands habitants des mers et de leurs rivages, par les squales, par les phoques, par les marsouins. Les gros oiseaux d'eau les attaquent aussi; et lespêcheurs leur font surtout une guerre cruelle.

Et comment ne seraient-ils pas, en effet, trèsrecherchés par les pêcheurs? ils sont en trèsgrand nombre; leurs dimensions sont trèsgrandes et leur chair, surtout celle des mâles, est, à la vérité, un peu difficile à dicérer, mais grasse, nourrissante, et très-agréable au goût. Elle plait d'ailleurs à l'oil par sa belle couleur cougeâtre. Ses nuances et sa délicatesse ne sont cependant par les mèmes dans toutes les eaux. En Ecosse, par exemple, le saumon de la Dée est, dit-on, plus gras que célui des rivières moins septentrionales du même pays; et en Allemagne, on préfére les saumons du Rhin et du Wéser à ceux de l'Elbe, et ceux que l'on prend dans la Warta, la Netze et le Kuddow, à ceux que l'on trouve dans l'Oder.

Mais dans presque toutes les rivières qu'ils fréquentent, et dans toutes les mers où on les trouve, les saumons dédommagent amplement des soins et du temps que l'on emploie pour les prendre.

Aussi a-t-on eu recours, dans la recherche de ces poissons, à presque toutes les manières de pêcher.

On les prend avec des filets, des pares, des caisses, de fausses caseades, des nasses, des hameçons, des tridents, des feux, etc.

Les filets sont des trubles, des trémails', semblables à ceux dont on se sert en Norvège, 'Voyez a l'article du Gade colin, lexplication du mot
irémail; et a celui du Misgurne fossile, celle du mot
truble.
DES POISSONS.

485

que Yon tend le long du rivage do la mer, qui funes des autres les extrémités de ces lames, forment des ares ou des triangles, et dans les- entrent facilement dans la caisse, ne peuvent quels on attire lès saumons en courrant les ro- pas sortir par un passage que ferment les lames chers de manièré à leur donner la couleur rapprochées, et s'engagent dans im réservoir blanche de l'embouchure d'un flẹve qui se d'oư on les retire parle moyen d'un filet attaché précipite dans l'Océan.

La ficelle dont on fait ces filêts doit être aussi grosse qu'une plume àécrire. Ils présentent jusqu'à cent brasses de longueur, sur quatre de hauteur; et leurs mailles ont communément de quatre à cinq pouces de large.

On place les pares auprès des bouches desrivières, ainsi qu'au-dessus des chutes d'eau. On leur donne une figure telle, que l'entrée de ces enclos est trè̀-large, et que le fond en est assez étroit pour qu'un saumon puisse à peine y passer et qu'on l'y saisisse facilement avec un harpon '.

On se sert de ces pares pour augmenter la rapidité des rivières en resserrant leur cours, pour en rendre le séjour plus agréable aux saumons; qui ne s'engagent que rarement dans les eaux trop lentes; et ce moyen a été particulièrement mis en usage auprès de Dessau, dans la Milde, qui se jette dans I'Elbe.

Derrièreces parcs, auprès des moulins, et dans d'autres endroits où le lit des rivières est rétréci par l'art ou par la nature, on forme des caisses à jour, qui ont une gorge comme une louve ${ }^{2}$, et dans lesquelles se prennent lés saumons qui descendent ou ceux qui montent, suivant la directión que l'on donne à ces caisses. Dans certaines contrées, et particulièrement à Chá. teaulin, lieu voisin de Brest, et fameux depuis longtemps par la pêche du saumon, on élève des digues qui déterminent le courant à se jeter dans une caisse composée de grilles, et dont chaque face a quinze ou dix-huit pieds de largeur. Au milieu de cette caisse on voit, à fleur d'eau, un trou dont le diamètre est d'un pied et demi à deux pieds. Autour de ce trou sont attachées par leur base des lames de fer-blane, allongées, pointues, un peu recourbées, qui forment dans l'intérieur de la caisse un cóne lorsque leur élasticité les rapproche, et un cylindre lorsqu'elles s'écartent les unes des autres. Les saumons, conduits par le courant, éloignent les

'Ces enceintes portent le nom de veir, auprès de Ballys. hannon, dans la partie occidentale du nord de l'Trlande. (Voyage de Twiss, déjà cité.) 'On trouvera, dans Iarticle da Petromyzon lamproie.
l'esplication da mot loupe au bout d'une perche. On tend cependant
d'autres filets le long des digues, pour arreter les-saumons qui pourraient se dérober au courant, et échapper au piége.

Dans quelques rivières, comme dans la Stolpe et le Wipper, on construit des éeluses dont les pieux sont placés très-près les uns des autres. Les saumons s'élancent par-dessus cet obstacle; mais il trouvent au delà une rangée de pieux plus élevés que les premiers, et ils no peuvent ni avancer ni reculer.

On prend aussi les saumons dans des nassies de neuf a douze pieds de longueur, et faites de branches de sapin que I'on réunit avec des ficelles, et que l'on tient assez écartées les unes des autres, pour qu'elles ne donnent pas une ombre qui effraierait ces poissons.

On ne néglige pas non plus de les pécher à la ligne, dont on garnit les hamecons de poissons très-petits, de vers, d'insectes, et particulièrement de demoiselles.

Pour mieux réussir, on a yecours à une gaule rès-longue et très-souple, qui se prête a tous les mouvements du saumon. Le pécheur qui la tient, suit tous les efforts de l'animal qui cherche à s'échapper; et, si la nature du rivage y oppose, il lui abandonne la ligne. Le saumon se débat avec violence et longtemps; il s'élance au-dessus de la surface de l'eau; et après avoir épuisé presque toutes ses force. pour se débarrasser du crochet qu'il a avalé, il vient se reposer prés de la rive. Le pécheur se ressaisit alors de sa ligne, et le tourmente de nouveau pour achever de le lasser, et le ther facilement à lui '

Lorsqu'on préfére de harponner les saumons, on lance ordinairement le trident à la distanee de trente-sixà quarante-cing pieds. Les saumons que le harpon a blessés sans les retenir, quittent l'espèce de bassin ou de canal dans lequel ils ontété attaqués, pour se réfugier dans le canal ou bassin supérieur. Si on les y poursuit, et qu'on les y entoure de filets, ils s'enfoncent sous les roches, au se collent contre le sable, et immobiles laissent glisser sur eux les Notes manuserites de s. Penteres. au bout d'une perche. On tend cependant 
plombs du bas des filets que trainent les pêcheurs. On les a vus aussi se précipiter dans un courant rapide, et cachés sous l'écume et les bouillons des eaux, souffrir avec constance, et sans changer de place, la douleur que feur causait une gaule qui frottait avec force, et comprimait leur dos'.

La pèche du saumon forme, dans plusieurs contrées, une branche d'industrie et de commerce, dont les produits peuvent servir à la nourriture d'un grand nombre de personnes. A Berghen, par exemple, il n'est pas rare de voir les pècheurs apporter deux mille saumons dans un jour. Nous lisons dans le Voyage de l'infortuné la Pérouse ${ }^{2}$, qu'auprès de la baie de Castries, sur la cote orientale de Tatarie, au fond de la manche du mème nom, on prit, dans un seul jour du mois de juillet, plus de deux mille saumons. Il est des pays ou l'on en pêche plus de deux cent mille par an. En Noryège, on a pris quelquefois plus de trois cents de ces animaux d'un seul coup de filet ${ }^{3}$. La pềche que I'on fait de ces poissons dans la Tweed, rivière de la Grande-Bretagne, est quelquefois si considérable, qu'on a vu un seul coup de filet en amener sept cents. Et, en $17 \overline{0} 0$, on prit d'u seul coup, dans la Ribble ${ }^{4}$, trois mille cinc cents saumons déjà parvenus à d'assez grandes dimensions.

Mais quelque nombreux que soient les individus de l'espèce que nous décrivons, plusieur gouvernements ontétéforcésd'en régler la péche pour qu'une avidité imprévoyante ne détruisit pas dans une seule saison l'espérance des années suivantes.

Au reste, les saumons meurent bientôt, nonseulement lorsqu'on les tient hors del'eau, mais encore lorsqu'on les met dans une huche qui n'est pas placée au milieu d'une rivière. Des pêcheurs prétendent que, pour empêcher ces poissons de perdre leur goût, il faut se presser de les tuer dès le moment où on les tire de l'eau; et qu'après cette précaution, leur chair, quoique très-grasse, peut se conserver peridant plusieurs semaines. Mais, lorsqu'après la mort de ces animaux, on veut les transporter à de grandes distances, et par conséquent les garder très-longtemps, on les vide, on les coupe 'Notes manuscrites de $\mathbf{M}$. Fénières. 'Voyage de la Pérouse, rédigé par le géáral Miltet-Múrean, t. III, p. 61.
'Peonant, Zool

'Richter. Ichb brit, t. IU, p. 289 en morceaux, on les saupoudre de sel, on les renferme dans des tonnes, on les couvre saumure; ou on les fend depuis la tête, que l'on sépare du corps, jusqu'à la nágeoire de queue, on leur Ote l'épine du dos, on les laiss dans le sel pendant trois ou quatre jours, et o les expose à la fumée pendant quinze jours o trois semaines.

Auprès de la baie de Castries dont nous ve nons de parler, les Tatares tanment la peau de grands saumons, et en forment.un habillemen très-souple '.

Les grands avantages que procure la pêche du saumon doivent faire désirer d'acelimater cette espèce dans les pays où elle manque. Nous pensons, avee Bloch, qu'il serait possible de la transporter, et de la faire multiplier dans les lacs dont le fond est de sable, et dont l'ean très-pure est sans cesse renouvelée par des rivières ou des ruisseaux. On y transporterait en même temps un grand nombre de goujons, qqui aiment les eaux limpides et courantes, et qui y pulluleraient de manière à fournir aux saumons une-nourriture abondante.

Les saumons sont sujets à une maladie particulière dont on ignore la cause, et qui leur fait donner le nom de Ladres dans quelques départements méridionaux de France. Leur chair est alors mollasse, sans consistance; et si on les garde après leur mort pendant quelques jours, ellese détache de l'épine dorsale, et glisse sous la peau, comme dans un sac ${ }^{2}$.

II paraít que l'on doit compter dans l'espèce du saumon quelques variétés plus ou moins constantes, et qui doivent dépendre, au moins en très-grande partie, de la nature des eaux dans lesquelles elles séjournent. Par exemple, on a observé en Eeosse, que les saumons de Cluden ont la tête et le corps plus gros et plus courts que ceux de la rivière de Nith. On assure aussi qu'à l'embouchure de l'Orne ${ }^{3}$, on voit des saumons sans tache, et un peu plus allongés que les saumons ordinaires ${ }^{4}$.

Voyage de la Pérouse, t. III, p. 10, 6 t.

'- Notés manuscrites de $\mathbf{M}$. Naél de Ronen.

112 rayons a la membrane brauchiale du salmone saumon,

if à chaque pectorale, 10 à chaque vestrale, 21 à la nageoire de la queue.
E SALMONE ILLANKEN '.

Salmo Illanken, Lac.; Salmo Salar, var. Illanken, Linn., Gmel. ${ }^{2}$.

On connait, sous le nom d'Illanken, des salmones que l'on pêche dans le lae de Coństance, et au sujet desquels $M$. Wartmann, médecin de Saint-Gall, a fait de très-bonnes observations. D'habiles naturalistes ont regardé ces poissons eomme une variété du saumon; mais nous pensons avee Bloch, qu'ils forment une espèce particulière.

Ces salmones passent I'hiver dans le lae de Constance, comme les saumons dans la mer. Ils ne quittent jamais l'eau douce. Ils sont une preuve de ce que nous avons dit sur la facilité avee laquelle on pourrait multiplier les saumons dans les laes entretenus par des courants limpides. Il ne faut pas croire cependant qu'ils vivent pendant 1 hiver dans Je lac de Constance, par une préférence particulière pour ce séjour ou par une convenance extraordinaire de leur nature aveo les eaux qui y coulent. Ils y restent, lorsque la mauvaise saison arrive, parce qu'un obstacle insurmontable les y retient. Ils ne peuvent franchir la grande cascade de Schaffhouse, qui barre le Thin inférieur, et par conséquent la seule route par laquelle ils pourraient aller du lac dans la mer. Ce lac est l'Océan pour eux. Mais s'ils présentent des signes de leur habitation constante au milieu de l'eau douce, ils offrent toujours les traits principaux de Jeur famille. Ils annoncent par ces caractères leur origine marine; et ils ne la rappellent pas moins par leurs habitudes; puisque, n'éprouvant pas, comme les saumons, le besoin de quitter l'eau salée pendant la belle saison, ils désertent cependant le lac de Constance lorsque le printemps arrive, et n'y revieńnent que vers la fin de l'automne. Ils remontent dans les rivières qui se jettent dans le lac. Ils entrent dans le Rhin supérieur.

Ils s'arrêtent pendant quelque temps auprès dé son embouchure, parce que, dans cet endroit, it coule avec rapidité sur un fond de cailloux. Ils vont jusqu’à Feldkirch, où ils pénètrent dans la rivière d'Ill, qui leur a donné son nom; c'est même dans cette rivière qu'ils aiment à frayer. Les mâles, néanmoins, ne remontent dans son

\section{SSONS.}

487

lit que lorsque le temps est serein, et que In lune éclaire; de sorte que si le ciel est couvert pendant plusieurs jours, un grand nombre d'oufs ne sont pas fécondés. Ils parviennent quelquefois jusqu'à Coire et â Rheinwald ; mais ils voyagent lentement, parce que si le Rhin est trouble, ils s'appuient contre des pierres, et attendent, presque immobiles, que l'eau ait repris sa transparence. Si au contraire le Rhin est limpide, et qu'il fasse un beau soleil, ils aimentà se jouer sur la surface du fleuve. - Ils pesent-souvent plus de quarante lives, et pondent ou fécondent une très-grande quantité d'œufs. Leur multiplication n'est pas cependant très-considérable : un grand nombro d'œufs servent d'aliment à l'anguille, a la lotte, au brochet, aux oiseaux d'eau; et une trespetite partie des illankens qui éelosent échappe aux poissons voraces.

Après le frai, leur poids est-ordinairement diminué d'un tiers ou de la moitié, lorsqu'ils sont remontés três-haut vers les sources du Rhio. Leur chair, au lieu d'etre rougo, de bon goùt, et facile à digérer, devient blánche et de mauvais goût : aussi ne sont-ils plus, a cette époque, les poissons lés plus recherchés du lae de Constance et du Rhin supérieur. Ils se hâtent lors de retourner dans le lae, et se laissent aller au courant, lo tête fréquemment toumée contre co méme courant, qui les entraine, et les délivre de la fatigue de la natation dans te temps oú ils nont pas encore réparé leurs forces. Ils vivent non-seulement de vers et d'insectes, mais encore de poissons. Ils sont surfout fort avides de salmones très-estimés dans les marchés; $e$ les pécheors du lac assurent que, dans certaine années, ils leur causent plus depertes qu'ils ne eur procurent d'avantages.

Malgré leur grandeur et leurs armes, ilsson poursuivis par le brochet, qui, conflant dan ses dents et dans sa légereté, lors même qu'il leur est trés-infórieur en grosseur, les attaque avec audace, les haveèle avec constance, et, it orce' de hardiesse; d'évolutions et de manoxures, parvient sous leur ventre qu'il déchire.

Cependant ils trouvent bien plus souvent une perte assurée dans les filets qu'on tend sur leur passage, particulièrement dans le Bhin supérieur. Pour qu'ils ne puissent pas échapper au piége, on construit de chaque coté du fleuve 


\section{HISTOIRE NATURELLE}

ane eloison composée de bois entrelacés. On l'assujettít avec des pieux, et on l'étend depuis le rivage jusque vers le milieu du courant le plus rapide. Les deux cloisons transversales ne laissentainsiqu'un intervalleassez étroit. On adapte à cette ouverture un verveux ', dans lequel les illankens vont s'enfermer, mais qu'ils déchirent cependant si ce verveux n'est pas très-fort, ou au-dessus duquel ils parviennent souvent a s'élancer.

Ils ont la tête moins petite que les saumons. Dès la seconde année de leur âge, leur mâchoire inférieure se termine par une sorte de crochet émoussé. On ne distingue pas aisément les taches noires, allongées et inégales, qui sont distribuées irrégulièrement sur leur corps et sur leur queue. Les pectorales, les ventrales, et la nageoire de Y'anus, sont grisâtres; la nageoire adipeuse est variée de noir et de gris, la caudale ordinairement bordće de noir. On trouve auprès du pylore soixante-huit appendices placés sur quatre rangs ${ }^{2}$.

\section{LE SALMONE SCHLFFERMULLER ${ }^{3}$,}

Salmo Schieffermulleri, BI., Lac., Cuv. ‘.

\section{ET LE SALMONE ÉRIOX}

Salmo Eriox, Lino., Gmel., Lac, ‘.

Le premier de ces salmones s̀e trouve dans la Baltique. On le pêche aussi dans plusieurs Jaes de l'Autriche, où on le prend dans les environ de mai; ce qui lui a fait donner, dans les contrées voisines de ces lacs, le nom de May forelle. Bloch I'a dédié à M. Schieffermuller do Lintz, qui lui avait envoyé des individus de cette espèce ?

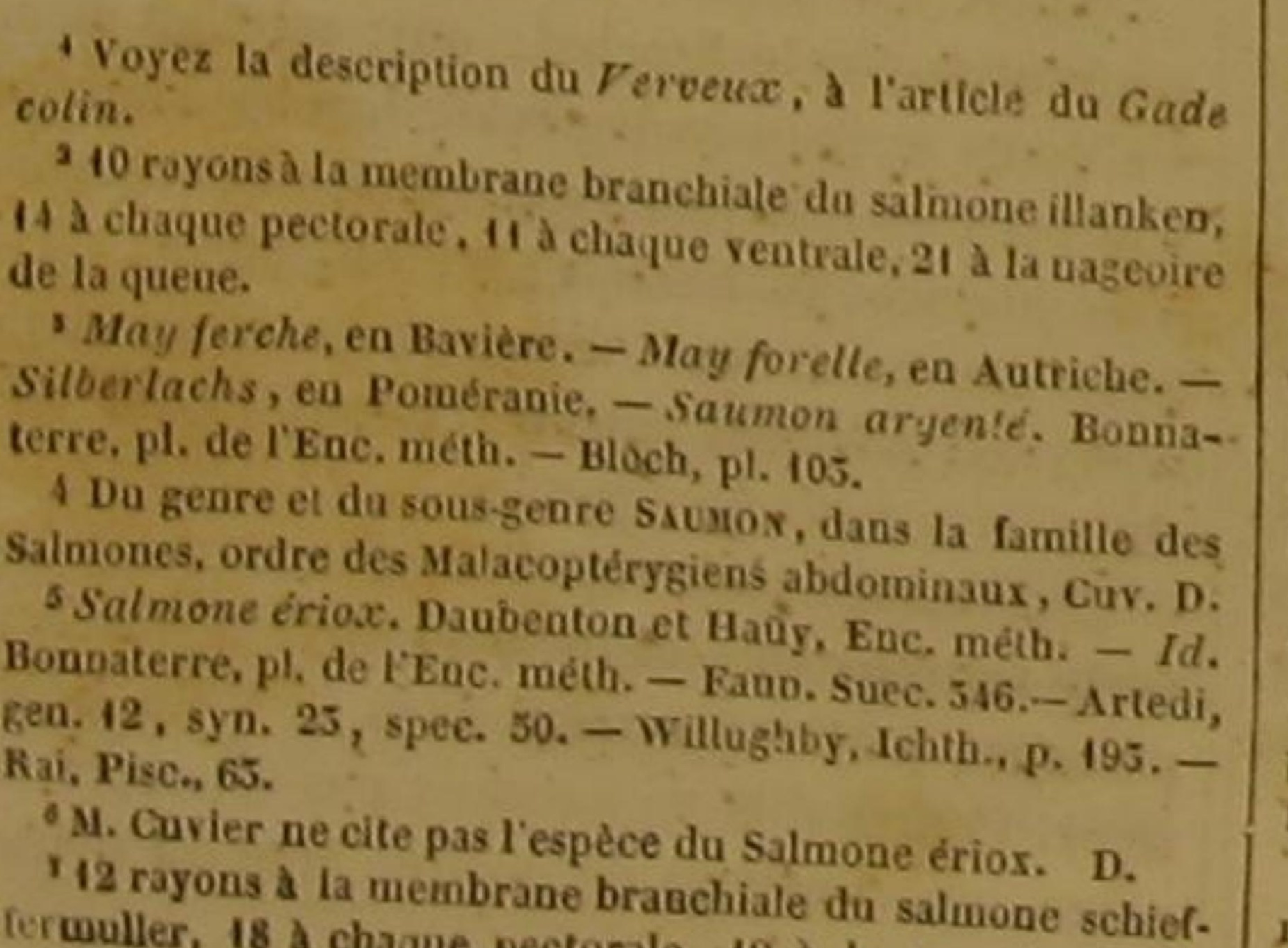

Il pèse de six à huit livres. Sa partie supé. rieure est brune ; ses joues, sa gorge, ses oper. cules, ses côtés et son ventre sont argentés; la ligne latérale est noire; les nageoires bleuâtres; les taches ont la forme de très-petits croissants. On voit un appendice triangulaire à côté de chaque ventrale; les écailles tombent facilement, et argentent la main à laquelle elles s'attachent. Le foie est petit, jaunátre, et divisé en deux lobes, l'estomac assez long, et la membrane de la vessie natatoire ordinairement très-mince.

L'ériox habite dans l'Océan d'Europe, et remonte, pendant la belle saison, dans les fleuves qui s'y jettent.

\section{LE SALMONE TRUITE}

Salmo Fario, Linn., Bl., Lac., Cuv, 3.

La truite n'est pas seulement un des poisson les plus agréables au goût; elle est encore un des plus beaux. Ses écailles brillent de l'écla del'argentet de l'or; un jaune doré mêlé de vert resplendit sur les côtés de la tête et du corps. Les pectorales sont d'un brun mêlé de violet Ies ventrales et la caudale dorées; la nageoire adipeuse est couleur d'or avec une bordure brune; l'anale variée de pourpre, d'or, et de gris de perle; ha dorsale parsemée de petites gouttes purpurines; le dos relevé par des taches

queue, -12 rayons a la membrane branchiale du salmoue eriox, 14 a claque pectorale.

Thotha, Torrentina, en Italie.-Fore, Bachfore, Forell. jar; en Livenie, - Dare, en Allemagoe. - Lashens, Nor. ryba, en Russic- - Porell. Stontit. Barie. - Kraspaja Suede. - Forelkra, Eir.kia, Muld Backra, Kofisk, eu vége. - Trout, en Angleterre. - Salmone Orrivite, en Norfario.-Daubenton et Hauy, Enc. méth. - Id. Bo Salmone pl. de TEnc. méth. - Favio, truite. Bloch, pl. Bonaterre, gen. 12, syn. 25 , spec. 31 - Tructa. Cub., I. 5. c. 94 . fig. 91 , c. 5 . - Id et sular sui, episcopi Mediolabi, Hexæmeron 5, b. - Trulta 'luviatilis. Pélonalvian, fol. $96 b$, et 97 a el p. 169. - Id. et trulla fario, Gesner. Rondelet, part. 2 , (germ.), fol. 475, a. Trutta lluviatilis. Aldrov, $5, \mathrm{c}$, 12 p. 589. - Jouston, I. 5, t. 1, c. I, tab. 26 ; fig. 1. - Williughby, p. (15, tav. 12,tig. 4. - Rai, p. 65. - - Trutta fluviatilis vulgaet forio, sctho p. 75. - Trulla, vel trulla vulgo, forina. scupoli, ann. 2, p. 77. - Kram. Eleach., p. 589, n. 5. n. 408. - Fand. Snec. 518 - Tiler, Prodr. Zool. Dan., p. 48, pisc. 5, p. 19, tab. 5, fig. 5. - Trou dentata Klein, Miss. a. 4. - Truite. Valmont de Bomare, Dict. Z Wist. s, p. Du sous.genre SAUMos, dans le grand gense nat. nom, famille des Salmones, ordre des Malacoptérygiens ab-

\section{DES POISSONS}

noires; et d'autres taches rouges, entourées, du niveau de la mer, dans ces Pyrénées qu'il d'un bleu clair, réfléchissent sur les côtés de l'animal les nuances vives et agréables des rubis et des saphirs.

On la trouve dans presque toutes les contrées du globe, ét particulièrement dàns presque tous les lacs élevés, tels que ceux du Léman, de Joux, de Neufchâtel; et cependant il parait que le poëte Ausone est le premier auteur qui en ait parlé.

Sa tête est assez grosse; sa máchoire inférieure un peu plus avanćée que la supérieure, et garnie, comme cette dernière, de dents pointues et recourbées. On compte six ou huit dents sur la langue; on en voit trois rangêes de chaque coté du palais. La ligne latérale est droite; les écailles sont très-petites; la peau de l'estomac est très-forte; et il y a soixante vertèbres a l'épine du dos, de chaque côté dé laquelle son disposées trente côtes.

Le savant anatomiste Searpa a vu, dans l'organe de l'ouíe de la truite, un osselet semblable à celuique Camper avait découvert dans l'oreille du brochet. Cet osselet est le troisième il est pyramidal, garni à sa base d'un grand nombre de petits aiguillons, et placé dans la cavité qui sert de communication auux trois canaux demi-circulaires.

La truite a ordinairement un pied ou quinze pouces de longueur, et pèse alors six à dix onces. On en pêche cependant, dans quelques rivières, du poids de quatre ou six livres ', Bloch a parlé d'une truite, qui pesait liuit livres, et qu'on avait prise en Saxe; et je trouve dans des notes manuscrites qui m'ont été envoyées, il ý a plus de douze ans, par l'évêque d'Uzès, qui les avait rédigées aveć beaucoup de soin, que l'on avait pêché, dans lê Gardon, des truites de dix-huit livres.

Le salmone truite aime une eau claire, froide, qui descende de montagnes élevées, qui s'échappe avec rapidité, et qui coule sur un fond pierreux. Voila pourquoi les truites sont très-rares dans la Seine, parce que les eaux de ce fleuve sont trop douces pour elles, et trop lentes dans leur cours ${ }^{2}$; et voilà pourquoi au contraire, mon célèbre confrère, M. Ramond, membre de l'Institut, a rencontré des truites dans des amas d'eau situés à près de six mille pieds au-dessus du niveau de la mer, dans ces Pyrénées qu'il connait si bien, et dont il a fait comme son
domnine $^{1}$. Il nous écrivait de Bagnères, en 1797 , que le fond de ces amas d'eau est rarement ealeaire ou schisteux, mais le plus souvent de granit ou de porphyre. On n'y voit en général aucun autre végétal que la plante nommée sparganium natans, et plus fréquemment des ulves solides, croissantes sur des bloes submergés : mais le fond est presque toujours enduit d'une couche mince de la partieinsolubl de l'humas que les eaux pluviales y entrainent des pentes environnantes.

Les grandes chaleurs peuvent incommoder In truite au point de la faire périr. Aussi la voit-on vers le solstice d'été, lorsque les nuits sont trèscourtes et qu'un soleil ardent rend les eaux presque tièdes, quitter les bassins pouraller habiter au milieu d'un courant, ou chercher près du rivage l'eau fraiche d'un ruisseau ou celle d'une fontaine.

Elle peut d'autant plus aisément choisir entre ces divers asiles, qu'elle nage contre la direction des eaux les plus rapides avec une vitesse qui étonne l'observateur, et qu'elle s'élance audessus de digues ou de cascades de plus de six pieds de haut.

Elle ne doit cependant changer de demeure qu'avec précaution. M. Peniéres assure que si pendant l'été les eaux sont très-chaudes, et qu'après y avoir pêché une truite, on la porte dans un réservoir très-frais, elle meurt bientot, saisie par le froid soudain qu'elle éprouve ${ }^{2}$.

Au reste, une habitation plus extraordinaire que celles que nous venons d'indiquer parait pouvoir convenir aux truites, méme pendant plusieurs mois, aussi bien et peut-être mieux qu'à d'autres espèces de poissons. M. Düchesne, professeur d'histoire naturelle à Versailles, et dont on connait le zele louable et les bons ou* vrages, m'a communiqué le fait suivant, qu'il tenait du célebre médecin Lemonnier, mon ancien collègue au Muséum d'histoire naturelle.

Environ à dix-huit cents pieds au-dessous du pic du Canigou dans les Pyrénées, on voit un petit sommet dont la forme est semblable à celle $d^{\prime}$ un ancien cratere de volcan. Ce cratère se remplit de neige pendant l'hiver. Après la fonte de la neige, le fond de cette sorte d'entonnoir de-

Toyze, ace sujet, le Discours iur ta nature des poissons. 2 Noles maniscrites deja citees. 
vient un petit lac, qui se vide par l'évaporation, au point qu'il est à sec à l'équinoxe d'automne. On y pêche d'excellentes truites pendant tout l'été. Celles qui restent dans la vase, à mesure que le lac se dessèche, périssent bientôt, ou sont dévorées par des chouettes. Cependant, l'année suivante, on retrouve dans les nouvelles eaux du cratère un grand nombre de truites trop giandes pour être âgées de moins d'un an, quoique aucun ruisseau ni aucune source d'eau vive ne communiquent avec le lac.

Ce fait, dont M. Duchesne a bien voulu me faire part, prouve que lé cratère est placé auprès de cavités souterraines pleines d'eau, dans lesquelles les truites peuvent se retirer lorsque le lac se déssèche, et qui, par des conduits plus ou moins nombreux, exhalent dans l'atmosphère des gaz dangereux pour la santé et même pouŕ vie despoissons; et dès lors il se trouve presque entièrement couforme à d'autres faits déjż connus depuis longtemps.

La truite se nourrit de petits poissons trèsjeunes, de petits animaux à coquillo, de vês d'insectes, et particulièrement d'éphémères et de friganes, qu'elle saisit avec adresse lorsqu'elles voltigent auprès de la surface de l'ear. Il parait que le tempsès de la surface de l'eau. e suivant le pays et peut-être suivant the vaeirconstances. Un habile naturaliste, M. Deean dolle, de Genève, nous a écrít que les truites du lac Léman et celles du lac de Neufchătel remontaient dans le printemps, pour frayer dons les rivières et même dans les ruisseanx $i$. Dans les trées sur lesquelles Bloch a eu desobs conces poissons fraient dach a cu des observations, ces poissons fraient dans l'automne; et dans le département de la Corrèze, selon M. Pénières ${ }^{2}$ les truites quittent également, au commencement ou vers le milieu de l'automne, les grandes rivières, pour aller frayer dans les petits ruisseaux. Elles montent quelquefois jusque dans des rigoles qui ne sont entretenues que pans eaux pluviales. Elles cherchent un que par les vert par un léger courant, s'agitent, se frottent, pressent leur ventre contre le gravier ou le ble, et y déposent des ceufs que le ou le saplusieurs fois dans des ceufs que le mâle arrose plusieurs fois dans le jour de sa liqueur fécon-
dante.

Bloch a trouvé, dans les ovaires d'une truite

des rangées d'œufs gros comme des pois;

Notes manuscrites données par $\mathbf{M}$. Decandolle.

Notes manuscrites déjaç cilépes . dont la couleur orange s'est conservée pendan longtemps même dans de l'alcool.

D'après cette grosseur des œufs des truites, il n'est pas surprenant qu'elles contiennènt moin d'œufs que plusieurs autres poissons d'eau douce; et cependant elles multiplient beaticoup douce; et cependant elles multiplient beaticoup, parce que la plupart des poissons voraces vivent loin des eaux froides, qu'elles préfèrent.

Mais si elles craignent peu la dent meurtrière de ces poissons dévastateurs, elles ne trouvent pas d'abri contre la poursuite des pêeheurs.

On les prend ordinairement avee la truble ', à la ligne, à la louve, ou à la nasse 2 .

Sil'on emploie la truble ou le truble, il faut le lever très-vite lorsque la truite y est entrie, pour ne pas lui donner le temps de s'élancer et de s'échapper.

La ligne doit être forte, afin que le poisson ne puisse pas la easser par ses mouvements variés, multipliés et rapides.

La manière de garnir l'hameçon n'est pas la même dans différents pays. On y attache de I chair tirée de la queue ou des pattes d'une ce visse; de petites boules, composées d'une partie de camphre, de deux parties de graisse de héron, de quatre parties de bois de saule pourri et d'un peu de miel; des vers de terre; des sangsues coupées par morceaux; des insectes artificlels faits avee des étoffes très-fines de différentes couleurs, des membranes, de la cire, des poils, de la laine, du crin, de la soie, du fil, des plumes de coq ou de coucou. On hange couleur de ces fils, de ces plumes, de ces solu de ces poils, non - seulement suivat la saies, et pour imiter les inectes qu' clle ant la saison encore encore suivant les heures du jour ${ }^{3}$; et on les agite de manière à leur imprimer det on les ments semblables à ceux des insectes les plus recherchés par les truites.

Dans 1'Arnon, auprès de Genève, on pjque ces poissons avee un trident, lorsqu'ils remon tent contre une chute d'eau produite par une digue 4 .

Mais on en fait une pêche bien plus considérable a l endroit ou le Rhône sort du lac Léman, dans lequel se jette cette rivière d'Arnon. Nous

Fossile. cription de la truble, a larticle du Misgurne ${ }^{2}$ La description de la touve et celle de la nasse sont dana
l'article du Petromyzon lamproie. 'Notes manuscrites de M. Pénie. Notes manuscrites de M. Decandolite.
DES POISSONS.

491

lisons dans une lettre que le savant professeur | très-chère dans un grand nombre d'endroits: Pictet, membre associé de l'Institut, adressa en 1788, aux auteurs du Journal de Genève, qu'à l'attention de l'économe, et voici les principaux cette épeque le Rhone était bamé, d sa sorie du lac, par un clayonnage en bois disposé en zigzag. Les angles de ce grillage, alternativement saillants du. côté du lac et du cóté du Rhône, présentaient de part tet d'autre des espèces d'avenues triangulaires, dont chacune se terminait par une nasse ou cage construite en fil de laiton, et arrangée de manière que les poissonsiqui y entraient ne pouvaient pas en sortir. Celles de ces nasses qul répondaient aux angles saillants du côté du-lac, se nommaient nasses de remonte; et les autres, nasses de descente. On laissait ordinairement tous les passages libres dès la fin de juin, afin de donner aux truites la liberté d'aller frayer dans ce fleuve; on les refermait vers le milieu d'octobre : ce qui divisait le temps de la péche en deux saisons : celle du printemps, qui durait depuis la fin de janvier jusqu'en juin; et celle de l'automne, qu commençait en octobre, et qui finissait avec le mois de janvier. Dans l'une et dans l'autre de ces saisons, on prenait des truites à la remonte et à la descente, mais dans des proportions bieu différentes. Sur quatre cent quatre-vingt-neuf truites on en pẹchait trente-six à la descente du printemps, trente-quatre à la descente de l'automne, seize à la remonte du printemps, quatre cent trois a la remonte de l'automne. Il est aisé de voir que cette-difference provenait de la liberté qu'avaient les truites de descendre dans le Rhone, depuis la fin de juin jusqu'au mois d'octobre.

Pour attirer un plus grand nombre de truites dans les nassés ou dans les louves, on y place un linge imbibé d'huile de lin, dans laquelle on a mêlê du castoreum et đu camphre fondús.

On marine la truite comme le saumon, et on la sale comme le hareng. Mais e'est surtout lorsqu'elle est fraiche que son goût est trêsagréable. Sa chair est tendre, particulièrement pendant l'hiver; les personnes même dont l'estomac est faible, la digèrent facilement. Pendant longtemps, ce salmone a été nommé, dans plusieurs pays, le roi des poissons d'eau douce; et dans quelques parties de l'Allemagne les princes s'en étaient réservé la pêche.

Comme on ne voit guère la truite séjourner naturellement que dans les lacs élevés et dans es rivières ou ruisseaux des montames; des soins qu'elle exige.

Pour former un bon étang a truites, il faut une vallée ombragée, une eau claire et froide, un fond dè sable ou decailloux placé sur de la glaise ou sur une autre terre qui retienne les eaux, une source abondante, ou un ruisseau qui, coulant sous des arbres touffus, et n'étant pas trèséloigné de son origine, amène, mème en été, une eau limpide et froide; des bords assez élevés, pour que les truites ne puissent pas s'élaneer pardessus ; de grands végétaux plantés assez près de ces bords, pour que leur ombre entretienne la fratcheur de l'eau; des racines d'arbres, ou de grosses pierres, entre lesquelles les coufs puissent êtro déposés ; des fossés ou des digues, pour prévenir les inondations des ravins ou des rivières bourbeuses; une profondeur de neuf pieds ou environ, sans laquelle les truites ne trouverajent pas un abri contre les effets de l'orage, monterajent à la surface de l'eau lorsqu'il menacerait, y présenteraient souvent. un grand nombre de points blanehátres ou livides, et periraient bientôt; une quantitê très-considérable de loches ou de goujons, et d'autres petifs cyprins dont les truites aiment à se nourrir ou une très-grande abondance de morceaux de foie hachés, d'entrailles d'animaux, de gateaux secs, faits de sang de bceuf et d'orge mondé; des bandes garnies d'une grille assez fine pour arrêter l'alevin, une attention soutenue pour éloigner les poissons voraces, les grenouilles, les oiseaux pecheurs, les loutres, et pour casser pendant I' hiver la glace qui peut se former sur la surface de l'eau '.

Lorsque, pour peupler cet étang, on est oblig d'y transporter des truites d'un endroit un pos éloigne; il faut ne placer dans chaque vase qu'ún petit nombre de ces salmones, renouveler l'eau dans laquelle on les a mis, et l'agiter souvent.

Différentes eaux peuvent cependant être assez claires, assez froides et assez rapides pour que les truites y vivent, et avoir néanmoins des propriétés particulieres qui induent sur ces salmonés au point de modifier leurs qualités, leurs couleurs, leurs formes et leurs habitudes, et de

- Voyez le Discours intitule a Des effots de lart do Thomme sur la naturedes poiscons. 
produire des variétés très-distinctes et plus ou moins constantes.

M. Decandolle assure que les truites prises dans le Rhône diffèrent de celles que l'on pèche dans le lac de Genève, par la grandeur de deux taches noirâties placées sur les joues '. Suivant le même naturaliste, celles de l'Arve sont plus minces et plus allongées.

On en voit, dit M. Pénières, d'effilées, et d'autres très-courtes. Le ruisseau appelé le Queyrou, près de Pénières, dans le département du Cantal, en nourrit d'arrondies, avec le dos voûté; dans celui de Narbois, les truites sont courtes, arrondies, et d'une nuance presque jaune; dans un autre ruisseau nommé Enlan, elles sont allongées, grises et légèrement tachetées.

M. Noēl de Rouen nous a écrit : a Les truites " de Palluel ont une grande réputation dans le " département dela Seine-Inférieure : ce sont les "plus délicates que nous possédions dans nos “ eaux donces. On m’a assuré à Cany qu'elles " ne remontaient pas au-dessus du pont de ce "gros bourg, qui n'est éloigné de la mer que " d'une lieue. Après les truites de Palluel vien" nent celles de la rivière de Robec, qui se perd " dans la Seine à Rouen... On connait dans nos " différentes rivières sept ou huit variétés de trui" tes, qui different entre elles par la couleur, " les taches, etc. *

Dans les eaux de Lethnot, comté de Forfar, en Écosse, les pêcheurs distinguent deux variétés de la truite: la première est jaune, et beancoup plus large ou haute que la truite ordinaire la seconde a la tête beaucoup plus petite, et les côtés tachetés d'une manière aussi élégante que

On péche aussi dans quelques lacs, ruisseaux ourivières d'Écosse, d'autres variétés de la truite auxquelles on a donné les noms de Truite de mousse, Truite de petite rivière, Truite noire, Truite blanche, et Truite rouge.

Bloch en a fait connaitre une, qu'il a désignée par la dénomination de Truite brune ${ }^{2}$. Cette variété a la tête et le ventre plus gros que la truite commune; le dos arrondi; la partie supérieure des cótés et la tête, d'un brun-noirave des taches violettes; la partie inférieure de ce mèmes côtés, jaunâtre, avee des táches rougo entourées de blane et renfermées dans un se-

'Notes manuscrites déja citées.

${ }^{2}$ Bloch, pl. 22. - Salmo fario, sylvaticus, B. Linuée
ed. de Gmelin.

cercle brunâtre; les nageoires du ventre de l'anus et de la queue, mélangées de jaune, la chair très-délicate, et rouge lorsqu'elle cuite, de mème que celle du saumon ct du mone truite-saumonée. Cette variété habite plusieurs des rivières qui se jettent dans la Baltique, ou dans la mer qui baigne les côtes de Norvège '.

\section{LE SALMONE BERGFORELLE 2}

Salmo punctatus, Cuv.; Salmo alpinus, BI., Lac. :

Ce salmone a de petites écailles sur le trone, un appendice étroit à cóté de chaque ventrale, la ligne latérale droite, la première dorsale jaune aveo des taches noires, les autres nageoires rougeâtres, le dos verdâtre, le ventre blane, la chair rouge, de bon goùt et facile à digérer.

On le trouve dans les eaux de très-hautes montagnes, particulièrement de celles de Lapo. nie, du pays de Galles, et du voisinage de Saint. Gall 4 .

\section{LE SALMONE TRUITE-SAUMONÉE 5 .}

Salmo Trulta, Linn., Gmel., BI., Cuv.; Salmo Trufta, Silar, Lac.; Salmo lacustris, Linn., Gmel.`.

On a prétendu que la truite-saumonée provenait d'un œư de saumon fécondé par une truite,

I0 rayons a la membrane branchiale do salmone truite,

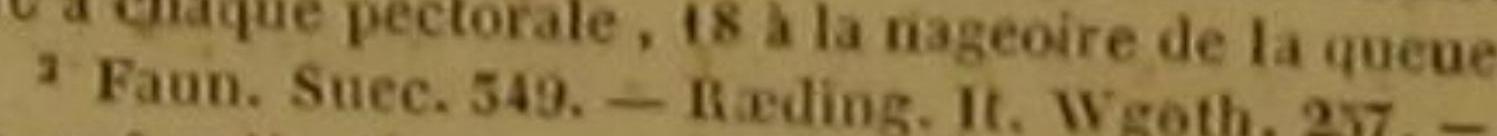
Sergforelle. Daubenton et Hany. Ene. méth. - Id. Bonne terre, pl. de I'Enc. méth. - Bloch, pl. 104. - IS Salmo vir ivedalis, pimnis ventris rabris, etc., Artedi, gen. 15, syn. Pisc., p 65. - - Chave. Bab. N, 1, fig, 4. - Red charre. Rai, 'Le texte de cet article se rool. 5, p. 265, n. 6. t. 15. tinnée; mais la pl. de Bloch 104 représente al mo alpinus de (Salmo punctatus) de M. Euvier, qui est peot-etre le $C$ ir. pione des lacs de Lombardie. Le Beraforelle apparlieit sous-genre Sscror, dans le grand genre du méme nom. D.

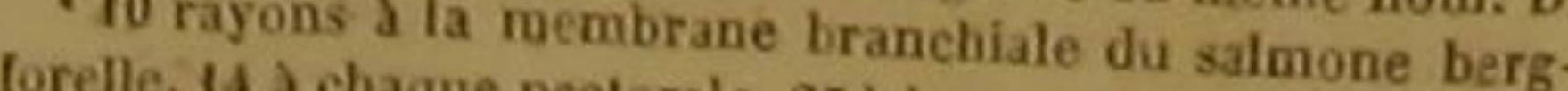
- Lachs forelie, en Allem 25 ia nageoire de la quene. lanke, sur le Rhio.- Aachskindechea, einanke, Rheinfahren, en Prusse. - Taimen, Taimini. Soborling, en Laponie. - Orlar, Tuanspol Lironie. Sickmal, Lodjor, en Suede. - Orlar, Tuanspol, Borting, forel, en - Lar-ort, Moskirog-ort, en Danemarck. - Salmterre. - Salmone. - Sea troub, Salmon-trout, en AngleErre. méth. $-I d$. Bonnaterre, plée. Daubenton et Haũy, - Dú sous-genre Sscratos, ding le l'Enc. méth. - Bloch, nom, Cuv. D.

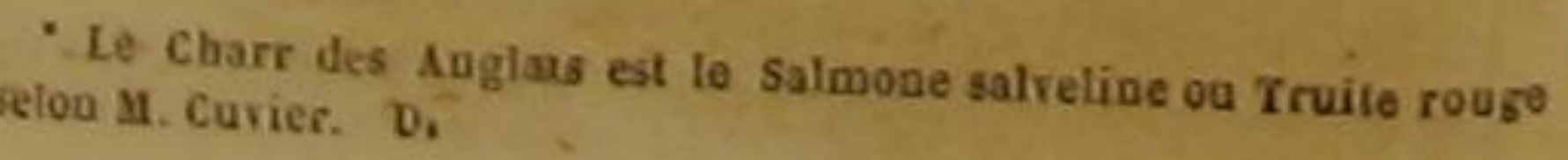

DES POISSONS.

on d'un œuf de truite fécondé par un saumon; fois plus considérable que celoj de la véritable qu'elle ne pouvait pas se reproduire; qu'elle ne truite-saumonée.

formait pas une espèce particulière. Cette opinion est contraire aux résultats des obsếrvations les plus nombreuses et les plus exactes. Mais la truite-saumonée n'en mérite pas moins le nona qu'on lui a donné : sa forme, ses couleurs et ses habitudes, la rapprochent beaucoup du saumon et de la truite; elle montre méme quelques-uns des traits qui caractérisent l'un ou l'autre de ces deux salmones, et c'est depuis bien du temps qu'on a reconnu ces caractères pour ainsi dire mi - partis. Non-seulement en effet Sehwenckfeld, Schoneveld, Charleton et John. son Pont distinguée et décrite; mais encore le consul Ausone l'a chantée, dès le cinquième siècle, dans son poëme de la Moselle, où if I'a nommée Fario, et où il l'a représentée comme tenant le milieu entre la truite et le saumon.

La truite-saumonée habite dans un très-grand nombre de contrées; mais on la trouve prineipalement dans les laes des hautes montagnes, et dans les rivières froides qui en sortent ou qui s'y jettent. Elle se nourrit de vers, d'insectes aquatiques et de très-petits poissons, Les eaux vives et courantes sont celles qui lui plaisent elle aime les fonds de sable ou de cailloux. Ce n'est ordinairement que vers le milieu du printemps qu'elle quitte la mer, pour aller dans les fleuves, les rivières, les laes et les ruisseaux choisir l'endroit commode et abrité où elle ré pand sa laite ou dépose ses oufs.

Elle parvient à une grandeur considérable. Quelques individus de cetfe espèce pèsent huit ou dix livres; et ceux méme qui n'en pèsen encore que six ont déjà plus de deux pieds de longueur.

On la confond souvent avec le salmone huch, auquel elle ressemble en effet beaucoup, et qu'on a nommé, dans plosieurs pays, Truitesaumonée. Ajoutons done aux traits indiqués dans le tableau générique pour l'espèce dont nous traitons, les autres principaux caractères qui lui appartiennent, afin qu'on puisse la distinguer plus facilement de ce salmone buch, qui, au reste, peut parvenir à un poids sept ou huit

d. 21. - Faun. Suec, s77. - Mall. Pros. Zool, Dan.,p. 48, C lis rubris Mus. 2, n. 164. - Truilla salmonata. Willaghby, Ichth. p. 195, 198. - Id. Rai, Pisc., p. 65. - Bull-troul. Peunant, Brit. Zool. 5, p. 2k9, n. 5. - Truile-saumonée. Salmont de petite, et en forme de coin ; ses màchoires sont presque également avancées; les is qui les garnissent sont pointues et recourbées, et celles d'une máchoire s'emboitent entre celles de la mâchoire opposée. On voit d'ailleurs trois rangées de dents sur le palais, et deux rangées sur la langue. Les yeux sont petits, ainsi que les écailles. La ligne latérale est presque droite.

Le nez et le front sont noirs; les joues d'un jaune mêlé de violet; lo dos et les cótés d'us noir plus ou moins méle de nuances violettes; la gorge et le ventre blanes; la caudale et I'adipeuse noires; les autres nageoires grises, les taches noires répandues sur le poisson, quelquefois angulaires, mais le plus souvent roudes.

Au reste, la forme et les nuances de ces taches varient un peu, suivant la nature des eaux dans lesquelles l'individu séjourne. La bonté de sa chair dépend aussi très-souvent de la qualite de ces eaux; mais en général, et surtout un peu avant le frai, cette chair est toujours tendre, exquise et facile à digérer. Elle perd beaucoup de son bon goût lorsque la rivière où Ia truitesaumonée se trouve, reçoit une grande quantité de saletés; il suffit mème que des usines y introduisent un grand volume de sciures de bois, pour que ce salmone contracte une maladie à laquelle on a donné le nom de consomption, et dans laquelle sa tête grossit, son corps devient maigre, et la surface de ses intestins se couvre de petites pustules.

On pêche les truites-saumonées avee des filets, des nasses et des lignes de fond, auxquelles on attache ordinairement des vers. Dans les endroits où l'on en prend un grand nombre, on ins sale, on les fume, on les marine.

Pour les fumer, on élève sur des plerres un tonneau sans fond et percé dans plusieurs endroits; an suspend ces salmones; et on les y expose, pendant troís jours, à la fumée de branches de chène, et de grains de genièvre.

Pour les mariner, on les vide, on les met dans du sel; on les en retire au bout de quelques heures, on les fait sécher, on les arrose de beurre ou d'huile d'olive, on les grille; on étend dans un tonneau une couche de ces poissons sur des feuilles de laurier et de romarin, des tranches de citron, du poivre, des clous de girofle; on place alternativement plusieurs cou- 
ches semblables de truites-saumonées, et de portrons de végétaux que nous venons d'indiquer; on verse par-dessus du vinaigre très-fort que l'on a faít bouillir, et l'on ferme le tonneau.

Bloch a observé, sur une truite-saumonée un phénomène qui s'accorde avec ce que nous avons dit de la phosphorescence des poissons, dans le Discours relatif à la nature de ces animaux. Entrant un soir dans sa chambre: il y aperçut une lumière blanchâtre et brillante, qui le surpritd'abord, mais dont il découvrit bientôt la cause : cette lumière provenait d'une têté de truite-saumonée. Lés yeux, la langue, le palais et les branchies, répandaient surtout une grande clarté, Quand il touchait ces parties, il en aúgmentait l'éclat; et lorsque; avec le doigt qui les avait touchées, il frottait une autre partie de la tête, il lui communiquait la même phosphorescence, Celles qui étaient le moins enduites de mucilage ou de matières gluantes, étrient moins lumineuses; et ces effets s'affaiblirent a mesure quela substance visqueuse se dessécha 1 .

LE SALMONE ROUGE 2 Salmo erytbrinus, Linn., Gmel., Lac.s.

Le Salmone gaden 4, Salmó GæJeni, Linn., Gmel, lac - Le S. Huch ', Salmo Hucho; Linn., Gm., Lac,, Guv. ?

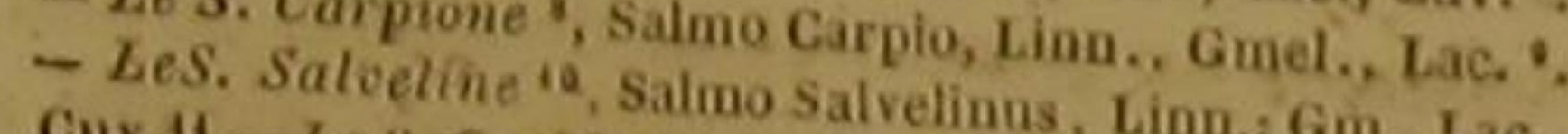
Guv.",-LeS. Omble Chevalier ${ }^{-2}$, Salmo Umbia, Lion.,
Gm., Bi., Lac., Cuv, ".

Le rouge habite des lacs et des fleures de ha Sibérie. Il parvient à deux pieds de longueur. Sa chair est rouge, grasse, tendre. Ses auf u 112 rayons à la membrane branchiale du salmone truite.
saumonée, 14 a chague pectrong queue.

:Georg. It. 1, p. 156, tab. 1, fig. I - Silberfordle Bloch, pl. 102. - 2ruile de mer. Bonnaterre, pl. de I'Bnic.
méth. - Heuch, ainsi que M. Cuvier. D. dans plus. autres contrées de l'allevière. - Hauch forelle, Daubenton et Hiay, Ene, méltr. - Id. Bongalmene huch. IEnc. méth. - Bloch, pl. 100. - Meidenger is - , pl, de . modò dentium lineis duabos palati, maxu - isalmo - branneo, maculis nibi, geo. 12, syn. 23. - - Salmo dir. Aquat., p. f015. Thierb, ete., Kram. Austr. 38s. - Gesn.

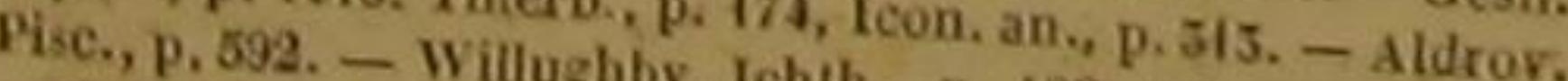
- Rai, Pisc., p. 69, n. 9. - Marsigli, Danub. 4, p. 81, tab. 28 ,
Fig.
, . nom. D. Chare, Gill charre, dans quelques contrées dis sale jrise ; son dos ést brun; sa première dor. sale grise, avee des taches rouges bordées d'un autre couleur; la nageoire adipense brine allongée; le front et les opercules sont gris. On voit des dents aux mâchoires, sur la langue qui est large, et sur le palais, où elles forment deux rangées dišnosées en are.

Le gæden, que Bloch dédia dans le temps à un de ses amis, le conseiller Gæden, de la basse Poméranie, vit dans la Baltique et dans l'Océan Atlantique bớéal. II pèse ordinairement deix livrés ou environ: sa longueur n'excède guère dix-huit pouces. Sachair est maigre, maís blanche et agréable au goût. Ses deux mâchoires et le palais sont garnis de dents pointues; louver bouche et les̃ oriflcts des bour ont une largeur considérable; les yeux sont gros, et les ventrales fortifićes chacune par un apnendice; la ligne latérale est droite. Les jowes, Ie opercules, les cótés et le ventre sont argentés lo dos, le front et les nageoires sont brunâtres; - dentium ordinibus quinque palati. - Salmo pede miner, syn. 21:- Ot. Fabric. Faun. Groenl., p. it7- - Salmone. 15

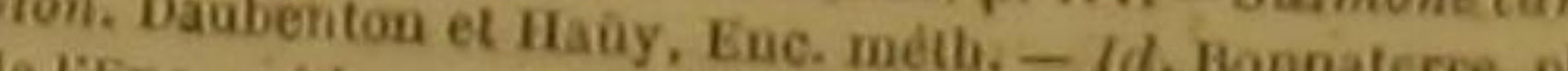
-M. Cuvier clte leagne, cab. 4, p. 2, pl, 52. die comme pourate nom da Carpione des lacs de Lombar

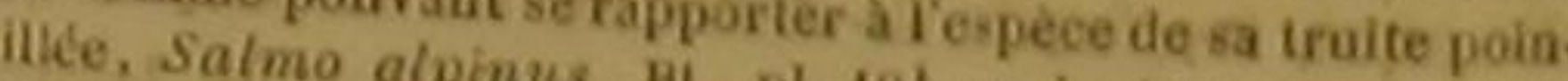

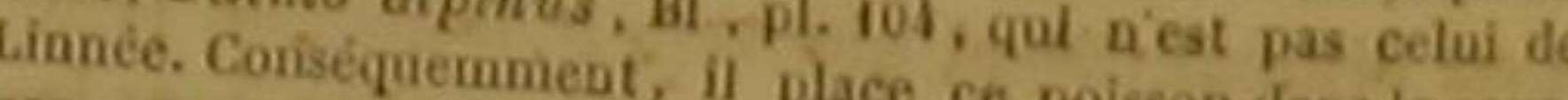

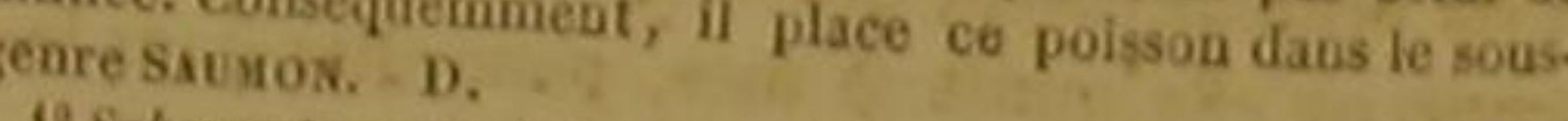
9Schwarlareution

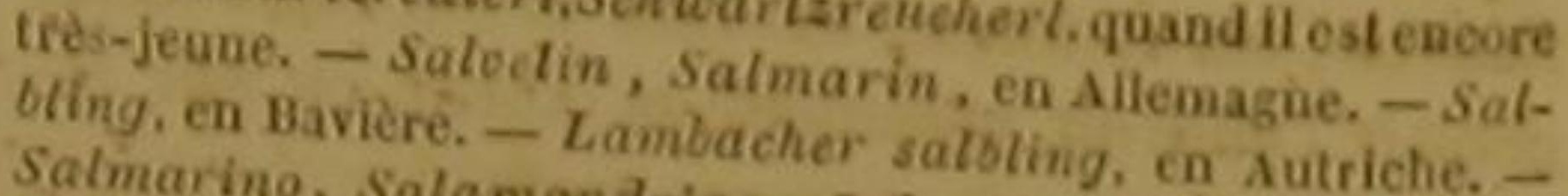
de Trente, - Omble, idno, Salmo salmarinus; aupres Salmone salmarine, Bloch; pl. $99^{\circ}$ - - Salmone saleeline. Ironnateree, pl. de l'Enc. métb. periore longiore. Artedi, gen. is, syno pedalis maxilli suTrue, maculis luteis, cauda bifuresta. - I Salrmo dorso Umbla dentala, ete., Klein, Miss. Pisc. 3. p. is . 24. 6ig. 2. - Uma, salbling. Marsigl. Danub. 4, p. 82, tab. 2 , tab. 29, fig. 2 - Sclia, lambactier salbling. Id. 4, p. 85, tio. Naturf. tr. I, p. 580 . Selerl. Schrank. Schr. der Berp. 101, 102. - Id. Jonst. Pisc, Salmarinus. Salvian, Aquat., "M. Cuvier donne à la Salveline lo tab. 28 Cest le Charr des Anglais, le Salmo aom de Truite rouge. . IT a place dans le sous-genre SaOMos, dus de Meidinger, 12 Salmone néth.-Id. Bonnaterre, checalier. Daubenton et Haoy, Eoc - Salmo lineis la, pl. del Enc, méth. - Bloch, I. 101. furca. , Artedi, gen. 15, syn sursum recurvis, canda bi1. 3. - Umble. Fondelef, Dera. Aldrov. Pisc., p. 607, - Will 12, p. 115:-Umbla b. n. 1, fig. 1. - Rai, Pisc., p. 61. _ Salmo achth., p. 195, "Do genre, Aquat., p. 1004. hamille des Malan sous-geare Sstnos de M. Caviar, dan

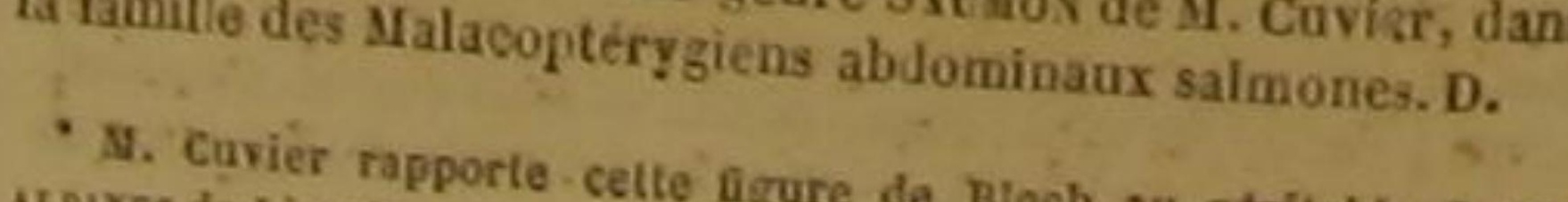

\section{DES POISSONS.}

des taches brumes distinguent d'ailleurs la première nageoire du dos.

On trouve deux rangées de dents sur le palais, ainsi que sur la langue du huch, et un appendice auprès de chacune de ses ventrales. Sa ligne latêrale est droite et déliée ; son anus trèsprès de la caudale; le dessus de sa tête brun; sa gorge argentée, ainsi que ses joues; la couleur de ses cotés, d'un rouge mêlé de teintes argentines; chacune de ses nageoires rouge pendant sa jeunesse, et jaunâtre ensuitè.

Son corps et sa queue sont très-allongés et très-charnus. II parvient à une longueur de près de six pieds, et à un poijds de plus de soixante livres. Sa chair est quelquefois molle, et n'a pas un goût aussi agréable que celle de la truite ou de la truite-saumonée : on l'a cependant confondu, dans beaucoup d'endroits, avec cette dernière, dont on lui a même donné le nom. On le prend à Thamecon, ainsi qu'au graud filet. On lo pêche particulièrement daas le Danube, dans les grands lacs de la Bavière et de Y'Autriche, dans plusieurs fleuves de la Russie et de la Sibérie: il parait qu'il habite aussi dans le lac de Genève; et, d'après une note manuscrite adressée dans le temps a Buffon, on ponyait crolre que, dans la partíe orientale de ce lac, il pèse quelquefois plus de cent livres. Peut-etre faut-il aussí rapporter à cette espéce un salmone dont $\mathrm{M}$. Decandolle parle dans ses observations manuscrites, et qui, suivant cet habile naturaliste, vit dans le lac de Morat, y porte le nom de Salut, s'en échappe souvent par la Thiole, pour aller dans le lac de Neufchâtel, et pèse de quatrevingts à cent livres.

Le earpion a beaucoup de rapports avee le salmone bergforelle. Son palais est garni de cinq rangées de dents; sa chair est rouge. On le trouve dais les rivières d'Angleterre et đans celles du Valais. On le conserve assez facilement dans les étangs.

La salveline ressemble aussi beaucoup à la bergforelle. Elle ne fait qu'un avec la salmaíne, que Linnée et plusieurs autres auteurs n'auraient pas dú considérer comme une espèce particulière. Elle a la téte comprimée; 1'ouverture de la bouche largé; les deux mâchoires armées de petites dents pointues; la langue cartilagineuse, un peu libre, dans ses mouvements, et garnie, comme le palais, de deux rangées de dents; l'orifice de chaque narine, double; la ligne latérale presque droite; un appendice auprès de chaque ventrale; cinquante vertèbres à l'épin du dos; trente-huit côtes de chaque cóté de l'épine.

La tête et le dos sont bruns, les joues et les opercules argentins; les côtés blanchâtres; les nuances du ventre orangées; les pectorales rouges; les dorsales et la caudale brumes; le corps ta queue parsemés de taches petites, roudes orangees et bordées de blane.

Plus l'eau dans laquelle elle séjourne est pure et froide, plus sa chair est ferme, et plus ses couleurs sont vives. Elle pèse jusqu'à dix livres. Elle fraie vers la fin de l'automne, et quelquefois au commencement de l'hiver. On la pèch particulièrement en Bavière, et dans tous les lacs qui s'étendent entre les montagnes depuis Salz hourg jusque vers la Hongrie. On la prend 'hameçon, aussi bien qu'au collered '. On li fume en l'exposant à un feu d'ócorce d'arbrế, dont on augmente la fumée en l'arrosant sans cesse.

L'omble chevalier doit son nom á la grandeur de ses dimensions. Il pèse quelquefois vingt lires ; et, suivant M. Decandolle, son poids peut s'élever jusqu'à soixante ou quatre-vingts ${ }^{2}$. On souvent confondu eồ salmone avec lo huch ou avec le Salut, qui parvient à un très-grand volume; et, dans quelques endroits, on l'a pris pour ue truite-saumonée: il constitue cependant une espece bien distincte. II habite dans le lac de Genève et dans celui de Neufchátel ; il s'y nourrit communément d'escargots, de petits animaux a coquille, et de très-jeunes poissons. On le peche près du rivage au filet et à l'hamecon. II devient très-gras ; sa chair est très-délicate, et il est très-recherche.

Il a une rancée de dents pointues à la máhoire d'en haut; deux rangs de dents semblales à la mâchoíre d'en bas; chaque opercule composé de deux piéces; l'ouverture branchiale assez grande; les écailles tendres et si petites, gu'on a peine à les distinguer au travers de in ubtánce visqueuse dont elles sont enduites; lo los verdâtre; les joues d'un verdâtre mêlé do blane; l'iris orangé et bordé d'argentin; les operéules et le ventre blanchâtres; toutes les nacoires d'un vert mêté de jaune; ces organes de mouvement ont d'ailleurs peu de longueur ${ }^{3}$. ¿Yoyez. pour la description du filet nommé colleret, Iar-
icle da Centropome sandal.

2 Notes manuscrites dija citees.
in 
LE SALMONE TAIMEN ;

Salmo Taimen, Linn., Gmẹl, Lac. .

Le Salmone Nelma 3, Salmo Nelma, Lima., Gmel., Lac, 4,-
Le S. Len ok ${ }^{8}$, Salmo Lenok, S. Kundscha ', salmo Kundscha, Linn., Gmel., Lac. - Le Le S. arclique ', Salmo areticus, Lìn., Gmel., Lac. Le S. Reidur ", Salmo Reidur, Limn., Gmel., Lac, 12,-
Le S. Icime 13, Salmo Icimus, Lac,; Salmo nivalis, Lion

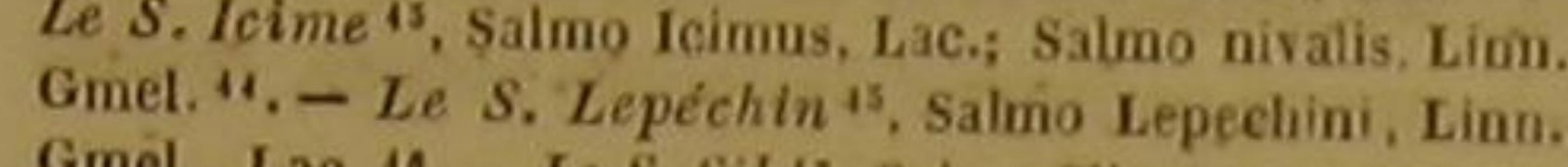
Gmel., Lac. 10. - Le S. Sil 17, Salmo Silus, Ascag., Lac.;
Coregonus Silus, Cav. "1. - Le S. Lodde "s, Nallows (salmo) groenlandicus, Cuv.; Salmo groenlandicus; Blocts Clupea villosa, Linn., Gmel. ?0, - Le. S. blane ${ }^{11}$, Salmo albos, Lac, "

Ces onze salmones vivent dans les mers on les rivières de l'Europe on de l'Amérique sep-

13 a chaque pectorale, 19 a la nageoire de la queue, -10 chaque pectorale, 18 à la candale, salmone gèden, 15 brane branchiale du salmone tuch, 17 a rayons à la mem16 a la nageoire de la queue. -12 rayons a la pectorale, tiranchiale du salmone carpion, 14 a cliaque pectorale, 30 i la nageoire de la queue. -10 rayons a la membrane des caudate. -15 rayons a s veline, 14 a chaque pectorale, 24 i 15 ohevalier, 18 a ta nageoire de pectorale du salmone omble

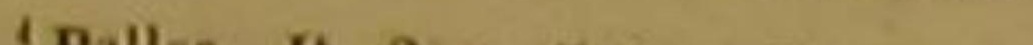

Pallas, It. 2, p. 716, n. 31. - Salmone taimen. Bonna lerre, pl. del lEnc. méth.

correspondent a ces numeros no aucune des espèces qui premier. Ce sont les salmos, it que Pallas a décrites le Kundscha et Arctique. D

'Pallas, It. 2, p, 716, n. 55 - Lepéchin, It. 2, p. 192,
ab. 9, fig. 1, 2, 5. - Salmone nelma. Bont. Enc, mét

'Pallas, It. 2, p. 716, n. 33,-Salmone ténok. Bonnalerre
pl. de I'Enc. mésh i. de Y Enc, méth.
'Pallas, $11.5, \mathrm{p}$.

aterre, pi. de l'Euc. méth. 46. - Salmone Kundschia. Bon- Pallas, It. 5, p. 706 , n. 47 . Urre, pl, de l'Enc. méth. "Ot. Fabric. Faup.

reidur. Bonnaterre, pl. de l'Euc. méth, H. 126. - Salmone

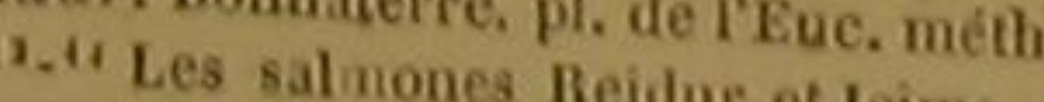
ts Ot Fabr. Faun. Groenl, par. 17, Cuvier. D, tonnaterre, pl. de l'Euc, meth. is Lepéchin, 11. 5, p. 229, tab. 14, fig. 2. crite dans son Voyage. D.
. if dascagson Voyage. D

méth.
atoe, pl. 24.-Salmone sil. Bonnaterre, pl. del'Enc. "M. Cuvier place le Sil d Ascagne dans le sous-geare Li-
vakkT, de son grand genre SArmor. "Capelan d'Amérique.-Car. D. Gronlander, par les Allemauds. - Ange Terre-Necive Jern lodde (le mate), Quetler todde (idem): Sild lodd, sild, Lodna, en Islodde (idem), ea Groenfand. - Looden. de l'Eno. méth. - Bloch, pl. 581 , fig lod de, Bonnaterre, pl. .

vier, sous le nom de LODDs, Mallo's-genre formé par M. Cusiusor. D. tentrionale. Nous devons à l'illustre Pạllas la. connaissance des cinq premiers.

Le taimen, des torrents et des fleuves de la Sibérie qui versent leurs eaux dans l'Océan glacial, a la chair blanche et grasse; des dents au palais, à la langue et aux mâchoires ; un appen. dice auprès de chaque ventrale; les côtés argentés; le ventre blanc; la caudale rougeâtre; l'analetrès-rouge; une longueur de plus d'un mètre.

Le nelma, des mêmes eaux, est long de plus de six pieds; et de larges lames sont placées au près de l'ouverture de sa bouche.

Le lénok, qui préfère les torrents rocailleux, les courants les plus rapides et les cataraetes ćcumeuses de la Sibérie orientale, a plus de trois pieds de longueur; la forme générale d'unétanche; des appendiees aux ventrales, qui son rougeâtres, ainsi que la caudale; le dessus do corps et de la queue brunâtre; le dessous jauuatre; l'anale trè̀s-rouge, èt la chair blanche.

Le kundscha, qui n'entre guère dańs les fleuves, et que l'on trouve pendant l'été dans les golfes et les détroits de l'Océan glacial arctique est long de plus d'un pied et demi, bleuâtre audessus et au-dessous de la ligne latérale; et ses ventrales ont chacune un appendice écailleux. L'arctique, qui habite dans les petits ruisseau. à fond de cailloux des monts les plus septentrionaux de l'Europe, ne parvient ordinairement qu'à la longueur de quatre pouces.

Le reidur des montagnes de Groenland a près d'un pied et demi de long; la tête grande et avale; le museaú pointu; la langue longue; le pa. ais garni de trois rangs de dents serrées; les nâchoires armées de dents fortes, recourbées, et très-pointues; les opercules grands, lisses, composés de deux pièces; Tes pectorales très-allongées; deux rayons de la première dorsale trèslongs; la chair blanche, et le ventre de la méme couleur.

Licime, dont le museau est arrandi, et la longueur de quatre à huit pouces, vit dans les petits ruisseaux et les étangs vaseux du Groen nd, $y$ dépose ses cuffs sur le limon du rivage, asse l'hiver enfoncé dans ce mème ciu rivage, le préserve des effets funestes du froid le plu rigoureux, et lorsquil est poursuivi, se cache avec précipitation sous cette mêtuivi, se cache n'abandonne, pour sous cette mème rive, qu'il Le Iepéche, pour ainsi dịre, jamais.

Le lepéchin, des fleuves de Russie et de Sibérie dont le fond est pierreux, a la chair rou- dents fortes, aiguês et recourbées à la mâcboire superieure ; soixante dents sembiables à la machoire d'en bas ; la tête grande; les yeux gros ; les joues argentées; des taches noires et carrées sur la première nageoire du dos; les auires nageoires couleur de feu.

Lesil, des mers du Nord, présente une tête large et aplatie; deux mâchoires presque égales; un dos convexe; un ventre plat; une anal placée au-dessous de la nageoire adipeuse; une longueur de deux pieds et demi.

Le lodde habite les mers de Norvège, d'Islande, de Groenland et de Terre-Neuve. Les individus de.cette espèce sont si multipliés en Islande, qu'on en sèche une très-grande quantité pour nourrir les bestiaux pendant l'hiver: et il parait que le voisinag̃e de cette ile leur convient depuis bien des siècles, puisqu'on y trouve dans des couches de glaise des squelettes de ces poissons.

Le lodde n'a ordinairement que six ou sep pouces de longueur. On le péche pendant tout l'été près des rivages du Groenland. Les femelles arrivent vers la fin du printemps, viennent par milliers dans les baies, $y$ déposent leurs cufs sur les f lantes marines, et en laissent tember un si grand nombre, que l'eau de la mer, quoique assez profonde au-dessus de ces plantes, parait d'une couleur jaunâtre.

Lorsque les loddes accourent vers les bords de la mer pour y popdre ou pour y féconder les cufs, ils ne sont arrétés ni par les vagues ni par les courants; ils franchissent avec aũdaco les obstacles; ils sautent par-dessus les barrières. S'ils sont poursuivis par quelque ennemi, ils s'élancent sur la rive, ou sur des pièces de glace; et, s'ils sont blessés mortellement, ils tournoient à la surface de l'eau, périssent et tombent au fond.

Ils se nourrissent d'oufs de crabe, d'aufs de poisson, et quelquefois de plantes aquatiques. Leurs chair est blanche, grasse, de bon goût. On les mange frais ou séchés; et ils sont un des aliments les plus ordinaires des Groenlandais.

Leur tête est comprimée, et cependant un peu large; les máchoires, dont l'inféricure excède la supérieure, sont héríssées de petites llents, ainsi que la langue et le palais. II n'y a qu'un orifice à chaque narine. La ligne latérale est droite; l'anus trè-près de la caudale. De petites écailles revêtent les opercules; celles qui couvrent le ct la queue, sont aussi tres-petites. Les geoires présentent un bord bleuâtre.

Les mâles ont le dos plus largequíe les femelles: presque tous ont d'ailleurs, depuis la poitrine jusqu'aux ventrales, au moins pendant le temps du frai, plusieurs filaments deliés et très-courts. Le péritoine des loddes est noir ; la membrane de l'estomac très-mince; la laite simple, ainsi que l'ovaire; l'épine dorsale composée de soixante-cinq vertèbres; chaque côté de eette épine fortifié par quaranfe-quatre cótes, et les os, auxquels sont attachés les rayons de la nageoire del'anus, sont très-longs; ce qui donne à la portion antérieure de la queue ta hauteur indiquée dans le tableau générique.

Le blane, qui, pendant l'été, remonte de la mer dans les rivieres de la grande-Bretagne, a deux rangées de dents à la máchoire d'en haut, une seule rangée à celle d'en bas; six dents sur la langue; le dos varié de bran et de blanc; et la première dorsale rougeâtre

\section{LE SALMONE VARIE ${ }^{2}$,} Salmo varius, Lac, :

Le Salmone Rene, Salmo renatus, Lacep. 4, - Te s. Rille, Lac.

Les quatre salmones dont nous parlons dans cet article sont encore inconnus des naturalistes. Le varié a été observé, par Commerson, près des rivages de l'ile de France. On ne l'y trouve que très-rarement. Sa longueur est de huit pouces ou environ.

Les couleurs dece poisson sont très-variées, et mariées avec élégance. Les nuances un peu brunes du dos sontrelevées par des taches rouges,

- 18 rayons a chaque pectorale du salmone taimen, $10 \mathrm{at}$ niembrane branchiale du salmone nelina, 16 a chajue pec. malmone kundscha, if a chaque pectorale -9 rayons a i membrane branchiale du salmone arctique, 16 a chaque pee. orale. -12 rayons a ta menbrane des bramehies du sakon reidur, 14 a chaque pectorale, 21 a la nageoire de la quene. 14 a chaque pectorale 20 a la nageoire de la gecae. -6 ravong

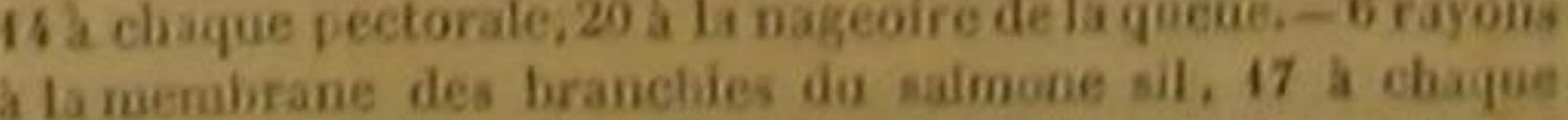
pectorale, 40 a da casdale, -6 rayous a da inembrane trau.

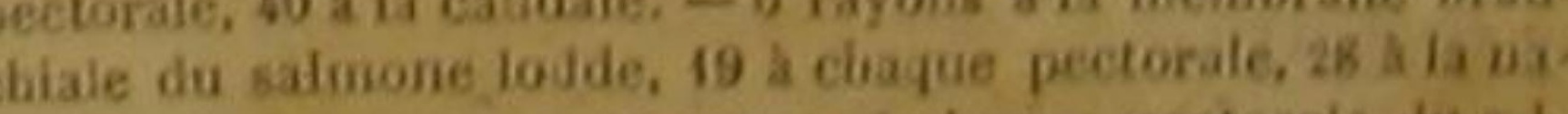
gevire de la quede -15 rayous a chaque pectoralo du a.t. mone bianc.

. - Gongitndina i vicibus ant

.
crits daus cet article. 1. 
et s'accordent très-bien avec le rouge, le jaune et le noir, que deux raies longitudinales présentent symétriquement de chaque côté du salmone, ainsi qu'avec le noir et le rouge dont les nageoires sont peintes. Le dessous de l'animal est blanchâtre ; et les iris, couleur de feu, brillent comme des escarboucles au milieu desteintes ombres de la tête.

La forme générale de cette dernière partie lui donne beaucoup de ressemblance avec la tête d'un anguis. L'ouverture de la bouche est trèsprolongée en arrière. Les dents de la mâchoire supérieure sont acérées, mais éloignées les unes des autres; celles de la mâchoire inférieure sont au contraire très-serrées.

Au reste, cette dernière mâchoíre est un peu plus avancée que la supérieure, qui n'est ni extensible ni rétractile.

Les dents semblables à des aiguillons recourbés hérissent la langue, qui d'ailleurs est trèscourte et très-dure; d'autres dents plus petites et moins nombreuses garnissent la surface palais.

Le bord supérieur de l'orbite est très-près du sommet de la tête. Deux lames composent chaque opercule. L'anus est très-près de ha caudale, et la ligne latérale presque droite.

On pêche dans la Moselle, et partičulièrement vers les sources de cette rivière, une espèce de salmone, à laquelle on a donné, dans la ci-devant Lorraine, le nom de René, et dont la ci-devant Lorraine, le nom de Rene, et dont un inpar Dom a été envoyé, il y a plus de deuze ans de Nancy.

Ce poisson a deux rangées de dents sur la langue, et trois sur le palais; le dessus de la tète et du corps, ainsi que les nageoires du dos et de la quene, d'une couleur foncée; le dessous du corps et ies autres nageoires, blanches ou
blanchátres.

Le rille parvient rarement à une grandeur plus considérable que celle d'un une grandeu bite dans plusieurs rivières, et particulièrement dans celle de la Rille, dont il porte le nom, qui se jette dans la Seineauprès le nom, et de ce fleuve.

On l'a souvent confendu avec de jeunes mons; ce qui n'a pas peu contribué aux fausses idées répandues parmi quelques observateurs sujet de sa conformation et de ses habituda Mais on est allé plus loin : on a prétendu que ce salmone rille ne montrait jamais ni œuf ni laite, qu'il était infécond, qu'il provenait de la ponte des saumons, qui, ayant en même tempset des œufs et de la laite, réunissent les deux sexes: et cette opinion a eu d'autant plus de partisans, qu'on aime à rapprocher les extrêmes, et qu'on a trouvé piquant de faire naitre d'un saumon heimaphrodite un poisson entièrement privéde sexe. If $y$ a dans cette assertion une double erreur. Premièrement, il n'y a pas de poisson qui présente les deux sexes, ou, ce qui est la même chose, qui ait ensemble et une laite et des ovaires : nous avons déja vu que des ceufs très. peu développés avaient été pris, par des observateurs peu éclairés ou peu attentifs, pour une laite placée à côté d'un véritable ovaire. Secondement, il est faux que le salmone dont nous traitons ne renferme ni œufs ni organe propre à leur fécondation : nous indiquerons au contraire dans cet artiele la nature de la laite de ce salmone de la Rille. Cépoisson constitue une espèce particulière, dont la description n'a pas encore été publiće. Nous allons le faire connaitre d'après un dessin très-exact, que M. Noël de Rouen nous a fait parvenir, et d'après une note trèsétendue que ce savant naturaliste a bien vouln $y$ joindre.

Le salmone rille a la tête petite; l'œil assez gros; les deux mảchoires et la langue garnies de petites dents; l'opercule composé de trois pièces; le bord inférieur de la pièce supérieure un peu crénelé; la ligne latérale droite; les écailles ovales, très-petites et serrées; le dos d'un gri olivâtre; les côtés blanchâtres et comme mo gr de gris; le ventre très-blanc; la première dorsale ornée de quelques points rougeâtres; I laite grande, double, ferme au toucher, et trèsblanche; la chair également très-blanche, agréable au goût, et imbibée d'une huile ou plutôt d'une graisse douce et légère; la colonne vertébrale composée de soixante vertèbres, ce qui suffirait pour séparer cette espèce de celle du saumon.

Au reste, il aime les equx froides, comme la truite, avec láquelle il a beaucoup de rapports. On trouve dans l'étang de Trouville, auprès de Rouen, un autre salmone, dont $M$. Noêl nous a communiqué une description, et à laquelle nous avons cru devoir conserver le nøm spécifique de Gadoïle qu'il lui a donné.

Ce poisson parvient à la longueur d'un pied et demi ou environ. Sa tête ressemble bea coup; par sa conformation, à celle des gades ,

DES P()ISSONS.

et particulièrement à celle du gade merlan. L'ouverture de la bouche peut étre très-agrandie par lextension des lèvres. On voit deux rangées de dents à la máchoire d'en haut, une rangée à celle d'en bas, plusieurs autres dents sur la langue, qui est grosse et rougeàtre, et des dents très-petites auprès du gosier'.

\section{LE SALMONE CUMBERLAND.}

Salmo Cumberland, Lac, '.

Les lacs du Cumberland et ceux de l'Écosse nourrissent ce salmone, dont les naturalistes ignorent encore l'existence, et dont M. Noël nous a envoyé une description, après son retoo d'Angleterre.

Ce salmone, auquel nous donnons le nom de sa patrie, a la ligne latérale droite; la tête petite; l'cil grand et rapproché du bout du museau; l'ouverture de la bouche grande; la langue un peu libre dans ses mouvements, et garnie de deux rangées de dents; les écailles petites; la nageoire adipeuse Iongue; la couleur générale blanche; le dos gris; la chair blanche, mais peu agréable au goût ${ }^{3}$.

\section{CENT SOIXANTE-DIX-NEUVIÈME} GENRE.

LES OSMİRES 4 .

La bouche d l'extrlmitt du museau; la leto comprimé ; des ecailles facilement visibles sur le corps et sur lo queue; point de grandes lames sur les cota, de cuirasse, de piquants aux opereules, de rayous denteles, rasse, de piquants aux opereules, de rayoas dentelds, adipeuse et demule de rayons; la prèmiere plus floiadipeuse et denude de rayons; la prèmière plus floi-
gree de la lele que les ventrales; plus de quatre rayons gnte de la lele que les ventrales; plus de quatre rayons
d la membrane des branehies; des dents forles aux machoires.

\section{espíces.}

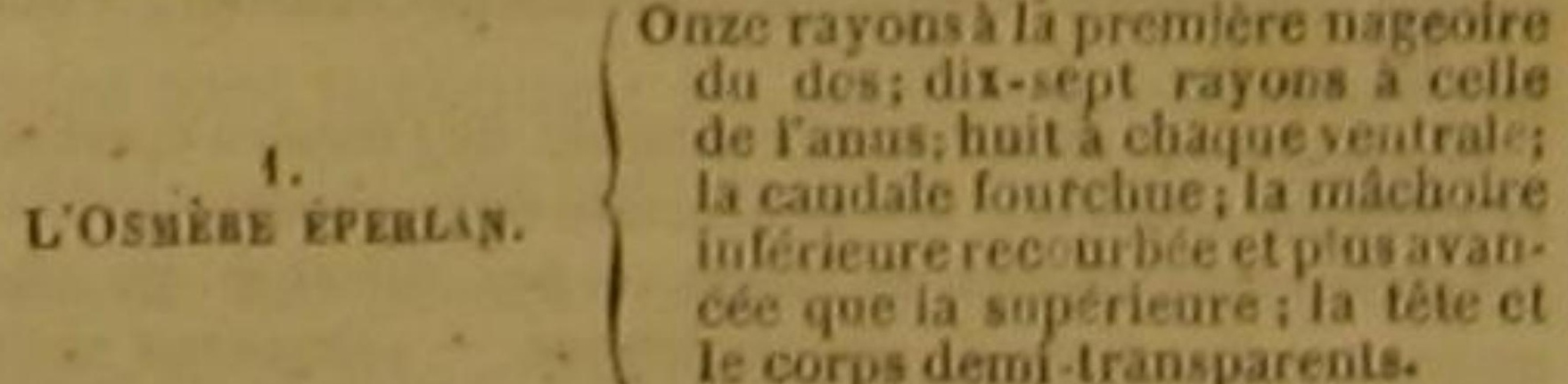

12 rayons 5 la membrane branchiale du salmone varié, 14 a chaque pectorale, 19 a la nageoire de ia queue- -12 rayons A la menibrane des brachiles chiale do simone rille, 41 a chăque pectorale, 35 a la naceoire de la quene- -11 rayons a la memtrane des bran chies da salmone gạdoide, 15 a chaque pectorale, 20 a la ciudale.

'Non mentionné par M.Cavier. D.

"Io rayons a la me prane branchiale da salmone cum-

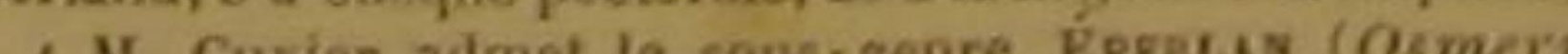

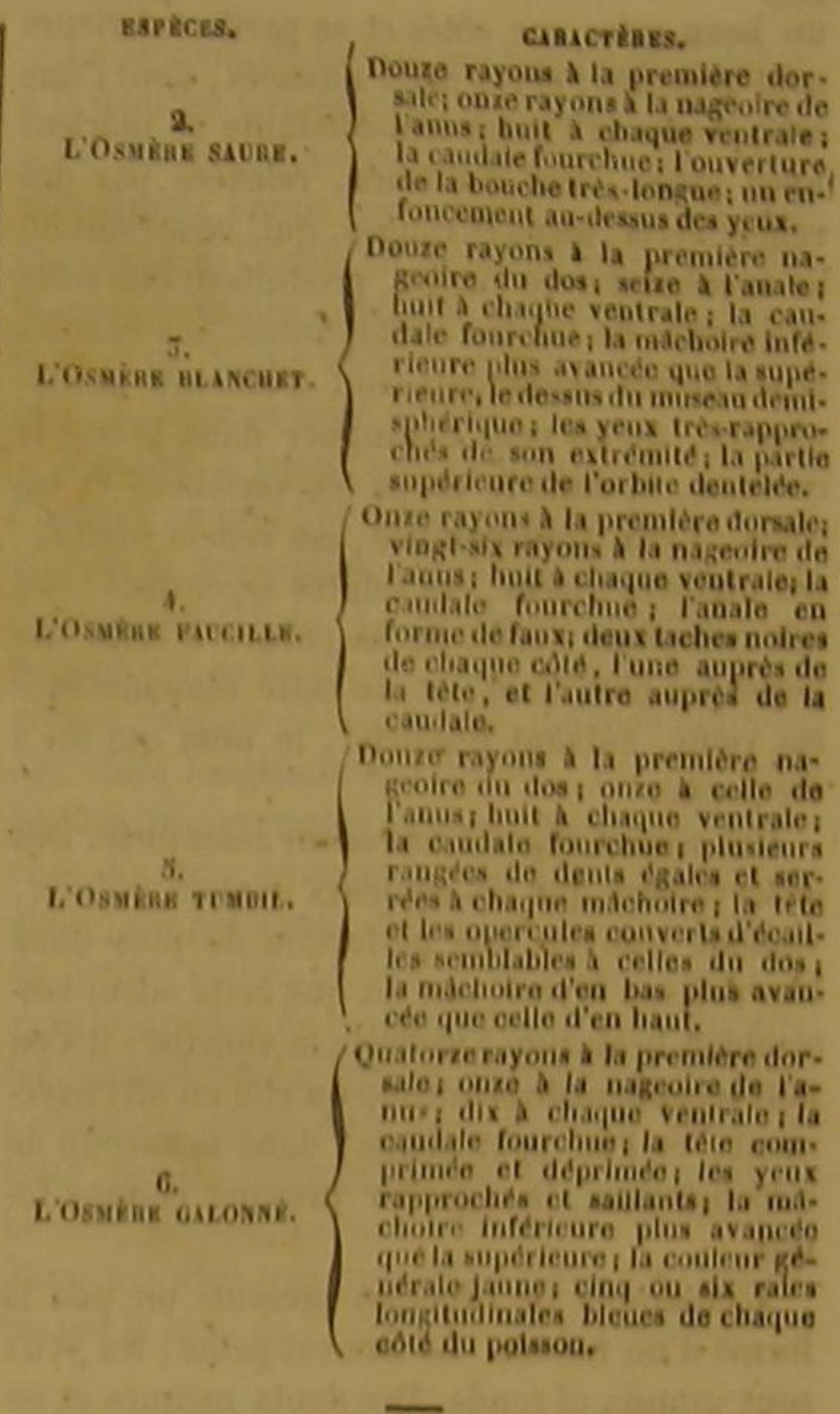

L'OSMĖRE ÉPERLAN'

Osmerus (salmo) Eperlanus, Cuv,; Salmo eperlanus,

Linn., Gmel,, Bl.; Osmęrus eperlanus, Lac. '.

L'éperlan n'a guère que six pouces ou environ de longueur; mais il brille de couleurs trèsagréables. Son dos et ses nageoires présentent

d'Artedi, dans te grand genre Ssusox; if n'y place que Ca

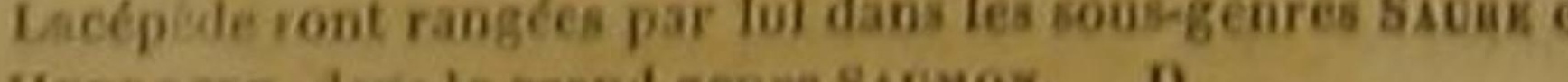

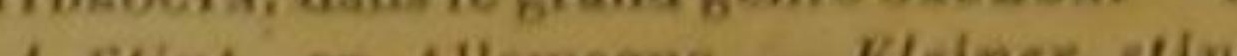

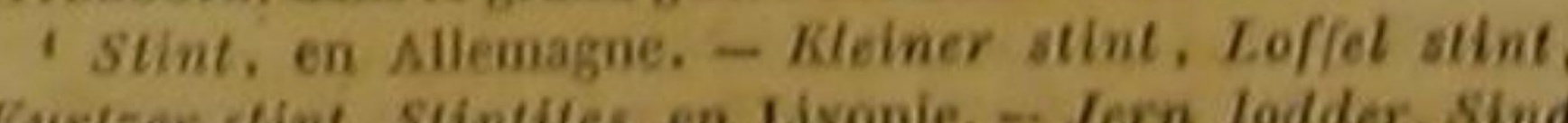
lodder, en Laponle. - Nars, en Suede. - Lodde, Magno sildtodde, Moke, Krochle, en Norvęge. - Splering, en Holtade. - Smelt, en Angleterre, - Sjiro iwo, au Japon. salmone eperian. Daubenton et diany, Bac. meth. -10,

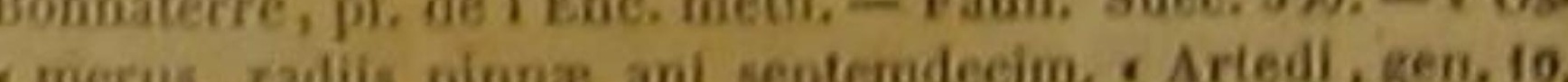

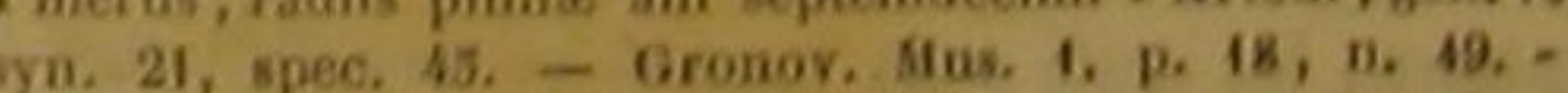
Bloch, pl. 28, fig. 2, - Klein, Miss, pise, 3 , p. 20, tab, 4 , fig. 3, 4. - Esperlan, Rondelet, part. 2, chap. 18. - Eper. anus fluciatitis. Gesner, Aquat, p. 302, Thierb., p. 18\%. Eperlanus. Aldrov, Pise, p, as6. - Id. Willoghily, Jeath,

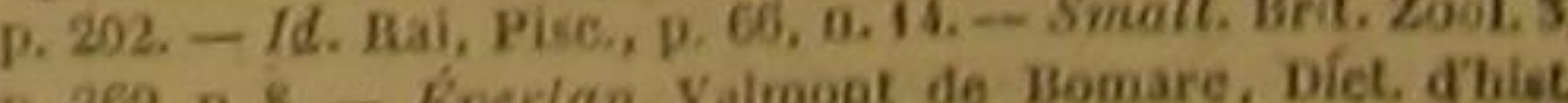
1. 269, n.8. - Eperian. Valmos pecies.

2Type da sou-geore Érsasas, das le graud geare SAEsos, Cur. D. 
Un beau gris; ses cótés et sa partie inférieu très-douce et ces deux nuances, dont l'une avec avec grace, sont d'ailleurs, relevées par des reflets verts, bleus et rouges, qui, se mêlant ou se succédant avec vitesse, produisent une suite très-variée de teintes chatoyantes. Ses écailles et ses autres téguments sont d'ailleurs si diaphanes, qu'on peut distinguer dans la tête le cerveau, et dans le corps les vertèbres et les cotes. Cette transparence, ces reflets fugitifs, ces nuances irisées, ces teintes argentines, ont fait comparer l'éclat de sa parure à celui des perles les plus fines; et de cette ressemblance est venu, suivant Rondelet, le nom qui lui a été donné.

Cet osmère répand une odeur assez forte. Des observateurs que ses couleurs avaient séduits, voulant trouver une perfection de plus dans leur poisson favori, ont dit que cette odeur ressemblait beaucoup à celle de la violette : il s'en faut eependant de beaucoup qu'elle en aitl'agré ment, et l'on peut mème, dans beaucoúp de circonstances, la regarder presque comme fétide.

L'ensemble de l'éperlan présente un peu la forme d'un fuseau. La tête est petite; los y sont grands ef ronds. Des dents me; les yeux courbées garnissent les deux mâchoires et le palais; on en voit quatre ou cing sur la langue. Les écailles tombent aisément.

Cet osmère se tient dáns les profondeurs lacs dont le fond est sablonneux. Vers le printemps, il quitte sa retraite, et remonte dan les rivières en troupes très-nombreuses, pour déposer ou féconder ses œufs. Il multiplie avee tant de facilité, qu'on élève dans plusieur's marchés de l'Allemagne, de la Suède et de l'Angleterre, des tas énormes d'individus de cett espèce.

Il vit de vers et de petits animaux à coquille. Son estomác est très-petit; quatre a coquille. pendicés sont placés auprès du pylore; la vessie natatoire est simple et pointue par les deux bouts; l'ovaire est simple comme la les deux tatoire; les cufs sont jaunes et tra vessie nacompter; des point jaunes et très-difficiles à compter; des points noirs sont répandus sur le péritoine, qui est argentin. On trouve cinquante-neuf vertèbres à l'épine du dos, et trentecinq côtes de chaque cốté

'Il est difficile de présenter I'histoire de lipper'an avec
Une variété de l'espèce que nous décrivons habite les profondeurs de la Baltique, de l'Océan atlantique horéal, et des environs du détroit de Magellan '. Elle differe de l'éperlan des laes pa son odeur, qui n'est pas aussi forte, et par ses dimensions, qui sont bien plus grandes. Elle parvient communément à la longueur d'un pied ou quinze pouces, et, dans l'hémisphère antaretique, on l'a vue longue de dix-huit pouces. Vers la fin de l'automne, elle s'approche des côtes; lorsque le printemps commence, elle remonte dans les fleuves; et l'on prend un si grand nombre d'individus de cette variété en Prusse, auprès de l'embouchure de l'Elbe, et en Angleterre, qu'on les y fait sécher à l'air pour les conserver longtemps et les envoyer à de grandes distances ${ }^{2}$.

\section{L'OSMERE SAURE ${ }^{3}$,}

Saurus..... Cuvi.; Salmo Saurus, Lino., Gmel.; Osmerus Saurus, Lac, ',

'Osmère blanchel :, Saurus (salmo) fetens, Cuv.; Salmo faucille 1 , Hydrocyon (simerus albidus, Lac. 4. - L'O. eatus, Bl,; Osmerus falcatuso) falcatus, Cuv,; Satmo fal. Saurue (salmo) Tumbil, Cav, Lalmo Tumbil, B. Tumbil " Tumbil, Lac. "O- $-L^{\prime} O$. galonne ", Saurus (salmo) lemenis catus, Cav,; Osmerus lemniscatus, Lac, ${ }^{12}$.

Le saure a la tête, le corps et la queue trèsallongés; les deux mâchoires garnies de dents

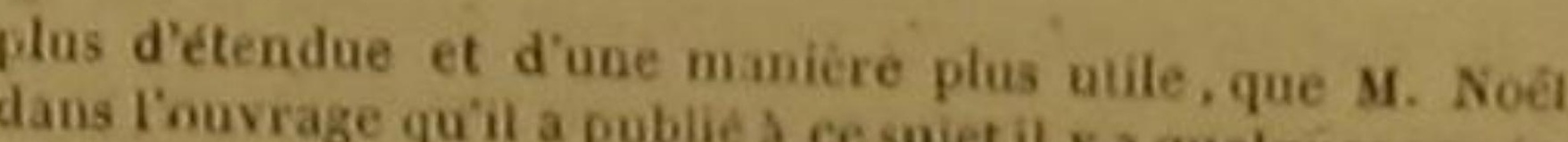
t Lperian de mer, auprés de Rouen - Stinues année. Grosser stint, ea Allemague - Stinter, Sallakas, Stint. Iisch, Tint, en Livonie.-Slom, en Suède. - Oualle, Jennlodde, en Norvége. - Smell, en Angleterre. - Salmo eperde mer, varieté de léde de Gmelin. - Salmone eperlan métl. - Id. Bomnaterre pl. de Daubenton et Haay, Enc. fig: 1. - Willughby, Ichth., dab n. métb. - Bloch, pl. 2s, Gesner, Thierb., p. 180, b. - Spirinchus. tab. 47, fig. 6.

11 à chayons à la membrane branchiale de l'osmère éperlan. 1. Thaque pechorale, 19 a la nageoire de la queve. magne. - Sea lizard de Rome, - See eidechse, en Alle

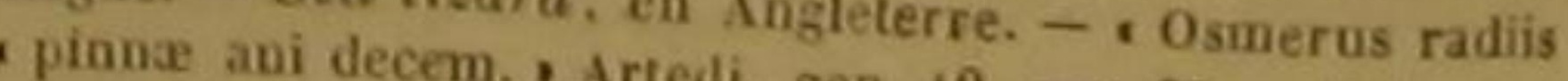
saure. Daulenton et Haăy, Enc, 10, syn. 22. - Salmone pli. de I'Enc, méth. - Bloct, pl. 584, fig. - Id. Bonnaterre, grand geare Sicmos. D.
a , en Allemagne. - Slender sal. Hae. - Salmons blanclea sparrow hawk, dans la Caro$-I d$. Bonnaterre, pl. de I Escenterton et It üy, Enc. méth. Catesby, Carolin. 2, ए. 2, tab. 2, fig. 2 .

\section{DES POISSONS.}

très-fortes, conformées et disposées comme celles de plusieurs lézards; un seul orifice à chaque narine; les opercules revêtus de petites écailles; le dos d'un vert mêté de bleu et de noir; des bandes transversales, étroites, irrégulières, sinueuses et roussátres, sur cette même partie; des raies de la mème couleur sur la première dorsale; d'autres raies également roussátres, et de plus tachetées de brun, sur chaque pectorale ; une raie longitudinale bleuâtre, et chargée de taches rondes et bleues, de chaque cóté du corps et de la queue; la partie inférieure de la queue et du corps argentée et très-brillante. On le péche dans les eaux des Antilles, danis la mer d'Arabie, dans la Méditerranée.

De petites écailles placées sur les opercules et sur presque toute la tête; une double rangée de dents sur la langue, au palais et aux máchoires; un seul orifice à chaque narine; le dos noirâtre; les flancs et le ventre argentins; les nageoires d'un rouge mélé de brun : tels sont les traits qui doivent compléter le portrait de l'osmère blanchet que l'on a péché dans la mer de la Caroline, et dont la longueur ordinaire est d'un pied ou quinze pouces, ainsi que celle du saure.

Surinam est la patrie de l'osmère faucille. La mâchoire supérieure de ce poisson est plus avancée que l'inférieure; les dents de ces deux machoires sont fortes et inégales; d'autres dents pointues garnissent les deux cotés du palais; la langue est étroite et lisse. Un os court, large, dentelé, et placé à l'angle de la bouche, s'avance lorsque la gueule s'ouvre, et reprend sa première position lorsqu'elle se referme; ce qui donne à l'osmère faucille un léger rapport de conformation avec l'odontognathe aiguillonné. II y a deux orifices à chaque narine; les opercules sont rayonnés; les écailles assez minces se détachent facilement; la ligne latérale se courbe vers le bas; lanus est à une distance presque égale de la tête et de la caudale; on voit un appendice à chaque ventrale. La couleur générale est argentée; 1e dos violet; chaque nageoire grise à sa base, et brune vers son extrémité.

- Du sous - genre Hydiocrx ( Hydrocyon ), Cuv,, dans le genre Sicmos. D.

"Tumbile, sur la cote de Malabar. - Bloch, pl. 450.

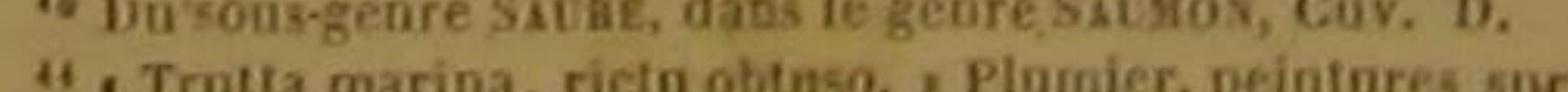
velin déjà citét.
Le tumbil, de la mer qui baigne le Malabar, à la bouche très-grande; la tête longue; le museáu pointu; l'opercule arrondi; la ligne latérale droite; , Yanus très-rapproché de la caudale, la dorsale et l'anale en forme de faux; les cotés jaunes; le ventre argentin ; des bandes transversales d'un jaune mélé de rouge; les nageoires bleues, avec la base jaune.

Plumier a laissé une peinture sur vélin de l'osmère auquel j’ai donné le nom de Galonné, et dont la description n'a encore été publiée par aucun naturaliste. La nageoire adipeuse de ce poisson est en forme de petite massue renversée vers la caudale '. II présente, indépendamment des raies longitudinales bleues, dix ou onze bandes transversales brunes; mais il offre encore d'autres ornements. Sa tête, couleur de chair, est parsemée de petites taches rouges et de petites taches bleues; deux raies bleues relèvent le jaunâtre de la première nageoire du dos; les ventrales sont variées de jaune et de bleu; l'anale est bleue avee une bordure jaune; et cette parure, composée de tant de nuances bleues, jaunes, brunes et rouges, distribuées d'une manière très-agréable à l'oil, est complétée par le blea de l'extrémitó de la caudale.

\section{CENT QUATRE-VINGTILME GENRE.} LES COHÉGONES ${ }^{2}$,

La bouche à l'extrémitte du museau; la lele comprimie, deg icailles facilement visibles sur le corpset sur 10 queue; point de grandes lames sur les coteds, de cuirasse, de piquants aux opereules, de rayons denteles. ni de barbillons; deno nageoires dorrales; la seconde adipeuse et deriue de rayons; plus de quatre rayond da la meribrane des branchies; les machoires rans dents, ou garnies de dents tres-petites et difficiles d voir.

sspices. canctikas.

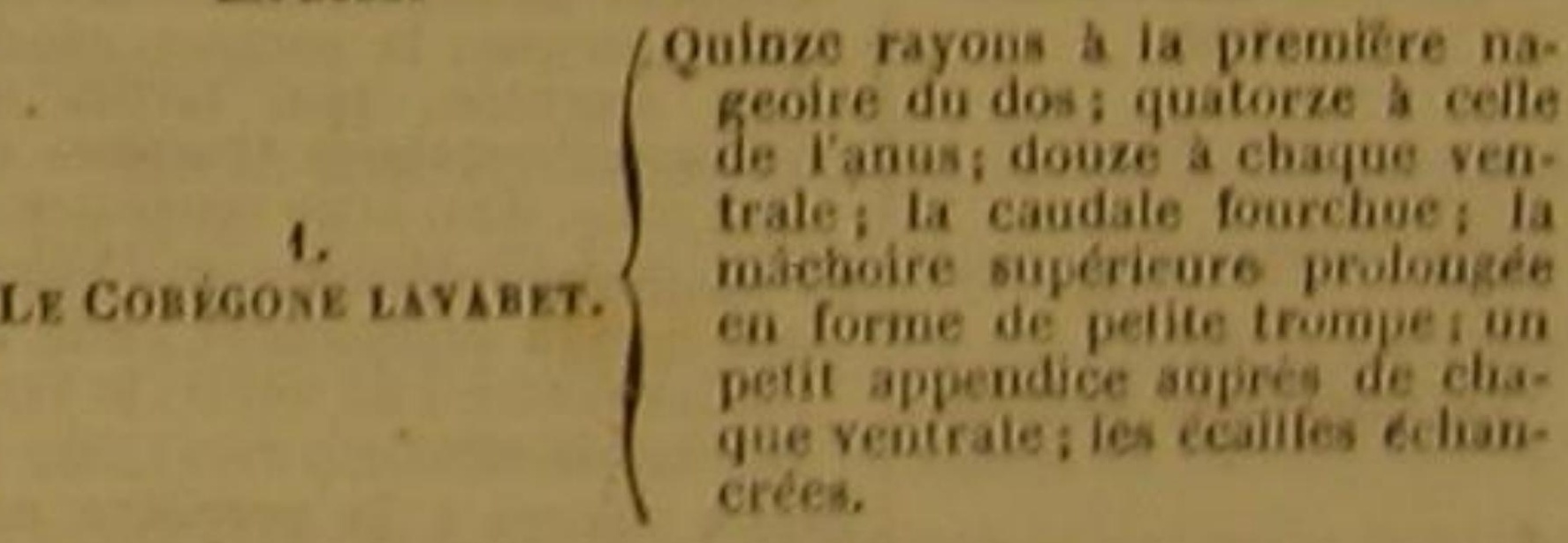

I 12 rayons a chaque pectorale de Tosmère saure, 18 als nageoire de la queue. - 12 rayoos a la membrane brancliale de osmere blanchet, 12 a chaque pectorale, 25 a i caudate. -5 rayons a la membrane des branchies de Tosmere tau
cille, 16 a chaque pectorale, 20 a la nageoire de la queue. 2s. Cuvier dosae le nom de Lsvisets aux Curégones de 
502

EsPĖCEs.

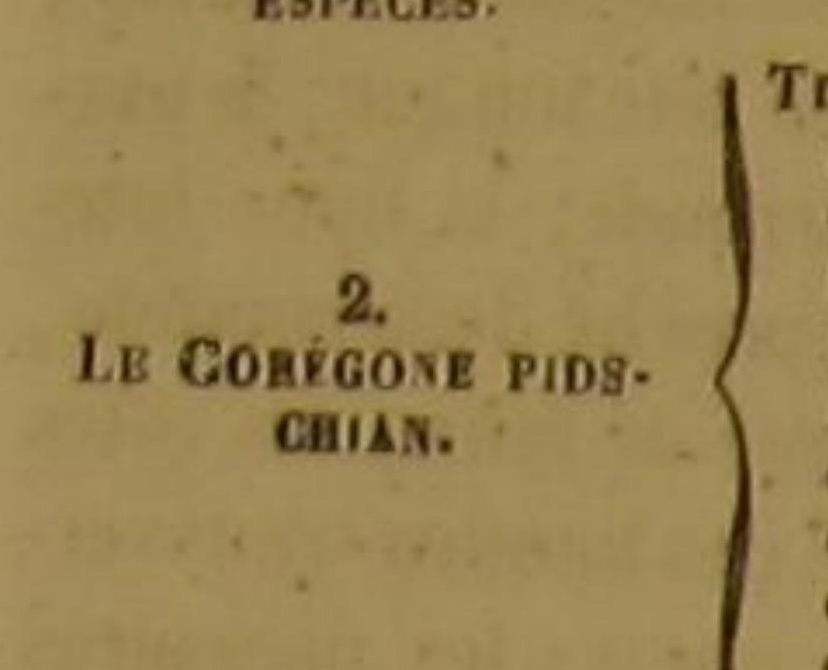
ciactè丶ass. Treize ou quatorze rayons à la pre-
miéredorsale; seize a la nag oire.

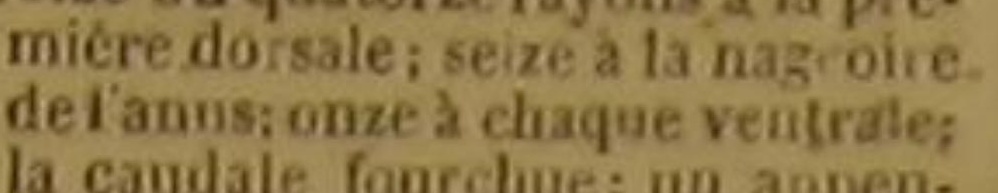
la caudale fourchue; un appen-
dice triangulize, algu, el plus ong que les ventrales, aupres de
chacune de ces nageoires; le dos

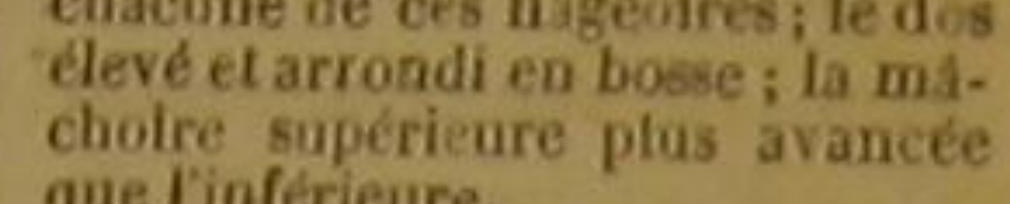
Douze rayons a la premiére na:
Beoire da dos; quatorze à la:
nale

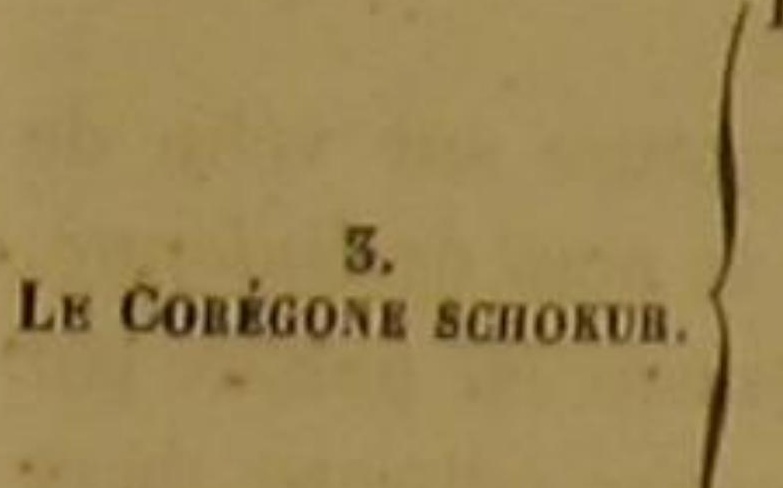
candale fourchue; in an appendice court et obtus aupres de spendicicio dos carénés; deax tubercules
sur le musean; la máchoire st-
púriemee phe tieure plus avancéte que tintét-<smiles>C1CC[Al]C1</smiles>

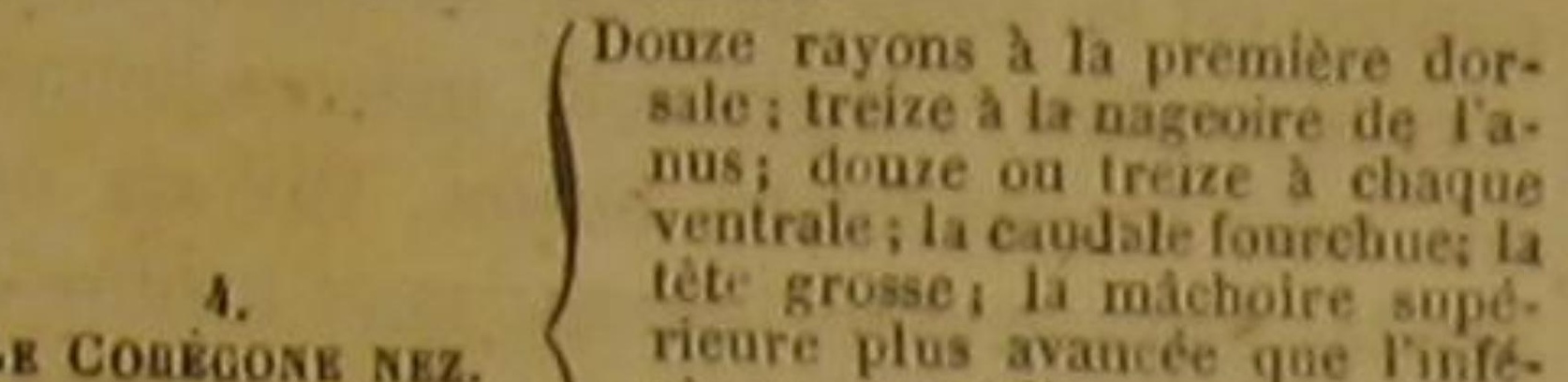
LE Coukcons NEZ. rieure plus avanace quire linfite
rieure, arrondie, eonvexe et bos-

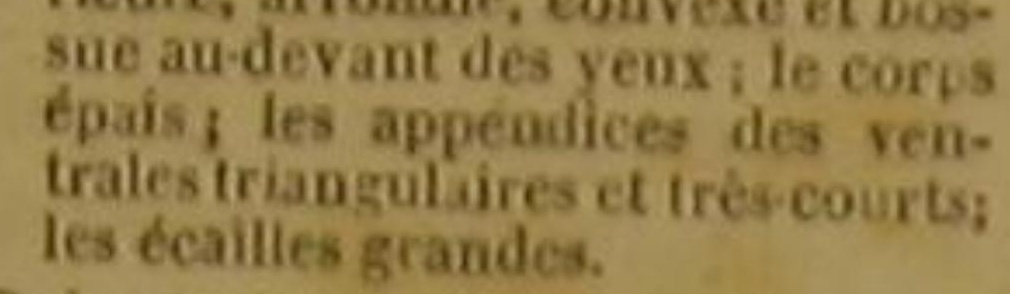

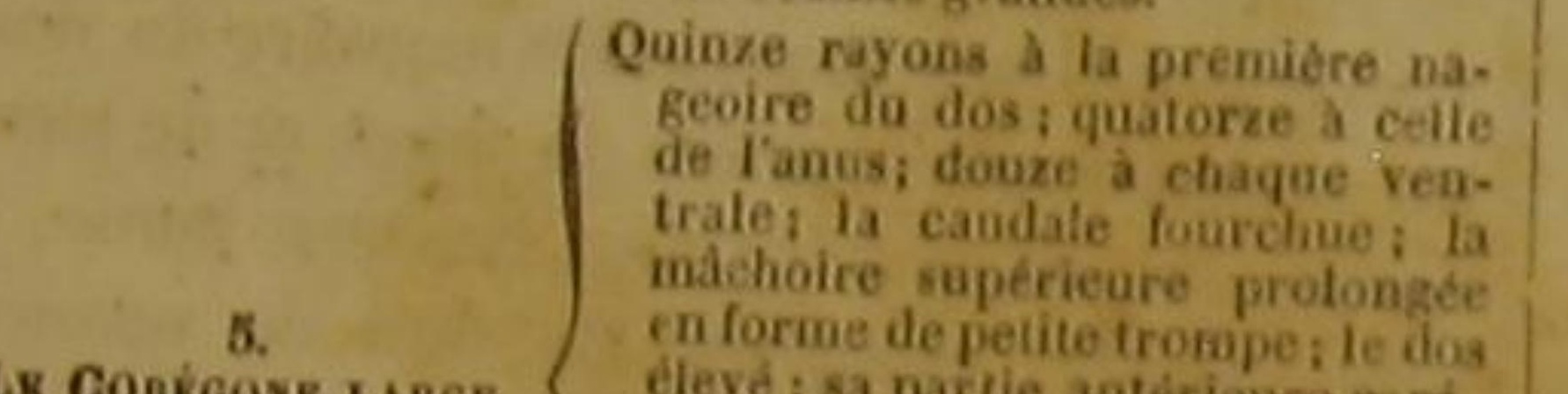

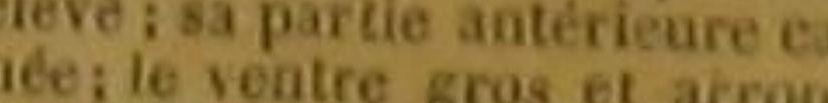

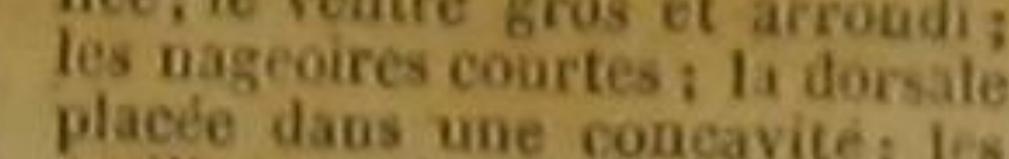
placée daus une concavite; les
ccailtes rondes ia pranelle an-
guleuse du cotie du museau; des
raies longitudinales.

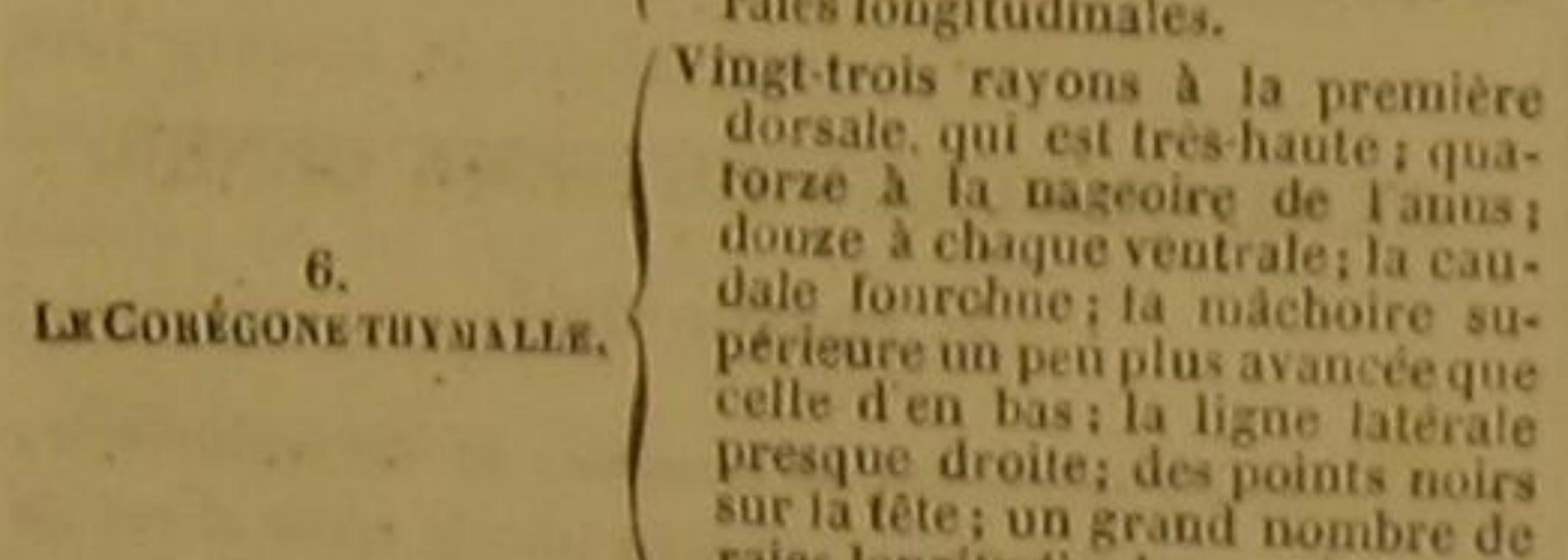

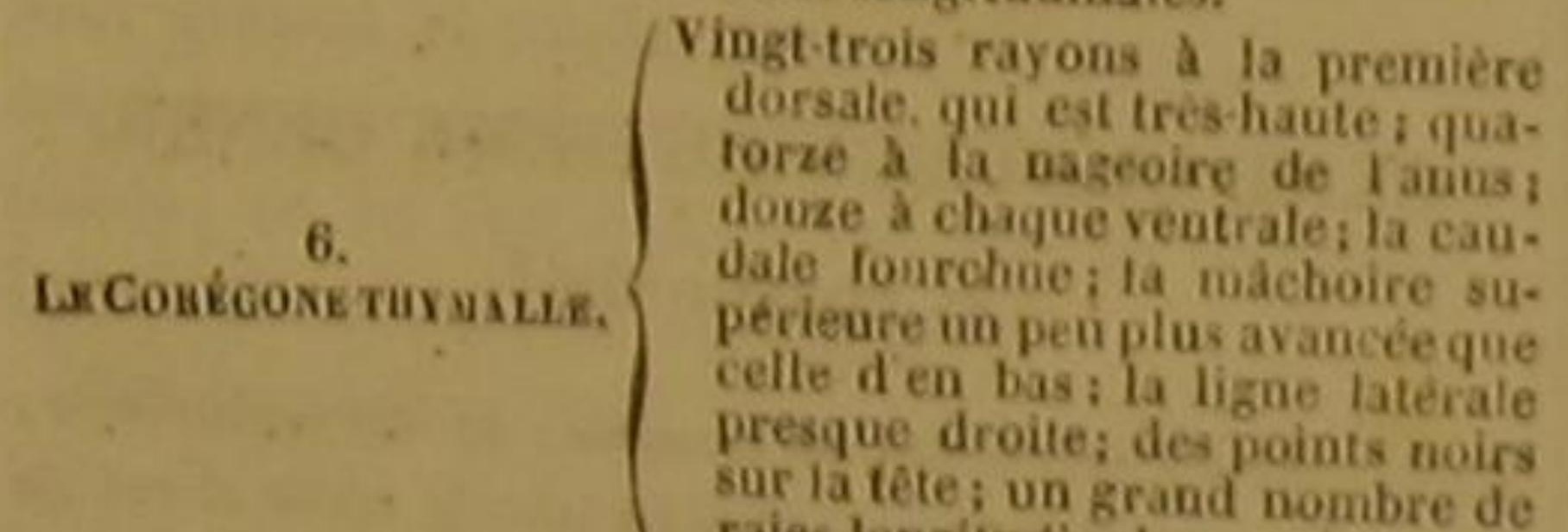
celle den bas; la ligane laterale
presque droile; des points noirs
sur la teter un grand nombre de
raies longitudinales.

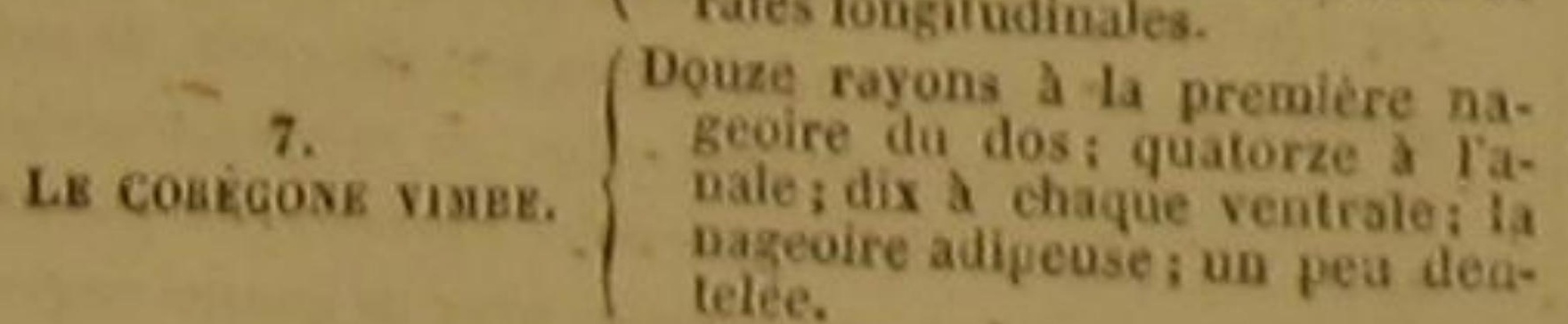

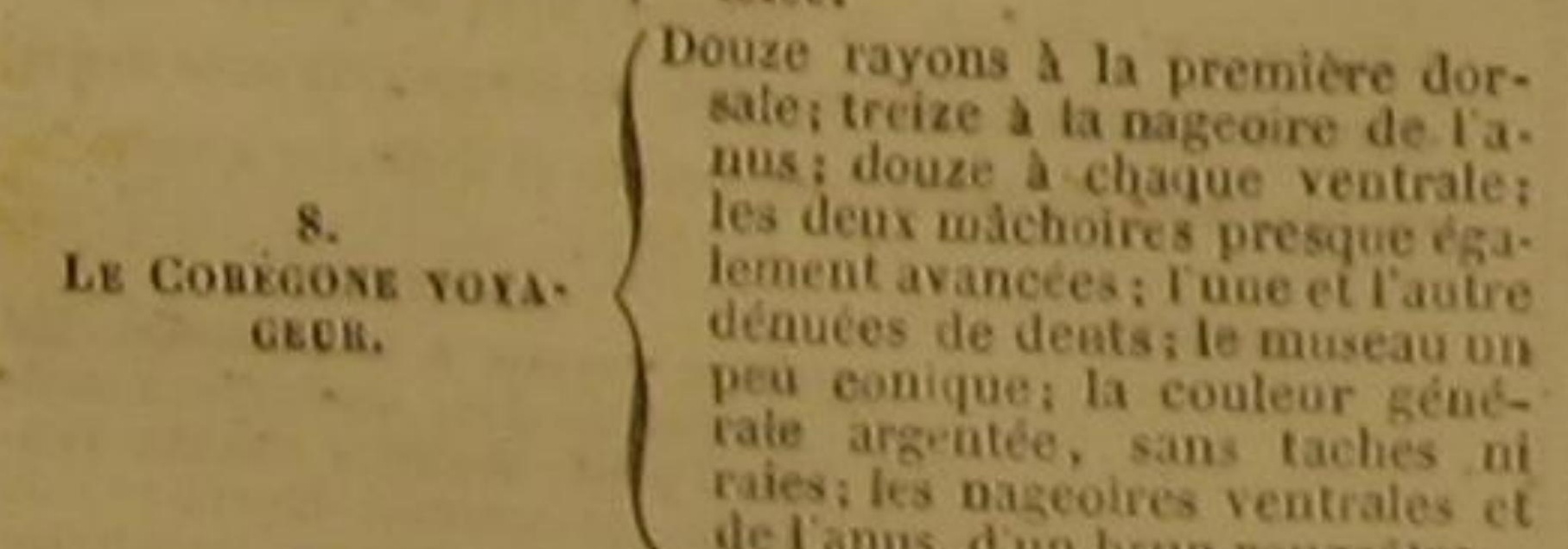

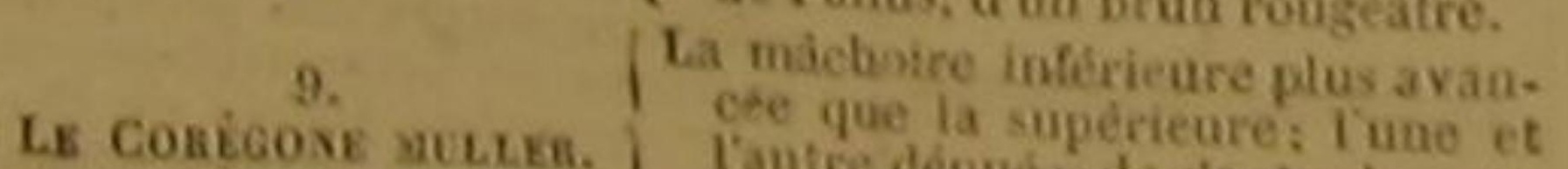
Tre monchieles.
te deats; le veu.

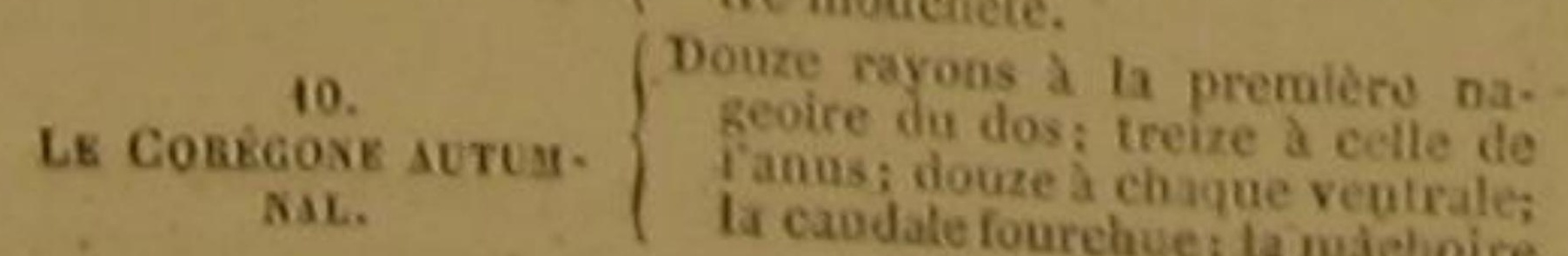
6 rayons a la meabrane branckiale de Posmère tumbil, 15 a chaque pectorale, 20 a la caudale. -7 rayons a chaque pec. bre des rayons de la membrane bra. Nous ignorons le nomcontre notre opinion, cette membrane n'en avait qué, qi, tre, il tandrait placer le galonné dans le genre des Chara-
cius.
CARsctìnes.

Le Corégone autus-
NaL, superieure plins avancie que la
nuées de dents: tout lautre dé. nuées de dents; Touverture dis
branchies trés:grande; la con.
leur générale argentée

'11.

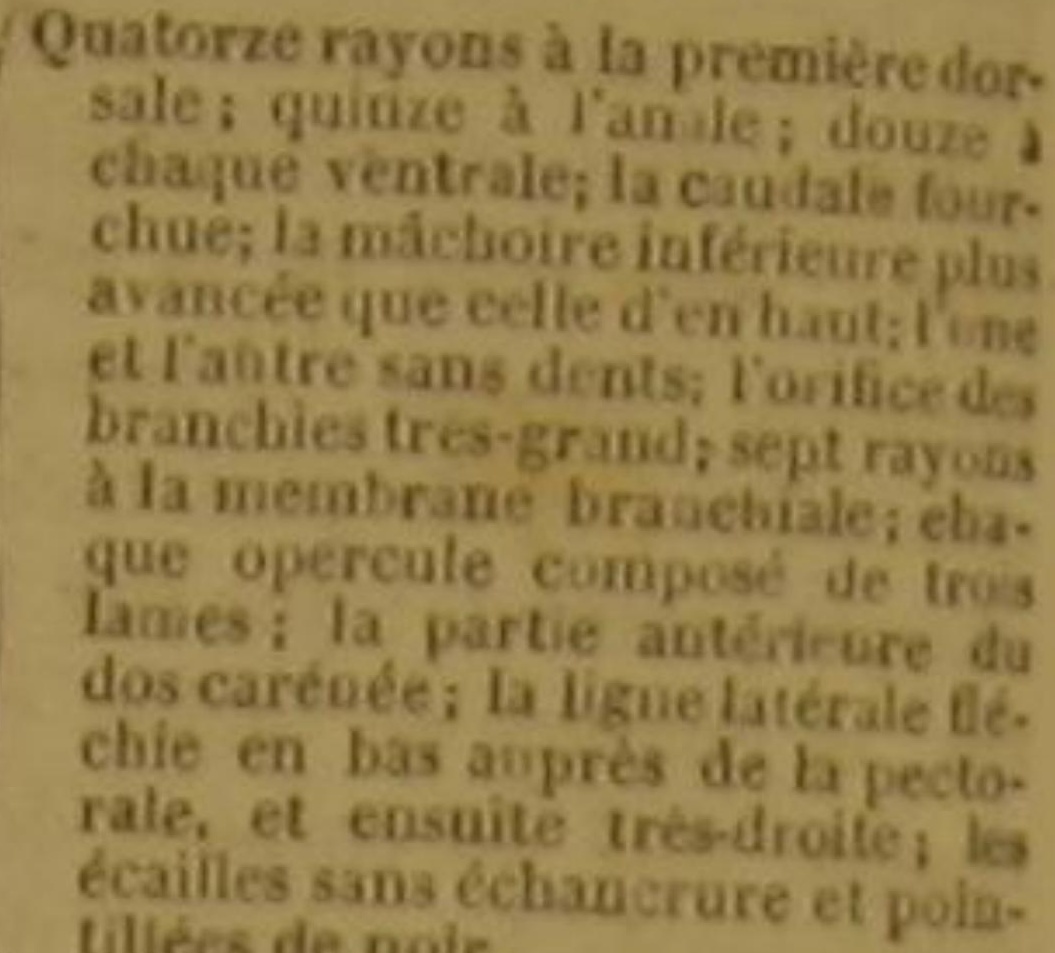

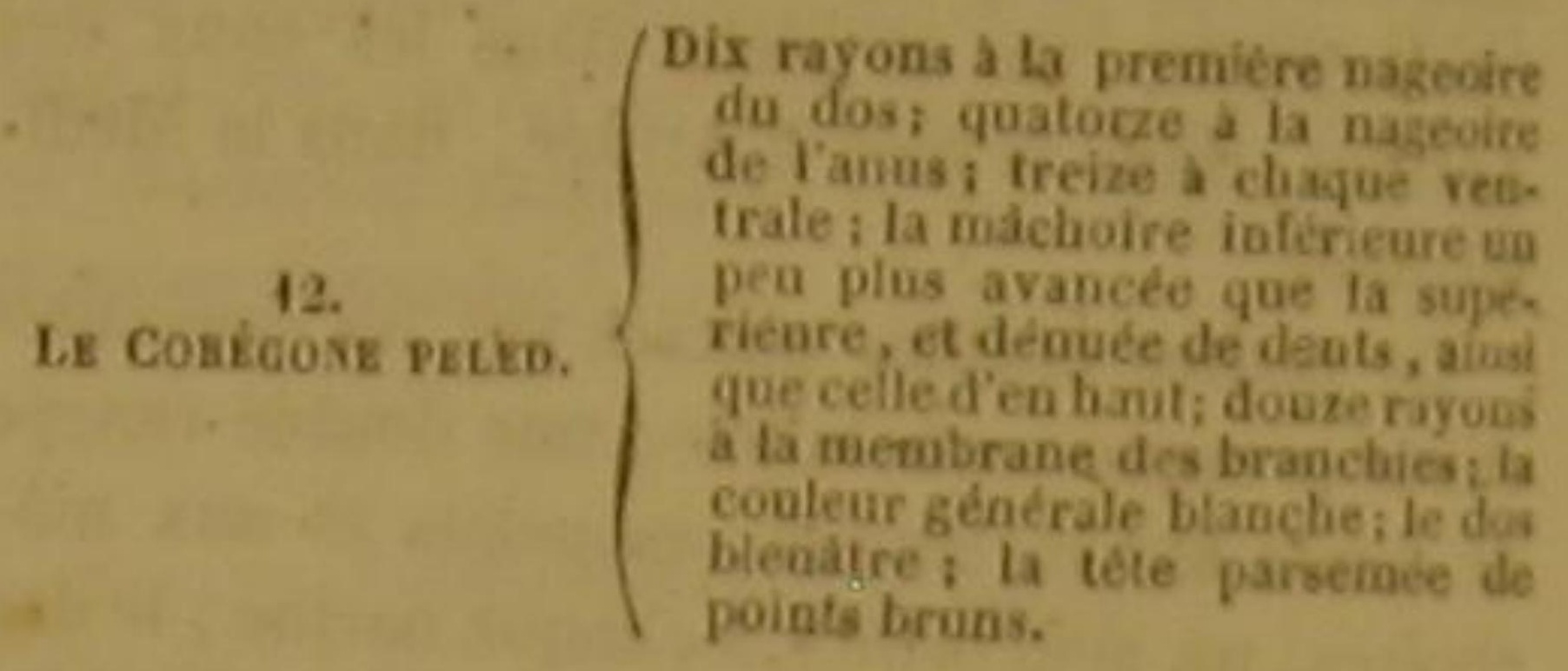

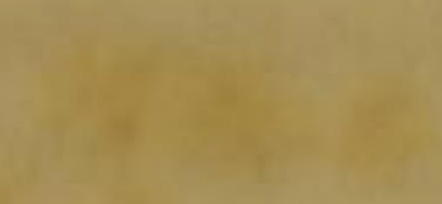

13. Quarze rayons a la première dor.
sale quimze a la nageoire de $F$. aus i onze a chaque ventrale: ia
candale fourchne; huit ayons la membrane bran hialei puini
de dents: une sorte de bourrelt

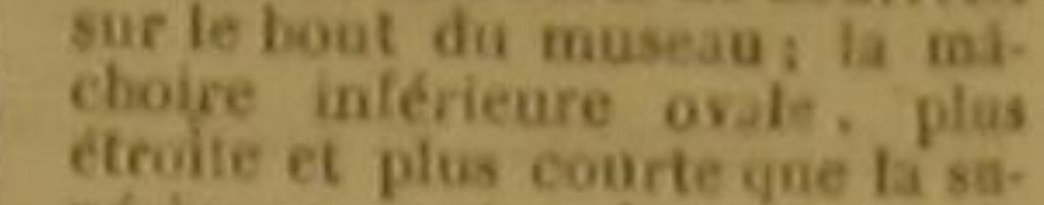
étruite et plus courte qne ta sa-
périeures poin- de ta lies. de
bundes ni de raies.

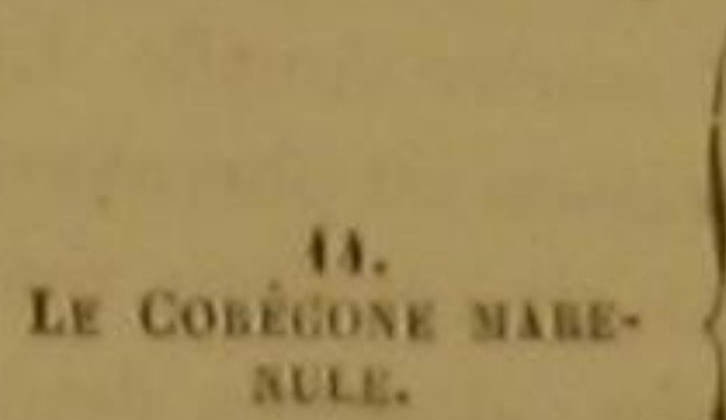

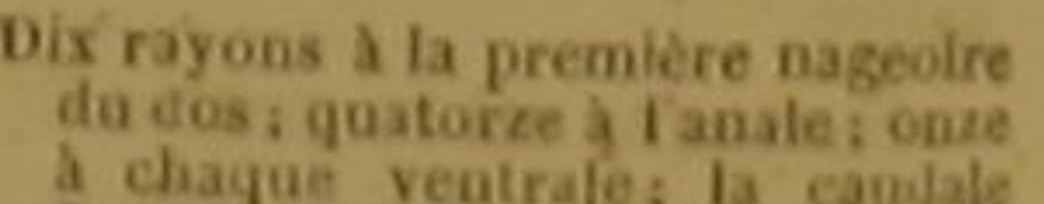

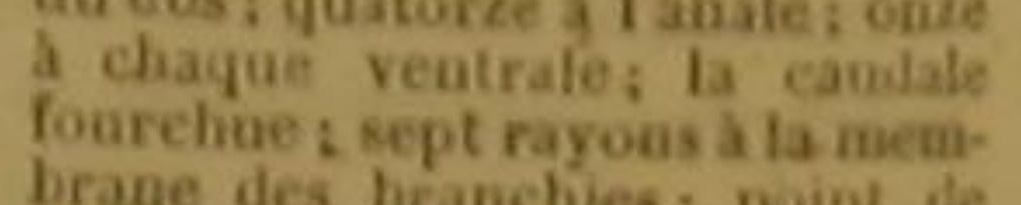
dents : la michoire we werieur

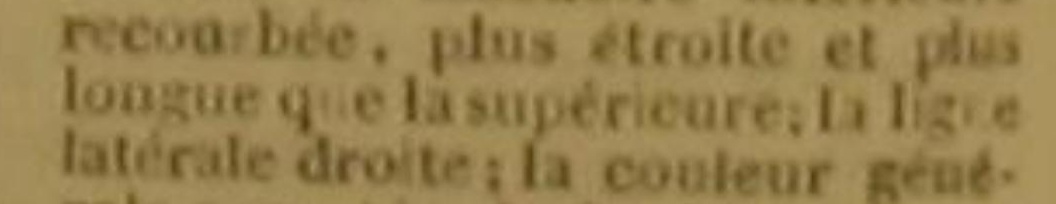
bleuatre.

15.
Le ConegoNe WAHT.
MLAN.

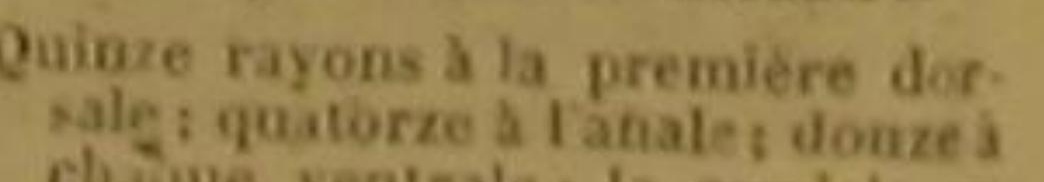

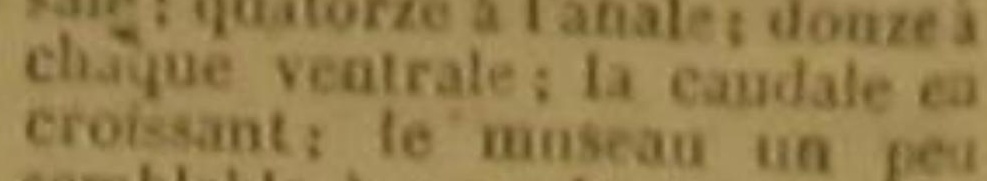
point de deuts; les den tronguét

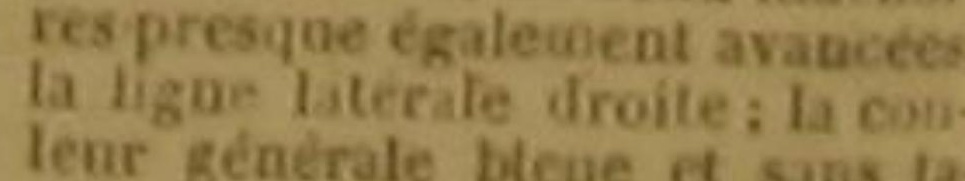
Clies.

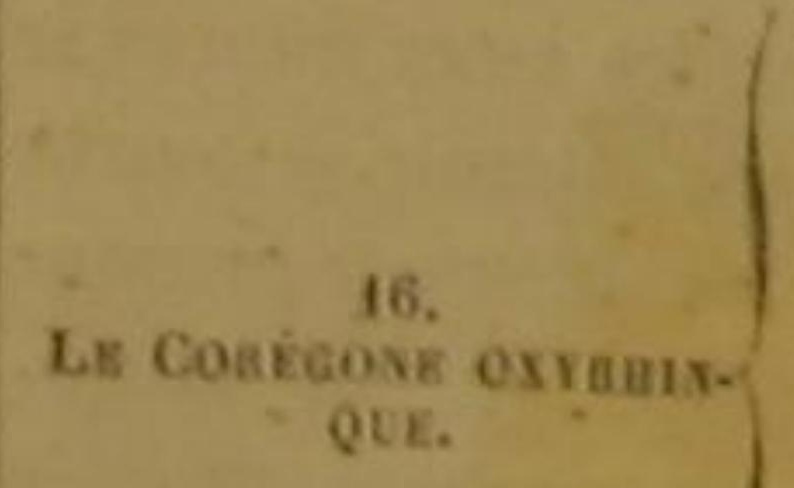
Quatorze rayons a la première n.
geoire di dos: quioze a celle de ranus; doure rane des branchies; point do máchoire supérieure plus arias

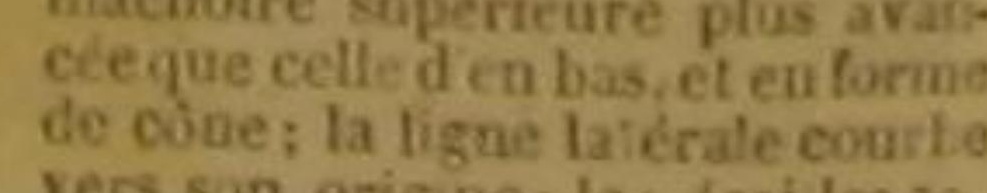
sez grandes; is couleur généraic
Hauntastre.

LE COREGoñ. LEUCI-
CHTHE. nze rayons a la première dorsale; quatorze à la nageonire de
Iamis : onze à chaque ventrale: la candale en croisant: la mi-
choire superieure trestarge et pius conrte que linferieure, qe
est recourbee et toberoutence

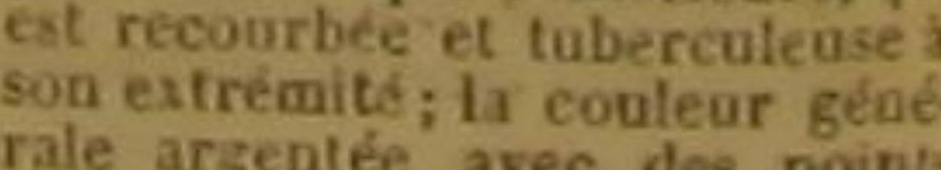

DES POISSONS.

Espècess.

/ Quatore rayoustiness.

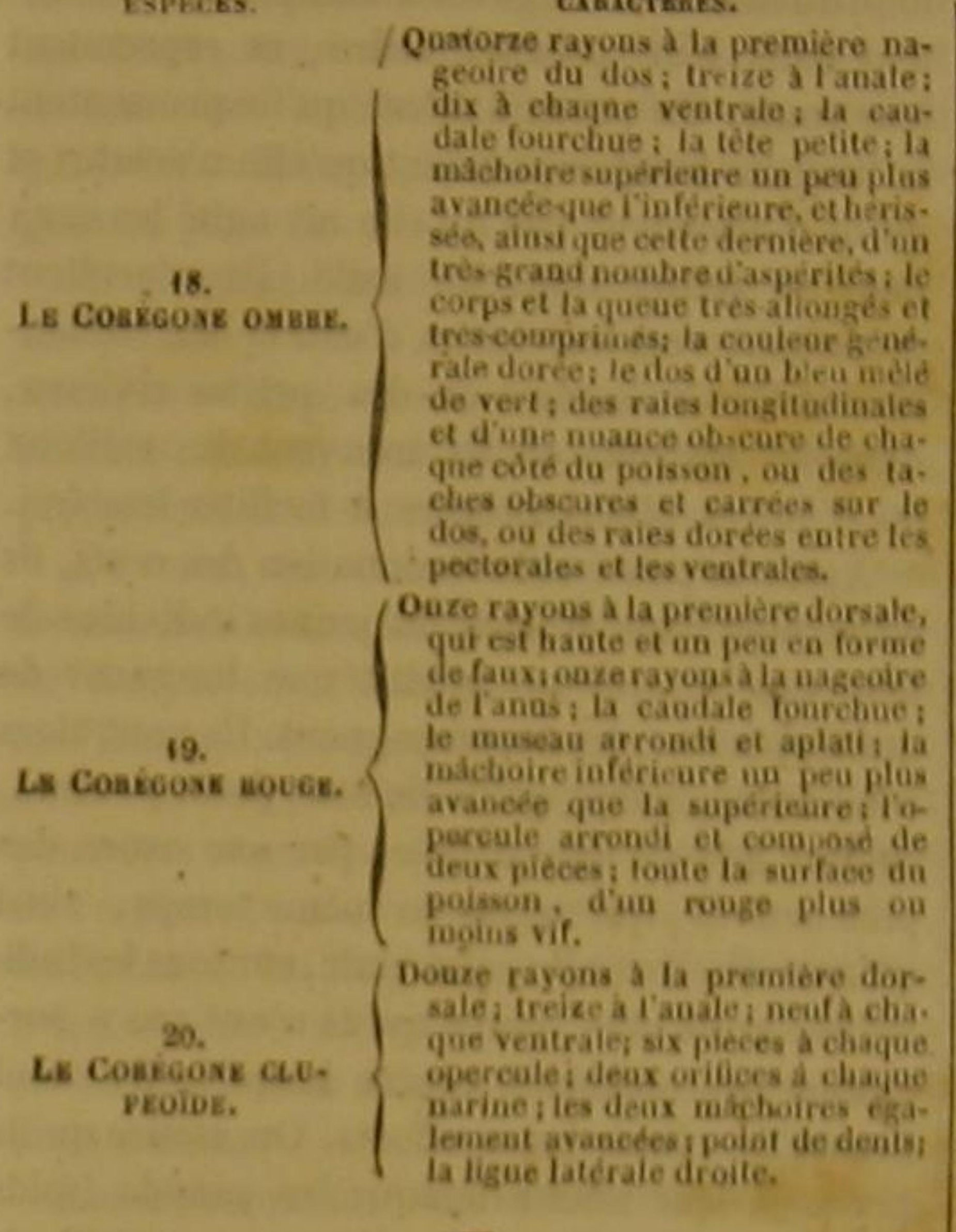

LE CORÉGONE LAVARET '

Coregonus (salmo) oxyrinchus et Coregonus ( satmo Wartmani, Cuv,; Salmo Lavarelus et S. oxyrinchus, Linn.; Salmo Lavaretus, Lac, ?.

Les corégones, ainsi que les osmères et les eharacins, ont de très-grands rapports avec les

- Fera, Ferrat, dans plus lacs de la Sulsse, on voisins de eette contree, - Sehnepel, en Allemigne. - Silkka, Sieg. Sia-kalle, en Livonie: - Sück, Stor sack, en Suéde et ei Norvége. - Hell, en Danemarek. - Guiniard, en AngleDaubeaton et Hasy, Enc, méth. - Id: Bonnaterre, pl, de

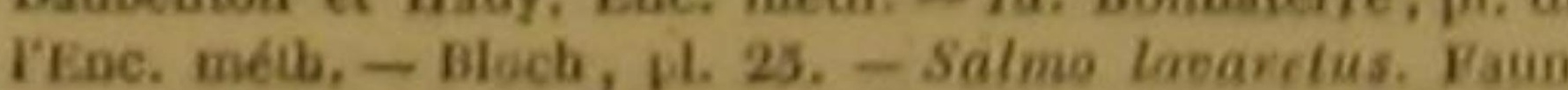

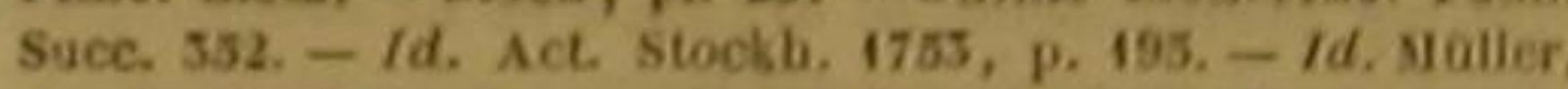
Prodr. Zool. Danie,, p. 48, n. 415. - Id Koelreuter, Now Comm. Petrop, 15, p. 504, - Id. Pallas, It. 3, p, 703, - Id S. G. Gmelin. It. 1, p. 60. - Id. Schranck, Schr. der Bert. a dorsali, ossiculorum quatuordecim. A Artedi, gen.-10. spec, 37, syn. 19. - Wiluzhby, Ichth., Lib. D, 6. fie. 1. Albula nobilis. Ilai, Pisc., p. 60, D. L - Lavarel. Rondelet, part. 2, cets.

' Sous le nom biquae de Lavarel, il est guestion de deax poissons differeats dans cet article, l'un est le Hculting ou

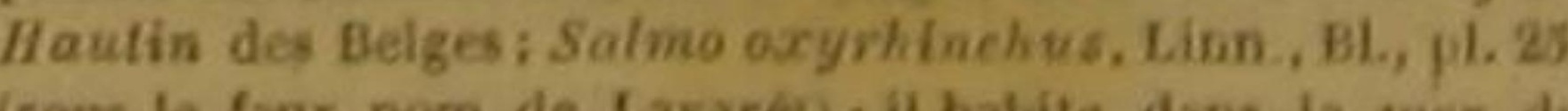

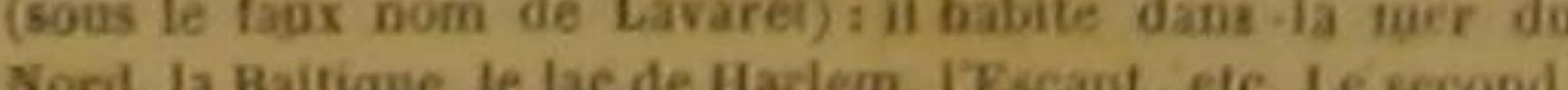

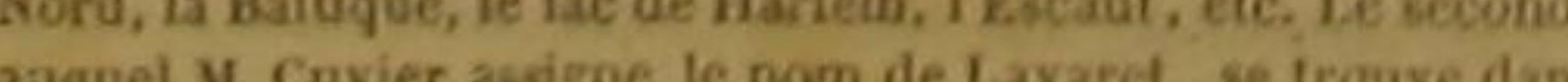
les lacs de la suisse, le Rthin, etc. : Bloch l'a figuré, fl. 15s, sous le nom de Salmo Wartmannii (V. ci apres, p. 507). I Ferat (Coregonus. Fera, Jurine), la Gravanche (Coregonus hyemalis, Jurine), et la Pales (Coregonus Paloea, Cav. sont trois autres especes anssi confondues avee les deux pre. dans ie sous-genre Lavakt, Coregonus, da grand genre

SAcnox. D salmones, dans le- menre desquels ils ont été compris par Linnée et par plusieurs autres auteurs. Les habitudes des corégones sont cependant moins semblables à celles des salmones que la manière de vivre des osmères et des characins, parce'que leurs milehoires ne sont pas garnies, comme celles de ces derniers, des dents très-fortes qui hérissent les máchoires des salmones, et que, moins bien mmés pour attaquer ou pour se défendre, ils sont forcés le plus souvent d'avoir recours a la ruse, ou de foir dans un asile.

Parmi ces corégones, une des espèces les plus remarquables est celle du lavaret.

Nous avons vu dans le tableau du genre des corégones, que la conformation de la téte du lavaret présente un trait particulier : la prolongation de la máchoire supérieure, qui compose ce trait, est molle et charnue. D'ailleurs, la tête est petite, et demi-transparento jusçn'aux yeux. La màchoire inférieure, plus courte que celle d'en haut, s'emboite dans cette dernière, et se trouve couverte par une grosse lèvre lorsque la bouche est fermée. Ces deux mäehoires sont dé. nućes de dents. La langue est blanche, cartilagineuse, courte et un peu rude; la ligne latérale presque droite, et ornée de petits points d'une nuance bsune; la couleur générale bleuâtre; to dos d'un bleu mêlé de gris; l'opercule, ainsi que les joues, d'un jaune varié par des reflets bleus; la partie ínferieure du poisson argentine, avec des teintes jaunes; presque toutes les nageoires ont la membrane bleuâtre, et les rayons blanchâtres à leur origine.

Le lavaret a d'ailleurs la membrane de l'estomae forte; le pylore entouré d'appendices; to canal intestinal court; I ovaire ou la laite double; cinquante-neuf vertebres à l'epine du dos; et trente-huit cótes de chaque cóté de cette colonne dorsalé.

On le trouve dans l'Océan Atlantique septentrional, dans la Baltique, dans plusieurs lacs, et notamment dans celui de Genève. II se tient ouvent dans le fond de ces lacs et deces mers : mais il quitte particulièrement sa retraite marine lorsque les harengs commeneent a frayer; il les suit alors pour dévoree leurs aufs. It se nourrit ausi d'insectes. M. Odier, navant médecin de Genève, ayant disséqué un individu de cette espèce, que l'on nomme Ferral 'sur I G'est le Coregonus Fera, Jurine, Espece partleuliere, D 
les bords du lac Léman, a trouvé dans son ca- | fond du fleuve. L'orage est-il dissipé, ils se remet. nal intestinal un grand nombre de larves de tent dans leur premier ordre, et reprennent libéllules ou demoiselles, mêlées avec une sub- leur route. On prétend même qu'ils pressentent trance d'une cour grise. II crut même voir la tempête longtemps avant qu'elle n'éclate; et la vessie natatoire pleine de cette même substance qu'ils n'attendent pas qu'elle ait agité les eaux la vessie natatoire pleine de cette mêmesubstance
vraisemblablement vaseuse, et de ces mêmes n'attendent pas qu' elle ait agité les eaux
pour se retirer dans un asile. Ils s'arrêtent larves; ce qui aurait prouvé que, par un excès cependant vers les chutes d'eau et les emboude voracité, l'individu qu'il examinait avait chures des ruisseaux ou des petites rivières, avalé une si grande quantité de larves et de dans les endroits où ils trouvent des cailloux matière grise, que de l'estomac elles étaient pas- ou d'autres objets propres à faciliter leur frai. matière grise, que de l'estomac elles étaient pas-
sées par le canal pneumatique jusque dans la
Après la ponte et la fécondation des cufs, ils vessie natatoire

Le lavaret multiplie peu, parce que beaucoup de poissons se nourrissent de ses aufs, parce qu'il les dévore lui-même, et qu'entourée d'ennemis, il est surtout recherché par les squales. On croirait néanmoins qu'il prend, pour la sûreté de sa ponte, autant de soin que la plupart des autres poissons. Il se rapproche des rivages lorsqu' il doit frayer; ce qui arrive ordinairement vers la fin de l'été ou au commencement de l'automne. Il fréquente alors les anses, les havres et les embouchures des fleuves dont les eaux coulent avecle plus de rapidité. La femelle, suivie du mále, frotte son ventre contre les pierrés ou les cailloux, pour se débarrasser pius facilement de ses œufs. Plusieurs lavarets remontent cependant dans les rivières : ils s'avancent en troupes; ils présentent deux rañgées réunies de manière à former un angle, et que précède un individu plus fort ou plus hardi. conducteur de ses compagnons dociles. On a cru remarquer que pius la vitesse de ces rivières est grande, plus ils la surmontent avee facilité, et font de chemin en remontant; ce qui confirmerait les idées que nous avons présentées sur la natation des poissons, dans notre Discours sur leur nature; et ce -qui prouverait particulièrement ce principe important, que les forces animales s'accroissent avee l'obstacle, et se multiplient par les efforts nécessaires pour le vaincre dans une proportion bien plus forte que les résistances, jusqu'au moment où ces mêmes résistances deviennent insurmontables. Lorsque les eaux du fleuve sont bouleversées par la tempête, les lavarets lutteraient contre les vaques avee trop de fatigue; ils se tiennent dans le

'Lettre écrite, en 1707 ou 1798 , par M. Odier à son fils, jeune homme d'une grande espérance, qui suivait slors mes couts

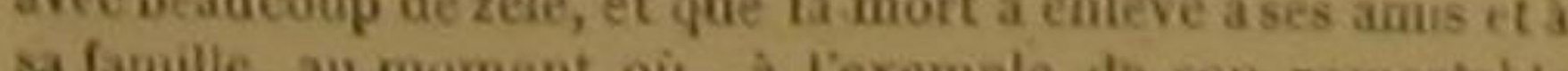
Dere, il allait parcourìr avec houneur la carrière des sciences retournent dans la mer; les jeunes individus de leur espece, qui ont atteint une longueur de quatre pouces, les accompagnent. Ils vont alor sans ordre, parce qu'ils ne sont point poussés, comme lors de leur arrivée, par une cause de plus actives, qui agisse en mème temps, ainsi qu'avec une force presqùe égale, sur tous les individus, et de plus, parce qu'ils n'ont pas à surmonter des obstacles contre lesquels ils aient besoin de réunir leurs efforts. On assure qu'ils pressent leur retour lorsque les grands froids doivent arriver de bonne heure, et qu'ils different au contraire lorsque I'hiver doit être retardé. Cepressentiment serait une confirmation de celui qu'on leur a supposé relativement aux tempêtes; et peut-être, en effet, les petites variations qui précèdent nécessairement les grand changements de P'atmosphère, produisent-elles au milieu des eaux, des développements de gaz des altérations de substances, ou d'autres accidents auxquels tes poissons peuvent être aussi sensibles que les oiseaux le sont aux plus légères modifications de l'air.

On pèche les lavarets avec de grands filets ; on les prend avee le tramail et la louve '; on es harponne avec un trident.

La chair des lavarets est blanche, tendre, et agréable au goût. Dans les endroits oủ la pêch de ces animaux est abondante, on les fume ou on les sale. Pour cette dernière opération, on les ide; on les lave en dedans et en dehors; on es met sur le ventre, de manière que l'eau don ils sont imbibés puisse s'égoutter; on les enduit le sel; on les laisse deux ou trois jours rangés ar couches; on les lave de nouveau. les sale une seconde fois, en les placant entre des couches de sel, et en les pressant dans des tonnes, que l'on bouche ensuite avec soin.
Si on lès prend pendant les grandes chaleurs, on est obligé, avantde les salẹ,, dé les fendre; et de leur ôter la tête et l'épine dorsale, qui se gáteraient aisément, et donneraient un mauvais goủt au poisson.

Ils meurent bientôt après être sortis de l'eau. On peut cependant, avec des précautions, les transporter dans des étangs, où ils prospèrent et croissent lorsque cespièces d'eau sont grandes, profondes, et ont un fond de sable.

Au reste, ils varient un peu et dans leurs formes et dans leurs habitudes, suivant la nature de leur séjour. Voilà pourquei les Ferrats-du lac Léman ne ressemblent pas tout ì fait aux autres lavarets. Voila pourquoi aussi on doit peut-être regarder comme de simples variétés de l'espèce que nousdéerivons, les Gravanches, les Palees et les Bondelles, dont M. Decandolle a fait mention dans les notes manuserites que ce naturaliste si digne d'estime a bien voulu nous adresser.

Les Gravanches ' ont le museau plus pointo le goût moins délicat, et ordinairement les dimensions plus petitesque les lavarets proprement dits. Elles habitent dans le lac de Genève, entre Rolle et Morges. Elles s'y tiennent trop conistamment dans les fonds; pendant onze mois de l'année, pour qu'alors on puisse les prendre : ce n'est que vers la fin de l'automne qu'elles paraissent. On les pèche à cette époque avec un filet, la nuit comme le jour, et on a essayé avec succès de les prendre á la lanterne.

Les Palées ${ }^{2}$ vívent dans le lac de Neufchátel. Ayantà peu près les mémes habitudes que le gravanches, elles ne paraissent que pendant un mois ou environ, vers le milieu ou la fin de l'automne. On en prend alors une grande quantite avee desfilets perpendiculaires, soutenus par de liéges, et maintenus par-des plombs et des pierres arrondies, qui roulent ou glissent facilement sur les fonds de cailloux, préférés par les palées. On sale beaucoup de ces eorégones, qu'on envoie -au loin daris de petites barriques.

Il parait que les Bondelles ne sont que de jeunes palées. On les péche pendant toute l'année sur tous les bords du lac de Neufchátel. On en mange beaucoup de fraiches en Suisse, et on sale les autres comme les sardines, auxquelles

'La Gravanclie est une espéce distincte, décrite par M. de 'M- Cuvier sêrare, corome espéce distincte, la Palée noir (Coregonus Palca.) D. on dit qu'elles ne sont pas inférieures par leur gout :

LE COREGONE PIDSCHINN?

Coregonus Pidschian, Licep.; Salmo Pidschian, Lino., Gmel, :.

Le Corkjone Sehokur 4, Coregonus Schokur, Lacep,i Salmo schokue, Linn., Gm. 3, - C. nes ?, Coregonus nasus, Lac: satmo, nasus, Limn.. Gmel. ', - C. farge ', Coregonus a

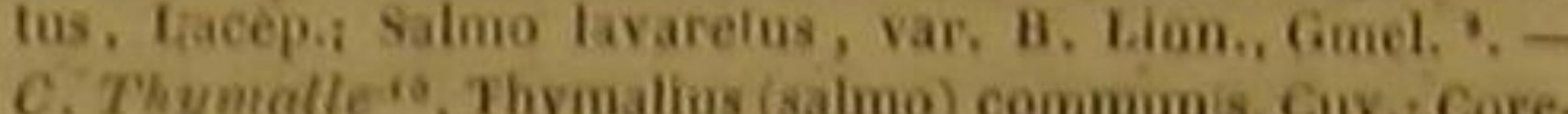
conus Thymallus, Lacep, s Salmo Thymallos, Linn Gere Bloch ", $-C$. Vimber', Coregonus Vimba, Lacep i Salme Vimba, Lhño, -Gmel, " - - c poyageur ", Coregonms migratories, Lae, i Satmo migratorias, Linn., Gm. ", - C. Muller a, Coregonus Mulleri, Lac, Satmo Motleri Cosimo stroemi, binn, Gmel, "r, $-c$, autumnal ",

Une variété du premier dó ces corégones, a laquelle on a donné le nom de muchsan, et is rayons a ta membrane branchiale décorégone lavaret,

'Pallas, It. 5, p. 705, n. 5.

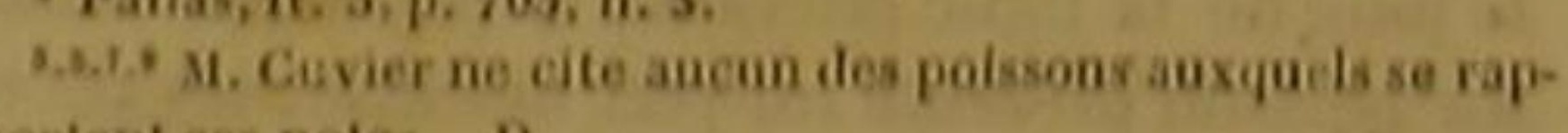
4 Salmone och bo

- Sotmone schecurer, Bonnatere, pl, de IEuc, méth. Pallas, I. 5, p. 703, a. 4. - Tschar, Lepéchio, 11. 3, p. 227. ab. 15 .

- II eisfisch, a Dantzig. - Bredte aesche, en Poméranie. - Sehnepel, A Hambourg, - Sack, en Daneciarch. - Lap1t. 26. - Salmone large, Bonnatere, pi. da I' Ene, méth. o Ombre d' Auvergne, - Temelo, en ilalie, - Kresiling avant Iago d'un an, lser, apres l'áge d'un an, et avant lage de deur aus, Rscher ling, apres l'age de deux ans, en suisse. - Asch, Escha, Escher, en Allemague - Sprensting. Mayling, en Autriche, - Charius, en hussie, - Hari, en Sialling - Id. en Norvege. - Z Jor hija, en Laponte. - spatt. en Angleterre - Salmone, ombre de rivitire Dabienton ei HaQy, Ene, méth. - Id, Bonnaterre, pl. de I'Enc, méli. Bloch, pl. 24. - Maller, Prodr. Zool. Dan., p. 49, n. 4t6. - Coregonus maxilta superiore long ore, pinna dorsi ossica. - borum vigint triom. Artedi, gen. 10, nyn. 20, ppec. A. Qjpanzos. Rlian, lib. 14, c. 22, p. 831, - Thymalus, seu hyymus. Gesner, p. 978,979 et 1471 . - Ascher, id. Thierb. 774. - Thymathus. Ambros. Hexam. 1. S, C. 25. S. 11.-

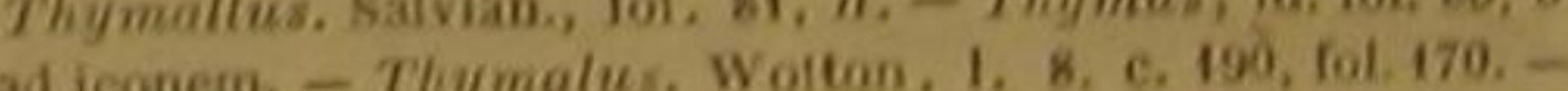
Thymalus. Aldrov, I. 5, c. 11. p 594-Jonston, i.5.t. 4. e.5,

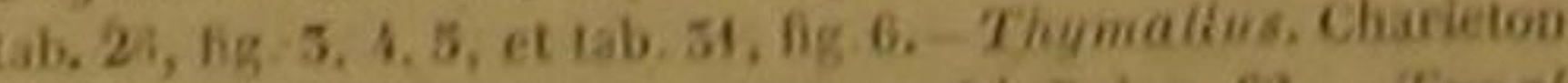
p. 155, - Id. Willogt by, p. 187, - Id. Mal, p. 62, - Tunato ius. Albert. Anim, 1.24. - Thymo. Nondelet part. 2, c.10. - Faun. Suecie, 55s. - Kram. Bl, p. 350, n. 2. - Grono

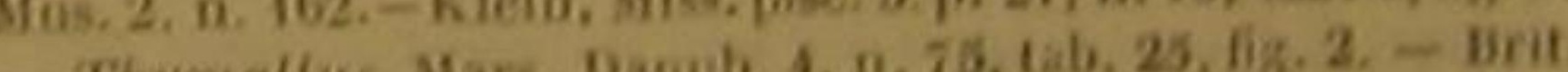
Zool, 5. p. 262 n. 7 "Da soms pare OsBar. Thymallus, dans le grand genr

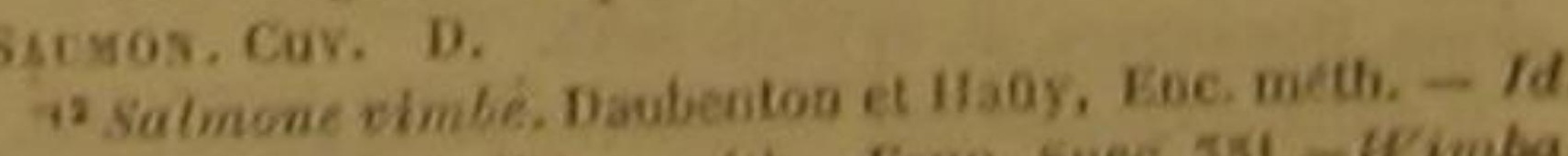
Bonnaterre, pl. de I'Eoc, wéth, - Fam, suec, 351 - Wimber. 11. Wgoth., p. 251 . 
on doit la connaissance, ainsi que celle du , vit en France : il a été d’ailleurs observé dans pidschian, à l'illustre Pallas, a le dos plus élevé presque toutes les contrées montueuses, tempéque ce dernier. On trouve l'un et l'autre en Si- rées ou froides de l'Europe et de la Sibérie; il bérie, de même que le schokur, dont la tête est même si commun en Laponie, que les habiest petite, moins comprimée et plus arrondie tants de ce pays se servent de ses intestins pour par-devant que celle du lavaret.

C'est également dans la Sibérie qu'habite le corégone nez, dont la longueur est ordinairement de dix-huit pouces.

mon et de de jeunes poissons, d'œuf́s de sau-

longueur de dix-huit pouces, et pèse quelquepartie des contrées dans lesquelles on pêche le fois plus de quatre livres.

lavaret, avec lequel il a beaucoup de rapports. Son poids est de quatre ou six livres.

On voit une rangée de petites dents sur les deux mâchoires du thymalle. On trouve aussi quelques dents très-petites sur le devant du palais, et près de l'œsophage. La langue est unie; le corps allongé, ainsi que la queue; le dos arrondi ; le ventre gros; les écailles sont dures et épaisses. La couleur générale est d’un gris plus ou moins mêlé de blanc; les raies longitudinales sont bleuảtres; une série de points noirs règne le long de la ligne latérale; la partie supérieure du poisson présente un vert noirâtre; les pectorales sont blanches; une nuance rougeàtre distingue les nageoires du ventre, de l'anus et de la queue. La première dorsale s'élève comme une petite voile au-dessus du corégone; elle est peinte d'un beau violet, avec la base et les rayons verdâtres, et des raies ainsi que des taches brunes.

La membrane de l'estomac du thymalle est presque aussi dure qu'un cartilage : le foie jaune et transparent; l'épine dorsale composée de cinquante-neuf vertèbres, et fortificé de chaque côté par trente-quatre cotes.

Les anciens ont connu le thymalle. Élien et l'évèque de Milan, saint Ambroise, en ont parlé. Ce poisson aime l'eau froide et pure, qui coule avec rapidité sur un fond de cailloux ou de sable. II n'est done pas surprenant qu'on le trouve particulièrement dans les ruisseaux ombragés des gorges des montagnes. Le nom d'Ombre d'Auvergne, qui lui a été donnë, indique qu'il

43.43.121 M. Cavier ne cite aucun des quatre poissons aux"Geore II 4, p. 182 .

"Georg. It 4, p. 182.

- valmo Stremii. Linnée. - Strom. Sondmor. 1, p. 292.

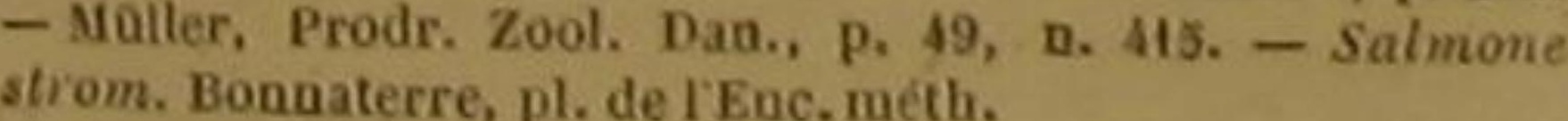
" Salmonesangchalle Bonaterre,

Pallas, It. 5, p. 705, n. 13- Omal. Lepéching II. méth. tab. 11, fig. 1.
En automne, il descend ordinairement dans les grands fleuves, et de là dans la mer, d'où il remonte, vers le milieu du printemps, danis les leuves, les rivières et les ruisseaux qui lui conviennent. On le prend surtout lors de ses passages, et notamment quand il remonte pour aller frayer. On le péche avee le colleret, la louve ', nasse, et à la ligne. Sa ehair est blanche, ferme, douce, très-bonne au goût, principalement dans les temps froids, très-grasse en automne, très-facile à digérer dans toutes les saions; et il est d'autant plus recherché, qu'on a attribué à son huile ou à sa graisse la propriété d'effacer les taches de la peau, et mème les marques de la petite vérole.

II ne multiplie pas beaucoup, parce qu'il est rès-délicat, et I'une des proies les plus agréables aux oiseaux d'eau. II meurt bientot, non-seulement quand il est hors de l'eau, mais encore lorsqu' il est dans une eau tranquille; et si l'on veut le conserver dans des huches, il faut qu'elles soient placées dans un courant.

Il-répand, dans plusieurs circonstances, une deur agréable, qu'Élien a comparée à celle du thym, et saint Ambroise à celle du miel, et qui parait provenir de certains insectes dont il se nourrit, et qui, tels que le tourniquel (gyrinus natator), sont plus ou moins odorants.

Le corégone vimbe habite en Suède.

Le voyageur se trouve en Sibérie, dans le lac Baīkal, d'oú il remonte, pour la ponte ou la féjettent. Il a un pied et demi de longueur, jaunes et très-bons à manger ${ }^{2}$.

' Voyez la description du colleret dans l'article du Centro. pome sandat; et celle de la louve, dans larticle du Pétro"10 rayog a is

20 rayous à la membrane des branchies du corégone pids. branchiale dn corégocetorale. - rayons a la membrane condation des aufs, dans les rivières qui s'y partie supérieure grise, la chair blanche, les œufs
Le müller a été pẻché dans les eaux du Danemarck. dans 10

Le corégone autumial passe l'hiver dans l'océan glacial arctique. Les individus de cette espèce en partent, après la fonte des glaces, pour remonter dans les fleuves. Ils vont jusqu'au lae Baikal, et dans d'autres lac̀s très-éloignés de la mer; et lorsque l'automne arrive ; ils se réunisent en grandes troupes, et redescendent jusqu dans l'Océan. Ils perdent très-promptement la vie lorsqu'ils sont hors de l'eau. Ils sont gras; $e t$ ont dix-huit pouces de longueur.

\section{LE CORÉGONE ABLE ',}

Coregonus Albula, Lac; Salmo Albula, Linn., Gmel. ,. Le Coregone Peled ", Coregonus Peled, Lacep., Cuv, Salpo

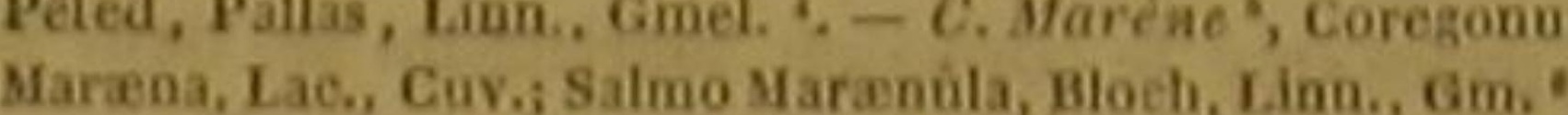
-C. marěnule J, Coregonus Marænula, Cuv, Lae; s salm Marenula. Bl., Lion., Ginel. @- - c, Wartmann', Coregonos Wartmannii, Cav, Lac.; Salmo Wartmanni, Bloch,

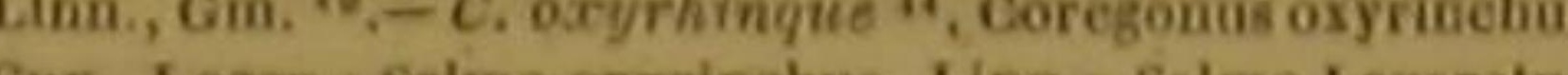
Cav,, Lacep; salmo oxyrinchus, Lian; sal wo Lavaretos,

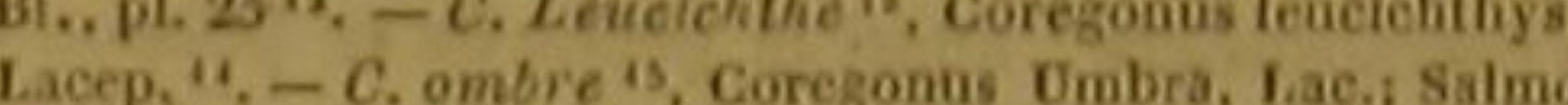
Thymus, Bonnaterre ", $-c$, rouge ", Coregonus ruber,
Lac, "1.

L'able, dont l'Europe est la patrie, a huit pouces, ou à peu près de longueur, le dos d'un ver

9 rayons a ta membrane des branchies du corégone nez, 18 a chaque pectorate. -8 rayons a la membrane branchiale do corégone large, 15 a chaque pectorale, 20 a la nageoire de in queae. - 10 rayous a ia membrave des branchies du corerayons a chaque pectorale du corerane 18 a la caudale. -16 la membrane branchiale do corégone voyagenr, 17 rayons pectorale, 20 s la nageoire de la queue -9 rayons a la menbrane des branchies du corezone autumnal, 16 a chaque pectorale.

Sik-loja, Stint, en Suède.-Moika, Rapis, en Finlande. Blicta, dans plus. contrées du nord de l'Europe. - Faun. Suec. s53. - Salmone able. Daubenton et Haay, Ene. méth. -Id. Bonnaterre, pi. de IEnc. meth. - Kaireoter, Nov. Comm. Petropol. 18, p. 505. - . Goregonas edentulas, 2 is. Cuvier ne dit rien de ce poison qui, anos doute, a te confondo avec d'antices expeces, Toutelois il appirtient an sous genre LAVABET, Coregonus, du grand genre SAUsos. D. "Lepéchin, It. s, p. 226, tab. 12 Du sous-genre LAvaEt (Coregonus), Cuv., dans le grand genre Sscmor. D

${ }^{5}$ Grande marene. Bloch, pl. 27. - Salmone marene Bonnaterre, pl. de l'Enc. méth.

selon M. Cuvier. D.

'Murcene, en Prusse. -Moréne, en Sibérie et dans le Mecklembourg. - Stint, en Danemarck. - Fikloja, en suede. - Smanfisk, Blege, Laki-sild, Vemme, en Nor-
vège. - Pelite maríne. Bloch, pl. 2s, fig. 5. - Cyprinus vège. - Pelite maríne. Bloch, pl, 28, fig. 5. - Cyprinus brunâtre, les cótés argentins, et des points noitres sur les nageoires.

Le peled vit dans la Russie septentrionale. S chair est grasse, et sa longueur ordinaire de dixhuit pouces.

La marène a la ligne latérale un peu courbée; les yeux gros, et les écailles grandes, minces et brillantes. Le nez, le front et le dos, sont noirs ou bleuátres; le menton et le ventre blanes; les cotés argentins; les joues jaunes; les opercules bleuâtres et bordés de blane; les nageoires, excepté l'adipeuse qui est noirátre, bleues, bordées de noir, et violettes à la base; les nuances de la ligne latérale relevées par une série de plus de quarante points blanchátrés.

On trouve ce corégone dans le lae Maduit, et dans quelques autres grands laes de la Poméranie ou de la nouvelle Marche de Brandebourg. Il est quelquefois long de plus de trois pieds. Sa chair grasse, blanche et tendre, a un trèsbon goût. Son canal intestinal est très-court; mais on compte près de cent cinquante appendices auprès du pylore.

Les marènes se plaisent dans les eaux profondes, dont le fond est de sable ou de glaise. Elles

Willoghby, Ichth., p. 229. - Nai, Pisc, p. 107, n. 12.Kleio, Miss. pisc. 8, p. 21, 10, tab, 6, fig.2.

'Da sous geare LAvaikt, dans le grand geare sauron,

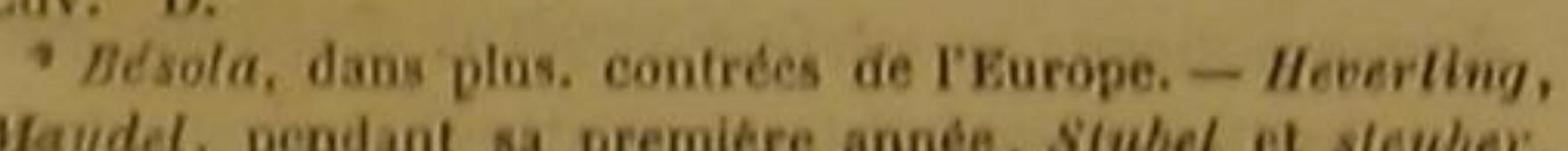
Maydel, pendant sa premiére année, Stubel et stenber, nnée, Rhenken, pendant sa quatriéme année, Malb felch, pendant sa cinquieme antée, Dreyer, pendant sa sixiem année, Blaufetchen, pendant sa septieme année et les années suivantes, en Allemagne, - Ombre-bleu. Bloch, pl. 105

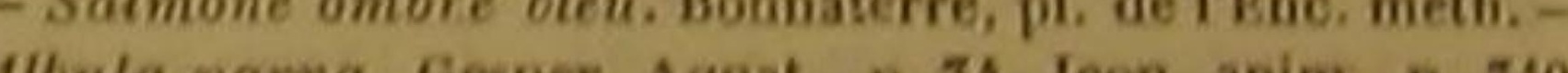
Thierb., p. 188, bener, Aquat, p. 3r. Icon. anim., p. 340 - Albula parra. Aldrov. Pisc, p. 6s9. - Id. Jonstom, Pise, p. 175. - 1d. Willnghthy, Ichth., p. 384. - Id. Mai, Pisc.

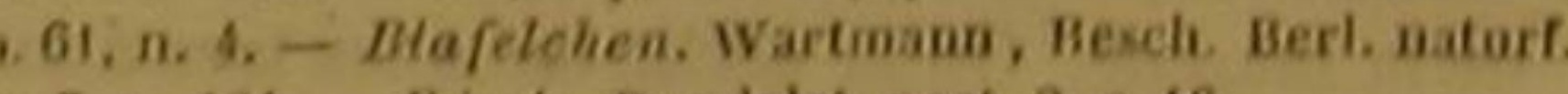
c. 5, p. 184. - Bisole. Rondelet, part, 2, c. 16 le genre suvior, selon

"Salnone oxyrhinque, Daubenton et Haßy, Enc, méth. - superiore longiore conica. , Artedi, gea. 10, sya. 21 . Gronov, Mus. 1, p. 48.

Da tousgenre LAvaget, dans le genre Sismos, Cav, D. Salmone leuciehthe. Bomaterno, plidet.

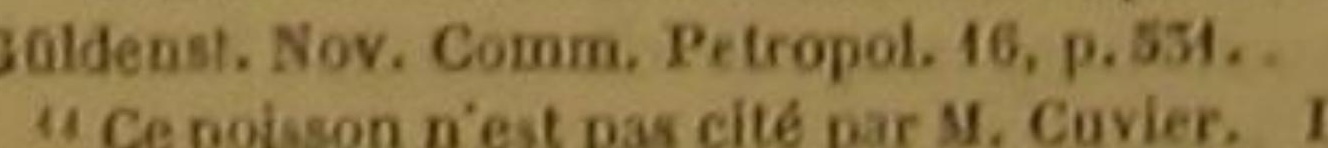

is Salmone ombre (almo thymns). Boomaterre, pl. de Enc. méth. Ombre de riviere. Rondelet, part, 2, poinos de riviére, c. 3. - - Coregonus maxilla superiore lon. a giore, etc., Var, B. Artedi, syn., p. 21.

"Non meationse par sl. Cavier. D. 17. Trutta masid

"Non cité par M. Cavier. D, 
y vivent en troupes nombreuses; elles ne quittent , Gall, qui l'a décrit avec beaucoup d'exactitude. leur retraite que vers la fin de l'automne, pour II se treuve dans plusieurs lacs de la Suisse, et frayer sur les endroits remplis de mousse ou surtout dans celui de Constance, où, depuis le d'autres herbes, et dans le printemps, pour cher- printemps jusqu'en automne, on prend plusieurs cher de petits animaux à coquille, dont elles aiment-beaucoupà se nourrir; et s'il survient une tempête, elles disparaissent subitement. Elles ne commencent à se reproduire qu'à l'áge de cinq ou six ans, et lorsqu'elles ont déjà un pied ou plus de longueur. Pendant l'hiver, on les pèche sous la glace avee de grands filets dont les mailles sont assez larges pour laisser échapper les individus trop petits. Elles meurent dès qu'elles sortent de l'eau. Cependant Blech nous apprend que M. de Marwitz de Zernickow est parvenu, en employant des vaisseaux larges, profonds, dont le fond était garni de glaise ou de sable, ot dans l'intérieur desquels la chaleur ne pouvait pas pénétrer, à transporter un très-grand nombre de ces corégones dans ses terres éloignées de huit lieues du lac Maduit, et à les acelimater dans ses étangs.

Bloch a le premier décrit la grande marène. La marénule; ou petite marène, est connue depuis longtemps. Schwenckfeld et Schoneveld en ont parlé dès le commencement du dix-septième siècle. Sa tête est demi-transparente; sa langue cartilagineuse et courte; sa longueur de huit à donze poncẹs; sa surface revêtue d'écailles minces, brillantes et faiblement attachées ; son épine dorsale composée de cinquante-huit vertèbres ; le nombre total de ses côtes, de trente-deux; sa ligne tatérale ornée de plus de cinquante points noirs; la couleur de ses nageoires, d'un gris blanc; sa eaudale bordée de bleu; sa chair blanche, tendre, et de très-bon goût.

Ses habitudes ressemblent beaucoup à celles de la marène. On la pêche dans les lacs à fond de sable ou de glaise, du Danemarck, de la Suede et de l'Allemagne septentrionale. Il est des endroits où on la fume après l'avoir arrosée de bière. Ses cufs sont plus petits que ceux de presque tous les autres corégones.

Le wartmann a les écailles grandes; un appenidice assez long auprès de chaque ventrale; Lestomac dur et étroit; plusieurs cocums; le foie gros; le fiel vert; la vessie natatoire simple et située le long du dos; la tête petite et argentine comme le ventre; les nageoires jaunâtres ou blanchâtres, et bordées de bleu; une série de points noirs le long de la ligne latérale.

II porte le nom d'un savant médecin de Saintmillions d'individus de cette espèce.

On le marine; on l'envoieau loin ; et lorsqu'il est frais, il est regardé comme le meilleur poisson du lac. Il n'est done pas surprenant qu'il ait été observé avec beaucoup de soin, et qu'on ache que e'est vers sa septième année qu'il a près de deux pieds de longueur. le recherche à cette époque, mais alors sa chair est moins tendre que pendant l'été. Voilà pourquoi c'est particulièrement dans cette dernière saison qu'un grand nombre de bateaux partent chaque soir pour aller le pècher. Les filets ont soixante ou soixante-dix brasses de hauteur, parce que le corégone wartmann se tient souvent à une profondeur de cinquante brasses. II s'approche cependant à vingt, et même à dix une grosse pluie, ou qu'un orage règne dans l'atmosphère : aussi la pêche de ce poisson estelle beaucoup plus abondante dans ces moments d'agitation. Mais lorsque le froid commence à régner, le wartmann se retire à une si grande distance de la surface du lac, que les filets ne peuvent pas y atteindre. Ce corégone se nourrit d'insectes, de vers, de plantes aquatiques. Vers l'age de trois ans, il a quelquefois une maladie qui lui donne une couleur rougeâtre, et qui empèche qu'on ne veuille en manger.

L'oxyrhinque est un des habitants de l'Océan Atlantique septentrional.

Le leucichthe a été vu dans la mer Caspienne. Sa longueur est de plus de trois pieds. Ses écailles sont unies et presque arrondies; le sommet de la tête est convexe, lisse, dénué de petites écailles; les yeux sont gros, et peu rapprochés l'un de l'autre; la langue est triangulaire et un peu rude; des dents, que l'on distingue au tact plutôt quà l'œil, hérissent le devant du palais; chaque opercule eșt composé de quatre lames. Les pectorales sont blanches; la nageoire adipeuse est transparente et pointillée de noir; les ventrales sont blanches, avec des points brunâtres et des appendices triangulaires; l'anale est rougeâtre et táchée de brun; le dos présente des nuances blanchâtres mêlées de noir.

C'est dans plusieurs rivières d'Allemagne et d'Angleterre, ainsi que d'autres contrées euro
Il fraie vers le commencement de l'hiver. On brasses de la surface de l'eau, lorsqu'il tombe

DES POISSUNS.

809

péennes, que sé píút le corégone ombre. Il a la foin, et a eu la bonté de me faire parvẻnir ie langue lisse; deux tubercules garnis de petites dents, et placés auprès du gosier; les nageoires tachetées de noir, et peintes d'un rouge noirâtre '.

Le corégone rouge est très-allongé. Ses ventrales sont presque aussi grandes que la première dorsale, ou que celle de l'anus ; elles sont aussi plus près de la tête que cette première nageoire du dos, et moins éloignées du bout du museau que de l'anale. La nageoire adipeuse est recourbée et en forme de massue; les pectorales ont un peu la figure d'une faux. Ce corégone appartient à la mer qui baigne les rivages américains et voisins des tropiques. $\mathrm{Si}$, contre mon attente, on ne trouvait pas plus de quatre rayon a la membrane branchiale de cet osseux, il faudrait l'inscrire parmi les characins.

LE CORÉGONE CLUPÉOIDE ${ }^{2}$.

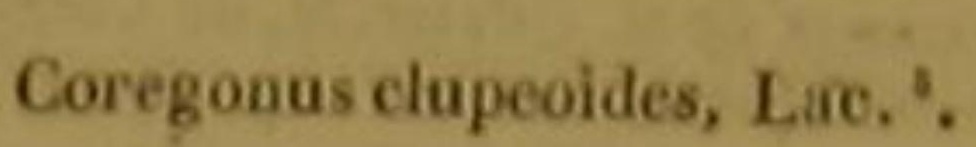

Les naturalistes ignorent encore l'existence de ce corégone, au sujet duquel M. Noël vient de m'adresser une note manuscrite très-détaillée Ce savant m'apprend que l'on désignè, en Ecosse, par la dénomination de Hareng d'eau douce, un poisson du Lochlomond, le plus beau lac des montagnes de I'Ecosse occidentale. On avait écrit à $M$. Noël que ce même poisson était un hareng de mer, acclimaté dans l'eau douce, et que cet osseux avait pu remonter dans le Lochlomond par la Clyde et la petite rivière de Leven. M. Noël, empressé de vérifier ce fait, alla visiter le Lochlomond en août 1802, se procura plusieurs clupéoïdes à Inchtonachon, une des fles de ce lae, les examina avec beaucoup de

46 rayons à chaque pectorale du corégone able, 55 a la nageoire de la queue. -16 rayonis a chaque pectorale din corégone pelcd, 22 a la carudale. - IA rayons a chaque peclorale du conch,

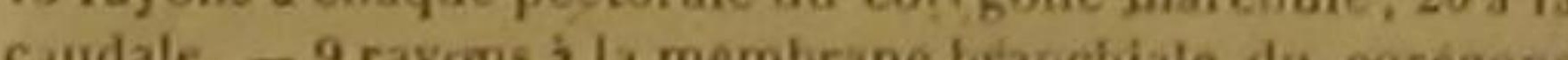
warimann, 17 a cha cue pectorale, 25 a la nagepie de queue. -17 rayons à chaque pectorale da corégone oxyrhin. que, -10 à la membrane branchiale du corégone leucichitlie, 44 à chaque pectorale, 27 à la eandale. -16 rayons à cliaque pectorale du corégone ombre, 19 à la nageoire de la quene.chasue ventrate. chaque pectorale da coregone rouge, 8 i 2 Wresh water hes *U. Cuvier ne Liit pas Span, Pollock, en Écosse. curime appartenant an sons genre Le poison, maisil cile, Salmo clupeoídes de Pallas, qui doit étre une espèce difItrente de celle qui fait le sujet de ost article. D. résultat de son observation.

J'ai dù placer, parmi les corégones, cé clupéoïde, qui a beauconp de rapports, en effet, avec les Chupees, et particulièrement avec le hareng, mais qui, d'après Mr. Noë, n'a pas les caractères des clupées, et présente la nageoire adipeuse des salmones, des osmères, des coregones, ete. '.

Ce clupéoìde a la tête petite, un peu convexe par-dessus, et dénuée de petites écailles; trol petites pièces autour de l'cil, qui est mand et vif. Ses oufs sont d'un rouge orangé, sa chair est blanche, feuilletée, et très-délicate. II frai au commencement de l'hiver. On to cherche, pendant l'été et pendant l'automne, dans les endroits du lac ou il y a le moins d'eau. On le prend avee un filet. Il vit en troupes; et sa longueur est quelquefois de plus de quinze pouces.

CENT QUATRE-VINGT -UNTEME GENRE. Les CHAMACINS ${ }^{2}$.

La bouelo di l'extrémild du museau; la tole comprimde; des ceailles facilement visibles sur le corps ot sur la queue; point de grandes lamessur les cotes, de cuirasse, de piquants aux opereutes, de rayons denteles. ni de barbillons; deux nageoires dorales; la seconde adipouse ef dénuée de rayons; quatro rayone an plus d la membrane des branchies.

esperes.

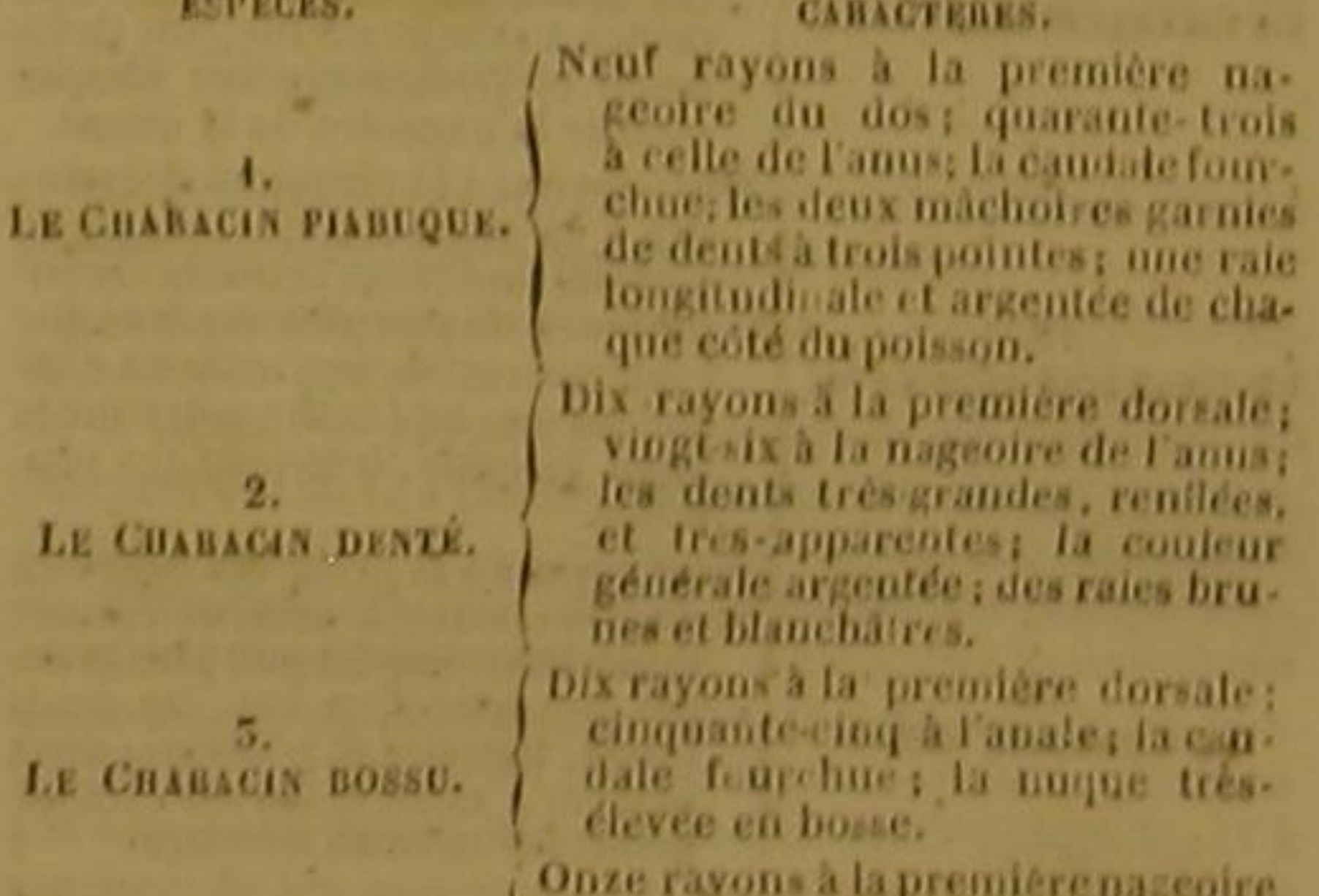

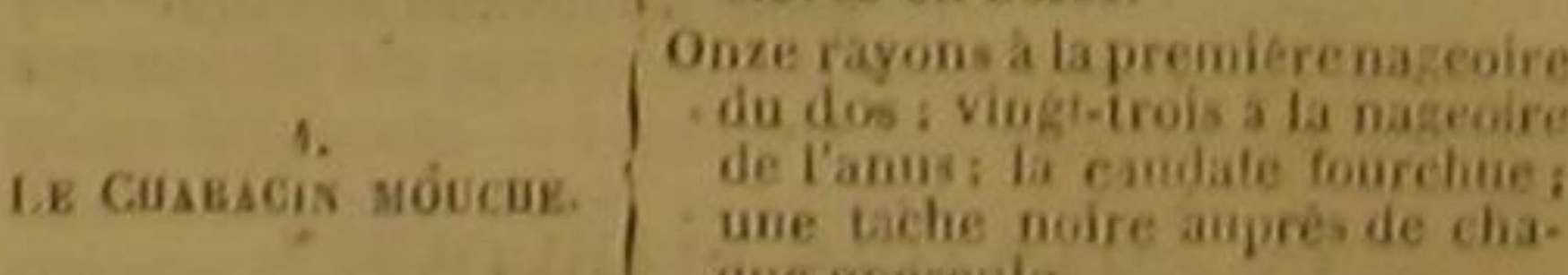

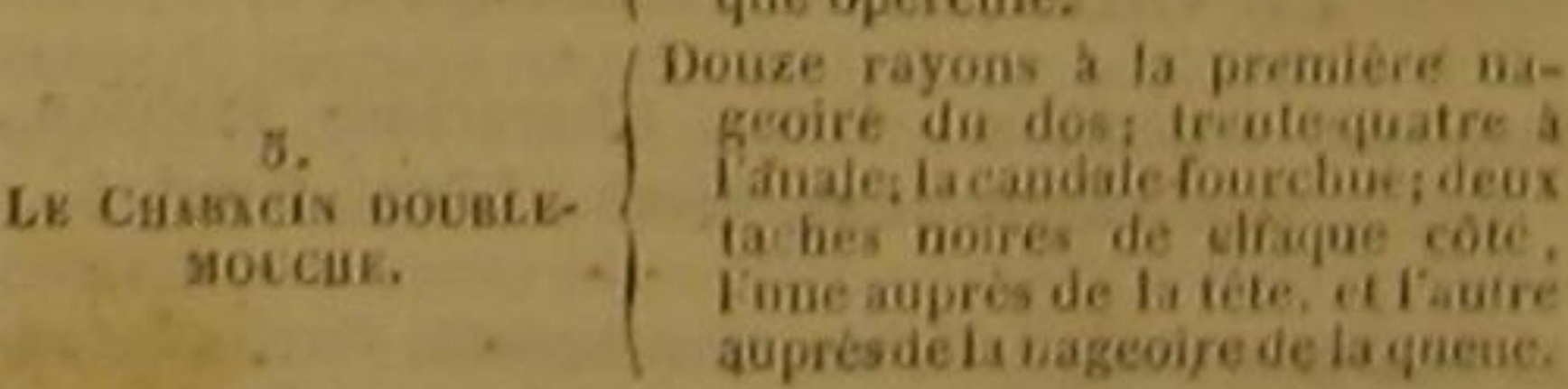
18 rayons à la membrane branchiale du coréngone clu.

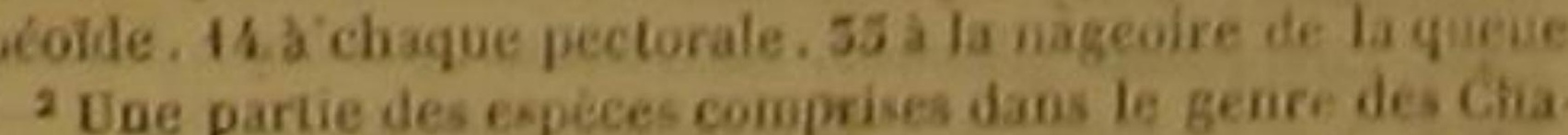
racins se rapporte sux sous geures que $\mathrm{Al}$. Cuvicr admet dias le grand genre Saumon, sous les noms de Pancequ, Rsii,
Cusinate el Citususs. D. 


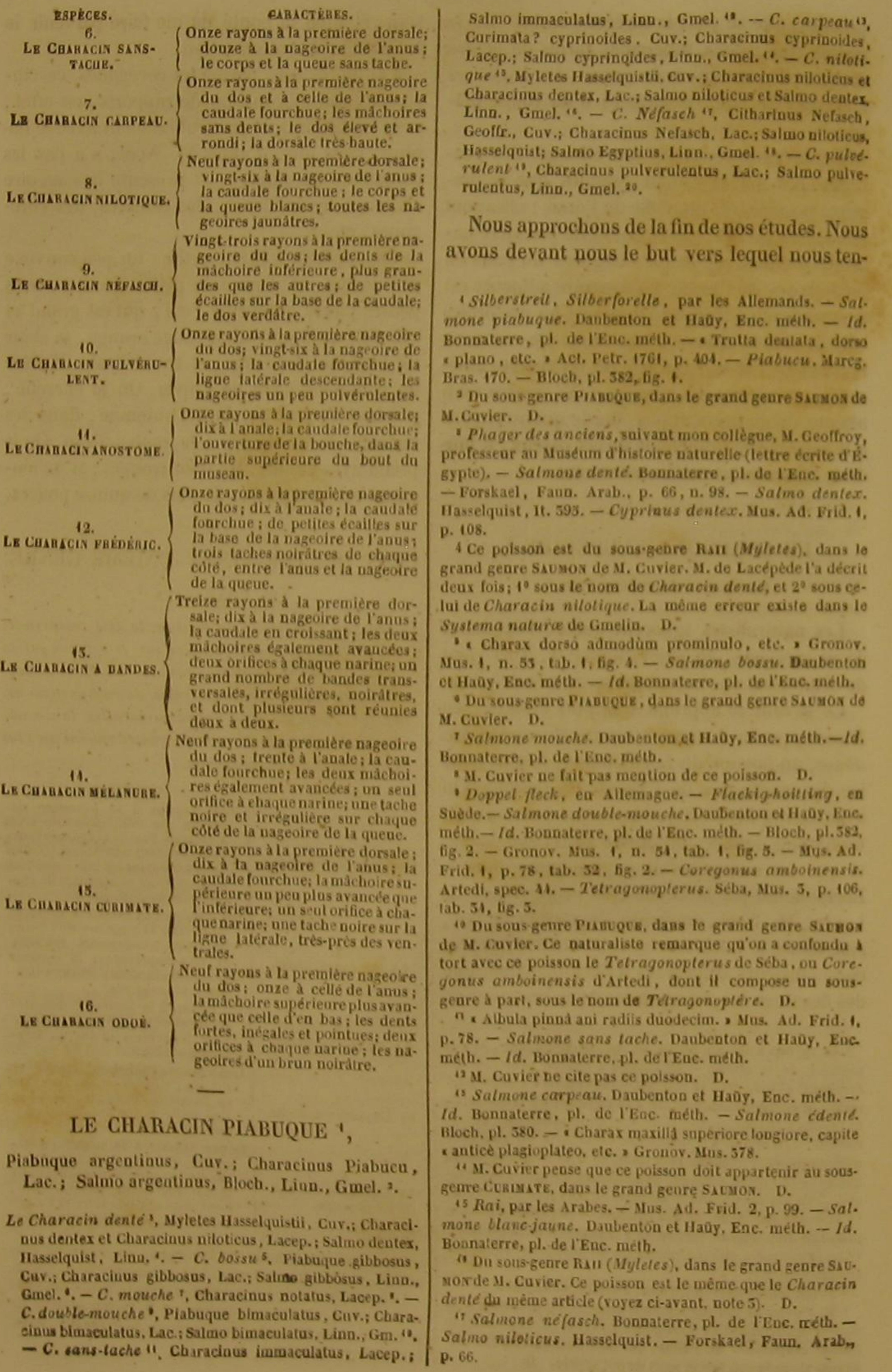

dons depuis si longtemps. Plus exercés maintenant, hâtons notre marche, et contentonsnous de remarquer rapidement :

La petitesse de la tête du piabuque; la saillie de sa mâchoire inférieure, au delà de celle d'en haut; la surface unie de sa langue; la membrane en forme de faucille, qui est tendue à son palais; l'orifice unique de chacune de ses narines; la courbure de sa ligne latérale; le verdâtre de son dos; le gris de ses nageoires; sa longueur, qui ne passe pas un pied; la blancheur et la délicatesse de sa chair; la facilite avec laquelle on te prend dans les rivières de l'Amérique méridionale, en attachant à l'hamecon un ver ou un mélange de sang et de farine :

La couleur blanchâtre des nageoires du denté et le rouge dont brille le lobe inférieur de sa caudale dans les eaux du Nil, ou dans celles de quelques fleuves de la Sibérie :

Le séjour de choix que fait dans la mer qui baigne Surinam le characin bossu; la petitesse de sa tête, que la bosse de la nuque fait paraitre comme rabaissée; l'aiguillon incliné vers la queve, et placé auprès de la base de chacune de ses pectorales; le roux argenté de sa couleur générale ; et la tache noire de chacun de ses cótés :

La forme pointue de la tête du characin mouche, qui vit à Surinam, comme le bossu.

Le peu de largeur de l'ouverture de la gueule du characin double-mouche; l'égale prolongation de ses deux mâchoires; la double rangée de dents qui garnit sa mâchoire d'en haut; la surface lisse de sa langue et de son palais; le donble orifice de chacune de ses narines; la forme tranchante du dessous de son ventre; l'arrondissement de son dos; la direction de sa ligne latérale, qui est droite, le bleu argentin de ses cốés; le verdâtre de sa partie supérieure; les nuances jaunes de sa dorsale, de ses pectorales et de ses ventrales; la couleur brune de ses autres nageoires; la blancheur et la graisse délicate que présente sa chair dans les rivières de Surinam et dans celles d'Amboine.

Le blanc argentin du characin sans tache, que l'on a pêché én Ámérique.

"Du sous-genre Citaiuse, dans le grand genre SAusox, Cuv. D.

Drid. 2, p. 99. - Salmone pointille. Dauberton 30
La tête comprimée et dénnée de petites écilles du carpeau; la grosseur de son museau arrondi; la forme de ses lèvres charnues, qui compense un peu son défaut de dents aux máchoires; la surface douce de sa langue; le donble orifice de chacune de ses narines; les trois pièces de ehacun de ses opereules; la convexité de son ventre; la carène de son dos; la rectitude de sa ligne latérale; la mollesse de ses écailles, le brunâtre de sa partie supérieure; l'argentin de ses côtés; le rougeâtre de ses nageoires; la bonté de sa chair; et l'intérêt qu'a Surinam on attache à sa prise 1 .

La brièveté de la nageoire adipeuse du nilotique, dont le nom indique la patrie:

La préférence que donne le néfaseh au fleuve qui nourrit le nilotique :

La force et l'inégalité des dents qui garnissent la mâchoire supérieure du characin pulvé rulent d'Amérique ${ }^{2}$, ainsi que sa máchoire inférieure, laquelle est un peu plus courte que celle d'en haut; la surface lisse de sa langue; le rayon aiguillonné de sa dorsale et de sa nageoire de I'anus; la blancheur d'un grand nombre de ses écailles.

En tout, les characins ont de très-grands rapports avec les salmones, parmi lesquels ils ont été placés par d'illustres naturalistes, mais dont nous avons dú les séparer pour obếr aux véritables prineipes d'une distribution méthodique des poissons.

- Nous n'avons pas cru, malgré Pautorite de Bloch, devoir Separer son edente de notre characin carpeas.

" 4 rayons a la membrane branchiale du characin plabuque, 12 a chaque pectorale, 8 a chaque ventrale, a a la nageoire de ha quene. - Aragous a la 25 a la candale - 1 rayons a la membrame branchiale da characin bosan, Il a charque pectorale, 8 a chaque ven. trale, 19 a la nageoire de la queue. -4 rayons a la membrane des branchies da characin mouche, 16 a chacune de sea pectorales, 7 a chacune de ses ventrales, 24 a lacaudale, -4 rayons cha me chacune de ses pectorales, 8 a chaque ventrale, 19 a ia 0 a.
geoire de la queue. -4 rayons a la membrane des branchies du characin sans tache, 14 a chaque pectorale, it a claque ventrale, 20 a la caudale. - 4 rayons a la membrane bran. chiale du characin carpeau, is a chaque pectorale, 10 a cha. que ventrale, 25 a $\mathrm{la}$ nageoire de la queue - is a chaque pectorale du characin nilotique. 9 a chaque venisse, 19 a ia cín nélasch, 4 a chaque peetorale, 0 à chaque ventrale it rayons a la membrane branchiale du characin pulvérulcat, 16 a chaque pectorale, 8 a claque ventrale, 18 a la nageoire de la queue. 
HISTOIRE NATURELLE

LE CHARACIN ANOSTOME ',

Anostomus....... Cuv.; Characinus anostormus, Lac. ${ }^{2}$.

Le Characin Fréderic ${ }^{8}$, Curimata Fridericii, Cuv.; Characinus Priderici, Lac.; Salmo Friderici, Bl. $4 .,-C$. à bandes 5 , Curimate fasciatus, Cuv.; Characinus hasciatus, i.ac, Salio Bloch o - - C Curimale " Curimate unlmaculatus, Cuv, Characinus Curimata, Lac.; Salmo unimaculatts, Bl. 10. -C. Odoe" ", Hydrocyon Odoe, Cuv.; Characiuus Odoe, Lac,; Salmo Odoe, B1. ' 2 .

L'anostome a la tête comprimée; la máchoire inférieure terminée par une sorte de mamelon arrondi; la nuque abaissée; la partie antérieure du dos convexé; les écailles grandes; la couleur générale brune; les raies longitudinale moins foncées.

Bloch a publié le premier la description des einq characins dont il nous restè à parler, et qu'il a inserits parmi les salmones.

Il faut compter au nombre des caractères principaux du frédéric le peu de grosseur de la tête, qui n'est pas revêtue de petites écailles; la force des lèvres; l'égal avancement des deux mâchoires; les six dents allongées et inégales de la mâchoire d'en bas ; les huit dents petites et pointues de celle d'en haut; la verrue qui est derrière le milieu de ces huit dents; la surface unie du palais, et de la langue qui est trèscourte; le double orifice de chaque narine; l'éfévation dé la partie antérieure du dos; la courbure de la ligne latérale; l'appendice de chaque nageoire du ventre; la grandeur des éeailles l'excellent goùt-de la chair; le jaune argentin de la couleur générale; les nuances violettes de la partie supérieure; le jaune et le bleu des nageoires.

Le characin à bandes, qui vit à Surinam,

- Salmone anostome. Danbenton èt Hany, Euc. méth.--Id. Bonnaterce, pl. de liEuc, méth.

genre A sоsтoms, que M. Cuvier ad fer me le type du sous. ST nov. D.

Bloch, pl. 578

Le Charaein Frédéric est placé par M. Cavier dans 5 Bloch, pl 579 .

Du sous-gente Cuanste, dans fe grand genre sausor, 'Bloch, pl, ssi, fiz. 2.

Du sousgenre PatuQue, dans le grand genre Sucnar. D - Capelani, par les Anglais, - Einfleck, par les Allemand - Bloch, pl. 581, fig. 5 .

Date dans le genre Sacrox. D.

"Du sous geare Hrorocir (Hydrocyon), daus le grand
geare Ssumes, selon M. Cuvier. D. comme le frédéric, a l'orifice de chaque nâriue double; son dos est caréné ; on voit un appendice auprès de chacune de ses ventrales.

Surinam est encore la patrie du mélanure et du curimate.

Le corps et la queue du mélanure sont argenés; son dos est gris; ses nageoires sont jaunâtres; des dents très - petites garnissent ses mâchoires, chacune de ses narines n'a qu'un orifice.

Le curimate a la langue libre et unie; le dos est brunâtre; les côtés et le ventre sont argenins ; une teinte grise distingue les nageoires. Ce charaein habite les eaux douces, et partieulièrement les lacs de l'Amérique méridionale. Sa chair est blanche, feuilletée et très-délicate.

L'odoé se trouve sur les côtes de Guinée '. Il est très-vorace, et d'autant plus dangereux pour les petits poissons, qu'it parvient à la longueur de trois piedś. Il est poursuivi à son tour par beaucoup d'ennemis; et les pécheurs lu font une guerre cruelle, parce que sa chair rougeátre est grasse et très-agréable au goût. Son museau est avancé; l louverture de sa bouche très-grande; le palais rude; la langue lisse; l'orifice de chaque narine double; le dessus de la tête comme ciselé et rayonné en deux endroits le ventre très-long; la première dorsale plus rapprochée de la caudale que les nageoires du ventre; la ligne latérảle un peu courbée; le dos presque noir ; la couleur des cótés, d'un brun ou d'un roux plus ou moins clair.

CENT QUATRE - VINGT - DEUXIÈVE GENRE.

LES SERRASALMES 2

\section{La bouche di lextrémite du musean; la tele; te corps el} la queue, comprimés; des ieailles fociliment vibitu 14 rayous a la membraue branchiale du characin anos.
tome, 15 a chaque pectorale, 7 a chaque ventrale, 25 a la na. geoire de fa queue. -4 rayons a la membrane des branchies da characin frédérice, 12 a chaque pectorale, 9 a chaque ven. trale, 20 a la cavdaie, -4 rayons à la membrane branchiale rentrate, 22 a bandes, 15 is chaque pectorale, 10 y' ehaque brane des hranchies du char la queue. - A rayons à la mento torale, 8 a chaque veutraie, 20 a la cindale. -4 cayens b b membrane bronchiale dn characin curimate, it à chaguc pectorale. 11 a chaque ventrale, 20 a la nageoire de fa queue. - 4 rayous a la membrane des branchies du characin odoe. 14 a chaque pectorale, 9 a cháque ventrale, 28 a la caudale.

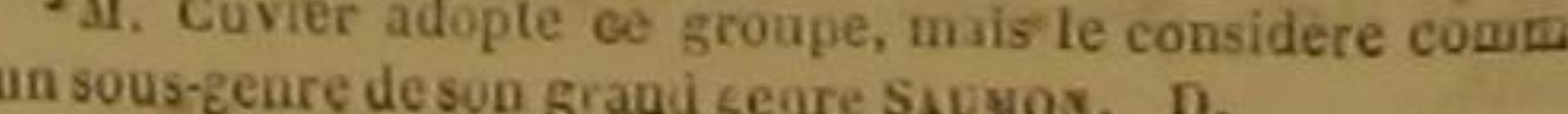

DLS POISSONS.

313

sur le corps el sur la queue; point de grandes lames
sur les coltes, de cuirasse, de piquants aux opereules, de rayons denteles, ni de barbillons; deux nageoires dorsales; la seconde adipeuse el denuie de rayons; la parlie infirieure du ventre corínto of dentelée comme une scie.

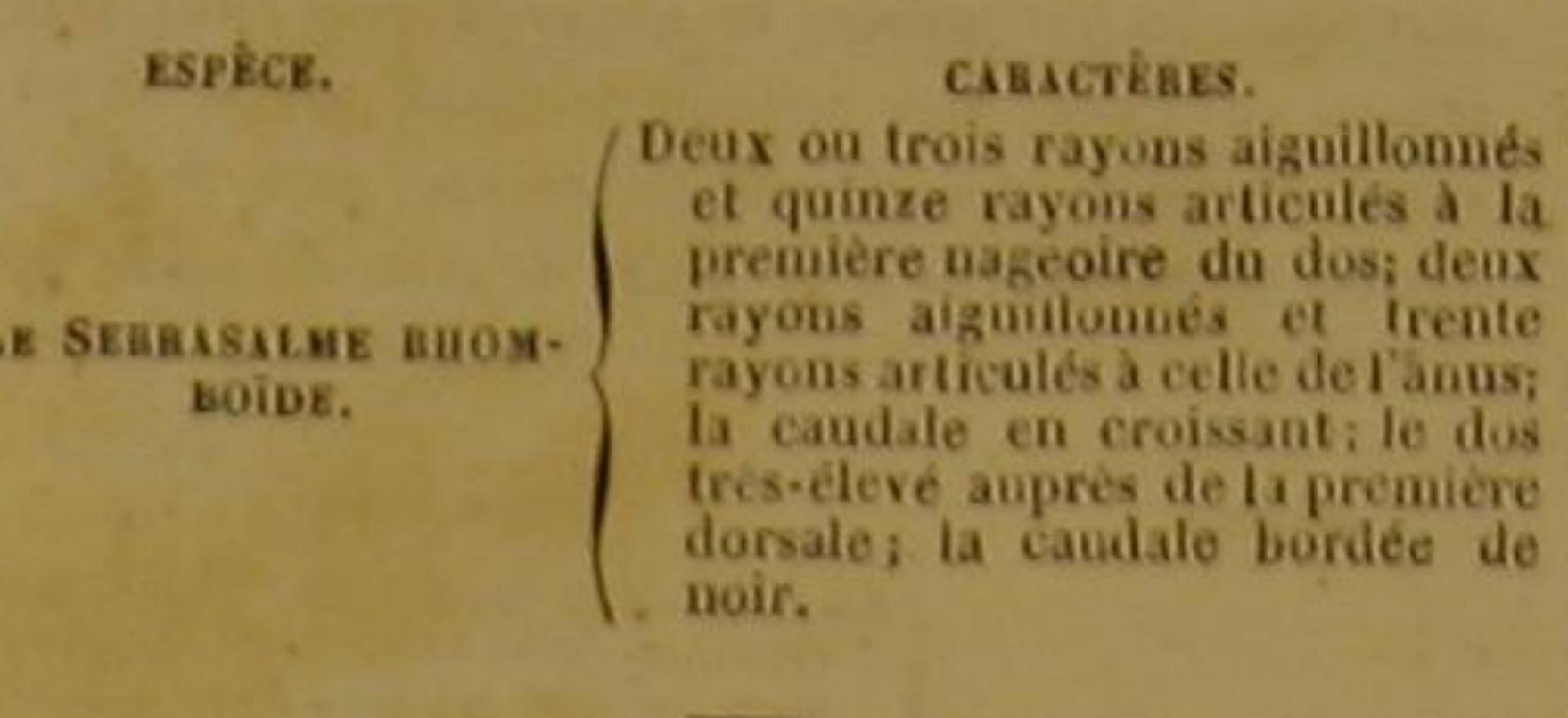

LE SERRASALME RHOMBOIDE '.

(Salmo.) Rhombeus, Lac., Cuv.; Salmo Khombeus, Bl., Limn., Gmel.?

Les serrasalmes ressemblent beaucoup aux clupées, dont nous parlerons dans un des articles suivants, et aux salmones, parmi lesquels ils ont été comptés. Ils ont, par exemple, sur la carène de leur ventre, une dentelure analogue à celle que l'on voit sur la partie inférieure des clupées; et ils présentent la nageoire dorsale et adipeuse des salmones. Leur nom désigne cette dentelure, ainsi que leur affinité avee le genre qui comprend les saumons et les truites.

Nous n'avons encore inscrit qu'une espèce parmi les serrasalmes; nous lui avons conservé la dénomination de Rhomboüle, pour rappeler celle qu'a employée le célèbre Pallas en faisant connaitre cette espèce remarquable.

Le rhomboide vit dans les rivières de Surinam; il y parvient à unegrosseur considérable; et il y est si vorace, qu'il poursuit souvent les jeunes oiseaux d'eau. L'ouverture de sa bouche est grande; la mâchoire inférieure est un peu plus avancée que la supérieure; l'une et l'autre, et surtout celle d'en bas, sont armées de dents larges, fortes et pointues. La langue est libre, mince et unie; mais les deux côtés du palais sont garnis d'une rangée de petites dents. Le front est presque vertical. Chaque narine a deux ouvertures très-rapprochées; les opercules sont rayonnés; la ligne latérale est droite; les écailles sont molles et petites; T'anus est à une égale distance de la tête et de la cau-

1 Sagebauch, par les Allemands. - Salmone rhomboìde. Daubenton et Haay, Enc. méth. $-T$. Bonnaterre, pl. de

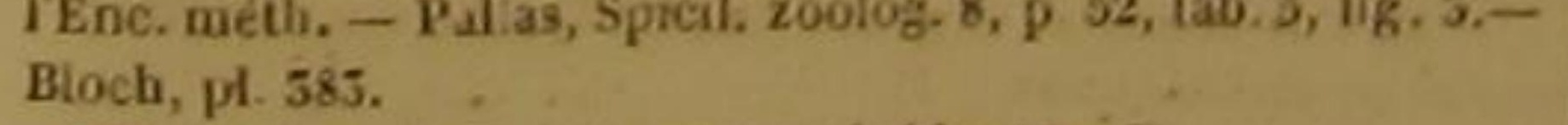
2 Voyez la oo le 2 de la page précédente. D. vale; des écailles semblables à celles du dos couvrent une grande partie de l'anale; on roit un appendice auprès de chaque nageoire du ventre; la dentelure qui règne sur la partie inferieure du poisson, est formée par une suite de piquants recoubés, dont chacun tient à deux lobes écailleux, placés sous la peau, des deux cótés de carène; le piquant le plus voisin de l'anus est double; il y a d'ailleurs au-devant de la première dorsale un autre piquant à trois pointes, dont la plus longue est inclinée vers la tête. Au reste, cette première dorsale et la nageoire de l'anus sont en forme de faux.

La chair du rhomboide est blanche, grasse délicate; la couleur générale de ce poisson montre des nuances rougeâtres, relevées par des points noirs; les cotés sont argentins; les nageoires sont grises '.

\section{CENT QUATRE - VINGT - TROISIEME} GENRE.

LES ELLONES ${ }^{2}$.

Trente rayons, ou plus, d la membrane des branchies les yeux gros, rapproehés l'un de l'autre, et presqu verticaux; une seulo nageaire dorsale; un appendice ecailleux aupres de cliaque nageoire du ventre.$$
\text { EPice. }
$$

cascerimes

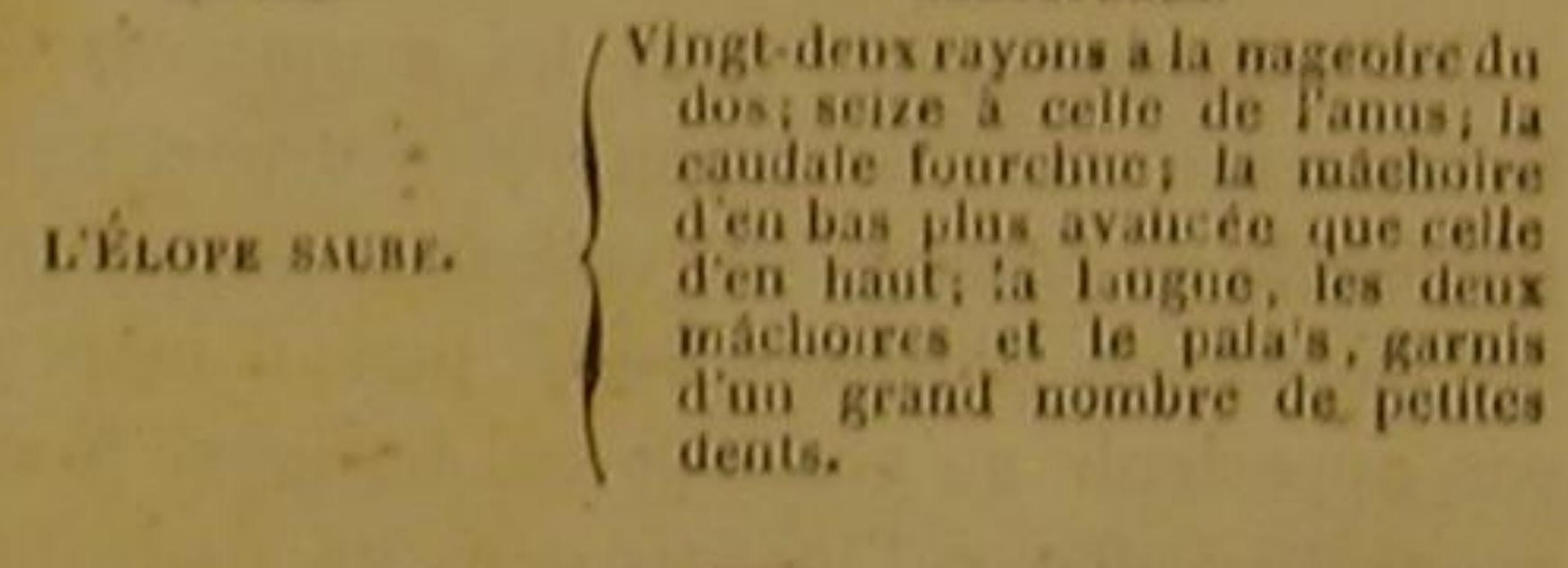

L'ÉLOPE SAURE ${ }^{3}$.

Saurus....., Cav.; Elops Saurus, Lac.; Salmo Saurus, Bl., Limn., Gimel. '.

Les élopes se rapprochent des salmones par plusieurs traits.

14 rayous a ta membrane branchiale du serrasime rhom hoide, 15 s cliaque ma
enire de la queue.

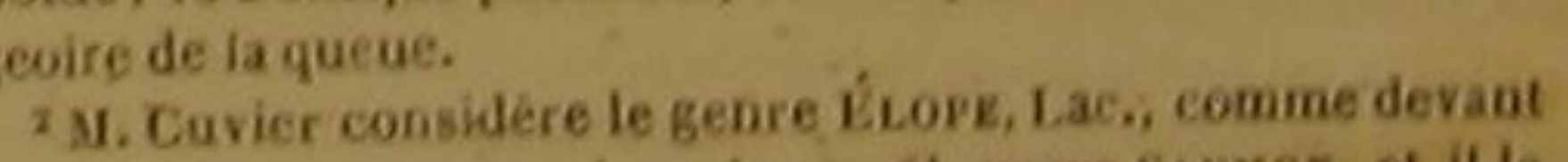
former uu sons-genre dans le grand geore sussos, et it to nomme Sivse, Saurus. M. Cuvier conserve da fuilite des genre BLore
Clups. D.

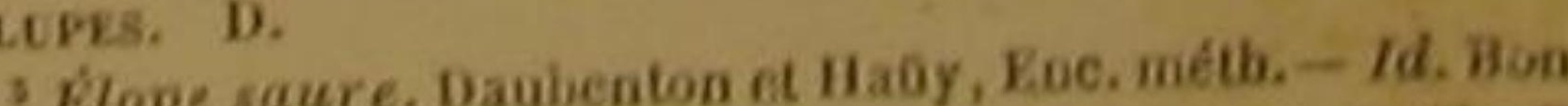
naterre, pl. de lEnc, méth. - Saurus maximus. slose. Jamaic. 2, p. 284, tab. 251, fig. 1.-Bloch, pL 505, 6g. I et - Du sons genre Saute de M. Cuvier, dans son grand gent 
Le saure a la tête longue, dénuée de petites

DES POISSONS.

515 écailles, comprimée et un peu aplatie dans sa surface supérieure; les os de ses lèvres sont longs, et leur bord est un peu dentelé; chacune de ses narines a deux orifices; son opercule est composé de deux pièces, mais ne couvre pas en entier la membrane branchiale; sa ligne latérale est dreite; son anus est une fois plus loin de la tète que de la nagcoire de la queue. Des nuances bleues et argentines composent ordinairement sa couleur générale; sa tète est souvent comme dorée ; et des teintes rouges brillent sur ses nageoires ${ }^{\prime}$
CENT QUATRE-VINGT-CINQUIÈME GENRE.

LES NOTACANTHES '.

Le corps el la queue très-allongés; la nuque élevée el arrondie; la lele grosse; la nageoire de l'anus trèslongue el réunie avec celle de la queue; point de nageoire dorsale; des aiguillons courls, gros, forts, el denués de membrane d la place de celle dernière no. geaire.

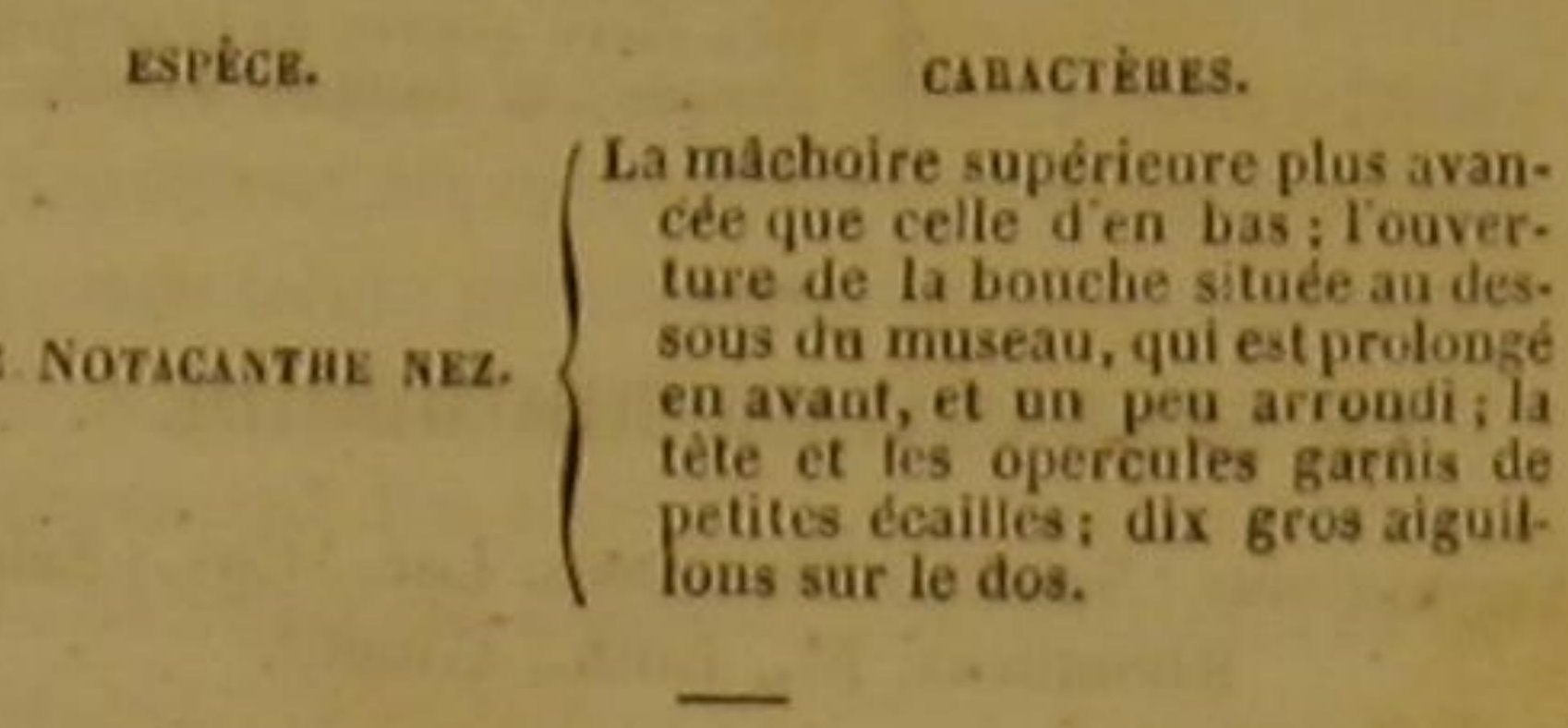

LE NOTACANTHE NEZ ${ }^{2}$.

Notacanthus nasus, Bl., Lac,, Cuv. '.

Bloch a fait graver la figure de cet animal, beau dans ses coulêurs, délié dàns ses formes , agile dans ses mouvements, rapide dans sa natation, vorace, hardi, dangereux pour les jeunes poissons, dont il aime à faire sa proie, et qui serait lié par les plus grands rapports avec les trichiures, si ces derniers, au lieu d'être entièrement privés de ces nageoires inférieures qu'on a comparées à des pieds, avaient des nageoires ventrales, comme le notacanthe. Cet osseux parvient à une longueur considérable. Sa couleur générale est argentine, variée par des teintes dorées; les reflets d'or et d'argent brillent d'autant plus sur sa surface, qu'en un clin d'œil il offre un grand nombre d'ondulations diverses, présente à la lumière mille faces différentes, réfléchit les rayons du soleil dans toutes les directions; et d'ailleurs ces nuances éclatantes sont relevées par quinze ou seize bandes transiversales et brunes, que l'on voit sur son corps et sur sa queue, ainsi que par les tons brunâtres qui distinguent ses nageoires.

Son iris est argenté; ses yeux sont gros; ehaque varine n'a qu'un orifice; les dents des deux mảchoires sont égales, fortes et serrées; on compte deux pièces arrondies à l'opercule; le commencement de la nageoire de l'anus montre une douzaine d'aiguillons écartés l'un de l'autre,

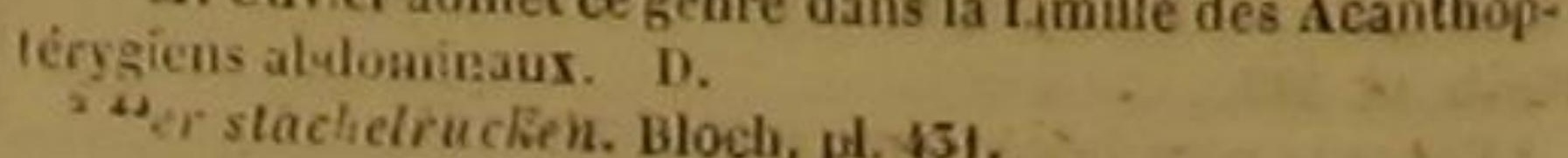

¿- M. Cuvier admet ce genre dans la Limille des Acanthop-

recourbés, et soutenus par une membrane que revêtent de petites écailles; la caudale est lancéolée; les pectorales sont grandes '.

\section{CENT QUATRE-VINGT-SIXIÈME GENRE.} LES ÉSOCES ?

E'ouverfure de la bouche grande; le gasier' large; les mdehoires garnies de dents nombreuses, fortes et pointues; le museau aplati; point do barbillons; l'operoule et t'orifice des branchies Iris-grands; le corps el la queue ires-allonges et comprimes lateralevent; les deailles dures; point de nageoire adipeuse; les na. geoires du dos et de l'anus courtes; une seute dorsate; celle derniere nàgeoire placie au-dessis de-l'anale, ou d peu pres, el beaucoup plus elloignele de la tel. que les ventrales.

PREMIER SOUS-GENRE.'

La nageoire de la queue fourchue, ou cehanerie on croissant.

Espǐces:

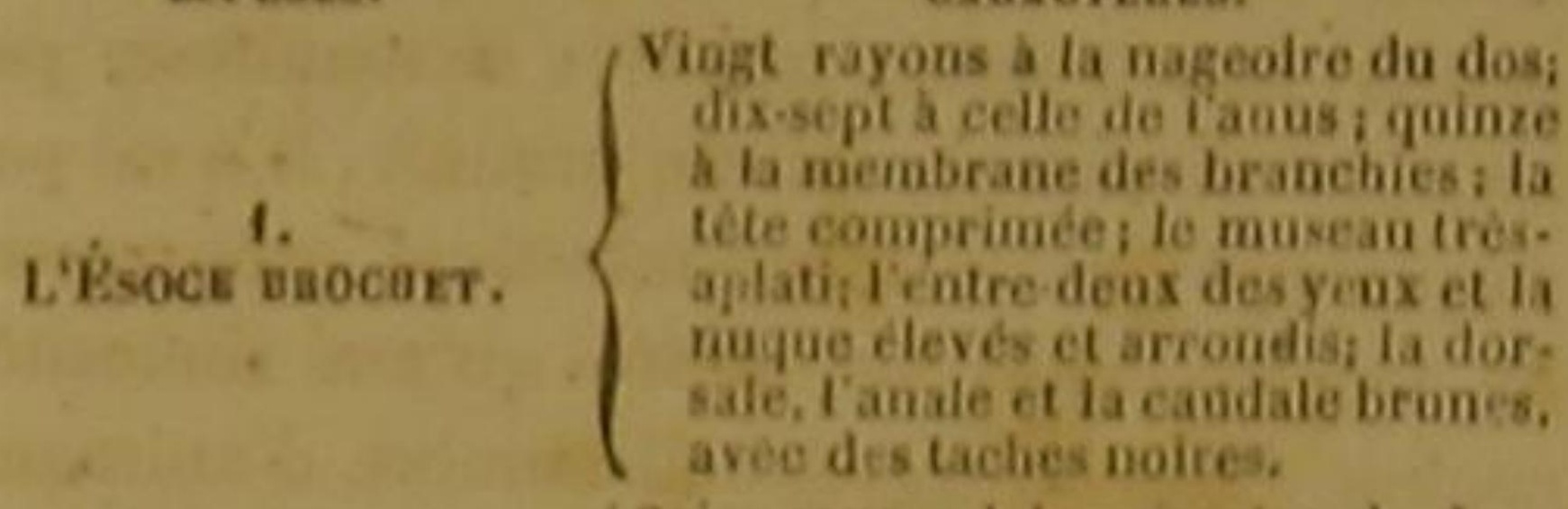

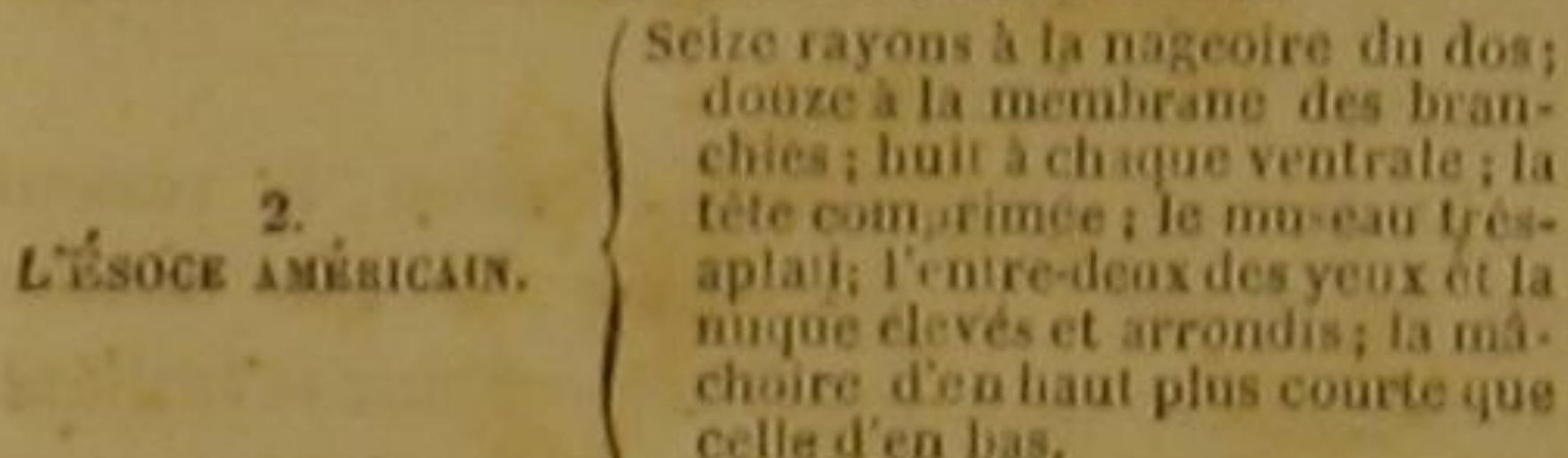
celle d'en bas.
Vingt rayons a la nageoire du dos

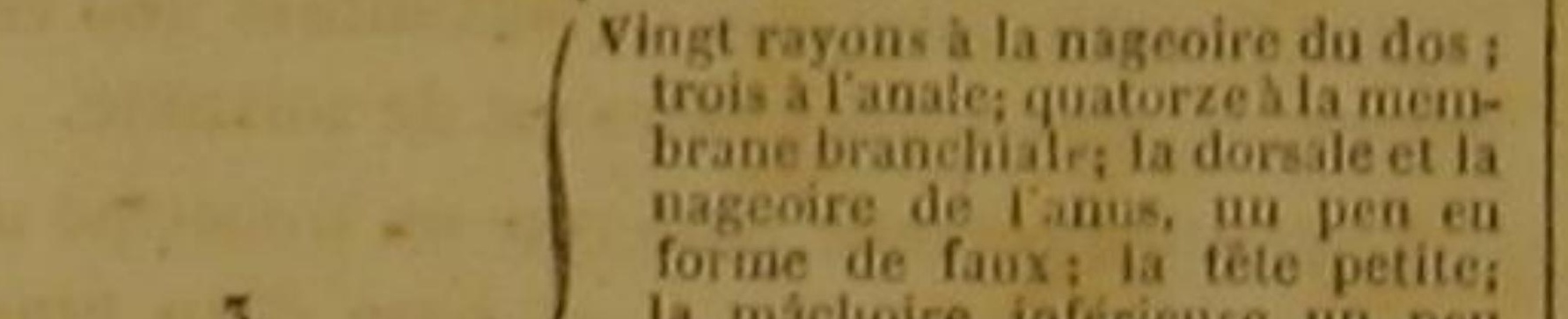

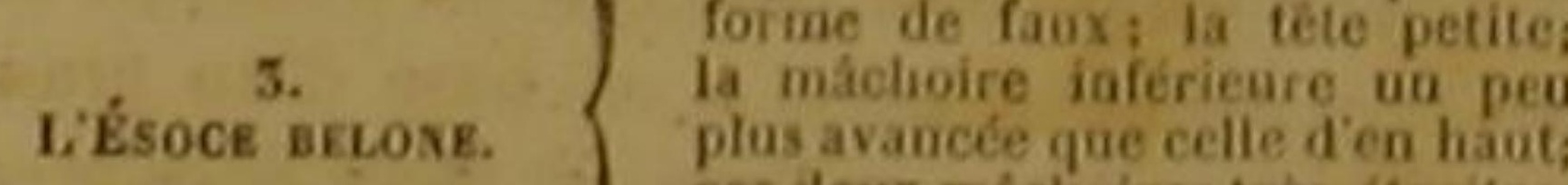

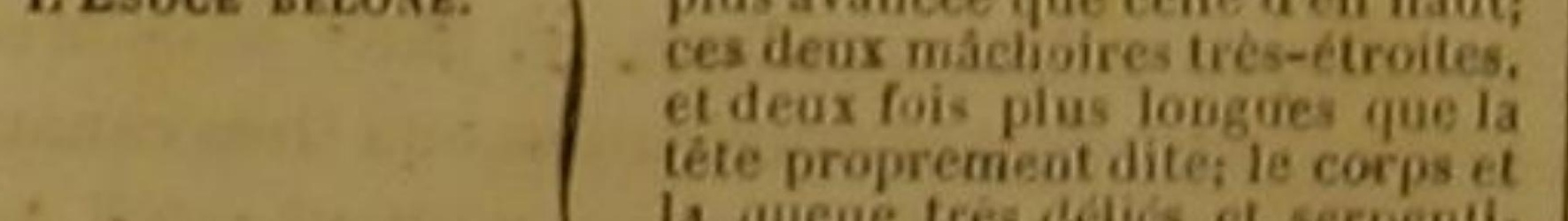
léte proprement dite; le corps el
is queeue tres délics et serpenti.
formes.

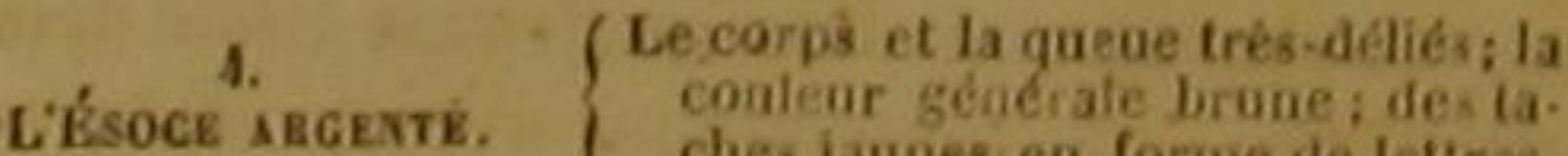

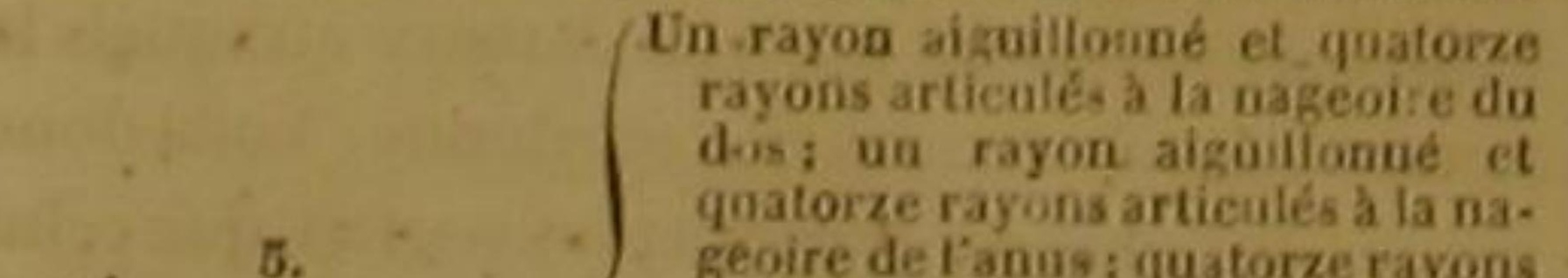

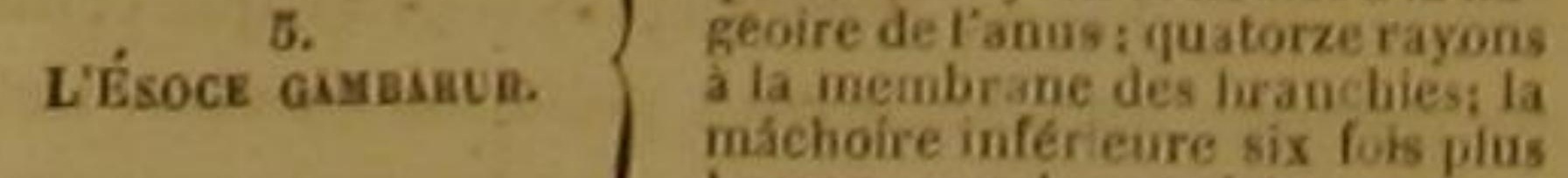
- dio, in selam longissimam reiroducto; vel,

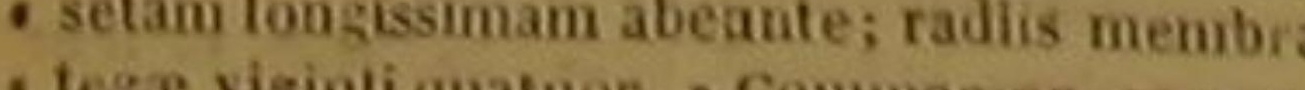

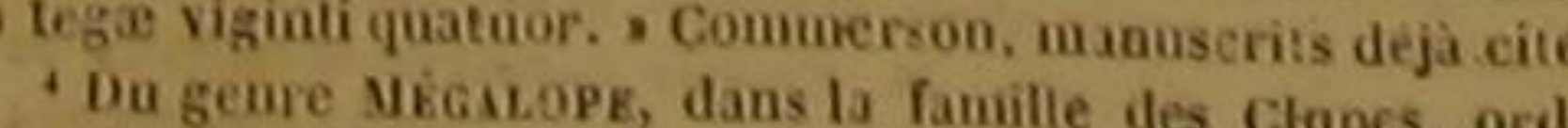

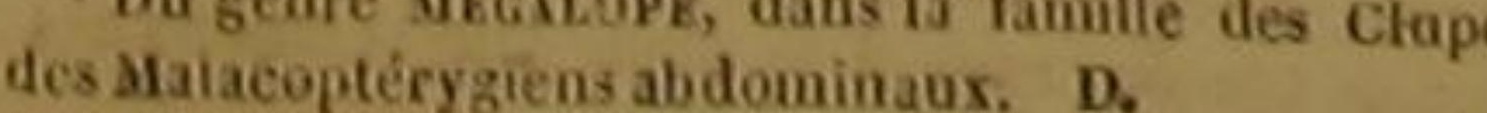

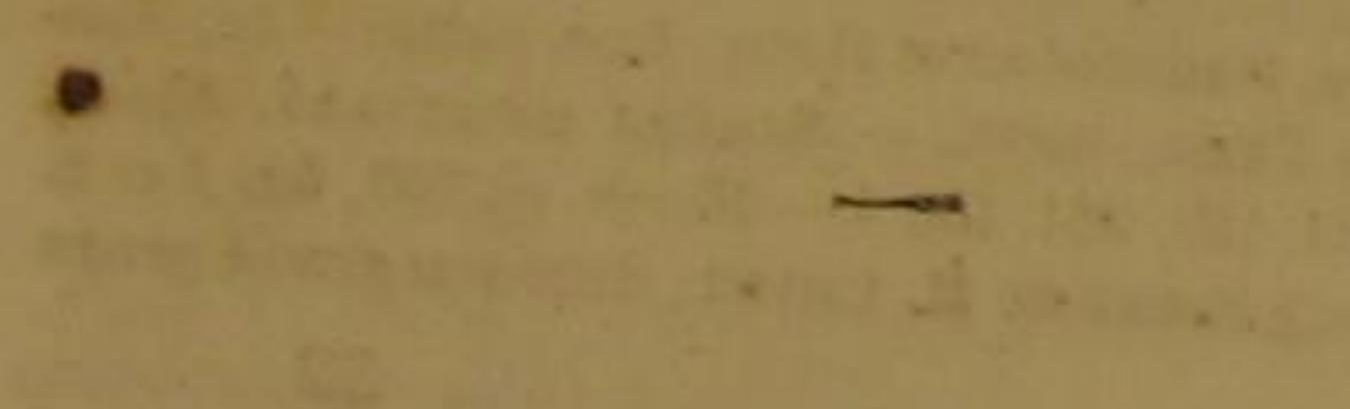

- 15 ou 16 rayons à chaque pectorale dn Notacanthenez,
2 rayous aiguillonnés et 8 rayons articalés a chaque ventrale de la queué réanies. ordre des Malacoptérygiens abdominaux, selon M. Covier. plus de 80 rayous_articulés à la nageoire de $\mathrm{I}$ anas el a cello

des Sxusors, famille des po'ssons Malacoptérygiens abdomi-
namx salmones. D.

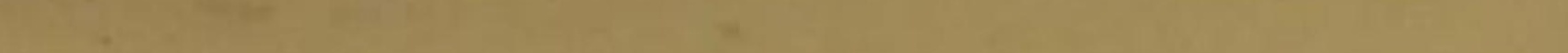

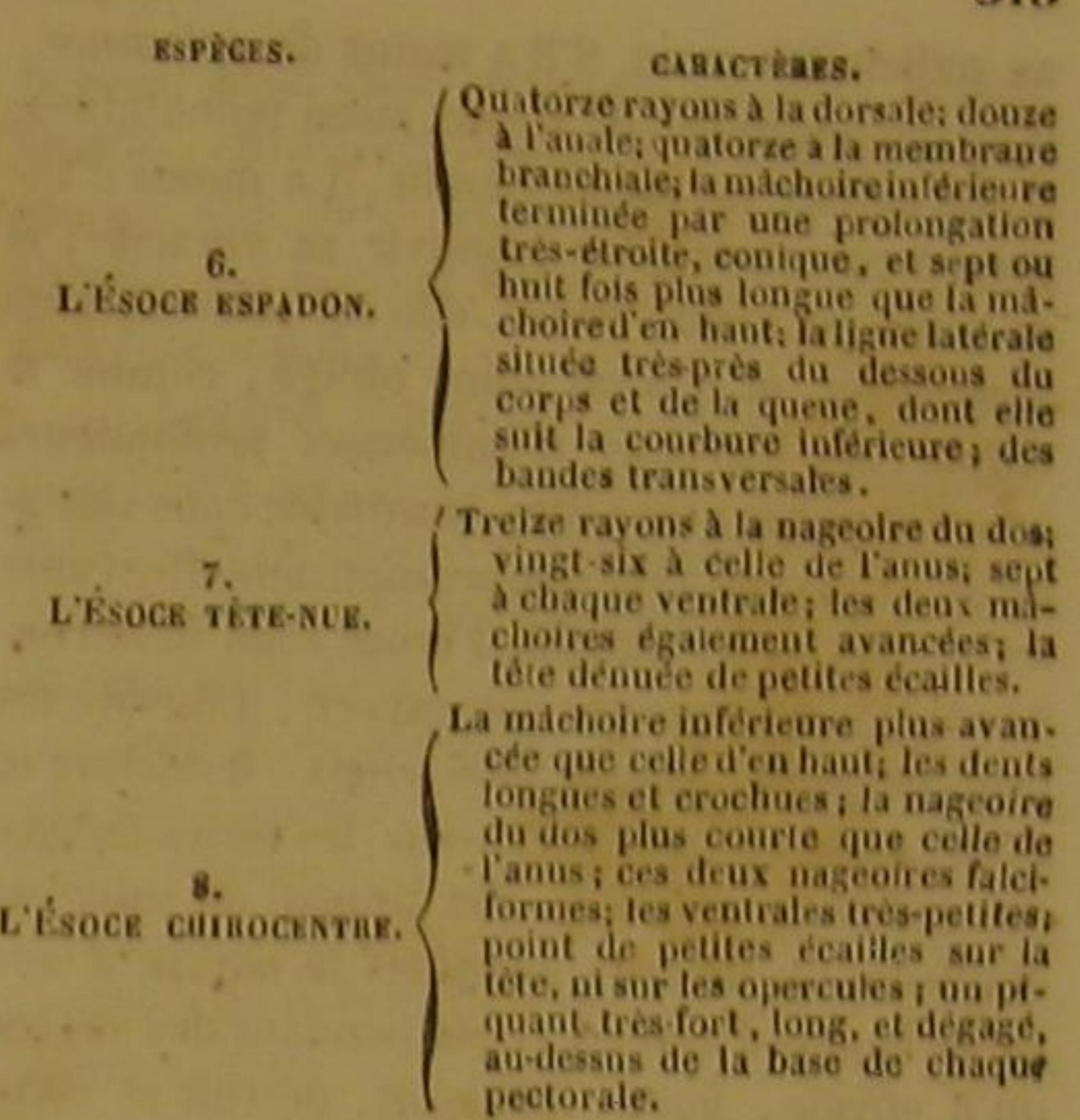

SECOND SOUS-GENRE.

Ea nagcoire de la queue arrondie ou rectiligne, el sans dehaneruro.

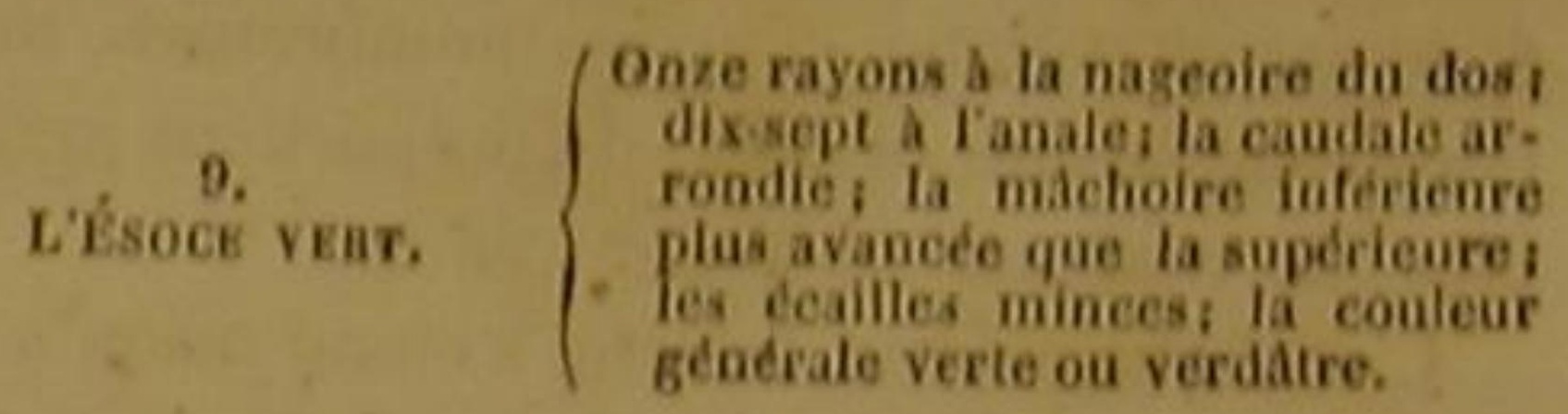

L'ÉSOCE BROCHET',

Esox Lucius, Lims. Bloch., Lac, Cur, ',

ET L'ÉSOCE AMÉRICAIN ${ }^{3}$

Esox Lucius, var. B. Linn., Gmel. ; Esox Americanus, Lacep. 4.

Le brochet est le requin des eaux douces; it y règne en tyrān dévastateur, comme lo requin

' Lançon, Lanceron, quand il est trés.jeune,-Poignard, faand il cat d ane grossear moyeone. - Carreau, quand if at plus gros. - Bequel, Bechit, Lucs, Lupule, dans quel.

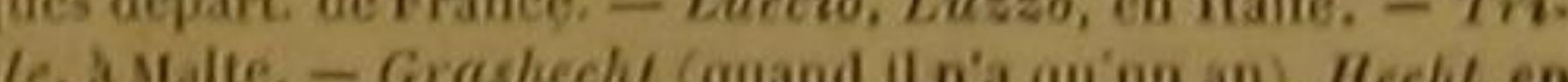
Allemagne. - Stukha, Csuka, en Hongrie, - Szuk, Ssula, en Poiogne. - Zurcha, ches les Calmou yues, - Tsehortau, en Tatarie.-Aug, en Livonie, - Tschuk, Tschuw, Schur. Ian, Scheschul, en hassie. - Giadue, en suede. - Gidde. ca Danemarck. - Snoek, Geep visch, en Hollasude. - Pike,

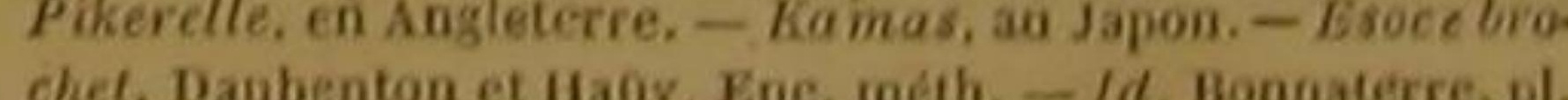

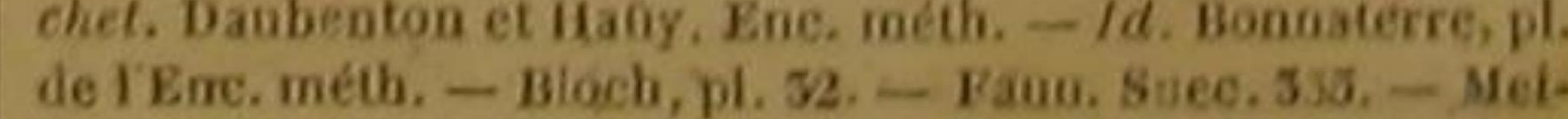
ding. Ic, pisc. Anstr., L, 10, .- , Esox rostro plagioplateo. Ariedi, gen. 10, spec, 53, syn. 26. - Lueius. Awson. Slos. v. 122, - Id. Wotton, 1. 8, e. 190, fol, 189. - Broctiet, thondelet, poissons de riviere, c. 11. - Luclus. Salvian, fol. 94.

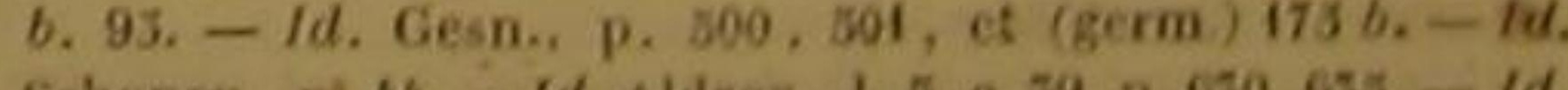

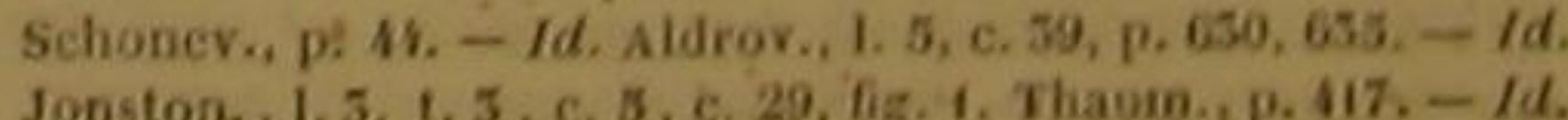

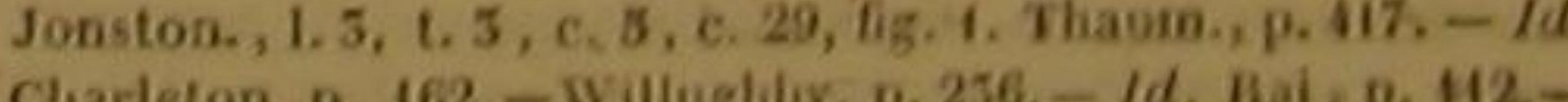
Gronov. Mus. 1, p. 28. - Belou, Aquat, p. 292, 11., p. 108.--

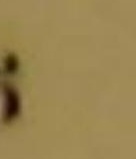

.


au milieu des mers. S'il a moins de puissance, il ne rencontre pas de rivaux aussi redoutable si son empire est moins étendu, il a moins d'es-
pace à parcourir pour assouvir sa voracité; $s$ s sa proie est moins variée, elle est souvent plus abondante, et il n'est point obligé, comme le requin, de traverser d'immenses profondeur pour l'arracher à ses asiles. Insatiable dans sesappétits, il ravage avec une promptitude effrayante les viviers et les étangs. Féroce sans discernement, il n'épargne pas son espèce, il dévore ses propres petits. Goulu sans choix, il déchire et avale, avec une sorte de fureur, les restes mèmes des cadavres putréfiés. Cet anima! de sang est d'ailleurs un de ceux auxquels la nature a accordé le plus d'années : c'est pendant des sièeles qu'il effraie, agite, poursuit, détruit et consomme les faibles habitants des eaux douces qu'il infeste; et commesi, malgré son insatiable cruauté, il devait avoir reçu tous les dons, il a èté doué non-seulement d'une grande force d'un grand volume, d'armes nombreuses, mais encore de formes déliées, de proportions agréables, de couleurs variées et riches.

L'ouverture de sa bouche s'étend jusqu'à ses yeux. Les dents qui garnissent ses mâchoires sont fortes, acérées et inégales : les unes sont immobiles, fixes et plantées dans les alvéoles; les autres, mobiles, et seulement attachées à la peau, donnent au brochet uń nouveau rapport de conformation avee le requin. On a compte sur le palais sept cents dents de différentes grandeurs, et disposées sur plusieurs rangs longitudinaux, indépendamment de celles qui entourent le gosier, Le corps et la queue, très-allongés, très-souples et très-vigoureux, ont depuis nuque jusqu'à la dorsale, la forme d'un prisme à quatie faces dont les arótes seraieut effacées.

Pendant sa première année, sa couleur géné rale est verte; elle devient, dans la second année, grise et diversifiée par des faches páles, qui, l'année suivante, présentent une nuance d'un beau jaune. Ces taches sont irrégulières distribuées presque sans ordre, et quelquefoi

Brochel. Camper, Mém. des sav. ér., 6, p. I77. - Pike. Brit.
Zool. 5. p. 270, u. 1. - Brochet. Valmoat de Bomare, Dict d'llist. uat.
'Le Brochet forme le type du sous genre des Brocuers, dans le grand genre du meme nom. D. Scliopf. Natarf. 20, N. 26.

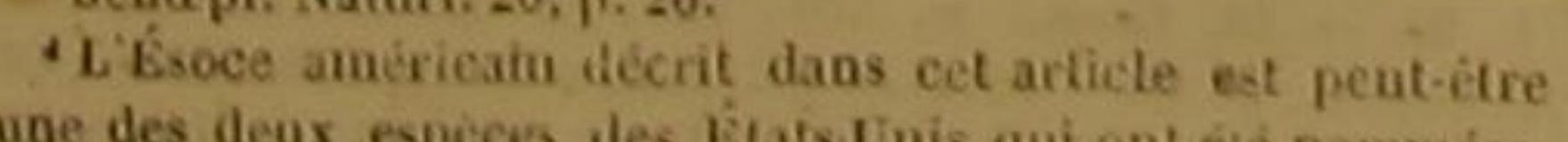
par Ml. Lesueur, I'Ac. des Sc. nat. de Plihidelt hie, tome I. - D. si nombreuses qu'elles se touchent et forment des bandes ou des raies. Elles acquièrent souven l'éclat de l'or pendant le temps du frai, et alor le gris de la couleur générale se change en un beau vert ' . Lorsque le brochet séjourne dans des eaux d'une nature particulière, qu'il éprouve la disette, ou qu'il peut se procurer une nourriture trop abondante, ses nuances varient. On le voit, dans certaines circonstances, jaun avec des taches noires. Au reste, parvenu à une certaine grosseur, il a presque toujours le dos noiràtre et le ventre blane avee des points noirs. L'osôpphage et l'estomac montrent de grands plis páles ou rouges, par le moyen desquels l'animal péut rejeter à volonté les substances qưil avale dans les accès de sa voracité, et qu'il ne peut pas digérer. Cettefaculté lui est commune avec la morue, ánsi qu'avec les squales, et particulièrement avec le requin, dont elle le rapproche encore. L'estomac est d'ailleurs trèslong; et, comme de ces grandes dimensions résulte une très-grande abondance de sucs digestifs, dont l'action très-vive se manifeste pa les appétits violents qu'elle produit, il n'est pas surprenant que le canal intestinal propremen dit soit très-court, et n'offre qu'une sinuosité, comme dans un très-grand nombre d'animaux féroces et carnassiers.

Le foie est long et sans division; la vésicule du fiel grosse; le fiel jaune; la laite double, ainsi que l'ovaire; le péritoine blanc et brillant l'épine dorsale composée de soixante et une vertèbres; le nombre des côtes est de soixante.

L'organe de l'oūe renferme un troisième osselet pyramidal, garni à sa base d'un grand nombre de petits aiguillons, et placé dans la cavité qui sert de communication aux trois canaux demi-circulaires. Cet organe contient aussi une sorte de rudiment d'un quatrième canal demicirculaire, qui communique avec le sinus par lequel se réunissent les trois canaux auxquels le nom de demi-circulaire a été donné. Voilà done le sens de l'ouĩe du brochet plus parfait que celui de presque tous les autres poissons osseux. Cet avantage lui donne un nouveau trait de ressemblance avee le requin et les squales; il lui donne de plus la facilité d'éviter de plus loin un ennemi dangereux, ou de s'assurer de l'approche d'une proie difficile à surprendre; et d'après
DES POISSONS.

l'organisation particulièrede son oreille, on doit | poisson avait done vécu près de trois siècles. être moins étonné que l'on ait remarqué, du Quelle effrảyante quantité d'animaux plus temps même de Pline, la finesse de son oủe, faibles que lui il avait dù dévorer pour aliet que, sous Charles IX, roi de France, des menter son énorme masse pendant une si lonindividus de l'espèce que nous décrivons, réunis gue suite d'années!

dans un basin du Loure, vinsent, lorstion les appelait, recevoir la nourriture qu'on leur avait préparée.

La vessie natatoire du brochet est simple, mais grande; et sans cet instrument, ce poisson ne parcourrait pas avee la rapidité qu'il développe, les espaces qu'il franchit, contre les courants des fleuves impétueux, et au milieu des eaux les plus pures, et par.conséquent le moins pesanteset les moins propres à le soutenir.

C'est en effet dans les riviêres, les fleuves, les lacs et les étangs, qu'il se plaít à séjourner. On ne le voit dans la mer que lorsqu'il y est entrainé par des aecidents passagers, et reten par des causes extraordinaires, qui ne rempéchent pas d'y dépérir; mais on l'a observé dans presque toutes les eaux douces de l'Europe.

Bélon a écrit qu'il l'avait vu dans le Nil, où il croyait que les anciens lui avaient donné le nom d'Oxyrhynchus' (museau pointu). Mon collègue, M. Geoffroy, professeur du Muséum d'histoire naturelle, va publier une dissertation très-savante sur les animaux de l'Égypte, dans laquelle on trouvera à quel poisson, different de celui quenous examinons, les anciens avaient réellement appliqué cette dénomination d'Oxyrhynque.

Le brochet parvient jusqu'à la longueur de six à neuf pieds, et jusqu'au poids de quatre-vingts ou cent livres. Il croit très-promptement. Dès sa première année, il est très-souvent long d'un pied; dès la seconde, de quinze pouces; des la troisième, de deux pieds; dès la sixième, de près de six pieds; dès la douzième, de huit pieds ou environ : et cependant cet animal destructeu arrive jusqu'à un âge très-avancé. Rzaczynsky parle d'un brochet de quatre-vingt-dix ans. En 1497 on prit à Kaiserslautern; près de Vanheim, un autre brochet qui avait plus de dix-huit pieds de longueur, qui pesait trois cent sôixante livres, et dont le squelette a été conservé pendant long-temps à Manheim. Il portait un anneau de cuivre doré, attaché, par ordre de l'empereur Frédéric-Barberousse, deux cent soixante-sept ans auparavant. Ce monstrueux

' Bélon, liv. 2, chap. 32.
Le brochet cependant n'est pas seulement dangereux par la grandeur de ses dimensions, la force de ses muscles, le nombre de ses armes; il l'est encore par les finesses de la ruse et les ressources de l'instinct.

Lorsqu'il s'est ểancé sur de gros poissons, sur des serpents, des grenouilles, des oiseaux d'eau, des rats, de jeunes ehats, ou mème de petits chiens tombés ou jetés dans l'eau, et que l'animal qu'il veut dévorer lui oppose un trop grand volume, il le saisit par la tête, le retient avee ses dents nombreuses et recourbées jusqu'à ce que la portion antérieure de sa proie soit ramollie dans son large gosier, en aspire ensuite le reste, et l'engloutit. S'il prend une perehe ou quelque autre poisson hérissé de piquants mobiles, il le serre dans sa gueule, le tient dans une position qui lui interdit tout mouvement, et l'écrase, ou attend qu'il meure de ses blessures.

Tous les brochets ne fraient pas à la méme époque : les uns pondent ou fécondent les aufs dés le milieu de février, d'autres en mars, et d'autres en avril. S'ils sont très-redoutables pou les habitants des eaux qu'ils fréquentent, ils sont très-souvent livrés sans défense à des ennemis intérieurs qui les tourmentent vivement. Bloch a vu dans leur canal alimentaire différents vers intestinaux, et il a compté dans un de ces poissons, qui ne pesait qu'unelivre et demie, jusqu'à cent vers, du genre des vers solitaires. Mais ils ont encore plus à craindre des pécheurs qui les poursuivent. On les prend de diverses manières : en hiver, sous les glaces; en ćté, pendant les orages, qui, en éloignant d'eu leurs victimes ordinaires, les portent davantage vers les appats; dans toutes les saisons, au clair de la lune; dans les nuits sombres, au feu des bois résinêux. On emploie, pour les pêcher, le trident, la liøne, le colleret, la truble, l'épervier, la louve, la nasse ${ }^{4}$.

iOn trouve ta description du collerel dans larticle du centropome sandat; de la truble, dans celui du misguroe fossite: de la loure et de la nasue, dans celai da petremyzo tamprota: Lépercier cst un tiet en for soinate pieds de circioche, dont Tette ciresonference eat garwie de balles de tomb, et le long de ce contour le filet est retrulyse en de. dans, et attactie de distance en distance, pour former des 
Leur chair est agréable au goutt. On les sale transporta de vivants dans les eaux douces de dans beaucoup d'endroits, après les avoir vidés, | cette île.

nettoyés, et coupés par morceaux.

Le professeur Gmelin regarde comme une va- riété du brochet, un ésoce d'Amérique dans ledant trois jours entourés de saumure.

Dans d'autres contrées et particulièrement en Allemagne, on fait du caviar avec leurs œufs. Dans la marche électorale de Brandebourg, on mêle ces mèmes $\propto u$ ús avec des sardines, on en compose un mets que l'on nomme nel zin, et que l'on regarde comme excellent. Cependant ce œufs de brochet passent, dans beaucoup de pays, au moins lorsqu'ils n'ont pas subi certaines préparations, pour difficiles à digérer, purgatifs et malfaisants.

C'est sur des brochets qu'on a essayé particulièrement cette opération de la castration dont nous avons déjà parté, et par le moyen de laquelle on est parvenu facilement à engraisse les individus auxquels on l'a fait subir.

Si l'on veut se procurer une grande abondance de gros brochets, il faut choisir, pour leur multiplication, des étangs qui ne soient pas propres aux carpes, à cause d'ombrages trop épais, de sources trop froides, ou de fonds trop marécageux : les brochets y réussiront, parce que toutes les eaux douces leur conviennent. On y placera, pour leur nourriture, des cyprins ou d'autres poissons de peu de valeur, comme des Rotengles et des Rougeâtres, si le fond de l'étang est sablonneux; et des bordelières ou des hamburges, si ce même fond est couvert de vase. Au reste, on peut les porter facilement d'un sejjour dans un autre, sans leur faire perdre la vie; et on assure qu'ils n'ont été connus en Angleterre que sous Henri VIII, où on en

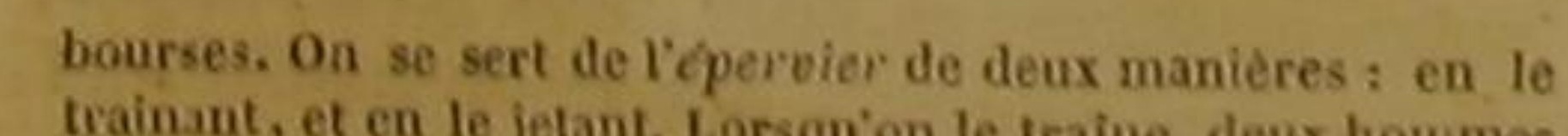
trainant, et en le jetant. Lorsqu'on le traine, denx hommes
placés sur les bords du conrant placés sur les bords du coorant d'ean maintiennent l'ouver.
ture du filet dans une position à peu prés verticale. par ture du flet dans une position a peu près verticale. par le
moyen de deux cordes attachees a deur points de cette ouverime. En troisierme pécheur tieat une corde qui répoud a la pointe du fitet. Si lon s'apergoit quill y ait du poisson de pris, et qu'on venille relever tépervier, les deüx preniers pécheurs lachent leurs cordes, de manière que toute la cir-
conférence de louverture du filet porte sur le fond; le troldéme tire a lui ta corde qui tient au sommet de ta cloche, se des autres, ot quand il les voit rémies. Lirechent les unes toutes ses forces, et le met sur ta rive. Lorsqu'on jette précautions. On deploie lézerverier par un élan qui titit fúre a roue au filet, et qui peut entrainer le pécbeur dans le con-

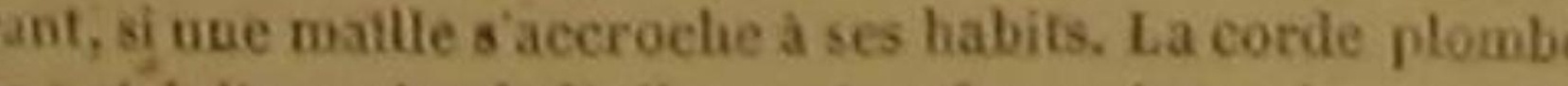
se precelpite au fond de leau, et eaferme les poissons com.
pris dans linterieur de la cloche. quel la mâchoire supérieure est plus courte proportion de celle d'en bas que dans le brochet d'Europe: mais le nombre des rayons de la membrane branchiale de ce poisson américain, de sa dorsale et de ses ventrales, nous oblige d̀ considérer comme appartenant à une espèce différente de celle đu brochet '.

\section{$\cdot$}

L'ÉSOCE BELONE ${ }^{2}$.

Belone........, Cuv., Esox Belone, Linn. Gmel., Blöh. Lac."3.

Le museau de cet ésoce ressemble au bee d'un harle, ou à une très-longue aiguille; son corps et sa'queue sont d'ailfeurs si déliés, que la longueur totale de l'animal est souvent quinze fois plus grande que sa hauteur : il n'est done pas surprenant qu'on lui ait donné le nom d' $A i$ -

14 rayons a chaque pectorale de lésoce brochet, $10 \mathrm{a}$ cha. gue ventrale, 17 a la nageoire de lanus, 20 a la nageoire de

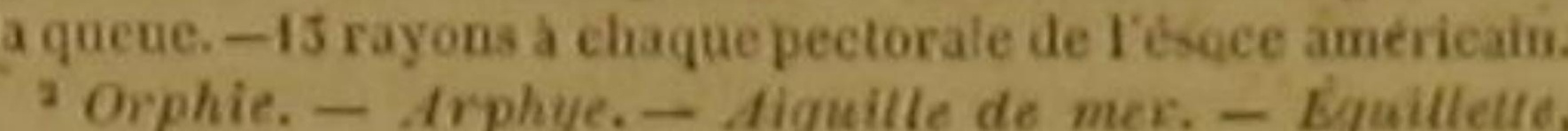
auprès de Brest. - Hagojo, Aguillo, auprés de Marseille. Aguio, dans le départ, da Var. (Note eavoyée par M. Faa. chet, prefet). - Acuchia, Angusicula, en Italie.- CharAllemagne, - Schneffel, auprés de Dantzig.-Nabtgiadda,
en Suede. - Horn-give, Nehhesild, Hornigel, en Norvege. - Gierne fur, en Islande, - Horn-fisk, en Danemark. Geep-wisch, en Hollanye.-Naedl-fish, Garfish, Mern-fish, Sea-needel, Garpike, en Aggleterre. - Timucu, Peisce agutha, au Bresili. - Ikan Isjakalang hidjoe, Grone Isjahatany of geep, daris les indes or. - Ablennes, par plus. au-
teurs. - Esoce belosie. Ianbenton et Hagy. Ea Id. Bonnaterre, pl. de IEnc, méth. - Orphice. Bloch, pi. 55 . - Esox belone. Ascagne, 5. pl. 6. - Brong Pise Nlassil. Faun. Suec. 356. - - Ksos rostro cuspidato, graedil, subte. reti et spittamali. Arledi, gen. 10, syo. 27. - Pappis. oppian., 1. 1, 172, et 5. 605, - Id. Athén, 1. 8, p. 555. - Aha. niger. Albert, 1. 24. p. 241 . a, ed. Hos. - Acus piscis. ledi Synonymia p scium, etc.. auclore J. G, schneider, etc - Gronov. Mus. 1, o. 59. Zooph., p. 117. D. Scholder, etc. cembelus mandibulis loogissimis, etc. , Klein, Miss. pisc. 4, p. 21, n. 1, tab. 5, fig. 2. - Aiguille. Rondelet, part. 1, I. 8, C.5. - Aquat., p. 9, 10. lebth., p. 251, tab. p. 2, fig. 4 , A ppeúud., tab. 5, fig. 2- Bai, Pisc., p. 109. - Seapike, Brit. Zool, p. 274, n. fo. - Timal, Marcgrav. Brasil., 168, - Oiphie. Valmont de Bomare, Dict. d'tist. nat. Du sous-genre Oapare, Belone, Cuv., dans le grand genre des BrocuEts, famille des Malacoptérygiens abdominaux éso-
Ces, D. Man, Choram, en Arabie. - Hornhecht, Nadelhecht, en p. 79, n. 95. - Moller, Prodr. Zool, Danic., p. 49. n. 420. Jrov, Pi . A8, - Acus valgaris, acus Oppiani., Al- guille. On l'a nommé aussi Anguille de mer, parce qu'il vit dans l'eau salée, et que ses formes générales ont beaucoup d'analogie avec celles de la murène anguille, La ressemblance dans la conformation amène nécessairement de grands rapports dans les mouvements et dans les habitudes; et en effet la manière de vivre de l'ésoce bélone est semblable, à plusieurs égards, à celle de l'anguille.

Les dents du belone sont petites, mais fortes, égales, et placées de manière que celles d'une máchoire occupent, lorsque la bouche est fermée, les intervalles de celles de l'autre. Lés yeux sont gros. La ligne latérale est située d'une maniêre remarquable; elle part de la portion inférieure de l'opercule, reste toujours très-près du dessous da corps ou de la queue, et se perd presque à l'extrémité inférieure de la base de la eaudale. La queue s'élargit, ou pour mieux dire, grossit à Vendroit où elle pénètre en quelque sorte dans la nageoire de la queue; les-autres nageoires sont courtes.

La partie supérieure du poissón est la seule sur laquelle on voie des écailles un peu grandes, tendres et arrondies.

Lorsque fe bélone serpente, pour ainsi dire, dans Yeau, ses évolutions, ses contours, ses re plis tortueux, ses élans rapides, sont d'autant plus agréables, que ses couleurs sont belles, brillantes et gracieuses ; le front, la nuque et le dos offrent un noir mélé d'azur; les opercules réfléchissent des teintes vertes, bleues et argentines : la moitié supérieure des cotés est d'un vert diversifié par quelques reflets bleuâtres; l'autre moitié répand, ainsi que le ventre, Y'éclat de l'argent le plus pur : du gris ou du bleu sont distribués sur les nageoires.

Ce poisson si bien paré et si svelte a été observé dans presque toutes les mers; il en quitte les profondeurs pour aller frayer près des rivages, où il annonce, par sa présence, la prochaine apparition des maquereaux. II n'a communément qu'un pied et demi de longueur, et ne pèse que deux à quatre livres; it devient alors très-souvent la proie des squales, des grandes éspèces de gades, ou d'autres habitants de la ner voraces et bien armés : mais il parvient quelquefois à de plus grandes dimensions. Le chevalier Hamilton a vu péeher, à Naples, un individu de cette espèce, qui pesait quatorze livres; et Renard assure qu'on trouve, dans les Indes orientales, des bélones de six à neuf pieds de longueur, dont la morsure est, dit-on, très-dangereuse, et mème mortelle, apparemment à eause de la nature de la blessure que font leurs dents nombreuses et acérées.

On prend les bélones pendant les nuits calmes et obseures, à l'aide d'une torehe allumée, qui les attire en contrastant avee des ténèbres épaisses, et par le moyen d'un instrument garmi d'une vingtaine de longues pointes de fer, qui les percent et les retiennent; on en pèche jusqu'à quinze cents dans une seule nuit.

En Europe, où le bélone a la chair sèche et maigre, on ne le recherche guère que pour en faire des appâts.

Son canal intestinal proprement dit n'offre pas de sinuosité, et n'est pas distinct, d'une manière sensible, de la fin de l'estomac.

L'épine dorsale est composée de quatre-vingt. huit vertèbres; elle soutient de chaque côté ein. quante et une cotes : lorsque ces cotes et ces vertèbres sont exposées à une chaleur très-forte, elles deviennent vertes. Un effet semblable a été observó dans quelques autres poissons, et particulièrement dans des espèces de blennies ; et ces phénomènes paraissent confirmer ce que nous avons dit de la Nature des poissons (voyez notre Discours sur ce sujet), surtout lorsqu'on rapproche cette coloration rapide de la lueur phosphorique que répandent dans l'obscurité ces os verdis par la chaleur'

\section{L'ÉSOCE ARGENTÉ ${ }^{2}$}

Butirinus indicus, Cur.; Esox argenteus, Forsk, Lae., Linn., Gmel.; Argentima Glossodouta, Forak.; Argentina Bonuk, Lac. '

\section{L'ESOCE GAMBARUR 4,}

Uemiramphus marginalus, Cuv.; Esox Gambarur, Lac.; Esos marginatus, Linn., Gmel. ".

\section{ET L'ÉSOCE ESPADON 6}

Uemiramphus brasiliensis, Cuv.; Esox brasiliemis. Lino., Bl., pl. 5̃21; Esos Giadies, Lac.'.

George Forster a découvert l'argenté dans les eaux douces de la Nouvelle-Lélande, et d'autres

i 15 rayons a chaque pectorale de résoce bélone, 7 a dia. que veotrale, 25 a la magecire de la queue. , 1. p. 159

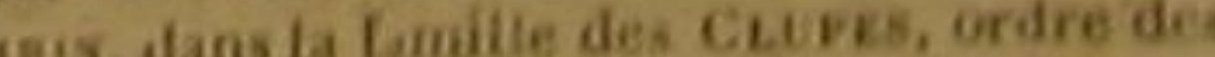

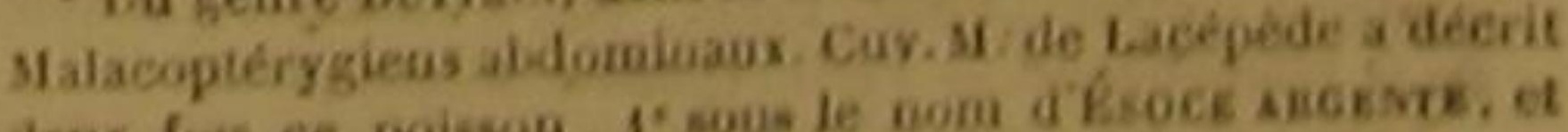

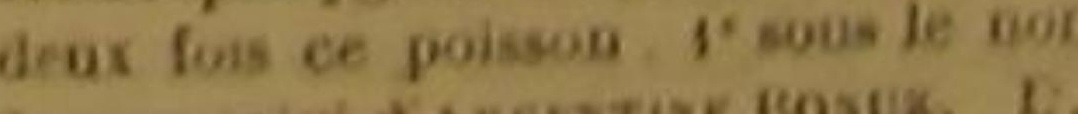

-Eoox hepselus, Lina, Gmel. - Vonkael, Faun. Arab., 
sles du grand Océan équinoxial. Nous n'avons | tres raies; chaque côté paré, ainsi que l'indique pas vu d'individu de cette espèce : si sa caudale le tableau générique, d'une raie longitudinale, n'est pas échanerée, il faudra la placer dans le large, argentée et éclatante; la dorsale ordingsecond sous-genre des ésoces.

Le gambarur nous a paru, ainsi qu'à Commerson, appartenir à la même espèce que le piquitingue ou l'hepsète, qu'on n'a séparé du premier poisson, suivant ce célèbre voyageur, que parce qu'on a eu sous les yeux des piquitingues alterés, et privés particulièrement de la plus grand partie de leur longue mâchoire inférieure.

Il habite dans les eaux de la mer d'Arabie, ainsi que dans celles qui arrosent les rivages du Brésil.

Son corps est un pèu trans̀parent, très-allongé, ainsi que la queue, et couvert comme cette dernière partie d'écailles assez grandes ; la mâchoire supérieure dure et très-courte; l'inférieure prolongée en aiguille, six fois plus longue que la mâchoire d'en haut, et un peu mollasse à son extrémité; l'ouverture de la bouche garnie sur ses deux bords de petites dents; l'œil grand et rond; le dessus du crâne aplati ; le lobe inférieur de la caudale près de deux fois plus long que le supérieur; la couleur générale un pẹ claire, le haut de la tête brun; le dos olivâtre à son sommet, et orné de raies longitudinales séparées par des taches brunes et carrées; la partie inférieure de l'animal marquée de quatre au-

p. 67, n. 08, - Argentina, pinna dorsali pinnw ani oppo sita.s Amenit. acad, 1. p. 521. - Piquitinga. Mregrav.

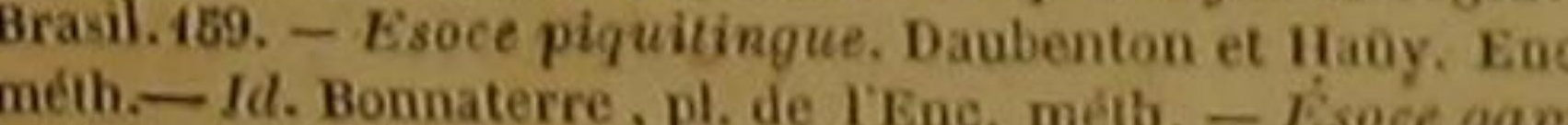
barur. Id. - Orphie de Rio Janciro, cesox - Lsoce gan terygio, rostro apice coccineo, lined laterali lata, argen¿teả, etc. > Commerson, manuscrits déja eités. - - Menidia - corpore subpellucido, linea laterali latierí argeuted. Browne, Jamaīe. 441, tab. 45, fig. 5.

Du sous-genre DEm-BEC, Hemiramphus, Cuv., dans 1 dominaux ésoces. $L$, $E$, de la familte des Malacoptéryglens ab. syoonymie de celte especee, est un composé de denx poissons: $1^{\circ}$ le Piquitinga de Marcgrave, ou Menidia de Browne, qui est un anchois; 20 Tautre que 3 . Cuvier ne peut

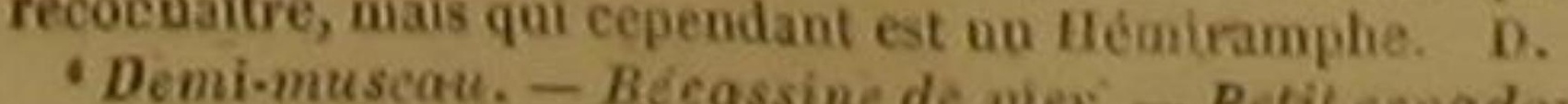
- Elephantennase, Kleiner schwerdifisch, par les Allemanós. - Hall-beo, Brasitianischen sioek par les Bolledais. - Under-sword fish, Piper, par les Auglais. - Balaon, aux Antilles. - Ikan moeloet betang, dans les Indes or. -

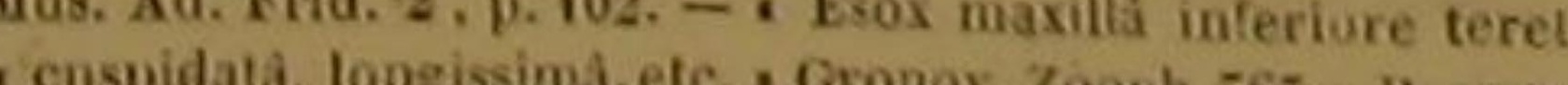
Jamalc. 415, tab. 45, fig. 2. - Under swon fish. 565 . - Browne, tab. 7. - Esoce petit espadon. Daabenton et Hañy, Fnce. métb.-Id. Bonnaterre, pl. de I'Euc. méth.- - Acus minor anternè rostrata, vulgo balou, ete. > Mumier, manuscrib de la Bibtiotheque. - Petit espadon. Bloch, pl. 391. ramphus, et parait se rapporter surtore bsil-nec, Hemibrasiliensis de M. Cuvier. D. rement très-noire, et le bout de la mâchoire inférieure d'un beau rouge.

Commerson a observé, en juin 1767, aupres de Rio-Janeiro, un gambarur, qui n'avait guère plus de huit pouces de longueur.

L'espadon a beaucoup de rapports avec le gambarur; il en a aussi avec le xiphias espadon et sa tète ressemble, au premier coup d'œil, une tête de xiphias renversée. La prolongation de la mâchoire inférieure est encore plus longue que dans le gambarur, aplatie et sillonnée auprès de l'ouverture de la bouche, dont les deux bord sont hérissés de plusieurs rangées de petitesdents pointues : d'autres dents sont situées autour du gosier; mais le palais et la langue sont unis. Le dessus de la tête est déprimé ; les opercules son rayonnés; le lobe inférieur de la caudale déargentée; la tête, la mâchoire inférieure, le dos et la ligne latérale sont communément d'un beat vert, et les nageoires bleuâtres '.

On trouve l'espadon dans les mers des deux Indes. Nieuhof et Valentyn l'ont vu dans les Indes orientales; Plumier, Du Tertre, Browne et Sloane l'ont observé en Amérique. Sa chair est délicate et grasse. On l'attire aisément dans les filets, par le moyen d'un feu allumé au milieu d'une nuit sombre, II parait qu'il multiplie beaucoup.

\section{L'ÉSOCE TÉTE-NUE ?}

Erythrims ...., Cuv.; Esox g!moocephalus, Liun., Gmel., Lac. '.

ET L'ÉSOCE CHIROCENTRE.

Chirocentrus....., Cur.; Esox Chirocentrus, Lac.;
Clupea dentex, Sčhneid; Clupea Dorab, Gmel. 4 .

Le premier de ees deux ésoces habite dans les

T10 ou ta rayons a chaque pectorale de l'ésoce gambarur. 6 a chaque ventrale, 14 a la nageoire de la queue. -10 ventrale, 18 a la cádale.

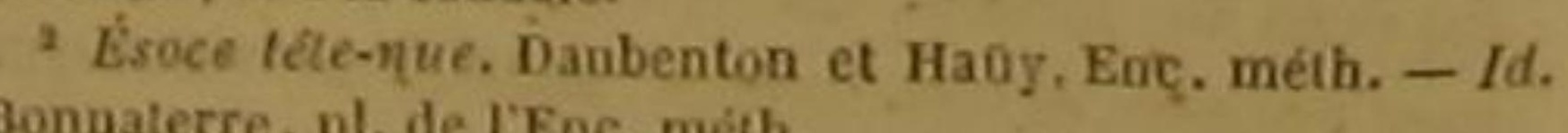
Ene, méth.

hrinus, de Gronow et de M. Cuvier, dans Ia Gruas, Ery. Clupes, ordre des Nalacopterygiens abdominaux. D. -Ce poisson est le type du genre Chizocestak, Chirocentrus, de M. Cuvier, dans la famille des Clopes, ordre des passe celui d'en haut. La couleur générale est woyons a cha que pectorale de l'ésoce espadon, 6 a chaque

Indes ; le second a été observé par Commerson, qui en a laissé un dessin dans ses manuscrits. Nous lui avons donné le nom de Chirocentre, pour indiquer le piquant ou aiguillon placé auprès de chacune de ces nageoires pectorales que l'on a comparées à des mains. Une sorte de loupe arondie paraít aut-dessus de ces mêmes pectorales. La ligne latérale règne près du dos, dont elle suit la courbure. Les écailles sont petites et serrées. Les deux lobes de la eaudale sont très-grands; l'inférieur est plus long que l'autre '.

L'ÉSOCE VERT ? Esox viridis, Lìnn., Gmel, Lac, '.

Ce poisson habite dans les eaux douces de la Caroline, où il a été observé par Catesby et par le docteur Garden 4.

\section{CENT QUATRE-VINGT-SEPTIEME GENRE.} LES SYNODES

Louverture de la bouche grande; le gosier large; les ndchofres garnies de dents nombreuses, forles et pointues; point de barbillons; l'opereule et T'orifice des branehies ires-grands; le corps el la queue trisallonges el comprimis latéralement; les écailles dures; pojnt de nageoire adipeuse; les nageoires du dos et de l'anus caurtes; une seule dorsale : cefle dernière nageoire placio au-dessus ou un peu audessus den
ventrales, ou plus près do la lele que ces dernières.

PREMIER SOUS-GENRE.

Ia nageoire de la queue fourchue ou echanerle en

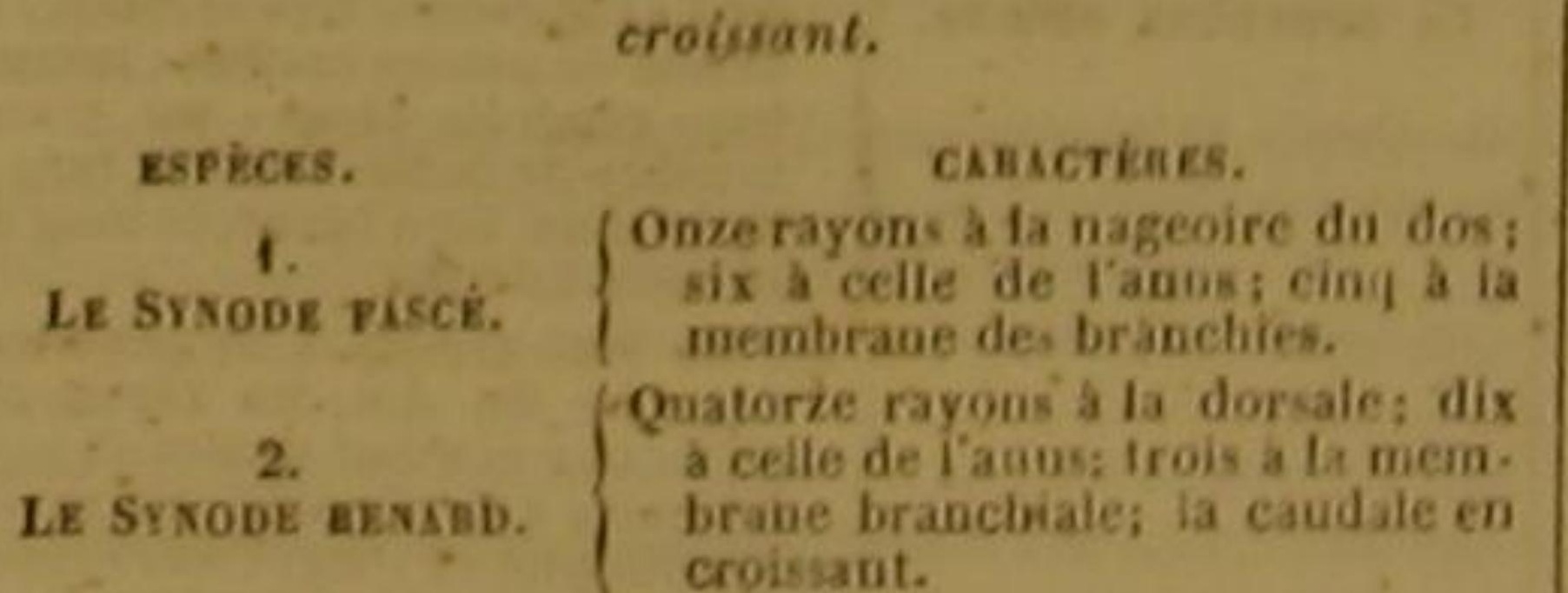

- 10 rayons à chaque pectorale de lésoce téte-nue, 19 a la ageoire de la queue.

'Ésoce verdel. Dàubenfon et Hañy, Enc, méth. - Éroce aiguille eccailleuse. Bonnaterre, pl. de IEnc. meth.

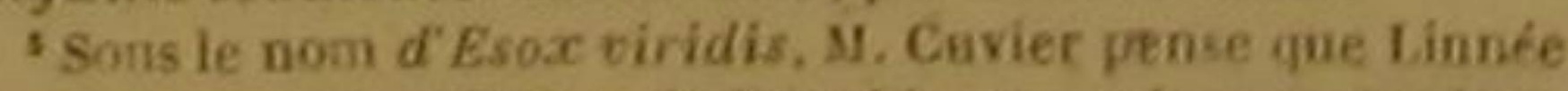
a reuni une description de lorpho eavoyee par Garjen,

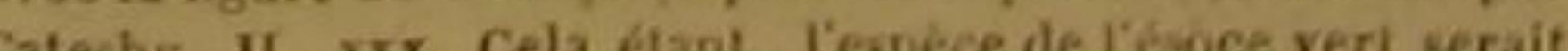
factice $\mathrm{D}$.

- 11 rayons à chaque pectorale de l'ésoce vert, 6 à chaque véntrale, 16 a la nageoire de la queue.

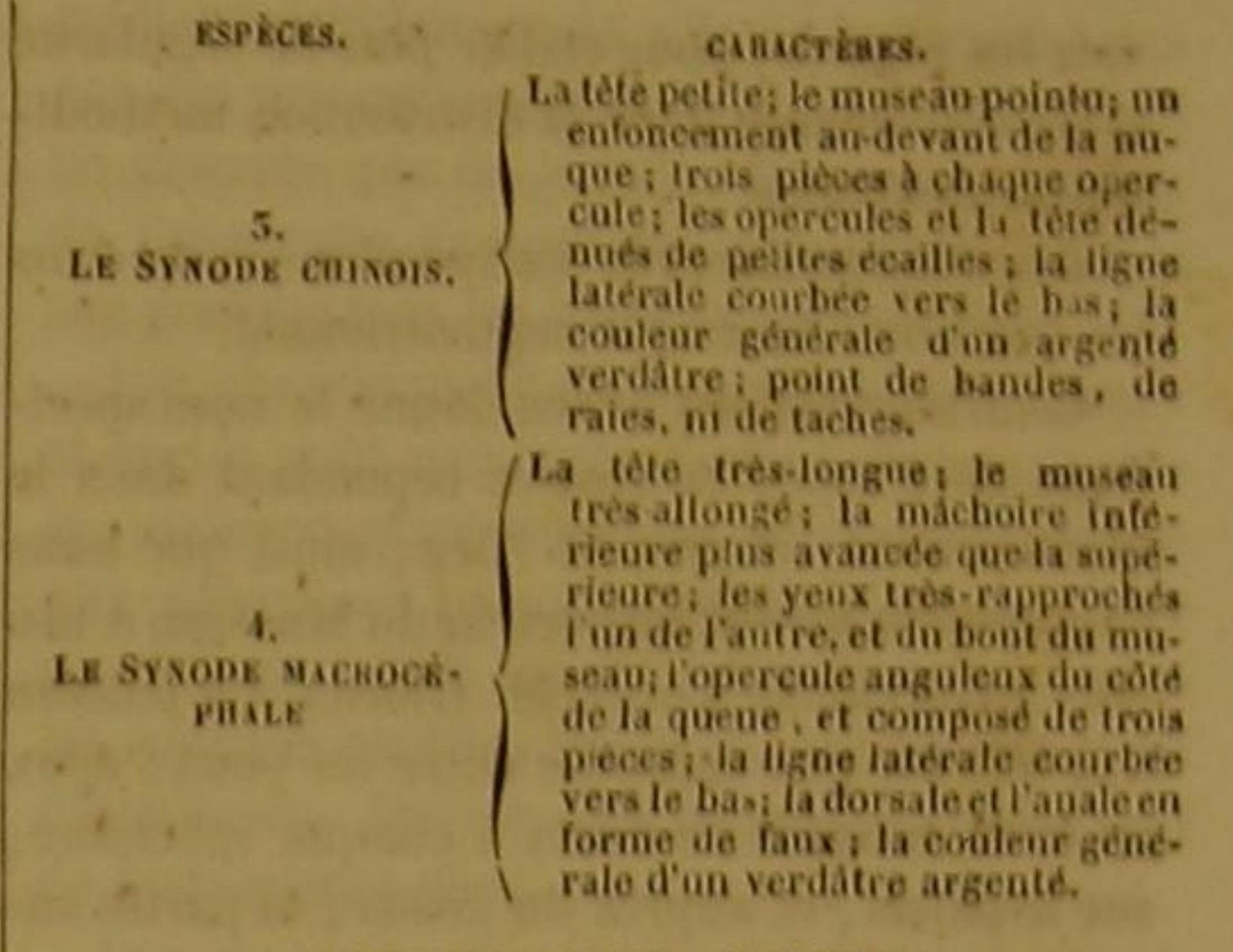

SECOND SOUS-GENRE. La nageoire de la queue, arrondie, ou rectiligne, a sans dehanerure.

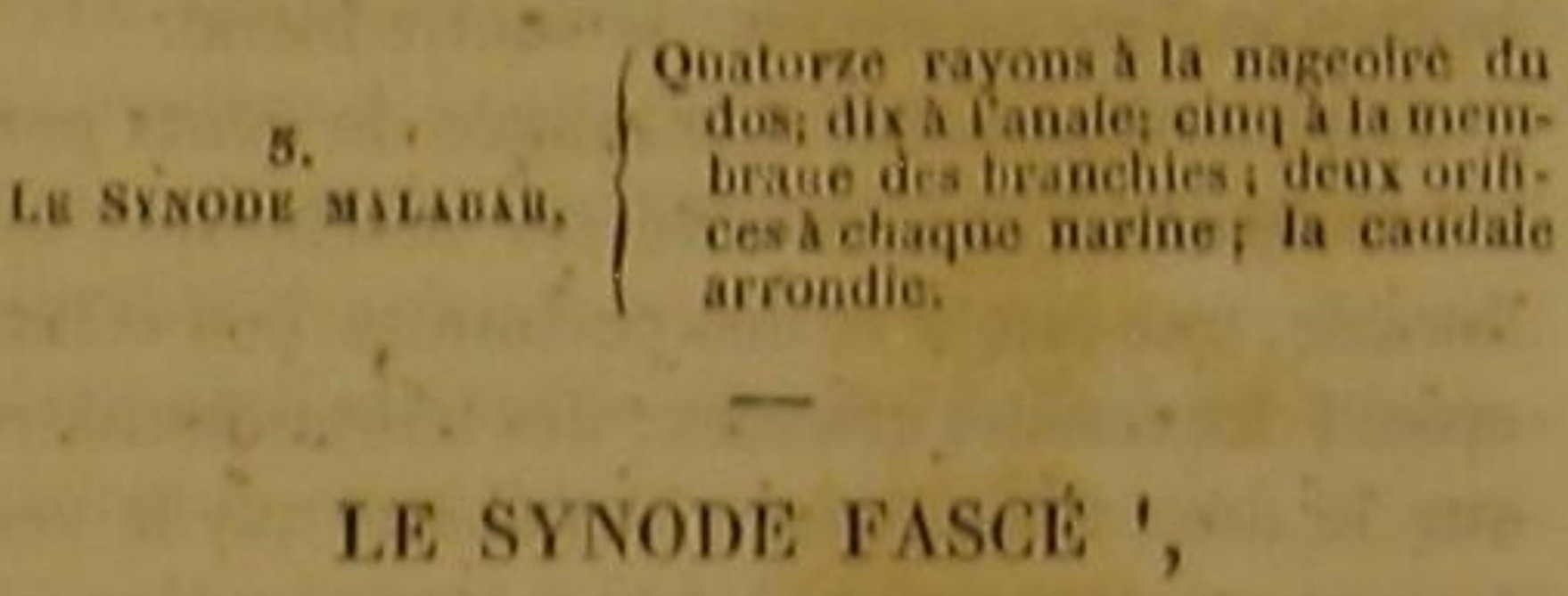

LE SYNODE FASCE ',

Saurus...., Cuv.; Synodus fascintus, Lac, ; Esox Syno dus, Limn., Gmel. '?

Synode Renard', Butirinus americanus, Cav , Synodus

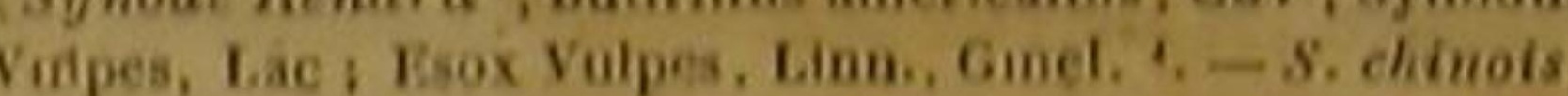
Elops indicus, Cov ; A rgentina machmata, Vorskael s Megi salmoueus, Rotsteri Synodus chinensis, Lacep, 5. $-s$, Macrocéphiale, Synodus macroceptalus, Lac,,$-s$, MaloSy

Nous n'avons pas besoin de faire remarquer combien les synodes ont de ressemblance avec les ésoces, dont nous ávons cru cependant dei Ésoce sunode. Daubenton et Haay, Enc, méth. - Id. Bonnaterre,
tab. 7, fig. 1 .

2Le synode fascé de Lacépede est seton M. Civier, mie spéce do sons-genre SAtaE (Saurus), dass le graad genr. Stesor, qui avait perdu sa nageoire adipeuse, Conse. quemment it apparticnt a ta famille des Salmo

des Salacopterybieas abdominaux. B.

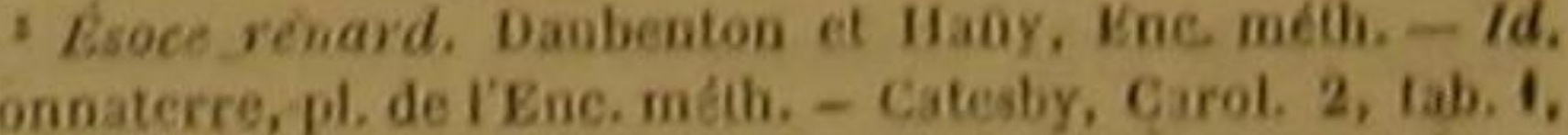
fig. 2.

Ce polsson est du genre Betimas, Butirinus, Comm. abtominaux, M. Lacépede l'a déa decrit soos ie nom de Butias bassak. et il te reproduil ane trobieme fois

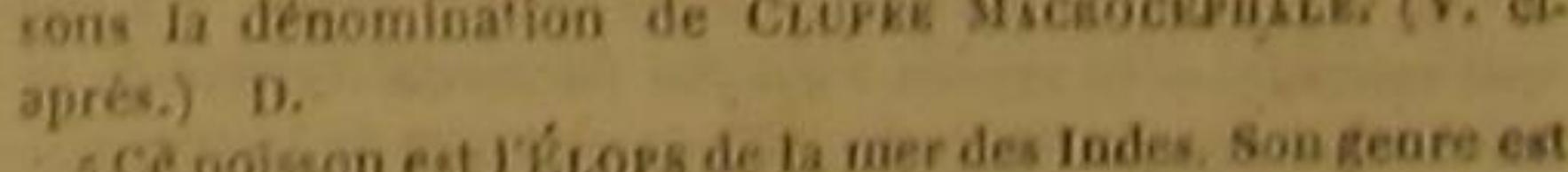
T. Wuilte dest Clopess dons Yordre des Malacoptéryzieas adominaux, Cav. D.

- M. Cuvier ne cite pas ce poisson. D.

"Esox malabarjeus. Bloch, pil. :52.

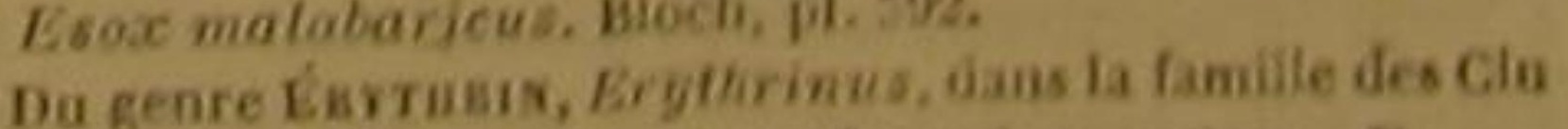

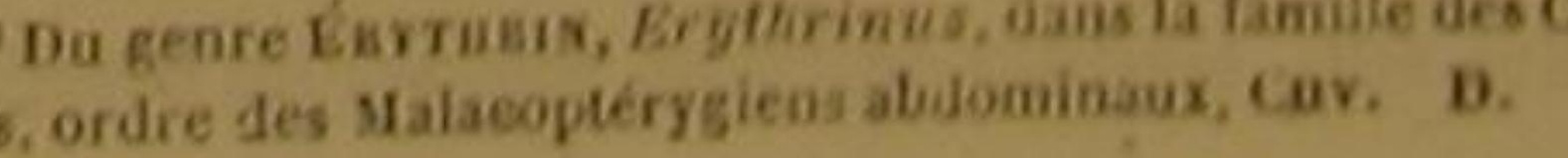


voir les séparer, pour établir plus de régularité et de convenance dans la distribution méthodique des poissons.

Les deux premiers de ces synodes vivent dans les mers de l'Amérique septentrionale.

Celui auquel nous avons donné le nom spécifique de Fascé, se trouve cependant dans la Méditerranée, auprès de Nice, ainsi que nous l'apprend le savant inspecteur du Muséum d'histoire naturelle de Turin, M. Giorna. Ce poisson a la tête un peu enfoncée entre les yeux; deux ou trois rangées de dents à chaque mâchoire, sur le palais, et auprès du gosier; la partie supérieure de la langue toute couverte de petites dents; la dorsale triangulaire; des écailles grandes; des bandes transversales brunes; des raies brunes sur les nageoires; le ventre blane:

Lẹ renard présente une rangée de dents petites et aiguës à chacune de ses mâchoires; une dorsale, une anale et des pectorales peu échancrées; des écailles grandes; des teintes jaunâtres sur le dos; une couleur blanchâtre sur le ventre, et une longueur de six à vingt pouces.

Nous avons vu les synodes, que nous avon nommés Chinois et Macrocephale, et qui n'ont encore été décrits par aucun naturaliste, trèsbien représentés dans la collection de peintures chinoises cédée à la France par la Hollande, et conservée dans la bibliothèque du Muséum d'histoire naturelle.

La ligne latérale du macrocéphale est dorée; ses ventrales sont très-petites; il ne montre ni aches, ni bandes, ni raies longitudinales.

La mâchoire inférieure du malabar excède un peu celle d'en haut '; l'une et l'autre sont armées de dents inégales, peu serrées, mais grandes, fortes et pointues : d'autres dents hérissent la langue et le palais. Les écailles sont larges et lisses. Le dos est verdâtre; la tête, les tlancs et le ventre sont jaunâtres; les nageoires, variées de jaune et de gris, présentent des raies brunes.

Le malabar habite dans les rivières de la côte dont il porte le nom; sa chair est blanche, agréable et saine.

CENT QUATRE-VINGT-HUITIÈME GENRF.

\section{LES SPHYRÈNES.}

Wouverlure de la bouche grande; le gosier largo; les mdchoires garnies de dents nombreuses, fortes el pointues; point de barbillons; l'opereule et l'orifice allonigés, et comprimés latiralops et la queue trisgeoire a comprimes lateratement; point de nageoire adipeuse; les nageoires du dos et de lanu.
courles; deux nageoires dorsales.

$$
\text { Espéces. }
$$

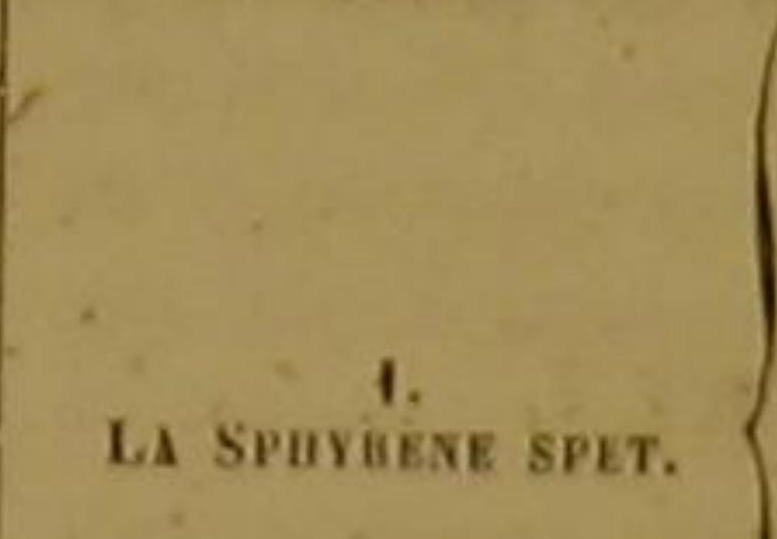
Quatre rayons a la première na.
geoire du dos ; dix a la seconde geoire du dos ; dix a la seconde;
dix a celle de lanus; la máchoire interieure plus avancée que celle
den hiant; les dents nombreuses,
inégalés, lortes et crochues: i

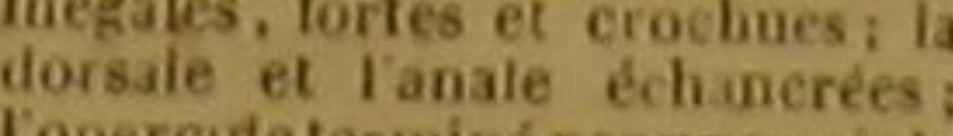
Topercuteterminé par une pointe
et couvert de petites écailles: couleur generale diun blecealtre
argenté point de taches, de banargenté; point de taches, de bal.
des, ni de rails : Tanale, les ven. trales et les pectorales reoges. ing rayons a la premiére dorsale;
neuf a la seconde; neuf a I'anale;

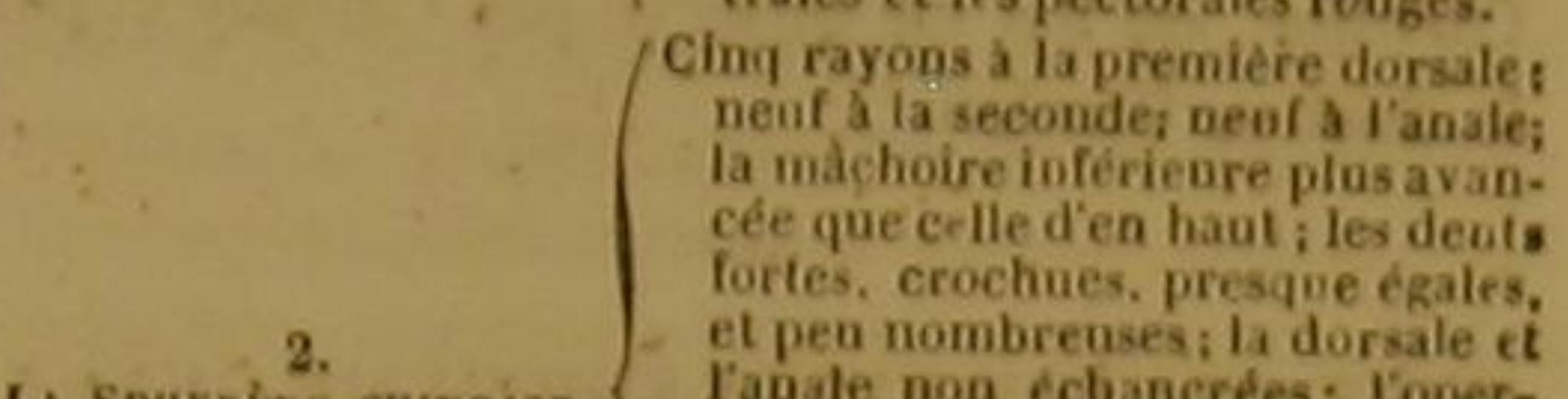

LA SPHYkikis cuisoise.

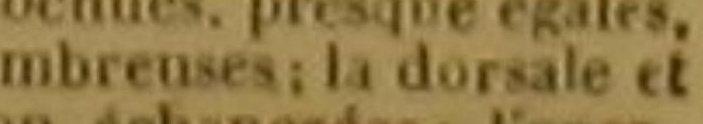
ranale non echanerées: Loper-
cule presque arrondi par der. cale presque arrondi par der-
riere, et denue de petitesécailiess
la conteur générate et celle de loutes tes nageorires d a un verua.
re argenté; point de taches, de the rayons a la premiere nagcoire

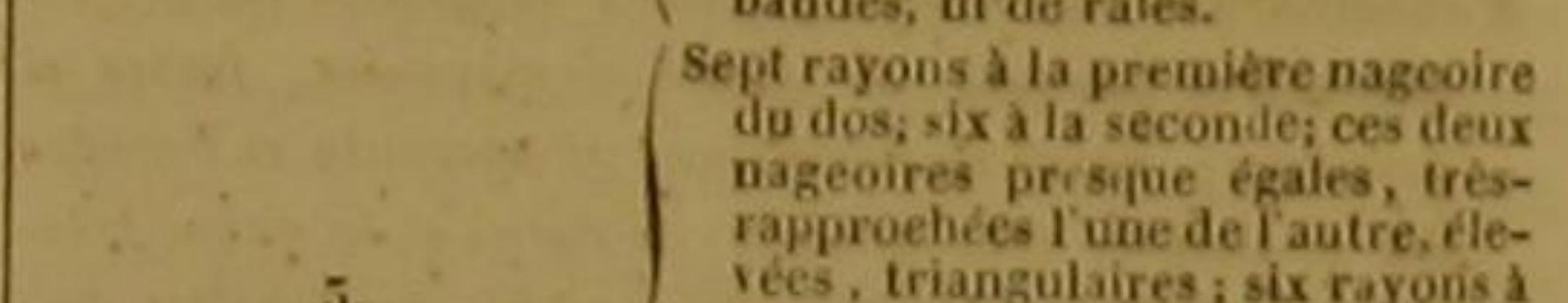

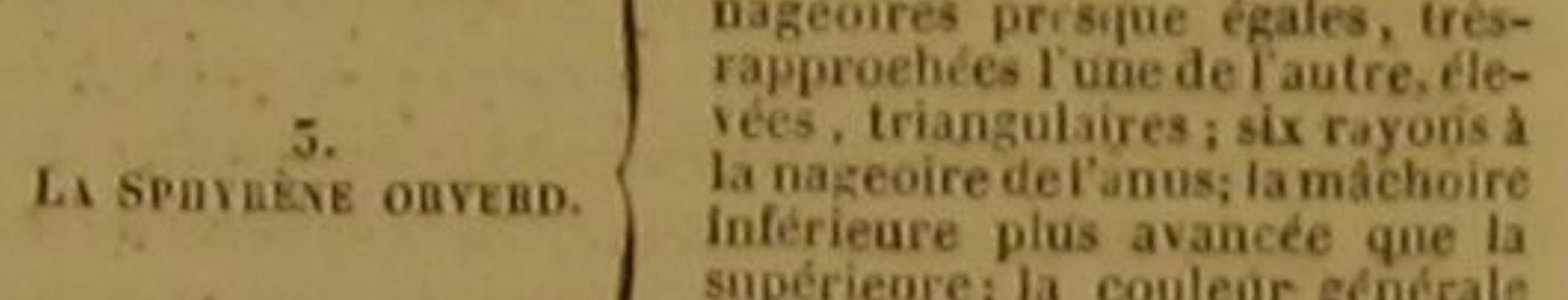

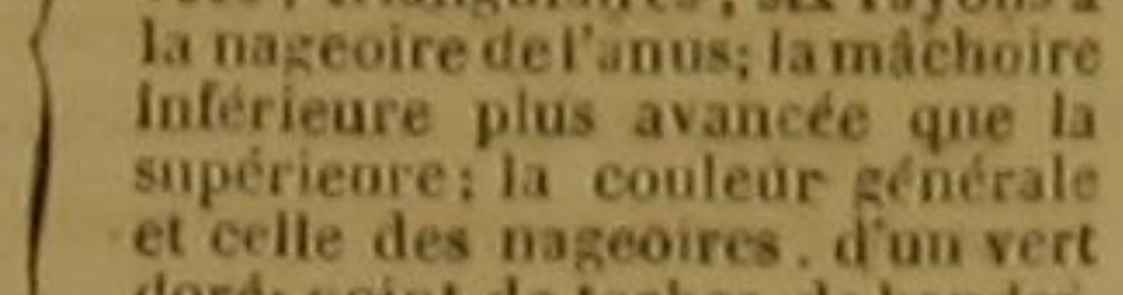
oré; point de taches, de bandes,
i de raies. qu rayons à la première dorsale;
lix a ta seconde ; huit a la na-

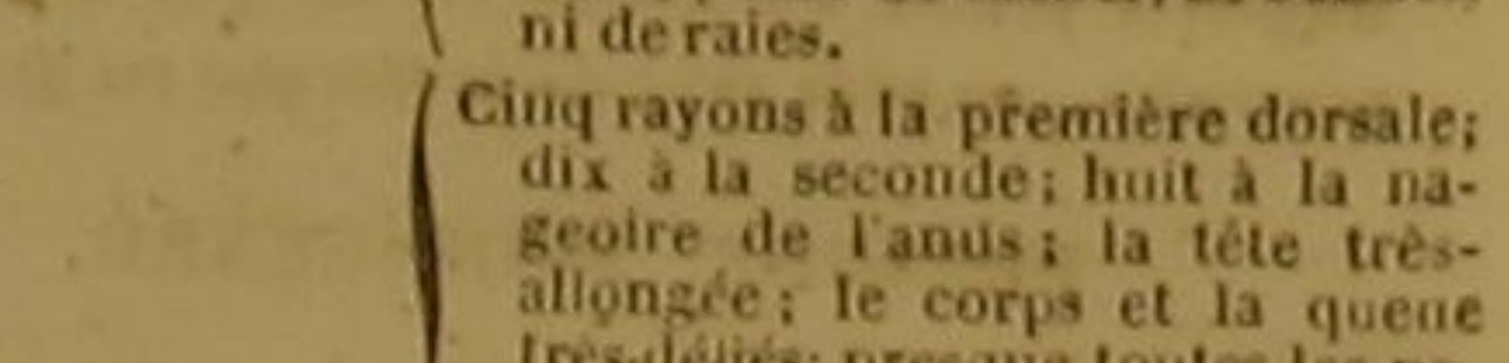

L. SPUYTÉNe Becune.

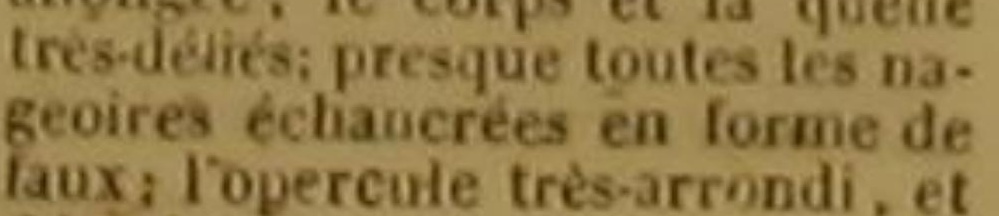
dénué de petites écailles; la couleur genérale bleue; ;n , rrand
nombre de taches rondes, inégaleset d' un bleu foncé, le iong ie de
las ligne lateraze. la ligne laterale.

LA SPHYRENE SPET , Sphyręua Spet, Cur.; Esox Sphyræna, Linn., Gmel, Sphyriena Spet, Lac. ?

La Sphyrène chinoise, Sphyrena....., Cuv.; Spbyrena chinensis, Lacep. ${ }^{3}-s$. Orverd ', Centropoma undecimalis, Cuv.; Sphyrrena aureuviridis, Lacep. ${ }^{3},-s$. Becune Sphyrena becasa, Lacep., Cav. - S. aiguilles, Be-

Les sphyrènes ont été placées parmi les ésoces; leurs deux nageoires dorsales, et quelques autres traits, doivent cependant les en séparer.

Des sues digestifs très-puissants, des besoins impérieux, une faim dévorante-très-souvent renouvelée, des dents fortes et aiguës, des formes très-déliées, de l'agilité dans les mouvements, de la rapidité dans la natation; voila ce que présentent les sphyrènes, vollà ce qui leur rend la guerre et nécessaire et facile; voilà ce qui leur faisant surmonter la crainte mutuelle qu elles doivent s'inspirer, les réunit en troupes nombreuses, dont tous les individus poursuivent si-

+Cestra, en grec, - Malleus.-Marteau. - Pel escome, dans le départ, du Var. (Note communiquée par le préfe

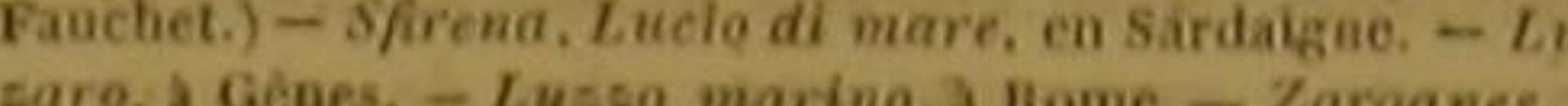
Grece-Mugesil, dgam, Goedd, en Arabie, - P feill hech, See hecht, en Allemagne, - Pyl-snork, en Hollande, - Sea pike, Spit-fish, en Angleterre- - Picuda, a la Havane. Espedon, en Espagae, - Esoce spel Daubenton et laany, Ene, méth. - Id, Bonnaterre, pl. do I'Enc. meth. - Mu

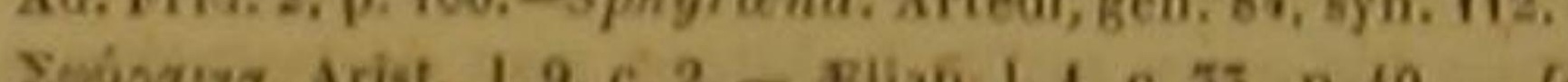

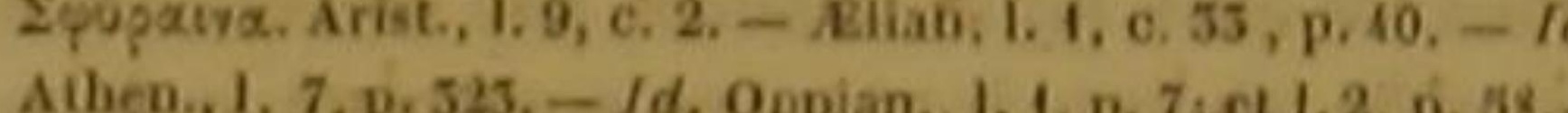

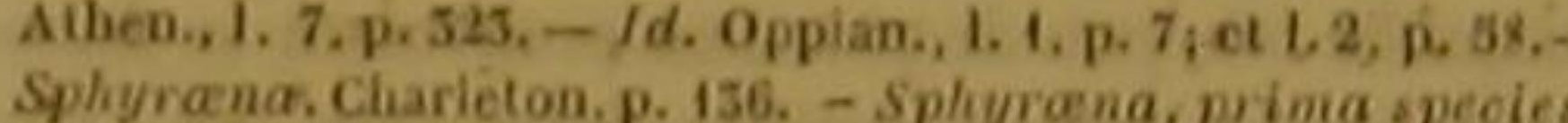
Sphyrano, Charieton, p. 136. - Sphyrana, prima speoies.
Bondelet, part. 1, 1.8, c. 1. - Id. Gesner, p. 882, 1059; $\mathrm{e}$

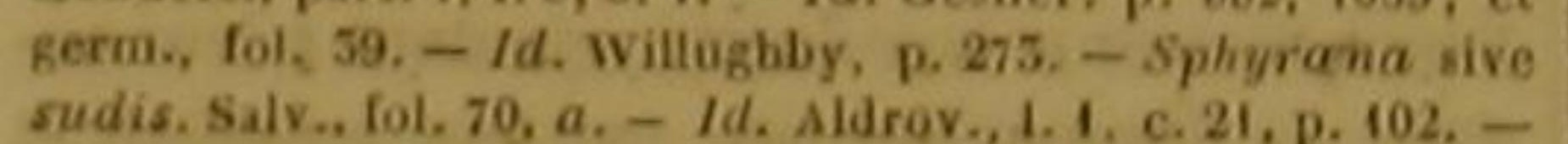
Id. Jonstoo, I. I, tit. 2, c. I, $a, 16$, tab. 18, tig. I. $-I d$, IIp. 84. - Bloch, pl. 389. - Spet. Valmont de Bomare, Diet d hist, nat.

'Ce poisson est du genre Sparaíaz, adopté par M. Cuvier. coídes. $\mathrm{D}$

- Dans la première édition da Règne animal, M. Cuvier dit quili considere la Sphyrène chinose de Lacépéde comme différant pas spécitiquenent de la Splyrène Spel. D. cités. 'L espece de la Sphyrène orverd, Lac., est fondée sur une mus undecimalis, Cav., famillo des Acanthoptérygien perenides. D.

- esphyrena antillana , argentocærulea., Plumier, peir'res sar vélin déja citées.

'I. Cusier, dans la première édition du nègne animal

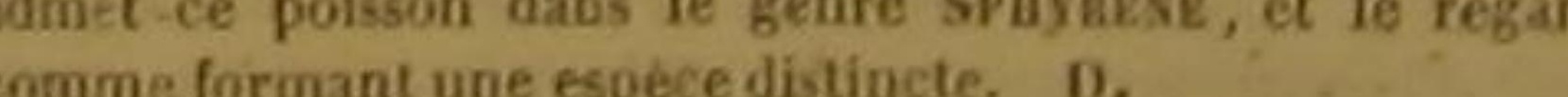

crits de la Biblioth. royale deja eités. 'L'espece de la Sphyrene aignilie, Lac,, ne paralt étre étahlie que sur une figare d'Orphie, où la position dupoisson miêre dorsale, Cúvier, Régne anim., premiêre édition. D. muitanément leur proie, s'ils ne l'attaquent pas par des manœuvres eoncertées, et auxquelles il ne manque que de grandes dimensions et plus de force pour exercer une domination terrible sur presque tous les habitants des mers.

Une chair blanche et qui plait à l'oeil, délicate et que le goût recherche, facile à digérer et que lá prudence ne repousse pas; voilà ce qui dỏnne aux sphyrènes presque autant d'ennemis que de vietimes; voila ce qui, dans presque toutes les contrées qu'elles habitent, fait amorcer tant d'hameçons, dresser tant de piéges, tendre tant de filets contre elles.

Des cinq sphyrènes que nous faisons connaire, les naturalistes n'ont encore décrit que la première; mais les formes ni les habitndes de cefte sphyrène spet n'avaient point échappé à 'attention d'Aristote, et des autres aneiens auleurs qui se sont oćeupés des poissons de la Médíteríanée.

Le spet se trouve en effet dans cette mer intérieure, aussi bien que dans l'Océan Atlantique, Il parvient à la longueur de deux pieds et demi. Ses conleurs sont relevées par l'éclat de la ligne latérale; qui est-un péu courbée vers le bas. Le palais est uni; mais des dents petites et pointues sont distribuées sur la langue et auprès du gosier. Chaque narine n'a qu'un orifice; les yeux sont gros et rapprochés; les écailles minces et petites; quarante coecums placés auprès du pylore; le canal intestinal est court et sans simuosités; la vésicule du fiel très-grande, et la vessie natatoire situće très-près du dos.

Les yeux de la chinoise sont très-gros; la prunelle est noire; l'iris argenté; la ligne latérale tortueuse. Commerson a laissé dans ses manuscrits un dessin de cette sphyrène, que nous avions déjà fait graver, lorsque nous avons vu ce poisson bien mieux représenté dans les peintures chinoises données à la France par la Hollande.

La sphyrène orverd est magnifique; son dos est élevé; son museau très-pointu; et son ail, dont-l'iris est d'un beau jaune, ressemble à un saphir énchâssé dans une topaze.

La parure de la bécune est moins riche, mais plus élégante; des reflets argentins ajoutent les nuances les plus gracicuses à l'azur et au bleu foncé dont elle est variée. L'óil rouge a le feu du rubis. Ses formes sveltes ressemblent plus à celles d'un serpent on d'une murène, que celles 
des autres sphyrènes dont nous venons de parler. La máchoire inférieure est un peu plus avancée que la supérieure; l'opercule composé de trois pièces; la ligne latérale presque droite.

La seconde dorsale et la nageoire de l'anus de la sphyrène aiguille sont échancrées de manière à représenter une faux. La mâchoire inférieure dépasse celle d'en haut. Chacune de ces mâchoires est armée d'une cinquantaine de dents étroites, crochues, longues, presque égales, et correspondantes aux intervalles laissés par les dents de l'autre mâchoire.

Nous devons à Plumier la connaissance de ces trois dernières sphyrènes '.

\section{$-$}

CENT QUATRE-VINGT-NEUVIÈME GENRE LES LÉPISOSTÉES.

L'ouverlure de la bouche grande; les machoires garnies de dents nombreuses, fortes el poinlues; point de barbillans ni de nageoire adipeuse; le corps el la queue geoire plus éloignée de lo wageire du dos; celle nacorps et la queue revitus da lete que les ventrales; cies les unes au-dessus des autres, très-ipaisses, treds-dures, et de naturo ous

EsPéces.

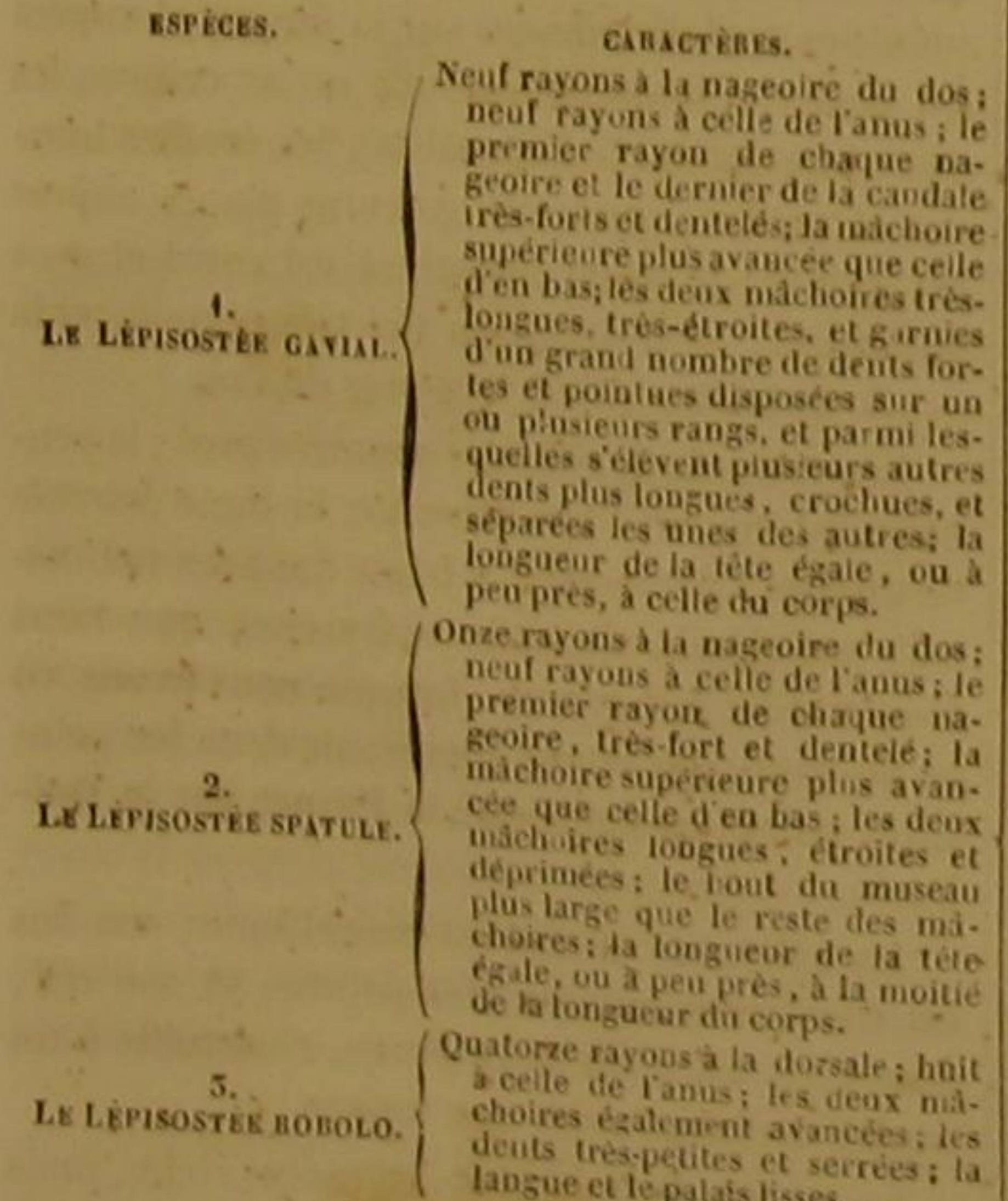
i $z$ rayons a la membrinne branchiale de la sphyrène spet. 4 a ch yque pectorale, 6 a cliaque ventrale, 20 a la naseore La queue -8 ou 9 rayons 2 la membrane des branchies de
ta ephyrene aignilie.

\section{LE LÉPISOSTÉE GAVLAL '}

Lepisosteus, osseus, Cav.; Lepisosteus Gavial, Lac.

LE LÉPISOSTÉE SPATULE,

Lepisosteus Spatula, Lac., Cuv. '.

\section{ET LE LÉPISOSTÉE ROBOLO 4.}

\section{Lepisosteas Robolo, Lac.; Esox chilensis, Molina, s,}

De tous les poissons osseux, les lépisostées sont ceux qui ont recu les armes défensives les plus sûres. Les écailles épaisses, dures et osseuses, dont toute leur surface est revêtue, forment une cuirasse impénétrable à la dent de presque tous les habitants des eaux, comme l'enveloppe des ostracions, les boucliers des acipensères, la carapace des tortues, et la couverture des caymans, dont nous avons conservé le nom à l'espèce de lépisostée la plus anciennement connue. A l'abri sous leur tégument privilégié, plus confiants dans leurs forces, plus hardis dans eurs attaques que les ésoces, les synodes et les sphyrènes, avec lesquels ils ont de très-grands rapports ; ravageant avee plus de séeurité le séjour qu'ils préferent, exercant sur leurs victimes une tyrannie moins contestée, satisfaisant avee plus de facilité leurs appétits violents, ils sont bientôt devenus plus voraces et porteraient dans les eaux qu'ils habitent une dévastation à laquelle très-peu de poissons pourraient se dêrober, si ces mèmes écaillès défensives qui, păr leur épaisseur et leur dureté, ajoutent à leur audace, ne diminuaient pas, par leur grandeur et leur inflexibilité, la rapidité de leurs mouvements, la facilité de leurs évolutions, l'inopituosité do leurs élans, et ne laissajent pas ainsi à

Trompelle de mer: - Aguja, en Espagne, - Knochen
hecht, par les AHemands. - shida dais, - par les AHemands. - Schild-snoek, par les Hollanglais des Indes occid - t - Green carfish, par les AnIndes or. - Balgeesche geeb, par les Hollang bali, dans les Indes. - Esoce cayman. Daubenton et Hañy, Enc, méth. C. Bonnaterre,pl. de IEnc. méth. - - Esox maxilli superiere longlore, cauda quadralâ. $>$ Artedi, gen. 14, syn. 27. Acus marim squanos, viridis. , Catesby, Garol. 2. 1. 50. Kai, p. 109. - Bloch, pl, $590,-$ Mus. Wd. Finghly, p. 22.Acus seu belóne americana, squamis durisinis p. 101."ptracta., Poisson armé de la rivière de saint- $L$ ataa

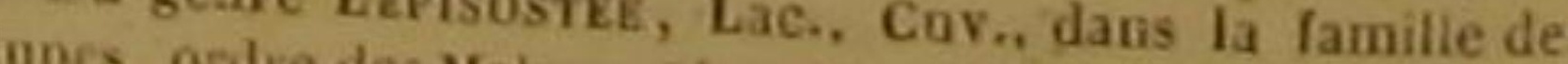
Clupes, ordre des Malacoptéryg ens abdominaux, Cuv. D. 4 Melina. Hist. natur. Chil., p. 196, - Cuvier. D. Bonuaierre, pl. de I'Eac. méth. p. 196, - Esoce robolo. leur proie quelque ressource dans l'adresse, l'agilité et la fuite précipitée. Mais cette mème voracité les livre souvent entre les mains des ennemis qui les poursuivent: elle les force à mordre sans précaution à l'hameçon préparé pour leur perte; et cet effet de leur tendance naturelle à soutenir leur existence leur est d'autant plus funeste par son excès, qu'ils sont très-recherchés à cause de la bonté de leur chair.

Le gavial particulièrement a la chair grasse et très-agréable au goût. On le trouve dans les lacs et dans les rivières des deux Indes, où il parvient à trois pieds de longueur. La dentelure remarquable qu'on voit áux premiers rayons de toutes ses nageoires et au dernier de sa eaudale, provient de deux séries d'écailles osseuses, allongées et pointues, placées en recouvrement le long et au-dessus de ce premier rayon, qui d'ailleurs est articulé. La forme générale de sa tête; le très-grand allongement de ses mậchoires ; leur peu de largeur; le sitton longitudinal creusé de chaque côté de la máchoire d'en hạt; les pièces osseuses, inégales, irrégulières, ciselées ou rayonnées, articulées fortement les unes avec lesautres, et enveloppant la tête proprement dite, ou composant les opercules; la quantité, la distribution, l'inégalité et la figure des dents ; la position des deux orifices de chaque narine, que l'on déconvre à l'extrémite du museau; la situation des yeux, très-près de l'angle de la bouche : tous ces traits lui donnent beaucoup de ressemblance avec le crocodile du Gange, auquel nous avons dans le temps conservé le nom de Gavial; et nous avons mieux aimé le désigner par cette dénomination de Gavial, que le distinguer, avec plusieurs naturalistes, par le nom de Cayman, ou Crocodile d'Amérique, auquel it ressemble beaucoup moins.

Les écailles osseuses dont ce lépisostée est revêtu lui donnent un nouveau rapport avec Ie gavial ou les crocodiles considérés en général. Ces écailles, arrangées de manière à former des séries obliques, sont taillées en losange, striées, relevées dans leur centre, et paraissent composées de quatre pièces triangulaires; celles qui s'étendent en rangée longitudinale, depuis la nuque jusqu'à la dorsale, sont échancrées, et réprésentent un cơur. La ligne fatérale est courbée vers le bas; l'anus deux fois plus voisin de la caudale que de la tête; la dorsale semblable, par sa forme presque ovale et par ses dimensions, à la nageoire de l'anus, qui règne directement au- dessous; la caudale obliqquement arrondie; la partie supérieure de la base de cette caudale couverte obliquement d'écailles ossêuses, qui doirent gèner un peu les mouvements de cette rame; la couleur génerale verte; celle des nageoires rougeâtre, sans taches, ou avee des taches foncées; et le ventre rougeâtre ou d'un violet très-clair. Aucun naturaliste n'a encore publlé de description du lépisostée spatule. Le Muséum d'bistoire naturelle renferme depuis longtemps un bel individu de cette espèce. La forme de son museau nous a suggéré son nom spécifique, de méme que nous avons voulu désigner les écailles osseuses des lépisostées par le nom générique que nous leur avons donné '.

La tête du spatule, comprimée et aplatie, est couverte de pièces osseuses, grandes, rayonnées et chargées d'aspérités. Le dessus de la màchoire supérieure offre de chaque coté quatre ou cinq lames également osseuses, et comme ciselées ou rudes. Un grand nombre de pièces petites, mais osseuses et articulées ensemble, couvrent, au delà des yeux, les parties latérales de la tete proprement dite, L'opercule, de même nature que ces lames, est rayonné, et composé de trois pièees. Chaque narine a deux orifices. Le palais est hérissé de petites dents. Les deux machoires sont garnies de deux rangées de dents courtes, inégales, crochues, et serrées. Indépendamment de ces deux rangs, la mâchoire d'en haut est armée de deux séries de dents longues, sillonnées, aiguêes, éloignées les unes des autres, et distribuées irrégulièrement. La mâchoire inférieure ne montre qu'une série de ces dents allongées : eette rangée répond à l'intervalle longitudinal qui sépare les deux séries d'en haut; et les grandes dents qui forment ces deux rangées supérieures, ainsi que la rangée d'en bas, sont recues chacune dans une cavite particulière de la mâchoire opposée.

On doit remarquer qu'au-devant des orifices des narines deux de ces dents longues et sillonnées de la mâchoire d'en bas traversent la máchoire supérieure lorsque la bouehe est fermée, et montrent leurs pointes acérées au-dessus de la surface dế cette mâchoire d'en hảut, comme nous l'avons fait observer dans le crocodile, en écrivant, en 1788, l'histoire de cet énorme ant-

La mâchoire supérieure, étant plus étroite que , Lepis, en gree, signifie dcallie. 
celle d'en bas, rend plus sensible l'élargissement qui donne au bout du museau la forme d'un spatule. L'ocil est très-près de l'angle de la boúche.

Les écailles osseuses forment, depuis la nuque jusqu'à la dorsale, cinquante rangées obliques ou environ : ces écailles sont en losange, rayonnées et dentelées ; celles qui recouvrentl'arête longitudinale du dos montrent une échancrure qui produit deux pointes. La ligne latérale est droite; la dorsale placée au-dessus de Yanale; et les ventrales sont à une distance presque égale de cette anale et des pectorales.

La mer qui arrose le Chili nourrit le robolo. Ce lépisostée a l'œil grand; l'opercule couvert d'écailles semblables à celles du dos, et composé de deux pièces; les nageoires courtes. La ligne latérale bleue; les écailles anguleuses, osseuses, mais faiblement attachées, dorées par-dessus, argentées par-dessous ; une longueur de près d'un mètre, la chair blanche, lamelleuse, un pen transparente, et très-aggréable au goùt '

CENT QUATRE-VINGT-DIXIEME GENRE. LES POLYPTĖRES 2

Un seul rayon d la membrane des branchies; deux events; un grand nombre de nageoires du dos.

ESTÉCE. cincrions.

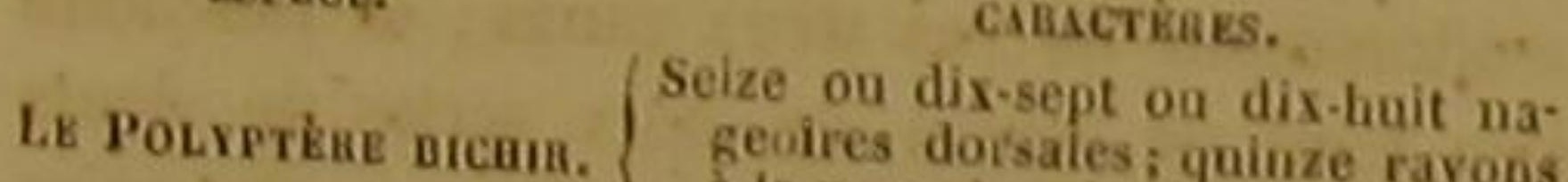
a la nagkoirc de i lauins rayons
dale arrondie. -

LE POLYPTĖRE BICHIR,

Polypterus Bichir, Geoff, Cur., Lac. s,

On doit la connaissance de ce poisson, dont
'organisation vant colletion est très-remarquable, à mon savant collegue M. Geoffroy, professeur au Muséum d'histoire naturelle. Cet habile et zélé naturaliste a vu le bichir dans les eaux du Nil, lorsqu'il a accompagné en Egypte, avee les autres membres de l'Institut du Caire, le les aufrançais et son adimirable du Caire, le héros français et son adimirable armée.

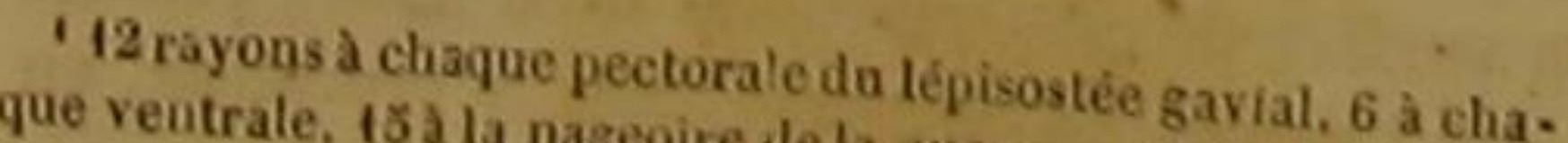
que peetorale du lépisostée spatule, 6 a che -15 rayons à cla10 rayons a la membraue des branchies do thue veatrale. II a chaque pectorale, 22 a la caudale. vier, gut bente forme par M. Geoffroy a ato

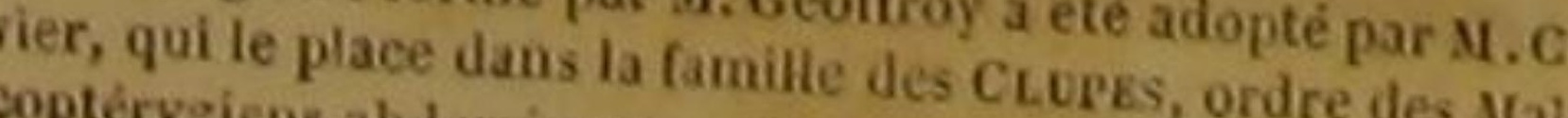
coptérygiens absominaus. D. des CLopes, ordre des Mala.
Il a publié la description et la figure de cet abdominal ' ; et voiei ce qu'il nous a appris de sa conformation.

Le bichir a beaucoup de rapports, par ses téguments, par la grandeur de ses écailles, par la solidité de ses lames, avec le lépisostée gavial. Mais combien de traits l'en distinguent !

Chaque nageoire pectorale est at tachée à une sorte d'appendice ou de bras qui renferme des osselets comprimés, réunis dans les individus adultes, et néanmoins analogues à ceux des extrémités antérieures des mammiferes. Chaque ventrale tient aussi à un appendice; mais cette prolongation est beaucoup plus courte que celle qui soutient les pectorales.

Chacune des seize, dix-sept ou dix-huit nageoires dorsales présente un rayon solide, comprimé de devant en ąrière, terminé par deux pointes, et vers l'extrémité supérieure duquel quatre ou eing pétits rayons, tournés obliquement vers la caudale, maintiennent le haut d'une membrane étroite, élevée, élargie par le bas, arrondie dans son bout supérieur.

Ce rayon solide s'articule sur une tête de l'apophyse épineuse de la vertèbre qui lui correspond. Son apophyse particulière est d'ailleurs très-pettite, et engagée dans le tissu cellulaire. Une-longue plaque osseuse remplaçant les rayons ordinaires de la membrane des branchies, la membrane branchiale du bichir ne peut ni se plisser ni s'étendre à la*volonté de l'animal. Le dessus de la têté est recouvert d'une grande plaque, composée de six pièces articulées les unes avee les autres. Entre cette plaque et l'opercule, on voit une série de petites pièces carrées, dont la plus allongée, libre dans un de ses bords, peut être soulevée comme une valvule, ontrer un véritable évent et laisser échapper 'eau de l'intérieur de la bouche.

Deux petits barbillons garnissent la lèvre inférieure; deux rangées de dents fines, égales et rapprochêes, hérissent les deux mâchoires; I angue est mobile, charnue et lisse.

La couleur générale est d'un vert de mer, relevé par quelqueś taches noires, irrégulières, La la caudaleque vers la tète. La longueur ordinaire du poisson n'excède pas vingt pouces: celle de sa queue n'étant égale qu au sixieme ou environ de cette longueur totale, l'abdomen est très-étendu.
L'ósophage est

Le canal intestinal proprement dit, a beaucoup de ressemblance avec celui des squales et des raies : sortant de la partie supérieure de l'estomac, et un peu arqué vers son origine, il se rend ensuite directement à l'anus; mais une large duplicature de la membrane interne forme une spirale, dont les replis prolongent le séjou des aliments dans ce canal.

On apercoit un cœecum très-court. La vessie natatoire est très-Iongue, composée de deux portions inégales, flottantes, presque cylindriques, et communique avè l'osophage par une large ouverture qu'un sphincter peut fermer '.

\section{CENT QUATRE-VINGT-ONZIĖME GENRE.}

Le corps et la queue trés-allonges; les deux mdehoiri très-longues, très-minees, tris-etroites, at-en formi daiguille; la nageoire dorsale siluée au-dessus do celle de l'anus; un' grand nombre da petites nageoir ou-dessus et au-dessous de la queve, ontre lo cautolo el les nageoires do l'anus el du dos.

KSPÉcE.

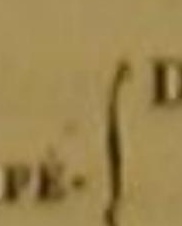

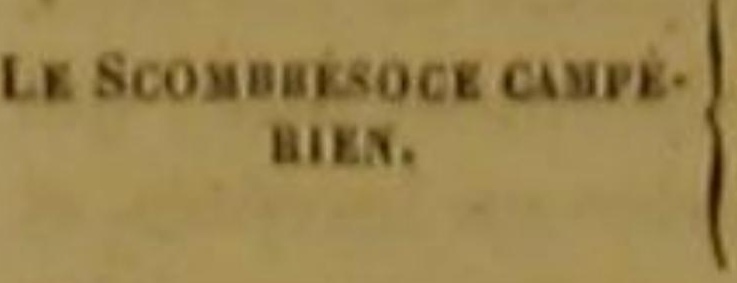
six petiles nageoires triangutai-
res au-dessus de la queue, et sept
and

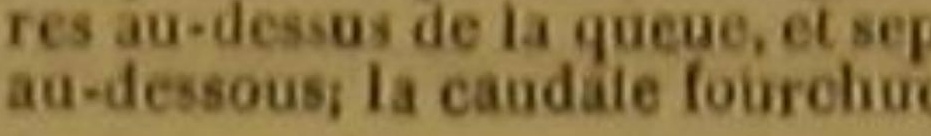

LE SCOMBRÉSOCE CAMPÉRIEN ${ }^{3}$.

Sairis Camperii, Cuv.; Scomberesox Camperii, Lac. ‘.

Parmi les animaux qui, par leur conformation ambiguẻ ou plutot composée, doivent être regardés comme des liens qui réunissent les divers groupes de l'ensemble immense que forment les êtres organisés, aucun ne mérite l'attention de l'observateur philosophe plus que le scombrésoce campérien. Non-seulement, en effet, 1 présente des traits distinctifs de deux genre très-différents, non-seulement il offre lés caractères des scombres et ceux des ésoces, mais en-

+ 52 rayons à chaque pectorale du polyptére bichir 12 chaque ventrale, 19 a la nageoire de la queue. 2 M. Cuvier admet les scombresoces de Lacépéde, comm formant, dans le gran 1 genre EROCUET, un sous-benre auque 1

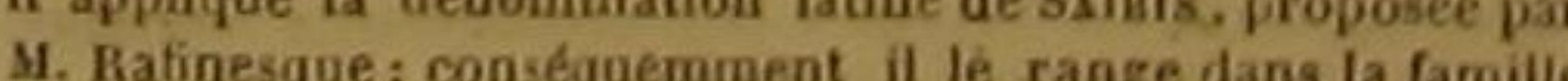

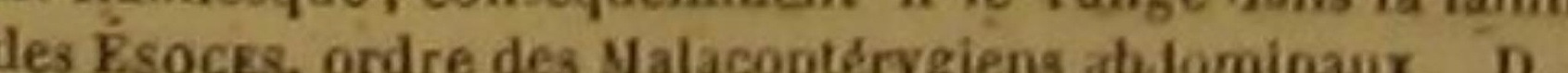
- Lacertus - Sauros - Sayn is. Bécased on autro espece d'aiguille. Rondelet, vart. 1,1.8, c. 5 . core les formes distinctives de ces deux genres sont rapprochées dans ce poisson mi-parti, sans être confondues, mèlées ni altérées. On croirait, en le voyant, avoir sous les yeux un de ces produits artificiels, fabriqués par une avide charlatanerie pour seduire la curiosité ignorante; et I'on serait tenté de le rejeter comme le résuitat grossier du rapprochement du corps d'un ésoce et de la queue d'un scombre. Aussi, malgré lautorité de Rondelet, qui l'a décrit en peu de mots, et qui en a fait graver la figure, avonsnous failli à imiter la réserve de Linnée, de Daubenton; de Haüy, de Gmelin, ainsi que des autres naturalistes modernes, et à n'en faire aucune mention dans cet ouvrage. Mais M. Camper, savant naturaliste de Hollande, et digne fils de feu notre illustre ami le grand anatomiste Camper, a eu la bonté de nous apprendre qu'il possédait dans sa colleetion un individu de cetto espèce que l'on ne doit rencontrer que très-rarement, puisqu'aucun observateur récent ne I'a trouvé. Il a bien voulu ajouter à cette attention celle de m'envoyer un dessin de cet abdominal, que je me suis empressé de faire graver, et une description très-détaillée et très-savante de cet osseux, d'après laquelle je ne puis que bien faire connaitre ce singulier poisson.

J'ai done criu que la reconnaissance m'oblia donner a l'objet de cet article le nom spécifique de campérien; de même quej'ai pensé devoir réunlr dans son nom générique ceux des deux genrés à chacun desquels on rapporterait sans balancer une de ses parties antérieure ou postérieure, si on la voyait sépazée de l'autre.

Ce scombrésoce, suivant Rondelet, parvient à la longueur d'un pied. L'individu qui appartient à M. Camper n'a que les trois quarts de cette longueur.

Les deux mâchoires sont assez effilées pour ressembler aux deux mandibules d'une béeasse; ou plutôt, comme elles sont courbées vers le haut, elles représenteot assez bien le bec d'une avocette : elles ont par conséquent beaucoup de rapports avec celles de l'ésoce bélone.

La máchoire supérieure, plus courte et plus étroite, s'emboite dans une sorte desillon formé par les deux branches de la máchoire inférieure. Ces deux mâchoires, dans l'indiviáu de Rondelet, étaient dentelées comme le bord d'une scie. Dans l'individu de M. Camper, moins grand et moins développé que le premier, on voit à la surface supérieure de la mâchoire d'en bas un 
bourrelet garni de quatre aspérités, et situé trèsprès de la cavité de la bouche proprement dite. La langue, qui est courte et rude, peut à peine atteindre jusqu'à ce bourrelet. L'ensemble de la tête a presque un tiers de la longueur totale de l'animal.

Les yeux sont grands; chaque narine a deux orifices; plusieurs pores muqueux paraissent autour des yeux et sur les mâchoires; le corps et la queue sont revêtus d'écailles d'une grandeur moyenne, qui se détachent avee facilité. Deux rangées de petites écailles, situées sur ie ventre, donnent à cette partie une saillie longitudinale. Les pectorales sont échancrées en forme de faux ; les ventrales très-petites et trèséloignées de la gorge ; la sixième petite nageoire dor'sale d'en haut et la septième d'en bas son plus longues et plus étroites que les autres. La couleur générale est d'un blane de nacre ou d'argent éelatant; la partie supérieure du poisson, la ligne latérale et la saillie du ventre présentent une nuance brune, mêlée de châtain ou de roux.

L'estomac est allongé; le canal intestinal menu et non sinueux; le foie long et rouge; la vésicule du fiel noirâtre; la chair semblable a celle du scombre maquereau '.

\section{CENT QUATRE-VINGT-DOUZIÈME GENRE.}

LES FISTULAIRES ?

Les machoires très-itroites, très-allongées, at en forme de lube; louverture de la bouche de l'extrémíté du museau; le corps el la queue très-allongés el trèsdelies; les nageoires petites; une seule dorsale; cell nate.

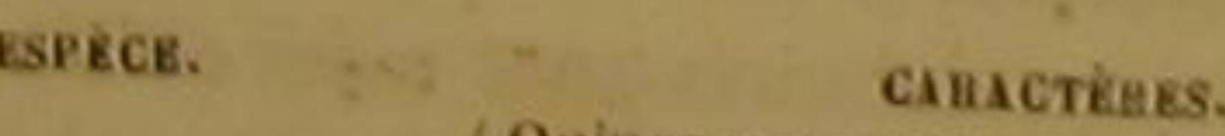

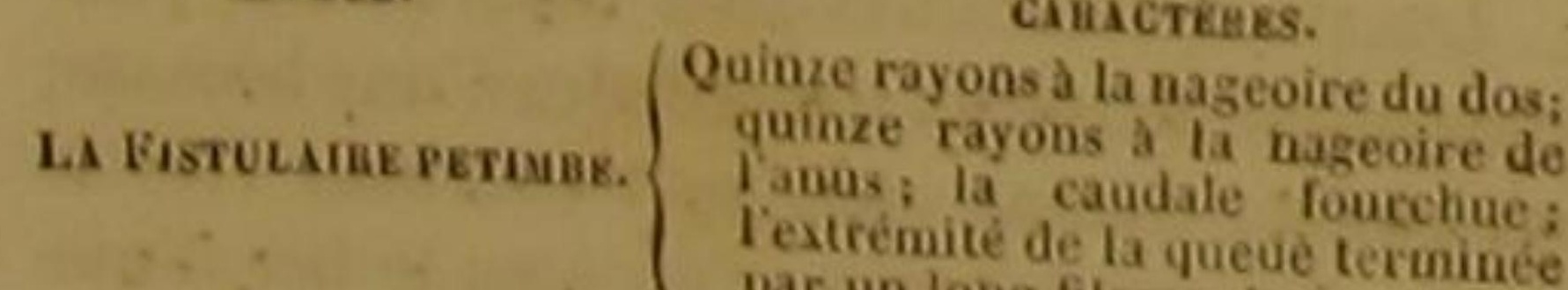
lestremite de la quate foucchine
par un loug filamineet

1'12 ou 15 rayons a chaque pectorale du scombrésoce can perien, 6 ou 7 a chaque ven rale.
2.M. Cusier adopte le genore

M. Cusier adopte le geure Fistulane de Linnée, et il le pariage en dille des Acanthopterygiens bouche en ol te tome, qui sont des genus-genres, I' Fistolaire, el $2^{\circ}$ A Aulosame, qui sont des geares pour $\mathrm{M}$, de Lacépede. $\mathrm{D}$.

\section{LA FISTULAIRE PETIMBE '.}

Fistularia Tabaearia, Bl., Linn, Gmel., Cuv.; Fista. laria Petimba, Lac. .

Nous pouvons donner de ce grand et singulier poisson une description beaucoup plus exacte que toutes celles qui en ont été publiées jusqu'ì présent; nous en avons trouvé une très-êtendue et très-bien faite dans les manuscrits de Commerson, qui avait vo cet animal en vie : d'ailleurs nous avons examiné plusieurs individus de cette espèce, qui faisaient partie de la collection de ce célebre voyageur, conservée dan le Muséum d'histoire naturelle; nous avons pu disséquer quelques-uns de ces individus, et découvrir dans la conformation intérieure de la fistulaire pétimbe des particularités dignes d'attention, que nous allons faire connaítre.

Cette fistulaire parvient à la longueur de plus de trois pieds. Elle est surtout remarquable par la forme de sa tête et par celle de sa queue.

La longueur de sa tête égale le quart ou environ de la longueur totale. De plus cette portion de l'animal est aplatie, et comprimée de manière à présenter un peu la forme d'une sorte de prisme à plusieurs faces.

On compte ordinairement quatre de ces faces longitudinales sur la tête proprent est sillonnée par-dessus et ciselée sur les côtés, et cing ou six sur les mâchoires, qui sont avaneées en forme de tube, et rayonnées sur une grande partie de leur surface.

Les deux côtés de la tête, depuis l'ouiverture des branchies jusque vers le milieu de la longueur du museau, sont dentelés eomme les bords d'une sciê; et les dentelures sont inelinées vers le bout de ce museau si étroit et si prolongé.

Sipe- Trompelle.-Flute. - Filencul.-Trompetro, par les Espagnols. - Tobackspleife, Rohir fisch, par les Atpar les Hollandai is. - Tabacofish, pas - Tolaypipe, visch, buaba, par les Bcasiliens: - Nus. Ad. Frid, 1, p. - Po Petim ig. 1. - Solenostomus canda bifurci, in setion by t. 26, ceam abeunte. Y Groñov, Mus. 1. n. 51 . - Trompetle pe. Ji. de l'Encenton et Haoy, Ene. méth. - Id. Bonnaterre, Maregrav. Brasil. 48, - Wipe. Bloch, pl. 587. - Pelimbuaba. Rai, Pisc. 110, n. 8. - Id, Catesby, Cylth. Append. 22. -

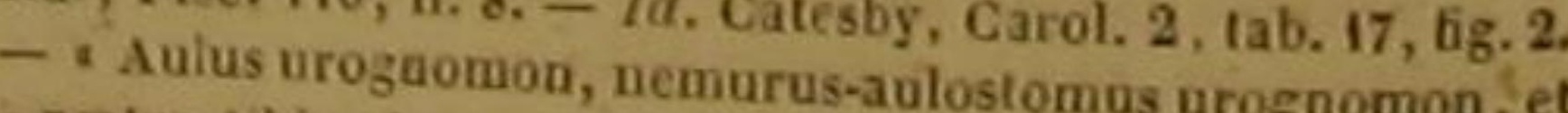
- rostro tibiz inslar elougato, stylo ex sinu caids retrorPipe. Aroilucto. , Commerson, manuscrits déja cités. a ${ }^{2}$ Du sous white, etc., pl. 64, fig. 2 . Famille des Aeane Fistcluar, dans le genre đu méme nom.
L'ouverture de la gueule, située à l'extremité du tuyau formé par les mâchoires, n’est pas aussi petite qu'on pourrait le eroire, parce que les deux måchoires s'élargissent un peu en forme de spatule vers leur extrémité. Ces deux mâchoires, dont l'inférieure est un peu plus avancée que la supérieure, sont hérissées de petites dents, dans toute la partie de leur longueur où elles ne sont pas réunies l'une à l'autre, et où elles sont, au contraire, assez séparées pour former l'orifice de la bouche.

La langue est lisse

Le tour du gosier est rude en haut et en bas.

Les narines, placées très-près des yeux, et par conséquent très-loin de l'ouverture de la bouche, ont chacune deux orifices.

Les yeux sont très-grands, saillants, ovales; et leur arand diamètre est dans le sens de la longueur du corps.

L'opercule, composé d'une-seule pièce, est allongé, arrondi par derrière, rayonné, et bordé d'une membrane dans une grande partie de sa eirconfêrence.

Les os demi-circulaires qui soutiennent les branchies sont lisses et sans dents.

On voit le rudiment d'une cinquième branchie. La partié antérieure du corps proprement dit est renfermée dans une cuirasse cachée sous la peau, mais composée de six lameslongues et os. peau, mais composée de six lamesiongues et osseuses. Deux de ces lames sont situées sur le dos; une, plus courte et plus étroite, couvre sont les inférieures; et leur surface présente plusieurs enfoncements très-petits et arrondis. plusieurs enfoncements très-petifs et arrondis.
Les ventrales sont très-séparées l'une de l'aure; la dorsale et l'anale ovales, et semblables l'une à Pautre.

La ligne latérale est droite; elle est, de plús, dentelée depuis l'anus jusqu'à l'endroit où elle se termine.

Entre les deux lobes de ta caudale, la queue, devenue plus arosse, a la forme d'une olive, et dowe nassance a un filoment, dont la longueur est à peu près égale à celle du corps progueur est à peu près égale à celle du corps prodeur, part de l'extrémité de l'épine du dos, a été comparé, pour sa nature, à un brin de fanon de baleine, en a la couleur et un peu l'apparence, mais ressemble entièrement par sa contexture aux rayons articulés des nageoires, et présente des articulations entièrement analogues à celles de ces derniers.
La peau est unie, et n'est pas carnie d'écailles facilement visibles.

La couleurgénérale de la fistulaire petimbeesi brune par-dessus et argentée par-dessous, Les nageoires sont rouges. Les individus vus par Commerson, dans les détroits de la NouvelleBretagne, au milieu des eaux du grand Océan equinoxial, et ceux qu'il a observés à l'ile Bourbon, ne présentaient pas d'autre parure: màs ceux que le prince Maurice de Nassau, Plumier, Catesby, Browne, ont examinés dans les Antilles ou dans l'Amérique méridionale, avaien sur leur partie supérieure une triple série lonitudinale de taches petites, inégales, ovales et d'un beau bleu.

Commerson a trouvé l'estomac des petimbes qu'il a disséquées, très-long, et rempli de petits poissons que les fistulaires peuvent pecher avee facilité, en faisant pénétrer leur museau trèsallongé et très-étroit dans les intervalles des rochers, sous les pierres, sous les fucus et parmi les coraux.

Le petimbe se nourrit aussi de jeunes crabes. Sa chair est maigre, et, dit-on, très-agréable au goût.

Yoici maintenant ce gue nous avons remáqué de particulier dans la conformation intérieure de cette fistulaire

L'épine dorsale ne présente que quatre verèbres, depuis la tête jusqu'au-dessus des nageoires ventrales. La premiere de ces quatre vertebres, n'a que deux apophyses latérales, petites rès-courtes et pointues; et cependant elle est d'une lonsueur démesurée, relativement aux trois qui la suivent. Cette longueur est égale ô celle de la moitié du tube formé par les mâchores. Cette première vertèbre montre d'ailleurs dans sa partie supérieure, une lame mince et longitudinale, qui tient lieu d'apophyse, et qu'une autre lame émalement mince, longitudinale, ot inclinée au lieu d'étre verticale, accompagne de chaque coté.

La seconde, la troisième et la quatrieme vertebre ont chacune une apophyse supérieure, et deux apophyses latérales droites et horizontales ou a peu près. Ces apophyses latérales sont terminées, dans la seconde vertèbre, par une sorto de palette.

La cinquième, la sixième et toutes les autres vertebres jusqu'a la nageoire de la queue, sont vertebres jusqu a la nageoire de la quede, sont mais elles sont plus courtes, et le sont d'autant 
mité de l'épine. On ne voit pas de cótes '.

\section{CENT QUATRE - VINGT - TREIZIĖME} GENRE.

LES AULOSTOMES ${ }^{2}$.

Les machoires diroites, très-allongées et en forme de iube; l'ouverlure de la bouche d l'extremilé du museau; le corps el la queue très-allongés; les nageoíres pelites; une nageoire dorsale siluée au-deld de l'anus et au-dessus de l'anale; une rangée longitudinale d'aiguillons; réunis chacun d une petite membrane placée sur le dos, et lenant lieu d'une première nageoire dorsale.

ESPÈCE.

CABACTÈ⿴囗十อ

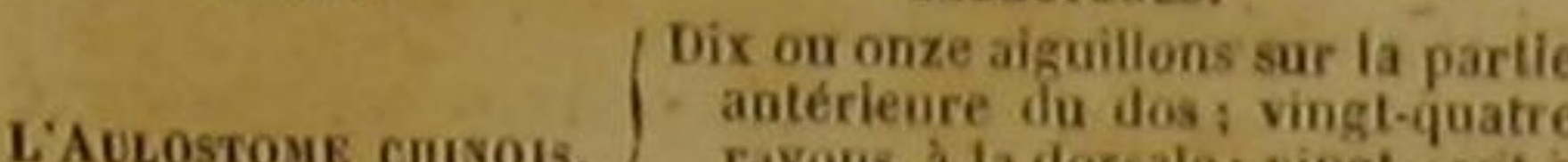

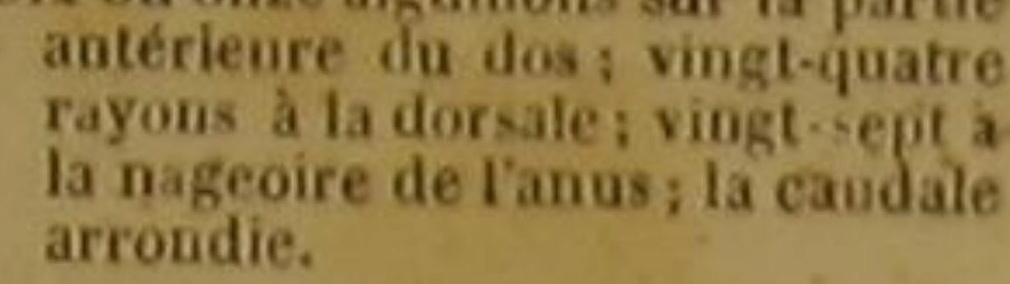

L'AULOSTOME CHINOIS ${ }^{3}$ Aulostoma chìnensis, Lac, Cuv, ; Fistularia chinensis.
Bloch. ${ }^{4}$,

On voit aisément les ressemblances qui rapprochent les aulostomes des fistulaires, et les différences qui empéchent de les confondre avec ces derniers poissons. Le nom générique $A$ lostome ${ }^{5}$ indique ces ressemblances, en même temps qu'il exprime que les abdominaux qui portent appartiennent à un groupe différent de celui des fistulaires.

L'aulostome chinois, vu dans la rade de Cavite des flles Philippines par Commerson, quie a laissê dans ses manuscrits une deseription trèsdétaillée, habite non-seulement dans la mer qui

$\cdot 7$ rayons à la membrane bra timbe, is a chaque pectorale, 6 a chasue de fistulaire penageoire de la quene.

2.4 Sous-gente da genre Fistulang de y Cuvier, plice par lui dans sa famille des Acanthoptérygiens boucho hate, $\mathbf{D}$

siguille tachelee, - Belone tachetee. - Chin fische ohrfisch, Trompeten fisch, par les Allemands, - Trem lais. - Penjol, Pedj jongandais, - Trumpet, par les ADaux Indes orientales. - Trompelle aig, Joulong joulong ILåy, Enc. méth. - Id . Bonuaterre, pl. de l'Babenton e a Solenostomus cauda rotundatí intezerrima lene, méth. Gronov, Zooph, 566. - Acus chinensis maxima, etc. Petiv. Gaz. $t .68$, fig. 1. - Valent. Ind. 5, f. $525,492$. corpore lineis tongitndinatibs pictos, cathethoplates, Commerson, manuscrits déja cités. - Trompelle. Vastý. de Bomare, Dicl. d'hist. nat.

'Atulos, en grec, signuifie fiûte ; et sloma, bonche. baigne les côtes de la Chine, mais encore dan. celle qui environne les rivages des Antilles, ainsi que dans la mer des Indes orientales.

Sa couleur générale est rougeâtre, et variée par un grand nombre de taches irrégulières, inégales, petites, noires ou brunes, et par huit raies longitudinales blanches.

Le corps et la queue sont couverts d'écailles petites, dentelées et serrées les unes au-đessus des autres. On apercoit de légères ciselures sur les grandes lames qui revêtent la tête. Les máchoires sont très-comprimées, et leur longueur égale souvent le cinquième de la longueur totale. L'ouverture de la bouche, que l'on voit au bout du tuyau formé par le museau, n’a que peu de diamètre; et la portion de la mâchoire inférieure qui en compose le bord d'en bas, se relève contre la supérieure. Ces mấchoires ne présentent pas de dents. L'animal n'a pas de langue; mais au-dessous de l'extrémité du-musean pend un barbillon flexible. Chaque narine a deux orifices. On découvre le rudiment d'une cinquième branchie sous l'opercule qui bat sur une lame triangulaire et striée. Les neufs rayons de la partie antérieure du dos se relèvent et s'inclinent à la volonté du poisson, comme ceux d'une véritable nageoire.

L'aulostome chinois parvient à une longueur de près de trois pieds; sa chair est coriace et maigre. Il se nourrit d'œufs de poisson; il mange aussi des vers.

On ne le rencontre que dans les mers voisines de l'équateur ou des tropiques, et cependant sa dépouille a été reconnue sous les conehes volcaniques du mont Bolea ', près de Vérone ${ }^{2}$.

\section{CENT QUATRE-VINGT-QUATORZIËE}

\section{GENRE.}

LES SOLÉNOSTOMES 3 .

Les mdehoiresétroites, très-allongies el en forme de tube; Pucerlure de la bouche d Texirémité du muscau; deux nageoires dorsales.

ESPICE.

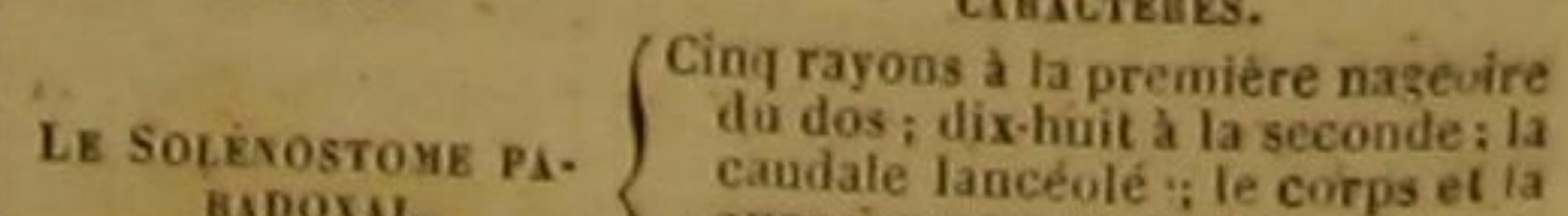

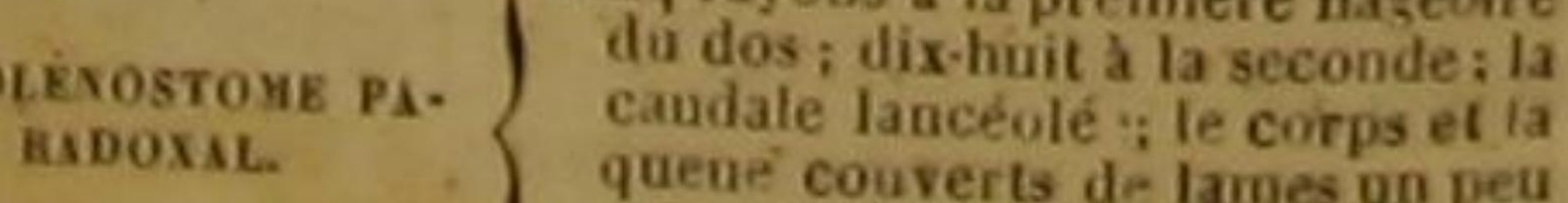

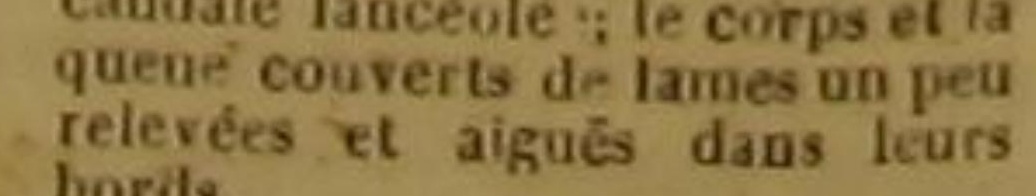

'Icblhyolithologie des environs de Vérone, par le savant Gazola, etc., pl. 5, 6ig. 1. nois, 17 à chaque pectorale, 6 a chaque de l'aulostome chi-
Geoire de la queue.
LE SOLÉNOSTOME PARADOXE '.

Solenostomus paradoxus, Lac, Cav. ; Fistularia paradora, Linu., Gmel. '.

Voici encore un de ces étres bizarres en apparence, sur lesquels nous voyons rétunis des traits disparates, ou, ce qui est la même chose, des caractères que nous sommes habitués à ne rencontrer que séparés les uns des autres. Offrant les formes distinctives de plusieurs genres très-peu semblables les uns aux autres, paraissant étroitement liés avee plusieurs, et r'appartenant réellement à aucun, attirés d'un côtépar plusieurs familles, mais repoussés de l'autre par ces mêmes tribus, on dirait que la nature les n produits en prenant au hasard dans divers groupes les portions dont ils sont composés.

Qu'on ne s'y méprenne pas cependant, et qu'on admire ici le sceau particulier que cette nature merveilleuse imprime sur tous ses ouvrages, et qui, pour des yeux accoutumés à contempler ses prodiges, ne jermet pas de confondre les effets de sa puissance intimé et pénétrante avec les résultats de l'action toujours superficielle de lart le plus perfectionné. Qu'on ne croie pas trouver ici un simple rapprochement de portions hétérogènes. En attachant les uns aux autres ces membres pour ainsi dire dispersés auparavant, en leur imprimant un mouvement commun et durable, en répandant dans leur intérieur le souflle de la vié, la nature en modifie toutes les parties, en pénètre la masse en adoucit les contrastes qui se repousseraient avec violence ; t sa main remaniant, pour ainsi dire, et le dehors et le dedans de ces organes, place des nuances coneiliatrices entre les formes incohérentes, introduit des liens secrets et donne au tout qu'elle fait naitre ces proportions dans les ressorts, cette correspondance dans les forces, cet accord dans les attributs, qui constituent la perfeetion de l'ensemble.

La nature ne cesse donc jamais de maintenir la convenance des rapports, de perpétuer l'ordre, de conserver ses lois. Elle agit d'après son plan admirable, lors même qu' elle parait ș'écarter de ses règles éternelles. Quelle lecon pour

3.2 Les Soltnostomes forment pour Mi. Cuvier un sousgenre dans le grand genre Srscsurie, de lordre des Lophobranches. D.

4 Pallas, Spicil. zool. 8, p. 32, tal., 4, fig.6. - Trompelt
I'homme! et qu'ils sont peu fondés les raisonnements de ceux qui ont voulu trouver dans les prétendus caprices de la nature l'excuse de leurs erreurs ou de leurs égarements! Mais descendons de ces considérations élevées pour suive notre route.

C'est à Pallas que nous devons la connaissance du solénostome, qui, par sa conformation extraordinaire, nous rappello plusieurs genres différents de poissons, et notamment ceux des syngnathes, des pégases, des cycloptères, des gobies, des aspidophores, des scorpènes, des lépisaeanthes, des péristédions, des loricaires, des fistulaires, et des aulostomes.

Cet abdominal ne parvient guère qu'à la longueur de trois pouces et demi. On l'a péché dans les eaux d'Amboine. Sa couleur générale est d'un grís blanchâtre, relevé par des raies ou petites bandes sinueuses et brunes. On voit sur la première nageoire du dos et sur celle de la queue, d'autres raies tortueuses et noires. Les lames qui-recouvrent le corps et la queue ont leurs bords hérissés de petites épines : elles sont d'ailleurs placées de manière que le corps res. semble à une sorte de prisme á neuf ou dix pans dans sa partie antérieure, et à six faces dans sa partie postérieure. La queue, dont le diamètre est moins grand que celui du corps, présente six. ou sept faces.

La tête proprement dite est petite; l'œil grand; le devant de l'orbite aarni, de chaque eôté, d'un piquant à trois facettes; lo tube formé par le museau, très-long, droit, dirigé, vers le bas, comprímé, aigu paî le haut, relevé en dessous par une double arête longitudinale, armé dans sa partie supérieure de deux aiguillons coniques; le bout du museau où est l'ouverture de la bouche, relevé ; la lèvre d'en bas moins avancée cependant que la supérieure; la nuque défendue pai trois piquants ; l'opercule petit, très-mince et rayonné; la premiere dorsale trés-laute, et inelinée vers ta queue; chaque peetorale trèslarge ; chaque ventrale très-grande; et l'espace qui sépare une ventrale de Vautre, recouver d'une membrane lâche, qui les réunit, et forme comme un saic longitudinal '.

.23 rayons a cliaque pectorale du soiénostome paradoul.

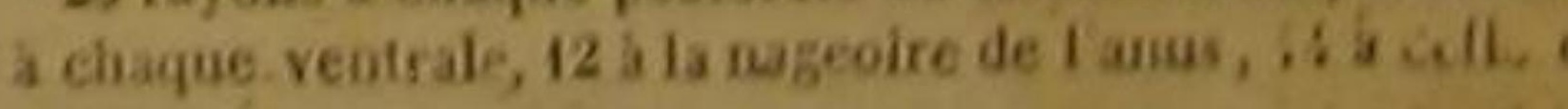
la quace. 
CENT QUATRE - VINGT - QUINZIEME GENRE.

LES ARGENTINES ।

Moins de trente rayons a ta membrane des branchies, ou moins de rayons a la membrane branchiale d'un colé qu'à celle de l'autre; des dents aux machoires, sur la langue el aux parois; plus de neuf rayons à ehaque ventrale; point d'appendice auprès des nageoires du ventre; le corps el la queue allongès; une seute nageoire du des; la couleur généraie argentée el lirèsbrillante.

Espíces.

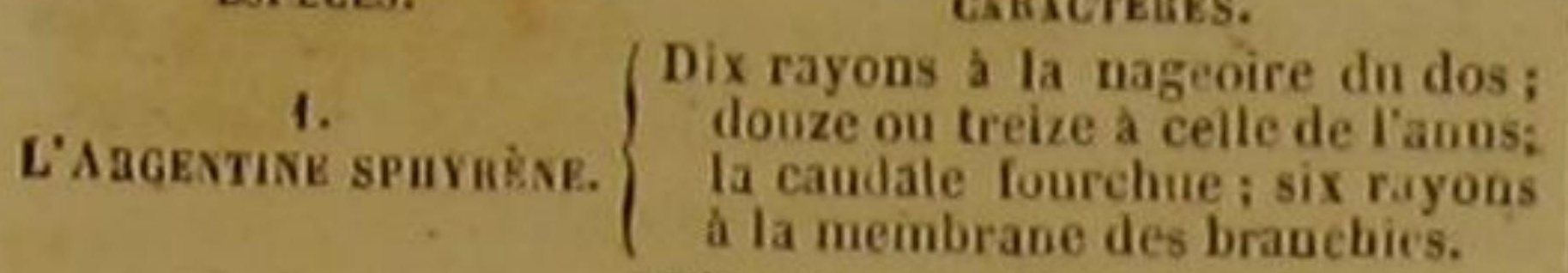
Dix.sept ou dix-huit rayons a la
dorsale; luit a la nasorise

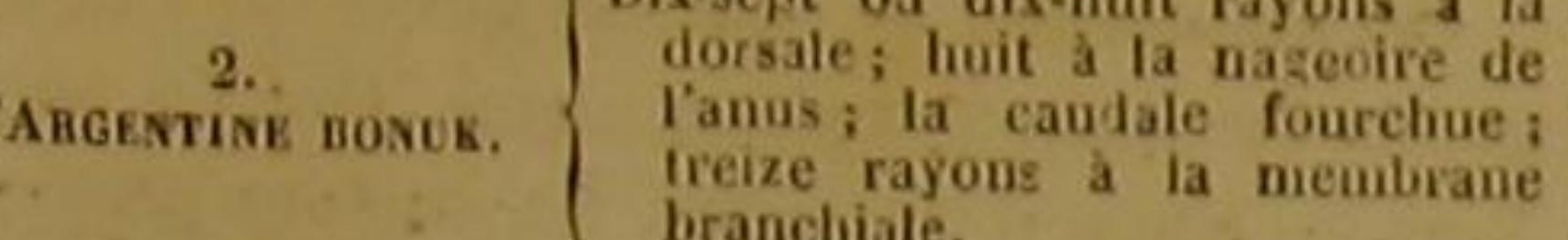

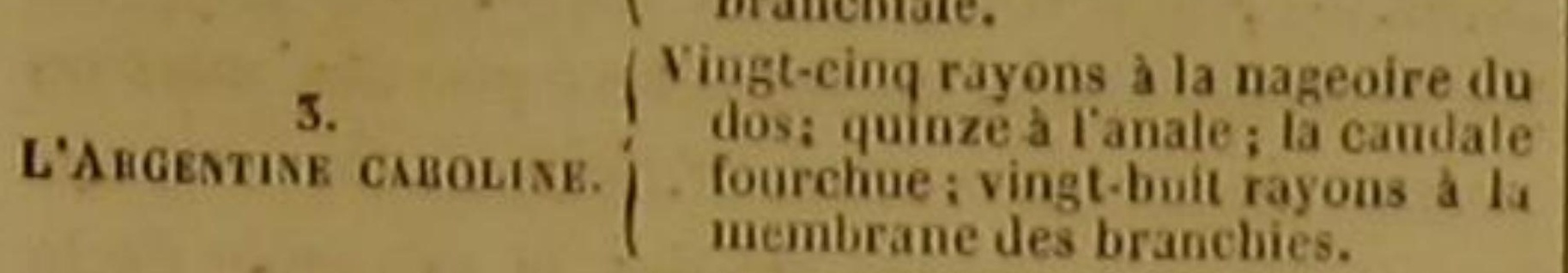

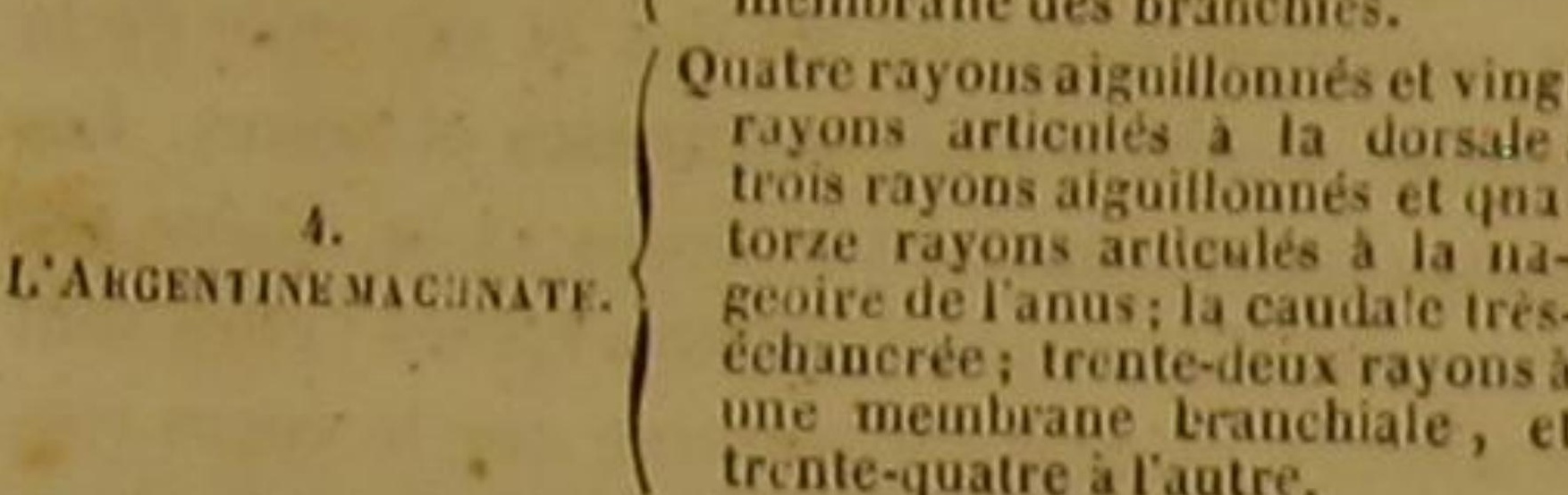

L'ARGENTINE SPHYRENE ${ }^{2}$, Argentina Sphyrana; Linn., Gmel., Lac., Cur. 3. L'Argentine Bonuk 4, Butirinus indicus, Cuv,; Argentina
glossodonta, Forsk, Lion, Gmo - L'A. Caroline ", Linn., Gm.; Arjentina Bonuk, Lac, diculatus, Bosc; Argeutina Carolina et Muv,.; Mugil aypenCaroliua, Lacep.; Argentina Carolina, Linn., Gmel. '. -
$L^{\prime} A$. Machnate - Elops indicus, Cuy.; Machnata, For.k., Limn., Gmel., Lac.; Synobus chinensi neus, Forsk.

La sphyrène est bien petite; elle ne parvient ordinairement qu'à la longueur de quatre pouees; mais sa parure est riche et élégante; elle a reçu de la nature les ornements que la mythologie grecque a donnés à plusieurs divinités de la mer; et la poésie verrait dans les effets de ses couleurs agréables et vives, une robe d'argent étendue sur presque toute sa surface, une sorte de voile de pourpre placé sur sa tête, et un manteau d'un vert argentin, comme jeté dans sa partie supérieure. Cependant cet éclat fait son malheur: un petit poisson perdu, pour ainsi dire, dans l'immensité des mers, est pour l'homme une leeon de sagesse; tant les lois de la nature sont immuaA M. Cuvier admet le genre ABGEstixe de Linnée, en niy

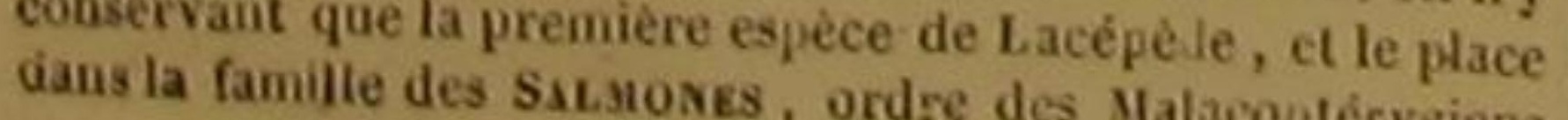

błes et générales. Revêtue d'écailles moins bəlles, l'argentine sphyrène n'aurait point à redouter le filet ou l'appât du pècheur; mais elle est couverte d'uné substance dont les nuances et les reflets sont ceux des perles orientales. Par une suite d'une conformation particulière, les élé. ments de -ses écailles ne se réunissent pas seulement sur sa peau en lames blanches et chatoyantes; ils se rassemblent dans son intérieur en poudre brillante et fine. Sa vessie natatoire, qui est assez grande à proportion de la longueur totale de l'animal, est particulièrement couverte d'une poussiêre d'argent, ou plutôt de petites feuilles argentées et éclatantes. Les arts inventés par le luxe ont eu recours à ces molécules argentines; ils les ont introduites dans de petits globes d'un verre très-pur et très-diaphane, les ont collées contre la surface intérieure de ces boules blanches et transparentes, ont produit des perles artificielles de toutes les grosseurs qu'ils ont pu désirer '; et la sphyrène a été tourmentée, poursuivie et prise, malgré sa petitesse et le nombre de ses asiles, comme les poissons les plus grands et les plus propres abdominaux. Les aulres espèces doivent étre rapportées aux ${ }_{2}^{2}$ Pei d'ans et KLopr de la famille des Clupes. D. quée par M. Fant, dans le départ. du Var. (Note cormmunibeuton et Hayachet, prefet.) - Argentine hautin. Daumétb. - Argentina. Artedi, gen. 8onnaterre, pl. de l'Enc. pece de spet. Rondelet, part. 1, 1. 8, e. 2. - Seconde es- parva, seu sphyrænæ sec. spec. $>$ Gesuer, p. 885 et 1061 , et (germ.) fol. 59, a. - - Piseiculus Romx argentioa dictus willoghby, p. 229. - Id. Rai, p. 108, - Gronov. Mus. I, 11. 24.

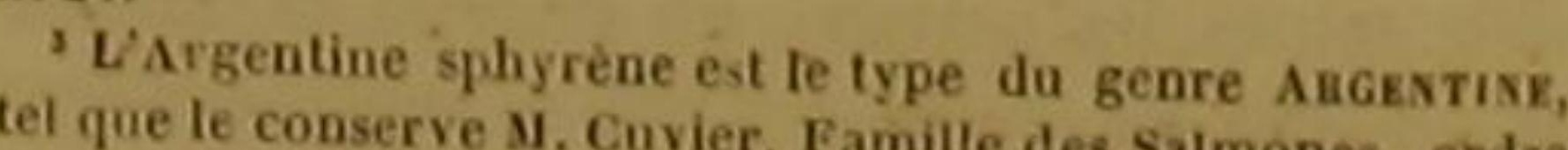
des Malacoptérygiens Cuvier. Famille des Salmones , ordr 'Argentine bonuk. Bonnaterre, pi. de I'Enc. métl. -
Forskael, Faun. Arab., p. 68, n. 99 . v L'Argentine bonuk est le Botiais nes Isdes de M. Cu. vicr. Famille des Clípes, ordre des Malacoptérygiens abdo-
minamx. D.

¿'Argentine caroline. Daubenton et Haûy, Enc. méth. -
Id. Bonnaterre, pl. de I'Enc. méth. bahamensis. Catesby, Carol. 2. p. 21. - Lab. Harengus minor 'L A Arentine curot, Carol. 2, p. 21, tab. 2

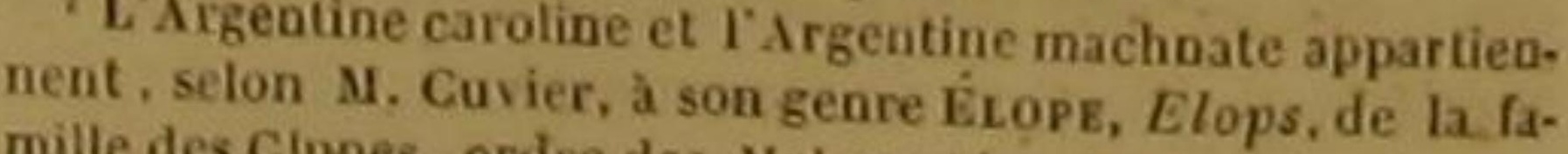
mille des Clopes, ordre des Malacoptérygiens abdominaux: la première est des cótes d' a mérique dans la mer Atlantique. trés-voisins l'un de later des Indes. Ces denx poissons sout une seule espéce. LatrGe, si mème ils n'appartiennentà par M. de Lacépéde, sous le nom de Sxropes couja decrito Argentine machnat. Bonaaterre, pl. de I'Enc. métb. -

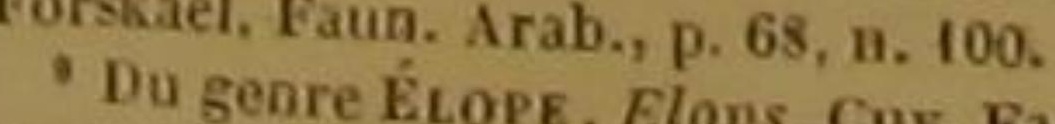

Wes Malücopterygiens atdominaux. Voyez la note ci dessus 7 . D.

Coloration, relativement da la production des eccailles et a la
coissons, notre Discours sur la natnre de ces

DES POISSONS.

satisfaire des besoins plus réels que ceux de la vanité.

On trouve cette argentine dans la Méditerranée, notamment auprès de la campagne de Rome et des rivages de l'Etrurie. La tête est si diaphane qu'on distingue aisément au travers de son crâne les lobes de son cerveau.

Le bonuk habite dans la mer d'Arabie. Ses écailles sont larges, arrondies, striées à leur base, et brillantes. On n'en voit pas de petites sur la tête. Le dos réfléchit des teintes un peu obscures; et la nuque ainsi que les nageoires offrent des nuances d'un bleu mẻlé de vert. De petits tubercules sont situés entre les yeux. $L a$ mâchoire supérieure finit en pointe, s'avance plus que l'inférieure, et montre une tache noire en forme d'anneau. Les dents sont petites, sélacées, très-serrées, roussâtres, placées sur plusieurs rangs; le fond du palais en présente do molaires, qui sont hémisphériques, blanches fortes, et distribuées en trois compartiments. On peut voir, à la base de la langue, des tubercules osseux, hérissés d'aspérités. La ligne latérale est droite. De petites écailles revêtent une partie de la membrane de la caudale.

L'argentine caroline, qui se plait dans les eaux douces de la contrée américaine dont elle porte le nom, a sur son opercule une sorte de suture longitudinale; et sa ligne latérale est droite.

La machnate, qui vit dans la mer d'Arabic comme le bonuk, parvient à la longueur de huit à douze pouces. Elle a le dos bleuatre ; la dorsale d'un bleu mêlé de vert; l'anale et la caudale de la mème couleur par-dessus, et jaunâtres par-dessous ; les pectorales et les ventrales jaunátres; les écailles petites et stríées ; le dessus de la tète horizontal, aplati, et creusé par un sillon très-large ; la lèvre supérieure moins avancée que l'inférieure; les dents nombreuses et trèsfines; l'ceil grand; l'opercule dénué de petites écailles.

L'inégalité du nombre des rayons des deux membranes branchiales est digne de remarque ${ }^{~}$.

II ray̧ons à rhaque pe torale de largentine sphyrène, 11 . chaque ventrale, $19 \mathrm{a}$ a candale. - 19 rayons a ciaque pectoralc de l'argentine bonnk, il a claque ventrale, 20 a la nageoire

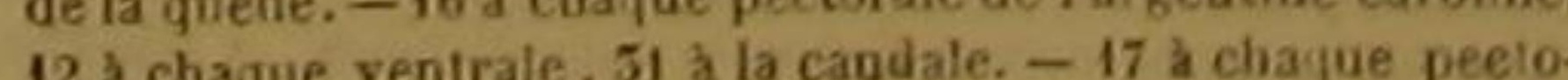
rale de l'argentine machoate, 15 à cha june ventrale, 18 a la nageoire de la quen
CENT QUATRE-VINGT-SEIZIÈME GENRE. LES ATÉRINES ‘

Yoins de Tuil rayons d ehaque ventrale et d la membrane des tranchies; point de dents au palais; le carps el la queue allongés, et plus ou moins transparents; deux nageoires du dos; une raie lengitudinale et argentée de chaque cold du poisson.

Espk̀cess.

cincerikss,

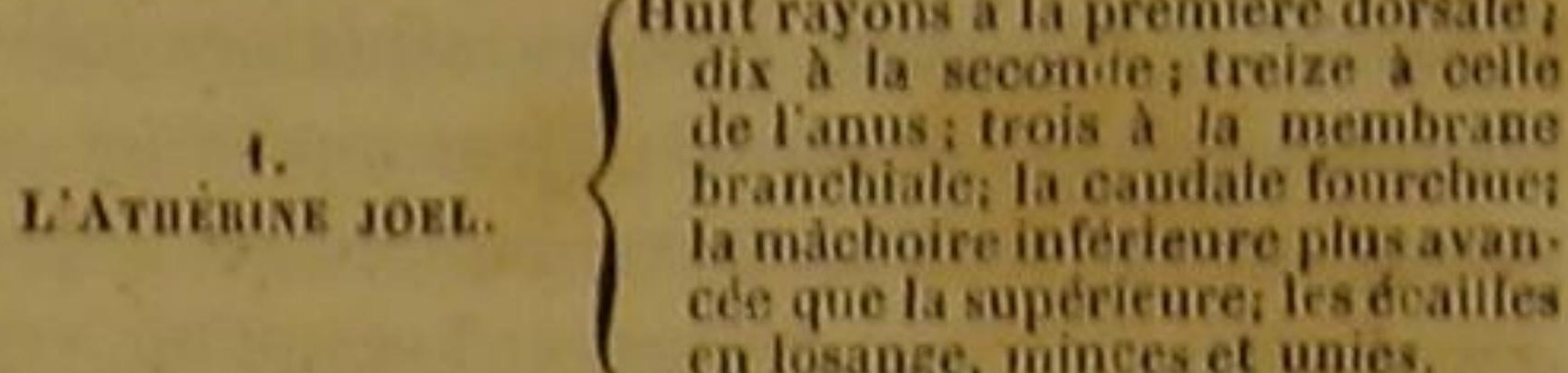

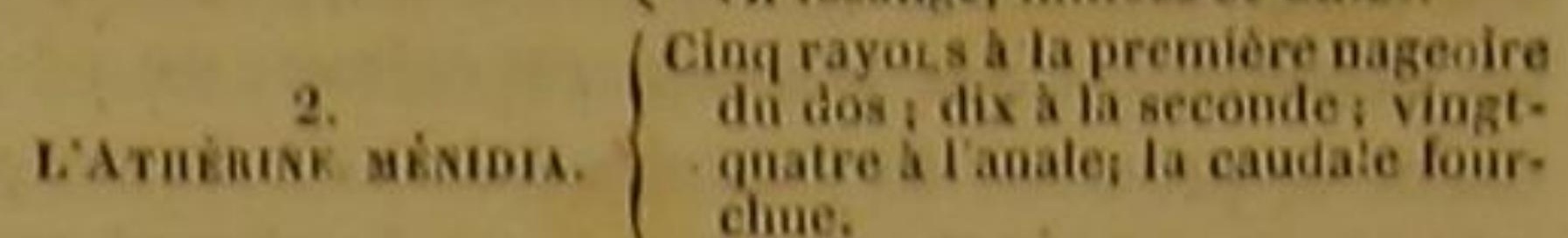

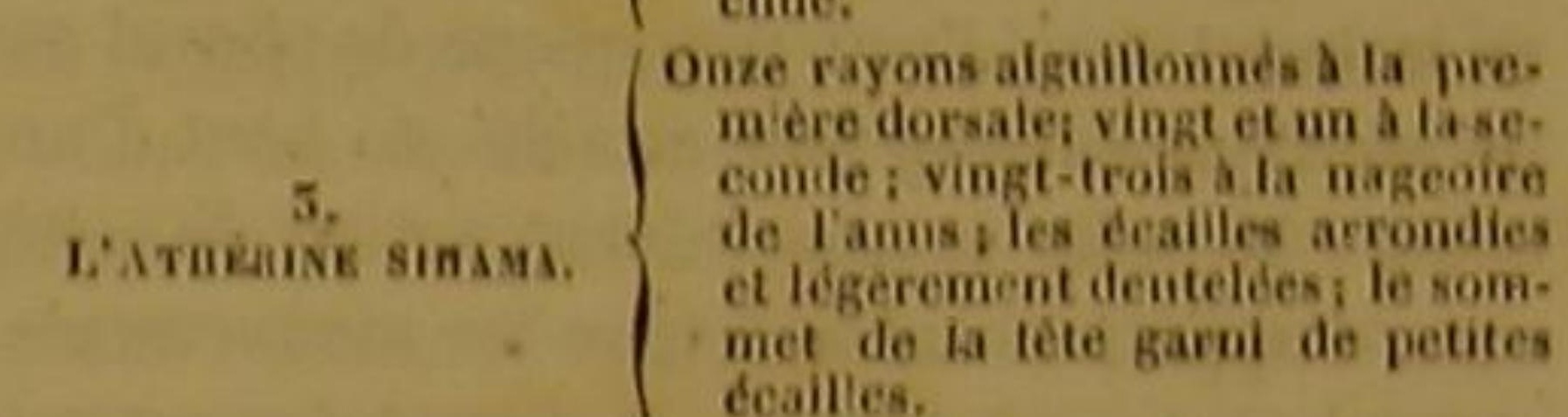

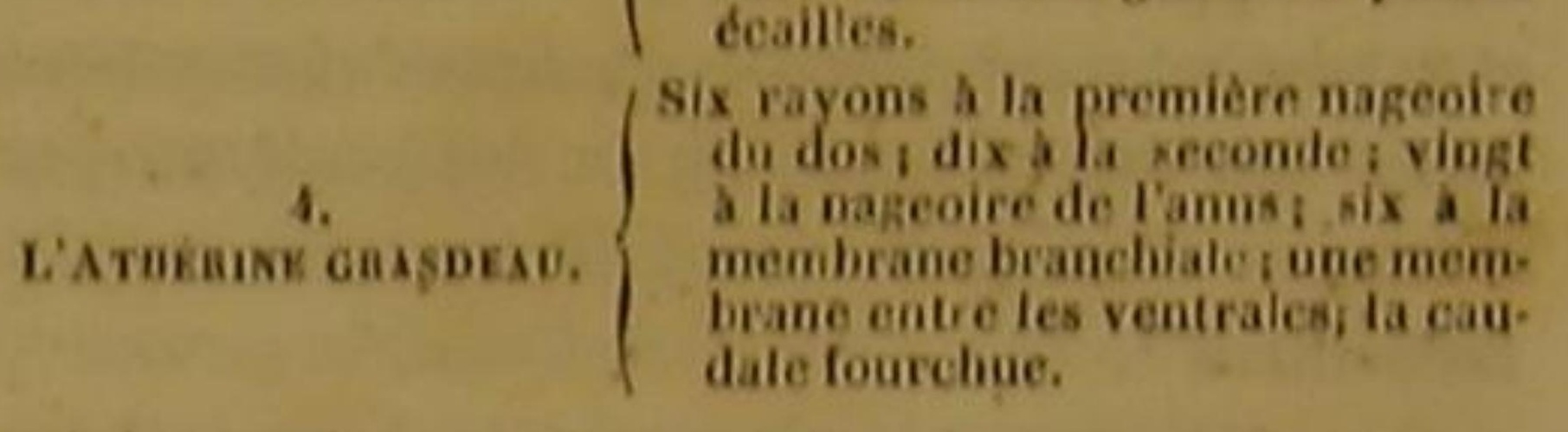

L'ATHÉRINE JOEL. *

Altierina Hepsetus, Linn., Gmel., Lac., Cuv. '

L'Alherine Menidia ', Atherina Menidia, Limn., Gmel., Lac, Cuv, ${ }^{\circ},-$ LA. Siliama ", Allicerina Silhama, Linn., guis, Lac, A Atherina..., Cuv.?.

Le joël a la tête dénuée de petites écailles, lo dos brunâtre, les flancs nuancés de bleu, le ven-

'M. Cuvier adopte ce genre, et le place a ta suite de la fa-

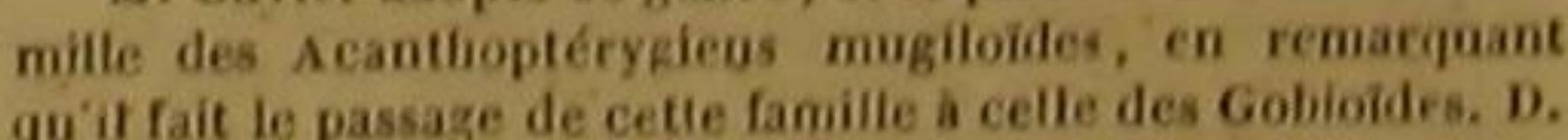
2 Prester. - Pretre, - Roserel. - Rosel. - Lou sau. clet, dans plus. départ. mérid. (Note communtquée par M. Faschet, prefet dn Var.) - Peic-rey. Peixi-rry, en Porugal-_Segreto, en Sardaigne, -Kesch kusch, Abu-kesckul, en Arabie. - Inmisch-baluk, en Turquie. - Spillancosg,

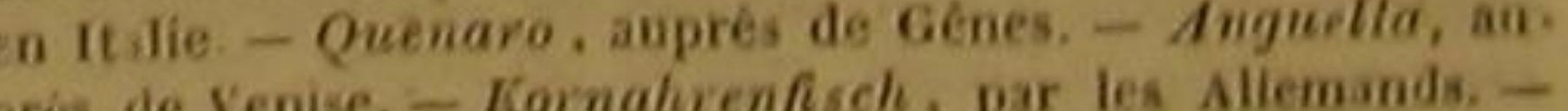

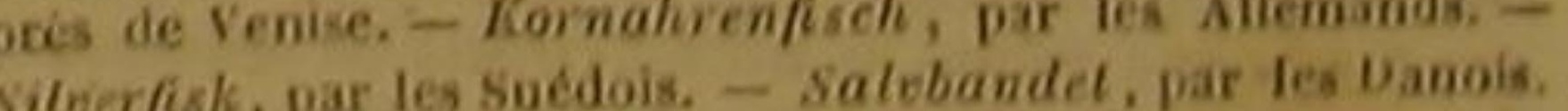
- Koona airreich, par les Hollamdais. - Smell, dans plos. contrees de l'Angleterre, - Atherina, Mos. Ad. Frid. 2 , p. 105. - Gronov. Mus. 1, I. 66. - Atherina hepsetus. Has. selquist, It. 582, - Id, Forskael, Yaun Arab., p. 69, n. 101. - Atherine joel. Danbenton et Way, Ene. Ges fi. - $3 . .$. Bonnaterre, pl. de Rnc. me.t. - 8. Hepielus Mondeleti. Alsrov, 1. 2, c. 35, p. 216. - - Pisciculns angueiti Venetiis diclus, willughby, p. 209, - Rai, p. 79. - Alieriag, Ar. tedi, syo. Append., p. 116. - Atherina, vertice ad rostrim

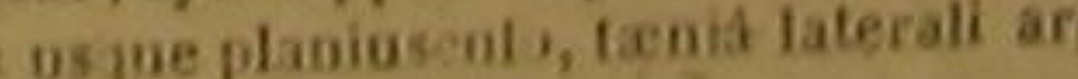

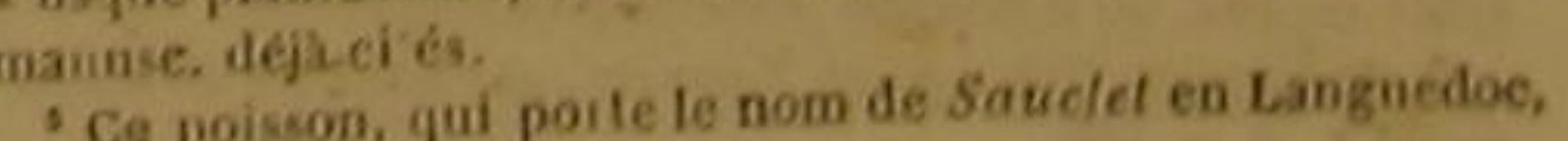


the argentin, les nageoires grises ; il ne présente fe Rouen, m'a écrit que l'on pêchait quelque que de très-petites dimensions; son corps est fois, sür les côtes voisines de Caen, des athéripresque diaphane; ses écailles se détachent fa- nes joëls; on les y nomme Roserets ou Rosets. cilement; sa chair est bonne, d'ailleurs on se Elles parviennent rarement à la longueur de sert de ce poisson pour faire des appâts.

On le trouve dans la mer d'Arabie, dans la

Méditerranée et dans l'Océan Atlantique boréal.

M. de Sonnini raconte, dans l'intéressant ouvrage qu'il a publié sous le titre de Voyage en Grèce el en Turquie, que les athérines joëls, nommées althernos par les Grees modernes, se réunissent en bandes très-nombreuses auprès des rivages des iles greeques. Lorsqu'on veut les prendre, et que le temps est calme, un pêcheur se promène le long des bords de la mer, en trainant dans l'eau une queue de cheval ou un morceau de drap noir attaché au bout d'un bâton; les joêls se rassemblent autour de cette sorte d'appat, en suivent tous les mouvements et se laissent conduire dans quelque enfoncement formé par des rochers, où on les renferme par le moyen d'un filet, et où on les saisit ensuite facilement '.

On péche une grande quantité de ces athérines dans les environs de Southampton, qu'elles fréquentent pendant toutes les saisons qui ne sont pas très-froides, mais particulièrement pendant le printemps, qui est le temps de leur frai

Notre habile et zélé correspondant, M. Noë

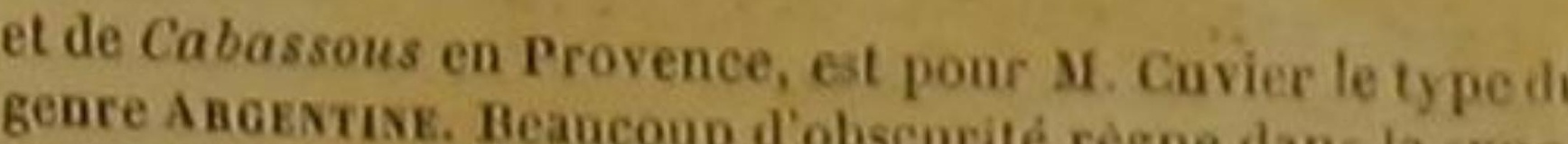
uymie de celle espèce. Plusieurs poissuns parans la syno eté coulondus sous te nom d'A Aherina hepsetus de Limné. I. Cuvier regarde conme véritable Atherina hepsetu. 1\%epsetus de Rondelet, 216, et le poisson représenté par

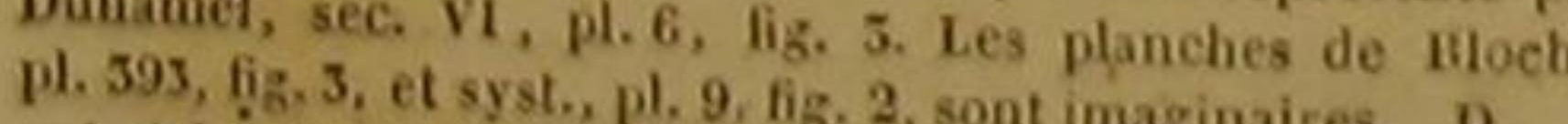
'Aikerine poisson d'argent. Daubenton at Hes. $\mathrm{D}$, méth. - Id Bonnaterre, pl. de IEnc. méth. - A A Eberih - menilia, pianà ani radilis vigintíti quatuor, caudá bifídá. Bóse, notes manuscrites déja citées.

dre des Acanthoptérygiens, Gav, Soulle des Magiloódes, orplusieurs espéces dAthérines, Sous le nom de Menidic, rina manidia de Linnće, celle de cel article, est Li Xl heque 1'Aherina notata de Mitchill, Quant au Monidia de Browne, c'est un autre poisson, mais da méme genre. $\mathrm{D}$. Ather ine siha ma. Bonnaterre, pl. de l'Ene, méth. Linnée que dans la premiente éde l'Atherina sihama de earactérise par la position de ses nageoiegne animal. 11 la sont presque sous les pectorales. D. - Le grádeau ou grasdeau, atheriat

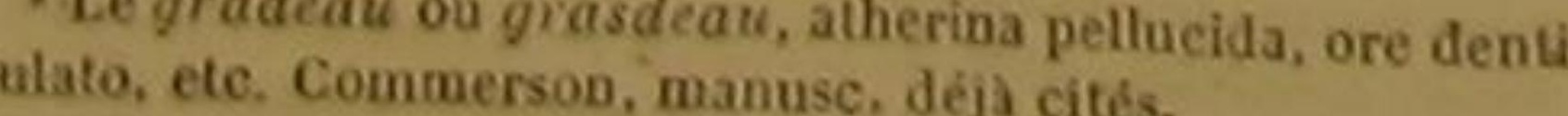
'L Alderine grasdean, Ath. pinguis du texte de M. de figure donnes pas citce par M. Cuvier; mais, selon lui, I antre es; éce, quill nomple dilec poisson, appartient à un

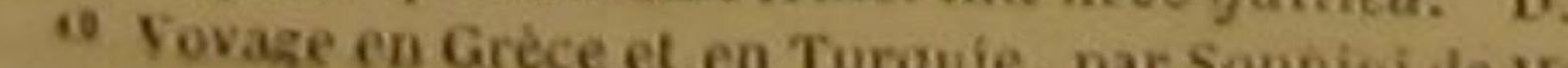

court, t. 2, p. 209 quatre pouces. Elles ont au-dessus de la tête une petite crête dentelée, des deux côfés de laquelle eșt un sillon dans la cavité duquel on voit deux trous ou pores différents des orifices des narines. Leur chair est extrêmement délicate: lorsque le poisson est sec, elle devient jaune et beaucoup plus transparente que pendant la vie de l'animal. La raie longitudinale et argentée reste cependant opaque, et parait, dit M. Noel, comme un pêtit galon d'argent sur un fond chamois.

M. Mesaize, pharmacien de Rouen, que j'ai déjà eu l'avantage de citer dans l'Histoire des poissons, vient de m'écrire que dans le port de Fécamp, on péche les joèls à la marée montante, vers la fín de l'été. On leur a donné le nom de Prélre, apparemment à cause de leur espece d'étole d'argent. On se sert, pour les prendre, ou d'un filet désigné par le nom de carre ', dans le fond duquel on met pour appát des erabes écrasés, ou d'une grande chaudrelle, nommée hommardiêre, qu'on laisse tomber du haut d'un mát placé sur le bord du bateau pêcheur.

L'athérine ménidia habite dans la Caroline Nous allons la faire connaitre daprès une excellente description qui nous a été communiquée par notre savant ami et confrère $\mathrm{M}$. Bosc.

Cette athérine, que M. Bose a vue vivante dans l'Amérique septentrionale, a la tête aplatic points bruns. Sa bouche peut s'allonger de plus de deux millimetres. Dix ou douze dents trescourtes garnissent ses lèvres. Sa hauteur est égale au cinquieme de la longueur du corps et de la queue. Sa couleur générale est d'un gris pâle : mais l'extrémité de la caudale est brune, et les écailles sont bordées, surtout sur le dos, de pétits points bruns. Ces écailles sont d'ailleurs presque circulaires. La raie argentée est large d'un millimètre ou environ.

Les athérines ménidia sont extrêmement com-

- Chaudrelte, chaudicre, caudrelte, caudelelle, savonceau, différents noms d'un truble qui n'a pass de manche. que l'on suspend comme le bassin d une balance, et que l'on releve avee une petite fourche de bois, Vejez la descrip-
tion du truble a l'article di Misgurne (ossile - Le flet nommé carré est le méme que le carretet décrit dans l'artipar-dessus, arrondie èn dessous, et tachetée de munes dans les rivières salées des environs de Charleston. Elles sont très-jolies à voir, trèsagréables au goutt, et de plus très-propres à sêrvir d'appât, leur longueur n'excédant pas quatre pouces.

Le sihama ressemble à un fuseau par sa forme générale. Des teintes de blane, de vert et de bleu, eomposent le fond de sa couleur. Sa lèvre supérieure peut s'avancer à sa volonté. Ses pectorales sont lancéolées. On l'a péchée dans la mer d'Arabie.

L'athérine Grasdeau est encore inconnue des naturalistes. Commerson l'a vue, déerite et fait dessiner. La couleur générale de ce poisson est semblable à celle d'une eau très-transparente ; des nuances plus obscures paraissent sur le dos : les nageoires supérieures sont brunes, ainsi que la eaudale; les inférieures blanches et diaphanes; les pectorales ornées d'une bande transversale, large, transparente et argentée. L'intérieur de la bouche-est aussi d'un blanc éclatant et diaphane; l'iris est argenté. Les yeux sont peu saillants ; la tête est dénuée de petites écailles; l'opercule composé de deux pièces, et pointu par derriére; la mâchoire supérieure extensible le péritoine noir; la chair très-délicate. Celle des cotes que l'on voit au delà de l'anus, sont réunies les unes aux autres, et leur surface inférieure présente une épine courbée en arrière ".

\section{CENT OUATRE-VINGT-DIX-SEPTIEME GENRE.}

LFS HYDRARGIBES ${ }^{2}$.

Soins de huil rayons a chaque venirale of a la membrano des branehies; point de dents au palais; te corps el la queus alionges et plus ou moinsiransparents; une nageoire sur le dos; une raie tongiludinale ples ou moins large, plus ou moins distinete, el argentee, de chaque côte du poisson.

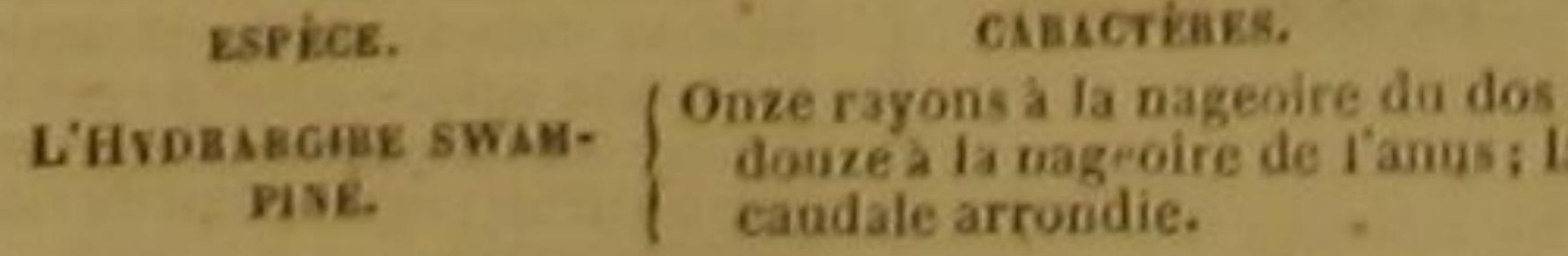

ifs rayone to chapne pectorale de l'athérinc joal, 6 a cha que ventrale, 20 a la nageoire de la quene, -15 rayons chaque pectorale de l'atherine mécidia, 6 a chaque ventrale, 22 a ia candale. -16 a chaque pectorale de Tatherine sibama 6 a chaque ventrale, 17 a la nageoire de la queve. -1 rayonsà chaque pectorale

rentrale, 17 a la caudale.
'. $\mathrm{A}$. Cuvier supprime ce genre fonde sur de jeanes indiridus d'une espece da geure FosptLe, Fundulus, Lac., gio appartient a la famille des Cyprimoides, dans Tordre des Malacopterygiens abdominaux, D.
L'HYDRARGIRE SWAMPINE ' Fundulus faseiatus, Valene, Cuv.; Hydrargirus
Swampina, Lacep. ?.

M. Bose a vu dans la Caroline, où il était agent des relations commerciales de la république francaise, ce poisson, dont les naturalistes n'ont pas encore publié de description.

Cette hydrargire a la tête aplatie en dessus et en dessous ; la bouche cartilagineuse; les li vres susceptibles de s'allonger, et garnies chacune de dix ou douze dents très-courtes; fa lèvre inférieure plus avancée que celle d'en haut; l'ensemble formé par le corps et la queue, demitransparent, et quatre fois plus long que large; les ventrales très-rappiochées de la nageoire de l'anus, les écailles demi-circulaires; les yeux jaunes; les nageoires souvent pointillées; un grand nombre de petíts points verdâtres distribués autour de chaque écaille, ou placés de manière à produire des raies longitudinales; et quelquefois onze ou douze bandes transversales et brunes réunies à ces points verdâtres, ou composant seules la parure de la swampine.

Les individus de cette espece paraissent par milliers dans toutes les eaux douces de la Caroline. Ils fourmillent surtout dans les marais et dans les lagunes des bois, Les mares dans lesquelles ils se trouvent étant souvent desséchée. au point de ne pas conserver assez d'eau pou les couvrir, ils sont obligés de changer fréquemment de séjour. Ils émigrent ainsi sans beaucoup de peine, parce qu'ils peuvent sauter avec beaucoup de facilité, et s'élancer à d'asser grandes hauteurs. M. Bose en a vu pareourir en un instant des espoces considérabiles, pour aller chercher une eau plus abondante. Iis ne parviennent cependant presque jamais à la longueur de quatre pouces. Leur chair n'est pas d'ailleur. agréable, et les pécheurs ne lesrecherchent pas ; mais ils servent de nourriture à un grand nombre d'oiseaux d'eau et de reptiles qui habitent dans leurs lagunes et dans leurs marais ${ }^{3}$.

1. Atherina swampina, pinna ani radis duoiecim, eauda r rotundata.'S Notes ma

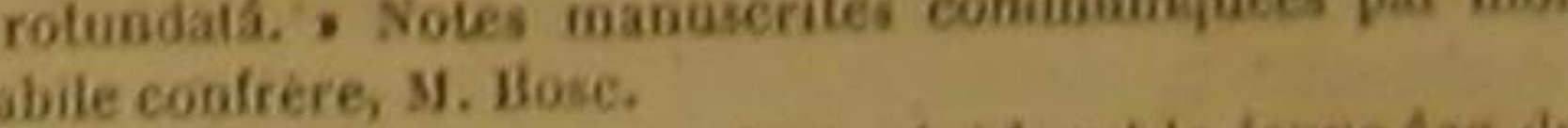
'L Hydrargire swaropine de Lacépede est le jemie Age du Pacilia fasciala, Schieid: Fundulus fascialus, Vali Gist cea rapprochements, remarque que is tigare donnee par y. de lacepede, sous le now diyydrarg re swampine ap partient a use espéce différente de ceile qui est decnite das le tesie. D

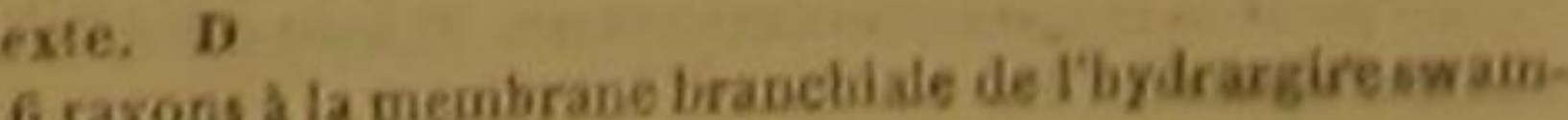




\section{CENT QUATRE-VINGT-DIX-HUITIÈME} GENRE.

LES STOLÉPHORES 4 .

Moins de neuf rayons à chaque ventrale et ḋ la membrane des branchies; point de dents; le corps el la queue allongès, el plus ou moins transparents; une nageoire sur le dos; une raie longitudinale el argentée de chaque colé du poisson.

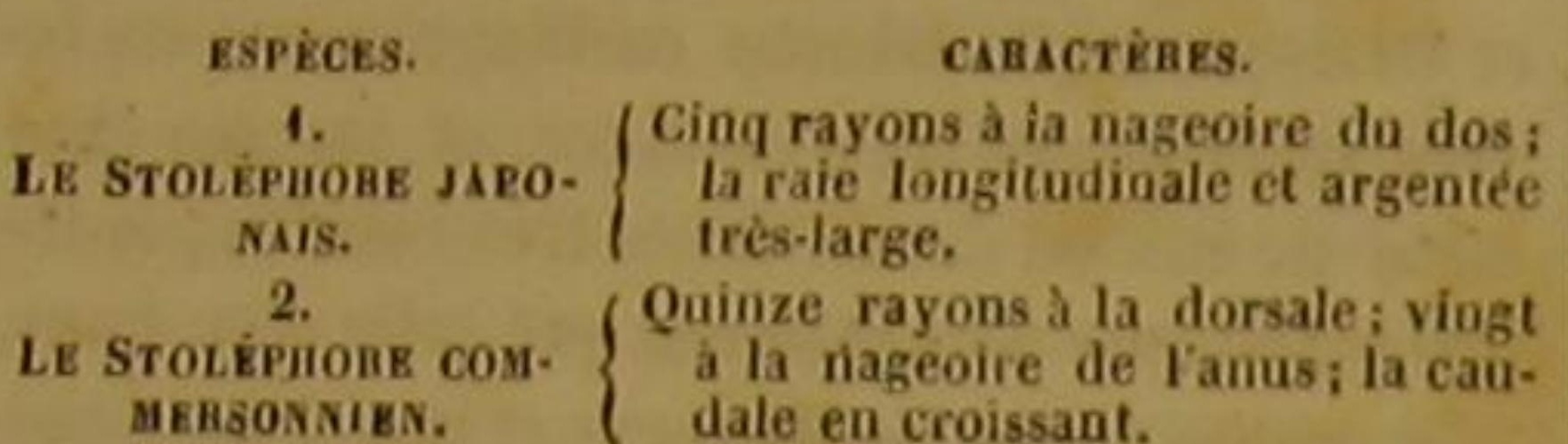

\section{LE STOLËPHORE JAPONAIS ${ }^{2}$}

Stolephorus japonicus, Lac.; Atherina japonica, Lino., Gmel. ".

ET LE STOLÉPHORE COMMERSONNIÉN.

Engraulis....., Cur.; Atherina australis, White; Stole phorus Commersonii et Clupea Vittargentea, Lac. :

Les stoléphores ont une parure très-semblable à celle des athérines; le nom générique que nous leur avons donné désigne l'ornement qu'ils ont reçu ${ }^{5}$. Houttuyn a fait connaitre le japonais ; et nous avons trouvé parmi les manuscrits de Commerson un dessin du stoléphore que nous dédions à ce voyageur, et qu'aucun naturaliste n'a encore décrit.

Le japonais vit dans la mer qui entoure les iles dont il porte le nom. Sa longueur ordinaire est de quatre pouces. Sa tête ne présente pas de petites écailles; celles qui garnissent le corps et la queue sont très-lisses. Sa couleur générale est d'un rouge mélé de brun.

Le commersonnien a la tête dénuée de petites écailles, comme le japonais; le museau pointu; la mâchoire supérieure terminée par une protubérance; les yeux gros et ronds; les écailles arpine, 15 à chaque pectorale, 7 a chaque ventrale, 26 a la naGeoire de la queue.

(1) graulis, famille des thpes, ordre des genre Axcнous, Endominaux. D.

3Houttuyn, Act. Haarl, XX, 2, p. 540, n.

'Ce poisson, décrit premièrement par Houttuyn, n'est is. Curier foit ro

men est one vór remarquer que ce stoléphore commersonson a été deux fois décrit par

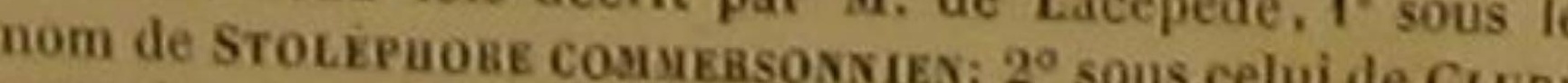
MAIE D'ARGENT. D. rondies; les ventrales très-petites; la caudale assez grande ${ }^{1}$

\section{CENT QUATRE-VINGT-DIX-NEUVIÈME} GENRE.

LES MUGES 2

La mdchoire inférieure carénée on dedans; la têle recetue de pelites écailles; les écailles striées; deux nageoires du dos.

EsPèces.

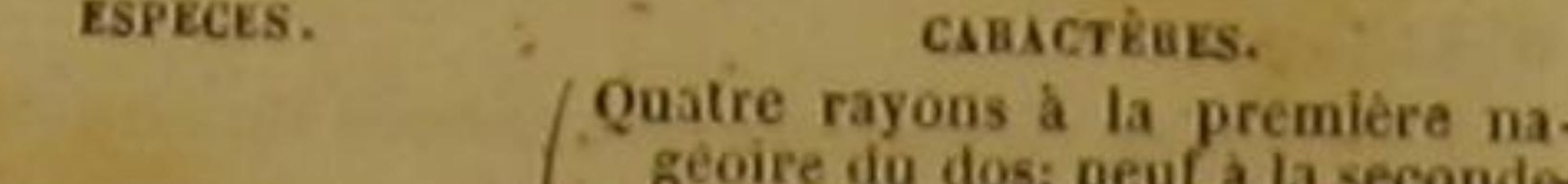

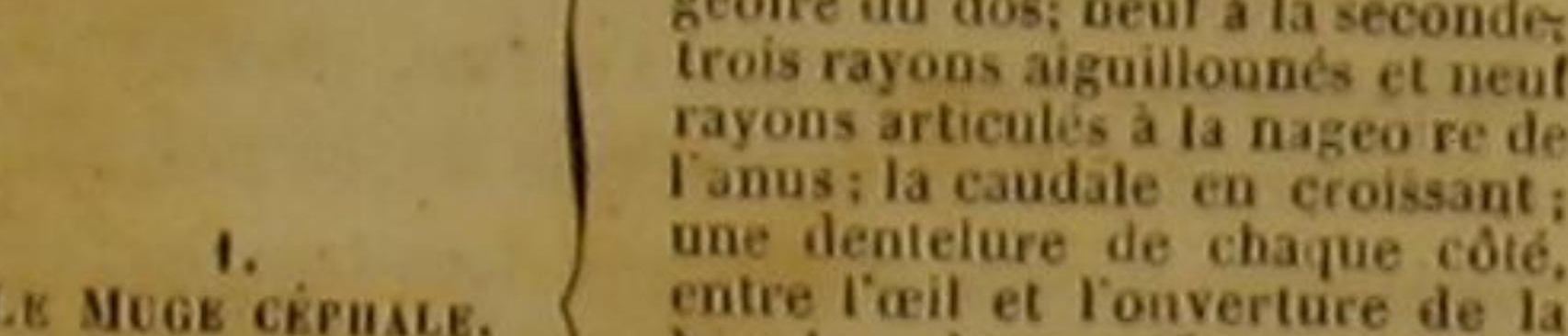
entre l'cil et lonverture de la narine; ; Iopercule an a chaque deriere, un grand nombre de
raies longitudiuales, érroites
aites rales longitudiuales, érroites
noiratitres, de chaque cóte du poisson

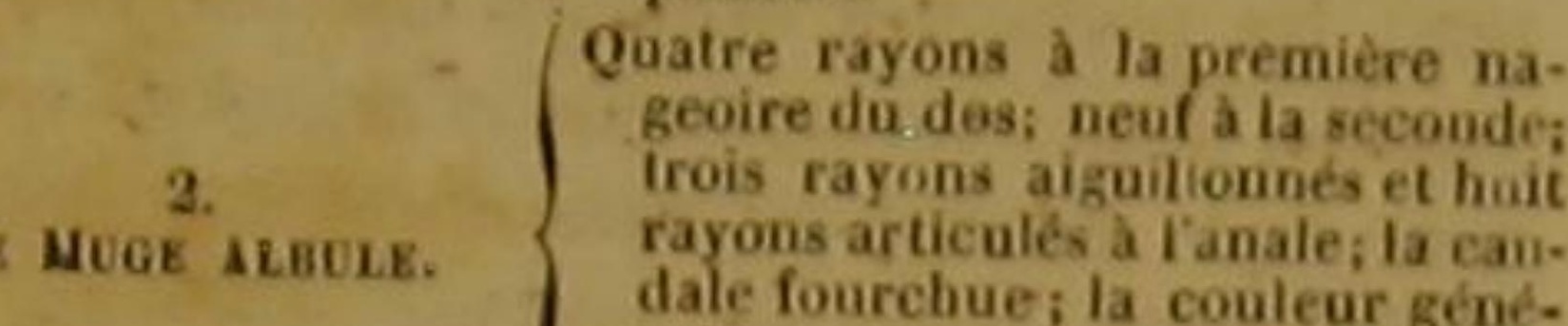
dale fourchues; la couleur géne-
rale argentee; point de raies
longitudinates

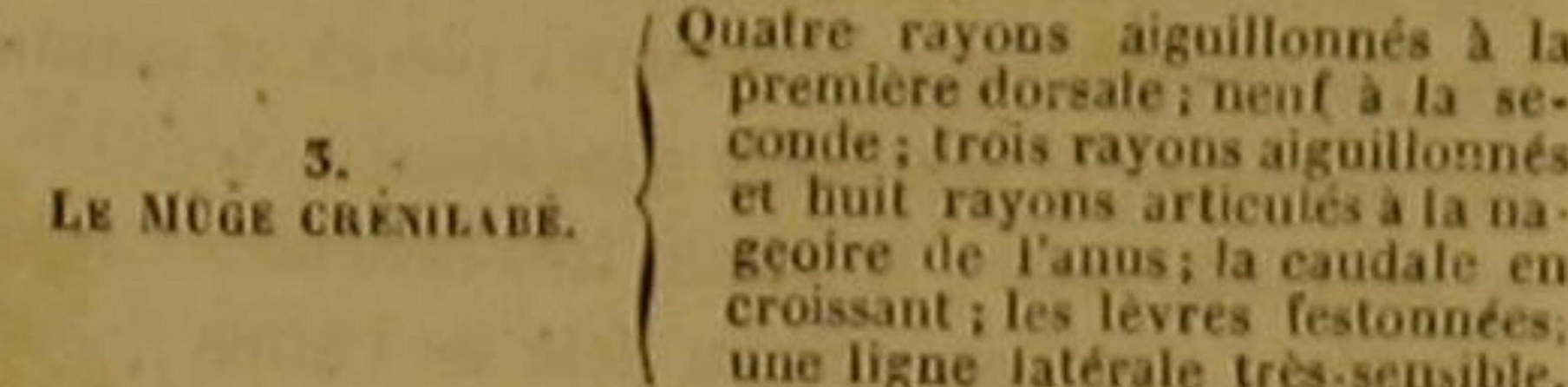

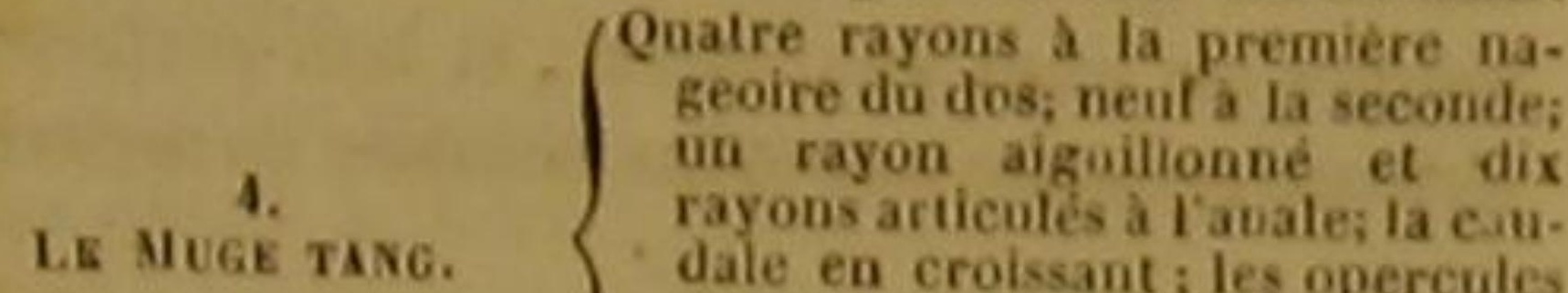

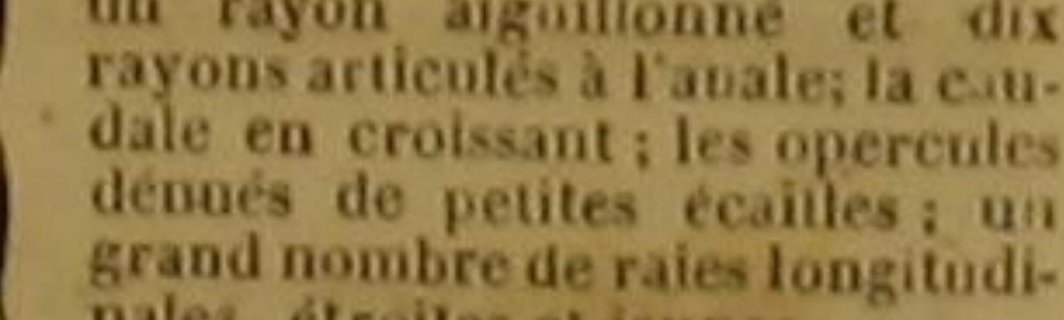
nales, étroites et jaunes. Mugil imberbis. Charleton, p. 151. - Mugil et mugilis. Salvan., fol. 75 a ad 76 a.-Mugil cephalus. Hasselquist. It. 585 , - Mugil. Gronov. Zoophi., 597.

'Tous les muges européens ont été confondus par Linnéc et ses successeurs, sous le nom de Mugil cephalus. Celui que $\mathrm{M}$. Cnvier distíngue sous ce nom est caractérisé, ${ }^{\circ} \mathrm{p}$ par rieur des orbites; $2^{*}$ parce que son maxillaire, quand $I$ a bouche est fermée, se cache entiérement sous le sous-orbitaire; $5^{\circ}$ et parce que la base de la pectorale est surmonté d'une écailie longue et carénée. Le muge céplale est de la

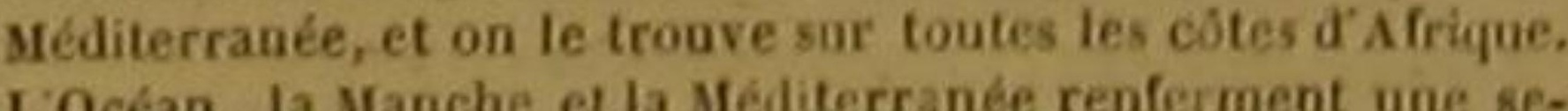
conde espèce, le Mugit capito de II. Cuvier, décrite par Pennant, Willoghby, et par M. Risso, sous le nom de Ra. mado. Il a le maxillaire visible dernere la commissure des máshoires. Ses ycux n'ont point de volle adipeux: I'écaille do dessis de ses pectorales est courte et obtuse. Ily a une

. tesby, Carol. 2, p. 6, tab. 6. - s Mugîl argentens minor, etc., Browsoe, Jam. 450.

'M. Cuvier remarque qrill y a en Amérique cing on six

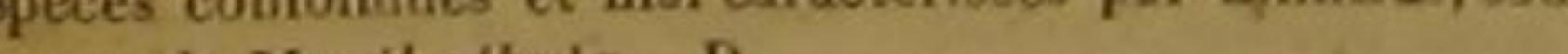
${ }_{5}^{5}$ Forskael, Faun. Arab,., p. 73, n. 109. - Mugile arabi. de ses mâchoires armée de très-petites dents; la langue rude; la gorge garnie de deux os hérissés d'aspérités; la lèvre supérieure soutenue par deux os étroits, qui finissent en pointe recourbée ; la partie antérieure de l'opercule placée audessus d'une demi-branchie; In base de l'anale, de la eaudale et de la seconde dorsale, revêtue de petites écailles; le dos brun; le ventre argentin; et la couleur des nageoires bleue.

Les céphales habitent dans presque toutes les ners.

Lorqu'ils s'approchent des rivages; qu'ils s'avancent vers l'embouchure des fleuves, et qu'ils remontent dans les rivières, ils forment ordinairement des troupes si nombreuses, que l'eau au travers de laquelle on les voit sans les distingaer parait bleuâtre. Les pécheurs qui poursuiventces légions de muges, les entourent de filets dont iis resserrent insensiblementl'enceinte; et, diminuant à grand bruit la circonférene de l'espace dans lequel ils ont renfermé ces poissons, ils les rapprochent, les pressent, les entassent, et les prennent avee facilité. Mais souvent les céphales se glissent au-dessous des filets, ou s'élancent par-dessus; et les pécheurs de certaines cotes ont recours à un filet particulier, nommé sautade, ou cannat, fait en forme de sac ou de verveux, qu'ils attachent au filet ordinaire, et dans lequel les muges se prennent d'eux-memes, lorsqu'ils veulent s'échapper en sautant. Cette manière de chercher leur salut dans la fuite, soit en franchissant I'obstaclequ' on leur oppose, soit en glissant au-dessous, ne suppose pas un instinct bien relevé ; mais elle suf-

- M. Cuvier place ce muge dans ta divifion des espéces a grosses levres, qui vivent dans la mer dés Indes. D. 'Bloch, pl. 395.

- M. Cavier ne cite pas cette espéce de muge. D. - Blochi, articie du Muge tang.

Cetle espece n est pas mentionnée par M. Cuvier. D.

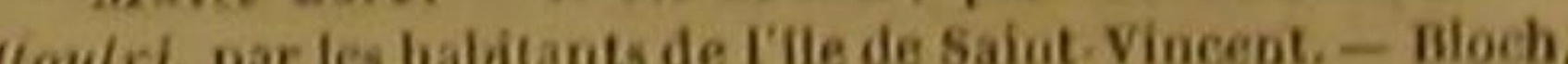
1. 396. - . Cephatus americanus, vulgó atoulri., Plumier, manusc, de la Bibl. déja cités. - Céphate damérique, on mulet daré de riviére, Gauthier, J. de plys., III, p. 40. a. 12.

vier regarde ce muge de Bloch comme constituant one des espéces d'Amérique, qui ont été confondues pur par Schoeider dins le genre Spuraiss, p. 110. D.

1. . Mugil macula ad basio pinnarum peotoralium arures, - pinná dorsi osgiculoram novem, ani decem, peciora ibu

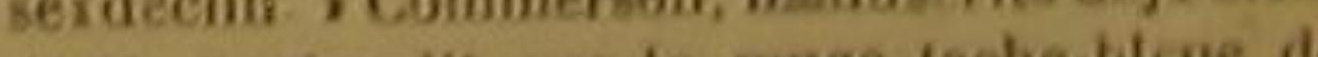
"A. Cavier dit que te moge tache-ilcue de Lachpele, labre, appartient aur groupe d'especes dans lequet if place son minge capito, céest-d-dire lépéce des cútes de l'océan. 
fit pour empêcher de placer les céphales au rang | le dos brun; les flanes blanes; les nageoires d'un

des poissons les plus hébétés, en leur attribuant, brun jaunâtre, presque de la mème couleur avec Pline et d'autres anciens anteurs, l'habitude de se croire en sûreté, comme plusieurs animaux stupides, lorsqu'ils ont caché leur tête dans quelque cavité, et de ne plus craindre le danger qu'ils ont cessé de voir.

Les muges céphales préfèrent les courant d'eau douce versla fin du printemps ou le commencement de l'été : cette eau leur convient très-bien; ils engraissent dans les fleuves et les rivières, et mème dans les lacs, quand le fond en est de sable. On fume et on sale les céphales que l'on a pris et qu'on ne peut pas manger frais; mais d'ailleurs on fait avee leurs ceufs assaisonnés de sel, pressés, lavés, séchés, une sorte de caviar, que l'on nomme boutargue, et que l'on recherche dans plusieurs contrées de l'Italie et de la France méridionale.

Au reste le foie du céphale est gros ; l'estomac, petit, charnu, et tapissé d'une membrane rugueuse facile à enlever; le canal intestinal plusieurs fois simueux; le pylore, entouré de sept appendices. Ces formes annoncent que ce muge se nourrit non-seulement de vers et de petits animaux, mais encore de substances végétales. Sa vessie natatoire, qui est noire comme son péritoine, offre de grandes dimensions.

L'albule habite dans l'Amérique septentrionale.

Le crénilabe vit dans la mer d'Arabie et dans le grand Océan. On a remarqué sa longueur de douze ou quinze pouces; ses écailles larges, et distinguées presque toutes par une tache brune; la grande mobilité de la lèvre supérieure; la double carène de la mâchoire inférieure; la tache noire de la base des pectorales; les nuances vertes, bleues et blanchâtres de toutes les nageoires.

On a observé aussi deux variétés de cette espèce. La première, suivant Forskael, est nommée Our ' ${ }^{\text {, }}$ et la seconde Tade. L'une et l'autre n'ont qu'une carène à la mâchoire d'en bas ; mais les Ours ont des cils aux deux lèvres; les Tádes n'en ont que de três-déliès, et n'en montrent qu'à la lèvre supérieure.

Le tang, que l'on a péché dans les fleuves dé la Guinée, a la chair grasse ét de bon goût ; bouche petite; l'orifice de chaque narine double;

'M. Cuvier remarque que lę Mugil our de Forskael, le mème aue le Bontah Russel, peut étre identique avec le
Muge céphale. D. que les raies longitudinales.

Nous avons cru devoir regarder comme une espèce distimcte des autres muges le poisson envoyé de Tranquebar à Bloch, par le zélé et habile missionnaire John, et que ce grand ichthyologiste n'a considéré que comme une variété du tang.

Les narines du tranquebar sont très-écartées P'une de l'autre; les os des lèvres très-étroites; ses dorsales plus basses et ses couleurs plus claires que celles du tang; les deux còtés du museau hérissés d'une petite dentelure, comme sur le tang et le céphale'.

Les Antilles nourrissent le muge plumier. Ses deux mâchoires sont également avancées, et armées l'une et l'autre d'une rangée de petites dents; le corps et la queue sont gros et charnus. Commerson a laissé dans ses manuscrits mne description du muge que nous nommons Tachebleue. Les côtés de ce poisson offrent des teintes d'un brun bleud́tre; sa partie inférieure resplendit de l'éclat de l'argent; ses dorsales et sa caudale sont brunes; ses ventroles et on no geoire de l'anus montrent une couleur plus ou moins pâle.

\section{DEUX CENTIÉME GENRE.}

LES MUGILOIDEES ${ }^{2}$,

La mdehoire inférieure carineie en dedans; la teto revelue de petites écailles; les éaillesstriées; une na-
geoire du dos.

EsPíce.

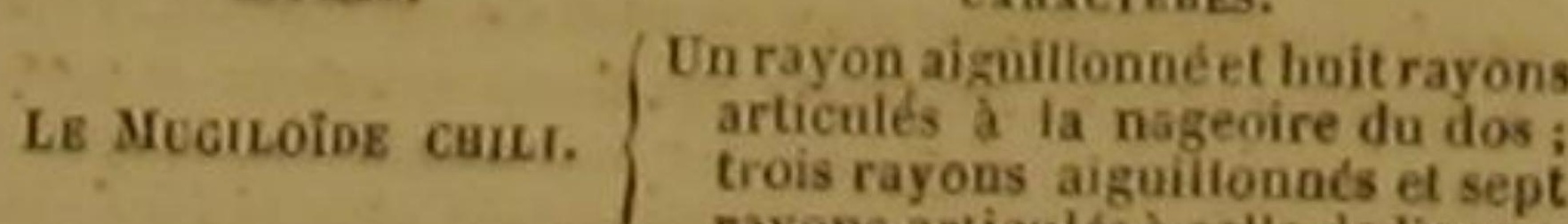

rayons articules a celle de lanus.

'6 rayons à la membrane branchiale du muge céphale, 17 a chaque pectorale, 1 rayon aiguillonné et 5 rayons articulés
i chaque ventrale, 16 rayons a la nageoire de la quene - -17 ayons a chaque pectorale du muge albule, 1 rayon aiguillonné et 5 rayons articulés a chaque ventrale, 20 rayons a la 16 rayons a la mage et 5 rayons articulés à chaque ventra'e, brane branchiale da me la queve. -6 rayons à la mem1 rayon aiguillonné et 5 rayons articnlés a que pectorale, trale, 16 rayons à la candale -6 rayons a la membraue venchiale du muge tranquebar, 12 a chaque pectorale, 1 rayon aiguillonné et 5 rayous articulés à chaque ventrale, 16 rayons a la nageoire de la queue. -12 rayons a chaque peetora'e du a chapuerier, 7 a chaque veatrale, 9 a la caudale. -16 rayons caudaie. -17 rayons à chaque pectorale du muge crénilabe,

\section{ES POISSONS.}

559

LE MUGILOIDE CHILI '. Mugiloides chilensis, Lac.; Mugil chilensis, Lino.,
Gmel. ?

Le savant naturaliste Molina a fait connaitre ce poisson. On trouve ce mugiloilde dans la mer qui baigne le Chili, et dans les fleuves qui portent leurs eaux á cette mér. Son nom générique indique la ressemblance de sa conformation à celle res muges, comme son nom spécifique désigne sa patrie. Sa longueur ordinaire est d'un pied ou quinze pouces ${ }^{3}$.

\section{DEUX CENT UNIEME GENRE.}

LES citanos 3 .

La mdehoire inferieure carenée en dedans; point de dents gux madehoires; les ecailles striées; une siule nageoire du dos; la caudale garnie, vers lo millieu de chacun de ses colis, d'uñe sarle d'aile membraneuse.

ESPÉCX.

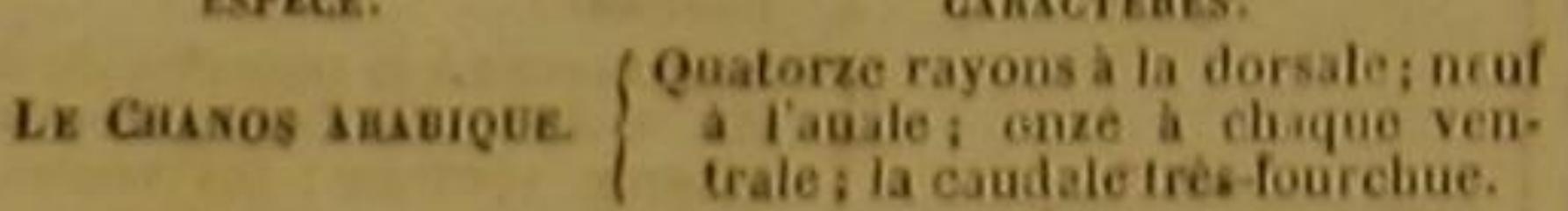
$-$

LE CHANOS ARABIQUE

Chanos arabicus, Lac,; Mugil Chanos, Forsk., Linn. Gmel, 4 .

Ce poisson habite dans la mer d'Arabie; et c'est ce qu'annonce le nom spécifique que nous lui avons donné en le séparant du genre des muges, dont il differe par des caraeteres tro remarquables pour ne pas devoir appartenir i un groupe distinct de ces derniers.

Il montre une longueur très-considérable : il en présente ordinairement une de trois ou quatre pieds; et des individus de cette espéce, qu forment une variété à laquelle on a attaché In dénomination d'Anged, ont jusqu'à onzé pied de long. Ses écailles sont larges, arrondies, argentées et brillantes; la tête est plus étroite que

4 Molina Hist. natur. Chil., p. 198, n. 5. - Mugile lisa. Bounaterre, pl. de I'Enc, méth.

${ }^{2} \mathrm{M}$. Cuvier ne fait aucane mention de ce genre. D.

: 7 rayous la membrane des hranchies du mugiloide chili, 22 a chaque pectoraie, 1 rayon agmilionne et 5 rayous arti-

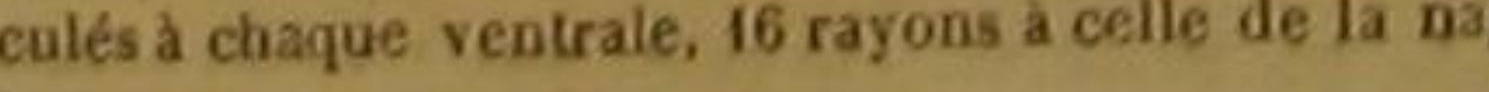
la queue.

I. Cavier remargne que le Mucri Carsos de Forskael,

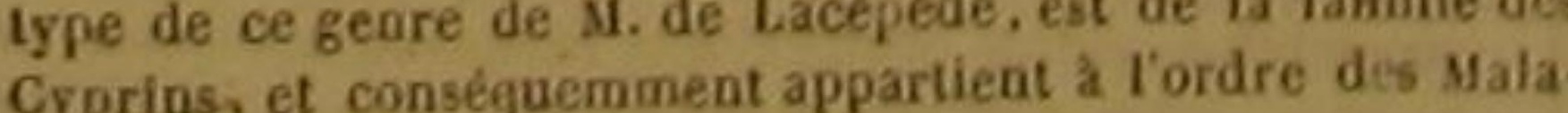
coptérygiens abdominaux. D.

'Forskael, Faun. Arab., p. 74, n. 110. - Mugile chani. Bonnaterre, pl. de l'Ena męth. le corps, aplatie, dénuée de petites écailles, et d'un vert méléde bleu; la lèvre supérieure échancrée et plus avancée que celle d'en bas; la ligne laterale courbée d'abord vers le haut, et ensuite très-droite '.

\section{DEUX CENT DEUXIÈME GENRE.}

LES MUGLOMORES "

La machoire inférieure cardnceen dedans; les mdchoires denuees de dents, et garnies de petites protuberances; une seute nageoire da dos; un appendice detanew des rayons de celle dorsale.

Esríck. Cancerkits.

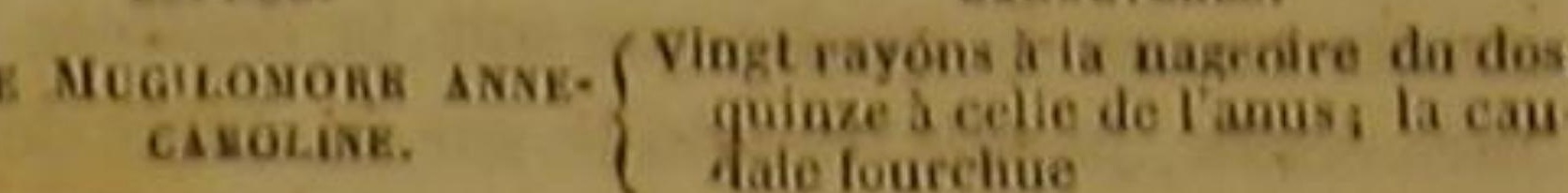$$
-
$$

LE MUGLOMORE? ANNE-CAROLINE 4 ,

Mugitomorus Anoa-Carolina, Lac, :

Ce poisson brille du doux éclat de f'argent le plus pur; une teinte d'azur est répandue sur son dos. Ses dimensions sont grandes; ses proportions agréables et sveltes. Il est rare; il est recherché. J'en dois la connaissance â mon ami et savant confrère M. Bose, ancien agent des relations commerciales de la France dans les Etats-Unis.

Je consacre à l'amour conjugal le don de l'amitice ; je le dédie â la compagne ${ }^{6}$ quí ne m'a jamais donné d'autre peine que celle de la voir', depuis un an, éprouver les souffrances les plus

14 rayôn a 14 membrane branchiale du elanos arabique, 16 a chaque pectorale, it a chaquo ventrale. 20 a la cauda 3.' M. Cuvier a reconna gue le posson qui sert de type

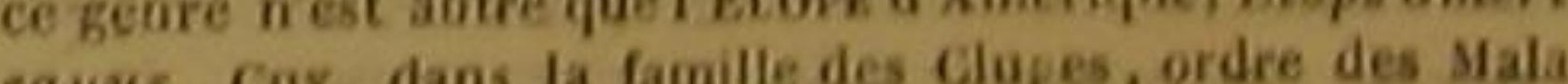
copterygiens abdominawx. D.

: Le nom générique de mugillomore désigne les rappori de ce genre avec celui des moges.

C. Sngit appendiculatus : mugil pinná dorsali unica vi. gioti radiats, omnibus appendiculatis. \& Bosc, notes manus-

te la erande edition de l'Histoire

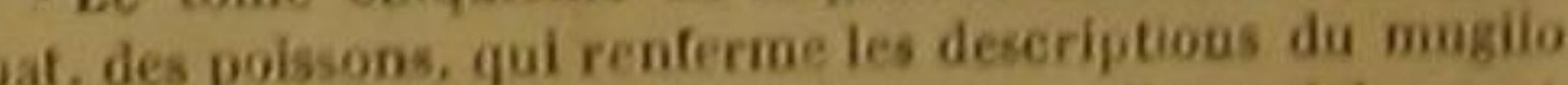
more Anne-Caroline, dn mené Anne-Caroline, et du cyprin Anne-Caroline, porte la dédieace suivante

A LA DOLCE BIESBASASCK,

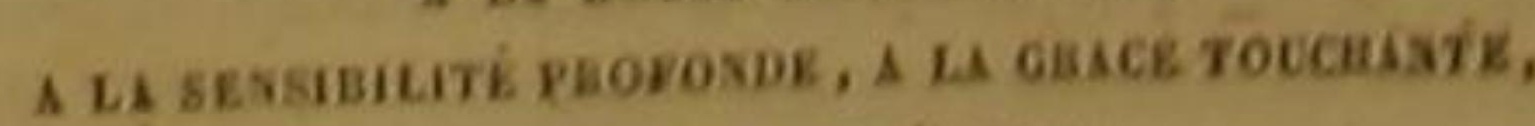
A L'YSRET SEPEALEA

DANNE - CAMOLINE HEGEAT - JUBÉ LACÉPÉDE ноМ⿻яс

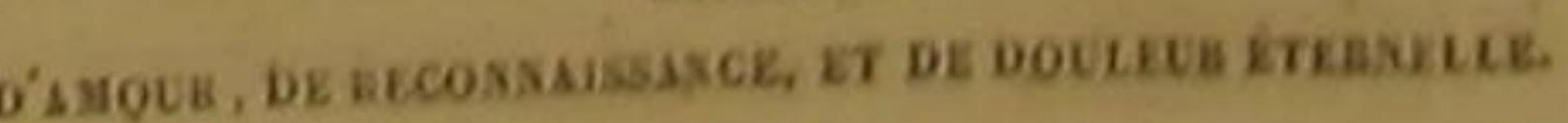


vives. C'est auprès de son lit de douleur que j'ai écrit une grande partie de l'Histoire des poissons. Que cet ouvrage renferme l'expression de ma tendresse, de mon estime, de ma reconnaissance : je l'offre, cette expression, à la sensibilité profonde qui répand un si grand charme sur mes jours; à la bonté qui fait le bonheur de tous ceux qui l'entourent; aux vertus qui ont, en secret, séché les larmes de tant d'infortunés; à cet esprit supérieur qui craint tant de se montrer, mais qui m'a accordé si souvent des conseils si utiles; au talent qui a mérité les suffrages du public '; à la douceur inaltérable, à la patience admirable avec laquelle elle supporte la longue et cruelle maladie qui la tourmente encore ${ }^{2}$. Quelle que soit la destinée de mes écrits, je suis tranquille sur la durée de ce témoignagne de mes sentiments; je le confie au cœur sensible des naturalistes; le nom d'AnneCaroline Hubert-Jubé LacÉPĖde leur sera toujours cher.Que le bonheur soit la récompense de leur justice envers elle, et de leur bienveillance pour son époux !

Le mugilomore-Anne-Caroline a la tête allongée, comprimée et déprimée; un sillon assez large s'étend longitudinalement entre les yeux ; l'ouverture de la bouche est grande; les deux cótés de la carène intérieure de la máchoire d'en bas forment, en se réunissant, un angle obtus ; la langue est épaisse, osseuse et unie; les yeux sont très-grands; l'iris est couleur d'or; la ligne latérale se dirige parallèlement au dos; toutes les nageoires sont accompagnées d'une membrane adipeuse, double, longue, égale dans la dorsale et dảans l'anale, inégale dans ies pectorales et dans les ventrales. Les trente-quatre rayoūs de la membrane branchiale sont égaux. La longueur ordinaire du poisson est de deux pieds; la hauteur, de quatre pouces; la largeur ou épaisseur, d'un pouce et demi à deux pouces.

Ce mugilomore se trouve dans la mer qui baine les côtes de la Caroline. Le goût desa chair est très-agréable ${ }^{3}$.

'Pendant la vie de son premier mari, M. Ganthier, que l'on joua asee succos sor le thesatre Fayart, de plusiens articles du Dictionaaire des sciences. de quelques parti de I'Histoire unicerselle, ete., elle publia , sous le nom de madame G...., un roman intitile Sophie, on Mémoinc de Lawenstein.

'Le 16 bramaire, an 14 de lère franģais.

35 rayons a ta membrane branchiale
DEUX CENT TROISIÈME GENRE,
LES EXOCETS '.

La tele entièrement, ou presque entièrement couverto de petites écailles; les nágeoires pectorales larges, et re

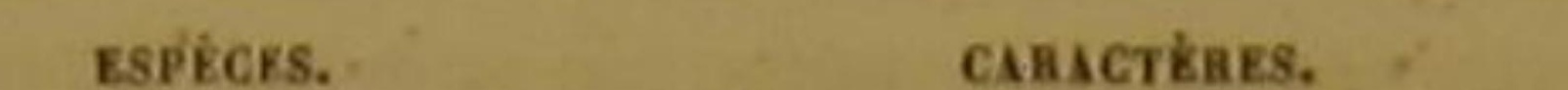

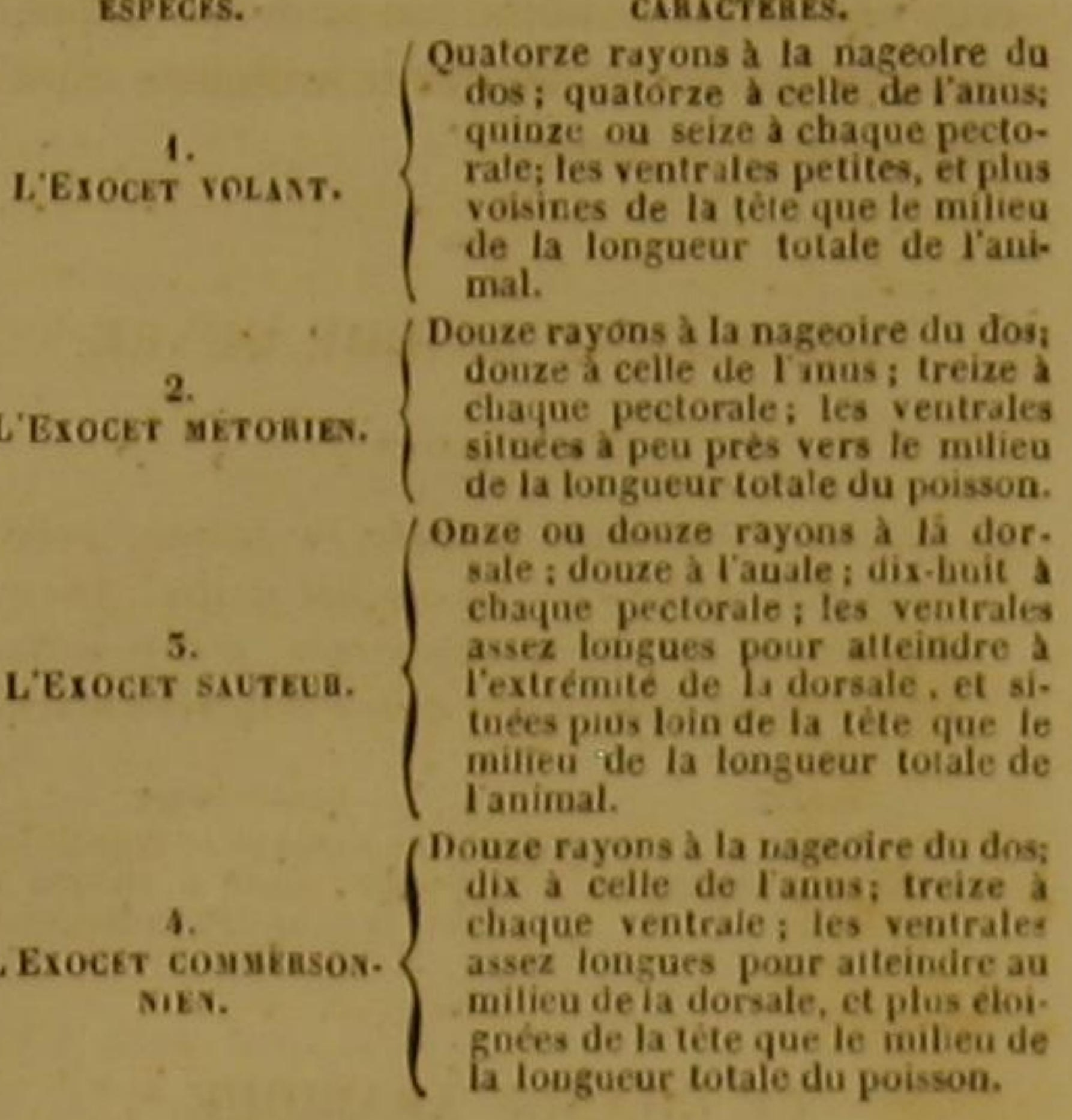

\section{L'EXOCET VOLANT ${ }^{2}$.} catus evolans, Linn ?'

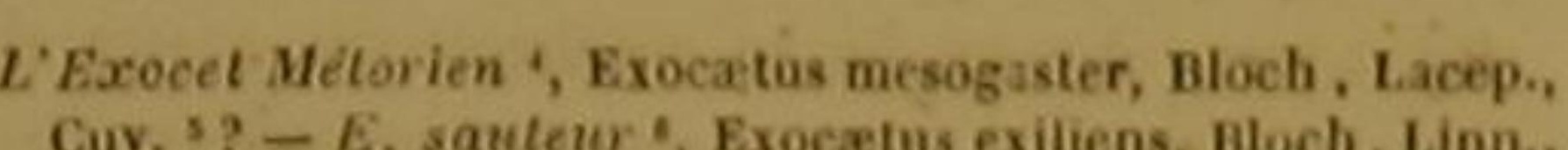
Gmel., Lacep.. Cuv, T, - E. Commersonnien', Exocerlus Commersonnit, Lae,

Ce genre ne renferme que des poissons volants, et e'est ce que désigne le nom qui le dis-

Anne-Caroline, 18 a chaque pectorale, 15 a chaque ventrale, 10 a la nageoire de la queue.

'M. Cuvier admet ce genre dans la famille des Ésoczs. Poiss Malacoptérygiens abdominaux. D.

Poisson volant, - Hochllieger, en Allemagne. - Flyg. (ish, en Suede. - Flyi/isken, en Danemarck. - Vliegender

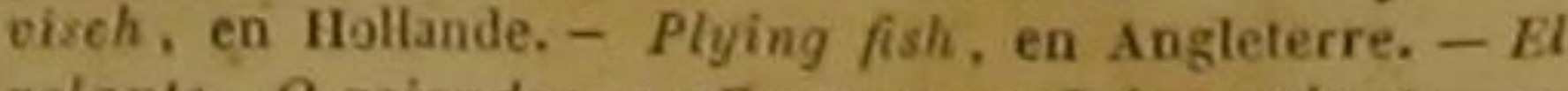
Pirabebe. Pis. Brasil. 61. - Gronov, Mus, 1, n. 27; et Zooph. 35s. - Bloch, pl. 538. - Appendix du Voyage a la Nouvelle. Galles méridionale, par Jean White. elc., pl. 52, tig. 2. C. Prerichthus pinnis pectoralibus radiorum sexdecim; ven-

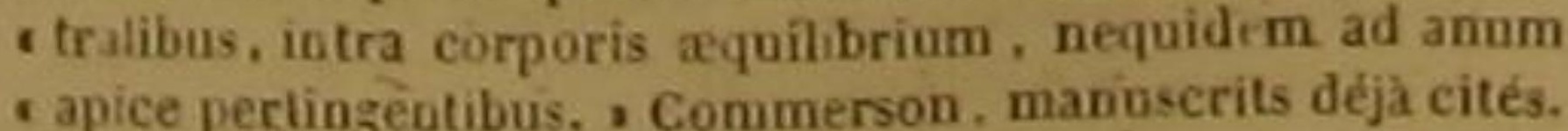
" Da genre Exocer, d dns la famille des Érocks, ordre des

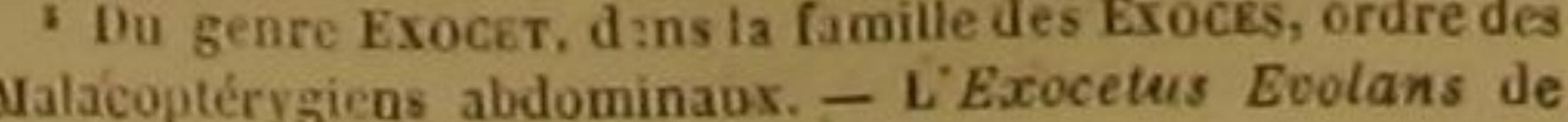
rayons d la membrane des branchies ; une seule dor-

Exocatus volitans, Linn., Gmel.; Bl., Lac., Cuv.; Exorolante, $O$ volandor, en Expagne. - Peixe rolante, en Lxocet pirabe. Daubenton et Hail. - Exocet muge volant. naterre, pl. de l'Enc. méth. - Amon it. acad. I, It.221. -
DES POISSONS.

$5 \sin$

tingue. Nous avons déjà vu des pégases, des | pidité de l'éclair. Veut-il chercher sa sûreté sur scorpènes, des dactyloptères, des prionotes, des le pont des vaisseaux dont il s'àpproche pendant trigles, jouir de la faculté de s'élancer à d'assez son espèce de vol? le bon goùt de sa chair lui grandes distances au-dessus de la surface des ote ce dernier asile; le passager avide lui a bieneaux : nous retrouvons parmi les exocetsle même tỏt donné la mort qu'il voulait éviter. Et comme attribut; et, comme, très-avancés déjà dans la si tout ce qui peut avoir rapport à cet animal, revue des poissons que nous avons entreprise, en apparence si privilégié, et dans la réalité si nous n'aurons plus d'ocension d'examiner cette disgracie, devait retracer le molheur de sa conAlronomes ont placé sou petit nombre des animaux dont nous sommes image dans le ciel, ils ont mis à cóté celle de la les historiens, jetons un dernier coup d'xil sur dorade, l'un de ses plus dangereux ennemis. ce phénomène remarquable, qui démontre si La parure brillante que nous devons compter bien ce que nous avons táché de prouver en tant parmi les causes de ses tourments et de sa perte, d'endroits de cet ouvrage; c'est-à-dire, que vo- se compose de l'éclat argentin qui resplendit sur ler est nager dans l'air, et que nager est voler presque toute sa surface, dont l'agrément est au sein des eaux.

L'exocet volant, comme les autres exocets, est bel à voir; mais sa beauté, ou plutôt son éclat, ne lui sert qu'à le faire découvrir de plus loin par des ennemis contre lesquels il a été laissé sans défense. L'un des plus misérables des habitantsdes eaux, continuellement inquiété, agité, poursuivi par des scombres ou dés coryphènes, s'il abandonne, pour leur échapper, l'élément dans lequel il est né, s'il s'élève dans l'atmosphère, s'il décrit dans l'air une courbe plus ou moins prolongée, il trouve, en retombant dans la mer, un nouvel ennemi, dont la dent meurtrière le saisit, le déchire et le dévore; ou pendant la durée de son court trajet, il devient la proie des frégates et des autres oiseaux carnassiers qui infestent la surface de l'Océan, le découvrent du haut des nues, et tombent sur lui avec la ra-

Lianée ne parait étre, selon M. Cavier, qu'un Volitans dont les écailles étaient tombées. D

'Bloch, pl. 593. vier remargue que ce poisson est difficile a distinguer de TExocel santeur. D.

plas. départ. mér. - Rondine, en llatier.- Lendola, dans en Arabie. - Gharara, a Dichadda - Sabari, a MoLha - Ikan terbang berampat sajap, aux Indes orientales. Springer, en Allemagae. - Vliegerde harder, en Har. lande. - Swallow fish, en Angleterre. - Exocet sauteur. spec. 55, syn. 18. - Muge volant. Mondelet, part. 1, I. c. 5. - Muge volant. Bloch, pl. 597. - Plerichthus spi- cius, exocatos longè volans, pinnis pectoralibus radiorum

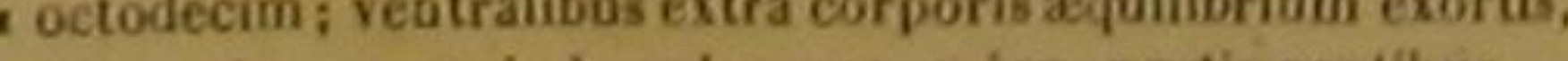
cultra pinam ani dorsilemedore pertingentibus. Commerson, manuscrits deja cité.

8 . Prerichthus sublimius pinnis pectoralibus radiorum - tredecim; ventralibus extra corporis æquilibrium exortis, - ad medias ani dorsique pinuas apice pertingentibus. , Commerson, manuscrits deja cite. augmenté par l'azur du sommet de la tête, du dos et des côtés, et dont les teintes sont relevées par le bleu plus foncé de la nageoire dorsale, insi -que de celles de la poitrine et de la queue. La tete du volant est un peu aplatie par-des sus, par les cótés et par devant. La máchoire d'en bas est plus avancéeque la supérieure; cette dernière peut s'allonger de manière à donner à l'ouverture de la bouche une forme tubuleuse et un peu eylindrique : l'une et l'autre sont garnies de dents si petites, qu'elles échappent presque à l' $\propto$ il, et ne sont guere sensibles qu' au tact. Le palais est lisse, ainsi que la langue, qui est d'ailleurs à demi cartilagineuse, courte, arrondie dans le bout, et comme taillée en biseau a cette extrémité. L'ouverture des narines, qui touche presque l'cil, est demi-circulaire, et enduite de mucosité. Les yeux sont ronds, très-grands, mais peu saillants. Le cristallin, qu'on apercoit au travers de la prunelle, et qui est d'un bleu noiraatre pendant la vie de l'animal, devient blane d'abord apres la mort du poisson. Les opercules, très-argentes, très-polis et tres-luisants, sont composés de deux lames, dont l'antérieure se termine en angle, et dont la postérieure présente une petite fossette. Les ares osseux qui soutiennent les branchies ont des dents comme celles d'un peigne. Les écailles, quoique un peu dures, se détachent, pour peu qu'on les touche. On voit de chaque côté de l'exocet deux lignes latérales: uné fausse, et très-droite, marque les interstices des muscles, et separe la partie du poisson qui est colorée en bleu, d'avec celle qui est argentée; l'autre, véritable, et qui uit la courbure du ventre, est composée d'écailles marquées d'un point et relevées par une strie longitudinale. Le dessous du poisson est
- Du genre Exocex, dans la famille des b́roces. M. Cu. 


\section{HISTOIRE NATURELLE}

aplati jusque vers l'anus, et ensuite un peu convexe.

Les grandes nageoires pectorales, que l'on a comparées à des ailes, sont un peu rapprochées du dos; elle donnent par leur position, à l'animal qui s'est élancé hors de l'eau, une situation moins fatigante, parce que, portant son centre de suspension au-dessus de son centre de gravité, elles lui ôtent toute tendance à se renverser et à tourner sur son axe longitudinal.

La membrane qui lie les rayons de ces pectorales est assez mince pour se prêter facilement à tous les mouvements que ces nageoires doivent faire pendant le vol du poisson; elle est en outre placée sur cés rayons, de manière que les intervalles qui les séparent puissent offrir une forme plus concave, agir sur une plus grande quantité d'air et éprouver dans ce fluide une résistance qui soutient l'exocet, et qui d'ailleurs est augmentée par la conformation de ces mêmes rayons que leur aplatissement rend plus propres à comprimer l'air frappé par la nageoire agitée.

Les ventrales sont très-écartées l'une de l'autre.

Le lobe inférieur de la caudale est plus long d'un quart ou environ que le lobe supérieur.

Tels sont les principaux traits que l'on peut remarquer dans la conformation extérieure des exocets volants, lorsqu'on les examine, non pas dans les muséums, où ils peuvent étré altérés mais au moment où ils viennent d'étre pris. Leur longueur ordinaire est de huit à douze pouces. On les trouve dans presque toutes les mers chatdes ou tempérées; et des agitations violentes de l'Océan et de l'atmosphère les entrainant quelquefois à de très-grandes distances des tropiques, des observateurs en ont vu d'égarés jusque dans le canal qui sépare la France de la Grande-Bretagne.

Leur estomac est à peine distingué du canal intestinal proprement dit; mais leur vessie natatoire, qui est très-grande, peut assez diminuer leur pesanfeur spécifique, lorsqu'elle est remplie d'un gaz léger, pour rendre plus faeile nonseulement leur natation, mais encore leur vol.

Bloch dit avoir lu dans un manuscrit de Plamier, que, dans la mer des Antilles, les œufs du Poisson volant (apparemment l'exocet volant) étaient si âcres, qu'ils pouvaient corroder la peau de la langue et du palais. Il invite avec raison les observateur's à s'àssurer de ce verte "?

DES POISSONS.

DEUX CENT QUATRIÈME GENRE.

LES POLYNĖMES ‘. réduit à l'effet local des qualités vénéneuses des aliments de l'exocet.

Le métorien montre une dorsale élevée et échancrée, et une nageoire de l'anus également échancrée, ou en forme de faux. On l'a pêché dans la mer qui entoure les Antilles.

Le sauteur a la chair grasse et délicate; une longueur de près d'un pied et demi, l'habitude de se nourrir de petits vers et de substances végétaleś. Il se plaít beaucoup dans la mer d'Arabie et dans la Méditerranée, particulièrement aux environs de l'embouchure du Rhône; mais on le rencontre, ainsi que le volant, dans presque toutes les parties de l'Océan un peu voisines des tropiques, et même à ylus de quarant degrés de l'équateur. Commerson l'a vu à trentequatre degrés de latitude australe, et à cinquante lienes des côtes orientales du Brésil.

La tête est plus aplatie par devant et par dessus que dans l'espèce du volant; l'intervalle des yeux plus large; le haut de l'orbite plus saillant; l'occiput plus relevé ; la mâchoire supérieure moins extensible; l'ouverture de la bouche moins tubuleuse; et la grande surface des ventrales doit faire considérer ces nageoires comme deux ailes supplémentaires, qui donnent à l'animal la faculté de s'élancer à des distances plus considérables que l'exocet volant.

Le commersonnien a l'entre-deux des yeux, le dessus de l'orbite, la machoire supérieure, comme ceux du sauteur; l'occiput déprimé; et la dorsale marquée, du côté de la nageoire de la queue, d'une grande tache d'un noir bleuâtre. Cette quatrième espèce d'exocet est encore in connue des naturalistes. Comment ne lui ąuraisje pas donné le nom du voyageur qui l'a décou-

- 6 rayons à chaque ventrale de l'exocet volant, 15 a la nigeoire de la queue. -6 rayous a clague venitrole de lesocet letorien, 20 a la caudale. -6 rayons à chaque ventrale de chaquerenteur, 16 a la nageoire de la queue. -6 rayons à

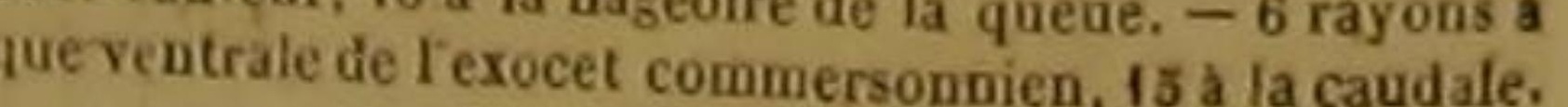
PREMIER SOUS-GENRE. eroissant.

Espíces.

Le PoLsieme nurk. libres
Fale. SECOND SOUS-GENRE. lancéolee, et sans échancrure.
Pres aupres de chaque pectorale; la tete retelue de petites icailles; deux nageoires dorsales.

La nageoire de la queue, fourchue, ou clchanerie en

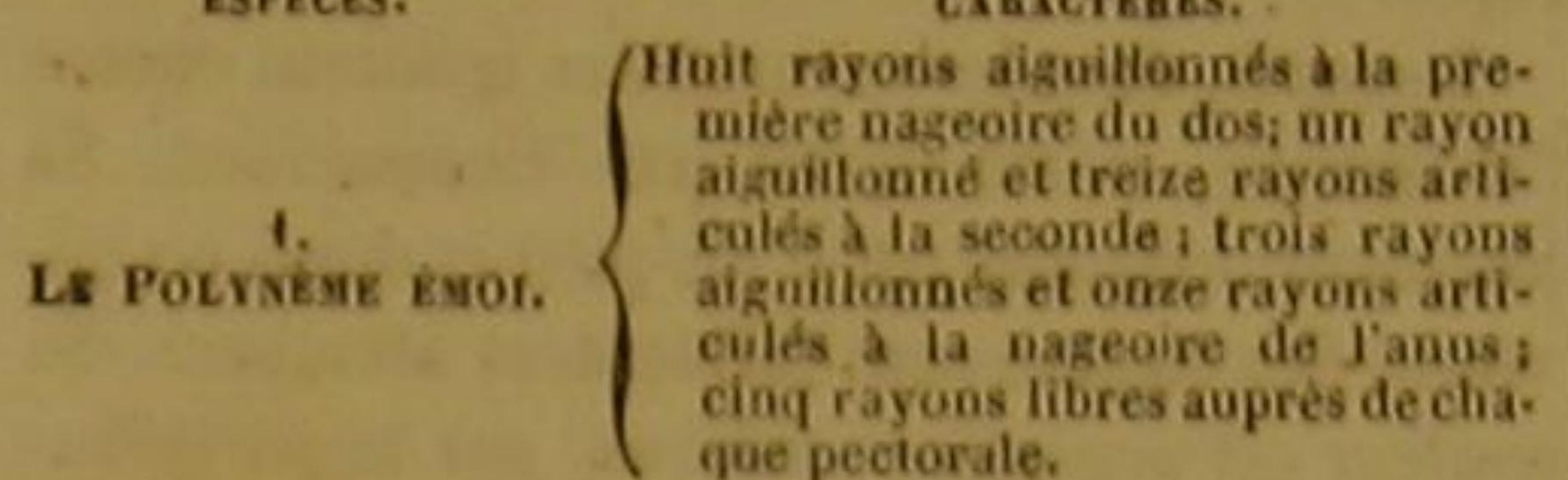
Sept rayons a la premiere dorsale:
seize a la seconde ; deux rayons

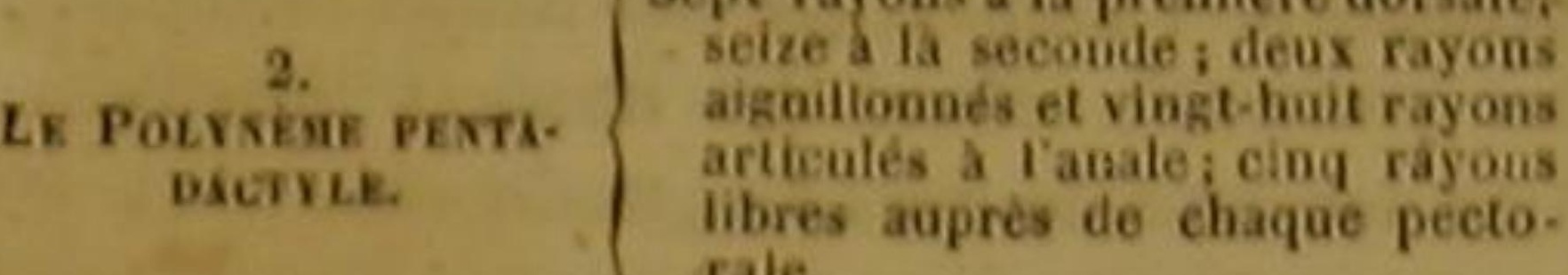
Dayons aiguillonnds a la pre.
piére nageoire du doss un rayon aguillonué et quatorze rayoos
urticoles a ta seconde; m rayon

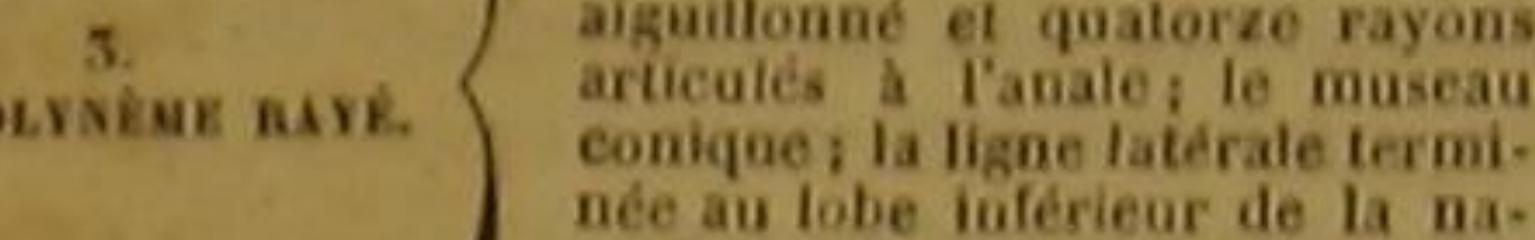
feoire de la queue ; cinq rayons

L. LE POLYNÈME ÉMOI ', Polynemus plebieus, Brouss, Cuv,, Lac,; Polynemus lineatus, Lac,; Polynemus Sele, Buchan. ².

Le Polynème pentadaclyle s, Polynemus longiflis, Cav.,

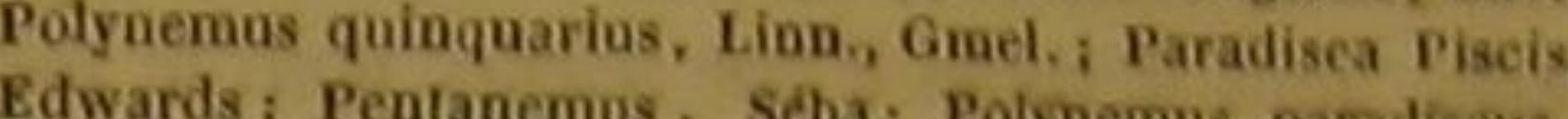
Linno, Gmel. ‘. - P, rayé s, Polynemns plebeius, Hrones, Ct.,$;$; Polynemus lineatus, Lac, $\bullet-P$. Paradis', Poly. nemus longifilis, Cuv.; Polynemus Paradiseus, Linn. Gmel, Lacep.; Polynemus plebeins et Pol. quinquarios, Edwards ', - P décadaclyle, Polynemus decus Fisci, Bl., Cuv, Lac, 10, $-P$, Mango ", Polynemus americanns, Cuv.; Polynemus virsinicus, Linn.? Polynempis Uamen ef Polydactylus Plumieri, Lacep-i Polynemus Paradiseus, BI. ${ }^{13}$.

Nous conservons au premier de ces polynèmes le nom d'Emoi ; il a été donné à ce poisson par les babitants de l'ile d'Otahiti, dont il fréquente les rivages. II est doux; il retrace des souvenirs touchants; il rappelle à notre sensibilité-ces fles fortunées du grand Océan équinoxial, ou la nature a tant fait pour le bonheur de I'homme, où notre imagination se hate de chercher un asile, lorsque, fatigués des orages de la vie, nous voulons oublier, pendant quel-

- Peire royal, par les Portugais de la côte de Malabar. Kalamin, par les Tamulaines. - Id. Broussonnet, Ichith.

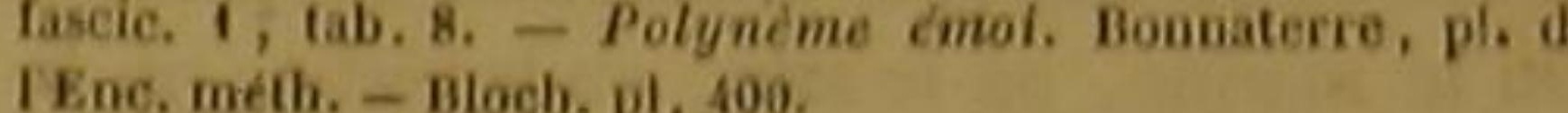

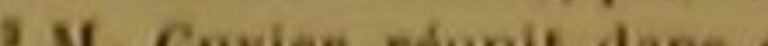

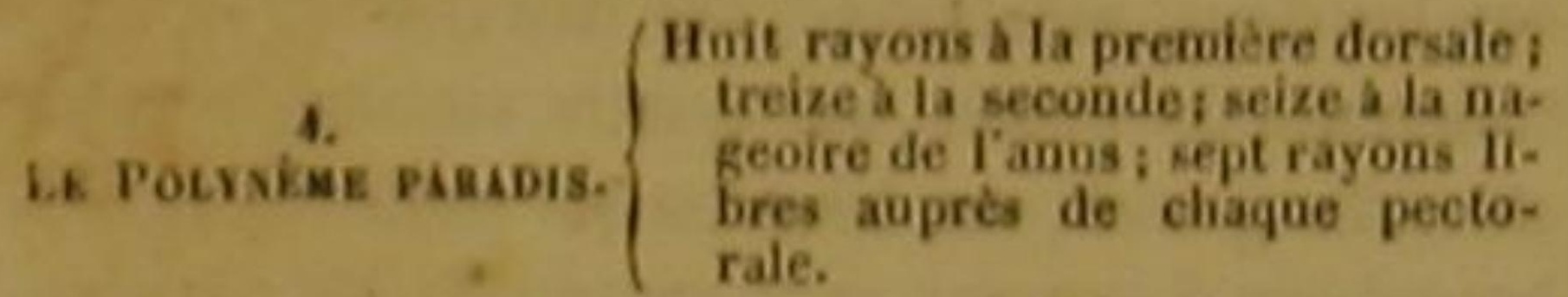

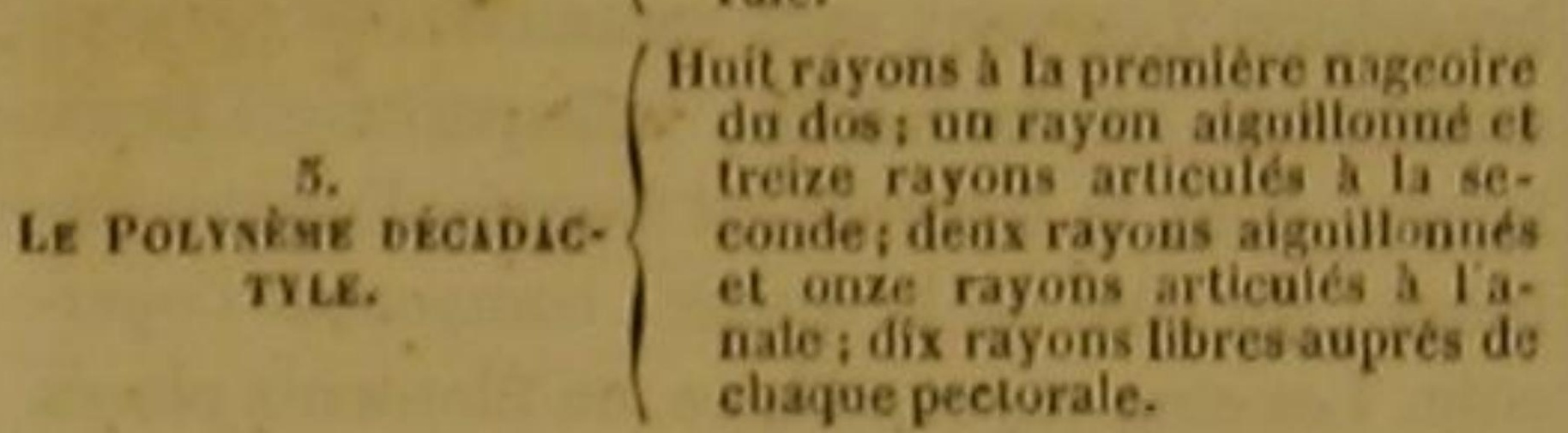

La nageoire de la queue, rectiligne, ou arrondie, ou

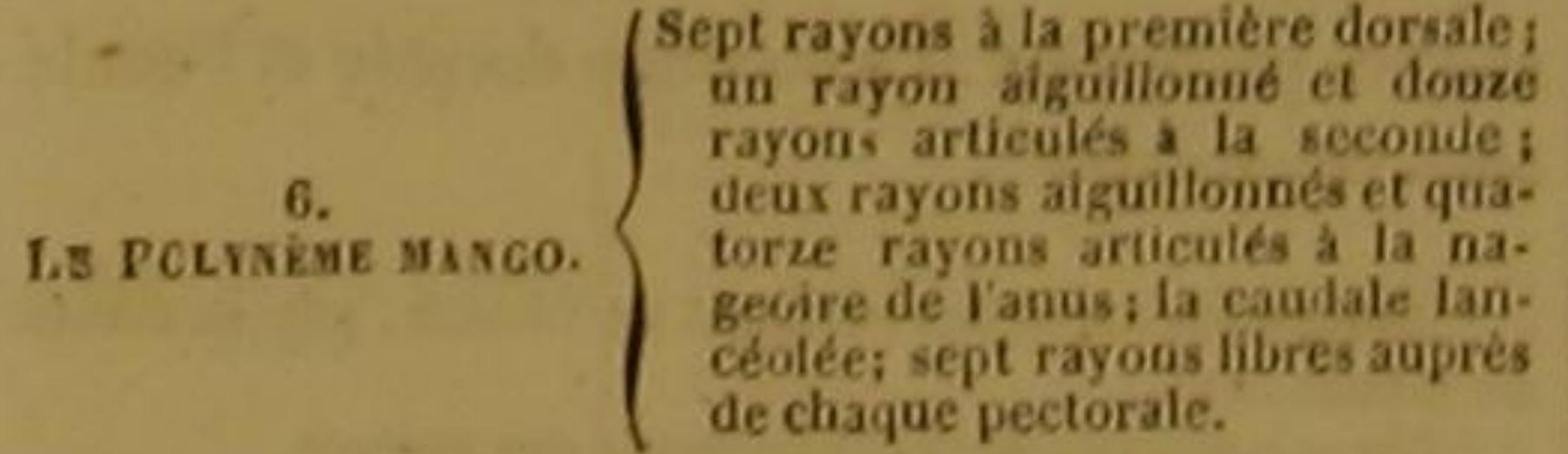

I Le genre PoLrséng, conservé par M. Cuvier, est placé par loi dans la famille des Acanthoptérygiens percoides, et il snpprime le genre PoLrDicTrLE, comme fondé sur une es. péce de véritable polynème. Les six Polynèmes de $\mathrm{M}$. de Lacépede et son Polydactyle Plumier se rapporteut à quatre

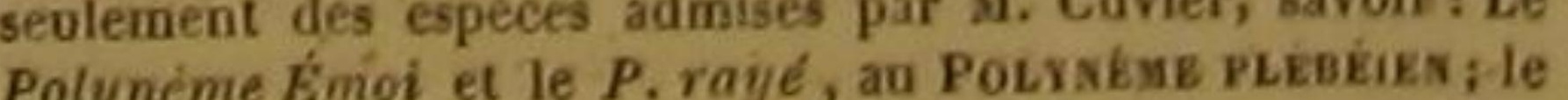
Polynème pentadactyle et le P. Paradis (Séba), au Poly-

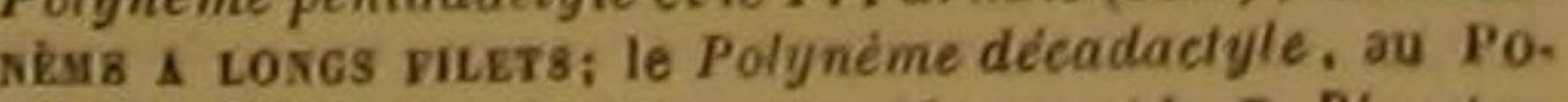
LYNíme a Dis guiss fle Polyneme Mango et le P. Plumies au PoLrsìue d'AMĖague. D
Jo Broussonnet, adopté par M. Lacécéde, et le Polynimo

rayé de ce dernier, fondé sur une tigure de Commerson. D.

- Polyneme pentadactyle. Danbenton et Haay, Ene, méth. - Id. Bonnaterre, pl. de I Eac. mieth. - Gronov, Mus. 1. 19. - Pontanemus. Sebs, Mus.3, tab. 27, fig. 2 .

st la snivante i séba, L III, pl. 27, fig. 2, Belon it. Cuvier, Polynemus quinquarinus, et $P_{0}$. paradiseus, Gimel Le Polynemus paradiseus de Bloch, pl. 402, est un tout autre poisson, le mème que le virginicus de Lionée ou quo Golydactrle de M. de Lacépède. D. - Polynemus cirris pectoralibus quinque ad anum vix

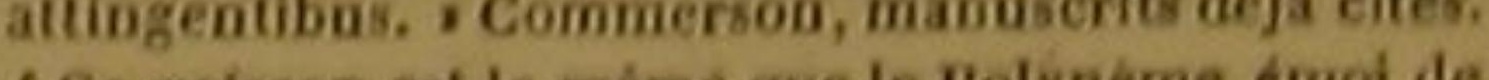
ticle. II n'est fondé que sur la description d'une figure de Commerson. D.

'Polyneme poision de paradis. Dabenton et Haay, Enc, méth. - Id. Bomnaterre, pl. Je IEnc, melis. - Bloch, il. 102. - Paradisea piscis. Eaw. Av. La, Lat. ceulement la figure de Bloeh, pl. 402 , ne sy rapporte pas : MoLxictrok de M. de Lacépéde. D. 'Polynemus decadactylus, Polyneme eamus. Bloch. . 401. iens percoides. D Bonnaterre, fi. de I'Eac. méth.

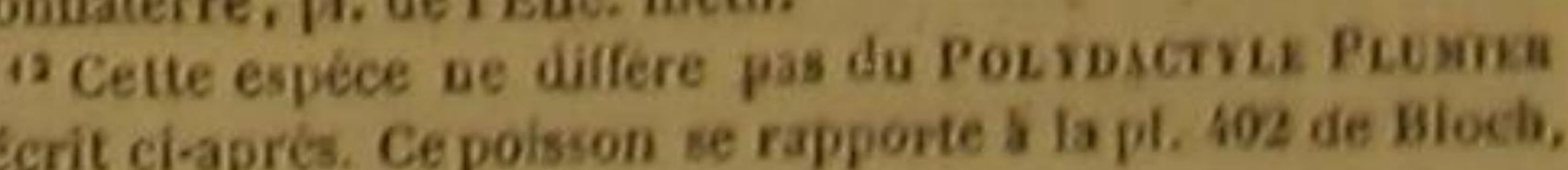
Cée a tapres. Ce poisson se rapporte a la pl. 402 de Bloch, citée a tort par M. de Lacépede comme appartenant a son elle représente le Polynemus virginicus de Limnée, ou le Du genre PoLssiase, Cuv. Famille des Acantboptéry. 
ques moments, les effets funestes des pas- rale droite; une grande partie de la surface des sions qu'une raison éclairée n'a pas encore calmées, des préjugés qu'elle n'a pas détruits, des institutions qu'elle n'a pas perfectionnées. Et qui doit mieux conserver un nom consolateur, que nous, amis dévoués d'une science dont le premier bienfait est de faire naitre ce calme doux, cette paix de l'âme, cette bienveillance aimante, auxquels l'espèce humaine pourrait devoir une félicité si pure? La reconnaissance seule aurait pu nous engager à substituer au nom d'Émoi celui de Broussonnet. Mais quel zoologiste ignore que c'est à ce savant que nous devons la connaissance du polynème émoi?

Les côtes riantes de l'íle d'Otahiti, celles de l'ile Tanna, et de quelques autres fles du grand Océan équinoxial, ne sont eependant pas lẹ seuls endroits où l'on ait pêché ce polynème : on le trouve en Amérique, particulièrement dans l'Amérique méridionale; il se plait aussi dans les eaux des Indes orientales; on le rencontre dans le golfe du Bengale, ainsi que dans les fleuves qui s'y jettent; il aime les eaux limpides et les endroits sablonneux des environs de Tranquebar. Les habitants de Malabar le regardent comme un de leurs meilleurs poissons : sa tête est surtout pour eux un mets très-délicat. On le marine, on le sale, on le sèche, on le prépare de différentes manières, au nord de la côte de Coromandel, et principalement dans les grands fleuves du Godaveri et du Krisehna. On le prend au filet et à l'hamecon. Mais comme il a quelquefois plus de quatre pieds et demi de longueur, et qu'il parvient à un poìds très-considérable, on est obligé de prendre des précautions assez grandes pour que la ligne lui résiste lorsqu'on veut le retirer. Le temps de son frai est plus ou moins avancé, suivant son âge, le climat, la température de l'eau. Il se nourrit de petits poissons, et il les attire en agitant les rayons fllamenteux placésauprès de ses nageoires pectorales, comme d'autres habitants des mers ou des rivières trompent leur proie en remuant avec ruse et adresse leurs barbillons semblables à des vers.

Sa tête est un peu allongée et aplatie, chacune de ses narines a deux orifices; les yeux sont grands et couverts d'une membrane; le museau est arrondi; la mâchoire supérieure plus avancée que celled'en bas; chaque mâchoíre garnie de petites dents; le palais hérissé d'autres dents très-petites; la langue lisse; la ligne laténageoires revêtue de petites écailles ; la couleu générale argentée; le dos cendré; les pectorales sont biunes, et parsemées, ainsi que le bord des autres nageoires, de points très-foncés.

Il est bon de remarquer que l'on a trouvé dans les couches du mont Bolca, près de Vérone ', des restes de poissons, qui avaient appartenu à l'espèce de l'émoi ${ }^{2}$.

Le polynème pentadactyle habite en Amérique. l'éxistence, a été décrit par Commerson. Sa longueur ordinaire est d'un pied et demi ou environ. Ses écailles sont faiblement attachées. $S_{a}$ couleur est argentine, relevée, sur la partie supérieure de l'animal, par des teintes bleuatres; les pectorales offrent des nuances brunâtres. Une douzaine de raies longitudinales et brunes augmentent de chaque cóté, par le contraste qu'elles forment, l'éclat de la robe argentée du polynème. Le museau, qui est transparent, s'avance au delà de l'ouverture de la bouche. La måchoire inférieure s'emboite, pour ainsi dire, dans celle d'en haut. On compte deux orifices à chaque narine. On voit de petites dents sur les deux mâchoires, sur deux os et sur un tubercule du palais, sur quatre éminences voisines du gosier, sur les ares qui soutiennent les branchies. Les yeux sont comme voilés par une membrane, à la vérité, transparente. Deux lames, dont la seconde est bordée d'une membrane, du côté de la queue, composent l'opercule. Les cinq rayons libres, ou filaments place un peu en dedans et au-devant de chaque pectorale, ne sont pas articulés, et s'étendent, avec une demi-rigidité, jusqu'aux nageoires ventrales. Cinq ou six écailles, situées dans la commissure superieure de chaque pectorale ; forment un caractère particulier. La seconde dorsale et l'anale sont échancrées ${ }^{3}$. Je Gazola, etc.

a chaque pectorale, 1 rayon anchiale du polynème émoi , 12 rayoss a la membraue des branchies da polynème penta. ryons articatís o cha pectorale, 1 rayon aiguilionne et 5 7 rayons à la membrane branchiale do polynèmè rayé, it ishaque pectorale, 6 à chaque ventrale, dont les deax rayons intériears sont joints dune manière partieutiere, 18 à la caudale, dont le lobe supérieur est un peu plus avancé que
liuférieur. -5 rayons à la membrane des branchies do pa.
Le rayé, dont les naturalistes ignorent encore

'Ichithyolitholo des environs de Vérone, par le comte

7 rayous j̀ la neours sur la durée des espèces. a chaque ventrale, 22 rayons a la nageoire de la queue. -

Le polynème rayé est apporté, pendant presque toute l'année, au marché de l'ìle Maurice. Celui qu'on a nommé Paradis a deux orifices à chaque narine; les màchoires garnies de petites dents; la langue lisse; le palais rude; la pièce antérieure de l'opiercule dentelée; le dos bleu; les côtés et le ventre argentins; les nageoires grises; une longueur considérable; la chair très-agréable au goùt; l'habitude de se nourrir de crustacées et de jeunes poissons ; les parages de Surinam, des Antilles et de la Caroline pour patrie.

Le devant du museau assez aplati pour présenter une face verticale; les yeux très-grands la màchoire inférieure plus étroite, moins avancée, moins garnie de petites dents que la mâchoire d'en haut; la langue unie et dégagée l'orifice unique de chaque narine; les articulations des rayons libres ; l'inégalité de ces rayons, dont cinq de chaque côté sont courts, et cinq sont allongés; la grandeur et la mollesse des écailles, l'argentin des côtés, le brun du dos et des nageoires, la bordure brune de chaqueécaille, peuvent servir à distinguer le décadactylo qui fait son séjour dans la mer de Guinée, qui re. monte dans les fleuves, pour y frayer sur les bas fonds, que l'on pêche au filet et à la ligne, qui devient assez grand et qui est très-bon à manger.

Le polynème mango a l'opercule dentelé, premier rayon de la première dorsale très-courı, la caudale large. C'est dans les eaux de l'Amérique qu'il a été péché.

DEUX CENT CINQUIÈTE GENRE. LES POLYDACTYLES ' Des rayons libres auprès de chaque peciorale; la tete
dénuee de petiles ecailles; deux nageoires dorsales.

ESPÈCE.

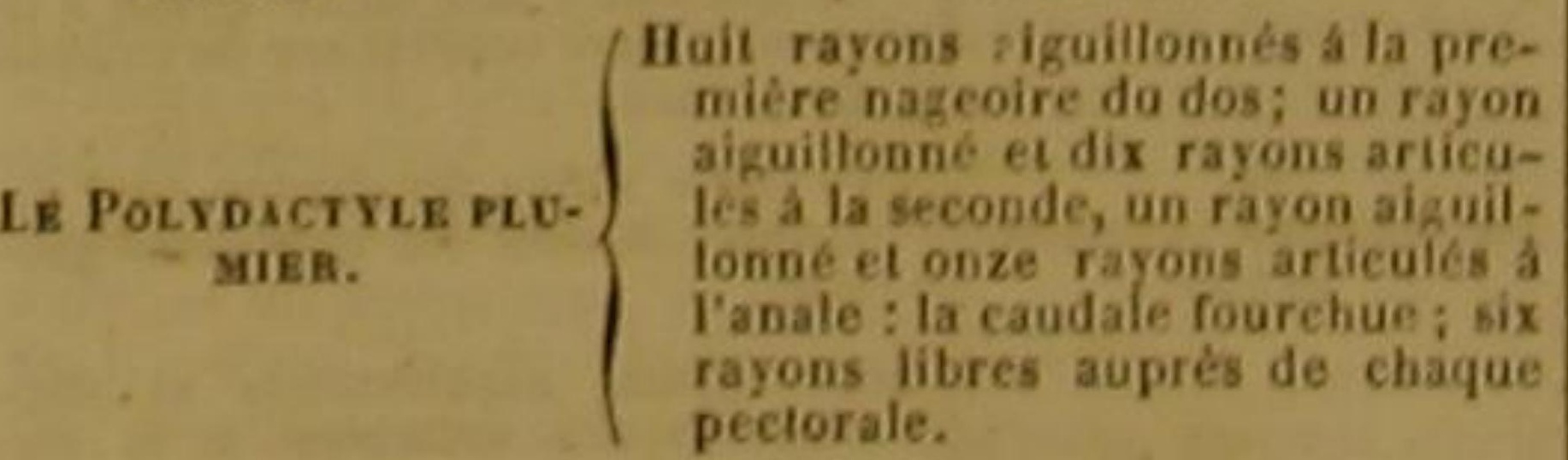

Innème paradis. 15 à chaque pectorale, 1 rayon aiguillonné et 5 rayons articulés à chaque ventrale, 18 rayons à la nadu polynéme décadactyle, 14 a chaque pectorale, 1 rayon aiguillonné et 5 rayons articulés à chaque ventrale, 16 rayons à la caudale. -7 rayons a la membrane des branehies du polyneme mango, 15 a chaque pectorale, 4 rayon aiguilionne eoire de la queu.
LE POLYDACTYLE PLUMIER ! Polynemus americauus, Cuv.; Polynemus virginicns,
Linn., Gmel.; Polynemus paradiseus, Bloch, jil. 403 ; Polydactylus Plumieri et Polynemus Mango, Lac, ?. La couleur générale de ce polydactyle est argentée, comme celle de la plupart des polynèmes. Son museau est saillant; sa màchoire supérieure plus avancée que l'inférieure. Les six rayons libres que l'on voit auprès de chaque pectorale ressemblent à de longs filaments; la seconde dorsale et la nageoire de l'anus sont égales en surface, placées l'une au-dessus de l'autre, et échancrées en forme de faux. Le corps proprentent dit a son diamètro vertical bien plus grand que celui de la queue. Plumier a laissó un dessin de ce poisson encore incomnu des naturalistes, et que nous avons cru devoir placer dans un genre particulier ${ }^{3}$.

DEUX CENT SIXIITME GENRE. LES Bunos'.

Un double plquant entre les nageotres ventiales; une seule nageoire du dos; cente nageoire très-tongue; les

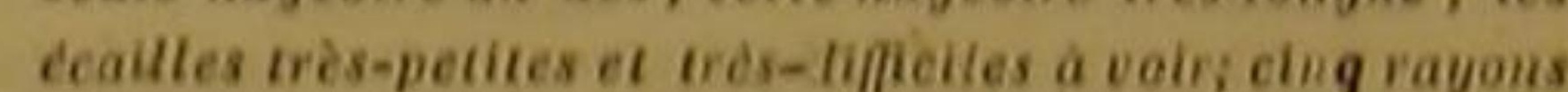
à la membrane brancliale.

Espìce.

cAlAcrìnes.

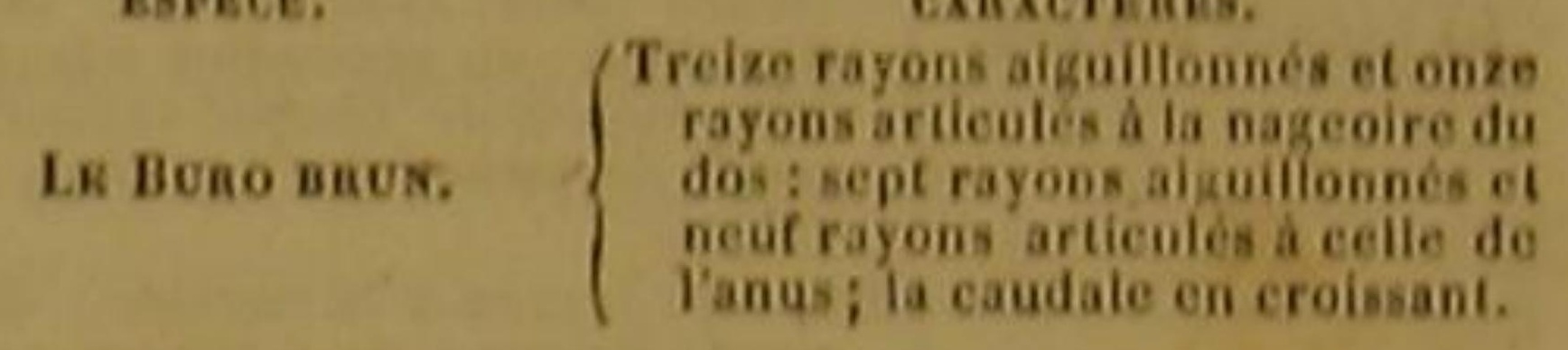
$-$

LE BURO BRUN.

Buro Brunneus, Lac. '.

Nous publions la description de ce genre d'après les manuscrils de Commerson ${ }^{6}$.

píce qu'il renferme à la derniére de celles que M. de Lacépéde admet dans le genre Potysíar. D.

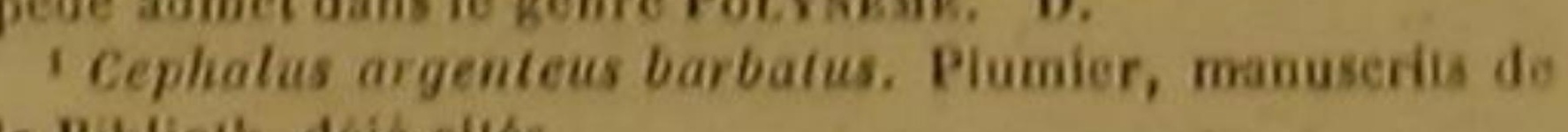

ur laquelle est établi le polye la 0gure, pl, ana de Bloch, n'est qu'une copie d'on dessin de Plamier, sur lequel M. de. Lacépéde a fondé son genre Polvoactrie el l'espéce quili y comprend. Cestee qui le determine a supprimer ee geare, pour éviter toute confusion dans sa synonymie. D.

33 rayons a chaque pectorale du polydaetyle plumier. 'M. Cuvier ne cite pas ce genre. D.
" u Buro brunneus gotlis exalbidis variegatus, dupliei in. « ira pinnas ventrales spind. $n$ Cormmerson, manuserits dejh

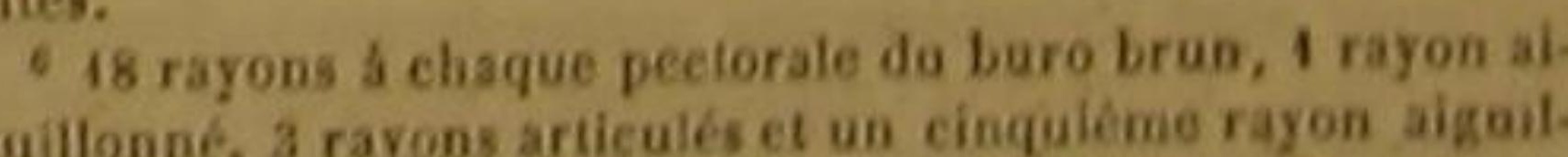
guillonne, 3 rayons articulés et un cinquiemene rayon aigail-
lonné a chaque ventrale, 16 rayons a la nageoire de la quecue. 
Le buro brun a toute sa surface parsemée de petites taches blançhes, l'iris doré et argenté; la tête menue; lo musèau un peu pointu; la mâchoire supérieure mobile, mais non estensible; et garnie, comme celle d'en bas, d'un scul rang de dents très-petites et très-aiguês; I'anus situé entre les deux piquants qui séparent les nageoires ventrales; la ligne latérale composée de points un peu élevés, et courbée comme le dos; le ventre et le dos carénés; le corps et la queue comprimés; une longueur de huit à douze pouces.

DEUX CENT SEPTIĖME GENRE. LES CLUPÉES '.

Des dents aux mâchoires; plus de trois rayons à la membrane des branchies; une seule nageoire du dos; le ventre caréné; la carène du ventre dentelée ou trèsaigue.

PREMIER SOUS-GENRE.

La nageoire de la queue, fourchue, ou échancrée en croissam.

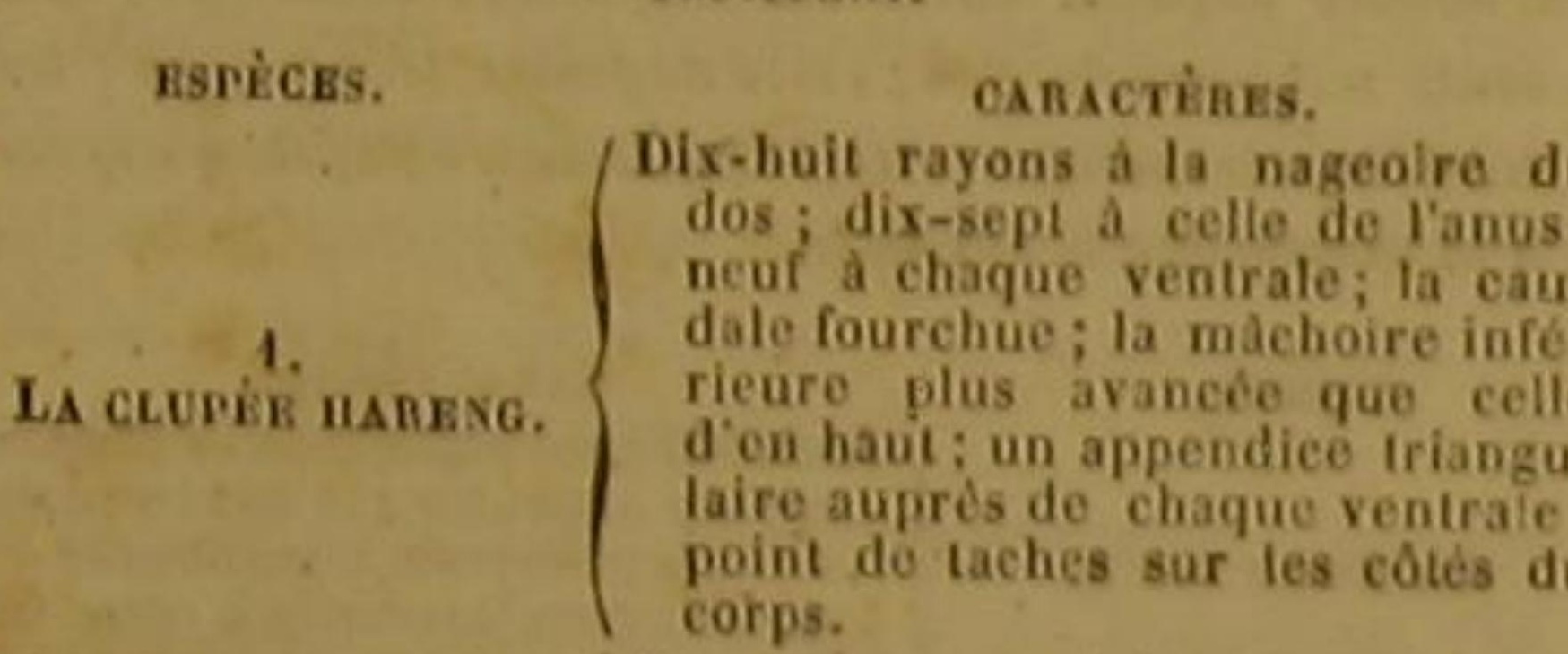

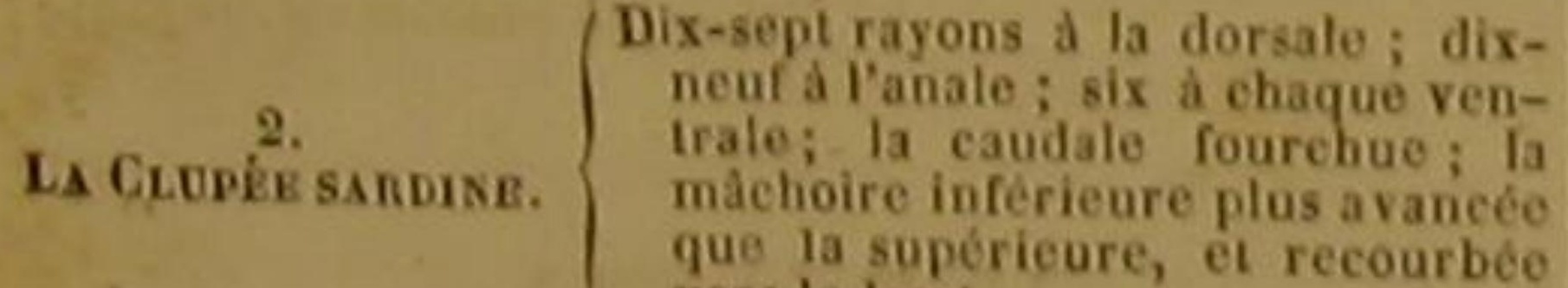

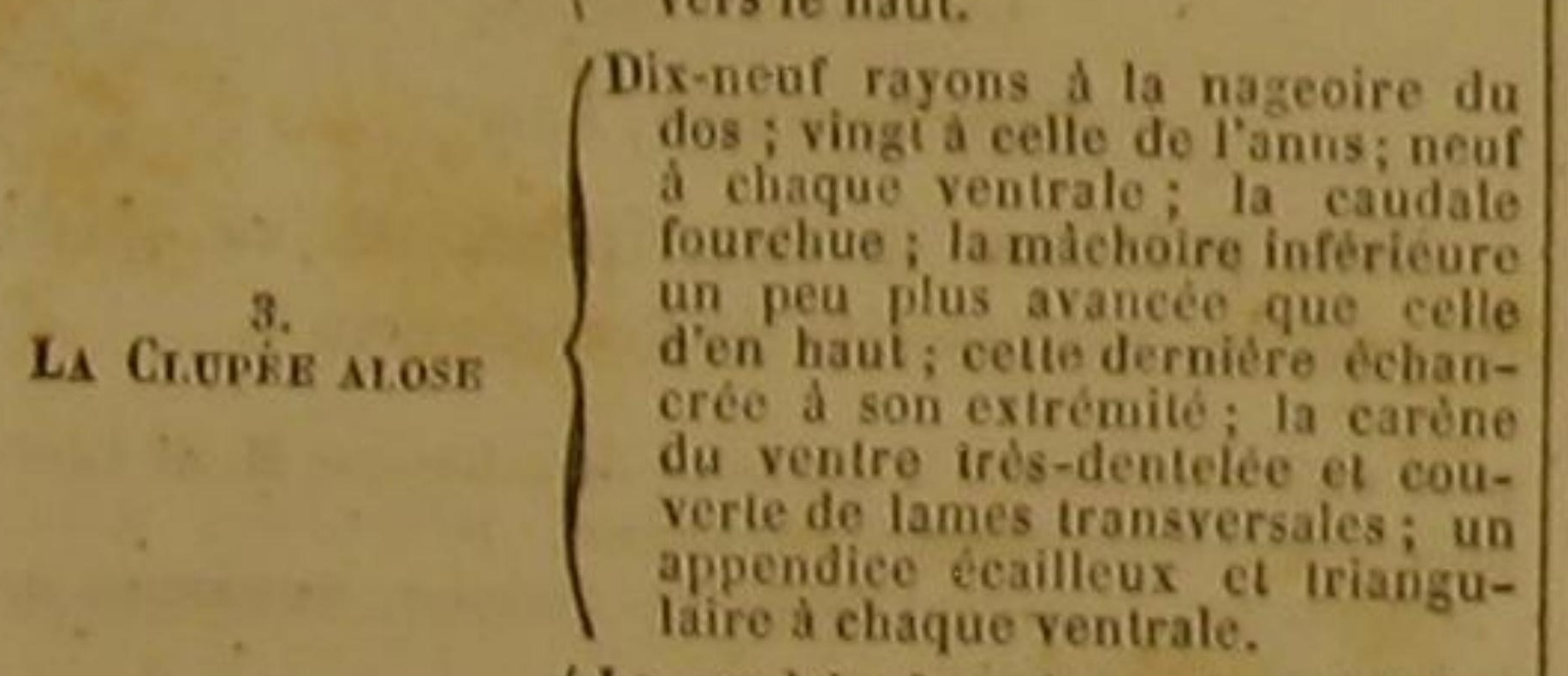

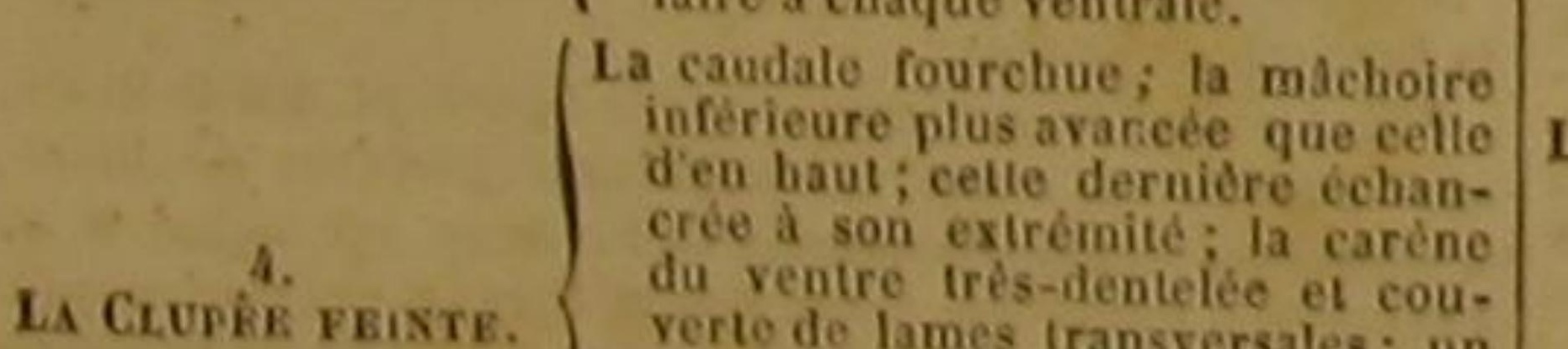

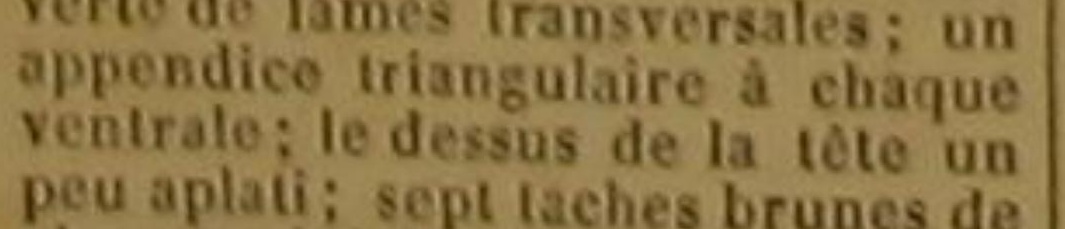
peu aplati: seppe lazhes
chaque eôte da corps.

I Le genre Clupié de Laeépide correspond en grande partie a celui de M. Cuvier, et notamment aux sous-genres renferme aussi les sous les noms de tiarengs et Aloses. II

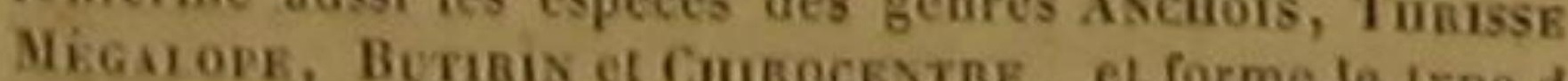
la famille des Clupes, ordre des Malacoptérygiens abdomi-
baux, D

\section{ESPĖCES.}

LA CLUPÉ Rousse.

L CLUPÉ ANCUOIS.

Dx-hair rayons a la dorsale; vingl-
quatre a la nageoire de lanus Ix a ehaque venirale, la caudale
fourchue, une cavite en forme
de losange sur le sommet de la de
tète. Qatorze rayons a la nageoire du
dos; dix-tuit a I'anale; sept a
chaque ventralo: la casdale chaque ventralo la; ceptale
fourchue ; la michoire sudep-
rieure pius avancée que l'infeLA CLupíe ATRERT-
Nó̃de. ayons a la nageoire du dos; Tue rentis anale; buit a eha chue; douze a la membrane des plus avancée que cedle d'en bas: une raie loguitudinale large ei
argentee, de chaque cote du
polsson. Quinze rayons à la dorsale; vingt
a la nageoire de l'anus; sept a chaque venirale; la ceaudale
fourchue; Ia máchoire d'en haul plus avancée que celle den bas:
une raie longlitudinale large ei argentee, de ehaque cote du
poisson. Dix-sept rayons à la dorsale, vingt-

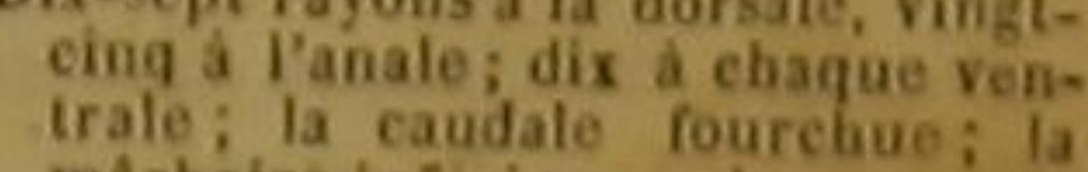
que la supérieure, plus avanece
et recourbi

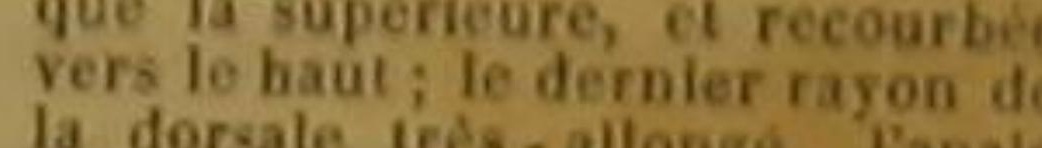
la dorsale très-allonge, Tana
éthancéée en forme do faus.

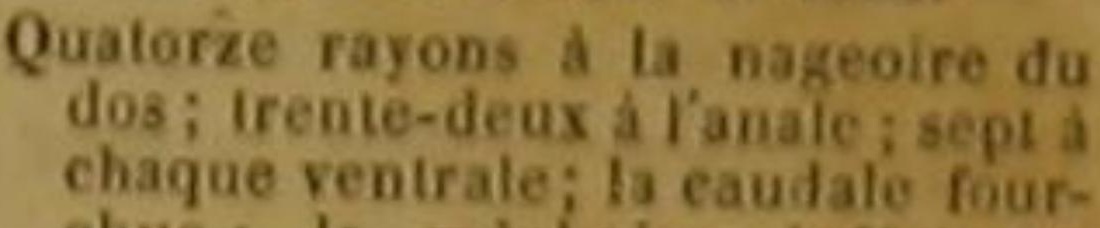
chae ; la máchoire inférieure
moins avancée que celle deen haul; les os de la lavre superieur
lerminés par un filameot.

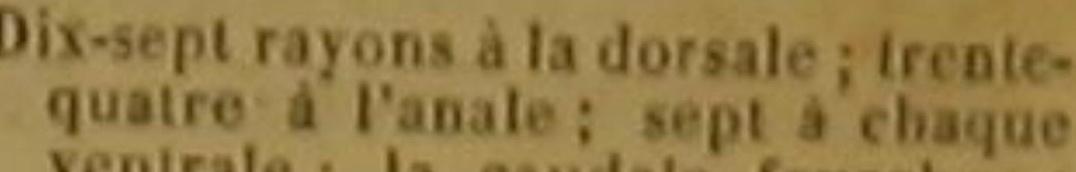
LA GLopé Belame.

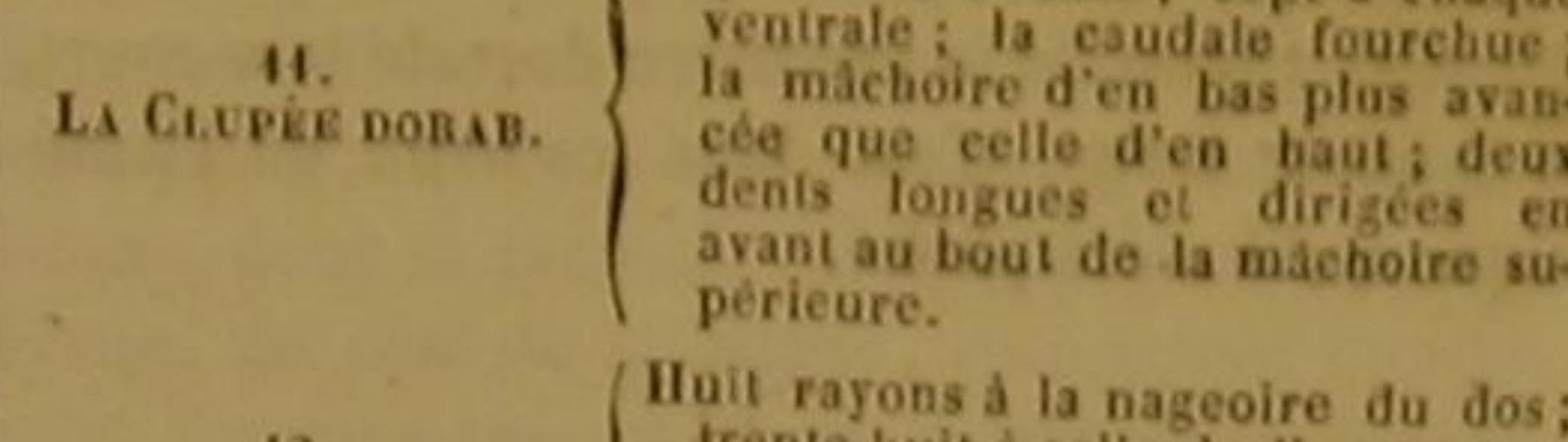

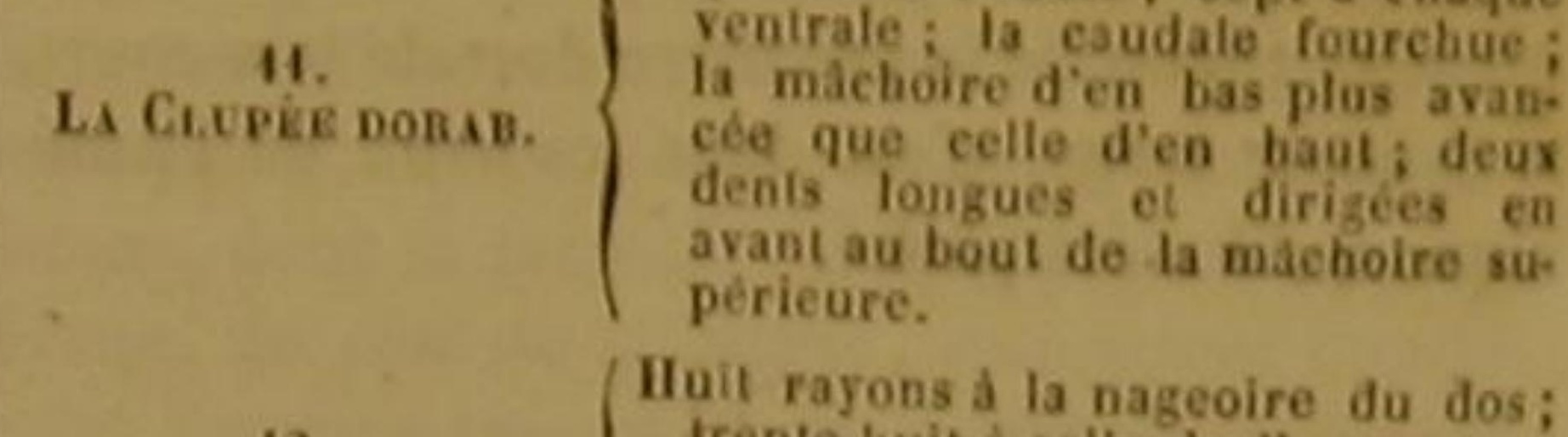

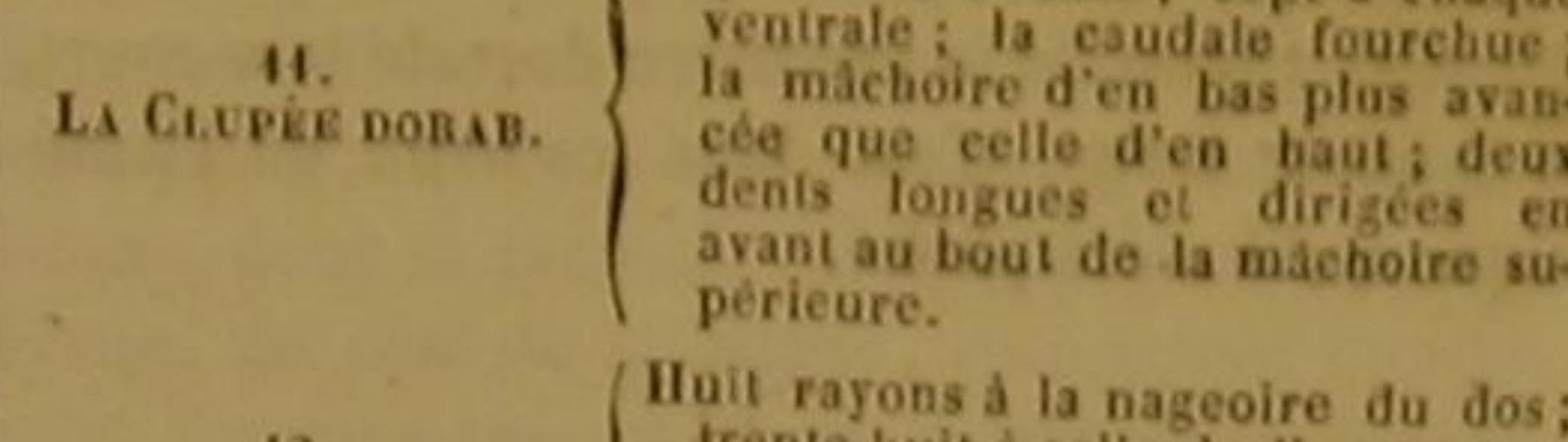

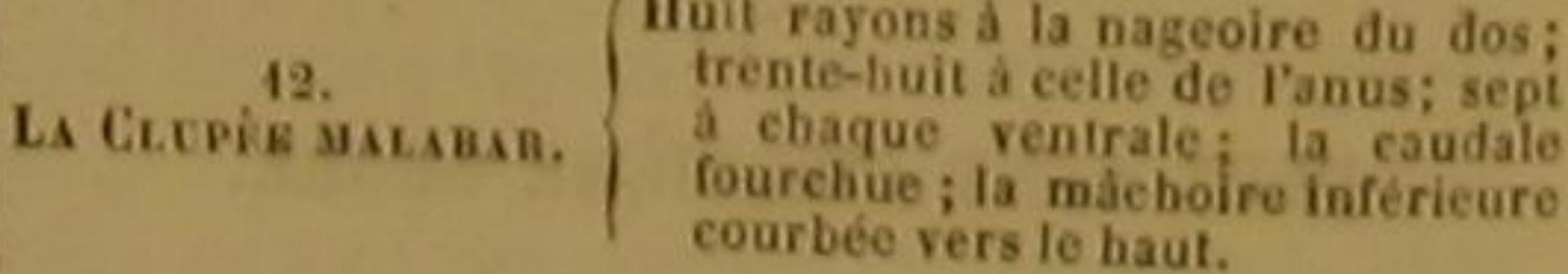

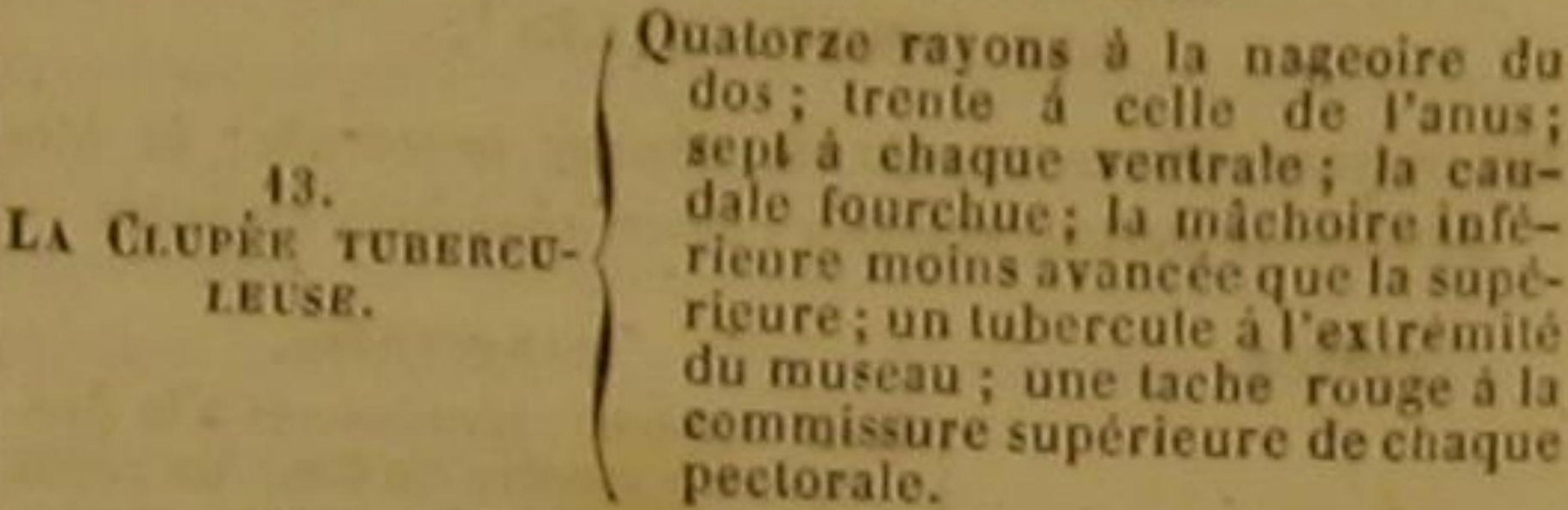

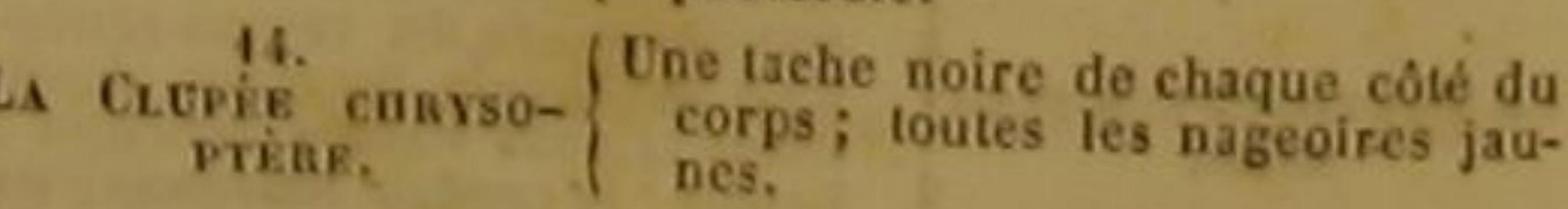

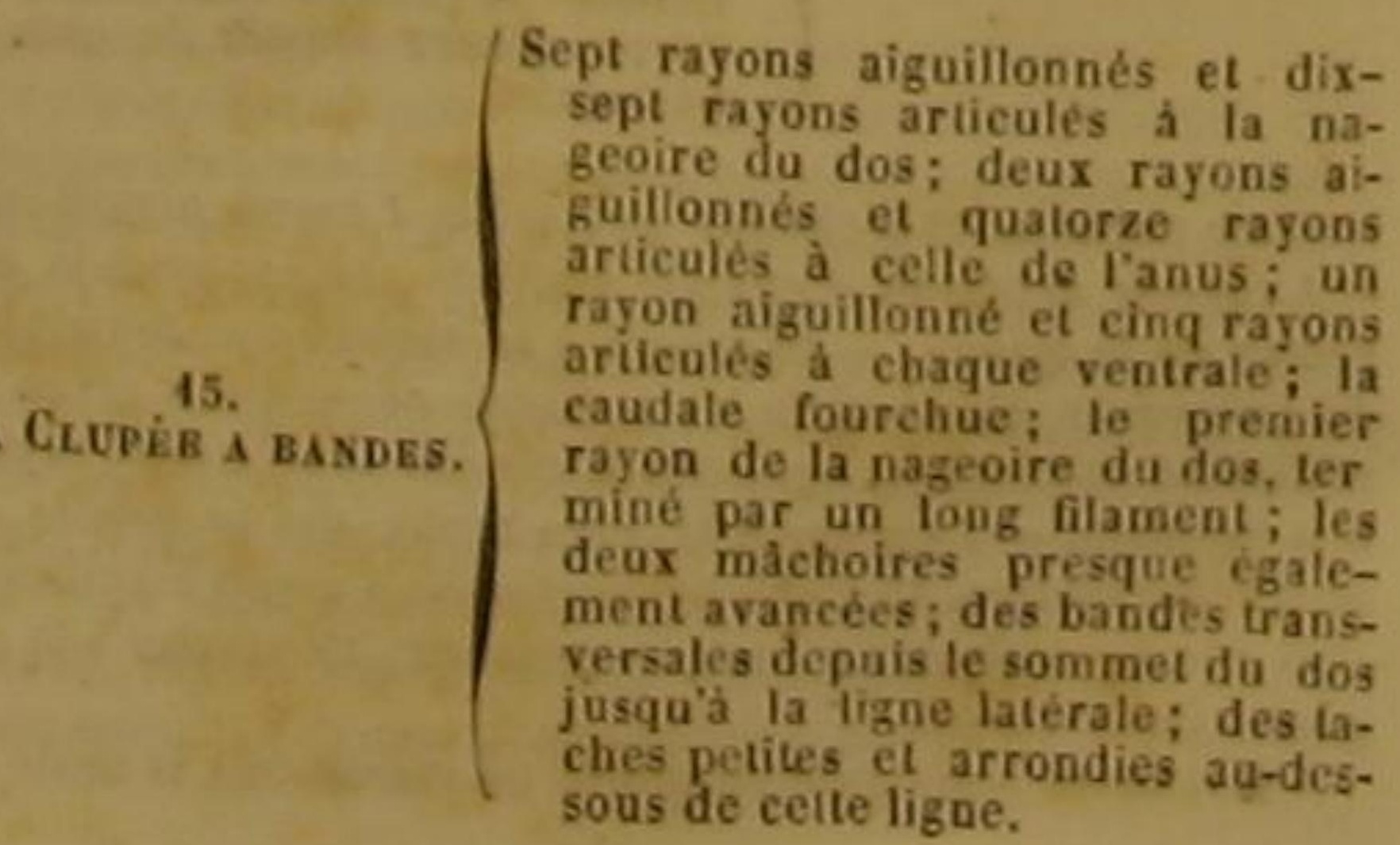

Espèces. CARACTìne.

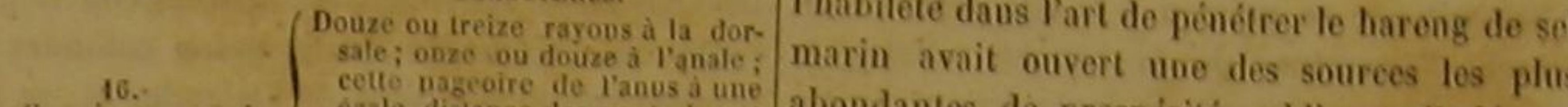

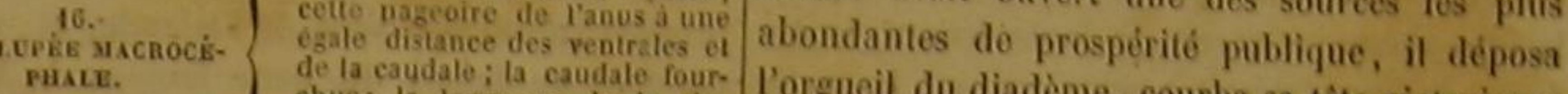

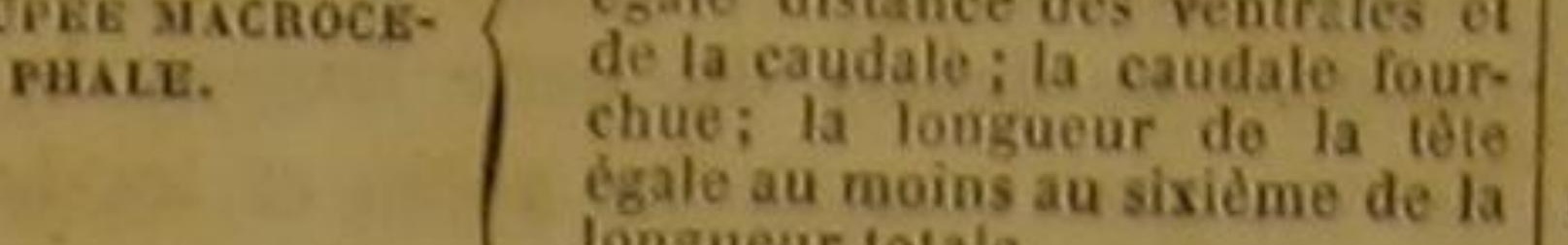
SECOND SOUS-GENRE.

La nageoire de la quene, rectiligne, ou arrondie, on lancéolée, et sansechancrive.

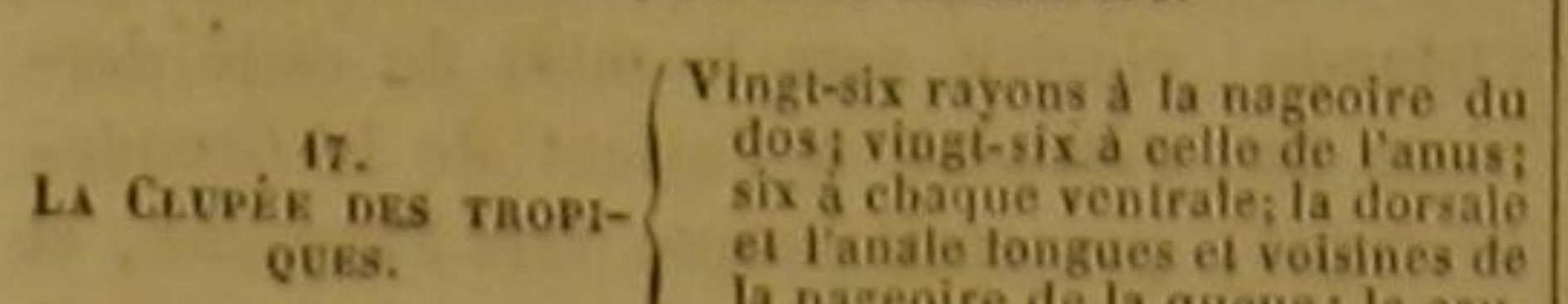
QUES. -

LA CLUPÉE HARENG '.

Clupea Harengus, Linn., Gmel., Bl., Lac, Cur, ?.

Honneur aux peuples de l'Europe qui ont vu dans les légions innombrables de harengs que chaque année amène auprès de leurs rivages, un don précieux de la nature!

Hlonneur à l'industrie éelairée qui a su, par des procédés aussi faciles quo sûrs, prolonger la durée de cette faveur maritime, el l'étendre jusqu'au centre des plus vastes continents!

Honneur aux chefs des uations, dont la tontepuissance s'est inclinée devant les heureux inventeurs qui ont perfectionné l'usage de ce bienfait annuel!

Que la sévère postérité, avant de prononcer son arrêt irrévocable sur ce Charles d'Autriche, dont le sceptre redouté faisait fléchir la moitié de l'Europe sous ses lois, rappelle que, plein de reconnaissance pour te simple pêcheur dont

' Heering Strolumling (quand it vient de la Baltique; barkling (quand it est fumé), en Allemagne. - Strimmelas, chalka. - sill (quand il est gros) ; stroming, aa Kamispetit), en Suède. - Sild, Quale sild, Grabeen sild (quand il est gros); Stromling (quand il est pelit), en Danemarck.
- Straale-sild, Qugale sild, en Norvége. - Kapiselikan, dans le Groenland. - Horeng, en Hollande. - Herring, en

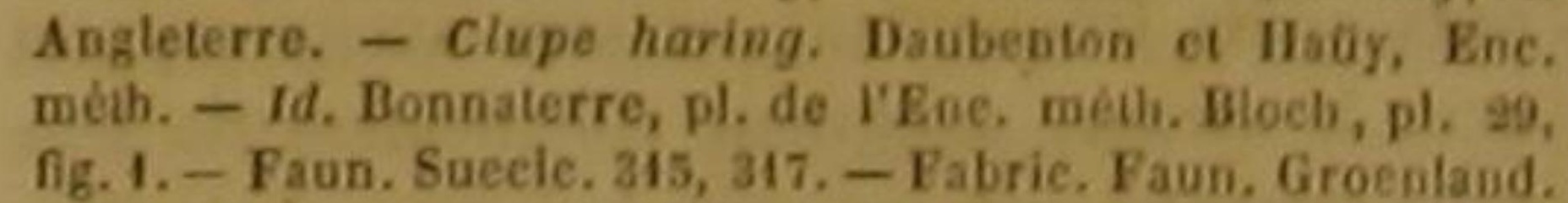
182. - a Clopea maxilla inferiore longiore, maculis nigris -a carens. , Arledi, gen. 7, spec. 37. syn. 14:- Harengus, Gesner (Franch.), p. 408 el 486 ; el Germ. I. 5. - Id. Seho-

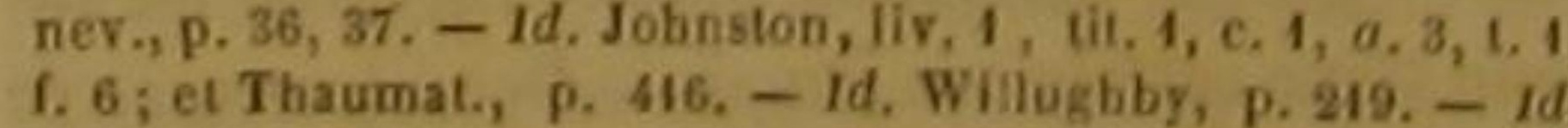

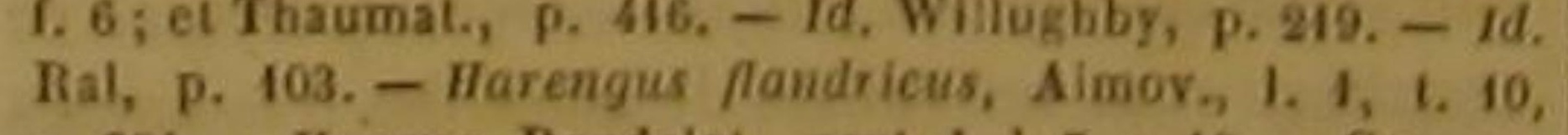
Rai, p. 103. - Harengus Nandricus, Aimov, I. 1, L. 10,
p. 294. - Hareng. Rondelet, part. 1, 1. 7, c. 13. - Gronov. Hareng. Vaimont de Bomare, Dicl. d'hist. nat. ${ }^{2}$ Do sousgenre des IIARescs proprement dits, dans le grand genre Hanesc famille des Clupes, ordre des Malal'orgueil du diadème, courba sa tête vielorieuse devant le tombeau de Guillaume Deukelzoon, et rendit un hommage public à son importante découverte.

Et nous, Français, n'oublions pas que si un pécheur de Biervliet a trouvé la véritable manière de saler et d'encaquer les harengs, c'est à nos compatriotes les habitants do Dieppe que l'on doit un art plas utile à la partie la plus nombreuse et la moins fortunée de l'espèce humaine, celui de lo fumer.

Le hareng est une de ces productions naturelles dont l'emploi décide de la destinée des empires, La graine du caféier, la feuille du thé, les épices de la zone torride, le ver qui flle la soie, ont moins influé sur les richiesses des nations, que le hareng de l'océan Allantique. Le luxe ou le caprice demandent les premiers : Ie besoin réclame to hareng. Le Batave en a porté la péche au plus haut degré. Ce peuple, qui avait été forcé de eréer un asile pour sa liberté, n'aurait trouvé que de faibles ressources sur son territoire factice : mais la mer lui a ouvert ses trésors; elle est devenue pour lui un champ fertile, où des myriades de harengs out présenté à son activité courageuse une moisson abondante et assurée. Il a, chaque annćo, fait partir des flottes nombreuses pour aller to cueillir. II a vu dans la peche du hareng la plus importante des expéditions maritimes; il l'a surnommée la grande plche; il l'a regardéo comme ses mines d'or. Mais au lieu d'un signe souvent stérile, il a eu une réalité féconde; au licu de voir ses richesses arrosées des sueurs, des larmes, du sang de l'esclave, il les a reçues de l'audace de I'homme libre; au lieu de précipiter sans cesse d'infortunées générations dans les gouffres de la terre, il a formé des hommes robustes, des marins intrépides, des navigateurs expérimentés, des citoyens heureux.

Jetons un coup d'eil sur ces grandes eutreprises, sur ces grandes maneuvres, sur ces grandes opérations; car qui mérite mieux lo nom de grand, que ce qui donne à un peuple sa nourriture, son commerce, sa force, son habileté, son indépendance et sa vertu?

Disons seulement auparavant que tout lo 
On sait que ce poisson a la tête petite; I' eil face des mers, ou en traversaient les couches sngrand; l'ouverture de la bouclie courte; la périeures. L'une de ces grandes colonnes se langue pointue et garnie de dents déliées; le dos pressait autour des côtes de l'Islande, et, se réépais; la ligne latérale à peine visible; la partie pandant au-dessus du banc fameux de Terre. supérieure noirâtre; l'opercule distingué par une Neuve, allait remplir les golfes et les baies du tache rouge ou violelte; les côtés argentins; les continent américain; l'outre, suirant des diect nageoires grises; la laite ou l'ovaire double; la tions orientales, descendait le long de la Norvessie natatoire simple et pointue à ses deux vège, pénétrait dans la Baltique, ou, faisant le bouts; l'estomac tapissé d'une peau mince; le tour des Orcades, s'avançait entre l'Écosse et canal intestinal droit, et par conséquent très- l'Irlande, cinglait vers le midi de celte der court; le pylore entouré de douze appendices; nière île, s'étendait à l'orient de la Grandesoixante-dix côtes; cinquante-six vertèbres. Bretagne, parvenait jusque vers l'Espagne, et Son ouverture branchiale est très-grande; il occupait tous les rivages de France, de la Batavie n'est donc pas surprenant qu'il ne puisse pas la et de l'Allemagne, qu'arrose l'Océan. Après fermer facilement quand il est hors de l'eau, et s'être offerts pendant longtempe focean. Après qu'il périsse bientôt par une suite du desséche- parages, aux filets des pêcheurs, les harengs ment de ses branchies '. $\quad$ voyageurs revenaient sur leur route, disparaisIl a une caudale très-haute el très-longue; il saient, et allaient regagner leurs retraites boa regu par conséquent une large rame; et voilà réales et profondes.

pourquoi il nage avec force et vitesse ${ }^{2}$.

Sa chair est imprégnée d'une sorte de oraisse Pendant longtemps, bien loin de révoquer en qui lui donne un goût très-agréable, et qui la doute ces merveillenses migrations, on s'est rend aus la efforcé d'en expliquer l'étendue, la constance, rend aussi plus propre à répandre dans l'ombre et le retour régulier; mais nous avons déjà an une lueur phosphorique. La nourriture à la- noncé, dans notre Discous nous avons déjả anquelle il doit ces qualités consiste communément nois la nature des eu cufs de poisson, en petits crabes et en vers. poissons, et dans l'histoire du scombre maqueLes habitants des rivages de la Norvigers. reau, qu'il n'était plas permis de croire à ces souvent trouvé ses intestins re Norvège ont grands et périodiques voyages. Bloch, et M. Noẽ souvent trouvé ses intestins remplis de vers de Rouen, ont prouvé, par un rapprochement d'aliment contenu dans le canal intestinal des iresexact de fails incontestables, qu'il était harengs fait qu'ils se corrompent beaucoup plus impossible d'admettre cette navigation ansuelle vite sil'on torde à les sarer extraordinaire, Pour continuer d'y croire, il avoir pe- faudrait rejeter les observations les plus sures, chés : aussi, lorsqu'on croit que ces poissons d'après lesquelles il est lors les plus sures, ont avalé de ces vers rouges, les laisse-t-on dans s'écoule soutios il est hors de doute qu'i l'eau jusqu'à ce qu'ils aient achevé de les di- voie des harengs plusieurs années sans qu'on gérer.

voie des harengs sur plusieurs des rivagés prinOn a cru pendant longtemps que les harengs cipaux indiqués comme les endroits les plus rese retiraient périodiquement que les harengs marqualles de la route de ces poissons; qu'ause retiraient périodiquement dans les régions du près de beaucoup d'antres prétendues stations cercle polaire; qu'ils y cherchaientannuellement,
sous les glaces des mers ces animaux, on en péche pendant toute l'anasile contre leurs ens me née une très-grande quantité; que la grosseur gueurs de I'hiver; que, n'y trouvant pas une de ceux qu'il furie souvent, selon la qualité des nourriture proportionnée à leur nombre pas une eaux qu'ils fréquentent, et sans aucun rapport gieux, ils envoyaient, au commencement de avec la saison, avec leur éloignement de leu chaque printemps, des colonies nombreuse re asile septentrional, ou avec la longueur de l'esdes rivages plus méridionaux de l'Eureters pace qu'ils auraient dû parcourir depuis len l'Amérique, On a trać la rou de sortie de leur habitation polaire; et enfin qu'ur'crantes. On a cégions cun signe certain n'a jamais indiqué leur qu'at-

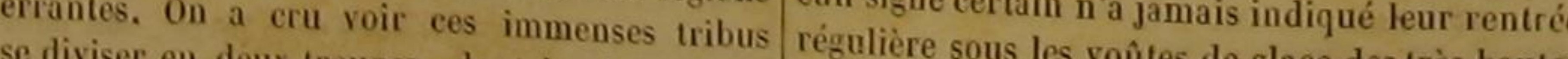
se diviser eu deux troupes, dont les innombra- retitiere sous les voûtes de glace des très-hautes bles détachements couvraient au loin a sur- latitudes. mieux, ou vers les rivages septentrionaux de / ver, ils paraissent en troupes, que des mìc I'Asie. Toutes les fois qu'ils ont besoin de cher- isolés précèdent souvent de quelques jours, et cher une nourriture nouvelle, et surtout lors- dans lesquelles il y a ordiuairement plus de miqu'ils doivent se débarrasser de leur laite ou de les que de femelles. Lorsque ensuile fe frai comleurs eufs, ils abandonnent les fonds de la mence, ils frottent leur ventro ennte fes reommer, soit dans le printemps, soit dans l'été, ou lo sable, s'agitent, impriment des mourosoit dans l'automne, et s'approchent des embou- ments rapides à leurs nageoires, se mettent chures des fleuves et des rivages propres à leur tantôt sur un côté et tantôt sur un autre, nspifrai. Voilà pourquoi la péche de ces poissons n'est rent l'eau avec force et la rejettent avec vivajamais plus abondante que lorsque leurs laites cité.

sont liquides, ou leurs aufs près de s'échapper. Les légions qu'ils composent dans ces temps La nécessité de frayer n'étant pas cependant la
seule cause qui les arrache à leurs profonds
fatigantes, mais commandées par un besoin seule cause qui les arrache à leurs profonds
asiles, il n'est pas surprenant qu'on en prenne qui n'ont plus d'oufs ni de liqueur prolifique, pendant elles offrent une image d'ordre. Les plus ou dont la laite ou les cufs ne sont pas encore grands, les plus forts ou les plus hardis, se pladéveloppés. On a employé différentes dénomi- cent dans les premiers rangs, que l'on a companations pour désigner ces divers états des ha- rés à une sorte d'avant-garde. Et qu'on ne croie rengs, ainsi que pour indiquer quelques autres pas qu'il ne faille compter que par milliers les manières d'être de ces animaux. On a nommé $\mathrm{Ha}$. individus renfermés dans ces rangées sí longues rengs gais ou Harengsvides, ceux qui ne mon- et si pressées. Combien de ces animaux meurent trent encore ni laite, ni oufs; Harengs pleins, victimes des cétacées, des squales, d'autres ceux qui ont déjà des cufs ou de la laite; Ha- grands poissons, des différents oiseaux d'eau! rengs vierges, ceux dont les aufs sont mûrs, et néanmoins combien do millions périssent dans ou dont la laite est liquide; Harengs à la bourse, les baies, où ils s'étouffent et s'écrasent, en se ceux qui, ayant déjà perdu une partie de leurs précipitant, se pressant, et s'entassant mutuelleaufs ou leur liqueur séminale, ont des ovaires, ment contre les bas-fonds et les rivages 1 comou des enveloppes de laite semblables a une bien tombent dans les filets des pecheurs! II est bourse à demi remplie; et Harengs marchais, telle petite anse de la Norvège où plus de vingt ceux qui, après le frai, ont repris leur chair, millions de ces poissons ont été le produit d'une leur graisse, leurs forces et leurs principales seule pêclie : il est peu d'années où l'on ne prenne qualités. Au reste, il est possible que les harengs dans ce pays, plus de quatro cents millions de fraient plus d'une fois dans la même année. ces clupées. Bloch a calculé que les habitants Le temps de leur frai est du moins avancé ou des environs de Gothembourg en Suède s'emparetardé, suivant leur âge et leurs rapports avec raient chaque année de plus de sept cents mille climat qu'ils habitent. C'est ce qui fait que, lions de ces osseux. Et que sont tous ces millions dans plusieurs parages, des harengs de gran- d'individus à côté de tous les harengs qu'amèdeur semblable ou différente viennent succes- nent dans leurs bâtiments les pêchieurs du Holsivement pondre des cufs ou les arroser de stein, de Mecklembourg, de la Poméranie, de leur laite, et que pendant près de trois saisons, la France, de l'Irlande, de l'Éeosse, de l'Angleon ne cesse de pêcher de ces poissons pleins et terre, des États-Unis, du Kamtschatka, et prinde ces poissons vides. Par exemple, vers plusieurs cipalement ceux de Ilollande, qui, au lieu de rivages de la Baltique, les Harengs du printemps les attendre sur leurs côtes, s'avancent au-defraient quand la glace commence à fondre, et vant d'eux, ot vont à leur rencontre en pleine contimuent jusqu'à la fin de la saison dont ils mer, montés sur de grandes et véritables flottes? portent le nom. Viennent ensuite les plus gros Ces poissons ne forment pour tant de peuples harengs, que l'on nomme Harengs d'été, et une branche immense de commerce, que depuis qui sont suivis par d'autres, que l'on dis- le temps où l'on a employé, pour les préserver tingue par la dénomination de Harengs d'au- de la corruption, les différentes préparations que tomne.

I'on a successivement inventées et perfection-

Mais, à quelque époque que les poissons dont nées. Avant la fin du quatorzième siècle, épo-

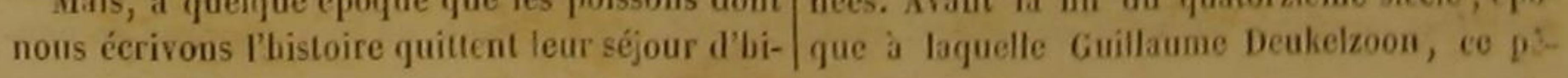


cheur célèbre de Biervliet en Flandre, dont nous tageux au commerce, selon la nature de ces déavons déjà parlé, trouva l'art de saler les ha- tails, ainsi que les soins, l'attention et l'expérengs, ces animaux devaient être et étaient en rience des préparateurs.

effet moins recherchés : mais, dès le commen- On sale en pleine mer les harengs que l'on cement du quinzième siècle, les Hollandais em- trouve les plus gras et que l'on croit les plus l'on ployèrent à la pêche de ces clupées, de grands culents. On les nomme Harenge nouves plus sucfilets et des bâtiments considérables et allongés, Harengs ver/s, lorsqu'ils sont le produit de la auxquels ils donnent le nom de buys; et, depuis pêche du printemps ou de l'été; et Hareng ce même siècle, il y a eu des années où ils ont pecs ou pekels, lorsqu'ils ont été pris pendan mis en mer trois mille vaisseaux et occupé quatre l'automne ou l'hiver. Communément ils sont cent einquante mille hommes pour la pêche fermes, de bon goùt, trìs-sains, sut is sont de ces osseux.

Les filets dont ces mêmes Hollandais se servent pour prendre les harengs ont de cing à six cents pieds de longueur : ils sont composés de cinquante ou soixante nappes, ou parties distinctes, On les fait avec une grosse soie que l'on fait venir de Perse, et qui dure deux ou trois fois plus que le chanvre, On les noircit à la fumée, pour que leur couleur n'effraie pas les harengs. La partie supérieure de ces instruments est souteuue par des tonnes vides ou par des morceaux de liége; ot leur partie inféricure est maintenue par des pierres ou par d'autres corp pesants, à la profondeur convenable.

On jette ces filets dans les endroits où une grande abondance de luarengs est indiquée par la présence des oiseaux d'eau, des squales, et des autres ennemis de ces poissons, ainsi que par une quantité plus ou moins considérable do substance huileuse ou visqueuse que l'on nomme graissin dans plusieurs pays, qui s'étend sur la surface de l'eau au-dessus des grandes troupes de ces clupées, et qu'on reconnait facilement lorsque le temps est calme. Cette matière graisseuse peut devenir, pendant une nuit sombre, mais paisible, un signe plus évident de la proximité d'une colomne de harengs, parce qu'étant phosphorique, elle paraît alors répandue sur la mer, comme une nappe un peu lumineuse. Cette dernière indication est d'autant plus utile, qu'ou préfère l'obscurité pour la pêche des hareugs. Ces animaux, comme plusieurs autres poissons, se précipitent
vers les feux qu'on leur présente; vers les feux qu'on leur présente; et on les attire dans les filets en les trompaut par le moyen des lumières que l'on place de la manière la plus convenable daus différents endroits des vais seaux, ou qu'ou élève sur des rivages voisins. On prépare les harengs de différentes manières, dont les détails varient un peu, suivant les contrées où on les emploie, et dont les résultats sont plus ou moins agréables au goût et avan- du printemps : on les mange sans les faire cuire, et sans en relever la saveur par aucun assaisonnement. En Islande et dans le Groenland, on se contente, pour faire sécher les harengs, de les exposer à l'air, et de les étendre sur des rochers. Dans d'autres contrées, on les fume ou saur de deux manières: premièrement, en les salant trìs-peu, et ne les exposant à la fumée que pendant peu de temps, et en leur dennant ainsi une couleur dorée; et secondement, en les sajour dans une saumure épaisse, en les enfilant par la tête à de menues branches, qu'on appelle aines, en les suspendant dans des espèces de cheminées que l'on nomme roussables, en faisant au-dessous de ces animaux un feu de bois qu'on ménage de manière qu'il donne beaucoup de fumée et peu de flamme, en les laissant longtemps dans la roussable, en changeant ainsi leur couleur en une teinte très-foncée, et en les mettant ensuite dans des tonnes ou dans de la paille.

Comme on choisit ordinairement des harengs Irès-gras pour ce saurage, on les voit, au milieu de l'opération, répandre une lumière phosphorique trìs-brillante, pendant que la substance huileuse dont ils sont pénétrés s'échappe, tombe en gouttes lumineuses et imite une pluie de feu.

Enfin, la préparation qui procure particulièrement au commerce d'immenses bénéfices, est celle qui fait donner le nom do Harengs blenes aux clupées harengs pour lesquelles on I'a employée.

Dès que les harengs dont on veut faire des Harengs blancs sont hors de la mer, on los out vre, on en ôte les intestins, la mer, on les ousaumure assez chargée pour que ces poissons y surnagent; on les en tire au bout de quinze ou dis-huit heures; on les met dans des tonnes; on les transporte i terre, on les y cricague de lant beaucoup plas, en les mettant pendant un

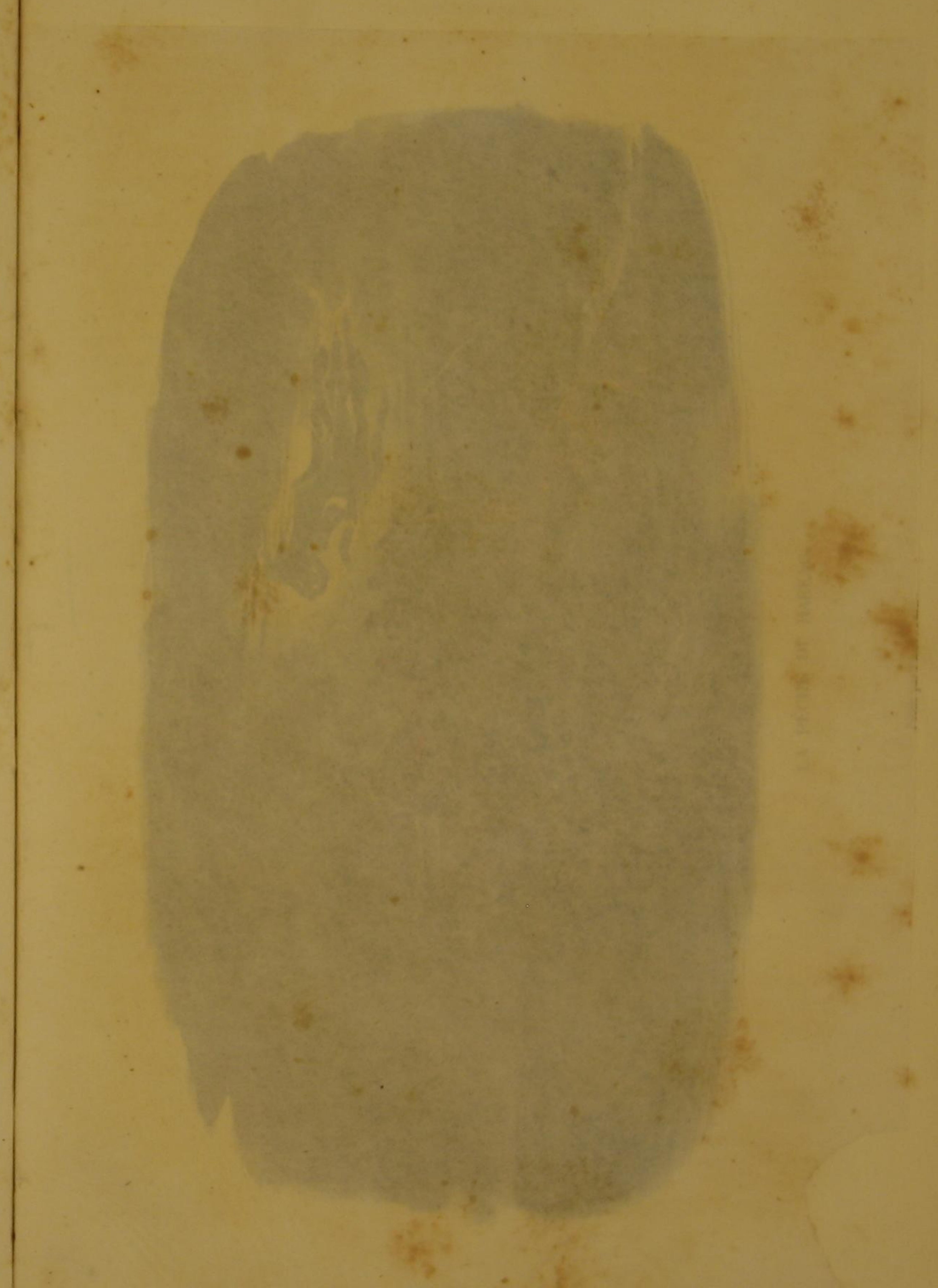


7. ploting
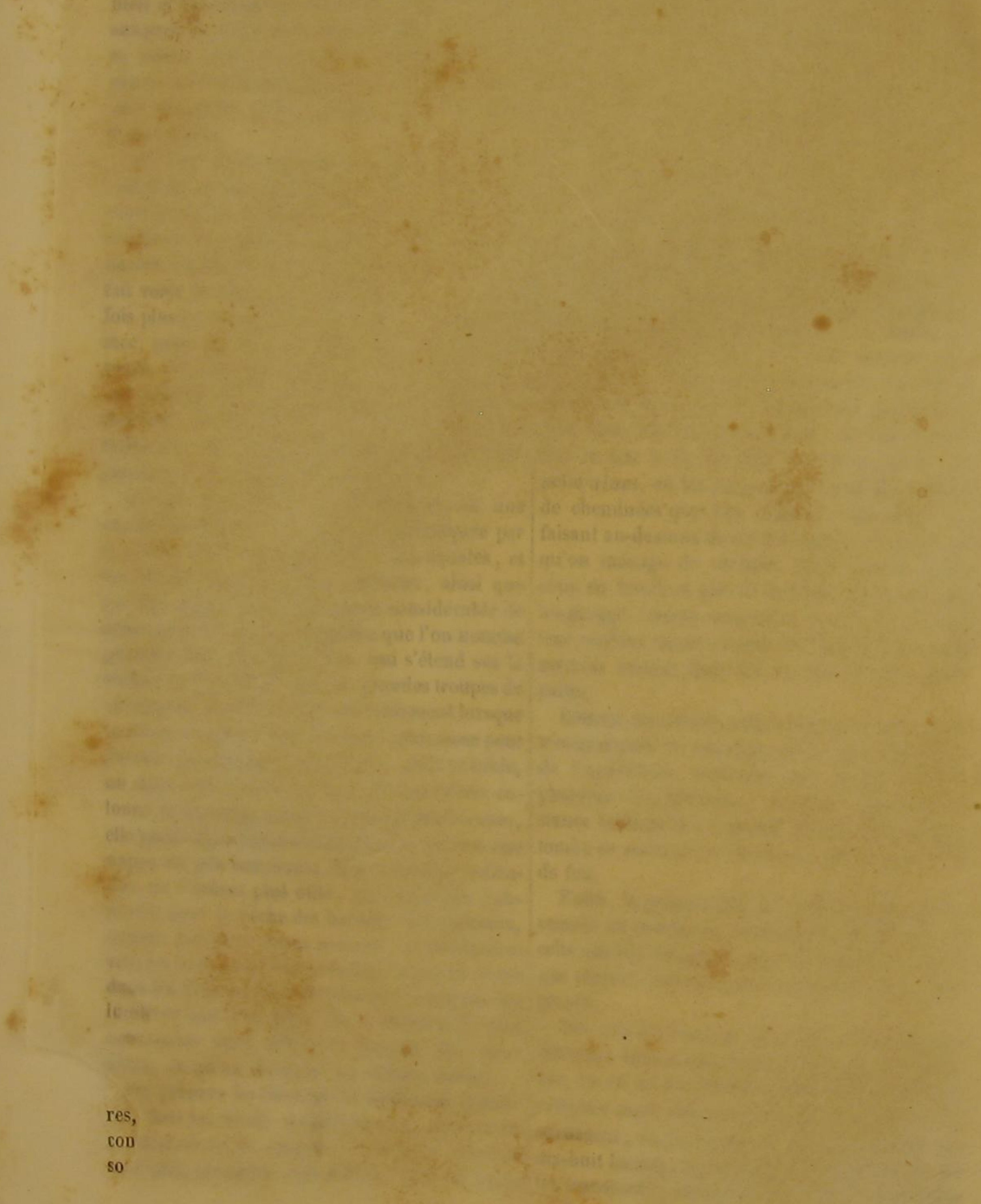
veau, on les place par lits dans les caques ou | employés à la pêche des harengs. Il a désiré tonnes qui doivent les conserver, et on sépare que l'on ne cherchàt à prendre ces poissons que ces lits par des couches de sel.

On a soin de choisir du bois de chêne pour les saisons où leurs qualités les rendent, on a soin de choisir du bois de chrno pour les après leurs différentes préparations, d'un goût les parties, de peur que la saumure ne se perde, et que les harengs ne se gàtent.

Il a voulu principalement qu'on ne nuisit pas à
l'abondance des récoltes à venir, en dérangeant Cependant Bloch assure que les Norrégiens le frai des harengs, ou en retenant dans les litets se servent de bois de sapin pour faire ces tonnes, ceux de ces osseux qui sont encore très-jeunes. et que le goùt communiqué par ce bois aux ha- En conséquence, il a ordonné que tout matetot rengs fait rechercher davantage ces poissons et tont pécheur seraient obligés, avant de partir daus certaines parties de la Pologne.

pour la grande péche, de s'engager par serment

Lorsque la pếche des harengs a été très-abon- à ne pas tendre les filets avant le 25 de juin ni dante en Suède, et que le prix de ces poissons y après le $f^{\text {er }}$ janvier, ot il a déterminé la granbaisse, on en extrait de l'huile, dont le volume deur des mailles de ces instruments.

s'cleve ordinairoment au vingt-denx on vingttroisième de celui des individus qui l'ont fourtroisième de celui des individus qui l'ont four-
nie. On retire cette huile en faisant bouillir les harengs dans de grandes chaudières; on la purifie avec soin, on s'en sert pour les lampes; et le résidu de l'opération qui l'a donnée est un des engrais les plus propres à augmenter la fertilité des terres.

II a prescrit les précautions nécessaires pour que les harengs fussent encaqués lo mieux possible. D'après ses ordres, on ne peut se servir, pour celte opóration, que du sel de la meillenre qualité. Les harengs pris dans to premier mois qui s'écoule après le 24 juin, sont préparés avec du gros sel; ceux que l'on péche entre le 24 juillet et le 15 septembre, sont conservés avee du Tant de soins n'ont pas été seulement l'effot sel fill. II n'est pas permis de mêler dans un do spéculations particulières : depuis longtemps mèmo baril des harengs au gros sel et des ha-

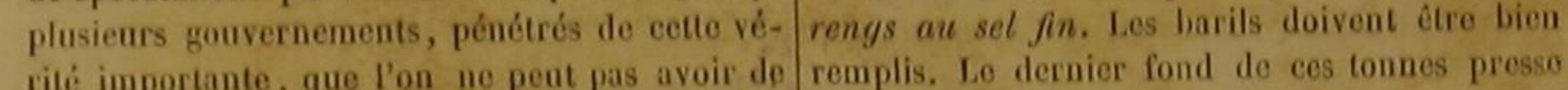

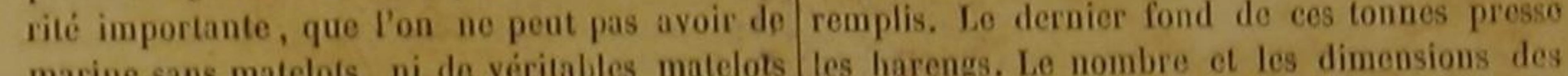
marine sans matelots, ni de véritables matelots les harengs. Le nombre et les dimensious des sans de grandes píches, et voyant, d'un autre cercles, des pièces, des fonds et des douves, sont còté, que de toutes celles qui peuvent former réglés avec exactitude; lo bois avec tequel on

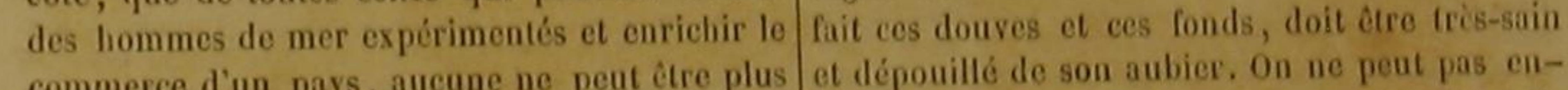
commerce d'un pays, aucune ne peut être plus et dépouillé de son aubier, On ne peut pas enutile, ni peut-être même aussi avantageuse à la caquer avec les bons harengs ceux dont la chair défense de l'État et à la prospérité des babitants est mollasse, le frai délayé, ou la salaison ma que la pêche du hareng, ont cherché à la favo-
riser de manière à augmenter ses heureux résul-
ques, indiquent le temps où l'ou a pris les hatats, non-seulement pour le présent, mais encore rengs que ces barils renferment, et assurent pour l'avenir. Des sociétés, dont tous les efforts que l'on n'a négligé, pour la préparation de ces pour l'avenir. Des sociétés, dont tous les efforts que lon n'a aus des soins convenables et déterdevaient se diriger vers cee but important, ont $\begin{aligned} & \text { poissons, } \\ & \text { minés. }\end{aligned}$

été établies et prolégées par le gouvernement, en minés. Sucide, en Danemarck, en Prusse. Le gouver- On n'a pas obtenu moins de suces darengs à nement hollandais surtout n'a jamais cessé de tentatives faites pour accoutumer les hás relatif́s prendre à cet égard les plus grandes précautions. de nouvelles eaux, que dans les procédés relatís prendre a cet écótuellement de soins pour la à leur préparation. On est parvenu, en Suède,

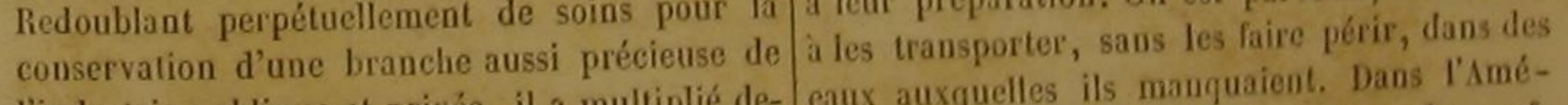
l'industrie publique ot privée, il a multiplié de- eaux auxquelles ils manquait. Dohe des eufs puis deux siècles, et varié, suivant les circon- rique septentrionale, on a fait étore des curs stances, les actes de sa surveillance attentive de ces animaux, à l'embouchure d'un fieave qui stances, les actes de sa surveillance attentive de ces anair le maintien, a-t-il toujours dit, du grand
n'avait jamais été fréquenté par ces poissons, et commerce et de la principale mine d'or de sa vers lequel les individus sortis do cos auns éc patrie. II a douné, lorsqu'il l'a jugé nécessaire, contracté l'habitude de revenir claque ane

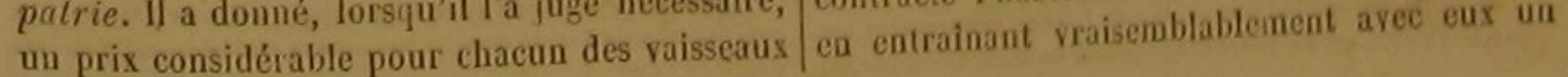




\section{HISTOIRE NATURELLE}

grand nombre d'autres individus de leur es- vers les rivages en troupes si nombreuses, que ia jèce'. pêche en est très-abondante. On les mange frais, ou salés ou fumés. La branche de commerce qu'ils forment est importante dans plusieurs con-

LA CLUPÉE SARDINE ${ }^{2}$. rées de l'Europe; et nous croyons que l'on doit rapporter à cette même espèce la clupée décrite :ulpea Sardina, Cuv.; Clupea Spratus, Linn., Gmel. Lac. ${ }^{3}$.

La sardine a la tête pointue, assez grosse, souvent dorée; le front noirâtre; les yeux gros; les opercules ciselés et argentés; la ligne latéral droite, mais à peine visible; les écailles tendres, larges et faciles à détacher; le ventre terminé par une carène longitudinale, aiguè, tranchante et recourbée; cinq à six pouces de longueur; les nageoires petites et grises; les côtés argentins ; le dos bleuâtre ; quarante-huit vertèbres; quinze côtes à droite et à gauche.

On la trouve non-seulement dans l'Océan Atlantique boréal et dans la Baltique, mais encore dans la Méditerranée, et particulièrement au environs de la Sardaigne, dont elle tire son nom Elle s'y tient daus les endroits très-profonds mais pendant l'automne, elle s'approche des còtes pour frayer.

Les individus de celte espèce s'avancent alors

I 8 rayons à la membrane branchiale de la clupée haren 18 à chaque peelorale. 18 a la nageoire de la queue.

ouest de la France. - Royan, à Bordeaux. - Breilling, en Prusse et en Pomeranie. - Hwasbuk, Kallosiromling, en
Suède. - Id. Kallositliud, en Livonie. - Hugs - sild en Danemarek. - Blaa-sild, Smaa-sild, Brisling - en Norvège. - Kop-sild, en Islande. - Garvock, à Inverness e Ecosse, - Garvies, a Kincardine. - Trichis. - Trichias.
- clupe sardine. Daubenton el Haïs. Ec.

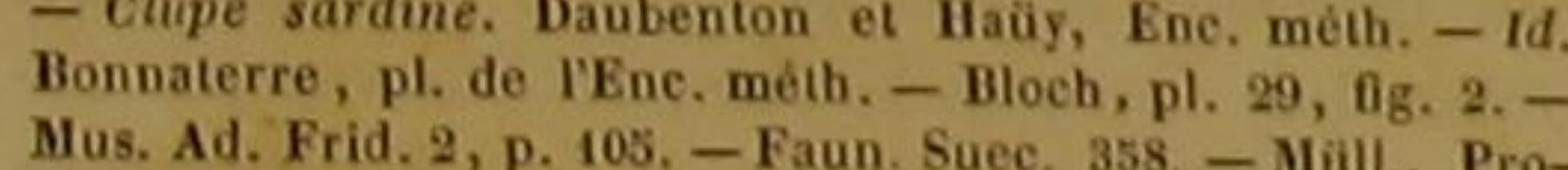
drom. Zool. Danic., p. 68, n. 422. - Brünn. Pisc. Massill, p. 82. - " Clupea quadruncialis, etc. $\gg$ Artedi, gen. 7, syn. 17, spec. 33. - Gronov, Mus. 4, p. 6 , n. $22 .-$ Klein, Miss
pisc, 5 , p. 73 , n. 7. - Sardina. Aldiøv., Pisc., p. $220 .-$ Sprautus. Willughby, Iehtb., p. 221 . - Rai, Pisc., p. 105 , n. 8. - Brit. Zool., 3, p. 294, n. 3. - Sardine. Rondelet, part, 1, 1. 7, c. 10. - Id. Valmont de Bomare, Dict. d' hist. ${ }^{3}$ Artedi et ses successeurs ont confondu, sous le nom do Clupea Spratus, deux especes que M. Cuvier distinzue crit el figuré par Bloch, pl. 29, fig. 2. II a les formes du hareng, mais il est beaucoup plus pelit; ses opereules ne sont pas veínés; il montre une bande dorée le long de ses nancs dans le temps du frai ; $2^{\circ}$ La SABDINE, proprement dite, figu-
rée par Duhamel (Péches, sect. III, pl. 26 , fig. rée par Duhamel (Pèchess, secl. III, pl. 26, fig. 4), de la taille
du précédent, et trés-semblable par ses formes au Pilcbarde. quoique beaucoup plus petite. Elle differe du bareng par son corps plus étroit; ses opercules marqués de stries en rayons; son subopercule coupé carrément au lieu de létre
eu rond, etc. D. eu rond, ete. D.

Le Pilchard, qui est une espece de hareng proprement dite
pur 3. Cuvier, est du senre par Rondelet, sous le nom de Célerin ${ }^{-1}$, et qui a la tête dorée et le corps argenté ${ }^{2}$.

\section{LA CLUPEE ALOSE ${ }^{3}$.}

Alosa vulgaris, Cuv.; Clupea Alosa, Linn., Gmel., Bl.,

$$
\text { Lac. ‘. }
$$

On doit remarquer dans l'alose la petitesse de la tête; la transparence des téguments qui couvrent le cerveau; la grandeur de l'ouverture de la bouche; les petites dents qui garnissent le bord de la màchoire supérieure ; la surface unie de la langue, qui est un peu libre dans ses mouvements; l'angle de la partie inférieure de la prunelle; le double orifice de chaque narine; les

\section{Rondelet, parl. 1, 1. 7, c. 11.}

8 rayons à la membrane branehiale de la elupée sardine, 3 Thrissa. - Thralla. - Thatta. - Triula, par les anciens auteurs. (Note communiquée par mon collézue, M. Geoffroy, professeur au Muséum.) - Coulac, à Bordeaux. - Cola, Alouze, dans plus. dép. mérid. - Loche Celang. - Halachia, a Marseille. - Saboga, Saccolos, en

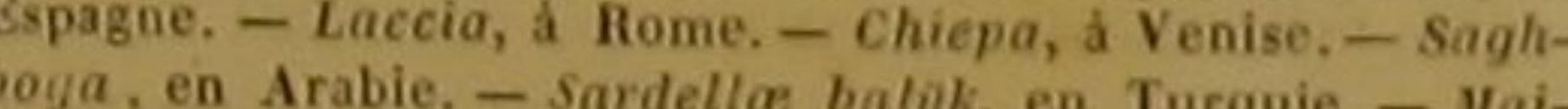
balik, en Tartarie. - Schelesniza, Beschenaja rubaiKussie. - Alse, Else, Mayfisch, Gold fisch, en Allemegne. - Perbel, en Poméranie, - Eristinq. Sildinger, Sardeller, on Danemarek. - Elft, en Hollande. - Shad, Morher of herring, en Angleterre. - Olupe alose. Daubenton el Bloch, pl. 30, fig. - - Id. Bonnaterre, pl. de I'Enc, méth. Prod. Zool Danic., p. 50, n. A23. Frid. 2, p. 105. - Mäller,
Plupea, apice masille superioris bifido, ete, , Artedi, gen. 7, syn. 15, maxilla

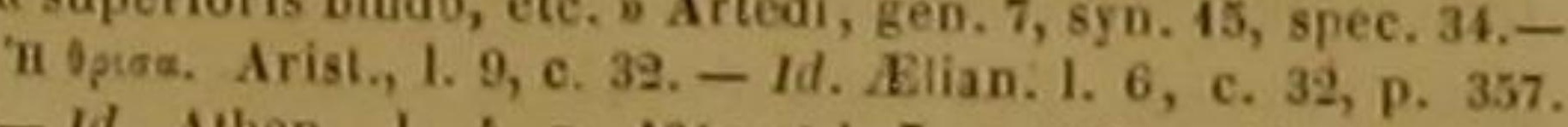
Id. Athen., 1. 4, p. 431 ; et 1. 7, p. 318. - Id. Oppian. Trisso, p. 10. - Alose. - Rondelel, part. 1, I. 7, c. 12. 501. - Trichis Belonii. La. Aldrove, I. 4, c. 4, F. 500 el Je Plumier, déposés à la Biblioth, volume initulé P. Puscrits Aves. - Clupea el alosa, Salvian. fol. 103, b, ad iconen et 104. - Id. Jonston, L. 2, I. 1, c. 3, I. 27, fig. 3, 4. - A Alosa, vel alausa, vel trissa. Sehonev., p. 13, 14.-Alausa, clu. Ig. 1. - Id. Rai, p. 105, - Id. Willughby, p. 227, tab. p. 3; Zooph., p. 111, n. 374 - H. 6. - Gronov. Mus. 1, p. 6, n. 23 ; Zool. 3, p. 296, n. 5. - Alose. Valmont de Bomare, Dicl. d'hist. nal.

Du sous-genre Alosk, Alosa, Cuv., dans le grand genre HARENG, famille des Clupes, ordre des Malacoptérygiens ab-
dominaur. D.

\section{DES POISSONS.}

ciselures des operenles; le très-grand aplatisse- prudents ou moins diffieiles, Le nombre de cos ment des côtés ; la rudesse de la carène longitudinale du ventre; la figure des lames transversales qui forment celte carène; la dureté de ces lames; le tranchant des pointes qu'elles présentent à l'endroit où elles sont pliées; la direction de la ligne latérale, qu'il est difficile de distinguer; la facilité avec laquelle les écailles se détachent; le peu d'étendue de presque toules les nageoires; les deux taches brunes de la caudale; la couleur grise et la bordure bleue des if autres; les quatre ou cinq taches noires que I'on voit de chaque côté du poisson, au moins lorsqu'il est jeune; les nuances argentées du corps et de la queue; le jaune verdàtre du dos; I brièveté du canal intestinal; les quatre-vingts appendices qui entourent le pylore; la laite, qui est double comme l'ovaire; la vessie natatoire dont l'intérieur n'offre pas de division; ot les côtes, qui sont au nombre de trente à droite et à gauche.

Les aloses liabitent non-seulement dans I'Océan Allantique septentrional, mais encore dans la Méditerranée el dans la mer Caspienne. Elles quittent leur séjour marin lorsque lo temps du frai arrive; elles remontent alors dáns les grands lleuves, et l'époque de ce voyago annuel est plas ou moins avancée dans le printemps, dans l'été, et même dans l'automne ou dans l'hiver, suivant le climat dans lequel coulent ces fleuves, les époques où la fonte des neiges, et des pluies abondantes, en remplissent le lit, et la saison où elles jouissent dans l'eau douce, avec le plus de facilité, du terrain qui convient à la ponte ainsi qu'à la fécondation de leurs aufs, de l'abri qu'elles recherchent, de l'aliment to plus analogue à leur nature, et des qualités qu'elles préferent dans le fluide sans lequel elles ne peuvent vivre.

Lorsqu'elles entrent ainsi dans le Wolga, dans I'Elbe, dans le Rhin, dans la Seine, dans la Garonne, dans le Tibre, dans le Nil et dans les autres fleuves qu'elles fréquentent, elles s'avancent communément très-près des sources de ces fleuves. Elles forment des troupes nombreuses, que les pêcheurs de la plupart des rivières oú elles s'engagent voient arriver avec une grande satisfaction, mais qui ne causent pas la mème joie à ceux du Wolga. Les Russes, persuadés que la chair de ces animaux peut être extrếmement funeste, les rejettent de leurs filets, on les vendent à vil prix à des Tatares moins clupées cependant varie beaucoup d'une année à l'autre. M. Noêl, de Rouen, m'a écrit que, dans la Seine inférieure, par exemple, on prenail treize ou quatorze mille aloses dans certaines années, et que, dans d'autres, on n'en prenait que quimze cents ou deux mille.

Elles sont le plus souvent maigres et de mauvais goùt en sortant de la mer; mais le séjour dans l'eau douce les engraisse. Elles parviennent la longueur de trois pieds : néanmoins, comme elles sont très-comprimées, ot par conséquent rès-minces, leur poids ne répond pas à létendue de celle dimension. Les femelles sont plus rosses et moins délicates que les màles. Dans plusieurs contrées de l'Europe, où on en pecho une très-grande quantité, on en fume un grand nombre, que l'on envoie au loin ; et les Arabes les fout sécher à l'air pour les manger avec des daltes.

M. Pénières dit, dans les notes manuscrites que j'ai déjà citées, que celles qui passent l'été dans la Dordogne, sont malades, faibles, extéauées, et périssent souvent pendant les trèsrandes chaleurs.

Le mème observateur rapporte que lorsque ces clupées fraient, elles s'agitent avec violence, font un bruit qui s'entend de très-toin.

Les aloses vivent de vers, d'insectes et de polits poissons.

On a écrit qu'elles redoutaient to fracas d'm connerre violent, mais que des sons ou des bruits modérés ne lear déplaisaient pas, leur étaient même très-agréables dans plusieurs circonstances, el que, dans certaines rivières, les pécheurs attachaient à leurs filets des ares de bois garnis de clochettes dont le tintement attirait les aloses'.

LA CLUPÉE FEINTE². Alosa Finta, Cuv.; Clupea Vallax, Lac. '.

ET LA CLUPÉE ROUSSE. Clupea rufa, Lac ‘.

M. Noêl, notre savant correspondant de

18 rayons á la membrane branchiale de ta clopée alose, 15 a chaque pectorale, 18 a la nageoire de la queue.
2 Serpe. - Calir hau. (nom donné aur males de celle es-
phe péce par les pécheurs de la Seine inférieure ). Du sous-genre ALosE, Alosa, Cuv., dans lo grand feere

' Dans la premiére édition du Règne animal, M. Cuvier des HasesGs, famill do 
Rouen, nous a envoyé des notes très-intéres- mais a l'écaille plus grande que celle que l'on santes sur celte clupée, que l'on a souvent con- pêche dans les mois d'aoùt et de septembre. Les fondue avec l'alose, et que l'on pêche dans la individus qui composent ces deux variétés préSeine.

La chair de la feinte, quoique agréablo au goût, est très-différente de celle de l'alose. Les femelles de celte espèce sont plus nombreuses, plus grandes, plus épaisses, d'une saveur plus ji délicate, et plus recherchées que les màles, auxquels on a donné un nom particulier, celui de

\section{Cahuhau.}

La feinte remonte dans la Seine comme l'atose; elle s'avance également par troupes : mais les habitudes de cette espèce diffèrent de celles de l'alose, en ce que les plus grands individus quittent la mer les premiers, au lieu que les aloses les plus petites, les plus maigres et les moins bonoes, sont celles qui se montrent les premières daus la rivière, en a remarqué à Villequier que ces premières feintes, plus grosses que les autres, ont aussi l'œil beaucoup plus gro et la peau plus brunàtre; ce qui les a fait appeler Feintes au gros ail, et Feintes noires. Elles sont non-seulement plus grandes, mais encore plus délicates que les individus qui ne paraissent qu'à la seconde époque, et surtout que ceux de la troisième, que l'on a désignés par la dénomination de Feinles brelonnes.

Ces feintes bretonnes ou noires, et en général tous les poissons de l'espèce qui nous oceupe, aiment les temps chauds et orageux. On en fai la péche depuis l'embouchure de la Seine jusqu'aux envirous de Rouen. On les prend avee des guideaux ou avec des seines ', qu'on appell quelquefois feintières.

M, Noēl nous assure que les feintes sont atjourd'lui beaucoup moins nombreuses qu'il a vingt ans. Il attribue cette diminution it destruction du frai de ces clupées, occasionnée par les guideaux du bas de la Seine, et aux qualités malfaisantes pour ces animaux, que conmunique à l'eau le suint des moutons que l'on ave, aux époques et dans les endroits préfér par ces osseux.

Voici maintenant ce que cet observateur nou a écrit au sujet de la rousse. Les pécheurs distinguent deux variétés dans celte espèce. Celle que l'on prend dans le printemps est plus petite,

remarque que la rousse de ta Mánche n'a pas encore été sufGsamment comparée a ' Yalose. D. 'Voyez, pour le guideau, larticle du Gade colin, et pou
la seine ou saine, celui do la Raie bouclée. sentent quelquefois des taches noires ou brunâsentent quelquefois des tach
tres comme celles de l'alose.

On prend peu de clupées rousses dans la Seine on ne les pêche que depuis la pointe du Hode jusqu'à Aisiers, c'est-à-dire dans les eaux sanmâtres de l'embouchure de la rivière. Il paraí qu'elles fraient dans les grandes eaux.

Elles ont les écailles plus tines, la chair plus délicate et moins blanchie que l'alose. Leur peau est d'un blanc de crème légèrement cuivré.

On n'en consomme que dans les eudroits oû on les pêche; et voilà pourquoi elles sont encore peu connues, On en a pris dans to lac du Tot qui pesaient de quatre à six livres.

Dans les mois de juillet et d'août, elles sont assez grasses pour éteindre, comme les harengs d'été de la Manche, les charbons sur lesquels on cherche à les faire cuire'

\section{LA CLUPEE ANCHOIS 2}

Engraulis vulgaris, Cuv.; Clupea Encrasicholus, Lian. Gmel., Bl., Lac. ?

Il n'est guère de poisson plus connu que l'anchois, de tous ceux qui aiment la bonne chère. Co n'est pas pour son volume qu'il est recherché, car il n'a souvent que cinq à sir pouees ou moins de longueur; il ne l'est pas non plus pour la saveur particulière qu'il présente lorsqu'il est frais : mais on consomme une énorme quantité I 15 rayons à chaque pectorale de la elupée rousse, 27 a $\mathrm{I}$ nageoire de la queue.

Sacella, a Malte. - Anjovis, en Allemagne. - Bykling,
Moderlose, en Danemarck. - Savilussal, dons land. - sprat des Anglais, a la Jamāique - Clupeenchois. Daubenton et Ilaũy, Enc. métb. - Id. Bonnaterre, 11. de IEnc. méth. - Bloch, pl. 30, ng. 9. - a Clupe maxila superiore longiore. n Artedi, gen. 7, syo. 17. of I 7 , p. $285,300,-5.17$. Id Athen., 1. 4, p. 148 Shian, I. 8, c. 18, p. 497. - Halecula. Belon. - Engrantis.
Wolton part. 1, I. 7, c. 3. 182, fol. 161, b. - Anchois. Rondelet, . 33, p. 214. - Id. Jonston, 1. 1, tit. 3, c. 1, a. 18, tab. 19, p. 107, n. 9. - Müill. Prod. Z, tab. P. 2, fig. 2. - Id. Rai Brǜn. Pisc. Massil P. Groenl., p. 183. - Brit. Zool. 3, p. 195, n. 4. - Anchois. Valmont de Bomare. Dict. d'hist. nat. Da genre Axeuols. Engraulis, forme par M. Cuvier, dans la famille des Clupes, ordre des Malacopterygieas abP. 68, el (germ.) fol. 4 b. Encrasicholus. Aldrov., I. 2 ,

DES POISSONS.

555

d'individus de cette espèce, lorsqu'après avoir été salés ils sont devenus un assaisonnement des plus agréables et des plus propres à ranimer l'appétit. On les prépare en leur ótant la tête et les entrailles; on les pénètre de sel ; on les renferme dans des barils avec des précautions particulières; on les envoie à de très-grandes distances sans qu'ils puissent se gàter. Ils sont employés sur les tables modestes comme dans les festius somptueux, à relever la saveur des végétaux, et à donner aux sauces un piquant do très-bon goût. Leur réputation est d'ailleurs aussi ancienne qu'étendue, Les Grees et les Romains, daus le temps où ils attachaient le plus d'importance å l'art de préparer les aliments, faisaient arec ces clupées une liqueur que l'on nommait garum, et qu'ils regardaient comme une de plus précieuses. Au reste, ils pouvaient satisfaire aisément leurs désirs à cet égard, les anchoi étant répandus dans la Méditerranée, ainsi quo le long des cotes occidentales de l'Espagno el do la France, dans presque tout l'océan Atlantique septentrional et dans la Baltique. On préfer de les pécher pendant la nuit; on les attiro, comme les harengs, par te moyen de feux distribués avec soin. Le temps où on les prend est celui où ils quittent la baute mer pour venir frayer auprìs des rivages, et celte dernière époque varie suivant les pays.

Les anchois ont la tête longue; le musea pointu; l'ouverture de la bouche très-grande; la langue pointue et étroite; l'orifice branchia un peu large; le corps et la queue allongés; In peau mince; les écailles tendres et peu attachées ; la ligne latérale droite et cachée par les écailles : les nageoires courtes et transparentes; Ie cana intestinal courbé deux fois ; dix-huit appendice auprès du pylore; trente-deux côtes de chaqu côté, et quarante-six vertèbres'.

LA CLUPÉE ATHÉRINOIDE, Engraulis atherinoides, Cuv.; Clupea atherinoides, BI. Linn., Gmel., Lac. '.

La Clupee raie-d'argent ', Engraulis..... Cuv.; Clupea vittargentea, Lac,; Stotephorus Commersounil, Lac.; Athe Clupea cyprinoîdes, Bi., Linn,, Gmel., Lac,, Clupea giganI 12 rayongs à la membrane branchiale de la clupée an

Bande đ̈argent. - Atherine, en Italie. - Naram, 'Bande a argent. - Aherine, en He bande d'argent. pea setirostris, Lacep,; Clapea Belama, Forsks, P. - C, Do-
rab 10, Chirocentrus Dorab, Coy. Clupea Corab, Laep,

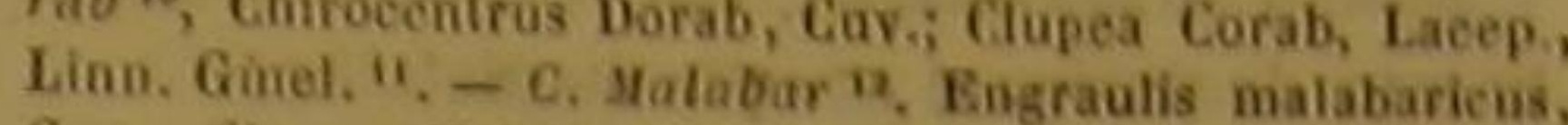
Cur.; Clupea Malabar, Lae,; Clupea malabarica, B1. is. - C. niberculense", Engraulis tuberculosus, Cav.; $\mathrm{Cl}$ pea tuberculosa, Lacep, is, $-c$. chriysoptere 16 . Clopea chrysoplera, Lacep, $11,-6$. in bandes 1". Clupea fasciats, Cur.; clupea macrocephata, Lac, Butirinus americanus,

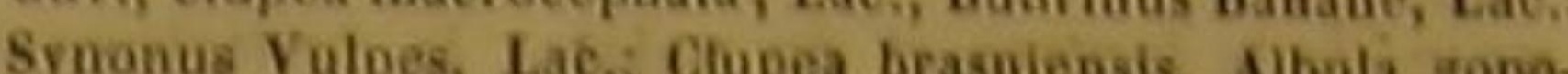
rhynehus ot Albula Plomieri, Bl., Schn, "1, - $-c$, des Tropiques "2, Clupes tropica, Lino, Gm, Lac, "3, Pour ne rien omettre d'essentiel dans la désignation de ces onze clupées, il faut indiquer :

Daubenton et Haäy, Enc, méth, - Id, Bonnaterro, pl. do Wne, meth. - Bloch., pl. 408, ng.

ba genro Axenoss, Engraulis, Cuvier, dans la famille Ies Clopes, ordre des Malacoptérygiens abdominaux, D. - terali argented. . I Commerson, manuserits deja cuds, S. Cuvier rapporte co polsson au genro Axenots, dans a famille des Glupes, ordro des Malacoptérygiens abdomiaaux. Il est décrit deux fols dans l'ourrage de M. de Lacé-

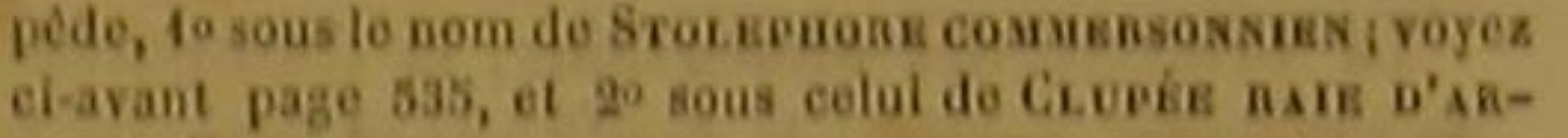

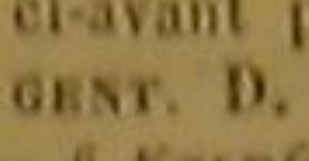

- Karpren-hering, par les Allemands. - Deep water Ash - ipugnacu, par les Brasillems, - Savalle, a ta Martinique, - Apalika, par los Olatilitioms. - Marakay, dañs l'́diomo

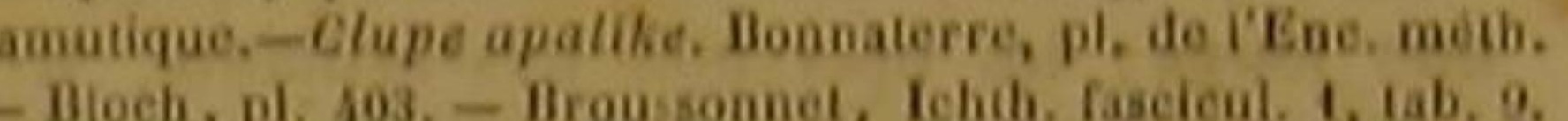

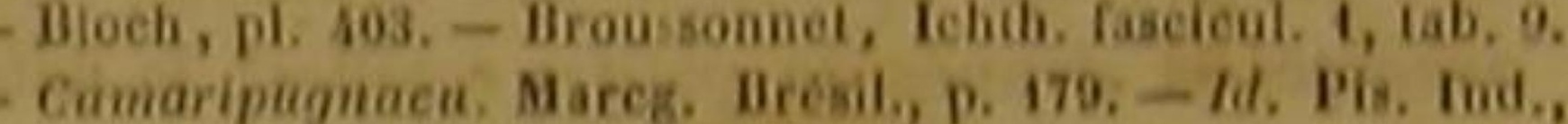
p. 65. - Alauda argenteg, pinnula, caudata valvò saealle a

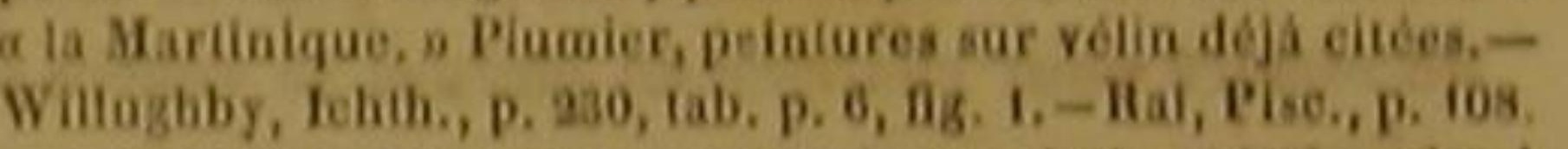
- "Cyprinus argenteus, squ dorsall appendice longissima suffulta : apalika, op Barréro, rance equinox., p. 17a.

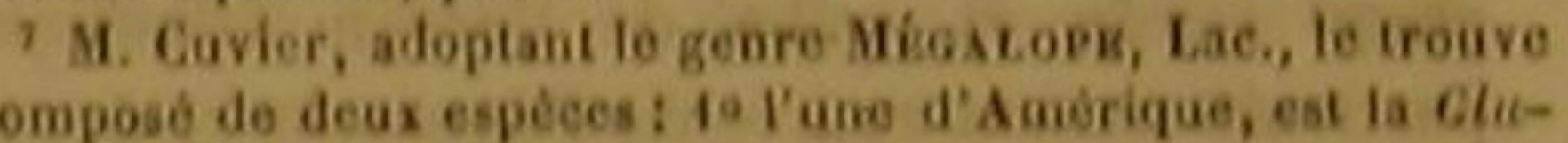
pee apalitie de Lacépéde, décrite dams cel arielé ; 20 V'autro qui se trouve dans les mers de l'Inde est te Megalope fitamenteux da mème naturaliste, dont nous arons donmé la
description. Le genro MíasLove est de la familte des Clupes, ordre des Malacopterygiens abdominaux. D.

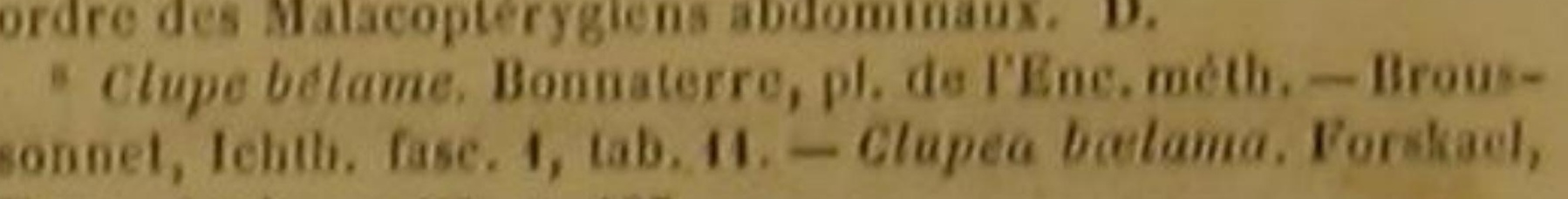
Vaun, Arab., D. 72, D. 107

- Du sous-genre Tusisse, Thrissa, dans le genre Axis Clupe lysan. Bonnaterre, pil. de IEne. métb. - Clupe

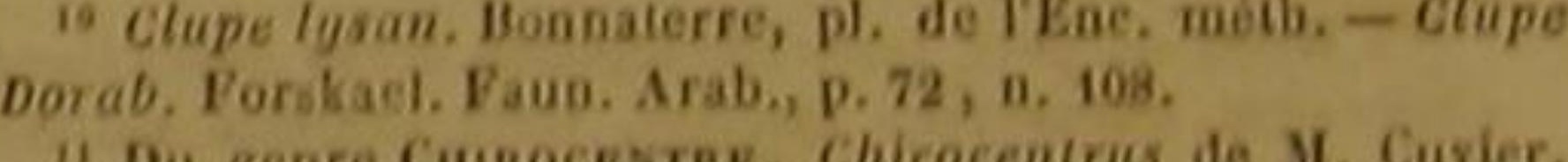
I" Du genre Cimnocestee, Chirocentrus de M, Cuvier, dans la famille des Clupes, ordre des Molacopterygiens ab-

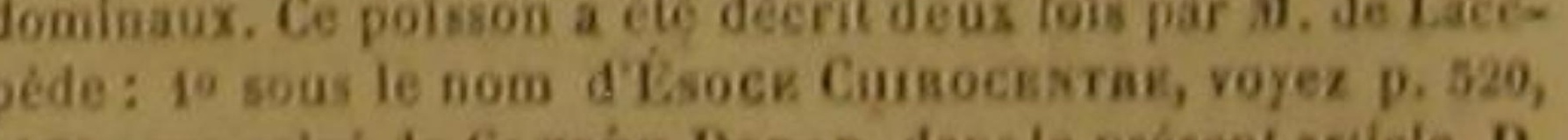

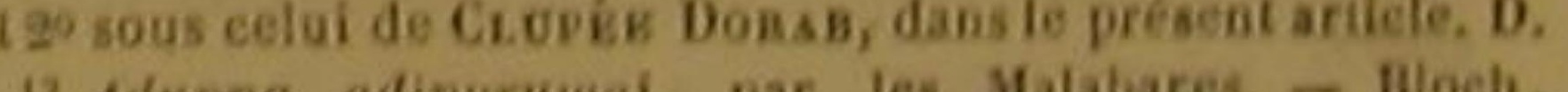
pl. 432.

M. Cuvier, dans la premiere edition du hìgne animal, place ce poisson dans le sour-zenre Ascuos, Engraulis. Dans la seconde, il u'en fait pluș meation. D. " sardine de life de Prance. - Clupea mandibula inferioro breviore, rosiro apice tube culo verrucaformi, macina minista ad superiores bith.

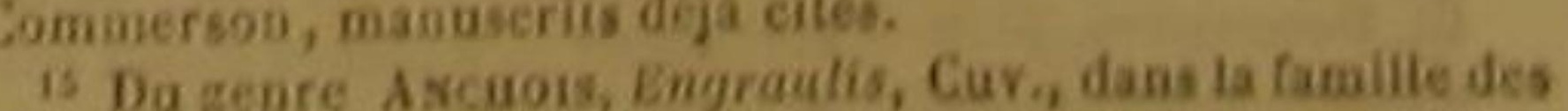
Clapes. D. 
Dans l'Athérinoìde, qui labitc l'Adriatique, gueur de l'animal peut excéder douze pieds, la mer de Surinam et celle du Natabar. $\quad$ que l'ouverture de la gueule est assez grand La petitesse de la tête; les grandes lames qui pour engloutir la tête d'un homme; la largeu couvrent celte partie; la largeur de l'orifice de la des écailles, qui égale énviron deux pouces; I bouche et de l'ouverture branchiale ; les rangées figure de ces lames, qui est hesagone; la graisse de petites dents de chaque mâchoire; la surface de la chair; la compression da corps et de la unie de la langue et du palais; la dentelure des queue; les lames écailleuses et étendués qui reos de la lèvre supérieure; l'orifice unique de couvrent la tête; les dents, dont les mâchoire claque narine; la matière brune et visqueuse sont, pour ainsi dire, parsemées; la courbure qui humecte la peau; la brièveté des nageoires des os de la lèvre supérieure; la rudesse de la du ventre; l'étendue et les écailles de celles de langue et des quatre os qui entourent le gosier l'anus; la longueur de l'animal, qui est ordi- les trois rangées de dents disposées en are sur nairement de huit pouces; la graisse et le bon devant du palais; le double orifice de chaque goût de la chair, que l'on mange fraiche ou narine; les teintes argentines de la couleur gésalće :

Dans la Raie-dargent, dont les manuscrits de Commerson nous ont présenté la deseription, et dont ce naturaliste a vu des myriades auprès des rivages de l'ile-de-France, La les autres; le pen d'épaisseur des écailles qu'un de plusieurs parties; la facilité avec laquelle les faible froissement peut faire tomber; la petitesse écailles se détachent; la saillie du museau au- et l'inégalité des dents des mâchoires; la rudesse devant des deux mâchoires; la petilesse des des environs da gosier; la couleur blanchâtre dents, qu'on ne peut souvent distinguer qu'avec des nageoires; la forme lancéolée de celles du une loupe; les opercules très-brillants, très- ventre et de celles de la poitrine :

argentés et dénués de petites écailles; le délaut d'une véritable ligne latérale; le peu de temps nécessaire pour changer en garum le ventre du poissou :

Daus I'Apalike, que nourrissent les eaux du grand Océan et celles de l'océan Atlantique, partieulièrement auprès de l'équateur et des tropiques,

Les dimensions, qui sont telles que la lon-

10 « Encrasicholus platygaster, cauda navescente. D) Commerson, manuscrits défja cittós.

"Ce poisson n'est pas eité par MI Cuyier Le nom lui a donné Commerson semble indiquer qu'il appartient au genre des ANchors. D.

lateralem transsersim cathetoplateo dorso supra lineau Commerson, manuserits deth cillo. M. Cuvier ne Rait pus deja cités.

20 Eamane, a la Mariniquention de co poisson. D. banane à la Marlinique. D Plumier, peint argenteus, vulgo eilées.

Ce poisson est l'espèce d'Amérique du genre Butros ordre des Malacoptérygiens abdomins la famille des Clupes, tionné daas l'ourrage de 11 . de Lacépéde, conis fois mer-

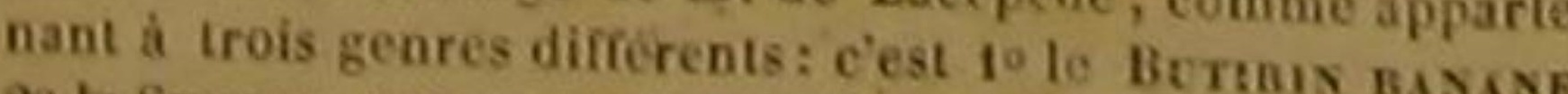

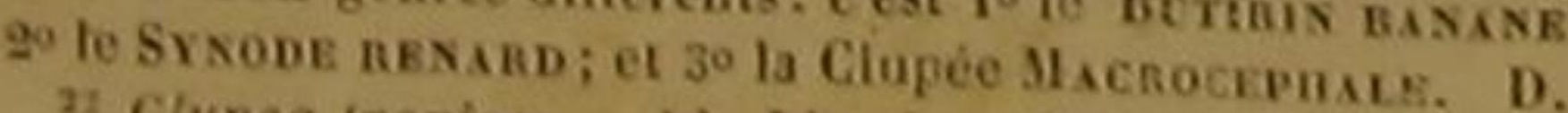
Hareng des tropiques. $1 d$. Linnee, édition de Gimelin. -

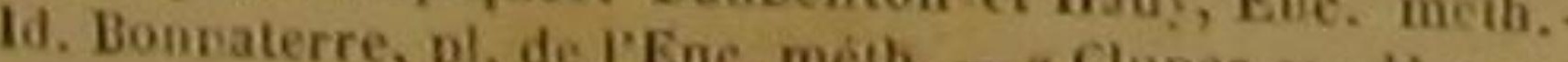
Dan 1

Lo brillant des côtés; le bleu du dos; les douze dents très-saillantes de la mấchoire inférieure; les stries ondulées des opercules; I direction droite de la ligne latérale; la position de la dorsale deux fois plus voisine de la caudale que de la tête; la petitesse très-remarquable des ventrales :

Dans la clupée Malabar, qu'on peut pêcher ioute l'année, près de la côte dont elle porte le nom

La finesse des dents; la dentelure des os de la lèvre d'en haut; l'opercule uni et compes de plusieurs lames dénués de petiles cesil bleu des pectorales et des vent autres nageoires; les taches jaunes qui relèvent 'argenté du dos :

Dans les Tuberculeuses, que Commerson a vues se jouer en troupes très-nombreuses à la surface de l'eau qui baigne les rivages de l'llede-France, et que, selon cet obsorvateur, on peut y prendre par milliers,

La petilesse des dimensions; la longueur to-

tale, qui surpasse à peine qualre pouces; le

blanc argentin des côtés et du ventre; les reflels

azurés du dos; le rouge-brun de la dorsale et de la nageoire de la queue; le peu d'adhérence des du corps et de la quene; la courbure du dessus écailles à la peau; la brièveté des dents qui gar- de la tète; l'avancement de la màchoire infénissent les màchoires, et que l'on sent'par le rieure au delà de celle d'en haut; les dents de toucher plus facilement qu'on ne les voit; l'ori- ichaque màchoire disposées sur un seul rang; les fice de la bouche, prolongé jusqu'au delà des petites écailles placées sur les opercules; la ligne yeux; la langue bordée de filaments ou soies latérale, qui est droite et plas près du dos que rudes; l'opercule, qu'aucune petite écaille ne du ventre '

recouvre; le défaut de véritable ligne latérale; le bon goùt de la chair :

Dans la Chrysoptère, dont nous devous la connaissance à Commerson,

La ressemblance de la tête à celle de l'anchois, du corps à celui de la sardine, de la grandeur à celle d'un petit lareng; le bleu melé de blano de la partie supérieure du poisson; les teintes argentines des côtés et du ventre; la dorure des joues et des opercules ; l'incarnat pale de l'intérieur de la bouche; l'éclat de la mâchoire inférieure; la transparence du devant des jeux :

Dans la Clupée à bandes, que Commerson a observée auprès des côtes de l'ile-de-Franco,

La couleur générale argentée; le dos bleuâtre; les éeailles si peu adhérentes que le poisson en est dénué très-fréquemment; les dents qui hérissent les màchoires et qui sont extrêmement petites; la grande facilité d'étendre le museau; le sillon large et peu profond que présente l'occiput; les yeux très-grands, arrondis, plats et rapprochés; I'opercule composé de deux pièces : le double orifice de chaque narine; la ligne latérale, qui consiste dans une série de petites lignes; la position des ventrales très près de nageoires de la poitrine :

Dans la Clupée macrocéphale, dont nou avons trouvé une figure sur une des peintures exécntées sous les yeux de Plumier, et conservées par les professeurs du Muséum d'listoir naturelle,

La saillie du museau; la prolongation de la mâchoire supérieure au delà de celle d'en bas; l'iris doré; les trois pièces des opercules; le défaut de potites écailles sur ces mêmes opercule et sur la lête ; l'arrondissement et la largeur de ćcailles du dos; l'échancrure de la dorsale, ainsi que de la nageoire de l'anus; les nuances rougeâtres des nageoires; les reflets argentés qui brillent sur le ventre de même que sur les cótés, et relèvent la couleur azurée de la partie supérieure du poisson :

El enfin, dans la Clupée des tropiques, qui fréquente l'île de l'Ascension,

La blancheur, la bauteur et la compression

\section{DEUX CENT HUITIEME GENRE.}

LES MYSTES 2 .

Plus de trois rayons a la membrane des branchies; le

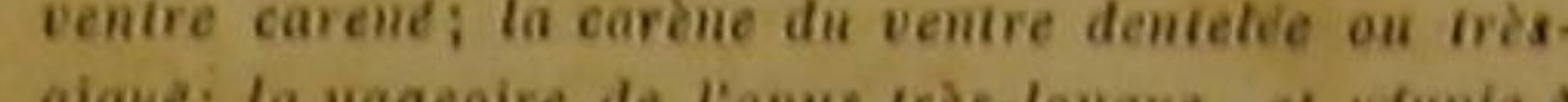

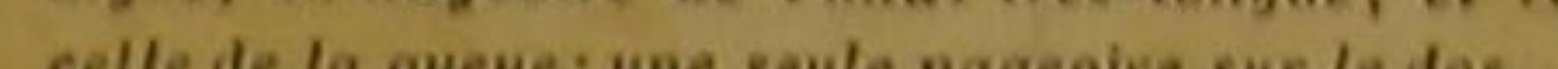

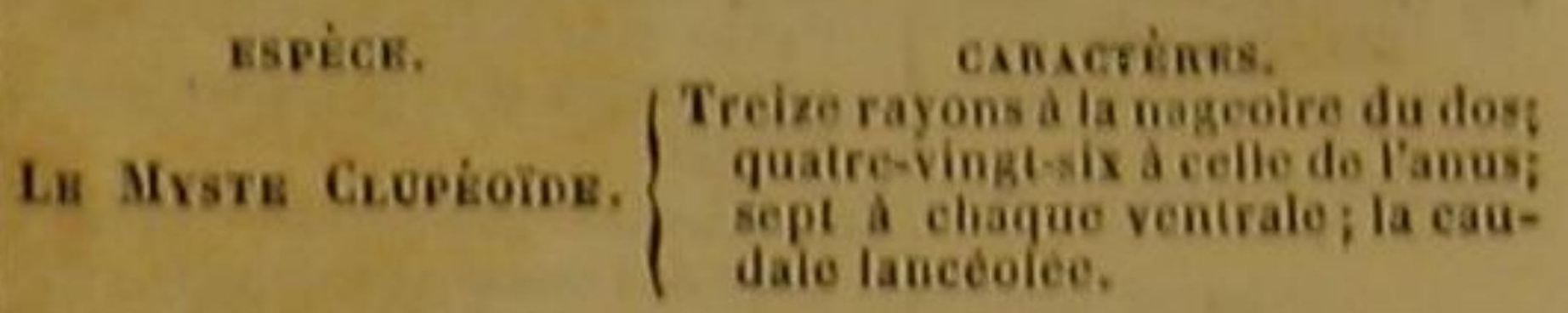

\section{LE MYSTE CLUPÉOIDE ${ }^{3}$.}

Thrissa clupeoides, Cuv.; Mysius clupeoides, Lac.; Clupea mystus, Linn. '.

La mee des Indes nourrit ce myste, dont la forme générale a été comparéo à une lame d'épée ; dont le corps est en effet très-comprimé, ainsi que la queue; et dont la mâchoiro supérieure, plus avancée que celle d'en bas, est garnie, de chaque côté, d'un os aplati, étroit, dentelé, et assez allongé pour atteindre jusqu'aux ventrales.

I 14 rayons à chaque pectorale de ta clupeo atherinoide, 22 a la nageoire de la queue, -12 rayons a la membrane branchiale de la elupée raie d'argent, 5 a claque pectorale, palike, 30 a la nageoire de la queue. -10 rayons a ta membrane des branchies de la clupúe bétame, in a chaque peetorale, 18 a la caudale. - $1 \mathrm{c}$ rayons a eliaque peetorale de la clupée dorab. - 8 rayons a la membirane branchiste de la clupée malabar, 14 a chaque pectorale, 22 a la nageoire de la queue, - 12 rayons a la membrane des branchies de 1 s elu18 rasons a chaque pactorale de lo clupese of bandes, 16 a ia rageoire de la queue, -7 rayons a ta membrane branchiale de la clupée des Iropiques, 6 a chaque pectorale, 20 a tis is cirle Jes Myses aree les autres poissons

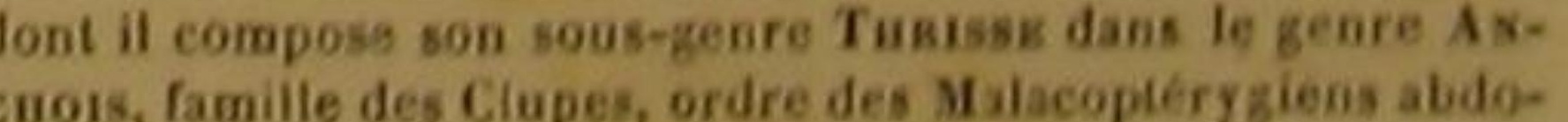
Minaux. D. 3 Mus. Ad. Frid. 2, p. 106. - Clupea mystus. Osbeek. II. 256. - Amowit. acad. 5, p. 252, 13b. 1, 0z. 12. - Clupe myste. Daubenton et Hauy, Ene, meth, - 1d. Bonnaterre. 
La coulcur générale de cet abdominal est blanche; et son dos présente une teinte foncíe ${ }^{\prime}$.

\section{EE GLUPANODON GALLEU-TASSART',}

Chatoessus Thrissa, Cuv.; Clupanodon Thrissa, Lac.; Clupea Thrissa, Linn., Gmel. ?.

DEUX CENT NEUVIL̀ME GENRE.

LES CLUPANODONS ${ }^{2}$.

Plus de trois rayons à la membrane des branchies; le ventre carene; la fcarène du ventre dentelee ou trèsaigué; la nageoire de l'anus separée de celle de la queue; une seule nageoire sur le dos; point de dents queue; une seule
aux machoires.

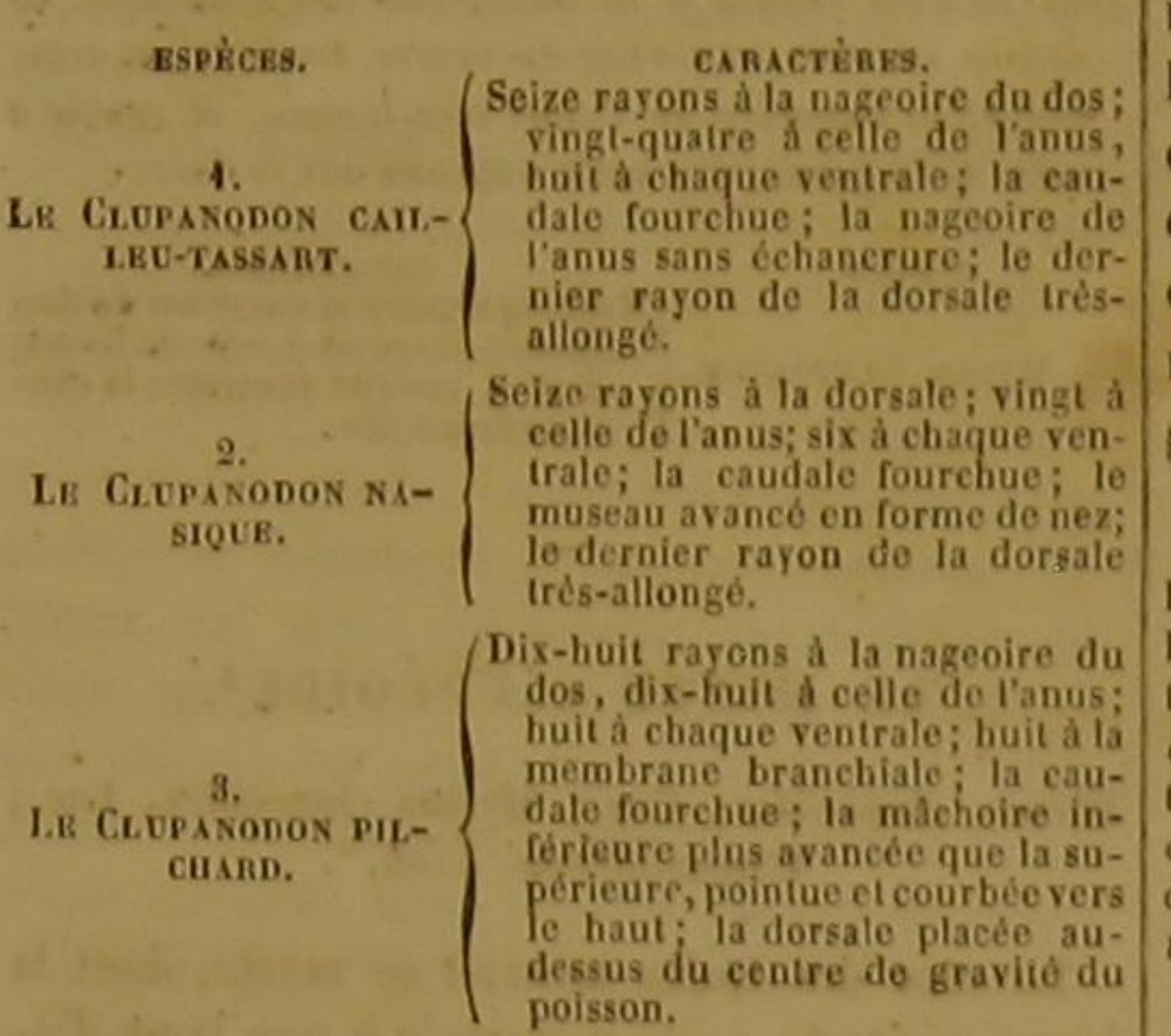

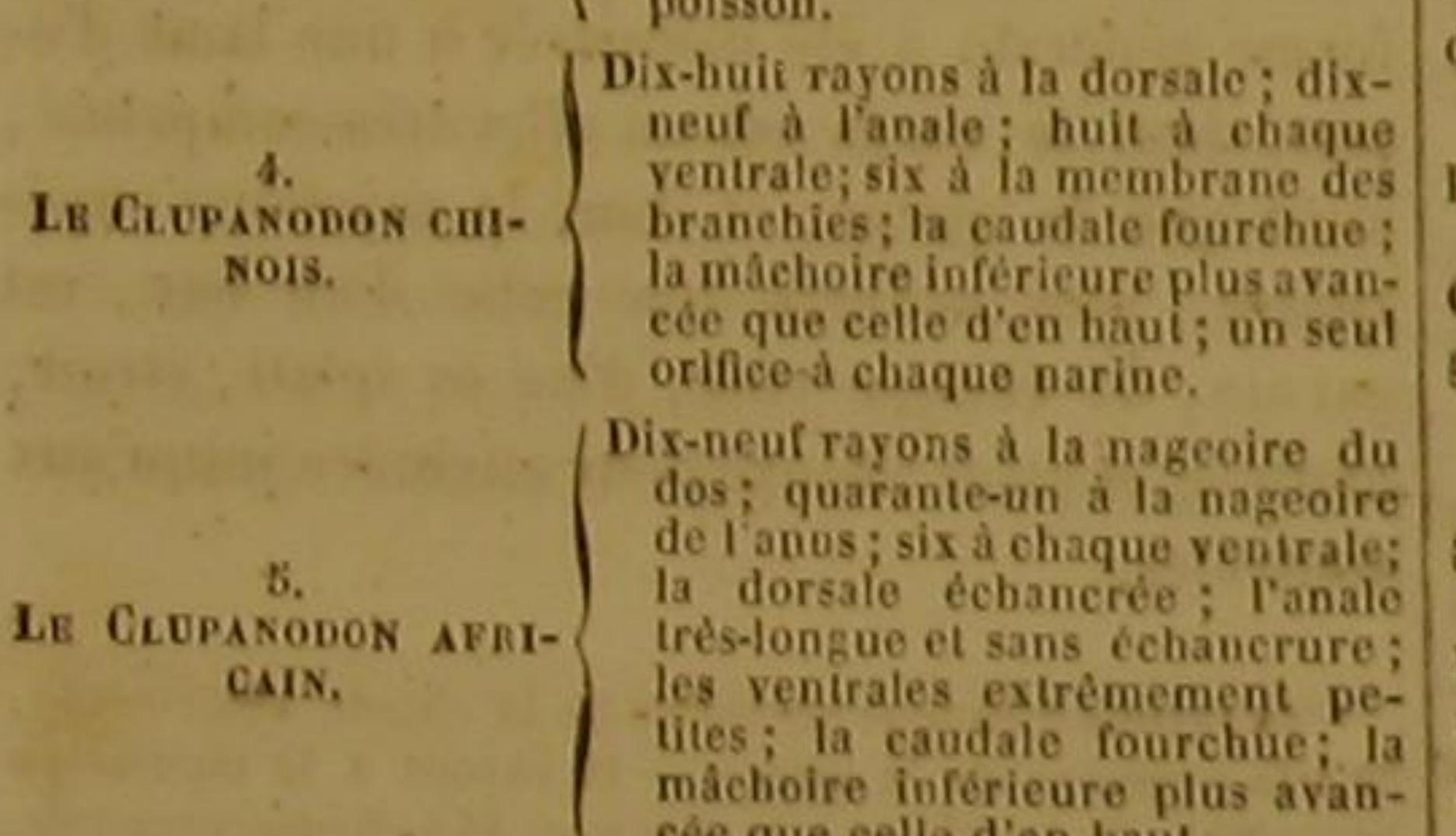

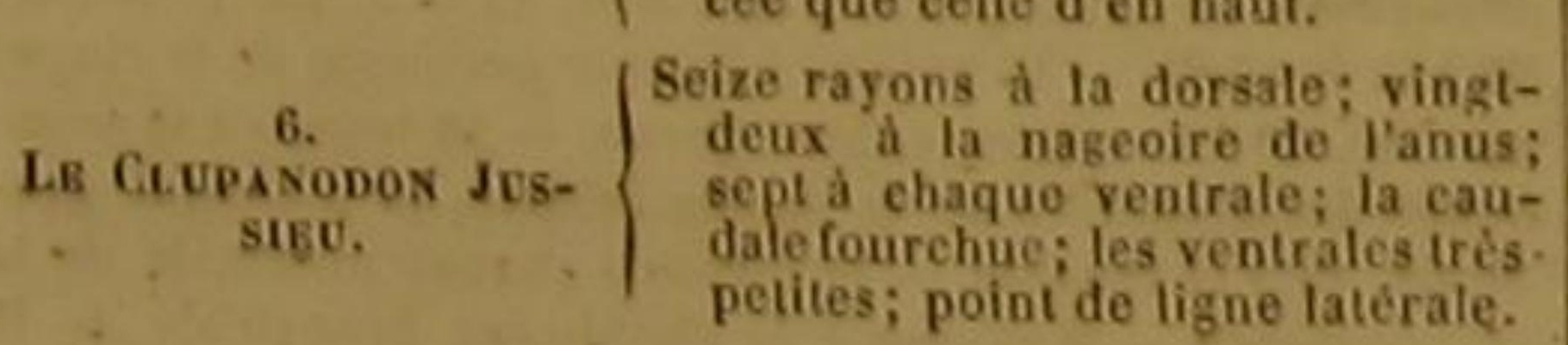
1 10 ruyons a ta membrane branchiale du myste clupéoìde, 17 à chaque peetorale, 13 à la nageoire de la queue.
3 M. Cuvier supprime le genre Clupang especes de poissons dont it se compose, partie dans lace les

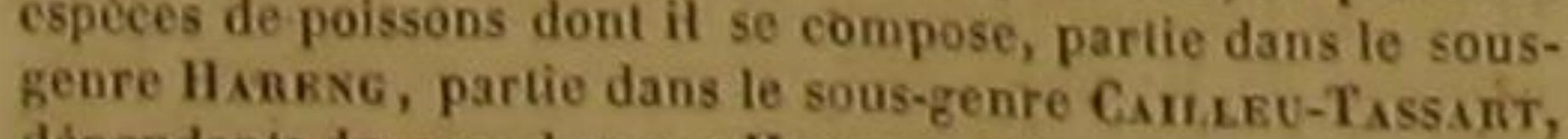
dépendants du grand genre Hanexo (Clupea), de la famille des Clopes, ordre des Malacoptérygiens abdouninaux. D.

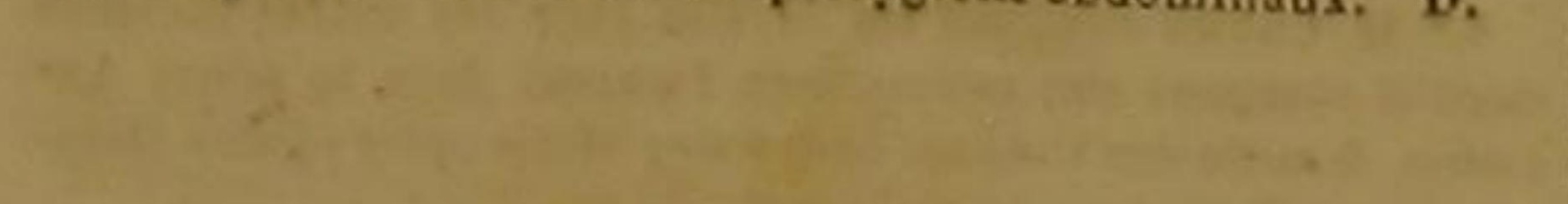

Le Clupanodon nasique ${ }^{3}$, Chatoessus Nasus, Cux.; Clupea Pilchardus Cuv., Bl., Linn., Gmel., Lac. ${ }^{6}$ - C. chinois : Alosa chinensis, Cur.; Clupea sinensis, Bl, Linn,, Gmel., Lac,; Clupanodon sinensis. Lac, 8.- - C. africain ", Alosa
Africana, Cuv.; Clupanodon africanus, Lac.; Clupea afriClupanodon Jussieu. Lac, ${ }^{12}$.

Les clupanodons ont leurs mâchoires dénuées de dents, ainsi que l'annonce leur nom générique. Il ne faut pas croire cependant que leurs habitudes soient très-différentes de celles des clupées. Presque tous ces derniers poissons ont en effet des dents très-petites. La conformation des clupanodons a d'ailleurs les plus grandes ressemblances avee celle des clupées. Ne négli-

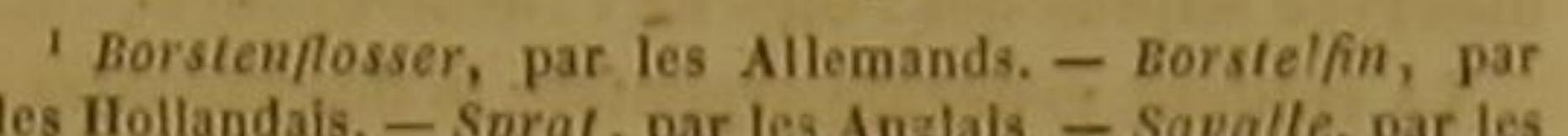
lerre, pl. de l'Ene, méth. - Bloch, pl. A0t. - Halex festucosus. Plumier, dessins el mannuscrits déposéśs à la Biblioth. 6. I, Pisces Ex Aves. - « Clupea minor, radio ultimo pinne a corpore ovato. o Amonit, acad. 5, p. 201, - Clupea

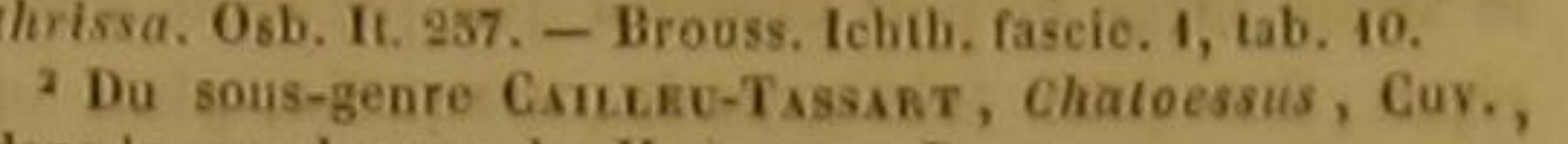

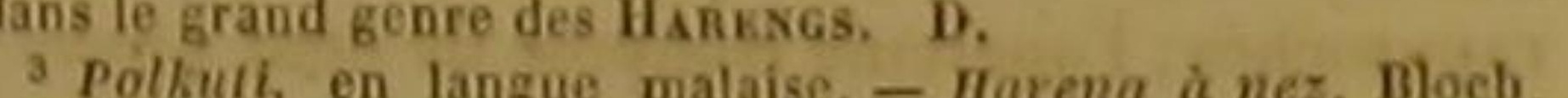
pl. 429. LLe Nasique est placé, par M. Cuvier, dans le sous-genre
Camber-TAssab, l'un de ceux qui subdivisent le grand

sclupanodon Pilchardus. Bloch, pl, 406.

Da sous-genre des HABRSGs proprement dits, dans le 'polken, Manualai, par les Malais, - Naerbleier, para ics Hollandais des Indes orientales. - Clupe-lunterg de la Chine. Daubenton et Haúy, Enc. métb. - Id. Bonnaterre, pl. de l'Enc. méth. - Bloch, pl. 405.

- Dace ce poisson dans le sons du Règne animal, M. Cuvier place ce poisson dans le sous-genre des ALosEs; mais dans que la figure donnée par M. de Lacépède, sons le remauer

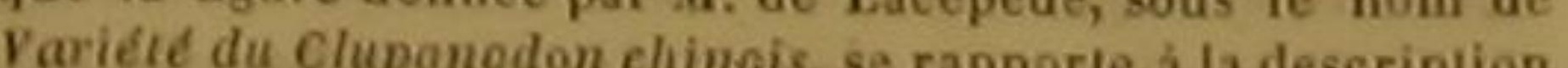
du Clupanodon Jussieu, Lac., admis par lui dans le sous-

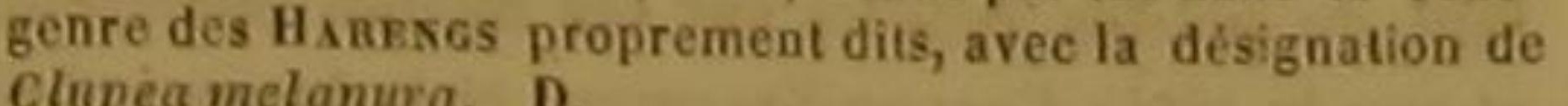
Clupea melanura. D.

Sild, par les Danois de la côte d'Afrique. - Clupea afri10. Bloch, pl. 407.

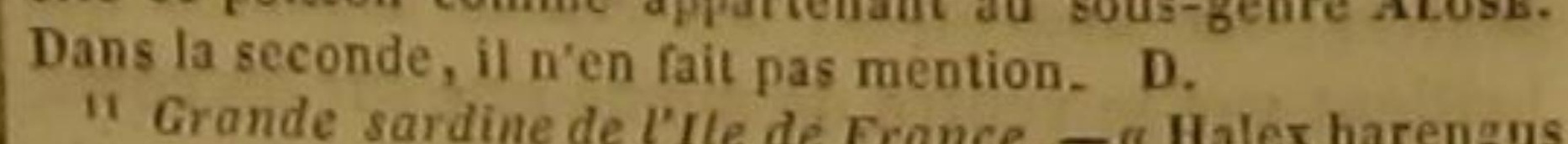
"I Grande sardine de l'Ile de France. - a Hales harengus
a immaculatus maxilla inferiore longiore, pinna dorsali, ra-

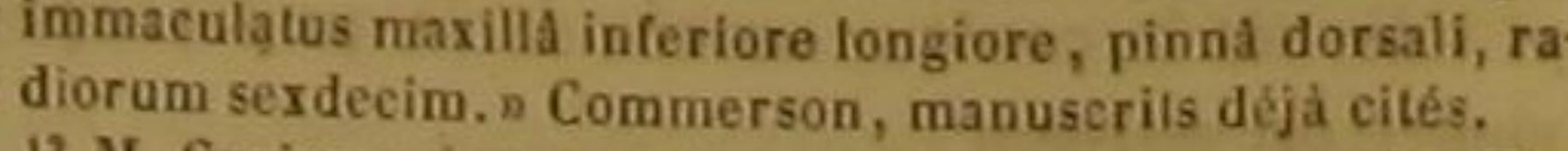
12 I. Cavier rapporte cette espéce au sous-genre des HAREKGS proprement dits, sous le nom de Clupea melamura. II figure que 31. de Lacépéde a donnée, sous la dénomination de Variéte du clupanoden chinois. B.
dous la dénomination Nasus, Bl.; Clupea nasica, Lac. $4 .-C$. Pllchard ${ }^{3}$. Clupea cana, Bloch ${ }^{10},-c$. Jussieu 11 , Clupea meladura, Cuv.; geons pas néanmoins de dire: les Hollandais. - sprat, par les Anglals - Savalte, par les a dorsalis longissimo. "Browne, Jamaie. 443. - "Clupea

cite ce poisson comme apparre édition dú Règne anima,
Que le cailleu-tassart a la tête petite et sans |leur ronte; que dus pî̀ écailles proprement dites; la mâchoire iuférieure placont sur los roùeheurs nommés Huers se courbée vers le haut, et terminée par une pointe pochers des rivages anglais pour qui remplit uno delapanodons; que qui remplit une celancrure de la màchoire su- l'approche de ces animaux est annoncée par lo périeure; le palais garni d'une membrane ridée concours des oiseaur d'eau, par la lueur phoset sans dents; la langue lisse, courte et cartila- phorique que ces poissons répandent, par l'odeur gineuse; deux orifices à chaque narine; le des- qui s'exhale de leur laite; que la pecthe de ces sous du ventre couvert d'une trentaine de lames pilchards est d'autant plus importante pour l'antransversales, Y'anus beaucoup plus éloigné de gleterre, qu'on peut en prendre plus de cent mille la gorge que de la caudale; la ligne latérale dun seul coup, et que dans une seule année on droite; les éeailles grandes, minces et fortement s'est emparé de plus d'un milliard de ces osseux; attachées; les flanes argentíns; le dos et les na. que leur chair est grasse el très-agréable; qu'on geoires bleuâtres :

Qu'il vil dans les eaux de la Chine, des Antilles, de la Jamaĩque, de la Caroline; qu'il fraic dans les fleuves; qu'il parvient à la longueur de douze ou quinze pouces; que sa chair est grasse et agréable au goôt; mais que, dans cerlains parages, la natare de ses aliments peut lui donne des qualités funestes :

Que le nasigue a les deux mâchoires également avancées; un seul orifice à chaque narine la tête couverte de grandes lames; les écailles épaisses; la ligne latérale droite et descendante; le dos bleu; la couleur générale argentée; une longueur de liuit à douze pouces; une ehair remplie de petites arêtes et quelquefois malsaine; la côte de Malabar pour patrie, et I'habitude de se tenir auprès des embouchures de rivières :

Que le pilchard, pris mal à propos pour une variété du hareng, montre uno tête sans petites écailles; une fosselte allongée sur le sommet de cette partie; un palais lisse; une langue large, mince et unie; un seul orifice à chaque nárine; des opercules rayonnés; une ligne latérale droite un appendice étroit et pointu auprès de chaque ventrale; des écailles larges; un péritoine endui d'une viscosité noirâtre; un canal intestinal sans sinuosités; un estomac composé d'une membrane épaisse ; plusieurs cecums auprès du pylore; une vessie natatoire longue et salis division; des reflets argentins sur presque toute 'sa surface; des teintes bleues sur le dos ainsi que sur plusieurs nageoires; une longueur de douze ou quinze pouces :

Que les clupanodons pilchards arrivent en grandes troupes près des côtes de Cornwallis au commencement de juillet, disparaissent en automne, et se remontrent vers la fin de décembre; que les très-grands froids retardent quelquefois opercules très-resplendissants, striés, et comleur retour; que les orages les détournent de posés de trois pièces; le dessus de la tête ciselé; 


\section{IIISTOIHE NATURELLE}

a mûchoire inféricure plus avancée que celle empêchent de le confendre avee les salmones, d'en lraut; la langue molle et très-courte; les L'éclat de l'argent qui lirille sur sa surface est pectorales reçues, pendant leur repos, dans une, relevé par des teintes d'un bleu d'acier. Ses mà. sorte de fosselte; la base de la dorsale située choires sont garnies de dents; l'inférieure avance dans un sillon longitudinal formé par deux au delà de la supérieure. L'ouverture de sa séries d'écailles; de petites écailles placées sur houche est grande, ainsi que l'orifice liranehial; la base dẹ la caudale; vingt-cinq côtes fortes et les écailles sont larges; la langue est blanche, très-longues, de cliaque côté de l'épine du dos, unie el épaisse; les opercules sont unis; la predaus laquelle on comple cinquante-quatre ver- mière dorsale est plus éloignée de la tête que le tèbres ' -2 .

DEUX CENT DIXIÈME GENRE. LES SERPES ${ }^{3}$.

La tete, le corps et la queure très-comprimés; la partie inferieure de l'animal terminee en dessous par une nayeoires dorsales ; les ventrales extrenement deux

EsPÈcrs.

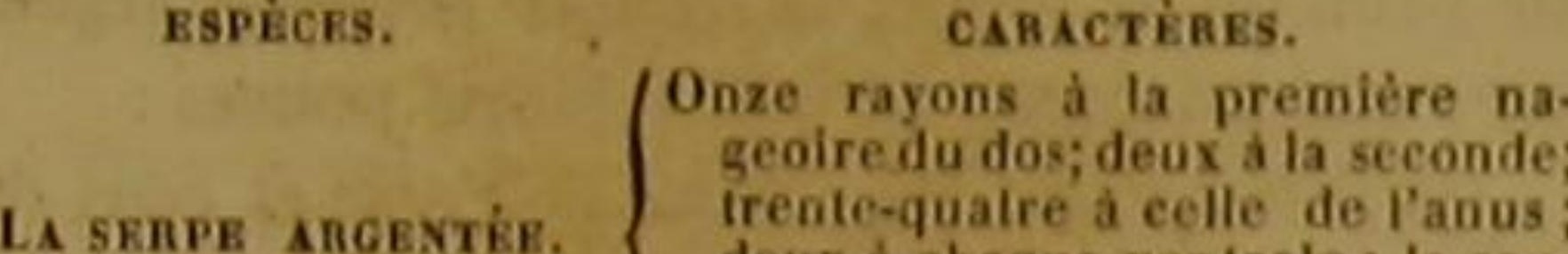

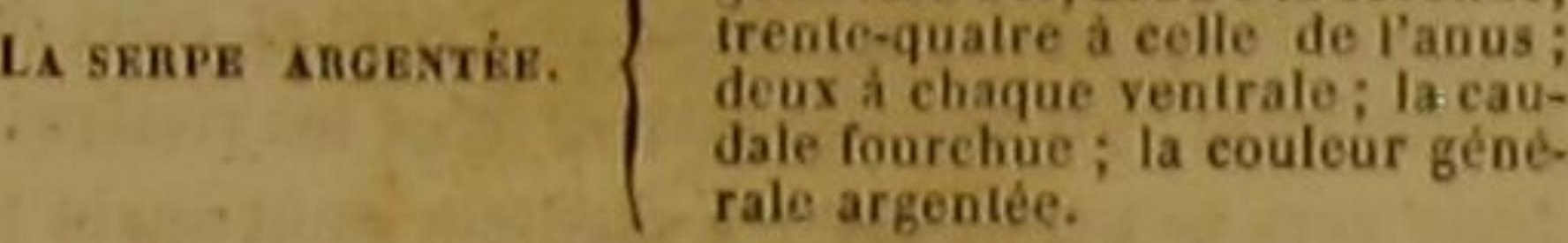

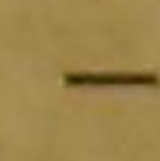

LA SERPE ARGENTÉE:

Gasteropelecus sternicla, Bloch., Cuv.; Gasteropeleru argenteus, Lac.; Salmo gasteropelecus, Linn., Gmel. ${ }^{5}$.

Nous pensons, avec Bloch, devoir séparer ce poisson des clupées et des salmones, et l'inserire dans un genre particulier. Indépendamment d'autres trails de dissemblance, ses deux nageoires dorsales l'écartent des clupées; et les rayons de la seconde de ces deux nageoires 13 rayons a chaque pectorale du clupanodon cailleu-assarl, 24 a la nageoire de la queue, -4 rayons à la membrane 20 a la caudale. -17 rayons a chaque pectorale da clupanodon pilchard, 22 a la nageoire de la queue. - 13 rayons a
chaque peclorale du clupanodon chinois, 22 a la caudale chaque pectorale du clupanodon chinois, 22 à la caudale. -
16 rayons à chaque pectorale du clupanodon jussieu, 24 d ta nageoire de la quene.

${ }^{2}$ Cette description da clopinodon Jasieu se raporas

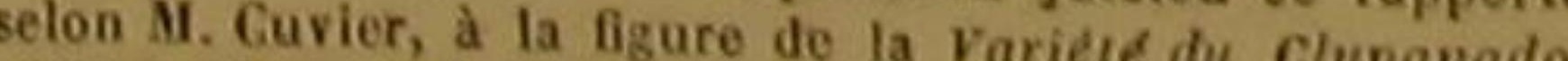
chinois, Lac, I. V, pl. 11, fig. 3, edit. Int. D. D.

3.5 LFs SRrpes (Gasteropelecus, B1.) forment, selon

des Mal copléryg-geure dans le grand genre SAUMos, ordre

'Salmone siernicle. Daubenton et Haüy. Falmones. D

1d. Bonnaterre; pl. de l'Enc, mélb. - a Clupea sima, pinnis

"Alavis, ventrafibus minutissimis; et clupea sternicla, pinnis

« ventralibus nullis, $)$ Lin. System. natura, ed. 12, 1, p. 524 ,

n. 7 et n. 8.-Pallas, Spieileg. zool. 8, p. 50, tab. 3, fig. 4-5.
- Kotreuter, Nov, Comment. Petrop.

fik. 1-3. - Serpe, Gesteropelecis stop. 8, p. 405, tab. 14,

fi. 3. - Gasteropelecus. Gronov. Mus. 2, p. 7, n. 155, ab.
7, fig.

DES POISSONS. commencement de l'anale; un os extrêmement miuce, tranchant, couvert d'écailles, et courhé en are comme une serpe, s'étend depuis la gorge jusqu'à I'anus ; les pectorales ont la forme d'une

\section{LA MÉNÉ ANNE-CAROLINE.}

Mene Anna-Carolina, Lac., Cuv. '.

Cetle belle espèce do poisson devait être placée dans un genre particulier. Elle est encore inconnue des naturalistes, J'en ai trouvé une image faite avec beaucoup de soin, daus la collection des peintures chinoises cédées à la France par la Hollande. Je la dédie à la compagne qui m'est si chère, et dont les vertus et le mallieur sont dignes d'un si grand intérêt ? faucille; leur couleur est grise comme celle des autres nageoires.

La serpe argentée a été pêchée dans les eaux de Surinam et dans celles de la Caroline; sa longueur est inférieure à celle d'un décimètre. Elle so maintiendrait très-difficilement en équilibre et nagerait avec peine, à cause de la grande compression de son corps et de l'étendue que présente chacune de ses faces latérales, si les effets de cette conformation n'étaient pas un peu compensés par la longueur des peetorales, qui peuvent lui servir de balanciers ' ${ }^{\prime}$ el de rames auxiliaires ${ }^{2}$.

\section{DEUX CENT ONZIĖME GENRE.} LES MÉNÉS ${ }^{3}$

téte, le corps et la queue tres-comprimes; la partie inferienre de l'animal termince par une carène aigue, courbée en demi-cercle; le dos relevé de manière que chaque face laterale du poisson représente un disque; the seule nageoire du dos; cette dorsale, el surtout Fanale, très-basses el très-longues; les ventrates troites et très-allongée.

ESPÈces.

LA MÉNÉ ANXE-Cano-
LANE.

I Voycz ce que nous avons dit de la nalation des poissons dans notre Discours sur la nature de ces animaux.
23 rayons a la membrane des branchies de la serpe argen. is 3 rayons à la membrane des branchies de la serpe argen3es Mténés de Lacépéde forment, pour $M$. Cuvier,
${ }^{3}$ a a

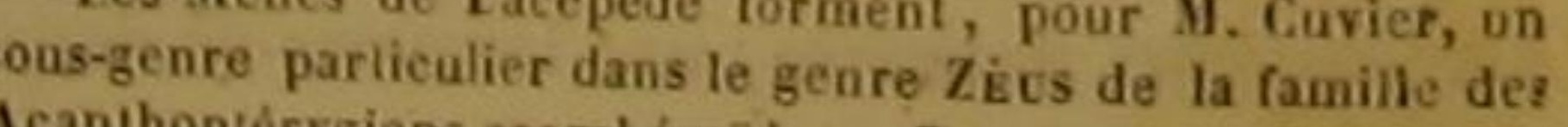
Acanthoptérygiens scombéroîdes. D taches mollement terminées et d'un violet foncé; les nageoires ont une teinte d'un vert léger. Les pectorales sont grandes, comme pour compenser par lear étendue les effets de l'extrême compression de l'animal sur sa natation ${ }^{3}$. La dorsale est triangulaire: elle comprend, ainsi que I'anale, un très-grand nombre de rayons. Les os de la lèvre supérieure sont larges. L'iris et la prunelle représentent un cercle d'argent autour d'un saphir.

Lorsqu'on regarde le disque formé par l'un ou l'autre côté de la méné que nous décrivons, on trouve une sorte d'analogie entre ce disque et celui de la lune presque plein ; analogie que nous avons voulu indiquer par le nom génériqu de ce poisson ${ }^{4}$.
La méné Anne-Caroline brille d'un éclat doux

LE DORSUAIRE NOIRATRE!

Dorsuarius nigrescens, Lacep. ?

Commerson a laissé dans ses manuscrits une courte description de ce poisson, qui a été vu auprès du fort Dauphin de Madagasear.

Ce dorsuaire a la partie supérieure relevée comme les ménés, de même que les serpes ont leur partie inférieure étendue vers le bas. II est aussi, parmi les abdominaux, ranalogue du kurte des jugulaires. Aucune tache, ancune congur ordinaire est d'un flets verdâtres, rendus plus agréables par des pied ou quioze pouces.
DEUX CENT DOUZIÉME GENRE.

LES DORSUARES ${ }^{5}$,

La partie anterieure du dos relevele en une bosse trèscomprimee, et terminee dans le haut par une carene wès-aigué; une seule dorsale.

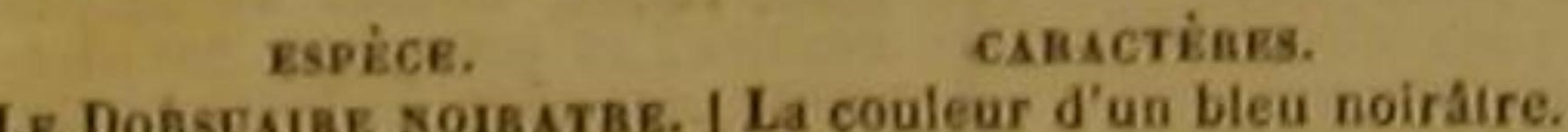

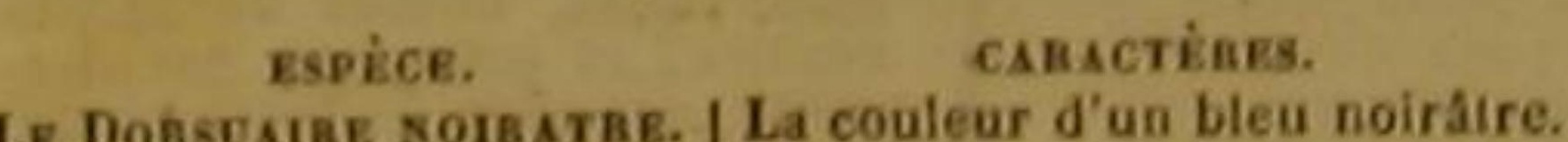
I Voyez la note a de la page précédente. D. ${ }_{2}^{2}$ Voycz les articles du Mugilomore anne-caroline, et du Cyprin anne-caroline. Voyez dacs lat Blseours sur la nature des poissons, noo iées sur ta nalakion de ces animaux.

5 Le gente DossdaIRE, selon M. Cuvier, ne diffère pas du genre Kyphose de Lacépéde, el pourrait bien aussi etre méme que le XYstikas (royez ci-apress). M. Cuvier consider de plus tous ces genres comme se rapportant à un quatrién des PIMELEPTĖREs, famille des Acanthoptérygiens squämm pennes. D.

\section{DEUX CENT TREIZIÈME GENRE.}

LES XYSTĖMES ${ }^{3}$

La tele, le corps el la queue tres-comprinds; le dos dleve, arience, conme le venire, par une carene aigue el courbee en periton de cercie; sepr rayons a la mem-

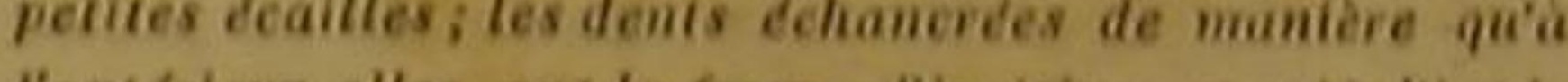
Fexierieur elles on la forme d'incisives el qu'a linte. fieur elles sont basses at un peu renfless; the fosselte aul dessous de chaque ventrale.

Еspìck.

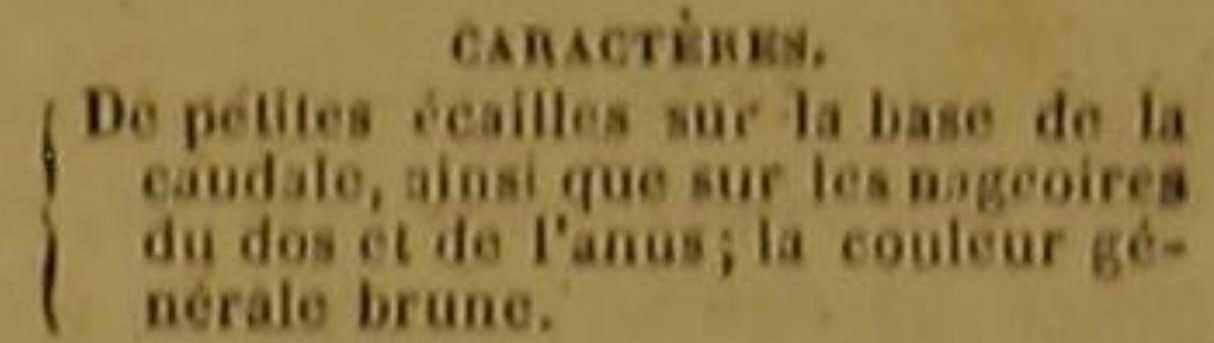

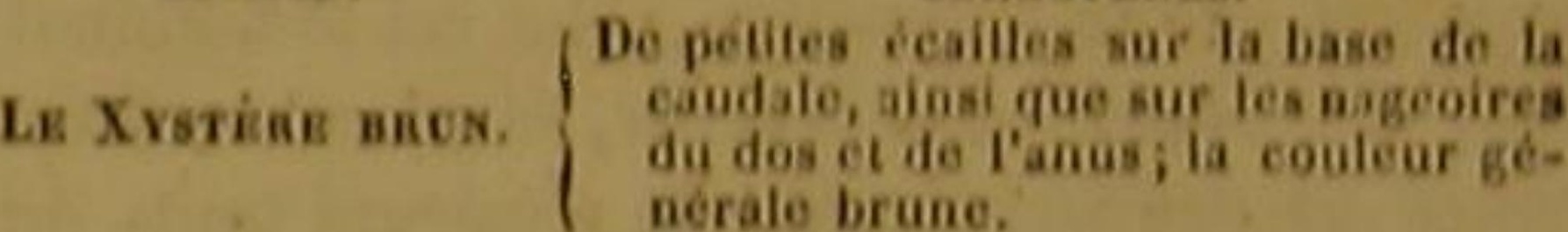

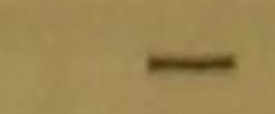

LE XYSTERE BRUN".

Xyster fuscus, Lac. ".

Ce poisson , observé et décrit par Commerson, parvient à la longueur de quinze à dix-huit

' u Dorsuarius tubero, novissimum genus, cyprino pro-

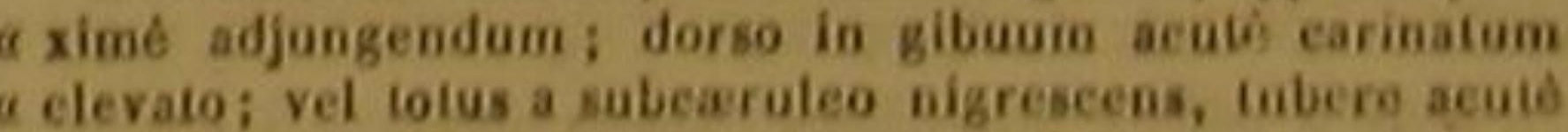

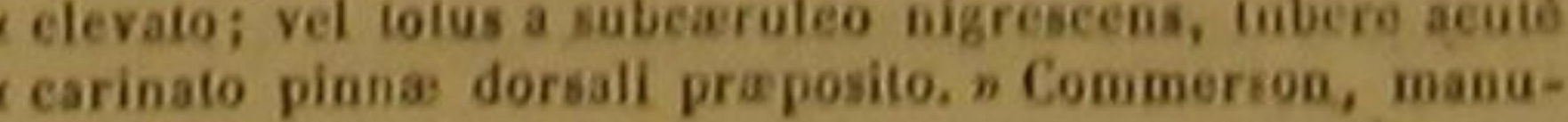
serits deja ciles.

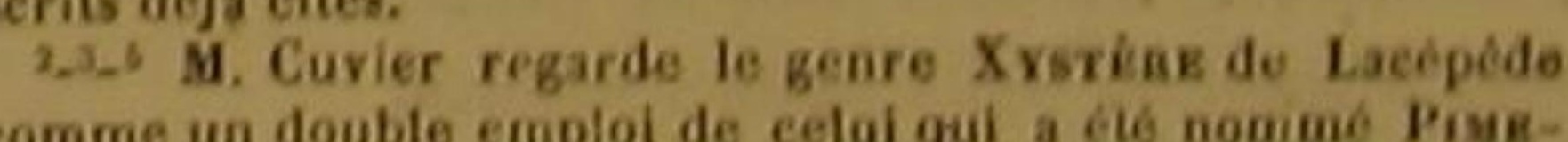
LEptika par le méme naiuraliste, et il crofit aussi quit ne différe pas de ceux que M. de Lacépède a désigués sous les

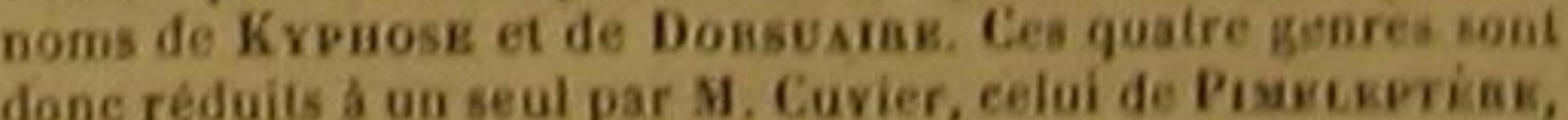
placé par lui dans la famille des Acanthoplerygiens rquasimipenses. $\mathbf{D}$.

Cousepar. - a Xyster, novissimam genus, cui pro chaa ractere, dentes ad angulum rectum infracli, a parte exa tail sessiles, acutiores, subulati; pinas ventrales iin fossula o subventrali deitescentes; corpus caputque squamosa; « membrana branchiostega seplem rad orum : eyprinis subbrame branchiale; la tete a les opercules garmis de a jungendum. $D$ - a Xysier tolus fuscus, $\boldsymbol{D}$ Commison, ma- 
pouces. Ses nuances brunes ne sont relevées par aucune autre couleur. Les deux mâchoires sont presque aussi avancées l'une que l'autre, et arroudies par devant. L'animal peut étendre et retirer la lèvere d'en haut. La langue est courte, très-large, et à demi cartilagineuse. on voit deux orifices à chaque narine.

\section{DEUX CENT QUATORZIĖME GENRE.} LES CYPRINODONS'.

La lete, le corps el la queue ayant un peu la forme d'un ovorle; trois rayons a la membrane des branchies; des dents aux machoires.

RsPĖer.

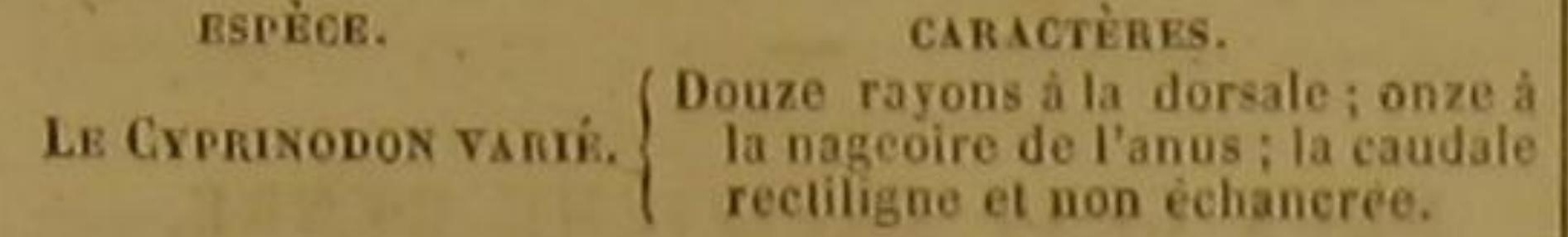

LE CYPRINODON VARIÉ2.

Cyprinodon variegatus, Lac., Cuv.

Notre confrère M. Bose, qui a va ce poisson à la Caroline, l'a décrit sous le nom de Cyprix varié, dans les notes manuscrites qu'il a bien voulu nous communiquer. Mais nous pensons, avec cet habile naturaliste, que cet abdominal doit être séparé des cyprins, et placé dans un genre particulier, à cause de plusieurs traits de sa conformation, et notamment des dents que l'on voit à ses mâchoires.

Le cyprinodou varié a l'ouverture de la bouch très-petite; la màehoire d'en bas plus avancé que la supérieure; les dents très-courtes; les opercules arrondis; une ligue latérale à pein visible; le corps et la queue revêtus d'écailles larges, argentines, légèrement pointillées; des taches brunes, irrégulières, très-variables, quelquefois à peine sensibles, mais tendant à former des bandes transversales et partagées souvent vers le haut en deux petites bandes.

Son iris est doré; ses dimensions sont trèspetites; sa longueur n'égale pas quatre pouces.
On le trouve très-fréquemment dons la bae do On le trouve
Charleston ${ }^{3}$.

'Ce genre est admis par M. Cuvier dans la famille des
Cyprinoides, ordre des Malacopterygiens obdoming 2 a Cyprinus variegatus. v- - Cyprinus cauda indivis

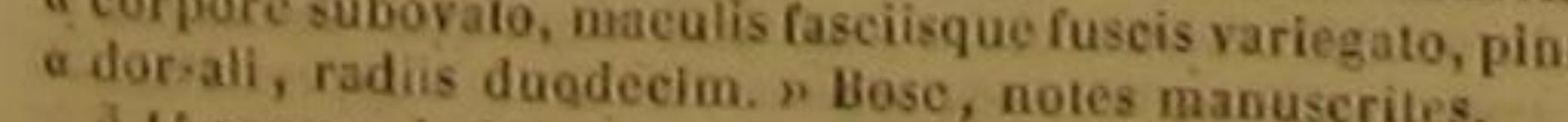
14 rayons à chaque pectorale du eyprinodon varié,
chaque ventrale, 20 i la nageoire de la queue.
DEUX CENT QUINZIÈME GENRE.

LES CXPRINS '.

Quatre rayons au plus à la membrane des branchies; poin.

PREMIER SOUS-GENRE

Quatre barbiltons aux machoires. RSPĖces. CARActínes.

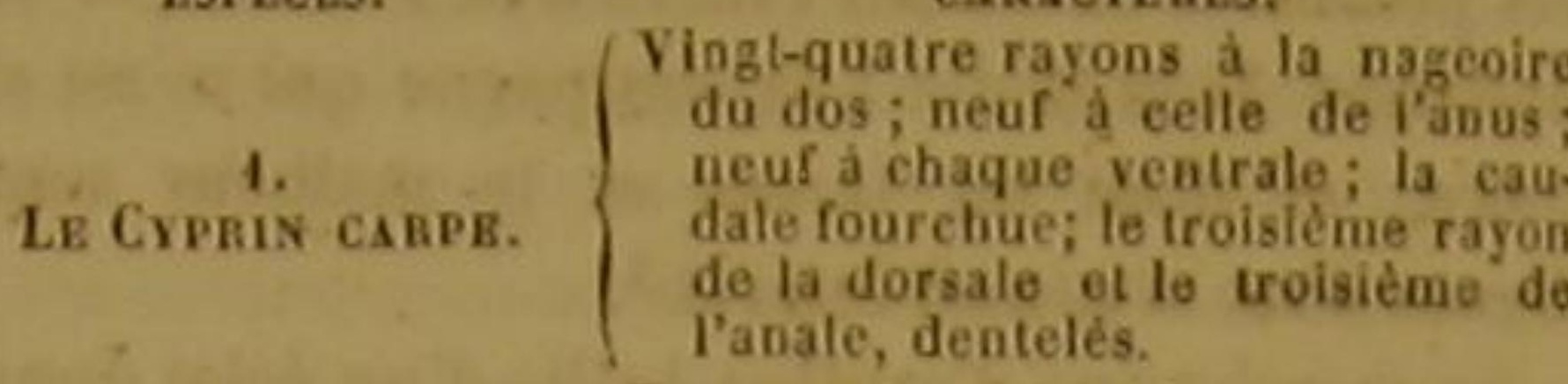
$\left\{\begin{array}{l}\text { Duze rayons a la dorsale; hoit } \\ \text { l'anale neuf a chaque ventrale } \\ \text { le troisiéme rayon de la nageoir }\end{array}\right.$

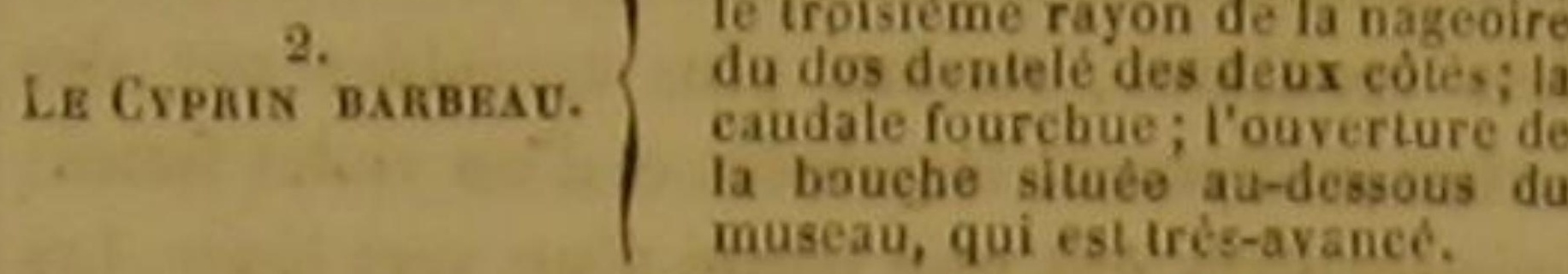
Vingl rayons a la nageoire du dos;

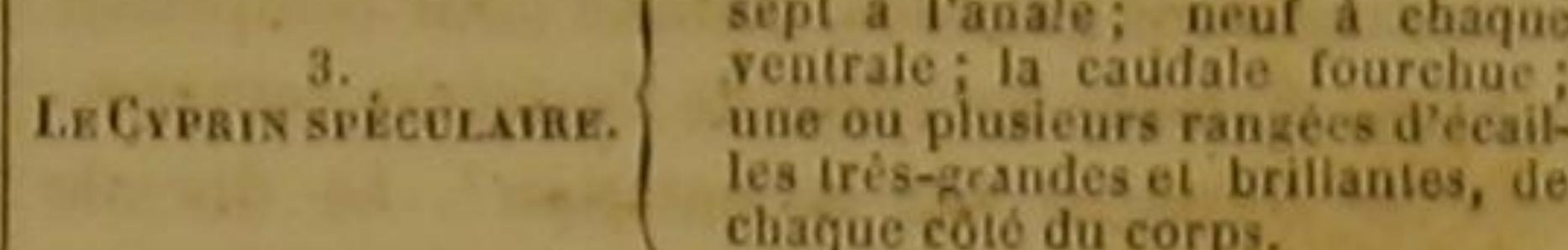
Le Crmí a coin. $\left\{\begin{array}{l}\text { La peau coriace, et entiérement } \\ \text { denuce d'ceailles facilement vi- } \\ \text { sibles. }\end{array}\right.$

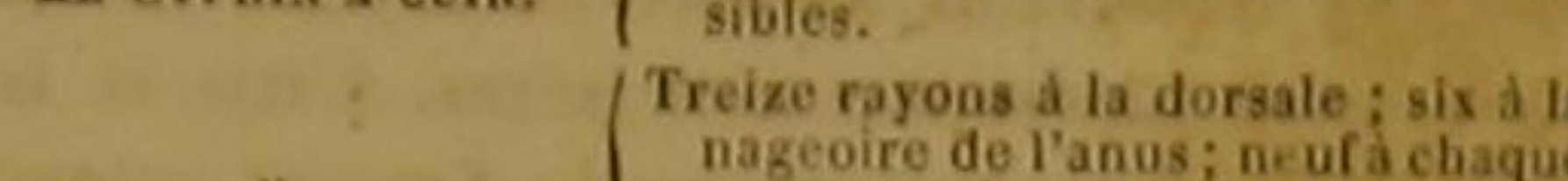

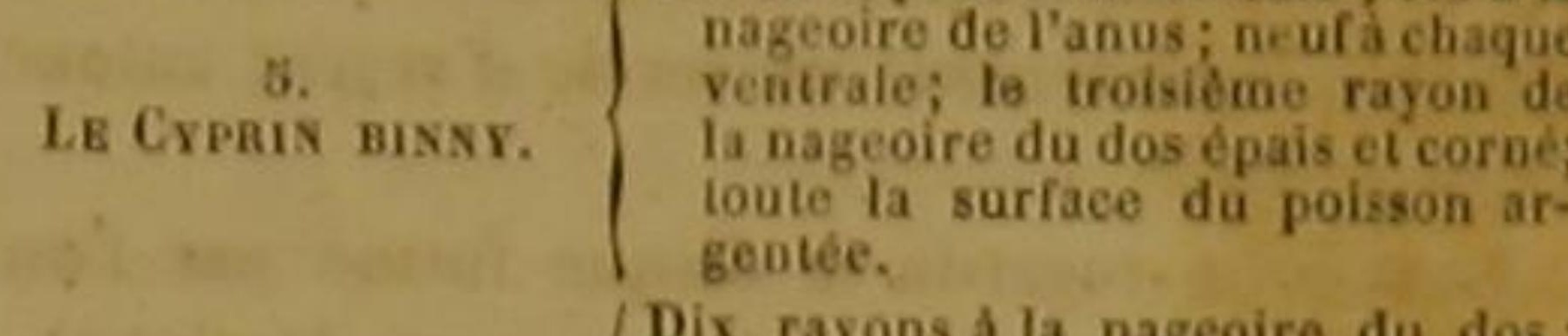

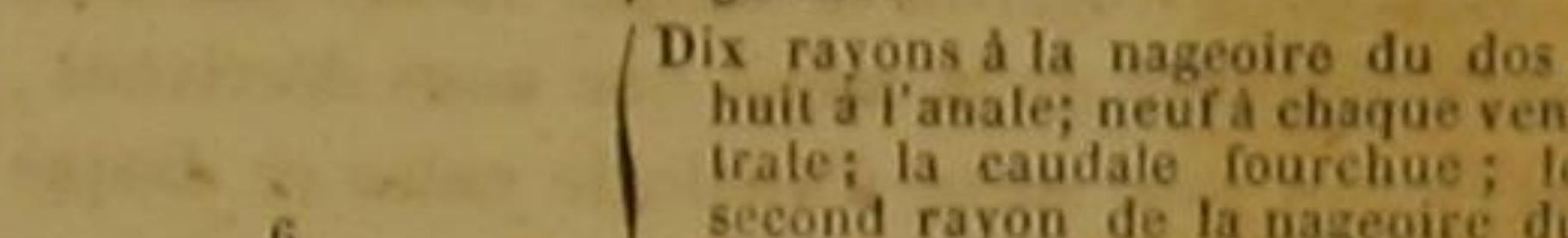

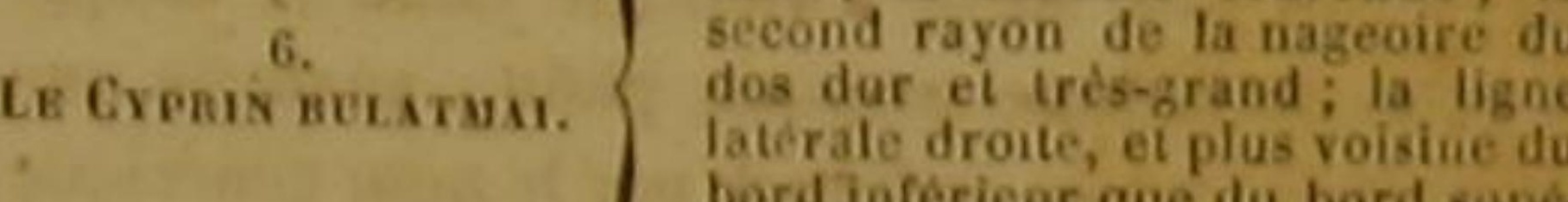
bord infériear que du bord supé
rieur de lanimal i la couleur gé-
nérate mélée d' or el d'argent.

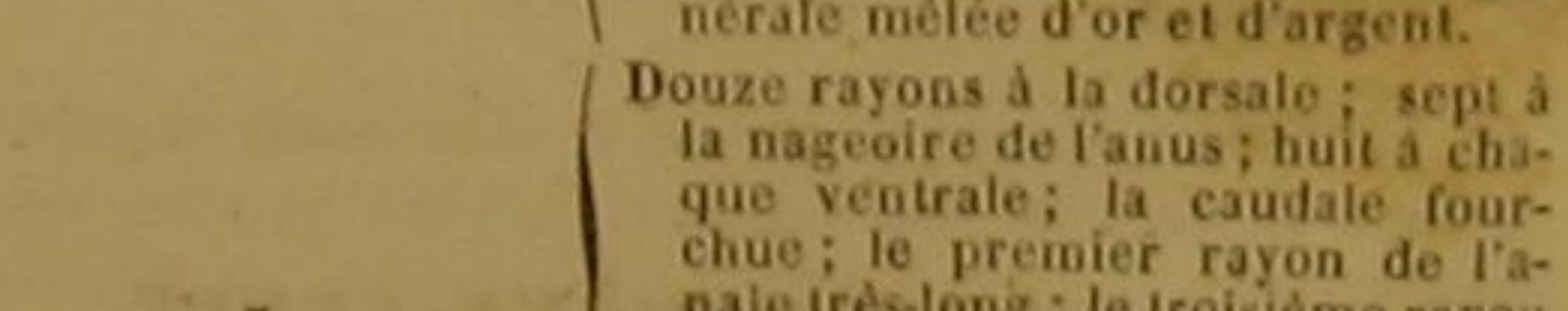
LR Crení Munse. nale irés-long; le iroisième rayou
de ta dorsale ir's-long, trés-cipais de la dorsale trés-long, trés-épais,
et dentele par derriêre dans la moitie de sa longueur; las ligne
laterale droite, el egalement eloignee du bord supériear el du
bord inferieur de l'animal.

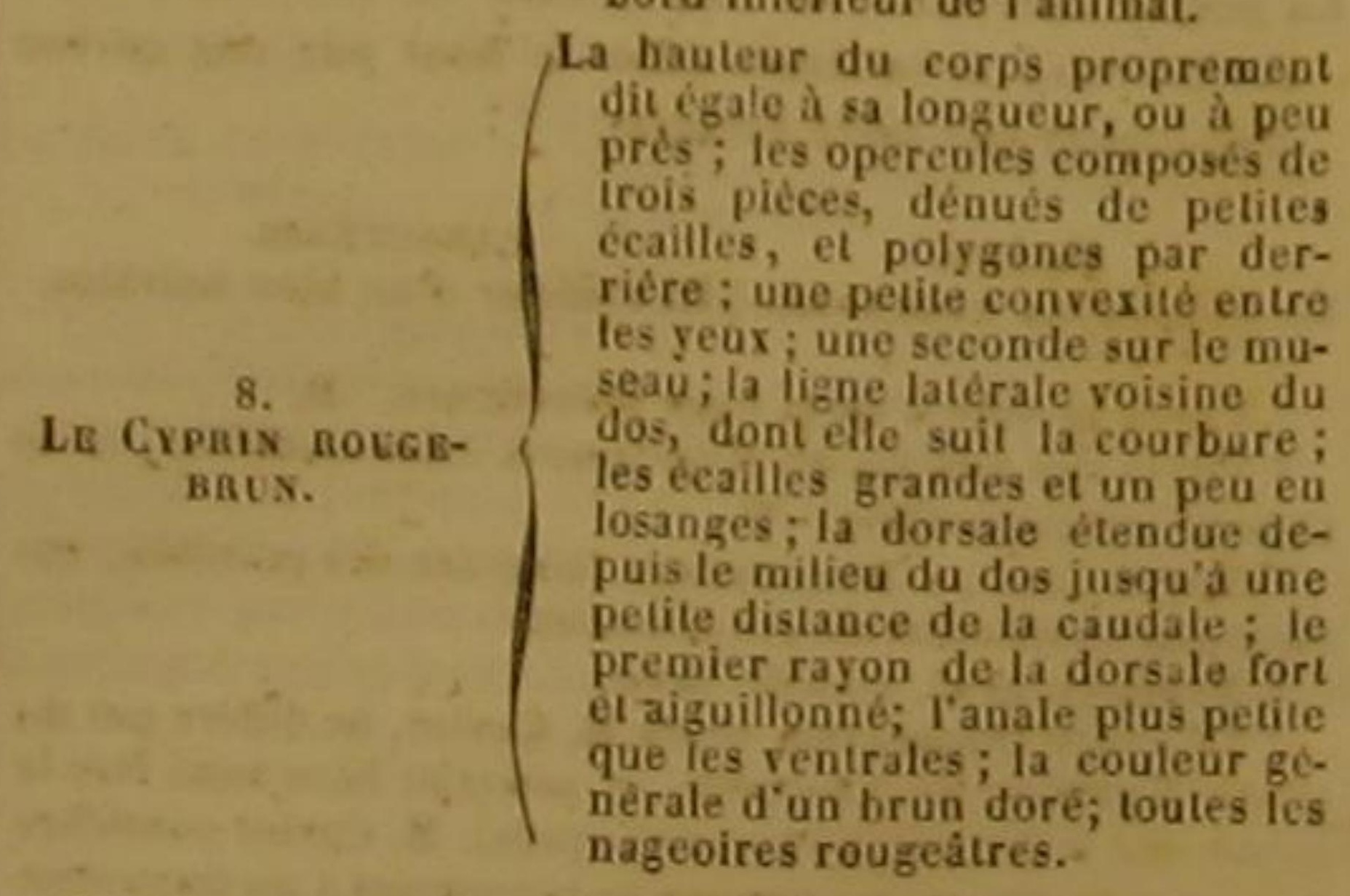

1 U. Cavier conserye le genre Crpar dans la famille des divise en plusieurs sous-gantétérygiens abdominaux. II le

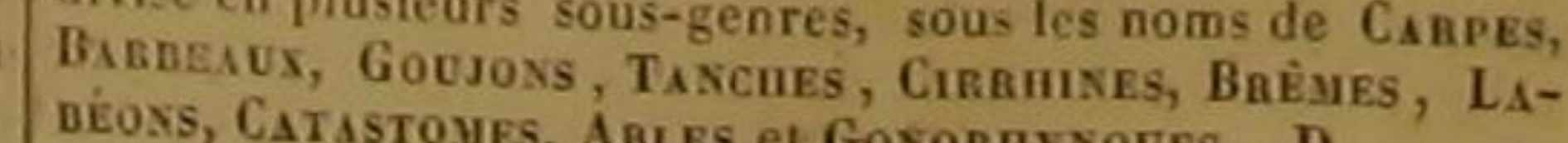

DES POISSONS

563

ARactènes.

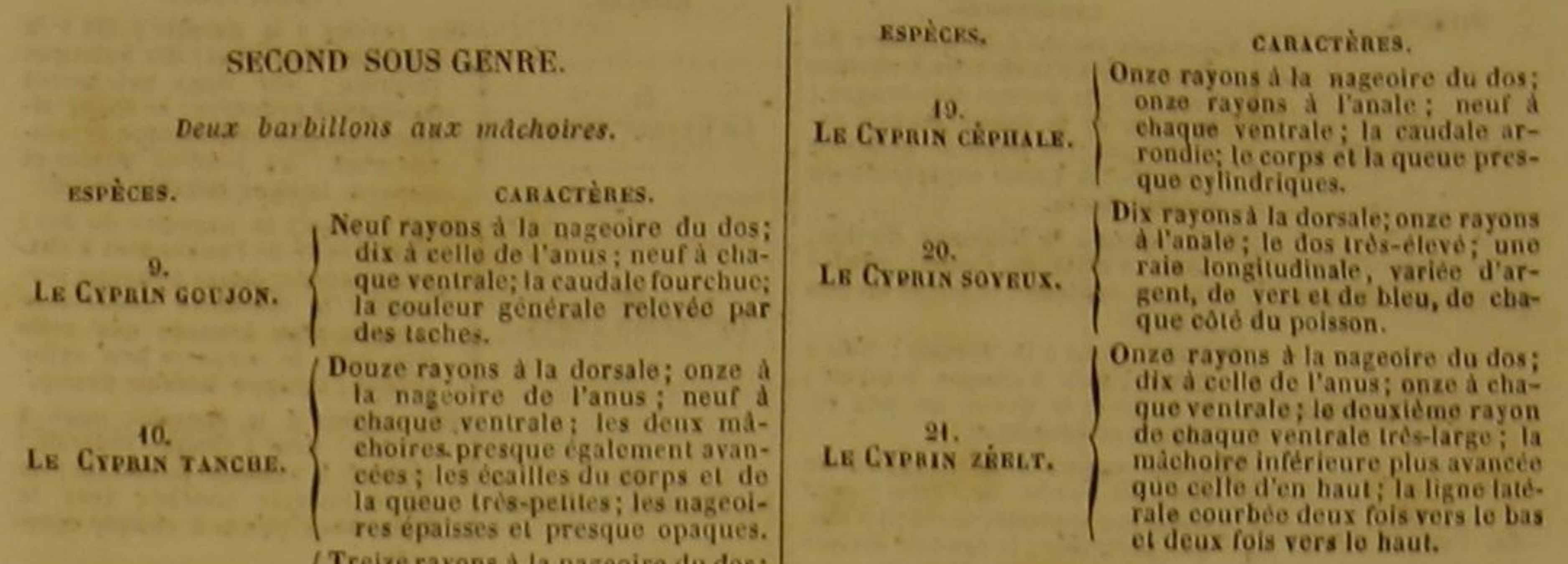

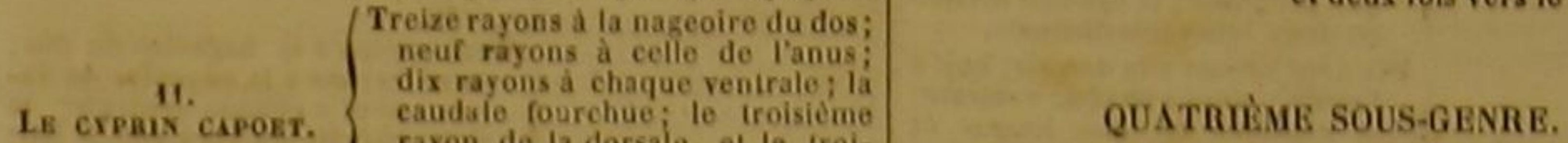

Poin de barbillons; la nageoire de ta queue fourchue ou echancrée en croissant.

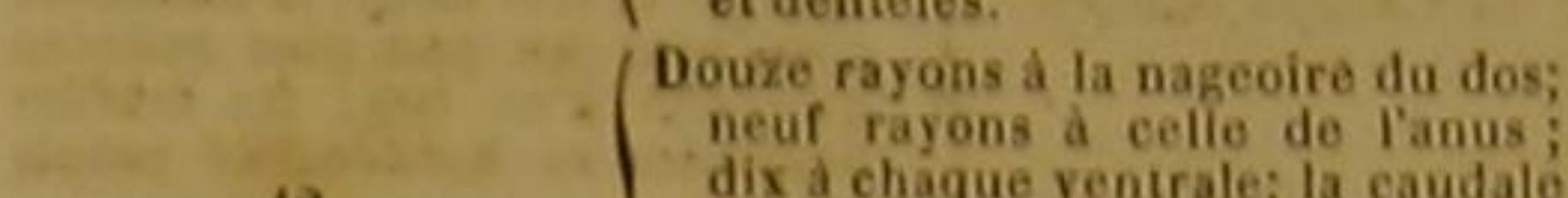
dix a chaque ventrale; la caudale
sans echanerure; les ceailles trós-

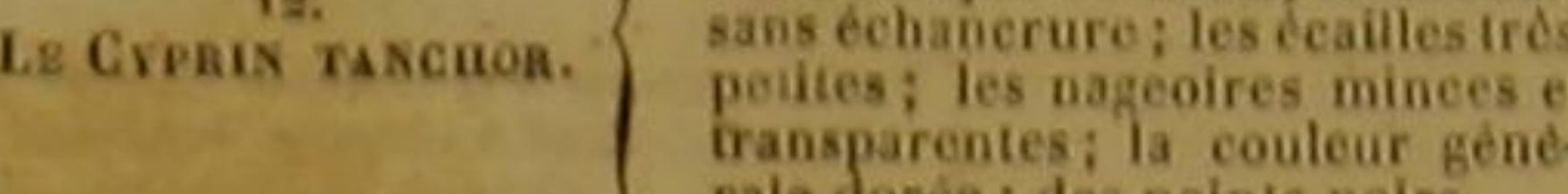

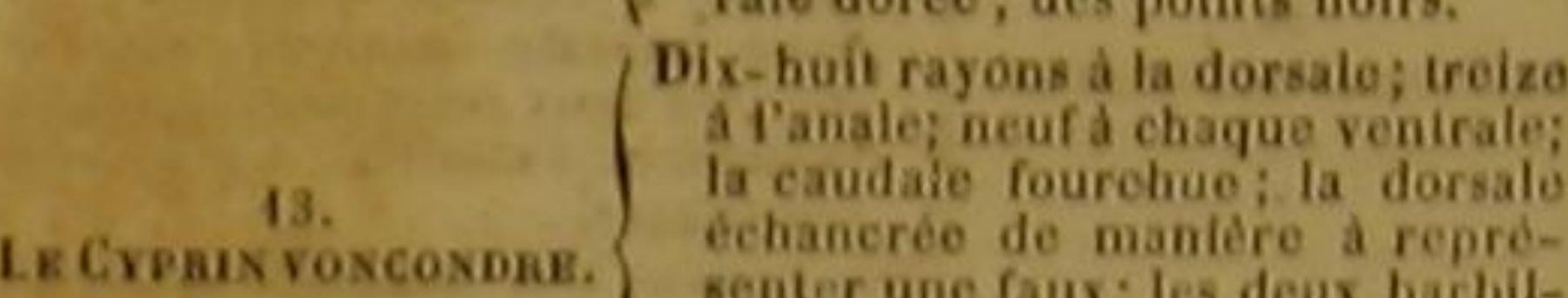

$\mid \begin{aligned} & \text { Vingt rayons a la nageoire du dos; } \\ & \text { neuf \& Vanale : neuf a chaque } \\ & \text { now }\end{aligned}$

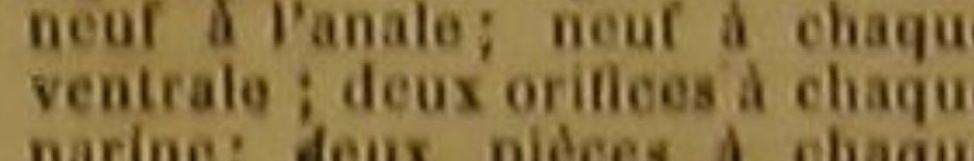
senter une faux; les deux barbi-
lons places au bout du museau
un seulorifee a chaque nurine, $\left\{\begin{array}{c}\text { La caudale sans échancruro: is } \\ \text { madchoire inferieure un peu plas } \\ \text { avancéo que celle d'en haut }\end{array}\right.$

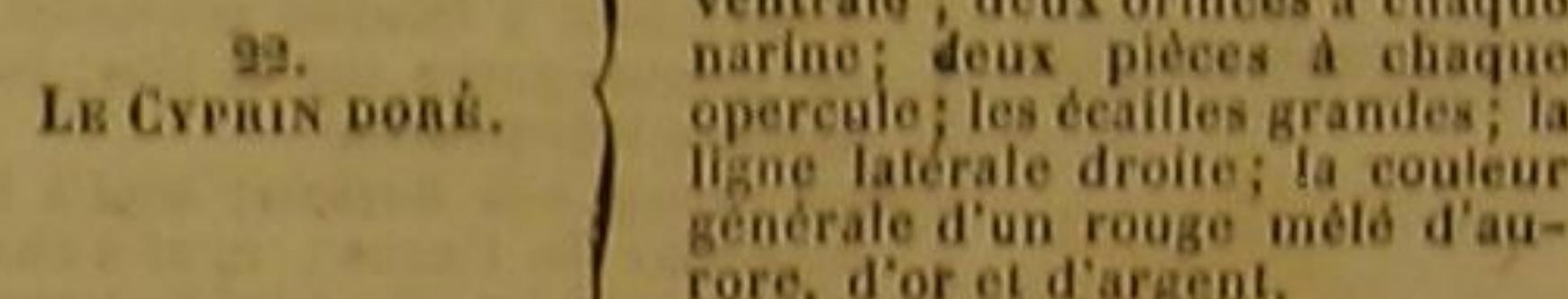

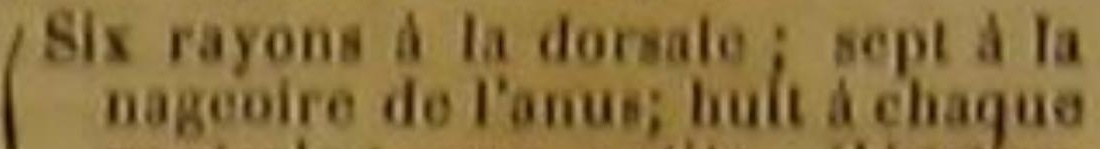
loutes los nageoires peutes e

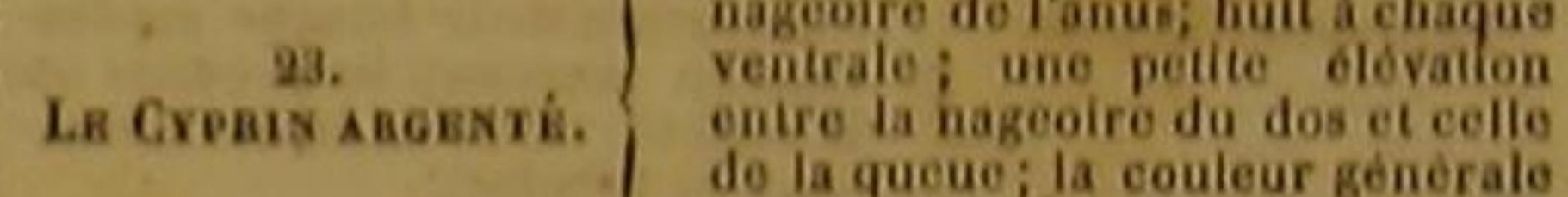

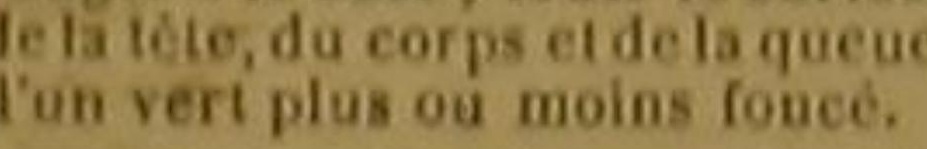

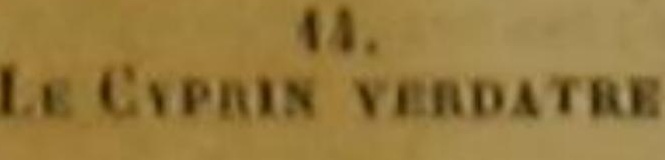
dun veri plus ou moins fouce.
Dineuf rayons a la nageolre do

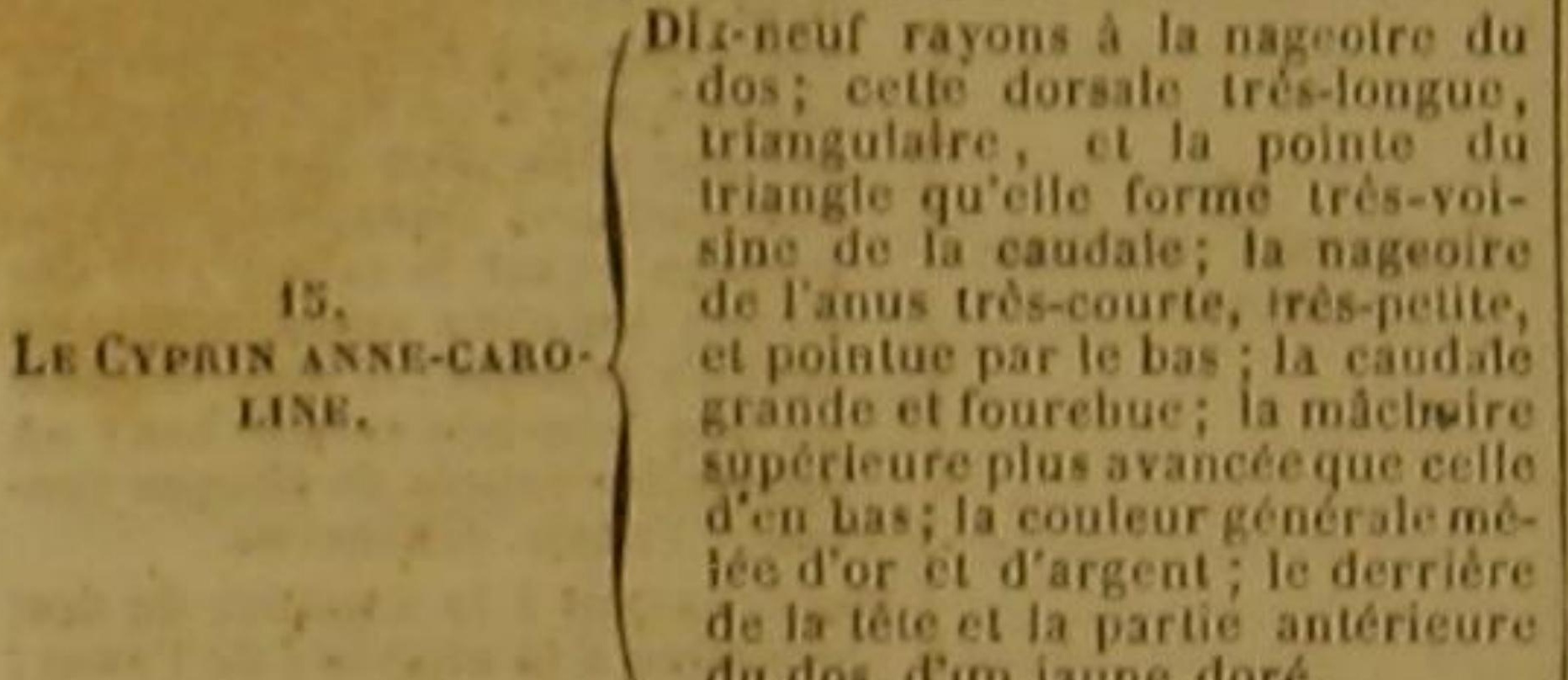

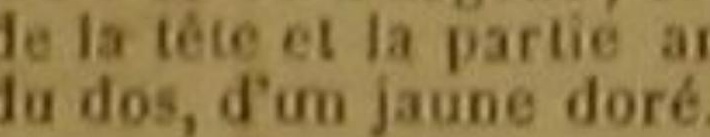

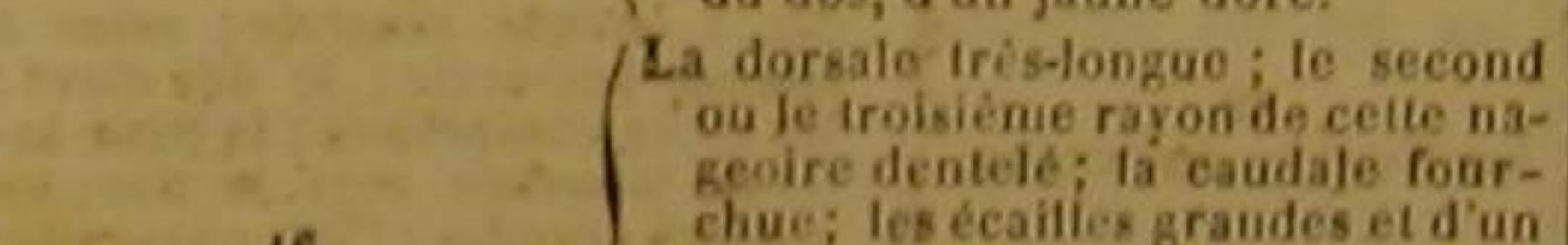

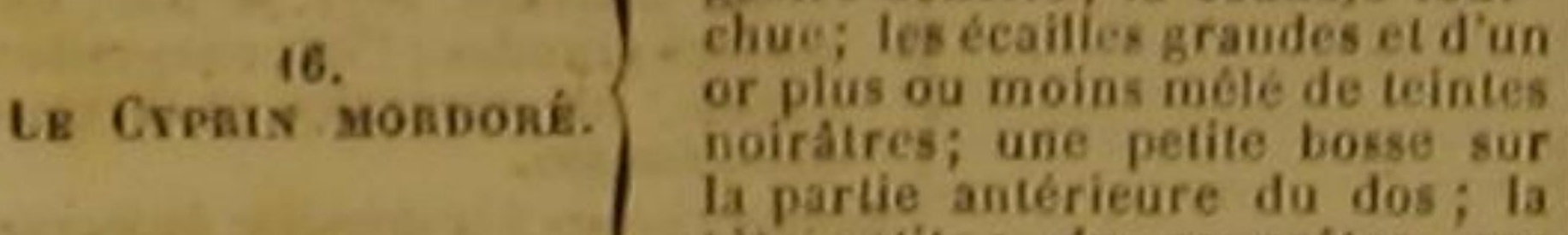
la parlie antérieure du dos; 13
telte petite; du rougeatre sur

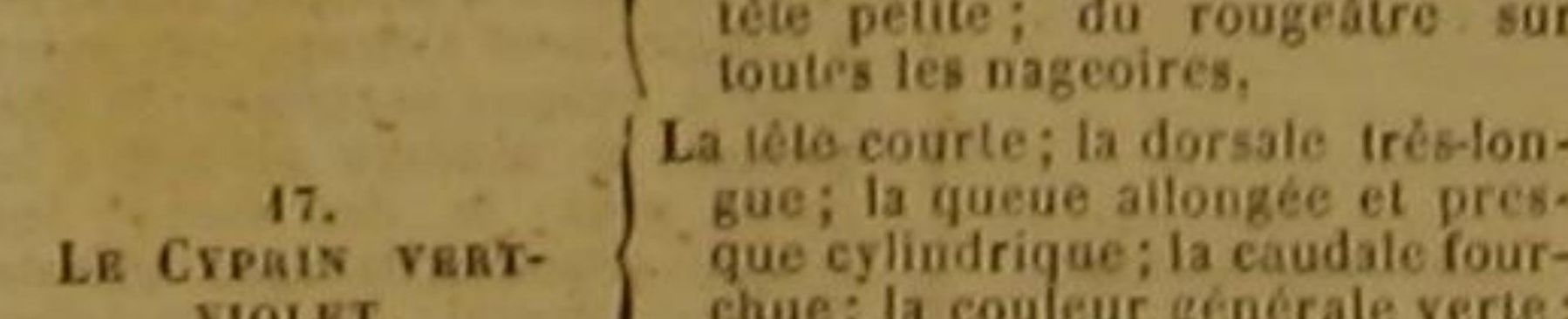

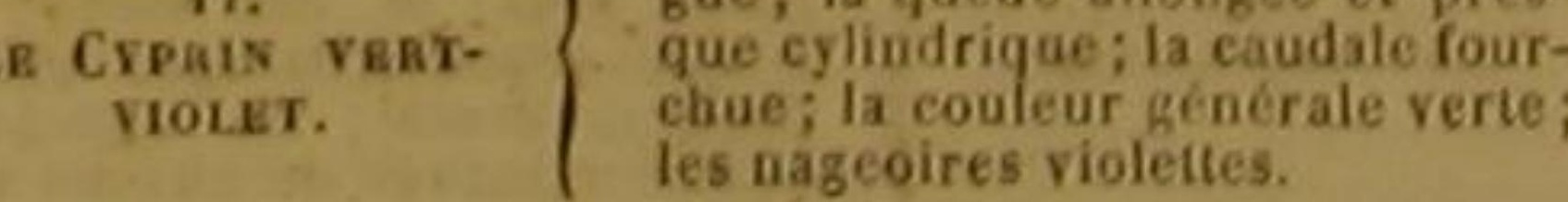

TROISLEME SOUS-GENRE. roint de barbillons, la nageoire de la quene rectiligne ou arrondie, el sans echancrure.

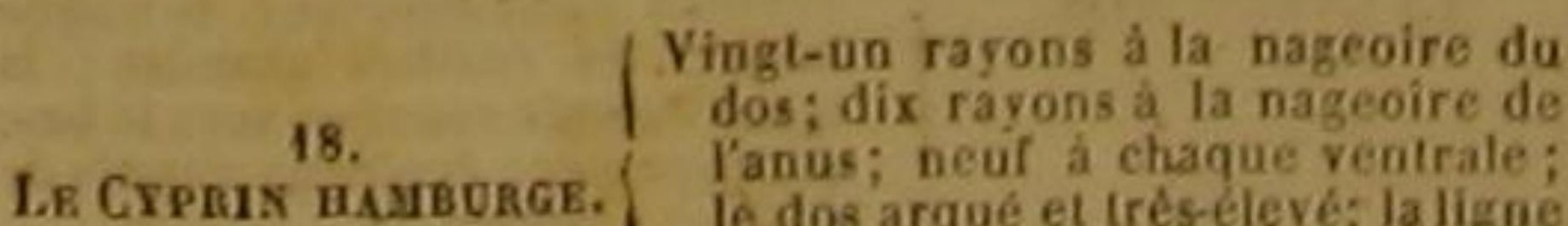
lanus; neú à chaque ventrale;
le dos argué el trés-elevé; la lignee
latérale droile. artentes

Dix-tiuil rayons a la dorasle ; neur a Vanate; six a chaque veritralo; lants; un seul orifice a d chaque narine; la ligno latérale inter-

Crpase tilisscope.

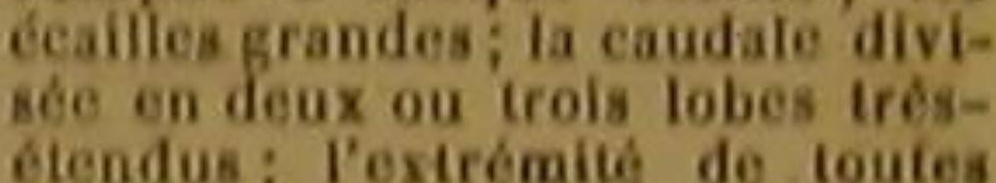
nas; Y'extrémité do touter
nageoires blanche ot trés ansparente; ta couleur genérale

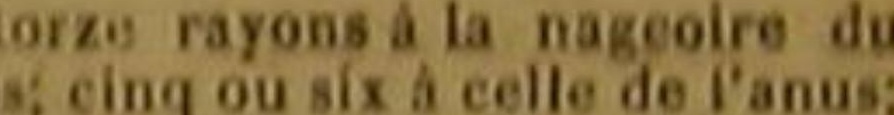
deux portions, dont chacun at profondémentéchancrée; le

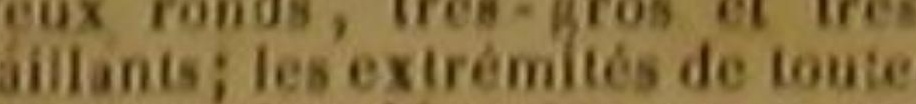
los nagcoires blanelies et trant-
parenles; ta coaleur géneral parento

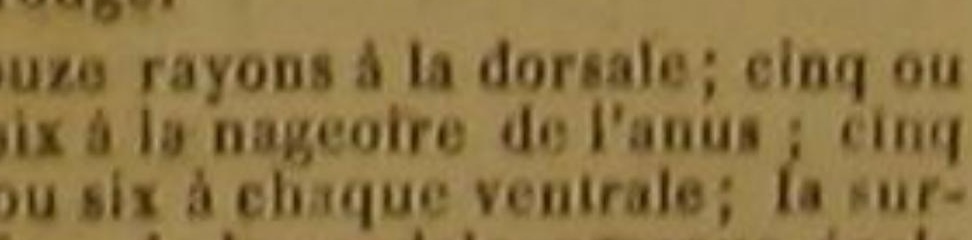
ace de la eaudale presque egal
a celle du corps ei de la quecue 26.
LE Crpix
Losess. lits et sans sailie ; les extre ches et trés-Lranspareates : ia culeur genérale rouge.

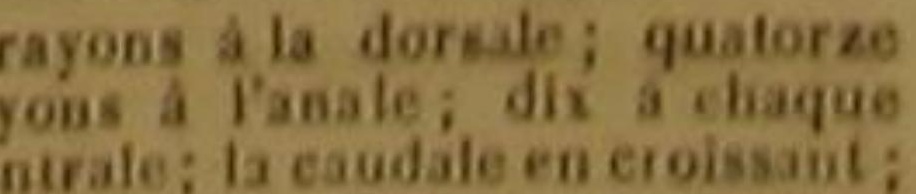

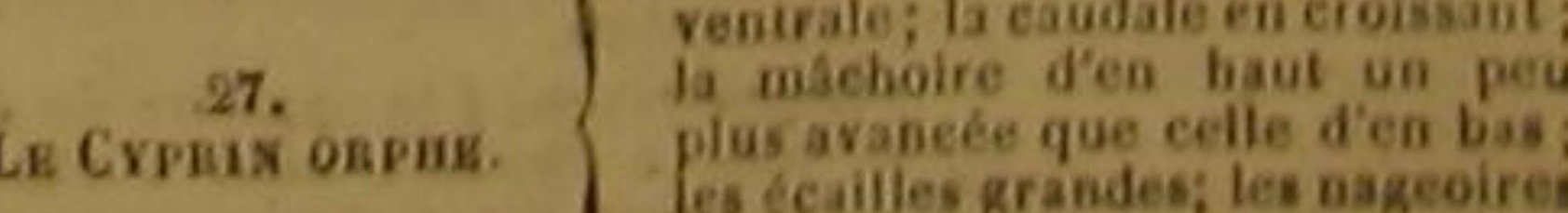
rouges; la couleur; generale drun
rouge đor 


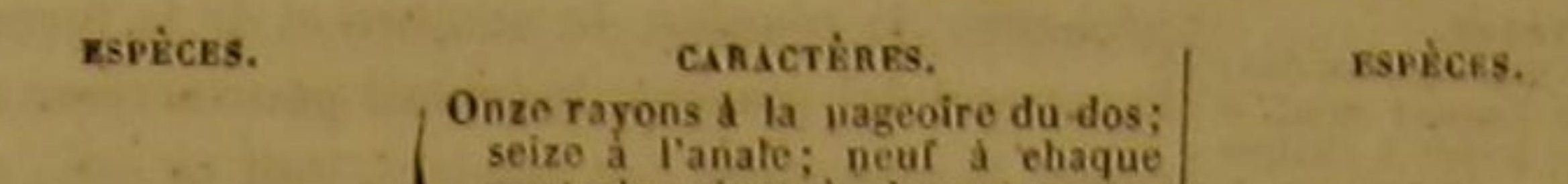

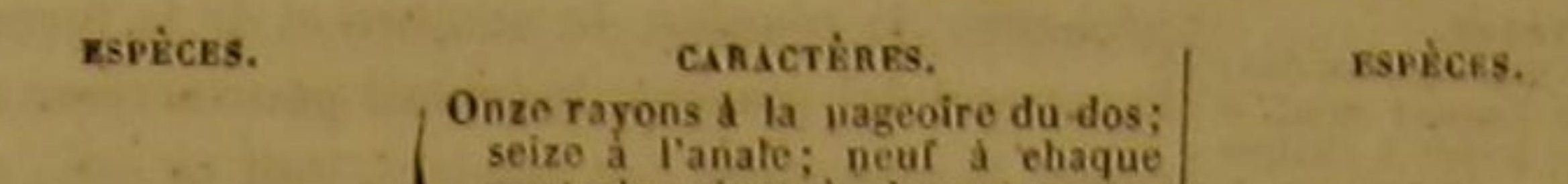

CARACTinEs.

Douze rayons a la nageoire du dos;

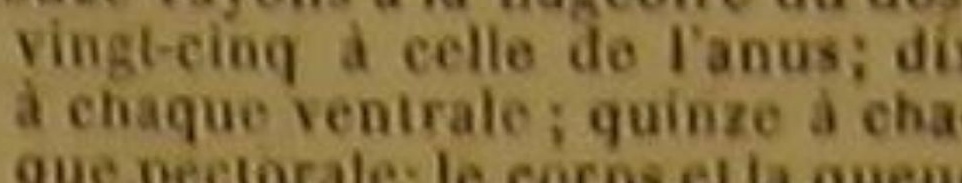

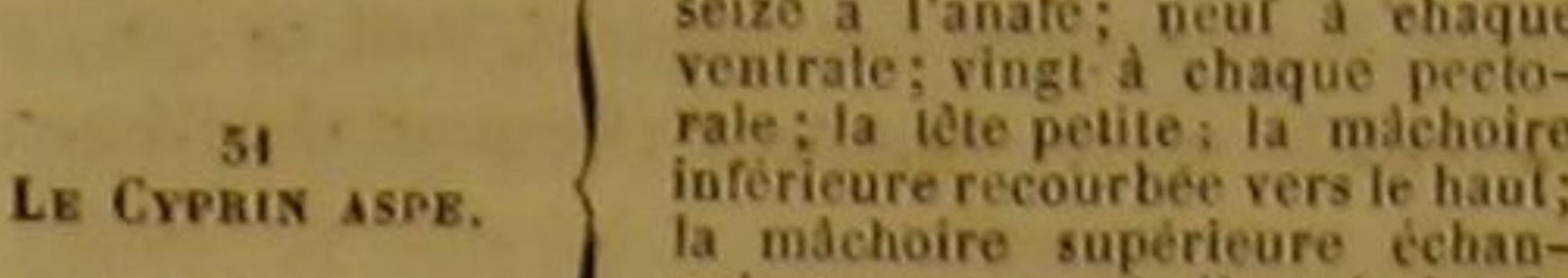
la máchoire supérieure echan-
erée pour recevoir lestrémite do
celle d'en bas; la nuque large;
l'a late

60
Le Cipmin laRge. fite et pointue : Iorilice de de is

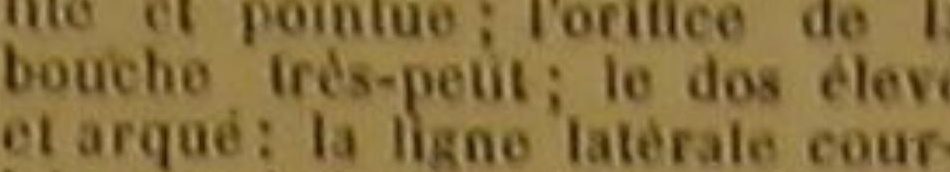
beo vers lo bas io lobe inferieur
do la caudalo plus long que lo
supérieur. Dix rayons a la dorsale; seize à la
nageoire de lanus; huit a chaque
ralo; Dix rayons a la dorsale; seize à la
nazeoire de lanos: huila chaque

Le Crpaix spiatis.

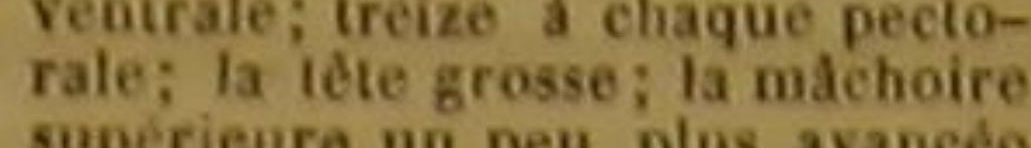

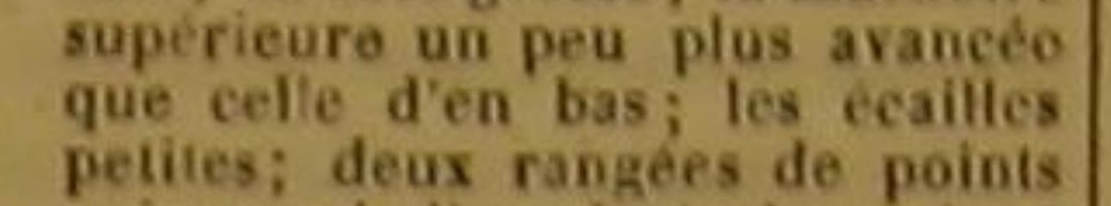
noirs sur las ligne later rale, points
reeourbée vers lo bas.

- 2.

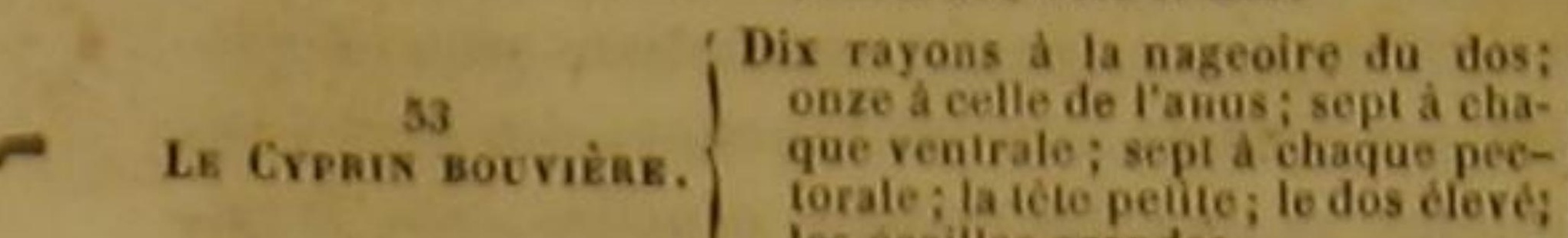

$$
\begin{aligned}
& \text { les ecailles grandes, } \\
& \text { Neuf rayons a la dorsale; seize } \\
& \text { l'seas }
\end{aligned}
$$

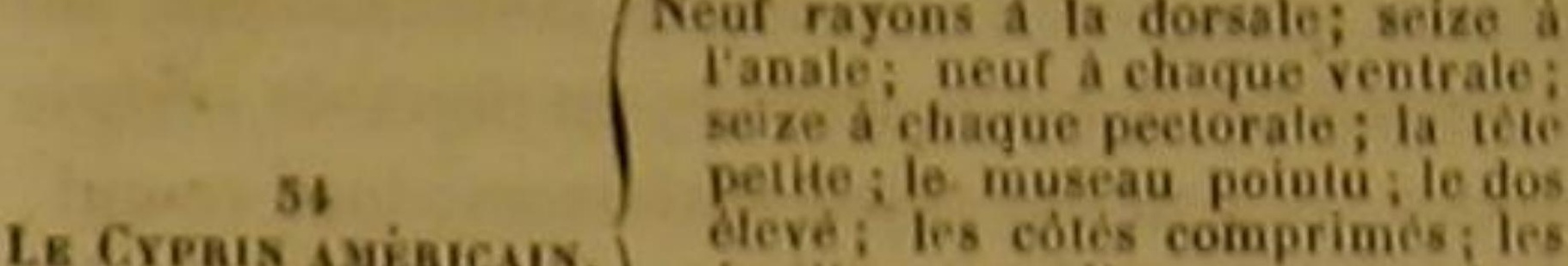

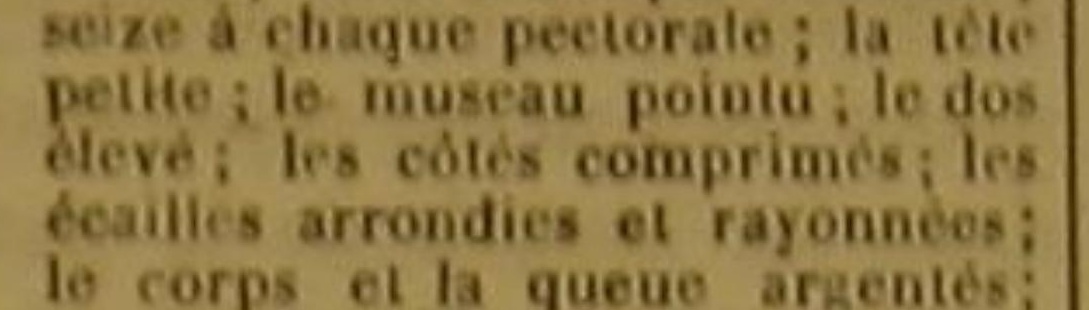
lo corps ei la queue arentés;
quelques points obscurs les na-
geoires fousses ou rougedires.

LE Crentí sope.

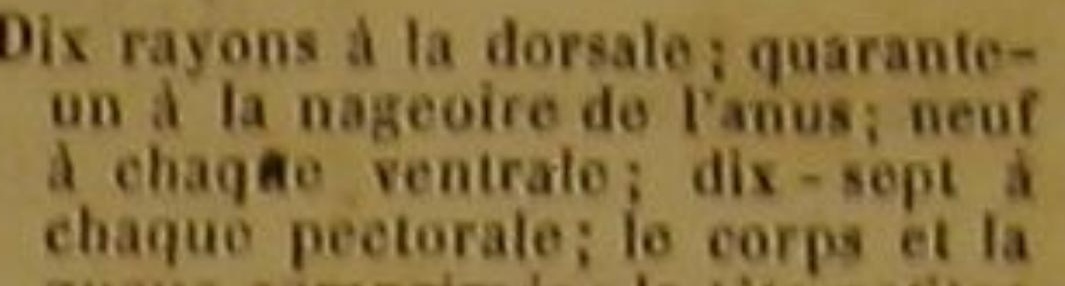
chaque pectorale; lo corps et la
quece comprimess la lace perito:

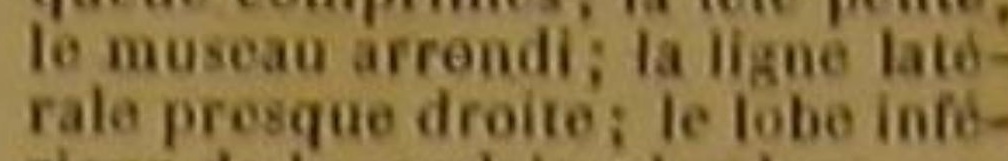
rale prosque droito: le lobe info-
rieur de la caudato plus loog quo
colui den haut; les deailles pe-

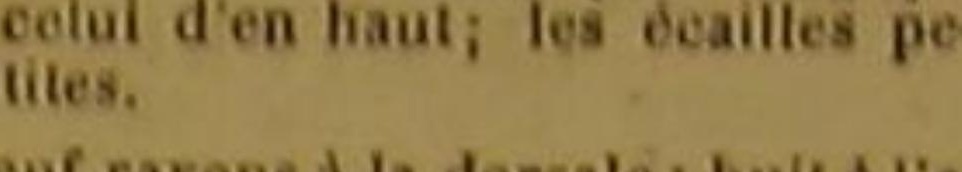

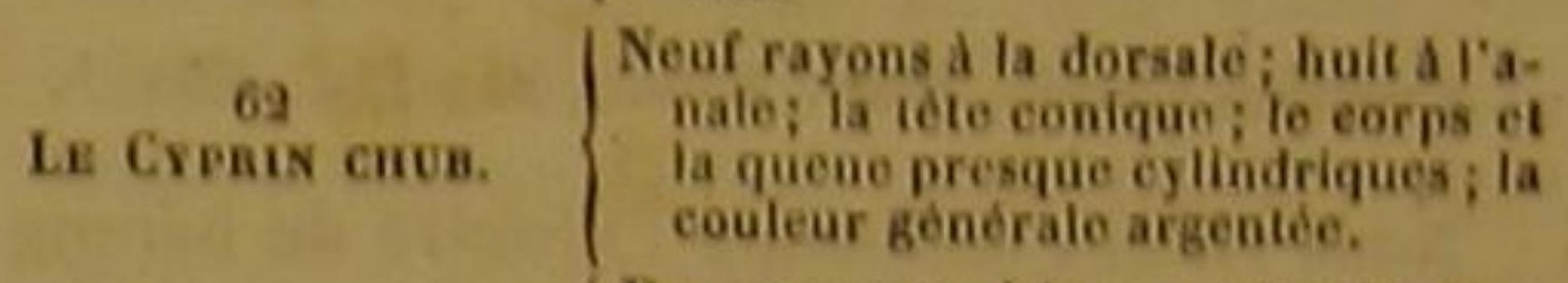

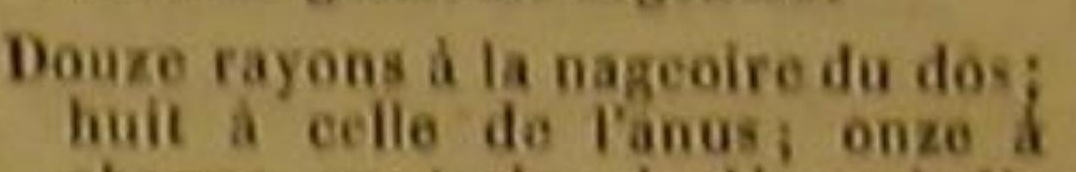
chaque ventralo; la livre info.
ricure ichancreo; des tubereule ricure ichancree; des tubereules
arrondis au bout du muscau i de

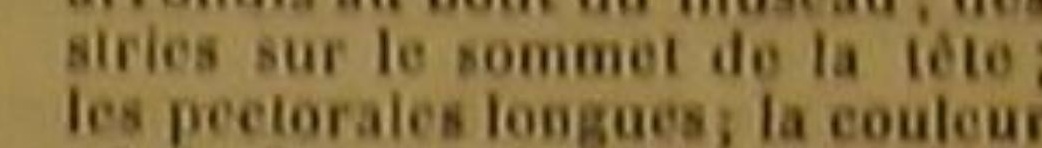
les peceorales longues; la couleu
fonerale argentece.

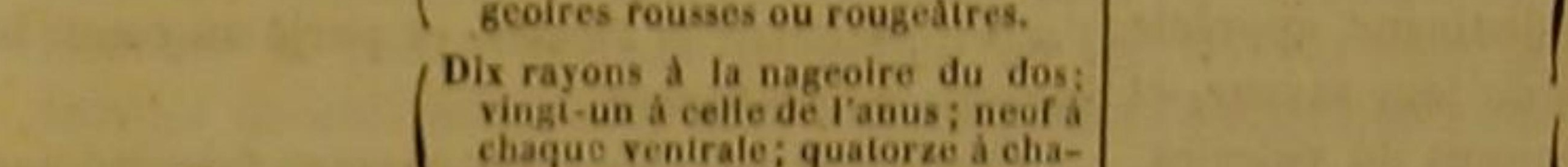

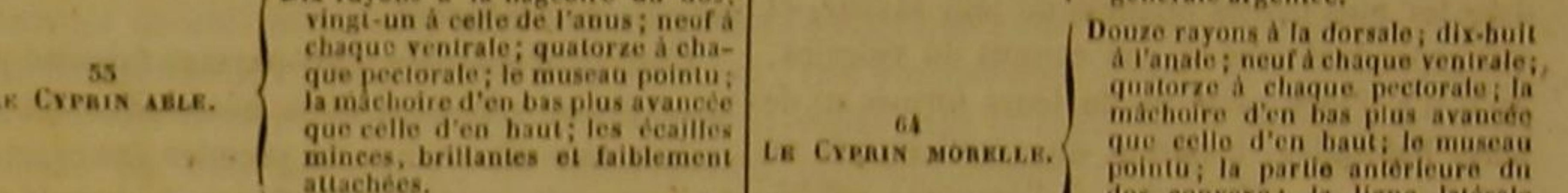
que celle den haut, les coailles
minces, brillantes et fablent

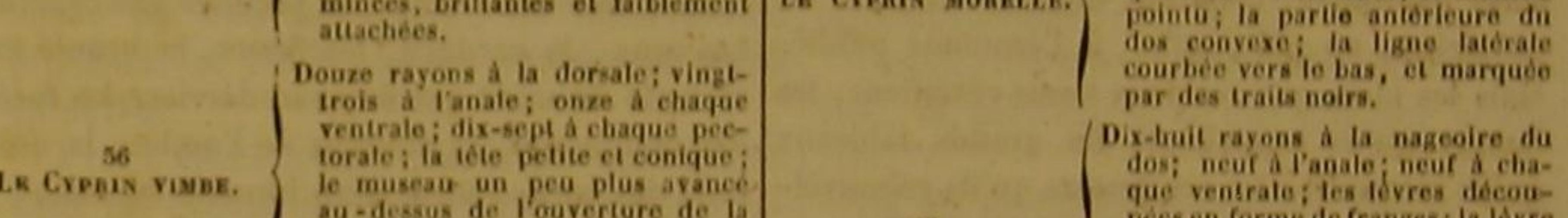

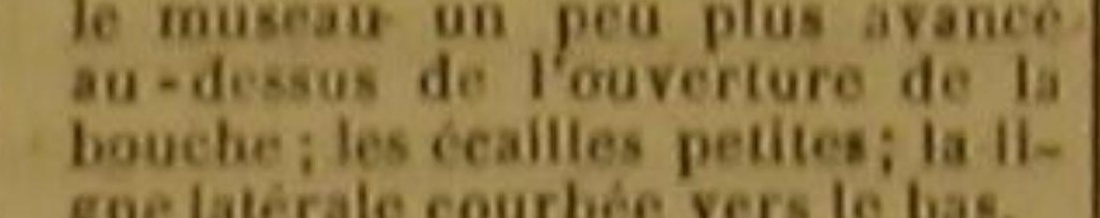

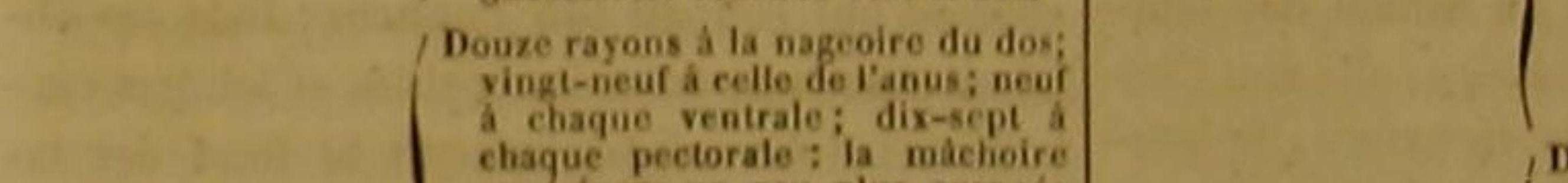

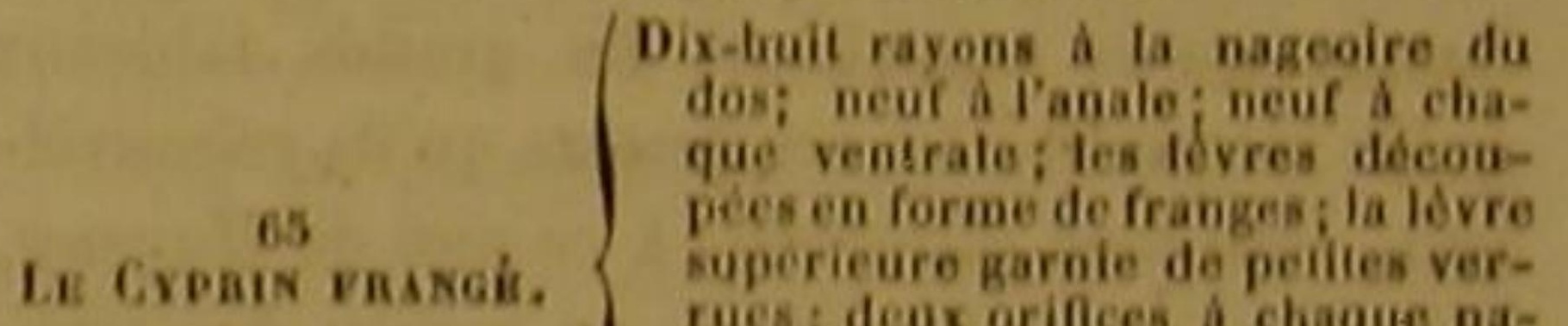
rine; la ligne laterale plus voisino
du bord supericur que du bord
laferieur du polsson. inferieur da poisson.

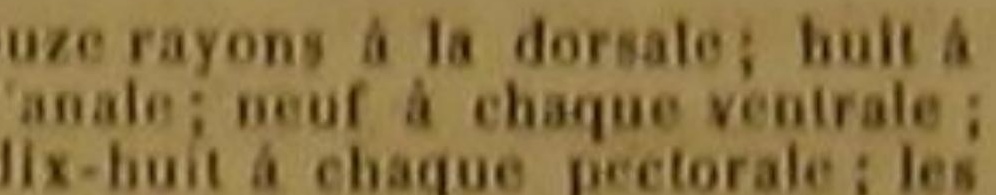

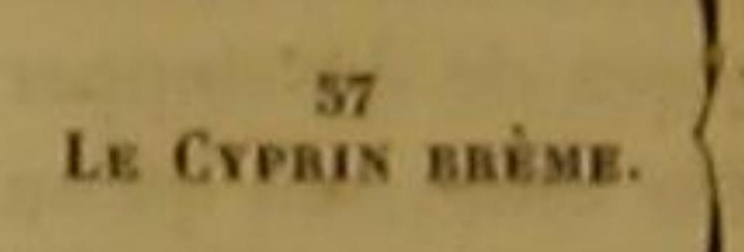

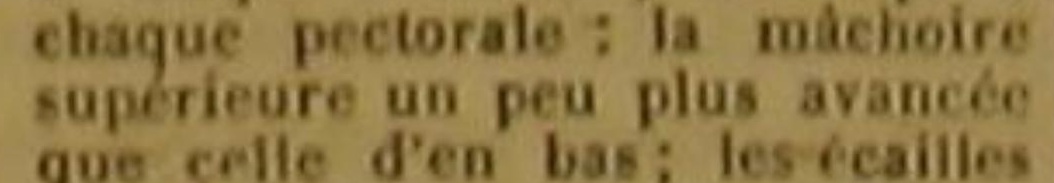
grandes, Io dos arqué, eleve ce
comprimét ia ligne laterale cour-

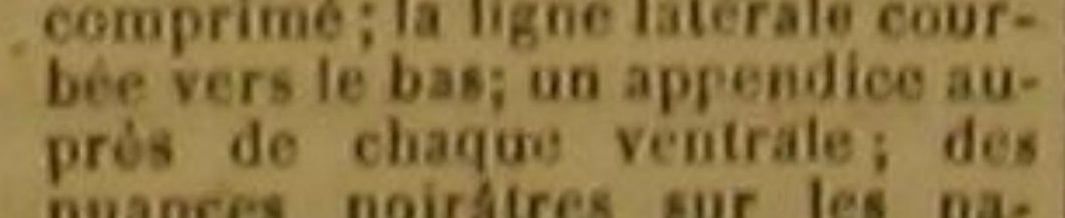

Le Cromis vauciele.

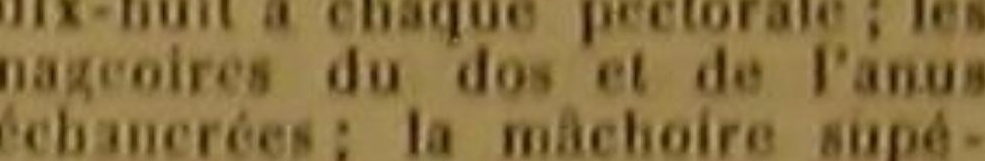
ecbancrices; la máchoire supe.
rieore plus avancie que celle d'en bas on seul orince á cha-
que narine; la ligne taterate droite les ceailles grandes: un
appendico auprés de chaque ven-

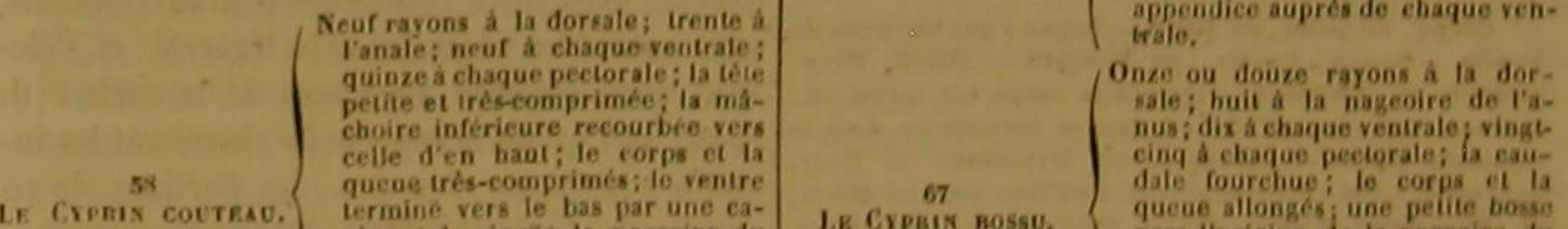

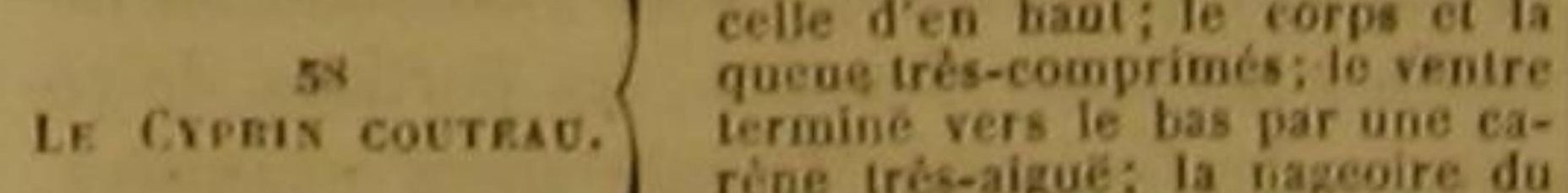

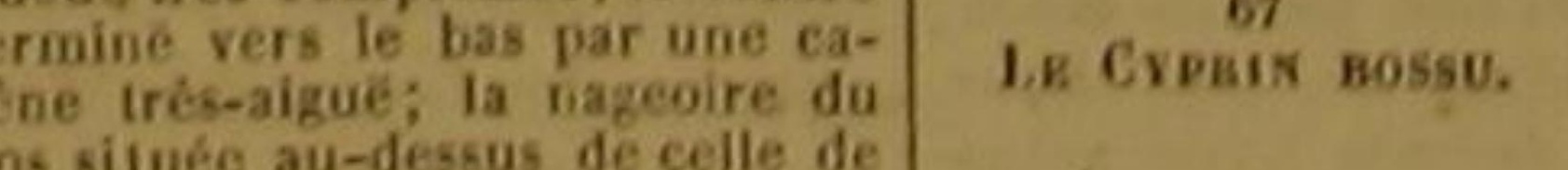

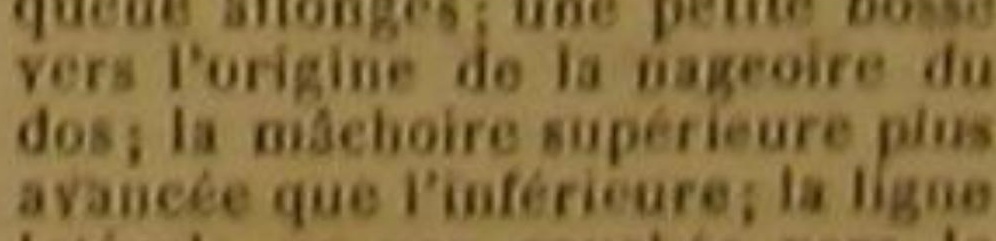

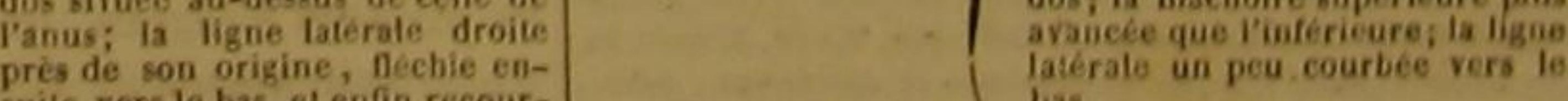
unite vers le bass fle enfin recour-
bee vers la caudalo el torlueuse.

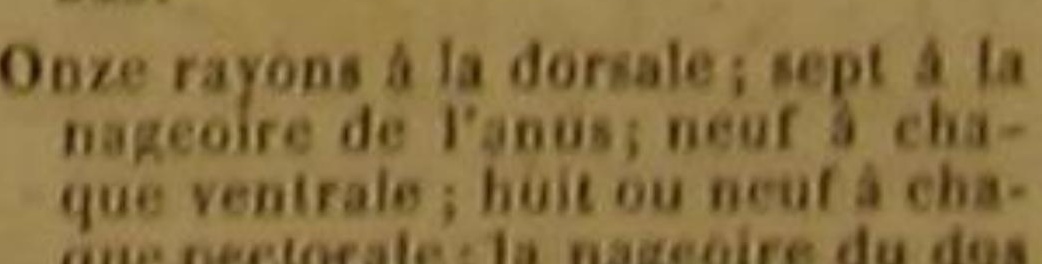

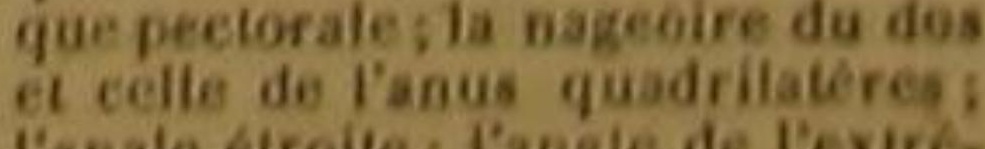
ranale etroite; langle de lexere
mite de celte dernere bageoire iresaigo la easdale nageoire

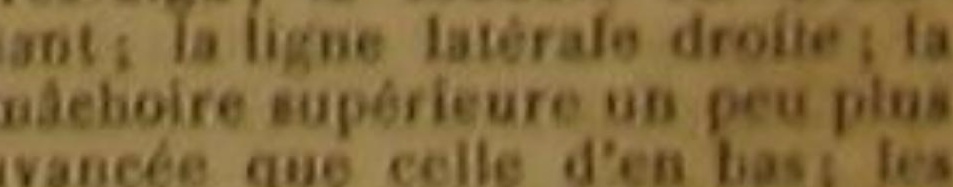


LB CXPMin pigo. le conert des moyens, le travail pour a force, repos, la prospérité des empires, lout ce qui, clarale; ta téte comprimée ct repos, la prosperité des empires, tout ce qui, en

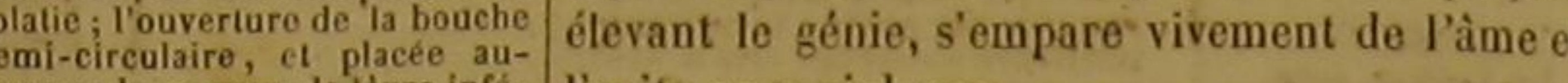

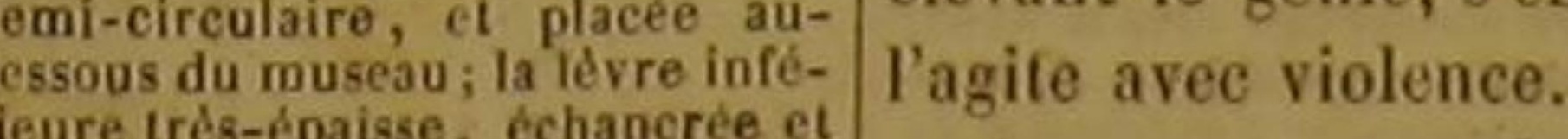

En prononçant le nom du eyprin que nou allons décrire, on ne rappelle que les contrées La dorsale el l'anale triangulaires; privilégiées des zones tempérées, un climat doux, prés de la caudale; la ligne late-
pane saison heureuse, un jour pur et sereìn, des rale un peu courbee vers le bas
les écailles grandes.

rivages fleuris, des rivières paisibles, des lacs enchanteurs, des étangs placés dans des vallées romantiques; des rapprochements comme pour

LE CYPRIN CARPE'

Cyprinus Carpio, Linn., Gmel., BI., Lac., Cuv. ${ }^{2}$.

Nous venons de donner l'histoire du hareng nous allons écrire celle de la carpe. Ces deux poissons, que l'on transporte dans tous les marchés, que l'on voit sur toutes les tables, que tout le monde nomme, recherche, distingue, apprécie dans les plus petites nuances de leur saveur, qui cependant sont si peu connus du vulgaire, qu'il n'a d'idée netle ni de leurs formes ni de leurs habitudes, inspirent un grand intérêt au physicien, au philosophe, à l'économe public. Mais les idées que ces deus noms réveillent, les images qu'ils rappellent, les grands tableaux qu'ils retracent, les sentiments qu'ils renouvelleut, sont bien différents. A ce mot de Hareng, l'imagination se transporte au milieu des tempêtes horribles de l'océan polaire; elle voil l'immensité des mers, les vents déchaìnés, le bouleversement des flots, le danger des naufrages, les horreurs des frimas, l'obscurité des nuits, l'épaisseur des brumes, l'audace des navigateurs, la longueur deș voyages, l'expérience des

' Carpa, Carpena, en Italie. - Rayna, aux environs Yenise. - Pontly, Poidka, en Hongrie. - Strich, Karprenbrut, en Allemagne, lorsque la carpe n'a qu'un an Saamen, Satz, lorsqu'elle est dans sa seconde ou dans
trolsième année. - Cyprin carpe. Dabenton ot Enc, méth. - Id. Bonnaterre, pl. đe l'Enc, méth. - Bloch,

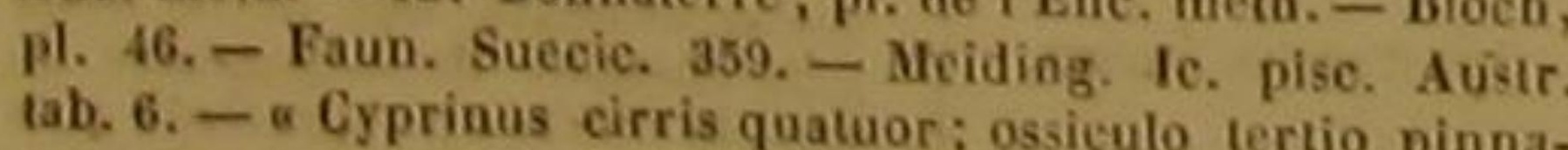
tab. 6. - "Cyprinus cirris quatuor; ossiculo lertio pinna-
" rum dorsi, anique serrato. A Artedi, gen. 4 , syn. 3, spec. 25 .

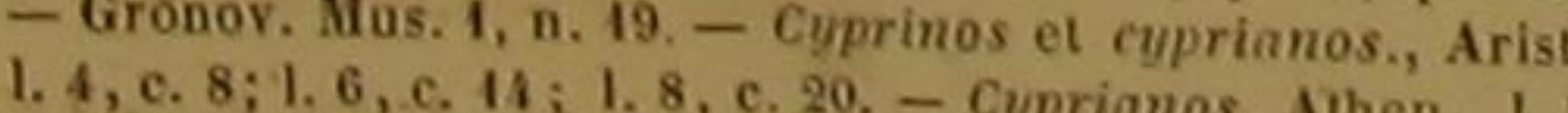
Deipnosopb., p. 309. - Id. Oppian, I. I et A. Athen., I. Plin, I. 32, c. 11. - Id. Aldrov, 1, 4, c. 40, p. 637. - IC. Jonston, I. 3, lit. 3, c. 6, tab. 29, fig. 5,4 et 6 .-Id. Willugh-
by, p. 2is. - Id. Rai, p. 45. - Cyprimus nobilis. Schong by, p. 2is. - Id. Rai, p. H5. - Cyprinus nobilis. Schonev.,
p. 32. - Carpe. Rondelet, Poissons des lacs, c. 4. - Id. Valp. 32. - Carpe. Rondelet, Poissons des lacs, c. 4. - Id. Vai-
moni de Bomare, Dict. d'hist. nal.
2 Du genre el du sous-genre Cyprix, Cyprinus, Cuy ler des dangers souvent funestes; des jeux tranquilles, et non des fatigues cruelles; une ocenpation quelquefois solitaire et mélancolique; un délassement après le travail ; un objet de rêverie douce, et non des sujets d'alarmes; tout ce qui, dans les beautés de la eampagne et dans les agréments da séjour des champs, plait le plus a l'esprit, satisfait la raison, et parle au cœur le langage du sentiment.

L'altrait irrésistible d'un paysage favorisé par a nature se répandra donc nécessairement sur ce que nous allons dire du premier des cyprins. Les eaux, la verdure, les fleurs, la beanté ravissante da soleil qui descend derrière les forêts des montagnes, la douceur de l'ombre, la quiéude des bords retirés d'un humble ruisseau, I chaumière si digne d'envie de l'habitant des champs qui connait son bonheur; tous ces objets si chers aux âmes innocentes et tendres embelliront done nécessairement le fond des tableaux, dans lesquels on tâchera de développer les habitudes du cyprin le plus utile, soit qu'on le montre dans une attitude de repos et livré à un sommeil réparateur, soit qu'on le fasse voir nageant avec force contre des courants violents, surmontant les obstacles avec légèreté, et s'élevant avec rapidité au-dessus de la surface de 'eau; soit qu'on le représente cherchant les insectes aquatiques, les vers, les portions de végétaux, les fragments de substances organisées les parcelles d'engrais, les molécules onctueuses d'une terre limoneuse et grasse, dont il aime à - nourrir ; soit entin qu'il doive, sous les yeux des amis de la mature, felapper a la pouruile des oiseaux palmipèdes, des poissons voraces, et du pêchear plus dangereux encore.

Les carpes se plaisent dans les étangs, dans Il y n mans les rivières qui coulent doucement.
DES POISSONS.

férences qui échappent le plus souvent aux ob-| leurs écarlles sont grandes et siriées; leur lonservateurs les plus attentifs, et qui sont si sen- gne nageoire du dos règne an-dessus de lasibles pour ces cyprins, qu'ils abondent quel- nale, des ventrales, et d'une portion des peequefois dans une autre partie d'un lac ou d'un fieuve, et sont très-rares dans une autre partie peu éloignée cependant de la première. Par sif́, lieurs, leur canal intestinal a cinq sinuosités; l'épine du dos est composée de trente-sept dit, dans des notes vertèbres, et chaque côté de cette colomne est manuscrites qu'il nous a communiquées, que soutenu par seize côtes.

dans la Seine on péche des carpes à Villequier, Ordinairement un bleu foncé paraît sur leur mais rarement au-dessous, à moins qu'elles n'y front et sur leurs joues; un bleu verdâtre sur

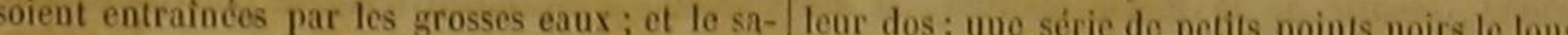
vant Pietet écrivait aux rédacteurs du Journal de leur ligne latérale; un jauné mếlé de bleu et de Genève, en 1788, que, dans le lac Léman, de noir sür leurs côtés; un jaume plus clair sur les carpes étaient aussi communes du côté du leurs lèves, ainsi que sur leur queno; umo Valais que rares à l'extrémité opposée.

nuanco blanchatro sur leur ventre; un rouge bron sur leur anale; une teinte violette sur leurs quand le printemps ost chaud. Ils cherchent ventrales et sur leur caudale, qui de plus est boralors les places couvertes de verdure, pour y dée de noirâtre ou de noir. Mais teurs couleurs dépóser ou leur laite ou leurs cufs, On dit quo penvent varier suivant les eaux dans lesquelles deux ou trois mâles suivent chaque femelle, pour elles séjournent: celles des grands lacs et des féconder sa ponte; et dans ce temps, où les rivières sont, par exemple, plus jaunes ou plus facultés de ces mâles sont plus exaltées, leurs dorées que celles qui vivent dans les étangs; et forces ranimées, et leurs besoins plus pressants, l'on conmait sous le nom de Carpes saumonées on les voit souvent indiquer par des taches, et celles dont la chair doit à des circonstances lomème par des tubercules, les modifications cales une couleur rongeâtre.

profondes et les sensations intérieures qu'ils Ouand elles sont bien nourries, elles croissent éprouvent.

A cette même époque, les carpes qui habitent rable. dans les fleuves ou dans les rivières s'empres- On en pêche dans plusieurs lacs de l'Allesent de quitter leurs asiles, pour remonter vers magne septentrionale qui pésent plus de trente des eaux plus franquilles. Si dans cette sorte de livres. On en a pris une du poids de plus de voyage annuel, elles rencontrent une barricre, trente-huit livres à Dertz, dans la nouvelle elles s'efforcent de la franchir. Elles peuvent, Marche de Brandebourg, sur les frontières de la pour la surmonter, s'élancer à une hauteur de Poméranie. On en trouve près d'Angerbourg en six pieds; et elles s'élèvent dans l'air par un Prusse, qui pèsent jusqu'à quarante livres. mécanisme semblable à celui que nous avons dé- Pallas dit que lo Wolga en nourrit de parvenues crit en traitant du saumon. Elles montent à la à une longueur de plus de quatre pieds et demi. surface de la rivière, se placent sur le côté, se En 1711 on ell pécha une à Bischofshause, près plient vers le haut, rapprochent leứ tête et de Francfort-sur-l'Oder, qui avait plus de neuf l'extrémité de leur queue, forment im cercle, dé- pieds de long, plus de trois pieds de hant, des bandent tout d'un coup le ressort que ce cercle écailles très-larges, et pesait soixante-dix livres. compose, s'étendent avec la rapidité de l'éclair, On assure qu'on en a pris du poids de quatrefrappent l'eau vivement, et rejaillissent en un vingt-dix livres dans le lac de Zug en Suisse; et

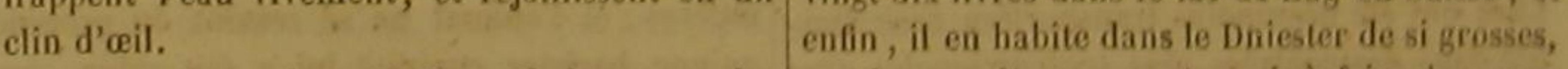

Leur conformation et la force de leurs muscles que leurs arêtes peuvent sèrvir à faire des manleur donnent une grande facilité pour celte ma- ches de couteau.

nœuvre. Leurs proportions indiquent, en cffet, Les cyprins dont nous nous occupons peuvent la viguerc ot la légèreté. d'autant plus montrer des développements trèsAu reste, lear tête est grosse; leurs lèvres remarquables, qu'ils sont favorisés par une des sont épaisses; leur front est large; leurs quatre principales causes de tout grand aceroissement, barlillons sont attachés à leur mâchoire supé- le temps. On sait qu'ils deviennent très-vieux; rieure; leur ligne latérale est un peu courte; et nous n'avons pas besoin de rappeler que Buf- 
fon a parlé de carpes de cent cinquante ans, dirait que la puissance de l'homme n'a pas envivantes dans les fossés de Pontchartrain, et que, core pu, dans les pays trop voisins du cercto dans les étangs de la Lusace, on a nourri des in- polaire, contre-balancer tous les effets d'un dividus de la même espèce âgés de plus de deux climat rigoureux. Les carpes sont moins grandes, cents ans'. Lorsque les carpes sont très-vieilles, elles sont et voilà pourquoi, suivant Bloch, on envoie sujettes à une maladie qui souvent est mortelle, tous les ans, de Prusse à Stockholm, plusieurs et qui se manifeste par des excroissances sem- vaisseaux chargés d'un grand nombre de ces blables à des mousses, et répandue sur la tête, cyprins.

ainsi que le long du dos. Elles peuvent, quoique Dans sa lutte avec la nature, la constance de jeunes, rnourir de la même maladie, si des l'homme a cependant d'autant plus de chances eaux de neige ou des eaux corrompues parvien- favorables pour modifier l'espèce de la carpe, nent en trop grande quantité dans leur séjour, qu'il peut agir sur un très-grand nombre de ou si leur habitation est pendant trop longtemps sujets. Les carpes, en effet, se multiplient avec recouverte par une couche épaisse de glace qui une facilité si grande, que les possesseurs d'éne permetle pas aux gaz malfiisants, produits tangs sont souvent embarrassés pour restreindre au fond des lacs, des étangs ou des rivières, de une reproduction qui ne peut accroître le nombre se dissiper dans l'atmosphère. Ces mêmes eaux des individus qu'en diminnant la part d'aliment de neige, ou d'autres causes moins connues, qui peut appartenir à chacun de ces poissons, et leur donnent une autre maladie, ordinaire- par conséquent en rapetissant leurs dimensions, ment moins dangereuse que la première, et en dénaturant leurs qualités, en altérant partiqui, faisant naitre des pustules au-dessous des culièrement la saveur de leur chair.

écailles, a reçu le nom de petite vérole. Les Lorsque, malgré ces chances et ces efforts, carpes peuvent aussi périr d'ulcères qui rongent l'espèce s'est soustraite à l'influence des soins le foie, l'un des organes essentiels des poissons. de l'homme, et qu'il n'a pas pu imprimer à des Elles ne sont pas moins exposées à être tour- individus des caractères transmissibles à plumentées par des vers intestinaux; et cette dis- sieurs générations, il peut agir sur des individus position à souffrir de plusieurs maladies doit isolés, les améliorer par plusieurs des individus moins etonner dans des animaux dont les nerfs rendre plus propres d salisfire ses gobs. et lo vant Michel Buniva, président du corait. Le sa- suffit d'indiquer, parmi ces moyens plus ou rieur de santé rieur de saaté do Turin, a prouvé, par plusieurs naître en traitant des efiets de l'art de l'homme experiences, que l'aimant exerce une influence sur la nature des poissons, l'opération imaginée très-marquée sur les carpes, même à quatre par un pêcheur anglais, et exécutée presque toupouces de distance de ces cyprins, et que la jours avec succès. On chàtre les carpes comme pile galvanique agissait vivement sur ces pois- les brochets; on leur ouvre le ventre; on enlève sons, principalement lorsqu'ils étaient hors de les ovaires ou la laite; on rapproche les bords de

la plaie; on coud ces bords avec soin: la blesC'est surtout dans leur patrie naturelle que sure est bientôt guérie, parce que la vitalité des lés carpes jouissent des facultés qui les distin- différents organes des poissons est moins dédepuis tant der que la nature. leur a prescrit pendante d'un ou de plusieurs centres comdepuis tant de siècles, et sur lequel l'art ne pa- muns, que si leur sang était chaud, et leur rait pas avoir influé, est l'Europe méridionale. organisation très-rapprochée de celle det leur Elles ont été néaumoins transportées avec faci- mifères; et l'animal ne se ressent du procédé lité dans des contrées plus septentrionales. Que qu'une barbare cupidité lui a fait subir, que l'on n'oublie pas que Maschal les porta en An- parce qu'il peut engraisser beaucoup plus qu'augleterre en 1514; que Pierre Oxe les habitna aux paravant.

eaux du Danemarck en 1560 ; qu'elles ont été Mais il est des soins plus doux que la sensiacclimatées en Hollande et en Suède ${ }^{2}$. Mais on bilité ne repers doux que la sensi' Voyez le Discours sur la nature des poissons. et qui conservent, multiplient et perfectionnent

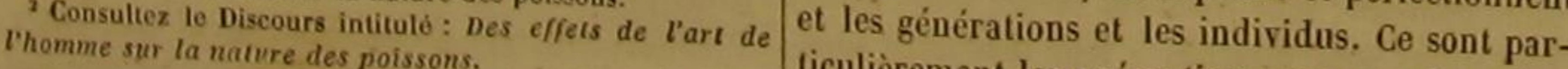
ticulièrement les précautions que prend un éco- nome lıabile, lorsqu'il veut retirer d'un étang dangereuses, parce qu'elles obligent à manier ot ̀̀ qui renferme des carpes, les avantages les plus presser les poissen qu elles obligent à manier ot à grands.

Il établit, pour y parvenir, trois sortes d'ètangs: des étangs pour le frai, des étangs pour l'accroissement, des étangs pour l'engrais.

on choissit, pour les former, des marais des bassins remplis de joncs et de roseaux, ou des prés dont le terrain, sans être froid et trèsmauvais, ne soit cependant pas trop bon pour étre sacrifié à la culture des eyprins. Il fant qu'une eau assez abondante pour couvrir à la hauteur de trois pieds les parties les plus élevées de ces prés, de ces bassins, de ces marais, puisse s'y réunir, et en sortir avec facilité. On retient cette eau par une digue; et pour lui donner l'écoulement que l'on peut désirer, on creuse dans les endroits les plus bas de l'étang un canal large et profond, qui en parcourt toute la longueur, et qui aboutit à un orifice que l'on ouvre ou ferme à volonté.

Les étangs pour le frai ne doivent renfermer qu'un hectare ou environ. Il est nécessaire que la chaleur du soleil puisse les pénétrer : il est donc avantageux qu'ils soieut exposés à l'orient ou au midi, et qu'on en écarte toutes sortes d'arbres; il faut surtout en éloigner les aunes, dont les feuilles pourraient nuire aux poissons. Les bords de ces étangs doivent présenter une pente insensible, et une assez grande quantité de joncs et d'herbages pour recevoir les aufs et les retenir à une distance convenable de la surface de l'eau. On n'y souffre ni grenouilles, ni autres animaux aquatiques et voraces. On les garantit, par des épouvantails, de l'approche des oiseaux palmés, et on n'en laisse point sortir de l'eau, de peur qu'une partie des æufs ne soit entraînće et perdue. On emploie pour la ponte et la fécondation de ces aufs, dẹs carpes de sept, de huit, et même de douze ans; mais on préfère celles de six, qui annoncent de la force, qui sont grosses, qui ont le dos presque noir, et dont le ventre résiste au doigt qui le presse. On ne les met dans l'étang que lorsque la saison est assez avancée pour que le soleil en ait échauffé l'eau. On place communément dans d'empêcher, pendant l'biver, les carpes de s'éune pièce d'eau d'un hectare, seize ou dix-sept chapper par les trous que l'on peut avoir faits mâtes, et sept ou huit femelles. On a cru quel- dans la glace. En effet, il arrive le plus souvent quefois augmenter leur verlu prolifique en frot- que, lorsque la surface de l'étang commence à tant leurs nageoires et les environs de leur anus avec du castoréum et des essences d'épiceries; I Voyex le Discours intitulée : Des effers de lart de mais ces ressources sont inutiles, et peuvent ĉtre l'homme sur la nature des poissons.

Les jeunes carpes halitent ordinairement, pendant deux ans, dans les étangs formés pour eur accroissement, et on les transporte ensuite dans un étang établi pour les engraisser, d'où , au bout de trois ans, on peut les retirer, déjà gandes, grasses et agréables au goùt. Elles s' sectes, de vers, de débris de plantes altérées, de racines pourries, de jeunes végétaux aq̨ualiques, de fragments de tiente de vache, de croltin de cheval, d'excréments de brebis mélés avec de la glaise, de fèves, de pois, de pommes de terre coupées, de navets, de fruits avancés,
de pain moisi, de pâte de chenevis, et de poisons gâtés.

On peut être obligé, après quelques années, de laisser à sec, pendant dix ou douze mois, fitang destiné à l'engrais des carpes. On pro-
intervalle pour y diminuer, s'il est nécessaire, la quantité des joncs et des roseaux, et pour y semer de l'avoine, du seigle, des raves, des vesces, des choux blanes, dont les d'aliment aux carpes qu'on introduit dans l'étang renouvelé.

Si la surface de l'étang se gèle, il faut en faire sortir un peu d'eau, afin qu'il se forme au-dessous de la glace un vide dans lequel puissent se rentre les gaz délétères, qui dès lors ne séjourplus dans le fluide labité par Ics carpes. II plus ou moins grands et plus ou moins nombreux, et de prendre des précautions pour que les carpes ne puissent pas s'élancer par ces outang, où le froid les ferait bientôt périr. Mais on assure que, lorsque le tonnerre est tombé dans l'étang, on ne peut en sauver le p'us souvent les carpes, qu'en renouvelant presque en entier l'eau qui les renferme, et que l'action de 
HISTOIRE NATURELLE

se prendre et à se durcir, les carpes cherchent . Dans les fleuves, les rivières et les grands lacs, les endroits les plus profonds, et par conséquent on pêche les carpes avec la seine: on emploie les plus garantis du froid de l'atmosphère, pour les prendre dans les étangs, des collerets, fouillent avec leur museau et leurs vageoires des louves et des nasses, dans lesquels on met dans la terre grasse, y font des trous en forme un appât. On peut donc aussi se servir de l'hade bassins, s'y rassemblent, s'y entassent, s'y mecon pour la pêche des carpes. Mais ces cypressent, s'y engourdissent, et y passent l'hiver prins sont très-souvent plus difficiles à prendre dans une torpeur assez grande pour n'avoir pas qu'on ne le croirait : ils se méfient des différentes besoin de nourriture. On a même observé assez substances avec lesquelles on cherehe à les allifréquemment et avec assez d'attention cette tor- rer. D'ailleurs, lorsqu'ils voient les filets s'appeur des carpes, pour savoir que, pendant leur procher d'eux, ils savent enfoncer leur tête dans long sommeil et leur long jeùne, ces cyprins ne la vase, et les laisser passer par-dessus leur corps, perdent guère que le douzième de leur poids. ou s'élancer au delà de ces instruments, par une Lorsqu'on ne surmonte pas, par les soins impulsion qui les élève à six pieds ou environ éclairés de l'art, les effets des causes naturelles, au-dessus de la surface de l'eau. Aussi les pêles carpes élevées dans les étangs ne sont pas cheurs ont-ils quelquefois le soin d'employer celles dont la chair est la plus agréable au goût; deux trubles ', dont la position est telle, que on leur trouve une odeur de vase, qu'on ne fait lorsque les carpes sautent pour échapper à l'un, passer qu'en les conservant, pendant près d'un elles retombent dans l'autre.

mois, dans une eau très-claire, ou en les renfer- La fréquence de leurs tentatives à cet égard, mant pendant quelques jours dans une huche et par conséquent l'étendue de leur insfinct, placée au milieu d'un courant. On leur préfère sont augmentées par la facilité avee laquelle celles qui vivent dans un lac, encore plus celles elles peuvent résister anx contusions, anx blesqui séjournent dans une rivière, et sentont celles qui thabilent un étang oul un lac traversé eaux fraîches et rapides d'un grand ruisseau, d'une rivière ou d'un fleuve. Tous les fleuves et toutes les rivières ne communiquent pas d'ailleurs les mêmes qualités à la chair des carpes. II est des rivières dont les eaux donnent à ceux do ces cyprins qu'elles uourrissent une saveur bien supérieure à celle des autres earpes; et parmi les rivières de France, on peut ciler particulièrement celle du Lot 4 .

'J'ai reçu, il y a plusieurs années, sur les carpes du Lot,
des observations précieuses eutrés-bien failes, do fou to ch, des observations précieuses el très-bien faltes, de feu le chef
de brigade Dauriére, dont la maison de cammagane éthil située sur le bord de cellte rivière, el qui avait consacré á
létude de la nature et aux progrés de l'art rural tous les l'étude de la nature et aux progrès de l'art rural tous les
moments que le service militaire avait laissés à sa disposimoments que le service militaire avait laissés à sa disposi-
tion. Les amis des sciences nalurelles me sauront gré de

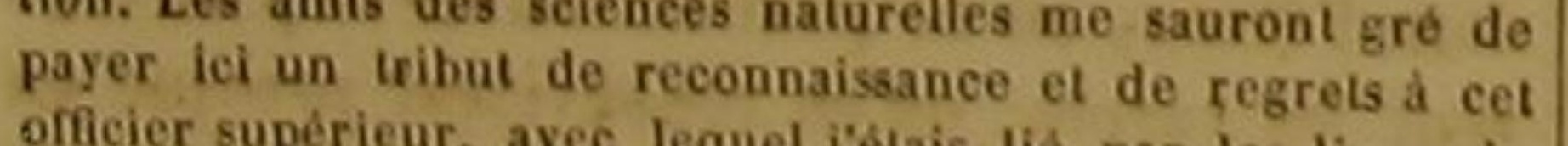
sang et de l'amiliée la plus fiéte jamais dans mon ame autendriee dont la loyauté, la valeur, la la
constance béroơque, l'humanité généreuse, lo dévous constance héroīque, l'humanité généreuse, le dévouement dans les emplois militaires, le zéle éélairé dans les fonction

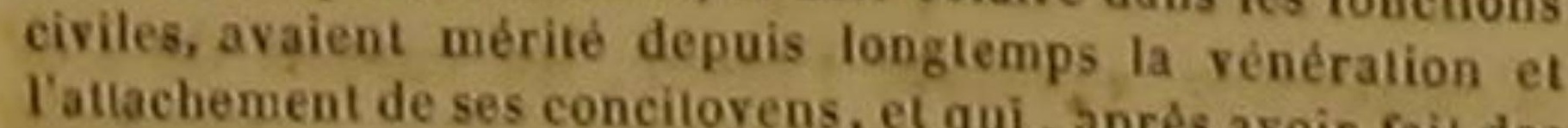
prodiges de bravoure dans la derniere guerre de la Belgique
et de la Hollande, $\mathbf{y}$ avoir conquis bien des cerurs a Ia et de la Hollande, y avoir conquis bien des ceurs à la répu-
blique, el s'étre dérobés sans cesse aux récompenses el à a renommée, a trouvó en llalie te prix de ses hauts faits el do ses verlus le plus digne de lui, dans la gloire de mourir pour

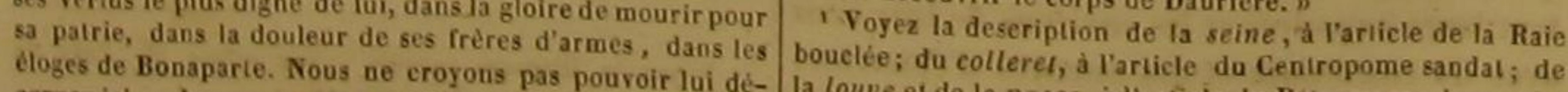
cerner icl un hommage plus cher à ses mânes, qưen trans- la louve et de la nasse, à l'article du Peiromyzon lamproie;
DES POISSONS.

sures, à un séjour prolongé dans l'atmosphère. la description : on en voit des exemples dans un C'est par une suite de cette faculté qu'on peut grand nombre de cabinets. Le Mluséum d'hisles trausporter à de très-grandes distances sans toiro naturelle a reçu dans le temps, de feu le les faire périr, pourvu qu'on les renferme dans président de Meslay, une carpe qui offrait cetle de la neige, et qu'on leur melte dans la bouche conformation monstrueuse, et que l'on avait un petit morceau de pain trempé dans de l'al- péchée dans l'étang de Meslay : et M. Noề de cool affaibli; et e'o pain trempé dans de lai- pectice dans l'áng do fait que, pendant l'biver, on pent los qui Kouen nous a iras a en vie dans des caves humides, et même les en- sou museau, que l'on avait prise dans un étang graisser heaucoup, eu les tenant suspendues voisin de Caen, et qui était remarquable d'ailaprès les avoir entourées de mousse, en arrosant leurs par l'uniformité de la couleur verte égalesouvent leur enveloppe végétale, et en leur don- ment répandue sur toule la surface de l'animal. nant du pain, des fragments de plantes et du Mais, indépendamment de ces monstruosités
lait. et des variétés dont nous avons déjà parlé, l'esDans le temps de Bélon, on faisait avec les pèce de la carpe est fréquemment moditiée, suiœufs de earpes du caviar, qui était très-recher- vant plusieurs naturalistes, par son mélange ché à Constantinople et dans les environs de la avec d'autres espèces du genro des cyprins, parmer Noire, ainsi que de l'Archipel, et qui était ticulièrement avec des carassins et des gibèles. acheté avee d'autant plus d'empressement par Il résulte de ce mélange, des individus plus gros les Juifs de ces contrées asiatiques et euro- que des gibèles ou des earassins, mais moins péennes, que leurs lois religieuses leur défendent grands que des carpes, et qui ne pèsent guère que de se nourrir de caviar fail avec des wufs d'aci- de deux à quatre livres. Gener, Ildrovanto, pensères.

Schwenckfeld, Schoneveld, Marsigli, Willughby La vésicule du fiel de ces eyprins contient un et Klein, ont parló do ces métis, auxquels les pôliquide d'un vert foncé, très-amer, et dont on cheurs de l'Allemagne septentrionale ont donné a fait usage en peinture pour avoir une couleur différents noms. On les reconmaít à leurs écailles, verte; et si nous écrivions l'histoiro des erreurs qui sont plus petites, plus attachées à la peau et des préjugés, nous parlerions de toutes les que celles des carpes, et montrent des stries tonvertus extraordinaires el ridicules que l'on a gitudinales; de plus, leur teto est plus grosse, supposées pour la guérison de plusieurs mala- plus courte, et dénuée de barbillons. Mais Bloch dies, dans une petite éminence osseuse du fond pense qu'on no voit ces dernières différences du palais des cyprins que nous considérons, que lorsque des œufs de carpes ont été fécondés que l'on a nommée Pierre de carpe, et que l'on par des carassins ou par des gibèles, parce que a souvent portée avec une confiance aveugle, les métis ont toujours la tete et la caudale du comme un préservatif infaillible contre des maux mâle. Si ce dernier fait est bien constaté, it fauredoutables.

On trouve parmi les carpes, comme dans les autres espèces de poissons, des monstruosités plus ou moins bizarres. La collection du Muséum d'histoire naturelle renferme un de ces $c y-$ prins, dont la bouclie n'a d'autre orifice extérieur que ceux des branchies. Mais ces poissons sont sujets à présenter dans leur tête, et plus particulièrement dans leur museau, une difformité qui a souvent frappé les physiciens, et qui a toujours étonné le vulgaire, à cause des rapporls qu'elle lui a paru avoir avec la tête d'un cadavre humain, ou au moins avec celle d'un dauphin. Rondelet ', Gesner, Aldrovande, et d'autres naturalistes, en ont donné la figure ou

Ecrange especce de carpe. Rondelet, parl. 2. Poissons des lacs, c. 7. dra le regarder comme un des phénomènes les propres à fonder la théorio de la génération des animaux '.

\section{LE CYPRIN BARBEAU ${ }^{2}$,}

arbus communis, Cuv.; Cyprinus Barbus, Limn. Gmel., BI , Lac.; Cyprinus Capito, Lion., Gmel. 3. Ce poisson a quelques rapports extérieurs I a rayons á la membrane branehiale du cyprin earpe, 16 peetorale, 19 a la nageoire de la queu. ${ }^{3}$ Du sous-genre Bansesu, Barbus, Cuv., dans le grand - Da sous-bor formille des Cyprinoides, ordre des Malacoarbio, en Espagne. - Id. Barbo, en lialie. - Merenne,
Hongrie. - Ssasana, Vssaleh, en Russie. - Barb, 
avec le brochet, à cause de l'allongement de sa tits poissons, aes vers, aes sangsues. du frotẹte, de son corps et de sa queue. La partie su- mage, du jaune d'œuf ou du camplire. Sa chopérieure de ce cyprin est olivâtre; les côtés sont est blanche et de bon goùt. On assure

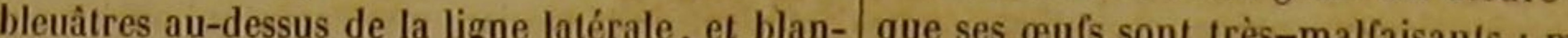
châtres au-dessous de celte même ligne, qui jest jue ses curs sont trè-maifaisants : mais Bloch, châtres au-dessous de celte même ligne, qui est je ne sais pourquoi, regarde comme fausses les droite et marquée par une série de points noirs; propriétés funestes qu'on leur altribue.

le ventre et la gorge sont blancs; une nuance Nous lisons dans les notes manuscrites de rougeâtre est répandue sur les pectorales, sur M. Pénières, que nous avons déjà cité plusieurs les ventrales, sur la nageoire de l'anus et sur fois, que, dans le département de la Corrèze, la caudale, qui d'ailleurs montre une bordure les barbeaux cherchent les bassins profonds et noire; la dorsale est bleuâtre. La lèvre supé- pierreux. Au moindre bruit, ils se caonds et rieure est rouge, forte, épaisse, et conformée les rochers saillants, et ils se tiennent sous cette de manière que l'animal peut l'étendre et la re- sorte de toit avec tant de constance que, lorstirer facilement. Les écailles sont strićes, dente- qu'on fouille leur asile, ils souffrent qu'on enlées et attachées fortement à la peau. L'épine lève leurs écailles, et reçoivent même souvent dorsale renferme quarante-six ou quarante-sept la mort plutôt que de se jeter contre le filet qui vertèbres, et s'articule, de chaque côté, avec entoure leur retraite, et dans les mailles duquel seize côtes.

Le barbeau se plait dans les eaux rapides qu coulent sur un fond de cailloux; il aime à se cacher parmi les pierres et sous les rives avanmacons, se nourrit de plantes aquatiques, de li- renferment dans une grotte commune, à laquelle maçons, de vers et de petits poissons; on l'a vu leur association doit le nom de nichée, que leu même rechorcher des cadavres. Il parvient au donnent les pécheurs. Lorsque les rivières qu'ils poids de dix-huit ou vingt livres. On le pêche fréquentent charrient des glaçons, ils choisissent dans les grands fleuves de l'Europe, et particu- des graviers abrités contre le froid, et exposés lièrement dans ceux de l'Europe méridionale. aux rayons du soleil; et si la surface de la rivière Suivant Bloch, il acquiert dans le Véser une se gèle et se durcit, ils viennent assez fréquengraisse très-agréable au goût, à cause du lin que ment auprès durcs, ils viennent assez fréquemon met dans ce fleuve. II ne produit que vers sa quatrième ou sa einquième année. Le prin- sour s'y pénétrer du peu de lemps est la saison pendant laquelle il fraie : il blis dur que peuvent leur donner les rayons affairemonte alors dans les rivit̀uelle il fraie : il blis du soleil de l'hiver.

remonte alors dans les rivières, et dẻpose ses Plusieurs barbeaux se trouvent-ils réunis dans œufs sur des pierres, à l'endroit oủ la rapidité un réservoir où ils manquent de nourriture, ils de l'eau est la plus grande. On le pêche avec des sucent la queue les uns des autres, au point que filets ou à la ligne, et on l'altire avec de très-pe- les plus gros ont bientôt exténué les plus pe. Barbet, Barme, Steinbarben, Rothbart, en Allemagno tits'.

terre. - Cyprin barbear, en Hollande. - Barbell, en Angle-1d. Bonnaterre, pl. de I'Bncenton et Haüy. Ene. méth. Comm. Petropol., p. 519 - Cyprin cabot. Bonnaterre de I'Enc. meth. - Mus. Ad. Frid., p. 2, p. 107. - Wutc Gimelin. It. 3, p. 242, tab. 25 , fig. 4 ., p. 39 , o. . 2. - S. G.

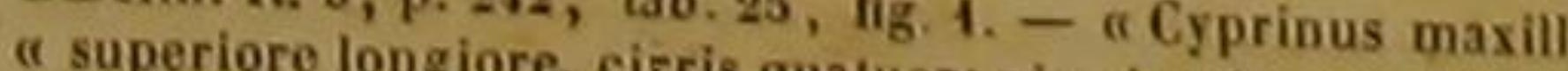
a septem. D Arledi, gen. A, syn. 8. - Bloch, pl, 18 - Dsiculorum beau. Rondelel, parl. 2, Poiss. de riviêre, c. 18. - Barbur-

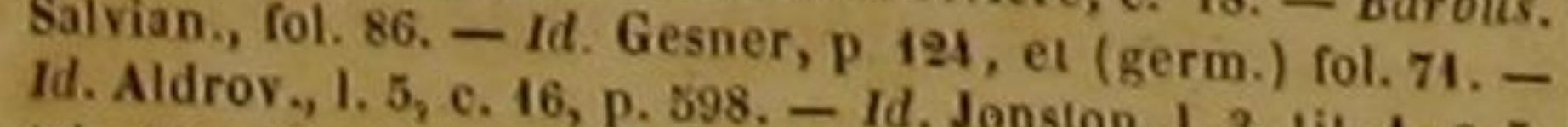
tab. 86, fol. 6. - Id C. p. 259. - Id. Rai, P. Coarieton, p. 156. - Id. Willughby, mullus nuviatilis nonnullis, Schonev, multus barbatus, Puviatilis. Bélon, - Gronov. Zoopb. 4, p. 104; Mus I, P. 5 , 1.. 20. - «Barbus oblongus, olivaceus.» Leske, Specim, P. 17. Danub., p. 18. tab. 7, pisc. 5, p. 64, n. 1.-Barbus. Marsig.

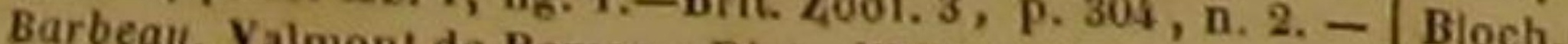

LE CYPRIN SPÉCULAIRE². Cyprinus Carpio, var. Gav.; Cyprinus specularis, Lac.; Cyprinus Rex cyprinorum, Bl. 3

ET LE CYPRIN A CUIR 4 . Cyprinus Carpio, var. Cuv.; Cyprinus coriaceus, Lac.; Cypriuus nudus, Bl. s.

Nous donnons le nom de Spéculaire à un cy-

I 17 rayons à chaque pectorale du cyprin barbeau, 19 à la 2 Spiegellarp queue. Bloch, pl. 17. - Reine des carpes. Bonnaterre, pl. de l'Enc.
I méth.

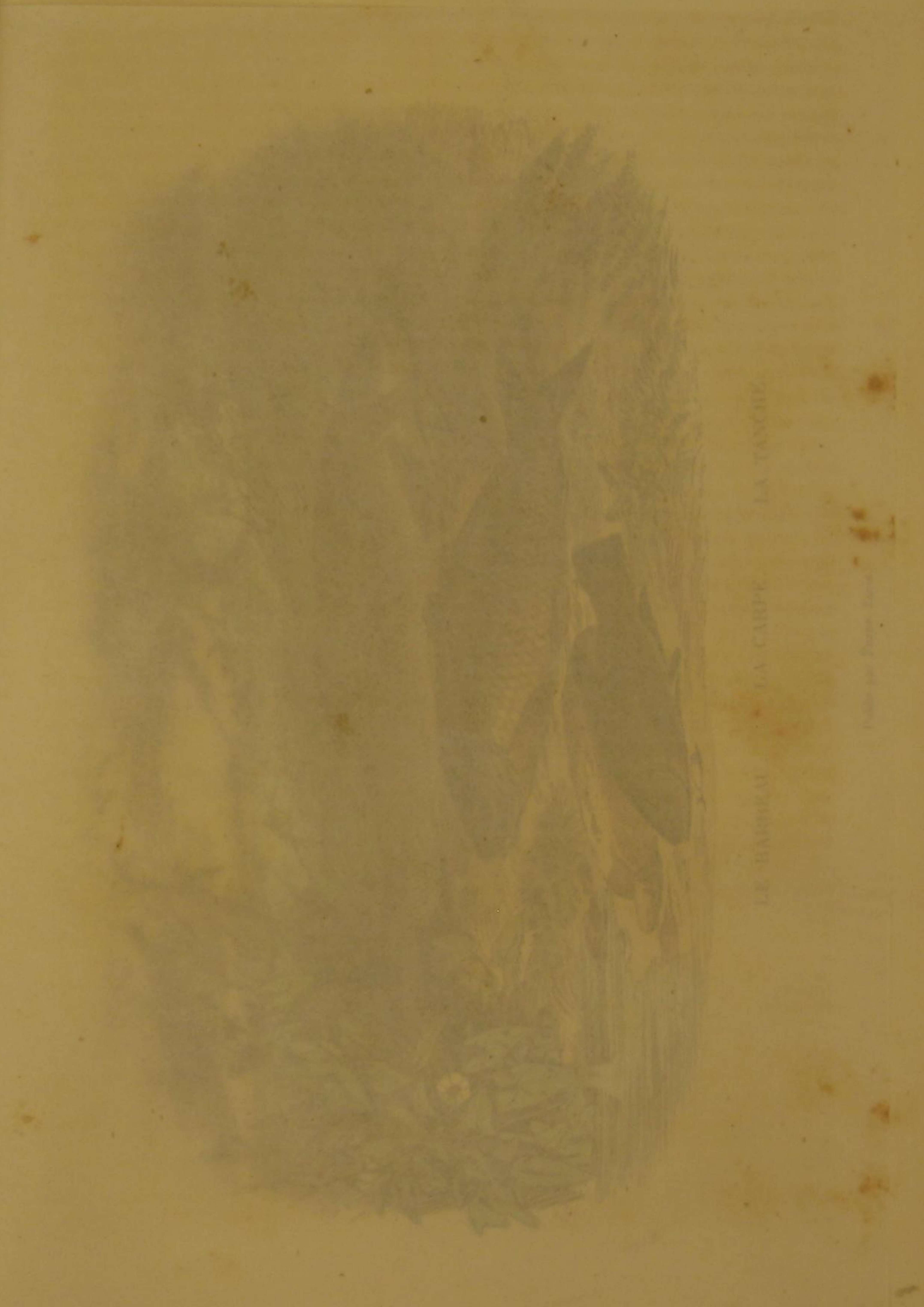




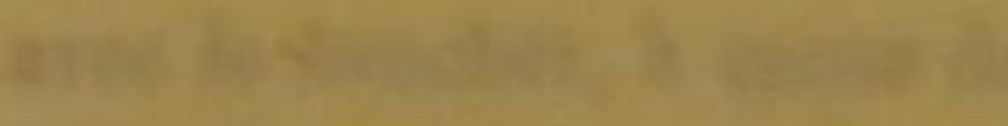
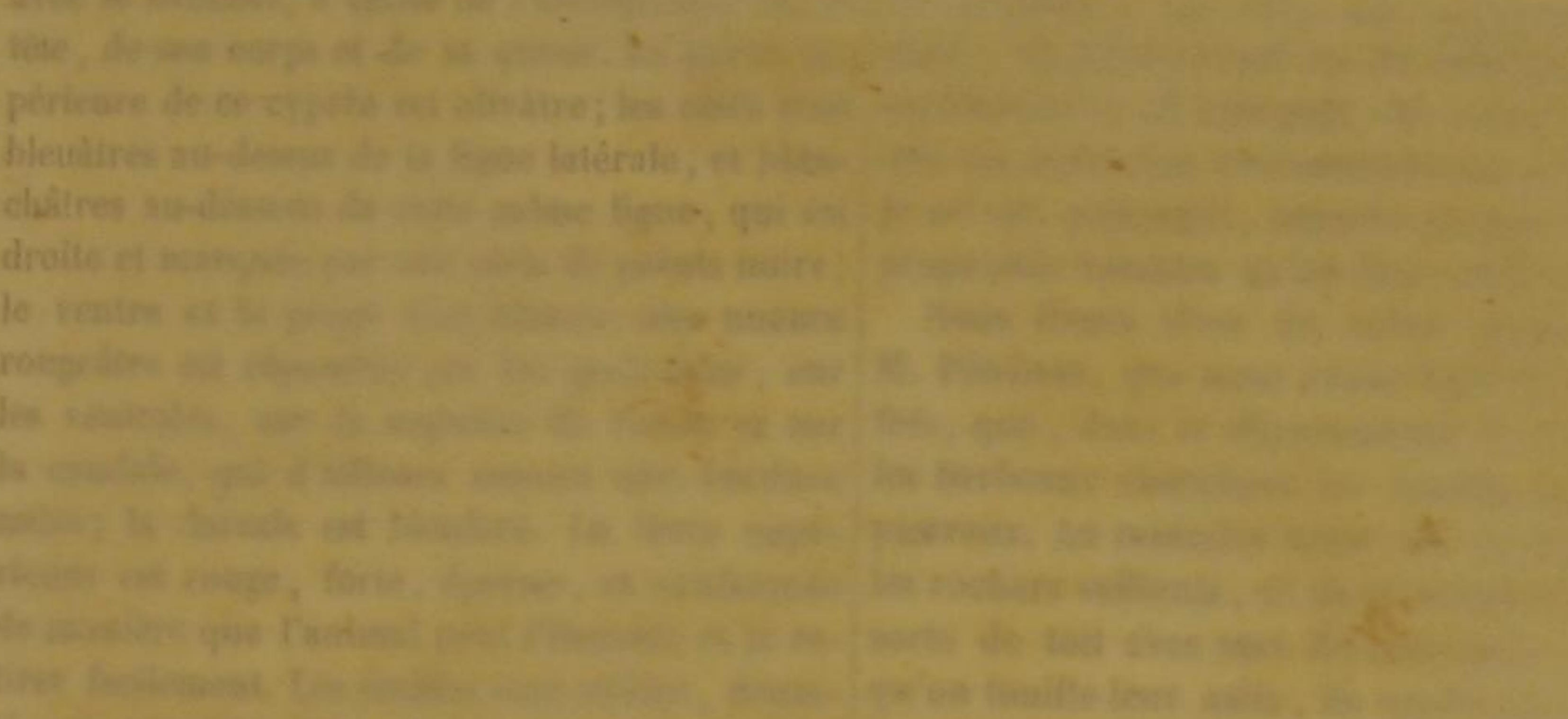

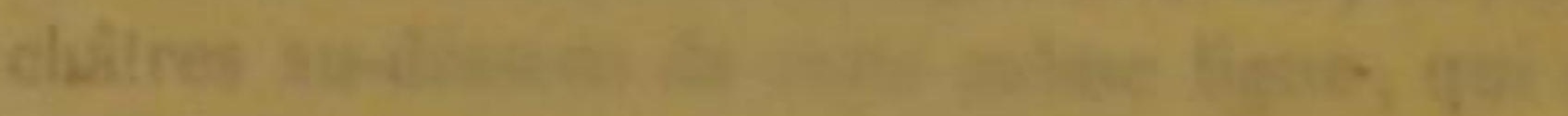

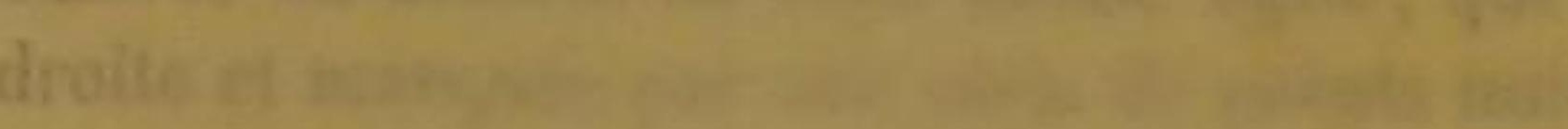

$i^{2}$
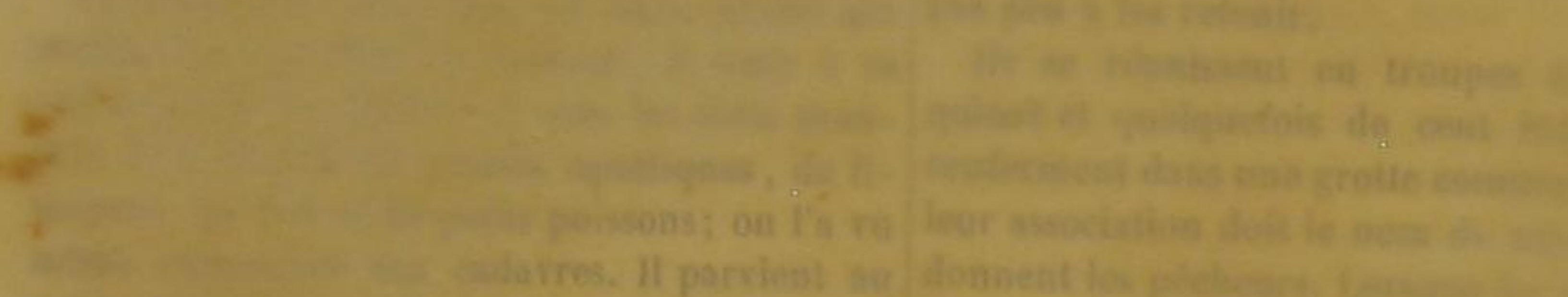

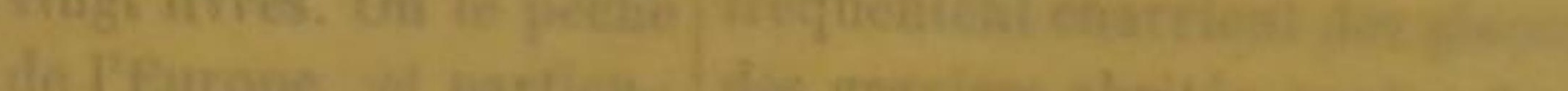

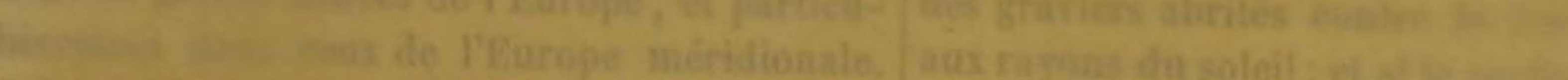

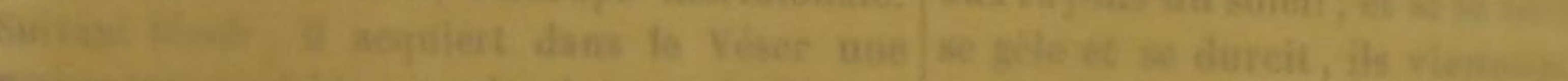
Vegi

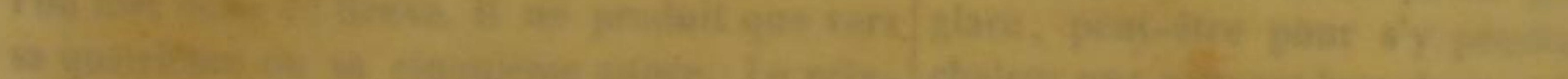

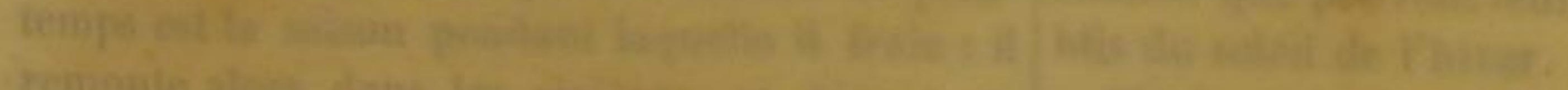

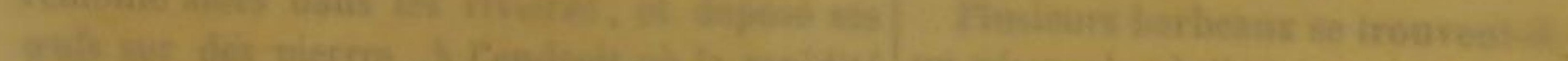

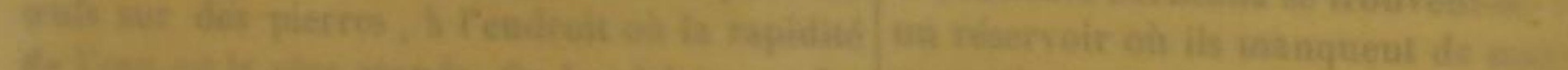

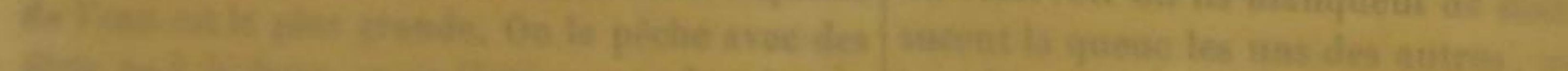

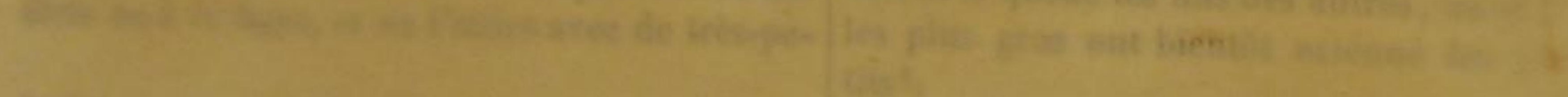
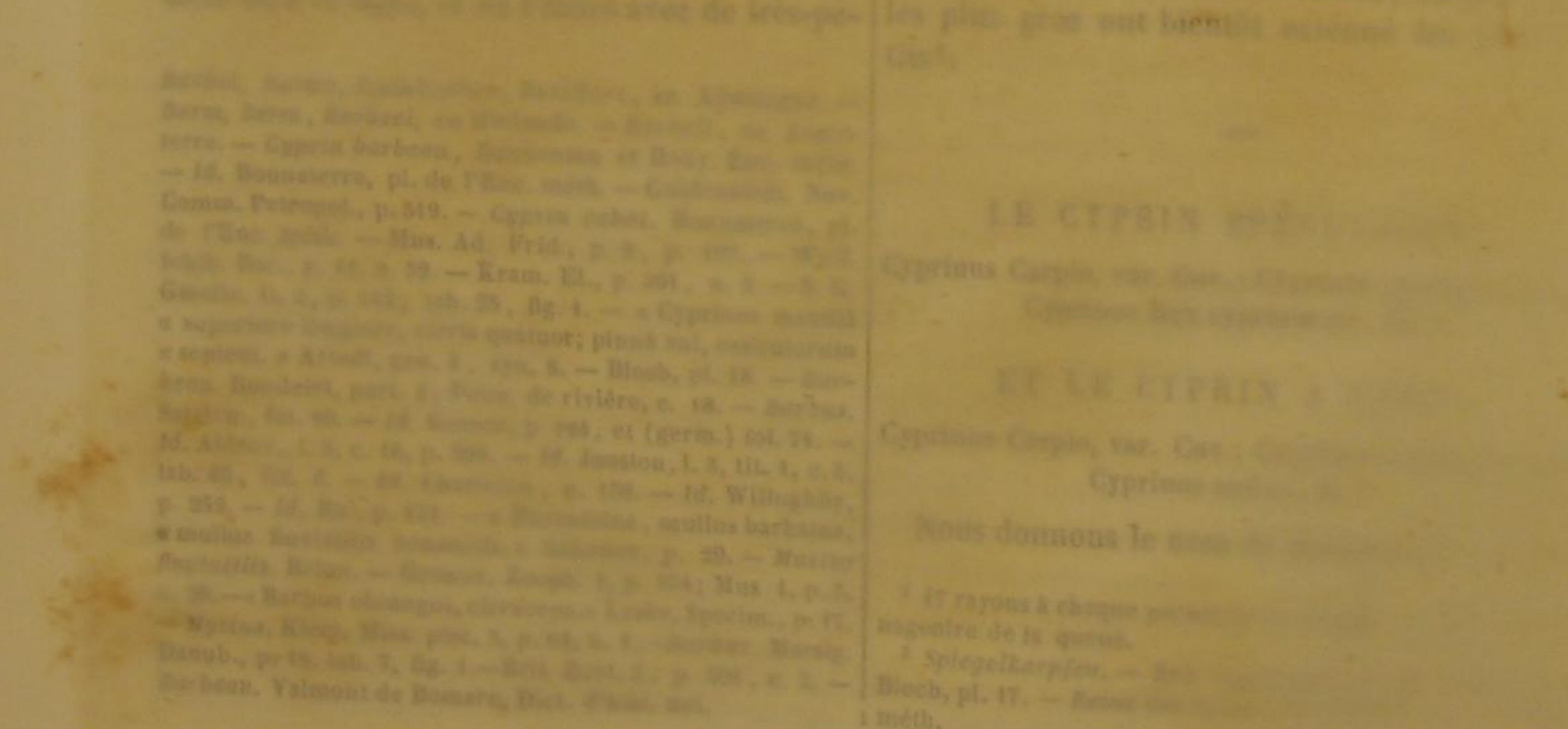

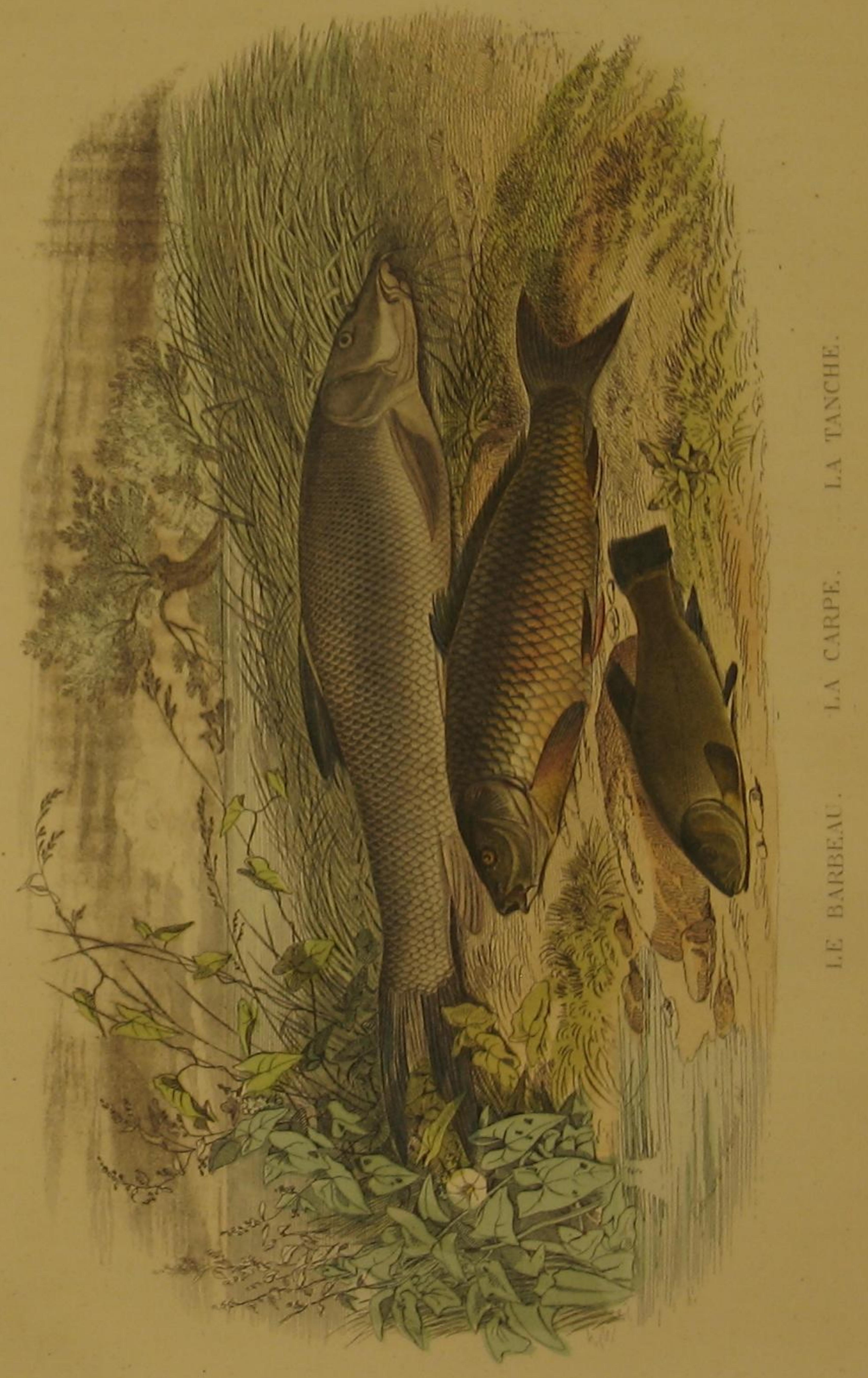


prin très-remarquable par les graudes écailles disposées en séries, et quelquefois distribuées d'ailleurs avec plus ou moins d'irrégularité sur sa surface. Ces écailles sont souvent quatre ou einq fois plus larges à proportion que celles de la carpe, et, quoique striées de manière à paraître comme rayonnées, elles ont assez d'éclat pour être comparées à de petits miroirs. Ces lames brillantes sont ordinairement placées de manière qu'elles forment de chaque côté deux ou trois rangées longitudinales. Leur couleur est jaune, et une bordure brune relève leurs nuances. Elles se détachent facilement de l'animal; ot lorsqu'elles ne sont pas répandues sur tout le corps du poisson, les places qu'elles laissent dénuées de substance écailleuse sont recouvertes d'une peau noirâtre, plus épaisse que celle qui croìt au-dessous de ces lames spéculaires. On trouve
les cyprins qui sont revêtus de ces écailles grandes et luisantes, dans plusieurs contrées de l'Europe; mais ils sont très-multipliés dans I'Allemagne septentrionale, particulierement dans le pays d'Anhalt, dans la Saxe, dans la Franconie, dans la Bobême, où on les élève dans des étangs, où ils parviennent à une grosseur trèscontangs, où ils parvienter et où leur chair acquiert une saveur que l'on a préférée au goût de celle de la carpe.

Si les cyprins spéculaires perdaient tous les miroirs écailleux qui sont disséminés sur leur miroirs écailleux qui sont disseaucoup aux $\mathrm{Cy}$ surface, ils ressembleraient beaucoup aux $C y$ prins à cuir. Ces derniers uéanmoins ont la peau plus brune, plus dure nom spécilique que nous leur conservons. Ces eyprins à cuir vivent en leur conservons. Ces eýs, où on peut les multiplier et les faire croître aussi promptement que les carpes. Bloch rapporte que M. le baron de Sierstorpff, qui en a eu dans ses étangs auprès de Breslau, et qui les a très-lien observés, a vu des cyir le milieu par leurs caractères paraissaient tenir le milieu entre les Cyprins à cuir et les Cyprins speculaires, et qu'il regardait comme des métis venus du mélange de ces deux espèces'.

3 .5 Ces deux poissons sont considérés, par M. Cuvier comme de simples variétés de la car carpio, voyez ci-avant, p. 566 . D.
\& Cyprinus nudus, carpe à cuir. Bloct. 18 rayons à chaque peciord la negeoire de la queue.

\section{LE GYPRIN BINNY',}

Barbus Binny, Cuv.; Cyprinus Binny, Forsk., Limn., Gmel, Lac.; Cyprinus lepidotus, Geoffroy. ?

Le Cyprin Bulatmai ${ }^{3}$, Barbus Bulatmai, Cuv: Cyprinus Barbus Mursa, 'Cuv.; Cyprinus Mursa, Guldenst., Linn, Gmel., Lac. ${ }^{6}$, - C. Rouge-brun, Cyprinus rubro fuscus, Lac.?

Le binny, que les eaux du Nil nourrissent, a a tête un peu comprimée: le dos élevé; le ventre arrondi; la ligne latérale courbée vers le bas; l'anale et la caudale rouges, avec du blanc à leur base, et les autres nageoires blanchâtres et bordées d'une couleur mêlée de roux. L'éclat de l'argent dont brillent ses écailles le fait remarquer, comme celui de l'or attire l'ail de l'observateur sur le luulatmai de la mer Caspienne. Ce dernier poisson présente en effet des reflets dorés au milieu des teintes argentines du ventre, et des nuances couleur d'acier de sa partie supérieure. Sa tête, brune par-dessus, el blanche pr-dessous ; la dorsale noirâtre; la nageoire de la queue rougeâtre; l'anale rouge, avec la base lanchâtre; l'extrémité des pectorales et celle des ventrales, d'un rouge plus ou moins vif; Ia base de ces ventrales et de ces pectorales, grise ou blanche, ou d'un blanc mêlé de gris.

La mer Caspienne, dans laquelle on trouve bulatmai, nourrit aussi le murse. Une couleur dorée, mêlée de brun dans la partie supérieure du poisson, et de blanc dans la partie inférieure de l'animal; des opercules bruns et lisses; une ande semblable par sa forme aux ventrales, et Hernières; les taches brunes banclie comme ces dernitres nade ces ventrales, la teinte foncée dos aures et de geoires; l'allongement de la tête, da coritesse des la queue; la convesité da crane, la pestéguments, écailles; la mucosité répandue murse, qui parver douze à seize pouces, et nuscrite que notre savant ami el confrère le professeur Geoo-

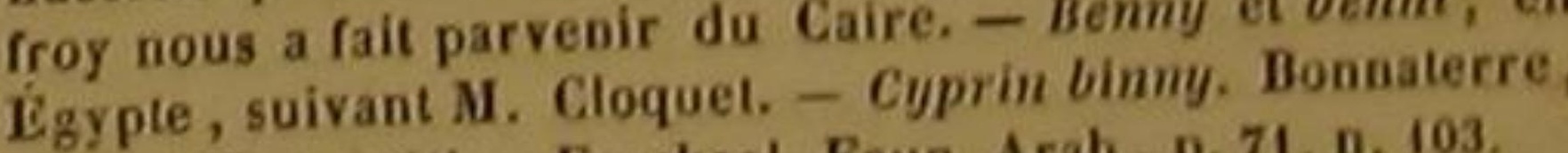

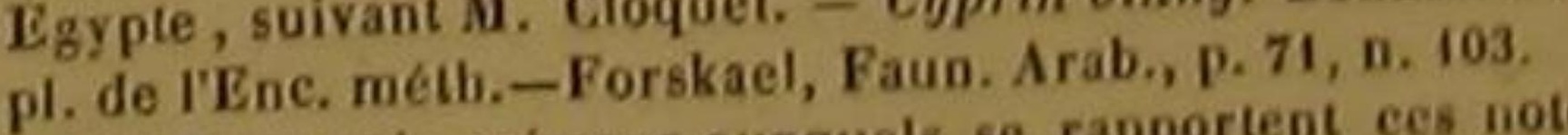
24. Les trois poissous auxquels se rapportent ces notes ont du sous-genre des Bambesux, Barbus, dans le grand genre Cxplas de A. Cuvier, fasur. D. des Malacoptérygiens abdominaux. D. N. Nord. Beyir. A, p. 6.

s. Cyprin murse. Bonnaterre, pl. de l'Ene. méth. - Guldenst. Nov. Cormm. Petropol. 17, p. sis, ab. 8, ig. a-s. is. Cuvier remarque que le cyprin rouge-brun, connuseulement par une peinturo
de Ia earpe commune. D. 
HISTOIRE NATURELLE

qui remonte dans la fleuve Cyrus, lorsque le liospitalières, où la modération ne plaça sur une printemps ramène le temps du frai ${ }^{\prime}$. Les deux nâchoires du rouge-brun sont pres- séjour du calme, asile du bonheur pour les que également avancées. Ce cyprin vit dans les ceurs sensibles que la perte d'un objet adoré eaux de la Chine : on peut en voir une figure n'a point condamnés à des regrets éternels, vos très-bien faite dans la collection des peintures images enchanteresses ne cessent d'entourer le chinoises données à la France par la Hollande. portrait du poisson que nous allons décrire. Son Nous en publions les premiers la description. nom rappelle et les rives fortunées près desquelles il éclôt, se développe et se reproduit, et I'habitation touchante et simple des vertus bien-

LE CYPRIN GOUJON², Gobio communis, Cuv.; Cyprinus Gobio, Linn., Gmel, Bl, Lac, 3 ,

ET LE CYPRIN TANCHEA. Tinca vulgaris, Cuv.; Cyprinus Tinca, Linn., Gmel., Bl, Lac. "

Lacs paisibles, rivières tranquilles, ombrages parfumés, rivages solitaires, et vous, retraites

1 17 rayons a chaque pectorale du cyprin binny, 19 da la nagcoire de la queue. -19 rayons à chaque peclorale du cyprin bulatmai, 21 a la caudale, -17 rayous à chaque peelorale du eyprin murse, 19 a ia nageoire de la queue.
a Gowjon de rivitere. - Goffon

départements de la France, - Grandling, Gressiting, Gos, en Allemagne. - Grandulis, Thops, en Livonio. - Grampel, Sandharl, Gympel, en Danemarek, - Grondel, en Hollande. - Greyling, Gudjeon, en Angleterre. - Cyprin
goujon. Daubenton el Haüy, Enc, métb. - Id. Bonnaterre, pl. de I'Enc. méth. - Goujon. Valmont de Bomare, Dic d'hist. nat. - Mus. Ad. Frid. 2, p. 107, - Müll. Prodr. Zoo
Danic., p. 50, n. 497, - Cyprings

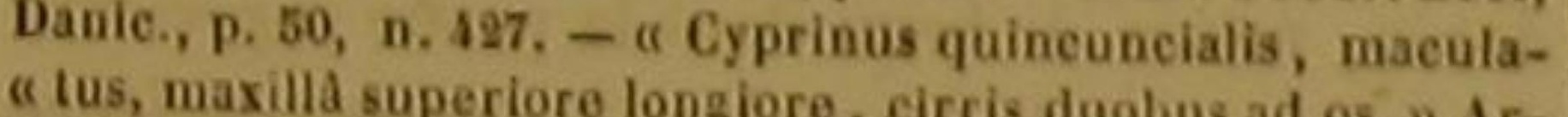
tedi, gen. A, spec. 13, syn. 14, - Fluviatilis gobio. Salvian f. 214 a.-Goujon de rivière. Rondelet, part. 2, poissons de riviêre, c. 28. - Gobio fluviatilis. Gesner, p. 399 el 474 ; (gerw.) f. 159.- Id. el fundulus, et gobio non capitaius. p. 612. - Gobius - Gobiuilis Ruviailitis. Aldrov., 1. 5, c. 27,

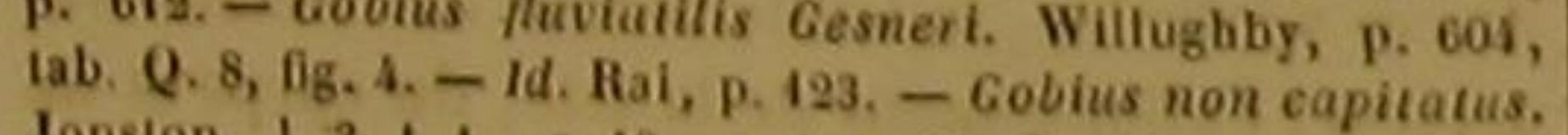

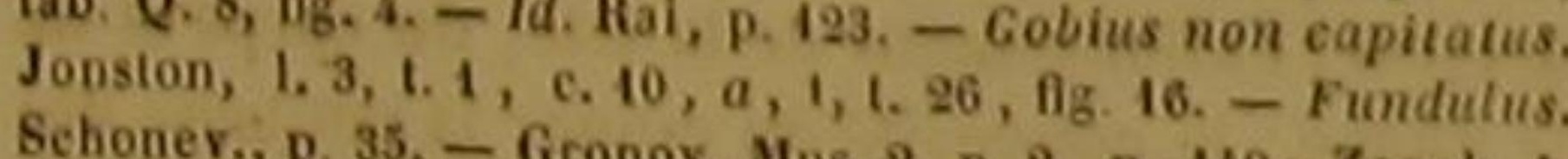
Sehoner, p. 35. - Gronor. Mus. 2, p. 2, n. 149; Zooph. 1 , p. 104. - Bloch, pl. 8, 08. 2, - Leske, Spec., p. 26, n. 3.
Klein, Miss. pisc. 4 , p. 60, D. 5, tab 15, fig. 5. - Marsi Danub, 1, p. 23, tab. 9, fig. 2. - Bril. Zool. 3, p. 308, n. 4 .
${ }^{3}$ Le goujon est lo lype dis Cuv., dans le grand gene du sous - geare Goujon. Gobio, ordre des Malacoptérygiens abdominaus. fes Cyprinoìdes, 'Tenca, en Italie. - Schlei, Knochen-schleye, le mâte
Bauch-sehleye, la femelle, en Bauch-schleye, la femelle, en Allemagne. - Schumacher, en Livonie. - Kkppesch, Lichnis, Line, Schleye, en Esto-
nie. - Skomacker, Limnore, Sulore, en Suède - Swler, nie. - Skomacker, Limnore, Sutore, en Suede. - Suder,
Slie, en Danemarck. - Muyhitionden, en Frise. - Zeel, Hollande. - Tench, en Angleterre, - Cyprin tanche. Dau-

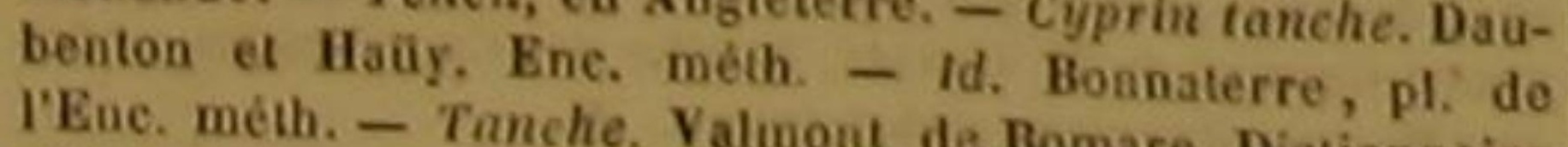
J'bist. nat. - Bloch, pl. 14. - Faun. Suecic, 263. - Wulfr. lehth. Boruss., p. 42, n. 55. - Müll. Prodr. Zool. Danic, p. 50, n. 428. - « Cyprinus mucosus nigrescens, n. Arledi,
gen. 4, spece. 27, syn. 5. - Tinca. Auson. Mosella, vers. 125. -Id. Jor. 124. - Tenche. Rondelet, part. 2, poissons des lacs, e. 10. - Tinea. Wollon, 1. 8, e. 190, r. 169 b. - Id.
Salvian., fol. 89-90.-Id. Gesner, p. 98 ; e (G) faisantes, des affections douces, de l'heureuse médiocrité dont il sert si souvent aux repas salutaires. On le trouve dans les eaux de l'Europe dont le sel n'altère pas la pureté, et particulièrement dans celles qui reposent ou coulent mollement et sans mélange sur un fond sablonneux. Il préfère les lacs que la tempête n'agite pas. Il y passe l'hiver; et lorsque le printemps porrive, il remonte dans les rivières, où il dé. pose sur les pierres sa laite ou ses cufs dont la couleur est bleuàtre et le volume très-petit. II ne se débarrasse de ce poids incommode que peu à peu, et en employant souvent près d'un mois à celte opération, dont la lenteur prouve que tous les œufs ne parviennent pas à la fois à la maturité, et que les diverses parties de la laite ne sont entièrement formées que successivement. Dans quelques rivières, et notamment dans eelle de la Corrèze, il ne fréquente ordinairement les frayères ${ }^{\prime}$ que depuis le coucher du soleil jusqu'au lever de cet astre.

M. Pénières, de qui nous tenons cette dermiere observation, nous a écrit que, dans le Cantal et la Corrèze, les femelles de l'espèce du goujon, et de plusieurs autres espèces de poissous, etaient cinq ou six fois plus nombreuses que les màles. les lacs; on les prend de plusieurs manières; on les pêche avec des filets et avec l'Lameçon. Ils sont d'ailleurs la proie des oiseaux d'eau, ainsi que des grands poissons, et cependant ils

d. Aldrov., 1. 5, c. 45, p. 646. - Id. Jonston, I. 3, L. 3, c. 10 p. 251 , tab. Q. 5. - id. Rai, phrlet., p. 162. $-1 d$. Willughby, prula fuviatilis. Schonev. p. 76. - id. el phycis, vel mea. 6. - Gronov. Mus. I, p. A, n. 18. - Klein, Miss, pisc. D. Mars. Danub., p. 47, tab. 15. - Bril. Zool. 3, p. 306 La Tanche est le type du sous-genre Taxcue, Tinca, s. D.
I. Cuvier, dans le grand genre Crpars, Cypri-

' Nom donné dans plusieurs contrécs aus endroils oủ
Vers l'automue, les goujons reviennent dans
DES POISSONS.

sont très-multipliés, Ils vivent de plantes, petits œufs, de vers, de débris de corps orga- dans les marais : les caur sog nisés. Ils paraissent se plaire plusieurs ensemble; sont celles qu'elles recherchent. Elles ne craion les rencontre presque toujours réunis en guent pas les rimours de l'tiver: on n'a pas-

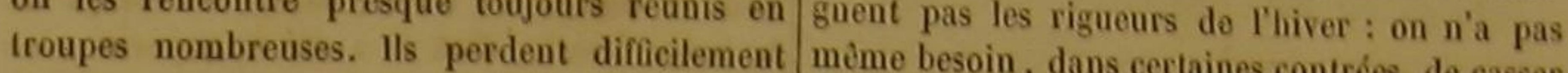
la vie. A peine parviennerdent difticilement mème besoin, dans certaines contrées, de casser la vie. A peine parviennent-ils à la longueur de en différents endroits la glace qui se forme auquatre à huit pouces.

Leur canal intestinal présente deux sinuosités; quatorze côtes soutiennent de chaque côté l'épine dorsale, qui renferme trente-neuf vertèbres.

Leur màchoire supérieure est un peu plus da avancée que celle de dessous; leurs écailles sont grandes, à proportion de leurs principales dimensions; leur ligne latérale est droite.

Leur couleur varie avec leur âge, leur nourriture, et la nature de l'eau dans laquelle ils sont plongés : mais le plus souvent un bleu noirâtce règne sur leur dos : leurs cotés sont blèus dans leur partie supérieure; lo bas de ces mêmes côtés et le dessous du corps offrent des teintes mêlées de blane et de jaune; des taches bleues sont placées sur la ligne latérale; et l'on voit des taches noires sur la caudale et sur la dorsale, qui sont jaunâtres ou rougeâtres, comme les autres nageoires.

Les tanches sont aussi sujeltes que les goujons à varier dans leurs nuances, suivant läge, le sexe, le climat, les aliments et les qualités de

l'eau. Communément on remarque da jaune verdâtre sur leurs joues, du blanc sur leur gorge, du vert foncé sur leur front et sur leur dos, du vert clair sur la partie supérieure de leur côtés, du jaune sur la partie inférieure de ces dernières portions, du blanchâtre sur le ventre, du violet sur les nageoires : mais plusieurs individus montrent un vert plus éclairci, ou plus voisin du noir ; les mâles particulièrement ont des teintes moins obscures. Ils ont aussi les ventrales plus grandes, les os plus forts, la chair plus grasse et plus agréable au goût. Dans les femelles comme dans les mâles, la tête est morceaux, et mises sous la plante des pieds, grosse; le front large; l'oil petit; la lèvre elles guérissaient de la peste et des fièvres brôépaisse; le dos un peu arqué; chacun des os qui lantes; qu’appliquées vivantes sur le front, elles retiennent les pectorales ou les ventrales, trìs- apaisaient les maux de tête; qu'attachées sur fort; la peau noire; toute la surface de l'animal la nuque, elles calmaient linflammation des converte d'une matière visqueuse assez abon- yeux; que placées sur le ventre, elles faisaient dante pour empêcher de distinguer facilement disparaître la jaunisse; que leur fiel chassait les les écailles; l'épine dorsale composée de trente- vers, et que les poissons guérissaient leurs blesneuf vertebres et soutenue a droite et a gauche par seize côtes.

I 16 rayons a chaque pectorale du cyprin goujon, 19 a ia
nageoire de la queue, -18 rayoas a chaque pectorale da On trouve des fanches dans presque toutes les $\mid \begin{aligned} & \text { nageoire de la queue, }-18 \mathrm{raj} \\ & \text { cyprin tanche, } 19 \text { a la caudale. }\end{aligned}$ 
sures, en se frottant contre la substance luileuse |sa ligne latérale. Il a celte même ligne latérale qui les enduit.

\section{LE CYPRIN CAPOET',}

Gobio Capoeta, Cuv.; Cyprinus Capoeta, Guldenst. Linn., Gmel., Lac. ?

Le Cyprin Tanchor ${ }^{3}$, Tanca vulgaris, var. aurea, Cur.; Cyprinus Tinica auratus, Bl., Lac,; Cyprinus Tinea, var aurea, Linn., Gmel. 4. - C. Voncondre ${ }^{3}$, Cirrhinus Vo conder, Lacep. $6-C$. verdatre, Cyprinus viridescens,

Le capoet labite dans la mer Caspienne; il remonte daus les fleuves qui se jettent dans celte mer : mais ce qui est remarquable, c'est qu'il passe la belle saison dans celle mer intérieure, et qu'il ne va dans l'eau douce que pendant l'hiver. Sa longueur est de douze ou quinze pouces. Il a les écailles arrondies, minces, striées, argentées, et pointillées de brun, excepté celles du ventre, qui sont blanches; la tête courte, très-large et lisse; le sommet de la tête brun et convese; le museau avancé; les opercule unis, bruns et pointillés; la ligne latérale cou bée vers le bas, auprès de son origine; les nageoires brunes et parsemées de points obsenrs un appendice auprès de chaque ventrale.

Le cyprin tanchor doit être compté parmi les plus beaux poissons. La dorure éclatante répandue sur sa surface, le noir brillant des points ou des taches que l'on voit sur son corps, sur sa queue et sur ses instruments de natation, le blanchàtre transparent de ses nageoires, les teintes noires de son front et de la partie anterieure de son dos, font paraître très vifs et rendent très-aǵréables le rose des lèvres et du nez, celui qui colore ses rayons d'ailleurs très-agiles, t le rouge qui, distribué en petites gontles plus ou moins rapprochées, marque le cours de

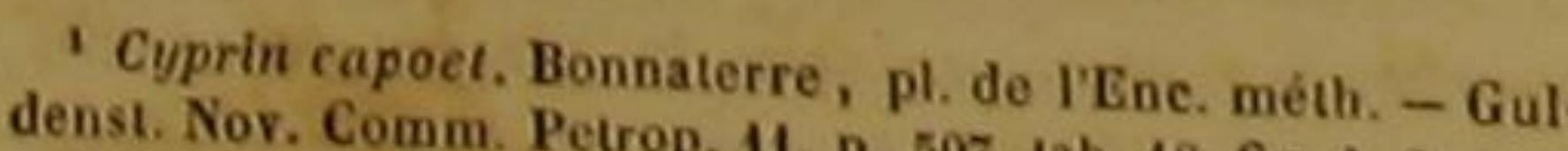

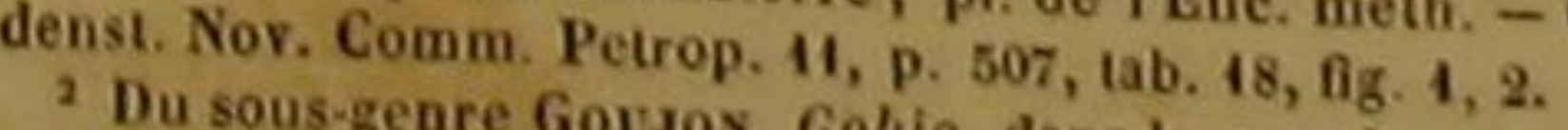
2 Du sous-geare Gousos, Gobio, dans le grand genre des
Cypass. Cur. D.

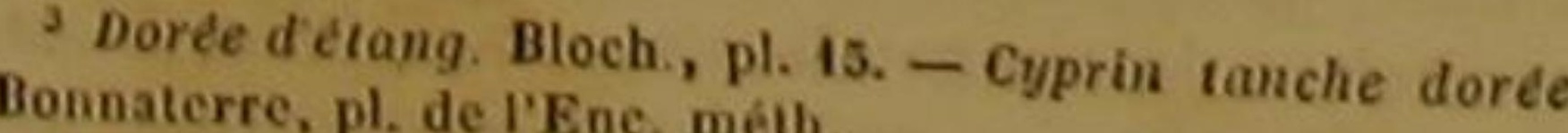
t Le Tanehor de M. Lacépếfte lanche vulgaire, remarquable pas une simple variété de la conséquemment il apparlient au sous-genre TAxCHE, dons seare Cxpmux. D.

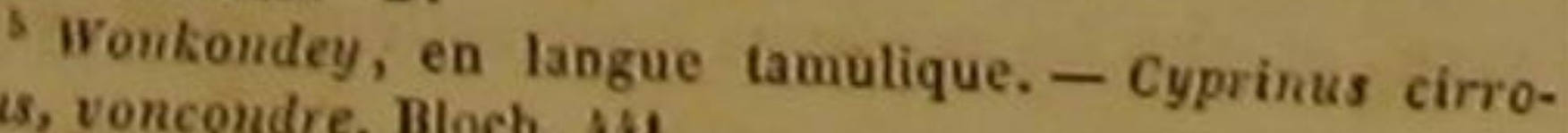

rhimus, formé par M. Cuvier, dans les-genre Cisnmine, $C$.

M. Cuvier ne fait pas meotion de celle espice. rage et droite; sa tête est petite.

Ce cyprin, qui peut faire l'ornemeut des canaux et des pièces d'eau, habite les étangs de la haute Silésie, d'où il a été transporté avec succès dans les eaux de Schœnhausen en Brandebourg, par les soins de la reine de Prusse, femme du grand Frédéric. Il résiste à beaucoup d'accidents. Il ne croit que lentement; mais il parvieut à une longueur de près de trois pieds. On peut le nourrir avec des débris de végétaux, des vers, du pain, des pois, des fèves cuiles. On a cru remarquer qu'il était moins sensible que les carpes au son de la cloche dont on se sert dans plusieurs viviers pour avertir ces derniers paire.

Le voncondre vit dans les lacs et daus les rivières de la côte du Málabar. Il parvient à la longueur d'un pied el demi. On ne doit pas oublier la compression de son corps; la surface unie de sa tête, de sa langue, de son palais; le peu de largeur des os de ses lèvres; la direction droite de sa ligne latérale; le violet argenté de sa couleur générale; le bleu de ses nageoires. Le verdàtre, dont la description n'a pas encore été publiée, et dont M. Noêl a bien voulu nous envoyer un dessin accompagné d'une note relative à cet abdominal, montre un barbillon blanc, court et délié à chacun des angles de ses mâchoires. Ses couleurs sont très-chatoyantes. Un individu de cette espèce a été péché, vers la in de mars, à la source d'un petit ruisseau, auprès de Rouen'.

\section{LE CYPRIN ANNE-CAROLINE.}

Cyprinus Anna-Carolina, Lac., Cuv. ${ }^{3}$

Voici le troisième hommage que mon cœur rend, dans cette histoire, aux vertus, à l'esprit superieur, aux charmes, aux talents d'une epouse adorée et si digne de l'ûtre. Ah! lors naguère j'exprimais, dans cet ourrage, mies senr 1 19 rayons à chaque pectorale du cyprin capoel, 19 a la rale du cyprin voncondre, 28 i a nagons à chaque pecto M. Lacépéde a établi celte espéce de poisson queue. daprés une peinture chinoise, qui fail partie de la collection du Musćum d'Histoire naturelle. M. Curier pense que celle
espéce se rapproeche beaucoup de la carpe commune. D. poissons qu'on leur apporte leur nourriture oriments immortels pour clle, je pourais encoro

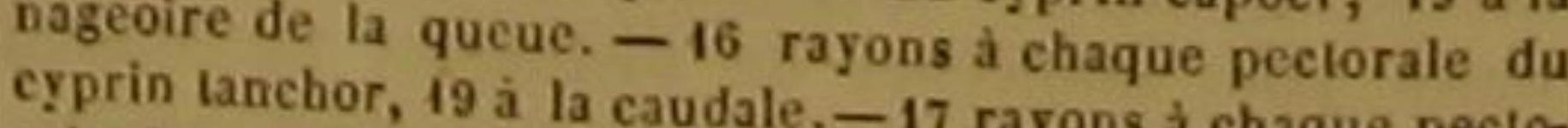

et la voir, et lui parler, et l'entendre. C'était aut- à une égale distance des ventrates et de la maprès d'elle que j'écrivais cet éloge si mérité, que geoire de la queue.

j'étais obligé de cacher avee tant de soin à sa On trouvera une image de ce cyprin dans la modestie. L'espérance me soutenait encore au collection des peintures sur vétin du Musém milieu des peines cruelles que ses douleurs hor- d'histoire naturelle.

ribles me faisaient soufrir, et de la tendre atmiration que m'inspirait celte patience si douce qu'une année de tourments n'a pu altérer.

Aujourd'hui j'écris seul, livré à la douleur profonde, condamné au désespoir par la mort de celle qui m'aimait. Ah! pour trouver quelque soulagement dans le malheur affreux qui ne cessera de m'accabler que lorsque je reposerai dans la tombe de ma bien-aimée ', que n'ai-je le style de mes maitres pour graver sur un monument plus durable que le bronze l'expression de mon amour et de mes regrets éternels !

Du moins, les amis de la nature, qui pareourront cette histoire, ne verront pas cette page arrosée de mes larmes amères sans penser avee attendrissement à ma Caroline, si bonne, si parfaite, si aimable, enlevée si jeune à son époux désolé.

Le cyprin que nous consacrons à sa mémoire, et dont la deseription n'a pas encore été publiće, est un des poissous les plus beaux et les plus utiles.

A l'éclat de l'or et de l'argent, qui brillent sur son corps et sur sa queue, se réunit celui de ses nageoires, qui sont d'un jaune doré

Au milieu de l'or qui resplendit sur le derrière de la tête et sur la partie antérieure du dos, on voit une taclie verdâtre placée sur la nuque, et trois taches d'un beau noir, la premic̀re ovale, la seconde allongée et sinueuse, et la troisième ronde, situées de chaque còté du poisson.

Des taches très-inégales, irréguličres, noires, et distribuées sans ordre, relevent avec grâce les nuances verdâtres qui règnent sur le dos.

Chaque commissure des lèvres présente un barbillon; l'ouverture de la bouche est petite; un grand orifice répond à chaque narine; les ćcailles sont striées et arrondies; les pectorales étroites et longues; les rayons de clraque ventrale allongés, ainsi que ceux de l'anale, qui est

Sa chair fournit une nourriture abondante of trìs-agréable.

\section{LE GYPRIN MORDORÉ,}

Cyprinus nigro-auratus, Lac, 1.

\section{ET LE CYPRIN VERT - VIOLET}

Cyprinus viridi-violaceus, Lac, ".

Ces deux poissons sont encore inconnus des naturalistes. Ils habitent dans les eaux de la Chine, On peut en voir lá figure et les couleurs dans les belles peintures elinoises que nous avons souvent citees, et qui sont déposées au Muséum d'histoire naturelle.

La parure du mordoré parait d'autant plus riche, que ces teintes dorées se marient aver des reflets rongeâtres, distribués sur sa partie inférieure. Indépendamment de la bosse que I'on voit sur la nuque, trois petites étévations convexes sont placées l'une au-devant de l'autre, sur la partie supéricure de la tête. Chaque opercule est composé de trois pièces. Les pectorales et les ventrales sont de la même grandeur et de la même forme. L'anale est plus petite que chacune de ces nageoires, triangulaire, et composée de rayons articulés, excepté le premier, qui est fort et légèrement dentelé. La ligne latérale est courbée vers to bas.

Le vert-violet a ses opercules anguleux parderrière, et composés cliacun de deux pièces. L'ouverture de la bouche est petito. Les peeto. rales, les ventrales et l'anale sont presque ovales; mais les premieres sont plus grandes que les secondes, et les secondes plus grandes que la nageoire de l'anus. La ligue latérale est presque droite. Les écailles sont en losange.

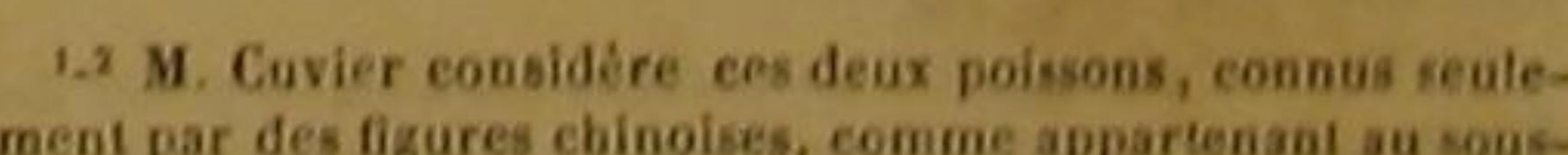
genre des Calprs, dans le grand genre Crpars, et mémo comme etant fort voisins de la earpe ordinaire. $D$.
cons

I Sa dépouille morlelle attend la mienne dans le cimcliêre de Leuville, viliage du deparlement de Seine-el-Oise, oú elle etait nee, ou Jai passe auprser au milieu de ses proches, Oî les lormes de lous les habitants prouvent, plus que tous les eloges, sa bienfaisance el sa bonté. Bénis soient ceux qui me déposeront auprés d'elle dans son dernier asile ! 
HISTOIRE NATURELLE

LE CYPRIN HAMBURGE ',

Cyprinus Carassius, Cuv., Linn., Gmel., Bl., Lac. ฯ.

Le Cyprin céphale ${ }^{3}$, Cyprinus Cephalus, Linn., Gmel. Lacep.4 - C. soyeux ${ }^{5}$, Cyprinus sericeus, Linn., Gmel. - c. Zeelt, Cyprinus Zeelt, Lac.?

Le museau de l'hamburge est arrondi; sa tête paraît d'autant plus petite, que son corps a une très-grande hauteur, que ce poisson est trèsépais, et que son dos se recourbe en arc de cercle. La partie supérieure est d'un brun foncé, qui se change en olivâtre sur la tête. Ses côtés sont verdâtres vers le haut, et jaunâtres vers le bas. Son ventre est d'un blanc mélé de rouge. Ses pectorales sont violettes; des nuances jaunâtres et une bordure grise distinguent les autres nageoires.

L'hamburge se plait dans les eaux dont le fond est de glaise ou marneux ; il aime les lacs et les élangs. Il ne contracte pas facilement de mauvais goût dans les eaux fangeuses : il vit dans celles qui sont dormantes, et qui n'ocenpent qu'un petit espace. Lorsque l'hiver règne, if peut même être conservé assez longtemp hors de l'eau sans périr; et, dans cette saison froide, on le transporte en vie à d'assez grandes distances en le plaçant dans de la neige, ic gne mérid, - Garois, dans plusieurs contrées de l'Allem

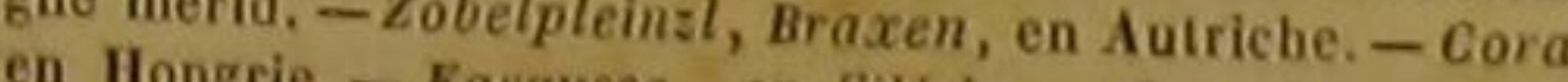
en Hongrie. - Karausse, en Silésie. - Karsche, dans i basse Silésie. - Karausche, en Saxe. - Karutz, en Westmarck. - Rambarussa, en Suede. - Karudse, en Danecian, en Angleterre. - Cyprin hamburge. Daubenton ei Haüy, Enc. méth. - Id , Bonn Faun. Suecic. 304. - Mütl. Prodr. Zool. Daric, p. 50, n. - uCyprinus pinna dorsi ossiculorum viginti, lined tot a recta, " Arledi, gen. 4, spec. 29, syn. 5. - " Charax, " 1275. - "Cyprinus. p. 229, tab. Q. 6, Ag. 1. - Id. Rai, p. 116. - c Cyprinus latus (a alius. D) Aldrov., 1. 5, c. 43, p. 644. - Id. Jonston, I. 3, L, 3, c. 9 , p. 165, lab. 97, fig. 12. - Kramer, El., p. 392, n. 7 . -
Gronov. Mus. 4. n. 14,

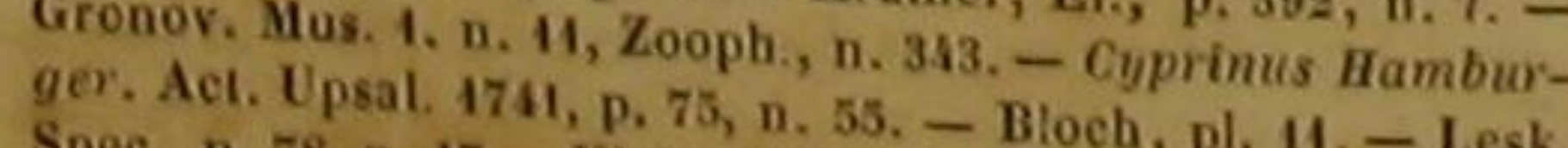
fig. 4. Carassius. Marsigl. Danub. 4, p. 59, n. 4, tab. 11,
fab. 14. Riud. Brit. Zool. 3, p. 310 . Danub. 4, p. 45, tab. 14 . CARpEs, dans le grand genre Carreau est du sous genre des Dubs, Ad. Frid., p. 77, lab. 30. - Cyprin cylindrique. I'Enc, méth. I C Cy, Kac. meth. - Id. Bonnaterre, pl. de

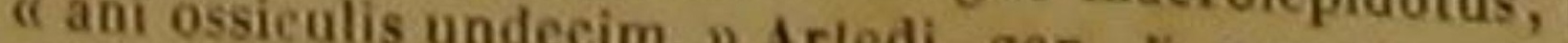
Mus. 1, n. 12, 2, p. 3 .

p. II. 3, p. 701, n. 44.

niêres especes. D.
D, en l'entourant de feuilles de chou, de laitue, ou d'autres végétaux analogues à ces dernières glantes.

Il se nourrit, comme les carpes, de vers, de végétaux, de débris de substances organisées, qu'il ramasse dans la vase. On l'engraisse avec des feves cuites, des pois, du pain de chènevis, poids n' de brebis. Il croît lentement. Son poids n'excède guère une livre; mais sa chair est blanche, tendre, saine, et pent devenir très. délicate.

C'est ordinairement à l'âge de deux ans qu'il cominence à frayer. On le prend avec des nases, au filet et à l'hameçon. Son canal intestinal présente cinq sinuosités. Quinze côtes sont placées de chaque côté de son épine dorsale, qui renferme trente vertèbres. Ses œufs sont jaude pavot.

Le Danube, le Rhin et d'autres fleuves nourrissent le céphale, dont la ligne latérale est située très-bas; ses écailles sont d'ailleurs grandes et arrondies; sa caudale est ovale. Des teintes bleuâtres paraissent sur son dos; son ventre et ses côtés, argentés pendant sa jeunesse, son ensuite d'un jaune doré, parsemé de points bruns. Sa longueur est de douze à seize pouces ' Le soyeux, qui habite les eaux dormantes de la Daurie, n'a le plus souvent que deux ou trois pouces de longueur. Il est très-brillant d'argent, de violet et d'azur; une couleur de rose pâle paraít sur son abdomen; brun rougeàtre; l'extrémité de ses ventrales et de sa nageoire de l'anus montre une nuance plus ou moins noire.

Le zéelt, que les naturalites ne connaissent pas encore, et dont nous avons vu un individn parmi les poissons desséchés donnés par la Hollande à la France, a les écailles petites, et les pectorales arrondies, ainsi que les ventrales.

1 13 rayons a chaque pectorale du cyprin hamburge, 91 a
la nageoire de la queue. -16 rayons à chaque pectorale du cyprin céphale, 17 d la caudale. -16 rayons à chaque pectorale du cyprin zéelt, 23 à la nageoire de la queue.
ta

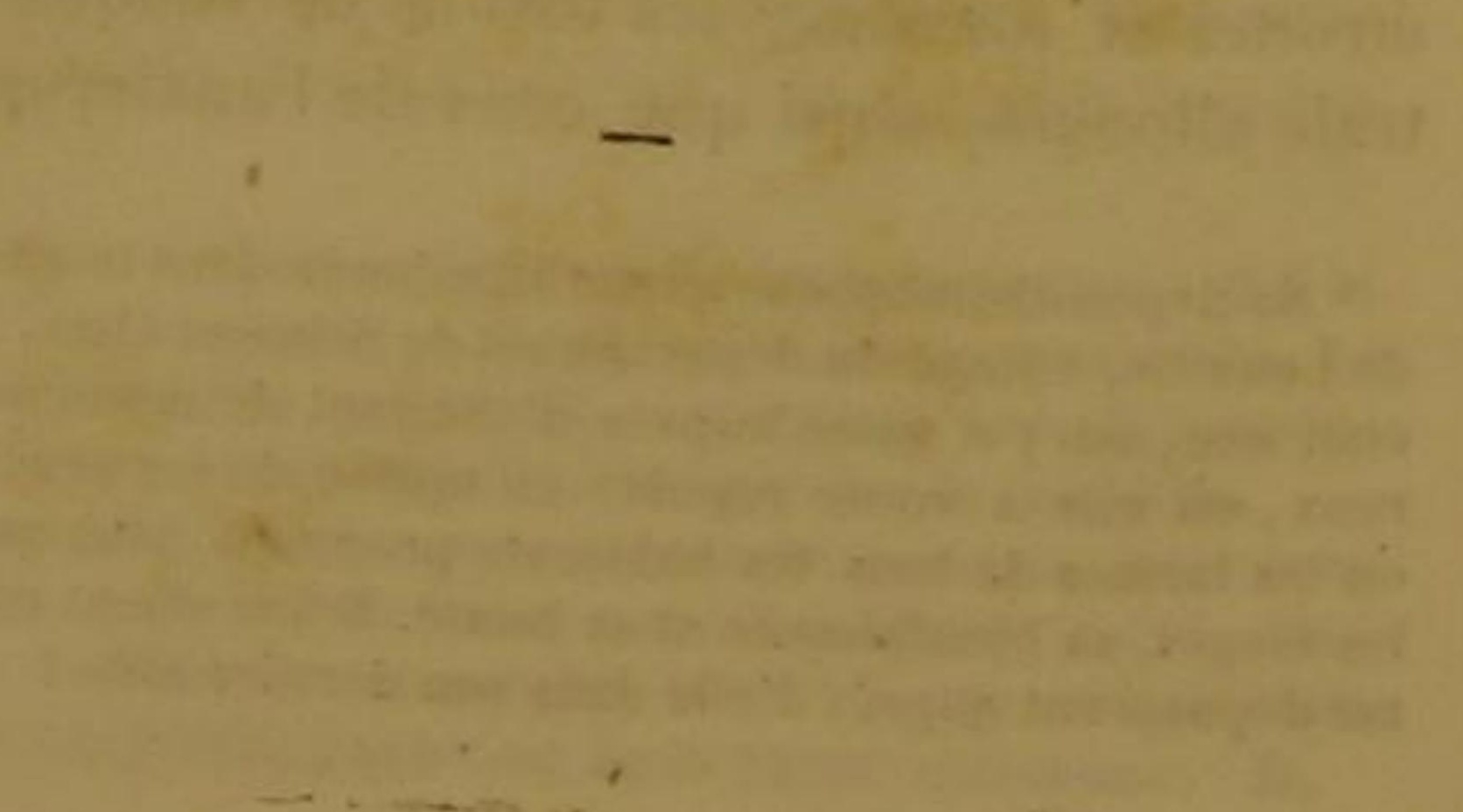



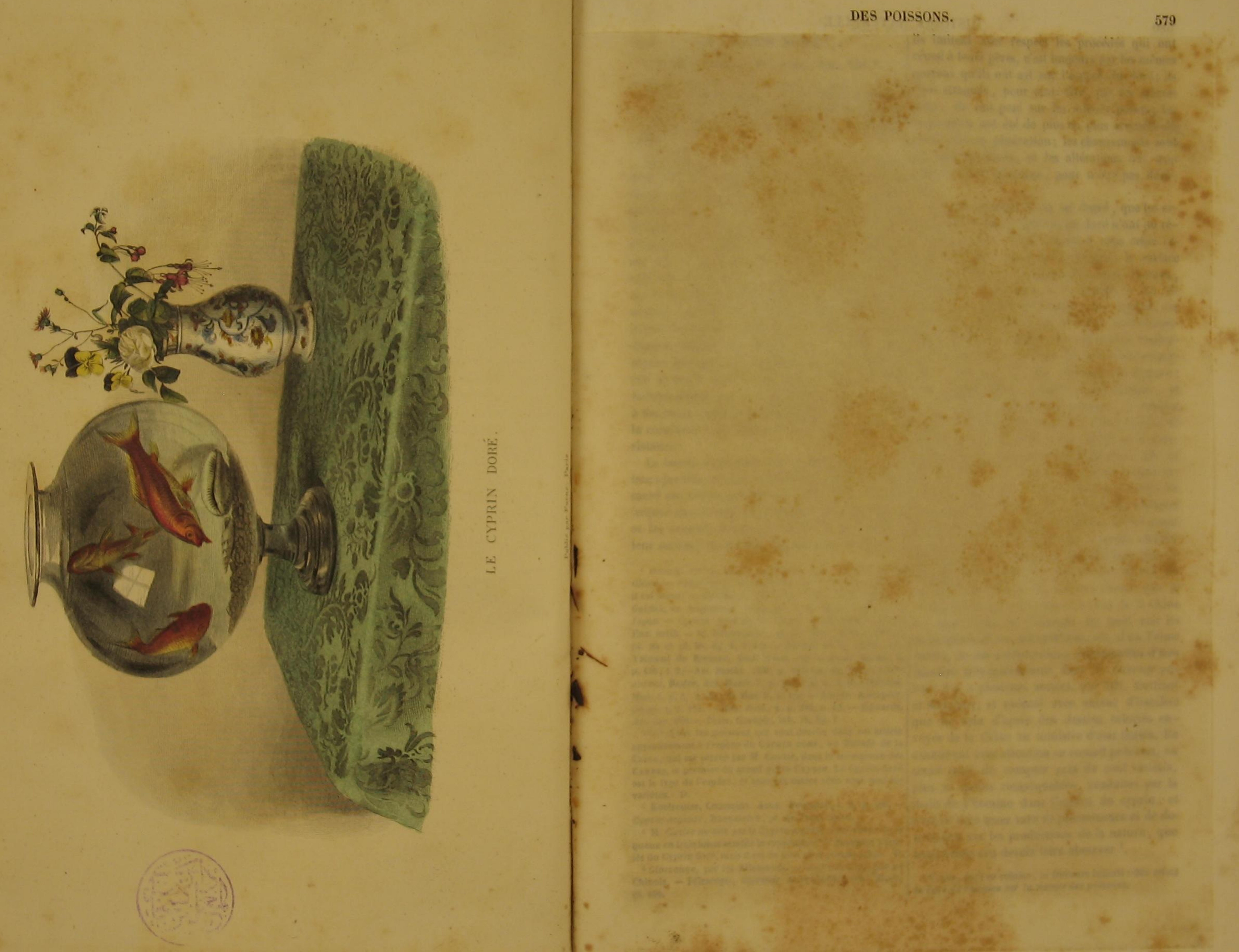


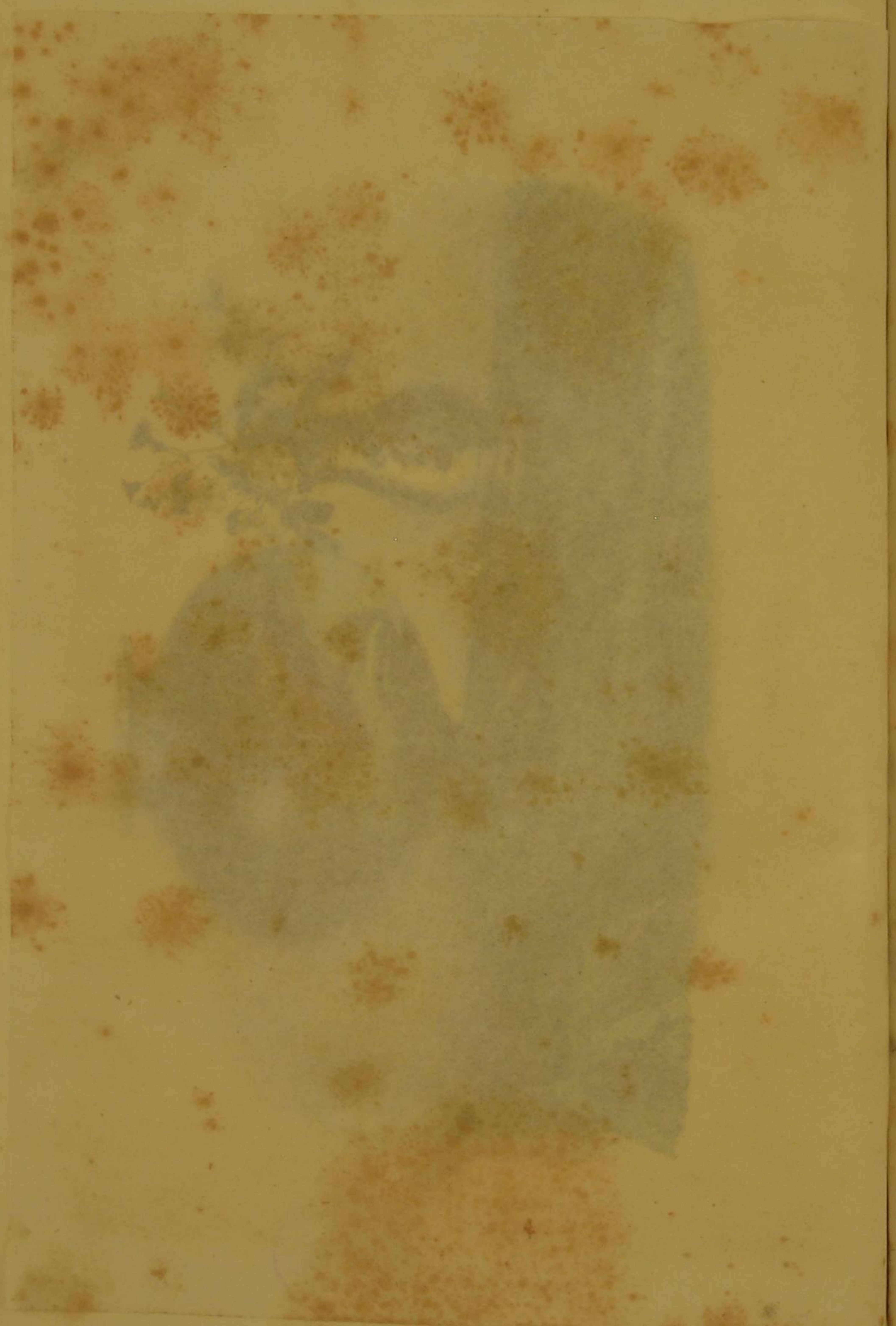

DES POISSONS.

LE GYPRIN DORÉ,

Cyprinus auratus, Limn., Gmel., Lac., Cuv, ?.

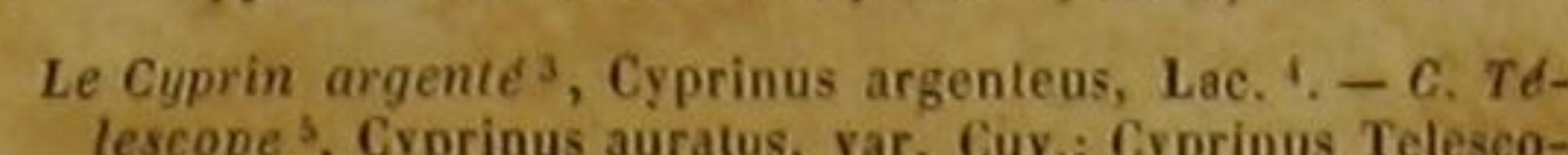

pus, Lac. $6 .-6$. gros-yeux, Cyprinus auratus, var. Cuy Cyprinus macrophthalmus, Lacep, ${ }^{\prime}-C$. quatre lobes
Cyprinus auratus, var. Cuv.; Cyprinus telralobatus Cyprinus
Lacep.
.

La beauté du eyprin doré inspire une sorte d'admiration; la rapidité de ses mourcments charme les regards. Mais élevons notre pensée : nous avons sous les yeux un des plus grand triomphes de l'art sur la nature. L'empire quo l'industrie européenne est parvenue à exercer sur des animaux utiles et affectionnés, sur ce compagnons courageux, infatigables et fidèles qui n'abandonnent l'homme ni dans ses courses, ni dans ses travaux, ni dans ses dangers, sur 1 chien si sensible, et le cheval si généreux, l'industrie chinoise l'a obtenu sur le Doré, celt espèce plus garantie cependant de son influence par le fluide dans lequel elle est plongée, plu indépendante par son instinct, et plus rebelle à ses soins, comme plus sourde à sa voix : mai la constance et le temps ont vaincu toutes les résistances.

Le besoin d'embellir et de vivifier les eaux de leurs jardins, de leurs retraites, d’un séjour consacré aux objets qui leur étaient les plus chers, inspiré aux Chinois les tentatives, les précaution et les ressources qui pouvaient le plus assure leur succès; et comme, depuis bien des siècles,

I Dorade de la Chine. - Poisson d'or. - Doré de la Chine, - Silberfisch, Goldkarpfen, en Allemagne, quand Golfish, en Angleterre, - Kingjo, à ta Chine. - Kinju, au Japon. - Cyprin doré de la Chine. Daubenton et Haüy, Enc. méth. - Id. Bonnaterre, pl. de l'Enc. méth. - Blocb, Valmont de Bomare, Dict. d'hist. nal. - Faun. Suecic. p. 125, L. 2, -Acl. Stockh. 1740, p. 403, lab. fig, 1-8. - Pisci aureus. Baster, Act. Haarl. 7, p. 215, tab. 2, 4, 6.-Gronov Mus. 1, p. 3, n. 15; el Mus. 2, n. 150 - - Kingio. Kompfer,

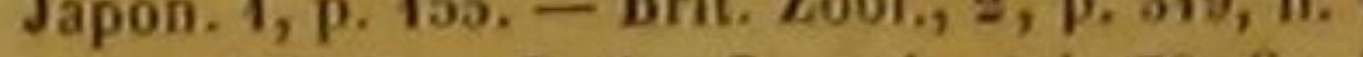
Av., lab. 209. - Petiv. Gazoph., lab. 78, ig. 7. Av. Chine, qui est placée par M. Cuvier, dans le sous-genre des CABPEs, le premier du grand genre Cypans. Le Cyprin dore est le type de l'espéce, el tous les autres n'en sont que des variétés. D.

${ }^{3}$ Koelreuter, Comment. Acad. Petropol, 1. 9, p. 420. cyprin argente. Bonnaterre, pl. de I'Enc, méth. 4 M. Cuvier ne cite pas le Gyprin argente. La division de sa queue en trois lobes semble le rapproch plus grande taille. D. tes da Cyprin dore, es Allemands, - Long-Ising ya, par leg Chinois, - Télescope, cyprinus macrophithalmus. Blocb, pl. 410. ils imitent avec respect les procédés qui on réussi à leurs pères, c'est toujours par les mémes moyens qu'ils ont agi sur l'espèce du doré; ils ont attaquée, pour ainsi dire, par les mêmes faces; ils ont pesé sur les mêmes points; les empreintes ont été de plus en plus creusées de génération en génération; les changements sont devenus profonds, et les altérations ont trop pénétré dans la masse, pour n'être pas durables.

Ils l'ont modifiée à un tel degré, que les organes mêmes de la natation du doré n'ont pu résister aux effels d'une attention sans cesse renouvelée. Dans plusieurs individus, la surface des nageoires a été augmentée; dans d'autres, diminuée : dans ceux-ci, la dorsale a été réduite à un très-petit nombre de rayons, ou remplacée par une sorte de bosse et d'excroissance double ou simple, ou retranchée entièrement, sans laisser de trace de son existence perdue; dans ceux-là, les ventrales ont disparu; daus quelques-uns, I'anale a été doubléo, et la caudale, doublement échancrée, a montré un croissant double, ou trois pointes au lieu de deux ; et si l'on réunit à ces signes de la puissance de l'homme toutes les différences que ce pouvoir de lart a introduites dans les proportions des organes du doré, ainsi que toutes les nuances que ce même art a mêlées aux couleurs naturelles de ce cyprin, et surtout si l'on pense ì toutes les combinaisons qui peuvent résulter des divers mélanges de ces modifications plus ou moins importantes, on ne sera pas étonné du nombre prodigieux de métamorphoses que le cyprin doré présente dans les eaux de la Chine ou dans celles de l'Europe. On peut voir les principales de ces dégradations, ou, si on l'aime mieux, de ces améliorations, représentées d'une manière très-intéressante dans un ouvrage publié, il y a plusieurs années, par MM. Martinet et Sauvigny, et exécuté avec autant d'habileté quo de soin d'après des dessins coloriés envoyés de la Chine au ministre d'état Bertin. En examinant avee attention ce recueil précieux, on serait tenté de compter près de cent variétés, plus ou moins remarquables, produites par la main de l'homme dans l'espèce du cyprin; et c'est ce titre asse\% rare de prééminence el de domination sur les productions de la nature, que nous avons cru devoir faire observer '

' Voyez, dans ce volume, lo Discours intitulé: Des effers

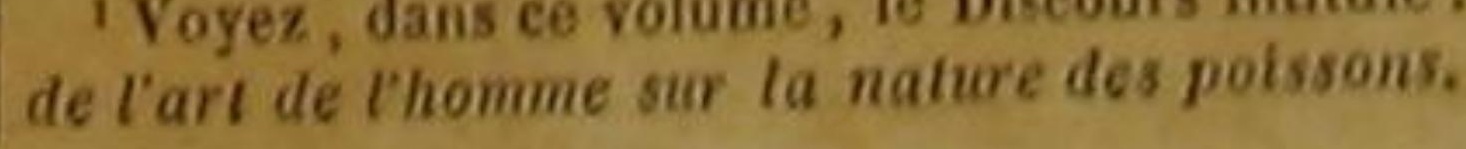


Le désir d'orner sa demeure a produit le per- Le fond du bassin est-il sablonneux? on donne fectionnement des cyprins dorés; la nouvelle aux dorés du fumier, du pain de froment et du parure, les nouvelles formes, les nouveaux mou- pain de chènevis. S'il est vrai, comme on l'a vements que leur a donnés l'éducation, ont éerit, que les Chinois ne jettent pendant l'hiver rendu leur domesticité plus nécessaire encore aucune nourriture aux dorés qu'ills conservent aux Chimois, Los dames de la Chine, plus sé- dans leurs jardins, ce ne doit être que dans les dentaires que celles des autres contrées, plus provinces de la Chine où celte saison est assez obligées de multiplier antour d'elles tout ce qui froide pour que ces cyprins y soient soumis au peut distraire l'esprit, amuser le cœur, et char- moius à un commencement de torpeur. Mais, mer des loisirs trop prolongés, se sont surtout quoi qu'il en soit, il faut procurer à ces poissons entourées de ces cyprins si décorés par la nature, un abri de feuillage dont l'ombre, s'étendant si favorisés par l'art, images de leur beauté ad- jusqu'à leur habitation, puisse les garantir de mirée, mais captive, et dont les évolutions, l'ardeur du soleil, ou des effets d'une vive lules jeux et les amours peuvent remplacer, dans mière, lorsque celte chaleur trop forte, ou celle des âmes mélancoliques, la peine de l'inaction, clarté trop grande, pourraient les incommoder l'ennui du déscuvrement, et le tourment de ou blesser leurs yeux.

vains désirs, par des sensations légères mais Préfère-t-on de rapprocher de soi ces abdodouces, des idées fugitives mais agréables, des minaux dont la parure est si superbe, et de les jouissances faibles mais consolantes et pures. garder dans des vases? on les nourrit avec des Non-seulement elles en peuplent leurs étangs, fragments de petites oublies, de mie de pain mais elles en remplissent leurs bassins, et elles blane bien fine, des jaunes d'œufs durcis et réen élèvent dans des vasés de porcelaine ou de duits en poudre, de la chair de porc hachée, eristal, au milieu de leurs asiles les plus secrets. des mouches ou de petits limacons bien onctuens.

Les dorés sont particulièrement originaires Pendant l'été, il faut renouveler l'eau de leur d'un lac pen éloigné de la haute montagne que vase tous les trois jonrs; et même plus souvent, les Chinois nomment Tsienking, et qui s'élève si la chaleur est vive et étouffante : mais, pendans la province de The-kiang, auprès de la dant l'hiver, il suffit de changer l'eau dans laville de Tchang-hou, vers le trentième degré de quelle ils nagent, tous les huit ou tous les quinze latitude. Leur véritable patrie appartient done à jours. L'ouverture du vase doit être telle qu'elle un climat assez chand. Mais on les a accoutu- suffise à la sortie des gaz qui doivent s'eshaler, més facilement à une température moins douce et cependant que les cyprins ne puissent pas que celle de leur premier séjour : on les a trans- s'élancer facilement par-dessus les bords de cet portés dans les autres provinces de la Chine, orifice.

au Japon, en France, en Allemague, en Ilol- Les dorés fraient dans le printemps, ont une lande, dans presque toute l'Europe, dans les grande abondance d'aufs ou de laite, multiautres parties du globe; et suivant Bloch, l'An-
gleterre en a nourri dès 1611 , squs le rèment beaucoup, et peuvent vivre quelque temps gleterre en a nourri dès 1611 , squs le règne de hors de l'eau. Leur instinct est un peu supérieur Jacques jer.

Le même savant rapporte que $M$. Oelrichs, bourgmestre de Brème, avait élevé avec succès un assez grand nombre de cyprins dorés dans un bassin de trente-six pieds de long, qu'il avait fai creuser exprès.

Lorsqu'on introduit ainsi de ces poissons dans un vivier ou dans un étang où l'on désire de les voir multiplier, il faut, si cette pièce d'eau ne présente ni bords unis, ni fonds tapissés d'lear ne y placer, dans le temps du frai, des branches et des rameaux veris.

Cetle même pièce d'eau renferme-t-elle du terreau ou de la terre grasse? les cyprins dorés trouvent dans cet humus un aliment suffisant. à celui de plusieurs autres poissons. L'organe de

l'ouie est en effet plus sensible dans ces abdominaux que dans beaucoup d'osseux et de cartilagineux; ils distinguent aisément le son particulier qui leur annonce l'arrivée de la nourriture qu'on leur donne. Les Chinois les accoutument ce son par le moyen d'un sifflet; et ces cyprins reconnaissent souvent l'approche de ceux qui leur apportent leur nourriture, par le bruit de leur demarche. Cette supériorité d'organisation et d'instinct doit les avoir rendus un peu plus susceptibles des impressions que l'art leur a fait prouver.

Les couleurs brillantes dont les dorés sont peints ne sont pas toujours effacées en entier par la mort de l'animal; mais si alors on met ces poissons dans l'alcool, ces riches et vives nuances disparaissent bientôt. Ces teintes dépendent, en très-grande partie, de la matière visqueuse dont les téguments des eyprins dorés sont enduits, et qui, emportée par l'alcool, co-
lore cette dernière substance, ainsi que Bloch l'a observé.

I a observé.

Au reste, pendant que ces abdominaux jouissent de toutes leurs facultés, ils ont ordinairement liris jaune; le dessous de la tite rouge; les joues dorées; le dos parsemé de diverses taches noires ; les côtés d'un rouge mêlé d'orangé le ventre varié d'argent et de couleur de rose toutes les nageoires d'un rouge de carmin.

Ces couleurs cèpendant n'appartiennent pas tous les âges du doré. Communément il est noir pendant les premières années de sa vie : des points argentins annoncent ensuite la maguifique parure à laquelle il est destiné; ces points s'étendent, se touchent, couvrent toute la surface de l'animal, et sont enfin remplacés par un rouge éclatant, auquel se mêlent, à mesure que le cyprin avance en àge, tous les tons admirables qui doivent I'embellir.

Quelquefois la robe argentine ne précède pas la conleur rouge; cette dernière nuance revê mẻme certaius individus dès leurs premières années : d'autres individus perdent, en vieillissant, celte lirrée si belle; leurs teintes s'affaiblissent; leurs taches pầissent; leur rouge leur or se changent en argent, ou se fondent dans une couleur blanche sans beaucoup d'éelat.

Lorsque le doré vil dans un ćlang spacieux il parvient à la longueur d'un pied ou quinze pouces. Sou canal intestinal présente trois sinuosités; la laite et l'ovaire sont doubles; la vessie natatoire est divisée en deux parties, dont une est plus étroite que l'autre.

Le cyprin argenté est quelquefois long de plus de deux pieds. Sa caudale parait souvent divisée en trois lobes; ce qui semble prouver que son espèce a été altérée par une sorte de domesticité. Sa tête est plus allongée que celle du doré.

On trouve dans les eaux douces de la Chine le télescope, dont la tête est courte et grosse, et l'orifice de la bouche petit' . 116 rayons à chaque pectorale du cyprin doré. 27 a la
nageoire de la queue. -15 rayons à chaque peciorale du "Ce poisson, indiqué plubót que déerit comme les deux cyprin argenté, 36 a la la caudale. -10 rayons à chaque pee- précédents et le suirant, par Molias, n'est pas mentionaé

Les peintures chinoises, que nous citons si fréquemment, offrent l'imaze du Cyprin arosyeux et du Cyprin quatre-lobes, qui, l'un el lautre, sont encore inconnus des naturalistes. La beauté de leurs formes, la transparenco do lenrs nageoires, el la vivacité de leurs couleur blanche et rouge, les rendent aussi propres que le doré à répandre le charme d'un mouvement rès-animé, réuni aux nuances les plus attrayanes, au milieu des jardins forlumés et des retraites tranquilles.

\section{LE CYPRIN ORPIE ',}

Leuciscus Orphus, Cuv.; Cyprinus Orphus, Limn., Gmel, Lac??

Cyprin royat3, Cyprinus regius, Molina, Linn, Gmel., Lacep. '- C. Cancus ", Gyprimus Caucus, Aolina, Limn.,

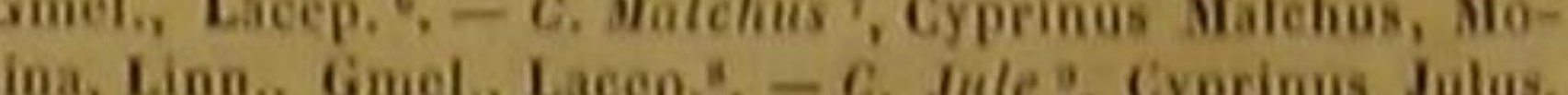

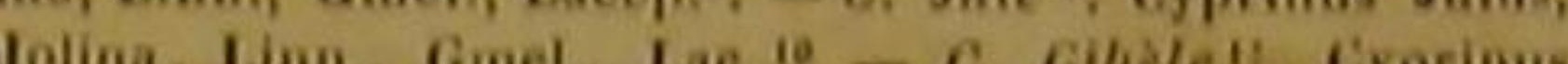
Gibelio, Cuv,., Limn., Gmel., Kacep.", - E. Goletam "1 Cyprinus rivularis, Limo,, Gm.; Gyprimus Goleian, Lac,". -c. Labéo ts, Cyprinus Labeo, Limn, Gmel., Lacep. 16, - C. Leptocéphate 1", Cyprinus leptocephatus, Linn, Gmel, Gacep, -6 . chatconde Cyprimus chaicoides, peoides, Curv; Cyprimus clupeoides, IIt. 408, 3; Lac.n.

Quelle est la patrie de ces onze poissons? L'orphe vit dans l'Allemagne méridionale; lo cyprin royal, dans la mer qui baigne te Chili;

Lorale du eyprin télescope, 22 a ta nageoire de la queue, ou 7 rayons a chaque peciorale du cyprin gros-yeax, 16 ou quatre lobes, 27 ou 28 a la nageoire de la queue.

inotele. - Finscale. - Orff, Eiff, OErve, OErmitu, Worfling, Elf, Frauen fisch, en Allemagne. - Jakesele,

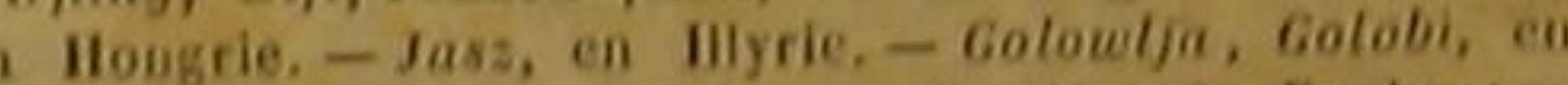

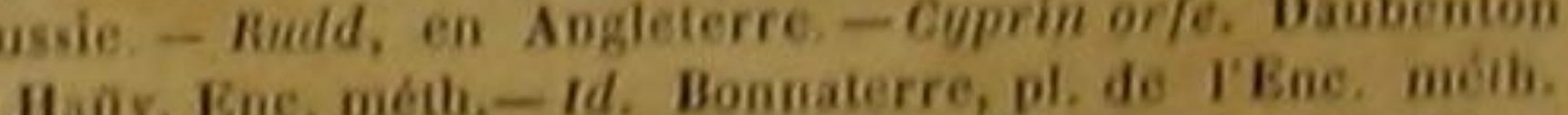

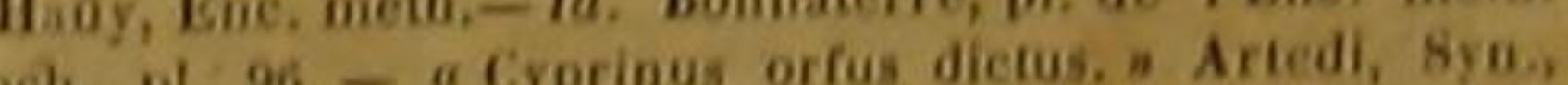

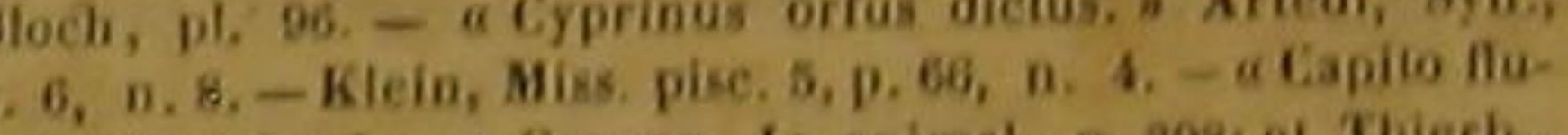

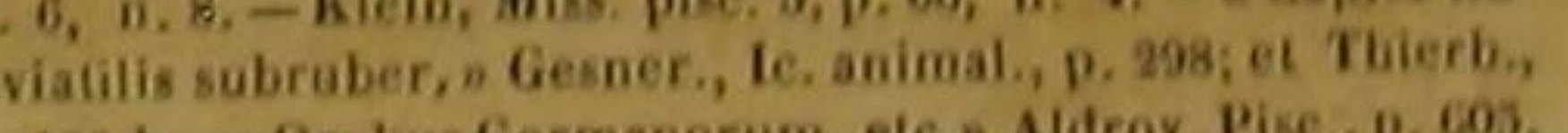

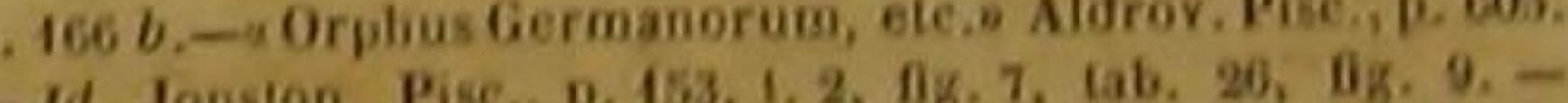
- Id, Jonsion, Pisc, p. 153, 1, 2, 0g. 7, lab. 20, ag. $0 .-$

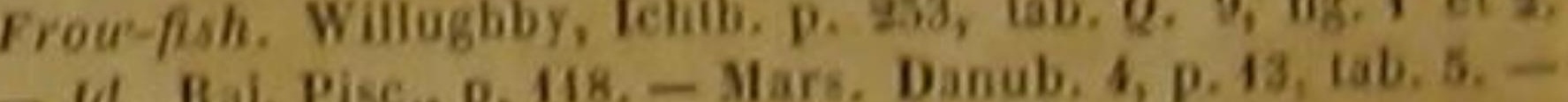
Meyer, Thierb. 2, p. 31, 1. 43.

C Du sous-genre ABs: Leuciscus, dans le grand genre Cipass, de la famille des Cyprinoides, ordre des Malacopte-

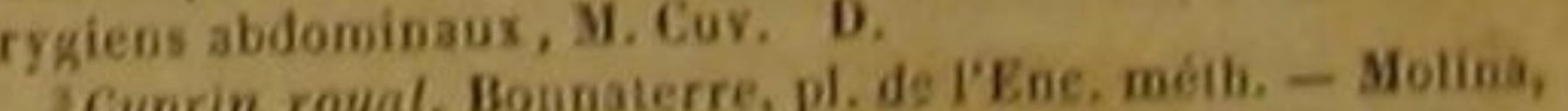

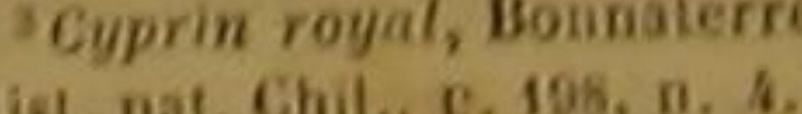

War. Ghil, F. 198, n. A.

.

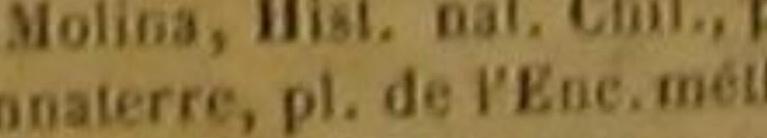


HISTOIRE NATURELLE

le caucus, le malchus, et le jule, habitent les de ses nuances; la diffieulté avec laquelle il vit eaux douces de cette partie de l'Amérique; on hors de l'eau; la couleur blanche et quelquetrouve le cyprin gibèle dans la Germanie et dans fois rougeâtre de sa chair, et son bon goùt, sur. plusieurs autres contrées de l'Furope ; on pèche tout pendant le frai, et par conséquent dans le le goleìn dans les petits ruisseaux et dans les printemps; l'avidité avec laquelle il saisit le pain lacs les plus petits de la chaîne des monts Al- que l'on jette dans les pièces d'eau qu'il habite; taiques; on rencontre le labéo et le leptocéphale sa fécondité; les vingt-deux côtes que chacun dans les fleuves pierreux et rapides de la Dau- de ses côtés présente; les quarante vertèbres qui rie, qui roulent leurs flots vers le grand Océan composent son épine dorsale.

Boréal; le chalcoĩde se plaît dans la mer Noire, Pour te royal :

d'où il passe dans le Dniéper; il so plaît aussi Ses dimensions, à peu près semblables à celles dans la Caspienne, d'où il remonte dans le Te- du bareng; le jaune et la mollesse de ses narek et dans le Cyrus, lorsque la fin de l'automne geoires; le goût exquis de sa chair.

ou le commencement de l'hiver amènent pour lui le temps du frai; et c'est auprès de Tranquebar que l'on a observé le clupéoìde.

Quels signes distinetifs peuvent servir à faire connaître ces onze cyprins?

Pour l'orphe :

La beauté des couleurs, qui l'a fait rechercher et nourrir dans les fossés de plusieurs villes d'Allemague, pour les orner et les animer; I petitesse de la tête; le jaune de l'iris; la facilite avec laquelle l'alcool fait disparaitre la vivacit

par M. Cuvier, qui, en général, n’accorde aucune con nangeo aux travaux de ce voyageur. D.

Hist Cyprin jule. Bonnaterre, pl. de l'Eno. méth. - Molina, Hist. nat. Chil, p. 199, n.

M. Cuvier espêce indiquée par Molina, et non citée par

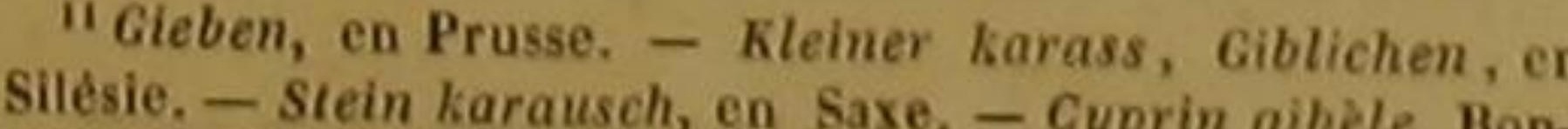
naterre, pl. de I'Enc. méth. - Bloech, pl. 12.- Wulf. Ichith. Boruss., p. 50, n. 67. - Carassi primum gemis, Wil-
lughby, lchth., p. 250. - Klein karas, etc. Gesner, Thierb. lughby, 16 chth., p. $250 .-K$ Kein karas, etc. Gesner, Thierb.
D. $166, b$.
12 La Gibele apppartient, selon M. Cuvier, au sous-genre

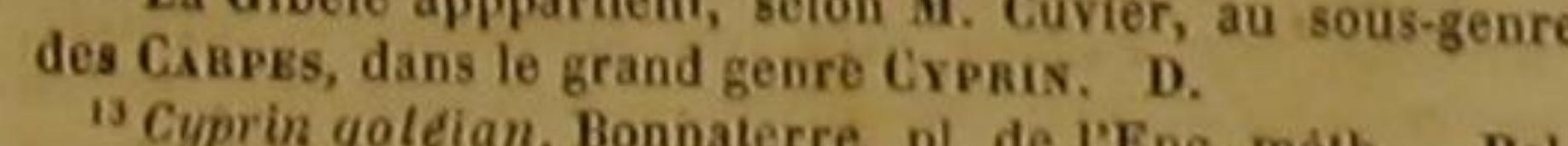
13 Cyprin goléian. Bonnaterre, pl. de i'Enc. méth. - Pal-
las, II. 2, p. 717, n. 36 .

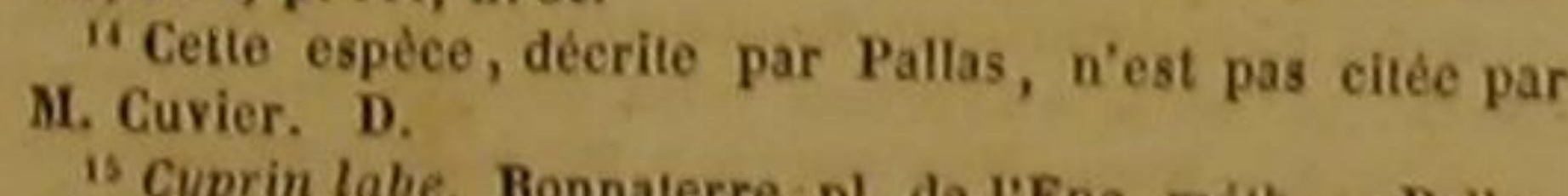

II. 3 , p. 703, n. $39-40$.

is n'est pas citée par M. Cuvier. II se pourrait nésnmois qu le sous-genre LAEkos, Labeo, du grand geore Crpans, étab par M. Cuvier, düt renfermer ce poisson. D.

Terre, pl. de l'Ene. méth.
telas,

as Pallasa Rence, méth. par M. Cuvier, a aucun des sous-genres qu'ili adpel rapportée, grand genre Cxpris. D.
10 Girnaya ziba, prés des bords de la Caspienne. bia, auprés du Doiéper. - Cyprin chalcotde. Bonnaterre p. s40, tab. 16. - Cyprinus clupeoides. Palls

p. 94 , n. 41 .

20. M. Cuvier ne cite pas ce poisson. D.
21 Du sous-"2 Du sous-genre ABLE, Leuciscus, dans le grand genre
Cxpass, famille des Cyprinoides, ordre des Malacoptérygiens
abdominaux, Cdur. D.
Sa tongueur d'un pied et demi.

Pour le malchus :

L'infériorité de ses dimensions à celles du aucus.

\section{Pour le jule :}

Sa longueur de huit à douze pouces.

Pour le gibèle :

La couleur générale, qui est souvent noirâtre,

t souvent d'un bleu tirant sur le vert dans la

partie supérieure de l'animal, et d'un jaune

doré dans la partie inférieure; les points bruns

de la ligne latérale; les nuances foncées de I

ête; le gris de la caudale; le jaune des autre

aageoires; la facilité avec laquelle ce eyprin

multiplie; la faculté de frayer, qu'il a dès sa

roisième année; son poids, qui est quelquefois

de deux ou quatre livres; la difficulté avec la-

quelle on l'attire vers l'bameçon; la nature de son organisation, qui est telle qu'on peut le trans. porter à d'assez grandes distances en l'enveloppant dans des herbes ou des feuilles vertes, qu'il ne meurt pas aisément dans les eaux dormantes, qu'il ne prend un goût de bourbe que difficilement, et que très-peu d'eau liquide lui suffit pour vivre longtemps sous la glace; la double sinuosité de son canal intestinal; ses vingt-sept vertèbres; ses côtes, qui sont au nombre de dix-sept de chaque côté.

Pour le goleīan :

La direction de la ligne latérale qui est presque droite; la petitesse du poisson; les taches de son corps et de sa queue; le brun argenté de sa couleur générale; les nuances pàles de ses nageoíres.

Pour le labéo :

Sa réunion en troupes nombreuses; la rapidité avee laquelle il nage ; l'excellent goût de sa chair ; sa longueur à peu près de trois pieds; sa
DES POISSONS.

tête épaisse; 'son museau arrondi; le brun de des environs de Cathérinopolis en Sibérie. Sa la caudale; le rouge des pectorales, des veutra- longueur est de quatre pouces. Il a des taches les, et de la nageoire de l'anus.

Pour le leptocéphale :

La couleur rouge de toutes les nageoires, excepté celle du dos.

Pour le chalcoide :

La forme générale qui ressemble beaucoup celle du hareng ; la longueur, qui est d'un pied les écailles arrondies et striées ; le museau pointu; la surface lisse de la langue et du palais ; l'osse. let aplati et rude du gosier; le verdàtre argenté el pointillé de brun de la partie supérieure de l'animal; le blanc de la partie inférieure; les points noirs du haut de l'iris, et la tache rouge du segment inférieur de celte partie; le brillant des opercules; les points blancs et saillants de la ligne latérale; la blancheur des ventrales et de presque toute la surface des pectorales; la couleur brune des nageoires du dos et de la queue.

Pour le clupéoide :

Qu'il ne parvient pas ordinairement à de grandes dimensions '.

LE CYPBIN GALIAN 2

Cyprinus Galian, Limn., Gmel. Lac.

Le Cyprin nitorique', Cyprinus niloticus, Lion., Gmell., Lac, b. - C. Gonorhingue s, Gonorhynchus...., Cuv,; CyLeuciscus Ploxinus, Cuv.; Cyprinus Phoxinus, Linn.,

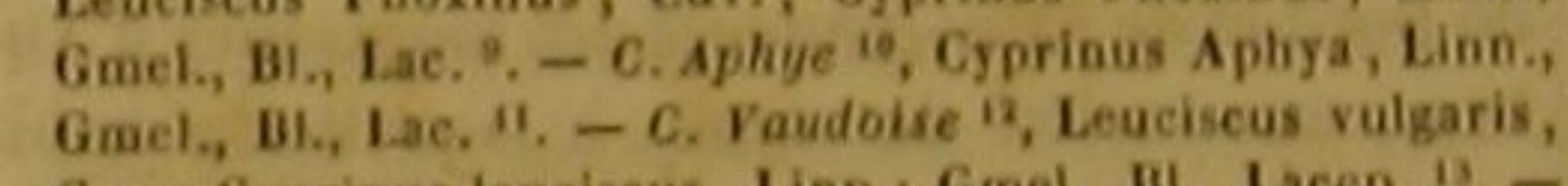
Cur.; Cyprinus leuciscus, Linn.; Gmel., BI, Lacep. 1".-
c. Dobule ", Leuciscus Dobula, Cur.; Cyprinus Dobula, C. Dobule ", Leuciscus Dobula, Cuv.; Cyprinus Dobula,
Linn., Gmel., Bloch., Lacep.; Gyprinus Gristagine, Linn., Linn., Gmel, Bloeh., Lacep.; Cyprinus Grislagine, Linn.,
Gmel. B. - c. rougeatre is, Leueiseas rutilus, Cuv.; Gyprinus rutilus, Lin., Gmel., Lac, Bl, 1", - C. Ide " ", Leueiscus Idus, Cuv.; Cyprinus Idus, Linn,, Gum, Lacep.? Cyprinns Iobarus, Linn., Gm. 19, - C. Buggenhagen 20
Abramis Buggenhagii, Bi., Linn., Gm., Lac. ${ }^{21},-$ C. Boiengle $n$, Leaciscus erythrophtthaimus,

Le galian habite dans les ruisseaux rocailleux

14 rayons à chaque pectorale du eyprin orphe, 22 a la nageoire de la queue, -15 rayons a chaque pectorale du eyprin royal, 21 a la caudale. -16 rayons a chaque pectorale
du cyprin caucus, 29 a la nageoire de la queue. -14 rayons

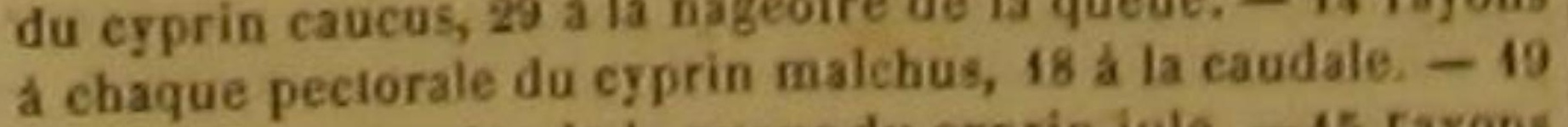
a chaqus à la nageoire de la que ue du cyprin jule. -15 rayons a chaque pectorale du cyprin gibele, 20 a la caudale. -17 rayons à chaque peclorale du eyprin chalcoide, 19 a la na-
geoire de la queue. -14 rayons a chaque pectorale du cygeoire de la queue. -14 rayons a chaque pechorale du cy-
prin clupeorde, 23 a la candale. p. 491 .

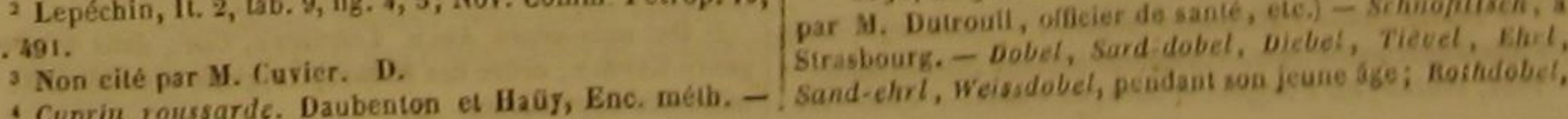

Bomaterre, pit de rEnc meth - Mus. Ad. Frid. 2 p. 108. - Cyprinus rufescens. Hasselquist, It. 393, n. 24.

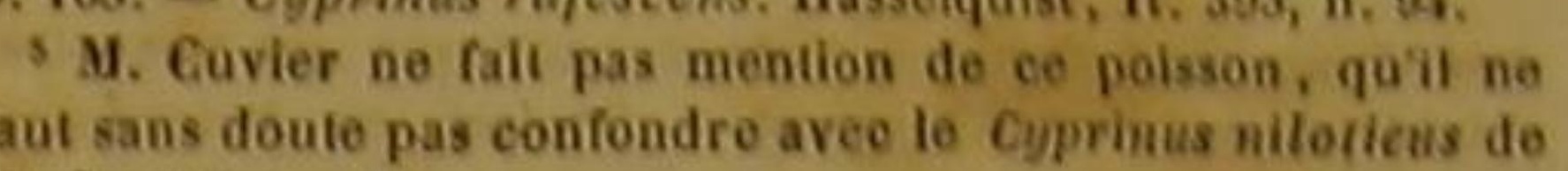
haut sans doute p.
II. Geofroy. D.

M. Geoffroy. D.
- Cuprin sauteur. Daubenton et Haüy, Bnc. méth. $-1 d$.

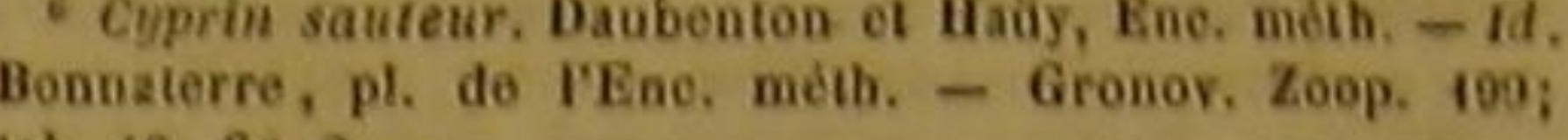
tab. $10,0 \mathrm{~g}, 2$.

I Du sous-genre Goxonurкour, Gonorhynchus, Cav,

dans to grand genre Crpais, famille des Cyprinoides, ordre des Malacopterygiens abdominaux. D.

Gairon. - Sanguinerolla, Pardela, en ftalie. - Mo-

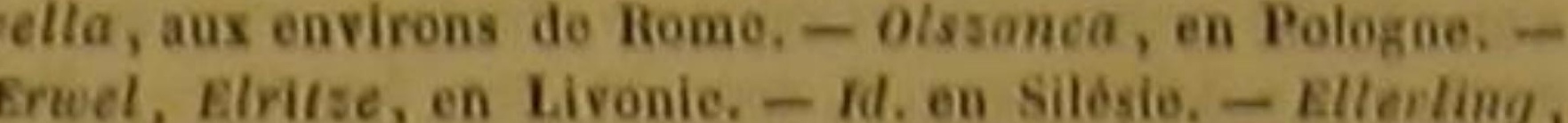
on basse saxe, - Grimpel, en Wostphalle, - Flbure, on Danemarek, - Elve-ritse, en Norvogo, - Pinek, Minow, Minim, en Angleterre, - Cyprin Véron. Daubeaton of Haay, Rne, méth, - Id. Bonnaterre, pl, do I'Einc, méth. -

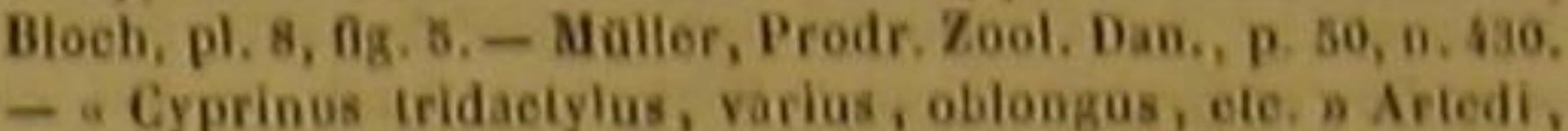
syn. 12. - "Phosinus qui vulgó veronus (quasi varius) dicia far Belonii. - - Piscleulus varius (ex phosinorum gea nere), w Gesner, p. 74 el 843 ; zerm.), p. $158 \mathrm{~b}$, - n Phoxinus a lavis seu varius. D Charleton, p. 160. - „ Variussou phoxi-

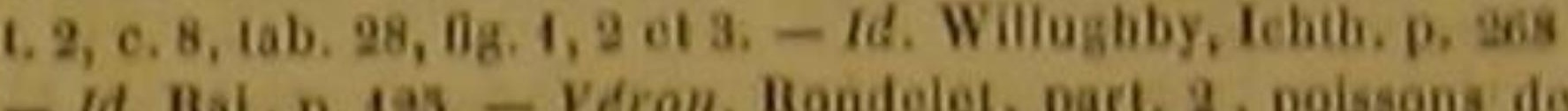

Crou sous-genro AвL, Leuciscus, dans to grand gonro is Spierling, Moderliepken, en Allemagno, - Prille, en Baviére, - Mutherloselen, en Prusse. - Gallies, en sibe-
rice - Solsensudg, en Laponie, - Loie, Gorlole, Kime, Gorkime, Gorkyute, en Norvéze. - Mudd, Budd, en Suéde, oudd, Igaling, en Dalcecarlie, - Gli, on Goltie, - Alkuta, Dalie, - Cyprin Aphye. Daubeaton et Haú, Bae, meth. - Id. Bonnaterre, pl. do I'Enc, mótb. - Bloch, pl. o7. Vaun. Sues, 374. - Cyprimus minimus, 11. Wgoilt. 23a, , Molter, Prodrom. Zool. Dan., p. 60 , 431. 12 Dard. - Sophio. - Saiffe. - Abugrgmby, Gugrumby, Dadjen, en Arabie. - Zimilisch; seele, pendasot soa jeuo Go; Agoneu, Lagonen, quand if apeinto tout son dévelop- Lauben, Windlauben, en Baviere -Weisfich, en Allemagne, - Vituerije, en Hotlande. ace, Dare, en Angleterre, - Cypria vaudoise, Daubenton

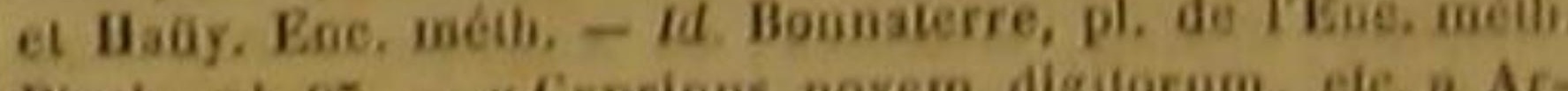
Bloch, pl. 97. - « Cyprinus noven digitorum, ele, $\mathrm{Ar}$ 1. 3, L., c. 7 ; el tab. 26 , fig. 11. - Id. Willogbby, p. 260. -

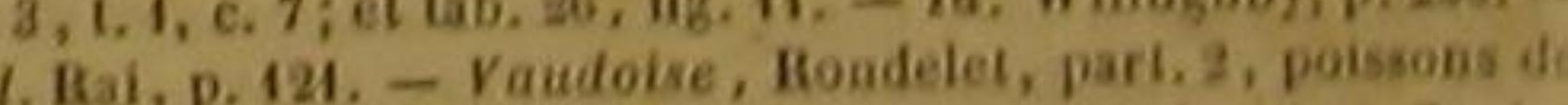
rière, e. 14. - a Leucisei secanda species; leueisci fluvia. - tilis seconda species; leaciecus Bellouit, qui albicilla, vel - albicula latiné dici polest.p Gesner, 26, 27, icon, animal. D. 290; el (gerno.) fol. 162. - a Lewiscus secandus Honde-

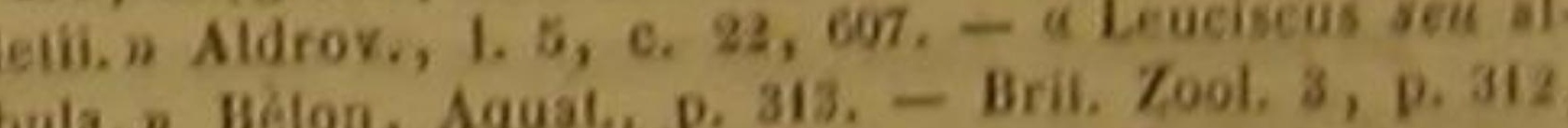
8. La vaudoise appartiens au sous-zenre AzLe, Leuciseus,
10 La varand genre Cyprin de Al Cuvier.

it Sege, Brigne batarde, a Bordeaux. (Nole communiques

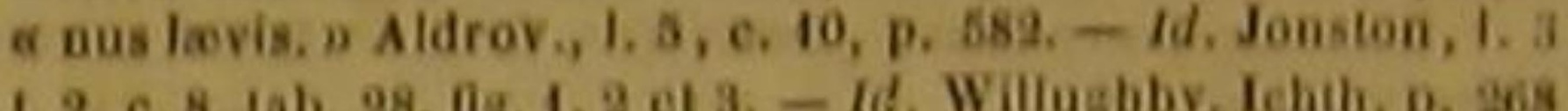
rivière, o. 20-Brit. Zool. 3, p. 318, D. 11 . 
corps est rouge. Ses écailles sont arrondies et On trouve le gonorhynque auprès du cap de fortement attachées à la peau.

Nil. Le verperance

Le véron a le dessus de la tête d'un vert noir. les mâchoires bordées de rouge; les opercules jaunes; l'iris couleur d'or; le dos tout noir ou d'un bleu clair; presque toujours des bandequand 'son age est assez avancé pour que ses nageoires leltes transversales bleues; des raies variées de Hassling, Weissfisch, en Silésie, en Saxe, en Poméranie. - bleu, de jaune et de noir, ou de rouge, d'azur Tabelle, Tabarre, en Prusse. - Dobeler, Mausebeisser,
dans quelques environs de VEIbe. - Dover, dans le Holstein. et d'argent; les nageoires bleuâtres et marquées dans quelques environs de VElbe. - Dover, dans le Holstein.
- Hes-sele, Hesling, en Danemarck. - Cyprin dobule, Cyprin grislagine. Daubenton et Haüy, Enc. méth. - Id. de l'arc-en-ciel ont donc été prodiguées à co joli Bonnaterre, pl. de TEnc. métb. - Bloch, pl. 5. - Müller,
Zool. Danic. Prodr., p. 50, n. 432. - a Cyprinus pedalis,
poisson, qui réunit d'ailleurs à l'agrément de " gracilis, oblongus, crassiusculus, etc.; el cyprinus oblon- proportions très-sveltes toute la gràce que peut

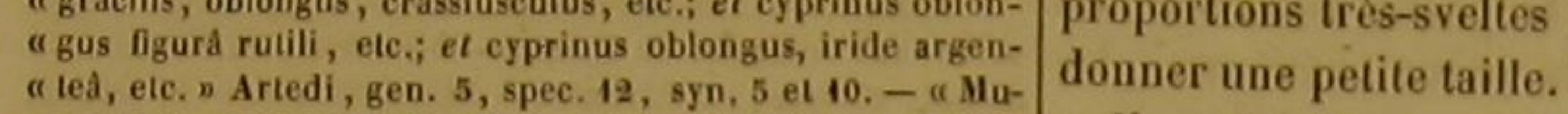

" gilis vel cephali nuviatilis genus minus, el capito vel squa- Il se plait dans plusieurs rivières de France, " lus fluviatilis minor., Gesner, p. 28 , el germ., fol. 170 a. de Silésie et de Westphalie. Sa chair est boce,

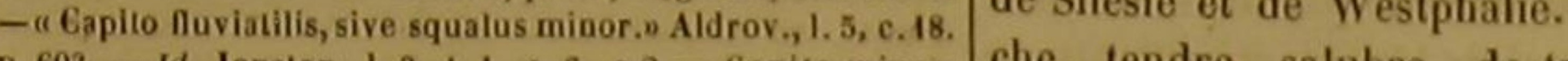
p. 603. - Id. Jonston, I. 3, 1. 1, c. 6, a 2. - Capito minor, che, tendre, salubre, de très-bon goût; et on

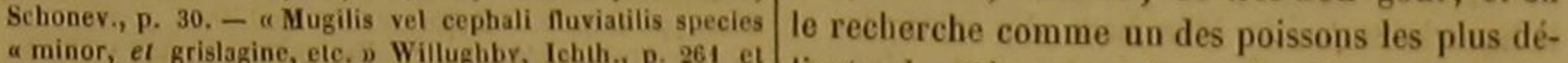
a minor, el grislagine, elc. p) Willughby, Ichth., p. 261 et
$263 .-1 d$. Rai, p. 122 et 123. - Lesk. Spec., p. 38, n. 6. - lu Véser. On le pêche dans toutes les Kram. El, p. 394, n. 10. - Klein. Miss. pisc. 5, p. 66, n. 5. - saisons, mais surtout vers le commencement de Faun. Suec. 387. - Acl. Ups. 1744, p. 35, tab. 3. - Gronov. Mus. $1, \mathrm{n} .148$

'Du sous-genre ABLE, Leueiscus, dans le grand genre
Cyphis, Cuv, D.

Io Rosse, - Plota, en Italie. - Rothflosser, Rodo, en Al-
lemagne. - Rothauge, Rolhethe, en Soxe, - Rothprieder, à Magdebourg. - Plotze, en Prusse. - Jorz, Gacica, en Pologre. - Radane, Raudi, en Livonie. - Flotwi, en Russie-
Reskalle, Flessroie, en Norvege. - Rudskalle, en Danemarck. - Woorn, en Hollande. - Roach, en Angleterre. naterre, pl. de I'Encion et Haüy, Enc, méth. - Id. Bonpaterre, pl. de IEnc, méth. - Faun. Suec. 372. - Blocb
pl. 2. - Koireuter, Nov. Comm. Petrop. 15, p. 494. - a Cy" prinus, iride, pinnis ventris ac ani plerumque rubentibus. Arledi, gen. 3 , spec. 10, syn. 10. - Rubiculus. Figul. fig. 5 a.
- Rosse. Belon. - " Rutilus sive rubellus Ouviabilis. Ges- Rosse. Belon. - " Rutilus sive rubellus nluviatilis. v Ges-
ner, p. 281, et (germ.) fol. 167 a. $-1 d$. Willughby, p. 262. ner, p. 281, et (germ.) fol. 167 a. - 1d. Willughby, p. 262 .
Id. Rai, p. 122. - Id. Charlet., p. 158. - Rutilus Gesneri,

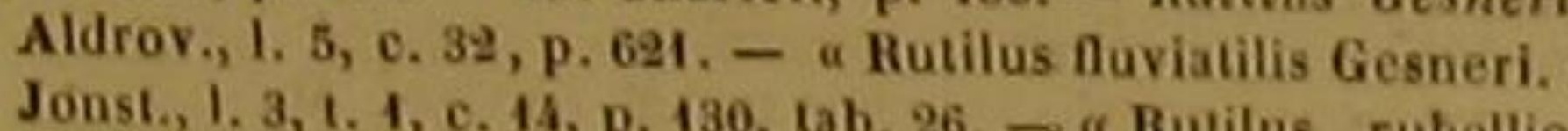

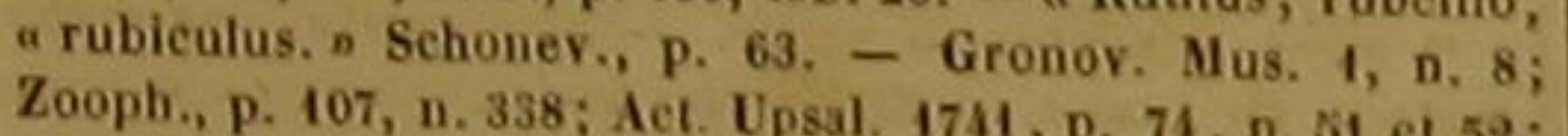
Zooph., p. 107, n. 338; Act. Upsal. 1744, p. 74 , n. 51 el 52 ;
Act. Helvel. 4 , p. 268 , n. 183. - Klein, Miss, pisc. 5 , . 67, Act. Helvel. 4 , p. 268, n. 183 . - Klein, Miss. pisc. 5 , p. 67
n. 9 , tab. 18 , fig. 1. - Brit. Zool. 3, p. 34, n. 7 . in Du sous-genre $A$ Brit. Zool. 3, p. 31, n. 7 . Cuv. D. 18 Kähling, en Westphalie, - Dabel, en Poméranie. -
Nerning, Erfling, Bradfisch,

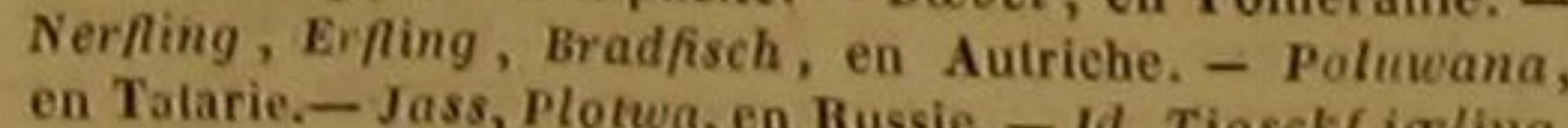
en Talarie.-Jass, Plotwa, en Russie. - Id. Tiosckf jicling,
en Suedde. - Rod ficrig, en Norvège. - End, en Danemarck. - Cyprin ide, Caprin idbare. Daubenton et Haüy, pl. 36. - Faun. Suecie. 362. - Müll. Prodrom. Zool. Danic,

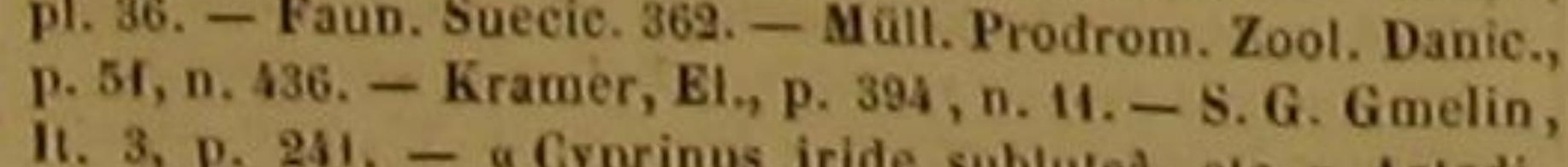

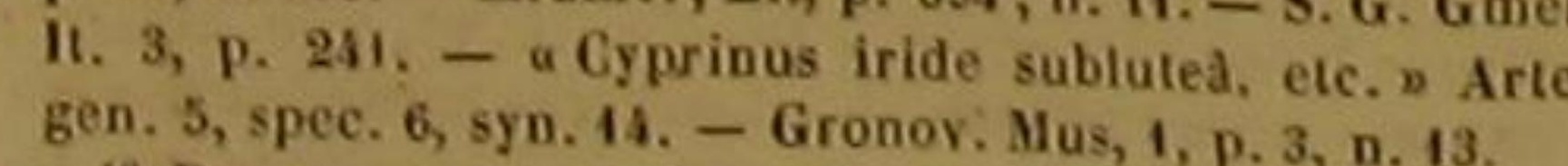
gen. 5, spec. 6, syn. A4. - Gronov, Mus, 1, p. 3, n. 13.
19. Du sous-genre ABL , Leuciscus, de M. Cuvier, dust genre Cxpsis. D.

${ }^{20}$ Bloch, pl. 95. - Cyprin de Buggenhliagen. Bonnaterre,
pl. de l'Enc. méd. "Du sous-genre BRèMs, Abramis, Cur., dans le grand
genre Cyran. D. 32 Plotze, dans l'Allemagne septent. - Rothauge, dan

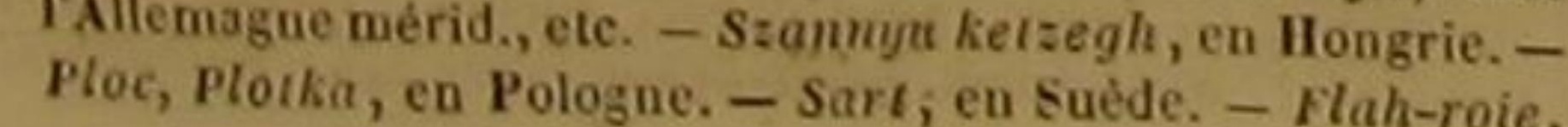

l'été, temps où il pond ou féconde ses eufs. On

e prend avec une ligne, ou avec de petits filet dont les mailles sont très-fines. Il ne peut vivre hors de l'eau qne pendant très-peu d'instants. I fraie dès l'àge de quatre ans, et multiplie eaucoup. Il aime quelquefois à se tenir à la surface des eaux pures et courantes, Les fonds pierreux ou sablonneux sont ceux qui lui convienuent. Il préfère surtout les endroits peu réquentés par les autres poissons.

Le professeur Bonnaterre a vu, dans les lacs de Bord et de Saint-Andenol des montagnes d'Aubrac, une variété du véron, à laquelle les habiauts de la ci-devant Auvergne donnent le nom de Vernhe. Les individus qui forment iété ont une longueur de deux pouces environ; la tête comprimée et striée sur le sommet; la màchoire supérieure un peu plus avancée que celle d'en bas; le dos grisâtre; des taches bleues, jaunes et verdâtres sur les côtés; la partie infé-

en Norvège. - Skalle, Rodskalle, en Danemarck. - Ruisch, - Coooren, en Hollande. - Rud, Finscale, en Angleterre. - Coprin arve. Daubenton el Hauy. Enc. méth. - Id - Faun.

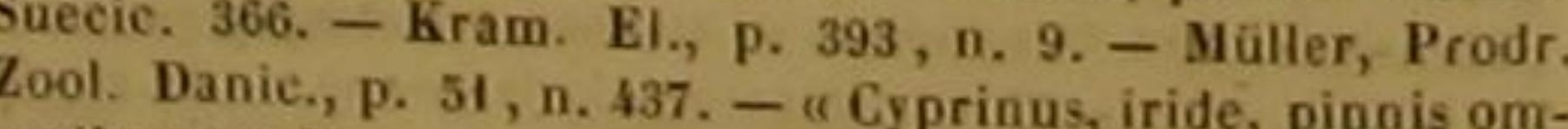
" nibus caudaque rubris n Arledi, gen. 3, spec, pionis omWillughby, 249, tab. Q. 3, fig. A. - Erythrophithalmus, ele. hai, p. 116. - Rutilus. Leske, Spec., p. 64, n. 14. - Gronov. H. 13, tig. 2. - Eubellus. Mars. Danub. 4, p. 39, tab. 13, 2, p. 15 ${ }^{23}$ Du sous-genre ABLE, Leuciscus, Cuv, dans le grand genre Crpnis, ordre des Mlalacoptérygiens abdominaux, fa-
nille des Cyprinoides. Wis. pisc. 5 , p. 63 , n. 5 rieure argentée ; une tache rouge et ovale à cha- corps et sur les nageoires des jeunes màles. Elle que coin de l'ouverture de la bouche, ainsi que aime quelquefois à se nourrir de petites sangsues sur la base des pectorales et des ventrales '.

Les anciens donnaient le nom d'A 'A hrye (A $p h y a)$ aux petits poissons qu'ils supposaient nés de l'écume de la mer. Le cyprin qui porte le même nom n'a ordinairement que dix-huit lignes à deux pouces de longueur. On le trouve sur les rivages de la Baltique, dans les fleuves qui s'y jettent, et dans presque tous les ruisseaux de la Norvège, de la Suède et de la Sibérie. Sa chair est blanche, agréable au goût, facile à digérer. Ses écailles se détachent aisément. Son dos est brunâtre; les côtés sont blanchâtres; le ventre es rouge ou blanc; les nageoires sont grises ou verdâtres.

La couleur générale de la vaudoise est argentée; les nageoires sont blanches ou grises; 1 dos est brunâtre. L'Allemagne méridionale, l'Italie, la France et l'Angleterre, sont la patrie de ce poisson, qui peut parvenir à la longueur de deux pouces. Il multiplie d'autant plus, que la rapidité de sa natation le dérobe souvent à l dent de ses ennemis. On le prend avec des filet on avec des nasses; mais, dans beaucoup do contrées, il est peu recherché á cause du grand nombre de petites arêtes qui traversent ses muscles. Son péritoine est d'ume blancheur éclatante, et parsemé de points noirs; la laite est double ainsi que l'ovaire; les aufs sont blanchâtres et très-petits.

La dohule a le dos verdâtre; le ventre argenté une série de points jáunes le long de la ligne latérale; toutes les nageoires blanches pendant sa première jeunesse; les pectorales jaunes, la dorsale verdâtre, l'anale et les ventrales rouges, caudale bleuâtre, quand il est plus âgé ; deux sinuosités au canal intestinal ; quarante vertèbres, et quinze côtes de cliaque côté.

On la pêche dans le Rhin, le Véser, l'Elbe, la Havel, la Sprée, l'Oder. Son poids est quelquefois de deux à quatre livres. Elle préfere les eaux elaires qui coulent sur un fond de marne ou de sable. Elle passe souvent l'liver dans le fond des grands lacs; mais lorsque le printemp arrive, elle remonte el fraie dans les rivières. peut voir alors de petites taches noires sur

I Le canal intestinal du cyprin véron présente deux sinuosités; son épine dorsale contient trente-quatre vertebres; $e t$ quatorze, quinze ou seize colles soli plate de celle épine. et de petits limaçons. La grande chaleur lui est contraire : olle perd promptement la vie lorsu'on la tire de l'eau. Sa chair est saine, mais

Le cyprin rougeâtro pèse près do deux livres. montre des lèvres rouges; un dos d'un noir rerdâtre; des côtés et un ventre argentins; des cailles larges. Il a une épine dorsale composée de quarante-quatre verlèbres; une grande prórérence pour les eaux claires, dont lo fond est marneux ou sablouneux.

Bloch rapporte que dans le temps où les marécages des environs de l'Oder n'avaient pas été desséchés, on y trouvait une si grande quantité de cyprins rougeàtres, qu'on les employait a engraisser les cochons. Leur chair est blanche et facilo à digérer, mais remplie d'arêtes petites et fourchues. La cuisson donne à ces animaux une nuance rouge. On les péche à l'hameçon, ainsi qu'avec des filets; et on les prendrait avee d'auantes les fout distinguer un peu do loin au milieu des eaux, s'ils n'étaient pas plus rusés que presque tous les autres poissons des eaux douce de l'Europe septentriouale. Ils restent caché dans lo fond des lacs ou des rivières, tant qu'ils entendent sur la rive ou sur l'eau un bruit qui peut les alarmer.

Lorsqu'ils vont frayer dans ces mémes rivières ou dans les fleuves, ils remontent en formant plusieurs troupes séparées. On a cru observer que la première troupe est composée de mâles la seconde de femelles, la troisième de mâles. Ils déposent leurs oufs, qui sont verdâtres, sur des branchies ou des herbes plus ou moins enfoncées sous I'eau.

Le cyprin ide a le front, la nuque et le dos nirs; le ventre blanc; les pectorales jaunâtres : la dorsale et la caudale grises; I'anale et les venIrales variées de blanc et de rouge, On le trouvo dans presque toute l'Europe, et particulièrement en France, dans l'Allemagne septentrionale, en Danemarck, en Norvège, en Suède et en Rusie. Il aime les grands lacs où il trouve de grosses pierres el des eaux límpides. Lorsque le printemps arrive, et qu'il remonte dans les rivières, il cherche les courants les plus rapides, et les rochers nus sur lesquels il se plaît à déposer ses cufs, dont la couleur est jaune, et la grosseur semblable à celle des graines de pavot. Il fraie dés remplie d'arêtes. ant plus de facilité, que leurs couleurs bril- 
HISTOIRE NATURELLE

Ja troisième année de son âge, et parvient à une longueur d'un pied et demi, et au poids de six ou huit livres. Sa chair est blanche, tendre, et agréable au goût; sa laite est double, ainsi que son ovaire; sa vessie natatoire grosse et séparée en deux cavités; son épine dorsale composée de quarante et une vertèbres, et articulée de chaque côté avec quinze côtes.

Mon savant collègue le professeur Fanjas de Saint-Fond a trouvé un squeletle d'ide dans la France méridionale, au-dessous de six cents pieds de lave compacte.

On pèche le cyprin bugghienhagen dans la Pène do la Poméranie suédoise, et dans les lacs qui communiquent avec cetle rivière. La chair de ce poisson, dont on doit la connaissance à M. de Buggenhagen, est blanche, mais garnie de petites arêtes. Il offre une longueur de douze ou quinze pouces. Il ressemble beaucoup aux brêmes, dont il précède souvent l'arrivée, et dont on l'a appelé le conducteur. Son dos est noiràtre; ses côtés et son ventre sont presque toujours argentés; des teintes bleues distinguent ses nageoires. Son anus est situé très-loin de- sa gorge.

Le rotengle a communément un pied de longueur. Son dos est verdâtre; ses côtés sont d'un blanc tirant sur le jaune; sa dorsale est d'u verdâtre melé de rouge ; ses pectorales sont d'un rouge brun. On doit le compter parmi les poissons les plus communs de I'Allemagne septentrionale. Il multiplie d'autant plus que sa pont dure ordinairement plusieurs jours, et que par conséquent un grand nombre de ses oufs doivent échapper aux effets d'un froid soudain, des inondations extraordinaires, et d'autres accidents analogues. Les écailles du màle présentent, pendant le frai, des excroissances petites, dures et pointues.

On peut le transporter facilement en vie : mais sa chair renferme beaucoup d'arêtes; elle est d'ailleurs blanche, agréable et saine.

On compte seize côtes do chaque côté de l'épine du dos, qui comprend trente-sept verlèbres '.

14 rayons à chaque pectorale du cyprin galian, 19 a
nageoire de ta queue lotique. - 18 rayons a la nageoire de la queue du cyprin nonorhynque. -17 rayons à chaque pectorale du cyprin véron, 20 a la caudale. -20 rayons a la nageoire de la queue du cyprin i ebaque pectorale du cyprin dobole, 18 i ta queue. -20 rayons à la caudale du cyprin rougeasire de $\mathrm{I}$.

\section{LE CYPRIN JESSE '.}

Leuciscus Jeses, Cuv.; Cyprinus Jeses, Linn., Gmel, Bl., Lac. 2 .

Le Cyprin Nase ${ }^{3}$ Leuciscus Nasus, Cuv; Cyprinus Nasus, Linn., Gmel., Bl, Lacep, $4 .-C$. Aspe
Cuv.; Lenciscus Aspius, Spirlin?', Lepeiseus bipunctalus, Guv.; Cyprinus bipuge tatus, BI, Linn., Gmel.; Cyprinus Spirling, Lacep. s. $^{-}$ Beuviere', Leueiscus amarus, Cuv,; Cyprinus amarus, BI., Linn., Gmel, Lacep. ${ }^{10},-c$. Americain 11, Cyprinus amerieanus, Lino., Gmel, Lac.12. - C. Able ${ }^{13}$, Leuciscus Alburnos, Cuv.; Cyprinus Alburnus, Linn., Gmel., Bloch,
Lac."1. - C. Vimbe' is, Abramis Vimba, Cuv.; Cyprines Lac."1, - C. Vimbe "1, Abramis Vimba, Cuv.; Cyprinus
Vimba, Bl., Linn., Gmel., Lac.16- $-c$. Breme 12, Abramis communis, Cuv.; Cyprinus Brama, Linn, Gmel, Lac. ${ }^{13}$ -C. Couteau ${ }^{19}$, Leuciscus cultratus, Cuv.; Cyprinus cultratus, Linn., Gmel., Bl., Lae 20, - C. Farène ${ }^{21}$, Cy. prinus Farenus, Lion., Gmel., Lac. ${ }^{22}$.

Le jesse a le front large et noírâtre; le dos et les opercules sont bleus; les côtés sont jaunes

rayons a la nageoire de la queue du cyprin ide. -18 rayon a la caudale du cyprin buggenbagen. -20 rayons a la nabeoire de la queue du cyprin rotengle.

vemne. - Testard. - Barbolleaun. - Garbollin. - Garbolleau. - Chaboisseaul. - Genglin, quand il ne pèse pas deu
livres; Bralfisch, quand il pése denx livres ot aud Autriche. - Deverekesogi, en Hongrie. - Deebel, quand il est encore trés-jeune; Giebel, Dikkopf, lorsqu'il est plu agé, en Saxe. - Aland, dans le Brandebourg. - Harikopt. Pagenfisch, Divel, dans la Poinéranie. - Gaese, en Prusse. - Cuprin jesse, Daubenton et Häy, Ene. méth. - Id Bonnaterre, pl. de l'Enc métb. - Blocb, pl. 6. - Cyprimus
cubitalis. Ariedi, syn. 7. - « Capito fluvialis caruleus, ct cubitalis. Artedi, syn. 7. - «Capito fluvialis caruleus, et

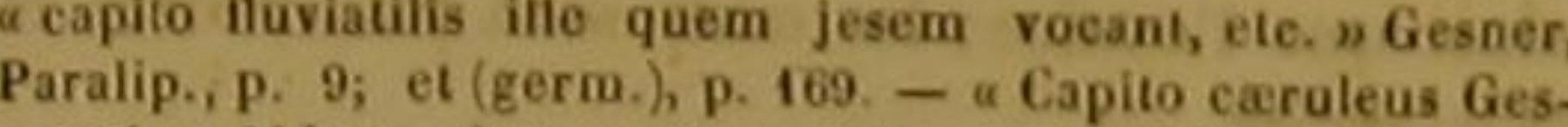
« neri., Aldrov., I. 5, c. 19, p. 603. - Id. Wiltughby, lehth. p. 256, tab. Q. 6, fig, $3 .-$ Id. Rai, p. $136,-a c$ Cyprinus
« dobula, ele. Leske, Spec., p. 34, n. 5 - Klein, Miss. iso. 5, p. 68, n. 13. - Munter, ou vilain, premiere espece de muge, Hondelet, part. 2). Poissons de rivièry, c. $12--$
Marsig. Danub. 4, p. 53, tab. 18, tig. I. - Meunier. Valmont de Bomare, Diel. d'hist. nat.

${ }^{2}$ Du sous-genre ABLE, Leuciscus, dans te grand genre CXpars, de la famille des Cyprinordes, ordre des Malacoplérygiens abdominaus, Cuv. D
JEcrivain. - Venure noir.

qu'il est jeune. - Savelta, Syetua, Poisson blane, pendan wriche. - Noting en Allemata, en Ftalie. - Nasting, en bauch, en Poméranie. - Schneider fisch, aux environaraDantzig. - Cyprin nàse. Daubenton et Haüy, Enc, méth Id. Bonnaterre, pl. de l'Bne. méth. - Bloch, pl. 3.

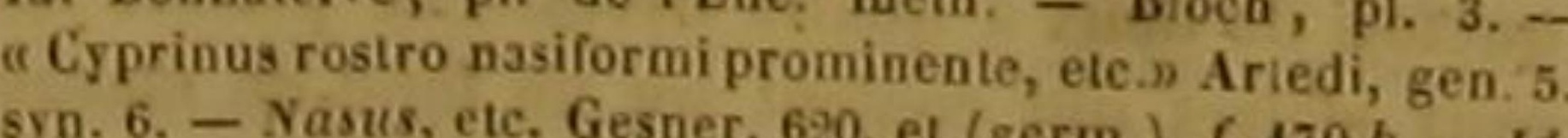
Aldrov , 5,5 , elc. Gesner, 620, et (germ.), f. $170 b .-I d$ Adrov, 1. 5, c. 26 , p. 610. - Id. Schonev., p. $52 .-I d$.

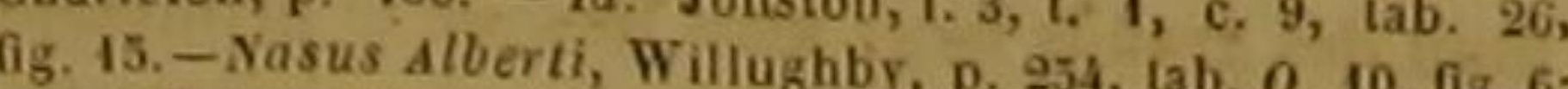
-Id. Rai, p. 119.-Gronov. Mus. 2, n. 197 ; Zooph, fo. 105 ,

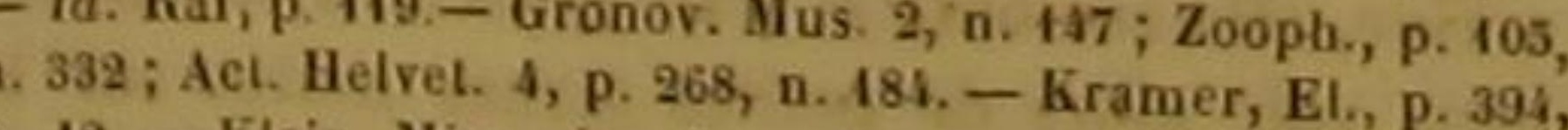
a. 19. - Klein, Miss. pisc. 5, p. 66, n. 6, tab. 16, fig. 4 Vhierb. Marsig. Danub. 4, p. 9, tab. 3. - Nase. Mejer. iDu sous-genre

Da sous-genre ABr., Leuciscus, Cuv., dans le grand
senre Cipan. D.

'Scheed, en Autriche. - Rappe, en Silésie. - Raubalel
Aland, en Saxe. - Rapen, en Prusse. - Asp, en Suède. -
DES POISSONS.

au-dessus de la ligne latérale, et d'un bleu ar- écailles est bordé de bleu, ainsi que la caudale; gentin au-dessous; une série de points d'un jaune les pectorales, les ventrales et l'anale sont d'un brun marque cette même ligne; le bas des violet clair.

Bla-spol, en Norvège. - Cyprin aspe, Daubenton et Haüy. Le cyprin jesse nage avec force; il aime à Ene, méth. - Id. Bonnaterre, pl. de l'Enc. méth. - Raphé Bloch, pl, 7. - Faun. Suecic, 36t. - "Cyprinus magnu-

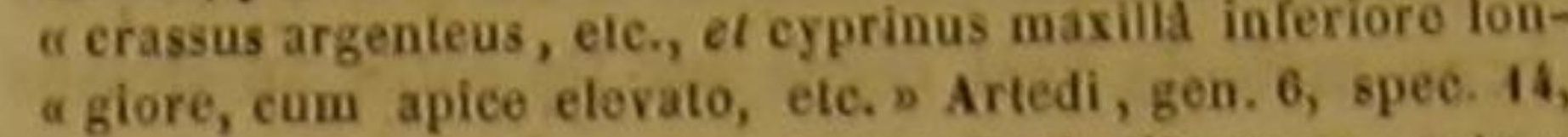
syn. 8 et $14 .-\alpha$ Rappe, et capito lluviatilis rapax, etc,,

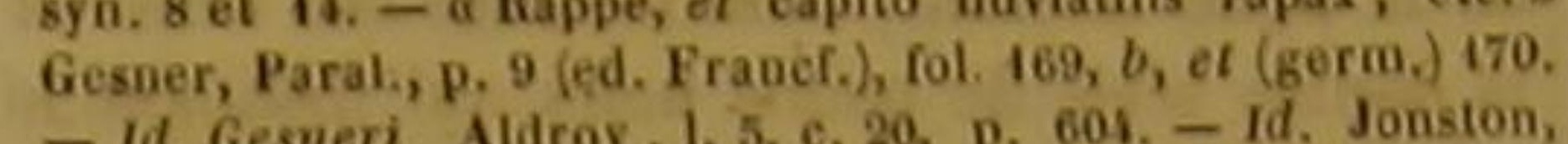

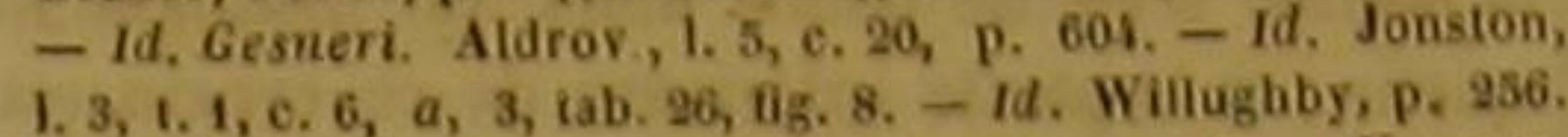

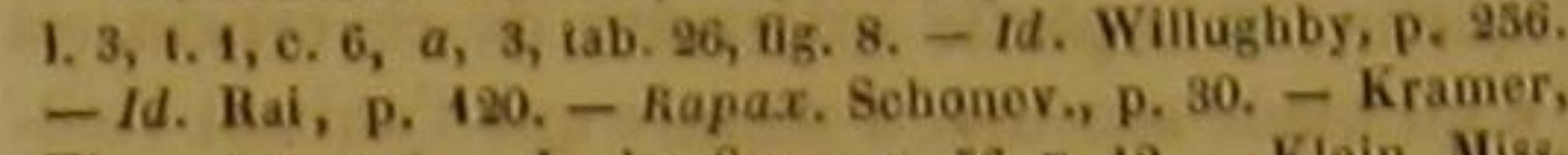
EL, p. 391, 0. 4. - Leske, Spee., p. 56, n. 12. - Klein, Mis.

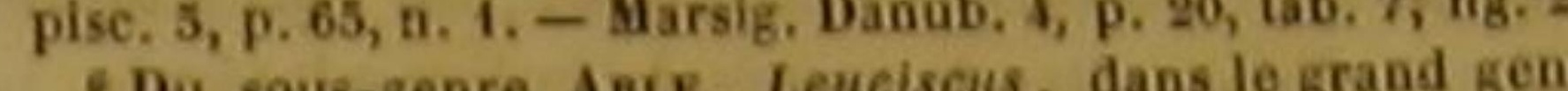
des Cxpanss, Cav. D.

'Lauben, en Bavière, - Aland bleke, en Westphali - Cyprin spirtin. Boneaterre, pl. de l'Euo, méth. - Blocis pl. $8,0 \mathrm{~g} .4$.

- Du sous-genre ABLe, Leuciscus, dans le grand genr Cxpars, Cur. D.

'Bituerling, en Allemagne. - Cyprin Bou
Lerre, pl. de I'Enc, méth. - Bloch, pl. 8, Oz,

lerre, pl. de IEnc, meth. - Bloch, pl. 8, ag. 3 .
10 Dans la première édition du Hègne animal, M. Cuvie eite ce poisson comme appartenant a son sous-genre ABLK, Leiciscus, dans le grand genre Cvpris. La citation do cello espèce est supprimèo dans la secondo édition du même ou-

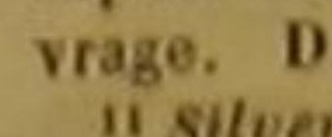

II Silverfish, dans la Caroline. - cyprin nsared. Dauben-

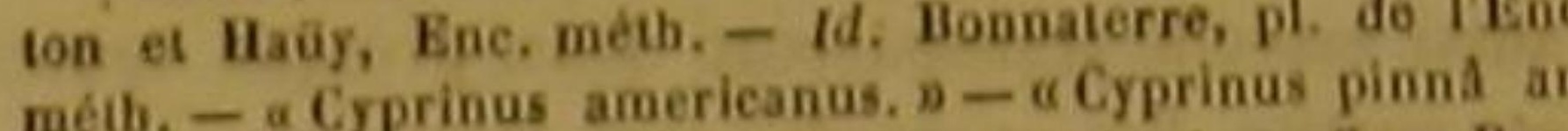
" radis sexdeeim, eorpore argenteo, pininis rulis. o Bose, notes manuscrites déa citées.

12 M. Cuvier n'a cité le eyprin américain que dans la premiére édition du Régne animal Il le rap,

ABLE, Leuciscus, da geore Crpais. D.

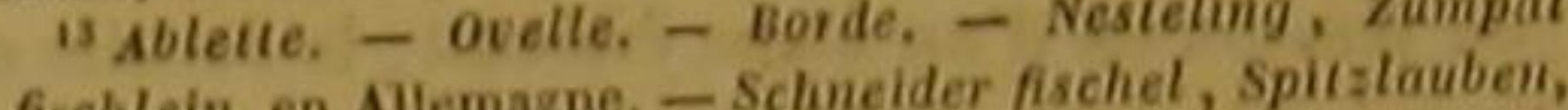
Wischlein, en Alo en Autriche. - Batte, Blercke, Ochelbetze, Veckeley, Weidenblati, en Saxe. - oekeley, en Silésie. Gusezovo, en Pologne. - Aukschie, en Lithuanie. - Plite, Maile, Walykalla, en Livònie. - Kalinkan, en Russie. Loja, en Suède. - Mort, en Norwe. - S a Schleswig. Blikke, en Danemarek, - Wilinck, Whecke, en Schleswig. - Mayblecke, en Wesiphalie, - Alphenaar, en Hollande. Haây, Enc. méth. - Id. Bonnaterre, pl. de l'Enc. méth.nal. - Faun. Suec. 377. - Kramer, Bl., p. 395, n. 14.Müll. Prodr. Zool. Danic., p. 51, n. 439. - Gyprinus quina cuncialis, ete. D Artedi, gen. 6, spee. 17, syn. 10. - A 19urnus. Auson. Mosell. v. 126. - Poissons de riviére, c. 30. -
169 b. - Rondelet, part. 2, Po Alburnus Ausonii. Gesner, p. 23; el (germ.) f. 159 a.

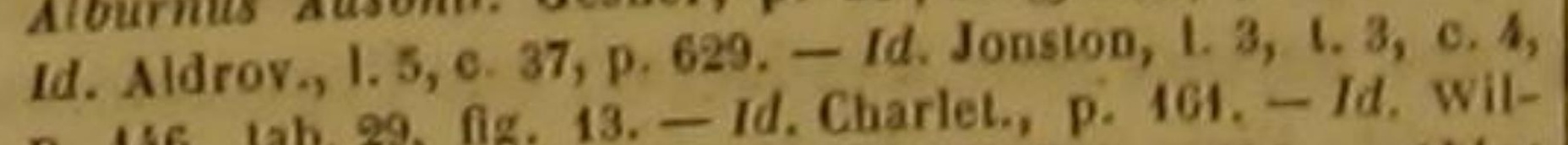
p. 146, tab. 29, fig. 13. - Id. Charlel., p. 161. - Id, wita

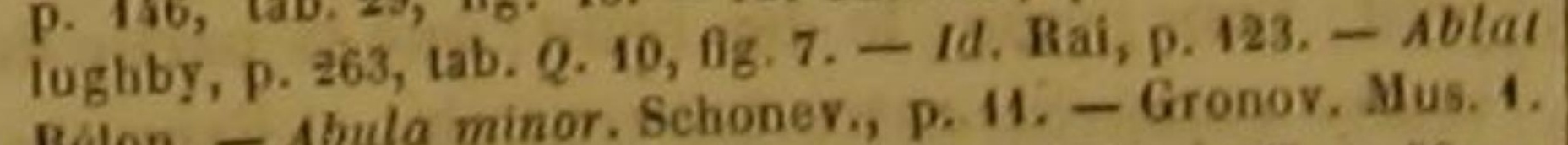
Bélon. - Abula minor. Schonev., p. 14. - Gonov, Aus.
n. 10; Zooph, p. 106, n. 336 ; Act. Ups. 174, p. 75, n. 58 . n. 10 ; Zooph, p. 106, n. 336 ; Act. Ups.
Leske, Spec., p. 40, n. . - Brit. Zool. 3, p. 315, Leske, Spec., p. 40, n. 7. - Brit.
Klein, Miss. pisc. 5, p. 68, n. 16, tab. 18 , fig. J. "Ce poisson est le type du sous-genre ABLE, Leuciscus,
" admis, par M. Cuvier, dans le grand genre des CxpRiss. B. is Zcerthe, en Allemagne. - Wengalle, Weingalle, bris, en Livonie. - Taraun, en
Daubenton, et Haūy, Enc. méth. - Id. Bonnaterre, pl. de Daubenton, et - Bloch, p. 4. - Faun. Sưecic. 368. - Müli
l'Enc. méth. Prodr. Zool. Dan., pl. latter contre les courants rapides, et cependant il se plait dans les eaux dont to mouvement est retardé par le voisinage des moulins. Le frai de poisson dure ordinairement pendant huit jours, a moins que le retour du froid ne le force dix livres; mais il croit lentement. It multiplie beaucoup: le défant d'eau ne lui ote pas rès-promptement la vie. Sa chair est grasse, molle, remplie d'aretes, et devient d'une couspec. 18, syn. 8 el 14. - Capito anadramus, Gess, , p. 11 et 1269 ; el (germ.) f, 180 ; et Paral, P. 11,-Id. Aldrov, I.

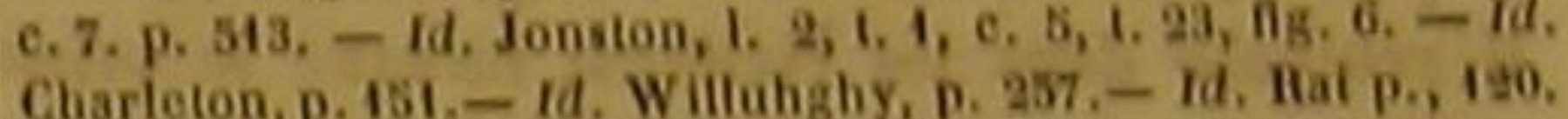
- Leske, Spec, p. 4, n. 8. - Kiein, Miss. pise. 5, p. 05, n. 3. Marsig. Danub. A, p. 17, lab. 6 . des Creraiss, Cav. D. Breilsen, Brassen, Braden, Windlauben, lorsque ec poisSrassle, en Saxe, - Schoss-bley, lorsque la brème p'a gu'un on ou deur: Bley-fimnk, lorsqu'olle a trois ans, dass la In ou deux; Becteclorale,-Bressmen, eu Prusse, - Mhein braxen, i Dantzig.-Klorsez, en Pologne, - Flussbrachsen, Ploudis, Latlikar, en Livonie,-Letsch, on Hussio, - Brax, en suedde, - Brasem, en Danemarck, - Bream, en Angleterre, -

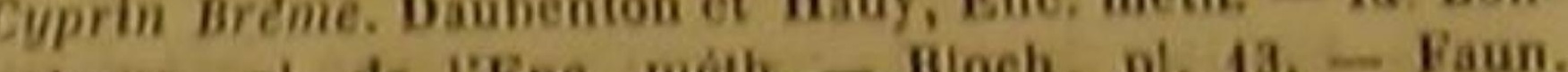
naterre, pl. de I'Ene. méth. - Bloch, pl. 43. - Faü. Zool. Danic p. 51, n. A4. - a Cyprinus pinnis ommibus a nlgrescentibus, etc, o Artedi, gen 6 , spec, 22, ayn. 4.Poissons des lacs, c, 6.- a Cyprinus latus sive brama.n

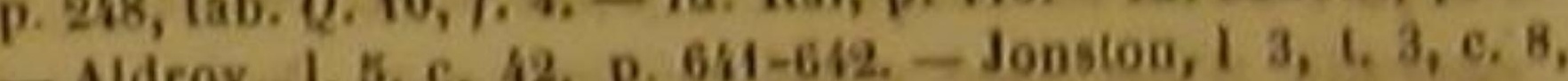
p. A65, tab. 29, Ag. 5 . - Gronor. Mus. 1, n. 14; Zooph. 1, n. 345,-Klein. Miss. pise. 5, p. 71, 0. A. - Ruyseb. Thealt.

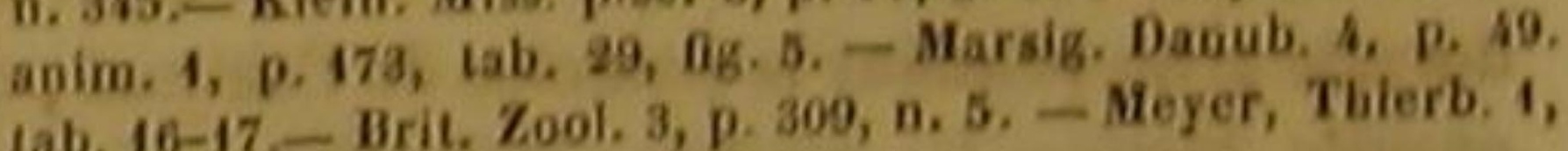

"La Bà̀ug est te typo d'un sous-genre particulier,

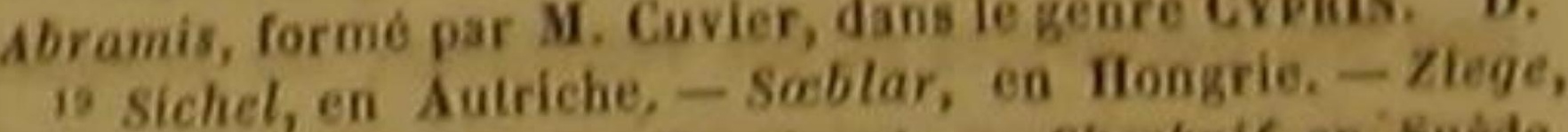
en Prusse, - Zicke, en Poméranie. - Sherhar, an buede. - Zable. Tschecha, en Kussie. - Tochekou, ar les riven

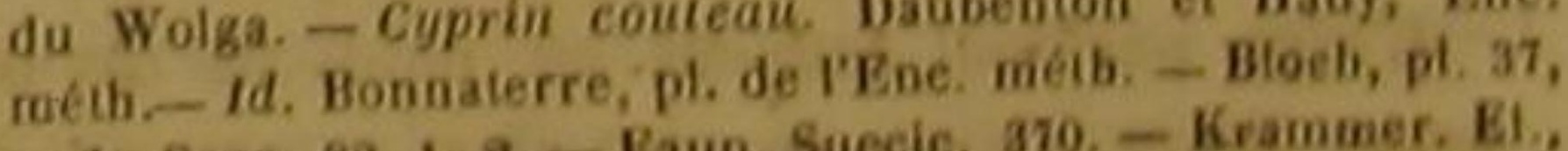
- I1. Sean. 82, 1. 2. - Paun. Suecic. 370. - Kramer. Klein. W. p. 21 , tab. 8 .

De couleau ou Rasoir, Cyprinus cultratus, Limn, appartient, selon M. Cuvier, a tous-genre ABL, Leaciscas, do nom de Chela. D.
"1 Faren. Arledi, spee. 23 - Faun. Suecie. 360. - Cyprin - Id. Bonaalerre, pl. de l'Bnc. métb. hâter la fin de cette opération. Il pèse de huí

"Braexen, en Portugal. - Searda, Seardola, en Hatio, Abramus, etc. Charleton, 162. - Brame, Hondelel, part.2,

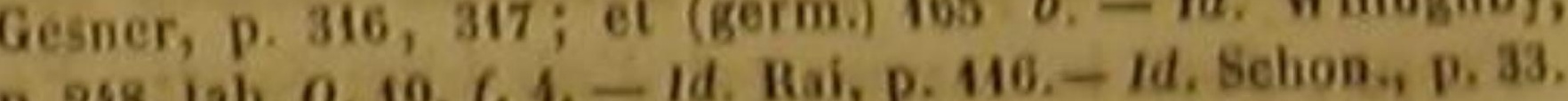




\section{HISTOIRE NATURELLE}

leur jaune lorsqu'elle est cuite. On le trouve dans | Les eaux douces de l'Allemagne nourrissent to les fleuves et dans les rivières de presque toute spirlin. Sa dorsale est plus éloignée de la tète l'Europe tempérée et septentrionale. $\quad$ que les ventrales. Cette nageoire est verdâtre, Ses œufs sont jaunes, et de la grosseur d'une ainsi que celle de la queue; les autres sont d'une graine de pavot. L'épine dorsale est composée de couleur rougeâtre. Une tache verte paraît sur quarante vertèbres. On comple dix-huit côtes de le haut de l'iris; les joues montrent des reflets quarante vé cháté.

Le nase a le péritoine noir. Les nageoires sont argentins et bleus; le dos est d'un gris foncé; un brun mêlé de vert règne sur les côtés au-dessus rougeâtres, excepté la dorsale qui est presque de la ligne latérale, dont le rouge fait ressortir noire, et la caudale, dont le lobe inférieur est la double série de points noirs qui distingue le rougeâtre, pendant qu'une nuance noirâtre règne spirlin ; et la partie inférieure de ce cyprin est sur le lobe supérieur, La nuque est noire; le dos d'un blanc argenté. A mesure que l'animal vieilnoirâtre, et chaque côté blanc, de même que le lit, ou que ses forces diminuent, on voit s'affaiventre. Lorsque ce cyprin pèse deux livres, il ar- blir et disparaître le rouge de la ligne latérale. rive souvent que ses nageoires offrent une cou- Le spirlin ne se plait que dans les courants leur grise.

II se plait dans le fond des grands lacs, d'où cailloux. Il se tient ordinairement très-près de il remonte dans les rivières, lorsque le prin- la surface de l'eau, excepté pendant le temps temps, c'est-à-dire la saison du frai, arrive. Ses du frai. Ses œufs sont très-petits et très-nomœufs sont blanchâtres, et de la grosseur d'un breux; sa chair est blanche et de bon goût; ses grain de millet. Pendant que cette espèce se dé- côtes sont au nombre de quinze de chaque côté, barrasse de sa laite ou de ses cufs, on voit sur et son épine dorsale est composće de trente-trois les jeunes mâles des taches noires dont le centre vertèbres.

est un petit point saillant. Sa chair est molle, La bouvière est un des plus petits cyprins : fade, et garnie de beaucoup d'arêtes. Son canal aussi est-elle transparente dans presque toutes intestinal présente plusieurs sinuosités; chaque ses parties. Ses opercules sont jaunâtres; le dos côté de l'épine dorsale, dix-huit côtes, et cette est d'un jaune mêlé de vert, les còtés sont même épine, quarante-quatre vertèbres. Le jaunes au-dessus de la ligne latérale, qui est nase habite dans la mer Caspienne, ainsi que noire ou d'un bleu d'acier; la partie inférieure

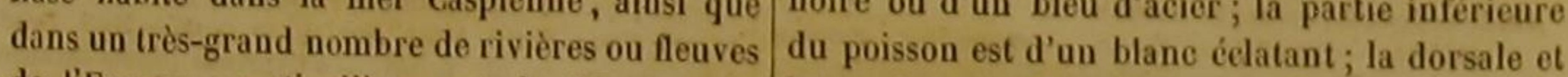
de l'Europe, particulièrement de l'Europe du la caudale sont verdâtres; une teinte rougeàtre nord.

On peche à peu près daus les mêmes eaux La bouvière habite les eaus pures et courantes le plusieurs contrées de l'Europe, et particupercule d'un bleu mêlé de jaune et de vert; le lièrement de l'Allemagne. Ón ne la voit commudos noirâtre; la partie inférieure blanchàtre; la nément dans des lacs que lorsqu'une rivic̀re les dorsale grise pendant la jeunesse de l'auimal, et traverse. Sa chair est amère; ses œufs sont trèsensuite bleue; la caudale également grise et tendres, très-blancs et très-petits '

bleue successivement; et l'anale peinte, ainsi Le savant naturaliste Bose a vu le cyprin améque les pectorales et les ventrales, de jaunàtre ricain daus les eaux douces de la Caroline. II quand le poisson est peu avancé en àge, et de nous a appris que ce poisson a les deux lèvres bleuàtre mêlé de rouge lorsqu'il est plus àgé.

L'aspe parvient sourent an poids do dix on des narines sont tris-lare très-larges; que l'opercule est très-petits poissons, ausi hetien l'iris jaune; le dos brun; que la partie du très-petits poissons, aussi bien que de vers, de ventre comprise entre les ventrales et l'anus est végétaux, et de débris de corps organisés. Il carénée, et que cet abdominal parvient à la lonpréfère les rivières dont le fond est propre, et le gueur de huit à douze pouces.

courant peu rapide. Il est rusé, perd aisément Le cyprin américain se prend facilement à la vie, a beaucoup d'arêtes, une chair molle et l'hameçon, suivant notre confrère facilement à grasse, trois sinuosités à son canal intestinal, dix-lıuit côtes de chaque côté, et quarante-quatre vertèbres.
DES POISSONS.

qu'il est très-jeune, on l'emploie comme une provenus de l'Able et du Rotengle. Ces mulets excellente amorcé pour pêcher les truites. Il sert avaient les écailles plus grandes que l'able, le pendant tout l'été à la nourriture des habitants corps plus haut, et moins de rayons à la nageoire de la Caroline, quoique sa chair sente la vase. II de l'anus.

varie heaucoup suivant son àge et la pureté des eaux dans lesquelles il passe sa vie.

l'eil grand ; l'iris jaunâtre; des points jonde; sei th ligo intis jaunatre; des points jannes (a) bien que les eaux douces de presque toutes les tre; I'inférieure argentine; le péritoine argenté ; contrées européennes, Ce cyprin a quelquefois une longuenr d'un pied et demi ; la chair blanhuit à douze pouces de longueur; et sa chair che et de bou goût; dix-sept côtes de chaque n'est pas désagréable au goût. Mais ce qui la côté; quarante-deux vertèbres à l'épine du fait principalement rechercher, éest l'éclat de dos.

ses écailles. L'art se sert de ces écailles blanches Elle quitto la mer Baltique vers le commenet polies, comme de cell quelques autres poissons, pour dédommager, vières, aime les eaux claires, cherche les fonds par des ornements de bon goût, la beauté que pierreux ou sablonneux, ne se laisse prendre la fortune a moius favorisée que la nature, et facilement que pendant le temps du frai, perd qui, privée des objels précieux que la richesse aisément la vie, a été cependant transporté , une sorte de convenance impérieuse, à montrer profonds et marneux, croit lentement, mai l'apparence de ces mêmes objets. Ces écailles multiplie beaucoup, et a été envoyće marinée argentées donnent aus perles factices le brillant de grāndes distances du lieu où elle avait été de celles de l'Orient. On enlève avec soin ces pêchée.

ácilles que la tête de la brème a été trond'eau claire; on les frotte les unes contre les quée. Sa bouche est petite; ses joues sont d'un autres; on répète celte opération dans différentes hleu varié de jaune; son dos est noirâtre; cineaux, jusqu’à ce que les lames écailleuses ne quanto points noirs, ou environ, sont disposés laissent plus éco colorée; la le long de la ligue latérale; du jaune, du blanc, 作 matière argentée se précipite au fond da vase du violet et du jaune sur les pectorales, du dont on verse avec préceution l'ean surabon- du viol ve dante : ce dépôt éclatant est une liqueur argen- violet sur les ventrales, du gris sur la nageoire tine, qu'on nomme essence orientale. On mêle de l'anus.

celle poisson habite dans la mer Caspienne; il in vit aussi dans presque toute l'Europe, On lo introduit, à l'aide d'un chalumeau, dans des
globes de verre creux, très-minces, couleur de trouve dans les grands lacs, et dans les rivières girasol; on agite ces petites boules, pour que la qui s'échappent paisiblement sur un fond comliqueur s'étende et s'attache sur toute leur surface posé de marne, de glaise et d'herbages.

intériest l'objet d'une peche importante. On le intérieure; cl perte fine la plas belle se troune prend fréquemment sous la glace; et il est si

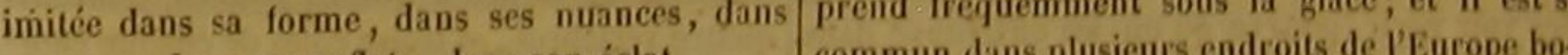
son eau, dans ses reflets, dans son éclat. comma dans pla t7 Toutes les écailles de l'able ne sont cependant réale, qu'en mars 4749 on prit a in seul coup pécalement propres à produire cette res- de filet, dans un grand lac de Suète, voisin de pas egatement propres a prón est en eff- Nordkiæping, cinquante mille brêmes qui pe-

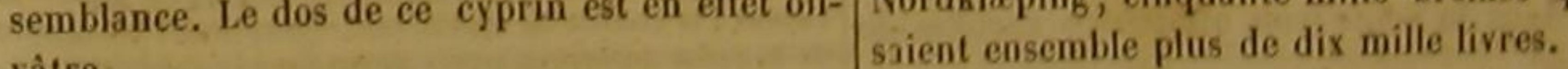

vâtre.

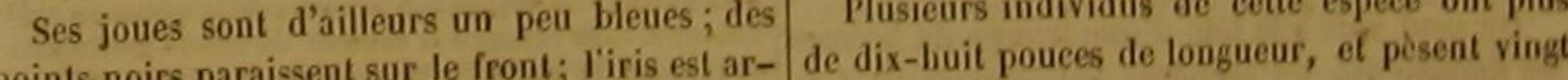
points noirs paraissent sur le front; l'iris est ar- de dix-l

gentin ; lès pectorales sont d'un blanc mêlé de livres. rouge ; l'anale est grise; la caudale verdâtre; la Lorsque, dans le printemps, los brentas cherdorsale moins proche de la tête que les ventrales; chent, pour frayer, des rivages unis ou des foild l'œil grand; la ligne latérale courbée; la chair de rivière garnis d'ierbages, chaque foules. Elles remplie d'arêtes. 
pes nombreuses; et cependant elles distinguent |pourpres et bordées de rouge; plusieurs tache le son des cloches, celui du tambour, ou tout rouges et irrégulières; la surface enduite d'une autre son analogue, qui quelquefois les effraie, matière visqueuse très-abondante.

les éloigne, les disperse, ou les pousse dans les Bloch considère aussi comme des métis de la filets du pêcheur. On remarque trois époques dans le frai des la tête petite ainsi que le corps très-haut du cy. brêmes. Les plus grosses fraient pendant la pre- prin large, et -les nageoires de la brême.

mière, et les plus petites pendant la troisième. Dans ce temps du frai, les mâles, comme ceux $\begin{array}{ll}\text { de presque toutes les autres espéces de cyprins, } & \text { sale. }\end{array}$

ont, sur les écailles du dos et des côtés, de petits boutons qui les ont fait désigner par différentes dénominations, que l'on avait observés dès le temps de Salvian, et que Pline même a remarqués.

Si la saison devient froide avant la fin du frai, les femelles éprouvent des accidents funestes. L'orifice par lequel leurs œufs seraient sortis, se ferme et s'enflamme; le ventre se gonfle, les cufs s'altèrent, se changent en une substance gramuleuse, gluante et rougeàtre; l'animal dépérit et meurt.

Les brèmes sont aussi très-sujeltes à renfermer des vers intestinaux, et très-exposées à une phithisie mortelle.

Elles sont poursuivies par l'homme, par les poissons voraces, par les oiseaux nageurs. Les buses et d'autres oiseaux de proie veulent aussi, dans certaines circonstances, en faire leur proie; mais il arrive que si la brême est grosse el forle, et que les serres de la buse aient pénétré assez avant dans son dos pour s'engager dans sa charpente osseuse, elle entraine au fond de l'eau son ennemi qui y trouve la mort.

Les brêmes croissent assez vite. Leur chair es agréable an goût par sa bonté, et à l'œil par sa blancheur. Elles perdent difficilement la vie lorsqu'on les tire de l'eau pendant le froid; et alor on peut les transporter à vingt-cing lieues sans les voir périr, pourvu qu'on les enveloppe dans de la neige, et qu'on leur mette dans la bouche du pain trempé dans de l'alcool.

M. Noēl nous a écrit qu'on avait cru reconnaître dans la Seine trois ou quatre variétés de la brême,

On peut voir à la tête d'une troupe de brểmes un poisson que les pêcheurs ont nommé chef de ces cyprins, et que Bloch était tenté de regarder comme un métis provenu d'une brême et d'un rotengle. Ce poisson a l'œil plus grand que brême; les écailles plus petites et plus épaisses l'iris bleuâtre; la tête pourpre; les nageoires
Ce dernier abdominal a trente-deux vertèbres, t quinze côtes de elraque còté de l'épine dor-

Lc cyprin couteau a été pêché non-seulement dans le Danube, dans l'Elbe, dans presque toutes les rivières de l'Allemagne et de la Suède, mais encore dans la Baltique, dans le golfe de Finlande, dans la mer Noire, dans la mer

La dorsale de ce cyprin est située au-dessus

de la nageoire de l'anus. Les yeux sont grands,

Presque toutes les écailles sont larges, minces, sculptées de manière à présenter cinq rayons divergents, et faiblement attachées. La nuque est d'un gris d'acier; les côteśs sont argentius; le dos est d'un gris-brun; les pectorales, dont la longueur est remarguable, l'anale et les ventrales, sont grises par-dessus et rougeâtres pardessous; la dorsale est grise, comme la nageoire de la queue.

Le cyprin couteau parvient à la longueu d'un pied et demi, et au poids de deux livres. Il peut échapper plus difficilement que plusieurs autres poissons aux oiseaux de proie et aux poissons destructeurs, parce que son éclat le rahit.

Ses ovaires sont grands, et divisés clracun en deux par une raie!

Le farène appartient au lac de Suède nommé Méler. Il a les yeux gros; l'iris doré et argenté; le dos et les nageoires noirâtres; uue ongueur de douze à quinze pouces; quarantequatre vertèbres, et treize côtes de chaque có: $e^{2}$. I Lo cypin in couteau a quarante-sept vertébres, el vingt Cóles de chaque côtté.

${ }^{2} 20$ rayons a la nageoire de la queue du cyprin jesse. -22 de la queve dudace du cyprin nase, -20 rayons à la nageoire prin spirlin - co rayin aspe. - 20 rayons a la caudale du cybouviére. - 18 rayons a la caudale de la queue du cyprin is rayons à la nageoire de la queue du cyprin able -20 rayons à la eaudale du cyprin vimbe. -19 rayons à la nageoire de la queue du cyprin brême. - 19 rayons à la caudale cyprin couteau. -19 rayons à la nageoire de la queue do eyrin farène.

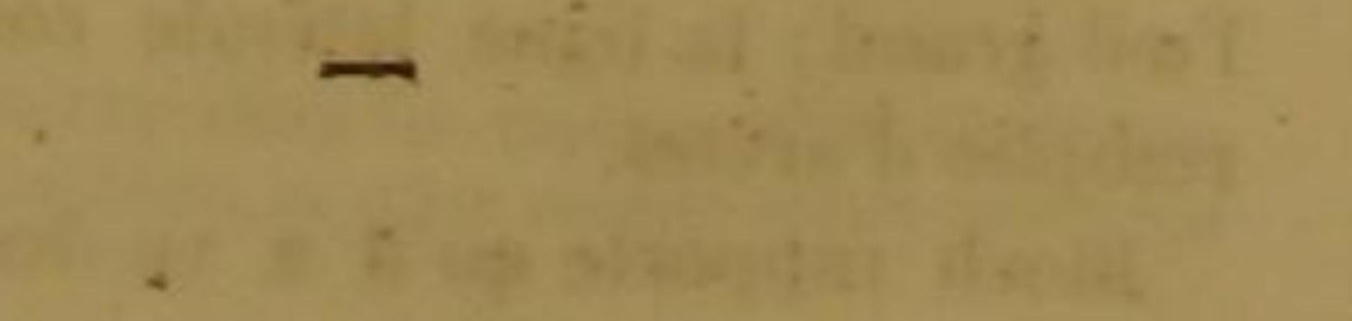
d'Asow et dans la Caspienne.

\section{LE CYPRIN LARGE',}

Abramis Blica, Cuv.; Cyprinus Blica, Bl.; Cyprinu Latus, Linn., Gmel., Lac.; Cyprinus Bjorkna, Linn. Gmel, ?

Le Cyprin Sope ${ }^{3}$, Abramis Ballerus, Cuv.; Cyprinus Batlerus, Bloeb, Linn., G mel., Laeep, $4,-\epsilon$. Chumb ${ }^{3}$, Cyprinu Chub, Lacep. 6 - C. Catostome ${ }^{2}$, Catastomius..., Cuv. Morella, Lacep. 10. - C. frange ", Labeo fimbrialus, Cuv.; Cyprinus fimbriatus, Bloch, Lion., Gmel, Lacep, 12, -
C. Faucille ${ }^{13}$, Leuciscus faleatus, Cur.; Cyprinus falcatus, Bloch, Lacep. "1. - c. bossu, Cyprinus gibbuis, Lacep. "1" - C. Commersonnien, Cyprinus Commersongii, Lacep ${ }^{16}$

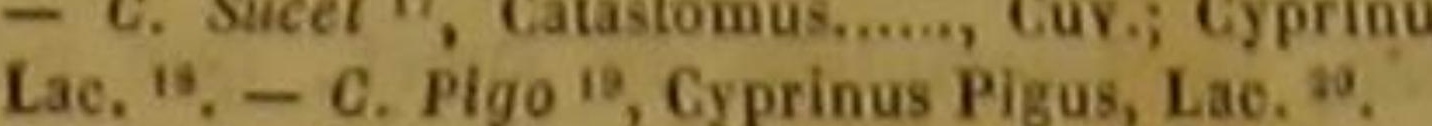

Nous n'avons pas besoin de répéter que, pour se représenter neltement les poissons dont nous

Plotze, Bleyer, en Saxe. - Geuster, Guchstern, Weis fisch, en Silésie. - Bleicke, Jasier, en Prusse. - Bley weis fisch Bleyblicke, à Danizig. - Brasen, Bunka, en Norvè́g - Pliten, Plitfisch, a Hambourg. - Bley, Blieeke, en Horlande. - "Cyprinus quincuneialis; pinna ani, ossiculorum a viginti quinque, o Artedi, gen. 3, spec, 20, syn. 13, - C prin plestie, Cyprin bierkna. Daubenton et Hauy, Enor delizre, Cyprimus blicca. Bloch, ph. 10. - Gronov, Zooph. I
p. 110, D. 34. - Leske, Spec., pl. 69, n. 15. - Klein, Miss. P. 110, o. 34. - Leske, Spec, pl. 69, n. 15. - Klein, Mi
pisc. 5, p. 62, n. 4. - Bordetiere. Hondelet, parl, 2, Poisso des laes, e. 8. - Wulff. Ichth. Bors, p. 51, n. 69. - Ballerus et blicke, Gesner, Aquat., D. 24 ; et (germ.) p. 167 b. - Id fig. 7. - Meidinger, Ie. pisc. Aust, L. 7.

a ce poissod, que M. Curier nomme en francais Bordelière pelite Brême, ou Hazelio, est placé par laí dans lo sougenre BaÉse, Abramis, du grand genre CxphIs. Z Zope, dans le Brandebourg. - Schwope, en Poméramie. - Bleyer, Rudulis, Sarg, en Livonle. - Ssapa, en Russic - Bin, en Suède. - Bunke, Brasen, en Norvêge. - Flire Blikka, en Danemarck. - Cyprin bordelière, Daubenton Hä̃y, Enc. méth. - Id. Bonnaterre, pl. de I'Ene. méth. Sope, Bloch, pl. 9. - Bordeliére. Valmont de Bomare, Dic d'hist. nat. - a Cyprinus admodòm latus el tenuis. $n$ Artesl gen. 3, spec. 23, syo. 12. - Zope, Wulfe. Ichllh. Bor., p. 50,
n. 68 . n. 68.

Cypras. - D.

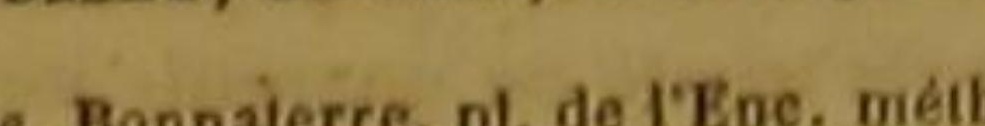
¿Cyprin chevanne. Bonnaterre, pl. de
¿Le Cyprin chub ou chevanne n'est pas cite par M. Cuvier

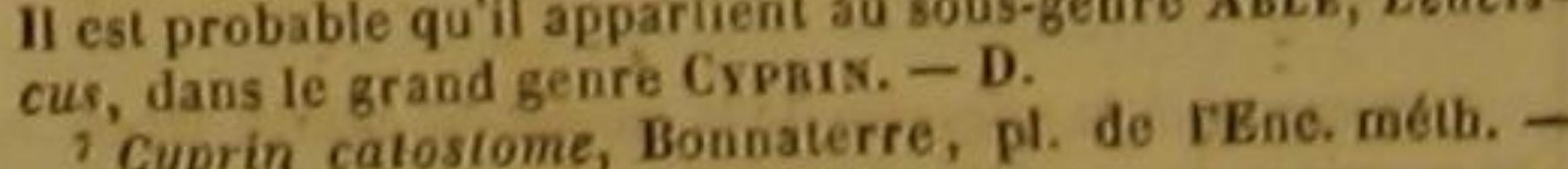
Forster, Trans. phil, L. 63, p. 158. - Ce poisson parait ére le type du sous-geure Catastose, tabli par M. Cuvier, dans le grand genre des Cyprins. L Calastomes, dont M. Lesueur a decrit et igure, de l'Amér gue septentrionale. II faut y ajouter le Cyprinus teres de Mitchill, et le Cyprin sucher de Lacépéde, décrit el-sprès. 'Cyprin morelle. Bonale
Iehth. Leips. Spec., p. 48 .
10 M. Cuvier ne fait aucune mention da Cyprio morelle.

D.

in Solkondei, en langue tamulique. - Blocb, pl. 42.

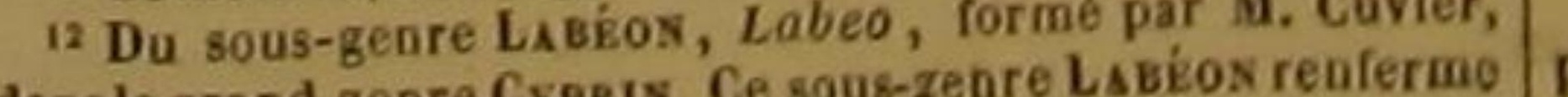

traitons, il fant ajouter les traits esquissés dan le tableau générique à ceux que nous indiquons dans le texte de leur histoire.

Le eyprin large a l'iris jaune et pointillé de noir; la courbure de sa nuque est excentrique à celle du dos; l'un et l'autre sont bleuâtres ; la ligne latérale est distinguéo par des points jaunes; les eótés sont d'un blane bleuâtre au-dessus de cette ligne, et blanes au-dessons; lo ventre esi bleu; les pectorales ot les ventrales sont ronges; a caudale est bleue; I'anale et la dorsale sont brunes et bordées d'azur.

Le large est très-commun dans les lacs ot les rivières d'une grande partie de la France, de I'Allemagne et du nord de l'Europe, II a beaucoup d'arêtes. Sa timidité le rend difficile à prendro, excepté dans le temps où it fraie, et oì il est, pour ainsi diro, si occupé à déposer ou ì réconder ses cufs, qu'on peut souvent le saisi avee la main. Il est d'ailleurs trahi par lo bruit qu'il fait dans l'eau pendant I'une et Yautre de deux opérations.

Dans celte espèce, les femellés les plus grosses pondent les premières, et leur ponte durs communément trois ou quatre jours. Huit ou neu jours après paraissent les fomelles d'une moyenne grosseur; et à une troisième époque, éloignée de la seconde également de huit ou neuf jours on voit arriver et frayer les plus petites.

Le large multiplie beaucoup, perd difficilement la vie, pèse une livre; son épine dorsale est composée de trente-neuf vertèbres.

Le eyprin sope a la nageoire du dos pla Cloignée de la tete que les ventrales. L'ail e rand; le front brun; l'iris jaune et marqué de

encore to Cyprinus nlloticus de M. Geoffroy, et to Catasiomus cyprinus de in.
${ }^{13}$ Bloch, pl. 412 .

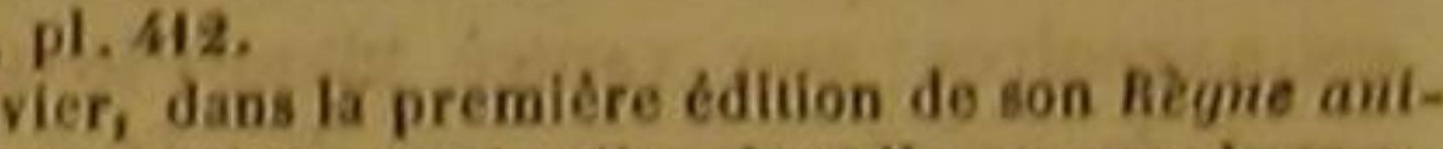
a al, cite cette espece parmi celles dont it compose lo sous- is II Cuvier ne cite pas cello espéce. D.

10 Dans la premiêre ćdition đu Regne animal, M. Cavier cite le Commersonnien comme appartenant au sous-genso "i, Le Cyprinus pinns ani, radils novem; doriall, due

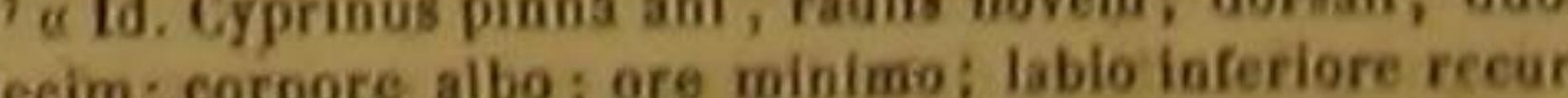
“ vato. D Bose, notes manuscrites deja ciúes. is Du sous-genre Catastosus, Cur., dans lo grand Cxpais. D. 19 Picho. - Piclo. - Pigo, Cyprinus acuiteatus, Roodelet, part. 2, Poissons des lass; c. 5. - a Cyprinus picio, ce.,
dictus. o Artedi, syn. 13. - Piclo, el pigus, Salvisn., fol. a a icon. 17, et fol. 83. - Pigo. Valmont do Bomare, biet. d'hist. nat. M. Cuvier ne fall aucune mention de cello deraiére esD. 
deux taches noires; la joure bleue, jaune el individu desséché, mais bien conservé, dans la rouge; l'opercule peint des mêmes couleurs que collection hollandaise cédée à la France. la joue; le ventre rougeâtre; la couleur générale nageoire dorsale est un peu échancrée en forme argentine; le dos noirâtre; la ligne latérale dis- de faux.

tinguée par des points noirs; le bord des na- Le commersonnien, dont nous publions les geoires d'un bleu plus ou moins vif. premiers la description, ot que le savant Com-

La sope se plaît dans les eaux du Have en Po- merson a observé, présente un double orifice méranie, et du Curiseh-Have en Prusse. Elle a pour chaque narine; sa tête est dénuée de petites peu de chair et beaucoup d'arêtes. Son poids est écailles; ses ventrales et ses pectorales sont arquelquefois de deux à quatre livres. On compte rondies à leur exirémité ; la dorsale s'élève vers dans cette espèce quarante-liuit vertèbres et dix- le milieu de la longueur totale du poisson.

huit côtes de chaque côté.

Dans plusicurs rivièrès de l'Europe habite Io chub. Son dos et sa nuque sont d'un vert sale; ses côtés variés de jaune et de blanc; ses pectorales jaunes; ses ventrales et son anale rouges le biun et lo bleuâtre, les couleurs de sa candale.

On a observé dans la baie d'Hudson le catostome, sur lequel il faut remarquer les écailles ovales et striées; la tête presque carrée et plus étroite que to corps; la strie longitudinale qu part du museau, passe au-dessous de l'ail, et va se réunir à la ligne latérale; la teinte dorée de cette dernière ligne; la forme rhomboîdale de la dorsale, et la position de celte nageoire audessus des ventrales.

La morelle a sept pouces et demi de longueur. Ses écailles sont parsemées de points noirs; le sommet de sa tête est d'un blen sale; ses nageoires sont couleur d'olive; son dos est verdâtre; le blanc règne sur sa partie inférieure. Elle a été observée dans plusieurs rivières d'Al. lemagne. Ello a trente-sept vertèbres et seize côtes de chaque côté.

La tête du frangé est petite; son iris argentin et entouré de deux cercles rouges; sa langue dégagée; son palais uni; son dos violet, ainsi que ses nageoires; son ventre blanc; le tronc parsemé de poiuts rouges. On l'a découvert dans les eaux donces de la côte de Malabar. Il est bon à manger; et, soigué dans un lac, il peut peser à manger; et, soigué dans un lac, il peut peser
six livres. six livres.

Les mêmes eaux du Malabar nourrissent eyprin faucille, dont l'anus est une fois plus éloigné de la tôte que de la caudale. La tète de ce poisson est petite; son palais et sa langue sont unis. Son iris est jaune; son corps et sa quew sont d'un argenté mêlé de bleu; le dos est bleu; les nageoires sont rougeàtres.

Les naturalistes ne connaissent pas encore l'espèce du cyprin bossu. Nous en avons vu un |

Nous avons trouve dans les notes intéressantes ue notre confrère Bose a bien voulu nous communiquer, la description du sucet, que nous vons fait graver d'après un dessin qu'il avai fait de cet abdominal. Ce cyprin est très-commun dans les rivières de la Caroline; sa chair ést peu recherchée, et il est très-rare qu’il parvienne à la longueur de quinze pouces ou environ. Il montre un iris jaune, des nageoires brunes, un dos d'un brun plus ou moins elair, des côtés argentés, avec des tachies brunes sur a base des écailles.

Plusieurs lacs d'Italie, et particulièrement le c de Côme et le lac Majeur nourrissent le Pigo. Son poids est quelquefois de six livres. Il fraie près des rivages. Sa partie supérieure est d'un bleu mẻlé de noir, et sa partie inférieure d'un ouge faible et blanchâtre. Les mâles de presque outes les espèces de-cyprins montrent, peudant e temps du frai, des excroissances aiguès sur leurs principales écailles : il parait que les pigos màles présentent, daus ce même têmps, des piquants qui ont quelque chose de particulier dans leur couleur blanchàtre, dans leur apparence cristalline, et dans leur forme pyramidale; et c'est de ces aiguillons quui n'étaient pas inconaus à Pline, qu'est venu le nom que nous leur vons conservé. Ces piquants ne disparaissent u'après trente ou quarante jours.

La chair des pigos est très-agréable au goùt '.

Ia rayons a la nageoíre de la queue du cyprin large. queue. -19 rayons à la caudsle du cyprin morelle -17
que rayons a chaque pectorale du evprin frangé, 25 i fo no de la queue. - 16 rayons a la caudale da cyprin faucille. rayons d la nageoire de la queae du cyprin bossa. - 19 la nageoire de la qu -cyprin commersonnien. -18 rayons tue du cyprin sucet.

\section{DES POISSONS.}

SECONDE SOUS-CLISSE.

POISSONS OSSEUX.

Les parties solides de linuérieur du corps, osse uses. $-\infty a$

SECONDE DIVISION

RE LA SECONDE SOLS-CLASSE,

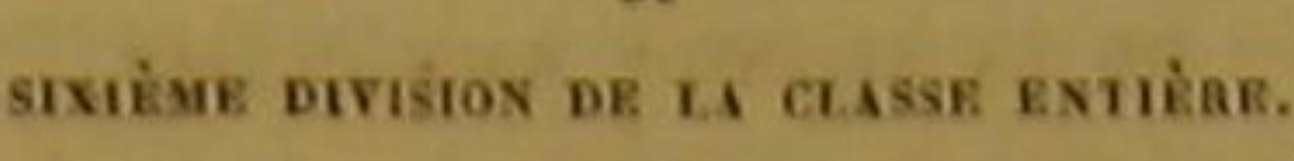

Poissons qui ont un opercule branchial, sans membrane branchiale. 19 rayous a la caudale du cyprin sope. -17 rayons à cha-
VINGT-UNIÈTE ORDRE DE LA CLASSE ENTIÈnE DEs roIssons, or

PREMIER ORDRE

DR LA SECOXDE DIFISTON DES OSSEUX

Poissons apodes, ou qui nont pas de nageoires infe-
rieures emire le museau el l'amus. $-$

DEUX CENT SEIZIEMAE GENRE. LES STEaNOPTYX ${ }^{\prime}$.

Le corps el la queue comprimes; le dessous du carps ca rene el transparent, une seule nageoire dorsa

Espice. Canactìnes.

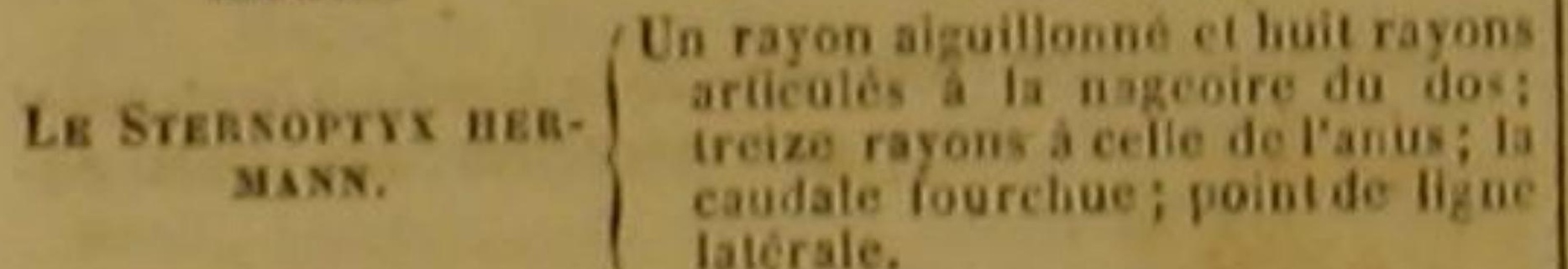
$-$

LE STERNOPTYX IERMANN22.

Sternoptyx diaphana, Herm., Limn., Gmcl.; Sternoptyx Hermann, Lac. ${ }^{3}$.

Ce poisson, que nous dédions à feu notre confrère. le professeur Hermano, et que ce savant a fail connaitre aux naturalistes, a sa surface dénuée d'écailles apparentes, mais argentée. son dos est d'un brun verdâtre; ses pectorales; sa caudale et sa cornée sont couleur de rales, sa cable entinaire ast a peine de succin. Sa longueur ortite bosse parait derrière quatre pouces. Une petite bosse parait derrière quement, immobile et très-fort, est non-seule1.3 II Cuvier adapte le genre Steasoptry d'Tlermann, el le place dans la famille des SALMoxis, ordre des Malacople-

rygiens abdominaux. D.
2 Hermann, Natorf. 16, p. \&, tab. I, fig. 12. ment aiguillonné, mas épineur, et dont la membrane est légèrement dentelée sur le bord. Les opercules sont mous; le devant du dos présente deux carènes qui divergent vers les narines; les yeux sont grands; la langue est épaisse et rude; les dents sont trìs-petites. La lèrro supérieure est conrte; l'inférienre se récève presque perpendiculairement, et montre quatro petités dépressions demi-eirculaires : on voit trois enfoncements semblables sous l'ouverture des branchies. Les cótés do la poitrine qui so réunissent dans la partio inférieure du poisson pour y former une carène transparente, offrent dix ou onze plis.

Le sternoptyx hermann vit dans l'ile de la Jamaĩque . $^{2}$

SECONDE SOUS-CLASSE.

polssons osseux.

Les parties solides de linterlewr du corps, ossenses.

\section{TROISIĖME DIVISION}

DE HA SECONDE SOUS-CLASSE,

GPTi Polssons qui ont une membrane branchiale, sans operente
branchial.

VINGT-CINQUIiENE ORDRE ${ }^{2}$ oe

PREMIER ORDRE

OE LA Thossíse Division DES Ossecr. Poissons apodes, ou qui n'out pas de nageoires inforicures
entre le museau et l'anus. a viogt-deuxieme, au vingt-troisieme nị au viogh-quatrièm ordre.

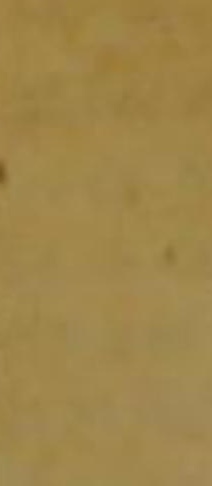

DE LA CLASSE ENTIERE DES PIIS ONS,

is rayons a chaque peetorale du sternoptix hermasu,

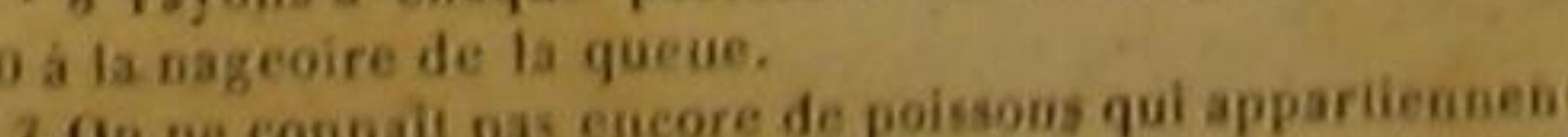




\section{DEUX CENT DIX-SEPTIE்ME GENRE.}

LES STYLÉPHORES ${ }^{\prime}$.

Le.museau avancé, relevée è susceptible d'êre courbé en arrière par le moyen d'une membrane, au point d'al-
ler toucher la partie anterieure de la ler toucher la partie antérieure de la tele proprement
dite; louverture de la bouche au bout du museau poim de dents; le corps et la queue très-allongés el conprimes; la queue terminée par un filament très-
long.

EspĖcr.

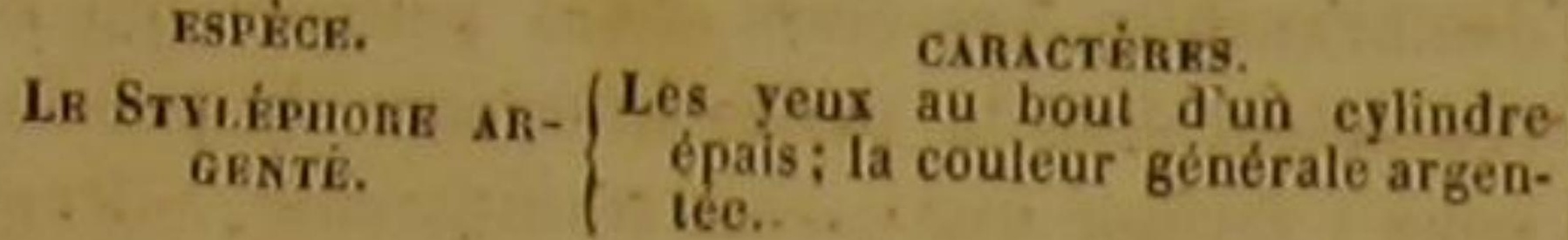
$2+2$

\section{LE STYLÉPHORE ARGENTÉ?}

Stylephorus chordatus, Straw, Guv.; Stylephorus argenteus, Lacep. ${ }^{3}$.

Un individu de cette singulière espèce, dont on doit la description à M: George Shaw, a été pris entre Cuba et la Martinique, à dix ou douze lieues du rivage, nageant près de la surface de l'eau. Sa longueur totale était de plus de vingthuit pouces; ot le filament qui terminait sa queue avait plus d'un pied et demi de longueur. On ne pouvait distinguep aucune écaille sur sa surface argentée. On apercevait sur son dos deux nageoires, dont la première partait de la tête, était très-longue, et n'était séparée de la seconde que par un intervalle très-court. Peutêtre ces deux nageoires n'étaient-elles que deux portions d'une nageoire unique, altérée et divisée en deux par quelque accident.

Le museau était d'un brun très-foncé; les na geoires, le long tilament, et le cylindre oculaire offraient des nuances d'un brun elair,

La caudale était courte, disposée en éventail, composée de einq rayons aiguillonnés. l'anim avait trois paires de branchies.

i.s M. Cuvier adopte te genre Styléphôre de Shaw, et
te place a la suite des Trichìres famillo des Acanthoptérygiens Taniogides, Gymêtres dans. Ia rubans. D.

Linnécene de chordatus. Georg. Shaw, Act. de la Sociét

Linnéenne de Loudres, décembre $1788,1.4$, p. 80.
SECONDE SOUS-CLASSE.

POISSONS OSSEUX,

Les parties solides de l'intérieur du corps, osseuses.

TROISIÈME DIVISION

DE LA SECONDE SOUS-CLASSE,

SEPTIĖMR DIVISION DB LA CLASSE ENTIĖRE

Poissons qui ont une membrane branchiale, sans opercule
branchial.

Granchial.

VINGT-HUITIE் ORDRE'

DE LA CLASSE ENTIÈnE DES. POISSONS,

QUATRIĖME ORDRE

DE $\mathrm{L}$ TROISIÈMR DIVISION DES OSSECX. *

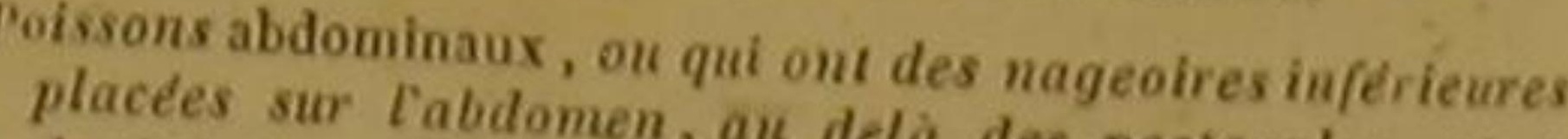
placees sur labdomen, au delà des pectorales, et en
deça de la nageoire de Vamus.

DEUX CENT DIX-HUITIEME GENRE, LES MовMYRES ?.

du museau; des dents anx me la bouche a l'exiremite geoire dorsale.
.

EspìcEs.

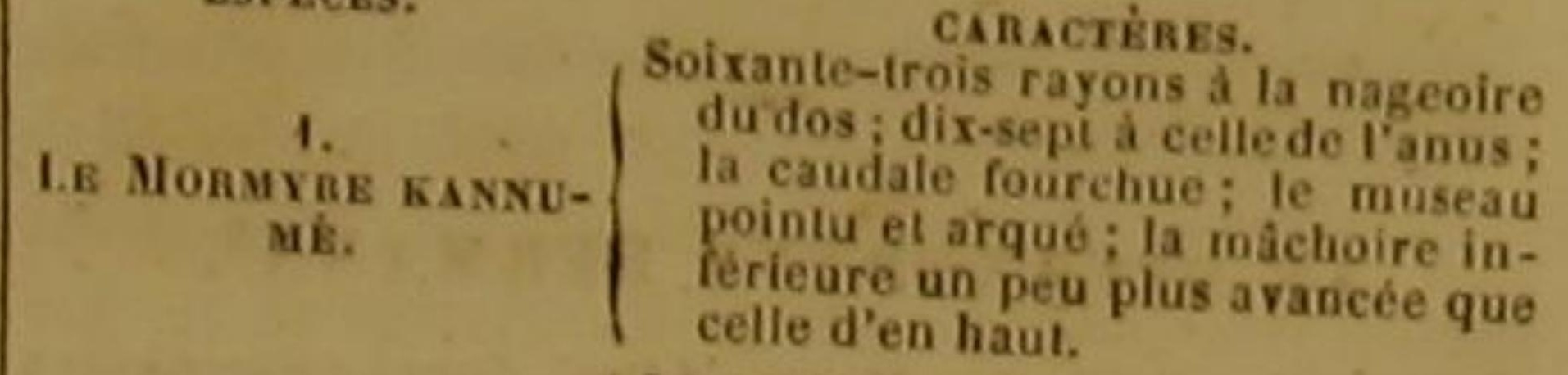

2.
LE Moniyn oxy-
RHYxeur.

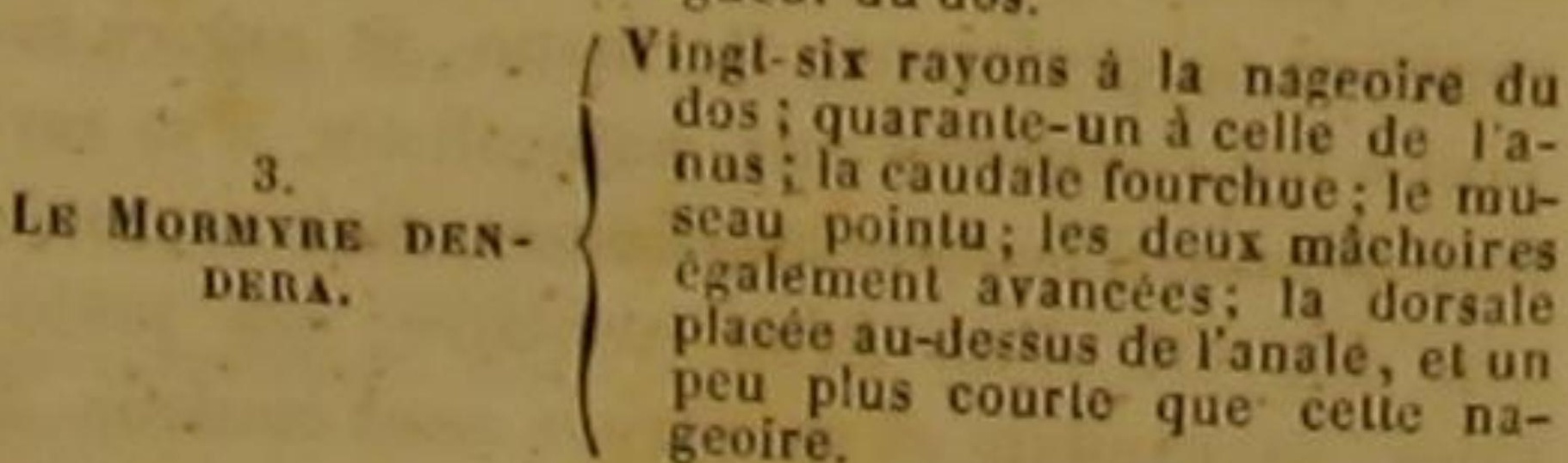

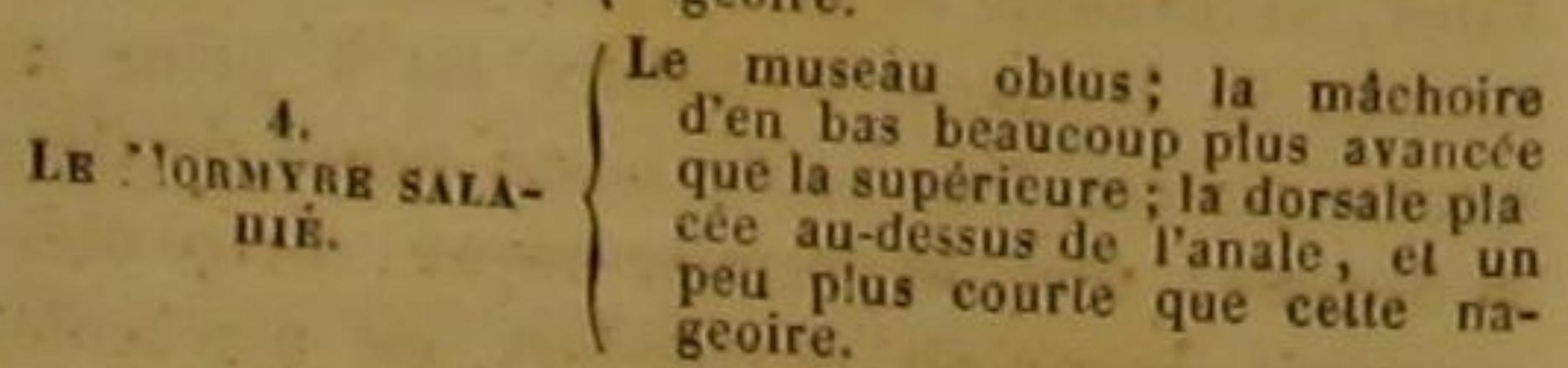

On ne connait pas encore de poissons qui appartiennen

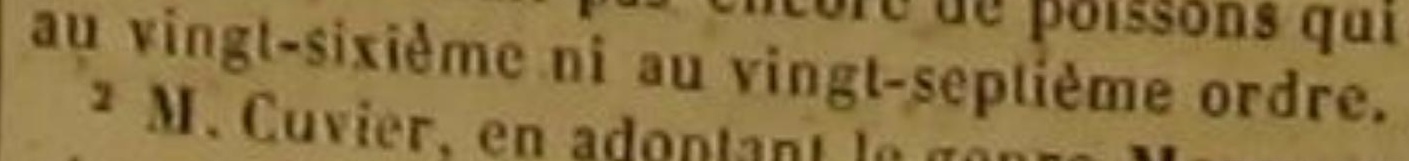

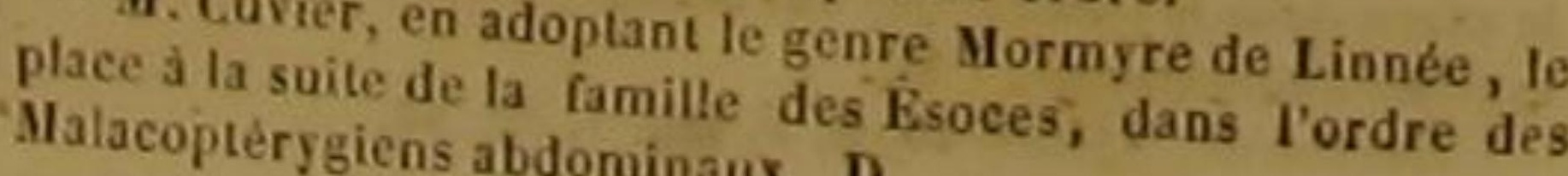

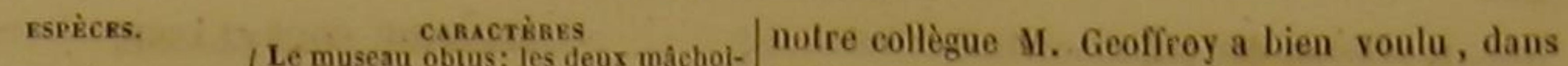

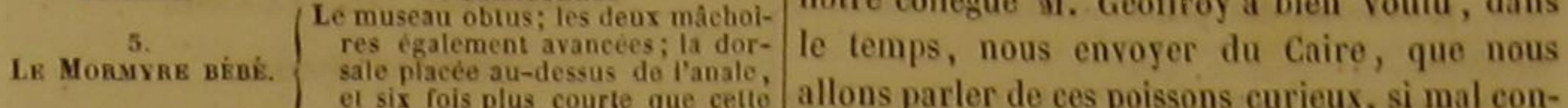
. $\begin{aligned} & \text { el six fois plus courte que cello } \\ & \text { nageoire. }\end{aligned}$

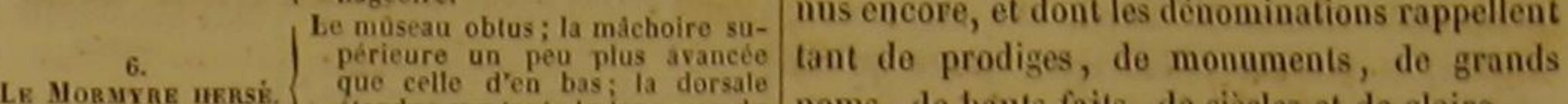
Vingl-sept rayons a la nageoire du Et d'abord, voici les traits généraux qu'a des7.
LE Monirg ctpr-
Noide.

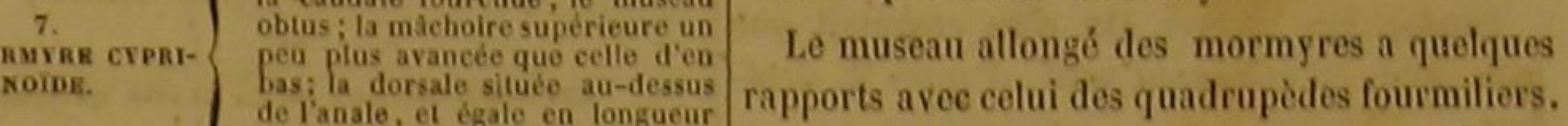

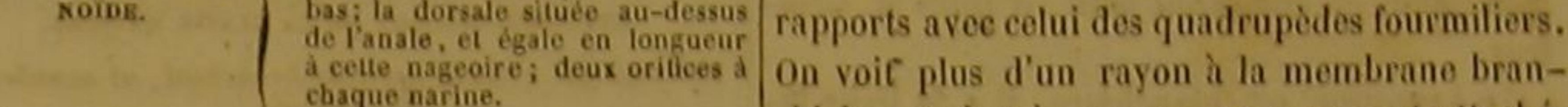

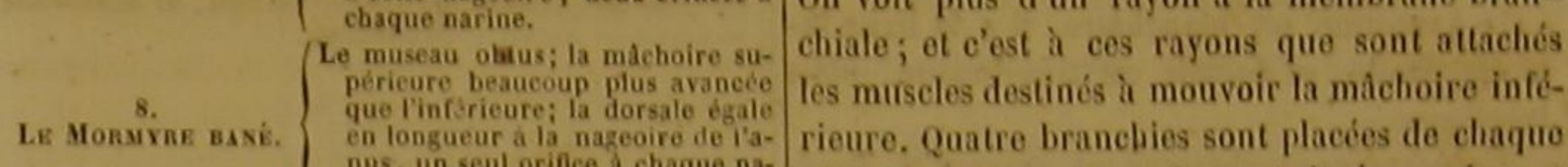

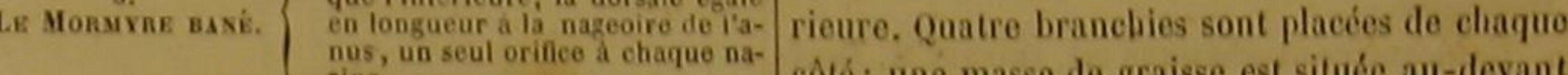
de l'ostomae, qu'un muscle épais peut contracter, et d'une partie du canal intestinal, qui, après avoir tourné autour de deux eøcums égaux, courts et roulés sur eux-mèmes, se rend droit à l'anus, toujours garni do deux bandes graisseuses.

LE MORMYRE KANNUMÉ'

Mormyrus Cannume, Forsk., Cuv.; Mormyrus Kannume, Linn., Gmel., Lac, "2

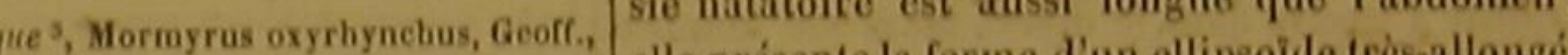

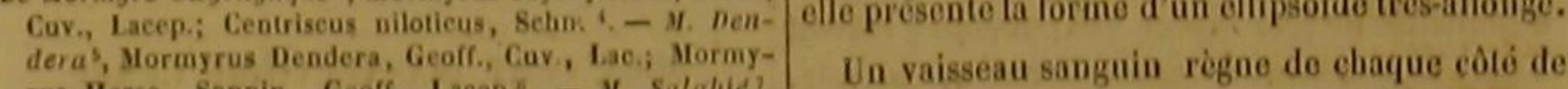
rus Derse, Sonnin., Geoff., Lacepz. - M. Salahice rus Salleshe, Cux.; Mormyrus Salahic, Lac." - M. Bertic

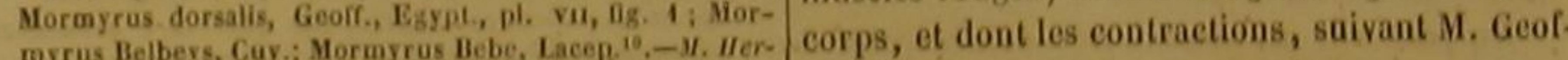
séli, Mermyrus Herse, Sonn., Geoff., Lae,; Mormyrus Dendera, Geoff., Lac., Cuv.12, - M. Cyprinoide 13, Mormyrus cyprinoldes, Geoff. Cuv., Lacep.; Mormyrus Bane, Geoff., Lacep,"14.- H. Bane 1", Mormyrus Bane, Geoff,
Lac., Mormyrus cyprinoides, Geoff., Cuv., Lac, 10 Lac.; Mormyrus cyprinoides, Geoff, Cuv., Lac, 10
M. Hasselyais 1", Mormyrus Hasselquist, Lacep; Mormyrus Caschire, Hasselq. "t.

Le Nil est la patriê des mormyres. C'est principalement d'après les notes manuscrites que

' Kachoué ommou bonete, c'est-â-dire kachoue mère du Waiser, en Arabie, suivant mon collegue Geoffroy, - Fors-

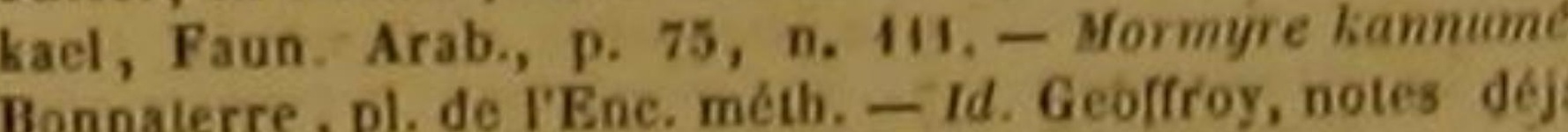

citées.
2. M. Cuvier admet le Kannumé de Porskael, comme for-
J mant une espece distincle dans le genre MonMYnE. D.

3 Mormyire oxyrlyynque. Geoffroy.

- M Cuvier cite celle espéce de Mosmyra, qui a clée représentée par M. Geoffroy, dans le grand ouvrage sur IÉgypte,

SMormyre dendera. Geoffroy. - Mormyre caschive. Daubenton et Haüy, Ence. mẹth. - Id. Bonnaterre, pl. do 'Enc. méth. - Mus. Ad. Frid. 140.

- Le Mormyre de Dendera étant, selon M. Cuvier, le mème poisson que le Herse de Sonnini, Geof́froy el Lacépède, s'ensuit que, dans cet a Sucle, fait aussi remarguer que c'eal mal à propos qu'on a confondu le mormyre dendera avec le Caschive d'Hasselquist, qui en paralt différent par plusicurs Irails essentiels, à en juger par sa doguta genre Monsiyere, en adop-

Aformyre bebe, Geoffroy.

topece disticte de sormyre pour M, Cuvier, qui fail Voyage en Egyple, pl. XXI, Ag. 3. D

"I Mormure hersed Geoffroy.

12 Le Mormyre hersé, selon M. Cuvier, ne difrère pas spé-

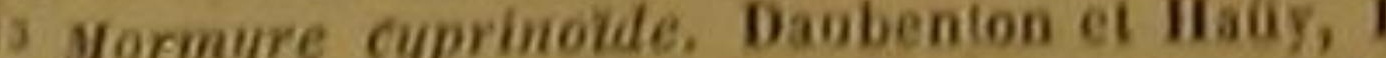

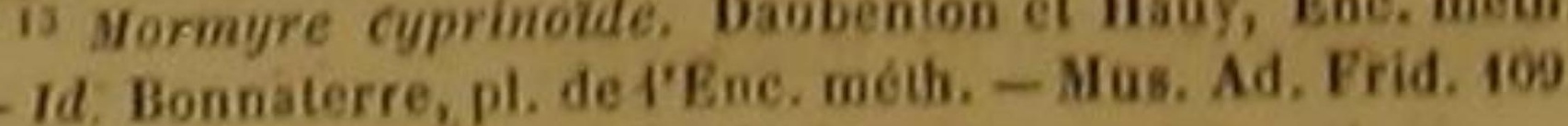
- Mormyre cyprinoide. Geoffroy.

"M. Cuvier rêunit les deux espèces distingáees par Mar. Geoffroy el Lacépède, sous les noms de Hormyre cy eule. D.

(i) Geoffroy.

16 Cetie espéce ne differe pas do la précédente, seton

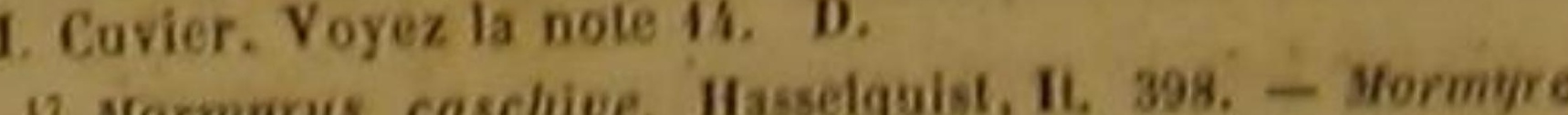
hasselquist, Geoffroy.

16. M. Cuvier regarde comme appartemant á deux espéces distincles: $\mathcal{T}^{\circ}$ Le Mormyre caschive, Hasselquis, decelarticle; ${ }_{20}$ le Mormyre hasselquist de Geofroy, Egypte, pi. Vi, gg. 2, que ce dernier naturalisto el in Lacepéde consideren comme n'en taisant qu'une seule. I y a chared cas le Xil et le Sénézal, suivant M. Cavier, pui
Mormyres non encore publicess. D.
Mormyre salahied, Geoffróy. 
froy, produisent des pulsations dans te vaisseau sanguin.

La queue est très-longue, et, au lieu d'être comprimée comme le corps, elle est grosse renflée, et presque cylindrique, parce qu'elle renferme des glandes, lesquelles filtrent la substance liuileuse qui s'écoule le lóng de la ligne latérale.

Passons aux espèces. On n’en comptait que trois; nous en comptons neuf, d'après M. Geoffroy.

Le kannumé est blanchâtre. Il a la ligne latérale droite; sa dorsale est très-longue, mais très-basse.

Le mormyre oxyrhynque est, suivant M. Geoffroy, l'oxyrhynque (oxyrhynchus) des anciens anteurs.

Le dendera labite particulièrement dans la partie du Nil qui coule auprès du temple antique, admirable et fameux, dont il porte le nom.

C'est auprès de Salahić que M. Geoffroy a vu pour la première fois le mormyre auquel il a donné le nom de la patrie de cet osseux. Ce naturaliste a trouvé dans le désert un grand nombre d'individus de celte espèce. Ces poissons y étaient à sec; ils y avaient été apportés par une inondation, et ils y étaient restés dans un enfoncement dont l'eau s'était évaporée.

On peut voir un nombre très-considérable de Bébés dans le voisinage d'un lieu nommé Bébé par les habitants de l'Égypte, et où l'on admire encore les ruines imposantes d'un magnifique temple d'Isis.

Le mormyre Hersé a reçu son nom spécifique des Arabes.

Le nom du Cyprinoidde indique les rapports de conformation qui le lient avec les Cyprins.

Les Arahes ont douné le nom de Bané à notr huitième espèce de mormyre.

M. Geoffroy dit, dans ses notes, qu'il a tout lieu de croire que le mormyre observé par İasselquist est différent des huit espèces que nous venons de rappeler. Nous sommes persuadés de celte diversité d'espèce.

Au reste, les Arabes désignent tous les mormyres par le nom générique de Kachoué'

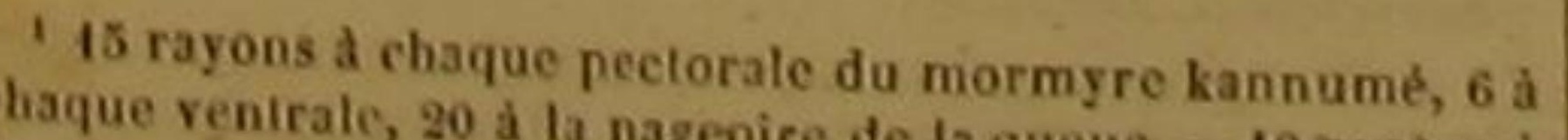
chaque ventrale, 20 a ta nageoire de la queue. -10 rayons a a
chaque peetorale du mormyre dendera, 6 a chaque ventrale,
19 a la caudale. -9 rayons a chaque pectorale du vormyre cyprinote, 6 a chaqrayons a chaque pectorale du mormyre -10 rayons à chaque pectorale du mormygre haselquist, 6 a
eliaque ventrale, 24 a la caudale.
SECONDE SOUS-CLASSE.

POISSONS OSSEUX.

Les parties solides de lintérieur du corps, osseuses.

\section{QUATRIĖME DIVISION}

DE LA SECONDE SOUS-CLASSE, or

HUTTĖMR DIVISION DE LA CLASSR ENTIÈRE. Poissons qui n'ont ni opercule branchial, ni membrane - branchiale.<smiles>[TlH]</smiles>

VINGT-NEUVIĖME ORDRE'

DE La classe ENTIÉre des polssons,

PREMIER ORDRE

DR LA QUATHĖME DIVISION DES OSSEOY Moissons apodes, ou qui n'ont pas de nageaires inférieures placees entre la gorge et l'anus.

DEUX CENT DIX-NEUVIĖE GENRE. LES MURÉNOPUIS ${ }^{2}$.

"oint de nageoires peetorales; me ouverture bramehiale

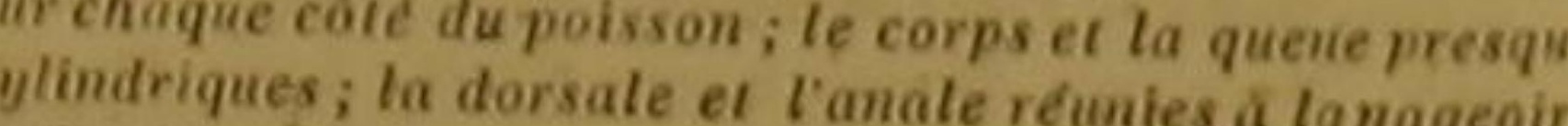
eylindriques;
de la queue.

Espḱcrs.

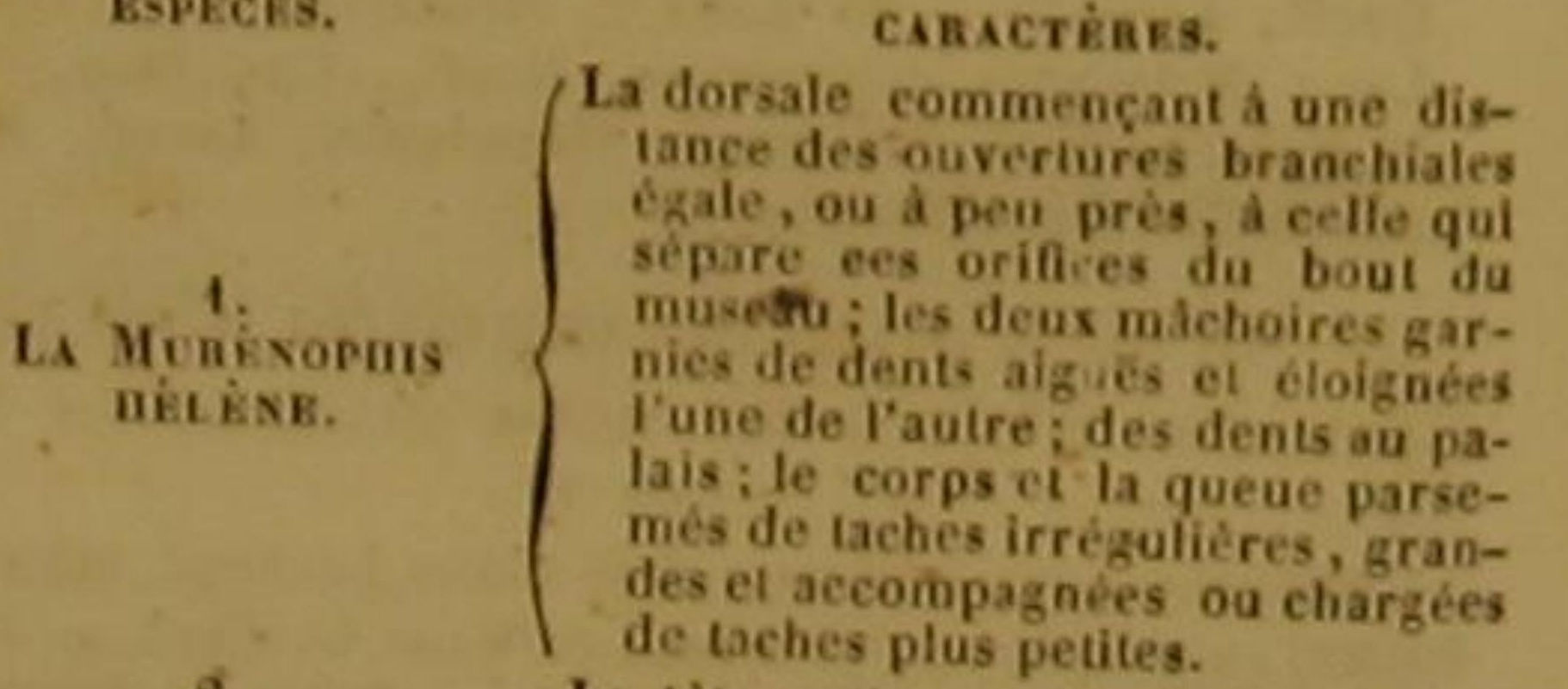

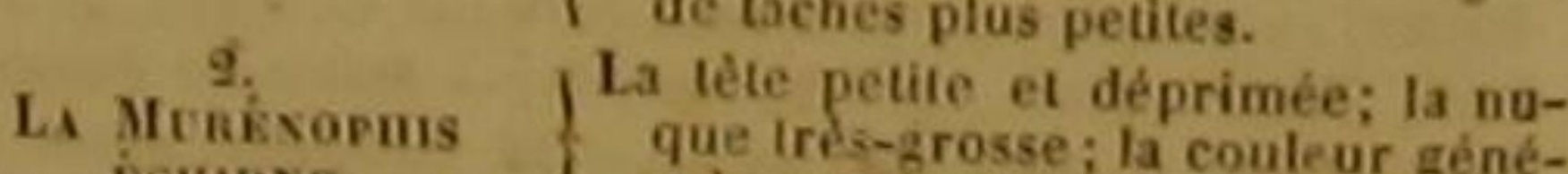

kCHbNe. $\quad$ rale variée de noir et de brun.

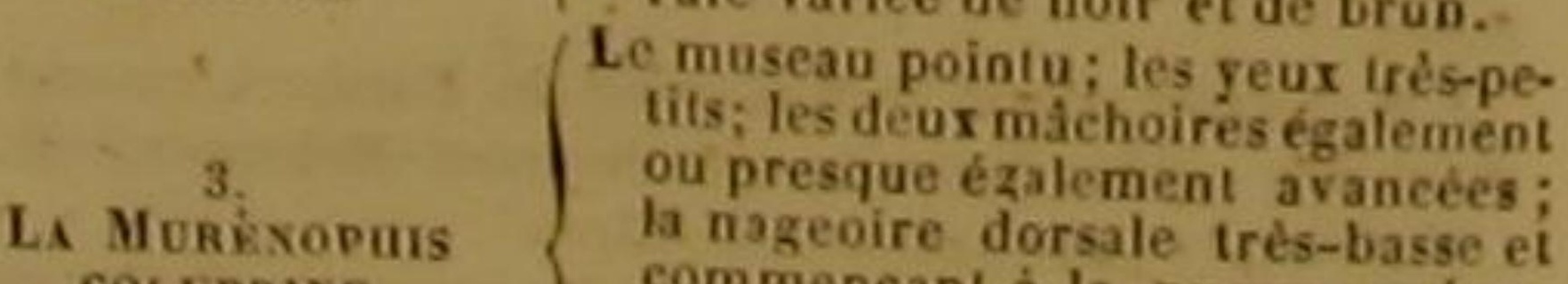

Colczeise.
comdes iransyersales, dont cha-

In ne connaît pas encore de poissons qui appartiennen a trentième, au trente et unième ni au trente-deuxième

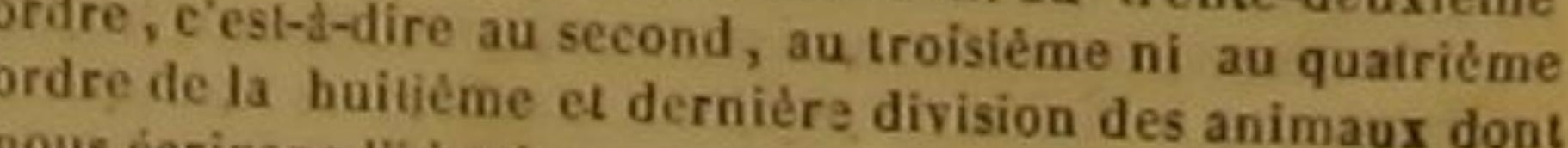

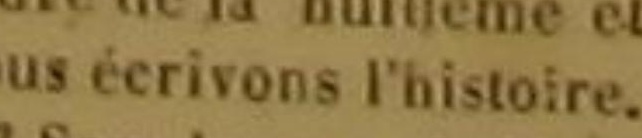

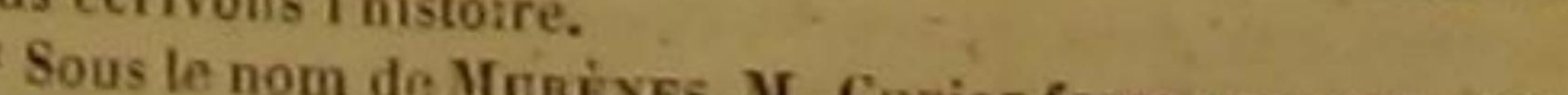
du grand genre AxGCILLE, Mureena, ordre des Maus-genre giens apodes, qui comprend les genres Morésopais, Graso-
DES POISSONS.

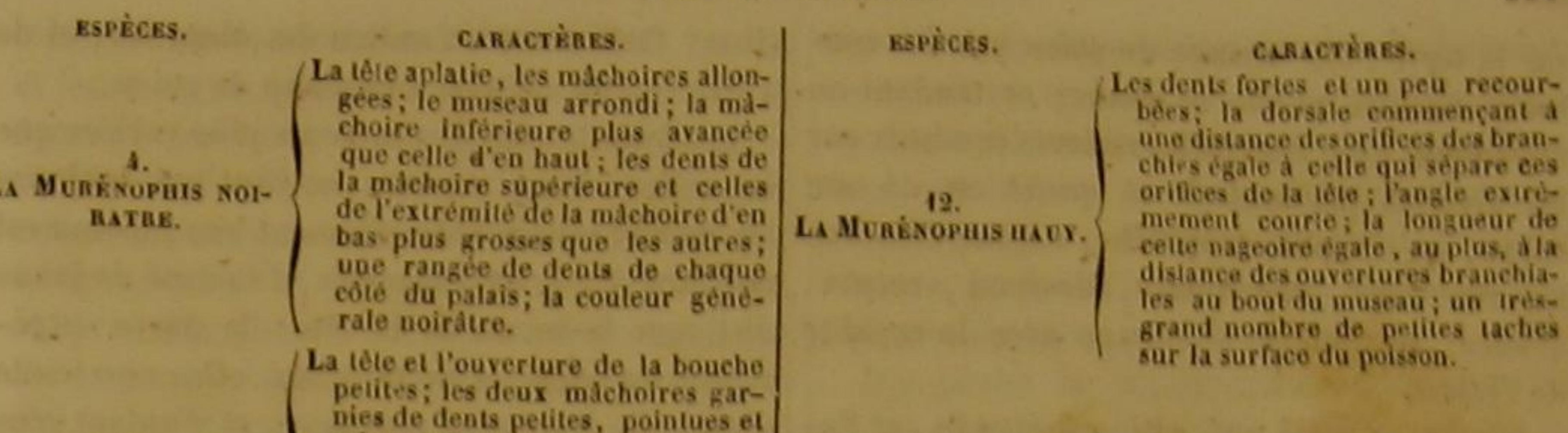

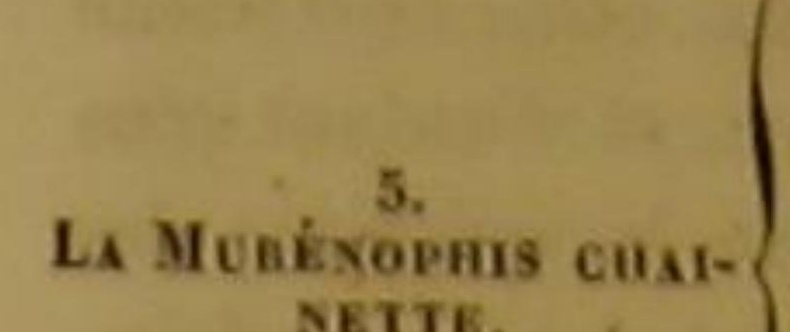
mies de dents petites, pointues el aigne des opyeriurses bes chiales que celles-cl du bout du
musesu; des laches en forme de
chenogi de léte el l'ouverture de la bouch

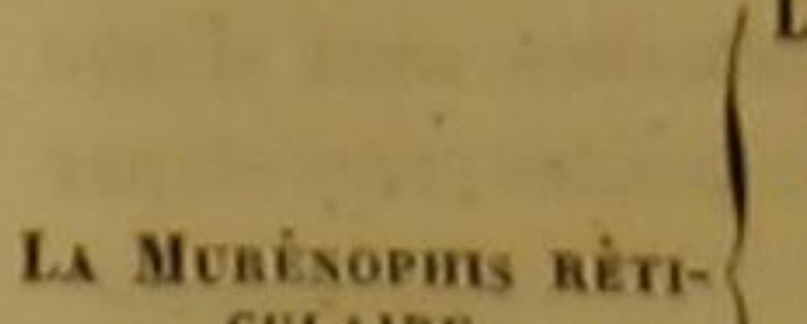

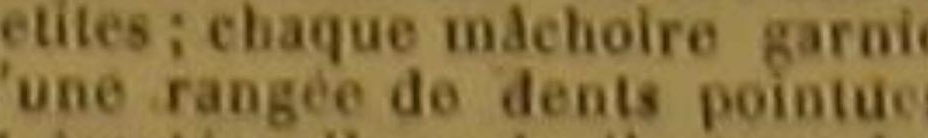

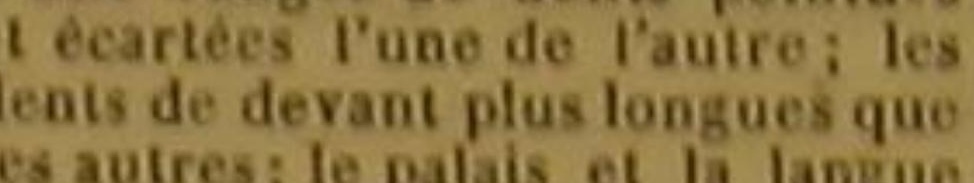
lisses; la nageoiro dorsale cont-
mençant a la nuque ; des tactes reuculaires

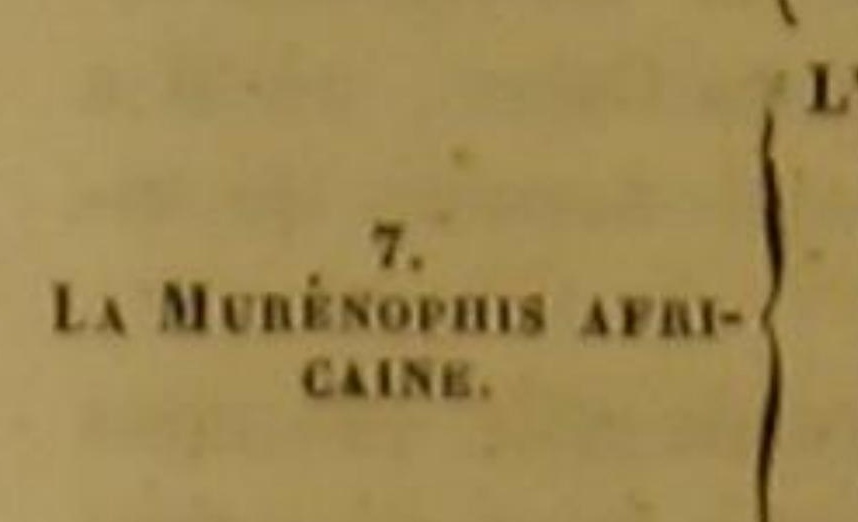
Worifice de la bouche grand: Ies deux máchoires armées de dents
fortes et recourbees en arriere; les dents de devani plus framdes
que les autres; la langue fisse; le que les autres; la langue hisse; le
palais garni de grandes dens i la
dorsale, commencant a la nuque; lo corps el la queue marbres.

8. $\left.\right|^{L}$

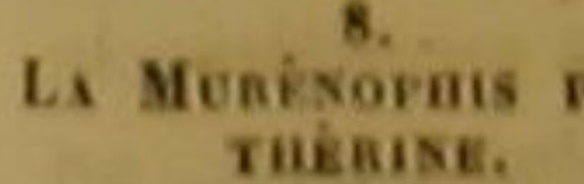

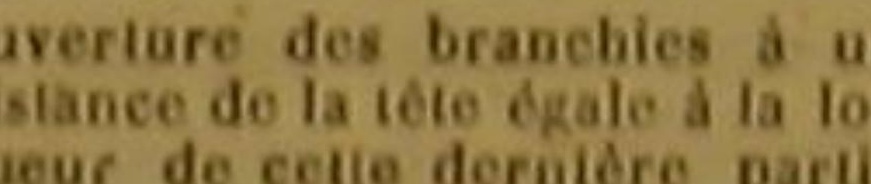
origine de la nageoire dorsale
aussi cloignce des orifices des

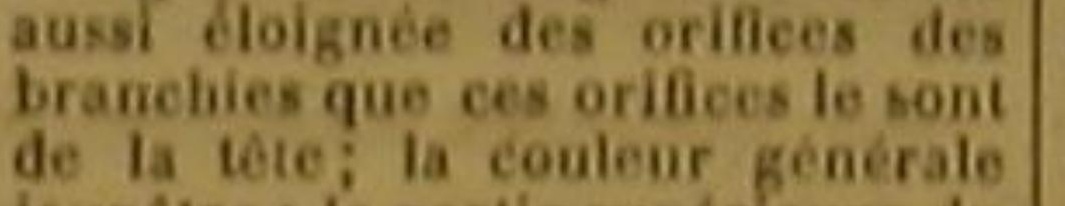

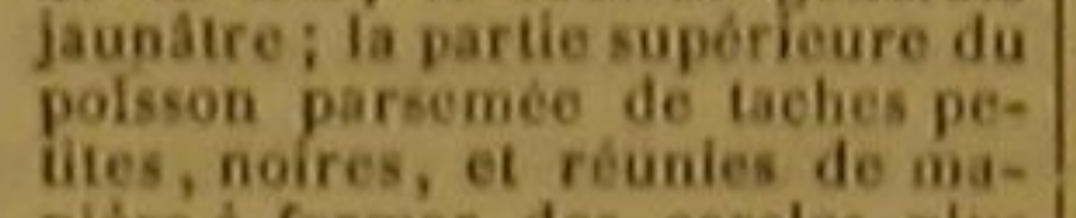
alére a former des cercles plus
oumoins ontiers el plus ou hooins
regulters.

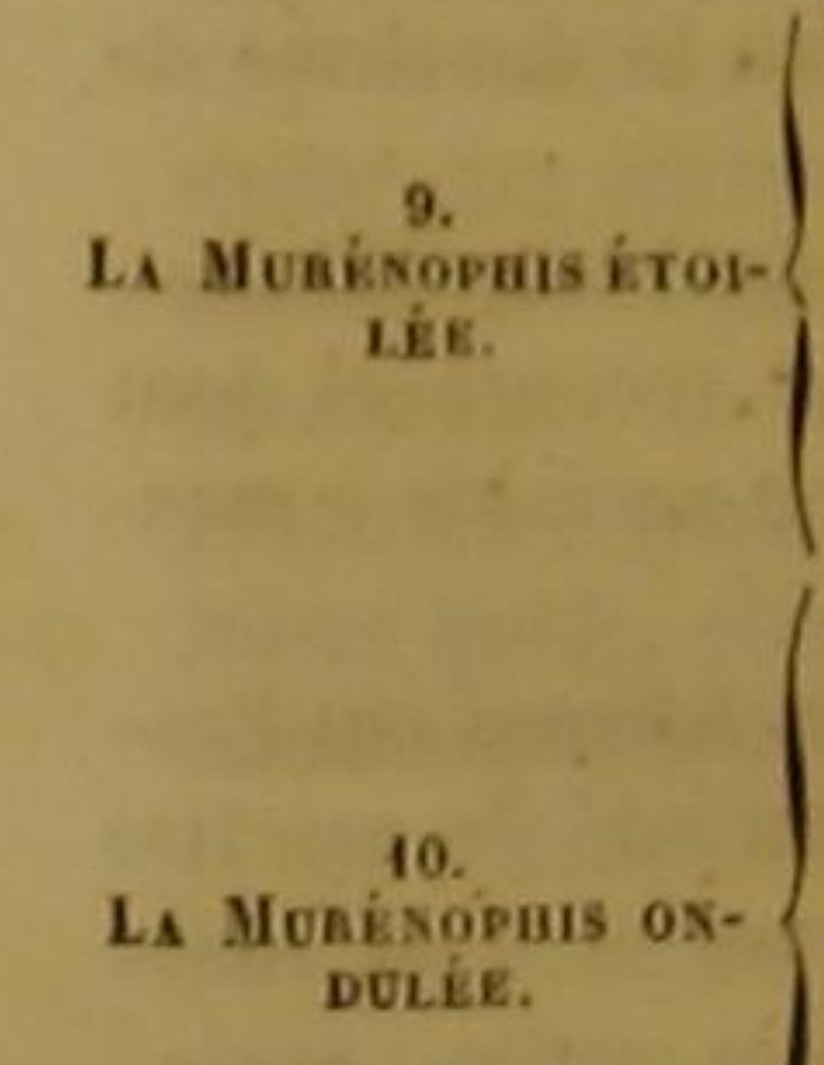
La dorsale trés-basse el commen-

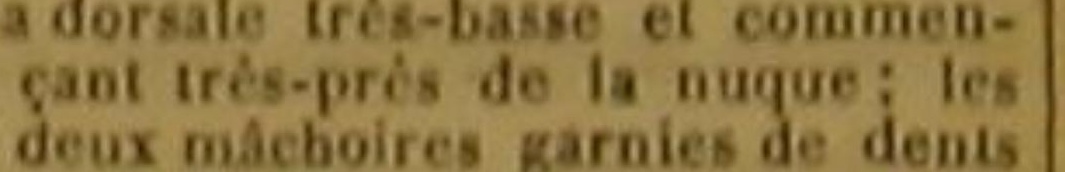

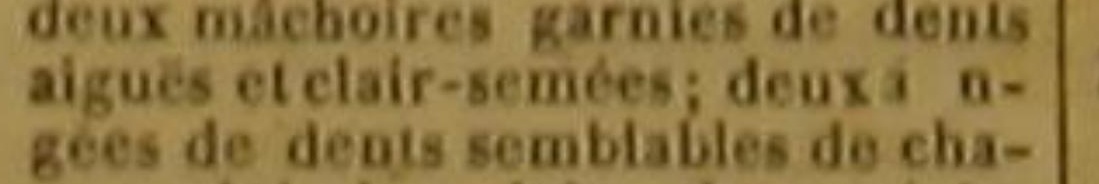
que corle du palais; deux séries
longitudinales de taches en forme
déloiles irréguliteres de chaque La tète grosse; le museau avane
el menu i les yeux trés-prés do do

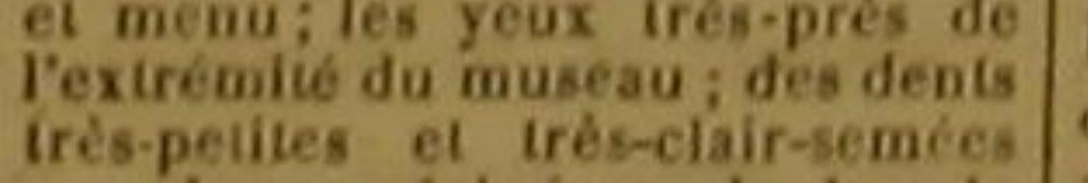

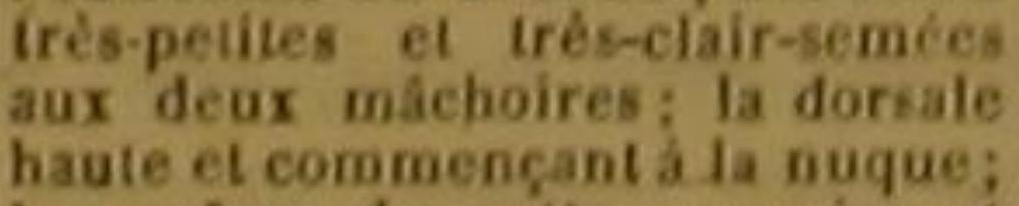
a surface de celle nageoire ei
celle do corps el de la queue va-
riées par des bandes transversarees par des bandes iransversi-
ies, Etroites, réunies plusieurs Id. Varro, Rustie., 1. 2, e. 6. - 1d. Plin, i. 9, e, 16, 10, 20,

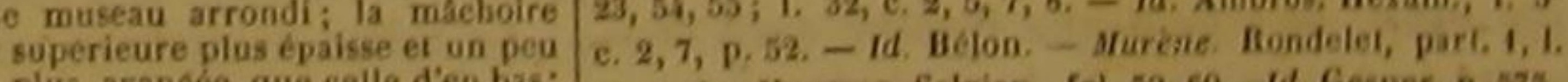

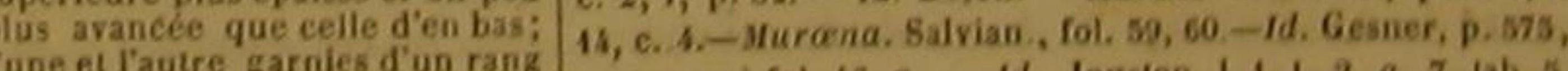
de dents recourbées, el séparées el (germ.) fol. $46 a$. -1 d. Jonston, L. 1, . . 2, a. 7, tab. s.

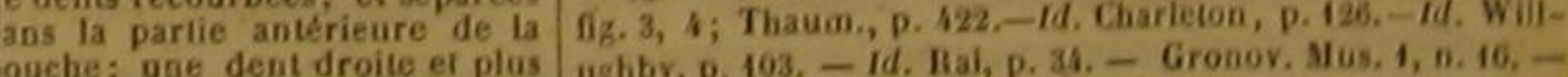

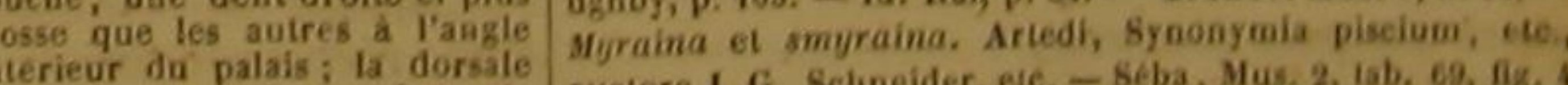
ate
lces des branchies ou a peu

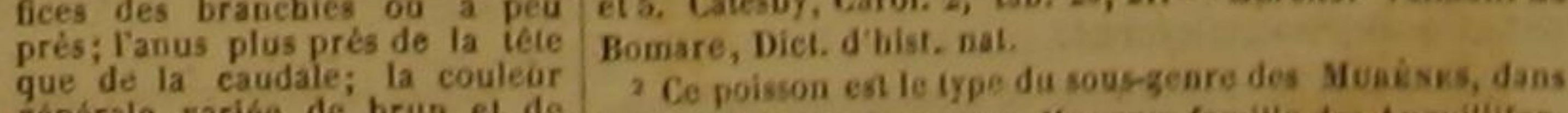
lanchátro par do trés-pelits
lratiog.

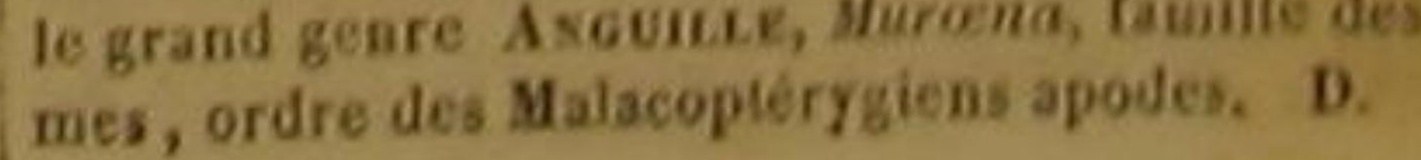


sur la terre; elle change de place par les con- glisser facilement au milieu des obstacles, et de tours sinueux qu'elle se donne; et tendant ou n'être retenu qu'avec beaucoup de peine. débandant avec énergie les ressorts produits par Les femelles ont des couleurs plus variées que les diverses portions de sa queué ou de son les mâles: ieurs nuances ne sont pas toujours corps, qu'elle plie, rapproche, déplie, étend en les mêmes; mais ordinairement leur museau est un clin d'œil, elle monte, descend, recule, noirâtre. Un brun rougeâtre et tacheté de jaune

$\begin{aligned} & \text { avance, se roule et s'échappe avec la rapidité } \\ & \text { de l'éclair. }\end{aligned}$
$\begin{aligned} & \text { disțingue le dessus de la tête; la partie supé- } \\ & \text { rieure du corps et de la queue offre une teinte }\end{aligned}$ de l'éclair. Aristote et Pline ont même prétendu, et l'o- d'un brun également rougeâtre, et d'autant plus pinion de ces grands hommes est assez vraisem- foncée qu'elle est plus près de la caudale ; des blable, que la murénophis pouvait, comme l'an- points noirs et des taches jaunes, larges et poinguille et-comme les serpents, ramper pendant tillécs ou mouchetées de rougeâtre, sont disquelques moments sur la terre sèche, et s'éloi- tribuées sur ce fond brun; la partie inférieure gner à quelque distance de son séjour habituel. et les côtés de ces mèmes femelles sont d'une Tant de rapports avec les vrais reptiles nous couleur fauve, relevée par de petites raies et par ont engagés a joindre le nom d'Ophis, qui veut des taches brunes.

dire Serpent, à celui do Murène, pour en faire Telles sont les couleurs que le savant et zélé le nom composé de Murénophis, lorsque nous observateur Sonnini a vues sur les hélènes foavons voulu séparer de l'anguille et de quelques melles pendant son voyage en Grèce, où il a autres osseux auxquels nous avons laissé la dé- pu en examiner un très-grand nomfire de vinomination simple de Murène, les poissons dont vantes '.

nous allons nous occuper.

Les murénophis établissent done des lien La livrée des màles différe de celle que nous venons d'indiquer, en ce que les taches sont des reptiles. Nous la classe des poissons et celle très-clair semées sur leur surface, pendant que des reptiles. Nous terminons donc l'examen de le corps el la queue des femelles en sont presque celte grande classe des poissons, comme nous entièrement couverts ${ }^{2}$.

l'avons commencé, e'est-à-dire en ayant sous Sur quelques individus femelles ou mâles, te nos yeux des animaux qui ont de très-grands fond de la couleur est vert ou blanchâtre, au rapports avec les serpents: les murénophis pla- lieu d'ếre fauve ou d'un rougeâtre brun.

cées à la fin de la longue chaine qui rassemble Lorsque les murénophis hélènes ont atteint tous les poissons, comme les pétromyzons à son une longueur de trois pieds, leur plus grand origine, rapprochent avec ces derniers les deux diamètre n'égale pas tout à fait le douzième de extrémités de celte immense réunion, et après leur longaeur.

avoir clos, pour aiusi dire, le cercle, le rattachent de nouveau aux véritables reptiles.

Les dents de la murénophis hélène étant elle est remplie, elle serait très-agréable à manfortes, nombreuses, et pointues ou recourbées, ger.

sa morsure a été souvent assez dangereuse pour Suivant M. de Sonnini, les hélènes ont l'esqu'on ait cru que ce poisson était venimeux. tomac assez grand, gris, et tacheté de noirâtre Chacune de ses deux narines a deux orifices, vers on origine; gris, et tacheté de noirâtre L'ourerture antérieure est placée au bout d'un jors ot d'un rouge petit tube voisin de l'extrémité du vessie natatoire petite, ovale, comme ce tube flevibe ren dedans, et formée très-court, on a écrit que l'hélène avait deux par une membrane très-épaisse.

petits barbillons vers le l'hélène avait deux Le même naturaliste nous apprend que les petits barbillons vers le bout de la màchoire œufs de ces murènes sont elliptiques et jaunes.
supérieure. Une conformation senta supérieure. Une conformation semblable peut Ces cufs sont fécondés comme ceux des raies, itre observée dans presque toutes les espèces du des squales et d'autres poissons, par l'effet
genre que nous déerivons. L'oritice des branchies est étroit, et silué d'une réunion intime du mâle et de la femelle, presque horizoutalement. Presque horizontalement.

Une humeur visqueuse et très-abondante en- Voyage en Gréce el en Turquie, par C. s. Sonnini, ete, duit la peau, et donne à l'animal la faculté de $t .4, \mathrm{p}$. $190 \mathrm{els}$. celui des coulenvres, entrelacent leurs quenes jaunàtres de diverses formos, et dont chacume et leurs corps déliés. Le témoiguage de II. de contenait un ver, sur la turique esterne de l'esSonnini confirme, à cet égard, l'opinion d'A- tomac, sur la surface extérieure du canal iutesristote et de Pline; et e'ost cette conformité tinal, sur le foie, ou sur les muscles du ventre, entre l'accouplement des couleuvres et eelui des entre les arétes, dans la tunique extérieure de bélènes, qui a fait croire à tant de naturalistes, l'ovaire, et dans l'intervalle qui séparo les deux et persuade encore aux Grecs modernes, que tuniques de la vessie urinaire.

les serpents s'accouplent avec les murénophis qui leur ressemblent par un si grand nombre de traits extérieurs.

Les œufs des hélènes étant fécondéz dans le ventre même de la mère, on doit regarder comme pośsible, et même comme très-probable, que dans beaucoup de circonstances ces oufs éclosent dans le corps de la femelle; et dès lors les murénophis hêtènés devraient être comptées parmi les poissons ovovivipares '.

Ces apodes vivent non-seulement dans reau salée, mais encore dans l'eau douce. On les trouve dans les mers chaudes ou tempérées do l'Europe et de l'Amérique, particulièrement dans la Méditerranée, et surtout près des cótes de la Sardaigne. Ils se retirent au fond de l'eau pendant que l'biver règne.

Dans toutes les saisons ils aiment à so loger dans les creux des rochers, Ouand to printem commence, ils fréquentent les rivages.

Ils dévorent une grande quantité de cancrẹs et de poissons. Ils recherehient avec avidité les polypes. Rondelet raconte que le polype le plus grand et le plus fort fuit l'approche de la muré. noplis bélène; que cependant, lorsqu'il ne peut éviter son attaque, il s'efforce de la retenir au milieu des replis tortueux de ses bras longs et nombreus, de la serrer, de la comprimer, de l'étouffer; mais qu'elle glisse comme une coTétouffer; mais qu'elle glisse comme une cochire avec ses dents aiguěs.

Les hélènes sont d'ailleurs si voraces, que lorsqu'elles manquent de nourriture, elles rongent la queue les unes des autres. Elles ne meurent pas pour avoir perdu une partie considerable de leur queue, non plus que lorsqu'elles sont longtemps hors de l'eau, dont elles peuvent se passer pendant quelques jours, si la sécheresse de l'atmosphère n'est pas trop grande, on si le froid n'est pas trop violent; mais on a remarqué que pendant l'hiver elles sont sujeltes à des maladies. Plusieurs de cés murénophi ont présenté, pendant cétle saison, des vessic

Voyez l'article du Blennie ovovivipare, etc.
On péche la murénophis hélène avec des stinct la fait souvent éetrapper à la ruso, Lorsqu'ello a mordu à l'lameçon, elle l'avale pour pouvoir couper la ligne avee ses dents, ou bien elle se renverse el se roule sur cette ligne, qui cède quelquefois à ses efforts. La renferme-ton dans un filet, elle sait choisir los mailles dans l'intervalle desquelles son corps glissant peut en queique sorte s'écouler.

Les Romains voisins de ces temps oû la république expirait opprimée par une ambition orgueilleuse, étouffée par une eupidité insatiable, et ensanglantée par une horrible tyrannie, recherchaient avec beaucoup de soin la murénophis hétène: elle servait et lo caprico, et to luxe, et la cruautó. Ils construisirent à grands frais des réservoirs situés sur to bord ou trèsprès de la mer, et y élevèrent des hiélènes. Columelle, qui savait combien la culture des poissons était utile à la chose publique, exposa, dans son fameux ouvrage sur l'agriculture, l'art de construire ces réservoirs, ot d'Y pratiquer des grottes tortueuses, où les hétènes pussent trouver des abris. Mais ee qu'it lit pour la prospérité de son pays et pour les progrès de l'économie publique, avait été fait avant lui pour les besoins du luxe et lo goût des riches habitants de Rome. Les murénophis hélènes étaient si multiplicées du temps de César, que, lors d’un de ses triomphes, il en donna six mille à sés amis; et on était parvenu à les apprivoiser au point que M. Licinius Crassus en nourrissait qui venaient à sa. voix et 's'élançaient vers lui pour recevoir l'aliment qu'il leur présentait.

La mode et l'art de la parure avaient trouvé dans les formes de ces poissons des modètes pour des pendants d'oreille et d'autres ornements der belles Romaines '. Le prix qu'on altactrait à la possession de ces animaux avait même fait paflice une sorite d'affection i vive, que ce erassus que nous venons de citer, et, ce qui est plus étonnant, Quintus Ilortensius, duquel Cicéron I Voyez l'ariciele de la Murene anguille, relativement aux braceless des Romaines, ele. nasses et avec des lignes de fond ; mais son in- 
a écrit qu Il avait été un orateur exceilent, un de six pieds de longueur; ses yeux sont petits, bon citoyen et un sage sénateur, ont pleuré la mais très-vifs; l'ouverture de sa bouche es perte de murénophis mortes dains leurs viviers. très-grande; plusieurs dents hérissent ses mâ-

Cela n'est que ridicule : mais ce qui est hor- choires; sa chair est très-agréable au goût : rible, et ce qui peint les efiets épouvantables mais les navigateurs anglais n'ont vu cet anide la corruption des mours, c'est qu'un Pollio, mal qu'avec une sorte d'horreur, à cause de sa qu'il ne faut pas confondre avec un orateur cé- ressemblance avec un serpent dangereux.

lèbre du mème nom, engraissait ses murénophis hélènes avec la chair et le sang des esclaves qu'il condamnait à périr; quo recevant Augus chez lui, il ordonna qu'on jetât dans la funest piscine un esclave qui venait de casser involontairement un plat précieux; et que l'empereur, révolté de celte atroce barbarie, n'os cependant punir ce monstre qu'en donnant la liberté à l'esclave et en faisant casser tous les vases de prix que Pollio avait ramassés. La plume tombe des mains après avoir tracé le nom de cet exécrable Pollio.

$-$

LA MURÉNOPHIS ÉCHIDNE'. Murenophis Echidna, Lac.

La Murenophis colubrine
Murapa Murapa colubrina, Líno, Gmel., Muræonophis colubrina

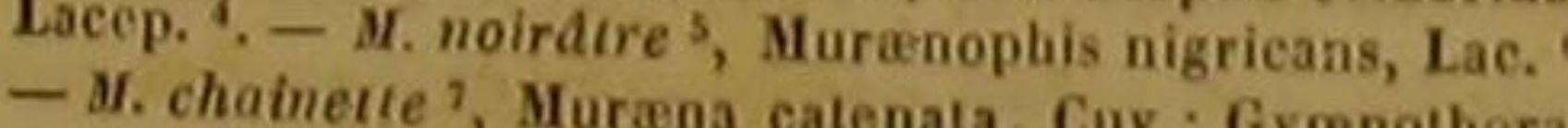
catenata, Bl.; Muranophis Catenula, Lae, ; Gymnothora laire ", Murana relleularis, Cav.; Gymnothoras relicutaris, Bl.; Murznophis reticularis, Lac. 10.-M. a africaine I Murana afra, Cuv,; Gymnothorax afor, Bl; ; Murænophis Guv. Lacep. 1 . - M. panthérine, Murana pantherina, Lac. is.-M. eloilee it, Murerg ; Murænophis pantherina,

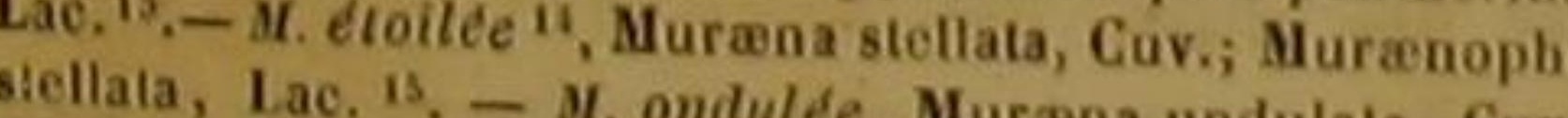
Murænophis undulata, Lacep. 16. - M. grise "n, Muræn
grisea, Cuv.; Murænophis gree,

L'échidne, que les compagnons de l'illustre Cook ont vue dans T'ile de Palmerston, a près

'Ellis, It. Cook bı Clerk, 1, p. 53.

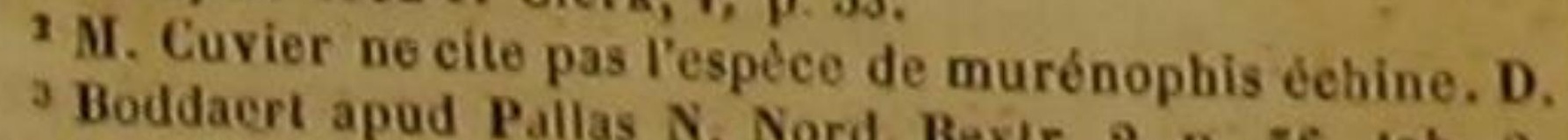
fi . 3. - - Conger faseiis brunneis el pallidé fuscis, tab. 2 , as sis, alternatis. n Commerson, manuserits deja cités.
i La Murénophis coltubrine do par M. Cuvier comme se rappor Lacépède est considéré res, dans le sons- senre des AxGEU aus proupe des Ophisu"Muréne noirä́re. Bonnaterre, Il. do I'Ene' dites. D Gronov. Zooph, n. 163.

'M. Cuvier ne aail pas mention de la Murécophis noiratro de Lacépède., D.

Blochmothorax à bracelets, gymnothorax catenatus. BDu sous-genre

DUILEs, ordre des Malacoptérygiens le grand genre d Gymuiothorax réticulaire. Bloch, pl. 416 . Cuv. D.

"ur. D.

Gymnothorax afer. Bloch, pl. 417.
Commerson a rencontré la colubrine a milieu des rochers détachés du rivage qui euvionnent la Nouvelle-Bretagne et les îles voiines. On la trouve aussi auprès des cótes d'Amboine.

On a comparé la grandeur de cette murénophis à celle de l'anguille. Les trente zones qui 'entourent sont alternativement d'un brun noiràtre et d'un brun mélé de blanc; le desșus de la tête est d'un vert jaunàtre; les iris sont couleur f'or. Les écailles qui révêtent la peau sont trèsdifficiles à distinguer. II n'y a pas de véritabl ligne latérale. L'anus est beaucoup plus près de la tête que de la nageoire de la queue. La chair de ce poisson fournit un aliment délicat; mais a forme aiguẻ de ses dents rend sa morsure dangereuse.

La noirâtre vit dans l'Amérique méridionale iusi que la réticulaire, dont Surinam est la parie. Celte dernière marénophis a les yeux petits; 'iris blane et fort étroit; les flanes un peu comprimés; l'anus plus voísin de la caudale que de la tête; la couleur générale brune, et les taches blanches.

Remarquez dans la réticulaire, que l'on pêche auprès do Tranquebar, la position des yeu rès-près de la lèvre supérieure; la situation de lanus à une distanée un peu plus grande de la lête que de la caudale; la blancheur de l'iris, qui est très-étroit; celle de la couleur générale les petites bandes brunes du dos et du ventre;

Cuv. D.

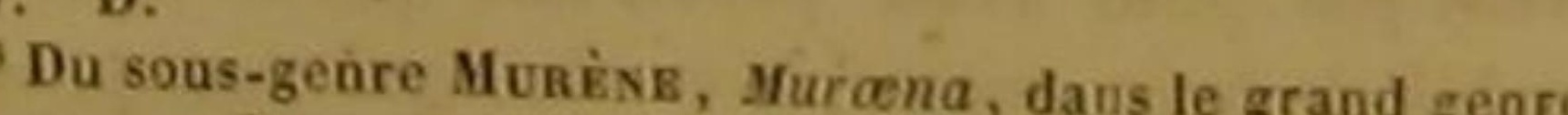
1" « Conger ex albido Intescens, ocellis atro-purpureis Gexuosè radiatis, maculosus, pectore apterygio.j Commernu crits déjà cilés.

ATGILLE, Cuv. DUE

I6 Du sous-genre
It

Es, selon M. Cuvier. D. dans te grand geore des ANSriseus, fusco varius, infimo ventre albus, late18 M. Cuvier ad, a Commerson, manuscrils déjá cités. le sous-geare Murése, dépendant du grand genre A A KG dalLE.
D. les nuances brunàtres et les taches jaunes de la dorsale.

L'africaine séjourne au rilieu des écueils de la còte de Guinée. Son wil est grand et ovale; son iris bleu; sa couleur générale brune, son corps comprimé; son anus situé au milieu de sa longueur totale; la peau qui revêt les nageoires, très-épaisse, comme dans presque toutes les murénophis.

La panthérine a les yeux gros et voilés par une membrane transparente, ainsi que presque tous les poissons de son genre; ses deux mãchoires sont à peu prés également avancées. Nous avons vu dans la collection hollandaise cédée à la France, un individu de cette espèce encore inconnue des naturalistes, et dont nous avons choisi le nom spécifique de manière à indiquer la ressemblance de la distribution el du ton de ses teintes, avee ceux de la robe de la panthère.

L'étoilée n'est pas plus connue que la panthérine. On l'a pêchée au milieu des rochers do la Nouvelle-Bretagne, sous les yeux de Commerson, qui en a laissé une très-bonnớ description dans ses manuscrits.

La longueur de celle murénophis est d'un pied et demi. Sa couleur générale parait d'un jaune mếé de bane ; le dessus du museau est bleuâtre les taches étoilćes sont d'un pourpre tirant sur le noir ; la série supérieure de ces taches étoilées en rênferme ordinairement vingt, et l'inférieure vingt et une; l'iris est doré. Une liqueur épaisse humecte les téguments; la mâchoire supérieure est un peu plusavancéo que celle d'en supérieure est un peu plus avancée que celle de bas; on voit l'anus situé vers le milieu de la longueur totale. On doif rechércher l'étoilée a
cause de la bonté de sa chair, mais avec précaution, parce que ses dents

faire des blessures fâcheuses.

L'ondulée a été observée par Commerson, qui en a laissé un dessin. La description de cette espèce n'a pas encore été publiée. Son anus est situé plus près de la tête que de la caudale.

La grise aime les mêmes eaux que l'étoilée et la colubrine, On en devra la connaissance à la colubrine. On en devra la connaissance d une deseription étendue. Cetle murénophis a la grandeur do l'anguille; l'iris doré, avec des prandeur do bruns; la peau dénuée d'écailles facilepoints bruns; la peau dénuée d écailles facileCommerson a éerit que l'effet de la morsure de ce poisson étail semblable à celui d'un rasoir.
LA MURÉNOPHIS HAUY.

Muræna Hauy, Cuv,; Murenophis Hauy, Lac. 1 .

Nous dédions cetle espèce, qui n'a pas encore é décrite, à notre célèbre collègue, confrère el mi, M. Haūy, membre de l'Institut, et professeur de minéralogie au Muséum d'histoire aturelle. Non-seulement l'Europe savante rend hommage, dans ce savant illustre, au physicien u premier ordre, au créateur de la cristalloraphie, à l'auteur du bel ouvrage qui répand ne lumière si vive sur fa science des minéaux; mais encoro elle sait, malgré la modestio de co grand naturaliste, que cest à lui qu'elle oit une très-grande partio du travail ichithyologique dont l'Encyelopédie méthodique a été onrichie.

La couleur générale de la Murénophis Haży est d'un jaune doré, mêté de teintes blanches ou argentines. A la place de la ligne latérale, on voit une raio longitudinale rouge. Les taches dout la surface du poisson est parseméc, sont d'un brun jaunâtre plus ou moins foncé; les nageoires présentent les ménes nuances que ces laches. L'ouverture branchiale, sitnée beaucou plus yers lo bas quo vers to laut de l'animal le les murénophis avee les Sphagebranches, dont nous allons bientôt nous occuper.

M. Noễ de Houen a vu, dans la collection d'un de ses amis, un individa de l'espéce que nous faisons connaitre, et a bien voulu nous en envoyer un dessin.

DEUX CENT VINGTIEME GENIE.

LES GYMNOMURĖNES ${ }^{2}$

point de nageoires pectorales; une ouverture branchiar gur chaque coie du polsson: le corps el la queue presque cylindriques; point de nageoire du dos, mi de nageoire de tamus; on ces deux nageoires si basses et al enveloppes dans une peau epalsse, qu'on ne peut recon-

Espèces. caBsctíass.<smiles>[Tl]</smiles>
Á.
CLEE.
CLE. Lanus beaucoup plus pres dy bout
do la queae que do ta tele: in in

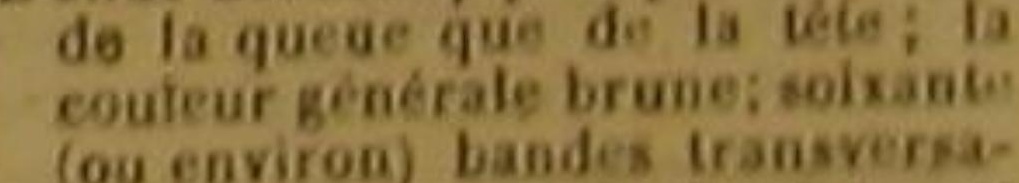

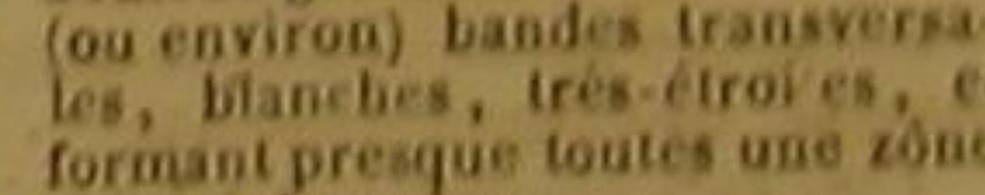
rormant presque
sulour du polsso I M Cuvier a ellé, dans la premiére édicion du Mé :ne

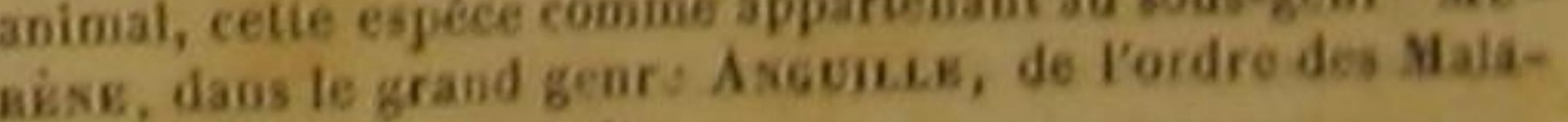

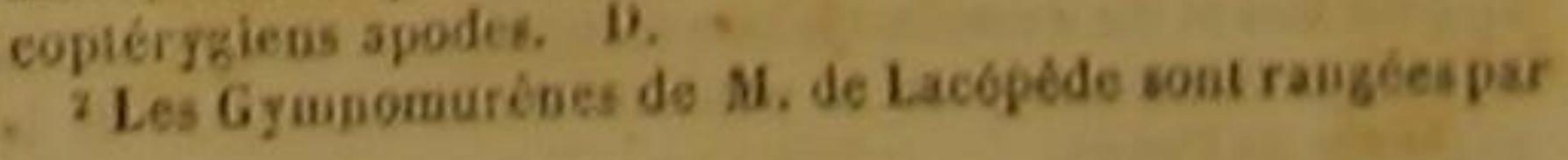


HISTOIRE NATURELLE

ESPĖors.

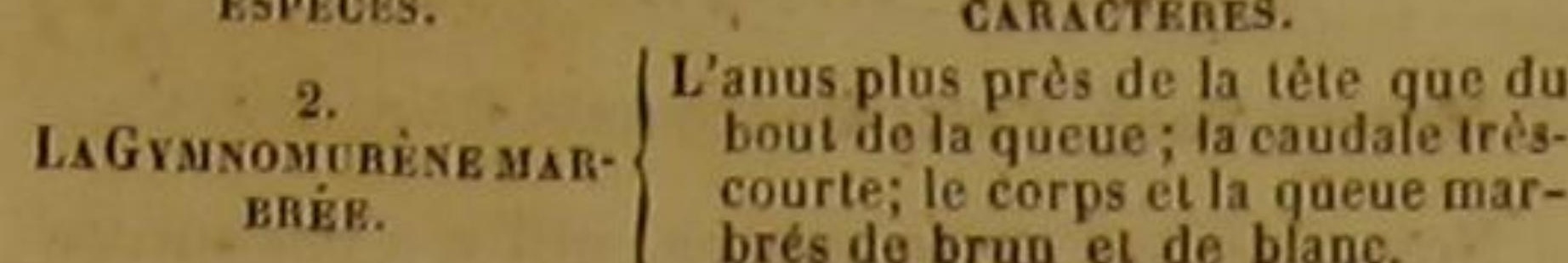
courte; le corps ét la queue
brés de brun el de blanc.

LA GYMNOMURÈNE CERCLÉE', Muræena Zebra, Cuv.; Grmnomuræna doliata, Lac. ${ }^{2}$

ET LA GYMNOMURÈNE MARBRÉE ${ }^{3}$ Gymnomuræna marmorata, Lac. 4 .

La description de ces poissons n'a pas encore été publiée. Ils ont été obșervés par Commerson, auprès des rivages de la Nouvelle-Bretagne, Nous les avons séparés des murénophis, parce qu'ils manquent de nageoire dorsale et de mageoire de l'anus, ou n'ont qu'une anale et une dorsale très-difficiles à distinguer ${ }^{5}$. Ces traits de conformation les placent à une distance de serpents encore plus petite que celle qui sépare ces reptiles des murénophis.

La longueur de la cerclée est de irois pieds ou environ. Outre les zones dont nous avons parlé dans la table générique, quelques bandes transversales plus ou moins longues, irrégulières et interrompues, paraissent sur les côtés de l'animal. La tête présente plusieurs petites raies irrégulières et blanches. Le corps et la queue sont un peu comprimés. La mâchoire d'un haut est peu plus avancée que celle d'en bas : des dents molaires garnissent le disque formé par chaque mâchoire. Les narines ont chacune deux orifices; et il paraìt que l'orifice antérieur est placé au bout d'un petit tube noir à son extrémité et qui ressemble à un barbillon. Les ares de cercle qui soutiennent les branchies sont entièrement lisses. On ne voit pas de véritable ligne latérale. On ne peut s'assurer de l'existence de la dorsale et de l'anale, ni reconnaître les rayons qui les composent, qu'après avoir enlevé la peau qui les recouvre,

M. Cuvier dans son sous-genre Monève, l'un de cecux qui
diviseot le grand genre treger I \& Conger brunous, zonis Lete, D

"ceireiter sexaginla; pinnis dorsi el anil dus albis, utrinque nullis, ano cauda multoties propiori quam capiit. 2 Dus manuscrits deja cites.

CuY. D.

dorsi el ani nullicus albo-marmoratus, pinnis pectoralibus, 'M. Cuvier ne cite pas cette espéce. D. D. Le mol gymas, qui, en grec, siggif die du dos et du dessous de la queue, c'est d-dire fe da nunageoire de l'onase, ou la petitesso de la dorsale et de la
Lors de la baśse mer, on trouve souvent les Cerclées sous de grosses pierres ou des blocs de rocher, qu'on retourue pour découvrir ces gymnomurènes laissées à sec. On tue alors ces osseur à coups de bâton; mais on ne les saisit qu'avec précaution, pour éviter les douleurs aiguês que peut causer leur morsure.

Les Marbrées ont des dimensions très-peu différentes de celles des Cerclées. On les voil souvent cachées à demi sous des roches peu submergées; levant leur tête au-dessus de l'eat dans l'altente de leur proie, la lançant, pour ainsi dire, avec rapidité contre leurs vietimes,

tes mordant avec force et même acharnement.

Elles peuvent d'autant plus déchirer cequ'elles saississent, qu'indépendamment d'une rangée de dents très-aiguẽs qui garnit chaque mâchoire, des dents semblables hérissent le palais.

Le museau est allongé; les joues sont comme gonflées, ainsi que le derrière des yeux. La mâchoire d'en bas est un peu moins avancée que celle d'en haut.

Nous croyons que l'orifice antérieur de chaque arine est placé au bout d'un petit tuyau, que on peut comparér à un barbillon, et qui s'éteve vers le bout du museau.

II n'y a pas de ligne latérale.

L'iris est doré.

On ne peut décourrir aucune nageoire, excep-

té à l'extrémité de la queue, où l'on aperçoit sur

bord un rudiment de caudale.

La peau, déuuće d'écailles facilement visibles, est enduite d'une humeur très-visqueuse.

\section{DEUX CENT VINGT-UNIEME GENRE.} LES MURÉNOBLENNES '.

\section{nageoires; le corps at in sos, poind d apparence d'autres} surface de lanimal ripuetue presque eylindriques; la dance, une humeur laitense er glunie. ESPÈce.

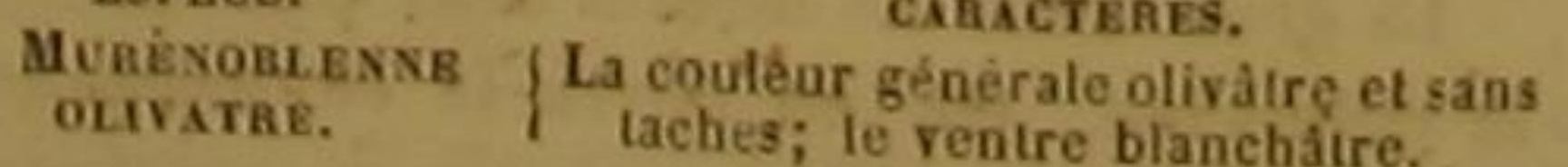
I M. Cuvier, dans la premiêre édition dì Règne animal, réunit les Murénoblennes et les Gymnomurènes de $\mathbf{M}$. de $\mathbf{L}$ ? le grand genre le grand genre AxGeiLLE, ordre des Malacoplérygiens apo-
des, Cur D.

DES POISSONS.

603

LA MURÉNOBLENNE' OLIVATRE? Muræna...., Cuv.; Murænoblenna olivacea, Lae, s. Commerson a vu, dans le détroit de Magellan, ce poisson que les naturalistes ne connaissent pas encore, et qui semble organisé de manière à répandre avee plus d'abondance que tout autre une matière visqueuse. Cette faculté et sa conformation extérieure uous ont obligés à l'inserire dans un genre particulier.

Il parvient à la longueur d'un pied et demi. Son diamètre est alors le dix-huitième ou à peu près de sa longueur totale.

La matière buileuse et gluante qui suinte de ses pores, paraît inépuisable: Commerson dit qu'elle donnait même aux matelots une trèsgrande répugnance pour la murénoblemne olivàtre, et qu'elle devait former une si grande partie du volume de ce singulier poisson, que lorsqu'on avait mis dans de l'alcool un individu de celte espèce, et qu'on l'y avait laissé pendan deux mois, on trouvait ce même individu rédui presque en éntier en une masse muqueuse, huileuse et gluante.

DEUX CENT VINGT-DEUXIEME GENRE. LES SPHAGEBHANC̈HES 4,

Point de nageoires pectorales, $n i$ d'autres nageoires; te

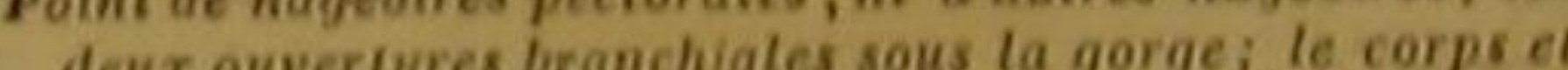
la queue presque collindriques.

$$
\text { espice. }
$$

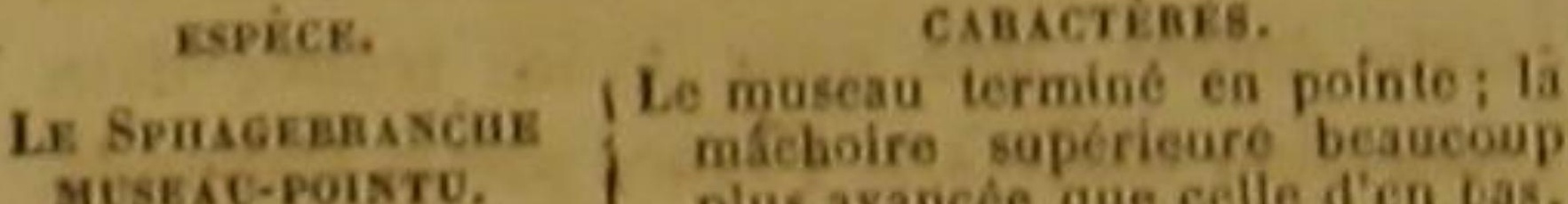

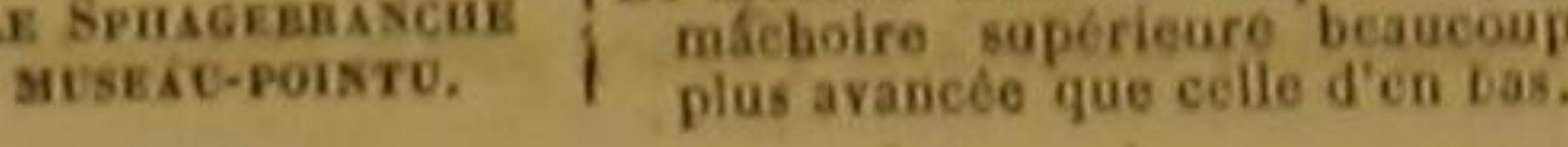

LE SPHAGEBRANCHE MUSEAU-POINTU ${ }^{5}$, Sphagebranchus rostratus, Bl., Lac, Cuv. ${ }^{\circ}$.

Bloch a recu dans le temps, des Indes orientales, un individu de cette espèce. L'anus de ce poisson était placé vers le milieu de sa longueu totale; sept petites dents garnissaient les mâ-

1 Blenna, en grec, signife mucosite. rits deja eites. 6 plurimum fundens. 3 Coyez la note 1 de la p. 602, col, 2 .

4 Les Sphagebranches de Lat péde forment pour M. Cuvier un pell south des.

Colleranche, - Doppelle kalskieme, en aliemand Double-chin-gill, en anglais. - Bloch, pl. 49, 18g. 2.

' $L$ Se Sphagebranchus rosiratus est te méme polisson que le choires ; quatre branchies étaient situées de chaque côté de l'animal. On ne pouvait distinguer aucune écaille sur la peau.

DEUX CENT VINGT-TROISIENE GENRE. LES UNIBRANCHAPEחTUัHES '.

Poim de nageoires peciorales; le corps et la queneserpenMformes; une seule ouver hure branchiale, el cet erifice

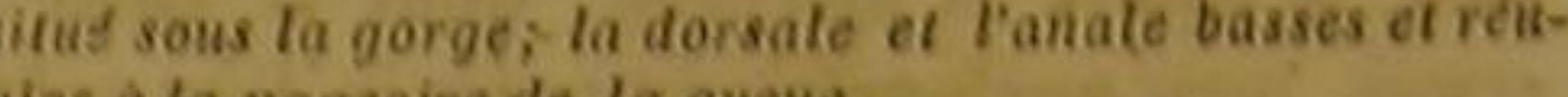

हspk̀ces.

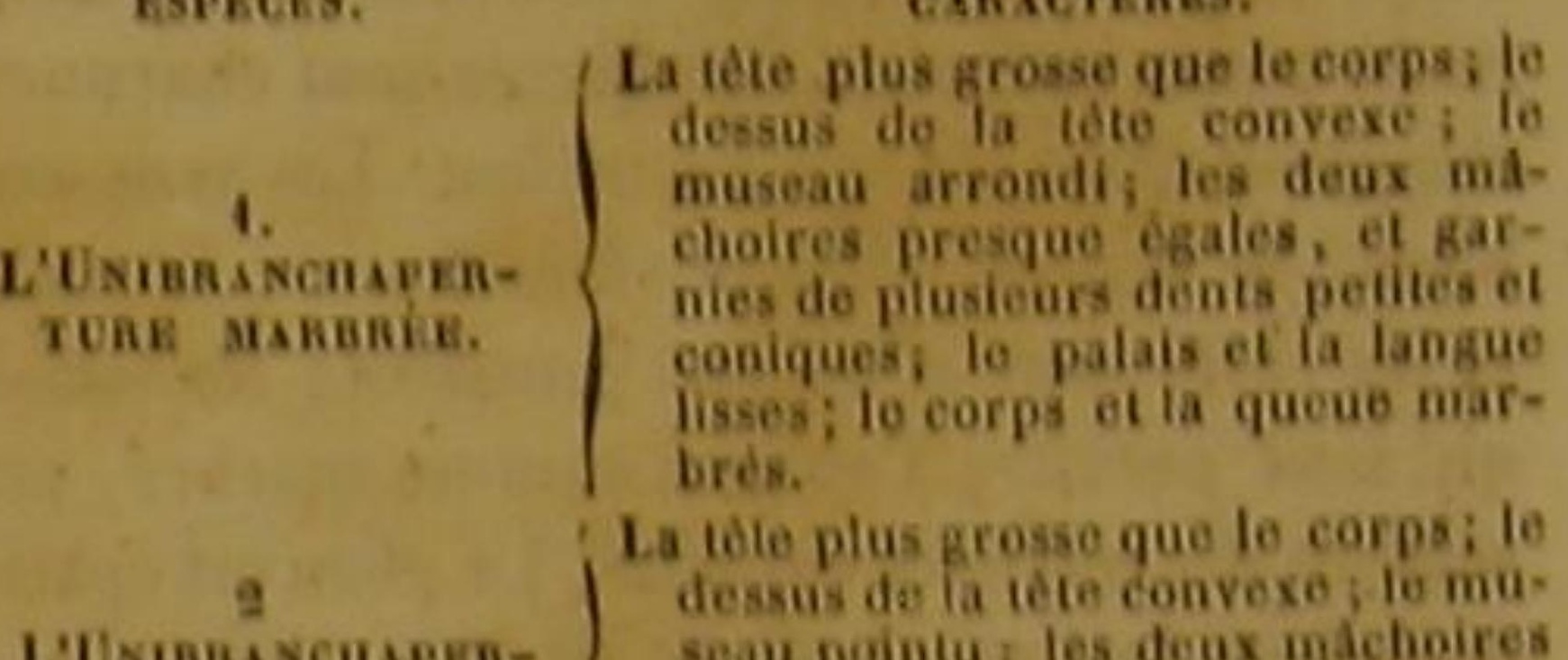

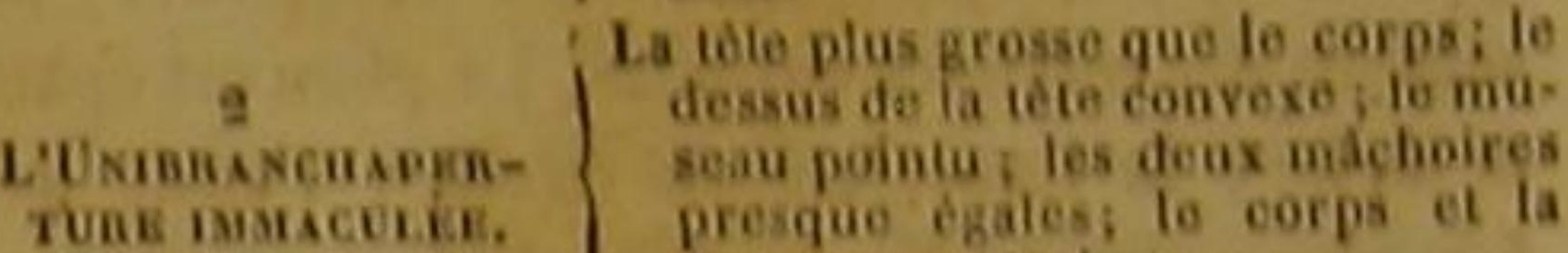

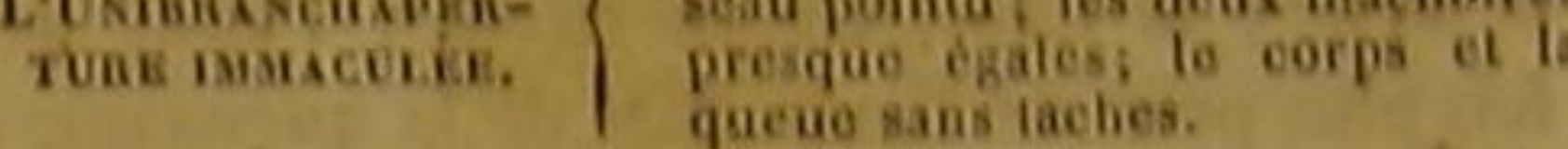

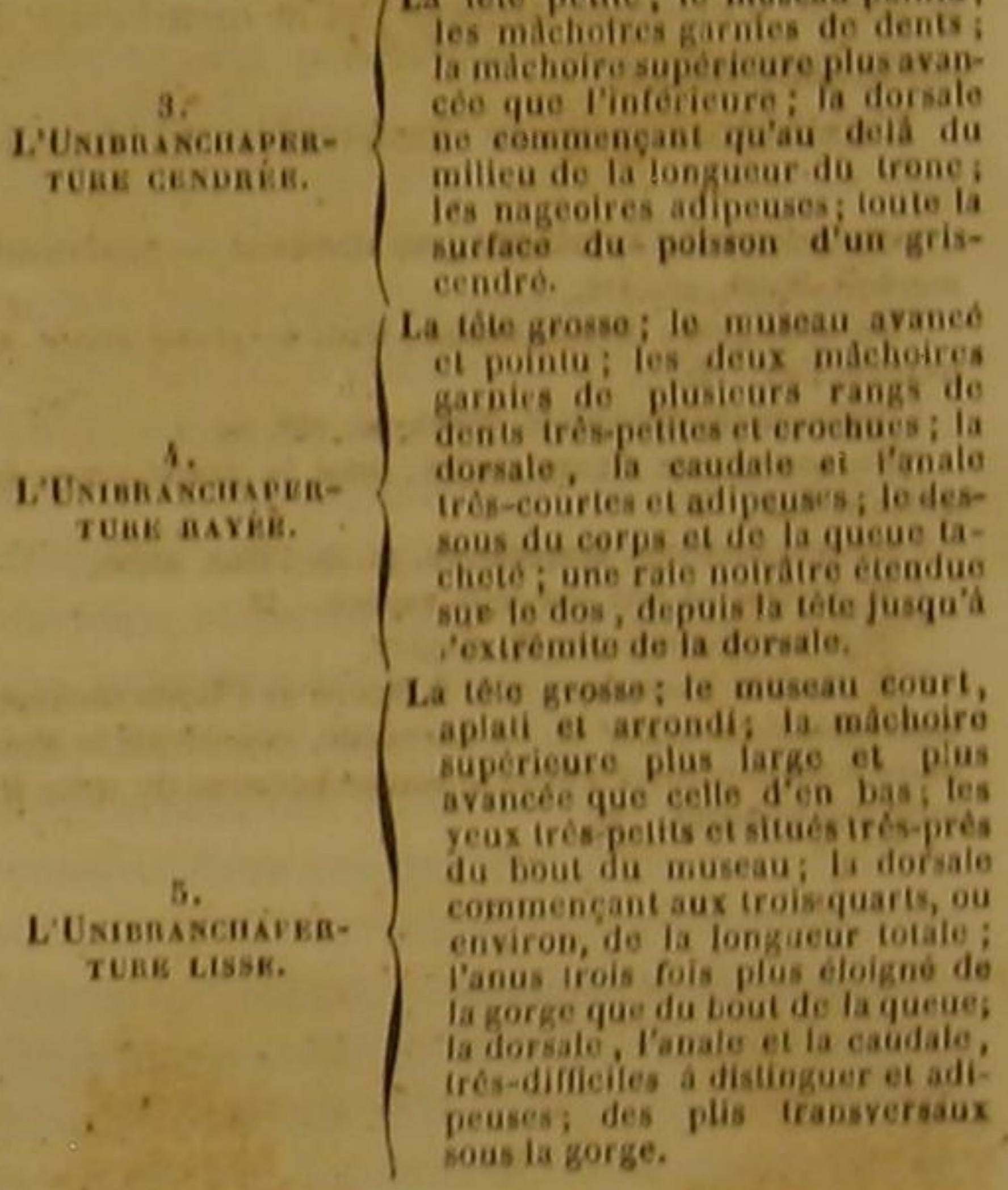

' M. Cuvier admet ce genre sous to nom de Symbranctica que lui a donne primitivement B'och; mais it n'en fail qu'u imple sous-geore dans le grand genre AscouLs, ordre des Malscopterygiens apodes. D. 

L'UNIBRANCHAPERT UR E MARBR ÉE', $\begin{aligned} & \text { eaux de Surioam et de Tranquebar. Sa peau est } \\ & \text { moins lâche que celle de la marbrée ; son corps }\end{aligned}$ Synbranchus marmoratus, Bl., Cuv.; Unibr.
tura marmorata, Lac. ?

La cendrée n'a pas de taches. Sa longueur

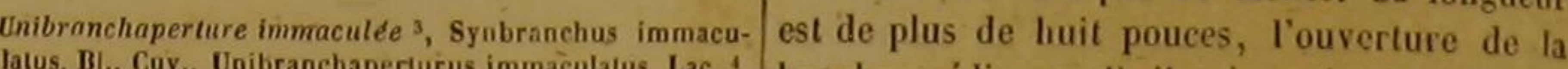
- V. cendrée :. Unibranchapertura grisea, Lacep. 6 - - bouche médiocre; l'aeil très-petit; la peau dé. U. rayee, Unibranchapertura lineala, Lacep. 1, - - V. lisse, Unibranchaperlura lævis, Lac. 8

Dans les eaux douces et bourbeuses de Surinam, se trouve la marbrée, dont la chair est grasse, mais quelquefois impréguée d'un goût et d'une odeur de vase; elle est vorace et se nourrit de petits animaux. Ses lèvres sont charnues ; chaque narine n'a qu'un orifice. Los yeux sont ler. bleus; le dos est d'un olivâtre foncé; le ventre et les côtés sont d'un vert jaunâtre; les taches, qui font paraitre l'animal comme marbré, présentent des nuances violettes. La peau est épaisse et làche; la ligne latérale droite ; l'anus deux fois plus près de l'extrémité de la quẹue que de la gorge; l'estomac allongé; ét la membrane de cet organe mince.

L'unibranchaperture immaculée vit dans les

I Surinamische kalskieme, en allemand. - Synbranche marbre. Bloch, pl. 418.

'Du sous-genre Sxnonancue, dans le grand genre AN-
Gulu, Cuy, D.

Symbranche immacule, Blocb, pl. 49, fig. 1. GUILE, Guv. D. D. SII Cuviendrée. Bonnaterre, pl. de l'Ene. méth. Non mentionnépe pas celle espéce. D. S M. Cuvier soupcon M. Cuvier.

lure lisse, donnée par M. de La figure de l'Unibranchaperpiere javanais, decrit dans le commencente to mona-

toire des poissons. unee d'écailles facilement visibles, Cetse mi-

hranchaperture a été pêchée dans les eaux de la Guinée.

M. Leblond nous a envoyé de Cayenne un individu qui appartenait à une espèce d'unibranchaperture encore inconnue des naturalistes, ainsi que la lisse, dont nous allons par-

Celle éspèce, que nous avons nommée la rayée, les yeux très-petits, et placés vers le milieu de la longueur des mâchoires; on voit dans l'intérieur de la bouche, et dans l'angle antérieur de chaque mâchoire, un groupe de dents crocliues et très-petites; l'ouverture branchiale est ovale, longitudinale et petite; on n'áperçoit pas de taches sur la partie supérieure du poisson. La rayée parvieut à la longueur de deux pieds. L'anus est silué aux trois quarts de la longueur (atale.

La lisse a la ligne latérale droite; l'orifice branchial assez grand, un peu triangulaire et allongé ; l'anale très-courte ; la peau très-lisse ct sans aucune apparence d'écailles; la couleur générale sans taches, el sans aucune bande ni raie.

Nous avons fait dessiner un bel individu de celte espèce, que nous avons trouvé dans la | collection cédée à la France par la Hollande.

\section{DES EFFETS DE L'ART DE L'HOMME}

\section{SUR LA NATURE DES POISSONS.}

1802.

C'est un beau spectacle que celui de l'intelli- tons, avee les sages de l'antiquité, ou, pour gence liumaine, disposant des forces de la na- mieur dire, avee ceux de tous les siècles qui ture, les divisant, les réunissant, les combinant, ont lo plus réuni l'amour de l'lumanité a la les dirigeant a son gré, et par l'usage habile connaissance des productions de la nature, la que l'expérience ét l'observation lui en ont ap- possession des poissons les plus analogues aux pris, modifiant les substances, transformant les besoins de I'homme.

Ćtres, et rivalisant, pour ainsi dire, avec la puis- Deux grands moỵens peuvent procurer ees sance eréatrice.

poissons que l'on a toujours recherchés, mai

L'amour-prope, l'intérêt, le sentiment et la auxquels, dans certains siècles et dans certairaison applaudissent surtout à ce noble specta- nes contrées, on a aftaché un si grand prix.

cle, lorsqu'il nous montre le génio de l'homme Le premier de ces moyens, résultat remarexerçant son empire, non-seulement sur la ma- quable du perfectionnement de la navigation, tièré brute qui ne lui résiste que par sa masse, multipliant chaque jour to nombre des marin ou ne lui oppose que ce pouvoir des affinités qu'il audacieux, et accroissant les progrès de l'admi-

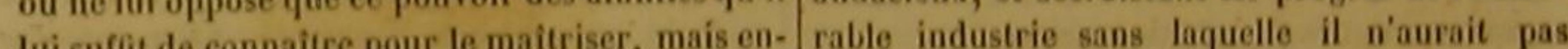

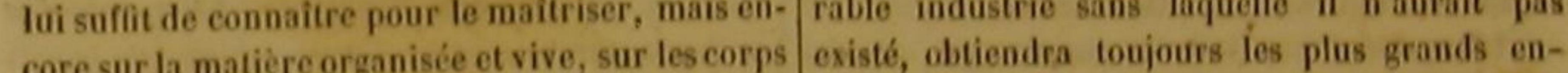

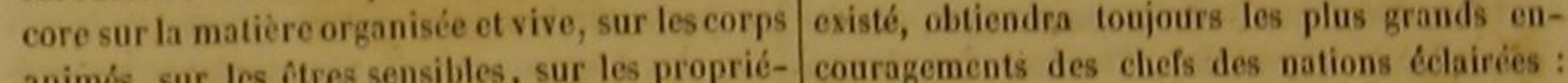
animés, sur les êtres sensibles, sur les proprie- cours consíste dans ces grandes pêches auxquelles tés des espèces, sur ces attikes profondes qu'il des hommes entreprenants et expérimentés von facultés secrètes, - ces qualités profor domine, sans même parvenir à dévoiler leưr se livich essence. Mais l'usago de ce moyen, limité par les

De quelques êtres organisćs et vivants que vents, les courants et les frimas, et troublé frél'on veuille dessiner l'image, on voit presque quemment par les innombrables aceidents do toujours sur quelques-uns de leurs traits l'em- t'atmosphiere et des mers, exige sans casso une preinte de l'art de l'liomme.

association constante, prévoyante et puissante,

Sans doute l'histoire de son industrie n'est pas une réunion difficile d'instruments variés, une Slle de la nature: mais comment ne pas en sorte d'alliance entre un grand nombre d'homcelle de la nues les récit de ses mes que l'on ne peut reneontrer que très-rare-

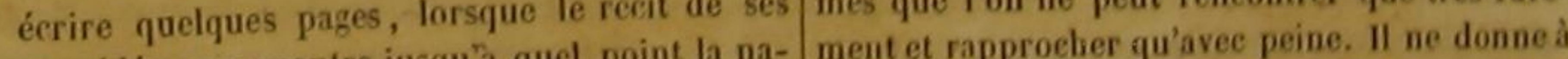
procédés nous montre jusqu a quet point la na- ment el nappo's artie des produits que l'on ture peut être contrainte a agir sur elle

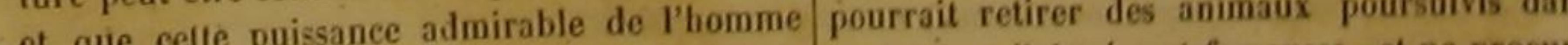
s' que cè pos objets d'une haute importance cespêches éloignées et fameuses, et ne procur s'applique à des oljets d'u la félieité pri- pour la nourriture de l'homme que des prépapour le bonheur public et pour la téticite pri- poutions peu substantielles, peu agréables, ou peu vée? salions per

Parmi ces objets si dignes de latention de salubs 
à tous les lieux, à tous les hommes. Il ne de- nous confions-les graines des végétaux précieux? mande que peu de précautions, que pen d'efforts, Et dans ses moments de loisir, lorsque l'ami que peu d'instants, quo peu de dépenses. Il ne de la nature et des champs portera ses espérancommande aucune absence du séjour que l'on ces, ses souvenirs, ses douces réveries, sa méaffectionne, aucune interruption de ses habitu- lancolie même, sur les rives des lacs, des ruisdes, aucune suspension de ses affaires; il se seaux ou des fontaines, et que, mollement montre avec l'apparence d'un amusement varié, étendu sur une herbe fleurie, à l'ombre d'ard'une distraction agréable, d'un jeu plutôt que bres élevés et touffus, il goûtera cette sorte d'erd'un travail; et cette apparence n'est pas trom- tase, cette quiétude touchante, celte volupté du peuse. Il doit plaire à tous les àges; il ne peut repos, cet abaudon de toute idée trop forte, celte être étranger à aucune condition. Il se com- absence de toute affection trop vive, dont te pose des soins par lesquels on parvient aisé- charme est si grand pour une âme sensible, n'é ment à transporter dans les eaux que l'on veut prouvera-t-il pas une jouissance d'autant plus rendre fertiles, les poissons que nos goûts ou douce qu'il aura sous ses yeux, au lieu d'une nos besoins réclament, à les y acclimater, à les onde stérile, déserte, inanimée, des eaux viviy conserver, à les $\mathrm{y}$ multiplier, à les y amé- fiées, pour ainsi dire, et embellies par la légè liorer.

reté des formes, la vivacité des couleurs, la va-

Nous traiterons des grandes pêches dans un riété des jeux, la rapidité des évolutions? discours particulier.

Occupons-nous dans celui-ci de cet ensombons donc comment on peut transporter, de soins qui nous rappelle ceux que les $\mathrm{X}$ a le acclimater, multiplier et perfectionner les poisXeno- sons; ou ce qui est la même ehose, montrons Ovide, les comment l'art modifie leur nature.

Columelle, les Ausone, se plaisaient à proposer Tàchons d'éclairer la route élevée du pliysioaux deux peuples les plus illustres de l'anti- logiste par les lumières de l'expérience, et de quité, que la sagesse de leurs préceptes, le diriger l'expérience par les vues du physiolocharme de leur éloquence, la beauté de leur giste.

poésie et l'autorité de leur renommée inspiraient Disons d'abord comment on transporte les avec tant de facilité aux Grecs et aux Romains, poissons d'une eau dans une autre.

et qui étaient en grand honneur chez ces vain- De toutes les saisons, la plus favorable an queurs de l'Asie et de l'Europe, que la gloire transport de ces animaux est I'hiver, à moins que avait couronnés de tant de lauriérs.

L'homme d'état doit les encourager, comme une seconde agriculture; l'homme des champs doit les adopter, comme une nouvelle source de richesses et de plaisirs.

En rendant en effet les eaux plus productives que la terre, en répandant les semences d'une abondante et utile récolte, dans tous les lacs, dans les rivières, dans les ruisseaux, dan tous les endroils que la plus faible source arrose ou qui conservent sur leur surface le produit des rosées et des pluies, ces soins que nous allons tâcher d'indiquer n'augmenteront-ils pa beaucoup celte surface fertile et nourricière geaucoup celte surface fertile et nourricière du
globe, de laquelle nous tirous nos véritables trésors? et l'aceroissement que nous deritables ves, ou dans des lacs immenses, dont la proces procédés simples et peu nombreux ra-t-jl pas d’ont pe ce feu électrique.

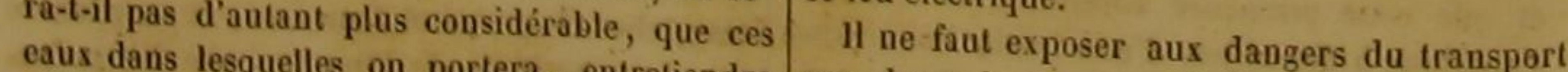
eaux dans lesquelles on portera, entretiendra que des poissons assez forts pour résister à la et multipliera le mouvement et la vie, offriront fatigue, à la contrainte, et aux autres inconvéune profondeur bien plus grande que la coucle nients de leur voyage, et aux autres inconvésèche fécondéo par la charrue, et à laquelle tients de leur voyage. A un an, ces animaus venable pour les faire passer d'une eau dans une autre, est celui de trois ou quatre ans.

On ne remplira pas entièrement d'eau les tonneaux dans lesquels on les renfermera. San cette précaution, les poissons, montant avec rapidité vers la surface de l'eau, blesseraient leur tête coutre la partie supérieure du vaisseau dans lequel ils seront placés. Ces tonueaux devront d'ailleurs présenter un assez grand espace. Bloch, qui a écrit des observations trèsutiles sur l'art d'élever les animaux dont nous nous occupons, demande qu'un tonneau destiné à transporter des poissons du poids de cent livres, ou à peu près, contienne trois cent vingt litres ou pintes d'eau.

Il est même nécessaire que vers̉ la fí du printemps, ou au commencement de l'automne, c'est-à-dire lorsque la chaleur est vive au moins pendant plusieurs heures du jour, celte quantité d'eau soit plus grande, et souvent double; et, quelle que soit la température de l'air, il faut qu'il y ait toujours une commúnication libre entre l'atmosphère et l'intérieur du tonneau, soit pour procurer aux poissons, suivant l'opinion de quelques physiciens, l'air qui peut leur être nécessaire, soit pour laisser échapper les miasmes malfaisants et les gaz funestes qui, ainsi que nous l'avons déjà dit dans celte listoire, se forment en abondance dans tous les endroits où les labitants des eaux sont réunis en très-grand nombre, même lorsque la chaleur n'est pas trèsforte, et leur donnent la mort souvent dans un espace de temps extrêmement court.

Mais comme ces soupiraux si nécessaires aux poissons que l'on fait voyager, pourraient, s'ils étaient faits sans attention, laisser à l'eau des mouvements trop libres et trop violents qui ta feraient jaillir, pousseraient les poissons, les uns contre les autres, les froisseraient et les blesseraient mortellement, il sera bon de suivre, à cet égard, les conseils de Bloch, qui recommande de prévenir la trop grande agitation de l'eau par une couronne de paille on de petites planches minces introduites dans le-tonneau, ou en adapIant à l'orifice qu'on laisse ouvert, un tuyau un lant à l'orifice qu' on laisse ouvert, ú vers le haut de plasieurs trous qui établissent une communicotion suffisante entrel'air extéricur el l'intérieur du vaisseau ',

Toutes les fois que la distance le permettra, $i$ Introduction à l'bistoire naturelle des poissons, par Blocb.
, oursi des bètes de somme tranquilles, ou même des porteurs attentís, plutố que des voitures exposées à des cahots rudes et des secousšes brusques el fréquentes. On prendra encore d'autres précautions, suivant les circonstances dans lesquelles on se trouvera, et les espèces dont on voudra porter des individus vivants à un assez grand éloignement le leur premier sêjour.

Si l'on veut, par exemple, conserver en vie malgré un lóng trajet, des truites, des loches, ou d'autres poissons qui pórissent facilement, et qui se plaisent au milieu d'une eau courante, on ehange souveut eelle du tonneau dans lequel on les renferme, et on ne cesse de communiquer celle dans laquelle on les tient plongés, un mouvement dous, mais sensible, qui subsiste lors même que la voịture qui les porte s'arréte, et qui, bien inférieur à une agitation danereuse, représente les courants naturels des rivières ou des ruisseaux.

Pour peu que l'on eraigne les effels de In chaleur, on voyagera la nuit; et l'on évitera avee to plus grand soin, en maniant les poissons, de les presser, de les froisser, de les heurter.

On ne les laissera hors de l'eau que pendant temps lo plus court possible, surtout quand un soleil sans nuages pourrait, en dessćchant promptement leurs organes, et particulièrcment lears branchies, les faire périr très-promptement. Cependant, lorsque le temps sera froid on pourra transporter des anguilles, des carpes, des brêmes, et d'autres poissons qui vivent assez. longtemps hors de l'ean, sans employer ni tonneau ni voiture, en les enveloppant dans de a neige, et dans des feuilles grandes, épaisses et fraiches, telles que celles du chou ou de la lailue. Un moyen presque semblable a réussi sur des brêmes que l'on a portées vivantes à plus de vingt-cinq lieues. On les avait entourées e neige, et on avait mis dans leur bouche un norceau de pain trempé dans de l'eau-deie.

C'est avec des précautions analogues que, des le seizième siècle, on a répandu, dans pluieurs contrées de l'Europe, des espèces préeuses de poisson dont on y était privé. C'est on les empleyant qu'il parail que Maschal a inIroduit la carpe en Angleterre en 1514; que Pierre Oxe l'a donnée au Danemarck en 1550 ; quà une époque plus rapprochée on a natura- 
lisé l'acipensère strelet en Suède, ainsi qu'en |pourra chaque année, pendant un mois ou enPoméranie, et qu'on a peuplé de cyprins dorés viron, chercher avec succès des cufs fécondés de la Chine les eaux non-seulement de France, de l'espèce qu'on voudra introduire dans une mais encore d'Augleterre, de Ilollande et d'Al- eau qui ne l'aura pas encore nourrie.

lemagne.

Si le trajet est long, on change souvent l'ean

Mais il est un procédé par le moyen duquel du vase dans lequel les œufs sont transportés. on parvient à son but avec bien plus de sûreté, Celte précaution a paru nécessaire même dans de facilité et d'économie, quoique beaucoup plus les premiers jours de la ponte, où l'embryon lentement.

contenu dans l'œuof ne peut être supposé respiIl consiste à transporter le poisson, non pas rer en aucune manière, puisque, dans ces predéveloppé et parveuu à une taille plus ou moins miers jours, non-seulement le petit animal est grande, mais encore dans l'état d'embryon, et renfermé dans ses enveloppes et dans la memrenfermé dans son œuf. Pour réussir plus aisé- brane qui entoure l'œuf, mais encore montre, ment, on prend les herbes ou les pierres sur au microscope, le cours de son sang dirigé de lesquelles les femelles ont déposé leurs œufs, manière à circuler sans passer par des branchies et les mâles leur laite, et on les porte dans un qui ne sont ni développées ni visibles. Elle ne vase plein d'eau, jusqu'au lac, à l'étang, à la sert donc, dans ce premier temṕs, qu'à préserrivière, ou au bassin que l'on désire de pen- ver les $\propto u f s$ et les embryons de l'action des gaz pler. On apprend facilement à distinguer les ou miasmes qui se-produiraient dans une eau oufs fécondés d'avec ceux qui n'ont pas été que l'on ne renouvellerait pas, et qui, pénéarrosés de la liqueur prolifique du màle, et que trant au travers de la membrane de l'œuf, agil'on doit rejeter : les premiers paraissent tou- raient d'une manière funeste sur les nerfs on jours plus jaunes, plus clairs, plus diaphianes. d'autres organes encore extrêmement délicats On remarque celte différence dès le premier des jeunes poissons. La nécessité de ce changejour de leur fécondation, si l'on se sert d'une ment d'eau est donc une nouvelle prenvè de ce loupe; et dès le troisième ou le quatrième jour que nous avons dit dans ce Discours, et dans on r'a plus besoin de cet instrument, pour voir celui que nous avons pablié sur la nature des que ceux qui n'ont pas été fécondés par le màle, poissons, au sujet du besoin que l'on a, pour deviennent à cliaque instant plus troubles, plus conserver ces animaux en vie, d'entretenir une opaques, plus ternes : ils perdent tout leur éclat, communication très-libre entre l'atmosphère et s'altèrent, se décomposent; et dans cet état de le fluide dans lequel ils sont plongés. demi-putréfaction, ils ont été comparés à de On favorise le développement de l'cuf et la petits grains de grêle qui commencent à se fondre 1 . ortie du fotus, en tes plaçant après le transpori dans un endroit éclairé par le soleil. On les hâte Pour pouvoir employer ce transport des même par cette attention; et Bloch nous apprend œufs fécondés, d'une eau dans une autre, il dans l'Introduction que nous avons déjà citée, faudra s'atlacher à connaître dans chaque pays qu'ayant fait quatre paquets d'herbes chargées

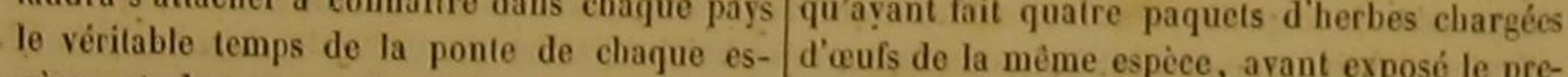
pèce, temps de la ponte de chaque es- d'oû́s de la même espèce, ayant exposé le prepéce, et du passage des mâles au-dessus des mier au soleil du mídi, le second au soleil leoufs; et comme dans presque toules les espè- vant, le troisième au couchant, et ayant fait ces, de poissons on comple trois ou quatre épo- mettre le quatrième à l'abri du soleil, les æufs ques du frai, les jeunes individus pondant du premier paquet furent ouverts ar les aufs leurs œufs plus tard que les femelles plus avan- $\begin{aligned} & \text { du premier paquet furent ouverts par le fotus } \\ & \text { deurs avant ceux du quatrième, et les œufs }\end{aligned}$ cées en âge, et celles ci plus tard que d'autres du second et du troisième un jour plus tôt que femelles plus âgées encore, que ces époques ceux du quatrième paquet, que la chaleur du sont ordinairement séparées par un intervalle soleil n'avait pas pénétrés.

coule toujours aurs, et que d'ailleurs il s'é- Cependant les eaux dans lesquelles vivent les coule toujours au moins près de neuf jours en- poisons peurent être salesquelles vivent les tre l'instant de la ficon pros de neul jours en- poissons peuvent chre salées on douces, troutus brise sa coque et vient a la lumien le fo- bles ou limpides, chandes ou froides, tranquilles ou agilées par des courants plus ou moins ra-

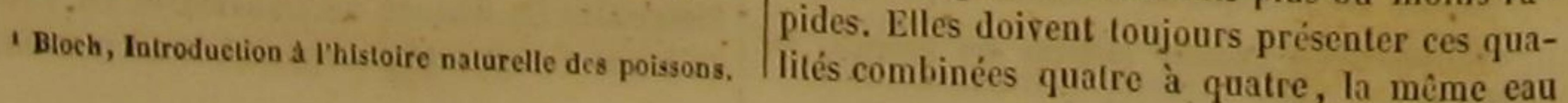

devant être nécessairement courante ou tran- les femelles puissent frotler leur ventre, et se quille, froide ou chande, claire ou limoneuse, débarrasser de leurs aufs,

douce ou salée. Mais ces huit modifications Aura-t-on à sa disposition des eaux thermaréunies quatre à quatre peuvent produire seize les assez abondantes pour remplir do vastes combinaisons : l'eau qui nourrit les poissons réservoirs, et y couler constamment en si grand pent done offrir seize manières d'être très-diffé- volume, que dans toutes les saisons la chaleu rentes l'une de l'autre, et très-faciles à distiñ- y soit très-sensible? On en profitera pour aceliguer. Nous en trouverions un nombre immense mater des espèces étrangères, utiles par la bonté si nous voulions faire attention à toutes les de leur chair, ou agréables aux yeux par la vínuances que chacune de ces modifications peut vacité de leurs couleurs, la beauté de leurs formontrer, et à toutes les combinaisons qui peu- mes et l'agilité de leurs mouvements, et qui vent résulter du mélange de tous ces degrés. n'auront vécu jusquuà co moment que dans les Néanmoins ne tenous compte que des seize ca- contrées renfermées dans la zone torrido ou ractères bien distincts qui peuvent appartenir très-voisines des tropiques.

à l'eau; et voyons. l'influence de la nature des Lorsque les poissons ne sont pas délicats, ils différentes eaux sur la conservation des poissons peuvent néanmoins supporter très-facilement to que l'on veut acclimater.

passage d'une eau à une eau très-différente de Il est évident que si l'on jette les yeux au la première. On l'a remarqué particulièrement hasard sur une des seize combinaisons que nous sur l'anguille; et M, de Septfontaines, observavenons d'indiquer, on ne la verra pas séparéo teur très-éclairé, que nous avons en to plaides quinze autres par un égal nombre de diffé- sir de citer très-souvent dans nos ouvrages, rences.

Que l'on dépose donc les poissons que l'on transporter des anguilles d'une eau bourbeuse viendra de transporter, dans les eaux les plus dans le vivier le plus limpide, d'une eau froide analogues à celles dans lesquelles ils auront dans une eau tempéréo, d'une eau tempéréo vécu; et lorsqu'on sera embarrassé pour trou- dans une eau froide, d'un vivier très-limpide ver de ces eaux adaptées aux individus que dans une eau limoneuse, etc.; qu'il avait fait l'on voudra conserver, que l'on préfere de les supporter ces transmigrations à plus de trois placer dans des laes, où ils jouiront à leur vo- cents individus; qu'il les y avait soumis dans lonté des eaux courantes qui s'y jeltent ou en différentes saisons; qu'il n'en était pas mort la sorlent, et des eaux paisibles qui y séjournent, vingtième partie; et que ceux qui avaient péri oì ils rencontreront des touffes de vénétaux n'avaient succombé qu'à la fatigue et à la gòne où is reneonte sa- que leur avait fait éprouver un séjour très-long

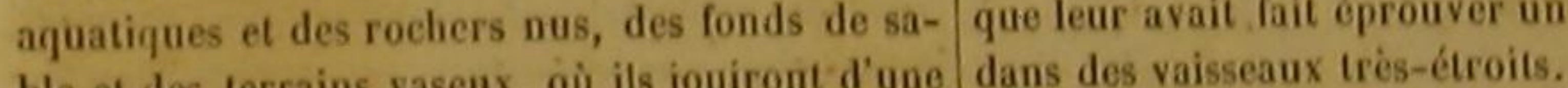

ble et des terrains vaseux, où ils jouiront d'une dans des vaisseaux trés-étroits.
On pourrait croire, au premier coup d'ail, température douce en s'enfonçant dans les en- On pourrait croire, au premier coup d on, droits les plus profonds, et où ils pourront se qu'une des habitudes les plus difficiles à donréchauffer aux rayons du soleil, en s'élevaut ner aux poissons serait celle de vivre dans l'eau réchauffer aux rayons du soleil, en s'élevaut ner aux pos̀n avoír vécu dans l'eau salée, ou
vers la surface.

Que l'on choisisse néanmoins les laes dont celle de cé continuellement plongés dans de l'eau les rives sont unies, plutot que ceux dont les avoir ater.

rivages sont très-liauts; et si l'on est obligé de douce. se servir de ces lacs à bords trés-exhaussés, et cete opinion, si l'on considere qu'à la vérité où par conséquent les æuf́s déposés sur des cette opinion, sil'o plus pesante, soutient dafonds trop éloignés de l'atmosphère ne peuvent l'eau salée, commo plas pesante, sother dapas receroir l'lueurense influence de la lumière vantage le poisson qui nage, et dés-lors lui pas recevoir Theureuse infuée do côtes basses donne, tout égal d'ailleurs, plus d'agilité et de et de la chaleur, qu'on supplée aux cotes basses dones dans ses mouvements, mais que lorset aux pentes douces, en faisant consıruire dans lespèces de qu'elle se décompose dans les branchics pour

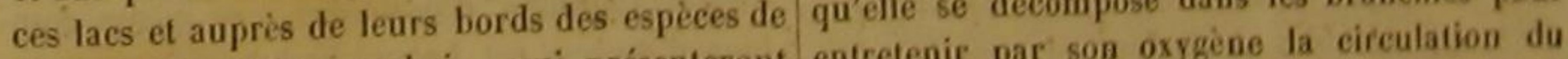
pares ou de viviers en bois, qui présenteront entretenir par son oxgens le canal intestinal des plans inclinés très-voisins de la surface de sang, ou seuleneat dans lo can intestial d'eas plans inclines tres dans la saison conve- pour servir par son hydrogene à la nourriture l'eau, el que l'on garnira, dans la saison conve- pour sernal, le sel dont elle est imprégnée n'alnable, de branches et de rameaux sur lesquẹls de l'animal, le sel dont elle car impera 
tère ni l'uu ni l'autre produit de cette décom- cun de leurs attributs, ont été plutôt améliorés position. L'oxygène et l'hydrogène retirés de qu'altérés par leur nouvelle manière de vivre, l'eau salée, ou obtenus par le moyen de l'eau y sont exposés à un froid assez rigoureux pour douce, offrent les mêmes propriétés, produi- qu'ils soient souvent obligés de chercher leur sent les mêmes effets. Si le poisson est plus nourriture sous la neige qu'ils écartent avec gèné dans ses mouvements au milieu d'un lac leurs pieds; et néanmoius on ne peut guère disd'eau douce que dans le sein de l'océan, il tire convenir que le cheval ne soit originaire du de l'eau de la mer et de celle du lac la même climat brûlant de l'Arabie.

nourriture; et il peut, au milieu de l'eau douce, Il n'y a que les animaux nés dans les envin'être privé que de cetle sorte de modification rons des cercles polaires, qui ont dès leurs prequ'impriment la substance saline et peut-être mières années supporté le poids des hivers les une matière particulière bitumineuse ou de toute plus rigoureux, et dont la nature, modifiée par autre nature, contenues dans l'eau de l'océan, les frimas, non-seulement dans eux, mais enet qui, l'environnant sans cesse, lorsqu'il vit core dans plusieurs des générations qui les ont dans la mer, peuvent traverser ses téguments, précédés, est devenue, pour ainsi diro, ana pénétrer sa masse, et s'identifier avec ses or- gue à tous les effets d'un froid extrême, qui ue ganes.

De plus, un très-grand nombre de poissons ne passent-ils pas la moitié de l'année dans l'Océan, et l'autre moitié dans les rivières ainsi que dans les fleuves? et ces poissons voyageur ne paraissent-ils pas avoir absolument la mème organisation que ceux qui, plus sédentaires, n’abandonnent dans aucune saison les rivières ou la mer?

Quant à la température, les eaux, au moins les eaux profondes, présentent presque la même, dans quelque contrée qu'on les examine. D'ailleurs les animaux s'accoutument beaucoup plus aisément qu'on ne le croit à des températures aisement qu'on ne le croit à des températures
trés-différentes de celle à laquelle la natura très-différentes de celle à laquelle la nature les
avait soumis. Ils s'y habituent même lorsques avait soumis. Ils $s^{\prime} y$ babituent même lorsque,
vivant dans une très-grande indépendance, ils pourraient trouver dans des contrées plus chandes ou plus froides que leur nouveau séjour une sûreté aussi grande, un espace aussi libre, une sûreté aussi grande, un espace aussi libre, une habitation aussi adaptée à leur organisation, une nourriture aussi abondante. Nous en avons un exemple frappant dans l'espèce du cheval. Lors de la découverte de l'Amérique méridionale, plusieurs individus de cette espèce, amenés dans cette partie du nouveau continent, furent abandonnés, ou s'échappèrent dans des contrées inhabitées voisines du rivage sur lequel on les ayait débarqués : ils s'y multiplièrent; et de leur postérité sont descendues des troupes très-nombreuses de chevanx sauvages, qui se sont répandus à des distances très-considérables de la mer, se sont très-éloigoés de la ligne équinoxiale, sont parvenus très-près de l'extrémité australe de l'Ámérique, y occupent de vastes déserts, n'y ont perdu aud'espèces cet engourdissement reme com-
SUR LES POISSONS.

concentrant la vie dans l'intérieur de l'animal, | ticles de celle llistoire, un arand nombre d'esen l'éloignant de la surface où elle serait trop pèces remarquables par leur beauté, par leur fortement attaquée, en la renfermant, pour grandeur et par le goùt esquis de leur chair, qui ainsi dire, dans une enveloppe qui ne conserve manquent aux eaux douces de notre patrie, et de la vitalité que cé qu'il faut pour ne pas qu’on pourrait aisément acclimater en France, éprouver de grandes décompositions, et en la avec les précautions ou par les movens que nous réduisant, en quelque sorte, à une circulation venons d'indiquer, ou en employant des procési leute et si limitée, qu'elle peut être indépen- dés analogues à cenx que nous venons de dédante des objets extérieurs ' ! S'il ne répare pas, crire, et qu'on préférerait d’après la longueur du comme le sommeil journalier, des organes usés trajet, la nature du voyage, le climat que les par la fatigue, it maintient ces organes; s'il ne poissons auraient quitté, la saison que l'on audonne pas de nouvelles forces, il garantit de rait été obligé de choisir, et plusieurs autres cirl'anéantissement; s'il ne ranime pas le souflle constances. De ce nombre seraient, par exemple, de la vie, il brise les traits de la mort, Quelles le centropome sandat de la. Prusse, Tholocentre que soient la canse la force on ln durée du post des contrées septentrionales de l'Allemagne ; sommeil, il est donc toujours un grand bienfait et on ne devrait mẻme pas être effrayé par la de la nature ; et pendant qu il charme les en- grandeur de la distance, surtout lorsque le transnuis de l'ctre pensant el sensible, non-seule- port pourrait avoir lieu par mer, ou par des riment il guérit ou suspend les douleurs, mais il vières, ou des canaus. On peut en effot, lorsprévient et écarte les maux de l'animal, qui, qu'on navigue sur l'océan, sur des canaux ou réduit à un instioct borné, n'existe que dans le sur des fleuves, attacher à l'arrièro du bâtiment présent, ne rappelle aucun souvenir, ot ne con- une sorte de vaisseau, ou pour mieux dire, do çoit aucun espoir.

Ia qualité et l'abondance de la nourriture, ces grandes causes des migrations volontaires de tous les animaux qui quittent leur pays, sont aussi les objets auxquels on doit faire le plus d'attention, lorsqu'on cherche à conserver des animaux en vie dans un autre séjour que leur pays natal, et par conséquent lorsquion veut acclimater des espèces de poisson.

L'aliment auquel le poisson que l'on vient de dépayser est le plus habitué, est celui qu'il faudra lui procurer, il retrouvera sa patrie partou où il aura sa nourriture familière. Par le moyen d'herbes, de feuilles, d'amas de végétaux, do fumiers de toute sorte, on donnera un aliment très-convenable aus espèces qui so nourrissen de débris de corps organisés; on cherchera, on de débris de corps organisés; on chierchera, on rassemblera des larves et des vers pour celles qui les preferent; cl lors puissons voraces, il faudr brochets ou d'uis poi les anront recus ceu mettre dans les aiment a faire leur proie, qui se plaisen dans les mêmes habitations que ees animaus carnassiers, ou qui sont peu recherchés par les cécéperlans, des cyprin péeheurs, comne desins gibèles, des cyprins-borgoujons, des delières, etc.

On trouvera, en pareourant les différents ar-

I Voyez le Discours sur la nature des quadrupèdes ovipares.

u'elle soit presque entièrement plongée dan

leau, et dont les parois sont percées de manièro Tue les poissons qui $y$ sont renfermés reçoivent out le fluide qui leur est nécossaire, et commuiquent avec l'atmosphicre de la manière la plus ivantageuse, sans pouvoir s'échapper et sans voir rien à craindre de la dent des squales ou les autres animaux aquatiques et féroces, Nous indiquons donc à la suite du post et du sandat, tentre plusieurs autres que les bornes de ce Discours ne nous permettent pas de rappeter ici, l'osphironème goramy, déjà apporté de la Chine à l'íle de France, le bodian aya des lacs Iu Brésil, et I'holocentre sogo des grandes Indes, de l'Afrique et des Antilles.

Quand on n'aura pas une eau courante à donaer à ces poissons arrivés d'une terre étrangère, principalement lorsque ces nouveaux fiotes ent vécu, jusqu'à leur migratiou, dans des ellement perpétuél du fluide environnant que le courant procure, par une grande étendue dongée à l'babitation, Ici comme dans plusieur utres phénomènes, un grand volume en repos a tiendra lieu d'un pelit rolume en et, dans un espace de temps déterminé, lanimal jouira de la même quantité de molécules de fluide, différentes de celles dont il aura déjà reçu rinfluence. 1 Voyez Yarlicle du Scombre maquereau. 
Sans cette précaution, les poissons que l'on | de ces lâmes, s'oblitèrent ou se dérangent; les voudrait acclimater épouveraient les mẻmes ac- écailles changent dans leurs dimensions; la macidents que ceux de nos contrées qu'on enlève tière qui les compose n'a plus les mêmes pro. aux petites rivières, et particulièrement à la priétés; elles ne sont plus ni aussi luisantes, ni partie de ces rivières la plus voisine de la source, aussi transparentes, ni aussi colorées; elles sont et qu'on veut conserver dans des vaisseaux ou clair-semées sur la peau de l'animal vieilli; elles même dans des bassins très-étroits. On est obli- se détachent avec facilité ; elles ne sont pas gé de renouveler très-souvent l'eau qui les en- remplacées par de nouvelles lames, ou elles toure; sans cela, les diverses émanations de cèdent la place, en tombant, à des excroissances leur corps, et l'effet nécessaire du rapproche- difformes, produites par une matière écailleuse ment d'une grande quantité de substances ani- de mauvaise qualité, mélangée avec des élémales, vicient l'eau, la corrompent par la pro- ments hétérogènes, et mal élaborée dans des duction de gaz que l'on voit s'élever en petites parties sans force, et dans des tuyaus qui ont bulles, et la rendent si funeste pour eux, qu'ils perdu leur première figure. Celte altération est périssent s'ils ne viennent pas à la surface cher- sans remède; il n'y a rien à opposer aux effets cher le voisinage de l'atmosphère, et respirer, nécessaires d'un àge très-avancé. Si dans les pour airsi dire, des couches de fluide plus poissons, comme dans les autres animaux, lart pures.

Ces fails sont conformes à de belles expériences faites par mon confrère M. Silvestre le fils, et à celles qui furent dans le temps communiquées à Buffon par une note que ce grand naturaliste me remit quelques années après, et qui avaient été tentées sur des gades lotes, des cottes chabots, des cyprins goujons, et d'autres cyprins, tels que des gardons, des vérons et des vaudoises.

Les poissons que l'on veut acclimater sont plus exposés que les anciens habitants des eaux dans lesquelles on les a placés, non-seulement aux altérations dont nous venons de parler, mais aux altérations dont nous venons de parler, mais encore à toutes les maladies

Ces maladies assaillent ces tribus aquatiques, même lorsque les individus sont encore renfer més dans l'œuf. On a observé que des embryonde saumon, de truite et de beaucoup d'autres espèces, périssaient lorsque des subslances grasses, onclueuses, et celles quie l'on désigne par le nom de saletés et d'ordures, s'atlachaient à l'enveloppe qui les contenait, et qu'une eau courante ne nettoyait pas promptement celte membrane.

On suppléera facilement à celte eau courante par une altention soutenue et divers petits moyens que les circonstances suggéreront.

Lorsque les poissons sont vieux, ils éprouvent souvent une altération particuliêre qui se manifeste à la surface de l'animal ; les canaux destinés à entretenir ou renouveler les écailles s'obstruent ou se déforment; les.organes gui filtrent la substance nourricière et réparatrice peut reculer l'époque de décomposition des o de ces grands cliangements, lorsqu'ils cepérés. S'il peut relarder la rapidité du cours de la vie, il ne peut pas la faire remonter vers sa source.

Mais les maux irréparables de la vieillesse ne sont pas à craindre pour les poissons que l'on cherehe à acclimater : dans la plupart des espèces de ces animaux, ils ne se font sentir qu'après des siècles, et l'éducation des individu que l'on transporte d'un pays dans un autre, est terminée longtemps avant la fin de ces nombreuses années. Leurs habitudes sont d'autan plus modifiées, leur nature est d'autant plus changée avant qu'ils approchent du terme de leur existence, qu'on a commencé d'agir sur xendant qu'ils étaient encore très-jeunes.

C'est d'autres maladies que celles de la décrépitude qu'il faut cherêtier à préserver ou a guérir les poissons qu'on élève. Et maintenan nous agrandissons le sujet de nos pensées; et tout ce que nous allons dire doit s'appliquer nonseulement aux poissons que l'on veut acclimater dans telle ou telle contrée, mais encore à dous ceux que la nature fait naitre sans le secours Ces

Ces maladies qui rendent les poissons languisants et les conduisent à la mort, proviennen quelquefois de la mauvaise qualité des plantes aquatiques ou des autres végétaux qui croissent pres des bords des fleuves ou des lacs, et don les feuilles, les fleurs ou les fruits sont saisis par l'animal qui se dresse, pour ainsi dire, sur la rive, ou tombent dans l'eau, y flottent, et / des étangs vaseux, L'air de l'almosphère n'a vont ensuite former au fond du lac ou de la pas pu pénétrer plus aisément dans les premiers rivière un sédiment de débris de corps organi- que dans les derniers; et cependant les poissons sés. Ces plantes peuvent être, dans cerlaines de ces étangs blanes ou récemment réparés ont saisons de l'année, viciées au point de ne four- véen, parce que le fond de leur séjour, n'étant nir qu'une substance malsaine, non-seulement pas couvert de substances végétales, n'a pas pn aux poissons qui en mangent, mais encore à produire les gaz funestes qui se sont dévelopceux qui dévorent les petits animaux dont elles pés dans les étangs vaseux. Et ce qui achève, ont composé la nourriture. On prévient ou on d'un auire côtê, de prouver l'opinion que nous arrête les suites funestes de la décomposition de exposons à ce sujet, et qui est importante pour ces végétaux en détruisant ces plantes auprès la physique des poissons, c'est que des oiseaux des rives de l'habitation des poissons, et en les de proie, des loups, des chiens et des cochons remplaçant par des herbes ou des fruits choisis mangèrent les restes des animaux rejetés après que l'on jette dans l'eau peuplée de ces ani- le dégel sur les rivages des étangs remplis do maux.

La plus terrible des maladies des poissons est celle qu'il faut rapporter aux miasmes produits dans le fluide qui les environne.

d'animaux morts d'une maladie véritablent Cest à ces miasmes qu'il faut attribuer la Ce sont encore ces gaz malfaisants que nons mortalité qui régna parmi ces animaux dans les devons regarder commela véritable origine d'une grands et nombreux étangs des environs de maladie épizootique qui fit de grands ravages. Bourg, elef-lieu du département de l'Ain, lors en $\mathbf{1 7 5 7}$, dans les environs de la forét de Crécy. de l'hiver rigoureux de la fin de 1788 et du com- M. de Chaignebrun, qui a domné dans te temps mencement de 1789, et dont l'estimable Va- un très-bon traité sur cette épizootie, rapporte renne de Fenille donna une notice très-bien qu'elle se manifesta sur tous les animaux; qu'elle faite dans te Journal de physique de novem- atteignit les chiens, les poules, et s'étendit jusbre 1789. Dès le 26 novembre 1788 , suivant ce qu'aux poissons de plusieurs élangs. II nomme très-bon observateur, la surface des étangs fut cette maladie fièvre épidémique contagieuse , profondément gelée; la glace ne fondit que vers inflammatoire, putride et gangréneuse. Un la fin de janvier. Dans le moment du dégel, les médecin d'un excellent esprit, dont les connaisrives des étangs furent couvertes d'une quan- sances sont très-variées, et qui sera bientôt cétité prodigieuse de cadavres de poissons, rejetés lèbre par des ouvrages importants, M. Chavaspar les eaux. Parmi ces animaux morts, on sien-Daudebert, lui donne, dans sa Nosologie compta beaucoup plus de carpes que de perches, comparée, le nom de charbon symptomatique. de brochets et de tanches. Les étangs blancs, Je pense que celte épizoolie ne serait pas parvec'est-à-dire ceux dont les eaux reposaient sur un nue jusqu'aux poissons, si elle n'avait pas tiré sol dur, ferme et argileux, n'offrirent qu'un son origine de gaz délétères. Je crois, avec petit nombre de signes de celte morlalité; ceux Aristote, que les poissons revêtus d'écailles qu'on avait récemment réparés et nelloyés, mon- se nourrissant presque toujours de substances trèrentaussi sur leurs bords très-peu devictimes : lavées par de grands volumes d'eau, respirant mais presque tous les poissons renfermés dans par un organe particulier, se servant, pour cet des étangs vaseux, encombrés de joncs ou de acte de la respiration, de l'oxygène de l'eau roseanx, et surchargés de débris de végétaux, pé- bien plus fréquemment que de celui de l'air, el rirent pendant la gelée. Ce qui prouve évidem- toujours environnés du fluide le plus propre a ment que la mort de ces derniers animaux n'a arrêter la plupart des contagions, ne peuvent ment que la mort de ces deffet du défant de l'air de l'atmosphère, pas recevoir de maladie pestilentielle desanimaux pas étél'effet du défant de I'air de Íatmosphere, pas recevoir de maladie pestilentielledesanimaux qu'elle ne doit être rapportée quà la produc- des environs de Crécy n'ont pas été à l'abri de qu'clle ne dit détres qui n'ont pas pu s'échapper Yépizootie, au-dessous des couches d'eau qui les tion de gaz dét au travers de la croble de glac a été aussi forte à la superficie des élangs blancs
et des étangs nouvellement nelloyés, qu'à celle
qui donnaient la mort aux chiens, aux poules, 
ot à d'autres espèces terrestres, le fond des le plus éloignés possible de la combinaison la étangs produisait des gaz aussi funestes que ces plus commune, et par conséquent la plus natumiasmes. Il n'y a pas eu de communication de relle des forces et des résistances, pendant que maladie; mais deux causes analogues, agissant les eaux trop échauffées ou trop impures donen même temps, l'une dans l'eau, et l'autre dans nent la mort à leurs habitants, celles quì sont l'atmosphère, ont produit des effets sembla- trop froides et trop vives les font aussi périr, bles.

On peut prévenir presque toutes ces mortalités que causent des gaz destructeurs, en ne laissant pas dans le fond des étangs ou des rivières, des tas de corps organisés qui puissent, en se décomposant, produire des émanations pestilentielles, en les entraînant par de l'eau courante que l'on introduit dans ces étangs, et par de l'eau très-pure et très-rapide que l'on condui dans ces rivières pour en renouveler le fluide, de la même manière que l'on renouvelle cèlui des temples, des salles de spectacle et d'autres grands édifices par les courants d'air que l'on y dirige, et enfin en brisant pendant l'hiver les glaces qui se forment sur la surface des étangs et des rivières, et qui retiendraient les gaz pernicieux dans l'habitation des poissons.

II parait que lorsque la chaleur est très-grande, elle agit sur les poissons indépendamment des fermentations, des décompositions et des exhalaisons qu'elle peut faire naitre. Elle influe directement sur ces animaux, surtout lorsAlue directement suŕ ces animaux, surtout lors-
qu'ils sont renfermés dans des réseryoirs qui ne contiennent' qu'un petit volume d'eau. Elle parvient alors jusqu'au fond du réservoir, qu'elle pénètre, ainsi que les parois; et réflẹchie ensuite par ce fond et ces parois très-échanffés, elle atlaque de toutes parts les poissons, qui se trouvent dès lors placés comme dans un foyer, et leur nuit au point de leur donner des maladies graves. C'est ainsi qu'on a vu des anguilles mises pendant l'été dans des bassius trop pen étendus, gagner une maladie qu'elles se communiquaient, et qui se manifestait par des taches blanches. On dit qu'on a les guéries par le moven du sel, et de la plante nommée Stratiotes alen du sel, et de la plante nommée Stratiotes aloides. Mais quoi qu'il en soit, it vaut mieux empécher cette maladie de naître, en préservant les poissons de l'exeès de la chaleur, en pratiquant dans leur habitation des endroils profonds où ils puissent trouver un abri contre les fonds où ils puissent trouver un abri contre les feux de l'astre du jour, en plantant sur une partie du rivage des arbres touffus qui leur donnent une ombre salutaire.

Et comme il est très-rare que tous les extrêmes ne, soient pas nuisibles, parce gu'ils sont vent, ou du moins les soumellent à diverses incom. modités, et particulièrement les rendent aveugles. Nous trouvons à ce sujet, dans les Memoires de l'académie des sciences pour 1748 , des observations curieuses du général Montalembert, faites sur des brochets; et le comte d'Achard en adressa d'analogues à Buffon, ei 1779, dans une lettre, dont mon illustre ami m'a remis dans le temps un extrait. ¿ Dans nne a terre que j'ai en Normandie, dit le comte d'Achard, il existe une fontaine abondante dans les plus grandes sécheresses. Je suis parvenu, au moyen de canaux de terre cuite, à amener lean de cette source dans trois bassins que " j'ai dans mon parterre. Ces bassins sont mua rés et pavés à ehaux et à sable; mais on n'y a mis l'eau qu'après qu'ils ont été parfaitement secs. Après les avoir bien nettoyés et fait écouler la première eau, on y a laissé séjourner celle qui y est venue depuis, et qui coule continuellement. Dans les deux premiers bassins, j'ai mis des carpes de la plus grande - beauté, avec des tanches; dans le troisième a des poissons de la Chine (des cyprins dorés): a tout cela existe depuis trois ans. Aujourd hui - les carpes, précieuses par leur beauté et a leur grandeur vraiment prodigieuse, sont 4 attaquées d'une maladie eruelle et dont elles " meurent journellement. Elles se couvrent peu a à peu d'un límon sur tout le corps, et sura tout sur les yeux, où il y a en sus une espéce a de taie blanche qui se forme peu à peu, a comme le limon, jusqu'à l'épaisseur de deux a ou trois lignes. Elles perdent d'abord un a cil, puis l'autre, et ensuite erèvent... Les a tanches et les poissons chinois ne sont pas a altaqués de cette maladie. Est-elle particu- d'où cela peut-il venir? de la vivacité de l'eau? etc., etc., etc. fondée; et ce que nous venons de dire devra faire trouver aisément le moyen de garantir ces poissons de celle cécité que la mort suit souCes poissons sont aussi quelquefois menacés "lière aux carpes? quel en est le remède?

Celte dernière conjecture nous parait très- de périr, parce qu'un de leurs organes les plus soin, lorsqu'on péchera, de ne garder que les essentiels est attaqué. Les branchies par les- mâles, et de rendre à l'ean les femelles, on disquelles ils respirent, et que composent des tinguera facilement, dans plusieurs espèces, les membranes si délicates et des vaisseaux san- femelles des mâtes, sans risquer de les blesser, guius si nombreux et si déliés, peuvent être dé- ou de nuire à la reproduction, et sans chercher, chirées par des insectes ou des vers aquatiques par exemple, dans le temps voisin du frai, ì qui s'y attachent, et dont ils ne peuvent pas se faire sortir de leur corps quelques oufs plus on débarrasser. Peut-être, après avoir bien reconnu moins avancés. En effet, dans ces espèces, les l'espèce de ces vers ou de ces insectes, parrien- femelles sout plus grandes quie les mâles; ot dra-t-on à trouver un moyen d'en empécher la d'ailleurs elles offrent dans les proportions de multiplieation dans les étangs et dans plusieurs leurs parties, dans la disposition de leurs conautres habitations des poissons que l'on voudra leurs, ou dans la nuance de leurs teintes, des préserver de ce flèau. cailtes dures et placées en partie les unés at- diquer en écrivant l'histoiro do cos espèces pardessus des autres, ou converts d'une peau ticulières,

épaisse et visqueuse, ne sont sensibles que dans Lorsqu'on ne vondra pas rendre à leur sếjour une très-petite étendue de leur surface. Mais natał toutes les femelles que l'on péchera, on lorsque quelque insecte, ou quelque-ver, s'a- préférera de couserver pour la production les charne contre la portion de celte surface qui plus longues et les plus grosses, comme pondant n'est pas défendue, et qu'il s'y place ou s'y ac- unc plus grande quantité d'ouls.

croche de manière que le poissoñ ne peut, en se De plus, et si des circonstances impérieusen

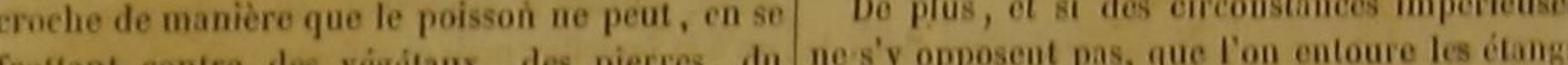
froftant contre des végétaux, des pierres, da ne-s'y opposent pas, que fon entoure les etang sable, ou de la vase, l'écraser, ou fe détacher, et el les viviers de claies ou de litets, qui, dans le le faire tomber, la grandeur, la force, lagilité, temps du frai, retiennent les lierbes ou les les dents du poisson, ne sont plus qu'un secours branehes chargées d'oufs, et les empéchen

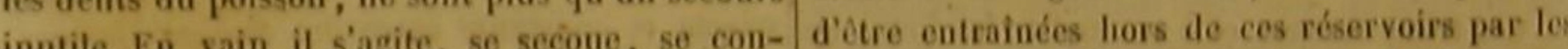

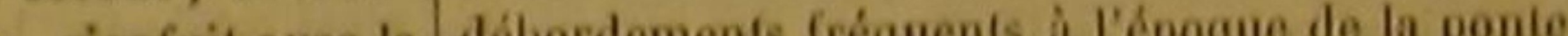

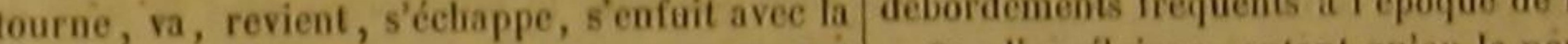
rapidité de l'éclair; il porte toujours avec lui Que Pon éloigne, autunt lu'on lo pourra, les l'ennemi átlaché à ses organes; tous ses efforts friganés, et les autres insectes aquatiques voraces rennemi attaché à ses organ ; laus ses pour qui détruisent les aufs et les poissons qui vien-

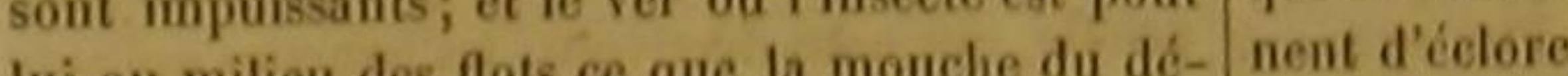

lui au milieu des flots ce que la mouche du de- nest d'on construise quelquefois dans les visert est, dans les sables brùlants de l'Afrique, Que l'on construise quelquetois dans les vinon-sculement pour la timide gazelle, mais en- viers différentes enceintes, lune pour les ons, core pour le tigre sanguinaire, et pour le fier el les autres pour les jeunes poissons, que for lion, qu'elle perce, tourmente et poursuit de sćparera en plusieurs bandes, formées a apre lion, qu'elfe perce, la diversité de leurs âges, el renfermées chacun son dard acéré, malgré leurs bonds, violents, la diversité dé lear particulier.

leurs mouvements impétueux et leur rugissement daus un réservoir partiétangs dans lesquels terrible.

Mais ce n’est pas assez pour l'intelligence des poissons très-rectierchés, et, par exemple, Mais ce n est pas asse produit: des truites, vivraient très-bien, et parviendraien

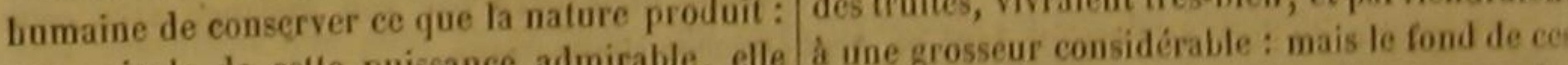
que, rivale de celle puissance admirable, elle à une grosseur còs-vaseux, éest en vain que les ajoute à la fécondité ordinaire des espéces; éangs ctant frent avec leor ventre, avant d'

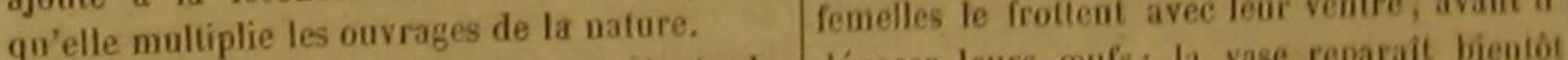
gu a remarqué que, dans presque toutes les déposer leurs cufs; la vase reparait bientôt, espèces de poissons, le nombre des màles était salit les oufs, les altère, les corrompt, et les espèces de poissous, le nombre des màes étail fœlus périssent avant d'éelore.

plus grand et mème quelquefois double de celui foetus périssent avant dát imaginer une manière des femelles; et comme cepéndant un senl Cet inconvénient a fort insos poissons, et par-

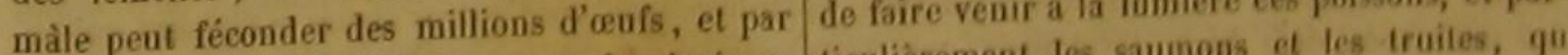

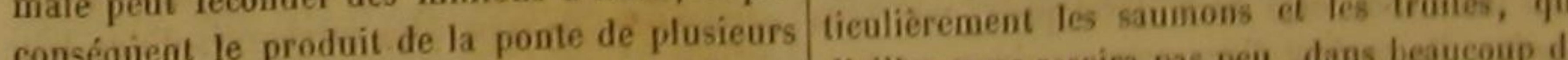
consénuent le prínident que l'on favorisera beau- d'ailleurs ne servira pas peu, dans leaucoup do femelles, il est évident que lond fridus, si on a le circonstances, à multiplier les individus des es- 
pèces les plus utiles ou les plus agréables. M. de melle doucement de haut en bas, et avec la Marolle, capitaine dans le régiment de la Marine, paume de la main.

tempérant les austérités des camps par le charme Dans plusieurs espèces de poissons, on peut de l'étude des sciences utiles à l'humanité, écrivit voir un organe particulier que nous avons rela deseription de ce procédé à Hameln en Alle- marqué aveé soin, qui n'a été observé que par magne, pendant la guerre de sept ans. Il rédigea un petit nombre de naturalistes, dont très-peu cetle description sur les mémoires de M. J. L. de zoologues ont connu le véritable usage, el Jacobi, lieutenant des miliciens du comté de que le savant Bloch a nommé nombril. Cet orLippe-Detmold, et l'envoya à Buffon, qui me la gane est une sorte d'appendice d'une forme remit lorsqu'il voulut bien m'engager à continuer allongée et un peu conique, et dont la place Ia l'Histoire naturelle. ordinairement douze pieds de longueur, communique avec les réservoirs de la laite dans un pied et demi de largeur, et six à sept pouces les mảes, et les ovaires dans les femetles. de hauteur.

A un bout de celte longue caisse, on pratique un trou carré, que l'on ferme avec un treillis de fer dont les fils sont éloignés les uns des autre de deux ou trois lignes.

On ménago un trou à peu près semblable dans la planchie du bout opposé, et vers le fond de la caisse.

Et enfin on en perce un troisième dans le couvercle de la caisse; et on le garnit, ainsi que le second, d'un treillis pareil à celui du premier.

petit tuyau est le conduit par lequel les auf sortent et la liqueur séminale s'échappe : nous le nommons en conséquence appendice génital.

L'urine du poisson sort aussi par cet appendice; ce qui donne à cel organe une analogie de plus avec les parties sexuelles et extérieures des mammiferes. Il ne peut pas servir à distinguer les sexes, puisqu'il appartient au màle aussi bien qu’à la femelle : mais sa présence ou son absence, et énsuite ses proportions et sa figure particuliere, peuvent être employées avec beaucoup d'avantage pour établir une ligne de démareation Ces trous servent et à soumettre les fœetus ou exacte et constante entre des espèces voisines, les jeunes poissons à l'influence des rayous du ainsi que nous le montrerons dans la suite de soleil, et à les préserver de gros insecles et de l'histoire que nous écrivons.

campagnols aquatiques, qui mangeraient et les C'est par cet appendice génital que, dans la œufs et les poissons éclos.

Un petit tuyau fait entrer l'eau d'un ruisseau ou d'une source par le premier treillis; ot cette eau courante s'échappe par la seconde oueau cou
verture.

méthode de reproduction, en quelque sorte artificielle, que nous décrivons, les femelles qui sont pourvues de cet organe extérieur laissent couler leurs oufs.

Lorsque les œufs sont tombés dans l'eau, on

On couvre tout le fond de la caisse d'un gra- prend le mâle, on le tient verticaleme vier bien lavé de la liauteur d'un pouce, et on sus de ces aufs; et pour peu que cela soit néétend sur ce gravier de petits cailloux serrés, de cessaire, on aide par un léger frottement l'épandimensions semblables à celles d'une noisette, et chement de la liqueur prolifique, dont on peut parmi lesquels on place d'autres cailloux de la arrêter l'écoulement au moment où l'eont on peu grosseur d'une noix.

A l'époque du frai de l'espèce dont on ventanchâtre par son mélange avec cette Aultiplier les individus, len so procure on veut liqueur spermatique.

et une femelle de cetle espèce est pàces de poissons, et notamment de cyprins, comme le nase, le roethens, dans de celle du saumon.

On prend un vase bien net, dans lequel lesquelles on peut choisir avec facilité un màle met deux ou trois pintes d'eau bien clacel on pour la fécondation des œufs que l'on a obtenus. tient le saumon femelle dans une situation. On Dans ces espèces, les mảles, surtout lorsqu'ils ticale, et la tête en haut au-dessus dua vaser- sont jeunes, présentent des taches, de petites proles cufs sont dája lien les cufs sont déja hien développés, ou bien noncent qu'ils sont déjà surchargés d'une laite
múrs, ils coulent d'eux-mèmes; sinon on faei- abondante.

lite leur cliute en frottant le ventre de la fe-
On met dans la grande caisse les œufs fécon- dés; on les y distribue de manière qu’ils soient digne, la rivière forme naturellement une sorte toujours couverts par l'eau courante; on em- de vivier ou de grand réservoir, dont l'eau píche que le mourement de cette cau ne soit tranquille, quoique suffisamment renouvelée, trop rapide, afin qu'il ne puisse pas entrainer pourra donner à un grand nombre d'individus les œufs. On écarte soigneusement avec des d'espèces très-utiles le volume de fluide, l'abri, plumes, ou par tout autre moyen, les saletés l'aliment, et la température les plus convoqui pourraient s'introduire dans la caisse; et au nables,

bout d'un temps qui varie suivant les espèces, Quelle est, en effet, la pièce d'eau que l'art la température de l'eau, et la chaleur de l'at- ne puissé pas féconder et vivifier?

mosphère, on voit éclore les poissons que l'on désirait.

Au reste, la sorte de fécondation artificielle opérée avec succès par M. Jacobi, peut avoir lieu sans la présence de la femelle : il suffit de ramasser les œufs qu'elle dépose dans son séjour naturel; il serait mème possible de connaître, à l'instant où on les recueillerait, s'ils auraient été déjà fécondés par le mâle, ou s'ils n'auraient pas reçu sa liqueur prolifique. M. Jacobi assure en effet que lorsqu'on observe avec un bon microscope des œufs de poisson arrosés de la liqueur séminale du mâle, on pent apercevoir très-distinctement dans ces wufs une petite ouverture qui ne paraissait presque pas, ou était presque insensible avant la fécondation, et dont il rapporte l'extension à l'introduction dans l'cuf d'une portion du fluide de la laite.

Quoi qu'il en soit, on peut aussi, en suivant le procédé de M. Jacobi, se passer de la présence du mâle. On peut n'employer la liqueu prolifique que quelque temps après sa sortie du corps de l'animal, pourvu qu'un froid excessi ou une chaleur violente ne dessèchent pas promptement ce fluide vivifiant; et même la mort do màle, pourvu qu'elle soit récente, n'empêche pas de se servir de sa laite pour la fécondation des œufs.

On a écrit que les digues par le moyen desquelles on retient les eaux des petites rivières quelles on retient lestiplication des poissons dans diminuaient la multiplication des poissons dans les contrées arrosées par ces eaux. Cela n' vrai cependant que pour les poissons qui ont besoin, à certaines époques, de remontance trèsles eaux courantes jusqua a de la mer, et qui ne peuvent grande des lacs ou de la mer, ét qui nacilement pas, comme les saumons, s'elancer facilement a de grandes hauteurs, à leur voyage périoque les digus transversales doivent, au dique. Les chaussées transversales loivent, au contraire, être très-favorables à la multiplica-
tion des poissons sédentaires, qui se plaisent dans des eaux peu agitées. Au-dessus de cliaque I Artiele de languille.
On a vu quelquefois des poissons remarquables par leur grosseur vivre dans de petites mares. Nous avons déjà dit dans cet ouvrage ', que M. de Septfontaines s'était assuré qu'un rande anguille avait passé un temps àssez long, ans perdre non-seulement la vie, mais méme me partie de sa graisse, dans une fosse quí conconait à peine la moitié d'un cube de trois pieds l'eau; et il est des contrées où des eyprins, ot particulièrement des carassins, réussissent assez bien dans de petits amas d'eau dormante, pour y donner une nourriture abondante aux habilants de la campagne.

On a bien senti les avantages de cette grande multiplication des poissons utiles dans presque lous les pays oì le progrès des lumières a mi 'économie publique en honneur, el où les gouvernements, profitant avec soin do tous les secours des seiences perfectionnées, ont cherché faire fleurir toutes les branches de l'industrie humaine. C'est principalement dans quelques Prusse et en Suède, qu'on s'est attaché à augmenter le nombre des individus dans ces espèce précieuses; et comme un gouveruement paternet ne néglige rien de ce qui peut accroitre I. subsistance du peuple dont le bonheur lui est confí, et que les soins en apparence les plus minutieux prent un grand caraction dis moment où ils sont dirigés vers l'utilité publique, on a porté en Suède l'attention pour l'aceroissement du nombre des poissons jusqu'à ne pas sonner les cloches pendant le temps du frai des cyprins brêmes, qui y sont très-recherchés, maux, efírayés par le son des cloches, ne se livraient pas d'une manière convenable aux opérations nécessaires à la reproduction de leur espece. Auch y a-ton sourent recueilli de grands pece. Aussi y a-t-on souvent rectejili do grands fruits de celte vigilance étendue aux plus petits
détails, et, par exemple, en 1749 , a-t-on pris tats du nord de l'Europe, et notamment en parce qu'on avait cru s'apercevoir que ces ani- 
d'un seul coup de filet, dans le lac voisin de La peau des grandes espèceś se métamorplrose Nordkiæping, cinquante mille brêmes, qui pe- dans les ateliers en forles lanières, en couversaient plus de dix-luit mille livres. $\quad$ tures solides et presque imperméables à l'tumiEt comment n’aurait-on pas cherché, dans dité, en garnilures agréables de bijoux donnés presque tous les temps et dans presque tous les au luxe par le goùt '.

pays civilisés, à multiplier des animaux si néces- Les vessies natatoires et toutes les memsaires aux jouissances du riche et aux besoins di branes des poissons peuvent être facilement pauvre, qu'il serait plus aisé à l'homme de se converties, dans toutes les contrées, en celte passer de la classe entière des oiseaux et d'une colle précieuse sans laquelle les arts cesseraient grande partie de celle des mammiferes, que de de produire le plus grand nombre de leurs oula c'asse des poissons?

En effet, il n'est pour ainsi dire, aucune espèce L'huile qu'on retire de ces animaux, assoude ces habilants des eaux douces ou salées, dont plit, améliore, et eonsérve dans presque toutes la chair ne soit une nourriture saine et très-sou- les manufactures les substances les plus néces-

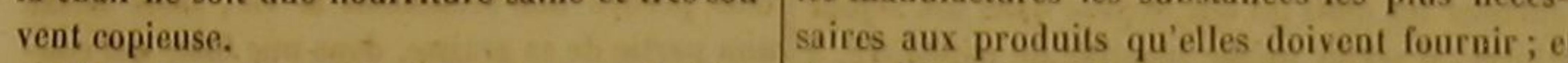
Délicate et savoureuse lorsqu'elle est fraîche, dans ces contrées boréales où règnent de si loncelte chair, recherehée avec tant de raison, de- gues nuits, entretenant seule la lampe du pauvre, vient, lorsqu'elle est transformée en garum, prolongeant son travail au delà de ces tristes un assaisonmement piquant; fait les délices des jours qui fuient avec tant de rapidité, et lui dontables somptueuses, même très-loin du rivage où nant tout le temps que peuvent exiger les soins le poisson a été pêché, quand elle a été marinée; nécessaires à sa subsistance el à celle de sa fapeut être transportée à de plus grandes dis- mille, elle tempère pour lui l'horreur de ces clitances, si on a eu le soin de l'imbiber d'une mats ténébreux et gelés, et l'affranchit, lui et ceus grande quantité de sel; se conserve pendant un qui lui sont chers, des horreurs plus grandes entemps très-long, après qu'elle a été séchée, et, core d'une extrême misère.

ainsi préparée, est la nourriture d'un très-grand Que l'on ne soit done pas étonné que Bélou, nombre d'hommes peu fortunés, qui ne sou- partageant l'opinion de plusieurs auteurs recomtiennent leur existence que par cet aliment abon- mandables, taut anciens que modernes, ait écrit dant et très-peu cher.

Les œufs de ces mèmes habitants des eaux servent à faire ce caviar qui convient au goùt de tant de nations; et les nageoires des espèces que l'on croirait les moins propres à satisfaire un goût délicat, sont regardees à la Chine, et dans d'autres contrées de l'Asie, comme un mets des plus exquis '.

Sur plusieurs rivages peu fertiles, on ne peut compléter la nourriture de plusieurs animaux utiles, et, par exemple, celle des chiens du Kamtschatka, que la nécessité force d'alteler à des traîneaux, ou des vaches de Norvège, destinées à fournir une grande quantité de lait, que par le moyen des vertèbres et des arêtes de plusieurs espèces de poissons.

Avee les éeailles des animaux dont nous nou occupons, on donne le brillant de la nacre an ciment destiné à couvrir les murs des palais les plus magnifiques, et on revêt des boules légères de verre de l'éclat argentin des perles les plus belles de l'Orient.

que la Propontide était plus utile par ses poissons, que des champs fertiles et de gras pâturages d'une égale étendue ne pourraient l'être par leurs fourrages et par leurs moissons.

Et douterait-on maintenant de l'influence prodigieuse d'une immense multiplication des poissons sur la population des empires? On doit voir avec facilité comment cette merveilleuse multiplication soutient, par exemple, sur le territoire de la Chine, l'innombrable quantité d'babitants qui y sont, pour ainsi dire, entassés. Et si des lemps présents on remonte aux temps anciens, an peut résoudre un grand problème historique : on explique comment l'ancienne Égypte nourrissait la grande population sans laquelle les admirables et immenses monuments qui ont résisté au ravage de tant de siècles, et subsistent encore sur cette terre célèbre, n’auraient pas pu tre élevés, et sans laquelle Sésostris n’aurait conquis ni les berds de l'Fuphrate, du Tigre, de l'lndus, et du Gage, ni les rives du Pont-
Euxin, ni les monts de la Thrace. Nous connais- D'ailleurs une nourriture convenable et abonsons l'étendue de l'Égypte: lorsque ses pyra- dante développe les poissons àvee rapidité, fait mides ont été construites, lorsque ses armées jouir beaucoup plus tôt du fruit des soins qque ont soumis une grande partie de l'Asie, elle l'on a pris de ces animaux, et leur donne la était bornée presque autant qu’à présent, par faculté de pondre et de féconder une très-grande les déserts stêriles qui la eirconserivent à l'o- quantité d'oufs pendant un très-grand nombre rient et à l'occident; et néanmoins nous appre- d'anmées,

nons de Diodore, que dix-sept cents Égyptiens On a observé dans tous les temps que le repos étaient nés le même jour que Sésostris : on doit et un aliment très-copieux engraissaient beatldonc admettre en Égypte, à l'époque de la coup les animaux, On s'est servi do co moyen naissance de ce conquérant fameux, au moins pour quelques poissons, et on l'a employé d'uno trente quatre millions d'habitants. Mais quel manière remarquable pour les carpes: on les a grand nombre de poissons ne renfermaient pas suspendues hors de l'eau, de manière à teur inalors et le fleuve, et les canaus, et les lacs d'une terdire lo plus faible mouvement des nageoires; cop̣trée, où T'ärt de multiplier ces animaux était et elles ont été enveloppées dans de la mousso un des principaux objets de la -sollicitude du épaisse qu'on a fréquemment arrosée. Par co gouvernement et des soins de chaque famille? procédé, ces cyprins ont été non-seulement rếIl est aisé de calculer que le seul lac Myris ou duits à un repos absolu, mais plongés perpétuelMøris pouvait nourrir plus de dix-huit cent mille lement dans une sorte d'humiditê ou de fluide millions de poissons de plus de dis-huit pouces aqueux qui, parvenant très-divisó à leur surface, de longueur.

Cependant, que l'homme ne se contente pas de fransporter à son gré, d'acclimater, de conserver, de multiplier les poissons qu'il préere; en nouriture frìs-abondante. Aussi ces earpes quil in in que Prort prétende à de notvear su'il tente de d'une motse liamectée presque continuelle-

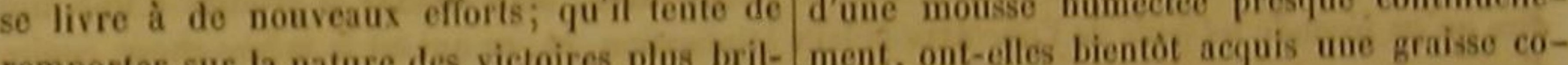
remporter sur la nature des victoires plus brit- ment, ont-elles bientó acétís très-agréable. lantes encore; qu'il perfectionne son ouvrage;
qu'il améliore les individus qu'il se sera soumis, et de plus un goùt tres-agreable,
Dès le temps de Willoghby, et même de celui On sait depuis longtemps que des poissons de de Gesner, on savait que l'on pouvait ouvrir le to dans testese à certains poissons, et surtout au brola même espece ne donnent pas diss tous ves vans qu'ils en les eaux, une chair également délicate. Plusiẹrs chet et à quelques autres ésoces, sans quis cn observations prouvent que, par exemple, dans périssent, et même sans qu'ils en parussent fongles mêmes rivières, leur chair est très-saine et temps incommodés. Il suffit de séparer les musles mèn très-bonne au-dessus des willos ou des très-mau- les téguments avec adresse, et de les recoudre fangeus, et au contraire insalubro et très-mau- les téguments arec aur qu'ils puissent plus facivaise au-dessous de ces torrents vaseux et de ces avec précaution, pour quilitíc a donné l'idée amas d'immondices, souvent inséparables des Iement se réunir. Celto fachite a doiné traé villes populenses. Ces faits ont été remarqués par d'employer, pour engraisser ces poissons, le villes populeuses. Ces faits ont car Rondelet. méme moyen dont on se sert pour donner un plusieurs auteurs, notamment par hecherche très-grand surcroit de graisse aux boufs, aux Qu'on profite de ces résultats; qu'on recherche très-grand surchic do gux poulardes, etc. On les qualités de l'eau les plus propres à donner moutons, aux chapons, ale puccès d'enlever aux un goût agréable ou des propriétés salutaires aux a essayé avec beaucoup do sux mêtes leurs laites. un gout agéch par- femelles leurs ovaires, et aux meless leurs laites. différentes espiees de poissons que lon sera par- fermestraction de ces organes, faite avec trabivenu à multiplier ou à conserver. La soustraction do ces orétention, n'a dérangé Qu'on n’oublie pas qu'il eșt des moyens faciles leté et avec beaucoop d'très-court la santé des et peu dispendieux d'engraisser promptement que pendant un temps trée; et toute la partie de plusieurs poissons, et particulièrement plusieurs poissons qui l'ont éprouveé ; et teute la pars laites ou plusieurs poissons, te par leur substance qui se portait vers lears laiks ou cyprins. On augmente en trés-peu de lain de chè- vers leurs ovaires, et qui y donnait naissance ou graisse, en leur donnant souvent du pais de che- à dés centaines de milliers d'eufs, ou à une quannevis, ou des fêves et des pois bouillis, ou du a des centaines dérable de liqueur fécondante, ne fumier, et notamment de celui de brebis. 
EFFETS DE L'ART

trouvant plus d'organe particulier pour l'éla- la matière brute et des substances mortes. Un borer ni même pour la recevoir, a reflué vers les obstacle tend les ressorts du corps organisé, de autres portions du corps, s'est jetée principale- manière que son énergie vitale en est augmentée, ment dans le tissu cellulaire, et y a produit une au point que lorsque cet obstacle est écarté, nongraisse non-seulement d'un goût exquis, mais seulement la puissance du corps vivant est égale encore d'un volume extraordinaire. $\quad$ à ce qu'elle était avant la résistance, mais même Mais que l'on ait surtout recours, pour l'amé- qu'elle est supérieure à la force dont il jouissait. lioration des poissons, à ce moyen dont on a re- Les disconvenances des deux races qui se raptiré de si grands avantages pour accroître les prochent font donc naitre un accroissement de bonnes qualités et les belles formes de tant d'au- vitalité, d'action et de développement, dans le tres animaux utiles, et qui produit des phéno- produit de leur réunion.

mènes physiologiques dignes de toute l'atten- Secondement, dans un màle et une femelle tion du naturaliste : c'est le croisement des races d'une race, il n'y a que certaines portions anaque nous recommandons. On sait que c'est par logues les unes aux autres qui agissent directece croisement que l'ou est parvenu à perfection- ment ou indirectement pour la reproduction de ner le bélier, le bœuf, l'âne et le cheval. Les l'espèce. Lorsqu'une nouvelle race s'en approche, espèces de poisson, et principalement celles elle met en mouvement d'autres portions qui, à qui vivent très-près de nous, qui préfèrent à la cause de lur repos antérieur, doirent produr haute mer les rivages de l'Océan, les fleuves, les de plus grands effets que les premières. séjour, sont plus soumises à l'influenco Troisièmement, les deux races melées l'une sour, sont plus soumises a l'influence de la avec l'autre ont entre elles des rapports desquels nourriture, du climat, de la saison, ou de la résulte un grand développemt dans les fruits qualité des eaux, présentent des races très-dis- de leur union, pacveloppement dans les fruits tinctes, et séparées l'une de l'autre, par leur doit pas êtreconement ne grandeur, leur force, leurs proprićtés ou la noit pas être considéré comme la somme de l'adture de leurs orgation des qualités de l'une et de l'autre des ture de leurs organes. Qu'on les croise, c'est-à- deux races, mais comme le produit d'une muldire qu'on féconde les œufs de l'une avec la laite liplication, et, ce qui est la même chose, comme d'une autre.

Les individus qui provienuent du mélange de deux races, non-seulement valent mieux que la race la moins bonne des deux qui ont concouru race la moins bonne des deux qui out concouru à les former, mais encore sont préférables à la meilleure de ces deux races qui se sont réunies. C'est un fait très-remarquable, très-constaté, et dout on n'a donné jusqu'à présent aucune explication véritablement satisfaisante, parce qu'on ne l'avait pas considéré dans la classe des poissons, dont l'acte de la génération est beaucoup plus soumis à l'examen dans quelques-unes de ses circonstances, que celui des mammifères et
des oiseaux qui avaient été des oiseaux qui avaient été les objets de l'étude et de la recherche des zoologues.

Rapprochons donc ce qu'on peut dire de ce curieux phénomène.

Premièrement, une race qui se réunit à une seconde, éprouve, relativement à l'influence qu'elle tend à exercer, une sorte de résistance que produisent les disparités et les disconvenances de ces deux races : celte résistance est cependant Et l'on ne près la réur aucune raison de suppposer qu'apeut plus ignorer en physiologie, qu'il n'en est rement enunion de deux races, il y ait nécessaipas des corps organisés et vivants comme de loppemite la matière qui doit servir au déve- 'effet d'une sorte d'intussusception et de combi-

d'une jonction superficielle.

C'est un fait semblable à celui qu'observent les

chimistes, lorsque, par une suite d'une pénétra-

tion plus ou moins grande, le poids de deux sub-

stances qu'ils ont combinées l'une avec l'autre,

est plus grand que la somme des poids de ces substances avant leur combinaison.

Le résultat du croisement de deux races n'est cependant pas nécessairement, et dans toutes les circonstances, le perfectionnement des especes : il peut arriver et il arrive quelquefois que ce croisement les détériore au lieu de les améliorer. En effet, et indépendamment d'autre raison, chacun des deux individus qui se rapprochent dans l'acte de la génération, peut être regardé come imprimant la forme à Pêtre qui provieat de leur union, ou comme fournissant la mavient qui doit être fo coince, ou come infuat a la qui doit être faẹonnée, ou comme influant à la loppement et le moule dans lequel elle doit être naison intime, au lieu d'une simple juxtaposition
SUR LES POISSONS.

figurée, plus de convenance qu'il n’y en avait felus, que l'on a vu éclore des poissons monsavant celte même réunion, dans les individus trueux, dont les uns avaient deux têtes et deux de chacune de ces deux races considérées sépa- avant-corps, pendant que d'autres présentaient rément.

Il y a done dans l'éloignement des races l'une de l'autre, c'est-à-dire daus le nombre des diffé. rencés qui les séparent, une limite en deçà et au delà de laquelle le croisement est par luimème plus nuisible qu'avantageux. L'expérience seule peut faire connaitre cette trainte d'obéir à l'art de l'homme, peut présenlimite : mais on sera toujours sùr d'éviter tous ter, comme lorsque indépendante de cet art elle les inconvénients qui peuvent résulter du croi- n'est soumise qu'aux hasards des aceidents : les sement considéré en lui-même, si dans cette produits de cette sorte d'accouplement extraoropération on n'emploie jamais que les meilleures dinaire ne constituent aucune amélioration ni races, et si, par exemple, en mêlant les races de l'espèce, ui même de l'individu; ils no se des poissons, on ne cesse de rechercher celles perpétuent pas par la génération; ils n'out en qui offrent le plus de propriétés utiles, soit pour général qu'une courte existence; ils sont étranobtenir les aufs que l'on voudra féconder, soit gers à notre sujet.

pour se procurer la liqueur active par le moyen Examinons des effets bien différents de ces de laquelle on désirera de vivifier ces oufs. pliénomènes, et par leur durée, et par leur esVoilà à quoi se réduit ce que nous pouvons sence.

dire du eroisement des races, après avoir réuni Voici tous les attributs des poissons que la dodans notre pensée les vérités dẹja publiées sur mestieité a déja pu changer:

celte partie de la physiologie, les avoir dégagées Les couleurs; elles ont été variées et dans leurs de tout appareil scientifique, les avoir débar- nuances et dans leur distribution.

rassées de toute idée étrangère, les avoir com- Les écailles; elles ont aequis ou perdu de leur parées, et y avoir ajouté le résultat de quelques épaisseur et de leur opacité; leur figure a été réflexions et de quelques observations nouvelles. altérée; leur surface étendue ou rétrécie; leu

adtiésion à la peau affuiblie ou fortiliće; leu

Considérons maintenant de plus haut ce que peut l'homme pour l'amélioration des poissons. Tâchons de voir dans toute son étendue l'influence qu'il peut exercer sur ces animaux par l'emploi des quatre grands moyens dont on s'est servi, toutes les fois qu'il a voulu modifier la nature vivante. Ces quatre moyens si puissants sont : la nourriture abondanto et convenable qu'il a donnée, l'abri qu'il a procuré, la contrainte qu'il a imposée, le chnix qu'il a fait des mâles et des femelles pour la propagation de l'espèce. nombre diminué ou augmenté.

Les dimensions générales; elles ont été agrandies ou rapetissćes.

Les proportions des principales parties de la tête; du corps, ou de la queue; elles ont montré de nouveaux rapports.

La nageoire dorsale; elle a disparu.

La nageoire de la queue; elle a offert une rouvelle forme, et de plus elle a ćté ou doubléo ou triplée, comme on a pu le voir, par exemple, en examinant les modifications que te cyprii En lespece. En réunissant ou ea eno la chine, où il est élevé avec ces quatre instruments de son pouvoir,

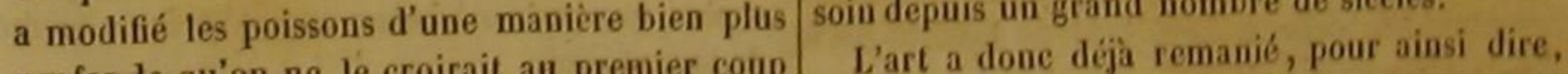
profonde qu'on ne le croirait au premier coup L'art a donc déja remanie, pour aimsi dire, d'œil. En rapprocbant un grand nombre de non-seulement les téguments des poissons, ê cespace assez étroit même un des plus puissants iustruments de leur germes, il a resserré dans un espace assez etroit matation, mais encore presque tous leurs orles œufs de ces animaux, pour que plusieurs de natation, mais encon a changé les proportions ces œufs se soient collés l'un à l'autre, eompri- ganes, puisqu'il en

més, pénétrés, entièrement réunis, et, pour ainsi que l'étendue. ainsi dire, identitiés, et de celte introduction C'est par ces grandes modifications quit a d'un cuf dans un antre, si je puis parler ainsi, produit des variétés remarquables. A mesur d'un œuf dans un autre, si je puis parler ainsi, produit des varicté réce forte, que l'impressiou a 
EFFETS DE L'ART

été vive, qu'elle a pénétré plus a vant, le chan- métis avec la gibèle, ou avec d'autres cyprins. gement a été plus profond, et par conséquent Qu'on suive celle indication.

plus durable. La nouvelle manière d'ètre, pro- Pour éprouver moins de difficultés, qu'on duite par l'empire de l'homme, a été assez in- cherche d'abord à réunir deux espèces qui fraien térieure, assez empreinte dans tous les organes dans le même temps, ou dont les époques du qui concourent à la génération, assez liée avec frai arrivent de manière que le commencemen toutes les forces qui contribuent à cet acte, pour de l'une de ces deux époques se rencontre avec qu'elle ait été transmise, au moins en grande la fin de l'autre.

partie, aux individus provenus de mâles et de Si l'on ne peut pas se procurer facilement de femelles déjà modifiés. Les variétés sont deve- la liqueur séminale de l'une des deux espèces, et nues des races plus ou moins durables; et lors- l'obtenir avant qu'elle n'ait perdu, en se desséque, par la constance des soins de l'homme, chant ou en s'altérant, sa qualité vivifiante, elles auront acquis tous les caractères de la sta- qu'on place des eufs de la seconde à une probilité, c'est-ì-dire lorsque toutes les parties de fondeur convenable, et à une exposition favol'animal qui, par une suite de leur dépendance rable, dans les eaux fréquentées par les màles mutuelle, peuvent agir les unes sur les autres, de la première. Qu'on les y arrange de manière auront reçu une modification proportionnelle, et que leur odeur attire facilement ces màles, que par conséquent il n'existera plus de cause et que leur position Ies invite, pour ainsi dire, intérieure qui tende à ramener les variétés vers à les arroser de leur fluide fécondant. Dans lenr état primitif, ces mêmes variétés, au moins quelques-circonstances, on pourrait les y consi elles sont séparées par d'assez grandes diffé- trajndre en quelque sorte, en détruisant autour de rences de la souche dont elles auront été déta- leur habitation ordinaire, et à une distance assez chées, constitueront de véritables espèces per- graude, les oufs do leurs propres femelles. manentes el distinctes.

Dans d'autres circonstances, on pourrait essayer

C'est alors que l'homme aura réellement exer- de les faire arriver en grand nombre au-dessus cé une puissance rivale de celle de la nature, et de ces eufs étrangers que l'on voudrait les voi qu'il aura conquis l'usage d'un mode nouveau vivifier, en mélant à ces œufs une substance comet bien important d'améliorer les poissons. posée, factice et odorante, que plusieurs tentaMais il peut déjà avoir recours à ce mode, tives feraient découvrir, et qui, agissant sur d'une manière qui marquera moins la puissance leur odorat comme les cufs de leurs espèces, de son art, mais qui sera bien plus courte et les déterminerait aussi efficacement que ces derbien plus facile. Qu'il fasse pour les espèces ce que nous avons pandre abondamment.

dit qu'il devait faire pour les races; qu'il mês une espèce avec une autre; qu'il emploie la laite de l'une à féconder les œufs de l'autre. Il ne craindra dans ses tentatives aucun des obstaeles que l'on a dù vaincre, toutes les fois qu'on a voulu tenter l'accouplement d'un mâle ou d'une femelle avec une femelle ou un mâle d'une espèce étrangère, et que l'on a choisi les objets de ses essais parmi les mammiferes ou parmi les Diseaux. On dispose avec tant de fucilité do laite et des cufs!

En renouvelant ses efforts, non-seulement on obtiendra des mulets, mais des mulets féconds, et qui trànsmettront leurs qualités générations qui leur devront le jour. On aura des espèces métives, mais durables, distinctes, et existantes par elles-mêmes.

niers à se débarrasser de leur laite, et à la ré-

Voudra-t-on se livrer à des essais plus hasardeux, et réunir deux espèces de poissons dont les époques du frai sont séparées par un intervalle de quelques jours? Que l'on garde des aufs de l'espèce qui fraie le plus tôt; que l'on se souvienne que l'on peut les préserver du degré de décomposition qui s'opposerait à leur fécondation; et qu'on les répande, avec les préeautions nécessaires, à la portée des mâles de la seconde espèce, lorsque cesderniers sont arrivés au terme de la maturité.

Au reste, les soins multipliés que l'on est obligé e se donner pour faire réussir ces unions que l'on pourrait nommer artificielles, expliquent pourquoi des réunious analogues sont très-pe fréquentes dans la nature, et par conséquen pourquoi cette nature, quelque puissante qu'elle On sait que la carpe produit facilement des $\begin{aligned} & \text { soit, ne produit cependant que très-rarement } \\ & \text { des especes nouvelles par le mélange des espèces }\end{aligned}$

\section{SUR LES POISSONS.}

anciennes. Cependant, depuis que l'on observe Celte opinion a été étendue et généraliséo avec plus d'attention les poissons, on remarque, au point de devenir une théorie sur la génération dans plusieurs genres de cèsanimaus, des indivi- des animaux, et même sur celle de l'homme. dusqui, présentant des caractères de deux espèces Mais l'existence des métis ne détruil-ollo pa différentes, et plus ou moins voisines, paraissent cette hypothèse? ne doit-on pas voir que si la appartenir à une race intermédiaire, que l'on de- liqueur fécondante du mảle n'était qu'un fluide vra regarder comme une espèce métive et dis- excitateur, n'iufluait en rien sur la forme du tincte, lorsqu'on l'aura vue se maintenir pen- fetus, ne donnait aucune partie à l'embrron, les dant un temps très-long avec toutes ses propriétés œufs de la même femelle, de quelque laite quils particulières, et du moins avec ses attributs fussent arrosés, feraient toujours naitre des inessentiels. Nous avons commencé de recueillir dividus semblables? le stimulus pourrait étre plus des fails curieux au sujet de ces espèces, ou moins actif; l'embryon serait plus fort ou pour ainsi dire, mi-parties, dans les lettres de plus faible; le fotus éclorait plus tot ou plus plusieurs de nos savants correspondants, et tard; l'animal jouirait d'une vitalité plus or notamment de M. Noêl de Rouen. Ce dernier moius grande; mais ses formes seraient toujours naturaliste pense, par exemple, que les nom- les mêmes; le nombre de ses organes no vabreuses espèces de raies qui se rencontrent sur les rierait pas; les dimeosions pourraient etre agranrives françaises de la Manche, lors du temps de dies ou diminuées; mais les proportions, les la fécondation des aufs, doivent, en se mêlant attributs, les signes distinctifs, no montreraient ensemble, avoir donné ou donner le jour à des aucun clangement, aucune modification; aucun espèces ou races nouvelles. Celte opinion de individu ne présenterait en méme temps et des M. Noêl rappelle celle des anciens au sujet des traits du mâle et des traits de la femelle; il ne monstres de l'Afriqué. Ils crojaient que lesgrands pourrait, dans aucune circonstance, exister un mammifères de cette partio du monde, qui ha- véritable métis.

bitent les environs des déserls, et que la chaleur Quoi qu'il en soit, les espèces que l'homme et la soif dévorantes contraiguaient de so rassem- produira, soit par l'influence qu'il osercera sur bler fréquemment en troupes très-nombreuses les individus soumis à son empire, soit par les autour des amas d'eau qui résistent aux rayons alliances qu'il ćtablira entre des espèces voisines ardents du soleil, dans ces régions voisines des ou éloignées, seront un grand moyen do compatropiques, doivent souvent s'accoupler les uns raison pour juger de celles que la nature a pu avee les autres; et que de leur union résultent ou pourra faire naítre dans le cours des siêceles. avee les autres; et que de leur union résultent
des mulets féconds ou inféconds, qui, par lémé-
Les modifications que l'homme imprime servides mulets féconds ou inféconds, qui, par lémé- Les modifications que llomme imparime servi等 quables, et de dimes premières, et

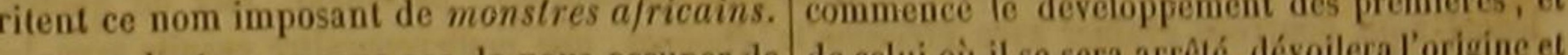
Cependant ne cessons pas de nous occuper de de celui où il se sera arrêté, dévoilera l'origine et ces poissons mulets que l'art peut produire, ou l'étendue des secondes. Les espéces artificielles que la nature fait naitre chaque jour par l'union seront la mesure des espèces naturelles, On sait que la nature fait aaitèle, ou par celle de plu- par exemple, que le cyprin doré de la Chine perd de la carpe arec la gibesticité, non-seulement des traits de sieurs autres espéces, sans faire ane renesion dans la dó l'ération de la forme de sa naimportante relativement à la génération des ani- son espèce par l'attération de la foime de sa inamaux dont nous ćcrivons l'histoịre, et même à geoire caudale, mais encore des signes distinctís celle de presque tous les animaux. - du groupe principat ou du genre auquel il apparDes anteurs d'une grande autorité ont écrit lient, puisque la nageoire du dos lui est ôtée par Des auteurs d une grandes poissons, la fe- Part, et même des caractères de la grande faque, daus la reproduction des poissons, la fe- le mille ou de l'ordre dans lequet il doit êtro commelle exerçait une si grande influence, que le mille ou de l'ordre das lequet le le prive deses fetus était entièrement formé dans T'œuf avant pris, puisque la main de l'homme le prive de ses. l'émission de la laite du mâle, et que la liqueur nageoires inférieures, dont la position ou lab-

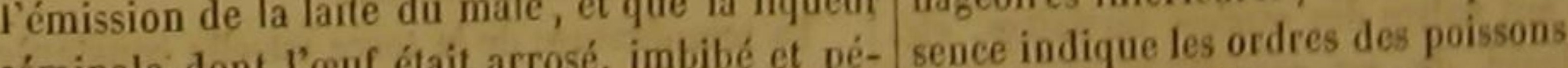

séminale dont l'œuf était arrosé, imbibé et pé- sence ia vérité, l'action de l'bomme n'a pas ennétré, ne devait être considérée que comme une A la vérite, laction de l'boséns l'intérieur de co sorte de stimulus propre à donner le mouve-
ment et la vie à l'embryon préexistant. 


\section{EFFETS DE L'ART}

générales de l'estomac, des intestins, du foie, distingués par des caractères moins sensibles; des reins, des ovaires, etc., qui constituent véri- et c'est ainsi que les produits animés de la créatablement la diversité des ordres, pendant que tion sont parvenus à celte multitude innombrable l'absence ou la position des nageoirés inférieures ef à cette admirable variété qui étonnent et enn'est qu'un signe extérieur qui, par ses relations chantent l'observateur.

avec la forme et les dimensions des organes in- D'un autre côté, on peut supposer que, dans ternes, annonce ces ordres sans en produire la les premiers àges, toutes les manières d'être ont diversité.

été employées par la nature, qu'elle a réalisé

Mais que sont quelques milliers d'annćes, pen- toutes̉ les formes, développé tous les organes, dant lesquels les Chinois ont manié, pour ainsi mis en jeu toutes les facultés, donné le jour à dire, leur eyprin doré, lorsqu'on les compare tous les êtres vivants que l'imagination la plus au temps dont la nature dispose? C'est celte len- bizarre peut concevoir; que dans ce nombre inteur dans lo travail, c'est celte série infinie fini d'espèces', celles qui n'avaient reçu que des d'actions successives, c'est celte accumulation moyens imparfaits de pourvoir à leur nourriperpétuelle d'efforts dirigés dans le même sens, ture, à leur conservation, à leur reproduction, c'est cette constance et dans l'intensité et dans sont tombées successivement dans le néant; et la tendance de la force, c'est cet emploi de tous que tout s'est réduit enfin à ces espèces majeures, les instants dans une durée non interrompue de à ces êtres mieux partagés qui figurent encore milliers de siècles, qui, survivant à tous les sur le globe.

obstacles qu'elle n'a pu ni dissoudre ni écarter, Quelque opinion qu'il faille préférer sur le est le véritable principe de la puissance irrésis- point de dapon the sens, la nature est le multiplication croissante, ou sur celte réduction tomps, qui règne sans contrainte sur la matière graduelle, l'état actuel des choses ne nous perqu'elle façonne, et sur l'espace dans lequel elle met pas de ne pas considérer la nature vivante distribue les ouvrages de ses mains immortelles. comme se balangnt entre les deux grandes li

Ce sera donc tonjours bien au-delà de la limite mites que lui oppont entre les deux grandes un pouvoir de l'homme, qu'il foudra placer cello de la force victorieuse qui appartient à la na- petit nombre d'espèces primitives, et à l'autr ture. Mais les jugements qui loutes lespèces que l'on ture. Mais les jugements que nous porterons de peut imaginer. Elle tend continuellement vers clle force d'après l'ćtendue de l'art, n'en seront l'une ou vers l' Elle tond contiaueliement vers ue plus fondés; on de dire que les espèce approcher, parce qu'elle lentes mesures des espèces aturelles, excel- obéit à des causes qui agissent en sens contrair dans la suit des unes des autres, et qui, tourà tour victorieudans la suite des àges, sont aussi le mètre d'après ses et vaincues, ne cèdent, lors de quelques lequel nous pourrons évaluer avec préeision le époques, que pour reparaitre ensuite avec leor nombre des espèces perdues, le nombre de celles première supériorité.

qui ont disparu avec les siècles. veux grandes manières de considérer l'uni- quelle élude que celle dẹ ces phénomènes! quelle vers animé sont dignes de toute l'altention du recherche que celle de ces causes! quelle hisvéritable naturaliste.

D'un côté, on peut voir, dans les temps très- $\begin{gathered}\text { toire que celle de ces époques! } \\ \text { Et pour les bien décrire, ou plutôt pour les }\end{gathered}$ dans quelque connaitre dans toute leur étendue, it faut les dans quelques espèces primitives, qui, par des contempler sous les différents points de vue que moyens analogues ì ceux que l'ort de l'lio des contempler sou peut employer, ont produit, par la foromme donnent trois suppositions, parmi lesquelles I ature, des espio do naturaliste doit choisir, lorsqu'il examine l'éta elles-mêmes, ou par lecondaires, lesquelles par passé, présent et futur du globe sur lequel s'opère tives, ont fait naître des espèces tertias primi- ce balancement merveilleux.

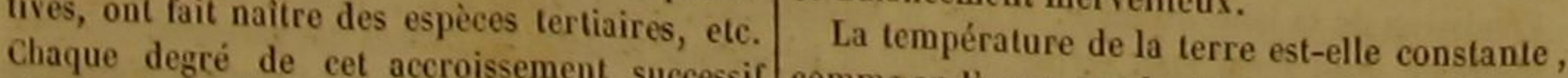
Chaque degcé de cet accroissement successif comme on l'a cru pendant longtemps, ou lante, offrant un plus grand nombre d'objets que le leur dont elle péne degré précédent, les a montrés séparés les les pénétrée, va-t-elle en croissant des autres par des intervalles plus petits, et laleur décroif-elle chaque jour, consé, ou cette
SUR LES POISSONS.

écrits de grands uaturalistes et de grands géo- $\mid$ Quels sujets sublimes pour la méditation du mètres, les Leibnitz, les Buffon, les Laplace? géologue et du zoologiste I quelle immensité d'obPrésentons la question sous un aspect plus jets! quelle voble fierté I'homme devra ressendirect. La nalure vivante est-elle toujours ani- tir, lorsqu'après les avoir contemplés, son génie mée par la méme température? ou la chaleur, les verra sans nuage, les peindra sans erreur ; co grand principe de son énergie, diminue-t-elle et, mettant chaque événement à sa place, fera la ou s'accroit-elle à mesure que les siècles aug- part et des tempsécoulés et des temps qui s'avanmentent? 


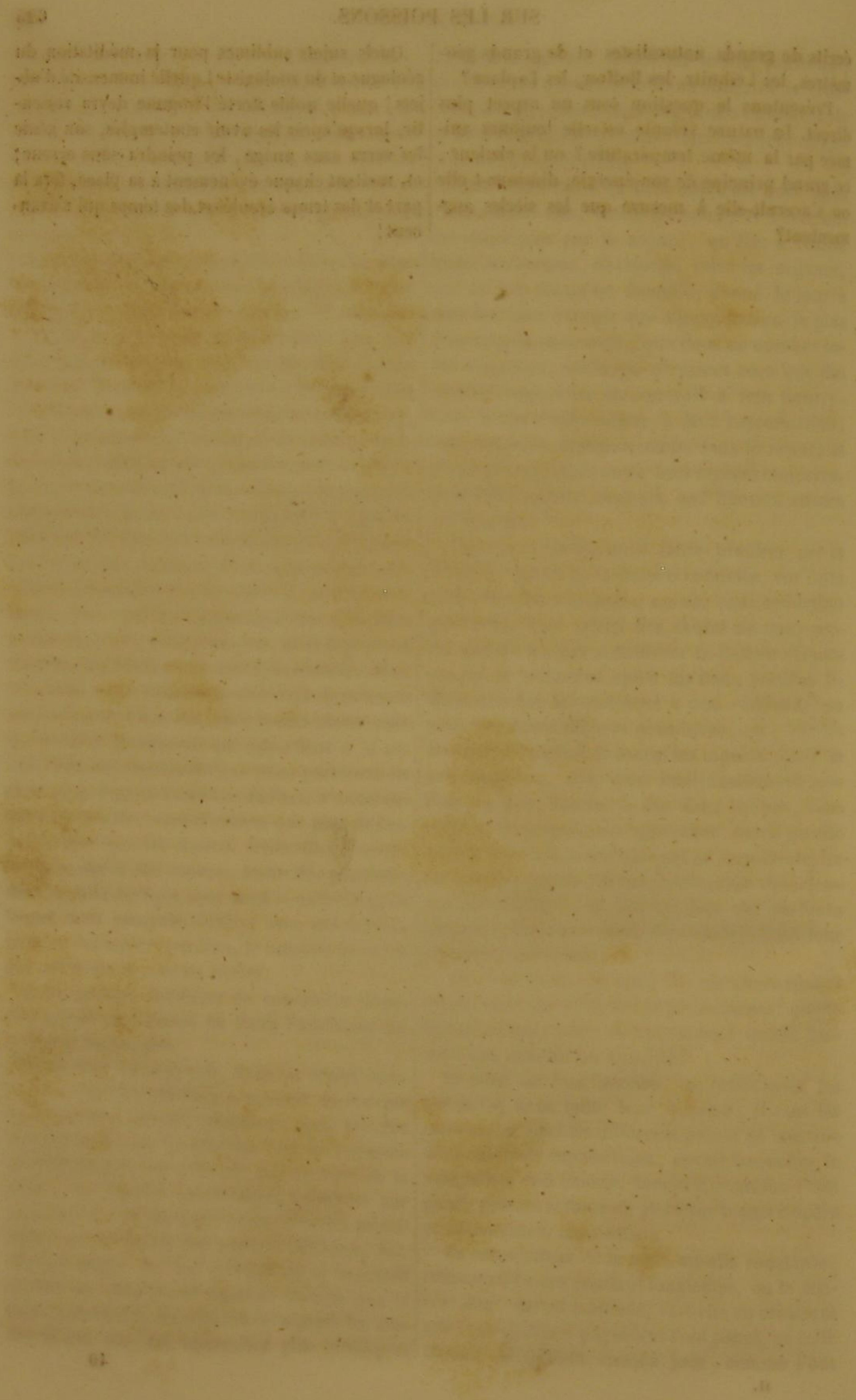

\section{DISCOURS}

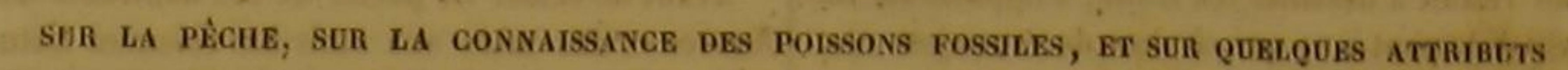
GÉNÉRAUX DES POISSONS.

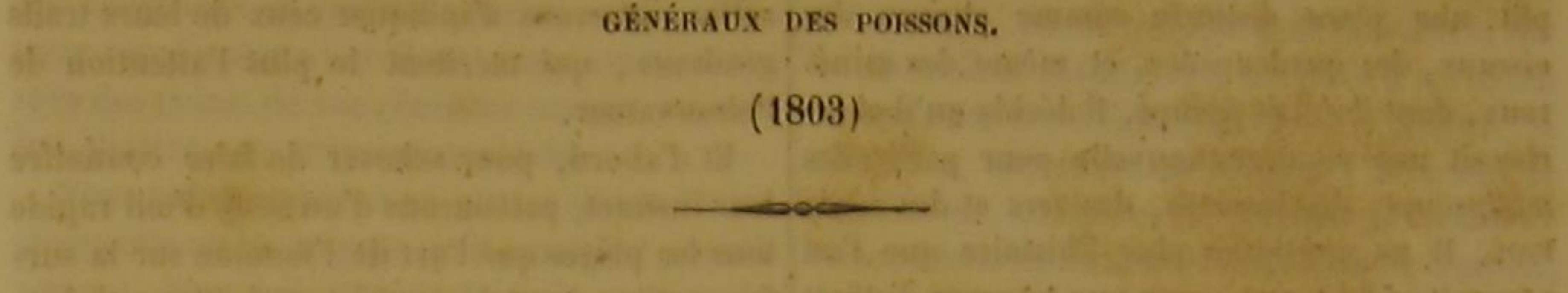

Nous allons terminer l'histoire des poissons. déjà présenté, dans de magnifiques tableaux, Mais tenons encore nos regards élevés vers des les nobles résultats de ses travaus assidus sur considérations générales : nous avons à contem- la structure de la terre, l'ouvrage do la mer, pler de grands spectacles.

Lorsque Buffon, il $y$ a plus de soixante ans, conçut le projet d'écrire l'histoire de la nature il se plaça au-dessus da globe, à un point si élevé, que toutes les petites différences des êtres disparurent pour lui; il n'aperẹt que des grou-

pes; il ne fut frappé que par dè grandes masses ; l'espace même sur lequel il dominait perdit, par jo la distance, de son immensité. origine des planètes, les premiers temps du monde. Aidé par les savantes recherches del'un * de ces pères de la seience, dont la mémoire sera toujours vénérée, éclairé par les avis de P'illustre Daubenton, il avait gravé sur. le bromzo 'image de l'homme et des quadrupèdes. Il peignait les oiseaux, lorsque, descendant chaque jour davantage des hauts points de vue qu'il avait d'abord ehoisis, découvrant des dissemD’un autre côté, son génie lui fit franchir les blances que l'éloignement lui avait dérobées, siècles. Sa vue s'étendit dans le passé; elle reconnaissant des intervalles où tout lui avait perça dans l'avenir. Les àges se rassemblèrent paru ne former qu'un ensemble, apercevant des devant lui : le temps s'agrandit à ses yeux à milliers de ntiances, de dégradations, et de mamesure que l'espace se rétrécissait; et le senti- nières d'étre, où il n'avail entrevu que de l'uniment de l'immortalité lui fit oublier les bornes formité, et contraint de cómpter des myriades de sa vie.

Il crut donc devoir tout embrasser dans son goupes principaus, it fut frappé par l'énorme vaste plan. Il se souvint que le naturaliste de disproportion qu'il trouva entre l'infinité des Rome avait écrit I'Histoire du monde; que ce- sujets de ses méditations, et le peu de jours qui lui de la Grèce avait donné celle des animaux : lui étaient réservés. Les Bougainville, les Cook, il compara ses forces a celles d'Aristoté et de abordaient les parties encore inconnues de la Pline, son siècle à ceux d'Alexandre el de Trajan, terre; d'habiles naturalistes, parcourant les con la nation francaise à la nation grecque et à-fa tinents et les îles, lui adressaient do toutes parts, la nation française à la nation grecque et à- la tinents et les iles, lui adressaient do toutes productions romaine; et il voulut être l'historien de la na- de nouveaux dénombrements des productions ture entiere. Au mon excepté le temps. Il voulut hâter ses pas, et, se Grecs et des Romains, le monde connu n'était, débarrassant sur son digne ami, Guénaud de en quelque sorte, que cette petite partie de l'an- Montbeliand, du soin d'ser cien continent dont les eaux coulent vers la Mé- celte admirable galerie où toutes les tribus des diterranée, et que cette petite mer intérieure oiseaux sont si bien représentées, il contimua sa était pour eux l'Océan.

course avec une nouvelle ardeur.

tait pour eux l'Océan.
Mais il voyait approcher le terme de sa vie, En méditant sa sublime entreprise, il résolut donc de soumettre à son examen les trois règnes et celui de ses glorieux travaux s'eloignait cha-

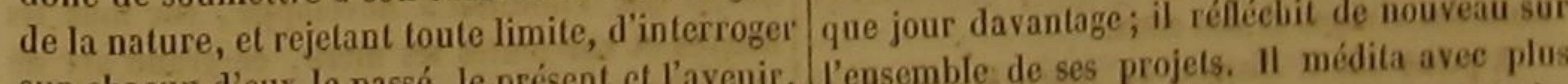
sur chacun d'eux le passé, le présent et l'avenir. lensembo do nature des objets dont il n'aCependant les années s'écoulèrent. Il avai 
vait pas encore présenté l'image.: il vit bientôt | Nous n'avions encore publié que l'Histoire des que la grandeur de ses cadres ne pourrait pas quadrupèdes ovipares; depuis nous avons donné longtemps convenir aux sujets de ses peintures; celle des serpents; et aujourd'hui nous sommes que la multitude innombrable de ceux dont il près de finir celle des poissons.

lui restait à dessiner les traits, s'opposerait in- Avant de cesser de parler de ces habitants des vinciblement à ce que chacun de ces sujets rem- fleuves et des mers aux amis des sciences natuplit une place distincte comme chacun des relles, achevons d'indiquer ceux de leurs traits oiseaux, des quadrupèdes, et même des miné- généraux, qui méritent le plus l'attention de raux, dont il s'était occupé. Il décida qu'il cher- l'observateur.

cherait une manière nouvelle pour parler des mollusques, des insectes, des vers et des végétaux. Il ne considéra plus l'histoire que l'on pourrait en faire que comme un ouvrage distinct et séparé du sien.

Se renfermant, relativement aux animaux, dans l'exposition de l'homme, des mammiferes, des oiseaux, des quadrupèdes ovipares, des serpents, et des poissons, il confondit les limites de son plan avec celles qui séparent des mollusques, des insectes et des vers, les légions remarquables des animaux vertébrés -et à sang rouge, lesquelles, par leur conformation, leurs mouvements, leurs affections, leurs habitudes, - leur grandeur, leur puissance et leur instinct, jouent les premiers rôles sur la scène du monde, et ne le cèdent qu'à l'homme, qui leur commande par le droit de son intelligenco dominatrice, et que la nature leur a donné pour roi.

L'Histoire des poissons devait done terminer dans celte vue nouvelle l'Histoire naturelle dont il avait enrichi son siècle et la postérité.

II venait de planer de nouveau sur les temp écoulés, de marquer les époques de la nature et de représenter, dans sept grands tableaux, les sept grands changements que la force irrésistible de la puissance créátrice lui paraissait avoir fait subir au globe de la terre; il allait écrire l'histoire des cétacées, pour compléter celle des mammifères, lorsqu'il se sentit frappé à des par les coups d'une maladie terrible. à mort par les coups d'une maladie terrible. II ne compta plus devant lui qu'un petit nombre d'instants; il ne se réserva, pour le complément de sa gloire, que l'histoire des cétacées ; et daign nous associer à ses travaux immortels, content d'avoir le premier tracé le plan le plus vastent d'en avoir exécuté d'ucé le plan le plus vaste, d en avoir exéeuté d'une manière admirable les principales parties, d'avoir particulièrement soumis à son génie les habitants de la terre et des airs, il nous ehargea de dénombrer et de décrire ceux des rivages et de dénom

A peine eut-il disposé en notre faveur de ce noble héritage, qu'il entra dans l'immeur de ce
Et d'abord, pour achever de faire connaitre leur instinct, parcourons d'un coup d'œil rapide tous les piéges que l'art de l'homme sur la surface entière du globe tend à leur faiblesse, à leur inexpérience, à leur audace, à leur voraeité. La pêche a précédé la culture des champs : elle est contemporaine de la chasse. Mais il y a cette différence entre la chasse et la pêche, que cetle dernière convient aux peuples les plus civilisés, et, que bien loin de s'opposer aux progrès de l'agriculture, du commerce et de l'industrie, elle en multiplic les heureux résultats.

Si, dans l'enfance des sociétés, la pêche pronourriture suffisante et salubre, si elle les accoutume à ne pas redouter l'ineonstance de l'onde, si elle les rend navigateurs, elle donne aux peuples policés d'abondantes moissons pour les besoins du pauvre, des tributs variés pour le luxe du riche, des préparations reeherchées pour le commerce lointain, des engrais fécondants pour les champs peu fertiles; elle force à traverser les mers, à braver les glaces du pole, à supporter les feux de l'équateur, à lutter contre les tempêtes; elle lance sur l'Océan des forêts de mâts, elle crée les marins expérimentés, les comerçants audacieux, les guerriers intrépides. Mère de la navigation, elle s'accroît avec co chef-d'œuvre de l'intelligence humaine. A mesure que les sciences perfectionnent l'art admirable de construire et de diriger les vaisseaux, elle muttiplie ses instruments, elle étend ses tilets, elle invente de nouveaux moyens de succès, elle s'attache un plus grand nombre d'hommes, elle pénètre dans les profondeurs des abimes, elle arrache aux asiles les plus secrets, elle poursuit jusqu'aux extrémités du globe les objets de sa constante recherche; et voilà pourquoi ce n'est que depuis un petit nombre de siecles que l'homme a développé, sur tous les fleuves et sur toutes les mers, ce grand art de concerter ses plans, de réunir ses efforts, de cure à des hommes encore à demi sauvages une
SUR LA PECHE.

629

de combiner ses opérations, de disposer du l'âge mùr, ses loisirs; à la vieillesse, ses distractemps, de franchir les distances, et d'atteindre tions; au cour sensible, le ruissean voisiu du sa proie en maitrisant, pour ainsi dire, les sai- toit pateruel; au voyageur, le repos oceupé des sons, les climats, les vents déchaìnés et les ondes peuplades dont il a envié la douce quiétude; au
bouleversées.

Mais si, au lieu de suivre l'ordre chronologi- philosophe, l'origine de l'art.

que des progrès de l'art de la péche, nous voulon- Et bientôt l'imagination franchit les espaces uous représenter ce qu'tl est, nous oxamineron et les temps; elle se transporte au moment et sur

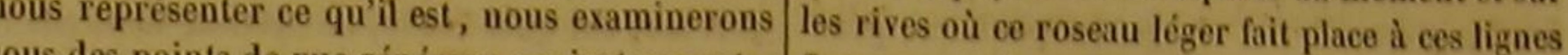
son théâtre, flottantes ou à ces lignes de fond si longues, si son théâtre, ses prineipaux objets.

Nous pouvons diviser en quatre classes les instruments ou les moyens qu'il emploie : premièrement, ceux qui attirent les poissons par des appâts trompeurs et les retiennent par des crochets funestes; deuxièmement, ceux avec lesqnels on les surprend, les saisit et les enlève, ou avec lesquels on va au-devant de leurs légions, on les cerne, on les resserre, on les presse, on les renferme dans une enceinte dont il leur est impossible de s'échapper, ou ceux avec lesquels on attend que les courants, les marées, leurs besoins, leur natation dirigée par une sorte de rivage artificiel, les entrainent dans un ospace étroit dont l'entrée est facile, et toute sortie interdite; troisièmement, les couleurs qui les blessent, les lueurs qui les trompent, les feux qui les éblouissent, les préparations qui les énervent, les odeurs qui les enivrent, les bruits qui les effraient, les traits qui les percent, les animaux exercés et dociles qui se précipitent sur eux, et ne leur laissent la ressource ni de la résistance, ni de la fuite; quatrièmement enfin, les instruments qui se composent de deux ou de plusieurs de ceux que l'on vient de voir distribués dans les classes précédentes.

Parmi les instruments de la première classe, le plus simple est celle ligne flexible, au bout de laquelle un til léger soutient un frêle hameçon caché sous un ver, sous une boulette artificielle, sous un petit fragment de substance organisée, ou sous toute autre amorce dont la forme ou l'odeur frappe l'œil ou l'odorat du poisson trop jeune, ou trop inexpérimenté, ou trop dénué d'instinct, ou trop entrainé pas un appétit vorace, pour u'être pas facilement séduit. Ouels souvenirs touchants celte ligne peut rappeler '! Elle retrace à l'enfance, ses jeux; à ramitiées, soutenues ou enfoncées avec tant do précautions, ramenées ou relevées avec tant de soins, liérissées de tant de haims ou de crochets, et répandant sur un si grand espace un danger inévitable.

Dans la seconde classe paraissent les filets; soit ceux que la main d'un seul homme peut placer, soutenir, manier, avancer, déployer, jeter, replier, retirer, ou qu'on traine comme les dragues et ganguys, après en avoir fait des manches, des poohes el des sacs; soit ceux qui, présentant une grande étendue, élevée à la sur. face de l'eau par des corps légers et flottants; maintenus dans la position la plus convenable par des poids attachés aux rangées les plus basses de leurs mailles, simples ou composés, formés d'une seule nappe ou de plusieurs réseaux paralic̀les, assez prolongés pour atteindro jusqu'au fond des rivières profondes, et assez longs pour barrer la largeur d'un grand fleuve, ou, dćployant lears extrémités de manièro à renfermer un grand espace maritime, composant une seule enceinte, ou repliés en plusieurs pares, développés comme une immense digue, ou contournés en prisons sinueuses, sont conduits, attachés, surveillés et ramenés par une entente remarquable, par un concert soutenu, par des combinaisons habilement conçues d'un grand nombre d'hommes réunis '.

et celle du 1 ibor

On trourera la description de la lowve dans Partiele du Petromyzon lamproie; celle de la folle, de la demi-folle, de celle de la madrague, de la chasse, et de la chambre de la morl, dans l'article de la Raie mobular ; celle du dranguel, Jans l'article de la Murène anguhle; chile do la drige, el du manel, dans Yarticle de la hre du tremail, des hamaux. de la loile, de la flué, dans l'arricle du Gade colin; celle da boulier, des aissaugues, des allas, des couranitiles, des engarres, dans larticle da Scombre ithon; celle du carrelet, ' Voyez la description des cordes fotlantes, des empiles,

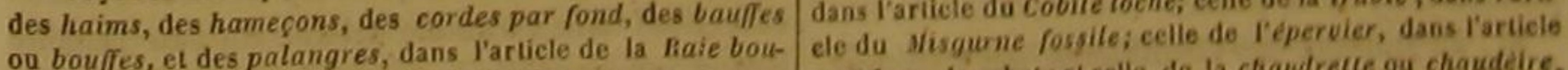

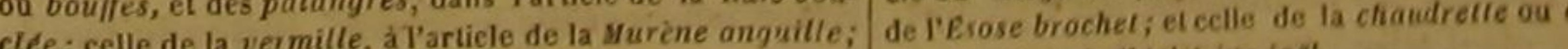
celle des lignes et des piles, à Yarticle de la Murène congre, dans l'article de l'atherine joet. 
A ta seconde classe appartiennent encore ces l'Asie, de toules les énormes chaines de monts asiles trompeurs, faits de jonc ou d'osier, ces qui dominent sur la partie sèche du globe, nou nasses perfides dans lesquelles le poisson, égaré descendons par ta pensée vers le rivage des par la crainte, ou entraîné par le besoin, ou mers, en nous abandonnant, pour ainsi dire, conduit sans précaution par le courant auquel cours des eaux qui se précipitent de ces hauteor il s'est livré, et croṿant trouver une retraite dans les bassins qu'entourent ces antiques monsemblable à celle que lui ont donnée plus d'une tagnes, sur quel ruisseau, sur quelle rivière, sur fois les grottes de ces rivages hospitaliers, pénè- quel lac, sur quel fleuve, ne verrons-nous pas la tre facilement en écartant les branches rappro- ligne ou le filet assurer au pecheur attentif la chées qui ne lui présentent, lorsqu'il veut en- récompense de ses soins et de sa peine? trer, que des tiges dociles, mais qui, lui offrant, Et lorsque, parvenus à l'Océan, nous nous lorsqu'il veut sortir, des pointes enlacées, le élèverons encore par la pensée au-dessus de sa retiennent dans une captivité que la mort seule surface pour en embrasser un b́́mieplisente termine.

Parmi les moyens de la troisième classe, doivent êtro compris ces feux que l'on allumait, dès le temps de Bélon, sur les rivages de la Propontide pour favoriser te succès des pêclies de muit ; ces plantes blanchàtres, vernies et luisantes, placées sur les bords des bateaux pêcheurs de la Chine, et qui, réfléchissant les rayons argentins de la lune, imitant la surface tranquille et lumineuse d'un lac, et trompant facilement par cette image les poissons qui se plaisent à s'élancer liors de l'eau, les séduisent au point qu'ils sautent d'eux-mêmes dans la barque, et, pour ainsi dire, dans la main du pêcheur en embuscado et caché; ces fouennes dont on perce les coryphènes chrysurus, et tant-d'autres osseux; ces tridents avec lesquels on harponne les redoutables habitants de la mer; ces cormorans apprivoisés, dont les Chinois se servent depuis si longtemps dans leurs pêches, qui saisissent avec tant d'adresse le poisson, et qu'un anneau placé autour de leur cou contraint de céder à leurs maitres une proie presque intacte.

Les grandes pêches, si remarquables par le tempsqu'elles demandent, les préparatifs qu'elles exigent, les arts qu'elles emploient, ls qu'elles exigent, les arts qu'elles emploient, les précautions qu'elles commandent, le grand nombre de bras qu'elles mettent en mouvement, et qui donnent au commerce la morue des grands bancs, le hareng des mers boréales, le thon de la Méditerrancé, et les acipensères de la Caspienne, nous offrent de grands exemples de ces moyen, composés, que l'on peut regarder comme formant une quatrième classe.

Et tous ces moyens si variés, sur quel im mense théâtre ne sont-ils pas employés par l'ar perfectionné de la pêche?

Si, du sommet des Cordillières, des Pyrénć

des Alpes, de l'Atlas, des haules des Pyrénées, usqu'a l'autre de nombreuses escadres voguer pour les progrès de l'industrie, l'accroissement de la population, la force de la marine protecrice des grands états, la prospérité générale, et a renommée des empires. Ah! dans celte moisson de bonheur et de gloire, puisse ma nation recueillir une part digne d'elle! puisse-t-elle ne mets, en faisant couler sur son territoire tant de fleuves fécondants, en la plaçant au centre des climats les plus favorisés par ses deuces et vives influenees, lui-a commandé dans tous les genres les plus nobles succès!

Quels prix attendent en effet, au bout de la carrière, le pêcheur intrépide! combien d'objets peuvent être ceux de sa recherchie, depuis les énormes poissons de trente pieds de longueur, jusqu'à ceux qui, par leur petitesse, échappeni aux mailles les plus serrées; depuis le féroce squale dont on redoute encore la queue gigan. tesque ou la dent meurtrière, lors même qu'on est parvenu a l'entourer de chaìnes pesantes, jusqu'à ces abdominaux transparents et mous, qu’aucun aiguillon ne défend; depuis ces poissons rares et délicats que le luxe paie au poids de l'or, jusqu'à ces gades, ces clupées, et ces cyprins si abondants, et nourriture si nécessaire de la múltitude peu fortunée ; depuis les argentines et les ables, dont les admirables écailles domnent à la beauté opulente les perles artificielles, rivales de celles que la nature fait croitre dans l'Orient, jusqu'aux espèces dont le grand volume, profondément pénétré d'un fluide abondant et visqueux, fournit cette huile qui accélère tant de machines, assouplit tant de substances et entretient dans l'humble cabane du pauvre cette ampe sans laquelle le travail, suspendu par de top longues nuits, ne pourrait plus a par de seul coup d'cil, nous verrons depuis un pôle jomais oublier que la nature, en l'entourant de sa nombreuse famille; depuis les poissons que ces sédiments épais, comme antant de témoins 'on ne peut consommer que très-près des para- des révolutions épronvées par le fond des ríges où ils ont été pris, jusqu'à ceux que des vières ou des mers. Les couehes qui les renferprécautions bien entendues, et des préparatifs ment sont comme autant de tables sur lesquelles précautions bien entendues, et des préparatifs ment sont comme autant de tables sur lesquelles
soignés, conservent pendant plusieurs années, la nature a éerit une partie de I'histoire du globe. et permettent de transporter au centre des plus Des hasards heureux qui donnent la facilité de grands continents; depuis les salmones, dont pénétrer jusque dans l'intérieur de la croùte de les arêtes sont abandonuées, dans les pays dis. la ferre, on la main du temps, qui l'entrourre graciés, au chien fidèle ou à la vache nourri- et en éearte les différentes portions, font découcière, jusqu’à ces gastérostées qui, répandus vrir de ces tables précieuses. On connail, par par myriades dans les sillons, s'y décomposent exemplo, eelles que l'on a trouvées au mont Bolca en engrais fertile; et enfin, depuis la raie, dont près de Vérone, non loin du lac de Constance, et la peau préparée donne cette garniture agréable dans plusieurs autres endroils de l'ancien el du la peau préparée donne cette garniture agréable dans plusieurs autres endroits do l'ancien et du
et utile, connue sous le nom de beau galuchat,
noureau continent. Mais en vain aurait-on sons $\begin{array}{ll}\text { et utile, connue sous le nom de beau galuchat, } & \text { nouveau continent. Mais en vain aurait-on sons } \\ \text { jusqu'aux acipensères et à tant d'autres poissons } & \text { les yeux ces inseriptions si importantes, si I'on }\end{array}$ dont les membranes, séparées avec attention ignorait la langue dans laqquelle elles sont écrites, de toute matière étrangère, se convertissent en sì l'on ne connaissait pas le sens des signes dont cette colle qui, dans certaines circonstances, elles sont composées.

peut remplacer les lames de verre, et que les Ces signes sont les formes des différentes pararls réclament du commerce dans tous les temps et dans tous les lieux!

Mais quelque prodigieux que doive paraitre le nombre des poissons que I'liomme eulève aux neuves et aux mers, des millions de millions de ces animaux ćchappent â sa vue, à ses instru. ments, à sa constance. Plusieurs de ces derniers périssent victimes des habitants des eaux, dont la force l'emporte sur la lear; ils sont dévorés, engloutis, anéantis, pour ainsi dire, ou platôt décomposés de manière qu'il ne reste ancune

trace de leur existence. Plusieurs antres cependant succombent isolément à la maladie, à la vieillesse, à des accidents particuliers ou menrent par troupes, empoisonnés, étouffés, ou écrasés par les suites d'un grand bouleverse écrasés par les suites d un grand bouleverse. circonstances, qu'avant de subir une altération très-marquée, leurs cadavres sont saisis par des dépôts terreux qui les enveloppent, les recouvrent, se durcissent, et, préservant leur corps vrent, se durcissent, et, préments destructeurs, de tout contact avec les éléments destructears, en font en quelque sorte des momies natu- ver Les parties solides des poissons, et notamment Actern les squelettes de poissons osseux, sont plus portant de savoir sur la conformation des parfacilement préservés de toute décomposition ties solidestinent à l'étode si instructive des pois-

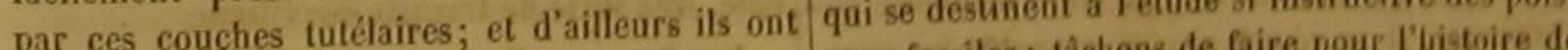
pu risister ì la corruption pendant un temps sons fosile; 1 pu res ani- la nature, ce que font pour Thistoire civile ceu bien plus long que les autres parties de ces ani- a mi enseignent à bien connaitre et la matière, el maux, avant le moment où ils ont été inerus- qui ensel le sens des diverses médailles '.

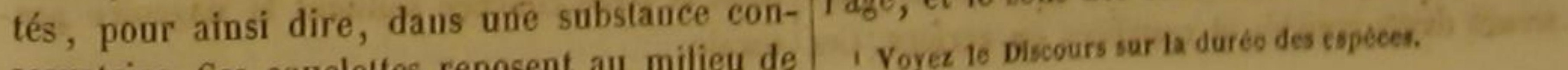


Le squelette des poissons cartilagineux, beau- / deux éminences touchent des os qui soutiennent coup plus simple que la charpente des poissons les arcs des branchies.

osseux, a été trop souvent l'objet de notre exa- Les orbites sont placées sur le sommet de la men, soit dans le Discours qui est à la tête de tête, de chaque côté d'une fossette qui reçoi cette Histoire, soit dans les articles particuliers deux branches horizontales de la màchoire sude cet ouvrage, pour que nous ne devions pas périeure.

nous borner aujourd'hui à nous occuper des

parties solides des poissons osseux. Nous a'entrerons mièce, dans les individus qui ont attrerons même pas dans la considération de tous teint un cerlain degré de développemeut.

Jes détails relatifs à ces parties solides et osseuses. Les ares des trois branchies extérieures sont Nous éviterons de répéter ce que nous avons composés de deux pièces. Ceux de lá droite se déjà dit en plusieurs endroils. Mais pour avoir réunissent en formant un angle aigu avec ceus une idée plus complète de cette charpente, de la gauche, dans l'intérieur de la mảchoire innous l'observerons dans les poissons du second, férieure.

du troisième et du quatrième ordre de la seconde Au-dessous du sommet de cet angle aigu, on sous-classe, comme dans ceux qui présentent le aperçoit deux lames osseuses, triangulaires, réuplus grand nombre des parties et des formes qui nies par devant, transparentes dans leur milieu, appartiennent aux animaux dont nous écrivons étroites vers leurs extrémités, inclinées ét étenl'histoire.

Et cependant, pour donner plus de préeision à notre pensée et à son expression, au lieu de nous contenter d'établir des principes généraus sur la conformation du squelette des jugulaires et des thoracins de la première division des osseux, c'est-à-dire des auimaux du second et du troisième ordre de cetle sous-classe, faisons connaître, dans chacun de ces ordres, la charpente d'une espèce remarquable.

Observons d'abord, parmi les jugulaires, l'Uranoscope rat, et disons ce qui compose son squelette.

Chaque côté de la màchoire inférieure est formé de trois os; ces deux côtis par un cartilage, et garuis d'un seul rang de dents grandes, pointues, et séparées l'une de l'autre.

La mâchoire supérieure est plus arrondie beaucoup moins avancée est plus arrondie et les deux côtés de cette mâcho dessous hérissés de plusieurs rangs de dents petites, herissés de plusieurs rangs de dents petites, à
presque égales et crochues.

Un os triangulaire et allongé règne au-dessus et un peu en arrière de chacun des côtés de mâchoire supérieure.

L'os du palais présente plusieurs rangées de dents crochues et petites. Il se divise en denx branches qui imitent une seconde màchoire supérieure. Il se réunit aux os auxquels les opercules sont attachés.

A la base de l'os du palais, on voit deux émideur de l'orbite, on voit un trou de la grannences un peu lenticulaires, garnies de plu- dont la pièce courbée soutient la nageoire pec-
sieurs dents courtes et courbées en arrière. Ces lorale. Ces lames sontiennent les rayons de la membrane branchiale, qui sont simples, sans articuation, et au nombre de cinq ou de six de chaque

Chaque opercule est de deux pièces. La première montre quatre pointes vers le bas, et la seconde en présente une.

L'opercule bat sur la clavicule. partie supérieure et postérieure de la seconde pièce de l'opercule, jusqu'au-dessous des os qui soutiennent les ares osseux des branchies. Elle s'y réunit, sous un angle aigu, avec la clavicule te la màchoire supérieure.

Le bout postérieur de la clavicule se termine par une épine longue, forte, sillonnée, et tour-

A la base de cette épine, la clavicule s'attache la partie postérieure du crâne par deus osse-

On remarque derrière la clavicule deux pic̀ces, l'une placée en bas et presque droite, l'autre située en arrière et courbée.

Ces deux pièces, dont la séparation disparait avec l'age de l'individu, forment, avec la claviune sorte de triangle curviligne.

Une torale.
La base des nageoires jugulaires est placée Dans l'angle formé par chacune des deux presque au-dessous des yeux. branches de la mâchoire d'en laut et le côte Les ailerons de ces nageoires, très-minces et qui lui correspond, on découvre un petit os lentransparents, se réunissent de manière à repré- ticulaire, ou à peu près.

senter une sorte de nacelle placée obliquement Ces deux branches, inclinées en arrière et de haut en bas, et d'avant en arrière. Cette na- vers le bas, pénètrent jusqu'à une cavité arcelle a sa concavité tournée du còté de la tête, rondie, creusée dans l'os frontal, et dont le et sa proue touche à l'angle formé près du mu- haut des parois est bizarrement plissé.

seau par la réunion des arcs osseux des branchies.

Faisons attention à celte position des ailerons : elle est un des caractères les plus distinctifs des ordres de poissons jugulaires.

La poupe de cetle même nacelle, à laquelle les nageoires jugulaires sont attachées, offre une épine forte, sillonnée, presque semblable à celle des clavicules, et dont l'estrémité abouti auprès de l'angle produit par la réunion de ces deux derniers os.

Le derrière de la tête montre une lame mince

La clavicule s'étend obliquement, depuis la du côté opposé, à peu près all-dessous du bord et tranchante; et cette lame est découpée de manière à finir par une pointe qui s'attache à l'apophyse supérieure de la première vertèbre.

Cette vertèbre et la seconde sont dénuées de côtes. Les neuf vertèbres suivantes ont chacune une côte double de chaque eôté.

Sur les troisième, quatrième et cinquième vertèbres, chaque côte double est placée au-dessus de l'apophyse transverse, et à une distance d'auttant plus grande de cetle apophyse, qu'elle est plus près de la tête.

Les douzièmes, treizième, quatorzième, quinzième et seizième vertèbres n'ont que des apoxième et seizième vertebres n'ont que des apo-
physes transverses extrêmement petites : mais elles offrent une apophyse inférieure; et quoiqu'elles soient siluées au delà de l'anus, chacun de leurs côtés est garni d'une cote simple, plus courte, à la vérité, que les côtes doubles.

La dix-septième vertèbre et les suivantes, jusqu"à la dernière qui est la vingt-cinquième, n'ont ni êtes ni apophy̧ses transverses.

Maintenant ayons sous nos yeux te squelette des poissons thoracins.

Voici celui de la Scorpène horrible.

Trois os forment chacun des côtés de la mâchoire inférieure. Ces côtés sont réunis par un cartilage, et garnis de dents très-petites, aiguès et rapprochées.

La màchoire supérieure, beancoup moins avancée que celle d'en bas, plus arrondie que arelte deribre, est d'allours hérissée de dents cette dernière, est d'aillours hère inférieure.
Un os allongé et triangulaire est appliqué an dessus et un peu en arrière de chaque cóté de la mâchoire supérieure. Il aboutit au petit os lenticulaire dont nous venons de parler.

L'os du palais se divise on deux branches, qui ressemblent à une seconde màchoire supérieure, que la première entourerait. Ces branches ne sont cependant garnies d'aucune dent: chacume se réunit à l'os latéral auquel l'opercule est attaché.

A la base de l'os du palais paraissent deux éminences osseuses, ovales, presque lenticuen arrière. Ces éminences touchent les os qui s'unissent aux ares des branchies.

L'orbito est placéo près du sommet de la tête, auprès de la fossette du milieu, et ses bords relevés diminuent le champ de la vue.

L'os de la pommette, un peu triangulaire el rés-plissé, présente plusieurs crêtes. Son angle le plus aigu aboutit à un petit os placé entre l'orbite et l'os triangulaire et latéral de la mâchoire supérieure.

Ce petit os représente une étoile à cinq ou six rayons relevés en arête.

La partie supérieure et postérieure de la tete est rehaussée par deux crêtes hautes et plissées, placées obliquement, et qui forment trois cavités, l'une postérieure et les autres latérales.

Les arcs des trois branchies extérieures d'un côté se réunissent, dans l'intérieur de la mâchoire d'en bas, avec les ares analogues de l'autre coté. Deux pièces composent chacun de ces ares. $\mathrm{Au}$-dessous du sommet de l'angle aigu que forment ces six arcs, on voit deux lames osseuses qui se séparent et s'étèndent jusqu'aux oper-

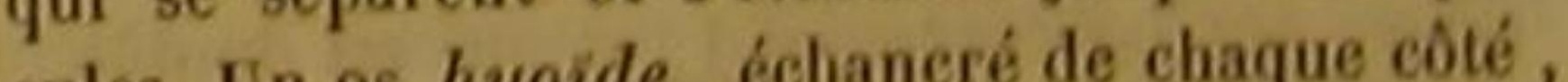
cules. Ua os hyossus de l'endroit où ces lames soní jointes; et un osselet aplati, découpé en losange et presque vertical, est situé au-dessous de ce mếme endroit.

Ces lames soutiennent les rayons de la memCes rames soutiennent les rayons sont au nomlaires, hérissées de dents petites et recourbées 
bre de cinq ou six, et leur contexture n'offre pas $\quad$ On peut la nommer articulation à choínette. d'articulation.

Elle est en effet, composée de deux anueaus os-

Deux pières forment chaque opercule. On seux et complets, dont l'un joue dans l'autre comple cinq pointes sur la première, et trois sur comme l'anneau d'une chaine se meut dan la secoude.

l'anneau voisin qui le retient.
line se meut dans L'opercule bat sur la clavicule, qui se réunit Il est aisé à tous ceux qui se sont occupés a vec la clavicule opposée, au-dessous des os qui d'ostéologie, de voir que, par une suite de cette soutiennent les arcs des branchies, et à peu près construction, l'annent qui se re suite de ct périeure.

Un os terminé par une petite épine, une apophyse aplatie et un peu arrondie, et un os aplati et plissé, font communiquer la clavicule avec la partie postérieure et latérale du erâne.

Au-dessous et au delà de la clavicule, on trouve une pièce étroite, et ensuite une autre pièce large, mince, un peu arrondie, qui montre dans son milieu plusieurs parties ovales, vides, ou trèstransparentes et cartilagineuses, et qui sert i maintenir la nageoire pectorale.
mai sert à Mais voici le caractère le plus distinetif des
thoracins.

La base des nageoires thoracines est placée au-deszous de la partie postérieure du crâne. Leurs ailerons sont très-minces et trausparents. La nacelle que forme leur réunion, est placée obliquement du haut en bas et d'avant en arrière.

La proue de la nacelle est bien moins avancée que dans les poissons jugulaires.

Au lieu de toucher à l'angle formé par la réunion des ares des branchies, elle aboutit seulement à l'angle que produit la jonetion des deux clavieules.

Les apophyses supérieures de l'épine du dos sont très-êlevées. Les einq premières vertèbres n'ont que des que verticalement. apophyses transverses, à peine sensibles; les sillons et des arêtes qui convergent vers la párla sixième vertèbre offrent point. Mais dès tie la plus basse; et c'est dans cette partie la la sixième vertèbre, les apophyses inférieures plus basse, située presque au-dessous de la londe l'anus, Aussi des peuf auprès de la nageoire gue apophyse, que l'on découvre deux véritachaque côté, chacine deuf cỏtes que l'on voit de bles anneaux.

elle altachée à l'estrémité duatre dernières est- Chacun de ces anneaux retient un des deux relle altachée à l'estrémité de l'apophyse infé- premiers rayons aiguillonnés de la nageoire de Avant de cesser de nous qui est double. l'anus, dont la base percée forme elle-même un pente des thoracins, indiquoner de la char- autre anneau engagé dans l'un de ceux du sphéd'une nature particulière, qui avaiticulation roide aplati.

tous ceux qui avaient traité de l'ostéchappé à Cependant, que nous reste-t-il à dire au sujet tous ceux qui avaient traité de l'ostéologie, et du squelette des poissons?
que nous avions découverte et erposée dans

que nous avions découverte et exposée dans nos
cours publics au Muséum d'bistoire natus plusieurs de ces animaux, comme dans dès l'an 3 de l'ère française. crâne n'est qu'un espace vide par lequel pas- vertèbre de la queue. Celle apophrse est sonvent sent les nerfs olfactifs'. Dans d'autres poissons, tels que les raies et très-grande, et quelquefois terminée par un less suales, ces mêmes nerfs sortent de l'inté aiguillon qui parait en deliors.

rieur du cràne par deux trous éloignés l'un de Dans les abdominaus, les ailerons des nal'autre. geoires ventrales, que l'on a nommés os du bas-

Les fosses nasales des raies, des squales, des $\sin$, ne s'articulent avee aucune portion de fa trigles et de plusieurs autres poissons, sont os- charpente osseuse de la tête, ni des clavicules, seuses; celles de beaucoup d'autres en partio ni de l'épine du dos.

osseuses et en partie membraneuses.

Ils sont, ou séparés l'un de l'autre, et main-

Le bord inférieur de l'orbite, au lieu d'être tenus par des ligaments; ou soudés, et quelquecomposé d'une seule pièce, est formé, dans fois épincux par devant, comme dans quelques quelques poissons, par plusieurs osselets articu- Silures; ou réunis en une. seule pièce éehanlés les uns avec les autres, ou suspendus par erée par derrière, comme dans les Loricaires; des ligaments.

Le tubercule placé aut-dessous du trou ooci- trímil qui soutient la ventrale, pital, et par lequel l'occiput s'altache à la co- comme dans l'Ésoce broohet; ou trìs-petits et lonne vertébrale daus le plus grand nombre de rapprochés, comme dans la Clupée hareng; ou poissons, s'articule avec celle colonne par le allongés et coutigus par derrièro, comme daus moven de cartilages, et par des surfaces telles, le Cyprin carpe.

que le mourement do la tote sur l'épine dersale Craignons cependant de fatiguer l'attention do est extrêmement borné dans tous les sens. ceus qui cultivent l'histoire naturelle, et pour-

Claque vertèbre de poisson présente, du cóté suivons notre route vers le but auquel nous tende la tête et du côté de la queue, une cavité dons depuis si longtemps, et que maintenant conique, quí se réunit avec celle de la vertébro nous sommes près d’atteindre. voisine.

En cherchant, dans le premier Discours de II résulte de celte forme, et de cette position, cel ouvrage ', à réunir dans un seul tableau les que la colonne dorsale renferme une suite de traits généraux qui appartiennent à tous les cavités dont la figure ressemble à celle de deux poissons, nous avons été obligés de laisser quelcônes opposés par leur base.

Ces cavités communiquent les unes avec les autres par un très-petit trou placé au sommet de chaque cone, au moins dans un grand nombre d'espèces. Leur série formẹ alors ce tuyau alternativement large et resserré, dont nous avon parlé dans le premier Discours de cette Histoire.

Les apophyses épineuses, supérieures et infé rieures, sont très-longues dans les poissons trèscomprimés, comme les Chélodons, les Zées, le Pleuronecles.

La dernière vertèbre de la queue est le plus souvent triangulaire, très-comprimée, et s'attache à la caudale par des facelles articulaires, dont le nombre correspond à celui des rayons de cette nageoire.

La cavité abdominale est communément terminée par l'apophyse inférieure de la première

- Tost lo monde sait combien notre savant collégue et ex- Tout le monde sail combien notre savant colleggue et excellent ami M. Cuvier a répandu de lumiertes nouvement sur les organes interieurs des polsons, cone l'on consulte ser les parties solides de ces asi. ques-uns de ces traits faibienent prononcés :

tâchons de leur donner plus de force et de viracité.

On peut se souvenie que nous avons expos dans ce Discours quelques conjectures sur I respiration des poissons. Nous y avons dit qu'il ri'était pas invraisemblable de supposer que les branchiés des poissons décomposent l'eau, comme les poumons des mammiferes el des oiseaux décomposent l'air.

Nous avons ajouté que, lors de cetle déeomreau, se combinait ayec le sang des poissons, peau, so combinail avec to sang des polsons, pour entretenir les qualités et la circulation do ce fluide, et que l'autre élément, le gaz inflammable ou hydrogène, s'échappait dans l'eau ot ensuite dans l'atmosphère, ou, dans certaines et l'es-

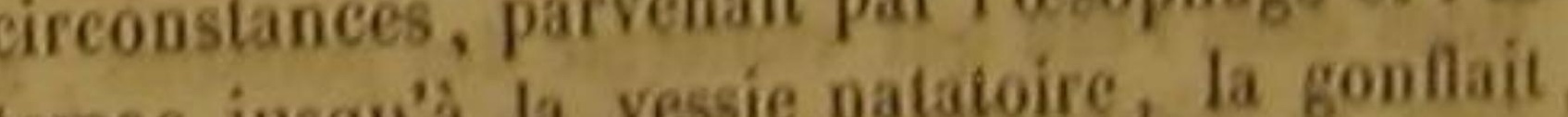
comac jasquá la vessie aa et, augmentant la légereté spéciuque do l'onimal, facilitait sa natation. Nous avons parlé, h i Discours sur la naluré des poissons. psition, l'oxygène, l'un des deux éléments de 
l'appui de cette opinion, du gaz inflammable imprégnée de gaz funestes pour faire périr des que nous avions trouvé dans la vessie natatoire poissons, conserve leur vie en neutralisant ces de quelques Tanches.

Une conséquence de celte conjecture est que les poissons doivent vivre dans l'eau qui contient le moins d'air atmosphérique répandu entre ses molécules.

M. Buniva, président du conseil supérieur de santé à Tứrin, vient de publier un mémoire dans lequel il rapporte des expériences qui prouvent la vérité de celte conséquence.

Ce savant physicien annonce que des $C_{y-}$ prins tanches, et par conséquent des individus de l'espèce de poisson dont la vessie natatoire nous a présenté de l'hydrogène, ont été mis dans une eau que l'on avait fait bouillir pendant une demi-heure, et jui s'était refroidie sans contact avec l'air atmosphérique, et qu'ils y ont vécu aussi bien que dans de l'eau du Pô bien aérée.

Cette faculté qu'ont les branchies de décomposer l'eau, rend plus probable la verlu que nous avons attribuée à plusieurs autres organes intérieurs des poissons, et par le moyen de laquelle ces animaux peuvent altérer ce fluide, le décomposer, se l'assimiler, et s'en nourrir.

Ces derniers faits sont d'ailleurs prouvés par l'expérience. On sait que l'on peut faire vivre pendant longtemps des individus de plusieurs espèces de poissons, en les teuant dans des vases dont on renouvelle l'eau avant que des exhalaisons malfaisantes l'aient corrompue, cependant sans leur donner aucun autre a cependat
ment.

A la vérité, M. Buniva nous apprend dan son mémoire que ces animalcules si difficiles voir, même avec une loupe, que l'on nomm infusoires, et qui pullulent dans presque toute les eaux, servent à la nourriture des poissons. Mais les faits suivants, dont nous dorons connaissance à cet habile naturaliste, dovons vent-ils pas l'action diecte nroul'eau l'eau sur les organes digestifs, et sur la nutrition des espèces dont nous achevons d'écrire
l'histoire?

Une dissolution de certaines substances salines dans l'eau qui renferme des poissons, altère et détruit les couleurs brillantes de alanimaux.

Et de plus, une quantité de soufre, mise dans quarante-huit fois son poids d'une eau assoz gaz.

Nous avons vu aussi dans le premier Discours Histoire, que les poissons supportaient, san mourir, le froid des contrées polaires, qu'ils s'y engourdissaient sous la glace, qu'ils y passaient l'hiver dans une torpeur profonde, et qu'au retour du printemps, ils étaient rappelés à la vie par la douce influence de la chaleur du soleil, après que la fonte des glaces avait ouvert leur prison. Quelque violent que soit le froid, ils peuvent résister à ses effets, pourvu qu'il ne se fasse sentir que par degrés, qu'il ne s'accroisse que lentement, et qu'il n'arrive que par des nuances très-nombreuses à toute son intensité.

Mais M. Buniva nous dit dans son important mémoire, qu'un refroidissement subit et violent, tel que celui qu'on opère par un mélange de glace et de muriate calcaire, donne la mort aux poissons qui en éprouvent l'attaque forte et soudaine.

C'est une grande preuve des suites funeste que tout changement brusque doit avoir dan les corps organisés. En effet, la chaleur naturelle des poissons, bien loin de s'élever à plus de trente degrés, comme celle de l'homme, des mammifères, et des oiseaux, n'est que de deux ou trois degrés au-dessus de celui de la congélation. Lorsqu'un poisson est exposé subitement à un refroidissement très-grand, la température de ses organes intérieurs parcourt, pour arrive à un froid extrême, une échelle bien plus court que celle qu'est forcée de parcourir la température d'un mammifère ou d'un oiseau placé dans les mêmes circonstances; et cependant il ne peut résister aux modifications qu'il ressent, i succombe sous l'action précipitée qu'il éprouve, il est détruit, pour ainsi dire, en mêne temps qu'attaqué.

Quand l'homme écoutera-t-il donc les leçons que la nature lui donne de tous côtés? quan ses passions lui permettront-elles de voir qu'en tout les commotions rapides renversent, brisent, aneantissent, et que les mouvements ordonnés, nés par de longues séries de variations insensibles, sont les seules qui produisent, dévelopent, perfectionnent et fécondent?

Nous avons eu sous les yeux de grands exemou dans plusieurs articles particuliers de celle les accélérations graduées, les changements ame-
SUR LA PECHE.

ples de celte importante vérité dans tout le cours modes de la matière, le signe éclatant de son de cet ouvrage.

essence merveilleuse,

Soit que nous ayons examiné les propriétés $\quad$ Mais il est temps de terminer ce Discours. dont jouissent les différentes espèces de pois- Peut-être est-ce le dernier que j'adresse aux sons ', et que, pour mieux les connaitre, nous amis des sciences naturelles. Trente ans, j'ai ayons comparé ces qualités aux altributs des travaillé pour leurs progrès. Le coup affreuy oiseaux; soit qu'abandonnant le présent, et qui m'a frappé lorsque la mort m'a enlevé une nous élançant dans l'avenir et dans le passé ${ }^{2}$, épouse accomplie, a marqué près de moi la fin nous ayons porté un œil curieux sur les modi- de ma carrière. Tant que je serai condamné à fications que ces espèces ont subies, et sur celles supporter un mallieur sans espoir, je m'efforqu'elles subiront encore, nous avons toujours cerai de consacrer quelque monument à la vu la nature nuancer son action ainsi que ses science. Mais le fardeau de la vie pèsera trop ouvrages, user de la durée comme du premier sur ma tête infortunee, pour ne pas amener bieninstrument de sa puissance, ne pas laisser plus tôt la fin de ma douleur. Des naturalistes plus d'intervalle entre les actes successifs de sa force favorisés que moi peindront d'une manière dicréatrice qu'entre les admirables produits do gne de la nature les immenses tableaux et les celte force souveraine, graduer les temps comme grandes catastrophes dont je n'ai pu donncr les choses, et appliqquer ainsi à toutes les mani- qu'une faible idée. Qu'ils daignent se souvenir festations de son pouvoir, comme à tous les que ma voix aura prédit leurs sucè̀s immortels, 1 Discours sur la nature des poissons, el trolsième Vue de el qu'ils chérissent ma mémoire.

la nature.

${ }^{2}$ Discours sur la durée des cespeces; etcelul qui est intitule Paris, lo s mars 1803. 


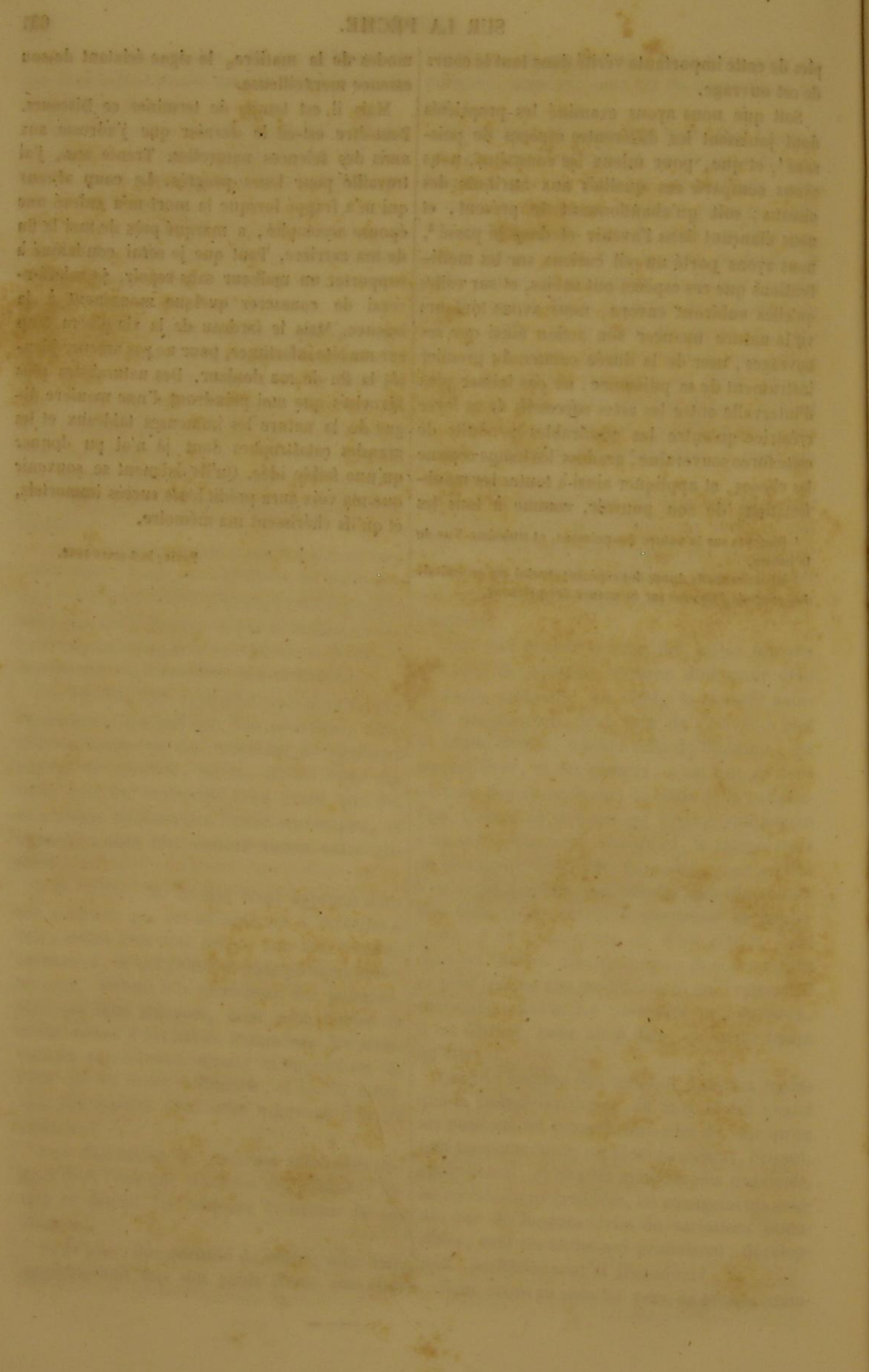

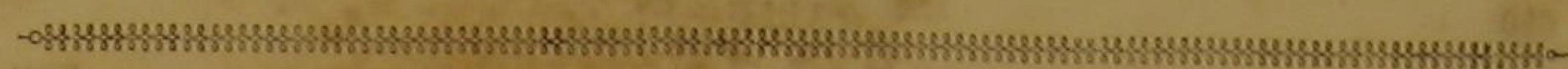

\section{TABLE}

\section{DES ARTICLES CONTENUS DANS CE VOLUME.}

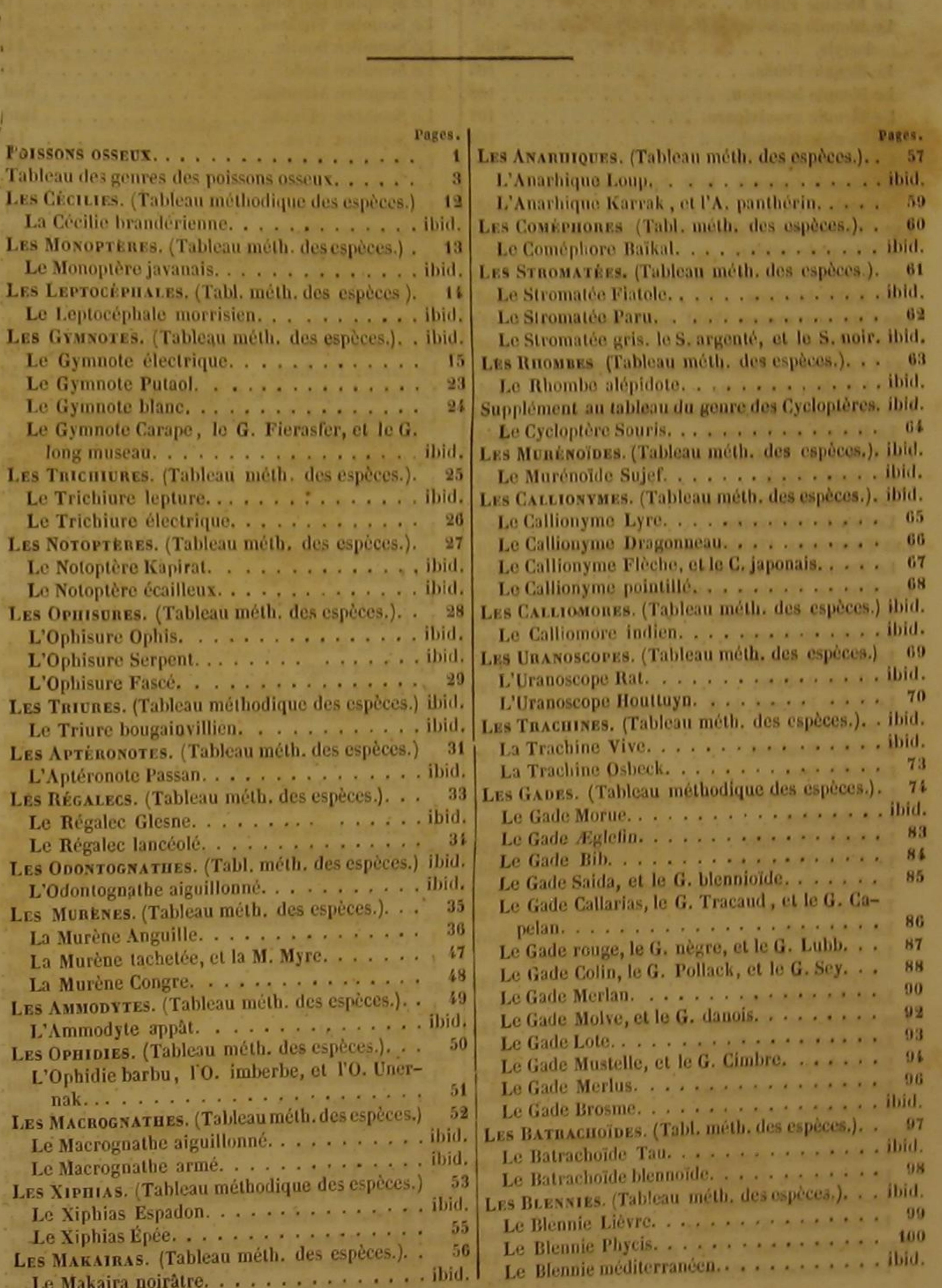

Les Maksiras. (Tableau méth. des espèces.).

Le Bennie méditerranéen........... ibid 
Le Blennie Gattorugine.

101 Les Gobiésoces. (Tableau méth. des espèces, Pages.

Le Blennie sourcilleux. .

Le Blennie cornu, le B. tentaculè, le B. Sujê-

fien, et le $B$. fasc

e Blennie Coquillade. . . . . . . . . . . .

e Blennie santeur.

Le Blennie Pinaru. . . . . . . . . . ibid

Le Blennie gadoìde, le B. Belette, et le B. tri-

dactyle.

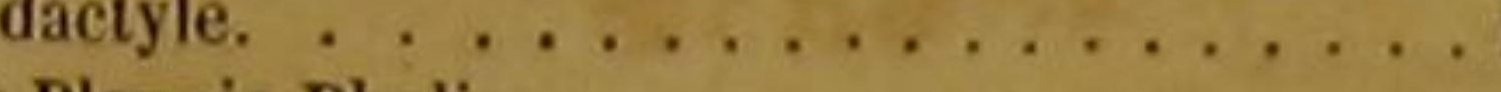

Le Blennie Pholis. . . . . . . . . . . 105

Le Blennie bosquien.

Le Blennie ovovivipar.

Le Blennie pointillé.

Blennie Garamit, le B. Lumpène, et le B.

Torsk.

LEs OLigopodes. (Tableau méth. des espèces.)

L'Oligopode vélifêre.

LEs Kontes (Tableau méth. des espèces.

Le Kurte blochien. . . . . . . . . . . . . . i ibi
Les Crnysostnomes. (Tabl. méth. des espèces.) Le Chrysostrome fiatoloīde. . . . . . . . . ib

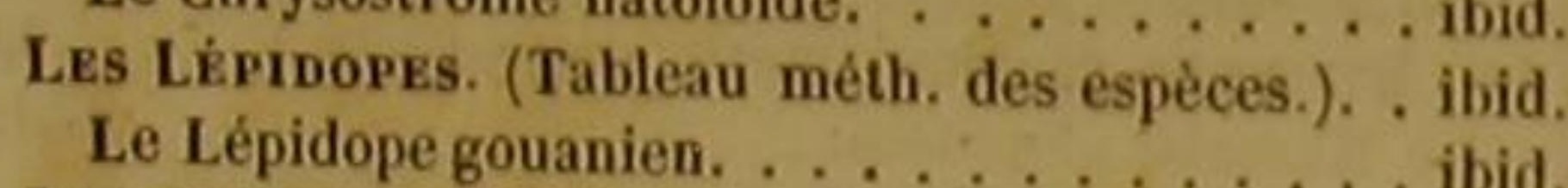

Hiatules, (Tableau méth, des espèces.)

La Hiatule gardénienne.

LEs Cépoles. (Tableau méthodique des espèces.

Le Cépole Tænia.

Le Cépole serpentiforme.

Le Cépole trachyptère.

LES Tanioīdes. (Tableau méth. des espèces) . .

Le Tæniō̃de hermannien.

LEs GoBiss. (Tableau méthodique des espèces . . i Le Gobie pectinirostre.

Le Gobie lancéolé. . . . .

Le Gobie lancéole.

$\ldots \ldots \ldots \ldots$ ibi

Le Gobie Paganel, le G. ensanglante , et le G.

noir-brun. .

Le Gobie Boulero

Le Gobie Bose. . . . . . . . . . . . 121

Le Gobie arabique, et le $\mathrm{G}$. Jozo. . . . . . . . ibid

Le Gobie blen. .

Le Gobie Plumier. .

Le Gobie Thumberg. . . . . . . . . . . . 123

Le Gobie Éléotre, et le G. nébuleux. . . . . . . . ibid
Le Gobie $A$ waou.

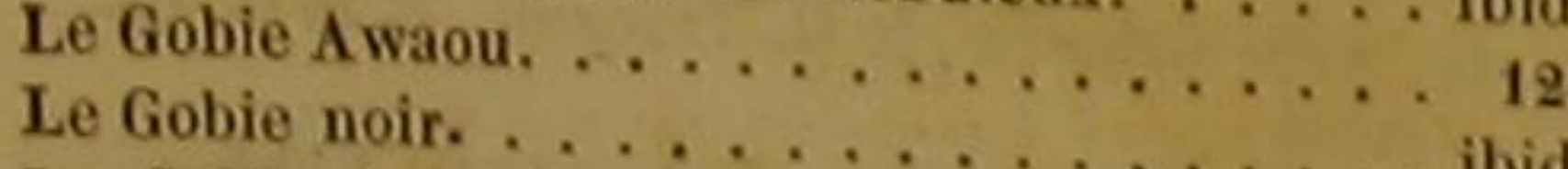

Le Golie Lagocéphale, le G. menu, et le G.

e Gobie Schlosser.

Le Gomie scher. ......... 12

Les Gosioioss. (Yableau méth. des espèces.). . .

Le Gobioìde smyrnéen... . . . . . . . . ibid

Le Gobioìde Broussonnet. . . . . . . . . . 127

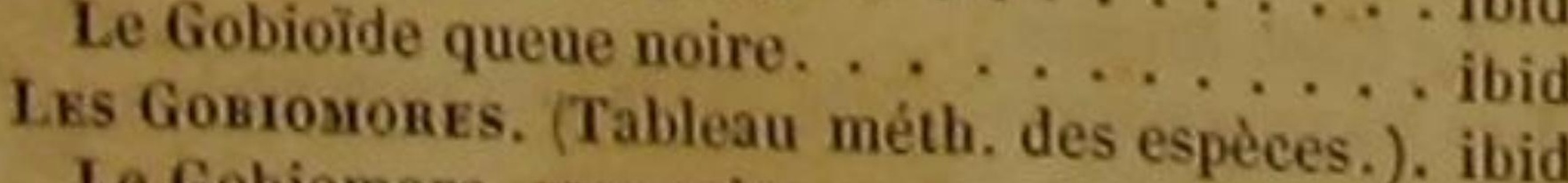

Le Gobiomore granovien. . . . . . . . . . . ibid

Le Gobiomore Taiboa. . . . . . . . . . 128

Le Gobiomore dormeur. . . . . . . . .

Le Gobiomore Koelreuter. . . . . . . . . 129

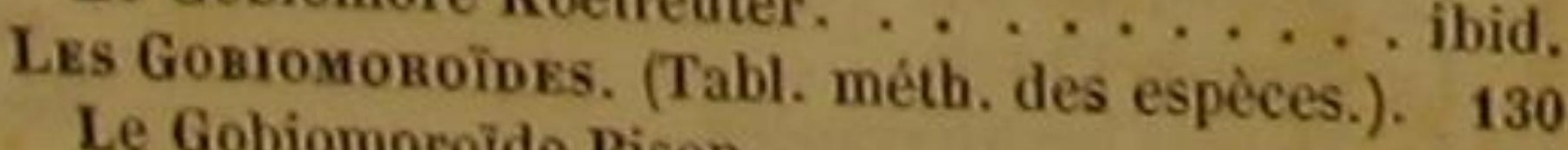

Le Gobiomoroìde Pison. . . . . . . . . ibid
Le Gobiésoce Testar.............. 130 Les Scombres. (Tableau méth. des espèces.). . . 131 Le Scombre Commerson. . . . . . . . . . . ibid Le Scombre Guare.. . . . . . . . . . . . . 13 Le Scombre Thon. . . . . . . . . . ibid Le Scombre Germon. . . . . . . . . . . . . Le Scombre Thazard. . . . . . . . . . . 14 Le Scombre Bonite. . . . . . . . . . . . 145 Le Scombre Alatunga. . . . . . . . . . ibid Le Scombre chinois. . . . . . . . . . . ibid Le Scombre Atun. . . . . . . . . . . . Le Scombre Maquerean. . . . . . . . . . . . ibid Le Scombre japonais. . . . . . . . . . . . 15 Le Scombre doré. . . . . . . . . . . . . . ibid Le Scombre Albacore. . . . . . . . . . . . . 155 Les Scosrékroīoes. (Tabl. méth. des espèces.). . . . ibid. Le Scombéroïde de Noēl . . . . . . . . . . . ibid Le Scombérō̃de commersonnien. . . . . . . . . . ibid 150

Le Scombéroìde sauteur. . . . . . . . . . . . ibid Les Caranx. (Tableau méthodique des espèces.) 157 Le Caranx Amie, et le C. queue-jaune. . . . . . 159 Le Caranx fascé, le C. chloris, et le C. crume-

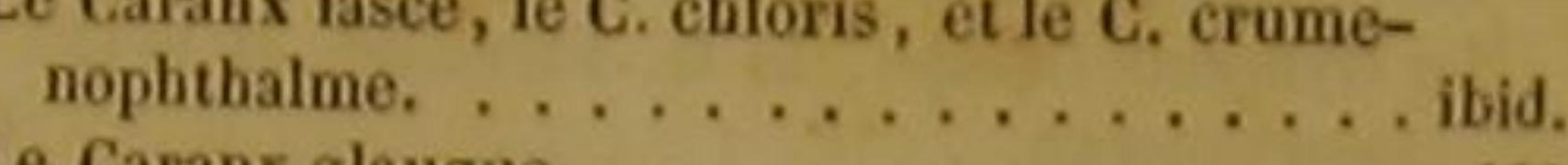

Le Caranx glauque. . . . . . . . . . 160 Le Caranx blange, et le $\mathrm{C}$. queue-rouge. . . . . ibid. Le Caranx filamenteux. . . . . . . . . . . . 161 Le Caranx Daubenton. . . . . . . . . . . . . . ibid. Le Caranx très-beau. . . . . . . . . . . . ibid. Le Caranx Ferdeau, le C. Gæoss, le C. Sansun,

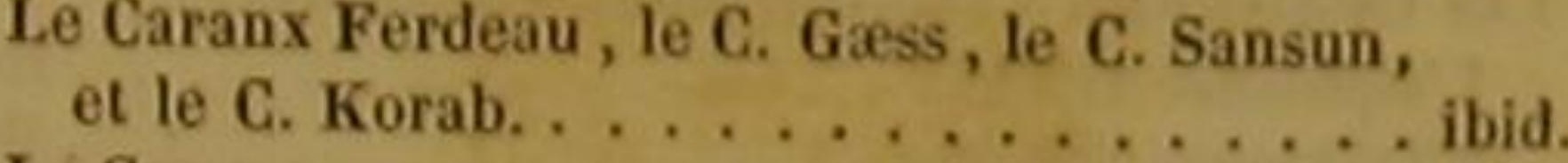

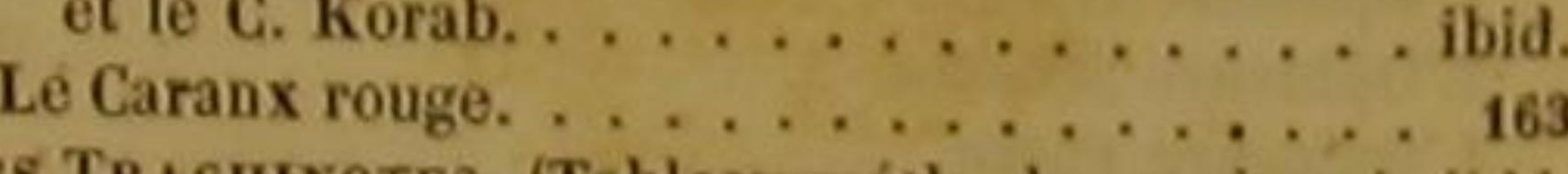
Les Trachivotes. (Tableau méth. des espèces.). ibid. Le Trachinote faucheur. . . . . . . . . ibid Le Caranxomore plumiérien. . . . . . . . . ibid. Le Caranxomore Pilitschei. . . . . . . . . . ibid. Le Caranxomore Sacrestin. . . . . . . . . . Les Casso. (Tableau méth. des espèces.). . . . . ibid. Le Cæsio Azuror. . . . . . . . . . . . . ibid

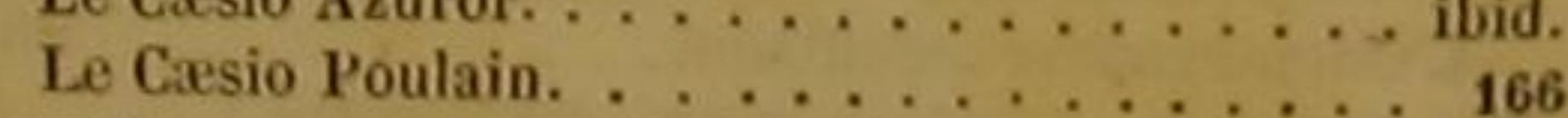
Ges Casionores (Tableau mèth. des espèces.). . . 167 Le Casiomore Baillon. . . . . . . . . . ibid. Le Casiomore Blocb. . . . . . . . . . . . . . ibid. Es Conis. (Tableau méthodique des espèces.). 168 Le Coris Aigrette. . . . . . . . . . ibid.

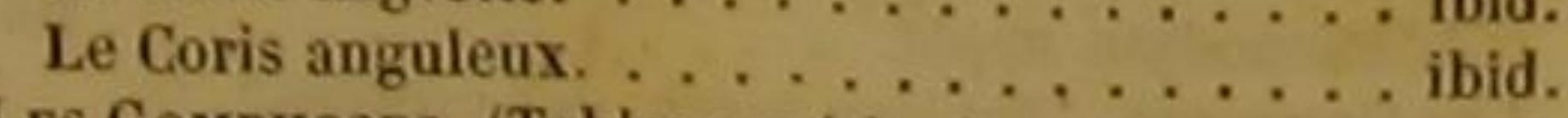
Les Gomphoses. (Tableau méth. des espèces ). . 169 Le Gomphose bleu. ............. . ibid. Le Gomphose varié. . . . . . . . . . . ibid. LEs Nasoss. (Tableau méth. des espèces.). . . . 170 Le Nason Licornet. . . . . . . . . . . . ibid. Le Nason Loupe. . . . . . . . . . . . 171 Le Kyphose double-bosse. . Les OspHronkmEs. (Tableau méth. des espèces.) ibid. Osphronème Goramy. . . . . . . . . . ibid. Le Scombre sarde. . . . . . . . . . . . Le Caranx Trachure. . . . . . . . . . . 158 Le Caranx Plumier, et le C. Klein. . . . . . . . ibid. Les Caranxomores. (Tabl. méth. des espèces.). 16
Les Trichopodes. (Tableau méth. des espèces). $\begin{array}{r}\text { Pages. } \\ 17 i\end{array}$ Le Trichopode mentonnier. . . . . . . . . ihis Le Trichopode trichoptère . . . . . . . . . 1775 Les Movod activess. (Tableau méth. des espèces). 176 Les Plectonuroves. (Tableau méth.des espèces) i ibid. Le Plectorhinque chétodonoìde. . . . . . . . .

Les Pogonias. (Tableau méth. des espèces). . . Le Pogonias fascé.

Les Bostrixcurs. (Tableau méth. des espèces)

Le Bostryche chinois.............

Le Bostryche tacheté ..............

Le Bostaychoĩdes. (Tableau méth des espèces)
Le cillé

Les Écuéxírs. (Tableau méth. des espèces).

L'Échénéis Rémora

L'Echènéis Naucrate.

Ls Macroores. (Tableau méth. des espèces)

Le Macroure Berglax

es Conypuexes. (Tableau mèth, des espêces)

Le Coryphène Hippuras.

Le Coryphène Doradon.

Le Coryphène Chrysurus .

Le Coryphène scombérō̃d

Le Coryphène onde.

Le Coryphène Pompile

Le Coryphène bleu .

Le Coryphène Plumier

Le Coryphène Rasoir

Le Coryphène Perroque

Le Coryphène camus...

Le Coryphène rayé.

Lo Coryphène chino

Le Coryphìne pointi

Le Coryphène vert, et lo C. casqu

Les Hе́мпте́нохотеs. (Tablean méth. des esp.). L'Hémiptéronote Cinq-Taches.

L'Hémiptéronote Gmelin

Les Consphexoiprs. (Tableau méth. des esp.).

Le Coryphénoīde Houttuynie

Les Aspidophones. (Tableau meth. des espèces) ibis.

L'Aspidophore armé .

L'Aspidophore Lisiz

es aspidophonoídes. (Tableau méth. des esp. .

L'Aspidophoroīde Tranquebar

LEs Cotrirs. (Tableau méth. des espèces)

Le Cotte grognan.

Scorpion.

Le Colte Quatre-Cornes.

Le Colte raboteux.

Le Cotte austral. .

Le Cotte insidiateur.

Le Cotte Madégasse.

Le Cotle noir...

Les Scorpexas. (Tableau méth. des espices)

La Scorpène horrible

La Scorpène africaine

La Scorpène épineuse. . .

La Scorpène aiguillonnée.

La Scorpène marseillaise ...
La Scorpène Brachion.

La Scorpène Rascasse, . . . . . . . . . . . . ibid

La Scorpène Mahe, . . . . . . . . . . . . . . ibid . . . . . . .

La Scorpène Truie. . . . . . . . . . . . . . . . 2.

La Scorpène Plumier. . . . . . . . . . . . . . . . ibid

La Scorpene didactsle. . . . . . . . . . 21

La Scorpène antemnio . . . . . . . . . . . . Bhid.

La Scorpène volante. . . . . . . . . . . . . ibid

Les Scomв́́

179 Le scomberomore Plumier. ............ ibid.

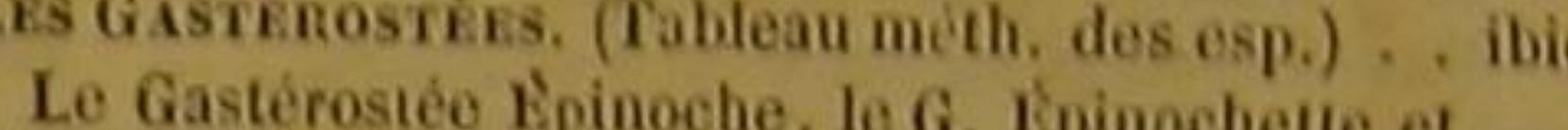
le $G$. Spinachie.

. Les Centropodes. (Tableau mèth. des espèces), 216

183 Le Centropode rhomboìdal.. . . . . . . . . 217

184 Les Centrogasténes. (Tableau méth. des esp.) ibid

185 Le Centrogastére brunâtro et le C. argente ., ibid

ibid. Les Censmonotes. (Tableau méth. des especes), ihid.

Le Centronote Pilote............ 21

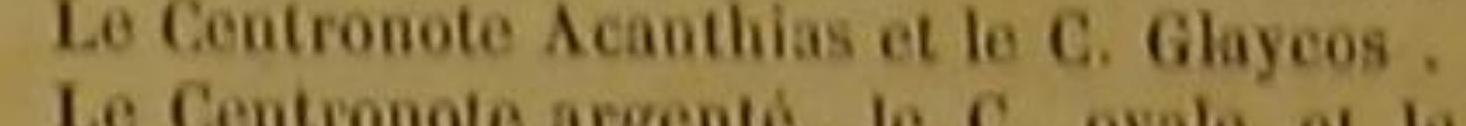
Lyzan. ................. ibid Le Centronote Carolinin, lo C. gardenien e te C. Vadigo ................. ibid

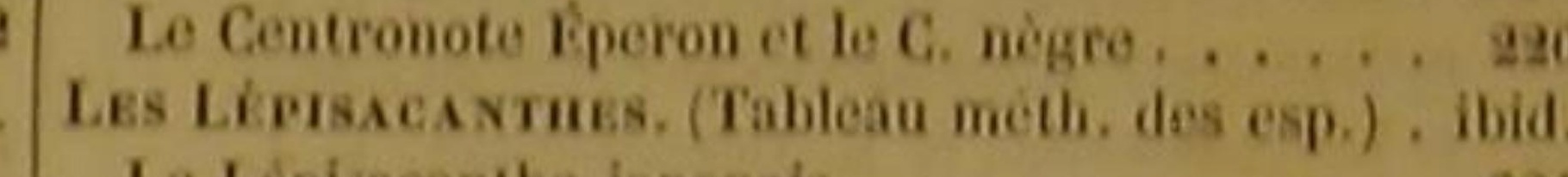

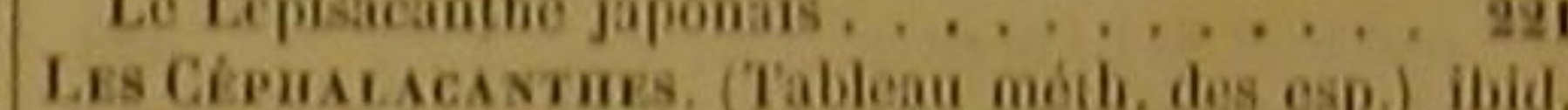

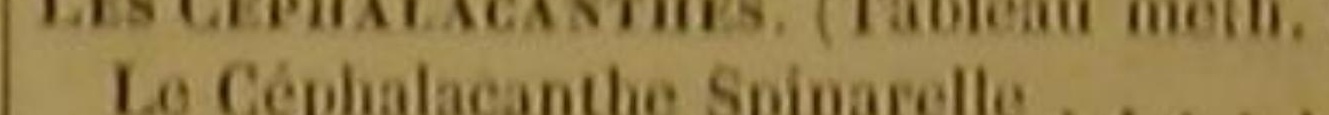
Les Dactruoprtan (Tablean méth. des esp.). Hhid Le Dactyloptère Pirapéde. ..... d. Le Dactyloptèro japonais ............. 22 195 Les Pnoxotes, (Tableau méth, des eqeéces) .. ibid. Le Prionote volast. .................. ibid. Les Trugces. (Tableau métli. des espècess). . . . . ibid. La Trigle asiatique. . . . . . . . . . . 225

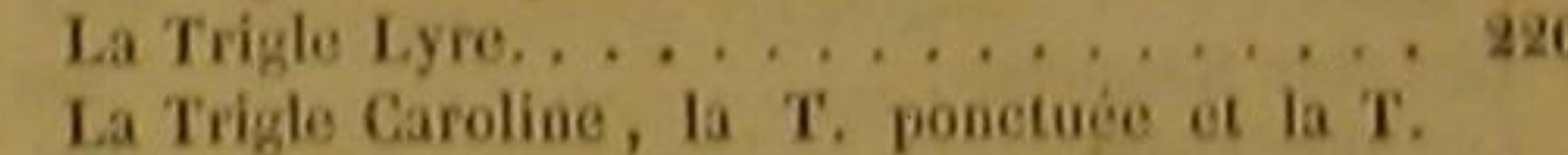
Lastoviza. . . . . . . . . . 22 La Trigle Hirondelle. . . . . . . . . 228 La Trigle Pin.................. ibid La Trigle Gurnan et la T, Grondin . . . . . . ibid

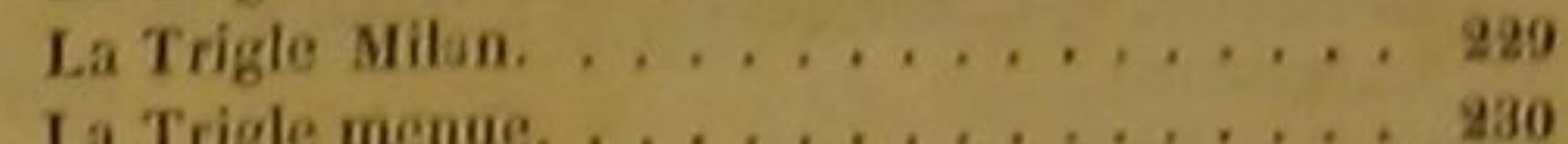
La Trigle menue. . . . . . . . . . 230 ibid.

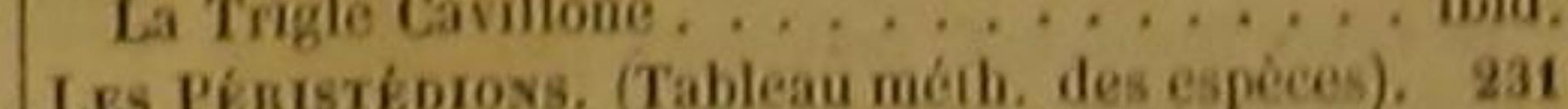
Les Pénistédoss. (Tableau mét. des especes). ibid Le Péristédion Chabrontère. . . . . . . . . . . 232 . Le Péristedion Chabrontere. ............... 20. 203 L'Istiophore Porte-Glaive. . . . . . . . . ihid.

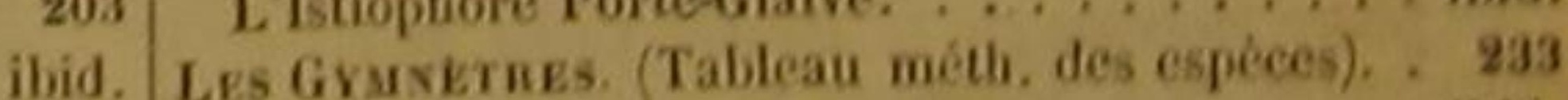
ibid. Les Gruserwes. lawken ............. ibid. . ibid. Les Moures. (Tableau méth. des especes). . . . . 234 20i Les Molles. Rouget............... ibid. Le Mulle Surmulet . . . . . . . . . . 237 Le Mulle japonais . . . . . . . . . 238 Le Mulle Auriflamme. . . . . . . . . . . . . ibid Le Mulle rayé. . . . . . . . . . . . . isid Le Mulle Deux-Bandes, ie M. cyclostome, le M. ibid. Trois-Bandes et le M. macronème 
Le Mulle Barberin, le M. rougeâtre, le M. Rongeor et le M. Cordon jaune.

Les Apogons. (Tableau meth des especes) LA pogon rouge. . . . . . .

Leś Lonchures. (Tableau méth. des espèces). . Le Lonchure Dianème . . . . . . . . . . . . Le Macropode vert-doré

Nomesclatune des Labres, Cheilines, Cheilodiptères, Ophicéphales, Hologymnoses, Scares, Ostorhinques, Spares, Diptérodons, Lutjans, Centropomes, Bodians, Tænianotes, Sciènes, Microplères, Hclocentres et Persìques. . . .

LEs LABnEs. (Tableau méth. des espèces). . .

Le Labre Hépate.

Le Labre opercule.

Le Labre Aurite, le L. Faucheur, le L Oyène,

le L. Sagittaire, le L. Cappat, le L. Lépisme, le $\mathbf{L}$. unimaculé, te $\mathbf{L}$. Bobar et le $\mathbf{L}$. bossu. . . ibid. Le Labre noir.

Le Labre argenté, le L. nébuleux, le L. grisătre, le L. armé, le L. Chapelet, le L. Long-Nuseau, le L. Thumberg, le L. Grison et le L. Croissant. ............... ibid

Le Labre de Ceylan, le L. Deux-Bandes, le I melagastre, le L.malaptère, le L à demi roume, le L. tétracanthe, le L. Demi-Disque, le I. cercle et le $\mathrm{L}$. hérissé.

Le Labre Fourche.

Le Labre Six-Bandes, le L. macrogastère, le L filamenteux, le L. anguleux, le $\mathbf{L}$. Huit-Baies, le $\mathbf{L}$. moucheté, le $\mathbf{L}$. commersonien, le $\mathbf{L}$. lisse et le $\mathrm{L}$. macroptère. . . . . . . . . . il

Le Labre Quinze-Épines .

Le Labre macrocéphale, le L: plumiérien, le I. Gouan, le L. ennéacanthe et le L. Rouges-

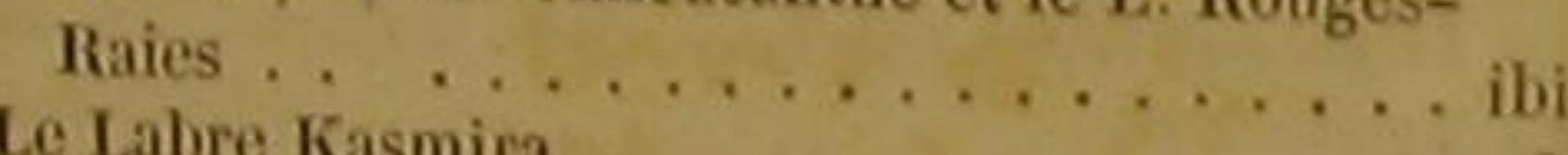

Le Labre Paon. . . . . . . . . . . 258

Le Labre borde.

Le Labre rouille, le L. wille, le $\mathrm{L}$. Melops, le

L. Nil, le L. lonche, le L. Triple-Tache,

L. cendre, le L. cornubien, le I. mele,

L. jaunåtre ............... . ibid

L. Echiquier, le Luligineux, le L. brun, le

Queue, le L. Girelle, le L. parolique et le

L. Bergsnylire.

Le Labre tancoïde, le $\mathbf{L}$. Double-Tache $\ldots 262$

ponctué, le L. ossiphage, le L. Onite, le I.

Perroquet, le L. Tourd, le L. Cinq- Kpines,

le L. chinois, et le L. japonais. ....... ibid.

Le Labre linéaire.

$\dddot{10}^{26}$

L. tacheté, le L. Cock, le L. Cannde, le I.

Lanches-Raies, le L. bleu et le L. rayé. ... ib

Le Lubre Bahlan, le L. Bergy, le L. Hasseck, le

le L. Téte-Bleue, le L. à gouttes, le L. bois

et le L. Cirqu-Taches... ........... 285
Le Labre microlépidote, le L. Vieille, le L. Karut, le L. Anei, le L. Ceinture, le E. digram-
me, le L. hololépidote, le L. tamioure, le L. Parterre, le I sparoïde, le L L copard t to I. malaptéronte................. Le Labre salmoïde et le Labre Iris. . . . . . . . ${ }_{260}^{266}$ Le Labre Diane, le L. macrodonte, le L. . . . trien, le $\mathbf{L}$. Calops, le L. ensanglante, neusPerruche, le L. Keslik e le L Comber le L. Le Labre brasilien, le L. ert, L L trilobs, . ibid L. Deux-Croissants, le I. herainge, be L. Deux-Croissairts, le L. hebraique, le $\mathbf{L}$. . 262 Les Chemunes. (Tableau méth. des espèces). . . . 269

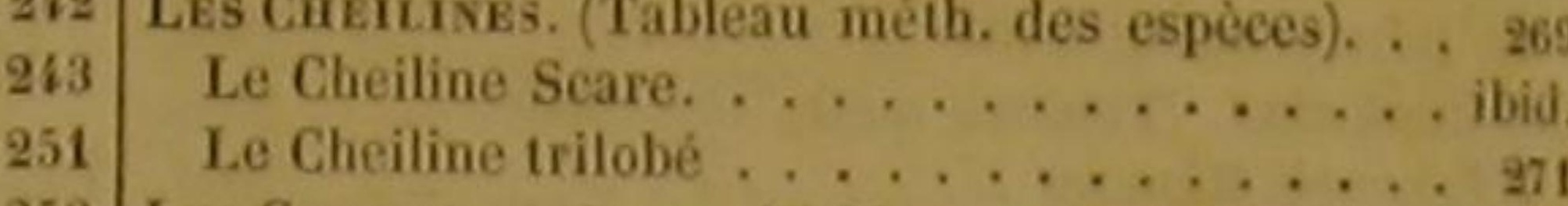
3 Les Cheilodiptkres. (Tableau méth. des esp.). . ibid Le,Cheilodiptère heptacanthe, le C. chrysoptere

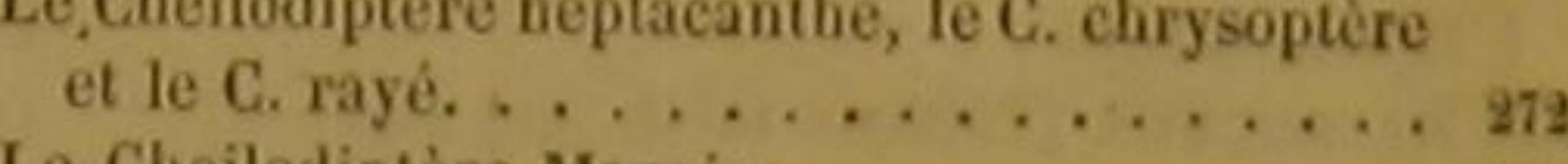
Le Cheilodiptère Maurice. ............ 273 Le Ciucilodiptère cyanoptère, le C. Boops et le C. Acoupa. . . . . . . . . . ibid

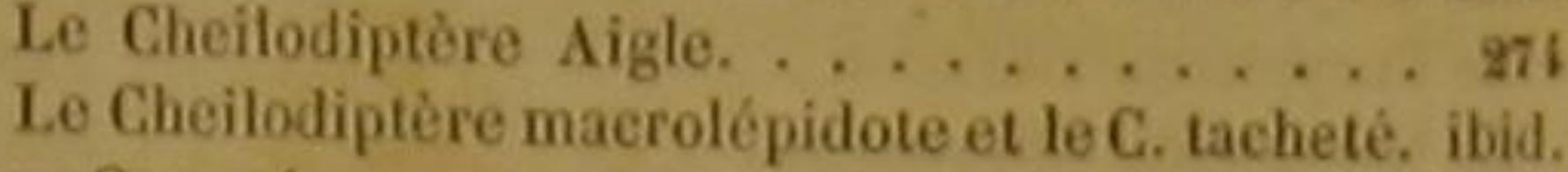
Le Cheilodiptère macrolépidote et le C. tacheté, ibid.

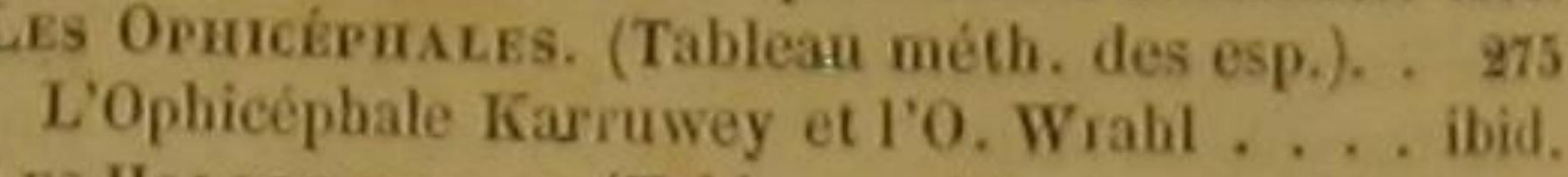
LEs Holog raxoses. (Tableau méth, des esp.). . . 276 L'Hologymnose fascé . . . . . . . . . . . ibid Les Scanes. (Tableau méth. des espèces). . . . . . m Le Scare Sidjan, le S. étoilé, le S, ennéacanthe
et le S. pourpre. Le Scare Harid, le S. Chadri, ie S....... 278 le S. Ka arid, le S. Chadri, le S. Perroquel, le S. Kakatoe, le S. dentículé et le S. bridé. 280
Le Scare Catesby. . . . . . . . . . 281 Le Scare vert, le S. Ghobban, le s. Ferrugineux, le S. Forskael, le S. Schlosser et le S
rouge

Le Scare trilobè et le $\mathrm{S}$. tacheté... . . . . . ibid Ls Оsтoнmixours. (Tableau méth. des esp.). . . ibid L'Ostorhinque Fleurieu . ........... ibid Es Spares. (Tableau méth. des espèces) . . . . . 283 Le spare Dorade. . . . . . . . . . . 290 Le Spare Sarpaillon, le S. Sargue, le S. Oblade et le s. Smaris. . ............. Le Spare Mendole, le S. argenté, le S. Hurta, le $\mathrm{S}$. Pagel et le S. Pagre. .......... 2 thère, le S. Saupe, le S. Bogue, le S. CanLe Spare Sy. Saupe et le S. Sarbe . . . . . . . Le Spare Synagre, le S. élevé, le S. strié, le S. Le Spare , S. Berda et le $\mathrm{S}$. Chili. ...... 30 tre, te S. bianné, le S. Morme, le S. brunàseillais. ................. I. marLe Spare Castagnole, le s. Bogaraveo, le $\mathrm{s}$. Mahséna, le S. Marak, le S. Ramak et le S. Grand-OEil . . . . . le . . . . . . . . 30 Le Spare Queue-Rouge, le S. Queue-d OOr, le $\mathbf{S}$. Cuning, le S. galonné, le S. Brême et le S. Le Spare rayé, le S Ancre, l. S...... 30 S. Porgy, le S. Zanthure te le S. trompeur, le Le Spare fascé, le S. Faucille, le S. jenté. .... S. Surinam, le S. Cynodon le S. joponais, ie canthe. ................. tétra-
Le Spare Vertor, le S. Mylostome, le S. Mylio, le $\mathrm{S}$. breton et le $\mathrm{S}$, rayé d'or.......... Le Spare Cateshy, le S. sauteur, le S. venime
le S. salin, le S. Jup el le S mélanote.

Le Spare Niphon, le S. Demi-Lune, le S. Hlolocyanose, le S. Lepisure, le S. bilote, te S. Cardinal, le S. chinois, le S. Bufonite of le S. Perroquet.

Le Spare orphe, le S. marron, le S. rhomboìde, lo S. bride, le S. gatiliéen et le S. Carndoe, Le Spare Paon, le S. rayonné, le S, plombé, I S. Clavière, le S. noir et le S. chloroptère. Le Spare Zonéphore, le S. pointillé, le S sanguinolent, le S. Aeara, le S. Nhoqumda et le $S$. atlantique........................... Le Spare Chrysomélane, le S. hémisphère, le $\mathrm{S}$ S. Desfonlaines................. Le Spare Abildgaard, le S. Quene-verte ot le S. Rougeor. . . . . . . . . . . . . .

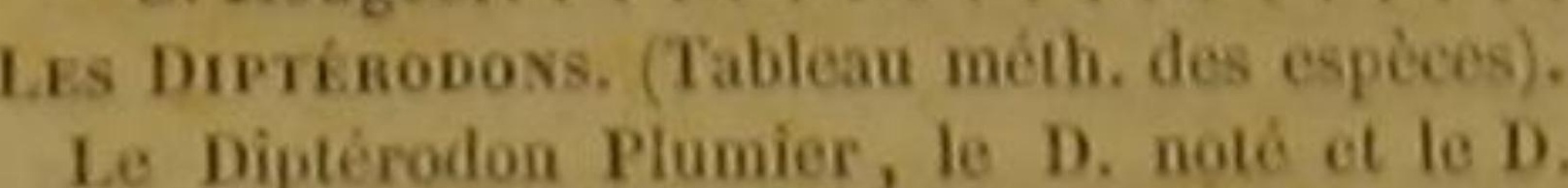
Le Diptérodon Plumier, le $\mathrm{D}$, noté et le D Le Diptérodon Apron et le D. Zingel. Le Diptérodon Oueve-jame.

Le Dipterodon Queve-jaune. Le Iutjon virginien, le I Anthias, te I de

I'Ascension, le L. Stigmate et lo L. strié.

Le Lotjan Pentagramme, te L araenté, le I Serran, le L Feurevil, le L. jaune, le L. OEi

dor et le L. Nageoires-rouges. ...........
Le Lutjan Hlamrur, te L. Diagramme, lo L.

Le Lutgan the le L. Macrophibalme. Le Lutian Vosmaer, le L. elliptique, te L japo-

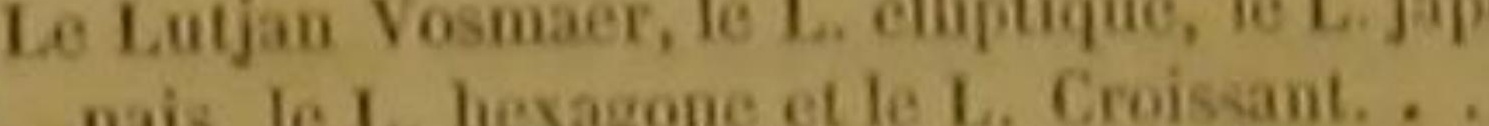
Le Lutjan Galon dior, le L. Gymnocéphale, I

L. Triangle et le Lutjan microstome.

Le. Triang a te Lajet.

Le Lutjan Décacantlie, le L. Scine, le L. La-

pine, lo $\mathrm{L}$ rameux, le $\mathrm{L}$. OFillet, te $\mathrm{L}$. bossi

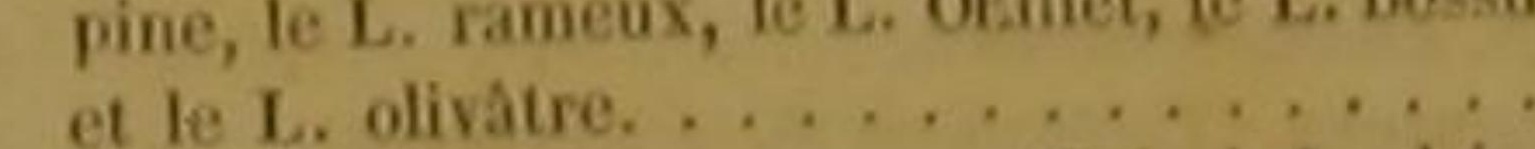
LeLtion Bronoich, ic

LeLutgn bra Le Lution Panpière, le L noir, le L chrysi-

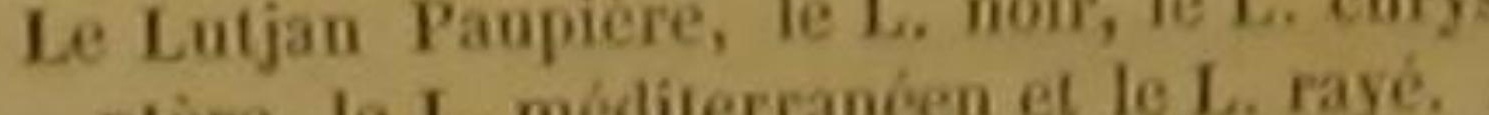
Le Lutian Ecriture te L. chinois, Ie L. Pique, Le Lujan Eonte, Deux-Dents.

Le Luljan marqué, le L. Linke, le L. Surinam, le $L$ verdatre, le $L$. Groin el le $L$ norvégien . . . . . . . . . . . . Le Lotjan Jourdin, le L. Argus, le L. John, le L. Tortue, le L. Plumier et le L. oriental . Le Lutjan tacheté, le L. Orauge, le L. Blanc-or, le L. Perchot, le L. Jaunellipse, le L. grimpeur, le L. chétodonoîde, le L. Diacanthe et le L. Cayenne . . . . . . . . . . . Le Lutian peint .

Le Lutjan peint . . . . . . . . . . . . . . . ibid

Les Cextropoyzs, (Tableau méth. des espéces). ibid.

Le Centropome Sandat, le C. Hober, le C. Safga, le C. Alburne, le C. Lophar, le C. arabique, et lo C. rayé . . . . . . . . . . . .

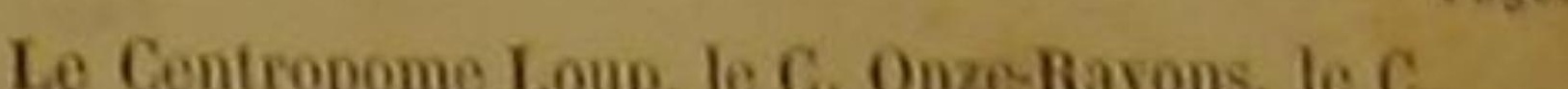
Plumier et le c. Mnlet. . . . . . . . . . si Le Centropome Ambasse, le C. de Roche, le $\mathrm{C}$. Macrodon, lo C. dore et le C. rouge....... an Le Centropome Nilotique et le $\mathrm{C}$. wille...... 3 s6 Le Centropome Sis-Raies. . . . . . . . . ibid Le Centropome fasce et le c. Perchot . . . . . . ibid. Les Bodıss. (Tableau méth. des espéces) . . . . i ibid

Le Bodian OEillère, lo B. Louti, lo B, Jaguar; le B. macrolépidote, le B. argenté, le B. Hloch et le B. Aya.............. Lo Bodian tachete, le B. Vivanet, lo B. do FisGrosse-Te e le B. cyelostome

Le Bodian Rogaa, le B. lunaire, le B, mélanoleuque, le B. Jacob-Ĺvertsen, le B. Benak, le B. Hiatule, le B. Apue et le B. étoilé, . . . . as Le Bodian tétracanthe ot to n. Six-Raies . . . 353

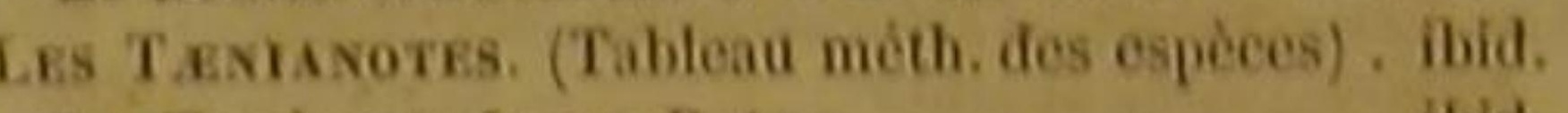
Le Tenianote Large-Rate. . . . . . . . . . ibid. Le Trenianote triacanthe.. . ........... . 35 . La Sciène Abusamf, la S. Coro, la S. ciliče ef la S. heptacantbe

La Sciène Chromis, la S. Croker, la S. Umbre, la Sciène cylindrique, la S. Sammara, la S. pentadactyle et la s. nayce. .......... ibid. Uus Mrcnopremes. (Tableau mèth, des espèces). 358 Le Microptère Dolomieu . . . . . . . . . . . . . itid.

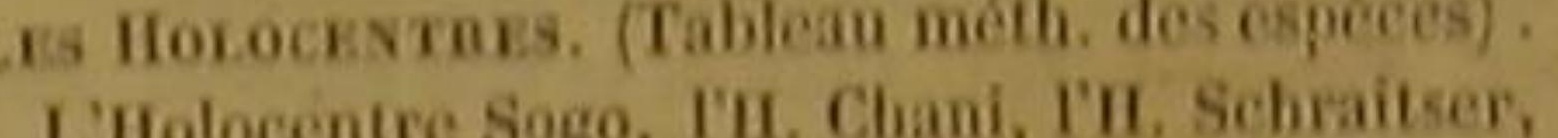
L'Holocentre Sogo, I'H. Clami, I'I. Schraitser,
I'II creenele, I'It. Ghanam, I'I. Gaterin of I'II crènelé,
I'II. Jarbua.

Holocentre verdatre, III. tigre I'II. CimqRaies, I'H. Bengali, TH. Ëpinephèce, I'H. Post, I'II. noir et I'H. Aćrine.

L'Holocentre Boutton, I'H. jaune et bleu, I'it Queuc-rayée, I'H. négrillon, I'It. Léopard, I'It. cilie ot I'It. Thunberg

Holocentre blanc-rouge, l'il. bande blanche, I'IL. diacanthe, I'Il. tripétate, I'H. tétracanthé,

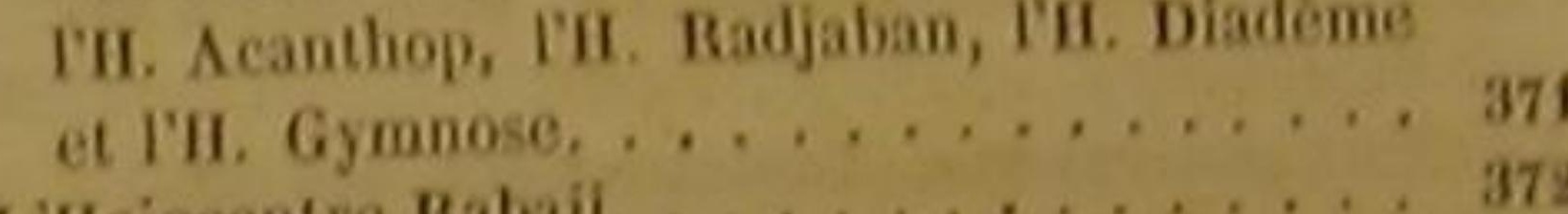

L'Hoiocentre Rabaji. . . . . . . . . . . L'flolocentre marim, fir. Thard, ins. philadel phien. PII. Merou, Fis. Forshsel, Iti. tria-

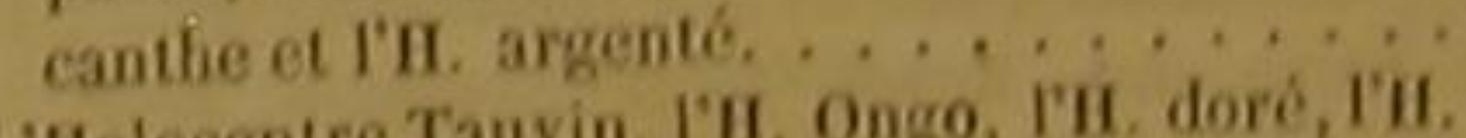

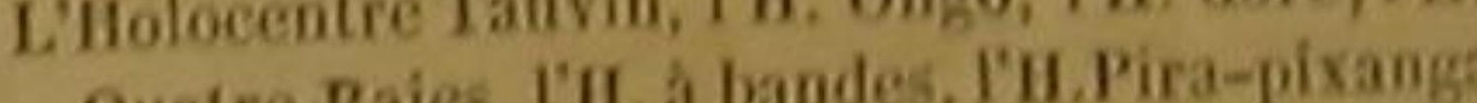

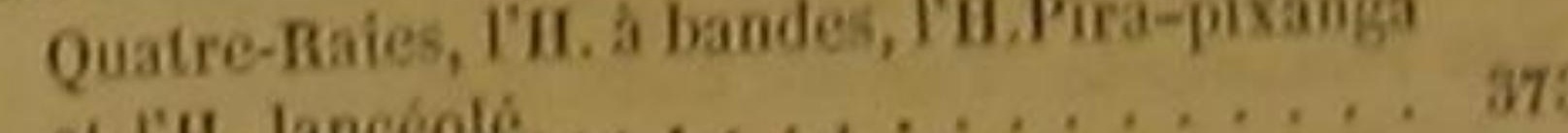

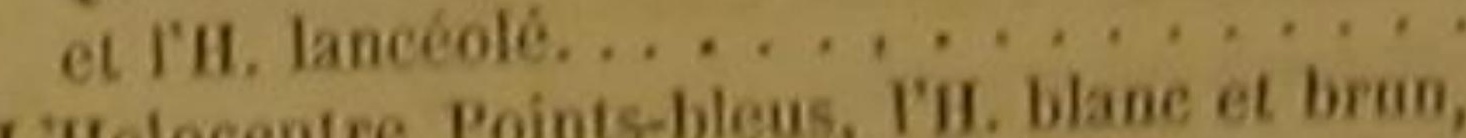
L'Holocentre Points-bicus, Iit. blanc et bro, I'H.

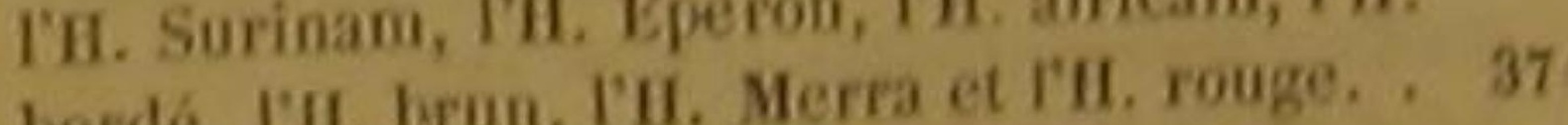

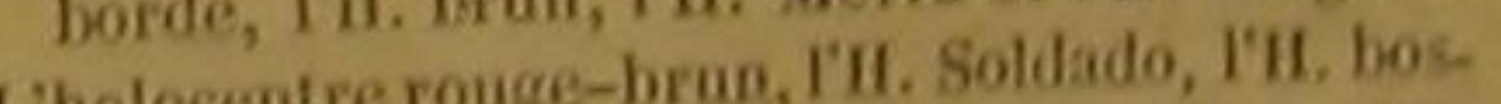
Lholl Sonnerat, I'H, heptadactyle, I'H su, IH. Son. Rosmare, l'H. océanique, I't p. salmoidect Tli. dableau mètb. des espèces). . . 37 37 La Persèque Perche. ..... . . . . . ....... 318

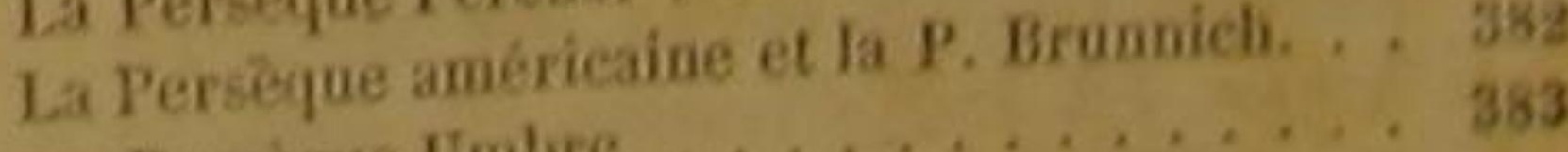

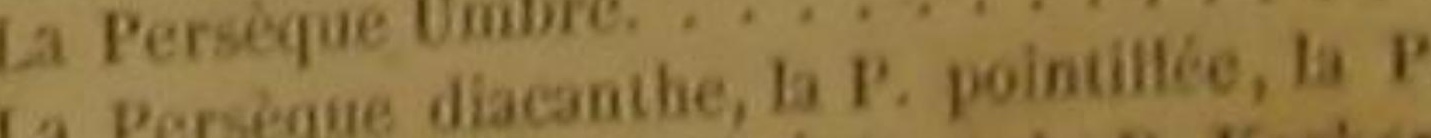
Murdian, la P. Porte-Épiue, la P Korkor,

194
367 169

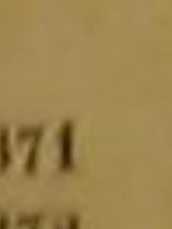

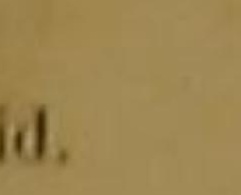

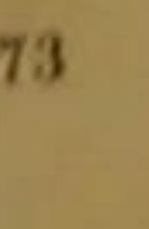
74 76

and

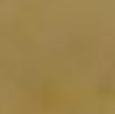


la P. Lourbine et la P. Praslin.

La Persèque triacanthe, la $P$. pentacanthe et la

P. Fourcroy ...

Les HaRpís. (Tableau méth. des espèces).

Le Harpé bleu-doré

Les Piméleptéres. (Tableau méth. des espèc Le Piméleptère bosquien.

Les Cheitions. (Tableau méth. des espèces) Le Cheilion doré et le C. brun

Les Роматомes. (Tableau méth. des espèces) Le Pomatome Skib.

Les Leiostomes. (Tableau méth. des espèces) Le Leiostome Queue-jaune.

LES Centmolopmes. (Tableau méth. des esp. Le Centrolophe Nègre.

Les Cuevaliers. (Tableau méth. des espèces). Le Chevalier américain.

Les Lérograthes. (Tableau méth. des espèces)

Le Léiognathe argenté

LEs Chérodons. (Tableau méth. des espèces)

Le Chétodon bordé, le C. Curaçao, le C. Mau-

rice et le C. Bengal.

Le Chétodon Faucheur, le C. Rondelle, le c sargoìle, le C. cornu, le C. tacheté, le C. Tache-noire, le C. Soufllet, le C. cannelé, le C. pentacanthe et le C. allonge.

Le Chélodon Couagga et le.C. tétracanthel. ......

Le Ghétodon pointu, le C. Queue-blanche, le C

Grande-ḱcaille, le C. Argus, le C.vagabond,

le C. Forgeron, le C. Chili et le C. à bandes,

Le Chétodon Cocher, le C. Hadjan et le C

peint.

Le Chétodon Museau-allongé.

Le Chétodon Orbe, le C. Zebre, le C. bridé, le

C. Vespertilion, le C. ceillé, le C. Huit-Bandes et le C. Collie,

Le Chétodon Teïra, le C. Surate, le C. chinois, le C. Klein, le C. bimac slé, le C. Gallinne et le C. Trois-Bandes.

Es Acanthinzons. (Tableau méth. des espèces) L'Acanthinion Rhomboïde, I'A. bleu, et I'A or-

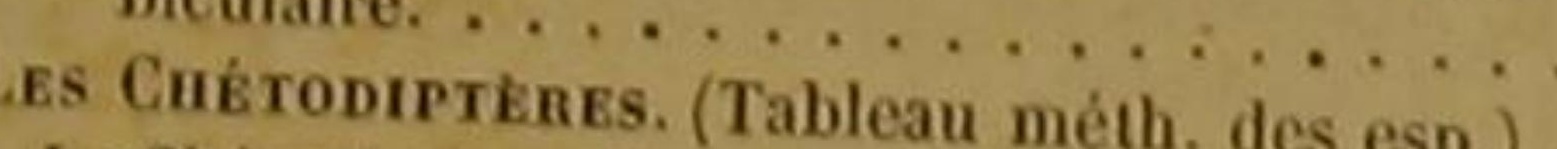

Le Chétodiptère Plumier. .

Les Pomacentres. (Tablean méth. des ....... ibid

Le Pomacentre Paon et le P. ennéadactyle.

Le Pomacentre Burdi, le P. Symman, le P.

Filament, le P. Faucille et le P. Croissant . .

Lrs Pomadssys. (Tableau méth. des espèces)...

Le Pomadasys argenté . . . .

Pomacanrass. (Tableau méth. des . . . . . . . . . .

Le Poncanthe Grison et le P. sale.

lo $\mathrm{P}$. d.anthe arqué, le $\mathbf{P}$. doré, le $\mathbf{P}$. P. . .

le P. Asfur et le $\mathbf{P}$. jaunâtre.

L'Holacanthe tricoloau méth. des espèces) marck.
tricolore, l'H. Ataja et l'H. Lamarck . . .

reur, l'H Anneau, l'H. Cilier, I'H. EmpeAruset, I'H. Derr. bicolor, l'H. Mulat, l'H. Aruset, I'H. Deux-Piquants, I'H. géométri-

Lis Éroploses. (Tableau méth. des espèces).... . .

L'Énoplose White ...............

8i Les Glyphisodons. (Tableau méth. des espices). Pages. Le Glyphisodon Moucharra el le G. Kakaitsel. Les ACANTHERES. (Tableau meth, des especes). . it L'Acanthure Chirurgien, I'A. Zèbre, I'A noiraud, I'A. Voilier, I'A. Thenthis et I'A. raye. Les Aspisunes. (Tableau méth. des espèces). L'Aspisure Sohar. . . . . . . . . ibid Les ACanthopodes. (Tableau méth. des esp.). . . ibid. L'Acanthopode argenté et l'A. Boddacrt. . . . 4 (1) LEs SÉLíkxes. (Tableau méth , des espèces). . . . . ibid. La Sélène argentée . . . . . . . . . ibid La Sélène quadrangulaire. . . . . . . . . 4 L.es AngYaéroses. (Tableau méth. des espèces). ibid. L’Argyréiose Vomer. . . . . . . . . . . . ibid Les ZéEs. (Tableau méthodique des espèces) Le Zée Longs-Cheveux et le Z. rusé . Le Zée Forgeron. LES GALS. (Tablean méth des espèces). . . Le Gal verdatre . . . . . . . . . . . . . Les Cunvsotoses. (Tableau méth. des espèces). ibid. Le Chrysotose Lune. . . . . . . . . . . . Les Capros. (Tableau méthodique des e. . . . . . . itsèces). . ibid Le Capros Sanglier. . . . . . . . . . . 426 LEs PLevronectes. (Tableau méth. des espèces) ibid.

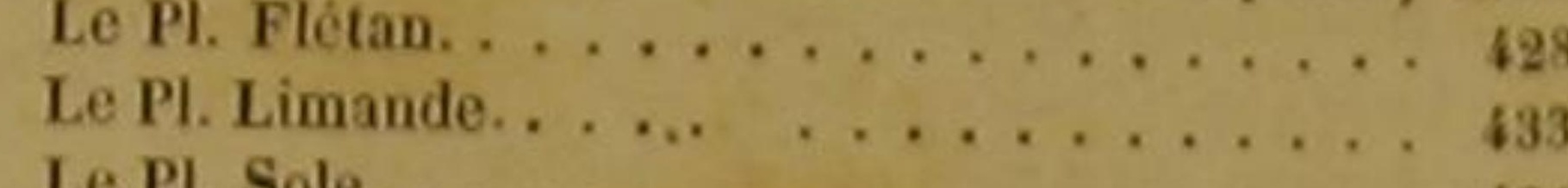
Lo Pl. Plie. Le Pl. Flez, le PI. Flyndre, le Pl. Pole, le PI. Languette, le PI. glacial, le PI. Limandelle, le N. chicos, lo Pl. limandoĩde et le PI. Pégouze.

1.e Pl. aillé et le PI. trichodactyle

Le Pl. Zèbre, le Pl. Plagieuse et le Pl. argente. 439 Le Pl. Turbot.

Le Pl. Targeur, le Pl. denté, le PI. Moineau, le tio Pl papilleux, le PI. Argus, le PI. japonais, le PI. Calimande, le PI. Grandes-Éeailles et le Pl. Commersonnien.

Les Acrires. (Tableau méth. des espèces) . . . . 4 i

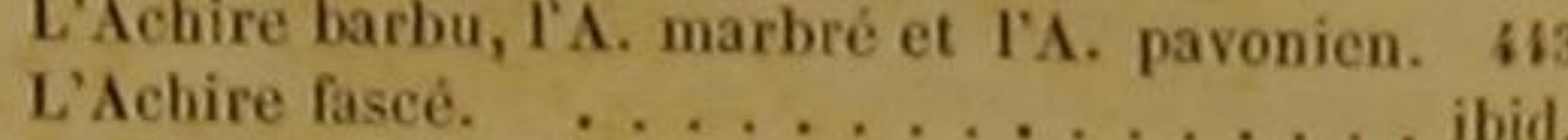
L'Achire Deux-Lignes et l'A. orné . . . . . . . ibid. seconde sous-classe, première division, vingtième ordre de la classe entière des Poissons ou quaDorssons AB-

Les Cimphites (Tableau méth des espe... Le Cirrhite tacheté . . . . . . . . . ibid. Les Cenemodactyles. (Tableau méth. des esp. . Le Cheilodactyle fascé............. Les Cobitrs. (Tableau méth. des espèces). . . . . . ibid. Le Cobite Loche, le C. Tænia et le C. TroisBarbillons. ............ TroisLes Misgurves. (Tableau méth. des espèces) . . . tit Le Misgurne fossile . . . . . . . . . . . ibid Les Ava BLEps. (Tableau méth. des espèces) . . . 450 Es Fuxdoutes. (Tableau méth. des épèe. . . . ibid. Le Fundule Mudfish et le Fundule jaeces). . . 455 Les Colubrines. (Tableau méth. des espenas ... ibid. La Colubrine chinoise. . . . . . des espèces). . ibid
DES ARTICLES.

$6 i 5$

Les Amies, (Tableau méth. des espèces.). . . . Pages. $45 i$ LA Amie chauve. . . . . . . . . . . . . . . . . ibid
LES Botrniss. (Tableau méth. des espèces.). . . ibid Less Botrniss. (Tableau méth. des espèces.). . . ibid Le Butyrin Banane. . .................... ibid.
Les Tripténoxotes. (Tableau méth.des especces.) ibid. Le Triptéronote Hautin. . . . . . . . . . . . 455
LEs Oмрокs. (Tableau méth. des espèces.). . . ibid. Les OMpoks. (Tableau méth. des espèces.). . . . ibid
L'Ompock siluroìde. . . . . . . . . ibid

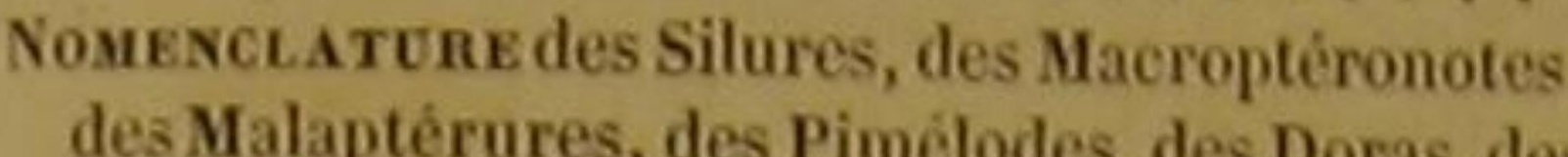
des Malaptérures, des Pimélodes, des Doras, des Pogonathes, des Cataphractez, des Plotoses, des
Agénéioses, des Macroramphoses et des CentraAgeneioses, des Macroramphoses et des Centra-

es Silures. (Tableau méth. des espèces.). . . Le Silure Glanis. Le S. verruqueux et le S. Asote. Le S. fossil

Le S. Deux-taches, le S. Schilde et le S. undé cimal.

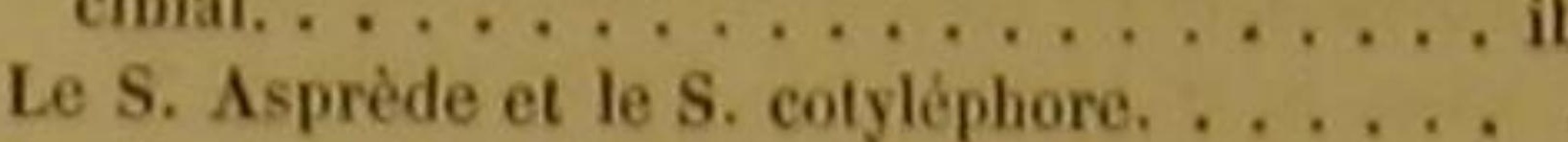
Le S. chinois et le S. hexadactyle. . . . . . 463 Les MAcropténonotes. (Tableau méth. desesp.).
Le Macroptéronote Charmuth et le M. grenouiller.

is

Fages,

S.L.roxes. (Tableau méth. des espéces,). . . 178

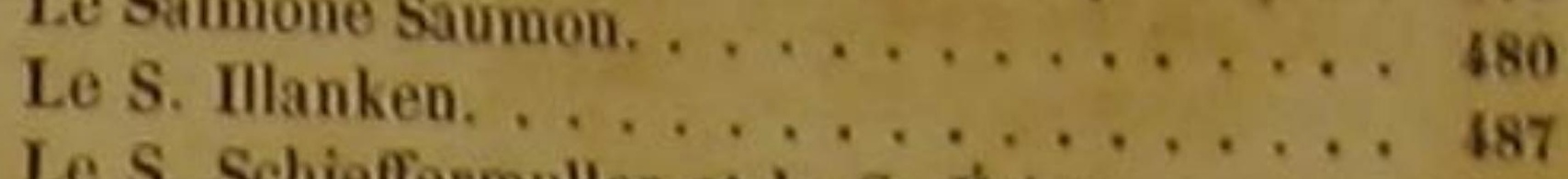
Le S. Schieffermuller ei le $\mathrm{S}$. Ëriox ...... Le S. Truite. . . . . . . . . . . ibid Le S. Bergforelle. .............. Le S. rouge, le S. Geden, le S. Huch, le S. Carpione, le S. Salveline et le S. Omble Che valier. . . Yaimen, le S. Nelma, le S. Lenok, lo s. Kundscha, le $\mathrm{S}$ arelique, le S. Reidur, le S. leime, le S. Lepéchin, le S. Sil, le S. Lodde

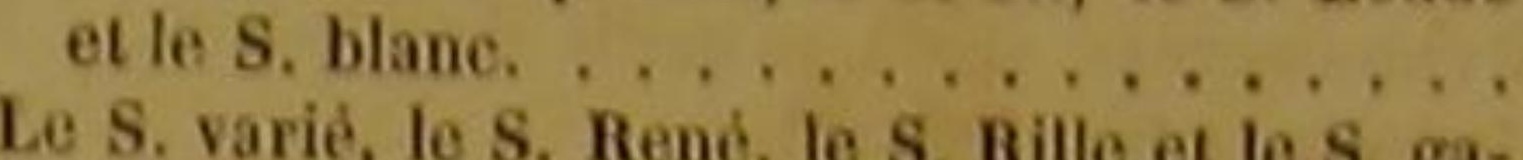
Le S. varié, le S. René, le S. Rille et le S. gadoìde. .................. ${ }_{497}^{497}$ Les Osmknzs. (Tableau méth. des espèces.). , . ibid L'Osmere Eperlan. . . . . . . . . . ibid L'O. Saure, I'o. Blanchel, I'O. Faucille, lo.

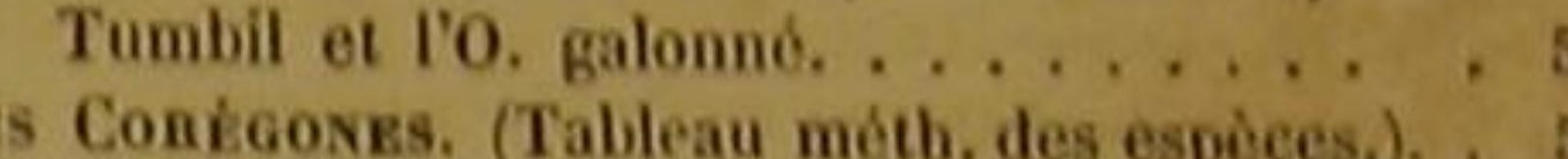

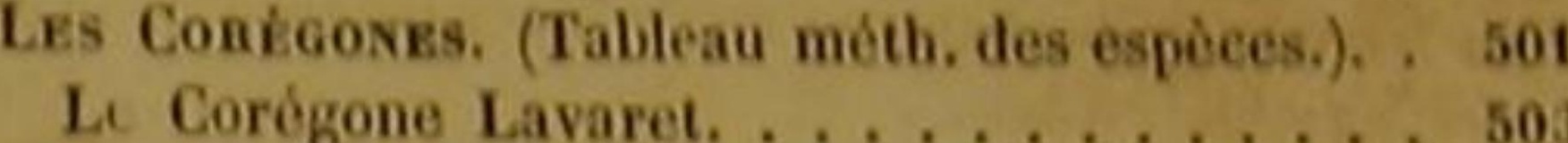
L Corégone Lavaret.

C. Iarge, le C, le C. Schokur, le C. Nez, le C. large, le C. Thymalle, le C. Vimbe, te C. Lo G. Abie, lo C. Peled, la C. Marène, lo C. ma-
Leser, Les Malaptínunes. (Tableau méth. des esp.). Le Malaptérure électrique.

LEs Pimílodes. (Tableau mét. des espèces).

Le Pimélode Bagre, le P. Chat, le P. Scheilan et le P. barre.

Le P. Ascite, le P, argenté, le P. ncud, le $\mathbf{P}$. Quatre-Taches, le P. barbu, le P. tacheté, le $\mathbf{P}$. bleuâtre, le P. doigt-de-Nègre et le P. Commersonnien.

Le P. Thumberg. . . . . . . . . . . . . P.
Le P. Matou, le P. Cous, le P. Docmac, le P.

Be P. Matou, le P. Cous, le P. Docmac, le P.
Bajad, le P. erythroptère, le P. Raie d'argent, Bajad, le P. erythroptère, le P. Raie d'argent, le P. raye et le P. mouchete.

Le $\mathbf{P}$. casque et le $\mathrm{P}$. Chith.

LEs DorAs. (Tableau méth. des espèces.). . . . .

Le Doras caréné et le D. Cote.

Les Pogosatines. (Tableau metth. des espèces.).

Le Pogonathe Courbine et le $\mathrm{P}$. doré.

Les Cataphractes. (Tableau méth. des esp.). Le Cataphracte Callichte, le C. américain et lo C. ponctué.

Les Plotoses. (Tableau méth. des espèces.). Le Plotose anguillé.
Le P. Thunbergien.

Le P. Thunbergien. . . . . . . . . 47 LES AGÉnétoses. (Tableau méth. des especces.), ibit

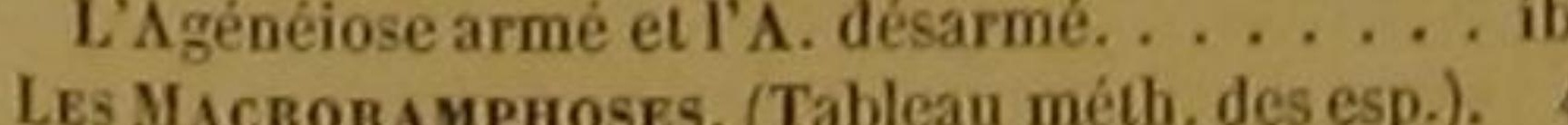
Les Macroramphoses. (Tableau méth. des esp.). ${ }^{476}$

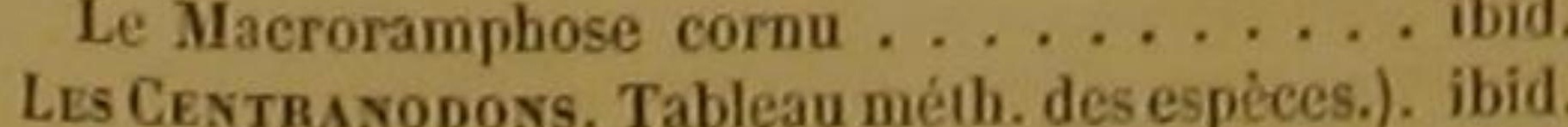
Les Centranodons. Tableau méth. des espèces.). ibi. Le Centranodon japonais. ............... ib La Loricaire sétifere et la $L$. tachetée. . . . . ibi La Loricaire sétifere el la $\mathbf{L}$. tachetée.

Les Hypostomes. (Tahleau méth. des espèces.).

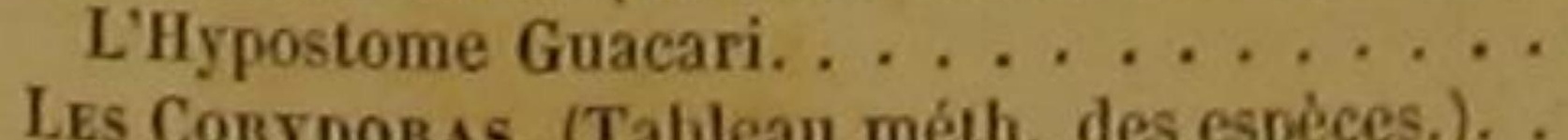

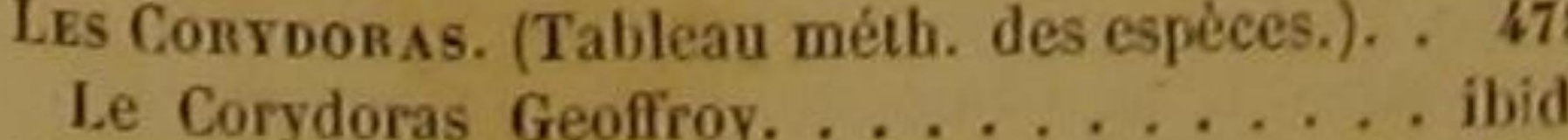
Le Corydoras Geoffroy. . . . . . . . . . . . . . ibid

Les Tacuysunes. (Tableau mélt. des espèces.). ibid.
Le Tachysure chinois. ........... ibid. renulé, le C. Warımann, le C. oxyrhynque, lit C. Leucichthe, to C. Ombre et le C. rougo. . . 507 Le C. clupeoìde. ................ 509 Les Cuanacins. (Tableau méth, des espèces.). , ith Le Characin Piabuque, le C. denté, le C. bossu, Le C. Mouche, lo C. Bouble-Mouche, lo $\mathrm{C}$ sans tache, le C. Carpeau, le C. nilotique, to Le C. Anostome, le C. Frédéric, le C. a bandes, le C. Mélanure, le C. Curimate et le C. Odoè, 51 le C. Metanure, lo C. Curimate et lo C. Odoe, 51

Le Serrasalme Rhomboïde. . . . . . . . . 51 Uus ÉLopes. (Tableau méth. des espèces) . . . . . . ibid. L'Élope Saure. . . . . . . . . . . . ibid. es Mégalopes. (Tableau méth. des espèces.). 511 Le Mégalope Filament. ............... ibic. Les Notacantues. (Tableau méth. des copreces.). hid Le Nolacanthe Nez. . . . . . . . . . . ibid

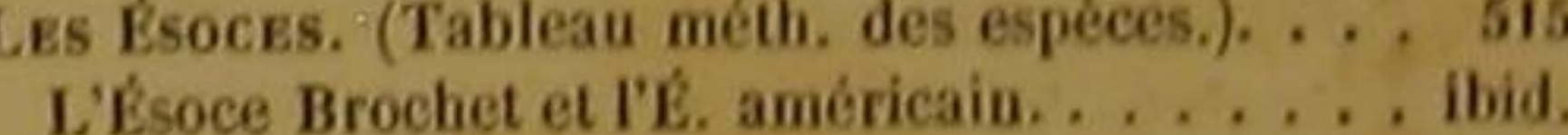
L'É. Bélone. . . . . . . . . . . . . . 518 L'É. Bélone. argenté, l'é. Gambarure et l'É. Espadon. 519 L'É. Téte-Nue el I'É. Chirocentre. . . . . . . 520 Le. Le Synode fascé, le S. Renard, le S. chinois, lo S. macrocépbale et le S. Malabar. ...... ibid. Les Sprrnerys. (Tableau méth. des espècess.). 522 La Sphyrène Spet, la S. chinoise, la S. Orverd,

la S. Bécume et la S. Aiguille. ...... 523 la $\mathrm{S}$. Brcuisos. (Tableau méth. des espéces.). 524 Le Lépisostée Gavial, te L. Spatule et le L. Ro-

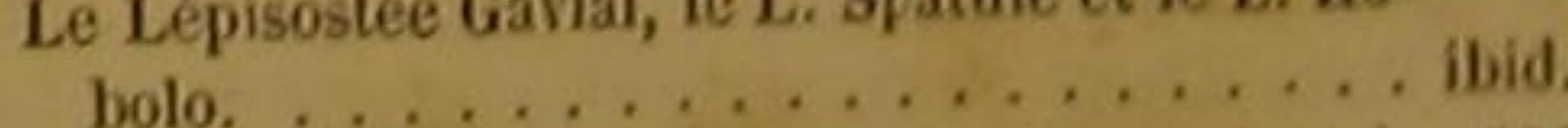
Bo Polyptkaes. (Tablesu méth. des equèces.). 526 Le Polyptère Bichir. ............. ibid Le Polyptere Bichir. .................. sit 
Le Scombrèsoce Campérien. . . . . . . . . . Les Fistulaires, (Tableau méth. des espèces.) La Fistulaire Petimbe. . . . . . . . . ibid La Lucostours, (Tableau méth des espèces... L'Aulostome chinois. . . . . . . . . . ibio I.rs Solíxostomes. (Tablesu méth. des espèces.). ibid. Le Solénostome paradoxe. . . . . . . . 531 Les Angentines. (Tableau méth. des espèces.). L'Argentine Sphyrène, l'A. Bonuk, I'A. Caroline el l'A Machnate. ............ ihid Les Aтnéris l'A Grasdeau. ............... ib ps Hypnangines, (Tableau méth. des espèces, . L'Hydrargire Swampine, . . . . . . . . . ibid. Ls SToĹepnones, (Tableau méth. des espèces.). 53 Le Stoléphore japonais, le S. Commersonnien. ibid. Les Mugrs. (Tableau meth. des espèces.). . . . i ibid. Le Muge Céphale, le M. Albule, le M. crénilabe, le M. Tang, le M. Tranquebar, le M. Plumier et le $\mathbf{M}$. Tache-Bleue. . ................ ges Mugroínes. (Tableau méth. des espèces.). . . 538 Le Mugilö̃de Chili. . . . . . . . . . . . 539 Les Crinos. (Tableau méth, des espèces.). . . . Le Chanos arabique. . . . . . . . . ibid Les MugrLomores, (Tableau méth. des espèces.), ibid. Le Mugilomore Anne-Caroline. . . . . . . ibid. LEs ExockTs. (Tableau méth. des espèces.). . . . L'Exocet volant, IE. Métorien, I'E. Sauteur et I'E. Commersonnien. ibid ps Polvnemes. (Tableau méth. des espèces.). . . 543

Le Polynème Êmoi, le P. pentadactyle, le P. rayé, le $\mathbf{P}$. Paradis, le $\mathbf{P}$. décadactyle et le $\mathbf{P}$. Mango................... Les Polyd actrues. (Tableauméth. des espèces.). $5 t^{5}$ Le Polydactyle Plumier. . . . . . . . . . . ibid Les Bonos. (Tableau méth. des espèces.). . . . . . ibid Le Buro brun. ............... . ibid LFs CuupíEs. (Tableau méth. des espèces.). . . $5 i 0$ La Clupie Hareng. . . . . . . . . . 54 La C. Sardine. . . . . . . . . . La C. Feinte et la c. Rousse. . . . . . . . 553

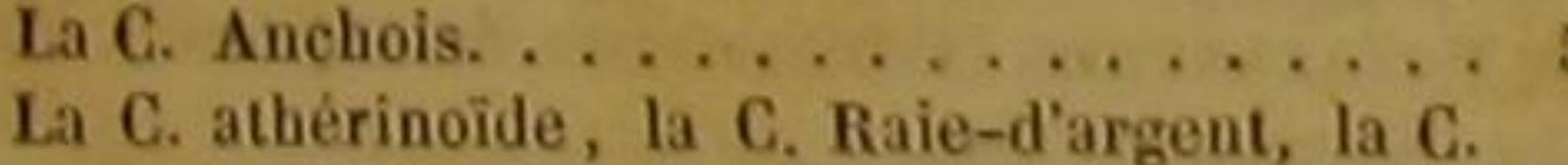
Apalike, la C. Bélame, la C. Dorab, la C. Malabar, la C. tuberculeuse, la C. Crysoptère, la C. à bandes, la C. macrocépbale et la C. des Tropiques. ................ 555

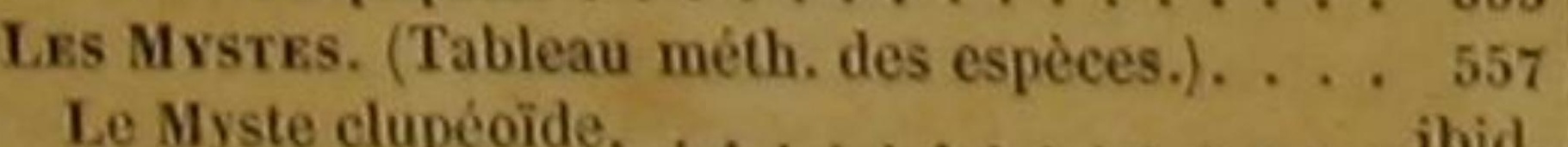

Le Myste clupéoìde. . . . . . . . . . . . . . . ibid,

LES Clupa xodoss. (Tableau méth. des espèces.).
Le Clupanodon Cailleu-Tassart, le C nasique, Le C. Pilchard, le C. chinois, le C. africain et
Le C... Le C. Pilchard, le C. chinois, le G. africain et

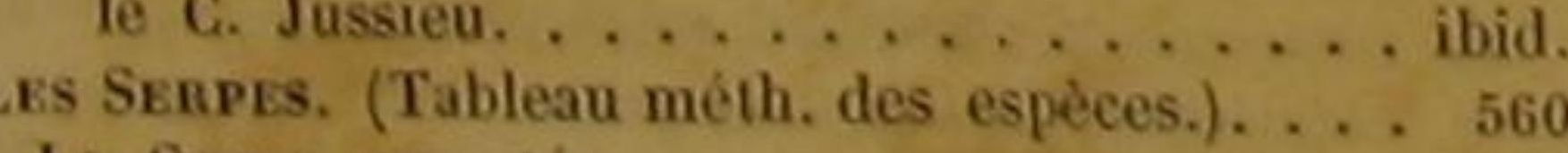
La serpe argentee. . . . . . . . . ibid 1. Mbs (Talmeau meth. des especes). . . . . ibit La Mene Anne-Caroline. . . . . . . . 56 Le Dorsmire. (Tableau meth. des especes.). ibid Le $\mathrm{XYsTh}$.

Le Xystere brum . . . . . . . . . . . . . . . . ibi. especes.). 562 ES Cypriss. (Tableau mèth. des espèces.). . . . . ibid Le Cyprin Carpe. . . . . . . . . . 56 Le C. Barbeau. . . . . . . . . . . 571 Le C. speculaire et le C. a cuir. . . . . . . . 572 Le C. Binny, le C. Bulatmai, le C. Murse et le C. Rouge-Brun. . . . . . . . . . 57 Le C. Goujon et le C. Tanche. . . . . . . . . 57 Le C. Capoet, le C. Tanchor, le C. Voncondre et le $\mathrm{C}$. verdàtre. . . . . . . . . . 57 Le C. Anne-Caroline. . . . . . . . . . ibid. Le C. Mordoré et le C. Vert-Violet. . . . . . . . Le C. Hamburge, le C. Céphale, le C. soyeus et le C. Zéelt.

Le C. doré, le C. argenté, le C. Télescope, le C. Gros-Yeux et le C. Quatre-lobes. . . . . . 579 Le C. Orphe, le C. royal, le C. Caucus, le C. Malehus, le C. Jule, le C. Gibèle, le C. Goleian, le G. Labéo, le C. leptocéphale, le C. clupeoide.

C. Galian, le C. nilotique, le C. Gonorliyn-

que, le C. Véron, le C. Aphye, le C. Vaudoise,

C. Buggenhagen et le C. Rotengle. ...... 583 Le C Jesse, le C Nase, le C Aspe, le C Spir-

lin le $\mathrm{C}$. Bouvière, le $\mathrm{C}$ américain, le $\mathrm{C}$.

le C. Vimbe, le C. Brème, le C. Coutean etle

C. Farène.

Le $\mathrm{C}$ large, le $\mathrm{C}$. Sope le $\mathrm{C}$ Chub le $\mathrm{C}$.

tostome, le $\mathrm{C}$. Morelle, lo $\mathrm{C}$ frange, lo $\mathrm{C}$ Fancille, le $\mathrm{C}$. le C. Sucet et le C. Pigo. . . . . . a dre de la classe entière des poissons on premier de l seconde division des os ens. Porsoxs ossexx. ses us STEnхортYx. (Tablean méth. des espèces.). ibil. Le Stornoptyx Hermann. . . . . . . . . . ilid . ordre de la classe entière des Poissons ou premier de la troisième division des osseux. Porsoxs os.

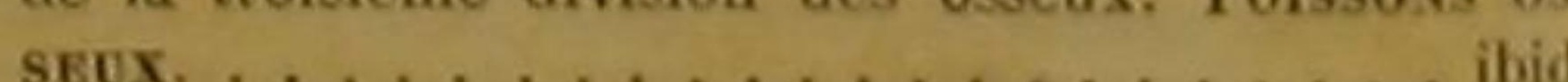
es Stviḱpนores. (Tableau méth. des espèces,) 59 Le Styléphore argenté. ............ ibid Seconde sous-classe, troisième division, vingt-huitième ordre de la classe entière des Poissons ou quatrième de la troisième division des osseux. Porssoxs osseux. . . . . . . . . . . . ihid LEs MonMyres. (Tableau méth. des espèces.). . . ibid. Le Mormyre Kannumé, le M. Oxyrhynque, le M. Dendera. le M. Salabiê, le M. Bébé, le M. Hersé, le M. cyprinoīde, le M. Bané et le M. Hasselquist. . . . . . . . . . . . . . . . 595 vième ordre de la classe entière des Poiscons ou premier de la quatrième division des osseux. Porssov APODES. . . . . . . . . . . . . . 596 Les MuréxopHis. (Tableau méth. des espèces.). ibid. La Murénophis Hélène. . . . . . . . . . 597 La M. Échidne, la M. Colubrine, la M. noirátre, la M. Chainette, la M. réticulaire, la M. africaine, la M. panthérine, la M. étoilée,
la M. ondulée, la M.
Pages.

Les Grunerronixis.s. (Tableau métb. des esp.). 601 L'Unibranchaperture marbrée, I'U. immaLa Gymnomurène cerclée et la G. marbrée. . 602 culée, l'U. cendrée, l'U. rayée et l'U. lisse. Les Munéxoвbenses. (Tableau méth. des esp.). ibid. Des effets de l'art de l'homme sur la nature des La Murénoblenne olivâtre. . . . . . 603 poissons. . . . . . . . . . . 60 Les Sphagéвraxenes. (Tableau mèth. des esp.). ibid. Discouns sur la péche, sur la connaissance des poisLe Sphagebranche Museau-Pointu. ....... ibid. sons fossiles, et sur quelques attributs généranx de

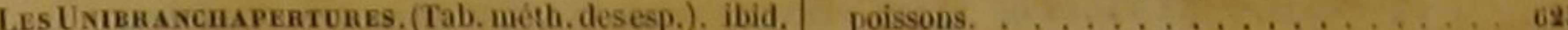

FIS DE IA TADLE. 


\section{TABLE DES PLANCHES}

\section{AVEC}

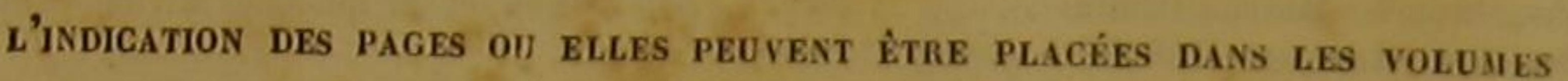

LORSQU'ON NE LES RÉUNIRA PAS EN ATLAS.

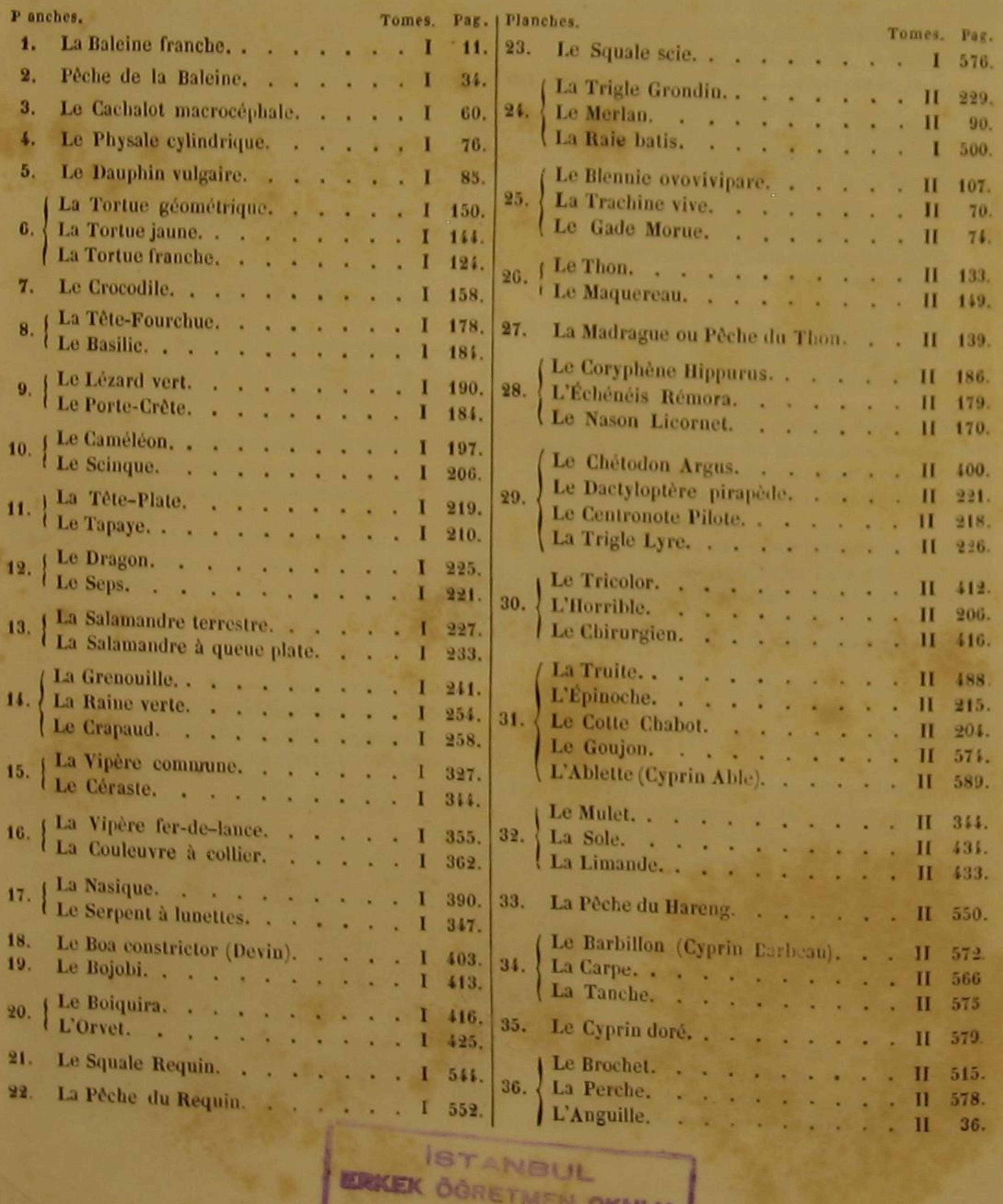

